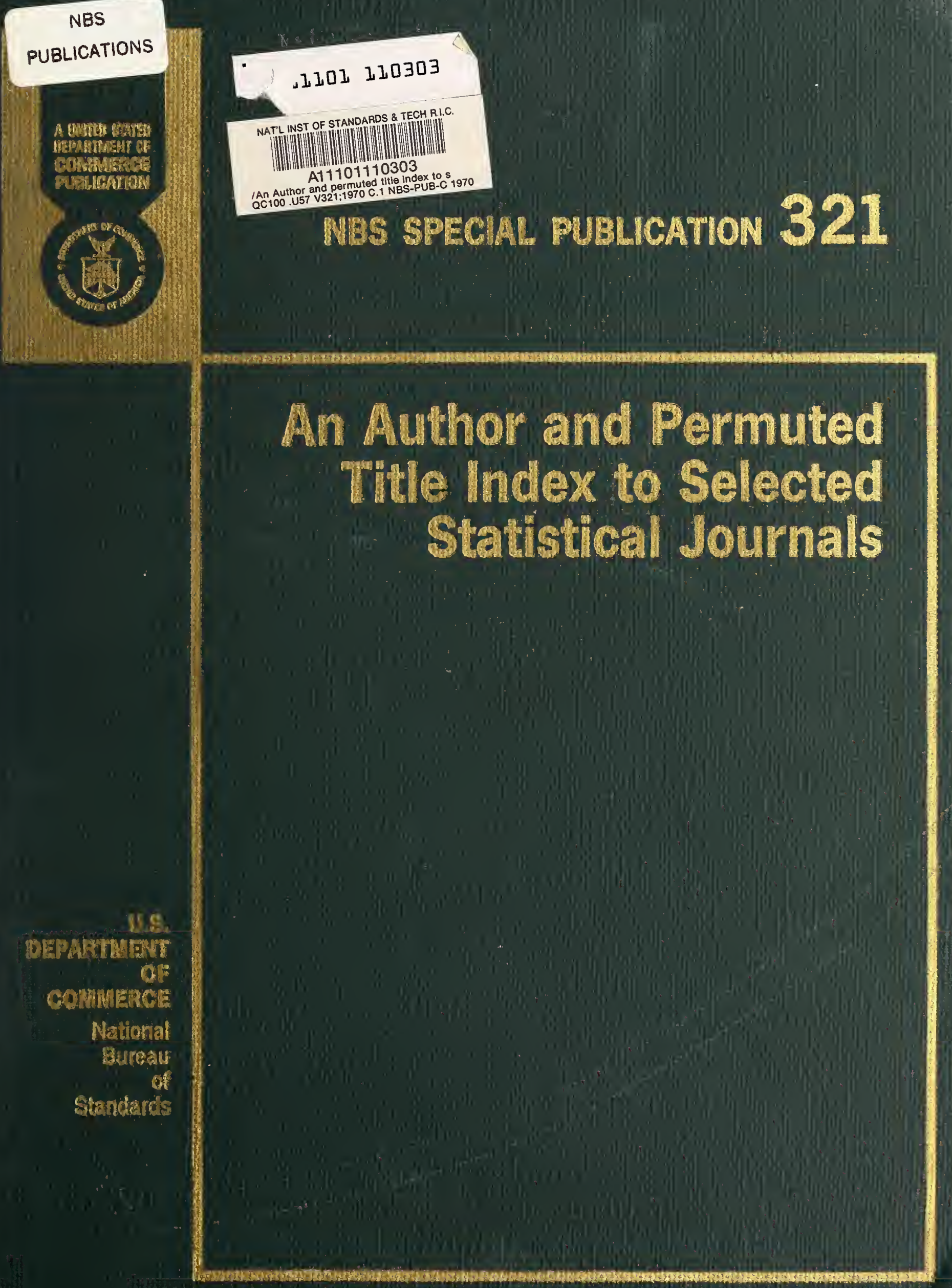







\section{An Author and Permuted Title Index to Selected Statistical Journals}

Brian L. Joiner, ${ }^{1}$ N. F. Laubscher, ${ }^{2}$ Eleanor S. Brown, ${ }^{1}$ and Bert Levy ${ }^{3}$

${ }^{1}$ Institute for Basic Standards, National Bureau of Standards, Washington, D.C. 20234

${ }^{2}$ National Research Institute for Mathematical Sciences,

South African C.S.I.R., Box 395, Pretoria, South Africa

${ }^{3}$ Harry Diamond Laboratories, U.S. Army Materiel Command,

Washington, D.C. 20438

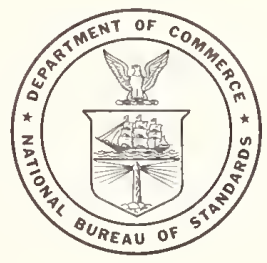

U. S. National Bureau of Standards Special Publication 321

Nat. Bur. Stand. (U.S.), Spec. Publ. 321, 510 pages (Sept. 1970) CODEN: XNBSA

Issued Sept. 1970 


\section{Contents}

Introduction

How to use the index.

Author index.... 


\title{
An Author and Permuted Title Index to Selected Statistical Journals
}

\author{
Brian L. Joiner, N. F. Laubscher, Eleanor S. Brown, and Bert Levy
}

\begin{abstract}
Over 5,000 articles appearing in the indicated issues of the following journals are indexed: Annals of Mathematical Statistics (1961-1969), Biometrics (1965-1969 \#3), Biometrika (1951-1969), Journal of the American Statistical Association (1956-1969), Journal of the Royal Statistical Society, Series B (1954-1969 \#2), South African Statistical Journal (1967-1969 \#2), Technometrics (1959-1969). The articles indexed correspond to those appearing since the most recent cumulative subject index was published for the first six named journals, while for Technometrics all articles have been included even though a subject index exists for the first seven volumes. The index consists of three sections, an author index, a permuted title index and a bibliographic listing. In the permuted title index each article is listed under every important word appearing in its title. This index should consequently serve many of the functions of a conventional subject index. The author index is similar to a conventional author index.
\end{abstract}

Key words: Bibliography; computer indexing; index; key word in context; KWIC; permuted title index; statistics.

\section{Introduction}

\section{How to Use the Index}

The index consists of three sections, a permuted title index, an author index, and a bibliographic listing. In the permuted title, or title word (key word in context) index, every article appearing in any of the seven journals during the included years, is listed in alphabetical order under all important words in its title. Each title reads from left to right except when the word being indexed occurs near the end or beginning of a long title, in which case it was sometimes necessary to "wrap" the title around to the other side of the page. When a title is too long to fit on one line a portion at the beginning and/or end may be chopped off.

This index may be used to retrieve an article if any part of its title is known or to find all articles whose titles include a particular word or phrase. It should consequently serve many of the same functions as a subject index. Some entries in the permuted title index corresponding to words considered of no indexing value have been omitted but no attempt has been made to eliminate all such nonsense entries. Entries corresponding to words that are sometimes hyphenated and sometimes not (e.g. non-linear versus nonlinear) may be slightly separated in the permuted title index. Numeral entries are given last after the letter $\mathrm{Z}$.

The location of each article is specified by an abbreviation of the journal name, the last two digits of the year in which the article was published, and the page on which the article begins. For example, BIOKA65 365 means that the article begins on page 365 of the 1965 issue of Biometrika. For some prepublication entries page numbers were not available and the issue number has been used instead.
In the author index every article is listed under each of its authors' names. Each author's name is followed by as much of the title as will fit on one computer line and by the "location" of the article. Authors will be found under the prefix when their last name is preceded by any of the following prefixes: DE, DEL, DEN, DER, DES, DI, LA, LE, ST, VAN, and VON. Authors may be listed with their given names in full and with one or more of their given names shortened to initials. This, plus the fact that authors whose names are followed by suffixes, such as JR, SR, II, and III, sometimes publish with the suffix dropped, means that occasionally several listings for the same author may become slightly separated.

The bibliography consists of a chronological listing of the table of contents of the seven journals for the included years and may be used to obtain any information that has had to be chopped from a long entry in either the title word or author sections.

In some cases it has been necessary to translate titles that were originally hand set using special fonts into the all-capital format required by the computer. For example " $2^{n "}$ factorial experiments are given as "2-TO-THE-N." A few titles have been annotated to improve their informativeness. Such annotations are always enclosed in parentheses and preceded by a + sign. "Notes" and "queries" are indexed with the main articles in this index, queries being identified as such. Book reviews are not covered. Corrigenda locations are given in two different ways, sometimes as part of the "title" of the article and sometimes as a completely separate entry. In either event, corrigenda should be readily locatable in one or more of the three sections. The indexes have been checked for obvious errors but 
no exhaustive proofreading has been attempted. It may also be noted that this index was prepared for the most part from the tables of contents appearing on the covers of the journals, which in some cases do not agree exactly with the titles and authors appearing inside the journal.

\section{Coverage and Related Indexes}

All articles, notes, queries, corrigenda, and obituaries appearing in the following journals during the indicated years are indexed. For all seven journals the years correspond one-for-one with volume years.

\begin{tabular}{|c|c|c|c|}
\hline Abbreviation & Journal Name & Years & Volumes \\
\hline $\begin{array}{l}\text { AMS } \\
\text { BIOCS } \\
\text { BIOKA } \\
\text { JASA } \\
\text { JRSSB } \\
\text { SASJ } \\
\text { TECH }\end{array}$ & 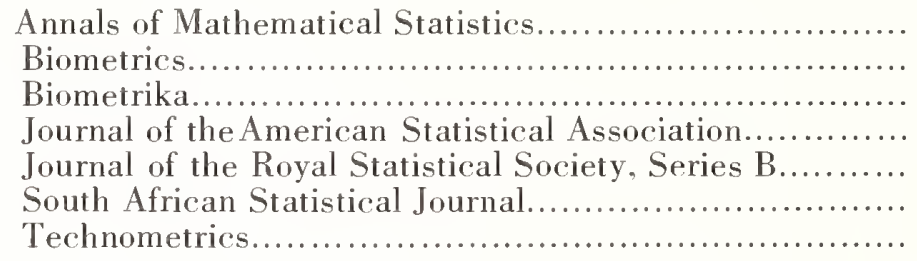 & $\begin{array}{l}1961-1969 \\
1965-1969 \# 3^{*} \\
1951-1969 \\
1956-1969 \\
1954-1969 \# 2 \\
1967-1969 \# 2 \\
1959-1969\end{array}$ & $\begin{array}{l}32-40 \\
21-25 \# 3^{*} \\
38-56 \\
51-64 \\
16-31 \# 2 \\
1-3 \# 2 \\
1-11\end{array}$ \\
\hline
\end{tabular}

*A portion of the contents of the fourth issue for volume 25,1969 , is also included.

Existing indexes to these journals include the following: A comprehensive index to AMS covering volumes 1-31 (1930-1960) including sections on authors, subject matter, tables, citations, and news items; an author and subject index to BIOCS covering volumes $1-20$ (1945-1964), (each volume of BIOCS since 1964 includes annual author and subject indexes); a subject index to BIOKA covering volumes 1-37 (1901-1950) and an author index covering volumes 1-48 (1901-1961); two author and subject indexes to JASA, the first covering volumes 1-34 (1888-1939) and the second covering volumes 35-50 (1940-1955), and an author index to JASA covering volumes 51-60 (1956-1965); combined author and subject indexes for JRSSB which are included in two general indexes to the Journal of the Royal Statistical Society covering JRSSB volumes 1-6 (1934-1939) and volume 7-15 (1940-1941 and 1946 thru 1953) respectively, (volumes 16-22 (1954-1960) of JRSSB contain annual combined author and subject indexes); and author and subject indexes to TECH covering volumes 1-7 (1959-1965).

The computer program used to prepare this index has been used previously in the preparation of volumes 1 and 2 of Computer Literature Bibliography, NBS Miscellaneous Publication 266 and Special Publication 309 respectively, by W. W. Youden. After this index was well under way we learned that John W. Tukey and coworkers at Princeton University and the Bell Telephone Laboratories have done extensive research on methods for improving the format and sorting order of permuted title indexes and have a working draft of an index to virtually all of the statistical literature appearing up to and including 1966.

The basic input to the computer program is a set of approximately 16,000 punched cards quite closely resembling the bibliographic listing. Most of the punched cards for AMS, BIOCS, JASA, JRSSB, and SASJ were provided by N. F. Laubscher, who wishes to acknowledge several of his assistants for their help. All of the cards for BIOKA and TECH and some of the cards for the other five journals were prepared by Eleanor S. Brown. Computer time was provided by Bert Levy and B. M. Kurkjian (then at Harry Diamond Laboratories and now at Headquarters, Army Materiel Command). Rubin Wagner of NBS arranged to have the index electronically phototypset thereby improving readability considerably. The editors of the seven journals contributed to the currentness of this index by supplying prepublication copies of the tables of contents of their journals. Other helpful assistance was provided by Sam Bonnano of Harry Diamond Laboratories, R. L. Chamberlain of Iowa State University, and James J. Filliben and Miss Bonnie Connor of the National Bureau of Standards. Brian L. Joiner served as initiator and coordinator.

This index was initiated for internal use at the National Bureau of Standards and evolved into a cooperative effort of the National Bureau of Standards, the National Research Institute for Mathematical Sciences of the South African Council for Scientific and Industrial Research, and the Harry Diamond Laboratories. Copies in the computer listing form were distributed to a limited number of individuals many of whom indicated that they found it quite useful and asked how copies could be obtained. Since it was prohibitively expensive to distribute more copies in the computer listing form, the decision was made to make it available for distribution as an NBS Special Publication.

The computer program used to prepare this index was written by the late W. W. Youden of the National Bureau of Standards to whom we wish to acknowledge our indebtedness. Without his program this index would not have been undertaken. 
ON THE DERIVATION AND APPLICABILITY OF NEYMAN'S TYPE A DISTRIBUTION BIVARIATE CENERALIZATIONS OF NEYMAN'S TYPE A DISTRIBUTION OF THE METHOD OF MOMENTS AND THE CRAM-CHARLIER TYPE A DISTRIBUTION ESTIMATION FOR THE NECATIVE BINOMIAL AND NEYMAN TYPE A DISTRIBUTIONS NOTE ON MR QUENOUILLE'S EDCEWORTH TYPE A TRANSFORMATION ON AN A.P.O. RULE IN SEQUENTIAL ESTIMATION WITH QUADRATIC LOSS IN THE ABBREVIATED EDCEWORTH AND CRAM-CHARLIER SERIES

THE REGIONS OF UNIMODALITY AND POSITIVITY NEW TECHNIQUES FOR THE ANALYSIS OF ABSENTEEISM DATA

\section{NORMAL DISTRIBUTION}

\section{INTEGRAL}

AL VARIATE

\section{ABSOLUTE AND INCOMPLETE MOMENTS OF THE MULTIVARIATE}

BIOKA62 215

BIOKA59 203

AMS $69 \quad 417$

JASA 57253

BIOCS67 45

JASA $64 \quad 987$ TECH $67 \quad 682$

AMS 681350 AMS $6 B \quad 261$ BIOKA54 77 BIOKA6I 77 AMS $61 \quad 33 B$ THE NON-ABSOLUTE CONVERCENCE OF CIL-PELAEZ' INVERSION THE CORRECT USE OF THE SAMPLE MEAN ABSOLUTE DEVIATION IN CONFIDENCE INTERVALS FOR A NORM CONFIDENCE INTERVALS BASED ON THE MEAN ABSOLUTE DEVIATION OF A NORMAL SAMPLE DISTRIBUTION OF THE ABSOLUTE MAXIMUM FOR CERTAIN BROWNIAN MOTIONS AMS 65311 THAN OR EQUAL TO R, R LES/ INEQUALITIES OF THE RTH ABSOLUTE MOMENT OF A SUM OF RANDOM VARIABLES, 1 LESS AMS 65 299 ION WITH SOME APPLICATIONS INCOMPLETE AND ABSOLUTE MOMENTS OF THE MULTIVARIATE NORMAL DISTRIBUT BI DISTRIBUTION AND POWER OF THE ABSOLUTE NORMAL SCORES TEST ESTIMATORS OF A LOCATION PARAMETER IN THE ABSOLUTELY CONTINUOUS CASE ON ABSOLUTELY CONTINUOUS COMPONENTS AND RENEWAL THEORY F LARCE NUMBERS FOR LINEAR STOCHASTIC PROCESSES WTTH ABSOLUTELY CONVERCENT COEFFICTENTS $F$ LARGE NUMBERS FOR LINEAR STOCHASTIC PROCESSES WITH ABSOLUTELY CONVERCENT COEFFICIENTS /HE STRONC LAW O
WITH SELECTION THE RANDOM WALK BETWEEN A REFLECTING AND AN ABSORBING BARRIER SOME STOCHASTIC PROCESSES WITH ABSORBING BARRIERS SOME PROBLEMS OF STATISTICAL INFERENCE IN ABSORBINC MARKOV CHAINS MARKOV CHAINS WITH ABSORBINC STATES, A CENETIC EXAMPLE

IES IN A SAMPLE OF AN ANIMAL POPULATION IN WHICH THE ABUNDANCES OF SPECIES ARE LOC-NORMALLY DISTRIBUTED USE AND ABUSE OF RECRESSION

ESTIMATION OF AN ACCELERATED DEPRECIATION LEARNING FUNCTION OPTIMAL ACCELERATED LIFE DESIGNS FOR ESTIMATION AN OPTIMAL SEQUENTIAL ACCELERATED LIFE TEST

THE REAL STABLE CHARACTERISTIC FUNCTIONS AND CHAOTIC ACCELERATION ESTIMATING THE FRACTION OF ACCEPTABLE PRODUCT

DOUBLE SAMPLING PLANS WHERE THE ACCEPTANCE CRITERION IS THE VARIANCE STATISTICAL LIFE TEST ACCEPTANCE PROCEDURES ABOUT THE NORMAL DISTRIBUTION WITH APPLICATIONS IN ACCEPTANCE SAMPLING CAMMA DISTRIBUTION IN ACCEPTANCE SAPLING SAMLINC BASED ON THEOREMS

PROCEDURES AND TABLES FOR EVALUATING DEPENDENT MIXED ACCEPTANCE SAMPLING PLANS NUMBER FOR TRUNCATED SINGLE AND DOUBLE ATTRIBUTES ACCEPTANCE SAMPLING PLANS ON THE EOUIVALENCE OF BINOMIAL AND INVERSE BINOMIAL ACCEPTANCE SAMPLING PLANS AND AN ACKNO AVERAGE SAMPLE THLEDGEMENT ON THE THEORY OF RUNS TECH 62 QUARE AND T-SQUARE TESTS AND THEIR APPLICATION TO AN ACCEPTANCE SAMPLING PROBLEM SEQUENTIAL CHI-S TECH $61 \quad 519$ ION ELLIPSOIDS MULTIVARIATE ACCEPTANCE SAMPLINC PROCEDURES FOR GENERAL SPECIFICAT J

SUMMARY OF RECENT WORK ON VARIABLES ACCEPTANCE SAMPLING WITH EMPHASIS ON NON-NORMALITY SERIAL SAMPLING ACCEPTANCE SCHEMES DERIVED FROM BAYES'S THEOREM TASA 6505 TECH $60 \quad 353$ HE MEAN QUALITY HAS A NORMAL PRIO/ SERIAL SAMPLING ACCEPTANCE SCHEMES FOR LARGE BATCHES OF ITEMS WHERE T BIOKAG8 393 VACCINES COMPARATIVE SAMPLING ACCEPTANCE SCHEMES IN TESTING ANTIGENICITY OF ACCURACY REQUIREMENTS FOR ACCEPTANCE TESTING OF COMPLEX SYSTEMS ECONOMICALLY OPTIMUM ACCEPTANCE TESTS

INCENTIVE CONTRACTS AND PRICE DIFFERENTIAL ACCEPTANCE TESTS F/ ERRATA, 'THE EFFECT OF SEQUENTIAL BATCHING FOR ACCEPTANCE-REJECTION SAMPLING UPON SAMPLE ASSURANCE O
OF TOTAL PR/ THE EFFECT OF SEQUENTIAL BATCHING FOR ACCEPTANCE, REJECTION SAMPLING UPON SAMPLE ASSURANCE FURTHER NOTES ON THE ANALYSIS OF ACCIDENT DATA

ON A CONTAGIOUS DISTRIBUTION SUGGESTED FOR ACCIDENT DATA A PROBLEM IN THE COMBINATION OF ACCIDENT FREQUENCIES

UNIQUENESS OF A RESULT IN THE THEORY OF ACCIDENT PRONENESS A RESULT ON ACCIDENT PRONENESS

DISTRIBUTION WITH SPECIAL REFERENCE TO THE THEORY OF ACCIDENT PRONENESS

A TEST FOR 'INTRINSIC CORRELATION' IN THE THEORY OF ACCIDENT PRONENESS (ACKNOWLEDGEMENT 66585 ) NOTE ON A UNIOUENESS RELATION IN CERTAIN ACCIDENT PRONENESS MODELS

A MATHEMATICAL MODEL WITH APPLICATIONS TO A STUDY OF ACCIDENT REPEATEDNESS AMONG CHILDREN

A CLASS OF DISTRIBUTIONS APPLICABLE TO ACCIDENTS

THE TIME INTERVALS BETWEEN INDUSTRIAL ACCIDENTS

$\mathrm{TECH} 61 \quad 131$ TECH $60 \quad 19$ BIOKA53 214 BI0CS67 BIOKA5B 331 BIOKA57 530 BIOKA67 324 JASA 651060 JRSSB $66 \quad 180$ JASA $67 \quad 2 B 8$ JASA 651046 JASA 61503 BIOKA52 168

ONS IN CONTINGENCY TABLES, WITH SPECIAL REFERENCE TO ACCIDENTS AND ABSENTEEISM ON THE EFFECT OF REMOVING PERSONS WITH N OR MORE ACCIDENTS FROM AN ACCIDENT PRONE POPULATION. PAPER TIME INTERVALS BETWEEN ACCIDENTS, A NOTE ON MACUIRE, PEARSON AND WYNN'S POPULATION DIFFERENCES BETWEEN SPECIES CROWING ACCORDINC TO SIMPLE BIRTH AND DEATH PROCESSES RELATION TO THOSE OF INDIVIDUAL FIRMS THE ACCURACY AND STRUCTURE OF INDUSTRY EXPECTATIONS IN ACCURACY BORROWINC IN THE ESTIMATION OF THE MEAN BY SHRINKAGE TO AN INTERVAL 
THE FORECASTINC ACCURACY OF CONSUMER ATTITUDE DATA

THE FOLDED NORMAL DISTRIBUTION, III. ACCURACY OF ESTIMATION BY MAXIMUM LIKELIHOOD

THE ACCURACY OF INTERNATIONAL TRADE DATA, THE CASE OF

SOUTHEAST ASIAN COUNTRIES

ASSESSINC THE ACCURACY OF MULTIVARIATE OBSERE DTIONS

INFLUENCE OF THE INTERVIEWER ON THE ACCURACY OF SURVEY RESULTS

ON THE ACCURACY OF WEIGHTED MEANS AND RATIOS

ACCURACY REQUIREMENTS FOR ACCEPTANCE TESTINC OF

COMPLEX SYSTEMS

SELECTED ECONOMIC DATA. ACCURACY VS. REPORTINC SPEED

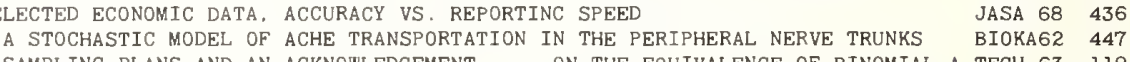

ND INVERSE BINOMIAL ACCEPTANCE SAMPLINC PLANS AND AN ACKNOWLEDCEMENT ON THE EQUIVALENCE OF BINOMIAL A

OF MAXIMUM BIKELTHOOD FSTTMATION' 60 I2OB ACKNOWLEDCEMENT OF PRIORITY FOR 'AN OPTIMUM PROPERTY

GENERAL MODELS FOR QUANTAL RESPONSE TO THE JOINT ACTION OF A MIXTURE OF DRUGS

MODELS FOR THE NON-INTERACTIVE JOINT ACTION OF A MIXTURE OF STIMULI IN BIOLOGICAL ASSAY

RETTE SMOKING AND A STOCHASTIC MODEL FOR THE MODE OF ACTION OF CARCINOGENS /UNG CANCER INCIDENCE TO CICA

TWO-STAGE NORMAL SAMPLING IN TWO-ACTION PROBLEMS WITH LINEAR ECONOMICS

JASA 69 NO. 4

TECH $62 \quad 249$

JASA $69 \quad 452$

JASA $66 \quad 403$

JASA $58 \quad 98$

JASA $58 \quad 635$

BIOKA56 304

JASA 59447

AMS $61 \quad 1343$

BIOKA64 413

BIOKA66 49

BIOCS65 839

JASA 69 NO. 4

XTURES OF POISONS UNDER CONDITIONS OF SIMPLE SIMILAR ACTION, THE ANALYSIS OF UNCONTROLLED DATA /ES TO MI BIOKA58 74

F A RADIO-ACTIVE TRACER EXPERIMENT TO DETERMINE ROOT ACTIVITY IN POTATO PLANTS /E STATISTICAL ANALYSIS O BIOCS6B 717

ESTIMATING THE SERVICE LIFE OF HOUSEHOLD GOODS BY ACTUARIAL METHODS. CORR. 57578

ESTIMATION OF SURVIVORSHIP IN CHRONIC DISEASE. THE 'ACTUARIAL' METHOD

NENTIAL PARAMETER FROM QUANTAL DATA. AND ITS RELA/ ADAPTATION OF KARBER'S METHOD FOR ESTIMATING THE EXPO BIOCS67 739

TO MISSPECIFICATION IN THE 'PARTIAL ADJUSTMENT' AND 'ADAPTIVE EXPECTATIONS' MODELS /ALL SAMPLE BIAS DUE JA ADAPTIVE NONPARAMETRIC CLASSIFICATION

SOME STATISTICAL ASPECTS OF ADAPTIVE OPTIMIZATION AND CONTROL (WITH DISCUSSION)

AN ADAPTIVE PROCEDURE FOR SEQUENTIAL CLINICAL TRIALS

ON THE SAMPLE FUNCTIONS OF PROCESSES WHICH CAN BE ADDED TO A GAUSSIAN PROCESS

ON ADDELMAN'S 2-TO-THE-(17-9) RESOLUTION V PLAN

THE FREQUENCY JUSTIFICATION OF SERUENTIAL TESTS, ADDENDUM

STATISTIC

ADDENDUM, THE LIMITING DISTRIBUTION OF KAMAT'S TEST

ADDING A POINT TO VECTOR DIAGRAMS IN MULTIVARIATE

ON ADDING INDEPENDENT STOCHASTIC PROCESSES

JASA $66 \quad 1130$

TECH 69 N0. 4

JRSSB62 297

JASA $69 \quad 759$

AMS $63 \quad 329$

TECH $66 \quad 705$

BI0KA53 46B

BIOKA56 3B6

BIOKA68 5B2

AMS $64 \quad 872$

ION ANALYSIS

DATA

SQUARE

EXTENSION OF COCHRAN'S FORMULAE FOR ADDITION OR OMISSION OF A VARIATE IN MULTIPLE RECRESS J

THREE FACTOR ADDITIVE DESIGNS MORE GENERAL THAN THE LATIN SQUARE TECH 62 1B7

$\begin{array}{lr}\text { AMS } & 67 \\ 1655\end{array}$

AMS $65 \quad 409$

SOME REMARKS ON CONTINUOUS ADDITIVE FUNCTIONALS

ADDITIVE FUNCTIONALS AND EXCESSIVE FUNCTIONS

DEPENDENT SOLUTION FOR AN INFINITE DAM WITH DISCRETE ADDITIVE INPUTS

REPRESENTING FINITELY ADDITIVE INVARIANT PROBABILITIES

VARIANCE UNBIASED ESTIMATION AND CERTAIN PROBLEMS OF ADDITIVE NUMBER THEORY

UFFICIENT CONDITIONS FOR THE EXISTENCE OF A FINITELY ADDITIVE PROBABILITY MEASURE

ON THRIFTY STRATEGIES AND MARTINGALES IN A FINITELY ADDITIVE SETTING WILLIAM D. SUDDERTH

OF STOCHASTIC SYSTEMS. ARBITRARY SYSTEM PROCESS WITH ADDITIVE WHITE NOISE OBSERVATIONS ERROR

NON-ADDITIVITIES IN A LATIN SQUARE DESIGN

THE INTERPRETATION OF THE EFFECTS OF NON-ADDITIVITY IN THE LATIN SQUARE

NON-ADDITIVITY IN TWO-WAY ANALYSIS OF VARIANCE

PRESIDENTIAL ADDRESS

PATTERNS IN RESIDUALS, A TEST FOR RECRESSION MODEL ADEQUACY IN RADIONUCLIDE ASSAY

ARIANCE IN SMALL SAMPLES. A MONTE CARLO STUDY OF THE ADEQUACY OF THE ASYMPTOTIC APPROXIMATION /YSIS OF V BI

DISTRIBUTIONS IN GENETICS

FLUCTUATIONS

THE ADEQUACY OF THE DIFFUSION APPROXIMATION TO CERTAIN

THE CONSISTENCY AND ADEQUACY OF THE POISSON-MARKOFF MODEL FOR DENSITY ADEQUATE SUBFIELDS AND SUFFICIENCY

THE DETECTION OF A CORRELATION BETWEEN THE SEXES OF ADJACENT SIBS IN HUMAN FAMILIES

NS 68 1025) ADJOINT MATRICES FOR POLYNOMIAL RECRESSION (CORRECTIO

EXPERIMENTAL DESIGNS TO ADJUST FOR TIME TRENDS

NOTE ON MULTIPLE COMPARISONS FOR ADJUSTED MEANS IN THE ANALYSIS OF COVARIANCE

ANALYSIS OF OUTLIERS WITH ADJUSTED RESIDUALS

ALTERNATIVE AXIOMATIZATIONS OF SEASONAL ADJUSTMENT

OBSERVATIONAL STUDIES THE EFFECTIVENESS OF ADJUSTMENT BY SUBCLASSIFICATION IN REMOVING BIAS IN MULTIPLE LINEAR REGRESSION ANALYSIS WITH ADJUSTMENT FOR CLASS DIFFERENCES

A METHOD OF ADJUSTMENT FOR DEFECTIVE DATA

I-SQUARE TEST FOR HETEROGENEITY OF PROPORTIONS AFTER ADJUSTMENT FOR STRATIFICATION (ADDENDUM 67 197) /CH J

LINEAR APPROXIMATIONS TO THE CENSUS AND BLS SEASONAL ADJUSTMENT METHODS

SEASONAL ADJUSTMENT OF DATA FOR ECONOMETRIC ANALYSIS

SEASONAL ADJUSTMENT OF ECONOMIC TIME SERIES AND MULTIPLE

REGRESSION ANALYSIS

MINIMUM VARIANCE, LINEAR, UNBIASED SEASONAL ADJUSTMENT OF ECONOMIC TIME SERIES, CORR. 65 1250

EVALUATION OF BLS AND CENSUS REVISED SEASONAL ADJUSTMENT PROCEDURES SPECTRAL JASA $68 \quad 472$

SAMPLE BIAS DUE TO MISSPECIFICATION IN THE 'PARTIAL ADJUSTMENT' AND 'ADAPTIVE EXPECTATIONS' MODELS /ALL JASA 66 I130 SEASONAL ADJUSTMENTS BY ELECTRONIC COMPUTER METHODS

JASA $57 \quad 415$

SSION TECHNIQUES APPLIED TO SEASONAL CORRECTIONS AND ADJUSTMENTS FOR CALENDAR SHIFTS REGRE JASA $56 \quad 615$

POPULATIONS, I

POPULATIONS, II

POPULATIONS. III

POPULATIONS. IV

POPULATIONS, $\mathrm{V}$

FUNCTIONS OF DISCRETE FINITE STATE MARKOV CHAINS

$$
\text { GENERALIZED BAYES DECISION FUNCTIONS, ADMISSIBILITY AND THE EXPONENTIAL FAMILY }
$$

IZED DESIGNS, OF BALANCED DESIGNS

THE PROBLEM OF A ONE PAY CLASSIFICATION

ON THE ADMISSIBILITY AT INFINITY, WITHIN THE CLASS OF RANDOM

ON THE ADMISSIBILITY OF A RANDOMIZED SYMMETRICAL DESICN FOR ADMISSIBILITY OF CONFIDENCE INTERVALS

IS U/ ON A NECESSARY AND SUFFICIENT CONDITION FOR ADMISSIBILITY OF ESTIMATORS WHEN STRICTLY CONVEX LOSS LOCATION PARAMETERS

LATIONS

A NOTE ON THE ADMISSIBILITY OF POOLING IN THE ANALYSIS OF VARIANCE

LOCATION PARAMETER
ADMISSIBILITY OF QUANTILE ESTIMATES OF A SINGLE

OPTIMUM PROPERTIES AND ADMISSIBILITY OF SEQUENTIAL TESTS
AMS 651707

AMS 651723

AMS 651730 AMS 661658 AMS $69 \quad 672$ AMS 6B 1646 AMS $67 \quad \mathrm{BlB}$ AMS 6B 197B AMS $69 \quad 356$ AMS $66 \quad 629$ AMS $6 \mathrm{~B} \quad 23$ AMS 66 10B7 AMS 661809 AMS $68 \quad 1744$ AMS 641019 AMS 63 
MEAN OF A FINITE POPULATION TRUNCATED SPACES

D OTHER FULLY INVARIANT TESTS FOR CLASSICAL MULTI/
AN OF A UNIVARIATE OR BIVARIATE NORMAL POPULATION
AMS $64 \quad 789$ AMS $6 \mathrm{~B} \quad 606$ ADMISSIBILITY OF THE SAMPLE MEAN AS ESTIMATE OF THE ADMISSIBILITY OF THE USUAL CONFIDENCE SETS FOR THE ME ADMISSIBLE AND MINIMAX ESTIMATES OF PARAMETERS IN ADMISSIBLE BAYES CHARACTER OF T-SQUARED, R-SQUARED AN ADMISSIBLE DESICNS FOR POLYNOMIAL SPLINE RECRESSION

ON A THEOREM OF KARLIN RECARDINC ADMISSIBLE ESTIMATES FOR EXPONENTIAL POPULATIONS

ALL ADMISSIBLE LINEAR ESTIMATES OF THE MEAN VECTOR

ON A CLASS OF ADMISSIBLE PARTITIONS

ADMISSIBLE TESTS IN MULTIVARIATE ANALYSIS OF VARIANCE

AMS 691042 AMS $61 \quad 136$

AMS $65 \quad 747$ AMS $69 \quad 1557$ AMS 69216 AMS $66 \quad 45 B$ AMS $66 \quad 1$ B9 AMS 67698
IDENCE INTERVALS FOR THE PARAMETER OF A DISTRIBUTION ADMITTINC A SUFFICIENT STATISTIC WHEN THE RANCE DEPEN JE EXACT FORMS OF SOME INVARIANTS FOR DISTRIBUTIONS ADMITTINC SUFFICIENT STATISTICS LIHOOD SURFACE OF A SAMPLE DRAWN FROM A DISTRIBUTION ADMITTINC SUFFICIENT STATISTICS /VATURE OF THE LIKE BI MODEL SOME RECENT ADVANCES IN SAMPLING THEORY

GRAPHIC METHODS BASED UPON PROPERTIES OF ADVANCING CENTROIDS

FURTHER COMMENTS ON THE 'FINAL REPORT OF THE ADVISORY COMMITTEE ON WEATHER CONTROL' LINEAR RELATIONSHIPS BETWEEN VARIABLES AFFECTED BY ERRORS

IZED BLOCK DESIGN AN EMPIRICAL STUDY INTO FACTORS AFFECTING THE F-TEST UNDER PERMUTATION FOR THE RANDOM JA A GUIDE TO THE LITERATURE ON STATISTICS OF RELIGIOUS AFFILIATION WITH REFERENCES TO RELATED SOCIAL STUDIES JA STATISTICS IN SOUTH AFRICA

ORIGINS AND GROWTH THE SOUTH AFRICAN STATISTICAL ASSOCIATION, A SKETCH OF ITS

WEIGHT-HEICHT RELATIONSHIPS OF YOUTHS OF MILITARY AGE

ASYMPTOTIC PROPERTIES OF AN AGE DEPENDENT BRANCHING PROCESS

AN INTEGRAL EQUATION IN AGE DEPENDENT BRANCHING PROCESSES

MONOTONE CONVERGENCE OF MOMENTS IN ACE DEPENDENT BRANCHING PROCESSES

ON THE SUPERCRITICAL ONE DIMENSIONAL AGE DEPENDENT BRANCHINC PROCESSES ON THE INTERPRETATION OF ACE DISTRIBUTIONS

AND ESTIMATING PARAMETERS IN HUMAN CENETICS IF THE AGE OF ONSET IS RANDOM 02 TO $1959-61$

\section{THE ACE REPLACEMENT PROBLEM}

AN AGE-DEPENDENT BIRTH AND DEATH PROCESS AGE-DEPENDENT BRANCHINC PROCESSES UNDER A CONDITION

OF ULTIMATE EXTINCTION ACE-DEPENDENT BRANCHINC PROCESSES UNDER A CONDITION

OF EXTINCTION FOR BIRTH-AND-DEATH PROCESSES THAT ARE AGE-DEPENDENT OR PHASE-DEPENDENT A DEMOGRAPHIC MODEL FOR ESTIMATINC ACE-ORDER SPECIFIC FERT
ON MEASURING THE EXTREME ACED IN THE POPULATION

A SCREENING SYSTEM FOR ANTI-CANCER ACENTS BASED ON THE THERAPEUTIC INDEX ON FORMING STRATA OF EQUAL AGGREGATE SIZE

ESTIMATORS AS A TOOL IN ALLOCATING PREDETERMINED AGCRECATES MATING SEEMINGLY UNRELATED REGRESSIONS AND TESTS FOR AGCRECATION BIAS SOME CRITERIA FOR AGING A LIFE TABLE THAT AGREES WITH THE DATA, II

PROBLEMS OF SAMPLE ALLOCATION AND ESTIMATION IN AN AGRICULTURAL SURVEY AN ECONOMETRIC MODEL FOR UNITED STATES ACRICULTURE

MODEL BUILDING WITH THE AID OF STOCHASTIC PROCESSES COMPUTER AIDED DESIGN OF EXPERIMENTS

LIKELIHOOD AIDS FOR FII

MEASUREMENT OF COST-QUANTITY RELATIONSHIPS IN THE AIRCRAFT INDUSTRY ED AGGREGATES AITKEN ESTIMATORS AS A TOOL IN ALLOCATINC PREDETERMIN JASA 69913 IVE BINOMIAL FREQUENCY FUNCTIONS IN CURVE FITTINC BY AITKEN'S METHOD YNOMIALS OF THE POSITIVE AND NEGAT BIOKAGI IIS IVE BINOMIAL FREQUENCY FUNCTIONS IN CURVE FITTING BY AITKEN'S METHOD' /POLYNOMIALS OF POSITIVE AND NECAT BIOKA6I 476 ALANCED INCOMPLETE BLOCK DESIGN THE RELATIONSHIP ALGEBRA AND THE ANALYSIS OF VARIANCE OF A PARTIALLY B AMS 65 1815 SOME PROPERTIES OF AN ALGEBRAIC REPRESENTATION OF STOCHASTIC PROCESSES

F SIGNIFICANCE ON THE DIMENSIONALITY OF NORMAL ON QUALITATIVE PROBABILITY SIGMA-ALGEBRAS

CONDITIONAL PROBABILITY ON SIGMA-COMPLETE BOOLEAN ALGEBRAS CONVERGENCE PROPERTIES OF A LEARNING ALGORITHM THE INVERSE YATES ALGORITHM NOTES. CHECKS ON YATES'S ALGORITHM

OWER N FACTORIAL EXPERIMENT AS CALCULATED BY YATES'S ALGORITHM THE INTERACTION ALGORITHM AND PRACTICAL FOURIER ANALYSIS

THE INTERACTION ALGORITHM AND PRACTICAL FOURIER ANALYSIS, AN ADDENDUM AN ALGORITHM FOR HIERARCHICAL CLASSIFICATIONS AN ALCORITHM FOR OBTAINING THE ZERO OF A FUNCTION OF THE AN ALGORITHM FOR THE DECOMPOSITION OF A DISTRIBUTION

DISPERSION MATRIX IN MULTIVARIATE ANALYSIS INTO GAUSSIAN COMPONENTS

$N$ OF $X$-CHARTS BASED ON DUNCAN'S MODEL AN ALGORITHM FOR THE DETERMINATION OF THE ECONOMIC DESIG THE EXTENSION OF YATES' 2-TO-THE-N ALGORITHM TO ANY COMPLETE FACTORIAL EXPERIMENT TIMES-3-TO-THE-M DESIGNS AND TWO-FACTOR INTERACTION ALIASINC ALIASING IN PARTIALLY CONFOUNDED FACTORIAL EXPERIMENTS ALIASING IN PARTIALLY CONFOUNDED FACTORIAL

229) (CORR. 69 229) ON A CLASS OF ALIGNED RANK ORDER TESTS IN TWO-WAY LAYOUTS A METHOD FOR JUDCING ALL CONTRASTS IN THE ANALYSIS OF VARIANCE (CORR, 69 OF RESPONSE TO SELECTION IN BREEDING PROGRAMMES WHEN ALL DAUGHTERS OF SELECTED PARENTS ARE RETAINED /ON TIC COMPONENTS FOR NON-INBRED DIPLOID SPECIES HAVING ALL DIGENIC EPISTATIC VAR A RANK SUM TEST FOR COMPARING ALL PAIRS OF TREATMENTS
EFFICIENT CALCULATION OF ALL POSSIBLE RECRESSIONS

OD ESTIMATOR IS UNBIASED AND OF MINIMUM VARIANCE FOR ALL SAMPLE SIZES /NS FOR WHICH THE MAXIMUM-LIKELIHO B RTHOGONAL MAIN-EFFECT PLANS PERMITTING ESTIMATION OF ALL TWO-FACTOR INTERACTIONS FOR THE 2-TO-THE-N TIMES THE MATCHED PAIRS DESIGN IN THE CASE OF ALL-OR-NONE RESPONSES MATCHING WITH MULTIPLE CONTROLS IN THE CASE OF ALL-OR-NONE RESPONSES ON THE PROBLEM OF SELF-INCOMPATABILITY ALLELES EQUILIBRIA UNDER SELECTION FOR K ALLELES EQUILIBRIUM UNDER SELECTION AT A MULTI-ALLELIC SEX-LINKED LOCUS (ACKNOWLEDGEMENT 68 1025)

IN A SEQUENCE OF TWO ALTERNATIVES. I. WILCOXON'S AND ALLIED TEST STATISTICS A NOTE ON WILCOXON'S AND ALLIED TESTS

\section{INDIVIDUAL} NON-RANDOMNESS AMS 64 17B AMS 69970 AMS 641819 TECH $66 \quad 177$ BIOCS67 573 BIOCS67 571 JRSSB5B 361 JRSSB $60 \quad 372$ BIOCS69 165 JASA 6B 304 TECH 6B 575 TECH $68 \quad 559$ BIOKA61 218 AMS 6B 1115 BIOKA53 B' BIOCS69 553 BIOCS69 545 TECH $60 \quad 197$ TECH 6B 769 BIOKA56 200 ECH 69 NO. 4 BIOCS6B 339 BIOCS66 111 BIOCS66 121 BIOCS68 187 BIOKA5B 166 BIOKA56 485 
THE LADY TASTING TEA, AND ALLIED TOPICS

AITKEN ESTIMATORS AS A TOOL IN ALLOCATINC PREDETERMINED AGCRECATES

PROBLEMS OF SAMPLE ALLOCATION AND ESTIMATION IN AN AGRICULTURAL SURVEY

ISOTOPE DILUTION

RANDOM ALLOCATION

SOLUTION

PRTOR INFORMAT ON

$R$ RESPONSES OF INTEREST

DISCUSSION ) PROBLEM OF OPTIMUM ALLOCATION ARISING IN CHEMICAL ANALYSES BY MULTIPLE
RANDOM ALLOCATION DESICNS II. APPROXIMATE THEORY FOR SIMPLE A NOTE ON OPTIMUM ALLOCATION FOR A ONE-WAY LAYOUT

THE USE OF RANDOM ALLOCATION FOR THE CONTROL OF SELECTION BIAS OPTIMUM ALLOCATION IN MULTIVARIATE SURVEYS, AN ANALYTICAL

OPTIMAL ALLOCATION IN RECRESSION AS APPLIED TO EXTRAPOLATION OPTIMAL ALLOCATION IN STRATIFIED AND MULTISTACE SAMPLES USING OPTIMUM ALLOCATION OF SAMPLING UNITS TO STRATA WHEN
OPTIMUM ALLOCATION OF SPARE COMPONENTS IN SYSTEMS

A NOTE ON AN ALLOCATION PROBLEM

ALLOCATION RULES AND THEIR ERROR RATES IWITH

SOME CONSIDERATIONS IN MULTIVARIATE ALLOMETRY

WEIGHTED PROBITS ALLOWINC FOR A NON-ZERO RESPONSE IN THE CONTROLS

COMBINATION OF ESTIMATES FROM SIMILAR EXPERIMENTS, ALLOWING FOR INTER-EXPERIMENT VARIATION

THE ALMOST FULL DAM WITH POISSON INPUT

THE ALMOST FULL DAM WITH POISSON INPUT, FURTHER RESULTS

ESTIMATES

ON INVARIANCE AND ALMOST INVARIANCE

ALMOST LINEARLY-OPTIMUM COMBINATION OF UNBIASED

AN INEQUALITY AND ALMOST SURE CONVERCENCE

EPENDENT AND RAN/ SOME RESULTS ON THE COMPLETE AND ALMOST SURE CONVERCENCE OF LINEAR COMBINATIONS OF IND INDEPENDENT RANDOM VARIABLES ALMOST SURE CONVERCENCE OF QUADRATIC FORMS IN

OM ENVIRONMENT

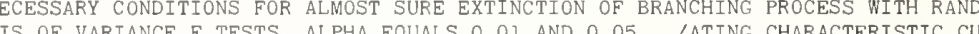
FOR SELECTINC THE T POPULATION WITH THE LARCEST ALPHA-QUANTILE

A SUBSET CONTAINING THE POPULATION WITH THE LARCEST ALPHA-QUANTILE NOTE ON DYNKIN'S 'ALPHA, XI' SUBPROCESS OF STANDARD MARKOV PROCESS

EAST SQUARES AND ANALYSIS OF VARIANCE PROCEDURES ARE ALSO BEST /STRUCTURES UNDER WHICH CERTAIN SIMPLE L JR OF ONE-SIDED KOLMOCOROV AND SMIRNOV TESTS FOR NORMAL ALTERNATIONS

I POWERFUL TEST FOR CERTAIN PROBLEMS WITH RESTRICTED ALTERNATIVE ALTERNATIVE ANALYSIS OF CONTINCENCY TABLES

ON THE COMPARISON OF SEVERAL MEAN VALUES. AN ALTERNATIVE APPROACH

ASYMPTOTICALLY NONPARAMETRIC INFERENCE, AN ALTERNATIVE APPROACH TO LINEAR MODELS ALTERNATIVE AXIOMATIZATIONS OF SEASONAL ADJUSTMENT

DISCRIMINATION

ALTERNATIVE AXIOMATIZATIONS OF SEASON

FFICIENT IN SHORT AUTOREGRESSIVE SEQUENCES ALTERNATIVE DEFINITIONS OF THE SERIAL CORRELATION COE J,

A CLASSIFICATION PROBLEM IN WHICH INFORMATION ABOUT ALTERNATIVE DISTRIBUTIONS IS BASED ON SAMPLES ALTERNATIVE EFFICIENCIES FOR SIGNED RANK TESTS

SAMPLE PROBLEM

EQUATION

IONS

ON SOME ALTERNATIVE ESTIMATES FOR SHIFT IN THE P-VARIATE ONE

THE EFFICIENCIES OF ALTERNATIVE ESTIMATORS FOR AN ASYMPTOTIC REGRESSION

SMALL SAMPLE PROPERTIES OF ALTERNATIVE ESTIMATORS OF SEEMINGLY UNRELATED REGRESS J

FOR TESTING A NULL HYPOTHESIS AGAINST A TWO SIDED ALTERNATIVE HYPOTHESIS

TESTS FOR RANDOMNESS IN A SERIES OF EVENTS WHEN THE ALTERNATIVE IS A TREND INEQUALITIES

MOST STRINGENT SOMEWHERE MOST POWERFUL TESTS AGAINST ALTERNATIVE RESTRICTED BY A NUMBER OF LINEAR INEQUALT ICAL MODELS FOR QUANTAL RESPONSES TO MIXTURES/ MONTE CARLO RESULTS

AN ALTERNATIVE SYSTEM FOR THE CLASSIFICATION OF MATHEMAT B. ALTERNATIVE TESTS FOR HETEROCENEITY OF VARIANCE, SOME

ANALYSIS OF VARIANCE AS AN ALTERNATIVE TO FACTOR ANALYSIS

THE USE OF CONTROL OBSERVATIONS AS AN ALTERNATIVE TO INCOMPLETE BLOCK DESICNS

EXPERIMENTS WITH MIXTURES

AN ALTERNATIVE TO THE SIMPLEX-LATTICE DESIGN FOR

TESTING HOMOCENEITY ACAINST ORDERED ALTERNATIVES

ON MODELS AND HYPOTHESES WITH RESTRICTED ALTERNATIVES

TESTING OF MEANS WITH DIFFERENT ALTERNATIVES

MINIMAX RESULTS FOR IFRA SCALE ALTERNATIVES

A OISTRIBUTION-FREE K-SAMPLE TEST ACAINST ORDERED ALTERNATIVES A TEST OF HOMOGENEITY FOR ORDERED ALTERNATIVES

A NON-NULL RANKINC MODEL FOR A SEQUENCE OF M ALTERNATIVES

FOR RANDOMNESS OF DIRECTIONS ACAINST TWO CIRCULAR ALTERNATIVES

NORMALITY OF SIMPLE LINEAR RANK STATISTICS UNDER ALTERNATIVES OF MANN-WHITNEY TEST FOR EXPONENTIAL AND RECTANCULAR ALTERNATIVES ONNECTED WITH GOODNESS-OF-FIT TESTS FOR EQUIPROBABLE ALTERNATIVES THE EQUALITY OF COVARIANCE MATRICES ACAINST CERTAIN ALTERNATIVES

THE ONE SAMPLE WILCOXON TEST FOR NON-NORMAL SHIFT ALTERNATIVES EFFICIENCY OF GOODNESS-OF-FIT TESTS AGAINST SCALAR ALTERNATIVES LOCATION IN MULTIVARIATE POPULATIONS FOR RESTRICTED ALTERNATIVES THE MANN-WHITNEY-WILCOXON U-STATISTIC UNDER LEHMANN ALTERNATIVES UTION OF THE MANN-WHITNEY U-STATISTICS UNDER LEHMANN ALTERNATIVES OF TWO NORMAL DISPERSION MATRICES AGAINST ONE-SIDED ALTERNATIVES ND MASSEY'S TWO SAMPLE TESTS AGAINST SOME PARAMETRIC ALTERNATIVES

A TEST OF HOMOCENEITY OF MEANS UNDER RESTRICTED ALTERNATIVES RANK TESTS FOR RANDOMIZED BLOCKS WHEN THE ALTERNATIVES ON CHERNOFF-SAVAGE TESTS FOR ORDERED ALTERNATIVES IN MODEL I ANALYSIS

TWO-SAMPLE COMPARISONS OF DISPERSION MATRICES FOR ALTERNATIVES OF INTERMEDIATE SPECIFICITY ALTERNATIVES TO A LATIN SQUARE

HYPOTHESIS OF EQUAL CELL FREQUENCIES TWO ALTERNATIVES

S NON-RANDOMNESS IN A SEQUENCE OF TWO ALTERNATIVES A TEST OF HOMOGENEITY FOR ORDERED ALTERNATIVES. NON-RANDOMNESS IN A SEQUENCE OF TWO ALTERNATIVES

K-ORDER SEQUENTIAL PROBABILITY RATIO TEST ON LEHMANN ALTERNATIVES. NORMALITY OF SIMPLE LINEAR RANK STATISTICS UNDER ALTERNATIVES, II FINITE SET OF REAL NUMBERS THE RANDOMIZATION BASES OF THE PROBLEM OF THE AMALGAMATION OF WEICHTED MEANS ACE PATTERNS OF MORTALITY OF AMERICAN NEGROES. 1900-02 TO 1959-61 NONPARAMETRIC PROCEDURES THE MOST STRINCENT SOMEWHERE MOS

JASA $59 \quad 776$

JASA 69913

JRSSB54 223

TECH 61509

AMS $61 \quad 3 \mathrm{~B} 7$

BIOKA62 563

BIOKA69 NO.3

JRSSB67 115

TECH $69 \quad 3 B 9$

JASA $68 \quad 964$

JASA $65 \quad 225$

TECH 61399

JRSSB69 119

JRSSB66 1

BIOCS66 747

BIOKA56 207

JASA $67 \quad 241$

JRSSB6 629

JRSSB6 6448

AMS $68 \quad 1573$

$\begin{array}{lll}\text { JASA } & 61 \quad 36\end{array}$

AMS 691091

AMS 6B 1549

AMS 6B 1502

AMS 682136

JASA $57 \quad 345$

AMS $67 \quad 1804$

AMS 671788

AMS 671647

A.SA 69 NO. 4

AMS $66 \quad 940$

AMS 6B 531

JRSSB6 6164

BIOKA5 1 330

AMS 631494

JASA $66 \quad 800$

BIOKA67 573

JASA $58 \quad 881$

AMS $62 \quad 213$

AMS 651759

AMS 641079

BIOKA58 370

JASA $68 \quad 1180$

JRSSB 69 NO. 2 JRSSB56 234 AMS $67 \quad 735$

AMS 661161

BIOCS65 181 BIOKA66 229 JRSSB57 31B JRSSB62 464 JRSSB69 NO. 2 AMS $63 \quad 945$ JASA $65 \quad 1153$ TECH 68195 AMS 69 1778 BIOKA54 133 BIOKA59 36 BIOKA61 441 TESTS JASA 69 2BO ASYMPTOTIC AMS 6B 325 EXACT POWER AMS $66 \quad 945$ TWO TABLES C BIOKA68 441 SIMULTANEOUS TESTS FOR AMS 681303 SMALL SAMPLE POWER FOR AMS 651767 THE ASYMPTOTIC RELATIVE JASA $65 \quad 410$ ON THE PROBLEM OF TESTING AMS $66 \quad 113$ $\begin{array}{llll} & \end{array}$ /A PROPERTY OF A TEST FOR THE EQUALITY AMS 621463 /TOTIC RELATIVE EFFICIENCY OF MOOD'S A AMS 621375 JRSSB61 239 AMS $67 \quad$ B 67 AMS $67 \quad 1740$ AMS $6 B \quad 967$ AMS $62 \quad 432$ BIOCS68 657 BIOKA62 107 BIOKA58 166 BIOKA59 32B BIOKA5B 253

AMS 661154 AMS 69 NO. 6 BIOKA59 317 JRSSB61 423 JASA $69 \quad 433$ 
CROUPED OBSERVATIONS IN THE ESTIMATION OF/

ON THE AMOUNT OF INFORMATION SUPPLIED BY CENSORED SAMPLES OF BIOKA62

$F$ GROUPED OBSERVATIONS IN THE ESTIMATION O/

ON THE AMOUNT OF INFORMATION SUPPLIED BY TRUNCATED SAMPLES 0 INHALATION IN RELATION TO TYPE AND AMOUNT OF SMOKINC

STATIONARY AMPLITUDE FLUCTUATIONS IN A RANDOM SERIES

-LINEAR RESIDUALS

A NOTE ON THE ESTIMATION OF AMPLITUDE SPECTRA FOR STOCHASTIC PROCESSES

A DISTRIBUTION-FREE METHOD OF ANALIZING A 2-TO-THE-M FACTORIAL EXPERIMENT

A DISTRIBUTION ANALOCOUS TO THE BOREL-TANNER

SOME SEQUENTIAL ANALOCS OF STEIN'S TWO-STACE TEST

ON AN ANALOGUE OF BHATTACHARYA BOUND

CRESSION, WITH APPLICATION TO MANIFOLD, I THE RANK ANALOCUE OF PRODUCT-MOMENT PARTIAL CORRELATION AND RE BIOKA59 24I CRAL RANCE

AN ANALOCUE OF TCHEBYCHEFF'S INEQUALITY IN TERMS OF THE TECH $62 \quad 133$ A MULTIVARIATE ANALOCUE OF THE ONE-SIDED TEST A K-SAMPLE ANALOGUE OF WATSON'S U-SQUARE STATISTIC

ON THE COMPLEX ANALOCUES OF T-SQUARED AND R-SQUARED TESTS ANALOCUES OF THE NORMAL DISTRIBUTION ON THE CIRCLE

AND THE SPHERE ANALYSES BY MULTIPLE ISOTOPE DILUTION

A PROBLEM OF OPTIMUM ALLOCATION ARISINC IN CHEMICAL ANALYSES BY MULTIPLE ISOTOPE DILUTION
SOME ANALYSES OF INCOME-FOOD RELATIONSHIPS EVALUATION OF CHEMICAL ANALYSES ON TWO ROCKS BIOKA63 BI TECH 61509 JASA 58905 TECH 59409 ION OF HERITABILITY ESTIMATES OBTAINED FROM VARIANCE ANALYSES' CORRECTION TO 'COEFFICIENTS OF VARIAT BIOCS65 265 ON THE USE OF THE DIRECT MATRIX PRODUCT IN ANALYSING CERTAIN STOCHASTIC POPULATION MODELS THE USE OF NON-LINEAR REGRESSION METHODS FOR ANALYSING SENSITIVITY AND QUANTAL RESPONSE DATA BIOKA66 397 THE USE OF NON-LINEAR REGRESSION METHODS FOR ANALYSING SENSITIVITY AND QUANTAL RESPONSE DATA
AL AND OTHER CONTAGIOUS DISTRIBUTIONS A METHOD OF ANALYSING UNTRANSFORMED DATA FROM THE NEGATIVE BINOMI LINEAR PROCRAMMING TECHNIQUES FOR REGRESSION ANALYSIS BIBLIOGRAPHY ON SEQUENTIAL ANALYSIS VARIATIONS FLOW ANALYSIS AN APPROACH TO TIME SERIES ANALYSIS A MODEL FOR MIGRATION ANALYSIS THIRD ORDER ROTATABLE DESIGNS IN THREE FACTORS. ANALYSIS ASYMPTOTIC THEORY FOR PRINCIPAL COMPONENT ANALYSIS ON AN ANALOG OF REGRESSION ANALYSIS A NOTE ON RESIDUAL ANALYSIS BAYESIAN ESTIMATION IN MULTIVARIATE ANALYSIS HYPERGEOMETRIC FUNCTIONS IN SEQUENTIAL ANALYSIS UNIFIED LEAST SQUARES ANALYSIS THE ANALYSIS OF DISTURBANCES IN REGRESSION ANALYSIS A REAPPRAISAL OF THE PERIODOGRAM IN SPECTRAL ANALYSIS INEQUALITY RESTRICTIONS IN REGRESSION ANALYSIS SEASONAL ADJUSTMENT OF DATA FOR ECONOMETRIC ANALYSIS THE ASSESSMENT OF PRIOR DISTRIBUTIONS IN BAYESIAN ANALYSIS QUERY, RESIDUAL ANALYSIS

SELECTION OF THE BEST SUBSET IN REGRESSION ANALYSIS DIVIDEND POLICY, AN EMPIRICAL ANALYSIS ESTIMATION OF ERROR RATES IN DISCRIMINANT ANALYSIS ONE SIDED PROBLEMS IN MULTIVARIATE ANALYSIS SOME EXACT TESTS IN MULTIVARIATE ANALYSIS TESTS OF SIGNIFICANCE IN CANONICAL ANALYSIS DISCRIMINATION IN TIME-SERIES ANALYSIS CAPTURE-RECAPTURE ANALYSIS TESTS OF SIGNIFICANCE IN CANONICAL ANALYSIS JUMP ANALYSIS

DEPARTURES FROM ASSUMPTION IN SEQUENTIAL ANALYSIS A THEOREM IN TREND ANALYSIS BAYESIAN SEQUENTIAL ANALYSIS

LINEAR AND NON-LINEAR MULTIPLE COMPARISONS IN LOGIT ANALYSIS SOME GENERAL RESULTS IN SEQUENTIAL ANALYSIS THE DISCARDING OF VARIABLES IN MULTIVARIATE ANALYSIS ADDING A POINT TO VECTOR DIAGRAMS IN MULTIVARIATE ANALYSIS ANALYSIS OF VARIANCE AS AN ALTERNATIVE TO FACTOR ANALYSIS ON THE EXACT DISTRIBUTION OF A TEST IN MULTIVARIATE ANALYSIS

THE INTERACTION ALGORITHM AND PRACTICAL FOURIER ANALYSIS MULTIVARIATE QUANTAL ANALYSIS BANDWIDTH AND RESOLVABILITY IN STATISTICAL SPECTRAL ANALYSIS MODELS OF THE SECOND KIND IN RECRESSION ANALYSIS MISSING DATA IN RECRESSION ANALYSIS A METHOD FOR CLUSTER ANALYSIS

MATRIX AND MULTIPLE DECREMENT IN POPULATION ANALYSIS A COMPARISON OF SOME METHODS OF CLUSTER ANALYSIS MISSING VALUES IN LINEAR MULTIPLE DISCRIMINANT ANALYSIS A DISCONTINUITY IN MIXED MODEL ANALYSIS THE POWER OF A TEST IN COVARIANCE ANALYSIS NOTE ON AN APPROXIMATE FACTORIZATION IN DISCRIMINANT ANALYSIS NON-CENTRAL DISTRIBUTION PROBLEMS IN MULTIVARIATE ANALYSIS APPLICATIONS OF MATRIX DERIVATIVES IN MULTIVARIATE ANALYSIS CONSEQUENCES OF SUPERIMPOSED ERROR IN TIME SERIES ANALYSIS FURTHER NOTES ON DISTURBANCE ESTIMATES IN RECRESSION ANALYSIS PROBLEMS INVOLVING LINEAR HYPOTHESES IN MULTIVARIATE ANALYSIS ON DIRECTION AND COLLINEARITY FACTORS IN CANONICAL ANALYSIS USE OF INCOMPLETE PRIOR INFORMATION IN REGRESSION ANALYSIS

THEOREM AND THE USE OF PRIOR KNOWLEDGE IN REGRESSION ANALYSIS GROUPING, REGRESSION AND CORRELATION IN ENGEL CURVE ANALYSIS 
OF SEPARATE FAMILIES OF HYPOTHESES IN TIME SERIES ANALYSIS OF STANDARDIZATION ON AN APPROXIMATION IN FACTOR ANALYSIS ANALYSIS PROBLEM IN CONSTRAINED QUADRATIC REGRESSION ANALYSIS DISTRIBUTION OF A STATISTIC IN PRINCIPAL COMPONENTS ANALYSIS OF CORRECT CLASSIFICATION IN DISCRIMINANT ANALYSIS IN THE STUDY OF VARIANCE FLUCTUATIONS IN TIME SERIES ANALYSIS EHAVIOR OF DENSITIES WITH APPLICATIONS TO SEQUENTIAL ANALYSIS OF THE LATENT VECTORS FOR PRINCIPAL COMPONENTS ANALYSIS OF THE LARGEST RDOT OF A MATRIX IN MULTIVARIATE ANALYSIS OF ECONOMIC TIME SERIES AND MULTIPLE REGRESSION ANALYSIS THE LARCEST OF SIX RODTS OF A MATRIX IN MULTIVARIATE ANALYSIS DIRECTION AND COLLINEARITY FACTORS IN DISCRIMINANT ANALYSIS ERRORS IN CLASSICAL LINEAR LEAST-SQUARES REGRESSION ANALYSIS OF THE LARGEST ROOT OF A MATRIX IN MULTIVARIATE ANALYSIS LARGEST OF SEVEN ROOTS OF A MATRIX IN MULTIVARIATE ANALYSIS LATENT ROOT AND VECTOR METHODS USED IN MULTIVARIATE ANALYSIS OF A MIXED MODEL WITH APPLICATION TO REGRESSION ANALYSIS CONNECTION BETWEEN ANALYSIS DF VARIANCE AND SPECTRUM ANALYSIS LIKELIHOOD AND THE METHOD OF MOMENTS IN PRDBIT ANALYSIS IENCY AND INVARIANCE WITH APPLICATIONS IN SEQUENTIAL ANALYSIS

IN DERIVING TESTS OF SIGNIFICANCE IN MULTIVARIATE ANALYSIS

OR THE SMALLEST ROOT OF A MATRIX IN MULTIVARIATE ANALYSIS OF THE GENERAL LINEAR HYPOTHESIS IN MULTIVARIATE ANALYSIS FUNCTIONS OF THE ROOTS OF A MATRIX IN MULTIVARIATE ANALYSIS A FUNCTION OF THE DISPERSION MATRIX IN MULTIVARIATE ANALYSIS NCTIONS FOR TWO PROBLEMS IN MULTIVARIATE STATISTICAL ANALYSIS RMINANT OF A NON-CENTRAL B STATISTIC IN MULTIVARIATE ANALYSIS TIDN OR OMISSION OF A VARIATE IN MULTIPLE REGRESSION ANALYSIS MATRICES IN RELATION TO A BEST LINEAR DISCRIMINATOR ANALYSIS RALIZATIDNS OF ANALYSIS OF VARIANCE AND MULTIVARIATE ANALYSIS ZED B STATISTIC AND F STATISTICS AND IN MULTIVARIATE ANALYSIS E CORRESPONDING LATENT VECTOR FOR PRINCIPAL COMPONENT ANALYSIS TION TO A STRESS VS. STRENGTH PROBLEM IN RELIABILITY ANALYSIS THE PROBABILITY OF MISCLASSIFICATION IN DISCRIMINANT ANALYSIS IDN IN MULTIPLE REGRESSION AND MULTIVARIATE DISTANCE ANALYSIS IENCY OF STATISTICAL TESTS IN TIME SERIES REGRESSION ANALYSIS MULTIPLE COVARIATE ANALYSIS

THE USE OF RANDOM WORK SAMPLING FOR COST ANALYSIS AND CONTROL, CORR. 58 1031

LATENT CLASS ANALYSIS AND DIFFERENTIAL MORTALITY

DIALLEL AND RELATED POPULATIONS ANALYSIS AND INTERPRETATION OF THE VARIETY CROSS STEPWISE LEAST SQUARES, RESIDUAL ANALYSIS ANO SPECIFICATION ERROR

INTERVAL ANALYSIS AND THE LOGARITHMIC TRANSFORMATION

PERIODOGRAM ANALYSIS AND VARIANCE FLUCTUATIONS

THE ANALYSIS OF VARIANCE

SEQUENTIAL ANALYSIS APPLIED TD CERTAIN EXPERIMENTAL DESIGNS IN

SOME EXPERIMENTAL SAMPLING RESULTS FOR REGRESSION ANALYSIS APPLIED TO GAMA RAY SPECTROMETER DATA, 2

SOME EXPERIMENTAL SAMPLING RESULTS FOR RECRESSION ANALYSIS APPLIED TO GAMMA RAY SPECTROMETER DATA, I

$Y$ OF A SIMPLE SYSTEM

SIAN DISTRIBUTION. AN INTRODUCTION

PROBIT ANALYSIS AS A TECHNIQUE FOR ESTIMATING THE RELIABILI STATISTICAL ANALYSIS BASED ON A CERTAIN MULTIVARIATE COMPLEX GAUS

SIAN DISTRIBUTION

STATISTICAL ANALYSIS BASED ON A CERTAIN MULTIVARIATE COMPLEX GAUS

THE EXTENT OF REPEATED MIGRATION. AND ANALYSIS BASED ON THE DANISH POPULATION REGISTER

SIDUALS TESTS FOR SERIAL CORRELATION IN RECRESSION ANALYSIS BASED ON THE PERIODOCRAM OF LEAST-SQUARES RE

TIME SERIES ANALYSIS BY MDDIFIED LEAST-SQUARES TECHNIQUES

ED INNER WINDOW

SPECTRAL ANALYSIS COMBINING A BARTLETT WINDOW WITH AN ASSOCIAT TR AN APPROXIMATE METHOD DF ANALYSIS FOR A TWD-WAY LAYOUT

MULTIPLE CLASSIFICATION ANALYSIS FOR ARBITRARY EXPERIMENTAL DESIGN

ULATIONS OF 'DRDSOPHILIA SUBDBSCURA' CD/ VECTORIAL ANALYSIS FOR GENETIC CLINES IN BODY DIMENSIONS IN PDP LEAST SQUARES REGRESSION ANALYSIS FOR TREND-REDUCED TIME SERIES ABOUT SENSITIVITY ANALYSIS IN LINEAR PROGRAMMING MODELS

REGRESSION ANALYSIS IN SAMPLE SURVEYS, CORR. 631162

SPECTRAL ANALYSIS IN THE PRESENCE OF VARIANCE FLUCTUATIONS QUICK ANALYSIS METHODS FOR RANDOM BALANCE SCREENING

EXPERIMENTS

NDOMIZED LAYOUTS

CENESIS

A SUGCESTED METHOD OF ANALYSIS OF A CERTAIN CLASS OF EXPERIMENTS IN CARCINO BIOCS66

ON AN ELECTRONIC CALCULATOR INTRABLOCK ANALYSTS OF A CLASS OF TWO ASSOCIATE PARTTALIY BALANC THE ANALYSIS OF A DIALLEL CROSSING EXPERIMENT WITH CERTAI BIOCS65 THE ANALYSIS OP A DIALLEL OF A FACTORIAL EXPERTMENT (WITH CONFOUNDINC) THE RANDOMIZATION ANALYSIS OF A GENERALIZED RANDOMIZED BLOCK DESIGN BIOKA55

CORRICENDA, 'THE RANDOMIZATION ANALYSIS OF A GENERALIZED RANDOMIZED BLOCK DESIGN' BIOKA56 235 ANALYSIS OF A GROUP OF BALANCED BLOCK EXPERIMENTS HAV BIOCS68 JRSSB66 526 BIOKA64 365 ON THE DISTRIBUTION OF THE F-TYPE STATISTICS IN THE ANALYSIS OF A GROUP OF EXPERIMENTS THE ROBUSTNESS OF THE COVARIANCE ANALYSIS OF A ONE-WAY CLASSIFICATION THREE-PARAMETER LOGNORMAL DISTRIBUTION AND BAYESIAN ANALYSIS OF A POINT-SOURCE EPIDEMIC

THE JASA $63 \quad 72$ JASA $61 \quad 235$ MULTIPLE REGRESSION ANALYSIS OF A POISSON PROCESS

MINE ROOT ACTTVITY IN POTA/ NOTES SUBJECTS MODEL

R'S 'EXACT' SIGNIFICANCE TEST

OTES. THE STATISTICAL ANALYSIS OF A RADIO-ACTIVE TRACER EXPERIMENT TO DETER BIOCS6B THE QUANTAL RESPONSE ANALYSIS OF A SERIES OF BIOLOGICAL ASSAYS ON THE SAME BIOKA60 23 BAYESIAN ANALYSIS OF A THREE-COMPONENT HTERARCHICAL DESIGN EXACT BAYESIAN ANALYSIS OF A TWO-BY-TWO CONTINGENCY TABLE, AND FISHE JRSSB69 NO.2 NEW TECHNIQUES FOR THE ANALYSIS OF ABSENTEEISM DATA FURTHER NOTES ON THE ANALYSIS OF ACCIDENT DATA

SUSCEPTIBLES THE MATHEMATICAL ANALYSIS OF AN EPIDEMIC WITH TWO KINDS OF ANTE-DEPENDENCE ANALYSIS OF AN ORDERED SET OF VARIABLES SOME EXPERIMENTS IN THE NUMERICAL ANALYSIS OF ARCHAEOLOGICAL DATA

THE ANALYSIS OF ASSOCIATION AMONG MANY VARIABLES (WITH

DISCUSSION

USE OF SCORES FOR THE ANALYSIS OF ASSOCIATION IN CONTINGENCY TABLES

BIOKA52 274 POINTS OF THE BETA DISTRIBUTION FOR USE IN BAYESIAN ANALYSIS OF BERNOULLI PROCESSES TR 
ICATION ON THE PROPERTIES OF CHI-SQUARE-TESTS IN THE ANA

THE COMPOUND MULTINOMIAL DISTRIBUTION AND BAYESIAN ANALYSIS OF CATERCORICAL DATA FROM FINITE POPULATIONS JASA 69 216 THE VALUE OF ORTHOCONAL POLYNOMIALS IN THE ANALYSIS OF CHANCE-OVER TRIALS WITH DAIRY COWS

FOR FIRST RESIDUAL EFFECTS

THE ANALYSIS OF CHANCEOVER DESICNS WITH COMPLETE BALANCE RANDOM POINTS IN A CIRCLE AND THE ANALYSIS OF CHROMOSOME PATTERNS ANALYSIS OF COMPETITION EXPERIMENTS

BIOCS67 57 B

BI0KA63 23

BIOCS65 975

A SEMI-CRAPHICAL METHOD FOR THE ANALYSIS OF COMPLEX PROBLEMS

TECH $60 \quad 387$

N) A BRANCHINC POISSON PROCESS MODEL FOR THE ANALYSIS OF COMPUTER FAILURE PATTERNS (WITH DISCUSSIO JR

SURVEYS

AN ANALYSIS OF CONSISTENCY OF RESPONSE IN HOUSEHOLD

THE BAYESIAN ANALYSIS OF CONTINGENCY TABLES

RESPONSE ALTERNATIVE ANALYSIS OF CONTINCENCY TABLES

ON THE ANALYSIS OF CONTINCENCY TABLES WITH A QUANTITATIVE RANK ANALYSIS OF COVARIANCE

ON MULTIPLE COMPARISONS FOR ADJUSTED MEANS IN THE ANALYSIS OF COVARIANCE

ANALYSIS OF COVARIANCE BASED ON GENERAL RANK SCORES

THE FACTORIAL ANALYSIS OF CROP PRODUCTIVITY

398

320

JRSSB $66 \quad 164$

BIOCS6B 329

JASA $67 \quad 1187$

BIOKA58 256

AMS 69610 JRSSB54 100

I-INDEPENDENCE, AND INTERACTIONS IN CONTINGEN/ THE ANALYSIS OF CROSS-CLASSIFIED DATA, INDEPENDENCE, QUAS JASA 68 IO9] QUERY, REGRESSION ANALYSIS OF CUMULATIVE DATA

MATRIX INVERSION, ITS INTEREST AND APPLICATION IN ANALYSIS OF DATA PROBABILITY PLOTTING METHODS FOR THE ANALYSIS OF DATA

A BAYESIAN APPROACH TO THE ANALYSIS OF DATA FROM CLINICAL TRIALS

ANALYSIS OF DATA WHEN THE RESPONSE IS A CURVE

TECH $64 \quad 225$

JASA 59755

BIOKA68 1

JASA $65 \quad$ B1

TECH $66 \quad 229$

BIOKA62 163

A THEORETICAL ANALYSIS OF DELAYS AT AN UNCONTROLLED INTERSECTION

AN ANALYSIS OF DEPARTURES FROM THE EXPONENTIAL

DISTRIBUTION

ON ONE OF THE CHARACTERS

MEANS OF STOCHASTIC MODELS

DISTRIBUTIONS
SEQUENTIAL ANALYSIS OF DEPENDENT OBSERVATIONS. I

ANALYSIS OF DISPERSION WITH INCOMPLETE OBSERVATIONS

THE ANALYSIS OF DISTURBANCES IN REGRESSION ANALYSIS

ANALYSIS OF EFFECTS OF ANTIBIOTICS ON BACTERIA BY

ANALYSIS OF EMPIRICAL BIVARIATE EXTREMAL

SOME PROBLEMS IN THE STATISTICAL ANALYSIS OF EPIDEMIC DATA (WITH DISCUSSION)

DESIGN AND ANALYSIS OF EXPERIMENTS WITH MIXTURES

THE ANALYSIS OF EXPONENTIALLY DISTRIBUTED LIFE-TIMES WITH JR

ANALYSIS OF EXTREME-VALUE DATA BY SAMPLE QUANTILES

TWO TYPES OF FAILURE

FOR VERY LARGE SAMPLES

D 2-CUBE)

D 2-CUBE

A GENERAL COMPUTER PROGRAMME

PUNCH CARDS, CORR. 56650

ONE TRANSFORMATIONS OF THE DATA

QUERY, ANALYSIS OF FACTORIAL EXPERIMENT (PARTIALLY CONFOUNDE QUERY, ANALYSIS OF FACTORIAL EXPERIMENT (PARTIALLY CONFOUNDE FOR THE ANALYSIS OF FACTORIAL EXPERIMENTS ANALYSIS OF FACTORIAL EXPERIMENTS AND THE USE OF JASA 56 ANALYSIS OF FACTORIAL EXPERIMENTS BY ESTIMATING MONOT JRSSB65 ON THE ANALYSIS OF FACTORIAL EXPERIMENTS WITHOUT REPLICATION TECH 59 IECH 593 BIOCS68 627 TECH $62 \quad 565$ AMS $6 \mathrm{~B} \quad 1507$ JASA $64 \quad 1217$ TECH $66 \quad 18 B$ BIOCS69 357 BIOCS68 192 BIOKA65 447 JASA 57204 BIOKA52 324 BIOKA54 502 BIOKA64 28B BIOKA55 450 BIOKA65 633 JASA $61 \quad 925$ TECH $67 \quad 149$ BIOKA53 279 BI0C566 4BB AMS 681849 JRSSB58 193 TECH $59 \quad 379$ TECH $59 \quad 9$ BIOKAGB 101 TECH 67 4BI BIOCS66 525 BIOKA57 67 JASA 58928 $\begin{array}{rrr}\text { JASA } & 58 & 928 \\ \text { JASA } & 65 & 1200\end{array}$ CO/ ESTIMATION OF MEANS AND STANDARD ERRORS IN THE ANALYSIS OF NON-ORTHOGONAL EXPERIMENTS BY ELECTRONIC JRSSB62 435 CO/ ESTIMATION OF MEANS AND STANDARD ERRORS IN THE ANALYSIS OF NON-ORTHOGONAL EXPERIMENTS BY ELECTRONIC JRSSB62 435 REPETITIONS AN ANALYSIS OF PAIRED COMPARISON DESIGNS WITH INCOMPLETE BIOKA57 THE ANALYSIS OF PERSISTENCE IN A CHAIN OF MULTIPLE EVENTS BIOKA64 405 ANALYSIS OF PLANT COMPETITION EXPERIMENTS FOR $\quad$ BIOKA67 471

DIFFERENT RATIOS OF SPECIES

VIROLOGY

H RATES DEPEND UPON SEVERAL FACTORS

RODUCT AND ITS COMPONENTS, OF SELEC

USE OF TRANSFORMATIONS AND MAXIMUM LIKELIHOOD IN THE A ERRORS

EMENT OF RESPONSE IS SUBJECT TO ERROR

ARIANCE. II. EFFECT OF AUTOCORRELATED ER/ SERIES

COMPUTER (WITH DISCUSSION)
THE SPECTRAL ANALYSIS OF POINT PROCESSES (WITH DISCUSSION)

THE ANALYSIS OF POISSON REGRESSION WITH AN APPLICATION IN BIOKA64 517

THE ANALYSIS OF POPULATION GROWTH WHEN THE BIRTH AND DEAT BIOCS69 NO 4

A STATISTI ANALYSIS OF QUANTAL EXPERIMENTS INVOLVING TWO TREATME BIOKA55 382 ANALYSIS OF QUANTAL RESPONSE ASSAYS WITH DOSAGE $\quad$ BIOCS67 747

AN ANALYSIS OF QUANTAL RESPONSE DATA IN WHICH THE MEASUR BIOCS65 81 NOTES. FURTHER ANALYSIS OF R. A. FISHER'S ENUMERATIONS IN GENETICS BIOCS65 1012 BAYESIAN ANALYSIS OF RANDOM-EFFECT MODELS IN THE ANALYSIS OF V BIOKA66 477 REGRESSION ANALYSIS OF RELATIONSHIPS BETWEEN AUTOCORRELATED TIME JRSSB56 240 ROUTINE ANALYSIS OF REPLICATED EXPERIMENTS ON AN ELECTRONIC JRSSB57 234 
HOG PRODUCTION

OF STIMULUS CANNOT BE CONTROLLED, CORR, $56 \quad 650$

RECRESSION ANALYSIS OF SEASONAL DATA

TECH $63 \quad 141$

JASA $64 \quad 402$

HARMONIC ANALYSIS OF SEASONAL VARIATION WITH AN APPLICATION TO JASA 62655

ANALYSIS OF SENSITIVITY EXPERIMENTS WHEN THE LEVELS

METHODS OF CONSTRUCTION AND ANALYSIS OF SERIALLY BALANCED SEQUENCES

A NOTE ON A METHOD FOR THE ANALYSIS OF SIGNIFICANCE EN MASSE

ON THE STRUCTURE AND ANALYSIS OF SINCULAR FRACTIONAL REPLICATES

DESIGNS

L FACTORIAL DESIGNS

EXPONENTIAL POPULATION

GENERAL CONSIDERATIONS IN THE ANALYSIS OF SPECTRA

CONSTRUCTION AND ANALYSIS OF SOME NEW SERIES OF CONFOUNDED ASYMMETRICA AN ANALYSIS OF SOME RELAY FAILURE DATA FROM A COMPOSITE

THE ANALYSIS OF STATIONARY PROCESSES WITH MIXED SPECTRA, ANALYSIS OF STATIONARY PROCESSES WITH MIXED SPECTRA,

COMPONENTS

A GRAPHICAZ METHOD FOR THE ANALYSIS OF STATISTICAL DISTRIBUTIONS INTO TWO NORMAL ON MATHEMATICAL ANALYSIS OF STYLE

PROBLEMS IN THE ANALYSIS OF SURVEY DATA. AND A PROPOSAL

ANALYSIS OF SURVIVAL DATA BY REGRESSION TECHNIQUES

NCE POLICIES

A GENERAL METHOD FOR THE RELIABILITY ANALYSIS OF SYSTEMS UNDER VARIOUS PREVENTIVE MAINTENA SOME ASPECTS OF THE STATISTICAL ANALYSIS OF THE 'MIXED MODEL'

JASA $56 \quad 257$ JRSSB57 2BE TECH $6 B \quad 5 B 6$ AMS 6B 657 BIOC\$65 948 BIOC\$67 813 TECH $61 \quad 423$ TECH $61 \quad 133$ JRSSB62 215 JRSSB62 511 BIOKA53 460 BIOKA52 122 JASA $63 \quad 415$ TECH $63 \quad 161$ AMS $62 \quad 137$ BIOGS6B 27 BY GAUSE WITH POPULATIONS OF THE PROTOZOA PAR/ AN ANALYSIS OF THE DATA FOR SOME EXPERIMENTS CARRIED OUT BIOKA57 314 A MARKOVIAN MODEL FOR THE ANALYSIS OF THE EFFECTS OF MARCINAL TESTTNG ON SYSTEM AMS G2 ANY NUMBER OF FACTORS MAIN-EFFECT ANALYSIS OF THE CENERAL NON-ORTHOGONAL LAYOUT WITH A MATHEMATICAL ANALYSIS OF THE GROWTH AND SPREAD OF BREAST CANCER HARMONIC ANALYSIS OF THE HUMAN FACE

AMS $65 \quad 88$ $\begin{array}{cr}\text { AMS } 65 & 88 \\ \text { BIOCS69 } & 95\end{array}$ BIOCS65 49]

HER MEAN NOR PRECISION KNOWN ERRORS 810 BAYESIAN ANALYSIS OF THE TNDEPENDENT MULTINORMAL PROCESS, NEIT JASA 65 BAYESIAN ANALYSIS OF THE RECRESSION MODEL WITH AUTO-CORRELATED JASA 64763 A STOCHASTIC ANALYSIS OF THE SIZE DISTRIBUTION OF FIRMS, CORR. 59 JASA 58 B93 A STOCHASTIC ANALYSIS OF THE SPATIAL CLUSTERINC OF RETAIL ESTABLIS JASA 651094 SOME GOMMENTS ON SPECTRAL ANALYSIS OF TIME SERIES THE SPECTRAL ANALYSIS OF TIME SERIES (WITH DISCUSSION) SOME REMARKS ON THE ANALYSIS OF TIME-SERIES

AN ANALYSIS OF TRANSFORMATIONS (WITH DISGUSSION) THE SPECTRAL ANALYSIS OF TWO-DIMENSIONAL POINT PROCESSES CORRICENDA, 'THE SPECTRAL ANALYSIS OF TWO-DIMENSIONAL POINT PROCESSES'

DISCONTINUOUS SPECTRA THE ANALYSIS OF TWO-DIMENSIONAL STATIONARY PROCESSES WITH ISONS UNDER CONDITIONS OF

\section{NON-ADDITIVITY IN TWO-WAY ANALYSIS OF VARIANCE
ROBUST ESTIMATION IN ANALYSIS OF VARIANCE PROGRAMMING UNIVARIATE AND MULTIVARIATE ANALYSIS OF VARIANCE ORTHOGONALITY IN ANALYSIS OF VARIANCE \\ PSEUDO-INVERSES IN THE ANALYSIS OF VARIANCE} ADMISSIBLE TESTS IN MULTIVARIATE ANALYSIS OF VARIANCE A NOTE ON THE ADMISSIBILITY OF POOLING IN THE ANALYSIS OF VARIANCE A NOTE ON ROBUST ESTIMATION IN ANALYSIS OF VARIANCE

A MULTIPLE COMPARISON RANK PROCEDURE FOR A ONE-WAY ANALYSIS OF VARIANCE FURTHER APPLICATIONS OF RANGE TO THE ANALYSIS OF VARIANCE CONFIDENCE INTERVALS FOR DISTANCE IN THE ANALYSIS OF VARIANCE ORDERED TESTS IN THE ANALYSIS OF VARIANCE SIMULTANIOUS TEST PROCEDURES IN MULTIVARIATE ANALYSIS OF VARIANCE HOTELLING'S GENERALIZED T SQUARE IN THE MULTIVARIATE ANALYSIS OF VARIANCE ON INFERRING ORDER RELATIONS IN ANALYSIS OF VARIANCE

OF WEIGHTINC FACTORS IN LINEAR REGRESSION AND ANALYSIS OF VARIANCE FOR COMBINATION OF INDEPENDENT EXPERIMENTS IN THE ANALYSIS OF VARIANCE STATISTICAL INDEPENDENCE OF QUADRATIC FORMS IN THE ANALYSIS OF VARIANCE

OF OPTIMAL DESICNS FOR THE ONE-WAY CLASSIFICATION ANALYSIS OF VARIANCE DISTRIBUTIONS OF TWO TEST CRITERIA IN MULTIVARIATE ANALYSIS OF VARIANCE NORMALITY ON THE POWER FUNCTION OF THE F-TEST IN THE ANALYSIS OF VARIANCE

PROPERTY OF THE THREE MAIN TESTS FOR MULTIVARIATE ANALYSIS OF VARIANCE

APPLIED TO CERTAIN EXPERIMENTAL DESIGNS IN THE ANALYSIS OF VARIANCE ATEGORICAL DATA CHI-SQUARE TESTS ANALOGOUS TO NORMAL ANALYSIS OF VARIANCE A METHOD FOR JUDGING ALL CONTRASTS IN THE ANALYSIS OF VARIANCE E OF COMPONENTS OF VARIANCE IN THE UNBALANCED NESTED ANALYSIS OF VARIANCE MODELS IN THE ANALYSIS OF VARIANCE (WITH DISCUSSION)

BIOCS65 337

ESTIMATION TECH 64 RANK METHODS AMS 62482 A NOTE ON THE BIOKA5I 482 THE CONSTRUCTION JRSSB6I 352 ON THE NON-CENTRAL AMS $68 \quad 215$ THE EFFECT OF NON- BIOKA5I 43 ON THE MONOTONICITY JRSSB64 77 SEQUENTIAL ANALYSIS BIOKA56 388 THE LIMITINC POWER OF C AMS 631432 TRODUCTION TO SOME NON-PARAMETRIC GENERALIZATIONS OF ANALYSIS OF VARIANCE AND MULTIVARIATE ANALYSIS /IN BIOKA56 36I

ON CONFIDENCE BOUNDS ASSOCIATED WITH MULTIVARIATE ANALYSIS OF VARIANCE AND NONINDEPENDENCE BETWEEN TWO AMS 66 1736 DISCUSSION, EMPHASIZING THE CONNECTION BETWEEN ANALYSIS OF VARIANCE AND SPECTRUM ANALYSIS ANALYSIS DISC ANALYSIS OF VARIANCE AS AN ALTERNATIVE TO FACTOR SOME OPERATORS FOR ANALYSIS OF VARIANCE CALCULATIONS

TECH $61 \quad 191$ JRSSB57 318 TECH $69 \quad 511$ HE OPERATING CHARACTERISTIC CURVES FOR FIXED EFFECTS ANALYSIS OF VARTANCE F TESTS. ALPHA EQUALS 0 . 1 AND 0 JASA 57 345 CORR. 641296 MULTIVARIATE ANALYSIS OF VARIANCE FOR A SPECIAL COVARIANCE CASE, FACTORIAL EXPERIMENTATION IN SCHEFFE'S ANALYSIS OF VARIANCE FOR PAIRED COMPARISONS

ON ANALYSIS OF VARIANCE FOR THE K-SAMPLE PROBLE JASA $63 \quad 660$ JASA $58 \quad 529$ AMS 661747

ORTIONATE SUBCLASS FREQUENCIES

TWO-WAY ANALYSIS OF VARIANCE FOR THE MIXED MODEL WITH DISPROP BIOCS65 308 DISTRIBUTION-FREE ANALYSIS OF VARIANCE FOR THE TWO-WAY CLASSIFICATION SASJ 6767 IXED EFFECTS MODEL WITH OBSERVATIONS WITHIN A/ THE ANALYSIS OF VARIANCE FOR THE TWO-WAY CLASSIFICATION F BIOKAG9 NO.3 ION-FREE EXPERIMENTS

CHAIN-POOLINC ANALYSIS OF VARIANCE FOR TWO-LEVEL FACTORIAL REPLICAT TECH 69 NO. 4 NON-PARAMETRIC ANALYSIS OF VARIANCE IN SMALL SAMPLES. A MONTE CARLO BIOCS69 593 MAXIMUM-LIKELIHOOD ESTIMATION FOR THE MIXED ANALYSIS OF VARIANCE MODEL BIOKAG7 93 WTH CURVE PROBLEMS A GENERALIZED MULTIVARIATE ANALYSIS OF VARIANCE MODEL USEFULL ESPECIALLY FOR GRO BIOKAG4 313 TE BLOCK DESICN THE RELATIONSHIP ALGEBRA AND THE ANALYSIS OF VARIANCE OF A PARTIALLY BALANCED INCOMPLE SUBSAMPLES

NAL CLASSIFICATIONS INTERACTION IS PRESENT THE ANALYSIS OF VARIANCE OF DATA FROM STRATIFIED AMS 651815 FREQUENGIES WITH SPLIT PLOTS AND RANDOM MODELS 110 THE ANALYSIS OF VARIANGE OF SOME NON-ORTHOGONAL DESIGNS BIOKAG9 43 COMPARISON OF ANALYSIS OF VARIANGE POWER FUNGTION IN THE PARAMETRIG BIOKA52 427 
UCTURES UNDER WHICH CERTAIN SIMPLE LEAST SQUARES AND ANALYSIS OF VARIANCE PROCEDURES ARE ALSO BEST /STR JASA 69 NO. 4 ON THE DISTRIBUTION OF VARIOUS SUMS OF SQUARES IN AN ANALYSIS OF VARIANCE TABLE FOR DIFFERENT CLASSIFICATI JRSSB59 IIA A DISTRIBUTION-FREE ANALYSIS OF VARIANCE TECHNIQUE FOR BLOCK DESICNS

ON THE BAYES CHARACTER OF A STANDARD MODEL II ANALYSIS OF VARIANCE TEST SAMPLES) EFFECT OF NON-NORMALITY ON THE POWER OF THE ANALYSIS OF VARIANCE TEST SASJ 68 AMS 691094 BIOKA59 114 BIOKA65 591 SASJ $67 \quad 75$ A CLASS OF DISTRIBUTION-FREE ANALYSIS OF VARIANCE TESTS

A COMPARISON OF THE POWERS OF TWO MULTIVARIATE ANALYSIS OF VARIANCE TESTS A COMPARISON OF THE POWERS OF TWO MULTIVARIATE ANALYSIS OF VARIANCE TESTS. BIOKA62 455 RAL F-DISTRIBUTI/ CHARTS OF THE POWER FUNCTION FOR ANALYSIS OF VARIANCE TESTS, DERIVED FROM THE NON-CENT BIOKA5I II ENTS APPLICATION OF MULTIVARIATE ANALYSIS OF VARIANCE TO REPEATED MEASUREMENTS EXPERIM BI / BAYESIAN ANALYSIS OF RANDOM-EFFECT MODELS IN THE ANALYSIS OF VARIANCE. I. POSTERIOR DISTRIBUTION OF VA BIOKA65 37 / BAYESIAN ANALYSIS OF RANDOM-EFFECT MODELS IN THE ANALYSIS OF VARIANCE. II. EFFECT OF AUTOCORRELATED ER BIOKA66 477 UNEQUAL CROUP VARIANCES IN THE FIXED-EFFECTS ONE-WAY ANALYSIS OF VARIANCE, A BAYESIAN SIDELICHT TESTING AGAINST ORDERED ALTERNATIVES IN MODEL I ANALYSIS OF VARIANCE, NORMAL THEORY AND NONPARAMETRIC AMS 67 I740 THE STATISTICAL FOURIER ANALYSIS OF VARIANCES

PROCEDURES BASED ON RANKS FOR CERTAIN PROBLEMS IN ANALYSIS OF VARIANCES ANALYSIS OF VITAL STATISTICS BY CENSUS TRACT ON THE MULTIVARIATE ANALYSIS OF WEAKLY STATIONARY STOCHASTIC PROCESSES RAPID ANALYSIS OF $2 \times 2$ TABLES

ANALYSIS

A NUMERTCAL ANALYSIS PROBLEM IN CONSTRAINED QUADRATIC RECRESSION APPLICATION OF METHODS IN SEQUENTIAL ANALYSIS TO DAM THEORY
USING FACTOR ANALYSIS TO ESTIMATE PARAMETERS APPLICATION OF METHODS IN SEQUENTIAL ANALYSIS TO DAM THEORY
USING FACTOR ANALYSIS TO ESTIMATE PARAMETERS JRSSB65 159 OF PROBIT ANALYSIS TO THE CASE OF MULTIPLE RESPONSES PHIC STOCHASTIC SERIES STATISTICAL ANALYSIS USINC LOCAL PROPERTIES OF SMOOTHLY HETEROMOR BIOKA57 454 PERTIES OF THE LEAST SQUARES ESTIMATOR IN REGRESSION ANALYSIS WHEN THE 'PREDICTOR' VARIABLES ARE STOCHASTI A LARGE-SAMPLE COVARIANCE ANALYSIS WHEN THE CONTROL VARIABLE IS FALLIBLE

A STRUCTURAL RECRESSION APPROACH TO COVARIANCE ANALYSIS WHEN THE COVARIABLE IS UNCONTROLLED DISCRIMINANT ANALYSIS WHEN THE INITIAL SAMPLES ARE MISCLASSIFIED OF LINEAR HYPOTHESES IN UNIVARIATE AND MULTIVARIATE ANALYSIS WHEN THE RATIOS OF THE POPULATION VARIANCES MENTARY VARIABLES REGRESSION ANALYSIS WHEN THERE IS PRIOR INFORMATION ABOUT SUPPLE MULTIPLE LINEAR RECRESSION ANALYSIS WITH ADJUSTMENT FOR CLASS DIFFERENCES SEQUENTIAL ANALYSIS WITH DELAYED OBSERVATIONS REGRESSION ANALYSIS WITH DEPENDENT VARIABLE CENSORED

ENT VARIABLES BINOMIAL CASE
LINEAR REGRESSION ANALYSIS WITH MISSING OBSERVATIONS AMONC THE INDEPEND J SPECTRAL ANALYSIS WITH RANDOMLY MISSED OBSERVATIONS, THE SPECTRAL ANALYSIS WITH RECULARLY MISSED OBSERVATIONS

GENERALISED COVARIANCE ANALYSIS WITH UNEQUAL ERROR SOMPONENT EST E

IMATION IN CORRELATION STUDIES TESTS OF THE WILKS-LAWLEY HYPOTHESIS IN MULTIVARIATE ANALYSIS NCTIONS OF THE ROOTS OF TWO MATRICES IN MULTIVARIATE ANALYSIS GEST CHARACTERISTIC ROOT OF A MATRIX IN MULTIVARIATE ANALYSIS IZATION OF NON-NUMERICAL INFORMATION IN QUANTITATIVE ANALYSIS HAZARD ANALYSIS

SERIAL CORRELATION IN REGRESSION ANALYSIS SERIAL CORRELATION IN REGRESSION ANALYSIS STIMATING THE NORMAL DISTRIBUTION FUNCTION BY NORMIT ANALYSIS ISCRIMINATO/MULTIVARIATE-COVARIANCE AND CANONICAL ANALYSIS THE INTERACTION ALGORITHM AND PRACTICAL FOURIER ANALYSIS. SE AND UNDERLYING MODELS OF FACTOR ANALYSIS IN RESEARCH FACTOR ANALYSIS FACTOR ANALYSIS ERTAIN MATRIX TRANSFORMATIONS USEFUL IN MULTIVARIATE ANALYSIS, RESIDUAL ANALYSIS THE FUTURE OF DATA ANALYSIS, SEQUENTIAL ANALYSIS,

MODEL BUILDINC FOR PREDICTION IN REGRESSION ANALYSIS, I D PROBABILITIES OF MISCLASSIFICATION IN DISCRIMINANT ANALYSIS
ON 'ESTIMATION OF ERROR RATES IN DISCRIMINANT ANALYSIS 'LINEAR AND NON-LINEAR MULTIPLE COMPARISONS IN LOGIT ANALYSIS ERTAIN MATRIX TRANSFORMATION USEFULL IN MULTIVARIATE ANALYSIS' 'RIDGE ANALYSIS' OF RESPONSE SURFACES ANALYTICAL GRADUATION OF FERTILITY RATES

DISTRIBUTIONS SOME ANALYTICAL PROPERTIES
AN ANALYTICAL SOLUTION

OPTIMUM ALLOCATION IN MULTIVARIATE SURVEYS, AN ANALYTICAL SOLUTION DESIGNING SOME MULTI-FACTOR ANALYTICAL STUDIES AN APPLICATION OF SEQUENTIAL SAMPLING TO ANALYTICAL SURVEYS ANALYTICAL SURVEYS WITH CLUSTER SAMPLINC A COMPARISON OF BIOKA65 149 ON ELEMENTARY SYMMETRIC FU BIOKA65 499 ON THE DISTRIBUTION OF THE LAR BIOKA65 405 GENERAL THEORY AND THE CASE OF SIMPLE ORDER AMS 631347 I II BIOKA64 175 BIOKA55 327 BIOKA56 436 AESCRIPION AND USE OF TABLES. PART BIOKA57 411 AN ADDENDUM JRSSB60 372 AN INTRODUCTION TO ESSENTIALS, 1. THE PURPO BIOCS65 190 AN INTRODUCTION TO ESSENTIALS. 2. THE ROLE BIOCS65 405 BASED ON LECTURES BY P.L. HSU /BIANS OF C BIOKA5I 345 CORR. 611005 CORR. 62812 JASA $61 \quad 98$ AMS 62 TECH $68 \quad 125$ SEQUENTIAL AMS $63 \quad 462$ $\begin{array}{lll}\text { SEQUENTIAL AMS } & 63 & 462 \\ \text { TION WITH } & \text { BIOCS68 } & 823\end{array}$ COMMENTARY TECH $68 \quad 204$ CORRIGENDA, BIOKA62 284 NOTE ON 'THE JACOBIANS OF C BIOKA53 r 43 TECH $63 \quad 469$ JASA $67 \quad 569$ JRSSB67 115 JASA $67 \quad 1121$ JASA $65 \quad 985$ BIOKA66 85 JRSSB65 264 ANALYTICAL TECHNIQUE FOR INCOMPLETE BLOCK EXPERIMENTS BIOCS66 B29 SOME STATISTICAL ASPECTS OF THE ECONOMICS OF ANALYTICAL TESTINC ESTIMATION OF POWER SPECTRA BY A WAVE ANALYZER

RESTRICTION

INCOMPLETE FOLLOW-UP

SOME TECHNIQUES FOR ANALYZING Á SET OF TIME SERIES SUBJECT TO A LINEAR TECH $59 \quad 49$ TECH 65553 JASA $63 \quad 513$ JASA $60 \quad 534$ JASA $68 \quad 242$ JASA $64 \quad 319$ JASA $60 \quad 245$ FACTORS A SIMPLIFICATION OF THE BLUS PROCEDURE FOR ANALYZING RECRESSION DISTURBANCES SIMPLE METHODS FOR ANALYZING THREE-FACTOR INTERACTION IN CONTINGENCY

IMENTS WITH APPLICATIONS A MULTIPLICATIVE MODEL FOR ANALYZING VARIANCES WHICH ARE AFFECTED BY SEVERAL SYSTEMATIC METHODS FOR ANALYZING 2-TO-THE-N-TIMES-3-TO-THE-M FACTORIAL EXPER AN EXAMPLE OF AN ANCILLARY STATISTIC AND THE COMBINATION OF TWO SAMPLE ANCILLARY STATISTICS AND PREDICTION OF THE LOSS IN

ESTIMATION PROBLEMS

THE STATISTICAL WORK OF OSKAR ANDERSON

SIGN OF MIXTURE EXPERIMENTS' BY R.A. MCLEAN AND V.L. ANDERSON R.A. MCLEAN AND V.L. ANDERSON DISCUSS
DISTRIBUTION OF THE ANDERSON-DARLINC STATISTIC

OSKAR ANDERSON, 1887-1960 THE ANGLE-COUNT METHOD
TECH 67245 AMS 61616 AMS 6B 1756 JASA $61 \quad 273$ TECH $66 \quad 455$ AMS $61111 B$ AMS $61 \quad 651$ BIOKA67 615 
A TABLE FOR COMPUTINC WORKINC ANCLES

AN OCCUPATION TIME THEOREM FOR THE ANCULAR COMPONENT OF PLANE BROWNIAN MOTION

BIOCS6B 413 RICHT ANCULAR DESICNS

CENERALIZED RICHT ANCULAR DESICNS

TABLES OF THE ANCULAR TRANSFORMATION COEFFICIENT
SOME PROPERTIES OF AN ANCULAR TRANSFORMATION FOR THE CORRELATION COEFFICIEN

AN ANCULAR TRANSFORMATION FOR THE SERIAL CORRELATION

BIOKA53 70

BIOKA54 261 FURTHER PROPERTIES OF AN ANCULAR TRANSFORMATION OF THE CORRELATION COEFFICIENT BIOKA57 273 A RECRESSION TECHNIQUE FOR ANCULAR VARIATES BIOCS69 NO. 4

ARE LO/ THE EXPECTED FREQUENCIES IN A SAMPLE OF AN ANTMAL POPULATION IN WHICH THE ABUNDANCES OF SPECIES BIOKA51 427 OF A METHOD OF ESTIMATINC THE SIZE OF MOBILE ANIMAL POPULATIONS

$S O M E$ PRO

A MATHEMATICAL THEORY OF ANIMAL TRAPPINC

CONTRIBUTIONS TO THE MATHEMATICS OF ANIMAL TRAPPINC

ESTIMATES OF SURVIVAL FROM THE SICHTINC OF MARKED ANIMALS

KARL PEARSON, AN APPRECIATION ON THE HUNDREDTH ANNIVERSARY OF IIS BIRTH

THE IDENTIFICATION OF ANNUAL PEAK PERIODS FOR A DISEASE

COMPARISON OF ANOVA AND HARMONIC COMPONENTS OF VARIANCE

THE SPECTRUM OF A MODEL II NESTED ANOVA AND ITS APPLICATIONS

ON EXPECTATIONS, VARIANCES, AND CONVARIANCES OF ANOVA MEAN SQUARES BY 'SYNTHESIS'

NOTES, ESTIMATION AFTER PRELIMINARY TESTINC IN ANOVA MODEL I

EXPECTATIONS, VARIANCES AND COVARIANCES OF 'ANOVA' MEAN SQUARES BY 'SYNTHESIS'

DISCUSSION OF THE PAPERS OF MESSRS. ANSCOMBE AND DANIEL

AUTHOR'S REPLY TO ANSCOMBE'S COMMENTS

SEQUENTIAL MEDICAL TRIALS SOME COMMENTS ON F I ANSCOMBE'S PAPER

RESPONSE, A SURVEY TECHNIQUE FOR ELIMINATINC EVASIVE ANSWER BIAS

EX ANTE AND EX POST DATA IN INVENTORY INVESTMEN

VARIABLES

ANTE-DEPENDENCE ANALYSIS OF AN ORDERED SET OF

A SCREENINC SYSTEM FOR ANTI-CANCER ACENTS BASED ON THE THERAPEUTIC INDEX

BIOKA69 407

BIOKA51 307

BIOCS66 925

BIOKA64 429

JASA $58 \quad 23$

BIOC\$65 645

TECH $69 \quad 75$

TECH 6991

BIOCS6B 963

BIOCS65 752

BI0CS67 105

TECH $60 \quad 157$

TECH $65 \quad 169$

JASA $63 \quad 3 B 4$

JASA $65 \quad 63$

JASA 61518

AMS $62 \quad 201$

BIOCS65

ANALYSIS OF EFFECTS OF ANTIBIOTICS ON BACTERIA BY MEANS OF STOCHASTIC MODELS BIOCS66 761

STATES MANUFACTURINC $1947-1960$ ANTICIPATIONS AND INVESTMENT BEHAVIOR IN UNITED JASA 69

COMPARATIVE SAMPLING ACCEPTANCE SCHEMES IN TESTINC ANTICENICITY OF VACCINES

BIOCS66 684

CED THE COMPUTATION OF THE UNRESTRICTED AOQL WHEN DEFECTIVE MATERIAL IS REMOVED BUT NOT REPLA JASA 69

ON OF THE ERRORS IS OF ANY CONTINUOUS FORM AND KNOWN APART FROM A SCALE PARAMETER/THE JOINT DISTRIBUTI BIOKAGI

DERINC AND VARIATION OF THE LONG-TAILED FIELD MOUSE APODEMUS SYLVATICUS III WANDERINC POWER AND DISTRIB BIOKA52

SAMPLINC RATES AND APPEARANCE OF STATIONARY CAUSSIAN PROCESSES APPENDIX TO 'EQUATORIAL DISTRIBUTIONS ON A SPHERE' BIOKA65

6691

ON THE DERIVATION AND APPLICABILITY OF NEYMAN'S TYPE A DISTRIBUTION BIOKA58

A COMP JRSSB5? BIOKA63

ARISON OF TWO SORTS OF TEST FOR A CHANCE OF LOCATION APPLICABLE F A STATIONARY BIRTH-DEATH PROCESS, AND ITS ECONOMIC APPLICATION

/ONSHIP BETWEEN THE MEAN AND VARIANCE O BIOKA62 TERIA FOR THE CONTINUITY OF PROCESSES WITH A V/ AN APPLICATION FOR THE SOBOLEV IMBEDDINC THEOREMS TO CRI MATRIX INVERSION, ITS INTEREST AND APPLICATION IN ANALYSIS OF DATA

A DYNAMIC PROCRAMMINC APPLICATION IN PRODUCTION LINE INSPECTION

ILITY APPROACH TO IRREVERSIBLE MARKOV CHAINS WITH AN APPLICATION IN STUDYINC THE DENTAL CARIES PROCESS A CENERALIZATION OF THE BALLOT PROBLEM AND ITS APPLICATION IN THE THEORY OF QUEUES THE ANALYSIS OF POISSON RECRESSION WITH AN APPLICATION IN VIROLOCY

AN APPLICATION OF A BALANCED INCOMPLETE BLOCK DESICN

NONLINEAR RECRESSION PROBLEMS

TION

BIVARIATE EXTREME VALUE THEORY

MENTS (WITH DISCUSSION) SOME PROPERTIES AND AN APPLICATION OF A STATISTIC ARISINC IN TESTINC CORRELA AMS 691736

AMS 69

JASA 59 TECH 67

/ BIOCS66 BIOKA64 517 TECH 6151

STOCHASTIC PO APPLICATION OF AN ESTIMATOR OF HICH EFFICIENCY IN THE APPLICATION OF AUTOMATIC COMPUTERS TO SAMPLINC EXPERI JRSSB54 39 AN APPLICATION OF BIORTHONORMAL EXPANSIONS IN THEORY OF JRSSB68 334 IONS OF CENERALIZED CLASSI/ REMARKS CONCERNINC THE APPLICATION OF EXACT FINITE SAMPLE DISTRIBUTION FUNCT JASA 63 943 MUNICATION' COMMENTS TO, EDWARD C, POSNER, 'THE APPLICATION OF EXTREME VALUE THEORY TO ERROR FREE COM TE COMMUNICATION

THE APPLICATION OF EXTREME VALUE THEORY TO ERROR -FREE DESICNS FOR THE SEQUENTIAL APPLICATION OF FACTORS MATINC POPULATIONS WITH SELECTION IN QUEUES $\begin{array}{llrr}\text { APPLICATION OF FACTORS } & \text { TECH } 64 & 365 \\ \text { APPLICATION OF FINITE ABSORBENT MARKOV CHAINS TO SIB } & \text { BIOCS69 } & 17\end{array}$ TECH 65517 NOTE ON AN APPLICATION OF FOUR MOMENT INEQUALITIES TO A PROBLEM TECH 65435 SION OF PARTITIONED MATRICES IN THE ANALYSIS OF N/ APPLICATION OF GREENBERC AND SARHAN'S METHOD OF INVER JASA 65 I200 EXISTENCE OF ORTHOCONAL LATIN SQUARES RAICHT-LINE RELATIONS WHEN BOTH VAR/ ON THE APPLICATION OF GROUP THEORY TO THE EXISTENCE AND NON- BIOKA69 NO.3 A GENERALIZED APPLICATION OF INSTRUMENTAL VARIABLE ESTIMATION OF ST TECH 6925 REPEATED MEASUREMENTS EXPERIMENTS PHOTOGRAPHIC PROCESSINC

STATISTICAL TOLERANCING

TO THE ESTIMATION OF RATIOS APPLICATION OF MINIMUM LOGIT CHI-SQUARE ESTIMATE TO A APPLICATION OF MULTIVARIATE ANALYSIS OF VARIANCE TO AN APPLICATION OF MULTIVARIATE QUALITY CONTROL TO AN APPLICATION OF NUMERICAL INTEGRATION TECHNIQUES TO BI0CS66 B10 JASA $57 \quad 186$ TECH $67 \quad 441$ BIOKA59 477 TECH 59139 TECH 59419 TECH 69285 BIOKA66 B5 SURVEYS

ERRATA. 'THE APPLICATION

EURVEYS AMPLINC MIXTURES OF MULTI-SIZED PARTICLES AN APPITCATION OF RENEWAL THEORY

ION OF PROBABILITY DISTRIBUTIONS ESTIMATION

CONTROL

TO A SET OF 2-BY-2 TABLES CONCORDANCE COEFFICIENT

AN APPLICATION OF SEQUENTIAL SAMPLING TO ANALYTICAL

SEQUENTIAL APPLICATION OF SIMPLEX DESIGNS IN OPTIMISATION AND APPLICATION OF SPECIAL FUNCTIONS IN THE CHARACTERIZAT

AN APPLICATION OF STEPWISE REGRESSION TO NON-LINEAR APPLICATION OF STOCHASTIC APPROXIMATION TO PROCESS TECH $62 \quad 441$ SASJ 69 TECH $6 \mathrm{~B} \quad 63$ JRSSB65 321 A NOTE ON THE APPLICATION OF THE COMBINATION OF PROBABILITIES TEST BIOKA55 404 AN APPLICATION OF THE DISTRIBUTION OF THE RANKING AN APPLICATION OF VARIABLE WEIGHT DISTRIBUTED LACS BIOKA5I 33 JASA $67 \quad 1277$ ALITY FOR THE SAMPLE COEFFICIENT OF VARIATION AND AN APPLICATION OF VARIABLES SAMPLING SOME INFERENCES ABOUT GAMMA PARAMETERS WITH AN APPLICATION TO A RELIABILITY PROBLEM

N FOR GENERALIZED POWER SERTES DISTRIBUTTONS AND ITS APPLICATTON TO A TRUNCATED BINOMIAL DTSTRTBUTION THE POI FOR THE INCOMPLETE BLOCK DESIGNS AMS 6940 SOLUTION OF A SET OF SIMULTANEOUS EQUATIONS WITH AN APPLICATION TO EXPERIMENTAL DESIGN /REGION FOR THE BIOKA54 190 THE STATISTICAL ANALYSIS OF INDUSTRY STRUCTURE, AN APPLICATION TO FOOD INDUSTRIES 
HARMONIC ANALYSIS OF SEASONAL VARIATION WITH AN APPLICATION TO HOW PRODUCTION

JASA $62 \quad 655$ DUCT-MOMENT PARTIAL CORRELATION AND REGRESSION, WITH APPLICATION TO MANIFOLD. ORDERED CONTINGENCY TABLES BIOKA59 241 ARIOUS ESTIMATORS OF THE LOGIT AND ITS VARIANCE WITH APPLICATION TO QUANTAL BIOASSAY

BAYESIAN COMPARISON OF MEANS OF A MIXED MODEL WITH APPLICATION TO REGRESSION ANALYSIS ON THE BIAS OF $V$ BIOKA67 181 BIOKA66 11 ROXIMATION TO THE NORMAL DISTRIBUTION FUNCTION. WITH APPLICATION TO SIMULATION A USEFUL APP TECH $67 \quad 647$ MODEL FOR TWO COMPETING SPEGIES OF TRIBOLIUM AND ITS APPLICATION TO SOME EXPERIMENTAL DATA A STOCHASTIC BIOKA62 PROBABILITY A FIDUCIAL ARGUMENT WITH APPLICATION TO SURVEY SAMPLING JRSSB 69 NO.2 WITH THE UNIFORM DISTRIBUTION, PERCENTAGE POINTS AND APPLICATION TO TESTING FOR RANDOMNESS OF DIRECTIONS BIOKA66 235 T SQUARES WHEN THE PARAMETERS ARE STOCHASTIC AND ITS APPLICATION TO THE ANALYSIS OF GROWTH CURVES. /LEAS BIOKA65 447 A STATISTICAL MODEL OF BOOK USE AND ITS APPLICATION TO THE BOOK STORAGE PROBLEM THE BIAS OF MOMENT ESTIMATORS WITH AN APPLICATION TO THE NEGATIVE BINOMIAL DISTRIBUTION

RIA FOR BEST SUBSTITUTE INTERVAL ESTIMATORS, WITH AN APPLICATION TO THE NORMAL DISTRIBUTION THE RANDOM WALK (IN CONTINUOUS TIME) AND ITS APFLICATION TO THE THEORY OF QUEUES APPROXIMATIONS TO THE NON-CENTRAL T, WITH APPLICATIONS

REDUCING A RANDOM SAMPLE TO A SMALLER SET, WITH APPLICATIONS BOUNDS OF THE PROBABILITY OF A UNION OF EVENTS. WITH APPLICATIONS THE SPECTRUM OF A MODEL II NESTED ANOVA AND ITS APPLIGATIONS HIERARCHICAL BIRTH AND DEATH PROCESSES. II. APPLIGATIONS INVERSE CUMULATIVE APPROXIMATION AND APPLICATIONS

MULTIDIMENSIONAL-INTEGRAL IDENTITIES WITH BAYESIAN APPLICATIONS DIVISIBLE DISTRIBUTIONS RECENT RESULTS AND APPLICATIONS PROCESS. TABLES OF THE STOGHASTIC EPIDEMIG CURVE AND APPLICATIONS STRIBUTION FOR AN OCCUPANCY PROBLEM WITH STATISTICAL APPLICATIONS TO THE MULTINOMIAL DISTRIBUTION, SOME PROPERTIES AND APPLICATIONS

OF THE MULTIVARIATE NORMAL DISTRIBUTION WITH SOME APPLICATIONS TO-THE-N-TIMES-3-TO-THE-M FACTORIAL EXPERIMENTS WITH APPLICATIONS OF ORDER STATISTICS OF DEPENDENT VARIABLES, AND SOME APPLICATIONS THE BAYESIAN OUTLOOK AND ITS APPLICATIONS

FOR INFERENCES ABOUT THE NORMAL DISTRIBUTION WITH ORDER STATISTICS

TWO FURTHER APP MEASUREMENT APPLIGATIONS OF A BALLOT THEOREM IN PHYSICS AND IN JASA 641133 BIOKA59 400 TECH $63 \quad 295$ JASA $67 \quad 510$ AMS 682154 TECH 6991 BIOKA60 245 BIOKAGB 29 THREE AMS 681615 INFINITELY AMS $62 \quad 68$ THE LOGISTIC JRSSB60 332 AN ASYMPTOTIC DI TECH $61 \quad 79$ AN APPROXIMATION BIOKAGO 93 INCOMPLETE AND ABSOLUTE MOMENTS BIOKA53 20 SYSTEMATIC METHODS FOR ANALYZING 2- TECH 67245 RENCE RELATIONS BETWEEN THE P.D.F.'S BIOKA67 $2 B 3$ BIOCS69 NO. 4 PF A MODEL FOR BINARY REGRESSION TWO APPLICATIONS OF BIVARIATE K-STATISTICS SOME APPLICATIONS OF EXPONENTIAL ORDERED SCORES

ON IN MULTTPLE REGRESSION AND MULTIVARIATE DISTAN/ APPLTCATIONS OF JORDAN 1 S PROCEDURE FOR MATRTY TNUERSI J ANALYSIS

PROBLEMS IN STATISTICS

POPULATION GENETICS

OF UNBIASED RATIO-TYPE ESTIMATION DIRECT) ASSAYS

HERE TREATMENTS OR BLOCKS ARE OF UNE THE STUDY OF INPUT-OUTPUT STREAMS

\section{SOME APPLICATIONS OF MATRIX DERIVATIVES IN MULTIVARIATE}

SOME APPLICATIONS OF MEIJER-G FUNCTIONS TO DISTRIBUTION

SOME APPLICATIONS OF MULTIPLE-TYPE BRANCHING PROCESSES IN APPLICATIONS OF MULTIVARIATE POLYKAYS TO THE THEORY JASA 57

SOME FURTHER APPLICATIONS OF NON-PARAMETRIC METHODS IN DILUTION (- BIOCS65

II

SOME APPLICATIONS OF PROBABILITY GENERATING FUNCTIONALS TO JRSSB68
SOME APPLICATIONS OF PROBABILITY THEORY IN CRIMINALISTICS JASA 65 APPLIGATIONS OF PROBABILITY THEORY IN GRIMINALISTICS JASA 651028

FURTHER APPLICATIONS OF RANGE TO THE ANALYSIS OF VARIANCE BIOKA5I 393

A STRESS VS. STRENGTH PROBLEM IN RELIABILITY ANAL/

$S$ I BLOCK AND DIRECT PRODUCT DESIGN APPLIGATIONS OF THE BIVARIATE NORMAL DISTRIBUTION TO TECH 64325 TIONS OF THE BIVARIATE NORMAL DISTRIBUTION TOF TE TACTORTAL ARRANGEMENT BTOKA63

RE-RECAPTURE METHOD. III. AN EXAMPLE OF THE PRACTICAL APPLICATIONS OF THE METHOD /D BY MEANS OF THE CAPTU BI A SURVEY OF PROPERTIES AND APPLICATIONS OF THE NONCENTRAL T-DISTRIBUTION APPLICATTONS OF THE PSEUDOINVERSE TO MODELTNG

MATRIX

CURRICULUM

START-UPS AND INVENTORY CONTROL

DISTRIBUTION

SOME APPLICATIONS OF THE SINGULAR DECOMPOSITION OF A APPLICATIONS OF TIME-SHARED COMPUTERS IN A STATISTICS JASA 6B 192 APPLICATIONS OF TRUNCATED DISTRIBUTIONS IN PROCESS TECH 61429

SOME APPLICATIONS OF TWO APPROXIMATIONS TO THE MULTINOMIAL BIOKA6O 463 SOME APPLICATIONS OF ZERO-ONE PROCESSES

G CHILDREN

A MATHEMATICAL MODEL WITH APPLICATIONS TO A STUDY OF ACCIDENT REPEATEDNESS AMON J JRSSB55 243 SPATTAL POINT PROCESSES, WITH APPLICATTONS TO ECOLOGY

LEMMA FOR PROVING THE EQUALITY OF TWO MATRICES WITH APPLICATIONS TO LEAST SQUARES TYPE QUADRATIC FORMS ON A GENERALIZED SAVAGE STATISTIC WITH APPLICATIONS TO LIFE TESTING

OPTIMAL ROBUSTNESS. A GENERAL METHOD. WITH APPLICATIONS TO LINEAR ESTIMATORS OF LOCATION

IVARIATE IMMIGRATION WITH MULTIPLE DEATH PROCESS AND APPLICATIONS TO LUNAR CRATERS

A NOTE ON A GENERALIZED INVERSE OF A MATRIX WITH APPLICATIONS TO PROBLEMS IN MATHEMATICAL STATISTICS JRSSB62 152

TAIN INEQUALITIES FOR NORMAL DISTRIBUTIONS AND THEIR APPLICATIONS TO SIMULTANEOUS CONFIDENCE BOUNDS /CER AMS 67 1853 THE EQUAL PROBABILITY TEST AND ITS APPLICATIONS TO SOME SIMULTANEOUS INFERENCE PROBLEMS JASA 69 986 EXTREMA OF QUADRATIC FORMS WITH APPLICATIONS TO STATISTICS

CORRIGENDA, 'EXTREMA OF QUADRATIC FORMS WITH APPLICATIONS TO STATISTICS'

SES WITH MULTI-DIMENSIONAL TIME/ INEQUALITIES WITH APPLICATIONS TO THE WEAK CONVERGENCE OF RANDOM PROCES THE INVERTED DIRICHLET DISTRI8UTION WITH APPLICATIONS, CORR, 651251

ERRATA, 'APPROXIMATIONS TO THE NON-CENTRAL T, WITH APPLICATIONS'

A NOTE ON TESTS OF HOMOGENEITY APPLIED AFTER SEQUENTIAL SAMPL,INC APPLIED MULTIPLEX SAMPLING

8IOKA59 483 8IOKA61 474 AMS 69681 JASA 65793 TECH $64 \quad 482$ JRSS860 368 TECH $63 \quad 341$

OF 2-TO-THE-P FACTORIAL EXPERIMENTS WITH THE FACTORS APPLIED SEQUENTIALLY

FRACTIONAL REPLICATION JASA $68 \quad 644$

IS OF VARIANCE SEQUENTIAL ANALYSIS APPLIED TO CERTAIN EXPERIMENTAL DESIGNS IN THE ANALYS BI

IN PRECISION FOR OPTIMAL ALLOCATION IN REGRESSION AS APPLIED TO EXTRAPOLATION IN S-N FATIGUE TESTING /N TE

A BAYESIAN APPROACH TO THE IMPORTANCE OF ASSUMPTIONS APPLIED TO THE COMPARISON OF VARIANCES

ON CERTAIN SUGGESTED FORMULAE APPLIED TO THE SEQUENTIAL T-TEST

A DIFFERENCE EQUATION TECHNIQUE APPLIED TO THE SIMPLE QUEUE

TERVAL DISTRIBUTI/ A DIFFERENCE EQUATION TECHNIQUE APPLIED TO THE SIMPLE QUEUE WITH ARBITRARY ARRIVAL IN JRSS858 168 OUTLIERS IN PATTERNED EXPERIMENTS, A STRATEGIC APPRAISAL

C COMPUTER FROM THE POINT OF VIEW OF THE USER AN APPRAISAL OF LEAST SQUARES PROGRAMS FOR THE ELECTRONI JA 8IRTH

APRIL, 1966) KARL PEARSO

AN APPRAISAL OF LEAST SQUARES PROGRAMS FOR THE ELEC
AN APPRECIATION ON THE HUNDREDTH ANNIVERSARY OF HIS TECH $61 \quad 91$

JASA $67 \quad 819$ WEAK APPROACHABILITY IN A TWO-PERSON GAME

MULTINOMIAL DISTRIBUTION AND THE DETERMINATION OF APPROPRIATE SCORES 
D T (TRIMMINC-WINSORIZATION 2)

APPROXIMATE BEHAVIOR OF THE DISTRIBUTION OF WINSORIZE TECH $6 B$

THE FITTING OF MULTIVARIATE AUTOF

TY

CORRECTION

UNKNOWN PARAMETER

VAR I ANCE

VARIATION IN GAMMA DISTRIBUTIONS

(CORR. 63234 )

SERIES AND PARALLEL SYSTEMS

ARIATE BEHRENS-FISHER PROBLEM

OF A SET OF INDEPENDENT OBSERVATIONS CASES

COEFFICIENTS

TWO STATIONARY LINEAR MARKOV SERIES

TWO STATIONARY LINEAR MARKOV SERIES II.

WITH TIES

E PROBABILITY INTEGRAL OF THE NON-CENTRAL CHI SQU/

$S$ OF EXTREME VALUES SOME MODIFIED KOLMOGOROV-SMTRNOV TESTS OF AI

63

FUNCTION

DATA

STANCES BETWEEN PERCENTACE POINTS OF FREQUENCY CU/

APPROXIATE HYPOTHESES AND THETR PROPERTIES

TESTINC APPROXIMATE HYPOTHESES IN THE COMPOSITE CASE, CORR.

APPROXIMATE LINEARIZATION OF THE INCOMPLETE BETAFROM LIKELIHOOD ESTIMATES FROM GROUPED TECH $67 \quad 599$ APPROXIMATE MEANS AND STANDARD DEVIATIONS BASED ON DI BIOKA65 533 AN APPROXIMATE METHOD OF ANALYSIS FOR A TWO-WAY LAYOUT BIOCS65 376 EVALUATION OF BODE'S LAW AND AN 'OBJECTIVE' TEST FOR APPROXIMATE NUMERICAL RATIONALITY A A SUBJECTIVE JASA 69 23 EVALUATION OF BODE'S LAW AND AN 'OBJECTIVE' TEST FOR APPROXIMATE NUMERICAL RATIONALITY' $/$ 'A SUBJECTIVE JASA 69 50 OF TENDENCY EXACT AND APPROXIMATE POWER FUNCTION OF THE NON-PARAMETRIC TEST AMS 62471 OLMO OROV-SMIRNOV CRITERION D-SU/ ON THE EXACT AND APPROXIMATE SAMPLING DISTRIBUTION OF THE TWO SAMPLE K JASA 69 NO. 4 OF ASSOCTATTON FOR CROSS CLASSIFTCATTONS III APPROXIMATE SAMPLING THEORY

RENEWAL THEORY

STOCHASTIC PROCESSES

ESTIMATOR

NT OPERATORS FOR POWER-SERIES DISTRIBUTIONS. AND THE RECRESSION

AN APPROXIMATE SOLUTION OF THE INTEGRAL EQUATION OF JRSSB63 432 APPROXIMATE SOLUTIONS OF GREEN'S TYPE FOR UNIVARIATE JRSSB6O 376 APPROXIMATE SPECIFICATION AND THE CHOICE OF A K-CLASS JASA 671265

HE APPROXIMATE STABILIZATION OF VARIANCE BY TRANSFORMATI JASA $6 B \quad 321$

AN APPROXIMATE TEST FOR SERIAL CORRELATION IN POLYNOMIAL BIOKAGO 111 EXACT AND APPROXIMATE TESTS FOR DIRECTIONS. I EXACT AND APPROXIMATE TESTS FOR DIRECTIONS. II APPROXIMATE TESTS FOR M RANKINCS

SOME SIMPLE APPROXIMATE TESTS FOR POISSON VARIATES

RANDOM ALLOCATION DESIUNS II, APPROXIMATE THEORY FOR SIMPLE RANDOM ALLOCATION

TESTING THE APPROXIMATE VALIDITY OF STATISTICAL HYPOTHESES

SIZE

SAMPLING PLANS WHICH APPROXIMATELY MINIMIZE THE MAXIMUM EXPECTED SAMPLE APPROXIMATELY OPTIMAL STRATIFICATION

FIRST THREE MOME/ USE OF THE PEARSON DENSITIES FOR APPROXIMATING A SKEW DENSITY WHOSE LEFT TERMINAL AND SAMPLINC DISTRIBUTIONS

(CORR, 69669 ) APPROXIMATINC THE GENERAL NON-NORMAL VARIANCE-RATIO APPROXIMATINC THE LOWER BINOMIAL CONFIDENCE LIMIT APPROXIMATINC THE NECATIVE BINOMIAL

ERRATA, 'APPROXIMATINC THE NECATIVE BINOMIAL'

ON APPROXIMATING THE POINT BINOMIAL, CORR 56651

MOMENTS

CRITERIA

DISPERSION BY A POWER OF CHI-SQUARE

SOME PROBLEMS ARISINC IN APPROXIMATINC TO PROBABILITY DISTRIBUTIONS USING

A GENERAL METHOD FOR APPROXIMATING TO THE DISTRIBUTION OF LIKELIHOOD RAT] APPROXIMATING TO THE DISTRIBUTIONS OF MEASURES OF

A NOTE ON APPROXIMATINC TO THE NON-CENTRAL F DISTRIBUTION

ON ASYMPTOTIC NORMALITY IN STOCHASTIC APPROXIMATION

TIONS, POISSON LIMITINC FORMS AND DERIVED METHODS OF APPROXIMATION

ON FREE TEST STATISTIC FOR DISPERSION AND ITS NORMAL APPROXIMATION

MONTE CARLO STUDY OF THE ADEQUACY OF THE ASYMPTOTIC APPROXIMATION

MULTINOMIAL DISTRIBUTION COMPARED WITH THE X-SQUARE APPROXIMATION INVERSE CUMULATIVE APPROXIMATION AND APPLICATIONS
A STATISTICAL BASIS FOR APPROXIMATION AND OPTIMIZATION

THE MATCHINC DISTRIBU JRSSB5B 73 /RITICAL VALUES FOR MOOD'S DISTRIBUTI TECH $68 \quad 497$ $\begin{array}{lll}\text { /YSIS OF VARIANCE IN SMALL SAMPLES, A BIOCS69 } & 593\end{array}$ $\begin{array}{lll}\text { /YSIS OF VARIANCE IN SMALL SAMPLES, A BIOCS69 } & 593 \\ \text { AN IMPROVEMENT TO IT A COMPLETE BIOKA64 } & 277\end{array}$

BIOKA68 29 AMS $66 \quad 59$

O BACTERIAL ENDOCARD/ A CENERAL USE OF THE POISSON APPROXIMATION FOR BINOMIAL EVENTS, WITH APPLICATION T BIOCS66 74 RELATED TAIL PROBABILTTIES, I A NORMAL APPROXIMATION FOR BINOMIAL, F, BETA, AND OTHER COMMON JASA 68 I416 RELATED TAIL PROBABILITIES, II

A NORMAL APPROXIMATION FOR BINOMIAL, F. BETA, AND OTHER COMMON JASA 681457 ON METHODS OF ASYMPTOTIC APPROXIMATION FOR MULTIVARIATE DISTRIBUTIONS STOCHASTIC APPROXIMATION FOR SMOOTH FUNCTIONS

AN IMPROVEMENT TO WALD'S APPROXIMATION FOR SOME PROPERTIES OF SEQUENTIAL TESTS JRSSB54 136 FORMULAE TO IMPROVE WALD'S APPROXIMATION FOR SOME PROPERTIES OF SEQUENTIAL TESTS JRSSB65 74 AN APPROXIMATION FOR STUDENT'S T-DISTRIBUTION $\quad$ BIOKA68 571

AN APPROXIMATION FOR THE EXAGT DISTRIBUTION OF THE $\quad$ JASA 64899

WILCOXON TEST FOR SYMMETRY NOTE ON A GHI SQUARE APPROXIMATION FOR THE MULTIVARIATE SIGN TEST

INTEGRAL

POPULATIONS

S

SPEED

BINOMIAL USEFUL IN LIFE TESTING LARGE POPULATION THE EFFEGT OF STANDARDIZATION ON AN APPROXIMATION IN FAGTOR ANALYSIS

AN AN APPROXIMATION IN FAGTOR ANALYSIS J

N THE USE OF THE NORMAL APPROXIMATION IN THE TREATMENT OF STOCHASTIG PROCESSE JRSSB57 268 A DYNAMIG STOCHASTIG APPROXIMATION METHOD

ON THE CHOICE OF DESIGN IN STOCHASTIC APPROXIMATION METHODS

STOCHASTIG APPROXIMATION OF MINIMA WITH IMPROVED ASYMPTOTIG

UNIFORM APPROXIMATION OF MINIMAX POINT ESTIMATES $\begin{array}{llrrr}\text { AN APPROXIMATION OF STUDENT'S T } & \text { TECH } 65 & 71 \\ \text { AN APPROXIMATION OF THE NEGATIVE MOMENTS OF THE POSITIVE TECH } 60 & 227\end{array}$ A PERTURBATION APPROXIMATION OF THE SIMPLE STOGHASTIG EPIDEMIG IN A BIOKA68 199 KIEFER-WOLFOWITZ APPROXIMATION PROGEDURE

SOME STOCHASTIG APPROXIMATION PROGEDURES FOR USE IN PROCESS CONTROL

AMS 671031

AMS 641136

NOTE ON THE MAXIMUM SAMPLE EXCURSIONS OF STOGHASTIG APPROXIMATION PROCESSES

\section{s} 29
12 12 37
306 
FINITE CAMES

REPAIR MEN

ON DVORETZKY STOCHASTIC APPROXIMATION THEOREMS APPROXIMATION TO BAYES RISK IN SEQUENCES OF NONTHE ADEQUACY OF THE DIFFUSION APPROXIMATION TO CERTAIN DISTRIBUTIONS IN CENETICS NORMAL APPROXIMATION TO MACHINE INTERFERENCE WITH MANY A SECOND-ORDER APPROXIMATION TO OPTIMAL SAMPLINC RECIONS APPLICATION OF STOCHASTIC APPROXIMATION TO PROCESS CONTROL

\section{LOCNORMAL APPROXIMATION TO PRODUCTS AND QUOTIENTS} APPROXIMATION TO THE BEHRENS-FISHER DISTRIBUTIONS.

PROBABILITY FUNCTIONS

NORMAL APPROXIMATION TO THE CHI-SQUARE AND NON-CENTRAL F APPROXIMATION TO THE CUMULATIVE T-DISTRIBUTION

SQUARE

NOTE ON AN APPROXIMATION TO THE DISTRIBUTION OF NON-CENTRAL CHIAN APPROXIMATION TO THE DISTRIBUTION OF NON-CENTRAL T

RELATED TO THE NON-CENTRAL T SEQUENTIAL TESTS. I. TESTS FOR SIMPLE HYPOTHESES FOR SEQUENTIAL TEST. II. TESTS OF COMPOSITE HYPOT/ BINOMIALS, CONDITIONAL ON FIXED SUM STIC IN THE CENERAL CASE SUBSET

IBUTION INVOLVINC THREE VARIATES PROPERTIES AND APPLICATIONS WITH APPLICATION TO SIMULATION

OF FIT TEST WITH SMALL BUT EQUAL/

AN APPROXIMATION TO THE DISTRIBUTION OF $O$. A VARIATE APPROXIMATION TO THE DISTRIBUTION OF SAMPLE SIZE FOR APPROXIMATION TO THE DISTRIBUTION OF THE SAMPLE SIZE NORMAL APPROXIMATION TO THE DISTRIBUTION OF TWO INDEPENDENT A FURTHER APPROXIMATION TO THE DISTRIBUTION OF WILCOXON'S STATI ASYMPTOTIC APPROXIMATION TO THE EXPECTED SIZE OF A SELECTED APPROXIMATION TO THE CENERALIZED BEHRENS-FISHER DISTR AN APPROXIMATION TO THE MULTINOMIAL DISTRIBUTION, SOME A USEFUL APPROXIMATION TO THE NORMAL DISTRIBUTION FUNCTION, TECH 67647 A DISTRIBUTION FOR SMALL VALUES OF THE SHAPE P/ AN APPROXIMATION TO THE PROBABILITY INTECRAL OF THE CAMM BIOKA62 276 DEGREES OF FREEDOM FOR SMALL SAMPLE SIZES FOR CHI APPROXIMATION TO THE RANCE SCALE FACTORS AND BIOKA53 3 S4 BOUNDS ON THE ERROR IN THE LINEAR APPROXIMATION TO THE RENEWAL FUNCTION

PROBLEMS

$\mathrm{N}$ WHEN ZERO DIFFERENCES ARE PRESENT FUNCTION

DISTRIBUTION

NORMAL POPULATIONS

ATIONS (ACKNOWLEDCEMENT 67587 )

\section{AN APPROXIMATION TO THE SAMPLE SIZE IN SELECTION}

THE NORMAL APPROXIMATION TO THE SICNED-RANK SAMPLINC DISTRIBUTIO

AN APPROXIMATION TO THE SYMMETRICAL INCOMPLETE BETA

AN APPROXIMATION TO THE WILCOXON-MANN-WHITNEY

AN APPROXIMATION TO TWO-SIDED TOLERANCE LIMITS FOR

LINEAR APPROXIMATION USINC THE CRITERION OF LEAST TOTAL DEVI J ON STOCHASTIC APPROXTMATIONS

ON THE MULTIPLYINC FACTORS FOR VARIOUS CHI-SQUARE APPROXIMATIONS AND COMPARISON WITH POINT ESTIMATES AND LARCE SAMPLE APPROXIMATIONS TIONS DATA AND THE INVESTMENT DECISION

CRITICAL VALUES IT STATISTICS. U-SQUARE-SUB-N AND W-SQ/ MARKOV CHAINS

A NOTE APPROXIMATIONS FOR MEAN SQUARE SUCCESSIVE DIFFERENCE CHI-SQUARE APPROXIMATIONS FOR THE DISTRIBUTIONS OF GOODNESS-OF-F APPROXIMATIONS FOR THE ENTROPY FOR FUNCTIONS OF

BOUNDS AND APPROXIMATIONS FOR THE MOMENTS OF ORDER STATISTICS APPROXIMATIONS FOR THE NULL DISTRIBUTION OF THE W-

STATISTIC + (TEST FOR NORMALITY) NUMERICAL RESULTS AND DIFFUSION APPROXTMATIONS IN A CENETIC PROCESS

INTERPOLATIONS AND APPROXIMATIONS RELATED TO THE NORMAL RANGE

SYMMETRIC FUNCTIONS OF THE ROOTS OF TWO MATRICES AND APPROXIMATIONS TO A DISTRIBUTION /TS OF ELEMENTARY SOME INCOMPLETELY SPECIFIED MODELS INVOLVINC NORMAL APPROXIMATIONS TO DISCRETE DATA HYPERCEOMETRIC SERIES ON THE MOMENTS OF THE TRACE OF A MATRIX AND APPROXIMATIONS TO ITS NON-CENTRAL DISTRIBUTION
CHEBYSHEV POLYNOMIAL AND OTHER NEW APPROXIMATIONS TO MILLS' RATIO NEW CHEBYSHEV POLYNOMIAL APPROXIMATIONS TO MILLS' RATIO

\section{IRRATIONAL FRACTION APPROXIMATIONS TO MILLS' RATTO}

PROBABILITIES

FOR SAMPLES FROM NON-NORMAL POPULATIONS SOM

ADJUSTMENT METHODS

SEQUENTIAL TESTS

MULTIPLE RANCE TEST

SOME COMMENTS ON THE ACCURACY OF BOX'S
APPROXIMATIONS TO MULTIVARIATE NORMAL ORTHANT

ON APPROXIMATIONS TO SAMPLINC DISTRIBUTIONS OF THE MEAN SEVERAL APPROXIMATIONS TO THE BINOMIAL DISTRIBUTION

LINEAR APPROXIMATIONS TO THE CENSUS AND BLS SEASONAL APPROXIMATIONS TO THE CHARACTERISTICS OF SOME APPROXIMATIONS TO THE CRITICAL VALUES FOR DUNCAN'S APPROXIMATIONS TO THE DISTRIBUTION OF M APPROXIMATIONS TO THE DISTRIBUTION OF QUADRATIC FORMS APPROXIMATIONS TO THE DISTRIBUTION OF THE RANCE IN SM

ALL SAMPLES FROM NORMAL POPULAT/

COMPARISON OF TWO APPROXIMATIONS TO THE DISTRIBUTIONS OF SOME MEASURES OF DISPERSION BASED ON SUCCESSIVE DIFFERENCES

\section{SIMPLIFIED BETA-APPROXIMATIONS TO THE KRUSKAL-WALLIS H TEST} APPROXIMATIONS TO THE MAXIMUM-LIKELIHOOD ESTIMATOR APPROXIMATIONS TO THE MEAN AND STANDARD DEVIATION OF APPROXIMATIONS TO THE MOMENTS OF THE SAMPLE MEDIAN

RECIPROCALS OF OBSERVATIONS

SOME APPLICATIONS OF TWO

DISTRIBUTION

APPLICATIONS

$S^{\prime}$

N PERCENTAGE POINTS OF A MULTIVARIATE ANALOCUE OF/

DISTRIBUTION OF RANGE

ON THE USE OF PATNAIK TYPE CHI PORIMATIONS TO THE MULTINOMIAL DISTRIBUTION APPROXIMATIONS TO THE NON-CENTRAL CHI-SQUARE APPROXIMATIONS TO THE NON-CENTRAL T, WITH APPROXIMATIONS TO THE NON-CENTRAL T, WITH APPLICATION TECH 64 4B2 APPROXIMATIONS TO THE PROBABILITY INTEGRAL AND CERTAI BIOKA55 $25 \mathrm{~B}$ APPROXIMATIONS TO THE PROBABILITY INTEGRAL OF THE

APPROXIMATIONS TO THE RANGE IN SIGNIFICANCE TESTS APPROXIMATIONS TO THE REQUIRED PROBABILITY R'S B DISTRIBUTION AND NON-CENTRAL CHI-SOUARE APPROXIMATIONS TO THE UPPER 5 PERCENT POINTS OF FISHE BIOKA57 528 ASTIC MODELS FOR BIOLOGICAL SYSTEMS A NOTE ON SOME APPROXIMATIONS TO THE VARIANCE IN DISCRETE-TIME STOCH BIOKA6O AND DOUBLE CLASSIFICATIONS. PART 2. DERIVATIONS AND APPROXIMATIONS,/LE COMPARISONS FOR BALANCED SINGLE BIOKA65 CY DISTRIBUTION. WITH ESPECIAL REFERENCE/ A LINEAR APPROXIMATOR FOR THE CLASS MARKS OF A GROUPED FREQUEN TH SIMULATION OF AN AQUATIC ECOSYSTEM

RANKING PROCEDURES FOR ARBITRARILY RESTRICTED OBSERVATION

A GENERALIZED WILCOXON TEST FOR COMPARING ARBITRARILY SINGLY-CENSORED SAMPLES

EQUATION TECHNIQUE APPLIED TO THE SIMPLE QUEUE WITH ARBITRARY ARRIVAL INTERVAL DISTRIBUTION

COVERACE TO THE LEFT OF THE I'TH ORDER STATISTIC FOR ARBITRARY DISTRIBUTIONS

MATRICES MULTIPLE CLASSIFICATION ANALYSIS FOR ARBITRARY EXPERIMENTAL DESIGN

A RELATIONSHIP BETWEEN ARBITRARY POSITIVE MATRICES AND DOUBLY STOCHASTIC ARBITRARY STATE MARKOVAIAN DECISION PROCESSES

SERVATIONS ERROR ESTIMATION OF STOCHASTIC SYSTEMS, ARBITRARY SYSTEM PROCESS WITH ADDITIVE WHITE NOISE OB A MODIFICATION OF KENDALL'S TAU FOR THE CASE OF ARBITRARY TIES IN BOTH RANKINGS

EXPECTED ARC LENCTH OF A CAUSSTAN PROCESS ON A FTNTTE TNTERVAL JRS

SELECTED STATISTICAL JOURNALS
BIOKA52 417 BIOKA66 24B BIOKA63 514

AMS $66 \quad 1534$

BIOCS65 386

JMSB 69734

JRSSB $65 \quad 321$

267

TECH $66 \quad 35 \mathrm{~B}$

364

AMS $64 \quad 315$

IOKA59 130

AMS $63 \quad 1593$

BIOKA64 355 AMS 69492 BIOKA52 204 JASA 69591 TECH $66 \quad 115$ AMS $63-343$ JRSSB54 296 ASA 69 TECH $68 \quad 397$ AMS $62 \quad 930$ JASA 69 NO. 4 241 AMS $68 \quad 1274$ 335 AMS $66 \quad 1312$ AMS $63 \quad$ B92 BIOKA64 339 AMS $63 \quad 191$ AMS 631308 JASA 69 NO. 4 BIOKA69 203 BIOCS66 179 IOKA69 219 BIOKA52 130 BIOKA57 349 BIOKA66 $2 \mathrm{~B} 2$ TECH $63 \quad 522$ AMS $62 \quad 15 \%$ BIOKA60 463 BIOKA63 $6 \mathrm{~B} 793$ BIOCS $6 \mathrm{~B} \quad \mathrm{B03}$ BIOCS67 65 BIOKA65 203 RSSB5B 16B AMS $69 \quad 644$ TECH $68 \quad 13$ AMS $64 \quad 876$ AMS $6 \mathrm{~B} 211 \mathrm{~B}$ AMS 6B $7 B 5$ ASA $57 \quad 33$ 257 

ESTIMATION OF CROP YIELDS FOR SMALL AREAS BIOCS66 374

EXPANSION TAIL AREAS OF THE T-DISTRIBUTION FROM A MILLS' RATIO-LIKE AMS $63 \quad 335$ GRATION OF EMPLOYED PERSONS TO AND FROM METROPOLITAN AREAS OF THE UNITED STATES ON THE NORMAL STATIONARY PROCESS, AREAS OUTSIDE GIVEN LEVELS THE MI JASA $67 \quad 1418$ JRSSB63 189 JRSSB61 154 AN UNBIASED ESTIMATOR FOR POWERS OF THE ARITHMETIC MEAN ROBABILITY AND STATISTICS VII THE PRINCIPLE OF THE ARITHMETIC MEAN NC BAYES AND MINIMAX PROCEDURES FOR ESTIMATING THE ARITHMETIC MEAN OF A POPULATION WITH TWO-STAGE SAMPLI AMS 66 1186 STUDIES IN THE HISTORY OF P BIOKA5B 130 ESTIMATORS FOR THE PRODUCT OF ARITHMETIC MEANS JRSSB62 180

GIVEN/ A CHART FOR SEQUENTIALLY TESTINC OBSERVED ARITHMETIC MEANS FROM LOCNORMAL POPULATIONS ACAINST A TECH 6B 605 NOTES ON ESTTMATINO THE ARTTHMETTC UEANS OF LOCNORMALLY-DISTRIBL CONSECUTIVE MEMBERS OF A SERIES OF RANDOM VARIABLES ARRANCED IN ORDER OF SIZE THE DIFFERENCE BETWEEN BIOKA57 211 A CALCULUS FOR FACTORIAL ARRANCEMENTS EDITORIAL ARRANCEMENTS

BIOKA65 1

DESIGN OF AN EXPERIMENT IN WHICH CERTAIN TREATMENT ARRANCEMENTS ARE INADMISSIBLE THE BIOKA54 287 APPLICATIONS OF THE CALCULUS FOR FACTORIAL ARRANCEMENTS II. TWO WAY ELIMINATION OF HETERO ENEITY AMS 64 65B UNIFORMLY BETTER COMBINED ESTIMATORS IN FACTORIAL ARRANGEMENTS WITH CONFOUNDINC SYMMETRICAL UNEQUAL BLOCK ARRANCEMENTS WITH TWO UNEQUAL BLOCK SIZES APPLICATIONS OF THE CALCULUS OF FACTORIAL ARRANCEMENTS I BLOCK AND DIRECT PRODUCT DESIGN ON ORTHOCONAL ARRAYS

JASA $67 \quad 638$ AMS 62620 BIOKA63 63 AMS 661355

SOME METHODS OF CONSTRUCTION OF PARTIALLY BALANCED ARRAYS

SOME MAIN-EFFECT PLANS AND ORTHOCONAL ARRAYS OF STRENCTH TWO

ON AMS 611181 AMS $61 \quad 1167$ JRSSB $60 \quad 285$ QUEUEINC AT A SINGLE SERVING POINT WTTH GROUP ARRIVAL

TECHNIQUE APPLIED TO THE SIMPLE QUEUE WITH ARBITRARY ARRIVAL INTERVAL DISTRIBUTION /DIFFERENCE EQUATION J POISSON PROCESSES WITH RANDOM ARRIVAL RATE

A QUEUEING PROBLEM IN WHICH THE ARRIVAL TIMES OF THE CUSTOMERS ARE SCHEDULED

SOME RESULTS FOR THE QUEUE WITH POISSON ARRIVALS

ON A GENERALIZED QUEUEINC SYSTEM WITH POISSON ARRIVALS A QUEUE WITH RANDOM ARRIVALS AND SCHEDULED BULK DEPARTURES

/TION TO THE SI JRSSB60 89 JRSSB $68 \quad 185$ BIBLIOCRAPHY ON SIMULATION. GAMING, ARTIFICIAL INTELLIGENCE AND ALLIED TOPICS JASA $60 \quad 736$ THE JOINT DISTRIBUTION OF ASCENDING PAIRS AND ASCENDING RUNS IN A RANDOM SEQUEN BIOKA67 330 THE JOINT DISTRIBUTION OF ASCENDINC PAIRS AND ASCENDING RUNS IN A RANDOM SEQUENCE BIOKA67 330 AMS $64 \quad 435$ A PROPERTY OF THE METHOD OF STEEPEST ASCENT

THAN MALE MORTALITY IN SOME COUNTRIES OF SOUTH ASIA. A DIGEST

OF INTERNATIONAL TRADE DATA. THE CASE OF SOUTHEAST ASIAN COUNTRIES AN ESTIMATION PROBLEM IN QUANTITATIVE ASSAY HICHER FEMALE JASA 69 NO.4 THE ACCURACY JASA $69 \quad 452$ BIOKA54 338 PRIOR INFORMATION TO DESIGN A ROUTINE PARALLEL LINE ASSAY

A TEST FOR REGRESSION MODEL ADEQUACY IN RADIONUCLIDE ASSAY JOINT ACTION OF A MIXTURE OF STIMULI IN BIOLOGICAL ASSAY QUANTAL RESPONSES TO MIXTURES OF DRUGS IN BIOLOCICAL ASSAY THE CHICK ASSAY OF LYSINE

\section{PLANNING A QUANTAL ASSAY OF POTENCY} OF NON-PARAMETRIC METHODS IN DILUTION (-DIRECT) ASSAYS
SOME FURTHER APPLICATIONS BIOCS65 799 USE OF BIOCS67 257 PATTERNS IN RESIDUALS TECH 65603 MODELS FOR THE NON-INTERACTIVE BIOKA66 49 /E CLASSIFICATION OF MATHEMATICAL MODELS FOR BIOCS65 181 BI0CS66 58 BIOCS66 322 QUANTAL RESPONSE ANALYSIS OF A SERIES OF BIOLOCICAL ASSAYS ON THE SAME SUBJECTS ANALYSIS OF QUANTAL RESPONSE ASSAYS WITH DOSACE ERRORS EXTREMES IN A RANDOM ASSEMBLY

ASSESSINC THE ACCURACY OF MULTIVARIATE OBSERVATIONS

THE BIOKA60 BIOCS67 747 BIOKA67 273 JASA $66 \quad 403$ TECH $6 B \quad$ B25 JASA $67 \quad 776$ JASA 691073

SAMPLES THE JOINT ASSESSMENT OF NORMALITY OF SEVERAL INDEPENDEN THE ASSESSMENT OF PRIOR DISTRIBUTIONS IN BAYESIAN

SCORING RULES AND THE EVALUATION OF PROBABILITY ASSESSORS JASA $60 \quad 469$ CONSUMERS' PROPENSITTES TO HOLD LIQUTD ASSETS ODS EXPENDITURES. WITH MAJOR EMPHASIS ON THE ROLE OF ASSETS. CREDIT AND INTENTIONS CONSUMER DURABLE GO JASA 63 64B
VARIANCES
A METHOD OF ASSIGNING CONFIDENCE LIMITS TO LINEAR COMBINATIONS OF BIOKA55 47I ODS EXPENDITURES. WITH MAJOR EMPHASIS ON THE ROLE OF ASSETS. CREDIT AND INTENTIONS CONSUMER DURABLE GO JASA 63 64B
VARIANCES
A METHOD OF ASSIGNING CONFIDENCE LIMITS TO LINEAR COMBINATIONS OF BIOKA55 471 QUERY, INADMISSIBLE RANDOM ASSICNMENTS TECH 64103 EPORTED BY A SAMPLE OF FAMILIES WHO RECEIVED WELFARE ASSISTANCE DURING 1959 CONSTRUCTION OF PARTIALLY BALANCED DESICNS WITH TWO ASSOCIATE CLASSES BALANCED INCOMPLETE BLOCK DESIGNS WITH MORE THAN TWO ASSOCIATE CLASSES THE VALIDITY OF INCOME R JASA $62 \quad 6 B 0$ ON A GEOMETRICAL METHOD OF AMS 611177 ANALYSIS OF A CLASS OF PARTIALLY. AMS $61 \quad 800$ F-TEST IN THE INTRABLOCK ANALYSIS OF A CLASS OF TWO ASSOCIATE PARTIALLY BALANCED INCOMPLETE BLOCK DESIGNS JASA 65 285 AND SECOND MOMENTS OF THE RANDOMIZATION TEST IN TWO ASSOCIATE PBIB DESIGNS ASSOCIATED DIRECTIONS

COMPARISONS. THE EXTENSION OF A UNIVARIATE MODEL AND ASSOCIATED ESTIMATION AND TEST PROCEDURES GENERALIZED MEANS AND ASSOCIATED FAMILIES OF DISTRIBUTIONS ANALYSIS COMBINING A BARTLETT WINDOW WITH AN ASSOCIATED INNER WINDOW

OF MAXIMUM LIKELIHOOD ESTIMATORS WHEN SAMPLINC FROM ASSOCIATED POPULATIONS IN A RANK-ORDER AND THE STOPPINC TIME OF SOME ASSOCIATED SPRT'S POINTS OF THE RATIO OF TWO RANCES AND POWER OF THE ASSOCIATED TEST AMS $69 \quad 339$ FIRST JASA 69 N0. 4 BIOCS69 BIOKA69 81 SPECTRAL TECH $61 \quad 235$ THE PROBABILITY OF REVERSAL ASSOCTATED IITTH A TEST PROCEDURE WHEN DATA ARE INCOM J ASA 6I 125 DISTRIBUTIONS ASSOCIATED WITH CELL POPULATIONS

LIMITINC DISTRIBUTIONS ASSOCIATED WITH CERTAIN STOCHASTIC LEARNINC MODELS

ON A DISTRIBUTION ASSOCIATED WITH CERTAIN STOCHASTTC PROCESSES ON DOMINATINC AN AVERAGE ASSOCIATED WITH DEPENDENT CAUSSIAN VECTORS SECOND PAPER ON STATISTICS ASSOCIATED WITH THE RANDOM DISOREINTATION OF CUBES BIOKA69 391 

DESICNS

THE ESTIMATION AND COMPARISON OF STRENCTHS OF ASSOCIATION IN CONTINGENCY TABLES

THE EFFECT OF NON-SAMPLINC ERRORS ON MEASURES OF ASSOCIATION IN 2-BY-2 CONTINCENCY TABLES

ASSOCIATION MATRICES AND THE KRONECKER PRODUCT OF ASSOCIATION RANDOM VARIABLES, WITH APPLICATIONS

AN EXTENSION OF THE TRIANCULAR ASSOGIATION SCHEME TO THREE ASSOCIATE CLASSES

JASA $59 \quad 123$

JASA $63 \quad 310$

BIOKA52 274

BIOKA53 105

JASA $69 \quad 852$

AMS 6B 676

AMS 671466

JRSSB $66 \quad 361$

PARAMETERS OF PARTIALLY BALANCED INCOMPLETE BLOCK ASSOCIATION SCHEMES

A NOTE ON THE AMS $65 \quad 331$

TNCOMPLTTE BLOCK DESTLNS FROM PARTIALLY BALANCED ASSOCIATION SCHEMES

ON OBTATNTNG BALANCED

MARKET ORIENTATION OF PRODUCTI/ MEASURINC SPATIAL ASSOCIATION WITH SPECIAL CONSIDERATION OF THE CASE OF JA

DISTRIBUTION OF THE SAMPLE VERSION OF THE MEASURE OF ASSOCIATION, GAMMA

THE DETECTION OF PARTIAL ASSOCIATION, 1, THE 2 BY 2 CASE

THE DETECTION OF PARTIAL ASSOCIATION, 2. THE GENERAL CASE

A TEST OF EQUALITY OF TWO NORMAL POPULATION MEANS ASSUMINC HOMOGENEOUS COEFFICIENTS OF VARIATION AN EXAMPLE OF ERRORS INCURRED BY ERRONEOUSLY ASSUMINC NORMALITY FOR CUSUM SCHEMES

PROTECTION AGAINST ASSUMINC THE WRONG DEGREE IN POLYNOMIAL RECRESSION

AMS 67618

JASA $56 \quad 597$

SASJ $67 \quad 1$

JASA $66 \quad 440$

JRSSB $64 \quad 313$

JRSSB65 111

AMS 691374

TECH $67 \quad 457$

TECH 69 NO. 4

OF ROBUST CRITERIA AND THE STUDY OF DEPARTURES FROM ASSUMPTION (WITH DISCUSSION) /ORY IN THE DERIVATION JRSSB55 DEPARTURES FROM ASSUMPTION IN SEQUENTIAL ANALYSIS

LUATION OF H 106 CONTINUOUS SAMPLING PLANS UNDER THE ASSUMPTION OF WORST CONDITIONS EXPNENTIAL, PART/ TESTS FOR THE VALIDITY OF THE ASSUMPTION THAT THE UNDERLYING DISTRIBUTION OF LIFE I TECH 60 B3 RELATIONSHIP TO THE JACKKNIFE METHOD. ASSUMPTION-FREE ESTIMATORS USING U STATISTICS AND A BIOCS67 567 NON-LINEAR REGRESSION WITH MINIMAL ASSUMPTIONS

RECRESSION OF DUMMY VARIATES UNDER NORMALITY ASSUMPTIONS

FOR DUMMY VARIATE REGRESSION UNDER NORMALITY ASSUMPTIONS

ASYMPTOTIC VARIANCES JASA 67 1305

A BAYESIAN APPROACH TO THE IMPORTANCE OF ASSUMPTIONS APPLIED TO THE COMPARISON OF VARIANCES BIOKA64 153

SAMPLING VARIANCE OF CORRELATION COEFFICIENTS UNDER ASSUMPTIONS OF FIXED AND MIXED VARIATES

SIMULTANEOUS-EQUATIONS ESTIMATORS TO THE STOCHASTIC ASSUMPTIONS OF THE MODELS ON THE SENSITIVITY OF JASA 66 136

IS EXPONENTIAL, PAR/ TESTS FOR THE VALIDITY OF THE ASSUMPTIONS THAT THE UNDERLYING DISTRIBUTION OF LIFE TECH 60 167 SEQUENTIAL RELIABILITY ASSURANCE IN FINITE LOTS

CHINC FOR ACCEPTANCE, REJECTION SAMPLINC UPON SAMPLE ASSURANCE OF TOTAL PRODUCT QUALITY /SEQUENTIAL BAT TECH 60 IS TCHING FOR ACCEPTANCE-REJECTTON SAMPLTNC UPON SAMPLE ASSURANCE OF TOTAL PRODUCT QUALTTY ON EVALUATION OF WARRANTY ASSURANCE WHEN LIFE HAS A WEIBULL DISTRIBUTION
BIOKA69 NO.3 THE ASYMMETRIC CAUCHY PROCESSES ON THE LINE AMS $69 \quad 137$

ON THE GONSTRUCTION AND ANALYSIS OF SOME CONFOUNDED ASYMMETRICAL FACTORIAL DESIGNS UCTION AND ANALYSIS OF SOME NEW SERIES OF CONFOUNDED ASYMMETRICAL FACTORIAL DESICNS ORTHOGONAL MAIN-EFFECT PLANS FOR ASYMMETRICAL FACTORIAL EXPERIMENTS

ERRATA, 'ORTHOGONAL MAIN-EFFECT PLANS FOR ASYMMETRICAL FACTORIAL EXPERIMENTS' BIOCS65 948 CONSTR BIOCS67 813 TECH 62 21 TECH $62 \quad 440$ TECH $62 \quad 47$ TECH $6 \mathrm{~B} \quad 313$ JASA $66 \quad 505$ TRANSFORMATIONS SYMMETRICAL AND ASYMMETRICAL FRACTIONAL FACTORIAL PLANS ASYMMETRICAL ROTATABLE DESIGNS AND ORTHOGONAL PRODUCER AND CONSUMER RISKS FOR ASYMMETRICAL TESTS AND SPECIFICATION LIMITS SAMPLES, A MONTE CARLO STUDY OF THE ADEQUACY OF THE ASYMPTOTIC APPROXIMATION /YSIS OF VARIANCE IN SMALL BIOCS69 593 ON METHODS OF ASYMPTOTIC APPROXIMATION FOR MULTIVARIATE DISTRIBUTIO ASYMPTOTIG APPROXIMATION TO THE EXPECTED SIZE OF A BIOKA69 207 SELECTED SUBSET THE ASYMPTOTIC BEHAVIOR OF A CERTAIN MARKOV CHAIN

\section{DISCRETE CASE II}

DISCRETE CASE SEQUENTIAL ANALYSIS

CERTAIN ONE-SIDED TESTS

NS IN MULTIPLE LINEAR RECRESSION

\section{MATCH BOX PROBLEM}

STATISTICAL APPLICATIONS

CENTRAL B STATISTIC IN MULTIVARIATE ANALYSIS THE WIENER PROCESS

STATISTICS FROM BIVARIATE POPULATIONS

BLY CENSORED SAMPLES, OF THE PARAMETERS OF THE FIRST CTIONS OF ORDER STATISTICS WITH APPLICATIONS TO E/ ORS IN A LINEAR MODEL WITH AUTOREGRESSIVE DISTURB/$$
\text { NOTE }
$$

OF THE TWO-SAMPLE RANK VECTOR

ON THE INFLUENCE OF MOMENTS

OF FIT CRITERIA FOR MARKOV CHAINS AND MAR/

SAMPLE FROM A LINEAR STOCHASTIC PROCESS

STATISTIC

A DENUMERABLE NUMBER OF STATES

PROBLEM

FOR SMALLER PERCENTILES OF A GAMMA DISTRIBUTION

TESTS FOR REGRESSION PARAMETERS

IMATOR SEQUENCE (CORR, 67 196)

TEST
ON THE ASYMPTOTIC BEHAVIOR OF BAYES ESTIMATES IN THE ASYMPTOTIC BEHAVIOR OF BAYES' ESTIMATES

ON THE ASYMPTOTIC BEHAVIOR OF BAYES' ESTIMATES IN THE

ON THE ASYMPTOTIC BEHAVIOR OF DENSITIES WITH APPLICATIONS TO ASYMPTOTIC BEHAVIOR OF EXPECTED SAMPLE SIZE IN ASYMPTOTIC BEHAVIOR OF WILCOXON TYPE CONFIDENCE REGIO

ON THE ASYMPTOTIC BEHAVIOUR OF POSTERIOR DISTRTBUTIONS

ON THE ASYMPTOTIC BEHAVIOUR OF QUEUES ASYMPTOTIC DISTRIBUTION FOR A GENERALIZED BANACH

AN ASYMPTOTIC DISTRIBUTION FOR THE DETERMINANT OF A NON- SASJ 6877 OF A CERTAIN FUNCTIONAL OF ASYMPTOTIC DISTRIBUTION OF DISTANCES BETWEEN ORDER ASYMPTOTIC DISTRIBUTION OF EXTREME VALUES/FROM DOU JASA $68 \quad 889$ ASYMPTOTIC DISTRIBUTION OF LINEAR COMBINATIONS OF FUN AMS $67 \quad 52$ ASYMPTOTIC DISTRIBUTION OF MAXIMUM LIKELIHOOD ESTIMAT AMS 69583 THE ASYMPTOTIC DISTRIBUTION OF SAMPLE QUANTILES

THE ASYMPTOTIC DISTRIBUTION OF SOME NON-LINEAR FUNCTIONS ON THE ASYMPTOTIC DISTRIBUTION OF SUMS OF RANDOM VARIABLES

ON THE ASYMPTOTIC DISTRIBUTION OF THE IPSI-SOUAREDI COODNESS ON THE ASYMPTOTIC DISTRIBUTION OF THE AUTOCORRELATIONS OF A JOINT ASYMPTOTIC DISTRIBUTION OF THE MEDIAN AND A UASYMPTOTIC DISTRIBUTORS FOR THE COUPON COLIECTORIS AMS 651835 ASYMPTOTIC EFFICIENCIES OF A NONPARAMETRIC LIFE TEST JASA 56467 ASYMPTOTIC EFFICIENCY IN POLYNOMIAL ESTIMATION

ASYMPTOTIC EFFICIENCY OF A CLASS OF NON-PARAMETRIC ON THE ASYMPTOTIC EFFICIENCY OF A SEQUENTIAL PROCEDURE FOR A NOTE ON THE ASYMPTOTIC EFFICIENCY OF AN ASYMPTOTICALLY NORMAL EST A NOTE ON THE ASYMPTOTIC EFFICIENCY OF BENNETT'S BIVARIATE SIGN
JRSSB $68 \quad 570$ AMS 691011 AMS 631042 AMS $61 \quad 49$ AMS 641296 $\begin{array}{llr}\text { ASA } & 56 & 467 \\ \text { AMS } & 61 & 1042\end{array}$ AMS $67 \quad 884$ AMS 661759 AMS $66 \quad 1173$ JRSSB 63195 JRSSB $66 \quad 146$ 
POWERFUL RANK TESTS

COMPARATIVE EXPERIMENT

CORRELATION COEFFICIENT

TEST

TEST

FOR A BALANCED INCOMPLETE BLOCK DESIUN

SMIRNOV TEST

S OF WILCOXON'S TWO SAMPLE TEST
CORRELATION COEFFICIENTS

ASYMPTOTIC EFFICIENCY OF CERTAIN LOCALLY MOST ASYMPTOTIC EFFICIENCY OF CERTAIN RANK TESTS FOR ASYMPTOTIC EFFICIENCY OF CLASS OF C-SAMPLE TESTS

THE ASYMPTOTIG EFFICIENCY OF DANIELS'S GENERALIZED

THE ASYMPTOTIC EFFICIENCY OF DANIELS'S CENERALIZED

A NOTE CN THE ASYMPTOTIC EFFICIENCY OF FRIEDMAN'S CHI-SQUARE-SUB-RON THE ASYMPTOTIC EFFICIENCY OF LEAST SQUARES ESTIMATORS ASYMPTOTIC EFFICIENCY OF MULTIVARIATE NORMAL SCORE

OF ASYMPTOTIC EFFICIENCY OF TESTS

THE ASYMPTOTIC EFFICIENCY OF THE CHI-SQUARE-SUB R-TEST

ON THE ASYMPTOTIC EFFICIENCY OF THE KOLMO OROV SMIRNOV TEST ASYMPTOTIC EFFICIENCY OF THE TWO SAMPLE KOLMOCOROVASYMPTOTIC EFFICIENCY OF TWO NONPARAMETRIC GOMPETITOR J THE ASYMPTOTIC ERROR OF ITERATIONS

ETRIC TWO-WAY CLASSIFICATION WITH PRESCRIBED MAXIMUM ASYMPTOTIC ERROR PROBABILITY

SEQUENTIAL NONPAR

AN ASYMPTOTIC EXPANSION FOR THE DISTRIBUTION OF THE

AN ASYMPTOTIC EXPANSION FOR THE DISTRIBUTION OF THE LATE

LINEAR DISCRIMINANT FUNCTION

NT ROOTS OF THE ESTIMATED GOVARIANLE MATRIX

INTECRAL AND MILL'S RATIO

OF A DENSITY

FUNCTIONS

FOR LINEAR AUTOREGRESSIVE SCHEMES

THE SERTAL CORRELATION COEFFICIENT

TION OF CORRELATION COEFFICIENT

A NEW ASYMPTOTIC EXPANSION FOR THE NORMAL PROBABILITY ASYMPTOTIC EXPANSIONS ASSOCIATED WITH THE N'TH POWER ASYMPTOTIC EXPANSIONS FOR A CLASS OF DISTRIBUTION ASYMPTOTIC EXPANSIONS FOR TESTS OF COODNESS OF FIT ASYMPTOTIC EXPANSIONS FOR THE MEAN AND VARIANCE OF ASYMPTOTIC EXPANSIONS FOR THE MOMENTS OF THE DISTRIBU

CENERALIZED ASYMPTOTIC EXPANSIONS OF CORNISH-FISHER TYPE

ELIHOOD RATIO CRITERIA FOR COVARIANCE MATRIX $F$ THE LIKELIHOOD RATIO CRITERIA FOR MULTIVARIATE/ ASYMPTOTIC EXPANSIONS OF THE DISTRIBUTIONS OF THE LIK ASYMPTOTIC EXPANSIONS OF THE NON-NULL DISTRIBUTIONS E ASYMPTOTIC EXPECTED SAMPLE SIZES OF TWO SEQUENTIAL PR ASYMPTOTIC EXTREMES FOR M-DEPENDENT RANDOM VARIABLES

AT ZERO A COMPARISON OF THE

AN ASYMPTOTIG FORMULA FOR THE DIFFERENCES OF THE POWERS

NOTES

ON-ASYMPTOTIC FUNCTION

ASYMPTOTIC INFERENCE IN MARKOV PROCESSES

ASYMPTOTIC JOINT DISTRIBUTION OF LINEAR SYSTEMATIC ASYMPTOTIC LINEARITY OF A RANK STATISTIC IN

RECRESSION PARAMETER

OCAL AND ASYMPTOTIC MINIMAX PROPERTIES OF MULTIVARIATE TESTS

ON ASYMPTOTIC MOMENTS OF EXTREME STATISTICS

ASYMPTOTIC NORMALITY AND CONSISTENCY OF THE LEAST SQU ASYMPTOTIC NORMALITY IN NONPARAMETRIC METHODS

ON ASYMPTOTIC NORMALITY IN STOCHASTIC APPROXIMATION ASYMPTOTIC NORMALITY OF BISPECTRAL ESTIMATES ASYMPTOTIC NORMALITY OF CERTAIN TEST STATISTICS OF ASYMPTOTIC NORMALITY OF LINEAR COMBINATIONS OF

EXPONENTIALITY
FUNCTIONS OF ORDER STATISTICS STATISTICS AN ELEMENTARY PROOF OF ASYMPTOTIC NORMALITY OF LINEAR FUNCTIONS OF ORDER ON THE ASYMPTOTIC NORMALITY OF ONE-SIDED STOPPINC RULES ASYMPTOTIC NORMALITY OF SAMPLE QUANTILES FOR MASYMPTOTIC NORMALITY OF SIMPLE LINEAR RANK STATISTICS ASYMPTOTIC NORMALITY OF SIMPLE LINEAR RANK STATISTICS

DEPENDENT PROCESSES

UNDER ALTERNATIVES

UNDER ALTERNATIVES. II

STATISTIG

D WITH THE TWO-SAMPLE PROBLEM

A NOTE ON THE ASYMPTOTIC NORMALITY OF THE MANN-WHITNEY-WILCOXON

THE ASYMPTOTIC NORMALITY OF TWO TEST STATISTICS ASSOCIATE

TESTS

EPSILON ASYMPTOTIC OPTIMALITY OF EMPIRICAL BAYES ESTIMATORS ASYMPTOTIC OPTIMUM PROPERTIES OF CERTAIN SEQUENTIAL ASYMPTOTIC OPTIMUM QUANTILES FOR THE ESTIMATION OF TH

E PARAMETERS OF THE NECATIVE EXPONENTIAL DISTRIBU/

LOCAL ASYMPTOTIC POWER AND EFFICIENCY OF TESTS OF KOLMOCORO

V-SMIRNOV TYPE

IRST AND SECOND DIFFERENCES, FOR SERIAL CORRELATI/

TRENDS IN PROPORTIONS

ELEMENTARY METHOD OF OBTAININC LOWER BOUNDS ON THE ASYMPTOTIC POWER OF CERTAIN TEST CRITERIA, BASED ON F ASYMPTOTIC POWER OF GHI SQUARE TESTS FOR LINEAR ASYMPTOTIC POWER OF RANK TESTS

ASYMPTOTIC POWER OF TESTS OF LINEAR HYPOTHESES USIN THE PROBIT AND LOCIT TRANSFORMATIONS, CORR. 6412 TESTS

CORRELATIONS

FOR TIME SERIES

DATA

PROCESS

PLANS (CORR. 67 586)

S WHEN SAMPLING FROM ASSOCIATED POPULATIONS

ESTIMATORS

WEIBULL PARAMETERS

OF CIRCULAR ERROR

ORDER

IN BIO-ASSAY

DISTRIBUTION

FICIENCIES OF ALTERNATIVE ESTIMATORS FOR AN ASYMPTOTIC RECRESSION EQUATION

TESTS FOR TESTING TREND IN DISPERSI/ A NOTE ON THE ASYMPTOTIC RELATIVE EFFICIENCIES OF COX AND STUART'S B

TESTS ACAINST SCALAR ALTERNATIVES

TWO SAMPLE TESTS ACAINST SOME PARAMETRIG ALTERNA/

THE ASYMPTOTIC RELATIVE EFFICIENCY OF COODNESS-OF-FIT ASYMPTOTIC RELATIVE EFFICIENCY OF MOOD'S AND MASSEY'S

THE AVERAGE CRITICAL VALUE METHOD AND THE A ORRELATION COEFFICI/ THE RELATION BETWEEN PITMAN'S ASYMPTOTIC RELATIVE EFFICIENCY OF TWO TESTS AND THE C AMS 63 1442 ON OF CLASSICAL RENEWAL THEORY ASYMPTOTIC RENEWAL RESULTS FOR A NATURAL CENERALIZATI JRSSB67 141 A SET OF CORRELATION COEFFICIENTS FOR EQUALITY SOME RANDOM VARIABLES

TRUNCATION PARAMETERS

DECISION PROBLEM

STOCHASTIC APPROXIMATION OF MINIMA WITH IMPROVED ASYMPTOTIC SPEED ASYMPTOTIC SEQUENTIAL DESILN OF EXPERIMENTS WITH TWO ASYMPTOTIC SHAPES FOR SEQUENTIAL TESTING OF ASYMPTOTIC SHAPES OF BAYES SEQUENTIAL TESTING REGIONS ASYMPTOTIC SOLUTIONS OF THE SEQUENTIAL COMPOUND

ON THE ASYMPTOTIC SUFFICIENCY OF CERTAIN ORDER STATISTICS

ON OPTIMAL ASYMPTOTIC TESTS OF COMPOSITE STATISTICAL HYPOTHESES ASYMPTOTIG THEORY FOR PRINCIPAL COMPONENT ANALYSIS $\begin{array}{lll}\text { AMS } & 61 & 8 B \\ \text { AMS } 67 & 90\end{array}$

AMS $64 \quad 102$

BIOKA63 499

JRSSB6I 128

AMS 6B 179

BIOKA59 475

JASA $67 \quad 932$

ASA $67 \quad 939$

AMS 6B 266

AMS $67 \quad 1 B 99$

AMS 631286

AMS $65 \quad 1153$

JRSSB $62 \quad 177$

AMS 671266

AMS $63 \quad 1302$

BIOKA64 459

BIOKA6I 85

AMS $68 \quad 1264$ AMS 69 NO. 6 AMS $69 \quad 942$ AMS 69 NO. 6 AMS 641322 AMS $61 \quad 249$ BI0C\$68 439 AMS $65 \quad 97 \mathrm{~B}$

JASA 69300

AMS 69 NO. 6

AMS 6421 AMS 641738 AMS $63 \quad 447$ AMS $68 \quad 905$ AMS $6 B 1327$ AMS 661257

BIOKA64 253 AMS 69 NO. 6 AMS 6B 263 AMS 681493 AMS 6B 1724 AMS $68 \quad 325$ AMS 69 N0.6 $\begin{array}{lll}\text { JASA } & 61 \quad 687\end{array}$ AMS 631513 BIOKA69 220 AMS $68 \quad 1244$ AMS $66 \quad 143$ AMS 671705 AMS $62 \quad 186$ BIOCS68 315 JASA $62 \quad 877$ AMS 651000 JRSSB56 227 JRSSB $58 \quad 143$ JRSSB68 338 AMS 651565 JRSSB67 162 BIOKA62 205 AMS 69633 TECH $65 \quad 423$ JASA $66 \quad 618$ BIOKA69 375 BIOKA61 212 BIOKA58 370 BIOKA68 381 ASA $65 \quad 410$ BIOKA68 513 JRSSB66 73 AMS 682038 AMS $62 \quad 224$ AMS 631079 AMS $67 \quad 191$ JRSSB62 167 AMS 671845 AMS $63 \quad 122$
JASA $65 \quad B 43$ AMS 671822 
OF A CIRCULAR DISTRIBUTION BOUNDS FOR LINEAR RECRESSION PARAMETERS E INTERVALS FOR THE MEAN

PROBABILITIES FROM A FINITE POPULATION

\section{RENEWAL PROCESSES}

RANCES ON FISHER'S BOUND FOR
D SAMPLES, OF THE P/

UNDER NORMALITY ASSUMPTIONS

F THE PARAMETERS OF THE TRUNCATED BINOMIAL AN/
SIMPLE ESTIMATE OF LOCATION

ASYMPTOTIC THEORY OF A CLASS OF TESTS FOR UNIFORMITY ON THE ASYMPTOTIC THEORY OF FIXED-SIZE SEQUENTIAL CONFTDENCE ON THE ASYMPTOTIC THEORY OF FIXED-WIDTH SEQUENTIAL CONFIDENC THE ASYMPTOTIC THEORY OF CALTON'S TEST AND A RELATED ASYMPTOTIC THEORY OF REJECTIVE SAMPLINC WITH VARYINC

THE ASYMPTOTIC VALUES OF CERTAIN COVERACE PROBABILITIES ASYMPTOTIC VALUES OF THE FIRST TWO MOMENTS IN MARKOV ASYMPTOTIC VARIANCE OF THE SAMPLE QUANTILES AND MIDASYMPTOTIC VARIANCES

ASYMPTOTIC VARIANCES AND COVARIANCES OF MAXIMUM-LIKEL ASYMPTOTIC VARIANCES FOR DUMMY VARIATE REGRESSION

PROCEDURE, TREATMENT VERSUS CONTROL THE ASYMPTOTIC VARIANCES OF METHOD OF MOM
NTEGRATED RISK OF ASYMPTOTICALLY BAYES SEQUENTIAL TESTS

AN ASYMPTOTIGALLY DISTRIBUTION-FREE MULTIPLE COMPARISON

LITY IN THE CASE OF THE WEIBULL DISTRIBU/

AN EXACT ASYMPTOTTCALLY EFFICIENT GONFIDENCE BOUND FOR RELIABI SPECTRAL DENSITY FUNCTION OF A STATIONARY TIME/ RANKINGS

RANKING AND SLIPPACE PROBLEMS

ON ASYMPTOTICALLY EFFICIENT CONSISTENT ESTIMATES OF THE ASYMPTOTICALLY EFFICIENT TESTS BY THE METHOD OF $N$

SOME ASYMPTOTICALLY EXTINCT SEQUENTIAL PROCEDURES FOR ASYMPTOTICALLY MINIMAX DISTRIBUTION-FREE PROCEDURES

PROBLEM

GROUPED DATA

SAMPLE PROBLEM WITH CENSORED DATA

LOCALLY AND ASYMPTOTICALLY MINIMAX TESTS OF A MULTIVARIATE ASYMPTOTICALLY MOST POWERFUL RANK ORDER TESTS FOR ASYMPTOTICALLY MOST POWERFUL RANK TESTS FOR THE TWOASYMPTOTICALLY MOST POWERFUL RANK-ORDER TESTS ASYMPTOTICALLY MOST POWERFUL TESTS IN MARKOV

PROCESSES

LTIPLIER TESTS OF LINEAR HYPOTHESES

RIATE LOCATION PARAMETERS

'S T-SQUARE, CORR. 651583

MODELS WITH ONE OBSERVATION PER CELL

E APPROACH TO LINEAR MODELS

STIRLING BEHAVIOR IS

IN SEQUENTIAL ESTIMATION

$\mathrm{R}$ COMPARING SEVERAL EXPERIMENTAL CATEGORIES WI/
$\mathrm{G}$ SEVERAL EXPERIMENTAL CATECORIES WITH A CONTR/

INCREASING FAILURE RATE AVERAGE

DISTRIBUTIONS

FOR RANDOMIZED EXPERIMENTS WITH NONCONTROLLED PRE/ DES IGN

DISTRIBUTIONS

LOCALLY ASYMPTOTICALLY MOST STRINCENT TESTS AND LAGRANGIAN MU ASYMPTOTICALLY NEARLY EFFICIENT ESTIMATORS OF MULTIVA

ON SOME ASYMPTOTICALLY NONPARAMETRIC COMPETITORS OF HOTELLING ASYMPTOTICALLY NONPARAMETRIC INFERENCE IN SOME LINEAR ASYMPTOTICALLY NONPARAMETRIC INFERENCE, AN ALTERNATIV ASYMPTOTICALLY NONPARAMETRIC TESTS OF SYMMETRY

ASYMPTOTICALLY NORMAL

ASYMPTOTICALLY OPTIMAL BAYES AND MINIMAX PROCEDURES

AN ASYMPTOTICALLY OPTIMAL FIXED SAMPLE SIZE PROCEDURE FO

AN ASYMPTOTICALLY OPTIMAL SEQUENTIAL DESICN FOR COMPARIN ASYMPTOTICALLY OPTIMAL STATISTICS IN SOME MODELS WITH ASYMPTOTICALLY OPTIMAL TESTS FOR MULTIVARIATE NORMAL ASYMPTOTICALLY OPTIMAL TESTS OF COMPOSITE HYPOTHESES ASYMPTOTICALLY OPTIMUM SEQUENTIAL INFERENCE AND ASYMPTOTICALLY OPTIMUM TESTS FOR MULTINOMIAL ASYMPTOTICALLY ROBUST ESTIMATORS OF LOCATION

THE ASYMPTOTICALLY UNBIASED PRIOR DISTRIBUTION

GRITIGAL PROBABILITY IN THE ONE-QUADRANT ORIENTED-ATOM PERCOLATION PROCESS LABOR FORCE ENTRY AND ATTACHMENT OF YOUNG PEOPLE, CORR. 661248 STOCHASTIC PHAGE ATTACHMENT TO BACTERIA

OF THE PARAMETER IN THE STOCHASTTC MODEL FOR PHAGE ATTACHMENT TO BACTERIA BULK SAMPLING. PROBLEMS AND LINES OF ATTACK THE FORECASTINC ACCURACY OF CONSUMER ATTITUDE DATA TEN YEARS OF CONSUMER ATTITUDE SURVEYS, THEIR FORECASTING RECORD RANKING METHODS AND THE MEASUREMENT OF ATTITUDES

THE PREDICTIVE ABILITY OF CONSUMER ATTITUDES, STOCK PRICES, AND NON-ATTITUDINAL VARIABLE

S STUDIES OF INTERVIEWER VARIANCE FOR ATTITUDINAL VARIABLES

ABILITY OF CONSUMER ATTITUDES, STOCK PRICES, AND NON-ATTITUDINAL VARIABLES CONVOLUTIONS OF DISTRIBUTIONS ATTRACTED TO STABLE LAWS

RUN OF CONSECUTIVE OBSERVATIONS HAVING A SPECIFIED ATTRIBUTE DISTANCE BETWEEN POPULATIONS ON THE BASIS OF ATTRIBUTE DATA

SOME EXPERIMENTAL DESIGN PROBLEMS IN ATTRIBUTE LIFE TESTING, CORR. 631161

RISK VALIDATINC RESULTS OF SAMPLING INSPECTION BY ATTRIBUTES CENSORED SAMPLINC IN CURTAILED SAMPLING PLANS BY ATTRIBUTES OF FRACTION DEFECTIVE IN CURTAILED SAMPLING PLANS BY ATTRTBUTES VERAGE SAMPLE NUMBER FOR TRUNCATED SINGLE AND DOUBLE ATTRIBUTES ACCEPTANCE SAMPLING PLANS ON TWO SUCCESSIVE CENS/ METHOD OF CONSTRUCTION OF ATTRITION LIFE TABLES FOR THE SINGLE POPULATION BASED JASA 67 I433 NTS OF THE MEAN IN SAMPLES FROM A FINITE POPULATION (ATY'S FORMULAE AND MADOW'S CENTRAL LIMIT) /ING MOME BIOKA6I I99 ON THE USE OF CORRELATION TO AUGMENT DATA N SIMPLE LEAST SQUARES AND ANALYSIS OF/ PARAMETRIG AUGMENTATIONS AND ERROR STRUCTURES UNDER WHICH CERTAI JASA. 69 NO. 4 A NOTE ON AUGMENTED DESIGNS

AUGMENTING EXISTINC DATA IN MULTIPLE REGRESSION AUGMENTINC 2-TO-THE-(N-I) DESICNS

BY GAUSE WITH POPULATIONS OF THE PROTOZOA PARAMECIUM AURELIA AND PARAMECIUM CAUDATUM /MENTS CARRIED OUT B B AUTHOR'S REPLY TO ANSCOMBE'S COMMENTS

CURTIUS SNODGRASS LETTERS, A STATISTICAL TEST OF AUTHORSHIP INFERENCE IN AN AUTHORSHIP PROBLEN

BAYESIAN ANALYSIS OF THE RECRESSION MODEL WITH AUTO-CORRELATED ERRORS ON HOTELLING'S WEICHING DESIGNS UNDER AUTO-CORRELATION OF ERRORS HER ORDER SCHEM/ TESTS OF HYPOTHESES IN THE LINEAR AUTO-REGRESSIVE MODEL. II. NULL DISTRIBUTIONS FOR HIG BIOKA56 186 THE ESTIMATION OF SLOPE WHEN THE ERRORS ARE AUTOCORRELATED

THE FITTING OF REGRESSION CURVES WITH AUTOCORRELATED DATA CT MODELS IN THE ANALYSIS OF VARIANCE. II. EFFECT OF AUTOCORRELATED ERRORS VERAL TWO-STACE RECRESSION METHODS IN THE CONTEXT OF AUTOCORRELATED ERRORS STIMATORS OF REGRESSION COEFFICIENTS FOR THE CASE OF AUTOCORRELATED RESIDUALS VAR IABLES THE ESTIMATION OF RELATIONSHIPS WITH AUTOCORRELATED RESIDUALS REGRESSION ANALYSIS OF RELATIONSHIPS BETWEEN AUTOCORRELATED TIME SERIES NOTE ON BIAS IN THE ESTTMATTON OF AUTOCORRELATION SAMPLING INSPECTION OF CONTINUOUS PROCESSES WITH NO AUTOCORRELATION BETWEEN SUCCESSIVE RESULTS AN INEQUALITY RELATING THE SPECTRAL DENSITY AND AUTOCORRELATION FUNCTION A LOWER BOUND FOR THE J JASA $62 \quad 92$ ASA 64987 AMS $6 B \quad 1381$ THE A TECH 6 B 685 MARK TWAIN AND THE QUINTUS JASA 63 JASA 63 AMS 651829

AMS 691196 AMS 65463 AMS $67 \quad 73$ AMS 641491 BIOKA67 597 RSSB61 453 AMS $67 \quad 557$ ASA 671305 AMS $67 \quad 1399$ AMS $66 \quad 735$ JRSSB58 303 RSSB68 312 AMS $66 \quad 619$ AMS $67 \quad 1729$ AMS $65 \quad 1243$ AMS 691207 KA65 459 AMS $65 \quad 160$ AMS $64 \quad 726$ AMS $67 \quad$ B49 AMS $67 \quad 410$ AMS $64 \quad 1571$ AMS $63 \quad 14 B 6$ AMS $67 \quad 1829$ ASA $65 \quad 699$ AMS $65 \quad 369$ JASA $67 \quad 950$ AMS $65 \quad 1137$ $\begin{array}{ll}\text { JASA } 66 & 117\end{array}$ BIOCS65 134 TECH $62 \quad 319$ JASA 69 NO 4 JASA $63 \quad 899$ JASA $58 \quad 720$ IOKA6I 461 BIOCS6B 859 TECH 68667 TECH 67401 TECH $63 \quad 23$ TECH $63 \quad 23$ ECH $66 \quad 1 B 4$ TECH 6B 73 TEGH $66 \quad 469$ BIOKA57 314 314 69 85 75 29 RSSB62 199 BIOKA56 468 /SIAN ANALYSIS OF RANDOM-EFFE BIOKA66 477 SMALL-SAMPLE PROPERTIES OF SE JASA 69253 MAXIMUM LTKELIHOOD E TECH 65 JRSSB 5991 JRSSB56 240 BIOKA54 403 BIOKA62 262 BIOKA60 363 
FUNCTION

DISTRIBUTED MODULO 1
THE AUTOCORRELATION FUNCTION AND THE SPECTRAL DENSITY THE AUTOCORRELATION FUNCTION OF A SEQUENCE UNIFORMLY
BIOKA55 151 AMS $63 \quad 1243$ BIOKA54 390 BIAS IN THE ESTIMATION OF AUTOCORRELATIONS

PROCESS

ON THE ASYMPTOTIC DISTRIBUTION OF THE AUTOCORRELATIONS OF A SAMPLE FROM A LINEAR STOCHASTIC THE AUTOMATIC COMPUTER IN INDUSTRY

DISCUSSION) THE APPLICATION OF AUTOMATIC COMPUTERS TO SAMPLING EXPERIMENTS (WITH A PROCEDURE FOR AUTOMATIC DATA EDITINC

STATISTICAL PROCESS CONTROL AND THE IMPACT OF AUTOMATIC PROCESS CONTROL FUTURE DEVELOPMENTS THE PRESENT STATUS OF AUTOMATIC PRODUCTION AND CONTROL DEVICES AND EXPECTED AUTOMATIC PROGRAMMING FOR AUTOMATIC COMPUTERS

CONTROLLINC DIMENSION IN CENTERLESS-CRINDING WITH AUTOMATIC RESET DEVICE ESTIMATING MACHINING ERRORS IN SET-UPS WITH AUTOMATIC RESETTING

TIME THE EFFICIENCY OF AUTOMATIC WINDING MACHINES WITH CONSTANT PATROLLINC INITIAL STOCK AND CONSUMER INVESTMENT IN AUTOMOBILES THE GASOLINE OCTANE NUMBER REQUIREMENT OF NEW MODEL AUTOMOBILES ON A FACTOR AUTOMORPHISM OF A NORMAL DYNAMICAL SYSTEM PARAMETER ESTIMATES AND AUTONOMOUS CROWTH, CORR. 59812 THE USE OF AUTOREGRESSION IN FITTING AN EXPONENTIAL CURVE

AMS 641296 JASA $56 \quad 565$ JRSSB5 439 JASA $67 \quad 341$ TECH 65283 TECH $66 \quad 73$ JASA 59744 TECH 69115 TECH $64 \quad 423$ JRSSB59 381 JASA $63 \quad 7 B 9$ TECH 60 AMS 661528 JASA 59389 BIOKA58 389 IZATION OF A SPECT/ ON THE FITTING OF MULTIVARIATE AUTORECRESSIONS, AND THE APPROXIMATE CANONICAL FACTOR BIOKA63 I29 TIONARITY CONDITIONS FOR STOCHASTIC PROCESSES OF THE AUTOREGRESSIVE AND MOVINC-AVERAGE TYPE MAXIMUM LIKELIHOOD ESTIMATORS IN A LINEAR MODEL WITH AUTORECRESSIVE DISTURBANCES/TOTIC DISTRIBUTION OF AMS 69 583 FINITE SAMPLE MONTE CARLO STUDIES. AND AUTOREGRESSIVE ILLUSTRATION TESTS OF HYPOTHESES IN THE LINEAR AUTOREGRESSIVE MODEL. PART I BIOKA54 405 BIOKA60 194 ON THE COVARIANCE DETERMINANTS OF MOVING-AVERAGE AND AUTOREGRESSIVE MODELS A NOTE ON PREDICTION FROM AN AUTOREGRESSIVE PROCESS USING PISTIMETRIC PROBABILITY JRSSB60 97 S PROPERTIES OF TESTS OF GOODNESS-OF-FIT FOR LINEAR AUTORECRESSIVE SCHEMES EXPANSIONS FOR TESTS OF GOODNESS OF FIT FOR LINEAR AUTORECRESSIVE SCHEMES

ENCIES OF METHODS OF ESTIMATINC PARAMETERS IN LINEAR AUTOREGRESSIVE SCHEMES CONFIDENCE INTERVALS FOR PARAMETERS IN MARKOV AUTORECRESSIVE SCHEMES TIONS OF THE SERIAL CORRELATION COEFFICIENT IN SHORT AUTOREGRESSIVE SEQUENCES NOTE ON THE VARIATE DIFFERENCES OF AUTORECRESSIVE SERIES THE ESTIMATION OF MIXED MOVING-AVERAGE AUTOREGRESSIVE SYSTEMS SAMPLING JRSSB62 492 ASYMPTOTIC BIOKA64 459 COMPARATIVE EFFICI BIOKA6I 427 $\begin{array}{lll}\text { COSION) } & \\ \text { JRSSB54 } & 195\end{array}$ ALTERNATIVE DEFINI JASA 58881 BIOKA5I 479 BIOKA69 NO. 3 JASA E5 164 AMS $63 \quad 1259$ BIOKA69 223 JASA $65 \quad 270$ JRSSB $67 \quad 374$ AMS $63 \quad 56$ JASA $62 \quad 1 B 4$ TECH $6 B \quad 594$ TECH $67 \quad 465$ A STATISTICAL TEST FOR EQUALITY OF TWO AVAILABILITIES A CONFIDENCE INTERVAL FOR THE AVAILABILITY RATIO

FITTING OF SOME CONTAGIOUS DISTRIBUTIONS TO SOME AVAILABLE DATA BY THE MAXIMUM LIKELIHOOD METHOD (CORR BIOCS65 34 RECREATION STATISTICAL DATA AVAILABLE FOR ECONOMIC RESEARCH ON CERTAIN TYPES OF JASA 59 281 IPALES, SON UTILISATION EN GENETIQUE ET SES RAPPORTS AVEC L'ANALYSE DISCRIMINATOIRE /N COMPOSANTES PRINC BIOCS66 343 OF THE COVARIANCE MATRIX OF A FIRST ORDER MOVING AVERAGE ATISTICS IN SOME MODELS WITH INCREASING FAILURE RATE AVERAGE ON THE INVERSE BIOKA69 NO.3 ASYMPTOTICALLY OPTIMAL ST AMS 671731

DENUMERABLE STATE MARKOVIAN DECISION PROCESSES, AVERAGE COST CRITERION RELATIVE EFFICIENCY OF TESTS THE AVERAGE CRITICAL VALUE METHOD AND THE ASYMPTOTIC EFFICIENCY OF STATISTICAL TESTS IN TIME SERIE/ THE AVERAGE CRITICAL VALUE METHOD FOR ADJUDGING RELATIVE THE USE OF AN ITERATED MOVING AVERAGE IN MEASURING SEASONAL VARIATIONS AMS 661545 $\begin{array}{rr}\text { AMS } 66 & 1545 \\ \text { BIOKA } 67 & 308\end{array}$ BIOKA66 109 JASA $62 \quad 149$ JASA $64 \quad 872$ RANKINGS CORRECTINC THE AVERAGE RANK CORRELATION COEFFICIENT FOR TIES IN JASA $63 \quad 756$ TECH $65 \quad 379$ AMS $63 \quad 396$ SOME STATISTTCAL CHARACTERISTICS OF A PEAK TO AVERAGE RATIO AVERAGE RENEWAL LOSS RATES

A MOVING AVERACE REPRESENTATION FOR RANDOM VARIABLES COVARIANC BIOKA65 295 THE AVERAGE RUN LENGTH OF THE CUMULATIVE SUM CHART WHEN A JRSSB6I 149 AVERACE RUN LENGTHS IN CUMULATIVE CHART QUALITY TECH 6111

E STATIONARY ON A FINITE TIME INTERVAL $\checkmark$-MASK IS USED

CONTROL SCHEMES

ATTRIBUTES ACCEPTANCE SAMPLING PLANS THE AVERAGE SAMPLE NUMBER FOR TRUNCATED SINGLE AND DOUBLE TECH $6 B \quad 6 B 5$ HE DETERMINATION OF THE OPERATINC CHARACTERISTIC AND AVERAGE SAMPLE NUMBER OF A SIMPLE SEQUENTIAL TEST / JRSSB67 24B TESTS LOWER BOUNDS FOR AVERAGE SAMPLE NUMBER OF SEQUENTIAL MULTIHYPOTHESIS AMS 67 1343 FOR GALCULATINC THE OPERATING GHARACTERISTIC AND THE AVERAGE SAMPLE NUMBER OF SOME SEQUENTIAL TESTS /AE JRSSB5B 379 EDURE FOR DETERMINING UPPER AND LOWER LIMITS FOR THE AVERACE SAMPLE RUN LENGTH OF A CUMULATIVE SUM SCHEME JRSSB67 263 THE USE OF WEALTH TO COMPARE HOUSEHOLDS' AVERAGE SAVING IDENTIFICATION OF VECTOR MIXED AUTOREGRESSIVE-MOVING AVERAGE SYSTEMS JASA $64 \quad 737$ $\begin{array}{ll}\text { JASA } 64 & 737 \\ \text { BIOKA69 } & 223\end{array}$ A LTMTT LAW CONCERNING MOVING AVERAGES PREDICTION BY EXPONENTIALLY WEIGHTED MOVING AVERAGES AND RELATED METHODS CONSIDERINC STATISTICAL AND TIME AVERAGES IN A RECULATION PROBLEM ALTERNATIVE AXIOMATIZATIONS OF SEASONAL ADJUSTMENT ON THE AXIOMS OF INFORMATION THEORY JASA $60 \quad 331$ TECH 59239 AMS $64 \quad 424$ JRSSB $61 \quad 414$ JRSSB $67 \quad 475$ JASA $66 \quad 800$ AMS $64 \quad 415$ THE RANGE OF THE DEVIATIONS ABOUT THE REDUCED MAJOR AXIS /R ESTIMATING THE CORRELATION COEFFICIENT FROM BIOKA53 21 B F A/ INTERVAL ESTIMATION OF THE SLOPE OF THE MAJOR AXIS OF A BIVARIATE NORMAL DISTRIBUTION IN THE CASE O BIOCS68 679 THE DISPLACED POISSON DISTRIBUTION-REGION B

FOR THE SOLUTION OF THE EXPONENTIAL EQUATION EXP $(B)-B /(1-P)=1$

OXIMATIONS TO THE UPPER 5 PERCENT POINTS OF FISHER'S B DISTRIBUTION AND NON-CENTRAL CHI-SQUARE

ING THE NORMAL DISTRIBUTION WITH COVARIANCE MATRIX A+B IN TERMS OF ONE WITH COVARIANCE MATRIX A ROOT AND THE SMALLEST LATENT ROOT OF THE GENERALIZED B STATISTIC AND F STATISTICS AND IN MULTIVARIATE ANAL AMS 67 1152 IC DISTRIBUTION FOR THE DETERMINANT OF A NON-GENTRAL B STATISTIG IN MULTIVARIATE ANALYSIS AS ANYMPTOT SASJ GB 77 A FAVORABLE SIDE BET IN NEVADA BAGGARAT

SURVEY OF HISTOGOMPATIBILITY TESTING, BIOLOGIGAL BAGKGROUND PROBABILISTIG AND STATISTTCAL MODELS AND P BIOGS69 207 SOME FEATURES OF THE GENERATION TIMES OF INDIVIDUAL BACTERIA STOGHASTIG PHAGE ATTACHMENT TO BAGTERIA
JASA $67 \quad 643$ TABLE BIOKA63 177 APPR BIOKA57 $52 \mathrm{~B}$ JASA $66 \quad 313$ BIOKA55 16 BIOGS65 134 
IN THE STOCHASTIC MODEL FOR PHACE ATTACHMENT TO BACTERIA LIMITED CENOME EXPRESSION DURING VIRAL INFECTION OF BACTERIA

ESTIMATION OF THE PARAMETER AMS 6B /MATION OF THE NUMBER OF CRITICAL SITES IN BIOCS69 537 HE ESTIMATION OF CONCENTRATION OF VIRUSES AND BACTERIA FROM DILUTION COUNTS DETERMINISTIC REMOVALS THE EXTINCTION OF A BACTERIAL COLONY BY PHAGES, A BRANCHINC PROCESS WITH THE EFFECT OF OVERLAPPINC IN BACTERIAL COUNTS OF INCUBATED COLONIES PROXIMATION FOR BINOMIAK EVENTS, WITH APPLICATION TO BACTERIAL ENDOCARDITIS DATA /USE OF THE POISSON AP PHENOMENON BACTERIAL EXTINCTION TIME AS AN EXTREME VALUE

MODELS FOR A BACTERIAL CROWTH PROCESS WITH REMOVALS

NOTES. ON THE DILUTION ERRORS INVOLVED IN ESTIMATINC BACTERIAL NUMBERS BY THE PLATINC METHOD A MODEL FOR CHEMICAL MUTACENESIS IN BACTERIOPHACE

ON A MEASURE OF TEST EFFICIENCY PROPOSED BY R, R. BAHADUR

ON A THEOREM OF BAHADUR AND COODMAN

UIPER ONE-SAMPLE AND TWO-SAMPLE STATISTICS EXACT BAHADUR EFFICIENCIES FOR THE KOLMOCOROV-SMIRNOV AND K NULL DISTRIBUTION AND BAHADUR EFFICIENCY OF THE HODGES BIVARIATE SIGN TEST ABILITIES FOR SAMPLING WITHOUT REPLACEMENT AND EXACT BAHADUR EFFICIENCY OF THE TWO-SAMPLE NORMAL SCORES TE ON BAHADUR'S REPRE ENTATION OF SAMPLE QUANTIKES

STOCHASTIC EPIDEMIC A NOTE ON BAILEY'S AND WHITTLE'S TREATMENT OF A GENERAL

THE OUTCOME OF A STOCHASTIC EPIDEMIC, A NOTE ON BAILEY'S PAPER

DEMAND FOR MANUFACTURERS' SERVICES FOR BAKERY PRODUCTS AND FRUITS AND VEGETABLES

A GENERALIZATION OF A THEOREM OF BALAKRISHNAN SUPPLEMENTED BALANCE

THE APPLICATION OF RANDOM BALANCE DESIGNS

ERRATA, 'THE APPLICATION OF RANDOM BALANCE DESIGNS'

RANDOM BALANCE EXPERIMENTATION

THE ANALYSIS OF CHANGEOVER DESIGNS WITH COMPLETE BALANCE FOR FIRST RESIDUAL EFFECTS

QUICK ANALYSIS METHODS FOR RANDOM BALANCE SCREENING EXPERIMENTS CORRICENDA, 'SUPPLEMENTED BALANCE'

GROUP SCREENING UTILIZING BALANCED AND PARTIALLY BALANCED INCOMPLETE BLOCK

DESIGNS

ON SOME METHODS OF CONSTRUCTION OF PARTIALLY BALANCED ARRAYS

SOME TREATMENTS IN COMMON ANALYSIS OF A GROUP OF BALANCED BLOCK EXPERIMENTS HAVINC ERROR VARIANCE AND HIP OF GENERALIZED POLYKAYS TO UNRESTRICTED SUMS FOR BALANCED COMPLETE FINITE POPULATIONS BALANCED CONFOUNDING OF FACTORIAL EXPERIMENTS

ON A PROPERTY OF BALANCED DESIGNS

THE COMBINATION OF INFORMATION IN GENERALLY BALANCED DESICNS

INFINITY, WITHIN THE CLASS OF RANDOMIZED DESIGNS, OF BALANCED DESIGNS

OR 7 TREATMENTS

OF TREATMENTS

DESIGNS

FOUR-WAY BALANCED DESIGNS BASED ON YOUDEN SQUARES WITH 5,6 ,

THE CONSTRUCTION OF BALANCED DESIGNS FOR EXPERIMENTS INVOLVINC SEQUENCES

ON A GEOMETRICAL METHOD OF CONSTRUCTION OF PARTIALLY BALANCED DESIGNS WITH TWO ASSOCIATE CLASSES

BALANCED DESIGNS WITH UNEQUAL NUMBERS OF REPLICATES

BALANCED FACTORIAL DESIGNS

SEQUENCES BAKANCED FOR PAIRS OF RESIDUAL EFFECTS

EFFECTS

CHANGEOVER DESIGNS BALANCED FOR THE LINEAR COMPONENT OF FIRST RESIDUAL A DESIGN BALANCED FOR TREND

ESTIMATORS OF VARIANCE COMPONENTS IN THE BALANCED INCOMPLETE BLOCK

A NOTE ON THE PARAMETERS OF PARTIALLY BALANCED INCOMPLETE BLOCK ASSOCIATION SCHEMES

AN APPLICATION OF A BALANCED INCOMPLETE BLOCK DESIGN

PTOTIC EFFICIENCY OF THE CHI-SQUARE-SUB-R-TEST FOR A BALANCED INCOMPLETE BLOCK DESIGN EQUENCES OF RANDOMIZATION IN A CENERALIZATION OF THE BAKANCED INCOMPLETE BLOCK DESIGN AKGEBRA AND THE ANALYSIS OF VARIANCE OF A PARTIALLY BALANCED INCOMPLETE BLOCK DESIGN TWO RANDOM COMPONENTS WITH SPECIAL REFERENCE TO THE BALANCED INCOMPLETE BLOCK DESIGN NULL-DISTRIBUTION OF THE F-STATISTIC IN A RANDOMIZED BALANCED INCOMPLETE BLOCK DESIGN UN AN INEQUALITY FOR BALANCED INCOMPLETE BLOCK DESIGNS THE EXISTENCE AND CONSTRUCTION OF BALANCED INCOMPLETE BLOCK DESICNS MULTIPLE COMPARISIONS WITH A CONTROL IN BALANCED INCOMPLETE BLOCK DESICNS ON THE PARAMETERS AND INTERSECTION OF BLOCKS OF BALANCED INCOMPLETE BLOCK DESIGNS CONSTRUCTION OF ROTATABLE DESIGNS THROUGH BALANCED INCOMPLETE BLOCK DESIGNS ON THE DUALS OF SYMMETRIC PARTIALLY-BALANCED INCOMPLETE BLOCK DESIGNS EXTENDED GROUP DIVISIBLE PARTIALLY BALANCED INCOMPLETE BLOCK DESIGNS ON A CLASS OF PARTIALLY BALANCED INCOMPLETE BLOCK DESIGNS INDUCTIVE METHODS FOR BALANCED INCOMPLETE BLOCK DESIGNS

A SERIES OF BALANCED INCOMPLETE BLOCK DESICNS A NOTE ON BALANCED INCOMPLETE BLOCK DESIGNS AN EXTENSION PROPERTY OF A CLASS OF BALANCED INCOMPLETE BLOCK DESIGNS NESTED BAKANCED INCOMPLETE BLOCK DESIGNS NOTES. CYCLIC GENERATION OF ROBINSON'S BALANCED INCOMPLETE BLOCK DESIGNS TREATMENTS BETWEEN BLOCKS OF CERTAIN PARTIALLY BALANCED INCOMPLETE BLOCK DESIGNS THE GEOMETRY OF QUADRICS FOR CONSTRUCTING PARTIALLY BALANCED INCOMPLETE BLOCK DESIGNS CED TWO-WAY CROSS CLASSIFICATION WITH APPLICATION TO BALANCED INCOMPLETE BLOCK DESIGNS OMMON TREATMENTS BETWEEN BLOCKS OF CERTAIN PARTIALLY BALANCED INCOMPLETE BLOCK DESIGNS ECT VALUE OF SIGMA-SQUARE-SUB-B-OVER-SIGMA-SQUARE IN BALANCED INCOMPLETE BLOCK DESIGNS EATMENTS BETWEEN ANY TWO BLOCKS OF CERTAIN PARTIALLY BALANCED INCOMPLETE BKOCK DESIGNS BLOCK ANALY IS OF A CLASS OF TWO ASSOCIATE PARTIALLY BALANCED INCOMPLETE BLOCK DESIGNS $R$ THE NUMBER OF DISJOINT BKOCKS IN CERTAIN PARTIALLY BALANCED INCOMPLETE BLOCK DESICNS E SYMMETRICAL AND UNSYMMETRICAL TRTANCULAR PARTIALLY BALANCED INCOMPLETE BLOCK DESICNS CE THEOREMS

DUALS OF ON THE EFFICIENCY OF MODIFIED BALANCED INCOMPLETE BLOCK DESIGNS FOR BIO-ASSAYS THE USE OF CYCLIC BALANCED INCOMPLETE BLOCK DESICNS FOR DIRECTIONAL THE USE OF CYCLIC BALANCED INCOMPLETE BLOCK DESICNS FOR NON-DIRECTIONAL SOME BALANCED INCOMPLETE BLOCK DESICNS FOR TWO SETS OF

THE ASYM BIOKA59 475 AMS 651815 INEAR MODELS WITH BIOKA68 101 AMS 631558 AMS $6190 \mathrm{~B}$ AMS 61361 TECH $61 \quad 103$ AMS $62 \quad 1200$ AMS 621421 AMS $63 \quad 528$ AMS $64 \quad 681$ AMS 651 BO7 AMS 661348 AMS 68681 AMS 69679 BIOKA57 27B BIOKA67 479 BIOCS67 574 COMMON AMS 68999 APPLICATION OF AMS 621175 /FOR THE UNBALAN AMS 69 40B /THE NUMBER OF C AMS 66739 /USING AN INCORR BIOKA68 254 /BER OF COMMON TR AMS 65337 /EST IN THE INTRA JASA 65 2B5 $\begin{array}{llll}\text { EST IN THE INTRA JASA } 65 & 2 B 5 \\ \text { AN UPPER BOUND FO AMS } & 64 & 39 B\end{array}$ SEED ORCHARDS SEED ORCHARDS TREATMENTS NCED ASSOCIATION SCHEMES BALANCED INCOMPLETE BLOCK DESICNS FROM PARTIALLY BALA AMS 67 61

C OF BLOCKS INTO REPLICATIONS BALANCED INCOMPLETE BLOCK DESICNS WITH DOUBLE CROUPIN BIOCS66 368 ASSOCIATE CLASSES ANALYSIS OF A CLASS OF PARTIALLY BALANCED INCOMPLETE BKOCK DESICNS WITH MORE THAN TWO AMS 1 BOO 8. $\mathrm{N} 1=12$, N2 $=/$ A NOTE ON CONSTRUCTION OF PARTIALLY BALANCED INCOMPLETE BLOCK DESICNS WITH PARAMETERS V 2 AMS 66 1783 
IDENTICAL BLOCKS ARE DESICN PROPERTIES FICATION OF TREATMENTS
BALANCED INCOMPLETE BLOCK DESIGNS WITH SETS OF ON THE BLOCK STR CTURES OF CERTAIN PARTIALLY PARTIALLY BALANCED INCOMPLETE BLOCK DESICNS WITH TWO-WAY CLASSI COMPARISON OF COMBINED ESTIMATORS IN BALANCED INCOMPLETE BLOCKS

A METHOD OF CONSTRUCTING BALANCED INCOMPLETE DESICNS.

DES IGNS

BALANCED L-RESTRICTIONAL PRIME POWERED LATTICE
TECH 69613

AMS 696717 AMS 661016 AMS 661832 BIOKA65 285

AMS 671127 THE ESTIMATION OF RESIDUAL VARIANCE IN QUADRATICALLY BALANCED LEAST-SQUARES PROBLEMS AND THE ROBUSTNESS OF BIOKA62 83 TIONS OF VARIANCE COMPONENTS I. EMPIRICAL STUDIES OF BALANCED NESTED DESIGN MATION OF MULTIVARIATE COVARIANCE COMPONENTS FOR THE BALANCED ONE-WAY LAYOUT METHODS OF GONSTRUCTION AND ANALYSIS OF SERIALLY BALANCED SEQUENCES SAMPLING DISTRIBU TECH 66457 MAXIMUM LIKELIHOOD ESTI AMS 691100 JRSSB57 2 B6 CONSTRUCTION OF CYCLIC COLLINEATIONS FOR OBTAINING A BALANCED SET OF L-RESTRICTIONAL PRIME-POWERED LATTICE AMS 67 1293 BLOCK SIZE THREE RESULTS ERIVATIONS AND/

SHORT-CUT MULTIPLE COMPARISONS FOR BALANCED SETS OF BALANCED TNCOMPIETE BLOCK DESICNS OF TECH 65 561 TECH 6595 BIOKA65 4B5 BIOKA62 561 BIOKA57 360 BIOKA65 643 BIOKA60 285 AMS $66 \quad 517$ JASA $62 \quad 327$ AMS 641356 $\begin{array}{ll}\text { JRSSB65 } & 130 \\ \text { BIOKA62 } & 570\end{array}$ QUEUES ON THE MEAN DURATION OF A BALL AND CELL GAME. A FIRST PASSACE PROBLEM A CENERALIZATION OF THE BALLOT PROBLEM AND ITS APPLICATION IN THE THEORY OF AN APPLIGATION OF A BALLOT THEOREM IN ORDER STATISTICS APPLICATIONS OF A BALLOT THEOREM IN PHYSICS AND IN ORDER STATISTICS BASED ON SINGLY CENSORED SA/ ON THE EFFICIENCY OF BAN ESTIMATES OF THE PARAMETERS OF NORMAL POPULATIONS BIOKA62 570
ASYMPTOTIC DISTRIBUTION FOR A GENERALIZED BANACH MATCH BOX PROBLEM

THE ROBBINS-ISBELL TWO-ARMED-BANDIT PROBLEM WITH FINITE MEMORY

RANDOMIZED RULES FOR THE TWO-ARMED BANDIT WITH FINITE MEMORY

CONTRIBUTIONS TO THE 'TWO-ARMED BANDIT' PROBLEM

A NOTE ON CONFIDENCE BANDS FOR A RECRESSION LINE OVER A FINITE RANGE

LINEAR SECMENT CONFIDENCE BANDS FOR SIMPLE LINEAR MODELS SHORTER CONFIDENCE BANDS IN LINEAR REGRESSION

INDEPENDENT VARIABLES CONFIDENCE BANDS IN LINEAR REGRESSION WITH CONSTRAINTS ON THE CONFIDENCE BANDS IN STRAIGHT LINE RECRESSION

AMS 651375 AMS 682103 AMS $62 \quad$ B47 JASA $68 \quad 1028$ JASA $67 \quad 403$ JASA 671050 JASA $6 B \quad 1020$ JASA $64 \quad 182$ BANDWIDTH AND RESOLVABILITY IN STATISTICAL SPEGTRAL JRSSB59 169 ANALYSIS

DIMENSIONAL RANDOM WALK WITH A PARTIALLY REFLECTING BARRIER

RANDOM WALK BETWEEN A REFLECTING AND AN ABSORBING BARRIER SOME STOCHASTIC PROCESSES WITH ABSORBINC BARRIERS

COMMENT ON THE NOTES BY NEYMAN. BARTLETT AND WELCH IN THIS JOURNAL (VOL. 18, NO. 2, A NOTE ON THE BARTLETT DECOMPOSITION OF A WISHART MATRIX

SPECTRAL ANALYSIS COMBINING A BARTLETT WINDOW WITH AN ASSOCIATED INNER WINDOW ONE AMS $63 \quad 405$ THE AMS 61765 JRSSB61 319 JRSSB57 179 JRSSB64 270 TECH $61 \quad 235$ LES OF PERCENTACE POINTS FOR HARTLEY'S CORRECTION TO BARTLETT'S CRITERION FOR TESTING THE HOMOGENEITY OF A BIOKA62 487 MPUTATION AND USE OF A TABLE OF PERCENTAGE POINTS OF BARTLETT'S M ON THE CO BIOKA69 273 VARIANCES ON BARTLETT'S TEST AND LEHMANN'S TEST FOR HOMOCENEITY OF AMS 69 NO.6 THE PROCRESS OF THE SCORE DURINC A BASEBALL GAME JASA $61 \quad 703$ QUERY. ERROR RATE BASES TECH $65 \quad 260$ THE NORMALITY AND VARIANCES OF RESID/ ORTHONORMAL BASES OF ERROR SPACES AND THEIR USE FOR INVESTICATING JASA 67 IO22 MEANS THE RANDOMIZATION BASES OF THE PROBLEM OF THE AMALGAMATION OF WEICHTED JRSSB6I 423 A STATISTICAL BASIS FOR APPROXIMATION AND OPTIMIZATION AMS $66 \quad 59$ A BASIS FOR THE SELECTION OF A RESPONSE SURFACE DESIGN JASA 59622 SELECTION BASIS IN ESTIMATION OF THE CENETIC CORRELATION B BOCS6B 95I DISTANCE BETWEEN POPULATIONS ON THE BASIS OF ATTRIBUTE DATA BIOCS6B 859 TECH $61 \quad 497$ AMS 611324 A GENERAL SIMULATION PROGRAMME FOR MATERIAL FLOW IN BATCH CHEMICAL PLANT QUEUES WITH BATCH DEPARTURES I QUEUES WITH BATCH DEPARTURES II AMS 641147 PRIO/ SERIAL SAMPLING ACCEPTANCE SCHEMES FOR LARGE BATCHES OF ITEMS WHERE THE MEAN QUALITY HAS A NORMAL BIOKA68 393 E ASSURANCE OF/ ERRATA. THE EFFECT OF SEQUENTIAL BATCHING FOR ACCEPTANCE-REJECTION SAMPLING UPON SAMPL TECH 61 131 LE ASSURANCE OF TOTAL PR/ THE EFFECT OF SEQUENTIAL BATCHINC FOR ACCEPTANCE. REJECTION SAMPLING UPON SAMP TECH 60 19 CONTENT) QUERY, BAULE'S EQUATION + (LEAST SQUARES ESTIMATE OF SOIL BIOCS69 159 METIC MEAN OF A POPULATION WITH TWO-STAGE SAMPLING BAYES AND MINIMAX PROCEDURES FOR ESTIMATINC THE ARITH AMS 66 1186 ASYMPTOTICALLY OPTIMAL BAYES AND MINIMAX PROCEDURES IN SEQUENTIAL ESTIMATION AMS $6 B \quad 422$ THE TWO MEANS PROBLEM A SECONDARILY BAYES APPROACH THE EMPIRICAL BAYES APPROACH ESTIMATINC POSTERIOR QUANTILES A BAYES APPROACH FOR COMBINING CORRELATED ESTIMATES A SUPPLEMENTARY SAMPLE NON-PARAMETRIC EMPIRICAL BAYES APPROACH TO SOME STATISTICAL DECISION PROBLEMS THE EMPIRICAL BAYES APPROACH TO STATISTICAL DEGISION PROBLEMS BIOKA67 85 BIOKA67 672 JASA $65 \quad 602$ BIOKA67 451 AMS $64 \quad 1$ UND DECISION PROBLEM HYPOTHESES

ON THE SMOOTH EMPIRICAL BAYES APPROACH TO TESTINC OF HYPOTHESES AND THE COMPO AN EMPIRICAL BAYES APPROACH TO THE TESTING OF CERTAIN PARAMETRIC THE EMPIRICAL BAYES APPROACH, ESTIMATINC THE PRIOR DISTRIBUTION ON THE BAYES CHARACTER OF A STANDARD MODEL I I ANALYSIS OF A6B B3 AMS 631370 BIOKA67 326 AMS 691094 VARIANCE TEST LY INVARIANT TESTS FOR CLASSICAL MULTI/ ADMISSIBLE BAYES CHARACTER OF T-SQUARED, R-SQUARED AND OTHER FUL AMS 65 747 LITIES AMETER A SIMPLE APPROACH TO THE BAYES CHOICE CRITERION. THE METHOD OF EXTREME PROBABI JASA 641227 THE RELATIONSHIP BETWEEN NEYMAN AND BAYES CONFIDENCE INTERVALS FOR THE HYPERGEOMETRIC PAR TECH 68 199 CENERALIZED BAYES DECISION FUNCTIONS, ADMISSIBILITY AND THE $\quad$ AMS 67818 A NOTE ON BAYES ESTIMATES

$$
\text { A NOTE ON BAYES ESTIMATES }
$$

AMS $67 \quad 871907$ AMS $65 \quad 454$ ON THE ASYMPTOTIC BEHAVIOR OF BAYES ESTIMATES IN THE DISCRETE CASE II BIOKA67 435 IONS SMOOTH EMPIRICAL BAYES ESTIMATION FOR CONTINUOUS DISTRIBUTIONS (CORR. SMOOTH EMPIRICAL BAYES ESTIMATION FOR ONE-PARAMETER DISCRETE DISTRIBUT EMPIRICAL BAYES ESTIMATION FOR THE POISSON DISTRIBUTION ADMISSIBILITY AND BAYES ESTIMATION IN SAMPLING FINITE POPULATIONS, I ADMISSIBILITY AND BAYES ESTIMATION IN SAMPLING FINITE POPULATIONS, II ADMISSIBILITY AND BAYES ESTIMATION IN SAMPLING FINITE POPULATIONS, III ADMISSIBILITY AND BAYES ESTIMATION IN SAMPLING FINITE POPULATIONS, IV ADMISSIBILITY AND BAYES ESTIMATION IN SAMPLING FINITE POPULATIONS, $V$ BAYES ESTIMATION WITH CONVEX LOSS 
MODEL

THE USE OF EMPIRICAL BAYES ESTIMATORS IN A LINEAR RECRESSION MODEL EMPIRICAL BAYES ESTIMATORS IN A MULTIPLE LINEAR RECRESSION

OBSERVATIONS BOUNDS FOR THE FREQUENCY OF MISLEADINC BAYES INFERENCE

ON BAYES PROCEDURES FOR A PROBLEM WITH CHOICE OF APPROXIMATION TO BAYES RISK IN SEQUENCES OF NON-FINITE GAMES

A BAYES RULE FOR THE SYMMETRIC MULTIPLE COMPARISONS BAYES RULES FOR A COMMON MULTIPLE COMPARISONS PROBLE PROBLEM AND RELATED STUDENT-T PROBLEMS

THE OUTER NEEDLE OF SOME BAYES SEQUENTIAL CONTINUATION RECIONS IMENTS FOR THE ESTIMATION OF A SUBCROUP OF PRE-AS/

BAYES SEQUENTIAL DESICN OF FRACTIONAL FACTORIAL EXPER BAYES SEQUENTIAL DESICNS OF FIXED SIZE SAMPLES FROM

FINITE POPULATIONS BOUNDS ON THE MAXIMUM SAMPLE SIZE OF A BAYES SEQUENTIAL PROCEDURE

A BAYES SEQUENTIAL SAMPLINC INSPECTION

ASYMPTOTIC SHAPES OF BAYES SEQUENTIAL TESTINC RECIONS

INTECRATED RISK OF ASYMPTOTICALLY BAYES SEQUENTIAL TESTS

MARKOV DEPENDENT OBSERVATIONS

AN EMPIRICAL BAYES SMOOTHINC TECHNIQUE

BAYES SOLUTION OF SEQUENTIAL DECISION PROBLEM FOR

GENERALIZED BAYES SOLUTIONS IN ESTTMATION PROBLEMS

A MODIFIED BAYES STOPPINC RULE

SOME EMPIRICAL BAYES TECHNIQUES IN POINT ESTIMATION

TOWARDS A THEORY OF CENERALIZED BAYES TESTS

INVARIANT PROPER BAYES TESTS FOR EXPONENTIAL FAMILIES

ABILITY AND STATISTICS. IX. BIOGRAPHICAL NOTE FOR T. BAYES' ESSAY TOWARDS SOLVINC A PROBLEM IN THE DOCTRIN BIOKA58 293 ASYMPTOTIC BEHAVIOR OF BAYES' ESTIMATES

ON THE ASYMPTOTTC BEHAVIOR OF BAYES' ESTIMATES IN THE DISCRETE CASE

BAYES' METHOD FOR BOOKIES

PROBABILITIES A PRIORI

SOME EXAMPLES OF BAYES'

FTDUCTAL DISTRTBUTTONS AND BAYES' THEOREM

STATISTIC AND THE COMBINATION OF TWO SAMPLES BY BAYES' THEOREM

SERIAL SAMPLING ACCEPTANCE SCHEMES DERIVED FROM BAYES'S THEOREM

A FURTHER LOOK AT ROBUSTNESS VIA BAYES'S THEOREM

DERIVATION OF A CLASS OF FREQUENCY DISTRIBUTIONS VIA BAYES'S THEOREM

REGRESSION ANALYSIS

BAYES'S THEOREM AND THE USE OF PRIOR KNOWLEDCE IN

CORRIGENDA, 'A FURTHER LOOK AT ROBUSTNESS VIA BAYES'S THEOREM THE ASSESSMENT OF PRIOR DISTRIBUTIONS IN BAYESIAN ANALYSIS

THE THREE-PARAMETER LOGNORMAL DISTRIBUTION AND BAYESIAN ANALYSIS OF A POINT-SOURCE EPIDEMIC DESIGN MODEL

AND FISHER'S 'EXACT' SIGNIFICANCE TEST

BAYESIAN ANALYSIS OF A THREE-COMPONENT HIERARCHICAL

作

THE COMPOUND

THE BAYESIAN ANALYSTS OF CONTINGENCY TABLES

MPONENTS WITH SPECIAL REFERENCE TO THE BALANCED I/

YSIS OF VARIANCE. I. POSTERIOR DISTRIBUTION OF VA/

YSIS OF VARIANCE. II. EFFECT OF AUTOCORRELATED ER/

ESS. NEITHER MEAN NOR PRECISION KNOWN

CORRELATED ERRORS

DISCUSSION )

RELATTONSHTPS BETWEEN BAYESIAN

A COMPARISON OF SOME BAYESIAN AND FREQUENTIST INFERENCES

A COMPARISON OF SOME BAYESIAN AND FREQUENTIST INFERENCES. II

THREE MULTIDIMENSIONAL-INTEGRAL IDENTITIES WITH BAYESIAN APPLICATIONS

BAYESIAN ANALYSIS OF LINEAR ANALYSIS OF RANDOM-EFFECT MODELS IN THE ANAL BIOKA65 37 BAYTSTAN ANALYSTS OF RANDOM-EFFECT MODELS IN THE ANAL BIOKA66 477 BAYESIAN ANALYSIS OF THE INDEPENDENT MULTINORMAL PROC JASA 65347 BAYESIAN ANALYSIS OF THE INDEPENDENT MULTINORMAL PROC JASA 65 S 347 JASA 64.763 BIOKA65 19 BIOKA66 262 AMS 681615 JRSSB $68 \quad 396$ JRSSB 66568 JASA $67 \quad 48$ TECH $65 \quad 171$ AMS $64 \quad 825$ BIOKA68 119 JASA $65 \quad 81$ BIOKA64 153 AMS $64 \quad 886$ BIOKA66 11 APPLIED TO THE COMPARISON OF VARIANCES

BAYESIAN APPROACH TO LIFE TESTING AND RELIABILITY

A BAYESIAN APPROACH TO MULTIPLE COMPARISONS

A BAYESIAN APPROACH TO SOME BEST POPULATION PROBLEMS

A BAYESIAN APPROACH TO SOME OUTLIER PROBLEMS

A BAYESIAN APPROACH TO THE ANALYSIS OF DATA FROM

A BAYESIAN APPROACH TO THE IMPORTANCE OF ASSUMPTIONS BAYESIAN BIO-ASSAY

BAYESIAN COMPARTSON OF MEANS OF A MIXED MODEL WITH BAYESIAN CONFTDENCE LIMITS FOR RELIABILITY OF REDUND NT SYSTEMS WHEN TESTS ARE TERMINATED AT FIRST FAI/ BINOMIAL PARAMETERS BAYESIAN CONFIDENCE LIMITS FOR THE PRODUCT OF $N$ INSENSITIVITY TO NON-OPTIMAL DESIGN IN BAYESIAN DECISION THEORY ROBUSTNESS OF UNIFORM BAYESIAN ENCODTNC BAYESIAN ESTIMATION IN MULTIVARIATE ANALYSIS

RELATIONSHIP BAYESIAN ESTIMATION OF A LINEAR FUNCTIONAL RESPONSES

THE BAYESIAN ESTIMATIO RESPONSES MODEL BAYESIAN ESTIMATION OF MEANS FOR THE RANDOM EFFECT BAYESIAN ESTIMATION OF MIXING DISTRIBUTIONS

ON THE BAYESIAN ESTIMATION OF MULTIVARIATE REGRESSION BAYESIAN ESTIMATION OF PARAMETERS OF A MULTIVARIATE BAYESIAN ESTIMATION OF THE VARIANCE OF A NORMAL

NORMAL DISTRIBUTION DISTRIBUTION

MAXIMUM LIKELIHOOD AND BAYESIAN ESTTMATION OF TRANSITION PROBABILITIES

A BAYESIAN INDIFFERENCE PROCEDURE

MULTIPARAMETER BAYESIAN INDIFFERENCE PROCEDURES (WITH DISCUSSION)

A GENERALTZATTON OF BAYESIAN INFERENCE (WITH DISCUSSION)

ON SOME EXTENSIONS OF BAYESIAN. INFERENCE PROPOSED BY MR LINDLEY

BAYESIAN INTERPRETATION OF STANDARD INFERENCE

STATEMENTS (WITH DISCUSSION) CONFIDENCE PROPERTIES OF BAYESIAN INTERVAL ESTIMATES

BAYESIAN MODEL OF DECISION-MAKING AS A RESULT OF

LEARNING FROM EXPERIENCE

DISCUSSION )

DISCUSSION

SUBJECTIVE BAYESIAN MODELS IN SAMPLING FINITE POPULATIONS (WITH

THE BAYESIAN OUTLOOK AND ITS APPLICATIONS (WITH

MULTIPARAMETER PROBLEMS FROM A BAYESIAN POINT OF VIEN

AND DECISION PROBLEMS IN REGRESSION MODELS FROM THE BAYESIAN POINT OF VIEW (CORR. 68 155I)
AMS 651468 PREDICTION JASA 65608 
IN THE FIXED-EFFECTS ONE-WAY ANALYSIS OF VARIANCE, A BAYESIAN SIDELIGHT

A BAYESIAN SICNIFICANCE TEST FOR MULTINOMIAL DISTRIBUTI JRSSB67 BAYESIAN SINGLE SAMPLING ATTRIBUTE PLANS FOR CONTINUO TECH $6 B$

IGATIONS TO SEQUENTIAL CLINICAL TRIALS

A BAYESIAN STUDY OF THE MULTINOMIAL DISTRIBUTION

BIOKA6B 587

TION IN BAYESIAN STATISTICS, FINITE SAMPLING AND TWO BAYESIANS TOLERANCE REGIONS (WITH DISCUSSION)
THE ROLE OF EXPERIMENTAL RANDOMIZA BIA ON BEALE'S MEASURES OF NON-LINEARITY

MORTALITY PATTERNS IN EICHT STRAINS OF FLOUR BEETLE

CANNIBALISM OF THE PUPAL STAGE BY ADULT FLOUR BEETLES, AN EXPERIMENT AND A STOCHASTIC MODEL ECONOMETRIC EXPLORATION OF INDIAN SAVING BEHAVIOR

TRAFFIC

FINITE CAPACITY

RRENT INPUT AND CAMMA SERVICE TIME

ON THE TRANSIENT BEHAVIOR OF A QUEUEING SYSTEM WITH BULK SERVICE AND THE TRANSIENT BEHAVIOR OF A SINCLE SERVER QUEUINC PROCESS WITH RECU ON THE ASYMPTOTIC BEHAVIOR OF BAYES ESTIMATES IN THE DISCRETE CASE II ASYMPTOTIC BEHAVIOR OF BAYES' ESTIMATES

ON THE ASYMPTOTIC BEHAVIOR OF BAYES' ESTIMATES IN THE DISCRETE CASE

ANALYSIS

TESTS

ON THE ASYMPTOTIC BEHAVIOR OF DENSITIES WITH APPLICATIONS TO SEQUENTIAL ASYMPTOTIC BEHAVIOR OF EXPECTED SAMPLE SIZE IN CERTAIN ONE-SIDED THE BEHAVIOR OF LIKELIHOOD RATIOS OF STOCHASTIC PROCESSES

RELATED BY GROUPS OF TRANSFORMATIONS

INCORRECT, CORR, 66745

G-WINSORIZATION 2)

PLE LINEAR RECRESSION

\section{A TWO-STATE MARKOV MODEL FOR BEHAVIORAL CHANGE}

THE LOCAL BEHAVIOR OF MARKOV TRANSITION PROBABILITTES

LIMITING BEHAVIOR OF POSTERIOR DISTRIBUTIONS WHEN THE MODEL IS

APPROXIMATE BEHAVIOR OF THE DISTRIBUTION OF WINSORIZED T ITRIMMIN
ASYMPTOTIC BEHAVIOR OF WILCOXON TYPE CONFIDENCE REGIONS IN MULTI QUASI-STATIONARY BEHAVIOUR OF A LEFT-CONTINUOUS RANDOM WALK

ON THE TRANSIENT BEHAVIOUR OF A SIMPLE QUEUE

THE BEHAVIOUR OF AN ESTIMATOR FOR A SIMPLE BIRTH AND

DEATH PROCESS

MEANS UNDER VARIANCE HETEROCENEITY

MEANS UNDER VARIANCE H/ CORRIGENDA,

SMALL SAMPLE BEHAVIOUR OF CERTAIN TESTS OF THE HYPOTHESIS OF EQUAL BIOKA61 230

TE ASYMPTOTIC BEHAVIOUR OF POSTERIOR DISTH
THE ERGODIC BEHAVIOUR OF RANDOM WALKS

AMS $63 \quad 992$

JRSSB $69 \quad 80$

BIOKA61 391

THE BEHAVIOUR OF SOME SIGNIFICANCE TESTS UNDER EXPERIMENT BIOKA69 231

AL RANDOMIZATION

BETWEEN TWO ESTIMATED RESPONSES

JECTS STATISTICAL TESTING OF DIFFERENCES IN CASUAL BEHAVIOUR OF TWO MORPHOLOCICALLY INDISTINGUISHABLE OB DISCUSSION BEHAVIOUR SEQUENCES AS SEMI-MARKOV CHAINS (WITH

NEW TABLES OF BEHREN'S TEST OF SICNIFICANCE THE BEHRENS-FISHER DISTRIBUTION AND WEICHTED MEANS

APPROXIMATION TO THE GENERALIZED BEHRENS-FISHER DISTRIBUTION INVOLVING THREE VARIATES APPROXIMATION TO THE BEHRENS-FISHER DISTRIBUTIONS.

USE OF THE WILCOXON STATISTIC FOR A GENERALIZED BEHRENS-FISHER PROBLEM A SEQUENTIAL ANALOQUE OF THE BEHRENS-FISHER PROBLEM

CONFIDENCE INTERVAL OF PREASSIGNED LENCTH FOR THE BEHRENS-FISHER PROBLEM SOME REMARKS ON SCHEFFE'S SOLUTION TO THE BEHRENS-FISHER PROBLEM DEGREES OF FREEDOM SOLUTION TO THE MULTIVARIATE BEHRENS-FISHER PROBLEM COMPARISON OF TWO TEST PROCEDURES PROPOSED FOR THE BEHRENS-FISHER PROBLEM ON SOME NONPARAMETRIC ESTIMATES FOR SHIFT IN THE BEHRENS-FISHER SITUATION BOUNDS ON THE DISTRIBUTION FUNCTIONS OF THE BEHRENS-FISHER STATISTIC SOME SCHEFFE-TYPE TESTS FOR SOME BEHRENS-FISHER-TYPE REGRESSION PROBLEMS AN APPROXIMATE BIOKA65 139 A CONFIDENCE INTERVAL JASA $66 \quad 454$ AMS $66 \quad 593$ AMS $66 \quad 639$ JASA 651163 ENCE BETWEEN THE MEA/ AN EXACT DISTRIBUTION OF THE BEHRENS-FISHER-WELCH STATISTIC FOR TESTING THE DIFFER JRSSB6I 377 NOTE ON A PAPER BY RAY AND PITMAN + (FISHER-BEHRENS-STATISTIC) TABLE OF O.I PERCENTAGE POINTS OF BEHRENS'S D

ON RANDOMIZED RANK SCORE PROCEDURE OF BELL AND DOKSUM

QUERY, COMPLETED RUNS OF LENCTH K ABOVE AND BELOW MEDIAN

' $N$ BENADERING VIR 'N MAGREEKS WAARSKYNLIKHEIDSVERDELING

A NOTE ON THE ASYMPTOTIC EFFICIENCY OF BENNETT'S BIVARIATE SICN TEST BERNARD FRIEDMAN'S URN

HISTORY OF PROBABILITY AND STATISTICS. XI. DANIEL BERNOULLI ON MAXIMUM LIKELIHOOD BETA DISTRIBUTION FOR USE IN BAYESIAN ANALYSIS OF BERNOULLI PROCESSES ON THE EFFICIENCY OF MATCHED PAIRS IN BERNOULLI TRIALS NOTE ON THE BERRY-ESSEN THEOREM

SELECTINC A SUBSET OF $K$ POPULATIONS CONTAININC THE BEST SQUARES AND ANALYSIS OF VARIANCE PROCEDURES ARE ALSO BEST VARIANCES VARIANCES ON THE CHOICE OF THE BEST AMO

/STRUCTURES UNDER WHICH CERTAIN SIMPLE LEAST AMONCST THREE NORMAL POPULATIONS WITH KNOWN JRSSB62 537 BIOKA66 267 AMS $66 \quad 1697$ TECH $67 \quad 682$ SASJ 69 NO.2 JRSSB66 146 $\begin{array}{rr}\text { AMS } 65 & 956 \\ \text { BIOKA6I } & 1\end{array}$ TESTS OF AN IMPORTANT/ A SIMPLE METHOD OF DERIVING BEST CRITICAL REGIONS SIMILAR TO THE SAMPLE SPACE IN A NOTE ON THE 'NECESSARY BEST ESTIMATOR'

PERCENTAGE POINTS OF THE TECH $66 \quad 687$ BIOKA68 365 AMS 631107 ON AMS $67 \quad 1072$

ONE OF THE HYPOTHESES NORMAL DISTRIBUTION UNDER/ INADMISSIBILITY OF THE BEST INVARIANT TEST WHEN THE MOHENT IS INFINITE UNDER INADMISSIBILITY OF THE BEST INVARIATE ESTIMATOR OF EXTREME QUANTILES OF THE BEST $\mathrm{K}$ OF $2 \mathrm{~K}-1$ COMPARISONS

CRAPHICAL PROCEDURE FOR FITTINC THE BEST LINE TO A SET OF POINTS EQUALITY OF TWO COVARTANCE MATRICES IN RELATON TO A BEST LINEAR DISCRIMTNATOR ANALYSIS METERS OF SINCLE EXPONENTIAL DISTRIBUT/ TABLES FOR BEST LINEAR ESTIMATES BY ORDER STATISTICS OF THE PARA JASA 57 58 
STRUCTION OF GOOD LINEAR UNBIASED ESTIMATES FROM THE BEST LINEAR ESTIMATES FOR A SMALLER SAMPLE SIZE /ON TECH 65 543

BEST LINEAR ESTIMATES UNDER SYMMETRIC CENSORING OF TH JASA $66 \quad 248$ PARAMETERS OF A TABLES FOR OBTAINING THE
AST-SQUARES ESTIMATORS BE

CONDITION THAT ORDINA

STATIONARY PROCESSES

THE LOGISTIC DISTRIBUTION USING ORDER STATISTICS

LINEAR REGRESSION MODEI

A MULTI-STAGE PROCEDURE FOR THE SELECTION OF THE BEST OF SEVERAL POPULATIONS SEQUENTIAL PROCEDURES FOR SELECTION OF THE BEST ONE OF SEVERAL BINOMIAL POPULATIONS USE OF DOUBLE SAMPLING FOR SELECTING BEST POPULATION A BAYESIAN APPROACH TO SOME BEST POPULATION PROBLEMS A NECESSARY AND SUFFICIENT JASA 671302 BEST LINEAR UNBIASED FSTIMATION FOR MULTIVARIATE $\quad$ TECH $68 \quad 523$ BEST I INEAR UNBIASED FSTIMATORS OF THE PARAMETERS OF TECH $67 \quad 43$ BEST LINEAR UNBIASED PREDICTION IN THE GENERALIZED JASA $62 \quad 369$ AMS $67 \quad 117$ BIOKA64 49 AMS 64 B25

ALES AND A CHARACTERISTIC PROPERTY A THE C/ A SHORT-CUT GRAPHIC METHOD FOR FITTING THE BEST STRAIGHT LINE TO A SERIES OF POINTS ACCORDING TO JASA 57 13 $\begin{array}{lll}\text { SELECTION OF THE BEST SUBSET IN REGRESSION ANALYSIS } & \text { TECH } 67 \quad 531\end{array}$

ION TO THE NORMAL DISTRIBUTION CRITERIA FOR BEST SUBSTITUTE INTERVAL ESTIMATORS, WITH AN APPLICAT JASA 641133 SELECTION OF THE BEST TREATMENT IN A PAIRED-COMPARISON EXPERIMENT ER OF TRAWINSKI AND DAVID ENTITLED 'SELECTION OF THE BEST TREATMENT IN A PAIRED-COMPARISON EXPERIMENT' LEAST SQUARES AND BEST UNBIASED ESTIMATES

A NOTE ON UNIFORMLY BEST UNBIASED ESTIMATORS FOR VARIANCE COMPONENTS NCIES IN SMALL SAMPLES OF THE MAXIMUM LIKELIHOOD AND BEST UNBIASED ESTIMATORS OF RELIABILITY FUNCTIONS A FAVORABLE SIDE BET IN NEVADA BACCARAT

GENERATION OF RANDOM SAMPLES FROM THE BETA AND F DISTRIBUTIONS THE NON-CENTRAL MULTIVARIATE BETA DISTRIBUTION

ADDITIONAL PERCENTAGE POINTS FOR THE INCOMPLETE BETA DISTRIBUTION NORMALITY MULTIVARIATE BETA DISTRIBUTION AND A TEST FOR MULTIVARIATE AMS $63 \quad 75$ AMS $63 \quad 92$ AMS $62 \quad 266$ JASA $56 \quad 266$ JASA $66 \quad 1033$ JASA $66 \quad 313$ TECH 63269 AMS $61 \quad 104$ BIOKA63 449 JRSSB 68 5l ES NOULLI PROCESSES PERCENTAGE POINTS OF THE BETA DISTRIBUTION FOR USE IN BAYESIAN ANALYSIS OF BER IE UPPER PERCENTAGE POINTS OF THE GENERALIZED BETA DISTRIBUTION I UPPER PERCENTAGE POINTS OF THE GENERALIZED BETA DISTRIBUTION. II UPPER PERCENTAGE POINTS OF THE GENERALIZED BETA DISTRIBUTION. III VARIATIONS OF THE NON-CENTRAL T AND BETA DISTRIBUTIONS THE NON-CENTRAL CHI-SQUARED AND BETA DISTRIBUTIONS ON THE MULTIVARIATE AND THE GENERALIZED MULTIVARIATE BETA DISTRIBUTIONS ULTIPLE CORRELATION MATRIX, NON-CENTRAL MULTIVARIATE BETA DISTRIBUTIONS WISHART DISTRIBUTIONS, CORR. 66297 MULTIVARIATE BETA DISTRIBUTIONS AND INDEPENDENCE PROPERTIES OF THE AN APPROXIMATION TO THE SYMMETRICAL INCOMPLETE BETA FUNCTION SAMPL ING THE USE OF INCOMPLETE BETA FUNCTIONS FOR PRIOR DISTRIBUTIONS IN BINOMIAL SOME STRIKING PROPERTIES OF BINOMIAL AND BETA MOMENTS
THE NONCENTRAL MULTIVARIATE BETA TYPE TWO DISTRIBUTION
SIMPLIFIED BETA-APPROXIMATIONS TO THE KRUSKAL-WALLIS H TEST
COMPOUND MULTINOMIAL DISTRIBUTION, THE MULTIVARIATE BETA-DISTRIBUTION, AND CORRELATIONS AMONG PROPORTIONS SOME STRIKING PROPERTIES OF BINOMIAL AND BETA MOMENTS
THE NONCENTRAL MULTIVARIATE BETA TYPE TWO DISTRIBUTION
SIMPLIFIED BETA-APPROXIMATIONS TO THE KRUSKAL-WALLIS H TEST
COMPOUND MULTINOMIAL DISTRIBUTION, THE MULTIVARIATE BETA-DISTRIBUTION, AND CORRELATIONS AMONG PROPORTIONS SOME STRIKING PROPERTIES OF BINOMIAL AND BETA MOMENTS
THE NONCENTRAL MULTIVARIATE BETA TYPE TWO DISTRIBUTION
SIMPLIFIED BETA-APPROXIMATIONS TO THE KRUSKAL-WALLIS H TEST
COMPOUND MULTINOMIAL DISTRIBUTION, THE MULTIVARIATE BETA-DISTRIBUTION, AND CORRELATIONS AMONG PROPORTIONS MA TECH 67607 BIOKA57 237 BIOKA57 44I BIOKA58 492 AMS 641583 BIOKA63 542 NOTE JASA 69230 AMS 6B 227 AMS 64261 BIOKA52 204 TECH $65 \quad 335$ AMS 691753 SASJ 69 NO.2 JASA 59225 作 N APPROXIMATE LINEARIZATION OF THE INCOMPLETE BETA-FUNCTION

BIOKA59 214 A CHART FOR THE INCOMPLETE BETA-FUNCTION AND THE CUMULATIVE BINOMIAL DISTRIBUTIO BIOKA5I 423 ON NORMALIZING THE INCOMPLETE BETA-FUNCTION FOR FITTING TO DOSE-RESPONSE CURVES BIOKAGO 173 0.5 PERCENT POINTS OF PEARSON CURVES (WITH ARGUMENT BETA-1 AND BETA-2) EXPRESSED IN STANDARD MEASURE /D BIOKA5I 4 POINTS OF PEARSON CURVES, FOR GIVEN ROOT(BETA-1) AND BETA-2 EXPRESSED IN STANDARD MEASURE /F PERCENTAGE BIOKA63 459 T POINTS OF PEARSON CURVES (WITH ARGUMENT BETA-1 AND BETA-2) EXPRESSED IN STANDARD MEASURE /D 0.5 PERCEN BIOKA5I 4 POINTS OF PEARSON CURVES, FOR GIVEN ROOT(BETA-1) AND BETA-2, EXPRESSED IN STANDARD MEASURE 1 /PERCENTAGE BIOKA65 669 II A NORMAL APPROXIMATION FOR BINOMIAL, F, BETA, AND OTHER COMMON, RELATED TAIL PROBABILITIES, I JASA 68 14I6 HOW TO SURVIVE A FIXED NUMBER OF FAIR BETS

WITH. CONFOUNDING WHICH PRODUCT IS BETTER UNIFORMLY BETTER COMBINED ESTIMATORS IN FACTORIAL ARRANGEMENTS AMS 671278 TECH $69 \quad 309$ JASA $67 \quad 638$ JASA $63 \quad 172$ AMS 641064 JRSSB55 22B BIOKA64 268 JASA 5952 AMS $61 \quad 436$ THE USE BIOKAG9 NO.3

OF RANDOM ALLOCATION FOR THE CONTROL OF SELECTION BIAS

A SURVEY TECHNIQUE FOR ELIMINATING EVASIVE ANSWER BIAS THE PARAMETERS OF THE GAMMA DISTRIBUTION AND THEIR BIAS NGLY UNRELATED REGRESSIONS AND TE TS FOR AGGREGATION BIAS APPROXIMATE CONFIDENCE INTERVALS III. A BIAS CORRECTION

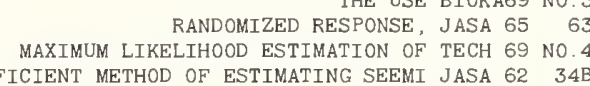
BIOKA55 201 NT' AND 'ADAPTIVE EXPECTATIONS' MODE/ SMALL SAMPLE BIAS DUE TO MISSPECIFTCATION IN THE IPARTIAL ADJUSTME JASA 66 II30 MINIMUM BIAS ESTIMATION AND EXPERIMENTAL DESIGN FOR RESPONSE SURFACES ATION AS INDICATED BY TRENDS IN DEATH RATES BIAS IN ESTIMATES OF THE UNITED STATES NONWHITE POPUL JASA 61 BIOKA56 353 NOTES ON BIAS IN ESTIMATION BIAS IN LULTINOMIAL CLASSIFICATION

ENESS OF ADJUSTMENT BY SUBCLASSIFICATION IN REMOVING BIAS IN OBSERVATIONAL STUDIES BIAS IN PSEUDO-RANDOM NUMBERS JASA $6 B$ B $6 B 29 B$ THE RATIO BIAS IN SURVEYS

NOTE ON BIAS IN THE ESTIMATION OF AUTOCORRELATION BIAS IN THE ESTIMATION OF AUTOCORRELATIONS

THE EFFECTIV BIOCS6B 295 JASA 61610 JASA 62 B63 BIOKA54 403 BIOKA54 390

MATRIX

NEGATIVE BINOMIAL DISTRIBUTION

ON THE BIAS OF FUNCTIONS OF CHARACTERISTIC ROOTS OF A RANDOM BIOKA65 THE BIAS OF MOMENT ESTIMATORS WITH AN APPLICATION TO THE BIOKA62

ON THE BIAS OF SOME LEAST-SQUARES ESTIMATORS OF VARIANCE IN BIOKA68 A GENERAL LINEAR MODEL ION AND SCALE PARAMETERS GIVEN A TYPE II CENS/ THE BIAS OF THE MAXIMUM LIKELIHOOD ESTIMATES OF THE LOCAT BI BIAS OF THE ONE-SAMPLE CRAMER-VON MISES TEST 448 NCE WITH APPLICATION TO QUANTAK BIOASSAY

ON THE BIAS OF VARIOUS ESTIMATORS OF THE LOGIT AND ITS VARIA BIOKA67 EFFECTS OF BIAS ON ESTIMATES OF THE CIRCULAR PROBABLE ERROR JASA 60 ON TWO METHODS OF BIAS REDUCTION IN THE ESTIMATION OF RATIOS A NOTE ON THE APPLICATION OF QUENOUILLE'S METHOD OF BIAS REDUCTION TO THE ESTIMATION OF RATIOS BIOKA66 571 BIOKA59 477 M A GRAPH CONSTRUCTED RANDOMLY EXCEPT FOR 'EXOGAMOUS BIAS'/FOR THE PROBABILITY OF OBTAINING A TREE FRO AMS 67 226 IONAL TO SIZE WITH REPLACEMENT

A NOTE ON A BIASED ESTIMATOR IN SAMPLING WITH PROBABILITY PROPORT 
INCOMPLETELY SPECIFIED MODELS

BIASES IN PREDICTION BY RECRESSION FOR CERTAIN

THE WILCOXON TWO-SAMPLE STATISTIC, TABLES AND BIBLIOGRAPHY

ON THE DEFINITION OF FIDUCIAL PROBABILITY WITH A BIBLIOGRAPHY

EXAMPLES
A BIBLIOGRAPHY ON LIFE TESTING AND RELATED TOPICS

BIOKA63 391

JASA $63 \quad 10 B 6$

AMS 621349

651249

A SUPPLEMENT TO MENDENHALK'S

BIBLIOCRAPHY ON SEQUENTIAL ANALYSIS

INTELLIGENCE AND ALLIED TOPICS

RELATED TOPICS

BIBLIOGRAPHY ON SIMULATION, GAMING, ARTIFICIAL JASA 60 T36

BIBLIOGRAPHY ON THE MULTIVARIATE NORMAL INTEGRALS AND AMS 63829

A BIBLIOCRAPHY ON THE THEORY OF QUEUES

THE BIG MATCH

ON THE LINE, GRAPH OF THE COMPLETE BIGRAPH

ON SOME BILHARZIA INFECTION AND IMMUNISATION MODELS

CENESTS OF BIMODAL DISTRIBUTIONS

QUADRATICS IN MARKOV-CHAIN FREQUENCIES, AND THE BINARY CHAIN OF ORDER 2

ON COMPARING INTENSITIES OF ASSOCIATION BETWEEN TWO BINARY CHARACTERISTICS IN TWO DIFFERENT POPULATIONS

ON THE FOUNDATIONS OF STATISTICAL INFERENCE, BINARY EXPERIMENTS

A MARKOV PROCESS ON BINARY NUMBERS

STATISTICAL PROPERTIES OF A CERTAIN PERIODIC BINARY PROCESS

TWO FURTHER APPLICATIONS OF A MODEL FOR BINARY RECRESSION

DISCRIMINATION BETWEEN ALTERNATIVE BINARY RESPONSE MODELS

THE RECRESSION ANALYSIS OF BINARY SEQUENCES (WITH DISCUSSION) (CORR. 59 23B)

APPROXIMATING THE NECATIVE BINOMIAL

ESTIMATTON OF PARAMETERS OF A TRUNCATED POISSONIAN BINOMIAL

ORMLY MOST POWERFUL RANDOMIZED UNBIASED TEST FOR THE BINOMIAL EXISTENCE AND UNIQUENESS OF A UNIF
MENT

TABLES OF SIMULTANEOUS CONFIDENCE LIMITS FOR THE BINOMIAL AND AND POISSON DISTRIBUTIONS SOME STRIKING PROPERTIES OF BINOMIAL AND BETA MOMENTS

SEQUENTIAL TESTS FOR BINOMIAL AND EXPONENTIAL POPULATIONS

MODIFIED SAMPLINC, BINOMIAL AND HYPERCEOMETRIC CASES

NS AND AN ACKNOWLEDGEMENT

ON THE EQUIVALENCE OF BINOMTAL AND INVERSE BINOMTAL ACCEP

TESTING FOR HOMOGENEITY. I. THE BINOMIAL AND MULTINOMIAL DISTRIBUTIONS

MOMENTS ESTIMATES OF THE PARAMETERS OF THE TRUNCATED BINOMIAL AND NEGATIVE BINOMIAL DISTRIBUTIONS /D OF JASA 6I G90 ON STABILIZING THE BINOMIAL AND NEGATIVE BINOMIAL VARIANCES

CY OF CERTAIN METHODS OF ESTIMATION FOR THE NEGATIVE BINOMIAL AND NEYMAN TYPE A DISTRIBUTIONS

MPLING, TWO DECISION PROBLEMS WITH LINEAR LOSSES FOR BINOMIAL AND NORMAL RANDOM VARIABLES. SEQU

OD OF ANALYSINC UNTRANSFORMED DATA FROM THE NECATIVE BTNOMTAL AND OTHER CONTACIOUS DTSTRTBUTIONS

SHORTER INTERVALS FOR THE PARAMETER OF THE BINOMIAL AND POISSON DISTRIBUTIONS

THE GENERALIZED MEAN DIFFERENCES OF THE BINOMIAL AND POISSON DISTRIBUTIONS

TABLES OF THE FREEMAN-TUKEY TRANSFORMATIONS FOR THE BTNOMIAL AND POISSON DISTRIBUTIONS

IBED BOUND ON THE VARIANCE FOR THE PARAMETERS IN THE BINOMIAL AND POISSON DISTRIBUTIONS BASED ON TWO-STACE JA

FINITE POPULATIONS

A NEW BINOMIAL APPROXIMATION FOR USE IN SAMPLINC FROM

OKA57 490

AMS 68159

AMS $63 \quad 664$

357

JRSSB $63 \quad 3 B 3$

JASA $61 \quad 889$

AMS $61 \quad 414$

AMS $63 \quad 416$

OKA58 562

BIOKA67 573

JRSSB5B 215

CH $66 \quad 345$

BIOC\$68 377

TECH $63 \quad 119$

BIOKA69 452

AMS 691753

BIOKA54 252

TECH 69 NO 4

JASA $61 \quad 143$

ANALYSIS WITH RANDOMLY MISSED OBSERVATIONS, THE BINOMIAL CASE NOTE ON TWO BINOMIAL COEFFICIENT SUMS FOUND BY RIORDAN

APPROXIMATING THE LOWER BINOMIAL CONFIDENCE LIMIT (CORR. 69 669)

AMS 65971

AMS $63 \quad 333$

JASA $6 B 1413$

TABLE OF TWELVE PROBABILITY LEVELS OF THE SYMMETRIC BINOMIAL CUMULATIVE DISTRIBUTION FOR SAMPLE SIZES TO JASA 59 I64 TABLES OF CONFIDENCE LIMITS FOR THE BINOMIAL DISTRIBUTION A NOTE ON THE NEGATIVE BINOMIAL DISTRIBUTION

ON ESTIMATING THE PARAMETER OF A DOUBLY TRUNCATED BINOMIAL DISTRIBUTION ESTIMATION OF THE PARAMETER N IN THE BINOMIAL DISTRIBUTION QUERY, TOLERANCE LIMITS FOR A BINOMIAL DISTRIBUTION THE TRUNCATED NEGATIVE BINOMIAL DISTRIBUTION

A NOTE ON THE MEAN DEVIATION OF THE BINOMIAL DISTRIBUTTON

JASA $60 \quad 521$

TECH 62609

JASA $66 \quad 259$

JASA 6 B 150

TECH 69201

BIOKA55 58

BIOKA57 532

BIOKA5B 59

BIOKA5B 275

BIOKA64 264

INTERVAL ESTIMATION FOR THE PARAMETER OF A BINOMIAL DISTRIBUTION A NOTE ON THE NEGATIVE BINOMIAL DISTRIBUTION

A CHART BIOKA5I 423

FOR THE INCOMPLETE BETA-FUNCTION AND THE CUMULATIVE BINOMIAL DISTRIBUTION MERICAL COMPARISONS OF SEVERAL APPROXIMATIONS TO THE BINOMIAL DISTRIBUTION

ESTIMATORS WITH AN APPLICATION TO THE NEGATIVE BINOMIAL DISTRIBUTION RECIPROCAL OF A VARIABLE FROM A DECAPITATED NEGATIVE BINOMIAL DISTRIBUTION IES DISTRIBUTIONS AND ITS APPLICATION TO A TRUNCATED BINOMIAL DISTRIBUTION OF P FOR A CONTINUOUS PRIOR DISTRIBUTION THE MIXED BINOMIAL DISTRIBUTION AND THE POSTERIOR DISTRIBUTION J

ON THE EVALUATION OF THE NEGATIVE BINOMIAL DISTRIBUTION WITH EXAMPLES TWO ESTIMATES OF THE BINOMIAL DISTRIBUTION, (CORR. 64 1B2)

CORRICENDA TO A NOTE ON THE MEAN DEVIATION OF THE BINOMIAL DISTRIBUTION' ESTIMATINC THE PARAMETERS OF MIXTURES OF BINOMIAL DISTRIBUTIONS

SOME NU JASA 69 NO. 4

THE BIAS OF MOMENT BIOKA62 193 /STANDARD DEVIATIONS OF THE JASA $62 \quad 439$ ION FOR GENERALIZED POWER SER BIOKA62 227 JRSSB6B 359 TECH 60501 AMS 64809 BIOKA5B 587 JASA $64 \quad 510$ ESTIMATORS FOR THE PARAMETERS OF A MIXTURE OF TWO BINOMIAL DISTRIBUTIONS

PARAMETERS OF THE LOGARITHMIC SERIES AND NEGATIVE BINOMIAL DISTRIBUTIONS NECATIVE BINOMIAL DISTRIBUTIONS WITH A COMMON

MOMENT AMS $62 \quad 444$ ON ESTIMATINC THE BIOKA69 411 BIOKA58 37

RD/ A CENERAL USE OF THE POISSON APPROXIMATION FOR BINOMIAL EVENTS, WITH APPLICATION TO BACTERIAL ENDOCA BIOCS66 74

ORTHOCONAL POLYNOMIALS OF THE POSITIVE AND NECATIVE BINOMIAL FREQUENCY FUNCTIONS IN CUPVF FITTINC BY AITK BIOKA6I II5

DEFECTIVES POISSON AND BINOMIAL FREQUENCY SURFACES

BIOKA66 617

NUMERICAL STUDIES IN THE SEQUENTIAL ESTIMATION OF A BINOMIAL PARAMETER

OPTIMUM PROCEDURES FOR UNBIASED ESTIMATION OF A BINOMIAL PARAMETER

SHORTEST UNBIASED CONFIDENCE INTERVALS FOR THE BINOMIAL PARAMETER

CONFIDENCE INTERVALS FOR THE PRODUCT OF TWO BINOMIAL PARAMETERS

BAYESIAN CONFIDENCE LIMITS FOR THE PRODUCT OF N BINOMIAL PARAMETERS

FOR THE SIGN TEST WHEN OBSERVATIONS ARE ESTIMATES OF BINOMIAL PARAMETERS ERRORS OF CLASSIFICATION IN A BINOMIAL POPULATION

AND VARIANCE OF THE SMALLER OF TWO DRAWINGS FROM A BINOMIAL POPULATION ERRATA, 'MISCLASSIFIED DATA FROM A BINOMIAL POPULATION OPTIMUM SAMPLING IN BINOMIAL POPULATIONS

TECH 66 631 BIOKA58 1

NOTE ON A THREE-DECISION TEST FOR COMPARINC TWO BINOMIAL POPULATIONS PROCEDURES FOR SELECTION OF THE BEST ONE OF SEVERAL BINOMIAL POPULATIONS 
BABILITIES, I BABILITIES, II DISTRIBUTIONS

ISTRIBUTION A NORMAL APPROXIMATION FOR BINOMIAL, F, BETA, AND OTHER COMMON, RELATED TAIL PRO JASA 68 I4I6 A NORMAL APPROXIMATION FOR BINOMIAL, F, BETA, AND OTHER COMMON, RELATED TAIL PRO JASA 68 I457 TRANSFORMATIONS OF THE BINOMIAL, NEGATIVE BINOMIAL, POISSON AND CHI-SQUARE BIOKA54 302 UENTIAL ESTIMATION APPLICABLE TO THE HYPERGEOMETRIC, BINOMIAL, POISSON, AND EXPONENTIAL DISTRIBUTIONS $/ Q$ AMS 65 1494 ERRATA, 'APPROXIMATING THE NEGATIVE BINOMIAL'

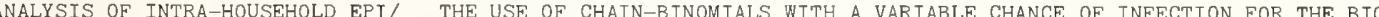
APPROXIMATION TO THE DISTRIBUTION OF TWO INDEPENDENT BINOMIALS, CONDITIONAL ON FIXED SUM AMS MISCLASSIFIED DATA FROM A BINOMINAL POPULATION BAYESIAN BIO-ASSAY

RANDOM WALK DESIGN IN BIO-ASSAY

PROPERTIES OF THE BLOCK UP-AND-DOWN METHOD IN BIO-ASSAY INCOMPLETE BLOCK DESIGNS FOR BIO-ASSAYS OF MODIFIED BALANCED INCOMPLETE BLOCK DESIGNS FOR BIO-ASSAYS THE MULTIPLE SAMPLE UP-AND-DOWN METHOD IN BIOASSAY SOME PROPERTIES OF THE SPEARMAN ESTIMATOR IN BIOASSAY THE MEANING OF BIOASSAY E LOGIT AND ITS VARIANCE WITH APPLICATION TO QUANTAL BIOASSAY ON THE BIAS OF VARIOUS ESTIMATORS OF TH CONCENTRATION RITERIA FOR THE BIOASSAY OF VITAMTN K

THE WITHIN-ANIMAL BIOASSAY WITH QUANTAL RESPONSES

ES IN THE HISTORY OF PROBABILITY AND STATISTICS. IX. BIOGRAPHICAL NOTE FOR T. BAYES' ESSAY TOWARDS SOLVING BIOKA58 293 MATHEMATICAL REPRESENTATION OF THE BIOLOGICAL AND PHYSICAL DECAY OF CHAMBER AEROSOLS BIOCS65 551 INTERACTIVE JOINT ACTION OF A MIXTURE OF STIMULI IN BIOLOGICAL ASSAY MODELS FOR THE NON- BIOKA66 MODELS FOR QUANTAL RESPONSES TO MIXTURES OF DRUGS IN BIOLOGICAL ASSAY O BIOLOGICAL EXAMPLES OF SMALL EXPECTED FREQUENCIES BIOCS65 49

A SYSTEM OF MODELS FOR THE LIFE CYCLE OF A BIOLOGICAL ORGANISM

ON A METHOD OF ESTTMATING BIOLOGICAL POPULATIONS IN THE FIELD

A STOCHASTIC MODEL FOR DISTRIBUTIONS OF BIOLOGICAL RESPONCE TIMES ON THEORETICAL MODELS FOR COMPETITIVE AND PREDATORY BIOLOGICAL SYSTEMS THE VARTANCE IN DISCRETE-TTME STOCHASTTC MODELS FOR BIOLOGICAL SYSTEMS

CHASTIC MODEL FOR STUDYING THE PROPERTIES OF CERTAIN BIOLOGICAL SYSTEMS BY NUMERICAL METHODS ON A TEST OF SIGNIFICANCE IN PEARSON'S BIOMETRIKA TABLES (NO. II) A STO BIOKA58 JRSSB56

HER'S PAPER, 'ON A TEST OF SIGNIFICANCE IN PEARSON'S BIOMETRIKA TABLES (NO. II)' /MENT ON SIR RONALD FIS JRSSB56 BIOMETRIKA, 1901-1951 TISTICS. XIV. SOME INCIDENTS IN THE EARLY HISTORY OF BIOMETRY AND STATISTICS, 1890-1894 /ABILITY AND STA BIOKA65 TEACHING BIOMETRY IN THE UNIVERSITY JRSSB68 334 AL NORMAL DISTRIBUTION PROCESSES AN APPLICATION OF BIORTHONORMAL EXPANSIONS IN THEORY OF STOCHASTIC AMS $64 \quad 883$ ON THE LINE GRAPH OF THE COMPLETE BIPARTITE GRAPH

POLYKAYS, AN EXTENTION OF SIMPLE POLYKAYS AND BIPOLYKAYS, CORR. 66746 A NOTE ON THE BIRKHOFF ERGODIC THEOREM AN APPRECIATION ON THE HUNDREDTH ANNIVERSARY OF HIS BIRTH

A MULTI-DIMENSIONAL LINEAR GROWTH BIRTH AND DEATH PROCESS AN AGE-DEPENDENT BIRTH AND DEATH PROCESS THE BEHAVIOUR OF AN ESTIMATOR FOR A SIMPLE BIRTH AND DEATH PROCESS AMS 67922 JASA $58 \quad 23$ AMS $68 \quad 727$ BIOKA55 291 BIOKA56 23 FERENCES BETWEEN SPECIES GROWING ACCORDING TO SIMPLE BIRTH AND DEATH PROCESSES HIERARCHICAL BIRTH AND DEATH PROCESSES. I. THEORY HIERARCHICAL BIRTH AND DEATH PROCESSES. II. APPLICATIONS

THE ANALYSIS OF POPULATION GROWTH WHEN THE BIRTH AND DEATH RATES DEPEND UPON SEVERAL FACTORS BIOKA60 235 BIOKAGO 245 BIOCS69 N0. 4 BIOKA64 258 PROBABILISTTC SOLUTION OF THE SIMPLE BIRTH PROCESS

FUNCTIONAL FOR THE CUMULATIVE POPULATION IN A SIMPLE BIRTH-AND-DEATH PROCESS /HE PROBABILITY GENERATING BI ON THE HOMOGENEOUS BIRTH-AND-DEATH PROCESS AND ITS INTEGRAL 245 BIOKA66 61 HASE-DEPENDENT THE PROBABILITIES OF EXTINCTION FOR BIRTH-AND-DEATH PROCESSES THAT ARE AGE-DEPENDENT OR P BIOKA67 579 CARCINOGENESIS BIRTH-AND-DEATH PROCESSES, AND THE THEORY OF THE BASIC BIRTH-DEATH MODEL FOR MICROBIAL INFECTIONS

BIOKA60 I3 JRSSB $65 \quad 338$ BIOK A65 581 THE DISTRIBUTION OF RESPONSE TIMES IN A BIRTH-DEATH PROCESS STRTBUTTON OF INANTMATE MARKS OVER A NON-HOMOCENEOUS BTRTH-DEATH PROCESS ONSHIP BETWEEN THE MEAN AND VARIANCE OF A STATIONARY BIRTH-DEATH PROCESS, AND ITS ECONOMIC APPLICATION / BIOKA62 253 DISTRIBUTED POPULATIONS STOCHASTIC BIRTH, DEATH AND MIGRATION PROCESSES FOR SPATIALLY BIOKA68 189 PARAMETER FROM QUANTAL DATA, AND ITS RELATIONSHIP TO BIRTH DEATH AND BRANCHING PROCESSES /EXPONENTIAL BIOCS67 739 
APPRECIATION, OTTOKAR HEINISCH (70TH BIRTHDAY, 23RD APRIL, 1966) A CHANCE MECHANISM OF THE VARIATION IN THE NUMBER OF BIRTHS PER COUPLE ROBABILITY MODELS FOR THE VARIATION IN THE NUMBER OF BIRTHS PER COUPLE ASYMPTOTIC NORMALITY OF BISPECTRAL ESTIMATES ESTIMATION OF THE BISPECTRUM

THE STATISTICAL SIGNIFICANCE OF ODD BITS OF INFORMATION

ACTERIZATIONS OF INDEPENDENCE IN CERTAIN FAMILIES OF BIVARIATE AND MULTIVARIATE DISTRIBUTIONS

A REPRESENTATION OF THE SYMMETRIC BIVARIATE CAUCHY DISTRIBUTION

AN INEQUALITY FOR A CLASS OF BIVARIATE CHI-SQUARE DISTRIBUTIONS

OF SOME CORRELATION COEFFICIENTS FOR A CENERAL BIVARIATE DISTRIBUTION

CORRELATIONS AND CANONICAL FORMS OF BIVARIATE DISTRIBUTIONS POLYNOMIAL EXPANSIONS OF BIVARIATE DISTRIBUTIONS

A CLASS OF BIVARIATE DISTRIBUTIONS

A NOTE ON CONTINGENCY-TYPE BIVARIATE DISTRIBUTIONS

OF SOME TESTS OF INDEPENDENCE FOR CONTINCENCY-TYPE BIVARIATE DISTRIBUTIONS FOR DISTRIBUTION FUNCTIONS OF ORDER STATISTICS FROM BIVARIATE DISTRIBUTIONS

SOME CONTRIBUTIONS TO CONTINGENCY-TYPE BIVARIATE DISTRIBUTIONS (CORR. $6 \mathrm{~B} 597$ )
CORRECTION. 'THE STRUCTURE OF BIVARIATE DISTRIBUTIONS $5 \mathrm{~B} 719$

DISTRIBUTION OF RADICAL ERROR IN THE BIVARIATE ELLIPTICAL NORMAL DISTRIBUTION BIVARIATE EXPONENTIAL DISTRIBUTIONS

A BIVARIATE EXTENSION OF THE EXPONENTIAL DISTRIBUTION

ANALYSIS OF EMPIRICAL BIVARIATE EXTREMAL DISTRIBUTIONS

SOME ANALYTICAL PROPERTIES OF BIVARIATE EXTREMAL DISTRIBUTIONS

APPLICATION OF AN ESTIMATOR OF HICH EFFICIENCY IN BIVARIATE EXTREME VALUE THEORY

THE CANONICAL CORRELATION COEFFICIENTS OF BIVARIATE CAMMA DISTRIBUTIONS

STATISTICAL INFERENCE WITH BIVARIATE CAMMA DISTRIBUTIONS

ESTIMATION OF THE CROSS-SPECTRUM OF A STATIONARY BIVARIATE CAUSSIAN PROCESS FROM ITS ZEROS

WITH TABLES FOR CERTAIN SPECIAL CASES

DISTRIBUTION

A BIVARIATE CENERALIZATION OF STUDENT'S T-DISTRIBUTION, BIVARIATE CENERALIZATIONS OF NEYMAN'S TYPE A

SAMPLINC DISTRIBUTION TWO APPLICATIONS OF BIVARIATE K-STATISTICS

BIVARIATE K-STATISTICS AND CUMULANTS OF THEIR JOINT BIVARIATE LOCISTIC DISTRIBUTIONS

ON THE PROBLEM OF ESTIMATION FOR THE BIVARIATE LOGNORMAL DISTRIBUTION

ON THE BIVARIATE MOMENTS OF ORDER STATISTICS FROM A LOGISTIC

DISTRIBUTION

A SPECIAL CASE OF A BIVARIATE NON-CENTRAL T-DISTRIBUTION

TRIBUTION OF RECRESSION COEFFICIENTS IN SAMPLES FROM BIVARIATE NON-NORMAL POPULATIONS. I. THEORETICAL INVE NORMAL DISTRIBUTIONS

SAMPLINC FROM BIVARIATE NON-NORMAL UNIVERSES BY MEANS OF COMPOUND

ESTIMATION OF PARAMETERS OF A TRUNCATED BIVARIATE NORMAL DISTRIBUTION MOMENTS OF A TRUNCATED BIVARIATE NORMAL DISTRIBUTION

PROPORTION OF OBSERVATIONS ABOVE SAMPLE MEANS IN A BIVARIATE NORMAL DISTRIBUTION

BETWEEN THE SAMPLE VARIANCES IN A SINCLY TRUNCATED BIVARIATE NORMAL DISTRIBUTION TENT ROOTS AND VECTORS WITH SPECIAL REFERENCE TO THE BIVARIATE NORMAL DISTRIBUTION OF A CONTINCENCY TABLE /IAN ESTIMATION OF LA BIOKAG9
CONSIDERED IN THE FORM BIOKA57 ERVAL ESTIMATION OF THE SLOPE OF THE MAJOR AXIS OF A BIVARIATE NORMAL DISTRIBUTION IN THE CASE OF A SMALL B. OF RANK CORREL/ CORRELATION IN A SINGLY TRUNCATED BIVARIATE NORMAL DISTRIBUTION IV. EMPIRICAL VARIANCES INTECRAL OF THE BIVARIATE NORMAL DISTRIBUTION OVER AN OFFSET CIRCLE

A TABLE OF THE INTECRAL OF THE BIVARIATE NORMAL DISTRIBUTION OVER AN OFSET CIRCLE

H PROBLEM IN RELIABILITY ANAL/APPLICATIONS OF THE BIVARIATE NORMAL DISTRIBUTION TO A STRESS VS. STRENGT TE BILITY ANAL/ APPLICATIONS OF THE BIVARIATE NORMAL DISTRIBUTION TO A STRESS VS. STRENGT TECH 64
CORRELATION IN A SINGLY TRUNCATED BIVARIATE NORMAL DISTRIBUTION. II. RANK CORRELATION
BIOKA65 CORRELATION IN A SINCLY TRUNCATED BIVARIATE NORMAL DISTRIBUTION. III. CORRELATION BETWE BIOKA66

EN RANKS AND VA/ CORRELATION IN A SINCLY TRUNCATED BIVARIATE NORMAL DISTRIBUT
THE BIVARIATE NORMAL INTEGRAL

CIONS UNDER SPHERICAL NORMAL DISTRIBUTIONS, III. THE BIVARIATE NORMAL INTECRAL PROBABILITY CONTENT OF RE A SUAL CONFIDENCE SETS FOR THE MEAN OF A UNIVARIATE OR BIVARIATE NORMAL POPULATION ESTIMATION FOR THE BIVARIATE POISSON DISTRIBUTION $N$ OF KENDALL'S TAU FOR SAMPLES OF FOUR FROM A NORMAL BIVARIATE POPULATION WITH CORRELATION RHO /TRIBUTIO BIOKA63 53B A CLASS OF NONPARAMETRIC TESTS FOR INDEPENDENCE IN BIVARIATE POPULATIONS TRIBUTION OF DISTANCES BETWEEN ORDER STATISTICS FROM BIVARIATE POPULATIONS $R$ COORDINATES FOLLOWS SOME KNOWN DISTRIBUTION ON BIVARIATE RANDOM VARIABLES WHERE THE QUOTIENT OF THEI ON THE DISTRIBUTION OF THE BIVARIATE RANCE

QUERY, BIVARIATE SAMPLES WITH MISSINC VALUES

QUERY, BIVARIATE SAMPLES WITH MISSINC VALUES, II

A NEW BIVARIATE SIGN TEST

A NOTE ON THE ASYMPTOTIC EFFICIENCY OF BENNETT'S BIVARIATE SICN TEST

DISTRIBUTION AND BAHADUR EFFICIENCY OF THE HODGES BIVARIATE SIGN TEST DISTRIBUTION AND BAHADUR EFFICIENCY OF THE HODGES BIVARIATE SIGN TEST
EL/ CORRECTIONS TO 'A RELATIONSHIP BETWEEN HODGES' BIVARIATE SIGN TEST AND A NON-PARAMETRIC TEST OF DANI
CIRCULAR DISTRIBUTION A A A RODGES'S BIVARIATE SIGN TEST AND A TEST FOR UNIFORMITY OF A

ON HODGES'S BIVARIATE SIGN TEST AND A TEST FOR UNIFORMITY OF A A BIVARIATE SIGN TEST FOR LOCATION

SMALL SAMPLE POWER OF THE BIVARIATE SIGN TEST OF BLUMEN AND HODCES

A BIVARIATE SIGNED RANK TEST BIVARIATE STRUCTURAL RELATION

CRITICAL VALUES FOR BIVARIATE STUDENT T-TESTS

AN INEQUALITY ON A BIVARIATE STUDENT'S 'T' DISTRIBUTION BIVARIATE SYMMETRY TESTS, PARAMETRIC AND

NONPARAMETRIC A BIVARIATE T DISTRIBUTION, CORR. 671594

NDER UNEQUAL VARI/ SOME EMPIRICAL DISTRIBUTIONS OF BIVARIATE T-SQUARE AND HOMOSCEDASTICITY

A NON-PARAMETRIC TEST FOR THE BIVARIATE TWO-SAMPLE LOCATION PROBLEM SMALL SAMPLE POWER OF A NON-PARAMETRIC TEST FOR THE BIVARIATE TWO-SAMPLE LOCATION PROBLEM IN THE NORMAL C J NULL DISTRIBUTION OF A NON-PARAMETRIC TEST FOR THE BIVARIATE TWO-SAMPLE PROBLEM

A BIVARIATE WARNING-TIME, FAILURE-TIME DISTRIBUTION

A BLACK BOX OR A COMPREHENSIVE MODEL

THE OPTIMUM STRATEGY IN BLACKJACK, CORR. 59810

OF THE EFFECTIVENESS OF VOIDING AS A DEFENCE AGAINST BLADDER INFECTION

A BLANCED INCOMPLETE BLOCK DESIGN

OF VARIANCE COMPONENTS IN THE BALANCED INCOMPLETE BLOCK

COMBINING INTRA AND INTER BLOCK ANALYSIS OF GROUP DIVISIBLE DESIGNS
ATIONS OF THE CALCULUS OF FACTORIAL ARRANGEMENTS. I. BLOCK AND DIRECT PRODUCT DESIGN ATIONS OF THE CALCULUS OF FACTORIAL ARRANGEMENTS, I BLOCK AND DIRECT PRODUCT DESIGN ON THE AMS $68 \quad 1350$ $\begin{array}{lr}\text { JASA } & 56 \\ \text { BIOCS66 } & 429\end{array}$

AMS $65 \quad 711$

BI0CS66 195

JASA 6B 209

AMS $66 \quad 1257$

AMS $65 \quad 1120$

BIOKA52 22B

$\begin{array}{rrr}\text { AMS } & 6 \mathrm{~B} & 433 \\ \text { AMS } & 62 & 1256\end{array}$

JASA 69333

AMS $64120 \mathrm{~B}$

JASA $65 \quad 516$

BIOKA6B 262

AMS $64 \quad 1388$

TECH $62 \quad 138$

IASA 61971

JASA $67 \quad 569$

AMS 691401

BIOKA54 153

BIOKA5I 368

BIOKA51 179

JASA $61 \quad 335$

IOKA64 522

BIOKAG5 437

289

IOKA68 437

ASA $62 \quad 75 \mathrm{~B}$

$27 \mathrm{~B}$

BIOKA5I 475

$\begin{array}{ll}\text { AMS } 64 & 138\end{array}$

AMS $64 \quad 748$

AMS 641673

TECH $67 \quad 476$

TECH 6B B67

$\begin{array}{lll}\text { JASA } & 58 \quad 448\end{array}$

JRSSB66 146

ULL AMS $62 \quad 803$

AMS $61 \quad 619$

BIOKA69 446

AMS $66 \quad 1771$

JRSSB $64 \quad 457$

BIOKA57 84

JASA $69 \quad 637$

JASA $67 \quad 603$

AMS $69 \quad 259$ AMS $67 \quad 162$

JASA 631048

67320

C JRSSB6B B3

N THE JRSSB69 98 JASA $67 \quad 5 B 9$

ESTIMATORS JASA $69 \quad 1014$

TECH 66 1BB

APPLIC BIOKA63 63
AMS $63 \quad 532$

JRSSB $68 \quad 145$

AMS 641576 
SYMMETRICAL UNEQUAL BLOCK ARRANCEMENTS WITH TWO UNEQUAL BLOCK SIZES

AMS 62620 ON THE PARAMETERS OF PARTIALLY BALANCED INCOMPLETE BLOCK ASSOCIATION SCHEMES NOTE ON THE MISSINC PLOT PROCEDURE IN A RANDOMIZED BLOCK DESICN AN APPLICATION OF A BALANCED INCOMPLETE BLOCK DESICN A BLANCED INCOMPLETE BLOCK DESICN A NOTE AMS $65 \quad 331$ JASA 61933 TECH 6151 AMS $65 \quad 711$ BIOKA57 275

HETEROCENEITY OF ERROR VARIANCES IN A RANDOMIZED BLOCK DESICN RANDOMIZATION ANALYSIS OF A CENERALIZED RANDOMIZED BLOCK DESICN THE CHI-SQUARE-SUB-R-TEST FOR A BALANCED INCOMPLETE BLOCK DESICN ATION IN A CENERALIZATION OF THE BALANCED INCOMPLETE BLOCK DESICN LYSIS OF VARIANCE OF A PARTIALLY BALANCED INCOMPLETE BLOGK DESICN TING THE F-TEST UNDER PERMUTATION FOR THE RANDOMIZED BLOCK DESICN TS WITH SPECIAL REFERENCE TO THE BALANCED INCOMPLETE BLOCK DESICN HE F-TEST UNDER PERMUTATION IN THE SIMPLE RANDOMIZED BLOCK DESIGN THE F-STATISTIC IN A RANDOMIZED BALANCED INCOMPLETE BLOCK DESIGN RANDOMIZATION ANALYSIS OF A GENERALIZED RANDOMIZED BLOCK DESIGN THE ANALYSIS OF INCOMPLETE BLOCK DESIGNS

AN INEQUALITY FOR BALANCED INCOMPLETE BLOGK DESICNS A PROCEDURE FOR CONSTRUCTING INCOMPLETE BLOCK DESIGNS ON A CLASS OF PARTIALLY BALANCED INCOMPLETE BLOCK DESIGNS ROBUST ESTIMATION IN INCOMPLETE BLOCK DESIGNS INDUCTIVE METHODS FOR BALANCED INCOMPLETE BLOCK DESICNS ON PARTIALLY LINKED BLOCK DESICNS

ON ROBUST ESTIMATION IN INCOMPLETE BLOCK DESIGNS A SERIES OF BALANCED INCOMPLETE BLOCK DESIGNS SOME EXAMPLES OF MULTI-DIMENSIONAL INCOMPLETE BLOCK DESIGNS A NOTE ON BALANCED INCOMPLETE BLOCK DESICNS THE EFFICIENCY OF BLOCKINC IN INCOMPLETE BLOCK DESIGNS ON BALANCED UNEQUAL BLOCK DESIGNS NESTED BALANCED INCOMPLETE BLOCK DESIGNS CYCLIC INCOMPLETE BLOCK DESICNS ON JOHN'S CYCLIC INCOMPLETE BLOCK DESIGNS DISTRIBUTION-FREE ANALYSIS OF VARIANCE TECHNIQUE FOR BLOCK DESICNS EXTENSION PROPERTY OF A CLASS OF BALANCED INCOMPLETE BLOCK DESICNS THE DUALS OF SYMMETRIC PARTIALLY-BALANCED INCOMPLETE BLOCK DESICNS

EXISTENCE AND CONSTRUCTION OF BALANCED INCOMPLETE BLOCK DESIGNS GYCLIC CENERATION OF ROBINSON'S BALANCED INCOMPLETE BLOCK DESIGNS CROUP DIVISIBLE PARTIALLY BALANCED INCOMPLETE BLOCK DESICNS COMPARISIONS WITH A CONTROL IN BALANCED INCOMPLETE BLOCK DESICNS GONTROL OBSERVATIONS AS AN ALTERNATIVE TO INCOMPLETE BLOCK DESIGNS

OF ROTATABLE DESICNS THROUGH BALANCED INCOMPLETE BLOCK DESICNS UTILIZING BALANCED AND PARTIALLY BALANCED INCOMPLETE BLOCK DESIGNS

BLOCKS OF GERTAIN PARTIALLY BALANCED INCOMPLETE BLOCK DESICNS DRICS FOR CONSTRUCTINC PARTIALLY BALANCED INCOMPLETE BLOCK DESIGNS ASSIFICATION WITH APPLICATION TO BALANCED INCOMPLETE BLOCK DESICNS QUARE-SUB-B-OVER-SIGMA-SQUARE IN BALANCED INCOMPLETE BLOCK DESIGNS TWO BLOCKS OF CERTAIN PARTIALLY BALANCED INCOMPLETE BLOCK DESIGNS CLASS OF TWO ASSOCIATE PARTIALLY BALANCED INCOMPLETE BLOCK DESICNS SYMMETRICAL TRIANGULAR PARTIALLY BALANCED INCOMPLETE BLOCK DESIGNS DUALS OF PARTIALLY BALANCED INCOMPLETE BLOCK DESICNS AND SOME NONEXISTENCE THEOREMS
INCOMPLETE BLOCK DESICNS FOR BIO-ASSAYS

THE ASYMPTOTIC EFFICIENCY OF BIOKA59 475 SOME CONSEQUENCES OF RANDOMIZ AMS $63 \quad 1569$ THE RELATIONSHIP ALCEBRA AND THE ANA AMS 651815 AN EMPIRICAL STUDY INTO FAGTORS AFFEC JASA 68902 /INEAR MODELS WITH TWO RANDOM COMPONEN BIOKA6B 1.01

/MONTE CARLO RESULTS ON THE POWER OF T BIOKA66 199 NDER THE NEYMAN MODEL /ISTRIBUTION OF AMS 631558 CORRICENDA, 'THE BIOKA56 235 JASA $57 \quad 204$ AMS 61908 TECH $64 \quad 389$ AMS 651807 AMS $66 \quad 1331$ AMS $66 \quad 134 \mathrm{~B}$ AMS 661401 AMS $67 \quad 1587$ AMS $68 \quad 681$ AMS 681577 AMS $69 \quad 679$ BIOKA60 273 BIOKA62 561 BIOKA67 479 JRSSB $66 \quad 345$ JRSSB67 243 A SASJ $6 B \quad 9$ AN BIOKA57 278 ON AMS $63 \quad 528$ THE AMS $61 \quad 361$ NOTES. BIOCS67 574 EXTENDED AMS 64681 MULTIPLE TECH $61 \quad 103$ THE USE OF JRSSB62 464 CONSTRUCTION AMS 621421 GROUP SCREENINC BIOCS65 865 COMMON TREATMENTS BETWEEN AMS 68999 APPLICATION OF THE GEOMETRY OF QUA AMS 621175 /FOR THE UNBALANCED TWO-WAY CROSS CL AMS 69408 /USING AN INCORRECT VALUE OF SICMA-S BIOKA68 254 /BER OF COMMON TREATMENTS BETWEEN ANY AMS 65337 /EST IN THE INTRABLOCK ANALYSIS OF A JASA 65285 AND BALANCED INCOMPLETE BLOCK DESIGNS AMS $63 \quad 348$

ON THE EFFICIENCY OF MODIFIED BALANCED INCOMPLETE BLOCK DESIGNS FOR BIO-ASSAYS THE USE OF CYCLIC BALANCED INCOMPLETE BLOCK DESIGNS FOR DIREGTIONAL SEED ORCHARDS THE USE OF CYCLIC BALANCED INCOMPLETE BLOCK DESICNS FOR NON-DIRECTIONAL SEED ORCHARDS SOME BALANCED INCOMPLETE BLOCK DESIGNS FOR TWO SETS OF TREATMENTS

SCHEMES ON OBTAINING BALANCED INCOMPLETE BLOGK DESICNS FROM PARTIALLY BALANCED ASSOCIATION BALANCED SETS OF BALANCED INCOMPLETE BLOCK DESIGNS OF BLOCK SIZE THREE BALANCED INCOMPLETE BLOCK DESIGNS WITH DOUBLE GROUPINC OF BLOCKS INTO

REPLICATIONS ANALYSIS OF A CLASS OF PARTIALLY BALANCED INCOMPLETE BLOCK DESICNS WITH MORE THAN TWO ASSOCIATE CLASSES
OTE ON CONSTRUCTION OF PARTIALLY BALANCED INCOMPLETE BLOCK DESIGNS WITH PARAMETERS V=2B, N1=12, N2=15 AND BALANCED INCOMPLETE BLOCK DESIGNS WITH SETS OF IDENTICAL BLOCKS

S A NEW FAMILY OF PARTIALLY BALANCED INCOMPLETE BLOCK DESIGNS WITH SOME LATIN SQUARE DESIGN PROPERTIE NUMBER OF TREATMENTS TS A NOTE ON INCOMPLETE BLOCK DESICNS WITH THE NUMBER OF BLOCKS EQUAL TO THE

PART IALLY BALANCED INCOMPLETE BLOCK DESICNS WITH TWO-WAY CLASSIFICATION OF TREATMEN RANK ANALYSIS OF INCOMPLETE BLOCK DESICNS. I THE METHOD OF PAIRED COMPARISONS. F PAIRED COMPARISONS RANK ANALYSIS OF INCOMPLETE BLOCK DESIGNS. II. ADDITIONAL TABLES FOR THE METHOD O BIOKA54 502 F PA/ CORRICENDA, 'THE RANK ANALYSIS OF INCOMPLETE BLOCK DESIGNS. II. ADDITIONAL TABLES FOR THE METHOD O BIOKA64 288 MATION AND POWER FOR/ RANK ANALYSIS OF INCOMPLETE BLOCK DESIGNS. III. SOME LARGE-SAMPLE RESULTS ON ESTI BIOKA55 45O SONS WHEN OBSERVATIONS ARE MISSINC FROM A RANDOMISED BLOCK EXPERIMENT WITH ADDITIONAL REPLICATION OF A CON BIOCS66 632 CENSORED OBSERVATIONS IN RANDOMIZED BLOCK EXPERIMENTS ANALYTICAL TECHNIQUE FOR TNCOMPLETE BLOCK EXPERIMENTS $\begin{array}{ll} & \text { ANALYTICAL TECHNIQUE FOR INCOMPLETE BLOCK EXPERIMENTS } \\ \text { TMENTS IN COMMON ANALYSIS OF A GROUP OF BALANCED BLOCK EXPERIMENTS HAVING ERROR VARIANCE AND SOME TREA BIOCS68 } 389\end{array}$ A NOTE ON THE ANALYSIS OF INCOMPLETE BLOCK EXPERIMENTS. USE OF INTER-BLOCK INFORMATION TO OBTAIN UNIFORMLY BETTER SETS OF BALANCED INCOMPLETE BLOCK DESICNS OF BLOCK SIZE THREE ON THE BLOCK STRUCTURE OF SINGULAR GROUP DIVISIBLE DESICNS ASYMPTOTIC PROPERTIES OF THE BLOCK UP-AND-DOWN METHOD IN BIO-ASSAY THE EFFICIENCY OF BLOCKING IN INCOMPLETE BLOCK DESICNS BLOCKINC OF 3-TTMES-2-TO-THE- $(\mathrm{N}-\mathrm{K})$

THE EFFECT OF FIELD BLOCKING ON GAIN FROM SELECTION

EXPERIMENTING WITH ORCANISMS AS BLOCKS ON A PROPERTY OF INCOMPLETE BLOCKS

INCOMPLETE BLOCK DESIGNS WITH SETS OF IDENTICAL BLOCKS OF COMBINED ESTIMATORS IN BALANCED INCOMPLETE BLOCKS OF THE WILCOXON TWO-SAMPLE STATISTIC FOR RANDOMIZED BLOCKS SAVAGE TESTS FOR ORDERED ALTERNATIVES IN RANDOMIZED BLOCKS 
REPLICATES OF THE TWO TO THE POWER OF M DESICNS WITH BLOCKS

ON CONSTRUCTINC THE FACTORIAL AMS 621440

ORTHOCONAL DESICNS TO SITUATIONS WHERE TREATMENTS OR BLOCKS ARE OF UNEQUAL STATUS OR SIZE /ATIONS OF NON BIOCS66 629 DESICNS AN UPPER BOUND FOR THE NUMBER OF DISJOINT BLOCKS IN CERTAIN PARTIALLY BALANCED INGOMPLETE BLOCK AMS 64 39B ON THE PARAMETERS AND INTERSECTION OF BLOCKS OF BALANCED INCOMPLETE BLOCK DESIGNS

AMS 621200 FOR THE NUMBER OF COMMON TREATMENTS BETWEEN ANY TWO BLOCKS OF CERTAIN PARTIALLY BALANCED INCOMPLETE BLOCK AMS 65 337 HE BOUNDS OF THE NUMBER OF COMMON TREATMENTS BETWEEN BLOCKS OF CERTAIN PARTIALLY BALANCED INCOMPLETE BLOCK AMS 66 739 HE BOUNDS OF THE NUMBER OF COMMON TREATMENTS BETWEEN BLOCKS OF SEMI-REGULAR GROUP DIVISIBLE DESIGNS ON T JASA 64 867 OF A 2-TO-THE-(17-9) RESOLUTION V PLAN IN EIGHT BLOCKS OF 32 RANK TESTS FOR RANDOMTZED BLOCKS WHEN THE ALTERNATIVES HAVE AN TA PR ORDERING

AMS $67 \quad 867$ NUMBERS THE COMPLETE AMALCAMATION INTO BLOCKS, BY WEIGHTED MEANS, OF A FINITE SET OF REAL A STUDY OF THE VA BIOCS67 67 RIABILITY DUE TO COINCIDENT PASSAGE IN AN ELECTRONIC BLOOD CELL COUNTER SPECTRAL EVALUATION OF BLS AND CENSUS REVISED SEASONAL ADJUSTMENT PROCEDURES JASA 68472 EDITING OF SURVEY DATA. FIVE YEARS OF EXPERIENCE IN BLS MANPOWER SURVEYS

LINEAR APPROXIMATIONS TO THE CENSUS AND BLS SEASONAL ADJUSTMENT METHODS COMPUTER JASA $66 \quad 375$ JASA $68 \quad 445$ SMALL SAMPLE POWER OF THE BIVARIATE SICN TEST OF BLUMEN AND HODGES

$$
\text { A NOTE ON BLUS ESTIMATION }
$$

ON THE POWER OF THE BLUS PROCEDURE

A SIMPLIFICATION OF THE BLUS PROCEDURE FOR ANALYZING REGRESSION DISTURBANCES JASA 6B 242 POWER OF THE DURBIN-WATSON TEST AND THE POWER OF THE BLUS TEST A COMPARISON BETWEEN THE JASA $6993 \mathrm{~B}$ MERICAL RATIONALITY A SUBJECTIVE EVALUATION OF BODE'S LAW AND AN 'OBJECTIVE' TEST FOR APPROXIMATE NU JASA 69 23 MERICAL/ DISCUSSION OF 'A SUBJECTIVE EVALUATION OF BODE'S LAW AND AN 'OBJECTIVE' TEST FOR APPROXIMATE NU JASA 69 50 CURA' CO/VECTORIAL ANALYSIS FOR GENETIC CLINES IN BODY DIMENSIONS IN POPULATIONS OF 'DROSOPHILIA SUBOBS BIOCS66 469 NOTE ON A 'MULTIVARIATE' FORM OF BONFERRONI'S INEQUALITIES THE HISTORY OF PROBABILITY AND STATISTICS. XII. THE BOOK OF FATE THE HISTORY OF PROBABILITY AND STATISTICS. XII. THE BOOK OF FATE
BOOK REVIEWS, 10 YEAR INDEX (1959-196B) AMS 69692 STUDIES IN BIOKA6I 220 TECH 69223 PROBLEM A STATISTICAL MODEL OF BOOK USE AND ITS APPLICATION TO THE BOOK STORACE BAYES' METHOD FOR BOOKIES SOME SOVIET STATISTIGAL BOOKS OF 1957

CONDITIONAL PROBABILITY ON SICMA-COMPLETE BOOLEAN ALGEBRAS A DERIVATION OF THE BOREL DISTRIBUTION

A BOREL SET NOT CONTAINING A GRAPH

A SHARPER FORM OF THE BOREL-CANTELLI LEMMA AND THE STRONG LAW A DISTRIBUTION ANALOGOUS TO THE BOREL-TANNER THE BOREL-TANNER DISTRIBUTION

TO AN INTERVAL ACCURACY BORROWING IN THE ESTIMATION OF THE MEAN BY SHRINKAGE ON AN ANALOGUE OF BHATTACHARYA BOUND ON FISHER'S BOUND FOR ASYMPTOTIC VARIANCES

AMS 691177 JASA $59 \quad 12$ AMS $69 \quad 970$ BIOKA61 222 AMS $68 \quad 1345$ AMS 65800 BIOKA61 167 BIOKA60 143 JASA $68 \quad 953$ BIOKA64 268 AMS 641545 RIBU/ AN EXACT ASYMPTOTICALLY EFFICIENT CONFIDENCE BOUND FOR RELIABILITY IN THE CASE OF THE WEIBULL DIST TECH 66 135 T ORIENTED-ATOM PERCOLATION PROCESS MARKOV PROCESSES RTIALLY BALANCED INCOMPLETE BLOCK DESIGNS A LOWER BOUND FOR THE CRITICAL PROBABILITY IN THE ONE-QUADRAN A BOUND FOR THE LAW OF LARCE NUMBERS FOR DISCRETE 401 AN UPPER BOUND FOR THE NUMBER OF DISJOINT BLOCKS IN CERTAIN PA AMS 64 39B AN UPPER BOUND FOR THE SAMPLE STANDARD DEVIATION

ERRATA, I AN UPPER BOUND FOR THE SAMPLE STANDARD DEVIATION

ERRATA, 'AN UPPER BOUND FOR THE SAMPLE STANDARD DEVIATION'

A BOUND FOR THE VARIATION OF CAUSSIAN DENSITIES

TECH $62 \quad 134$

TECH $62 \quad 440$

TECH $63 \quad 417$

AMS 69 NO.6

LOWER BOUND FORMULAS FOR THE MEAN INTERCORRELATTON

JASA 59275

TOCHASTIC PROCESSES WITH ABSOLUTEL/ AN EXPONENTIAL BOUND ON THE STRONG LAW OF LARGE NUMBERS FOR LINEAR S AMS 61 5B3 IAL AND POISSON DISTRI/ ESTIMATORS WITH PRESCRIBED BOUND ON THE VARIANCE FOR THE PARAMETERS IN THE BINOM JASA 66 220 WITH A SAMPLE FROM A NORMAL POPULATION WHEN AN UPPER BOUND TO THE STANDARD DEVIATION IS KNOWN /ROCEDURE JASA 60 94 ERROR CORRECTINC CODES ON A BOUND USEFUL IN THE THEORY OF FACTORIAL DESIGNS AND AMS 64 408 THE OTHER SIDE OF THE LOWER BOUND. A NOTE WITH A CORRECTION $\begin{array}{rrr}\text { AMS } & 64 & 408 \\ \text { JASA } & 61 & 670\end{array}$ BOUNDARIES FOR CLOSED (WEDCE) SEQUENTIAL T TEST PLANS BIOKA66 431

TEST STATISTIC WHEN THE TRUE PARAMETER IS 'NEAR' THE BOUNDARIES OF THE HYPOTHESIS RECIONS /LIHOOD RATIO METHOD FOR A GENERAL RANDOM WALK WITH A TWO-SIDED BOUNDARY OF TWO POISSON VARIAB/ ON A LOCALLY MOST POWERFUL BOUNDARY RANDOMIZED SIMILAR TEST FOR THE INDEPENDENCE

OF A DISTRIBUTION FUNCTION, II OF A DISTRIBUTION FUNCTION, III RECRESSION FUNCTION

$$
\text { PROBABI }
$$

\section{BOUNDED EXPECTED UTILITY}

EXISTENCE OF BOUNDED LENGTH CONFIDENCE INTERVALS BOUNDED LENGTH CONFIDENCE INTERVALS FOR THE P-POINT BOUNDED LENGTH CONFIDENCE INTERVALS FOR THE P-POINT BOUNDED LENGTH CONFIDENCE INTERVALS FOR THE ZERO OF A BOUNDED RANDOM VARIABLES

SOME KOLMOROFF-TYPE INEOUALTTTES FOR BOUNDED RANDOM VARIABLES

PROBABILITY INEQUALITY FOR THE SUM OF INDEPENDENT, BOUNDED RANDOM VARIABLES PROBABILITY INEQUALITIES FOR THE SUM OF INDEPENDENT, BOUNDED RANDOM VARIABLES. REQUIRED TO ESTIMATE THE RATIO OF VARIANCES WITH BOUNDED RELATIVE ERROR

NTIAL DISTRIBUTION

NORMAL DISTRIBUTIONS

OF LARCE DEVIATIONS FROM THE EXPECTATION ESTIMATES OF BOUNDED RELATIVE ERROR FOR THE RATIO OF VARIANCES OF

FURTHER CONTRIBUTIONS TO MULTIVARIATE CONFIDENCE BOUNDS ON SHARPENING SCHEFFE BOUNDS

SMIRNOV TESTS OF FIT BASED ON SOME GENERAL BOUNDS

NS AND THEIR APPLICATIONS TO SIMULTANEOUS CONFIDENCE BOUNDS

STATISTICS

NCE AND NONINDEPENDENCE BETWEEN TWO/

ON CONFIDENCE BOUNDS

/CERTAIN INEQUALITIES FOR NORMAL DISTRIBUTIO

/UNDS ON THE MOMENTS AND BIOKA65 559

SAMPLE SIZE JASA $63 \quad 1044$

MULTIHYPOTHESIS TESTS

II

TABLES OF BOUNDS FOR DISTRIBUTIONS WITH MONOTONE HAZARD RATE
TAR

BOUNDS FOR DISTRIBUTIONS WITH MONOTONE HAZARD RATE, BOUNDS FOR DISTRIBUTIONS WITH MONOTONE HAZARD RATE, I

ON NON-REGULAR ESTIMATION, I. VARIANCE BOUNDS FOR ESTIMATORS OF LOCATION PARAMETERS

SOME BOUNDS FOR EXPECTED VALUES OF ORDER STATISTICS SYMPTOTIC THEORY OF FIXED-SIZE SEQUENTIAL CONFIDENCE BOUNDS FOR LINEAR REGRESSION PARAMETERS
RECRESSION PROBLEMS ON THE A
LOWER BOUNDS FOR MINIMUM COVARIANCE MATRICES IN TIME SERIES 
ON FIXED-WIDTH CONFIDENCE BOUNDS FOR REGRESSION PARAMETERS AND MEAN VECTOR

SOME OPTIMUM CONFIDENCE BOUNDS FOR ROOTS OF DETERMINANTAL EQUATIONS

LINC WITH VARYINC PROBABILITIES FROM A FINITE POP

PROBABILITY RATIO TEST

INFERENCE

BOUNDS FOR THE ERROR-VARIANCE OF AN ESTIMATOR IN SAMP BOUNDS FOR THE EXPECTED SAMPLE SIZE IN A SEQUENTIAL BOUNDS FOR THE FREQUENCY OF MISLEADINC BAYES

ON BOUNDS FOR THE NORMAL INTECRAL

$Y$ TWO BLOCKS OF CERTAIN PARTIALLY BALANCED INCOMP/ BOUNDS FOR THE NUMBER OF COMMON TREATMENTS BETWEEN AN BOUNDS FOR THE RATIO OF RANGE TO STANDARD DEVIATION BIOKA55

THE USE OF SAMPLE RANCES IN SETTING EXACT CONFIDENCE STATISTIC BOUNDS FOR THE VARIANCE OF KENDALL'S RANK CORRELATION BOUNDS IN A MINIMAX CLASSIFICATION PROCEDURE

ON BOUNDS OF SERIAL CORRELATIONS OF COMMON TREATMENTS BETWEEN BLO JASA 64867 CKS OF CERTAIN PARTIALLY BALANC/ COMPARISON OF THE BOUNDS OF THE NUMBER OF COMMON TREATMENTS BETWEEN BLO AMS 66 739 FOUR MOMENTS ARE GIVEN APPLICATIONS TABLE OF THE BOUNDS OF THE PROBABILITY INTEGRAL WHEN THE FIRST BOUNDS OF THE PROBABILITY OF A UNION OF EVENTS, WITH IMPROVED BOUNDS ON A MEASURE OF SKEWNESS

PROBLEMS DETERMINING BOUNDS ON EXPECTED VALUES OF CERTAIN FUNCTIONS BOUNDS ON INTECRALS WITH APPLICATIONS TO RELIABILITY BOUNDS ON MOMENTS OF MARTINCALES BOUNDS ON MOMENTS OF SUMS OF RANDOM VARIABLES

RESSIVE C/ EXACT THREE, ORDER STATISTIC CONFIDENCE BOUNDS ON RELIABLE LIFE FOR A WEIBULL MODEL WITH PROG JA AN THE RENEWAL FUNCTION SEQUENTIAL PROCEDURE $R$ THE SUM OF INDEPENDENT, BOUNDED RANDOM VA/ MEMORYLESS CHANNEL

INVARIANT SEQUENTTAL PROBABILITY RATIO TESTS VA/ UPPER BOUNDS ON THE MOMENTS AND PROBABILITY INEQUALITIES FO BOUNDS ON THE ASYMPTOTTC PONER OF RANK TESTS BOUNDS ON THE DISTRIBUTION FUNCTIONS OF THE BEHRENSBOUNDS ON THE ERROR IN THE LINEAR APPROXIMATION TO BOUNDS ON THE MAXIMUM SAMPLE SIZE OF A BAYES BOUNDS ON THE SAMPLE SIZE DISTRTBUTION FOR A CLASS OF AMS 681048 AT Y IS LESS THAN/ NONPARAMETRIC UPPER CONFIDENCE BOUNDS, AND CONFIDENCE LIMITS. FOR THE PROBABILITY TH JASA 64 906 $R$ OF AN EXPONENTIAL POPULATION EXACT CONFIDENCE BOUNDS, BASED ON ONE ORDER STATISTIC FOR THE PARAMETE TECH 64 30I $R$ OF A ONE-PARAMETER NE/ ERRATA. 'EXACT CONFIDENCE BOUNDS, BASED ON ONE ORDER STATISTIC FOR THE PARAMETE TECH 64 4B3 ON 'FURTHER CONTRIBUTIONS TO MULTIVARIATE CONFIDENCE BOUNDS'

'FURTHER CONTRIBUTIONS TO MULTIVARIATE CONFIDENCE BOUNDS'

A BLACK BOX OR A COMPREHENSIVE MODEL

DISTRIBUTTON FOR A GENERALIZED BANACH MATCH BOX PROBLEM SOME COMMENTS ON THE ACCURACY OF BOX'S APPROXIMATIONS TO THE DISTRIBUTION OF

IRED-COMPARISON EXPERIMENTS. A GENERALIZATION OF THE BRADLEY-TERRY MODEL (CORR. 68 (1550) COMPUTER FAILURE PATTERNS (WITH DISCUSSION) A BRANCHING POISSON PROCESS MOD NON-HOMOGENEOUS BRANCHING POISSON PROCESSES

ON MULTI-TYPE GALTON-WATSON PROCESSES WITH RANDOM BRANCHING PROBABILITIES ASYMPTOTIC PROPERTIES OF AN AGE DEPENDENT BRANCHING PROCESS

THE STATIONARY MEASURE OF THE CRITICAL CASE SIMPLE BRANCHING PROCESS

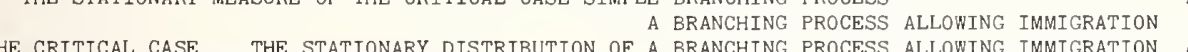
A NOTE BIOKA5B $5 B 1$ CORRICENDA, BIOKA61 474 TECH $6 B \quad 219$ ASYMPTOTIC JASA $67 \quad 1252$ MIOKA69 219 TIES IN PA JASA $67 \quad 194$ CASE THE STATIONARY DISTRIBUTION OF A BRANCHING PROCESS ALLOWING IMMIGRATION,
CORRECTIONS AND COMMENTS ON THE PAPER 'A BRANCHINC PROCESS ALLOWING IMMIGRATION' JRSSB66 213 LIFETIMES A BRANCHINC PROCESS IN WHICH INDIVIDUALS HAVE VARIABLE BI THE EXTINCTION OF A BACTERIAL COLONY BY PHAGES. A BRANCHINC PROCESS WITH DETERMINISTIC REMOVALS ON THE GALTON-WATSON BRANCHING PROCESS WTTH MEAN LESS THAN ONE NECESSARY CONDITIONS FOR ALMOST SURE EXTINCTION OF BRANCHING PROCESS WITH RANDOM ENVIRONMENT A BRANCHING PROCESS WITHOUT REBRANCHING

AN INTEGRAL EQUATION IN AGE DEPENDENT BRANCHING PROCESSES MONOTONE CONVERGENCE OF MOMENTS IN ACE DEPENDENT BRANCHING PROCESSES SLOWLY BRANCHING PROCESSES

SOME RESULTS ON MULTITYPE CONTINUOUS TIME MARKOV BRANCHING PROCESSES ON THE SUPERCRITICAL ONE DIMENSIONAL AGE DEPENDENT BRANCHING PROCESSES INTECRALS OF BRANCHING PROCESSES TRANSPOSED BRANCHING PROCESSES NTAL DATA, AND ITS RELATIONSHIP TO BIRTH, DEATH, AND BRANCHING PROCESSES EMBEDDING OF URN SCHEMES INTO CONTINUOUS TIME MARKOV BRANCHING PROCESSES AND RELATED LIMIT THEOREMS SOME APPLICATIONS OF MULTIPLE-TYPE BRANCHING PROCESSES IN POPULATION GENETICS ON BRANCHING PROCESSES IN RANDOM ENVIRONMENTS MIT THEOREM OF EVERETT, ULAM AND HARRIS ON MULTITYPE BRANCHING PROCESSES TO A BRANCHING PROCESS WITH COUNT
EXTINCTION
AGE-DEPENDENT BRANCHINC PROCESSES UNDER A CONDITION OF ULTIMATE AGE-DEPENDENT BRANCHINC PROCESSES UNDER A CONDITION OF ULTIMATE LIMIT DISTRIBUTIONS OF A BRANCHING STOCHASTIC PROCESS

L T/ USE OF A REGRESSION TECHNIQUE TO PRODUCE AREA BREAKDOWNS OF THE MONTHLY NATIONAL ESTIMATES OF RETAI JA A DISTRIBUTION-FREE TESTS IN TIME-SERIES BASED ON THE BREAKINC OF RECORDS (WITH DISCUSSION) A MATHEMATICAL ANALYSIS OF THE GROWTH AND SPREAD OF BREAST CANCER ADDITIVE COMBINING ABILITIES FITTED TO PLANT BREEDINC DATA

RENTS/ THE PREDICTION OF RESPONSE TO SELECTION IN BREEDING PROGRAMMES WHEN ALL DAUGHTERS OF SELECTED PA LEADING BRITISH STATISTICI
THE FIRST 945 BRITISH STEAMSHIPS

THE CONVEX HULL OF PLANE BROWNIAN MOTION

THE LOOSE SUBORDINATION OF DIFFERENTIAL PROCESSES TO BROWNIAN MOTION THE EXISTENCE OF CERTAIN STOPPING TIMES ON BROWNIAN MOTION TIME THEOREM FOR THE ANGULAR COMPONENT OF PLANE BROWNIAN MOTION THE RELATION OF THE EQUIVALENCE CONDITIONS FOR THE BROWNIAN MOTION TO THE EQUIVALENCE CONDITIONS FOR CER DISTRIBUTION OF THE ABSOLUTE MAXIMUM FOR CERTAIN BROWNIAN MOTIONS

A PERSISTENCE PROBLEM IN RENEWAL THEORY, ROBERT THE BRUCE'S SP ER OF THE PAPERS OF MESSRS. SATTERTHWAITE AND BUDNE A USEFUL METHOD FOR MODEL BUILDING

MODEL BUILDING WITH THE AID OF STOCHASTIC PROCESSES LIGHT BULB STATISTICS, CORR. 661248

A QUEUE WITH RANDOM ARRIVALS AND SCHEDULED BULK DEPARTURES A RENEWAL PROBLEM WITH BULK ORDERINC OF COMPONENTS THE GENERAL BULK QUEUE AS A HILBERT PROBLEM (CORR. 64487 ) BIOKA6B 589 AMS 651565 AMS $67 \quad 977$ JRSSB65 138 BIOKA64 262 BIOKA62 272 AMS $67 \quad 264$ AMS $6 \mathrm{~B} 2136$ AMS 691850 AMS 651569 AMS 661 B06 AMS $67 \quad 919$ AMS $68 \quad 347$ AMS $69 \quad 743$ BIOKA67 263 JRSSB54 76 BIOCS67 739 AMS 68 1B01 JRSSB6B 164 AMS $67 \quad 992$ BIOKA68 291 AMS $64 \quad 557$ JASA $66 \quad 496$ JRSSB54 I BIOCS69 95 BIOCS67 45 JASA $60 \quad 38$ JASA $58 \quad 360$ AMS $63 \quad 327$ AMS 691603 AMS $69 \quad 715$ AMS $67 \quad 25$ AMS 69 N0. 6 AMS $65 \quad 311$ BIOKA66 255 DISCUSSION TECH $59 \quad 157$ TECH $62 \quad 301$ TECH $64 \quad 133$ JASA $66 \quad 633$ JRSSB $68 \quad 185$ JRSSB59 180 JRSSB62 344
JRSSB $67 \quad 343$ BIOCS69 553 
ON QUEUEINC PROCESSES WITH BULK SERVICE

ON THE TRANSIENT BEHAVIOR OF A QUEUEINC SYSTEM WITH 8ULK SERVICE AND FINITE CAPACITY

$\begin{array}{rr}\text { TECH } & 62 \\ \text { JRSSB } 54 & 819\end{array}$

A COMPARISON OF A MODIFIED 'HANNAN' AND THE BUREAU OF LABOR STATISTICS

JASA $65 \quad 442$

THE USE OF ROTATINC SAMPLES IN THE CENSUS BUREAU'S MONTHLY SURVEYS

AN INVESTIGATION OF THE BURN-IN PROBLEM

STATISTICAL ESTIMATION PROCEDURES FOR THE 'BURN-IN' PROCESS

JASA $63 \quad 454$

TECH $66 \quad 61$

TECH $68 \quad 51$

A CROSS-SECTION ANALYSIS OF NON-BUSINESS AIR TRAVEL

JASA $58 \quad 928$

1

THE BUSY PERIOD IN RELATION TO THE QUEUEING PROCESS GI-M-

SEVERAL TYPES

MENT IN SURVEY DESIGN

ON THE BUSY PERTOD OF A FACILITY WHICH SERVES CUSTOMERS OF CONSUMER BUYING INTENTIONS AND PURCHASE PROBABILITY. AN EXPERI J

TABLES OF PERCENTAGE POINTS OF ROOT'BI' AND BZ IN NORMAL SAMPLES. A ROUNDINC OFF ASYMPTOTIC EFFICIENCY OF GLASS OF C-SAMPLE TESTS CTIONS IN A 2 TO THE POWER N FACTORIAL EXPERIMENT AS CALCULATED BY YATES'S ALCORITHM /EFFECTS AND INTERA B
NOTE ON A METHOD FOR CALCULATING CORRETED SUMS OF SQUARES AND PRODUCTS

A COMPUTER METHOD FOR CALCULATING KENDALL'S TAU WITH UNGROUPED DATA

MEANS. FURTHER DISCUSSION OF ITERATIVE METHODS FOR CALCULATINC TABLES

JASA 66

ISTRIBUTION OF AVERAGE TAU WITH A CRITE/ A NOTE ON CALCULATING TAU AND AVERAGE TAU AND ON THE SAMPLING D JASA 62 CY TABLES WITH SMALL MARGINAL/A SIMPLE METHOD OF CALGULATING THE EXACT PROBABILITY IN 2-BY-2 CONTINGEN BIOKA55 ACE SAMPLE NUMBER OP SOME SEQUENT TAL/ FORMULAE FOR CALCULATING THE OPERATING CHARACTERISTIC $S$ FROM A NORMAL DISTRIBUTION FACTORS FOR GALCULATING TWO-SIDED PREDICTION INTERVALS FOR SAMPLE EFFICIENT CALCULATION OF ALL POSSIBLE RECRESSIONS

A Q-TECHNIQUE FOR THE CALCULATION OF CANONICAL VARIATES

ON THE CALCULATION OF CERTAIN CONSTRAINED MAXIMA

FROM A 2-BY-N TABLE THE RAPID CALCULATION OF CHI-SOUAPE AS A TEST OF HOMOGENEITY

PE STATISTTCS INCLUDING A TABLE OF SIGNIFTCAN/ THE CALCULATION OF DISTRIBUTIONS OF KOLMOGOROV-SMIRNOV TY ENCY TABLES FROM A DISCRETE POPULATION

USE OF THE LAPLACE-BELTRAMI OPERATOR NOTES. RAPID CALCULATION OF EXACT PROBABILITIES FOR 2-BY-3 CONTING BIOCS68 CORRECTION, 'CALCULATION OF EXACT SAMPLING DISTRIBUTION OF RANGES QUERY, CALCULATION OF THE SAMPLING DISTRIBUTION OF THE RANGE CALCULATION OF ZONAL POLYNOMIAL COEFFICIENTS BY THE SOME OPERATORS FOR ANALYSIS OF VARIANCE CALCULATIONS CONDENSED CALCULATIONS

EXPERIMENT (WITH CONFOUNDING) ON AN ELECTRONIC CALCULATOR AND STATISTICS. II. THE BEGINNINGS OF A PROBABILITY CALCULUS A CALCULUS FOR FACTORIAL ARRANGEMENTS $\begin{array}{rrrr}\text { THE ANALYSIS OF A FACTORIAL JRSSB54 } & 242 \\ \text { STUDIES IN THE HISTORY OF } & \text { PROBABILITY BIOKA56 } & \text { I }\end{array}$ AMS 62600 NATION OF HETEROGENEITY CT PRODUCT DESICN APPLICATIONS OF THE CALCULUS FOR FACTORIAL ARRANCEMENTS II. TWO WAY ELIMI AMS 64 APPLICATIONS OF THE CALCULUS OF FACTORIAL ARRANCEMENTS. I. BLOCK AND DIRE BIOKA63 APPLIED TO SEASONAL CORRECTIONS AND ADJUSTMENTS FOR CALENDAR SHIFTS CLASSICAL AND INVERSE REGRESSION METHODS OF CALIBRATION A NOTE ON RECRESSION METHODS IN CALIBRATION A BAYESIAN APPROACH TO CALIBRATION
CLASSICAL AND INVERSE RECRESSION METHODS OF CALIBRATION IN EXTRAPOLATION ESTIMATION OF A LINEAR FUNCTION FOR A CALIBRATION LINE, CONSIDERATION OF A RECENT PROPOSAL NOTE ON A CALIBRATION PROBLEM

THE NEW DESICN OF THE CANADIAN LABOUR FORCE SURVEY

ANALYSIS OF THE GROWTH AND SPREAD OF BREAST GANCER RE. I. BLOCK AND DIRE

JASA 56 TECH 67 TECH $69 \quad 189$ JRSSB 6B 396 TECH 69605 TECH 69 NO. 4 BIOKA69 NO. 3 JASA $67 \quad 421$ $\begin{array}{lrr}\text { A MATHEMATICAL BIOCS69 } & 95 \\ \text { INDEX } & \text { BIOCS65 } & 150\end{array}$ A SCREENING SYSTEM FOR ANTI-CANCER AGENTS BASED ON THE THERAPEUTIC INDEX 150 SPECIAL REFERENCE TO THE CIGARETTE SMOKING AND LUNG CANCER CONTROVERSY /STICAL INFERENCE IN HEALTH WITH JASA 69 739
C MODEL FOR THE MO/ EMPERICAL RELATIONSHIP OF LUNG CANCER INCIDENCE TO CIGARETTE SMOKING AND A STOCHASTI BIOCS65 839 C MODEL FOR THE MO/ EMPERICAL RELATIONSHIP OF LUNG CANCER INCIDENCE TO CIGARETTE SMOKING AND A STOCHASTI BIOCS65 839
PARAMETER MODEL FOR THE SURVIVAL CURVE OF TREATED CANCER PATIENTS ARTICULAR REFERENCE TO THE STUDY OF SMOKING AND LUNG CANCER, CORR. 60754 /ING EXPONENTIAL RISKS, WITH P JASA 60 4I5 SMOKING AND LUNG CANCER, SOME OBSERVATIONS ON TWO RECENT REPORTS CANNIBALISM OF THE PUPAL STAGE BY ADULT FLOUR BEETLES BIOCS68 247 PRIOR DISTRIBUTIONS, AN EXAMPLE IN WHICH THE FORMER CANNOT BE ASSOCIATED WITH THE LATTER /RIBUTIONS AND JRSSB56 217 TESTS OF SIGNIFICANCE IN CANONICAL ANALYSIS TESTS OF SICNIFICANCE IN CANONICAL ANALYSIS

A NOTE ON DIRECTION AND COLLINEARITY FACTORS IN CANONICAL ANALYSIS BIOKA52 58 BIOKA59 59 BIOKA62 255 FFEGTIVE DISCRIMINATO/ MULTIVARIATE-COVARIANCE AND CANONICAL ANALYSIS, A METHOD FOR SELECTING THE MOST E BIOCS6B B45 ON THE NONCENTRAL DISTRIBUTION OF THE LARGEST CANONICAL GORRELATION COEFFICIENT DISTRIBUTIONS THE CANONICAL CORRELATION COEFFICIENTS OF BIVARIATE GAMMA KOLMOGOROV'S REMARK ON THE HOTELLING CANONICAL CORRELATIONS OF MULTIVARIATE AUTOREGRESSIONS, AND THE APPROXIMATE CANONICAL FACTORIZATION OF A SPECTRAL DENSITY MATRIX BIOKA63 129 CORRELATIONS AND CANONICAL FORMS OF BIVARIATE DISTRIBUTIONS

8EST AND SIMPLE LEAST SQUARES LINEAR ESTIMATO/ ON CANONICAL FORMS. NON-NEGATIVE COVARIANCE MATRICES AND A Q-TECHNIQUE FOR THE CALCULATION OF CANONICAL VARIATES

A SHARPER FORM OF THE BOREL-CANTELLI LEMMA AND THE STRONG LAW ON THE GLIVENKO-CANTELLI THEOREM FOR INFINITE INVARIANT MEASURES THE CONCEPT OF CAPACITY

LENGTH DISTRIBUTION FOR QUEUEING SYSTEMS WITH FINITE CAPACITY

OF A QUEUEING SYSTEM WITH BULK SERVICE AND FINITE CAPACITY ON A NEW METHOD OF CAPACITY ESTIMATION THE CAPACITY OF AN UNCONTROLLED INTERSECTION

STOCHASTIC MODELS OF CAPITAL INVESTMENT (WITH DISCUSSION)

SCOOLING, EXPERIENCE, AND CAINS AND LOSSES IN HUMAN CAPITAL THROUGH MIGRATION THE PROBABILITY OF COVERINC A SPHERE WITH $N$ CIRCULAR CAPS

FILL WEIGHT VARIATION RELEASE AND CONTROL OF CAPSULES, TABLETS, AND STERILE SOLIDS THE ESTIMATION OF DEATH-RATES FROM CAPTURE-MARK-RECAPTURE SAMPLING CAPTURE-RECAPTURE ANALYSIS THE TWO-SAMPLE CAPTURE-RECAPTURE CENSUS WHEN TAGGING AND SAMPLING JASA $62 \quad 826$ THE ERGODIC QUEUE JRSS866 190 ON THE TRANSIENT 8EHAVIOR AMS 62973 JASA $64 \quad 529$ 8IOKA67 657 JRSSB69 I JASA $67 \quad 875$ BIOKA65 323 TECH $69 \quad 161$ $8 I 0 K A 52 \quad 181$ 8I0KA53 265 BIOKA61 241 N-STOCHASTIC MODEL

AMS $63 \quad 532$

AMS 671092

IOKA66 588

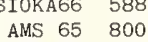
AMS 67

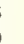


LATION PARAMETERS FROM DATA OBTAINED BY MEANS OF THE CAPTURE-RECAPTURE METHOD. I. THE MAXIMUM LIKELIHOOD E BIOKA5I LATION PARAMETERS FROM DATA OBTAINED BY MEANS OF THE CAPTURE-RECAPTURE METHOD. II. THE ESTIMATION OF TOTAL BIOKA52 LATION PARAMETERS FROM DATA OBTAINED BY MEANS OF THE CAPTURE-RECAPTURE METHOD. III. AN EXAMPLE OF THE PRACT BIOKA53 LIKELIHOOD FUNCTION FOR CAPTURE-RECAPTURE SAMPLES RELATIONSHIP BETWEEN EARNING EXPECTATIONS AND NEW CAR PURCHASES NOTYPIQUES DANS LA SELECTION PAR INDEX SUR PLUSIEURS CARACTERES A NOTE ON THE JASA 59575 BIRTH-AND-DEATH PROCESSES, AND THE THEORY OF CARCINOGENESIS

OF ANALYSIS OF A CERTAIN CLASS OF EXPERIMENTS IN CARCINOCENESIS

PONDERATION DES VALEURS CE BIOCS69 295

A SUGCESTED METHOD BIOCS66

OF PROBABILITY AND STATISTICS. V.A NOTE ON PLAYINC CARDS

OF FAGTORIAL EXPERIMENTS AND THE USE OF PUNCH CARDS, CORR. 56650

OF POISSON-TYPE CHARACTERISTIC FUNCTIONS OF SEVERAL CARIABLES

OV CHAINS WTTH AN APPLICATION IN STUDYING THE DENTAL CARIES PROCESS/ILITY APPROACH TO IRREVERSIBLE MARK BIOCS66 A POOR MAN'S MONTE CARLO (WITH DISCUSSION)

PLOYING SATTERTHWAITE'S SYNTHETIC MEAN SQ/ A MONTE CARLO INVESTIGATION OF THE SIZE AND POWER OF TESTS EM BIOKAG8 43 I

IN ESTIMATING THE DISTRIBUTION OF A RATIO BY MONTE CARLO METHODS USE OF WILGOXON TEST THEORY AMS 62 1194 A SIMPLIFIED MONTE CARLO SIGNIFICANCE TEST PROCEDURE JRSSB68 582

TIONARY GAUSSIAN ORNSTEIN-UHLENBECK PROCESS BY MONTE CARLO SIMULATION /E-TIME MAXIMA AND MINIMA OF A STA JASA 68 1517 A MONTE CARLO SOLUTION OF A TWO-DIMENSIONAL UNSTRUCTURED
SEQUENTIAL RANK TESTS I. MONTE CARLO STUDIES OF THE TWO-SAMPLE PROCEDURE FINITE SAMPLE MONTE CARLO STUDIES. AND AUTOREGRESSIVE ILLUSTRATION JASA 67801 A MONTE CARLO STUDY COMPARING VARIOUS TWO-SAMPLE TESTS FOR TECH $68 \quad 509$

DIFFERENCES IN MEAN

ETRIC ANALYSIS OF VARIANCE IN SMALL SAMPLES. A MONTE CARLO STUDY OF THE ADEQUACY OF THE ASYMPTOTIC APPROXI BIOCS69

PAR/ AN ANALYSIS OF THE DATA FOR SOME EXPERIMENTS CARRIED OUT BY GAUSE WITH POPULATIONS OF THE PROTOZOA BIOKA57 THE ULTIMATE SIZE OF CARRIER-BORNE EPIDEMICS

A MODEL FOR THE SPREAD OF EPIDEMICS BY CARRIERS

DESIGNS FOR SEQUENCES OF TREATMENTS WITH CARRY-OVER EFFECTS

BIOKA68 277

BIOCS65 481

BI0CS66 292

ONS UNDER UNCERTAINTY, PARTS I, II, AND III ON CASH EQUIVALENTS AND INFORMATION EVALUATION IN DECISI JASA 68 25 2 ABLE OBJECTS STATISTICAL TESTING OF DIFFERENCES IN CASUAL BEHAVIOUR OF TWO MORPHOLOGICALLY INDISTINGUISH BIOCSG7 137 MODELS FOR CATALOGUING PROBLEMS AMS 671255

A TEST FOR EQUAL CATCHABILITY

SOME TESTS FOR CATEGORICAL DATA

TEST PROGEDURES FOR MULTIPLE COMPARISONS ON CATEGORICAL DATA

EQUIVALENCE OF TWO TEST CRITERIA FOR HYPOTHESES IN CATEGORICAL DATA

ANALYSIS OF CATEGORICAL DATA BY LINEAR MODELS

BIOCS66 330

AMS $61 \quad 72$

SIMULTANEOUS JASA $66 \quad 1081$

A NOTE ON THE JASA $66 \quad 228$

BIOCS69 489

ANALYSIS OF VARIANCE

THE LIMITING POWER OF CATEGORICAL DATA CHI-SQUARE TESTS

AMS $63 \quad 1432$

ANALYSIS OF CATEGORICAL DATA.

HE PROPERTIES OF CHI-SQUARE-TESTS IN THE ANALYSIS OF CATEGORICAL DATA.

/EFFECT OF MISCLASSIFICATION ON T BIOKA65

ON THE ANALYSIS OF MULTIPLE REGRESSION IN K CATEGORIES

SEQUENTIAL DESIGN FOR COMPARING SEVERAL EXPERIMENTAL CATEGORIES WITH A CONTROL

LE SIZE PROCEDURE FOR GOMPARING SEVERAL EXPERIMENTAL CATEGORIES WTTH A CONTROL

UENTIAL PROGEDURE FOR COMPARING SEVERAL EXPERIMENTAL CATEGORIES WITH A STANDARD OR CONTROL MULTINOMIAL SAMPLING WITH PARTIALLY CATEGORIZED DATA

ND MULTINOMIAL DISTRIBUTION AND BAYESIAN ANALYSIS OF CATERGORICAL DATA FROM FINITE POPULATIONS

VARIANCE OF THE MEDIAN OF SAMPLES FROM A CAUCHY DISTRIBUTION

A REPRESENTATION OF THE SYMMETRIC BIVARIATE CAUCHY DISTRIBUTION

A CHARACTERIZATION OF THE CAUCHY DISTRIBUTION

ANOTHER CHARACTERISTIC PROPERTY OF THE CAUCHY DISTRIBUTION

ORDER STATISTICS ESTIMATORS OF THE LOCATION OF THE CAUCHY DISTRIBUTION

ON THE ESTIMATION OF THE LOCATION PARAMETER OF THE CAUCHY DISTRIBUTION

DISTRIBUTED FUNCTIONS AND A CHARACTERIZATION OF THE CAUGHY DISTRIBUTION

THE ASYMMETRIC CAUCHY PROCESSES ON THE LINE

A NOTE ON ESTIMATION FROM A CAUCHY SAMPLE

OF THE CAUCHY DISTRIBUTION

CAUCHY-DISTRIBUTED FUNCTIONS AND A CHARACTERIZATION

CAUCHY-DISTRIBUTED FUNCTIONS OF CAUCHY VARIATES

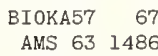

/ASYMPTOTICALLY OPTIMAL AMS 631486 JASA $68 \quad 542$

/E COMPOU JASA $69 \quad 216$

JASA $60 \quad 322$

AMS 621256

AMS 621267

AMS $66 \quad 289$

JASA $66 \quad 1205$

A NOTE JASA $66 \quad 852$

CAUCHY - AMS 691083

AMS $69 \quad 137$

JASA $64 \quad 460$

AMS 691083

AMS 67916

NS OF THE PROTOZOA PARAMECIUM AURELIA AND PARAMECIUM CAUDATUM /MENTS CARRIED OUT BY GAUSE WITH POPULATIO BIOKA57 314

A NOTE ON THE STATISTICAL TESTABILITY OF 'EXPLICIT CAUSAL CHAINS' AGAINST THE CLASS OF 'INTERDEPENDENT' JASA 65 IO80

POPULATION ESTIMATION BASED ON GHANGE OF COMPOSITION CAUSED BY A SELECTIVE REMOVAL

FOR SOME LINEAR MODELS WITH ONE OBSERVATION PER CELL

RENCE IN SOME LINEAR MODELS WITH ONE OBSERVATION PER CELL

DUE TO COINCIDENT PASSAGE IN AN ELECTRONIC BLOOD CELL COUNTER

STANDARD CHI-SQUARE-TEST OF THE HYPOTHESIS OF EQUAL CELL FREQUENCIES

ON THE MEAN DURATION OF A BALL AND CELL GAME, A FIRST
DISTRIBUTIONS ASSOCIATED WITH CELL POPULATIONS

SMOOTHED ESTIMATES FOR MULTINOMIAL CELL PROBABILITIES

ON THE EMPTY CELL TEST

INDICES OF SYNCHRONY IN CELLULAR CULTURES

REGRESSION ANALYSIS WITH DEPENDENT VARTABLE CENSORED

ROBUST PROCEDURES

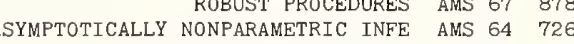

A STUDY OF THE VARIABILITY BIOCS67 671

TWO ALTERNATIVES TO THE BIOKA62 107

AMS $66 \quad 517$

BIOKA69 391

AMS 68561

TECH $62 \quad 235$

BIOCS67 693

BIOCS65 300

PARAMETRIC COMPARISON OF TWO SAMPLES ONE OF WHICH IS CENSORED

ON TWO K-SAMPLE RANK TESTS FOR CENSORED DATA

POWERFUL RANK TESTS FOR THE TWO-SAMPLE PROBLEM WITH CENSORED DATA STATISTICAL TREATMENT OF CENSORED DATA

A GENERALIZED TWO-SAMPLE WILCOXON TEST FOR DOUBLY-CENSORED DATA

PART I. FUNDAMENTAL FORMULAE

EX JASA $60 \quad 125$

AMS 671520

AMS 651243

ENTIALLY DISTRIBUTED FAILURE TIME DISTRIBUTIONS FROM CENSORED LIFE TEST DATA /PARAMETERS OF MIXED EXPON BIOKA58 504 BLES ARE DEPENDENT WITH SPECIAL REFERENCE TO TYPE II CENSORED NORMAL DATA /ENT ESTIMATORS WHEN THE VARIA BIOKA62 155 THE ESTIMATION OF THE MEAN OF A CENSORED NORMAL DISTRIBUTION BY ORDERED VARIABLES BIOKA56 482

THE FITTING OF GROUPED TRUNCATED AND GROUPED CENSORED NORMAL DISTRIBUTIONS

ESTIMATING THE MEAN AND STANDARD DEVIATION FROM A CENSORED NORMAL SAMPLE

OF THE LOGATION AND SGALE ARAMETERS GIVEN A TYPE II CENSORED NORMAL SAMPLE LIKELIHOOD ESTIMATES BIOKA6I 448

FOR THE NORMAL DISTRIBUTION WHEN SAMPLES ARE SINGLY CENSORED OR TRUNCATED

OF THE NORMAL POPULATION PARAMETERS GIVEN A SINGLY CENSORED SAMPLE

OF THE NORMAL POPULATION PARAMETERS GIVEN A TYPE I CENSORED SAMPLE STMPLIFIED ESTIMATORS TECH 59 ESTIMATION BIOKAGI 367 
AND STANDARD DEVIATION OF A NORMAL POPULATION FROM A CENSORED SAMPLE CONFIDENCE INTERVALS FROM CENSORED SAMPLES A THEOREM ON RANK ORDERS FOR TWO CENSORED SAMPLES THE PARAMETERS OF LOG-NORMAL DISTRIBUTION FROM CENSORED SAMPLES WILCOXON TEST FOR COMPARINC ARBITRARILY SINCLY-CENSORED SAMPLES LIKELIHOOD ESTIMATES. SINGLY TRUNCATED AND SINGLY CENSORED SAMPLES TERS OF TWO PARAMETER EXPONENTIAL DISTRIBUTIONS FROM CENSORED SAMPLES SCALE PARAMETERS FOR THE RECTANGULAR POPULATION FROM CENSORED SAMPLES A MULTIVARIATE NORMAL POPULATION FROM TRUNCATED AND CENSORED SAMPLES IN THE WEIBULL DISTRIBUTION BASED ON COMPLETE AND ON CENSORED SAMPLES GAMMA AND WEIBULL POPULATIONS FROM COMPLETE AND FROM CENSORED SAMPLES GLE EXPONENTIAL DISTRIBUTIONS FROM SINGLY AND DOUBLY CENSORED SAMPLES THE PARAMETERS OF NORMAL POPULATIONS BASED ON SINGLY CENSORED SAMPLES AL DISTRIBUTION BASED ON OPTIMUM ORDER STATISTICS IN CENSORED SAMPLES METER GENERALIZED GAMMA POPULATION FROM COMPLETE AND CENSORED SAMPLES MATING THE PARAMETERS OF EXPONENTIAL DISTRIBUTION IN CENSORED SAMPLES AMETERS OF NORMAL POPULATIONS FROM SINGLY AND DOUBLY CENSORED SAMPLES MOMENTS OF SAMPLE MOMENTS OF CENSORED SAMPLES CORRICENDA TO 'MOMENTS OF SAMPLE MOMENTS OF CENSORED SAMPLES FROM A NORMAL POPULATION' DISTRIBUTIONS

PROGRESSIVE SOLUTION OF
TRUNCATED AND

\section{ND} CENSORED SAMPLES

ATION OF/ ON THE AMOUNT OF INFORMATION SUPPLIED BY CENSORED SAMPLES OF EE-PARAMETER LOGNORMAL POPULATIONS FROM COMPLETE AND CENSORED SAMPLES, TRIBUTION MAXIMUM-LIKELIHOOD ESTIMATION, FROM CENSORED SAMPLES, PTOTIC/ MAXIMUM-LIKELIHOOD ESTIMATION, FROM DOUBLY CENSORED SAMPLES, OF THE PARAMETERS OF THE FIRST ASYM JASA 68 889 D COVARIANCES OF MAXIMUM-LIKELIHOOD ESTIMATORS, FROM CENSORED SAMPLES, OF THE PARAMETERS OF WEIBULL AND GA AMS 67 557 NDITIONAL MAXIMUM-LIKELIHOOD ESTIMATION, FROM SINCLY CENSORED SAMPLES, OF THE SCALE PARAMETERS OF TYPE II TECH 6B 349 ARAMETERS BY ORDER STATISTICS FROM SINCLY AND DOUBLY CENSORED SAMPLES, PART I. THE NORMAL DISTRIBUTION UP AMS 39325 IN THE WEIBULL DISTRIBUTION BASED ON COMPLETE AND ON CENSORED SAMPLES CAMMA AND WEIBULL POPULATIONS FROM COMPLETE AND FROM CENSORED SAMPLES ATTRIBUTES

$$
\text { A NOTE ON TOLERANCE LIMITS WITH TYPE I CENSORINC }
$$

TWO-SAMPLE TESTS IN SMALL SAMPLES WITH AND WITHOUT CENSORING TION OF SEVERAL NON-PARAMETRIC TEST STATISTICS UNDER CENSORING N RELIABLE LIFE FOR A WEIBULL MODEL WITH PROGRESSIVE CENSORINC OPULATION BEST LINEAR ESTIMATES UNDER SYMMETRIC CENSORI THE MULTI-SAMPLE SINCLE RECAPTURE CENSUS

LINEAR APPROXIMATIONS TO THE CENSUS AND BLS SEASONAL ADJUSTMENT METHODS

THE PERFORMANCE OF SOME BIOKA69 127 RECURSIVE GENERATION OF THE DISTRIBU JASA 68353 THE USE OF ROTATING SAMPLES IN THE CENSUS BUREAU'S MONTHLY SURVEYS ERRORS IN THE 1960 CENSUS ENUMERATION OF NATIVE WHITES

DEATH THE MULTIPLE-RECAPTURE CENSUS II. ESTIMATION WHEN THERE IS IMMIGRATION OR THE ACCURACY OF CENSUS LITERACY STATISTICS IN IRAN MEMORIAL MEETINC FOR WILLIAM N HURWITZ. CHANCES IN CENSUS METHODS WASHINGTON STATISTICAL SOCIETY JA SPECTRAL EVALUATION OF BLS AND CENSUS REVISED SEASONAL ADJUSTMENT PROCEDURES NET MIGRATION A NOTE ON THE CENSUS SURVIVAL RATIO METHOD OF ESTIMATING NET MIGRATION A NOTE ON THE CENSUS SURVIVA
STATISTICS BY CENSUS TRACT ANALYSIS OF VITAL STATISTICS BY CENSUS TRACT A NOTE ON THE MULTIPLE-RECAPTURE CENSUS THE MULTIPLE-RECAPTURE CENSUS. I. ESTIMATION OF A CLOSED POPULATION BIOKA62 339 JASA $6 B \quad 445$ JASA $63 \quad 454$ JASA $64 \quad 437$ BIOKA59 336 JASA 59578 $\begin{array}{lrr}\text { JASA } & 69 & \text { NO. } 4 \\ \text { JASA } & 68 & 472\end{array}$ JASA 62 B41 JASA $62 \quad 175$ JASA 59730 BIOKA61 241 BIOKA65 249 BIOKA5B 343 /URE OF ENUMERATORS TO MAKE ENTRIES OF ZER JASA $61 \quad 909$ CONTROL OF QUALITY OF CODINC IN THE 1960 CENSUSES 0. ERRORS IN RECORDING CHILDLESS CASES IN POPULATION CENSUSES /URE OF ENUMERATORS TO MAKE ENTRIES OF ZER JASA 61 909
ES FOR THE SINGLE POPULATION BASED ON TWO SUCCESSIVE CENSUSES (CORR. 68 1550) /ON OF ATTRITION LIFE TABL JASA 67 1433 THE TWENTY-SEVEN PER CENT RULE CENTENARY LECTURE, KARL PEARSON, 1857-1957

CONTROLLING DIMENSION IN CENTERLESS-GRINDING WITH AUTOMATIC RESET DEVICE SOME INEQUALITIES FOR CENTRAL AND NON-CENTRAL DISTRIBUTIONS

REPRESENTATIONS OF THE CENTRAL AND NON-CENTRAL T DISTRIBUTIONS

AMS 64214

BIOKA57 303 TECH $69 \quad 115$ AMS 651521 8IOKA64 451 RIBUTIONS OF QUADRATIC FORMS IN NORMAL VARIABLES, I, CENTRAL CASE IONS OF QUADRATIC FORMS IN NORMAL VARIABLES, II, NON-CENTRAL CASE A CONTOUR-INTEGRAL DERIVATION OF THE NON-CENTRAL CHI-SQUARE DISTRIBUTION LINEAR COMBINATIONS OF NON-CENTRAL CHI-SQUARE VARIATES THE TRACE OF A MATRIX AND APPROXIMATIONS TO ITS NON-CENTRAL DISTRIBUTION ANALYSIS SOME NON-CENTRAL DISTRIBUTION SERIES REPRESENTATIONS OF DIST $\begin{array}{rr}810 K A 64 & 451 \\ \text { AMS } 67 & 823\end{array}$ AMS 67838 AMS $62 \quad 796$ AMS $66 \quad 480$ AMS 661312 AMS 631270 AMS 65808 AMS 671915 AMS $69 \quad 475$ AMS 691236 AMS 69203 AMS 69601 MOMENTS OF A STOPPING RULE RELATED TO THE CENTRAL LIMIT THEOREM
THE CENTRAL LIMIT THEOREM FOR CENERALIZED RANDOM FIELDS THE REMAINDER IN THE GENTRAL LIMIT THEOREM FOR MIXINC STOCHASTIC PROCESSES A CENTRAL LIMIT THEOREM FOR PARTLY DEPENDENT VARIABLES A MULTIVARIATE CENTRAL LIMIT THEOREM FOR RANDOM LINEAR VECTOR FORMS RANDOM INTERSEGTION OF TWO GRAPHS (CORR. 69151 / A CENTRAL LIMIT THEOREM FOR THE NUMBER OF EDGES IN THE RANDOM VARIABLES NEW CONDTTIONS FOR CENTRAL LIMTT THEOREMS (CORR. 691855 ) CENTRAL LIMIT THEOREMS FOR FAMILIES OF SEQUENCES OF

CONTRIBUTIONS TO CENTRAL LIMIT THEORY FOR DEPENDENT VARIABLES AMS $61 \quad 677$ AMS $66 \quad 1825$ AMS $69 \quad 144$ AMS $69 \quad 319$ AMS $63 \quad 439$ AMS $68 \quad 1158$ FROM A FINITE POPULATION (ATY'S FORMULAE AND MADOW'S CENTRAL LIMIT) /INC MOMENTS OF THE MEAN IN SAMPLES THE NON-CENTRAL MULTIVARIATE BETA DISTRIBUTION

EFINITE AND OF INDEFINITE QUADRATIC FORMS FROM A NON-CENTRAL NORMAL DISTRIBUTION D

DISTRIBUTION OF A DEFINITE QUADRATIC FORM FOR NON-CENTRAL NORMAL VARIATES, CORR. 63 673 AMS $61 \quad 104$ AMS 63186 AMS 621016 A FINITE POPULATION (ATY'S FORMULAE AND MADOW/ THE CENTRAL SAMPLING MOMENTS OF THE MEAN IN SAMPLES FROM BIOKA6I 199 VARIATIONS OF THE NON-CENTRAL T AND BETA DISTRIBUTIONS 
THE COMPUTATION OF PERCENTACE POINTS OF THE NON-CENTRAL T-DISTRIBUTION

TABLES TO FACILITATE AMS $62 \quad 580$ DISTRIBUTION A CENTRAL TOLERANCE RECION FOR THE MULTIVARIATE NORMAL JRSSB6B 599

GRAPHIC METHODS BASED UPON PROPERTIES OF ADVANCINC CENTROIDS

LEADING AMERICAN STATISTICIANS IN THE NINETEENTH CENTURY

LEADING BRITISH STATISTICIANS OF THE NINETEENTH CENTURY

LEADING AMERICAN STATISTICIANS OF THE NINETEENTH CENTURY II

TESTS AUXILIARY TO CHI-SQUARED TESTS IN A MARKOV CHAIN AN INTRINSICALLY DETERMINED MARKOV CHAIN

THE ASYMPTOTIC BEHAVIOR OF A CERTAIN MARKOV CHAIN THE TAIL FIELD OF A MARKOV CHAIN

SOME DISTRIBUTION AND MOMENT FORMULAE FOR THE MARKOV CHAIN

INVARIANCE PRINCIPLES FOR FUNCTIONALS OF A MARKOV CHAIN

THE COMPARISON OF SEVERAL REALIZATIONS OF A MARKOFF CHAIN ATIONARY PROCESS TO BE A FUNCTION OF A FINITE MARKOV CHAIN

OF RANDOM VARIABLES DEFINED ON A FINITE MARKOV CHAIN

REALIZATION OF A NON-HOMOGENEOUS FINITE-STATE MARKOV CHAIN ESTIMATOR OF AN UNKNOWN PARAMETER IN A SIMPLE MARKOV CHAIN

THE TAIL SIGMA-FIELD OF A MARKOV CHAIN AND A THEOREM OF OREY
THE FREQUENCY COUNT OF A MARKOV CHAIN AND THE TRANSITION TO CONTINUOUS TIME

ESTIMATION OF PARAMETERS IN A TRANSIENT MARKOV CHAIN ARISINC IN A RELIABILITY CROWTH MODEL

ND TRANSITION PROBABILITIES OF A FINITE-STATE MARKOV CHAIN FROM THE SAME DATA /IMATING THE EQUILIBRIUM A BIOCS68 185

DEPENDENCE THE ANALYSIS OF PERSISTENCE IN A CHAIN OF MULTIPLE EVENTS

$\begin{array}{rrr}\text { SOME } & \text { AMS } 67 & 1 \\ \text { NOTE ON BIOKA59 } & 412 \\ \text { NOR A ST AMS } 63 & 1033\end{array}$

SUFFICIENT CONDITIONS FOR A ST AMS 631033
A CONVEXITY PROPERTY IN THE THEORY AMS $61 \quad 1260$

JASA 59 66B

JASA $57 \quad 301$

JASA $58 \quad 689$

AMS $63 \quad 56$

AMS $67 \quad 934$

AMS 69665

AMS $69 \quad-127$

IN MARKOV-CHAIN FREQUENCIES, AND THE BINARY CHAIN OF ORDER 2 Q ON MARKOV CHAIN POTENTIALS

INFERENCE ON A GENETIC MODEL OF THE MARKOV CHAIN TYPE

IFICANCE TESTS FOR A VARIABLE CHANCE OF INFECTION IN CHAIN-BINOMIAL THEORY

BIOKA64 405

BIOKA62 351

RSSB63 383

AMS 61 1 709

OR THE ANALYSIS OF INTRA-HOUSEHOLD EPI/ THE USE OF CHAIN-BINOMIALS WITH A VARIABLE CHANCE OF INFECTION F BIOKA53 279 FACTORIAL REPLICATION-FREE EXPERIMENTS CHAIN-POOLING ANALYSIS OF VARIANCE FOR TWO-LEVEL TECH 69 NO. 4 ESTIMATOR OF AN UNKNOWN PARAMETER IN A STMPLE MARKOV CHATN' SOME PROPERTIES OF REGULAR MARKOV CHAINS

TESTS FOR CONTINGENCY TABLES AND MARKOV CHAINS FUNCTIONS OF FINITE MARKOV CHAINS

SOME THEOREMS ON FUNCTIONALS OF MARKOV CHAINS ON STOCHASTIC PROCESSES DERIVED FROM MARKOV CHAINS SOME LIMIT THEOREMS FOR NON-HOMOGENEOUS MARKOV CHAINS A SYSTEM OF DENUMERABLY MANY TRANSIENT MARKOV CHAINS A NOTE ON LIMIT THEOREMS FOR THE ENTROPY OF MARKOV CHAINS FUNCTIONS OF FINITE MARKOV CHAINS

OPTIMAL STOPPING FOR FUNCTIONS OF MARKOV CHAINS

PROBABILISTIC FUNCTIONS OF FINITE STATE MARKOV CHAINS

A NOTE ON SEQUENCES OF CONTINUOUS PARAMETER MARKOV CHAINS

A TEST FOR MARKOFF CHAINS

THE LIKELIHOOD RATIO TEST FOR MARKOFF CHAINS

A NOTE ON SUFFICIENCY IN REGULAR MARKOV CHAINS

PROXIMATIONS FOR THE ENTROPY FOR FUNCTIONS OF MARKOV CHAINS CTERIZATION OF A CLASS OF FUNCTIONS OF FINITE MARKOV CHAINS TEST OF THE CHI-SQUARE THEORY FOR PROBABILITY CHAINS

RUNS TESTS AND LIKELIHOOD RATIO TESTS FOR MARKOFF CHAINS

PROCESSES WHICH ARE FUNCTIONS OF STATIONARY MARKOV CHAINS

OF STATE-CALCULABLE FUNCTIONS OF FINITE MARKOV CHAINS

DESICNS FOR CLINICAL TRIALS BASED ON MARKOV CHAINS

FOR PROBABILISTIC FUNCTIONS OF FINITE STATE MARKOV CHAINS

LAW OF LARGE NUMBERS FOR NON-HOMOGENEOUS MARKOV CHAINS BABILISTIC FUNCTIONS OF DISCRETE FINITE STATE MARKOV CHAINS BEHAVIOUR SEQUENCES AS SEMI-MARKOV CHAINS

SUFFICIENCY CONDITIONS IN REGULAR MARKOV CHAINS AND CERTAIN RANDOM WALKS

$\begin{array}{lrr}\text { STATISTICAL INFERENCE AMS } & 66 & 1554 \\ \text { CONCERNING THE STRONG AMS } & 64 & 566\end{array}$ $\begin{array}{rlrr}\text { SOME THEOREMS CONCERNING THE STRONG AMS } & 64 & 566 \\ \text { ADMISSIBILITY AND DISTRIBUTION OF SOME PRO AMS } & 68 & 1646\end{array}$ FUNCTIONS OF FINITE MARKOV CHAINS AND EXPONENTIAL TYPE PROCESSES

HE 'PSI-SQUARED' COODNESS OF FIT CRITERIA FOR MARKOV CHAINS AND MARKOV SEQUENCES /OTIC DISTRIBUTION OF T AMS 6I 49

COLLAPSED MARKOV CHAINS AND THE CHAPMAN-KOLMOGOROV EQUATION

DIMENSIONAL CHAINS INVOLVINC RECTANGULAR AND NORMAL ERROR-

PATHS AND CHAINS OF RANDOM STRAIGHT-LINE SEGMENTS

APPLICATION OF FINITE ABSORBENT MARKOV CHAINS TO SIB MATING POPULATIONS WITH SELECTION

SOME ASYMPTOTIC DISTRIBUTION THEORY FOR MARKOV CHAINS WITH A DENUMERABLE NUMBER OF STATES MARKOV CHAINS WITH ABSORBING STATES, A GENETIC EXAMPLE

AMS $63 \quad 233$

TECH $63 \quad 404$

TECH $66 \quad 303$

BIOCS69 17

BIOKA56 285

AMS $61 \quad 716$

A PATH-PROBABILITY APPROACH TO IRREVERSIBLE MARKOV CHAINS WITH AN APPLICATION IN STUDYING THE DENTAL CAR BIOCS66 79 OF STATISTICAL INFERENCE IN ABSORBING MARKOV CHAINS

STATISTICAL METHODS IN MARKOV CHAINS, CORR. 611343

SOME PROBLEMS BIOKA65 127

AMS $61 \quad 12$

BIOKA57 301

CORRICENDA TO 'THE LIKELIHOOD RATIO TEST FOR MARKOFF CHAINS

E ON THE STATTSTTCAL TESTABILITY OF IEXPITCTT CAUSAL CHATNS 1 AGAINST THE CLASS OF ITNTERDEPENDENT' MODELS JASA 65 IOBO

PRESENTATION OF THE BIOLOGICAL AND PHYSICAL DECAY OF CHAMBER AEROSOLS

ON THE CUMULATIVE EFFECT OF CHANCE DEVTATIONS

MATHEMATICAL RE BIOCS65 551

BIRTHS PER COUPLE

A CHANCE MECHANISM OF THE VARIATION IN THE NUMBER OF

JRSSB54 269

LD EPI/ THE USE OF CHAIN-BINOMIALS WITH A VARIABLE CHANCE OF INFECTION FOR THE ANALYSIS OF INTRA-HOUSEHO BIOKA53 279
SIGNIFICANCE TESTS FOR A VARIABLE CHANCE OF INFECTION IN CHAIN-BINOMIAL THEORY

ESSAY TOWARDS SOLVING A PROBLEM IN THE DOCTRINE OF CHANCES. /STICS. IX. BIOGRAPHICAL NOTE FOR T. BAYES BIOKA58 293

(REPRODUCED FROM PHIL.

ON AN INDEX OF QUALITY CHANGE

TWO-STATE MARKOV MODEL FOR BEHAVTORAL CHANCE

CHANGE CONSTRAINTS AND NORMAL DEVIATES

A TEST FOR A CHANCE IN A PARAMETER OCCURRINC AT AN UNKNOWN POINT

ON PROBLEMS IN WHICH A CHANGE IN A PARAMETER OCCURS AT AN UNKNOWN POINT

A CHANCE IN LEVEL OF A NON-STATIONARY TIME SERIES

POPULATION ESTIMATION BASED ON CHANCE OF COMPOSITION CAUSED BY A SELECTIVE REMOVAL

A COMPARISON OF TWO SORTS OF TEST FOR A CHANGE OF LOCATION APPLICABLE TO TRUNCATED DATA

JASA 68993

JASA 69

JASA $62 \quad 134$

BIOKA55 523

BIOKA57 248

BIOKA65 181

BIOKA55 279

JRSSB57 119 
A RANDOM TIME CHANCE RELATINC SEMI-MARKOV AND MARKOV PROCESSES

AMS $68 \quad 35 \mathrm{~B}$

作

THE TWO-PERIOD CHANGE-OVER DESICN AND ITS USE IN CLINICAL TRAILS

FOUR EQUALLY SPACED LEVELS (CORR. 67 586)

A CHANCE-OVER DESICN FOR TESTINC A TREATMENT FACTOR AT

JASA 68 12BO

BIOCS65 467 CYCLIC CHANCE-OVER DESICNS

SOME OBSERVATIONS ON CHANCE-OVER TRIALS

VALUE OF ORTHOCONAL POLYNOMIALS IN THE ANALYSIS OF CHANCE-OVER TRIALS WITH DAIRY COWS

INCOME, INCOME CHANCE, AND DURABLE COODS DEMAND

BIOKA69 2B3

BIOCS69 413

OF FIRST RESIDUAL EFFECTS

CHANCEOVER DESTCNS BALANCED FOR THE LINEAR COMPONENT

RESIDUAL EFFECTS

FACTORIAL DESICNS

THE ANALYSIS OF CHANCEOVER DESICNS WITH COMPLETE BALANCE FOR FIRST

FACTOR CHANCES AND LINEAR TRENDS IN EICHT-RUN TWO LEVEL

THE 8IOCS67 297

JASA 641194

BIOKA68 297

CAL SOCIETY MEMORIAL MEETINC FOR WILLIAM N. HURWITZ.

CHANCES IN CENSUS METHODS

WASHINCTON STATI

BIOCS67 578

ESTABLISHMENT OUTPUT 1939-195B

CHANCES IN CONCENTRATION OF DOMESTIC MANUFACTURINC

TECH $68 \quad 301$

THE MEASUREMENT OF PRICE CHANCES IN CONSTRUCTION

$\begin{array}{rrr}\text { JASA } & 69 & \text { NO. } 4 \\ \text { JASA } & 62 & 797\end{array}$ JASA $69 \quad 771$

CURINC AT UNKNOWN TI/ TEST PROCEDURES FOR POSSIBLE CHANCES IN PARAMETERS OF STATISTICAL DISTRIBUTIONS OC

FORMATION ON DETECTINC CHANCES IN THE MEAN OF NORMAL VARIATES

\section{CHANCES IN THE RATE AND COMPONENTS OF HOUSEHOLD}

AMS 661196

AMS $69 \quad 116$

CHANCES IN THE SIZE DISTRIBUTION OF DIVIDEND INCOME

JASA $60 \quad 26 \mathrm{~B}$

MEAN OF A NORMAL DISTRIBUTION WHICH IS SUBJECTED TO CHANCES IN TIME

PROBLEMS ABOUT PARAMETERS WHICH ARE SUBJECTED TO CHANCES OVER TIME

ESTTMATIC THE CURRENT AMS 64 25 INFERENCE AMS $68 \quad 840$

2. EXTSTENCE/ SOME EXPERIMENTAL DESICNS OF USE IN CHANGINC FROM ONE SET OF TREATMENTS TO ANOTHER, PART EQUENTIAL LIFE FOR THE EXPONENTIAL DISTRIBUTION WITH CHANCINC PARAMETER THE ESTIMATION OF A CHANCINC SEASONAL

INFORMATION AND STATTSTTCAL INFERENCE IN A RAPTDLY CHANCINC WORLD ON THE CODINC THEOREM FOR NOISELESS CHANNEL

THE PROBABILITY OF ERROR FOR A DISCRETE MEMORYLESS CHANNEL

CONVERCENCE THEOREMS FOR MULTIPLE CHANNEL LOSS PROBABILITIES

CORR. 661247

S TECH 66 217 JASA 641063

THE QUALITY OF STATISTICAL JASA 67

AMS $61 \quad 594$

EXPONENTIAL BOUNDS ON AMS 61577

AMS 63260

A FINITE CRITERION FOR INDECOMPOSABLE CHANNELS

THE REAL STABLE CHARACTERISTIC FUNCTIONS AND CHAOTIC ACCELERATION

ON THE CHAPMAN-KOLMOCOROV EQUATION

TEST

SIMPLEST CASE

ARIANT TESTS FOR CLASSICAL MULTI/

TESTS

\section{COLLAPSED MARKOV CHAINS AND THE CHAPMAN-KOLMOCOROV EQUATION}

ON THE BAYES CHARACTER OF A STANDARD MODEL II ANALYSIS OF VARIANCE MINIMAX CHARACTER OF HOTELLINC'S T-SQUARED TEST IN THE

ADMISSIBLE BAYES CHARACTER OF T-SQUARED, R-SQUARED AND OTHER FULLY INV ON THE MONOTONIC CHARACTER OF THE POWER FUNCTIONS OF TWO MULTIVARIATE MINIMAX CHARACTER OF THE R-SQUARED-TEST IN THE SIMPLEST CASE

REMARK ON THE OPTIMUM CHARACTER OF THE SEQUENTIAL PROBABILITY RATIO TEST FREQUENCIES OF INTECERS WITH A CIVEN PARTITIONAL CHARACTERISTIC CREENBERC'S INDEX OF LINCUISTIC DIVERSITY AND YULE'S CHARACTERISTIC THE MATHEMATTCAL RELATTON BETWEEN H CAN BE USED FOR THE DETERMINATION OF THE OPERATINC CHARACTERISTIC AND AVERACE SAMPLE NUMBER OF A SIMPLE JR FORMULAE FOR CALCULATINC THE OPERATINC CHARACTERISTIC AND THE AVERACE SAMPLE NUMBER OF SOME JRSSB58 379 ITY RATIO TEST OPTIMALITY AND THE OPERATINC CHARACTERISTIC CURVE FOR THE WALD SEQUENTIAL PROBABIL JASA 64 464 HE 10 PERCENT AND 50 PERCENT POINTS OF THE OPERATINC CHARACTERISTIC CURVES FOR FIXED EFFECTS ANALYSIS OF V JASA 57 345 OF PATTERNED MATRICES EVALUATION OF DETERMINANTS, CHARACTERISTIC EQUATIONS AND THETR ROOTS FOR A CLASS JRSSB6O 348 THE EXPONENTIAL CASE EXACT OPERATINC CHARACTERISTIC FOR TRUNCATED SEQUENTIAL LIFE TESTS IN REDUCTION OF THE MULTIVARIATE NORMAL INTECRAL TO CHARACTERISTIC FORM DISTRIBUTION

IN COMPI EX NORMAL VARTABLES

NOTE ON THE CHARACTERISTIC FUNCTION OF A SERIAL-CORRELATION THE CHARACTERISTIC FUNCTION OF HERMITIAN QUADRATIC FORMS ON THE ORDER AND THE TYPE OF ENTIRE CHARACTERISTIC FUNCTIONS LIPSCHITZ BEHAVIOR AND INTECRABILITY OF CHARACTERISTIC FUNCTIONS SOME INTEGRAL TRANSFORMS OF CHARACTERISTIC FUNCTIONS A NOTE ON CHARACTERISTIC FUNCTIONS

THE REAL STABLE CHARACTERISTIC FUNCTIONS AND CHAOTIC ACCELERATION ON FINTTE PRODUCTS OF POISSON-TYPE CHARACTERISTIC FUNCTIONS OF SEVERAL CARIA8LES A BEST POSSI8LE KOLMOGOROFF-TYPE INEQUALITY FOR MARTINGALES AND A CHARACTERISTIC PROPERTY ANOTHER CHARACTERISTIC PROPERTY OF THE CAUCHY DISTRIBUTION

DISTRI8UTION

ON THE DISTRIBUTION OF THE LARGEST CHARACTERISTIC ROOT OF A MATRIX IN MULTIVARIATE ANALY
COMPL/DISTRI8UTION OF THE LARCEST OR THE SMALLEST CHARACTERISTIC ROOT UNDER NULL HYPOTHESIS CONCERNING ON THE BIAS OF FUNCTIONS OF CHARACTERISTIC ROOTS OF A RANDOM MATRIX SOME INEQUALITIES ON CHARACTERISTIC ROOTS OF MATRICES

CORRIGENDA, 'SOME INEQUALITIES ON CHARACTERISTIC ROOTS OF MATRICES'

ATE/ SOME DISTRIBUTION PROBLEMS CONNECTED WITH THE CHARACTERISTIC ROOTS OF THE PRODUCT OF A WISHART VARI PAIRED COMPARISONS FOR PAIRED CHARACTERISTICS

BAYESIAN STRATIFIED TWO-PHASE SAMPLINC RESULTS, K CHARACTERISTICS

CENERAL SYSTEM OF DISTRIBUTIONS, I. ITS CURVE-SHAPE CHARACTERISTICS II. THE SAMPLE MEDIAN

PARINC INTENSITIES OF ASSOCIATION BETWEEN TWO 8INARY CHARACTERISTICS IN TWO DIFFERENT POPULATIONS SOME STATISTICAL CHARACTERISTICS OF A PEAK TO AVERAGE RATIO

RATES, OCCURRENCESं PER PERSON YEAR OF EXPOSURE CHARACTERISTICS OF A RATIO USED TO ESTIMATE FAILURE ON CERTAIN CHARACTERISTICS OF SOME DISCRETE DISTRIBUTIONS OPERATING CHARACTERISTICS OF SOME SEQUENTIAL DESIGN RULES APPROXIMATIONS TO THE CHARACTERISTICS OF SOME SEQUENTIAL TESTS ON CERTAIN CHARACTERTSTICS OF THE DISTRIBUTION OF THE LATENT ROO

TS OF A SYMMETRIC RANDOM MATRIX UNDER VALIDATION OF CONSUMER FINANCIAL CHARACTERISTICS, COMMON STOCK A CHARACTERIZATION OF A CLASS OF FUNCTIONS OF FINITE
A MEAN-SQUARE-ERROR CHARACTERIZATION OF BINOMIAL-TYPE DISTRIBUTIONS

MARKOV CHAINS A CHARACTERIZATION OF CERTAIN SEQUENCES OF NORMINC

CONSTANTS MAXIMUM LIKELIHOOD

DISTRIBUTIONS

STATISTICS

NORMAL DISTRIBUTIONS USING ORDER STATISTICS
A CHARACTERIZATION OF CERTAIN SEQUE
CHARACTERIZATION OF DISTRIBUTIONS CHARACTERIZATION OF GEOMETRIC AND EXPONENTIAL CHARACTERIZATION OF MULTISAMPLE DISTRIBUTION-FREE CHARACTERIZATION OF NORMAL AND CENERALIZED TRUNCATED A CHARACTERIZATION OF NORMALITY

60348 $\begin{array}{rrr}\text { AMS } & 62 & 1403 \\ \text { BIOKA67 } & 293\end{array}$ BIOKA5B 559 BIOKA60 199 AMS 62 123B AMS $67 \quad 32$ AMS 681923 AMS $69 \quad 303$ JRSSB61 180 AMS $69 \quad 434$ AMS $69 \quad 764$ AMS $66 \quad 289$ AMS 661829 BIOKA65 405 AMS 641807 8IOKA65 87 BIOKA63 522 8I0KA65 669 AMS $67 \quad 944$ AMS $68 \quad 200$ BIOKA68 587 ON A JASA 68627 ON COM JASA $61 \quad 889$ TECH $65 \quad 379$ $810 \mathrm{CS} 66 \quad 310$ BIOKA60 473 AMS 681176 BIOKA69 203 AMS 61864 JASA $69 \quad 415$ AMS $65 \quad 524$ AMS $67 \quad 620$ AMS $68 \quad 391$ AMS $61 \quad 1214$ AMS $66 \quad 1790$ AMS $64 \quad 735$ AMS 661011 AMS 671924 SASJ $69 \quad 27$ 
A CHARACTERIZATION OF THE EXPONENTIAL-TYPE DISTRIBUTION BIOKA63 205 CHARACTERIZATION OF THE INVERSE CAUSSIAN DISTRIBUTION AMS 62800

DISTRIBUTION

COMPACT TOPOLOCICAL CROUP

TERMS OF CONVERCENCE RATES

SYSTEMS

PROBABILITY DISTRIBUTIONS

PROBABILITY DISTRIBUTIONS

OF BIVARIATE AND MULTIVARIATE DISTRIBUTIONS OF LINEAR STATISTICS ON ANOTHER LINEAR STATISTIC CONDITIONAL MOMENTS

N A PARAMETER BY RECURRENCE RELATIONS FOR FUNCTIO/ ON THE ROBUSTNESS OF SOME

STUDENT LAW

\author{
ON THE ROBUSTNESS OF SOME
}

LAW

A CHARACTERIZATION OF THE UNIFORM DISTRIBUTION ON A

A CHARACTERIZATION OF THE UPPER AND LOWER CLASSES IN

A CHARACTERIZATION OF THE WEAK CONVERCENCE OF MEASURES

A CHARACTERIZATION OF THE WISHART DISTRIBUTION

A STOCHASTIC CHARACTERIZATION OF WEAR-OUT FOR COMPONENTS AND CHARACTERIZATION THEOREMS FOR SOME UNIVARIATE CHARACTERIZATION THEOREMS FOR SOME UNIVARIATE CHARACTERIZATIONS OF CONDITIONAL EXPECTATIONS CHARACTERIZATIONS OF INDEPENDENCE IN CERTAIN FAMILIES CHARACTERIZATIONS OF NORMALITY BY CONSTANT RECRESSION CHARACTERIZATIONS OF SOME DISTRIBUTIONS BY

CHARACTERIZATIONS OF THE LINEAR EXPONENTIAL FAMILTY I CHARACTERIZATIONS OF THE NORMAL DISTRIBUTION

ON CHARACTERIZING THE NORMAL DISTRIBUTION BY STUDENT'S

OPTIMUM STRATIFICATION WTTH TWO CHARACTERS

ISPERSION WITH INGOMPLETE OBSERVATIONS ON ONE OF THE CHARACTERS CHARLES JORDAN, 1871-1959

SMALL SAMPLE PROBABILITY LIMITS FOR THE RANGE CHART (CORR, 6B 1549) $\begin{array}{rrr}\text { AMS } 63 & 866\end{array}$

AMS $62 \quad 533$

AMS $63 \quad 319$

AMS 691120

AMS 61561

AMS 621272

AMS $66 \quad 816$

JRSSB64 286

JRSSB $66 \quad 143$

AMS $67 \quad 415$

AMS $68 \quad 433$

AMS 671894

AMS $65 \quad 703$

AMS $\begin{array}{ll}69 & 1721\end{array}$ AMS $68 \quad 1747$

JASA $66 \quad 976$ BIOCS6B 437 BIOKA66 603 AMS 61 JASA 67 14BB

A CHART FOR SEQUENTIALLY TESTING OBSERVED ARITHMETIC ME TECH 68605 A CHART FOR THE INCOMPLETE BETA-FUNCTION AND THE CUMULA BIOKA51 423 ANS FROM LOGNORMAL POPULATIONS AGAINST A GIVEN/ OL CHART PROCEDURES A COMPARISON OF SOME CONTROL CHART PROCEDURES AVERAGE RUN LENGTHS IN CUMULATIVE CHART QUALITY CONTROL SCHEMES

CONTROL CHART TESTS BASED ON CEOMETRIC MOVING AVERAGES A MODIFIED CONTROL CHART WITH WARNING LINES CUMULATIVE SUM CHARTS

WHEN AND HOW TO USE CU-SUM CHARTS THE ECONOMIC DESIGN OF CUMULATIVE SUM CONTROL CHARTS THEORETICAL APPROACH TO CUMULATIVE SUM CONTROL CHARTS

CONTROL CHARTS AND STOCHASTIC PROCESSES (WITH DISCUSSIO CONTROL CHARTS AND THE MINIMIZATION OF COSTS (WITH

DISCUSSION

CUMULATIVE SUM CONTROL CHARTS AND THE WEIBULL DISTRIBUTION

CUMULATIVE SUM CHARTS FOR THE FOLDED NORMAL DISTRIBUTION

CONTROL CHARTS FOR THE MEAN OF A NORMAL POPULATION TECH $66 \quad 41$ TECH $61 \quad 11$ TECH 59239 BIOKA62 171 TECH 61 TECH 63 TECH $6 \mathrm{~B} \quad 479$ SIMPLE JASA $61 \quad 835$ JRSSB59 239 JRSSB $63 \quad 49$ TECH $66 \quad 481$ TECH $63 \quad 451$ JRSSB54 131 TESTS, DERIVED FROM THE NON-CENTRAL F-DISTRIBUTI/ CHARTS OF THE POWER FUNCTION FOR ANALYSIS OF VARIANCE BIOKA5I II OPERATING CHARACTERISTIC CURVES FOR FIXED EFFECT/CHARTS OF THE 10 PERCENT AND 50 PERCENT POINTS OF THE JASA 57 345 THE ECONOMIC DESIGN OF MEAN CHARTS USED TO MAINTAIN CURRENT CONTROL OF A PROCESS JASA 56 228 CONTROL CHARTS WITH WARNING LINES $\quad$ BIOKA55 243

SMOOTHINC BY CHEATING

PARAMETER PROCESSES MILLS' RATIO

SOME MULTIVARIATE CHEBYSHEV INEQUALITIES WITH- EXTENSIONS TO CONTINUOUS CHEBYSHEV POLYNOMIAL AND OTHER NEW APPROXIMATIONS TO NEW CHEBYSHEV POLYNOMIAL APPROXIMATIONS TO MILLS' RATIO A SIMPLE SOLUTION FOR OPTIMAL CHEBYSHEV REGRESSION EXTRAPOLATION INEQUALITIES OF CHEBYSHEV TYPE INVOLVING CONDITIONAL EXPECTATIONS ON A CHEBYSHEV-TYPE INEQUALITY FOR SUMS OF INDEPENDENT A CHECK ON CROSS ERRORS IN CERTAIN VARIANCE

RANDOM VARIABLES COMPUTATIONS THE POWER N FACTORIAL E/ NOTES. CHECKS ON YATES'S ALGORITHM

A PROBLEM OF OPTIMUM ALLOCATION ARISING IN CHEMICAL ANALYSES BY MULTIPLE ISOTOPE DILUTION EVALUATION OF CHEMICAL ANALYSES ON TWO ROCKS

METHOD OF FITTING EMPIRICAL SURFACES TO PHYSICAL AND CHEMICAL DATA OPTIMIZATION OF QUALITY CONTROL IN THE CHEMICAL LABORATORY A MODEL FOR CHEMICAL MUTAGENESIS IN BACTERIOPHAGE SIMULATION PROCRAMME FOR MATERIAL FLOW IN BATCH CHEMICAL PLANTS SEQUENTIAL COMBINATION CHEMOTHERAPY EXPERIMENTS TECH $61-509$ TECH 59409 A TECH $69 \quad 411$ TECH $66 \quad 519$ BI0C565 B75 A CENERAL TECH $61 \quad 497$ BIOCS66 730 AMS $6 \mathrm{~B} \quad 967$ AMS $6 \mathrm{~B} \quad 755$ AMS 6 B 1675 AMS 691116 BIOKA69 255

RANDOMIZED BLOCKS ON CHERNOFF-SAVAGE TESTS FOR ORDERED ALTERNATIVES IN A TWO-SAMPLE EMPIRICAL PROCESS AND A NEW APPROACH TO CHERNOFF-SAVAGE THEOREM WEAK CONVERGENCE OF WEAK CONVERGENCE AND A CHERNOFF-SAVAGE THEOREM FOR RANDOM SAMPLE SIZES A NOTE ON CHERNOFF-SAVAGE THEOREMS

TABLE OF PERCENTAGE POINTS OF NON-CENTRAL CHI

AND DEGREES OF FREEDOM FOR SMALL SAMPLE SIZES FOR CHI APPROXIMATION TO THE RANGE SCALE FACTORS BIOKA53 449 ON THE USE OF PATNAIK TYPE CHI APPROXIMATIONS TO THE RANGE IN SIGNIFICANCE TESTS BIOKA66 248 NOTES. A DEFIGIENCY IN THE SUMMATION OF CHI PROCEDURE

ON CHARACTERIZING THE GHI SQUARE DISTRIBUTION BY THE STUDENT LAW THE POWER OF CHI SQUARE TESTS FOR CONTINGENCY TABLES

ASYMPTOTIC POWER OF CHI SQUARE TESTS FOR LINEAR TRENDS IN PROPORTIONS NOTE ON CHI SQUARE TESTS FOR MATCHED SAMPLES

OWER MOMENTS OF ORDER STATISTICS IN SAMPLES FROM THE CHI-DISTRIBUTION, ONE DEGREE OF FREEDOM QUERY, DEGREES OF FREEDOM OF CHI-SQUARE SUBSTITUTES FOR CHI-SQUARE

AN APPROXIMATION TO THE DISTRIBUTION OF NON-CENTRAL CHI-SQUARE ISTRIBUTIONS OF MEASURES OF DISPERSION BY A POWER OF CHI-SQUARE

POINTS OF FISHER'S B DISTRIBUTION AND NON-CENTRAL CHI-SQUARE LAGUERRE SERIES FORMS OF NON-CENTRAL CHI-SQUARE AND F DISTRIBUTIONS
RESPECT TO VALIDITY, / A COMPARISON OF THE PEARSON CHI-SQUARE AND KOLMOGOROV GOODN $\begin{array}{lll}\text { APPROXIMATING TO THE D BIOKA53 } & 336 \\ \text { TO THE UPPER } 5 \text { PERCENT BIOKA57 } & 52 B\end{array}$ BIOCS66 407 JASA $66 \quad 976$ JASA $66 \quad 965$ BI0CS68 315 JRSSB 6B 36B AMS 621292 TECH $67 \quad 489$ BIOKA55 265 NOTE ON BIOKA59 364 BIOKA65 415 $F$ PROBABILITY FUNCTIONS BIOKA60 411 TO AN ACGEPTANCE SAMPLING PROBLEM SEQUENTIAL CHI-SQUARE AND T-SQUARE TESTS AND THEIR APPLIGATION TECH 61 $T$ TESTS FOR SMALL BUT/ COMPARATIVE VALIDITY OF THE CHI-SQUARE AND TWO MODIFIED CHI-SQUARE GOODNESS-OF-FI BIOKA66 
MULTINOMIAL PROBABILITIES AND THE CHI-SQUARE AND X-SQUARE DISTRIBUTIONS

CORRIGENDA, 'MULTINOMIAL PROBABILITIES AND THE CHI-SQUARE AND X-SQUARE DISTRIBUTIONS

TEST

NOTE ON A CHI-SQUARE APPROXIMATION FOR THE MULTIVARIATE SIGN

BIOKA63

BIOKA63 546

NOTE ON A CHI-SQUARE APPROXIMATION
A NOTE ON THE MULTIPLYING FACTORS FOR VARIOUS CHI-SQUARE APPROXIMATIONS

JRSSB65 B2

JRSSB54 296

ODNESS-OF-FIT STATISTICS, U-SQUARE-SUB-N AND W-SQ/ CHI-SQUARE APPROXIMATIONS FOR THE DISTRIBUTIONS OF GO B

TABLE THE RAPID CALCULATION OF CHI-SQUARE AS A TEST OF HOMOCENEITY FROM A 2-BY-N

A CONTOUR-INTEGRAL DERIVATION OF THE NON-CENTRAL CHI-SQUARE DISTRIBUTION

ANOTHER DERIVATION OF THE NON-CENTRAL CHI-SQUARE DISTRIBUTION

BIOKA55 519

AMS 62796

JASA 64957

99.9 PERCENT AND 0.1 PERCENT POINTS OF THE CHI-SQUARE DISTRIBUTION

BIOKA53 421

ON THE NON-CENTRAL CHI-SQUARE DISTRIBUTION

BIOKA59 235

APPROXIMATIONS TO THE NON-CENTRAL CHI-SOUARE DISTRIBUTION

BIOKA63 199

A NEW TABLE OF PERCENTAGE POINTS OF THE CHI-SQUARE DISTRIBUTION

INTS AND THE PROBABILITY INTEGRAL OF THE NON-CENTRAL CHI-SQUARE DISTRIBUTION

BIOKA64 23I

AN INEQUALITY FOR A CLASS OF BIVARIATE CHI-SQUARE DISTRIBUTIONS

/ULAE FOR THE PERCENTAGE PO BIOKA54 53B

JASA $69 \quad 333$

BIOKA59 352

ON AN EXTENSION OF THE CONNEXION BETWEEN POISSON AND CHI-SQUARE DISTRIBUTIONS

OF THE BINOMIAL, NEGATIVE BINOMIAL, POISSON AND CHI-SQUARE DISTRIBUTIONS

TRANSFORMATIONS BIOKA54 302

BIOKA65 305

TEF PERCENACE 'POTNS OF THE CHITSQUARE DTSTRIBUTIONS'

IONS OF THE BINOMIAL, NECATIVE BINOMIAL, POISSON AND CHI-SQUARE DISTRIBUTIONS

/RRIGENDA TO 'TRANSFORMAT BIOKA56 235

F TABLES. PART II COMPARISON BETWEEN MINIMUM NORMIT CHI-SQUARE ESTIMATE AND THE MAXIMUM LIKELIHOOD ESTIMA BIOKA57 41

TATION ON THE PROBLE/APPLICATION OF MINIMUM LOGIT CHI-SQUARE ESTIMATE TO A PROBLEM OF CRIZZLE WITH A NO BIOCS6B 75

A SIMPLIFIED EXPRESSION FOR THE VARIANCE OF THE CHI-SQUARE FUNCTION ON A CONTINGENCY TABLE

ACCURACY OF AN APPROXIMATION TO THE POWER OF THE CHI-SQUARE COODNESS OF FIT TEST WITH SMALL BUT EQUAL JASA 6B

OF DEPENDENT OBSERVATIONS

DISTRIBUTIONS

DISTRIBUTIONS (WITH DISCUSSION)

THE CHI-SQUARE GOODNESS-OF-FTT TEST FOR A CLASS OF CASES BIOKA64

THE CHI-SQUARE COODNESS-OF-FIT TEST FOR NORMAL

250

RS OF THE LOGISTIC FUNCTION, USINC THE MINIMUM LOCIT CHI-SQUARE METHOD /N THE ESTIMATION OF THE PARAMETE BIOKAG OF FREEDOM

CHI-SQUARE PROBABILITIES FOR LARCE NUMBERS OF DECREES BIOKA56

A NOTE ON THE MAXIMIZATION OF A NON-CENTRAL CHI-SQUARE PROBABILITY

OF SEVERAL OBSERVATIONS

CHI-SQUARE STATISTIC BASED ON THE POOLED FREQUENCIES

THE NUMBER AND WIDTH OF CLASSES IN THE CHI-SQUARE TEST

$R$ ADJUSTMENT FOR STRATIFICATION (ADDENDUM 67/

THE CHI-SQUARE TEST FOR HETEROCENEITY OF PROPORTIONS AFTE JRSSB66

DITH SPECIAL REFERENCE TO ACCIDENTS/

THE CHI-SQUARE TEST FOR SMALL EXPECTATIONS IN CONTINCENCY BIOKA59 365

CHI-SQUARE TESTS WITH ONE DECREE OF FREEDOM, EXTENSIO

CHI-SQUARE TESTS WITH ONE DECREE OF FREEDO
CHI-SQUARE THEORY FOR PROBABILITY CHAINS

AMS 631432

A SAMPLING TEST OF THE CHI-SQUARE THEORY POT

MATE OF THE NON-CENTRALITY PARAMETER OF A NONCENTRAL CHI-SQUARE VARIATE

LINEAR COMBINATIONS OF NON-CENTRAL CHI-SQUARE VARIATES
OFUCT OF TWO CENTRAL OR NON-CENTRAL CHI-SQUARE VARIATES

IBUTION OF THE PRODUCT OF TWO CENTRAL OR NON-CENTRAL CHI-SQUARE VARIATES

A MULTIVARIATE EXTENSION OF FRIEDMAN'S CHI-SQUARE-SUB-R-TEST

A NOTE ON THE ASYMPTOTIC EFFIGIENCY OF FRIEDMAN'S GHI-SQUARE-SUB-R-TEST

DESICN THE ASYMPTOTIC EFFICIENCY OF THE CHI-SQUARE-SUB-R-TEST

ENCIES

THE EFFECT OF MISCLASSIFICATION ON THE PROPERTIES OF CHI-SQUARE-TESTS IN THE ANALYSIS OF CATEGORICAL DATA. ON THE STUDENTIZED SMALLEST CHI-SQUARE, CORR 59812

A NOMOGRAM FOR CHI-SQUARE, CORR. 661246

QUERY, COMBININC VALUES OF OBSERVED CHI-SQUARE'S

THE NON-CENTRAL CHI-SQUARED AND BETA DISTRIBUTIONS

SEQUENTIAL CHI-SQUARED AND T-SQUARED TESTS

CONDITIONS FOR A QUADRATIC FORM TO HAVE A CHI-SQUARED DISTRIBUTION

ON CORRECTIONS TO THE CHI-SQUARED DISTRIBUTION

MINIMUM CHI-SQUARED ESTIMATION USINC INDEPENDENT STATISTICS

THE MULTIVARIATE SADDLE POINT METHOD AND CHI-SQUARED FOR THE MULTINOMIAL DISTRIBUTION

TESTS AUXILIARY TO CHI-SQUARED TESTS IN A MARKOV CHAIN

THE CHICK ASSAY OF LYSINE

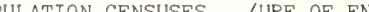

PLICATIONS TO A STUDY OF ACCIDENT REPEATEDNESS AMONG CHILDREN

INTERSECTIONS OF RANDOM CHORDS OF A CIRCLE

FOR THE MEAN

A MATHEMATICAL MODEL WITH AP JASA 651046

BIOKA64 373

AMS 69667

JRSSB69 NO. 2

RANDOM POINTS IN A CIRCLE AND THE ANALYSIS OF CHROMOSOME PATTERNS

ESTIMATION OF SURVIVORSHIP IN CHRONIC DISEASE, THE 'ACTUARIAL' METHOD

ON THE THEORY OF SCREENING FOR CHRONIC DISEASES

NOTE ON A THEOREM OF KINCMAN AND A THEOREM OF CHUNG

BIOKA63 23

JASA $58 \quad 420$

BIOKA69 NO. 3

AMS 661844

EMPERTCALRE

AL INFERENCE IN HEALTH WITH SPECIAL REFERENCE TO THE CIGARETTE SMOKING AND LUNG CANCER CONTROVERSY /STIC JASA 69 739 GOODNESS-OF-FIT TESTS ON A CIRCLE RANDOM WALK ON A CIRCLE

BIOKA61 109

BIOKA63 385

BIOKA64 256

BIOKA64 373

A DISTRIBUTION-FREE TWO-SAMPLE TEST ON A CIRCLE
INTERSECTIONS OF RANDOM CHORDS OF A CIRCLE

INTEGRAL JASA $62 \quad 758$

OF THE BIVARIATE NORMAL DISTRIBUTION OVER AN OFFSET CIRCLE

OF THE BIVARIATE NORMAL DISTRIBUTION OVER AN OFSET CIRCLE

A TABLE OF THE INTEGRAL JRSSB60 177

RANDOM POINTS IN A CIRCLE AND THE ANALYSIS OF GHROMOSOME PATTERNS B

ON THE CONSTRUCTION OF SIGNIFICANCE TESTS ON THE CIRCLE AND THE SPHERE

BIOKA56 344

BIOKA63 81

ANALOGUES OF THE NORMAI DISTRIBUTTON ON THE CTRCLE AND THE SPHERE

THE COVERING CIRCLE OF A SAMPLE FROM A CIRCULAR NORMAL DISTRIBUTIO BIOKA52 13'

GOODNESS-OF-FIT TESTS ON A CIRGLE. II

COODNESS-OF-FIT STATTSTIC FOR THE CIRCLE. WTTH SOME COMPARISONS BIOKA62 57

BIOKA69 161

DISTANCES BETWEEN RANDOM POINTS IN TWO CONCENTRIC CIRCLES

RANDOM CIRCLES ON A SPHERE

TESTS FOR RANDOMNESS OF DIRECTIONS AGAINST TWO CIRCULAR ALTERNATIVES

THE PROBABILITY OF COVERINC A SPHERE WITH N CIRCULAR CAPS

SOME CIRCULAR COVERACE PROBLEMS

ANOTHER TEST FOR THE UNIFORMITY OF A CIRCULAR DISTRIBUTION

A SIMPLE TEST FOR UNTFORMTTY OF A CIRCULAR DISTRIBUTTON

THEORY OF A CLASS OF TESTS FOR UNIFORMITY OF A CIRCULAR DISTRIBUTION

THE BIOKA64 275

BIOKA62 3B9

JASA 69280

BIOKA65 323

BIOKA6I 313

BIOKA67 675

BIOKA6B 343

ASYMPTOTIC AMS 691196 
BIVARIATE SICN TEST AND A TEST FOR UNIFORMITY OF A CIRCULAR DISTRIBUTION TRIC TWO-SAMPLE TESTS FROM TESTS FOR UNIFORMITY OF A CIRCULAR DISTRIBUTION ON A CLASS OF NONPARAMETRIC TWO-SAMPLE TESTS FOR CIRCULAR DISTRIBUTIONS NONPARAMETRIC SYMMETRY TESTS FOR CIRCULAR DISTRIBUTIONS SOME ESTIMATORS OF QUANTILES OF CIRCULAR ERROR

PROPERTIES OF SOME ESTIMATORS OF QUANTILES OF CIRCULAR ERROR
CIRCULAR ERROR PROBABILITIES

ON CIRCULAR FUNCTIONAL RELATIONSHIPS

A NOTE ON THE CIRCULAR MULTIVARIATE DISTRIBUTION

THE DERIVATION OF NONPARAME BIOKA69 NO.3

AMS 691791

BIOKA69 NO.3

THE COVERINC CIRCLE OF A SAMPLE FROM A CIRCULAR NORMAL DISTRIBUTION

EFFECTS OF BIAS ON ESTIMATES OF THE CIRCULAR PROBABLE ERROR SOME MORE ESTIMATES OF CIRCULAR PROBABLE ERROR

COMPARISON OF ESTIMATES OF CIRCULAR PROBABLE ERROR, CORR. 60755

ON THE JOINT DISTRIBUTION OF THE CIRCULAR SERIAL CORRELATION COEFFICIENTS

TESTINC AND ESTIMATION FOR A CIRCULAR STATIONARY MODEL

THE DISTRIBUTION OF THE NUMBER OF CIRCULAR TRIADS IN PAIRED COMPARISONS

OF GAUSSIAN PROCESSES ON AN INTERVAL

A CLARIFICATION CONCERNING CERTAIN EQUIVALENCE CLASSES

ASYMPTOTIC JASA $66 \quad 61 B$

JASA $60 \quad 723$

JRSSB $65 \quad 45$

BIOKA56 467

BIOKA52 137

JASA $60 \quad 732$

JASA $62 \quad 191$

JASA 59794

BIOKA56 161

AMS 691358

BIOKA62 265 ABILITY THAT AN OBSERVATION WILE FALL IN A SPECIFIED CLASS ESTIMATION OF THE PROB JASA $64 \quad 225$ LATENT CLASS ANALYSIS AND DIFFERENTIAL MORTALITY

LINEAR REGRESSION ANALYSIS WITH ADJUSTMENT FOR CLASS DIFFERENCES

A SIMPLE MATHEMATICAL RELATIONSHIP AMONG K-CLASS ESTIMATORS

SENSITIVITY TO SPECIFICATION ERROR OF DIFFERENT K-CLASS ESTIMATORS

JASA $61 \quad 729$

JASA $66 \quad 36 \mathrm{~B}$ NOTE ON THE UNIMODALITY OF DISTRIBUTION FUNCTIONS OF CLASS L

ESPECIAL REFERENCE/ A LINEAR APPROXIMATOR FOR THE CLASS MARKS OF A GROUPED FREQUENCY DISTRIBUTION, WITH TECH 68 793 TESTABILITY OF 'EXPLICIT CAUSAL CHAINS' ACAINST THE CLASS OF 'INTERDEPENDENT' MODELS /N THE STATISTICAL JASA 65 1080 ON A CLASS OF ADMISSIBLE PARTITIONS AMS $66 \quad 1 B 9$

ON A CLASS OF ALIGNED RANK ORDER TESTS IN TWO-WAY LAYOUTS AMS 681115

AN EXTENSION PROPERTY OF A CLASS OF BALANCED INCOMPLETE BLOCK DESICNS AN INEQUALITY FOR A CLASS OF BIVARIATE CHI-SQUARE DISTRIBUTIONS

A CLASS OF BIVARIATE DISTRIBUTIONS

A GENERAL CLASS OF BULK QUEUES WITH POISSON INPUT

ASYMPTOTIC EFFICIENCY OF CLASS OF C-SAMPLE TESTS

THE CHI-SQUARE GOODNESS-OF-FIT TEST FOR A CLASS OF CASES OF DEPENDENT OBSERVATIONS

JASA $69 \quad 333$

JASA $65 \quad 516$

AMS $67 \quad 759$

AMS $64 \quad 102$

ON FROM ANOTHER A GENERAL CLASS OF COEFFICIENTS OF DIVERGENCE OF ONE DISTRIBUTI JRSSB66 131 SIMILAR TO THE SAMPLE SPACE IN TESTS OF AN IMPORTANT CLASS OF COMPOSITE HYPOTHESES /ST CRITICAL REGIONS BIOKA53 23I INTERACTIONS IN FACTORIAL EXPERIMENTS ON A CLASS OF CONDITIONALLY DISTRIBUTION-FREE TESTS FOR A PROPERTY OF THE MEAN DEVIATION FOR A CLASS OF CONTINUOUS DISTRIBUTIONS.

ON A GENERAL CLASS OF DESICNS FOR MULTIRESPONSE EXPERIMENTS

A NEW CLASS OF DESIGNS, CORR, 651250

OF JOHNSON'S PROPERTY OF THE MEAN DEVIATION FOR A CLASS OF DISCRETE DISTRIBUTIONS

AMS 69658

BI OKA.65 288

AMS $68 \quad 1 B 25$

JASA $64 \quad 817$ A CLASS OF DISTRIBUTION-FREE ANALYSIS OF VARIANCE TESTS SASJ $67 r 7$ A. CLASS OF DISTRIBUTIONS APPLICABLE TO ACCIDENTS JASA 61 503 OD ESTIMATOR IS UNBIASED AND OF MINIMUM VARIANC/ A CLASS OF DISTRIBUTIONS FOR WHICH THE MAXIMUM-LIKELIHO BIOKA56 200 A GENERAL CLASS OF ENUMERATIONS ARISING IN GENETICS BIOCS67 517 ON A MINIMAL ESSENTIALLY COMPLETE CLASS OF EXPERIMENTS A SUGGESTED METHOD OF ANALYSIS OF A CERTAIN CLASS OF EXPERIMENTS IN CARCINOCENESIS DERIVATION OF A CLASS OF FREQUENCY DISTRIBUTIONS VIA BAYES'S THEOREM AMS $66 \quad 435$ BIOCS66 142 JRSSB $65 \quad 290$ AMS $65 \quad 524$ JRSSB $67 \quad 489$ AMS $6 \mathrm{~B} 1153$ AMS 68 104B AMS $67 \quad 18 B 2$ JASA $65 \quad 637$ AMS $63 \quad 769$ BIOKA69 415

PROBABILITIES WITHOUT REPLACEMENT
FACTORIAL EXPERIMENT

ON A CLASS OF GAUSSIAN PROCESSES FOR WHICH THE MEAN RATE A CLASS OF INFINITELY DIVISIBLE MIXTURES

BOUNDS ON THE SAMPLE SIZE DISTRIBUTION FOR A CLASS OF INVARIANT SEQUENTIAL PROBABILITY RATIO TESTS ON HOROVITZ AND THOMPSON'S T-ONE CLASS OF IINEAR ESTIMATION

ON A CLASS OF LINEAR ESTIMATORS IN SAMPLING WITH VARYINC ORDER STATISTICS FROM A CLASS OF NON-NORMAL DISTRIBUTIONS

N F/ A UNIFIED APPROACH FOR CONSTRUCTING A USEFUL CLASS OF NON-ORTHOGONAL MAIN EFFECT PLANS IN K TO THE JRSSBG8 371 RS ASYMPTOTIC EFFICIENCY OF A CLASS OF NON-PARAMETRIC TESTS FOR REGRESSION PARAMETE FREE METHOD OF ESTIMATING ASYMPTOTIC EFFICIENCY OF A CLASS OF NONPARAMETRIC TESTS BIVARIATE POPULATIONS A CLASS OF NONPARAMETRIC TESTS FOR INDEPENDENCE IN DISTRIBUTIONS

ON A CLASS OF NONPARAMETRIC TWO-SAMPLE TESTS FOR CIRCULAR

ON A CLASS OF PARTIALLY BALANCED INCOMPLETE BLOCK DESICNS ON INVERTING A CLASS OF PATTERNED MATRICES

ANTS, CHARACTERISTIC EQUATIONS AND THEIR ROOTS FOR A CLASS OF PATTERNED MATRICES

EVALUATION OF DETERMIN A LOCAL LIMIT THEOREM FOR A CERTAIN CLASS OF RANDOM WALKS

ON THE ADMISSIBILITY AT INFINITY, WITHIN THE CLASS OF RANDOMIZED DESIGNS, OF BALANCED DESIGNS HYPOTHESIS SEVERAL REGRESSION LINES A CLASS OF RANK ORDER TESTS FOR A CENERAL LINEAR ON THE SAMPLE SIZE AND SIMPLIFICATION OF A CLASS OF SEQUENTIAL PROBABILITY RATIO TESTS HYPOTHESES CONCERNING THE UNKNOWN DRIFT PARAMET/ A CLASS OF SEQUENTIAL PROCEDURES FOR CHOOSING ONE OF K PARAMETER A CLASS OF SEQUENTIAL PROCEDURES FOR CHOOSING ONE EQUATIONS OF THE SINGLE CHANNEL QUEUE WITH A GENERAL CLASS OF SERVICE-TIME DISTRIBUTIONS BY THE METHOD OF PROCEDURE IS NON-SEQUENTIAL

ON A CIASS OF STMPLE SEQUENTIAL TESTS ON MEANS

A CLASS OF SITUATIONS IN WHICH A SEQUENTIAL ESTIMATION

ON THE EXTRAPOLATION OF A SPECIALS OF SKEW DISTRIBUTION FUNCTI

ON THE PROPERTY. W, OF THE CLASS OF STATISTICAL DECISION FUNCTIONS

ON A CLASS OF STOCHASTIC PROCESSES

ON CROSSINGS OF LEVELS AND CURVES BY A WIDE CLASS OF STOCHASTIC PROCESSES

ION ASYMPTOTIC THEORY OF A CLASS OF TESTS FOR UNIFORMITY OF A CIRCULAR DISTRIBUT PROBLEMS IN MULTIVARIATE STATISTICAL ANALYSIS A CLASS OF TESTS WITH MONOTONE POWER FUNCTIONS FOR TWO BLO/ ON THE F-TEST IN THE INTRABLOCK ANALYSIS OF A CLASS OF TWO ASSOCIATE PARTIALLY BALANCED INCOMPLETE ON SOME MULTISAMPLE PERMUTATION TESTS BASED ON A CLASS OF U-STATISTICS THE TRIANGULAR ASSOCIATION SCHEME TO THREE ASSOCIATE CLASSES ION OF PARTIALLY BALANCED DESICNS WITH TWO ASSOCIATE CLASSES UPANCY PROBLEM, UNBIASED ESTIMATION OF THE NUMBER OF CLASSES NCOMPLETE BLOCK DESIGNS WITH MORE THAN TWO ASSOCIATE CLASSES ON A CEOMETRICAL METHOD OF CONSTRUCT AMS $61 \quad 1177$ STATISTICAL INFERENCE IN THE CLASSICAL OCC JASA $6 B \quad$ B37 ANALYSIS OF A CLASS OF PARTIALLY BALANCED I AMS 61800 


\section{OPTIMUM CHOICE OF CLASSES FOR CONTINCENCY TABLES}

SOME EQUIVALENCE CLASSES IN PAIRED COMPARISONS

A CHARACTERIZATION OF THE UPPER AND LOWER CLASSES IN TERMS OF CONVERCENCE RATES

THE NUMBER AND WIDTH OF CLASSES IN THE CHI-SQUARE TEST

JASA $68 \quad 291$

AMS $66 \quad 488$

AMS 691120

JASA $63 \quad 678$

AMS 66 I593

TECH $68 \quad 36 I$

AMS 68 I078

BIOKA63 2BI

TECH 67425

CALIBRATION

ON IN EXTRAPOLATION

CLINICAL TRIALS

CLASSICAL AND INVERSE RECRESSION METHODS OF

CLASSICAL AND INVERSE REGRESSION METHODS OF CALIBRATI TECH 69605

A BAYESIAN TEST OF SOME CLASSICAL HYPOTHESES, WITH APPLICATIONS TO SEQUENTIAL JASA 66577 ACT FINITE SAMPLE FREQUENCY FUNCTIONS OF GENERALIZED CLASSICAL LINEAR ESTIMATORS IN A LEADING THREE-EQUATI JASA 63 I6I ON/ ON THE EXACT DISTRIBUTIONS OF THE CENERALIZED CLASSICAL LINEAR ESTIMATORS IN A LEADINC THREE-EQUATI JASA 64 B8I FINITE SAMPLE DISTRIBUTION FUNCTIONS OF CENERALIZED CLASSICAL LINEAR ESTIMATORS IN ECONOMETRIC STATISTICA JASA 63 943 ACT FINITE SAMPLE FREQUENCY FUNCTIONS OF GENERALIZED CLASSICAL LINEAR ESTIMATORS IN TWO LEADING OVER-IDENT JASA 6I 6I9 A NOTE ON THE EXACT DISTRIBUTIONS OF THE GENERALIZED CLASSICAL LINEAR ESTIMATORS IN TWO LEADING OVER-IDENT JASA 63 535 ON FINITE SAMPLE DISTRIBUTIONS OF GENERALIZED CLASSICAL LINEAR IDENTIFIABILITY TEST STATISTICS TESTS FOR SPECIFTCATION ERRORS TN CLASSICAL LINEAR LEAST-SQUARES RECRESSION ANALYSTS UARED, R SQUARED AND OTHER FULLY INVARIANT TESTS FOR CLASSICAL MULTIVARIATE NOPMAL PROBLEMS /TER OF T-SQ AMS 65 747 ESTIMATION OF A PARAMETER IN THE CLASSICAL OCCUPANCY PROBLEM BIOKA6O IBO

HE NUMBER OF CLASSES STATISTICAL INFERENCE IN THE CLASSICAL OCCUPANCY PROBLEM. UNBIASED ESTIMATION OF T JASA 68 837 ON THE THEORY OF CLASSICAL RECRESSION AND DOUBLE SAMPLINC ESTIMATION JRSSB6O I3I RENEWAL RESULTS FOR A NATURAL CENERALIZATION OF CLASSICAL RENEWAL THEORY ASYMPTOTIC JRSSB67 I4I ON THE CLASSICAL RUIN PROBLEMS $\begin{array}{llrr}\text { CLASSICAL RUIN PROBLEMS } & \text { JASA } & 69 & 889 \\ \text { CLASSICAL STATISTICAL ANALYSIS BASED ON A CERTAIN MUL AMS } & 65 & 9 \mathrm{~B}\end{array}$

TIVARIATE COMPLEX GAUSSIAN DISTRIBUTION $S$ ON THE DISTRIBUTION OF TWO RANDOM MATRICES USED IN CLASSIFICATION PROCEDURES, CORR, 64 924 SOME RESULT AMS 63 181 VARIANCE COMPONENTS IN THE UNBALANCED TWO WAY NESTED CLASSIFICATION A NOTE ON CLASSIFICATION BIAS IN MULTINOMIAL CLASSIFICATION ADAPTIVE NONPARAMETRIC CLASSIFICATION ONE-WAY VARIANCES IN A TWO-WAY CLASSIFICATION SEQUENTIAL OCCUPANCY WITH CLASSIFICATION POSTERIOR ODDS FOR MULTIVARIATE NORMAL CLASSIFICATION A BAYESIAN APPROACH TO CLASSIFICATION TESTING THE HOMOGENEITY OF VARIANCES IN A TWO-WAY CLASSIFICATION STRIBUTION-FREE ANALYSIS OF VARIANCE FOR THE TWO-WAY CLASSIFICATION ROBUSTNESS OF THE COVARIANCE ANALYSIS OF A ONE-WAY CLASSIFICATION OF ESTIMATES OF VARIANCE COMPONENTS IN A THREE-WAY CLASSIFICATION THE DETERMINATION OF CONNECTEDNESS IN AN N-WAY CROSS CLASSIFICATION MOGENEITY OF THE MARGINAL DISTRIBUTIONS IN A TWO-WAY CLASSIFICATION ESTIMATION OF VARIANCE COMPONENTS OF THE ONE-WAY CLASSIFICATION ATORS OF VARIANCE COMPONENTS IN THE UNBALANCED R-WAY CLASSIFICATION IZED SYMME'TRICAL DESICN FOR THE PROBLEM OF A ONE WAY CLASSIFICATION COMPONENTS OF VARIANCE FROM A NON-ORTHOGONAL TWO-WAY CLASSIFICATION IN THE SUBCLASSES FOR THE TWO-WAY COMPLETELY-RANDOM CLASSIFICATION ONS ON THE EFFECTS FOR THE UNBALANCED ONE-WAY RANDOM CLASSIFICATTON RIANCE COMPONENTS IN THE UNBALANCED THREE-WAY NESTED CLASSIFICATION DESIGN MULTIPLE CLASSIFICATION ANALYSIS FOR ARBITRARY EXPERIMENTAL

THE CONSTRUCTION OF OPTIMAL DESICNS FOR THE ONE-WAY CLASSIFICATION ANALYSIS OF VARIANCE CONTROLLING THE PROPORTION DEFECTIVE FROM CLASSIFICATION DATA

WITHIN A/ THE ANALYSIS OF VARIANCE FOR THE TWO-WAY CLASSIFICATION FIXED EFFECTS MODEL WITH OBSERVATIONS ERRORS OF CLASSIFICATION IN A BINOMIAL POPULATION PROBABILITIES OF CORRECT CLASSIFICATION IN DISCRIMINANT ANALYSIS A NOTE ON TECH $64 \quad 3$ I9 VARIANCES BIOCS66 553 QUADRATIC UNBIASED BIOKA69 313 VARIANCES OF MOMENT ESTIM BIOCS68 527 ON THE ADMISSIBILITY OF A RANDOM AMS 69356 SAMPLINC VARIANCES OF ESTIMATES OF BIOKA64 $49 I$ /ANS AND THE NUMBERS OF OBSERVATIONS JASA 681484 /FFECTS AND THE NUMBERS OF OBSERVATI JASA 671375 NC VARIANCES OF THE ESTIMATES OF VA AMS $63 \quad 521$ TECH 68 I3 JRSSB 6I 352 TECH 6499 BIOKA69 NO. 3 JASA $65 \quad 217$ BIOCS66 908 IONS WITH DIFFERENT COVARIANCE MATRICES MINIMAL SUFFICIENT STATISTICS FOR THE TWO-WAY CLASSIFICATION MIXED MODEL DESIGN

VARIANCE COMPONENTS IN TWO-WAY CLASSIFICATION MODELS WITH INTERACTION A CLASSIFICATION OF FALLACIOUS ARGUMENTS AND
AN ALTERNATIVE SYSTEM FOR THE CLASSIFICATION OF MATHEMATICAL MODELS FOR QUAN AMS $62 \quad 420$ JASA 65 IB2 BIOKA63 327 TECH 62 I25

INTERPRETATIONS BALANCED INCOMPLETE BLOCK DESIGNS WITH TWO-WAY CLASSIFICATION OF TREATMENTS NOTE ON A SEQUENTIAL CLASSIFICATION PROBLEM A CLASSIFICATION PROBLEM IN WHICH INFORMATION ABOUT ALT ERNATIVE DISTRIBUTIONS IS BASED ON SAMPLES DD CLASSTFTCATTON PROBLEMS (WITH DISCUSSION) A GENERAL APPROACH TO SOME SCREENIN AN THE CHOICE OF VARIABLES IN CLASSIFICATION PROBLEMS WITH DICHOTOMOUS VARIABLES ON THE CHOICE OF VARIABLES IN CLASSIFICATION PROBLEMS
BOUNDS IN A MINIMAX CLASSIFICATION PROCEDURE OPTIMUM CLASSIFICATION RULES FOR CLASSIFICATION INTO TWO MULT

IVARIATE NORMAL POPULATIONS BOUNDS IN A MINIMAX CLASSIFICATION PROCEDURE

OMPONENT ESTIMATORS FOR THE UNBALANCED TWO-WAY CROSS CLASSIFICATION WITH APPLICATION TO BALANCED INCOMPLET MULTIVARIATE-NORMAL CLASSIFICATION WITH COVARIANCE KNOWN

ESTIMABILITY OF VARIANCE COMPONENTS FOR THE TWO-WAY CLASSIFICATION WITH ITERATION

OR PROBABILITY SEQUENTIAL NONPARAMETRIC TWO-WAY CLASSIFICATION WITH PRESCRIBED MAXIMUM ASYMPTOTIC ERR STATISTICAL CLASSIFICATION WITH QUADRATIC FORMS

STUDENT'S T IN A TWO-WAY CLASSIFICATION WITH UNEQUAL VARIANCES

THE DETERMINATION OF CONNECTEDNESS IN AN N-WAY CROSS CLASSIFICATION'

RANK SUM MULTIPLE COMPARISIONS IN ONE AND TWO-WAY CLASSIFICATIONS AN ALGORITHM FOR HIERARCHICAL CLASSIFICATIONS ERRATA, A NOTE ON BIOCS65 I8I AMS $69 \quad 175$ AMS 63 I095 AMS $62 \quad 213$ JRSSB $68 \quad 407$ BIOKA67 668 BIOKA65 653 AMS 65 II74 AMS $69 \quad 408$ AMS $65 \quad 1787$ AMS 67 150B AMS $69 \quad 445$ BIOKA63 439 AMS 651248 TECH 65281 BIOKA67 487 BIOCS69 I 65 BIOCS69 427 EXPECTED MEAN SQUARES FOR NESTED CLASSIFICATIONS

OF VARIANCE OF DESIGNS WITH MANY NON-ORTHOGONAL CLASSIFICATIONS UNCTIONS OF VARIANCE COMPONENTS FROM TWO-WAY CROSSED CLASSIFICATIONS ED FROM ONE WAY-CLASSIFICATION TABLES WHEN THE CROSS CLASSIFICATIONS UARES IN AN ANALYSIS OF VARIANCE TABLE FOR DIFFERENT CLASSIFICATIONS WI ANALYSIS OF MULTIFACTOR CLASSIFICATIONS MULTIPLE COMPARISONS FOR BALANCED SINGLE AND DOUBLE CLASSIFICATIONS MULTIPLE COMPARISONS FOR BALANCED SINCLE AND DOUBLE CLASSIFICATIONS. MEASURES OF ASSOCIATION FOR CROSS CLASSIFICATIONS. MEASURES OF ASSOCIATION FOR CROSS CLASSIFICATIONS, 11] SIMULTANEOUS BIOKA64 439 THE ANALYSIS JRSSB66 110 /OR THE SIMUTANEOUS ESTIMATION OF F BIOKA67 I27 ARE UNKNOWN /N COEFFICIENTS ESTIMAT JASA $66 \quad 720$ WITH CORRELATED AND NON-HOMOCENEOUS E JRSSB59 1 I4 WITH UNEQUAL NUMBERS OF OBSERVATIONS BIOCS6 $6 \quad 525$ PART I. RESULTS SHORT-CUT TECH 6595 PART 2. DERIVATIONS AND APPROXIMATIO BIOKA65 485 II. FURTHER DISCUSSION AND REFERENCE JASA 59 I23 $\mathrm{S}$ MINATION OF A SAFE LIFE FOR CLASSES OF DISTRIBUTIONS CLASSIFIED BY FAILURE RATE

ON THE DETER TECH 68 361 
LIA SUBOBSCURA' CO/VECTORIAL ANALYSIS FOR CENETIC CLINES IN BODY DIMENSIONS IN POPULATIONS OF 'DROSOPHI BIOCS66 469 THE TWO-PERIOD CHANCE-OVER DESICN AND ITS USE IN CLINICAL TRAILS PLAY THE WINNER RULE AND THE CONTROLLED CLINICAL TRIAL

A BAYESIAN APPROACH TO THE ANALYSIS OF DATA FROM CLINICAL TRIALS AN ADAPTIVE PROCEDURE FOR SEQUENTIAL CLINICAL TRIALS TWO-STACE DESICNS FOR CLINICAL TRIALS

LASSICAL HYPOTHESES, WITH APPLICATIONS TO SEQUENTIAL CLINICAL TRIALS TRUNCATED SEQUENTIAL DESICNS FOR CLINICAL TRIALS BASED ON MARKOV CHAINS

A BAYESIAN TEST OF SOME C J ON COMBININC THE RESULTS FROM CLINICAL TRIALS OF A VACCINE

THE COVARIANCE AND SPECTRAL DENSITY FUNCTIONS FROM A CLIPPED STATIONARY TIME SERIES ESTIMATION OF SPECTRA AFTER HARD CLIPPINC OF CAUSSIAN TIME PROCESSES BOUNDARIES FOR CLOSED (WEDGE) SEQUENTIAL T TEST PLANS SOME NON-CENTRAL F-DISTRIBUTIONS EXPRESSED IN CLOSED FORM

UPPER AND LOWER PROBABILITIES GENERATED BY A RANDOM CLOSED INTERVAL

THE MULTIPLE-RECAPTURE CENSUS. I. ESTIMATION OF A CLOSED POPULATION MACHINE INTERFERENCE MODEL CLOSED QUEUEING SYSTEMS, A GENERALIZATION OF THE SEQUENTIAL ESTIMATION AND CLOSED SEQUENTIAL DECISION PROCEDURES

\section{A FAMILY OF CLOSED SEQUENTIAL PROCEDURES (CORR. 69457 ) CLOSED SEQUENTIAL T-TESTS} CLOSED SEQUENTIAL TESTS FOR AN EXPONENTIAL PARAMETER CLOSED SEQUENTIAL TESTS FOR BINOMIAL PROBABILITIES

$\begin{array}{ll}\text { BIOCS65 } & 467\end{array}$ JASA $69 \quad 131$ JASA $65 \quad 81$ JASA 69759 8I0CS69 111 JASA $66 \quad 577$ BIOCS68 159 8I0CS65 616 JRSSB 67 1BO TECH $67 \quad 391$ 8IOKA66 431 BIOKA64 107 AMS 6B 957 BIOKA58 343 JRSSB $61 \quad 385$ AMS 64 104B BIOKA62 41 BIOKA62 359 BIOKA68 387 BIOKA66 73 NORMAL DISTRIBUTION HAVING A PRESCRIBED PROPORTIONAL CLOSENESS/D SAMPLE ESTIMATOR OF THE MEAN OF A LOGNORMAL DISTRIBUTION HAVING A PRESCRIBED PROPORTIONAL CLOSENESS /UENTIAL ESTIMATION OF THE MEAN OF A LOCSTATISTICAL EVALUATION OF CLOUD SEEDING OPERATIONS

A METHOD FOR CLUSTER ANALYSIS

A COMPARISON OF SOME METHODS OF CLUSTER ANALYSIS

THE DISTRIBUTION OF THE SIZE OF THE MAXIMUM CLUSTER OF POINTS ON A LINE

A THREE-DIMENSIONAL CLUSTER PROBLEM A THREE-DIMENSIONAL CLUSTER PROBLEM
CARLO SOLUTION OF A TWO-DIMENSIONAL UNSTRUCTURED CLUSTER PROBLEM
POST CLUSTER SAMPLING

NOTE ON A MINIMAX DESIGN FOR CLUSTER SAMPLING ANALYTICAL SURVEYS WITH CLUSTER SAMPLING

GLUSTERS OF UNEQUAL SIZES METHODS OF CLUSTER SAMPLINC WITH AND WITHOUT REPLACEMENT FOR A POWER COMPARISON OF TWO TESTS OF NON-RANDOM CLUSTERING CLUSTERING OF RANDOM POINTS IN TWO DIMENSIONS

A STOGHASTIC ANALYSIS OF THE SPATIAL CLUSTERING OF RETAIL ESTABLISHMENTS STEP-WISE CLUSTERING PROCEDURES AMS 67949 AMS 661688 JASA $60 \quad 446$ BIOCS65 362 BIOCS67 623 JASA $65 \quad 532$ BIOKA6B 258 MONTE BIOKA67 625 AMS $63 \quad 587$ AMS $68 \quad 278$ JRSSB $65 \quad 264$ BIOKA62 27 TECH $66 \quad 493$ BIOKA65 263 $\begin{array}{lr}\text { JASA } & 65 \quad 1094\end{array}$ JASA $67 \quad 86$

E DETECTION OF SPACE-TIME INTERACTIONS DISEASE CLUSTERINC, A GENERALIZATION OF KNOX'S APPROACH TO TH PERCENTACE POINTS OF A TEST FOR CLUSTERS

EXPECTATIONS AND VARIANGES FOR THE SIZE OF LARGEST CLUSTERS AND SMALLEST INTERVALS SOME PROBABILITIES JA POWER OF NORMAL TESTS FOR INDEPENDENCE CO-ORDINATE TRANSFORMATIONS TO NORMALITY AND THE STOCHASTIC COALESCENCE BIOCS68 541 JASA 69 NO. 4 ATE IN MULTIPLE REGRESSION ANALYSIS EXTENSION OF COCHRAN'S FORMUL NOTES.A NOTE ON COCHRAN'S Q TEST

THE SPECTRAL THEOREM FOR FINITE MATRICES AND COCHRAN'S THEOREM THE THEORY OF FACTORIAL DESICNS AND ERROR CORRECTING CODES CONTROL OF QUALITY OF CODINC IN THE 1960 CENSUSES ON THE CODING THEOREM FOR NOISELESS CHANNEL

LOWER BOUND FORMULAS FOR THE MEAN INTERCORRELATION COEFFICIENT AN ANGULAR TRANSFORMATION FOR THE SERIAL CORRELATION COEFFICIENT A REMARK ON SPEARMAN'S RANK CORRELATION COEFFICIENT A QUICK ESTIMATE OF THE REGRESSION COEFFICIENT

ON NAIR'S TRANSFORMATION OF THE CORRELATION COEFFICIENT NOTE ON FISHER'S TRANSFORMATION OF THE CORRELATION COEFFICIENT MOMENTS OF A SERIAL CORRELATION COEFFIGIENT A GENERALIZATION OF THE INBREEDING COEFFICIENT THE DISTRIBUTION OF THE MATCHING COEFFICIENT NOTE ON THE PROBA8ILITY INTEGRAL OF THE CORRELATION COEFFICIENT NULL DISTRIBUTION OF THE FIRST SERIAL CORRELATION COEFFICIENT PROOF OF DR HARLEY'S THEOREM ON THE CORRELATION COEFFICIENT

FOR A VARIANGE COMPONENT WITH AN EXACT CONFIDENCE COEFFICIENT OF THE DISTRIBUTION OF THE RANKING CONCORDANCE COEFFICIENT EFFIGIENCY OF DANIELS'S GENERALIZED GORRELATION COEFFICIENT OF AN ANGULAR TRANSFORMATION FOR THE CORRELATION COEFFICIENT ON THE DISTRIBUTION OF THE SAMPLE CORRELATION COEFFICIENT DISTRIBUTION OF THE LARCEST CANONICAL CORRELATION COEFFICIENT

OF AN ANGULAR TRANSFORMATION OF THE CORRELATION COEFFICIENT FORM OF THE DISTRIBUTION OF THE MULTIPLE CORRELATION GOEFFICIENT THE DISTRIBUTION OF THE SAMPLE GENETIC CORRELATION COEFFICIENT FOR THE MEAN AND VARIANCE OF THE SERIAL CORRELATION COEFFICIENT FOR THE MOMENTS OF THE DISTRIBUTION OF CORRELATION COEFFICIENT FOR SMALL N OF KENDALL'S PARTIAL RANK CORRELATION COEFFICIENT CONFIDENCE LIMITS ON THE MULTIPLE CORRELATION COEFFICIENT

OF NON-CENTRAL T AND OF A TRANSFORMED CORRELATION COEFFICIENT E SIZE. AND A RELATION WITH THE MULTIPLE CORRELATION COEFFICIENT TO THE DISTRIBUTION OF THE AVERAGE RANK CORRELATION COEFFICIENT REPRODUGINC FI/ EXPECTED EFFECTS ON THE INBREEDING COEFFICIENT ESTIMATES OF THE REGRESSION COEFFICIENT BASED ON KENDALL'S TAU

RELATIVE EFFICIENCY OF TWO TESTS AND THE CORRELATION COEFFICIENT BETWEEN TH
THE EXACT DISTRIBUTION OF A STRUCTURAL COEFFICIENT ESTIMATOR A PARTIAL COEFFICIENT FOR GOODMAN AND KRUSKAL'S CAMMA CORRECTING THE AVERAGE RANK CORRELATION COEFFICIENT FOR TIES IN RANKINGS ON A BOUND USEFUL IN AMS $64 \quad 408$ JASA $66 \quad 1191$ BIOKA69 139 TECH $68 \quad 133$ JASA $63 \quad 527$ BIOCS65 1008 JASA $64 \quad 120$ AMS $61 \quad 594$ JASA 59275 BIOKA54 261 BIOKA5B 273 BIOKA5B 431 BIOKA58 567 JRSSB59 409 JRSSB 65 30B BIOCS65 665 BIOCS67 647 A BIOKA54 27B THE BIOKA66 623 SHORT BIOKA58 571 LIMITS AMS $61 \quad 466$ AN APPLICATION BIOKA5I 33 THE ASYMPTOTIC BIOKA63 499 SOME PROPERTIES BIOKA56 219 SOME NEW RESULTS JRSSB66 513 ON THE NONCENTRAL SASJ 69 NO.2 FURTHER PROPERTIES BIOKA57 273 A RELATIVELY SIMPLE JRSSB6B 276 AN EMPIRICAL STUDY OF BIOCS69 63 ASYMPTOTIC EXPANSIONS BIOKA61 B5 ASYMPTOTIC EXPANSIONS BIOKA66 25B SIMULATED DISTRIBUTIONS 8IOKA63 520 TABLES FOR CONSTRUCTING JASA 631082 RELATION BETWEEN THE DISTRIBUTIONS BIOKA57 219 /DISCRIMINANT ANALYSIS, NECESSARY SAMPL BIOCS68 823 $\begin{array}{lll}\text { /DISCRIMINANT ANALYSIS, NECESSARY SAMPL BIOCS68 } & 823 \\ \text { /E AVERAGE RANK CORRELATION METHODS AND JASA } 63 & 756\end{array}$ BIOCS65 447 JASA $6 B \quad 1379$ AMS 631442 JASA $68 \quad 1214$ JASA $67 \quad 1$ B9 JASA $64 \quad 872$ NT/ INFERENCES CONCERNING A POPULATION CORRELATION COEFFICIENT FROM ONE OR POSSIBLY TWO SAMPLES SU8SEQUE JRSSB67 282 MAXIMUM LIKELIHOOD/ ESTIMATION OF THE IN8REEDING COEFFICIENT FROM PHENOTYPE FREQUENCIES 8Y A METHOD OF BIOCS68 915 
E R/ A RAPID METHOD FOR ESTIMATINC THE CORRELATION COEFFICIENT FROM THE RANCE OF THE DEVIATIONS ABOUT TH BIOKA53 $21 \mathrm{~B}$ UENCY DISTRIBUTION OF THE PRODUCT-MOMENT CORRELATION COEFFICIENT IN RANDOM SAMPLES OF ANY SIZE DRAWN FROM BIOKA51 219 THE DISTRIBUTION OF THE RECRESSION COEFFICIENT IN SAMPLES FROM A NON-NORMAL POPULATION BIOKA54 548 ALTERNATIVE DEFINITIONS OF THE SERIAL CORRELATION COEFFICIENT IN SHORT AUTORECRESSIVE SEQUENCES

A COEFFICIENT MEASURINC THE COODNESS OF FIT

ERRATA, 'A COEFFICIENT MEASURINC THE COODNESS OF FIT'

STOCHASTIC PROCESSES

ON THE COEFFICIENT OF COHERENCE FOR WEAKLY STATIONARY

VARIANCE FORMULAS FOR THE MEAN DIFFERENCE AND COEFFICIENT OF CONCENTRATION

CRAPHIC COMPUTATION OF TAU AS A COEFFICIENT OF DISARRAY

JASA $58 \quad 881$

TECH $66 \quad 327$

TECH $67 \quad 195$

AMS $64 \quad 532$

JASA $62 \quad 64 \mathrm{~B}$

JASA $5 B \quad 441$

ON CRIFFIN'S PAPER 'CRAPHIC COMPUTATION OF TAU AS A COEFFICIENT OF DISARRAY'

A NOTE JASA $61 \quad 736$ HESIS OF INDEPENDENCE

CRITICAL VALUES OF THE COEFFICIENT OF RANK CORRE
DE POINTS OF THE SAMPLE COEFFICIENT OF VARIATION

ON THE PERCENTACE POINTS OF THE SAMPLE COEFFICIENT OF VARIATION

IMATINC THE MEAN

AN INEQUALITY FOR THE SAMPLE COEFFICIENT OF VARIATION

LES SAMPLINC

L DISTRIBUTIONS

ORT

APPROXIMATE CONETE INTE THE UTT

FROM NON-NORMAL POPULATIONS THE MEAN AND COEFFICIENT OF VARIATION OF RANCE IN SMALL SAMPLES BIOKA54 469 OM NON-NORMAL POPULATIO/ CORRICENDA, 'THE MEAN AND COEFFICIENT OF VARIATION OF RANCE IN SMALL SAMPLES FR BIOKA55 277 BY KOOPMANS, OWEN AND RO/ THE DISTRIBUTTON OF THE COEFFICIENT OF VARTATTON COMMENT ON A CRITICISM MADE BTOKA65 303 NOTE ON TWO BINOMIAL COEFFICIENT SUMS FOUND BY RIORDAN

MOMENTS OF THE RANK CORRELATION COEFFICIENT TAU IN THE CENERAL CASE

CRAPHTC COMPUTATION OF THE MULTIPLE CORRELATION COEFFICTENT, CORR, 58 1031

SOME ESTIMATORS FOR A LINEAR MODEL WITH RANDOM COEFFICIENTS RAPID METHODS FOR ESTIMATING CORRELATION COEFFICIENTS

THE APPROXIMATE DISTRIBUTION OF SERIAL CORRELATION COEFFICIENTS LINEAR ESTIMATES WITH POLYNOMIAL COEFFICIENTS

THE JOINT DISTRIBUTION OF THE STUDENTIZED RECRESSION COEFFICIENTS

MULTIVARIATE STOCHASTIC PROCESSES WITH PERIODIC COEFFICIENTS FISHER, WRICHT, AND PATH COEFFICIENTS

DISTRIBUTION OF THE CIRCULAR SERIAL CORRELATION COEFFICIENTS

TRANSFORMATIONS OF VARIABLES UPON THEIR CORRELATION COEFFICIENTS

EFFICIENCY OF DANIELS'S CENERALIZED CORRELATION COEFFICIENTS

OF TWO METHODS OF COMPUTINC DISCRIMINANT FUNCTION COEFFICIENTS

CORRELATION COEFFICIENTS AND PARTIAL CORRELATION COEFFICIENTS NIMUM VARIANCE AND WEICHTED LEAST SQUARES RECRESSION COEFFICIENTS NEAR STOCHASTIC PROCESSES WITH ABSOLUTELY CONVERCENT COEFFICIENTS RIBUTION IV. EMPIRICAL VARIANCES OF RANK CORRELATION COEFFICIENTS TERIA FOR TESTINC LINEAR HYPOTHESES ABOUT RECRESSION COEFFICIENTS A NOTE ON THE SICNS OF CROSS CORRELATION COEFFICIENTS CALCULATION OF ZONAL POLYNOMIAL COEFFICIENTS

TOR BY THE USE OF THE LAPLACE-BELTRAMI OPERA AMS 6B 1711

BLES WHEN THE CROSS/ UNBIASED MULTTPLE RECRESSTON COEFFTCIFNTS ESTIMATED FROM ONE-WAY-CLASSTFICATION TA JASA 66 720 THE SAMPLINC VARIANCE OF THE CORRELATION COEFFICIENTS ESTIMATED IN CENETIC EXPERIMENTS THE PERFORMANCE OF SOME CORRELATION COEFFICIENTS FOR A CENERAL BIVARIATE DISTRIBUTION BIOKA60 307 ON TESTINC A SET OF CORRELATION COEFFICIENTS FOR EQUALITY ON TESTINC A SET OF CORRELATION COEFFICIENTS FOR EQUALITY. SOME ASYMPTOTIC RESULTS LACRANCIAN COEFFICIENTS FOR INTERPOLATION BETWEEN TABLED

AMS $63 \quad 149$ BIOKA68 513

PERCENTAGE POINTS BIOKA6B 19 COMPLETE SET OF LEADINC COEFFICIENTS FOR ORTHOCONAL POLYNOMTALS UP TO N $=26 \quad$ TECH $65 \quad 644$ MAXIMUM LIKELIHOOD ESTIMATORS OF REGRESSION COEFFICIENTS FOR THE CASE OF AUTOCORRELATED RESIDUALS TECH 6551 IONS AND COVARIANCES OF SERIAL AND CROSS-CORRELATION COEFFICIENTS IN A COMPLEX STATIONARY TIME SERIES/T BIOKA63 213 DISTRIBUTIONS OF CORRELATION COEFFICIENTS IN ECONOMIC TIME SERIES IMPROVED ESTIMATORS FOR COEFFICIENTS IN LINEAR RECRESSION

JASA $6 B \quad 596$ ULATIONS. I. THEOR/ THE DISTRIBUTION OF RECRESSION COEFFICIENTS IN SAMPLES FROM BIVARIATE NON-NORMAL POP BIOKA6O 61 CORRELATION COEFFICIENTS MEASURED ON THE SAME INDIVIDUALS JASA 69366 THE CANONICAL CORRELATION COEFFICIENTS OF BIVARIATE GAMMA DISTRIBUTIONS AMS 691401

ANOTHER

FINITE POPULATION A GENERAL CLASS OF COEFFICIENTS OF DIVERGENCE OF ONE DISTRIBUTION FROM MOMENT COEFFICIENTS OF THE K-STATISTICS IN SAMPLES FROM A

$\begin{array}{rr}\text { AMS } 69 & 1401 \\ \text { JRSSB } 66 & 131\end{array}$

OF TWO NORMAL POPUL

OBTAINED FROM VARIANCE ANALYSES

A TEST OF EOUALTTY BIOKA52

THE SAMPLING VARIANCE OF CORRELATION COEFFICIENTS UNDER ASSUMPTIONS OF FIXED AND MIXED VAR BIOKA5B 471

RICTED NOTES CORRECTED CORRELATION COEFFICIENTS WHEN OBSERVATION ON ONE VARIABLE IS REST BIOCS66 182 TESTS FOR RANK CORRELATION COEFFICIENTS. I

NDALL COEFFICIENT TESTS FOR RANK CORRELATION COEFFICIENTS. III. DISTRIBUTION OF THE TRANSFORMED KE BIOKA62 18 TESTS FOR RANK CORRELATION COEFFICTENTS. II

A PROCEDURE FOR COMPUTINC REGRESSION COEFFICIENTS, CORR. 59 BII

A NOMOGRAPH FOR COMPUTINC PARTIAL CORRELATION COEFFICIENTS, CORR. 62917 PHASE FREE ESTIMATION OF COHERENCE

ON THE COEFFICIENT OF COHERENCE FOR WEAKLY STATIONARY STOCHASTIC PROCESSES COHERENT STRUCTURES OF NON-IDENTICAL COMPONENTS

THE LAST RETURN TO EQUILIBRIUM IN A COIN TOSSING GAME

A REMARK ON THE COIN TOSSING GAME

ON A COINCIDENCE PROBLEM CONCERNING PARTICLE COUNTERS

THE TRANSIENT BEHAVIOR OF A COINCIDENCE VARIATE IN TELEPHONE TRAFFIC

BIOKA61 29

JASA $58 \quad 144$

JASA 61995

AMS 69540

AMS $64 \quad 532$

TECH 63191

AMS 641344

AMS 641345

AMS $61 \quad 739$

AMS 61230

PROBABILITY AND STATTSTICS XVIII THOMAS YOUNG ON COINCIDENCES STISIES IN THE HISTORY OF BIOKA6B 249

$R$ A STUDY OF THE VARIABILITY DUE TO COINCIDENT PASSAGE IN AN ELECTRONIC BLOOD CELL COUNTE BIOCS67 671 IMENSIONS IN POPULATIONS OF 'DROSOPHILIA SUBOBSCURA' COLL. AND A COMPARISON WITH THOSE OF 'D. ROBUSTA' STU BIOCS66 469 EQUATION

A CRITICAL COMPARISON OF THREE STRATEGIES OF COLLECTING DATA FROM HOUSEHOLDS

ON THE RUIN PROBLEM OF COLLECTIVE RISK THEORY

ASYMPTOTIC DISTRIBUTORS FOR THE COUPON COLLECTOR'S PROBLEM

A NOTE ON DIRECTION AND COLLINEARITY FACTORS IN CANONICAL ANALYSIS

ON THE DISTRIBUTIONS OF DIRECTION AND COLLINEARITY FACTORS IN DISCRIMINANT ANALYSIS

AMS 63233

JASA 67976 AMS $61 \quad 757$ AMS 651 1B35

BIOKA62 255 AMS 6 B $\quad$ B55

ICTIONAL PRIME-POWE/ ON THE CONSTRUCTION OF CYCLIC COLLINEATIONS FOR OBTAININC A BALANCED SET OF L-RESTR AMS 67 I293 APPLICATION OF CYCLIC COLLINEATIONS TO THE CONSTRUCTION OF

OF OVERLAPPING IN BACTERIAL COUNTS OF INCUBATED COLONIES THE EFFECT BIOKA53 220 TIC REMOVALS THE EXTINCTION OF A BACTERIAL COLONY BY PHACES, A BRANCHING PROCESS WITH DETERMINIS BIOKA62 272 
ALLOWINC FOR INTER-EXPERIMENT VARIATION $S$ OF VARIANCE

THE COMBINATION OF ESTIMATES FROM SIMILAR EXPERIMENTS,

DESIGNS

ON THE COMBINATION OF INDEPENDENT TEST STATISTICS

THE COMBINATION OF INFORMATION IN GENERALLY BALANCED

QUERY, THE COMBINATION OF PROBABILITIES

TABLES

CONTINCENCY TABLES

A NOTE ON THE APPLICATION OF THE COMBINATION OF PROBABILITIES TEST TO A SET OF 2-BY-2 COMBINATION OF RESULTS FROM SEVERAL 2 BY 2

ON THE WEIGHTED COMBINATION OF SIGNIFICANCE TESTS

IONS.' CORRIGENDA, 'ON QUESTIONS RAISED BY THE COMBINATION OF TESTS BASED ON DISCONTINUOUS DISTRIBUT BI THE COMBINATION OF TESTS BASED ON DISCRETE DISTRIBUTIONS AN EXAMPLE OF AN ANCILLARY STATISTIC AND THE COMBINATION OF TWO SAMPLES BY BAYES' THEOREM ALMOST LINEARLY-OPTIMUM COMBINATION OF UNBIASED ESTIMATES PEAKEDNESS OF DISTRIBUTIONS OF CONVEX COMBINATIONS PERIMENT SIZES FOR DECISION REGARDINC CERTAIN LINEAR COMBINATIONS F SONE SCHEMES REQUIRING NOT MORE THAN 256 TREATMENT COMBINATIONS CE RATES FOR THE LAW OF LARCE NUMBERS FOR THE LINEAR COMBINATIONS OF EXCHANGEABLE AND MIXINC STOCHASTIC PR ASYMPTOTIC NORMALITY OF LINEAR COMBINATIONS OF FUNCTIONS OF ORDER STATISTICS

PLICATIONS TO E/ ASYMPTOTIC DISTRIBUTION OF LINEAR COMBINATIONS OF FUNCTIONS OF ORDER STATISTICS WITH AP N THE COMPLETE AND ALMOST SURE CONVERGENCE OF LINEAR COMBINATIONS OF INDEPENDENT AND RANDOM VARIABLES AND XPRESSION OF VARIANCE-COMPONENT ESTIMATORS AS LINEAR COMBINATIONS OF INDEPENDENT NONCENTRAL CHI-SOUARE VAR VERGENCE RATE OF THE LAW OF LARCE NUMBERS FOR LINEAR COMBINATTONS OF TNDEPENDENT RANDOM VARIABLES RCENCE RATES FOR THE LAW OF LARCE NUMBERS FOR LINEAR COMBINATIONS OF MARKOV PROCESSES GONVE ULA

ESTIMATING THE DECREES OF FREEDOM FOR LINEAR COMBINATIONS OF MEAN

LINEAR COMBINATIONS OF NON-CENTRAL CHI-SQUARE VARIATES

FAMILIES

INEQUALITIES FOR LINEAR COMBINATIONS OF ORDER STATISTICS FROM RESTRICTED

ON LINEAR COMBINATIONS OF SEVERAL VARIANCES

A COMPLETE FACTORIAL EXPERIMENT AS ORTHOGONAL LINEAR COMBINATIONS OF THE OBSERVATIONS /FOR FRACTIONS OF A MULTIVARIATE DISTRIBUTION ESTIMATES OF LINEAR COMBINATIONS OF THE PARAMETERS IN THE MEAN VECTOR OF CONSIDER INEQUALITY OF UNKNOWN VARIANCES

A METHOD OF ASSIGNING CONFIDENCE LIMITS TO LINEAR COMBINATIONS OF VARIANCES TRUNCATED POISSON SUFFICIENT STATISTIG

A COMBINATORIAL DERIVATION OF THE DISTRIBUTION OF THE A FAMILY OF COMBINATORIAL IDENTITIES

A COMBINATORIAL LEMMA FOR COMPLEX NUMBERS

IZED K-STATISTICS

WITH SOME GENERAL FORMULAE

SOME RULES FOR A COMBINATORIAL METHOD FOR MULTIPLE PRODUCTS OF CENERAL

A COMBINATORIAL METHOD FOR PRODUCTS OF TWO POLYKAYS COMBINATORIAL RESULTS IN FLUCTUATION THEORY COMBINATORIAL RESULTS IN MULTI-DIMENSIONAL FLUCTUATIO

N THEORY, CORR. 64924

RESPONSES

A COMBINATORIAL TEST FOR INDEPENDENCE OF DICHOTOMOUS COMBINATORIAL THEOREM FOR PARTIAL SUMS

CONFOUNDINC

WINDOW

COMPARISON OF COMBINED ESTIMATORS IN BALANCED INCOMPLETE BLOCKS

UNIFORMLY BETTER COMBINED ESTIMATORS IN FACTORIAL ARRANGEMENTS WITH

SPECTRAL ANALYSIS COMBINING A BARTLETT WINDOW WITH AN ASSOCIATED INNER ADDITIVE COMEINING ABILITIES FITTED TO PLANT BREEDING DATA A BAYES APPROACH FOR COMBINING CORRELATED ESTIMATES

A NOTE ON COMBINING CORRELATED ESTIMATES OF A RATIO OF MULTIVAR

IATE MEANS

MIXED FACTORIALS COMBININC ELEMENTS FROM DISTINCT FINITE FIELDS IN

ON COMBINING ESTIMATES OF A RATIO OF MEANS

COMBINING INTRA AND INTER BLOGK ANALYSIS OF GROUP

DIVISIBLE DESIGNS

VACCINE

ON COMBINING THE RESULTS FROM CLINICAL TRIALS OF A

QUERY, COMBININC VALUES OF OBSERVED CHI-SQUARE'S

MULTIPLE RECRESSION COMBINING WITHIN- AND BETWEEN-PLOT INFORMATION

NOTES SMALL SAMPLE CONSIDERATTONS IN COMBININC 2 BY 2 TABLES

PUBLIGATION DECISIONS AND TESTS OF SIGNIFICANCE, A COMMENT

THE DISTRIBUTION OF THE COEFFICIENT OF VARIATION, COMMENT ON A CRITICISM MADE BY KOOPMANS, OWEN AND ROS

A COMMENT ON D.V. LINDLEY'S STATISTICAL PARADOX

COMMENT ON SIR RONALD FISHER'S PAPER, ION A TEST OF S JR

IGNIFICANCE IN PEARSON'S BIOMETRIKA TABLES (NO. 1)
THIS JOURNAL (VOL. 1B, NO. 2, 1956)

DISCRIMINANT ANALYSIS'

AUTHOR'S REPLY TO ANSCOMBE'S COMMENT ON THE NOTES BY NEYMAN, BARTLETT AND WELCH IN COMMENTARY ON 'ESTIMATION OF ERROR RATES IN

COMMENTS

SOCIETY MEMORIAL MEETING FOR WILLIAM N. HURWITZ, COMMENTS OSSETT, R.A. FISHER AND KARL PEARSON, WITH NOTES AND COMMENTS SOME EARLY CORRESPONDENCE BETWEEN W S O COMMENTS ON 'THE SIMPLEST SIGNED-RANK TESTS '

COMMENTS ON A POSTERIOR DISTRIBUTION OF GEISSER AND CORNFIELD

SEQUENTIAL MEDICAL TRIALS, SOME COMMENTS ON F. J. ANSCOMBE'S PAPER

COMMENTS ON PAPER BY KJTTZ LINK, TUKEY AND WALLACE

SOME COMMENTS ON SPECTRAL ANALYSIS OF TIME SERIES

EE ON WEATHER CONTROL'

THE DISTRIBUTION OF $M$

GOODMAN

IMMIGRATION '

FURTHER COMMENTS ON THE 'FINAL REPORT OF THE ADVISORY COMMITT

SOME COMMENTS ON THE ACCURACY OF BOX'S APPROXIMATIONS TO

COMMENTS ON THE DISCUSSIONS OF MESSRS. TUKEY AND

CORRECTIONS AND COMMENTS ON THE PAPER 'A BRANCHINC PROCESS ALLOWING

TREME VALUE THEORY TO ERROR FREE COMMUNICATION'

COMMENTS TO EDWARD C POSNER, 'THE APPLICATION OF EX

COMMENTS ON THE ' FTNAL REPORT OF THE ADVISORY COMMITTEE ON WEATHER CONTROL'

RIMENTS HAVING ERROR VARIANCE AND SOME TREATMENTS IN COMMON

NEGATIVE BINOMIAL DISTRIBUTIONS WITH A COMMON $K$

ANALYSIS OF A CROUP OF BALANCED BLOCK EXPE

NEGATIVE
L SAMPLES OF EQUAL SIZE

UNBAISED ESTIMATION OF THE THE BAYESIAN ESTIMATION OF

VALIDATION OF CONSUMER FINANCIAL CHARACTERISTICS,

COMMON MEAN OF TWO NORMAL DISTRIBUTIONS BASED ON SMAL COMMON PARAMETERS FROM SEVERAL RESPONSES

ARTIALLY BALANCED INCOMP/ BOUNDS FOR THE NUMBER OF COMMON TREATMENTS BETWEEN ANY TWO BLOCKS OF CERTAIN P

BALANC/ COMPARISON OF THE BOUNDS

BALANCED INCOMPLETE BLOCK DESIGNS
BIOKA58 331

JASA $67 \quad 241$

AMS $62 \quad 482$

AMS $67 \quad 659$

JRSSB68 303

BIOC 567840

BIOKA55 404

BIOGS65 86

JRSSB55 264

BIOKA5I 265

JASA $62 \quad 10$

AMS 61616

JASA $61 \quad 36$

AMS $65 \quad 1703$

JRSSB67 503

AMS 69 NO. 6 AMS $67 \quad 52$ AMS 6B 1549 AMS 69 NO. 6 AMS $65 \quad 559$ AMS $66 \quad 711$ TECH 69 NO. 4 JASA $64 \quad 1141$ AMS $66 \quad 4 B 0$ AMS $66 \quad 1574$ JASA $56 \quad 132$ AMS 631068 AMS $65 \quad 7 \mathrm{~B}$ JASA 691042 BIOKA55 471 AMS $61 \quad 904$ AMS $66 \quad 509$ AMS 61901 AMS $689 B 3$ AMS $64 \quad 1174$ AMS $63 \quad 1233$ AMS $63 \quad 402$ JASA $65 \quad 437$ AMS 631600 AMS $66 \quad 1832$ JASA $67 \quad 638$ TECH 61235 BIOCS67 45 JASA 65602 TECH $64 \quad 463$ AMS $69 \quad 49 \mathrm{~B}$ JRSSB63 201 TECH $66 \quad 188$ BIOCS65 616 TECH 66709 BIOCS66 26 BIOCS67 349 JASA 59593 BIOKA65 303 BIOKA57 533 JRSSB56 295 JRSSB57 179 TECH 6B 204 TECH $65 \quad 169$ JASA 69 NO. 4 BIOKA68 445 JASA 59213 JRSSB64 274 JASA $63 \quad 384$ TECH $65 \quad 163$ TECH 61221 JASA 61580 BIOKA69 219 TECH $61 \quad 229$ JRSSB66 213 ICH $66 \quad 363$ SA 61580 IOCS68 389 BIOKA58 37 JASA $66 \quad 467$ BIOKA65 355 JASA 69415 AMS $65 \quad 337$ AMS 68999 
P DIVISIBLE DESIGNS ON THE BOUNDS OF THE NUMBER OF COMMON TREATMENTS BETWEEN BLOCKS OF SEMI-REGULAR CROU JASA 64 B67 EDURE FOR RANKING MEANS OF NORMAL POPULATIONS WITH A COMMON UNKNOWN VARIANCE /PLE MULTIPLE DECISION PROC BIOKA54 170 ORMAL APPROXIMATION FOR BINOMIAL, F, BETA, AND OTHER COMMON, RELATED TAIL PROBABILITIES, I A NASA 68 1416 ORMAL APPROXIMATION FOR BINOMIAL, F, BETA, AND OTHER COMMON, RELATED TAIL PROBABILITIES, II A N JASA 6B 1457 IAISONS ENTRE LES ESPECES ET LES VARI/ L'ETUDE DES COMMUNAUTES VECETALES PAR L'ANALYSE STATISTIQUE DES L BIOCS65 B9O IAISONS ENTRE LES ESPECES ET LES VARI/ L'ETUDE DES COMMUNAUTES VECETALES PAR L'ANALYSE STATISTIQUE DES L BIOCS65 345 APPLICATION OF EXTREME VALUE THEORY TO ERROR-FREE COMMUNICATIONHE APPLICATION OF EXTREME VALUE THEORY TO ERROR FREE COMMUNICATION' COMMENTS TO, EDWARD C. POSNER, 'T TECH 66363 A COMMUNICATIONS SATELLITE REPLENISHMENT POLICY T TECH $66 \quad 399$ MODEL OF A SIMPLE EPIDEMIC FOR MORE THAN ONE COMMUNITY

THE DETERMINISTIC BIOKA55 126 ISTRIBUTION AS A PROBABILITY MODEL IN POPULATION AND COMMUNITY ECOLOGY AND SOME OF ITS STATISTICAL PROPERT JASA 67 655 THREE SOURCES OF DATA ON COMMUTING. PROBLEMS AND POSSIBILITIES SOME NONPARAMETRIC TESTS FOR COMOVEMENTS BETWEEN TIME SERIES

MINIMAX THEOREMS ON CONDITIONALLY COMPACT SETS

A COMPACT TABLE FOR POWER OF THE T-TEST JASA $60 \quad B$ JASA $61 \quad 11$ AMS 631536 AMS $6 B 1629$ A CHARACTERIZATION OF THE UNIFORM DISTRIBUTION ON A COMPACT TOPOLOGICAL CROUP AMS $63 \quad 319$

$1947-1954$

A QUTCK COMPACT TWO SAMPLE TEST TO TECH 5931

AMETERS IN LINEAR AUTORECRESSIVE SCHEMES MARKET GROWTH COMPANY DIVERSIFICATION AND PRODUCT CONCENTRATION COMPARATIVE COST OF TWO LIFE TEST PROCEDURES JASA $60 \quad 640$ COMPARATTE $62 \quad 140$ ASYMPTOTIC EFFICIENCY OF CERTAIN RANK TESTS FOR COMPARATIVE EXPERIMENT ANTIGENICITY OF VACCINES FIT TESTS COMPARATIVE SAMPLING ACCEPTANCE SCHEMES IN TESTINC

A COMPARATTVE STUDY OF SEVERAL ONE-SIDED GOODNESS-OF-

A COMPARATIVE STUDY OF VARIOUS TESTS FOR NORMALITY

PLANNING SOME TWO-FACTOR COMPARATIVE SURVEYS

THE USE OF WEALTH TO COMPARE HOUSEHOLDS' AVERAGE SAVINC

BIOKA61 427 AMS $67 \quad 90$ BIOCS66 6B4 AMS 651583 JASA $6 B \quad 1343$ JASA 69560 JASA $64 \quad 737$

VEMENT TO IT A COMPLETE MULTINOMIAL DISTRIBUTION COMPARED WITH THE X-SQUARE APPROX A RANK SUM TEST FOR COMPARING ALL PAIRS OF TREATMENTS

A CENERALIZED WILCOXON TEST FOR COMPARING ARBITRARILY SINGLY-CENSORED SAMPLES

BIOKA64 277 TECH $60 \quad 197$ BIOKA65 203 ON COMPARING DIFFERENT TESTS OF THE SAME HYPOTHESIS BIOKA60 297 THE PROBLEM OF MINIMUM DISTANCES COMPARING DISTANCES BETWEEN MULTIVARIATE POPULATIONS, AMS 67550 RY CHARACTERISTICS IN TWO DIFFERENT POPULATIONS ON COMPARING INTENSITIES OF ASSOCIATION BETWEEN TWO BINA JA AN EXACT TEST FOR COMPARING MATCHED PROPORTIONS IN CROSSOVER DESICNS

SOME PROCEDURES FOR COMPARING POISSON PROCESSES OR POPULATIONS

BBS 61 BB9 BIOKA69 75 BIOKA53 447 R/ AN ASYMPTOTICALLY OPTIMAL SEQUENTIAL DESIGN FOR COMPARING SEVERAL EXPERIMENTAL CATECORIES WITH A CONT AMS 63 14B6 YMPTOTTCALLY OPTTMAL FTXED SAMPLE STZE PROCEDURE FOR COMPARING SEVERAL EXPERTMENTAL CATEGORIES WITH A CONT AMS 64 1571 DARD OR CONTROL A SEQUENTIAL PROCEDURE FOR COMPARING SEVERAL EXPERIMENTAL CATEGORIES WITH A STAN VARIABLES

ON COMPARING THE CORRELATIONS WITHIN TWO PAIRS OF

AMS 6243 B $\begin{array}{rr}\text { AMS } 62 & 43 \text { B } \\ \text { BIOCS68 } & 987\end{array}$ BIOKA59 106 TECH $60 \quad 103$ SASJ $68 \quad 33$ BIOKA58 544 PROGRAMMINC FISHER'S EXACT METHOD OF COMPARING TWO PERCENTAGES

ON COMPARING TWO SIMPLE LINEAR RECRESSION LINES

MEAN A TWO-SAMPLE DISTRIBUTTON FREE TEST FOR COMPARING VARIANCES

A. MONTE CARLO STUDY COMPARINC VARIOUS TWO-SAMPLE TESTS FOR DIFFERENCES IN TECH $6 B$ 509 QUERY, SAVINCS IN TEST TIME WHEN COMPARING WEIBULL SCALE PARAMETERS TECH $64 \quad 471$

A NOTE ON TABLES FOR THE COMPARISION OF THE SPREAD OF TWO NORMAL DISTRIBUTIONS BIOKA67 683 RANK SUM MULTTPLE COMPARTSTONS TN ONE AND TWO-TMY CLASSIFICA

MATRICES BASED ON FOUR CRITERIA

BLOCK DESIGNS

SUM PROCEDURE

SIS PART I DESCRIPTION AND USE OF TABLES. TEST AND THE POWER OF THE BLUS TEST REDUCED GROUP D

\section{POWER COMPARISIONS OF TESTS OF EQU
MULTIPLE COMPARISIONS USING RANK SUMS}

MULTIPLE COMPARISIONS WITH A CONTROL IN BALANCED INCOMPLETE

PAIRWISE COMPARISON AND RANKING IN TOURNAMENTS

JUDCES

$$
\text { A COMPARISON BETWEEN THE POWER OF THE DURBIN-WATSON }
$$

PAIRED COMPARISON DESIGNS

PAIRED COMPARISON DESIGNS FOR TESTINC CONCORDANCE BETWEEN AN ANALYSIS OF PAIRED COMPARISON DESICNS WITH INCOMPLETE REPETITIONS SELECTION OF THE BEST TREATMENT IN A PAIRED-COMPARISON EXPERIMENT

NTITLED 'SELECTION OF THE BEST TREATMENT IN A PAIRED-COMPARISON EXPERIMENT'//ER OF TRAWINSKI AND DAVID E RANK TESTS FOR PAIRED-COMPARISON EXPERIMENTS INVOLVINC SEVERAL TREATMENTS A SIMPLE EXAMPLE OF A COMPARISON INVOLVING QUANTAL DATA

A REMARK ON MULTIPLE COMPARISON METHODS

PAIRED COMPARISON MODELS WITH TESTS FOR INTERACTION

A COMPARISON OF A MODIF IED 'HANNAN' AND THE BUREAU OF COMPARISON OF ANALYSIS OF VARIANCE POWER FUNCTION IN COMPARISON OF ANOVA AND HARMONIC COMPONENTS OF

A COMPARISON OF CERTAIN TESTS OF NORMALITY

COMPARISON OF COMBINED ESTIMATORS IN BALANCED

A COMPARISON OF CONTINUOUS DISTRIBUTIONS OF PARAMETERS

THE COMPARISON OF CORRELATIONS IN TIME-SERIES AN EMPIRICAL COMPARISON OF DISTANCE STATISTICS FOR POPULATIONS WIT BIOCS68 683 COMPARISON OF ESTIMATES OF CIRCULAR PROBABLE ERROR, JASA 59794 COMPARISON OF FOUR RATIO-TYPE ESTIMATES UNDER A MODEL JASA 69574 COMPARISON OF LEAST SQUARES AND MINIMUM VARIANCE ESTI AMS 62462 A COMPARISON OF MAJOR UNITED STATES RELIGIOUS GROUPS JASA $6156 \mathrm{~B}$ MATES OF RECRESSION PARAMETERS, (ACKNOWLEDGEMENT/ TO RECRESSION ANALYSIS IONS OF INDEPENDENT STOCHASTIC SERIES BAYESIAN COMPARISON OF MEANS OF A MIXED MODEL WITH APPLICATION

THE COMPARISON OF MEANS OF SETS OF OBSERVATIONS FROM SECT THE COMPARISON OF REGRESSION VARIABLES PLACEMENT POLTCTES, AND RENEWHAL

QUERY, COMPARISON OF SAMPLE SIZES IN INVERSE BINOMIAL HRS 64577

THEORY IMPLICATIONS

SAMPLING

SIZE OF A POPULATION

RATIOS OF THE POPULATION VARIANCES ARE UNKNO/ APPROACH

COMPARISON OF SEQUENTIAL RULES FOR ESTIMATION OF THE

THE COMPARTSON OF SEVERAL CROUPS OF OBSERVATTONS WHEN THE BIOKA5 ON THE COMPARISON OF SEVERAL MEAN VALUES. AN ALTERNATIVE BIOKA51 330 NOTE ON THE COMPARISON OF SEVERAL REALIZATIONS OF A MARKOFF CHAIN BIOKA59 412 A COMPARISON OF SEVERAL VARIANCE COMPONENT ESTIMATORS BIORA67 301 A COMPARISON OF SOME BAYESIAN AND FREQUENTIST $\quad$ BIOKA65 19 A COMPARISON OF SOME BAYESIAN AND FREQUENTIST
INFERENCES
INFERENCES. II 
A COMPARISON OF SOME CONTROL CHART PROCEDURES

A COMPARISON OF SOME METHODS OF CLUSTER ANALYSIS

TECH $66 \quad 411$

COMPARISON OF SOME RATIO ESTIMATORS

BIOCS67 623

COMPARISON OF SOME SEQUENTIAL DESICNS

JASA $65 \quad 294$

IAL DIACNOSIS OF NONTOXIC COITRE TABLES

OF STATISTICAL TECHNIQUES IN THE DIFFERENT FUNCTION TECHNIQUES IN MEDICAL TAXONOMY LINE

MULTIVARIATE ANALYSIS.

TWO SEQUENTIAL PROCEDURES FOR RANKINC PROBLEM TMENTS BETWEEN BLOCKS OF CERTAIN PARTIALLY BALANC/ THE ESTIMATION OF A PARAMETER

NT SOMEWHERE MOST POWERFUL TEST FOR CERTAIN PRO/ OODNESS-OF-FIT TESTS WITH RESPECT TO VALIDITY, INDEPENDENCE IN 2 X2 CONTINCENCY TABLES OF VARIANCE TESTS OF VARIANCE TESTS.

T AND NON-INDEPENDENT EXPERIMENTS IGHTED LEAST SQUARES REGRESSION COEFFICIENTS SOME STOCHASTIC POPULATION MODELS NC VARIANCE COMPONENTS FROM HOUSEHOLDS

ODELS FOR QUANTAL RESPONSES TO MTXTURES OF DRUCS OF THE RANGE IN SMALL SAMPLES PR

IVE METHODS FOR CALCULATING TABLES CONFIDENCE INTERVALS FOR SYSTEM RELIABILITY

A NON-PARAN

COMPARISON OF STRENCTHS OF ASSOCIATION IN CONTINCENCY

A. COMPARISON OF SUCCESSIVE SCREENINC AND DISCRIMINANT COMPARISON OF TESTS FOR RANDOMNESS OF POINTS ON A BIOKA63 315

A COMPARISON OF TESTS OF THE WILKS-LAWLEY HYPOTHESIS IN BIOKA65 149

A COMPARISON OF THE ASYMPTOTIC EXPECTED SAMPLE SIZES OF AMS 69 NO.6 COMPARISON OF THE BOUNDS OF THE NUMBER OF GOMMON TREA AMS 66739 A COMPARISON OF THE DIRECT AND FIDUCIAL ARCUMENTS IN JRSSB63 95 A COMPARISON OF THE EFFECTIVENESS OF TOURNAMENTS BIOKA60 253

A COMPARISON OF THE MOST STRINCENT AND THE MOST STRINGE AMS 68 531

A COMPARISON OF THE PEARSON CHI-SQUARE AND KOLMOCOROV G JASA 65854 COMPARISON OF THE POWER FUNCTIONS FOR THE TEST OF AMS 641115

A COMPARISON OF THE POWERS OF TWO MULTIVARIATE ANALYSIS BIOKA62 455

A COMPARISON OF THE POWERS OF TWO MULTIVARIATE ANALYSIS BIOKA63 546 ON THE COMPARISON OF THE SENSITIVITIES OF EXPERIMENTS $\quad$ JRSSB62 447 COMPARISON OF THE SENSITIVITIES OF SIMILAR INDEPENDEN BIOKA69 17 COMPARISON OF THE VARIANCE OF MINIMUM VARIANCE AND WE AMS 63984

A COMPARISON OF THEORETICAL AND EMPIRICAL RESULTS FOR BIOKA6O I A COMPARISON OF THREE DIFFERENT PROCEDURES FOR ESTIMATI TECH 63421

CAL COMPARISON OF THREE STRATEGIES OF COLLECTING DATA JASA 67976

A COMPARTSON OF TWO APPROACHES TO THE CONSTRUCTION OF M BIOCS67 COMPARISON OF TWO APPROXIMATIONS TO THE DISTRIBUTION BIOKA52 130 A COMPARISON OF TWO LIFE TABLE METHODS BIOCS67 51

ON THE COMPARISON OF TWO MEANS, FURTHER DISCUSSION OF ITERAT BIOKA54 361 COMPARISON OF TWO METHODS OF OBTAININC APPROXIMATE TECH 6837 COMPARISON OF TWO SAMPLES ONE OF WHICH IS CENSORED BIOKA66 599 A COMPARISON OF TWO SORTS OF TEST FOR A CHANGE OF LOCAT JRSSB57 119 ION APPLICABLE TO TRUNCATED DATA BEHRENS-FTSHER PROBLEM A CONFIDENCE INTERVAL COMPARISON OF TWO TEST PROCEDURES PROPOSED FOR THE

A POWER COMPARISON OF TWO TESTS OF NON-RANDOM CLUSTERING 119 TECH $66 \quad 493$

TO THE IMPORTANCE OF ASSUMPTIONS APPLIED TO THE COMPARISON OF VARIANCES A BAYESIAN APPRO AN ASYMPTOTICALLY DISTRIBUTION-FREE MULTIPLE COMPARISON PROCEDURE TREATMENT VERSUS CONTROL SOME DISTRIBUTION-FREE MULTIVARIATE COMPARISON PROCEDURES

VARIANCE A MULTIPLE COMPARISON RANK PROCEDURE FOR A ONE-WAY ANALYSIS OF MAXIMUM LIKELIHOOD PAIRED COMPARISON RANKINC BY LINEAR PROGRAMMINC MAXIMUM-LIKELIHOOD PAIRED COMPARISON RANKINCS

A MULTIPLE COMPARISON SICN TEST, TREATMENTS VERSUS CONTROL

A COMPARISON TEST FOR MARTINGALE INEQUALITIES COMPARISON TESTS FOR THE CONVERCENCE OF MARTINGALES

NONPARAMETRIC RANKINC PROGEDURES FOR COMPARISON WITH A CONTROL

OXIMATIONS EXAMPLES OF LIKELIHOODS AND COMPARISON WTTH POINT ESTIMATES AND LARGE SAMPLE APPR

'DROSOPHTL A SUBOBSCURA' COLL. AND A COMPARTSON WTTH THOSE OF ' D. ROBUSTA' STURT MATHEMATICAL MODELS FOR RANKINC FROM PAIRED COMPARISONS RANKINCS FROM PAIRED COMPARISONS

A BAYESIAN APPROACH TO MULTIPLE COMPARISONS SOME EQUIVALENCE CLASSES IN PAIRED COMPARISONS BEST $K$ OF $2 \mathrm{~K}-1$ COMPARISONS

A TABLE FOR RANK SUM MULTIPLE PAIRED COMPARISONS A TREATMENT OF TIES IN PAIRED COMPARISONS RANK ORDER TESTS FOR MULTIVARIATE PAIRED COMPARISONS A GENERALIZATION OF THE T-METHOD OF MULTIPLE COMPARISONS ON A CORRECTION TERM IN THE METHOD OF PAIRED COMPARISONS TOURNAMENTS AND PAIRED COMPARISONS INCONSISTENCIES IN A SCHEDULE OF PAIRED COMPARISONS COODNESS-OF-FIT STATISTIC FOR THE CIRCLE, WITH SOME COMPARISONS IMULTANEOUS TEST PROCEDURES, SOME THEORY OF MULTIPLE COMPARISONS ROBABILITY DISTRIBUTION OVER SAMPLE SPACES OF PAIRED COMPARISONS OF THE NUMBER OF CIRCULAR TRIADS IN PAIRED COMPARISONS BETWEEN TWO REPRESENTATIONS OF A MODEL FOR PAIRED COMPARISONS NTATION IN SCHEFFE'S ANALYSIS OF VARIANCE FOR PAIRED COMPARISONS ICNS. II, ADDITIONAL TABLES FOR THE METHOD OF PAIRED COMPARISONS SULTS ON ESTIMATION AND POWER FOR A METHOD OF PAIRED COMPARISONS
HYPOTHESIS

THE CASE OF A SINGLE PARAMETER

LECTION OF THE POPULATION WITH THE GOVARIANCE

TIONS. PART 1, RESULTS

TIONS. PART 2. DERIVATIONS AND/ MULTIPLE COMPARISONS SENSITIVITY COMPARISONS

FACTORIAL EXPERIME JASA 58529 OF INCOMPLETE BLOCK DES BIOKA54 502 JOCK DESIGNS. III. SOME LARGE-SAMPLE RE BIOKA55 450 $\begin{array}{lrr}\text { AMONC MEANS } & \\ \text { JASA } 61 & 52\end{array}$ $\begin{array}{rrr}\text { JASA } & 61 & 52 \\ \text { JASA } & 66 & 415\end{array}$ JRSSB 65 SE BIOKA58 581 NOTE ON MULTIPLE COMPARISONS FOR ADJUSTED MEANS IN THE ANALYSIS OF BIOKA58 256 SHORT-CUT MULTIPLE GOMPARISONS FOR BALANCED SINGLE AND DOUBLE CLASSIFICA TECH 65 95

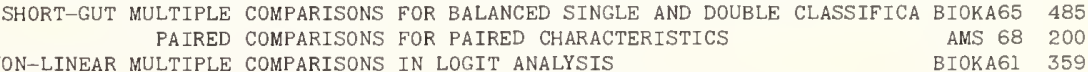
LINEAR AND NON-LINEAR MULTIPLE COMPARISONS IN LOGIT ANALYSIS

'LINEAR AND NON-LINEAR MULTIPLE COMPARISONS IN LOGIT ANALYSIS'

CRAPHICAL METHODS FOR INTERNAL COMPARISONS IN MULTIRESPONSE EXPERIMENTS BIOKAG2 284 AMS $64 \quad 613$ ESTIMATINC PARAMETERS IN A TWO-STAGE NESTED PROCE/ COMPARISONS OF DESIGNS AND ESTIMATION PROCEDURES FOR TECH 67 499 OF INTERMEDIATE SPECIFICITY NTS INVOLVING LOCATION PARAMETERS TWO-SAMPIE COMPARTSONS OF DISPERSTON MATRICES FOR ALTERNATTVES NON-EQUIVALENT COMPARISONS OF EXPERIMENTS AND THEIR USE FOR EXPERIME AMS $62 \quad 432$ AMS $61 \quad 326$ TECH $69 \quad 321$ CURVE FOR SMALL SAMPLES A GRAPHICAL METHOD FOR MAKING MULTIPLE COMPARISONS OF FREQUENCIES

SOME COMPARISONS OF METHODS OF FITTING THE DOSAGE RESPONSE JASA 64779 DISTR IBUTION

SOME NUMERICAL COMPARISONS OF SEVERAL APPROXIMATIONS TO THE BINOMIAL J COMPARISONS OF SOME TWO STAGE SAMPLING METHODS BASED ON FOUR CRITERIA POWER COMPARISONS OF TESTS OF TWO MULTIVARIATE HYPOTHESES SIMULTANEOUS TEST PROCEDURES FOR MULTIPLE COMPARISONS ON CATECORICAL DATA A BAYES RULE FOR THE SYMMETRIC MULTIPLE COMPARISONS PROBLEM AMS $66 \quad 891$ BIOKA67 195 JASA 661081 JASA 69 NO. 4 
BAYES RULES FOR A COMMON MULTIPLE COMPARISONS PROBLEM AND RELATED STUDENT-T PROBLEMS

TABLES FOR A TREATMENTS VERSUS CONTROL MULTIPLE COMPARISONS SIGN TEST
AMS 611013 TECH 65293 BIOCS67 539 TECH 65255

OMISED BLOCK EXPERIMEN/ NOTES. ERRORS OF TREATMENT COMPARISONS WHEN OBSERVATIONS ARE MISSING FROM A RAND BIOCS66 632 ASSOCIATED ESTIMATION AND TES/ MULTTVATATE PAIRED GOMPARISONS THE EXTENSION OF A UNTVARTATE MODEL AND BIOKAG ICNS. II. ADDITIONAL TABLES FOR THE METHOD OF PAIRED COMPARISONS. /ANK ANALYSIS OF INCOMPLETE BLOCK DES SPEARMAN SIMULTANEOUS ESTIMATION FOR A COMPARTMENTAL MODEL

STMULTANEOUS ESTIMATION BY PARTIAL TOTALS FOR COMPARTMENTAL MODELS BIOKA64 288 TECH 69551 JASA $68 \quad 573$ AN EXTENSION OF QUENOUILLE'S TEST FOR THE COMPATIBILITY OF CORRELATION STRUCTURES IN TIME SERIE JRSSB6B I80 E TO THE STUDY OF SMOKING AND LUNC CANCER, CORR./ COMPETING EXPONENTIAL RISKS, WITH PARTICULAR REFERENC JASA 60 4I5 NOTE ON EXTREME VALUES, COMPETING RISKS AND SEMI-MARKOV PROCESSES AMS 631104 MODELS FOR THE ESTIMATION OF COMPETING RISKS FROM GROUPED DATA B BIOCS69 329

THE PROPERTIES OF A STOCHASTIC MODEL FOR TWO COMPETINC SPECIES

$\begin{array}{ll}\text { BIOCS69 } & 329 \\ \text { BIOKA58 } & 316\end{array}$

XPERIMENTAL DATA A STOCHASTIC MODEL FOR TWO COMPETING SPECIES OF TRIBOLIUM AND ITS APPLICATION TO BIOKA62

'THE PROPERTIES OF A STOCHASTIC MODEL FOR TWO COMPETING SPECIES.'
MATHEMATIGAL MODEL FOR THE ESTIMATION OF INTER-PLANT GOMPETITION (CORRECTION TO REFERENCE 6B 1025 )

CORRIGENDA BIOKA59 ANALYSIS OF COMPETITION EXPERIMENTS

SPECIES

ANALYSIS OF PLANT COMPETITION EXPERIMENTS FOR DIFFERENT RATIOS OF MULTIVARIATE COMPETITION PROCESSES

PLANT COMPETITION, THREE SPECIES PER POT

ON THEORETICAL MODELS FOR COMPETITIVE AND PREDATORY BIOLOGICAL SYSTEMS COMPETITIVE QUEUEING, IDLENESS PROBABILITIES UNDER

PRIORITY DISCIPLINES ON SOME ASYMPTOTICALLY NONPARAMETRIC COMPETITORS OF HOTELLING'S T-SQUARE, CORR. 651583 ASYMPTOTTC EFFICIENCY OF TWO NONPARAMETRIC COMPETITORS OF WILCOXON'S TWO SAMPLE TEST

BIOCS67 189 BI0CS65 975

BIOKA67 471 AMS $64 \quad 350$ JRSSB 6B 93 BIOKA57 27 JRSSB $63 \quad 4 B 9$ AMS $65 \quad 160$ JASA $67 \quad 939$ OF A FINITE SET OF REAL NUMBERS THE COMPLETE AMALGAMATION INTO BLOCKS, BY WEICHTED MEANS, BIOKA59 317 ATIONS OF INDEPENDENT AND RAN/ SOME RESULTS ON THE COMPLETE AND ALMOST SURE CONVERGENGE OF LINEAR COMBIN AMS 68 I549 A FOUR- PARAMETER GENERALIZED GAMMA POPULATION FROM COMPLETE AND CENSORED SAMPLES /OF THE PARAMETERS OF TECH 67 159 METERS OF THREE-PARAMETER LOGNORMAL POPULATIONS FROM COMPLETE AND CENSORED SAMPLES. (CORR. 66 1247. CORR. JASA 66 842 THE PARAMETERS OF CAMMA AND WEIBULL POPULATIONS FROM COMPLETE AND FROM CENSORED SAMPLES /ESTIMATION OF TECH 65 639 THE PARAMETERS OF CAMMA AND WEIBULL POPULATIONS FROM COMPLETE AND FROM CENSORED SAMPLES' /ESTIMATION OF TECH 67 195 HOOD ESTIMATION IN THE WEIBULL DISTRIBUTION BASED ON COMPLETE AND ON CENSORED SAMPLES HOON ESTIMATION IN THE WEIBULL DISTRIBUTION BASED ON COMPLETE AND ON CENSORED SAMPLES'

ON THE LINE, CRAPH OF THE COMPLETE BIGRAPH

ON THE LINE CRAPH OF THE COMPLETE BIPARTITE GRAPH

CONDITIONAL PROBABILITY ON SICMA-COMPLETE BOOLEAN ALGEBRAS

ON A MINIMAL ESSENTIALLY COMPLETE CLASS OF EXPERIMENTS

RANDOMIZED FACTORIAL EXPERIMENT

ON A COMPLETE CLASS OF LINEAR UNBIASED ESTIMATORS FOR

SAMPLINC ENTROPY FOR RANDOM HOMOGENEOUS SYSTEMS WITH COMPLETE CONNECTIONS (CORR. 69 NO.6)

MAXIMUM LIKELI TECH $65 \quad 579$

/ MAXIMUM LIKELI TECH 66570

AMS $63 \quad 664$

AMS $64 \quad$ B 83

AMS $69 \quad 970$

AMS $66 \quad 435$

AMS $63 \quad 769$

AMS $65 \quad 1433$

ECTS IN A LATIN SQUARE DESICN, CORR. 5B 1030 COMPLETE COUNTERBALANCING OF IMMEDIATE

CORRELATION AND COMPLETE DEPENDENCE OF RANDOM VARIABLES

THE EXTENSION OF YATES' 2-TO-THE-N ALGORITHM TO ANY COMPLETE FACTORIAL EXPERIMENT MBINATIONS OF THE/ ON ESTIMATES FOR FRACTIONS OF A COMPLETE FACTORIAL EXPERIMENT AS ORTHOGONAL LINEAR CO AMS 63 IO68 NERALIZED POLYKAYS TO UNRESTRICTED SUMS FOR BALANCED COMPLETE FINITE POPULATIONS

PROBLEMS IN SCIENCE. THE SYMMETRIG TEST OF A GOMPLETE HYPOTHESIS

PROCEDURES FOR FINITE DECISION PROBLEMS UNDER COMPLETE IGNORANCE

PROCEDURES FOR FINITE DECISION PROBLEMS UNDER COMPLETE IGNORANCE EXPANSIONS OF T DENSITIES AND RELATED COMPLETE INTECRALS

PROBABILITIES FOR A RECORD MATCHINC PROCESS WITH COMPLETE INVARIANT INFORMATION RELATIONSHIP OF GE AMS $6 \mathrm{~B} \quad 643$ STATISTICAL JASA 69 NO. 4 DECISION AMS 641644 NOTE ON DECISION AMS 65691 AMS 67503 SQUARE APPROXIMATION AND AN IMPLEMENT TO IT A COMPLETE MULTINOMTAL DISTRIBUTIC OUTCOME JASA $67 \quad 454$ ON THE USE OF PARTIALLY JASA $61 \quad 299$ POLYNOMIALS UP TO $\mathrm{N}=26$

COMPLETE ORDER ICIENTS FOR ORTHOGONAL TECH $65 \quad 644$ COMPLETE SET OF LEADING COEFFICIENS

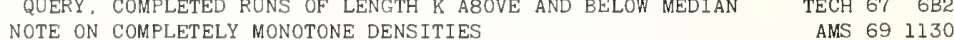

RESULTS ON VARIANCE RATIOS UNDER PERMUTATION IN THE COMPLETELY RANDOMIZED DESIGN STATISTICAL ANALYSIS OF 'SPLIT PLOT' EXPERIMENTS IN COMPLETELY RANDOMIZED LAYOUTS CONVERGENCE IN THE COMPOUND DECISION PRORLEM FOR TWO COMPLETELY SPECIFIED DISTRTBUTTONS RS OF OBSERVATIONS IN THE SUBCLASSES FOR THE TWO-WAY COMPLETELY-RANDOM CLASSIFICATION SOME EMPIRICAL JASA $66 \quad 813$ PROBABILITY RATIO TESTS THE ESSENTIAL COMPLETENESS OF THE CLASS OF GENERALIZED SEQUENTIAL AMS 61 . 602 $\begin{array}{lrrr}\text { RATES OF AMS } & 65 & 1743 \\ \text { THE NUMBE JASA } & 68 & 1484\end{array}$

RESPONSE CURVES MODELS FOR COMPLEX CONTINCENCY TABLES AND POLYCHOTOMOUS DOSACE

AMS $66 \quad 495$ TEST FOR REALITY OF A COVARIANCE MATRIX IN A CERTAIN COMPLEX GAUSSIAN DISTRIBUTION STATISTICAL ANALYSIS 8ASED ON A CERTAIN MULTIVARIATE COMPLEX CAUSSIAN DISTRIBUTION STATISTTCAL ANALYSIS BASED ON A CERTAIN MULTIVARTATE COMPLEX GAUSSIAN DISTRIBUTION, AMS $65 \quad 115$ AMS $65 \quad 98$ AMS $63 \quad 152$ A GRAPHICAL METHOD FOR THE STUDY OF COMPLEX CENETI CHARACTERISTIC ROOT UNDER NULL HYPOTHESIS CONCERNING COMPLEX MULTIVARIATE NORMAL POPULATIONS THE MULTIVARIATE DISTRIBUTION OF COMPLEX NORMAL VARIABLES RACTERISTIC FUNCTION OF HERMITIAN QUADRATIC FORMS IN COMPLEX NORMAL VARIA8LES A COMBINATORIAL LEMMA FOR COMPLEX NUMBERS

CENERALIZATION OF F'TELLER'S THEOREM TO THE RATIO OF COMPLEX PARAMETERS A SEMI-GRAPHICAL METHOD FOR THE ANALYSIS OF COMPLEX PROBLEMS

ON THE GENERALIZED MELLIN TRANSFORM OF A COMPLEX RANDOM VARIABLE AND ITS APPLICATIONS STANDARD ERRORS FOR INDEXES FROM COMPLEX SAMPLES ES OF SERIAL AND CROSS-CORRELATION COEFFICIENTS IN A COMPLEX STATIONARY TIME SERIES /TIONS AND COVARIANC BIOKA63 213 ACCURACY REQUIREMENTS FOR ACCEPTANCE TESTINC OF COMPLEX SYSTEMS THE DISTRIBUTION OF THE DETERMINANT OF A COMPLEX WISHART DISTRIBUTED MATRIX ON THE COMPLEX WISHART DISTRIBUTION

JASA $59 \quad 447$ AMS $63 \quad 178$ AMS $65 \quad 313$ CONSIN STATE INDIVIDUAL INCOME TAX TAXPAYER COMPLIANCE IN REPORTINC INTEREST INCOME UNDER THE WIS JASA 63 487 FIDUCIAL LIMITS FOR A VARIANCE COMPONENT

OF A SINGLE (NON-ISOTROPIC) HYPOTHETICAL PRINCIPAL COMPONENT ASYMPTOTIC THEORY FOR PRINCIPAL COMPONENT ANALYSIS OOT AND THE CORRESPONDING LATENT VEGTOR FOR PRINCIPAL COMPONENT ANALYSIS
COVARIANCE ANALYSIS WITH UNEQUAL SUBGLASS NUMBERS. GOMPONENT ESTIMATI JRSSB $63 \quad 128$ $\begin{array}{rrr}\text { THE COODNESS-OF-FIT BIOKA61 } & 397 \\ & \text { AMS 63 } & 122 \\ \text { THE LARCEST LATENT R AMS } 66 & 995\end{array}$ COVARIANCE ANALYSIS WITH UNEQUAL SUBGLASS NUMBERS. GOMPONENT ESTIMATION IN CORRELATION STUDIES 8 I0GS68 49 
NDENT NONCENTRAL CHI-SQUAR/ EXPRESSION OF VARIANCE-COMPONENT ESTIMATORS AS LINEAR COMBINATIONS OF INDEPE AMS 69 NO 6 RELATTONSHTP BETWEEN SYSTEM FAILURE RATE AND COMPONENT FATLURE RAT

TECH $63 \quad 183$

OF A COMPONENT OF A CONVOLUTION, WHEN THE OTHER COMPONENT IS OF EXPONENTIAL TYPE

TION OF A COMPONENT OF A CONVOLUTION, WHEN THE OTHER COMPONENT IS OF EXPONENTIAL TYPE'

METHODS FOR ESTIMATING THE COMPOSITION OF A THREE COMPONENT LIQUID MIXTURE

ENSIONAL MODELS OF EXTREME VERTICES DESIGNS FOR FOUR COMPONENT MIXTURES

IS OF EXPONENTIAL TYPE

IS OF EXPONENTIAL TYPE

ERRATA, 'ESTTMATION OF A COMPONENT OF A CONVOLUTION WHEN THE OTHER COMPONENT GHANGEOVER DESIGNS BALANCED FOR THE LINEAR COMPONENT OF FIRST RESIDUAL EFFECTS

AN OCCUPATION TIME THEOREM FOR THE ANGULAR COMPONENT OF PLANE BROWNIAN MOTION

LIMITS FOR A VARIANCE COMPONENT WITH AN EXACT CONFIDENCE COEFFICIENT

THE PROBLEM OF NEGATIVE ESTIMATES OF VARIANCE COMPONENTS

COHERENT STRUCTURES OF NON-IDENTICAL COMPONENTS

NON-NEGATIVE ESTIMATES OF VARIANCE COMPONENTS

AN OPTIMAL PROPERTY OF PRINCIPAL COMPONENTS

A CENERAL APPROACH TO THE ESTIMATION OF VARIANCE COMPONENTS

MEAN SQUARE EFFICIENCY OF ESTIMATORS OF VARIANCE COMPONENTS

A CONFIDENCE INTERVAL FOR VARIANCE COMPONENTS

A RENEWAL PROBLEM WITH BULK ORDERINC OF COMPONENTS

LISTINC EXPECTED MEAN SQUARE COMPONENTS

ESTIMATION TECH $64 \quad 222$

ERRATA, 'ESTIMA TECH $65 \quad 462$

TECH 64343

THREE DIM TECH $67 \quad 472$

ON UNIFORMLY BEST UNBIASED ESTIMATORS FOR VARIANCE COMPONENTS EVIDENCE ON THE CONSISTENCY OF ESTIMATES OF VARIANCE COMPONENTS METHOD OF RESOLUTION OF A DISTRIBUTION INTO CAUSSIAN COMPONENTS

CURVE AND THE EQUIVALENT MIXED BINOMIAL WITH TWO COMPONENTS AMONC GENERALIZED DISTRIBUTIONS AND THEIR GOMPONENTS

THREE DIFFERENT PROCEDURES FOR ESTIMATING VARIANCE COMPONENTS

EIGENVALUES OF A MATRIX AND OPTIMALITY OF PRINCIPAL COMPONENTS

THE DECOMPOSITION OF A DISTRIBUTION INTO GAUSSIAN COMPONENTS STIMATION FROM THE ORDER STATISTICS OF UNEQUAL GAMMA COMPONENTS PECTRAL DENSITY FUNCTION IN THE PRESENCE OF HARMONIC COMPONENTS NALYSIS OF STATISTICAL DISTRIBUTIONS INTO TWO NORMAL COMPONENTS ETS OF TESTS ON A SYSTEM SIMULATED FROM TESTS ON ITS COMPONENTS

LOOK AT HENDERSON'S METHODS OF ESTIMATING VARIANCE COMPONENTS

THE DISTRIBUTION OF THE LATENT VECTORS FOR PRINCIPAL COMPONENTS ANALYS

NON-NULL DISTRIBUTION OF A STATISTIC IN PRINCIPAL COMPONENTS ANALYSIS

ON ABSOLUTELY CONTINUOUS COMPONENTS AND RENEWAL THEORY

A STOCHASTIC CHARACTERIZATION OF WEAR-OUT FOR COMPONENTS AND SYSTEMS

A NOTE ON THE ESTIMATION OF VARIANCE COMPONENTS BY THE METHOD OF FITTING CONSTANTS

THE RELIABILITY OF COMPONENTS EXHIBITING CUMULATIVE DAMAGE EFFECTS

DIGENIC EPISTATIC VARIANCES OF EQUAL MAGN/ GENETIC COMPONENTS FOR NON-INBRED DIPLOID SPECIES HAVING ALL

ITERATTVE ESTIMATION OF VARIANCE COMPONENTS FOR NON-ORTHOGONAL DATA

MUM LIKELIHOOD ESTIMATION OF MULTIVARIATE COVARIANCE COMPONENTS FOR THE BALANCED ONE-WAY LAYOUT

ION ESTIMABILITY OF VARIANCE COMPONENTS FOR THE TWO-WAY CLASSIFICATION WITH ITERAT AMS 67 1508

THE SIMULTANEOUS ESTIMATION OF FUNCTIONS OF VARIANCE COMPONENTS FROM TWO-WAY CROSSED CLASSIFICATIONS /OR BIOKA67 I27

SAMPLINC DISTRIBUTIONS OF VARIANCE COMPONENTS I. EMPIRICAL STUDIES OF BALANCED NESTED

DESIGNS SAMPLING DISTRIBUTIONS OF VARIANCE COMPONENTS II. EMPIRICAL STUDIES OF UNBALANCED NESTED TECH 68 7I

VARIANCES OF ESTIMATES OF VARIANCE COMPQNENTS IN A THREE-WAY CLASSIFICATION B

PROCEDURE FOR ESTIMATING FIXED EFFECTS AND VARIANCE COMPONENTS IN MIXED MODEL SITUATIONS AN ITERATIVE BIOCS68 THE OPTIMUM ALLOCATION OF SPARE COMPONENTS IN SYSTEMS

ESTIMATORS OF VARIANCE COMPONENTS IN THE BALANCED INCOMPLETE BLOCK

INFERENCE ABOUT VARIANCE COMPONENTS IN THE ONE-WAY MODEL

VARIANCES OF MOMENT ESTIMATORS OF VARIANCE COMPONENTS IN THE UNBALANCED R-WAY CLASSIFICATION

I/ SAMPLING VARIANCES OF THE ESTIMATES OF VARIANCE COMPONENTS IN THE UNBALANCED THREE-WAY NESTED CLASSIF AMS 63 521 CLASSIFICATION

SAMPLES

INTERACTION

VARIANCE COMPONENTS IN THE UNBALANCED TWO-WAY NESTED

AMS 611161

ESTIMATION OF VARIANCE COMPONENTS IN TWO-STAGE NESTED DESIGNS WITH COMPOSITE TECH 67373

VARIANCE COMPONENTS IN TWO-WAY CLASSIFICATION MODELS WITH B BOKA63 327

OPTIMUM INVARIANT TESTS IN UNBALANCED VARIANCE COMPONENTS MODELS

ESTIMATING THE COMPONENTS OF A MIXTURE OF NORMAL DISTRIBUTIONS

LEAST SQUARES ESTIMATION OF THE COMPONENTS OF A SYMMETRIC MATRIX

EXACT FIRST AND SECOND ORDER MOMENTS OF ESTIMATES OF COMPONENTS OF COVARIANCE

OCCUPATIONAL COMPONENTS OF EDUCATIONAL DIFFERENCES IN INCOME

CHANGES IN THE RATE AND COMPONENTS OF HOUSEHOLD FORMATION

QUADRATIC UNBIASED ESTIMATION OF VARIANCE COMPONENTS OF THE ONE-WAY CLASSIFICATION

COMPARISON OF ANOVA AND HARMONIG COMPONENTS OF VARIANCE

THE INTERPRETATION OF NEGATIVE COMPONENTS OF VARIANCE

APPROXIMATE CONFIDENCE LIMITS FOR COMPONENTS OF VARIANCE

ON THE EFFECT OF NON-NORMALITY ON THE ESTIMATION OF COMPONENTS OF VARTANCE

AMS $67 \quad 422$

BIOKA69 NO.3

TECH $66 \quad 360$ BIOKA69 N0.3

JASA $61 \quad 783$

JASA $60 \quad 268$

BIOKA69 313

TECH 6975

BIOKA54 544

BIOKA57 159

JRSSB62 140

OLASSIFICATTON

SAMPL ING VARI ANCES OF FSTIMATES OF COMPONENTS OF VARTANCE

140

SIS OF VARIANCE/ NOTES. ON TESTING SIGNIFICANCE OF COMPONENTS OF VARIANCE IN THE UNBALANCED NESTED ANALY

RESEARCH SEQUENTIAL RANCE TESTS FOR COMPONENTS OF VARIANCE, CORR, 651249 PRINCIPAL COMPONENTS REGRESSION IN EXPLORATORY STATISTICAI

ESTIMATION OF GENETIC CONTRIBUTION OF PRINGIPAL COMPONENTS TO INDIVIDUAL VARIATES GONCERNED

BI0CS68 423

JASA $65 \quad$ B26

JASA $65 \quad 234$

BIOCS69 9

BAYESIAN ANALYSIS OF LINEAR MODELS WITH TWO RANDOM COMPONENTS WITH SPECIAL REFERENCE TO THE BALANCED INC BIOKA68 101

VISIONAL ESTIMATES OF GROSS NATIONAL PRODUCT AND ITS COMPONENTS OF SELECTED NATIONAL TNCOME COMPONENTS A JASA 58 54

'A CENERAL APPROACH TO THE ESTIMATION OF VARIANCE COMPONENTS' SOME FURTHER REMARKS CONCERNING TECH 68 551

UNBIASED COMPONENTWISE RATIO ESTIMATION, CORR. $631163 \quad$ JASA $61 \quad 350$

ET SES RAPPORTS AVEC L'ANALYSE DISC/ L'ANALYSE EN COMPOSANTES PRINCIPALES, SON UTILISATION EN GENETIQUE BIOCS66 343 VESTICATION OF A TEST OF HOMOGENEITY FOR POPULATIONS COMPOSED OF NORMAL DISTRIBUTIONS TESTING APPROXIMATE HYPOTHESES IN THE COMPOSITE CASE, CORR. 63 AMS 621356 FACTORIALS (CORR. 65 1036) COMPOSITE DESIGNS BASED ON IRREGULAR FRACTIONS OF BIOCS65 324

AN ANALYSIS OF SOME RELAY FAILURE DATA FROM A COMPOSITE EXPONENTIAL POPULATION

THE USE OF LEAST FAVORABLE DISTRIBUTIONS IN TESTING COMPOSITE HYPOTHESES NCOMITANT INFORMATION FOR DISCRIMINATION BETWEEN TWO COMPOSITE HYPOTHESES 0 THE SAMPLE SPACE IN TESTS OF AN IMPORTANT CLASS OF COMPOSITE HYPOTHESES OF THE SAMPLE SIZE FOR SEQUENTIAL TEST. II. TESTS OF COMPOSITE HYPOTHESES 
DISCRIMINANT FUNCTION BETWEEN COMPOSITE HYPOTHESES AND RELATED PROBLEMS

NONCONTROLLED PRE/ ASYMPTOTICALLY OPTIMAL TESTS OF COMPOSITE HYPOTHESES FOR RANDOMIZED EXPERIMENTS WITH JASA 65 699 FAMILY. CORR. 67 192B TESTS OF COMPOSITE HYPOTHESES FOR THE MULTIVARIATE EXPONENTIAL AMS 67 6B1 VARIANCE COMPONENTS IN TWO-STACE NESTED DESICNS WITH COMPOSITE SAMPLES

ON OPTIMAL ASYMPTOTIC TESTS OF COMPOSITE STATISTICAL HYPOTHESES

POPULATION ESTIMATION BASED ON CHANGE OF COMPOSITION CAUSED BY A SELECTIVE REMOVAL METHODS FOR ESTIMATINC THE COMPOSITION OF A THREE COMPONENT LIQUID MIXTURE

AN ESTIMATION PROCEDURE FOR RANCE COMPOSITION PROBLEMS

SOME INTERRELATIONS AMONG COMPOUND AND CENERALIZED DISTRIBUTIONS

STIMATION OF TECH $67 \quad 373$

AMS $67 \quad 1845$

$\begin{array}{rr}\text { AMS } & 1845 \\ \text { B OKA55 } & 279\end{array}$

TECH 64343

JASA $65 \quad 308$

BIOKA57 265

AMS 631079

ASYMPTOTIC SOLUTIONS OF THE SEQUENTIAL COMPOUND DECISION PROBLEM

AMS 691536

ON AN EXTENDED COMPOUND DECISION PROBLEM

JRSSB $65 \quad 238$

ON SIMPLE RULES FOR THE COMPOUND DECISION PROBLEM

LOSSES OF CERTAIN DECISION RULES FOR THE SEQUENTIAL COMPOUND DECISION PROBLEM

CONVERCENCE OF THE AMS 641606 ICAL BAYES APPROACH TO TESTINC OF HYPOTHESES AND THE COMPOUND DECISION PROBLEM

ON THE SMOOTH EMPIR BIOKA68 83 D DISTRIBUTIONS RATES OF CONVERCENCE IN THE COMPOUND DECISION PROBLEM FOR TWO COMPLETELY SPECIFIE AMS 65 I743 MATRIX THE COMPOUND DECISION PROBLEM WITH M-BY-N FINITE LOSS

MATRIX THE SEQUENTIAL COMPOUND DECISION PROBLEMS WTTH M-BY-N FINTTE LOSS SEQUENTIAL COMPOUND ESTIMATION SEQUENTIAL COMPOUND ESTIMATORS

AMS 681890 AMS $65 \quad 879$

SINCLE SAMPLINC INSPECTION PLANS BASED ON PRI/ THE COMPOUND HYPERCEOMETRIC DISTRIBUTION AND A SYSTEM OF TECH 60 275 IS OF CATERCORICAL DATA FROM FINITE POPULATIO/ THE COMPOUND MULTINOMIAL DISTRIBUTION AND BAYESIAN ANALYS JASA 69 216 ETA-DISTRIBUTION, AND CORRELATIONS AMONC P/ ON THE COMPOUND MULTINOMIAL DISTRIBUTION, THE MULTIVARIATE B BIOKA62 65 ATIONS AMONC INUERSELY SAMPLED POLLEN COUN/ ON THE COMPOUND NECATIVE MULTINOMIAL DISTRIBUTION AND CORREL BIOKA63 47 FROM BIVARIATE NON-NORMAL UNIVERSES BY MEANS OF COMPOUND NORMAL DISTRIBUTIONS A MODIFIED COMPOUND POISSON PROCESS WITH NORMAL COMPOUNDINC JASA 68637 SEQUENTIAL COMPOUND RULES FOR THE FINITE DECISION PROBLEM JRSSB66 63 EXACT DISTRIBUTIONS OF VOTAW'S CRITERIA FOR TESTINC COMPOUND SYMMETRY OF A COVARIANCE MATRIX A COMPOUNDED MULTIPLE RUNS DISTRIBUTION

A MODIFIED COMPOUND POISSON PROCESS WITH NORMAL COMPOUNDINC PROCESS THE SEPARATION OF MOLECULAR COMPOUNDS BY COUNTERCURRENT DIALYSIS, A STOCHASTIC A BLACK BOX OR A COMPREHENSIVE MODEL

SYSTEMATIC STATISTICS USED FOR DATA COMPRESSION IN SPACE TELEMETRY CONSTANTS AND COMPROMISE IN THE CONSUMER PRICE INDEX

THE HANKEL TRANSFORM IN STATISTICS. I I METHODS OF COMPUTATION COMPUTATION AND STRUCTURE OF OPTIMAL RESET POLICIES

OF BARTLETT'S $M$ ON THE COMPUTATION AND USE OF A TABLE OF PERCENTACE POINTS MACHINE COMPUTATION OF HICHER MOMENTS COMPUTATION OF INDIRECT-ADJUSTED RATES IN THE

PRESENCE OF CONFOUNDINC T-DISTRIBUTION

TABLES TO FACILITATE THE COMPUTATION OF PERCENTACE POINTS OF THE NON-CENTRAL CRAPHIC COMPUTATION OF TAU AS A COEFFICIENT OF DISARRAY

A NOTE ON CRIFFIN'S PAPER 'CRAPHIC COMPUTATION OF TAU AS A COEFFICIENT OF DISARRAY'

CORR. $58 \quad 103$

MATERIAL IS REMOVED BUT NOT REPLACED
CRAPHIC COMPUTATION OF THE MULTIPLE CORRELATION COEFFICIENT,

THE COMPUTATION OF THE UNRESTRICTED AOQL WHEN DEFECTIVE COMPUTATION WITH MULTIPLE K-STATISTICS

A CHECK ON CROSS ERRORS IN CERTAIN VARIANCE COMPUTATIONS PARTIAL CORRELATIONS IN RECRESSION COMPUTATIONS

LIKELIHOOD RATIO COMPUTATIONS OF OPERATINC COMPUTATIONS

THE WILCOXON, TIES, AND THE COMPUTER

SETS OF MUTUALLY ORTHOCONAL LATIN SQUARES USING A COMPUTER ULTIVARIATE DATA SUITABLE FOR USE WITH AN ELECTRONIC COMPUTER ANALYSIS OF NON-ORTHOCONAL EXPERIMENTS BY ELECTRONIC COMPUTER ANALYSIS OF REPLICATED EXPERIMENTS ON AN ELECTRONIC COMPUTER COMPUTER AIDED DESICN OF EXPERIMENTS

ON METHODS OF CONSTRUCTINC TECH $60 \quad 50 \%$ /THOD OF ESTIMATION OF MISSINC VALUES IN M JRSSB60 302 /TION OF MEANS AND STANDARD ERRORS IN THE JRSSB62 435 NITH DISCUSSION)

ROUTINE JRSSB57 234 TECH $69 \quad 137$ ORY OF DISTRIBUTION SAMPLINC PRIOR TO THE ERA OF THE COMPUTER AND ITS RELEVANCE TO SIMULATION, CORR. 65 12 JASA 65 27 ENCE IN BLS MANPOWER SURVEYS

DISTRIBUTION FUNCTIONS BRANCHINC POISSON PROCESS MODEL FOR THE ANALYSIS OF COMPUTER FAILURE PATTERNS (WITH DISCUSSION)
PRAISAL OF LEAST SQUARES PROCRAMS FOR THE ELECTRONIC COMPUTER FROM THE POINT OF VIEW OF THE USER DOTA. FTVE YEARS OF EXPERI JASA $66 \quad 375$ COMPUTER EVALUATION OF THE NORMAL AND INVERSE NORMAL TECH 69 NO.4 THE AUTOMATIC COMPUTER IN INDUSTRY

A COMPUTER METHOD FOR CALCULATINC KENDALL'S TAU WITH

UNCROUPED DATA

SEASONAL ADJUSTMENTS BY ELECTRONIC COMPUTER METHODS

A COMPUTER PROCRAM FOR FITTINC THE RICHARDS FUNCTION

EXPERIMENTS

THE PROBLEM OF EXPERIMENTAL DESICN

A CENERAL COMPUTER PROCRAMME FOR THE ANALYSIS OF FACTORIAL COMPUTER SIMULATION EXPERIMENTS WITH ECONOMIC SYSTEMS

A COMPUTER SIMULATION MODEL OF THE TEXTILE INDUSTRY A JRSSB 64398 JASA 67 B19 JASA $56 \quad 565$ JASA $66 \quad 436$ JASA $57 \quad 415$ BIOCS69 401 BIOCS66 503 JASA 671315 JASA 671338 SETS OF MUTUALLY ORTHOGONAL LATIN SQUARES USING A COMPUTER. II RELATIVE COSTS OF COMPUTERIZED ERROR INSPECTION PLANS AUTOMATTC PROGRAMMTNG FOR AUTOMATIC COMPUTERS

TIAL, ITEM BY ITEM, SELECTION TECHNIQUES AND DIGITAL COMPUTERS /OPMENT OF SAMPLING PLANS BY USING SEQUEN J APPLICATIONS OF TIME-SHARED COMPUTERS IN A STATISTICS CURRICULUM

THE APPLICATTON OF AUTOMATIC COMPUTERS TO SAMPLING EXPERIMENTS (WITH DISCUSSION) ATED RANDOM NORMAL DEVIATES' PUBLISHED IN TRACTS FOR COMPUTERS, NO. 26 CORRICENDA TO ' CORRE FIRST FISHER MEMORIAL LECTURE) COMPUTERS, THE SECOND REVOLUTION IN STATISTICS (THE 917 NOTES, EQUIVALENCE OF TWO METHODS OF COMPUTING DISCRIMINANT FUNCTION COEFFICIENTS

A NOMOGRAPH FOR COMPUTINC PARTIAL CORRELATION COEFFICIENTS, CORR. 62

MENSIONALITY OF NORMAL MU/ NORMAL VARIABLES NORMAL VARIABLES

A PROCEDURE FOR COMPUTING REGRESSION COEFFICIENTS, CORR. 59811 TECH $61 \quad 111$ JASA 69 NO, 4 JASA $59 \quad 744$ JASA $62 \quad 387$ JASA $68 \quad 192$ JRSSB54 39 BIOKA56 496 BI0CS66 233 BI0GS67 153 JASA 61995 JASA $58 \quad 144$ ALCEBRAIC THEORY OF THE COMPUTINC ROUTINE FOR TESTS OF SICNIFICANCE ON THE DI JRSSB56 70 COMPUTING THE DISTRIBUTION OF QUADRATIC FORMS IN CORRICENDA, 'COMPUTING THE DISTRIBUTION OF QUADRATIG FORMS IN BIOKA62 284 DELY USED/ A TWO-VARIABLE GENERATING FUNCTION FOR COMPUTING THE SAMPLING PROBABILITIES OF A CLASS OF WI JASA 64 487 A TABLE FOR COMPUTING WORKING ANGLES

REGIONAL DISPARITIES IN HOUSEHOLD COMSUMPTION IN INDIA MEASURES OF CONCENTRATION

MARKET CROWTH AND INDUSTRY CONCENTRATION

FORMULAS FOR THE MEAN DIFFERENCE AND COEFFICIENT OF CONCENTRATION BIOASSAY DESICN WITH RANDOM DOSES AND UNCERTAIN CONCENTRATION 
COUNTS

MARKET CROWTH, COMPANY DIVERSIFICATION AND PRODUCT CONCENTRATION 1947-1954 THE DISTANCES BETWEEN RANDOM POINTS IN TWO CONCENTRIC CIRCLES

PROBLEMS

THE USE OF THE CONCEPT OF A FUTURE OBSERVATION IN COODNESS-OF-FIT THE CONCEPT OF CAPACITY

BINOMIAL SAMPLINC SCHEMES AND THE CONCEPT OF INFORMATION

AMS $68 \quad 466$

BI0CS65 600

JASA $60 \quad 640$

BIOKA64 275

JRSSB $67 \quad 83$

JASA $62 \quad 826$

BIOKA57 179

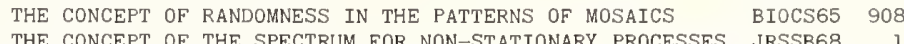

(WITH DISCUSSION)

ON THE CONCEPT OF THE SPECTRUM FOR NON-STATIONARY PROCESSES

TAN AREAS THE METROPOLITAN AREA CONCEPT AN EVALUATION OF THE 1950 STANDARD METROPOL STATISTICAL CONCEPTS IN THEIR RELATION TO REALITY

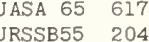

SOME CONCEPTS OF DEPENDENCE

AMS 661137

ERALIZATION OF THE DIRICHLET DISTRIBUTION

CONCEPTS OF INDEPENDENCE FOR PROPORTIONS WITH A A CEN

THE TWO CONCEPTS OF INFORMATION

UTION OF PRINCIPAL COMPONENTS TO INDIVIDUAL VARIATES CONCERNED

CONCISE DERIVATION OF GENERAL ORTHOCONAL POLYNOMIALS JRSSB58 406 CONCLUSIONS VS DECISIONS

STIMATION OF EXPONENTIAL SURVIVAL PROBABILITIES WITH CONCOMITANT INFORMATION

TECH $60 \quad 423$

E BIOCS65 826

O COMPOSITE/ A LARCE SAMPLE SEQUENTIAL TEST USINC CONCOMITANT INFORMATION FOR DISCRIMTNATION BETINEFN TN

DESIGN THE USE OF RESIDUALS AS A CONCOMITANT VARIABLE

THE USE OF A CONCOMITANT VARIABLE IN SELECTINC AN EXPERIMENTAL

CORRIGENDA TO 'THE USE OF A CONCOMITANT VARIABLE IN SELECTING AN EXPERIMENTAL

BIOKA69 33

BIOKA57 150

BIOKA57 534

TION IN THE ESTIMATION OF AN EXPONENTIAL S/ USE OF CONCOMITANT VARIABLES AND INCOMPLETE SURVIVAL INFORMA A NOTE ON AVERACE TAU AS A MEASURE OF CONCORDANCE

PAIRED COMPARISON DESICNS FOR TESTINC CONCORDANCE BETWEEN JUDCES

AN APPLICATION OF THE DISTRIBUTION OF THE RANKINC CONCORDANCE COEFFICIENT

ON THE CONCURRENCE OF A SET OF RECRESSION LINES

PROBLEMS

A CONSERVATIVE TEST FOR THE CONCURRENCE OF SEVERAL REGRE

CONDENSED CALCULATIONS FOR EVOLUTIONARY OPERATION

PROCRAMS

DISCOUNTING AN OPTIMALITY CONDITION FOR DISCRETE DYNAMIC PROCRAMMING WITH NO THE CONDITION FOR LOT SIZE PRODUCTION

PROBABILITY DENSITY FUNCTION

CAMMA

SUFFICIENT CONDITION FOR THE MIXTURE OF EXPONENTIALS TO BE A A NECESSARY AND SUFFICIENT CONDITION FOR THE SQUARE OF A RANDO
ACE-DEPENDENT BRANCHINC PROCESSES UNDER A CONDITION OF ULTIMATE EXTINCTION

ON THE NUMERICAL REPRESENTATION OF QUALITATIVE CONDITION PROBABILITY

BEST LINEAR UNBIASED A NECESSARY AND SUFFICIENT CONDITION THAT ORDINARY LEAST-SQUARES ESTIMATORS BE

RIBUTION OF THE REDUCED ITH ORDER STATISTIC OF TH/ CONDITIONAL DISTRIBUTION OF ORDER STATISTICS AND DIST SIMULATED FROM TESTS ON ITS COMPONENTS THE CONDITIONAL DISTRIBUTION OF SETS OF TESTS ON A SYSTEM NON-EXISTENCE OF EVERYWHERE PROPER CONDITTONAL DISTRIBUTIONS INVARIANT CONDITIONAL DISTRIBUTIONS SUBSTITUTION IN CONDITIONAL EXPECTATION

AN EXTREMAL PROPERTY OF THE CONDITIONAL EXPECTATION

CONDITIONAL EXPECTATION CIVEN A SICMA-LATTICE AND

APPLICATIONS A NOTE ON THE RECIPROCAL OF THE CONDITIONAL EXPECTATION INEQUALITIES OF CHEBYSHEV TYPE INVOLVINC CONDITIONAL EXPECTATIONS A REPRESENTATION FOR CONDITIONAL EXPECTATIONS GIVEN SIGMA-LATTICES SUCCESSIVE CONDITIONAL EXPECTATIONS OF AN INTECRABLE FUNCTION ON CONDITTONAL EXPECTATIONS OF LOCATION STATISTICS CONDITIONAL EXPECTATIONS OF RANDOM VARIABLES WITHOUT

EXPECTATIONS

Y CENSORED SAMPLES, OF THE SCALE PARAMETERS OF TY/ WITH SINCULAR COVARIANCE MATRIX

CHARACTERIZATIONS OF SOME DISTRIBUTIONS BY CONDITIONAL MOMENTS
TO THE DISTRIBUTION OF TWO INDEPENDENT BINOMIALS, CONDITIONAL ON FIXED SUM PERFECT PROBABILITY MEASURES AND REGULAR CONDITIONAL PROBABILITIES

ON THE DISTINCTION BETWEEN THE CONDITIONAL PROBABILITY AND ALGEBRAS

CONDITIONAL PROBABILITY OPERATORS

NOTE ON A CONDITIONAL PROPERTY OF STUDENT'S T

LOCAL CONDITIONAL SUFFICIENCY

THE CONDITIONAL WISHART, NORMAL AND NONNORMAL CONDITIONAL-NORMAL RECRESSION MODELS

S IN FACTORIAL EXPERIMENTS

MINIMAX THEOREMS ON CONDITIONALLY COMPACT SETS

ON A CLASS OF CONDITIONALLY DISTRIBUTION-FREE TESTS FOR INTERACTION CONDITIONED LIMIT THEOREMS

CORRICENDA, CONDITIONED MARKOFF PROCESSES

CONDITIONED MARKOFF PROCESSES.

STUDENT'S T-TEST UNDER SYMMETRY CONDITIONS

TINUOUS SAMPLING PLANS UNDER THE ASSUMPTION OF WORST CONDITIONS ENT ROOTS OF A SYMMETRIC RANDOM MATRIX UNDER CENERAL CONDITIONS SUFFICIENT CONDITIONS FOR A STATIONARY PROCESS TO BE A FUNCTION DISTRIBUTION

OF A FINITE MARKOV CHAIN UNDER A LIE CROUP

PROCESS WITH RANDOM ENVIRONMENT

CONDTTTONS FOR A QUADRATIC FORM TO HAVE A CHI-SQUARED ECESSARY AND SUFFICIENT CONDITIONS FOR A STATISTICAL PROBLEM TO BE INVARIAN' NECESSARY CONDITTONS FOR ALMOST SURE EXTINCTION OF BRANCHINC NEW CONDITIONS FOR CENTRAL LIMIT THEOREMS (CORR, 69 1855) ONDITIONS FOR THE BROWNIAN MOTION TO THE EQUIVALENCE CONDITIONS FOR CERTAIN STATIONARY PROCESSES /ENCE C LEAST SQUARES THEORY

SIVE AND MOVINC-AVERACE TYPE CONDITIONS FOR OPTIMALITY AND VALIDITY AND SIMPLE

STATIONARITY CONDITIONS FOR STOCHASTIC PROCESSES OF THE AUTORECRES CONDITIONS FOR C/ PROBABILITY MEASURE THE RELATION OF THE UNSYMMETRICAL TRIANGULAR PARTIALLY B/
STATIONARITY CONDITIONS FOR STOCHASTIC PROCESSES OF THE AUTORECRES
EQUIVALENCE CONDITIONS FOR THE BROWNIAN MOTION TO THE EQUIVALENCE SUFFICIENT CONDITIONS FOR THE EXISTENCE OF A FINITELY ADDITIVE ON NECESSARY CONDITIONS FOR THE EXISTENCE OF SOME SYMMETRICAL AND $\begin{array}{ll}\text { BIOCS66 } & 665 \\ \text { JASA } 60 & 331\end{array}$

BIOKA56 113

BIOKA51 33

BIOKA52 109

BIOKA66 272

BIOKA53 297

TECH $59 \quad 77$

AMS 63668

AMS $68 \quad 23$ AMS 6B 1220 JASA $56 \quad 627$ AMS 69 N0.6 BIOKA66 275 BIOKA6B 291 AMS $68 \quad 481$ JASA $67 \quad 1302$ AMS $63 \quad 652$ AMS 631585 AMS $63 \quad 223$ AMS $65 \quad 829$ AMS 6B 377 BIOKA66 594 AMS 651339 AMS 651302 AMS $67 \quad 415$ AMS 69 NO. 6 AMS $66 \quad 1279$ AMS 62 BB7 JASA $60 \quad 714$ AMS $65 \quad 1556$ AMS 671068

TECH 6B 349 JASA 641203 AMS $65 \quad 703$ AMS 631593 AMS $66 \quad 1273$ BIOKA64 481 AMS 69970 AMS $62 \quad 634$ AMS $63 \quad 109 B$ JRSSB $64 \quad 52$ AMS $68 \quad 593$ JASA $66 \quad 477$ AMS $63 \quad 1536$ AMS $6965 \mathrm{~B}$ AMS $63 \quad 1147$ BIOKA59 279 BIOKA58 241 JASA 69 NO. 4 JASA $66 \quad$ B33 AMS $61 \quad$ B64 OKA69 215 AMS 631033 AMS $63 \quad 492$ AMS 682136 AMS $69 \quad 319$ AMS 69 NO. 6 AMS 691617 IOKA56 215 AMS 69 NO. 6 AMS $67 \quad 780$ AMS $63 \quad 348$ 

CONDITIONS FOR WISHARTNESS AND INDEPENDENCE OF SECOND

AMS 621002 RANDOM WALKS

SUFFICIENCY CONDITIONS IN REGULAR MARKOV CHAINS AND CERTATN BIOKA56 276 UN QUANTAL RESPONSES TO MTXTURES OF POISONS UNDER CONDITIONS OF STMPLE STMTLAR ACTION, THE ANALYSTS OF BTOKA5B 74 RVES ARE POSITIVE DEFTNITE AND UNTMODAL

THE CONDITIONS UNDER WHTCH GRAM-CHARLIER AND EDGEWORTH CU BI BIOKA52 425 PROBABILITY BOUNDS FOR A UNION OF HYPERSPHERICAL CONES

RANGE

A NOTE ON CONFIDENCE BANDS FOR A REGRESSION LINE OVER A FINITE LINEAR SEGMENT CONFIDENCE BANDS FOR SIMPLE LINEAR MODELS

SHORTER CONFIDENCE BANDS IN LINEAR REGRESSION CONFIDENCE BANDS IN LINEAR RECRESSION WITH CONSTRAINT CONFIDENCE BANDS IN STRAIGHT LINE REGRESSION

CONFIDENCE BANDS OF UNIFORM AND PROPORTIONAL WIDTH

FOR LINEAR MODELS

EIBULL DISTRIBU/ AN EXACT ASYMPTOTICALLY EFFICIENT CONFIDENCE BOUND FOR FURTHER CONTRIBUTIONS TO MULTIVARIATE CONFIDENCE BOUNDS

BO STMU TANEOUS CONFTDENCE BOUN IS OF VARIANCE AND NONINDEPENDENCE BETWEEN TWO/ ON CONFIDENCE BOUNDS ASSOCIATED WITH MULTIVARIATE ANALYS ON THE ASYMPTOTIC THEORY OF FIXED-SIZE SEQUENTIAL CONFIDENCE BOUNDS FOR LINEAR REGRESSION PARAMETERS VECTOR

EQUATIONS

ON FIXED-WIDTH CONFIDENCE BOUNDS FOR REGRESSION PARAMETERS AND MEAN SOME OPTIMUM CONFIDENCE BOUNDS FOR ROOTS OF DETERMINANTAL JASA $67 \quad 540$ $\begin{array}{rrr}\text { JASA } & 6 B & 1028\end{array}$ JASA $67 \quad 403$ JASA 671050 JASA $6 B 1020$ JASA 64 1B2 $\begin{array}{lll}\text { JASA } & 66 & 182\end{array}$ TECH $66 \quad 135$ BIOKA57 399 AMS 671853 AMS 661736 AMS $65 \quad 463$ JRSSB67 132 AMS $65 \quad 468$ TANGULA/ THE USE OF SAMPLE RANGES IN SETTING EXACT CONFIDENCE BOUNDS FOR THE STANDARD DEVIATION OF A REC JASA 61 601 L WITH PROGRESSIVE C/ EXACT THREE, ORDER STATISTIC CONFIDENCE BOUNDS ON RELIABLE LIFE FOR A WEIBULL MODE JASA 69 306 BABILITY THAT Y IS LESS THAN/ NONPARAMETRIC UPPER CONFIDENCE BOUNDS. AND CONFIDENCE LIMITS, FOR THE PRO JASA 64906 HE PARAMETER OF AN EXPONENTIAL POPULATION EXACT CONFIDENCE BOUNDS, BASED ON ONE ORDER STATISTIC FOR T TECH 64301 HE PARAMETER OF A ONE-PARAMETER NE/ ERRATA, 'EXACT CONFIDENCE BOUNDS, BASED ON ONE ORDER STATISTIC FOR T TECH 64 483

A NOTE ON 'FURTHER CONTRIBUTIONS TO MULTIVARIATE CONFIDENCE BOUNDS' BAON' BIOKA58

CORRICENDA, 'FURTHER CONTRIBUTIONS TO MULTIVARIATE CONFIDENCE BOUNDS' LIMITS FOR A VARTANCE COMPONENT WITH AN EXACT CONFIDENCE COEFFTCIENT N AND TESTING STATISTICAL HYPOTHESES CONFIDENCE CURVES, AN OMNIBUS TECHNIQUE FOR ESTIMATIO JASA 61246 PARAMETERS

PROPOSED FOR THE BEHRENS-FISHER PROBLEM RECRESSION

FIXED SIZE CONFIDENCE ELLIPSOIDS FOR LINEAR RECRESSION AMS 661602

A CONFIDENCE INTERVAL COMPARISON OF TWO TEST PROCEDURES JASA $66 \quad 454$ CONFIDENCE INTERVAL ESTIMATTON IN NON-LINEAR_JRSSB63 330

A CRAPHICAL VERSION OF TUKEY'S CONFIDENCE INTERVAL FOR SLIPPAGE QUERY, CONFIDENCE INTERVAL FOR STANDARD DEVIATION FROM A TECH $66 \quad 367$ A CONFIDENCE INTERVAL FOR THE AVAILABILITY RATIO TECH $67 \quad 465$

SINCLE OBSERVATION

NOT KNOWING THE VARIANCE WHEN MAKING A FIXED WIDTH CONFIDENCE INTERVAL FOR THE MEAN ON ON THE
A CONFIDENCE INTERVAL FOR VARIANCE COMPONENTS ON THE COST OF AMS 681946 CONFIDENCE INTERVAL OF PREASSIGNED LENGTH FOR THE

BEHRENS-FISHER PROBLEM

LENCTH OF CONFIDENCE INTERVALS

MORE ON LENGTH OF CONFIDENCE INTERVALS

OF BOUNDED LENGTH CONFIDENCE INTERVALS

EXISTENCE OF BOUNDED LENGTH CONFIDENCE INTERVALS
ADMISSIBILITY OF CONFIDENCE INTERVALS
OF DETERMINING FIXED-WIDTH CONFIDENCE INTERVALS

A CENERAL METHOD OF DETERMINING FIXED-WIDTH CONFIDENCE INTERVALS
APPROXIMATE CONFIDENCE INTERVALS
SEQUENTIALLY DETERMINED CONFIDENCE INTERVALS

NORMAL CORRELATION

SEQUENTIALLY DETERMINED CONF IDENCE INTERVALS

DEVIATION OF A NORMAL SAMPLE

CONFIDENCE INTERVALS BASED ON THE MEAN ABSOLUTE

TESTS AND CONFIDENCE INTERVALS BASED ON THE METRIC D2

STRATIFIED SAMPLING AND DISTRIBUTION-FREE CONFIDENCE INTERVALS FOR A MEDIAN

CORRECT USE OF THE SAMPLE MEAN ABSOLUTE DEVIATION IN CONFIDENCE INTERVALS FOR A NORMAL VARIATE CONFIDENCE INTERVALS FOR A PROPORTION

CORRIGENDA TO 'CONFIDENCE INTERVALS FOR A PROPORTION'

NONPARAMETRIC CONFIDENCE INTERVALS FOR A SHIFT PARAMETER

BIOKA62 27B

AMS 671175

JASA $61 \quad 549$

JASA $62 \quad 5 B 6$

AMS 631474

AMS $66 \quad 629$

AMS $69 \quad 704$

BI0KA53 12

BIOKA57 279

BIOCS68 434

JASA $65 \quad 257$

AMS $63 \quad 618$

JASA $65 \quad 772$

TECH $66 \quad 663$

BIOKA56 423

BI0KA58 291

AMS 631507

STMULTANEOUS CONFIDENCE INTERVALS FOR CONTRASTS AMONG MULTTNOMIAL AMS 64716 CONFIDENCE INTERVALS FOR DISTANCE IN THE ANALYSIS OF BIOKA5B 360

POPULATIONS

VARIANCE

DISCRETE CASE

WILCOXON CONFIDENCE INTERVALS FOR LOCATION PARAMETERS IN THE CONFIDENCE INTERVALS FOR MEASURES OF HERITABILTTY

LARGE SAMPLE SIMULTANEOUS CONFIDENCE INTERVALS FOR MULTINOMIAL PROPORTIONS

JASA $67 \quad 184$

BIOCS69 424

TECH 64 191

TECH $65 \quad 247$

ON SIMULTANEOUS CONFIDENCE INTERVALS FOR MULTINOMIAL PROPORTIONS CONFIDENCE INTERVALS FOR PARAME'TERS IN MARKOV AUTOREG JRSSB54 195

SSIVE SCHEMES (WITH DISCUSSION) CONFIDENCE INTERVALS FOR SYSTEM RELIABILITY

TABLE OF NEYMAN-SHORTEST UNBIASED CONFIDENCE INTERVALS FOR THE BINOMIAL PARAMETER $\quad$ BIOKA60 381

FOR THE NORMAL AND LOC NORMAL DISTRIBUTIONS $\begin{array}{llll}\text { CONFIDENCE INTERVALS FOR THE EXPECTATION OF A POISSON BIOKA59 } & 441 \\ \text { CONFIDENCE INTERVALS FOR THE HYPERCEOMETRIC PARAMETER TECH } 68 & 199\end{array}$

VARIABLE

THE RELATIONSHIP BETWEEN NEYMAN AND BAYES CONFIDENCE INTERVALS FOR THE HYPERCEOMETRIC PARAMETER TECH 68 199

ON THE ASYMPTOTIC THEORY OF FIXED-WIDTH SEQUENTIAL CONFIDENCE INTERVALS FOR THE MEAN

NSION OF A THEOREM OF CHOW AND ROBBINS ON SEQUENTIAL CONFIDENCE INTERVALS FOR THE MEAN POPULATION

UTION WITH KNOWN VARIANCE CONFTDENCE INTERVALS FOR THE MEAN OF A FINITE

ION WITH UNKNOWN VARTANCE

SHORTER CONFIDENCE INTERVALS FOR THE MEAN OF A NORMAL DISTRIB AMS 63574 NORMALLY DISTRIBUTED VARIABLES N FUNCTION, II N FUNCTION, III

TOUENTIAL CONFIDENCE INTERVALS FOR THE MEAN OF A NORMAL POPULAT JR CONFIDENCE INTERVALS FOR THE MEANS OF DEPENDENT

A 133 BOUNDED LENCTH CONFIDENCE INTERVALS FOR THE P-POINT OF A DISTRIBUTIO AMS 66 581 BOUNDED LENGTH CONFIDENCE INTERVALS FOR THE P-POINT OF A DISTRIBUTTO AMS 6658 ION ADMITTING A SUFFICIENT STATISTIC WHEN THE RAN/ CONFIDENCE INTERVALS FOR THE PARAMETER OF A DISTRIBUT JRSSB55 86 TABLES OF NEYMAN-SHORTEST UNBIASED CONFIDENCE INTERVALS FOR THE POISSON PARAMETER $\quad$ BIOKAG1 191 ATION THE USE OF SAMPLE QUASI-RANGES IN SETTING CONFIDENCE INTERVALS FOR THE POPULATION STANDARD DEVI JASA 61260 FICATION I/ AN ALMOST UNBIASED METHOD OF OBTAINING CONFIDENCE INTERVALS FOR THE PROBABILITY OF MISCLASSI BIOCS67 639 PARAMETERS COMPLEX ITEM ES AND SOME MEASURES OF EFFECTIVENESS DISTRIBUTION CONFIDENCE INTERVALS FOR THE PRODUCT OF TWO BINOMIAL JASA 57482 ONE-SIDED CONFIDENCE INTERVALS FOR THE QUALITY INDICES OF A TECH 63400 TWO CONFIDENCE INTERVALS FOR THE RATIO OF TWO PROBABILITI JASA $57 \quad 36$ OPTIMAL CONFIDENCE INTERVALS FOR THE VARIANCE OF A NORMAL JASA 59674 FUNCTION 
TABLE FOR BOTH THE SICN TEST AND DISTRIBUTION-FREE CONFIDENCE INTERVALS OF THE MEDIAN FOR SAMPLE SIZES T JASA 64935 SHORTER CONFIDENCE INTERVALS USINC PRIOR OBSERVATIONS

JASA 69378 APPROXTMATE CONFIDENCE TNTERVALS. II MORE THAN ONE UNKNOWN

ON FAILURE RATE, CORR. 67950

TOLERANCE AND CONFIDENCE LIMITS FOR CLASSES OF DISTRIBUTIONS BASED

APPROXIMATE CONFIDENCE LIMITS FOR COMPONENTS OF VARIANCE

JASA $58 \quad 482$

AMS 661593

BIOKA57 159

ENCY TABLES

SIMULTANEOUS CONFIDENCE LIMITS FOR CROSS-PRODUCT RATIOS IN CONTINC CONFIDENCE LIMITS FOR MULTIVARIATE RATIOS

JRSSB64 86

JRSSB61 10B

JRSSB64 176

BI0CS69 176

DISTRIBUTIONS

CONFIDENCE LIMITS FOR QUANTILES OF MORTALITY

TECH $66 \quad 368$

BAYESIAN CONEIDENCE LTMTS FOR REL TABILITY OF REDUNDANT SYSTEM TECH 68

DISTRIBUT

TABLES OF

QUERY, JOINT CONFIDENCE LIMITS FOR RANKED OBSERVATIONS

BIOKA69 452 JASA $60 \quad 521$

GAMMA DISTRIBUTIONS

FUNCTIONAL RELATIONSHIP

PARAMETERS

234)

SYSTEMS

PARALLEL SYSTEMS

TABLES OF CONFIDENCE LIMITS FOR THE BINOMIAL DISTRIBUTION

BTOCS65

APPROXTMATE CONFIDENCE LTMITS FOR THE COEFFICIENT OF VARIATION IN BIOC CONFIDENCE LIMITS FOR THE GRADIENT IN THE LINEAR

BAYESIAN CONFIDENCE LIMITS FOR THE PRODUCT OF N BINOMIAL

APPROXIMATE CONFIDENCE LIMITS FOR THE RELATIVE RISK (CORR. 63 CONFIDENCE LIMITS FOR THE RELIABILITY OF SERIES

$\begin{array}{rr}\text { JRSSB56 } & 65 \\ \text { BIOKA66 } & 611\end{array}$

JRSSB62 454

JASA $67 \quad 1452$

APPROXIMATE CONFIDENCE LIMITS FOR THE RELIABILITY OF SERIES AND

ON CONFIDENCE LIMITS FOR THE RELIABILITY OF SYSTEMS

TECH 65495

AMS $68 \quad 1463$

QUERY CONFIDENCE LIMITS FROM RANK TESTS

CONFIDENCE LIMITS IN THE CASE OF THE GEOMETRIC

DISTRIBUTION

CONFIDENCE LIMITS OF AN INDEX

TECH $65 \quad 257$

BIOKA59 260

BI0CS66 603

IENT

ONC CONFTDENCE LTMTTS ON THE MULTIPLE CORRELATTON COEFFTC JASA

A METHOD OF ASSIGNING CONFIDENCE LIMITS TO LINEAR COMBINATIONS OF VARIANCES BIOKA55 471 SOME REMARKS ON CONFIDENCE OF FIDUCIAL LIMITS

PARAMETER

ON COMPARISONS BETWEEN CONFIDENCE POINT PROCEDURES IN THE CASE OF A SINGLE

THE CASE OF SEVERAL PARAMETERS

ON CONFIDENCE POINTS AND BAYESIAN PROBABILITY POINTS I

LIKELIHOODS

ON FORMULAE FOR CONFIDENCE POINTS BASED ON INTEGRALS OF WEIGHTED CONFIDENCE PROPERTIES OF BAYESIAN INTERVAL ESTIMATES CONFIDENCE RECION FOR A LINEAR RELATION

BIOKA54 275

JRSSB 65

JRSSB65

JRSSB $63 \quad 318$

JRSSB6B 535

AMS $64 \quad 780$

A CONFIDENCE REGION FOR THE LOG-NORMAL HAZARD FUNCTION TECH 69387

ANEOUS EQUATIONS WITH AN APPLICATION TO EXPERIM/ A CONFIDENCE REGION FOR THE SOLUTION OF A SET OF SIMULT BIOKA54 190

NONPARAMETRIC CONFIDENCE REGIONS FOR SOME MULTIVARIATE LOCATION

NORMAL

NORMAL DISTRIBUTIONS

REGRESSION LAWS

A NOTE ON CONSERVATIVE CONFIDENCE REGIONS FOR THE MEAN OF A MULTIVARIATE

JASA $68 \quad 1373$

AMS $67 \quad 27 B$

RECTANGULAR CONFIDENCE REGIONS FOR THE MEANS OF MULTIVARIATE

EXACT CONFIDENCE REGIONS FOR THE PARAMETERS IN NON-LINEAR CONFIDENCE REGIONS FOR VARIANCE RATIOS OF RANDOM

MODELS

ASYMPTOTIC BEHAVIOR OF WILCOXON TYPE CONFIDENCE REGIONS IN MULTIPLE LINEAR REGRESSION CONFIDENCE REGIONS IN NON-LINEAR ESTIMATION (WITH

JASA $67 \quad 626$

BIOKA64 347

JASA 69660

AMS 69 N0.6

JRSSB60 41

JASA $67 \quad 1365$

AMS $61 \quad 477$

STRAIGHT LINE CONFIDENCE REGIONS OF LINEAR MODELS

AMS 671868

POPULATION CONFIDENCE SETS FOR MULTIVARIATE MEDIANS

JRSSB62 265

DISTRIBUTION (WITH DISCUSSION)

IATE NORMAL POPULATION ADMISSIBILITY OF THE USUAL CONFIDENCE SETS FOR THE MEAN OF A UNIVARIATE OR BIVAR

NOTE ON THE CONFIDENCE-PRIOR OF WELCH AND PEERS

CONFIDENCE-REGION TESTS

AMS 691042

JRSSB6 655

JRSSB64 462

LIKELIHOOD RATIO AND CONFIDENCE-REGION TESTS

JRSSB $65 \quad 245$

MULTIVARIATE NORMAL DISTRIBUTION CONFIDENCE, PREDICTION, AND TOLERANCE RECIONS FOR THE JASA 66605

BIORTHOGONAL AND DUAL CONFIGURATIONS AND THE RECIPROCAL NORMAL DISTRIBUTION AMS 69393 CONFIRMING STATISTICAL HYPOTHESES

ON THE CONSTRUCTION AND ANALYSIS OF SOME CONFOUNDED ASYMMETRICAL FACTORIAL DESIGNS

JRSSB57 125

BIOCS65 $94 \mathrm{~B}$

BIOCS67 813

BIOKA61 21 B

ALIASINC IN PARTIALLY CONFOUNDED FACTORIAL EXPERIMENTS

OF INDIRECT-ADJUSTED RATES IN THE PRESENCE OF CONFOUNDING

COMBINED ESTIMATORS IN FACTORIAL ARRANCEMENTS WITH CONFOUNDING

PARTIAL CONFOUNDING IN FRACTIONAL REPLICATION

BALANCED CONFOUNDING OF FACTORIAL EXPERIMENTS

CONSTRUCTION OF CONFOUNDING PLANS FOR MIXED FACTORIAL DESIGNS

THE ANALYSIS OF A FACTORIAL EXPERIMENT (WITH CONFOUNDING) ON AN ELECTRONIC CALCULATOR ON THE DISTRIBUTION OF TRIBOLIUM CONFUSUM IN A CONTAINER

A SIMPLE CONGESTION SYSTEM WITH INCOMPLETE SERVICE

365) ENTROPY AND CONJUGACY

ALTERNATIVES
SOME STATISTICAL PROBLEMS CONNECTED WITH CRYSTAL LATTICES (WITH DISCUSSION)

TWO TABLES CONNECTED WITH GOODNESS-OF-FIT TESTS ON A PROBLEM CONNECTED WITH QUADRATIC REGRESSION

SOME STATISTICAL METHODS CONNECTED WITH SERIES OF EVENTS (WITH DISCUSSION)

A NOTE ON THE DETERMINATION OF CONNECTEDNESS IN AN N-WAY CROSS CLASSIFICATION

ERRATA, A NOTE ON THE DETERMINATION OF CONNECTEONESS IN AN N-WAY CROSS CLASSIFICATION'

DISCUSSION, EMPHASIZING THE CONNECTION BETWEEN ANALYSIS OF VARIANCE AND SPECTRUM

ANALYSIS $L P /$ INDEX NUMBERS FOR FACTORIAL EFFECTS AND THEIR CONNECTION WITH A SPECIAL KIND OF IRREGULAR FRACTIONA J THE SAMPLING DISTRIBUTION OF AN ESTIMATOR ARISINC IN CONNECIION WITH THE TRUNCATED EXPONENTIAL DISTRIBUTIO SYSTEMS WITH COMPLETE CONNECTIONS (CORR, 69 NO.6)
ON AN EXTENSION OF THE CONNEXION BETWEEN POISSON AND CHI-SQUARE DISTRIBUTION BIOKA5 $\mathrm{S}$

ON 'A K-SAMPLE MODEL IN ORDER STATISTICS' BY W. J. CONOVER A NOTE AMS 66 THE DIFFERENCE BETWEEN CONSECUTIVE MEMBERS OF A SERIES OF RANDOM VARIABLES A BIOKA5
VARIANCE OF A SAMPLE OF CONSECUTIVE OBSERVATIONS FROM A MOVING-AVERAGE PROCES BIOKA6 RRANGED IN ORDER OF SIZE FOR THE LIMITING GENERALIZED VARIANCE OF A SAMPLE OF CONSECUTIVE OBSERVATIONS FROM A MOVING-AVERAGE PROCES BIOKA6I
FOR THE LIMITINC GENERALIZED VARIANCE OF A SAMPLE OF CONSECUTIVE OBSERVATIONS FROM A MOVING-AVERAGE PROCES BIOKA61 
THEOREM

THE BALANCED INCOMPLETE BLOCK DESIGN ANALYSIS

MULTIVARIATE NORMAL

ESSION LINES AND RELATED PROBLEMS OMBINATIONS OF UNBIASED ESTIMATORS C FOR A CALTBRATION LINE, CONSTDERATION OF A RECENT PROPOSAL CONSECUTIVE OBSERVATIONS HAVING A SPECIFIED ATTRIBUTE CONSENSUS OF SUBJECTIVE PROBABILTTTES A CONVERGENCE

SOME CONSEQUENCES OF RANDOMIZATION IN A GENERALIZATION OF

SOME CONSEQUENCES OF SUPERIMPOSED ERROR IN TIME SERIES A NOTE ON CONSERVATIVE CONFIDENCE REGIONS FOR THE MEAN OF A

CORRECTION TO 'A CONSERVATIVE PROPERTY OF BINOMIAL TESTS' 601205 A CONSERVATIVE TEST FOR THE GONCURRENCE OF SEVERAL REGR BIOKA66 272 ODUCTI/ MEASURING SPATIAL ASSOCIATION WITH SPECIAL CONSIDERATION OF THE CASE OF MARKET ORIENTATION OF PR JASA 56 597 NOTES. SMALL SAMPLE CONSIDERATIONS IN COMBINING 2 BY 2 TABLES

SOME CONSIDERATIONS IN MULTIVARIATE ALLOMETRY

GENERAL CONSIDERATIONS IN THE ANALYSIS OF SPECTRA

MATHEMATICAL CONSIDERATIONS IN THE ESTIMATION OF SPECTRA

BASIC CONSIDERATIONS IN THE ESTTMATION OF SPECTRA

NDOMIZATION FOR CROSS-CLASSIFICATIONS

THEORETICAL CONSIDERATIONS REGARDING H. R. B. HACK'S SYS

SOME PROPERTIES OF THE BIVARIATE NORMAL DISTRIBUTION CONSIDERED IN THE FORM OF A CONTINGENCY TABLE

MATION OF PARAMETERS FROM THE SPREAD OF A DISEASE BY CONSIDERING HOUSEHOLDS OF TWO.

THE CONSTSTENCY

FIDUCIAL CONSISTENCY AND GROUP STRUCTURE

FIDUCIAL CONSISTENCY AND GROUP STRUCTURE
PARAMETERS IN EXPLOSIVE STOCHASTIC DIFFERENCE EQU/ CONSISTENCY AND LIMIT DISTRIBUTIONS OF ESTIMATORS OF EQUATIONS

(WITH DISCUSSION) (CORR. 66 252)

A NOTE ON THE CONSISTENCY AND MAXIMA OF THE ROOTS OF LIKEITHOOD CONSISTENCY IN STATISTICAL INFERENCE AND DECISION

STRONG CONSISTENCY OF CERTAIN SEQUENTIAL ESTIMATORS THE CONSISTENCY OF CERTAIN SEQUENTIAL ESTIMATORS

ON STRONG CONSISTENCY OF DENSITY ESTIMATES

FURTHER EVIDENCE ON THE CONSISTENCY OF ESTIMATES OF VARIANCE COMPONENTS

AN ANALYSIS OF CONSISTENCY OF RESPONSE IN HOUSEHOLD SURVEYS

NOTE ON THE CONSISTENCY OF SOME DISTRIBUTION-FREE TESTS FOR

UNIFORM CONSISTENCY OF SOME ESTIMATES OF A DENSITY FUNCTION

ON THE CONSISTENCY OF THE FIDUCIAL METHOD

IES OF LINEAR REGRESSIONS ASYMPTOTIC NORMALITY AND CONSISTENCY OF THE LEAST SQUARES ESTIMATORS FOR FAMIL CONSISTENT ESTIMATES AND ZERO-ONE SETS

CONSISTENT ESTIMATES OF THE PARAMETERS OF A LINEAR

SYSTEM

OF A STATIONARY TIME/ ON ASYMPTOTICALLY EFFICIENT PRESENCE OF AN INCIDENTAL SCALE PARAMETER MIXTURES

ON IN CERTAIN CASES

ON THE LACK OF A UNIFORMLY

HYPOTHESES FROM GROUPED SAMPLES

CONSISTENT ESTIMATES OF THE SPECTRAL DENSITY FUNCTION

CONSISTENT ESTIMATION OF A LOCATION PARAMETER IN THE

A CONSISTENT ESTIMATOR FOR THE IDENTIFTCATION OF FINITE

HALLY PATROLLED BY ONE OPERATOR WHEN WALKING TTME IS

ION OF THE QUEUEING PROBLEM WITH A SINGLE SERVER AND CONSTANT PARAMETERS

THE EFFICIENCY OF AUTOMATIC WINDING MACHINES WITH CONSTANT PATROLLINC TIME

INEAR STATISTIC CHARAGTERIZATIONS OF NORMALITY BY CONSTANT RE

A CHARACTERIZATION OF CERTAIN SEQUENCES OF NORMING GONSTANTS

OF VARIANCE COMPONENTS BY THE METHOD OF FITTINC CONSTANTS

ONE OPERATOR UHEN WALKTNG TIME AND REPAIR TIMES ARE CONSTANT

SAMPLES

A NOTE ON THE ESTTMATION BIOKA69 NO.3

TAN AND COMPROMISE IN THE CONSUMER PRICE INDEX JASA 6281

EXPERIMENTS

ON THE CALCULATION OF CERTAIN CONSTRAINED MAXIMA

CONSTRAINED MAXIMISATION AND THE DESIGN OF

A NUMERICAL ANALYSIS PROBLEM IN CONSTRAINED QUADRATIC RECRESSION ANALYSIS

AN INEQUALITY IN CONSTRAINED RANDOM VARIABLES

OR CONVEX LEAST-SQUARES FITTING OF A POLYNOMIAL CONSTRAINED TO BE EITHER NON-NEGATIVE, NON-DECREASING J CHANCE CONSTRAINTS AND NORMAL DEVIATES

CONFIDENCE BANDS IN LINEAR REGRESSION WITH CONSTRAINTS ON THE INDEPENDENT VARIABLES

DISCRIMINATION BETWEEN K POPULATIONS WITH CONSTRAINTS ON THE PROBABILITIES OF MISCLASSIFICATION JRSSB69 I23

FOR THE PROBABILITY OF OBTAININC A TREE FROM A CRAPH CONSTRUCTED RANDOMLY EXCEPT FOR 'EXOGAMOUS BIAS'

FECT PLANS IN K TO THE N F/ A UNIFIED APPROACH FOR CONSTRUCTING A USEFUL CLASS OF NON-ORTHOGONAL MAIN EF JR CONSTRUCTING AN UNBIASED RANDOM SEQUENCE

A METHOD OF CONSTRUCTING BALANCED INCOMPLETE DESIGNS.

ATION COEFFICIENT

TABLES FOR CONSTRUCTING CONFIDENCE LIMITS ON THE MULTIPLE CORREL SOME METHODS OF CONSTRUCTING EXACT TESTS

CORRECTION, 'SOME METHODS OF CONSTRUCTING EXACT TESTS,

TECHNIQUES FOR CONSTRUCTING FRACTIONAL REPLICATE PLANS

A PROCEDURE FOR CONSTRUCTINC INCOMPLETE BLOCK DESIGNS

S USINC A COMPUTER

S USINC A COMPUTER. II

ON METHOD

CONSTRUCTING SETS OF MUTUALLY ORTHOGONAL LATIN SQUARE TECH $60 \quad 507$

ON THE TWO SAMPLE PROBLEM. A HEURISTIC METHOD FOR CONSTRUCTINC TESTS

THE POWER OF M DESIGNS WITH BLOCKS

ON CONSTRUCTING THE FACTORIAL REPLICATES OF THE TWO TO CONSTRUCTING UNIFORMLY BETTER ESTIMATORS

USE OF VARYING SEASONAL WEICHTS IN PRICE INDEX CONSTRUCTION

SOME METHODOLOGICAL NOTES ON THE DEFLATION OF CONSTRUCTION

A REGRESSION METHOD FOR REAL ESTATE PRICE INDEX CONSTRUCTION THE MEASUREMENT OF PRICE CHANGES IN CONSTRUCTION A SIMPLE METHOD OF TREND CONSTRUCTION

SEQUENCES

ICAL FACTORIAL DESIGNS

UNDED ASYMMETRICAL FACTORIAL DESIGNS
METHODS OF CONSTRUCTION AND ANALYSIS OF SERIALLY BALANCED

ON THE CONSTRUCTION AND ANALYSIS OF SOME CONFOUNDED ASYMMETR CONSTRUCTION AND ANALYSIS OF SOME NEW SERIES OF CONFO

ON ESTIMATION AND CONSTRUCTION IN FRACTIONAL REPLICATION

APPLICATION OF CYCLIC COLLINEATTONS TO THE CONSTRUCTION OF

SIGNIFICANCE IN MULTIVARIATE ANALYSIS

IN EIGHT BLOCKS OF 32

THE CONSTRUCTION OF A

CONSTRUCTION OF A 2-TO-THE-(17-9) RESOLUTION V PLAN

ON THE CONSTRUCTION OF AN INDEX FOR INDIRECT SELECTION

POPULATION BASED ON TWO SUCCESSIVE CENS/
ETHOD OF GONSTRUGTION OF ATTRITION LIFE TABLES FOR THE SINGLE

\section{(12)}

AMS 67221

AMS 631569

BIOCS66 747

TECH $61 \quad 133$

167

$\begin{array}{ll}\text { BIOKA58 } & 265 \\ \text { BIOKA57 } & 289\end{array}$

271
BIOKA57

BIOKA65 55

BIOKA54 56

691492

AMS 691765

JASA $61 \quad 320$

JASA $64 \quad 105$

RSSB62 425

AMS $63 \quad 447$

AMS 69 NO 6

AMS $69 \quad 1353$

$\begin{array}{lll}69 & 1728\end{array}$

$\begin{array}{ll}\text { AMS } 67 & 471 \\ \text { IOKA66 } & 545\end{array}$

ASA $68 \quad 1201$

TECH 69616

TECH $62 \quad 426$

AMS 681080

JRSSB69 113 JASA $68 \quad 1526$ BIOKA65 285 BIOKA6I 41 BIOKA66 629 JASA $63 \quad 45$ TECH $64 \quad 389$ TECH $61 \quad 111$ AMS 611091 AMS 621440 JASA $63 \quad 172$ JASA $58 \quad 66$ JASA $59 \quad 535$ JASA $63 \quad 933$ JASA $69 \quad 771$ JRSSB61 91 JRSSB57 286 IOCS65 948 AMS $66 \quad 1033$ AMS $67 \quad 1127$ BIOKA64 503 TECH $65 \quad 439$ BI0CS65 291 JASA $67 \quad 1433$ 
INVOLVINC SEQUENCES OF TREATMENTS

DESICNS

BALANCED SET OF L-RESTRICTTONAL PRTME-POWE/ ON HETEROCENEITY, I HE BEST LINEAR ESTIMATES FOR A SMALLER SAMPLE/
THE CONSTRUCTION OF BALANCED DESICNS FOR EXPERIMENTS THE EXISTENCE AND CONSTRUCTION OF BALANCED INCOMPLETE BLOCK DESICNS CONSTRUCTION OF CONFOUNDINC PLANS FOR MIXED FACTORIAL
BIOKA52 32 AMS $61 \quad 361$ AMS 651256 AMS 671293 JASA $66 \quad 1153$ CONSTRUCTION OF JOINT PROBABILITY DISTRIBUTIONS AMS 681354 RES OF DRUCS A COMPARISON OF TWO APPROACHES TO THE CONSTRUCTION OF MODELS FOR QUANTAL RESPONSES TO MIXTU BIOCS67 27 IFIGATION ANALYSIS OF VARIANCE THE CONSTRUCTION OF OPTIMAL DESIGNS FOR THE ONE-WAY CLASS JRSSB6I 352 RECURRENCE FORMULA

NUMERICAL CONSTRUCTION OF ORTHOGONAL POLYNOMIALS FROM A GENERAL BIOCS68 695 ON SOME METHODS OF GONSTRUCTION OF PARTIALLY BALANCED ARRAYS AMS 611181 ASSOCIATE CLASSES ON A GEOMETRICAL METHOD OF CONSTRUCTION OF PARTIALLY BALANCED DESIGNS WITH TWO ESIGNS WITH PARAMETERS $V=28, N 1=12, N 2=/ \quad$ A NOTE ON CONSTRUCTION OF PARTIALLY BALANCED INCOMPLETE BLOCK D CONSTRUCTION OF ROOM SQUARES CONSTRUCTION OF ROTATABLE DESIGNS THROUCH BALANCED INCOMPLETE BLOCK DESIGNS DESIGNS DIMENSIONS DISTRIBUTION THE SPHERE

THE CONSTRUCTION OF SATURATED TWO TO THE POWER OF $\mathrm{K}-\mathrm{P}$ A METHOD FOR THE CONSTRUCTION OF SECOND ORDER ROTATABLE DESICNS IN K CONSTRUCTION OF SEQUENCES ESTIMATINC THE MIXINC

ON THE CONSTRUCTION OF SICNIFICANCE TESTS ON THE CTRGLE AND ION GREATER THEN OR EQUAL TO 5 AND THE SET OF EVE/ CONSTRUCTION OF THE SET OF 256-RUN DESICNS OF RESOLUT THE STATISTICAL CONSULTANT IN A SCIENTIFIC LABORATORY

ERRORS OF THE THTRD KIND IN STATISTICAL CONSULTING

SOME OBSERVATIONS ON THE TEACHING OF STATISTICAL CONSULTINO SOME GENERAL REMARKS ON CONSULTING IN STATISTICS THE FORECASTINC ACCURACY OF GONSUMER ATTITUDE DATA TEN YEARS OF CONSUMER ATTITUDE' SURVEYS. THETR FORECASTTNG RECORD

VARIABLES THE PREDICTIVE ABILITY OF AN EXPERIMENT IN SURVEY DESIGN

SIS ON THE ROLE OF ASSETS, CREDIT AND INTENTIONS CONSUMER ATTITUDES, STOCK PRICES, AND NON-ATTITUDINAL CONSUMER BUYINC INTENTIONS AND PURCHASE PROBABILITY, VALIDATION OF CONSUMER FINANCIAL CHARACTERISTICS, COMMON STOCK INITIAL STOCK AND CONSUMER INVESTMENT IN AUTOMOBILES

SOME ASPECTS OF SEASONALTTY IN THE CONSUMER PRICE INDEX CONSTANTS AND COMPROMISE IN THE CONSUMER PRICE INDEX

POTENTIALS IN APPLYING LINEAR PROGRAMMING TO THE CONSUMER PRICE INDEX SAMPLINC ERROR IN THE CONSUMER PRICE INDEX PRODUCER AND CONSUMER RISKS FOR ASYMMETRICAL TESTS AND SPECIFICATI PRODUCER AND GONSUMER RISKS IN NON-NORMAL POPULATION

THE RELIABILITY OF CONSUMER SURVEYS OF FINANCTAL HOLDING

JASA $66 \quad 91$ DEPOSITS

THE RELIABILITY OF CONSUMER SURVEYS O

SAMPLING ATTRIBUTE PLANS WITH CIVEN PRODUCER'S AND CONSUMER'S RISK ENTIAL SAMPLING BY VARIABLES WHEN THE PRODUCER'S AND CONSUMER'S RISKS ARE EQUAL /TERISTIC CURVE FOR SEQU JASA 56 108 CONSUMERS' PROPENSITIES TO HOLD LIQUID ASSETS JASA 60469 CONTAGION IN STOCHASTIC MODELS FOR EPIDEMICS

TESTING FOR LINEAR CONTAGION, INVERSE SAMPLINC

ON A CONTAGIOUS DISTRIBUTION SUGGESTED FOR ACCIDENT DATA A NOTE ON CONTAGIOUS DISTRIBUTIONS

RANSFORMED DATA FROM THE NECATIVE BINOMIAL AND OTHER CONTAGIOUS DISTRIBUTIONS RANSFORMED DATA FROM THE NECATIVE BINOMIAL AND OTHER CONTAGIOUS DISTRIBUTIONS A METHOD OF ANALYSING UNT BIOKA6B 163
EXPERIMENTAL EVIDENCE CONCERNING CONTAGIOUS DISTRIBUTIONS IN ECOLOCY AMS 681863 JRSSB 69 NO. 2 BIOCS67 241 8IOKA54 268 E MAXIMUM LIKELIHOOD METHOD ICORR/ FTTING OF SOME CONTAGIOUS DISTRIBUTTONS TO SOHE AVAILABLE DATA BY TH BIOCSG5 ON THE DISTRIBUTION OF TRIBOLIUM GONFUSUM IN A CONTAINER

A BOREL SET NOT CONTAINING A GRAPH

ON SELECTINC A SUBSET CONTAINING THE POPULATION WITH THE SMALLEST VARIANCE

SOME NONRESPONSE SAMPLING THEORY WHEN THE FRAME GONTAINS AND UNKNOWN AMOUNT OF DUPLICATION ON EQUATIONS WHEN DISTURBANCES ARE BOTH SERIALLY AND GONTEMPORANEOUSLY CORRELATED /A SYSTEM OF RECRESSI JASA 67 500 S. IV, THE DISTRIBUTION OF HOMOGENEOU/ PROBABILITY CONTENT OF REGIONS UNDER SPERICAL NORMAL DISTRI8UTION AMS 62 542 NS, III. THE BIVARIATE NORMAL INTEGRAL PROBABILITY CONTENT OF RECIONS UNDER SPHERICAL NORMAL DISTRIBUTIO AMS 61 171 NS/ CORRECTION. THE TITLE SHOULD READ 'PROBABILITY CONTENT OF REGIONS UNDER SPHERICAL NORMAL DISTRIBUTIO AMS 6I G20 BAULE'S EQUATION + (LEAST SQUARES ESTIMATE OF SOIL GONTENT)

THE MULTI-TYPE CALTON-WATSON PROCESS IN A GENETICAL CONTEXT RTIES OF SEVERAL TWO-STACE REGRESSION METHODS IN THE CONTEXT OF AUTOCORRELATED ERRORS SMALL-SAMPLE PROPE JA TABLES FOR TESTING SICNTFICANCE IN A 2-BY-3 CONTINGENCY TABLE THE POWER FUNCTION OF THE EXACT TEST FOR THE 2-BY-3 CONTINGENCY TABLE A QUASI-MULTINOMIAL TYPE OF CONTINGENCY TABLE THE GEOMETRY OF A R-BY-C CONTINGENCY TABLE SYMMETRY AND MARGINAL HOMOGENEITY OF AN R-BY-R CONTINGENCY TABLE MEAN AND VARIANCE OF AN ENTRY IN A CONTINGENCY TABLE

THE POWER FUNCTION OF THE EXACT TEST FOR THE 2-BY-2 CONTINGENCY TABLE FOR THE VARIANCE OF THE CHI-SQUARE FUNCTION ON A CONTINGENCY TABLE IATE NORMAL DISTRIBUTION CONSIDERED IN THE FORM OF A CONTINGENCY TABLE ON PLACKETT'S TEST FOR CONTTNGENCY TABLE

TEST A SIMPLIFIED EXPRESSION BIOKA54
PROPERTIES OF THE BIVAR BIOKA57
289 JRSSB $63 \quad 179$ JRSSB69 NO.2 $\begin{array}{rlll}\text { TESTS OF SIGNIFICANCE IN A 2-BY-2 CONTINGENCY TABLE, EXTENSION OF FINNEY'S TABLE } & \text { BIOKA53 } 74 \\ \text { N OF THE EXACT TEST FOR THE 2-BY-2 CONTINGENCY TA8LE' } & \text { CORRICENDA, ION BIOKA6I } 475\end{array}$ THE POWER FUNCTION OF THE EXACT TEST FOR THE 2-BY-2 CONTINGENCY TA8LE'

A NOTE ON THE GRAPHICAL ANALYSIS OF MULTIDIMENSIONAL CONTINGENCY TABLES ASSOCIATION AND ESTIMATION IN CONTINCENCY TA8LES OPTIMUM CHOICE OF CLASSES FOR CONTINGENCY TABLES

HYPOTHESES OF 'NO INTERACTION' IN MULTI-DIMENSIONAL CONTINGENCY TABLES EXACT TESTS OF SIGNIFICANCE IN CONTINGENCY TABLES

USE OF SCORES FOR THE ANALYSIS OF ASSOCIATION IN CONTINCENCY TABLES TA8LES FOR SIGNIFICANCE TESTS OF 2-BY-2 CONTINGENCY TABLES ON THE ESTIMATION OF SMALL FREQUENCIES IN CONTINCENCY TABLES INTERACTIONS IN MULTI-FACTOR CONTINGENCY TABLES
TECH $67 \quad 481$

JASA 68

JASA $68 \quad 291$

TECH 68 107

TECH $69 \quad 393$ 8IOKA52 274 8IOKA55 494 JRSS856 113 JRSS862 251 
A NOTE ON INTERACTIONS IN CONTINCENCY TABLES MAXIMUM LIKELIHOOD IN THREE-WAY CONTINCENCY TABLES ALTERNATIVE ANALYSIS OF CONTINGENCY TABLES

COMBINATION OF RESULTS FROM SEVERAL 2 BY 2 CONTINGENCY TABLES ON THE HYPOTHESES OF 'NO INTERACTION' IN CONTINGENCY TABLES INCOMPLETE TWO-DIMENSIONAL GONTINGENCY TABLES

FULL CONTINCENCY TABLES, LOGITS, AND SPLIT CONTINGENCY TABLES AND THE HYPOTHESES OF NO THREE FAGTOR INTERACTION IN CONTINGENCY TABLES RAPID CALCULATION OF EXACT PROBABILITIES FOR 2-BY-3 CONTINGENCY TABLES METHODS FOR ANALYZING THREE-FACTOR INTERACTION IN CONTINGENCY TABLES

CONFIDENCE LIMITS FOR CROSS-PRODUCT RATIOS IN CONTINGENCY TABLES AND COMPARISON OF STRENCTHS OF ASSOCIATION IN CONTINGENCY TABLES POWER FUNCTIONS FOR THE TEST OF INDEPENDENCE IN 2 X2 CONTINGENCY TABLES SAMPLING ERRORS ON MEASURES OF ASSOCIATION IN 2-BY-2 CONTINGENCY TABLES OTHESIS FORMULATION, ESPECIALLY FOR MULTIDIMENSIONAL CONTINGENCY TABLES ND REGRESSION, WITH APPLICATION TO MANIFOLD, ORDERED CONTINCENCY TABLES
CURVES

2I TEST

\section{TESTS FOR CONTINGENCY TABLES}

MODELS FOR
JRSSB62 162 JRSSB 63220 JRSSB $66 \quad 164$ BIOCS65 86 BI0CS68 567 BI0CS69 119 BIOCS69 383 LAMST JASA 69207 NOTES. BIOCS68 714 SIMPLE JASA $64 \quad 319$ SIMULTANEOUS JRSSB64 86 THE ESTIMATION BIOKA53 105 COMPARISON OF THE AMS 641115 THE EFFECT OF NON- JASA 69852 MAXIMUM ENTROPY FOR HYP AMS $63 \quad 911$ /CT-MOMENT PARTIAL CORRELATION A BIOKA59 24I ND MARKOV CHAINS TECH $62 \quad 573$ $\begin{array}{rr}\text { TECH } 62 & 573 \\ \text { BIOCS66 } & 83\end{array}$ TECH $63 \quad 398$ $\begin{array}{lrlll}\text { ON THE ANALYSIS OF CONTINCENCY TABLES WITH A QUANTITATIVE RESPONSE } & \text { BIOCS68 } & 329 \\ & \text { CONTINCENCY TABLES WITH GIVEN MARGINALS } & \text { BIOKA68 } \\ \text { AND INTERACTIONS IN CONTINCENCY TABLES WITH OR WITHOUT MISSINC ENTRIES S JASA } 68 \text { I091 }\end{array}$ $\begin{array}{lrlll}\text { ON THE ANALYSIS OF CONTINCENCY TABLES WITH A QUANTITATIVE RESPONSE } & \text { BIOCS68 } & 329 \\ & \text { CONTINCENCY TABLES WITH GIVEN MARGINALS } & \text { BIOKA68 } \\ \text { AND INTERACTIONS IN CONTINCENCY TABLES WITH OR WITHOUT MISSINC ENTRIES S JASA } 68 \text { I091 }\end{array}$ ON THE ANALYSIS OF CONTINCENCY TABLES WITH A QUANTITATIVE RESPONSE
CONTINCENCY TABLES WITH GIVEN MARGINALS
NDEPENDENCE, QUASI-INDEPENDENCE. AND INTERACTIONS IN CONTINCENCY TABLES WITH OR WITHOUT MISSINC ENTRIES JACS68 329
ETHOD OF CALCULATING THE EXACT PROBABILITY IN 2-BY-2 CONTINGENCY TABLES WITH SMALL MARGINAL TOTALS /LE M BIOKA55 522 TABLES FULL CONTINGENCY TABLES, LOGITS, AND SPLIT CONTINGENCY BIOCS69 383 TS/ THE CHI-SQUARE TEST FOR SMALL EXPECTATIONS IN CONTINCENCY TABLES, WITH SPECIAL REFERENCE TO ACCIDEN BIOKA59 365 A NOTE ON CONTINGENCY-TYPE BIVARIATE DISTRIBUTIONS

THE PERFORMANCE OF SOME TESTS OF INDEPENDENCE FOR CONTINCENCY-TYPE BIVARIATE DISTRIBUTIONS PROBABILISTIC INTERPRETATIONS FOR THE MEAN SQUARE CONTINCENCY. CORR. 58 1030 SIGNIFICANCE NOTE ON AN EXACT TREATMENT OF CONTINGENCY. GOODNESS OF FIT AND OTHER PROBLEMS OF BIOKA5I 14I PRICING POLICIES CONTINGENT ON OBSERVED PRODUCT QUALITY

THE OUTER NEEDLE OF SOME BAYES SEQUENTIAL CONTINUATION REGIONS INEQUALITIES FOR THE NORMAL INTEGRAL INCLUDING A NEW CONTINUED FRACTION VARIATION QUADRATIQUE DES MARTINGALES CONTINUES A DROITE

ON THE USE AND MISUSE OF CORRECTIONS FOR CONTINUITY IONS INTRODUCED BY L. TACAKS ON THE INTEGRABILITY, CONTINUITY AND DIFFERENTIABILITY OF A FAMILY ON FUNCT AMS 63̈ 1045 THE CONTINUITY CORRECTION IN 2-BY-2 TABLES

PROBABTLITY AND STATISTICS. XVIT SOME REFIEYIONS ON CONTI NUTTY IN THE DEVELOPMENT OF MATHEMATICAL STATIST BIOKA67 $R$ THE SOBOLEV IMBEDDING THEOREMS TO CRITERIA FOR THE CONTINUITY OF PROCESSES WITH A VECTOR PARAMETER /FO AMS 69 5I7 DISTRIBUTION FUNCTIONS ON CONTINUITY PROPERTIES OF INFINITELY DIVISIBLE

MINATION OF REQUIREMENT THAT CUMULATIVE FUNCTIONS BE CONTINUOUS DISTRIBUTION FREE TOLERANCE LIMITS. ELI TEC SOME REMARKS ON CONTINUOUS ADDITIVE FUNCTIONALS

THE COVARIANCE MATRIX OF A CONTINUOUS AUTORECRESSIVE VECTOR TIME-SERIES

ESTIMATORS OF A LOCATION PARAMETER IN THE ABSOLUTELY CONTINUOUS CASE

ON ABSOLUTELY CONTINUOUS COMPONENTS AND RENEWAL THEORY

ESTIMATION OF THE LOCATION OF THE CUSP OF A CONTINUOUS DENSITY

SMOOTH EMPIRICAL BAYES ESTIMATION FOR CONTINUOUS DISTRIBUTIONS (CORR. 68597 )

ON CHI-SQUARE GOODNESS-OF-FIT TESTS FOR CONTINUOUS DISTRIBUTIONS (WITH DISCUSSION)

DECAY CURVES A GOMPARISON OF CONTINUOUS DISTRIBUTIONS OF PARAMETERS OF EXPONENTIAL

A PROPERTY OF THE MEAN DEVIATION FOR A CLASS OF CONTINUOUS DISTRIBUTIONS.

WHEN THE JOINT DISTRIBUTION OF THE ERRORS IS OF ANY CONTINUOUS FORM AND KNOWN APART FROM A SCALE PARAMETE CONTINUOUS INSPECTION SCHEMES

A CONTINUOUS KIEFER-WOLFOWITZ PROCEDURE FOR RANDOM

PROCESSES, CORR. 66745

INTER-PLANT STORAGE IN CONTINUOUS MANUFACTURING
IEOUS FIELDS ARE EITHER CONTINUOUS OR VERY IRREGULAR

OGENEOUS FIELDS ARE EITHER CONTINUOUS OR VERY IRREGULAR
RECTIFYING INSPECTION OF A CONTINUOUS OUTPUT, CORR. 59810

A NOTE ON SEQUENCES OF CONTINUOUS PARAMETER MARKOV CHAINS

SAMPLE FUNCTIONS AMS 671579

JASA $58 \quad 702$

AMS 691078

SOME MUL AMS $61 \quad 687$

TIVARIATE CHEBYSHEV INEQUALITIES WITH- EXTENSIONS TO CONTINUOUS PARAMETER PROCESSES

AIN LINEAR SYSTEMATIC STATISTICS OF SAMPLES FROM ANY CONTINUOUS POPULATION INT

NTERRELATIONS BETWEEN CERT BIOKA5I 377

STRIBUTION AND THE POSTERIOR DISTRIBUTION OF P FOR A CONTINUOUS PRIOR DISTRIBUTION THE MIXED BINOMIAL DI JRSSBG8 359 BAYESIAN SINGLE SAMPLING ATTRIBUTE PLANS FOR CONTINUOUS PRIOR DISTRIBUTIONS

TECH $68 \quad 667$

THE SPECTRUM OF A CONTINUOUS PROCESS DERIVED FROM A DISCRETE PROCESS BIOKA63 517

SUCCESSIVE RESULTS

SAMPLINC INSPECTION OF CONTINUOUS PROCESSES WITH NO AUTOCORRELATION BETWEEN

CISION MODELS FOR THE EVALUATION OF A LARGE CLASS OF CONTINUOUS SAMPLING INSPECTION PLANS

MARKOVIAN DE A PRODUCTION MODEL AND CONTINUOUS SAMPLING PLAN

NEW CRITERIA FOR SELECTING CONTINUOUS SAMPLINC PLANS

CONTINUOUS SAMPLING PLANS UNDER DESTRUCTIVE TESTING

WORST CONDITIONS

FUNCTIONS

THE EVALUATION OF H 106 CONTINUOUS SAMPLINC PLANS UNDER THE ASSUMPTION OF

RES FOR SMOOTHING PERIODOCRAMS FROM TIME SERIES WITH CONTINUOUS SPECTRA

E SUPREMUM FUNCTIONAL FOR SEMI-MARKOV PROCESSES WITH CONTINUOUS STATE SPACES

ON CONTINUOUS SUFFICIENT STATISTICS

DISTRIBUTION-FREE TOLERANCE INTERVALS FOR CONTINUOUS SYMMETRICAL POPULATIONS

COUNT OF A MARKOV CHAIN AND THE TRANSITION TO CONTINUOUS TIME

SOME RESULTS ON MULTITYPE CONTINUOUS TIME MARKOV BRANCHING PROCESSES

D LIMIT THEOREMS

EMBEDDING OF URN SCHEMES INTO CONTINUOUS TIME MARKOV BRANCHING PROCESSES AND RELATE

LE CHANNEL QUEUE WITH A GENERAL CLASS OF SERV/ THE CONTINUOUS TIME SOLUTION OF THE EQUATIONS OF THE SING JR,

GENERATINC FUNCTIONS

A CONTINUOUS TIME TREATMENT OF A SIMPLE QUEUE USING

THE RANDOM WALK (IN CONTINUOUS TIME) AND ITS APPLICATION TO THE THEORY OF

ESTIMATING THE INFINITESIMAL CENERATOR OF A CONTINUOUS TIME, FINITE STATE MARKOV PROCESS

UNDER MIXING WHICH CENERALIZE DE FINETTI'S THEOREM. CONTINUOUS TIMES PARAMETER

PROXMANTS TO THE INVERSE DISTRIBUTION FUNGTION OF A GONTINUOUS UNIVARIATE POPULATION FROM THE ORDER STATT BIOKA69 NO.3

MULTIVARIATE TWO SAMPLE TESTS WITH DIGHOTOMOUS AND GONTINUOUS VARIABLES I THE LOGATION MODEL

THE THEORY OF CORRELATION BETWEEN TWO GONTINUOUS VARIABLES WHEN ONE IS DICHOTOMIZED

AMS 69290

BIOKA55 205

TIVARIATE GORRELATION MODELS WITH MIXED DISGRETE AND GONTINUOUS VARIABLES, GORR. 65343

TIME DENSITY FOR HOMOGENEOUS SKIP-FREE WALKS ON THE GONTINUUM
THE FIRST PASSAGE AMS 61 448 
SQUARE DISTRIBUTION

(CORR. 69 229)

VARIATES CONCERNED

(WITH DISCUSSION)

VARIABLES

IONS (CORR, 68 597)
A CONTOUR-INTECRAL DERIVATION OF THE NON-CENTRAL CHION THE ESTIMATION OF CONTRASTS IN LINEAR MODELS

A METHOD FOR JUDCINC ALL CONTRASTS IN THE ANALYSIS OF VARIANCE (CORR, 69229 ) ESTIMATION OF MULTIPLE CONTRASTS USING T-DISTRIBUTIONS

ESTIMATION OF CENETIC CONTRIBUTION OF PRINCIPAL COMPONENTS TO INDIVIDUAL

A CONTRIBUTION TO COUNTER THEORY

A CONTRIBUTION TO THE 'TRAVELLINC-SALESMAN' PROBLEM

A CONTRIBUTION TO THE THEORY OF BULK QUEUES

THE CONTRIBUTIONS OF KARL PEARSON

CONTRIBUTIONS TO CENTRAL LIMIT THEORY FOR DEPENDENT

SOME CONTRIBUTIONS TO CONTINCENCY-TYPE BIVARIATE DISTRIBUT

FURTHER CONTRIBUTIONS TO MULTIVARIATE CONFIDENCE BOUNDS

A NOTE ON 'FURTHER CONTRIBUTIONS TO MULTIVARIATE CONFIDENCE BOUNDS'

CORRICENDA, 'FURTHER CONTRIBUTIONS TO MULTIVARIATE CONFIDENCE BOUNDS'

TRIBUTIONS OF SUMS OF RATIOS OF SPACINGS

THE PARAMETRIC COODNESS OF FIT AND TWO-SAMPLE PR/ AND TO THE DISTRIBUTION OF THE AVERACE RANK/ STATISTIC

CONTRIBUTIONS TO SAMPLE SPACINCS THEORY, I. LIMIT DI. CONTRIBUTIONS TO SAMPLE SPACINGS THEORY, II. TESTS OF CONTRIBUTIONS TO THE AVERAGE RANK CORRELATION METHODS
CONTRIBUTIONS TO THE K-SAMPLE PROBLEM, A SYMMETRIC CONTRIBUTIONS TO THE MATHEMATICS OF ANIMAL TRAPPING

SOME CONTRIBUTIONS TO THE THEORY OF MACHINE INTERFERENCE

A MULTIPLE COMPARISON SIGN TEST, TREATMENTS VERSUS CONTROL

A MINIMUM COST MODEL OF SPARE PARTS INVENTORY CONTROL

APPLICATION OF STOCHASTIC APPROXIMATION TO PROCESS CONTROL PROCESS CONTROL AND THE IMPACT OF AUTOMATIC PROCESS CONTROL RANKING PROCEDURES FOR COMPARISON WITH A CONTROL APPROXIMATION PROCEDURES FOR USE IN PROCESS CONTROL DISTRIBUTIONS IN PROCESS START-UPS AND INVENTORY CONTROL FREE MULTIPLE COMPARISON PROCEDURE, TREATMENT VERSUS CONTROL POPULATIONS BY THEIR LOCATIONS WITH RESPECT TO A CONTROL SEVERAL EXPERIMENTAL CATEGORIES WITH A STANDARD OR CONTROL FOR COMPARING SEVERAL EXPERIMENTAL CATECORIES WITH A CONTROL FOR COMPARING SEVERAL EXPERIMENTAL CATEGORIES WITH A CONTROL STATISTICAL ASPECTS OF ADAPTIVE OPTIMIZATION AND CONTRO

STATISTICAL PROCESS CONTROL AND THE IMPACT OF AUTOMATIC PROCESS CONTROL A COMPARISON OF SOME CONTROL CHART PROCEDURES

CONTROL CHART TESTS BASED ON GEOMETRIC MOVING

AVERAGES A MODIFIED CONTROL CHART WITH WARNING LINES

A SIMPLE THEORETTCAL APPROACH TO CUMULATTVE SUM CONTROL CHARTS THE ECONOMIC DESIGN OF CUMULATIVE SUM CONTROL CHARTS

DISCUSSION )

DISCUSSION)

CONTROL CHARTS AND STOCHASTIC PROCESSES (WITH CONTROL CHARTS AND THE MINIMIZATION OF COSTS (WITH

CUMULATIVE SUM CONTROL CHARTS AND THE WEIBULL DISTRIBUTION
CONTROL CHARTS FOR THE MEAN OF A NORMAL POPULATION CONTROL CHARTS WITH WARNING LINES

THE PRESENT STATUS OF AUTOMATIC PRODUCTION AND CONTROL DEVICES AND EXPECTED FUTURE DEVELOPMENTS POPULATIONS MULTIPLE COMPARISONS WITH A CONTROL FOR MULTIPLY-CLASSIFIED VARIANCES OF NORMAL MULTIPLE COMPARISIONS WITH A CONTROL IN BALANCED INCOMPLETE BLOCK DESICNS OPTIMIZATTON OF OUALITY CONTROL IN THE CHEMICAL LABORATORY

THE FIRST-MEDIAN TEST. A TWO-SIDED VERSION OF THE CONTROL MEDIAN TEST QUALITY CONTROL METHODS FOR SEVERAL RELATED VARIABLES TABLES FOR A TREATMENTS VERSUS CONTROL MULTIPLE COMPARISONS SIGN TEST

THE USE OF CONTROL OBSERVATIONS AS AN ALTERNATIVE TO INCOMPLETE STATISTICAL CONTROL OF A GAUSSIAN PROCESS

BLOCK DESIGNS

STOCHASTIC INPUT

ON THE LINEAR CONTROL OF A LINEAR SYSTEM HAVING A NORMAL STATIONAR

DESIGN OF MEAN CHARTS USED TO MAINTAIN CURRENT CONTROL OF A PROCESS FILL WEIGHT VARIATION RELEASE AND CONTROL OF CAPSULES, TABLETS, AND STERILE SOLIDS STATISTICAL CONTROL OF COUNTING EXPERIMENTS CONTROL OF PERCENTACES IN BOTH TAILS OF THE NORMAL

DISTRIBUTION

DISTRIBUTIONS' ERRATA, 'CONTROL OF PERCENTAGES IN BOTH TAILS OF THE NORMAL
CONTROL OF QUALITY OF CODING IN THE 1960 CENSUSES

THE USE OF RANDOM ALLOCATTON FOR THE CONTROL OF SELECTION BIAS SOME PROPERTIES OF RUNS IN QUALITY CONTROL PROCEDURES

CORRIGENDA, SOME PROPERTIES OF RUNS IN QUALITY CONTROL PROCEDURES ON SEQUENTIAL CONTROL PROCESSES

NOTE ON MEMORYLESS RULES FOR CONTROLLING SEQUENTIAL CONTROL PROCESSES AVERAGE RUN LENGTHS IN CUMULATIVE CHART QUALITY CONTROL SCHEMES VARIABLES

QUALITY CONTROL SYSTEMS BASED ON INACCURATELY MEASURED

AN APPLICATTON OF MULTIVARTATE OUALITY CONTROL TO PHOTOCRAPHIC PROCESSING

ED BLOCK EXPERIMENT WITH ADDITIONAL REPLICATION OF A CONTROL TREATMENT /IONS ARE MISSING FROM A RANDOMIS BI LARGE-SAMPLE COVARIANCE ANALYSIS WHEN THE CONTROL VARIABLE IS FALLIBLE

SAMPLING WITH CONTROL VARIABLES

USE OF RANDOM WORK SAMPLING FOR COST ANALYSIS AND CONTROL, CORR, 581031

'FINAL REPORT OF THE ADVISORY COMMITTEE ON WEATHER CONTRCL',

FITTING STRAIGHT LINES WHEN ONE VARIABLE IS CONTROLLED

PLAY THE WINNER RULE AND THE CONTROLLED CLINICAL TRIAL

EXPERIMENTS WHEN THE LEVELS GF STIMULUS CANNOT BE CONTROLLED, CORR. 56650

AL PROJECTING PROPERTI

AUTOMATIC RESET DEVICE

ION DATA

WARNING LINES

TON NON-STATIONARY TIME SERIES POLYNOMI JR CONTROLLING THE PROPORTION DEFECTIVE FROM CLASSIFICAT TECH 64 CONTROLLING THE STANDARD DEVIATION BY CUSUMS AND TECH 63 WET GHTED BIOKA56

AMS $62 \quad 796$

JASA $65 \quad 573$

JRSSB63 169

JRSSB55 185

JRSSB59 320

JASA $58 \quad 11$

S 68 115B

OKA58 581

925

ASA $63 \quad 756$

925

AMS $6 \mathrm{~B} 2075$

AMS 641136

AMS 691300

AMS $62 \quad 438$

$\begin{array}{ll}64 & 1571\end{array}$

TECH $65 \quad 2 \mathrm{~B} 3$

TECH $66 \quad 411$

TECH 59239

$\begin{array}{ll}\text { SA } & 61 \quad 835\end{array}$

49

243

TECH 6B 715

TECH $61 \quad 103$

ЕCH $66 \quad 519$

JASA $68 \quad 692$

TECH $59 \quad 359$

$\mathrm{CH} \quad 65293$

464

TECH $64 \quad 377$

TECH $66 \quad 570$

JASA 64120

BIOKA69 NO. 3

BIOKA58 89

BIOKA59 279

AMS $64 \quad 341$

AMS $66 \quad 276$

TECH 61 1I

BIOKA51 472

JASA $57 \quad 186$ BIOCS66 632 KA54 494

THE JASA 5B 3B2 $\begin{array}{rrrr}\text { FURTHER COMMENTS ON THE JASA } & 61 & 5 B 0 \\ & \text { JASA } & 58 & 106 \\ \text { JASA } & 69 & 131 \\ \text { ANALYSIS OF SENSITIVITY JASA } & 56 & 257 \\ \text { TIME SERTES POLYNOMI JRSSB65 } & 144\end{array}$ \begin{tabular}{rrrr} 
FURTHER COMMENTS ON THE JASA & 61 & $5 B 0$ \\
& JASA 58 & 106 \\
& JASA 69 & 131 \\
ANALYSIS OF SENSITIVITY JASA 56 & 257 \\
\hline
\end{tabular} $\begin{array}{rrrr}\text { FURTHER COMMENTS ON THE JASA } & 61 & 5 B 0 \\ & \text { JASA } & 58 & 106 \\ \text { JASA } & 69 & 131 \\ \text { ANALYSIS OF SENSITIVITY JASA } & 56 & 257 \\ \text { TIME SERTES POLYNOMI JRSSB65 } & 144\end{array}$ $\begin{array}{rrrr}\text { FURTHER COMMENTS ON THE JASA } & 61 & 5 \mathrm{BO} \\ & \text { JASA } & 58 & 106 \\ & \text { JASA } 69 & 131 \\ \text { ANALYSIS OF SENSITIVITY JASA } 56 & 257 \\ \text { TIME SERIES POLYNOMI JRSSB65 } & 144\end{array}$ 115 207 
THE EFFECTIVE USE OF BOTH POSITIVE AND NECATIVE CONTROLS IN SCREENINC EXPERIMENTS

INDIVIDUAL MATCHINC WITH MULTIPLE CONTROLS IN THE CASE OF ALL-OR-NONE RESPONSES

BI0CS67 285

A STATISTICAL INUESTICATION OF THE INDUSTRIALIZATION CONTROVERSY

L REFERENCE TO THE CICARETTE SMOKINC AND LUNC CANCER CONTROVERSY /STICAL INFERENCE IN HEALTH WITH SPECIA JASA 69 739 ON EXPECTATIONS. VARIANCES, AND CONVARIANCES OF ANOVA MEAN SQUARES BY 'SYNTHESIS"

JASA $60 \quad 284$

AN INEQUALITY AND ALMOST SURE CONVERCENCE

THE SPEED OF CLIVENKO-CANTELLI CONVERCENCE

SAMPLE SIZES

WEAK CONVERCENCE AND A CHERNOFE-SAVACE THEOREM FOR RANDOM

AMS 691091

AMS $69 \quad 40$

AMS 681675

AMS 69 N0.6

ON THE RATE OF CONVERCENCE FOR THE LAW OF LARCE NUMBERS CONVERCENCE IN NON-LTNEAR RECRESSTON

TECH $63 \quad 513$

UTIONS RIGHT HAAR MEASURE FOR CONVERGENCE IN PROBABILITY TO QUASI POSTERIOR DISTRIB

ON CONVERGENCE IN R-MEAN OF NORMALIZED PARTIAL SUMS FURTHER REMARKS ON TOPOLOGY AND CONVERCENGE IN SOME ORDERED FAMILIES OF DISTRIBUTION COMPLETELY SPECIFIED DISTRIBUTIONS RATES OF CONVERGENCE IN THE COMPOUND DECISION PROBLEM FOR TWO CONVERCENCE OF A HUMAN POPULATION TO A STABLE FORM

A NOTE ON THE RATE OF CONVERCENCE OF A MEAN

PROBLEMS

NEW APPROACH TO CHERNOFF-SAVAGE THEOREM ATION OF RAMANUJAN'S EQUATION

TION TO MAXIMUM LIKELIHOOD ESTIMATION
WEAK CONVERGENCE OF A SEQUENCE OF QUICKEST DETECTION

WEAK CONVERGENCE OF A TWO-SAMPLE EMPIRICAL PROCESS AND A

MONOTONE CONVERGENCE OF BINOMIAL PROBABILITIES AND A GENERALIZ MONOTONE CONVERGENCE OF BINOMIAL PROBABILITIES WITH AN APPLICA RATES OF CONVERCENCE OF ESTIMATES AND TEST STATISTICS

UNIFORM CONVERGENCE OF FAMILIES OF MARTINGALES

THE NON-ABSOLUTE CONVERGENCE OF GIL-PELAEZ' INVERSION INTECRAL

RAN/ SOME RESULTS ON THE COMPLETE AND ALMOST SURE CONVERCENCE OF LINEAR COMBINATIONS OF INDEPENDENT AND COMPARISON TESTS FOR THE CONVERCENCE OF MARTINGALES

LOCAL CONVERGENCE OF MARTINCALES AND THE LAW OF LARGE

NUMBERS

A CHARACTERIZATION OF THE WEAK CONVERGENCE OF MEASURES

RELATIONS BETWEEN WEAK AND UNIFORM CONVERGENCE OF MEASURES WITH APPLICATIONS

PROCESSES

MONOTONE CONVERGENCE OF MOMENTS IN AGE DEPENDENT BRANCHING

ON THE GONVERGENCE OF MOMENTS IN THE CENTRAL LIMIT THEOREM

ON THE CONVERGENCE OF ORDINARY INTECRALS TO STOCHASTIC CONVERGENCE OF QUADRATIC FORMS IN INDEPENDENT RANDOM

VARIABLES

VARIABLES

L TIME/

ALMOST SURE CONVERGENCE OF QUADRATIC FORMS IN INDEPENDENT RANDOM

INEQUALITIES WITH APPLICATIONS TO THE WEAK CONVERCENCE OF RANDOM PROCESSES WITH MULTI-DIMENSIONA MOMENT CONVERCENCE OF SAMPLE EXTREMES

A NOTE ON CONVERGENCE OF SUB-MARTINGALES CONVERGENCE OF SUMS OF SQUARES OF MARTINGALE

DIFFERENCES

ON CONVERGENCE OF THE KIEFER-WOLFOWITZ APPROXIMATION CONVERCENCE OF THE LOSSES OF CERTAIN DECISION RULES CONVERCENCE PROPERTIES OF A LEARNING ALGORITHM CONVERGENCE PROPERTIES OF CONVERCENCE WITH

PROBABILITY ONE

AR COMBTNATTONS OF TNDEPENDENT RANDOM VARI/

ON THE ERIZATION OF THE UPPER AND LOWER CLASSES IN TERMS OF DEVIATIONS

LINEAR COMBINATIONS OF MARKOV PROCESSES

E LINEAR COMBINATIONS OF EXCHANGEABLE AND MIXING/ LOGARITHM CONVERGENCE RATE

CONVERGENCE RATES FOR PROBABILITIES OF MODERATE CONVERCENCE RATES FOR THE LAIL OF LARGE NUMBERS CONVERGENCE RATES FOR THE LAW OF LARGE NUMBERS FOR TH CONVERCENCE RATES FOR THE LAW OF THE ITERATED

ON CONVERCENCE RATES IN THE CENTRAL LTMTT THEOREM

OME RESULTS RELATING MOMENT GENERATING FUNCTIONS AND CONVERGENCE RATES IN THE LAW OF LARGE NUMBERS ON EXTENDED RATE OF CONVERCENCE RESULTS FOR THE INVARIANCE PRINCIPLE ON THE SEMIMARTINGALE CONVERGENCE THEOREM GONSENSUS OF SUBJECTIVE PROBABILITIES. A GONVERGENCE THEOREM AN L-TO-THE-P CONVERGENCE THEOREM

SOME CONVERGENCE THEOREMS FOR INDEPENDENT RANDOM VARIABLES GONVERGENCE THEOREMS FOR MULTIPLE CHANNEL LOSS

PROBABILITIES

(ACKNOWLEDGEMENT OF PRIORITY 631111 )

ON CONVERGENCE TO INFINITY IN THE LAW OF LARGE NUMBERS

PRESERVATTON OF WEAK CONVERGENCE UNDER MAPPINGS

BERS FOR LINEAR STOCHASTIG PROGESSES WITH ABSOLUTELY CONVERGENT COEFFICIENTS /HE STRONC LAW OF LARCE NUM PROBABILITIES, DIRECT AND INVERSE A QUICKLY CONVERCENT EXPANSION FOR CUMULATIVE HYPERGEOMETRIC TRAINED TO BE EITHER NON-NEGATIVE, NON-DECREASING OR CONVEX LEAST-SQUARES FITTING OF A POLYNOMIAL CONS JR PEAKEDNESS OF DISTRIBUTIONS OF CONVEX COMBINATIONS

UNBIASED ESTIMATION IN CONVEX FAMILIES

ON MINIMIZINC A CONVEX FUNCTION SUBJECT TO LINEAR INEQUALITIES (WITH

THE CONVEX HULL OF A RANDOM SET OF POINTS

THE CONVEX HULL OF PLANE BROWNIAN MOTTON

DISCUSSION

LIMITING SETS AND CONVEX HULLS

BAYES ESTIMATION WITH CONVEX LOSS

DESICNS IN REGRESSION PROBLEMS WITH A GENERAL CONVEX LOSS FUNCTION

$\begin{array}{ll}\text { DITION FOR ADMISSIBILITY OF ESTIMATORS WHEN STRICTLY CONVEX LOSS IS USED /A NECESSARY AND SUFFICIENT CON } \\ \text { RIBUTIONS } & \text { ON THE EVALUATION OF PROBABILITIES OF CONVEX POLYHEDRA UNDER MULTIVARIATE NORMAL AND T-DIST J }\end{array}$

RIBUTIONS RESTRICTED LEAST SQUARES REGRESSION AND CONVEX QUADRATIC PROGRAMMING

MAXIMIZING A FUNCTION IN A CONVEX REGION

A TEST OF LINEARITY VERSUS CONVEXITY OF A MEDIAN REGRESSION CURVE

DEFINED ON A FINITE MARKOV CHAIN A CONVEXITY PROPERTY IN THE THEORY OF RANDOM VARIABLES

ESTIMATING THE PARAMETERS OF A CONVOLUTION

AL TYPE

AL TYPE' ERRATA, 'ESTIMATION OF A COMPONENT OF A CONVOLUTION, WHEN THE OTHER COMPONENT IS OF EXPONENTI THE LIMIT OF A RATIO OF CONVOLUTIONS

LAWS

CONVOLUTIONS OF DISTRIBUTIONS ATTRACTED TO STABLE COOPERATION AMONG STATISTICAL AND OTHER SOCIETIES

MARKOV AND LEAST SQUARES ESTIMATORS IDENTICAL. A COORDINATE-FREE APPROACH WHEN ARE GAUSS- AMS $68 \quad 70$

VARIATE RANDOM VARIABLES WHERE THE QUOTIENT OF THEIR COORDINATES FOLLOWS SOME KNOWN DISTRIBUTION COMMENTS ON A POSTERIOR DISTRIBUTION OF GEISSER AND CORNFIELD

GENERALIZED ASYMPTOTIC EXPANSIONS OF CORNISH-FISHER TYPE

JRSSB 64274

AMS $68 \quad 1264$

JASA $56 \quad 304$ 
PROBABILITIES OF CORRECT CLASSIFICATION IN DISCRIMINANT ANALYSIS

BI0CS66 908

CONFIDENCE INTERVALS FOR A NORMAL VARIATE ON ONE VARIABLE IS RESTRICTED

NOTE ON A METHOD FOR

THE 'STUDENTIZED' RANCE

USEFUL IN THE THEORY

THE CORRECT USE OF THE SAMPLE MEAN ABSOLUTE DEVIATION IN

NOTES. CORRECTED CORRELATION COEFFICIENTS WHEN OBSERVATION CALCULATINC CORRECTED SUMS OF SQUARES AND PRODUCTS

EXTENDED AND CORRECTED TABLES OF THE UPPER PERCENTAGE POINTS OF

ON A BOUND CORRECTING THE AVERAGE RANK CORRELATION COEFFICIENT SOURCES OF STATISTICS ON CRIME AND CORRECTION

APPROXIMATE CONFIDENCE INTERVALS III. A BIAS CORRECTION PREDICTION BY PROCRESSIVE CORRECTION CUSTOMER IMPATIENCE IN THE QUEUEINC SYSTEM GI-M-1, A CORRECTION

INSPECTION AND CORRECTION ERROR IN DATA PROCESSING

DECIMAL CORRECTION ERROR, AN EXAMPLE IN STATISTICS

THE CONTINUITY CORRECTION IN 2-BY-2 TABLES

ON A CORRECTION TERM IN THE METHOD OF PAIRED COMPARISONS CORRECTION TO 'A CONSERVATIVE PROPERTY OF BINOMIAL

CORRECTION TO 'A PROOF OF WALD'S THEOREM ON CUMULATIV CORRECTION TO 'DISTRIBUTION OF DEFINITE AND OF INDEFI CORRECTION TO 1 ON A CLASS OF PROBLEMS RELATED TO THE CORRECTION TO 'ON THE MUTUAL INDEPENDENCE OF CERTAIN CORRECTION TO 'TABLES OF EXPECTED VALUES OF ORDER STA

CORRECTION TO BARTLETT'S CRITERION FOR TESTINC THE HO CORRECTION. 'A COMPARATIVE STUDY OF SEVERAL ONE-SIDED CORRECTION. 'SOME EXTENSIONS OF THE WISHART

CORRECTION. 'THE NON-CENTRAL WISHART DISTRIBUTION AND CORRECTION. ITHE STRUCTURE OF BIVARIATE DISTRIBUTIONS CORRECTION. THE TITLE SHOULD READ 'PROBABILITY CONTEN CORRECTION, 'CALCULATION OF EXACT SAMPLING DISTRIBUTI CORREGTION, 'DISTRIBUTION FREE TESTS BASED ON THE CORRECTION, 'SOME METHODS OF CONSTRUCTING EXACT CORRECTIONS AND ADJUSTMENTS FOR CALENDAR SHIFTS

CORRECTIONS FOR CONTINUITY

REGRESSION TECHNIQUES APPLIED TO SEASONAL ON THE USE AND MISUSE

ATE SIGN TEST AND A NON-PA ITS APPLICATIONS' 50206

IAL DISTRIBUTIONS' 57861

NS OF POINTS ON A LATTICE' 58256

CORRECTIONS TO 'A RELATIONSHIP BETWEEN HODGES' BIVARI CORRECTIONS TO 'A THEOREM ON FACTORIAL MOMENTS AND CORRECTIONS TO 'SADDLE POINT METHODS FOR THE MULTINOM CORRECTIONS TO 'THE THEORY OF PROBABILITY DISTRIBUTIO ON EXACT GROUPING CORRECTIONS TO MOMENTS AND CUMULANTS

ON CORRECTIONS TO THE CHI-SQUARED DISTRIBUTION

TIMATION IN NON-LINEAR REGRESSION WHEN RESPONSES ARE CORRELATED DISTURBANCES ARE BOTH SERIALLY AND CONTEMPORANEOUSLY CORRELATED FFECTS MODEL WITH OBSERVATIONS WITHIN A ROW SERIALLY CORRELATED A A SYSTEM OF REGRESSION EQUATIONS WHEN

/FOR THE TWO-WAY CLASSIFICATION FIXED E BIOKA69 NO.3 OF VARIANGE TABLE FOR DIFFERENT CLASSIFICATIONS WITH CORRELATED AND NON-HOMOGENEOUS ERRORS /AN ANALYSIS J FITTING A POLYNOMIAL TO CORRELATED EQUALLY SPACED OBSERVATIONS

BAYESIAN ANALYSIS OF THE REGRESSION MODEL WITH AUTO-GORRELATED ERRORS DESIGNS FOR REGRESSION PROBLEMS WITH CORRELATED ERRORS

CORRELATED ERRORS IN THE RANDOM MODEL

DESIGNS FOR REGRESSION PROBLEMS WITH CORRELATED ERRORS MANY PARAMETERS

A BAYES APPROACH FOR COMBINING CORRELATED ESTIMATES

A NOTE ON COMBINING CORRELATED ESTIMATES OF A RATIO OF MULTIVARIATE MEANS IV

ON THE SMALLEST OF SEVERAL CORRELATED F STATISTICS

TION OF SUM OF IDENTICALLY DISTRIBUTED EXPONENTIALLY GORRELATED GAMMA-VARIABLES, (ACKNOWLEDGEMENT OF PRIOR RESERVOIRS WITH SERIALLY CORRELATED INPUTS

ON LINEAR FUNCTIONS OF ORDERED CORRELATED NORMAL RANDOM VARIABLES

ON THE RATIO OF TWO CORRELATED NORMAL RANDOM VARIABLES

ON THE RATIO OF TWO CORRELATED NORMAL RANDOM VARIABLES
FUNCTIONS AND RATIOS OF LINEAR FUNCTIONS OF ORDERED CORRELATED NORMAL RANDOM VARIABLES WITH EMPHASIS ON R BIOKA64 I43 A NOTE ON THE CORRELATION OF RANGES IN CORRELATED NORMAL SAMPLES

GENERATING FUNCTIONS OF QUADRATIC FORMS IN SERIALLY CORRELATED NORMAL VARIABLES EXPERIMENTAL DESIGNS FOR SERIALLY CORRELATED OBSERVATIONS

FURTHER REMARKS ON EXPONENTIAL REGRESSION WITH CORRELATED OBSERVATIONS

EXPONENTIAL REGRESSION WITH CORRELATED OBSERVATIONS

VARIANCES FOR EXPERIMENTAL DESIGNS WITH SERIALLY CORRELATED OBSERVATIONS

S FOR COMPUTERS. NO 26

CORRIGENDA TO 'CORRELATED RANDOM NORMA

TESTS OF HOMOCENEITY FOR CORRELATED SAMPLES

CORRELATION OF THE RANGES OF CORRELATED SAMPLES

THE CORRELATED UNRESTRICTED RANDOM WALK

THE USE OF CORRELATED VARIABLES FOR PRELIMINARY CULLINC

N LIMIT

A SINGLE SAMPLING PLAN FOR CORRELATED VARIABLES WITH A SINGLE-SIDED SPECIFICATIO QUERY, TESTING TWO CORRELATED VARIANCES

TESTING THE HOMOGENEITY OF A SET OF GORRELATED VARIANCES

EQUALLY CORRELATED VARIATES AND THE MULTINORMAL INTEGRAL ON SERIAL CORRELATION

PARTIAL AND MULTIPLE RANK CORRELATION

SOME QUESTIONS OF DISTRIBUTION IN THE THEORY OF RANK CORRELATION EXACT TESTS FOR SERIAL CORRELATION

THE GAMBLER'S RUIN PROBLEM WITH CORRELATION TESTING EQUALITY OF MEANS IN THE PRESENCE OF CORRELATION

SELECTION BASIS IN ESTIMATION OF THE GENETIC CORRELATION AND AN APPLICATION OF A STATISTIC ARISING IN TESTING CORRELATION IDENCE INTERVALS AND EXPERIMENTAL DESIGN WITH NORMAL CORRELATION TS OF NORMAL VARIATES IN THE PRESENCE OF INTRA-CLASS CORRELATION VARIABLES

ION OF SUMS OF SQUARES AND CROSS PRODUC GORRELATION AND COMPLETE DEPENDENCE OF RANDOM

MODIFIED DOOLITTLE APPROACH FOR MULTIPLE AND PARTIAL GORRELATION AND RECRESSION

OLD. I THE RANK ANALOGUE OF PRODUCT-MOMENT PARTIAL CORRELATION AND REGRESSION, WITH APPLICATION TO MANIF MUTUAL INFORMATION AND MAXIMAL CORRELATION AS MEASURES OF DEPENDENCE

A RATIO AND ITS DENOMINATOR THE CORRELATION
BI0CS66 663

TECH $62 \quad 419$

BIOKA52 192

AMS 64408

JASA $59 \quad 582$

BIOKA55 201

JRSSB $64 \quad 113$

JASA 69 NO, 4

TECH $62 \quad 421$

BIOKA64 327

IOKA52 211

MS 611343

AMS $62 \quad 813$

AMS $62 \quad \mathrm{~B} 12$

AMS 611344

AMS $61 \quad 1345$

487

AMS $64 \quad 923$

MS 64923

MS 641388

AMS $67 \quad 2 B 0$

BIOKA67 333

BIOKA66 629

JASA $56 \quad 615$

ASJ $68 \quad 85$

AMS 61619

61620

AMS $61 \quad 619$

AMS 61619

BIOKA65 275

JASA $64 \quad 763$

AMS $66 \quad 66$

JASA 67 13B7

AMS $68 \quad 49$

JASA $65 \quad 602$

CH $64 \quad 463$

BIOKA62 509

AMS $64 \quad 277$

TECH $63 \quad 85$

BIOKA65 367

MOMENT BIOKA58 19B

BIOKA52 15I

BIOKA6B 575

BIOKA6B 149

$\begin{array}{lll} & \text { BIOKA6B } & 149 \\ \text { TREATMENT } & \text { BIOKA56 } & 208\end{array}$

BIOKA56 496

BIOKA67 529

JRSSB63 394

BIOCS67 55]

JASA $59 \quad 24 \mathrm{~B}$

TECH $65 \quad 447$

BIOKA6B 317

JRSSB58 373

AMS 69188

BIOKA51 26

BIOKA51 13]

BIOKA55 133

BI0KA55 4B6

BI0KA69 119

BI0CS68 951

AMS 691736

BIOGS68 434

AMS $62 \quad 1461$

AMS $63 \quad 1315$

JASA 5B 133

IOKA59 241

587
739

385
BIOKA68 595 

TRUNCATED BIVARIATE NORMAL DISTRIBUTION CORRELATION BETWEEN THE SAMPLE VARIANCES IN A SINGLY B HUMAN FAMILIES

THE DETECTION OF A CORRELATION BETWEEN THE SEXES OF ADJACENT SIBS IN BIOKA6B 433 JASA 651035 BIOKA55 316 IS DICHOTOMIZED AN EXACT TEST FOR CORRELATION BETWEEN TIME SERIES $\begin{array}{rllll}\text { EXACT TEST FOR CORRELATION BETWEEN TIME SERIES } & \text { BIOKA55 } & 316 \\ \text { THE THEORY OF CORRELATION BETWEEN TWO CONTINUOUS VARIABLES WHEN ONE BIOKA55 } & 205 \\ \end{array}$ ES ES. II. THE APPROXIMATE DISTRIBUTION OF THE CORRELATION BETWEEN TWO STATIONARY LINEAR MARKOV SERI BIOKA62 379 DOUBLY TRUNCATED NORHAL DISTRIBUTION THE CORRELATION BETWEEN TWO STATIONARY LINEAR MARKOV SERI
THE CORRELATION BETWEEN VARIATE-VALUES AND RANKS IN A AN ANCULAR TRANSFORMATION FOR THE SERIAL CORRELATION COEFFICIENT A NOTE ON THE PROBABILITY INTEGRAL OF THE CORRELATION COEFFICIENT SOME PROPERTIES OF AN ANGULAR TRANSFORMATION FOR THE CORRELATION COEFFICIENT A REMARK ON SPEARMAN'S RANK CORRELATION COEFFICIENT ON NAIR'S TRANSFORMATION OF THE CORRELATION COEFFICIENT SHORT PROOF OF DR HARLEY'S THEOREM ON THE CORRELATION COEFFICIENT THE ASYMPTOTIC EFFICIENCY OF DANIELS'S GENERALIZED CORRELATION COEFFICIENT THE NULL DISTRIBUTION OF THE FIRST SERIAL CORRELATION COEFFICIENT NOTE ON FISHER'S TRANSFORMATION OF THE CORRELATION COEFFICIENT MOMENTS OF A SERIAL CORRELATION COEFFICIENT $\begin{array}{ll}\text { BIOKA65 } & 301 \\ \text { BIOKA66 } & 281\end{array}$ BIOKA54 261 BIOKA54 278 BIOKA56 219 BIOKA58 273 BIOKA5B 567 BIOKA5B 571 BIOKA63 499 BIOKA66 623 JRSSB59 409 JRSSB 65 30B JRSSB $66 \quad 513$ SOME NEW RESULTS ON THE DISTRIBUTION OF THE SAMPLE CORRELATION COEFFICIENT THE NONCENTRAL DISTRIBUTION OF THE LARGEST CANONICAL CORRELATION COEFFICIENT FOR CONSTRUCTING CONFIDENCE LIMITS ON THE MULTIPLE CORRELATION COEFFICIENT PROPERTIES OF AN ANGULAR TRANSFORMATION OF THE CORRELATION COEFFICIENT DISTRIBUTIONS FOR SMALL N OF KENDALL'S PARTIAL RANK CORRELATION COEFFICIENT EXPANSIONS FOR THE MEAN AND VARIANCE OF THE SERIAL CORRELATION COEFFICIENT

EXPANSIONS FOR THE MOMENTS OF THE DISTRIBUTION OF CORRELATION COEFFIGIENT

SIMPLE FORM OF THE DISTRIBUTION OF THE MULTIPLE CORRELATION COEFFICIENT

STUDY OF THE DISTRIBUTION OF THE SAMPLE GENETIC CORRELATION COEFFICIENT DISTRIBUTIONS OF NON-CENTRAL T AND OF A TRANSFORMED CORRELATION COEFFICIENT ESSARY SAMPLE SIZE, AND A RELATION WITH THE MULTIPLE CORRELATION COEFFICIENT ASYMPTOTIC RELATIVE EFFICIENCY OF TWO TESTS AND THE CORRELATION COEFFICIENT CORRECTING THE AVERAGE RANK CORRELATION COEFFICIENT LES SUBSEQUENT/ INFERENCES CONCERNING A POPULATION GORRELATION COEFFICIENT FROM ONE OR POSSIBLY TWO SAMP JRSSB67 282 CORRECTING THE AVERAGE RANK CORRELATION COEFFICIENT FOR TIES IN RANKINGS
LES SUBSEQUENT/ INFERENCES CONCERNING A POPULATION GORRELATION COEFFICIENT FROM ONE OR POSSIBLY TWO SAMP JRSSB67 282 ONS ABOUT THE R/ A RAPID METHOD FOR ESTIMATINC THE CORRELATION COEFFICIENT FROM THE RANCE OF THE DEVIATI BIOKA53 218 / THE FREQUENCY DISTRIBUTION OF THE PRODUCT-MOMENT GORRELATION COEFFICIENT IN RANDOM SAMPLES OF ANY SIZE BIOKA5I 219 THE PRODUCT-MOMENT GORRELATION COEFFICIENS IN RANDOM SAMPLES OF ANY SIZE

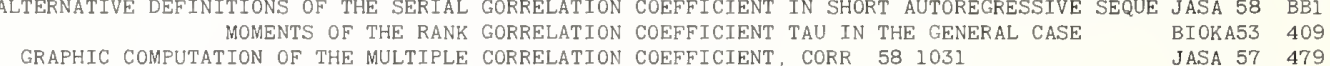

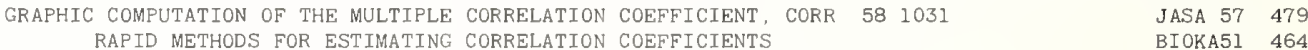
BIOKA56 161 BIOKA56 169 JRSSB 61 12B THE APPROXIMATE DISTRIBUTION OF SERIAL CORRELATION COEFFICIENTS

THE ASYMPTOTIC EFFICIENCY OF DANIELS'S GENERALIZED CORRELATION COEFFICIENTS

EFFECT OF TRANSFORMATIONS OF VARIABLES UPON THEIR CORRELATION COEFFICIENTS SIGNS OF CROSS CORRELATION COEFFICIENTS AND PARTIAL CORRELATION COEFFICIENTS NORMAL DISTRIBUTION IV EMPIRICAL VARIANCES OF RANK CORRELATION COEFFICIENTS FICIENTS A NOTE ON THE SIGNS OF GROSS CORRELATION COEFFICIENTS A A NOTE ON THE BIOKA56 480 ENTS THE SAMPLING VARIANCE OF THE CORRELATION COEFFICIENTS

DISTRIBUT ION THE PERFORMANCE OF SOME CORRELATION COEFFICIENTS ON TESTING A SET OF CORRELATION COEFFICIENTS $\begin{array}{ll}\text { BIOKA56 } & 480 \\ \text { BIOCS66 } & \text { IB7 }\end{array}$ C RESULTS ON TESTING A SET OF CORRELATION GOEFFICIENTS FOR EQUALITY. SOME ASYMPTOTI AMS $63 \quad 149$ INDIVIDUALS DISTRIBUTIONS OF CORRELATION COEFFICIENTS IN ECONOMIC TIME SERIES CORRELATION COEFFICIENTS MEASURED ON THE SAME BIOKA68 513

IONS AND MIXED VARIATES ABLE IS RESTRICTED THE CANONICAL CORRELATION COEFFICIENTS OF BIVARIATE GAMMA DISTRIBUT AMS 691401 THE SAMPLING VARIANCE OF CORRELATION COEFFICIENTS UNDER ASSUMPTIONS OF FIXED BIOKA58 471 NOTES. CORRECTED CORRELATION COEFFICIENTS WHEN OBSERVATION ON ONE VARI BIOCS66 182 TESTS FOR RANK CORRELATION COEFFICIENTS. I TESTS FOR RANK CORRELATION COEFFICIENTS. III. DISTRIBUTION OF THE TR BIOKA62 18 TESTS FOR RANK CORRELAT'ION COEFFICIENTS II

ANSFORMED KENDALL COEFFICIENT A NOMOCRAPH FOR COMPUTING PARTIAL CORRELATION COEFFICIENTS, CORR. 62917 BIOKA61 29 JASA 61995 E CRITICAL VALUES OF THE COEFFICIENT OF RANK CORRELATION FOR TESTING THE HYPOTHESIS OF INDEPENDENC BIOKA6I 444 DISTRIBUTION. II, RANK CORRELATION STRIBUTION. III CORRELATION BETWEEN RANKS AND VA/ STRIBUTION IV. EMPIRICAL VARIANCES OF RANK CORREL/ FURTHER MODELS FOR ESTIMATING CORRELATION IN DISCRETE DATA ALIZED MULTINOMIAL DISTRIBUTION IN THE ESTIMATION OF CORRELATION IN DISCRETE DATA EFFICIENT GROUPING, RECRESSION AND CORRELATION IN ENGEL CURVE ANALYSIS TESTINC FOR SERIAL CORRELATION IN LEAST SQUARES REGRESSION TESTINC FOR SERIAL CORRELATION IN LEAST SQUARES RECRESSION. II A THEOREM ON LEAST SQUARES AND VECTOR CORRELATION IN MULTIVARIATE LINEAR REGRESSION AN APPROXIMATE TEST FOR SERIAL CORRELATION IN POLYNOMIAL REGRESSION

DOGRAM OF LEAST-SQUARES RESIDUALS TESTS FOR SERIAL CORRELATION IN RECRESSION ANALYSIS BASED ON THE PERIO BI SERIAL CORRELATION IN REGRESSION ANALYSIS. I. SERIAL CORRELATION IN REGRESSION ANALYSIS. II

EQUATIONS TESTING FOR SERIAL CORRELATION IN SYSTEMS OF SIMULTANEOUS REGRESSION ON MEASURES OF CORRELATION IN TIME SERIES OF EVENTS TESTS FOR CORRELATION MATRICES

ON LOOKING AT LARGE CORRELATION MATRICES SOME TESTS FOR CORRELATION MATRICES SIGNIFIGANGE FOR THE LATENT ROOTS OF GOVARIANGE AND GORRELATION MATRIGES THE GENERALIZED MULTIPLE GORRELATION MATRIX

DISTRIBUTION OF THE 'GENERALIZED' MULTIPLE CORRELATION MATRIX IN THE DUAL GASE TESTS OF BIOKA56 128 SASJ 69 NO.2 AMS 641801 ON THE DISTRIBUTION OF A MULTIPLE CORRELATION MATRIX, NON GENI ERAGE RANK/ SOME GONTRIBUTIONS TO THE AVERAGE RANK CORRELATION METHODS AND TO THE DISTRIBUTION OF THE AV JASA 63 756 SOME TESTS FOR THE INTRAGLASS CORRELATION MODEL

QUERY, MAXIMUM LIKELIHOOD ESTIMATE IN INTRAGLASS GORRELATION MODEL 
PLES OF FOUR FROM A NORMAL BIVARIATE POPULATION WITH CORRELATION RHO KTRIBUTION OF KENDALL'S TAU FOR SAM BIOKA63 538 BOUNDS FOR THE VARIANCE OF KENDALL'S RANK CORRELATION STATISTIC

BIOKA56 474 QUEUE WITH ONE SERVER. WHILE THE INTERARR/ ON THE CORRELATION STRUCTURE OF THE DEPARTURE PROCESS OF THE JRSSB66 336 SINGLE SERVER SYSTEMS

THE CORRELATTON STRUCTURE OF THE OUTPUT PROCESS OF SOME AMS 6B 1007 ENSION OF QUENOU SERIES

DIFFUSION

NOWLEDGEMENT 66 5B5)
TESTINC FOR SERIAL CORRELATTON WITH EXPONENTIALLY DISTRIBUTED VARIATES

TOPOCRAPHIC CORRELATION, POWER-LAW COVARIANCE FUNCTIONS, AND
ON BOUNDS OF SERIAL CORRELATIONS

KOLMOGOROV'S REMARK ON THE HOTELLING CANONICAL CORRELATIONS

ASYMPTOTIC POWERS OF CERTAIN TESTS BASED ON MULTIPLE CORRELATIONS

N THE GOMPOUND NEGATIVE MULTINOMTAL DISTRIBUTION AND CORRELATIONS AMONG TNVERSELY SAMPLED POLLEN COUNTS 227. DISTRIBUTIONS

GORRELATIONS AND CANONICAL FORMS OF BIVARIATE

CORRELATIONS BETWEEN SIMILAR SETS OF MEASUREMENTS

PARTIAL CORRELATIONS IN REGRESSION COMPUTATIONS

THE COMPARISON OF CORRELATIONS IN TIME-SERIES

ON COMPARING THE CORRELATIONS WITHIN TWO PAIRS OF VARIABLES

HISTORY OF PROBABILITY AND STATISTICS. XX.SOME EARLY BINOMIAL DISTRIBUTION'

LISHED IN TRACTS FOR COMPUTERS, NO. 26

SAMPLES FROM A NORMAL POPULATION '

ITS RATIO TO THE ROOT MEAN SQUARE' PEDESTRIANS AND ROAD TRAFFIC'

NS FOR THE MAXIMUM-LIKELIHOOD ESTIMATOR OF AN UNK/ CHAINS'

SELECTING AN EXPERIMENTAL DESIGN '

IVE BINOMIAL, POISSON AND CHI-SQUARE DISTRIBUTION/ ARIATE ANALYSIS OF VARIANGE TESTS.

THEOREM.

CHI-SQUARE DISTRIBUTIONS

ATIVE HYPERGEOMETRIC PROBABILITIES, DIRECT AND IN/

FORMS IN NORMAL VARIABLES

DISTRIBUTION USING ORDER STATISTICS.

STATISTICS

WILCOXON'S TEST STATISTIG

IONS TO STATISTICS'

CONFIDENCE BOUNDS'

NS IN LOGIT ANALYSIS'

LIKEL IHOOD

LIKELIHOOD

SQUARE AND X-SQUARE DISTRIBUTIONS

ERALIZED VARIANCE OF A SAMPLE OF CONSECUTIVE OBSE OF TESTS BASED ON DISCONTINUOUS DISTRIBUTIONS.

SAMPLES FROM NORMAL POPULATIONS'

FOR THE 2-BY-2 CONTINGENCY TABLE'

EQUATION BY ITERATION PROCESSES

ATIG FORMS IN NORMAL VARIATES.

OM CERTAIN SIMPLE TRANSFORMATIONS OF THE NORMAL D/ REGRESSION TESTS

EXPER IMENTS

OF THE HYPOTHESIS OF EQUAL MEANS UNDER VARIANCE H/ OF GENERALIZED MEAN DIFFERENCES '

ROOTS OF MATRICES

IN THE QUEUE E-SUB-K-M-1

CONTROL PROCEDURES

RVES, FOR GIVEN ROOT(BETA-1) AND BETA-2, EXPRESSE/ VARIANCE OF A NORMAL DISTRIBUTION

'STUDENTIZED' RANGE'

2 TABLES'

DESIGN '

NON-NORMAL POPULATIONS

RANGE IN SMALL SAMPLES FROM NON-NORMAL POPULATIO/

IFFERENCE BETWFEN TWO PROPORTIONS IN A 2-BY-2 TAB/

TWO COMPETING SPECIES

ZED RANDOMIZED BLOCK DESICN

SIGNS. II. ADDITIONAL TABLES FOR THE METHOD OF PA/ POINT PROCESSES

CORRESPONDENCE BETWEEN W.S. COSSETT, R.A. FISHER AND CORRICENDA TO 'A NOTE ON THE MEAN DEVIATION OF THE CORRIGENDA TO 'CONFIDENCE INTERVALS FOR A PROPORTION' BIOKA58 587 BIOKA5B 291 CORRICENDA TO 'MOMENTS OF SAMPLE MOMENTS OF CENSORED BIOKA58 587 CORRICENDA TO 'MULTIPLE RUNS'

CORRICENDA TO 'ON THE MEAN SUCCESSIVE DIFFERNCE AND BIOKA57 534 CORRIGENDA TO 'SOME FURTHER RESULTS IN THE THEORY OF BIOKA58 291 CORRIGENDA TO 'SOME THEOREMS AND SUFFICIENCY CONDITIO BIOKA56 497 CORRIGENDA TO 'THE LIKELIHOOD RATIO TEST FOR MARKOFF BIOKA57 301 CORRIGENDA TO 'THE USE OF A CONCOMITANT VARIABLE IN BIOKA57 534 GORRIGENDA TO TRANSFORMATIONS OF THE BINOMIAL, NECAT BIOKA56 235 CORRIGENDA, 'A COMPARISON OF THE POWERS OF TWO MULTIV BIOKA63 546 CORRIGENDA. 'A NEW TABLE OF PERCENTAGE POINTS OF THE BIOKA65 CORRIGENDA, 'A QUICKLY CONVERCENT EXPANSION FOR CUMUL BIOKA55 ' COMPUTING THE DISTRTBUTTON OF OUADRATIC CORRICENDA, 'CONDITIONED MARKOFF PROCESSES

CORRIGENDA, 'ESTIMATION OF PARAMETERS OF THE CAMMA

CORRIGENDA .

CORRIGENDA

CORRIGENDA

CORRIGENDA ,

CORRIGENDA

CORRIGENDA

CORRIGENDA

CORRIGENDA,

CORRIGENDA

CORRIGENDA

CORRIGENDA

GORRICENDA

CORRIGENDA,

CORRICENDA,

CORRIGENDA

CORRIGENDA

CORRIGENDA,

CORRI CENDA

CORRIGENDA

CORRICENDA,

CORRIGENDA.

CORRIGENDA

CORRIGENDA

CORRIGENDA.

CORRIGENDA,

CORRIGENDA

GORRIGENDA ,

CORRIGENDA,

CORRIGENDA.

CORRIGENDA.

CORRIGENDA.

CORRIGENDA.

CORRIGENDA

CORRIGENDA ,

CORRIGENDA

CORRIGENDA

CORRIGENDA ,

CORRIGENDA

CORRIGENDA
'EXPECTED VALUES OF NORMAL ORDER

EXTENDED TABLES OF CRITIGAL VALUES FOR BIOKA64

'EXTREMA OF QUADRATIC FORMS WITH APPLICAT BIOKA6]

'FURTHER CONTRIBUTIONS TO MULTTVARIATE

LINEAR AND NON-LINEAR MULTIPLE COMPARISO BIOKA62

'MOMENT ESTIMATORS AND MAXIMUM

MOMENT ESTIMATORS AND MAXIMUM

BIT

ON A TWO-SIDED SEQUENTIAL T-TEST

BIOKA54 568

DURBIN'S FORMULA FOR THE LIMITING CEN BIOKA6I 476

ON QUESTIONS RAISED BY THE COMBINATION BIOKA51 265

'ON STATIONARY PROCESSES IN THE PLANE' BIOKA55 277

ON THE MOMENTS OF ORDER STATISTICS IN BIOKA54 56

ON THE POWER FUNCTION OF THE EXACT TEST BIOKA6I 475

'ON THE SOLUTION OF THE LIKELIHOOD BIOKA62 284

ON THE STATISTICAL INDEPENDENCE OF QUADR BIOKA59 279 'ON THE SUM OF SQUARES OF NORMAL SCORES' BIOKA65 669 'PROPERTIES OF DISTRIBUTIONS RESULTINC FR BIOKA53 236 'ROBUSTNESS TO NON-NORMALITY OF B BIOKA65 669 'SIGNIFICANT TESTS FOR PAIRED-COMPARISON BIOKA6I 475 'SMALL SAMPLE BEHAVIOUR OF CERTAIN TESTS BIOKA6I 230 'SOME DISTRIBUTIONS ARISING IN THE STUDY BIOKA6I 230 'SOME INEQUALITIES ON CHARACTERISTIG SOME NUMERICAL RESULTS FOR WAITING TIMES BIOKA6O 4B4 'SOME PROPERTIES OF RUNS IN QUALITY BIOKA59 279 'SUPPLEMENTED BALANCE' BIOKA6I 475 ITABLE OF PERCENTAGE POINTS OF PEARSON CU BIOKA65 669 'TABLES FOR MAKINC INFERENCES ABOUT THE BIOKA6I 230 'TABLES OF PERCENTAGE POINTS OF THE BIOKA53 236 'TEST OF INDEPENDENCE IN INTRACLASS 2-BY-BIOKA6I 476 THE CHOICE OF A SECOND ORDER ROTATABLE BIOKA65 305 'THE DISTRIBUTION OF RANGE IN CERTAIN BIOKA55 277 THE MEAN AND COEFFICIENT OF VARIATION OF BIOKA55 277 THE POWER FUNCTION OF THE TEST FOR THE D BIOKA59 502 THE PROPERTIES OF A STOCHASTIC MODEL FOR BIOKA59 279 'THE RANDOMIZATION ANALYSIS OF A GENERALI BIOKA56 235 'THE RANK ANALYSTS OF INCOMPLETE BLOCK DE BIOKA64 'THE SPECTRAL ANALYSIS OF TWO-DIMENSIONAL BIOKA65 305
'ON THE CUMULANTS OF RENEWAL PROCESSES BIOKA59 502 
ITIVE AND NEGATIVE BINOMIAL FREQUENCY FUNCTIONS I/ DEVIATION IN THE T-TEST

WEIGHT OF EVIDENCE,

TPRIMENTS

CORRIGENDA, TTHE USE OF RANGE IN PLAE OF STANDARD

BIOKA61

BIOKA52 442

FROM A RANDOM POINT TO THE NEAREST POINT OF A COSELY PACKED LATTICE.

STATISTICAL APPROACH TO PROBLEMS OF COSMOLOGY (WITH DISCUSSION)

THE USE OF RANDOM WORK SAMPLINC FOR COST ANALYSIS AND CONTROL, CORR. 581031

STATE MARKOVIAN DECISION PROCESSES, AVERAGE COST CRITERION

A MINIMUM COST MODEL OF SPARE PARTS INVENTORY CONTROI

PRODUCT DIVERSIFICATION AND THE COST OF LIVING, CORR. 641296

WIDTH CONFIDENCE INTERVAL FOR THE MEAN

ON THE COST OF NOT KNOWING THE VARIANCE

COMPARATIVE COST OF TWO LIFE TEST PROCEDURES

A NOTE ON THE MEASUREMENT OF COST-OUANTITY REEATIONSHTPS TN THE AIRCRAFT INDUSTRY

SAMPLINC PROCEDURES BASED ON PRIOR DISTRIBUTIONS AND COSTS

SAMPLINC PROCEDURES BASED ON PRIOR DISTRIBUTIONS AND COSTS

NG INSPECTION PLANS BASED ON PRIOR DISTRIBUTIONS AND COSTS

CONTROL CHARTS AND THE MINIMIZATION OF COSTS

RELATIVE COSTS OF COMPUTERIZED ERROR INSPECTION PLANS

PRODUCT DIVERSIFICATION AND LIVING COSTS, A FURTHER COMMENT

CONTINUOUS TIME

DECISION PROCESSES

THE FREQUENCY COUNT OF A MARKOV CHAIN AND THE TRANSITION TO

ION AND THE JRSSB60 319

JRSSB58 58 JASA $58 \quad 382$

DENUMERABLE AMS 661545

TECH 67661 JASA $63 \quad 807$ AMS 681946 TECH $62 \quad 140$ JASA $68 \quad 1247$

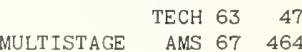
C DISTRIBUTION AND A SYSTEM OF SINGLE SAMPLI TECH 60275 JRSSB $63 \quad 49$ JASA 69 NO. 4 JASA $66 \quad 788$ AMS $61 \quad 41$ A SOLUTION TO A COUNTABLE SYSTEM OF EQUALITIES ARISING IN MARKOVIAN AMS 67582 TYPE BRANCHING PROCESSES TO A BRANCHING PROCESS WITH COUNTABLY MANY TYPES /ETT, ULAM AND HARRIS ON MULTI A

TO COINCIDENT PASSAGE IN AN ELECTRONIC BLOOD CELL COUNTER A CONTRIBUTION TO COUNTER THEORY

GENERALIZATIONS OF T AND F

LEE RTING TO CERTAIN MULTIVARIATE

COUNTERBALANCING IN LATIN SQUARES

COMPLETE COUNTERBALANCING OF IMMEDIATE SEQUENTIAL EFFECTS IN A JASA $5 B 525$

LATIN SQUARE DESIGN, CORR, 581030 THE SEPARATION OF MOLECULAR COMPOUNDS BY COUNTERCURRENT DIALYSIS, A STOCHASTIC PROCESS

ON A COINCIDENCE PROBLEM CONCERNINC PARTICLE COUNTERS

LIMIT DISTRIBUTION IN THE THEORY OF COUNTERS, CORR. 621466

A METHOD OF ESTIMATING THE INTERCENSAL POPULATION OF COUNTIES

COUNTING DISTRIBUTIONS FOR RENEWAL PROCESSES.

STATISTICAL CONTROL OF COUNTING EXPERIMENTS

A REPRODUCIBLE METHOD OF COUNTING PERSONS OF SPANISH SURNAME

A TREE COUNTING PROBLEM

NATIONAL INCOME STATISTICS OF UNDERDEVELOPED COUNTRIES

NTERNATIONAL TRADE DATA, THE CASE OF SOUTHEAST ASIAN COUNTRIES

HICHER FEMALE THAN MALE MORTALITY IN SOME COUNTRIES OF SOUTH ASIA, A DIGEST

INVESTMENT ESTIMATES OF UNDERDEVELOPED COUNTRIES, AN APPRAISAL

CONCENTRATION OF VIRUSES AND BACTERIA FROM DILUTION COUNTS

TON AND CORRELATTONS AMONG TNUERSELY SAMPLED POLLEN COUNTS

TTHE COMPOUND NEGATTVE POISSON COUNTS FOR RANDOM SEQUENCES OF EVENTS

SOME PROPERTIES OF COUNTS OF EVENTS FOR CERTAIN TYPES OF POINT PROCESS

THE EFFECT OF OVERLAPPING IN BACTERIAL COUNTS OF INCUBATED COLONIES

MODELS FOR THE VARIATION IN THE NUMBER OF BIRTHS PER COUPLE

OF THE VARIATION IN THE NUMBER OF BIRTHS PER GOUPLE

ASYMPTOTIC DISTRIBUTORS FOR THE COUPON COLLECTOR'S PROBLEM

ATION PAR LA METHODE DU MAXIMUM DE VRAISEMBLANCE DES COURBES DE SURVIE DE MICROORGANISMES IRRADIES ESTIM BIOCS66 673 TAKING A COVARIABLE INTO ACCOUNT

A NOTE ON TAKING A COVARIABLE INTO ACCOUNT

REGRESSION APPROACH TO COVARIANCE ANALYSIS WHEN THE COVARIABLE IS UNCONTROLLED

THE DISTRIBUTION OF NONCENTRAL MEANS WITH KNOWN COVARIANCE

RANK ANALYSIS OF COVARIANCE

EXPONENTIAL SURVIVAI. WTTH COVARIANCE

SECOND ORDER MOMENTS OF ESTIMATES OF COMPONENTS OF COVARIANCE

COMPARISONS FOR ADJUSTED MEANS IN THE ANALYSIS OF COVARIANCE

THE POWER OF A TEST IN COVARIANCE ANALYSIS

THE ROBUSTNESS OF THE GOVARIANCE ANALYSIS OF A ONE-WAY CLASSIFIGATION

AARE-SAMPLE COVARIANCE ANALYSIS WHEN THE CONTROL VARIABLE IS

FALLIBLE

JASA 671037

AMS $61 \quad 874$

JASA $67 \quad 1187$

JASA $67 \quad 561$

EXACT FIRST AND BIOKA69 NO.3

EXACT FIRST AND BIOKA69 NO.3

BIOCS69 NO.4

BIOKA64 365 JASA 60307

ED

A STRUCTURAL REGRESSION APPROACH TO GOVARIANCE ANALYSIS WHEN THE COVARIAB

COVARIANCE ANALYSIS WITH UNEQUAL SUBCLASS NUMBERS,

COMPONENT ESTIMATION IN CORRELATION STUDIES TESTS OF SIGNIFICANCE FOR THE LATENT ROOTS OF GOVARTANCE AND CORREIATION MATRICES

PED STATIONARY TIME SERIES

ESTIMATING THE COVARIANCE AND SPECTRAL DENSITY FUNCTIC

ANALYSIS OF COVARIANCE BASED ON GENERAL RANK SCORES

ULTIVARIATE PREDICTION INTERVALS FOR SAMPLE MEAN AND COVARIANCE BASED ON PARTIAL OBSERVATIONS ESTIMATION IN THE UNIFORM COVARIANCE CASE

MULTIVARIATE ANALYSIS OF VARIANCE FOR A SPECIAL COVARIANCE CASE, CORR. 641296

MAXIMUM LIKELIHOOD ESTIMATION OF MULTIVARIATE COVARIANCE COMPONENTS FOR THE BALANCED ONE-WAY LAYOUT AUTOREGRESSIVE MODELS

ON THE COVARTANCE DETERMTNANTS OF MOVINC-AVERACE AND

TOPOGRAPHIC CORRELATION, POWER-LAW COVARIANCE FUNCTIONS. AND DIFFUSION

MULTIVARIATE-NORMAL CLASSIFICATION WITH COVARIANCE KNOWN

ON TESTS OF THE EOUALITY OF TWO COVARIANCE MATRICES

A NOTE ON DISCRIMINATION IN THE CASE OF UNEQUAL COVARIANCE MATRICES

ON TESTING THE EQUALITY OF $K$ COVARIANCE MATRICES

OF SOME TEXT CRITERIA FOR THE EQUALITY OF ONE OR TWO COVARIANCE MATRICES

TWO MULTIVARIATE NORMAL DISTRIBUTIONS WITH DIFFERENT COVARIANCE MATRICES

OF DISTANCE STATISTICS FOR POPULATIONS WITH UNEQUAL COVARIANCE MATRICES

CLASSIFICATION INTO

STIMATO/ ON CANONICAL FORMS, NON-NEGATIVE COVARIANCE MATRICES AND BEST AND SIMPLE LEAST SQUARES

DISTRIBUTION OF DISCRIMINANT FUNCTION WHEN COVARIANCE MATRICES ARE PROPORTIONAL

A TEST FOR EQUALITY OF MEANS WHEN COVARIANCE MATRICES ARE UNEQUAI

POWER COMPARISIONS OF TESTS OF EQUALITY OF TWO COVARIANCE MATRICES BASED ON FOUR CRITERIA

ASA 671037 BIOGS69 NO. 4 BIOCS68 49

BIOKA56 128

JRSSB $67 \quad 180$

AMS 69610

JASA $67 \quad 634$

JRSSB $64 \quad 47^{7}$

JASA $63 \quad 660$

AMS 691100

BIOKA60 194

BIOKA62 305

AMS 651787

AMS $68 \quad 275$

BIOKA68 586

BIOKA69 216

AMS 681686 $\begin{array}{rr}\text { AMS } 62 & 420 \\ \text { BIOCS68 } & 683\end{array}$

AMS 681303

AMS 671092

AMS $69 \quad 979$

AMS $63 \quad 671$

BIOKA68 335

RIMINATOR ANALYSIS TESTS FOR THE EQUALITY OF TWO COVARIANCE MATRICES IN RELATION TO A BEST LINEAR DISC AMS 64 I9I

S

LOWER BOUNDS FOR MINIMUM COVARIANCE MATRICES IN TIME SERIES REGRESSION PROBLEM

FUNCTION

THE EFFECT OF UNEQUAI VARTANCE-COVARTANCE MATRTCES ON FISHER'S LTNEAR DISCRIMINANT

TESTS FOR THE EQUALITY OF COVARIANCE MATRICES UNDER THE INTRACLASS CORRELATION

MODEL 

NTS IN A COMPLEX STATIONARY TIME/ EXPECTATIONS AND COVARIANCES OF SERIAL AND CROSS-CORRELATION COEFFICIE BIOKA63 213 MULTIPLE COVARIATE ANALYSIS (CORR. 66 962) THE ASYMPTOTIC VALUES OF CERTATN GOVERAGE PROBABTLITTES A REVIEW OF THE LITERATURE ON A CLASS OF COVERACE PROBLEMS SOME CIRCULAR COVERACE PROBLEMS

AMS $63 \quad 847$

BIOKA69 NO.3

AMS 64232

BIOKA61 313

TARCETS

A SURVEY OF COVERAGE PROBLEMS ASSOCIATED WITH POINT AND AREA

ARBITRARY DISTRIBUTIONS

THE EXPEGTED COVERAGE TO THE LEFT OF THE I'TH ORDER STATISTIC FOR

UMBER OF NEW SPECIES, AND THE INCREASE IN POPULATION COVERACE, WHEN A SAMPLE IS INCREASED

TECH 69561 THE PROBABILITY OF COVERTNG A SPHERE WTTH N CIRCULAR CAPS.

THE N BIOKA56 45

DISTRIBUTION THE COVERING CIRCLE OF A SAMPLE FROM A CIRCULAR NORMAL

BIOKA65 323

IN THE ANALYSIS OF CHANGE-OVER TRIALS WITH DAIRY COWS OF THE PAPERS OF MESSRS. HALD, WETHERILL AND GOX BIOKA52 AND GOX THE VALUE OF ORTHOGONAL POLYNOMIALS ON COX AND SNELL'S DEFINITION OF RESIDUALS $\begin{array}{lll}\text { DISCUSSION TECH } 60 & 361\end{array}$ JRSSB $69 \quad 103$ A NOTE ON THE ASYMPTOTIC RELATIVE EFFICIENCIES OF COX AND STUART'S TESTS FOR TESTINC TREND IN DISPERSIO BIOKA68 381 POWER FUNCTIONS FOR COX'S TEST OF RANDOMNESS AGAINST TREND A NOTE ON CRAIC'S PAPER ON THE MINIMUM OF BINOMIAL VARIATES

ON A THEOREM OF CRAMER AND LEADBETTER

ON THE DISTRIBUTION OF THE TWO SAMPLE CRAMER-VON MISES CRITERION DISTRIBUTION OF THE TWO-SAMPLE CRAMER-VON MISES CRITERION FOR SMALL EQUAL SAMPLES FURTHER PERCENTACE POINTS FOR W-SQUARE-SUB-N + (CRAMER-VON MISES GOODNESS-OF-FIT STATISTIC) BIAS OF THE ONE-SAMPLE CRAMER-VON MISES TEST

SMALL-SAMPLE DISTRIBUTIONS OF THE TWO-SAMPLE CRAMER-VON MISES' W-SQUARED AND WATSON'S U-SQUARED TECH $62 \quad 430$ BIOKA66 614 AMS $66 \quad 682$ AMS 621148 AMS $63 \quad 95$ BIOKA68 428 JASA $66 \quad 246$ AMS 641091 MULTIPLE DEATH PROCESS AND APPLICATIONS TO LUNAR CRATERS NDITURES, WITH MAJOR EMPHASIS ON THE ROLE OF ASSETS, CREDIT AND INTENTIONS THE DEVELOPMENT OF NUMERICAL CREDIT EVALUATION SYSTEMS A STOCHASTIC MODEL OF CREDIT SALES DEBT

SOURCES OF STATISTICS ON CRIME AND CORRECTION PROBABILITY AND CRIMINALISTICS

APPLICATIONS OF PROBABILITY THEORY IN GRIMINALISTIGS APPLICATIONS OF PROBABILITY THEORY IN CRIMINALISTICS, II A MULTIVARIATE IMMIGRATION WITH BIOKA67 251 CONSUMER DURABLE GOODS EXPE JASA $63 \quad 648$ JASA 63799 JASA $66 \quad 1010$ JASA 59582 JASA $6362 B$ JASA $65 \quad 70$ JASA $65 \quad 1028$ THE EFFECT OF TIES ON THE MOMENTS OF RANK CRITERIA

EXACT DISTRIBUTION OF A CLASS OF MULTIVARIATE TEST CRITERIA PROGRAMMING WITH SENSITIVE DISCOUNT OPTIMALITY CRITERIA

TESTS OF TWO MULTIVARIATE HYPOTHESES BASED ON FOUR CRITERIA PPROXIMATING TO THE DISTRIBUTION OF LIKELIHOOD RATIO CRITERIA OF EQUALITY OF TWO COVARIANCE MATRICES BASED ON FOUR CRITERIA

(W) PERMUTATION THEORY IN THE DERIVATION OF ROBUST CRITERIA AND THE STUDY OF DEPARTURES FROM ASSUMPTION JR BIOKA57 526 H AN APPLICATION TO THE NORMAL DISTRIBUTION
ANSIONS OF THE DISTRIBUTIONS OF THE LIKELIHOOD RATIO CRITERIA FOR COVARIANCE MATRIX ON SOME INVARIANT CRITERIA FOR GROUPING DATA

A NOTE ON THE EQUIVALENCE OF TWO TEST CRITERIA FOR HYPOTHESES IN CATEGORICAL DATA

AMS 69 NO.6 JASA 671159 JASA $66 \quad 228$ IC DISTRIBUTION OF THE 'PSI-SQUARED' GOODNESS OF FIT CRITERIA FOR MARKOV CHAINS AND MARKOV SEQUENCES /OT AMS 6I 49 F THE NON-NULL DISTRIBUTIONS OF THE LIKELIHOOD RATIO CRITERIA FOR MULTIVARIATE LINEAR HYPOTHESIS AND INDEP AMS 69 942 NEW CRITERIA FOR SELEGTING CONTINUOUS SAMPLINC PLANS E MATRIX ON THE EXACT DISTRIBUTIONS OF VOTAW'S CRITERIA FOR TESTING COMPOUND SYMMETRY OF A COVARIANC U/ ON THE EXACT DISTRIBUTIONS OF LIKELIHOOD RATIO GRITERIA FOR TESTINC INDEPENDENCE OF SETS OF VARIATES ON THE EXACT DISTRIBUTIONS OF THE LIKELIHOOD RATIO CRITERIA FOR TESTING LINEAR HYPOTHESES ABOUT REGRESSI RESPONSE CRITERIA FOR THE BIOASSAY OF VITAMIN K

AN APPLICATION FOR THE SOBOLEV IMBEDDING THEOREMS TO CRITERIA FOR THE CONTINUITY OF PROCESSES WITH A VECTO MATRICES UNBIASEDNESS OF SOME TEXT CRITERIA FOR THE EQUALITY OF ONE OR TWO COVARIANCE GOODNESS CRITERIA FOR TWO-SAMPLE DISTRIBUTION-FREE TESTS

STATISTICAL EVALUATION OF SPLITTING LIMIT CRITERIA IN MEASUREMENT DISPUTES

ON THE NON-CENTRAL DISTRIBUTIONS OF TWO TEST CRITERIA IN MULTIVARIATE ANALYSIS OF VARIANCE

SERIAL CORRELATI/ASYMPTOTIC POWER OF CERTAIN TEST CRITERIA, BASED ON FIRST AND SECOND DIFFERENCES, FOR A REMARK ON THE KOLMOGOROFF-PETROVSKII CRITERION EXACT DISTRIBUTIONS OF WILKS'S LIKELIHOOD RATIO CRITERION ON THE EXACT DISTRIBUTION OF WILKS'S CRITERION THE DISTRIBUTION OF THE TWO SAMPLE CRAMER-VON MISES CRITERION THE MOMENT GENERATING FUNCTION OF PILLAI'S V-SUPER-S CRITERION

STATE MARKOVIAN DECISION PROCESSES, AVERAGE COST CRITERION RANDOM VARIABLES DENUMERAB LE A REJECTION CRITERION BASED UPON THE RANCE 
NG DISTRIBUTION OF THE TWO SAMPLE KOLMOCOROV-SMIRNOV CRITERION D-SUB-MN, M LESS THAN OR EQUAL TO N /MPLI JASA 69 NO.4

A FINITE CRITERION FOR INDECOMPOSABLE CHANNELS

A TEST OF THE MEAN SQUARE ERROR CRITERION FOR RESTRICTIONS IN LINEAR RECRESSION

AMS $63 \quad 337$

JASA $6 B \quad 55 B$

DISTRIBUTION OF THE TWO-SAMPLE CRAMER-VON MISES CRITERION FOR SMALL EQUAL SAMPLES

AMS $63 \quad 95$

ENTACE POINTS FOR HARTLEY'S CORRECTION TO BARTLETT'S CRITERION FOR TESTINC THE HOMOCENEITY OF A SET OF VAR BIOKAG2 487 ATIOS OF THE ROOTS OF A COVARIANCE MATRIX AND WILKS' CRITERION FOR TESTS OF THREE HYPOTHESES /S OF THE R AMS 69 NO.6 N AND PARAMETER ESTIMATION

A JOINT DESIGN CRITERION FOR THE DUAL PROBLEM OF MODEL DISCRIMINATIO TECH $6 B \quad 145$ DOUBLE SAMPLINC PLANS WHERE THE ACCEPTANCE CRITERION IS THE VARIANCE

RIBUTIONS OF BIVARIATE T-SQUARE AND HOMOSCEDASTICITY CRITERION M UNDER UNEQUAL VARIANCE AND LEPTOKURTOSIS JASA 63 1048 STRAICHT LINE TO A SERIES OF POINTS ACCORDINC TO THE CRITERION OF LEAST SQUARES /D FOR FITTING THE BEST JASA 57 13 ACCORDINC TO D ON THE SAMPLINC DISTRIBUTION OF AVERACE TAU WITH A CRITERION RANKINC /LCULATINC TAU AND AVERAGE TAU AN JASA 62567 A NOTE ON CRITERION ROBUSTNESS AND INFERENCE ROBUSTNESS BIOKA64 169

MAL DISTRIBUTION ON THE EXACT DISTRIBUTIONS OF THE CRITERION W FOR TESTINC SPHERICITY IN A P-VARIATE NOR AMS 671170 A SIMPLE APPROACH TO THE BAYES CHOICE CRITERION. THE METHOD OF EXTREME PROBABILITIES JASA 641227 NCHINC PROCESS ALLOWINC IMMICRATION, A REMARK ON THE CRITICAL CASE THE STATIONARY DISTRIBUTION OF A BRA JRSSB6B 176 PROPERTIES OF THE STATIONARY MEASURE OF THE CRITICAL CASE SIMPLE BRANCHINC PROCESS DATA FROM HOUSEHOLDS A CRITICAL COMPARISON OF THREE STRATEGIES OF COLLECTINC JASA 67976 OCCUPANCY PROBABILITY DISTRIBUTION CRITICAL POINTS

BIOKA61 175

M PERCOLATION PROCESS A LOWER BOUND FOR THE CRITICAL PROBABILITY IN THE ONE-QUADRANT ORIENTED-ATO JRSSB63 401 M PERCOLATHON PROCESS CRITICAL RECIONS FOR TESTS OF INTERVAL HYPOTHESES JASA $66 \quad 204$ OF AN IMPORTANT/ $\begin{array}{ll}\text { JASA } 66 & 204 \\ \text { BIOKA53 } & 231\end{array}$ RAL INFECTION OF BACT/ ESTIMATION OF THE NUMBER OF CRITICAL SITES IN TIMTTED CENOME EXPRESSTON DURING VI BIOCS69 537 THE AVERACE CRITICAL VALUE METHOD AND THE ASYMPTOTIC RELATIVE $\begin{array}{ll}\text { EFFICIENCY OF TESTS } & \text { THE AVERACE CRITICAL VALUE METHOD AND THE ASYMPTOTIC RELATIVE } \\ \text { CY OF STATISTICAL TESTS IN TIME SERIE/ THE AVERACE CRITICAL VALUE METHOD FOR ADJUDCINC RELATIVE EFFICIEN }\end{array}$ APPROXIMATIONS FOR MEAN SQUARE SUCCESSIVE DIFFERENCE CRITICAL VALUES CRITICAL VALUES FOR BIVARIATE STUDENT T-TESTS
NOTES APPROXIMATIONS TO THE CRTTICAL VALUES FOR DUNCAN'S MULTIPLE RANCE CRITICAL VALUES FOR BIVARIATE STUDENT T-TESTS
NOTES. APPROXIMATIONS TO THE CRITICAL VALUES FOR DUNCAN'S MULTIPLE RANCE TEST BIOKA67 $30 \mathrm{~B}$ TECH 68 (397 JASA 69637 TISTIC FOR DISPERSION AND ITS NORMAL APPROX/ EXACT CRITICAL VALUES FOR MOOD'S DISTRIBUTION-FREE TEST STA SAMPLE STATISTIC

AN EXTENDED TABLE OF CRITICAL VALUES FOR THE MANN-WHITNEY-WILCOXON
FURTHER CRITICAL VALUES FOR THE SUM OF TWO VARIANCES FURTHER CRITICAL VALUES FOR THE TWO-MEANS PROBLEM

EXTENDED TABLE OF CRITICAL VALUES FOR WILCOXON'S TEST STATISTIC CORRICENDA, 'EXTENDED TABLES OF CRITICAL VALUES FOR WILCOXON'S TEST STATISTIC.

FINITE SAMPLE SIZES TABLES OF CRITICAL VALUES OF SOME RENYI TYPE STATISTICS FOR JASA 69 B 637

N FOR TESTINC THE HYPOTHESIS OF INDEPENDENCE CRITICAL VALUES OF THE COEFFICIENT OF RANK CORRELATIO TECH 6B 497 JASA $64 \quad 925$ BIOKA58 279 BIOKA56 203 BIOKA63 177 BIOKA64 527 JASA 69 B70 BUTION OF THE COEFFICIENT OF VARIATION, COMMENT ON A CRITICISM MADE BY KOOPMANS, OWEN AND ROSENBLATT. $/ 1$ B BIOKA65 303 ESTIMATION OF INCIDENCE OF RED SPIDER MITE ON TEA CROP IN NORTH-EAST INDIA SAMPLING TECHNIQUES FOR BIOCS66 3B5 THE FACTORIAL ANALYSIS OF CROP PRODUCTIVITY ESTIMATION OF CROP YIELDS FOR SMALL AREAS JRSSB54 100 BIOCS66 374 PLANT YIELD WITH ARRANCEMENT FOR RECULARLY SPACED CROPS

ON THE DETERMINATION OF CONNECTEDNESS IN AN N-WAY CROSS CLASSTFICATION A MATHEMATICAL MODEL RELATINC BIOCS67 505 A NOTE TECH $64 \quad 319$ ANCE-COMPONENT ESTIMATORS FOR THE UNBALANCED TWO-WAY CROSS CLASSIFICATION WITH APPLICATION TO BALANCED INC AMS 69 408

ON THE DETERMINATION OF CONNECTEDNESS IN AN N-WAY CROSS CLASSIFICATION' STTMATED FROM ONE-WAY-CLASSIFICATION TABLES WHEN THE CROSS CLASSIFICATIONS ARE UNKNOWN REFERENCES MEASURES OF ASSOCIATION FOR CROSS CLASSIFICATIONS, II. FURTHER DISCUSSION AND THEORY JASA $59 \quad 123$ JASA $63 \quad 310$ BIOCS66 439 BIOCS6B 903 ANALYSIS AND INTERPRETATION OF THE VARIETY CROSS DIALLEL AND RELATED POPULATIONS MISSTNC VALUES IN PARTIAL DIALLEL CROSS EXPERIMENTS

ON THE CROSS PERIODOCRAM OF A STATIONARY CAUSSIAN VECTOR

PROCESS

ARES AND CROSS PRODUCTS OF NORMAL VARIATES IN THE PRESENCE OF AMS 67593 INTRACROSS SPECTRAL OP NUVSTS OF CAUSSTAN VECTOR PROCE THE PRESENCE OF VARTANCE FLUCTUATIONS EGARDINC H. R. B. HACK'S SYSTEM OF RANDOMIZATION FOR CROSS-CLASSIFICATIONS THEORETICAL CONSIDERAT'IONS R BIOKA5B 265 CE. AND INTERACTIONS IN CONTINCEN/ THE ANALYSIS OF CROSS-CLASSIFIED DATA, INDEPENDENCE, QUASI-INDEPENDEN JASA 68 1091 Y TTME/ EXPECTATTONS AND COVARIANCES OF SERIAL AND CROSS-CORRELATION COEFFICIENTS IN A COMPLEX STATIONAR BIOKA63 213 MIXED SELF- AND CROSS-FERTILIZATION IN A TETRASOMIC SPECIES BIOCS6B 4 B5 STOCHASTIC CROSS-INFECTION BETWEEN TWO OTHERWISE ISOLATED CROUPS BIOKA57 193

$\begin{array}{rlrl}\text { SIMULTANEOUS CONFIDENCE LIMITS FOR CROSS-PRODUCT RATIOS IN CONTINGENCY TABLES } & \text { JRSSB64 } & \text { B6 } \\ \text { A CROSS-SECTION ANALYSIS OF NON-BUSINESS AIR TRAVEL } & \text { JASA } 58 \text { 92B }\end{array}$

$\begin{array}{rl}\text { SIMULTANEOUS CONFIDENCE LIMITS FOR CROSS-PRODUCT RATIOS IN CONTINGENCY TABLES } & \text { JRSSB64 } \\ \text { A CROSS-SECTION ANALYSIS OF NON-BUSINESS AIR TRAVEL JASA } 58 & 928\end{array}$

WEALTH, AND THE DEMAND FOR MONEY, SOME EVIDENCE FROM CROSS-SECTION DATA INCOME, JASA 64 746 ESTIMATION OF THE CROSS-SPECTRUM 1012

PROCESS FROM ITS ZEROS

ESTIMATION OF THE CROSS-SPECTRUM OF A STATIONARY BIVARIATE GAUSSIAN JRSSB $6 B \quad 145$

ION OF FUNCTIONS OF VARIANCE COMPONENTS FROM TWO-WAY CROSSED CLASSIFICATIONS /OR THE SIMULTANEOUS ESTIMAT TWO CLASSES OF CROUP DIVISIBLE PARTIAL DIALLEL CROSSES

THE DELAY TO PEDESTRIANS CROSSINC A ROAD

NOTES. THE ANALYSIS OF A DIALLEL CROSSINC EXPERIMENT WITH CERTAIN CROSSES MISSINC ZERO CROSSINC PROBABILITIES FOR CAUSSIAN STATIONARY

PROCESSES

N O/ SIMULTANEOUS SELFINC AND PARTIAL DIALLEL TEST CROSSING 2. AN EVALUATION OF TWO METHODS OF ESTIMATIO MOMENT CROSSINCS AS RELATED TO DENSITY CROSSINGS

ON THE MEAN NUMBER OF CURVE CROSSINCS BY NON-STATIONARY NORMAL PROCESSES

OF CAUSSIAN PROCESSES FOR WHTCH THE MEAN RATE OF CROSSINGS IS INFINITE

THE MOMENTS OF THE NUMBER OF CROSSINCS OF A LEVEL BY A STATIONARY NORMAL PROCESS

ON A LIMIT DISTRIBUTION OF HICH LEVEL CROSSINCS OF A STATIONARY CAUSSIAN PROCESS

STOCHASTIC PROCESSES

ON CROSSINCS OF LEVELS AND CURVES BY A WIDE CLASS OF

AN EXACT TEST FOR COMPARINC MATCHED PROPORTIONS IN CROSSOVER DESICNS

FEDERAL STATISTICAL SYSTEM

CROSSROAD CHOICES FOR THE FUTURE DEVELOPMENT OF THE

NOTE ON SOME CRTICISMS MADE BY SIR RONALD FISHER

SOME STATISTICAL PROBLEMS CONNECTED WITH CRYSTAL LATTICES (WITH DISCUSSION)

RANDOM SUBDIVISIONS OF SPACE INTO CRYSTALS

WHEN AND HOW TO USE CU-SUM CHARTS

ASSOCIATED WITH THE RANDOM DISORIENTATION OF CUBES

ASSOCIATED WITH THE RANDOM DISOREINTATION OF CUBES

CUBIC DESICNS

CUBICAL AND SPHERICAL ESTIMATION OF MULTIVARIATE $\mathrm{TECH} 63 \quad 1$

BIOKAG3 281

BIOKA51 3 B3

BIOCS65 216

AMS 621306

BIOCS67 325 JRSSB65 91 AMS $65 \quad 509$ JRSSB $67 \quad 489$ AMS 651656 AMS $68 \quad 2108$ AMS $66 \quad 260$ BIOKA69 75 $\begin{array}{lll}\text { JASA } & 6 B & \text { BOI }\end{array}$ JRSSB56 297 JRSSB64 367 AMS 62 95B 
THE USE OF CORRELATED VARIABLES FOR PRELIMINARY CULLINC

D THE APPROXIMATE STABILIZATION/THE INVERSION OF CUMULANT

THE PERCENTILE POINTS OF DISTRIBUTIONS HAVINC KNOWN CUMULANTS

SOME PROPERTIES OF A DISTRIBUTION SPECIFIED BY ITS CUMULANTS

ON EXACT CROUPINC CORRECTIONS TO MOMENTS AND CUMULANTS

A PARAMETER BY RECURRENCE RELATIONS FOR FUNCTIONS OF CUMULANTS

ANS OF THE LINEAR EXPONENTIAL FAMILTY IN

CUMULANTS OF A TRANSFORMED VARIATE

TENSOR NOTATION AND THE SAMPLINC CUMULANTS OF K-STATISTICS

TRACES AND CUMULANTS OF QUADRATIC FORMS IN NORMAL VARIABLES

ON THE CUMULANTS OF RENEWAL PROCESSES

CORRICENDA, 'ON THE CUMULANTS OF RENEWAL PROCESSES

BIVARIATE K-STATISTICS AND CUMULANTS OF THEIR JOINT SAMPLINC DISTRIBUTION

CUMULANTS OF TRUNCATED MULTINORMAL DISTRIBUTIONS

'SOME PROPERTIES OF A DISTRIBUTION SPECIFIED BY ITS CUMULANTS'

'THE PERCENTILE POINTS OF DISTRIBUTIONS HAVING KNOWN CUMULANTS'

INVERSE CUMULATIVE APPROXIMATION AND APPLICATIONS

JRSSB $62 \quad 535$

ERRATA, TECH $63 \quad 417$

TECH $60 \quad 523$

BIOKA68 29

BIOKA51 423

TECH 61

TECH $61 \quad 413$

JASA $57 \quad 552$

THE RELIABILITY OF COMPONENTS EXHIBITINC CUMULATIVE DAMACE EFFECTS

FITTING A STRAIGHT LINE TO CERTAIN TYPES OF CUMULATIVE DATA

QUERY, RECRESSION ANALYSIS OF CUMULATIVE DATA

OF TWO METHODS OF FITTING A STRAIGHT LINE THROUCH CUMULATIVE DATA

TECH $64 \quad 225$

作

F LARGE DEVIATIONS OF FUNCTIONS OF SEVERAL EMPIRICAL CUMULATIVE DISTRIBUTION FUNCTIONS /HE PROBABILITY 0 AMS 67 360 ON THE CUMULATIVE EFFECT OF CHANCE DEVIATIONS

THE NEGATIVE EXPONENTIAL WITH CUMULATIVE ERROR

JRSSB54 269

BIOCS6B 363

EE TOLERANCE LIMITS, ELIMINATION OF REQUIREMENT THAT CUMULATIVE FUNCTIONS BE CONTINUOUS DISTRIBUTION FR TECH 63 518 INVERSE A QUICKLY CONVERGENT EXPANSION FOR CUMULATIVE HYPERGEOMETRIC PROBABILITIES. DIRECT AND BIOKA54 3I7 N/ CORRIGENDA. 'A QUICKLY CONVERGENT EXPANSION FOR CUMULATIVE HYPERGEOMETRIC PROBABILITIES, DIRECT AND I BIOKA55 277 IMAL SEQUENTIAL SCHEMES FOR ESTTMATING THE MEAN OF A CUMULATIVE NORMAL QUANTAL RESPONSE CURVE I ON THE PROBABTLITY CENERATTHG PUNCTIONAL POR I

NON-EQUILIBRIUM THEORY OF SIMPLE QUEUES BY MEANS OF CUMULATIVE PROBABILITIES TREATMENT OF THE JRSSB $63 \quad 457$ THE AVERAGE RUN LENCTH OF THE CUMULATIVE SUM CHART WHEN A V-MASK IS USED CUMULATIVE SUM CHARTS

DISTRIBUTION CUMULATIVE SUM CHARTS FOR THE FOLDED NORMAL JRSSB61 149 TECH $61 \quad 1$ TECH 63 451 JASA $61 \quad 835$ TECH $68 \quad 479$ A SIMPLE THEORETICAL APPROACH TO CUMULATIVE SUM CONTROL CHARTS THE ECONOMIC DESICN OF CUMULATIVE SUM CONTROL CHARTS CUMULATIVE SUM CONTROL CHARTS AND THE WEIBULL

DISTRIBUTION TECH $66 \quad 481$ LOWER LIMITS FOR THE AVERAGE SAMPLE RUN LENGTH OF A CUMULATIVE SUM SCHEME /RE FOR DETERMINING UPPER AND JRSSB67 263 CUMULATIVE SUM SCHEMES USING GAUGING

ON MOMENTS OF CUMULATIVE SUMS

CORRECTION TO 'A PROOF OF WALD'S THEOREM ON CUMULATIVE SUMS' 591245 APPROXIMATION TO THE CUMULATIVE T-DISTRIBUTION

THE ESTIMATION OF PROBABILITY DENSITIES AND CUMULATIVES BY FOURIER SERIES METHODS

TECH $62 \quad 97$ AMS $661 \mathrm{BO3}$ AMS 611344 TECH 66 35B JASA $68 \quad 925$ JASA $56 \quad 228$ THE ECONOMIC DESICN OF MEAN CHARTS USED TO MAINTAIN CURRENT CONTROL OF A PROCESS TED TO CHANGES IN TIME MILITARY AGE PPLICATIONS OF TIME-SHARED COMPUTERS IN A STATISTICS CURRICULUM CURTAILED SAMPLINC FOR VARIABLES

MISCLASSIFIED DATA FROM CURTAILED SAMPLING PLANS ESTIMATION OF FRACTION DEFECTIVE IN CURTAILED SAMPLINC PLANS BY ATTRIBUTES CENSORED SAMPLINC IN CURTAILED SAMPLINC PLANS BY ATTRIBUTES

FROM A DISTRIBUTION ADMITTINC/A FORMULA FOR THE CURVATURE OF THE LIKELIHOOD SURFACE OF A SAMPLE DRAWN B THE ANALYSIS OF LATIN SQUARE DESICNS WITH INDIVIDUAL CURVATURES IN ONE DIRECTION ESTIMATING THE LOGISTIC CURVE ANALYSIS OF DATA WHEN THE RESPONSE IS A CURVE THE USE OF AUTOREGRESSION IN FITTING AN EXPONENTIAL CURVE MEASURING THE LENCTH OF A CURVE

SELECTION FOR AN OPTIMUM CROWTH CURVE

OF LINEARITY VERSUS CONVEXITY OF A MEDIAN REGRESSION CURVE

NOTE ON A SIMPLE METHOD FOR FITTING AN EXPONENTIAL CURVE OF HARTLEY'S METHOD FOR FITTING AN EXPONENTIAL CURVE

ING THE MEAN OF A CUMULATIVE NORMAL QUANTAL RESPONSE CURVE GROUPING, REGRESSION AND CORRELATION IN ENGEL CURVE ANALYSIS

LOGISTIC PROCESS. TABLES OF THE STOCHASTIC EPIDEMIC CURVE AND APPLICATIONS CURVE AND PERIODOGRAM SMOOTHINC (WITH DISCUSSION) JRSSB57 AMS 64999 JASA $62 \quad 895$ A JASA $68 \quad 192$ JASA $58 \quad 862$ TECH $6 B \quad 489$ TECH $67 \quad 219$ TECH $68 \quad$ B54 BIOKA60 203 JRSSB58 193 JASA $57 \quad 567$ TECH $66 \quad 229$ BIOKA58 389 BIOKA66 359 BIOCS6B 169

PROGRAMMING, CORR. 62917 A NOTE ON CURVE FITTING WITH MINIMUM DEVIATIONS BY LINEAR 
ON A CENERAL SYSTEM OF DISTRIBUTIONS, I. ITS CURVE-SHAPE CHARACTERISTICS II. THE SAMPLE MEDIAN THE FITTINC OF MARKOFF SERIAL VARIATION CURVES A PROBABILITY STRUCTURE FOR CROWTH CURVES

NOTES. A NOTE ON THE ANALYSIS OF CROWTH CURVES

ANALYSIS OF CROWTH AND DOSE RESPONSE CURVES

OF METHODS FOR FITTINC EXPONENTIAL RECRESSION CURVES

MODELS RELATINC TIME AND DOSACE IN RESPONSE CURVES CONTINCENCY TABLES AND POLYCHOTOMOUS DOSACE RESPONSE CURVES NCOMPLETE BETA-FUNCTION FOR FITTINC TO DOSE-RESPONSE CURVES

DISTRIBUTIONS OF PARAMETERS OF EXPONENTIAL DECAY CURVES

$S$ OF THE 5 PERCENT AND 0.5 PERCENT POINTS OF PEARSON CURVES SEQUENTIAL ESTIMATION OF QUANTAL RESPONSE CURVES (WITH DISCUSSION)

CONDITIONS UNDER WHICH GRAM-CHARLIER AND FDCEWORTH CURVES ARE POSTTIVE DEFINITE AND UNIMODAL

ON CROSSINCS OF LEVELS AND CURVES BY A WIDE CLASS OF STOCHASTIC PROCESSES

JASA $68 \quad 627$ JRSSB58 120 BIOCS67 217 BIOCS68 192 BIOCS69 357

THE DERIVATION BIOKA64 504 SOME STOCHASTIC BIOCS65 583 MODELS FOR COMPLEX BIOCS66 83 ON NORMALIZINC THE I BIOKA60 173 A COMPARISON OF CONTINUOUS BIOCS68 117 50 PERCENT POINTS OF THE OPERATING CHARACTERISTIC CURVES FOR FIXED EFFECTS ANALYSIS OF VARIANCE SMALL SAMPLE POWER CURVES FOR THE TWO SAMPLE LOCATION PROBLEM FITTING CURVES TO LONGITUDINAL DATA FITTING SEGMENTED CURVES WHOSE JOIN POINTS HAVE TO BE ESTIMATED THE FITTTNC OF RECRESSTON CURVES WTTH AUTOCORRELATED DATA

TABLES TO FACILITATE FITTING S-SUB-U FREQUENCY CURVES HASTIC AND ITS APPLICATION TO THE ANALYSIS OF CROWTH CURVES. ON DISTANCES BETWEEN PERCENTAGE POINTS OF FREQUENCY CURVES SEQUENTIAL ESTIMATION OF QUANTAL RESPONSE CURVES, NG STATISTICAL HYPOTHESES CONFIDENCE CURVES,

/LEAST SQUARES WHEN THE PARAMETERS ARE STOC BIOKA65 447 /XIMATE MEANS AND STANDARD DEVIATIONS BASED BIOKA65 533 A NEW METHOD OF ESTTMATTON

BIOKA66 439 AN OMNIBUS TECHNIQUE FOR ESTIMATION AND TESTI JASA 61246 CURVE, FOR GIVEN ROOT (BETA-1) AND BETA-2 EXPRESSED I BIOKA63 459 CORRIGENDA. 'TABLE OF PERCENTAGE POINTS OF PEARSON CURVES. FOR GIVEN ROOT(BETA-1) AND BETA-2, EXPRESSED BIOKA65 669 A NOTE ON 'LEARNING CURVES'

ESTIMATION OF THE LOCATION OF THE CUSP OF A CONTINUOUS DENSITY

JASA 69 NO. 4 AMS $68 \quad 76$

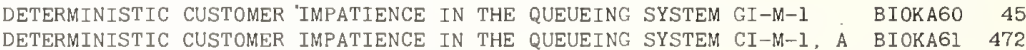

CORRECTION DETERMINISTIC CUSTOMER IMPATIENCE IN THE
TIMES OF THE CUSTOMERS ARE SCHEDULED

A QUEUEINC PROBLEM IN WHICH THE ARRIVAL TMES OF TIV CUSTOMERS IN A FINITE QUEUE

ON THE BUSY PERIOD OF A FACILITY WHICH SERVES CUSTOMERS OF SEVERAL TYPES INCURRED BY ERRONEOUSLY ASSUMING NORMALITY FOR CUSUM SCHEMES

CONTROLLING THE STANDARD DEVIATION BY CUSUMS AND WARNING LINES

DISTRIBUTIONS DETERMINED BY CUTTINC SIMPLEX WITH HYPERPLANES

A SYSTEM OF MODELS FOR THE LIFE CYCLE OF A BIOLOGICAL ORGANISM MANUFACTURERS' INVENTORY CYCLES AND MONETARY POLICY

JRSSB $60 \quad 108$

JRSSB55 262 JRSSB $65 \quad 361$

AN EXAMPLE OF ERRORS TECH $67 \quad 457$

TECH $63 \quad 307$

AMS $68 \quad 1473$

BIOKA68 211

JASA 58680

ES, 1914-1953, CORR. 60755

NAL SEED ORCHARDS

DIRECTIONAL SEED ORCHARDS

L-RESTRICTIONAL PRIME-POWE/

BLOCK DESIGNS

NAL FACTORIAL PLANS
REGIONAL CYCLES OF MANUFACTURING EMPLOYMENT IN THE UNITED STAT JASA 60151 THE USE OF CYCLIC BALANCED INCOMPLETE BLOCK DESIGNS FOR DIRECTIO BIOCS67 761 THE USE OF CYCLIC BALANCED INCOMPLETE BLOCK DESIGNS FOR NON- BIOCS69 561 CYCLIC CHANGE-OVER DESIGNS

ON THE CONSTRUCTION OF CYCLIC COLLINEATIONS FOR OBTAINING A BALANCED SET OF APPLICATION OF CYCLIC COLLINEATIONS TO THE CONSTRUCTION OF CYCLIC DESIGNS

NOTES. CYCLIC GENERATION OF ROBINSON'S BALANCED INCOMPLETE CYCLIC INCOMPLETE BLOCK DESIGNS

ON JOHN'S CYCLIC INCOMPLETE BLOCK DESIGNS CYCLIC QUEUES WITH FEEDBACK

A FLUCTUATION THEOREM FOR CYCLIC RANDOM VARIABLES

NEAR-CYCLTC REPRESENTATTONS FOR SOME RESOLUTTON VI FRACTIO THEORY OF CYCLIC ROTATION EXPERIMENTS (WITH DISCUSSION)

AN EXPERIMENT WITH WEIGHTED INDEXES OF CYCLICAL DIFFUSION

CYLINDRICALLY ROTATABLE DESIGNS

CYLINDRICALLY ROTATABLE DESICNS OF TYPES 1, 2, AND 3

TABLE OF 0.1 PERCENTACE POINTS OF BEHRENS'S D

SIZE REQUTRED FOR ESTTMATING THE VARIANCE WITIN D UNITS OF THE TRUE VALUE

SAMPLE AMS $64 \quad 438$

IA SUBOBSCURA' COLL. AND A COMPARISON WITH THOSE OF 'D. ROBUSTA' STURT /ONS IN POPULATIONS OF 'DROSOPHIL BIOCS66 469 MARTINGALES IN A

TWO MORE CRTTERTA EQUTVALENT TO D-OPTTMALTTY OF DESTGNS

A NOTE ON THRIFTY STRATECIES AND AMS 69 NO.6

AMS 62792

UTION OF THE TWO SAMPLE KOLMOCOROV-SMIRNOV CRITERION D-SUB-MN, M LESS THAN OR EQUAL TO N /MPLINC DISTRIB JASA 69 NO. 4

LYNOMIALS IN THE ANALYSIS OF CHANCE-OVER TRIALS WITH DAIRY COWS

FIRST EMPTINESS IN A FINITE DAM

OF THE NEGATIVE EXPERIMENTAL TYPE FOR THE INFINITE DAM A NOTE ON THE SOLUTION OF DAM EQUATIONS

THE ESTIMATION OF GENETIC PARAMETERS FROM DAUGHTER-DAM REGRESSION

APPLTCATION OF METHODS IN SEQUENTIAL ANALYSIS TO DAM THEORY

DISTRIBUTION OF THE TIME-TO-EMPTINESS OF A DISCRETE DAM UNDER STEADY DEMAND

THE TIME-DEPENDENT SOLUTION FOR AN INFINITE DAM WITH DISCRETE ADDITIVE INPUTS

INEQUALITIES FOR FIRST EMPTINESS PROBABILITIES OF A DAM WITH ORDERED INPUTS

THE ALMOST FULL DAM WITH POISSON INPUT

THE ALMOST FULL DAM WITH POISSON INPUT, FURTHER RESULTS

THE RELIABILITY OF COMPONENTS EXHIBITING CUMULATIVE DAMACE EFFECTS

SOME PROBLEMS IN THE THEORY OF PROVISIONING AND OF DAMS

OF HERITABILITY FROM EXPERIMENTS WITH RELATED DAMS

OF THE RANDOM WALKS DESCRTBING SIMPLE QUEUES AND DAMS

SOME PROBLEMS IN THE THEORY OF DAMS (WITH DISCUSSION)

FIRST EMPTINESS OF TWO DAMS IN PARALLEL

DISCUSSION OF THE PAPERS OF MESSRS. ANSCOMBE AND DANIEL

THE VALUE OF ORTHOGONAL PO BIOCS67 297 JRSSB 61

STATIONARY DISTRIBUTIONS JRSSB57 342

JRSSB $64 \quad 338$

SOME TRANSFORMATIONS OF SCALE AND BIOCS67 823

AMS $63 \quad 1588$

THE JRSSB63 137

JRSSB61 173

JRSSB $62 \quad 102$

JRSSB $66 \quad 329$

JRSSB $66 \quad 448$

TECH $61 \quad 413$

BIOKA55 179

ESTIMATION BIOCS69 NO. 4

ON A PROPERTY JRSSB65 125

JRSSB57 207

AMS $61 \quad 219$

TECH $60 \quad 157$

AMS $61 \quad 619$

$\begin{array}{llll}\text { THE ASYMPTOTIC EFFICIENCY OF DANIELS'S GENERALIZED CORRELATION COEFFICIENT } & \text { BIOKA63 } & 499 \\ \text { THE ASYMPTOTIC EFFICIENCY OF DANIELS'S GENERALIZED CORRELATION COEFFICIENTS } & \text { JRSSB61 } & 128\end{array}$

THE ASYMPTOTIC EFFICIENCY OF DANIELS'S GENERALIZED CORRELATION COEFFICIENT
THE ASYMPTOTIC EFFICIENCY OF DANIELS'S GENERALIZED CORRELATION COEFFICIENTS

LES MANQUANTS DANS L'ESSAI THERAPEUTIQUE

BIOCS67 145

BIOCS69 295

AMS 611118 
RESEARCH ON METROPOLITAN POPULATION, EVALUATION OF DATA A METHOD OF ADJUSTMENT FOR DEFECTIVE DATA THE ANALYSIS OF LIFE TEST DATA ESTIMATION FROM LIFE TEST DATA SOME TESTS FOR CATEGORICAL DATA

ON THE USE OF CORRELATION TO AUCMENT DATA RECRESSION ANALYSIS OF SEASONAL DATA QUERY, RECRESSION ANALYSIS OF CUMULATIVE DATA A LIFE TABLE THAT ACREES WITH THE DATA SELECTION OF VARIABLES FOR FITTINC EQUATIONS TO DATA RECONSTRUCTINC PATTERNS FROM SAMPLE DATA ON TWO K-SAMPLE RANK TESTS FOR CENSORED DATA ON SOME INVARIANT CRITERIA FOR GROUPING DATA ESTIMATING FROM MISCLASSIFIED DATA MULTINOMIAL SAMPLINC WITH PARTIALLY CATEGORIZED DATA THE EXCEEDANCE TEST FOR TRUNCATION OF A SUPPLIER'S DATA THE FORECASTINC ACCURACY OF CONSUMER ATTITUDE DATA FURTHER NOTES ON THE ANALYSIS OF ACCIDENT DATA

NEW TECHNIQUES FOR THE ANALYSIS OF ABSENTEEISM DATA THE FITTINC OF REGRESSION CURVES WITH AUTOCORRELATED DATA ON ESTIMATINC EPIDEMIC PARAMETERS FROM HOUSEHOLD DATA

A SIMPLE EXAMPLE OF A COMPARISON INVOLVINC QUANTAL DATA A NOTE ON ESTIMATION FOR QUANTAL RESPONSE DATA PROBABILITY PLOTTINC METHODS FOR THE ANALYSIS OF DATA QUICK POWERFUL TESTS WITH GROUPED DATA FITTING CURVES TO LONGITUDINAL DATA

STEREOSCOPIC MODELS OF MULTIVARIATE STATISTICAL DATA ON A CONTAGIOUS DISTRIBUTION SUGGESTED FOR ACCIDENT DATA ASYMPTOTIC POWERS OF MULTIVARIATE TESTS WITH GROUPED DATA

FOR THE ESTIMATION OF COMPETING RISKS FROM GROUPED DATA A STRAIGHT LINE TO CERTAIN TYPES OF CUMULATIVE DATA MODELS FOR ESTIMATING CORRELATION IN DISCRETE DATA

LIKELIHOOD ESTIMATION WITH INCOMPLETE MULTIVARIATE DATA GOMBINING ABILITIES FITTED TO PLANT BREEDING DATA BETWEEN POPULATIONS ON THE BASIS OF ATTRIBUTE DATA

TESTS FOR MONOTONE FAILURE RATE BASED ON INCOMPLETE DATA ESTIMATION OF A SHIFT PARAMETER FROM GROUPED DATA METHOD FOR CALCULATING KENDALL'S TAU WITH UNGROUPED DATA ESTIMATION OF VARIANGE COMPONENTS FOR NON-ORTHOGONAL DATA FITTING EMPIRICAL SURFACES TO PHYSICAL AND CHEMICAL DATA MAXIMUM LIKELIHOOD ESTIMATES FROM CROUPED DATA THE PROPORTION DEFECTIVE FROM CLASSIFICATION DATA

OF A QUANTUM HYPOTHESIS BASED ON A SINGLE SET OF DATA THE SIZE OF MOBILE POPULATIONS FROM RECAPTURE DATA METHOD AND THE FITTING OF POLYNOMIALS TO WEIGHTED DATA TO THE MAXIMUM-LIKELIHOOD ESTIMATOR USING GROUPED DATA MOST POWERFUL RANK ORDER TESTS FOR GROUPED DATA OF LOCATION AND SGALE PARAMETERS FROM GROUPED DATA FOR A ONE-SIDED TEST OF HYPOTHESIS FOR QUALITATIVE DATA IN THE NUMERICAL ANALYSIS OF ARCHAEOLOGICAL DATA ITS INTEREST AND APPLICATION IN ANALYSIS OF DATA PROCEDURES FOR MULTIPLE COMPARISONS ON CATEGORICAL DATA DEMAND FOR MONEY, SOME EVIDENCE FROM CROSS-SECTION DATA OF TWO TEST CRITERIA FOR HYPOTHESES IN CATEGORICAL DATA

TOWARDS POSTERIOR DISTRIBUTIONS BASED ON SAMPLE DATA IMENTS BY ESTIMATING MONOTONE TRANSFORMATIONS OF THE DATA RANK TESTS FOR THE TWO-SAMPLE PROBLEM WITH CENSORED DATA

FOR A CHANGE OF LOCATION APPLICABLE TO TRUNCATED DATA MATION OF A POPULATION MEAN USING TRANSFORMED SAMPLE DATA ETHODS OF FITTINC A STRAIGHT LINE THROUGH CUMULATIVE DATA THODS FOR ANALYSINC SENSITIVITY AND QUANTAL RESPONSE DATA

MODELS INVOLVING NORMAL APPROXIMATIONS TO DISCRETE DATA IBUTION IN THE ESTIMATION OF CORRELATION IN DISCRETE DATA D FAILURE TIME DISTRIBUTIONS FROM CENSORED LIFE TEST DATA L EVENTS, WITH APPLICATION TO BACTERIAL ENDOCARDITIS DATA RTITIONED MATRICES IN THE ANALYSIS OF NON-ORTHOGONAL DATA NT WITH SPECIAL REFERENCE TO TYPE II CENSORED NORMAL DATA SIMPLE SIMILAR ACTION, THE ANALYSIS OF UNCONTROLLED DATA ILITIES OF A FINITE-STATE MARKOV CHAIN FROM THE SAME DATA NOTE ON THE HISTORY OF THE GRAPHICAL PRESENTATION OF DATA F TRIBOLIUM AND ITS APPLICATION TO SOME EXPERIMENTAL DATA STATISTICAL TREATMENT OF CENSORED DATA GROUPING ESTIMATORS IN HETEROSCEDASTIC DATA

PROBLEMS IN THE STATISTICAL ANALYSIS OF EPIDEMIC DATA (WTTH DISCUSSION)

THE FUTURE OF DATA ANALYSIS, CORR. $62 \quad 812$ APPROXIMATIONS DATA AND THE INVESTMENT DECISION

OF REVERSAL ASSOCIATED WITH A TEST PROCEDURE, WHEN DATA ARE INCOMPLETE OF RECREATION STATISTICAL DATA AVAILABLE FOR ECON ANALYSIS OF CATEGORICAL DATA BY LINEAR MODELS ANALYSIS OF SURVIVAL DATA BY REGRESSION TECHNIQUES ANALYSIS OF EXTREME-VALUE DATA BY SAMPLE QUANTILES FOR VERY LARGE SAMPLES A NOTE ON THE EQUIVALENCE JASA $66 \quad 228$ NEW METHODS FOR REASONING AMS $66 \quad 355$ ANALYSIS OF FACTORIAL EXPER JRSSB65 25] ASYMPTOTICALLY MOST POWERFUL AMS 651243 A COMPARISON OF TWO SORTS OF TEST JRSSB57 119 DIFFICULTIES INVOLVED IN THE ESTI TECH $66 \quad 535$ A NOTE ON THE EQUIVALENCE OF TWO M JASA 64863 THE USE OF NON-LINEAR RECRESSION ME BIOCS67 563 FERENCE FOR SOME INCOMPLETELY SPECIFIED BIOCS67 335 THE USE OF A GENERALIZED MULTINOMIAL DISTR JRSSB62 530 OF THE POISSON APPROXIMATION FOR BINOMIA BIOCS66 74 TO MIXTURES OF POISONS UNDER CONDITIONS OF BIOKA5B 74 /IMATING THE EQUILIBRIUM AND TRANSITION PROBAB BIOCS68 185 /ISTORY OF PROBABILITY AND STATISTICS. III. A BIOKA56 241 A STOCHASTIC MODEL FOR TWO COMPETING SPECIES O BIOKA62 I PART I FUNDAMENTAL FORMULAE BIOKA54 228 JASA $68 \quad 1 B 2$ SOME JRSSB55 35 AMS $62 \quad 1$ JASA $65 \quad 503$ $\begin{array}{lll}\text { THE PROBABILITY JASA } & 61 & 125 \\ & \end{array}$ BIOCS69 489 TECH $63 \quad 161$ JASA $68 \quad 877$ $G$ OF SOME CONTAGIOUS DISTRIBUTIONS TO SOME AVAILABLE DATA BY THE MAXIMUM LIKELIHOOD METHOD (CORR. 65514 ) BIOCS65 34
VARIANCE
THE LIMITING POWER OF CATEGORICAL DATA CHI-SQUARE TESTS ANALOGOUS TO NORMAL ANALYSIS OF AMS 63 I432 VARIANCE HE LIMITING PONER OF CATEGORTCAL DATA CHI-SQUARE TESTS ANALOGOUS TO NORMAL ANALYSIS OF JASA $65 \quad 97$ SYSTEMATIC STATISTICS USED FOR DATA COMPRESSION IN SPACE TELEMETRY

JASA $67 \quad 34$ 
MAMMALIAN REPRODUCTIVE DATA FITTED TO A MATHEMATICAL MODEL

SEASONAL ADJUSTMENT OF DATA FOR ECONOMETRIC ANALYSIS

OPULATIONS OF THE PROTOZOA PAR/ AN ANALYSIS OF THE DATA FOR SOME EXPERIMENTS CARRIED OUT BY GAUSE WITH P BIOKA57 314

ERRATA, 'MISCLASSIFIED DATA FROM A BINOMIAL POPULATION' MISCLASSIFIED DATA FROM A BINOMINAL POPULATION

TECH $66 \quad 215$

TECH $60 \quad 109$

AN ANALYSIS OF SOME RELAY FAILURE DATA FROM A COMPOSITE EXPONENTIAL POPULATION

TECH $61 \quad 423$

FITTINC A STRAIGHT LINE TO DATA FROM A TRUNCATED POPULATION

BI0CS65 715

PROCESSING UNDERDEVELOPED DATA FROM AN UNDERDEVELOPED AREA

A BAYESIAN APPROACH TO THE ANALYSIS OF DATA FROM CLINICAL TRIALS

JASA $60 \quad 23$

JASA $65 \quad 81$

MISCLASSIFIED DATA FROM CURTAILED SAMPLING PLANS

TECH $68 \quad 489$

L DISTRIBUTION AND BAYESIAN ANALYSIS OF CATERGORICAL DATA FROM FINITE POPULATIONS /E COMPOUND MULTINOMIA JASA 69 216

A STUDY OF RESPONSE ERRORS IN EXPENDITURES DATA FROM HOUSEHOLD INTERVIEWS

COMPARISON OF THREE STRATECIES OF COLLECTINC DATA FROM HOUSEHOLDS

THE ANALYSIS OF VARIANCE OF DATA FROM STRATIFIED SUBSAMPLES

DISTRIBUTIONS A METHOD OF ANALYSINC UNTRANSFORMED DATA FROM THE NECATIVE BINOMIAL AND OTHER CONTAGIOUS EX ANTE AND EX POST DATA IN INVENTORY INVESTMENT AUCMENTINC EXISTINC DATA IN MULTIPLE REGRESSION

JASA $64 \quad 18$

JASA $67 \quad 976$

JASA $68 \quad 64$

BIOKA68 163

JASA $61 \quad 518$

TECH $68 \quad 73$

MISSING DATA IN REGRESSION ANALYSIS

JRSSB68 67

TO ERROR

AN ANALYSIS OF QUANTAL RESPONSE DATA IN WHICH THE MEASUREMENT OF RESPONSE IS SUBJECT BIOCS65

D. I/ THE ESTIMATION OF POPULATION PARAMETERS FROM DATA OBTAINED BY MEANS OF THE CAPTURE-RECAPTURE METHO BIOKA5 I

D. I/ THE ESTIMATION OF POPULATION PARAMETERS FROM DATA OBTAINED BY MEANS OF THE CAPTURE-RECAPTURE METHO BIOKA52 363

D I/ THE ESTIMATION OF POPULATION PARAMETERS FROM DATA OBTAINED BY MEANS OF THE CAPTURE-RECAPTURE METHO BIOKA53 137 THREE SOURCES OF DATA ON COMMUTINC, PROBLEMS AND POSSIBILITIES

INSPECTION AND CORRECTION ERROR IN DATA PROCESSING

DATA REVISIONS AND ECONOMIC FORECASTING

THOD OF ESTIMATION OF MISSING VALUES IN MULTIVARIATE DATA SUITABLE FOR USE WITH AN ELECTRONIC COMPUTER

JASA $60 \quad 8$

JASA 69 N0. 4

JASA $67 \quad 470$

JRSSB $60 \quad 302$

DATA TRANSFORMATIONS AND THE LINEAR MODEL

ANALYSIS OF VARIANCE OF DISPROPORTIONATE DATA WHEN INTERACTION IS PRESENT ANALYSIS OF DATA WHEN THE RESPONSE IS A CURVE

AMS 671456

BI0CS65 115

TECH $66 \quad 229$

THE ROLE OF SIGNIFICANCE TESTING, SOME DATA WITH A MESSACE

BIOKA69 NO. 3

TES OF POPULATION PARAMETERS FROM MULTIPLE RECAPTURE DATA WITH BOTH DEATH AND DILUTION-DETERMINISTIC MODEL BIOKA63 II3 EXPLICIT ESTIMATES FROM CAPTURE-RECAPTURE DATA WITH BOTH DEATH AND IMMIGRATION-STOCHASTIC MODEL BIOKA65 225

OF ANALYZING LOG-NORMALLY DISTRIBUTED SURVIVAL DATA WITH INCOMPLETE FOLLOW-UP

THE FITTING OF POLYNOMIALS TO EQUIDISTANT DATA WITH MISSING VALUES

ATES OF HERITABILITY FROM TRANSFORMED PERCENTAGE SIB DATA WITH UNEQUAL SUBCLASS NUMBERS ANALYSIS OF CATEGORICAL DATA

TWO-SAMPLE WILCOXON TEST FOR DOUBLY-CENSORED DATA

S OF CHI-SQUARE-TESTS IN THE ANALYSIS OF CATEGORICAL DATA

A LIFE TABLE THAT AGREES WITH THE DATA

MINIMIZING RESPONSE ERRORS IN FINANCIAL DATA SELECTED ECONOMIC DATA.

PROBLEMS IN THE ANALYSIS OF SURVEY DATA.

WEICHTED REGRESSION, QUANTAL RESPONSE DATA. II

A GENERALIZED BIOKA65 650

A METHOD JASA $60 \quad 534$

BIOKA5I 410

ESTIM BIOCS65 1001

BIOKA65 654

THE POSSIBILITIES

JASA $68 \quad 1253$

JASA $68 \quad 217$

JASA $68 \quad 436$

PEPORTINC SPEED

JASA $63 \quad 415$

BIOCS68 979

OR ESTIMATINC THE EXPONENTIAL PARAMETER FROM QUANTAL DATA, AND ITS RELATIONSHIP TO BIRTH, DEATH, AND BRANC BIOCS67 739 S COMPUTER EDITINC OF SURVEY DATA, FIVE YEARS OF EXPERIENCE IN BLS MANPOWER SURVEY JASA 66 375 ONS IN CONTINCEN/ THE ANALYSIS OF CROSS-CLASSIFIED DATA, INDEPENDENCE, QUASI-INDEPENDENCE, AND INTERACTI JASA 68 IO9I THE ACCURACY OF INTERNATIONAL TRADE DATA, THE CASE OF SOUTHEAST ASIAN COUNTRIES J52 ECRESSION ANALYSIS APPLIED TO GAMMA RAY SPECTROMETER DATA, 1 SOME EXPERIMENTAL SAMPLING RESULTS FOR R BIOCS67 II RECRESSION ANALYSIS APPLIED TO CAMA RAY SPECTROMETER DATA, 2 SOME EXPERIMENTAL SAMPLING RESULTS FOR BIOCS68 353 SCALE AND THE ESTIMATION OF GENETIC PARAMETERS FROM DAUGHTER-DAM REGRESSION SOME TRANSFORMATIONS OF BIOCS67 823 ESPONSE TO SELECTION IN BREEDING PROGRAMMES WHEN ALL DAUCHTERS OF SELECTED PARENTS ARE RETAINED /ON OF R BIOCS69 553 PAIRED-COMPA/ A REMARK ON A PAPER OF TRAWINSKI AND DAVID ENTITLED 'SELECTION OF THE BEST TREATMENT IN A AMS 63 92

A NOTE ON THE ERROR AFTER A NUMBER OF TERMS OF THE DAVID-JOHNSON SERIES FOR THE EXPECTED VALUES OF NORMA BIOKA6O 79 APPLICATION OF A MODIFIGATION OF DAVIDON'S METHOD TO NONLINEAR REGRESSION PROBLEMS TECH 68 843 INVARIANTS UNDER MIXING WHICH CENERALIZE DE FINETTI'S THEOREM INVARIANTS UNDER MIXING WHICH GENERALIZE DE FINETTI'S THEOREM CONTINUOUS TIMES PARAMETER IN THE HISTORY OF PROBABILITY AND STATISTICS. VIII DE MORGAN AND THE STATISTICAL STUDY OF LITERARY STYLE BIOKA58 282 L DISTRIBUTION, 2. EST/ INVESTIGATION OF RULES FOR DEALING WITH OUTLIERS IN SMALL SAMPLES FROM THE NORMA TECH 69 527 CENSUS II ESTIMATION WHEN THERE IS IMMIGRATION OR DEATH THE MULTIPLE-RECAPTURE BIOKA59 336 ON PARAMETERS FROM MULTIPLE RECAPTURE DATA WITH BOTH DEATH AND DILUTION-DETERMINISTIC MODEL /OF POPULATI BIOKA63 II3 ICIT ESTIMATES FROM CAPTURE-RECAPTURE DATA WITH BOTH DEATH AND IMMIGRATION-STOCHASTIC MODEL. ED POPULATIONS STOCHASTIC BIRTH, DEATH AND MICRATION PROCESSES FOR SPATIALLY DISTRIBUT BIOKA68 189 A MULTI-DIMENSIONAL LINEAR CROWTH BIRTH AND DEATH PROCESS AMS $68 \quad 727$ BIOKA55 291 BIOKA56 23 BIOKA67 251 THE BEHAVIOUR OF AN ESTIMATOR FOR A SIMPLE BIRTH AND DEATH PROCESS

A MULTIVARIATE IMMIGRATION WITH MULTIPLE DEATH PROCESS AND APPLICATIONS TO LUNAR CRATERS ETWEEN SPECIES CROWINC ACCORDING TO SIMPLE BIRTH AND DEATH PROCESSES HIERARCHICAL BIRTH AND DEATH PROCESSES. I. THEORY $53 \quad 370$ HIERARCHICAL BIRTH AND DEATH PROCESSES. II. APPLICATIONS BIOKA60 235 BIOKA60 245 BIAS IN ESTIMATES OF THE UNTTED JASA $61 \quad 44$ STATES NONWHITE POPULATION AS INDICATED BY TRENDS IN DEATH RATES
THE ANALYSIS OF POPULATION CROWTH WHEN THE BIRTH AND DEATH RATES DEPEND UPON SEVERAL FACTORS THE ANALYSIS OF POPULATION CROWTH WHEN THE BIRTH AND DEATH RATES DEPEND UPON SEVERAL FACTORS
THE MAXIMUM LIKELIHOOD EQUATIONS FOR ESTIMATING THE DEATH-RATE/ANS OF THE CAPTURE-RECAPTURE METHOD. I. BIOKA51 269 BIOCS69 NO. 4 THE ESTIMATION OF DEATH-RATES FROM CAPTURE-MARK-RECAPTURE SAMPLING BIOKA52 181 ER FROM QUANTAL DATA, AND ITS RELATIONSHIP TO BIRTH, DEATH, AND BRANCHING PROCESSES /EXPONENTIAL PARAMET BIOCS67 739 SEASONAL VARIATION OF DEATHS IN THE UNITED STATES, 1951-1950

A STOCHASTIC MODEL OF CREDIT SALES DEBT JASA $66 \quad 706$ JASA 661010

RD DEVIATIONS OF THE RECIPROCAL OF A VARIABLE FROM A DECAPITATED NECATIVE BINOMIAL DISTRIBUTION /STANDA JASA 62 439 THE RECIPROCAL OF THE DECAPITATED NEGATIVE BINOMIAL VARIABLE, CORR. 63 II62 JASA 62906 ONTINUOUS DISTRIBUTIONS OF PARAMETERS OF EXPONENTIAL DECAY CURVES ATICAL REPRESENTATION OF THE BIOLOGICAL AND PHYSICAL DECAY OF CHAMBER AEROSOLS

FOR QUEUES SERVICINC MESSAGES WITH EXPONENTIALLY DECAYING UTILITY A COMPARISON OF C BIOCS68 117 MATHEM BIOCS65 551 APPROXIMATIONS DATA AND THE INVESTMENT DECISION ON AN EXTREME RANK SUM TEST WITH EARLY DECISION ON SOME MULTIPLE DECISION (SELECTION AND RANKING) RULES GONSISTENCY IN STATISTIGAL INFERENGE AND DEGISION (WITH DISGUSSION) (GORR. 66 252) EXPECTED UTILITY AMS $61 \quad 587$ 
NON-DISCOUNTED DENUMERABLE MARKOVIAN DECISION MODELS

ON MUT

67 B 18 JASA $63 \quad 713$ AMS $62 \quad 248$

AMS 6B 412

F CONTINUOUS SAMPLINC INSPECTION PLANS MARKOVIAN DECISION MODELS FOR THE EVALUATION OF A LARGE CLASS O ASYMPTOTIC SOLUTIONS OF THE SEQUENTIAL COMPOUND DECISION PROBLEM ON AN EXTENDED COMPOUND DECISION PROBLEM AMS $65140 \mathrm{~B}$ AMS 631079 AMS 691536 ON SIMPLE RULES FOR THE COMPOUND DECISION PROBLEM JRSSB 65 23B SEQUENTIAL COMPOUND RULES FOR THE FINITE DECISION PROBLEM JRSSB6 63 THE DEGREE OF A POLYNOMIAL REGRESSION AS A MULTIPLE DECISION PROBLEM APPROACH TO TESTING OF HYPOTHESES AND THE COMPOUND DECISION PROBLEM

ON THE SMOOTH EMPTRTCAL BAYES BIOKA68 83

UTIONS BAYES SOLUTION OF SEQUENTIAL DECISION PROBLEM FOR MARKOV DEPENDENT OBSERVATIONS AMS 641656 RATES OF CONVERCENCE IN THE COMPOUND DECISION PROBLEM FOR TWO COMPLETELY SPECIFIED DISTRIB THE COMPOUND DECISION PROBLEM WITH M-BY-N FINITE LOSS MATRIX TEAM DECISION PROBLEMS

THE EMPIRICAL BAYES APPROACH TO STATISTICAL DECISION PROBLEMS AMS 651743 AMS $66 \quad 412$ AMS $62 \quad$ B57 AMS 64 STRINGENT SOLUTIONS TO STATISTICAL DECISION PROBLEMS AMETRIC EMPIRICAL BAYES APPROACH TO SOME STATISTICAL DECISION PROBLEMS MINIMAX SOLUTION OF STATISTICAL DECISION PROBLEMS BY ITERATION AMS $67 \quad 447$

A SUPPLEMENTARY SAMPLE NON-PAR BIOKA67 451 AMS 661643 IAN POINT OF VIEW (CORR. 68 1551) PREDICTION AND DECISION PROBLEMS IN REGRESSION MODELS FROM THE BAYES JASA 65 608 MINIMAX RISK AND UNBIASEDNESS FOR MULTIPLE DECISION PROBLEMS OF TYPE I AMS 691684 NORMAL RANDOM VARIABLES. SEQUENTIAL SAMPLING, TWO DECISION PROBLEMS WITH LINEAR LOSSES FOR BINOMIAL AND BIOKA65 507 THE SEQUENTIAL COMPOUND DECISION PROBLEMS WITH M-BY-N FINITE LOSS MATRIX AMS 66954 ONCERNINC THE UNKNOWN MEAN OF A NORM/ A SEQUENTIAL DECISION PROCEDURE FOR CHOOSINC ONE OF K HYPOTHESES C AMS 63 549 TIONS WITH A COMMON UNKNOWN/ A TWO-SAMPLE MULTIPLE DECISION PROCEDURE FOR RANKING MEANS OF NORMAL POPULA BIOKA54 I7O ROBUSTNESS OF NON-IDEAL DECISION PROCEDURES

SEQUENTIAL ESTIMATION AND CLOSED SEQUENTIAL DECISION PROCEDURES MS IN ANALYSIS OF VARIANCES

\section{A NOTE ON SEQUENTIAL MULTIPLE DECISION PROCEDURES}

MULTIPLE DECISION PROCEDURES BASED ON RANKS FOR CERTAIN PROBLE OPTIMUM DECISION PROCEDURES FOR A POISSON PROCESS PARAMETER DEGISION PROCEDURES FOR FINITE DECISION PROBLEMS NOTE ON DECISION PROCEDURES FOR FINITE DECISION PROBLEMS

UNDER COMPLETE IGNORANCE UNDER COMPLETE IGNORANGE

\section{ARBITRARY STATE MARKOVIAN DECISION PROCESSES}

ON RECURRENT DENUMBEABLE DECISION PROCESSES

AN EXAMPLE IN DUNUMERABLE DECISION PROCESSES

COUNTABLE SYSTEM OF EQUALITIES ARISING IN MARKOVIAN DECISION PROCESSES

DENUMERABLE STATE MARKOVIAN DECISION PROCESSES

A SOLUTION TO A

PROBLEM CONVERGENCE OF THE LOSSES OF GERTAIN DECISION RULES FOR THE SEQUENTIAL COMPOUND DECISION NOTE ON A THREE-DECISION TEST FOR COMPARING TWO BINOMIAL POPULATIONS

INSENSITIVITY TO NON-OPTIMAL DESIGN IN BAYESIAN DECTSION THEORY DISCUSSION

$\mathrm{CE}$ THE FOUNDATIONS OF DECISION UNDER UNCERTAINTY, AN ELEMENTARY EXPOSITION BAYESIAN MODEL OF DECISION-MAKING AS A RESULT OF LEARNING FROM EXPERIEN CONCLUSIONS VS DECISIONS

SAMPLING INSPECTION AND STATISTICAL DECISIONS (WITH DISCUSSION)

PUBLICATION DECISIONS AND TESTS OF SIGNIFICANCE, A COMMENT

AWN FROM TESTS OF SIGNIFICANCE, OR VI/ PUBLICATION DECISIONS AND THEIR POSSIBLE EFFECTS ON INFERENCES DR
ON CASH EQUIVALENTS AND INFORMATION EVALUATION IN DECISIONS UNDER UNCERTAINTY, PARTS I, II, AND III NTS

AN ALGORITHM FOR THE DECOMPOSITION OF A DISTRIBUTION INTO GAUSSIAN COMPONE SOME APPLICATIONS OF THE SINGULAR DECOMPOSITION OF A MATRIX

A NOTE ON THE BARTLETT DECOMPOSITION OF A WISHART MATRIX

A DECOMPOSITION OF LI-BOUNDED MARTINGALES

DECOMPOSITION OF SYMMETRIC MATRTCES AND DISTRIBUTIONS DECOMPOSITION OF WISHART DISTRIBUTION

A DECOMPOSITION THEOREM FOR VECTOR VARIABLES WITH A

LINEAR STRUCTURE

ED DECREASE FAILURE RATE

THEORETICAL EXPLANATION OF OBSERVED DECREASE FAILURE RATE

A METHOD OF ADJUSTMENT FOR DEFECTIVE DATA

ESTIMATION OF THE PROBABILITY OF DEFECTIVE FAILURE FROM DESTRUCTIVE TESTS CONTROLLING THE PROPORTION DEFECTIVE FROM CLASSIFICATION DATA

ESTIMATION OF FRACTION DEFECTIVE IN CURTAILED SAMPLING PLANS BY ATTRIBUTES

THE COMPUTATION OF THE UNRESTRICTED AOQL WHEN DEFECTIVE MATERIAL IS REMOVED BUT NOT REPLACED

BINOMIAL GROUP-TESTTNG WITH AN UNKNOWN PROPORTION OF DEFECTIVES

TIVE DISCUSSION OF THE EFFECTIVENESS OF VOIDING AS A DEFENCE AGAINST BLADDER INFECTION NOTES. A DEFICIENCY IN THE SUMMATION OF CHI PROCEDURE

A SYSTEMATIC METHOD OF FINDING DEFINING CONTRASTS

AMS 64 1048 AMS 69653 AMS 69619

AMS $62 \quad 13 B 4$ AMS $64 \quad 1644$ AMS $65 \quad 691$ AMS 682118 AMS $68 \quad 424$ AMS 6B 674 AMS 661545 AMS 641606 BIOKA59 106 JASA $65 \quad 584$ RSSB 66 381 64353 AMS 69 NO.6 TECH $60 \quad 423$ JRSSB54 15 JASA 59593 ASA $59 \quad 30$ ASA $68 \quad 252$ 79 TECH 69 NO. 4 JRSB 64270 AMS 6B 134 BIOKA64 267 AMS 691845 TECH $63 \quad 375$ BIOCS67 485 JASA $5 B \quad 736$ TECH $63 \quad 459$ TECH 6499 TECH $67 \quad 219$ JASA 69665 TECH $66 \quad 631$ BIOCS66
BIOCS66 JASA $57 \quad 46$ $\begin{array}{rrrr}\text {-CENTRAL NORMAL DISTRIBUTION } & \text { DISTRIBUTION OF DEFINITE AND OF INDEFINITE QUADRATIC FORMS FROM A NON AMS 63 IB6 } \\ \text { CORRECTION TO 'DISTRIBUTION OF DEFINITE AND OF INDEFINITE QUADRATIG FORMS } 55 \text { 122 } & \text { AMS 62 B13 }\end{array}$ $\begin{array}{rrrr}\text {-CENTRAL NORMAL DISTRIBUTION } & \text { DISTRIBUTION OF DEFINITE AND OF INDEFINITE QUADRATIC FORMS FROM A NON AMS 63 IB6 } \\ \text { CORRECTION TO 'DISTRIBUTION OF DEFINITE AND OF INDEFINITE QUADRATIG FORMS } 55 \text { 122 } & \text { AMS 62 B13 }\end{array}$ HICH GRAM-CHARLIER AND EDGEWORTH CURVES ARE POSITIVE DEFINITE AND UNIMODAL THE CONDITIONS UNDER W BIOKA52 425 TNFINITELY DIFFERENTIABLE POSITIVE DEFINITE FUNGTTONS DISTRIBUTION OF A DEFINITE QUADRATIC FORM FOR NON-CENTRAL NORMAL VARIAT ES, CORR. 63673 BASED ON POSITIVE DEFINITE QUADRATIC FUNCTIONS IN NORMAL VECTORS

AMS $66 \quad 504$ AMS $61 \quad$ B83 AMS $66 \quad 468$

EXAMPLES BEARING ON THE DEFINITION OF FIDUCIAL PROBABILITY WITH A BIBLIOGRAPH ON COX AND SNELL'S DEFINITION OF RESIDUALS

A GENERAL DEFINITION OF RESIDUALS (WITH DISCUSSION)

A DEFINITION OF SUBJECTIVE PROBABILITY

THE THEORY OF EXPERIMENT OPERATIONAL DEFINITION OF THE PROBABILTTY SPACE

MARKOV RENEWAL PROCESSES. DEFINITIONS AND PRELIMINARY PROPERTIES

PREFERENCE-BASED DEFINITIONS OF SUBJECTIVE PROBABILITY

ALTERNATIVE DEFINITIONS OF THE SERIAL CORRELATION COEFFICIENT IN

SHORT AUTOREGRESSIVE SEQUENCES SOME METHODOLOGICAL NOTES ON THE DEFLATION OF CONSTRUCTION

A DEFORMATION METHOD FOR QUADRATIC PROCRAMMING

SUPPLEMENT TO'A DEFORMATION METHOD FOR QUADRATIC PROCRAMMINC

TESTS
AMS $62 \quad 1349$

JRSSB69 103 JRSSB68 24B AMS 63199 AMS $67 \quad 401$ AMS 61 1231 AMS 671605 JASA 5B B81 JASA 59535 JRSSB64 14 JRSSB 65166 AMS 681654 
ON THE EQUIVALENCE OF POLYKAYS OF THE SECOND DECREE AND SICMA'S, CORR. 651069 PROTECTION ACAINST ASSUMINC THE WRONG DEGREE IN POLYNOMIAL RECRESSION ON TESTINC FOR THE DECREE OF A POLYNOMIAL

THE CHOICE OF THE DECREE OF A POLYNOMIAL MODEL

DECISION PROBLEM

THE CHOICE OF THE DECREE OF A POLYNOMIAL REGRESSION AS A MULTIPLE

OTES. STATISTICAL TESTS OF HYPOTHESES CONCERNINC THE DECREE OF DOMINANCE IN MONOFACTORIAL INHERITANCE STATISTICS IN SAMPLES FROM THE CHI-DISTRIBUTION, ONE DECREE OF FREEDOM EXACT LOWER MOMENTS OF ORDER PROCEDURE CHI-SQUARE TESTS WITH ONE DECREE OF FREEDOM, EXTENSIONS OF THE MANTEL-HAENSZEL THE DECREE OF RANDOMNESS IN A STATIONARY TIME SERIES

AMS 641663 TECH 69 NO. 4 TECH $68 \quad 757$ JRSSB $68 \quad 469$ AMS $62 \quad 255$ $\begin{array}{rr}\text { AMS } 62 & 255 \\ \text { BI } 0 \text { CS68 } & 429\end{array}$ AMS 621292 JASA $63 \quad 690$ AMS 631253 ONDITIONS FOR WISHARTNESS AND INDEPENDENCE OF SECOND DECREE POLYNOMIALS IN NORMAL VECTOR CHI-SQUARE PROBABILITIES FOR LARCE NUMBERS OF DECREES OF FREEDOM

C AMS 621002 BIOKA56 92 UARES BY SATTERTHWAITHE'S FORMULA ROXIMATION TO THE RANCE

NS-FISHER PROBLEM EXPENDITURES

ESTIMATINC THE DECREES OF FREEDOM FOR LINEAR COMBINATIONS OF MEAN SQ TECH 69 NO.4 SCALE FACTORS AND DECREES OF FREEDOM FOR SMALL SAMPLE SIZES FOR CHI APP BIOKA53 449 QUERY, DEGREES OF FREEDOM OF CHI-SQUARE

TECH 67

$4 \mathrm{~B} 9$ AN APPROXIMATE DECREES OF FREEDOM SOLUTION TO THE MULTIVARIATE BEHRE BIOKA65 139 EFFECT OF VARYING DECREES OF TRANSITORY INCOME ON INCOME ELASTICITY OF JASA 58348 DELAY AT TRAFFIC INTERSECTIONS

THE DELAY TO PEDESTRIANS CROSSING A ROAD

SEQUENTIAL ANALYSIS WITH DELAYED OBSERVATIONS

A PROBLEM OF DELAYED SERVICE, I

A PROBLEM OF DELAYED SERVICE, 2

A THEORETICAL ANALYSIS OF DELAYS AT AN UNCONTROLLED INTERSECTION

A SIMPLIFIED MODEL FOR DELAYS IN OVERTAKINC ON A TWO-LANE ROAD

THE DEPENDENCE OF DELAYS IN TANDEM QUEUES

TRAFFIC DELAYS ON A TWO-LANE ROAD

DELAYS ON A TWO-LANE ROAD (WITH DISCUSSION)

STNG STABLE PROCESSES (ADDENDUM, 69 , 1B55)

INCOME, INCOME CHANGE, AND DURABLE GOODS DEMAND

THE TIME-TO-EMPTINESS OF A DISCRETE DAM UNDER STEADY DEMAND

LIABILITY OF CONSUMER SURVEYS OF FINANCIAL HOLDINGS. DEMAND DEPOSITS

THE DISTRIBUTION OF JASA 641194

THE RE JASA $66 \quad 91$

SOME EMPIRICAL MEASUREMENTS AND RELATED PROBLEMS DEMAND FOR FARM PRODUCTS AT RETAIL AND THE FARM LEVEL JASA 58 65

THE DEMAND FOR FERTILIZER IN 1954, AN INTER-STATE STUDY JASA 59377 DEMAND FOR MANUFACTURERS' SERVICES FOR BAKERY PRODUCT JASA 65740

S AND FRUITS AND VEGETABLES

FUNCTIONAL FORM IN THE DEMAND FOR MONEY

INCOME, WEALTH, AND THE DEMAND FOR MONEY, SOME EVIDENCE FROM CROSS-SECTION JASA 64746

DATA

INDETERMINTSM IN SCIENCE AND NEW DEMANDS ON STATTSTICTANS

A DEMOGRAPHIC MODEL FOR ESTIMATING AGE-ORDER SPECIFIC JASA $63 \quad 774$

FERTILITY RATES

FEED EFFICIENCY AND RATE OF GAIN, A RATIO AND ITS DENOMINATOR

KINDS AND THE CORRELATION BETWEEN THE NUMERATOR AND DENOMINATOR OF THE F-RATIO THE MAXIMUM DEVIATION OF SAMPLE SPECTRAL DENSITIES

A BOUND FOR THE VARIATION OF GAUSSIAN DENSITIES NOTE ON COMPLETELY MONOTONE DENSITIES

CORRELATION BETWEEN BIOCS65 739

(-TEST TO ERRORS OF BOTH JASA $68 \quad 660$

AMS 671558

AMS 69 No. 6

AMS 691130

AMS 691261

AMS 691503

JRSSB $62 \quad 185$

BI0CS68 135

OF A PRODUCT AND THE STRUCTURAL SETUP OF DENSITIES

DISTRI8UTION AMS 691439

THE ESTIMATION OF PROBABILITY DENSITIES AND CUMULATIVES BY FOURIER SERIES METHODS JASA 68925 EXPANSIONS OF T DENSITIES AND RELATED COMPLETE INTEGRALS

AMS $67 \quad 503$

TERMINAL AND FIRST THREE MOME/ USE OF THE PEARSON DENSITIES FOR APPROXIMATINC A SKEW DENSITY WHOSE LEFT BIOKA68 559 ON THE ASYMPTOTIC BEHAVIOR OF DENSITIES WITH APPLICATIONS TO SEQUENTIAL ANALYSIS AMS 65 615 PROBABILITY DENSITIES WITH CIVEN MARGINALS

THE LIMIT OF THE NTH POWER OF A DENSITY ESTIMATION OF PROBABILITY DENSITY

ON THE MAXIMUM DEVIATION OF THE SAMPLE DENSITY

A NOTE ON ESTIMATING A UNIMODAL DENSITY

NOTE ON A DISCONTINUOUS PROBABILITY DENSITY

AND SPHERICAL ESTIMATION OF MULTIVARIATE PROBABILITY DENSITY

EXPANSIONS ASSOCIATED WITH THE N'TH POWER OF A DENSITY OF THE LOCATION OF THE CUSP OF A CONTINUOUS DENSITY

THE ESTIMATION OF THE SPECTRAL DENSITY AFTER TREND REMOVAL

AN INEQUALITY RELATINC THE SPECTRAL DENSITY AND AUTOCORRELATION FUNCTION

ESTIMATION OF PROBABILITY DENSITTY BY AN ORTHOGONAL SERIES

MOMENT CROSSINGS AS RELATED TO DENSITY CROSSINGS

ON STRONG CONSISTENCY OF DENSITY ESTIMATES

DENSITY ESTIMATION IN A TOPOLOGICAL GROUP

DENSITY ESTIMATION OF ORTHOGONAL SERIES

AND ADEQUACY OF THE POISSON-MARKOFF MODEL FOR DENSITY FLUCTUATIONS

AMS 6B 1236

AMS 651878

AMS 651027

AMS $67 \quad 475$

AMS 691661

BIOKA58 270

CUBICAL JASA 681495 ASYMPTOTIC AMS 671266 ESTIMATION AMS $68 \quad 76$

JRSSB $5 B \quad 323$

BIOKA62 262

AMS 671261

JRSSB 6591

AMS 691765

AMS 651047

AMS 691496

CONTINUUM THE FIRST PASSACE TIME DENSITY FOR HOMOGENEOUS SKIP-FREE WALKS ON THE

A NONPARAMETRIC ESTIMATE OF A MULTIVARIATE DENSITY FUNCTION

ON A SIMPLE ESTIMATE OF THE RECIPROCAL OF THE DENSITY FUNCTION

EFFICIENT ESTIMATION OF A PROBABILITY DENSITY FUNCTION

UNIFORM CONSISTENCY OF SOME ESTIMATES OF A DENSITY FUNCTION

THE AUTOCORRELATION FUNCTION AND THE SPECTRAL DENSITY FUNCTION

FOR THE MIXTURE OF EXPONENTIALS TO BE A PROBABILITY DENSITY FUNCTION

ESTIMATION OF A PROBABILITY DENSITY FUNCTION AND ITS DERIVATIVES

ON ESTIMATION OF A PROBABILITY DENSITY FUNCTION AND MODE

A UNIFORMLY CONSISTENT SEQUENCE OF ESTIMATORS OF A DENSITY FUNCTION IN CERTAIN CASES

BIOKA55 151

AMS 631003

AMS 651049

AMS 6B 1083

AMS $69 \quad$ B54

AMS 691499

AMS 69 NO.6

AMS 691187

AMS 621065 ON THE LACK OF AMS $67 \quad 471$ ESTIMATION OF THE SPECTRAL DENSITY FUNCTION IN THE PRESENCE OF HARMONIC COMPONEN JRSSB64 123 CALLY EFFICIENT CONSISTENT ESTIMATES OF THE SPECTRAL DENSITY FUNCTION OF A STATIONARY TIME SERIES /PTOTI JRSSB5B 303 SION) ON ESTIMATING THE SPECTRAL DENSITY FUNCTION OF A STOCHASTTC PROCESS (WITH DISCUS JRSSB57 I3 ON THE SMOOTHING OF PROBABILITY DENSITY FUNCTIONS JRSS858 334 ES ESTIMATING THE COVARIANCE AND SPECTRAL DENSITY FUNCTIONS FROM A CLIPPED STATIONARY TIME SERI JRSSB67 180 SOME MULTIVARIATE DENSITY FUNCTIONS OF PRODUCTS OF GAUSSIAN VARIATES

A METHOD FOR DISCRIMINATING 8ETWEEN FAILURE DENSITY FUNCTIONS USED IN RELIA8ILITY PREDICTIONS 
HE APPROXIMATE CANONICAL FACTORIZATION OF A SPECTRAL DENSITY MATRIX INFERENCES FOR FAMILIES OF HYPOTHESES WITH MONOTONE DENSITY RATIOS LATTICE

MULTIVARIATE AUTORECRESSIONS, AND T BIOKA63 129 UPPER AND LOWER PROBABILITY AMS 69953 ON THE ESTIMATION OF THE PROBABILITY DENSITY I

LE MARKOV CHAINS WITH AN APPLICATION IN STUDYINC THE DENTAL CARIES PROCESS /ILITY APPROACH TO IRREVERSIB BIOCS66 791 ON RECURRENT DENUMBEABLE DECISION PROCESSES

NON-DISCOUNTED DENUMERABLE MARKOVIAN DECISION MODELS

MPTOTIC DISTRIBUTION THEORY FOR MARKOV CHAINS WITH A DENUMERABLE NUMBER OF STATES (2) AVERACE COST CRITERION DENUMERABLE STATE MARKOVIAN DECISION PROCESSES

\section{A SYSTEM OF DENUMERABLY MANY TRANSTENT MARKOV CHAINS} TESTING FOR DEPARTURE FROM THE EXPONENTIAL DISTRIBUTION SOME ASY BIOKA56 285 AMS $66 \quad 1545$ AMS $66 \quad 406$ BIOKA57 253

THE INTERARR ON THE CORRELATION STRUCTURE OF THE DEPARTURE PROCESS OF THE QUEUE WITH ONE SERVER, WHILE JRSSB66 336 A QUEUE WITH RANDOM ARRIVALS AND SCHEDULED BULK DEPARTURES

N THE DERIVATION OF ROBUST CRITERIA AND THE STUDY OF DEPARTURES FROM ASSUMPTION (WITH DISCUSSION) /ORY I JRSSB55 I DEPARTURES FROM ASSUMPTION IN SEQUENTIAL ANALYSIS BS BIOKA6I 206 AN ANALYSIS OF DEPARTURES FROM THE EXPONENTIAL DISTRIBUTION QUEUES WITH BATCH DEPARTURES I QUEUES WITH BATCH DEPARTURES II

OF POPULATION GROWTH WHEN THE BIRTH AND DEATH RATES DEPEND UPON SEVERAL FACTORS SOME CONCEPTS OF DEPENDENCE

INFORMATION AND MAXIMAL CORRELATION AS MEASURES OF DEPENDENCE IN A CHAIN OF MULTIPLE EVENTS WHEN THERE IS SIMPLE DEPENDENCE THE WILGOXON ESTIMATE OF LOCATION AGAINST A CERTAIN DEPENDENCE

ROBUSTNESS OF

OBSERVATIONS ON THE EFFECTS FOR THE U/ OBSERVATIONS IN THE SUBCLASSES FOR TH/ NEGATTVE VARTANCE ESTIMATES A STATISTICAL DEPENDENGE BETWEEN RANDOM EFFECTS AND THE NUMBERS OF STATISTICAL DEPENDENCE BETWEEN SUBCLASS MEANS AND THE NUMBERS OF STATISTICAL DEPENDENCE IN NESTED SAMPLING T AND GENERAL SERVICE TIMES

THE TIME DEPENDENCE OF A SINCLE-SERVER QUEUE WITH POISSON INPU THE DEPENDENCE OF DELAYS IN TANDEM QUEUES

RULE

CORRELATION AND COMPLETE DEPENDENCE OF RANDOM VARIABLES DEPENDENCE OF THE FIDUCIAL ARGUMENT ON THE SAMPLING ASYMPTOTIC PROPERTIES OF AN ACE DEPENDENT BRANCHING PROCESS AN INTEGRAL EQUATION IN AGE DEPENDENT BRANCHING PROCESSES MONOTONE CONVERGENCE OF MOMENTS IN AGE DEPENDENT BRANCHINC PROCESSES ON THE SUPERCRITICAL ONE DIMENSIONAL AGE DEPENDENT BRANCHING PROCESSES ON DOMINATING AN AVERAGE ASSOCIATED WITH DEPENDENT GAUSSIAN VECTORS SEQUENTIAL HYPOTHESIS TESTS FOR THE R-DEPENDENT MARGINALLY STATIONARY PROCESSES PROCEDURES AND TABLES FOR EVALUATING DEPENDENT MIXED ACCEPTANCE SAMPLING PLANS LINEAR TRANSFORMATION TO A SET OF STOCHASTICALLY DEPENDENT NORMAL VARIABLES CONFIDENCE INTERVALS FOR THE MEANS OF DEPENDENT NORMALLY DISTRIBUTED VARIABLES SOLUTION OF SEQUENTIAL DECISION PROBLEM FOR MARKOV DEPENDENT OBSERVATIONS SQUARE GOODNESS-OF-FIT TEST FOR A CLASS OF CASES OF DEPENDENT OBSERVATIONS SEQUENTIAL ANALYSIS OF DEPENDENT OBSERVATIONS,

A RENEWAL THEOREM FOR RANDOM VARIABLES WHICH ARE DEPENDENT OR NON-IDENTICALLY DISTRIBUTED ON THE GENERAL TIME DEPENDENT QUEUE WITH A SINCLE SERVER

A NOTE ON MAXIMUM-LIKELIHOOD IN THE CASE OF DEPENDENT RANDOM VARIABLES

DISTRIBUTION OF THE MAXIMUM TERM IN SEQUENCES OF DEPENDENT RANDOM VARIABLES ON DEPENDENT TESTS FROM A NON-ORTHOGONAL DESIGN SOME NON-PARAMETRIC TESTS FOR M-DEPENDENT TIME SERIES RIBUTION OF THE NUMBER OF SUCCESSES IN A SEQUENCE OF DEPENDENT TRIALS INFERENCE FOR LINEAR MODELS IN WHICH SUBSETS OF THE DEPENDENT VARIABLE ARE CONSTRAINED REGRESSION ANALYSIS WITH DEPENDENT VARIABLE CENSORED

A CENTRAL LIMIT THEOREM FOR PARTLY DEPENDENT VARIABLES PAIRWISE INDEPENDENCE OF JOINTLY DEPENDENT VARIABLES CONTRIBUTIONS TO CENTRAL LIMIT THEORY FOR DEPENDENT VARIABLES $\begin{array}{cc}\text { AMS } 64 & 1147 \\ \text { BIOCS69 N0.4 }\end{array}$ MUTUAL AMS $62 \quad 587$ PERSISTENCE BIOKA62 351 AMS 681196 AMS $62 \quad 201$ JASA $67 \quad 1375$ JASA $68 \quad 1484$ JASA 681000 AMS 621340 AMS $64 \quad 874$ AMS $63 \quad 1315$ BIOKA57 464 AMS 651565 AMS 651569 AMS 661806 AMS $69 \quad 743$ AMS 68 1B44 AMS $66 \quad 90$ TECH 69341 JASA $57 \quad 247$ JASA 59613 BAYES AMS 641656 THE CHI- BIOKA64 250 BIOKA65 157 AMS $63 \quad 390$ AMS $62 \quad 767$ JRSSB61 444 LIMITING AMS $62 \quad 894$ JASA $66 \quad 803$ JASA $65 \quad 134$ THE DIST BIOKA59 454 ESTIMATION AND JASA $68 \quad 1201$ BIOCS65 300 AMS $61 \quad 677$ AMS 62,290 AMS $68 \quad 115 \mathrm{~B}$ ELATIONS BETWEEN THE P.D.F.'S OF ORDER STATISTICS OF DEPENDENT VARIABLES, AND SOME APPLICATIONS /RENCE R BIOKA67 283 TION ADMITTING A SUFFICIENT STATISTIC WHEN THE RANGE DEPENDS ON THE PARAMETER /E PARAMETER OF A DISTRIBU JRSSB55 86 OF CONSUMER SURVEYS OF FINANCIAL HOLDINGS. TIME-DEPOSITS ESTIMATION OF AN ACCELERATED DEPRECIATION LEARNING FUNCTION THE RELIABILITY JASA $65 \quad 148$ DISTRIBUTION ON THE DERIVATION AND APPLICABILITY OF NEYMAN'S TYPE JASA $66 \quad 995$ BIOKA58 32 $\begin{array}{rr}\text { BIOKA58 } & 32 \\ \text { JRSSB } 65 & 290\end{array}$ BAYES'S THEOREM DERIVATION OF A CLASS OF FREQUENCY DISTRIBUTIONS VIA JRSSB65 290 $\mathrm{N}$ FUNCTION OF A CONTINUOUS UNIVARIATE POPULATION/ DERIVATION OF APPROXIMANTS TO THE INVERSE DISTRIBUTIO BIOKA69 NO. 3
A CONCISE DERIVATION OF GENERAL ORTHOGONAL POLYNOMIALS REGRESSION CURVES THE DERIVATION OF METHODS FOR FITTING EXPONENTIAL BIOKA64 504 TS FOR UNIFORMITY OF A CIRCULAR DISTRIBUTION THE DERIVATION OF NONPARAMETRIC TWO-SAMPLE TESTS FROM TES BIOKA69 NO 3 URES FROM ASSUMPTION (W/ PERMUTATION THEORY IN THE DERIVATION OF ROBUST CRITERIA AND THE STUDY OF DEPART JRSSB55 A NOTE ON THE DERIVATION OF SOME EXACT MULTIVARIATE TESTS A UNIFIED DERIVATION OF SOME NONPARAMETRIC DISTRIBUTIONS A DERIVATION OF THE BOREL DISTRIBUTION

ON SUFFICIENT STATISTIC A GOMBINATORIAL DERIVATION OF THE DISTRIBUTION OF THE TRUNCATED POISS AMS 61904 AN ALTERNATIVE DERIVATION OF THE HERMITE DISTRIBUTION $\quad$ BIOKA66 627 A GONTOUR-INTEGRAL DERTVATION OF THE NON-CENTRAL CHI-SQUARE DISTRTBUTION AMS 62796 ANOTHER DERIVATION OF THE NON-CENTRAL CHI-SQUARE DISTRIBUTION JASA 64957 $\begin{array}{llll}\text { A DERIVATION OF THE PROBABILISTIC EXPLICATION OF } & \text { JRSSB } 6 & 578\end{array}$

INFORMATION DERIVATIONS AND APPROXIMATIONS

MEASURES NDOM VARIABLES AND THE DISPERSION OF A RADON-NIKODYM DERIVATIVE (CORR. 65533 ) LLE COMPARISONS FOR BIOKA65 485 EQUIVALENT GAUSSIAN AMS 671027 N RELEVANCE OF THE DISPERSION OF A RADON-NIKODYM DERIVATIVE TO THE PROBLEM OF MEASURING ASSOCIATION

ESTIMATION OF A PROBABILITY DENSITY FUNCTION AND ITS DERIVATIVES STOCHASTIC INTEGRALS AND DERIVATIVES

MULTIVARIATE MAXIMA AND MINIMA WITH MATRIX DERIVATIVES

SOME APPLICATIONS OF MATRIX DERIVATIVES IN MULTIVARIATE ANALYSIS RADON-NIKODYM DERIVATIVES OF GAUSSIAN MEASURES
JRSSB $65 \quad 108$ AMS 691187 AMS 691610 JASA 69 NO. 4 JASA $67 \quad 607$ AMS $66 \quad 321$ 
EQUATIONS

RADON-NIKODYM DERIVATIVES OF STATIONARY CAUSSIAN MEASURES

AMS $64 \quad 517$ BIOKA51 470 BIOKA63 517 TECH $60 \quad 353$ TECH $61 \quad 29$ THE ROBUSTNESS OF LIFE TESTING PROCEDURES DERIVED FROM THE EXPONENTIAL DISTRIBUTION F THE PONER FUNCTION FOR ANALYSIS OF VARIANCE TESTS, DERIVED FROM THE NON-CENTRAL F-DISTRIBUTION MATCHTNC DISTRTBUTTONS POISSON LIMITTNC FORMS AND DERTVED METHODS OF APPROXTMATION SPACE IN TESTS OF AN IMPORTANT/ A SIMPLE METHOD OF DERIVINC BEST CRITICAL RECIONS SIMILAR TO THE SAMPLE BIOKA53 23 IS THE CONSTRUCTION OF A MATRIX USED IN DERIVING TESTS OF SIGNIFIGANCE IN MULTIVARIATE ANALYS BIOKA64 50 A POTENTIAL THEORETIC PROOF OF A THEOREM OF DERMAN AND VEINOTT VARIATION QUADRATIQUE DES MARTINGALES CONTINUES A DROITE

SUR PLUSIEURS CARACTERES PONDERATION DES VALEURS GENOTYPIQUES DANS LA SELECTION PAR INDEX

E LOGNORMAL DISTRIBUTION AND THE TRANSLATION METHOD, DESCRIPTION AND ESTIMATION PROBLEMS, CORR. 63 II63 NON-ADDITIVITIES IN A LATIN SQUARE DESIGN

A BASIS FOR THE SELECTION OF A RESPONSE SURFACE DESIGN AN APPLICATION OF A BALANCED INCOMPLETE BLOCK DESIGN ASYMPTOTICALLY OPTIMUM SEQUENTIAL INFERENCE AND DESIGN A BLANCED INCOMPLETE BLOCK DESIGN OPTIMAL STOPPING AND EXPERTMENTAL DESIGN ON DEPENDENT TESTS FROM A NON-ORTHOCONAL DESIGN GENERALIZED LATTICE SQUARE DESIGN ESTIMATES IN SUCCESSIVE SAMPLING USINC A MULTI-STAGE DESIGN THE CHOICE OF A SECOND ORDER ROTATABLE DESIGN SERIAL FACTORIAL DESICN ON THE MISSINC PLOT PROCEDURE IN A RANDOMIZED BLOCK DESIGN ON A NON-PARAMETRIC APPROACH TO THE 2-CUBE FACTORIAL DESICN CLASSIFICATION ANALYSIS FOR ARBITRARY EXPERIMENTAL DESICN A CONCOMITANT VARIABLE IN SELECTING AN EXPERIMENTAL DESIGN

OF ERRORS IN THE FACTOR LEVELS AND EXPERIMENTAL DESICN OF ERROR VARIANCES IN A RANDOMIZED BLOCK DESICN

MIXTURES, A CENERALIZATION OF THE SIMPLEX-LATTICE DESIGN ANALYSIS OF A CENERALIZED RANDOMIZED BLOCK DESIGN TATISTIGS FOR THE TWO-WAY CLASSIFICATION MIXED MODEL DESIGN AND PURCHASE PROBABILITY. AN EXPERIMENT IN SURVEY DESICN FACTORIAL ARRANGEMENTS. I BLOCK AND DIRECT PRODUGT DESIGN WITH ECONOMIC SYSTEMS. THE PROBLEM OF EXPERIMENTAL DESICN COMPONENTS I. EMPIRICAL STUDIES OF BALANCED NESTED DESIGN IN A GENERALIZATION OF THE BALANCED INCOMPLETE BLOCK DESIGN ATIOS UNDER PERMUTATION IN THE COMPLETELY RANDOMIZED DESICN SQUARE-SUB-R-TEST FOR A BALANCED INCOMPLETE BLOCK DESIGN - 1 TO Q-SUB-N BY M-SUB-I TO M-SUB-N MULTIPLE-LATTICE DESIGN OF VARIANCE OF A PARTIALLY BALANCED INCOMPLETE BLOCK DESICN ANEOUS EQUATIONS WITH AN APPLICATION TO EXPERIMENTAL DESICN HE F-TEST UNDER PERMUTATION FOR THE RANDOMIZED BLOCK DESIGN MAYS L. UTILIZINC INFORMATION FROM A DIALLEL MATING DESIGN H SPECIAL REFERENCE TO THE BALANCED INCOMPLETE BLOCK DESIGN EST UNDER PERMUTATION IN THE SIMPLE RANDOMIZED BLOCK DESIGN SOME CENERAL RESULTS IN SEQUENTIAL DESICN USE OF PRIOR INEORMATION TO DESIGN A ROUTINE PARALLEL LINE ASSAY

DESIGN AND ANALYSIS OF EXPERIMENTS WITH MIXTURES DESIGN AND ESTIMATION IN TWO-WAY STRATIFICATION

PLAN DESIGN AND EVALUATION OF A REPETITIVE GROUP SAMPLING DESICN AND OPERATION OF A DOUBLE-LIMIT VARIABLES

A DESIGN BALANCED FOR TREND

MINATION AND PARAMETER ESTIMATION $\begin{array}{lrl}\text { A DESIGN BALANCED FOR TREND } & \text { BIOKA6B } & 535 \\ \end{array}$ OFERESSION FUNCTION OF THE Q-SUB JRSSB69 NO.2 THE RELATIONSHIP ALCEBRA AND THE ANALYSIS AMS 651 B15 ANECION FOR THE SOLUTION OF A SET OF SIMULT BIOKA54 190 /AL RELATIONSHIP AMONG EICHT POPULATIONS ZEA BIOCS68 867 /INEAR MODELS WITH TWO RANDOM COMPONENTS WIT BIOKA68 101 $\begin{array}{llll}\text { /INEAR MODELS WITH TWO RANDOM COMPONENTS WIT BIOKA68 } & 101 \\ \text { /MONTE CARLO RESULTS ON THE POWER OF THE F-T BIOKA66 } & 199\end{array}$ JRSSB65 371 BIOCS67 257 AMS $68 \quad 1517$ JASA $60 \quad 105$ TECH $65 \quad 11$ JASA $5 B \quad 543$ \begin{tabular}{rlrr}
\multicolumn{1}{c}{ A JOINT DESIGN CRITERION FOR THE DUAL PROBLEM OF MODEL DISCRI TECH 68} & 145 \\
NOTE ON A MINIMAX DESICN FOR CLUSTER SAMPLING & AMS 68 & 278
\end{tabular} WITH A CONTR/ AN ASYMPTOTICALLY OPTIMAL SEQUENTIAL DESICN FOR COMPARING SEVERAL EXPERIMENTAL CATEGORIES AMS 63 1486 EXAMINATION OF A REPEAT MATING DESICN FOR ESTIMATINC ENVIRONMENTAL AND GENETIC TREND BI AN ALTERNATIVE TO THE SIMPLEX-LATTICE DESIGN FOR EXPERIMENTS WITH MIXTURES 63
JRSSB 69 NO 2 THE SIMPLEX-CENTROID DESICN FOR EXPERIMENTS WITH MIXTURES (WITH DISCUSSION DESICN FOR INTERACTIONS DESIGN FOR OPTIMAL PREDICTION IN SIMPLE LINEAR JRSSB63 235 TECH $68 \quad 389$ JASA 65205 TECH 69461

RECRESSION MINIMUM BIAS ESTIMATION AND EXPERIMENTAL DESICN FOR RESPONSE SURFACES

A CHANGE-OVER DESIGN FOR TESTING A TREATMENT FAGTOR AT FOUR EQUALLY J A CHANGE-OVER DESIGN FOR TESTING A TREATMENT FAGTOR A A PORE PROBLEMS OF THE HOUSEHOLD INTERVIEW DESIGN FOR THE NATIONAL HEALTH SURVEY
SOMA

ON THE ADMISSIBILITY OF A RANDOMIZED SYMMETRICAL DESICN FOR THE PROBLEM OF A ONE WAY CLASSIFICATION INSENSITIVITY TO NON-OPTIMAL DESIGN IN BAYESIAN DEGISION THEORY RANDOM WALK DESIGN IN BIO-ASSAY

ON THE CHOICE OF DESIGN IN STOCHASTIC APPROXIMATION METHODS

THE MATCHED PAIRS DESIGN IN THE CASE OF ALL-OR-NONE RESPONSES BAYESIAN ANALYSIS OF A THREE-COMPONENT HIERARCHICAL DESIGN MODEL ARRANGEMENTS ARE INADMISSIBLE SAMPLINC PLANS

THE DESICN OF AN EXPERIMENT IN WHICH CERTAIN TREATMENT DESTGN OF AN OPTIMAL SEQUENCE OF INTERRELATED

THE ECONOMIC DESICN OF CUMULATIVE SUM CONTROL CHARTS

APPROXIMATE DESICN OF DIGITAL FILTERS

COMPUTER AIDED DESIGN OF EXPERIMENTS

CONSTRAINED MAXIMISATION AND THE DESIGN OF EXPERIMENTS SOLUTION OF SOME NON-LINEAR EQUATIONS, USEFUL IN THE DESIGN OF EXPERIMENTS

THE SEQUENTIAL DESIGN OF EXPERIMENTS FOR INFINTTELY MANY STATES OF NATURE

THE CHOICE OF VARIABLES IN THE DESIGN OF EXPERIMENTS FOR LINEAR REGRESSION

THE DESIGN OF EXPERIMENTS FOR PARAMETER ESTIMATION DESIGN OF EXPERIMENTS FOR PARAMETER ESTIMATION IN $\begin{array}{rrr}\text { JRSSB } 67 & 370 \\ \text { JASA } & 59 & 69\end{array}$ AMS $69 \quad 356$ JASA $65 \quad 584$ JASA $67 \quad$ B42 AMS $68 \quad 457$ BIOCS68 339 BIOKA67 109 BIOKA54 287 JASA $64 \quad 96$ TECH $68 \quad 479$ TECH $65 \quad 387$ TECH $69 \quad 137$ TECH $69 \quad 616$ JRSSB 65466 AMS $61 \quad 771$ BIOKA69 55 TECH 68 271 MULTIRESPONSE SITUATIONS BIOKA66 -LINEAR SIT/ THE USE OF PRIOR DISTRIBUTIONS IN THE DESTGN ON -LINEAR SIT/ THE USE OF PRIOR DISTRIBUTIONS IN THE DESIGN OF EXPERIMENTS FOR PARAMETER ESTIMATION IN NON DESIGN OF EXPERIMENTS IN NON-LINEAR SITUATIONS 

TIMATION OF A SUBCROUP OF PRE-AS/ BAYES SEQUENTIAL DESICN OF FRACTIONAL FACTORIAL EXPERIMENTS FOR THE ES AMS 68 973

L OF A PROCESS

THE ECONOMIC DESICN OF MEAN CHARTS USED TO MAINTAIN CURRENT CONTRO JASA 56228

ANDERSON $\begin{array}{lllrl}\text { EXTREME VERTICES DESICN OF MIXTURE EXPERIMENTS } & \text { TECH } 66 & 447 \\ \text { 'EXTREME VERTICES DESICN OF MIXTURE EXPERIMENTS' BY R. A. MCLEAN AND V. L TECH } 66 & 455\end{array}$ THE DESIGN OF SCREENINC TESTS

THE NEW DESICN OF THE CANADIAN LABOUR FORCE SURVEY

AN ALCORITHM FOR THE DETERMINATION OF THE ECONOMIC DESIGN OF X-CHARTS BASED ON DUNCAN'S MODEL TECH $63 \quad 481$ JASA $67 \quad 421$ JASA $68 \quad 304$ BIOK A52 189 1161 A NOTE ON THE DESICN PROBLEM

SOME EXPERIMENTAL DESICN PROBLEMS IN ATTRIBUTE LIFE TESTINC, CORR. 63 JASA 62668 DESIGN RELATIONS FOR NON--STATIONARY PROCESSES JRSSB66 228 OPERATINC CHARACTERISTICS OF SOME SEQUENTIAL DESIGN RULES AMS 681176 ND WITHOUT STACES

ON SIMPLIFICATIONS OF SAMPLINC DESICN THROUGH REPLICATION WITH EQUAL PROBABILITIES A JASA 56 -STATISTIC IN A RANDOMIZED BALANCED INCOMPLETE BLOCK DESICN UNDER THE NEYMAN MODEL /ISTRIBUTION OF THE F AMS 63 1558 AN UNNESTED FIXED FACTOR IN AN UNBALANCED HIERARCHAL DESIGN WITH A MIXED MODEL /E. THE QUASI-F TEST FOR BIOCS66 937 OPTIMAL SAMPLE DESIGN WITH NONRESPONSE

SIMULTANEOUS CONFIDENCE INTERVALS AND EXPERIMENTAL DESICN WITH NORMAL CORRELATION A LARCE-SAMPLE BIOASSAY DESIGN WITH RANDOM DOSES AND UNCERTAIN CONCENTRATION BIOKA55 307 A TWO-PERIOD DESIGN WITH T-SQUARE EXPERIMENTAL UNITS

ON BAYES SEQUENTIAL DESICN WITH TWO RANDOM VARIABLES BIOKA66 469 MIZATION DISTRIBUTION OF F-RATIOS FOR THE SPLIT-PLOT DESIGN, AN EMPIRICAL INVESTIGATION OF IMMEDIATE SEQUENTIAL EFFECTS IN A LATIN SQUARE DESICN, CORR. 581030 COMPLETE COUNTER8ALANCING JASA 58 525 CORRIGENDA. 'THE CHOICE OF A SECOND ORDER ROTATA8LE DESIGN' OMIZATION ANALYSIS OF A GENERALIZED RANDOMIZED 8LOCK DESIGN' A CONCOMITANT VARIABLE IN SELECTING AN EXPERIMENTAL DESIGN CORRT CENDA, ITHE RAND

TIONAL TO SIZE WHEN THE SIZ/ SEVERAL METHODS OF RE-DESIGNING AREA SAMPLES UTILIZING PRO8ABILITIES PROPOR JASA 68 1280 DESIGNING SOME MULTI-FACTOR ANALYTICAL STUDIES JASA 671121

THE ANALYSIS OF INCOMPLETE BLOCK DESIGNS THE APPLICATION OF RANDOM 8ALANCE DESIGNS PARTIAL DUPLICATION OF RESPONSE SURFACE DESIGNS AN INEQUALITY FOR BALANCED INCOMPLETE 8LOCK DESIGNS VARIANCE ESTIMATES IN 'OPTIMUM' SAMPLE DESIGNS

FACTORIAL TREATMENTS IN RECTANGULAR LATTICE DESIGNS THE 2-TO-THE-(K-P) FRACTIONAL FACTORIAL DESIGNS FINDING NEW FRACTIONS OF FACTORIAL EXPERIMENTAL DESIGNS MISSING VALUES IN RESPONSE SURFACE DESICNS TWO MORE CRITERIA EQUIVALENT TO D-OPTIMALITY OF DESICNS SOME SYSTEMATIC SUPERSATURATED DESIGNS RIGHT ANGULAR DESIGNS

PARTIALLY DUPLICATED FRACTIONAL FACTORIAL DESIGNS CU8IC DESIGNS SINGULAR WEIGHING DESIGNS

ON THE ANALYSIS OF GROUP DIVISIBLE DESIGNS A PROCEDURE FOR CONSTRUCTING INCOMPLETE 8LOCK DESIGNS CYCLIC DESIGNS

GENERALIZED RIGHT ANGULAR DESIGNS

ON A CLASS OF PARTIALLY 8ALANCED INCOMPLETE 8LOCK DESIGNS GENERAL THEORY OF PRIME-POWER LATTICE DESICNS A NOTE ON FRACTIONS OF 3-TO-THE-(4N+1) DESIGNS ON NON-RANDOMIZED FRACTIONAL WEIGHINC DESIGNS CYLINDRICALLY ROTATABLE DESIGNS OPTIMAL EXPERIMENTAL DESIGNS ROBUST ESTIMATION IN INCOMPLETE 8LOCK DESICNS INDUCTIVE METHODS FOR BALANCED INCOMPLETE 8LOCK DESIGNS RANDOMIZED FRACTIONAL WEIGHING DESIGNS ON THE 8LOCK STRUCTURE OF SINGULAR GROUP DIVISIBLE DESIGNS ON PARTIALLY LINKED BLOCK DESIGNS A NOTE ON AUGMENTED DESIGNS AUGMENT ING 2-TO-THE-(N-1) DESIGNS

BALANCED L-RESTRICTIONAL PRIME POWERED LATTICE DESIGNS ON ROBUST ESTIMATION IN INCOMPLETE 8LOCK DESIGNS REDUCED GROUP DIVISI8LE PAIRED COMPARISON DESIGNS ASSOCIATION MATRICES AND THE KRONECKER PRODUCT OF DESIGNS A SERIES OF BALANCED INCOMPLETE 8LOCK DESIGNS SOME EXAMPLES OF MULTI-DTMENSIONAL INCOMPLETE BLOCK DESIGNS FURTHER SECOND ORDER ROTATA8LE DESIGNS SATURATED SEQUENTIAL FACTORIAL DESICNS

A NOTE ON BALANCED INCOMPLETE BLOCK DESIGNS SOME SYSTEMATIC EXPERIMENTAL DESIGNS THE EFFICIENCY OF BLOCKING IN INCOMPLETE 8LOCK DESIGNS ON A PROPERTY OF BALANCED DESIGNS ON BALANCED UNEQUAL BLOCK DESIGNS NESTED BALANCED INCOMPLETE BLOCK DESIGNS THE MEAN EFFICIENCY OF EQUI-REPLICATE DESIGNS CYCLIC CHANCE-OVER DESIGNS A COMPARISON OF SOME SEQUENTIAL DESIGNS CYCLIC INCOMPLETE 8LOCK DESIGNS 8ALANCED FACTORIAL DESIGNS

ON JOHN'S CYCLIC INCOMPLETE BLOCK DESIGNS THE COM8INATION OF INFORMATION IN GENERALLY 8ALANCED DESIGNS SOME NONORTHOGONAL FRACTIONS OF 2-TO-THE-N DESICNS INCOMPLETE SPLIT PLOT DESIGNS CONSTRUCTION OF SATURATED TWO TO THE POWER OF K-P DESIGNS OBSERVATIONS ON THE PRACTICAL ASPECTS OF WEIGHTING DESIGNS TEST FOR COMPARING MATCHED PROPORTIONS IN CROSSOVER DESIGNS $\begin{array}{rrr}\text { JASA } & 67 & 1121 \\ \text { JASA } & 57 & 204\end{array}$ TECH $59 \quad 139$ TECH $60 \quad 185$ AMS 61908 JASA $61 \quad 135$ JASA $61 \quad 368$ TECH 61 311 TECH $61 \quad 359$ TECH $61 \quad 389$ AMS $62 \quad 792$ TECH $62 \quad 489$ AMS 631057 TECH $63 \quad 71$ AMS $64 \quad 389$ AMS $64 \quad 673$ $\begin{array}{lll}\text { JASA } & 64 \quad 1217\end{array}$ TECH $64 \quad 389$ AMS 651526 AMS 651535 AMS $65 \quad 1807$ JASA $65 \quad 891$ TECH $65 \quad 69$ AMS $66 \quad 1836$ AMS $66 \quad 242$ AMS $66 \quad 783$ AMS $66 \quad 1331$ AMS 661348 AMS 661382 AMS 661398 AMS $\begin{array}{ll}66 & 1401\end{array}$ TECH $66 \quad 184$ TECH $66 \quad 469$ AMS $67 \quad 1127$ AMS $67 \quad 1587$ AMS $67 \quad 1887$ AMS $68 \quad 676$ AMS $68 \quad 681$ AMS $68 \quad 1577$ AMS 681995 TECH $68 \quad 535$ AMS 69679 BIOKA51 312 BIOKA60 273 8IOKA61 215 BIOKA62 561 BIOKA67 479 BIOKA68 251 BIOKA69 283 BIOKA69 301 JRSSB $66 \quad 345$ JRSSB $66 \quad 559$ JRSS867 243 JRSSB $68 \quad 303$ JRSSB 69 NO.2 8I0CS67 793 
CROUP DIVISIBLE PARTIALLY BALANCED INCOMPLETE BLOCK DESIGNS INTRA AND INTER BLOCK ANALYSIS OF CROUP DIVISIBLE DESIGNS FRACTIONS OF 2-TO-THE-N AND 3-TO-THE-N FACTORIAL DESICNS PROPERTY OF A CLASS OF BALANCED INCOMPLETE BLOCK DESIGNS OF CONFOUNDING PLANS FOR MIXED FACTORIAL DESIGNS

ESTIMATES OF THE INTERCLASS VARIANCE FOR UNBALANCED DESIGNS OF SYMMETRIC PARTIALLY-BALANCED INCOMPLETE BLOCK DESIGNS GENERATION OF ROBINSON'S BALANCED INCOMPLETE BLOCK DESIGNS AND CONSTRUCTION OF BALANCED INCOMPLETE BLOCK DESIGNS AND LINEAR TRENDS IN EIGHT-RUN TWO LEVEL FACTORIAL DESIGNS

OF SECOND-ORDER TENSORS, WITH RELATED TESTS AND DESIGNS FREE ANALYSIS OF VARIANCE TECHNIQUE FOR BLOCK DESIGNS ROTATABLE DESIGNS THROUGH BALANCED INCOMPLETE BLOCK DESICNS OBSERVATIONS AS AN ALTERNATIVE TO INCOMPLETE BLOCK DESIGNS WITH A CONTROL IN BALANCED INCOMPLETE BLOCK DESIGNS INTERSECTION OF BLOCKS OF BALANCED INCOMPLETE BLOCK DESIGNS ANALYSIS OF SOME CONFOUNDED ASYMMETRICAL FACTORIAL DESIGNS OF THE RANDOMIZATION TEST IN TWO ASSOCIATE PBIB DESIGNS ESTIMATORS FOR RANDOMIZED FRACTIONAL REPLICATION DESIGNS BALANCED AND PARTIALLY BALANCED INCOMPLETE BLOCK DESIGNS AND MIXED-UP OBSERVATIONS IN SEVERAL EXPERIMENTAL DESIGNS SOME NEW SERIES OF CONFOUNDED ASYMMETRICAL FACTORIAL DESICNS OF CERTAIN PARTIALLY BALANCED INCOMPLETE BLOCK DESIGNS REPRESENTATIVES WITH APPLICATIONS TO STATISTICAL DESIGNS ALANCED DESIGNS OF THE LATIN SQUARE TYPE AND RELATED DESIGNS WITHIN THE CLASS OF RANDOMIZED DESICNS, OF BALANCED DESIGNS OMPONENTS II EMPIRICAL STUDIES OF UNBALANCED NESTED DESIGNS FOR CONSTRUCTING PARTIALLY BALANCED INCOMPLETE BLOCK DESICNS CATION WITH APPLICATION TO BALANCED INCOMPLETE BLOCK DESIGNS ALANCED SET OF L-RESTRICTIONAL PRIME-POWERED LATTICE DESIGNS LOCKS OF CERTAIN PARTIALLY BALANCED INCOMPLETE BLOCK DESIGNS SUB-B-OVER-SICMA-SQUARE IN BALANCED INCOMPLETE BLOCK DESIGNS LOCKS OF CERTAIN PARTIALLY BALANCED INCOMPLETE BLOCK DESIGNS TO 6 WITH SPECIAL REFERENCE TO THE UNIQUE SATURATED DESIGNS OF TWO ASSOCIATE PARTIALLY BALANCED INCOMPLETE BLOCK DESICNS THE 2-TO-THE-N TIMES 3-TO-THE-N FACTORIAL SERIES OF DESIGNS $T$ OF TREATMENTS TO ANOTHER, PART 2, EXISTENCE OF THE DESIGNS LOCKS IN CERTAIN PARTIALLY BALANCED INCOMPLETE BLOCK DESIGNS MENTS BETWEEN BLOCKS OF SEMI-REGULAR GROUP DIVISIBLE DESIGNS OPTIMUM EXPERIMENTAL DESIGNS

SINGULARITY IN HOTELLINC'S WEIGHING DESIGNS RICAL TRIANGULAR PARTIALLY ON A BOUND USEFUL IN THE THEORY OF FACTORIAL DESIGNS AND ERROR CORRECTING CODES

METERS IN A TWO-STAGE NESTED PROCE/ COMPARISONS OF DESIGNS AND ESTIMATION PROCEDURES FOR ESTIMATING PARA TEC A.SYMMETRICAL ROTATABLE DESIGNS AND ORTHOGONAL TRANSFORMATIONS

DUALS OF PARTIALLY BALANCED INCOMPLETE BLOCK DESIGNS AND SOME NONEXISTENCE THEOREMS

ORTHOGONAL MAIN-EFFECT 2-TO-THE-N-TIMES-3-TO-THE-M DESICNS AND TWO-FACTOR INTERACTION ALIASINC RESIDUAL EFFECTS

(GORR 65 1036)

TREATMENTS

CHANGEOVER DESIGNS BALANCED FOR THE LINEAR COMPONENT OF FIRST

COMPOSITE DESIGNS BASED ON IRREGULAR FRACTIONS OF FACTORIALS FOUR-WAY BALANCED DESIGNS BASED ON YOUDEN SQUARES WITH 5, 6, OR 7 INCOMPLETE BLOCK DESICNS FOR BIO-ASSAYS

THE EFFICIENCY OF MODIFIED BALANCED INCOMPLETE BLOCK DESICNS FOR BIO-ASSAYS

TWO-STAGE DESIGNS FOR CLINICAL TRIALS

TRUNCATED SEQUENTIAL DESIGNS FOR CLINICAL TRIALS BASED ON MARKOV CHAINS

THE USE OF CYCLIC BALANCED INCOMPLETE BLOCK DESICNS FOR DIRECTIONAL SEED ORCHARDS DESIGNS FOR DISGRIMINATING BETWEEN TWO RIVAL MODELS

RECRESSION

ENTS

OPTIMAL EXPERIMENTAL DESIGNS FOR ESTIMATING THE INDEPENDENT VARIABLE IN OPTIMAL ACCELERATED LIFE DESIGNS FOR ESTIMATION

THE CONSTRUCTION OF BALANCED DESIGNS FOR EXPERIMENTS INVOLVING SEQUENGES OF TREATM RESPONSE SURFACE DESICNS FOR FACTORS AT TWO AND THREE LEVELS

THREE DIMENSIONAL MODELS OF EXTREME VERTICES DESIGNS FOR FOUR COMPONENT MIXTURES MIXTURE DESIGNS FOR FOUR FACTORS

RESPONSE SURFACE DESIGNS FOR MIXTURE PROBLEMS

A NOTE ON DESIGNS FOR MODEL DISCRIMINATION, VARIANCE UNKNOWN

CASE

ON A GENERAL CLASS OF DESIGNS FOR MULTIRESPONSE EXPERIMENTS

SIMPLEX LATTICE DESIGNS FOR MUTICOMPONENT SYSTEMS

THE USE OF CYCLIC BALANCED INCOMPLETE BLOCK DESIGNS FOR NON-DIRECTIONAL SEED ORCHARDS OPTIMUM DESIGNS FOR POLYNOMIAL EXTRAPOLATION

ADMISSIBLE DESIGNS FOR POLYNOMIAL SPLINE RECRESSION

ERRORS

ERRORS MANY PARAMETERS

ON

NOTES. OPTIMUM EXPERIMENTAL DESIGNS FOR REALIZED HERITABILITY ESTIMATES DESICNS FOR REGRESSION PROBLEMS WITH CORRELATED DESIGNS FOR REGRESSION PROBLEMS WITH CORRELATED

SERIAL DESIGNS FOR ROUTINE QUALITY CONTROL AND EXPERIMENTAT

ROTATION DESIGNS FOR SAMPLING ON REPEATED OCCASIONS DESIGNS FOR SEQUENCES OF TREATMENTS WITH CARRY-OVER

EFFECTS

EXPERIMENTAL DESICNS FOR SERIALLY CORRELATED OBSERVATIONS

SEQUENTIAL DESICNS FOR SPHERICAL WEIGHT FUNCTIONS

PAIRED COMPARISON DESICNS FOR TESTING CONCORDANCE BETWEEN JUDGES

VARIANCE THE CONSTRUCTION OF OPTIMAL DESIGNS FOR THE ONE-WAY GLASSIFICATION ANALYSIS OF DESIGNS FOR THE SEQUENTIAL APPLICATION OF FACTORS

F VARIANCE COMPONENTS FROM TWO-WAY CROSSED CLASSI/ DESIGNS FOR THE SIMULTANEOUS ESTIMATION OF FUNCTION
SOME NEW THREE LEVEL DESIGNS FOR THE STUDY OF QUANTITATIVE VARIABLES ERRATA, 'SOME NEW THREE LEVEL DESIGNS FOR THE STUDY OF QUANTITATIVE VARIABLES' MIXTURE DESTGNS FOR THREE FACTORS

RESPONSE SURFACE DESIGNS FOR THKEE FAGTORS AT THREE LEVELS SOME BALANCED INCOMPLETE BLOCK DESIGNS FOR TWO SETS OF TREATMENTS
681 $18 \mathrm{~B}$ 569 278 256 493 528 574 361 301 9 421 464 200 0.4 696 865 91 813 999 978 MS $62 \quad 1175$ AMS $69 \quad 40 B$ AMS 671293 AMS $66 \quad 739$ IOKA68 254 254
337 337 46 285 0. 4 B67 272 AMS 661021 AMS $63 \quad 34 \mathrm{~B}$ AMS $64 \quad 408$ TECH $67 \quad 499$ TECH $68 \quad 313$ AMS 661048 TECH 6B 559 BIOKA68 297 BIOCS65 324 BIOCS67 803 BIOCS66 706 ON BIOCS69 591 BIOCS69 111 BIOCS68 159 BIOCS67 761 TECH $65 \quad 307$ TECH $68 \quad 811$ TECH $62 \quad 381$ BIOKA52 32

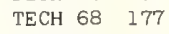
TECH $67 \quad 472$ JRSSB $65 \quad 473$ TECH $68 \quad 739$ TECH $69 \quad 396$ AMS $68 \quad 1825$ TECH 62463 BI0CS69 561 AMS 651483 AMS 691557 BIOCS67 361 AMS $66 \quad 66$ AMS $68 \quad 49$ TECH $64 \quad 77$ JASA $64 \quad 492$ BIOCS66 292 BIOKA52 151 TECH $67 \quad 517$ BIOKA56 113 JRSSB $61 \quad 352$ TECH $64 \quad 365$ BIOKA67 127 TECH $60 \quad 455$ TECH $61 \quad 576$ JRSSB 65450 TECH 59 BIOKA66 497 
SOME ROW AND COLUMN DESICNS FOR TWO SETS OF TREATMENTS

SOME METHODS OF CONSTRUCTION OF DESICNS FOR TWO-WAY ELIMINATION OF HETEROCENEITY, I ON OBTAINING BALANCED INCOMPLETE BLOCK DESIGNS FROM PARTIALLY BALANCED ASSOCIATION SCHEMES

IDENTITY RELATIONSHIPS FOR TWO TO THE POWER OF N-R DESICNS HAVINC WORDS OF EQUAL LENCTHS ALLOCATION TWO THIRD ORDER ROTATABLE DESICNS IN FOUR DIMENSIONS

FOR THE CONSTRUCTTON OF SECOND ORDER ROTATABLE DESICNS IN K DIMENSIONS

LOSS FUNCTION OPTIMAL DESICNS IN RECRESSION PROBLEMS WITH A GENERAL CONVEX OPTIMUM DESIGNS IN REGRESSION PROBLEMS, II

SEQUENTIAL ANALYSIS APPLIED TO CERTAIN EXPERIMENTAL DESIGNS IN THE ANALYSIS OF VARIANCE

THE USE OF SEGOND-ORDER 'SPHERICAL' AND 'CUBOIDAL' DESIGNS IN THE WRONG REGIONS

THIRD ORDER ROTATABLE DESICNS IN THREE DIMENSIONS, SOME SPECIFIC DESIGNS

THIRD ORDER ROTATABLE DESIGNS IN THREE FACTORS. ANALYSIS MINIMAX DESIGNS IN TWO DIMENSIONAL REGRESSION

FOUR FACTOR ADDITIVE DESIGNS MORE GENERAL THAN THE GRECO-LATIN SQUARE

THREE FACTOR ADDITIVE DESICNS MORE GENERAL THAN THE LATIN SQUARE

BALANCED SETS OF BALANCED INGOMPLETE BLOCK DESIGNS OF BLOCK SIZE THREE NON-ORTHOGONAL DESICNS OF EVEN RESOLUTION

OPTIMAL AND EFFTCTENT DESIGNS OF EXPERTMENTS

LINEAR/ THE OCCURRENCE OF REPLICATIONS IN OPTIMAI, DESICNS OF EXPERIMENTS TO ESTIMATE PARAMETERS IN NON- JE MULTI-FACTOR DESIGNS OF FIRST ORDER

BAYES SEQUENTIAL DESIGNS OF FIXED SIZE SAMPLES FROM FINITE POPULATIONS REDUCED DESIGNS OF RESOLUTION FIVE EATER THEN OR EQUAL TO 5 AND THE SET OF EVEN 512-RUN DESIGNS OF RESOLUTION CREATER THEN OR EQUAL TO 6 WITH AMS 68 246 THE-N TTMES 3-TO-THE-M SERIES RESULTS ON FACTORTAL DESTGNS OF RESOLUTTON IV FOR THE 2-TO-THE-N AND 2-TO - TECH 69 431 SOME NEW FAMILIES OF PARTIALLY BALANCED DESIGNS OF THE LATIN SQUARE TYPE AND RELATED DESIGNS TECH 67 229 SOME FURTHER DESIGNS OF TYPE O-PP

CYI INDRTCALLY ROTATABLE DESIGNS OF TYPES 12 AND 3

AMS 611186

AMS $67 \quad 167$

TO ANOTHER, PART 1

SOME EXPERIMENTAL DESIGNS OF USE IN CHANGING FROM ONE SET OF TREATMENTS JRSSB57 154

SOME EXPERIMENTAL DESIGNS OF USE IN CHANCING FROM ONE SET OF TREATMENTS JRSSB57 163 SOME DESIGNS OF USE IN SEROLOGY OPTIMAL DESIGNS ON TCHEBYSCHEFF POINTS

CONSTRUCTION OF ROTATABLE DESIGNS THROUGH BALANCED INCOMPLETE BLOCK DESICNS EXPERIMENTAL DESIGNS TO ADJUST FOR TTME TRENDS

OF UNEQUAL S/ NOTES. APPLICATIONS OF NONORTHOGONAL DESIGNS TO SITUATIONS WHERE TREATMENTS OR BLOCKS ARE ON HOTELLING'S WEIGHING DESIGNS UNDER AUTO-CORRELATION OF ERRORS WEIGHING DESIGNS WHEN N IS ODD

REGIONS OF INTEREST DESIGNS WHICH MINIMIZE MODEL INADEQUACIES. CUBOIDAL

FACTORIAL REPLICATES OF THE TWO TO THE POWER OF M DESIGNS WITH BLOCKS ON CONSTRUCTINC THE EFFECTS THE ANALYSIS OF CHANCEOVER DESIGNS WITH COMPLETE BALANCE FOR FIRST RESIDUAL STIMATION OF VARIANCE COMPONENTS IN TWO-STAGE NESTED DESIGNS WITH COMPOSITE SAMPLES ONS

BALANCED INCOMPLETE BLOCK DESIGNS WITH DOUBLE GROUPING OF BLOCKS INTO REPLICATI AN ANALYSIS OF PAIRED COMPARISON DESIGNS WITH INCOMPLETE REPETITIONS

THE ANALYSIS OF LATIN SQUARE DESIGNS WITH INDIVIDUAL CURVATURES IN ONE DIRECTION

THE ANALYSIS OF VARIANCE OF DESIGNS WITH MANY NON-ORTHOGONAL CLASSIFICATIONS

IS OF A CLASS OF PARTIALLY BALANCED INCOMPLETE BLOCK DESIGNS WITH MORE THAN TWO ASSOCIATE CLASSES ANALYS CONSTRUCTION OF PARTIALLY BALANCED INCOMPLETE BLOCK DESIGNS WITH PARAMETERS V=28, N1=12, N2=15 AND P2 ( 1 , TREATMENT VARIANCES FOR EXPERIMENTAL DESIGNS WITH SERIALLY CORRELATED OBSERVATIONS BALANCED INCOMPLETE BLOCK DESIGNS WITH SETS OF IDENTICAL BLOCKS

A NEW FAMILY OF PARTIALLY BALANCED INCOMPLETE BLOCK DESIGNS WITH SOME LATIN SQUARE DESIGN PROPERTIES THE ANALYSIS OF VARIANCE OF SOME NON-ORTHOGONAL DESIGNS WITH SPLIT PLOTS OF TREATMENTS A NOTE ON INCOMPLETE BLOCK DESIGNS WITH THE NUMBER OF BLOCKS EQUAL TO THE NUMBER ETRICAL METHOD OF CONSTRUCTION OF PARTIALLY BALANCED DESIGNS WITH TWO ASSOCIATE CLASSES PARTIALLY BALANCED INCOMPLETE BLOCK DESIGNS WITH TWO-WAY CLASSIFICATION OF TREATMENTS BALANCED DESIGNS WITH UNEQUAL NUMBERS OF REPLICATES

A METHOD OF CONSTRUCTING BALANCED INCOMPLETE DESIGNS. RANK ANALYSIS OF INCOMPLETE BLOCK DESIGNS. I THE METHOD OF PAIRED COMPARISONS. ON A CEOM AMS 611177 AMS $69 \quad 175$ AMS $64 \quad 897$ BIOKA65 285 BIOKA52 324 $\begin{array}{lll}\text { ED COMPARISONS } & \text { RANK ANALYSIS OF INCOMPLETE BLOCK DESIGNS. II. ADDITIONAL TABLES FOR THE METHOD OF PAIR BIOKA54 502 } \\ \text { CORRIGENDA, 'THE RANK ANALYSIS OF INCOMPLETE BLOCK DESIGNS. II. ADDITIONAL TABLES FOR THE METHOD OF PAIR BIOKA64 } 288\end{array}$ AND POWER FOR/ RANK ANALYSIS OF INCOMPLETE BLOCK DESICNS. III. SOME LARGE-SAMPLE RESULTS ON ESTIMATION BIOKA55 450 A NEW CLASS OF DESICNS, CORR, 651250

TURES OF CERTAIN PARTIALLY BALANCED INCOMPLETE BLOCK DESIGNS, CORR. 67624 THE 2-TO-THE-(K-P) FRACTIONAL FACTORIAL DESICNS, II

SIBILITY AT INFINITY, WITHIN THE CLASS OF RANDOMIZED DESIGNS, OF BALANCED DESIGNS ERRATA. 'THE APPLICATION OF RANDOM BALANCE DESIGNS'

ERRATA, 'THE 2-TO-THE-(K-P) FRACTIONAL FACTORIAL DESIGNS'

'FINDING NEW FRACTIONS OF FACTORIAL EXPERIMENTAL DESIGNS'

CONTINUOUS SAMPLING PLANS UNDER DESTRUCTIVE TESTINC ESTIMATION FROM QUANTILES IN DESTRUCTIVE TESTINC

OF THE PROBABTI ITY OF DEFECTIVE FAILURE FROM DESTRUCTIVE TESTS

ON DETECTING CHANGES IN THE MEAN OF NORMAL VARIATES AMS 69116 PROCEDURES FOR DETECTING OUTLYING OBSERVATIONS IN SAMPLES $\quad$ TECH 69

A NOTE ON MEASUREMENT ERRORS AND DETECTTNG REAL DTFFERENCES

ADJACENT SIBS IN HUMAN FAMILIES WITH KNOWN VARIANCES

THE DETECTION OF A CORRELATION BETWEEN THE SEXES OF DETECTION OF BEST AND OUTLYING NORMAL POPULATIONS

JASA $61 \quad 314$ JASA $65 \quad 1035$ BIOKA61 457 THE DETECTION OF PARTIAL ASSOCIATION, 1. THE 2 BY 2 CASE JRSSB64 313 THE DETECTION OF PARTIAL ASSOCIATION, 2. THE GENERAL CASE JRSSB65 111 USTERING, A GENERALIZATION OF KNOX'S APPROACH TO THE DETECTION OF SPACE-TIME INTERACTIONS ON A QUICKEST DETECTION PROBLEM WEAK CONVERGENCE OF A SEQUENCE OF OUTCKEST DETECTION PROBLEMS

THE DISTRIBUTION OF THE DETERMINANT OF A COMPLEX WISHART DISTRIBUTED MATRIX A $67 \% 11$ AMS 682149 AMS $63 \quad 178$ ATE ANALYSIS AN ASYMPTOTIC DISTRIBUTION FOR THE DETERMINANT OF A NON-CENTRAL B STATISTIC IN MULTIVARI SASJ 68 77 MODELS 
IONS CLASSIFIED BY FAILURE RATE ON THE DETERMINATTON OF A SAFE LIFE FOR CLASSES OF DISTRIBUT TECH 68

A PROPERTY OF THE MULTINOMIAL DISTRIBUTION AND THE DETERMINATION OF APPROPRIATE SGORES

ON THE DETERMINATION OF CONFIDENCE LIMITS OF AN INDEX

CLASSIFICATION

A NOTE ON THE DETERMINATION OF CONNECTEDNESS IN AN N-WAY CROSS

BIOCS66 603

SIFICATION'

TECH $64 \quad 319$

PROBABILITY DISTRIBUTIONS ERRATA, ' A NOTE ON THE DETERMINATION OF CONNECTEDNESS IN AN N-WAY CROSS CLAS DETERMINATION OF PARAMETERS IN THE JOHNSON SYSTEM OF

SOME EXAMPLES OF BAYES' METHOD OF THE EXPERIMENTAL DETERMINATION OF PROBABILITIES A PRIORI

NERATING FUNCTIONS BY SOLVING DIFFERENTIAL EQ/

GIVEN PRODUCER'S AND CONSUMER'S RISK

D ON DUNCAN'S MODEL

THE DETERMINAIION OF SINGLE SAMPLING ATTRIBUTE PLANS WITH TECH 67

DETERMINATION OF THE EXACT OPTIMUM ORDER STATISTICS F TECH $6 \%$

RACE/ FORMAL EXPRESSIONS WHICH CAN BE USED FOR THE DETERMINATION OF THE OPERATING CHARACTERISTIC AND AVE JRSSB67 THE USE OF INTEGRAL TRANSFORMS TO DETERMINE EXPANSIONS OF DISTRIBUTION FUNCTIONS

ICAL ANALYSIS OF A RADIO-ACTIVE TRACER EXPERIMENT TO DETERMINE ROOT ACTIVITY IN POTATO PLANTS /E STATIST BI REPORTS

A METHOD TO DETERMINE THE RELIABILITY OF TELEMETRY SYSTEMS

BIOKA60

460

DISTRIBUTIONS DETERMINED BY CUTTING SIMPLEX WITH HYPERPLANES

JASA $62 \quad 686$

SEQUENTIALLY DETERMINED CONFIDENCE INTERVALS

FUNCTIONS

AN INTRINSICALLY DETERMINED MARKOV CHAIN

DETERMINING BOUNDS ON EXPECTED VALUES OF CERTAIN

AMS 681473

BIOKA57 279

AMS $67 \quad 934$

AMS 621454

AMS 69704

A CENERAL METHOD OF DETERMINING FIXED-WIDTH CONFIDENCE INTERVALS

QUERY + (ON FORMULA FOR DETERMINING THE INCIDENCE OF MUTANT GENES)

BIOCS65 750

N VARIANCE A SEQUENTIAL THREE HYPOTHESIS TEST FOR DETERMINING THE MEAN OF A NORMAL POPULATION WITH KNOW AMS 67 I365 MPLE RUN LENGTH OF A CUMUL/A SIMPLE PROCEDURE FOR DETERMINING UPPER AND LOWER LIMITS FOR THE AVERACE SA JRSSB67 263 R/ DISTRIBUTIONS DE FREQUENCES. INTERPRETATION DU DETERMINISME CENETIQUE DES CARACTERES QUANTITATIFS ET BIOCS68 277 WHILE THE INTERARRIVAL AND SERVING DISTRIBUTIONS ARE DETERMINISTIC AND CAMMA OF ORDER K RESPECTIVELY /. JRSSB63 477 SYSTEM GI-M-1

SYSTEM GI-M-1, A CORRECTION

THAN ONE COMMUNITY

DETERMTNISTTC CUSTOMER IMPATIENCE IN THE QUEUEING DETERMINISTIC CUSTOMER IMPATIENCE IN THE QUEUEING

THE DETERMINISTIC MODEL OF A SIMPLE EPIDEMIC FOR MORE

BIOKA60 45

BIOKA61 472

BIOKA55 126

WITH DETERMINISTIC REMOVALS SOME DEVELOPEMENTS IN 'DISTANCE SAMPLINC'

MULTIPLE REGRESSION IN PROCESS DEVELOPMENT

PHILIPPINE STATISTICAL PROCRAM DEVELOPMENT AND THE SURVEY OF HOUSEHOLDS

BIOCS67 207

TECH $68 \quad 257$

JASA 58 7B

SOCIETY MEMORIAL MEETING FOR WILLIAM N. HURWITZ. THE DEVELOPMENT OF HOUSEHOLD SAMPLE SURVEYS

ATISTICS. XVII. SOME REFLEXIONS ON CONTINUITY IN THE DEVELOPMENT OF MATHEMATICAL STATISTICS, 18B5-1920

THE DEVELOPMENT OF NUMERICAL CREDIT EVALUATION SYSTEMS

EXPERIMENTAL DEVELOPMENT OF NUTRITIVE MEDIA FOR MICRO-ORGANISMS

JASA 69 NO. 4

/ BIOKA67 341

JASA $63 \quad 799$

BIOKA68 43

ION PROBABILITIES BASED ON A MARKOV PROCESS DEVELOPMENT OF RANDOMIZED LOAD SEQUENCES WITH TRANSIT TECH 66

EM BY ITEM SELECTION TECHNIQUES AND DIGITAL COMP/ DEVELOPMENT OF SAMPLING PLANS BY USING SEQUENTIAL, IT JASA 62 CROSSROAD CHOICES FOR THE FUTURE DEVELOPMENT OF THE FEDERAL STATISTICAL SYSTEM

RY OF PROBABILITY AND STATISTICS. XV THE HISTORICAL DEVELOPMENT OF THE CAUSS LINEAR MODEL /IN THE HISTO BIOKAG

RELIABILITY GROWTH DURING A DEVELOPMENT TESTING PROGRAM

PRODUCTION AND CONTROL DEVICES AND EXPECTED FUTURE DEVELOPMENTS

THE PRESENT STATUS OF AUTOMATIC TECI

66 5 53

HOW DEVIANT CAN YOU BE

ON THE DISTRIBUTION OF THE EXTREME STUDENTIZED DEVIATE FROM THE SAMPLE MEAN

UPPER PERCENTAGE POINTS OF THE EXTREME STUDENTIZED DEVIATE FROM THE SAMPLE MEAN

OF PERCENTACE POINTS OF THE 'STUDENTIZED' EXTREME DEVIATE FROM THE SAMPLE MEAN

UPPER PERCENTAGE POINTS OF THE EXTREME STUDENTIZED DEVIATE FROM THE SAMPLE MEAN CHANCE CONSTRAINTS AND NORMAL DEVIATES

PROPERTIES OF POLYKAYS OF DEVIATES

CORRELATION OF RANGES OF CORRELATED DEVIATES

AN UPPER BOUND FOR THE SAMPLE STANDARD DEVIATION

ING CONFIDENCE INTERVALS FOR THE POPULATION STANDARD DEVIATION

ERRATA, AN UPPER BOUND FOR THE SAMPLE STANDARD DEVIATION

CONTROLLINC THE STANDARD DEVIATION BY CUSUMS AND WARNING LINES

CKNOWLEDGEMENT OF PRIORITY). 'A PROPERTY OF THE MEAN DEVIATION FOR THE PEARSON TYPE DISTRIBUTIONS'

ESTIMATINC THE MEAN AND STANDARD DEVIATION FROM A CENSORED NORMAL SAMPLE

73

JASA 681522

BIOKA59 467

BIOKA59 473

TABLES BIOKA52 189

REVISED BIOKA56 449

JASA $62 \quad 134$

AMS $64 \quad 1167$

BIOKA66 191

BIOKA56 496

TECH $62 \quad 134$

JASA 61260

TECH $63 \quad 307$

QUERY, CONFIDENCE INTERVAL FOR STANDARD DEVIATION FROM A SINGLE OBSERVATION

(A BIOKA67 333

BIOKA67 155

TECH $66 \quad 367$

E THE CORRECT USE OF THE SAMPLE MEAN ABSOLUTE DEVIATION IN CONFIDENCE INTERVALS FOR A NORMAL VARIAT

THE USE OF THE RANCE IN PLACE OF THE STANDARD DEVIATION IN STEIN'S TEST

ORMAL POPULATION WHEN AN UPPER BOUND TO THE STANDARD DEVIATION IS KNOWN /ROCEDURE WITH A SAMPLE FROM A N JASA 60 94 THE TRENTILE DEVIATION METHOD OF WEATHER FORECAST EVALUATION JASA 58 39B

TESTING THE MEAN AND STANDARD DEVIATION OF A NORMAL DISTRIBUTION USING QUANTILES TECH 6B 781

CONFIDENCE INTERVALS BASED ON THE MEAN ABSOLUTE DEVIATION OF A NORMAL SAMPLE

IN SETTINC EXACT CONFIDENCE BOUNDS FOR THE STANDARD DEVIATION OF A RECTANGULAR POPULATION /AMPLE RANGES JASA 6I 601 APPROXIMATIONS TO THE MEAN AND STANDARD DEVIATION OF RECIPROCALS OF OBSERVATIONS THE MAXIMUM DEVIATION OF SAMPLE SPECTRAL DENSITIES $\quad$ AMS $67 \quad 155 \mathrm{~B}$ ON THE MAXIMUM DEVIATION OF THE SAMPLE DENSITY AMS $67 \quad 475$

A NOTE ON THE FIRST TWO MOMENTS OF THE MEAN DEVIATION OF THE SYMMETRICAL MULTINOMIAL DISTRIBUTION BIOKA67 312 ARE NOT ATTRACTED TO THE NORMAL LAW ON LARGE DEVIATION PROBLEMS FOR SUMS OF RANDOM VARIABLES WHICH ERRATA, 'AN UPPER BOUND FOR THE SAMPLE STANDARD DEVIATION'

LINEAR CURVE FITTINC USING LEAST DEVIATIONS

CONVERGENCE RATES FOR PROBABILITIES OF MODERATE DEVIATIONS

ON THE CUMULATIVE EFFECT OF CHANCE DEVIATIONS

APPROXIMATION USING THE CRITERION OF LEAST TOTAL DEVIATIONS (ACKNOWLEDGEMENT 67 587)

NC THE CORRELATION COEFFTCIENT FROM THE RANGE OF THE DEVTATIONS ABOUT THE REDUCED MAJ ON THE PROBABILITY OF LARCE DEVIATIONS AND EXACT SLOPES

A NOTE ON CURVE FITTING WITH MINIMUM DEVIATIONS BY LINEAR PROGRAMMING, CORR 62917

INDEPENDENT RANDOM VA/ ON THE PROBABILITY OF LARGE DEVIATIONS FROM THE EXPECTATION FOR SUMS OF BOUNDED, ON THE PROBABILITY OF LARGE DEVIATIONS OF FAMILIES OF SAMPLE MEANS AMS 671575 TECH $63 \quad 417$ JASA 5B 11B AMS 682016 JRSSB 44269

LINEAR JRSSB $67 \quad 101$ MAJOR AXIS /R ESTIMATI BIOKA53 21B AMS 69 N0.6 JASA $61 \quad 359$ BI OKA63 528 AMS 641304 VE DISTRIBUTION FUNCT/ ON THE PROBABILITY OF LARGE DEVIATIONS OF FUNCTIONS OF SEVERAL EMPIRICAL CUMULATI AMS 67 360 GULAR EVENTS DISPLACED IN TIME BY INDEPENDENT RANDOM DEVIATIONS OF LARCE DISPERSION /NTERVALS BETWEEN RE JRSSB6I 476 ERVAL OF LENCTH ONE

ON THE PROBABILITY OF LARGE DEVIATIONS OF THE MEAN FOR RANDOM VARIABLES IN AN INT

AMS $65 \quad 2 B 0$ 
THE DISTRIBUTION OF THE MEAN HALF-SQUARE SUCCESSIVE DIFFERENCE

\section{REGRESSION} PPROXIMATIONS FOR MEAN SQUARE SUCCESSIVE DIFFERENCE CRITICAL VALUES

QUEUE EFFICIENT DIFFERENCE EQUATION ESTIMATORS IN EXPONENTIAL $\begin{array}{rrr}\text { TECH } & 68 & 397 \\ \text { AMS } & 68 & 163 \mathrm{~B}\end{array}$ JRSSB58 165

UEUE WITH ARBITRARY ARRIVAL INTERVAL DISTRIBUTI/A DIFFERENCE EQUATION TECHNIQUE APPLIED TO THE SIMPLE Q JR A NOTE ON STOCHASTIC DIFFERENCE EQUATIONS

OF NON-STATIONARY SYSTEMS OF LINEAR STOCHASTIC DIFFERENCE EQUATIONS

OF ESTTMATORS OF PARAMETERS IN EXPLOSIVE STOCHASTIC DIFFERENCE EOUATIONS STABI ITY OF SOTERS A SIGNIFICANCE TEST FOR THE DIFFERENCE IN EFFICIENCY BETWEEN TWO PREDICTORS ON THE DISTRIBUTION OF THE WEIGHTED DIFFERENCE OF TWO INDEPENDENT STUDENT VARIABLES GINI'S MEAN DIFFERENCE REDISCOVERED

A NOTE ON MEAN SQUARE SUCCESSIVE DIFFERENCES

A NOTE ON MEASUREMENT FRRORS AND DETEGTING REAL DIFFERENCES CONVERGENCE OF SUMS OF SQUARES OF MARTINGALE DIFFERENCES DISCRIMINATION IN THE CASE OF ZERO MEAN DIFFERENCES STRIBUTIONS ARISING IN THE STUDY OF GENERALIZED MEAN DIFFERENCES LINEAR REGRESSION ANALYSIS WITH ADJUSTMENT FOR CLASS DIFFERENCES MATES FOR STANDARD DEVIATION BASED ON SECOND VARIATE DIFFERENCES

OF SOME MEASURES OF DISPERSION BASED ON SUCCESSIVE DIFFERENCES

$S$ OF INDEPENDENT AND RANDOM VARIABLES AND MARTTNGALE DIFFERENCES

LE BIRTH AND DEATH PROCESSES PERENCES MULTTPLE JASA 61

DISTRIBUTION THEORY OF TWO ESTI BIOKA54 APPROXIMATIONS TO THE DISTRIBUTIONS BIOKA57 349 /SURE CONVERGENCE OF LINEAR COMBINATION AMS 681549 NORMAL APPROXIMATION JASA 67 DIFFERENCES BETWEEN SPECIES GROWING ACCORDINC TO SIMP BIOKA53 370 OCCUPATIONAL COMPONENTS

CARLO STUDY COMPARING VARIOUS TWO-SAMPLE TESTS FOR DIFFERENCES IN MEAN JASA $61 \quad 783$ ON VARIANCES OF RATIOS AND THEIR DIFFERENCES IN MULTI-STACE SAMPLES, CORR, 631162 OBABILITY TABLE FOR NUMBER OF RUNS OF SIGNS OF FIRST DIFFERENCES IN ORDERED SERIES NOTE ON THE VARIATE DIFFERENCES OF AUTOREGRESSIVE SERIES BIOKA5I 479 THE GENERALIZED MEAN DIFFERENCES OF THE BINOMIAL AND POISSON DISTRIBUTIONS BIOKA59 223 AN ASYMPTOTIC FORMULA FOR THE DIFFERENCES OF THE POWERS AT ZERO STRIBUTIONS ARISINC IN THE STUDY OF GENERALIZED MEAN DIFFERENCES '

VAN WAARSKYNLIKHEIDSVERDELINGS DEUR DIE GEBRUIK VAN DIFFERENSIAALVERCELYKINCE CORRIGENDA, 'SOME DI BIOKA6I 230 TESTINC OF MEANS WITH DIFFERENT ALTERNATIVES

TION INTO TWO MULTIVARIATE NORMAL DISTRIBUTIONS WITH DIFFERENT COVARIANCE MATRICES

RELATIONSHIPS AMONG THE VON MISES DISTRIBUTIONS OF DIFFERENT DIMENSIONS ECTS OF PARTIAL ISOLATION (DISTANCE), MIGRATION, AND DIFFERENT FITNESS REQUIREMENTS AMONG ENVIRONMENTAL PO BIOCS66 453

THE RELATIVE SENSITIVITY TO SPECIFICATION ERROR OF DIFFERENT K-CLASS ESTIMATORS POPULATIONS

DIFFERENT LOSS FUNCTION FOR THE CHOICE BETWEEN TWO

PARTITIONING OF A PATIENT POPULATION WITH RESPECT TO DIFFERENT MORTALITY RISKS SSOCIATION BETWEEN TWO BINARY CHARACTERISTICS IN TWO DIFFERENT POPULATIONS ON COMPARING INTENSITIES OF A JASA 61 889 TS

A COMPARISON OF THREE DIFFERENT PROCEDURES FOR ESTIMATING VARIANCE COMPONEN TECH 63

ANALYSIS OF PLANT COMPETITION EXPERIMENTS FOR DIFFERENT RATIOS OF SPECIES

EXPECTATIONS OF ORDER STATISTICS IN SAMPLES OF DIFFERENT SIZES

ON COMPARING DIFFERENT TESTS OF THE SAME HYPOTHESIS

ON THE PROBABILITY OF WINNING WITH DIFFERENT TOURNAMENT PROCEDURES

BY L. TACAKS ON THE INTEGRABILITY, CONTINUITY AND DIFFERENTIABILITY OF A FAMILY ON FUNCTIONS INTRODUCED INFINITELY DIFFERENTIABLE POSITIVE DEFINITE FUNCTIONS INCENTIVE CONTRACTS AND PRICE DIFFERENTIAL ACCEPTANCE TESTS 
ESTIMATION OF PARAMETERS IN SYSTEMS OF STOCHASTIC DIFFERENTIAL EQUATIONS

ON MEAN USING TRANSFORMED SAMPLE DATA ON THE DIFFICULTIES INHERENT IN FISHER'S FIDUCIAL ARGUMENT JASA 69953 DIFFICULTIES INVOLVED IN THE ESTIMATION OF A POPULAT JASA $64 \quad 56$

AN EXPERIMENT WITH WEIGHTED INDEXES OF CYCLICAL DIFFUSION

TECH $66 \quad 535$ CORRELATION, POWER-LAW COVARIANCE FUNCTIONS, AND DIFFUSION

DEVICE

ERROR-DISTR IBUTIONS

FOUR COMPONENT MIXTURES

FUNCTION ON THE SQUARE

BARRIER
DIMENSIONAL CHAINS INVOLVING RECTANGULAR AND NORMAL

THREE DIMENSIONAL MODELS OF EXTREME VERTICES DESICNS FOR DIMENSIONAL PROPERTIES OF A RANDOM DISTRIBUTION

ONE DTMENSIONAL RANDOM WALK WITH A PARTIALLY REFLECTINC
MINIMAX DESICNS IN TWO DIMENSIONAL RECRESSION

AMS 691474 AMS $69 \quad 743$

TECH $63 \quad 404$ TECH $67 \quad 472$ AMS $66 \quad 849$ AMS $63 \quad 405$ AMS 651097 E COMPUTING ROUTINE FOR TESTS OF SIGNIFICANCE ON THE DIMENSIONALITY OF NORMAL MULTIVARIATE SYSTEMS /F TH JRSSB56 70 TWO THIRD ORDER ROTATABLE DESICNS IN FOUR DIMENSIONS CONSTRUCTION OF SECOND ORDER ROTATABLE DESICNS IN K DIMENSIONS PROBLEM RELATED TO STATISTICAL DISTRIBUTIONS IN TWO DIMENSIONS AMONG THE VON MISES DISTRIBUTIONS OF DIFFERENT DIMENSIONS

CO/VECTORIAL ANALYSIS FOR CENETIC CLINES IN BODY DIMENSIONS CLUSTERINC OF RANDOM POINTS IN TWO DIMENSIONS

THIRD ORDER ROTATABLE DESICNS IN THREE DIMENSIONS, SOME SPECIFIC DESIGNS

A METHOD FOR $64 \quad 445$ A MAXIMUM-MINIMUM BIOKA57 384 SOME RELATIONSHIPS BIOKA66 269 IN POPULATIONS OF 'DROSOPHILIA SUBOBSCURA' BIOCS66 .469 BIOKA65 263 AMS 61910 E OF GENE LOSS OF FOUR METHODS OF REPRODUCING FINITE DIPLOID POPULATIONS /INBREEDING COEFFICIENT AND RAT BIOCS65 447 $S$ OF EQUAL MAGN/ GENETIC COMPONENTS FOR NON-INBRED DIPLOID SPECIES HAVING ALL DIGENIC EPISTATIC VARIANCE BIOCS69 545 PARAMETER A COMPARISON OF THE DIRECT AND FIDUCIAL ARGUMENTS IN THE ESTIMATION OF A JRSSB63 PANSION FOR CUMULATIVE HYPERCEOMETRIC PROBABILITIES, DIRECT AND INVERSE A QUICKLY CONVERGENT EX BIOKA54 A NOTE ON DIRECT AND INVERSE BINOMIAL SAMPLING
PANSION FOR CUMULATIVE HYPERCEOMETRIC PROBABILITIES, DIRECT AND INVERSE' /ENDA, 'A QUICKLY CONVERCENT EX BIOKA55 277 A NOTE ON DIRECT AND INVERSE BINOMIAL SAMPLING
PANSION FOR CUMULATIVE HYPERCEOMETRIC PROBABILITIES, DIRECT AND INVERSE' /ENDA, 'A QUICKLY CONVERCENT EX BIOKA55 277 SOME DIRECT ESTIMATES OF THE MODE AMS $65 \quad 131$ POPULATION MODELS ON THE USE OF THE DIRECT MATRIX PRODUCT IN ANALYSING CERTAIN STOCHASTIC BIOKA66 397 SEQUENTIAL ANALYSIS, DIRECT METHOD

OF THE MEAN OF A NORMAL DISTRIBUTION

DIRECT METHODS FOR EXACT TRUNCATED SEQUENTIAL TESTS

TECH $68 \quad 125$ TECH 69 NO 4 JRSSB $63 \quad 100$ ON DIRECT PROBABILITIES

THE CALCULUS OF FACTORIAL ARRANGEMENTS. I. BLOCK AND DIRECT PRODUCT DESICN APPLICATIONS OF NON-PARAMETRIC METHODS IN DILUTION (-DIRECT) ASSAYS

IN THE ESTIMATION OF RELATIVE POTENCY IN DILUTION (-DIRECT) ASSAYs

SQUARE DESIGNS WITH INDIVIDUAL CURVATURES IN ONE DIRECTION

SOME FURTHER BIOCS65 799 $\begin{array}{lll}\text { TRIBUTION-FREE METHODS BIOCS66 } & 610 \\ \text { THE ANALYSIS OF LATIN JRSSB5B } & 193\end{array}$ ANALYSIS A NOTE ON DIRECTION AND COLLINEARITY FACTORS IN CANONICAL BIOKA62 255 ANALYSI ON THE DISTRIBUTIONS OF DIRECTION AND COLLINEARITY FACTORS IN DISCRIMINANT AMS $68 \quad 855$ USE OF CYCLIC BALANCED INCOMPLETE BLOCK DESIGNS FOR DIRECTIONAL SEED ORCHARDS THE BIOCS67 761 NOTES EXPECTED SELECTION DTFFERENTIAL FOR POSTTIVE DIRECTIONAL SELECTION ON NORMAL VARIABLES WITHIN SETS BIOCS67 842 MULTI-SAMPLE TESTS FOR THE FISHER DISTRIBUTION FOR DIRECTIONS ASSOCIATED DIRECTIONS POINTS AND APPLICATION TO TESTING FOR RANDOMNESS OF DIRECTIONS /TH THE UNIFORM DISTRIBUTION, PERCENTAGE BIOKA66 235 TESTS FOR RANDOMNESS OF DIRECTIONS ACAINST TWO CTRCULAR ALTERNATIVES EXACT AND APPROXIMATE TESTS FOR DIRECTIONS. I EXACT AND APPROXIMATE TESTS FOR DIRECTIONS. II

DENCE FOR PROPORTIONS WITH A A GENERALIZATION OF THE DIRICHLET DISTRIBUTION 1251 THE INVERTED DIRICHLET DISTRIBUTION NONCENTRAL MULTIVARIATE DIRICHLET DISTRIBUTIONS

CRAPHIC COMPUTATION OF TAU AS A COEFFICIENT OF DISARRAY

'CRAPHIC COMPUTATION OF TAU AS A COEFFICIENT OF DISARRAY THE DISCARDING

QUEUEING, IDLENESS PROBABILITIES UNDER PRIORITY DISCIPLINES A DISCONTINUITY IN MIXED MODEL ANALYSIS

THE MEAN DIFFERENCE AND THE MEAN DEVIATION OF SOME DISCONTINUOUS DISTRIBUTIONS UESTIONS RAISED BY THE COMBINATION OF TESTS BASED ON DISCONTINUOUS DISTRIBUTIONS. NOTE ON A DISCONTINUOUS PROBABILITY DENSITY OF TWO-DIMENSIONAL STATIONARY PROCESSES WITH DISCONTINUOUS SPECTRA BIOKA62 463 BIOKA62 547

CONCEPTS OF INDEPEN JASA 69194 JASA $65 \quad 793$ SASJ $67 \quad 21$ JASA $58 \quad 441$ A NOTE ON GRIFFIN'S PAPER JASA 6I 736 BIOKA67 357 JRSSB63 489 BIOCS69 573 BIOKA5B 549

CORRIGENDA, 'ON Q BIOKA5I 265 BIOKA5B 270 THE ANALYSIS BIOKA64 195 
AN OPTIMALITY AMS $68 \quad 1220$ POLICIES IN DISCRETE DYNAMIC PROCRAMMING WITH NO DISCOUNTINC ON FINDING OPTIMAL AMS 661284 STOPPING RULES

OF TESTS

AN EXAMPLE OF DISCREPANCIES IN INFERENCES UNDER NON-INFORMATIVE

BIOKA67 329

AN EXAMPLE OF LARCE DISCREPANCY BETWEEN MEASURES OF ASYMPTOTIC EFFICIENCY

THE TIM

ON THE STATISTICAL DISCREPANCY IN THE REVISED UNITED STATES NATIONA

AMS $68 \quad 179$

JASA $66 \quad 1219$

JRSSB61 173

AMS 61448 MULTIVARTATE CORRELATION MODELS WTTH MTED DTSCRETE AND CONTINUOUS VARIABLES, CORR, 65343

THE ASYMPTOTIC BEHAVIOR OF BAYES' ESTIMATES IN THE DISCRETE CASE

CONFIDENCE INTERVALS FOR LOCATION PARAMETERS IN THE DISCRETE CASE

TESTS FOR THE MEAN OF A NORMAL DISTRIBUTION IV, DISCRETE GASE

ON THE ASYMPTOTIC BEHAVIOR OF BAYES ESTIMATES IN THE DISCRETE CASE II

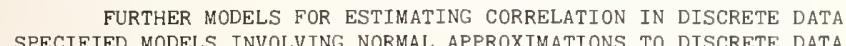

ON AMS $63 \quad 13 B 6$

IAL DISTRIBUTION IN THE ESTIMATION OF CORRELATION IN DISCRETE DATA

EQUATION FOR PROBABILITIES

THEORY OF AGCIDENT PRONENESS

ON A DISCRETE DISTRIBUTION WITH SPECIAL REFERENCE TO THE

THE COMBINATION OF TESTS BASED ON DISCRETE DISTRIBUTIONS

REMARKS ON LARGE SAMPLE ESTIMATORS FOR SOME DISCRETE DISTRIBUTIONS

NOTE ON A CERTAIN FAMILY OF DISCRETE DISTRIBUTIONS

WILCOXON JASA $67 \quad 184$

SEQUENTIAL AMS $65-55$

AMS $65 \quad 454$

JRSSB64 82

ON GERTAIN CHARACTERTSTTCS OF SOME DISCRETE DISTRIBUTTONS

SMOOTH EMPIRICAL BAYES ESTIMATION FOR ONE-PARAMETER DISCRETE UISTRIBUTIONS

ON A SYSTEM OF DISCRETE DISTRIBUTIONS

NSON'S PROPERTY OF THE MEAN DEVIATION FOR A CLASS OF DISGRETE DISTRIBUTIONS

\section{SIGNIFICANCE TESTS IN DISCRETE DISTRIBUTIONS, CORR. 62919}

DISCRETE DYNAMIC PROGRAMMING

RATE

DISCRETE DYNAMIC PROGRAMMING WITH A SMALL INTEREST

ON FINDING OPTIMAL POLICIES IN DISCRETE DYNAMIC PROGRAMMING WITH NO DISCOUNTING

AN OPTIMALITY CONDITION FOR DISCRETE DYNAMIC PROCRAMMING WITH NO DISCOUNTING

DISCRETE DYNAMIC PROGRAMMING WITH SENSITIVE DISCOUNT

OPTIMALITY GRITERIA

AND DISTRIBUTION OF SOME PROBABILISTIC FUNCTIONS OF DISCRETE FINITE STATE MARKOV CHAINS
S/ A STUDY OF THE MATRIX OF FITTINC OF A SERIES OF DISCRETE FREQUENCY FUNCTIONS ANALOCOUS TO THE TYPE A A SIMPLE PROBABILISTIC PROOF OF THE DISCRETE GENERALIZED RENEWAL THEOREM

INTERPOLATION OF HOMOGENEOUS RANDOM FIELDS ON DISCRETE GROUPS

SOME METHODS OF ESTIMATING THE PARAMETERS OF DISCRETE HETEROCENEOUS POPULATIONS

A BOUND FOR THE LAW OF LARCE NUMBERS FOR DISCRETE MARKOV PROCESSES

EXPONENTIAL BOUNDS ON THE PROBABILITY OF ERROR FOR A DISCRETE MEMORYLESS CHANNEL

A NOTE ON CERTAIN DISCRETE MIXED DISTRIBUTIONS

TION OF EXAGT SAMPLING DISTRIBUTION OF RANGES FROM A DISCRETE POPULATION"

THE EFFICIENCY OF TWO-SAMPLE MANN-WHITNEY TEST FOR DISCRETE POPULATIONS

ORDER STATISTICS FOR DISCRETE POPULATIONS AND FOR GROUPED SAMPLES

CORRECTION

ORDER STATISTICS FOR DISCRETE POPULAT
THE SPECTRUM OF A CONTINUOUS PROCESS DERIVED FROM A DISCRETE PROCESS

ON OF THE SUM OF INDEPENDENT IDENTICALLY DISTRIBUTED DISCRETE RANDOM VARIABLES, CORR. 66 I246 /ISTRIBUTI J STOGHASTIC PROCESSES

\{WITH DISCUSSION

DISCRETE SAMPLES AND MOVING SUMS IN STATIONARY

ON DISCRETE STABLE POPULATION THEORY

DISCRETE STOCHASTIC PROCESSES IN POPULATION GENETICS

THE DISCRETE STUDENT'S DISTRIBUTION

TIVE METHOD OF DYNAMIG PROGRAMMING ON A FINITE SPACE DISCRETE TIME MARKOV PROCESS

A TRANSIENT DISCRETE TIME QUEUE WITH FINITE STORACE

ON THE ITERA

ON CERTAIN REDUNDANT SYSTEMS WHTCH OPERATE AT DISCRETE TIMES

SIAN NOISE LARGE SAMPLE ESTIMATION OF AN UNKNOWN DISCRETE WAVEFORM WHICH IS RANDOMLY REPEATING IN GAUS AMS 65 4B9

S A NOTE ON SOME APPROXIMATIONS TO THE VARIANCE IN DISCRETE-TIME STOCHASTIC MODELS FOR BIOLOGICAL SYSTEM BIOKA6O 196 A GENERAL MAXIMUM LIKELIHOOD DISCRIMINANT

ESTIMATION OF ERROR RATES IN DISCRIMINANT ANALYSIS

A NOTE ON AN APPROXIMATE FACTORIZATION IN DISCRIMINANT ANALYSIS

PROBABILITIES OF CORRECT CLASSIFICATION IN DISCRIMINANT ANALYSIS MISSING VALUES IN LINEAR MULTIPLE DISCRIMINANT ANALYSIS

STRIBUTIONS OF DIRECTION AND COLLINEARITY FACTORS IN DISCRIMINANT ANALYSIS

VTERVALS FOR THE PROBABILITY OF MISCLASSIFICATION IN DISCRIMINANT ANALYSIS

MISGLASSIFIED

DISCRIMINANT ANALYSIS /OD OF OBTAINING CONFIDENCE
DISCRIMINANT ANALYSIS WHEN THE INITIAL SAMPLES ARE

WHEN THE INITIAL SAMPLES ARE

BIOCS67 313

TECH $6 \mathrm{~B}$

BIOKA67 665

BIOCS66 908

BI OCS68 835

ON THE DI AMS $68 \quad 855$

COMMENTARY ON ' ESTIMATION OF ERROR RATES IN DISCRIMINANT ANALYSIS

ON THE PERFORMANCE OF THE LINEAR DISCRIMINANT FUNCTION

MPTOTIC EXPANSION FOR THE DISTRIBUTION OF THE LINEAR DISCRIMINANT FUNCTION

VARIANCE-COVARIANCE MATRICES ON FISHER'S LINEAR DISCRIMINANT FUNCTION

AND RELATED PROBLEMS

THE EFFECT OF UNEQUAL

NOTES. EQUIVALENCE OF TWO METHODS OF COMPUTING DISCRIMINANT FUNCTION COEFFICIENTS

NOTES.COMPUTING A DISCRIMINANT FUNCTION FROM WITHIN-SAMPLE DISPERSIONS

A COMPARISON OF SUCCESSTVE SCREENTNG AND DISCRIMINANT FUNCTTON TECHNIQUES IN MEDICAL TAXONOMY

PROPORTIONAL

DISTRIBUTION OF DISCRIMINANT FUNCTION WHEN COVARIANCE MATRICES ARE

GROWTH-INVARIANT DISCRIMINANT FUNCTIONS AND GENERALIZED DISTANCES

TECH $66 \quad 657$

BIOCS68 823

TECH $68 \quad 204$

TECH $64 \quad 179$

AN ASY AMS $63 \quad 12 B 6$

SHIPS

SIGNIFICANCE TESTS FOR DISCRIMINANT

ESTIMATION ASSOCIATED WITH LINEAR DISCRIMINANTS

IN RELIABILITY PREDICTIONS

A METHOD FOR DISCRIMINATING BETWEEN FAILURE DENSITY FUNCTIONS USED

A TEST FOR DISCRIMINATING BETWEEN MODELS

DESICNS FOR DISCRIMINATING BETWEEN TWO RIVAL MODELS

SAMPLING INSPECTION PLANS FOR DISCRIMINATING BETWEEN TWO WEIBULL PROCESSES

ERRORS IN DISCRIMINATION

A REMARK ON SEQUENTIAL DISCRIMINATION

GEOMETRY AND LINEAR DISCRIMINATION

PREDICTIVE ZERO-MEAN UNIFORM DISCRIMINATION
BI0CS69 505

BIOKA66 339

BIOCS67 153

BI0CS65 1011

BIOCS69 No.4 AMS 69979 BIOCS66 96 I OKA55 360 AMS $67 \quad 807$ PECH 65 TECH $65 \quad 307$ TECH $65 \quad 5 B 9$ AMS 611125 AMS 671666 BIOKA60 185 BIOKA68 519 
DISCRIMINATION AMONG MECHANISTIC MODELS MODELS

DISCRIMINATION BETWEEN K POPULATIONS WITH CONSTRAINTS JRSSB69 123

ON THE PROBABILITIES OF MISCLASSIFICATION OR DISCRIMINATION BETWEEN TWO COMPOSITE HYPOTHESES THE DISCRIMINATION BETWEEN TWO WEIBULL PROCESSES

MATRICES ERRATA, 'THE DISCRIMINATION BETWEEN TWO WEIBULL PROCESSES A NOTE ON DISCRIMINATION IN THE CASE OF UNEQUAL COVARIANCE DISCRIMINATION IN THE CASE OF ZERO MEAN DIFFERENCES DISCRIMINATION IN TIME-SERIES ANALYSIS

A NOTE ON MINIMUM DISCRIMINATION INFORMATION

NOTES. MINIMUM DISCRIMINATION INFORMATION ESTIMATION DISCRIMINATION INTERVALS FOR PERCENTILES IN

REGRESSION UNL IMITED SIMUTANEOUS DISCRIMINATION INTERVALS

\section{ELIMINATION OF VARIATES IN LINEAR DISCRIMINATION PROBLEMS$$
\text { SINGLE AND MULTIPLE DISCRIMINATION REGIONS IN MULTIPLE LINEAR REGRESSION }
$$
ON DISCRIMINATION USING QUALITATIVE VARIABLES

NONPARAMETRIC DISCRIMINATION USING TOLERANCE REGIONS A NOTE ON DESIGNS FOR MODEL DISCRIMINATION, VARIANCE UNKNOWN CASE

PL JASA $66 \quad 357$ TECH $64 \quad 57$ TECH 64240 BIOKA68 586 BIOKA63 17 BIOKA52 434 AMS $66 \quad 279$ BIOCS68 707 JASA 691031 BIOKA67 133 BIOCS66 268 SASJ $68 \quad 67$ JASA 681399 AMS $6 B \quad 664$ TECH 69396 LISATION EN GENETIQUE ET SES RAPPORTS AVEC L'ANALYSE DISCRIMINATOIRE /N COMPOSANTES PRINCIPALES, SON UTI BIOCS66 343 TWO COVARIANCE MATRICES IN RELATION TO A BEST LINEAR DISCRIMINATOR ANALYSIS TESTS FOR THE EQUALIIY OF AMS 64 ANALYSIS, A METHOD FOR SELECTING THE MOST EFFECTIVE DISCRIMINATORS IN A MULTIVARIATE SITUATION /NONICAL BIOCS68 PLATO ON A DISCRIMINATORY PROBLEM CONNECTED WITH THE WORKS OF JRSSB59

ASSOCTATTON FOR CROSS CLASSIFTCATTONS. II FURTHER DISCUSSTON AND REFERENCES AND AN 'OBJECTIVE' TEST FOR APPROXIMATE NUMERICAL/ DISCUSSION OF 'A SUBJECTIVE EVALUATION OF BODE'S LAW JASA 69 OF NORMAL DISTRIBUTIONS' BY VICTOR HASSELBLAD ERIMENTS' BY R.A. MCLEAN AND V.L. ANDERSON INFERENCE' DISCUSSION OF 'ESTIMATION OF PARAMETERS FOR A MIXTURE TECH 66 DISCUSSION OF 'EXTREME VERTICES DESIGN OF MIXTURE EXP TECH 66 DISCUSSION OF 'ON THE FOUNDATIONS OF STATISTICAL JASA 62 DISCUSSION OF HOEFFDINGS PAPER

$S$

ON THE COMPARTSON OP TWO MEANS, FURTHER DI A QUANTITATIVE DISCUSSION OF THE EFFECTIVENESS OF VOIDING AS A DEFEN BIOCS66 DISCUSSION OF THE PAPERS OF MESSRS. ANSCOMBE AND TECH 60 DISCUSSION OF THE PAPERS OF MESSRS. HALD, WETHERILL TECH 60 DISCUSSION OF THE PAPERS OF MESSRS. SATTERTHWAITE AND TECH 59 DANIEL

AND COX

BUDNE DISCUSSION

A POOR MAN'S MONTE CARLO (WITH DISCUSSION)

SAMPLING INSPECTION AND STATISTIGAL DECISIONS (WITH DISCUSSION) SOME PROBLEMS IN INTERVAL ESTIMATION (WITH DISCUSSION) LIMITS FOR THE RATIO OF MEANS (WITH DISCUSSION)

GENERALIZATIONS OF TCHEBYCHEFF'S INEQUALITIES (WITH DISCUSSION) THE SPECTRAL ANALYSIS OF TIME SERIES (WITH DISCUSSION) CURVE AND PERIODOGRAM SMOOTHING (WITH DISCUSSION) SOME PROBLEMS IN THE THEORY OF DAMS (WITH DISCUSSION) STATISTICAL APPROACH TO PROBLEMS OF COSMOLOGY (WITH DISCUSSION) RENEWAL THEORY AND ITS RAMIFICATIONS (WITH DISCUSSION) BEHAVIOUR SEQUENCES AS SEMI-MARKOV CHAINS (WITH DISCUSSION) CONTROL CHARTS AND STOCHASTIC PROCESSES (WITH DISCUSSION) OPTIMUM EXPERIMENTAL DESIGNS (WITH DISCUSSION) CONFIDENCE REGIONS IN NON-LINEAR ESTIMATION (WITH DISCUSSION) MODELS IN THE ANALYSIS OF VARIANCE (WITH DISGUSSION) DELAYS ON A TWO-LANE ROAD (WITH DISCUSSION) A QUEUEING MODEL FOR ROAD TRAFFIC FLOW (WITH DISCUSSION)

OPTIMAL PROGRAMMERS FOR VARIETAL SELECTION (WITH DISCUSSION) SOME RESULTS ON INVENTORY PROBLEMS (WITH DISCUSSION) CONTROL CHARTS AND THE MINIMIZATION OF GOSTS (WITH DISCUSSION)

THE SPECTRAL ANALYSIS OF POINT PROCESSES (WITH DISCUSSION) THEORY OF CYCLIC ROTATION EXPERIMENTS (WITH DISCUSSION) BAYESIAN TOLERANCE REGIONS (WITH DISCUSSION) AN ANALYSIS OF TRANSFORMATIONS (WITH DISCUSSION) SOME GENERAL RESULTS IN SEQUENTIAL DESIGN (WITH DISCUSSION) SPACINGS (WITH DISCUSSION)

ALLOCATION RULES AND THEIR ERROR RATES (WITH DISCUSSION) AN APPROACH TO THE STUDY OF MARKOV PROCESSES (WITH DISGUSSION) THE THEORY OF RISK (WITH DISCUSSION) THE CHOICE OF VARIABLES IN MULTIPLE REGRESSION (WITH DISCUSSION)

A GENERALIZATION OF BAYESIAN INFERENCE (WITH DISCUSSION) A GENERAL DEFINITION OF RESIDUALS (WITH DISCUSSION)

STOGHASTIC MODELS OF CAPITAL INVESTMENT (WITH DISCUSSION)

THE BAYESIAN OUTLOOK AND ITS APPLICATIONS (WITH DISCUSSION) ULT IPARAMETER BAYESIAN INDIFFERENCE PROCEDURES (WITH DISCUSSION) ANALYSIS OF ASSOCIATION AMONG MANY VARIABLES (WITH DISCUSSION) TATISTICAL PROBLEMS IN EXPERIMENTAL PSYCHOLOGY (WITH DISCUSSION) STOCHASTIC PROCESSES IN POPULATION GENETICS (WITH DISCUSSION)

IN THE PROBABILITY THEORY OF STORAGE SYSTEMS (WITH DISCUSSION) DISTRIBUTIONS IN THE THEORY OF QUEUES (WITH DISCUSSION) NTERPRETATION OF STANDARD INFERENCE STATEMENTS (WITH DISCUSSION) ESTIMATION OF QUANTAL RESPONSE CURVES (WITH DISCUSSION)

BAYESIAN MODELS IN SAMPLING FINITE POPULATIONS (WITH DISCUSSION)

IGNIFICANCE TEST FOR MULTINOMIAL DISTRIBUTIONS (WITH DISCUSSION) SPECTRAL AND NON-STATIONARY PROCESSES (WITH DISCUSSION)

THE LARGEST OF K NORMAL POPULATION MEANS (WITH DISCUSSION) THEORY APPROACH TO SAMPLING INSPECTION (WITH DISCUSSION) CENTROID DESIGN FOR EXPERIMENTS WITH MIXTURES (WITH DISCUSSION)

IN THE STATISTICAL ANALYSIS OF EPIDEMIC DATA (WITH DISCUSSION) TO THE 'TRAVELLING-SALESMAN' PROBLEM (WITH DISCUSSION)

OF THE SPECTRUM FOR NON-STATIONARY PROCESSES (WITH DISCUSSION) SOCIATED WITH RANDOM WALK AND RECURRENT EVENTS (WITH DISCUSSION)
JRSSB54 23

JRSSB54 151

JRSSB54 175

JRSSB54 186

JRSSB56 139

JRSSB57

JRSSB57 38

JRSSB57 207

JRSSB58 1

JRSSB5B 243

JRSSB59 36

JRSSB59 239

JRSSB59 272

JRSSB $60 \quad 41$

JRSSB $60 \quad 195$

JRSSB 61 3B

JRSSB $61 \quad 64$

JRSSB61 2B2

JRSSB62

JRSSB $63 \quad 49$

JRSSB $63 \quad 264$

JRSSB 64

JRSSB64 211

JRSSB65 395

JRSSB 66

JRSSB $66 \quad 417$

JRSSB $67 \quad 432$

JRSSB6B 31

JRSSB $68 \quad 205$

JRSSB68 24B

JRSSB 69

BIOCS69 No. 4

M JRSSB 6929

THE JRSSB67 199

SOME S JRSSB56 177

DISCRETE JRSSB60 218

PROBLEMS JRSSB57 1B

GEOMETRIC JRSSB59

BAYESIAN I JRSSB65 169

SEQUENTIAL JRSSB63 I

SUBJECTIVE JRSSB69 N0.2

A BAYESIAN S JRSSB67 399

EVOLUTIONARY JRSSB65 204

ON SELECTING JRSSB60 I

E DECISION JRSSB 66 3B1

THE SIMPLEX - JRSSB63 235

SOME PROBLEMS JRSSB55 35

A CONTRIBUTION JRSSB55 185

ON THE CONCEPT JRSSB68

DISTRIBUTIONS AS JRSSB57
JRSSB64 161

JRSSB $65 \quad 371$ 
CONVEX FUNCTION SUBJECT TO LINEAR INEQUALITIES (WITH DISCUSSION) DISTRIBUTIONS AND TIME-REVERSION IN GENETICS (WITH DISCUSSION) METHODS CONNECTED WITH SERIES OF EVENTS (WITH DISCUSSION) ASPECTS OF A.DAPTIVE OPTIMIZATION AND CONTROL (WITH DISCUSSION) PROBLEMS CONNECTED WITH CRYSTAL LATTICES (WITH DISCUSSION) OF AUTOMATIC COMPUTERS TO SAMPLINC EXPERIMENTS (WITH DISCUSSION) TO SOME SCREENINC AND CLASSIFICATION PROBLEMS (WITH DISCUSSION) PROGRAMMING AN OUTLINE OF LINEAR PROCRAMMINC (WITH DISCUSSION) THE MEAN OF A MULTIVARIATE NORMAL DISTRIBUTION (WITH DISCUSSION) OF MEANS UNDER RESTRICTED ALTERNATIVES (WITH DISCUSSION)

BAYESIAN AND CONFIDENCE LIMITS FOR PREDICTIONS (WITH DISCUSSION) PLICATED EXPERIMENTS ON AN ELECTRONIC COMPUTER (WITH DISCUSSION) OPTIMUM INFERENCE PROCEDURES IN LARCE SAMPLES (WITH DISCUSSION) OF-FIT TESTS FOR CONT DNUOUS DISTRIBUTIONS (WITH DISCUSSION) PARAMETERS IN MARKOV AUTOREGRESSIVE SCHEMES (WITH DISCUSSION) TIME-SERIES BASED ON THE BREAKING OF RECORDS (WITH DISCUSSION) DENSITY FUNCTION OF A STOCHASTIC PROCESS (WITH DISCUSSION)

APPROACH TO LINEAR FUNCTIONAL RELATIONSHIPS (WITH DISCUSSION) METHODS OF ESTIMATING VARIANCE COMPONENTS (WITH DISCUSSION) FOR THE ANALYSIS OF COMPUTER FAILURE PATTERNS (WITH DISCUSSION) IA AND THE STUDY OF DEPARTURES FROM ASSUMPTION (WITH DISCUSSION) ELATIONS FITTED BY THE METHOD OF LEAST SQUARES (WITH DISCUSSION)

THE REGRESSION ANALYSIS OF BINARY SEQUENCES IS OF VARIANCE AND SPECTRUM ANALYSIS SAMPLE SIZE IS TREATED AS A RANDOM VARIABLE (WITH DISCUSSION) SISTENCY IN STATISTICAL INFERENCE AND DECISION

ON MINIMIZING A JRSSB55 173 QUASI-STATIONARY JRSSB66 253 SOME STATISTICAL JRSSB55 129 SOME STATISTICAL JRSSB62 297 SOME STATISTICAL JRSSB64 367 THE APPLICATION JRSSB54 39 A CENERALL APPROACH JRSSB68 407 AN OUTLINE OF LINEAR JRSSB55 165 CONFIDENCE SETS FOR JRSSB62 265 A TEST OF HOMOCENEITY JRSSB6I 239 RELATIONSHIPS BETWEEN JRSSB64 176 ROUTINE ANALYSIS OF RE JRSSB57 234 EFFICIENT ESTIMATES AND JRSSB62 46 ON CHI-SQUARE GOODNESS- JRSSB58 44 CONFIDENCE INTERVALS FOR JRSSB54 195 DISTRIBUTION-FREE TESTS IN JRSSB54 I ON ESTIMATING THE SPECTRAL JRSSB57 13 A GENERALIZED LEAST-SQUARES JRSSB $66 \quad 27 \mathrm{~B}$ ANOTHER LOOK AT HENDERSON'S BIOCS68 749 HYPOTHESIS TESTING WHEN THE JRSSB67 53

A BRANCHING POISSON PROCESS MODEL JRSSB64 398 /ORY IN THE DERIVATION OF ROBUST CRITER JRSSB55 I TOPICS IN THE INVESTIGATION OF LINEAR R JRSSB67 I (CORR, 59 238)

JRSSB58 215 CON JRSSB 61 DISCUSSION, EMPHASIZING THE CONNECTION BETWEEN ANALYS TECH 61 191 TECH $61 \quad 229$ BIOCS65 645 BIOKA65 271

THE IDENTIFICATION OF ANNUAL PEAK PERIODS FOR A DISEASE

THE ESTIMATION OF PARAMETERS FROM THE SPREAD OF A DISEASE BY CONSIDERING HOUSEHOLDS OF TWO BIOCS68 541 JASA $67 \quad 409$ JASA $5 B \quad 420$ BIOKA54 266 BIOKA69 N0. 3 $\begin{array}{llllr}\text { SPREAD OF DISEASES IN A RECTANGULAR PLANTATION WITH VACANCIES } & \text { BIOKA53 } & 287 \\ \text { NUMBER OF DISJOINT BLOCKS IN CERTAIN PARTIALLY BALANCED INCOMPL AMS } 64 & 39 B\end{array}$ A DISTRIBUTION ARISING IN THE STUDY OF INFECTIOUS DISEASES ETE BLOCK DESIGNS AN UPPER BOUND FOR THE NUMBER OF DISJOINT BLOCKS IN CERTAIN PARTIALLY BALANCED INCOMPL AMS 64 39B
PAPER ON STATISTICS ASSOCIATED WITH THE RANDOM DISOREINTATION OF CUBES SOME STATISTICS ASSOCIATED WITH THE RANDOM DISORIENTATION OF CUBES

REGIONAL DISPARITIES IN HOUSEHOLD COMSUMPTION IN INDIA

RANDOM DISPERSAL IN THEORETICAL POPULATIONS

RANK TESTS OF DISPERSION

NOTE ON THE POISSON INDEX OF DISPERSION

SOME QUICK SIGN TESTS FOR TREND IN LOCATION AND DISPERSION THE POWER OF THE POISSON INDEX OF DISPERSION

LARGE-SAMPLE SIGN TESTS FOR TREND IN DISPERSION

THE CONSISTENCY OF SOME DISTRIBUTION-FREE TESTS FOR DISPERSION

OF HOTELLING'S GENERALIZED MEASURE OF MULTIVARIATE DISPERSION

ED IN TIME BY INDEPENDENT RANDOM DEVIATIONS OF LARGE DISPERSION

ON A SPHERE

TESTS FOR THE DISPERSION AND FOR THE MODAL VECTOR OF A DISTRIBUTION BIOKA67

BIOKA57 205

JASA $67 \quad 143$

BIOKA5I 196

AMS $63 \quad 973$

BIOKA53 225

BIOKA55 BO

BIOKA57 286

BIOKA66 289

NOTE ON JASA $64 \quad 105$

LUES FOR MOOD'S DISTRIBUTION-FREE TEST STATTSTIC FOR DISPERSION AND ITS NORMAL APPROXTMATION THE INDEX OF DISPERSION AS A TEST STATISTIC.

ROXIMATIONS TO THE DISTRIBUTIONS OF SOME MEASURES OF DISPERSION BASED ON SUCCESSIVE DIFFERENCES

APPROXIMATING TO THE DISTRIBUTIONS OF MEASURES OF DISPERSION BY A POWER OF CHI-SQUARE

A DISTRIBUTION-FREE TWO SAMPLE TEST FOR DISPERSION FOR SYMMETRICAL DISTRIBUTIONS

A PROPERTY OF A TEST FOR THE EQUALITY OF TWO NORMAL DISPERSION MATRICES AGAINST ONE-SIDED ALTERNATIVES BIOKA65 627

APP BIOKA57 349 BIOKA53 336

SASJ 69 NO.2 AMS 621463 AMS $62 \quad 432$ TWO-SAMPLE COMPARISONS OF DISPERSION MATRICES FOR ALTERNATIVES OF INTERMEDIATE OPERTIES OF POWER FUNCTIONS OF SOME TESTS CONCERNING DISPERSION MATRICES OF MULTIVARIATE NORMAL DISTRIBUTI AMS 69 697
LGORITHM FOR OBTAININC THE ZERO OF A FUNCTION OF THE DISPERSION MATRIX IN MULTIVARIATE ANALYSIS LGORITHM FOR OBTAININC THE ZERO OF A FUNCTION OF THE DISPERSION MATRIX IN MULTIVARIATE ANALYSIS
THE DISPERSION OF A NUMBER OF SPECIES NCIES OF COX AND STUART'S TESTS FOR TESTING TREND IN DISPERSION OF A P-DEPENDENT TIME SERIES (CORR. 69 457 BIOKA68 3B1 3) ASSOCIATION BETWEEN RANDOM VARIABLES AND THE DISPERSION OF A RADON-NIKODYM DERIVATIVE (CORR. 65 53 JRSSB65 100 EM OF ME/ A FURTHER RESULT ON THE RELEVANCE OF THE DISPERSION OF A RADON-NIKODYM DERIVATIVE TO THE PROBL JRSSB65 I08 CHARACTERS ANALYSIS OF DISPERSION WITH INCOMPLETE OBSERVATIONS ON ONE OF THE JRSSB56 259 A DISCRIMINANT FUNCTION FROM WITHIN-SAMPLE DISPERSIONS NOTES. COMPUTING BIOCS65 1011 LARGE DISPE/ THE INTERVALS BETWEEN REGULAR EVENTS DISPLACED IN TIME BY INDEPENDENT RANDOM DEVIATIONS OF JRSSB6I 476 THE DISPLACED POISSON DISTRIBUTION-REGION B $\quad$ JASA $67 \quad 643$ ANALYSIS OF VARIANCE OF DISPROPORTIONATE DATA WHEN INTERACTION IS PRESENT BIOCS65 115

WAY ANALYSIS OF VARIANCE FOR THE MIXED MODEL WITH DISPROPORTIONATE SUBCLASS FREQUENCIES TWO- BIOCS65 308 VALUATION OF SPLITTING LIMIT CRITERIA IN MEASUREMENT DISPUTES

IX INVERSION IN MULTIPLE REGRESSION AND MULTIVARIATE DISTANCE ANALYSIS /S OF JORDANIS PROCEDURE FOR MATR JRSSBG3 ATTRIBUTE DATA A COSELY PACKED LATTICE DISTANCE BETWEEN POPULATIONS ON THE BASIS OF BIOCS68 859 THE DISTANCE FROM A RANDOM POINT TO THE NEAREST POINT OF BIOKA65 261 BIOKA58 360 BIOKA65 345 USED IN MULTIVARIATE ANALYSIS

CONFIDENCE INTERVAIS FOR DISTANCE IN THE ANALYSIS OF VARIANCE BIOKA66 325 BIOCS67 207

RIANCE MATRICES SOME DISTANCE PROPERTIES OF LATENT ROOT AND VECTOR METHODS SOME DEVELOPEMENTS IN 'DISTANCE SAMPLING'

AN EMPIRICAL COMPARISON OF DISTANCE STATISTICS FOR POPULATIONS WITH UNEQUAL COVA BIOCS68 633 NTS AMONG ENVIRONME/ EFFECTS OF PARTIAL ISOLATION (DISTANCE), MIGRATION, AND DIFFERENT FITNESS REQUIREME BIOCS66 453 INVARIANT DISCRIMINANT FUNCTIONS AND GENERALIZED DISTANCES EM OF MINIMUM DISTANCES

GROWTH- BIOCS66 96 COMPARINC DISTANCES BETWEEN MULTIVARIATE POPULATIONS, THE PROB MS 67550 APPROXIMATE MEANS AND STANDARD DEVIATIONS BASED ON DISTANCES BETWEEN PERCENTAGE POINTS OF FREQUENCY CURV BIOKA65 533 CIRCLES VARIABLES THE DISTANCES BETWEEN RANDOM POINTS IN TWO CONCENTRIC BIOKA64 275 DISTANCES OF PROBABILITY MEASURES AND RANDOM

ICAL DESIGNS 
SURVEY INVOLVING UNEQUAL NUMBERS OF ORCHARDS OF DISTINCT TYPE

ON DISTINGUISHING TRANSLATES OF MEASURES

TARTABLES WHTCH ARE DEPENDENT OR NON-TDENTTCALLY DISTRTBUTED A RENEWAL THEOREM FOR RANDOM AMS $63 \quad 390$ IN WHICH THE ABUNDANCES OF SPECIES ARE LOG-NORMALLY DISTRIBUTED /ES IN A SAMPLE OF AN ANIMAL POPULATION BIOKA5I 427

L AN APPLICATION OF VARIABLE WEIGHT DISTRIBUTED LAGS JASA 671277 THE ANALYSIS OF EXPONENTIALLY DISTRIBUTED LIFE-TIMES WITH TWO TYPES OF FAILURE JRSSB59 4II

THE AUTOCORRELATION FUNCTION OF A SEQUENCE UNIFORMLY DISTRIBUTED MODULO 1

BIRTH, DEATH AND MIGRATION PROCESSES FOR SPATIALLY DISTRIBUTED POPULATIONS

AN EXTENSION OF ROSEN'S THEOREM TO NON-IDENTICALLY DISTRIBUTED RANDOM VARIABLES THE Z-TEST AND SYMMETRICALLY DISTRIBUTED RANDOM VARIABLES

AMS 631243 STOCHASTIC BIOKA68 189 AMS 68897 INTERVALS FOR THE MEANS OF DEPENDENT NORMALLY DISTRIBUTED VARIABLES

TESTING FOR SERIAL CORRELATION WITH EXPONENTIALLY DISTRIBUTED VARIATES ESTIMATING THE PARAMETERS OF A MODIFIED POISSON DISTRIBUTION VARIANCE OF THE MEDIAN OF SAMPLES FROM A CAUCHY DISTRIBUTION

TABLES OF CONFIDENCE LIMITS FOR THE BINOMIAL DISTRIBUTION ORDER STATISTICS FROM THE GAMMA DISTRIBUTION THE NON-CENTRAL MULTIVARIATE BETA DISTRIBUTION

A BIVARIATE EXTENSION OF THE EXPONENTIAL DISTRIBUTION THE FOLDED NORMAL DISTRIBUTION

A CHARACTERIZATION OF THE MULTIVARIATE NORMAL DISTRIBUTION CHARACTERIZATION OF THE INVERSE GAUSSIAN DISTRIBUTION A GENERALIZATION OF THE GAMMA DISTRIBUTION A REPRESENTATION OF THE SYMMETRIC BIVARIATE CAUCHY DISTRIBUTION A CHARACTERIZATION OF THE CAUCHY DISTRIBUTION

A CHARACTERIZATION OF THE WISHART DISTRIBUTION PROBABILITY PLOTS FOR THE GAMMA DISTRIBUTION A NOTE ON THE NEGATIVE BINOMIAL DISTRIBUTION

SIMPLIFIED ESTIMATES FOR THE EXPONENTIAL DISTRIBUTION THE POISSON TENDENCY IN TRAFFIC DISTRIBUTION THE PROBABILITY IN THE TAIL OF A DISTRIBUTION THE POSTERIOR T DISTRIBUTION

ON THE RENEWAL FUNCTION FOR THE WEIBULL DISTRIBUTION CUMULATIVE SUM CHARTS FOR THE FOLDED NORMAL DISTRIBUTION TABLES OF THE LOGARITHMIC SERIES DISTRIBUTION

ON TWO-SIDED TOLERANCE INTERVALS FOR A NORMAL DISTRIBUTION

A CHARACTERIZATION OF THE EXPONENTIAL DISTRIBUTION

A NOTE ON THE TRUNCATED EXPONENTIAL DISTRIBUTION

AN APPLICATION OF A GENERALIZED GAMMA DISTRIBUTION

ORTHANT PROBABILITIES FOR THE QUADRIVARIATE NORMAL DISTRIBUTION

A NOTE ON THE POISSON TENDENCY IN TRAFFIC DISTRIBUTION ANOTHER DERIVATION OF THE NON-CENTRAL CHI-SQUARE DISTRIBUTION GENERATING A VARIABLE FROM THE TAIL OF THE NORMAL DISTRIBUTION QUERY, THE MEAN OF THE TAIL OF A DISTRIBUTION CONTROL OF PERCENTAGES IN BOTH TAILS OF THE NORMAL DISTRIBUTION THE ASYMPTOTICALLY UNBIASED PRIOR DISTRIBUTION ON THE COMPLEX WISHART DISTRIBUTION A PROPERTY OF THE MULTIVARIATE T DISTRIBUTION PROPERTIES OF THE EXTENDED HYPERGEOMETRIC DISTRIBUTION TOLERANCE LIMITS FOR THE GENERALIZED GAMMA DISTRIBUTION PARAMETER ESTIMATION FOR A GENERALIZED GAMMA DISTRIBUTION QUERY, COMBINATION OF A NORMAL AND A UNIFORM DISTRIBUTION ANOTHER CHARACTERISTIC PROPERTY OF THE CAUCHY DISTRIBUTION A CHARACTERISTIC PROPERTY OF THE MULTIVARIATE NORMAL DISTRIBUTION

LINEAR ESTIMATES OF PARAMETERS IN THE EXTREME VALUE DISTRIBUTION CUMULATIVE SUM CONTROL CHARTS AND THE WEIBULL DISTRIBUTION A BAYESIAN STUDY OF THE MULTINOMIAL DISTRIBUTION A MULTIVARIATE EXPONENTIAL DISTRIBUTION

A NOTE ON REGRESSION IN THE MULTIVARIATE POISSON DISTRIBUTION

A BIVARIATE WARNING-TIME, FAILURE-TIME DISTRIBUTION

AN INEQUALITY ON A BIVARIATE STUDENT'S 'T' DISTRIBUTION

A NOTE ON ESTIMATION FROM A TYPE I EXTREME-VALUE DISTRIBUTION

VARIABLES SAMPLING PLANS BASED ON THE NORMAL DISTRIBUTION ESTIMATION OF PARAMETERS IN THE WEIBULL DISTRIBUTION

CONSTRUCTION OF SEQUENCES ESTIMATING THE MIXING DISTRIBUTION THE DISCRETE STUDENT'S DISTRIBUTION

ESTIMATION OF THE PARAMETER N IN THE BINOMIAL DISTRIBUTION PARAMETER ESTIMATION FOR A MULTIVARIATE EXPONENTIAL DISTRIBUTION THE T-RATIO DISTRIBUTION

AN APPROXIMATION TO THE WILCOXON-MANN-WHITNEY DISTRIBUTION

A TABLE FOR ESTIMATING THE MEAN OF A LOGNORMAL DISTRIBUTION A COMPOUNDED MULTIPLE RUNS DISTRIBUTION A STEPWISE MULTIVARIATE T-DISTRIBUTION

THE NONCENTRAL MULTIVARIATE BETA TYPE TWO DISTRIBUTION INFORMATION AND SAMPLING FROM THE EXPONENTIAL DISTRIBUTION

QUERY, TOLERANCE LIMITS FOR A BINOMIAL DISTRIBUTION

INFERENCES ON THE PARAMETERS OF THE WEIBULL DISTRIBUTION TWO SAMPLE TESTS IN THE WEIBULL DISTRIBUTION THE TRUNCATED NEGATIVE BINOMIAL DISTRIBUTION A NOTE ON THE CIRCULAR MULTIVARIATE DISTRIBUTION 
THE MOMENTS OF THE LEIPNIK DISTRIBUTION A NOTE ON THE MEAN DEVIATION OF THE BINOMIAL DISTRIBUTION INTERVAL ESTIMATION FOR THE PARAMETER OF A BINOMIAL DISTRIBUTION THE MEAN DEVIATION OF THE POISSON DISTRIBUTION TABLES FOR WALD TESTS FOR THE MEAN OF A NORMAL DISTRIBUTION ON THE NON-CENTRAL CHI-SQUARE DISTRIBUTION CONFIDENCE LIMITS IN THE CASE OF THE CEOMETRIC DISTRIBUTION THE BOREL-TANNER DISTRIBUTION

A DERIVATION OF THE BOREL DISTRIBUTION THE MOMENTS OF THE NON-CENTRAL T-DISTRIBUTION A NOTE ON THE EQUICORRELATED MULTIVARIATE NORMAL DISTRIBUTION APPROXIMATIONS TO THE NON-CENTRAL CHI-SQUARE DISTRIBUTION

A CHARACTERIZATION OF THE EXPONENTIAL-TYPE DISTRIBUTION ADDITIONAL PERCENTAGE POINTS FOR THE INCOMPLETE BETA DISTRIBUTION A NEW TABLE OF PERCENTACE POINTS OF THE CHI-SQUARE DISTRIBUTION ESTIMATION FOR THE BIVARIATE POISSON DISTRIBUTION

A NOTE ON THE NECATIVE BINOMIAL DISTRIBUTION DECOMPOSITION OF WISHART DISTRIBUTION

ON CUPTA'S ESTIMATES OF THE PARAMETERS OF THE NORMAL DISTRIBUTION THE MODE OF A MULTINOMIAL DISTRIBUTION SOME PROPERTIES OF THE 'HERMITE' DISTRIBUTION A SPECIAL CASE OF A BIVARIATE NON-CENTRAL T-DISTRIBUTION TESTING FOR HOMOGENEITY. II. THE POISSON DISTRIBUTION BIVARIATE GENERALIZATIONS OF NEYMAN'S TYPE A DISTRIBUTION ESTIMATION OF THE PARAMETERS OF THE LOCISTIC DISTRIBUTION A NOTE ON APPROXIMATINC TO THE NON-CENTRAL F DISTRIBUTION AN ALTERNATIVE DERIVATION OF THE HERMITE DISTRIBUTION THE EMPIRICAL BAYES APPROACH, ESTIMATING THE PRIOR DISTRIBUTION ANOTHER TEST FOR THE UNIFORMITY OF A CIRCULAR DISTRIBUTION A SIMPLE TEST FOR UNIFORMITY OF A CIRCULAR DISTRIBUTION TESTS FOR THE VON MISES DISTRIBUTION

EMPIRICAL BAYES ESTIMATION FOR THE POISSON DISTRIBUTION ON CORRECTIONS TO THE CHI-SQUARED DISTRIBUTION MOMENTS OF A TRUNCATED BIVARIATE NORMAL DISTRIBUTION ON A PROPERTY OF THE LOCNORMAL DISTRIBUTION BAYESIAN ESTIMATION OF THE VARIANCE OF A NORMAL DISTRIBUTION USINC THE OBSERVATIONS TO ESTIMATE THE PRIOR DISTRIBUTION ESTIMATION OF THE PARAMETER OF AN EXPONENTIAL DISTRIBUTION AN ANALYSIS OF DEPARTURES FROM THE EXPONENTIAL DISTRIBUTION A CENERALISED LOCIT-NORMAL DISTRIBUTION A NEW RESPONSE TIME DISTRIBUTION

NOTES. CHARACTERIZINC THE EXPONENTIAL DISTRIBUTION THE ESTIMATION OF THE 'SHORT' DISTRIBUTION NOTE ON REPRESENTATIONS OF THE DOUBLY NON-CENTRAL T DISTRIBUTION CENTRAL TOLERANCE RECION FOR THE MULTIVARIATE NORMAL DISTRIBUTION THE DERIVATION AND APPLICABILITY OF NEYMAN'S TYPE A DISTRIBUTION COVERING CIRCLE OF A SAMPLE FROM A CIRCULAR NORMAL DISTRIBUTION

ESTIMATION OF THE POISSON PARAMETER FROM A TRUNCATED DISTRIBUTION PERCENT AND O.I PERCENT POINTS OF THE CHI-SQUARE DISTRIBUTION TABLE OF PERCENTACE POINTS OF THE PEARSON TYPE III DISTRIBUTION LINEAR SEQUENTIAL TESTS FOR THE MEAN OF A NORMAL DISTRIBUTION STATISTICS ESTIMATORS OF THE LOCATION OF THE CAUCHY DISTRIBUTION FORMS IN THE ORDER STATISTICS FROM AN EXPONENTIAL DISTRIBUTION ROBUSTNESS OF SOME CHARACTERIZATIONS OF THE NORMAL DISTRIBUTION PROBLEM OF ESTIMATION FOR THE BIVARIATE LOCNORMAL DISTRIBUTION PPLICATIONS OF TWO APPROXIMATIONS TO THE MULTINOMIAL DISTRIBUTION THE CHARACTERISTIC FUNCTION OF A SERIAL-CORRELATION DISTRIBUTION CONFIDENCE INTERVALS FOR THE VARIANCE OF A NORMAL DISTRIBUTION FOR MAKING INFERENCES ABOUT THE VARIANCE OF A NORMAL DISTRIBUTION AND INCOMPLETE MOMENTS OF THE MULTIVARIATE NORMAL DISTRIBUTION ESTIMATION OF PARAMETERS OF A MULTIVARIATE NORMAL DISTRIBUTION

TABLES OF THE PERCENTAGE POINTS OF STUDENT'S T-DISTRIBUTION K-STATISTICS AND CUMULANTS OF THEIR JOINT SAMPLING DISTRIBUTION INTECRAL DERIVATION OF THE NON-CENTRAL CHI-SQUARE DISTRIBUTION SOME ASYMPTOTIC PROPERTIES OF THE LOCARITHMIC SERIES DISTRIBUTION FOR A QUADRATIC FORM TO HAVE A CHI-SQUARED DISTRIBUTION OF PARAMETERS OF A TRUNCATED BIVARIATE NORMAL DISTRIBUTION OF THE SHAPE AND SCALE PARAMETERS OF THE WEIBULL DISTRIBUTION POINTS OF THE RANCE FROM A SYMMETRIC MULTINOMIAL DISTRIBUTION SUM OF VALUES FROM A NORMAL AND A TRUNCATED NORMAL DISTRIBUTION METHODS OF FITTING THE TRUNCATED NECATIVE BINOMIAL DISTRIBUTION GENERATING FUNCTION OF THE TRUNCATED MULTI-NORMAL DISTRIBUTION POINTS AND MODES OF ORDER STATISTICS FROM THE NORMAL DISTRIBUTION

OF HYPOTHESES CONCERNINC THE THREE-PARAMETER WEIBULL DISTRIBUTION AND DUAL CONFIGURATIONS AND THE RECIPROCAL NORMAL DISTRIBUTION OF RADICAL ERROR IN THE BIVARIATE ELLIPTICAL NORMAL DISTRIBUTION ABILITIES FOR THE EQUICORRELATED MULTIVARIATE NORMAL DISTRIBUTION ESTIMATION OF THE LOCATION PARAMETER OF THE CAUCHY DISTRIBUTION TEST FOR THE LOCATION PARAMETER OF AN EXPONENTIAL DISTRIBUTION THE METHOD OF MOMENTS AND THE CRAM-CHARLIER TYPE A DISTRIBUTION THE PARAMETER OF A DOUBLY TRUNCATED BINOMIAL DISTRIBUTION OF WARRANTY ASSURANCE WHEN LIFE HAS A WEIBULL DISTRIBUTION INCOMPLETE BETA-FUNCTION AND THE CUMULATIVE BINOMIAL DISTRIBUTION MOMENTS OF ORDER STATISTICS FROM A LOCISTIC DISTRIBUTION OMPARISONS OF SEVERAL APPROXIMATIONS TO THE BINOMIAL DISTRIBUTION OF THE EQUALITY OF PROBABILITIES IN A MULTINOMIAL DISTRIBUTION

BIOKA57 270 BIOKA57 532 BIOKA5B 275 BIOKA5B 556 BIOKA59 169 BIOKA59 235 BIOKA59 260 BIOKA60 143 BIOKA6I 222 BIOKA6I 465 BIOKA62 269 BIOKA63 199 BIOKA63 205 BIOKA63 449 BIOKA64 231 BIOKA64 241 BIOKA64 264 BIOKA64 267 BIOKA64 498 BIOKA64 513 BIOKA65 3BI BIOKA65 437 BIOKA66 183 BIOKA66 241 BIOKA66 565 BIOKA66 606 BIOKA66 627 BIOKA67 326 BIOKA67 675 BIOKA6B 343 BIOKA69 149 BIOKA69 349 JRSSB5B 387 JRSSB61 405 JRSSB63 392 JRSSB 6463 JRSSB $65 \quad 17$ JRSSB $67 \quad 525$ JRSSB $67 \quad 540$ BIOCS65 721 BI0C\$67 227 BIOC $568 \quad 437$ BIOCS69 417 A JASA $68 \quad 1013$ A JRSSB68 599 ON BIOKA5B 32 THE BIOKA52 137 THE BIOKA52 247 99.9 BIOKA53 421 A NEW TECH $69 \quad 177$ EXACT BIOKA56 452 ORDER JASA $66 \quad 1205$ LINEAR AMS 64270 ON THE AMS $68 \quad 1747$ ON THE BIOKA64 522 SOME A BIOKA6O 463 NOTE ON BIOKA58 559 OPTIMAL JASA $59 \quad 674$ TABLES BIOKA6O 433 ABSOLUTE BIOKA61 77 BAYESIAN JRSSB 65279 EXTENDED JASA $596 \mathrm{~B} 3$ BIVARIATE BIOKA51 179 A CONTOUR- AMS 62796 A NOTE ON BIOKA61 212 CONDITIONS BIOKA69 215 ESTIMATION JASA $63 \quad 519$ ESTIMATION TECH $63 \quad 175$ PERCENTACE BIOKA68 377 QUERY, THE TECH 64104 SIMPLIFIED BIOKA58 59 THE MOMENT JRSSB61 223 PERCENTACE AMS 61 BBB SOME TESTS JASA $6 B \quad 853$ BIORTHOGONAL AMS 69393 DISTRIBUTION TECH 62 13B ORTHANT PROB BIOKA62 433 A NOTE ON THE JASA 66 B52 A NOTE ON THE AMS 691838 EFFICIENCY OF BIOKA5I 58 ON ESTIMATING JASA 66259 ON EVALUATION BIOKA69 NO. 3 A CHART FOR THE BIOKA5I 423 ON THE BIVARIATE AMS 661002 SOME NUMERICAL C JASA 69 NO. 4 A SEQUENTIAL TEST JASA 62769 
OF A CLASS OF TESTS FOR UNIFORMITY OF A CIRCULAR DISTRIBUTION OF THE PROBABILITY INTECRAL OF THE MULTIVARTATE T DISTRIBUTION FUNCTIONS AND A CHARACTERIZATION OF THE CAUCHY DISTRIBUTION LIFE TESTINC PROCEDURES DERIVED FROM THE EXPONENTIAL DISTRIBUTION OF A COVARIANCE MATRIX IN A CERTAIN COMPLEX GAUSSIAN DISTRIBUTION TOPOLOCY AND CONVERCENCE IN SOME ORDERED FAMILIES OF DISTRIBUTION ATISTICS FROM THE EQUICORRELATED MULTIVARIATE NORMAL DISTRIBUTION

RELATIVE ERROR FOR THE MEAN LIFE OF AN EXPONENTIAL DISTRIBUTION ON A TEST FOR THE SCALE PARAMETER OF THE EXPONENTIAL DISTRIBUTION ABILITY ESTIMATION FOR THE TWO PARAMETER EXPONENTIAL DISTRIBUTION

SICN TEST AND A TEST FOR UNIFORMITY OF A CIRCULAR DISTRIBUTION BSERVATIONS ABOVE SAMPLE MEANS IN A BIVARIATE NORMAL DISTRIBUTION IMATORS WITH AN APPLICATION TO THE NECATIVE BINOMIAL DISTRIBUTION

AND TOLERANCE RECIONS FOR THE MULTIVARIATE NORMAL DISTRIBUTION

THE RANCE AND MEAN RANGE FOR SAMPLES FROM A NORMAL DISTRIBUTION POINT METHOD AND CHI-SQUARED FOR THE MULTINOMIAL DISTRIBUTION CORRELATION COEFFICIENTS FOR A CENERAL BIVARIATE DISTRIBUTION

TRUNCATED SEQUENTIAL TESTS OF THE MEAN OF A NORMAL DISTRIBUTION ARIATE-VALUES AND RANKS IN A DOUBLY TRUNCATED NORMAL DISTRIBUTION SCALE PARAMETERS IN A TRUNCATED GROUPED SECH SQUARE DISTRIBUTION

OF A MATRIX AND APPROXIMATIONS TO ITS NON-CENTRAL DISTRIBUTION SIDED PREDICTION INTERVALS FOR SAMPLES FROM A NORMAL DISTRIBUTION PROPORTIONS WITH A A CENERALIZATION OF THE DIRICHLET DISTRIBUTION IMATION OF RELIABILITY FOR THE TRUNCATED EXPONENTIAL DISTRIBUTION

BASED ON A CERTAIN MULTIVARIATE COMPLEX GAUSSIAN DISTRIBUTION

VARIANCES IN A SINGLY TRUNCATED BIVARIATE NORMAL DISTRIBUTION FOR ESTIMATINC THE PARAMETERS OF A MIXED EXPONENTIAL DISTRIBUTION TERVAL ESTIMATORS, WITH AN APPLICATION TO THE NORMAL DISTRIBUTION OF THE MEAN DEVIATION OF THE SYMMETRICAL MULTINOMIAL DISTRIBUTION OF THE ORDER STATISTICS FROM THE TRUNCATED LOCISTIC DISTRIBUTION EAR INVARIANT ESTIMATES OF PARAMETERS OF THE WEIBULL DISTRIBUTION AMETRIC LIFE TEST FOR SMALLER PERCENTILES OF A CAMMA DISTRIBUTION

THE PARAMETERS IN THE MEAN VECTOR OF A MULTIVARIATE DISTRIBUTION

CENSORED SAMPLES, OF THE PARAMETERS OF A LOCISTIC DISTRIBUTION THE QUOTIENT OF THEIR COORDINATES FOLLOWS SOME KNOWN DISTRIBUTION SAMPLE TESTS FROM TESTS FOR UNIFORMITY OF A CIRCULAR DISTRIBUTION L OF A VARIABLE FROM A DECAPITATED NEGATIVE BINOMIAL DISTRIBUTION ARISINC IN CONNECTION WITH THE TRUNCATED EXPONENTIAL DISTRIBUTION IS OF VARIANCE TESTS, DERIVED FROM THE NON-CENTRAL F-DISTRIBUTION AGE POINTS OF A MULTIVARIATE ANALOCUE OF STUDENT'S T-DISTRIBUTION K HYPOTHESES CONCERNING THE UNKNOWN MEAN OF A NORMAL DISTRIBUTION TO THE SIMPLE QUEUE WITH ARBITRARY ARRIVAL INTERVAL DISTRIBUTION $S$ OF ITEMS WHERE THE MEAN QUALITY HAS A NORMAL PRIOR DISTRIBUTION CTORS WITH SPECIAL REFERENCE TO THE BIVARIATE NORMAL DISTRIBUTION MATION OF THE PARAMETERS OF THE NEGATIVE EXPONENTIAL DISTRIBUTION EM COMPRISED OF K ELEMENTS FROM THE SAME EXPONENTIAL DISTRIBUTION OF THE ROOTS OF TWO MATRICES AND APPROXIMATIONS TO A DISTRIBUTION E PROBABILITY INTEGRAL OF THE NON-CENTRAL CHI-SQUARE DISTRIBUTION NCE BOUND FOR RELIABILITY IN THE CASE OF THE WEIBULL DISTRIBUTION ERION W FOR TESTING SPHERICITY IN A P-VARIATE NORMAL DISTRIBUTION

SUM OF VALUES FROM A NORMAL AND A TRUNCATED NORMAL DISTRIBUTION OME E RAN/ CONFIDENCE INTERVALS FOR THE PARAMETER OF A DISTRIBUTION ADMITTING A SUFFICIENT STATISTIC WHEN TH JRSSB55 E OF THE LIKELIHOOD SURFACE OF A SAMPLE DRAWN FROM A DISTRIBUTION ADN TWINNING

\section{NOTES, DISTRIBUTION AMONG RELATIVES OF GENOTYPES FOR}

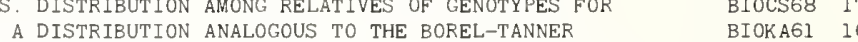

ASYMPTOTIC THEORY AMS 691196 ON THE EVALUATION BIOKA6I 409 CAUCHY-DISTRIBUTED AMS 691083 THE ROBUSTNESS OF TECH $61 \quad 29$ A TEST FOR REALITY AMS $65 \quad 115$ FURTHER REMARKS ON AMS 6951 MOMENTS OF ORDER ST AMS 62 12B6 ESTIMATES OF BOUNDED TECH $61 \quad 107$ EFFECT OF TRUNCATION AMS 64209 LIFE TESTINC AND RELI JASA 69621 ON HODCES'S BIVARIATE BIOKA69 446 ON THE PROPORTION OF O AMS 6B 1350 THE BIAS OF MOMENT EST BIOKAG2 193 CONFIDENCE, PREDICTION, JASA 66605 ON THE DISTRIBUTIONS OF BIOKA66 245 THE MULTIVARIATE SADDLE AMS 61535 THE PERFORMANCE OF SOME BIOKA60 307 DIRECT METHODS FOR EXACT TECH 69 NO.4 THE CORRELATION BETWEEN V BIOKA66 2BI ESTIMATION OF LOCATION AND JASA 61692 ON THE MOMENTS OF THE TRACE AMS $66 \quad 1312$ FACTORS FOR CALCULATINC TWO- JASA $6987 \mathrm{~B}$ CONCEPTS OF INDEPENDENCE FOR JASA 69194 MINIMUM VARIANCE UNBIASED EST TECH 69609 CLASSICAL STATISTICAL ANALYSIS AMS $65 \quad 9 B$ CORRELATION BETWEEN THE SAMPLE BIOKA6B 433

THE USE OF FRACTIONAL MOMENTS TECH 68 161

CRITERIA FOR BEST SUBSTITUTE IN JASA 641133 ON TAE FIRST TWO MOMENTS BIOKA67 312

MOMENTS AND PRODUCT MOMENTS JASA $66 \quad 514$ TABLES FOR OBTAININC THE BEST LIN TECH 67629 OF LINEAR COMBINATIONS OF AMS 6578 MAXIMUM-LIKELIHOOD ESTIMATION, FROM JASA 67675 THE DERIVATION OF NONPARAMETRIC TWO- BIOKA69 N0.3 /STANDARD DEVIATIONS OF THE RECIPROCA JASA $62 \quad 439$ DISTRIBUTION OF AN ESTIMATOR AMS $69 \quad 702$ /ARTS OF THE POWER FUNCTION FOR ANALYS BIOKA51 112 /BABILITY INTECRAL AND CERTAIN PERCENT BIOKA55 25B /DIFFERENCE EQUATION TECHNIQUE APPLIED JRSSB58 168 /G ACCEPTANCE SCHEMES FOR LARGE BATCHE BIOKA68 393 PTOTIC OPTIMUM QUANTILES FOR THE ESTI AMS 66143 TT ESTIMATION OF RELIABILITY OF A SYST JASA 661029 /TS OF ELEMENTARY SYMMETRIC FUNCTIONS AMS 681274 ULAE FOR THE PERCENTAGE POINTS AND TH BIOKA54 53B /XACT ASYMPTOTICALLY EFFICIENT GONFIDE TECH $66 \quad 135$ ON THE EXAGT DISTRIBUTIONS OF THE CRIT AMS 671170 CONTD JRSSB 262 ON PLANS BASED ON PRI/ THE COMPOUND HYPERGEOMETRIC DISTRIBUTION AND A SYSTEM OF SINGLE SAMPLING INSPECTI TECH 60 275

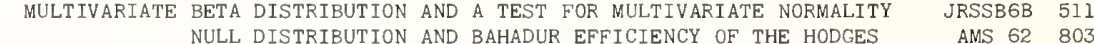
FINITE POPULATIO/ THE COMPOUND MULTINOMIAL DISTRIBUTION AND BAYESIAN ANALYSIS OF CATERGORICAL DA JASA 69 216 TISTICS', 46/ CORRECTION. 'THE NON-CENTRAL WISHART DISTRIBUTION AND CERTAIN PROBLEMS OF MULTIVARIATE STA AMS 64 923 POLLEN COUN/ ON THE GOMPOUND NEGATIVE MULTINOMIAL DISTRIBUTION AND CORRELATIONS AMONG INVERSELY SAMPLED BIOKA63 47 SOME DISTRIBUTION AND MOMENT FORMULAE FOR THE MARKOV CHAIN JRSSB55 235

SOME RESULTS ON THE NON-CENTRAL MULTIVARIATE BETA DISTRIBUTION AND MOMENTS OF TRACES OF TWO MATRIGES AMS 65 I5II IMATIONS TO THE UPPER 5 PERCENT POINTS OF FISHER'S B DISTRIBUTION AND NON-CENTRAL CHI-SQUARE
ON THE DISTRIBUTION AND POWER OF A TEST FOR A SINGLE OUTLIER SASJ 69 TEST DISTRIBUTION AND POWER OF THE ABSOLUTE NORMAL SGORES JASA 6796 ON THE RANDOMIZATION DISTRIBUTION AND POWER OF THE VARIANCE RATIO TEST JRSSB63 334 STUDENT'S DISTRIBUTION AND RIEMANN'S ELLIPTIC GEOMETRY BIOKA57 264 THE GOODNESS OF FIT STATISTIC V-SUB-N, DISTRIBUTION AND SIGNIFICANCE POINTS 309 SCORES A PROPERTY OF THE MULTINOMIAL DISTRIBUTION AND THE DETERMINATION OF APPROPRIATE MATRICVARIATE GENERALIZATIONS OF THE MULTIVARIATE T DISTRIBUTION AND THE INVERTED MULTIVARIATE T DISTRIBU AMS 67 511 LENGTH AND IT/ THE RELATION BETWEEN THE DICTIONARY DISTRIBUTION AND THE OCCURRENCE DISTRIBUTION OF WORD BIOKA58 222 A CONTINUOUS PRIOR DISTRIBUTION THE MIXED BINOMIAL DISTRIBUTION AND THE POSTERIOR DISTRIBUTION OF P FOR JRSSB68 359 AND ESTIMATION PROBLEMS, CORR. $631 /$ THE LOGNORMAL DISTRIBUTION AND THE TRANSLATION METHOD, DESCRIPTION JASA 63 231 LIKELIHOOD ESTIMATION OF THE PARAMETERS OF THE GAMMA DISTRIBUTION AND THEIR BIAS TEGH 69 NO. 4 TON AND THETR RELATION TO INVERSE SAMPLINC A JASA G7 DISEASES THE BEHRENS-FISHER DISTRIBUTION AND WEIGHTED MEANS

A DISTRIBUTION ARISING IN THE STUDY OF INFECTIOUS JRSSB59 73 BIOKA54 266 COMMUNITY ECOLOC/ MULTIVARIATE LOGARITHMIC SERIES DISTRIBUTTON AS A PROBABILITY MODEL IN POPULATION AND JASA 67 655 PROCESSES ON A DISTRIBUTION ASSOCIATED WITH CERTAIN STOCHASTIC JRSSB 6 B 160 S MAXIMUM LIKELIHOOD ESTIMATION IN THE WEIBULL DISTRIBUTION BASED ON COMPLETE AND ON CENSORED SAMPLE TECH 65 579 RRATA, 'MAXIMUM LIKELIHOOD ESTIMATION IN THE WEIBULL DISTRIBUTTON BASED ON GOMPLETE AND ON CENSORED SAMPLE TECH 66 570 PARTIGLES ESTIMATION OF PARTICLE SIZE DISTRIBUTION BASED ON OBSERVED WEIGHTS OF GROUPS OF TECH 65 505 S/ ESTIMATION OF THE PARAMETERS OF THE EXPONENTIAL DISTRIBUTION BASED ON OPTIMUM ORDER STATISTICS IN CEN AMS 66 I7I7 
AIDS FOR FITTINC THE CAMMA DISTRIBUTION BY MAXIMUM LIKELIHOOD

THE ESTIMATION OF THE MEAN OF A CENSORED NORMAL DISTRIBUTION BY ORDERED VARIABLES

TECH $60 \quad 55$ ESTIMATION OF THE PARAMETERS OF THE GAMMA DISTRTBUTTON BY SAMPLE QUANTILES ESTIMATION OF THE PARAMETERS OF THE LOCISTIC DISTRIBUTION BY SAMPLE QUANTILES ON CHARACTERIZINC THE NORMAL DISTRIBUTION BY STUDENT'S LAW ON CHARACTERIZING THE CHI SQUARE DISTRIBUTION BY THE STUDENT LAW

BIOKA56 482 TECH $64 \quad 405$ BIOKA69 NO.3 BIOKA66 603 JASA $66 \quad 976$ ESTIMATION OF THE PARAMETERS OF THE EXTREME VALUE DISTRIBUTION BY USE OF TWO OR THREE ORDER STATISTICS BIOKAG9 429 AND AN IMPROVEMENT TO IT A GOMPLETE MULTINOMIAL DISTRIBUTION COMPARED WITH THE X-SQUARE APPROXIMATION BIOKA64 277 TABLE SOME PROPERTIES OF THE BIVARIATE NORMAL DISTRIBUTION CONSIDERED IN THE FORM OF A CONTINGENCY BI OCGUPANCY PROBABILITY DISTRIBUTION CRITICAL POINTS DIFFERENTIAL EQUATIONS FOR PROBABILITIES ABILITY RATIO TESTS THE WISHART DISTRIBUTION DERIVED BY SOLVING SIMULTANEOUS LINEAR BIOKA5l 470 JASA 69602 PROBLEM L. APPLICATIONS BOUNDS ON THE SAMPLE SIZE DTSTRTBUTTON FOR A CLASS OF INVARTANT SEQUENTIAL PROB AMS 68 1048 ASYMPTOTIC DISTRIBUTION FOR A GENERALIZED BANACH MATCH BOX JASA 671252 AN ASYMPTOTIC DISTRIBUTION FOR AN OCCUPANCY PROBLEM WITH STATISTICA TECH 6179 MULTI-SAMPLE TESTS FOR THE FISHER DISTRIBUTION FOR DIRECTIONS INDEPENDENT OBSERVATIONS SOME PROPERTIES OF PASCAL DISTRTBUTION FOR FTNTTE POPUL JASA $62 \quad 172$ APPROXIMATE DISTRIBUTION FOR LARGEST AND FOR SMALLEST OF A SET OF THE ERGODIC QUEUE LENCTH DISTRIBUTION FOR QUEUEING SYSTEMS WITH FINITE CAPACIT JRSSB66 190 ON THE WAITING-TIME DISTRIBUTION FOR QUEUES IN SERIES

BABILITY LEVELS OF THE SYMMETRIC BINOMIAL CUMULATIVE DISTRIBUTION FOR SAMPLE SIZES TO 1.000 , CORR. 59811 JASA 59 164 PROXIMATION TO THE PROBABILITY INTEGRAL OF THE GAMMA DISTRIBUTION FOR SMALL VALUES OF THE SHAPE PARAMETER BIOKA62 276 A TECHNIQUE FOR DISCUSSING THE PASSAGE TIME DISTRIBUTION FOR STABLE SYSTEMS

JRSSB $66 \quad 477$ TATISTIC IN MULTIVARIATE ANALYSIS AN ASYMPTOTIC DISTRIBUTION FOR THE DETERMINANT OF A NON-CENTRAL B S SASJ 6B 77 I PROCESSES PERCENTACE POINTS OF THE BETA DISTRIBUTION FOR USE IN BAYESIAN ANALYSIS OF BERNOULL TECH 66 6B

DISTRIBUTION FUNGTION ION FUNCTION' A TWO-SAMPLE DISTRTBUTTON FREE TEST FOR COMPARTNG VARTANCES

CORRECTION, DISTRIBUTION FREE TESTS BASED ON THE SAMPLE DISTRIBUT BIOKA58 544 BIOKA66 99 DISTRIBUTIONS

SAMPLE DISTRIBUTION FUNCTION

QUIREMENT THAT CUMULATIVE FUNCTIONS BE CONTINUOUS DISTRTBUTION FREE TESTS FOR MTXED PROBABILITY DISTRIBUTION FREE TESTS OF INDEPENDENCE BASED ON THE AMS 614 4B5 DISTRIBUTION FREE TOLERANCE LIMITS. ELIMINATION OF RE TECH 63 5IB TEST IN THE P-VARIATE CASE

A DISTRIBUTION FREE VERSION OF THE SMTRNOV TWO SAMPLE TAIL AREAS OF THE T-DISTRIBUTION FROM A MILLS' RATIO-LIKE EXPANSION A GENERAL CLASS OF COEFFICIENTS OF DIVERGENCE OF ONE DISTRIBUTION FROM ANOTHER ESTIMATING THE PARAMETERS OF LOG-NORMAL DISTRIBUTION FROM CENSORED SAMPLES LIKELIHOOD ESTIMATION OF THE PARAMETERS OF THE BETA DISTRIBUTION FROM SMALLEST ORDER STATISTICS LIKELIHOOD ESTIMATION OF THE PARAMETERS OF THE BETA DISTRIBUTION FROM SMA
ON THE INVERSE GAUSSIAN DISTRIBUTION FUNCTION
A TEST FOR SYMMETRY USING THE SAMPLE DISTRIBUTION FUNCTION LIKELIHOOD ESTIMATION OF THE PARAMETERS OF THE BETA DISTRIBUTION FROM SMALL
ON THE INVERSE GAUSSIAN DISTRIBUTION FUNCTION
A TEST FOR SYMMETRY USING THE SAMPLE DISTRIBUTION FUNCTION AMS $69 \quad 1$ AMS $63 \quad 335$ JRSSB $66 \quad 131$ JASA $6 B \quad 134$ TECH 67607 JASA $6 B \quad 1514$ AMS 69 NO. 6 ON THE RANGE OF THE DIFFERENCE BETWEEN HYPOTHETICAL DISTRIBUTION FUNCTION AND PYKE'S MODIFIED EMPIRICAL D AMS 62 525 CRIPTION/ TABLES FOR USE IN ESTIMATING THE NORMAL DISTRIBUTION FUNCTION BY NORMIT ANALYSIS. PART I. DES BIOKA57 4II GHT LINES THE PROBABILITY THAT THE SAMPLE DISTRIBUTION FUNCTION LIES BETWEEN TWO PARALLEL STRAI AMS 68 39B LATION/DERIVATION OF APPROXIMANTS TO THE INVERSE DISTRIBUTION FUNCTION OF A CONTINUOUS UNIVARIATE POPU BIOKA69 NO 3 NONPARAMETRIC ESTIMATION OF THE TRANSITION DISTRIBUTION FUNCTION OF A MARKOV PROCESS DIMENSIONAL PROPERTIES OF A RANDOM DISTRIBUTION FUNCTION ON THE SQUARE

LENGTH CONFIDENCE INTERVALS FOR THE P-POINT OF A DISTRIBUTION FUNCTION, II LENGTH GONFIDENCE INTERVALS FOR THE P-POINT OF A DISTRIBUTION FUNCTION, III LENGTH GONFIDENCE INTERVALS FOR THE P-POINT OF A DISTRIBUTION FUNCTION,
A USEFUL APPROXIMATION TO THE NORMAL DISTRIBUTION FUNCTION. AMS $6913 B 6$ AMS $66 \quad 849$ 'DISTRIBUTION FREE TESTS BASED ON THE SAMPLE DISTRIBUTION FUNCTION' ASYMPTOTIC EXPANSIONS FOR A CLASS OF DISTRIBUTION FUNCTIONS ON CONTINUOUS SINGULAR INFINITELY DIVISIBLE DISTRIBUTION FUNCTIONS

ON GONTINUITY PROPERTIES OF INFINITELY DIVISIBLE DISTRIBUTION FUNCTIONS ON THE EVALUATION OF DISTRIBUTION FUNCTIONS $\begin{array}{rrrr}\text { BOUNDED AMS } & 66 & 586 \\ \end{array}$ GOMPUTER EVALUATION OF THE NORMAL AND INVERSE NORMAL DISTRIBUTION FUNCTIONS
ON A CLASS OF SKEW DISTRIBUTION FUNCTIONS GOMPUTER EVALUATION OF THE NORMAL AND INVERSE NORMAL DISTRIBUTION FUNCTIONS
ON A CLASS OF SKEW DISTRIBUTION FUNCTIONS LOCAL LIMIT THEOREM FOR NONLATTICE MULTI-DIMENSIONAL DISTRIBUTION FUNCTIONS

OF INTEGRAL TRANSFORMS TO DETERMINE EXPANSIONS OF DISTRIBUTION FUNCTIONS OF TWO-SAMPLE RANK TESTS ON THE EQUALITY OF TWO DISTRIBUTION FUNCTIONS IATIONS OF FUNCTIONS OF SEVERAL EMPIRICAL CUMULATIVE DISTRIBUTION FUNCTIONS A NOTE ON THE UNIMODALITY OF DISTRIBUTION FUNGTIONS OF CLASS $L$ CORRECTION, BIOKA67 333 AMS 631302 AMS $64 \quad 330$ AMS $68 \quad 936$ JASA. $68 \quad 715$ TECH 69 N0.4 BIOKA55 425 A AMS $65 \quad 546$ THE USE BIOKA60 460 ON THE POWER JRSSB64 293 OF LARCE DEV AMS $67 \quad 360$ KS CONCERNING THE APPLICATION OF EXACT FINITE SAMPLE DISTRIBUTION FUNCTIONS OF CENERALIZED CLASSICAL LINEA JASA 63 943 IATE DISTRIBUTIONS A RECURRENCE RELATION FOR DISTRIBUTION FUNCTIONS OF ORDER STATISTICS FROM BIVAR JASA 69 600 NORMAL RESID/ A GOODNESS OF FIT TEST FOR SPEGTRAL DISTRIBUTION FUNCTIONS OF STATIONARY TIME SERIES WITH BIOKA56 25\% STATISTIC STATISTIGS SERIES BOUNDS ON THE DISTRIBUTION FUNCTIONS OF THE BEHRENS-FISHER THE DISTRIBUTION FUNCTIONS OF TSAO'S TRUNCATED SMIRNOV AMS $67120 B$ APPROXIMATIONS TO DISTRIBUTION FUNCTIONS WHICH ARE HYPERGEONETRIC B BIOKA68 243 $\begin{array}{rr}\text { AMS } 65 & 322\end{array}$ JASA $67 \quad 54 B$

SOME RENYI TYPE LIMIT THEOREMS FOR EMPIRICAL DISTRIBUTION FUNCTIONS, CORR. 651069 EXPONENTIAL LIFE TEST PROCEDURES WHEN THE DISTRIBUTION HAS MONOTONE FAILURE RATE

SEQUENTIAL ESTIMATION OF THE MEAN OF A LOG-NORMAL DISTRIBUTION HAVING A PRESCRIBED PROPORTIONAL CLOSENE AMS 66 I6BB
FIXED SAMPLE ESTIMATOR OF THE MEAN OF A LOG-NORMAL DISTRIBUTION HAVING A PRESCRIBED PROPORTIONAL CLOSENE AMS 67 949 SEQUENTIAL TESTS FOR THE MEAN OF A NORMAL DISTRIBUTION II, LARCE T SEQUENTIAL TEST FOR THE MEAN OF A NORMAL DISTRIBUTION III, SMALL T

TESTS GAMMA DISTRIBUTION IN ACCEPTANCE SAMPLING BASED ON LIFE AMS $64 \quad 162$ AMS $65 \quad 28$ JASA $61 \quad 942$ TISTICS FOR ESTIMATING THE PARAMETERS OF EXPONENTIAL DISTRIBUTION IN CENSORED SAMPLES /OPTIMUM ORDER STA TECH 67 279 ON THE USE OF THE GENERALIZED EXTREME-VALUE DISTRIBUTION IN ESTIMATING EXTREME PERCENTILES OF THE SLOPE OF THE MAJOR AXIS OF A BIVARIATE NORMAL DISTRIBUTION IN THE CASE OF A SMALL SAMPLE /MATION BIOCS6B 679 RETE DATA THE USE OF A GENERALIZED MULTINOMIAL DISTRIBUTION IN THE ESTIMATION OF CORRELATION IN DISC JRSSB62 53O LIMIT DISTRIBUTION IN THE THEORY OF COUNTERS, CORR. 621466 AMS 611271 SOME QUESTIONS OF DISTRIBUTION IN THE THEORY OF RANK CORRELATION A SIMPLE METHOD OF RESOLUTION OF A DISTRIBUTION INTO GAUSSIAN COMPONENTS AN ALGORITHM FOR THE DECOMPOSITION OF A DISTRIBUTION INTO GAUSSIAN COMPONENTS APPROXIMATION TO THE GENERALIZED BEHRENS-FISHER DISTRIBUTION INVOLVING THREE VARIATES

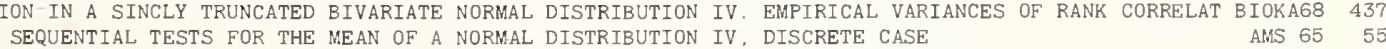
ON THE DISTRIBUTION OF 'STUDENTIZED' RANGE BIOKA52 194 ION, A REMARK ON THE CRITICAL CASE THE STATIONARY DISTRIBUTION OF A BRANCHING PROCESS ALLOWINC IMMIGRAT JRSSB68 I76 PROCESS THE STATIONARY DISTRIBUTION OF A BRANCHING PROCESS ALLOWINC IMMIGRAT JRSSB68 176
THE ASYMPTOTIC DISTRIBUTION OF A CERTAIN FUNCTIONAL OF THE WIENER AMS 691409 
TE TWO-SAMPLE PROBLEM

DENSITIES

VARIABLES

ON THE NULL DISTRIBUTION OF A NON PARAMERIC TEST POR DISTRIBUTION OF A PRODUCT AND THE STRUCTURAL SETUP OF THE DISTRIBUTION OF A QUADRATIC FORM OF NORMAL RANDOM

QUERY, DISTRIBUTION OF A RANKED OBSERVATION ANALYSIS

USE OF WILCOXON TEST THEORY IN ESTIMATING THE DISTRIBUTION OF A RATIO BY MONTE CARLO METHODS COVARIANCE MATRIX

THE NON-NULL DISTRIBUTION OF A STATISTIC IN PRINCIPAL COMPONENTS

ON THE DISTRIBUTION OF A STATISTIC USED FOR TESTINC A

THE EXACT DISTRIBUTION OF A STRUCTURAL COEFFICIENT ESTIMATOR ON THE EXACT DISTRIBUTION OF A TEST IN MULTIVARIATE ANALYSIS

THE SAMPLING DISTRIBUTTON OF AN ESTIMATE ARTSING IN LIFE TESTING

TH THE TRUNCATED EXPONENTIAL DISTRIB/ THE SAMPLING DISTRIBUTION OF AN ESTIMATOR ARISINC IN CONNECTION WI AMS 69 702

A RANDOM SEQUENCE

THE JOINT DISTRIBUTION OF ASCENDING PAIRS AND ASCENDING RUNS IN BIOKA67 330

CALCULATINC TAU AND AVERACE TAU AND ON THE SAMPLINC DISTRIBUTION OF AVERAGE TAU WITH A CRITERION RANKING J VARIATES

ON THE DISTRIBUTION OF CERTAIN QUADRATIC FORMS IN NORMAL

THE MULTIVARIATE DISTRIBUTION OF COMPLEX NORMAL VARIABLES

ASYMPTOTIC EXPANSIONS FOR THE MOMENTS OF THE DISTRIBUTTON OF CORRFLATION COEFFICTENT

FORMS' 55122

CORRECTION TO 'DISTRIBUTION OF DEFINITE AND OF INDEFINITE QUADRATIC FORMS FROM A NON-CENTRAL NORMAL DISTRIBUTION

MATRICES ARE PROPORTIONAL

FROM BIVARIATE POPULATIONS

ASYMPTOTI

DISTRIBUTION OF DEFINITE AND OF INDEFINITE QUADRATIC DISTRIBUTION OF DISCRTMTNANT FUNCTION WHEN COVARIANCE CHANGES IN THE SIZE DISTRIBUTION OF DIVIDEND INCOME

IN SAMPLES FROM A NORMAL DISTRIBUTTON

THE DISTRIBUTTON OF EXTREMAL AND NEARLY EXTREMAL VALUES D SAMPIES OF THE PARAMETERS OF THE FIRST ASYMPTOTIC DISTRIBUTION OF EXTREME VALUES /FROM DOUBLY CENSORE J

APPROXIMATE DISTRIBUTION OF EXTREMES FOR NONSAMPLE CASES

AN EMPIRIGAL INVESTIGATION

THE RANDOMIZATION DISTRIBUTION OF F-RATIOS FOR THE SPLIT-PLOT DESIGN, A STOCHASTIC ANALYSIS OF THE SIZE DISTRIBUTION OF FIRMS, CORR, 59810

ON THE DISTRIBUTION OF FIRST SIGNIFICANT DIGITS THE DISTRIBUTION OF GALTON'S STATISTICS

COMMENTS ON A POSTERIOR DISTRIBUTION OF GEISSER AND CORNFIELD THE DISTRIBUTION OF HETEROGENEITY UPON INBREEDING
MULTIVARIATE DISPERSION

A SYSTEM OF LINEAR DIFFERENTIAL EQUATIONS FOR S BIRTH-DEATH PROCESS

IN A SERIES OF RANDOM NUMBERS
GAUSSIAN PROCESS THE DISTRIBUTION OF INTERVALS BETWEEN SUCCESSIV
THE FACTORIAL MOMENTS OF THE DISTRIBUTION OF JOINS BETWEEN LINE SEGMENTS

DISTRIBUTION OF HIGH LEVEL CROSSINGS OF A STATIONARY THE DISTRIBUTION OF HOTELLING'S GENERALIZED MEASURE OF

JASA $62 \quad 567$

JRSSB $62 \quad 14 B$

BIOKA56 212

BIOKA66 258

AMS $62 \quad$ B13

AMS $63 \quad 186$

AMS $69 \quad 979$

AMS $64 \quad 74 \mathrm{~B}$

JASA $61 \quad 250$

BIOKA63 B9

JASA $68 \quad 889$

JASA $64 \quad 429$

BIOKA63 43.

JASA $58 \quad 893$

AMS $61 \quad 1223$

AMS 682114

JRSSB64 274

JRSSB54 88

AMS $6 B \quad 210 B$

AMS $66 \quad 215$ AMS $68 \quad 815$

BIOKA69 225

AMS $69 \quad 1124$

BIOKA57 524

BIOKA54 555

BIOKA56 3B6 THE DISTRIBUTION OF KENDALL'S SCORE S FOR A PAIR OF TIED BIOKA6O 151

RANKINGS ADDENDUM. THE DISTRIBUTION OF KENDALL'S TAU FOR SAMPLES OF FOUR FRO BIOKA63 538 THE VALIDITY OF THE ASSUMPTIONS THAT THE UNDERLYINC DISTRIBUTION OF LIFE IS EXPONENTIAL. PART II /S FOR TECH 60 I67 A GENERAL METHOD FOR APPROXIMATING TO THE DISTRIBUTION OF LIKELIHOOD RATIO CRITERIA TREND DISTRIBUTION OF LIKELIHOOD RATTO IN TESTING AGATNST AMS 69 - 371 RDER STATISTICS WITH APPLICATIONS TO E/ ASYMPTOTIG DISTRIBUTION OF LINEAR COMBINATIONS OF FUNCTIONS OF O AMS 67 52 FUNCTIONS OF ORDERED CORRELATED NORMAL RA/ ON THE DISTRIBUTION OF LINEAR FUNCTIONS AND RATIOS OF LINEAR BIOKA64 I43 TIVARIATE DISTRIBUTIONS ASYMPTOTIC JOINT DISTRIBUTION OF LINEAR SYSTEMATIC STATISTICS FROM MUL JASA 69 ACCURACY OF BOY'S APPROXIMATIONS TO THE DISTRIBUTION OF M NEAR MODEL WITH AUTORECRESSIVE DISTURB/ ASYMPTOTIC DISTRIBUTION OF MAXIMUM LIKELIHOOD ESTIMATORS IN A LI AMS 69 583 THE DISTRIBUTION OF MOMENT ESTIMATORS

NOTE ON AN APPROXIMATION TO THE DISTRIBUTION OF NON-CENTRAL CHI-SQUARE

AN APPROXIMATION TO THE DISTRIBUTION OF NON-CENTRAL T

THE DISTRIBUTION OF NONCENTRAL MEANS WITH KNOWN

THE REDUCED ITH ORDER STATISTIC OF TH/ CONDITIONAL DISTRIBUTION OF ORDER STATISTICS AND DISTRIBUTION OF LEAST SQUARES ESTIMATORS

THE EXACT SAMPLING DISTRIBUTION OF ORDINARY LEAST SQUARES AND TWO-STAGE THE DISTRIBUTION OF ORGANISMS

PERCENTAGE POINTS FOR THE DISTRIBUTION OF OUTGOING QUALITY

BIOKA59 296

BIOKA59 364

BIOKA58 484

AMS $61 \quad$ B 74

AMS $63 \quad 652$

JASA $69 \quad 923$

BIOCS65 543

JASA 59689

FOUR-LETTER WORDS. THE DISTRIBUTION OF PATTERN FREQUENCIES IN RINC PERMUTATI JRSSB67 550

ONS POSTERIOR DISTRIBUTION OF PERCENTILES BAYES' THEOREM FOR SAMPL JASA 68

ING FROM A POPULATION POSTERI OF MAXIMUM VA ON THE DISTRIBUTION OF PRODUCTS OF RANDOM VARIABLES

CENTRAL T

TO THE DISTRIBUTION OF $Q$, A VARIATE RELATED TO THE NON-

JASA 64

JRSSB67 513

AMS $64 \quad 315$

AMS 631582

AMS $65 \quad 677$

BIOKA61 419

BIOKA62 284

BIOKA52 207

TECH $62 \quad 138$

BIOKA52 417

BIOKA54 463

LIPTICAL NORMAL DISTRIBUTION

THE DISTRIBUTION OF QUANTILES OF SMALL SAMPLES

DISTRIBUTION OF RADICAL ERROR IN THE BIVARIATE

POPULATIONS

NS '

THE DISTRIBUTION OF RANGE IN CERTAIN NON-NORMAL

BIOKA55 277

BIOKA51 463

BIOKA57 257

CORRECTION, 'CALCULATION OF EXACT SAMPLINC DISTRIBUTION OF RANCES FROM A DISCRETE POPULATION' AMS 67 280 OM BIVARIATE NON-NORMAL POPULATIONS. I. THEOR/ THE DISTRIBUTION OF REGRESSION COEFFICIENTS IN SAMPLES FR BIOKA6O 6I PROCESS

THE DISTRIBUTTON OF RESPONSE TTMES IN A BIRTH-DEATH

$\begin{array}{ll}\text { BIOKA65 } & 581 \\ \text { TEGH } 66 & 700\end{array}$ JRSSB6B 570 BIOKA59 130 JASA 69 N0. 4 BIOKA56 169 
FROM TESTS ON ITS COMPONENTS

THE CONDITIONAL DISTRIBUTION OF SETS OF TESTS ON A SYSTEM SIMULATED AMS 631585 $S$ UNDER CENSORING PROBLEMS

RECURSIVE GENERATION OF THE DISTRIBUTION OF SEVERAL NON-PARAMETRIC TEST STATISTIC ON THE DISTRIBUTION OF SOLUTIONS IN LINEAR PROGRAMMING SAMPLE RANK VECTOR

THE ASYMPTOTIC DISTRTBUTION OF SOME NON-LINEAR FUNCTIONS OF THE TWO- AMS ETE FINITE STATE MARKOV CHAINS ADMISSIBILITY AND DISTRIBUTION OF SOME PROBABILISTIC FUNCTIONS OF DISCR AMS 68 I646 ENTIAL AND POWER-FUNCTION POPULATIONS DISTRIBUTION OF SOME STATISTICS IN SAMPLES FROM EXPON JASA 67259 $S$ OF JOINTLY STATIONARY TIME SERIES RAINFALL STIMULATION EXPERIMENTS

ON THE DISTRIBUTION OF SOME STATTSTICS USEFUL IN THE ANALYSI AMS 681849 B-0. Y-SUB-1..) IS A REALIZATION OF A NON-/ THE DISTRIBUTION OF SUM-0-T0-M OF F(Y-SUB-T) WHERE (Y-SU BIOKAG5 277 ON THE INFLUENCE OF MOMENTS ON THE ASYMPTOTIC DISTRIBUTION OF SUMS OF RANDOM VARIABLES

NORMAL VARIATES IN THE PRESENCE OF INTRA-/ ON THE DISTRIBUTION OF SUMS OF SQUARES AND CROSS PRODUCTS OF N MATRIX IN THE DUAL CASE

TERIA FOR MARKOV CHA TNS AND MAR/ BROWNIAN MOTIONS DISTRIBUTION OF THE 'GENERALIZED' MULTIPLE CORRELATIO ON THE ASYMPTOTIC DISTRIBUTION OF THE 'PSI-SQUARED' GOODNESS OF FIT CRI DISTRIBUTION OF THE ABSOLUTE MAXIMUM FOR CERTAIN AMS 631042 AMS 621461 AMS 641801 AMS $61 \quad 49$ AMS $65 \quad 311$

AMS 611118

A LINEAR STOCHASTIC PROCESS DISTRTBUTION OF THE ANDERSON-DARLING STATISTIC $S$ TO THE AVERAGE RANK CORRELATION METHODS AND TO THE DISTRIBUTION OF THE AVERAGE RANK CORRELATION COEFFICI JASA 63 756 $R$ TESTING THE DIFFERENGE BETWEEN THE MEA/ AN EXACT DISTRIBUTION OF THE BEHRENS-FISHER-WELCH STATISTIC FO JRSSB6I 377 ON THE DISTRIBUTTON OF THE BIVARIATE RANGE

COEFFICIENTS

ON THE JOINT DISTRIBUTION OF THE CIRCULAR SERIAL CORRELATION

TECH $67 \quad 476$ $Y$ LINEAR MARKOV SERIES $Y$ LINEAR MARKOV SERIES. II

THE DISTRIBUTION OF THE COEFFICIENT OF VARIATION, COMMENT BIOKA65 THE APPROXIMATE DISTRIBUTION OF THE CORRELATION BETWEEN TWO STATIONAR BIOKA62 THE APPROXIMATE DISTRIBUTION OF THE CORRELATION BETWEEN TWO STATIONAR BIOKA65 301 ON THE A PRIORI DISTRIBUTION OF THE COVARIANCE MATRIX

AMS 691098

DISTRIBUTED MATRIX THE DISTRIBUTION OF THE DETERMINANT OF A COMPLEX WISHART EGRESSION AND ERROR-SCALE PARAMETERS, WHEN THE JOINT DISTRIBUTION OF THE ERRORS IS OF ANY CONTINUOUS FORM THE SAMPLE MEAN JOINT DISTRIBUTION OF THE ERRORS IS OF ANY CONTINUOUS FORM BIOKA6I ORMAL POPULAT/AN EMPIRICAL INVESTIGATION INTO THE DISTRIBUTION OF THE F-RATIO IN SAMPLES FROM TWO NON-N BIOKA58

OF A GROUP OF EXPERIMENTS NOISE COEFFICIENT

ON THE DISTRIBUTION OF THE F-TYPE STATISTICS IN THE ANALYSIS J

ON THE DISTRIBUTION OF THE FIRST SAMPLE MOMENTS OF SHOT TECH 64287

THE NULL DISTRIBUTION OF THE FIRST SERIAL CORRELATION THE DISTRIBUTION OF THE GENERALIZED VARIANCE

SQUARE-SUB-N. II THE DISTRIBUTION OF THE GOODNESS-OF-FIT STATISTIC USQUARE-SUB-N. THE DISTRIBUTION OF THE GOODNESS-DF-FIT STATISTIC, UCOEFFICIENT

MATRIX IN MULTIVARIATE ANALYSIS ON THE NONCENTRAL DISTRTBUTION OF THE LARCEST CANONTCAL CORRELATION BIOKA66 623 AMS 65120 BIOKA64 393 BIOKA63 303 SASJ 69 N0.2 ON THE DISTRIBUTION OF THE LARGEST CHARACTERISTIC ROOT OF A BIOKA65 405 SPONDING LATENT VECTOR FOR PRICIPAL COMPON/ ON THE DISTRIBUTION OF THE LARGEST LATENT ROOT AND THE CORRE AMS 66 995 EST LATENT ROOT OF THE GENERALIZED B STATISTIC AN/ DISTRIBUTION OF THE LARCEST LATENT RO0T AND THE SMALL AMS 67 1152 COVARIANCE MATRIX $X$ IN MULTIVARIATE ANALYSIS IN MULTIVARIATE ANALYSIS ON THE DISTRTBUTION OF THE LARGEST LATENT ROOT OF THE ON THE DISTRIBUTION OF THE LARGEST OF SEVEN ROOTS OF A MATRI BIOKA64 27 ON THE DISTRIBUTION OF THE LARCEST OF SIX ROOTS OF A MATRIX BIOKA59 237 POTHESTS CONCERNINC COMPL/ ISTIC ROOT UNDER NULL HYPOTHESIS CONCERNINC COMPL/
MATRIX IN MULTIVARIATE ANALYSIS ON THE DISTRIBUTION OF THE LARGEST OR THE SMALLEST ROOT OF A BIOKA56 122 MULTIVARIATE ANALYSIS

ON THE DISTRIBUTION OF THE LARGEST OR THE SMALLEST ROOT OF A BIOKA56 122 M MATRIX UNDER/ ON CERTAIN CHARACTERISTICS OF THE DISTRIBUTION OF THE LATENT ROOTS OF A SYMMETRIG RANDO ARIANCE MATRIX AN ASYMPTOTIC EXPANSION FOR THE DISTRIBUTION OF THE LATENT ROOTS OF THE ESTIMATED COV COMPONENTS ANALYSIS

MULTIVARIATE LINEAR HYPOTHESES

ON THE DISTRIBUTION OF THE LATENT VECTORS FOR PRINCIPAL DISTRIBUTION OF THE LIKELIHOOD RATIO FOR TESTINC

AMS $61 \quad$ B64 AMS 651153 AMS 651875 AMS $61 \quad 333$ AMS 631286 IC WHEN THE TRUE PARAMETER IS 'NEAR' THE B/ ON THE DISTRIBUTION OF THE LOC LIKELIHOOD RATIO TEST STATIST AMS 68 2044 SOME PROPERTIES OF THE DISTRIBUTION OF THE LOGARITHM OF NON-CENTRAL F

NORMAL VARIATES THE DISTRIBUTION OF THE LOGARITHM OF THE SUM OF TWO LOG- JASA 69655 EHMANN ALTERNATIVES RECURSIVE GENERATION OF THE DISTRIBUTION OF THE MANN-WHITNEY U-STATISTICS UNDER L UNDER LEHMANN ALTERNATIVES

TABLES OF THE DISTRIBUTION OF THE MANN-WHITNEY-WILCOXON U-STATISTIC THE DISTRIBUTION OF THE MATCHING COEFFICIENT

ORDER STATISTICS

ON THE DISTRIBUTION OF THE MAXIMUM AND MINIMUM OF RATIOS OF LIMITING DISTRIBUTION OF THE MAXIMUM OF A DIFFUSION PROCESS THE DISTRIBUTION OF THE MAXIMUM OF A SEMI-MARKOV PROCESS THE DISTRIBUTION OF THE MAXIMUM SUM OF RANKS

DEPENDENT RANDOM VARIABLES LIMITINC DISTRIBUTION OF THE MAXIMUM TERM IN SEQUENCES OF THE DISTRIBUTION OF THE MEAN HALF-SQUARE SUCCESSIVE

DIFFERENCE JOINT ASYMPTOTIC DISTRIBUTION OF THE MEDIAN AND A U-STATISTIC

PAIRED COMPARISONS A RELATIVELY SIMPLE FORM OF THE DISTRIBUTION OF THE MULTIPLE CORRELATION COEFFICIENT OF DEPENDENT TRIALS T TRIALS

D GAMMA VARIABLES WITH THE SAME SHAPE PARAM/ CENTRAL CHI-SQUARE VARIATES THE DISTRIBUTION OF THE NUMBER OF SUCCESSES IN A SEQUEI ON THE DISTRIBUTION OF THE NUMBER OF SUCCESSES IN INDEPENDEN

EXACT DISTRIBUTION OF THE PRODUCT OF INDEPENDENT GENERALIZE THE DISTRIBUTION OF THE PRODUCT OF TWO CENTRAL OR NON-

CIENT IN RANDOM SAMPLES OF ANY SIZE/ THE FREQUENCY DISTRIBUTION OF THE PRODUCT-MOMENT CORRELATION COEFFI QUERY, CALCULATION OF THE SAMPLING DISTRIBUTION OF THE RANGE

E POPULATIONS AND A RANGE TEST FOR H/ THE SAMPLING DISTRIBUTION OF THE RANGE FROM DISCRETE UNIFORM FTNIT J ND PERCENTAGE POINTS OF THE ORDER STATISTICS AND THE DISTRIBUTION OF THE RANCE FROM THE LOGISTIC DISTRIBUT ECIONS UNDER SPHERICAL NORMAL DISTRIBUTIONS, II. THE DISTRIBUTION OF THE RANCE IN NORMAL SAMPLES' 60 III3 L POPULAT/ COMPARISON OF TWO APPROXIMATIONS TO THE DISTRIBUTION OF THE RANGE IN SMALL SAMPLES FROM NORMA OF RANGE TO STANDARD DEVIATION FROM A NON-NORMAL POPULATION AN APPLICATION OF THE DISTRIBUTION OF THE RANKING CONCORDANCE COEFFICIENT THE DISTRIBUTION OF THE RATIO, IN A SINGLE NORMAL SAMPLE, THE DISTRIBUTION OF THE REGRESSION COEFFICIENT IN SAMPLES DISTRIBUTION OF THE RESIDUAL SUM OF SQUARES IN FITTING INEQUALITIES

SOME NEW RESULTS ON THE DISTRIBUTION OF THE SAMPLE CORRELATION COEFFICIENT

CIENT

AN EMPIRICAL STUDY OF THE DISTRIBUTION OF THE SAMPLE GENETIC CORRELATION COEFF THE SAMPLE IS DRAWN FROM A DIFFEREN/ THE FREQUENCY DISTRIBUTION OF THE SAMPLE MEAN WHERE EACH MEMBER OF II. TESTS OF COMPOSITE HYPOT/ APPROXIMATION TO THE DISTRIBUTION OF THE SAMPLE SIZE FOR SEQUENTIAL TEST. ASSOCIATION, GAMMA

ION OF THE ROOTS OF A MATRIX DISTRIBUTION OF THE SAMPLE VERSION OF THE MEASURE OF POINTS ON A LINE

ON THE NON-CENTRAL DISTRIBUTION OF THE SECOND ELEMENTARY SYMMETRIC FUNCT THE DISTRIBUTION OF THE SIZE, OF THE MAXIMUM CLUSTER OF

AMS $66 \quad 2 \mathrm{~B} 4$

BI0CS67 647 AMS 69918 AMS $64 \quad 319$ AMS 68947 TECH $67 \quad 271$ AMS 62894 BIOKA67 419 JRSSB57 144 JRSSB $68 \quad 276$ BIOKA62 265 BIOKA59 454 AMS 641317 AMS 681751 AMS 621016 BIOKA51 219 TECH $65 \quad 73$ ASA 69 NO.4 AMS $65 \quad 907$ AMS 61620 BIOKA52 130 BIOKA51 33 BIOKA54 482 BIOKA54 548 BIOKA67 69 JRSSB66 513 BI0CS69 63 BI0KA63 508 BIOKA60 190 JASA $66 \quad 440$ AMS $68 \quad 833$ JASA $65 \quad 532$ 
TS STRIBUTED DISCRETE RANDOM VARIABLES, CORR, / OV PROCESSES WITH CONTINUOUS STATE SPACES DAM UNDER STEADY DEMAND

THE

JOINT DISTRIBUTION OF THE STUDENTIZED REGRESSION COEFFICIEN BIOKA68

STRIBUTION OF THE SUM OF INDEPENDENT IDENTICALLY DI JASA 65

ISTRIBUTION OF THE SUPREMUM FUNCTIONAL FOR SEMI-MARK AMS 69 B

THE DISTRIBUTION OF THE TIME-TO-EMPTINESS OF A DISCRETE JRSSB63 137 A COMBINATORTAL DERTVATION OF THE DTSTRIBUTION OF THE TRUNCATED POISSON SUFFICIENT STAT CRITERION

TERION D-SU/ ON THE EXACT AND APPROXIMATE SAMPLINC DISTRIBUTION OF THE TWO SAMPLE KOLMOCOROV-SMIRNOV CRI JAS CRITERION FOR SMALL EQUAL SAMPLES SMALL EQUAL SAMPLES
DISTRIBUTION OF THE TWO-SAMPLE CRAMER-VON MISES BIOKA62 185 AMS 62 114B EXTREME TAIL PROBABILITIES FOR THE NULL DISTRIBUTION OF THE TWO-SAMPLE WILCOXON \$TATISTIC BIOKA67 629 APPROXIMATIONS FOR THE NULL DTSTRIBUTTON OF THE W-STATTSTTC + (TEST FOR NORMALITY) TECH 6B

NDENT STUDENT VARIABLES ON THE DISTRIBUTION OF THE WEICHTED DIFFERENCE OF TWO INDEPE OBSERVATION INTERVAL AN APPROXIMATION FOR THE EXACT DISTRIBUTION OF THE WILCOXON TEST FOR SYMMETRY DISTRIBUTION OF TOTAL SERVICE TIME FOR A FIXED ON THE DISTRIBUTION OF TRIBOLIUM CONFUSUM IN A CONTAINER L ON FIXED SUM NORMAL APPROXIMATION TO THE DISTRIBUTION OF TWO INDEPENDENT BINOMIALS, CONDITIONA ATION PROCEDURES, CORR. 64924 SOME RESULTS ON THE DISTRIBUTION OF TWO RANDOM MATRICES USED IN CLASSIFIC THE DISTRIBUTION OF VACANCIES ON A LINE ECT MODELS IN THE ANALYSIS OF VARIANCE. I. POSTERIOR DISTRIBUTION OF VARIANCE-COMPONENTS /OF RANDOM-EFF BIOKA65 37 S OF VARIANCE TABLE FOR DIFFERENT CLASSIFI/ PN ON THE EXACT DISTRIBUTION OF WILKS'S CRITERION
2) APPROXIMATE BEHAVIOR OF THE DISTRIBUTION OF WINSORIZED T (TRIMMI ON

TWEEN THE DICTIONARY DISTRIBUTION AND THE OCCURRENCE DISTRIBUTION OF WORD LENCTH AND ITS IMPORTANCE FOR TH B A CHARACTERIZATION OF THE UNIFORM DISTRIBUTION ON A COMPACT TOPOLOCICAL CROUP

FOR THE DISPERSION AND FOR THE MODAL VECTOR OF A DISTRIBUTION ON A SPHERE TIMATION OF ONE OF TWO PARAMETERS OF THE EXPONENTIAL DISTRIBUTION ON THE BASIS OF SUITABLY CHOSEN ORDER ST AMS 63 I4I9 ANALOCUES OF THE NORMAL DISTRIBUTION ON THE CIRCLE AND THE SPHERE 81 INTECRAL OF THE BIVARIATE NORMAL DISTRIBUTION OVER AN OFFSET CIRCLE JASA 62 758

A TABLE OF THE INTECRAL OF THE BIVARIATE NORMAL DISTRIBUTION OVER AN OFSET CIRCLE

JRSSB $60 \quad 177$ AN EXACT PROBABILITY DISTRIBUTION OVER SAMPLE SPACES OF PAIRED COMPARISONS BIOCS65 $9 B 6$ RATIC FUNCTIONS IN NORMAL VECTORS ON CERTAIN DISTRIBUTION PROBLEMS BASED ON POSITIVE DEFINITE QUAD AMS 66 46B IC ROOTS OF THE PRODUCT OF A WISHART VARIATE/ SOME DISTRIBUTION PROBLEMS CONNECTED WITH THE CHARACTERIST AMS 67 944 SOME NON-CENTRAL DISTRIBUTION PROBLEMS IN MULTIVARIATE ANALYSIS AMS 631270 SOME APPLICATIONS OF MEIJER-G FUNCTIONS TO DISTRIBUTION PROBLEMS IN STATISTICS R AND ITS ROMEVANCE TO STMULATTON C/ A HTSTORY OF DISTRIBUTTON SAMPLINC PRTOR TO THE ERA OF THE COMPUTE JASA 65 FAILURES OCCUR PER LOT ESTIMATION OF WEIBULL DISTRIBUTION SHAPE PARAMETER WHEN NO MORE THAN TWO ? SOME PROPERTIES OF A DISTRIBUTION SPECIFIED BY ITS CUMULANTS

ERRATA, 'SOME PROPERTIES OF A DISTRIBUTION SPECIFIED BY ITS CUMULANTS' $\begin{array}{rllll}\text { ERRATA. 'SOME PROPERTIES OF A DISTRIBUTION SPECIFIED BY ITS CUMULANTS' } & \text { TECH 63 } 417 \\ & \text { ON A CONTAGIOUS DISTRIBUTION SUCCESTED FOR ACCIDENT DATA } & \text { BIOCS67 } & 241\end{array}$ ON A CONTAGIOUS DISTRIBUTION SUCCESTED FOR ACCIDENT DATA
SOME EXACT RESULTS FOR ONE-SIDED DISTRIBUTION TESTS OF THE KOLMOCOROV-SMIRNOV TYPE VERDRUP'S LEMMA AND SOME ASYMPTOTIC DISTRIBUTION THEORY FOR MARKOV CHAINS WITH A DENUMERA BIOKA56 BLE NUMBER OF STATES
IATION BASED ON SECOND VARIATE DIFFERENCES DISTRIBUTION THEORY OF TWO ESTIMATES FOR STANDARD DEV BIOKA54 ABILITY ANAL/APPLICATTONS OF THE BIVARIATE NORMAL DISTRIBUTION TO A STRESS VS. STRENCTH PROBLEM IN RELI TECH 64 325 VARIATE ESTIMATOR OF EXTREME QUANTILES OF THE NORMAL DISTRIBUTION UNDER SQUARED ERROR LOSS /THE BEST IN AMS 69 I8O1 NCLY AND DOUBLY CENSORED SAMPLES, PART I. THE NORMAL DISTRIBUTION UP TO SAMPLES OF SIZE 10 ' /ICS FROM SI AMS 39 325 ESTIMATION OF PARAMETERS OF THE GAMMA DISTRIBUTION USINC ORDER STATISTICS NBIASED ESTIMATORS OF THE PARAMETERS OF THE LOCISTIC DISTRIBUTION USINC ORDER STATISTICS ESTIMATION OF SCALE OR SHAPE PARAMETERS OF THE GAMMA DISTRIBUTION USING ORDER STATISTICS CORRIGENDA, 'ESTIMATION OF PARAMETERS OF THE GAMMA DISTRIBUTION USING ORDER STATISTICS. TESTING THE MEAN AND STANDARD DEVIATION OF A NORMAL DISTRIBUTION USING QUANTILES A RAPID TEST FOR THE POISSON DISTRIBUTION USING THE RANGE BIOKA62 525 $\begin{array}{lrr}\text { /UM-LIKELIHOOD BIOKA63 } & 217\end{array}$ BIOKA63 546 TECH 68 781 BIOCS67 685 TIMATION OF THE PARAMETERS FOR A MULTIVARIATE NORMAL DISTRIBUTION WHEN ONE VARIABLE IS DICHOTOMISED. CATED SIMPLIFIED ESTIMATORS FOR THE NORMAL DISTRIBUTION WHEN SAMPLES ARE SINCLY CENSORED OR TRUN TECH 59 2I7 XIMUM LIKELIHOOD ESTIMATES FOR A MULTIVARIATE NORMAL DISTRIBUTION WHEN SOME OBSERVATIONS ARE MISSING MA JASA 57 2OO SOME TESTS OF HYPOTHESES RELATINC TO THE EXPONENTIAL DISTRIBUTION WHEN SOME OUTLIERS ARE PRESENT, CORR. 65 JASA 65 548 THE NORMAL APPROXIMATION TO THE SIGNED-RANK SAMPLING DISTRIBUTION WHEN ZERO DIFFERENCES ARE PRESENT ESTIMATION IN THE TRUNCATED POISSON DISTRIBUTION WHEN ZEROS AND SOME ONES ARE MISSINC

JASA 671068 $\begin{array}{rrr}\text { JASA } & 67 & 1068 \\ \text { JASA } & 60 & 342\end{array}$ ESTIMATING THE CURRENT MEAN OF A NORMAL DISTRIBUTION WHICH IS SUBJECTED TO CHANCES IN TIME AMS 64 999 TWO THEOREMS FOR INFERENCES ABOUT THE NORMAL DISTRIBUTION WITH APPLICATIONS IN ACCEPTANCE SAMPLINC JASA 64 89 THE INVERTED DIRICHLET DISTRIBUTION WITH APPLICATIONS, CORR. 651251 SEQUENTIAL LIFE FOR THE EXPONENTIAL DISTRIBUTION WITH CHANGING PARAMETER JASA 65793 TECH $66 \quad 217$ RIX A TB IN TERMS OF O BTOKA63 535 ON THE EVALUATION OF THE NEGATIVE BINOMIAL DISTRIBUTION WITH EXAMPLES

A NOTE ON ESTIMATINC THE MEAN OF A NORMAL DISTRIBUTION WITH KNOWN COEFFICIENT OF VARIATION HORTER CONFIDENCE INTERVALS FOR THE MEAN OF A NORMAL DISTRIBUTION WITH KNOWN VARIANCE

ON THE KOLMOGOROV-SMIRNOV TEST FOR THE EXPONENTIAL DISTRIBUTION WITH MEAN UNKNOWN

ESTIMATION OF PARAMETERS IN THE MULTIVARIATE NORMAL DISTRIBUTION WITH MISSING OBSERVATIONS LETE AND ABSOLUTE MOMENTS OF THE MULTIVARIATE NORMAL DISTRIBUTION WITH SOME APPLICATIONS ACCIDENT PRONENESS ON A DISCRETE DISTRIBUTION WITH SPECIAL REFERENCE AND THE PROBABILITY INTEGRAL FOR A PEARSON TYPE IV DISTRIBUTION RANDOM VARIABLES WHOSE PRODUCT FOLLOWS THE GAMMA DISTRIBUTION. MOUSE, APODEMUS SYLVATICUS. III WANDERING POWER AND DISTRIBUTION UPPER PERCENTAGE POINTS OF THE CENERALIZED BETA DISTRIBUTION. UPPER PERCENTAGE POINTS OF THE GENERALIZED BETA DISTRIBUTION II CORRELATION IN A SINCLY TRUNCATED BIVARIATE NORMAL DISTRIBUTION UPPER PERCENTAGE POINTS OF THE CENERALIZED BETA DISTRIBUTION CORRELATION IN A SINGLY TRUNCATED BIVARIATE NORMAL DISTRIBUTION FROM MOMENTS THE FOLDED NORMAL DISTRIBUTION FOR MAKING INFERENCES ABOUT THE VARIANCE OF A NORMAL DISTRIBUTION. WAY CLASSIFICATION BLOCK DESIGNS DISTRIBUTION-FREE ANALYSIS OF VARIANCE FOR THE TWOA DISTRIBUTION-FREE ANALYSIS OF VARIANCE TECHNIQUE FOR A CLASS OF DISTRIBUTION-FREE ANALYSIS OF VARIANCE TESTS STRATIFIED SAMPLING AND DISTRIBUTION-FREE CONFIDENCE INTERVALS FOR A MEDIAN FOR SAMPLE SIZES/ TABLE FOR BOTH THE SIGN TEST AND DISTRIBUTION-FREE CONFIDENCE INTERVALS OF THE MEDIAN THE MILLS RATIO BIOKA65 119 ON PAIRS OF INDEPENDENT BIOKA65 289 /VARIATION OF THE LONG-TAILED FIELD BIOKA52 389 BIOKA57 237 BIOKA65 639 BIOKA58 492 BIOKA66 278 TECH $61 \quad 551$ BIOKA6I 230 SASJ $67 \quad 67$ SASJ $68 \quad 9$ SASJ $67 \quad 75$ JASA $65 \quad 772$ JASA $64 \quad 935$ BIOKA57 441 
ALTERNATIVES

FACTORIAL EXPERIMENT

ICIENCY OF A CLASS OF NONPARAMETRIC TESTS VE POTENCY IN DILU/ TMENT VERSUS CONTROL NONPARAMETRIC TESTS
A DISTRIBUTION-FREE K-SAMPLE TEST ACAINST ORDERED DISTRIBUTION-FREE LIFE TEST SAMPLINC PLANS

A DISTRIBUTTON-FREE METHOD OF ANALIZINC A 2-TO-THE-
BIOKA54 133 $\mathrm{TECH} 66 \quad 591$ SASJ $68 \quad 101$

ON A DISTRIBUTION-FREE METHOD OF ESTIMATING ASYMPTOTIC EFF AMS 661759 AN ASYMPTOTICALLY DISTRIBUTION-FREE MULTIPLE COMPARISON PROCEDURE, TREA SOME DISTRIBUTION-FREE MULTIVARIATE COMPARISON PROCEDURES ASYMPTOTICALLY MINIMAX DISTRIBUTION-FREE PROCEDURES SOME BASIC THEOREMS OF DISTRIBUTION-FREE STATISTICS CHARACTERIZATION OF MULTISAMPLE DISTRTBITION-FREE STATISTICS SOME NEW DISTRIBUTION-FREE STATISTICS, (ACKNOWLEDCEMENT OF DISTRIBUTION-FREE SUFFICIENCY IN SAMPLINC FINITE

PRIORITY 65 1901) POPULATIONS BIOCS66 610 AMS $66 \quad 735$ AMS 691486 AMS $66 \quad 619$ AMS $64 \quad 150$ AMS $64 \quad 735$ AMS 65203 JRSSB 68551
FLUCTUATION THEOREM AND A DISTRIBUTION-FREE TEST

A TWO-SAMPLE DISTRIBUTION-FREE TEST

AMS 641359 BIOKA56 377 OF PAIRED OBSERVATIONS A DISTRIBUTION-FREE TEST OF INDEPENDENCE WITH A SAMPLE JASA $62 \quad 116$ EXACT CRTTICAL VALUES FOR MOOD'S DISTRIBUTION-FREE TEST STATISTIC FOR DISPERSION AND I TECH 6B 497 GOODNESS CRITERIA FOR TWO-SAMPLE DISTRIBUTION-FREE TESTS AMS $66 \quad 133$ EFFICIENCY LOSS DUE TO CROUPING IN DISTRIBUTION-FREE TESTS SUFFICIENT STATISTICS, SIMILAR REGIONS AND DISTRIBUTION-FREE TESTS

JRSSB57 262

NS

'OPTIMAL' ONE-SAMPLE DISTRIBUTION-FREE TESTS AND THEIR TWO-SAMPLE EXTENSIO NOTE ON THE CONSISTENCY OF SOME DISTRIBUTION-FREE TESTS FOR DISPERSION

EXPERIMENTS BREAKING OF RECORDS (WITH DISCUSSION)

SYMMETRICAL POPULATIONS NATURE DISTRIBUTION FREE TESTS IN TIMEDISTRIBUTION-FREE TESTS OF INDEPENDENCE DISTRIBUTION-FREE TOLERANCE INTERVALS FOR CONTINUOUS SOME TWO-SIDED DISTRIBUTION-FREE TOLERANCE INTERVALS OF A GENERAL TABLES OF DISTRIBUTION-FREE TOLERANCE LIMITS

A DISTRIBUTION-FREE TWO SAMPLE TEST FOR DISPERSION FOR

A DISTRIBUTION-FREE TWO-SAMPLE TEST ON A CIRCLE

THE DISPLACED POISSON DISTRIBUTION-REGION B

TWO ESTIMATES OF 'THE BINOMIAL DISTRIBUTION, (CORR. 64 182)

SIS BASED ON A CERTAIN MULTIVARIATE COMPLEX GAUSSIAN DISTRIBUTION, AN INTRODUCTION SOME PERCENTAGE POINTS OF THE NON-CENTRAL T-DISTRIBUTION, CORR. 631163 A BIVARIATE T DISTRIBUTION, CORR. 671594 LIKEL IHOOD THE FOLDED NORMAL DISTRIBUTION, III. ACCURACY OCESS, MARKOV OR POISSON INPUT, GENERAL SERVICE TIME DISTRIBUTION, ONE SERVER ON THE QUEUEING PR
STING FOR R/ STATISTICS CONNECTED WITH THE UNIFORM DISTRIBUTION, PERCENTAGE POINTS AND APPLICATION TO TE AN APPROXIMATION TO THE MULTINOMIAL DISTRIBUTION, SOME PROPERTIES AND APPLICATIONS AMS 64 (609 STATISTICAL ANALY AMS $63 \quad 152$ JASA $63 \quad 176$ AMS $67 \quad 162$ CORRELATIONS AMONG P/ B. ROXIMATOR FOR THE CLASS MARKS OF A GROUPED FREQUENCY DISTRIBUTION, WITH ESPECIAL REFERENCE TO THE UNEQUAL TECH 68 793 A BIVARIATE GENERALIZATION OF STUDENT'S T-DISTRIBUTION, WITH TABLES FOR CERTAIN SPECIAL CASES BIOKA54 I53
ALING WITH OUTLIERS IN SMALL SAMPLES FROM THE NORMAL DISTRIBUTION, 2 ESTIMATION OF THE MEAN

ERRATA, 'ORDER STATISTICS FROM THE GAMMA DISTRIBUTION'

TO 'A NOTE ON THE MEAN DEVIATION OF THE BINOMIAL DISTRIBUTION' NG FROM CERTAIN SIMPLE TRANSFORMATIONS OF THE NORMAL DISTRIBUTION' FOR SAMPLES OF SIZE TWENTY AND LESS FROM THE NORMAL DISTRIBUTION' 56410 CORRECTION. 'SOME EXTENSIONS OF THE WISHART DISTRIBUTION', 44345 BIVARIATE EXPONENTIAL DISTRIBUTIONS

TABLES OF TOLERANCE-LIMIT FACTORS FOR NORMAL DISTRIBUTIONS MAXIMUM LIKELIHOOD CHARACTERIZATION OF DISTRIBUTIONS

A PROBLEM CONCERNED WITH WEIGHTING OF DISTRIBUTIONS BIVARIATE LOCISTIC DISTRIBUTIONS

THE COMBINATION OF TESTS BASED ON DISCRETE DISTRIBUTIONS

ITERATED TESTS OF THE EQUALITY OF SEVERAL DISTRIBUTIONS

LIFE TEST SAMPLING PLANS FOR NORMAL AND LOGNORMAL DISTRIBUTIONS NON-EXISTENCE OF EVERYWHERE PROPER CONDITIONAL DISTRIBUTIONS

CORRELATIONS AND CANONICAL FORMS OF BIVARIATE DISTRIBUTIONS PROPERTIES OF GENERALIZED RAYLEIGH DISTRIBUTIONS

GENERATION OF RANDOM SAMPLES FROM THE BETA AND F DISTRIBUTIONS INVARIANT PRIOR DISTRIBUTIONS POLYNOMIAL EXPANSIONS OF BIVARIATE DISTRIBUTIONS

VARIATIONS OF THE NON-CENTRAL T AND BETA DISTRIBUTIONS

A TWO-PARAMETER FAMILY OF HYPER-POISSON DISTRIBUTIONS

ESTIMATING THE PARAMETERS OF MIXTURES OF BINOMIAL DISTRIBUTIONS

ANALYSIS OF EMPIRICAL BIVARIATE EXTREMAL DISTRIBUTIONS

A UNIFIED DERIVATION OF SOME NONPARAMETRIC DISTRIBUTIONS GENESIS OF BIMODAL DISTRIBUTIONS

POISSON LIMITS OF MULTIVARIATE RUN DISTRIBUTIONS ASYMPTOTICALLY OPTIMUM TESTS FOR MULTINOMIAL DISTRIBUTIONS
INVARIANT CONDITIONAL DISTRIBUTIONS
FACTORIAL DISTRIBUTIONS ASYMPTOTICALLY OPTIMUM TESTS FOR MULTINOMIAL DISTRIBUTIONS
INVARIANT CONDITIONAL DISTRIBUTIONS
FACTORIAL DISTRIBUTIONS ASYMPTOTICALLY OPTIMUM TESTS FOR MULTINOMIAL DISTRIBUTIONS
INVARIANT CONDITIONAL DISTRIBUTIONS
FACTORIAL DISTRIBUTIONS

SOME INEQUALITIES FOR CENTRAL AND NON-CENTRAL DISTRIBUTIONS A CLASS OF BIVARIATE DISTRIBUTIONS

ESTIMATION OF MULTIPLE CONTRASTS USING T-DISTRIBUTIONS

A UNTOUENESS THEOREM CONCERNING MOMENT DISTRTBUTIONS CHARACTERIZATION OF GEOMETRIC AND EXPONENTIAL DISTRIBUTIONS ON THE ESTIMATION OF MIXING DISTRIBUTIONS ON MIXTURES OF DISTRIBUTIONS ON TESTING THE EQUALITY OF UNIFORM AND RELATED DISTRIBUTIONS

ESTIMATION OF PARAMETERS FOR A MIXTURE OR NORMAL DISTRIBUTIONS ASYMPTOTICALLY OPTIMAL TESTS FOR MULTIVARIATE NORMAL DISTRIBUTIONS AN ASYMPTOTIC EXPANSION FOR POSTERIOR DISTRIBUTIONS SOME ANALYTICAL PROPERTIES OF BIVARIATE EXTREMAL DISTRIBUTIONS ON THE INTERPRETATION OF AGE DISTRIBUTIONS NONCENTRAL MULTIVARIATE DIRICHLET DISTRIBUTIONS ESTIMATION IN MIXTURES OF TWO NORMAL DISTRIBUTIONS
TECH $60 \quad 523$ CORRIGENDA BIOKA58 $5 \mathrm{~B} 7$ PROPERTIES OF DISTRIBUTIONS RESULTI BIOKA53 236 410 /PRODUCTS OF ORDER STATISTICS AMS 611345 JASA $60 \quad 698$ TECH $60 \quad 4 \mathrm{~B} 3$ AMS $61 \quad 1214$ JASA $61 \quad 281$ JASA $61 \quad 335$ JASA $62 \quad 10$ JASA $62 \quad 579$ TECH $62 \quad 151$

AMS $63 \quad 223$ AMS $63 \quad 532$ AMS $63 \quad 903$ TECH $63 \quad 269$ AMS $64 \quad 836$ AMS 641208 AMS 641583 JASA $64 \quad 133$ JASA $64 \quad 510$ JASA $64 \quad 794$ JASA $64 \quad 1042$ TECH $64 \quad 357$ AMS $65 \quad 215$ AMS $65 \quad 369$ AMS $65 \quad$ B29 AMS 651066 AMS $\begin{array}{ll}65 & 1521\end{array}$ JASA $65 \quad 516$ JASA $65 \quad 573$ JASA $65 \quad 1203$ AMS $66 \quad 1790$ AMS $66 \quad 177$ AMS $66 \quad 281$ JASA $66 \quad$ B56 TECH $66 \quad 431$ AMS 671829 AMS 671 B99 JASA $67 \quad 569$ JASA $67 \quad$ B62 SASJ $67 \quad 21$ TECH $67 \quad 15$ AMS $64 \quad 923$ 

BAYESIAN ESTIMATION OF MIXINC DISTRIBUTIONS MULTIVARIATE EXPONENTIAL-TYPE DISTRIBUTIONS

CONSTRUCTION OF JOINT PROBABILITY DISTRIBUTIONS CENERALIZED HYPERBOLIC SECANT DISTRIBUTIONS SOME PROPERTIES OF SYMMETRIC STABLE DISTRIBUTIONS A NOTE ON LINEAR RECRESSION IN TRIVARIATE DISTRIBUTIONS GENERALIZED MEANS AND ASSOCIATED FAMILIES OF DISTRIBUTIONS PRODUCT ENTROPY TO CAUSSIAN DISTRIBUTIONS INFINITELY DIVISIBLE RENEWAL DISTRIBUTIONS THE MAXIMUM VARIANCE OF RESTRICTED UNIMODAL DISTRIBUTIONS AN INEQUALITY FOR A CLASS OF BIVARIATE CHI-SQUARE DISTRIBUTIONS UNFOLDING PARTICLE SIZE DISTRIBUTIONS

NOTE ON A CERTAIN FAMILY OF DISCRETE DISTRIBUTIONS A NOTE ON CONTACIOUS DISTRIBUTIONS

CENSORED SAMPLES FROM TRUNCATED NORMAL DISTRIBUTIONS SOME INTERRELATTONS AMONG COMPOUND AND GENERALIZED DISTRTBUTTONS

THE CHI-SQUARE GOODNESS-OF-FIT TEST FOR NORMAL DISTRIBUTIONS

TABLES OF RANDOM OBSERVATIONS FROM STANDARD DISTRIBUTIONS ON CERTAIN PROPERTIES OF POWER-SERIES DISTRIBUTIONS

ON CERTAIN CHARACTERISTICS OF SOME DISCRETE DISTRIBUTIONS

THE NON-CENTRAL CHI-SQUARED AND BETA DISTRIBUTIONS

REPRESENTATIONS OF THE CENTRAL AND NON-CENTRAL T DISTRIBUTIONS A PARADOX INVOLVING QUASI PRIOR DISTRIBUTIONS ON A SYSTEM OF DISCRETE DISTRIBUTIONS SOME RELATIONSHIPS BETWEEN THE NORMAL AND VON MISES DISTRIBUTTONS A NOTE ON CONTINGENCY-TYPE BIVARIATE DISTRIBUTIONS STATISTICAL INFERENCE WITH BIVARIATE GAMMA DISTRIBUTIONS NONPARAMETRIC SYMMETRY TESTS FOR CIRCULAR DISTRIBUTIONS DISTRIBUTION FREE TESTS FOR MIXED PROBABILITY DISTRIBUTIONS ORDER STATISTICS FROM A CLASS OF NON-NORMAL DISTRIBUTIONS ESTIMATING THE COMPONENTS OF A MIXTURE OF NORMAL DISTRIBUTIONS SPECIES FREQUENCY DISTRIBUTIONS CENERALIZED HYPERGEOMETRIC DISTRIBUTIONS MIXTURES OF GEOMETRIC DISTRIBUTIONS CUMULANTS OF TRUNCATED MULTINORMAL DISTRIBUTIONS AN ESTIMATION PROCEDURE FOR MIXTURES OF DISTRIBUTIONS

ESTIMATION OF PARAMETERS OF A FINITE MIXTURE OF DISTRIBUTIONS ON THE ASYMPTOTIC BEHAVIOUR OF POSTERIOR DISTRIBUTIONS UNUSUAL FREQUENCY DISTRIBUTIONS

A NOTE ON CERTAIN DISCRETE MIXED DISTRIBUTIONS CONFIDENCE LIMITS FOR QUANTILES OF MORTALITY DISTRIBUTIONS MEAN-SQUARE-ERROR CHARACTERIZATION OF BINOMIAL-TYPE DISTRIBUTIONS PROPERTY OF THE MEAN DEVIATION FOR THE PEARSON TYPE DISTRIBUTIONS NOTE ON QUEUEING SYSTEMS WITH ERLANGIAN SERVICE TIME DISTRIBUTIONS METHODS OF ASYMPTOTIC APPROXIMATION FOR MULTIVARIATE DISTRIBUTIONS CTERIZATION THEOREMS FOR SOME UNIVARIATE PROBABILITY DISTRIBUTIONS CTERIZATION THEOREMS FOR SOME UNIVARIATE PROBABILITY DISTRIBUTTONS CLASS OF NONPARAMETRIC TWO-SAMPLE TESTS FOR CIRCULAR DISTRIBUTIONS

TOPOLOGICAL STRUCTURE OF SOME ORDERED FAMILIES OF DISTRIBUTIONS

FOR HOMOGENEITY I THE BINOMIAL AND MULTINOMIAL DISTRIBUTIONS SERIES FORMS OF NON-CENTRAL CHI-SQUARE AND F DISTRIBUTIONS SINGLE SAMPLING ATTRIBUTE PLANS FOR CONTINUOUS PRIOR DISTRIBUTIONS PROCEDURES FOR RESTRICTED FAMILIES OF PROBABILITY DISTRIBUTIONS RATIO TESTS FOR RESTRICTED FAMILITES OF PROBABILITY DISTRIBUTIONS PLAY IN FINITE STATISTICAL GAMES WITH UNKNOWN DISTRIBUTIONS

OF MOMENTS APPLIED TO A MIXTURE OF TWO EXPONENTIAL DISTRIBUTIONS PROBABILITIES AND THE CHI-SQUARE AND $X$-SQUARE DISTRIBUTIONS MULTIVARIATE AND THE GENERALIZED MULTIVARIATE BETA DISTRIBUTIONS

OF GROUPED TRUNCATED AND GROUPED CENSORED NORMAL DISTRIBUTIONS

THE GENERAL NON-NORMAL VARIANCE-RATIO SAMPLING DISTRIBUTIONS OF PARAMETERS IN THE JOHNSON SYSTEM OF PROBABILITY DISTRIBUTIONS CENSORED SAMPLES FROM LOG-NORMAL AND LOGISTIC DISTRIBUTIONS CORRELATION COEFFICIENTS OF BIVARIATE GAMMA DISTRIBUTIONS

FREE TWO SAMPLE TEST FOR DISPERSION FOR SYMMETRICAL DISTRIBUTIONS OF THE CONNEXION BETWEEN POISSON AND CHI-SQUARE DISTRIBUTIONS FIDENCE REGIONS FOR THE MEANS OF MULTIVARIATE NORMAL DISTRIBUTIONS MEAN DIFFERENCES OF THE BINOMIAL AND POISSON DISTRIBUTIONS

FOR THE COMPARISION OF THE SPREAD OF TWO NORMAL DISTRIBUTIONS BAYES ESTIMATION FOR ONE-PARAMETER DISCRETE DISTRIBUTIONS OLYNOMIALS OF THE FACTORIAL POWER SERIES PROBABILITY DISTRIBUTIONS FOR THE PARAMETERS OF A MIXTURE OF TWO BINOMIAL DISTRIBUTIONS FOR THE PARAMETER OF THE BINOMIAL AND POISSON DISTRIBUTIONS FOR CONVERGENCE IN PROBABILITY TO QUASI POSTERIOR DISTRIBUTIONS OF THE SAMPLE MEDIAN FOR MANY FAMILIAR SYMMETRIC DISTRIBUTIONS AND THE MEAN DEVTATION OF SOME DISCONTINUOUS DISTRIBUTTONS RELATIVE ERROR FOR THE RATIO OF VARIANCES OF NORMAL DISTRIBUTIONS FOR TESTINC THE EQUALITY OF SEVERAL EXPONENTIAL DISTRIBUTIONS FUNCTIONS IN THE CHARACTERIZATION OF PROBABILITY DISTRIBUTIONS LIMITS FOR THE COEFFICIENT OF VARIATION IN GAMMA DISTRIBUTIONS OF RANK ORDERS FOR TWO WIDELY SEPARATED NORMAL DISTRIBUTIONS CONFIDENCE LIMITS FOR THE BINOMIAL AND AND POISSON DISTRIBUTIONS TUKEY TRANSFORMATIONS FOR THE BINOMIAL AND POISSON DISTRIBUTIONS BINOMIAL, NEGATIVE BINOMIAL, POISSON AND CHI-SQUARE DISTRIBUTIONS

FUNCTIONS OF THE ROOTS OF A MULTIVARIATE MATRIX. DISTRIBUTIONS

TECH $67 \quad 587$ AMS $68 \quad 1759$ AMS $6 \mathrm{~B} \quad 12 \mathrm{~B} 9$ AMS 681316 AMS 681354 JASA $6 \mathrm{~B} \quad 329$ JASA $68 \quad 817$ JASA $68 \quad 1042$ AMS $69 \quad 339$ AMS $69 \quad 870$ AMS 691109 AMS 691746 JASA $69 \quad 333$ TECH 69 NO. 4 BIOKA52 196 BIOKA54 26B BIOKA55 516 BIOKA57 265 BIOKA57 336 BIOKA59 178 BIOKA59 4B6 BIOKA60 473 BIOKA63 542 BIOKA64 45I BIOKA65 623 BIOKA67 649 BIOKA67 684 BIOKA68 262 BIOKA69 N0.3 BIOKA69 N0.3 BIOKA69 NO.3 BIOKA69 415 BIOKA69 NO.3 BIOKA69 N0.3 JRSSB56 202 JRSSB $61 \quad 409$ JRSSB62 535 JRSSB $68 \quad 444$ JRSSB $68 \quad 472$ JRSSB $69 \quad 80$ BIOCS65 159 BI0CS66 566 BIOCS69 176

A AMS 67620

A BIOKA66 287

A AMS $65 \quad 1574$

ON BIOKA67 367 CHARA JRSSB64 2B6 CHARA JRSSB6 $6 \quad 143$ ON A AMS 691791 ON THE AMS 641216

TESTING BIOKA66 167 LAGUERRE BIOKA65 415 BAYESIAN TECH $6 \mathrm{~B} \quad 667$ SELECTION AMS 69905 LIKELIHOOD AMS $6 B \quad 547$ REPETITIVE AMS $66 \quad 976$ THE METHOD AMS $61 \quad 143$ MULTINOMIAL BIOKA63 145 NOTE ON THE JASA 69230 THE FITTING BIOKA52 252 APPROXIMATING BIOKA64 B3 DETERMINATION BIOKA59 229 PROGRESSIVELY TECH 69 NO.4 THE CANONICAL AMS 691401 A DISTRIBUTION- SASJ 69 N0.2 ON AN EXTENSION BIOKA59 352 RECTANGULAR CON JASA $67 \quad 626$ THE GENERALIZED BIOKA59 223 A NOTE ON TABLES BIOKA67 683 SMOOTH EMPIRICAL BIOKA66 417 THE ORTHOGONAL P SASJ $67 \quad 49$ MOMENT ESTIMATORS AMS $62 \quad 444$ SHORTER INTERVALS BIOKA57 436 RIGHT HAAR MEASURE AMS $65 \quad 440$ THE 'INEFFICIENCY' BIOKA55 520 THE MEAN DTFFERENCE BIOKA58 549 ESTIMATES OF BOUNDED JASA 56481 AN ITERATED PROCEDURE JASA $63 \quad 435$ APPLICATION OF SPECIAL SASJ $69 \quad 27$ APPROXIMATE CONFIDENCE BIOCS65 733 ON EXACT PROBABILITIES AMS 671491 TABLES OF SIMULTANEOUS BIOKA69 452 TABLES OF THE FREEMAN- BIOKA6I 433 TRANSFORMATIONS OF THE BIOKA54 302 ON ELEMENTARY SYMMETRIC AMS 64 IlB6 
NON-NORMAL UNIVERSES BY MEANS OF COMPOUND NORMAL DISTRIBUTIONS LEE-FISHER FUNCTIONS OF SINGLY TRUNCATED NORMAL DISTRIBUTIONS THE LEFT OF THE I'TH ORDER STATISIIC FOR ARBITRARY DISTRIBUTIONS TESTS OF INDEPENDENCE FOR CONTINGENCY-TYPE BIVARIATE DISTRIBUTIONS ESTIMATING PARAMETERS OF SOME GENERALIZED POISSON DISTRIBUTIONS OF THE LOGARITHMIC SERIES AND NEGATIVE BINOMIAL DISTRIBUTIONS OF LINEAR SYSTEMATIC STATISTICS FROM MULTIVARIATE DISTRIBUTIONS PROPORTIONS IN MIXTURES OF EXPONENTIAL AND NORMAL DISTRIBUTIONS MPOUND DECISION PROBLEM FOR TWO COMPLETELY SPECIFIED DISTRIBUTIONS IBUTION FUNCTIONS OF ORDER STATISTICS FROM BIVARIATE DISTRIBUTIONS EFFICIENT OF VARIATION FOR THE NORMAL AND LOG NORMAL DISTRIBUTIONS

OF HOMOGENEITY FOR POPULATIONS COMPOSED OF NORMAL DISTRIBUTIONS OPERTY OF THE MEAN DEVIATION FOR A CLASS OF DISCRETE DISTRIBUTIONS

IN CERTAIN FAMILIES OF BIVARIATE AND MULTIVARIATE DISTRIBUTIONS

CORRELATION MATRIX, NON-CENTRAL MULTIVARIATE BETA DISTRIBUTIONS TIMATION FOR THE NEGATIVE BINOMIAL AND NEYMAN TYPE A DISTRIBUTIONS ULL DISTRIBUTIONS FOR HIGHER ORDER SCHEMES, NON-NULL DISTRIBUTIONS DATA FROM THE NEGATIVE BINOMIAL AND OTHER CONTAGIOUS DISTRIBUTIONS URES FOR THE TWO-PARAMETER WEIBULL AND EXTREME-VALUE DISTRIBUTIONS TERS OF THE TRUNCATED BINOMIAL AND NEGATIVE BINOMIAL DISTRIBUTIONS E HYPERGEOMETRIC, BINOMIAL, POISSON, AND EXPONENTIAL DISTRIBUTIONS ES, OF THE SCALE PARAMETERS OF TYPE II EXTREME-VALUE DISTR IBUTIONS LOCATION PARAMETER OF THE WEIBULL AND CERTAIN OTHER DISTRIBUTIONS SOME CONTRIBUTIONS TO CONTINGENCY-TYPE BIVARIATE DISTRIBUTIONS SMOOTH EMPIRICAL BAYES ESTIMATION FOR CONTINUOUS DISTRIBUTIONS ON CHI-SQUARE GOODNESS-OF-FIT TESTS FOR CONTINUOUS DISTRIBUTIONS A BAYESIAN SIGNIFICANCE TEST FOR MULTINOMIAL DISTRIBUTIONS NECESSARY RESTRICTIONS FOR DISTRIBUTIONS

SIMILARITIES BETWEEN LIKELIHOODS AND ASSOCIATED DISTRIBUTIONS FIDUCIAL DISTRIBUTIONS AND BAYES ' THEOREM
SAMPLING PROCEDURES BASED ON PRIOR DISTRIBUTIONS AND COSTS MULTISTAGE SAMPLING PROCEDURES BASED ON PRIOR DISTRIBUTIONS AND COSTS 作 CTS OF RANDOM VARIABLES M LIKELIHOOD ESTIMATION FOR GENERALIZED POWER SERIES DISTRIBUTIONS AND ITS APPLICATION TO A TRUNCATED BINO BIOKA62 ING DIFFERENTIAL EQ/ THE DETERMINATION OF SAMPLING DISTRIBUTIONS AND MOMENT GENERATING FUNCTIONS BY SOLV JRSSBG5 CONFIDENCE BOU/ ON CERTAIN INEQUALITIES FOR NORMAL DISTRIBUTIONS AND THEIR APPLICATIONS TO SIMULTANEOUS INTERRELATIONS AMONG GENERALIZED DISTRIBUTIONS AND THEIR COMPONENTS

ORTHOGONAL POLYNOMIALS OF POWER SERIES PROBABILITY DISTRIBUTIONS AND THEIR USES DISCUSSION QUASI-STATIONARY DISTR IBUTIONS A CLASS OF DISTRIBUTIONS ND TIME-REVERSION IN GENETICS (WIT) PPLICABLE TO ACCIDENTS BIOCS66 44 JRSSB 66 253 JASA $61 \quad 503$ WITH ONE SERVER, WHILE THE INTERARRIVAL AND SERVING DISTRIBUTIONS ARE DETERMINISTIC AND GAMMA OF ORDER K JRSSB63 477
WITH ONE SERVER, WHILE THE INTERARRIVAL AND SERVING DISTRIBUTIONS ARE EXPONENTIAL AND GAMMA OF ORDER LAMB JRSSB66 336 $M$ WITH ONE SERVER AND WHICH INTERARRIVAL AND SERVING DISTRIBUTIONS ARE EXPONENTIAL AND GENERAL INDEPENDENT JRSSBS9 PROBABILITY DISTRIBUTIONS ARISINC FROM POINTS ON A LINE ON LIMITING DISTRIBUTIONS ARISINC IN BULK SERVICE QUEUES

MEAN DIFFERENCES MEAN DIFFERENCES ' SOME DISTRIBUTIONS ARISINC IN THE STUDY OF GENERALIZED BTOKA54 JRSSB56 BIOKA60 469 BIOKA61 230 BIOKA69 391 AMS 621281

LEARNING MODELS NT EVENTS (WITH DISCUSSION) CORRIGENDA, 'SOME DISTRIBUTIONS ARISING IN THE STUDY OF GENERALIZED DISTRIBUTIONS ASSOCIATED WITH CELL POPULATIONS LIMITING DISTRIBUTIONS ASSOCIATED WITH CERTAIN STOCHASTIC DISTRIBUTIONS ASSOCIATED WITH RANDOM WALK AND RECURRE JRSSB57 64 CONVOLUTIONS OF DISTRIBUTIONS ATTRACTED TO STABLE LAWS

TOLERANCE AND CONFIDENCE LIMITS FOR CLASSES OF DISTRIBUTIONS BASED ON FAILURE RATE, CORR. 67 950 NEW METHODS FOR REASONING TOWARDS POSTERIOR DISTRIBUTIONS BASED ON SAMPLE DATA

UNBAISED UNBAISEDESTIMATIN OF IANCE FOR THE PARAMETERS IN THE BINOMIAL AND POISSON DISTRIBUTIONS BASED ON TWO-STAGE SAMPLING /THE VAR JASA 66 220 CHARACTERIZATIONS OF SOME DISTRIBUTIONS BY CONDITIONAL MOMENTS

E CHANNEL QUEUE WITH A GENERAL CLASS OF SERVICE-TIME DISTRIBÚTIONS BY THE METHOD OF GENERATING FUNCTIONS JI ON THE DETERMINATION OF A SAFE LIFE FOR CLASSES OF DISTRIBUTIONS CLASSIFIED BY FAILURE RATE INISME GENETIQUE DES CARACTERES QUANTITATIFS ET R/ DISTRIBUTIONS DE FREQUENCES, INTERPRETATION DU DETERM BIC HYPERPLANES

ABLES ARE SUBJECT TO ERROR SOME NON-CENTRAL F-DISTRIBUTIONS EXPRESSED IN CLOSED FORM LIKELIHOOD DISTRIBUTIONS FOR ESTIMATING FUNCTIONS WHEN BOTH VARI TECH 67261 THESES IN THE LINEAR AUTO-REGRESSIVE MODEL. II. NULL DISTRIBUTIONS FOR HICHER ORDER SCHEMES, NON-NULL DIST BIOKA56 IBG POSTERIOR DISTRIBUTIONS FOR MULTIVARIATE NORMAL PARAMETERS

SOME WAITING TIME DISTRIBUTIONS FOR REDUNDANT SYSTEMS WITH REPAIR COUNTING DISTRIBUTIONS FOR RENEWAL PROCESSES

STATIONARY WAITING-TIME DISTRIBUTIONS FOR SINGLE-SERVER QUEUES

SIMULATED DISTRIBUTIONS FOR SMALL N OF KENDALL'S PARTIAL RANK LIMITING DISTRIBUTIONS FOR SOME RANDOM WALKS ARISING IN

CORRELATION COEFFICIENT LEARNING MODELS ENT RANDOM VECTORS

ON LIMITING DISTRIBUTIONS FOR SUMS OF A RANDOM NUMBER OF INDEPEND EXACT AND APPROXIMATE DISTRIBUTIONS FOR THE WILCOXON STATISTIC WITH TIES

ON SOME RESULTS OF N. V. SMIRNOV CONCERNING LIMIT DISTRIBUTIONS FOR VARIATIONAL SERIES OF THE MOMENT-PROBLEM IS EXACT ON DISTRIBUTIONS FOR WHICH THE HARTLEY-KHAMIS SOLUTION TOR IS UNBTASED AND OF MTNIMUM VARIANC/ A CLASS OF DISTRIBUTIONS FOR WHTCH THE MAXIMUM-LIKELTHOOD ESTIMA BIOKA56 TERS OF MIXED EXPONENTIALLY DISTRIBUTED FAILURE TIME DISTRIBUTIONS FROM CENSORED LIFE TEST DATA /PARAME BIOKA5B 50 ATION OF THE PARAMETERS OF TWO PARAMETER EXPONENTIAL DISTRIBUTIONS FROM CENSORED SAMPLES ESTIMATORS OF THE PARAMETERS OF NEGATIVE EXPONENTIAL DISTRIBUTIONS FROM ONE OR TWO ORDER STATISTICS /UM AMS 63 117 $R$ STATISTICS OF THE PARAMETERS OF SINGLE EXPONENTIAL DISTRIBUTIONS FROM SINGLY AND DOUBLY CENSORED SAMPLES JASA 57 5B
ESTIMATION OF FINITE MIXTURES OF DISTRIBUTIONS FROM THE EXPONENTIAL FAMILY ESTIMATION OF FINITE MIXTURES OF DISTRIBUTIONS FROM THE EXPONENTIAL FAMILY THE PERCENTILE POINTS OF DISTRIBUTIONS HAVING KNOWN CUMULANTS ERRATA, 'THE PERCENTILE POINTS OF DISTRIBUTIONS HAVING KNOWN CUMULANTS' TECH $60 \quad 209$ TECH $60 \quad 523$ GAME VALUE DISTRIBUTIONS I 
GAME VALUE DISTRIBUTIONS II

A TEST FOR HOMOGENEITY OF THE MARCINAL DISTRIBUTIONS IN A TWO-WAY CLASSIFICATION

AMS 67251

BIOKA55 412

JASA $67 \quad 776$

TECH $65 \quad 335$

BIOKA53 IB6

THE USE OF INCOMPLETE BETA FUNCTIONS FOR PRIOR DISTRIBUTIONS IN BINOMIAL SAMPLING

EXPERIMENTAL EVIDENCE CONCERNING CONTAGIOUS DISTRIBUTIONS IN ECOLOGY

ADEQUACY OF THE DIFFUSION APPROXIMATION TO CERTAIN DISTRIBUTIONS IN CENETICS CONTROL

APPLICATIONS OF TRUNCATED DISTRIBUTIONS IN PROCESS START-UPS AND INVENTORY

THE USE OF LEAST FAVORABLE DISTRIBUTIONS IN TESTING COMPOSITE HYPOTHESES

THE BIOCS65 3B6

TECH $61 \quad 429$

AMS 611034 DISCUSSION

THE USE OF PRIOR DISTRIBUTIONS IN THE DESIGN OF EXPERIMENTS FOR PARAME GEOMETRIC DISTRIBUTIONS IN THE THEORY OF QUEUES (WTTH

A MAXTMUM-MTNTMUM PROBLEM RELATED TO STATISTICAL DISTRIBUTIONS IN TWO DIMENSIONS

A GRAPHICAL METHOD FOR THE ANALYSIS OF STATISTICAL DISTRIBUTIONS INTO TWO NORMAL COMPONENTS ATION PROBLEM IN WHICH INFORMATION ABOUT ALTERNATIVE DISTRIBUTIONS IS BASED ON SAMPLES ES FOR POSSIBLE CHANCES IN PARAMETERS OF STATISTICAL DISTRIBUTIONS OCCURING AT UNKNOWN TIME POINTS LIMIT DISTRIBUTIONS OF A BRANCHING STOCHASTIC PROCESS DISTRIBUTIONS OF A M. KAC STATISTIC

A STOCHASTIC MODEL FOR DISTRIBUTIONS OF BIOLOGICAL RESPONCE TIMES IOKA67 147 JRSA67 662 BIOKA57 3B4 BIOKA53 460 AMS $62 \quad 213$ BIOKA54 450 /EDUR AMS $66 \quad 1196$ AMS $64 \quad 557$ AMS 671919 BIOCS65 562 ITY CRITERION M UNDER UNEQUAL VARI/ SOME EMPIRICAL DISTRIBUTIONS OF BIVARIATE T-SQUARE AND HOMOSCEDASTIC JASA 63 IO4B TIME SERIES PEAKEDNESS OF DISTRIBUTIONS OF CONVEX COMBINATIONS

AMS 651703 DISTRIBUTIONS OF CORRELATION COEFFICIENTS IN ECONOMIC JASA $61 \quad 637$ SOME RELATIONSHIPS AMONC THE VON MISES DISTRIBUTIONS OF DIFFERENT DIMENSIONS IN DISCRIMINANT ANALYSIS

ON THE DISTRIBUTIONS OF DIRECTION AND COLLINEARITY FACTORS E STOCHASTIC DIFFERENCE EQU/ CONSISTENCY AND LIMIT DISTRIBUTIONS OF ESTIMATORS OF PARAMETERS IN EXPLOSIV APPROXIMATE FORMULAE FOR THE STATISTICAL DISTRIBUTIONS OF EXTREME VALUES

AMS $6 B \quad B 55$

AMS $61 \quad 195$ BIOKA58 447 IABILITY TEST STATISTICS ON FINITE SAMPLE DISTRIBUTIONS OF GENERALIZED CLASSICAL LINEAR IDENTIF JASA 60650 -SUB-N AND W-SQ/ CHI-SQUARE APPROXIMATIONS FOR THE DISTRIBUTIONS OF GOODNESS-OF-FIT STATISTICS, U-SQUARE BIOKA65 630 ORDERED SYSTEMS DISTRIBUTTONS OF KENDALI'S TAU BASED ON PARTIALLYARE BIOKA55 417 NCLUDING A TABLE OF SICNIFICAN/ THE CALCULATION OF DISTRIBUTIONS OF KOLMOGOROV-SMIRNOV TYPE STATISTICS I AMS 6B 233 G INDEPENDENCE OF SETS OF VARIATES U/ ON THE EXACT DISTRIBUTIONS OF LIKELIHOOD RATIO CRITERIA FOR TESTIN AMS 67 1160 DERIVED FROM NORMAL SAMPLES

CHI-SQUARE

CORRELATION COEFFICIENT CURVES DISTRIBUTIONS OF MATRIX VARIATES AND LATENT ROOTS

AMS $64 \quad 475$ APPROXIMATING TO THE DISTRIBUTIONS OF MEASURES OF DISPERSION BY A POWER OF BIOKA53 336 RELATION BETWEEN THE DISTRIBUTIONS OF NON-CENTRAL T AND OF A TRANSFORMED BIOKA57 219 A COMPARISON OF CONTINUOUS DISTRIBUTIONS OF PARAMETERS OF EXPONENTIAL DECAY B B BOCS6B 117 AMS 61619 ANCULAR POPULATIONS SOME GENERALIZATIONS OF THE DISTRIBUTIONS OF PRODUCT STATISTICS ARISING FROM RECT JASA 64 557 DISTRIBUTIONS OF PRODUCTS OF INDEPENDENT VARIABLES TECH $62 \quad 277$ DECOMPOSITION OF SYMMETRIC MATRICES AND DISTRIBUTIONS OF QUADRATIC FORMS I. CENTRAL CASE II. NON-CENTRAL CASE PARAME'TERS SERIES REPRESENTATIONS OF DISTRIBUTIONS OF QUADRATIC FORMS IN NORMAL VARIABLES. SERIES REPRESENTATIONS OF DISTRIBUTIONS OF QUADRATIC FORMS IN NORMAL VARIABLES. DISTRIBUTIONS OF RANDOM VARIABLES WITH RANDOM LIMITING DISTRIBUTIONS OF RESPONSE PROBABILITIES $\begin{array}{lll}\text { AMS } & 65 & 6 B 3 \\ \text { AMS } & 67 & 823\end{array}$ AMS 6787838 SASJ $69 \quad 1$ AMS $65 \quad 706$

SUCCESSIVE DIFFERENCES APPROXIMATIONS TO THE DISTRIBUTIONS OF SOME MEASURES OF DISPERSION BASED ON

PROXIMATIONS TO THE DISTRIBUTIONS OF SOME MEASURES OP DISPERSION

349

AMS $66 \quad 904$ TY IN A P-VARIATE NORMAL DISTRIBUTION ON THE EXACT DISTRIBUTIONS OF THE CRITERION W FOR TESTING SPHERICI AMS 67 1170 IMATORS IN TWO LEADING OVER-I/ A NOTE ON THE EXACT DISTRIBUTIONS OF THE GENERALIZED CLASSICAL LINEAR EST JASA 63 535 IMATORS IN A LEADING THREE-EQUATION/ ON THE EXACT DISTRIBUTIONS OF THE GENERALIZED CLASSICAL LINEAR EST JASA 64 BBI VARIANCE MATRIX ASYMPTOTIC EXPANSIONS OF THE DISTRIBUTIONS OF THE LIKELIHOOD RATIO CRITERIA FOR CO AMS 69 NO.6 LTIVARIATE/ ASYMPTOTIC EXPANSIONS OF THE NON-NULL DISTRIBUTIONS OF THE LIKELIHOOD RATIO CRITERIA FOR MU AMS 69 942 STING LINEAR HYPOTHESES ABOUT RECRES/ ON THE EXACT DISTRIBUTIONS OF THE LIKELIHOOD RATIO CRITERIA FOR TE AMS 66 1319 POPULATIONS THE INFINITE DAM

FROM A NORMAL DISTRIBUTION

ON THE DISTRIBUTIONS OF THE RANCE AND UEAN RANGE FOR SAMPLES BIOKA66 245 NARY STREAM OF EVENTS

SQUARED AND WATSON'S U-SQUARED MAXIMUM LIKELIHOOD EST RIABLES ANALYSIS OF VARIANCE

DIES OF BALANCED NESTED DESICN UDIES OF UNBALANCED NESTED DESIGNS D SYMMETRY OF A COVARIANCE MATRIX

ON THE NON-CENTRAL DISTRIBUTTONS OF TWO TEST CRITERIA IN MULTIVARIATE

SAMPLING DISTRIBUTIONS OF VARIANCE COMPONENTS I. EMPIRICAL STU TECH 66457

SAMPLING DISTRIBUTIONS OF VARIANCE GOMPONENTS II. EMPIRICAL ST TECH 68719

ON THE EXACT DISTRIBUTIONS OF VOTAW'S CRITERIA FOR TESTING COMPOUN AMS 69836

EXACT DISTRIBUTIONS OF WILKS'S LIKELIHOOD RATIO CRITERION BIOKA66 347 GIRDLE DISTRIBUTIONS ON A SPHERE

EQUATORIAL DISTRIBUTIONS ON A SPHERE

APPENDIX TO 'TOUATORIAL DISTRIBUTIONS ON A SPHERE '

SOME EFFECTS OF FLUCTUATING OFFSPRING DISTRIBUTIONS ON THE SURVIVAL OF A GENE

BIOKA64 3BI

BIOKA65 193

BIOKA65 200

BIOKA66 391

DISTRIBUTIONS POSSESSING A MONOTONE LIKELIHOOD RATIO JASA $56 \quad 637$

ATIONS OF THE NORMAL DISTRIBUTTON_ PROPERTTES OF DISTRIBUTIONS RESUITTNG FROM CERTATN SIMPLF TRANSFORM BTOKA52 290 ATIONS OF THE NORMAL D/ CORRIGENDA. 'PROPERTIES OF DISTRIBUTIONS RESULTING FROM CERTAIN SIMPLE TRANSFORM BIOKA53 236 IKELIHOOD METHOD (CORR/ FITTING OF SOME CONTAGIOUS DISTRIBUTIONS TO SOME AVAILABLE DATA BY THE MAXIMUM L BIOCS65 34 ESTIMATES OF RELIABILITY FOR SOME DISTRIBUTIONS USEFUL IN LIFE TESTINC

PROBLEMS ARISING IN APPROXIMATING TO PROBABILITY DTSTRIBUTIONS USING MOMENTS

ERIZATION OF NORMAL AND GENERALIZED TRUNCATED NORMAL DISTRIBUTIONS USING ORDER STATISTICS DERIVATION OF A CLASS OF FREQUENCY DISTRIBUTIONS VIA BAYES'S THEOREM

SOME BIOKA63 215 BIOKA63 95

CHARACT AMS $66 \quad 1011$ JRSSB65 290 BIOKA56 224 AMS $66 \quad 51$ BIOKA5B 37 AMS $62 \quad 420$ AMS 641561 AMS $65 \quad 69$ AMS $63 \quad 375$ JASA $65 \quad 872$ AMS 641234 AMS $64125 B$ AMS $65 \quad 286$ 
A NOTE ON MULTIVARIATE DISTRIBUTIONS WITH SPECIFIED MARCINALS

ESTIMATINC PARAMETERS IN TRUNCATED PEARSON FREQUENCY DISTRIBUTIONS WITHOUT RESORT TO HICHER MOMENTS

JASA $67 \quad 1460$ APPROXIMATION TO THE BEHRENS-FISHER DISTRIBUTIONS

OF THE MEAN DEVIATION FOR A CLASS OF CONTINUOUS DISTRIBUTIONS ONCERNING DISPERSION MATRICES OF MULTIVARIATE NORMAL DISTRIBUTIONS. BILITIES OF THE MULTINOMIAL AND NECATIVE MULTINOMIAL DISTRIBUTIONS TRUNCATED LOCNORMAL DISTRIBUTIONS NOMIAL PROBABILITIES AND THE CHI-SQUARE AND X-SQUARE DISTRIBUTIONS

BY THE COMBINATION OF TESTS BASED ON DISCONTINUOUS DISTRIBUTIONS BE ASSOCIATED WI/ FUDUCIAL DISTRIBUTIONS AND PRIOR DISTRIBUTIONS, PIVOTAL QUANTITIES FOR WISHART'S AND RELATED DISTRIBUTIONS, THE INVERSION OF CUMULANT OPERATORS FOR POWER--SERIES DISTRIBUTIONS, SICNIFICANCE TESTS IN DISCRETE DISTRIBUTIONS, MULTIVARIATE PARETO DISTRIBUTIONS

AND SCALE PARAMETERS IN EXPONENTIAL FAMILIES OF DISTRIBUTIONS, A RELATION BETWEEN T AND F-DISTRIBUTIONS

THE SAMPLE MEDIAN ON A CENERAL SYSTEM OF DISTRTBUTIONS ROBABILITY CONTENT OF REGIONS UNDER SPHERICAL NORMAL DISTRIBUTIONS, ON A GENERAL SYSTEM OF DISTRIBUTIONS, PROBABILITY CONTENT OF REGIONS UNDER SPERICAL NORMAL DISTRIBUTIONS, METHODS OF APPROXIMATION THE MATCHING DISTRIBUTIONS, INFINITELY DIVISIBLE DISTRIBUTIONS,

HALF-RECTIFIED TRUNCATED DISTRIBUTIONS,

ON 'THE ESTIMATION OF THE PARAMETERS OF TOLERANCE DISTRIBUTIONS'

'TABLES OF TOLERANCE-LIMIT FACTORS FOR NORMAL DISTRIBUTIONS 'CONTROL OF PERCENTACES IN BOTH TAILS OF THE NORMAL DISTRIBUTIONS' 'A NEW TABLE OF PERGENTAGE POINTS OF THE CHI-SQUARE DISTRIBUTIONS' PROPERTY OF THE MEAN DEVIATION FOR THE PEARSON TYPE DISTRIBUTIONS ' BINOMIAL, NEGATIVE BINOMIAL, POISSON AND CHI-SQUARE DISTRIBUTIONS' OF 'ESTIMATION OF PARAMETERS FOR A MIXTURE OF NORMAL DISTRIBUTIONS' TO 'SADDLE POINT METHODS FOR THE MULTINOMIAL DISTRIBUTIONS' CORRECTION. 'THE STRUCTURE OF BIVARIATE DISTRIBUTIONS' $5 \mathrm{~B} \quad 71$ A PROPERTY BIOKA65 288 /OF POWER EUNCTIONS OF SOME TESTS C AMS 69697 INTECRAL EXPRESSIONS FOR TAIL PROBA BIOKA65 167 I. SOLUTION BY MOMENTS

BIOKA51 414 CORRICENDA, 'MULTI BIOKA63 546 CORRIGENDA, 'ON QUESTIONS RAISED BIOKA5I 265 AN EXAMPLE IN WHICH THE FORMER CANNOT JRSSB56 217 AND A PARADOX IN FIDUCIAL THEORY JRSSB55 79 AND THE APPROXIMATE STABILIZATION OF V JASA $6 B \quad 321$ CORR, 62919

CORR. 631603

CORR. 631603

JASA 61223 AMS 621008 CORR. 651249

LOCATION AMS 62986 JASA $65 \quad 528$ I. ITS CURVE-SHAPE CHARACTERISTICS II. JASA 68627 III. THE BIVARIATE NORMAL INTEGRAL P AMS 61 171 III. THE SAMPLE RANGE JASA $68 \quad 636$ IV, THE DISTRIBUTION OF HOMOGENEOUS AN AMS $62 \quad 542$ POISSON LIMITING FORMS AND DERIVED JRSSB58 73 RECENT RESULTS AND APPLICATIONS AMS $62 \quad 68$ SAMPLING THEORY AND HYPOTHESIS TESTING TECH 6947 A NOTE BIOKA.52 439 ERRATA, TECH 61576 ERRATA, TECH $66 \quad 570$ CORRIGENDA, BIOKA65 305 (ACKNOWLEDGEMENT OF PRIORITY), 'A BIOKA67 333 /RRIGENDA TO 'TRANSFORMATIONS OF THE BIOKA56 235 BY VICTOR HASSELBLAD DISCUSSION TECH $66 \quad 445$ CORRECTIONS AMS 61619 AMS 641388 JASA 62607 AMS 651 B35 JASA $67 \quad 169$ JASA $61 \quad 793$ ASYMPTOTIG DISTRIBUTORS FOR THE COUPON COLLECTOR'S PROBLEM SOME FURTHER NOTES ON DISTURBANCE ESTIMATES IN RECRESSION ANALYSIS TESTING THE INDEPENDENCE OF REGRESSION DISTURBANCES OF THE BLUS PROCEDURE FOR ANALYZING REGRESSION DISTURBANCES OOD ESTIMATORS IN A LINEAR MODEL WITH AUTOREGRESSIVE DISTURBANCES ICTION OF AN AUTOREGRESSIVE VARIABLE SUBJECT BOTH TO DISTURBANCES ESTIMATION OF A SYSTEM OF REGRESSION EQUATIONS WHEN DISTURBANCES

A SIMPLIFICATION JASA $68 \quad 242$ /TOTIC DISTRIBUTION OF MAXIMUM LIKELIH AMS 69583 ND TO ERRORS OF OBSERVATION PRED JASA 65 i 64 THE ANALYSIS OF DISTURBANCES IN REGRESSION ANALYSIS
A GENERAL CLASS OF COEFFIGIENTS OF DIVERGENCE OF ONE DISTRIBUTION FROM ANOTHER DIVERGENCE PROPERTIES OF SOME MARTINGALE TRANSFORMS PRODUCT DIVERSIFICATION AND LIVING COSTS, A FURTHER COMMENT

MARKET GROWTH, COMPANY DIVERSIFICATION AND PRODUCT CONCENTRATION 1947-1954 1296 JASA 63 BO7 CAL RELATION BETWEEN GREENBERG'S INDEX OF LINGUISTIC DIVERSITY AND YULE'S CHARACTERISTIC THE MATHEMATI BIOKA58 $26 B$ CHANGES IN THE SIZE DISTRIBUTION OF DIVIDEND INCOME DIVIDEND POLICY, AN EMPIRICAL ANALYSIS

ZEROES OF INFINITELY DIVISIBLE DENSITIES

ON THE ANALYSIS OF GROUP DIVISIBLE DESIGNS

ON THE BLOCK STRUCTURE OF SINGULAR GROUP DIVISIBLE DESIGNS

COMBINING INTRA AND INTER BLOCK ANALYSIS OF GROUP DIVISIBLE DESIGNS MMON TREATMENTS BETWEEN BLOCKS OF SEMI-REGULAR GROUP DIVISIBLE DESIGNS ON CONTINUOUS SINGULAR INFINITELY DIVISIBLE DISTRIBUTION FUNCTIONS

ON CONTINUITY PROPERTIES OF INFINITELY DIVISIBLE DISTRIBUTION FUNCTIONS RANDOM VARIABLES
APPLICATIONS

INFINITELY DIVISIBLE DISTRIBUTIONS, RECENT RESULTS AND

ON INFINITELY DIVISIBLE LAWS AND A RENEWAL THEOREM FOR NON-NEGATIVE OF INFINITELY DIVISIBLE MIXTURES REDUCED GROUP DIVISIBLE PAIRED COMPARISON DESICNS

TWO CLASSES OF CROUP DIVISIBLE PARTIAL DIALLEL CROSSES

EXTENDED GROUP DIVISIBLE PARTIALLY BALANCED INCOMPLETE BLOCK DESIGNS INFINITELY DIVISIBLE RENEWAL DISTRIBUTIONS

AN EVALUATION OF A FUNCTIONAL ON INFINITELY DIVISIBLE STOCHASTIC PROCESSES

TO 'ON A CLASS OF PROBLEMS RELATED TO THE RANDOM DIVISION OF AN INTERVAL' 53239

NOTE ON THE INFINITE DIVISIVILITY OF EXPONENTIAL MIXTURES

INFINITE DIVISIVILITY OF INTEGER-VALUED RANDOM VARIABLES

ON A THEOREM OF DOBRUSHIN

FOR T. BAYES' ESSAY TOWARDS SOLVING A PROBLEM IN THE DOCTRINE OF CHANCES. /STICS. IX. BIOGRAPHIGAL NOTE

$\mathrm{Y}$. SOC. $17 /$ ESSAY TOWARDS SOLVINC A PROBLEM IN THE DOCTRINE OF CHANCES. (REPRODUCED FROM PHIL. TRANS. RO A SOLUTION TO THE PROBLEM OF LINKING MULTIVARIATE DOCUMENTS

SOME LIMIT THEOREMS FOR THE DODCE-ROMIG LTPD SINGLE SAMPLING INSPECTION PLANS A CENERAL VERSION OF DOEBLIN'S CONDITION

ON RANDOMIZED RANK SCORE PROCEDURE OF BELL AND DOKSUM
SURVEYS

USE OF DOMAIN ESTIMATORS WITH UNEQUAL PROBABILITY IN SAMPLE J DOMAINS OF OPTIMALITY OF TESTS IN SIMPLE RANDOM SAMPLING
JASA 651067

JRSSB66 131

JASA $66 \quad 7 \mathrm{BB}$

$\begin{array}{ll}\text { JASA } 61 & 250\end{array}$

JASA 681132

AMS 691503

JASA 641217

AMS $66 \quad 1398$

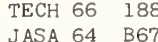

AMS $64 \quad 330$

AMS $6 B \quad 936$ AMS $62 \quad 6 B$ AMS $68 \quad 139$ AMS 6B 1153 AMS $67 \quad 1 \mathrm{~B} 87$ BIOKA63 281 AMS $64 \quad 681$ AMS 691109 AMS $64 \quad 336$ AMS $62 \quad 812$ AMS 671303 AMS $67 \quad 1306$ AMS $6 B \quad 1391$ BIOKA58 293 BIOKA58 296 JASA $69 \quad 163$ TECH $62 \quad 497$ AMS 63668 AMS 661697 JASA $68 \quad 9 B 4$ AMS $69 \quad 308$

CHANCES IN CONCENTRATION OF DOMESTIC MANUFACTURING ESTABLISHMENT OUTPUT 1939-195B JASA 62 797 ISTICAL TESTS OF HYPOTHESES CONCERNING THE DEGREE OF DOMINANCE IN MONOFACTORIAL INHERITANCE NOTES. STAT BIOCS6B 429 GAUSSIAN VECTORS ON AND REGRESSION WEIGHTED DATA ON DOMINATING AN AVERAGE ASSOCIATED WITH DEPENDENT AMS $68 \quad 1 B 44$ A MODIFIED DOOLITTLE APPROACH FOR MULTIPLE AND PARTIAL CORRELATI JASA 58133 THE DOOLITTLE METHOD AND THE FITTING OF POLYNOMIALS TO BIOKA53 229 ANALYSIS OF QUANTAL RESPONSE ASSAYS WITH DOSAGE ERRORS

SOME STOCHASTIC MODELS RELATING TIME AND DOSAGE IN RESPONSE CURVES

SOME COMPARISONS OF METHODS OF FITTING THE DOSAGE RESPONSE CURVE FOR SMALL SAMPLES

FOR COMPLEX CONTINGENCY TABLES AND POLYCHOTOMOUS DOSAGE RESPONSE CURVES MONRO METHOD FOR ESTIMATING THE MEDIAN LETHAL DOSE
BIOCS67 747 BIOCS65 583 JASA $64 \quad 779$ MODELS BIOCS66 83 THE ROBBINS- JRSSB65 28 
ANALYSIS OF GROWTH AND DOSE RESPONSE CURVES

METHOD OF TESTINC THE LINEAR TRENDS OF RESPONSES IN DOSE TRIALS

MALIZINC THE INCOMPLETE BETA-FUNCTION FOR FITTINC TO DOSE-RESPONSE CURVES

A LARCE-SAMPLE BIOASSAY DESICN WITH RANDOM DOSES AND UNCERTAIN CONCENTRATION

THE AVERAGE SAMPLE NUMBER FOR TRUNCATED SINCLE AND DOUBLE ATTRIBUTES ACCEPTANCE SAMPLINC PLANS

CUT MULTIPLE COMPARISONS FOR BALANCED SINGLE AND DOUBLE CLASSIFICATIONS. PART 1 , RESULTS

A SEQUENTIAL BIOCS68 663

ON NOR BIOKA6O 173

BIOKA55 307

TECH 6B 685

SHORT- TECH 6595

ORT-CUT MULTIPLE COMPARISONS FOR BALANCED SINCLE AND DOUBLE CLASSIFICATIONS. PART 2. DERIVATIONS AND APPRO BIOKA65 485

TES UNDER SYMMETRIC CENSORING OF THE PARAMETERS OF A DOUBLE EXPONENTIAL POPULATION

BALANCED INCOMPLETE BLOCK DESICNS WITH DOUBLE GROUPINC OF BLOCKS INTO REPLICATIONS

A NOTE ON A DOUBLE SAMPLE TEST

ESTIMATION BY DOUBLE SAMPLINC

ON THE THEORY OF CLASSICAL RECRESSION AND DOUBLE SAMPLINC ESTIMATION

ON DOUBLE SAMPLING FOR PROBABILITY PROPORTIONATE TO SOME AMS 64900

MEASURE OF SIZE ESTIMATION

USE OF DOUBLE SAMPLINC FOR SELECTING BEST POPULATION

DOUBLE SAMPLINC FOR STRATIFICATION ON SUCCESSIVE

SOME REMARKS ON DOUBLE SAMPLING FOR STRATIFICATION

DOUBLE SAMPLINC PLANS WHERE THE ACCEPTANCE CRITERION

A DOUBLE SAMPLINC SCHEME FOR ANALYTICAL SURVEYS

DESIGN AND OPERATION OF A DOUBLE-LIMIT VARIABLES SAMPLINC PLAN

OF SINCLE EXPONENTIAL DISTRIBUTIONS FROM SINGLY AND DOUBLY CENSORED SAMPLES /ATISTICS OF THE PARAMETERS JASA 57 5B
ST ASYMPTOTIC/ MAXIMUM-LIKELIHOOD ESTIMATION, FROM DOUBLY CENSORED SAMPLES, OF THE PARAMETERS OF THE FIR JASA 6B 889 SCALE PARAMETERS BY ORDER STATISTICS FROM SINGLY AND DOUBLY CENSORED SAMPLES, PART I. THE NORMAL DISTRIBUT AMS 39 325 A NOTE ON REPRESENTATIONS OF THE DOUBLY NON-CENTRAL T DISTRIBUTION THE MOMENTS OF A DOUBLY NONCENTRAL T-DISTRIBUTION

SERIES REPRESENTATIONS OF THE DOUBLY NONCENTRAL T-DISTRIBUTION

RELATIONSHIP BETWEEN ARBITRARY POSITIVE MATRICES AND DOUBLY STOCHASTIC MATRICES

ON ESTIMATING THE PARAMETER OF A DOUBLY TRUNCATED BINOMIAL DISTRIBUTION

PARAMETERS OF NORMAL POPULATIONS BASED ON SINGLY AND DOUBLY TRUNCATED SAMPLES/OF THE ESTIMATES OF THE J

A GENERALIZED TWO-SAMPLE WILCOXON TEST FOR DOUBLY-CENSORED DATA.

ON THE MEAN AND VARIANCE OF THE SMALLER OF TWO DRAWINGS FROM A BINOMIAL POPULATION

F THE SAMPLE MEAN WHERE EACH MEMBER OF THE SAMPLE TS DRAWN FROM A DIFFERENT RECTANGULAR DISTRTBUTION

THE CURVATURE OF THE LIKELIHOOD SURFACE OF A SAMPLE DRAWN FROM A DISTRIBUTION ADMITTING SUFFICIENT STATIS BIOKA60 203

ORRELATION COEFFICIENT IN RANDOM SAMPLES OF ANY SIZE DRAWN FROM NON-NORMAL UNIVERSES /E PRODUCT-MOMENT C BIOKA5I 219

TWO SPECIFIED SAMPLING UNITS WILL OCCUR IN A SAMPLE DRAWN WITH UNEQUAL PROBABILITIES AND WITHOUT REPLACEM JASA 66 384

CHOOSING ONE OF K HYPOTHESES CONCERNING THE UNKNOWN DRIFT PARAMETER OF THE WIENER PROCESS /OCEDURES FOR AMS 67 1376

VARIATION QUADRATIQUE DES MARTINCALES CONTINUES A DROITE

GENETTC CLTNES IN BODY DTMENSTONS TN POPULATTONS OF IDROSOPHILA SUBOBSCURA' COLL. AND A COMPARISON IITH T BIC

MEASUREMENT OF THE POTENCIES OF DRUG MIXTURES

OPTIMAL REPLICATION IN SEQUENTIAL DRUG SCREENING

OPTTMAL DRUG SCREENING PLANS

QUANTAL RESPONSE TO THE JOINT ACTION OF A MIXTURE OF DRUGS

CTION OF MODELS FOR QUANTAL RESPONSES TO MIXTURES OF DRUGS

作

THE 'GENERALIZED' MULTIPLE CORRELATION MATRIX IN THE DUAL CASE

DISTRIBUTION

DISTRIBUTION OF

AND DUAL CONFIGURATIONS AND THE RECIPROCAL NORMAL

THE DUAL FUNCTION OF STATISTICS

ESTIMATION A JOINT DESIGN CRITERION FOR THE DUAL PROBLEM OF MODEL DISCRIMINATION AND PARAMETER

AND SOME NONEXISTENCE THEOREMS

BLOCK DESIGNS

DUALS OF PARTIALLY BALANCED INCOMPLETE BLOCK DESIGNS

ON THE DUALS OF SYMMETRIC PARTIALLY-BALANCED INCOMPLETE

A QUICK COMPACT TWO SAMPLE TEST TO DUCKWORTH'S SPECIFICATIONS

EFFICIENCY LOSS DUE TO GROUPING IN DISTRIBUTION-FREE TESTS

A NOTE ON THE LOSS OF INFORMATION DUE TO GROUPINC OF OBSERVATIONS

USE OF DUMMY VARIABLES IN REGRESSION EQUATIONS

ASYMPTOTIC VARIANCES FOR DUMMY VARIATE REGRESSION UNDER NORMALITY ASSUMPTIONS

MULTIVARIATE REGRESSION OF DUMMY VARIATES UNDER NORMALITY ASSUMPTIONS

MINATION OF THE ECONOMIC DESIGN OF X-CHARTS BASED ON DUNCAN'S MODEL

NOTES. APPROXIMATIONS TO THE CRITICAL VALUES FOR DUNCAN'S MULTIPLE RANGE TEST

AN EXAMPLE IN DUNUMERABLE DECISION PROCESSES

PARTIALLY DUPLICATED FRACTIONAL FACTORIAL DESIGNS

THEORY WHEN THE FRAME CONTAINS AND UNKNOWN AMOUNT OF DUPLICATION SOME NONRESPONSE SAMPLING J PARTIAL DUPLICATION OF FACTORIAL EXPERIMENTS

PARTIAL DUPLICATION OF RESPONSE SURFACE DESIGNS

INCOME, INCOME CHANGE, AND DURABLE GOODS DEMAND

BIOCS66 469

BIOCS69 477

BIOKA64 I

BIOKA63 31

181

AMS 641801

AMS $69 \quad 393$

JASA 60

TECH $68 \quad 145$

AMS $66 \quad 104 \mathrm{~B}$

AMS $63 \quad 52 B$

TECH 5931

JASA $67 \quad 954$

BIOKA64 495

JASA $57 \quad 54 \mathrm{~B}$

JASA $67 \quad 1305$

JASA $63 \quad 1054$

JASA $68 \quad 304$

BI0CS66 179

AMS 6 B 674

TECH $63 \quad 71$

JASA $68 \quad 87$ TECH 5963

TECH $60 \quad 185$

JASA $64 \quad 1194$

E ROLE OF ASSETS, CREDIT AND INTENTIONS

CONSUMER DURABLE GOODS EXPENDITURES, WITH MAJOR EMPHASIS ON TH JASA 63648

PROBLEM

ON THE MEAN DURATION OF A BALL AND CELL GAME, A FIRST PASSAGE

A NOTE ON THE EARLY SOLUTIONS OF THE PROBLEM OF THE DURATION OF PLAY /F PROBABILITY AND STATISTICS. VI. SOME SIMPLE DURATION-DEPENDENT STOCHASTIC PROCESSES

A COMPARTSON BETWEEN THE POWFR OF THE DURBIN WATSON TEST AND THE POWER OF THE BLUS TEST

E OF A SAMPLE OF CONSECUTIVE OBSE/ CORRICENDA, 'ON DURBIN'S FORMULA FOR THE LIMITING GENERALIZED VARIANC BIOKA6I 476

E OF A SAMPLE OF CONSECUTIVE OBSERVATIONS FROM/ ON DURBIN'S FORMULA FOR THE LIMITING GENERALIZED VARIANC BIOKA6I I97

RELIABILITY GROWTH DURINC A DEVELOPMENT TESTING PROGRAM

UMBER OF CRITICAL SITES IN LIMITED CENOME EXPRESSION DURING VIRAL INFECTION OF BACTERIA /MATION OF THE N BIOCS69 537 ON DVORETZKY STOCHASTIC APPROXIMATION THEOREMS AMS $66 \quad 1534$

INCREASE IN RENT OF DWELLING UNITS FROM 1940 TO $1950 \quad 358$

ON NONCOVERAGE OF SAMPLE DWELLINGS

RZEUGUNG VON SYMBOLFOLGEN MIT VORGEGEBENER RELATIVER DYADENKONTEXTREDUNDANZ /N EINFACHES VERFAHREN ZUR E BIOCS68 703

THE EQUILIBRIUM COVARIANCE MATRIX OF DYNAMIC ECONOMETRIC MODELS DISCRETE DYNAMIC PROGRAMMING

MEMORYLESS STRATEGIES IN FINITE-STACE DYNAMIC PROGRAMMING

DISCOUNTED DYNAMIC PROGRAMMING

NEGATIVE DYNAMIC PROGRAMMING

A NOTE ON UNDISCOUNTED DYNAMIC PROGRAMMING

A NOTE ON POSITIVE DYNAMIC PROGRAMMING

INSPECTION

MARKOV PROCESS
A DYNAMIC PROGRAMMING APPLICATION IN PRODUCTION LINE

ON THE ITERATIVE METHOD OF DYNAMIC PROGRAMMING ON A FINITE SPACE DISCRETE TIME DISCRETE DYNAMIC PROGRAMMING WITH A SMALL INTEREST RATE
AMS $62 \quad 719$

AMS $64 \quad 863$

AMS $65 \quad 226$

AMS $66 \quad 871$

AMS 661042

AMS $69 \quad 316$

TECH $67 \quad 73$

AMS 651279

AMS $69 \quad 366$ 
ON FINDINC OPTIMAL POLICIES IN DISCRETE DYNAMIC PROCRAMMINC WITH NO DISCOUNTINC AN OPTIMALITY CONDITION FOR DISCRETE DYNAMIC PROCRAMMINC WITH NO DISCOUNTINC

Y CRITERIA DISCRETE DYNAMIC PROCRAMMINC WITH SENSITIVE DISCOUNT OPTIMALIT

A. DYNAMIC STOCHASTIC APPROXIMATION METHOD DYNAMIC STOCHASTIC PROCESSES

ON A FACTOR AUTOMORPHISM OF A NORMAL DYNAMICAL SYSTEM

VERSIONS OF THE MATRIX MODEL FOR POPULATION DYNAMICS NOTE ON A THEOREM OF DYNKIN ON THE DIMENSION OF SUFFICIENT STATISTICS

PROCESS

TESTS AND CONFIDENCE INTERVALS BASED ON THE METRIC D2 NOTE ON DYNKIN'S 'ALPHA, XI' SUBPROCESS OF STANDARD MARKOV

AMS $66 \quad 1284$ AMS $68 \quad 1220$ AMS 691635 AMS 651695 AMS $63 \quad 274$ AMS $66 \quad 1528$ SOME EQUILIBRIUM RESULTS FOR THE QUEUEINC PROCESS E-SUB-K-M-I NUMERICAL RESULTS FOR WAITING TIMES IN THE QUEUE E-SUB-K-M-I NUMERICAL RESULTS FOR WAITINC TIMES IN THE QUEUE E-SUB-K-M-1. ON THE MONOTONICITY OF E-SUB-P(S-SUB-T-OVER-T) A METHOD OF FITTING THE REGRESSION CURVE $E(Y)=A+D X+B C-T 0-X$ AMS $69 \quad 1474$ AMS 671647 AMS $63 \quad 618$ JRSSB56 275 ALLINC IN THE SHORTEST SAMPLE SPACINGS DETERMINED BY EARLIER OBSERVATIONS
$\mathrm{N}$ THE HISTORY OF PROBABILITY AND STATISTICS. XX.SOME EARLY CORRESPONDENCE ON AN EXTREME RANK SUM TEST WITH EARLY DECISION EARLY DECISION IN THE WILCOXON TWO-SAMPLE TEST

QUERY, LIFE TESTING AND EARLY FAILURE

EARLY FAILURES IN LIFE TESTING

CORRICENDA， ISOME BIOKA60

AMS $68 \quad 1755$ TECH $65 \quad 59$

NCE BETWEEN W.S. GOSSETT, R.A. FISHE BIOKA68 445 JASA $65 \quad 859$ JASA $63 \quad 713$ TECH $66 \quad 539$ JASA 60491 HE HISTORY OF PROBABILITY AND STATISTICS. XXI. ON THE EARLY HISTORY OF THE LAW OF LARGE NUMBERS /IES IN T BIOKA68 459 ON CROWTH PARAMETER ESTIMATION FOR EARLY LIFE STAGES AND TENSILE STRENGTH
TWO EARLY PAPERS ON THE RELATION BETWEEN EXTREME VALUES
ORY OF PROBABILITY AND STATISTICS. VI. A NOTE ON THE EARLY SOLUTIONS OF THE PROBLEM OF THE DURATION OF PLA BIOKA57 559 BIOGS66 162 BIOKA54 559 A NOTE ON THE RELATIONSHIP BETWEEN EARNING EXPECTATIONS AND NEW CAR PURCHASES J 595 RESPONSE ERROR IN SURVEY REPORTS OF EARNINCS INFORMATION JASA 66 IQUE DES LIAISONS ENTRE LES ESPECES ET LES VARIABLES ECOLOGIQUES. PRINCIPES FONDAMENTAUX /NALYSE STATIST BIOCS65 345 IQUE DES LIAISONS ENTRE LES ESPECES ET LES VARIABLES ECOLOGIQUES. UN EXEMPLE /ALES PAR L'ANALYSE STATIST BIOCS65 890 SPATIAL POINT PROCESSES, WITH APPLIGATIONS TO ECOLOCY

EVIDENCE CONCERNINC CONTAGIOUS DISTRIBUTIONS IN ECOLOCY BIOKA55 102 N AS A PROBABILITY MODEL IN POPULATION AND COMMUNITY ECOLOCY AND SOME OF ITS STATISTICAL PROPERTIES /TIO JASA 67 655 STUDIES IN STATISTICAL ECOLOCY. I. SPATIAL PATTERN SEASONAL ADJUSTMENT OF DATA FOR ECONOMETRIC ANALYSIS ECONOMETRIC EXPLORATION OF INDIAN SAVING BEHAVIOR AN ECONOMETRIC MODEL FOR UNITED STATES ACRICULTURE CROSS STATE PRODUCT AND AN ECONOMETRIC MODEL OF A STATE A QUARTERLY ECONOMETRIC MODEL OF THE UNITED STATES

THE EQUILIBRIUM COVARIANCE MATRIX OF DYNAMIC ECONOMETRIC MODELS THE EQUILIBRIUM COVARIANCE MATRIX OF DYNAMIC ECONOMETRIC MODELS 277 ARIANCE OF A STATIONARY BIRTH-DEATH PROCESS, AND ITS ECONOMIC APPLICATION /ONSHIP BETWEEN THE MEAN AND V BIOKA62 253 FORECASTINC SHORT-TERM ECONOMIC CHANGE FORE

CURRENT CONTROL OF A PROCESS ON THE ECONOMIC CHOICE OF EXPERIMENT SIZES FOR DECISION RECA ECONOMIC CHOICE OF THE AMOUNT OF EXPERIMENTATION SELECTED ECONOMIC DATA, ACCURACY VS. REPORTING SPEED THE ECONOMIC DESIGN OF CUMULATIVE SUM CONTROL CHARTS THE ECONOMIC DESIGN OF MEAN CHARTS USED TO MAINTAIN AN ALGORITHM FOR THE DETERMINATION OF THE ECONOMIC DESIGN OF $X$-GHARTS BASED ON DUNCAN'S MODEL DATA REVISIONS AND ECONOMIC FORECASTING TINBERGEN ON ECONOMIC POLICY THE PRESIDENT'S ECONOMIC REPORT

STATISTICAL DATA AVAILABLE FOR ECONOMIC RESEARCH ON CERTAIN TYPES OF RECREATION BIOKA52 346 JASA $67 \quad 137$ JASA $69 \quad 90$ JASA $59 \quad 556$ JASA 69 7B7 JASA $61 \quad 379$ JASA 69 $\begin{array}{lr}\text { JRSA } & 69 \\ \text { JRSSB } 67 & 503\end{array}$ JRSSB56 32 JASA $68 \quad 436$ TECH $68 \quad 479$ JASA $56 \quad 228$ JASA $68 \quad 304$ JASA $67 \quad 470$ JASA 58 B9 $\begin{array}{ll}\text { JASA } & 57 \quad 257\end{array}$ $\begin{array}{ll}\text { JASA } & 59 \quad 281\end{array}$ COMPUTER SIMULATION EXPERIMENTS WITH ECONOMIC SYSTEMS. THE PROBLEM OF EXPERIMENTAL DESIGN JASA 67 13I5 DISTRIBUTIONS OF CORRELATION COEFFICIENTS IN EGONOMIC TIME SERIES JASA $61 \quad 637$ SEASONAL ADJUSTMENT OF ECONOMIC TIME SERIES AND MULTIPLE REGRESSION ANALYSIS JASA 63993 THE ESTIMATION OF SEASONAL VARIATION IN ECONOMIC TIME SERIES, CORR. 631162 JASA $63 \quad 31$

VARIANCE, LINEAR, UNBIASED SEASONAL ADJUSTMENT OF ECONOMIG TIME SERIES, CORR. 651250 MINIMUM JASA $64 \quad 6 \mathrm{BI}$ BY VARIABLES THE MOST ECONOMICAL BINOMIAL SEQUENTIAL PROBABILITY RATIO TEST BIOKA60 103 THE MOST ECONOMICAL SEQUENTIAL SAMPLING SCHEME FOR INSPECTION JRSSB59 400 ECONOMICALLY OPTIMUM ACCEPTANCE TESTS

NORMAL SAMPLING IN TWO-ACTION PROBLEMS WITH LINEAR ECONOMICS SOME STATISTICAL ASPECTS OF THE ECONOMICS OF ANALYTIGAL TESTINC
THE ECONOMICS OF THE PRESIDENT'S ECON THE ECONOMICS OF THE PRESIDENT'S ECONOMIC REPORTS JASA $56 \quad 243$ SIMULATION OF AN AQUATIC ECOSYSTEM TWO-STACE JASA 69 NO. 4 TECH $59 \quad 49$ JASA $56 \quad 454$ BIOCS68 803

69 151/ A CENTRAL LIMIT THEOREM FOR THE NUMBER OF EDGES IN THE RANDOM INTERSECTION OF TWO GRAPHS (CORR. AMS 69 I44 OF PROBABILITY AND STATISTICS. XIX. FRANCIS YSIDRO EDGEWORTH (1845-1926) STUDIES IN THE HISTORY BIOKA68 269 OF UNIMODALITY AND POSITIVITY IN THE ABBREVIATED EDCEWORTH AND GRAM-CHARLIER SERIES THE CONDITIONS UNDER WHICH GRAM-CHARLIER AND EDGEWORTH CURVES ARE POSITIVE DEFINITE AND UNIMODAL BIOKA52 425 NOTE ON MR QUENOUILLE'S EDGEWORTH TYPE A TRANSFORMATION A PROCEDURE FOR AUTOMATIC DATA EDITING

BLS MANPOWER SURVEYS COMPUTER EDITING OF SURVEY DATA, FIVE YEARS OF EXPERIENCE IN EDITORIAL EDITORIAL ARRANCEMENTS EDITORIAL, JOHN WISHART, 1898-1956

QUALITY AND QUANTITY IN HICHER EDUCATION OGCUPATIONAL COMPONENTS OF EDUCATIONAL DIFFERENCES IN INCOME PRACTICAL VALUE OF INTERNATIONAL EDUCATIONAL STATISTICS

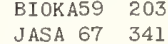
JASA $66 \quad 375$ TECH $66 \quad 1$ BIOKA65 I BIOKA57 1 JASA $65 \quad 1$ JASA $61 \quad 7 B 3$ JASA $56 \quad 605$ CANONICAL ANALYSIS, A METHOD FOR SELECTING THE MOST EFFECTIVE DISCRIMINATORS IN A MULTIVARIATE SITUATION BIOCS6B B45 THE IDENTIFICATION OF EFFECTIVE INTERVIEWERS JASA 641165 IN SCREENING EXPERIMENTS THE EFFECTIVE USE OF BOTH POSITIVE AND NECATIVE CONTROLS $\begin{array}{rr}\text { JASA } & 64 \\ \text { BIOCS } 67 & 2 \text { B5 }\end{array}$ THE RATIO OF TWO PROBABILITIES AND SOME MEASURES OF EFFECTIVENESS THE EFFECTIVENESS OF ADJUSTMENT BY SUBCLASSIFICATION IN REMOVING BIAS IN OBSERVATIONAL STUDIES A COMPARISON OF THE EFFECTIVENESS OF TOURNAMENTS

INFECTION A QUANTITATIVE DISCUSSION OF THE EFFECTIVENESS OF VOIDING AS A DEFENCE AGAINST BLADDER SEQUENCES BALANCED FOR PAIRS OF RESIDUAL EFFECTS A CENERAL MODEL FOR CENETIC EFFECTS 
OF COMPONENTS EXHIBITING CUMULATIVE DAMAGE EFFECTS BALANCED FOR THE LINEAR COMPONENT OF FIRST RESIDUAL EFFECTS

THE RELIABILITY TECH $61 \quad 413$ CHANGEOVER DESIGNS BIOKA68 297 IAL E/ NOTES. THE SQUARE-SUMMING CHECK ON THE MAIN EFFECTS AND INTERACTIONS IN A 2 TO THE POWER N FACTOR BIOCS67 57I S FOR THE U/ STATISTICAL DEPENDENCE BETWEEN RANDOM EFFECTS AND THE NUMBERS OF OBSERVATIONS ON THE EFFECT JASA 67 1375 RREGULAR FRACTIONAL P/ INDEX NUMBERS FOR FACTORIAL EFFECTS AND THEIR CONNECTION WITH A SPECIAL KIND OF I JASA 63 497 IONS AN ITERATIVE PROCEDURE FOR ESTIMATING FIXED EFFECTS AND VARIANCE COMPONENTS IN MIXED MODEL SITUAT BIOCS68 13 ESTIMATES OF EFFECTS FOR FRACTIONAL REPLICATES

AMS 64711

ANDOM EFFECTS AND THE NUMBERS OF OBSERVATIONS ON THE EFFECTS FOR THE UNBALANCED ONE-WAY RANDOM CLASSIFICAT JASA 67 1375

COMPLETE COUNTERBALANCING OF IMMEDIATE SEQUENTIAL EFFECTS IN A LATIN SQUARE DESIGN, GORR. 5B 1030 TESTING THE HYPOTHESIS OF NO FIXED MAIN-EFFECTS IN SCHEFFE'S MIXED MODEL

NOTE ON TESTING HYPOTHESES IN AN UNBALANCED RANDOM EFFEGTS MODEL PROCEDURE TO ESTIMATE THE POPULATION MEAN IN RANDOM EFFECTS MODELS

STOCHASTIC MODELS ERROR

AL DESIGN

SURVIVAL OF A GENE ANALYSIS OF EFFECTS OF ANTIBIOTICS ON BACTERIA BY MEANS OF

A TECH $67 \quad 577$ BIOCS66 761 EFFECTS OF BIAS ON ESTIMATES OF THE CIRCULAR PROBABLE JASA $60 \quad 732$

THE EFFECTS OF ERRORS IN THE FACTOR LEVELS AND EXPERIMENT TECH 63247 SOME EFFECTS OF FLUCTUATING OFFSPRING DISTRIBUTIONS ON THE BIOKA66 391 A MARKOVIAN MODEL FOR THE ANALYSIS OF THE EFFECTS OF MARGINAL TESTING ON SYSTEM RELIABILITY THE INTERPRETATION OF THE EFFECTS OF NON-ADDITIVITY IN THE LATIN SQUARE A NOTE ON THE EFFECTS OF NONRESPONSE ON SURVEYS JASA $57 \quad 29$ ND DIFFERENT FITNESS REQUIREMENTS AMONG ENVIRONME/ EFFECTS OF PARTIAL ISOLATION (DISTANCE), MIGRATION, A BIOCS66 453 SERVICE SYSTEMS EFFECTS OF SLOW-DOWNS AND FAILURE ON STOCHASTIC TECH 63 TE E LOSS OF FOUR METHODS OF REPRODUCING FI/ EXPECTED EFFECTS ON THE INBREEDING COEFFICIENT AND RATE OF GEN THE RELATIVE EFFICACY OF INVESTMENT ANTICIPATIONS

ALTERNATIVE EFFICIENCIES FOR SIGNED RANK TESTS EFFICIENCIES FOR STEPWISE REGRESSIONS 5930 BIOCS65 447 JASA $66 \quad 104$ AMS 651759 JASA 641179 E-SAMPLE AND TWO-SAMPLE STATISTICS EXACT BAHADUR EFFICIENCIES FOR THE KOLMOGOROV-SMIRNOV AND KUIPER ON AMS 671475 TIC REGRESSION EQUATION

ASYMPTOTIG EFFICIENCIES OF A NONPARAMETRIG LIFE TEST FOR SMALLER JASA 56467 THE EFFICIENCIES OF ALTERNATIVE ESTIMATORS FOR AN ASYMPTO BIOKA58 370 END IN DISPERSI/ A NOTE ON THE ASYMPTOTIC RELATIVE EFFICIENCIES OF COX AND STUART'S TESTS FOR TESTING TR BIOKA68 381 LINEAR AUTOREGRESSIVE SCHEMES REGRESSION COMPARATIVE EFFICIENCIES OF METHODS OF ESTIMATING PARAMETERS IN BIOKA6I THE EFFICIENCIES OF TESTS OF RANDOMNESS AGAINST NORMAL JASA 56285 TOR THE CORRELATION BETWEEN FEED EFFICIENCY AND RATE OF GAIN, A RATIO AND ITS DENOMINA BIOCS65 739 SYSTEM EFFICIENCY AND RELIABILITY

ON THE RELATION BETWEEN ESTIMATING EFFICIENCY AND THE POWER OF TESTS A SIGNIFICANGE TEST FOR THE DIFFERENCE IN EFFICIENCY BETWEEN TWO PREDICTORS SCORES TESTS SMALL SAMPLE POWER AND EFFICIENCY FOR THE ONE SAMPLE WILCOXON AND NORMAL LEAST-SQUARES EFFICIENCY FOR VECTOR TIME SERIES APPLIGATION OF AN ESTIMATOR OF HIGH EFFICIENCY IN BIVARIATE EXTREME VALUE THEORY ASYMPTOTIC EFFICIENCY IN POLYNOMIAL ESTIMATION

TESTS

REGRESSION PARAMETERS DISTRIBUTION-FREE

A DISTRIBUTION-FREE METHOD OF ESTIMATING ASYMPTOTIC EFFICIENCY OF A CLASS OF NONPARAMETRIC TESTS MISSING OBSERVATIONS IN MULTIVARIATE REGRESSION, EFFICIENCY OF A FIRST ORDER METHOD THE MEAN
ENCE (CORR. 67 196) CONSTANT PATROLLING TIME ON THE ASYMPTOTIG EFFICIENCY OF A SEQUENTIAL PROCEDURE FOR ESTIMATINC TECH $60 \quad 43$ BIOKA54 542 JRSSB55 266 AMS $63 \quad 624$ JRSSB 68490 JASA 69 NO. 4 AMS $61 \quad 1042$ AMS $67 \quad 884$ ON AMS $66 \quad 1759$ JASA 69 NO. 4 AMS 661173 A NOTE ON THE ASYMPTOTIC EFFICIENCY OF AN ASYMPTOTICALLY NORMAL ESTIMATOR SEQU J THE EFFIGIENCY OF AUTOMATIC WINDING MACHINES WITH AL POPULATIONS BASED ON SINGLY CENSORED SA/ ON THE EFFICIENCY OF BAN ESTIMATES OF THE PARAMETERS OF NORM A NOTE ON THE ASYMPTOTIC EFFICIENCY OF BENNETT'S BIVARIATE SIGN TEST THE EFFICIENCY OF BLOCKING IN INCOMPLETE BLOCK DESIGNS

TESTS ASYMPTOTIC EFFICIENCY OF CERTAIN LOCALLY MOST POWERFUL RANK $\begin{array}{llll}\text { EGATIVE BINOMIAL AND NEYMAN TYPE A DISTRIBUTIONS } & \text { EFFICIENCY OF CERTAIN METHODS OF ESTIMATION FOR } \\ \text { EXPERIMENT } & \text { ASYMPTOTIC EFFIGIENCY OF CERTAIN RANK TESTS FOR COMPARATIVE }\end{array}$

COEFFICIENT COEFFICIENTS EFF CERTAIN RANK TESTS FOR COMPARATIVE ASYMPTOTIC EFFICIENCY OF CLASS OF C-SAMPLE TESTS

THE ASYMPTOTIC EFFICIENCY OF DANIELS'S GENERALIZED CORRELATION THE ASYMPTOTIC EFFICIENCY OF DANIELS'S GENERALIZED CORRELATION THE MEAN EFFICIENCY OF EQUI-REPLICATE DESIGNS

MEAN SQUARE EFFICIENCY OF ESTIMATORS OF VARIANCE COMPONENTS A NOTE ON THE ASYMPTOTIC EFFICIENCY OF FRIEDMAN'S CHI-SQUARE-SUB-R-TEST THE ASYMPTOTIC RELATIVE EFFICIENCY OF GOODNESS-OF-FIT TESTS AGAINST SCALAR THE EXPONENTIAL REGRESSION THE EFFICIENCY OF INTERNAL REGRESSION FOR THE FITTING OF ON THE ASYMPTOTIC EFFICIENCY OF LEAST SQUARES ESTIMATORS

A NOTE ON THE EFFICIENCY OF LEAST-SQUARES ESTIMATES

ON THE EFFICIENCY OF MATCHED PAIRS IN BERNOULLI TRIALS THE EFFICIENCY OF MATCHED SAMPLES

DESIGNS FOR BIO-ASSAYS AINST SOME PARAMETRIC ALTERNA/

ON THE EFFICIENCY OF MODIFIED BALANCED INCOMPLETE BLOCK JRSSB 63195 JRSSB59 381 BIOKA62 570 JRSSB $66 \quad 146$ BIOKA60 273 AMS $61 \quad 88$ BIOKA62 215 AMS $67 \quad 90$ AMS $64 \quad 102$ BIOKA63 499 JRSSB61 128 BIOKA68 251 JASA 69 NO. 4 BIOKA67 677 JASA $65 \quad 410$ BIOKA59 293 AMS $66 \quad 1676$ JRSSB68 284 BIOKA68 365 BIOCS65 623 BIOCS69 591 AMS $62 \quad 1375$ AMS 671753 ASYMPTOTIC EFFICIENCY OF MULTIVARIATE NORMAL SCORE TEST

BY ONE OPERATOR WHEN WALKING TIME AND REPAIR/ THE EFFICIENCY OF N MACHINES UNI-DIRECTIONALLY PATROLLED THE EFFICIENCY OF $N$ MACHINES UNI-DIRECTIONALLY PATROLLED FOR NORMAL ALTERNATIONS TWO

FROM TIME SERIES WITH CONTINUOUS SPECTRA

ON THE ON THE EFFICIENCY OF OPTIMAL NONPARAMETRIC PROCEDURES IN THE

ON THE EFFICIENCY OF PROCEDURES FOR SMOOTHING PERIODOGRAMS APPROACH TO DEGENERACY AND THE EFFICIENCY OF SOME MULTIVARIATE TESTS

THE RELATIVE EFFICIENCY OF SOME TWO-PHASE SAMPLING SCHEMES THE EFFICIENCY OF STATISTICAL SIMULATION PROCEDURES TECH

RSSB57 166 JRSSB57 173 AMS $66 \quad 940$ BIOKA55 143 AMS $68 \quad 1654$ AMS $67 \quad 937$

TECH $62 \quad 257$ AVERAGE CRITICAL VALUE METHOD FOR ADJUDGING RELATIVE EFFICIENCY OF STATISTICAL TESTS IN TIME SERIES REGRES BIOKA66 109 OF LARGE DISCREPANCY BETWEEN MEASURES OF ASYMPTOTIC EFFICIENCY OF TESTS

CRITICAL VALUE METHOD AND THE ASYMPTOTIC RELATIVE EFFICIENCY OF TESTS AN EXAMPLE AMS $68 \quad 179$ THE AVERAGE BIOKAG7 308 LOCAL ASYMPTOTIC POWER AND EFFICIENCY OF TESTS OF KOLMOGOROV-SMIRNOV TYPE AMS 671705 $\begin{array}{rr}\text { AMS } 67 & 1705 \\ \text { IOKA59 } & 475\end{array}$ 
AL POPULATIONS BASED ON SINCLY AND D/ ON THE JOINT EFFICIENCY OF THE ESTIMATES OF THE PARAMETERS OF NORM JASA 62 46 NULL DISTRIBUTION AND BAHADUR EFFICIENCY OF THE HODCES BIVARIATE SIGN TEST ON THE ASYMPTOTIC EFFICIENCY OF THE KOLMOCOROV-SMIRNOV TEST EFFICIENCY OF THE METHOD OF MOMENTS AND THE GRAM- BIOKA5I 58

CHARLIER TYPE A DISTRIBUTION

F-TEST

RECRESSION

FIRST-ORDER STATIONARY MARKOFF PROCESS
ON THE EFFICIENCY OF THE NORMAL SCORES TEST RELATIVE TO THE AMS 651306

THE EFFICIENCY OF THE RECORDS TEST FOR TREND IN NORMAL JRSSB57 149 EFFICIENCY OF THE SAMPLE MEAN WHEN RESIDUALS FOLLOW A JASA 681237

ASYMPTOTIC EFFICIENCY OF THE TWO SAMPLE KOLMOGOROV-SMIRNOV TEST JASA 67932 S FOR SAMPLING WITHOUT REPLACEMENT AND EXACT BAHADUR EFFICIENCY OF THE TWO-SAMPLE NORMAL SCORES TEST /IE BIOKA68 371 TEST A NOTE ON THE LIMITING RELATIVE EFFICIENCY OF THE WALD SEQUENTIAL PROBABILITY RATIO JASA 60 660 RANDOMIZED BLOCKS

ON'S TWO SAMPLE TEST EFFICIENCY OF THE WILCOXON TWO-SAMPLE STATISTIC FOR JASA 63894 THE RELATION BETWEEN PITMAN'S ASYMPTOTIG RELATIVE EFFICIENCY OF TWO TESTS AND THE CORRELATION COEFFICIE AMS 63 1442 DISCRETE POPULATIONS

ON A MEASURE OF TEST EFFICIENCY PROPOSED BY $R$ R. BAHADUR EFFICIENCY ROBUST TWO-SAMPLE RANK TESTS

AMS 641537 JASA 671241 TECH $68 \quad 769$

E OF THE WEIBULL DISTRIBU/ AN EXACT ASYMPTOTICALLY EFFICIENT CONFTDENCE BOUND FOR RELTABILTTY IN THE CAS TECH 66 135 SPECTRAL DENSIT JRSSB58 303

EXPONENTIAL REGRESSION

IN LARGE SAMPLES (WITH DISCUSSION)

FUNCTION

CERTAIN SECOND ORDER PROCESSES

GROUPED DATA

ONS WHEN DISTURBANCES ARE BOTH SERIALLY AND CONTE/ MODELS

ERS

ASYMPTOTICALLY NEARLY

ENGEL CURVE ANALYSIS

GRESSIONS AND TESTS FOR AGCREGATION BIAS

PENDENT WITH SPECIAL REFERENCE TO TYPE II CENSORE/ EFFICIENT GROUPING, RECRESSION AND CORRELATION IN JASA 64233

EFFICIENT MOMENT ESTIMATORS WHEN THE VARIABLES ARE DE BIOKA62 155

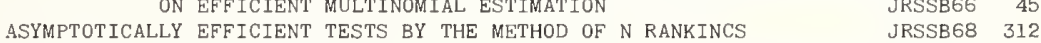

QUANTITATIVE ANALYSIS, GENERAL THEORY AND THE CA/ EFFICIENT UTILIZATION OF NON-NUMERICAL INFORMATION IN AMS 63 I347 LIMIT THEOREMS FOR THE MULTI URN EHREFEST MODEL GEBRUIK VAN DIFFERENSIAALVERGELYKINGE COMPONENTS

MTNTMTZATTON OF EIENSKAPPE VAN WAARSKYNLIKHEIDSVERDELINGS DEUR DIE EIGENVALUES OF A MATRIX AND OPTIMALITY OF PRINCIPAL EIGENVALUES OF NON-NEGATIVE MATRICES

NSTRUCTION OF A 2-TO-THE-(17-9) RESOLUTION V PLAN IN EIGHT BLOCKS OF 32 AMS $6 B \quad 864$ AMS 68 B59 AMS $64 \quad 1797$ ROM A DIALLEL MATING D/ SPATIAL RELATIONSHIP AMONG EIGHT POPULATIONS ZEA MAYS L. UTILIZING INFORMATION F BIOCSGB BG7 MORTALITY PATTERNS IN EIGHT STRAINS OF FLOUR BEETLE

FACTOR CHANGES AND LINEAR TRENDS IN EIGHT-RUN TWO LEVEL FACTORIAL DESIGNS

BIOCS65 99 TECH $68 \quad 301$ T VORGEGEBENER RELATIVER DYADENKONTEXT/ NOTES. EIN EINFACHES VERFAHREN ZUR ERZEUGUNG VON SYMBOLFOLCEN MI BIOCS68 703 THEOREMS CONCERNING EISENHART'S MODEL II
ST-SQUARES FITTING OF A POLYNOMIAL CONSTRAINED TO BE EITHER NON-NEGATIVE, NON-DECREASING OR CONVEX WAGE, PRICE, AND TAX ELASTICITIES OF OUTPUT AND DISTRIBUTIVE SHARES

OF VARYING DEGREES OF TRANSITORY INCOME ON INGOME ELASTICITY OF EXPENDITURES WILLIAM PALIN ELDERTON, 1877-1962

THE ENUMERATION OF ELECTION RETURNS BY NUMBER OF LEAD POSITIONS

LEA JRSSB B

JRSSB 69113 JASA 62607 EFFECT JASA $58 \quad 34 \mathrm{~B}$ BIOKA62 297 AMS $64 \quad 369$

TIMATION OF MIXED WEIBULL PARAMETERS IN LIFE TESTING ELECTRON TUBES

OF THE VARIABILITY DUE TO COINCIDENT PASSACE IN AN ELECTRONIC BLOOD CELL COUNTER

OF A FACTORIAL EXPERIMENT (WITH CONFOUNDING) ON AN ELECTRONIG CALGULATOR

VALUES IN MULTIVARIATE DATA SUITABLE FOR USE WITH AN ELECTRONIC COMPUTER

ORS IN THE ANALYSIS OF NON-ORTHOGONAL EXPERIMENTS BY ELECTRONIC COMPUTER

ROUTINE ANALYSIS OF REPLICATED EXPERIMENTS ON AN ELECTRONIC COMPUTER /THOD OF ESTIMATION OF MISSING

A GRAPHICAL ES TECH 59389

A STUDY BIOCS67 671 THE ANALYSIS JRSSB54 242 OF ESTIMATION OF MISSING JRSSB60 302 TION OF MEANS AND STANDARD ERR JRSSB62 435 JRSSB57 234 $R$ AN APPRAISAL OF LEAST SQUARES PROGRAMS FOR THE ELECTRONIC COMPUTER FROM THE POINT OF VIEW OF THE USE JASA 67 8I9 SEASONAL ADJUSTMENTS BY ELECTRONIC COMPUTER METHODS T ERROR IN NONDESTRUCTIVE EVALUATION OF REACTOR FUEL ELEMENT QUALITY A PROGRAM TO ESTIMATE MEASUREMEN TECH 64 293 ASYMPTOTIC POWER OF RANK TESTS

AN ELEMENTARY METHOD OF OBTAINING LOWER BOUNDS ON THE AMS $68212 B$

WITH A SINGLE SERVER AND CONSTANT PARAMETERS

AN ELEMENTARY METHOD OF SOLUTION OF THE QUEUEING PROBLFM FUNCTIONS OF ORDER STATISTICS AN ELEMENTARY PROOF OF ASYMPTOTIC NORMALITY OF LINEAR $X$ ON THE NON-CENTRAL DISTRIBUTION OF THE SEGOND ELEMENTARY SYMMETRIC FUNCTION OF THE ROOTS OF A MATRI MULTIVARIATE MATRIX. DISTRIBUTIONS

IX IN MULTIVARIATE ANALYSIS MATRICES

MATRIGES IN MULTIVARIATE ANALYSIS.

ON ELEMENTARY SYMMETRIC FUNCTIONS OF THE ROOTS OF A

ON ELEMENTARY SYMMETRIC FUNCTIONS OF THE ROOTS OF TWO

TRICES AND APPROXIMATIONS TO A DIST/ ON MOMENTS OF ELEMENTARY SYMMETRIC FUNCTIONS OF THE ROOTS OF TWO MA ON THE APPLICATION TO STATISTICS OF AN ELEMENTARY THEOREM IN PROBABILITY

QUADRATIC FORMS AND IDEMPOTENT MATRICES WITH RANDOM ELEMENTS

FACTORIALS

COMBINTNG ELEMENTS FROM DISTINCT FINITE FIELDS IN MIXED

ESTIMATION OF RELIA8ILITY OF A SYSTEM COMPRISED OF K ELEMENTS FROM THE SAME EXPONENTIAL DISTRIBUTION ELEMENTS OF THE THEORY OF EXTREME VALUES

RANDOMIZED RESPONSE. A SURVEY TECHNIQUE FOR ELIMINATING EVASIVE ANSWER 8IAS

8ILITY OF IMPROVING THE MEAN USEFUL LIFE OF ITEMS BY ELIMINATING THOSE WITH SHORT LIVES

THE CALCULUS FOR FACTORIAL ARRANGEMENTS II. TWO WAY ELIMINATION OF HETEROGENEITY

SOME METHODS OF CONSTRUCTION OF DESIGNS FOR TWO-WAY ELIMINATION OF HETEROGENEITY, I

BE CONTINUOUS DISTRIBUTION FREE TOLERANCE LIMITS, ELIMINATION OF REQUIREMENT THAT PROBLEMS

ELIMINATION OF REQUIREMENT THAT CUMULATIVE FUNCTION

125

AMS 68263

AMS $68 \quad 833$

AMS 611152 AMS 641704 BIOKA65 499 $6 B 1274$ 8IOKA56 B5 AMS 691430 AMS 69498 JASA 661029 TECH $60 \quad 27$ JASA $65 \quad 63$ AMS 64658 JASA 661153 TECH $63 \quad 518$ BIOCS66 268 SAMPLING PROCEDURES FOR GENERAL SPECIFICATION ELLIPSOIDS MULTIVARIATE ACCEPTANCE JASA 65905 FIXED STZE CONFIDENCE ELLIPSOIDS FOR LINEAR RECRESSION PARAMETERS STUDENT'S DISTRIBUTION AND RIEMANN'S'ELLIPTIC GEOMETRY ELLIPTICAL AND RADIAL TRUNCATION IN NORMAL

POPULATIONS ELLIPTICAL NORMAL DISTRIBUTION

DISTRI8UTION OF RADICAL ERROR IN THE 8IVARIATE 8RANCHING PROCESSES AND RELATED LIMIT THEOREMS EMBEDDING OF URN SCHEMES INTO SOME ASPECTS OF THE EMIGRATION-IMMIGRATION PROCESS IMATION OF A FUNDAMENTAL INTERACTION PARAMETER IN AN EMICRATION-IMMIGRATION PROCESS

AMS 661602 8 IOKA57 264 AMS $63 \quad 940$ TECH $62 \quad 138$ AMS 681801 AMS 62119 HE EST AMS 63238 
GARETTE SMOKINC AND A STOCHASTIC MODEL FOR THE MO/

EMPERICAL RELATIONSHIP OF LUNC, CANCER INCIDENCE TO CI BIOCS65 839 OF RECENT WORK ON VARIABLES ACCEPTANCE SAMPLING WITH EMPHASIS ON NON-NORMALITY

SUMMARY TECH 69 NO 4

S OF ORDERED CORRELATED NORMAL RANDOM VARIABLES WITH EMPHASIS ON RANCE /NS AND RATIOS OF LINEAR FUNCTION BIOKA64 I43

CONSUMER DURABLE COODS EXPENDITURES, WITH MAJOR EMPHASIS ON THE ROLE OF ASSETS, CREDIT AND INTENTIONS JASA 63 648

CE AND SPECTRUM ANALYSIS

POPULATIONS COMPOSED OF NORMAL DISTRIBUTIONS

EMPIRIC INVESTIGAT
DIVIDEND POLICY, AN EMPIRICAL ANALYSIS

JASA $58 \quad 551$

JASA $6 B \quad 1132$

THE EMPIRICAL BAYES APPROACH ESTIMATING POSTERIOR

QUANTILES

TRIC EMPIRICAL BAYES APPROACH TO SOME STATISTICAL DECISION BIOKA67

PROBLEM
PROBLEMS

THE EMPIRICAL BAYES APPROACH TO STATISTICAL DECISION

AMS $64 \quad 1$

THE COMPOUND DECISION PROBLEM

PARAMETRIC HYPOTHESES

DISTRIBUTION

NS (CORR. 6B 597)

DISTRIBUTIONS

DISTRIBUTION

AN EMPIRICAL BAYES APPROACH TO THE TESTING OF CERTAIN AMS 631370

KA68 B3

THE EMPIRICAL BAYES APPROACH, ESTIMATING THE PRIOR

SMOOTH EMPIRICAL BAYES ESTIMATION FOR CONTINUOUS DISTRIBUTIO BIOKA67 435

SMOOTH EMPIRICAL BAYES ESTIMATION FOR ONE-PARAMETER DISCRETE BIOKA66 417 EMPIRICAL BAYES ESTIMATION FOR THE POISSON $\quad$ BIOKA69 349

MODEL

EPSILON ASYMPTOTIC OPTIMALITY OF EMPIRICAL BAYES ESTIMATORS

BIOKA69 220

BIOKA68 525

EMPIRICAL BAYES ESTIMATORS IN A MULTIPLE LINEAR 3 BIOKA69 367

AN EMPIRICAL BAYES SMOOTHING TECHNIQUE

SOME EMPIRICAL BAYES TECHNIQUES IN POINT ESTIMATION

8IOKA69 361

BIOKA69 133

ANALYSIS OF EMPIRICAL BIVARIATE EXTREMAL DISTRIBUTIONS

JASA $64 \quad 794$

ATIONS WITH UNEQUAL GOVARIANCE MATRIGES

AN EMPIRICAL COMPARISON OF DISTANCE STATISTIGS FOR POPUL BIOCS68 68

BABILITY OF LARGE DEVIATIONS OF FUNCTIONS OF SEVERAL EMPIRICAL CUMULATIVE DISTRIBUTION FUNCTIONS /HE PRO AMS 67 360 POTHETICAL DISTRIBUTION FUNCTION AND PYKE'S MODIFIED EMPIRICAL DISTRIBUTION FUNCTION /FERENCE BETWEEN HY AMS 62 525 SOME RENYI TYPE LIMIT THEOREMS FOR EMPIRICAL DISTRIBUTION FUNCTIONS, CORR. 651069

OSCEDASTICITY CRITERION M UNDER UNEQUAL VARI/ SOME EMPIRICAL DISTRIBUTIONS OF BIVARIATE T-SQUARE AND HOM JASA 63 IO4B PROCEDURE FOR TESTINC MEANS

AN EMPIRICAL EVALUATION OF MULTIVARIATE SEQUENTIAL

AMS 621413

A SIMPLE SYSTEM OF EVOLUTIONARY OPERATION SUBJECT TO EMPIRICAL FEEDBACK

TECH $66 \quad 19$

STRIBUTION OF F-RATIOS FOR THE SPLIT-PLOT DESIGN, AN EMPIRICAL INVESTIGATION

THE RANDOMIZATION DI BIOKA63 431

F-RATIO IN SAMPLES FROM TWO NON-NORMAL POPULAT/ AN EMPIRICAL INVESTIGATION INTO THE DISTRIBUTION OF THE BIOKA58 260 FOR FARM PRODUCTS AT RETAIL AND THE FARM LEVEL. SOME EMPIRICAL MEASUREMENTS AND RELATED PROBLEMS DEMAND JASA 58 656 GE THEOREM WEAK CONVERGENCE OF A TWO-SAMPLE EMPIRICAL PROCESS AND A NEW APPROACH TO CHERNOFF-SAVA AMS 68 755 MODELS A COMPARISON OF THEORETICAL AND EMPIRICAL RESULTS FOR SOME STOCHASTIC POPULATION $\mathrm{N}$ IN THE COMPLETELY RANDOMIZED DESIGN SOME EMPIRICAL RESULTS ON VARIANCE RATIOS UNDER PERMUTATIO JASA 66 8I3

SAMPLING DISTRIBUTIONS OF VARIANCE COMPONENTS I. EMPIRICAL STUDIES OF BALANCED NESTED DESIGN

SAMPLTNG DISTRTBUTIONS OF VARTANCE ER PERMUTATION FOR THE RANDOMIZED BLOCK DESIGN AN EMPIRICAL STUDY INTO FACTORS AFFECTING THE F-TEST UND JASA 6B 902 GENETIC CORRELATION COEFFICIENT

VARTANCE ESTTMATORS IN UNEQUAL PROBABILITY SAM/

FMPIRICAL STUDY OF THE DISTRIBUTION OF THE SAMPLE

BIOGS69 63

AN EMPIRICAL STUDY OF THE STABILITIES OF ESTIMATORS AND JASA 69540

A METHOD OF FITTING EMPIRICAL SURFACES TO PHYSICAL AND CHEMICAL DATA

A SINGLY TRUNCATED BIVARIATE NORMAL DISTRIBUTION IV EMPIRIGAL VARIANCES OF RANK GORRELATION COEFFICIENTS

THE UNITED STATES THE MIGRATION OF EMPLOYED PERSONS TO AND FROM METROPOLITAN AREAS OF

INVESTIGATING THE PROPERTIES OF A SAMPLE MEAN BY EMPLOYING RANDOM SUBSAMPLE MEANS

TECH 69411

BIOKA6B 437

JASA 671418

JASA $56 \quad 54$

E CARLO INVESTIGATION OF THE SIZE AND POWER OF TESTS EMPLOYING SATTERTHWAITE'S SYNTHETIC MEAN SQUARES /T BIOKA68 43I 755 FIRST EMPTINESS IN A FINITE DAM

THE EPOCHS OF EMPTINESS OF A SEMI-INFINITE DISCRETE RESERVOIR FIRST EMPTINESS OF TWO DAMS IN PARALLEL

AMS 61219

JRSSB $62 \quad 102$

AMS $64 \quad 600$

TECH $62 \quad 235$

TECH $68 \quad 586$

TECH $63 \quad 121$

A NOTE ON A METHOD FOR THE ANALYSIS OF SIGNIFICANCE EN MASSE

ROBUSTNESS OF UNIFORM BAYESIAN ENCODINC

N FOR BINOMIAL EVENTS WITH APPLICATION TO BACTERIAL ENDOCARDITIS DATA

EFFICIENT CROUPING, REGRESSION AND CORRELATION IN ENCEL CURVE ANALYSIS

/USE OF THE POISSON APPROXIMATIO BIOCS6

JASA $64 \quad 233$

JASA $58 \quad 336$

BIOKA69 401

NEAREST NETCHBOURS IN A POISSON ENSEMBLE

TES VECETALES PAR L'ANALYSE STATISTIQUE DES LIAISONS ENTRE LES ESPECES ET LES VARIABLES ECOLOGIQUES, PRINC BIOCS65 345

TES VEGETALES PAR L'ANALYSE STATISTIQUE DES LIAISONS ENTRE LES ESPECES ET LES VARIABLES ECOLOGIQUES, UN EX BIOCS65 890 CTIONS IN CONTINGENCY TABLES WITH OR WITHOUT MISSING ENTRIES /DEPENDENCE, QUASI-INDEPENDENCE, AND INTERA JASA 68 IO9I ENTROPY AND CONJUGACY

APPROXIMATIONS FOR THE ENTROPY FOR FUNCTIONS OF MARKOV CHAINS AMS $63 \quad 226$ AMS 62930 MULTIDIMENSIONAL CONTINGENCY TABLES CONNECTIONS (CORR. 69 NO.6) MAXIMUM ENTROPY FOR HYPOTHESIS FORMULATION ESPECIALLY FOR SAMPLING ENTROPY FOR RANDOM HOMOGENEOUS SYSTEMS WITH COMPLETE EPSILON ENTROPY OF GAUSSIAN PROCESSES

A NOTE ON LIMIT THEOREMS FOR THE ENTROPY OF MARKOV CHAINS EPSILON ENTROPY OF STOCHASTIC PROCESSES

THE EPSILON ENTROPY ON CERTAIN MEASURES ON $(0,1)$ PRODUCT ENTROPY TO GAUSSIAN DISTRI8UTIONS MEAN AND VARIANCE OF AN ENTRY IN A CONTINCENCY TABLE

THE ENUMERATION OF ELECTION RETURNS BY NUMBER OF LEAD ENUMERATION OF LINEAR GRAPHS FOR MAPPINGS OF FINITE

SETS ERRORS IN THE 1960 CENSUS ENUMERATION OF NATIVE WHITES

AN ENUMERATION PROBLEM IN SELF-STERILITY

A GENERAL CLASS OF ENUMERATIONS ARISING IN GENETICS

AMS $63 \quad 911$

AMS $65 \quad 1433$

AMS 691272

AMS $66 \quad 522$

AMS 671000

AMS $68 \quad 1310$

AMS 69870

8IOKA.51 468

AMS $64 \quad 369$

AMS $62 \quad 178$

JASA $64 \quad 437$ 8I0CS69 39 $810 \mathrm{CS} 67517$ $8 I 0 \operatorname{CS} 651012$

NOTES. FURTHER ANALYSIS OF R. A, FISHER'S ENUMERATIONS IN GENETICS

ING CHILDLESS CASES IN POPULATION CENS/ FAILURE OF ENUMERATORS TO MAKE ENTRIES OF ZERO, ERRORS IN RECORD JASA 61 909 SURE EXTINCTION OF RRANCHING PROCESS WITH RANDOM ENVIRONMENT NECESSARY CONDITIONS FOR ALMOST AMS 682136 EXAMTNATION OF A REPEAT MATTNC DESION FOR ESTIMATTNC ENVIRONMENTAL AND CENETIC TRENDS $810 \operatorname{CS} 65 \quad 63$ MIGRATION, AND DIFFERENT FITNESS REQUIREMENTS AMONG ENVIRONMENTAL POCKETS UPON STEADY STATE GENE FREQUENC 8IOCS66 453 ALUATION OF TWO METHODS OF ESTIMATION OF GENETIC AND ENVIRONMENTAL VARIANCE /LLEL TEST CROSSING 2 . AN EV BIOCS67 ON BRANCHING PROCESSES IN RANDOM ENVIRONMENTS

THE TOTAL SIZE OF A GENERAL STOCHASTIC EPIDEMIC

AMS $69 \quad 814$ 8IOKA53 177 A NOTE ON THE ULTIMATE SIZE OF A GENERAL STOCHASTIC EPIDEMIC 
AL INFECTIVES

THE SIMPLE STOCHASTIC EPIDEMIC FOR SMALL POPULATIONS WITH ONE OR MORE INITI BIOKA69

PERTURBATION APPROXIMATION OF THE SIMPLE STOCHASTIC EPIDEMIC IN A LARGE POPULATION

THE PROBABILITIES OF SOME EPIDEMIC MODELS

ON ESTIMATING EPIDEMIC PARAMETERS FROM HOUSEHOLD DATA

ON A PARTIAL DIFFERENTIAL EQUATION OF EPIDEMIC THEORY. I.

THE SPREAD OF AN EPIDEMIC TO FIXED CROUPS WITHIN THE POPULATION

SUSCEPTIBLES THE MATHEMATICAL ANALYSIS OF AN EPIDEMIC WITH TWO KINDS OF A SOLUTION OF THE GENERAL STOCHASTIG EPIDEMIC.

FUNCTIONS

THE SIMPLE STOCHASTIC EPIDEMIC, A COMPLETE SOLUTION IN TERMS OF KNOWM

THE OUTCOME OF A STOCHASTIC EPIDEMIC A NOTE ON BAILEYIS PAPER

CONTAGION IN STOCHASTIC MODELS FOR EPIDEMICS

THE ULTIMATE SIZE OF CARRIER-BORNE EPIDEMICS

A BIOKA68 199

BIOKA69 197

BIOKA64 511

BIOKA65 617

BIOCS68 557

BIOKA65 613

BIOKA63 235

BIOKA55 116

AMS 681863

BIOKA68 277

NCE OF INFEGTION FOR THE ANALYSIS OF INTRA-HOUSEHOLD EPIDEMICS

A MODEL FOR THE SPREAD OF EPIDEMICS BY CARRIERS

279

RESERVOIR

ESTIMATORS

THE $E$ POCHS OF EMPTINESS OF A SEMI-INFINITE DISCRETE

EPSILON ASYMPTOTIC OPTIMALITY OF EMPIRICAL BAYES

EPSILON ENTROPY OF GAUSSIAN PROCESSES

EPSILON ENTROPY OF STOCHASTIC PROCESSES

THE EPSILON ENTROPY ON CERTAIN MEASURES ON $(0,1)$

RIABLES WHEN THE PRODUCER'S AND CONSUMER'S RISKS ARE EQUAL /TERISTIC CURVE FOR SEQUENTIAL SAMPLING BY VA JASA 56 IOB

ON FORMING STRATA OF EQUAL AGGREGATE SIZE

EQUAL AND PROPORTIONAL FREQUENCY SQUARES

A TEST FOR EQUAL CATCHABILITY

JASA $64 \quad 481$

JASA $67 \quad 226$

BIOCS66 330

TO THE STANDARD CHI-SQUARE-TEST OF THE HYPOTHESIS-OF EQUAL CELL FREQUENCIES

IFIED CHI-SQUARE GOODNESS-OF-FIT TESTS FOR SMALL BUT EQUAL EXPEGTED FREQUENCIES

TWO ALTERNATIVES BIOKA62 107

F THE CHI-SQUARE GOODNESS OF FIT TEST WITH SMALL BUT EQUAL EXPECTED FREQUENCIES

FOR TWO TO THE POWER OF N-R DESIGNS HAVING WORDS OF EQUAL LENGTHS

ID SPECIES HAVING ALL DICENIC EPISTATIC VARIANCES OF EOUAL MACNITUDE

ON IDENTITY RELATIONSHIPS AMS $66 \quad 1842$

/CHI-SQUARE AND TWO MOD BIOKA66 619

/XIMATION TO THE POWER O JASA 68912 MPLE BEHAVIOUR OF CERTAIN TESTS OF THE HYPOTHESIS OF EQUAL MEANS UNDER VARIANCE HETEROGENEITY' /SMALL SA BIOKA6I 230

ICATIONS OF SAMPLING DESIGN THROUGH REPLICATION WITH EQUAL PROBABILITIES AND WITHOUT STAGES ON SIMPLIF JASA 56 T SIMULTANEOUS INFERENCE PROBLEMS THE EQUAL PROBABILITY TEST AND ITS APPLICATI THE TWO-SAMPLE CRAMER-VON MISES CRITERION FOR SMALL EQUAL SAMPLES DISTRIBUTION OF AMS $63 \quad 95$ OLMOGOROV-SMIRNOV CRITERION D-SUB-MN, M LESS THAN OR EQUAL TO N /MPLING DISTRIBUTION OF THE TWO SAMPLE K JASA 69 NO. 4 INCOMPLETE BLOCK DESIGNS WITH THE NUMBER OF BLOCKS EQUAL TO THE NUMBER OF TREATMENTS A NOTE ON AMS 65 1877 SET OF 256-RUN DESICNS OF RESOLUTTON GREATER THEN OR EQUAL TO 5 AND THE SET OF EVEN $512-R U N$ DESIGNS OF RES AMS 68 246 F EVEN 5I2-RUN DESIGNS OF RESOLUTION GREATER THEN OR EQUAL TO MS $68 \quad 246$ A NOTE ON EQUALISING THE MEAN WAITING TIMES OF SUCCESSIVE CUSTO IN A FINITE QUEUE

ON TESTING A SET OF CORRELATION GOEFFICIENTS FOR EQUALITY NATIVES CORRELATION MODEL

\section{SIMULTANEOUS TESTS FOR THE EQUALITY} TESTS FOR THE EQUALITY OF COVARIANCE MATRICES UNDER THE INTRACLASS ON TESTING THE EQUALITY OF $K$ COVARIANCE MATRICES TESTING EQUALITY OF MEANS AFTER A PRELIMINARY TEST OF TESTING EQUALITY OF MEANS IN THE PRESENCE OF CORRELATION

EQUALITY OF VARIANCES

A TEST FOR EQUALITY OF MEANS WHEN COVARIANCE MATRICES ARE

UNEQUAL UNBIASEDNESS OF SOME TEXT CRITERIA FOR THE EQUALITY OF ONE OR TWO COVARIANCE MATRICES ON TESTING THE EQUALITY OF PARAMETERS IN K RECTANGULAR POPULATIONS JRSSB55 262 AMS $67 \quad 582$ AMS $63 \quad 149$ AMS 681303 AMS 671286 BIOKA69 216 BIOKA62 403 BIOKA69 119 AMS 63671 AMS $68 \quad 1686$ JASA $60 \quad 144$ ON A SEQUENTIAL TEST OF THE EQUALITY OF PROBABILITIES IN A MULTTNOMIAL DISTRIBUTI JASA 62769 $S$ OCCURRING RA/ ON THE EQUIVALENCE OF TWO TESTS OF EQUALITY OF RATE OF OCCURRENCE IN TWO SERIES OF EVENT ITERATED TESTS OF THE EQUALITY OF SEVERAL DISTRIBUTIONS

AN ITERATED PROCEDURE FOR TESTING THE EQUALITY OF SEVERAL EXPONENTIAL DISTRIBUTIONS A STATISTICAL TEST FOR EQUALITY OF TWO AVAILABILITIES ON TESTS OF THE EQUALITY OF TWO COVARIANCE MATRICES

CRITERIA ONS OF TESTS OF EQUALITY OF TWO COVARIANCE MATRICES BASED ON FOUR BEST LINEAR DISCRIMINATOR ANALYSIS TESTS FOR THE EQUALITY OF. TWO COVARIANCE MATRICES IN RELATION TO A PROPERTY OF THE POWER FUNCTIONS OF SOME TESTS OF THE EQUALITY OF TWO GOVARIANCE MATRICES. CORR. 65 1318 ON THE POWER OF TWO-SAMPLE RANK TESTS ON THE EQUALITY OF TWO DISTRIBUTION FUNCTIONS

QUARES TYPE QUADRA/A USEFUL LEMMA FOR PROVING THE EQUALITY OF TWO MATRICES WITH APPLICATIONS TO LEAST S JASA GO E-SIDED ALTERNATI/ ON A PROPERTY OF A TEST FOR THE EQUALITY OF TWO NORMAL DISPERSION MATRICES ACAINST ON GENEOUS COEFFICIENTS OF VARIATION

A TEST OF EQUALITY OF TWO NORMAL POPULATION MEANS ASSUMING HOMO

ON TESTING THE EQUALITY OF UNIFORM AND RELATED DISTRIBUTIONS

ON TESTING A SET OF CORRELATION COEFFICIENTS FOR EQUALITY. SOME ASYMPTOTIC RESULTS INTEGRAL EQUALLY CORRELATED VARIATES AND THE MULTINORMAL

OVER DESIGN FOR TESTINC A TREATMENT FACTOR AT FOUR EQUALLY SPACED LEVELS (CORR. 67 586)

GROUPING METHODS IN THE FITTING OF POLYNOMIALS TO EQUALLY SPACED OBSERVATIONS FITTING A POLYNOMIAL TO CORRELATED EQUALLY SPACED OBSERVATIONS ON THE CHAPMAN-KOLMOGOROV EQUATION

COLLAPSED MARKOV CHAINS AND THE CHAPMAN-KOLMOCOROV EQUATION ALTERNATIVE ESTIMATORS FOR AN ASYMPTOTIC REGRESSION EQUATION PROBABILITIES AND A GENERALIZATION OF RAMANUJAN'S EQUATION SQUARES ESTIMATE OF SOIL CONTENT THE DIFFUSION EQUATION AND A PSEUDO-DISTRIBUTION IN GENETICS ON THE SOLUTION OF THE LIKELIHOOD EQUATION BY ITERATION PROCESSES CORRIGENDA, 'ON THE SOLUTION OF THE LIKELIHOOD EQUATION BY ITERATION PROCESSES'
JASA $62 \quad 579$

JASA $63 \quad 435$

TECH $68 \quad 594$

AMS $68 \quad 275$

BIOKA6B 335

AMS 64191 AMS 641059 AMS 64 JRSS64 1059 AMS 621463 AMS 691374 JASA $66 \quad 856$ JRSSB58 373 JRSSB $67 \quad 370$ BIOKA54 62 BIOKA65 275 AMS 611333 AMS $63 \quad 233$ THE EFFICIENCIES OF BIOKA58 370 AMS $68 \quad 1191$ BI0C569 159 JRSSB 33405 BIOKA6I 452 BIOKA62 284 BIOKA68 513 
LIZED CLASSICAL LINEAR ESTIMATORS IN A LEADINC THREE-EQUATION CASE /HE EXACT DISTRIBUTIONS OF THE GENERA JASA 64 BBI

LIZED CLASSICAL LINEAR ESTIMATORS IN A LEADING THREE-EQUATION CASE

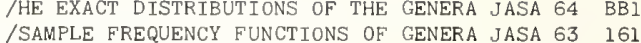
EFFICIENT DIFFERENCE EQUATION ESTIMATORS IN EXPONENTIAL REGRESSION

TABLE FOR THE SOLUTTON OF THE EXPONENTIAL EOUATION EXP $(B)-B /(1-P)=1$

DISCRETE DISTRIBUTION ESTIMATORS FROM THE RECURRENCE EQUATION FOR PROBABILITIES MAXIMUM-LIKELIHOOD ESTIMATOR WHERE THE LIKELIHOOD EQUATION HAS MULTIPLE ROOTS

AN INTEGRAL EQUATION IN ACE DEPENDENT BRANC

ON A PARTIAL DIFFERENTIAL EQUATION OF EPIDEMIC THEORY. I

AN APPROXIMATE SOLUTION OF THE INTEGRAL EQUATION OF RENEWAL THEORY

A DIFFERENCE EQUATION TECHNIQUE APPLIED TO THE SIMPLE QUEUE

BIOKA63 177

EVALUATION OF THE BIOKA66 151

RBITRARY ARRIVAL INTERVAL DISTRIBUTI/ A DIFFERENCE EQUATION TECHNIQUE APPLIED TO THE SIMPLE QUEUE WITH A JRSSB58 I68

AMS 651569

BIOKA65 617 JRSSB63 432 JRSSB58 165 TABLES FOR THE SOLUTION OF THE EXPONENTIAL EQUATION, EXP $(-A)+K A=1 \quad$ BIOKA6O 439 USE OF DUMMY VARIABLES IN REGRESSION EQUATIONS

ITERATIVE ESTIMATION OF A SET OF LINEAR REGRESSION EQUATIONS A NOTE ON STOCHASTIC DIFFERENCE EQUATIONS JASA 57 54B JASA $64 \quad 845$ AMS $6 B \quad 270$ A NOTE ON THE SOLUTION OF DAM EQUATIONS OPTIMUM CONFIDENCE BOUNDS FOR ROOTS OF DETERMINANTAL EQUATIONS CONSISTENCY AND MAXIMA OF THE ROOTS OF LIKELIHOOD EQUATIONS

OF PARAMETERS IN SYSTEMS OF STOCHASTIC DIFFERENTIAL EQUATIONS

CORRELATION IN SYSTEMS OF SIMULTANEOUS REGRESSION EQUATIONS FOR SOLVING LESER'S LEAST-SQUARES CRADUATION EQUATIONS

DERIVED BY SOLVING SIMULTANEOUS LINEAR DIFFERENTIAL EQUATIONS METHOD FOR SOLVINC AN OVERDETERMINED SYSTEM OF EQUATIONS STATIONARY SYSTEMS OF LINEAR STOCHASTIC DIFFERENCE EQUATIONS MOMENT CENERATINC FUNCTIONS BY SOLVINC DIFFERENTIAL EQUATIONS ORS OF PARAMETERS IN EXPLOSIVE STOCHASTIC DIFFERENCE EQUATIONS TRICES EVALUATION OF DETERMINANTS, CHARACTERISTIC EQUATIONS SOME AMS $65 \quad 338$ A NOTE ON THE BIOKA54 56 THE ESTIMATION BIOKA59 67 TESTING FOR SERIAL BIOKA57 370 SUBSIDIARY SEQUENCES JRSSB62 112 THE WISHART DISTRIBUTION BIOKA5I 470 AN A POSTERIORI PROBABILITY TECH $66 \quad 675$ SPECTRAL PROPERTIES OF NON- JASA 69581 /ERMINATION OF SAMPLING DISTRIBUTIONS AND JRSSB65 86 /TENCY AND LIMIT DISTRIBUTIONS OF ESTIMAT AMS $61 \quad 195$ ON THE SOLUTTON OF LTKELIHOOD EQUATTONS BY ITERATION PROCESSES MULTIPARAMETRIC CASE BIOKAG2 479 ASEDNESS OF ZELLNER'S SEEMINGLY UNRELATED RECRESSION EQUATIONS ESTIMATORS THE UNBI JASA G7 THE MODELS ON THE SENSITIVITY OF SIMULTANEOUS-EQUATIONS ESTIMATORS TO THE STOCHASTIC ASSUMPTIONS OF JASA G6 CAPTURE-RECAPTURE METHOD. I THE MAXIMUM LIKELIHOOD EQUATIONS FOR ESTIMATING THE DEATH-RATE /ANS OF THE BIOKA5I IZED T-SQUARE-SUB/ A SYSTEM OF LINEAR DIFFERENTIAL EQUATIONS FOR THE DISTRIBUTION OF HOTELLING 'S GENERAL AMS 68 MAL POPULATIONS ON THE SOLUTION OF ESTIMATINC EQUATIONS FOR TRUNCATED AND CENSORED SAMPLES FROM NOR SIMULTANEOUS RECRESSION EQUATIONS IN EXPERIMENTATION SOME INTEGRAL EQUATIONS IN GEOMETRICAL PROBABILITY

A REMARK ON SOLVINC EQUATIONS IN SUMS OF POWERS BIOKA58

BIOKA66 JRSSB $6 B$ ST BIOCS69 ABILITY OF SOLUTIONS TO CERTAIN NONLINEAR DIFFERENCE EQUATIONS OF POPULATION GENETICS CLASS OF SERV/ THE CONTINUOUS TIME SOLUTION OF THE EQUATIONS OF THE SINGLE CHANNEL QUEUE WITH A GENERAL JRSSB5B SELECTION OF VARIABLES FOR FITTING EQUATIONS TO DATA TE/ EFFICIENT ESTIMATION OF A SYSTEM OF REGRESSION EQUATIONS WHEN DISTURBANCES ARE BOTH SERIALLY AND CON JASA 67 500 NCE RECTON FOR THE SOLUTION OF A SET OF SIMULTANEOUS EQUATIONS WTTH AN APPLTCATTON TO EXPERTMENTAL DESIGN BIOKA54 I9O ESTIMATORS FOR SEEMINGLY UNRELATED REGRESSION EQUATIONS, SOME EXACT FINITE SAMPLE RESULTS THE NUMERICAL SOLUTION OF SOME NON-LINEAR EQUATIONS, USEFUL IN THE DESIGN OF EXPERIMENTS EQUATORIAL DISTRIBUTIONS ON A SPHERE. APPENDIX TO 'EQUATORIAL DISTRIBUTIONS ON A SPHERE' THE MEAN EFFICIENCY OF EQUI-REPLICATE DESIGNS

MOMENTS OF ORDER STATISTICS FROM THE EQUTCORRELATED MULTIVARIATE NORMAL DISTRIBUTION A NOTE ON THE EQUICORRELATED MULTIVARIATE NORMAL DISTRIBUTION ORTHANT PROBABILITIES FOR THE EQUICORRELATED MULTIVARIATE NORMAL DISTRIBUTION THE FITTING OF POLYNOMIALS TO EQUIDISTANT DATA WITH MISSING VALUES COMPLEX GENETICAL SYSTEMS WITH SPECIAL REFERENCE TO EQUILIBRIA A GRAPHICAL METHOD FOR THE STUDY OF BIOCS69 NO. EQUILIBRIA UNDER SELECTION FOR K ALLELES

JASA $63 \quad 977$ JRSSB65 466 BIOKA65 193 BIOKA65 200 BIOKA6B 251 AMS $6212 B 6$ BIOKA62 269 BIOKA62 433 BIOKA5I 410 MODELS

NOTES, ON ESTIMATING THE EQUILIBRIUM AND TRANSITION PROBABILITIES OF A FINITETHE EQUILIBRIUM COVARIANCE MATRIX OF DYNAMIC ECONOMETRIC THE LAST RETURN TO EQUILIBRIUM IN A COIN TOSSING CAME CS6B IB5 JASA 69277 AMS 641344 $M-1$ SOME EQUILIBRIUM RESULTS FOR THE QUEUEINC PROCESS E-SUB-K-

LINKED LOCUS (ACKNOWLEDCEMENT 68 1025)

GENETIC EQUTLIBRIUM UNDER SELECTION (INVITED PAPER) EQUILIBRIUM UNDER SELECTION AT A MULTI-ALLELIC SEXTWO TABLES CONNECTED WITH COODNESS-OF-FIT TESTS FOR EQUIPROBABLE ALTERNATIVES A NOTE ON STATISTICAL EQUIVALENCE EQUIVALENCE AND SINGULARITY FOR FRIEDMAN URNS

SOME EQUIVALENCE CLASSES IN PAIRED COMPARISONS JRSSB56 275 BI0CS67 397 BIOCS68 187 BIOKA68 44 AMS $67 \quad 7 \mathrm{~B} 7$ AMS $66 \quad 268$ AMS $66 \quad 4 B B$

VAL A CLARTFICATTON CONCERNTNC CERTAIN FQUTVALFNCE CLASSES OF GAUSSIAN PROCESSES ON AN INTER QUIVALENCE CONDITIONS FOR THE BROWNIAN MOTION TO THE EQUIVALENCE CONDITIONS FOR CERTAIN STATIONARY PROCESS EQUIVALENCE CONDITIONS FOR C/ THE RELATION OF THE EQUIVALENCE CONDITIONS FOR THE BROWNIAN MOTION TO THE CE SAMPLING PLANS AND AN ACKNOWLEDGEMENT

ON THE EQUTVALENCE OF BINOMIAL AND INVERSE BINOMIAL ACCEPTAN TE EQUIVALENCE OF GAUSSIAN STATIONARY PROCESSES

AMS $6 \mathrm{~B}$ 107B AMS 69 NO.6 AMS 69 NO. 6

MOMENTS IN PROBIT ANALYSIS

SIGMA'S, CORR. 651069

NOTES. EQUIVALENCE OF MAXIMUM LIKELIHOOD AND THE METHOD OF

ON THE EQUTVALENCE OF POLYKAYS OF THE SECOND DEGREE AND EQUIVALENCE OF TWO ESTIMATES OF PRODUCT VARIANCE AMS $69 \quad 197$ 154 AMS 641663

FUNCTION COEFFICIENTS

THROUGH CUMULATIVE DATA.

NOTES. EQUIVALENCE OF TWO METHODS OF COMPUTING DISCRIMINANT BIOCS67 153

CATEGORICAL DATA

A NOTE ON THE EQUTVALENCE OF TWO METHODS OF FITTING A STRAIGHT LINE JASA 64863

RENCE IN TWO SERIES OF EVENTS OCCURRING RA/

THE EQUIVALENCE OF TWO TEST CRITERIA FOR HYPOTHESES IN

JASA $66 \quad 228$

OR EXPERIMENTS INVOLVING LOCATION PARAMETERS SIMPLE RADON-NIKODYM DERIVATIVE

ON TWO EQUIVALENCE RELATIONS BETWEEN MEASURES

NON-EQUIVALENT COMPARISONS OF EXPERIMENTS AND THEIR USE F EQUIVALENT GAUSSIAN MEASURES WITH A PARTICULARLY THE PROCESS CURVE AND THE EQUIVALENT MIXED BINOMIAL WITH TWO COMPONENTS

TWO MORE CRITERIA EQUIVALENT TO D-OPTIMALITY OF DESIGNS

ON MEASURES EQUIVALENT TO WIENER MEASURE

ON CASH EQUIVALENTS AND INFORMATION EVALUATION IN DECISIONS

UNDER UNCERTAINTY, PARTS I, II, AND III ONTURE AND EQUTVARIANT ESTTMATTON

C/ A HISTORY OF DISTRIBUTION SAMPLING PRIOR TO THE ERA OF THE COMPUTER AND ITS RELEVANCE TO SIMULATION, THE ERGODIC BEHAVIOUR OF RANDOM WALKS

A UNIQUENESS THEOREM FOR STATIONARY MEASURES OF ERGODIC MARKOV PROCESSES

ERGODIC PROPERTIES OF SOME PERMUTATION PROCESSES AMS $66 \quad 686$ AMS $61 \quad 326$ AMS 671027 JRSSB59 63 AMS $62 \quad 792$ AMS $67 \quad 261$ JASA $6 B \quad 252$ AMS 671436 JASA $65 \quad 27$ BIOKA61 391 AMS 641781 BIOKA62 151 
ON THE FIXED POINT PROBABILITY VECTOR OF RECULAR OR ERCODIC TRANSITION MATRICES
PROCESSES

PRIORITIES
ON THE ERCODICITY FCR NON-STATIONARY MULTIPLE MARKOV

THE ERGODICITY OF SERIES OF QUEUES WITH CENERAL

A GENERALIZED SINCLE-SERVER QUEUE WITH ERLANC INPUT

ON ERLANC'S FORMULA

A NOTE ON QUEUEING SYSTEMS WITH ERLANCIAN SERVICE TIME DISTRIBUTIONS
JRSSB $66 \quad 190$ AMS $66 \quad 866$ AMS 651292 AMS 651853 AMS $67 \quad 922$ AMS 6979 AMS 691126 AMS 682145 AMS $61 \quad 612$ JRSSB6B 499 AMS 681107 JASA $67 \quad 600$ AMS $68 \quad 1448$ AMS 651664 BIOKA62 242 AMS 6971 AMS 651574 UEUEINC SYSTEM WITH CENERAI INDEPENDENT ARRIVALS AND ERIANCIAN SERVICE-TIME /TTON TO THE SINCLE-SERVER Q JRSSBGO B ERRATA ISTMULTANEOUS NONLINEAR ESTIMATION' ERRATA IN 'TABLES OF SYMMETRIC FUNCTIONS' ERRATA, ' A NOTE ON THE DETERMINATION OF CONNECTEDNES TECH 65281 ERRATA, ' AN UPPER BOUND FOR THE SAMPLE STANDARD TECH $62 \quad 440$ ERRATA, 'AN UPPER BOUND FOR THE SAMPLE STANDARD TECH 63417 ERRATA 'APPROXIMATINC THE NECATIVE BINOMIAL' TECH $67 \quad 498$ ERRATA, 'APPROXIMATIONS TO THE NON-CENTRAL T. WITH TECH 64482 ERRATA. 'CONTROL OF PERCENTACES IN BOTH TAILS OF THE TECH 66570 ERRATA, 'DTAMOND-PTN LOCATION' ERRATA, 'ESTIMATION OF A COMPONENT OF A CONVOLUTION, TECH 65462 ERRATA, 'EXACT CONFIDENCE BOUNDS, BASED ON ONE ORDER TECH 64483 ERRATA, 'FACTORIAL EXPERIMENTS IN LIFE TESTINC' TECH 60121 ERRATA, 'FINDING NEW FRACTIONS OF FACTORIAL TECH $63 \quad 134$ ERRATA, 'MAXIMUM LIKELIHOOD ESTIMATION IN THE WEIBULL TECH 66570 ERRATA, 'MAXIMUM-LIKELIHOOD ESTIMATION OF THE PARAMET TECH $67 \quad 195$ ERRATA, 'MISCLASSIFIED DATA FRCM A BINOMIAL TECH 66215 ERRATA, 'MODIFIED SQUARE ROOT METHOD OF MATRIX $\quad$ TECH '62 622 ERRATA, 'ORDER STATISTICS FROM THE CAMMA TECH $60 \quad 523$ ERRATA, 'ORTHOGONAL MAIN-EFFECT PLANS FOR ASYMMETRICA TECH 62440 ERRATA, 'SEQUENTIAL FACTORIAL ESTIMATION' ERRATA, 'SOME NEW THREE LEVEL DESIGNS FOR THE STUDY TECH 61576 ERRATA, 'SOME PROPERTIES OF A DISTRIBUTION SPECIFIED TECH $63 \quad 417$ ERRATA, 'TABLES OF TOLERANCE-LIMIT FACTORS FOR NORMAL TECH 61576 ERRATA, 'THE APPLICATION OF RANDOM BALANCE DESICNS' TECH 59419 ERRATA, 'THE DISCRIMINATION BETWEEN TWO WEIBULL TECH 64240 ERRATA, 'THE EFFECT OF SEQUENTIAL BATCHING FOR ACCEPT TECH $61 \quad 131$ ERRATA, 'THE ORTHOCONALIZATION OF UNDESICNED $\quad$ TECH 66731 ERRATA. 'THE PERCENTILE POINTS OF DISTRIBUTIONS TECH $60 \quad 523$ ERRATA, 'THE 2-TO-THE-' K-P' FRACTIONAL FACTORIAL TECH 63417 TECH $67 \quad 457$ $\begin{array}{lll}\text { TECH } & 67 & 457 \\ \text { JASA } & 62 & 191\end{array}$ BIOCS68 363 BIOCS69 NO 4 A NOTE TECH $6 \mathrm{~B} \quad 393$ EFFECTS JASA $60 \quad 732$ STEPWISE JASA 61998 SOME THEORY TECH $67 \quad 1$ OF BIAS ON ESTIMATES OF THE CIRCULAR PROBABLE ERROR
OF EAST SQUARES, RESIDUAL ANALYSIS AND SPECIFICATION ERROR OF SAMPLINC WHEN THE STRATIFICATION IS SUBJECT TO ERROR OF SOME ESTIMATORS OF QUANTILES OF CIRCULAR ERROR

LINEAR RECRESSION WHEN BOTH VARIABLES ARE SUBJECT TO ERROR AND PREDICTION WHEN BOTH VARIABLES ARE SUBJECT TO ERROR STIMATE THE RATIO OF VARIANCES WITH BOUNDED RELATIVE ERROR IMATINC FUNCTIONS WHEN BOTH VARIABLES ARE SUBJECT TO ERROR

IN WHICH THE MEASUREMENT OF RESPONSE IS SUBJECT TO ERROR HT-LINE RELATIONS WHEN BOTH VARIABLES ARE SUBJECT TO ERROR YSTEM PROCESS WITH ADDITIVE WHITE NOISE OBSERVATTONS ERROR RIES FOR THE EXPECTED VALUES OF NOR/ A NOTE ON THE ERROR R AFTER A NUMBER OF TERMS OF THE DAVID-JOHNSON SE BIOKA6O 79 A MEAN-SQUARE-ERROR CHARACTERIZATION OF BINOMIAL-TYPE DISTRIBUTIONS AMS $67 \quad 620$ BOUND USEFUL IN THE THEORY OF FACTORIAL DESICNS AND ERROR CORRECTINC CODES DN A AMS $64 \quad 408$ A TEST OF THE MEAN SQUARE ERROR CRITERION FOR RESTRICTIONS IN LINEAR REGRESSION JASA 68 558 EXPONENTIAL BOUNDS ON THE PROBABILITY OF ERROR FOR A DISCRETE MEMORYLESS CHANNEL N ESTIMATES OF BOUNDED RELATIVE ERROR FOR THE MEAN LIFE OF AN EXPONENTIAL DISTRIBUTIO TECH 6I 107 ONS ESTIMATES OF BOUNDED RELATIVE ERROR FOR THE RATIO OF VARIANCES OF NORMAL DISTRIBUTI JASA 56 48I POSNER, 'THE APPLICATION OF EXTREME VALUE THEORY TO ERROR FREE COMMUNICATION' INSPECTION AND CORRECTION ERROR IN DATA PROCESSINC JASA 69 NO. 4

EMENT QUALITY A PROCRAM TO ESTTMATE MEASUREMENT ERROR IN NONDESTRUCTTVE EVALUATION OF REACTOR FUEL EL TECH 64 293 RESPONSE ERROR IN SURVEY REPORTS OF EARNINCS INFORMATION $\quad$ JASA $66 \quad 729$ DISTRIBUTION OF RADICAL ERROR IN THE BIVARIATE ELLIPTICAL NORMAL DISTRIBUTION TECH 62 138 SAMPLINC ERROR IN THE CONSUMER PRICE INDEX

FUNCTION BOUNDS ON THE ERROR IN THE LINEAR APPROXIMATION TO THE RENEWAL

SOME CONSEQUENCES OF SUPERIMPOSED ERROR IN TIME SERIES ANALYSIS

RELATIVE COSTS OF COMPUTERTZED ERROR INSPECTION PLANS

A NOTE ON THE RISKS OF ERROR INVOLVED IN THE SEQUENTIAL RATTO TEST

E QUANTILES OF-THE NORMAL DISTRIBUTION UNDER SQUARED ERROR LOSS/THE BEST INVARIATE ESTIMATOR OF EXTREM THE RELATIVE SENSITIVITY TO SPECIFICATION ERROR OF DIFFERENT K-CLASS ESTIMATORS THE ASYMPTOTIC ERROR OF ITERATIONS

A PARAMETRIC ESTIMATE OF THE STANDARD ERROR OF THE SURVIVAL RATE, CORR, 631161 CIRCULAR ERROR PROBABILITIES
JASA $67 \quad 899$

BIOKA64 355 BIOKA60 33 JASA 69 NO. 4 BIOKA56 231 AMS 691801 JASA $66 \quad 345$ AMS $68 \quad 266$ JASA 61 111 JASA $60 \quad 723$ 

ARES AND ANALYSIS OF/ PARAMETRIC AUGMENTATIONS AND ERROR STRUCTURES UNDER WHICH CERTAIN SIMPLE LEAST SQU JASA 69 NO. 4

TABLES FOR THE MEAN SQUARE ERROR TEST FOR EXACT LINEAR RESTRICTIONS IN REGRESSIO JASA 69 NO 4 YSIS OF A GROUP OF BALANCED BLOCK EXPERIMENTS HAVING ERROR VARIANCE AND SOME TREATMENTS IN COMMON ESTIMATION OF ERROR VARIANCE FROM SMALLEST ORDERED CONTRASTS ANAL BIOCS6B $3 B 9$ HETEROGENEITY OF ERROR VARIANCES IN A RANDOMIZED BLOCK DESIGN JASA $63 \quad 152$ HETEROGENEOUS ERROR VARIANCES IN SPLIT-PLOT EXPERIMENTS DIMENSIONAL CHAINS INVOLVING RECTANGULAR AND NORMAL ERROR-DISTRIBUTIONS

THE APPLICATION OF EXTREME VALUE THEORY TO ERROR-FREE COMMUNICATION

F THE ERRORS IS/ THE ESTIMATION OF REGRESSION AND ERROR-SCALE PARAMETERS. WHEN THE JOINT DISTRIBUTION O BIOKAGI

NG PROBABILITIES FROM A FINITE POP/ BOUNDS FOR THE ERROR-VARIANCE OF AN ESTIMATOR IN SAMPLING WITH VARYI JASA 6B DECIMAL CORRECTION ERROR, AN EXAMPLE IN STATISTICS

OF STRAIGHT LINES WHEN BOTH VARIABLES ARE SUBJECT TO ERROR, CORR. 59812 COMPARISON OF ESTIMATES OF CIRCULAR PROBABLE ERROR. CORR, 60755 MOMENTS OF THE RADIAL ERROR. CORR. 651251

DESIGNS FOR REGRESSION PROBLEMS WITH CORRELATED ERRORS MULTIPLE, REGRESSION WITH STATIONARY ERRORS

LINEAR RELATIONSHIPS BETWEEN VARIABLES AFFECTED BY ERRORS ANALYSIS OF QUANTAL RESPONSE ASSAYS WITH DOSAGE ERRORS OF MIS-MATCHING ON THE MEASUREMENT OF RESPONSE ERRORS WEIGHING DESIGNS UNDER AUTO-CORRELATION OF ERRORS

OF THE REGRESSION MODEL WITH AUTO-CORRELATED ERRORS CLASSIFICATIONS WITH CORRELATED AND NON-HOMOGENEOUS ERRORS E ANALYSIS OF VARIANCE. II. EFFECT OF AUTOCORRELATED ERRORS REGRESSION METHODS IN THE CONTEXT OF AUTOCORRELATED ERRORS A NOTE ON MEASUREMENT ERRORS AND DETECTING REAL
THE ESTIMATION OF SLOPE WHEN THE ERRORS ARE AUTOCORRELATED THE FITTING JASA 59 JASA $59 \quad 173$ JASA $59 \quad 794$ JASA $62 \quad 187$ AMS $66 \quad 66$ JASA $66 \quad 917$ BIOCS66 252 BIOCS67 747 JRSSB62 199 ANCE OF WEIGHTED REGRESSION ESTIMATORS WHEN SAMPLING ERRORS ARE INDEPENDENT AND HETEROSCEDASTIC STANDARD ERRORS FOR INDEXES FROM COMPLEX SAMPLES

\section{OF ORCHARDS OF DISTINCT TYPE}

ANALYSIS
SAMPLING ERRORS IN AN ORCHARD SURVEY INVOLVING UNEQ

A CHECK ON GROSS ERRORS IN CERTAIN VARIANCE COMPUTATIONS
VARI JASA 69 NO. 4 JASA $68 \quad 512$ BIOCS65 55 JASA 59741 JRSSB 69 NO.2 AMS $61 \quad 1125$ ERRORS IN DISCRIMINATION

A STUDY OF RESPONSE ERRORS IN EXPENDITURES DATA FROM HOUSEHOLD INTERVIEWS MINIMIZING RESPONSE ERRORS IN FINANCIAL DATA. THE POSSIBILITIES SYSTEMATIC ERRORS IN PHYSICAL CONSTANTS

S/ FAILURE OF ENUMERATORS TO MAKE ENTRIES OF ZERO, ERRORS IN RECORDING CHILDLESS CASES IN POPULATION CEN J ESTIMATING MACHINING ERRORS IN SET-UPS WITH AUTOMATIC RESETTING

BY ELECTRONIC CO/ ESTIMATION OF MEANS AND STANDARD ERRORS IN THE ANALYSIS OF NON-ORTHOGONAL EXPERIMENTS STUDIES OF INTERNAL MIGRATION ERRORS IN THE ESTIMATION OF NET MIGRATION IN THE

THE EFFECTS OF ERRORS IN THE FACTOR LEVELS AND EXPERIMENTAL DESIGN CORRELATED ERRORS IN THE RANDOM MODEL

ERRORS IN THE 1960 CENSUS ENUMERATION OF NATIVE

WHITES

A NOTE ON AN 'ERRORS IN VARIABLES' MODEL

AN EXAMPLE OF ERRORS INCURRED BY ERRONEOUSLY ASSUMING NORMALITY FOR

CUSUM SCHEMES

THE PLATING METHOD

NOTES. ON THE DILUTION ERRORS INVOLVED IN ESTIMATING BACTERIAL NUMBERS BY

SCALE PARAMETERS, WHEN THE JOINT DISTRIBUTION OF THE ERRORS IS OF ANY CONTINUOUS FORM AND KNOWN APART FROM B DESIGNS FOR REGRESSION PROBLEMS WITH CORRELATED ERRORS MANY PARAMETERS

NUMERATOR AND DENOMIN/ ROBUSTNESS OF THE F-TEST TO ERRORS OF BOTH KINDS AND THE CORRELATION BETWEEN THE ERRORS OF CLASSIFICATION IN A BINOMIAL POPULATION

THE ERRORS OF LATTICE SAMPLING

PROBLEMS IN MENTAL TEST THEORY ARISING FROM ERRORS OF MEASUREMENT REGRESSION FOR TIME SERIES WITH ERRORS OF MEASUREMENT

ERRORS OF MEASUREMENT IN STATISTICS

$\begin{array}{rrr}\text { AMS } & 61 & 1125 \\ \text { JASA } & 64 & 1 B\end{array}$

$\begin{array}{lll}\text { JASA } & 6 \mathrm{~B} & 217\end{array}$

TECH $62 \quad 111$ JASA 61909 TECH $64 \quad 423$ JRSSB62 435 JASA 69 NO 4 TECH $63 \quad 247$ JASA 671387 JASA $64 \quad 437$ JASA $66 \quad 12 B$ TECH $67 \quad 457$ BIOCS67 15B IOKA61 125 AMS 6B 49 JASA $6 B \quad 660$ JASA $65 \quad 217$ JRSSB54 140 JASA 59472 BIOKA63 293 TECH $68 \quad 637$

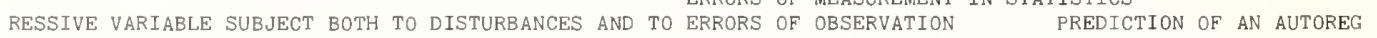
PREDICTION OF AN AUTOREG JASA $65 \quad 164$ OF PREDICTION IN UULTPLE REGRESSION ERRORS OF THE THIRD KIND IN STTTI MISSING FROM A RANDOMISED BLOCK EXPERIMEN/ NOTES. ERRORS OF TREATMENT COMPARISONS WHEN OBSERVATIONS ARE BIOCS66 632 CY TABLES THE EFFECT OF NON-SAMPLING ERRORS ON MEASURES OF ASSOCIATION IN 2-BY-2 CONTINGEN JASA 69 852

DYADENKONTEXT

NOTES. ERZEUGUNG VON SYMBOLFOLGEN MIT VORCEG

IOCS68 703

LES PAR L'ANALYSE STATISTIQUE DES LIAISONS ENTRE LES ESPECES ET LES VARIABLES ECOLOGIQUES, PRINCIPES FONDA BIOCS65 345 LES PAR L'ANALYSE STATISTIQUE DES LIAISONS ENTRE LES ESPECES ET LES VARIABLES ECOLOGIQUES, UN EXEMPLE /A BIOCS65 890 LASS MARKS OF A GROUPED FREQUENCY DISTRIBUTION, WITH ESPECIAL REPERENCE TO THE UNEQUAL INTERVAL CASE IZED MULTIVARIATE ANALYSIS OF VARIANCE MODEL USEFULL ESPECIALLY FOR GROWTH CURVE PROBLEMS A GENERAL BIOKA64 313 AND STATISTICS. IX. BIOGRAPHICAL NOTE FOR T. BAYES' ESSAY TOWARDS SOLVING A PROBLEM IN THE DOCTRINE OF CH BIOKA58 293 ESSAY TOWARDS SOLVING A PROBLEM IN THE DOCTRINE OF CH BIOKA58 NOTE ON THE BERRY-ESSEN THEOREM

SEQUENTIAL PROBABILITY RATIO TESTS

THE ESSENTIAL COMPLETENESS OF THE CLASS OF GENE

ON A MINIMAL ESSENTIALLY COMPLETE CLASS OF EXPERIMENTS

FACTOR ANALYSIS, AN INTRODUCTION TO ESSENTIALS. 1. THE PURPOSE AND UNDERLYING MODELS AMS 631107 AMS 61602 AMS $66 \quad 435$ BIOCS65 190 H FACTOR ANALYSIS, AN INTRODUCTION TO ESSENTIALS. 2. THE ROLE OF FACTOR ANALYSIS IN RESEARC B CHANGES IN CONCENTRATION OF DOMESTIC MANUFACTURING ESTABLISHMENT OUTPUT 1939-1958 ANALYSIS OF THE SPATIAL CLUSTERING OF RETAIL ESTABLISHMENTS A REGRESSION METHOD FOR REAL ESTATE PRICE INDEX CONSTRUCTION JASA $62 \quad 797$ $\begin{array}{rrr}\text { JASA } & 62 & 797 \\ \text { JASA } & 65 & 1094\end{array}$ JASA $63 \quad 933$ ESTIMABILITY OF VARIANCE COMPONENTS FOR THE TWO-WAY ADDITIONAL RESULTS CONCERNING ESTIMABLE FUNCTIONS AND GENERALIZED INVERSE MATRICES A NOTE ON THE VARIANCE OF THE RATIO ESTIMATE REMARK ON THE LINEARIZED MAXIMUM LIKELIHOOD ESTIMATE AN OPTIMUM PROPERTY OF THE HORVITZ-THOMSON ESTIMATE AMS 671508 JRSSB 65486 JASA $64 \quad 895$ AMS 671876 JASA $67 \quad 1013$ 
ART II. COMPARISON BETWEEN MINIMUM NORMIT CHI-SQUARE ESTIMATE AND THE MAXIMUM LIKELIHOOD ESTIMATE /ES. P BIOKA57 41I THE SAMPLING DISTRIBUTION OF AN ESTIMATE ARISING IN LIFE TESTING

OF EXPOSURE

CHARACTERISTICS OF A RATIO USED TO ESTIMATE FAILURE RATES, OCCURRENCES PER PERSON YEAR QUERY, MAXIMUM LIKELIHOOD ESTIMATE IN INTRACLASS CORRELATION MODEL

A PROGRAM TO ESTIMATE MEASUREMENT ERROR IN NONDESTRUCT

TECH 69 NO.

ON OF REACTOR FUEL ELEMENT QUALITY

A NONPARAMETRIC FSTIMATE OF A MULTIVARIATE DENSITY FUNCTION

MPTOTIC THEORY OF CALTON'S TEST AND A RELATED SIMPLE ESTIMATE OF LOCATION

ROBUSTNESS OF THE WILCOXON ESTIMATE OF LOCATION AGAINST A CERTAIN DEPENDENCE

AMS 651049

AMS $67 \quad 73$

AMS 681196

BIOCS69 159

BIOCS69 5BB

Q BERY. BAULE'S EQUATION + (LEAST SQUARES ESTIMATE OF SOIL CONTENT)

A MODIFIED TECHNIQUE FOR IMPROVING AN ESTIMATE OF THE MEAN

ADMISSIBILITY OF THE SAMPLE MEAN AS ESTIMATE OF THE MEAN OF A FINITE POPULATION

AMS $6 B \quad 606$

RAL CHI-SQUARE VARIATE

THE MAXIMUM LIKELIHOOD ESTIMATE OF THE NON-CENTRALITY PARAMETER OF A NONCENT

ON A SIMPLE ESTIMATE OF THE RECIPROCAL OF THE DENSITY FUNCTION

A QUICK ESTIMATE OF THE REGRESSION COEFFICIENT

CORR, 631161

A PARAMETRIC ESTIMATE OF THE STANDARD ERROR OF THE SURVIVAL RATE,

USING FACTOR ANALYSIS TO ESTIMATE PARAMETERS

OF REPLICATTONS IN OPTTMAL DESTCNS OF EXPERTMENTS TO ESTIMATE PARAMETERS IN NON-LINEAR MODELS

D UNITS OF THE TRUE VALUE SAMPLE SIZE REQUIRED TO ESTIMATE THE PARAMETER IN THE UNIFORM DENSITY WITHIN JASA 64 550

A PROCEDURE TO ESTIMATE THE POPULATION MEAN IN RANDOM EFFECTS MODELS TECH 67577

USING THE OBSERVATIONS TO ESTIMATE THE PRIOR DISTRIBUTION JRSSB65 17

ERROR

SAMPLE SIZE REQUIRED TO ESTIMATE THE RATIO OF VARIANCES WITH BOUNDED RELATIVE JASA 631044

HE PROBLE/ APPLICATION OF MINIMUM LOGIT CHI-SQUARE ESTIMATE TO A PROBLEM OF GRIZZLE WITH A NOTATION ON T BIOCS68 75 SECMENTED CURVES WHOSE JOIN POINTS HAVE TO BE ESTIMATED

SION FOR THE DISTRIBUTION OF THE LATENT ROOTS OF THE ESTIMATED COVARIANCE MATRIX AN ASYMPTOTIC EXPAN AMS 65 1153

CROSS/ UNBIASED MULTIPLE REGRESSION COEFFICIENTS ESTIMATED FROM ONE-WAY-CLASSIFICATION TABLES WHEN THE JASA 66 720

-N BY M-SUB- 1 TO M-SUB-N MULTIPLE-LATTICE DESIGN THE VARIANCE FUNCTION OF THE DIFFERENCE BETWEEN TWO ESTIMATED RESPONSES THE REGRESSION OF TRUE VALUE ON ESTIMATED VALUE

ALMOST LINEARLY_OPTIMUM COMBINATION OF UNBIASED ESTIMATES LEAST SQUARES AND BEST UNBIASED ESTIMATES UNIFORM APPROXIMATION OF MINIMAX POINT ESTIMATES ASYMPTOTIC BEHAVIOR OF BAYES' ESTIMATES A BAYES APPROACH FOR COMBINING CORRELATED ESTIMATES QUERY, NECATIVE VARIANCE ESTIMATES ASYMPTOTIC NORMALITY OF BISPECTRAL ESTIMATES A NOTE ON BAYES ESTIMATES

ON STRONG CONSISTENCY OF DENSITY ESTIMATES A NOTE ON THE EFFICIENCY OF LEAST-SQUARES ESTIMATES THE BEHAVIOUR OF JRSSB $67 \quad 174$ BIOKAGO 457 JASA $61 \quad 36$ AMS $62 \quad 266$ AMS 641031 AMS $64 \quad$ B46 JASA $65 \quad 602$ TECH $65 \quad 75$ AMS 661257 AMS 671907 AMS 691765 JRSSB $68 \quad 284$ JRSSB $6 B \quad 535$ CONFIDENCE PROPERTIES OF BAYESIAN INTERVAL ESTIMATES EXPERIMENTAL DESICNS FOR REALIZED HERITABILITY ESTIMATES

PARAMETER ESTIMATES AND AUTONOMOUS GROWTH, CORR. 59812 JASA 59 389

ESTIMATES AND LARGE SAMPLE APPROXIMATIONS SAMPLES (WITH DISCUSSION) CATION FOR THE STATIONARY POINT SAMPLING EFFICIENT ESTIMATES AND OPTIMUM INFERENCE PROCEDURES IN LARGE ASA $6946 \mathrm{~B}$ JRSSB $62 \quad 46$ LEAST SQUARES ESTIMATES AND PARABOLIC REGRESSION WITH RESTRICTED LO JASA 64564 NECATIVE VARIANCE ESTIMATES AND STATISTICAL DEPENDENCE IN NESTED JASA 681000 AMS $67 \quad 303$

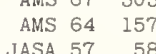
RATES OF CONVERGENCE OF ESTIMATES AND TEST STATISTICS CONSISTENT ESTIMATES AND ZERO-ONE SETS NGLE EXPONENTIAL DISTRIBUT/ TABLES FOR BEST LINEAR ESTIMATES BY ORDER STATISTICS OF THE PARAMETERS OF SI JASA 57 58 GOOD LINEAR UNBIASED ESTIMATES FROM THE BEST LINEAR ESTIMATES FOR A SMALLER SAMPLE SIZE /ONSTRUCTION OF TECH 65 543 ON A THEOREM OF KARLIN RECARDING ADMISSIBLE ESTIMATES FOR EXPONENTIAL POPULATIONS

IMENT AS ORTHOGONAL LINEAR COMBINATIONS OF THE/ ON ESTIMATES FOR FRACTIONS OF A COMPLETE FACTORIAL EXPER SMOOTHED ESTIMATES FOR MULTINOMIAL CELL PROBABILITIES ROBUSTNESS OF THE HODGES-LEHMANN ESTIMATES FOR SHIFT AMS 69216 AMS $63106 \mathrm{~B}$ AMS $6 \mathrm{~B} \quad 561$ AMS $65 \quad 174$ AMS $66 \quad 593$ AMS 641079

PROBLEM ON SOME NONPARAMETRIC ESTIMATES FOR SHIFT IN THE BEHRENS-FISHER SITUATION ATE DIFFERENCES ON SOME ALTERNATIVE ESTIMATES FOR SHIFT IN THE P-VARIATE ONE SAMPLE

POLYNOMIAL REGRESSIONS AND IMMICRATION-STOCHASTIC MODEL DISTRIBUTION THEORY OF TWO ESTIMATES FOR STANDARD DEVIATION BASED ON SECOND VARI BIO 1 SIMPLIFIED ESTIMATES FOR THE EXPONENTIAL DISTRIBUTION \begin{tabular}{l} 
ESTIMATES FOR THE POINTS OF INTERSECTION OF TWO JASA $64 \quad 214$ \\
\hline
\end{tabular} EXPLICIT ESTIMATES FROM CAPTURE-RECAPTURE DATA WITH BOTH DEATH BIOKA65 225 TECH $67 \quad 599$

R-EXPERIMENT VARIATION $R$ SAMPLE/ THE CONSTRUCTION OF GOOD LINEAR UNBIASED ESTIMATES FROM THE BEST LINEAR ESTIMATES FOR A SMALLE TECH 65 543 VARIANCE ESTIMATES IN 'OPTIMUM' SAMPLE DESIGNS JASA $61 \quad 135$

THEOREM OF KARLIN REGARDING ADMISSIBILITY OF LINEAR ESTIMATES IN EXPONENTIAL POPULATIONS SOME FURTHER NOTES ON DISTURBANCE ESTIMATES IN RECRESSION ANALYSIS DESIGN ESTIMATES IN SUCCESSIVE SAMPLING USING A MULTI-STAGE JASA 6899

ON THE ASYMPTOTIC BEHAVIOR OF BAYES' ESTIMATES IN THE DISCRETE CASE ON THE ASYMPTOTIC BEHAVIOR OF BAYES ESTIMATES IN THE DISCRETE CASE II ON THE INADMISSIBILITY OF SOME STANDARD ESTIMATES IN THE PRESENCE OF PRIOR INFORMATION ECTION TO 'COEFFICIENTS OF VARIATION OF HERITABILITY ESTIMATES OBTAINED FROM VARIANCE ANALYSES' UNIFORM CONSISTENCY OF SOME ESTIMATES OF A DENSITY FUNCTION

LINEAR ESTIMATES OF A POPULATION SCALE PARAMETER ON COMBINING ESTIMATES OF A RATIO OF MEANS

A NOTE ON COMBINING CORRELATED ESTIMATES OF A RATTO OF MULTIVARIATE MEANS ADMISSIBILITY OF QUANTILE ESTIMATES OF A SINGLE LOCATION PARAMETER TABLES FOR THE SIGN TEST WHEN OBSERVATIONS ARE ESTIMATES OF BINOMIAL PARAMETERS AMS 631386 AMS $65 \quad 454$ AMS $63 \quad 539$ CORR BIOCS65 265 AMS 691499 BIOKA67 551 JRSSB63 201 TECH 64463 AMS 641019 JASA 59784 OF AN EXPONENTIAL DISTRIBUTION VARIANCES OF NORMAL DISTRIBUTIONS

ESTIMATES OF BOUNDED RELATIVE ERROR FOR THE MEAN LIFE ESTIMATES OF BOUNDED RELATIVE ERROR FOR THE RATIO OF SOME MORE ESTIMATES OF CIRCULAR PROBABLE ERROR

COMPARISON OF ESTIMATES OF CIRCULAR PROBABLE ERROR, CORR. 60755 EXACT FIRST AND SECOND ORDER MOMENTS OF ESTIMATES OF COMPONENTS OF COVARIANCE 107 $\begin{array}{llll}56 & 481\end{array}$ JASA $62 \quad 191$ JASA $59 \quad 794$ BIOKA69 NO.3 ONAL TWO-WAY CLASSIFICATION SAMPLING VARIANCES OF ESTIMATES OF COMPONENTS OF VARIANCE FROM A NON-URTHOG BIOKA64 491 $\begin{array}{llll}\text { ESTIMATES OF EFFECTS FOR FRACTIONAL REPLICATES AMS } 64 & 711\end{array}$ 
S, OF SELEC/ A STATISTICAL ANALYSis OF PROVISIONAL ESTIMATES OF GROSS NATIONAL PRODUCT AND ITS COMPONENT JASA 58 PROBABILITY OF OBTAININC NEGATIVE ESTIMATES OF HERITABILITY

BTOCS68 517

SIB DATA WITH UNEQUAL SUBCLASS NUMBERS

THE MEAN VECTOR OF A MULTIVARIATE DISTRIBUTION ESTIMATES OF HERITABILITY FROM TRANSFORMED PERCENTAGE BIOCS65 1001 ESTIMATES OF LINEAR COMBINATIONS OF THE PARAMETERS IN AMS 6578 ON SOME ROBUST ESTIMATES OF LOCATION ESTIMATES OF LOCATION BASED ON RANK TESTS

AMS $65 \quad 847$

REMOVAL RECORDS ESTIMATES OF MORALITY AND POPULATION FROM SURVEY-

DISTRIBUTION

LINEAR ESTIMATES OF PARAMETERS IN THE EXTREME VALUE

BIOCS65 921

TECH 663

AMS $61 \quad 136$

ADMISSIBLE AND MINIMAX ESTIMATES OF PARAMETERS IN TRUNCATED SPACES

TABLES FOR OBTAINING THE BEST LINEAR INVARIANT ESTIMATES OF PARAMETERS OF THE WEIBULL DISTRIBUTION TECH 67 629

PTURE DATA WITH BOTH DEATH AND DILUTION-DETERMINI/ ESTIMATES OF POPULATION PARAMETERS FROM MULTIPLE RECA BIOKA63 II3

TESTS EQUIVALENCE OF TWO ESTIMATES OF PRODUCT VARIANCE

JASA $56 \quad 451$ ESTIMATES OF REGRESSION PARAMETERS BASED ON RANK AMS $67 \quad 894$

COMPARISON OF LEAST SQUARES AND MINIMUM VARIANCE ESTIMATES OF REGRESSION PARAMETERS, (ACKNOWLEDGEMENT AMS 62462 USEFUL IN LIFE TESTING ESTIMATES OF RELIABILITY FOR SOME DISTRIBUTIONS

E TO PRODUCE AREA BREAKDOWNS OF THE MONTHLY NATIONAL ESTIMATES OF RETAIL TRADE /OF A RECRESSION TECHNIQU

SELECTED FROM EACH STRATUM
ASYMPTOTIC PROPERTIES OF SPECTRAL

ESTIMATES OF SAMPLING VARIANCE WHERE TWO UNITS ARE

TECH $64 \quad 215$

STTMATES OF SECOND ORDER

182)

ESTIMATES OF SURVIVAL FROM THE SICHTINC OF MARKED

JASA $66 \quad 496$

JASA $57 \quad 503$

BIOKA69 375

BIOKA64 429

AMS $64 \quad 809$

TWO ESTIMATES OF THE BINOMIAL DISTRIBUTION, (CORR. 64

EFFECTS OF BIAS ON ESTIMATES OF THE CIRCULAR PROBABLE ERROR

DESIGNS

ON QUADRATIC ESTIMATES OF THE INTERCLASS VARIANCE FOR UNBALANCED

JASA $60 \quad 732$

JRSSB $61 \quad 493$

A TYPE II CENS/ THE BIAS OF THE MAXIMUM LIKELIHOOD ESTIMATES OF THE LOCATION AND SCALE PARAMETERS GIVEN BIOKA6I 448

ALL ADMISSIBLE LINEAR ESTIMATES OF THE MEAN VECTOR

AMS $66 \quad 458$

SOME DIRECT ESTIMATES OF THE MODE

AMS $65 \quad 131$

FITTING

A METHOD OF OBTAINING INITIAL ESTIMATES OF THE PARAMETERS IN EXPONENTIAL CURVE

CONSISTENT ESTIMATES OF THE PARAMETERS OF A LINEAR SYSTEM

BIOCS69 580

AMS 69 NO. 6 ED ON SINGLY AND D/ ON THE JOINT EFFICIENCY OF THE ESTIMATES OF THE PARAMETERS OF NORMAL POPULATIONS BAS JASA 62496 ED ON SINGLY CENSORED SA/ ON THE EFFICIENCY OF BAN ESTIMATES OF THE PARAMETERS OF NORMAL POPULATIONS BAS BIOKA62 570 ON CUPTA'S ESTTMATES OF THE PARAMETERS OF THE NORMAL DISTRIBUTIO BIOKAG4 498 AN/ THE ASYMPTOTIG VARIANCES OF METHOD OF MOMENTS ESTIMATES OF THE PARAMETERS OF THE TRUNCATED BINOMIAL JASA 61990 KENDALL'S TAU ESTIMATES OF THE REGRESSION COEFFICIENT BASED ON JASA 68 I379 ONARY TIME/ ON ASYMPTOTICALLY EFFICIENT CONSISTENT ESTIMATES OF THE SPECTRAL DENSITY FUNCTION OF A STATI JRSSB58 303 INDICATED BY TRENDS IN DEATH RATES BIAS IN ESTIMATES OF THE UNITED STATES NONWHITE POPULATION AS JASA 6144 INVESTMENT ESTIMATES OF UNDERDEVELOPED COUNTRIES, AN APPRAISAL JASA 58 669
INTS

THE PROBLEM OF NEGATIVE ESTIMATES OF VARIANCE COMPONENTS NON-NEGATIVE ESTIMATES OF VARIANCE COMPONENTS FURTHER EVIDENCE ON THE CONSISTENCY OF ESTIMATES OF VARIANCE COMPONENTS

TECH $63 \quad 441$ CLASSIFICATION VARIANCES OF ESTIMATES OF VARIANCE COMPONENTS IN A THREE-WAY B BIOCS66 553 REE-WAY NESTED CLASSIFI/ SAMPLING VARIANCES OF THE ESTIMATES OF VARIANCE COMPONENTS IN THE UNBALANCED TH AMS 63521 COMPARISON OF FOUR RATIO-TYPE ESTIMATES UNDER A MODEL $\quad$ JASA 69574 OF A DOUBLE EXPONENTIAL POPULATION BEST LINEAR ESTIMATES UNDER SYMMETRIC CENSORINC OF THE PARAMETERS JASA 66248 SPECTRAL ESTIMATES USING NONLINEAR FUNCTIONS AMS 661237 LINEAR ESTIMATES WITH POLYNOMIAL COEFFICIENTS BIOKA66 129

ES TABLES FOR MAXIMUM LIKELIHOOD ESTIMATES. SINGLY TRUNCATED AND SINGLY CENSORED SAMPL TECH 61535 DN DSTTMATNO A DENSITY THE MAXIMUM LIKELIHOOD SOLUTION TO THE PROBLEM OF ESTIMATING A LINEAR FUNCTIONAL RELATIONSHIP JRSB69 NO.2 ESTIMATING A MIXED-EXPONENTIAL RESPONSE LAW JASA 61493

A NOTE ON ESTTMATING A UNTMODAL DENSITY

ST POISSON TYPE

AMETRIC TESTS

A DEMOCRAPHIC MODEL FOR ESTIMATING AGE-ORDER SPECIFIC FERTILITY RATES

CONSISTENT STATISTICS FOR ESTIMATING AND TESTING HYPOTHESES F'ROM GROUPED SAMPLE BIOKA66 545 ESTIMATING AND TESTING TREND IN A STOCHASTIC PROCESS AMS 661564 ON A DISTRIBUTION-FREE METHOD OF ESTIMATINC ASYMPTOTIC EFFICIENCY OF A CLASS OF NONPAR AMS 661759 ON ESTIMATING BACTERIAL NUMBERS BY THE PLAT

ON A METHOD OF ESTIMATING BIOLOGICAL POPULATIONS IN THE FIELD

RAPID METHODS FOR ESTIMATING CORRELATION COEFFICIENTS

FURTHER MODELS FOR ESTIMATING CORRELATION IN DISCRETE DATA

ON THE RELATION BETWEEN ESTIMATINC EFFICIENCY AND THE POWER OF TESTS

EXAMINATION OF A REPEAT MATING DESIGN FOR ESTIMATING ENVIRONMENTAL AND GENETIC TRENDS

ON ESTIMATING EPIDEMIC PARAMETERS FROM HOUSEHOLD DATA

ES FROM NORMAL POPULATIONS

ON THE SOLUTION OF ESTIMATING EQUATIONS FOR TRUNC

USE OF THE GENERALIZED EXTREME-VALUE DISTRIBUTION IN ESTIMATING EXTREME PERCENTILES

PROBLEMS IN ESTIMATING FEDERAL COVERNMENT EXPENDITURES

ARY CAUSSIAN ORNSTEIN-UHLENBECK PROCESS BY MONTE/

a

IXED MODEL SITUATIONS

AN ITERATIVE PROCEDURE FOR

ESTIMATING FINITE-TIME MAXIMA AND MINIMA OF A

ESTIMATING FIXED EFFECTS AND VARIA
ESTIMATING FROM MISCLASSIFIED DATA

LIKELIHOOD DISTRIBUTIONS FOR ESTIMATINC FUNCTIONS WHEN BOTH VARIABLES ARE SUBJECT

LINE TRANSECT METHOD OF ESTIMATING CROUSE POPULATION DENSITIES

TO ERROR

EVALUATION OF CENSUS SURVIVAL RATES IN ESTIMATINC INTERCENSAL STATE NET MICRATION

ESTIMATING MACHINING ERRORS IN SET-UPS WITH AUTOMATIC ON ESTIMATING MONOTONE PARAMETERS

RESETTING

ANALYSIS OF FACTORIAL EXPERIMENTS BY ESTIMATING MONOTONE TRANSFORMATIONS OF THE DATA

A NOTE ON THE CENSUS SURVIVAL RATIO METHOD OF ESTIMATING NET MICRATION

TESTING AND ESTIMATING OF SCALE PAREMENTERS

NOTE ON ESTIMATING ORDERED PARAMETERS

ESTIMATING ORDERED PROBABILITIES

THE FOLDED NORMAL DISTRIBUTION. TWO METHODS OF ESTIMATING PARAMETERS FROM MOMENTS THE FOLDED NORMAL DISTRIBUTION. TWO METHODS OF ESTIMATING PARAMETERS FROM MOMENTS
COMPARISONS OF DESIGNS AND ESTIMATION PROCEDURES FOR ESTIMATING PARAMETERS IN A TWO-STAGE NESTED PROCESS
ONSET IS RANDOM
TESTING HYPOTHESES AND ESTIMATING PARAMETERS IN HUMAN GENETICS IF THE AGE OF

TESTING HYPOTHESES AND ESTIMATING PARAMETERS IN HUMAN GENETICS IF THE AGE OF $\begin{array}{lll}\text { S } & \text { COMPARATIVE EFFICIENCIES OF METHODS OF ESTIMATING PARAMETERS IN LINEAR AUTORECRESSIVE SCHEME } \\ \text { DISTRIBUTIONS WITHOUT RESORT TO HIGHER MOMENTS } & \text { ESTIMATING PARAMETERS IN TRUNCATED PEARSON FREQUENCY }\end{array}$ DISTRIBUTIONS ESTIMATING PARAMETERS IN TRUNCATED PEARSON FREQUENCY SIMPLIFIED TECHNIQUES FOR ESTIMATING PARAMETERS OF SOME GENERALIZED ON THE UTILIZATION OF MARKED SPECIMENS IN ESTIMATING POPULATIONS OF FLYINC INSECTS THE EMPIRICAL BAYES APPROACH ESTIMATINC POSTERIOR QUANTILES

NOTES. ON ESTIMATING RECESSIVE FREQUENCIES FROM TRUNCATED
BIOCS67 158

BIOKA56 461

BIOKA53 216

BIOKA51 464

JRSSB64 82

BIOCS65 63

BIOKA64 511

BIOKA57 225

BIOCS67 79 JASA $59 \quad 717$

JASA $68 \quad 1517$

BIOCS68 13 $\begin{array}{lll}\text { JASA } & 68 \quad 123\end{array}$

TECH 67261 BIOCS68 135 JASA $62 \quad 841$

ECH $64 \quad 423$ AMS $68 \quad 1030$ JRSSB $65 \quad 251$ JASA $62 \quad 175$

JASA 69999

AMS 65698

AMS $63 \quad 967$

TECH 61 551

TECH $67 \quad 499$

BIOKA63 265

IOKA6I 427

BIOKA53 50 BIOKA67 555 BIOKA53 170 BI0CS67 356
BIOKA54 542 BIOKA67 672 
A SIMPLE METHOD OF ESTIMATING RELATIVE POTENCY FROM TWO PARABOLAS

ON ESTIMATINC SCALE AND LOCATION PARAMETERS

BIOCS65 140 JASA $63 \quad 658$

FOR ACGRECATION BIAS WO-STACE SAMPLINC BAYES DISTRIBUTED POPULATIONS DISTRIBUTIONS

LIQUID MIXTURE

OF THE DEVIATIONS ABOUT THE R/ A RAPID METHOD FOR ONS FROM A CLIPPED STATIONARY TIME SERIES WHICH IS SUBJECTED TO CHANGES IN TIME

TURE METHOD. I. THE MAXIMUM LIKELIHOOD EQUATIONS FOR IONS OF MEAN SQUARES BY SATTERTHWAITHE'S FORMULA TWO STACE PROCEDURES

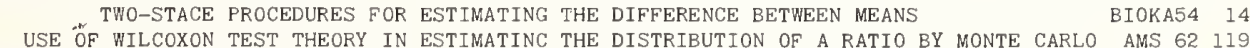
ES OF A FINITE-STATE MARKOV CHAIN FROM/ NOTES. ON ESTIMATING THE EQUILIBRIUM AND TRANSITION PROBABILITI BIOCS68 185 A, AND ITS RELA/ ADAPTATION OF KARBER'S METHOD FOR ESTIMATING THE EXPONENTIAL PARAMETER FROM QUANTAL DAT BIOCS67 739 ESTIMATING THE FRACTION OF ACCEPTABLE PRODUCT $\quad$ TECH 6543

OPTIMAL EXPERIMENTAL DESIGNS FOR ESTIMATING THE INDEPENDENT VARIABLE IN REGRESSION TECH 6B 8II S TIME. FINITE STATE MARKOV PROCESS ESTIMATING THE INFINITESIMAL GENERATOR OF A CONTINUOU AMS $62 \quad 727$ ES, I. FAMILIES WITH TWO SUSCEPTIBLES ONLY.

A METHOD OF ESTIMATING THE INTERCENSAL POPULATION OF COUNTIES JASA 56587 ON ESTMATING TAE INTERCENSAL POPULATION OF COUNTIES JASA 56587 ON ESTIMATING THE LATENT AND INFECTIOUS PERIODS OF MEASL BIOKA56 322 ESTIMATING THE LOGISTIC CURVE

SOME SHRINKAGE TECHNIQUES FOR ESTIMATING THE MEAN ASYMPTOTIC EFFICIENCY OF A SEQUENTIAL PROCEDURE FOR ESTIMATING THE MEAN CENSORED NORMAL SAMPLE SPONSE CURVE

SOME OPTIMAL SEQUENTIAL ESTIMATING THE MEAN AL

ON WITH GENERAL QUADRATIC LOSS FUNCTION KNOWN COEFFICIENT OF VARIATION THE ROBBINS-MONRO METHOD FOR ESTIMATING THE MEDIAN LETHAL DOSE

TEMES FOR ESTTMATTNG THE MEAN OF A CUMULTIVE NORMAL QUANTA JASA 6 B 113 ON THE AMS $66 \quad 1173$ $\begin{array}{rr}\text { AMS } & 66 \\ \text { BIOKA67 } & 155\end{array}$ TABLE FOR ESTIMATING THE MEAN OF A LOGNORMAL DISTRIBUTION JASA $69 \quad 632$ ESTIMATING THE MEAN OF A MULTIVARIATE NORMAL POPULATI AMS 661819 JASA 681039 JRSSB $65 \quad 28$ AMS $68 \quad 2 B 6$ ANALYSIS. PART I. DESCRIPTION/ TABLES FOR USE IN ESTIMATING THE NORMAL DISTRIBUTION FUNCTION BY NORMIT BIOKA57 4I BINOMIAL DISTRIBUTION

ON ESTIMATING THE PARAMETER OF A DOUBLY TRUNCATED ESTIMATING THE PARAMETERS OF A CONVOLUTION JASA $66 \quad 259$ JRSSB69 181

RIBUTION DISTRIBUT ION POPULATIONS THE USE OF FRACTIONAL MOMENTS FOR ESTIMATING THE PARAMETERS OF A MIXED EXPONENTIAL DIST ESTIMATING THE PARAMETERS OF A MODIFIED POISSON SOME METHODS OF ESTIMATING THE PARAMETERS OF DISCRETE HETEROGENEOUS JRSSB56 222 FROM CENSORED SAMPLES

DISTRIBUTIONS

ULATIONS FROM ONE OR TWO ORDER STATISTICS, CORR. / AND NEGATIVE BINOMIAL DISTRIBUTIONS ARE TRUNCATED ON THE RIGHT THE EMPIRICAL ESTIMATING THE PARAMETERS OF LOG-NORMAL DISTRIBUTION JASA $68 \quad 134$ ESTIMATING THE PARAMETERS OF MIXTURES OF BINOMIAL JASA 64510 ESTIMATING THE PARAMETERS OF NEGATIVE EXPONENTIAL POP AMS 611078

ON ESTIMATING THE PARAMETERS OF THE LOGARITHMTC SERIES BIOKA69 4II ESTIMATING THE POTSSON PARAMETER PROM SAMPLES THAT TECH $61 \quad 433$ BIOKA67 326 AND NORMAL DISTRIBUTTONS PROBIT ANALYS
ACTUARIAL METHODS. CORR. 57578 INFORMATI A SOME PROPERTIES OF A METHOD OF ESTIMATING THE SIZE OF MOBILE ANIMAL POPULATIONS RECAPTURE DATA TIC PROCESS (WITH DISCUSSION) ON ESTIMATING THE SIZE OF MOBILE POPULATIONS FROM ON ESTIMATING THE SPECTRAL DENSITY FUNCTION OF A STOCHAS ASA $6391 B$ TECH $67 \quad 197$ JASA $57 \quad 175$ BIOKA69 407 BIOKA51 293 $\begin{array}{rr}\text { JRSSB57 } & 13\end{array}$ BIOKA66 559 AMS $68 \quad 256$ AMS $64 \quad 438$ BIOKA69 NO. 3 TECH $63 \quad 421$ BIOCS68 749 AMS 611042 TECH $62 \quad 381$ AMS 631452 AMS 641099 JASA $64 \quad 529$ JASA 641016 TECH $64 \quad 41$ AMS $65 \quad 638$ AMS $66 \quad 643$ TECH $66 \quad 319$ AMS 671436 AMS 67 1BB2 JASA $67 \quad 1179$ $\begin{array}{lll}\text { JASA } & 67 \quad 48\end{array}$ AMS 681890 TECH 6863 TECH $68 \quad 271$ JASA $69 \quad 949$ BIOKA51 150 BIOKA53 457 BIOKA55 527 BIOKA56 353 BIOKA58 565 BIOKA59 231 BIOKA62 553 BIOKA62 560 BIOKA63 540 BIOKA69 133 JRSSB $61 \quad 469$ 
ON THE CHOICE OF A STRATECY FOR A RATTO METHOD OF ESTTMATION

ETE BLOCK DESIGNS. III. SOME LARGE-SAMPLE RESULTS ON ESTIMATION AND POWER FOR A METHOD OF PAIRED COMPARISO BIOKA55 450 THE EXTENSION OF A UNIVARIATE MODEL AND ASSOCIATED ESTIMATION AND TEST PROCEDURES /PAIRED GOMPARISONS BIOKA69 8I CONFIDENCE CURVES. AN OMNIBUS TECHNIQUE FOR ESTIMATION AND TESTINC STATISTICAL HYPOTHESES
SPECTRA LINEAR ESTIMATION AND THE ANALYSIS OF CAMMA RAY PULSE-HEIGHT TECH 62 565 POISSON, AND EXPONENTIAL/A METHOD OF SEQUENTIAL ESTIMATION APPLICABLE TO THE HYPERGEOMETRIC, BINOMIAL AMS 65 1494 SELECTIVE REMOVAL ESTIMATION ASSOCIATED WITH LINEAR DISGRIMINANTS AMS $67 \quad 807$ POPULATION ESTIMATION BASED ON CHANGE OF COMPOSITION CAUSED BY A BIOKA55 279 ESTTMATION BY DOUBLE SAMPLTNG BIOKA52 217

THE FOLDED NORMAL DISTRIBUTION . IIT ACCURACY OF ESTI TECH $62 \quad 249$ SIMULTANEOUS ESTIMATION BY PARTIAL TOTALS FOR COMPARTMENTAL MODELS JASA $6 B \quad 573$ THE USE OF A STRATIFICATION VARIABLE IN ESTIMATION BY PROPORTIONAL STRATIFIED SAMPLINC ESTIMATION BY RANKING PARAMETERS

ON ESTIMATION BY THE SWEEP-OUT METHOD (CORR. 69 229) ESTIMATION EMPLOYINC POST STRATA

TESTING AND ESTIMATION FOR A CIRCULAR STATIONARY MODEL SPEARMAN SIMULTANEOUS ESTIMATION FOR A COMPARTMENTAL MODEL

PARAMETER ESTIMATION FOR A GENERALIZED CAMMA DISTRIBUTION

JASA $6 B \quad 1310$ JRSSB $66 \quad 32$ BIOKA6B 305 JASA 661172 AMS 691358 TECH 69551 TEGH $65 \quad 349$

PARAMETER ESTIMATION FOR A MULTIVARIATE EXPONENTIAL DISTRI ESTIMATION FOR A ONE-PARAMETER EXPONENTIAL MODEL

SPEARMAN ESTTMATION FOR A SIMPLE EXPONENTIAL MODEL ESTIMATION FOR A SIMPLE EXPONENTIAL MODEL
$597)$

RATE

AND ITS APPLICATION TO A TRUN/
SMOOTH EMPIRICAL BAYES ESTIMATION FOR CONTINUOUS DISTRIBUTIONS (CORR. 6B MAXIMUM LIKELIHOOD ESTIMATION FOR DISTRIBUTIONS WITH MONOTONE FAILURE ON CROWTH PARAMETER ESTIMATION FOR EARLY LIFE STAGES

MULTIVARIATE RATIO ESTIMATION FOR FINITE POPULATIONS

MAXIMUM LIKELIHOOD ESTIMATION FOR GENERALIZED POWER SERIES DISTRIBUTIONS INTERVAL ESTIMATION FOR LINEAR COMBINATIONS OF MEANS

BEST LINEAR UNBIASED ESTIMATION FOR MULTIVARIATE STATIONARY PROCESSES SMOOTH EMPIRICAL BAYES ESTIMATION FOR ONE-PARAMETER DISCRETE DISTRIBUTIONS A NOTE ON ESTIMATION FOR QUANTAL RESPONSE DATA

ON LINEAR ESTIMATION FOR REGRESSION PROBLEMS ON TIME SERIES

ON THE PROBLEM OF ESTIMATION FOR THE BIVARIATE LOGNORMAL DISTRIBUTION ESTIMATION FOR THE BIVARIATE POISSON DISTRIBUTION

SEQUENTIAL INTERVAL ESTIMATION FOR THE MEANS OF NORMAL POPULATIONS

MAXIMUM-LIKELIHOOD ESTIMATION FOR THE MIXED ANALYSIS OF VARIANCE MODEL
A DISTRIBUTIONS ON TION

COMPONENTS EFFICIENCY OF CERTAIN METHODS OF ESTIMATION FOR THE NEGATIVE BINOMIAL AND NEYMAN TYPE INTERVAL ESTIMATION FOR THE PARAMETER OF A BINOMIAL DISTRIBUTI EMPIRICAL BAYES ESTIMATION FOR THE POISSON DISTRIBUTION

NOTES MAXIMUM LIKELIHOOD ESTIMATION FOR THE TRUNCATED POISSON LIFE TESTINC AND RELIABILITY ESTIMATION FOR THE TWO PARAMETER EXPONENTIAL DISTRIBU JA A NOTE ON ESTIMATION FROM A CAUCHY SAMPLE ESTIMATION FROM A LINEAR MARKOV PROCESS

INDEX SELECTION AND ESTIMATION FROM A SINGLE SAMPLE A NOTE ON ESTIMATION FROM A TYPE I EXTREME-VALUE DISTRIBUTION NONPARAMETRIC ESTIMATION FROM INCOMPLETE OBSERVATIONS ESTIMATION FROM LIFE TEST DATA ESTIMATION FROM QUANTILES IN DESTRUCTIVE TESTING JASA $68 \quad 848$ JASA 65560 BI0CS65 858 BI0CS67 717 BIOKA67 435 AMS $65 \quad 69$ BI0C566 162 BIOKA58 154 BIOKA62 227 JASA 641141 TECH $68 \quad 523$ BIOKA66 417 BIOKA68 578 AMS $62 \quad 1077$ BIOKA64 522 BIOKA64 241 AMS 69509 BIOKA67 93 BIOKA62 215 BIOKA58 275 BIOKA69 349 BI0CS66 620 JASA 69621 JASA $64 \quad 460$ BIOKA60 482 BIOKA63 195 TECH $67 \quad 325$ JASA $58 \quad 457$ TECH $60 \quad 447$ JRSSB61 434 SGALE PARAMETER ESTIMATION FROM THE ORDER STATISTICS OF UNEQUAL GAMMA AMS.66 152 ESTIMATION IN A HETEROSCEDASTIC REGRESSION MODEL JASA 68552 DENSITY ESTIMATION IN A TOPOLOGIGAL GROUP PROBLEMS OF SAMPLE ALLOCATION AND ESTIMATION IN AN AGRICULTURAL SURVEY ROBUST ESTIMATION IN ANALYSIS OF VARIANCE

A NOTE ON ROBUST ESTIMATION IN ANALYSIS OF VARIANCE ASSOCIATION AND ESTIMATION IN CONTINGENCY TABLES UNBIASED ESTIMATION IN CONVEX FAMILIES ANALYSIS WITH UNEQUAL SUBCLASS NUMBERS, COMPONENT ESTIMATION IN CORRELATION STUDIES ROBUST ESTIMATION IN INCOMPLETE BLOCK DESIGNS AMS 651047 JRSSB54 223 AMS $63 \quad 957$ AMS 681486 JASA $68 \quad 1$ AMS 691523 N ROBUST ESTTMATION IN INCOMPLETE BLOCK DESIGNS COVARIANCE BIOCS68 49 AMS $66 \quad 1331$ AMS 671587 INTERVAL ESTIMATION IN LINEAR REGRESSION WHEN BOTH VARIABLES ESTIMATION IN MIXTURES OF TWO NORMAL DISTRIBUTIONS ESTIMATION IN MULTI-STAGE SURVEYS

ARE SUBJECT TO ERROR

DESIGN OF EXPERIMENTS FOR PARAMETER ESTIMATION IN MULTIRESPONSE SITUATIONS BAYESIAN ESTIMATION IN MULTIVARIATE ANALYSIS CONFIDENCE INTERVAL ESTIMATION IN NON-LINEAR REGRESSION NOTE ON INTERVAL ESTIMATION IN NON-LINEAR REGRESSION WHEN RESPONSES
JASA 641112 TECH $67 \quad 15$ JASA $69 \quad 830$ BIOKA66 525 AMS $65 \quad 150$ JRSSB63 330 JRSSB $64 \quad 267$ 
RIBUTIONS IN THE DESIGN OF EXPERIMENTS FOR PARAMETER ESTIMATION IN NON-LINEAR SITUATIONS /OF PRIOR DIST BIOKA67 147 RIBUTIONS IN THE DESICN OF EXPERIMENTS FOR PARAMETER ESTIMATION IN NON-LINEAR SITUATIONS MULTIRESPONSE CAS BIOKA67 662 BABILITY PROPORTIONATE TO SIZE

VARIANCE ESTIMATION IN RANDOMIZED SYSTEMATIC SAMPLING WITH PRO JASA 65278 ADMISSIBILITY AND BAYES ESTIMATION IN SAMPLINC FINITE POPULATIONS, I

ADMISSIBILITY AND BAYES ESTIMATION IN SAMPLINC FINITE POPULATIONS, II

ADMISSIBILITY AND BAYES ESTIMATION IN SAMPLINC FINITE POPULATIONS, III

ADMISSIBILITY AND BAYES ESTIMATION IN SAMPLINC FINITE POPULATIONS, IV

ADMISSIBILITY AND BAYES ESTIMATION IN SAMPLINC FINITE POPULATIONS, V

OBSERVATIONS IN MULTIVARIATE STATISTICS II. POINT ESTIMATION IN SIMPLE LINEAR REGRESSION

A NOTE ON ESTIMATION IN THE TRUNCATED POISSON

AMS 651707

AMS 651723

AMS 651730

AMS 661658

AMS 69672

ZEROS AND SOME ONES ARE MISSING

ESTIMATION IN THE TRUNCATED POISSON DISTRIBUTION WHEN JASA $60 \quad 342$ ESTIMATION IN THE UNIFORM GOVARIANCE CASE $\quad$ JRSSB64 477

ETE AND ON CENSORED SAMPLES MAXIMUM LIKELIHOOD ESTIMATION IN THE WEIBULL DISTRIBUTION BASED ON COMPL TECH 65 579 ETE AND ON CENSORED S/ ERRATA, 'MAXIMUM LIKELTHOOD ESTIMATION IN THE WEIBULL DISTRIBUTION BASED ON COMPL TECH 66 57O THE ROLE OF SUFFICIENCY AND OF ESTIMATION IN THERMODYNAMICS

ON FIXED PRECISION ESTIMATION IN TIME SERIES

DESIGN AND ESTIMATION IN TWO-WAY STRATIFICATION

METHODS OF ESTIMATION INVOLVING DISCOUNTING

THE ESTIMATION OF 'TRANSFER FUNCTIONS ' OF QUADRATIC

SYSTEMS

SEQUENTIAL OPTIMUM PROCEDURES FOR UNBIASED ESTIMATION OF A BINOMIAL PARAMETER NUMERICAL STUDIES IN THE SEQUENTIAL ESTIMATION OF A BINOMIAL PARAMETER

1247 THE ESTIMATION OF A CHANGING SEASONAL PATTERN, CORR. 66

THE MULTIPLE-RECAPTURE CENSUS. I ESTIMATION OF A CLOSED POPULATION

OTHER COMPONENT IS OF EXPONENTIAL TYPE

OTHER COMPONENT IS OF EXPONENTIAL TYPE'

ESTIMATION OF A COMPONENT OF A CONVOLUTION, WHEN THE

AN EMIGRATION-IMMIGRATION PROGESS

ERRATA, 'ESTIMATION OF A COMPONENT OF A CONVOLUTION, WHEN THE ESTIMATION OF A FUNCTIONAL RELATIONSHIP

THE ESTIMATION OF A FUNDAMENTAL INTERACTION PARAMETER IN

THE ESTIMATION OF A LAGGED REGRESSION RELATION ESTIMATION OF A LINEAR FUNCTION FOR A CALIBRATION

LINE, CONSIDERATION OF A RECENT PROPOSAL

MAXIMUM LIKELIHOOD ESTIMATION OF A LINEAR FUNCTTONAL RELATTONSHIP

THE BAYESIAN ESTIMATION OF A LINEAR FUNCTIONAL RELATIONSHIP

A NOTE ON THE MAXIMUM LIKELIHOOD ESTIMATION OF A LINEAR STRUCTURAL RELATIONSHIP

ROBUST ESTIMATION OF A LOCATION PARAMETER

INVARIANT INTERVAL ESTIMATION OF A LOCATION PARAMETER

CONSISTENT ESTIMATION OF A LOCATION PARAMETER IN THE PRESENCE OF AMS 621021 AMS 691021

JASA $60 \quad 105$ JRSSB $67 \quad 355$ TECH 61563 TECH 64259 BIOKA5B 1 JASA $64 \quad 1063$ BIOKA58 343 TECH $64 \quad 222$ TECH $65 \quad 462$ BIOKA53 47 AMS $63 \quad 238$ BIOKA67 409 TECH 69 NO. 4 AMS $61 \quad 1048$ JRSSB $68 \quad 190$ JASA $64 \quad 1175$ AMS $64 \quad 73$ AMS $68 \quad 193$ AN INCIDENTAL SCALE PARAMETER SPURIOUS ESTIMATION OF A MEAN WHEN ONE OBSERVATION MAY BE MPARISON OF THE DIRECT AND FIDUCIAL ARGUMENTS IN THE ESTIMATION OF A PARAMETER AMS 691353 PROBLEM ESTIMATION OF A PARAMETER IN THE CLASSICAL OCCUPANCY BIOKA60 18 SAMPLE DATA
DERIVATIVES

MOMENTS ARE KNOWN SECOND ORDER PROCESSES
DIFFICULTIES INVOLVED IN THE ESTIMATION OF A POPULATION MEAN USING TRANSFORMED

EFFICIENT ESTIMATION OF A PROBABILITY DENSITY FUNCTION ESTIMATION OF A PROBABILITY DENSITY FUNCTION AND ITS

ON ESTIMATION OF A PROBABILITY DENSITY FUNCTION AND MODE MINIMAX ESTIMATION OF A RANDOM PROBABILITY WHOSE FIRST $N$ EFFICIENT ESTIMATION OF A REGRESSION PARAMETER FOR CERTAIN ITERATIVE ESTIMATION OF A SET OF LINEAR REGRESSION EQUATIONS UNBIASED ESTIMATION OF A SET OF PROBABILITIES

EFFICIENT ESTIMATION OF A SHIFT PARAMETER FROM GROUPED DATA

L DESIGN OF FRACTIONAL FACTORIAL EXPERIMENTS FOR THE ESTIMATION OF A SUBGROUP OF PRE-ASSIGNED PARAMETERS FRACTIONAL FACTORIAL E/ GENERALIZED LEAST-SQUARES ESTIMATION OF A SUBVECTOR OF PARAMETERS IN RANDOMIZED ISTURBANCES ARE BOTH SERIALLY AND GONTE/ ESTIMATION OF A SYSTEM OF REGRESSI ESTIMATION OF A TRUNCATION POINT

ECH $66 \quad 535$ AMS $69 \quad 854$ AMS 691187 AMS 621065 AMS $68 \quad 492$ AMS 611299 JASA 64845 BIOKA61 227 AMS 671770 AMS $68 \quad 973$ AMS 691344 JASA 67500 BIOKA64 33 O-THE-N T/ ORTHOGONAL MAIN-EFFECT PLANS PERMITTING ESTIMATION OF ALL TWO-FACTOR INTERACTIONS FOR THE 2-T TECH 69 NO, SES MITH QUASI LINEAR RESID FUNCTION A NOTE ON THE ESTIMATION OF AMPITTUDE SPECTRA FOR STOCHASTTC PROCES J ESTIMATION OF AN ACCELERATED DEPRECIATION LEARNING JASA $66 \quad 995$ BIOCS66 665 ARIABLES AND INCOMPLETE SURVIVAL INFORMATION IN THE ESTIMATION OF AN EXPONENTIAL SURVIVAL PARAMETER LARGE SAMPLE ESTIMATION OF AN UNKNOWN DISCRETE WAVEFORM WHICH IS $R$ NOTE ON BIAS IN THE ESTIMATION OF AUTOCORRELATION

BIAS IN THE ESTIMATION OF AUTOCORREIATTONS

A SINGULARITY IN THE ESTIMATION OF BINOMIAL VARIANCE PHASE FREE ESTIMATION OF COHERENCE

RESPONSES$$
\text { PHASE FRE ESTIMATION OF COHERENCE }
$$

THE BAYESIAN ESTIMATION OF COMMON PARAMETERS FROM SEVERAL

MODELS FOR THE ESTIMATION OF COMPETING RISKS FROM GROUPED DATA

FROM DILUTION COUNTS ON THE EFFECT OF NON-NORMALITY ON THE ESTIMATION OF COMPONENTS OF VARIANCE

THE ESTIMATION OF CONCENTRATION OF VIRUSES AND BACTERIA

ON THE ESTIMATION OF CONTRASTS IN LINEAR MODELS

USE OF A GENERALIZED MULTINOMIAL DISTRIBUTION IN THE ESTIMATION OF CORRELATION IN DISGRETE DATA ESTIMATION OF CROP YIELDS FOR SMALL AREAS AMS 65198 BIOKA54 403 BIOKA54 390 BIOKA57 262 AMS 69540 BIOKA65 355 BIOCS69 329 JRSSB62 140 BIOCS65 600 $\begin{array}{ll}\text { JRSSB62 } & 530 \\ \text { BIOCS66 } & 374\end{array}$ SAMPLING

THE ESTIMATION OF DEATH-RATES FROM CAPTURE-MARK-RECAPTURE ESTIMATION OF ERROR RATES IN DISCRIMINANT ANALYSIS COMMENTARY ON 'ESTIMATION OF ERROR RATES IN DISCRIMINANT ANALYSIS' ESTIMATION OF ERROR VARIANCE FROM SMALLEST ORDERED ESTIMATION OF EXPONENTIAL SURVIVAL PROBABILITIES WITH ESTIMATION OF FINITE MIXTURES OF DISTRIBUTIONS FROM ESTIMATION OF FRACTION DEFECTIVE IN CURTAILED

BIOKA52 181 TECH 68 TECH $68 \quad 204$ JASA $63 \quad 152$

CONTRASTS

CONCOMITANT INFORMATION

THE EXPONENTIAL FAMILY

SAMPLING PLANS BY ATTRIBUTES

WO-WAY CROSSED CLASSI/ DESIGNS FOR THE SIMULTANEOUS ESTTMATTON OF FUNCTTONS OF VARIANCE COMPONENTS FROM T BIOKAG7 I27 LEL TEST CROSSING 2. AN EVALUATION OF TWO METHODS OF ESTIMATION OF GENETIC AND ENVIRONMENTAL VARIANCE /L BIOCS67 325 NENTS TO INDIVIDUAL VARIATES CONCERNED CRESSION RELATED DAMS ESTIMATION OF GENETIC CONTRIBUTION OF PRINCIPAL COMPO BIOCS69 ESTIMATION OF GENETIC PARAMETERS FROM DAUGHTER-DAM RE BIOCS67 82 ESTIMATION OF HERITABILITY FROM EXPERIMENTS WITH BIOCS69 NO.4 $P$ IN NORTH-EAST INDIA REFERENCE 68 1025)

SAMPLING TECHNIQUES FOR ESTIMATION OF INCIDENCE OF RED SPIDER MITE ON TEA CRO BIOCS66 385 A MATHEMATICAL MODEL FOR THE ESTIMATION OF INTER-PLANT COMPETITION (CORRECTION TO BIOCS67 189 ESTIMATION OF JUMPS, RELIABILITY AND HAZARD RATE AMS 651032 EFERENCE TO THE BIVARIATE NORMAL DISTRIB/ BAYESIAN ESTIMATION OF LATENT ROOTS AND VECTORS WITH SPECIAL R BIOKA69 97 AN EXAMPLE OF THE ESTIMATION OF LINEAR OPEN LOOP TRANSFER FUNCTION TECH $63 \quad 227$ ROBUST ESTIMATION OF LOCATION UNBIASED ESTIMATION OF LOCATION AND SCALE PARAMETERS AMS 661671. 
STATISTICS FROM SINGLY/

LINEAR-LOSS INTERVAL ESTIMATION OF LOCATION AND SCALE PARAMETERS RECTANGULAR POPULATION FROM CENSORED SAMPLES GROUPED DATA

CATED GROUPED SECH SQUARE DISTRIBUTION ORDER STATISTICS

ORDER STATISTICS
IS OF NON-ORTHOGONAL EXPERIMENTS BY ELECTRONIC CO/

S OF UNKNOWN SIZE, CORR. 641297

BAYESIAN
FOR THE
'ESTIMATION OF LOCATION AND SCALE PARAMETERS BY ORDER ESTIMATION OF LOCATION AND SCALE PARAMETERS FOR THE

THE ESTIMATION OF LOCATION AND SCALE PARAMETERS FROM ESTTMATION OF LOCATTON AND SCALE PARAMETERS BNOKA54 296 ESTIMATION OF MEANS AND STANDARD ERRORS IN THE ANALYS JRSSB62 435 ESTIMATION OF MEANS AND TOTALS FROM FINITE POPULATION JASA 62 STIMATION OF MEANS FOR THE RANDOM EFFECT MODEL JASA $68 \quad 174$ ESTIMATION OF MEANS OF NORMAL POPULATIONS $\quad$ BIOCS67 846 ESTIMATION OF MEANS OF NORMAL POPULATIONS FROM BIOKA57 $2 B 2$

THE ESTIMATION OF MISSING AND MIXED-UP OBSERVATIONS IN BIOKA59 9] SEVERAL EXPERIMENTAL DESTGNS

RIMENTS WHERE WHOLE-PLOTS ARE MISSING OR MIXED UP ESTIMATION OF MISSING OBSERVATIONS IN SPLIT-PLOT EXPE BIOKA6I 468 TABLE FOR USE WITH AN ELECTRONIC COMP/ A METHOD OF ESTIMATION OF MISSING VALUES IN MULTIVARIATE DATA SUI JRSSB6O 302 SYSTEMS

G ELECTRON TUBES

ICAL ESTTMATION OF MIXED WEIBULL PARAMETERS IN LIFE TESTIN TECH $59 \quad 389$ $\begin{array}{llll}\text { ON THE ESTIMATION OF MIXING DISTRIBUTIONS } & \text { AMS } & 66 & 177\end{array}$ BAYESIAN ESTIMATION OF MIXING DISTRIBUTIONS AMS 68 12B9

THE ESTIMATION OF MORTALITY AND RECRUITMENT FROM A SINGLE BIOCS65 529 ESTIMATION OF MULTIPLE CONTRASTS USING T-

TAGGING EXPERIMENT

DISTRIBUTIONS

THE BALANCED ONE-WAY LAYOUT

L MIGRATION

ASYMPTOTIC FUNCTION

MAXIMUM LIKELIHOOD ESTIMATION OF MULTIVARIATE COVARIANCE COMPONENTS FOR CUBICAL AND SPHERICAL ESTIMATION OF MULTIVARIATE PROBABILITY DENSITY ON THE BAYESIAN ESTIMATION OF MULTIVARIATE REGRESSION

ERRORS IN THE ESTIMATION OF NET MIGRATION IN THE STUDIES OF INTERNA NOTES. ESTIMATION OF NON-LINEAR PARAMETERS FOR A NONINTERVAL ESTIMATION OF NON-LINEAR PARAMETRIC FUNCTIONS

INTERVAL ESTIMATION OF NON-LINEAR PARAMETRIC FUNCTIONS, II

INTERVAL ESTIMATION OF NON-LINEAR PARAMETRIC FUNCTIONS, 11

ON THE LEAST SQUARES ESTIMATION OF NON-LINEAR RELATIONS ESTIMATION OF NON-UNIQUE QUANTILES ESTIMATION OF ONE OF TWO PARAMETERS OF THE EXPONENTIA L DISTRIBUTION ON THE BASIS OF SUITABLY CHOSEN OR/ ESTIMATION OF ONE OF TWO PARAMETER

RIBUTIONS' BY VICTOR HASSELBLAD DISTRIBUTIONS

WITH MOVING-AVERAGE RESIDUALS

SAMPLES

BY CONSIDERING HOUSEHOLDS OF TWO

ARISING IN A RELIABILITY GROWTH MODEL

DISCUSSION OF 'ESTIMATION OF PARAMETERS FOR A MIXTURE OF NORMAL DIST ESTIMATION OF PARAMETERS FOR A MIXTURE OR NORMAL

LARGE-SAMPLE ESTIMATION OF PARAMETERS FOR AUTOREGRESSIVE PROCESSES

LARGE-SAMPLE ESTIMATION OF PARAMETERS FOR MOVING-AVERAGE MODELS

THE ESTIMATION OF PARAMETERS FROM THE SPREAD OF A DISEASE BIOKA65 271 ESTIMATION OF PARAMETERS IN A TRANSIENT MARKOV CHAIN AMS 691542

EFFICIENT ESTIMATION OF PARAMETERS IN MOVING-AVERAGE MODELS BIOKA59 306 THE ESTIMATION OF PARAMETERS IN SYSTEMS OF STOCHASTIC BIOKA59 67 ESTIMATION OF PARAMETERS IN THE MULTIVARIATE NORMAL JASA 68 159 ESTIMATION OF PARAMETERS IN THE WEIBULL DISTRIBUTION TECH 67621 ESTIMATION OF PARAMETERS IN TIME-SERTES REGRESSION JRSSB60 139 ESTIMATION OF PARAMETERS OF A FINITE MIXTURE OF JRSSB6B 472

DISTRIBUTION WITH MISSING OBSERVATIONS

MODELS

DISTRIBUTIONS

DISTRIBUTION

ULATION FROM TRUNCATED AND CENSORED SAMPLES

BAYESIAN ESTIMATION OF PARAMETERS OF A MULTIVARIATE NORMAL ESTTMATTON OF PARAMETERS OF A MULTIVARTATE NORMAL POP JRSSB 60307 ESTIMATTON OF PARAMETERS OF A TRUNCATED BIVARIATE JASA 63519 ESTIMATION OF PARAMETERS OF A TRUNCATED POISSONIAN BIOCS6B 377 ESTIMATION OF PARAMETERS OF MIXED EXPONENTIALLY DISTR BIOKA58 504 ESTIMATION OF PARAMETERS OF THE GAMMA DISTRIBUTION BIOKA62 525 IBUTED FAILURE TIME DISTRIBUTIONS FROM CENSORED L/ USING ORDER STATISTICS

USING ORDER STATISTICS.

OBSERVED WEIGHTS OF GROUPS OF PARTICLES CORRIGENDA, 'ESTIMATION OF PARAMETERS OF THE GAMMA DISTRIBUTION ESTIMATION OF PARTICLE SIZE DISTRIBUTION BASED ON THE POPULATION FREOUENCIES OF SPECTES AND THE ESTIMATION OF POPULATION PARAMETERS

D BY MEANS OF THE CAPTURE-RECAPTURE METHOD. I/ THE ESTIMATION OF POPULATION PARAMETERS FROM DATA OBTAINE BI D BY MEANS OF THE CAPTURE-RECAPTURE METHOD. I/ THE ESTIMATION OF POPULATION PARAMETERS FROM DATA OBTAINE BIC MEMBERS

BY FOURIER SERIES METHODS

ON THE ESTIMATION OF POPULATION PARAMETERS FROM MARKED ESTIMATION OF POWER SPECTRA BY A WAVE ANALYZER

THE ESTIMATION OF PROBABILITY DENSITIES AND CUMULATIVES ESTIMATION OF PROBABILITY DENSITY

ESTIMATION OF PROBABILITY DENSITY BY AN ORTHOGONAL

SERIES

DISCUSSION)

OF ESTIMATION

SEQUENTIAL ESTIMATION OF QUANTAL RESPONSE CURVES (WITH

SEQUENTIAL ESTIMATION OF QUANTAL RESPONSE CURVES, A NEW METHOD

SOME ASPECTS OF THE ESTIMATION OF QUANTILES

ESTIMATION OF QUASI-LINEAR TREND AND SEASONAL

VARIATION

ON TWO METHODS OF BIAS REDUCTION IN THE ESTIMATION OF RATIOS

TION OF QUENOUILLE'S METHOD OF BIAS REDUCTION TO THE ESTIMATION OF RATIOS

A NOTE ON THE

BIOKA63 546

TECH $65 \quad 505$

BIOKA53 237 BIOKA55 269 TECH $65 \quad 553$ JASA $6 B \quad 925$ AMS $65 \quad 1027$ AMS 671261 JRSSB63 3 BIOKA66 439 JRSSB66 497 JASA $63 \quad 1033$ BIOKA66 571 BIOKA65 647 WHEN THE JOINT DISTRIBUTION OF THE ERRORS IS/ UALS BY THE USE OF INSTRUMENTAL VARIABLES

THE ESTIMATION OF REGRESSION AND ERROR-SCALE PARAMETERS, BIOKA6I 125

THE ESTIMATION OF RELATIONSHIPS WITH AUTOCORRELATED RESID JRSSB59 91 ROCEDURES FOR USING DISTRIBUTION-FREE METHODS IN THE ESTIMATION OF RELATIVE POTENCY IN DILUTION (-DIRECT) BIOCS66 6IO ON MINIMUM VARIANCE UNBIASED ESTIMATION OF RELIABILITY

AL DISTRIBUTION MINIMUM VARIANCE UNBIASED ESTIMATION OF RELIABILITY FOR THE TRUNCATED EXPONENTI TECH 69 609 ELEMENTS FROM THE SAME EXPONENTIAL DISTRIBU/ POINT ESTIMATION OF RELIABILITY OF A SYSTEM COMPRISED OF K JASA 66 IO29 NCED LEAST-SQUARES PROBLEMS AND THE ROBUSTNES/ THE ESTIMATION OF RESIDUAL VARIANCE IN QUADRATICALLY BALA BI ESTIMATION OF SAMPLE SIZE

DISTRIBUTION USING OR/ SEPARATE MAXIMUM-LIKELIHOOD ESTIMATION OF SCALE OR SHAPE PARAMETERS OF THE GAMMA SERIES, CORR 631162

TESTS AND DESIGNS

THE ESTIMATION OF SEASONAL VARIATION IN ECONOMIC TIME

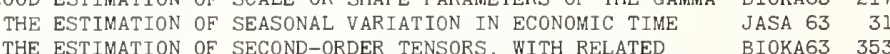

83

TECH $62 \quad 59$ ON 
D BY CENSORED SAMPLES OF GROUPED OBSERVATIONS IN THE ESTIMATION OF STATISTICAL PARAMETERS /ATION SUPPLIE BIOKA62 245 OCESS WITH ADDITTVE WHITE NOTSE OBSERVATIONS ERROR ESTTMATTON OF STOCHASTIC SYSTEMS, ARBTTRARY SYSTEM PR AMS GB TB5 A GENERALIZED APPLICATION OF INSTRUMENTAL VARIABLE ESTIMATION OF STRAIGHT-LINE RELATIONS WHEN BOTH VARIA TECH 69 255 'ACTUARIAL' METHOD MAXIMUM LIKELIHOOD ESTIMATION OF SURVIVAL CURVE PARAMETERS BIOCS68 595 ESTIMATION OF SURVIVORSHIP IN CHRONIC DISEASE, THE JASA 58420

$\begin{array}{ll}\text { THE ESTIMATION OF THE 'SHORT' DISTRIBUTION } & \text { BIOCS69 } 417\end{array}$ ESTIMATION OF THE BISPECTRUM AMS 651120

IONS BASED ON SMALL SAMPLES OF EQUAL SIZE UNBAISED ESTIMATION OF THE COMMON MEAN OF TWO NORMAL DISTRIBUT JASA 66 467 LEAST SQUARES ESTIMATION OF THE COMPONENTS OF A SYMMETRIC MATRIX TECH $66 \quad 360$ ESTIMATION OF THE CROSS-SPECTRUM AMS 631012 ESTIMATION OF THE CROSS-SPECTRUM OF A STATIONARY BIVA JRSSB68 145

RIATE GAUSSIAN PROCESS FROM ITS ZEROS

MAXIMUM LIKELIHOOD ESTIMATION OF THE DISTRIBUTIONS OF TWO STOCHASTICALLY JASA 661067

ORDERED RANDOM VARIABLES

STATISTICAL ESTIMATION OF THE GASOLINE OCTANE NUMBER REQUIREMENT

TECH 60 SELECTION BASIS IN ESTIMATION OF THE GENETIC CORRELATION BI0CS6B 951

SELECTION BASIS
PE FREQUENCIES BY A METHOD OF MAXIMUM LIKELIHOOD/ ESTIMATION OF THE INBREEDING COEFFICIENT FROM PHENOTY BIOCS68 ESTIMATION OF THE INNOVATION VARIANCE OF A STATIONARY JASA 68 TIME SERIES

POINT PROCESS

ON THE ESTIMATION OF THE INTENSITY FUNCTION OF A STATIONARY JRSSB65 332 ESTIMATION OF THE LARGER TRANSLATION PARAMETER AMS 68502

S WITH KNOWN VARIANCES

INTERVAL ESTIMATION OF THE LARGEST MEAN OF K NORMAL POPULATION JASA 69296 ESTIMATION OF THE LARGEST OF TWO NORMAL MEANS JASA $6 B \quad 861$ ESTIMATION OF THE LOCATION OF THE CUSP OF A AMS 6876

CONTINUOUS DENSITY

DISTRIBUTION

ESTIMATION OF THE LOCATION OF THE CUSP OF
A NOTE ON THE ESTIMATION OF THE LOCATION PARAMETER OF THE

JASA $66 \quad 852$

JASA $66 \quad 697$

A SEQUENTIAL PROCEDURE FOR THE FIXED-WIDTH INTERVAL ESTIMATION OF THE MEAN THE PERFORMANCE OF AMS 66 36 RS IN SMALL SAMPLES FROM THE NORMAL DISTRIBUTION, 2. ESTIMATION OF THE MEAN /LES FOR DEALING WITH OUTLIE TECH 69 527 NORMAL POPULATION FROM A CENSORED SAMPLE

ESTIMATION OF THE MEAN AND STANDARD DEVIATION OF A BIOKA52 260

ION BY ORDERED VARIABLES ACCURACY BORR

AVING A PRESCRIBED PROPORTIONAL CLOSEN/

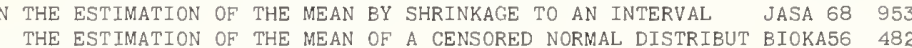

A SINGLY CENSORED SAMPLE

AL ESTIMATION OF THE MEAN OF A LOG-NORMAL DISTRIBUTION H AMS 661688

ON ESTIMATION OF THE MODE

AMS 671446

A TYPE I CENSORED SAMPLE

FERENCE IN THE CLASSICAL OCCUPANCY PROBLEM. UNBIASED

GENOME EXPRESSION DURING VIRAL INFECTION OF BACT/

FOR PHAGE ATTACHMENT TO BACTERIA

DISTRIBUTION

SYSTEM OBEYING TWO SEPARATE REGIMES

DISTRIBUTION

L DISTRIBUTION WHEN ONE VARIABLE IS DICHOTOMISED.

SEQUENCES

ERALIZED GAMMA POPULATION FROM/

RELATION

ESTIMATION OF THE NORMAL POPULATION PARAMETERS GIVEN BIOKA59 150 ESTIMATION OF THE NORMAL POPULATION PARAMETERS GIVEN BIOKA6I 367 ESTIMATION OF THE NUMBER OF CLASSES STATISTICAL IN JASA $6 B 837$ ESTIMATION OF THE NUMBER OF CRITICAL SITES IN LIMITED BIOCS69 537 ESTIMATION OF THE PARAMETER IN THE STOCHASTIC MODEL AMS 68183 ESTIMATTON OF THE PARA

THE ESTIMATION OF THE PARAMETER OF A LINEAR REGRESSION JASA 58873 ESTIMATION OF THE PARAMETER OF AN EXPONENTIAL $\quad$ JRSSB67 525 ESTIMATION OF THE PARAMETERS FOR A MULTIVARIATE NORMA BIOKA65 664 ESTIMATION OF THE PARAMETERS IN SHORT MARKOV JRSSB63 206

ESTIMATION OF THE PARAMETERS OF A LINEAR FUNCTIONAL JRSSB61 160 ULATIONS FROM COMPLETE AND FRO/ MAXIMUM LIKELIHOOD ESTIMATION OF THE PARAMETERS OF GAMMA AND WEIBULL POP TECH 65 639 ULATIONS FROM COMPLET/ ERRATA. 'MAXIMUM-LIKELIHOOD ESTIMATION OF THE PARAMETERS OF GAMMA AND WEIBULL POP TECH 67 195 BY TRUNCATED SAMPLES OF GROUPED OBSERVATIONS IN THE ESTIMATION OF THE PARAMETERS OF NORMAL POPULATIONS BIOKA63 207 OM SINGLY AND DOUBLY/ITERATIVE MAXIMUM-LIKELIHOOD ESTIMATION OF THE PARAMETERS OF NORMAL POPULATIONS FR BIOKAG6 2O5 FROM SMALLEST ORDER STATISTICS MAXIMUM LIKELIHOOD ESTIMATION OF THE PARAMETERS OF THE BETA DISTRIBUTION TECH 67 607 IBUTION BASED ON OPTIMUM ORDER STATISTICS IN CENS/ ESTIMATION OF THE PARAMETERS OF THE EXPONENTIAL DISTR AMS 66 I7I7 TRTBUTION BV USE OF TWO OR THREE ORDER STATISTTCS

N BY SAMPLE QUANTILES

$N$ AND THEIR BIAS

DISTRIBUTION

TION BY SAMPLE QUANTILES

MAXIMUM LIKELIHOOD ESTTMATTON OF THE PARAMETERS OF THE EXTREME VALUE DIS BIOKA69 429 ESTIMATION OF THE PARAMETERS OF THE GAMMA DISTRIBUTIO TECH 64405 ESTIMATION OF THE PARAMETERS OF THE GAMMA DISTRIBUTIO TECH 69 NO.4 ESTIMATION OF THE PARAMETERS OF THE LOGISTIC $\quad$ BIOKA66 565 ESTIMATION OF THE PARAMETERS OF THE LOGISTIC DISTRIBU BIOKA69 NO. 3 - USING THE MINIMUM LOGIT CHI-SQUAR/ A NOTE ON THE ESTIMATION OF THE PARAMETERS OF THE LOGISTIC FUNCTION BIOKA62 250 IAL DISTRIBU/ ASYMPTOTIC OPTIMUM QUANTILES FOR THE ESTIMATION OF THE PARAMETERS OF THE NEGATIVE EXPONENT AMS 66 I43 RMAL POPULATTONS FROM NS A NOTE ON 'THE ESTIMATION OF THE PARAMETERS OF TOLERANCE DISTRIBUTIO BIOKA52 JOINT ESTIMATION OF THE PARAMETERS OF TWO NORMAL JASA $62 \quad 446$ POPULATIONS

TIAL DISTRIBUTIONS FROM CENSORED SAMPLES DISTRIBUTION

ESTIMATION OF THE PARAMETERS OF TWO PARAMETER EXPONEN ON THE ESTIMATION OF THE PROBABILITY DENSITY. I ESTIMATION OF THE PROBABILITY OF AN EVENT AS A ESTIMATION OF THE PROBABILITY OF DEFECTIVE FAILURE ESTIMATION OF THE PROBABILITY OF ZERO FAILURES IN $M$ ESTIMATION OF THE PROBABILITY THAT AN OBSERVATION ESTIMATION OF THE SHAPE AND SCALE PARAMETERS OF THE

FROM DESTRUCTIVE TESTS

BINOMIAL TRIALS

WILL FALL IN A SPECIFIED CLASS

WEIBULL DISTRIBUTION

SEQUENTIAL MAXIMUM LIKELIHOOD ESTIMATION OF THE SIZE OF A POPULATION COMPARISON OF SEQUENTIAL RULES FOR ESTIMATION OF THE SIZE OF A POPULATION

60303 BIOKA52 247 AMS $63 \quad 480$ TECH $63 \quad 459$ JASA $67 \quad 272$ JASA $64 \quad 225$ TECH $63 \quad 175$ AMS 6B 1057 BIOCS69 517 ATE NORMAL DISTRIBUTION IN THE CASE OF A/ REMOVAL THE ESTIMATION OF THE SPECTRAL DENSITY AFTER TREND PRESENCE OF HARMONIC COMPONENTS ESTIMATION OF THE SPECTRAL DENSITY FUNCTION IN THE ESTIMATION OF THE SPECTRUM

A MARKOV PROCESS BANDWIDTH AND VARIANCE IN ESTIMATION OF THE SPECTRUM NONPARAMETRIC ESTIMATION OF THE TRANSITION DISTRIBUTION FUNCTION OF JRSSB58 323 JRSSB64 123 AMS $61 \quad 730$ JRSSB5B 152 AMS 691386 TECH $67 \quad 332$ RELIABILITY ESTIMATION OF THE TRUNCATED EXPONENTIAL MODEL TECH 6733 BAYESIAN ESTIMATION OF THE VARIANCE OF A NORMAL DISTRIBUTION JRSSB64 63 ED BY MEANS OF THE CAPTURE--RECAPTURE METHOD. II. THE ESTIMATION OF TOTAL NUMBERS /ETERS FROM DATA OBTAIN BIOKA52 363
MAXIMUM LIKELIHOOD AND BAYESIAN ESTIMATION OF TRANSITION PROBABILITIES. MAXIMUM LIKELIHOOD AND BAYESIAN ESTIMATION OF TRANSITION PROBABILITIES.

FITTING CONSTANTS

DATA

DESIGNS WITH COMPOSITE SAMPLES

CLASSIFICATION

URTHER REMARKS

TRANSFORMATION A GENERAL APPROACH TO THE ESTIMATION OF VARIANCE COMPONENTS

A NOTE ON THE ESTIMATION OF VARIANCE COMPONENTS BY THE METHOD OF

ITERATIVE ESTIMATION OF VARIANCE COMPONENTS FOR NON-ORTHOGONAL ESTIMATION OF VARIANCE COMPONENTS IN TWO-STAGE NESTED QUADRATIC UNBIASED ESTIMATION OF VARIANCE COMPONENTS OF THE ONE-WAY

TECH $67 \quad 93$ BIOKA69 NO. 3 BIOCS69 NO. 4 373 BIOKA69 313 AMS $68 \quad 1125$ 
WHEN NO MORE THAN TWO FAILURES OCCUR PER LOT AND ANALYSIS OF VARIANCE

DES COURBES DE SURVIE DE MICROORCANISMES IRRADIES PRELIMINARY RECIONAL FORECASTS FOR THE OUTCOME OF

CENERALIZED BAYES SOLUTIONS

ANCILLARY STATISTICS AND PREDICTION OF THE LOSS TY IS PRESENT IN THE SAMPLE

ILIZATION OF A KNOWN COEFFICIENT OF VARIATION IN THE ESTIMATION PROCEDURE

ESIMATION OF WEIBULL DISTRIBUTION SHAPE PARAMETER

TECH $64 \quad 415$

ESTMATION OF WEICHTINC FACTORS IN LINEAR RECRESSION TECH 64 ESTIMATION PAR LA METHODE DU MAXIMUM DE VRAISEMBLANCE BIOCS66 673 AN ESTIMATION PROBLEM

AN ESTIMATION PROBLEM IN QUANTITATIVE ASSAY

JASA 631104

BIOKA54 338

AMS $63 \quad 751$

AMS 681756

AN ESTIMATION PROCEDURE FOR RANGE COMPOSITION PROBLEMS JASA 65308

A CLASS OF SITUATIONS IN WHICH A SEQUENTIAL ESTIMATION PROCEDURE IS NON-SEQUENTIAL

CANCE

MAXIMUM-LIKELIHOOD ESTIMATION PROCEDURES AND ASSOCIATED TESTS OF SIGNIFI JRSSB60 154

TWO-STAGE NESTED PROCE/ COMPARISONS OF DESIGNS AND ESTIMATION PROCEDURES FOR ESTIMATING PARAMETERS IN A TECH 67 499

STATTSTICAL ESTTMATION PROCEDURES FOR THE ' BURN-IN' PROCESS

TECH 6B 51

ND EXTREME-VALUE DISTRIBUTIONS POINT AND INTERVAL ESTIMATION PROCEDURES FOR THE TWO-PARAMETER WEIBULL A

SOME REMARKS ON A METHOD OF A MAXIMUM-LIKELIHOOD ESTIMATION PROPOSED BY RICHARDS

A NEW ESTIMATION THEORY FOR SAMPLE SURVEYS

MINIMUM CHI-SQUARED ESTIMATION USING INDEPENDENT STATISTICS

THE MULTIPLE-RECAPTURE CENSUS II. ESTIMATION WHEN THERE IS IMMIGRATION OR DEATH

ON TWO METHODS ON UNBIASED ESTIMATION WITH AUXILIARY VARIATES

BAYES ESTIMATION WITH CONVEX LOSS

MAXIMUM LIKELIHOOD ESTIMATION WITH INCOMPLETE MULTIVARIATE DATA

VARIANCE ESTIMATION WITH ONE UNIT PER STRATUM

ON AN A.P.O. RULE IN SEQUENTIAL ESTIMATION WITH QUADRATIC LOSS

UNBIASED COMPONENTWISE RATTO ESTIMATION, CORR 631163

OF A LOGISTIC DISTRIBUTION E PARAMETERS OF TY/ CONDITIONAL MAXTMUM-LIKELTHOOD ESTTMATION. FROM SINGLY CENSORED SAMPLES, OF THE SCAL TECH 68 349

LOCATION PARAMETERS A UNIFIED THEORY OF ESTIMATION, I ON NON-REGULAR ESTIMATION. I. VARIANCE BOUNDS FOR ESTIMATORS OF

AMS $61 \quad 112$

JASA 691056 TECH $65 \quad 93$ TECH $67 \quad 353$

ERRTA, SEQUENTIAL FACTORIAL ESTIMATION'

ERRATA 'SIMULTANEOUS NONLINEAR ESTIMATION'

ORITY FOR 'AN OPTIMUM PROPERTY OF MAXIMUM LIKELIHOOD ESTIMATION' 60 12OB

INVARIANCE OF MAXIMUM LIKELIHOOD ESTIMATIONS

THE EXACT DISTRIBUTION OF A STRUCTURAL COEFFICIENT ESTIMATOR

ON THEIL'S MIXED REGRESSION ESTIMATOR

ON A RESTRICTED LEAST SQUARES ESTIMATOR

THE PRECISION OF MICHEY'S UNBIASED RATIO ESTIMATOR

SPECIFICATION AND THE CHOICE OF A K-CLASS ESTIMATOR

ACKNOWLEDGEMENT OF PRI AMS 611343

AMS $66 \quad 744$

JASA $68 \quad 1214$

JASA 69273

JASA 69964

BIOKAG7 321

APPROXIMATE JASA $67 \quad 1265$

PONENTIAL DISTRIB/ THE SAMPLINC DISTRIBUTION OF AN ESTIMATOR ARISING IN CONNECTION WITH THE TRUNCATED EX AMS 69 702

ON A FURTHER ROBUSTNESS PROPERTY OF THE TEST AND ESTIMATOR BASED ON WILCOXON'S SIGNED RANK STATISTIC AMS GB 2B2

AN ESTTMATOR FOR A POPULATION MEAN WHICH REDUCES THE

THE BEHAVIOUR OF AN ESTIMATOR FOR A SIMPLE BIRTH AND DEATH PROCESS

THE HALF-TABLE RATIO ESTIMATOR FOR A SIMPLE EXPONENTIAL MODEL

AN UNBIASED ESTIMATOR FOR POWERS OF THE ARITHMETIC MEAN

A CONSISTENT ESTIMATOR FOR THE IDENTIFICATION OF FINITE MIXTURES

CENERALIZED MULTIVARIATE ESTIMATOR FOR THE MEAN OF FINITE POPULATIONS

A ROBUST POINT ESTIMATOR IN A GENERALIZED REGRESSION MODEI

SOME PROPERTIES OF THE SPEARMAN ESTIMATOR IN BIOASSAY

VARIABLES A/ SOME PROPERTIES OF THE LEAST SQUARES ESTIMATOR IN RECRESSION ANALYSIS WHEN THE 'PREDICTOR TO SIZE WITH REPLACEMENT

A NOTE ON A BIASED ESTIMATOR IN SAMPLING WITH PROBABILITY PROPORTIONAL

A FINITE POP/ BOUNDS FOR THE ERROR-VARIANCE OF AN ESTIMATOR IN SAMPLING WITH VARYING PROBABILITIES FROM J

ON THE HODGES AND LEHMANN SHIFT ESTIMATOR IN THE TWO SAMPLE PROBLEM

SAMPLE SELECTION AND THE CHOICE OF ESTIMATOR IN TWO-WAY STRATIFIED POPULATIONS

JASA $66 \quad 1200$

BIOKA56 23

BIOCS69 420

JRSSB $61 \quad 154$

AMS $69 \quad 1728$

JASA 671009

AMS 691784

BIOKA61 293

AMS 621365

AMS 661045

JASA 68

AMS $66 \quad 1 B 14$

JASA 641054

SS OF DISTRIBUTIONS FOR WHICH THE MAXIMUM-LTKELTHOOD ESTIMATOR IS UNBIASED AND OF MINIMUM VARIANCE FOR ALL BIOKA56 200 ND SUFFICIENCY CONDTTIONS FOR THE MAXIMUM-LIKELIHOOD ESTIMATOR OF AN UNKNOWN PARAMETER IN A SIMPLE MARKOV BIOKA55 342 ND SUFFICIENCY CONDITIONS FOR THE MAXIMUM-LIKELIHOOD ESTIMATOR OF AN UNKNOWN PARAMETER IN A SIMPLE MARKOV BIOKA56 497 TION UNDER/ INADMISSIBILITY OF THE BEST INVARIATE ESTIMATOR OF EXTREME QUANTILES OF THE NORMAL DISTRIBU AMS 69 1BOI APPLICATION OF AN ESTIMATOR OF HIGH EFFICTENCY IN BIVARIATE EXTREME

VING A PRE/ ON THE NON-EXISTENCE OF A FIXED SAMPLE ESTIMATOR OF THE MEAN OF A LOG-NORMAL DISTRIBUTION HA

THE MIDRANGE OF A SAMPLE AS AN ESTIMATOR OF THE POPULATION MIDRANGE

ASYMPTOTIC EFFICIENCY OF AN ASYMPTOTICALLY NORMAL ESTIMATOR SEQUENCE (CORR. 67 196) APPROXTMATTONS TO THE MAXIMUM-LTKELIHOOD ESTTMATOR USTNG CROUPED DATA

ROOTS

EVALUATION OF THE MAXIMUM-LIKELIHOOD ESTIMATOR WHERE THE LIKELIHOOD EQUATION HAS MULTIPLE THE VARIANCE OF AN ESTIMATOR WITH POST-STRATIFIED WEIGHTINC

A NOTE ON THE 'NECESSARY BEST ESTIMATOR'

CONSTRUCTING UNIFORMLY BETTER ESTIMATORS

ON SAMPLINC SCHEMES PROVIDING UNBIASED RATIO ESTIMATORS SEQUENTIAL COMPOUND ESTIMATORS

COMPARTSON OF SOME RATIO ESTIMATORS

ON THE ASYMPTOTIC EFFICIENCY OF LEAST SQUARES ESTIMATORS

A SIMPLE MATHEMATICAL RELATIONSHIP AMONG K-CLASS ESTIMATORS

THE VARIANCE OF WEICHTED REGRESSION ESTIMATORS

A STUDY OF ROBUST ESTIMATORS

THE CONSISTENCY OF CERTAIN SEQUENTIAL ESTIMATORS

ASYMPTOTIC PROPERTIES OF NON-LINEAR LEAST SQUARES ESTIMATORS

ON ROBUST LINEAR ESTIMATORS

STRONG CONSISTENCY OF CERTAIN SEQUENTIAL ESTIMATORS

THE DISTRIBUTION OF MOMENT ESTIMATORS

A COMPARISON OF SEVERAL VARTANCE COMPONENT ESTIMATORS

EPSILON ASYMPTOTIC OPTIMALITY OF EMPIRTCAL BAYES ESTIMATORS

ON MULTIVARIATE RATIO AND PRODUCT ESTIMATORS

INTER-BLOCK INFORMATION TO OBTAIN UNIFORMLY BETTER ESTIMATORS

SITIVITY TO SPECIFICATION ERROR OF DIFFERENT K-CLASS ESTIMATORS
JASA 69 NO. 4

AMS $67 \quad 949$

JASA $57 \quad 537$

JRSSB $63 \quad 195$

BIOKA66 2B2

JASA $62 \quad 622$

JASA 69 NO. 4

JASA $63 \quad 172$

AMS $64 \quad 222$

AMS $65 \quad 879$

JASA $65 \quad 294$

AMS $66 \quad 1676$

$\begin{array}{lll}\text { JASA } & 66 \quad 368\end{array}$

JASA $67 \quad 1290$

AMS $6956 \mathrm{~B}$

AMS $69 \quad 633$

AMS $69 \quad 24$

AMS 691492

BIOKA67 301

BIOKAG9 220

BIOKA69 NO. 3

USE OF AMS 641064

THE RELATIVE SEN JASA $66 \quad 345$
BIOKA66 15I

TECH $67 \quad 652$

BIOKA59 296 
ZELLNER'S SEEMINGLY UNRELATED REGRESSION EQUATIONS ESTIMITORS ORDINARY LEAST SQUARES AND TWO-STAGE LEAST SQUARES ESTIMATORS UARES, WEIGHTED LEAST SQUARES AND MAXIMUM LIKELIHOOD ESTIMATORS MOMENT ESTIMATORS MOMENT ESTIMATORS AI

CORRIGENDA AND MAXIMUM LIKELIHOOD

CORRICENDA, 'MOMENT ESTIMATORS AND MAXIMUM LIKELIHOOD'

LITY SAM/ AN EMPIRICAL STUDY OF THE STABILITIES OF ESTIMATORS AND VARIANCE ESTIMATORS IN UNEQUAL PROBABI JA AGGREGATES AITKEN ESTIMATORS AS A TOOL IN ALLOCATING PREDETERMINED

ENTRAL CHI-SQUAR/ EXPRESSION OF VARIANCE-COMPONENT ESTIMATORS AS LINEAR COMBINATIONS OF INDEPENDENT NONC AND SUFFICIENT CONDITION THAT ORDINARY LEAST-SQUARES ESTIMATORS BE BEST LINEAR UNBIASED COEFFICIENTS SOME ESTIMATORS FOR A LINEAR MODEL WITH RANDOM

THE EFFICIENCIES OF ALTERNATIVE ESTIMATORS FOR AN ASYMPTOTIC REGRESSION EQUATION IMPROVED ESTIMATORS FOR COEFFICIENTS IN LINEAR REGRESSION

TOTIC NORMALITY AND CONSISTENCY OF THE LEAST SQUARES ESTIMATORS FOR FAMILIES OF LINEAR REGRESSIONS ASYMP PARAMETERS MINIMUM VARIANCE UNBIASED ESTIMATORS FOR POISSON PROBABILITTES

DESIGNS ON A COMPLETE CLASS OF LINEAR UNBIASED ESTIMATORS FOR RANDOMIZED FACTORIAL EXPERIMENT GENERALIZED LEAST SQUARES ESTIMATORS FOR RANDOMIZED FRACTIONAL REPLICATION HYPER-ADMISSIBILITY AND OPTIMUM ESTIMATORS FOR SAMPLING FINITE POPULATIONS NS, SOME EXACT FINITE SAMPLE RESULTS ESTIMATORS FOR SEEMINGLY UNRELATED REGRESS REMARKS ON LARGE SAMPLE ESTIMATORS FOR SOME DISCRETE DISTRIBUTIONS SIMULATION STUDY OF ESTIMATORS FOR THE LINE TRANSECT SAMPLING METHOD

ARE SINGLY CENSORED OR TRUNCATED BINOMIAL DISTRIBUTIONS MOMENT EST

THE UNBIASEDNESS OF JASA 67

141 THE EXACT SAMPLING DISTRIBUTION OF JASA 69923 BIOCS68 607 BIOKA58 411 BIOKA59 502 BIOKA6I 474 JASA 69540 JASA 69913 AMS 69 NO.6 JASA $67 \quad 1302$ JASA $68 \quad 584$ BIOKA5B 370 JASA $68 \quad 596$ AMS $63 \quad 447$ AMS 69 NO. 6 TECH $62 \quad 409$ AMS 63769 AMS 64696 AMS $68 \quad 621$ JASA $63 \quad 977$ TECH 67 5B7 BIOCS69 317 TECH 59217 AMS $62 \quad 444$ JRSSB6 2180 AMS $6940 B$ JASA $56 \quad 266$ $\begin{array}{lll}\text { ON ESTIMATORS FOR VARIANCES AND COVARIANCES } & \text { BIOKA62 } & 259 \\ \text { ILE ESTIMATORS FOR WEIBULL PARAMETERS } & \text { TECH } 67 & 119\end{array}$ $\begin{array}{lll}\text { ON ESTIMATORS FOR VARIANCES AND COVARIANCES } & \text { BIOKA62 } & 259 \\ \text { ILE ESTIMATORS FOR WEIBULL PARAMETERS } & \text { TECH } 67 & 119\end{array}$

TIES SOME PERCENTILE ESTIMATORS FOR WEIBULL PARAMETERS $\begin{array}{llllr}\text { DISCRETE DISTRIBUTION ESTIMATORS FROM THE RECURRENCE EQUATION FOR PROBABILI JASA } & 69 & 602 \\ \end{array}$ WHEN ARE GAUSS-MARKOV AND LEAST SQUARES ESTIMATORS IDENTICAL. A COORDINATE-FREE APPROACH CT DISTRIBUTIONS OF THE GENERALIZED CLASSICAL LINEAR ESTIMATORS IN A LEADING THREE-EQUATION CASE $/$ HE EXA JASA 64 BB1 URB/ ASYMPTOTIC DISTRIBUTION OF MAXIMUM LIKELIHOOD ESTIMATORS IN A LINEAR MODEL WITH AUTOREGRESSIVE DIST AMS 69 5B3 THE USE OF EMPIRICAL BAYES ESTIMATORS IN A LINEAR REGRESSION MODEL EMPIRICAL BAYES ESTIMATORS IN A MULTIPLE LINEAR REGRESSION MODEL B BIOKA69 367 COMPARISON OF COMBINED ESTIMATORS IN BALANCED INCOMPLETE BLOCKS AMS $66 \quad 1832$ STRIBUTION FUNCTIONS OF GENERALIZED CLASSICAL LINEAR ESTIMATORS IN ECONOMETRIC STATISTICAL INFERENCE. CORR JASA 63 943 EFFICIENT DIFFERENCE EQUATION ESTIMATORS IN EXPONENTIAL REGRESSION

UNIFORMLY BETTER COMBINED ESTIMATORS IN FACTORIAL ARRANGEMENTS WITH CONFOUNDING JASA 67 638 GROUPING ESTIMATORS IN HETEROSCEDASTIC DATA (CORR. 68 1550) JASA $6 B$ 1B2 CE MATRICES AND BEST AND SIMPLE LEAST SQUARES LINEAR ESTIMATORS IN LINEAR MODELS /NON-NEGATIVE COVARIAN AMS 67 IO92 SOME ESTIMATORS IN SAMPLING WITH VARYING PROBABILITIES WITHOUT REPLACEMENT ON THE EFFECT OF STRAGGLERS ON THE RISK OF SOME MEAN ESTIMATORS IN SMALL SAMPLES UNBIASED RATIO ESTIMATORS IN STATIFIED SAMPLING, CORR, 64 129B FREQUENCY FUNCTIONS OF GENERALIZED CLASSICAL LINEAR ESTIMATORS IN TWO LEADING OVER-IDENTIFIED CASES CT DISTRIBUTIONS OF THE GENERALIZED CLASSICAL LINEAR ESTIMATORS IN TWO LEADING OVER-IDENTIFIED CASES SOME RATIO-TYPE ESTIMATORS IN TWO-PHASE SAMPLING

STUDY OF THE STABILITIES OF ESTIMATORS AND VARIANCE ESTIMATORS IN UNEQUAL PROBABILITY SAMPLING OF TWO UNI JA ON THE LACK OF A UNIFORMLY CONSISTENT SEQUENCE OF ESTIMATORS OF A DENSITY FUNCTION IN CERTAIN CASES CONTINUOUS CASE ESTIMATORS OF A LOCATION

TNESS. A GENERAL METHOD, WITH APPLICATIONS TO LINEAR ESTIMATORS OF LOCATION

ON NON-REGULAR ESTIMATION, I. VARIANCE BOUNDS FOR ESTIMATORS OF LOCATION PARAMETERS ASYMPTOTICALLY NEARLY EFFICIENT ESTIMATORS OF MULTIVARIATE LOCATION PARAMETERS ON THE ADMISSIBILITY OF INVARIANT ESTIMATORS OF ONE OR MORE LOCATION PARAMETERS

ERENCE EQU/CONSISTENCY AND LIMIT DISTRIBUTIONS OF ESTIMATORS OF PARAMETERS IN EXPLOSIVE STOCHASTIC DIFF ASYMPTOTIC PROPERTIES OF SOME ESTIMATORS OF QUANTILES OF CIRCULAR ERROR

AUTOCORRELATED RESTDUALS MAXIMUM LIKELIHOOD ESTIMATORS OF REGRESSION COEFFICIENTS FOR THE CASE OF SAMPLES OF THE MAXIMUM LIKELIHOOD AND BEST UNBIASED ESTIMATORS OF RELIABILITY FUNCTIONS /NCIES IN SMALL JAS
MINIMUM VARIANCE UNBIASED AND MAXIMUM LIKELIHOOD ESTIMATORS OF RELIABILITY FUNCTIONS FOR SYSTEMS IN SE JAS WN LOCATION AND SCAL/ INADMISSIBILITY OF THE USUAL ESTIMATORS OF SCALE PARAMETERS IN PROBLEMS WITH UNKNO SMALL SAMPLE PROPERTIES OF ALTERNATIVE ESTIMATORS OF SEEMINGLY UNRELATED REGRESSIONS ORDER STATISTICS ESTIMATORS OF THE LOCATION OF THE CAUCHY DISTRIBUTION JASA 661205 ND CERTAIN OTHER DISTRIBUTIONS ON SOME PERMISSIBLE ESTIMATORS OF THE LOCATION PARAMETER OF THE WEIBULL A TECH 67 293 TION TO QUANTAL BIOASSAY ON THE BIAS OF VARIOUS ESTIMATORS OF THE LOGIT AND ITS VARIANCE WITH APPLICA BIOKA67 181 UNKNOWN VARIANCES $\begin{array}{llll}\text { ON THE BIAS OF VARIOUS ESTIMATORS OF THE LOGIT AND ITS VARIANCE WITH APPLICA BIOKA67 } & 181 \\ \text { COMBINATIONS OF UNBIASED ESTIMATORS OF THE MEAN WHICH CONSIDER INEQUALITY OF } & \text { JASA } 691042\end{array}$ DISTRIBUTIONS FROM ONE OR TWO ORDER STATI/ OPTIMUM ESTIMATORS OF THE PARAMETERS OF NEGATIVE EXPONENTIAL AMS 63 117 BEST LINEAR UNBTASED ESTTMATORS OF THE PARAMETERS OF THE LOGISTIC DISTRTBU TECH 67 INCOMPLETE BLOCK BEST LINEAR UNBIASED ESTIMATORS OF THE PARAMETERS OF T
MEAN SQUARE EFFICIENCY OF ESTIMATORS OF VARIANCE COMPONENTS ESTIMATORS OF VARIANCE COMPONENTS IN THE BALANCED

R-WAY CLASSIFICATION VARIANCES OF MOMENT ESTIMATORS OF VARIANCE COMPONENTS IN THE UNBALANCED ON THE BIAS OF SOME LEAST-SQUARES ESTIMATORS OF VARIANCE IN A GENERAL LINEAR MODEL ASYMPTOTIC PROPERTIES OF SEVERAL ESTIMATORS OF WEIBULL PARAMETERS

S ON THE SENSITIVITY OF SIMULTANEOUS-EQUATIONS ESTIMATORS TO THE STOCHASTIC ASSUMPTIONS OF THE MODEL J THE JACKKNIFE METHOD.

NOTES . ASSUMPTION-PREE ESTIMATORS USING U STATISTICS AND A RELATI HETEROSCEDASTIC VARIANCE OF WEIGHTED REGRESSION ESTIMATORS WHEN SAMPLING ERRORS ARE INDEPENDENT AND THE ASYMPTOTIC PROPERTIES OF MAXIMUM LIKELIHOOD ESTIMATORS WHEN SAMPLING FROM ASSOCIATED POPULATIONS TAL REFERENE TO TYPE II CENSORE/ AL DISTRIBUTION EFFICIENT MOMENT ESTIMATORS WHEN THE VARIABLES ARE DEPENDENT WITH SPEC BIOKA6? THE BIAS OF MOMENT ESTIMATORS WITH AN APPLICATION TO THE NEGATIVE BINOMI BIOKA6? THE PARAMETERS IN THE BINOMIAL AND POISSON DISTRI/ ESTIMATORS WITH PRESCRIBED BOUND ON THE VARIANCE FOR JASA 66 USE OF DOMAIN ESTIMATORS WITH UNEQUAL PROBABILITY IN SAMPLE SURVEYS JASA 68 E PARAMETER OF A WEIBULL POPUL/ POINT AND INTERVAL ESTIMATORS, BASED ON M ORDER STATISTICS, FOR THE SGAL TEGH 65 SOME FINITE POPULATION UNBAISED RATIO AND REGRESSION ESTIMATORS, GORR. 60755 
THE PRECISION OF UNBIASED RATIO-TYPE ESTIMATORS, CORR. 631162

JASA $58 \quad 491$

OTIC VARIANCES AND COVARIANCES OF MAXIMUM-LIKELIHOOD ESTIMATORS, FROM CENSORED SAMPLES. OF THE PARAMETERS AMS 67557 PROCEDURES AND TABLES FOR EVALUATING DEPENDENT MIXED ACCEPTANCE SAMPLING PLANS TECH 69341

ON THE DISTRIBUTION OF STATISTICS SUITABLE FOR EVALUATING RAINFALL STIMULATION EXPERIMENTS 149

TS MANUFACTURINC HAZARDOUS/A STATISTICAL MODEL OF EVALUATING THE RELIABILITY OF SAFETY SYSTEMS FOR PLAN TECH 59293

THE TRENTILE DEVIATION METHOD OF WEATHER FORECAST EVALUATION

II. AND III ON CASH EQUIVALENTS AND INFORMATION EVALUATION IN DECISIONS UNDER UNCERTAINTY, PARTS I, JASA 68252 AN EVALUATION OF A FUNCTIONAL ON INFINTTELY DIVISIBLE SPECTION PLANS MARKOVIAN DECISION MODELS FOR THE EVALUATION OF A LARGE CLASS OF CONTINUOUS SAMPLINC IN AMS 65 140B

ENT PROCEDURES

$\begin{array}{rlrrr}\text { DESICN AND EVALUATION OF A REPETITIVE CROUP SAMPLING PLAN } & \text { TECH } & 65 & 11 \\ \text { SPECTRAL EVALUATION OF BLS AND CENSUS REVISED SEASONAL ADJUSTM JASA } 68 & 472\end{array}$ APPROXIMATE NUMERICAL RATIONALITY A SUBJECTIVE EVALUATION OF BODE'S LAW AND AN 'OBJECTIVE' TEST FOR JASA 6923 APPROXIMATE NUMERICAL/ DISCUSSION OF 'A SUBJECTIVE EVALUATION OF BODE'S LAW AND AN 'OBJECTIVE' TEST FOR JASA 69 5O EVALUation OF CEnSUS SURVtVAL RATES IN ESTTMATING

THE NUMERICAL EVALUATION OF CERTAIN MULTIVARIATE NORMAL INTECRALS AMS $62 \quad 571$ EVALUATION OF CHEMICAL ANALYSES ON TWO ROCKS TECH 59409

STATISTICAL EVALUATION OF CLOUD SEEDING OPERATIONS

RESEARCH ON METROPOLITAN POPULATION, EVALUATION OF DATA

AND THEIR ROOTS FOR A CLASS OF PATTERNED MATRICES EVALUATION OF DETERMINANTS. CHARACTERISTIC EQUATIONS

ON THE EVALUATION OF DISTRIBUTION FUNCTIONS

THE ASSUMPTION OF WORST CONDITIONS

TESTINC MEANS

THE EVALUATTON OF H 106 CONTINUOUS SAMPLING PLANS UNDER

MULTIVARIATE NORMAL AND T-DISTRIBUTIONS ON THE EVALUATION OF PROBABILITIES OF CONVEX POLYHEDRA UNDER JRSSB66 366 SCORING RULES AND THE EVALUATION OF PROBABILITY ASSESSORS

GRAM TO ESTIMATE MEASUREMENT ERROR IN NONDESTRUCTIVE EVALUATION OF REACTOR FUEL ELEMENT QUALITY A PRO TECH 64293 THE USE OF STATISTICS IN THE FORMULATION AND EVALUATION OF SOCIAL PROGRAMMES DISPUTES

THE LIKELIHOOD EQUATION HAS MULTIPLE ROOTS

EVALUATION OF SPLITTING LIMIT CRITERIA IN MEASUREMEN

A NOTE ON THE EVALUATION OF THE MAXIMUM-LIKELIHOOD ESTIMATOR

BIOKA66 151

EXAMPLES

BIOKADS 458

ION FUNCTIONS

RIATE T DISTRIBUTION

COMPUTER EVALUATION OF THE NORMAL AND INUERSE NORMAL DISTRIBUT TECH 69 NO.4

ON THE EVALUATION OF THE PROBABILITY INTEGRAL OF THE MULTIVA BIOKA6I 409

THE METROPOLITAN AREA CONCEPT AN EVALUATTON OF THE 1950 STANDARD METROPOLITAN AREAS JASA $65-617$

EOUS SELFING AND PARTIAL DIALLEL TEST CROSSINC 2. AN EVALUATION OF TWO METHODS OF ESTIMATION OF GENETIC AN BIOCS67 325

WEIBULL DISTRIBUTION NOTES. ON THE EVALUATION OF VARIABILITY IN ISOGENIC HYBRIDS

BIOCS66 623

BIOKA69 NO. 3

JASA $63 \quad 799$

THE DEVELOPMENT OF NUMERICAL CREDIT EVALUATION SYSTEMS

RESPONSE, A SURVEY TECHNIQUE FOR ELIMINATINC EVASIVE ANSWER BIAS

NON-ORTHOGONAL DESIGNS OF EVEN RESOLUTION

ESTIMATION OF THE PROBABILITY OF AN EVENT AS A FUNCTION OF SEVERAL VARIABLES

ON A SPECIAL CLASS OF RECURRENT EVENTS

POISSON COUNTS FOR RANDOM SEQUENCES OF EVENTS

AMS $61 \quad 1201$

AMS 631217

BIOKA64 405

BIOKA66 3B3

JRSSB $69 \quad 72$

BIOCS69 73

ON MEASURES OF CORRELATION IN TIME SERIES OF EVENTS

OF SEVERAL STRICTLY PERIODIC SEQUENCES OF EVENTS

THE TIMES BETWEEN EVENTS IN A STATIONARY STREAM OF EVENTS

SOME STATISTICAL METHODS CONNECTED WITH SERIES OF EVENTS (WITH DISCUSSION)

THE SUPERPOSITION BIOKA53 I

TRIBUTIONS ASSOCTATED WITH RANDOM WALK AND RECURRENT EVENTS (WITH DISCUSSTON)

ON THE DISTRIBUTTONS OF JRSSB69 NO.2 JRSSB55 129

IONS OF LARCE DISPE/ THE INTERVALS BETWEEN RECULAR EVENTS DISPLACED IN TIME BY INDEPENDENT RANDOM DEVIAT JRSSB61 476 SOME PROPERTIES OF COUNTS OF EVENTS FOR CERTAIN TYPES OF POINT PROCESS

ON THE DISTRIBUTIONS OF THE TIMES BETWEEN EVENTS IN A STATIONARY STREAM OF EVENTS

A SEQUENTIAL TEST OF RANDOMNESS FOR EVENTS OCCURRING IN TIME OR SPACE JRSSB64 325 JRSSB69 N0.2

BIOKA56 64

S OF EQUALITY OF RATE OF OCCURRENCE IN TWO SERIES OF EVENTS OCCURRINC RANDOMLY IN TIME /ENCE OF TWO TEST BIOKA58 267 TESTS FOR RANDOMNESS IN A SERIES OF EVENTS WHEN THE ALTERNATIVE IS A TREND

PERSISTENCE IN A CHATN OF MULTTPLE EVENTS WHEN THERE IS SIMPLE DEPENDENCE

JRSSB56 234

BIOKA62 351

AMS 682154

BOUNDS OF THE PROBABILITY OF A UNION OF EVENTS. WITH APPLICATIONS

SSES TO A BRANCH/ EXTENSIONS OF A LIMIT THEOREM OF EVERETT, ULAM AND HARRIS ON MULTITYPE BRANCHING PROCE AMS 67992 NON-EXISTENCE OF EVERYWHERE PROPER CONDITIONAL DISTRIBUTTONS

ECOLOCY

EXPERIMENTAL EVIDENCE CONCERNING CONTAGIOUS DISTRIBUTIONS IN

AMS 63 IOKA53 186

$\begin{array}{ll}\text { BIOKA53 } & 186 \\ \text { JASA } 64 & 746\end{array}$

INCOME, WEALTH, AND THE DEMAND FOR MONEY, SOME EVIDENCE FROM CROSS-SECTION DATA 2 JASA 64746

ON AND THE UTILITY OF EXPERIMENTS (CORR/ WEIGHT OF EVIDENCE, CORROBORATION, EXPLANATORY POWER, INFORMATI JRSSB6O 319

APPLICATION OF SIMPLEX DESIGNS IN OPTIMISATION AND EVOLUTIONARY OPERATION

CONDENSED CALCULATIONS FOR EVOLUTIONARY OPERATION PROCRAMS

SEQUENTIAL TECH $62 \quad 441$

A SIMPLE SYSTEM OF EVOLUTIONARY OPERATION SUBJECT TO EMPIRICAL FEEDBACK EVOLUTIONARY OPERATION. A REVIEW

(WITH DISCUSSION) EVOLUTIONARY SPECTRAL AND NON-STATIONARY PROCESSES

FOURIER METHODS FOR EVOLVINC SEASONAL PATTERNS

ISN'T MY PROCESS TOO VARIABLE FOR EVOP

TECH 5977

TECH $66 \quad 19$

TECH $66 \quad 389$

JRSSB 65204

JASA $65 \quad 492$

TECH $68 \quad 439$

JASA $61 \quad 518$

EX POST DERXTNATI

REGRESSION WHEN THE INDEPENDENT VARIABLES ARE OR/ EX POST DETERMINATION OF SICNIFICANCE IN MULTIVARIATE JRSSBG7 154
THE HARTLEY-KHAMIS SOLUTION OF THE MOMENT-PROBLEM IS EXACT METHOD OF HANURAV

STATISTIC WITH TIES

AN EXACT (PI)PS SAMPLINC SCHEME, A GENERALIZATION OF A

JRSSB68 556 EXACT AND APPROXTMATE DISTRTBUTIONS FOR THE WILCOXON JASA 61 293 EXACT AND APPROXIMATE POWER FUNCTION OF THE NONAMS $62 \quad 471$

PARAMETRIC TEST OF TENDENCY

O SAMPLE KOLMOGOROV-SMIRNOV CRITERION D-SU/

ON THE EXACT AND APPROXIMATE SAMPLING DISTRIBUTION OF THE TW EXACT AND APPROXIMATE TESTS FOR DIRECTIONS. I EXACT AND APPROXIMATE TESTS FOR DIRECTIONS. II BIOKA62 547

ELIABILITY IN THE CASE OF THE WEIBULL DISTRIBU/ AND KUIPER ONE-SAMPLE AND TWO-SAMPLE STATISTICS L PROBABILITIES FOR SAMPLING WITHOUT REPLACEMEN AN EXACT ASYMPTOTICALLY EFFICIENT CONFIDENCE BOUND FOR R TECH $66 \quad 135$ EXACT BAHADUR EFFICIENCIES FOR THE KOLMOGOROV-SMIRNOV AMS 671475 EXACT BAHADUR EFFICIENCY OF THE TWO-SAMPLE NORMAL SCO BIOKA68
EXACT BAYESIAN ANALYSIS OF A TWO-BY-TWO CONTINGENCY JRSSB69 NO.2 
A RECTANGULA/ THE USE OF SAMPLE RANCES IN SETTING EXACT CONFIDENCE BOUNDS FOR THE STANDARD DEVIATION OF JASA 61 601 FOR THE PARAMETER OF AN EXPONENTTAL POPULATTON EXACT CONFIDENCE BOUNDS, BASED ON ONE ORDER STATISTIC TECH $64 \quad 301$ FOR THE PARAMETER OF A ONE-PARAMETER NE/ ERRATA EXACT CONFIDENCE BOUNDS, BASED ON ONE ORDER STATISTTC TECH 64483 LINEAR RECRESSION LAWS LIMITS FOR A VARIANCE COMPONENT WITH AN $\begin{array}{rlr}\text { EXACT CONFIDENCE COEFFICIENT } & \text { AMS } 61 & 466\end{array}$ EXACT CONEIDENCE REGIONS FOR THE PARAMETERS IN NON- BIOKA64 347 ON THE EXACT COVARIANCE OF PRODUCTS OF RANDOM VARIABLES JASA 69 NO.4 ST STATISTIC FOR DISPERSION AND ITS NORMAL APPROX/ EXACT CRITICAL VALUES FOR MOOD'S DISTRIBUTION-FREE TE TECH 68 497 CRITERIA ESTIMATOR

ON THE EXACT DISTRIBUTION OF A CLASS OF MULTIVARIATE TEST AMS 621197 THE EXACT DISTRIBUTION OF A STRUCTURAL COEFFICIENT JASA 68 I2I4 ON THE EXACT DISTRIBUTION OF A TEST IN MULTIVARIATE ANALYSIS JRSSB58 108 TIC FOR TESTING THE DIFFERENCE BETWEEN THE MSA/ AN EXACT DISTRIBUTION OF THE BEHRENS-FISHER-WELCH STATIS JRSSB6I 377 RALIZED GAMMA VARIABLES WITH THE SAME SHAPE PARAM/ EXACT DISTRIBUTION OF THE PRODUCT OF INDEPENDENT GENE AMS 68 1751 EXACT DISTRIBUTION OP THE PRODUT OF INDEPENDENT GETE AMS 68 1751 AN APPROXIMATION FOR THE EXACT DISTRIBUTION OF THE WILCOXON TEST FOR SYMMETRY JASA 64899 ON THE EXACT DISTRIBUTION OF WILKS'S CRITERION BIOKA69 109 TESTING INDEPENDENCE OF SETS OF VARIATES U/ ON THE EXACT DISTRIBUTIONS OF LIKELIHOOD RATIO CRITERIA FOR AMS 671160 HERICITY IN A P-VARIATE NORMAL DISTRIBUTION AR ESTIMATORS IN TWO LEADING OVER-I/ A NOTE AR ESTIMATORS IN A LEADING THREE-EQUATION/ FOR TESTING LINEAR HYPOTHESES ABOUT REGRES/ COMPOUND SYMMETRY OF A COVARIANCE MATRIX CRITERION

ON THE EXACT DISTRIBUTIONS OF THE CRITERION W FOR TESTINC SP AMS 671170 ON THE EXACT DISTRIBUTIONS OF THE CENERALIZED CLASSICAL LINE JASA 63535 ON THE EXACT DISTRIBUTIONS OF THE CENERALIZED CLASSICAL LINE JASA 64881 ON THE EXACT DISTRIBUTIONS OF THE LIKELIHOOD RATIO CRITERIA AMS 661319 ON THE EXACT DISTRIBUTIONS OF VOTAW'S CRITERIA FOR TESTING AMS 69836 EXACT DISTRIBUTIONS OF WILKS'S LIKELIHOOD RATIO BIOKA66 347 EXACT FIDUCIAL LIMITS IN NON-LINEAR ESTIMATION IZED CLASSI/ REMARKS CONCERNING THE APPLICATION OF EXACT FINITE SAMPLE DISTRIBUTION FUNCTIONS OF GENERAL JASA 63 943 D CLASSICAL LINEAR ESTIMATORS IN TW/ A NOTE ON THE FXACT FINITE SAMPLF FREQUENCY FUNCTIONS OF GENERALIZE JASA 61 619 D CLASSICAL LINEAR ESTIMATORS IN A/ A NOTE ON THE EXACT FINITE SAMPLE FREQUENCY FUNCTIONS OF CENERALIZE JASA 63 16I FOR SEEMINGLY UNRELATED REGRESSION EQUATIONS, SOME EXACT FINITE SAMPLE RESULTS COMPONENTS OF COVARIANCE ADMITTING SUFFICIENT STATISTICS

SAMPLING UNITS WILL OCCUR IN A SAMPLE DRAWN WI/

EXACT FIRST AND SECOND ORDER MOMENTS OF ESTIMATES OF BIOKA69 NO 3 EXACT FORMS OF SOME INVARIANTS FOR DISTRIBUTIONS BIOKA55 533 AN EXACT FORMULA FOR THE PROBABILITY THAT TWO SPECIFIED JASA 66384 ON EXACT CROUPING CORRECTIONS TO MOMENTS AND CUMULANTS BIOKA52 429 TABLES FOR THE MEAN SQUARE ERROR TEST FOR EXACT LINEAR RESTRICTIONS IN REGRESSION

NORMAL DISTRIBUTION

OM THE CHI-DISTRIBUTION, ONE DEGREE OF FREEDOM

PROGRAMMING FISHER S

ISTICS AND THE DISTRIBUTION OF THE RANGE FROM THE/

TICS FROM THE TRUNCATED LOGISTIC DISTRIBUTION

C DISTRIBUTION AND THEIR RELATION TO INVERSE SAMP/ A NOTE ON THE DERIVATION OF SOME

AL LIFE TESTS IN THE EXPONENTIAL CASE AMETERS OF EXPONENTIAL DISTR/ RECTANGULAR ALTERNATIVES

DETERMINATION OF THE

NOTES

SEPARATED NORMAL DISTRIBUTIONS

PAIRED COMPARISONS

MALL MARGINAL/A SIMPLE METHOD OF CALCULATINC KOLMOGOROV-SMIRNOV TYPE

AND TWO-STAGE LEAST SQUARES ESTIMATORS THE EXACT SAMPLING DISTRIBUTION OF ORDINARY LEAST SQUARES JASA 69923 POPULATION CORRECTION, 'CALCULATION ON THE

CROSSOVER DESIGNS
EXACT LINEAR SEQUENTIAL TESTS FOR THE MEA

TTICS IN SAMPLES FR AMS 621292 EXACT MOMENTS AND PRODUCT MOMENTS OF THE ORDER STATIS JASA $66 \quad 514$ EXACT MOMENTS OF THE ORDER STATISTICS OF THE CEOMETRI JASA 67 915 EXACT MULTIVARIATE TESTS BIOKA60 480 EXACT OPERATING CHARACTERISTIC FOR TRUNCATED SEQUENTI AMS 621403 EXACT OPTIMUM ORDER STATISTICS FOR ESTIMATING THE PAR TECH 67279 EXACT POWER OF MANN-WHITNEY TEST FOR EXPONENTIAL AND AMS 66945 PROBABILITIES FOR 2-BY-3 CONTINCENCY TABLES ON EXACT PROBABILITIES OF RANK ORDERS FOR TWO WIDELY AMS 671491 AN EXACT PROBABILITY DISTRIBUTION OVER SAMPLE SPACES OF BIOCS65 986 THE EXACT PROBABILITY IN 2-BY-2 CONTINGENCY TABLES WITH S BIOKA55 522 SOME EXACT RESULTS FOR ONE-SIDED DISTRIBUTION TESTS OF THE AMS 61499 AMS $67 \quad 280$ AMS 69 NO. 6 BIOKA69 75 BIOKA55 316 BIOKA60 393 BIOKA6I 475 TECH $64 \quad 439$ BIOKA6I 41 BIOKA55 133 BIOKA52 17 TECH 69393 BIOKA66 629

SOME EXACT TESTS IN MULTIVARIATE ANALYSIS
EXACT TESTS OF SIGNIFICANCE IN CONTINGENCY TABLES IABLE LIFE FOR A WEIBULL MODEL WITH PROGRESSIVE C/ EXACT THREE, ORDER STATISTIC CONFIDENCE BOUNDS ON REL JASA 69 306
OTHER PROBLEMS OF SIGNIFICANCE NORMAL DISTRIBUTION

DIRECT METHODS FOR EXACT TRUNCATED SEQUENTIAL TESTS OF THE MEAN OF A ON THE EXACT VARIANCE OF PRODUCTS, CORR, 61917

SIS OF A TWO-BY-TWO CONTINGENCY TABLE, AND FISHER'S 'EXACT' SIGNIFICANCE TEST A METHOD OF SAMPLING WITH PROBABILITY EXACTLY PROPORTIONAL TO SIZE EXACT BAYESIAN ANALY JP

THE EXAMINATION AND ANALYSIS OF RESIDUALS

SET OF DATA

ENVIRONMENTAL AND GENETIC TRENDS MARKOV CHAINS WITH ABSORBING STATES, A GENETIC EXAMPLE

EXAMINATION OF A QUANTUM HYPOTHESIS BASED ON A SINGLE EXAMINATION OF A REPEAT MATING DESIGN FOR ESTIMATING TECH 69 NO. 4 JASA $60 \quad 708$ JRSSB 69 NO.2 JRSSB54 236 TECH $63 \quad 141$ BIOKA56 32 BIOCS65 63 AMS $61 \quad 716$ AMS $68 \quad 674$ TECH $62 \quad 421$ DECIMAL CORRECTION ERROR, AN EXAMPLE IN STATISTICS

FUDUCIAL DISTRIBUTIONS AND PRIOR DISTRIBUTIONS, AN EXAMPLE IN WHICH THE FORMER CANNOT BE ASSOCIATED WITH J ON A FIDUCIAL EXAMPLE OF C. STEIN

INFORMATIVE STOPPING RULES NORMALITY FOR CUSUM SCHEMES ASYMPTOTIC EFFICIENCY OF TESTS PROKHOROV METRICS TRANSFER FUNCTION

NED BY MEANS OF THE CAPTURE-RECAPTURE METHOD. IT AN EXAMPLE OP TEP OF THE NEGATIVE BINOMIAL DISTRIBUTION WITH EXAMPLES

TRANSFORM IN STATISTICS. I. CENERAL THEORY AND EXAMPLES

NATION OF PROBABILITIES A PRIORI

ESTIMATES AND LARGE SAMPLE APPROXIMATIONS DESIGNS A SIMPLE EXAMPLE OF A COMPARISON INVOLVING QUANTAL DATA

AN EXAMPLE OF DISCREPANCIES IN INFERENCES UNDER NON-

AN EXAMPLE OF ERRORS INCURRED BY ERRONEOUSLY ASSUMINC

AN EXAMPLE OF LARGE DISCREPANCY BETWEEN MEASURES OF

AN EXAMPLE OF THE DIFFERENCE BETWEEN THE LEVY AND LEVY-

AN EXAMPLE OF THE ESTIMATION OF LINEAR OPEN LOOP ON THE EVALUATION TECH 60 THE USE OF THE HANKEL BIOKA54 BIOKA66 21 JRSSB 66 BIOKA67 329 TECH $67 \quad 457$ AMS $68 \quad 179$ AMS $69 \quad 322$ TECH $63 \quad 227$ AND EXAMPLES THE USE OF THE HANKE EXAMPLES OF LIKELIHOODS AND COMPARISON WITH POINT JRSSB 62118 JASA $69 \quad 468$ AMS $68 \quad 1577$ 
RELATIONS BETWEEN MOMENTS OF ORDER STATISTICS FOR EXCHANGEABLE VARIATES

ON THE METHOD OF INCLUSION AND EXCLUSION
A NOTE ON THE MAXIMUM SAMPLE EXCURSIONS OF STOCHASTIC APPROXIMATION PROCESSES
$S$ ENTRE LES ESPECES ET LES VARIABLES ECOLOGIQUES, UN EXEMPLE /ALES PAR L'ANALYSE STATISTIQUE DES LIAISON
THE RELIABILITY OF COMPONENTS EXHIBITING CUMULATIVE DAMAGE EFFECTS

ON THE METHOD OF INCLUSION AND EXCLUSION
A NOTE ON THE MAXIMUM SAMPLE EXCURSIONS OF STOCHASTIC APPROXIMATION PROCESSES
$S$ ENTRE LES ESPECES ET LES VARIABLES ECOLOGIQUES, UN EXEMPLE /ALES PAR L'ANALYSE STATISTIQUE DES LIAISON
THE RELIABILITY OF COMPONENTS EXHIBITING CUMULATIVE DAMAGE EFFECTS

AMS 69 NO.6 BLOCK DESICNS THE RELIABILITY OF COMPONENTS EXHIBITING CUMULATIVE DAMAGE EFFECTS
THE EXISTENCE AND CONSTRUCTION OF BALANCED INCOMPLETE THE RELIABILITY OF COMPONENTS EXHIBITING CUMULATIVE DAMAGE EFFECTS
BLOCK DESICNS

JASA $67 \quad 102$ AMS $66 \quad 513$ ES ON THE APPLICATION OF GROUP THEORY TO THE EXISTENCE AND NON-EXISTENCE OF ORTHOGONAL LATIN SQUAR BIOKA69 NO.3 RANDOMIZED UNBIASED TEST FOR THE BINOMIAL MARKOV RENEWAL PROCESSES EXISTENCE AND UNIO ENESS OF A UNTFORMLY MOST PONERFUL BIOKA56 465 THE EXISTENCE AND UNIQUENESS OF STATIONARY MEASURES FOR AMS 661439 SUFFICIENT CONDITIONS FOR THE EXISTENCE OF A FINITELY ADDITIVE PROBABILITY MEASURE AMS 67780 A LOG-NORMAL DISTRIBUTION HAVING A PRE/ ON THE NON-EXISTENCE OF A FIXED SAMPLE ESTIMATOR OF THE MEAN OF ERGOD IC THEOREM SYSTEMS STRUCTURE AND THE EXISTENCE OF A SYSTEM LIFE

\section{MOTION}

DISTRIBUTIONS

RELATED TO S-SUB-N-OVER-N

APPLICATI

MARGINALS

GULAR PARTIALLY B/ ON NECESSARY CONDITIONS FOR THE EXISTENCE OF SOME SYMMETRICAL AND UNSYMMETRICAL TRIAN GING FROM ONE SET OF TRE PROBABILITY RATIO TESTS

\section{EXISTENCE. UNIQUENESS AND MONOTONICI
AUGMENTING EXISTING DATA IN MULTIPLE REGRESSION}

NOTE ON SOME SQUARED RANK TESTS WITH EXISTING TIES

A TREE FROM A GRAPH CONSTRUCTED RANDOMLY EXCEPT FOR 'EXOGAMOUS BIAS'

TABLES FOR THE SOLUTION OF THE EXPONENTIAL EQUATION, EXP $(-A)+K A=1$

TABLE FOR THE SOLUTION OF THE EXPONENTIAL EQUATION EXP $(B)-B /(1-P)=1$

AREAS OF THE T-DISTRIBUTION FROM A MILLS' RATIO-LIKE EXPANSION

/FOR THE PROBABILITY OF OBTAINING

- DIRECT AND INVERSE

DIRECT AND INVERSE A QUICKLY CONVERCENT EXPANSION FOR CUMULATIVE HYPERGEOMETRIC PROBABILITIES
DIRECT AND IN/ CORRIGENDA, 'A QUICKLY CONVERGENT EXPANSION FOR CUMULATIVE HYPERGEOMETRIC PROBABILITIES

THE ESTIMATED COVARIANCE MATRIX

NANT FUNCTION

MILL'S RATIO

DENS ITY

AUTORECRESSIVE SCHEMES

CORRELATION COEFFICIENT

CORRELATION COEFFICIENT
AN ASYMPTOTIC EXPANSION FOR POSTERIOR DISTRIBUTIONS

AN ASYMPTOTIC EXPANSION FOR THE DISTRIBUTION OF THE LATENT ROOTS OF

AN ASYMPTOTIC EXPANSION FOR THE DISTRIBUTION OF THE LINEAR DISCRIMI

A NEW ASYMPTOTIC EXPANSION FOR THE NORMAL PROBABILITY INTEGRAL AND PROCESSES GENERATING PERMUTATION EXPANSIONS ASYMPTOTIC EXPANSIONS ASSOCIATED WITH THE N'TH POWER OF A ASYMPTOTIC EXPANSIONS FOR TESTS OF GOODNESS OF FIT FOR LINEAR ASYMPTOTIC EXPANSIONS FOR THE MEAN AND VARIANCE OF THE SERIAL ASYMPTOTIC EXPANSIONS FOR THE MOMENTS OF THE DISTRIBUTION OF TWO EXPANSIONS FOR THE QUADRIVARIATE NORMAL INTEGRAL ON SERIES EXPANSIONS FOR THE RENEWAL MOMENTS

AN APPLICATION OF BIORTHONORMAL EXPANSIONS IN THEORY OF STOCHASTIC PROCESSES POLYNOMIAL EXPANSIONS OF BIVARIATE DISTRIBUTIONS GENERALIZED ASYMPTOTIC EXPANSIONS OF CORNISH-FISHER TYPE INTEGRALS THE USE OF INTEGRAL TRANSFORMS TO DETERMINE EXPANSIONS OF DISTRIBUTION FUNCTIONS

IO CRITERIA FOR COVARIANCE MATRIX EXPANSIONS OF T DENSITIES AND RELATED COMPLETE

IHOOD RATIO CRITERIA FOR MULTIVARIATE/ ASYMPTOTIC EXPANSIONS OF THE DISTRIBUTIONS OF THE LIKELIHOOD RAT ASYMPTOTIC EXPANSIONS OF THE NON-NULL DISTRIBUTIONS OF THE LIKEL MIGRATION EXPECTANCY IN THE UNITED STATES

SUBSTITUTION IN CONDITIONAL EXPECTATION AN EXTREMAL PROPERTY OF THE CONDITIONAL EXPECTATION

AMS $67 \quad 949$ TECH $64 \quad 459$ AMS $69 \quad 79$ AMS $63 \quad 1474$ AMS $69 \quad 715$ AMS $63 \quad 223$ AMS $68 \quad 122 B$ BIOKA69 N0.3 AMS $65 \quad 423$ AMS $63 \quad 34 \mathrm{~B}$ RSSB57 163 AMS $63 \quad 1541$ TECH $68 \quad 73$ TECH $67 \quad 312$ AMS $67 \quad 226$ BIOKA60 439 BIOKA63 177 AMS $63 \quad 335$ BIOKAE4 317 IOKA55 277 AMS 671899 AMS 651153 AMS $63 \quad 12 B 6$ JRSSB62 1777 BIOKA62 139 AMS $67 \quad 1266$ AMS 631302 BI0KA64 459 BIOKA6I B5 BIOKA66 25B BIOKA60 325 BIOKA63 75 JRSSB68 334 AMS $64 \quad 120 B$ AMS $68 \quad 1264$ BIOKA60 460 AMS 67503 AMS 69 NO. 6 AMS $69 \quad 942$ JASA $63 \quad 444$ AMS 6B 377 BIOKA66 594 A ON THE PROBABILITY OF LARGE DEVIATIONS FROM THE EXPECTATION FOR SUMS OF BOUNDED. INDEPENDENT RANDOM $V$ BIOKAG3 52B CONDITIONAL EXPECTATION GIVEN A SIGMA-LATTICE AND APPLICATIONS AMS 651339 CONFIDENCE INTERVALS FOR THE EXPECTATION OF A POISSON VARIABLE

A NOTE ON THE RECIPROCAL OF THE CONDITIONAL EXPECTATION OF A POSITIVE RANDOM VARIABLE CHARACTERIZATIONS OF CONDITIONAL EXPECTATIONS INEQUALITIES OF CHEBYSHEV TYPE INVOLVING CONDITIONAL EXPECTATIONS OR SUM OF INDEPENDENT RANDOM VARIABLES WITH INFINITE EXPECTATIONS ELATION COEFFTCTENTS IN A COMPLEX STATIONARY TME/ A NOTE ON THE RELATIONSHIP BETWEEN EARNING EXPECTATIONS AND NEW CAR PURCHASES $\begin{array}{rr}\text { AMS } & 65 \\ \text { BIOKA59 } & 441\end{array}$ AMS 651302 AMS $67 \quad 415$ AMS 69 N0.6 USTERS AND SMALLEST INTERVALS SOME PROBABILITIES. EXPECTATIONS AND VARIANCES FOR THE IOKA63 213 JASA $59 \quad 575$ FOR GOODNESS-OF-FIT OF THE NEGATIVE BINOMIAL WHEN EXPECTATIONS ARE SMALI FOR GOODNESS-OF-FIT OF THE NEGATIVE BINOMIAL WHEN EXPECTATIONS ARE SMALL
A REPRESENTATION FOR CONDITIONAL EXPECTATIONS GIVEN SIGMA-LATTICES $\begin{array}{rrr}\text { SIZE OF } & \text { LARCEST CL JASA' } 66 & 1191 \\ \text { ON TESTING } & \text { BIOCS69 } & 143\end{array}$ AMS $66 \quad 1279$ RENCE TO ACCIDENTS/ THE CHI-SQUARE TEST FOR SMALL EXPECTATIONS IN CONTINGENCY TABLES. WITH SPECIAL REFE BIOKA59 365 THE ACCURACY AND STRUCTURE OF INDUSTRY EXPECTATIONS IN RELATION TO THOSE OF INDIVIDUAL FIRMS JASA 5B 3I7 SUCCESSIVE CONDITIONAL EXPECTATIONS OF AN INTEGRABLE FUNCTION ON CONDITIONAL EXPECTATIONS OF LOCATION STATISTICS JASA $60 \quad 714$

ENT SIZES SOME RELATIONS BETWEEN EXPECTATIONS OF ORDER STATISTICS IN SAMPLES OF DIFFER BIOKA64 259 CONDITIONAL EXPECTATIONS OF RANDOM VARIABLES WITHOUT EXPECTATIONS AMS 651556 ON EXPECTATIONS OF SOME FUNCTIONS OF POISSON VARIATES BIOGS68 97 EXPECTATIONS, VARIANCES AND COVARIANCES OF 'ANOVA' BIOCS67 105

MEAN SQUARES BY 'SYNTHESIS'

MEAN SQUARES BY 'SYNTHESIS' INTERVAL

STIG FOR ARBITRARY DISTRIBUTIONS

TE OF GENE LOSS OF FOUR METHODS OF REPRODUCING FI

ON EXPECTATIONS, VARIANCES, AND GONVARIANCES OF ANOVA BIOLOGIGAL EXAMPLES OF SMALL EXPEGTED FREQUENGIES E EXPEGTATIONS * MODELS/ALL SAMPLE BIAS DUE TO MISSPE JASA 661130 EXPECTED ARC LENGTH OF A GAUSSIAN PROCESS ON A FINITE JRSSB56 257

THE EXPECTED COVERAGE TO THE LEFT OF THE I'TH ORDER STATI AMS 69644 EXPEGTED EFFEGTS ON THE INBREEDING COEFFICIENT AND RA BIOGS65 447 CHI-SQUARE GOODNESS-OF-FIT TESTS FOR SMALL BUT EQUAL EXPEGTED FREQUENCIES 
CHI-SQUARE GOODNESS OF FIT TEST WITH SMALL BUT EQUAL EXPECTED FREQUENCIES /XIMATION TO THE POWER OF THE JASA 68 912 ION IN WHICH THE ABUNDANCES OF SPECIES ARE LO/ THE EXPECTED FREQUENCIES IN A SAMPLE OF AN ANIMAL POPULAT BIOKA5I 427 ATUS OF AUTOMATIC PRODUCTION AND CONTROL DEVICES AND EXPECTED FUTURE DEVELOPMENTS THE PRESENT ST TECH 66 TECH $66 \quad 73$ LISTING EXPECTED MEAN SQUARE COMPONENTS EXPECTED MEAN SQUARES FOR NESTED CLASSIFICATIONS

ONLY ONE PARENT IS IDENTIFIED PROCESS

THE EXPECTED MEAN SQUARES IN GENETIC EXPERIMENTS WHEN THE EXPECTED NUMBER OF ZEROS OF A STATIONARY GAUSSIAN AMS 651043

MINANT ANALYSIS, NECESSARY SAMPLE SIZE, AND A/ ON EXPECTED PROBABILITIES OF MISCLASSIFICATION IN DISCRI BIOCS68 823 ON SEQUENTIAL TESTS WHICH MINIMIZE THE MAXIMUM EXPECTED SAMPLE SIZE PLANS WHICH APPROXIMATELY MINIMIZE THE MAXIMUM EXPECTED SAMPLE SIZE

RATIO TEST ASYMPTOTIC BEHAVIOR OF EXPECTED SAMPLE SIZE IN CERTAIN ONE-SIDED TESTS
$R$ RANKING PROBLEM A COMPARISON OF THE ASYMPTOTIC EXPECTED SAMPLE SIZES OF TWO SEQUENTIAL PROCEDURES FO AMS 69 NO.6 NAL SELECTION ON NORMAL VARIABLES WITHIN S/ NOTES. EXPECTED SELECTION DIFFERENTIAL FOR POSITIVE DIRECTIO BIOCS67 842 FOR TEST STATISTICS EXPECTED SICNTEICANCE LEVEL AS A SENSITIVITY INDEX ASYMPTOTIC APPROXIMATION TO THE EXPECTED SIZE OF A SELECTED SUBSET FINITE STOPPING TIME AND FINITE EXPECTED STOPPING TIME

A GENERAL THEORY OF SUBJECTIVE PROBABILITIES AND EXPECTED UTILITIES BOUNDED EXPECTED UTILITY EXPECTED UTILITY FOR QUEUES SERVICING MESSAGES WITH

EXPONENTIALLY DECAYING UTILITY ON THE EXPECTED VALUE OF A STOPPED MART TNGALE ON THE EXPECTED VALUE OF A STOPPED STOCHASTIC SEQUENCE ON THE EXPECTED VALUE OF A STOPPED SUBMARTINGALE

A NOTE ON THE EXPECTED VALUE OF AN INVERSE MATRIX OCAL OF A VARTABLE FROM A DECAPITATED NEGATIVE BI/ EXPECTED VALTES AND STANDARD DEVIATIONS OF THE RECIPR JASA 62 439 DETERMINING BOUNDS ON EXPECTED VALUES OF CERTAIN FUNCTIONS A NOTE ON RECURRENCE RELATIONS BETWEEN EXPECTED VALUES OF FUNCTIONS OF ORDER STATISTICS EXPECTED VALUES OF NORMAL ORDER STATISTICS BIOKA6I 151 NUMBER OF TERMS OF THE DAVID-JOHNSON SERIES FOR THE EXPECTED VALUES OF NORMAL ORDER STATISTICS /AFTER A BIOKA6O 79 CORRIGENDA. 'EXPECTED VALUES OF NORMAL ORDER STATISTICS' SOME BOUNDS FOR EXPECTED VALUES OF ORDER STATISTICS AMS 651055 UARES OF NORMAL SCORES THE CURVE THROUGH THE EXPECTED VALUES OF ORDERED VARIATES AND THE SUM OF SQ BIOKA66 252 AN INEQUALITY FOR EXPECTED VALUES OF SAMPLE QUANTILES AMS 671817 EXPECTED-COVER AND LINEAR-UTILITY TOLERANCE INTERVALS JRSSB66 57

PROBLEMS IN ESTIMATING FEDERAL GOVERNMENT EXPENDITURES DEGREES OF TRANSITORY INCOME ON INCOME ELASTICITY OF EXPENDITURES JASA 59717 A STUDY OF RESPONSE ERRORS IN EXPENDITURES EFFECT OF
S DATA FROM HOUSEHOLD INTERVIEWS CREDIT AND INTENTIONS CONSUMER DURABLE GOODS EXPENDITURES
OF DECISION-MAKING AS A RESULT OF LEARNING FROM EXPERIENCE COMPUTER EDITING OF SURVEY DATA, FIVE YEARS OF EXPERIENCE IN BLS MANPOWER SURVEYS THROUGH MIGRATION SCOOLING, EXPERIENCE THE INFORMATION IN AN EXPERIMENT

OF THE BEST TREATMENT IN A PAIRED-COMPARISON EXPERIMENT EFFICIENCY OF CERTAIN RANK TESTS FOR COMPARATIVE EXPERIMENT TOTAL PROBABILITY OF THE UNOBSERVED OUTCOMES OF AN EXPERIMENT OF MORTALITY AND RECRUITMENT FROM A SINGLE TAGGING EXPERIMENT

FREE METHOD OF ANALIZING A 2 TO THE M FACTORIAL EXPERIMENT LINEAR UNBIASED ESTIMATORS FOR RANDOMIZED FACTORIAL EXPERIMENT 2-TO-THE-N ALGORITHM TO ANY COMPLETE FACTORIAL EXPERIMENT

METHOD FOR CULLING RECRUITS FROM A MARK-RECAPTURE EXPERIMENT FRACTIONAL REPLICATE OF A 2 TO THE POWER N FACTORIAL EXPERIMENT QUERY, ANALYSIS OF FACTORIAL EXPERIMENT QUERY, ANALYSIS OF FACTORIAL EXPERIMENT ROLE OF ASSE JASA 03 - 48 54
18 JASA 63648 AMS 69 N0.6 JASA $66 \quad 375$ JASA $67 \quad 875$ $\begin{array}{cr}\text { JRSSB59 } & 67 \\ \text { AMS } 63 & 75\end{array}$ SELECTION AMS $63 \quad 75$ $\begin{array}{rrrr}\text { ASYMPTOTIC } & \text { AMS } & 67 & 90 \\ \text { TMATING THE } & \text { AMS } & 68 & 256\end{array}$ $\begin{array}{lll}\text { ESTIMATING THE AMS } 68 & 256 \\ \text { THE ESTIMATION BIOCS65 } & 529\end{array}$ A DISTRIBUTION- SASJ 68101 N A COMPLETE CLASS OF AMS 63769 THE EXTENSION OF YATES' TECH $68 \quad 575$ A NONPARAMETRIC STATISTICAL BIOCS65 936 ON A SPECIAL SUBSET GIVING AN IRREGULAR JRSSB67 292 (PARTIALLY CONFOUNDED 2-CUBE) TECH $67 \quad 170$ (PARTIALLY CONFOUNDED 2-CUBE) TECH 67490

ATOR RIAL EXPERIMENT (PARTTALLY CONFOUNDED 2-CUBE) (WTTH CONFOUNDTNC) ON AN ELECTRONTC CALCUL JRS BALISM OF THE PUPAL STAGE BY ADULT FLOUR BEETLES, AN EXPERIMENT AND A STOCHASTIC MODEL CANNI BIOCS68 247 CTS AND INTERACTIONS IN A 2 TO THE POWER N FACTORIAL EXPERIMENT AS CALCULATED BY YATES'S ALGORITHM /EFFE BIOCS67 571

ON ESTTMATES FOR FRACTIONS OF A COMPLETE FACTORTAL EXPERTMENT AS ORTHOGONAL LINEAR COMBINATIONS OF THE O AMS 63 IO68 BUYING INTENTIONS AND PURCHASE PROBABILITY. AN EXPERIMENT IN SURVEY DESIGN ARE INADMISSIBLE TREND IN A TIME SERIES R COMBINATIONS THE DESIGN OF AN EXPERIMENT IN WHICH CERTAIN TREATMENT ARRANGEMENTS BIOKA54 287 A SAMPLING EXPERTMENT ON THE POWERS OF THE RECORDS TESTS FOR JRSSB55 115 HEN OBSERVATIONS ARE MISSING FROM A RANDOMISED BLOCK EXPERIMENT WITH ADDITIONAL REPLICATION OF A CONTROL T BIOCS66 632 NOTES. THE ANALYSTS OF A DIAELEL CROSSTNG EXPERTMENT WITH CERTAIN CROSSES MTSSTNG SPACE AN EXPERIMENT WITH WEIGHTED INDEXES OF CYCLICAL BIOCS65 216 JASA $58 \quad 39$ AN EXPERIMENT
OF EXPERIMENT
THE THEORY OF EXPERIMENT . NOTE

A NOTE ON 'A STUDY OF THE GROUP SCREENTNG EXPERTMENT

TECH $63 \quad 39$ ALLY OPTIMAL SEQUENTIAL DESIGN FOR COMPARING SEVERAL EXPERIMENTAL CATEGORIES WITH A CONTROL/ASYMPTOTIC AMS 63 I486 AL FIXED SAMPLE SIZE PROCEDURE FOR COMPARING SEVERAL EXPERIMENTAL CATEGORIES WITH A CONTROL /CALLY OPTIM AMS 64 1571 A SEOUENTIAL PROCEDURE FOR COMPARTNG SEVERAL EXERT ING SPECIES OF TRIBOLIUM AND ITS APPLICATION TO SOME EXPERIMENTAL DATA A STOCHASTIC MODEL FOR TWO COMPET BIOKAG2 THE EFFECTS OF ERRORS IN THE FACTOR LEVELS AND EXPERIMENTAL DESIGN OPTIMAL STOPPING AND EXPERIMENTAL DESIGN MULTIPLE CLASSIFICATION ANALYSIS FOR ARBITRARY EXPERIMENTAL DESIGN THE USE OF A CONCOMITANT VARIABLE IN SELECTING AN EXPERIMENTAL DESIGN EXPERIMENTS WITH ECONOMIC SYSTEMS. THE PROBLEM OF EXPERIMENTAL DESIGN SET OF SIMULTANEOUS EQUATIONS WITH AN APPLICATION TO EXPERIMENTAL DESIGN MINIMUM BIAS ESTIMATION AND EXPERIMENTAL DESIGN NOX RESPNSE SURFACE

TESTING, CORR. 631161 SOME EXPERIMENTAL DESIGN PROBLEMS IN ATTRIBUTE NOTES. STMULTANEOUS CONFIDENCE INTERVALS AND EXPERIMENTAL DESIGN
USE OF A CONCOMITANT VARIABLE IN SELECTING AN EXPERIMENTAL DESIGN FINDING NEW FRACTIONS OF FACTORIAL EXPERIMENTAL DESIGNS OPTIMAL EXPERIMENTAL DESIGNS SOME SYSTEMATIC EXPERIMENTAL DESIGNS

$\begin{array}{crr}\text { MODEL FOR TWO COMPET } & \text { BIOKA62 } \\ & \text { TECH } 63 & 247 \\ & \text { AMS } 66 & 7 \\ & \text { TECH } 68 & 13 \\ & \text { BIOKA57 } & 150 \\ \text { COMPUTER SIMULATION } & \text { JASA } 67 & 1315 \\ \text { R THE SOLUTION OF A } & \text { BIOKA54 } & 190 \\ \text { SURFACES } & \text { TECH } 69 & 461 \\ \text { TTRIBUTE LIFE } & \text { JASA } 62 & 668 \\ \text { ORRELATION } & \text { BIOCS68 } & 434 \\ \text { CORRIGENDA } & \text { TO BIOKA57 } & 534 \\ & \text { TECH } 61 & 359 \\ & \text { AMS } 66 & 783 \\ & \text { BIOKA5 } & 312\end{array}$

BIOKA5I 312 
OF MISSINC AND MIXED-UP OBSERVATIONS IN SEVERAL EXPERIMENTAL DESICNS

MICRO-ORGANISMS EXPERIMENTAL DEVELOPMENT OF NUTRITIVE MEDIA FOR EXPERTMENTAL DVIDENCE CONCERNTNC CONTACTOUS DTSTRTBUT BIOKA68 43 IONS IN ECOLOGY

SOME ASPECTS OF EXPERIMENTAL INFERENCE

THE BEHAVIOUR OF SOME SIGNTFTCANCE TESTS UNDER EXPERTMENTAL RANDOMTZATTON

NITE SAMPLING AND TWO BAYESIANS

THE ROLE OF EXPERIMENTAL RANDOMIZATION IN BAYESIAN STATISTICS, FI BIOKA69 NO.3

SOME EXPERIMENTAL SAMPLING RESULTS FOR REGRESSION ANALYSIS BIOCS67

SOME EXPERIMENTAL SAMPLING RESULTS FOR REGRESSTON ANALYSIS BIOCS68 353

AN EXPERIMENTAL STUDY OF CERTAIN SCREENINC PROCESSES JRSSBG6 BB

THE EXPERIMENTAL STUDY OF PHYSICAL MECHANISMS

STATIONARY DISTRIBUTIONS OF THE NEGATIVE EXPERIMENTAL TYPE FOR THE INFINITE DAM

A TWO-PERIOD DESIGN WITH T-SQUARE EXPERIMENTAL UNITS

A SEQUENTIAL METHOD FOR SCREENINC EXPERIMENTAL VARIABLES

RANDOM BALANCE EXPERIMENTATION

SERIAL DESICNS FOR ROUTINE QUALTTY CONTROL AND EXPERIMENTATTON

SIMULTANEOUS REGRESSION EQUATIONS IN EXPERIMENTATION ECONOMIC CHOICE OF THE AMOUNT OF EXPERIMENTATION

PAIRED COMPARISONS

FACTORIAL EXPERTMENTATION IS EXPER IMENTINC WITH ORGANISMS AS BLOCKS

PARTIAL DUPLICATION OF FACTORIAL EXPERIMENTS

QUICK ANALYSIS METHODS FOR RANDOM BALANCE SCREENING EXPERIMENTS

LOCATINC OUTLIERS IN FACTORIAL EXPERIMENTS

RANDOMIZATION AND FACTORIAL EXPER IMENTS

ON THE FOUNDATIONS OF STATISTICAL INFERENCE, BINARY EXPERTMENTS

IRREGULAR FRACTIONS OF THE 2-TO-THE-N FACTORIAL EXPERIMENTS

UNCERTAINTY, INFORMATION, AND SEQUENTIAL EXPERIMENTS

OPTIMAL STRATECIES IN FACTORIAL EXPERIMENTS

QUERY, MISSING VALUES IN FACTORIAL EXPERIMENTS

ON A MINIMAL ESSENTIALLY COMPLETE CLASS OF EXPERIMENTS

THE ORTHOCONALIZATION OF UNDESIGNED EXPERIMENTS

EXTREME VERTICES DESIGN OF MIXTURE EXPERIMENTS

TESTING HYPOTHESES IN RANDOMIZED FACTORIAL EXPERIMENTS

ON A GENERAL CLASS OF DESIGNS FOR MULTIRESPONSE EXPERIMENTS SEQUENTIAL SELECTION OF EXPERIMENTS

OPTIMAL AND EFFICIENT DESICNS OF EXPERIMENTS COMPUTER AIDED DESIGN OF EXPERIMENTS

CONSTRAINED MAXIMISATION AND THE DESICN OF EXPERIMENTS

THE INTERPRETATION OF INTERACTIONS IN FACTORIAL EXPERIMENTS STATISTICAL CONTROL OF COUNTING EXPERIMENTS

HETEROGENEOUS ERROR VARIANCES IN SPLIT-PLOT EXPERIMENTS SIGNIFICANCE TESTS FOR PAIRED-COMPARISON EXPERIMENTS

ALIASINC IN PARTIALLY CONFOUNDED FACTORIAL EXPERIMENTS

BALANCED CONFOUNDING OF FACTORIAL EXPERIMENTS

CENSORED OBSERVATIONS IN RANDOMIZED BLOCK EXPERIMENTS

ON THE COMPARISON OF THE SENSITIVITIES OF EXPERIMENTS ANALYSIS OF COMPETTTION EXPERIMENTS

SEQUENTIAL COMBINATION CHEMOTHERAPY EXPERIMENTS

ANALYTICAL TECHNIQUE FOR INCOMPLETE BLOCK EXPERIMENTS REFERENCE POPULATIONS FOR DIALLEL EXPERIMENTS

MISSINC VALUES IN PARTIAL DIALLEL CROSS EXPERIMENTS

ON SMALL ORTHOGONAL MAIN EFFECT PLANS FOR FACTORIAL EXPERIMENTS COMPUTER PROGRAMME FOR THE ANALYSIS OF FACTORIAL EXPERIMENTS METHODS FOR INTERNAL COMPARISONS IN MULTIRESPONSE EXPERTMENTS

MAIN-EFFECT PLANS FOR ASYMMETRICAL FACTORIAL EXPERIMENTS

ORIENTED TESTS FOR HOST VARTABILITY IN DILUTTON EXPERTMENTS

NORMAL PLOTS IN INTERPRETING FACTORIAL TWO LEVEL EXPER IMENTS

OF BOTH POSITIVE AND NEGATIVE CONTROLS IN SCREENINC EXPERIMENTS ARIATE ANALYSIS OF VARIANCE TO REPEATED MEASUREMENTS EXPERIMENTS ITIVITIES OF SIMILAR INDEPENDENT AND NON-INDEPENDENT EXPERIMENTS

THE F-TYPE STATISTICS IN THE ANALYSIS OF A CROUP OF EXPERIMENTS OF THE CORRELATION COEFFICIENTS ESTIMATED IN GENETIC EXPERIMENTS OF VARIANCE FOR TWO-LEVEL FACTORIAL REPLICATION-FREE EXPERIMENTS

SOME NON-LINEAR EQUATIONS, USEFUL IN THE DESIGN OF EXPERIMENTS TISTICS SUITABLE FOR EVALUATING RAINFALL STIMULATION EXPERIMENTS ISTRIBUTION-FREE TESTS FOR INTERACTIONS IN FACTORIAL EXPERIMENTS BASED ON PARTIAL OBSERVATIONS IN CERTAIN LIFE TEST EXPERIMENTS TOR OF PARAMETERS IN RANDOMIZED FRACTIONAL FACTORIAL EXPERIMENTS CIAL KIND OF IRREGULAR FRACTIONAL PLANS OF FACTORIAL EXPERIMENTS N. EXPLANATORY POWER, INFORMATION AND THE UTILITY OF EXPERIMENTS

THE APPLICATION OF AUTOMATIC COMPUTERS TO SAMPLING EXPERIMENTS

THEORY OF CYCLIC ROTATION EXPERIMENTS (WITH DISCUSSION)
JRSSB64

OCATION PARAMETERS

NON-EQUIVALENT COMPARISONS OF EXPERIMENTS AND THEIR USE FOR EXPERIMENTS INVOLVING L AMS 61 A NOTE TECH $64 \quad 220$ A CENERAL BIOCS66 503 CRAPHICAL AMS $64 \quad 613$ ORTHOGONAL TECH $62 \quad 21$ GRAPHICALLY BIOCS67 269 USE OF HALF- TECH 59311 THE EFFECTIVE USE BIOCS67 285 APPLICATION OF MULTIV BIOCS66 810 COMPARISON OF THE SENS BIOKA69 17 ON THE DISTRIBUTION OF JRSSB66 526 THE SAMPLING VARIANCE BIOCS66 187 CHAIN-POOLINC ANALYSIS TECH 69 NO 4 THE NUMERICAL SOLUTION OF JRSSB65 466 ON THE DISTRIBUTION OF STA TECH 69 I49 ON A CLASS OF CONDITIONALLY D AMS 69658 A NOTE ON PREDICTION INTERVALS TECH $68 \quad 850$ /D LEAST-SQUARES ESTIMATION OF A SUBVEC AMS 691344 /FFECTS AND THEIR CONNECTION WITH A SPE JASA $63 \quad 497$

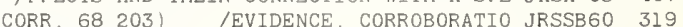
$\begin{array}{lrr}\text { (CORR, } 68 \text { 203) } & \text { JEVIDENCE, CORROBORATIO JRSSB60 } & 319 \\ \text { (WITH DISCUSSION) } & \text { JRSSB54 } & 39\end{array}$ TH THE USE OF PUNCH CARDS, CORR 56650 JASA $56 \quad 149$ 112 
THE DATA

THE PROTOZOA PAR
ANALYSTS OF FACTORIAL EXPERIMENTS BY ESTIMATINC MONOTONE TRANSFORMATIONS OF JRSSB65 N ANALYSIS OF THE DATA FOR SOME EXPERIMENTS CARRIED OUT BY CAUSE WITH POPULATIONS OF BIOKA57 ANALYSIS OF PLANT COMPETITION EXPERIMENTS FOR DIFFERENT RATIOS OF SPECIES

THE SEQUENTIAL DESICN OF EXPERIMENTS FOR INFINITELY MANY STATES OF NATURE THE CHOICE OF VARIABLES IN THE DESIGN OF EXPERIMENTS FOR LINEAR REGRESSION THE DESIGN OF EXPERIMENTS FOR PARAMETER ESTIMATION

SITUATIONS
T/ THE USE OF PRIOR DISTRIBUTIONS IN THE DESIGN OF EXPERIMENTS FOR PARAMETER ESTIMATION IN NON-LINEAR SI BIOKA67

T/ THE USE OF PRIOR DISTRIBUTIONS IN THE DESIGN OF EXPERIMENTS FOR PARAMETER ESTIMATION IN NON-LINEAR SI BIOKA67

S/ BAYES SEQUENTIAL DESIGN OF FRACTIONAL FACTORIAL EXPERIMENTS FOR THE ESTIMATION OF A SUBGROUP OF PRE-A AMS 68 ANALYSTS OF A GROUP OF BALANCED BLOCK EXPERIMENTS HAVINC ERROR VARIANCE AND SOME TREATMENTS BIOC A SUGGESTED METHOD OF ANALYSIS OF A CERTAIN CLASS OF EXPERIMENTS IN CARCINOGENESIS

ASPECTS OF THE STATISTICAL ANALYSIS OF 'SPLIT PLOT' EXPERIMENTS IN COMPLETELY RANDOMIZED LAYOUTS FACTORIAL EXPERIMENTS IN LIFE TESTING

ERRATA. 'FACTORIAL EXPERIMENTS IN LIFE TESTINC'

DESIGN OF EXPERIMENTS IN NON-LINEAR SITUATIONS

RANK METHODS FOR COMBINATION OF INDEPENDENT EXPERIMENTS IN THE ANALYSIS OF VARIANCE

AL DATA

THE CONSTRUCTION OF BALANCED DESIGNS FOR EXPERIMENTS INVOLVING SEOUENCES OF TREATMENTS

RANK TESTS FOR PAIRED-COMPARISON EXPERIMENTS INVOLVING SEVERAL TREATMENTS

BI0CS66 142

SOME JASA $69 \quad 485$

TECH 59269

TECH $60 \quad 121$

BIOKA59 77

AMS $62 \quad 482$

BIOKA52 32

AMS $64 \quad 122$

NS AND MAXIMUM LIKELIHOOD IN THE ANALYSIS OF QUANTAL EXPERIMENTS INVOLVING TWO TREATMENTS /TRANSFORMATIO BIOKA55 3B2

N) ROUTINE ANALYSIS OF REPLICATED EXPERIMENTS ON AN ELECTRONIC COMPUTER (WITH DISCUSSIO JRSSB57

SOME EXPERIMENTS ON THE PREDICTION OF SUNSPOT NUMBERS JRSSB54

THE OCCURRENCE OF REPLICATIONS IN OPTIMAL DESICNS OF EXPERIMENTS TO ESTIMATE PARAMETERS IN NON-LINEAR MODE JRSSB68

THE EXPECTED MEAN SQUARES IN GENETIC EXPERIMENTS WHEN ONLY ONE PARENT IS IDENTIFIED B

TROLLED, CORR. 56650

ANALYSIS OF SENSITIVITY EXPERIMENTS WHEN THE LFVELS OF STTMULUS CANNOT BE CON JASA 56

TIC OBSERVATIONS TN SPLIT PLOT EXPERIMENTS

SYSTEMATIC METHODS TECH 67

EXPERIMENTAL DESIGN

COMPUTER SIMULATION EXPERIMENTS WITH ECONOMIC SYSTEMS. THE PROBLEM OF

JASA 671315

WITH NON-CONSTANT UNKNOWN ERROR VARTANCES, SAMPLINC EXPERI DESIGN AND ANALYSIS OF EXPERIMENTS WITH MIXTURES EXPERIMENTS WITH MIXTURES

AN ALTERNATIVE TO THE SIMPLEX-LATTICE DESIGN FOR EXPERIMENTS WITH MIXTURES EXPERIMENTS WITH MIXTURES (CORR. 59 238)

SIMPLEX-LATTICE DESIGN THE SIMPLEX-CENTROID DESIGN FOR EXPERIMENTS WITH MIXTURES (WITH DISCUSSION) EXPERIMENTS WITH MIXTURES, A GENERALIZATION OF THE

OPTIMAL TESTS OF COMPOSITE HYPOTHESES FOR RANDOMIZED EXPERIMENTS WITH NONCONTROLLED PREDICTOR VARIABLES EXPERIMENTS WITH P-COMPONENT MIXTURES

ESTIMATION OF HERITABILITY FROM EXPERIMENTS WITH RELATED DAMS

2 TO THE POWER OF P FACTORIAL EXPERIMENTS WITH THE FACTORS APPLIED SEQUENTIALLY

FRACTIONAL REPLICATION OF 2-TO-THE-P FACTORIAL EXPERIMENTS WITH THE FACTORS APPLIED SEQUENTIALLY

ASYMPTOTIC SEQUENTIAL DESICN OF EXPERIMENTS WITH TWO RANDOM VARIABLES

ON THE ANALYSIS OF FACTORIAL EXPERIMENTS WITHOUT REPLICATION

A NOTE ON THE ANALYSIS OF INCOMPLETE BLOCK EXPERIMENTS

DEL (CORR. 68 1550) TIES IN PAIRED-COMPARISON EXPERIMENTS OUTLIERS IN PATTERNED EXPERIMENTS

ORE THAN 256 TREATMENT CO/ THE DESIGN OF FACTORIAL EXPERIMENTS, THE COMBINATION OF ESTIMATES FROM SIMILAR EXPERIMENTS,

OF LINEAR AND LOGLINEAR HYPOTHESES IN MULTINOMIAL EXPERIMENTS ERRATA, 'THE ORTHOGONALIZATION OF UNDESIGNED EXPERIMENTS'

A GENERALIZATION OF THE BRADLEY-TERRY MO A STRATEGIC APPRAISAL

AMS $6 B \quad 1517$ JRSSB59 201 JRSSB 69 NO 2

JRSSB5B 344 JRSSB 63235 JRSSB $68 \quad 123$ JASA $65 \quad 699$ JRSSB6B 137 BIOCS69 N0. 4 JASA $64 \quad 1205$ JASA $68 \quad 644$ JRSSB66 73 TECH 59343 BIOKA65 633 A SURVEY OF SOME SCHEMES REQUIRING NOT M BIOKA59 251 ALLOWING FOR INTER-EXPERIMENT VARIATION JASA 67241 CORR. $66 \quad 1246$

LAMP TESTS JASA 6 TECH $66 \quad 731$ BIOKA6I 475 CORRIGENDA, 'SIGNIFICANT TESTS FOR PAIRED-COMPARISON EXPERIMENTS MAIN-EFFECT PLANS FOR ASYMMETRICAL FACTORIAL EXPERIMENTS

DISCUSSION OF 'EXTREME VERTICES DESICN OF MIXTURE EXPERIMENTS ERRATA, 'ORTHOGONAL TECH $62 \quad 440$ THEORETICAL EXPLANATION OF OBSERVED DECREASE FAILURE RATE TECH $66 \quad 455$ TECH $63 \quad 375$ ERIMENTS /CORR/ WEIGHT OF EVIDENCE, CORROBORATION, EXPLANATORY POWER, INFORMATION AND THE UTILITY OF EXP JRSSB6O 319 A DERIVATION OF THE PROBABILISTIC EXPLICATION OF INFORMATION

PENDENT/A NOTE ON THE STATISTICAL TESTABILITY OF 'EXPLICIT CAUSAL CHAINS' ACAINST THE CLASS OF 'INTERDE JA BOTH DEATH AND IMMIGRATION-STOCHASTIC MODEL STOPPING ESTIMATES FROM CAPTURE-RECAPTURE DATA WITH BIOKA65 225 EXPLICIT SOLUTIONS TO SOME PROBLEMS OF OPTIMAL

ECONOMETRIC EXPLORATION OF INDIAN SAVING BEHAVIOR

PRINCIPAL COMPONENTS REGRESSION IN EXPLORATORY STATISTICAL RESEARCH

AMS 69993

JASA $69 \quad 90$

JASA $65 \quad 234$

D LIMIT DISTRIBUTIONS OF ESTIMATORS OF PARAMETERS IN EXPLOSIVE STOCHASTIC DIFFERENCE EQUATIONS /TENCY AN AMS 61 195 DHILE THE INERARRTVAL AND SERVING DISTR TBUTTONS ARE EXPONTT AND WHICH INTERARRIVAL AND SERVING DISTRIBUTIONS ARE EXPONENTIAL AND CENERAL INDEPENDENT RESPECTIVELY / JRSSB59 375 MATION FOR ESTIMATING THE PROPORTIONS IN MIXTURES OF EXPONENTIAL AND NORMAL DISTRIBUTIONS

DISTRIBUTION OF SOME STATISTICS IN SAMPLES FROM EXPONENTIAL AND POWER-FUNCTION POPULATIONS EXACT POWER OF MANN-WHITNEY TEST FOR EXPONENTIAL AND RECTANGULAR ALTERNATIVES FOR LINEAR STOCHASTIC PROCESSES WITH ABSOLUTEL/ DISCRETE MEMORYLESS CHANNEL

AN EXPONENTIAL BOUND ON THE STRONC LAW OF LARGE NUMBERS EXPONENTIAL BOUNDS ON THE PROBABILITY OF ERROR FOR A

FREE AND NON-PARAMETRIC TOLERANCE LIMITS, THE EXPONENTIAL CASE CTERISTIC FOR TRUNCATED SEQUENTIAL LIFE TESTS IN THE EXPONENTIAL CASE THE USE OF AUTOREGRESSION IN FITTING AN EXPONENTIAL CURVE AN INVESTIGATION OF HARTLEY'S METHOD FOR FITTING AN EXPONENTIAL CURVE

A FURTHER NOTE ON A SIMPLE METHOD FOR FITTING AN EXPONENTIAL CURVE OF OBTAINING INITIAL ESTIMATES OF THE PARAMETERS IN EXPONENTIAL CURVE FITTING PARISON OF CONTINUOUS DISTRIBUTIONS OF PARAMETERS OF EXPONENTIAL DECAY CURVES A BIVARIATE EXTENSION OF THE EXPONENTIAL DISTRIBUTION SIMPLIFIED ESTIMATES FOR THE EXPONENTIAL DISTRIBUTION LINEAR FORMS IN THE ORDER STATISTICS FROM AN EXPONENTIAL DISTRIBUTION A CHARACTERIZATION OF THE EXPONENTIAL DISTRIBUTION A NOTE ON THE TRUNCATED EXPONENTIAL DISTRIBUTION A MULTIVARIATE EXPONENTIAL DISTRIBUTION PARAMETER ESTIMATION FOR A MULTIVARIATE EXPONENTIAL DISTRIBUTION A NOTE ON THE TEST FOR THE LOCATION PARAMETER OF AN EXPONENTIAL DISTRIBUTION INFORMATION AND SAMPLING FROM THE EXPONENTIAL DISTRIBUTION TESTING FOR DEPARTURE FROM THE EXPONENTIAL DISTRIBUTION $\begin{array}{rrr}\text { PARAMETER- TECH } & 62 & 75 \\ \text { EXACT OPERATING CHARA AMS } & 62 & 1403\end{array}$ BIOKA58 389

BIOKA59 281 BIOKA60 177 A METHOD BIOCS69 580 A COM BIOCS68 117 AMS $63 \quad 102$ AMS $64 \quad 270$ AMS 641199 AMS 641366 JASA $67 \quad 30$ JASA $68 \quad 848$ AMS 691838 TECH 69 BIOKA57 253 JASA $61 \quad 971$ 
ESTIMATION OF THE PARAMETER OF AN EXPONENTIAL DISTRIBUTION AN ANALYSIS OF DEPARTURES FROM THE EXPONENTIAL DISTRIBUTION NOTES, CHARACTERIZING THE EXPONENTIAL DISTRIBUTION

BUSTNESS OF LIFE TESTING PROCEDURES DERIVED FROM THE EXPONENTIAL DISTRIBUTION TRUNCATION ON A TEST FOR THE SCALE PARAMETER OF THE EXPONENTIAL DISTRIBUTION

OF BOUNDED RELATIVE ERROR FOR THE MEAN LIFE OF AN EXPONENTIAL DISTRIBUTION

AND RELIABILITY ESTIMATION FOR THE TWO PARAMETER EXPONENTIAL DISTRIBUTION UNBIASED ESTIMATION OF RELIABILITY FOR THE TRUNCATED EXPONENTIAL DISTRIBUTION

MOMENTS FOR ESTIMATING THE PARAMETERS OF A MIXED EXPONENTIAL DISTRIBUTION N ESTIMATOR ARISING IN CONNECTION WITH THE TRUNCATED EXPONENTIAL DISTRIBUTION FOR THE ESTIMATION OF THE PARAMETERS OF THE NEGATIVE EXPONENTIAL DISTRIBUTION TY OF A SYSTEM COMPRISED OF $K$ ELEMENTS FROM THE SAME EXPONENTIAL DISTRIBUTION IN CENS/ ESTIMATION OF THE PARAMETERS OF THE EXPONENTIAL DISTRIBUTION BASED ON OPTIMUM ORDER STATI AMS 66 17I7 UM ORDER STATISTICS FOR ESTIMATING THE PARAMETERS OF EXPONENTIAL DISTRIBUTION IN CENSORED SAMPLES /OPTIM TECH 67 279 SEN OR/ ESTIMATION OF ONE OF TWO PARAMETERS OF THE EXPONENTIAL DISTRIBUTION ON THE BASIS OF SUITABLY CHO AMS 63 14I9 NT, C/ ON SOME TESTS OF HYPOTHESES RELATING TO THE EXPONENTIAL DISTRIBUTION WHEN SOME OUTLIERS ARE PRESE JASA 65 54B SEQUENTIAL LIFE FOR THE EXPONENTIAL DISTRIBUTION WITH CHANGING PARAMETER 217 ON THE KOLMOGOROV-SMIRNOV TEST FOR THE EXPONENTIAL DISTRIBUTION WITH MEAN UNKNOWN JBPA BIVARIATE EXPONENTIAL DISTRIBUTIONS

THE METHOD OF MOMENTS APPLIED TO A MIXTURE OF TWO EXPONENTIAL DISTRIBUTIONS JASA $6069 B$ AMS $61 \quad 143$ AMS $66 \quad 1790$ CHARACTERIZATION OF GEOMETRIC AND EXPONENTIAL DISTRIBUTIONS
PROCEDURE FOR TESTING THE EQUALITY OF SEVERAL EXPONENTIAL DISTRIBUTIONS ICABLE TO THE HYPERGEOMETRIC, BINOMIAL, POISSON, AND EXPONENTIAL DISTRIBUTIONS AN ITERATED JASA $63 \quad 435$ / OPTIMUM ESTIMATORS OF THE PARAMETERS OF NEGATIVE EXPONENTIAL DISTRIBUTIONS FROM ONE OR TWO ORDER STATI AMS 63 117 ATES BY ORDER STATISTICS OF THE PARAMETERS OF SINGLE EXPONENTIAL DISTRIBUTIONS FROM SINGLY AND DOUBLY CENS JASA 57 5B TABLE FOR THE SOLUTION OF THE EXPONENTIAL EQUATION EXP(B)-B/(1-P)=1 TABLES FOR THE SOLUTION OF THE EXPONENTIAL EQUATION, EXP $(-A)+K A=1$ LARGE DEVIATIONS THEORY IN EXPONENTIAL FAMILIES

GROUPS INVARIANT PROPER BAYES TESTS FOR EXPONENTIAL FAMILIES ONE-PARAMETER EXPONENTIAL FAMILIES GENERATED BY TRANSFORMATION LOCATION AND SCALE PARAMETERS IN EXPONENTIAL FAMILIES OF DISTRIBUTIONS, CORR, 63 1603
TIONS FOR FUNCTIO/ CHARACTERIZATIONS OF THE LINEAR EXPONENTIAL FAMILTY IN A PARAMETER BY RECURRENCE RELA BIOKA63 177 BIOKA60 439 AMS 681402 AMS 69270 AMS $65 \quad 261$ AMS $62,9 B 6$ AMS 691721 AMS 65 11B5 A HYBRID PROBLEM ON THE EXPONENTIAL FAMILY ON SUFFICIENCY AND THE EXPONENTIAL FAMILY

OF FINITE MIXTURES OF DISTRIBUTIONS FROM THE EXPONENTIAL FAMILY BAYES DECISION FUNCTIONS, ADMISSIBILITY AND THE EXPONENTIAL FAMILY TESTS OF COMPOSITE HYPOTHESES FOR THE MULTIVARIATE EXPONENTIAL FAMILY, CORR, $67 \quad 1928$ N HAS MONOTONE FAILURE RATE ESTIMATION JASA 69 NO. 4 GENERALIZED AMS $67 \quad 818$ AMS 67681 NOTE ON THE INFINITE DIVISIVILITY OF EXPONENTIAL MIXTURES ESTIMATION FOR A ONE-PARAMETER EXPONENTIAL MODEL RELIABILITY ESTIMATION OF THE TRUNCATED EXPONENTIAL MODEL SPEARMAN ESTIMATION FOR A SIMPLE EXPONENTIAL MODEL ESTIMATION FOR A SIMPLE EXPONENTIAL MODEL

THE HALF-TABLE RATIO ESTIMATOR FOR A SIMPLE EXPONENTIAL MODEL THE HALF-TABLE RATIO ESTIMATOR FOR A SIMPLE EXPONENTIAL MODEL
STRIBUTION OF THE REDUCED ITH ORDER STATISTIC OF THE EXPONENTIAL MODEL /UTION OF ORDER STATISTICS AND DI AMS 63 652 SOME APPLICATIONS OF EXPONENTIAL ORDERED SCORES

A CLASS OF SEQUENTIAL TESTS FOR AN EXPONENTIAL PARAMETER CLOSED SEQUENTIAL TESTS FOR AN EXPONENTIAL PARAMETER JASA $67 \quad 548$ AMS 671303 JASA 65560 TECH $67 \quad 332$ BIOC\$65 85B BI0CS67 717 JRSSB 64103 JASA 69 N0. 4 BIOKAGB $3 B 7$ / ADAPTATION OF KARBER'S METHOD FOR ESTIMATING THE EXPONENTIAL PARAMETER FROM QUANTAL DATA. AND ITS RELA BIOCS67 739 ANALYSIS OF SOME RELAY FAILURE DATA FROM A COMPOSITE EXPONENTIAL POPULATION ER SYMMETRIC CENSORING OF THE PARAMETERS OF A DOUBLE EXPONENTIAL POPULATION BASED ON ONE ORDER STATISTIC FOR THE PARAMETER OF AN EXPONENTIAL POPULATION TISTIC FOR THE PARAMETER OF A ONE-PARAMETER NEGATIVE EXPONENTIAL POPULATION ' SEQUENTIAL TESTS FOR BINOMIAL AND EXPONENTIAL POPULATIONS THEOREM OF KARLIN REGARDING ADMISSIBLE ESTIMATES FOR EXPONENTIAL POPULATIONS ARLIN REGARDING ADMISSIBILITY OF LINEAR ESTIMATES IN EXPONENTIAL POPULATIONS ICS, CORR. ESTIMATING THE PARAMETERS OF NEGATIVE EXPONENTIAL POPULATIONS FROM ONE OR TWO ORDER STATIST GENERATING EXPONENTIAL RANDOM VARIABLES

EFFICIENT DIFFERENCE EQUATION ESTIMATORS IN EXPONENTIAL REGRESSION

OF INTERNAL REGRESSION FOR THE FITTING OF THE EXPONENTIAL REGRESSION THE DERIVATION OF METHODS FOR FITTING EXPONENTIAL REGRESSION CURVES BEST LINEAR ESTIMATES UND JASA $66 \quad 24 \mathrm{~B}$ EXACT CONFIDENCE BOUNDS, TECH 64301 IDS, BASED ON ONE ORDER STA TECH $64 \quad 4 B 3$

BIOKA54 252 ON A AMS 69216 ON A THEOREM OF $K$ AMS 661809 AMS 611078 AMS 61899 AMS 6B 1638

THE EFFICIENCY BIOKA59 293 EXPONENTIAL REGRESSION WITH CORRELATED OBSERVATIONS BIOKA6B 149 FURTHER REMARKS ON EXPONENTIAL REGRESSION WITH CORRELATED OBSERVATIONS BIOKA6B 575 ESTIMATING A MIXED-EXPONENTIAL RESPONSE LAW

JASA $61 \quad 493$ TUDY OF SMOKING AND LUNG CANCER, CORR./ COMPETING EXPONENTIAL RISKS. WITH PARTICULAR REFERENCE TO THE S JASA 60 4I5 EXPONENTIAL SMOOTHING FOR MULTIVARIATE TIME SERIES JRSSB66 241 OMPLETE SURVIVAL INFORMATION IN THE ESTIMATION OF AN EXPONENTIAL SURVIVAL PARAMETER /T VARIABLES AND INC BIOCS66 665 INFORMATION ESTIMATION OF EXPONENTIAL SURVIVAL PROBABILITIES WITH CONCOMITANT BIOCS65 826 EXPONENTIAL SURVIVAL WITH COVARIANCE JASA $67 \quad 561$

OF A CONVOLUTION, WHEN THE OTHER COMPONENT IS OF EXPONENTIAL TYPE ESTIMATION OF A COMPONENT TECH 64222 ENT OF A CONVOLUTION, WHEN THE OTHER COMPONENT IS OF EXPONENTIAL TYPE' ERRATA, 'ESTIMATION OF A COMPON TECH 65 462 THE NEGATIVE EXPONENTIAL WITH CUMULATIVE ERROR $\quad$ BIOCS68 363

A CHARACTERIZATION OF THE EXPONENTIAL-TYPE DISTRIBUTION MULTIVARIATE EXPONENTIAL-TYPE DISTRIBUTIONS

ON CERTAIN PROPERTIES OF THE EXPONENTIAL-TYPE FAMILIES

BIOKA63 205 AMS $6 B \quad 1316$ JRSSB65 94 SUMPTION THAT THE UNDERLYING DISTRIBUTION OF LIFE IS EXPONENTIAL, PART I /STS FOR THE VALIDITY OF THE AS TECH 60 83 UMPTIONS THAT THE UNDERLYING DISTRIBUTION OF LIFE IS EXPONENTIAL, PART II /S FOR THE VALIDITY OF THE ASS TECH 60 167 ASYMPTOTIC NORMALITY OF CERTAIN TEST STATISTICS OF EXPONENTIALITY EM/ DISTRIBUTION OF SUM OF IDENTICALLY DISTRIBUTED EXPONENTIALLY CORRELATED GAMMA-VARIABLES, (ACKNOWLEDG AMS 64 277 EXPECTED UTILITY FOR QUEUES SERVICING MESSAGES WITH EXPONENTIALLY DECAYING UTILITY FROM CENSORED L/ ESTIMATION OF PARAMETERS OF MIXED EXPONENTIALLY DISTRIBUTED FAILURE TIME DISTRIBUTIONS OF FAILURE

THE ANALYSIS OF EXPONENTIALLY DISTRIBUTED LIFE-TIMES WITH TWO TYPES AMS $615 B 7$ BIOKA5B 504 JRSSB59 411 BI0KA67 395 TESTING FOR SERIAL CORRELATION WITH EXPONENTIALLY DISTRIBUTED VARIATES OPTIMAL PROPERTIES OF EXPONENTIALLY WEIGHTED FORECASTS, CORR, 62919 

EXPRESSION FOR THE VARIANCE OF THE CHI-SQUARE FUNCTIO BIOKA54 2BO ON THE INDEPENDENCE OF QUADRATIC EXPRESSIONS (CORR 66584 ) AND NEGATIVE MULTINOMI INTEGRAL EXPRESSIONS FOR TAIL PROBABILITIES OF THE MULTINOMIAL BIOKA65 167 F THE OPERATINC CHARACTERISTIC AND AVERAGE/ FORMAL EXPRESSIONS WHICH CAN BE USED FOR THE DETERMINATION O JRSSB67 248 POINTS OF THE 'STUDENTIZED' RANGE EXTENDED AND CORRECTED TABLES OF THE UPPER PERCENTAGE BIOKA52 192

ON AN EXTENDED COMPOUND DECISION PROBLEM AMS 691536

E BLOCK DESIGNS

INVARI ANCE PRINCIPLE TEST STATISTIC

T-DISTRIBUTION RANK STATISTIC

IAL CONFIDENCE INTERVALS FOR THE MEAN TION AND TES/ MULTIVARIATE PAIRED COMPARISONS. THE ION OF A VARIATE IN MULTIPLE REGRESSION ANAL) EXTENDED GROUP DIVISIBLE PARTIALLY BALANCED INCOMPLET PROPERTIES OF THE EXTENDED HYPERGEOMETRIC DISTRIBUTION

ON EXTENDED RATE OF CONVERGENCE RESULTS FOR THE AMS $64 \quad 681$ AMS $65 \quad 938$ AMS 69 NO.6 CORRIGENDA, 'EXTENDED TABLES OF CRITICAL VALUES FOR WILCOXON'S BIOKA64 527 EXTENDED TABLES OF THE PERCENTAGE POINTS OF STUDENT'S JASA 59683 EXTENDED TABLES OF THE WILCOXON MATCHED PAIR SIGNED JASA 65864

AN EXTENSION OF A THEOREM OF CHOW AND ROBBINS ON SEQUENT AMS 69667 HE EXTENSION OF A UNIVARIATE MODEL AND ASSOCIATED ESTIMA BIOKA69 B] EXTENSION OF COCHRAN'S FORMULAE FOR ADDITION OR OMISS JASA $63 \quad 527$ EXTENSION OF FINNEY'S TABLE

A MULTIVARIATE EXTENSION OF FRIEDMAN'S CHI-SQUARE-SUB-R-TEST

ON AN EXTENSION OF GEARY'S THEOREM

AN EXTENSION OF PAULSON'S SELECTION PROCEDURE

AN EXTENSION OF QUENOUILLE'S TEST FOR THE COMPATIBILITY

OF CORRELATION STRUCTURES IN TIME SERIES DISTRIBUTED RANDOM VARIABLES ST VARIANCE RATIO S-SQUARE-MAX-OVER-S-SQUARE-SUB-O AN EXTENSION OF ROSEN'S THEOREM TO NON-IDENTICALLY AN EXTENSION OF THE ARC SINE LAN

SQUARE DISTRIBUTIONS

STATISTIC

THREE ASSOCIATE CLASSES

S CENSORED AT THE SAME FIXED POINT, CORR, 60755 COMPLETE FACTORIAL EXPERIMENT

BLOCK DESIGNS

SAMPLE DISTRIBUTION-FREE TESTS AND THEIR TWO-SAMPLE EXTENSIONS

MARTINGALE EXTENSIONS OF A THEOREM OF MARCINKIEWICZ AND ZYGMUND

ON SOME EXTENSIONS OF BAYESIAN INFERENCE PROPOSED BY MR

SOME EXTENSIONS OF SOMERVILLE'S PROCEDURE FOR RANKING

SOME EXTENSIONS OF THE IDEA OF BIAS

MEANS OF NORMAL POPULATIONS

CHI-SQUARE TESTS WITH ONE DEGREE OF FREEDOM EXTENSIONS OF THE MANTEL-HAENSZEL PROCEDURE CORRECTION. 'SOME EXTENSIONS OF THE WISHART DISTRIBUTION', 44345

THE DANISH POPULATION REGISTER E PROBLEMS

BRANCHING PROCESSES UNDER A SOME ASYMPTOTICALLY EXTINCT SEQUENTIAL PROCEDURES FOR RANKING AND SLIPPAG JRSSB66 370 AGE-DEPENDENT BIOKA6B 291 -DEPENDENT OR PHASE-DEPENDENT THE PROBABILITIES OF EXTINCTION FOR BIRTH-AND-DEATH PROCESSES THAT ARE AGE BIOKA67 579 / HOW TO MINIMIZE OR MAXIMIZE THE PROBABILITIES OF EXTINCTION IN A GALTON-WATSON PROCESS AND IN SOME REL AMS 68 17O0 NG PROCESS WITH DETERMINISTIC REMOVALS THE EXTINCTION OF A BACTERIAL COLONY BY PHAGES. A BRANCHI BIOKA62 272 DECESSARY CONDITIONS FOR ALMOST SURE EXTTNCTTON OF BRANCHING PROCESS WTTH RANDOM ENVIRONME AMS 6B 2I36 BACTERIAL EXTINCTION TIME AS AN EXTREME VALUE PHENOMENON $\quad$ BIOCS67 835 OPTIMUM DESIGNS FOR POLYNOMIAL EXTRAPOLATION ON A THEOREM OF HOEL AND LEVINE ON EXTRAPOLATION A SIMPLE SOLUTION FOR OPTIMAL CHEBYSHEV REGRESSION EXTRAPOLATION A PROBLEM IN MINIMAX VARIANCE POLYNOMIAL EXTRAPOLATION AND INVERSE REGRESSION METHODS OF CALIBRATION IN EXTRAPOLATION QUADRATIC EXTRAPOLATION AND A RELATED TEST OF HYPOTHESES AMS $66 \quad 898$ AMS $66 \quad 720$ QUADRATIC EXTRAPOLATION AND A RELATED TEST OF HYPOTHESES
$N$ FOR OPTIMAL ALLOCATION IN REGRESSION AS APPLIED TO EXTRAPOLATION IN S-N FATIGUE TESTING/N IN PRECISIO TE SERIES STATISTICS STATISTICS NORMAL DISTRIBUTION ON THE EXTRAPOLATION OF A SPECIAL CLASS OF STATIONARY TIME EXTREMA OF QUADRATIC FORMS WITH APPLICATIONS TO CORRIGENDA, 'EXTREMA OF QUADRATIC FORMS WITH APPLICATIONS TO THE OISTRIBUTION OF EXTREMAL AND NEARLY EXTREMAL VALUES IN SAMPLES FROM A ANALYSIS OF EMPIRICAL BIVARIATE EXTREMAL DISTRIBUTIONS SOME ANALYTICAL PROPERTIES OF BIVARIATE EXTREMAL DISTRIBUTIONS

ON EXTREMAL FACTORIZATION AND RECURRENT EVENTS EXTREMAL PROCESSES

AN EXTREMAL PROPERTY OF THE CONDITIONAL EXPECTATION PROBABILITY TABLES FOR THE EXTREMAL QUOTIENT

ON MEASURING THE EXTREME AGED IN THE POPULATION

TABLES OF PERCENTAGE POINTS OF THE 'STUDENTIZED' EXTREME DEVIATE FROM THE SAMPLE MEAN THE SAMPLE MEAN AMONG THE EXTREME NORMAL ORDER STATISTICS ON THE LIMIT BEHAVIOUR OF EXTREME ORDER STATISTICS ON EXTREME ORDER STATISTICS

ON THE MOMENTS OF THE RANGE AND PRODUCT MOMENTS OF EXTREME ORDER STATISTICS IN NORMAL SAMPLES PPROACH TO THE BAYES CHOICE CRITERION. THE METHOD OF EXTREME PROBABILITIES

INADMISSIBILITY OF THE BEST INVARIATE ESTIMATOR OF EXTREME QUANTILES OF THE NORMAL DISTRIBUTION UNDER SQ ON AN EXTREME RANK SUM TEST FOR OUTLIERS ON AN EXTREME RANK SUM TEST WITH EARLY DECISION PERCENTAGE POINTS OF THE EXTREME ROOTS OF A WISHART MATRIX ON ASYMPTOTIC MOMENTS OF EXTREME STATISTICS
60 JASA $56 \quad 644$ AMS 651426 BIOKA59 483 BIOKA61 474 BIOKA63 JASA $64 \quad 794$ JASA $67 \quad 569$ JRSSB69 72 AMS 641718 BIOKA66 594 AMS 671541 BIOKA52 189 AMS $63 \quad 33$ AMS $63 \quad 992$ AMS $64 \quad 1726$ BIOKA56 458 JASA 641227 AMS 691801 BIOKA63 375 JASA $65 \quad 859$ BIOKA68 505 JASA $68 \quad 29$ AMS $64 \quad 1738$ 
REVISED UPPER PERCENTAGE POINTS OF THE EXTREME STUDENTIZED DEVIATE FROM THE SAMPLE MEAN ON THE DISTRIBUTION OF THE EXTREME STUDENTIZED DEVIATE FROM THE SAMPLE MEAN

BIOKA56 449 BIOKA59 467 BIOKA59 473 UPPER PERCENTAGE POINTS OF THE EXTREME STUDENTIZED DEVIATE FROM THE SAMPLE MEAN CEMENT AND EXACT BAHADUR EFFICIENCY OF THE TWO-SA/ EXTREME TAIL PROBABILITIES FOR THE NULL DISTRIBUTION 371 BIOKA67 629 TECH $66 \quad 3$ LINEAR ESTIMATES OF PARAMETERS IN THE EXTREME VALUE DISTRIBUTION

BIOKA69 429 BIOCS67 835 BACTERIAL EXTINCTION TIME AS AN EXTREME VALUE PHENOMENON

OF AN ESTIMATOR OF HIGH EFFICIENCY IN BIVARIATE EXTREME VALUE THEORY ELEMENTS OF THE THEORY OF EXTREME VALUES

FORMULAE FOR THE STATISTICAL DISTRIBUTIONS OF EXTREME VALUES

\section{ICATION}

JASA 69 NO. 4 TECH $66 \quad 363$ TECH $65 \quad 517$ TECH $60 \quad 27$ APPROXIMATE BIOKA58 447 E PARAMETERS OF THE FIRST ASYMPTOTIC DISTRIBUTION OF EXTREME VALUES POPULATIONS DOUBLY CENSORED SAMPLES, O JASA $6 B \quad B 89$ BIOKA67 541 BIOKA54 559 AMS 65993 AMS $63 \quad 1104$ TECH $66 \quad 447$ TECH $66 \quad 455$ PROCESSES

R. A MCLEAN AND V L. ANDERSON THREE DIMENSIONAL MODELS OF EXTREME VERTICES DESIGNS FOR FOUR COMPONENT MIXTURES

SAMPLES THREE DIMENSIONAL MODELS OF EXTREME VERTICES DESIGNS FOR
ANALYSIS OF EXTREME-VALUE DATA BY SAMP

A NOTE ON ESTIMATION FROM A TYPE I EXTREME-VALUE DISTRIBUTION

ENTILES ON THE USE OF THE GENERALIZED EXTREME-VALUE DISTRIBUTION IN
THE TWO-PARAMETER WEIBULL AND EXTREME-VALUE DISTRIBUTIONS IMATION PROCEDURES FOR THE TWO-PARAMETER WEIBULL AND EXTREME-VALUE DISTRIBUTIONS MOMENT CONVERGENCE OF SAMPLE EXTREMES ASYMPTOTIG EXTREMES FOR M-DEPENDENT RANDOM VARIABLES $\begin{array}{lll}\text { POINT AND INTERVAL EST TECH } & 68 & 231 \\ \text { /TIMATION, FROM SINGLY TECH } & 68 & 349\end{array}$

AMS $68 \quad 381$ APPROXIMATE DISTRIBUTION OF EXTREMES FOR NONSAMPLE CASES AMS 641322 EXTREMES IN A RANDOM ASSEMBLY

OF THE DISTRIBUTION OF THE LOGARITHM OF NON-CENTRAL F TO CERTAIN MULTIVARIATE GENERALIZATIONS OF T AND F A NOTE ON APPROXIMATING TO THE NON-CENTRAL F DISTRIBUTION GENERATION OF RANDOM SAMPLES FROM THE BETA AND F DISTRIBUTIONS SOME PROPERTIES BIOKA60 417 A COUNTER-EXAMPLE RELATING AMS $67 \quad 613$ BIOKA66 606 TECH $63 \quad 269$ BIOKA65 415 LAGUERRE SERIES FORMS OF NON-CENTRAL CHI-SQUARE AND F DISTRIBUTIONS APPROXIMATION TO THE CHI-SQUARE AND NON-CENTRAL F PROBABILITY FUNCTIONS ON THE SMALLEST OF SEVERAL CORRELATED F STATISTICS

NORMAL BIOKAGO 411 BIOKA62 509 LLEST LATENT ROOT OF THE GENERALIZED B STATISTIC AND F STATISTICS AND IN MULTIVARIATE ANALYSIS /THE SMA AMS 67 I152 HIERARCHAL DESIGN WITH A MIXED MO/ NOTE. THE QUASI-F TEST FOR AN UNNESTED FIXED FACTOR IN AN UNBALANCED BIOCS66 937 RISTIC CURVES FOR FIXED EFFECTS ANALYSIS OF VARIANCE F TESTS. ALPHA EQUALS 0.01 AND 0.05 YSIS OF VARIANCE TESTS, DERIVED FROM THE NON-CENTRAL F-DISTRIBUTION /ARTS OF THE POWER FUNCTION FOR ANAL BIOKA5I II2 SOME NON-CENTRAL F-DISTRIBUTIONS EXPRESSED IN CLOSED FORM BIOKA64 107 A RELATION BETWEEN T AND F-DISTRIBUTIONS, CORR 651249

UPPER 5 AND 1 PERCENT POINTS OF THE MAXIMUM F-RATIO ELATION BETWEEN THE NUMERATOR AND DENOMINATOR OF THE F-RATIO /-TEST TO ERRORS OF BOTH KINDS AND THE CORR JASA 68 660 EMPIRICAL INVESTIGATION INTO THE DISTRIBUTION OF THE F-RATIO IN SAMPLES FROM TWO NON-NORMAL POPULATIONS BIOKA58 260 NOTES F-RATIO PROBABILITTES FROM BINOMIAL TABLES BIOGS66 404 UPPER PERCENTAGE POINTS OF A SUBSTITUTE F-RATIO USING RANGES BIOKA6I 195

STIGATION THE RANDOMIZATION DISTRIBUTION OF F-RATIOS FOR THE SPLIT-PLOT DESIGN, AN EMPIRICAL INVE BIOKA63 431 DESIGN UNDER THE/ ON THE NULL-DISTRIBUTION OF THE F-STATISTIC IN A RANDOMIZED BALANCED INCOMPLETE BLOCK AMS 63 155B EFFTCIENCY OF THE NORMAL SCORES TEST RELATIVE TO THE F-TEST ON THE CED LEAST-SQUARES PROBLEMS AND THE ROBUSTNESS OF THE F-TEST /OF RESIDUAL VARIANCE IN QUADRATICALLY BALAN BIOKA62 B3 TABLES OF THE POWER OF THE F-TEST (GORR 68 1551)

THE EFFECT OF UNEQUAL GROUP VARIANCES ON THE F-TEST FOR THE HOMOGENEITY OF GROUP MEANS EFFECT OP NONSSOCIATE PARTIALLY BALANCED INCOMPLETE BLO/ ON THE F-TEST IN THE INTRABLOCK ANALYSIS OF A CLASS OF TWO A JASA 65 285 TWEEN THE NUMERATOR AND DENOMIN/ ROBUSTNESS OF THE F-TEST TO ERRORS OF BOTH KINDS AND THE CORRELATION BE JASA 68 660 IGN AN EMPIRICAL STUDY INTO FACTORS AFFECTING THE F-TEST UNDER PERMUTATION FOR THE RANDOMIZED BLOCK DES JASA 68 902 CK D/ SOME MONTE CARLO RESULTS ON THE POWER OF THE F-TEST UNDER PERMUTATION IN THE SIMPLE RANDOMIZED BLO BIOKA66 199 ON THE DISTRIBUTTON OF THE F-TYPE STATISTICS IN THE ANALYSIS OF A GROUP OF EXPER JRSSB66 526 A NORMAL APPROXTMATTON FOR BINOMIAL, F, BETA, AND OTHER COMMON, RELATED TAIL PROBABILITIES JASA 68 IZ II A NORMAL APPROXIMATION FOR BINOMIAL, F, BETA, AND OTHER GOMMON, RELATED TAIL PROBABILITIES JASA 68 1457 HARMONIC ANALYSIS OF THE HUMAN FACE

TABLES TO FACILITATE FITTING S-SUB-U FREQUENCY CURVES

TABLES TO FACILITATE THE COMPUTATION OF PERCENTAGE POINTS OF

THE NON-CENTRAL T-DISTRIBUTION ON THE BUSY PERIOD OF A FACILITY WHICH SERVES CUSTOMERS OF SEVERAL TYPES

LATIN SQUARE

FOUR FACTOR ADDITIVE DESIGNS MORE GENERAL THAN THE GRECO

SQUARE

THREE FACTOR ADDITIVE DESIGNS MORE GENERAL THAN THE LATIN

THE EFFECT OF STANDARDIZATION ON AN APPROXIMATION IN FACTOR ANALYSIS

ANALYSIS OF VARIANCE AS AN ALTERNATIVE TO FACTOR ANALYSIS

USING FACTOR ANALYSIS TO ESTIMATE PARAMETERS

THE PURPOSE AND UNDERLYING MODELS

FACTOR ANALYSIS, AN INTRODUCTION TO ESSENTIALS. I

FACTOR ANALYSIS, AN INTRODUGTION TO ESSENTIALS. 2

THE ROLE OF FACTOR ANALYSIS IN RESEARCH

A CHANGE-OVER DESIGN FOR TESTING A TREATMENT FACTOR AT FOUR EQUALIY SPACED LEVELS (CORR 67 586)

ON A FACTOR AUTOMORPHISM OF A NORMAL DYNAMICAL SYSTEM

IN THE PRESENCE OF RANDOM VARIABILITY THE SINGLE FACTOR CASE NUMERICAL OPTIMIZATIC

FACTOR CHANGES AND LINEAR TRENDS IN EIGHT-RUN TWO

D

SIMPLE METHODS FOR ANALYZING THREE-FACTOR INTERACTION IN CONTINGENCY TABLES

LAMST AND THE HYPOTHESES OF NO THREE FACTOR INTERACTION IN CONTINGENCY TABLES THE EFFECTS OF ERRORS IN THE FACTOR LEVELS AND EXPERIMENTAL DESIGN

INVERSE POLYNOMIALS, A USEFUL GROUP OF MULTI-FACTOR RESPONSE FUNCTIONS

THE FACTORIAL ANALYSIS OF CROP PRODUCTIVITY

A CALCULUS FOR FACTORIAL ARRANGEMENTS

BIOCS65 491

BIOKA65 547

AMS $62 \quad 580$

JRSSB65 361

TECH $62 \quad 361$

TECH $62 \quad 187$ BIOKA51 337 JRSSB57 318

JASA $69 \quad 808$

BIOCS65 190

BIOCS65 405

JRSSB67 370

AMS $66 \quad 1528$

BIOKA69 65 TECH $68 \quad 301$

BI0C\$66 937 JASA $64 \quad 319$ JASA 69207 TEGH $63 \quad 247$ BIOCS66 128 JRSSB54 100 AMS $62 \quad 600$ 


\section{KIND OF IRREGULAR FRACTIONAL P/ SEQUENTIAL FACTORIAL ESTIMATION}

ERRATA, 'SEQUENTIAL FACTORIAL ESTIMATION

A DISTRIBUTION-FREE METHOD OF ANALIZING A 2 TO THE M FACTORIAL EXPERIMENT

CLASS OF LINEAR UNBIASED ESTIMATORS FOR RANDOMIZED FACTORIAL EXPERIMENT OF YATES' 2-TO-THE-N ALGORITHM TO ANY COMPLETE FACTORIAL EXPERIMENT IRREGULAR FRACTIONAL REPLICATE OF A 2 TO THE POWER N FACTORIAL EXPERIMENT QUERY, ANALYSIS OF FACTORIAL EXPERIMENT QUERY, ANALYSIS OF FACTORIAL EXPERIMENT

NIC CALCULATOR ASA $63 \quad 497$ TECH $64 \quad 41$ TECH 6593 SASJ $68 \quad 101$

MAIN EFFECTS AND INTERACTIONS IN A 2 TO THE POWER N FACTORIAL EXPERIMENT AS CALCULATED BY YATES'S ALGORIT BIOCS67 571 $S$ OF THE/ ON ESTIMATES FOR FRACTIONS OF A COMPLETE FACTORIAL EXPERIMENT AS ORTHOGONAL LINEAR COMBINATION AMS 63 1068 FINDING NEW FRACTIONS OF FACTORIAL EXPERIMENTAL DESIGNS ERRATA, 'FINDING NEW FRACTIONS OF FACTORIAL EXPERIMENTAL DESIGNS'

VARIANCE FOR PAIRED COMPARISONS FACTORIAL EXPERIMENTÁTION IN SCHEFFE'S ANALYSIS OF PARTIAL DUPLICATION OF FACTORIAL EXPERIMENTS LOCATING OUTLIERS IN FACTORIAL EXPERIMENTS RANDOMIZATION AND FACTORIAL EXPERIMENTS IRREGULAR FRACTIONS OF THE 2-TO-THE-N FACTORIAL EXPERTMENTS THE EXTENSION TECH $68 \quad 575$ ON A SPECIAL SUBSET GIVING AN JRSSB67 292 (PARTIALLY CONFOUNDED 2-CUBE) TECH $67 \quad 170$ TECH $67 \quad 490$ TECH $61 \quad 359$ TECH $63 \quad 134$ JASA $58 \quad 529$ TECH 5963 TECH $60 \quad 149$ AMS 61270 TECH $61 \quad 479$ TECH $62 \quad 21$ AMS 63780 TECH 64220 TECH $65 \quad 649$ AMS $67 \quad 1494$ BIOKA52 65 BIOKA61 218 BIOKA66 507 BI0CS66 503 ANAL COMPUTER PROGRAMME FOR THE ANALYSIS OF FACTORIAL EXPERIMENTS DISTRIBUTION-FREE TESTS FOR INTERACTIONS IN FACTORIAL EXPERIMENTS F A SUBVECTOR OF PARAMETERS IN RANDOMIZED FRACTIONAL FACTORIAL EXPERIMENTS CORR. 56650

MATIONS OF THE DATA TABULAR ANALYSIS OF FACTORIAL EXPERIMENTS ADD THE USE OF PUNCH CARDS,

P OF PRE-AS/ BAYES SEQUENTIAL DESTGN OF FRACTTONAL FACTORIAL EXPERIMENTS FOR THE ESTIMATION OF A SUBGROU AMS 68 FACTORIAL EXPERIMENTS IN LIFE TESTING ERRATA, 'FACTORIAL EXPERIMENTS IN LIFE TESTING' TECH 59269 TECH $60 \quad 121$ IC METHODS FOR ANALYZING 2-TO-THE-N-TIMES-3-TO-THE-M FACTORIAL EXPERTMENTS WITH APPLICATIONS SEQUENTIALLY 2 TO THE PONER OF P FACTORIAL EXPERIMENTS WITH THE FACTORS APPLIED TIALLY $\begin{array}{rrr}\text { JASA } & 64 & 1205 \\ \text { JASA } & 68 & 644\end{array}$ FRACTIONAL REPLICATION OF 2-TO-THE-P FACTORIAL EXPERIMENTS WITH THE FACTORS APPLI ON THE ANALYSIS OF FACTORIAL EXPERIMENTS WITHOUT REPLICATION RING NOT MORE THAN 256 TREATMENT CO/ THE DESTGN OF FACTORTAL EXPERTMENTS A SURVEY OF SOME SCHEMES REQUI BTOKA59 25I 'ORTHOGONAL MAIN-EFFECT PLANS FOR ASYMMETRICAL FACTORIAL EXPERIMENTS' CORRECTIONS TO 'A THEOREM ON FACTORIAL MOMENTS AND ITS APPLICATIONS' 50206 ERRATA, TECH $62 \quad 440$ AMS $61 \quad 620$ BIOKA54 555 TECH $62 \quad 47$ TECH $69 \quad 477$ BETWEEN LINE SEGMENTS THE FACTORTAL MOMENTS OF THE DISTRIBUTION OF JOINS SYMMETRICAL AND ASYMMETRICAL FRACTIONAL FACTORIAL PLANS SEQUENCES OF TWO-LEVEL FRACTIONAL FACTORIAL PLANS REPRESENTATIONS FOR SOME RESOLUTION VI FRACTIONAL FACTORIAL PLANS SOME TWO-LEVEL FACTORIAL PLANS WTTH SPLIT PLOT CONFOUNDING THE ORTHOGONAL POLYNOMIALS OF THE FACTORIAL POWER SERIES PROBABILITY DISTRIBUTIONS ON CONSTRUCTING THE FACTORIAL REPLICATES OF THE TWO TO THE POWER OF M DESIGNS WITH BLOCKS RIANCE FOR TWO-LEVEL FACTORTAL REPLICATTON-FREE EXPERIMENTS

CHAIN-POOLING ANALYSIS OF VARIANCE FOR TWO-LEVEL FACTORIAL REPLICATION-FREE EXPERIMENTS
TOR INTERACTIONS FOR THE 2-TO-THE-N TIMES 3-TO-THE-N FACTORIAL SERIES OF DESIGNS/IMATION OF ALL TWO-FAC FACTORIAL TREATMENTS IN RECTANGULAR LATTICE DESIGNS USE OF HALF-NORMAL PLOTS IN INTERPRETING FACTORIAL TWO LEVEL EXPERIMENTS AND QUADRATIC TRENDS FACTORTAL 2-TO-THE-'P-Q' PLANS ROBUST AGATNST LINEAR ELEMENTS FROM DISTINCT FINITE FIELDS IN MIXED FACTORIALS SS OF NON-ORTHOGONAL MAIN EFFECT PLANS IN K TO THE N FACTORIALS/APPROACH FOR CONSTRUCTING A USEFUL CLA J COMPOSITE DESTGNS BASED ON IRREGULAR FRACTIONS OF FACTORIALS (CORR. 65 1036)

ON EXTREMAL FACTORIZATION AND RECURRENT EVENTS A NOTE ON AN APPROXIMATE FACTORIZATION IN DISCRIMINANT ANALYSIS

RIATE AUTOREGRESSIONS, AND THE APPROXIMATE CANONICAL FACTORIZATION OF A SPECTRAL DENSITY MATRIX FACTORTZATION OF MATRICES BY LEAST-SQUARES SPECTRAL FACTORIZATION OF MULTIPLE TIME SERIES

DESIGNS FOR THE SEQUENTIAL APPLICATION OF FACTORS MIXTURE DESIGNS FOR THREE FACTORS MIXTURE DESIGNS FOR FOUR FACTORS THE GENERAL NON-ORTHOGONAL LAYOUT WITH ANY NUMBER OF FACTORS ANALYZING VARIANCES WHICH ARE AFFECTED BY SEVERAL FACTORS WHEN THE BIRTH AND DEATH RATES DEPEND UPON SEVERAL FACTORS MAIN-EFFECT ANALYSIS OF AMS $65 \quad 88$ A MULTIPLICATIVE MODEL FOR JASA $60 \quad 245$ E RANDOMTZED BLOCK DESTGN AN FMPIRTCAL STUDY INTO FACTORS AN EMPIRICAL STUDY INTO FACTORS AFFECTING THE F-TEST UNDER PERMUTATION FOR TH JASA 68902 
FOR CHI APPROXIMATION TO THE RANCE

SCALE FACTORS AND DECREES OF FREEDOM FOR SMALL SAMPLE SIZES BIOKA53 449

2 TO THE POWER OF P FACTORIAL EXPERIMENTS WITH THE FACTORS APPLIED SEQUENTIALLY

ICATION OF 2-TO-THE-P FACTORIAL EXPERIMENTS WITH THE FACTORS APPLIED SEQUENTIALLY

RESPONSE SURFACE DESIGNS FOR THREE FACTORS AT THREE LEVELS

RESPONSE SURFACE DESIGNS FOR FACTORS AT TWO AND THREE LEVELS

FRACTIONAL REPL JASA $6 B \quad 644$

$S$ FOR SAMPLES FROM A NORMAL DISTRIBUTION

FACTORS FOR CALCULATING TWO-SIDED

TECH $6 \mathrm{~B} \quad 177$

TABLES OF TOLERANCE-LIMIT FACTORS FOR NORMAL DISTRIBUTIONS

ERRATA, 'TABLES OF TOLERANCE-LIMIT FACTORS FOR NORMAL DISTRIBUTIONS

A NOTE ON THE MULTIPLYING FACTORS FOR VARIOUS CHI-SQUARE APPROXIMATIONS

JASA $69 \quad$ B7

TECH 60483

TECH $61 \quad 576$

JRSSB54 296

BIOKA62 255

A NOTE ON DIRECTION AND COLLINEARITY FACTORS IN CANONICAL ANALYSIS

ON THE DISTRIBUTIONS OF DIRECTION AND COLLINEARITY FACTORS IN DISCRIMINANT ANALYSIS

AMS $68 \quad 855$

ESTIMATION OF WEIGHTING FACTORS IN LINEAR REGRESSION AND ANALYSIS OF VARIANCE TECH 64

THIRD ORDER ROTATABLE DESICNS IN THREE FACTORS ANALYSIS QUERY, LIFE TESTINC AND EARLY FAILURE

TECH $62 \quad 219$

TECH $66 \quad 539$

PONENTIALLY DISTRIBUTED LIFE-TIMES WITH TWO TYPES OF FAILURE

REDUNDANT SYSTEMS WHEN TESTS ARE TERMINATED AT FIRST FAILURE

AN /SIAN CONFIDENCE LIMITS FOR RELIABILITY OF

JRSSB59 41

IONS A METHOD FOR DISCRIMINATING BETWEEN FAILURE DENSITY FUNCTIONS USED IN RELIABILITY PREDICT

ESTIMATION OF THE PROBABILITY OF DEFECTIVE FAILURE FROM DESTRUCTIVE TESTS

29

EFFECTS OF SLOW-DOWNS AND FAILURE ON STOCHASTIC SERVICE SYSTEMS

POISSON PROCESS MODEL FOR THE ANALYSIS OF COMPUTER FAILURE PATTERNS (WITH DISCUSSION) THEORETICAL EXPLANATION OF OBSERVED DECREASE FAILURE RATE

IKELIHOOD ESTIMATION FOR DISTRIBUTIONS WITH MONOTONE FAILURE RATE

TEST PROCEDURES WHEN THE DISTRIBUTION HAS MONOTONE FAILURE RATE

SAFE LIFE FOR CLASSES OF DISTRIBUTIONS CLASSIFIED BY FAILURE RATE

RELATIONSHIP BETWEEN SYSTEM FAILURE RATE AND COMPONENT FAILURE RATES

OPTIMAL STATISTICS IN SOME MODELS WITH INCREASING FAILURE RATE AVERACE

A NOTE ON TESTS FOR MONOTONE FAILURE RATE BASED ON INCOMPLETE DATA TEST FOR MONOTONE FAILURE RATE BASED ON NORMALIZED SPACING

FIDENCE LIMITS FOR CLASSES OF DISTRIBUTIONS BASED ON FAILURE RATE, CORR, 67950 TOLERANCE AND CON TESTS FOR MONOTONE FAILURE RATE, II

LATIONSHIP BETWEEN SYSTEM FAILURE RATE AND COMPONENT FAILURE RATES

TECH $61 \quad 423$

TECH $63 \quad 459$

JASA $61 \quad 909$ TECH $63 \quad 3 B 5$

A BRANCHING JRSSB64 398

TECH $63 \quad 375$

MAXIMUM L AMS $65 \quad 69$

EXPONENTIAL LIFE JASA $67 \quad 548$

ON THE DETPUINATION OF A TECH 68 361 TECH $63 \quad 183$ ASYMPTOTICALLY AMS $67 \quad 1731$ AMS 69595 AMS 691216

AMS 691250

ONARACIERISTICS OF A RATIO USED TO ESTIMATE FAILURE RATES, OCCURRENCES PER PERSON YEAR OF EXPOSUR BIOCS66 310

F PARAMETERS OF MIXED EXPONENTIALLY DISTRIBUTED FAILURE TIME DISTRIBUTIONS FROM CENSORED LIFE TEST DA BIOKA5B 504 A BIVARIATE WARNING-TIME, FAILURE-TIME DISTRIBUTION EARLY FAILURES IN LIFE TESTINC

ESTIMATION OF THE PROBABILITY OF ZERO FAILURES IN M BINOMIAL TRIALS

DISTRIBUTION SHAPE PARAMETEI HOW TO SURVIVE A FIXED NUMBER OF FAIR BETS CONFESSION OF FAITH 1955

A CLASSIFICATION OF FALLACIOUS ARGUMENTS AND INTERPRETATIONS

67272

$\begin{array}{rrr}\text { TECH } & 64 & 415 \\ \text { AMS } & 67 & 1278\end{array}$

JASA 56

TECH $62 \quad 125$

COVARIANCE ANALYSIS WHEN THE CONTROL VARIABLE IS FALLIBLE LARCE-SAMPLE JASA $60 \quad 307$

/ TESTS OF FIT BASED ON THE NUMBER OF OBSERVATIONS FALLING IN THE SHORTEST SAMPLE SPACINGS DETERMINED BY AMS 61 B3B PERMUTATION WITHOUT RISING OR FALLING OMEGA-SEQUENCES

A RECURRENCE FOR PERMUTATIONS WITHOUT RISINC OR FALLING SUCCESSIONS ON THE QUESTION OF WHETHER A DISEASE IS FAMILIAL

THE 'INEFFICIENCY' OF THE SAMPLE MEDIAN FOR MANY FAMILIAR SYMMETRIC DISTRIBUTIONS

MOST POWERFUL TESTS FOR SOME NON-EXPONENTIAL FAMILIES

LARCE DEVIATIONS THEORY IN EXPONENTIAL FAMILIES

INVARIANT PROPER BAYES TESTS FOR EXPONENTIAL FAMILIES UNBIASED ESTIMATION IN CONVEX FAMILIES

AMS 671245 AMS $6570 \mathrm{~B}$ JASA $67 \quad 409$

BIOKA55 520 AMS 6B 772 AMS 681402 AMS 69270 AMS 691523 JRSSB65 94

ON CERTAIN PROPERTIES OF THE EXPONENTIAL-TYPE FAMILIES

RELATION BETWEEN THE SEXES OF ADJACENT SIBS IN HUMAN FAMILIES

COMBINATIONS OF ORDER STATISTICS FROM RESTRICTED FAMILIES

THE DETECTION OF A COR JASA 651035 ONE-PARAMETER EXPONENTIAL FAMILIES CENERATED BY TRANSFORMATION GROUPS

CHARACTERIZATIONS OF INDEPENDENCE IN CERTAIN FAMILIES OF BIVARIATE AND MULTIVARIATE DISTRIBUTIONS REMARKS ON TOPOLOGY AND CONVERGENCE IN SOME ORDERED FAMILIES OF DISTRIBUTION

ON THE TOPOLOGICAL STRUCTURE OF SOME ORDERED FAMILIES OF DISTRIBUTIONS FURTHER GENERALIZED MEANS AND ASSOCIATED FAMILIES OF DISTRIBUTTONS SOME RESULTS ON TESTS OF SEPARATE FAMILIES OF HYPOTHESES

FURTHER RESULTS ON TESTS OF SEPARATE FAMILIES OF HYPOTHESES SOME TESTS OF SEPARATE FAMILIES OF HYPOTHESES IN TIME SERIES ANALYSIS

UPPER AND LOWER PROBABILITY INFERENCES FOR FAMILIES OF HYPOTHESES WITH MONOTONE DENSITY RATIOS UNIFORM CONVERGENCE OF FAMILIES OF MARTINGALES

INVARIANT SETS FOR TRANSLATION-PARAMETER FAMILIES OF MEASURES

AMS 661574 AMS 65261 AMS 6 B 433 AMS $69 \quad 51$ AMS 641216 AMS $69 \quad 339$ BIOKA6B 355 JRSSB $62 \quad 406$ BIOKA67 39 AMS 69953 AMS 691071 AMS 69162 TECH 67229 $\begin{array}{rr}\text { SQUARE TYPE AND RELATED DESIGNS } & \text { SOME NEW FAMILIES OF PARTIALLY BALANCED DESIGNS OF THE LATIN } \\ \text { SELECTION PROCEDURES FOR RESTRICTED FAMILIES OF PROBABILITY DISTRIBUTIONS } & \end{array}$ $\begin{array}{rr}\text { SQUARE TYPE AND RELATED DESIGNS } & \text { SOME NEW FAMILIES OF PARTIALLY BALANCED DESIGNS OF THE LATIN } \\ \text { SELECTION PROCEDURES FOR RESTRICTED FAMILIES OF PROBABILITY DISTRIBUTIONS } & \end{array}$

THE VALIDITY OF INCOME REPORTED BY A SAMPLE OF FAMILIES WHO RECEIVED WELFARE ASSISTANCE DURING 1959 J ADA 62 680
LATENT AND INFECTIOUS PERIODS OF MEASLES, II. FAMILIES WITH THREE OR MORE SUSCEPTIBLES NC THE LATENT AND INFECTIOUS PERIODS OF MEASLES, II. FAMILIES WITH THREE OR MORE SUSCEPTIBLES
ING THE LATENT AND INFECTIOUS PERIODS OF MEASLES, I. FAMILIES WITH TWO SUSCEPTIBLES ONLY. LIKELIHOOD RATIO TESTS FOR RESTRICTED FAMILITES OF PROBABILITY DISTRIBUTIONS NCTIO/ CHARACTERIZATIONS OF THE LINEAR EXPONENTIAL FAMILTY IN A PARAMETER BY RECURRENCE RELATIONS FOR FU AMS 69 1721 A HYBRID PROBLEM ON THE EXPONENTIAL FAMILY ON SUFFICIENCY AND THE EXPONENTIAL FAMILY AMS 651185 JRSSB 63115

MIXTURES OF DISTRIBUTIONS FROM THE EXPONENTIAL FAMILY FUNCTIONS, ADMISSIBILITY AND THE EXPONENTIAL FAMILY ESTIMATION OF FINITE JASA 69 NO 4 A FAMILY OF CLOSED SEQUENTIAL PROCEDURES (CORR, 69457 ) BIOKA62 4] A FAMILY OF COMBINATORIAL IDENTITIES

NOTE ON A CERTAIN FAMILY OF DISCRETE DISTRIBUTIONS

A TWO-PARAMETER FAMILY OF HYPER-POISSON DISTRIBUTIONS

AMS $66 \quad 509$ BIOKA52 196 JASA $64 \quad 133$ OMPOSITE HYPOTHESES FOR THE MULTIVARIATE EXPONENTIAL FAMILY, CORR 67 I928 RICAL MEASUREMENTS AND RELATED PROBLEMS DEMAND FOR FARM PRODUCTS AT RETAIL AND THE FARM LEVEL. SOME EMPI JASA 5B 656 OF PROBABILITY AND STATISTICS. XII. THE BOOK OF FATE ION IN REGRESSION AS APPLIED TO EXTRAPOLATION IN S-N FATIGUE TESTING- 
THE USE OF LEAST FAVORABLE DISTRIBUTIONS IN TESTING COMPOSITE HYPOTHES AMS 611034 PROBLEMS IN ESTIMATING FEDERAL GOVERNMENT EXPENDITURES

A FORECASTING MODEL OF FEDERAL PURCHASES OF GOODS AND SERVICES

CROSSROAD CHOICES FOR THE FUTURE DEVELOPMENT OF THE FEDERAL STATISTICAL SYSTEM THE AMERICAN STATISTICAL ASSOCIATION AND FEDERAL STATISTICS

DENOMINATOR

THE CORRELATION BETWEEN FEED EFFICIENCY AND RATE OF GAIN, A RATIO AND ITS

CYCLIC QUEUES WITH FEEDBACK

OF EVOLUTIONARY OPERATION SUBJECT TO EMPIRICAL FEEDBACK

DEMOGRAPHIC MODEL FOR ESTIMATING ACE-ORDER SPECIFIC FERTILITY RATES

MIXED SELF - AND CROSS-FERTILIZATION IN A TETRASOMIC SPECIES

THE DEMAND FOR FERTILIZER IN 1954, AN INTER-STATE STUDY

LIFE-TESTING RESULTS BASED ON A FEW HETEROGENEOUS LOGNORMAL OBSERVAITONS

A JASA 63

BIOCS68 485

JASA $59 \quad 377$

JASA $67 \quad 45$

AMS 63 B44

FURTHER EXAMPLES OF INCONSISTENCIES IN THE FIDUCIAL ARGUMENT

ON THE DIFFICULTIES INHERENT IN FISHER'S FIDUCIAL ARGUMENT

SOME LOGICAL ASPECTS OF THE FIDUCIAL ARGUMENT

DEPENDENCE OF THE FIDUCIAL ARGUMENT ON THE SAMPLTNG RULE

A FIDUCIAL ARGUMENT WITH APPLTCATION TO SURVEY SAMPLING

A COMPARISON OF THE DIRECT AND FIDUCIAL ARGUMENTS IN THE ESTIMATION OF A PARAMETER FIDUCIAL CONSISTENCY AND GROUP STRUCTURE

FIDUCIAL DISTRIBUTIONS AND BAYES' THEOREM

ON A FIDUCIAL EXAMPLE OF C. STEIN

ON FIDUCIAL INFERENCE

FIDUCIAL INFERENCE FOR LOCATION AND SCALE PARAMETERS

SOME REMARKS ON CONFIDENCE OF FIDUCIAL LIMITS

FIDUCIAL LIMITS FOR A VARIANCE COMPONENT

EXACT FIDUCIAL LIMITS IN NON-LINEAR ESTIMATION

ON THE CONSISTENCY OF THE FIDUCIAL METHOD

THE FIDUCIAL METHOD AND INVARIANCE

EXAMPLES BEARING ON THE DEFINITION OF FIDUCIAL PROBABILITY WITH A BIBLIOGRAPHY

JASA $64 \quad 56$

JRSSB63 111

BIOKA57 464

JRSSB69 NO 2

JRSSB63 95

BIOKA65 55

JRSSB58 102

JRSSB $66 \quad 53$

AMS 61661

BIOKA64 17

BIOKA54 275

JRSSB $63 \quad 128$

JRSSB $62 \quad 125$

JRSSB62 425

BIOKA6I 261

AMS 621349

ISHART'S AND RELATED DISTRIBUTIONS, AND A PARADOX IN FIDUCIAL THEORY

PIVOTAL QUANTI

REGRESSION ON A RANDOM FIELD

FIDUCIAL THEORY AND INVARIANT ESTIMATION

FIDUCIAL THEORY AND INVARIANT PREDICTION

A METHOD OF ESTIMATING BIOLOGICAL POPULATIONS IN THE FIELD

THE EFFECT OF FIELD BLOCKING ON GAIN FROM SELECTION

SURVIVAL, WANDERING AND VARIATION OF THE LONG-TAILED FIELD MOUSE, APODEMUS SYLVATICUS. III. WANDERING POWE THE TAIL FIELD OF A MARKOV CHAIN

THE CENTRAL LIMIT THEOREM FOR GENERALIZED RANDOM FIELDS

HOMOGENEOUS GAUSS-MARKOV RANDOM FIELDS

SAMPLE FUNCTIONS OF GAUSSIAN RANDOM HOMOGENEOUS FIELDS ARE EITHER CONTINUOUS OR VERY IRREGULAR COMBINING ELEMENTS FROM DISTINCT FINITE FIELDS IN MIXED FACTORIALS INTERPOLATION OF HOMOGENEOUS RANDOM FIELDS ON DISCRETE GROUPS

ON A MULTIVARIATE VERSION OF FIELLER'S THEOREM

FIELLER'S THEOREM AND A GENERALIZATION

A GENERALIZATION OF FIELLER'S THEOREM TO THE RATIO OF COMPLEX PARAMETERS

R. A. FISHER AND THE LAST FIFTY YEARS OF STATISTICAL METHODOLOGY

TABLETS, AND STERILE SOLIDS FIFT A RANDOM INTERVAL FTLLING PROBLEM

ON THE PROBABILITY DISTRIBUTION OF A FILTERED RANDOM TELEGRAPH SIGNAL

APPROXIMATE DESIGN OF DIGITAL FI

FILTERING NON-STATIONARY SIGNALS

INTERFERENCE IN THE MANUFACTURE OF NUCLEPORE FILTERS

CONTROL

FURTHER COMMENTS ON THE 'FINAL REPORT OF THE ADVISORY COMMITTEE ON WEATHER

VALIDATION OF CONSUMER FINANCIAL CHARACTERISTICS, COMMON STOCK

MINIMIZING RESPONSE ERRORS IN FINANCIAL DATA. THE POSSIBILITIES

THE RELIABILITY OF CONSUMER SURVEYS OF FINANCIAL HOLDINGS. DEMAND DEPOSITS

THE RELIABILITY OF CONSUMER SURVEYS OF FINANCIAL HOLDINGS. TIME-DEPOSITS

RANK ORDERS IN THE TWO SAMPLE CASE

FINE STRUCTURE OF THE ORDERING OF PROBABILITIES OF

INVARIANTS UNDER MIXING WHICH GENERALIZE DE FINETTI'S THEOREM

INVARIANTS UNDER MIXING WHICH GENERALIZE DE FINETTI'S THEOREM, CONTINUOUS TIMES PARAMETER

AMS $66 \quad 643$

AMS $67 \quad 795$

JASA 69 NO. 4

ON BTOKA53 216

BIOCS66 843

IOKA52 389

AMS $69 \quad 127$

AMS 69203

AMS 691625

AMS 671579

AMS $69 \quad 498$

AMS 69251

JRSSB59 59

BIOKA67 56?

JRSSB67 126

JASA $65 \quad 395$

AMS 62702

AMS $68 \quad 890$

JRSSB69 150

TECH $65 \quad 387$

TECH $67 \quad 319$

JASA 61580

JASA 69415

JASA $68 \quad 217$

JASA $66 \quad 91$

JASA $65 \quad 148$

AMS $66 \quad 98$

AMS $62 \quad 916$

AMS $63 \quad 1194$

ONS WITH SELECTION APPLICATION OF FINITE ABSORBENT MAR

ON A GENERALIZATION OF THE FINITE ARC-SINE LAN

QUEUE LENGTH DISTRIBUTION FOR QUEUEING SYSTEMS WITH FINITE CAPACITY

BEHAVIOR OF A QUEUEING SYSTEM WITH BULK SERVICE AND FINITE CAPACITY

A FINITE CRITER

FIRST EMPTINESS IN A FINTTE DAM

SEQUENTIAL COMPOUND RULES FOR THE FINITE DECISION PROBLEM

DECISION PROCEDURES FOR FINITE DECISION PROBLEMS UNDER COMPLETE IGNORANCE

NOTE ON DECISION PROCEDURES FOR FINITE DECISION PROBLEMS UNDER COMPLETE IGNORANCE

AND RATE OF GENE LOSS OF FOUR METHODS OF REPRODUCING FINITE DIPLOID POPULATIONS /INBREEDING COEFFICIENT

COMBINING ELEMENTS FROM DISTINCT FINITE FIELDS IN MIXED FACTORIALS

EXPECTED ARC LENGTH OF A GAUSSIAN PROCESS ON A FINITE INTERVAL

THE COMPOUND DECISION PROBLEM WITH M-BY-N FINITE LOSS MATRIX

SEQUENTIAL COMPOUND DECISION PROBLEMS WITH M-BY-N FINITE LOSS MATRIX SEQUENTIAL RELIABILITY ASSURANCE IN FINITE LOTS

TIONS FOR A STATIONARY PROCESS TO BE A FUNCTION OF A FINITE MARKOV CHAIN IN THE THEORY OF RANDOM VARIABLES DEFINED ON A FINITE MARKOV CHAIN FUNCTIONS OF FINITE MARKOV CHAINS

A CHARACTERIZATION OF A CLASS OF FUNCTIONS OF FINITE MARKOV CHAINS

IDENTIFICATTON OF STATE-CALCULABLE FUNCTIONS OF FINITE MARKOV CHAINS FUNCTIONS OF FINITE MARKOV CHAINS 
FUNCTIONS OF FINITE MARKOV CHAINS AND EXPONENTIAL TYPE PROCESSES

THE SPECTRAL THEOREM FOR FINITE MATRICES AND COCHRAN'S THEOREM

CHARACTERIZATION OF SYMMETRIC STABLE PROCESSES WITH FINITE MEAN

THE ROBBINS-ISBELL TWO-ARMED-BANDIT PROBLEM WITH FINITE MEMORY RANDOMIZED RULES FOR THE TWO-ARMED BANDIT WITH FINITE MEMORY HYPOTHESIS TESTING WITH FINITE MEMORY

ESTIMATION OF PARAMETERS OF A FINITE MIXTURE OF DISTRIBUTIONS IDENTIFIABILITY OF FINITE MIXTURES

ON THE IDENTIFIABILITY OF FINITE MIXTURES

A CONSISTENT ESTIMATOR FOR THE IDENTIFICATION OF FINITE MIXTURES FAMILY ESTIMATION OF FINITE MIXTURES OF DISTRIBUTIONS FROM THE EXPONENTIAL SAMPLING MOMENTS OF MEANS FROM FINITE MULTIVARIATE POPULATIONS

ON THE RANCE OF PARTIAL SUMS OF A FINITE NUMBER OF INDEPENDENT NORMAL VARIATES

THE VARIANCE OF THE MAXIMUM OF PARTIAL SUMS OF A FINITE NUMBER OF INDEPENDENT NORMAL VARIATES

ON THE MOMENTS OF THE MAXIMUM OF PARTIAL SUMS OF A FINITE NUMBER OF INDEPENDENT NORMAL VARIATES FINDING THE SIZE OF A FINITE POPULATION

CONFIDENCE INTERVALS FOR THE MEAN OF A FINITE POPULATION MOMENT-STATISTICS IN SAMPLES FROM A FINITE POPULATION

COEFFICIENTS OF THE K-STATISTICS IN SAMPLES FROM A FINITE POPULATION

OF THE SAMPLE MEAN AS ESTIMATE OF THE MEAN OF A FINITE POPULATION REJECTIVE SAMPLING WITH VARYING PROBABILITIES FROM A FINITE POPULATION IMATOR IN SAMPLINC WITH VARYING PROBABILITIES FROM A FINITE POPULATION IMATOR IN SAMPLINC WITH VARYING PROBABILITIES FROM A FINITE POPULATION /FOR THE ERROR-VARIANCE OF AN EST J
NTRAL SAMPLING MOMENTS OF THE MEAN IN SAMPLES FROM A FINITE POPULATION (ATY'S FORMULAE AND MADOW'S CENTRAL ESTIMATORS, CORR, 60755 AN OLD APPROACH TO FINITE POPULATION SAMPLING THEORY SOME FINITE POPULATION UNBAISED RATIO AND REGRESSION SOME PROPERTIES OF PASGAL DISTRIBUTION FOR FINITE POPULATION, CORR, 62919

GENERALIZED MULTIVARIATE ESTIMATOR FOR THE MEAN OF FINITE POPULATIONS BAYES SEQUENTIAL DESIGNS OF FIXED SIZE SAMPLES FROM FINITE POPULATIONS MULTIVARIATE RATIO ESTIMATION FOR FINITE POPULATIONS ON THREE PROCEDURES OF SAMPLING FROM FINITE POPULATIONS A UNIFIED THEORY OF SAMPLINC FROM FINITE POPULATIONS DISTRIBUTION-FREE SUFFICIENCY IN SAMPLING FINITE POPULATIONS NEW BINOMIAL APPROXIMATION FOR USE IN SAMPLINC FROM FINITE POPULATIONS ADMISSIBILITY AND OPTIMUM ESTIMATORS FOR SAMPLING FINITE POPULATIONS POLYKAYS TO UNRESTRICTED SUMS FOR BALANCED COMPLETE FINITE POPULATIONS TION AND BAYESIAN ANALYSIS OF GATERGORICAL DATA FROM FINITE POPULATIONS SUBJECTIVE BAYESIAN MODELS IN SAMPLINC FINITE POPULATIONS

(WTH DISCUSSION) ESTIMATION OF MEANS AND TOTALS FROM FINITE POPULATIONS OF UNKNOWN SIZE, CORR, 641297 TWO-STAGE SUBSAMPLING PROCEDURE FOR RANKING MEANS OF FINITE POPULATIONS WITH AN APPLICATION TO BULK SAMPLI A NEW APPROACH TO SAMPLINC FROM FINITE POPULATIONS A NEW APPROACH TO SAMPLING FROM FINITE POPULATIONS. II ADMISSIBILITY AND BAYES ESTIMATION IN SAMPLING FINITE POPULATIONS, I ADMISSIBILITY AND BAYES ESTIMATION IN SAMPLING FINITE POPULATIONS, II ADMISSIBILITY AND BAYES ESTIMATION IN SAMPLING FINITE POPULATIONS, III ADMISSIBILITY AND BAYES ESTIMATION IN SAMPLING FINITE POPULATIONS, IV ADMISSIBILITY AND BAYES ESTIMATION IN SAMPLING FINITE POPULATIONS, V ONS OF SEVERAL CA ON FINITE PRODUCTS OF POISSON-TYPE CHARAGTERISTIG FUNCTI THE MEAN WAITINC TIMES OF SUCCESSIVE CUSTOMERS IN A FINITE QUEUE

ON CONFIDENCE BANDS FOR A RECRESSION LTNE OVER A FINITE RANGE

A NOTE ON EXCHANGEABLE PROCESSES WITH STATES OF FINITE RANK REMARKS CONCERNING THE APPLICATION OF EXACT FINITE SAMPLE DISTRIBUTION FUNCTIONS OF CENERALIZED C JASA 63 943 LINEAR IDENTIFIABILITY TEST STATISTICS ON FINITE SAMPLE DISTRIBUTIONS OF GENERALIZED CLASSICAL JASA 60 650 SICAL LINEAR ESTIMATORS IN TW/ A NOTE ON THE EXACT FINITE SAMPLE FREQUENCX FUNCTIONS OF CENERALIZED CLAS JASA 61 619 SICAL LINEAR ESTIMATORS IN A/ A NOTE ON THE EXACT FINITE SAMPLE FREQUENCY FUNCTIONS OF CENERALIZED CLAS JASA 63 I6I ILLUSTRATION FINITE SAMPLE MONTE CARLO STUDIES. AND AUTOREGRESSIVE JASA 67 BOI SEEMINGLY UNRELATED REGRESSION EQUATIONS, SOME EXACT FINITE SAMPLE RESULTS

OF CRITICAL VALUES OF SOME RENYI TYPE STATISTICS FOR FINITE SAMPLE SIZES

EXPERIMENTAL RANDOMIZATION IN BAYESIAN STATISTICS, FINITE SAMPLING AND TWO BAYESIANS

AMALGAMATION INTO BLOCKS, BY WETGHTED MEANS, OF A FINITE SET OF REAL NUMBERS ENUMERATION OF LINEAR GRAPHS FOR MAPPINCS OF FINITE SETS WEAK QUALITATIVE PROBABILITY ON FINITE SETS

ON THE ITERATIVE METHOD OF DYNAMIC PROGRAMMING ON A FINITE SPACE DISCRETE TIME MARKOV PROCESS STATISTICAL INFERENCE FOR PROBABILISTIC FUNCTIONS OF FINITE STATE MARKOV CHAINS PROBABILISTIC FUNCTIONS OF FINITE STATE MARKOV CHAINS RIBUTION OF SOME PROBABILISTIC FUNCTIONS OF DISCRETE FINITE STATE MARKOV CHAINS THE INFINITESIMAL GENERATOR OF A CONTINUDUS TIME. FINITE STATE MARKOV PROCESS THEOREMS FOR STATIONARY PROBABILITY MEASURES ON FINITE STATE SEQUENCES ADMISSIBILITY AND DIST AMS 6 B 1646 ESTIMATINC AMS $62 \quad 727$ SOME STRUCTURE AMS $64 \quad 550$ REPETITIVE PLAY IN FINITE STATISTICAL CAMES WITH UNKNOWN DISTRIBUTIONS AMS 66976 TIME FINITE STOPPING TIME AND FINITE EXPECTED STOPPING JRSSB65 284 A TRANSIENT DISCRETE TIME QUEUE WITH FINITE STORACE

A TRANSIENT DISCRETE TIME QUEUE WITH FINITE STORACE
CTIONAL SELECTION ON NORMAL VARIABLES WITHIN SETS OF FINITE SUBPOPULATIONS /FFERENTIAL FOR POSITIVE DIRE BIOCS67 B42 TTON FOR RANDOM VARTABLFS COVARIANCE STATIONARY ON A FINTTE TTME INTERVAL OWER PROBABILITY INFERENCES BASED ON A SAMPLE FROM A FINITE UNIVARIATE POPULATION ON PRODUCT MOMENTS FROM A FINITE UNIVERSE

MORE RESULTS ON PRODUCT MOMENTS FROM A FINTTE UNIVERSE MEMORYLESS STRATEGIES IN FINITE-STACE DYNAMIC PROGRAMMING A MOVING AVERACE REPRESENTA BIOKA65 295 UPPER AND L BIOKA67 515 JASA $6 B \quad 535$ JASA $69 \quad 864$ AMS $64 \quad 863$ Y-SUB-1....) IS A REALIZATION OF A NON-HOMOGENEOUS FINITE-STATE MARKOV GHAIN /-SUB-T), WHERE (Y-SUB-0, BIOKA65 277 NG THE EQUILIBRIUM AND TRANSITION PROBABILITIES OF A FINITE-STATE MARKOV CHAIN FROM THE SAME DATA /IMATI BIOGS6B IB5 $\mathrm{N}$ ORNSTEIN-UHLENBECK PROGESS BY MONTE/ ESTIMATING FINITE-TIME MAXIMA AND MINIMA OF A STATIONARY GAUSSIA JASA 68 I5I7 REPRESENTING FINITELY ADDITIVE INVARIANT PROBABILITIES

SUFFICIENT CONDITIONS FOR THE EXISTENGE OF A FINITELY ADDITIVE PROBABILITY MEASURE

A NOTE ON THRIFTY STRATEGIES AND MARTINGALES IN A FINITELY ADDITIVE SETTING WILLIAM D. SUDDERTH MARKOV RENEWAL PROCESSES WITH FINITELY MANY STATES

IFICANCE IN A 2-BY-2 GONTINGENCY TABLE, EXTENSION OF FINNEY'S TABLE THE VARIABILITY OF PROFITIBILATY WITH SIZE OF FIRM, 1947-195B
AMS 682131 AMS $67 \quad 7 \mathrm{BO}$ AMS 69 NO. 6 AMS $61 \quad 1243$ TESTS OF SIGN BIOKA53 74 JASA 641183 
STRY EXPECTATIONS IN RELATION TO THOSE OF INDIVIDUAL FIRMS

A STOCHASTIC ANALYSIS OF THE SIZE DISTRIBUTION OF FIRMS, CORR. 59810

THE ACCURACY AND STRUCTURE OF INDU JASA 5B 317

JASA 58 B93

ASYMPTOTTC POWER OF CERTATN TEST CRI TWO ASSOCIATE PBIB DESIGNS

COMPONENTS OF COVARIANCE

FIRST AND SECOND MOMENTS OF THE RANDOMIZATION TEST IN JASA 69 NO.4

OF THE PARAMETERS OF

PROBABILITY TABLE FOR NUMBER OF RUNS OF SIGNS OF FIRST DIFFERENCES IN ORDERED SERIES

FIRST EMPTINESS IN A FINITE DAM

BIOKA69 NO. 3

FIRST EMPTINESS OF TWO DAMS IN PARALLEL

IFR JASA $68 \quad 889$

JASA $61 \quad 156$

JRSSB61 343

AMS $61 \quad 219$

TY OF REDUNDANT SYSTEMS WHEN TESTS ARE TERMINATED AT FIRST FAILURE/SIAN CONFIDENCE LIMITS FOR RELIABILI TECH 68 29

COMPUTERS. THE SECOND REVOLUTION IN STATISTICS (THE FIRST FISHER MEMORIAL LECTURE)

OF THE BOUNDS OF THE PROBABILITY INTEGRAL WHEN THE FIRST FOUR MOMENTS ARE GIVEN

SUMS OF INDEPENDENT RANDOM VARIABLES WITH INFINITE FIRST MOMENT

MINIMAX ESTIMATION OF A RANDOM PROBABILITY WHOSE FIRST N MOMENTS ARE KNOWN

RENEWAL THEOREMS WHEN THE FIRST OR THE SECOND MOMENT IS INFINITE

MULTI-FACTOR DESIGNS OF FIRST ORDER

RVATIONS IN MULTIVARIATE REGRESSION, EFFICIENCY OF A FIRST ORDER METHOD

ON THE INVERSE OF THE COVARIANCE MATRIX OF A FIRST ORDER MOVING AVERAGE

ON THE MEAN DURATION OF A BALL AND CELL GAME, A FIRST PASSAGE PROBLEM

SOME RENEWAL THEOREMS WITH APPLICATION TO A FIRST PASSAGE PROBLEM

A FIRST PASSAGE PROBLEM FOR THE WIENER PROCESS

WALKS ON THE CONTINUUM

SOME FIRST PASSAGE PROBLEMS FOR S-SUB-N-OVER-ROOT-N

THE FIRST PASSAGE TIME DENSITY FOR HOMOGENEOUS SKIP-FREE

FIRST PASSAGE TIME FOR A PARTICULAR GAUSSIAN PROCESS

CERTAIN PROPERTIES OF GAUSSIAN PROCESSES AND THEIR FIRST PASSAGE TIMES

R. AND ACKNOWLEDGEMENT OF PRIORITY 611345 FIRST PASSAGE TIMES O

DESIGNS BALANCED FOR THE LINEAR COMPONENT OF FIRST RESIDUAL EFFECTS

OF CHANGEOVER DESIGNS WITH COMPLETE BALANCE FOR FIRST RESIDUAL EFFECTS

ON THE DISTRIBUTION OF THE FIRST SAMPLE MOMENTS OF SHOT NOISE

THE NULL DISTRIBUTION OF THE FIRST SERIAL CORRELATION COEFFICIENT

ON THE DISTRIBUTION OF FIRST SIGNIFICANT DIGITS

APPROXIMATING A SKEW DENSITY WHOSE LEFT TERMINAL AND FIRST THREE MOMENTS ARE KNOWN /ARSON DENSITIES FOR BI ASYMPTOTIC VALUES OF THE FIRST TWO MOMENTS IN MARKOV RENEWAL PROCESSES

RICAL MULTINOMIAL DISTRIBUTION

A NOTE ON THE FIRST TWO MOMENTS OF THE MEAN

THE FIRST 1.945 BRITISH STEAMSHIPS
THE FIRST-MEDIAN TEST. A TWO-SIDED

BIOCS66 233

TABLE BIOKA60 399

A NOTE ON AMS $67 \quad 751$

AMS $68 \quad 492$

AMS $68 \quad 1210$

BIOKA52 49

MISSING OBSE JASA 69 NO.

BIOKA69 NO. 3 AMS $66 \quad 517$

AMS $66 \quad 699$

AMS 671912

AMS 69648

AMS 631003

AMS 61610 JRSSB 65505

MEDIAN TEST

THE FIRST-MEDIAN TEST. A TWO-SIDED VERSION

FIRST-PASSAGE PERCOLATION

FISCAL-YEAR REPORTING FOR CORPORATE INCOME TAX

NOTE ON AN ARTICLE BY SIR RONALD FISHER

NOTE ON SOME CRTICISMS MADE BY SIR RONALD FISHER

SOME EARLY CORRESPONDENCE BETWEEN W.S. GOSSETT, R.A. FISHER AND KARL PEARSON, WITH NOTES AND COMMENTS

METHODOLOGY

R. A. FISHER AND THE LAST FIFTY YEARS OF STATISTICAL

THE BEHRENS-FISHER DISTRTBUTTON AND WETGHTED MEANS

MULTI-SAMPLE TESTS FOR THE FISHER DISTRIBUTION FOR DIRECTIONS

APPROXIMATION TO THE GENERALIZED BEHRENS-FISHER DISTRIBUTION INVOLVING THREE VARIATES APPROXIMATION TO THE BEHRENS-FISHER DISTRIBUTIONS

CHANGEOVER BIOKA6B 297

THE ANALYSIS BIOCS67 57 B

TECH $64 \quad 2 B 7$

BIOKA66 623

AMS 611223

BIOKA68 559

BIOKA67 597

BIOKA67 312 JASA $58 \quad 360$

JASA $68 \quad 692$

JASA $68 \quad 1237$

JRSSB66 491

JASA $56 \quad 304$

JRSSB56 288

JRSSB56 297

BIOKA $68 \quad 445$

JASA $65 \quad 395$

JRSSB 5973

BIOKA69 169

BIOKA69 NO.3

BIOKA65 267

IONS

STNG Y TRUNCATED NORMAL DISTRIBUT BIO

THE SECOND REVOLUTION IN STATISTICS (THE FIRST FISHER MEMORIAL LECTURE)

A SEQUENTIAL ANALOQUE OF THE BEHRENS-FISHER PROBLEM

COMPUTERS. BIOCS66 233

AMS 671384

JASA 69 NO. 4

SOME REMARKS ON SCHEFFE'S SOLUTION TO THE BEHRENS-FISHER PROBLEM

OF THE WILCOXON STATISTIC FOR A GENERALIZED BEHRENS-FISHER PROBLEM

INTERVAL OF PREASSIGNED LENGTH FOR THE BEHRENS-FISHER PROBLEM

OF FREEDOM SOLUTION TO THE MULTIVARIATE BEHRENS-FISHER PROBLEM

ISON OF TWO TEST PROCEDURES PROPOSED FOR THE BEHRENS-FISHER PROBLEM

NONPARAMETRIC ESTIMATES FOR SHIFT IN THE BEHRENS-FISHER SITUATION

BOUNDS ON THE DISTRIBUTION FUNCTIONS OF THE BEHRENS-FISHER STATISTIC

A NOMOGRAM FOR THE 'STUDENT' *FISHER T TEST

A NEW PROOF OF THE PEARSON-FTSHER THEREM- (ACKNOWLEDGEMNT OF PRIORITY 65 344)

NOTE ON A PAPER BY RAY AND PITMAN + (FISHER-BEHRENS-STATISTIC)

SOME SCHEFFE-TYPE TESTS FOR SOME BEHRENS-FISHER-TYPE REGRESSION PROBLEMS

USE AMS $63 \quad 1596$

CONFIDENCE AMS 671175

AN APPROXIMATE DEGREES BIOKA65 139

A CONFIDENCE INTERVAL COMPAR JASA $66 \quad 454$

ON SOME AMS $66 \quad 593$

AMS $66 \quad 639$

JASA 69 NO. 4

AMS $64 \quad 817$

JRSSB $62 \quad 537$

JASA $65 \quad 1163$

WEEN THE MEA/ AN EXACT DISTRTBUTION OF THE BEHRENS-FISHER-WELCH STATTSTIC FOR TESTING THE DIFFERENCE BET JRSSBGI 377 FISHER, WRIGHT, AND PATH COEFFICIENTS

MEMORIAL TO SIR RONALD AYLMER FISHER, IB90-1962

RONALD AYLMER FISHER, 1890-1962

SIAN ANALYSIS OF A TWO-BY-TWO CONTINGENCY TABLE, AND FISHER'S 'EXACT' SIGNIFICANCE TEST

APPROXIMATIONS TO THE UPPER 5 PERCENT POINTS OF FISHER'S B DISTRIBUTION AND NON-CENTRAL CHI-SQUARE

ON FISHER'S BOUND FOR ASYMPTOTIC VARIANCES

NOTES FURTHER ANALYSIS OF $R$ A FISHER'S ENUMERATIONS TN GENETICS

PROGRAMMING FISHER'S EXACT METHOD OF COMPARING TWO PERCENTAGES

ON THE DIFFICULTIES INHERENT IN FISHER'S FIDUCIAL ARGUMENT

EFFECT OF UNEQUAL VARIANCE-COVARIANCE MATRICES ON FISHER'S LINEAR DISCRIMINANT FUNCTION

BIOCS68 471

JASA $62 \quad 727$

BIOKA63

JRSSB 69 NO. 2

BIOKA57 $52 \mathrm{~B}$

AMS 641545

BIOCS65 1012

TECH $60 \quad 103$

JASA $64 \quad 56$

'S BIOMETRIKA TABLES (NO. I COMMENT ON SIR RONALD FISHER'S PAPER, 'ON A TEST OF SIGNIFICANCE IN PEARSON JRSSB56 295 COEFFICIENT

\section{A COEFFICIENT MEASURING THE GOODNESS OF FIT}

NOTE ON FISHER'S TRANSFORMATION OF THE CORRELATION JRSSB59 409 COODNESS OF FIT

ON AN EXACT TREATMENT OF CONTINGENCY, GOODNESS OF FIT AND OTHER PROBLEMS OF SIGNIFICANCE

KOLMOGOROV-SMIRNOV TESTS OF FIT BASED ON SOME GENERAL BOUNDS

TECH $66 \quad 327$

JASA $67 \quad 390$

NOTE BIOKA51 141

JASA $6 B \quad 919$

E SHORTEST SAMPLE SPACINGS DETERMINED BY/ TESTS OF FIT BASED ON THE NUMBER OF OBSERVATIONS FALLING IN TH AMS 61 838 PTOTIC DISTRIBUTION OF THE 'PSI-SQUARED' GOODNESS OF FIT CRITERIA FOR MARKOV CHAINS AND MARKOV SEQUENCES AMS 61 49

ASYMPTOTIC POWERS OF CERTAIN TESTS OF GOODNESS OF FIT FOR TIME SERIES

TESTS OF FIT IN TIME SERIES

THE JRSSB58 143

BIOKA52 309

AMS 671240

POINTS

AN INEQUALITY CONCERNING TESTS OF FIT OF THE KOLMOGOROV-SMIRNOV TYPE

BIOKA65 309

ONARY TIME SERIES WITH NORMAL RESID/A GOODNESS OF FIT TEST FOR SPECTRAL DISTRIBUTION FUNCTIONS OF STATI BIOKA56 257

OXIMATION TO THE POWER OF THE CHI-SQUARE GOODNESS OF FIT TEST WITH SMALL BUT EQUAL EXPECTED FREQUENCIES

JASA $6 \mathrm{~B} \quad 912$ 
ERRATA. 'A COEFFICIENT MEASURING THE COODNESS OF FIT'

TECH $67 \quad 195$

RTIAL ISOLATION (DISTANCE). MICRATION, AND DIFFERENT FITNESS REOUIREMENTS AMONC ENVIRONMENTAL POCKETS UPON BTOCSG6 MAMMALIAN REPRODUCTIVE DATA FITTED TO A MATHEMATICAL MODEL

AODITIVE COMBININC ABILITIES FITTED TO PLANT BREEDINC OATA

BIOCS69 529

BI0CS67 45

IN POLYNOMIAL RECRESSION FOR MINIMAX VARIANCE OF THE FITTED VALUES /NESS OF THE SPACINC OF OBSERVATIONS AMS 62 BIO

ORTHOCONAL POLYNOMIAL FITTING

ON A POINT ARISINC IN POLYNOMIAL REGRESSION FITTING

BIOKA53 361

BIOKA64 501

ESTIMATES OF THE PARAMETERS IN EXPONENTIAL CURVE FITTING

A METHOD OF OBTAINTNC INITIAL BIOCS69 580

LINEARITY

NOTE. A METHOD OF FITTING A NON-LINEAR CURVE CONTAINING A SINGLE NON-

FITTING A POLYNOMIAL TO CORRELATED EQUALLY SPACED

BIOC 565506

BIOKA65 275

A NOTE ON THE EQUIVALENCE OF TWO METHODS OF FITTING A STRATGHT LINE THROUGH CUMULATIVE DATA

CUMULATIVE DATA

FITTING A STRAIGHT LINE TO CERTAIN TYPES OF

POPULATION

FITTING A STRAIGHT LINE TO DATA FROM A TRUNCATED

JASA 64863

JASA $57 \quad 552$

BIOCS65 715

BI0KA58 3B9

THE USE OF AUTORECRESSION IN FITTING AN EXPONENTIAL CURVE

BI0KA59 281

N INVESTIGATION OF HARTLEY'S METHOD FOR FITTING AN EXPONENTIAL CURVE

BIOKA60 177

E AND NEGATIVE BINOMIAL FREQUENCY FUNCTIONS IN CURVE FITTING BY AITKEN'S METHOD.

E AND NEGATIVE BINOMIAL FREQUENCY FUNCTIONS IN CURVE FITTING BY AITKEN'S METHOD'

/YNOMIALS OF THE POSITIV BIOKA6I 115

CURVE FITTING BY SECMENTED STRAIGHT LINES

ESTIMATION OF VARIANCE COMPONENTS BY THE METHOD OF FITTING CONSTANTS

FITTING CURVES TO LONGITUDINAL DATA

JASA 691079

DATA

A METHOD OF FITTING EMPIRICAL SURFACES TO PHYSICAL AND CHEMICAL

SELECTION OF VARIABLES FOR FITTING EQUATIONS TO DATA

THE DERIVATTON OF METHODS FOR FITTING EXPONENTIAL REGRESSION CURVES

DISTRIBUTION OF THE RESIDUAL SUM OF SQUARES IN FITTING INEQUALITIES

BIOKA69 NO. 3

BIOCS66 276

TECH $69 \quad 411$

TECH $66 \quad 27$

BIOKA64 504

BIOKA67 69

NEGATIVE, NON-DECREASINC OR CONVEX LEAST-SQUARES FITTING OF A POLYNOMIAL CONSTRAINED TO BE EITHER NON- JRSSB69 II3

NALOGOUS TO THE TYPE A S/ A STUDY OF THE MATRIX OF FITTING OF A SERIES OF DISCRETE FREQUENCY FUNCTIONS A SASJ 67 55 NORMAL DISTRIBUTIONS

THE FITTING OF CROUPED TRUNCATED AND GROUPED CENSORED BIOKA52

THE FITTING OF MARKOFF SERIAL VARIATION CURVES

JRSSB5B 120

OXIMATE CANONICAL FACTORIZATION OF A SPECT/ ON THE FITTING OF MULTIVARIATE AUTOREGRESSIONS, AND THE APPR BIOKA63 I29 TRIZATION OP A SPECT/ ON THE FITING OF MULTIVARIATE AUTOREGRESSIONS, AND THE APPR BIOKA

MISSING VALUES

NS

GROUPINC METHODS IN THE FITTING OF POLYNOMIALS TO EQUALLY SPACED OBSERVATIONS BIOKA54

THE FITTTNC OF POLYNOMTALS TO EQUTDISTANT DATA WTTH

BIOKA51 410

GROUPING METHODS IN THE FITTTNC OF POLYNOMTALS TO UNEQUALLY SPACED OBSERVATIO BIOKA56 I49

THE DOOLITTLE METHOD AND THE FITTING OF POLYNOMIALS TO WEIGHTED DATA

BIOKA53 229

THE FITTING OF REGRESSION CURVES WITH AUTOCORRELATED DATA BIOKA56 468

LABLE DATA BY THE MAXIMUM LIKELIHOOD METHOD (CORR/

FITTING OF SOME CONTAGIOUS DISTRIBUTIONS TO SOME AVAI BIOCS65

FITTING OF STRAICHT LINES AND PREDICTION WHEN BOTH JASA 61657

VARIABLES ARE SUBJECT TO ERROR

SUBJECT TO ERROR, CORR, 59812

THE EFFTCIENCY OF INTERNAL REGRESSION FOR THE FTTTTNG OF THE EXPONENTTAL RECRESSTON

EST IMATED

CONTROLLED

TABLES TO FACILITATE

FITTING S-SUB-U FREQUENCY CURVES

SEGMENTED CURVES WHOSE JOIN POINTS HAVE TO BE JASA 661097

JASA $58 \quad 106$

TECH $60 \quad 477$

A SHORT-CUT GRAPHIC METHOD FOR FITTINC THE BEST STRAIGHT LINE TO A SERIES OF POINTS

SOME COMPARISONS OF METHODS OF FITTING THE DOSAGE RESPONSE CURVE FOR SMALL SAMPLES

AIDS FOR FITTINC THE CAMMA DISTRIBUTION BY MAXIMUM LIKELIHOOD

NOMOGRAMS FOR FITTING THE LOGISTIC FUNCTION BY MAXIMUM LIKELIHOOD

FITTING THE RECTANGULAR HYPERBOLA

A METHOD OF FITTING THE RECRESSION CURVE $E(X)=A+D X+B C-T O-X$

A COMPUTER PROGRAM FOR FITTING THE RICHARDS FUNCTION

SIMPLIFIED METHODS OF FITTING THE TRUNCATED NECATIVE BINOMTAL DISTRIBUTION

ON NORMALIZINC THE INCOMPLETE BETA-FUNCTION FOR FITTING TO DOSE-RESPONSE CURVES

LINEAR CURVE FITTING USING LEAST DEVIATIONS

CORR. 62917

A NOTE ON CURVE FITTING WITH MINIMUM DEVIATIONS BY LINEAR PROGRAMMTNG

REDUCED DESIGNS OF RESOLUTION FIVE

COMPUTER EDITING OF SURVEY DATA. FIVE YEARS OF EXPERIENCE IN BLS MANPOWER SURVEYS

ASA $57 \quad 13$

JASA $64 \quad 779$

TECH $60 \quad 55$

BIOKA60 121

BIOCS66 573

TECH $65 \quad 59$

BI0CS69 401

BIOKA58 59

BIOKA60 173

JASA $58 \quad 118$

TECH $61 \quad 459$

JASA $66 \quad 375$

OF CORRELATION COEFFICIENTS UNDER ASSUMPTIONS OF FIXED AND MIXED VARIATES THE SAMPLING VARIANCE BIOKA58 471 NT POINTS OF THE OPERATTNG CHARACTERISTTC CURVES FOR FIXED EFFECTS ANALYSIS OF VARIANCE F TESTS, ALPHA EQU JASA 57 345 SITUATIONS AN ITERATIVE PROCEDURE FOR ESTIMATING FIXED EFFECTS AND VARIANCE COMPONENTS IN MIXED MODEL BIOCS68 13

ANALYSIS OF VARIANCE FOR THE TWO-WAY CLASSIFICATION FIXED EFFECTS MODEL WITH OBSERVATIONS WITHIN A ROW SE BIOKA69 NO. 3

A MTXED MO NOTE THE QUASI-F TEST FOR AN UNNESTED FIXED FACTOR IN AN UNBALANCED HIERARCHAL DESIGN WITH BTOCS66 937

THE SPREAD OF AN EPIDEMIC TO FIXED GROUPS WITHIN THE POPULATION

TESTING THE HYPOTHESIS OF NO FIXED MAIN-EFFECTS IN SCHEFFE'S MIXED MODEL

HOW TO SURVTVE A FIXED NUMBER OF FAIR BETS

DISTRIBUTION OF TOTAL SERVICE TIME FOR A FIXED OBSERVATION INTERVAL

BI0CS68 1007

AMS $6210 B 5$

AMS 671278

JASA $62 \quad 376$

JASA $67 \quad 600$

TRANSITION MATRICES

ON THE FIXED POINT PROBABILITY VECTOR OF REGULAR OR ERGODIC

ON-MANN-WHITNEY TEST TO SAMPLES CENSORED AT THE SAME FIXED POINT, CORR, 60755 EXTENSION OF THE WILCOX J, ON FIXED PRECISION ESTIMATION IN TIME SERIES

STRIBUTION HAVINC A PRE/ ERIMENTAL CATEGORIES WI/ REGRESSION PARAMETERS

ON THE NON-EXISTENCE OF A FIXED SAMPLE ESTIMATOR OF THE MEAN OF A LOG-NORMAL DI

AN ASYMPTOTICALLY OPTIMAL FIXED SAMPLE SIZE PROCEDURE FOR COMPARING SEVERAL EXP FIXED SIZE CONFIDENCE ELLIPSOIDS FOR LINEAR

BAYES SEQUENTIAL DESIGNS OF FIXED SIZE SAMPLES FROM FINITE POPULATIONS

A FIXED SUBSET-SIZE APPROACH TO THE SELECTION PROBLEM

IBUTION OF TWO INDEPENDENT BINOMIALS, CONDITIONAL ON FTXED SUM NORMAL APPROXIMATION TO THE DO

THE COST OF NOT KNOWING THE VARIANCE WHEN MAKING A FIXED WIDTH CONFIDENCE INTERVAL FOR THE MEAN N SIDELIGHT

UNEQUAL GROUP VARIANCES IN THE FIXED-EFFECTS ONE-WAY ANALYSIS OF VARIANCE, SOME FIXED-SAMPLE RANKING AND SELECTION PROBLEMS

GRESSION PARAMETERS

ON THE ASYMPTOTIC THEORY OF FIXED-SIZE SEQUENTIAL CONFIDENCE BOUNDS FOR LINEAR RE SOME RESULTS FOR FIXED-TIME TRAFFIC SIGNALS

ON FIXED-WTDTH CONFTDENCE BOUNDS FOR REGRESSION PARAMETE

RS AND MEAN VECTOR

A GENERAL METHOD OF DETERMINING FIXED-WIDTH CONFIDENCE INTERVALS MAN

A GENERAL METHOD OF DETERMINING FIXED-WIDTH CONFIDENCE INTERVALS
THE PERFORMANCE OF A SEQUENTIAL PROCEDURE FOR THE FIXED-WIDTH INTERVAL ESTIMATION OF THE MEAN

ON THE ASYMPTOTIC THEORY OF FIXED-WIDTH SEQUENTIAL CONFIDENCE INTERVALS FOR THE MORTALITY PATTERNS IN EIGHT STRAINS OF FLOUR BEETLE

CANNIBALISM OF THE PUPAL STAGE BY ADULT FLOUR BEETLES, AN EXPERIMENT AND A STOCHASTIC MODEL
60125

AMS 691021

AMS $\$ 7949$

AMS 661602 JASA 69 NO. 4 R AMS 631593 N AMS $68 \quad 1946$ BIOKA66 27 AMS 671079 AMS $65 \quad 463$ JRSSB64 133 RSSB $67 \quad 132$ AMS $69 \quad 704$ AMS $66 \quad 36$ AMS $65 \quad 457$ BI0CS65 99 BIOCS68 247 BIOKA68 401 
THE NEW DESIGN OF THE CANADIAN LABOUR FORCE SURVEY

OPTIMAL PROPERTIES OF EXPONENTIALLY WEIGHTED FORECASTS, CORR 62919

THE CHARACTERISTIC FUNCTION OF HERMITIAN QUADRATIC FORMS IN COMPLEX NORMAL VARIABLES ALMOST SURE CONVERGENCE OF QUADRATIC FORMS IN INDEPENDENT RANDOM VARIABLES COMPUTING THE DISTRIBUTION OF QUADRATIC FORMS IN NORMAL VARIABLES TRACES AND CUMULANTS OF QUADRATIC FORMS IN NORMAL VARIABLES SERIES REPRESENTATIONS OF DISTRIBUTIONS OF QUADRATIC FORMS IN NORMAL VARIABLES, I, CENTRAL CASE SERIES REPRESENTATIONS OF DISTRIBUTIONS OF QUADRATIC FORMS IN NORMAL VARIABLES, II, NON-CENTRAL CASE CORRIGENDA, 'COMPUTING THE DISTRIBUTION OF QUADRATIC FORMS IN NORMAL VARIABLES' AN INEQUALITY FOR THE RATIO OF TWO QUADRATIC FORMS IN NORMAL VARIATES GENDA, 'ON THE STATISTICAL INDEPENDENCE OF QUADRATIC FORMS IN NORMAL VARIATES. MOMENT GENERATING FUNCTIONS OF QUADRATIC FORMS IN SERIALLY CORRELATED NORMAL VARIABLES A NOTE ON THE STATISTICAL INDEPENDENCE OF QUADRATIC FORMS IN THE ANALYSIS OF VARIANCE DISTRIBUTION LINEAR FORMS IN THE ORDER STATISTICS FROM AN EXPONENTIAL JASA 69969 AMS 691430 BIOKA60 199 AMS 6B 1502 BIOKA61 419 JRSSB $54 \quad 247$ AMS 67 B23 AMS 67 B3B BIOKA62 284 AMS $6 B \quad 1762$ $\begin{array}{rrr} & \text { CORRELATIONS AND CANONICAL FORMS OF BIVARIATE DISTRIBUTIONS } \\ \text { SUFFICIENT STATISTICS } & \text { EXACT FORMS OF SOME INVARIANTS FOR DISTRIBUTIONS ADMITTING BIOKA55 } 533 \\ & \text { EXTREMA OF QUADRATIC FORMS WITH APPLICATIONS TO STATISTICS }\end{array}$ CORRIGENDA, 'EXTREMA OF QUADRATIC FORMS WITH APPLICATIONS TO STATISTICS' BIOKA59 $4 B 3$ BIOKA61 474 AMS 671092 ON CANONICAL FORMS, NON-NEGATIVE COVARIANCE MATRICES AND BEST AND SIMPLE LEAST SQUARES LINEAR ESTIMATO/ON CANONICAL FORMS,
ONORLANG'S FORMULA
OF ORTHOGONAL POLYNOMIALS FROM A GENERAL RECURRENCE FORMULA OF ORTHOGONAL POLYNOMIALS FROM A GENERAL RECURRENCE FORMULA GENES) A REDUCTION FORMULA FOR NORMAL MULTIVARIATE INTEGRALS

MPLE OF CONSECUTIVE OBSERVATIONS FROM/ ON DURBIN'S FORMULA FOR THE LIMITING GENERALIZED VARIANCE OF A SA BIOKA6I 197 MPLE OF CONSECUTIVE OBSE/ CORRIGENDA, 'ON DURBIN'S FORMULA FOR THE LIMITING GENERALIZED VARIANCE OF A SA BIOKA6I 476 A GRAPH CONSTRUCTED RANDOMLY EXCEPT FOR 'EXOGAM/ A FORMULA FOR THE PROBABILITY OF OBTAINING A TREE FROM AMS 67 226 NG UNITS WTLL OCCUR IN A SAMPLE DRAWIN TREATMENT OF CENSORED DATA. PART I. FUNDAMENTAL FORMULAE FOR PRODUCTS OF TWO POLYKAYS WITH SOME GENERAL FORMULAE STATISTICAL BIOKA54 22B A COMBINATORIAL METHOD AMS 641174 THE ON CERTAIN SUGGESTED FORMULAE APPLIED TO THE SEQUENTIAL T-TEST BIOKA64 97 TIPLE REGRESSION ANALYSIS EXTENSION OF COCHRAN'S FORMULAE FOR ADDITION OR OMISSION OF A VARIATE IN MUL JASA 63 527 AND THE AVERAGE SAMPLE NUMBER OF SOME SEQUENTIAL/ FORMULAE FOR CALCULATING THE OPERATING CHARACTERISTIC JRSSB5B 379 
Y INTECRAL OF THE NON-CENTRAL CHI-SQU/ VALUES

PROPERTIES OF SEQUENTIAL TESTS CONCENTRATION APPROXIMATE FORMULAE FOR THE STATISTICAL DISTRIBUTIONS OF EXTREME FORMULAE TO IMPROVE WALD'S APPROXIMATION FOR SOME

VARIANCE FORMULAS FOR THE MEAN DIFFERENCE AND COEFFICIENT OF LOWER 8OUND FORMULAS FOR THE MEAN INTERCORRELATION COEFFICIENT

THE USE OF STATISTICS IN THE FORMULATION AND EVALUATION OF SOCIAL PROGRAMMES

NCY TA8LES

ELEMENTARY EXPOSITION

EXPERIMENTS

ON THE FOUNDATIONS OF STATISTICAL INFERENCE. BINARY
DISCUSSION OF 'ON THE FOUNDATIONS OF STATISTICAL INFERENCE'

FORMULATION, ESPECIALLY FOR MULTIDIMENSIONAL CONTINGE FOUNDATIONS FOR THE THEORY OF LEAST SQUARES

THE FOUNDATIONS OF DECISION UNDER UNCERTAINTY. AN

ON THE FOUNDATIONS OF STATTSTIGAL INFERENCE

AL MODELS OF EXTREME VERTICES DESIGNS FOR FOUR COMPONENT MIXTURES

F TESTS OF TWO MULTIVARIATE HYPOTHESES BASED ON FOUR CRITERIA

OF EQUALITY OF TWO COVARIANCE MATRICES 8ASED ON FOUR CRITERIA

TWO THIRD ORDER ROTATA8LE DESIGNS IN FOUR DIMENSIONS

POWER COMPARISONS 8IOKA67 195

POWER GOMPARISIONS OF TESTS 8IOKA68 335

AMS $64 \quad 445$

(

GRECO-LATIN SQUARE

MIXTURE DESIGNS FOR FOUR FACTORS

TECH $62 \quad 361$

JRSS865 473

BIOKA63 538

AMS $69 \quad 152$

THE ORTHANT PROBABILITIES OF FOUR GAUSSIAN VARIATES

THE INBREEDING COEFFICIENT AND RATE OF GENE LOSS OF FOUR METHODS OF REPRODUCING FINITE DIPLOID POPULATION

TECH 65535

8OUNDS OF THE PROBABILITY INTEGRAL WHEN THE FIRST FOUR MOMENTS ARE GIVEN COMPARISON OF FOUR RATIO-TYPE ESTIMATES UNDER A MODEL

QABLE OF THE BIOKAGO 399 JASA $69 \quad 574$

MAXIMUM-LIKELIHOOD ESTIMATION OF THE PARAMETERS OF A FOUR- PARAMETER CENERALIZED GAMMA POPULATION FROM COM TH FREQUENCIES IN RING PERMUTATIONS

WITH 5,6, OR 7 TREATMENTS

FOUR-LETTER WORDS. THE DISTRIBUTION OF PATTERN

FOUR-WAY BALANCED DESIGNS BASED ON YOUDEN SQUARES

THE INTERACTION ALGORITHM AND PRACTICAL FOURIER ANALYSIS

THE STATISTICAL FOURIER ANALYSIS OF VARIANCES

THE INTERACTION ALCORITHM AND PRACTICAL FOURIER ANALYSIS, AN ADDENDUM

FOURIER METHODS FOR EVOLVING SEASONAL PATTERNS

IN TIME SERIES ANALYSIS

FOURIER SERIES METHODS

IMATION OF PROBA8ILITY DENSITIES AND CUMULATIVES BY FOURIER
FOR THE NORMAL INTEGRAL INCLUDING A NEW CONTINUED FRACTION

IRRATIONAL FRACTION APPROXIMATIONS TO MILLS' RATIO

ATTRIBUTES

ESTIMATION OF FRAGTION DEFECTIVE IN CURTAILED SAMPLING PLANS BY
ESTIMATING THE FRACTION OF ACCEPTABLE PRODUCT

THE 2-TO-THE-(K-P) FRACTIONAL FACTORIAL DESIGNS

PART IALLY DUPLICATED FRACTIONAL FACTORIAL DESIGNS

THE 2-TO-THE-(K-P) FRACTIONAL FACTORIAL DESIGNS, II

ERRATA, 'THE 2-TO-THE-(K-P) FRACTIONAL FACTORIAL DESIGNS'

CH 67159

JRSSB67 550

BIOGS67 803

JRSSB58 361

JRSS865 159

JRSS860 372

JASA $65 \quad 492$

THE INEQUALITIES BIOKA54 177

BIOKA64 339

TEGH $67 \quad 219$

TECH $65 \quad 43$

TECH $61 \quad 311$

TECH $63 \quad 71$

TECH $61 \quad 449$

TECH $63 \quad 417$

STIMATION OF A SU8VECTOR OF PARAMETERS IN RANDOMIZED FRACTIONAL FACTORIAL EXPERIMENTS /D LEAST-SQUARES E AMS 69 1344 BAYES SEQUENTTAL DESTGN OF FRACTIONAL FACTORTAL EXPERTMENTS FOR THE ESTIMATION 0 SYMMETRICAL AND ASYMMETRICAL FRACTIONAL FACTORIAL PLANS

NEAR-CYCLIC REPRESENTATIONS FOR SOME RESOLUTION VI FRACTIONAL FACTORIAL PLANS SEQUENCES OF TWO-LEVEL FRACTIONAL FACTORIAL PLANS

TECH $62 \quad 47$

AMS 691840

TECH $69 \quad 477$

MIXED EXPONENTIAL DISTRIBUTION THE USE OF FRACTIONAL MOMENTS FOR ESTIMATING THE PARAMETERS OF A TECH 68 161 ND THEIR CONNECTION WITH A SPECIAL KIND OF IRREGULAR FRACTIONAL PLANS OF FACTORIAL EXPERIMENTS /FFECTS A JASA 63 497 ON FRACTIONAL POWERS OF A MATRIX

TRANSFORMATIONS TO NORMALITY USING FRACTIONAL POWERS OF THE VARIABLE

JASA 671018

JASA $57 \quad 237$

JRSS867 292

JASA $63 \quad 45$

TECH 60263

AMS $64 \quad 711$

AMS 68657

ESTIMATES OF EFFECTS FOR FRACTIONAL REPLICATES

ON THE STRUCTURE AND ANALYSIS OF SINGULAR FRACTIONAL REPLICATES

SEQUENCES OF FRACTIONAL REPLICATES IN

PARTIAL CONFOUNDING IN FRACTIONAL REPLICATION

ON ESTIMATION AND CONSTRUGTION IN FRACTIONAL REPLICATION

GENERALIZED LEAST SQUARES ESTIMATORS FOR RANDOMIZED FRACTIONAL REPLICATION DESIGNS

MENTS WITH THE FACTORS APPLIED SEQUENTIALLY

FRACTIONAL REPLICATION OFIG

RANDOMIZED FRACTIONAL WEIGHING DESIGNS

ON NON-RANDOMTZED FRACTTONAL WETGHTNG DESIGNS

GONAL LINEAR COMBINATIONS OF THE/ ON ESTIMATES FOR FRACTIONS OF A COMPLETE FACTORIAL EXPERIMENT AS ORTHO

FINDING NEW FRACTIONS OF FACTORIAL EXPERIMENTAL DESIGNS

ERRATA, 'FINDING NEW FRACTIONS OF FACTORIAL EXPERIMENTAL DESIGNS'

COMPOSITE DESIGNS BASED ON IRREGULAR FRACTIONS OF FACTORIALS (CORR. 65 1036)

IRREGULAR FRACTIONS OF THE 2-TO-THE-N FACTORIAL EXPERIMENTS

DESIGNS

SATURATED FRACTIONS OF 2-TO-THE-N AND 3-TO-THE-N FACTORIAL

SOME NONORTHOGONAL FRACTIONS OF 2-TO-THE-N DESIGNS

A NOTE ON FRACTIONS OF 3-TO-THE- $(4 \mathrm{~N}+1)$ DESIGNS

OBITUARY, C. G. FRAGA, JR

SOME NONRESPONSE SAMPLING THEORY WHEN THE FRAME CONTAINS AND UNKNOWN AMOUNT OF DUPLICATION QUESTION RANDOMIZED RESPONSE MODEL, THEORETICAL FRAMEWORK

OBITUARY, ADOLPHE FRANCESCHETTI

JASA $69 \quad 520$

BIOCS68 726

IN THE HISTORY OF PROBABILITY AND STATISTICS. XIX. FRANCIS YSIDRO EDGEWORTH (1845-1926)

STUDIES BIOKA68 269

DST QUERY, DEGREES OF FREEDOM OF CHI-SQUARE

TABLES OF THE FREEMAN-TUKEY TRANSFORMATIONS FOR THE BINOMIAL AND

FRENCH SUMMARTES OF PAPERS IN JUNE 1967 ISSUE

TECH $67 \quad 489$

BIOKAGI 433

BIOCS67 581

BIOCS68 277

JASA $63 \quad 1133$

BIOKA58 331

BIOCS65 49 
GRAPHICAL METHOD FOR MAKING MULTIPLE COMPARISONS OF FREQUENCIES DARD CHI-SQUARE-TEST OF THE HYPOTHESIS OF EQUAL CELL FREQUENCIES FOR THE MIXED MODEL WITH DISPROPORTIONATE SUBCLASS FREQUENCIES E GOODNESS-OF-FIT TESTS FOR SMALL BUT EQUAL EXPECTED FREQUENCIES

S AMONG ENVIRONMENTAL POCKETS UPON STEADY STATE GENE FREQUENCIES

E GOODNESS OF FIT TEST WITH SMALL BUT EQUAL EXPECTED FREQUENCIES A NOTE ON CONTINGENCY TABLES INVOLVING ZERO FREQUENCIES

THO ALTERNATIVES TO THE STAN BIOKAG2 TWO-WAY ANALYSIS OF VARIANCE BIOCS65 /CHI-SQUARE AND TWO MODIFIED CHI-SQUAR BIOKA66 /ION, AND DIFFERENI FITNESS REQUIREMENT BIOCS66 /XIMATION TO THE POWER OF THE CHI-SQUAR JASA 68 TECH 63

IMATION OF THE INBREEDING COEFFICIENT FROM PHENOTYPE FREQUENCIES BY A METHOD OF MAXIMUM LIKELIHOOD SCORING BIOCS68

NOTES. ON ESTIMATING RECESSIVE FREQUENCIES FROM TRUNCATED SAMPLES BIOCS6

ICH THE ABUNDANCES OF SPECIES ARE LO/ THE EXPECTED FREQUENCIES IN A SAMPLE OF AN ANIMAL POPULATION IN WH BIOKA51 427 ON THE ESTIMATION OF SMALL FREQUENCIES IN CONTINGENCY TABLES JRSSB56 II3

FOUR-LETTER WORDS, THE DISTRIBUTION OF PATTERN FREQUENCIES IN RING PERMUTATIONS

CHARACTERISTIC THE LIMITING FREQUENCIES OF INTEGERS WITH A GIVEN PARTITIONAL

JRSSB 67550

JRSSB59 134 BIOKA63 524 ON PARAMETERS CHI-SQUARE STATISTIC BASED ON THE POOLED FREQUENCIES OF SEVERAL OBSERVATIONS BIOKA53 237 QUADRATICS IN MARKOV-CHAIN FREQUENCIES, AND THE BINARY CHAIN OF ORDER 2 JRSSB63 THE FREQUENCY COUNT OF A MARKOV CHAIN AND THE TRANSITION AMS 61 TO CONTINUOUS TIME TABLES TO FACILITATE FITTING S-SUB-U FREQUENCY CURVES BIOKA65 547 IONS BASED ON DISTANCES BETWEEN PERCENTAGE POINTS OF FREQUENCY CURVES /XIMATE MEANS AND STANDARD DEVIAT BIOKAG ION COEFFICIENT IN RANDOM SAMPLES OF ANY SIZE/ THE FREQUENCY DISTRIBUTION OF THE PRODUCT-MOMENT CORRELAT BIOKA5I MEMBER OF THE SAMPLE IS DRAWN FROM A DIFFEREN/ THE FREQUENCY DISTRIBUTION OF THE SAMPLE MEAN WHERE EACH BIOKA63 50 LINEAR APPROXIMATOR FOR THE CLASS MARKS OF A GROUPED FREQUENCY DISTRIBUTION, WITH ESPECIAL REFERENCE TO TH TECH 68 793 SPECIES FREQUENCY DISTRIBUTIONS UNUSUAL FREQUENCY DISTRIBUTIONS

PROCESSES

THE GOODNESS OF FIT OF FREQUENCY DISTRIBUTIONS OBTAINED FROM STOCHASTIC BIOKA69 N0.3 BIOCS65 159 BIOKA54 450 JRSSB 65290 NTS DERIVATION OF A CLASS OF FREQUENCY DISTRIBUTIONS VIA BAYES'S THEOREM IOKA53 50 AMS $65 \quad 272$ INCREASING PROPERTIES OF POLYA FREQUENCY FUNCTIONS

UDY OF THE MATRIX OF FITTING OF A SERIES OF DISCRETE FREQUENCY FUNCTIONS ANALOGOUS TO THE TYPE A SERIES SASJ 67 55 OGONAL POLYNOMIALS OF POSITIVE AND NEGATIVE BINOMIAL FREQUENCY FUNCTIONS IN CURVE FITTING BY AITKEN'S METH BIOKA6I 476 AL POLYNOMIALS OF THE POSITIVE AND NEGATIVE BINOMIAL FREQUENCY FUNCTIONS IN CURVE FITTING BY AITKEN'S METH BIOKA6I 115 STIMATORS IN TW/ A NOTE ON THE EXACT FINITE SAMPLE FREQUENCY FUNCTIONS OF GENERALIZED CLASSICAL LINEAR E JASA 6I 6I9 A NOTE ON THE EXACT FINITE SAMPLE FREQUENCY FUNCTIONS OF GENERALTZED CLASSICAL LTNEAR E JASA 63 THE FREQUENCY JUSTIFICATION OF CERTAIN THE FREQUENCY JUSTIFICATION OF SEQUENTIAL TESTS, ADDENDUM BIOKA53 468

HISTORIES

BOUNDS FOR THE FREQUENCY OF MISLEADING BAYES INFERENCE

FREQUENCY RESPONSE FROU STATIONARY NOISE, TWO CASE

TECH $61 \quad 245$

JASA $67 \quad 226$

BIOKA66 617

EQUAL AND PROPORTIONAL FREQUENCY SQUARES

OF SOME BAYESIAN AND FREQUENTIST INFERENCES

A COMPARISON OF SOME BAYESIAN AND FREQUENTIST INFERENCES. II

COMPARISON OF SOME BAYESIAN AND FREQUENTIST INF
EQUIVALENCE AND SINGULARITY FOR FRIEDMAN URNS

A MULTIVARIATE EXTENSION OF FRIEDMAN'S CHI-SQUARE-SUB-R-TEST

A NOTE ON THE ASYMPTOTIC EFFICIENCY OF FRIEDMAN'S CHI-SQUARE-SUB-R-TEST BERNARD FRIEDMAN'S URN

STATISTICAL FRONTIERS

THE LOG (-LOG) TRANSFORMATION IN THE ANALYSIS OF FRUIT RETENTION RECORDS FOR MANUFACTURERS' SERVICES FOR BAKERY PRODUCTS AND FRUITS AND VEGETABLES AMPLE IN WHICH THE FORMER CANNOT BE ASSOCIATED WI/ FUDUCIAL DISTRIBUTIONS AND PRIOR DISTRIBUTIONS, AN EX JRSSB56 217 REMENT ERROR IN NONDESTRUCTIVE EVALUATION OF REACTOR FUEL ELEMENT QUALITY A PROGRAM TO ESTIMATE MEASU TECH 64 293 OPT IMAL SAMPLING FOR QUOTA FULFILMENT

QUOTA FULFILMENT USING UNRESTRICTED RANDOM SAMPLING

CONTINGENCY TABLES

$$
\begin{array}{r}
\text { QUOTA FULFILMENT USING UNRESTRICTED RANDOM SAMPLING } \\
\text { FULL CONTINGENCY TABLES, LOGITS, AND SPLIT }
\end{array}
$$

BIOKA65 19

BIOKA66 262

AMS $66 \quad 26 \mathrm{~B}$

JASA 69 NO 4

BIOKA67 677

AMS 65956

JASA 57

627

GENERALIZED INVERSES IN THE LINEAR HYPOTHESIS NOT OF FULL RANK

SUCCESSIVE CONDITIONAL EXPECTATIONS OF AN INTEGRABLE FUNCTION

HIERARCHICAL GROUPING TO OPTIMIZE AN OBJECTIVE FUNCTION

ON THE PERFORMANCE OF THE LINEAR DISCRIMINANT FUNCTION

A NONPARAMETRIC ESTIMATE OF A MULTIVARIATE DENSITY FUNCTION

ESTIMATION OF AN ACCELERATED DEPRECIATION LEARNING FUNCTION

ON THE INVERSE GAUSSIAN DISTRIBUTION FUNCTION

EFFICIENT ESTIMATION OF A PROBABILITY DENSITY FUNCTION

A TEST FOR SYMMETRY USING THE SAMPLE DISTRIBUTION FUNCTION

UNIFORM CONSISTENCY OF SOME ESTIMATES OF A DENSITY FUNCTION

A CONFIDENCE REGION FOR THE LOG-NORMAL HAZARD FUNCTION

AN APPROXIMATION TO THE SYMMETRICAL INCOMPLETE BETA FUNCTION TESTING FOR A JUMP IN THE SPECTRAL FUNCTION

A COMPUTER PROGRAM FOR FITTING THE RICHARDS FUNCTION

A SIMPLE ESTIMATE OF THE RECIPROCAL OF THE DENSITY FUNCTION

OF HYPOTHESES ABOUT THE PARAMETERS OF THE LOGISTIC FUNCTION

OF THE ESTIMATION OF LINEAR OPEN LOOP TRANSFER FUNCTION

THE ERROR IN THE LINEAR APPROXIMATION TO THE RENEWAL FUNCTION

MAXIMUM LIKELIHOOD ESTIMATION OF THE LOGISTIC GROWTH FUNCTION

FREE TESTS BASED ON THE SAMPLE DISTRIBUTTON FUNCTION

RELATING THE SPECTRAL DENSITY AND AUTOCORRELATION FUNCTION

CONFIDENCE INTERVALS FOR THE ZERO OF A REGRESSION FUNCTION

IN REGRESSION PROBLEMS WITH A GENERAL CONVEX LOSS FUNCTION

OF NON-LINEAR PARAMETERS FOR A NON-ASYMPTOTIC FUNCTION

FOR THE DISTRIBUTION OF THE LINEAR DISCRIMINANT FUNCTION

OF INDEPENDENCE BASED ON THE SAMPLE DISTRIBUTION FUNCTION

MIXTURE OF EXPONENTIALS TO BE A PROBABILITY DENSITY FUNCTION

ARIATE NORMAL POPULATION WITH GENERAL QUADRATIC LOSS FUNCTION

COVARIANCE MATRICES ON FISHER'S LINEAR DISCRIMINANT FUNCTION ESTIMATION OF A PROBABILITY DENSITY FUNCTION AND ITS DERIVATIVES 
A DIFFERENT LOSS FUNCTION FOR THE CHOICE BETWEEN TWO POPULATIONS ON THE RENEWAL FUNCTION FOR THE WEIBULL DISTRIBUTION

\section{NOTES.COMPUTING A DISCRIMINANT FUNCTION FROM WITHIN-SAMPLE DISPERSIONS} MAXIMIZING A FUNCTION IN A CONVEX REGION

ORMLY CONSTSTENT SEQUENCE OF ESTIMATORS OF A DENSITY FUNCTION IN CERTAIN CASES

\section{ON ESTIMATING THE SPECTRAL DENSITY FUNCTION OF A STOCHASTIC PROCESS (WITH DISCUSSION)}

NORMAL VARIABLES

JRSSB57 $\begin{array}{rr}\text { JRSSB57 } & 13 \\ \text { BIOKA60 } & 199\end{array}$ THE CHARACTERISTIC FUNCTION OF HERMITIAN QUADRATIC FORMS IN COMPLEX

ESTIMATION OF THE PROBABILITY OF AN EVENT AS A FUNCTION OF SEVERAL VARIABLES THE POWER FUNCTION OF SOME TESTS BASED ON RANGE THE DUAL FUNCTION OF STATISTICS

AMS $68 \quad 877$ BIOKA67 167 $\begin{array}{ll}\text { BIOKA67 } & 167 \\ \text { BIOKA53 } & 347\end{array}$ JASA $60 \quad 1$ BIOKA5B 429 BIOKA5B 421 NOTE ON MR SRIVASTAVA'S PAPER ON THE PONER FUNCTION OF STUDENT'S TEST EFFECT OF NON-NORMALITY ON THE POWER FUNCTION OF T-TEST THE BEHAVIOUR OF THE VARIANCE FUNCTION OF THE DIFFERENCE BETWEEN TWO ESTIMATED RESP JRSSB67 174

ONSES

LYSIS

TABLE

TABLE'

TABLE

AN ALGORITHM FOR OBTATNING THE ZERO ( ON THE POWER FUNCTION OF THE EXACT TEST FOR THE 2-BY-2 CONTINGENCY BIOKA6O CORRIGENDA, ON THE POWER FUNCTION OF THE EXACT TEST FOR THE 2-BY-2 CONTINGENCY BIOKA61 475 THE POWER FUNCTION OF THE EXACT TEST FOR THE 2-BY-3 CONTINGENCY TECH 64439 THE EFFECT OF NON-NORMALITY ON THE POWER FUNCTION OF THE F-TEST IN THE ANALYSIS OF VARIANCE BIOKA5I 43 EXACT AND APPROXIMATE POWER FUNCTION OF THE NON-PARAMETRIC TEST OF TENDENCY AMS 62471 B-N MULTIPLE-LATTICE DESIGN ESTIMATED REGRESSION FUNCTION OF THE Q-SUB-1 TO Q-SUB-N BY M-SUB-1 TO M-SU JRSSB69 NO.2 TRAL DISTRIBUTION OF THE SECOND ELEMENTARY SYMMETRIC FUNCTION OF THE ROOTS OF A MATRIX ON THE NON-CEN AMS 68 B33 EFFECT OF NON-NORMALITY ON THE POWER FUNCTION OF THE SIGN TEST 142 ROPORTIONS IN A 2-BY-2 TAB/ CORRIGENDA, "THE POWER FUNCTION OF THE TEST FOR THE DIFFERENCE BETWEEN TWO P BIOKA59 502 THE MOMENT GENERATING FUNCTION OF THE TRUNCATED MULTI-NORMAL DISTRIBUTION JRSSB6I 223 LIFIED EXPRESSION FOR THE VARIANCE OF THE CHI-SQUARE FUNCTION ON A CONTINGENCY TABLE DIMENSIONAL PROPERTIES OF A RANDOM DISTRIBUTION FUNCTION ON THE SQUARE F QUOTIENT OF MAXIMUM VALUES IN SAMPLES FROM A POWER-FUNCTION POPULATION DISTRIBUTION OF PRODUCT AND O JASA 64 877 A SAMPLE FUNCTION PROPERTY OF MARTINGALES

SOME BASIC PROPERTIES OF THE INCOMPLETE GAMMA FUNCTION RATIO. CORR. 65 15B4 AMS 661396 AMS $65 \quad 926$ ION ) ON MINIMIZING A CONVEX FUNCTION SUBJECT TO LINEAR INEQUALITIES (WITH DISCUSS JR MONOMTAL-MONOMIAL SYMMETRTC FUNCTION TABLES COMPARISON OF SUCCESSIVE SCREENING AND DISCRIMINANT FUNCTION TECHNIQUES IN MEDICAL TAXONOMY DISTRIBUTION OF DISCRIMINANT FUNCTION WHEN COVARIANCE MATRICES ARE PROPORTIONAL A NOTE ON THE RENEWAL FUNCTION WHEN THE MEAN RENEWAL LIFETIME IS INFINITE NFIDENCE INTERVALS FOR THE P-POINT OF A DISTRIBUTION FUNCTION, II NFIDENCE INTERVALS FOR THE P-POINT OF A DISTRIBUTION FUNCTION, III JRSSB6] 230 BOUNDED LENGTH CO AMS $66 \quad 581$ OF THEIR RECIPROCALS THE NORMAL PROBABILITY FUNCTION, TABLES OF CERTAIN AREA-ORDINATE RATIOS AND BI

ON THE ESTIMATION OF THE PARAMETERS OF THE LOGISTIC FUNCTION, USING THE MINIMUM LOGIT CHI-SQUARE METHOD

A USEFUL APPROXIMATION TO THE NORMAL DISTRIBUTION FUNCTION, WITH APPLICATION TO SIMULATION RIBUTION FREE TESTS BASED ON THE SAMPLE DISTRIBUTION FUNCTION" STATE SPACES BIRTH-AND-DEATH PRO/ ON THE PROBABILITY GENERATING FUNCTIONAL FOR THE CUMULATIVE POPULATION IN A SIMPLE FUNCTIONAL FORM IN THE DEMAND FOR MONEY

ON THE ASYMPTOTIC DISTRIBUTION OF A CERTAIN FUNCTIONAL OF THE WIENER PROCESS

PROCESSES AN EVALUATION OF A FUNCTIONAL ON INFINITELY DIVISIBLE STOCHASTIC AN EVALUATION OF A FUNCTIONAL ON INFIN
AMETERS OF A LINEAR FUNCTIONAL RELATION ESTIMATION OF THE PARAMETERS OF A LINEAR FUNCTIONAL RELATION
MAXIMUM LIKELIHOOD ESTIMATION OF A LINEAR FUNCTIONAL RELATIONSHIP REGRESSION, STRUCTURE AND FUNCTIONAL RELATIONSHIP ESTIMATION OF A FUNCTIONAL RELATIONSHIP

CONFIDENCE LIMITS FOR THE GRADIENT IN THE LINEAR FUNCTIONAL RELATIONSHIP THE BAYESIAN ESTIMATION OF A LINEAR FUNCTIONAL RELATIONSHIP IHOOD SOLUTION TO THE PROBLEM OF ESTIMATING A LINEAR FUNCTIONAL RELATIONSHIP A NOTE ON TESTS OF SIGNIFICANCE FOR LINEAR FUNCTIONAL RELATIONSHIPS ON CIRCULAR FUNCTIONAL RELATIONSHIPS

IFICANCE TESTS FOR DISCRIMINANT FUNCTIONS AND LINEAR FUNCTIONAL RELATIONSHIPS

A GENERALIZED LEAST-SQUARES APPROACH TO LINEAR FUNCTIONAL RELATIONSHIPS (WITH DISCUSSION) REGRESSION, STRUCTURE AND FUNCTIONAL RELATIONSHIPS. II SOME REMARKS ON CONTINUOUS ADDITIVE FUNCTIONALS ADDITIVE FUNCTIONALS AND EXCESSIVE FUNCTIONS SOME INVARIANCE PRINCIPLES FOR FUNCTIONALS OF A MARKOV CHAIN SOME THEOREMS ON FUNCTIONALS OF MARKOV CHAINS

SOME APPLICATIONS OF PROBABILITY GENERATING FUNCTIONALS TO THE STUDY OF INPUT-OUTPUT STREAMS USE OF RANDOMIZATION IN THE INVESTIGATION OF UNKNOWN FUNCTIONS ON THE ORDER AND THE TYPE OF ENTIRE CHARACTERISTIC FUNCTIONS BIOKA59 205 AIOCS69 N0.4 AMS $69 \quad 979$ AMS $66 \quad 586$ BIOKA55 217 BIOKA62 250 TECH $67 \quad 647$ BIOKA67 333 BIOKA64 245 JASA 68502 AMS 691409 AMS $64 \quad 336$ JRSSB61 160 AMS $61 \quad 1048$ BIOKA5I 11 BIOKA53 47 $\begin{array}{ll}\text { BIOKA53 } & 47 \\ \text { JRSSB56 } & 65\end{array}$ JRSSB68 190 THE MAXIMUM LIKEL JRSSB 69 NO.2 BIOKA57 268 JRSSB $65 \quad 45$ BIOKA55 360 JRSSB66 278 BIOKA52 96 AMS 671655 AMS $65 \quad 409$ AMS $67 \quad 1$ AMS 641275 JRSSB68 321 JASA $58 \quad 176$ AMS 621238 
DETERMINING BOUNDS ON EXPECTED VALUES OF CERTAIN FUNCTIONS ASYMPTOTIC EXPANSIONS FOR A CLASS OF DISTRIBUTION FUNCTIONS INTERVAL ESTIMATION OF NON-LINEAR PARAMETRIC FUNCTIONS INCREASING PROPERTIES OF POLYA FREQUENCY FUNCTIONS ADDITIVE FUNCTIONALS AND EXCESSIVE FUNCTIONS INFINITELY DIFFERENTIABLE POSITIVE DEFINITE FUNCTIONS SOME PROPERTIES OF STATISTICAL RELIABILITY FUNCTIONS SPECTRAL ESTIMATES USING NONLINEAR FUNCTIONS SEQUENTIAL DESIGNS FOR SPHERICAL WEIGHT FUNCTIONS SOME INTEGRAL TRANSFORMS OF CHARACTERISTIC FUNCTIONS ON THE EVALUATION OF DISTRIBUTION FUNCTIONS STOCHASTIC APPROXIMATION FOR SMOOTH FUNCTIONS A NOTE ON CHARACTERISTIC FUNCTIONS SIMPLIFIED DECISION FUNCTIONS

ON A CLASS OF SKEW DISTRIBUTION FUNCTIONS ON THE SMOOTHING OF PROBABILITY DENSITY FUNCTIONS PROPERTY, W, OF THE CLASS OF STATISTICAL DECISION FUNCTIONS POLYNOMIALS, A USEFUL GROUP OF MULTI-FACTOR RESPONSE FUNCTIONS BEHAVIOR AND INTEGRABILITY OF CHARACTERISTIC FUNCTIONS TIME TREATMENT OF A SIMPLE QUEUE USING GENERATING FUNCTIONS

PROPERTIES OF INFINITELY DIVISIBLE DISTRIBUTION FUNCTIONS SINGULAR INFINITELY DIVISIBLE DISTRIBUTION FUNCTIONS AND INVARIANT MEASURES FOR MARKOFF TRANSITION FUNCTIONS OF THE NORMAL AND INVERSE NORMAL DISTRIBUTION FUNCTIONS TRANSFORMS TO DETERMINE EXPANSIONS OF DISTRIBUTION FUNCTIONS EPARAMETERIZATION OF SOME SIGMOID OR OTHER NONLINEAR FUNCTIONS

TO THE CHI-SQUARE AND NON-CENTRAL F PROBABILITY FUNCTIONS FOR NONLATTICE MULTI-DIMENSIONAL DISTRIBUTION FUNCTIONS

EPIDEMIC, A COMPLETE SOLUTION IN TERMS OF KNOWM FUNCTIONS

RANK TESTS ON THE EQUALITY OF TWO DISTRIBUTION FUNCTIONS RVICE-TIME DISTRIBUTIONS BY THE METHOD OF GENERATING FUNCTIONS KELIHOOD AND BEST UNBIASED ESTIMATORS OF RELIABILITY FUNCTIONS MATRIX OF FITTING OF A SERIES OF DISCRETE FREQUENCY FUNCTIONS DISTRIBUTION

$$
\text { CAUCHY-DISTRIBUTED FUNCTIONS AND }
$$
THE REAL STABLE CHARACTERISTIC FUNCTIONS AND CHAOTIC ACCELERATION

NUMBERS SOME RESULTS RELATING MOMENT GENERATING FUNCTIONS AND CONVERGENCE RATES IN
GROWTH-INVARIANT DISCRIMINANT FUNCTIONS AND GENERALIZED DISTANCES

GROWTH-INVARIANT DISCRIMINANT FUNCTIONS AND GENERALIZED DISTANCES
ADDITIONAL RESULTS CONCERNING ESTIMABLE FUNCTIONS AND GENERALIZED INVERSE MATRICES

SIGNIFICANCE TESTS FOR DISCRIMINANT FUNCTIONS AND LINEAR FUNCTIONAL RELATIONSHIPS

AMS 621454 AMS 631302 JASA $63 \quad 611$ AMS $65 \quad 272$ AMS $65 \quad 409$ AMS $66 \quad 504$ AMS $66 \quad 826$ AMS $66 \quad 1237$ TECH $67 \quad 517$ AMS $68 \quad 1923$ JASA $68 \quad 715$ AMS 69299 AMS $69 \quad 303$ BIOKA54 241 BIOKA55 425 JRSSB58 334 ON THE AMS 661631 INVERSE BIOCS66 128 LIPSCHITZ AMS $67 \quad 32$ A CONTINUOUS JRSSB54 288 ON CONTINUITY AMS 68936 ON CONTINUOUS AMS $64 \quad 330$ INTEGRAL KERNELS AMS $65 \quad 517$ COMPUTER EVALUATION TECH 69 NO. 4 THE USE OF INTEGRAL BIOKA60 460 GENERALIZATION AND R BIOCS65 7OB NORMAL APPROXIMATION BIOKA6O 411 A LOCAL LIMIT THEOREM AMS 65546 THE SIMPLE STOCHASTIC BIOKA63 235 ON THE POWER OF TWO-SAMPLE JRSSB64 293 /CHANNEL QUEUE WITH A GENERAL CLASS OF SE JRSSB5B 176 NNCIES IN SMALL SAMPLES OF THE MAXIMUM LI JASA 661033 $\begin{array}{llr}\text { ANCIES IN SMALL SAMPLES OF THE MAXIMUM LI JASA } 66 & 1033 \\ \text { ALOGOUS TO THE TYPE A SERIES /DY OF THE SASJ } 67 & 55\end{array}$ AMS $6910 \mathrm{B3}$ JRSSB $61 \quad 180$ AMS $67 \quad 742$ BIOCS66 96 JRSSB65 4B6 BIOKA55 360 ORRELATED NORMAL RA/ ON THE DISTRIBUTION OF LINEAR FUNCTIONS AND RATIOS OF LINEAR FUNCTIONS OF ORDERED C BIOKA64 I43 ON MOMENT GENERATING FUNCTIONS AND RENEWAL THEORY

A SYSTEM OF INEQUALITIES FOR THE INCOMPLETE GAMMA FUNCTIONS AND THE NORMAL INTEGRAL AMS 651298 AMS $65 \quad 139$ E LIMITS. ELIMINATION OF REQUIREMENT THAT CUMULATIVE FUNCTIONS BE CONTINUOUS DISTRIBUTION FREE TOLERANC TECH 63 5 . WTON METHOD FOR THE FITTING OF NON-LINEAR REGRESSION FUNCTIONS BY LEAST SQUARES THE MODIFIED GAUSS-NE TECH 6I 269 TION OF SAMPLING DISTRIBUTIONS AND MOMENT GENERATING FUNCTIONS BY SOLVING DIFFERENTIAL EQUATIONS /ERMINA JRSSB65 86 POWER FUNCTIONS FOR COX'S TEST OF RANDOMNESS AGAINST TREND TECH 62430 GENERATING FUNCTIONS FOR MARKOV RENEWAL PROCESSES $\quad$ AMS 64431 G THE USE OF INCOMPLETE BETA FUNCTIONS FOR PRIOR DISTRIBUTIONS IN BINOMIAL SAMPLIN TECH 65 335 SED AND MAXIMUM LIKELIHOOD ESTIMATORS OF RELIABILITY FUNCTIONS FOR SYSTEMS IN SERIES AND IN PARALLEL /IA JASA 66 IO52 ENCY TABLES COMPARISON OF THE PONER FUNCTIONS FOR THE TEST OF INDEPENDENCE IN $2 X 2$ CONTING AMS 64 1115 L ANALYSIS A CLASS OF TESTS WITH MONOTONE POWER FUNCTIONS FOR TWO PROBLEMS IN MULTIVARIATE STATISTICA AMS 65 I794 ESTIMATING THE COVARIANCE AND SPECTRAL DENSITY FUNCTIONS FROM A CLIPPED STATIONARY TIME SERIES IBO IALS OF THE POSITIVE AND NEGATIVE BINOMIAL FREQUENCY FUNCTIONS IN CURVE FITTING BY AITKEN'S METHOD /YNOM BIOKA6I II5 YNOMIALS OF POSITIVE AND NEGATIVE BINOMIAL FREQUENCY FUNCTIONS IN CURVE FITTING BY AITKEN'S METHOD' /POL BIOKA6I 476 BUTION PROBLEMS BASED ON POSITIVE DEFINITE QUADRATIC FUNCTIONS IN NORMAL VECTORS HYPERGEOMETRIC FUNCTIONS IN SEQUENTIAL ANALYSIS AMS 65 1870 DISTRIBUTIONS APPLICATION OF SPECIAL FUNCTIONS IN THE CHARACTERIZATION OF PROBABILITY ITY, CONTINUITY AND DIFFERENTIABILITY OF A FAMILY ON FUNCTIONS INTRODUCED BY L. TACAKS ON THE INTEGRABIL AMS 63 1045 ON FINDING LOCAL MAXIMA OF FUNCTIONS OF A REAL VARIABLE BIOKA67 310 CAUCHY-DISTRIBUTED FUNCTIONS OF CAUCHY VARIATES $\quad$ AMS 67916 ON THE BIAS OF FUNCTIONS OF CHARACTERISTIC ROOTS OF A RANDOM MATRIX BIOKA65 87

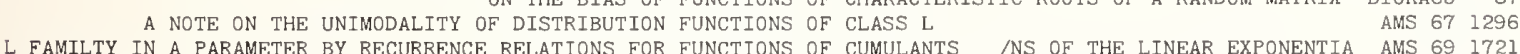
ADMISSIBILITY AND DISTRIBUTION OF SOME PROBABILISTIC FUNCTIONS OF DISCRETE FINITE STATE MARKOV CHAINS FUNCTIONS OF FINITE MARKOV CHAINS

A CHARACTERIZATION OF A CLASS OF FUNCTIONS OF FINITE MARKOV CHAINS IDENTIFICATION OF STATE-CALCULABLE FUNCTIONS OF FINITE MARKOV CHAINS FUNCTIONS OF FINITE MARKOV CHAINS FUNCTIONS OF FINITE MARKOV CHAINS AND EXPONENTIAL TYPE PROCESSES

STATISTICAL INFERENCE FOR PROBABILISTIC FUNCTIONS OF FINITE STATE MARKOV CHAINS PROBABILISTIC FUNCTIONS OF FINITE STATE MARKOV CHAINS SAMPLE FUNCTIONS OF GAUSSIAN RANDOM HOMOGENEOUS FIELDS ARE EITHER CONTINUOUS OR VERY IRREGULAR IN TW/ A NOTE ON THE EXACT FINITE SAMPLE FREQUENCY FUNCTIONS OF GENERALIZED CLASSICAL LINEAR ESTIMATORS THE APPLICATION OF EXACT FINITE SAMPLE DISTRIBUTION FUNCTIONS OF GENERALIZED CLASSICAL LINEAR ESTIMATORS IN A/ A NOTE ON THE EXACT FINITE SAMPLE FREQUENCY FUNCTIONS OF GENERALIZED CLASSICAL LINEAR ESTIMATORS OPTIMUM ESTIMATORS FOR LINEAR FUNCTIONS OF LOCATION AND SCALE PARAMETERS

APPROXIMATIONS FOR THE ENTROPY FOR FUNCTIONS OF MARKOV CHAINS OPTIMAL STOPPING FOR FUNCTIONS OF MARKOV CHAINS

IBUTION OF HOMOGENEOUS AND NON-HOMOGENEOUS QUADRATIC FUNCTIONS OF NORMAL VARIABLES /TIONS, IV, THE DISTR OF A HIGHER ORDER ON CERTAIN FUNCTIONS OF NORMAL VARIATES N UNCORRELATED LINEAR FUNCTIONS OF ORDER STATISTICS LINEAR FUNCTIONS OF ORDER STATISTICS ASYMPTOTIC NORMALITY OF LINEAR COMBINATIONS OF FUNCTIONS OF ORDER STATISTICS ELEMENTARY PROOF OF ASYMPTOTIC NORMALITY OF LINEAR FUNCTIONS OF ORDER STATISTICS ON RECURRENCE RELATIONS BETWEEN EXPECTED VALUES OF FUNCTIONS OF ORDER STATISTICS TIONS A RECURRENCE RELATION FOR DISTRIBUTION FUNCTIONS OF ORDER STATISTICS $\begin{array}{lll}\text { AMS } & 6 \mathrm{~B} & 1646 \\ \text { AMS } & 63 & 1022\end{array}$ AMS $65 \quad 524$ AMS $67 \quad 201$ AMS $67 \quad 206$ AMS $68 \quad 1020$ AMS $66 \quad 1554$ AMS $69 \quad 97$ AMS $67 \quad 1579$ JASA $61 \quad 619$ JASA $63 \quad 943$ JASA $63 \quad 161$ AMS 69 NO.6 AMS $62 \quad 930$ AMS 681905 $\begin{array}{lrr}\text { AMS } & 68 & 1905 \\ \text { AMS } & 62 & 542\end{array}$ BIOKA60 175 JASA $63 \quad 245$ AMS $69 \quad 770$ AMS 69 N0.6 AN AMS $68 \quad 263$ A NOTE AMS $66 \quad 733$ 
ASYMPTOTIC DISTRIBUTION OF LINEAR COMBINATIONS OF FUNCTIONS OF ORDER STATISTICS WITH APPLICATIONS TO ES RECURRENCE RELATIONS BETWEEN THE PROBABILITY DENSITY FUNCTIONS OF ORDER STATISTICS, AND SOME APPLICATIONS VARI ABLES

ON LINEAR FUNCTIONS OF ORDERED CORRELATED NORMAL RANDOM

GAUSSIAN PROCESS ON EXPECTATIONS OF SOME FUNCTIONS OF POISSON VARIATES

ON THE SAMPLE FUNCTIONS OF PROGESSES WHICH CAN BE ADDED TO A FUNCTIONS OF PROCESSES WITH MARKOVIAN STATES FUNCTIONS OF PROCESSES WITH MARKOVIAN STATES. II

NORMAL VARIABLES

SOME MULTIVARIATE DENSITY FUNCTIONS OF PRODUCTS OF GAUSSIAN VARIATES. MOMENT GENERATING FUNCTIONS OF QUADRATIC FORMS IN

ON FINITE PRODUCTS OF POISSON-TYPE CHARACTERISTIC FUNCTIONS OF SEVERAL CARIABLES
FUNCT/ ON THE PROBABILITY OF LARGE DEVIATIONS OF FUNCTIONS OF SEVERAL EMPIRICAL CUMULATIVE DISTRIBUTIO N FUNCT/ ON THE PROBABILITY OF LARGE DEVIATIONS OF FUNCTIONS OF SEVERAL EMPIRICAL CUMULATIVE DISTRIBL
RELATED TEST
LIMIT THEOREMS FOR FUNCTIONS OF SHORTEST TWO-SAMPLE SPACINGS AND A NOTES. TABLES OF PEARSON-LEE-FISHER FUNCTIONS OF SINGLY TRUNCATED NORMAL DISTRIBUTIONS S OF MULTIVARIATE NORMAL DIST/PROPERTIES OF POWER FUNCTIONS OF SOME TESTS CONCERNING DISPERSION MATRICE SETS OF VARIATES MONOTONICITY OF THE POWER FUNCTIONS OF SOME TESTS OF INDEPENDENCE BETWEEN TWO ANCE MATRICES. MONOTONICITY PROPERTY OF THE POWER FUNCTIONS OF SOME TESTS OF THE EQUALITY OF TWO COVARI HYPOTHESIS MONOTONICITY OF THE POWER FUNCTIONS OF SOME TESTS OF THE MULTIVARIATE LINEAR EXCHANGEABLE PROCESSES WHICH ARE FUNCTIONS OF STATIONARY MARKOV CHAINS

AMS 67 BIOCS 6 B 97 AMS $63 \quad 329$ AMS 68 93B AMS 69 B65 BIOKA65 645 BIOKA5B 198 AMS $69 \quad 434$ AMS $67 \quad 360$ AMS $67 \quad 108$ BIOCS65 219 AMS 69697 AMS 64206 AMS 641059 AMS 64200 AMS $64 \quad 429$

A GOODNESS OF FIT TEST FOR SPECTRAL DISTRIBUTION FUNCTIONS OF STATIONARY TIME SERIES WITH NORMAL RESID BIOKA56 257 BOUNDS ON THE DISTRIBUTION FUNCTIONS OF THE BEHRENS-FISHER STATISTIC

ANALYSIS THE MOMENTS OF ELEMENTARY SYMMETRIC FUNCTIONS OF THE ROOTS OF A MATRIX IN MULTIVARIATE

DISTRIBUTIONS ON ELEMENTARY SYMMETRIC FUNCTIONS OF THE ROOTS OF A MULTIVARIATE MATRIX.

ON THE MOMENTS OF ELEMENTARY SYMMETRIC FUNCTIONS OF THE ROOTS OF TWO MATRTCES

IONS TO A DIST/ ON MOMENTS OF ELEMENTARY SYMMETRIC FUNCTIONS OF THE ROOTS OF TWO MATRICES AND APPROXIMAT E ANALYSIS

POISSON VARIATE

ON ELEMENTARY SYMMETRIC FUNCTIONS OF THE ROOTS OF TWO MATRICES IN MULTIVARIAT FUNCTIONS OF THE SAMPLE MEAN AND SAMPLF VARTANCE OF A BIOCS69 171 THE ASYMPTOTIC DISTRIBUTION OF SOME NON-LINEAR FUNCTIONS OF THE TWO-SAMPLE RANK VECTOR

THE DISTRIBUTION FUNCTIONS OF TSAO'S TRUNCATED SMIRNOV STATISTICS AMS $66 \quad 639$ AMS 611152 AMS 641186 AMS 641704 AMS $68 \quad 1274$ IOCS69 171 AMS 691011 AMS 671208 AMS 611145 ON THE MONOTONIC CHARACTER OF THE POWER FUNCTIONS OF TWO MULTIVARIATE TESTS

GLASSI/ DESIGNS FOR THE SIMULTANEOUS ESTIMATION OF FUNCTIONS OF VARIANCE COMPONENTS FROM TWO-WAY GROSSED SOME APPLICATIONS OF MEIJER-G FUNCTIONS TO DISTRIBUTION PROBLEMS IN STATISTIGS

A METHOD FOR DISCRIMINATING BETWEEN FAILURE DENSITY FUNCTIONS USED IN RELIABILITY PREDICTIONS LIKELIHOOD DISTRIBUTIONS FOR ESTIMATING FUNCTIONS WHEN BOTH VARIABLES ARE SUBJECT TO ERROR APPROXIMATIONS TO DISTRIBUTION FUNCTIONS WHICH ARE HYPERGEOMETRIC SERIES TABLES OF SYMMETRIC FUNCTIONS. PART IV TABLES OF SYMMETRIC FUNCTIONS. PART V TABLES OF SYMMETRIC FUNCTIONS. PARTS II AND III GENERALIZED BAYES DECISION FUNCTIONS, ADMISSIBILITY AND THE EXPONENTIAL FAMILY
ATION, POWER-LAW COVARIANCE FUNCTIONS, AND DIFFUSION TOPOGRAPHIC CORRELATION, POWER-LAW COVARIANCE FUNCTIONS TYPE LTMTT THEOREMS FOR EMPIRICAL DISTRIBUTION FUNCTIONS, CORR 651069 INTERVAL ESTIMATION OF NON-LINEAR PARAMETRIC FUNCTIONS, II INTERVAL ESTIMATION OF NON-LINEAR PARAMETRIC FUNGTIONS, ERRATA IN ITABLES OF SYMMETRIC FUNCTIONS'

THE ESTIMATION OF 'TRANSFER FUNCTIONS' OF QUADRATIC SYSTEMS

STATISTICAL TREATMENT OF CENSORED DATA. PART I. FUNDAMENTAL FORMULAE IMMIGRATION PROCESS THE ESTIMATION OF A FUNDAMENTAL INTERACTION PARAMETER IN AN EMIGRATION-

TWO FURTHER APPLICATTONS OF A MODEL FOR BINARY REGRESSION FURTHER APPLICATIONS OF RANGE TO THE ANALYSIS OF BIOKA62 305 BIOKA5B 578 TECH $65 \quad 1$ TECH $67 \quad 261$ BIOKA68 243 BIOKA53 427 BIOKA55 223 BIOKA51 435 AMS $67 \quad 81 \mathrm{~B}$ JASA $64 \quad 168$ JASA $65 \quad 1191$ BIOKA58 292 TEGH $61 \quad 563$ BIOKA54 22B AMS $63 \quad 23 \mathrm{~B}$

VARIANCE 'S STATISTIC IN THE GENERAL CASE BOUNDS

BOUNDS '

A FURTHER APPROXIMATION TO THE DISTRIBUTION OF WILCOX FURTHER CONTRIBUTIONS TO MULTIVARIATE CONFIDENCE A NOTE ON 'FURTHER CONTRIBUTIONS TO MULTIVARIATE GONFIDENCE CORRIGENDA. 'FURTHER CONTRIBUTIONS TO MULTIVARIATE CONFIDENCE FURTHER CRITICAL VALUES FOR THE SUM OF TWO VARIANCES FURTHER CRITICAL VALUES FOR THE TWO-MEANS PROBLEM BIOKA5I 393 JRSSB54 255 BIOKA57 399 BIOKA58 5BI BIOKA61 474 BIOKA5B 279 BIOKA56 203 NG TABLES ON THE COMPARISON OF TWO MEANS. FURTHER DISCUSSION OF ITERATIVE METHODS FOR CALCULATI A FURTHER LOOK AT ROBUSTNESS VIA BAYES'S THEOREM CORRIGENDA, 'A FURTHER LOOK AT ROBUSTNESS VIA BAYES'S THEOREM A FURTHER NOTE ON A SIMPLE METHOD FOR FITTING AN A FURTHER NOTE ON THE GEOMETRY OF LINEAR ESTIMATION

EXPONENTIAL CURVE

SOME FURTHER NOTES ON DISTURBANCE ESTIMATES IN REGRESSION FURTHER NOTES ON THE ANALYSIS OF ACCIDENT DATA FURTHER PERCENTAGE POINTS FOR W-SQUARE-SU8-N + (CRAMER FURTHER PROPERTIES OF AN ANGULAR TRANSFORMATION OF

-VON MISES GOODNESS-OF-FIT STATISTIC)

THE CORRELATION COEFFICIENT

ESTIMATION OF VARIANCE COMPONENTS '

CORRELATED OBSERVATIONS

ORDERED FAMILIES OF DISTRIBUTION

SOME FURTHER REMARKS CONCERNING 'A GENERAL APPROACH TO THE FURTHER REMARKS ON EXPONENTIAL REGRESSION WITH FURTHER REMARKS ON TOPOLOGY AND CONVERGENCE IN SOME THE ALMOST FULL DAM WITH POISSON INPUT FURTHER RESULTS

SIMPLE QUEUE

TRAFFIC

TRAFFIC

SOME FURTHER RESULTS IN THE NON-EQUILIBRIUM THEORY OF A

BIOKA54 361

BIOKA62 419

BIOKA63 546

BIOKA60 177

BIOKA63 540

JASA $67 \quad 169$

8IOKA53 214

8IOKA68 428 BIOKA57 273

TECH $68 \quad 551$ BIOKA68 575 AMS 6951

JRSS866 448 JRSS $857 \quad 326$

CORRIGENDA TO SOME FURTHER RESULTS IN THE THEORY OF PEDES'TRIANS AND ROAD BI FURTHER SECOND ORDER ROTATABLE DESIGNS
CROSSROAD CHOICES FOR THE FUTURE DEVELOPMENT OF THE FEDERAL STATISTICAL SYSTEM

IOKA58 291
UTOMATIC PRODUCTION AND CONTROL DEVICES AND EXPECTED FUTURE DEVELOPMENTS OPTIMAL STOPPING WHEN THE FUTURE IS DISCOUNTED

THE FUTURE OF DATA ANALYSIS, CORR. 62812

SOME APPLICATIONS OF MEIJER-G FUNGTIONS TO DISTRIBUTION PROBLEMS IN STATISTICS THE EFFEGT OF FIELD BLOGKING ON GAIN FROM SELEGTION

$N$ AS APPLIED TO EXTRAPOLATION IN S-/ A NOTE ON THE GAIN IN PRECISION FOR OPTIMAL ALLOGATION IN REGRESSIO THE GORRELATION BETWEEN FEED EFFICIENGY AND RATE OF GAIN, A RATIO AND ITS DENOMINATOR

SGOOLING, EXPERIENGE, AND GAINS AND LOSSES IN HUMAN GAPITAL THROUGH MIGRATION ON THE GALTON-WATSON BRANGHING PROCESS WITH MEAN LESS THAN ONE A THEOREM ON THE GALTON-WATSON PROCESS

ON RECENT THEOREMS GONCERNING THE SUPERGRITIGAL GALTON-WATSON PROCESS

IZE OR MAXIMIZE THE PROBABILITIES OF EXTINGTION IN A GALTON-WATSON PROGESS AND IN SOME RELATED MULTIPLIGAT THE MULTI-TYPE GALTON-WATSON PROGESS IN A GENETIGAL CONTEXT

2

(1)

5

8

8

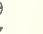

.


ON THE MEAN DURATION OF A BALL AND CELL GAME, A FIRST PASSACE PROBLEM TO BAYES RISK IN SEQUENCES OF NON-FINITE GAMES

\section{RECURRENT GAMES AND THE PETERSBURG PARADOX}

GAMES ASSOCIATED WITH A RENEWAL PROCESS

REPETITIVE PLAY IN FINITE STATISTICAL GAMES WITH UNKNOWN DISTRIBUTTONS HISTORY OF PROBABILITY AND STATISTICS. I. DICING AND GAMINC (A NOTE ON THE HISTORY OF PROBABILITY)
BIBLIOCRAPHY ON SIMULATION, GAMINC, ARTIFICIAL INTELLICENCE AND ALLIED TOPICS

A PARTIAL COEFFTCIENT FOR GOODMAN AND KRUSKAL'S CAMMA OF THE SAMPLE VERSION OF THE MEASURE OF ASSOCIATION. CAMMA CONDITION FOR THE SQUARE OF A RANDOM VARIABLE TO BE GAMMA

'MAXIMUM-LIKELIHOOD ESTIMATION OF THE PARAMETERS OF GAMMA AND WEIBULL POPULATIONS FROM COMPLETE AND FROM TE ESTIMATION FROM THE ORDER STATISTICS OF UNEQUAL GAMMA COMPONENTS

ORDER STATISTICS FROM THE GAMMA DISTRIBUTION

A GENERALIZATION OF THE CAMMA DISTRIBUTION

PROBABILITY PLOTS FOR THE GAMMA DISTRIBUTION

AN APPLICATION OF A GENERALIZED GAMMA DISTRIBUTION

TOLERANCE LIMTTS FOR THE GENERALIZED GAMMA DISTRIBUTION

PARAMETER ESTIMATION FOR A GENERALIZED GAMMA DISTRIBUTION NONPARAMETRIC LIFE TEST FOR SMALLER PERCENTILES OF A CAMMA DISTRIBUTION

XIMUM LIKELIHOOD ESTIMATION OF THE PARAMETERS OF THE GAMMA DISTRIBUTION AND THEIR BIAS AIDS FOR FITTING THE GAMMA DISTRIBUTION BY MAXIMUM LIKELIHOOD

SCALE PARAMETER AMS 6966 JASA $61 \quad 703$ AMS 641344 AMS 641345 AMS $69 \quad 789$ AMS 661796 AMS $67 \quad 242$ AMS $67 \quad 251$ AMS $66 \quad 517$ AMS $69 \quad 467$ AMS $61 \quad 187$ AMS $62 \quad 697$ AMS $66 \quad 976$ BIOKA55 1 JASA $60 \quad 736$ ASA $67 \quad 189$ BIOKA66 275 TECH $65 \quad 639$ TECH $67 \quad 195$ AMS $66 \quad 152$ TECH $60 \quad 243$ AMS 62 11B7 TECH 62 AMS 641368 JASA 651142 TECH $65 \quad 349$ ESTIMATION OF THE PARAMETERS OF THE GAMMA DISTRIBUTION BY SAMPLE QUANTILES

AN APPROXIMATION TO THE PROBABILITY INTEGRAL OF THE GAMMA DISTRIBUTION FOR SMALL VALUES OF THE SHAPE PARA BI LIFE TESTS GAMMA DISTRIBUTION IN ACCEPTANCE SAMPLING BASED ON TECH $60 \quad 55$ TECH $64 \quad 405$ GAMMA DISTRIBUTION IN ACCEPTANCE SAMPLING
GAMMA DISTRIBUTION USING ORDER STATISTICS ESTIMATION OF PARAMETERS OF THE GAMMA DISTRIBUTION USING ORDER STATISTICS IHOOD ESTIMATION OF SCALE OR SHAPE PARAMETERS OF THE CAMMA DISTRIBUTION USING ORDER STATISIICS CORRIGENDA, 'ESTIMATION OF PARAMETERS OF THE GAMMA DISTRIBUTION
DNT RANDOM VARIABLES WHOSE PRODUCT FOLLOWS THE GAMMA DISTRIBUTION ERRATA, 'ORDER STATISTICS FROM THE CAMMA DISTRIBUTION' ON PAIRS OF IN BIOKA62 BIOKA63 BIOKA63 TECH $60 \quad 523$ AMS 691401 BIOKA69 NO.3 THE CANONICAL CORRELATION COEFFICIENTS OF BIVARIATE GAMMA DISTRIBUTIONS
STATISTICAL INFERENCE WITH BIVARIATE GAMMA DISTRIBUTIONS ONFIDENCE LIMITS FOR THE COEFFICIENT OF VARIATION IN CAMMA DISTRIBUTIONS SOME BASIC PROPERTIES OF THE INCOMPLETE GAMMA FINCTION RATIO CORR 65 I5B4 APPROXIMATE C BIOCS65 733 AMS 65926 A SYSTEM OF INEQUALITIES FOR THE INCOMPLETE GAMMA FUNCTIONS AND THE NORMAL INTEGRAL IVAL AND SERVING DISTRIBUTIONS ARE DETERMINISTIC AND GAMMA OF ORDER K RESPECTIVELY /. WHILE THE INTERARR JRSSB63 477 RRIVAL AND SERVING DISTRIBUTIONS ARE EXPONENTIAL AND GAMMA OF ORDER LAMBDA RESPECTIVELY /HILE THE INTERA JRSSB66 336 PROBLEM A NOTE ON MOMENTS OF GAMMA ORDER STATISTICS TECH $67 \quad 315$ SOME INFERENCES ABOUT GAMMA PARAMETERS WITH AN APPLICATION TO A RELIABILITY JASA 63670 N OF THE PARAMETERS OF A FOUR- PARAMETER GENERALIZED CAMMA POPULATION FROM COMPLETE AND CENSORED SAMPLES TECH 67 159 M CENSORED SAMPLES OF THE PARAMETERS OF WETBULL AND CAMMA POPULATIONS /XIMUM-LIKELIHOOD ESTIMATORS, FRO AMS 67 LINEAR ESTIMATION AND THE ANALYSIS OF GAMMA RAY PULSE-HEIGHT SPECTRA SAMPLING RESULTS FOR RECRESSION ANALYSIS APPLIED TO GAMMA RAY SPECTROMETER DATA, SAMPLING RESULTS FOR REGRESSTON ANALYSIS APPLIED TO GAMMA RAY SPECTROMETER DATA, NGLE SERVER QUEUING PROCESS STRIBUTION OF THE PRODUCT OF INDEPENDENT GENERALIZED VARIABLES

SOME EXPERTMENTAL BTOCS6 SOME EXPERIMENTAL BIOCS6B 353 WARIABLES WITH THE SAME SHAPE PARAMETER /T DI AMS 68175 GAMMA-DISTRIBUTED PRODUCTS OF INDEPENDENT RANDOM BIOKA62 564 INVERSE DISTRIBUTIONS AND INDEPENDENT GAMMA-DISTRIBUTED PRODUCTS OF RANDOM VARIABLES OF IDENTICALLY DISTRIBUTED EXPONENTIALLY CORRELATED GAMMA-VARIABLES, (ACKNOWLEDGEMENT OF PRIORITY 64925 ) AMS 64 277 THE GAP TEST FOR RANDOM SEQUENCES QUEUEINC FOR CAPS IN TRAFFIC.

OBILES AMS 61524 TECH $60 \quad 5$ JRSSB54 11B TECH $62 \quad 97$ GRADING WITH A GAUGE SUBJECT TO RANDOM OUTPUT FLUCTUATIONS TECH 62 CUMULATIVE SUM SCHEMES USING GAUGINC

YSIS OF THE DATA FOR SOME EXPERIMENTS CARRIED OUT BY GAUSE WITH POPULATIONS OF THE PROTOZOA PARAMECIUM AUR BIOKA57 314 ND STATISTICS. XV. THE HISTORICAL DEVELOPMENT OF THE GAUSS LINEAR MODEL /IN THE HISTORY OF PROBABILITY A BIOKA67 I A COORDINATE-FREE APPROACH WHEN ARE GAUSS-MARKOV AND LEAST SQUARES ESTIMATORS IDENTICAL. AMS 68 70 HOMOGENEOUS GAUSS-MARKOV RANDOM FIELDS A GENERALIZATION OF THE GAUSS-MARKOV THEOREM JASA $66 \quad 1063$ RESSION FUNCTIONS BY LEAST SQUARES THE MODIFIED GAUSS-NEWTON METHOD A SIMPLE METHOD OF RESOLUTION OF A DISTRIBUTION INTO GAUSSIAN COMPONENTS FOR THE DECOMPOSITION OF A DISTRIBUTION INTO CAUSSIAN COMPONENTS A BOUND FOR THE VARIATION OF GAUSSIAN DENSITIES CHARACTERIZATION OF THE INVERSE GAUSSIAN DISTRIBUTION REALITY OF A COVARIANCE MATRIX IN A CERTAIN COMPLEX GAUSSIAN DISTRIBUTION ANALYSIS BASED ON A CERTAIN MULTIVARIATE COMPLEX GAUSSIAN DISTRIBUTION ON THE INVERSE GAUSSIAN DISTRIBUTION FUNCTION

CAL ANALYSIS BASED ON A CERTAIN MULTIVARIATE COMPLEX GAUSSIAN DISTRIBUTION, AN INTRODUCTION PRODUCT ENTROPY TO CAUSSIAN DISTRIBUTIONS RADON-NIKODYM DERIVATIVES OF STATIONARY GAUSSIAN MEASURES RADON-NIKODYM DERIVATIVES OF GAUSSIAN MEASURES 
OF THE CROSS-SPECTRUM OF A STATIONARY BIVARIATE GAUSSIAN PROCESS FROM ITS ZEROS

OF THE CROSS-SPECTRUM OF A STATIONARY BIVARIATE GAUSSIAN PROCESS FROM ITS ZEROS
EXPECTED ARC LENCTH OF A GAUSSIAN PROCESS ON A FINITE INTERVAL

ON LIMIT THEOREMS FOR GAUSSIAN PROCESSES

AMS 682108

SAMPLING RATES AND APPEARANCE OF STATIONARY GAUSSIAN PROCESSES

ESTIMATION JRSSB68 145

JRSSB56 257

AMS $65 \quad 304$

EPSILON ENTROPY OF CAUSSIAN PROCESSES

TECH $66 \quad 91$

AMS 69 I272

CERTAIN PROPERTIES OF CAUSSIAN PROCESSES AND THEIR FIRST PASSAGE TIMES ON A CLASS OF GAUSSIAN PROCESSES FOR WHICH THE MEAN RATE OF CROSSIN JRSSB67 489

S. IS INFTNTTE

RIFICATION CONCERNING CERTAIN EQUIVALENCE CLASSES OF

OUS OR VERY TRREGULAR A NOTE ON

LAW OF LAFGE NUMBERS F

AUSSIAN PROCESSES ON SEVERAL PARAMETERS

A CLA AMS 681078 AMS $65 \quad 771$

AMS $67 \quad$ I579 AMS $68 \quad 261$ AMS $62 \quad 93$

AMS 621306 AMS 69 I 97 TECH $67 \quad 391$

AMS $69 \quad 152$ BIOKA65 645 AMS $67 \quad 593$ AMS 681507 AMS 681844 AMS 68 II 25 BIOKA53 228 JRSSB64 274 SOME MULTIVARIATE DENSITY FUNCTIONS OF PRODUCTS OF GAUSSIAN VARIATES ON THE CROSS PERIODOCRAM OF A STATIONARY GAUSSIAN VECTOR PROCESS

CROSS SPECTRAL ANALYSIS OF CAUSSIAN VECTOR PROCESS IN THE PRESENCE OF VARIANCE ON DOMINATINC AN AVERAGE ASSOCIATED WITH DEPENDENT GAUSSIAN VECTORS

THE ESTIMATION OF VARIANCES AFTER USINC A GAUSSIANATING TRANSFORMATION ON AN EXTENSION OF CEARY'S THEOREM

COMMENTS ON A POSTERIOR DISTRIBUTION OF GEISSER AND CORNFIELD OFFSPRINC DISTRIBUTIONS ON THE SURVIVAL OF A GENE GMENTS AMONG ENVTRONMENTAL POCKETS UPON STEADY STATE GENE FREQUENCIFS /ION. AND DIFFERENT FITNESS REQUTR BIOCS66 453 ED EFFECTS ON PROBLEMS (WITH DISCUSSION) COMPONENTS ENTS' A CENERAL APPROACH TO SOME SCREENINC AND CLASSIFICATION JRSSB68 A CENERAL APPROACH TO THE ESTIMATION OF VARIANCE TECH 67

SOME FURTHER REMARKS CONCERNTNC ,

PERFORMANCE OF SOME CORRELATION COEFFICIENTS FOR A GENERAL BIVARIATE DISTRIBUTION KOLMOGOROV-SMIRNOV TESTS OF FIT BASED ON SOME CENERAL BOUNDS

487)

THE GENERAL BULK QUEUE AS A HILBERT PROBLEM JCORR, 64

THE BIOKA60 307 JASA 68919 JRSSB $62 \quad 344$ JRSSB65 111

THE UETECTION OF PARTIAL ASSOCIATION, 2. THE GENERAL CASE

OF THE RANK CORRELATION COEFFICIENT TAU IN THE GENERAL CASE

TO THE DISTRIBUTION OF WILCOXON'S STATISTIC IN THE GENERAL CASE

MOMENTS BIOKA53 409 A GENERAL CLASS OF BULK QUEUES WITH POISSON INPUT AMS $67 \quad 759$ A GENERAL CLASS OF COEFFICIENTS OF DIVERCENCE OF ONE JRSSB66 I3I

ON A GENERAL CLASS OF DESICNS FOR MULTTRESPONSE EXPERTMENTS A GENERAL CLASS OF ENUMERATIONS ARISING IN CENETICS AMS 681825 BIOCS67 517 DF THE EQUATIONS OF THE SINGLE CHANNEL QUEUE WITH A GENERAL CLASS OF SERVICE-TIME DISTRIBUTIONS BY THE ME JRSSB58 176 FACTORIAL EXPERTMENTS A GENERAL COMPUTER PROGRAMME FOR THE ANALYSIS OF BIOCS66 503 $\begin{array}{llllll}\text { CENERAL CONDITIONS /ERISTICS OF THE DISTRIBUTION OF AMS } 61 & 864 \\ \text { GENERAL CONSIDERATIONS IN THE ANALYSIS OF SPECTRA } & \text { TECH } 61 & 133\end{array}$ GENERAL CONSIDERATIONS IN THE ANALYSIS OF SPECTRA TECH 61133

OPTIMAL DESICNS IN REGRESSION PROBLEMS WITH A GENERAL CONVEX LOSS FUNCTION

A CENERAL DEFINITION OF RESIDUALS (WITH DISCUSSION) JRSSB $68 \quad 248$ $\begin{array}{ll}\text { JRSSB } 68 & 248 \\ \text { BIOKA54 } & 272\end{array}$ STOCHASTIC EPIDEMIC A CENERAL EXPRESSION FOR THE MEAN IN A SIMPLE

A COMBINATORIAL AMS 64 II74 METHOD FOR PRODUCTS OF TWO POLYKAYS WITH SOME CENERAL FORMULAE N RELATION TO THE SINGLE-SERVER QUEUEING SYSTEM WITH GENERAL INDEPENDENT ARRIVALS AND ERLANGIAN SERVICE-TI JRSSB6O 89 RRIVAL AND SERVING DISTRIBUTIONS ARE EXPONENTIAL AND GENERAL INDEPENDENT RESPECTIVELY /AND WHICH INTERA. JRSSB59 375 A CLASS OF RANK ORDER TESTS FOR A GENERAL LINEAR HYPOTHESIS

POWER OF THE LIKELIHOOD-RATIO TEST OF THE GENERAL LINEAR HYPOTHESIS IN MULTIVARIATE ANALYSIS BIOKAG4 467

OF SOME LEAST-SQUARES ESTIMATORS OF VARIANCE IN A GENERAL LINEAR MODEL

THE STRONG RATIO LIMIT PROPERTY FOR SOME GENERAL MARKOV PROCESSES

ON THE BIAS BIOKA68 313

AMS 69986 A CENERAL MAXIMUM LIKELIHOOD DISCRIMINANT $\quad$ BIOCS67 313 A GENERAL METHOD FOR APPROXIMATING TO THE DISTRIBUTION BIOKA56 295

OF LIKELIHOOD RATIO CRITERIA

$S$ LNDER VARTOUS PREVENTTVE MAINTENANCE POLICIES INTERVALS

S OF LOCATION

ACTION OF A MIXTURE OF DRUGS
OPTIMAL ROBUSTNESS
A CENERAL METHOD FOR THE RELTABILITY ANALYSIS OF SYSTEM AMS 62 I37 A GENERAL METHOD OF DETERMINING FIXED-WIDTH CONFIDENCE AMS 69704 A GENERAL METHOD. WITH APPLICATIONS TO LINEAR ESTIMATOR JASA 671230 A GENERAL MODEL FOR GENETTC EFFECTS CENERAL MODELS FOR QUANTAL RESPONSE TO THE JOTNT THE CENERAL MOMENT PROBLEM. A CEOMETRIC APPROACH BIOCS66 864 BIOKA64 413 AMS $68 \quad 93$ TWO-SIDED DISTRIBUTION-FREE TOLERANCE INTERVALS OF A CENERAL NATURE ONS FACTORS ATURE MAIN-EFFECT ANALYSIS OF THE CENERAL NON-ORTHOGONAL LAYOUT WITH ANY NUMBER OF A CONCISE DERIVATION OF CENERAL ORTHOCONAL POLYNOMIALS

THE ERGODICITY OF SERIES OF QUEUES WITH CENERAL PRIORITIES

INVARIANT SEQUENTIAL PROBABILITY RATIO TESTS BASE/ CENERAL PROOF OF TERMINATION WITH PROBABILITY ONE OF THE MEAN OF A MULTIVARIATE NORMAL POPULATION WITH CENERAL QUADRATIC LOSS FUNCTION

A WIENER-HOPF TYPE METHOD FOR A GENERAL RANDOM WALK WITH A TWO-SIDED BOUNDARY ANALYSIS OF COVARIANCE BASED ON GENERAL RANK SCORES

CONSTRUCTION OF ORTHOGONAL POLYNOMIALS FROM A GENERAL RECURRENCE FORMULA ESTIMATINC

SOME GENERAL REMARKS ON CONSULTING IN STATISTICS

DISCUSSION)

SOME GENERAL RESULTS IN SEQUENTIAL DESIGN (WITH

ON THE QUEUEING PROCESS, MARKOV OR POISSON INPUT, GENERAL SERVICE TIME DISTRIBUTION, ONE SERVER

THE TIME DEPENDENCE 
THE USE OF THE HANKEL TRANSFORM IN STATISTICS I GENERAL THEORY AND EXAMPLES

EXPECTED UTILITIES

GENERAL THEORY AND THE CASE OF SIMPLE ORDER /ION OF AMS 631347 GENERAL THEORY OF PRIME-POWER LATTICE DESIGNS JASA 65891

A GENERAL THEORY OF SUBJECTIVE PROBABILITIES AND

AMS 691419 AMS $62 \quad 767$ BIOCS66 74 THE QUOTIENT OF A RECTANGULAR OR TRIANGULAR AND A GENERAL VARIATE

A GENERAL VERSION OF DOEBLIN'S CONDITION

GENERALISED COVARIANCE ANALYSIS WITH UNEQUAL ERROR

BIOKA54 330

AMS 63668

BIOCS69 NO. 4

BIOCS65 721

BIOKA66 I

STRUCTURAL PROBABILITY AND A GENERALIZATION

OR OTHER NONLINEAR FUNCTIONS FIELLER'S THEOREM AND A GENERALIZATION

BIOKA67 567 GENERALIZATION AND REPARAMETERIZATION OF SOME SIGMOID BIOCS65 708 AN EXACT (PI)PS SAMPLING SCHEME, A GENERALIZATION OF A METHOD OF HANURAV

JRSSB 68556 A GENERALIZATION OF A THEOREM OF BALAKRISHNAN AMS $61 \quad 1337$ DISCUSSION A GENERALIZATION OF BAYESIAN INFERENCE (WITH

JRSSB 68205 JRSSB $67 \quad 141$ COMPLEX PARAMETERS POINTWISE ERGODIC THEOREM ATION FOR A CLASS OF DISCRETE DISTRIBUTIONS A GENERALIZATION OF FIELLER'S THEOREM TO THE RATIO OF JRSSB $67 \quad 126$ AMS $68 \quad 2145$

A GENERALIZATION OF ITO'S THEOREM CONCERNING THE BIOKA66 285 MULTIPLE RESPONSES DISEASE CLUSTERING. A GENERALIZATION OF KNOX'S APPROACH TO THE DETECTION OF ON SLIPPAGE TESTS I. A GENERALIZATION OF NEYMAN PEARSON'S LEMMA THE GENERALIZATION OF PROBIT ANALYSIS TO TH AMS 681693 BI0KA57 131 MONOTONE CONVERGENCE OF BINOMIAL PROBABILITIES AND A GENERALIZATION OF RAMANUJAN'S EQUATION ES FOR CERTAIN SPECIAL CASES NS TO MULTIVARIATE DISTRIBUTION THEORY GENERALIZATION OF SVERDRUP'S LEMMA AND ITS APPLICATIO AMS 65 67I A BIVARIATE GENERALIZATION OF STUDENT'S T-DISTRIBUTION, WITH TABL BIOKA54 153 TON IN THE THEORY OF QUEUES A GENERALIZATION OF THE BALLOT PROBLEM AND ITS APPLICAT CONCEPTS OF INDEPENDENCE FOR PROPORTIONS WITH A A GENERALIZATION OF THE DIRICHLET DISTRIBUTION

ON A GENERALIZATION OF THE FINITE ARC-SINE LAW A GENERALIZATION OF THE GAMMA DISTRIBUTION A. GENERALIZATION OF THE GAUSS-MARKOV THEOREM A GENERALIZATION OF THE INBREEDING COEFFICIENT A GENERALIZATION OF THE LOGISTIG LAW OF GROWTH CLOSED QUEUEING SYSTEMS. A GENERALIZATION OF THE MACHINE INTERFERENCE MODEL
COMPARISONS EXPERIMENTS WTTH MIXTURES,
A GENERALIZATION OF THE SIMPLEX-LATTICE DESIGN

A GENERALIZATION OF THE T-METHOD OF MULTIPLE

A GENERALIZATION OF WALD'S IDENTITY WITH APPLICATIONS ON HOTELLING'S GENERALIZATION T-SOUARE
AMS 631569 JASA $62 \quad 327$ JASA $67 \quad 194$ JASA 69194 AMS 62909 AMS 621187 JASA 661063 BIOCS65 665 BIOCS69 577 JRSSB61 385 JRSSB $68 \quad 123$ JASA 69290 AMS 61549 BIOKA59 160 ATE ANALYS/ AN INTRODUCTION TO SOME NON-PARAMETRIC GENERALIZATIONS OF ANALYSIS OF VARIANCE AND MULTIVARI BIOKA56 361 ICATIONS TO STATISTICAL DESIGNS

SOME GENERALIZATIONS OF DISTINCT REPRESENTATIVES WITH APPL AMS $66 \quad 525$ BIVARIATE GENERALIZATIONS OF NEYMAN'S TYPE A DISTRIBUTION BIOKA66 241

A COUNTER-EXAMPLE RELATING TO CERTAIN MULTIVARIATE DISCUSSION

STICS ARISING FROM RECTANGULAR POPULATIONS GENERALIZATIONS OF TCHEBYCHEFF'S INEQUALITIES (WITH JRSSB56 139 GENERALIZATIONS OF THE DISTRIBUTIONS OF PRODUCT STATI JASA 64557 GENERALIZATIONS OF THE MAXIMAL ERGODIC THEOREM

D THE INVERTED MULTIVARIATE T DISTR/ MATRICVARIATE GENERALIZATIONS OF THE MULTIVARIATE T DISTRIBUTION AN INVARIANTS UNDER MIXING WHICH GENERALIZE DE FINETTI'S THEOREM

PARAMETER

INVARIANTS UNDER MTXTNG WHICH GENERALIZE DE FTNETTIIS THEOREM.

TYPE

GENERALIZED APPLICATION OF INSTRUMENTAL VARIABLE ESTI GENERALIZED ASYMPTOTIC EXPANSIONS OF CORNISH-FISHER

GEST LATENT ROOT AND THE SMALLEST LATENT ROOT OF THE GENERALIZED B STATISTIC AND F STATISTICS AND IN MULTI AND THE EXPONENTIAL FAMILY ASYMPTOTIC DISTPIBUTION FOR A GENERALIZED BANACH MATCH BOX PROBLEM

GENERALIZED BAYES DECISION FUNCTIONS, ADNISSIBILITY GENERALIZED BAYES SOLUTIONS IN ESTIMATION PROBLEMS

TOWARDS A THEORY OF GENERALIZED BAYES TESTS

THREE VARIATES

TOWARDS A THEORY OF GENERALIZED BAYES TESTS
APPROXIMATION TO THE GENERALIZED BEHRENS-FISHER DISTRIBUTION INVOLVING

USE OF THE WILCOXON STATISTIC FOR A GENERALIZED BEHRENS-FISHER PROBLEM

UPPER PERCENTAGE POINTS OF THE GENERALIZED BETA DISTRIBUTION. I

UPPER PERCENTAGE POINTS OF THE GENERALIZED BETA DISTRIBUTION. II

UPPER PERCENTAGE POINTS OF THE GENERALIZED BETA DISTRIBUTION. III

TE ON THE EXACT FINITE SAMPLE FREQUENCY FUNCTIONS OF GENERALIZED CLASSICAL LINEAR ESTTMATORS IN A LEADING THREE-EQUATION/ ON THE EXACT DISTRIBUTIONS OF THE GENERALIZED CLASSICAL LINEAR ESTIMATORS IN A LEADING ION OF EXACT FINITE SAMPLE DISTRIBUTION FUNCTIONS OF GENERALIZED CLASSICAL LINEAR ESTIMATORS IN ECONOMETRI J TE ON THE EXACT FINITE SAMPLE FREQUENCY FUNCTIONS OF GENERALIZED CLASSICAL LINEAR ESTIMATORS IN TWO LEADIN J J G OVER-I/ A NOTE ON THE EXACT DISTRIBUTIONS OF THE GENERALIZED CLASSICAL LINEAR ESTIMATORS IN TWO LEADIN J TISTICS

ON FINITE SAMPLE DISTRIBUTIONS OF GENERALIZED CLASSICAL LINEAR IDENTIFIABILITY TEST STA THE ASYMPTOTIC EFFICIENCY OF DANIELS'S GENERALIZED CORRELATION COEFFICIENT

THE ASYMPTOTIC EFFICIENCY OF DANIELS'S GENERALIZED CORRELATION COEFFICIENTS

GROWTH-INVARIANT DISCRIMINANT FUNCTIONS AND GENERALIZED DISTANCES SOME INTERRELATIONS AMONG COMPOUND AND GENERALIZED DISTRIBUTIONS

INTERRELATIONS AMONG GENERALIZED DISTRIBUTIONS AND THEIR COMPONENTS
AMS 651292 AMS $67 \quad 511$ AMS $62 \quad 916$ AMS 631194 TECH 69255 AMS $68 \quad 1264$ AMS 671152 JASA 671252 AMS $67 \quad 818$ AMS $63 \quad 751$ AMS $68 \quad 1$ BIOKA69 NO. 3 AMS 631596 BIOKA57 237 EIOKA57 44I BIOKA58 492 JASA $63 \quad 161$ JASA 64881 JASA $63 \quad 943$ ASA $63 \quad 535$ ASA $60 \quad 650$ IOKA63 499 JRSSB61 128 BIOCS66 96 BIOKA57 265 BI0CS66 44 BI0CS67 79 $\begin{array}{lll}\text { JASA } 61 & 619\end{array}$ 
AN APPLIGATION OF A GENERALIZED GAMMA DISTRIBUTION

AMS 641368 TOLERANGE LIMITS FOR THE GENERALIZED GAMMA DISTRTBUTION JASA 651142 PARAMETER ESTTMATION FOR A GENERALIZED GAMMA DISTRIBUTION TEGH $65 \quad 349$ OD ESTIMATION OF THE PARAMETERS OF A FOUR- PARAMETER GENERALIZED GAMMA POPULATION FROM GOMPLETE AND GENSOR TECH 67 I59 / EXAGT DISTRIBUTION OF THE PRODUGT OF INDEPENDENT GENERALIZED GAMMA VARIABLES WITH THE SAME SHAPE PARAM AMS 6B I75I GENERALIZED HYPERBOLIG SEGANT DISTRIBUTIONS J J $68 \quad 329$ GENERALIZED HYPERGEOMETRIG DISTRIBUTIONS JRSSB56 202 $\begin{array}{lrr}\text { GENERALIZED INVERSE (CORR. } 69719 \text { ) } & \text { JMS } 66 & 1021\end{array}$

SINGULARITY IN HOTELLING'S WEIGHING DESIGNS AND A GENERALIZED INVERSE (CORR. 69 719) DDITIONAL RESULTS GONGERNING ESTIMABLE FUNGTIONS AND GENERALIZED INVERSE MATRICES

ARSSB $55 \quad 486$ PROBLEMS IN MATHEMATIGAL STATISTIGS FULL RANK

A NOTE ON A GENERALIZED INVERSE OF A MATRIX WITH APPLIGATIONS TO JRSSB62 152 A NOTE ON GENERALIZED INVERSES IN THE LINEAR HYPOTHESIS NOT OF AMS 67271 TABLES OF GENERALIZED K-STATISTIGS FOR A GOMBINATORIAL METHOD FOR MULTIPLE PRODUGTS OF GENERALIZED K-STATISTIGS SOME RULES AMS 6B 983 FRAGTIONAL REPLIGATION DESIGNS GENERALIZED LEAST SQUARES ESTIMATORS FOR RANDOMIZED AMS 64696 AL RELATIONSHIPS (WITH DISCUSSION)

A GENERALIZED LEAST-SQUARES APPROAGH TO LINEAR FUNGTION JRSSB66 278 BEST LINEAR UNBIASED PREDIGTION IN THE GENERALIZED LINEAR REGRESSION MODEL JASA 62 369 SOME DISTRIBUTIONS ARISING IN THE STUDY OF GENERALIZED MEAN DIFFERENGES

POISSON DISTRIBUTTONS

THE GENERALIZED MEAN DIFFERENGES OF THE BINOMIAL AND RIGENDA. 'SOME DISTRIBUTIONS ARISING IN THE STUDY OF GENERALIZED MEAN DIFFERENGES DISTRIBUTIONS

THE DISTRI VARIABLE AND ITS APPLIGATIONS N OF CORRELATION IN DISGRETE DATA

USEFULL ESPEGIALLY FOR GROWTH GURVE PROBLEMS GENERALIZED MEANS AND ASSOCIATED FAMILIES OP ON THE GENERALIZED MELLIN TRANSFORM OF A COMPLEX RANDO THE GENERALIZED MULTIPLE GORRELATION MATRIX

A GENERALIZED MULTIVARIATE ANALYSIS OF VARIANGE MODEL BIOKA60 469 BIOKA59 223 GOR BIOKA6I 230 AMS 69339 AMS $66 \quad 215$ AMS 651459 THE USE OF A GENERALIZED MULTINOMIAL DISTRIBUTION IN THE ESTIMATIO JRSSB62 530 NOTE ON THE MULTIVARIATE AND THE GENERALIZED MULTIVARIATE BETA DISTRIBUTIONS

SASJ 69 NO. 2 BIOKA64 313 JASA 69230

FINITE POPULATIONS GENERALIZED MULTTVARIATE ESTIMATOR FOR THE MEAN OF

JASA 671009 PLIFIED TEGHNIQUES FOR ESTIMATING PARAMETERS OF SOME GENERALIZED POISSON DISTRIBUTIONS D GOMPLETE FINITE POPULATIONS RELATIONSHIP OF GENERALIZED POLYKAYS TO UNRESTRIGTED SUMS FOR BALANGE AMS 68 643 AND BIPOLYKAYS CORR 66746 GENERALIZED POLYKAYS, AN EXTENTION OF SIMPLE POLYKAYS AMS 66226 ATION TO A TRUN/ MAXIMUM LIKELIHOOD ESTIMATION FOR GENERALIZED POWER SERIES DISTRIBUTIONS AND ITS APPLIG BIOKA62 227 ON A GENERALIZED QUEUEING SYSTEM WITH POISSON ARRIVALS JRSSB66 456 THE GENTRAL LIMIT THEOREM FOR GENERALIZED RANDOM FIELDS AMS 69203 PRIORITY $61 \quad 1345$ FIRST PASSAGE TIMES OF A GENERAIZED RANDOM INALK GORR AND AGKNOWLEDGEMENT OP THE RANDOMIZATION ANALYSIS OF A GENERALIZED RANDOMIZED BLOGK DESIGN
'THE RANDOMIZATION ANALYSIS OF A GENERALIZED RANDOMIZED BLOGK DESIGN' PROPERTIES OF GENERALIZED RAYLEIGH DISTRIBUTIONS

A ROBUST POINT ESTIMATOR IN A GENERALIZED REGRESSION MODEL A SIMPLE PROBABILISTIG PROOF OF THE DISGRETE GENERALIZED RENEWAL THEOREM GENERALIZED RIGHT ANGULAR DESIGNS

LIFE TESTING ON A GENERALIZED SAVAGE STATISTIG WITH APPLIGATIONS TO THE ESSENTIAL GOMPLETENESS OF THE GLASS OF GENERALIZED SEQUENTIAL PROBABILITY RATIO TESTS

A GENERALIZED SINGLE-SERVER QUEUE WITH ERLANG INPUT A NOTE ON RISK AND MAXIMAL REGULAR GENERALIZED SUBMARTINGALES IN STOPPING PROBLEMS

VARIANGE HOTELLING'S NG'S GENERALIZED T-SQUARE-SUB-ZERO /TEM OF LINEAR DIFFER R STATISTICS GENSORED DATA

GHARAGTERIZATION OF NORMAL AND GENERALIZED TRUNGATED NORMAL DISTRIBUTIONS USING ORDE A GENERALIZED TWO-SAMPLE WILGOXON TEST FOR DOUBLY-

THE DISTRIBUTTON OF THE GENERALIZED VARIANGE

OP A SAMPLE OP GONSEGUTIVE OBSEF VATIONS FROM/ ON DURBIN'S FORMULA FOR THE LIMITING GENERALIZED VARIANGE OF A SAMPLE OF GONSEGUTIVE OBSER BIOKAGI I97 SINGLY-GENSORED SAMPLES THE GENERALIZED VARIANGE, TESTING AND RANKING PROBLEM A GENERALIZED WILGOXON TEST FOR GOMPARING ARBITRARILY AMS 6794 CASE ON THE LARGE SAMPLE PROPERTIES OF A GENERALIZED WILGOXON-MANN-WHITNEY STATISTIG DISTRIBUTION OF THE 'GENERALTZED' MULTIPLE GORRELATION MATRIX IN THE DUAL THE COMBINATION OF INFORMATION IN GENERALLY BALANGED DESIGNS

A NUMERIGAL PROGEDURE TO GENERATE A SAMPLE GOVARIANGE MATRIX, GORR. 661248

UPPER AND LOWER PROBABILITIES GENERATED BY A RANDOM GLOSED INTERVAL

ONE-PARAMETER EXPONENTIAL FAMILIES GENERATED BY TRANSFORMATION GROUPS

DISTRIBUTION

ILITIES OF A GLASS OF WIDELY USED/

DISTRIBUTION STREAMS

A GONTI CLASS OF SERVIGE-TIME DISTRIBUTIONS BY THE OF LARGE NUMBERS SOME RESULTS RELATING MOMENT G ON MOMENT GENERATING A VARIABLE FROM THE TAIL OF THE NORMAL GENERATING EXPONENTIAL RANDOM VARIABLES

A TWO-VARIABLE GENERATING FUNGTION FOR GOMPUTING THE SAMPLING PROBAB JA ON THE MOMENT GENERATING FUNGTION OF PILLAI'S V-SUPER-S GRITERION THE MOMENT GENERATING FUNGTION OF THE TRUNGATED MULTI-NORMAL

N THE PROBABILITY GENERATING FUNGTIONAL FOR THE GUMULATIVE POPULATION I SOME APPLIGATIONS OF PROBABILITY GENERATING FUNGTIONALS TO THE STUDY OF INPUT-OUTPUT

/CHANNEL QUEUE WITH A GENERAL GENERATING FUNCTIONS AND GONVERGENGE RATES IN THE LAW GENERATING FUNGTIONS AND RENEWAL THEORY GENERATING FUNGTIONS FOR MARKOV RENEWAL PROGESSES MOMENT GENERATING FUNGTIONS OF QUADRATIC FORMS IN SERIALLY

GORRELATED NORMAL VARIABLES SOME QUANTITATIVE TESTS FOR STOGK PRIGE GENERATING MODELS AND TRADING FOLKLORE PROGESSES GENERATING PERMUTATION EXPANSIONS

ON THE GENERATION OF NORMAL RANDOM VEGTORS GENERATION OF RANDOM SAMPLES FROM THE BETA AND F

DESIGNS

RIG TEST STATISTIGS UNDER GENSORING STATISTIGS UNDER LEHMANN ALTERNATIVES NOTES GYGLIG GENERATION OF ROBINSON'S BALANGED INGOMPLETE BLOGK REGURSIVE GENERATION OF THE DISTRIBUTION OF SEVERAL NON-PARAMET REGURSIVE GENERATION OF THE DISTRIBUTION OF THE MANN-WHITNEY USOME FEATURES OF THE GENERATION TIMES OF INDIVIDUAL BAGTERIA

PROGESS ESTIMATING THE INFINITESIMAL GENERATOR OF A GONTINUOUS TIME, FINITE STATE MARKOV NETIQUE DES GARAGTERES QUANTITATIFS ET REGHERGHE DE 'GENES MAJEURS' /. INTERPRETATION DU DETERMINISME GE BI + (ON FORMULA FOR DETERMINING THE INGIDENGE OF MUTANT GENES)

GENESIS OF BIMODAL DISTRIBUTIONS
BIOKA65 203 AMS 67905

AMS 641801 JRSSB $68 \quad 303$ JASA $66 \quad 199$ AMS $68 \quad 957$ AMS $65 \quad 261$ TEGH $64 \quad 101$ AMS 61899 JASA $64 \quad 487$ AMS $68 \quad 877$ JRSSB 61223 IOKA64 245 JRSSB $68 \quad 321$ JRSSB54 288 JRSSB58 176 AMS $67 \quad 742$ AMS $65 \quad 1298$ RSSB65 86 AMS $64 \quad 431$ BIOKA58 198 JASA $67 \quad 321$ BIOKA62 139 TECH $62 \quad 278$ TEGH $63 \quad 269$ BIOGS67 574 JASA $68 \quad 353$ AMS $66 \quad 284$ BIOKA55 16 AMS $62 \quad 727$ BIOGS68 277 BIOCS65 750 TEGH $64 \quad 357$ 
INC 2. AN EVALUATION OF TWO METHODS OF ESTIMATION OF CENETIC AND ENVIRONMENTAL VARIANCE /LLEL TEST CROSS BIOCS67 325 DROSOPHILIA SUBOBSCURA' CO/ VECTORIAL ANALYSIS FOR CENETIC CLINES IN BODY DIMENSIONS IN POPULATIONS OF I BIOCS66 469 ING ALL DIG EQUAL MACN/ GENETIC COMPONENTS FOR NON-TNBRED DIPLOTD SPECIES HAV BIOCSG ESTIMATION OF GENETIC CONTRIBUTION OF PRINCIPAL COMPONENTS TO INDIV BIOCS69

SELECTION BASIS IN ESTIMATION OF THE GENETIC CORRELATION
AN EMPIRICAL STUDY OF THE DISTRIBUTION OF THE SAMPLE GENETIC CORRELATION COEFFICIENT

A GENERAL MODEL FOR GENETIC EFFECTS

MARKOV CHAINS WITH ABSORBINC STATES, A GENETIC EXAMPLE

GENETIC EQUILIBRIUM UNDER SELECTION (INVITED PAPER) BIOGS67 397

ARIANCE OF THE CORRELATION COEFFICIENTS ESTIMATED IN GENETIC EXPERIMENTS

THE SAMPITNG $V$ BIO THE EXPECTED MEAN SQUARES IN GENETIC EXPERIMENTS WHEN ONLY ONE PARENT IS IDENTIFIE BIOCS65 QN THE STOCHASTIC MATRIX IN A GENETIC MODEL OF MORAN

INFERENCE ON A GENETIC MODEL OF THE MARKOV CHAIN TYPE

SOME TRANSFORMATIONS OF SCALE AND THE ESTIMATION OF GENETIC PARAMETERS FROM DAUCHTER-DAM REGRESSION NUMERIGAL RESULTS AND DIFFUSION APPROXIMATIONS IN A GENETIC PROCESS

SOME STATISTICAL PROPERTIES OF A GENETIC SELECTION INDEX

MATING DESIGN FOR ESTIMATING ENVIRONMENTAL AND GENETIC TRENDS

THE MULTI-TYPE CALTON-WATSON PROCESS IN A CENETICAL CONTEXT

203

BIOKA63 25I

BIOCS67 B23

241

EXAMINATION OF A REPEAT BIOCS65 63 BIOCS6B 147

A A CRAPHICAL METHOD FOR THE STUDY OF COMPLEX CENETICAL SYSTEMS WITH SPECIAL REFERENCE TO EQUILIBRI BIOCS69 NO.4 THE DIFFUSION EQUATION AND A PSEUDO-DISTRIBUTION IN GENETICS

A GENERAL CLASS OF ENUMERATIONS ARISING IN GENETICS

JRSSB $63 \quad 405$

BI0CS67 517

FURTHER ANALYSIS OF R A FISHER'S ENUMERATIONS IN GENETICS

NOTES BIOCS65 1012

OF MULTIPLE-TYPE BRANCHING PROCESSES IN POPULATION GENETICS

DIFFUSION APPROXIMATION TO CERTAIN DISTRIBUTIONS IN GENETICS

CERTAIN NONLINEAR DIFFERENCE EQUATIONS OF POPULATION GENETICS

DISCRETE STOCHASTIC PROCESSES IN POPULATION GENETICS (WITH DISCUSSION)

QUASI-STATIONARY DISTRIBUTIONS AND TIME-REVERSION IN GENETICS (WITH DISCUSSION)

ESTING HYPOTHESES AND ESTIMATING PARAMETERS IN HUMAN GENETICS IF THE ACE OF ONSET IS RANDOM

HEORETICAL ASPECTS OF DIFFUSION THEORY IN POPULATION GENETICS, CORR 63352

SOME APPLICATTONS JRSSB68 164

THE ADEQUACY OF THE BIOCS65 386

UTIONS DE FREQUENCES, INTERPRETATION DU DETERMINISME CENETIQUE DES CARACTERES QUANTITATIFS ET RECHERCHE DE BIOCS6B 277

ALYSE EN COMPOSANTES PRINCIPALES, SON UTILISATION EN CENETIQUE ET SES RAPPORTS AVEC L'ANALYSE DISCRIMINATO BIOCS66 343

STIMATION OF THE NUMBER OF CRITICAL SITES IN LIMITED CENOME EXPRESSION DURING VIRAL INFECTION OF BACTERIA BIOCS69 537 NOTES. DTSTRTBUTION AMONG RELATIVES OF CENOTYPES FOR THINNING

BIOCS6B 179

S CARACTERES

PONDERATION DES VALEURS CENOTYPIQUES DANS LA SELECTION PAR INDEX SUR PLUSIEUR BIOCS69 295 CHARACTERIZATION OF GEOMETRIC AND EXPONENTIAL DISTRIBUTIONS

THE GENERAL MOMENT PROBLEM, A GEOMETRIC APPROACH

CONFIDENGE LIMITS IN THE CASE OF THE GEOMETRIC DISTRIBUTION

DISCUSSION

MIXTURES OF GEOMETRIC DISTRIBUTTONS

GEOMETRIC DISTRIBUTIONS IN THE THEORY OF QUEUES (WITH JRSSB59

CONTROL CHART TESTS BASED ON GEOMETRIC MOVING AVERACES

ON A GEOMETRTCAL METHOD OF CONSTRUCTION OF PARTIALLY BALAN AMS 6] 1177 SOME INTEGRAL EQUATIONS IN GEOMETRICAL PROBABILITY

HYPERSPHERE

STUDENT'S DISTRIBUTION AND RIEMANN'S ELLIPTIC GEOMETRY EEOMETRICAL PROBABILITY AND RANDON POINTS ON A

BIOKA66 365

AMS 67213

BIOKA57 264

GEOMETRY AND LINEAR DISCRIMINATION

THE CEOMETRY OF A R-BY-C CONTINGENCY TABLE

THE GEOMETRY OF ESTIMATION

A NOTE ON THE GEOMETRY OF LINEAR ESTTMATION

BIOKA60 185

AMS 6B 1186

BIOKA51 150

BIOKA62 560

BIOKA63 540

A FURTHER NOTE ON THE GEOMETRY OF LINEAR ESTIMATION

AMS 621175

CED INCOMPLETE BLOCK DESIGNS APPLICATION OF THE CEOMETRY OF QUADRICS FOR CONSTRUCTING PARTIALLY BALAN FE TABLES FOR MALES IN GHANA

SOME INEQUALITIES FOR THE QUEUE GI/GI

THE BUSY PERIOD IN RELATION TO THE QUEUEING PROCESS GI-M-I PERIOD IN RELATION TO THE QUEUEING PROCESS GI-M-I

RMINISTIC CUSTOMER IMPATIENCE IN THE QUEUEING SYSTEM GI-M-1, A CORRECTION THE NON-ABSOLUTE CONVERGENCE OF GIL-PELAEZ' INVERSION INTECRAL THE THIRD MOMENT OF GINI'S MEAN DIFFERENCE

GINI'S MEAN DIFFERENCE REDISCOVERED

GIRDLE DISTRIBUTIONS ON A SPHERE

THE SPEED OF CLIVENKO-CANTELLI CONVERGENCE

ON THE CLIVENKO-CANTELLI THEOREM FOR INFINITE INVARIANT

MEASURES

ON MEASURABLE, NONLEAVABLE GAMBLING HOUSES WITH A COAL

A COMPARISON OF STATISTICAL

COMMENTS ON THE DISCUSSIONS OF MESSRS. TUKEY AND GOODMAN ON A THEOREM OF BAHADUR AND GOODMAN

A PARTIAL COEFFICIENT FOR GOODMAN AND KRUSKAL'S GAMMA

JASA 69102

BIOKA62 315

BIOKA59 246

DETERMINISTIC BIOKA60 45

DETE BIOKA61 472

AMS $61 \quad 33 B$

BIOKA53 451

BIOKA68 573

BIOKA64 3BI

AMS $69 \quad 40$

AMS 671273

AMS 6966

BIOCS6B 103

TECH 61

AMS 66

JASA $67 \quad 189$

ARTIAL INTERPRETATION OF THE/ A SIMTLARITY BETWEEN GOODMAN AND KRUSKAL'S TAU AND KENDALL'S TAU, WITH A P JASA 62 BO4 TESTS

A COEFFICIENT MEASURING THE GOODNESS OF FIT

GOODNESS OF FIT

TESTS OF GOODNESS OF FIT

TECH $66 \quad 327$

JRSSB 63 81

NOTE ON AN EXACT TREATMENT OF CONTINGENCY, GOODNESS OF FIT AND OTHER PROBLEMS OF SICNIFICANCE BIOKA5I I4I ON THE ASYMPTOTIC DISTRIBUTION OF THE 'PSI-SQUARED' GOODNESS OF FIT CRITERIA FOR MARKOV CHAINS AND MARKOV AMS 61 49 ASYMPTOTIC EXPANSIONS FOR TESTS OF GOODNESS OF FIT FOR LINEAR AUTOREGRESSIVE SCHEMES BSIOKA64 459

THE ASYMPTOTIC POWERS OF CERTAIN TESTS OF GOODNESS OF FIT FOR TTME SERIES

FROM STOCHASTIC PROCESSES

SIGNIFICANCE POINTS

THE GOODNESS OF FTT OF FREQUENCY DTSTRIBUTIO

Y OF AN APPROXIMATION TO THE POWER OF THE CHT-SQUARE GOODNESS OF FIT TEST WITH SMALL BUT EQUAL EXPECTED FR JASA 68 912 ERRATA, 'A COEFFICIENT MEASURING THE GOODNESS OF FIT'

CAL PRINCTPAL COMPONENT

SAMPLINC PROPERTIES OF TESTS OF GOODNESS-OF-FIT FOR LINEAR AUTORECRESSIVE SCHEMES JRSSB62 492

TIONS ARE SMALL

THE COODNESS OF-FTT OF A STNGLE (NON-TSOTROPIC) HYPOTHETT BIOKA61 397 ON TESTING FOR GOODNESS-OF-FIT OF THE NEGATIVE BINOMIAL WHEN EXPECTA BIOCS69 143 
THE USE OF THE CONCEPT OF A FUTURE OBSERVATION IN COODNESS-OF-FIT PROBLEMS COMPARISONS

NOTE ON MULTIVARIATE GOODNESS-OF-FIT TESTS

THE ASYMPTOTIC RELATIVE EFFICIENCY OF GOODNESS-OF-FIT TESTS AGAINST SCALAR ALTERNATIVES

SQUARE-SUB-N

(WITH DISCUSSION)

THE COODNESS-OF-FIT TESTS BASED ON W-SQUARE-SUB-N AND U

ON CHI-SQUARE GOODNESS-OF-FIT TESTS FOR CONTINUOUS DISTRIBUTIONS

JASA $65 \quad 410$

BIOKA62 397 JRSSB5B 44 BIOKA68 44I TWO TABLES CONNECTED WITH GOODNESS-OF-FIT TESTS FOR EQUIPROBABLE ALTERNATIVES LIDITY OF THE CHI-SQUARE AND TWO MODIFIED GHI-SQUARE GOODNESS-OF-FIT TESTS FOR SMALL BUT EQUAL EXPECTED FR COODNESS-OF-FIT TESTS ON A CIRCLE

GOODNESS-OF-FIT TESTS ON A CIRCLE II

COMPARISON OF THE PEARSON CHI-SQUARE AND KOLMOGOROV GOODNESS-OF-FIT TESTS WITH RESPECT TO VALIDITY, CORR ORRECTION. 'A COMPARATIVE STUDY OF SEVERAL ONE-SIDED GOODNESS-OF-FIT TESTS'

A FORECASTING MODEL OF FEDERAL PURCHASES OF GOODS AND SERVICES ESTIMATING THE SERVIGE LIFE OF HOUSEHOLD GOODS BY ACTUARIAL METHODS, GORR. 57578 INCOME. INCOME CHANGE. AND DURABLE COODS DEMAND

F ASSETS, CREDIT AND INTENTIONS CONSUMER DURABLE COODS EXPENDITURES, WITH MAJOR EMPHASIS ON THE ROLE O J TATISTICS. XX. SOME EARLY CORRESPONDENCE BETWEEN W.S. GOSSETT, R.A. FISHER AND KARL PEARSON, WITH NOTES AND PROBLEMS IN ESTIMATING FEDERAL GOVERNMENT EXPENDITURES CONFIDENCE LIMITS FOR THE GRADIENT IN THE LINEAR FUNCTTONAL RELATIONSHIP

FLUCTUATIONS CRADING WITH A GAUGE SUBJECT TO RANDOM OUTPUT JRSSB54 SEQUENCES FOR SOLVINC LESER'S LEAST-SQUARES GRADUATION EQUATIONS ANALYTICAL GRADUATION OF FERTILITY RATES SUBSIDIARY JRSSB62 112 JASA $56 \quad 461$

ITE AND UNIMODAL

CONDITIONS UNDER WHICH GRAM-CHARLIER AND ED EFFICIENCY OF THE METHOD OF MOMENTS AND THE CRAM-CHARLIER TYPE A DISTRIBUTION

A BOREL SET NOT CONTAINING A CRAPH MAJORANTS OF THE CHROMATIC NUMBER OF A RANDOM GRAPH

RMULA FOR THE PROBABILITY OF OBTAINING A TREE FROM A GRAPH CONSTRUCTED RANDOMLY EXCEPT FOR 'EXOCAMOUS BIAS ON THE LINE, GRAPH OF THE COMPLETE BIGRAPH

ON THE LINE GRAPH OF THE COMPLETE BIPARTITE GRAPH GRAPHIC COMPUTATION OF TAU AS A COEFFICIENT OF

DISARRAY

AY GRAPHIC COMPUTATION OF THE MULTIPLE CORRELATION

COEFFICIENT, CORR, 581031 A NOTE ON CRIFFIN'S PAPER A SERIES OF POINTS ACCORDING

CENTROIDS

TABLES

LIFE TESTING ELECTRON TUBES

FREQUENCIES

RIBUTIONS INTO TWO NORMAL COMPONENTS SYSTEMS WITH SPECIAL REFERENCE TO EQUILIBRIA MULTIRESPONSE EXPERIMENTS TY AND STATISTICS. III. A NOTE ON THE HISTORY OF THE SET OF POINTS

ODS IN THE ESTIMATION OF RELATIVE POTENCY IN DILU/ SLIPPACE

DILUTION EXPERIMENTS OM INTERSECTION OF TWO GRAPHS (CORR. 69 1510) /CENTRAL
ENUMERATION OF LINEAR GRAPHS FOR MAPPINGS OF FINITE SETS

SOME GRAPHS USEFUL FOR STATISTICAL INFERENCE

GRAPHIC METHOD IN STATISTICAL MEASUREMENT

GRAPHIC METHODS BASED UPON PROPERTIES OF ADVANCING A NOTE ON THE GRAPHICAL ANALYSIS OF MULTIDIMENSIONAL CONTINGENCY

A GRAPHICAL ESTIMATION OF MIXED WEIBULL PARAMETERS IN

A GRAPHICAL METHOD FOR MAKING MULTIPLE COMPARISONS OF

A SEMI-GRAPHICAL METHOD FOR THE ANALYSIS OF COMPLEX PROBLEMS A GRAPHICAL METHOD FOR THE ANALYSIS OF STATISTICAL DIST A GRAPHICAL METHOD FOR THE STUDY OF COMPLEX GENETICAL GRAPHICAL METHODS FOR INTERNAL COMPARISONS IN BIOKA52 425 JASA $57 \quad 253$ AMS $68 \quad 1345$ JRSSB69 NO.2 AMS $67 \quad 226$ AMS $63 \quad 664$ AMS 64 BB3 JASA $58 \quad 441$ ASA $61 \quad 736$ JASA $57 \quad 479$ JASA $57 \quad 13$ JASA $57 \quad 472$ JASA $5966 \mathrm{~B}$ TECH $67 \quad 481$ TECH 59 3B9 TECH $69 \quad 321$ TECH $60 \quad 3 B 7$ BIOKA53 460 BIOCS69 NO. 4 AMS $64 \quad 613$ TISTORY OF PROBABILI BIOKA56 241 GRAPHICAL PROCEDURE FOR FITTING THE BEST LINE TO A TECH $60 \quad 477$ GRAPHICAL PROCEDURES FOR USING DISTRIBUTION-FREE METH BIOCS66 610 A GRAPHICAL VERSION OF TUKEY'S CONFIDENCE INTERVAL FOR TECH 68193 BI0CS67 269 AMS 69144 AMS 62178 JASA $65 \quad 334$ TRUCTION OF THE SET OF 256-RUN DESIGNS OF RESOLUTION GREATER THEN OR EQUAL TO 5 AND THE SET OF EVEN $512-$ RU AMS 68 246 5 AND THE SET OF EVEN 512-RUN DESICNS OF RESOLUTION GREATER THEN OR EQUAL TO 6 WITH SPECIAL REFERENCE TO AMS 68 246 FOUR FACTOR ADDITIVE DESIGNS MORE GENERAL THAN THE GRECO-LATIN SQUARE APPROXIMATE SOLUTIONS OF CREEN'S TYPE FOR UNIVARIATE STOCHASTIC PROCESSES

TECH $62 \quad 361$ JRSS860 376 ONED MATRICES IN THE ANALYSIS OF N/ APPLICATION OF GREENBERG AND SARHAN'S METHOD OF INVERSION OF PARTITI JASA 65 I2OO CHARACTERISTIC THE MATHEMATICAL RELATION 8ETWEEN GREENBERG'S INDEX OF LINCUISTIC DIVERSITY AND YULE'S 8 IOKA58 268 MAJOR GREENWOOD, 1880-1949 A NOTE ON GRIFFIN'S PAPER 'GRAPHIC COMPUTATION OF TAU AS A 8IOKA51 I JASA $61 \quad 736$ TECH $69 \quad 115$ CONTROLLINC DIMENSION IN CENTERLESS-GRINDINC WITH AUTOMATIC RESET DEVICE OF MINIMUM LOCIT CHI-SQUARE ESTIMATE TO A PRO8LEM OF GRIZZLE WITH A NOTATION ON THE PRO8LEM OF NO INTERACT 8IOCS68 75 $N$ COEFFICIENTS A NOTE ON THE SIGNS OF CROSS CORRELATION COEFFICIENTS ANL PARTIAL CORRELATIO BI A CHECK ON GROSS ERRORS IN CERTAIN VARIANCE COMPUTATIONS

A STATISTICAL ANALYSIS OF PROVISIONAL ESTIMATES OF CROSS NATIONAL PRODUCT AND ITS COMPONENTS, OF SELECTE J STATE

DENSITY ESTIMATION IN A TOPOLOCICAL CROUP JASA $58 \quad 54$ JASA 69,787 AMS $65^{\circ} 1047$ OF THE UNIFORM DTSTRTBUTTON ON A COMPACT TOPOLOGICAL GROUP A STATISTICAL PROBLEM TO BE INVARIANT UNDER A LIE GROUP QUEUEING AT A SINGLE SERVING POINT WITH GROUP ARRIVAL

ON THE ANALYSIS OF GROUP DIVISIRLE DESIGNS

ON THE 8LOCK STRUCTURE OF SINCULAR GROUP DIVISI8LE DESIGNS COMBININC INTRA AND INTER BLOCK ANALYSIS OF GROUP DIVISIBLE DESICNS

OF COMMON TREATMENTS BETWEEN BLOCKS OF SEMI-REGULAR GROUP DIVISIBLE DESTCNS REDUCED GROUP

ON THE 8OUNDS OF

TWO GLASSES OF GROUP DIVISIBLE PARTIAL DIALLEL CROSSES

DESIGNS

ANGE AND SOME TREATMENTS IN GOMMON ANALYSIS OF A GROUP OF BALANGED BLOGK EXPERIMENTS HAVING ERROR VARI 8UTION OF THE F-TYPE STATISTIGS IN THE ANALYSIS OF A GROUP OF EXPERIMENTS ON THE DISTRI JRSSB66 F THE F-TYPE STATISTIGS IN THE ANALYSIS OF A GROUP OF EXPERIMENTS
A TA8LE FOR PREDIGTING THE PRODUCTION FROM A GROUP OF MAGHINES UNDER THE GARE OF ONE OPERATIVE INVERSE POLYNOMIALS, A USEFUL GROUP OF MULTI-FAGTOR RESPONSE FUNGTIONS
A. CHARACTERIZATION AMS $63 \quad 319$ $\begin{array}{rr}\text { AMS } 63 & 492 \\ \text { JRSSB } 60 & 285\end{array}$ JASA 641217 AMS 661398 TECH $66 \quad 188$ JASA $64 \quad 867$ AMS 671887 8IOKA63 281 AMS 64681 BIOGS6 6128 
A NOTE ON G.S. WATSON'S PAPER 'A STUDY OF THE CROUP SCREENINC METHOD' BALANCED INCOMPLETE BLOCK DESICNS

THE ASYMPTOTIC POWERS OF MULTIVARIATE TESTS WTTH GROUPED DATA

CE/ A LINEAR APPROXIMATOR FOR THE CLASS MARKS OF A GROUPED FREOUENCY DISTRIBUTION, WITH ESPECIAL REFEREN TECH 68 793 MOUNT OF INFORMATION SUPPLIED BY CENSORED SAMPLES OF GROUPED OBSERVATIONS IN THE ESTIMATION OF STATISTICAL BIOKA62 245 OUNT OF INFORMATION SUPPLIED BY TRUNCATED SAMPLES OF GROUPED OBSERVATIONS IN THE ESTIMATION OF THE PARAMET BIOKA63 207

ORDER STATISTICS FOR DISCRETE POPULATIONS AND FOR GROUPED SAMPLES

TATISTICS FOR ESTIMATING AND TESTING HYPOTHESES FROM GROUPED SAMPLES

OF LOCATION AND SCALE PARAMETERS IN A TRUNCATED GROUPED SECH SQUARE DISTRIBUTION DISTRIBUTIONS THE FITTING OF GROUPED TRUNCATED AND GROUPED CENSORED NORMAL NOTE ON GROUPING

INTEGER PROGRAMMING AND THE THEORY OF GROUPING ON EXACT GROUPING CORRECTIONS TO MOMENTS AND CUMULANTS

1550) ON SOME INVARIANT CRITERIA FOR GROUPING DATA CROUPING ESTIMATORS IN HETEROSCEDASTIC DATA (CORR ON GROUPING FOR MAXIMUM HOMOGENEITY

EQUALLY SPACED OESERVATIONS UNEQUALLY SPACED OBSERVATIONS CROUPING METHODS IN THE FITTING OF POL
BALANCED INCOMPLETE BLOCK DESIGNS WITH DOUBLE GROUPING OF BLOCKS INTO REPLICATIONS
A NOTE ON THE LOSS OF INFORMATION DUE TO GROUPING OF OBSERVATIONS

EFFICIENCY LOSS DUE TO GROUPING IN DISTRIBUTION-FREE TESTS GROUPING METHODS IN THE FITTING OF POLYNOMIALS TO CROUPING METHODS IN THE FITTING OF POLYNOMIALS TO

ANALYSIS HIERARCHICAL CROUPING TO OPTIMIZE AN OBJECTIVE FUNCTION EFFICIENT GROUPING, REGRESSION AND CORRELATION IN ENGEL CURVE

A COMPARISON OF MAJOR UNITED STATES RELIGIOUS GROUPS

CROSS-INFECTION BETWEEN TWO OTHERWISE ISOLATED CROUPS OF HOMOGENEOUS RANDOM FIELDS ON DISCRETE GROUPS

EXPONENTIAL FAMILIES GENERATED BY TRANSFORMATION CROUPS TICLE SIZE DISTRIBUTION BASED ON OBSERVED WEIGHTS OF GROUPS OF PARTICLES LIKELIHOOD RATIOS OF STOCHASTIC PROCESSES RELATED BY GROUPS OF TRANSFORMATIONS THE SPREAD OF' AN EPIDEMIC TO FIXED GROUPS WITHIN THE POPULATION LINE TRANSECT METHOD OF ESTIMATING GROUSE POPULATION DENSITIES JASA 64233 ONE-PARAMETER AMS $65 \quad 261$ $\begin{array}{ccc}\text { IOS OF THE POPULAT BIOKA5I } & 324 \\ \text { ESTIMATION OF PAR TECH } 65 & 505\end{array}$ THE BEHAVIOR OF AMS $65 \quad 529$ BIOCS68 1007 BIOCS6B 135 POPULATION DIFFERENCES BETWEEN SPECIES GROWING ACCORDING TO SIMPLE BIRTH AND DEATH PROCESSES BIOKA53 370 A GENERALIZATION OF THE LOGISTIC LAW OF GROWTH STATISTIGAL ASSOGIATION, A SKETCH OF ITS ORIGINS AND GROWTH ANALYSIS OF GROWTH AND DOSE RESPONSE CURVES MARKET GROWTH AND INDUSTRY CONCENTRATION LINEAR RELATIONSHIPS IN GROWTH AND SIZE STUDIES

A MATHEMATICAL ANALYSIS OF THE CROWTH AND SPREAD OF BREAST CANCER A MULTI-DIMENSIONAL LINEAR GROWTH BIRTH AND DEATH PROCESS SELECTION FOR AN OPTIMUM CROWTH CURVE ANALYSIS OF VARIANCE MODEL USEFULL ESPECIALLY FOR GROWTH CURVE PROBLEMS A PROBABILITY STRUCTURE FOR GRONTH CURVES

NOTES. A NOTE ON THE ANALYSIS OF GROWTH CURVES BI0CS68 169 A CENERALIZED MULTIVARIATE BIOKA64 313 BI0CS67 217 BIOCS6B 192 RE STOGHASTIC AND ITS APPLICATION TO THE ANALYSIS OF GROWTH CURVES. /LEAST SQUARES WHEN THE PARAMETERS A BIOKA65 447 RELIABILITY GROWTH DURING A DEVELOPMENT TESTING PROGRAM TECH 6653 OF MAXIMUM LIKELIHOOD ESTIMATION OF THE LOGISTIC GROWTH FUNCTION PROBLEMS IN MEASURING LONG TERM CROWTH IN INCOME AND WEALTH THE STUDY OF POPULATION GROWTH IN ORGANISMS GROUPED BY STAGES

IN A TRANSIENT MARKOV CHAIN ARISING IN A RELIABILITY GROWTH MODEL THE GROWTH OF A RANDOM WALK THE GROWTH OF A RECURRENT RANDOM WALK STOCHASTIC MODELS FOR THE POPULATION GROWTH OF THE SEXES

ON GROWTH PARAMETER ESTIMATION FOR EARLY LIFE STAGES

A MULTIVARIATE PALEONTOLOCICAL GROWTH PROBLEM A TWO-DIMENSIONAL POISSON GROWTH PROCESS

ERAL FACTORS GENERALIZED DISTANCES TION $1947-1954$ MODELS FOR A BACTERIAL GROWTH PROCESS WITH REMOVALS

THE ANALYSIS OF POPULATION GROWTH WHEN THE BIRTH AND DEATH RATES DEPEND UPON SEV GROWTH-INVARIANT DISCRIMINANT FUNCTIONS AND BI0CS65 I AMS 691542 AMS 69 NO. 6 AMS $66 \quad 1040$ BIOKA68 469 BI0CS66 162 BI0CS69 I JRSSB65 497 JRSSB $63 \quad 140$ MARKET GROWTH, COMPANY DIVERSIFICATION AND PRODUCT CONCENTRA JASA $60 \quad 640$ PARAMETER ESTIMATES AND AUTONOMOUS GROWTH, CORR. 59812 JASA $59 \quad 389$ -TAILED FIELD MOUSE, APODEMUS SYLVATICUS. III/ THE GROWTH, SURVIVAL, WANDERING AND VARIATION OF THE LONG BIOKA52 389 FILIATION WITH REFERENCES TO RELATED SOCIAL STU/ A GUIDE TO THE LITERATURE ON STATISTICS OF RELIGIOUS AF JASA 59 335 DISTRIBUTION

ON GUPTA'S ESTIMATES OF THE PARAMETERS OF THE NORMAL

BIOKA64 498

SAMPLE OBSERVATIONS ARE LOGNORMAL AND THE PRECISION H IS KNOWN /LE SIZE IN TWO-ACTION PROBLEMS WHEN THE JASA 68 653 SIMPLIFIED BETA-APPROXIMATIONS TO THE KRUSKAL-WALLIS H TEST JASA 59225 OF WORST CONDITIONS POSTERIOR DISTRIBUTIONS RIGHT HAAR MEASURE FOR CONVERGENCE IN PROBABILITY TO QUASI AMS 65 44O

THE FVALUATION OF H POSTERIOR DISTRIBUTIONS RIGHT HAAR MEASURE FOR CONVERGENCE IN PROBABILITY TO QUASI AMS 65 440 ONS THEORETICAL GONSIDERATIONS REGARDING H. R. B. HACK'S SYSTEM OF RANDOMIZATION FOR CROSS-CLASSIFICATI BIOKA58 265 WITH ONE DEGREE OF FREEDOM, EXTENSIONS OF THE MANTEL-HAENSZEL PROCEDURE CHI-SQUARE TESTS JASA 63 69O 
EXPERIMENTS USE OF HALF-NORMAL PLOTS IN INTERPRETINC FACTORIAL TWO LEVEL
HALF-RECTIFIED TRUNCATED DISTRIBUTIONS. SAMPLINC

MEAN HALF-SQUARE SUCCESSIVE DIFFERENCE

THE HALF-TABLE RATIO ESTIMATOR FOR A SIMPLE EXPONENTIAL

MODEL

EXAMPLES

COMPUTATION THE USE OF THE HANKEL TRANSFORM IN STATISTICS. I. CENERAL THEORY AND
THE USE OF THE HANKEL TRANSFORM IN STATISTICS. II. METHODS OF OF A MODIFIED 'HANNAN' AND THE BUREAU OF LABOR STATISTICS A COMPARISON OF A MODIFIED 'HANNAN'

PS SAMPLING SCHEME. A GENERALIZATION OF A METHOD OF HANURAV
ESTIMATION OF SPECTRA AFTER HARD CLIPPING OF GAUSSIAN TIME PROCESSES SHORT PROOF OF DR HARLEY'S THEOREM ON THE CORRELATION COEFFICIENT HARMONIC ANALYSIS OF SEASONAL VARIATION WITH AN HARMONIC ANALYSIS OF THE HUMAN FACE

APPLICATION TO HOG PRODUCTION

OF THE SPECTRAL DENSITY FUNCTION IN THE PRESENCE OF HARMONIC COMPONENTS
COMPARISON OF ANOVA AND HARMONIC COMPONENTS OF VARIANCE

\begin{tabular}{ll} 
BIOCS65 491 \\
\hline
\end{tabular}

ESTIMATION JRSSB64 123 TECH $69 \quad 75$

EXTENSIONS OF A LIMIT THEOREM OF EVERETT, ULAM AND HARRIS ON MULTITYPE BRANCHING PROCESSES TO A BRANCHIN AMS 67992 EXACT ON DISTRIBUTIONS FOR WHICH THE HARTLEY-KHAMIS SOLUTION OF THE MOMENT-PROBLEM IS ING/ LARGE SAMPLE TABLES OF PERCENTAGE POINTS FOR HARTLEY'S CORRECTION TO BARTLETT'S CRITERION FOR TEST AN INVESTIGATION OF HARTLEY'S METHOD FOR FITTINC AN EXPONENTIAL CURVE OBITUARY, GORDON M. L. HASKELL

ERS FOR A MIXTURE OF NORMAL DISTRIBUTIONS' BY VICTOR HASSELBLAD BIOCS67 850 PROBABILITY

A CONFIDENCE REGION FOR THE LOC-NORMAL HAZARD FUNCTION HAZARD ANALYSIS. I

RANDOM HAZARD IN RELIABILITY PROBLEMS

ESTIMATION OF JUMPS, RELTABILITY AND HAZARD RATE

TABLES OF BOUNDS FOR DISTRIBUTIONS WITH MONOTONE HAZARD RATE OF PROBABILITY DISTRIBUTIONS WITH MONOTONE HAZARD RATE

FOR THE CLASS OF DISTRIBUTIONS WITH INCREASINC HAZARD RATE

BOUNDS FOR DISTRIBUTIONS WITH MONOTONE HAZARD RATE. I

BOUNDS FOR DISTRIBUTIONS WITH MONOTONE HAZARD RATE. II SOME APPROXIMATIONS TO THE REQUIRED BIOKA63 514 $\begin{array}{ll}\text { BIOKA63 } & 514 \\ \text { BIOKA64 } & 175\end{array}$ TECH $69 \quad 387$ TECH $63 \quad 211$ AMS 651032 JASA $65 \quad 872$ PROPERTIES AMS $63 \quad 375$ TOLERANCE LIMITS AMS 641561 AMS 641234 AMS 641258

LIABILITY OF SAFETY SYSTEMS FOR PLANTS MANUFACTURING HAZARDOUS PRODUCTS /ICAL MODEL OF EVALUATING THE RE TECH 59293 TIME-DEPENDENT SOLUTION OF THE 'HEAD-OF-THE-LINE' PRIORITY QUEUE

OF THE HOUSEHOLD INTERVIEW DESIGN FOR THE NATIONAL HEALTH SURVEY $\begin{array}{rr}\text { JRSSB62 } & 91 \\ \text { SOME PROBLEMS JASA } 59 & 69\end{array}$ G AND LUNG C/ PROBLEMS OF STATISTICAL INFERENCE IN HEALTH WITH SPECIAL REFERENCE TO THE CIGARETTE SMOKIN JASA 69739 A REVIEW OF 'SMOKING AND HEALTH'

ON THE SIZE OF AN EPIDEMIC AND THE NUMBER OF PEOPLE HEARING A RUMOUR ON QUEUES IN HEAVY TRAFFIC

APPRECIATION OTTOKAR HEINISCH (70TH BIRTHDAY, 23RD APRIL, 1966) ANOTHER LOOK AT HENDERSON'S METHODS OF ESTIMATINC VARIANCE

(WITH DISCUSSION) ANOTHER LOOK AT HENDERSON'S METHODS

OF THE VARIANCE UNDER TRUNCATION AND VARIATIONS OP HENSEN

PROBABILITY OF OBTAINING NEGATIVE ESTIMATES OF HERITABILITY

CONFIDENCE INTERVALS FOR MEASURES OF HERITABILITY

NOTES OPTIMUM EXPERIMENTAL DESICNS FOR REALIZED HERITABILITY ESTIMATES

$s^{2}$

ESTIMATION OF HERITABILITY FROM EXPERIMENTS WITH RELATED DAMS

H UNEQUAL SUBCLASS NUMBERS ESTIMATES OF HERITABILITY FROM TRANS AN ALTERNATIVE DERIVATION OF THE HERMITE DISTRIBUTION

SOME PROPERTIES OF THE 'HERMITE' DISTRIBUTION

JASA $65 \quad 722$ JRSSB $66 \quad 487$ JRSSB $62 \quad 383$ BIOCS66 195 MONOTONICITY AMS 691106 JASA $60 \quad 80$ BIOCS68 517 BIOCS69 424 BIOCS67 361 BIOCS65 265 IOCS65 1001 BIOKA66 627 BIOKA65 381

THE CHARACTERISTTC FUNCTION OF HERMITTAN QUADRATIC FORMS IN COMPLEX NORMAL VARTABLES BIOKA60 199 FACTORIAL ARRANGEMENTS II TWO WAY ELIMINATION OF HETEROGENEITY ESTS OF THE HYPOTHESIS OF EQUAL MEANS UNDER VARIANCE HETEROGENEITY PLICATIONS OF THE CALCULUS FOR AMS $64 \quad 658$ SMALL SAMPLE BEHAVIOUR OF CERTAIN T BIOKA60 345 A TEST FOR VARIANCE HETEROGENEITY IN THE RESIDUALS OF A GAUSSIAN MOVING JRSSB63 451 AVERAGE ESTIMATION PROBLEMS WHEN A SIMPLE TYPE OF HETEROCENEITY IS PRESENT IN THE SAMPLE

BLOCK DESIGN ATIFICATION (ADDENDUM 67) HETEROGENEITY OF ERROR VARIANCES IN A RANDOMIZED

BIOKA51 90 BIOKA57 275 THE CHI-SQUARE TEST FOR HETEROGENEITY OF PROPORTIONS AFTER ADJUSTMENT FOR STR JRSSB66 150 USE OF RANCE IN TESTINC HETEROGENEITY OF VARIANCE

ALTERNATIVE TESTS FOR HETEROGENEITY OF VARIANCE, SOME MONTE CARLO RESULTS THE DISTRIBUTION OF HETEROCENEITY UPON INBREEDINC

CONSTRUCTION OF DESICNS FOR TWO-WAY ELIMINATION OF HETEROGENEITY, I SOME METHODS OF JASA $66 \quad 1153$ ESTS OF THE HYPOTHESIS OF EQUAL MEANS UNDER VARIANCE HETEROGENEITY'; /SMALL SAMPLE BEHAVIOUR OF CERTAIN T BI EXPERIMENTS HETEROGENEOUS ERROR VARIANCES IN SPLIT-PLOT

LIFE-TESTING RESULTS BASED ON A FEW HETEROCENEOUS LOCNORMAL OBSERVAITONS

METHODS OF ESTIMATING THE PARAMETERS OF DISCRETE HETEROGENEOUS POPULATIONS TISTICAL ANALYSIS USINC LOCAL PROPERTIES OF SMOOTHLY HETEROMORPHIC STOCHASTIC SERIES ESTTMATORS WHEN SAMPLING ERRORS ARE TNDEPENDENT AND HETEROSCEDASTIC

VARIANCE OF GROUPING ESTIMATORS IN HETEROSCEDASTIC DATA (CORR. 68 1550) ESTIMATION IN A HETEROSCEDASTIC REGRESSION MODEL A NEW TEST FOR HETEROSKEDASTICITY

ON THE TWO SAMPLE PROBLEM, A HEURISTIC METHOD FOR CONSTRUCTING TESTS F TEST FOR AN UNNESTED FIXED FACTOR IN AN UNBALANCED HIERARCHAL DESICN WITH A MIXED MODEL /E. THE QUASI- BIOCS66 937 APPLICATIONS HIERARCHICAL BIRTH AND DEATH PROCESSES. I. THEORY HIERARCHICAL BIRTH AND DEATH PROCESSES. II SIMULTANEOUS TESTS BY SEQUENTIAL METHODS IN HIERARCHICAL CLASSIFICATIONS AN ALGORITHM FOR HIERARCHICAL CLASSIFICATIONS BAYESIAN ANALYSIS OF A THREE-COMPONENT HIERARCHICAL DESICN MODEL HIERARCHICAL CROUPING TO OPTIMIZE AN OBJECTIVE

FUNCTION APPLICATION OF AN ESTIMATOR OF HICH EFFICIENCY IN BIVARIATE EXTREME VALUE THEORY

ON A LIMIT DISTRIBUTION OF HIGH LEVEL CROSSINGS OF A STATIONARY CAUSSIAN PROCESS STATISTICAL THEORY OF A HIGH-SPEED PHOTOELECTRIC PLANIMETER QUALITY AND QUANTITY IN HIGHER EDUCATION
BIOKA57 378 SOME JRSSB56 222 STA BIOKA57 454 JASA 69 NO. 4 JASA $68 \quad 182$ JASA $68 \quad 552$ JASA $69 \quad 316$ BIOKA6O 235 BIOKA60 245 BIOKA64 439 BI0C\$69 165 BIOKA67 109 JASA $63 \quad 236$ JASA 69 NO. 4 AMS 682108 BIOKA68 419 JASA $65 \quad 1$ 
OF NORMAL VARIATES WHICH ARE UNCORRELATED OF A HICHER ORDER ON CERTAIN FUNCTIONS BIOKA60 175

AR AUTO-REGRESSIVE MODEL. II NULL DISTRIBUTIONS FOR HICHER ORDER SCHEMES, NON-NULL DISTRIBUTIONS HICHER-ORDER PROPERTIES OF A STATIONARY POINT PROCESS JRSSB63 413

THE CENERAL BULK QUEUE AS A HILBERT PROBLEM (CORR. 64487 ) JRSSB62 344

BABILISTIC AND STATISTICAL MODELS AND P/ SURVEY OF HISTOCOMPATIBILITY TESTINC, BIOLOGICAL BACKCROUND PRO BIOCS69 207 N THE HISTORY OP PROBABILITY AND STATISTICS XV THE HISTORICAL DEVELOPMENT OF THE GAUSS LINEAR MODEL TEST HISTORICAL NOTES ON THE WILCOXON UNPAIRED TWO-SAMPLE JASA 57

LABOR FORCE, A CASE STUDY IN THE INTERPRETATION OF HISTORICAL STATISTICS THE FEMALE JASA 60 JASA 6071

FREQUENCY RESPONSE FROM STATIONARY NOISE, TWO CASE HISTORIES STATES POPULATION RESIDENCE HISTORIES AND EXPOSURE RESIDENCES FOR THE UNITED TECH $61 \quad 245$ A HISTORY OF DISTRIBUTION SAMPLINC PRIOR TO THE ERA OF JASA 65 GAMING (A NOTE ON THE HISTORY OF P) INGS OF A PROBABILITY CALCULUS

THE HISTORY OF THE GRAPHICAL PRES/ AN EARLY STATISTICAL STUDY OF LITE/ AL NOTE FOR T. BAYES' ESSAY TOWARD/ PLAYING CARDS

THE EARLY SOLUTIONS OF THE PROBLEM/ IPLE OF THE ARITHMETIC MEAN N AND THE STATISTICAL STUDY OF LIT/ THE HISTORY OF STATISTICS BEGIN NOULLI ON MAXIMUM LIKELIHOOD OF FATE

DHUNTER'S HISTORY OF THE MATHEMATI/ DENTS IN THE EARLY HISTORY OF BIOM/ YSIDRO EDGEWORTH (1B45-1926)

IGAL DEVELOPMENT OF THE GAUSS LINE/ LEXIONS ON CONTINUITY IN THE DEVEL/ YOUNG ON COINCIDENCES

GORRESPONDENCE BETWEEN W.S. GOSSET/ LY HISTORY OF THE LAW OF LARGE NUM/ ITY IN THE TALMUD STUDIES IN THE HISTORY OF PROBABILITY AND STATISTICS XVI RANDOM RAN BIOKA67 STUDIES IN THE HISTORY OF PROBABILITY AND STATISTICS. I. DICING AND BIOKA55 STUDIES IN THE HISTORY OF PROBABILITY AND STATISTICS. II. THE BEGINN BIOKA56 STUDIES IN THE HISTORY OF PROBABILITY AND STATISTICS. III. A NOTE ON BIOKA56 STUDIES IN THE HISTORY OF PROBABILITY AND STATISTICS. IV. A NOTE ON BIOKA56 STUDIES IN THE HISTORY OF PROBABILITY AND STATISTICS. IX. BIOGRAPHIC BIOKA58 STUDIES IN THE HISTORY OF PROBABILITY AND STATISTICS. V.A NOTE ON BIOKA57 STUDIES IN THE HISTORY OF PROBABILITY AND STATISTICS VI A NOTE ON BIOKA57 STUDIES IN THE HISTORY OF PROBABILITY AND STATISTICS. VII. THE PRINC BIOKA58 STUDIES IN THE HISTORY OF PROBABILITY AND STATISTICS. VIII. DE MORCA BIOKA5B STUDIES IN THE HISTORY OF PROBABILITY AND STATISTICS. $X$. WHERE SHALL BIOKA6O STUDIES IN THE HISTORY OF PROBABILITY AND STATISTICS. XI. DANIEL BER BIOKA6I STUDIES IN THE HISTORY OF PROBABILITY AND STATISTICS. XII. THE BOOK BIOKA6I STUDIES IN THE HISTORY OF PROBABILITY AND STATISTICS. XIII. ISAAC TO BIOKA63 STUDIES IN THE HISTORY OF PROBABILITY AND STATISTICS. XIV. SOME INCI BIOKA65 STUDIES IN THE HISTORY OF PROBABILITY AND STATISTICS, XIX. FRANCIS BIOKA68 STUDIES IN THE HISTORY OF PROBABILITY AND STATISTICS. XV. THE HISTOR BIOKA67 STUDIES IN THE HISTORY OF PROBABILITY AND STATISTICS. XVII. SOME REF BIOKA67 STUDIES IN THE HISTORY OF PROBABILITY AND STATISTICS. XVIII. THOMAS BIOKA68 STUDIES IN THE HISTORY OF PROBABILITY AND STATISTICS. XX. SOME EARLY BIOKA6B STUDIES IN THE HISTORY OF PROBABILITY AND STATISTICS. XXI.ON THE EAR BIOKA68 STUDIES IN THE HISTORY OF PROBABILITY AND STATISTICS. XXII. PROBABIL BIOKA69 PROBABILITY AND STATISTICS. XIII. ISAAC TODHUNTER'S HISTORY OF THE MATHEMATICAL THEORY OF PROBABILITY BIOKA63 20 PROBLEM ON THE HODGES AND LEHMANN SHIFT ESTIMATOR IN THE TWO SAMPLE AMS 641576 NULL DISTRIBUTION AND BAHADUR EFFICIENCY OF THE HODGES BIVARIATE SICN TEST

ROBUSTNESS OF THE HODGES-LEHMANN ESTIMATES FOR SHIFT AMS $661 \mathrm{Bl} 4$ AMS $62 \quad 803$ AMS $65 \quad 174$

OF DANIEL/ GORREGTIONS TO 'A RELATIONSHIP BETWEEN HODGES' BIVARIATE SIGN TEST AND A NON-PARAMETRIC TEST AMS 6I 6I9 $Y$ OF A GIRCULAR DISTRIBUTION BIOKA69 446 AMS $67 \quad 382$ ON AN INEQUALITY OF HOEFFDING

A NOTE ON HOEFFDING'S INEQUALITY

DISCUSSION OF HOEFFDINGS PAPER

ON A THEOREM OF HOEL AND LEVINE ON EXTRAPOLATION OF SEASONAL VARIATION WITH AN APPLICATION TO HOC PRODUCTION CONSUMERS' PROPENSITIES TO HOLD LIQUID ASSETS THE RELIABILITY OF CONSUMER SURVEYS OF FINANCIAL HOLDINCS, TIME-DEPOSITS ON CROUPING FOR MAXIMUM HOMOCENEITY ASA 69907 AMS $65 \quad 401$ AMS 651627 TESTINC HOMOCENEITY AGAINST ORDERED ALTERNATIVES

A NOTE ON TESTS OF HOMOCENEITY APPLIED AFTER SEQUENTIAL SAMPLING TESTS OF HOMOCENEITY FOR CORRELATED SAMPLES

A TEST OF HOMOGENEITY FOR ORDERED ALTERNATIVES

A TEST OF HOMOCENEITY FOR ORDERED ALTERNATIVES. II

A TEST OF HOMOCENEITY FOR ORDERED VARIANCES AMS $63 \quad 945$ JRSSB 60368 JASA $63 \quad 97$ BIOKA59 36 BIOKA59 328 JRSSB61 195

BUTIONS EMPIRIC INVESTIGATION OF A TEST OF HOMOCENEITY FOR POPULATIONS COMPOSE THE RAPID CALCULATION OF CHI-SQUARE AS A TEST OF HOMOGENEITY FROM A 2-BY-N TABLE
TESTINC FOR HOMOGENEITY OF A BINOMIAL SERIES TESTINC THE HOMOGENEITY OF A SET OF CORRELATED VARIANCES ASA $58 \quad 551$ BIOKA55 519 BIOKA68 426 BIOKA6B 317 S CORRECTION TO BARTLETT'S CRITERION FOR TESTING THE HOMOGENEITY OF A SET OF VARIANCES /NTS FOR HARTLEY' BIOKAG2 487 SYMMETRY AND MARCINAL HOMOGENEITY OF AN R-BY-R CONTINGENCY TABLE OF UNEQUAL GROUP VARIANCES ON THE F-TEST FOR THE HOMOGENEITY OF GROUP MEANS THE EFFECT BIOKA53 128 WITH DISCUSSION WAY CLASSIFIGATION A TEST OF HOMOGENEITY OF MEANS UNDER RESTRICTED ALTERNATIVES ON BARTLETT'S TEST AND LEHMANN'S TEST FOR HOMOCENETTY OF VARIANCES TESTING THE HOMOGENEITY OF VARIANCES IN A TWO-WAY CLASSIFICATION

THE ROBUSTNESS OF HOMOGENEITY TESTS IN 2-BY-N TABLES TESTING FOR HOMOGENEITY. I. THE BINOMIAL AND MULTINOMIAL TESTING FOR HOMOGENEITY II THE POISSON DISTRIBUTION JRSSB61 239 $\begin{array}{ll}\text { JRSSB61 } & 239 \\ \text { BIOKA55 } & 412\end{array}$ AMS 69 NO.6 BIOCS69 153 BIOCS65 19 BIOKA66 167 BIOKA66 IB3

DISTRIBUTIONS

ERICAL NORMAL DISTRIBUTIONS, IV, THE DISTRIBUTION OF HOMOGENEOUS AND NON-HOMOGENEOUS QUADRATIC FUNCTIONS O
ON THE HOMOGENEOUS BIRTH-AND-DEATH PROCESS AND ITS INTECRAL
NON-HOMOGENEOUS BRANCHING POISSON PROCESSES

ERICAL NORMAL DISTRIBUTIONS, IV, THE DISTRIBUTION OF HOMOGENEOUS AND NON-HOMOGENEOUS QUADRATIC FUNCTIONS O
ON THE HOMOGENEOUS BIRTH-AND-DEATH PROCESS AND ITS INTECRAL
NON-HOMOGENEOUS BRANCHING POISSON PROCESSES

ERICAL NORMAL DISTRIBUTIONS, IV, THE DISTRIBUTION OF HOMOGENEOUS AND NON-HOMOGENEOUS QUADRATIC
ON THE HOMOGENEOUS BIRTH-AND-DEATH PROCESS AND
NON-HOMOGENEOUS BRANCHING POISSON PROCESSES

OF EQUALITY OF TWO NORMAL POPULATION MEANS ASSUMING HOMOCENEOUS COEFFICIENTS OF VARIATION
SAMPLE FUNCTIONS OF GAUSSIAN RANDOM HOMOGENEOUS FIELDS ARE EITHER CONTINUOUS OR VERY IRRE $\begin{aligned} & \text { GULAR } \text { SAMPLE FUNCTIONS OF GAUSSIAN RANDOM HOMOGENEOUS FIELDS ARE EITHER CONTINUOUS } \\ & \text { HOMOGENEOUS GAUSS-MARKOV RANDOM FIELDS }\end{aligned}$ CONCERNING THE STRONG LAW OF LARGE NUMBERS FOR NON-HOMOGENEOUS MARKOV CHAINS SOME THEOREMS SAMPLE PATH VARIATIONS OF HOMOGENEOUS PROCESSES 
SOME TESTS FOR HOMOSCEDASTICITY

JASA $65 \quad 539$ ME EMPIRICAL DISTRIBUTIONS OF BIVARIATE T-SQUARE AND HOMOSCEDASTICITY CRITERION M UNDER UNEQUAL VARIANCE A JASA 63 IO48 TWO-SIDED BOUNDARY ESTIMATION

A WIENER-HOPF TYPE METHOD FOR A GENERAL RANDOM WALK WITH A

ON HOROVITZ AND THOMPSON'S T-ONE CLASS OF LINEAR

AMS $63 \quad 1168$

AMS $67 \quad 1882$

AN OPTIMUM PROPERTY OF THE HORVITZ-THOMSON ESTIMATE

GRAPHICALLY ORIENTED TESTS FOR HOST VARIABILITY IN DILUTION EXPERIMENTS

OPTIMIZATTON OF A HOT ROLLING MILL

KOLMOGOROV'S REMARK ON THE HOTELLING CANONICAL CORRELATIONS

ON HOTELLING'S GENERALIZATION T-SQUARE

JASA 671013

BIOCS67 269

JRSSB67 300

BIOKA66 585

BIOKA59 160

AMS $66 \quad 215$

DISPERSION

THE DISTRIBUTION OF HOTELLING'S GENERALIZED MEASURE OF MULTIVARIATE

$\begin{array}{ll}\text { ANALYSIS OF VARIANCE } & \text { HOTELLING'S GENERALIZED T SQUARE IN THE MULTIVARIATE JRSSB63 } 358 \\ \text { INEAR DIFFERENTIAL EQUATIONS FOR THE DISTRIBUTION OF HOTELLING'S GENERALIZED T-SQUARE-SUB-ZERO /TEM OF L AMS 6B B15 }\end{array}$ THE ROBUSTNESS OF HOTELLING'S T-SQUARE

ON SOME ASYMPTOTICALLY NONPARAMETRIC COMPETITORS OF HOTELLING'S T-SQUARE, CORR. 651583

E (CORR. 69719 )

MINIMAX CHARACTER OF HOTELLING'S T-SQUARED TEST IN THE SIMPLEST CASE

JASA $67 \quad 124$

AMS 65160

AMS $63 \quad 1524$

OF ERRORS

SINGULARITY IN HOTELLING'S WEIGHING DESIGNS AND A GENERALIZED INVERS ON HOTELLING'S WEIGHING DESIGNS UNDER AUTO-CORRELATION

REGIONAL DISPARITIES IN HOUSEHOLD COMSUMPTION IN INDIA

AMS 661021

AMS 651829

JASA $67 \quad 143$

ON ESTIMATING EPIDEMIC PARAMETERS FROM HOUSEHOLD DATA

BIOKA64 511

RIABLE CHANCE OF INFECTION FOR THE ANALYSIS OF INTRA-HOUSEHOLD EPIDEMICS /E OF CHAIN-BINOMIALS WITH A VA BIOKA53 279

CHANGES IN THE RATE AND COMPONENTS OF HOUSEHOLD FORMATION

JASA $60 \quad 268$

ESTIMATING THE SERVICE LIFE OF HOUSEHOLD GOODS BY ACTUARIAL METHODS, CORR $5757 \mathrm{~B}$ JASA 57 175

SURVEY

SOME PROBLEMS OF THE HOUSEHOLD INTERVIEW DESIGN FOR THE NATIONAL HEALTH

JASA $59 \quad 69$

JASA $64 \quad 18$

A STUDY OF RESPONSE ERRORS IN EXPENDITURES DATA FROM HOUSEHOLD INTERVIEWS

L MEETING FOR WILLIAM N. HURWITZ. THE DEVELOPMENT OF HOUSEHOLD SAMPLE SURVEYS /ATISTICAL SOCIETY MEMORIA JASA 69 NO.4

AN ANALYSIS OF CONSISTENCY OF RESPONSE IN HOUSEHOLD SURVEYS

STATISTICAL PROGRAM DEVELOPMENT AND THE SURVEY OF HOUSEHOLDS

MPARISON OF THREE STRATEGIES OF COLLECTING DATA FROM HOUSEHOLDS

RAMETERS FROM THE SPREAD OF A DISEASE BY CONSIDERING HOUSEHOLDS OF TWO

THE USE OF WEALTH TO COMPARE HOUSEHOLDS' AVERAGE SAVING

PHILIPPINE JASA $5 B \quad 78$

A CRITTCAL CO JASA 67976

THE ESTIMATION OF. PA BIOKA65 271

JASA $64 \quad 737$

AMS $69 \quad 66$

ON MEASURABLE NONLEAVABLE GAMBLING HOUSES WITH A GOAL

IN MULTIVARIATE ANALYSIS, BASED ON LECTURES BY P. L. HSU /BIANS OF CERTAIN MATRIX TRANSFORMATIONS USEFUL BIOKA5I 345

R TESTING INDEPENDENCE OF SETS OF VARIATES UNDER THE HULL HYPOTHESIS /NS OF LIKELIHOOD RATIO CRITERIA FO AMS 67 II6O THE CONVEX HULL OF A RANDOM SET OF POINTS

THE CONVEX HULL OF PLANE BROWNIAN MOTION

LIMITING SETS AND CONVEX HULLS OF SAMPLES FROM PRODUCT MEASURES

SCOOLING. EXPERIENCE, AND GAINS AND LOSSES IN HUMAN CAPITAL THROUGH MIGRATION

HARMONIC ANALYSIS OF THE HUMAN FACE

A CORRELATION BETWEEN THE SEXES OF ADJACENT SIBS IN HUMAN FAMILIES

TESTING HYPOTHESES AND ESTIMATING PARAMETERS IN HUMAN GENETICS IF THE AGE OF ONSET IS RANDOM CONVERGENCE OF A HUMAN POPULATION TO A STABLE FORM

KARL PEARSON. AN APPRECIATION ON THE HUNDREDTH ANNIVERSARY OF HIS BIRTH

BIOKA65 331

AMS $63 \quad 327$

AMS 591824

JASA $67 \quad$ B75

BIOCS65 491

THE DETECTION OF JASA $65 \quad 1035$

BIOKA63 265

JASA $6 B \quad 395$

JASA $58 \quad 23$

MEMORIAL MEETING FOR WILLIAM N HURWITZ ON WILLIAM HURWITZ

STATISTICAL SOCIETY MEMORIAL MEETING FOR WILLIAM N. HURWITZ, CHANGES IN CENSUS METHODS

STATISTICAL SOCIETY MEMORIAL MEETING FOR WILLIAM N HURWITZ COMMENTS

STATISTICAL SOCIETY MEMORIAL MEETING FOR WILLIAM N. HURWITZ, ON WILLIAM HURWITZ

STATISTICAL SOCIETY MEMORIAL MEETING FOR WILLIAM N. HURWITZ. PROFESSOR WILLIAM N HURWITZ

WASHINGTON JASA 69 NO. 4

STATISTICAL SOCIETY MEMORIAL MEETING FOR WILLIAM N. HURWITZ SOME BASIC PRINCIPLES OF STATISTICAL SURVEYS JASA 69 NO 4

STATISTICAL SOCIETY MEMORIAL MEETING FOR WILLIAM N. HURWITZ. THE DEVELOPMENT OF HOUSEHOLD SAMPLE SURVEYS JASA 69 NO. 4

A HYBRID PROBLEM ON THE EXPONENTIAL FAMILY

\begin{tabular}{l} 
A HYBRID PROBLEM ON THE EXPONENTIAL FAMILY AMS 651185 \\
\hline
\end{tabular}

NOTES ON THE EVALUATION OF VARIABILITY IN ISOGENIC HYBRIDS

RANDOM HYDRODYNAMIC FORCES ON OBJECTS

SAMPLING FINITE POPULATIONS HYPER-ADMISSIBILITY AND OPTIMUM ESTIMATORS FOR

BI0CS66 623

AMS $67 \quad 37$

AMS $68 \quad 621$

JASA $64 \quad 133$

A TWO-PARAMETER FAMILY OF HYPER-POISSON DISTRIBUTIONS

FITTING THE RECTANGULAR HYPERBOLA

GENERALIZED HYPERBOLIC SECANT DISTRIBUTIONS

MODIFIED SAMPLING. BINOMIAL AND HYPERGEOMETRIC CASES

PROPERTIES OF THE EXTENDED HYPERGEOMETRIC DISTRIBUTION

THE COMPOUND HYPERGEOMETRTC DISTRIBUTTON AND A SYSTEM OF SINGLE

JASA $68 \quad 329$

TECH 69 NO. 4 GENERALIZED HYPERGEOMETRIC DISTRIBUTIONS HYPERGEOMETRIC FUNCTIONS IN SEQUENTIAL ANALYSIS AMS $65 \quad 1 B 70$

ETWEEN NEYMAN AND BAYES CONFIDENCE INTERVALS FOR THE HYPERGEOMETRIC PARAMETER

THE RELATIONSHIP B TECH $68 \quad 199$

A QUICKLY CONVERGENT EXPANSION FOR CUMULATIVE HYPERGEOMETRIC PROBABILITIES, DIRECT AND INVERSE

ENDA, 'A QUICKLY CONVERGENT EXPANSION FOR CUMULATIVE HYPERGEOMETRIC PROBABILITIES, DIRECT AND INVERSE' / BIOKA55 277

APPROXIMATIONS TO DISTRIBUTION FUNCTIONS WHICH ARE HYPERGEOMETRIC SERIES

A METHOD OF SEQUENTTAL ESTTMATION APPLICABLE TO THE HYPERGEOMETRIC BTNOMTAL, POISSON, AND EXPOMENTIAL DI AMS 65 I494

DISTRIBUTIONS DETERMINED BY CUTTING SIMPLEX WITH HYPERPLANES

GEOMETRICAL PROBABILITY AND RANDOM POINTS ON A HYPERSPHERE

PROBABILITY BOUNDS FOR A UNION OF HYPERSPHERICAL CONES

QUADRATIC EXTRAPOLATION AND A RELATED TEST OF HYPOTHESES

ON THE INDEPENDENCE OF TESTS OF RANDOMNESS AND OTHER HYPOTHESES

ON THE RESOLUTION OF STATISTICAL HYPOTHESES

ON OPTIMAL ASYMPTOTIC TESTS OF COMPOSITE STATISTICAL HYPOTHESES ON ITERATED TESTS OF HYPOTHESES QUANTUM HYPOTHESES

SIMULTANEOUS TESTS' OF LINEAR HYPOTHESES

AMS $68 \quad 1473$

AMS $67 \quad 213$

JRSS865 57

JASA $56 \quad 644$

JASA $57 \quad 53$

JISA $61 \quad 978$

AMS $67 \quad 1845$

JiSA $67 \quad 520$

BIrKA55 45

BIOKA55 44I

BIOKA68 355

JRSSB54 261

JRSSB57 125

JRSSB $60 \quad 402$

JRSSB62 406

JRSSB $68 \quad 483$

FURTHER RESULTS ON TESTS OF SEPARATE FAMILIES OF HYPOTHESES

RANK ORDER TESTS OF LINEAR HYPOTHESES

THE USE OF AMS $61 \quad 1034$

LEAST FAVORABLE DISTRIRUTIONS IN TESTING COMPOSITE HYPOTHESES

BAYES APPROACH TO THE TESTING OF CERTAIN PARAMETRIC HYPOTHESES

THE LIKELIHOOD RATIO FOR TESTING MULTIVARIATE LINEAR HYPOTHESES

TECHNIQUE FOR ESTIMATION AND TESTING STATISTICAL HYPOTHESES

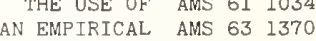

DISTRIRUTION OF AMS $61 \quad 333$

CONFIDENCE CURVES, AN OMNIBUS JASA $61-246$ 
TEST WHEN THE MOMENT IS INFINITE UNDER ONE OF THE HYPOTHESES AMPLE SIZE FOR SEQUENTIAL TESTS. I. TESTS FOR SIMPLE HYPOTHESES INFORMATION FOR DISCRIMINATION BETWEEN TWO COMPOSITE HYPOTHESES IANCE MATRIX AND WILKS' CRITERION FOR TESTS OF THREE HYPOTHESES LE SPACE IN TESTS OF AN IMPORTANT CLASS OF COMPOSITE HYPOTHESES PLE SIZE FOR SEQUENTIAL TEST, II. TESTS OF COMPOSITE HYPOTHESES OF THE LIKELIHOOD RATIO CRITERIA FOR TESTINC LINEAR HYPOTHESES FUNCTION

CRITICAL RECIONS FOR $S$ IF THE ACE OF ONSET IS RANDOM TS OF HYPOTHESES A

INADMISSIBILITY OF THE BEST INVARIANT AMS 691483 APPROXIMATION TO THE DISTRIBUTION OF S BIOKA59 130 /PLE SEQUENTIAL TEST, USINC CONCOMITANT JASA $66 \quad 357$ /S OF THE RATIOS OF THE ROOTS OF A COVAR AMS 69 NO. 6 /ST CRITICAL RECIONS SIMILAR TO THE SAMP BIOKA53 231 /XIMATION TO THE DISTRIBUTION OF THE SAM BIOKA6O 190 ABOUT RECRESSION COEFFICIENTS/RIBUTIONS AMS $66 \quad 1319$ BOUT THE PARAMETERS OF THE LOGISTIC BOUT THE VARIANCE JASA $66 \quad 204$ TESTINC HYPOTHESES AND ESTIMATINC PARAMETERS IN HUMAN GENETIC BIOKA63 265 LINEAR HYPOTHESES AND INDUCED TESTS

DISCRIMINANT FUNCTION BETWEEN COMPOSITE HYPOTHESES AND RELATED PROBLEMS

ON THE SMOOTH EMPIRICAL BAYES APPROACH TO TESTINC OF HYPOTHESES AND THE COMPOUND DECISION PROBLEM MODIFIED KOLMOGOROV-SMIRNOV TESTS OF APPROXIMATE HYPOTHESES AND THEIR PROPERTIES POWER COMPARISONS OF TESTS OF TWO MULTIVARIATE HYPOTHESES BASED ON FOUR CRITERIA $\begin{array}{llll} & \end{array}$ DISTRIBUTION SEQUENTIAL DECISION PROCEDURE FOR CHOOSING ONE OF K HYPOTHESES CONCERNING THE UNKNOWN MEAN OF A NORMAL DI AMS 63 549 TEST FOR LINEAR RANKS ORDERED HYPOTHESES FOR MULTIPLE TREATMENTS. A SIGNIFICANCE JASA 63216 THE EFFECT OF TRUNCATION ON TESTS OF HYPOTHESES FOR NORMAL POPULATIONS

LED PRE/ ASYMPTOTICALLY OPTIMAL TESTS OF COMPOSITE HYPOTHESES FOR RANDOMIZED EXPERIMENTS WITH NONCONTROL JASA 65 699 CORR. $67 \quad 1928$

TESTS OF COMPOSITE HYPOTHESES FOR THE MULTIVARIATE EXPONENTIAL FAMILY, CONSISTENT STATISTICS FOR ESTIMATING AND TESTING HYPOTHESES FROM GROUPED SAMPLES NOTE ON TESTING HYPOTHESES IN AN UNBALANCED RANDOM EFFECTS MODEL

A NOTE ON THE EQUIVALENCE OF TWO TEST CRITERIA FOR HYPOTHESES IN CATEGORICAL DATA

LAMP TESTS OF LINEAR AND LOGLINEAR HYPOTHESES IN MULTINOMIAL EXPERIMENTS, CORR. 661246 SOME PROBLEMS INVOLVING LINEAR HYPOTHESES IN MULTIVARIATE ANALYSIS TESTING HYPOTHESES IN RANDOMIZED FACTORIAL EXPERIMENTS

TESTING APPROXIMATE HYPOTHESES IN THE COMPOSITE CASE, CORR. 63

ULL DISTRIBUTIONS FOR HIGHER ORDER SCHEM/ TESTS OF HYPOTHESES I SOME TESTS OF SEPARATE FAMIITES OF HYPOTHESES IN TTME SERIES ANALYSIS CONTINGENCY TABLES HYPOTHESES OF 'NO INTERACTION' IN MULTI-DIMENSIONAL TECH $6 B$. NCY TABLES HEN SOME OUTLIERS ARE PRESENT, C/ ON SOME TESTS OF HYPOTHESES RELATING TO THE EXPONENTIAL DISTRIBUTION W JASA 65 548 - CORR. 64 12/ ASYMPTOTIC POWER OF TESTS OF LINEAR HYPOTHESES USING THE PROBIT AND LOGIT TRANSFORMATIONS JASA 62 877 AND LOWER PROBABILITY INFERENCES FOR FAMILIES OF HYPOTHESES NITH MONOTONE DENSITY RATIOS ON MODELS AND HYPOTHESES WITH RESTRICTED ALTERNATIVES UPPER AMS $69 \quad 953$ JASA 651153 GENT TESTS AND LAGRANGIAN MULTIPLIER TESTS OF LINEAR HYPOTHESES TRIALS A BAYESIAN TEST OF SOME CLASSICAL HYPOTHESES ON TESTING MORE THAN ONE HYPOTHESIS

A CLASS OF RANK ORDER TESTS FOR A GENERAL LINEAR HYPOTHESIS LOCALLY ASYMPTOTICALLY MOST STRIN BIOKA65 459 WITH APPLICATIONS TO SEQUENTIAL CLINICAL JASA $66 \quad 577$ AMS $63 \quad 555$ AMS 691325 BIOKA60 297 ON COMPARING DIFFERENT TESTS OF THE SAME HYPOTHESTS SOME BIOKA64 508 NOTES ON VARIANCE-RATIO TESTS OF THE GENERAL LINEAR HYPOTHESIS COMPARISONS AMONG TESTS OF THE GENERAL LINEAR HYPOTHESIS

IN SCIENCE. THE SYMMETRIC TEST OF A COMPLETE HYPOTHESIS FUNCTIONS OF SOME TESTS OF THE MULTIVARIATE LINEAR HYPOTHESIS

A NULL HYPOTHESIS AGAINST A TWO SIDED ALTERNATIVE HYPOTHESIS TING INDEPENDENCE OF SETS OF VARIATES UNDER THE HULL HYPOTHESIS A SEQUENTIAL PROCEDURE FOR TESTING A NULL HYPOTHESIS A THE LINEAR HYPOTHESIS AND ATE LINEAR HYPOTHESIS AND INDEPENDENCE/ULL EXAMINATION OF A QUANTUM HYPOTHESIS BASED ON A SINCLE SET OF DATA SENSITIVITY JASA $66 \quad 415$ STATISTICAL PROBLEMS JASA 69 NO. 4 MONOTONICTTY OF THE POWER AMS 64200 A SEQUENTIAL PROCEDURE FOR TESTING JRSSB69 NO.2 /NS OF LIKELIHOOD RATIO CRITERIA FOR TES AMS 671160 ATNT A TWO SIDED ALTERNATIVE HYPOTHESIS JRSSB69 N0.2 JRSSB 64261 AMS $69 \quad 942$ AMS 64773 BIOKA56 32 RGEST OR THE SMALLEST CHARACTERISTIC ROOT UNDER NULL HYPOTHESIS CONCERNING COMPLEX MULTIVARIATE NORMAL POP AMS 64 1807 A SHORT-CUT RULE FOR A ONE-SIDED TEST OF HYPOTHESIS FOR QUALITATIVE DATA I97 OF THE LIKELIHOOD-RATIO TEST OF THE GENERAL LINEAR HYPOTHESIS IN MULTIVARIATE ANALYSIS POWER BIOKA64 467 A COMPARISON OF TESTS OF THE WILKS-LAWLEY HYPOTHESIS IN MULTIVARIATE ANALYSIS.

A NOTE ON GENERALIZED INVERSES IN THE LINEAR HYPOTHESIS NOT OF FULL RANK

ALTERNATIVES TO THE STANDARD CHI-SQUARE-TEST OF THE HYPOTHESIS OF EQUAL CELL FREQUENCIES

AMS $67 \quad 271$ TWO BIOKA62 107 Y SMALL SAMPLE BEHAVIOUR OF CERTAIN TESTS OF THE HYPOTHESIS OF EQUAL MEANS UNDER VARIANCE HETEROGENEIT BIOKA6O 345 NDA, 'SMALL SAMPLE BEHAVIOUR OF CERTAIN TESTS OF THE HYPOTHESIS OF EQUAL MEANS UNDER VARIANCE HETEROCENEIT BIOKA6I 230 THE COEFFICIENT OF RANK CORRELATION FOR TESTING THE HYPOTHESIS OF INDEPENDENCE CRITICAL VALUES OF BIOKA6I 444 MIXED MODEL TESTING THE HYPOTHESIS OF NO FIXED MAIN-EFFECTS IN SCHEFFE'S AMS 621085 N THE TRUE PARAMETER IS 'NEAR' THE BOUNDARIES OF THE HYPOTHESIS REGIONS /LIHOOD RATIO TEST STATISTIC WHE AMS 68 2044 POPULATION WITH KNONN VARIANCE A SEQUENTIAL THREE HYPOTHESTS TEST FOR DETERMINTNG THE MEAN OF A NORMAL AUS 67 I365 TRUNCATED DISTRIBUTIONS, SAMPLING THEORY AND HYPOTHESIS TESTING HALF-RECTIFIED TECH 69 4' A RANDOM VARIABLE (WITH DISCUSSION) HYPOTHESIS TESTING WHEN THE SAMPLE SIZE IS TREATED AS JRSSB67 HYPOTHESIS TESTING WITH FINITE MEMORY

STATIONARY PROCESSES SEPARATE RECIMES AND RESTRICTED ORDER

SEQUENTIAL HYPOTHESIS TESTS FOR THE R-DEPENDENT MARGINALLY TESTS OF THE HYPOTHESIS THAT A LINEAR REGRESSION SYSTEM OBEYS TWO JASA 60 TESTING A MARKOV HYPOTHESIS WITH INDEPENDENCE OF INTERMEDIATE STATES BIOKA67 MULTIVARIATE LINEAR HYPOTHESIS WITH LINEAR RESTRICTIONS

D EMPIRICA/ ON THE RANCE OF THE DIFFERENCE BETWEEN HYPOTHETICAL DISTRIBUTION FUNCTION AND PYKE'S MODIFIE AMS 62 52 THE GOODNESS-OF-FIT OF A SINGLE (NON-ISOTROPIC) HYPOTHETICAL PRINCIPAL COMPONENT UNBIASEDNESS FOR MULTIPLE DECISION PROBLEMS OF TYPE I

OF THE NORMAL POPULATION PARAMETERS GIVEN A TYPE I CENSORED SAMPLE A NOTE ON ESTIMATION FROM A TYPE I EXTREME-VALUE DISTRIBUTION SOME EXTENSIONS OF THE IDEA OF BIAS ROBUSTNESS OF NON-IDEAL DECISION PROCEDURES A NOTE ON IDEMPOTENT MATRICES
MINIMAX RISK AND AMS 69 168 TECH $67 \quad 325$ AMS $61 \quad 436$ JASA $63 \quad 480$ AMS $64 \quad 880$ 
VARIABLES

DESIGNS HAVING WORDS OF EQUAL LENGTHS

ONENTITY FOR THE VARIANCE OF A RATIO OF TWO RANDOM

A GENERALIZATION OF WALD'S IDENTITY WITH APPLICATIONS TO RANDOM WALKS COMPETITIVE QUEUEING, IDLENESS PROBABILITIES UNDER PRIORITY DISCIPLINES

JRSSB 64 4B4

AMS 66 IB42

AMS $6 I \quad 549$

JRSSB $63 \quad 4 B 9$

POTHESES AND ESTTMATING PARAMETERS IN HUMAN GENETIGS IF THE AGE OF ONSET IS RANDOM MINIMAX RESULTS FOR IFRA SCALE ALTERNATIVES

FOR FINITE DECISION PROBLEMS UNDER COMPLETE IGNORANCE

OCEDURES FOR FINITE DECISION PROBLEMS UNDER COMPLETE TGNORANCE

THE EFFECT OF RESPONDENT IGNORANCE ON SURVEY RESULTS

ES OF THE LOCATION AND SCALE PARAMETERS GIVEN A TYPE II CENSORED NORMAL SAMPLE

A NEW TABLE OF PERCENTAGE POINTS OF THE PEARSON TYPE III DISTRIBUTION

SPEGIAL REFERENCE TO SAMPLES FROM A PEARSON TYPE III POPULATION

SAMPLE MONTE CARLO STUDIES. AND AUTOREGRESSIVE ILLUSTRATION

TESTING HY BIOKA63 265 AMS $69177 \mathrm{~B}$ DECISION PROCEDURES AMS 64 I644 NOTE ON DECISION PR AMS 65 69I JASA $56 \quad 576$ /XIMUM LIKELIHOOD ESTIMAT BIOKA6I 448 TECH $69 \quad 177$ ILLUSTRATIVE TABLES OF SCHOOL LIFE, CORR, 64 I299 JASA 63 III3

PROCESSES WITH A V/AN APPLICATION FOR THE SOBOLEV IMBEDDING THEOREMS TO CRITERIA FOR THE CONTINUITY OF AMS 69 517 CN A BRANCHING PROCESS ALLOWING IMMIGRATION

RECAPTURE CENSUS II ESTIMATION WHEN THERE IS IMMIGRATION OR DEATH SOME ASPECTS OF THE EMIGRATION-IMMIGRATION PROCESS A FUNDAMENTAL INTERACTION PARAMETER IN AN EMIGRATION-IMMIGRATION PROCESS JRSSB 65 13B BIOKA59 336 AMS $62 \quad 119$ ONS TO LUNAR CRATERS

A MULTIVARTATE IMMIGRATION WITH MULTTPLE THE U ATES FROM CAPTURE-RECAPTURE DATA WITH BOTH DEATH AND IMMIGRATION-STOCHASTIC MODEL TIONARY DISTRIBUTION OF A BRANCHING PROCESS ALLOWING IMMIGRATION, A REMARK ON THE CRITICAL CA COMMENTS ON THE PAPER 'A BRANCHING PROCESS ALLOWING IMMIGRATION' ON SOME BILHARZIA INFECTION AND IMMUNISATION MODELS STATISTICAL PROCESS CONTROL AND THE IMPACT OF AUTOMATIC PROCESS CONTROL DETERMINISTIC CUSTOMER IMPATIENCE IN THE QUEUEING SYSTEM GI-M-1 $\mathrm{N}$ DETERMINISTIC CUSTOMER IMPATIENCE IN THE QUEUEING SYSTEM GI-M-1

AND APPLICATI BIOKA67 EXPLICIT ESTIM BIOKA65 225 CASE THE STA JRSSB68 176 CORRECTIONS AND JRSSB66 213 SASJ $6 \mathrm{~B} \quad 61$ TECH $65 \quad 2 B 3$ BIOKA60 45 DETERMINISTIC CUSTOMER IMPATIENCE I
OF REPLACEMENT POLICIES. AND RENEWAL THEORY IMPLICATIONS A CORRECTIO BIOKA6I 472 COMPARISON AMS $64 \quad 577$ D THE OCCURRENCE DISTRIBUTION OF WORD LENGTH AND ITS IMPORTANCE FOR THE STUDY OF QUANTITATIVE LINGUISTICS BIOKA5B 222 TO L REGIONS SIMILAR TO THE SAMPLE SPACE IN TESTS OF AN IMPORTANT CLASS OF COMPOSITE HYPOTHESES /ST CRITICA BIOKA53 231 RECENT EFFORTS TO IMPROVE LAND USE INFORMATION

STOCHASTIC APPROXIMATION OF MINIMA WITH IMPROVED ASYMPTOTIC SPEED IMPROVED BOUNDS ON A MEASURE OF SKEWNESS IMPROVED ESTIMATORS FOR COEFFICIENTS IN LINEAR JASA $66 \quad 647$ AMS 67 I9I AMS 621 I92 REGRESSION A COMPLETE MULTINOMIAL DISTRIBU BIOKA64 277 TION COMPARED WITH THE X-SQUARE APPROXIMATION AND AN IMPROVEMENT TO IT ES OF SEQUENTIAL TESTS

AN IMPROVEMENT TO WALD'S APPROXIMATION FOR SOME PROPERTI JRSSB54 I3 SIDED TOLERANCE LIMITS FOR NORMAL POPULATIONS, SOME IMPROVEMENTS A MODIFIED TECHNIQUE FOR IMPROVING AN ESTIMATE OF THE MEAN TWO- JASA 69610 BI0CS69 5BB

G THOSE WITH SHORT LIVES ON THE POSSTBILTTY OF TMPROVTNG THE MEAN USEFUL LIFE OF INACCURACY AND INFERENCE

QUALITY CONTROL SYSTEMS BASED ON INACCURATELY MEASURED VARIABLES DESIGNS WHICH MINIMIZE MODEL INADEQUACIES CUBOTDAL REGIONS OF INTEREST

PRESENCE OF PRIOR INFORMATION ON THE INADMISSIBILITY OF SOME STANDARD ESTIMATES IN THE MOMENT IS INFINITE UNDER ONE OF THE HYPOTHESES TREME QUANTILES OF THE NORMAL DISTRIBUTION UNDER/ MEAN OF A MULTIVARIATE NORMAL POPULATION INADMISSIBILITY OF SOME STANDARD ESTIMATES IN THE
INADMISSIBILITY OF THE BEST INVARIANT TEST WHEN THE INADMISSIBILITY OF THE BEST INVARIATE ESTIMATOR OF EX INADMTSSIBILITY OF THE USUAL CONF IDENCE SETS FOR THE TECH $6 I$ 2BI JRSSB6I I84 BIOKA51 472 BI0KA65 III AMS 63539 AMS 69 I $4 \mathrm{~B} 3$ AMS 69 1BOI AMS 67 1B6B METERS IN PROBLEMS WITH UNKNOWN LOCATION AND SCAL/ INADMISSIBILITY OF THE USUAL ESTIMATORS OF SCALE PARA
PERIMENT IN WHICH CERTAIN TREATMENT ARRANGEMENTS ARE INADMISSIBLE TESTS INGENTIVE GONTRAGTS AND PRICE DIFFERENTIAL AGGEPTANGE J JASA $64 \quad 149$ BI0GS65 750

T INDIA SAMPLING TEGHNIQUES FOR ESTIMATION OF INGIDENGE OF RED SPIDER MITE ON TEA CROP IN NORTH-EAS BIOGS66 3B5 FOR THE MO/ EMPERIGAL RELATIONSHIP OF LUNG GANGER INGIDENGE TO GIGARETTE SMOKING AND A STOGHASTIC MODEL BIOGS65 B39 
MATION OF A LOCATION PARAMETER IN THE PRESENCE OF AN INCIDENTAL SCALE PARAMETER

OMISATION TECHNIQUE (ERRATA, 69 6/ TESTINC FOR THE INCLUSION OF VARIABLES IN LINEAR RECRESSION BY A RAND TECH 66 695 CHANGES IN THE SIZE DISTRIBUTION OF DIVIDEND INCOME

NAL PRODUCT AND ITS COMPONENTS, OF SELECTED NATIONAL INCOME COMPONENTS, AND OF PERSONAL SAVINC /SS NATIO JASA 58 54 EFFECT OF VARYINC DECREES OF TRANSITORY INCOME ON INCOME ELASTICITY OP EXPENDITURES

WELFARE ASSISTANCE DURINC 1959 THE VALIDITY OF INCOME REPORTED BY A SAMPLE OF FAMILIES WHO RECEIVED JASA 62 6BO NATIONAL INCOME STATISTICS OF UNDERDEVELOPED COUNTRIES JASA $57 \quad 162$

FISCAL-YEAR REPORTING FOR CORPORATE INCOME TAX INTEREST INCOME UNDER THE WISCONSIN STATE INDIVIDUAL INCOME TAX

EVIDENCE FROM CROSS-SECTION DATA INCOME, INCOME CHANGE, AND DURABLE GOODS DEMAND ON THE PROBLEM OF SELF-INCOMPATABILITY ALLELES

ASSOCIATED WITH A TEST PROCEDURE, WHEN DATA ARE INCOMPLETE INCOMPLETE TND ABSOLUTE PROBABILITY OF REVERSAL NORMAL DISTRIBUTION WITH SOME APPLICATIONS ADDITIONAL PERCENTAGE POINTS FOR THE INCOMPLETE BETA DISTRIBUTION

\section{AN APPROX IMATION TO THE SYMMETRTCAL INCOMPLETE BETA FUNCTION}

BINOMIAL SAMPLING

THE USE OF INCOMPLETE BETA FUNCTIONS FOR PRIOR DISTRIBUTIONS IN

\section{DISTRIBUTION}

CURVES APPROXIMATE LINEARIZATION OF THE INCOMPLETE BETA-FUNCTION

A CHART FOR THE INCOMPLETE BETA-FUNCTION AND THE CUMULATIVE BINOMIAL. ON NORMALIZING THE INCOMPLETE BETA-FUNGTION FOR FITTING TO DOSE-RESPONSE

A NOTE ON THE PARAMETERS OF PARTIALLY BALANCED INCOMPLETE BLOCK ASSOCIATION SCHEMES

$$
\text { AN APPLICATION OF A BALANCED INCOMPLETE BLOCK DESIGN }
$$

A BLANCED INCOMPLETE BLOCK DESIGN

FICIENCY OF THE CHI-SQUARE-SUB-R-TEST FOR A BALANCED INCOMPLETE BLOCK DESIGN OF RANDOMIZATION IN A GENERALIZATION OF THE BALANCED INCOMPLETE BLOCK DESIGN AND THE ANALYSIS OF VARIANCE OF A PARTIALLY BALANGED INCOMPLETE BLOCK DESICN OM COMPONENTS WITH SPECIAL REFERENCE TO THE BALANCED INCOMPLETE BLOCK DESIGN RIBUTION OF THE F-STATISTIC IN A RANDOMIZED BALANCED INCOMPLETE BLOCK DESIGN THE ANALYSIS OF INCOMPLETE BLOCK DESIGNS AN INEQUALITY FOR BALANCED INCOMPLETE BLOCK DESIGNS THE EXISTENCE AND CONSTRUCTION OF BALANCED INCOMPLETE BLOCK DESIGNS MULTIPLE COMPARISIONS WITH A CONTROL IN BALANCED INCOMPLETE BLOCK DESIGNS CONSTRUCTION OF ROTATABLE DESIGNS THROUGH BALANCED INCOMPLETE BLOCK DESIGNS ON THE DUALS OF SYMMETRIC PARTIALLY-BALANCED INCOMPLETE BLOCK DESIGNS EXTENDED GROUP DIVISIBLE PARTIALLY BALANCED INCOMPLETE BLOCK DESIGNS A PROCEDURE FOR CONSTRUCTING INCOMPLETE BLOCK DESIGNS ON A CLASS OF PARTIALLY BALANCED INGOMPLETE BLOCK DESIGNS ROBUST ESTIMATION IN INGOMPLETE BLOCK DESIGNS INDUCTIVE METHODS FOR BALANGED INCOMPLETE BLOCK DESIGNS ON ROBUST ESTIMATION IN INCOMPLETE BLOCK DESIGNS A SERIES OF BALANCED INGOMPLETE BLOCK DESIGNS SOME EXAMPLES OF MULTI-DIMENSIONAL INCOMPLETE BLOCK DESIGNS A NOTE ON BALANCED INCOMPLETE BLOCK DESIGNS AN EXTENSION PROPERTY OF A CLASS OF BALANCED INCOMPLETE BLOCK DESIGNS THE EFFICIENCY OF BLOCKING IN INGOMPLETE BLOCK DESIGNS NESTED BALANCED INCOMPLETE BLOCK DESIGNS THE USE OF CONTROL OBSERVATIONS AS AN ALTERNATIVE TO INCOMPLETE BLOCK DESIGNS GYCLIC INCOMPLETE BLOCK DESIGNS ON JOHN'S CYCLIC INCOMPLETE BLOCK DESIGNS NOTES. CYCLIC GENERATION OF ROBINSON'S BALANCED INGOMPLETE BLOCK DESIGNS SCREENING UTILIZINC BALANCED AND PARTIALLY BALANCED INGOMPLETE BLOCK DESIGNS PARAMETERS AND INTERSECTION OF BLOCKS OF BALANCED INCOMPLETE BLOCK DESIGNS ATMENTS BETWEEN BLOCKS OF CERTAIN PARTIALLY BALANCED INCOMPLETE BLOCK DESICNS ETRY OF QUADRICS FOR CONSTRUCTING PARTIALLY BALANCED INCOMFLETE BLOCK DESIGNS AY CROSS CLASSIFICATION WITH APPLICATION TO BALANCED INCOMPLETE BLOGK DESIGNS ATMENTS BETWEEN BLOCKS OF CERTAIN PARTIALLY BALANCED INCOMPLETE BLOCK DESIGNS OF SIGMA-SQUARE-SUB-B-OVER-SICMA-SQUARE IN BALANCED INCOMPLETE BLOCK DESIGNS BETWEEN ANY TWO BLOCKS OF GERTAIN PARTIALLY BALANCED INCOMPLETE BLOCK DESIGNS LYSIS OF A CLASS OF TWO ASSOCIATE PARTIALLY BALANCED INCOMPLETE BLOCK DESIGNS BER OF DISJOINT BLOCKS IN CERTAIN PARTIALLY BALANCED INCOMPLETE BLOCK DESIGNS ICAL AND UNSYMMETRICAL TRIANGULAR PARTIALLY BALANCED INCOMPLETE BLOCK DESIGNS MS DUALS OF PARTIALLY BALANCED INCOMPLETE BLOCK DESIGNS
INCOMPLETE BLOCK DESIGNS

ON THE EFFICIENCY OF MODIFIED BALANCED INCOMPLETE BLOCK DESIGNS THE USE OF CYCLIC BALANCED INCOMPLETE BLOCK DESIGNS FOR DIRECTSTS $S$
ORCHARDS THE USE OF CYCLIC BALANCED INCOMPLETE BLOCK DESIGNS FOR NON-DIREGTIONAL SEED SOME BALANCED INCOMPLETE BLOCK DESIGNS FOR TWO SETS OF TREATMENTS

CIATION SCHEMES

ON OBTAININC BALANCED INCOMPLETE BLOCK DESIGNS FROM PART IALLY BALANCED ASSO BALANCED SETS OF BALANCED INCOMPLETE BLOCK DESIGNS OF BLOCK SIZE THREE BALANCED INCOMPLETE BLOCK DESIGNS WITH DOUBLE GROUPING OF

BLOCKS INTO REPLICATIONS BALANCED INCOMPLETE BLOCK DESIGNS WITH DOUBLE GROUPING OF CLASSES ANALYSIS OF A CLASS OF PART IALLY BALANCED INCOMPLETE BLOCK DESIGNS WITH MORE THAN TWO ASSOCIATE
$\mathrm{N} 2=1$ A NOTE ON CONSTRUCTION OF PARTIALLY BALANCED INCOMPLETE BLOCK DESIGNS WITH PARAMETERS V=28, NI=12. $\mathrm{N} 2=/$
BLOCKS BLOCKS
N PROPERTIES BALANCED INCOMPLETE BLOCK DESIGNS WITH SETS OF IDENTICAL SOME CONSEQUENCES AMS 631569 THE RELATIONSHIP ALGEBRA AMS 651 B15 /INEAR MODELS WITH TWO RAND BIOKA68 101 UNDER THE NEYMAN MODEL /IST AMS 63 155B JASA $57 \quad 204$ AMS 61908 AMS $61 \quad 361$ TECH $61 \quad 103$ AMS 621421 AMS $63 \quad 528$ AMS 64681 TECH $64 \quad 3 B 9$ AMS 651807 AMS $66 \quad 1331$ AMS $66 \quad 1348$ AMS 67 15B7 AMS 6B 681 AMS $68 \quad 1577$ AMS $69 \quad 679$ BIOKA57 278 BIOKA60 273 BIOKA67 479 JRSSB $62 \quad 464$ JRSSB $66 \quad 345$ JRSSB $67 \quad 243$ BIOCS67 574 GROUP BIOCS65 B65 ON THE AMS 621200 COMMON TRE AMS 68999 APPLICATION OF THE GEOM AMS 621175 /FOR THE UNBALANCED TWO-W AMS $69 \quad 408$ /THE NUMBER OF COMMON TRE AMS 66739 /USING AN INCORRECT VALUE BIOKA6B 254 /BER OF COMMON TREATMENTS AMS $65 \quad 337$ /EST IN THE INTRABLOCK ANA JASA 652 B5 AN UPPER BOUND FOR THE NUM AMS $64 \quad 398$ AN BALAED INCOMPLETE BLOG AMS $63 \quad 34 B$ AMS $66 \quad 1048$ $\begin{array}{rr}\text { AMS } & 66 \\ \text { BIOCS66 } & 706\end{array}$ BIOCS69 591 BI0CS67 76I BIOCS69 561 BIOKA66 497 AMS 67618 TECH 65561 BI0CS66 36B AMS 61800 AMS $66 \quad 17 \mathrm{~B} 3$ TECH 69613 A NEW FAMILY OF PARTIALLY BALANCED INCOMPLETE BLOCK DESIGNS WITH SOME LATIN SQUARE DESIG AMS 67 57I EQUAL TO THE NUMBER OF TREATMENTS OF TREATMENTS COMPARISONS

A NOTE ON INCOMPLETE BLOCK DESIGNS WITH THE NUMBER OF BLOCKS PARTIALLY BALANCED INCOMPLETE BLOCK DESIGNS WITH TWO-WAY CLASSIFICATION RANK ANALYSIS OF INCOMPLETE BLOCK DESIGNS. I. THE METHOD OF PAIRED BIOKA52 324 RANK ANALYSIS OF INCOMPLETE BLOCK DESIGNS. II ADDITIONAL TABLES FOR T BIOKA54 502 HE METHOD OF PA/ CORRIGENDA, 'THE RANK ANALYSIS OF INCOMPLETE BLOCK DESIGNS. II. ADDITIONAL TABLES FOR T BIOKA64 288 
LTS ON ESTIMATION AND POWER FOR/ RANK ANALYSIS OF INCOMPLETE BLOCK DESICNS. III. SOME LARCE-SAMPLE RESU BIOKA55 450

THE BLOCK STRUCTURES OF CERTAIN PARTIALLY BALANCED INCOMPLETE BLOCK DESIGNS, CORR. 67.624

ANALYTICAL TECHNIQUE FOR INCOMPLETE BLOCK EXPERIMENTS

A NOTE ON THE ANALYSIS OF INCOMPLETE BLOCK EXPERIMENTS

ON AMS

BIOCS66 B29

BIOKA65 633

AMS 66 1B32

COMPARISON OF COMBINED ESTIMATORS IN BALANCED INCOMPLETE BLOGKS

JRSSB59 I72

ON A PROPERTY OF INCOMPLETE BLOCKS

A NOTE ON TESTS FOR MONOTONE FAILURE RATE BASED ON INCOMPLETE DATA

A METHOD OF CONSTRUCTINC BALANCED INCOMPLETE DESIGNS.

NALYZING LOG-NORMALLY DISTRIBUTED SURVIVAL DATA WITH INCOMPLETE FOLLOW-UP

69595

SOME BASIC PROPERTIES OF THE INCOMPLETE GAMMA FUNCTION RATIO, CORR. 65 15B4
STEM OF INEQUALITIES FOR THE INCOMPLETE CAMMA FUNCTIONS AND THE NORMAL INTECR

BIOKA65 285 ABSOLUTE AND INCOMPLETE MOMENTS OF THE MULTIVARIATE NORMAL
TIMATION WITH INCOMPLETE MULTIVARIATE DATA

DISTRIBUTION MAXIMUM LIKELIHOOD ESTIMATION WITH INCOMPLETE MULTIVARIATE DATA

ESTIMATION OF PARAMETERS FROM INCOMPLETE MULTIVARIATE
NONPARAMETRIC ESTIMATION FROM INCOMPLETE OBSERVATIONS

ANALYSIS OF DISPERSION WITH INCOMPLETE OBSERVATIONS ON ONE OF THE CHARACTERS ON THE USE OF INCOMPLETE PRIOR INFORMATION IN REGRESSION ANALYSIS

AN ANALYSIS OF PAIRED COMPARISON DESICNS WITH INCOMPLETE REPETITIONS

A SIMPLE CONGESTION SYSTEM WITH INCOMPLETE SERVICE

CONCESTION SYSTEMS WITH INCOMPLETE SERVICE (CORR, 64 365)

INCOMPLETE SPLIT PLOT DESIGNS

AN EXPONENTIAL S/ USE OF CONCOMITANT VARIABLES AND INCOMPLETE SURVIVAL INFORMATION IN THE ESTIMATION OF INCOMPLETE TWO-DIMENSIONAL CONTINGENCY TABLES

BTASES IN PREDICTION BY REGRESSION FOR CERTAIN INCOMPLETELY SPECTFIED MODELS

IMATIONS TO DISCRETE DATA

INFERENCE FOR SOME INCOMPLETELY SPECIFIED MODELS INVOLVING NORMAL APPROX INCONSISTENCIES IN A SCHEDULE OF PAIRED COMPARISONS

FURTHER EXAMPLES OF INCONSISTENCIES IN THE FIDUCIAL ARGUMENT

AMS $65 \quad$ I39

BIOKA6I 77

AMS $64 \quad 647$

JASA $57 \quad 523$

JASA $58 \quad 457$

JRSSB 56259

JASA $63 \quad 40 I$

BIOKA57 97

JRSSB6I 215

JRSSB62 107

BIOCS67 793

BIOCS66 665

BI0CS69 119

BIOKA63 39]

BIOCS67 335

BIOKA6I 303

AMS $63 \quad$ B44

RE IN BALANCED INCOMPLETE BLOCK DESIG/ ON USINC AN INCORRECT VALUE OF SIGMA-SQUARE-SUB-B-0VER-SIGMA-SQUA BIOKA6B 254 EHAVIOR OF POSTERIOR DISTRIBUTIONS WHEN THE MODEL IS INCORRECT, CORR. 66745 L 74 AMITING B 6151

REASED THE NUMBER OF NEW SPECIES, AND THE INCREASE IN POPULATION COVERACE, WHEN A SAMPLE IS INC BIOKA56 45 INCREASE IN RENT OF DWELLING UNITS FROM 1940 TO 1950 JASA 59358

INCREASE IN POPULATION COVERACE. WHEN A SAMPLE IS INCREASED THE NUMBER OF NEW SPECIES, AND THE BIOKA56 45 SYMPTOTTCALLY OPTTMAL STATISTTCS IN SOME MODELS WITH INCREASING FAILURE RATE AVERAGE TOLERANCE LIMITS FOR THE CLASS OF DISTRIBUTIONS WITH INCREASING HAZARD RATE

A AMS 67

AMS 64 I561 AMS $62 \quad 882$ MERCINC OF OPINIONS WITH INCREASING INFORMATION

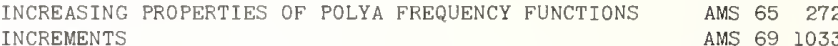

MARTINGALES WITH INDEPENDENT INCREMENTS

ON AMS 69688

BIOKA53 220

A FLUCTUATION THEOREM FOR PROCESSES WITH INDEPENDENT INCREMENTS, II
THE EFFECT OF OVERLAPPING IN BACTERIAL COUNTS OF INCUBATED COLONIES

TECH $67 \quad 457$ SCHEMES

AN EXAMPLE OF ERRORS INCURRED BY ERRONEOUSLY ASSUMINC NORMALITY FOR CUSUM

ES

DISTRIBUTION

TOR INDECOMPOSABLE MULTIDIMEN

PABLE MULTIDIMENSIONAL GALTON-WATSON FROCESS

CORRECTION TO 'DISTRIBUTION OF DEFINITE AND OF INDEFINITE QUADRATIC FORMS' 55122 PAIRWISE STATISTICAL INDEPENDENCE

DISTRIBUTION-FREE TESTS OF INDEPENDENCE

TO NORMALITY AND THE POWER OF NORMAL TESTS FOR INDEPENDENCE

OF RANK CORRELATION FOR TESTING THE HYPOTHESIS OF INDEPENDENCE ATIO CRITERIA FOR MULTIVARIATE LINEAR HYPOTHESIS AND INDEPENDENCE

$\mathrm{N}$

DISTRIBUTION FREE TESTS OF II

INDEPENDENCE

THE PERFORMANCE OF SOME TESTS OF INDEPENDENCE FOR CONTINGENCY-TYPE BIVARIATE DISTRIBUT OF THE DIRICHLET DISTRIBUTION CONCEPTS OF INDEPENDENCE FOR PROPORTIONS WITH A A GENERALIZATION A GLASS OF NONPARAMETRIC TESTS FOR INDEPENDENCE IN BIVARIATE POPULATIONS

CHARACTERIZATIONS OF INDEPENDENCE IN CERTAIN FAMILIES OF BIVARIATE AND MUL TESTS OF INDEPENDENCE IN INTRACLASS 2-BY-2 TABLES

CORRIGENDA, 'TEST OF INDEPENDENCE IN INTRACLASS 2-BY-2 TABLES'

COMPARISON OF THE POWER FUNCTIONS FOR THE TEST OF INDEPENDENCE IN 2 X2 CONTINGENCY TABLES CORRECTION TO 'ON THE MUTUAL INDEPENDENCE OF CERTAIN STATISTICS' 59 I258

ON THE INDEPENDENCE OF CERTAIN WISHART VARIABLES

A COMBINATORIAL TEST FOR INDEPENDENCE OF DICHOTOMOUS RESPONSES

ORDER

TESTING A MARKOV HYPOTHESIS WITH INDEPENDENCE OF INTERMEDIATE STATES AND RESTRICTED

PAIRWISE INDEPENDENCE OF JOINTLY DEPENDENT VARIABLES

ON THE INDEPENDENCE OF QUADRATIC EXPRESSIONS (CORR. 66 5B4)

ON THE INDEPENDENCE OF QUADRATIC FORMS

VARIANCE

CORRIGENDA, 'ON THE STATISTICAL INDEPENDENCE OF QUADRATIC FORMS IN NORMAL VARIATES.'

A NOTE ON THE STATISTICAL INDEPENDENCE OF QUADRATIC FORMS IN THE ANALYSIS OF TESTING THE INDEPENDENCE OF REGRESSION DISTURBANCES

VECTOR

CONDITIONS FOR WISHARTNESS AND INDEPENDENCE OF SECOND DEGREE POLYNOMIALS IN NORMAL

STRIBUTIONS OF LIKELIHOOD RATIO CRITERIA FOR TESTING INDEPENDENCE OF SETS OF VARIATES UNDER THE HULL HYPOT HYPOTHESES

ON THE INDEPENDENCE OF TESTS OF RANDOMNESS AND OTHER

ST POWERFUL BOUNDARY RANDOMIZED SIMILAR TEST FOR THE INDEPENDENCE OF TWO POISSON VARIABLES /A LOCALLY MO

A LARCE SAMPLE TEST FOR THE INDEPENDENCE OF TWO RENEWAL PROCESSES

CORR. 66297 MULTIVARIATE BETA DISTRIBUTIONS AND INDEPENDENCE PROPERTIES OF THE WISHART DISTRIBUTIONS,

A DISTRIBUTION-FREE TEST OF INDEPENDENCE WITH A SAMPLE OF PAIRED OBSERVATIONS

AMS $63 \quad 337$

AMS 66 I 463

AMS $63 \quad$ I86

AMS $62 \quad 813$

AMS 651313

AMS $67 \quad 429$

BIOKA69 139

IOKA6I 444

AMS 69942

AMS $61 \quad 485$

AMS $64 \quad 206$

BIOKA69 449

JASA $69 \quad 194$

AMS 64 I38

BIOKAGI $18 I$

BIOKA6I 476

AMS 641115

AMS $61 \quad 1344$

AMS $63 \quad 935$

JASA $65 \quad 437$

BIOKA67 605

AMS $62 \quad 290$

JRSSB $63 \quad 377$

JRSSB66 582

BIOKA59 279

BIOKA5I 482

JASA $61 \quad 793$

AMS 62 I002

AMS 67 II 60

JASA $57 \quad 53$

AMS $6 I 809$

AMS $67 \quad 1037$

AMS 64261

JASA 62 II6

CONTINCEN/ THE ANALYSIS OF CROSS-CLASSIFIED DATA, INDEPENDENCE, QUASI-INDEPENDENCE, AND INTERACTIONS IN JASA 68 IO9I GHTED REGRESSION ESTIMATORS WHEN SAMPLING ERRORS ARE INDEPENDENT AND HETEROSCEDASTIC VARIANCE OF WEI JASA 69 NO. 4 COMPARISON OF THE SENSITIVITIES OF SIMILAR INDEPENDENT AND NON-INDEPENDENT EXPERIMENTS ND ALMOST SURE CONVERGENCE OF LINEAR COMBINATIONS OF INDEPENDENT AND RANDOM VARIABLES AND MARTINCALE DIFFE AMS 68 I549 ON TO THE SINGLE-SERVER QUEUEINC SYSTEM WITH CENERAL INDEPENDENT ARRIVALS AND ERLANGIAN SERVICE-TIME /TI JRSSB6O 89 NORMAL APPROXIMATION TO THE DISTRIBUTION OF TWO INDEPENDENT BINOMIALS, CONDITIONAL ON FIXED SUM RANK METHODS FOR GOMBINATION OF INDEPENDENT EXPERIMENTS IN THE ANALYSIS OF VARIANCE INVERSE DISTRIBUTIONS AND INDEPENDENT GAMMA-DISTRIBUTED PRODUGTS OF RANDOM AMS 631593 AMS $62 \quad 482$ BIOKA63 505 VARIABLES SHAPE PARAM/ ARIABLES, CORR
EXACT DISTRIBUTION OF THE PRODUGT OF INDEPENDENT GENERALIZED GAMMA VARIABLES WITH THE SAME EXAGT DISTRIBUTION OF THE SUM OF INDEPENDENT IDENTICALLY
AMS 68 I75I MARTINGALES WITH INDEPENDENT INCREMENTS $\begin{array}{rrr}\text { JASA } & 65 & 837 \\ \text { AMS } & 69 & 1033\end{array}$ 
ON A FLUCTUATION THEOREM FOR PROCESSES WITH INDEPENDENT INCREMENTS, II

AMS 69688 PRECISION KNOWN

BAYESIAN ANALYSTS OF THE INDEPENDENT MULTINORMAL PROCESS, NEITHER MEAN NOR IANCE-COMPONENT ESTIMATORS AS LINEAR COMBINATIONS OF INDEPENDENT NONCENTRAL CHI-SQUARE VARIATES /OF VAR

ON THE RANGE OF PARTIAL SUMS OF A FINITE NUMBER OF INDEPENDENT NORMAL VARIATES OF THE MAXIMUM OF PARTIAL SUMS OF A FINITE NUMBER OF INDEPENDENT NORMAL VARIATES OF THE MAXIMUM OF PARTIAL SUMS OF A FINITE NUMBER OF INDEPENDENT NORMAL VARIATES OF THE MAXIMUM OF PARTIAL SUMS OF A FINITE NUMBER OF INDEPENDENT NORMAL VARIATES
ISTRIBUTION FOR LARGEST AND FOR SMALLEST OF A SET OF INDEPENDENT OBSERVATIONS $\begin{array}{ll}\text { BIOKA53 } & 35 \\ \text { BIOKA55 } & 96\end{array}$ NTERVALS BETWEEN REGULAR EVENTS DISPLACED IN TIME BY INDEPENDENT RANDOM DEVIATIONS OF LARGE DISPERSION / JRSSB6I 476 PROBABILITY INEQUALITIES FOR THE SUM OF INDEPENDENT RANDOM VARIABLES SUFFICIENT STATISTICS IN THE CASE OF INDEPENDENT RANDOM VARIABLES SOME CONVERGENCE THEOREMS FOR INDEPENDENT RANDOM VARIABLES

ON A CHEBYSHEV-TYPE INEQUALITY FOR SUMS OF INDEPENDENT RANDOM VARIABLES CONVERGENCE OF QUADRATIC FORMS IN INDEPENDENT RANDOM VARIABLES ALMOST SURE CONVERGENCE OF QUADRATIC FORMS IN INDEPENDENT RANDOM VARIABLES THE MARKOV INEQUALITY FOR SUMS OF INDEPENDENT RANDOM VARIABLES GAMMA-DISTRIBUTED PRODUCTS OF INDEPENDENT RANDOM VARIABLES ON WEYL'S CRITERION AND THE UNIFORM DISTRIBUTION OF INDEPENDENT RANDOM VARIABLES THE LAW OF LARGE NUMBERS FOR LINEAR COMBINATIONS OF INDEPENDENT RANDOM VARIABLES DEVIATIONS FROM THE EXPECTATION FOR SUMS OF BOUNDED. INDEPENDENT RANDOM VARIABLES THE GAMMA DISTRIBUTION /PROBABILITY OF LARGE

1124 MOMENT
IMITING DISTRIBUTIONS FOR SUMS OF A RANDOM NUMBER OF INDEPENDENT RANDOM VECTORS
ND SERVING DISTRIBUTIONS ARE EXPONENTIAL AND GENERAL INDEPENDENT RESPECTIVELY THE JOINT ASSESSMENT OF NORMALITY OF SEVERAL INDEPENDENT SAMPLES INDEPENDENT SEQUENCES WITH THE STEIN PROPERTY

MINIMUM CHI-SQUARED ESTIMATION USING INDEPENDENT STATISTICS MAXIMAL INDEPENDENT STOCHASTIC PROCESSES ON ADDING INDEPENDENT STOCHASTIC PROCESSES

OF MEANS OF SETS OF OBSERVATIONS FROM SECTIONS OF INDEPENDENT STOCHASTIC SERIES THE DISTRIBUTION OF THE WEIGHTED DIFFERENCE OF TWO INDEPENDENT STUDENT VARIABLES ON THE COMBINATION OF INDEPENDENT TEST STATISTICS
ON THE DISTRIBUTION OF THE NUMBER OF SUCCESSES IN INDEPENDENT TRIALS JASA $62 \quad 33$ AMS 641456 AMS $66 \quad 1482$ AMS $66 \quad 248$ AMS 66567 AMS 681502 AMS 69 NO.6 BIOKA62 564 NOTE AMS $69 \quad 1124$ ON THE NUMBER OF SUCCESSES IN INDEPENDENT TRIALS

OPTIMAL EXPERIMENTAL DESIGNS FOR ESTIMATING THE INDEPENDENT VARIABLE IN REGRESSION DISTRIBUTIONS OF PRODUCTS OF INDEPENDENT VARIABLES TRANSFORMATION OF THE INDEPENDENT VARIABLES

REGRESSION WITH MISSING OBSERVATIONS AMONG THE INDEPENDENT VARIABLES BANDS IN LINEAR REGRESSION WITH CONSTRAINTS ON THE INDEPENDENT VARIABLES RESSION ANALYSIS WITH MISSING OBSERVATIONS AMONG THE INDEPENDENT VARIABLES OF SIGNIFICANCE IN MULTIVARIATE REGRESSTON WHEN THE INDEPENDENT VARIABLES ARE ORTHOGONAL UCT OF A WISHART VARIATE WITH THE INVERSE OF ANOTHER INDEPENDENT WISHART VARIATE/STIC RO

A ONE-SIDED PROBABILITY INEQUALITY FOR THE SUM OF INDEPENDENT, BOUNDED RANDOM VARIABLES MOMENTS AND PROBABILITY INEQUALITIES FOR THE SUM OF INDEPENDENT, BOUNDED RANDOM VARIABLES INDETERMINISM IN SCIENCE AND NEW DEMANDS ON

A TEST OF THE ACCURACY OF A PRODUCTION INDEX

SOME ASPECTS OF SEASONALITY IN THE CONSUMER PRICE INDEX

CONSTANTS AND COMPROMISE IN THE CONSUMER PRICE INDEX SAMPLING ERROR IN THE CONSUMER PRICE INDEX

SOME STATISTICAL PROPERTIES OF A GENETIC SELECTION INDEX

ON THE DETERMINATION OF CONFIDENCE LIMITS OF AN INDEX NOTE ON THE PERIODOGRAM OF THE BEVERIDGE WHEAT PRICE INDEX IN APPLYING LINEAR PROGRAMMING TO THE CONSUMER PRICE INDEX FOR ANTI-CANCER AGENTS BASED ON THE THERAPEUTIC INDEX BOOK REVIEWS, 10 YEAR INDEX (1959-1968) A NEW SIMILARITY INDEX BASED ON PROBABILITY USE OF VARYING SEASONAL WEIGHTS IN PRICE INDEX CONSTRUCTION A REGRESSION METHOD FOR REAL ESTATE PRICE INDEX CONSTRUCTION

A PRICE AND PRODUCTIVITY INDEX FOR A NONHOMOGENEOUS PRODUCT

ON THE CONSTRUCTION OF AN INDEX FOR INDIRECT SELECTION

EXPECTED SIGNIFICANCE LEVEL AS A SENSITIVITY INDEX FOR TEST STATISTICS AMS $64 \quad$ B72

ON JRSSB6O IBB AMS $67 \quad 659$ AMS 641317 AMS 651272 TECH 6B 811 TECH $62 \quad 277$ TECH $62 \quad 531$ MULTIPLE JASA $56 \quad 122$ CONFIDENCE JASA 6B 1020 LINEAR REG JASA $59 \quad 834$ /DETERMINATION JRSSB67 154 DOTS OF THE PROD AMS $67 \quad 944$

$\begin{array}{rrr} & \text { BIOKA68 } & 565 \\ \text { /UNDS ON THE } & \text { BIOKA65 } & 559\end{array}$ JASA $60 \quad 625$ JASA $56 \quad 17$ JASA $61 \quad 27$ JASA $62 \quad 813$ JASA $67 \quad 899$ BIOKA62 325 BIOCS66 603 A JRSSB55 22B OTENTIALS JASA $66 \quad 982$ $\begin{array}{rrr}\text { POTENTIALS JASA } 66 & 982 \\ \text { A SCREENING SYSTEM BIOCS65 } & 150\end{array}$ TECH 69223 BIOCS66 882 JASA $58 \quad 66$ JASA $63 \quad 933$ JASA $64 \quad 469$ BIOCS65 29I JASA $65 \quad 420$ ION WITH A SPECIAL KIND OF IRREGULAR FRACTIONAL P/ INDEX NUMBERS FOR FACTORIAL EFFECTS AND THEIR CONNECT JASA 63 497 NOTE ON THE POISSON INDEX OF DISPERSION THE POWER OF THE POISSON INDEX OF DISPERSION THE INDEX OF DISPERSION AS A TEST STATISTIC BIOKA53 225 BIOKA57 286 BIOKA65 627

IC THE MATHEMATICAL RELATION BETHEN AN INDEX OF MANUFACTURING PRODUCTION IN NEW ENGLAND JASA $5 B \quad 336$ THE USE OF LAMBDA AS AN INDEX OF PRECISION

ON AN INDEX OF QUALITY CHANGE INDEX SELECTION AND ESTIMATION FROM A SINGLE SAMPLE INDEX SELECTION WITH RESTRICTIONS

ATION DES VALEURS GENOTYPIQUES DANS LA SELECTION PAR INDEX SUR PLUSIEURS CARACTERES INDEX TO TECHNOMETRICS, VOLUMES $1-7$ ERRATA TO INDEX TO TECHNOMETRICS, VOLUMES $1-7$ STANDARD ERRORS FOR INDEXES FROM COMPLEX SAMPLES

AN EXPERIMENT WITH WEIGHTED INDEXES OF CYCLICAL DIFFUSION REGIONAL DISPARITIES IN HOUSEHOLD COMSUMPTION IN INDIA CIDENCE OF RED SPIDER MITE ON TEA CROP IN NORTH-EAST INDIA ECONOMETRIC EXPLORATION OF INDIAN SAVING BEHAVIOR THE CASE OF THE INDIANS AND THE TEEN-AGE WIDOWS STIMATES OF THE UNITED STATES NONWHITE POPULATION AS INDICATED BY TRENDS IN DEATH RATES SELECTION INDICES FOR QUADRATIC MODELS OF TOTAL MERIT ONE-SIDED CONFIDENCE INTERVALS FOR THE QUALITY INDICES OF A COMPLEX ITEM INDICES OF SYNCHRONY IN CELLULAR CULTURES A BAYESIAN INDIFFERENCE PROCEDURE BIOCS69 174 JASA $61 \quad 535$ BI0KA63 195 BIOCS68 1015 BIOCS69 295 TECH $66 \quad 216$ TECH $66 \quad 387$ JASA $68 \quad 512$ JASA 5B 39 JASA $67 \quad 143$ BIOC\$66 3B5 JASA $69 \quad 90$ JASA $62 \quad 338$ JASA $61 \quad 44$ BIOCS6B 937 TECH $63 \quad 400$ BIOCS67 693 JASA 651104 JRSSB69 29 

SOME SHARP MULTIVARIATE TCHEBYCHEFF INEQUALITIES ALTERNATIVE PROOFS FOR CERTAIN UPCROSSING INEQUALITIES A COMPARISON TEST FOR MARTINGALE INEQUALTTIES NOTE ON A 'MULTIVARIATE' FORM OF BONFERRONI'S INEQUALITIES OF THE RESIDUAL SUM OF SQUARES IN FITTING INEQUALITIES AGAINST ALTERNATIVE RESTRICTED BY A NUMBER OF LINEAR INEQUALITIES ON MINIMIZING A CONVEX FUNCTION SUBJECT TO LINEAR INEQUALITIES GENERALIZATIONS OF TCHEBYCHEFF'S INEQUALITIES

DAM WITH ORDERED INPUTS ICS FROM RESTRICTED FAMILIES CATIONS TO SIMULTANEOUS CONFIDENCE BOU/

THE NORMAL INTEGRAL

CONTINUED FRACTION

VARIABLES OM VA/ UPPE EXPECTATIONS

ANDOM VARIABLES, I LESS THAN OR EQUAL TO $R$, R LES/ INEQUALITIES OF THE RTH ABSOLUTE MOMENT OF A SUM OF R A SOME INEQUALITIES ON CHARACTERISTIC ROOTS OF MATRICES

CORRTGENDA, SOME INEQUALITIES ON CHARACTERISTIC ROOTS OF MATRICES

INEQUALITIES FOR LINEAR COMBINATIONS OF ORDER STATIST AMS $66 \quad 1574$

ON CERTAIN INEQUALITIES FOR NORMAL DISTRIBUTIONS AND THEIR APPLI AMS 67 1B53 PROBABILITY INEQUALITIES FOR SUMS OF BOUNDED RANDOM VARIABLES JASA 63 A SYSTEM OF INEQUALITIES FOR THE INCOMPLETE GAMMA FUNCTIONS AND AMS 65 139 INEQUALITIES FOR THE NORMAL INTEGRAL INCLUDING A NEW BIOKA54 177

SOME TNEQUALITIES FOR THE QUEUE GT/GI PROBABILITY INEQUALITIES FOR THE SUM OF INDEPENDENT RANDOM $\quad$ JIOKA62 31 JASA $62 \quad 33$ AMS 69 NO.6 AMS $65 \quad 299$ BIOKA63 522 BIOKA65 669 TECH $65 \quad 435$ NOTE ON AN APPLICATION OF FOUR MOMENT INEQUALITIES TO A PROBLEM IN QUEUES

\section{E OF RANDOM PROCESSES WITH MULTI-DIMENSIONAL TIME/ INEQUALITIES WITH APPLICATIONS TO THE WEAK CONVERGENC PROCESSES} SOME MULTIVARIATE CHEBYSHEV INEQUALITIES A NOTE ON HOEFFDING'S INEQUALITY VARIANCE UNDER TRUNCATION AND VARIATIONS OF HENSEN'S INEQUALITY AN INEQUALITY AND ALMOST SURE CONVERGENCE MONOTONICITY OF THE

SMIRNOV TYPE DISTRIBUTIONS

AN INEQUALITY CONCERNING TESTS OF FIT OF THE KOLMOGOROVAN INEQUALITY FOR A CLASS OF BIVARIATE CHI-SQUARE AN INEQUALITY FOR BALANCED INCOMPLETE BLOCK DESIGNS AN INEQUALITY FOR EXPECTED VALUES OF SAMPLE QUANTILES

RTY A BEST POSSIBLE KOLMOGOROFF-TYPE INEQUALITY FOR MARTINGALES AND A CHARACTERISTIC PROPE ON A CHEBYSHEV-TYPE INEQUALITY FOR SUMS OF INDEPENDENT RANDOM VARIABLES THE MARKOV INEQUALITY FOR SUMS OF INDEPENDENT RANDOM VARIABLES AN INEQUALITY FOR THE RATIO OF TWO QUADRATIC FORMS IN

NORMAL VARIATES AND AN APPLICATION OF VARIABLES SAMPLING VARIABLES A ONE-SIDED PROBABI AN INEQUALITY FOR THE SAMPLE COEFFICIENT OF VARIATION ITY INEQUALITY FOR THE SUM OF INDEPENDENT. BOUND
AN INEQUALITY IN CONSTRAINED RANDOM VARIABLES AN ANALOGUE OF TCHEBYCHEFF'S INEQUALITY IN TERMS OF THE RANGE AN INEQUALITY INVOLVING MULTINOMIAL PROBABILITIES ON AN INEQUALITY OF HOEFFDING AMS $66 \quad 24 \mathrm{~B}$ AMS 69 NO. 6 AMS 6B 1762 TECH $65 \quad 67$ BIOKA68 565

OF UNBIASED ESTIMATORS OF THE MEAN WHICH CONSIDER INEQUALITY OF UNKNOWN VARIANCES AN INEQUALITY ON A BIVARIATE STUDENT'S 'T' DISTRIBUTION JASA 67603 ELATION FUNCTION AN INEQUALITY RELATING THE SPECTRAL DENSITY AND AUTOCORR BIOKA62 262 QUADRATIC REGRESSION WITH INEQUALITY RESTRAINTS ON THE PARAMETERS INEQUALITY RESTRICTIONS IN REGRESSION ANALYSIS JASA $66 \quad 166$ FFECTIVENESS OF VOIDING AS A DEFENCE AGAINST BLADDER INFECTION R A RUANTTATIVE DISCUSSION OF THE E BIOCS66 53 ON SOME BILHARZIA INFECTION AND IMMUNISATION MODELS SASJ 6B 6I THE USE OF CHAIN-BINOMIALS WITH A VARIABLE CHANCE OF INFECTION FOR THE ANALYSIS OF INTRA-HOUSEHOLD EPIDEMI BIOKA53 279 STCNIFICANCE TESTS FOR A VARIABLE CHANCE OF INFECTION IN CHATN BINOMTAL THEORY BIOKA56 332 SIGNIFICANCE TESTS FOR A VARIABLE CHANCE OF INFECTION IN CHAIN-BINOMIAL THEORY
ICAL SITES IN LIMITED GENOME EXPRESSION DURING VIRAL INFECTION OF BACTERIA /MATION OF THE NUMBER OF CRIT BIOCS69 537 THE BASIC BIRTH-DEATH MODEL FOR MICROBIAL INFECTIONS

A DISTRIBUTION ARISING IN THE STUDY OF INFECTIOUS DISEASES SUSCEPTIBLES ONLY. ON ESTIMATING THE LATENT AND INFECTIOUS PERIODS OF MEASLES. I. FAMILIES WITH TWO BIOKA56 I. E OR MORE SUSCEPTIBL/ ON ESTIMATING THE LATENT AND INFECTIOUS PERIODS OF MEASLES. II. FAMILIES WITH THRE BIOKA56 322 DEMIC FOR SMALL POPULATIONS WITH ONE OR MORE INITIAL INFECTIVES THE SIMPLE STOCHASTIC EPI BIOKA69 IB3 ON FIDUCIAL INFERENCE 
ON THE FOUNDATIONS OF STATISTICAL INFERENCE BOUNDS FOR THE FREQUENCY OF MISLEADINC BAYES INFERENCE A LEMMA FOR MULTIPLE INFERENCE

SOME GRAPHS USEFUL FOR STATISTICAL INFERENCE SOME ASPECTS OF EXPERIMENTAL INFERENCE

ON PARTIAL 'A PRIORI' INFORMATION IN STATISTICAL INFERENCE SOME NOTES ON PISTIMETRIC INFERENCE INACCURACY AND INFERENCE

A CENERALIZATION OF BAYESIAN INFERENCE (WITH DISCUSSION)

ON A PARADOX CONCERNING INFERENCE ABOUT A COVARIANCE MATRIX

INFERENCE ABOUT THE INTERSECTION IN TWO-PHASE

REGRESSION

MODEL

INFERENCE ABOUT VARIANCE COMPONENTS IN THE ONE-WAY

CONSISTENCY IN STATISTICAL INFERENCE AND DECISION (WITH DISCUSSION) (CORR. 66

ASYMPTOTICALLY OPTIMUM SEQUENTIAL INFERENCE AND DESIGN

ON LOCAL INFERENCE AND INFORMATION

INFERENCE CONCERNINC PROBABILITIES AND QUANTILES

EPENDENT VARIABLE ARE CONSTRAINED

ESTIMATION AND INFERENCE FOR LINEAR MODELS IN WHICH SUBSETS OF THE

FIDUCIAL INFERENCE FOR LOCATION AND SCALE PARAMETERS

JASA $62 \quad 269$

AMS 631109

AMS 651873

JASA $65 \quad 334$

JASA $66 \quad 11$

AMS 671671

JRSSB60 338

JRSSB 61

JRSSB 68205

AMS 631414

BIOKA69 NO. 3

JASA 65 BO6

JRSSB 61

AMS $63 \quad 705$

JRSSB 64253 JRSSB 69 NO. 2

MARKOV CHAINS

LVING NORMAL

STATISTICAL INFERENCE FOR PROBABILISTIC FUNCTIONS OF FINITE STATE INFERNCE FOR SOME INCOMPLETELY SPECIFIED MODELS INVO BIOCS67 33 INFERENCE FROM A KNOCKOUT TOURNAMENT

QUALITY OF STATISTICAL INFORMATION AND STATISTICAL INFERENCE IN A RAPIDLY CHANCING WORLD SOME PROBLEMS OF-STATISTICAL INFERENCE IN ABSORBING MARKOV CHAINS INFERENCE IN AN AUTHORSHIP PROBLEM

BIOKA65 127 JASA $63 \quad 275$

ARETTE SMOKING AND LUNG C/ PROBLEMS OF STATISTICAL INFERENCE IN HEALTH WITH SPECIAL REFERENCE TO THE CIG JASA 69 739 ASYMPTOTIC INFERENCE IN MARKOV PROCESSES

AMS 65978

PER CELL

ASYMPTOTICALLY

D ESTIMATION OF THE NUMBER OF CLASSES

STATISTICAL

TEST AND ITS APPLICATIONS TO SOME SIMULTANEOUS INFFRE TN THE CLASSTCAL OCCUPANCY PROBLEM UNBTASE JASA GB INFERENCE ON A GENETIC MODEL OF THE MARKOV CHAIN TYPE BIOKA63 251 THE EQUAL PROBABILITY JASA 69 ED TO CHANGES OVER TIME

N) EFFICIENT ESTIMATES AND OPTIMUM INFERENCE PROCEDURES IN LARGE SAMPLES (WITH DISCUSSIO JR MULTIVARIATE REGRESSION PROBLEMS SEQUENTIAL INFERENCE PROCEDURES OF STEIN'S TYPE FOR A CLASS OF

AMS $6 B \quad 840^{\circ}$ RSSB $62 \quad 46$ AMS $62 \quad 1039$ BIOKA64 169 JRSSB65 169 BIOKA69 NO. 3 AMS $63 \quad 1494$ BIOCS69 457 AMS $61 \quad 414$

ON THE FOUNDATIONS OF STATODTIS. INFERENCE, AND STRATEGY

A NOTE ON CRITERION ROBUSTNESS AND INFERENCE ROBUSTNESS

BAYESIAN INTERPRETATION OF STANDARD INFERENCE STATEMENTS (WITH DISCUSSION)

STATISTICAL INFERENCE WITH BIVARIATE CAMMA DISTRIBUTIONS

ASYMPTOTICALLY NONPARAMETRIC INFERENCE, AN ALTERNATIVE APPROACH TO LINEAR MODELS MODELS. INFERENCE, AND STRATEGY

ASSICAL LINEAR ESTIMATORS IN ECONOMETRIC STATISTICAL INFERENCE, CORR, 64 1296/NCTIONS OF CENERALIZED CL JASA 63 O43 DISCUSSION OF 'ON THE FOUNDATIONS OF STATISTICAL INFERENCE' SOME INFERENCES ABOUT GAMMA PARAMETERS WITH AN APPLICATION JASA 63 JASA $63 \quad 670$ JASA $67 \quad 763$

INFORMATIVE STOPPING RULES AND INFERENCES ABOUT POPULATION SIZE
TWO THEOREMS FOR INFERENCES ABOUT THE NORMAL DISTRIBUTION WITH APPLICA JASA 64 TIONS IN ACCEPTANCE SAMPLING $\mathrm{N}$

TWO THEOREMS FOR INFERENCES ABOUT THE NORMAL DISTRIBUTION WITH APPLICA JASA 64
TABLES FOR MAKING INFERENCES ABOUT THE VARIANCE OF A NORMAL DISTRIBUTIO BIOKA60

TABLES FOR MAKING INFERENCES ABOUT THE VARIANCE OF A NORMAL DISTRIBUT IO BIOKA60
'TABLES FOR MAKING INFERENCES ABOUT THE VARIANCE OF A NORMAL DISTRIBUTIO BIOKA6I

CORRIGENDA, TABLES FOR MAKING INFERENCES ABOL UPPER AND LOWER PROBABILITY INFERENCES BASED ON A SAMPLE FROM A FINITE UNIVARIATE BIOKA6'

POPULATION UPPER AND LONER PROBABILITY CIENT FROM ONE OR POSSIBLY TWO SAMPLES SUBSEQUENT/ INFERENCES CONCERNINC A POPULATION CORRELATION COEFFI JRSSB67
PUBLICATION DECISIONS AND THEIR POSSIBLE EFFECTS ON INFERENCES DRAWN FROM TESTS OF SIGNIFICANCE, OR VICE JASA 59

PUBLICATION DECISIONS AND THEIR POSSIBLE EFFECTS ON INFERENCES DRAWN FROM TESTS OF SIGNIFICANCE, OR VICE JASA 59

DENSITY RATIOS

UPPER AND LOWER PROBABILITY INFERENCES FOR FAMILIES OF HYPOTHESES WITH
INFERENCES ON THE PARAMETERS OF THE WEIBULL

AN EXAMPLE OF DISCREPANCIES IN INFERENCES UNDER NON-INFORMATIVE STOPPING RULES

DISTRIBUTION

SOME BAYESIAN AND FREQUENTIST INFERENCES

A COMPARISON OF SOME BAYESIAN AND FREQUENTIST INFERENCES

\author{
II
} $\begin{array}{llll} & & \text { BIOKA66 } & 262 \\ \text { ON INFERRING ORDER RELATIONS IN ANALYSIS OF VARIANCE } & \text { BIOCS65 } & 337\end{array}$

THEOREMS WHEN THE FIRST OR THE SECOND MOMENT IS INFINITE

RENEWAL FUNCTION WHEN THE MEAN RENEWAL LIFETIME IS INFINITE

PROCESSES FOR WHICH THE MEAN RATE OF CROSSINGS IS INFINITE TRIBUTIONS OF THE NEGATIVE EXPERIMENTAL TYPE FOR THE INFINITE DAM

THE TIME-DEPENDENT SOLUTION FOR AN INFINITE DAM WITH DISCRETE ADDITIVE INPUT

NOTE ON THE INFINITE DIVISIVILITY OF EXPONENTIAL MIXTURES

INFINITE DIVISIVILITY OF INTECER-VALUED RANDON

VARIABLES

INFINITE EXPECTATIONS

/HORT PROOF OF A KNOWN LIMIT

A NOTE ON SUMS OF INDEPENDENT RANDOM VARIABLES WITH INFINITE FIRST MOMENT

ON THE GLIVENKO-CANTELLI THEOREM FOR INFINITE INVARIANT MEASURES

BILITY OF THE BEST INVARIANT TEST WHEN THE MOMENT IS INFINITE UNDER ONE OF THE HYPOTHESES

INADMISSI INFINITELY DIFFERENTIABLE POSITIVE DEFINITE FUNCTIONS

ZEROES OF INFINITELY DIVISIBLE DENSITIES

ON CONTINUOUS SINGULAR INFINITELY DIVISIBLE DISTRIBUTION FUNCTIONS

ON CONTINUITY PROPERTIES OF INFINITELY DIVISIBLE DISTRIBUTION FUNCTIONS

AND APPLICATIONS

NON-NECATIVE RANDOM VARIABLES
INFINITELY DIVISIBLE DISTRIBUTIONS, RECENT RESULTS

ON INFINITELY DIVISIBLE LAWS AND A RENEWAL THEOREM FOR

A CLASS OF INFINTTELY DIVISIBLE MIXTURES

INFINITELY DIVISIBLE RENEWAL DISTRIBUTIONS

AN EVALUATION OF A FUNCTIONAL ON INFINITELY DIVISIBLE STOCHASTIC PROCESSES

THE SEQUENTIAL DESIGN OF EXPERIMENTS FOR INFINITELY MANY STATES OF NATURE
STATE MARKOV PROCESS

T OF PRIORITY 631111 )

BALANCED DESIGNS

OF SUMS OF RANDOM VARIABLES

SURVEY RESULTS
ESTIMATING THE INFINITESIMAL GENERATOR OF A CONTINUOUS TIME FTNITE

ON CONVERGENCE TO INFINITY IN THE LAW OF LARGE NUMBERS, (ACKNOWLEDGEMEN ON THE ADMISSIBILITY AT INFINITY, WITHIN THE CLASS OF RANDOMIZED DESIGNS, OF ON THE INFLUENCE OF MOMENTS ON THE ASYMPTOTIC DISTRIBUTION INFLUENCE OF THE INTERVIEWER ON THE ACCURACY OF
MERCING OF OPINIONS WITH INCREASING INFORMATION

OPTIMUM STRATIFIED SAMPLING USING PRIOR INFORMATION

A NOTE ON MINIMUM DISCRIMINATION INFORMATION

RECENT EFFORTS TO IMPROVE LAND USE INFORMATION
AMS 69953

TECH 69445

BIOKA67 329

BIOKA65 19

AMS 6B 1210 JRSSB61 230 JRSSB57 342 JRSSB61 173 AMS 671303 AMS 671306 AMS 691114 AMS $67 \quad 751$ AMS 671273 AMS 691483 AMS $66 \quad 504$ AMS 691503 AMS $64 \quad 330$ AMS $68 \quad 936$ AMS $62 \quad 68$ AMS 6B 139 AMS 681153 AMS 691109 AMS $64 \quad 336$ AMS $61 \quad 771$ AMS $62 \quad 727$ AMS $63 \quad 219$ AMS 681978 AMS $63 \quad 1042$ JASA $58 \quad 635$ AMS $62 \quad 882$ JASA $65 \quad 750$ AMS $66 \quad 279$ JASA $66 \quad 647$ 
THE TWO CONCEPTS OF INFORMATION ON THE OPTIMUM RATE OF TRANSMITTING INFORMATION THE STATISTICAL SIGNIFICANCE OF ODD BITS OF INFORMATION BINOMIAL SAMPLING SCHEMES AND THE CONCEPT OF INFORMATION ON LOCAL INFERENCE AND INFORMATION

JASA $67 \quad 685$ AMS 69 NO. 6 BIOKA52 228 BIOKA57 179

JRSSB6 4253 ESTIMATION OF BIOCS65 826 EXPONENTIAL SURVIVAL PROBABILITIES WITH CONCOMITANT INFORMATION IN STRATIFIED AND MULTISTAGE SAMPLES USING PRIOR INFORMATION OF SOME STANDARD ESTIMATES IN THE PRESENCE OF PRIOR INFORMATION A RECORD MATCHING PROCESS WITH COMPLETE INVARIANT INFORMATION ON SAMPLES OPTIMAL ALLOCATION JASA 6B 964 ON THE INADMISSIBILITY AMS 63539 OUTCOME PROBABILITIES FOR JASA $67 \quad 454$ A CLASSIFICATION PROBLEM IN WHICH INFORMATION ABOUT ALTERNATIVE DISTRIBUTIONS IS BASED AMS 62213

DEPENDENCE REGRESSION ANALYSIS WHEN THERE IS PRIOR INFORMATTON ABOUT SUPPLEMENTARY VARIABLES

DISTRIBUTION

MUTUAL INFORMATION AND MAXIMAL CORRELATION AS MEASURES OF

CHANGING WORLD

THE QUALITY OF STATISTICAL INFORMATION AND STATISTICAL INFERENCE IN A RAPIDLY INFORMATION AND SUFFICIENT SUB-FIELDS

A NOTE ON THE LOSS OF INFORMATION DUE TO GROUPING OF OBSERVATIONS

NOTES. MINIMUM DISCRIMINATION INFORMATION ESTIMATION

JRSSB60 172

AMS $62 \quad 587$

TECH $69 \quad 41$

JASA 67

AMS 682056

BIOKA64 495

BIOCS68 707

ON CASH EQUIVALENTS AND INFORMATION EVALUATION IN DECISTONS UNDER UNCERTAINTY JASA 68252 PARTS I, II, AND III $\begin{array}{cl}\text { A LARGE SAMPLE SEQUENTIAL TEST, USING CONCOMITANT INFORMATION FOR DISCR IMINATION BETWEEN TWO COMPOSITE JASA } 66 & 357 \\ \text { S OF EXPONENTIAL AND NORMAL DISTRIBUTIONS } & \text { INFORMATION FOR EST IMATING THE PROPORTIONS IN MIXTURE JASA } 63 \text { 91B }\end{array}$ ONSHIP AMONG EIGHT POPULATIONS ZEA MAYS L UTILIZING INFORMATION FROM A DIALLEL MATING DESIGN /AL RELATI BIOCS68 B67 VARIANCE WEIGHTING ON UTILIZTNG TNFORMATION FROM A SECOND SAMPLE IN ESTIMATING

BIOKA69 NO. 3 ON COMBINABILITY OF INFORMATION FROM UNCORRELATED LINEAR MODELS BY SIMPLE AMS 661338 THE INFORMATION IN A RANK-ORDER AND THE STOPPING TIME OF AMS 681661 THE INFORMATION IN AN EXPERIMENT

THE COMBINATION OF INFORMATION IN GENERALLY BALANCED DESIGNS AND THE CA/ EFFICIENT UTILIZATION OF NON-NUMERICAL INFORMATION IN QUANTITATIVE ANALYSIS. GENERAL THEORY AMS 63 1347 ON THE USE OF INCOMPLETE PRIOR INFORMATION IN REGRESSION ANALYSIS $\quad$ JASA 63401 ON A METHOD OF USING MULTI-AUXILIARY INFORMATION IN SAMPLE SURVEYS

ON PARTIAL 'A PRIORI' INFORMATION IN STATISTICAL INFERENCE ON INFORMATION IN STATISTICS

JASA $65 \quad 270$

AMS 671671

AMS 65890

ON THE AMOUNT OF INTFORMATION SUPPLIED BY CENSORED SAMPLES OF GROUPED O BIOKASR 245 OBSERVATIONS IN THE ESTIMATION O/ ON THE AMOUNT OF INFORMATION SUPPLIED BY TRUNCATED SAMPLES OF GROUPED BIOKA63 207 NOTE ON THE ERGODIC THEOREM OF INFORMATION THEORY

ON THE AXIOMS OF INFORMATIION THEORY

DESTGN A ROUTTNE PARALLEL LINE ASSAY

USE OF INTER-BLOCK INFORMATION TO OBTAIN UNIFORMLY BETTER ESTIMATORS AMS 641064

ATUM (ADDENDUM 6/ OPTIMUM UTILIZATTON OF AUXILIARY INFORMATION (PI)PS SAMPLING OF TWO UNITS FROM A STR JRSSB67 374 UNCERTAINTY. INFORMATION, AND SEQUENTIAL EXPERIMENTS INFORMATIVE STOPPING RULES AND INFERENCES ABOUT $\quad$ JASA 67 767 INHALATION IN RELATION TO TYPE AND AMOUNT OF SMOKING JASA $59 \quad 35$ POPULATION SIZE

ON THE DIFFICULTIES INHERENT IN FISHER'S FIDUCIAL ARGUMENT

JASA $64 \quad 56$ CONCERNING THE DEGREE OF DOMINANCE IN MONOFACTORIAL INHERITANCE NOTES. STATISTICAL TESTS OF HYPOTHESES BIOCS68 429 CURVE FITTING A METHOD OF OBTAINING INITIAL ESTIMATES OF THE PARAMETERS IN EXPONENTIAL EPIDEMIC FOR SMALL POPULATIONS WITH ONE OR MORE INITIAL INFECTIVES DISCRIMINANT ANALYSIS WHEN THE INITIAL SAMPLES ARE MISCLASSIFIED

580

BIOKA69 IB3 TECH $66 \quad 657$ INITIAL STOCK AND CONSUMER INVESTMENT IN AUTOMOBILES JASA $63 \quad 7 \mathrm{Bg}$

COMBINING A BARTLETT WINDOW WTTH AN ASSOCIATED INNER WINDON SPECTRAL ANALYSIS TECH 61235 ESTIMATION OF THE INNOVATION VARIANCE OF A STATIONARY TIME SERIES

A GENERAL CLASS OF BULK QUEUES WITH POISSON INPUT

A GENERALIZED SINGLE-SERVER QUEUE WITH ERLANG INPUT THE ALMOST FULL DAM WITH POISSON INPUT

LINEAR SYSTEM HAVING A NORMAL STATIONARY STOCHASTIC INPUT OR OF A SINGLE SERVER QUEUING PROCESS WITH RECURRENT INPUT AND GAMMA SERVICE TIME

PROBABILITY GENERATING FUNCTIONALS TO THE STUDY OF INPUT-OUTPUT STREAMS THE ALMOST FULL DAM WITH POISSON INPUT, FURTHER RESULTS

ON THE QUEUEING PROCESS. MARKOV OR POISSON INPUT, GENERAL SERVICE TIME DISTRIBUTION, ONE SERVER RESERVOIRS WITH SERTALLY CORRELATED INPUTS

FIRST EMPTINESS PROBABILITIES OF A DAM WITH ORDERED INPUTS SOLUTION FOR AN INFINITE DAM WITH DISCRETE ADDITIVE INPUTS MARKED SPECTMENS IN ESTIMATING POPULATTONS OF FLYING INSECTS DECISION THEORY

$$
\text { A BAYES SEQUENTIAL SAMPLING INSPECTION }
$$

A DYNAMIC PROGRAMMTNG APPLICATTON IN PRODUCTTON LINE INSPECTTON

\section{THE DECISION THEORY APPROACH TO SAMPLING INSPECTION (WITH DISCUSSION)}

INSPECTION AND CORRECTION ERROR IN DATA PROCESSING

DISCUSSION

SAMPLING INSPECTION AND STATISTICAL DECISIONS (WITH

INEQUALITIES FOR JRSSB62 102 THE TIME-DEPENDENT JRSSB61 173 ON THE UTILIZATION OF BIOKA53 170 JASA $65 \quad 584$ AMS 651387 TECH $67 \quad 73$ JRSSB66 381 JASA 69 NO. 4 JRSSB54 151 TECH 6323 JRSSB59 400 JASA $58 \quad 702$ JRSSB58 111

THE MOST ECONOMICAL SEQUENTIAL SAMPLING SCHEME FOR INSPECTION BY VARIABLES

RECTIFYING INSPECTION OF A CONTINUOUS OUTPUT, CORR, 59810

THE INSPECTTON OF A MARKOV PROCESS

\section{ATION BETWEEN SUCCESSIVE RESULTS RECTIFYING INSPECTION OF LOTS}

SAMPLING INSPECTION OF CONTINUOUS PROCESSES WITH NO AUTOCORREL

SOME THEORETICAL ASPECTS OF THE LOT PLOT SAMPLING INSPECTION PLAN

A RECTIFYING INSPECTION PLAN

RELATIVE COSTS OF COMPUTERIZED ERROR INSPECTION PLANS

THEOREMS FOR THE DODGE-ROMIG LTPD SINGLE SAMPLING INSPECTION PLANS E EVALUATTON OF A LARGE CLASS OF CONTTNUOUS SAMPLING INSPECTION PLANS OF ATIONGE CLASS OP CONTINUOU SAMPING INSPECTION PLANS WEIBULL PROCESSES

SAMPLING INSPECTION PLANS BASED ON PRIOR DISTRIBUTIONS AND COS

SAMPLING INSPECTION PLANS

ON THE BAYESIAN SOLUTION OF THE SINGLE SAMPLING INSPECTION SCHEME

SOME REMARKS TECH 60341

BIOKA54 100

ATIONS WHEN BOTH VAR/A GENERALIZED APPLICATION OF INSTRUMENTAL VARIABLE ESTIMATION OF STRAIGHT-LINE REL TECH 69 255 IONSHIPS WITH AUTOCORRELATED RESIDUALS BY THE USE OF INSTRUMENTAL VARIABLES ON LEAST SQUARES WITH INSUFFICIENT OBSERVATIONS, CORR. 651249

THE ESTIMATION OF RELAT JRSSB59 91 
A NOTE ON THE EVALUATION OF THE MULTIVARIATE NORMAL INTECRAL

ON THE HOMOGENEOUS BIRTH-AND-DEATH PROCESS AND ITS INTEGRAL

BIOKA66 GI

EQUALLY CORRELATED VARIATES AND THE MULTINORMAL INTEGRAL

NON-ABSOLUTE CONVERCENCE OF CIL-PELAEZ' INVERSION INTEGRAL

JRSSB58 373

PPROXIMATION FOR THE SYMMETRIC QUADRIVARIATE NORMAL INTECRAL

FOR THE INCOMPLETE GAMMA FUNCTIONS AND THE NORMAL INTEGRAL

DISTRIBUTION

PROCESSES
A CONTOUR-INTECRAL DERIVATION OF THE NON-CENTRAL CHI-SQUARE

AN INTEGRAL EQUATION IN ACE DEPENDENT BRANCHINC

AN APPROXIMATE SOLUTTON OF THE INTEGRAL EQUATION OF RENEWAL THEORY

SOME INTEGRAL EQUATIONS IN GEOMETRICAL PROBABILITY INTECRAL EXPRESSIONS FOR TAIL PROBABILITIES OF THE MU

LTINOMIAL AND NECATIVE MULTINOMIAL DISTRIBUTIONS INTEGRAL FOR A PEARSON TYPE IV DISTRIBUTION

THE MILLS RATIO AND THE PROBABILITY INTEGRAL FOR A PEARSON TXPE IV DISTRIBUTION

INCLUDINC A NEW CONTINUED FRACTION B BIOKA54 177 INTECRAL KERNELS AND INVARIANT MEASURES FOR MARKOFF AMS $65 \quad 517$ TRANSITION FUNCTIONS INTEGRAL OF THE BIVARIATE NORMAL DISTRIBUTION OVER AN JASA 62758 OFFSET CIRCLE OFSET CIRCLE

A TABLE OF THE INT A NOTE ON THE PROBABILITY INTEGRAL OF THE CORRELATION COEFFICIENT BIOKA54 278 BIOKA52 417 F THE SHAPE P/ AN APPROXIMATION TO THE PROBABILITY INTECRAL OF THE GAMMA DISTRIBUTION FOR SMALL VALUES O BIOKA62 276 ON THE EVALUATION OF THE PROBABILITY INTECRAL OF THE MULTIVARIATE T DISTRIBUTION

RMULAE FOR THE PERCENTAGE POINTS AND THE PROBABILITY INTECRAL OF THE NON-CENTRAL CHI-SQUARE DISTRIBUTION REDUCTION OF THE MULTIVARIATE NORMAL INTEGRAL TO CHARACTERISTIC FORM

ON THE PROBABILITY INTEGRAL TRANSFORMATION

SOME INTEGRAL TRANSFORMS OF CHARACTERISTIC FUNCTIONS

BUTION FUNCTIONS THE USE OF INTEGRAL TRANSFORMS TO DETERMINE EXPANSIONS OF

TABLE OF THE BOUNDS OF THE PROBABILITY INTEGRAL WHEN THE FIRST FOUR MOMENTS ARE GIVEN

EXPANSIONS OF T DENSITIES AND RELATED COMPLETE INTEGRALS A REDUCTION FORMULA FOR NORMAL MULTIVARIATE INTEGRALS

NUMERICAL EVALUATION OF CERTAIN MULTIVARIATE NORMAL INTECRALS

STOCHASTIC INTECRALS AND DERIVATIVES

BIBLIOGRAPHY ON THE MULTIVARIATE NORMAL INTEGRALS AND RELATED TOPICS

INTEGRALS OF BRANCHING PROCESSES

PROBABILITY INTEGRALS OF MULTIVARIATE NORMAL AND MULTIVARIATE T

ON FORMULAE FOR CONFIDENCE POINTS BASED ON INTEGRALS OF WEICHTED LIKELIHOODS

ON THE CONVERGENCE OF ORDINARY INTEGRALS TO STOCHASTIC INTEGRALS

BOUNDS ON INTEGRALS WITH APPLICATIONS TO RELIABILITY PROBLEMS

EDCEMENT OF PRIORITY ON 'ON INTERCHANGINC LIMITS AND INTEGRALS'. 6074

INTEGRATED RISK OF ASYMPTOTICALLY BAYES SEQUENTIAL

TESTS

AN APPLICATION OF NUMERICAL INTEGRATION TECHNIQUES TO STATISTICAL TOLERANCING

BIBLIOCRAPHY ON SIMULATION, GAMING, ARTIFICIAL INTELLIGENCE AND ALLIED TOPICS

ERISTICS IN TWO DIFFERENT POPULATIONS ON COMPARING INTENSITIES OF ASSOCIATION BETWEEN TWO BINARY CHARACT J ON THE ESTIMATION OF THE INTENSITY FUNCTION OF A STATIONARY POINT PROCESS

LIMIT THEOREMS FOR QUEUES WITH TRAFFIC INTENSITY ONE

BIOKA61 409

BIOKA54 538

BIOKA67 293

BIOKA59 481

AMS $68 \quad 1923$

BIOKA60 460

BIOKA60 399

AMS $67 \quad 503$

BIOKA54 351

THE AMS $62 \quad 571$

AMS 691610

AMS $63 \quad$ B29

BIOKA 67263

AMS 63792

JRSSB 63 31B

AMS 651560

AMS $65 \quad 565$

AMS $66 \quad 1407$

AMS 671399

TECH 67 44] JASA $60 \quad 736$

JASA $61 \quad$ BB9 JRSSB65 332 AMS $65 \quad 1437$

ITH MAJOR EMPHASIS ON THE ROLE OF ASSETS, CREDIT AND INTENTIONS CONSUMER DURABLE GOODS EXPENDITURES, W JASA 63 64B COMBININC INTRA AND INTER BLOCK ANALYSIS OF GROUP DIVISIBLE DESIGNS ESTIMATORS USE OF INTER-BLOCK INFORMATION TO OBTAIN UNIFORMLY BETTER AMS 641064

OF ESTIMATES FROM SIMILAR EXPERIMENTS. ALLOWING FOR INTER-EXPERIMENT VARIATION THE COMBINATION JASA 67 24I

TARDIZATION OF INTER-INDUSTRY TABLES, CORR, 641299 A MATHEMATICAL MODEL FOR THE ESTIMATION OF INTER-PLANT COMPETITION (CORRECTION TO REFERENCE 68 I INTER-PLANT STORAGE IN CONTINUOUS MANUFACTURING

THE DEMAND FOR FERTILIZER IN 1954, AN INTER-STATE STUDY

PAIRED COMPARISON MODELS WITH TESTS FOR INTERACTION

COMPONENTS IN TWO-WAY CLASSIFICATION MODELS WITH INTERACTION OF LATIN SQUARES WITHIN A CERTAIN TYPE OF ROW-COLUMN INTERACTION BLEM OF GRIZZLE WITH A NOTATION ON THE PROBLEM OF NO INTERACTION AN ADDENDUM THE INTERACTION ALGORITHM AND PRACTICAL FOURIER ANALYSIS, JRSSB6O

2-TO-THE-N-TIMES-3-TO-THE-M DESIGNS AND TWO-FACTOR INTERACTION ALIASING

OF A STOCHASTIC MODEL FOR THE PREDATOR-PREY TYPE OF INTERACTION BETWEEN TWO SPECIES SIMPLE METHODS FOR ANALYZING THREE-FACTOR INTERACTION IN CONTINGENCY TABLES LAMST AND THE HYPOTHESES OF NO THREE FACTOR INTERACTION IN CONTINCENCY TABLES

ANALYSIS OF VARIANCE OF DISPROPORTIONATE DATA WHEN INTERACTION IS PRESENT PROCESS THE ESTIMATION OF A FUNDAMENTAL INTERACTION PARAMETER IN AN EMIGRATION-IMMIGRATION ON THE HYPOTHESES OF 'NO INTERACTION' IN CONTINGENCY TABLES HYPOTHESES OF 'NO INTERACTION' IN MULTI-DIMENSIONAL CONTINGENCY TABLES DESIGN FOR INTERACTIONS

ON PLACKETT'S TEST FOR CON'TINGENCY TABLE INTERACTIONS OF KNOX'S APPROACH TO THE DETECTION OF SPACE-TIME INTERACTIONS DISEASE CLUSTERING. A GENERALIZATION BIOCS68 541 作 ES THE SQUARE-SUMMING CHECK ON THE MAIN EFFECTS AND INTERACTIONS IN A 2 TO THE POWER N FAGTORIAL EXPERIME BIOCS67 57 A NOTE ON INTERACTIONS IN CONTINGENCY TABLES JRSSB62 162 ASSIFIED DATA, INDEPENDENCE, QUASI-INDEPENDENCE, AND INTERACTIONS IN CONTINGENCY TABLES WITH OR WITHOUT MI JASA 68 IO9I THE INTERPRETATION OF INTERACTIONS IN FACTORIAL EXPERTMENTS 
S FOR THE QUEUEING SYSTEM WITH ONE SERVER, WHILE THE INTERARRIVAL AND SERVING DISTRIBUTIONS ARE DETERMINIS JRSSB63 477

ESS OF THE QUEUEING SYSTEM WITH ONE SERVER AND WHICH INTERARRIVAL AND SERVING DISTRIBUTIONS ARE EXPONENTIA JRSSB59 375

TURE PROCESS OF THE QUEUE WITH ONE SERVER, WHILE THE INTERARRIVAL AND SERVING DISTRIBUTIONS ARE EXPONENTIA JRSSB66 336 A. METHOD OF ESTIMATING THE INTERCENSAL POPULATION OF COUNTIES

EVALUATION OF CENSUS SURVIVAL RATES IN ESTIMATING INTERCENSAL STATE NET MIGRATION

ACKNOWLEDGEMENT OF PRIORITY ON 'ON INTERCHANGINC LIMITS AND INTEGRALS', 6074

JASA 56587

JASA $62 \quad 84$

AMS 661407

JRSSB61 493

LOWER BOUND FORMULAS FOR THE MEAN INTERCORRELATION COEFFICIENT

JASA $59 \quad 275$

TY OF 'EXPLICIT CAUSAL CHAINS' AGAINST THE CLASS OF 'INTERDEPENDENT' MODELS /N THE STATISTICAL TESTABILI JASA 65 IOBO

MINIMIZE MODEL INADEQUACIES. CUBOIDAL REGIONS OF INTEREST

MPLING UNITS TO STRATA WHEN THERE ARE R RESPONSES OF INTEREST OPTIMUM ALLOCATION OF SA JASA 65 22

DESIGNS WHICH BIOKA65 III

MATRIX INVERSION, ITS INTEREST AND APPLICATION IN ANALYSIS OF DATA

INCOME TAX TAXPAYER COMPLIANCE IN REPORTING INTEREST INCOME UNDER THE WISCONSIN STATE INDIVIDUAL JASA 63 487

DISCRETE DYNAMTC PROGRAMMING WITH A SMALL INTEREST RATE

SOME CONTRIBUTIONS TO THE THEORY OF MACHINE INTERFERENCE

ON MACHINE INTERFERENCE

ON SOME PROBLEMS OF MACHINE INTERFERENCE

A PROBLEM OF INTERFERENCE BETWEEN TWO QUEUES

AMS 69366

BIOKA63 135

JRSSB56 280

JRSSB59 106

INTERFERENCE IN THE MANUFACTURE OF NUCLEPORE FILTERS TECH 67319

QUEUEING SYSTEMS, A CENERALIZATION OF THE MACHINE INTERFERENCE MODEL

NORMAL APPROXIMATION TO MACHINE INTERFERENCE WITH MANY REPAIR MEN

CLOSED JRSSB61 385

JRSSB57 334

USE OF MEAN DEVIATION IN THE ANALYSIS OF INTERLABORATORY TESTS

MPARISONS OF DISPERSION MATRICES FOR ALTERNATIVES OF INTERMEDIATE SPECIFICITY

TESTINC A MARKOV HYPOTHESIS WITH INDEPENDENCE OF INTERMEDIATE STATES AND RESTRICTED ORDER

CRAPHICAL METHODS FOR INTERNAL COMPARISONS IN MULTIRESPONSE EXPERIMENTS

TECH $67 \quad 149$

IN THE ESTIMATION OF NET MIGRATION IN THE STUDIES OF INT ERRORS INTERNAL MIGRATION STATISTICS FOR THE UNITED STATES

L RECRESSION

THE EFFICIENCY OF INTERNAL REGRESSION FOR THE FITTING OF THE EXPONENTIA A NOTE ON WILKS' INTERNAL SCATTER

S. CORR, 641299

PRACTICAL VALUE OF INTERNATIONAL EDUCATIONAL STATISTICS AMS $62 \quad 432$

COUNTRIES

PROBLEMS IN THE INTERNATIONAL STANDARDIZATION OF INTER-INDUSTRY TABLE THE ACCURACY OF INTERNATIONAL TRADE DATA. THE CASE OF SOUTHEAST ASIAN REPLICATED, OR INTERPENETRATING, SAMPLES OF UNEQUAL SIZES

IOKA67 605

AMS 64613 JASA 69 NO. 4 JASA $60 \quad 664$ KA59 293 AMS $65130 B$ JASA $56 \quad 605$

\section{DISCRETE GROUPS}

LAGRANGIAN COEFFICIENTS FOR INTERPOLATION BETWEEN TABLED PERCENTAGE POINTS INTERPOLATION OF HOMOGENEOUS RANDOM FIELDS ON

THE INTERPOLATION OF TIME SERIES BY RELATED SERIES INTERPOLATIONS AND APPROXIMATIONS RELATED TO THE

NORMAL RANGE ES QUANTITATIFS ET R/

DISTRIBUTIONS DE FREQUENCES, INTERPRETATION DU DETERMINISME GENETI ON THE INTERPRETATION OF AGE DISTRIBUTIONS

EXPERIMENTS THE FEMALE LABOR FORCE, A CASE STUDY IN THE INTERPRETATION OF HISTORICAL STATISTICS THE INTERPRETATION OF INTERACTIONS IN FACTORIAL THE INTERPRETATION OF NEGATIVE COMPONENTS OF VARIANCE

BAYESIAN INTERPRETATION OF STANDARD INFERENCE STATEMENTS (WITH
THE INTERPRETATION OF THE EFFECTS OF NON-ADDITIVITY IN

DISCUSSION)

THE LATIN SQUARE

AND KRUSKAL'S TAU A CLASSIFICATION OF FALLACIOUS ARCUMENTS AND INTERPRETATIONS

CORR. 581030

PROBABILISTIC INTERPRETATIONS FOR THE MEAN SQUARE CONTINGENCY,

USE OF HALF-NORMAL PLOTS IN INTERPRETINC FACTORIAL TWO LEVEL EXPERIMENTS DESIGN OF AN OPTIMAL SEQUENCE OF INTERRELATED SAMPLINC PLANS

DISTRIBUTIONS

THEIR COMPONENTS

ISTICS OF SAMPLES FROM ANY CONTINUOUS POPULATION

SOME INTERRELATIONS AMONC COMPOUND AND CENERALIZED INTERRELATIONS AMONG GENERALIZED DISTRIBUTIONS AND INTERRELATIONS BETWEEN CERTATN LINEAR SYSTEMATIC STAT A WAITING LINE WITH INTERRUPTED SERVICE. INCLUDING PRIORITIES QUEUES SUBJECT TO SERVICE INTERRUPTION

A THEORETICAL ANALYSIS OF DELAYS AT AN UNCONTROLLED INTERSECTION THE CAPACITY OF AN UNCONTROLLED INTERSECTION

INFERENCE ABOUT THE INTERSECTION IN TWO-PHASE REGRESSION

DESIGNS

ON THE PARAMETERS AND INTERSECTION OF BLOCKS OF BALANCED I

LIMIT THEOREM FOR THE NUMBER OF EDGES IN THE RANDOM INTERSECTION OF TWO CRAPHS (CORR. 69 I5IO)

ESTIMATES FOR THE POINTS OF INTERSECTION OF TWO POLYNOMIAL RECRESSIONS DELAY AT TRAFFIC INTERSECTIONS INTERSECTIONS OF RANDOM CHORDS OF A CIRCLE

ON THE NUMBER OF RENEWALS IN A RANDOM INTERVAL AND LOWER PROBABILITIES GENERATED BY A RANDOM CLOSED INTERVAL ARC LENCTH OF A GAUSSIAN PROCESS ON A FINITE INTERVAL OF TOTAL SERVICE TIME FOR A FIXED OBSERVATION INTERVAL

IN THE ESTIMATION OF THE MEAN BY SHRINKAGE TO AN INTERVAL

EQUIVALENCE CLASSES OF CAUSSIAN PROCESSES ON AN INTERVAL DOM VARIABLES COVARIANCE STATIONARY ON A FINITE TIME INTERVAL ACCURACY BORROWING

A CLARIFICATION CONCERNING CERTAIN AMS 68 1078 A MOVING AJERAGE REPRESENTATION FOR RAN BIOKA65 295 INTERVAL ANALYSIS AND THE LOCARITHMIC TRANSFORMATION JRSSB58 187 DISTRIBUTION, WITH ESPECIAL REFERENCE TO THE UNEQUAL INTERVAL CASE/CLASS MARKS OF A CROUPED FREQUENCY TECH 68 793 FOR THE BEHRENS-FISHER PROBLEM A CONFIDENCE INTERVAL COMPARISON OF TWO TEST PROCEDURES PROPOSED E APPLTED TO THE SIMPLE QUEUE WTTH ARBTTRARY ARRTVAL INTERVAL DTSTRIBUTTON /DTFFERENCE EQUATTON TECHUIQU CONFIDENCE PROPERTIES OF BAYESIAN INTERVAL ESTIMATES

SOME PROBLEMS IN INTERVAL ESTIMATION (WITH DISCUSSION)

INTERVAL ESTTMATION FOR LINEAR COMBINATIONS OF MEANS

POPULATIONS

DISTRIBUTION

VARIABLES ARE SUBJECT TO ERROR

RESPONSES ARE CORRELATED
SEQUENTIAL INTERVAL ESTIMATION FOR THE MEANS OF NORMAL INTERVAL ESTIMATION FOR THE PARAMETER OF A BINOMIAL INTERVAL ESTIMATION IN LINEAR REGRESSION WHEN BOTH

CONFIDENCE INTERVAL ESTIMATION IN NON-LINEAR REGRESSION NOTE ON INTERVAL ESTIMATION IN NON-LINEAR REGRESSION WHEN
JASA $66 \quad 454$

JRSSB58 168 JRSSB68 535 JRSSB54 175 JASA $64 \quad 1141$ AMS $69 \quad 509$ BIOKA58 275 JASA 641112 JRSSB $63 \quad 330$ JRSSB64 267 
FUNCTIONS

FUNCTIONS, II

FUNCTIONS, 111

POPULATIONS WITH KNOWN VARIANCES

RMANCE OF A SEQUENTIAL PROCEDURE FOR THE FIXED-WIDTH

A BIVARIATE NORMAL DISTRIBUTION IN THE CASE OF A/

THE SCALE PARAMETER OF A WEIBULL POPUL/ POINT AND INTERVAL ESTIMATION PROCEDURES FOR THE TWO-PARAMETER TECH $68 \quad 231$

L DISTRIBUTION POINT AND INTERVAL ESTIMATORS, BASED ON M ORDER STATISTICS, FOR TECH 65405 SUBSTITUTE INTERVAL ESTIMATORS, WITH AN APPLICATION TO THE NORMA JASA 641133 A RANDOM INTERVAL FILLINC PROBLEM

A CRAPHICAL VERSION OF TUKEY'S CONFIDENCE INTERVAL FOR SLIPPACE
OBSERVATION

A CONFIDENCE INTERVAL FOR THE AVAILABILITY RATIO

THE VARIANCE WHEN MAKINC A FIXED WIDTH CONFIDENCE INTERVAL FOR THE MEAN ON THE COST OF NOT KNOWINC A CONFIDENCE INTERVAL FOR VARIANCE COMPONENTS

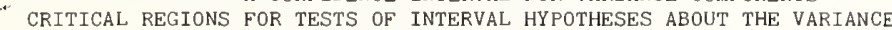
QUERY, TOLERANCE INTERVAL IN RECRESSION

PROBLEM CONFIDENCE INTERVAL OF PREASSICNED LENCTH FOR THE BEHRENS-FISHER

A LIMTT THEOREM FOR RANDOM INTERVAL SAMPLINC OF A STOCHASTIC PROCESS

OF PROBLEMS RELATEO TO THE RANOOM DIVISION OF AN INTERVAL' 53239 LENCTH OF CONFIDENCE INTERVALS MORE ON LENCTH OF CONFIOENCE INTERVALS CORRECTION TO ION A CLASS OF BOUNDED LENGTH CONFIOENCE INTERVALS EXISTENCE OF BOUNDED LENGTH CONFIOENCE INTERVALS
ADMISSIBILITY OF CONFIOENCE INTERVALS
SIMULTANEOUS PREDICTION INTERVALS
APPROXIMATE CONFIDENCE INTERVALS EXISTENCE OF BOUNDED LENGTH CONFIOENCE INTERVALS
ADMISSIBILITY OF CONFIOENCE INTERVALS
SIMULTANEOUS PREDICTION INTERVALS
APPROXIMATE CONFIDENCE INTERVALS EXISTENCE OF BOUNDED LENGTH CONFIOENCE INTERVALS
ADMISSIBILITY OF CONFIOENCE INTERVALS
SIMULTANEOUS PREDICTION INTERVALS
APPROXIMATE CONFIDENCE INTERVALS SEQUENTIALLY OETERMINEO CONFIOENCE INTERVALS
SOME NOTES ON ORDERED RANOOM INTERVALS A SEQUENTIAL TEST FOR RANDOMNESS OF INTERVALS EXPECTEO-COVER AND LINEAR-UTILITY TOLERANCE INTERVALS CENERAL METHOD OF DETERMININC FIXED-WIOTH CONFIOENCE INTERVALS IANCES FOR THE SIZE OF LARCEST CLUSTERS ANO SMALLEST INTERVALS TTON NOTES. SIMULTANEOUS CONFIDENCE INTERVALS LIFE TEST EXPERIMENTS A NOTE ON PREDICTION TESTS ANO CONFIDENCE INTERVALS BASED ON THE METRIC D2

TIME INTERVALS BETWEEN ACCIDENTS, A NOTE ON MAGUIRE, THE TIME INTERVALS BETWEEN INDUSTRIAL ACCIDENTS

PEARSON ANO WYNN'S PAPER

INOEPENOENT RANDOM DEVIATIONS OF LARGE OISPE/ THE INTERVALS BETWEEN RECULAR EVENTS DISPLACED IN TIME BY JR RANOOM NUMBERS THE DISTRIBUTION OF INTERVALS BETWEEN SUCCESSIVE MAXIMA IN A SERIES OF STRATIFIED SAMPLING AND OISTRIBUTION-FREE CONFIDENCE INTERVALS FOR A MEOIAN ON TWO-SIDED TOLERANCE INTERVALS FOR A NORMAL DISTRIBUTION OF THE SAMPLE MEAN ABSOLUTE DEVIATION IN CONFIDENCE INTERVALS FOR A NORMAL VARIATE CONFIDENCE INTERVALS FOR A PROPORTION

CORRICENDA TO 'CONFIDENCE INTERVALS FOR A PROPORTION'

NONPARAMETRIC CONFIDENCE INTERVALS FOR A SHIFT PARAMETER

OISTRIBUTION-FREE TOLERANCE INTERVALS FOR CONTINUOUS SYMMETRICAL POPULATIONS

SIMULTANEOUS CONFIDENCE INTERVALS FOR CONTRASTS AMONC MULTINOMIAL POPULATIONS CONFIOENCE INTERVALS FOR DISTANCE IN THE ANALYSIS OF VARIANCE

CASE WILCOXON CONFIDENCE INTERVALS FOR LOCATION PARAMETERS IN THE OISCRETE CONFIDENCE INTERVALS FOR MEASURES OF HERITABILITY

LARCE SAMPLE SIMULTANEOUS CONFIDENCE INTERVALS FOR MULTINOMIAL PROPORTIONS ON SIMULTANEOUS CONFIDENCE INTERVALS FOR MULTINOMIAL PROPORTIONS

SCHEMES (WITH DISCUSSION) CONFIDENCE INTERVALS FOR PARAMETERS IN MARKOV AUTORE DISCRIMINATION INTERVALS FOR PERCENTILES IN RECRESSION AMS $64 \quad 762$ TECH $66 \quad 663$ BIOKA56 423 BIOKA58 291 AMS $63 \quad 1507$ AMS $62 \quad 1167$ AMS $64 \quad 716$ BIOKA58 360 JASA $67 \quad 184$ BIOCS69 424 TECH 64191 TECH $65 \quad 247$ JRSSB54 195 JASA 69 1031

TIAL OBSERVATIONS FACTORS FOR CALCULATIC JASA $67 \quad 634$ JASA 69878 OF TWO METHODS OF OBTAININC APPROXIMATE CONFIOENCE INTERVALS FOR SYSTEM RELIABILITY COMPAR TABLE OF NEYMAN-SHORTEST UNBIASEO CONFIDENCE INTERVALS FOR THE BINOMIAL PARAMETER COMPARISON TECH $68 \quad 37$ BIOKA60 381 RMAL AND LOC NORMAL OISTRIBUTIONS CONFIDENCE INTERVALS FOR THE COEFFICIENT OF VARIATION FOR THE NO CONFIDENCE INTERVALS FOR THE EXPECTATION OF A POISSON VARIABLE THE RELATIONSHIP BETWEEN NEYMAN AND BAYES CONFIDENCE INTERVALS FOR THE HYPERCEOMETRIC PARAMETER YMPTOTIC THEORY OF FIXED-WIOTH SEQUENTIAL CONFIDENCE INTERVALS FOR THE MEAN THEOREM OF CHOW AND ROBBINS ON SEQUENTIAL CONFIDENCE INTERVALS FOR THE MEAN CONFIDENCE INTERVALS FOR THE MEAN OF A FINITE POPULATION THEOREM OF CHON

KNOWN VARIANCE

UNKNOWN VARIANCE

UTEO VARIABLES II

III NC A SUFFICIENT STATISTIC WHEN THE RAN/ SHORTER CONFIDENCE INTERVALS FOR THE MEAN OF A NORMAL DISTRIBUTION WITH
SEQUENTIAL CONFIDENCE INTERVALS FOR THE MEAN OF A NORMAL POPULATION WITH INTERVALS FOR THE MEAN OF A NORMAL DISTRIBUTION WITH CONFIDENCE INTERVALS FOR THE MEANS OF DEPENDENT NORMALLY DISTRIB BOUNOED LENCTH CONFIDENCE INTERVALS FOR THE P-POINT OF A OISTRIBUTION FUNCTION, BOUNOEO LENGTH CONFIDENCE INTERVALS FOR THE P-POINT OF A OISTRIBUTION FUNCTION POISSON OISTRIBUTIONS CONFIOENCE INTERVALS FOR THE PARAMETER OF A OISTRIBUTION AOMITTI SHORTER INTERVALS FOR THE PARAMETER OF THE BINOMIAL ANO TABLES OF NEYMAN-SHORTEST UNBIASEO CONFIOENCE INTERVALS FOR THE POISSON PARAMETER

THE USE OF SAMPLE QUASI-RANGES IN SETTING CONFIOENCE INTERVALS FOR THE POPULATION STANDARD DEVIATION

AN ALMOST UNBIASED METHOD OF OBTAINING CONFIDENCE INTERVALS FOR THE PROBABILITY OF MISCLASSIFICATION IN CONFIOENCE INTERVALS FOR THE PRODUCT OF TWO BINOMIAL PARAMETERS

ONE-SIDED CONFIDENCE INTERVALS FOR THE QUALITY INOICES OF A COMPLEX ITEM MEASURES OF EFFECTIVENESS

TWO CONFIDENCE INTERVALS FOR THE RATIO OF TWO PROBABILITIES ANO SOME OPTIMAL CONFIOENCE INTERVALS FOR THE VARIANCE OF A NORMAL OISTRIBUTION BOUNOEO LENGTH CONFIDENCE INTERVALS FOR THE ZERO OF A REGRESSION FUNCTION SIMULTANEOUS CONFIDENCE INTERVALS FOR VARIANCES CONFIOENCE INTERVALS FROM CENSOREO SAMPLES CONFIDENCE INTERVALS FROM CENSOREO SAMPLES, II APPROXIMATE CONFIOENCE INTERVALS III. A BIAS CORRECTION $\begin{array}{rr}\text { BIOKA64 } & 25 \\ \text { BIOKA59 } 441\end{array}$ TECH $68 \quad 199$ $\begin{array}{lll}\text { AMS } & 65 & 457 \\ \text { AMS } & 69 & 667\end{array}$ AMS 671180 AMS $63 \quad 574$ JRSSB57 133 JASA 59613 AMS $66 \quad 581$ AMS $66 \quad 586$ RSSB55 86 BIOKA57 436 BIOKA61 191 JASA $61 \quad 260$ BI0CS67 639 JASA $57 \quad 482$ TECH $63 \quad 400$ JASA $57 \quad 36$ JASA $59 \quad 674$ AMS $62 \quad 237$ JASA $69 \quad 324$ AMS $61 \quad 828$ TECH $66 \quad 291$ BIOKA55 201 

H $\mathrm{H}$ A VARIABLE CHANCE OF INFECTION FOR THE ANALYSIS OF INTRA-HOUSEHOLD EPIDEMICS /E OF CHAIN-BINOMIALS WIT BIOKA53 279 ALLY BALANCED INCOMPLETE BLO/ ON THE F-TEST IN THE INTRABLOCK ANALYSIS OF A CLASS OF TWO ASSOCIATE PARTI JASA 65 285 SOME TESTS FOR THE INTRACLASS CORRELATION MODEL QUERY, MAXIMUM LIKELIHOOD ESTIMATE IN INTRACLASS CORRELATION MODEL

FOR THE EQUALITY OF COVARIANCE MATRICES UNDER THE INTRACLASS CORRELATION MODEL $\begin{array}{ll}\text { TESTS OF INDEPENDENCE IN INTRACLASS } 2-B Y-2 & \text { TABLES } \\ \text { CORRIGENDA, } & \text { 'TEST OF INDEPENDENCE IN INTRACLASS } 2-B Y-2 \text { TABLES ' }\end{array}$ AMS 651802 TECH 69 NO. 4

YINC MODELS

ANALYSIS IN RESEARCH

$F$ ANALYSIS OF VARIANCE AND MULTIVARIATE ANALYSIS

FACTOR ANALYSIS, AN INTRODUCTION TO ESSENTIALS. 1. THE PURPOSE AND UNDERL

FACTOR ANALYSIS, AN INTRODUCTION TO ESSENTIALS, 2. THE ROLE OF FACTOR STATISTICAL ANALYSIS OF INTROCRESSION

STATISTICAL MODELS AND INVARIANCE

ON INVARIANCE AND ALMOST INVARIANCE

THE FIDUCIAL METHOD AND INVARIANCE

ON INVARIANCE AND ALMOST INVARIANCE

INVARIANCE OF MAXIMUM LIKELIHOOD ESTIMATIONS

ON EXTENDED RATE OF CONVERGENCE RESULTS FOR THE INVARIANCE PRINCIPLE

VARIABLES

THE INVARIANCE PRINCIPLE FOR A LATTICE OF RANDOM

AN INVARIANCE PRINCIPLE IN RENEWAL THEORY

THE LIKELIHOOD AND INVARIANCE PRINCIPLES

CHAIN

SOME INVARIANCE PRINCIPLES FOR FUNCTIONALS OF A MARKOV THE RELATIONSHIP BETWEEN SUFFICIENCY AND INVARIANCE WITH APPLICATIONS IN SEQUENTIAL ANALYSIS INVARIANT CONDITIONAL DISTRIBUTIONS

ON SOME INVARIANT CRITERIA FOR GROUPING DATA

RIBUTION

RS TABLES FOR OBTAINING THE BEST LINEAR INVARIANT ESTIMATES O
FIDUCIAL THEORY AND INVARIANT ESTIMATION

ON THEUCIAL THEORY AND INVARIANT ESTIMATION

BILITIES FOR A RECORD MATCHING PROCESS WITH COMPLETE INVARIANT ESTIMATORS INVARIANT INTERVAL ESTIMATION OF A LOCATION PARAMETER

SOME INVARIANT LAWS RELATED TO THE ARC SINE LAW

EXISTENCE OF AN INVARIANT MEASURE AND AN ORNSTEIN'S ERGODIC THEOREM A. NOTE ON INVARIANT MEASURES

ON THE GLIVENKO-CANTELLI THEOREM FOR INFINITE INVARIANT MEASURES

INTEGRAL KERNELS AND INVARIANT MEASURES FOR MARKOFF TRANSITION FUNCTIONS

QUASI-LINEARLY INVARIANT PREDICTION

FIDUCIAL THEORY AND INVARIANT PREDICTION

INVARIANT PRIOR DISTRIBUTIONS

REPRESENTING FINITELY ADDITIVE INVARIANT PROBABILITIES

INVARIANT PROBABILITIES FOR CERTAIN MARKOV PROCESSES

INVARIANT PROPER BAYES TESTS FOR EXPONENTIAL FAMILIES

OPTIMAL INVARIANT RANK TESTS FOR THE K-SAMPLE PROBLEM

OUNDS ON THE SAMPLE SIZE DISTRIBUTION FOR A CLASS OF INVARIANT SEQUENTIAL PROBABILITY RATIO TESTS GENERAL PROOF OF TERMINATION WITH PROBABILITY ONE OF INVARIANT SEQUENTIAL PROBABILITY RATIO TESTS BASED ON
MEASURES

OF THE HYPOTHESES

INVARIANT SETS FOR TRANSLATION-PARAMETER FAMILIES OF ES CHARACTER OF T-SQUARED, R-SQUARED AND OTHER FULLY INVARIANT TESTS FOR CLASSICAL MULTIVARIATE NORMAL PRO MODELS OPTIMUM INVARIANT TESTS IN UNBALANCED VARIANCE COMPONENTS UFFICIENT CONDITIONS FOR A STATISTICAL PROBLEM TO BE INVARIANT UNDER A LIE GROUP NECESSARY AND S A STATISTICS THEOREM THEOREM. CONTINUOUS TIMES PARAMETER EXACT FORMS OF SOME INVARIANTS FOR DISTRIBUTIONS ADMITTING SUFFICIENT INVARIANTS UNDER MIXING WHICH GENERALIZE DE FINETTI'S
INVARIANTS UNDER MIXING WHICH GENERALIZE DE FINETTI'S

L DISTRIBUTION UNDER/

INADMISSIBILITY OF THE BEST INVARIATE ESTIMATOR OF EXTREME QUANTILES OF THE NORMA SOME RESULTS IN THE THEORY OF INVENTORY

A MINIMUM COST MODEL OF SPARE PARTS INVENTORY CONTROL

OF TRUNCATED DISTRIBUTIONS IN PROCESS START-UPS AND INVENTORY CONTROI MANUFACTURERS ' INVENTORY CYCLES AND MONETARY POLICY

EX ANTE AND EX POST DATA IN INVENTORY INVESTMENT

THE SOLUTION OF QUEUEING AND INVENTORY MODELS BY SEMI-MARKOV PROCESSES

A CORRECTION TO 'THE SOLUTION OF QUEUEING AND INVENTORY MODELS BY SEMI-MARKOV PROCESSES ' SOME RESULTS ON INVENTORY PROBLEMS (WITH DISCUSSION)

CUMULATIVE HYPERGEOMETRIC PROBABILITIES, DIRECT AND INVERSE

IN HOTELLING'S WEICHING DESIGNS AND A GENERALIZED INVERSE (CORR. 69719 ) $\begin{array}{lrr}\text { (WITH DISCUSSION) } & \text { JRSSB62 } & 1 \\ \text { A QUICKLY CONVERGENT EXPANSION FOR BIOKA54 } & 317\end{array}$ NOWLEDGEMENT

ON THE EQUIVALENCE OF BINOMALIZ IND INVERSE BINOMIAL ACCEPTAN QUERY, COMPARISON OF SAMPLE SIZES IN INVERSE BINOMIAL SAMPLING A NOTE ON DIRECT AND INVERSE BINOMIAL SAMPLING INVERSE CUMULATIVE APPROXIMATION AND APPLICATIONS BIOKA68 29 ATE POPULATION/DERIVATION OF APPROXIMANTS TO THE INVERSE DISTRIBUTION FUNCTION OF A CONTINUOUS UNIVARI BIOKA69 NO. 3 ED PRODUCTS OF RANDOM VARIABLES BIOCS65 190 BIOCS65 405

BIOKA56 361 $\begin{array}{rr}\text { BIOCS66 } & 4 B B \\ \text { AMS } 67 & 1061\end{array}$ AMS $68 \quad 1573$

BIOKA61 261 AMS $68 \quad 1573$ AMS $66 \quad 744$ AMS 69 N0.6 AMS $68 \quad 3 B 2$ AMS 6E $6 B 5$ $\begin{array}{lr}\text { AMS } 67 & 533 \\ \text { AMS } & 1\end{array}$ AMS $65 \quad 575$ AMS $65 \quad 829$ JASA 671159 AMS $66 \quad 643$

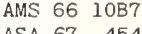
AMS $68 \quad 193$ AMS $68 \quad 25 B$ AMS $69 \quad 79$ AMS $66 \quad 729$ AMS $67 \quad 1273$ AMS $65 \quad 517$ AMS $66 \quad 1684$ AMS $67 \quad 795$ AMS $64 \quad 836$ AMS 6B 2131 AMS $66 \quad 837$ AMS $69 \quad 270$ AMS 651207 AMS 681048 AMS $67 \quad 8$ AMS $69 \quad 162$ AMS $69 \quad 1483$ AMS $65 \quad 747$ AMS $67 \quad 422$ AMS $63 \quad 492$ BIOKA55 533 AMS $62 \quad 916$ AMS $63 \quad 1194$ AMS 691801 TECH $67 \quad 661$ APPLICATIONS TECH $61 \quad 429$ JASA $58 \quad 680$ JASA $61 \quad 518$ JRSSB61 113 JRSSB63 455 SINGULARITY AMS $66 \quad 1021$ INVERSE DISTRIBUTIONS AND INDEPENDENT GAMMA-DISTRIBUT BIOKA63 505 CHARACTERIZATION OF THE INVERSE GAUSSIAN DISTRIBUTION 
ERRATA, IMODIFIED SQUARE ROOT METHOD OF MATRIX INVERSION

A NOTE ON MATRIX INVERSION BY THE SQUARE ROOT METHOD

AMS $64 \quad$ B95

AMS $67 \quad 271$

TECH $62 \quad 2 B 2$

TECH $62 \quad 622$ JASA $56 \quad 288$

TAN/ APPLICATIONS OF JORDAN'S PROCEDURE FOR MATRIX INVERSION IN MULTIPLE REGRESSION AND MULTIVARIATE DIS JRSSB63 352 THE NON-ABSOLUTE CONVERGENCE OF GIL-PELAEZ' INVERSION INTEGRAL

RIBUTIONS, AND THE APPROXIMATE STABILIZATION/ THE INVERSION OF CUMULANT OPERATORS FOR POWER-SERIES DIST JA AMS $61 \quad 338$ N/ APPLICATION OF CREENBERG AND SARHAN'S METHOD OF INVERSION OF PARTITIONED MATRICES IN THE ANAL $: S I S$ OF JASA 65 I2OO NOTE ON THE INVERSION THEOREM

(ACKNOWLEDGEMENT OF PRIORITY), 'NOTE ON THE INVERSION THEOREM' MATRIX INVERSION WITH THE SQUARE ROOT METHOD

OF DATA

MATR IX INERSION WITH THE SQUARE ROOT METHOD

CORR. $65 \quad 125$

SURVIVAL PROBABILITIES OF NEW INVERIION, ITS INEREST AND APPL

THE INVERTED DIRICHLET DISTRIBUTION WITH APPLICATIONS,
LIZATIONS OF THE MULTIVARIATE T DISTRIBUTION AND THE INVERTED MULTIVARIATE T DISTRIBUTION /ARIATE GENERA ON INVERTING A CLASS OF PATTERNED MATRICES

ORTHONORMAL BASES OF ERROR SPACES AND THEIR USE FOR INVESTIGATING THE NORMALITY AND VARIANCES OF RESIDUAL JA EMPLOYING RANDOM SUBSAMPLE MEANS INVESTIGATING THE NORMALITY AND VARIANCES OF REST

STRATIFICATION, A PRACTICAL INVESTIGATION

OF F-RATIOS FOR THE SPLIT-PLOT DESIGN, AN EMPIRICAL INVESTIGATION SAMPLES FROM TWO NON-NORMAL POPULAT/ AN EMPIRICAL INVESTIGATION INTO THE DISTRIBUTION OF THE F-RATIO IN BIOKA58 TWO SAMPLE TEST OF LEHMANN'S $S$ COMPOSED OF NORMAL DISTRIBUTIONS EXPONENTIAL CURVE

TREND-REDUCED MARKOFF SERIES AN INVESTIGATION INTO THE SMALL SAMPLE PROPERTIES OF A JASA $6 B$

EMPIRIC INVESTIGATION OF A TEST OF HOMOGENEITY FOR POPULATION JASA 58 AN INVESTICATION OF HARTLEY'S METHOD FOR FITTINC AN DURES IN NONLINEAR REGRESSION PROBLEMS A NUMERICAL INVESTIGATION OF SEVERAL ONE-DIMENSIONAL SEARCH PROCE TECH 69 $\begin{array}{ll}\text { HE PROPERTIES OF CHI-SQUARE-TESTS IN THE ANALY/ AN INVESTICATION OF THE BURN-IN PROBLEM } & \text { AN INVETIGATION OF THE EFFECT OF MISCLASSIFICATION ON T BIOKA65 }\end{array}$ A STATISTICAL INVESTIGATION OF THE INDUSTRIALIZATION CONTROVERSY JASA 60 C SATTERTHWAITE'S SYNTHETIC MEAN SQ/ A MONTE CARLO INVESTIGATION OF THE SIZE AND POWER OF TESTS EMPLOYIN BIOKAG8 USE OF RANDOMIZATION IN THE INVESTIGATION OF UNKNOWN FUNCTIONS EX ANTE AND EX POST DATA IN INVENTORY INVESTMENT STOCHASTIC MODELS OF CAPITAL INVESTMENT (WITH DISCUSSION) THE RELATIVE EFFICACY OF INVESTMENT ANTICIPATIONS

$1947-1960$ ANTICIPATIONS AND INVESTMENT BEHAVIOR IN UNITED STATES MANUFACTURING

JASA 61 JRSSB 69 JASA $66 \quad 10$

APPRAISAL APPROXIMATIONS DATA AND THE INVESTMENT DECISION INVESTMENT ESTIMATES OF UNDERDEVELOPED COUNTRIES, AN INITIAL STOCK AND CONSUMER INVESTMENT IN AUTOMOBILES

THE VARYING QUALITY OF INVESTMENT TRUST MANAGEMENT GENETIC EQUILIBRIUM UNDER SELECTION (INVITED PAPER)

D PROBABILISTIC AND STATISTICAL MODELS AND PROBLEMS (INVITED PAPER) THE ACCURACY OF CENSUS LITERACY STATISTICS IN IRAN IRRATIONAL FRACTION APPROXIMATIONS TO MILLS' RATIO BIOKA64 339

HOMOCENEOUS FIELDS ARE EITHER CONTINUOUS OR VERY IRREGULAR SARP EFFECTS AND THEIR CONNECTION WITH A SPECIAL KIND OF IRRECULAR FRACTIONAL PLANS OF FACTORIAL EXPERIMENTS JASA 63 497 FACTORIAL EXPERIMENT ON A SPECIAL SUBSET GIVING AN IRREGULAR FRACTIONAL REPLICATE OF A 2 TO THE POWER N JR

EXPERIMENTS COMPOSITE DESIGNS BASED ON IRREGULAR FRACTIONS OF FACTORIALS (CORR. 65 1036) 497 BIOCS65 324 DYING THE DENTAL C/ A PATH-PROBABILITY APPROACH TO IRREVERSIBLE MARKOV CHAINS WITH AN APPLICATION IN STU BIOCS66 791 THE ROBBINS-TSBELL TWO-ARMED-BANDIT PROBLFM INITH FINITE MEMORY ISN'T MY PROCESS TOO VARIABLE FOR EVOP. TECH 68439 NOTES. ON THE EVALUATION OF VARIABILITY IN ISOGENIC HYBRIDS TECH $68 \quad 439$ BIOKA57 193 STOCHASTIC CROSS-INFECTION BETWEEN TWO OTHERWISE ISOLATED CROUPS S REQUIREMENTS AMONG ENVIRONME/ EFFECTS OF PARTIAL ISOLATION (DISTANCE), MIGRATION, AND DIFFERENT FITNES BIOCS66 453 STATISTICAL ISOMORPHISM

ALLOCATION ARISING IN CHEMICAL ANALYSES BY MULTIPLE ISOTOPE DILUTION INTERVALS FOR THE QUALITY INDICES OF A COMPLEX ITEM A PROBLEM OF OPTIMUM TECH 61 509 ONE-SIDED CONFIDENCE TECH $63 \quad 400$ DEVELOPMENT OF SAMPLING PLANS BY USINC SEQUENTIAL, ITEM BY ITEM, SELECTION TECHNIQUES AND DIGITAL COMPUT JASA 62 3B7 THE POSSIBILITY OF IMPROVING THE MEAN USEFUL LIFE OF ITEMS BY ELIMINATING THOSE WITH SHORT LIVES IAL SAMPLING ACCEPTANCE SCHEMES FOR LARGE BATCHES OF ITEMS WHERE THE MEAN QUALITY HAS A NORMAL PRIOR DISTR BIOKA68 393 A REMARK ON THE LAW OF THE ITERATED LOGARITHM $\quad$ AMS 67599 
S (ADDENDUM, 69 1855)

VARIATIONS

L EXPONENTIAL DISTRIBUTIONS
A DELICATE LAW OF THE ITERATED LOGARITHM FOR NON-DECREASING STABLE PROCESS THE USE OF AN ITERATED MOVING AVERAGE IN MEASURINC SEASONAL

AN ITERATED PROCEDURE FOR TESTING THE EQUALITY OF SEVERA JA

ON ITERATED TESTS OF HYPOTHESES

ITERATED TESTS OF THE EQUALITY OF SEVERAL

MINIMAX SOLUTION OF STATISTICAL DECISION PROBLEMS BY ITERATION COMPONENTS FOR THE TWO-WAY CLASSIFICATION WITH ITERATION ON THE SOLUTION OF THE LIKELIHOOD EQUATION BY ITERATION PROCESSES ON THE SOLUTION OF LIKELIHOOD EQUATIONS BY ITERATION PROCESSES

'ON THE SOLUTION OF THE LIKELIHOOD EQUATION BY ITERATION PROCESSES'

CORRIGENDA, BIOKA62 $2 \mathrm{~B} 4$ THE ASYMPTOTIC ERROR OF ITERATIONS AMS 68266 EQUATIONS ITERATIVE ESTIMATION OF A SET OF LINEAR REGRESSION JASA 64 B45 ORTHOGONAL DATA ITERATIVE ESTIMATION OF VARIANCE COMPONENTS FOR NON- BIOCS69 NO 4 TERS OF NORMAL POPULATIONS FROM SINGLY AND DOUBLY/ ITERATIVE MAXIMUM-LIKELIHOOD ESTIMATION OF THE PARAME BI SPACE DISCRETE TIME MARKOV PROCESS ON THE ITERATIVE METHOD OF DYNAMIC PROGRAMMING ON A FINITE AMS 651279

THE COMPARISON OF TWO MEANS, FURTHER DISCUSSION OF ITERATIVE METHODS FOR CALCULATING TABLES

VARIANCE COMPONENTS IN MIXED MODEL STTUATIONS $\begin{array}{ll}\text { THEOREM A GENERALIZATION OF ITO'S THEOREM CONCERNING THE POINTWISE ERGODIC } & \text { AMS 6B 2145 }\end{array}$

AN ITERATIVE PROCEDURE FOR ESTIMATING FIXED EFFECTS AND BIOCS6B AND THE PROBABILITY INTEGRAL FOR A PEARSON TYPE IV DISTRIBUTION THE MIILIS RATTO BIOK SERIES RESULTS ON FACTORIAL DESICNS OF RESOLUTION IV FOR THE 2-TO-THE-N AND 2-TO-THE-N TIMES 3-TO-THE-M TECH 69 43I IN A SINCLY TRUNCATED BIVARIATE NORMAL DISTRIBUTION IV. EMPIRICAL VARIANCES OF RANK CORRELATION COEFFICIE BIOKA68 437 A TRUSTWORTHY JACKKNIFE

IMATORS USINC U STATISTICS AND A RELATIONSHIP TO THE JACKKNIFE METHOD. JACKKNIFING U-STATISTICS JACKKNIFING VARIANCES AMS 641594

MULTIVARIATE ANALYSIS '

NOTE ON ITHE JACOBIANS OF CERTAIN MATRIX TRANSFORMATION USEFUL IN BIOKA5 MULTIVARIATE ANALYSIS, BASED ON LECTURES BY/ THE JACOBIANS OF CERTAIN MATRIX TRANSFORHATIONS USEFUL IN BIOKA5I ON THE SAMPLE SIZE AND COVERAGE FOR THE JIRINA SEQUENTIAL PROCEDURE

TREND SOME APPLICATIONS OF THE JIRINA SEQUENTIAL PROCEDURE TO OBSERVATIONS WITH AN APPROACH TO THE SCHEDULING OF JOBS ON MACHINES

ON JOHN'S CYCLIC INCOMPLETE BLOCK DESIGNS AMS $63 \quad$ B57 JRSSB6I 484 JRSSB67 243 TE ON THE ERROR AFTER A NUMBER OF TERMS OF THE DAVID-JOHNSON SERIES FOR THE EXPECTED VALUES OF NORMAL ORDE BIOKA6O 79 DETERMINATION OF PARAMETERS IN THE JOHNSON SYSTEM OF PROBABILITY DISTRIBUTIONS OF DISCRETE DISTRIBUTIONS A GENERALIZATION OF JOHNSON'S PROPERTY OF THE MEAN DEVIATION FOR A CLASS B FITTING SEGMENTED CURVES WHOSE JOIN POINTS HAVE TO BE ESTIMATED

THE FACTORIAL MOMENTS OF THE DISTRIBUTION OF JOINS BETWEEN LINE SEGMENTS CENERAL MODELS FOR QUANTAL RESPONSE TO THE JOINT ACTION OF A MIXTURE OF DRUGS

ASSAY

SAMPLES

STATISTIC

DISCRIMINATION AND PARAMETER ESTIMATION RUNS IN A RANDOM SEQUENCE

FROM MULTIVARIATE DISTRIBUTIONS COEFFICIENTS

N OF REGRESSION AND ERROR-SCALE PARAMETERS COEFFICIENTS

F NORMAL POPULATIONS BASED ON SINGLY AND D/ POPULATIONS

TINCTION BETWEEN THE CONDITIONAL PROBABILITY AND THE JOINT PROBABILITY APPROACHES IN THE SPECIFICATION OF BI CONSTRUCTION OF JOINT PROBABILITY DISTRIBUTIONS

BIVARIATE K-STATISTICS AND CUMULANTS OF THEIR JOINT SAMPLING DISTRIBUTION PAIRWISE INDEPENDENCE OF JOINTLY DEPENDENT VARIABLES

IBUTION OF SOME STATISTICS USEFUL IN THE ANALYSIS OF JOINTLY STATIONARY TIME SERIES CHARLES JORDAN, IB7I-I959 JOINT ASYMPTOTIC DISTRIBUTION OF THE MEDIAN AND A UQUERY, JOINT CONFIDENCE LIMITS FOR RANKED OBSERVATIONS A JOINT DESIGN CRITERION FOR THE DUAL PROBLEM OF MODEL ON THE JOINT DISTRIBUTION OF THE CIRCULAR SERIAL CORRELATION THE JOINT DISTRIBUTION OF THE STUDENTIZED RECRESSION JOINT DISTRIBUTIONS WITH PRESCRIBED MOMENTS

BIOKA59 229 BIOKA66 285 JASA 661097 BIOKA54 555 BIOKA64 413 BIOKA66 49 TECH $68 \quad 825$ JRSSB57 144 TECH $66 \quad 368$ TECH 6B I45 BIOKA67 330 JASA 69300 BIOKA56 I6I BIOKA6I I25 BIOKA68 424 AMS $65 \quad 286$ JASA $62 \quad 446$ BIOKA64 4BI AMS 681354 BIOKA5I I79 AMS 62290 AMS 681849 AMS $61 \quad 1$ ECRESSION AND MULTIVARIATE DISTAN/ APPLICATIONS OF JORDAN'S PROCEDURE FOR MATRIX INVERSION IN MULTIPLE R JRSSB63 352 ON THE NOTES BY NEYMAN. BARTLETT AND WELCH IN THIS JOURNAL (VOL. 18, NO, 2, 1956) COMPARISON DESICNS FOR TESTING CONCORDANCE BETWEEN JUDCES RR. 69 229) (CORR. 69 229) COMMENT JRSSB57 I79 PAIRED BIOKA56 II3 THE GUANTTFICATION OF JUDCMENT SOME METHODOLOGICAL SUGGESTTONS SEQUENTIAL SEARCH PROCEDURE FOR LOCATING A RESPONSE JUMP JUMP ANALYSIS

TESTING FOR A JUMP IN THE SPECTRAL FUNCTION

ESTIMATION OF JUMPS, RELIABILITY AND HAZARD RATE

THE FREQUENCY JUSTIFICATION OF SEQUENTIAL TESTS, ADDENDUM

RESPONSE CRITERIA FOR THE BIOASSAY OF VITAMIN K

QUERY COMPLETED RUNS OF LENCTH K ABOVE AND BELOW MEDIAN

EQUILIBRIA UNDER SELECTION FOR K ALLELES

BAYESIAN STRATIFIED TWO-PHASE SAMPLING RESULTS, K CHARACTERISTICS ON TESTING THE EQUALITY OF K COVARIANCE MATRICES CONSTRUCTION OF SECOND ORDER ROTATABLE DESICNS IN K DIMENSIONS A METHOD FOR THE BIOKA69 216 JASA 67 IIO5 TECH 62 6I0 BIOKA59 386 JRSSB61 394 AMS 65 I032 BIOKA53 46B BIOC\$69 NO. 4 TECH $67 \quad 682$ BI0CS66 I2I BIOKA68 58? A CLASS OF SEQUENTIAL PROCEDURES FOR CHOOSING ONE OF K HYPOTHESES CONCERNING THE UNKNOWN DRIFT PARAMETER O A. SEQUENTIAL PROCEDURE FOR SELECTING THE LARCEST OF K MEANS

ON SELECTING THE LARGEST OF K NORMAL POPULATION MEANS (WITH DISCUSSION)

INTERVAL ESTIMATION OF THE LARGEST MEAN OF $K$ NORMAL POPULATIONS WITH KNOWN VARIANCES

ON SELECTING A SUBSET OF K POPULATIONS CONTAINING THE BEST AMS $67 \quad 1376$ AMS $6 B \quad B B$ JRSSB 60 JASA 69296 AMS 67 IO72 OF MISCLASSIFICATION DISCRIMINATION BETWEEN K POPULATIONS WITH CONSTRAINTS ON THE PROBABILITIES JRSSB69 I23 N USEFUL CLASS OF NON-ORTHOGONAL MAIN EFFECT PLANS IN K TO THE N FACTORIAL APPROXIMATE SPECIFICATION AND THE CHOICE OF A K-CLASS ESTIMATOR

A SIMPLE MATHEMATICAL RELATIONSHIP AMONC K-CLASS ESTIMATORS

SENSITIVITY TO SPECIFICATION ERROR OF DIFFERENT K-CLASS ESTIMATORS
/APPROACH FOR CONSTRUCTING A

JASA $67 \quad 126$

JASA $66 \quad 36 B$

THE RELATIVE JASA $66 \quad 345$ 
A K-SAMPLE ANALOGUE OF WATSON'S U-SQUARE STATISTIC

A K-SAMPLE EXTENSION OF THE ONE-SIOED TWO-SAMPLE

SEVERAL K-SAMPLE KOLMOGOROV-SMIROV TESTS

A K-SAMPLE MODEL IN OROER STATISTICS

A NOTE ON 'A K-SAMPLE MODEL IN ORDER STATISTICS' BY $W$. J. CONOVER

OPTIMAL INVARIANT RANK TESTS FOR THE K-SAMPLE PROBLEM

ON ANALYSIS OF VARIANCE FOR THE K-SAMPLE PROBLEM

CONTRIBUTIONS TO THE K-SAMPLE PROBLEM. A SYMMETRIC STATISTIC

ON TWO K-SAMPLE RANK TESTS FOR CENSORED OATA

TWO K-SAMPLE SLIPPAGE TESTS

A DISTRIBUTION-FREE K-SAMPLE TEST AGAINST OROERED ALTERNATIVES

COMPUTATION WITH MULTIPLE K-STATISTICS

TWO APPLICATIONS OF BIVARIATE K-STATISTICS

TENSOR NOTATION AND THE SAMPLING CUMULANTS OF K-STATISTICS

TABLES OF GENERALIZED K-STATISTICS

NATORIAL METHOD FOR MULTIPLE PRODUCTS OF GENERALIZED K-STATISTICS DISTRIBUTION

BIVARIATE K-STATISTICS

MOMENT COEFFICIENTS OF THE K-STATISTICS IN

DISTRIBUTIONS OF A M. KAC STATISTIC

ADDENDUM, THE LIMITING DISTRIBUTION OF KAMAT'S TEST STATISTIC

SOME RULES FOR A COMBI AMS 68 9B3

BIOKA5I 179

BIOKA52

AMS 671919

BIOKA56 386

TER FROM QUANTAL DATA. AND ITS RELA/ ADAPTATION OF KARBER'S METHOD FOR ESTIMATING THE EXPONENTIAL PARAME BIOCS67 739

ON A THEOREM OF KARLIN REGARDING ADMISSIBILITY OF LINEAR ESTIMATES IN AMS 661809 POPULATIONS

ON A THEOREM OF KARLIN REGARDING ADMISSIBLE ESTIMATES FOR EXPONENTIAL COEFFICIENTS. III. DISTRIBUTION OF THE TRANSFORMED KENDALL COEFFICIENT FOR SMALL N OF KENDALI'S PARTTAL RANK CORRELATION CORT RANT BOUNDS FOR THE VARIANCE OF KENDALL'S RANK CORRELATION STATISTIC

THE DISTRIBU'TION OF KENDALL'S SCORE S FOR A PAIR OF TIED RANKINGS

ESTIMATES OF THE REGRESSION COEFFICIENT BASED ON KENDALL'S TAU

DISTRIBUTIONS OF KENDALL'S TAU BASED ON PARTIALLY ORDEREO SYSTEMS

BIOKA56 474

BIOKA60 15I

JASA $6 B \quad 1379$

BI0KA55 417

$\begin{array}{lrl}\text { IATE POPULATION WITH CORRELAT/ THE DISTRIBUTION OF KENDALL'S TAU FOR SAMPLES OF FOUR FROM A NORMAL BIVAR } \\ \text { RANKINGS } & \text { A MODIFICATION OF KENDALL'S TAU FOR THE CASE OF ARBITRARY TIES IN BOTH }\end{array}$

IATE POPULATION WITH CORRELAT/ THE DISTRIBUTION OF KENDALL'S TAU FOR SAMPLES OF FOUR FROM A NORMAL BIVAR BIOKA63 53B
RANKINGS

THE THIRD MOMENT OF KENDALL'S TAU IN NORMAL SAMPLES

A COMPUTER METHOD

BIOKA62 177

JASA $66 \quad 436$

A SIMILARITY BETWEEN GOODMAN AND KRUSKAL'S TAU AND KENDALL'S TAU, WITH A PARTIAL INTERPRETATION OF THE L JASA 62 BO4 FUNCTIONS INTEGRAL KERNELS AND INVARIANT MEASURES FOR MARKOFF TRANSITION

ON DISTRIBUTIONS FOR INHTCH THE HARTLY-KHAMIS SOLUTION OF THE MOMENT-PROBLEM IS EXACT SOME REMARKS CONCERNING KHATRI'S RESULT ON QUADRATIC FORMS

KHINCHIN'S WORK IN MATHEMATICAL PROBABILITY

CORR. $66 \quad 745$

ON CONVERGENCE UF THE KIEFER-WOLFOWITZ APPROXIMATION PROCEDURE

A CONTINUOUS KIEFER-WOLFOWITZ PROCEDURE FOR RANDOM PROCESSES,

ERRORS OF THE THIRD KIND IN STATISTICAL CONSULTING

TOKA51 74

BIOKA68 593

AMS 621227

AMS 671031

AMS 64590 JASA $57 \quad 133$

ACTORIAL EFFECTS AND THEIR CONNECTION WITH A SPECIAL KIND OF IRREGULAR FRACTIONAL PLANS OF FACTORIAL EXPER JASA 63 497 ENOMIN/ ROBUSTNESS OF THE F-TEST TO ERRORS OF BOTH KINDS AND THE CORRELATION BETWEEN THE NUMERATOR AND D JASA 68 660

THE MATHEMATICAL ANALYSIS OF AN EPIDEMIC WITH TWO KINDS OF

NOTE ON A THEOREM OF KINGMAN AND A THEOREM OF CHUNC

PROBABILISTIC COMPLETION OF A KNOCKOUT TOURNAMENT

INFERENCE FROM A KNOCKOUT TOURNAMENT

ENCE INTERVAL FOR THE MEAN

ON THE COST OF NOT KNOWING THE VARIANCE WHEN MAKING A FIXED WIDTH CONFID

BAYES'S THEOREM AND THE USE OF PRIOR KNOWLEDGE IN REGRESSION ANALYSIS

OF A RANDOM PROBABILITY WHOSE FIRST N MOMENTS ARE KNOWN RELATIONSHIPS WHEN BOTH RESIDUAL VARIANCES ARE KNOWN NIMODAL DISTRIBUTIONS WHEN ONE OR BOTH TERMINALS ARE KNOWN SITY WHOSE LEFT TERMINAL AND FIRST THREE MOMENTS ARE KNOWN LE OBSERVATIONS ARE LOGNORMAL AND THE PRECISION H IS KNOWN ON ESTIMATING THE MEAN OF A NORMAL DISTRIBUTION WITH KNOWN COEFFICIENT OF VARIATION A NOTE JA PROCEDURE

THE UTILIZATION OF A KNOWN COEFFICIENT OF VARIATION IN THE ESTIMATION

THE DISTRIBUTTON OF NONCENTRAL MEANS WITH KNOWN COVARIANCE

THE PERCENTILE POINTS OF DISTRIBUTIONS HAVING KNOWN CUMULANTS

'THE PERCENTILE POINTS OF DISTRIBUTIONS HAVING KNOWN CUMULANTS'

WHERE THE QUOTIENT OF THEIR COORDINATES FOLLOWS SOME KNOWN DISTRIBUTION

IABLES WITH INFINITE EXFECTATI/A SHORT PROOF OF A KNOWN LIMIT THEOREM FOR SUM OF INDEPENDENT RANDOM VAR

FOR THE SCALE PARAMETER OF A WEIBULL POPULATION WITH KNOWN SHAPE PARAMETER /ASED ON M ORDER STATISTICS. MEASUREMENTS MADE BY MATCHING WITH KNOWN STANDARDS

INTERVALS FOR THE MEAN OF A NORMAL DISTRIBUTION WITH KNOWN VARIANCE FOR DETERMINING THE MEAN OF A NORMAL POPULATION WITH KNOWN VARIANCE

OF BEST AND OUTLYING NORMAL POPULATIONS WITH KNOWN VARIANCES

OF THE BEST AMONGST THREE NORMAL POPULATIONS WITH KNOWN VARIANCES

OF THE LARGEST MEAN OF $K$ NORMAL POPULATIONS WITH KNOWN VARIANCES

SHORTER CONFIDENCE AMS $63 \quad 574$ A SEQUENTIAL THREE HYPOTHESIS TEST AMS $67 \quad 1365$ DETECTION BIOKA6I 457 ON THE CHOICE BIOKA5B 436 INTERVAL ESTTMATION JASA $69-296$ CTIONS DISEASE CLUSTERING. A GENERALIZATION OF KNOX'S APPROACH TO THE DETECTION OF SPACE-TIME INTERA BIOCS6B 54I VARIABLES A REMARK ON THE KOLMOGOROFF-PETROVSKII CRITERION

SOME KOLMOGOROFF-TYPE INEQUALITIES FOR BOUNDED RANDOM

CHARACTERISTIC PROPERTY A BEST POSSIBLE KOLMOGOROFF-TYPE INEQUALITY FOR MARTINGALES AND A

ON THE PITMAN EFFICIENCY OF ONE-SIDED KOLMOGOROV AND SMIRNOV TESTS FOR NORMAL ALTERNATIONS ON THE CHAPMAN-KOLMOGOROV EQUATION

COLLAPSED MARKOV CHAINS AND THE CHAPMAN-KOLMOGOROV EQUATION

DITY, A COMPARISON OF THE PEARSON CHI-SQUARE AND KOLMOGOROV GOODNESS-OF-FIT TESTS WITH RESPECT TO VALI JA TABLE OF PERCENTAGE POINTS OF KOLMOGOROV STATISTICS

AMS 691086

BIOKA67 641 AMS $69 \quad 764$ AMS $66 \quad 940$ AMS 611333 AMS 63233 JASA $65 \quad 854$ JASA $56 \quad 111$ LE STATISTICS EXACT BAHADUR EFFICIENCIES FOR THE KOLMOGOROV-SMIRNOV AND KUIPER ONE-SAMPLE AND TWO-SAMP AMS 67 I475 APPROXIMATE SAMPLING DISTRIBUTION OF THE TWO SAMPLE KOLMOGOROV-SMIRNOV CRITERION D-SUB-MN. M LESS THAN OR JASA 69 NO 4 ON THE ASYMPTOTIC EFFICIENCY OF THE KOLMOGOROV-SMIRNOV TEST ASYMPTOTIC EFFICIENCY OF THE TWO SAMPLE KOLMOGOROV-SMIRNOV TEST JASA $65 \quad 843$ $\begin{array}{lll}\text { JASA } & 65 & 843 \\ \text { JASA } & 67 & 932\end{array}$ VARIANCE UNKNOWN ON THE KOLMOGOROV-SMIRNOV TEST FOR NORMALITY WITH MEAN AND JASA $67 \quad 399$ ION WITH MEAN UNKNOWN ON THE KOL COROV -SMTRNOV TEST FOR THE EXPONENTIAI DISTRIBUT JASA 69387 ON THE ASYMPTOTIC POWER OF THE ONE-SAMPLE KOLMOGOROV-SMIRNOV TESTS 
AND THEIR PROPERTIES

KOLMOCOROV-SMIRNOV TESTS AND RENYI'S MODIFICATION
KOLMOGOROV-SMIRNOV TESTS OF APPROXIMATE HYPOTHESES BOUNDS

BIOCS6B 1019

LOCAL ASYMPTOTIC POWER AND EFFICIENCY OF TESTS OF KOLMOGOROV-SMIRNOY TYPE AN INEQUALITY CONCERNING TESTS OF FIT OF THE KOLMOGOROV-SMIRNOV TYPE

RESULTS FOR ONE-SIDED DISTRIBUTION TESTS OF THE KOLMOGOROV-SMIRNOV TYPE JASA $68 \quad 919$

AMS 671705 AMS 671240 CORRELATIONS SEVERAL K-SAMPLE KOLMOGOROV-SMTROV TESTS KOLMOGOROV'S REMARK ON THE HOTELLINC CANONICAL AMS 65 BIOKA66 5 5B5 FROM THE RELATION BETWEEN TWO STATISTICS OF THE KOLOMOGOROV-SMIRNOV TYPE FICIENT OF VARIATION, COMMENT ON A CRITICISM MADE BY KOOPMANS, OWEN AND ROSENBLATT ON MATRIX DIFFERENTIATION WITH SPECIAL REFERENCE TO KRONECKER MATRIX PRODUCTS
ASSOCIATION MATRICES AND THE KRONECKER PRODUCT OF DESIGNS ON MATRIX DIFFERENTIATION WITH SPECIAL REFERENCE TO KRONECKER MATRIX PRODUCTS
ASSOCIATION MATRICES AND THE KRONECKER PRODUCT OF DESIGNS RESULTS AMS 691833

/IBUTION OF THE COEF BIOKA65 303 SOME THEOREMS JASA 69953 AMS 68676 SIMPLIFIED BETA-APPROXIMATIONS TO THE KRUSKAL-WALLIS H TEST

A PARTIAL COEFFICIENT FOR GOODMAN AND KRUSKAL'S CAMMA

JASA $59 \quad 225$

JASA $67 \quad 1 B 9$

PRETATION OF THE/ A SIMILARITY BETWEEN GOODMAN AND KRUSKAL'S TAU AND KENDALL'S TAU. WITH A PARTIAL INTER JASA 62 BO4 BAHADUR EFFICIENCIES FOR THE KOLMOCOROV-SMIRNOV AND KUIPER ONE-SAMPLE AND TWO-SAMPLE STATISTICS EXACT AMS 67 I475 A NOTE ON RECIONS FOR TESTS OF KURTOSIS A NOTE ON KURTOSIS

COMMENTS ON PAPER BY KURTZ, LINK, TUKEY AND WALLACE

THE UNIMODALITY OF DISTRIBUTION FUNCTIONS OF CLASS L

BIOKA53 465 JRSSB64 111 TECH 65163 PATIAL RELATIONSHIP AMONG EIGHT POPULATIONS ZEA MAYS L. UTILIZING INFORMATION FROM A DIALLEL MATING DESIGN BIOCSGB BG? BALANCED L-RESTRICTIONAL PRIME POWERED LATTICE DESIGNS CYCLIC COLLINEATIONS FOR OBTAINING A BALANCED SET OF L-RESTRICTIONAL PRIME-POWERED LATTICE DESIGNS $10 F$ AMS 67 I293 AN L-TO-THE-P CONVERGENCE THEOREM

AMS $69106 \mathrm{~B}$ S, SON UTILISATION EN CENETIQUE ET SES RAPPORTS AVEC L'ANALYSE DISCRIMINATOIRE /N COMPOSANTES PRINCIPALE BIOCS66 343 EN CENETIQUE ET SES RAPPORTS AVEC L'ANALYSE DISC/ L'ANALYSE EN COMPOSANTES PRINCIPALES, SON UTILISATION BIOCS66 343 ET LES VARI/ L'ETUDE DES COMMUNAUTES VEGETALES PAR L'ANALYSE STATISTIQUE DES LIAISONS ENTRE LES ESPECES BIOCS65 890

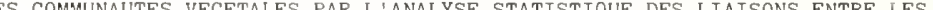
LES MANQUANTS DANS L'ESSAI THERAPEUTIQUE

STIQUE DES LIAISONS ENTRE LES ESPECES ET LES VARI/

STIQUE DES LIAISONS ENTRE LES ESPECES ET LES VARI/

L'ETUDE DES COMMUNAUTES VECETALES PAR L'ANALYSE STATI BIOCS65 345

CORR. 661248 PONDERATION DES VALEURS GENOTYPIQUES DANS LA SELECTION PAR INDEX SUR PLUSIEURS CARACTERES

LABOR FORCE ENTRY AND ATTACHMENT OF YOUNG PEOPLE,

OPTIMIZATION OF QUALITY CONTROL IN THE CHEMICAL LABORATORY

THE STATISTICAL CONSULTANT IN A SCIENTIFIC LABORATORY

THE NEW DESIGN OF THE CANADIAN LABOUR FORCE SURVEY

THE LADY TASTING TEA, AND ALLIED TOPICS

THE ESTIMATION OF A LAGGED REGRESSION RELATION

THE USE OF LACRANCE, MULTIPLIERS WITH RESPONSE SURFACES

LACRANGIAN COEFFICIENTS FOR INTERPOLATION BETWEEN
LACRANGIAN MULTIPLIER TESTS OF LINEAR HYPOTHESES.

TABLED PERCENTAGE POINTS

LOCALLY ASYMPTOTICALLY MOST STRINGENT TESTS AND LACRANC DISTRIBUTIONS

LACUERRE SERIES FORMS OF NON-CENTRAL CHI-SQUARE AND

THE USE OF LAMBDA AS AN INDEX OF PRECISION

ING DISTRIBUTIONS ARE EXPONENTIAL AND GAMMA OF ORDER LAMBDA RESPECTIVELY /HILE THE INTERARRIVAL AND SERV JRSSB66 336

MULTINOMIAL EXPERIMENTS. CORR. $66 \quad 1246$ LAMP TESTS OF LINEAR AND LOGLINEAR HYPOTHESES IN ON IN CONTINGENCY TABLES

LAMST AND THE HYPOTHESES OF NO THREE FACTOR INTERACTI JASA 69207

RECENT EFFORTS TO IMPROVE LAND USE INFORMATION

OF ZONAL POLYNOMIAL COEFFICIENTS BY THE USE OF THE LAPLACE-BELTRAMI OPERATOR

JASA $66 \quad 647$

ORMAL PRIO/ SERIAL SAMPLING ACCEPTANCE SCHEMES FOR LARGE BATCHES OF ITEMS WHERE THE MEAN QUALITY HAS A N BIOKA68 393 ON LOOKING AT LARGE CORRELATION MATRICES

WHICH ARE NOT ATTRACTED TO THE NORMAL LAW ON LARGE DEVIATION PROBLEMS FOR SUMS OF RANDOM VARIABLES BIOKA69 249

NDED, INDEPENDENT RANDOM VA/

ON THE PROBABILITY OF LARGE DEVIATIONS AND EXACT SLOPES

AMS 671575

ON THE PROBABILITY OF LARGE DEVIATIONS OF FAMILIES OF SAMPLE MEANS

IOKA63 52B

MULATIVE DISTRIBUTION FUNCT/

AN INTERVAL OF LENGTH ONE

ON THE PROBABILITY OF LARCE DEVIATIONS OF FUNCTIONS OF SEVERAL EMPIRICAL CU

ON THE PROBABILITY OF LARCE DEVIATIONS OF THE MEAN FOR RANDOM VARIABLES IN

LARCE DEVIATIONS THEORY IN EXPONENTIAL FAMILIES

EFFICIENCY OF TESTS

AN EXAMPLE OF LARCE DISCREPANCY BETWEEN MEASURES OF ASYMPTOTIC AMS 641304 AMS $67 \quad 360$

AMS $65 \quad 2 B 0$

AMS 681402

LOCAL CONVERCENCE OF MARTINGALES AND THE LAW OF LARGE NUMBERS A NOTE ON THE WEAK LAW OF LARGE NUMBERS

ON THE RATE OF CONVERGENCE FOR THE LAW OF LARGE NUMBERS

RATING FUNCTIONS AND CONVERGENCE RATES IN THE LAW OF LARGE NUMBERS

D STATISTICS. XXI.ON THE EARLY HISTORY OF THE LAW OF LARGE NUMBERS

\section{A BOUND FOR THE LAW OF LARGE NUMBERS FOR DISCRETE MARKOV PROCESSES}

RSSB61 476

AMS $65 \quad 552$

AMS 69 N0.6

RANDOM VARI/ ON THE CONVERCENCE RATE OF THE LAW OF LARCE NUMBERS FOR LINEAR COMBINATIONS OF INDEPENDENT

SSES CONVERGENCE RATES FOR THE LAW OF LARGE NUMBERS FOR LINEAR COMBINATIONS OF MARKOV PROCE

SOLUTEL/ AN EXPONENTIAL BOUND ON THE STRONC LAW OF LARCE NUMBERS FOR LINEAR STOCHASTIC PROCESSES WITH AB ON THE STRONG LAW OF LARGE NUMBERS FOR MARTINGALES

SOME THEOREMS CONCERNTNG THE STRONG LAW OF LARCE NUMBERS FOR NON-HOMOGENEOUS MARKOV CHAINS

ABLE AND MIXING/ CONVERGENCE RATES FOR THE LAW OF LARGE NUMBERS FOR THE LINEAR COMBINATIONS OF EXCHANGE

GAUSSIAN SEQUENCE A LAW OF LARGE NUMBERS FOR THE MAXIMUM IN A STATIONARY

CHI-SQUARE PROBABILITIES FOR LARCE NUMBERS OF DEGREES OF FREEDOM

AMS $67 \quad 742$

IOKA6B 459 AMS $61 \quad 336$ AMS $65 \quad 559$ AMS $66 \quad 711$ AMS $615 B 3$ AMS 67610 AMS 64566 AMS $651 B 40$ AMS $62 \quad 93$ ON CONVERGENCE TO INFTNTTY IN THE LAW OF LARCE NUMBERS, (ACKNOWLEDGEMENT OF PRIORITY 63 1111 ) AMS 63 219 APPROXIMATION OF THE SIMPLE STOCHASTIC EPIDEMIC IN A LARGE POPULATION SURVIVAL PROBABILITIES OF NEW INVERSIONS IN LARGE POPULATIONS

THE SIMPLE STOCHASTIC EPIDEMIC CURVE FOR LARCE POPULATIONS OF SUSCEPTIBLES LIKELIHOODS AND COMPARISON WITH POINT ESTIMATES AND LARGE SAMPLE APPROXIMATIONS A PERTURBATION BIOKA68 199 BIOCS6B 501 BIOKA65 571 RM WHICH IS RANDOMLY REPEATING IN GAUSSIAN NOISE

EXAMPLES OF JASA $69 \quad 46 B$ NS REMARKS ON LARGE SAMPLE ESTIMATORS FOR SOME DISCRETE DISTRIBUTIO TECH 67 MANN-WHITNEY STATISTIC ON THE LARGE SAMPLE PROPERTIES OF A GENERALIZED WILCOXON- 
MULTINOMIAL PROPORTIONS

S CORRECTION TO BARTLETT'S CRITERION FOR TESTING/ PROCESSES
LARCE SAMPLE SIMULTANEOUS CONFIDENCE INTERVALS FOR

LARCE SAMPLE TABLES OF PERCENTAGE POINTS FOR HARTLEY

A LARCE SAMPLE TEST FOR THE INDEPENDENCE OF TWO RENEWAL

THE LINEAR HYPOTHESIS AND LARCE SAMPLE THEORY

A NOTE ON QUANTILES IN LARCE SAMPLES

OF EXTREME-VALUE DATA BY SAMPLE QUANTILES FOR VERY LARCE SAMPLES

ICIENT ESTIMATES AND OPTIMUM INFERENCE PROCEDURES IN LARCE SAMPLES (WITH DISCUSSION)

SAMPLING WITH PROBABILITY PROPORTIONATE TO SIZE IN A LARCE SCALE SURVEY

FOR A POPULATION MEAN WHICH REDUCES THE EFFECT OF LARCE TRUE OBSERVATIONS UNCERTAIN CONCENTRATION

VARIABLE IS FALLIBLE

IVE PROCESSES WITH MOVING-AVERAGE RESIDUALS

AVERAGE MODELS

LARGE-SAMPLE COVARIANCE ANALYSIS WHEN THE CONTROL

LARGE-SAMPLE ESTIMATION OF PARAMETERS FOR AUTORECRESS

LARCE-SAMPLE ESTIMATION OF PARAMETERS FOR MOVING-

LARCE-SAMPLE RESTRICTED PARAMETRIC TESTS

AMS $66 \quad 577$

ANALYSIS JASA $68 \quad 877$

EFF JRSSB62 46

\section{ESTIMATION OF THE LARCER TRANSLATION PARAMETER}

PROCEDURES FOR SELECTING THE T POPULATION WITH THE LARGEST ALPHA-QUANTILE

TE ANALYSIS.

MULTIVARIA BIOKA65 405 BILITIES. EXPECTATIONS AND VARIANCES FOR THE SIZE OF LARGEST GLUSTERS AND SMALLEST INTERVALS SOME PROBA JASA 66 I191 OR FOR PRICIPAL COMPON/ ON THE DISTRIBUTION OF THE LARGEST LATENT ROOT AND THE GORRESPONDING LATENT VECT AMS 66 995 HE GENERALIZED B STATISTIC AN/ DISTRIBUTION OF THE LARGEST LATENT ROOT AND THE SMALLEST LATENT ROOT OF T ON THE DISTRIBUTION OF THE LARCEST LATENT ROOT OF THE COVARIANCE MATRIX

AMS 671152 AMS 671148 TIAL PROCEDURE FOR SELECTING THE POPULATION WITH THE LARGEST MEAN FROM K NORMAL POPULATIONS RS INTERVAL ESTIMATION OF THE LARGEST MEAN OF K NORMAL POPULATIONS WITH KNOWN VARIA JASA 69296

EST A SEQUENTIAL PROCEDURE FOR SELECTING THE LARGEST OF K MEANS

AMS 68 (1) ON SELECTING THE LARCEST OF K NORMAL POPULATION MEANS (WITH DISCUSSION JRSSB60 ANALYSIS ON THE DISTRIBUTION OF THE LARGEST OF SEVEN ROOTS OF A MATRIX IN MULTIVARIATE BIOKA64 270 ANALYSIS ON THE DISTRIBUTION OF THE LARGEST OF SIX ROOTS OF A MATRIX IN MULTIVARIATE ESTIMATION OF THE LARGEST OF TWO NORMAL MEANS

$\begin{array}{ll}\text { BIOKA59 } & 237 \\ \text { JASA } 68 & 861\end{array}$ L HYPOTHESIS CONGERNING COMPL/ DISTRIBUTION OF THE LARGEST OR THE SMALLEST CHARACTERISTIC ROOT UNDER NUL AMS 64 1BO' ATE ANALYSIS ON THE DISTRIBUTION OF THE LARGEST OR THE SMALLEST ROOT OF A MATRIX IN MULTIVARI BIOKA56 122 ON THE DISTRIBUTION OF THE LARGEST ROOT OF A MATRIX IN MULTIVARIATE ANALYSIS UPPER PERCENTAGE POINTS OF THE LARGEST ROOT OF A MATRIX IN MULTIVARIATE ANALYSIS B BIOKA67 $1 B 9$ -0 EXTENSION OF TABLES OF PERCENTAGE POINTS OF THE LARGEST VARIANCE RATIO S-SQUARE-MAX-OVER-S-SQUARE-SUB BIOKA67 225

R. A. FISHER AND THE LAST FIFTY YEARS OF STATISTICAL METHODOLOGY 395 WITH TWO SUSCEPTIBLES ONLY $\begin{array}{llllr} & \text { THE LAST RETURN TO EQUILIBRIUM IN A COIN TOSSING GAME AMS } & 64 & 1344 \\ \text { ON ESTIMATING THE LATENT AND INFECTIOUS PERIODS OF MEASLES, I. FAMILIES BIOKA56 } & 15\end{array}$ S WITH THREE OR MORE SUSCEPTIBL/ ON ESTIMATING THE LATENT AND INFECTIOUS PERIODS OF MEASLES, II. FAMILIE BIOKA56 322 LATENT CLASS ANALYSIS AND DIFFERENTIAL MORTALITY JASA 62430 RINGIPAL COMPON/ ON THE DISTRIBUTION OF THE LARGEST LATENT ROOT AND THE CORRESPONDING LATENT VECTOR FOR P AMS 66 995 ALIZED B STATISTIC AN/ DISTRIBUTION OF THE LARCEST LATENT ROOT AND THE SMALLEST LATENT ROOT OF THE GENER AMS 67 II52 ANALYSIS

SOME DISTANCE PROPERTIES OF LATENT ROOT AND VECTOR METHODS USED IN MULTIVARIATE ON THE DISTRIBUTION OF THE LARGEST LATENT ROOT OF THE COVARIANCE MATRIX

BIOKA66 325 AMS 671148 E BIVARIATE NORMAL DISTRIB/ BAYESIAN ESTIMATION OF LATENT ROOTS AND VECTORS WITH SPECIAL REFERENCE TO TH BIOKA69 97 DISTRIBUTIONS OF MATRIX VARIATES AND LATENT ROOTS DERIVED FROM NORMAL SAMPLES AMS 64 475 N CERTAIN CHARAGTERISTICS OF THE DISTRIBUTTON OF THE LATENT ROOTS OF A SYMMETRIC RANDOM MATRIX UNDER CENER AMS GI THE LATENT ROOTS OF CERTAIN STOCHASTIC MATRICES BIOKA62 264 TESTS OF SICNIFICANCE FOR THE LATENT ROOTS OF COVARIANCE AND CORRELATION MATRICES BIOKA56 128 AN ASYMPTOTIC EXPANSION FOR THE DISTRIBUTION OF THE LATENT ROOTS OF THE ESTIMATED COVARIANCE MATRIX ON THE DISTRIBUTION OF THE LATENT VECTORS FOR PRINCIPAL COMPONENTS ANALYSIS LATENT VECTORS OF RANDOM SYMMETRIC MATRICES

THREE FACTOR ADDITIVE DESIGNS MORE GENERAL THAN THE LATIN SQUARE THE MODIFIED LATIN SQUARE ALTERNATIVES TO A LATIN SQUARE TERPRETATION OF THE EFFECTS OF NON-ADDITIVITY IN THE LATIN SQUARE NON-ADDITIVITIES IN A LATIN SQUARE DESIGN ARTIALLY BALANCED INCOMPLETE BLOCK DESIGNS WITH SOME LATIN SQUARE DESIGN PROPERTIES OUNTERBALANCING OF IMMEDIATE SEQUENTIAL EFFECTS IN A LATIN SQUARE DESIGN, CORR. 5B I030 ONE DIRECTION THE ANALYSIS OF LATIN SQUARE DESIGNS WITH INDIVIDUAL

NEW FAMILIES OF PARTIALLY BALANCED DESIGNS OF THE LATIN SQUARE TYPE AND RELATED DESIGNS SOME NON-ORTHOGONAL PARTITIONS OF 4 X4, $5 \times 5$, AND 6 X6 LATIN SQUARES SEQUENTIAL COUNTERBALANCING IN LATIN SQUARES ORY TO THE EXISTENCE AND NON-EXISTENCE OF ORTHOGONAL LATIN SQUARES METHODS OF CONSTRUCTING SETS OF MUTUALLY ORTHOGONAL LATIN SQUARES USING A COMPUTER METHODS OF CONSTRUCTING SETS OF MUTUALLY ORTHOGONAL LATIN SQUARES USING A COMPUTER: II INTERACTION ANALYSIS OF LATIN SQUE KENDALL'S TAU, WITH A PARTIAL INTERPRETATION OF THE LATTER LE IN WHICH THE FORMER CANNOT BE ASSOCIATED WITH THE LATTER DENSITY WHICH IS MEASURABLE WITH RESPECT TO A SIGMA-LATTICE CONDITIONAL EXPECTATION GIVEN A SIGMA-LATTICE AND APPLICATIONS
HE Q-SUB-1 TO Q-SUB-N BY M-SUB-1 TO M-SUB-N MULTIPLE-LATTICE DESIGN /ARITY BETWEEN GOODMAN AND KRUSKAL'S TAU AND JASA 62804 /RIBUTIONS AND PRIOR DISTRIBUTIONS, AN EXAMP JRSSB56 217 ESTIMATED REGRESSION FUNCTION OF T JRSSB69 NO.2 RIAL TREATMENTS IN RECTANGULAR LATTICE DESIGNS GENERAL THEORY OF PRIME-POWER LATTICE DESICNS

BALANCED L-RESTRICTIONAL PRIME POWERED LATTICE DESIGNS NING A BALANCED SET OF L-RESTRICTIONAL PRIME-POWERED LATTICE DESIGNS SIMPLEX LATTICE DESICNS FOR MUTICOMPONENT SYSTEMS THE INV'ARIANCE PRINCIPLE FOR A LATTICE OF RANDOM VARIABLES THE ERRORS OF LATTICE SAMPLINC GENERALIZED LATTICE SQUARE DESICN AMS $66 \quad 741$ BE BIOKA69 NO.3 ON TECH 60507 TECH $61 \quad 111$ AMS $65 \quad 1339$ JRSSB69 NO.2 JASA $61 \quad 368$ JASA $65 \quad 891$ AMS 671127 THE INV'ARIANCE PRINCI TECH $62 \quad 463$ AMS $68 \quad 382$ JRSSB54 140 JASA $66 \quad 821$ RANDOM POINT TO THE NEAREST POINT OF A COSELY PACKED LATTICE. 
THEORY OF PROBABILITY DISTRIBUTIONS OF POINTS ON A LATTICE' 58256 RESENTATION FOR CONDITIONAL EXPECTATIONS GIVEN SIGMA-LATTICES

SOME STATISTICAL PROBLEMS CONNECTED WITH CRYSTAL LATTICES (WITH DISCUSSION)

CORRECTIONS TO 'THE AMS 616 619 A REP AMS 66 I279 JRSSB 64367 JASA $61 \quad 493$ ESTIMATING A MIXED-EXPONENTIAL RESPONSE LAW AN EXTENSION OF THE ARC SINE LAW

ON A GENERALIZATION OF THE FINITE ARC-SINE LAW AMS 62681 AMS $62 \quad 909$ SOME INVARIANT LAWS RELATED TO THE ARC SINE LAW

AMS 68258 A NOTE ON THE WEAK LAW AMS $6 B \quad 2159$

CHARACTERIZING THE NORMAL DISTRIBUTION BY STUDENT'S LAW FORM OF THE BOREL-CANTELLI LEMMA AND THE STRONG LAW THE CHI SQUARE DISTRIBUTION BY THE STUDENT LAW NDOM VARIABLES WHICH ARE NOT ATTRACTED TO THE NORMAL LAW

ON BIOKAG6 603

A SHARPER AMS 65 BOO ON CHARACTERIZING JASA $66 \quad 976$ ON LARGE DEVIATION PROBLEMS FOR SUMS OF RA AMS 67 I575 / DISCUSSION OF 'A SUBJECTIVE EVALUATION OF BODE'S LAW AND AN 'OBJECTIVE' TEST FOR APPROXIMATE NUMERICAL JASA 69 50 A LIMIT LAW CONCERNING MOVING AVERAGES AMS 64424 A GENERALIZATION OF THE LOGISTIC LAW OF GROWTH LOCAL CONVERGENCE OF MARTINGALES AND THE LAW OF LARGE NUMBERS A NOTE ON THE WEAK LAW OF LARGE NUMBERS ON THE RATE OF CONVERGENCE FOR THE LAW OF LARGE NUMBERS

BIOCS69 577 AMS $65 \quad 552$ AMS 68 I348 AMS 69 N0.6 GENERATING FUNCTIONS AND CONVERGENCE RATES IN THE LAW OF LARGE NUMBERS LITY AND STATISTICS. XXI.ON THE EARLY HISTORY OF THE LAW OF LARGE NUMBERS

SOME RESULTS RELATING MOMENT AMS $67 \quad 742$ ENDENT RANDOM VARI/ON THE CONVERGENCE V PROCESSES CONVERGENCE RATES FOR THE LAW OF LARGE NUMBERS FOR LINEAR COMBINATIONS OF MARKO WITH ABSOLUTEL/ AN EXPONENTIAL BOUND ON THE STRONG LAW OF LARGE NUMBERS FOR LINEAR STOCHASTIC PROCESSES ON THE STRONG LAW OF LARGE NUMBERS FOR MARTINGALES

5 SOME THEOREMS CONCERNING THE STRONG LAW OF LARGE NUMBERS FOR NON-HOMOGENEOUS MARKOV CHAIN XCHANGEABLE AND MIXING/ CONVERGENCE RATES FOR THE LAW OF LARGE NUMBERS FOR THE LINEAR COMBINATIONS OF E GAUSSIAN SEQUENCE

III 1 A LAW OF LARGE NUMBERS FOR THE MAXIMUM IN A STATIONARY

AMS $6 I \quad 336$ AMS 65559 AMS 66 7II AMS $61 \quad 583$ AMS $67 \quad 610$ AMS $64 \quad 566$ AMS 65 IB40 AMS $62 \quad 93$ AMS $63 \quad 2 I 9$ AMS $67 \quad 599$ AMS $68 \quad 1479$ AMS 69 NO.6

PROCESSES A REMARK ON THE LAW OF THE ITERATED LOGARITHM CONVERGENCE RATES FOR THE LAW OF THE ITERATED LOGARITHM THE LAW OF THE ITERATED LOGARITHM FOR MIXING STOCHASTIC

LE PROCESSES (ADDENDUM, 69 I855) A COMPARISON OF TESTS OF THE WILKS-LAWLEY HYPOTHESIS IN MULTIVARIATE ANALYSIS

AMS $68 \quad 1 \mathrm{~B} 1 \mathrm{~B}$ BIOKA65 I 49 AMS 68 I381 CONVOLUTIONS OF DISTRIBUTIONS ATTRACTED TO STABLE LAWS

REGTONS FOR THE PARAMETERS IN NON-LINEAR REGRESSTON LAWS VARIABLES ON INFINITELY DIVISIBLE LAWS AND A RENEWAL THEOREM FOR NON-NEGATIVE RANDOM SOME INVARIANT LAWS RELATED TO THE ARC SINE LAW AMS $68 \quad 139$ AMS $68 \quad 258$ BIOKA62 563 A NOTE ON OPTIMUM ALLOCATION FOR A ONE-WAY LAYOUT AN APPROXIMATE METHOD OF ANALYSIS FOR A TWO-WAY LAYOUT RIATE COVARIANCE COMPONENTS FOR THE BALANCED ONE-WAY LAYOUT MAIN-EFFECT ANALYSIS OF THE MENERAL NON-ORTHOGONAL LAYOUT WITH MAXIMUM LIKELIHOOD ESTIMATION OF MULTIVA ON SOME OPTIMUM NONPARAMETRIC PROCEDURES IN TWO-WAY LAYOUTS ON A CLASS OF ALIGNED RANK ORDER TESTS IN TWO-WAY LAYOUTS OF 'SPLIT PLOT' EXPERIMENTS IN COMPLETELY RANDOMIZED LAYOUTS THE ENUMERATION OF ELECTION RETURNS BY NUMBER OF LEAD POSITIONS ON A THEOREM OF CRAMER AND LEADBETTER CONVERGENCE PROPERTIES OF A LEARNING ALGORITHM A NOTE ON 'LEARNING CURVES

MAXIMUM LIKELIHOOD ESTIMATION OF MULTIVA AMS 69 IIOO AMS $65 \quad$ BB JA.SA $67 \quad 1214$ AMS $68 \quad 1115$ JASA $69 \quad 4 B 5$ AMS $64 \quad 369$ AMS $66 \quad 6 B 2$ AMS 641819 JASA 69 NO. 4 AMS 69 NO. 6 JASA $66 \quad 995$ TECH $6 B \quad 379$

BAYESIAN MODEL OF DECISION-MAKING AS A RESULT OF LEARNING FROM EXPERIENCE ESTIMATION OF AN ACCELERATED DEPRECIATION LEARNING FUNCTION A LEARNING MODEL FOR PROCESSES WITH TOOL WEAR

DISTRIBUTIONS ASSOCIATED WITH CERTAIN STOCHASTIC LEARNING MODELS DISTRIBUTIONS FOR SOME RANDOM WALKS ARISING IN LEARNING MODELS LINEAR CURVE FITTING USING LEAST DEVIATIONS

HYPOTHESES

LIMITING AMS 62 12B1 $\begin{array}{rll}\text { JASA } & 5 B & \text { II8 }\end{array}$ AMS $6 I$ I034 JASA $6 I \quad 105$ JRSSB 63 I24 JRSSB $69 \quad 89$ THE LOGIC OF LEAST SQUARES FOUNDATIONS FOR THE THEORY OF LEAST SQUARES OR THE FITTING OF NON-LINEAR REGRESSION FUNCTIONS BY LEAST SQUARES TO A SERIES OF POINTS ACCORDING TO THE CRITERION OF LEAST SQUARES TIGATION OF LINEAR RELATIONS FITTED BY THE METHOD OF LEAST SQUARES (WITH DISCUSSION) TOPICS IN THE INVES JRSSB67 I UNIFIED LEAST SQUARES ANALYSIS

TONS AND ERROR STRUCTURES UNDER WUTCH CERTAIN LEAST SQUARES AND BEST UNBIASED ESTIMATES AMS $62 \quad 266$

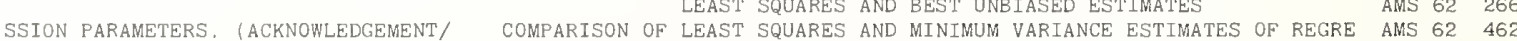
THE EXACT SAMPLING DISTRIBUTTON OF ORDTNARY LEAST SQUARES AND TWO-STAGE LEAST SQUARES ESTIMATORS JASA 69 923 LINEAR REGRESSION A THEOREM ON LEAST SQUARES AND VECTOR CORRELATION IN MULTIVARIATE

JASA $66 \quad 413$ BIOCS69 159 RESTRICTED LOCATTON FOR THE STATTONARY POT LEAST SQUARES ESTIMATE OF SOIL CONTENT JASA 64564

TERS USING ORDER STATISTICS

SYMMETRIC MATRIX HE 'PREDICTOR' VARIABLES A/ ON A RESTRICTED LEAST SQUARES ESTIMATOR ON THE ASYMPTOTIC EFFTCIENCY OF LEAST SQUARES ESTIMATORS ASYMPTOTIC PROPERTIES OF NON-LINEAR LEAST SQUARES ESTIMATORS DISTRIBUTION OF ORDINARY LEAST SQUARES AND TWO-STAGE LEAST SQUARES ESTIMATORS REPLICATION DESIGNS APPROACH GENERALIZED LEAST SQUARES ESTIMATORS FOR RANDOMIZED FRACTIONAL
WHEN ARE GAUSS-MARKOV AND LEAST SQUARES ESTIMATORS IDENTICAL. A COORDINATE-FREE A THEOREM ON LEAST SQUARES IN MULTIVARIATE LINEAR REGRESSION AMS $65 \quad 638$ LEAST SQUARES ESTIMATES LEAST SQUARES ESTIMATION
LEAST SQUARES ESTIMATION OF LOCATION AND SCALE PARAME LEAST SQUARES ESTIMATION OF LOCATION AND SCALE PAR P
ON THE LEAST SQUARES ESTIMATION OF NON-LINEAR RELATIONS
LEAST SQUARES ESTIMATION OF THE COMPONENTS OF A IOKA52 88 AMIS $69 \quad 462$ TECH $66 \quad 360$ JASA 69964 AMS 62 I365 AMS 661676 AMS 69633 JASA 69923 AMS $63 \quad 447$ AMS 64696 AMS $68 \quad 70$ $\begin{array}{rrr}\text { JASA } 67 & \text { I } 494\end{array}$ NON-NEGATIVE COVARIANCE MATRICES AND BEST AND SIMPLE LEAST SQUARES LINEAR ESTIMATORS IN LINEAR MODELS / AMS 67 1O92

OM THE POINT OF VIEW OF THE USER AN APPRAISAL OF LEAST SQUARES PROGRAMS FOR THE ELECTRONIC COMPUTER FR JASA 67 8I9 
LINEAR LEAST SQUARES REGRESSION

TTS APPLICATION TO THE ANALYSIS OF/ 651249 ERROR

ON LEAST SQUARES MHEN THE PARAMETERS ARE STOCHASTIC AND STEPWISE LEAST SQUARES, RESIDUAL ANALYSIS AND SPECIFICATION

LINEAR APPROXTMATION USTNG THE CRITERION OF LEAST TOTAL DEVIATIONS (ACKNONLEDGEMENT 67587 ) FACTORIZATION OF MATRICES BY LEAST-SQUARES

HIPS (WITH DISCUSSION)

A GENERALIZED

969

BIOKA65 447 JASA $64 \quad 1078$ JASA 61998 JRSSB67 101 BIOKA62 239 $\begin{array}{ll}\text { BIOKA62 } & 239 \\ \text { JRSSB66 } & 278\end{array}$ JRSSB68 490 JRSSB6B 284 BIOKA53 457

A NOTE ON THE EFFICIENCY OF LEAST-SQUARES ESTIMATES A NOTE ON ORDERED LEAST-SQUARES ESTIMATION

IN RANDOMIZED FRACTIONAL FACTORIAL E/ GENERALIZED LEAST-SQUARES ESTIMATION OF A SUBVECTOR OF PARAMETERS

A NECESSARY AND SUFFICIENT CONDITION THAT ORDINARY LEAST-SQUARES ESTIMATORS BE BEST LINEAR UNBIASED LINEAR MODEL ON THE BIAS OF SOME LEAST-SQUARES ESTIMATORS OF VARIANCE IN A GENERAL BE EITHER NON-NEGATIVE. NON-DECREASING OR CONVEX LEAST-SQUARES FITTING OF A POLYNOMIAL CONSTRAINED TO SUBSIDIARY SEQUENCES FOR SOLVING LESER'S LEAST-SQUARES GRADUATION EQUATIONS

ATION OF RESIDUAL VARIANCE IN QUADRATICALLY BALANCED LEAST-SQUARES PROBLEMS AND THE ROBUSTNESS OF THE F-TE B TESTS FOR SPECIFICATION ERRORS IN CLASSICAL LINEAR LEAST-SQUARES REGRESSION ANALYSIS N IN REGRESSION ANALYSIS BASED ON THE PERIODOGRAM OF LEAST-SQUARES RESIDUALS TIME SERIES ANALYSIS BY MODIFIED LEAST-SQUARES TECHNIQUES

REVOLUTION IN STATISTICS (THE FIRST FISHER MEMORIAL LECTURE) CENTENARY LECTURE, KARL PEARSON, 1B57-1957 TESTS FOR SERIAL CORRELATIO COMPUTTERS, THE SECOND BIOKA57 303 FORMATIONS USEFUL IN MULTIVARIATE ANALYSIS. BASED ON LECTURES BY P.L. HSU /BIANS OF CERTAIN MATRIX TRANS BIOKA5I 345 OBITUARY SULTY IEDERMANI

BIOCS67 366

IBUTIONS

NOTES.TABLES OF PEARSON-LEE-FISHER FUNCTIONS OF SINGLY TRUNCATED NORMAL DISTR BIOCS65 219 BUTIONS THE EXPECTED COVERAGE TO THE LEFT OF THE I'TH ORDER STATISTIC FOR ARBITRARY DISTRI AMS 69 644 SON DENSITIES FOR APPROXIMATING A SKEW DENSITY WHOSE LEFT TERMINAL AND FIRST THREE MOMENTS ARE KNOWN /AR BIOKA68 559 QUASI-STATIONARY BEHAVIOUR OF A LEFT-CONTINUOUS RANDOM WALK UTION OF THE MANN-WHITNEY-WILCOXON U-STATISTIC UNDER LEHMANN ALTERNATIVES DISTRIBUTION OF THE MANN-WHITNEY U-STATISTICS UNDER LEHMANN ALTERNATIVES OF A RANK-ORDER SEOUENTIAL PROBABILITY RATIO TEST ON LEHMANN ALTERNATIVES CORR GT I3OS PR SEQUENTIAL PROBABILITY RATIO TEST ON LEHMANN ALTERNATIVES, CORR, 67 1309 STOPPING TIME
ROBUSTNESS OF THE HODGES-LEHMANN ESTIMATES FOR SHIFT ON THE HODGES AND LEHMANN SHIFT ESTIMATOR IN THE TWO SAMPLE PROBLEM AMS $69 \quad 532$ THE SMALL SAMPLE PROPERTIES OF A TWO SAMPLE TEST OF LEHMANN'S AN INVESTIGATION INTO J ON BARTLETT'S TEST AND LEHMANN'S TEST FOR HOMOGENEITY OF VARIANCES THE MOMENTS OF THE LEIPNIK DISTRIBUTION ON THEORY TESTS I. A GENERALIZATION OF NEYMAN PEARSON'S LEMMA GENERALIZATION OF SVERDRUP'S LEMMA AND ITS APPLICATIONS TO MULTIVARIATE DISTRIBUTI A SHARPER FORM OF THE BOREL-CANTELLI LEMMA AND THE STRONG LAW A COMBINATORIAL LEMMA FOR COMPLEX NUMBERS A TECHNICAL LEMMA FOR MONOTONE LIKELIHOOD RATIO FAMILIES A LEMMA FOR MULTIPLE INFERENCE PPLICATIONS TO LEAST SQUARES TYPE QUADRA/A USEFUL LEMMA FOR PROVING THE EQUALITY OF TWO MATRICES WITH A JASA 69 969 DISTRIBUTION AND THE OCCURRENCE DISTRIBUTION OF WORD LENGTH AND ITS IMPORTANCE FOR THE STUDY OF QUANTITATI BIOKA5B 222 DISTRIBUTION FUNCTION, II DISTRIBUTION FUNCTION, III REGRESSION FUNCTION CAPACITY EXISTENCE OF BOUNDED LENGTH CONFIDENCE INTERVALS BOUNDED LENGTH CONFIDENCE INTERVALS FOR THE P-POINT OF A BOUNDED LENGTH CONFIDENCE INTERVALS FOR THE P-POINT OF A BOUNDED LENGTH CONFIDENCE INTERVALS FOR THE ZERO OF A AMS $66 \quad 581$ AMS $66 \quad 586$ AMS $62 \quad 237$ JRSSB $66 \quad 190$ AMS $67 \quad 1175$ TECH $67 \quad 682$ CONFIDENCE INTERVAL OF PREASSIGNED LENGTH FOR THE BEHRENS-FISHER PROBLEM QUERY, COMPLETED RUNS OF LENGTH K ABOVE AND BELOW MEDIAN NG UPPER AND LOWER LIMITS FOR THE AVERAGE SAMPLE RUN LENGTH OF A CUMULATIVE SUM SCHEME /RE FOR DETERMINI J MEASURING THE LENGTH OF A CURVE

EXPECTED ARC LENGTH OF A GAUSSIAN PROCESS ON A FINITE INTERVAL LENGTH OF CONFIDENCE INTERVALS

MORE ON LENGTH OF CONFIDENCE INTERVALS

PROPORTIONAL SAMPLING IN IIFE LENGTH STUDIES

TO THE POWER OF N-R DESIGNS HAVING WORDS OF EQUAL LENGTHS

ON IDENTITY RELATIONSHIPS FOR TWO AVERAGE RUN LENGTHS IN CUMULATIVE CHART QUALITY CONTROL SCHEMES ON THE LENGTHS OF INTERVALS IN A STATIONARY POINT PROCESS

(CORR. 63 500) OSCEDASTICITY CRITERION M UNDER UNEQUAL VARIANCE AND LEPTOKURTOSIS /UTIONS OF BIVARIATE T-SQUARE AND HOM JA GETALES PAR L'ANALYSE STATISTIQUE DES LIAISONS ENTRE LES ESPECES ET LES VARIABLES ECOLOGIQUES, PRINCIPES F
GETALES PAR L'ANALYSE STATISTIQUE DES LIAISONS ENTRE LES ESPECES ET LES VARIABLES ECOLOGIQUES, UN EXEMPLE LES MANOUANTS DANS IESSAI THERAPEUTIQUE SUBSIDIARY SEQUENCES FOR SOLVING LESER'S LEAST-SQUARES GRADUATION EQUATIONS OPSOMMING VAN LESINGS. (SUMMARY OF PAPERS)

263 BIOKA66 359 JRSSB56 257 JASA $61 \quad 549$ JASA $62 \quad 586$ TECH 67205 AMS 66 1B42 TECH $61 \quad 11$ JRSSB62 364 JASA 631048 BIOCS65 345 BI0CS65 890 BI0CS67 145 JRSSB62 112 SASJ 6B 55 TWO SAMPLE KOLMOGOROV-SMIRNOV CRITERION D-SUB-MN, M LESS THAN OR EQUAL TO N /MPLING DISTRIBUTION OF THE JASA 69 NO. 4 AND CONFIDENCE LIMITS, FOR THE PROBABILITY THAT Y TS LESS THAN X WHEN X AND Y ARE NORMAL /ENCE BOUNDS.

THE ROBBINS-MONRO METHOD FOR ESTIMATING THE MEDIAN LETHAL DOSE MARK TWAIN AND THE QUINTUS CURTIUS SNODGRASS LETTERS, A STATISTICAL TEST OF AUTHORSHIP

JASA 64906 JRSSB65 2B JASA $63 \quad 85$ NCY THE MEDIAN SIGNIFICANCE LEVEL AND OTHER SMALL SAMPLE MEASURES OF TEST EFFICIE JASA 6997 EXPECTED SIGNIFTCANCE LEVEL AS A SENSITIVITY INDEX FOR TEST STATISTICS 420 THE MOMENTS OF THE NUMBER OF CROSSINGS OF A LEVEL BY A STATIONARY NORMAL PROCESS AMS 65 1656 AMS 682108 ON A LIMIT DISTRIBUTION OF HIGH LEVEL CROSSINGS OF A STATIONARY GAUSSIAN PROCESS TECH 60 SOME NEW THREE LEVEL DESIGNS FOR THE STUDY OF QUANTITATIVE VARIABLES TEC ERRATA, 'SOME NEW THREE LEVEL DESIGNS FOR THE STUDY OF OUANTITATIVE VARIABLES TECH 61576 OF HALF-NORMAL PLOTS IN INTERPRETING FACTORIAL TWO LEVEL EXPERIMENTS

FACTOR CHANGES AND LINEAR TRENDS IN EIGHT-RUN TWO LEVEL FACTORIAL DESIGNS A CHANGE IN LEVEL OF A NON-STATIONARY TIME SERIES USE TECH 59 TII TECH $68 \quad 301$ BIOKA65 181 
MS DEMAND FOR FARM PRODUCTS AT RETAIL AND THE FARM LEVEL. SOME EMPIRICAL MEASUREMENTS AND RELATED PROBLE JASA 58 656

RESPONSE SURFACE DESICNS FOR THREE FACTORS AT THREE LEVELS

TECH $59 \quad 1$

THE NORMAL STATIONARY PROCESS, AREAS OUTSIDE CIVEN LEVELS

SURFACE DESICNS FOR FACTORS AT TWO AND THREE LEVELS

TESTINC A TREATMENT FACTOR AT FOUR EQUALLY SPACED LEVELS (CORR. 67586 )

ON JRSSB63 189

RESPONSE TECH $68 \quad 177$ PROCESSES

ON CROSSINCS OF LEVELS AND CURVES BY A WIDE CLASS OF STOCHASTIC THE EFFECTS OF ERRORS IN THE FACTOR LEVELS AND EXPERIMENTAL DESICN
CHOICE OF LEVELS OF POLYNOMIAL RECRESSION WITH ONE OR TWO THE EFFECTS OF ERRORS IN THE FACTOR LEVELS AND EXPERIMENTAL DESICN
CHOICE OF LEVELS OF POLYNOMIAL RECRESSION WITH ONE OR TWO JRSSB $67 \quad 370$

VARIABLES

AMS $66 \quad 260$

TECH $63 \quad 247$ TECH $65 \quad 325$ ION FOR SAMPL/S OF SENSITIVITY EXPERIMENTS WAEN THE LEVELS OF STIMULUS CANNOT BE CONTROLLED, CORR. 56 650 JASA 56 257 ION FOR SAMPL/ COMPACT TABLE OF TWELVE PROBABILITY LEVELS OF THE SYMMETRIC BINOMIAL CUMULATIVE DISTRIBUT JASA 59 164 ON A THEOREM OF HOEL AND LEVINE ON EXTRAPOLATION A THEOREM OF LEVY AND A PECULIAR SEMIGROUP

AN EXAMPLE OF THE DIFFERENCE BETWEEN THE LEVY AND LEVY-PROKHOROV METRICS AMS 69322 AMS $69 \quad 322$ AN EXAMPLE OF THE DIFFERENCE BETWEEN THE LEVY AND LEVY-PROKHOROV METRICS COMMUNAUTES VEGETALES PAR L'ANALYSE STATISTIQUE DES LIAISONS ENTRE LES ESPECES ET LES VARIABLES ECOLOGIQU BIOCS65 B9O COMMUNAUTES VEGETALES PAR L'ANALYSE STATISTIQUE DES LIAISONS ENTRE LES ESPECES ET LES VARIABLES ECOLOGIQU BIOCS65 345 FOR A STATISTICAL PROBLEM TO BE INVARIANT UNDER A LIE GROUP NECESSARY AND SUFFICIENT CONDITIONS AMS 63 49 PROBABILITY THAT THE SAMPLE DISTRIBUTION FUNCTION LIES BETWEEN TWO PARALLEL STRAIGHT LINES SYSTEMS STRUCTURE AND THE EXISTENCE OF A SYSTEM LIFE

A SYSTEM OF MODELS FOR THE LIFE CYCLE OF A BIOLOGICAL ORGANISM OPTIMAL ACCELERATED LIFE DESIGNS FOR ESTIMATION

THREE ORDER STATISTTC CONFTDENCE BOUNDS ON RELIABLE LIFE FOR A WETBULL MODEL WITH PROGRESSTVE CENSORING ON THE DETERMINATION OF A SAFE LIFE FOR CLASSES OF DISTRIBUTIONS CLASSIFIED BY FAILU PARAMETER SEQUENTIAL LIFE FOR THE EXPONENTIAL DISTRIBUTION WITH CHANGING ON EVALUATION OF WARRANTY ASSURANCE WHEN LIFE HAS A WEIBULL DISTRIBUTION

ON EVALUATION OF WARRANTY ASSURANCE WHEN LIFE HAS A WEIBULL DISTRIBUTION THE ASSUMPTIONS THAT THE UNDERLYING DISTRIBUTION OF LIFE IS EXPONENTIAL, PART II /S FOR THE VALIDITY OF TECH 60 167 PROPORTTONAL SAMPLING IN LTFE LENCTH STUDIES

ESTIMATES OF BOUNDED RELATIVE ERROR FOR THE MEAN LIFE OF AN EXPONENTIAL DISTRIBUTION 57578 ESTIMATING THE SERVICE LIFE OF HOUSEHOLD GOODS BY ACTUARIAL METHODS. CORR.

ON THE POSSIBILITY OF IMPROVING THE MEAN USEFUL LIFE OF ITEMS BY ELIMINATING THOSE WITH SHORT LIVES ON GROWTH PARAMETER ESTIMATION FOR EARLY LIFE STACES A COMPARISON OF TWO LIFE TABLE METHODS A LIFE TABLE THAT AGREES WITH THE DATA A LIFE TABLE THAT ACREES WITH THE DATA. II WORKINC LIFE TABLES FOR MALES IN CHANA 1960 CCESSIVE CENS/ METHOD OF CONSTRUCTION OF ATTRITION LIFE TABLES FOR THE SINGLE POPULATION BASED ON TWO SU JASA 67 1433 TABLES FOR A PRECEDENCE LIFE TEST STATISTICAL LIFE TEST ACCEPTANCE PROCEDURES THE ANALYSIS OF LIFE TEST DATA ESTIMATION FROM LIFE TEST DATA

DTSTRIBUTED FAILURE TTME DISTRTBUTTONS

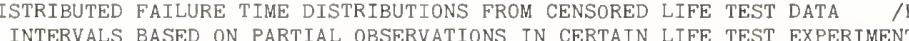

NE FAILURE RATE

DISTRIBUTIONS
COMPARATIVE COST OF TWO LIFE TEST PROCEDURES EXPONENTIAL LIFE TEST PROCEDURES WHEN THE DISTRIBUTION HAS MONOTO J DISTRIBUTION-FREE LIFE TEST SAMPLING PLANS

LIFE TEST SAMPLING PLANS FOR NORMAL AND LOGNORMAL

AN OPTIMAL SEQUENTIAL ACCELERATED LIFE TEST

A PROBLEM IN LIFE TESTING

FACTORIAL EXPERIMENTS IN LIFE TESTINC

EARLY FATLURES IN LIFE TESTING

PROGRESSIVELY CENSORED SAMPLES IN LIFE TESTING

THE SAMPLING DISTRIBUTION OF AN ESTIMATE ARISING IN LIFE TESTING

ON PRECEDENCE LIFE TESTINC

A GENERALIZED SAVAGE STATISTIC WITH APPLICATIONS TO LIFE TESTING

OF RELIABILITY FOR SOME DISTRIBUTIONS USEFUL IN LIFE TESTING

NEGATIVE MOMENTS OF THE POSITIVE BINOMIAL USEFUL IN LIFE TESTING

QUERY LIFE TESTINC AND EARLY FATLURE

A BIBLIOCRAPHY ON LIFE TESTING AND RELATED TOPICS

A SUPPLEMENT TO MENDENHALL'S BIBLIOCRAPHY ON LIFE TESTING AND RELATED TOPICS. CORR. 65 1249 BAYESIAN APPROACH TO LIFE TESTING AND RELIABILITY ESTIMATION

PARAMETER EXPONENTIAL DISTRIBUTION

LIFE TESTING AND RELIABILITY ESTIMATION FOR THE TWO

CRAPHICAL ESTIMATION OF MIXED WEIBULL PARAMETERS IN LIFE TESTINC ELECTRON TUBES

DISTRIBUTION THE ROBUSTNESS OF LIFE TESTING PROCEDURES DERIVED FROM THE EXPONENTIAL

SOME FXPERTMENTAL DESIGN PROBLEMS IN ATTRIBUTE LIFE TESTING, CORR. 631161

ERRATA, 'FACTORIAL EXPERIMENTS IN LIFE TESTINC'

GAMMA DISTRIBUTION IN ACCEPTANCE SAMPLING BASED ON LIFE TESTS ON THE POWER OF PRECEDENCE LIFE TESTS

OPERATING CHARACTERISTIC FOR TRUNCATED SEQUENTIAL LIFE TESTS IN THE EXPONENTIAL CASE

$$
\text { A STATISTICAL MODEL FOR LIFE-LENGTH OF MATERIALS }
$$

LIFE-TESTINC RESULTS BASED ON A FEW HETEROGENEOUS

LOCNORMAL OBSERVAITONS

THE ANALYSIS OF EXPONENTIALLY DISTRIBUTED LIFE-TIMES WITH TWO TYPES OF FAILURE

ILLUSTRATIVE TABLES OF SCHOOL LIFE, CORR, 641299

A NOTE ON THE RENEWAL FUNCTION WHEN THE MEAN RENEWAL LIFETIME IS INFINITE

BRANCHING PROCESS IN WHICH INDIVIDUALS HAVE VARIABLE LIFETIMES

ON THE LIFTING PROPERTY, V

OVERFLOW AT A TRAFFIC LIGHT

LIGHT BULB STATISTICS, CORR. 661248

ON THE TRAFFTC LIGHT QUEUE

AIDS FOR FITTING THE CAMMA DISTRIBUTION BY MAXIMUM LIKELIHOOD

MOMENT ESTIMATORS AND MAXIMUM LIKELIHOOD

FOR FITTING THE LOGISTIC FUNCTION BY MAXIMUM LIKELIHOOD

DISTRIBUTTON. III ACCURACY OF ESTIMATION BY MAXIMUM LIKELIHOOD

LITY AND STATISTICS. XI. DANIEL BERNOULLI ON MAXIMUM LIKELIHOOD
TECH $62 \quad 140$

JASA $67 \quad 548$

TECH $66 \quad 591$

TECH $62 \quad 151$

TECH $62 \quad 367$

JASA $57 \quad 350$

TECH 59269

JASA $60 \quad 491$

TECH $63 \quad 327$

TECH $63 \quad 361$

TECH $65 \quad 359$

ON AMS 68 1591

ESTIMATES TECH $64 \quad 215$

$\begin{array}{rll}\text { ESTIMATES TECH } & 64 & 215 \\ \text { ION OF THE TECH } & 60 & 227\end{array}$

TECH $66 \quad 539$

BIOKA5B 521

JASA $64 \quad 1231$

JASA $67 \quad 48$

$\begin{array}{llll} & \text { JASA } & 69 & 621\end{array}$

A TECH 59389

TECH 6129

JASA $62 \quad 66 \mathrm{~B}$

TECH $60 \quad 121$

JASA 61942

TECH $67 \quad 154$

EXACT AMS 621403

JASA $58 \quad 151$

JASA $67 \quad 45$

JRSSB59 411

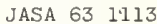

JRSSB61 230

A BIOKA64 262

AMS $65 \quad 819$

BIOKA59 420

JASA $66 \quad 633$

AMS $64 \quad 380$

TECH $60 \quad 55$

BIOKA58 41]

NOMOGRAMS BIOKA60 121

THE FOLDED NORMAL TECH $62 \quad 249$ STUDIES IN THE HISTORY OF PROBABI BIOKA61 


\section{A GENERAL MAXIMUM LIKELIHOOD DISCRIMINANT}

WHEN BOTH VARIABLES ARE SUBJECT TO ERROR

LIKELIHOOD DISTRIBUTIONS FOR ESTIMATING FUNCTIONS

ON THE SOLUTION OF THE LIKELIHOOD EQUATION BY ITERATION PROCESSES

CORRIGENDA, ON THE SOLUTION OF THE LIKELIHOOD EQUATION BY ITERATION PROCESSES

UATION OF THE MAXIMUM-LIKELIHOOD ESTIMATOR WHERE THE LIKELIHOOD EQUATION HAS MULTIPLE ROOTS

A NOTE ON THE CONSISTENCY AND MAXIMA OF THE ROOTS OF LIKELIHOOD EQUATIONS

METRIC CASE

ON THE SOLUTION OF LIKELIHOOD EQUATIONS BY ITERATION PROCESSES MULTIPARA

EANS OF THE CAPTURE-RECAPTURE METHOD. I. THE MAXIMUM LIKELIHOOD EQUATIONS FOR ESTIMATING THE DEATH-RATE

REMARK ON THE LINEARIZED MAXIMUM LIKELIHOOD ESTIMATE

N MINIMUM NORMIT CHI-SQUARE ESTIMATE AND THE MAXIMUM LIKELIHOOD ESTIMATE /ES. PART II. COMPARISON BETWEE BI

OF A NONCENTRAL CHI-SQUARE VARIATE

QUERY, MAXIMUM LIKELIHOOD ESTIMATE IN INTRACLASS CORRELATION MODEL

THE MAXIMUM LIKELIHOOD ESTIMATE OF THE NON-CENTRALITY PARAMETER MAXIMUM LIKELIHOOD ESTIMATES FOR A MULTIVARIAT
APPROXIMATE MAXIMUM LIKELIHOOD ESTIMATES FROM GROUPED DATA

TERS GIVEN A TYPE II CENS/ THE BIAS OF THE MAXIMUM LIKELIHOOD ESTIMATES OF THE LOCATION AND SCALE PARAME

CENSORED SAMPLES

TABLES FOR MAXTMUM LIKEL

BIOCS67 154

AMS 611214

BI0CS67 313

TECH 67261

BIOKA61 452

BIOKA62 284

BIOKA66 151

BIOKA62 479

BIOKA5I 269

AMS $67 \quad 1876$

TABLES FOR MAXIMUM LIKELIHOOD ESTIMATES.
PICATION TO MAXIMUM LIKELIHOOD ESTIMATION

MONOTONE CONVERGENCE OF

BIOKA57 411

INOMIAL PROBABILITIES WITH AN APPLICATION

STRIBUTIONS AND ITS APPLICATION TO A TRUN/

LIKELIHOOD ESTIMATION FOR DISTRIBUTIONS WITH MONOTONE AMS 65 6 69

ED ON COMPLETE AND ON CENSORED SAMPLES MAX IMUM LIKELIHOOD ESTIMATION FOR GENERALIZED POWER SERIES DI JASA $67 \quad 125 B$ JASA 57200 TECH 67599 ED ON COMPLETE AND ON CENSORED S/ ERRATA. RELATIONSHIP

SHIP MAXIMUM LIKELIHOOD ESTIMATION FOR THE TRUNCATED POISSON

BIOKA62 227 MAX IMUM LTKEI IHOOD ESTIMATION IN MAXIMUM LIKELIHOOD ESTIMATION OF A LINEAR FUNCTIONAL AMS 6I 104B ONENTS FOR THE BALANCED ONE-WAY LAYOUT MAXIMUM LIKELIHOOD ESTIMATION OF A LINEAR STRUCTURAL RELATION JASA 64 1175 MAXIMUM LIKELIHOOD ESTIMATION OF MULTIVARIATE COVARIANCE COMP AMS 691100 MAXIMUM LIKELIHOOD ESTIMATION OF SURVIVAL CURVE PARAMETERS BIOCS6B 595 $\begin{array}{llllll}\text { MAXIMUM LIKELIHOOD ESTIMATION OF THE DISTRIBUTIONS OF TWO STO JASA } & 66 & 1067 \\ \text { MAXIMUM LIKELIHOOD ESTIMATION OF THE LOGISTIC GROWTH FUNCTION JASA } 66 & 697\end{array}$ CHASTICALLY ORDERED RANDOM VARIABLES ASPECTS OF MAXIMUM LIKELIHOOD ESTIMATION OF THE LOGISTIC GROWTH FUNCTION JASA 66 697 WEIBULL POPULATIONS FROM COMPLETE AND FRO/ ISTRIBUTION FROM SMALLEST ORDER STATISTICS MAXTMUM LTKELIHOOD ESTIMATION OF THE PARAMETERS OF THE BETA D TECH $67 \quad 607$ MAXIMUM LIKELIHOOD ESTIMATION OF THE PARAMETERS OF THE GAMMA TECH 69 NO.4 DISTRIBUTION AND THEIR BIAS METER LOGNORMAL POPULATIONS FROM CO/ LOCAL-MAXIMUM-LIKELIHOOD ESTIMATION OF THE PARAMETERS OF THREE-PARA J

SEQUENTIAL MAXIMUM LIKELIHOOD ESTIMATION OF THE SIZE OF A POPULATION

DATA MAXIMUM LIKELIHOOD ESTIMATION WITH INCOMPLETE MULTIVARIATE

MENT OF PRIORITY FOR 'AN OPTIMUM PROPERTY OF MAXIMUM LIKELIHOOD ESTIMATION' 60 1208 ACKNOWLEDGE ASA $66 \quad 842$ AMS 681057 AMS $64 \quad 647$ AMS $61 \quad 1343$ AMS $66 \quad 744$ INVARIANCE OF MAXIMUM LIKELIHOOD ESTIMATIONS

TH LEAST SQUARES WEICHTED LEAST SQUARES AND MAXIMUM LIKELIHOOD ESTTMATORS

CES, SAMPLING EXPERIMENTS WI BIOCS68 607 ESSIVE DISTURB/ ASYMPTOTIC DISTRIBUTION OF MAXIMUM LIKELIHOOD ESTIMATORS IN A LINEAR MODEL WITH AUTOREGR AMS 69 583 THE CASE OF AUTOCORRELATED RESIDUALS MAXIMUM LIKELIHOOD ESTIMATORS OF REGRESSION COEFFICIENTS FOR TECH 65 STEMS IN SE/ MINIMUM VARIANCE UNBIASED AND MAXIMUM LIKELIHOOD ESTIMATORS OF RELIABILITY FUNCTIONS FOR SY JASA 66 IO52 OPULATIONS THE ASYMPTOTIC PROPERTIES OF MAXIMUM LIKELIHOOD ESTIMATORS WHEN SAMPLING FROM ASSOCIATED P BIOKAGR P/ ASYMPTOTIC VARIANCES AND COVARIANCES OF MAXIMUM-LIKELIHOOD ESTIMATORS, FROM CENSORED SAMPLES, OF THE AMS 67 557 LIKELIHOOD FUNCTION FOR CAPTURE-RECAPTURE SAMPLES BIOKA56 488

OLVING TWO/ THE USE OF TRANSFORMATIONS AND MAXIMUM LIKELIHOOD IN THE ANALYSIS OF QUANTAL EXPERIMENTS INV BIOKA55 3B2 MAXIMUM LIKELIHOOD IN THREE-WAY CONTINGENCY TABLES

JRSSB 63220 DISTRIBUTIONS TO SOME AVAILABLE DATA BY THE MAXIMUM LIKELIHOOD METHOD (CORR, 65 514) /F SOME CONTAGIOUS BIOCS65 34 PROGRAMMING MAXIMUM LIKELIHOOD PAIRED COMPARISON RANKING BY LINEAR ON THE SUFFICIENCY AND LIKELIHOOD PRINCIPLES DISTRIBUTIONS POSSESSING A MONOTONE LIKELIHOOD RATIO

LIKELIHOOD RATIO AND CONFIDENCE-REGION TESTS

COMPUTATIONS LIKELIHOOD RATIO COMPUTATIONS OF OPERATING

METHOD FOR APPROXIMATING TO THE DISTRIBUTION OF LIKELIHOOD RATIO CRITERIA

ASYMPTOTIC EXPANSIONS OF THE DISTRIBUTIONS OF THE LIKELIHOOD RATIO CRITERIA FOR COVARIANCE MATRIX OTIC EXPANSIONS OF THE NON-NULL DISTRIBUTIONS OF THE LIKELIHOOD RATIO CRITERIA FOR MULTIVARIATE LINEAR HYP SETS OF VARIATES U/ ON THE EXACT DISTRIBUTIONS OF LIKELIHOOD RATIO CRITERIA FOR TESTING INDEPENDENCE OF ES ABOUT REGRES/ ON THE EXACT DISTRIBUTIONS OF THE LIKELIHOOD RATIO CRITERIA FOR TESTING LINEAR HYPOTHES EXACT DISTRIBUTIONS OF WILKS'S LIKELIHOOD RATIO CRITERION A TECHNTCAL LEMMA FOR MONOTONE LIKELIHOOD RATIO FAMILIES

HYPOTHESES

DISTRIBUTION OF THE LIKELIHOOD RATIO FOR TESTING MULTIVARIATE LINEAR DISTRIBUTION OF LIKELIHOOD RATIO IN TESTING AGAINST TREND THE POWER OF THE LIKELIHOOD RATIO TEST

THE LIKELIHOOD RATIO TEST FOR MARKOFF CHAINS CORRIGENDA TO 'THE LIKELIHOOD RATIO TEST FOR MARKOFF CHAINS'

ON THE LIKELIHOOD RATIO TEST OF A NORMAL MULTIVARIATE BIOKA69 N0.3 JASA 63641 JASA $56 \quad 637$ JRSSB 65245 AMS $66 \quad 1704$ IOKA56 295 AMS 69 N0.6 AMS $69 \quad 942$ AMS $67 \quad 1160$ AMS $66 \quad 1319$ BIOKA66 347 AMS $67 \quad 611$ AMS 61 333 AMS $69 \quad 37$ AMS $67 \quad 802$ BIOKA55 531 BIOKA57 301 AMS 651061

TESTING PROBLEM II G PROBLEM, CORR. 641388 ER IS 'NEAR' THE B/
ON THE LIKELIHOOD RATIO TEST OF A NORMAL MULTIVARIATE TESTIN SIMPLIFIED RUNS TESTS AND LIKELIHOOD RATIO TESTS FOR MARKOFF CHAINS LIKELIHOOD RATIO TESTS FOR RESTRICTED FAMILITES OF AMS $54 \quad 1 B 1$ AMS 682044 BIOKA58 1BI AMS $6 \mathrm{~B} \quad 547$ AMS 65529 GROUPS OF TRANSFORMATIONS

THE BEHAVIOR OF LIKELIHOOD RATIOS OF STOCHASTIC PROCESSES RELATED BY NT FROM PHENOTYPE FREQUENCIES BY A METHOD OF MAXIMUM LIKELIHOOD SCORING /ION OF THE INBREEDING COEFFICIE LINEAR FUNCTIONAL RELATIONSHIP THE MAXIMUM LIKELIHOOD SOLUTION TO THE PROBLEM OF ESTIMATING A

ION ADMITTING/ A FORMULA FOR THE CURVATURE OF THE LIKELIHOOD SURFACE OF A SAMPLE DRAWN FROM A DISTRIBUT CORRIGENDA, 'MOMENT ESTIMATORS AND MAXIMUM LIKELIHOOD.'

$S$ IN MULTIVARIATE ANALYSIS POWER OF THE LIKELIHOOD-RATIO TEST OF THE GENERAL LINEAR HYPOTHESI B CORRIGENDA, 'MOMENT ESTIMATORS AND MAXIMUM LIKELIHOOD'

FOR CONFIDENCE POINTS BASED ON INTEGRALS OF WEIGHTED LIKELIHOODS

BIOKA6I 474

ON FORMULAE JRSSB63 31 B SIMILARITIES BETWEEN LIKELIHOODS AND ASSOCIATED DISTRIBUTIONS A POSTERIORI JRSSB6I 460 EXAMPLES OF LIKELIHOODS AND COMPARISON WITH POINT ESTIMATES AND JASA $6946 \mathrm{~B}$

LARGE SAMPLE APPROXIMATIONS

LARGE SAMPLE APPROXIMATIONS
RRELATED VARIABLES WITH A SINGLE-SIDED SPECIFICATION LIMIT
APPROXIMATING THE LOWER BINOMIAL CONFIDENCE LIMIT APPROXIMATING THE LOWER BINONIAL CONFIDE
A SINGLE SAMPLING PLAN FOR CO JASA $6 B \quad 1413$ AMS 63992 
621466

STATIONARY CAUSSIAN PROCESS

ON SOME RESULTS OF
STATISTICAL EVALUATION OF SPLITTINC LIMIT CRITERIA IN MEASUREMENT DISPUTES

LIMIT DISTRIBUTION IN THE THEORY OF COUNTERS, CORR.

ON A LIMIT DISTRIBUTION OF HICH LEVEL CROSSINCS OF A LIMIT DISTRIBUTIONS FOR VARIATIONAL SERIES

LIMIT DISTRIBUTIONS OF A BRANCHINC STOCHASTIC PROCESS

PLOSIVE STOCHASTIC DIFFERENCE EQU/ CONSISTENCY AND LIMIT DISTRIBUTIONS OF ESTIMATORS OF PARAMETERS IN EX CONTRIBUTIONS TO SAMPLE SPACINCS THEORY, I, LIMIT DISTRIBUTIONS OF SUMS OF RATIOS OF SPACINCS A LIMIT LAW CONCERNINC MOVING AVERACES

THE LIMIT OF A RATIO OF CONVOLUTIONS

THE LIMIT OF THE NTH POWER OF A DENSITY A LOCAL LIMIT THEOREM

ON THE CONVERGENCE OF MOMENTS IN THE CENTRAL LIMIT THEOREM

ON A STOPPING RULE AND THE CENTRAL LIMIT THEOREM

ON CONVERGENCE RATES IN THE CENTRAL LIMIT THEOREM

MOMENTS OF A STOPPINC RULE RELATED TO THE CENTRAL LIMIT THEOREM

A LOCAL LIMIT THEOREM FOR A CERTAIN CLASS OF RANDOM WALKS

A 'RENEWAL' LIMIT THEOREM FOR GENERAL STOCHASTIC PROCESSES

THE CENTRAL LIMIT THEOREM FOR CENERALIZED RANDOM FIELDS

A STABLE LIMIT THEOREM FOR MARKOV TESTS

THE REMAINDER IN THE CENTRAL LIMIT THEOREM FOR MIXING STOCHASTIC PROCESSES

PROCESSES A LIMIT THEOREM FOR MULTIDIMENSIONAL GALTON-WATSON

DISTRIBUTION FUNCTIONS

A LOCAL LIMIT THEOREM FOR NONLATTICE MULTI-DIMENSIONAL

A CENTRAL LIMIT THEOREM FOR PARTLY DEPENDENT VARIABLES

A LIMIT THEOREM FOR PASSAGE TIMES IN ERGODIC REGENERATI

A LIMIT THEOREM FOR RANDOM INTERVAL SAMPLING OF A

STOCHASTIC PROCESS

A MULTIVARIATE CENTRAL LIMIT THEOREM FOR RANDOM LINEAR VECTOR FORMS

WITH INFINITE EXPECTATI/ A SHORT PROOF OF A KNOWN LIMIT THEOREM FOR SUM OF INDEPENDENT RANDOM VARIABLES

VARIABLES

A LIMIT THEOREM FOR SUMS OF MINIMA OF STOCHASTIC

NTERSECTION OF TWO GRAPHS (CORR. 69 151/ A CENTRAL LIMIT THEOREM FOR THE NUMBER OF EDGES IN THE RANDOM I

E BRANCHING PROCESSES TO A BRANCH/ EXTENSIONS OF A LIMIT THEOREM OF EVERETT, ULAM AND HARRIS ON MULTITYP

ON AN OPERATOR LIMIT THEOREM OF ROTA

CONDITIONED LIMIT THEOREMS

STOCHASTIC POINT PROCESSES. LTMIT THEOREMS

NTINUOUS TIME MARKOV BRANCHINC PROCESSES AND RELATED LIMIT THEOREMS

NEW CONDITIONS FOR CENTRAL LIMIT THEOREMS (CORR. 69 1855)

CORR. 651069

VARIABLES

SOME RENYI TYPE LIMIT THEOREMS FOR EMPIRICAL DISTRIBUTION FUNCTIONS,

SPACINGS AND A RELATED TEST

CENTRAL LIMIT THEOREMS FOR FAMILIES OF SEQUENCES OF RANDOM

LIMIT THEOREMS FOR FUNCTIONS OF SHORTEST TWO-SAMPLE

GALTON-WATSON PROCESSES

ON LIMIT THEOREMS FOR CAUSSIAN PROCESSES

ADDITIONAL LIMIT THEOREMS FOR INDECOMPOSABLE MULTIDIMENSIONAL LIMIT THEOREMS FOR MARKOV RENEWAL PROCESSES

SOME LIMIT THEOREMS FOR NON-HOMOGENEOUS MARKOV CHAINS LIMIT THEOREMS FOR QUEUES WITH TRAFFIC INTENSITY ONE LIMIT THEOREMS FOR RANDOMLY SELECTED PARTIAL SUMS LIMIT THEOREMS FOR STOPPED RANDOM WALKS LIMIT THEOREMS FOR STOPPED RANDOM WALKS, II LIMIT THEOREMS FOR STOPPED RANDOM WALKS, II

SAMPLINC INSPECTION PLANS

SOME LIMIT THEOREMS FOR THE DODGE-ROMIG LTPD SINGLE

A NOTE ON LIMIT THEOREMS FOR THE ENTROPY OF MARKOV CHAINS LIMIT THEOREMS FOR THE MAXIMUM TERM IN STATIONARY LIMIT THEOREMS FOR THE MULTI-URN EHREFEST MODEL CONTRIBUTIONS TO CENTRAL LIMIT THEORY FOR DEPENDENT VARIABLES DESIGN AND OPERATION OF A DOUBLE-LIMIT VARIABLES SAMPLING PLAN
THE STRONG RATIO LIMIT PROPERTY FOR SOME GENERAL MARKOV PROCESSES

TECH $63 \quad 263$

AMS $61 \quad 1271$

AMS 682108

AMS $69 \quad 480$

AMS 64557

AMS $61 \quad 195$

AMS $66 \quad 904$

AMS $64 \quad 424$

AMS $63 \quad 457$

AMS 651878

AMS $69 \quad 986$

AMS $64 \quad 419$

AMS $65 \quad 808$

AMS 671915

AMS $69 \quad 475$

AMS 691236

AMS $66 \quad 855$

AMS $62 \quad 98$

AMS 69203

AMS 691467

AMS 69601

AMS 661211

AMS $65 \quad 546$

AMS $61 \quad 677$

AMS $66 \quad 866$

AMS $64 \quad 866$

AMS 661825

AMS $69 \quad 1114$

AMS 651041

AMS $69 \quad 144$

AMS $67 \quad 992$

AMS 651864

AMS 631147

AMS $67 \quad 771$

AMS 681801

AMS $63 \quad 319$

AMS $65 \quad 322$

AMS $63 \quad 439$

AMS $67 \quad 108$

AMS $65 \quad 304$

AMS 661463

AMS $64 \quad 1746$

AMS 661224

AMS $65 \quad 1437$

AMS $62 \quad 85$

AMS 641332

AMS $66 \quad 860$

AMS 661510

TECH $62 \quad 497$

AMS $66 \quad 522$

AMS $64 \quad 502$

AMS $68 \quad 864$

AMS 681158

JASA $58 \quad 543$

INITE POPULATION (ATY'S FORMULAE AND MADOW'S CENTRAL LIMIT) /ING MOMENTS OF THE MEAN IN SAMPLES FROM A F BIOKA6I I99

ACT/ ESTIMATION OF THE NUMBER OF CRITICAL SITES IN LIMITED GENOME EXPRESSION DURINC VIRAL INEECTION OF B BIOCS69 537

A SYSTEM OF TWO SERVERS WITH LIMITED WAITING ROOMS AND CERTAIN ORDER OF VISITS BIOKA68 223

MODEL IS INCORRECT, CORR, 66745 LIMTTNG BEHAVIOR OF POSTERTOR DISTRIBUTIONS WHEN THE AMS 66

PROCESS

S OF DEPENDENT RANDOM VARIABLES ADDENDUM, THE LIMITING DISTRIBUTION OF KAMAT'S TEST STATISTIC

BIOKA56 386 $\begin{array}{lllrl}\text { LIMITINC DISTRIBUTION OF } & \text { THE MAXIMUM OF A DIFFUSION } & \text { AMS } 64 & 319\end{array}$ LIMITING DISTRIBUTION OF THE MAXIMUM TERM IN SEQUENCE AMS $62 \quad 894$

ON LTMITING DTSTRIBUTIONS ARISING IN BULK SERVICE QUEUES JRSSB56 265 LIMITINC DISTRIBUTIONS ASSOCIATED WITH CERTAIN

DIRIBUTIONS FOR SUMS OF A RANDOM NUMBER OF AMS 69935 LTMTTINC DISTRIBUTIONS OF RESPONSE PROBABILITIES

AMS $65 \quad 706$ JRSSB58 73 IN LEARNING MODELS

INDEPENDENT RANDOM VECTORS

THE MATCHINC DISTRIBUTIONS ،

THE LIMITINC FREQUENCIES OF INTEGERS WITH A GIVEN PARTITI JRSSB59 134

ONAL CHARACTERISTIC

IVE OBSERVATIONS FROM/ ON DURBIN'S FORMULA FOR THE LIMITING GENERALIZED VARIANCE OF A SAMPLE OF CONSECUT BIOKAGI 197 IVE OBSE/ CORRIGENDA, ION DURBIN'S FORMULA FOR THE LIMITING GENERALIZED VARIANCE OF A SAMPLE OF CONSECUT BIOKAGI 476 ANALOGOUS TO NORMAL ANALYSIS OF VARIANCE THE LIMITING POWER OF CATEGORICAL DATA CHI-SQUARE TESTS PROBABILITY RATIO TEST PRODUCT MEASURES A NOTE ON THE LIMITING RELATIVE EFFICIENCY OF THE WALD SEQUENTIAL LIMITING SETS AND CONVEX HULLS OF SAMPLES FROM

AMS 631432

JASA $60 \quad 660$

AMS 691824

JASA $58 \quad 482$

JASA 59260

AMS $64 \quad 1361$

TECH $68 \quad 343$

BIOKA54 275

TABLES OF DTSTRIBUTTON-FREE TOLFRANCE LIMITS

SAMPLE SIZE DETERMINATION FOR TOLERANCE LIMITS

SOME REMARKS ON CONFIDENCE OF FIDUCIAL LIMITS

RISKS FOR ASYMMETRICAL TESTS AND SPECIFICATION LIMITS

ACKNOWLEDGEMENT OF PRIORITY ON ION INTERCHANCING LIMITS AND INTEGRALS' 6074

PRODUCER AND CONSUMER JASA $66 \quad 505$

QUERY, TOLERANCE LIMITS FOR A BINOMIAL DISTRIBUTION

AND RANCE OR MEAN RANGE

TABLES FOR TOLERANCE LIMITS FOR A NORMAL POPULATION BASED ON SAMPLE MEAN NOTES CONFIDENCE LIMITS FOR A RATIO USING WILCOXON'S SICNED RANK TEST

CONFIDENCE COEFFICIENT

RATE, CORR 67950
LIMITS FOR A VARIANCE COMPONENT WITH AN EXACT

\section{FIDUCIAL LIMITS FOR A VARIANCE COMPONENT}

TOLERANCE AND CONFIDENCE LIMITS FOR CLASSES OF DISTRIBUTIONS BASED ON FAILURE
AMS $66 \quad 1407$

TECH 69201

JASA $57 \quad 88$

BIOCS65 231

JRSSB $63 \quad 128$

AMS 61466

AMS $66 \quad 1593$ 
APPROXIMATE CONFIDENCE LIMITS FOR COMPONENTS OF VARIANCE

SIMULTANEOUS CONFIDENCE LIMITS FOR CROSS-PRODUCT RATIOS IN CONFIDENCE LIMITS FOR MULTIVARIATE RATIOS

AN APPROXIMATION TO TWO-SIDED TOLERANCE LIMITS FOR NORMAL POPULATIONS

TWO-SIDED TOLERANCE LIMITS FOR NORMAL POPULATIONS, SOME IMPROVEMENTS RELATIONSHIPS BETWEEN BAYESIAN AND CONFIDENCE LIMITS FOR PREDICTIONS (WITH DISCUSSION) CONFIDENCE LIMITS FOR QUANTILES OF MORTALITY DISTRIBUTIONS

QUERY, JOINT CONFIDENCE LIMITS FOR RANKED OBSERVATIONS

TABLES OF CONFIDENCE IIMTS FOR THE BINOMTAL DISTRIBUTION JASA $60 \quad 521$

HAZARD RATE

DISTRIBUTIONS

RELATIONSHIP TOLERANCE LIMITS FOR THE CLASS OF DISTRIBUTIONS WITH INCREASING

APPROXIMATE CONFIDENCE LIMITS FOR THE COEFFICIENT OF VARIATION IN GAMMA TOLERANCE LIMITS FOR THE GENERALIZED GAMMA DISTRIBUTION CONFIDENCE LIMITS FOR THE GRADIENT IN THE LINEAR FUNCTIONAL

BAYESIAN CONFIDENCE LIMITS FOR THE PRODUCT OF N BINOMIAL PARAMETERS SMALL SAMPLE PROBABILITY LIMITS FOR THE RANGE CHART (CORR. 68 1549) LIMITS FOR THE RATIO OF MEANS (WITH DISCUSSION)

SYSTEMS APPROXIMATE CONFIDENCE LIMITS FOR THE RELATIVE RISK (CORR. 63 234) APPROXIMATE CONFIDENCE LIMITS FOR THE RELIABILITY OF SERIES AND PARALLEL CONFIDENCE LIMITS FOR THE RELIABILITY OF SERIES SYSTEMS ON CONFIDENGE LIMITS FOR THE RELIABILITY OF SYSTEMS QUERY, CONFIDENCE LIMITS FROM RANK TESTS

EXACT FIDUCIAL LIMITS IN NON-LINEAR ESTIMATION CONFIDENCE LIMITS IN THE CASE OF THE GEOMETRIC DISTRIBUTION ON THE DETERMINATION OF CONFIDENCE LIMITS OF AN INDEX POISSON LIMITS OF MULTIVARIATE RUN DISTRIBUTIONS ONE SAMPLE LIMITS OF SOME TWO-SAMPLE RANK TESTS

TABLES FOR CONSTRUGTING CONFIDENCE LIMITS ON THE MULTIPLE CORRELATION COEFFICIENT

A METHOD OF ASSIGNING CONFIDENCE LIMITS TO LINEAR COMBINATIONS OF VARIANCES A NOTE ON TOLERANCE LIMITS WITH TYPE I CENSORING

NCTIONS BE CONTINUOUS DISTRIBUTION FREE TOLERANCE LIMITS. ELIMINATION OF REQUIREMENT THAT GUMULATIVE FU ONPARAMETRIC UPPER CONFIDENCE BOUNDS, AND CONFIDENCE LIMITS, FOR THE PROBABILITY THAT Y IS LESS THAN X, WH J PARAMETER-FREE AND NON-PARAMETRIC TOLERANCE LIMITS. THE EXPONENTIAL CASE THE LINDISFARNE SCRIBES' PROBLEM SOME EXTENSIONS OF BAYESIAN INFERENCE PROPOSED BY MR LINDLEY A COMMENT ON D.V. LINDLEY'S STATISTICAL PARADOX ESGAPE PROBABILITY FOR A HALF LINE

THE ASYMMETRIG CAUCHY PROCESSES ON THE LINE PROBABILITY DISTRIBUTIONS ARISING FROM POINTS ON A LINE TESTS FOR RANDOMNESS OF POINTS ON A LINE GOMPARISON OF TESTS FOR RANDOMNESS OF POINTS ON A LINE THE DISTRIBUTION OF VACANCIES ON A LINE A NOTE ON VACANCIES ON A LINE OF THE SIZE OF THE MAXIMUM CLUSTER OF POINTS ON A LINE FOR SEVERAL PREDICTIONS FROM A SINGLE REGRESSION LINE OF PRIOR INFORMATION TO DESIGN A ROUTINE PARALLEL LINE ASSAY STRAIGHT LINE CONFIDENCE REGIONS OF LINEAR MODELS

ON THE LINE GRAPH OF THE COMPLETE BIPARTITE GRAPH

A DYNAMIC PROGRAMMING APPLICATION IN PRODUCTION LINE INSPECTION

A NOTE ON CONFIDENCE BANDS FOR A REGRESSION LINE OVER A FINITE RANGE CONFIDENCE BANDS IN STRAIGHT LINE REGRESSION

MOMENTS OF THE DISTRIBUTION OF JOINS BETWEEN LINE SEGMENTS

THE EQUIVALENGE OF TWO METHODS OF FITTING A STRAIGHT LINE THROUGH CUMULATIVE DATA ORT-CUT GRAPHIC METHOD FOR FITTING THE BEST STRAIGHT LINE TO A SERIES OF POINTS
GRAPHICAL PROCEDURE FOR FITTING THE BEST LINE TO A SET OF POINTS

FITTING A STRAIGHT LINE TO CERTAIN TYPES OF CUMULATIVE DATA

FITTING A STRAIGHT LINE TO DATA FROM A TRUNCATED POPULATION

LINE TRANSECT METHOD OF ESTIMATING GROUSE POPULATION

DENSITIES

SIMULATION STUDY OF ESTIMATORS FOR THE LINE TRANSECT SAMPLING METHOD A WAITING LINE WITH INTERRUPTED SERVICE. INCLUDING PRIORITIES ESTIMATION OF A LINEAR FUNCTION FOR A CALIBRATION LINE, CONSIDERATION OF A RECENT PROPOSAL ON THE LINE, GRAPH OF THE COMPLETE BIGRAPH

MENTS, CORR. 661246 ANALYSIS ANALYSIS LAMP TESTS OF LINEAR AND LOGLINEAR HYPOTHESES IN MULTINOMIAL EXPER
LINEAR AND NON-LINEAR MULTIPLE COMPARISONS IN LOGIT CORRIGENDA, 'LINEAR AND NON-LINEAR MULTIPLE COMPARISONS IN LOGIT

FACTORIAL 2-TO-THE-(P-Q) PLANS ROBUST AGAINST LINEAR AND QUADRATIC TRENDS BOUNDS ON THE ERROR IN THE LINEAR APPROXIMATION TO THE RENEWAL FUNCTION TOTAL DEVIATIONS (ACKNOWLEDGEMENT 67 5B7) ADJUSTMENT METHODS

LINEAR APPROXIMATION USING THE CRITERION OF LEAST

LINEAR APPROXIMATIONS TO THE CENSUS AND BLS SEASONAL

FREQUENCY DISTRIBUTION, WITH ESPECIAL REFERENCE/A LINEAR APPROXIMATOR FOR THE CLASS MARKS OF A GROUPED FOR HIGHER ORDER SCHEM/ TESTS OF HYPOTHESES IN THE LINEAR AUTO-REGRESSIVE MODEL. II. NULL DISTRIBUTIONS TESTS OF HYPOTHESES IN THE LINEAR AUTOREGRESSIVE MODEL. PART I,

SAMPLING PROPERTIES OF TESTS OF GOODNESS-OF-FIT FOR LINEAR AUTOREGRESSIVE SCHEMES YMPTOTIC EXPANSIONS FOR TESTS OF GOODNESS OF FIT FOR LINEAR AUTOREGRESSIVE SCHEMES

EFFICIENCIES OF METHODS OF ESTIMATING PARAMETERS IN LINEAR AUTOREGRESSIVE SCHEMES

OF EXPERIMENT SIZES FOR DECISION REGARDING CERTAIN LINEAR COMBINATIONS

NVERGENCE RATES FOR THE LAW OF LARGE NUMBERS FOR THE LINEAR COMBINATIONS OF EXCHANGEABLE AND MIXING STOCHA WITH APPLICATIONS TO E/ ASYMPTOTIC DISTRIBUTION OF LINEAR COMBINATIONS OF FUNCTIONS OF ORDER STATISTICS ASYMPTOTIC NORMALITY OF LINEAR COMBINATIONS OF FUNCTIONS OF ORDER STATISTICS SULTS ON THE COMPLETE AND ALMOST SURE GONVERGENCE OF LINEAR COMBINATIONS OF INDEPENDENT AND RANDOM VARIABL AR/ EXPRESSION OF VARIANCE-COMPONENT ESTIMATORS AS LINEAR COMBINATIONS OF INDEPENDENT NONCENTRAL CHI-SQU THE CONYERGENCE RATE OF THE LAW OF LARGE NUMBERS FOR LINEAR COMBINATIONS OF INDEPENDENT RANDOM VARIABLES

CONVERGENCE RATES FOR THE LAW OF LARGE NUMBERS FOR LINEAR COMBINATIONS OF MARKOV PROCESSES is FORMULA
AMS 641561

BIOCS65 733

JASA $65 \quad 1142$

JRSSB56 65

BIOKAG6 611

JASA $67 \quad 14 B B$

JRSSB54 186

JRSSB62 454

TECH $65 \quad 495$

JASA $67 \quad 1452$

AMS $68 \quad 1463$

TECH $65 \quad 257$

JRSSB $62 \quad 125$

BIOKA59 260

BI0CS66 603

AMS $65 \quad 215$

JASA $64 \quad 645$

JASA 63 10B2

BIOKA55 471

TECH $68 \quad 392$

TECH 63 51B

JASA 64906 TECH 6275 JRSSB58 93

ON JRSSB60 299 BIOKA57 533 AMS 641351 AMS $69 \quad 137$ BIOKA54 553 BIOKA56 104 BI0KA63 315 JRSSB59 364 JRSSB $61 \quad 207$

JASA $65 \quad 532$ TECH 6121 E BI0CS67 257 JASA $67 \quad 1365$ AMS $64 \quad 8 B 3$ TECH $67 \quad 73$ $\begin{array}{lll}\text { JASA } & 68 \quad 1028\end{array}$ JASA 64 1B2 FACTORIAL BIOKA54 555 JASA $64 \quad$ B63 ASA $57 \quad 13$ TECH $60 \quad 477$ JASA $57 \quad 552$ BI0C565 715 BI0CS68 135 BIOCS69 317 JRSSB $62 \quad 73$ TECH 69 NO. 4 AMS $63 \quad 664$ JASA $66 \quad 236$ BIOKA6I 359 BIOKA62 284 TECH $66 \quad 259$ BIOKA64 355 JRSSB67 101 JASA $68 \quad 445$ TECH $68 \quad 793$ BIOKA56 186 BIOKA54 405 JRSSB62 492 AS BIOKA64 459 \begin{tabular}{ll} 
E BIOKA61 427 \\
\hline
\end{tabular} JRSSB $67 \quad 503$ AMS 651840 AMS $67 \quad 52$ AMS 69 No. 6 AMS $68 \quad 1549$ AMS 69 No. 6 AMS $65 \quad 559$ AMS $66 \quad 711$ 
VARIATES ED FAMILIES
INTERVAL ESTIMATION FOR LINEAR COMBINATIONS OF MEANS

LINEAR COMBINATIONS OF NON-CENTRAL CHI-SQUARE

INEQUALITIES FOR LINEAR COMBINATIONS OF ORDER STATISTICS FROM RESTRICT A METHOD OF ASSIGNING CONFIDENCE LIMITS TO LINEAR COMBINATIONS OF VARIANCES CHANGEOVER DESIGNS BALANCED FOR THE LINEAR COMPONENT OF FIRST RESIDUAL EFFECTS TESTING FOR LINEAR CONTAGION, INVERSE SAMPLING

ON THE LINEAR CONTROL OF A LINEAR SYSTEM HAVING A NORMAL LINEAR CURVE FITTINC USING LEAST DEVIATIONS

STATIONARY STOCHASTIC INPUT
ON LINEAR COMBINATIONS OF SEVERAL VARIANCES

JASA $64 \quad 1141$

AMS $66 \quad 480$

AMS 661574

AMS 65 (1068 BIOKA55 471 BIOKA68 297 JRSSB 69 N0.2 JRSSB68 381 JASA $58 \quad 118$ WISHART DISTRIBUTION DERIVED BY SOLVINC SIMULTANEOUS LINEAR DIFFERENTIAL EQUATIONS HOTELLING'S GENERALIZED T-SQUARE-SUB/A AYSTEM OF LINEAR DIFFERENTIAL EQUATIONS FOR THE DISTRIBUTION OF AMS 68 BI5
AN ASYMPTOTIC EXPANSION FOR THE DISTRIBUTION OF THE LINEAR DISCRIMINANT FUNCTION ON THE PERFORMANCE OF THE LINEAR DISCRIMINANT FUNCTION OF UNEQUAL VARIANCE-COVARIANCE MATRICES ON FISHER'S LINEAR DISCRIMINANT FUNCTION ESTTMATION ASSOCIATED WTTH LINEAR DISCRIMTNANTS GEOMETRY AND LINEAR DISCRIMINATION ELIMINATION OF VARIATES IN LINEAR DISCRIMINATION PROBLEMS ITY OF TWO COVARIANCE MATRICES IN RELATION TO A BEST LINEAR DISCRIMINATOR ANALYSIS STAGE NORMAL SAMPLING IN TWO-ACTION PROBLEMS WITH LINEAR ECONOMICS S OF SINGLE EXPONENTIAL DISTRIBUT/ TABLES FOR BEST LINEAR ESTIMATES BY ORDER STATISTICS OF THE PARAMETER JASA 57 58 TION OF GOOD LINEAR UNBIASED ESTIMATES FROM THE BEST LINEAR ESTIMATES FOR A SMALLER SAMPLE SIZE $/ O N S T R U C$ TECH 65 543

ON A THEOREM OF KARLIN REGARDING ADMTSSIBILITY OF LINEAR ESTIMATES IN EXPONENTIAL POPULATIONS LINEAR ESTTMATES OF A POPULATION SCALE PARAMETER AMS 661809 BIOKA67 551 TECH $66 \quad 3$ AMS $66 \quad 458$ DISTRIBUTION LINEAR ESTIMATES OF PARAMETERS IN THE EXTREME VALUE TECH $64 \quad 179$ BIOCS69 505 AMS 67807 BIOKA60 185 BIOC\$66 268 ALL ADMISSIBLE LINEAR ESTIMATES OF THE MEAN VECTOR $\begin{aligned} \text { AMETERS OF A DOUBLE EXPONENTIAL POPULATION } & \text { BEST LINEAR ESTIMATES UNDER SYMMETRIC CENSORINC OF THE PAR JASA 66 248 } \\ \text { LINEAR ESTIMATES WITH POLYNOMIAL COEFFICIENTS } & \text { BIOKA66 } 129\end{aligned}$

ON HOROVITZ AND THOMPSON'S T-ONE CLASS OF LINEAR ESTIMATION A NOTE ON THE GEOMETRY OF LINEAR ESTIMATION A FURTHER NOTE ON THE GEOMETRY OF LINEAR ESTIMATION

LINEAR ESTIMATION AND THE ANALYSIS OF GAMMA RAY PULSE-HEICHT SPECTRA SERIES

ON LTNEAR ESTIMATTON FOR REGRESSION PROBLEMS ON TTME ON ROBUST LINEAR ESTIMATORS

SAMPLE FREQUENCY FUNCTIONS OF GENERALIZED CLASSICAL LINEAR ESTIMATORS IN A LEADING THREE-EQUATION CASE THE EXACT DISTRIBUTIONS OF THE GENERALIZED CLASSICAL LINEAR ESTIMATORS IN A LEADING THREE-EQUATION CASE MPLE DISTRIBUTION FUNCTIONS OF GENERALIZED CLASSICAL LINEAR ESTIMATORS IN ECONOMETRIC STATISTICAL INFERENC OVARIANCE MATRICES AND BEST AND SIMPLE LEAST SQUARES LINEAR ESTIMATORS IN LINEAR MODELS /NON-NEGATIVE C AMS 67 IO92 IES WITHOUT REPLACEMENT

ON A CLASS OF LINEAR ESTIMATORS IN SAMPLING WITH VARYING PROBABILIT JASA 65637 SAMPLE FREQUENCY FUNCTIONS OF GENERALIZED CLASSICAL LINEAR ESTIMATORS IN TWO LEADING OVER-IDENTIFIED GASE JASA 61 619 THE EXACT DISTRIBUTIONS OF THE GENERALIZED CLASSICAL LINEAR ESTIMATORS IN TWO LEADINC OVER-IDENTIFIED CASE JASA 63 535 ROBUSTNESS. A GENERAL METHOD, WITH APPLICATIONS TO LINEAR ESTIMATORS OF LOCATION OPTIMAL JASA 67 I23O CE RELATIONS FOR FUNCTIO/ CHARACTERIZATIONS OF THE LINEAR EXPONENTIAL FAMILTY IN A PARAMETER BY RECURREN AMS 69 1721 EXPONENTIAL DISTRIBUTION LINEAR FORMS IN THE ORDER STATISTICS FROM AN AMS $64 \quad 270$ OF A RECENT PROPOSAL ESTIMATION OF A LINEAR FUNCTION FOR A CALIBRATION LINE. CONSIDERATION JRSSB61 160 AMS 611048 JRSSB56 65 JRSSB68 190 MAXIMUM LIKELIHOOD ESTIMATION ON THE LINEAR FUNCTIONAL RELATIONSHIP THE BAYESIAN ESTIMATION OF A LINEAR FUNCTIONAL RELATIONSHIP

LIKELIHOOD SOLUTION TO THE PROBLEM OF ESTIMATING A LINEAR FUNCTIONAL RELATIONSHIP

SIGNIFICANCE TESTS FOR DISCRIMINANT FUNCTIONS AND LINEAR FUNCTIONAL RELATIONSHIPS A NOTE ON TESTS OF SIGNIFICANCE FOR LINEAR FUNCTIONAL RELATIONSHIPS

THE MAXIMUM JRSSB69 N0.2 BIOKA55 360 $\begin{array}{ll}\text { BIOKA55 } & 360 \\ \text { BIOKA57 } & 268\end{array}$ A CENERALIZED LEAST-SQUARES APPROACH TO LINEAR FUNCTIONAL RELATIONSHIPS (WITH DISCUSSION) JRSSB66 278 DERED CORRELATED NORMAL RA/ ON THE DISTRIBUTION OF LINEAR FUNCTIONS AND RATIOS OF LINEAR FUNCTIONS OF OR BIOKA64 I43 $\begin{array}{rlrr}\text { OPTIMUM ESTIMATORS FOR LINEAR FUNCTIONS OF LOCATION AND SGALE PARAMETERS } & \text { AMS } 69 \text { NO.6 } \\ \text { ON UNCORRELATED LINEAR FUNCTIONS OF ORDER STATISTICS } & \text { JASA } 63 & 245\end{array}$

AN ELEMENTARY PROOF OF ASYMPTOTIC NORMALITY OF LINEAR FUNCTIONS OF ORDER STATISTICS

AMS $68 \quad 263$ AMS $69 \quad 770$ VARIABLES LINEAR FUNCTIONS OF ORDER STATISTICS

ON LINEAR FUNCTIONS OF ORDERED GORRELATED NORMAL RANDOM ENUMERATION OF LINEAR GRAPHS FOR MAPPINGS OF FINITE SETS A MULTI-DIMENSIONAL LINEAR GROWTH BIRTH AND DEATH PROCESS SIMULTANEOUS TESTS OF LINEAR HYPOTHESES RANK ORDER TESTS OF LINEAR HYPOTHESES

OF THE LIKELIHOOD RATIO FOR TESTING MULTIVARIATE LINEAR HYPOTHESES BUTIONS OF THE LIKELIHOOD RATIO CRITERIA FOR TESTINC LINEAR HYPOTHESES ABOUT REGRESSION COEFFICIENTS /RI LINEAR HYPOTHESES AND INDUCED TESTS

SOME PROBLEMS INVOLVING LINEAR HYPOTHESES IN MULTIVARIATE ANALYSIS BIOKA65 367 AMS $62 \quad 178$ AMS $68 \quad 727$ BIOKA55 441 JRSSB68 483

DISTRIBUTION AMS 61333 BIOKA64 41 YSIS WHEN THE RATIOS OF THE POPULATION V/ TESTS OF LINEAR HYPOTHESES IN UNIVARIATE AND MULTIVARIATE ANAL BIOKA54 19
MATIONS. CORR. $64 \mathrm{l2} / \mathrm{ASYMPTOTIC} \mathrm{POWER} \mathrm{OF} \mathrm{TESTS} \mathrm{OF} \mathrm{LINEAR} \mathrm{HYPOTHESES} \mathrm{USING} \mathrm{THE} \mathrm{PROBIT} \mathrm{AND} \mathrm{LOCIT} \mathrm{TRANSFOR} \mathrm{JASA} \mathrm{62} \mathrm{877}$ STRINGENT TESTS AND LAGRANGIAN MULTIPLIER TESTS OF LINEAR HYPOTHESES. SENSITIVITY COMPARISONS AMONG TESTS OF THE GENERAL LINEAR HYPOTHESIS A CLASS OF RANK ORDER TESTS FOR A GENERAL LINEAR HYPOTHESIS JASA $66 \quad 415$ AMS $69 \quad 1325$ BIOKA64 508 SOME NOTES ON VARIANCE-RATIO TESTS OF THE GENERAL LINEAR HYPOTHESIS POWER FUNCTIONS OF SOME TESTS OF THE MULTIVARIATE LINEAR HYPOTHESIS THE LINEAR HYPOTHESIS AND IDEMPOTENT MATRICES NS OF THE LIKELTHOOD RATIO CRITERIA FOR MULTIVARIA THE LINEAR HYPOTHESIS AND LARGE SAMPLE THEORY
POWER OF THE LIKELIHOOD-RATIO TEST OF THE GENERAL LINEAR HYPOTHESIS IN MULTIVARIATE ANALYSIS A NOTE ON CENERALIZED INVERSES IN THE LINEAR HYPOTHESIS NOT OF FULL RANK MULTIVARIATE LINEAR HYPOTHESIS WITH LINEAR RESTRICTIONS FINITE SAMPLE DISTRIBUTIONS OF GENERALIZED CLASSICAL LINEAR IDENTIFIABILITY TEST STATISTICS TESTS AGATNST ALTERNATIVE RESTRICTED BY A NUMBER OF LINEAR INEQUALITIES /INGENT SOMEWHERE MOST POWERFUL AMS 66 II61 ON MINIMIZING A CONVEX FUNCTION SUBJECT TO LINEAR INEQUALITIES (WITH DISCUSSION) LL DISTRIBUTION TABLES FOR OBTAINING THE BEST LINEAR INVARIANT ESTIMATES OF PARAMETERS OF THE WEIBU TECH 67 629 LINEAR LEAST SQUARES REGRESSION 
TESTS FOR SPECIFICATION ERRORS IN CLASSICAL LINEAR LEAST-SQUARES RECRESSION ANALYSIS ESTIMATION FROM A LINEAR MARKOV PROCESS

STRIBUTION OF THE CORRELATION BETWEEN TWO STATIONARY LINEAR MARKOV SERIES

STRIBUTION OF THE CORRELATION BETWEEN TWO STATIONARY LINEAR MARKOV SERIES. II. DATA TRANSFORMATIONS AND THE LINEAR MODEL

LEAST-SQUARES ESTIMATORS OF VARIANCE IN A CENERAL LINEAR MODEL TISTICS XV THE HISTORICAL DEVELOPMENT OF THE GAUSS LINEAR MODEL /IN THE HISTORY OF PROBABILITY AND STA BIOKAG7 BIOKA6O 482 SOME ESTIMATORS FOR A LINEAR MODEL WITH RANDOM COEFFICIENTS ON THE ESTIMATION OF CONTRASTS IN LINEAR MODELS STRAICHT LINE CONFIDENCE REGIONS OF LINEAR MODELS $\begin{array}{lll} & \text { BIOKA60 } & 482 \\ \text { THE APPROXIMATE DI BIOKA62 } & 379\end{array}$ THE APPROXIMATE DI BIOKA65 301 AMS 671456 N THE BIAS OF SOME BIOKAG8 313 LINEAR SEGMENT CONFIDENCE BANDS FOR SIMPLE LINEAR MODELS JASA 68 5B4 AMS 65198 JASA $67 \quad 1365$ JASA $67 \quad 403$ AMS 681913 BIOCS69 489 ROBUSTNESS OF SOME NONPARAMETRIC PROCEDURES IN LINEAR MODELS ANALYSIS OF CATECORICAL DATA BY LINEAR MODELS

BANDS OF UNIFORM AND PROPORTIONAL WIDTH FOR LINEAR MODELS NONPARAMETRIC INFERENCE, AN ALTERNATIVE APPROACH TO LINEAR MODELS

ON COMBINABILITY OF INFORMATION FROM UNCORRELATED LINEAR MODELS BY SIMPLE WEICHTING CONFIDENCE JASA $66 \quad 182$ ASYMPTOTICALLY AMS $63 \quad 1494$ AMS 661338 BLE ARE CONSTRAINED ESTIMATION AND INFERENCE FOR LINEAR MODELS IN WHICH SUBSETS OF THE DEPENDENT VARIA JASA 68 1201 ASYMPTOTICALLY NONPARAMETRIC INFERENCE IN SOME LINEAR MODELS NITH ONE OBSERVATTON PER CELL AMS 64726 ROBUST PROCEDURES FOR SOME LINEAR MODELS WITH ONE OBSERVATION PER CELL AMS $67 \quad 878$ REFERENCE TO THE BALANCED I/ BAYESIAN ANALYSIS OF LINEAR MODELS WITH TWO RANDOM COMPONENTS WITH SPECIAL BIOKA68 101 MISSINC VALUES IN LINEAR MULTIPLE DISCRIMINANT ANALYSIS $\quad$ BIOCS68 835 AN EXAMPLE OF THE ESTIMATION OF LINEAR OPEN LOOP TRANSFER FUNCTION MAXIMUM LIKELIHOOD PAIRED COMPARISON RANKING BY LINEAR PROGRAMMING

AN OUTLINE OF LINEAR PROGRAMMING AN OUTLINE OF LINEAR PROGRAMMING (WITH DISCUSSION) (WITH DISCUSSION)

AN OUTLINE OF LINEAR PROGRAMMING AN OUTLINE OF LINEAR PROGRAMMING ABOUT SENSITIVITY ANALYSIS IN LINEAR PROGRAMMINC MODELS ON THE DISTRIBUTION OF SOLUTIONS IN LINEAR PROGRAMMING PROBLEMS POTENTIALS IN APPLYING LINEAR PROGRAMMING TO THE CONSUMER PRICE INDEX A NOTE ON CURVE FITTING WITH MINIMUM DEVIATIONS BY LINEAR PROGRAMMING, CORR. 62 917 ASYMPTOTIC NORMALITY OF SIMPLE LINEAR RANK STATISTICS UNDER ALTERNATIVES ASYMPTOTIC NORMALITY OF SIMPLE LINEAR RANK STATISTICS UNDER ALTERNATIVES, II FOR MULTIPLE TREATMENTS, A SIGNIFICANCE TEST FOR LINEAR RANKS STEPWISE MULTIVARIATE LINEAR REGRESSION DESIGN FOR OPTIMAL PREDICTION IN SIMPLE LINEAR REGRESSION SHORTER CONFIDENCE BANDS IN LINEAR REGRESSION

A THEOREM ON LEAST SQUARES IN MULTIVARIATE LINEAR REGRESSION IMPROVED ESTIMATORS FOR COEFFICIENTS IN LINEAR REGRESSION CHOICE OF VARIABLES IN THE DESIGN OF EXPERIMENTS FOR LINEAR REGRESSION AND MULTIPLE DISCRIMINATION REGIONS IN MULTIPLE LINEAR REGRESSION THE MEAN SQUARE ERROR CRITERION FOR RESTRICTIONS IN LINEAR REGRESSION LEAST SQUARES AND VECTOR CORRELATION IN MULTIVARIATE LINEAR REGRESSION OF WILCOXON TYPE CONFIDENCE REGIONS IN MULTIPLE LINEAR REGRESSION LTIVARIATE STATISTICS II. POINT ESTIMATION IN SIMPLE LINEAR REGRESSION

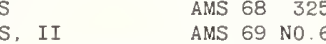
AMS 69 N0.6 TECH $63 \quad 227$ BIOKA69 N0.3 JRSSB55 165 JRSSB55 165 SASJ $67 \quad 33$ JASA $58 \quad 161$ JASA 59206 JASA 66 9B2 JASA $61 \quad 359$ JASA $63 \quad 770$ JASA $65 \quad 205$ JASA $67 \quad 1050$ JASA $67 \quad 1494$ JASA $68 \quad 596$ THE BIOKA69 55 SINGLE SASJ $68 \quad 67$ A TEST OF JASA $6 B \quad 55 B$ A THEOREM ON JASA $66 \quad 413$ DIFFERENCES

AMONG THE INDEPENDENT VARIABLES $\begin{array}{llr}\text { ASYMPTOTIC BEHAVIOR AMS } 69 & \text { NO. } 6 \\ \text { OBSERVATIONS IN MU JASA } 67 & 10\end{array}$ $\begin{array}{llr}\text { MISSING OBSERVATIONS IN MU JASA } & 67 & 10 \\ \text { WITH ADJUSTMENT FOR CLASS JASA } & 61 & 729\end{array}$ ESTIMATION OF WEIGHTING FACTORS IN LINEAR REGRESSION AND ANALYSIS OF VARIANCE

JASA 59 B34 TECH 64 A, 69 6/ TESTING FOR THE INCLUSION OF VARIABLES IN LINEAR REGRESSION BY A RANDOMISATION TECHNIQUE (ERRAT TECH 66 695 ITERATIVE ESTIMATION OF A SET OF LINEAR REGRESSION EQUATIONS A NOTE ON LINEAR REGRESSION IN TRIVARIATE DISTRIBUTIONS ON COMPARING TWO SIMPLE LINEAR REGRESSION LINES THE USE OF EMPIRICAL BAYES ESTIMATORS IN A LINEAR REGRESSION MODEL EMPIRICAL BAYES ESTIMATORS IN A MULTIPLE LINEAR REGRESSION MODEL LINEAR REGRESSION ON PROPORTIONS FIXED SIZE CONFIDENCE ELLIPSOIDS FOR LINEAR REGRESSION PARAMETERS JASA $64 \quad 845$ JASA $68 \quad 1042$ SASJ $6 B \quad 33$ BIOKA68 525 BIOKA69 367 BI0CS69 5B5 AMS 661602 HEORY OF FIXED-SIZE SEQUENTIAL CONFIDENCE BOUNDS FOR LINEAR REGRESSION PARAMETERS

THE ESTTMATION OF THE PARAMETER OF A LINEAR REGRESSION SYSTEM OBEYI TESTS OF THE HYPOTHESIS THAT A LINEAR RECRESSION SYSTEM OBEYS TWO SEPARATE REGIMES INTERVAL ESTIMATION IN LINEAR REGRESSION WHEN BOTH VARIABLES ARE SUBJECT TO

ERROR NOTE ON INTERVAL ESTIMATION IN NON-LINEAR RECRESSION WHEN RESPONSES ARE CORRELATED

VARIABLES CONFIDENCE BANDS IN LINEAR REGRESSION WITH CONSTRAINTS ON THE INDEPENDENT J, ENCY OF THE LEAST SQUARES ESTIMATORS FOR FAMILIES OF LINEAR REGRESSIONS ASYMPTOTIC NORMALITY AND CONSIST AMS 63 447 CONFIDENCE REGION FOR A LINEAR RELATION ON A TEST FOR SEVERAL LINEAR RELATIONS AMS $64 \quad 7 B 0$ JRSSB69 65 S (WITH DISCUSSION) TOPICS IN THE INVESTIGATION OF LINEAR RELATIONS FITTED BY THE METHOD OF LEAST SQUARE JRSSB67
ERRORS
LINEAR RELATIONSHIPS BETWEEN VARIABLES AFFECTED BY LINEAR RELATIONSHIPS BETWEEN VARIABLES AFFECTED BY BIOCS66 25 MPLITUDE SPECTRA FOR STOCHASTIC PROCESSES WITH QUASI-LINEAR RESIDUALS A NOTE ON THE ESTIMATION OF A JASA 66 397 FOR ANALYZING A SET OF TIME SERIES SUBJECT TO A LINEAR RESTRICTION TABLES FOR THE MEAN SQUARE ERROR TEST FOR EXACT LINEAR RESTRICTIONS IN REGRESSION SOME TECHNIQUES JASA 63513 MODELS LINEAR SEGMENT CONFIDENCE BANDS FOR SIMPLE LINEAR DISTRIBUTION EXACT LINEAR SEQUENTIAL TESTS FOR THE MEAN OF A NORMAL ACTERIZATIONS OF NORMALITY BY CONSTANT RECRESSION OF LINEAR STATISTICS ON ANOTHER LINEAR STATISTIC

SPECTRAL PROPERTIES OF NON-STATIONARY SYSTEMS OF LINEAR STOCHASTIC DIFFERENCE EQUATIONS TRIBUTION OF THE AUTOCORRELATIONS OF A SAMPLE FROM A LINEAR STOCHASTIC PROCESS NENTIAL BOUND ON THE STRONG LAW OF LARGE NUMBERS FOR LINEAR STOCHASTIC PROCESSES WITH ABSOLUTELY CONVERGEN AMS 61 5B3 MULTIVARIATE LINEAR STRUCTURAL RELATIONS

A NOTE ON THE MAXIMUM LIKELIHOOD ESTIMATION OF A LINEAR STRUCTURAL RELATIONSHIP SIMULTANEOUS PAIRWISE LINEAR STRUCTURAL RELATIONSHIPS

VARIANCES ARE KNOWN A NOTE ON LINEAR STRUCTURAL RELATIONSHIPS WHEN BOTH RESIDUAL

A DECOMPOSITION THEOREM FOR VECTOR VARIABLES WITH A LINEAR STRUCTURE CONSISTENT ESTIMATES OF THE PARAMETERS OF A LINEAR SYSTEM JASA 69 NO. 4 JASA $67 \quad 403$ BIOKA56 452 
INUOUS POPULATION DEPENOENT NORMAL VARIABLES
INTERREL TERRELATIONS BETWEEN CERTAIN LIN $\begin{array}{rrrr}\text { LINEAR TRANSFORMATION TO A SET OF STOCHASTICALLY } & \text { JASA } & 57 & 247 \\ \text { ESTIMATION OF QUASI-LINEAR TRENO AND SEASONAL VARIATION } & \text { JASA } 63 \text { 1033 } \\ \text { FACTOR CHANCES AND LINEAR TRENDS IN EIGHT-RUN TWO LEVEL FACTORIAL } & \text { TECH } 6 B & 301\end{array}$

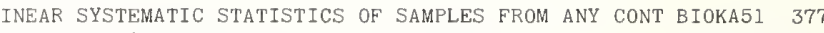
DESIGNS ASYMPTOTIC POWER OF CHI SQUARE TESTS FOR LINEAR TRENDS IN PROPORTIONS

A SEQUENTIAL METHOD OF TESTING THE LINEAR TRENDS OF RESPONSES IN DOSE TRIALS

JASA 631033 TECH $6 \mathrm{~B} \quad 301$ BI0CS68 315 BI0CS68 663 ITION THAT ORDINARY LEAST-SQUARES ESTIMATORS BE BEST LINEAR UNBIASED A NECESSARY AND SUFFICIENT COND JASA 67 I302 TES FOR A SMALLER SAMPLE/ THE CONSTRUCTION OF GOOD LINEAR UNBIASED ESTIMATES FROM THE BEST LINEAR ESTIMA TECH 65 543 $Y$ PROCESSES EXPERIMENT BEST LINEAR UNBIASED ESTIMATION FOR MULTIVARIATE STATIONAR TECH $6 B \quad 523$ OGISTIC DISTRIBUTION USING ORDER STATISTICS BEST LINEAR UNBIASED ESTIMATORS OF THE PARAMETERS OF THE L TECH 67 43 REGRESSION MODEL A MULTIVARIATE CENTRAL LIMIT THEOREM FOR RANDOM LINEAR VECTOR FORMS PARAMETERS BEST LINEAR UNBIASED PREDICTION IN THE GENERALIZED LINEAR

LINEAR-LOSS INTERVAL ESTIMATION OF LOCATION AND SCALE SERIES, CORR, $65 \quad 1250$ EXPECTED-COVER AND LINEAR-UTILITY TOLERANCE INTERVALS ASA $62 \quad 369$ AMS $66 \quad 1 B 25$ BIOKA68 141 JRSSB $66 \quad 57$ ON BEALE'S MEASURES OF NON-LINEARITY SIGN AND WILCOXON TESTS FOR LINEARITY

CURVE ASYMPTOTIC LINEARITY OF A RANK STATISTIC IN REGRESSION PARAMETER A TEST OF LINEARITY VERSUS CONVEXITY OF A MEDIAN REGRESSION APPROXIMATE LINEARIZATION OF THE INCOMPLETE BETA-FUNCTION REMARK ON THE LINEARIZED MAXIMUM LIKELIHOOD ESTIMATE QUASI-LINEARLY INVARIANT PREDICTION

ALMOST LINEARLY-OPTIMUM COMBINATION OF UNBIASED ESTIMATES

ON COMPARING TWO SIMPLE LINEAR REGRESSION LINES CURVE FITTINC BY SEGMENTED STRAIGHT LINES

TESTS OF SIGNIFICANCE FOR CONCURRENT REGRESSION LINES CONTROL CHARTS WITH WARNING LINES

A MODIFIED CONTROL CHART WITH WARNING LINES

THE STANDARD DEVIATION BY CUSUMS AND WARNING LINES TESTS FOR THE PARALLELISM OF SEVERAL RECRESSION LINES RIBUTION FUNCTION LIES BETWEEN TWO PARALLEL STRAIGHT LINES TO ERROR TECH 64 68 $\begin{array}{rrr}\text { AMS } & 67 & 1759\end{array}$ AMS 69 NO. 6 AMS 621096 BIOKA59 214 AMS 671876 AMS 661684 JASA $61 \quad 36$ SASJ $68 \quad 33$ JASA 691079 BIOKA53 297 BIOKA55 243 BIOKA62 171 ON A CLASS OF RANK ORDER AMS 691668 THE PROBABILITY THAT THE SAMPLE DIST AMS $6 \mathrm{~B} \quad 39 \mathrm{~B}$ ATIVE TEST FOR THE CONCURRENCE OF SEVERAL REGRESSION LINES AND RELATED PROBLEMS

FITTING OF STRAIGHT LINES AND PREDICTION WHEN BOTH VARIABLES ARE SUBJECT JASA 6165 A CONSERV BIOKA66 272 59 B 12 BULK SAMPLING. PROBLEMS AND LINES OF ATTACK

$$
\text { THE FITTING OF STRAIGHT LINES WHEN BOTH VARIABLES ARE SUBJECT TO ERROR, CORR. }
$$
FITTING STRAIGHT LINES WHEN ONE VARIABLE IS CONTROLLED

ON THE CONCURRENCE OF A SET OF REGRESSION LINES GTH AND ITS IMPORTANCE FOR THE STUDY OF QUANTITATIVE LINGUISTICS /HE OCCURRENCE DISTRIBUTION OF WORD LEN BIOKA58 222 COMMENTS ON PAPER BY KURTZ. LINK, TUKEY AND WALLACE A THEORY FOR RECORD LINKAGE A MODEL FOR OPTIMUM LINKAGE OF RECORDS ON PARTIALLY LINKED BLOCK OESIGNS

A SOLUTION TO THE PROBLEM OF LINKING MULTIVARIATE DOCUMENTS

C FUNCTIONS LINKING MULTIVARIATE DOCUMENTS CONSUMERS' PROPENSITIES TO HOLD LIQUTD ASSETS FOR ESTIMATING THE COMPOSITION OF A THREE COMPONENT LIQUID MIXTURE FOR ESTIMATING THE COMPOSITION OF A THREE COMPONENT LIQUID MIXTURE

ON THE PROBLEM OF MATCHING LISTS BY SAMPLES ON MATCHING LISTS BY SAMPLES THE ACCURACY OF CENSUS LITERACY STATISTICS IN IRAN TECH $65 \quad 163$ JASA 69 NO 4 JASA $68 \quad 1321$ AMS 661401 JASA 69163 AMS $67 \quad 32$ JASA $60 \quad 469$ METHODS TECH $64 \quad 343$ BI0CS65 459 JASA 59403 JASA $61 \quad 151$ JASA $5957 B$ TISTICS. IV A NOTE ON AN EARLY STATISTICAL STUDY OF LITERARY STYLE /THE HISTORY OF PROBABILITY AND STA BIOKA56 248 ISTICS. VIII, DE MORGAN AND THE STATISTICAL STUDY OF LITERARY STYLE /THE HISTORY OF PROBABILITY AND STAT BIOKA5B 2B2 ON NAHORDNUNG AND FERNORDNUNC IN SAMPLES OF LITERARY TEXTS VALUES IN MULTIVARIATE STATISTICS. I. REVIEW OF THE LITERATURE BI0KA54 116 STATISTICS XVI. RANDOM RANDOM MECHANISMS IN TALMUDIC LITERATURE /DIES IN THE HISTORY OF PROBABILITY AND BIOKA67 316 A REVIEW OF THE LITERATURE ON A CLASS OF COVERAGE PROBLEMS H REFERENCES TO RELATED SOCIAL STU/ A GUIDE TO THE LITERATURE ON STATISTICS OF RELIGIOUS AFFILIATION WIT JASA 59 335
A REVIEW OF RESPONSE SURFACE METHODOLOGY. A LITERATURE SURVEY A REVIEW OF RESPONSE SURFACE METHODOLOGY. A LITERATURE SURVEY STATISTICS WE LIVE BY

USEFUL LIFE OF ITEMS BY ELIMINATING THOSE WITH SHORT LIVES ON THE POSSIBILITY OF IMPROVING THE MEAN Th PRODUCT DIVERSIFICATION AND LIVING COSTS. A FURTHER COMMENT PRODUCT DIVERSIFICATION AND THE COST OF LIVING, CORR. 641296 JASA 62 TECH $61 \quad 281$ JASA 66788 JASA $63 \quad 807$ A MARKOV PROCESS MULTIVARIATE TESTS KOLMOGOROV-SMIRNOV TYPE

DEVELOPMENT OF RANDOMIZED LOAD SEQUENCES WITH TRANSITION PROBABILITIES LOCAL AND ASYMPTOTIC MINIMAX PROPERTIES OF LOCAL ASYMPTOTIC POWER AND EFFICIENCY OF TESTS OF

ON THE LOCAL BEHAVIOR OF MARKOV TRANSITION PROBABILITIES LOCAL CONDITIONAL SUFFICIENCY

NUMBERS LOCAL CONVERGENCE OF MARTINGALES AND THE LAW OF LARGE ON LOCAL INFERENCE AND INFORMATION

A LOCAL LIMIT THEOREM

A LOCAL LIMIT THEOREM FOR A CERTAIN CLASS OF RANDOM

A LOCAL LIMIT THEOREM FOR NONLATTICE MULTI-DIMENSIONAL

WALKS
DISTRIBUTION FUNCTIONS ON FINDING LOCAL MAXIMA OF FUNCTIONS OF A REAL VARIABLE STATISTICAL ANALYSIS USING LOCAL PROPERTIES OF SMOOTHLY HETEROMORPHIC STOCHASTIC
SAMPLING PROPERTIES OF LOCAL STATISTICS IN STATIONARY STOCHASTIC SERIES

ON LOCAL UNBIASED ESTIMATION

SERIES

OF THREE-PARAMETER LOGNORMAL POPULATIONS FROM CO/ LOCAL-MAXIMUM-LIKELIHOOD ESTIMATION OF THE PARAMETERS JA MULTIVARIATE PROBLEM NGIAN MULTIPLIER TESTS OF LINEAR HYPOTHESES

T FOR THE INDEPENDENCE OF TWO POISSON VARIAB/ LOCALLY AND ASYMPTOTICALLY MINIMAX TESTS OF TECH $66 \quad 107$ AMS $64 \quad 21$ AMS 671705 AMS $6 B \quad 2123$ JRSSB $64 \quad 52$ AMS $65 \quad 552$ JRSSB 64253 AMS $64 \quad 419$ AMS $66 \quad 855$ AMS $65 \quad 546$ BIOKA67 310 BIOKA57 454 BI0KA55 160 JRSSB $64 \quad 46$ LOCALLY ASYMPTOTICALLY MOST STRINGENT TESTS AND LAGRA BIOKA65 459 LOCALLY MINIMAX TESTS ASYMPTOTIC EFFICIENCY OF CERTAIN LOCALLY MOST POWERFUL RANK TESTS LOCALLY UNBIASED TYPE M TEST

A SEQUENTIAL SEARCH PROCEDURE FOR LOCATING A RESPONSE JUMP 
THE RIAS OF THE SECH SQUARE DISTRIBUTION

OF DISTRIBUTIONS, CORR. 631603 ESTIMATION OF LOCATION AND SCALE PARAMETERS IN A TRUNCATED GROUPED JASA 61 LOCATION AND SCALE PARAMETERS IN EXPONFNTIAL FAMILIES AMS 62

A COMPARISON OF TWO SORTS OF TEST FOR A CHANGE OF LOCATION APPLICABLE TO TRUNCATED DATA ESTIMATES OF LOCATION BASED ON RANK TESTS

ESTIMATES AND PARABOLIC REGRESSION WITH RESTRICTED LOCATION FOR THE STATIONARY POINT LEAST SQUARES JA AMS 63598 ALTERNATIVES ON THE PROBLEM OF TESTING LOCATION IN MULTIVARIATE POPULATIONS FOR RESTRICTED AMS 66 113 ON THE THEORY OF RANK ORDER TESTS FOR LOCATION IN THE MULTIVARIATE ONE SAMPLE PROBLEM AMS G7 I21G WITH DICHOTOMOUS AND CONTINUOUS VARIABLES I. THE LOCATION MODEL MULTIVARIATE TWO SAMPLE TESTS ORDER STATISTICS ESTIMATORS OF THE LOCATION OF THE CAUCHY DISTRIBUTION ESTIMATION OF THE LOCATION OF THE CUSP OF A CONTINUOUS DENSITY ROBUST ESTIMATION OF A LOCATION PARAMETER

ADMISSIBILITY OF QUANTILE ESTIMATES OF A SINGLE LOCATION PARAMETER INVARIANT INTERVAL ESTIMATION OF A LOCATION PARAMETER ESTIMATORS OF A LOCATION PARAMETER IN THE ABSOLUTELY CONTINUOUS CASE CONSISTENT ESTIMATION OF A LOCATION PARAMETER IN THE PRESENCE OF AN INCIDENTAL A NOTE ON THE TEST FOR THE LOCATION PARAMETER OF AN EXPONENTIAL DISTRIBUTION A NOTE ON THE ESTIMATION OF THE LOCATION PARAMETER OF THE CAUCHY DISTRIBUTION AMS 69290 JASA $66 \quad 1205$ AMS $68 \quad 76$ AMS $64 \quad 73$ AMS 641019 AMS 68193 AMS $64 \quad 949$ AMS 691353 AMS 691838 JASA $66 \quad 852$ ISTRIBUTIONS ON SOME PERMISSIBLE ESTIMATORS OF THE LOCATION PARAMETER OF THE WEIBULL AND CERTAIN OTHER D TECH 67 293 ON ESTIMATING SCALE AND LOCATION PARAMETERS OTICALLY NEARLY EFFICIENT ESTIMATORS OF MULTIVARIATE LOCATION PARAMETERS ADMISSIBILITY OF INVARIANT ESTIMATORS OF ONE OR MORE LOCATION PARAMETERS ESTIMATION, I. VARIANCE BOUNDS FOR ESTIMATORS OF LOCATION PARAMETERS EXPERIMENTS AND THEIR USE FOR EXPERIMENTS INVOLVING LOCATION PARAMETERS WILCOXON CONFIDENCE INTERVALS FOR LOCATION PARAMETERS IN THE DISCRETE CASE

ROBUSTNESS OF SOME PROCEDURES FOR THE TWO-SAMPLE LOCATION PROBLEM SMALL SAMPLE POWER CURVES FOR THE TWO SAMPLE LOCATION PROBLEM

A NON-PARAMETRIC TEST FOR THE BIVARIATE TWO-SAMPLE LOCATION PROBLEM NPARAMETRIC CONFIDENCE REGIONS FOR SOME MULTIVARIATE LOCATION PROBLEMS ON CONDITIONAL EXPECTATIONS OF LOCATION STATISTICS ERRATA, 'DIAMOND-PIN LOCATION'

THE TWO-SAMPLE SCALE PROBLEM WHEN LOCATIONS ARE UNKNOWN

ON PARTITIONING A SET OF NORMAL POPULATIONS BY THEIR LOCATIONS WITH RESPECT TO A CONTROL IBRIUM UNDER SELECTION AT A MULTI-ALLELIC SEX-LINKED LOCUS (ACKNOWLEDGEMENT 68 1025) RETENTION RECORDS

THE LOC (-OOG) TRANSFORMATTON IN THE ANALYSIS OF FRUTT AMETER IS 'NEAR' THE B/ ON THE DISTRIBUTION OF THE LOG LIKELIHOOD RATIO TEST STATISTIC WHEN THE TRUE PAR AMS 68 2O44 FOR THE COEFFICIENT OF VARIATION FOR THE NORMAL AND LOG NORMAL DISTRIBUTIONS CONFIDENCE INTERVALS BIOKA64 25 N RECORDS

THE LOG (-LOG) TRANSFORMATION IN THE ANALYSIS OF FRUIT RETENTIO A NOTE ON LOG-LINEAR REGRESSION

PROGRESSIVELY CENSORED SAMPLES FROM LOG-NORMAL AND LOGISTIC DISTRIBUTIONS ESTIMATING THE PARAMETERS OF LOG-NORMAL DISTRIBUTION FROM CENSORED SAMPLES

NAL CLOSEN/ SEQUENTIAL ESTTMATION OF THE MEAN OF A LOG-NORMAL DISTRTBUTION HAVING A PRESCRTBED PROPORTIO AMS 66 1688 ISTENCE OF A FIXED SAMPLE ESTIMATOR OF THE MEAN OF A LOG-NORMAL DISTRIBUTION HAVING A PRESCRIBED PROPORTIO AMS 67 949 A CONFIDENCE REGION FOR THE LOG-NORMAL HAZARD FUNCTION THE DISTRIBUTION OF THE LOGARITHM OF THE SUM OF TWO LOG-NORMAL VARIATES AL POPULATTON IN WHTCH THE ABUNDANCES OF SPECIES ARE LOG-NORMALLY DISTRIBUTED /ES IN A SAMPLE OF AN ANIM BIOKA5I 427 E FOLLOW-UP A METHOD OF ANALYZING LOG-NORMALLY DISTRIBUTED SURVIVAL DATA WITH INCOMPLET THE MOMENTS OF LOG-WEIBULL ORDER STATISTICS

A REMARK ON THE LAW OF THE ITERATED LOGARITHM CONVERGENCE RATES FOR THE LAW OF THE ITERATED LOGARITHM THE LAW OF THE ITERATED LOGARITHM FOR MIXING STOCHASTIC PROCESSES

UM, 691855

A DELICATE LAW OF THE ITERATED LOGARITHM FOR NON-DECREASING STABLE PROCESSES (ADDEND THE DISTRIBUTION OF THE LOGARITHM OF NON-CENTRAL F THE DISTRIBUTION OF THE LOGARITHM OF THE SUM OF TWO LOG-NORMAL VARIATES JASA 60 TECH $69 \quad 373$ AMS 67599 AMS $68 \quad 1479$ AMS 69 NO.6 AMS 681818 BIOKA60 417 JASA 69655 TABLES OF THE LOGARITHMIC SERIES DISTRIBUTION

A NOTE ON SOME ASYMPTOTIC PROPERTIES OF THE LOGARITHMTC SERIES DISTRIBUTION INTERVAL ANALYSIS AND THE LOGARITHMIC TRANSFORMATION

THE LOGIC OF LEAST SQUARES SOME LOGICAL ASPECTS OF THE FIDUCIAL ARGUMENT ESTIMATING THE LOGISTIC CURVE JRSSB58 187 JRSSB63 124 JRSSB63 111 JASA $57 \quad 567$ AMS $66 \quad 1002$ BIOKA66 565

ON THE BIVARIATE MOMENTS OF ORDER STATISTICS FROM A LOGISTIC DISTRIBUTION ESTIMATION OF THE PARAMETERS OF THE LOUISTIC DISTRIBUTION ATION, FROM CENSORED SAMPLES, OF THE PARAMETERS OF A LOGISTIC DISTRIBUTION 
TATISTICS AND THE DISTRIBUTION OF THE RANCE FROM THE LOCISTIC DISTRIBUTION /ENTACE POINTS OF THE ORDER 5 AMS 65 907 ESTIMATION OF THE PARAMETERS OF THE LOCISTIC DISTRIBUTION BY SAMPLE QUANTILES

LINEAR UNBIASED ESTIMATORS OF THE PARAMETERS OF THE LOCISTIC DISTRIBUTION USINC ORDER STATISTICS BIVARIATE LOCISTIC DISTRIBUTIONS

PROCRESSIVELY CENSORED SAMPLES FROM LOG-NORMAL AND LOCISTIC DISTRIBUTIONS TESTS OF HYPOTHESES ABOUT THE PARAMETERS OF THE LOCISTIC FUNCTION

NOMOCRAMS FOR FITTINC THE LOCISTIC FUNCTION BY MAXIMUM LIKELIHOOD

A NOTE ON THE ESTIMATION OF THE PARAMETERS OF THE LOGISTIC FUNCTION, USINC THE MINIMUM LOCIT CHI-SQUARE ASPECTS OF MAXIMUM LIKELIHOOD ESTIMATION OF THE LOCISTIC CROWTH FUNCTION

$$
\text { A CENERALIZATION OF THE LOCISTIC LAW OF CROWTH }
$$

LOGISTIC ORDER STATISTICS

CURVE AND APPLICATIONS THE LOCISTIC PROCESS, TABLES OF THE STOCHASTIC EPIDEMIC

PROPERTIES OF THE MEDIAN AND OTHER STATISTICS OF LOCISTIC VARIATES

LINEAR AND NON-LINEAR MULTIPLE COMPARISONS IN LOCIT ANALYSIS

'LINEAR AND NON-LINEAR MULTIPLE COMPARISONS IN LOGIT ANALYSIS'

A TABLE FOR ESTIMATINC THE MEAN OF A LOCNORMAL DISTRIBUTION

ON THE PROBLEM OF ESTIMATION FOR THE BIVARIATE LOCNORMAL DISTRIBUTION

ON A PROPERTY OF THE LOCNORMAL DISTRIBUTION

THE THREE-PARAMETER LOGNORMAL DISTRIBUTION AND BAYESIAN ANALYSIS OF A BIOCS65 721 BIOCS69 3B3 JASA $66 \quad 236$ JASA $6 B \quad 653$ BIOKA56 404 JASA 69632 BIOKA64 522 JRSSB63 392

POINT-SOURCE EPIDEMIC JASA $63 \quad 72$

SCRIPTION AND ESTIMATION PROBLEMS, CORR. $63 \mathrm{l} /$ THE LOCNORMAL DISTRIBUTION AND THE TRANSLATION METHOD. DE J LIFE TEST SAMPLINC PLANS FOR NORMAL AND LOCNORMAL DISTRIBUTIONS

TRUNCATED LOCNORMAL DISTRIBUTIONS. I. SOLUTION BY MOMENTS JASA 6323 TECH $62 \quad 151$ IRUNCATED LOCNORMAL DISTRIBUTIONS

LIFE-TESTINC RESULTS BASED ON A FEW HETEROCENEOUS LOCNORMAL OBSERVAITONS

BIOKA51 414 JASA $67 \quad 45$ SEQUENTIALLY TESTINC OBSERVED ARITHMETIC MEANS FROM LOGNORMAL POPULATIONS ACAINST A CIVEN STANDARD /FOR TECH 68 605 HOOD ESTIMATION OF THE PARAMETERS OF THREE-PARAMETER LOGNORMAL POPULATIONS FROM COMPLETE AND CENSORED SAMP JASA 66 842 NOTES. ON ESTIMATINC THE ARITHMETIC MEANS OF LOCNORMALLY-DISTRIBUTED POPULATIONS PROBLEMS IN MEASURINC LONC TERM CROWTH IN INCOME AND WEALTH BIOCS65 235 JASA $57 \quad 450$ THE CROWTH, SURVIVAL, WANDERINC AND VARIATION OF THE LONG-TAILED FIELD MOUSE. APODEMUS SYLVATICUS. III. WA BIOKA52 389 LONCEST RUN OF CONSECUTIVE OBSERVATIONS HAVINC A COMPONENTS (WITH DISCUSSION) FITTINC CURVES TO LONCITUDINAL DATA ANOTHER LOOK AT HENDERSON'S METHODS OF ESTIMATINC VARIANCE BIOKA61 461 BIOCS66 276 BIOCS68 749 BIOKA62 419 BIOKA63 546 A FURTHER LOOK AT ROBUSTNESS VIA BAYES'S THEOREM

CORRICENDA, 'A FURTHER LOOK AT ROBUSTNESS VIA BAYES'S THEOREM.' BIOKA69 249 AN EXAMPLE OF THE ESTIMATION OF LINEAR OPEN LOOP TRANSFER FUNCTION B WNIAN MOTION BAYES ESTIMATION WITH CONVEX LOSS A.P.O. RULE IN SEQUENTIAL ESTIMATION WITH QUADRATIC LOSS TILES OF THE NORMAL DISTRIBUTION UNDER SQUARED ERROR LOSS CRNA LOSS DUE TO CROUPINC IN DISTRIBUTION-FREE TESTS AMS 691603 AMS $63 \quad$ B39 DESIGNS IN REGRESSION PROBLEMS WITH A CENERAL CONVEX LOSS FUNCTION ULTIVARIATE NORMAL POPULATION WITH CENERAL QUADRATIC LOSS FUNCTION ANCILLARY STATISTICS AND PREDICTION OF THE LOSS IN ESTIMATION PROBLEMS

FOR ADMISSIBILITY OF ESTIMATORS WHEN STRICTLY CONVEX LOSS IS USE

THE COMPOUND DECISION PROBLEM WITH M-BY-N FINITE LOSS MATRIX

COMPOUND DECISION PROBLEMS WITH M-BY-N FINITE LOSS MATRIX

A NECESSARY AND SUFFICIENT CONDITION ESTIMATINC THE MPTIMAL AMS $69 \quad 417$ A NOTE ON THE LOSS OF INFORMATION
CONVERGENCE THEOREMS FOR MULTIPLE CHANNEL LOSS PROBABILITIES AVERAGE RENEWAL LOSS RATES

QUENTIAL SAMPLING. TWO DECISION PROBLEMS WITH LINEAR LOSSES FOR BINOMIAL AND NORMAL RANDOM VARIABLES. SE BIOKA65 507 SCOOLINC. EXPERIENCE. AND CAINS AND LOSSES IN HUMAN CAPITAL THROUCH MICRATION

FECTS ON THE INBREEDINC COEFFICIENT AND RATE OF CENE LOSS OF FOUR METHODS OF REPRODUCING FINITE DIPLOID PO AMS 691 1B01 JASA $67 \quad 954$ BIOKA6B 53 AMS 661819 AMS 6B 1756 AMS $6 \mathrm{~B} \quad 23$ AMS $66 \quad 412$ AMS $66 \quad 954$ BIOKA64 495 AMS 63260 AMS $63 \quad 396$

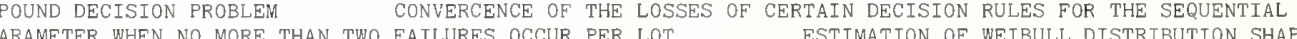
SOME THEORETICAL ASPECTS OF THE LOT PLOT SAMPLING INSPECTION PLAN THE CONDITION FOR LOT SIZE PRODUCTION RECTIFYINC INSPECTION OF LOTS

SEQUENTIAL RELTABILITY ASSURANCE IN FINITE LOTS

SURVEILLANCE PROGRAMS FOR LOTS IN STORACE APPROXIMATINC THE LOWER BINOMIAL CONFIDENCE LIMIT (CORR. 69669 ) $\begin{array}{rrr}\text { JASA } & 67 & 875 \\ \text { AMS } & 64 & 1606\end{array}$ AMS 641606 JASA $56 \quad$ B4 JASA $56 \quad 627$ JASA $61 \quad 807$ TECH 6961 TECH $62 \quad 515$ JASA $68 \quad 1413$ QUADRANT ORIENTED-ATOM PERCOLATION PROCESS A LOWER BOUND FOR THE CRITICAL PROBABILITY IN THE ONECOEFFICIENT LOWER BOUND FORMULAS FOR THE MEAN INTERCORRELATION

401 JASA $59 \quad 275$ JASA $61 \quad 670$ AMS 671343 AMS $64 \quad 362$ AMS 682128 AMS 691120 SERIES RECRESSION PROBLEMS LOWER BOUNDS FOR AVERAGE SAMPLE NUMBER OF SEQUENTIAL LOWER BOUNDS FOR MINIMUM COVARTANCE MATRICES IN TIME AN ELEMENTARY METHOD OF OBTAININC LOWER BOUNDS ON THE ASYMPTOTIC POWER OF RANK TESTS A CHARACTERIZATION OF THE UPPER AND LOWER CLASSES IN TERMS OF CONVERGENCE RATES JRSSB67 263

UMUL/ A SIMPLE PROCEDURE FOR DETERMININC INTERVAL

FINITE UNIVARIATE POPULATION

ES WITH MONOTONE DENSITY RATIOS

EXACT LOWER LOMENTS OF ORDER STATTSTTCS TN SAMPLES FROM THE UPPER AND LOWER PROBABILITIES GENERATED BY A RANDOM CLOSED

AMS $68 \quad 957$ UPPER AND LOWER PROBABILITIES INDUCED BY A MULTIVALUED MAPPING AMS 6732 UPPER AND LOWER PROBABILITY INFERENCES BASED ON A SAMPLE FROM A BIOKAG7 515 UPPER AND LOWER PROBABILITY INFERENCES FOR FAMILIES OF HYPOTHES AMS 69953 SOME LIMIT THEOREMS FOR THE DODCE-ROMIG LTPD SINCLE SAMPLING INSPECTION PLANS 19. WITH MULTIPLE DEATH PROCESS AND APPLICATIONS TO LUNAR CRATERS A MULTIVARIATE IMMIGRATION BIOKAG7 251 WITH SPECTAL REFERENCE TO THE CICARETTE SMOKINC AND LUNG CANCER CONTROVERSY /STTCAL INFERENCE IN HEALTH JASA 69 739 HASTIC MODEL FOR THE MO/ EMPERICAL RELATIONSHIP OF LUNC CANCER INCIDENCE TO CIGARETTE SMOKING AND A STOC BIOCS65 839 
ITH PARTICULAR REFERENCE TO THE STUDY OF SMOKINC AND LUNC CANCER, CORR, 60 754 /ING EXPONENTIAL RISKS. W JASA 60 415 SMOKINC AND LUNC CANCER, SOME OBSERVATIONS ON TWO RECENT REPORTS JASA 5828

A PERFECT MEASURABLE SPACE THAT IS NOT A LUSIN SPACE

THE CHICK ASSAY OF LYSINE

A DECOMPOSITION OF LI-BOUNDED MARTINCALES

USE OF A TABLE OF PERCENTACE POINTS OF BARTLETT'S M

OF BOX'S APPROXIMATIONS TO THE DISTRIBUTION OF M

ESTIMATION OF THE PROBABILITY OF ZERO FAILURES IN M BINOMIAL TRIALS

THE FACTORIAL REPLICATES OF THE TWO TO THE POWER OF M DESIGNS WITH BLOCKS

AMS 671918

BIOCS66 58

AMS $68 \quad 134$

HE TWO SAMPLE KOLMOGOROV-SMIRNOV CRITERION D-SUB-MN, M LESS THAN OR EQUAL TO

SOME COMMENTS ON THE ACCURACY BIOKA69 219

JASA $67 \quad 272$

ULL POPUL/ POINT AND INTERVAL ESTIMATORS, BASED ON M ORDER STATISTICS, FOR THE SCALE PARAMETER OF A INETB TECH 65 405 LOCALLY UNBIASED TYPE M TEST

OF BIVARIATE T-SQUARE AND HOMOSCEDASTICITY CRITERION M UNDER UNEQUAL VARIANCE AND LEPTOKURTOSIS /UTIONS J

THE SEQUENTIAL COMPOUND DECISION PROBLEMS WITH M-BY-N FINITE LOSS MATRIX

THE COMPOUND DECISION PROBLEM WITH M-BY-N FINITE LOSS MATRIX

ASYMPTOTIC NORMALITY OF SAMPLE QUANTILES FOR M-DEPENDENT PROCESSES

ASYMPTOTIC EXTREMES FOR M-DEPENDENT RANDOM VARIABLES

SOME NON-PARAMETRIC TESTS FOR M-DEPENDENT TIME SERIES

A NOTE ON THE QUEUEING SYSTEM M-M-1 WITH BALKINC

THE OUTPUT PROCESS OF A STATIONARY M/M/S QUEUEINC SYSTEM

MCHINE COMPUTATION OF HIGHER MOMENTS

SOME CONTRIBUTIONS TO THE THEORY OF MACHINE INTERFERENCE

ON MACHINE INTERFERENCE

ON SOME PROBLEMS OF MACHINE INTERFERENCE

CLOSED QUEUEINC SYSTEMS, A GENERALIZATION OF THE MACHINE INTERFERENCE MODEL

NORMAL APPROXIMATION TO MACHINE INTERFERENCE WITH MANY REPAIR MEN

AN APPROACH TO THE SCHEDULING OF JOBS ON MACHINES

TABLE FOR PREDICTING THE PRODUCTION FROM A CROUP OF MACHINES UNDER THE CARE OF ONE OPERATIVE

WHEN WALKING TIME AND REPAIR/ THE EFFICIENCY OF N MACHINES UNI-DIRECTIONALLY PATROLLED BY ONE OPERATOR WHEN WALKING TIME IS CONSTANT/ THE EFFICIENCY OF N MACHINES UNI-DIRECTIONALLY PATROLLED BY ONE OPERATOR THE EFFICIENCY OF AUTOMATIC WINDINC MACHINES WITH CONSTANT PATROLLING TIME ESTIMATING MACHINING ERRORS IN SET-UPS WITH AUTOMATIC RESETTING TECH $64 \quad 423$ SAMPLES FROM A FINITE POPULATION (ATY'S FORMULAE AND MADOW'S CENTRAL LIMIT) (ING MOMENTS OF THE MEAN IN CIES HAVING ALL DIGENIC EPISTATIC VARIANCES OF EQUAL MAGNITUDE/IC COMPONENTS FOR NON-INBRED DIPLOID SPE ' $N$ BENADERING VIR ' $N$ MAGREEKS WAARSKYNLIKHEIDSVERDELING

TIME INTERVALS BETWEEN ACCIDENTS, A NOTE ON MAGUIRE, PEARSON AND WYNN'S PAPER

A SAMPLING PROCEDURE FOR MAILED QUESTIONNAIRES

A NOTE ON SMALL ORTHOGONAL MAIN EFFECT PLANS FOR FACTORIAL EXPERIMENTS JRSSB 66298 JASA 631048 AMS 66954 AMS $66 \quad 412$ AMS $68 \quad 1724$ AMS 641322 JASA $65 \quad 134$ BIOKA65 643 AMS $68 \quad 1144$ JASA $56 \quad 489$ BIOKA63 135 JRSSB56 280 JRSSB59 106 JRSSB61 385 JRSSB57 334 JRSSB6I 484 A JRSSB54 285 JRSSB57 JRSSB57 173 JRSSB59 38 BIOKA61 199 BIOCS69 545 SASJ 69 NNO.2 BIOKA53 212 JASA $56 \quad 209$ TECH 64220 CH FOR CONSTRUCTING A USEFUL CLASS OF NON-05FZOGONAL MAIN EFFECT PLANS IN K TO THE N FACTORIALS /APPROA JRSSB68 37I ACTORIAL E/ NOTES THE SOUARE-SUMMTNG CHECK ON THE MAIN EFFECTS AND INTERACTIONS IN A 2 TO THE PONER N F BIOCS67 571 ON THE MONOTONICITY PROPERTY OF THE THREE MAIN TESTS FOR MULTIVARIATE ANALYSIS OF VARIANCᄅ LAYOUT WITH ANY NUMBER OF FACTORS TWO

MAIN-EFFECT ANALYSIS OF THE GENERAL NON-ORTHOGONAL
SOME MAIN-EFFECT PLANS AND ORTHOGONAL ARRAYS OF STRENCTH JRSSB $64 \quad 77$ AMS $65 \quad 88$ AMS 611167 EXPERIMENTS

NTS '

TECH $62 \quad 21$ CTOR INTERACTIONS FOR THE 2-TO-THE-N T/ 'ORTHOGONAL MAIN-EFFECT PLANS FOR ASYMMETRICAL FACTORIAL EXPERIME TECH 62440 ORTHOGONAL MAIN-EFFECT PLANS PERMITTING ESTIMATION OF ALL TWO-FA TECH 69 NO.4 ORTHOGONAL MAIN-EFFECT 2-TO-THE-N-TIMES-3-TO-THE-M DESIGNS AND TECH 68 559 TESTING THE HYPOTHESIS OF NO FIXED MAIN-EFFECTS IN SCHEFFE'S MIXED MODEL $\begin{array}{rrr}\text { AMS } & 62 & 1085 \\ \text { JASA } & 56 & 228\end{array}$ THE ECONOMIC DESIGN OF MEAN CHARTS USED TO MAINTAIN CURRENT CONTROL OF A PROCESS ABILITY ANALYSIS OF SYSTEMS UNDER VARIOUS PREVENTIVE MAINTENANCE POLICIES A GENERAL METHOD FOR THE RELI AMS 62 137 T FROM THE RANGE OF THE DEVIATIONS ABOUT THE REDUCED MAJOR AXIS//R ESTIMATINC THE CORRELATION COEFFICIEN BIOKA53 218 CASE OF A/ INTERVAL ESTIMATION OF THE SLOPE OF THE MAJOR AXIS OF A BIVARIATE NORMAL DISTRIBUTION IN THE BIOCS68 679 NTIONS CONSUMER DURABLE COODS EXPENDITURES, WTTH MAJOR EMPHASIS ON THE ROLE OF ASSETS, CREDIT AND INTE JASA 63 648 A COMPARISON OF MAJOR UNITED STATES RELIGIOUS GROUPS JASA 61568 MAJORANTS OF THE CHROMATIC NUMBER OF A RANDOM GRAPH JRSSB69 NO.2 ASES IN POPULATION CENS/ FAILURE OF ENUMERATORS TO MAKE ENTRIES OF ZERO, ERRORS IN RECORDING CHILDLESS C JASA 6I 909 DIGEST STATISTTCIAN AND POLTCY MAKER A PARTNERSHIP IN THE MAKINC HIGHER FEMALE THAN MALE MORTALITY IN SOME COUNTRTES OF SOUTH ASIA, JASA $56 \quad 12$ JASA 69 NO. JASA $69 \quad 102$ WORKING LIFE TABLES FOR MALES IN GHANA 1960 MAMMALIAN REPRODUCTIVE DATA FITTED TO A MATHEMATICAL BIOCS69 529

MODEL A POOR MAN'S MONTE CARLO (WITH DISCUSSION)

THE VARYING QUALITY OF INVESTMENT TRUST MANACEMENT A MATRIX MODEL FOR FOREST MANAGEMENT

TIAL CORRELATION AND RECRESSION, WITH APPLICATION TO MANIFOLD, ORDERED CONTINCENCY TABLES AN APPROXIMATION TO THE WILCOXON-MANN-WHITNEY DISTRIBUTION NOTE ON THE WILCOXON-MANN-WHITNEY STATISTIC ON THE TRIMMED MANN-WHITNEY STATISTIC

LARCE SAMPLE PROPERTIES OF A GENERALIZED WILCOXON-MANN-WHITNEY STATISTIC ON THE EFFICIENCY OF TWO-SAMPLE MANN-WHITNEY TEST FOR DISCRETE POPULATIONS EXACT POWER OF MANN-WHITNEY TEST FOR EXPONENTIAL AND RECTANGULAR JRSSB54 23 JASA 631011 BIOCS69 309 LTERNATIVES

ED POINT, CORR. 60755 EXTENSION OF THE WILCOXON-MANN-WHITNEY TEST TO SAMPLES CENSORED AT THE SAME FIX RECURSIVE GENERATION OF THE DISTRIBUTION OF THE MANN-WHITNEY U-STATISTICS UNDER
A NOTE ON THE ASYMPTOTIC NORMALITY OF THE MANN-WHITNEY-WILCOXON STATISTIC

AN EXTENDED TABLE OF CRITICAL VALUES FOR THE MANN-WHITNEY-WILCOXON TWO-SAMPLE STATISTIC TABLES OF THE DISTRIBUTION OF THE MANN-WHITNEY-WILCOXON U-STATISTIC UNDER LEHMANN ALTER ON THE ADMISSIBILITY OF SOME TESTS OF MANOVA NATIVES

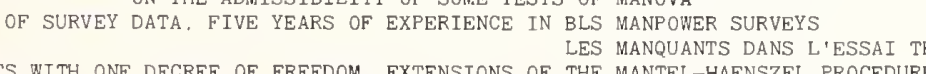

OF SURVEY DATA. FIVE YEARS OF EXPERIENCE IN BLS MANPOWER SURVEYS
LES MANQUANTS DANS L'ESSAI THERAPEUTIQUE TESTS WITH ONE DECREE OF FREEDOM. EXTENSIONS OF THE MANTEL-HAENSZEL PROCEDURE
INTERFERENCE IN THE MANUFACTURE OF NUCLEPORE FILTERS AMS $64 \quad 789$ JASA $66 \quad 375$ BIOCS67 145 MANUFACTURERS' INVENTORY CYCLES AND MONETARY POLICY JASA 58680 FRUITS AND VEGETABLES DEMAND FOR MANUFACTURERS' SERVICES FOR BAKERY PRODUCTS AND INTER-PLANT STORACE IN CONTINUOUS MANUFACTURING 1953. CORR. 60755 REGIONAL CYCLES OF MANUFACTURING EMPLOYMENT IN THE UNITED STATES, 1914-
CHANCES IN CONCENTRATION OF DOMESTIC MANUFACTURING ESTABLISHMENT OUTPUT 1939-1958 JASA $65 \quad 740$ TECH $60 \quad 393$ JASA 60 151 JASA $62 \quad 797$ 
UATINC THE RELIABILITY OF SAFETY SYSTEMS FOR PLANTS MANUFACTURINC HAZARDOUS PRODUCTS /ICAL MODEL OF EVAL TECH 59 293 AN INDEX OF MANUFACTURINC PRODUCTION IN NEW ENGLAND

TICIPATIONS AND INVESTMENT BEHAVIOR IN UNITED STATES MANUFACTURING 1947-1960

AND LOWER PROBABILITIES INDUCED BY A MULTIVALUED MAPPING

PRESERVATION OF WEAK CONVERCENCE UNDER MAPPINGS

ENUMERATION OF LINEAR GRAPHS FOR MAPPINGS OF FINITE SETS

MAPS BASED ON PROBABILITIES

MARTINGALE EXTENSIONS OF A THEOREM OF MARCINKIEWICZ AND ZYGMUND

THE MARTINGALE VERSION OF A THEOREM OF MARCINKIEWICZ AND ZYGUMD

A TEST FOR HOMOGENEITY OF THE MARCINAL DISTRIBUTIONS IN A TWO-WAY CLASSIFICATION SYMMETRY AND MARGINAL HOMOGENEITY OF AN R-BY-R CONTINGENCY TABLE

A MARKOVIAN MODEL FOR THE ANALYSIS OF THE EFFECTS OF MARCINAL TESTING ON SYSTEM RELIABILITY JASA $5 \mathrm{~B} \quad 336$

JASA $59 \quad 385$

AMS $69 \quad 427$

AMS $67 \quad 725$

BIOKA55 412

JASA 69 NO. 4 AMS 62754

PROBABILITY IN 2-BY-2 CONTINGENCY TABLES WITH SMALL MARCINAL TOTALS /LE METHOD OF CALCULATINC THE EXACT BIOKA55 522 SEQUENTIAL HYPOTHESIS TESTS FOR THE R-DEPENDENT MARGINALLY STATIONARY PROCESSES

THE EXISTENCE OF PROBABILITY MEASURES WITH GIVEN MARGINALS

A NOTE ON MULTIVARIATE DISTRIBUTIONS WITH SPECIFIED MARGINALS

AMS $65 \quad 423$

$\begin{array}{rrr}\text { AMS } & 65 & 423 \\ \text { JASA } & 67 & 1460\end{array}$

AMS $6 \mathrm{~B} 1236$

PROBABILITY DENSITIES WITH GIVEN MARGINALS CONTINGENCY TABLES WITH GIVEN MARGINALS

ETRIC STATISTICAL METHOD FOR CULLING RECRUITS FROM A MARK-RECAPTURE EXPERIMENT EST IMATES OF SURVIVAL FROM THE SIGHTING OF MARKED ANIMALS

ON THE ESTIMATION OF POPULATION PARAMETERS FROM MARKED MEMBERS

BIOKA6B $\quad 179$

BIOCS65 936

BIOKA64 429 BIOKA55 269 INSECTS ON THE UTILIZATION OF MARKED SPECIMENS IN ESTIMATING POPULATIONS OF FLYINC MARKET GROWTH AND INDUSTRY CONCENTRATION

CONCENTRATION $1947-1954$ MARKET GROWTH, COMPANY DIVERSIFICATION AND PRODUCT

170

JASA $68 \quad 228$

JASA $60 \quad 640$ MARKET MAKING AND REVERSAL OF THE STOCK EXCHANGE JASA 66 B97

SSOCIATION WITH SPECIAL CONSIDERATION OF THE CASE OF MARKET ORIENTATION OF PRODUCTION /ASURING SPATIAL A JASA 56 597 ON SOME MEASURES OF FOOD MARKETING SERVICES $\quad$ JASA 61.65 BIOKA59 412 BIOKA54 430 BIOKA55 531 BIOKA5B 181 BIOKA57 301 BIOKA57 43 NOTE ON THE COMPARISON OF SEVERAL REALIZATIONS OF A MARKOFF CHAIN A TEST FOR MARKOFF CHAINS

THE LIKELIHOOD RATIO TEST FOR MARKOFF CHAINS SIMPLIFIED RUNS TESTS AND LIKELIHOOD RATIO TESTS FOR MARKOFF CHAINS CORRIGENDA TO 'THE LIKELIHOOD RATIO TEST FOR MARKOFF CHAINS'

THE CONSISTENCY AND ADEQUACY OF THE POISSON-MARKOFF MODEL FOR DENSITY FLUCTUATIONS MEAN WHEN RESIDUALS FOLLOW A FIRST-ORDER STATIONARY MARKOFF PROCESS CORRIGENDA, 'CONDITIONED MARKOFF PROCESSES. THE FITTING OF MARKOFF SERIAL VARIATION CURVES EFFICIENCY OF THE SAMPLE JASA $6 B \quad 1237$ BIOKA59 279 JRSSB 5B 120 OF LEAST SQUARES REGRESSION INVOLVINC TREND-REDUCED MARKOFF SERIES INTEGRAL KERNELS AND INVARIANT MEASURES FOR MARKOFF TRANSITION FUNCTIONS SOME RESULTS ON MULTITYPE CONTINUOUS TIME MARKOV BRANCHING PROCESSES EMBEDDINC OF URN SCHEMES INTO CONTINUOUS TIME MARKOV BRANCHING PROCESSES AND RELATED LIMIT THEOREMS

TESTS AUXILIARY TO CHI-SQUARED TESTS IN A MARKOV CHAIN AN INTRINSICALLY DETERMINED MARKOV CHAIN SOME INVARIANCE PRINCIPLES FOR FUNCTIONALS OF A MARKOV CHAIN THE TAIL FIELD OF A MARKOV CHAIN A NUMERICAL INVESTIGATION JRSSB55 105 AMS $65 \quad 517$ JRSSB54 195 AMS 6B 347 AMS 68 1B01 AMS $63 \quad 56$ AMS $67 \quad 934$ AMS 67 AMS $69 \quad 127$ AMS 69665 THE ASYMPTOTIC BEHAVIOR OF A CERTAIN MARKOV CHAIN JRSSB55 235 SOME DISTRIBUTION AND MOMENT FORMULAE FOR THE MARKOV CHAIN THE THEORY OF RANDOM VARIABLES DEFINED ON A FINITE MARKOV CHAIN A STATIONARY PROCESS TO BE A FUNCTION OF A FINITE MARKOV CHAIN IS A REALIZATION OF A NON-HOMOGENEOUS FINITE-STATE MARKOV CHAIN LIHOOD ESTIMATOR OF AN UNKNOWN PARAMETER IN A SIMPLE MARKOV CHAIN THE TAIL SIGMA-FIELD OF A MARKOV CHAIN AND A THEOREM OF OREY THE FREQUENCY COUNT OF A MARKOV CHAIN AND THE TRANBITION TO CONTINUOUS TIME
PARAMETERS IN A TRANSIENT MARKOV CHAIN ARISING IN A RELIABILITY CROWTH MODEL

LIHOOD ESTIMATOR OF AN UNKNOWN PARAMETER IN A SIMPLE MARKOV CHAIN'_/ENCY CONDITIONS FOR THE MAXIMUM-LIKE BIOKA56 497 SOME PROPERTIES OF REGULAR MARKOV CHAINS

APPROXIMATIONS FOR THE ENTROPY FOR FUNCTIONS OF MARKOV CHAINS TESTS FOR CONTINCENCY TABLES AND MARKOV CHAINS FUNCTIONS OF FINITE MARKOV CHAINS

SOME THEOREMS ON FUNCTIONALS OF MARKOV CHAINS

A CHARACTERIZATION OF A CLASS OF FUNCTIONS OF FINITE MARKOV CHAINS ON STOCHASTIC PROCESSES DERIVED FROM MARKOV CHAINS

A SYSTEM OF DENUMERABLY MANY TRANSIENT MARKOV CHAINS A NOTE ON LIMIT THEOREMS FOR THE ENTROPY OF MARKOV CHAINS

SOME LIMIT THEOREMS FOR NON-HOMOGENEOUS MARKOV CHAINS FUNCTIONS OF FINITE MARKOV CHAINS

OPTIMAL STOPPING FOR FUNCTIONS OF MARKOV CHAINS

AMS $61 \quad 59$ AMS $62 \quad 930$ TECH $62 \quad 573$

AMS 631022 AMS 641275 AMS $65 \quad 524$ AMS 651286 AMS $66 \quad 406$ AMS $66 \quad 522$ AMS 661224 AMS $67 \quad 206$ AMS 681905 AMS $69 \quad 97$ AMS $69107 \mathrm{~B}$ PROBABILISTIC FUNCTIONS OF FINITE STATE MARKOV CHAINS A NCTE ON SEQUENCES OF CONTINUOUS PARAMETER MARKOV CHAINS A NOTE ON SUFFICIENCY IN RECULAR MARKOV CHAINS BIOKA60 452 ID AMS $67 \quad 201$ ENTIFICATION OF STATE-CALCULABLE FUNCTIONS OF FINITE MARKOV CHAINS SEQUENTIAL DESICNS FOR CLINICAL TRIALS BASED ON MARKOV CHAINS PROCESSES WHICH ARE FUNCTIONS OF STATIONARY MARKOV CHAINS NFERENCE FOR PROBABILISTIC FUNCTIONS OF FINITE STATE MARKOV CHAINS THE STRONC LAW OF LARGE NUMBERS FOR NON-HOMOCENEOUS MARKOV CHAINS OME PROBABILISTIC FUNCTIONS OF DISCRETE FINITE STATE MARKOV CHAINS BEHAVIOUR SEQUENCES AS SEMI-MARKOV CHAINS (WITH DISCUSSION)

SUFFICIENCY COND FUNCTIONS OF FINITE MARKOV CHAINS AND EXPONENTIAL TYPE PROCESSES

ON OF THE 'PSI-SQUARED' GOODNESS OF FIT CRITERIA FOR MARKOV CHAINS AND MARKOV SEQUENCES /OTIC DISTRIBUTI COLLAPSED MARKOV CHAINS AND THE CHAPMAN-KOLMOGOROV EQUATION JRSSB59 36 BIOKA56 276 AMS 6B 1020 $\begin{array}{lrr}\text { AMS } & 6 \mathrm{~B} & 1020 \\ \text { AMS } & 49\end{array}$ AMS $63 \quad 233$ BI0CS69 17 SOME ASYMPTOTIC DISTRIBUTION THEORY FOR MARKOV CHAINS WITH A DENUMERABLE NUMBER OF STATES 
BAYES SOLUTION OF SEQUENTIAL DECISION PROBLEM FOR MARKOV DEPENDENT OBSERVATIONS

STATES AND RESTRICTED ORDER VARIABLES

UTION, ONE SERVER

NOTE ON DYNKIN'S

TESTINC A MARKOV HYPOTHESIS WITH INDEPENDENCE OF INTERMEDIATE THE MARKOV INEQUALITY FOR SUMS OF INDEPENDENT RANDOM

A TWO-STATE MARKOV MODEL FOR BEHAVIORAL CHANCE

N THE QUEUEINC PROCESS, MARKOV OR POISSON INPUT, CENERAL SERVICE TIME DISTRIB SUBPROCESS OF STANDARD MARKOV PROCESS

OPTIMAL STOPPINC IN A MARKOV PROCESS

ESTIMATION FROM A LINEAR MARKOV PROCESS THE INSPECTION OF A MARKOV PROCESS

IMATION OF THE TRANSITION DISTRIBUTION FUNCTION OF A MARKOV PROCESS TESIMAL CENERATOR OF A CONTINUOUS TIME, FINITE STATE MARKOV PROCESS DYNAMIC PROCRAMMINC ON A FINITE SPACE DISCRETE TIME MARKOV PROCESS SEQUENCES WITH TRANSITION PROBABILITIES BASED ON A MARKOV PROCESS$$
\text { A MARKOV PROCESS ON }
$$

A BOUND FOR THE LAW OF LARCE NUMBERS FOR DISCRETE MARKOV PROCESSES REMARK CONCERNINC TWO-STATE SEMI-MARKOV PROCESSES MIXTURES OF MARKOV PROCESSES

NOTE ON EXTREME VALUES. COMPETINC RISKS AND SEMI-MARKOV PROCESSES SOME APPLICATIONS OF MONOTONE OPERATORS IN MARKOV PROCESSES ASYMPTOTIC INFERENCE IN MARKOV PROCESSES INVARIANT PROBABILITIES FOR CERTAIN MARKOV PROCESSES ON STATIONARY MARKOV PROCESSES

ON THE ERCODICITY FOR NON-STATIONARY MULTIPLE MARKOV PROCESSES A RANDOM TIME CHANCE RELATINC SEMI-MARKOV AND MARKOV PROCESSES THE STRONC RATIO LIMIT PROPERTY OR SOME CENERAL MARKOV PROCESSES ASYMPTOTICALLY MOST POWERFUL TESTS IN MARKOV PROCESSES CONDITIONED MARKOV PROCESSES

NIQUENESS THEOREM FOR STATIONARY MEASURES OF ERCODIC MARKOV PROCESSES

SOLUTION OF QUEUEING AND INVENTORY MODELS BY SEMI-MARKOV PROCESSES THE LAW OF LARCE NUMBERS FOR LINEAR COMBINATIONS OF MARKOV PROCESSES AN APPROACH TO THE STUDY OF MARKOV PROCESSES (WITH DISCUSSION) AN APPROACH TO THE STUDY OF MARKOV PROCESSES (WITH DISCUSSION)
MULTIVARIATE WIDE-SENSE MARKOV PROCESSES AND PREDICTION THEORY
NON-SINCULAR RECURRENT MARKOV PROCESSES HAVE STATIONARY MEASURES AN APPROACH TO THE STUDY OF MARKOV PROCESSES (WITH DISCUSSION)
MULTIVARIATE WIDE-SENSE MARKOV PROCESSES AND PREDICTION THEORY
NON-SINCULAR RECURRENT MARKOV PROCESSES HAVE STATIONARY MEASURES

NONPARAMETRIC EST ESTIMATINC THE INFIN ON THE ITERATIVE METHOD OF DEVELOPMENT OF RANDOMIZED LOAD BINARY NUMBERS

BI0C\$66 791 BIOKA65 127 AMS $61 \quad 12$ AMS 641656 BIOKA67 605 AMS 69 NO. 6 JASA $68 \quad 993$ AMS $61 \quad 770$ AMS $67 \quad 1647$ AMS $68 \quad 1333$ BIOKA60 482 JRSSB58 111 AMS 691386 AMS $62 \quad 727$ AMS $65 \quad 1279$ TECH $66 \quad 107$ AMS $63 \quad 416$ BIOKA66 37 AMS $61 \quad 336$ AMS $61 \quad 615$ AMS $62 \quad 114$ AMS 631104 AMS $65 \quad 1421$ AMS $65 \quad 978$ AMS $66 \quad 837$ AMS $67 \quad 588$ AMS $68 \quad 1448$ AMS $68 \quad 358$ AMS 69986 AMS 691207 BIOKA58 24] A U AMS 641781 THE JRSSB61 113 SOLUTION OF QUEUEINC AND INVENTORY MODELS BY SEMI-MARKOV PROCESSES ' HOMOCENEOUS CAUSS-MARKOV RANDOM FIELDS

CENERATINC FUNCTIONS FOR MARKOV RENEWAL PROCESSES LIMIT THEOREMS FOR MARKOV RENEWAL PROCESSES ON THE MATRIX RENEWAL FUNCTION FOR MARKOV RENEWAL PROCESSES ASYMPTOTIC VALUES OF THE FIRST TWO MOMENTS IN MARKOV RENEWAL PROCESSES EXISTENCE AND UNIQUENESS OF STATIONARY MEASURES FOR MARKOV RENEWAL PROCESSES PROPERTIES MARKOV RENEWAL PROCESSES WITH FINITELY MANY STATES MARKOV RENEWAL PROCESSES, DEFINITIONS AND PRELIMINARY A CORRECTION ON 'THE JRSS AMS $66 \quad 711$ JRSSB $66 \quad 417$ AMS $63 \quad 424$ AMS $64 \quad 869$ AMS $69 \quad 844$ SSB63 455 AMS 691625 AMS $64 \quad 431$ AMS 641746 AMS 69 NO. 6 BIOKA67 597 THE AMS $66 \quad 1439$ AMS $61 \quad 1243$ AMS 611231 JRSSB 63206

OF THE CORREF ION OF THE CORRELATION BETWEEN TWO STATIONARY LINEAR MARKOV SERIES. II A STABLE LIMIT THEOREM FOR MARKOV TESTS

ON THE LOCAL BEHAVIOR OF MARKOV TRANSITION PROBABILITIES

THE APPROXIMATE DISTRIBUTION BIOKA62 379 HE APPROXIMATE DISTRIBUT BIOKA65 301 AMS 691467 AMS $68 \quad 2123$ JRSSB $63 \quad 383$ AMS $68 \quad 2118$ AMS $68 \quad 412$ NON-DISCOUNTED DENUMERABLE MARKOVIAN DECISION PROCESSES

ORDER 2 QUADRATICS IN MARKOV-CHAIN FREQUENCIES, AND THE BINARY CHAIN OF ARBITRARY STATE MARKOVIAN DECISION PROCESSES

CE CLASS OF CONTINUOUS SAMPLINC INSPECTION PLANS MARKOVIAN DECISION MODELS TO A COUNTABLE SYSTEM OF EQUALITIES ARISINC IN MARKOVIAN DECISION PROCESSES MARGINAL TESTINC ON SYSTEM RELIABILITY DENUMERABLE STATE MARKOVIAN DECISION PROCESSES, AVERAGE COST CRITERION A RANDOM SET PROCESS IN THE PLANE WITH A MARKOVIAN PROPERTY MARKOVIAN SEQUENTIAL REPLACEMENT PROCESSES

FUNCTIONS OF PROCESSES WITH MARKOVIAN STATES

A SINGLE STATE OF A STATIONARY PROCESS INTO MARKOVIAN STATES FUNCTIONS OF PROCESSES WITH MARKOVIAN STATES, II

SPLITTINC IAL REFERENCE/ A LINEAR APPROXIMATOR FOR THE CLASS MARKS OF A GROUPED FREQUENCY DISTRIBUTION, WITH ESPEC
THE DISTRIBUTION OF INANIMATE MARKS OVER A NON-HOMOGENEOUS BIRTH-DEATH PROCESS ON THE EXPECTED VALUE OF A STOPPED MARTINCALE

CONVERCENCE OF SUMS OF SQUARES OF MARTINCALE DIFFERENCES

COMBINATIONS OF INDEPENDENT AND RANDOM VARIABLES AND MARTINCALE DIFFERENCES /SURE CONVERCENCE OF LINEAR AND ZYCMUND

\section{A COMPARISON TEST FOR MARTINCALE INEQUALITIES MARTINCALE TRANSFORMS}

ZYGUMD

DIVERCENCE PROPERTIES OF SOME MARTINCALE TRANSFORMS

THE MARTINCALE VERSION OF A THEOREM OF MARCINKIEWICZ AND

A NOTE ON CONVERGENCE OF SUB-MARTINCALES

A SAMPLE FUNCTION PROPERTY OF MARTINCALES

ON THE STRONG LAW OF LARCE NUMBERS FOR MARTINCALES

A DECOMPOSITION OF LI-BOUNDED MARTINCALES BOUNDS ON MOMENTS OF MARTINCALES

COMPARISON TESTS FOR THE CONVERGENCE OF MARTINCALES UNIFORM CONVERGENCE OF FAMILIES OF MARTINGALES

A BEST POSSIBLE KOLMOCOROFF-TYPE INEQUALITY FOR MARTINGALES AND A CHARACTERISTIC PROPERTY LOCAL CONVERCENCE OF MARTINGALES AND THE LAW OF LARGE NUMBERS

VARIATION QUADRATIQUE DES MARTINGALES CONTINUES A DROITE

SUDDERTH

A NOTE ON THRIFTY STRATECIES AND MARTINCALES IN A FINITELY ADDITIVE SETTINC WILLIAM D.
AMS 651408 AMS $67 \quad 582$ AMS $66 \quad 1545$ AMS $62 \quad 754$ AMS 651859 AMS 651677 AMS $68 \quad 938$ AMS 681069 AMS 69865 TECH $68 \quad 793$ BIOKA69 225 AMS 661505 AMS $68 \quad 123$ AMS $68 \quad 1549$ AMS $69 \quad 427$ AMS $69 \quad 505$ AMS $66 \quad 1494$ AMS 691852 AMS $67 \quad 725$ AMS 641811 AMS 661396 AMS $67 \quad 610$ AMS $68 \quad 134$ AMS $68 \quad 1719$ AMS 682141 AMS 691071 AMS $69 \quad 764$ AMS $65 \quad 552$ AMS $69 \quad 284$ AMS 69 No. 6 
THE VALUE OF INDIRECT SELECTION, 1 MASS SELECTION

AMS 691033 BIOCS65 682 A TECH $68 \quad 586$ NOTE ON A METHOD FOR THE ANALYSIS OF SICNIFICANCE EN MASSE

ERNA/ ASYMPTOTIC RELATIVE EFFICIENCY OF MOOD'S AND MASSEY'S TWO SAMPLE TESTS ACAINST SOME PARAMETRIC ALT THE BIC MATCH

ASYMPTOTIC DISTRIBUTION FOR A CENERALIZED BANACH MATCH BOX PROBLEM EXTENDED TABLES OF THE. WILCOXON MATCHED PAIR SICNED RANK STATISTIC

RESPONSES THE MATCHED PAIRS DESICN IN THE CASE OF ALL-OR-NONE

ON THE EFFICIENCY OF MATCHED PAIRS IN BERNOULLI TRIALS

AN EXACT TEST FOR COMPARING MATCHED PROPORTIONS IN CROSSOVER DESIGNS

NOTE ON CHI SQUARE TESTS FOR MATCHED SAMPLES

THE EFFICIENCY OF MATCHED SAMPLES

TESTS OF HYPOTHESES CONCERNINC MATCHED SAMPLES (CORR. 69 194)

THE DISTRIBUTION OF THE MATCHING COEFFICIENT

DERIVED METHODS OF APPROXIMATION

THE MATCHING DISTRIBUTIONS. POISSON LIMITINC FORMS AND

ON THE PROBLEM OF MATCHING LISTS BY SAMPLES

ON MATCHING LISTS BY SAMPLES

THE EFFECT OF MIS-MATCHING ON THE MEASUREMENT OF RESPONSE ERRORS THE TWO-PACK MATCHING PROBLEM

OUTCOME PROBABILITIES FOR A RECORD MATCHING PROCESS WITH COMFLETE INVARIANT INFORMATION MEASUREMENTS MADE BY MATCHING WITH KNOWN STANDARDS INDIVIDUAL MATCHING WITH MULTIPLE CONTROLS IN THE CASE OF ALL-

OR-NONE RESPONSES

A GENERAL SIMULATION PROGRAMME POR MATER MATERIAL IS REMOVED BUT NOT REPLACED

COMPUTATION OF THE UNRESTRICTED AOQL WHEN DEFECTIVE MATERIAL
A STATISTICAL MODEL FOR LIFE-LENGTH OF MATERIALS

OF

SUSCEPTIBLES THE MATHEMATICAL ANALYSIS OF AN EPIDEMIC WITH TWO KINDS

ON MATHEMATICAL ANALYSIS OF STYLE

BREAST CANCER

SPECTRA

A MATHEMATICAL ANALYSIS OF THE GROWTH AND SPREAD OF MATHEMATICAL CONSIDERATIONS IN THE ESTIMATION OF

MAMMALIAN REPRODUCTIVE DATA FITTED TO A MATHEMATICAL MODEL

COMPETITION (CORRECTION TO REFERENCE 68 1025) ENT FOR REGULARLY SPACED CROPS ACCIDENT REPEATEDNESS AMONG CHILDREN

A MATHEMATICAL MODEL FOR THE ESTIMATION OF INTER-PLANT

A MATHEMATICAL MODEL RELATINC PLANT YIELD WITH ARRANGEM

A MATHEMATICAL MODEL WITH APPLICATIONS TO A STUDY OF

AN ALTERNATIVE SYSTEM FOR THE CLASSIFICATION OF MATHEMATICAL MODELS FOR QUANTAL RESPONSES TO MIXTURES B COMPARISONS MATHEMATICAL MODELS FOR RANKING FROM PAIRED

KHINCHIN'S WORK IN MATHEMATICAL PROBABILITY

MATHEMATICAL PROBABILITY IN THE NATURAL SCIENCES

NCUISTIC DIVERSITY AND YULE'S CHARACTERISTIC

A SIMPLE MATHEMATICAL RELATIONSHIP AMONG K-CLASS ESTIMATORS MATHEMATICAL REPRESENTATION OF THE BIOLOGICAL AND

PHYSICAL DECAY OF CHAMBER AEROSOLS

INVERSE OF A MATRIX WITH APPLICATIONS TO PROBLEMS IN MATHEMATICAL STATISTICS A NOTE ON A GENERALIZED
SOME REFLEXIONS ON CONTINUITY IN THE DEVELOPMENT OF MATHEMATICAL STATISTICS, 1885-1920 /ATISTICS. XVII.

A MATHEMATICAL THEORY OF ANIMAL TRAPPING

A MATHEMATICAL THEORY OF PATTERN RECOGNITION

D STATISTICS, XIII, ISAAC TODHUNTER'S HISTORY OF THE MATHEMATICAL THEORY OF PROBABILITY

CONTRIBUTIONS TO THE MATHEMATICS OF ANIMAL TRAPPING

ONS ZEA MAYS L UTILIZING INFORMATION FROM A DIALLEL MATING DESIGN /AL RELATIONSHIP AMONG EIGHT POPULATI BIOCS68 B67 C TRENDS EXAMINATION OF A REPEAT MATING DESIGN FOR ESTIMATING ENVIRONMENTAL AND GENETI B APPLICATION OF FINITE ABSORBENT MARKOV CHAINS TO SIB MATING POPULATIONS WITH SELECTION A NOTE ON IDEMPOTENT MATRICES

EICENVALUES OF NON-NEGATTVE MATRICES ON IDEMPOTENT MATRICES

ON TESTS OF THE EQUALITY OF TWO COVARIANCE MATRICES

ON INVERTINC A CLASS OF PATTERNED MATRICES

LATENT VECTORS OF RANDOM SYMMETRIC MATRICES

THE LATENT ROOTS OF CERTAIN STOCHASTIC MATRICES SOME INEQUALITIES ON CHARACTERISTIC ROOTS OF MATRICES

TESTS FOR CORRELATION MATRICES

ON TESTING THE EQUALITY OF $K$ COVARIANCE MATRICES

ON LOOKINC AT LARCE CORRELATION MATRICES SOME TESTS FOR CORRELATION MATRICES

THE LINEAR HYPOTHESIS AND IDEMPOTENT MATRICES ON DISCRIMINATION IN THE CASE OF UNEQUAL COVARIANCE MATRICES ELEMENTARY SYMMETRIC FUNCTIONS OF THE ROOTS OF TWO MATRICES PROBABILITY VECTOR OF REGULAR OR ERGODIC TRANSITION MATRICES NCERNING ESTIMABLE FUNCTIONS AND GENERALIZED INVERSE MATRICES FOR THE LATENT ROOTS OF COVARIANCE AND CORRELATION MATRICES CRITERIA FOR THE EQUALITY OF ONE OR TWO COVARIANCE MATRICES RIATE NORMAL DISTRIBUTIONS WITH DIFFERENT COVARIANCE MATRICES STATISTICS FOR POPULATIONS WITH UNEQUAL COVARIANCE MATRICES RIATE BETA DISTRIBUTION AND MOMENTS OF TRACES OF TWO MATRICES C EQUATIONS AND THEIR ROOTS FOR A CLASS OF PATTERNED MATRICES SIMULTANEOUS TESTS FOR THE EQUALITY OF COVARIANCE MATRICES

OF A TEST FOR THE EQUALITY OF TWO NORMAL DISPERSION MATRICES AGAINST CERTAIN ALTERNATIVES $F$ ELEMENTARY SYMMETRIC FUNCTIONS OF THE ROOTS OF TWO MATRICES AND APPROXIMATIONS TO A DISTRIBUTION /TS O

IMATO/ ON CANONICAL FORMS, NON-NEGATIVE COVARIANCE MATRICES AND BEST AND SIMPLE LEAST SQUARES LINEAR EST THE SPECTRAL THEOREM FOR FINITE MATRICES AND COCHRAN'S THEOREM DECOMPOSITION OF SYMMETRIC MATRICES AND DISTRIBUTIONS OF QUADRATIC FORMS

A RELATTONSHIP BETWEEN ARBITRARY POSITIVE MATRICES AND DOUBLY STOCHASTIC MATRICES ASSOCIATION MATRICES AND THE KRONECKER PRODUCT OF DESIGNS ARIATE ANALYSIS OF VARIANCE WHEN VARIANCE-COVARIANCE MATRICES ARE NOT EQUAL/SQUARE-SUB-O TEST IN MULTIV BIOKA64 71 ISTRIBUTION OF DISCRIMINANT FUNCTION WHEN COVARIANCE MATRICES ARE PROPORTIONAL A TEST FOR EQUALITY OF MEANS WHEN COVARIANCE MATRICES ARE UNEQUAL

COMPARISIONS OF TESTS OF EQUALITY OF TWO COVARIANCE MATRICES BASED ON FOUR CRITERIA FACTORIZATION OF MATRICES BY LEAST-SQUARES REPRESENTATION OF SIMILARITY MATRICES BY TREES
A NOTE ON A GENERALIZE

PROBABILITY AN

JASA $67 \quad 125$

JASA $65 \quad 864$

IOCS68 339

JRSSB 68368

BIOCS65 623

JRSSB67 46B

BIOC $567 \quad 647$

73
JASSB58

$\begin{array}{lll}\text { JASA } & 61 & 151\end{array}$

JASA 651005

JRSSB60 114

JASA $67 \quad 454$ TECH $59 \quad 101$

339

JASA 69665 JASA $58 \quad 151$ BIOCS68 557 BIOKA52 122 BIOCS69 95 \begin{tabular}{ll}
967 \\
\hline
\end{tabular} 189 BIOCS67 505 ASA $65 \quad 1046$ JASA $60 \quad 503$ AMS $62 \quad 1227$ TECH 5921 $\begin{array}{ll}\text { BIOKA5B } & 268 \\ \text { JASA } 66 & 368\end{array}$ BIOCS65 551 JRSB62 152 BIOKA67 341 307 BIOCS65 63 BIOC\$69 I' AMS $64 \quad$ BBO AMS $64 \quad 1797$ AMS $68 \quad 275$ BIOKA56 227 BIOKA61 133 BIOKA62 264 BIOKA63 522 BIOKA68 327 BIOKA69 216 BIOKA69 249 BIOKA69 443 JRSSB64 261 A NOTE BIOKA68 586 ON THE MOMENTS OF AMS 641704 ON THE FIXED POINT JASA $67 \quad 600$ ADDITIONAL RESULTS C0 JRSSB65 4B6 TESTS OF SICNIFICANCE BIOKA56 128 UNBIASEDNESS OF SOME TEXT AMS 6B $16 \mathrm{~B} 6$ CLASSIFICATTON INTO TWO MULTIVA AMS $62 \quad 420$ AN EMPIRICAL COMPARISON OF DISTANCE BIOCS6B 683 SOME RESULTS ON THE NON-CENTRAL MULTIVA AMS 651511 JRSSB $60 \quad 34 \mathrm{~B}$ AMS $68 \quad 1303$ AMS 621463 AMS $68 \quad 1274$ AMS 671092 AMS $64 \quad 443$ AMS $64 \quad 876$ AMS 63671 BIOKA68 335 BIOKA62 239 JASA $67 \quad 1140$ AMS $66 \quad 295$ AMS $65 \quad 6 B 3$ 
NALYSIS TESTS FOR THE EQUALITY OF TWO COVARIANCE MATRICES IN RELATION TO A BEST LINEAR DISCRIMINATOR A AMS 64 19 BERG AND SARHAN'S METHOD OF INVERSION OF PARTITIONED MATRICES IN THE ANALYSIS OF NON-ORTHOGONAL DATA /EN JASA 65 1200 LOWER BOUNDS FOR MINIMUM COVARIANCE MATRICES IN TTME SERIES REGRESSION PROBLEMS

POWER FUNCTIONS OF SOME TESTS CONCERNING DISPERSION MATRICES OF MULTIVARIATE NORMAL DISTRIBUTIONS

\section{THE EFFECT OF UNEQUAL VARIANCE-COVARIANCE MATRICES ON FISHER'S LINEAR DISCRIMINANT FUNCTION}

TESTS FOR THE EQUALITY OF COVARIANCE MATRICES UNDER THE INTRACLASS CORRELATION MODEL ISTRIBUTION AND THE INVERTED MULTIVARIATE T DISTR/ MATRICVARIATE GENERALIZATIONS OF THE MULTIVARIATE T D AMS 67 5II ON A PARADOX CONCERNING INFERENCE ABOUT A COVARIANCE MATRIX ON FRACTIONAL POWERS OF A MATRIX

ON THE A PRIORI DISTRIBUTION OF THE COVARIANCE MATRIX THE GENERALIZED MULTIPLE CORRELATION MATRIX SOME APPLICATIONS OF THE SINGULAR DECOMPOSITION OF A MATRIX

PERCENTAGE POINTS OF THE EXTREME ROOTS OF A WISHART MATRIX A NOTE ON THE EXPECTED VALUE OF AN INVERSE MATRIX

A NOTE ON THE BARTLETT DECOMPOSITION OF A WISHART MATRIX COMPOUND DECISION PROBLEM WITH M-BY-N FINITE LOSS MATRIX SQUARES ESTIMATION OF THE COMPONENTS OF A SYMMETRIC MATRIX OF FUNCTIONS OF CHARACTERISTIC ROOTS OF A RANDOM MATRIX COMPOUND DECISION PROBLEMS WITH M-BY-N FINITE LOSS MATRIX

OF THE DETERMINANT OF A COMPLEX WISHART DISTRIBUTED MATRIX OF THE LARGEST LATENT ROOT OF THE COVARIANCE MATRIX OF A STATISTIC USED FOR TESTING A COVARIANCE MATRIX RIANCES OF NORMAL VARIABLES WITH SINGULAR COVARIANCE MATRIX IONS OF THE LIKELIHOOD RATIO CRITERIA FOR COVARIANCE MATRIX TION OF THE LATENT ROOTS OF THE ESTIMATED COVARIANCE MATRIX ITERIA FOR TESTING COMPOUND SYMMETRY OF A COVARIANCE MATRIX COND ELEMENTARY SYMMETRIC FUNCTION OF THE ROOTS OF A MATRIX XIMATE CANONICAL FACTORIZATION OF A SPECTRAL DENSITY MATRIX OVARIANCE MATRIX A+B IN TERMS OF ONE WITH COVARIANCE MATRIX A AMS 631414 JASA $67 \quad 1018$ AMS $69109 \mathrm{~B}$ SASJ 69 NO. 2 TECH 69 N0.4 BIOKA68 505 BIOKA69 NO.3 JRSSB 64270 
WATSON PROCESS AND IN SOME REL/ HOW TO MINIMIZE OR MAXIMIZE THE PROBABILITIES OF EXTINCTION IN A GALTONMAXIMIZING A FUNCTION IN A CONVEX REGION ON THE DISTRIBUTION OF THE MAXIMUM AND MINIMUM OF RATIOS OF ORDER STATISTICS AMS 69 $91 B$ NONPARAMETRIC TWO-WAY CLASSIFTCATION WITH PRESCRIBED MAXIMUM ASYMPTOTIC ERROR PROBABILITY SEQUENTIAL A THE DISTRIBUTION OF THE SIZE OF THE MAXIMUM CLUSTER OF POINTS ON A LINE

SAMPLING PLANS WHICH APPROXIMATELY MINIMIZE THE MAXIMUM EXPECTED SAMPLE SIZE UPPER 5 AND 1 PERCENT POINTS OF THE MAXIMUM F-RATIO

DISTRIBUTION OF THE ABSOLUTE MAXIMUM FOR CERTAIN BROWNIAN MOTIONS ON GROUPING FOR MAXIMUM HOMOGENEITY

A LAW OF LARGE NUMBERS FOR THE MAXIMUM IN A STATIONARY GAUSSIAN SEQUENCE

AIDS FOR FITTING THE GAMMA DISTRIBUTION BY MAXIMUM LIKELIHOOD MOMENT ESTIMATORS AND MAXIMUM LIKELIHOOD MAXIMUM LIKELIHOOD CHARACTERIZATION OF DISTRIBUTIONS AMS 611214

NED BY MEANS OF THE CAPTURE-RECAPTURE METHOD. I. THE MAXIMUM LIKELIHOOD EQUATIONS FOR ESTIMATING THE DEATH BIOKA5I 269 REMARK ON THE LINEARIZED MAXIMUM LIKELIHOOD ESTIMATE AMS 671876 N BETWEEN MINIMUM NORMIT CHI-SQUARE ESTIMATE AND THE MAXIMUM LIKELTHOOD ESTIMATE /ES. PART II. COMPARISO BIOYA57 4II BETNEE QUERY, MAXIMUM LIKELIHOOD ESTIMATE IN INTRACLASS CORRELATION TECH 69 NO.4 AMETER OF A NONCENTRAL CHI-SQUARE VARIATE THE MAXIMUM LIKELIHOOD ESTIMATE OF THE NON-CENTRALITY PAR JASA $67125 B$ L DISTRIBUTION WHEN SOME OBSERVATIONS ARE MISSING MAXIMUM LIKELIHOOD ESTIMATES FOR A MULTIVARIATE NORMA JASA 57 200 APPROXIMATE MAXIMUM LTKELTHOOD ESTIMATES FROM GROUPED DATA TECH 67599 E PARAMETERS GIVEN A TYPE II CENS/ THE BIAS OF THE MAXIMUM LIKELIHOOD ESTIMATES OF THE LOCATION AND SCAL BIOKA61 448 SINGLY CENSORED SAMPLES TABLES FOR MAXIMUM LIKELIHOOD ESTIMATES. SINGLY TRUNCATED AND TECH 61 535 NCE OF BINOMIAL PROBABILITIES WITH AN APPLICATION TO MAXIMUM LIKELIHOOD ESTIMATION MONOTONE FAILURE RATE

ERIES DISTRIBUTIONS AND ITS APPLICATION TO A TRUN/ POISSON MAXIMUM LIKELIHOOD ESTIMATION FOR DISTRIBUTIONS WITH AMS 65 MAXIMUM LIKELIHOOD ESTIMATION FOR GENERALIZED POWER S BIOKA62 227 MAXIMUM LIKELIHOOD ESTIMATION FOR THE TRUNCATED BIOCS66 620 TION BASED ON COMPLETE AND ON CENSORED SAMPLES MAXIMUM LIKELTHOOD ESTIMATION IN THE WEIBULL DISTRIBU TECH 65579 'MAXIMUM LIKELIHOOD ESTIMATION IN THE WEIBULL DISTRIBU TECH 66570 MAXIMUM LIKELIHOOD ESTIMATION OF A LINEAR FUNCTIONAL AMS 611048 TION BASED ON COMPLETE AND ON CENSORED S/ ERRATA. RELATIONSHIP

RELATIONSHIP NCE COMPONENTS FOR THE BALANCED ONE-WAY LAYOUT PARAMETERS

TWO STOCHASTICALLY ORDERED RANDOM VARIABLES FUNCTION

THE GAMMA DISTRIBUTION AND THEIR BIAS ASPECTS OF MMA AND WEIBULL POPULATIONS FROM COMPLETE AND FRO/ E BETA DISTRIBUTION FROM SMALLEST ORDER STATISTICS POPULATION MULTIVARIATE DATA SEQUENTIAL MXIMUM LIKELIHOOD ESTIMATION OF A LINEAR STRUCTURAL MAXIMUM LIKELIHOOD ESTIMATION OF MULTIVARIATE COVARIA AMS 691100 MAXIMUM LIKELIHOOD ESTIMATION OF SURVIVAL CURVE BIOCS6B 595 MAXIMUM LIKELIHOOD ESTIMATION OF THE DISTRIBUTIONS OF JASA 661067 MAXIMUM LIKELIHOOD ESTIMATION OF THE LOGISTIC GROWTH JASA $66 \quad 697$ MAXIMUM LIKELIHOOD ESTIMATION OF THE PARAMETERS OF TECH 69 NO.4 MAXIMUM LIKELIHOOD ESTIMATION OF THE PARAMETERS OF GA TECH 65639 MAXIMUM LIKELIHOOD ESTIMATION OF THE PARAMETERS OF TH TECH 67607 MAXIMUM LIKELIHOOD ESTIMATION OF THE SIZE OF A MAXIMUM LIKELIHOOD ESTIMATION WITH INCOMPLETE AMS 681057 NOWLEDGEMENT OF PRIORITY FOR 'AN OPTIMUM PROPERTY OF MAXIMUM LIKELIHOOD ESTIMATION' 601208 INVARIANCE OF MAXIMUM LIKELIHOOD ESTIMATIONS AUTOREGRESSIVE DISTURB/ ASYMPTOTIC DISTRIBUTION OF MAXIMUM LIKELIHOOD ESTIMATORS IN A LINEAR MODEL WITH AMS 69 5B3 NTS FOR THE CASE OF AUTOCORRELATED RESIDUALS MAXIMUM LIKELIHOOD ESTIMATORS OF REGRESSION COEFFICIE TECH 65 5I S FOR SYSTEMS IN SE/ MINIMUM VARIANCE UNBIASED AND MAXIMUM LIKELIHOOD ESTIMATORS OF RELIABILITY FUNCTION JASA 66 IO52 CIATED POPULATIONS THE ASYMPTOTIC PROPERTIES OF MAXIMUM LIKELIHOOD ESTIMATORS WHEN SAMPLING FROM ASSO BIOKA62 205 ENTS INVOLVING TWO/ THE USE OF TRANSFORMATIONS AND MAXIMUM LIKELIHOOD IN THE ANALYSIS OF QUANTAL EXPERIM BIOKA55 382 MAXIMUM LIKELIHOOD IN THREE-WAY CONTINGENCY TABLES JRSSB63 220 NTAGIOUS DISTRIBUTIONS TO SOME AVAILABLE DATA BY THE MAXIMUM LIKELIHOOD METHOD (CORR. 65514 ) /F SOME CO BIOCS65 34 LINEAR PROGRAMMING MAXIMUM LIKELIHOOD PAIRED COMPARISON RANKING BY OEFFICIENT FROM PHENOTYPE FREQUENCIES BY A METHOD OF MAXIMUM LIKELIHOOD SCORING /ION OF THE INBREEDING C BIOCS68 915 ING A LINEAR FUNCTTONAL RELATTONSHIP THE MAXIMUM LIKELIHOOD SOLUTION TO THE PROBLEM OF ESTIMAT JRSSB69 NO.2 CORRIGENDA, 'MOMENT ESTIMATORS AND MAXIMUM LIKELIHOOD.' BIOKA59 502 CORRIGENDA, 'MOMENT ESTIMATORS AND MAXIMUM LIKELIHOOD'

BIOKA61 474 AMS $64 \quad 319$ LIMITING DISTRIBUTION OF THE MAXIMUM OF A DIFFUSION PROCESS THE DISTRIBUTION OF THE MAXIMUM OF A SEMI-MARKOV PROCESS AMS $68 \quad 947$ RECOGNIZING THE MAXIMUM OF A SEQUENCE

ON MOMENTS OF THE MAXIMUM OF NORMED PARTIAL SUMS

DENT NORMAL VARIATES DENT NORMAL VARIATES PROCESSES

JASA $66 \quad 35$ AMS $69 \quad 527$ THE VARIANCE OF THE MAXIMUM OF PARTIAL SUMS OF A FINITE NUMBER OF INDEPEN BIOKA55 ON THE MOMENTS OF THE MAXIMUM OF PARTIAL SUMS OF A FINITE NUMBER OF INDEPEN BIOKA56 A NOTE ON THE MAXIMUM SAMPLE EXCURSIONS OF STOCHASTIC APPROXIMATION AMS 66513 BOUNDS ON THE MAXIMUM SAMPLE SIZE OF A BAYES SEQUENTIAL PROCEDURE AMS 65859 THE DISTRIBUTION OF THE MAXIMUM SUM OF RANKS 
THE MAXIMUM VARIANCE OF RESTRICTED UNIMODAL DISTRIBUTIONS AMS 691746 THE SAMPLING DISTRIBUTION OF A MAXIMUM-LIKELIHOOD ESTIMATE

ETERS OF THE GAMMA DISTRIBUTION USING OR/ FOUR - PARAMETER GENERALIZED GAMMA POPULATION MMA AND WEIBULL POPULATIONS FROM COMPLET/ RMAL POPULATIONS FROM SINGLY AND DOUBLY/ REE-PARAMETER LOGNORMAL POPULATIONS FROM CO/

SEPARAT FROM/ ION OF SCALE OR SHAPE PARAM B ITERATIVE MAXIMUM-LIKELIHOOD ESTIMATION OF THE PARAMETERS OF NO BIOKAG6 ED TESTS OF SIGNIFICANCE SOME REMARKS ON A METHOD OF A OF THE PARAMETERS OF A LOGISTIC DISTRIBUTION AMPLES, OF THE PARAMETERS OF THE FIRST ASYMPTOTIC/ AMPLES, OF THE SCALE PARAMEPERS OF TY/ CONDITIONAL MAXIMUM-LIKELIHOOD ESTIMATION, FROM SINGLY CENSORED S TECH 68 UM VARIANC/ A CLASS OF DISTRIBUTIONS FOR WHICH THE MAXIMUM-LIKELIHOOD ESTIMATOR IS UNBIASED AND OF MINIM BIOKA56 SOME THEOREMS AND SUFFTCIENCY CONDITTONS FOR THE MAXTMUM-LIKELTHOOD ESTTMATOR OF AN UNKNOHN PARAMETER BIOKA55 TO 'SOME THEOREMS AND SUFFICIENCY CONDITIONS FOR THE MAXIMUM-LIKELIHOOD ESTIMATOR OF AN UNKNOWN PARAMETER BI APPROXIMATIONS TO THE MAXIMUM-LIKELIHOOD ESTIMATOR USING GROUPED DATA

BIOKA56 ATION HAS MULTIPLE ROOTS EVALUATION EVAL OF THE P/ VARIABLES A NOTE ON MAXIMUM-LIKELIHOOD IN THE CASE OF DEPENDENT RANDOM MAXIMUM-LIKELIHOOD PAIRED COMPARISON RANKINGS JRSSB61 444 JIOKA66 143 BUTIONS IN TWO DIMENSIONS A MAXIMUM-MINIMUM PROBLEM RELATED TO STATISTICAL DISTRI BIOKA57 ESTIMATION OF A MEAN WHEN ONE OBSERVATION MAY BE SPURIOUS

/ SPATIAL RELATIONSHIP AMONG EIGHT POPULATIONS ZEA MAYS L. UTILIZING INFORMATION FROM A DIALLEL MATING D BIOCS6B REME VERTICES DESIGN OF MIXTURE EXPERIMENTS' BY R.A. MCLEAN AND V.L. ANDERSON SOME SHRINKAGE TECHNIQUES FOR ESTIMATING THE MEAN A NOTE ON THE RATE OF CONVERGENCE OF A MEAN

EFFECT OF NON-NORMALITY ON A SEQUENTIAL TEST FOR MEAN AN UNBIASED ESTIMATOR FOR POWERS OF THE ARITHMETIC MEAN A MULTI-STAGE TEST FOR A NORMAL MEAN A NOTE ON THE POSTERIOR MEAN OF A POPULATION MEAN MODIFIED TECHNIQUE FOR IMPROVING AN ESTIMATE OF THE MEAN TERIZATION OF SYMMETRIC STABLE PROCESSES WITH FINITE MEAN OF THE EXTREME STUDENTIZED DEVIATE FROM THE SAMPLE MEAN OMPARING VARIOUS TWO-SAMPLE TESTS FOR DIFFERENCES IN MEAN OF THE EXTREME STUDENTIZED DEVIATE FROM THE SAMPLE MEAN FIXED-WIDTH SEQUENTIAL CONFIDENCE INTERVALS FOR THE MEAN OF A SEQUENTIAL PROGEDURE FOR ESTIMATING THE MEAN OF THE 'STUDENTIZED' EXTREME DEVIATE FROM THE SAMPLE MEAN OF THE EXTREME STUDENTIZED DEVIATE FROM THE SAMPLE MEAN EDURE FOR THE FIXED-WIDTH INTERVAL ESTIMATION OF THE MEAN

ROBBINS ON SEQUENTIAL CONFIDENCE INTERVALS FOR THE MEAN AND STATISTICS. VII. THE PRINCIPLE OF THE ARITHMETIC MEAN HEN MAKING A FIXED WIDTH CONFIDENCE INTERVAL FOR THE MEAN S FROM THE NORMAL DISTRIBUTION. 2. ESTIMATION OF THE MEAN NORMAL VARIATE THE CORRECT USE OF THE SAMPLE MEAN CONFIDENCE INTERVALS BASED ON THE MEAN ABSOLUTE DEVIATION OF A NORMAL SAMPLE THE SAMPLE MEAN AMONG THE EXTREME NORMAL ORDER STATISTICS THE SAMPLE MEAN AMONG THE MODERATE ORDER STATISTIGS

SAMPLES FROM NON-NORMAL POPULATIONS THE MEAN AND COEFFICIENT OF VARIATION OF RANGE IN SMALL BIOKA54 AMPLES FROM NON-NORMAL POPULATTO/ OM NON-NORMAL POPULATIO/ CORRIGENDA. ON MULTIVARIATE PREDICTION INTE ON MULTIVARIATE PREDICTION INTERVALS FOR SAMPLE MEAN AND COVARIANCE BASED ON
RANCE LIMITS FOR A NORMAL POPULATION BASED ON SAMPLE MEAN AND RANGE OR MEAN RANGE INTERVALS FOR SAMPLE MEAN AND COVARIANCE BASED ON PARTIAL OBSERVATIONS
J J

SAMPLE

USING QUANTILES

FROM A CENSORED SAMPLE TIONS ESTIMATING THE MEAN AND STANDARD DEVIATION FROM A CENSORED NORMAL BI0CS69 BIOKA67 TESTING THE MEAN AND STANDARD DEVIATION OF A NORMAL DISTRIBUTION TECH $6 B$ ESTIMATION OF THE MEAN AND STANDARD DEVIATION OF A NORMAL POPULATION BIOKA52 APPROXIMATIONS TO THE MEAN AND STANDARD DEVIATION OF RECIPROCALS OF OBSERVA TECH 63 AND ITS ECONOMIC A/ THE RELATIONSHIP BETWEEN THE MEAN AND VARIANCE OF A STATIONARY BIRTH-DEATH PROCESS BIOKA62 NT MEAN AND VARIANCE OF AN ENTRY IN A CONTINGENCY TABLE BIOKA5I ASYMPTOTIC EXPANSIONS FOR THE MEAN AND VARIANCE OF THE SERIAL CORRELATION COEFFICIE BIOKA6I

A BINOMIAL POPULATION ON THE MEAN AND VARIANCE OF THE SMALLER OF TWO DRAWINGS FROM BIOKA62 ON THE KOLMOGOROV-SMIRNOV TEST FOR NORMALITY WITH MEAN AND VARIANCE UNKNOWN

ADMISSIBILITY OF THE SAMPLE MEAN AS ESTIMATE OF THE MEAN OF A FINITE POPULATION INVESTIGATING THE PROPERTIES OF A SAMPLE MEAN BY EMPLOYING RANDOM SUBSAMPLE MEANS ACCURAGY BORROWING IN THE ESTIMATION OF THE MEAN BY SHRINKAGE TO AN INTERVAL

PROCESS THE ECONOMIC DESIGN OF MEAN CHARTS USED TO MAINTAIN CURRENT CONTROL OF A THE STATISTICAL TREATMENT OF MEAN DEVIATION MOMENTS OF THE MEAN DEVIATION A GENERALIZATION OF JOHNSON'S PROPERTY OF THE MEAN DEVIATION FOR A CLASS OF DISCRETE DISTRIBUTIONS A PROPERTY OF THE MEAN DEVIATION FOR THE PEARSON TYPE DISTRIBUTIONS

(ACKNOWLEDGEMENT OF PRIORITY), 'A PROPERTY OF THE MEAN DEVIATION FOR THE PEARSON TYPE DISTRIBUTIONS'

USE OF MEAN DEVIATION IN THE ANALYSIS OF INTERLABORATORY
THE MEAN DIFFERENCE AND THE MEAN DEVIATION OF SOME DISCONTINUOUS DISTRIBUTIONS TESTS A NOTE ON THE MEAN DEVIATION OF THE BINOMIAL DISTRIBUTION

CORRIGENDA TO 'A NOTE ON THE MEAN DEVIATION OF THE BINOMIAL DISTRIBUTION' THE MEAN DEVIATION OF THE POISSON DISTRIBUTION 566 AMS $6 B \quad 606$ JASA $56 \quad 54$ JASA 6B 953 JASA $56 \quad 228$ BIOKA54 12 BIOKA54 541 BIOKA65 288 BI0KA66 2B5 BIOKA66 2B7 BIOKA67 333 TECH $67 \quad 149$ BIOKA58 549 BIOKA57 532 BIOKA58 587 BIOKA58 556 UTION A NOTE ON THE FIRST TWO MOMENTS OF THE MEAN DEVIATION OF THE SYMMETRICAL MULTINOMIAL DISTRIB B FROM A PEARSON TYPE III POPULATION THE MEAN DEVIATION, WITH SPECIAL REFERENCE TO SAMPLES THE THIRD MOMENT OF GINI'S MEAN DIFFERENCE

VARIANCE FORMULAS FOR THE MEAN DIFFERENCE AND COEFFICIENT OF CONCENTRATION THE MEAN DIFFERENCE AND THE MEAN DEVIATION OF SOME GINI'S MEAN DIFFERENCE REDISCOVERED 
ON THE EFFECT OF STRAGCLERS ON THE RISK OF SOME MEAN ESTIMATORS IN SMALL SAMPLES AMS $66 \quad 441$

ON THE PROBABILITY OF LARCE DEVIATIONS OF THE MEAN FOR RANDOM VARIABLES IN AN INTERVAL OF LENGTH ON ON APPROXIMATIONS TO SAMPLING DISTRIBUTIONS OF THE MEAN FOR SAMPLES FROM NON-NORMAL POPULATIONS CEDURE FOR SELECTING THE POPULATION NIT PRO THE DISTRIBUTION OF THE MEAN HALF-SQUARE SUCCESSIVE DIFFERENCE

A GENERAL EXPRESSION FOR THE MEAN IN A SIMPLE STOCHASTIC EPIDEMIC

AMS 631308

\section{A PROCEDURE TO ESTIMATE THE POPULATION MEAN IN RANDOM EFFECTS MODELS}

BIOKA67 419

BIOKA54 272 TECH $67 \quad 577$

LAE AND MADOW/ THE CENTRAL SAMPLING MOMENTS OF THE MEAN IN SAMPLES FROM A FINITE POPULATION (ATY'S FORMU BIOKA61 I99 LOWER BOUND FORMULAS FOR THE MEAN INTERCORRELATION COEFFICIENT

ON THE GALTON-WATSON BRANCHING PROCESS WITH MEAN LESS THAN ONE

ESTIMATES OF BOUNDED RELATIVE ERROR FOR THE MEAN LIFE OF AN EXPONENTIAL DISTRIBUTION

JASA 59275

AMS 67264

TECH $61 \quad 107$

OF THE INDEPENDENT MULTINORMAL PROCESS, NEITHER MEAN NOR PRECISION KNOWN NORMAL PROCESSES

ON THE MEAN NUMBER OF CURVE CROSSINGS BY NON-STATIONARY

VARIABLES

THE ESTIMATION OF THE MEAN OF A CENSORED NORMAL DISTRIBUTION BY ORDERED

AMS 65509

BIOKA56 482

JRSSB62 393

AMS 671180 CONFIDENCE INTERVALS FOR THE MEAN OF A FINITE POPULATION

ADMISSIBILITY OF THE SAMPLE MEAN AS ESTIMATE OF THE MEAN OF A FINITE POPULATION A TABLE FOR ESTIMATING THE MEAN OF A LOGNORMAL DISTRIBUTION

A NOTE ON CONSERVATIVE CONFIDENCE REGIONS FOR THE MEAN OF A MULTIVARIATE NORMAL DISCUSSION)

CONFIDENCE SETS FOR THE MEAN OF A MULTIVARIATE NORMAL DISTRTBUTION (WITH

AMS 67949 JASA 69632 AMS $67 \quad 278$ JRSSB $62 \quad 265$ INADMISSIBILITY OF THE USUAL CONFIDENCE SETS FOR THE MEAN OF A MULTIVARIATE NORMAL POPULATION AMS 671868 QUADRATIC LOSS FUNCTION ESTIMATING THE MEAN OF A MULTIVARIATE NORMAL POPULATION WITH GENERAL EXACT LINEAR SEQUENTIAL TESTS FOR THE MEAN OF A NORMAL DISTRIBUTION TABLES FOR WALD TESTS FOR THE MEAN OF A NORMAL DISTRIBUTION METHODS FOR EXACT TRUNCATED SEQUENTIAL TESTS OF THE MEAN OF A NORMAL DISTRIBUTION CHOOSING ONE OF K HYPOTHESES CONCERNING THE UNKNOWN MEAN OF A NORMAL DISTRIBUTION /CISION PROCEDURE FOR AMS 63 549 SEqUENTIAL TESTS FOR THE MEAN OF A NORMAL DISTRIBUTION II, LARGE T SEQUENTIAL TEST FOR THE MEAN OF A NORMAL DISTRIBUTION III, SMALL T SEQUENTIAL TESTS FOR THE MEAN OF A NORMAL DISTRIBUTION IV. DISCRETE CASE ESTIMATING THE CURRENT MEAN OF A NORMAL DISTRIBUTION WHICH IS SUBJECTED TO

CHANGES IN TIME A NOTE ON ESTIMATING THE MEAN OF A NORMAL DISTRIBUTION WITH KNOWN COEFFICIENT OF VARIATION A NOTE ON ESTIMATING THE MEAN OF A NORMAL DISTRIBUTION WITH KNOWN COEFFIC
FIDENCE INTERVALS FOR THE MEAN OF A NORMAL DISTRIBUTION WITH KNOWN VARIANCE CONTROL CHARTS FOR THE MEAN OF A NORMAL POPULATION

SEQUENTIAL THREE HYPOTHESIS TEST FOR DETERMININC THE MEAN OF A NORMAL POPULATION WITH KNOWN VARIANCE SEQUENTIAL CONFIDENCE INTERVALS FOR THE MEAN OF A NORMAL POPULATION WITH UNKNOWN VARIANCE A NOTE ON THE POSTERIOR MEAN OF A POPULATION MEAN

AND MINIMAX PROCEDURES FOR ESTIMATING THE ARITHMETIC MEAN OF A POPULATION WITH TWO-STAGE SAMPLING BAYES THE VARIANCE OF THE MEAN OF A STATIONARY PROCESS

ADMISSIBILITY OF THE USUAL CONFIDENCE SETS FOR THE MEAN OF A UNIVARIATE OR BIVARIATE NORMAL POPULATION GENERALIZED MULTIVARIATE ESTIMATOR FOR THE MEAN OF FINITE POPULATIONS

INTERVAL ESTIMATION OF THE LARGEST MEAN OF K NORMAL POPULATIONS WITH KNOWN VARIANCES ON DETECTING CHANGES IN THE MEAN OF NORMAL VARIATES THE VARIANCE OF THE MEAN OF SYSTEMATIC SAMPLES QUERY, THE MEAN OF THE TAIL OF A DISTRIBUTION

AMS $64 \quad 162$ AMS $65 \quad 28$ AMS $65 \quad 55$ AMS $64 \quad 999$ JASA $68 \quad 1039$ AMS $63 \quad 574$ JRSSB 54131 AMS 671365 JRSSB57 133 JRSSB 69 NO. 2 AMS 661186 JRSSB $57 \quad 282$ AMS 691042 JASA 671009 JASA 69296 AMS $69 \quad 116$ BIOKA56 137 TECH $64 \quad 331$

ES OF EQUAL SIZE UNBAISED ESTIMATION OF THE COMMON MEAN OF TWO NORMAL DISTRIBUTIONS BASED ON SMALL SAMPL JASA 66 467 TPTANCE SCHEMES FOR LARGE BATCHES OF ITEMS WHERE THE MEAN OUALITY HAS A NORMAL PRIOR DTSTRIBUTTON ON THE DISTRIBUTIONS OF THE RANGE AND MEAN RANGE FOR SAMPLES FROM A NORMAL DISTRIBUTION BIOKA66 245 ON A CLASS OF GAUSSIAN PROCESSES FOR WHICH THE MEAN RATE OF CROSSINGS IS INFINITE A NOTE ON THE RENEWAL FUNCTION WHEN THE MEAN RENEWAL LIFETIME IS INFINITE MEAN SUCCESSIVE DIFFERENCE AND ITS RATIO TO THE ROOT MEAN SQUARE LISTING EXPECTED MEAN SQUARE COMPONENTS JRSSB67 489 JRSSB $61 \quad 230$

PROBABILISTIC INTERPRETATIONS FOR THE MEAN SQUARE CONTINGENCY CORR 5B 1030

ON THE BIOKA53 116

COMPONENTS MEAN SQUARE EFFICIENCY OF ESTIMATORS OF VARIANCE LINEAR REGRESSION IN RECRESSION APPROXIMATIONS FOR MEAN SQUARE SUCCESSIVE DIFFERENCE CRITICAL VALUES TECH $6 \mathrm{~B} 397$ A NOTE ON MEAN SQUARE SUCCESSIVE DIFFERENCES JASA 59 BOI

MEAN SUCCESSIVE DIFFERENCE AND ITS RATIO TO THE ROOT MEAN SQUARE'

D POWER OF TESTS EMPLOYINC SATTERTHWAITE'S SYNTHETIC MEAN SQUARES

EXPECTATIONS, VARIANCES AND COVARIANCES OF 'ANOVA' MEAN SQUARES BY 'SYNTHESIS'

EXPECTATIONS, VARIANCES, AND CONVARIANCES OF ANOVA MEAN SQUARES BY 'SYNTHESIS'

CORRIGENDA TO 'ON THE BIOKA58 587

NG THE DEGREES OF FREEDOM FOR LINEAR COMBINATIONS OF MEAN SQUARES BY SATTERTHWAITHE'S FORMULA

PARENT IS IDENTIFIED

MEAN SQUARE

MEAN SQUARE'

SMIRNOV TEST

SHORT LIVES

FICULTTES XXPECTED MEAN SQUARES FOR NESTED CLASSIFICATIONS

THE EXPECTED MEAN SQUARES IN GENETTC EXPERIMENTS ON THE MEAN SUCCESSIVE DIFFERENCE AND ITS RATIO TO THE ROOT BIOKA53 116 CORRIGENDA TO 'ON THE MEAN SUCCESSIVE DIFFERENCE AND ITS RATIO TO THE ROOT BIOKA5B 5B' FOR THE EXPONENTIAL DISTRIBUTION WITH MEAN UNKNOWN
ON THE POSSIBILITY OF IMPROVING THE MEAN USEFUL LIFE OF ITEMS BY ELIMINATING THOSE WITH TECH 6I $2 B 1$ DIF TECH $66 \quad 535$ BIOKA51 330 ON THE COMPARISON OF SEVERAL MEAN VALUES, AN ALTERNATIVE APPROACH AMS $66 \quad 45 B$ ALL ADMISSIBLE LINEAR ESTIMATES OF THE MEAN VECTOR CONFIDENCE BOUNDS FOR REGRESSION PARAMETERS AND MEAN VECTOR ON FIXED-WIDTH JRSSB $67 \quad 132$ ATES OF LINEAR COMBINATIONS OF THE PARAMETERS IN THE MEAN VECTOR OF A MULTIVARIATE DISTRIBUTION E QUEUE A NOTE ON EQUALISING THE MEAN WAITING TIMES OF SUCCESSIVE CUSTOMERS IN A FINIT JRSSB55 262 SELECTION OF THE POPULATION WITH THE LARGEST MEAN WHEN COMPARISONS CAN BE MADE ONLY IN PAIRS BIOKA5B 5BI ESTIMATION OF A MEAN WHEN ONE OBSERVATION MAY BE SPURIOUS TECH $69 \quad 331$ 
ONS DISTRIBUTIONS
COMBINATIONS OF UNBIASED ESTIMATORS OF THE MEAN WHICH CONSIDER INEQUALITY OF UNKNOWN VARIANCES AN ESTIMATOR FOR A POPULATION MEAN WHICH REDUCES THE EFFECT OF LARGE TRUE OBSERVAT THE MEANINC OF BIOASSAY

TRUNCATION TO MEET REQUIREMENTS ON MEANS MULTIPLE COMPARISONS AMONC MEANS

ON MULTIPLE DECISION METHODS FOR RANKING POPULATION MEANS ON A CLASS OF SIMPLE SEQUENTIAL TESTS ON MEANS

INTERVAL ESTIMATION FOR LINEAR COMBINATIONS OF MEANS ESTIMATION OF THE LARCEST OF TWO NORMAL MEANS

THE BEHRENS-FISHER DISTRIBUTION AND WEICHTED MEANS ESTIMATORS FOR THE PRODUCT OF ARITHMETIC MEANS

ON COMBINING ESTIMATES OF A RATIO OF MEANS

NOTES. ORTHOGONAL POLYNOMIALS FOR UNEQUALLY WEIGHED MEANS

SEQUENTIAL PROCEDURE FOR SELECTING THE LARGEST OF K MEANS PROCEDURES FOR ESTIMATING THE DIFFERENCE BETWEEN MEANS OF LARGE DEVIATIONS OF FAMILIES OF SAMPLE MEANS CORRELATED ESTIMATES OF A RATIO OF MULTIVARIATE MEANS OF MULTIVARIATE SEQUENTIAL PROCEDURE FOR TESTING MEANS VARIANCES ON THE F-TEST FOR THE HOMOCENEITY OF GROUP MEANS LIMITS FOR THE RATIO OF MEANS VARIANCES NORMAL POPULATION MEANS (WITH DISCUSSION)

TESTING EQUALITY OF MEANS AFTER A PRELIMINARY TEST OF EQUALITY OF CENERALIZED MEANS AND ASSOCIATED FAMILIES OF DISTRIBUTIONS CONDITIONAL MEANS AND COVARIANCES OF NORMAL VARIABLES WITH SINCUL

AR COVARIANCE MATRIX
A MEAN-SQUARE-ERROR CHARACTERIZATION OF BINOMIAL-TYPE

BASES OF THE PROBLEM OF THE AMALGAMATION OF WEIGHTED MEANS

JASA 691042 JASA $66 \quad 1200$ AMS $67 \quad 620$ BIOCS65 785 JASA $57 \quad 527$ JASA $61 \quad 52$ AMS $62 \quad 248$ TECH $62 \quad 345$ JASA 641141 JASA $68 \quad 861$ JRSSB59 73 JRSSB 62180 JRSSB 63201 BIOCS65 226 A AMS $6 B \quad 88$

TWO-STAGE BIOKA54 146 ON THE PROBABILITY AMS 641304 THE RANDOMIZATION JRSSB6I 423 A NOTE ON COMBINING TECH $64 \quad 463$ AN EMPIRICAL EVALUATTON AMS $62 \quad 1413$ THE EFFECT OF UNEQUAL CROUP BIOKA53 $12 B$ JRSSB54 186 JRSSB $60 \quad 1$ BIOKA62 403 AMS $69 \quad 339$ JASA 641203 BI0KA56 304 JASA $59 \quad 465$ ON THE ACCURACY OF WETGHTED MEANS AND RATIOS CORRELATION BETWEEN SAMPLE MEANS AND SAMPLE RANGES

EEN PERCENTAGE POINTS OF FREQUENCY CU/ APPROXIMATE MEANS AND STANDARD DEVIATIONS BASED ON DISTANCES BETW BIOKA65 533 OGONAL EXPERIMENTS BY ELECTRONIC CO/ ESTIMATION OF MEANS AND STANDARD ERRORS IN THE ANALYSIS OF NON-ORTH JRSSB62 435 ES FOR TH/ STATISTTCAL DEPENDENCE BETWEEN SUBCLASS MEANS AND THE NUMBERS OF OBSERVATTONS TN THE SUBCLASS JASA 68 I4B SIZE, CORR. 641297 ESTIMATION OF MEANS AND TOTALS FROM FINITE POPULATIONS OF UNKNOWN A TEST OF EQUALITY OF TWO NORMAL POPULATION MEANS ASSUMING HOMOGENEOUS COEFFICIENTS OF VARIATION BAYESIAN ESTIMATION OF MEANS FOR THE RANDOM EFFECT MODEL SAMPLING MOMENTS OF MEANS FROM FINITE MULTIVARIATE POPULATIONS

A CHART FOR SEQUENTIALLY TESTING OBSERVED ARITHMETIC MEANS FROM LOGNORMAL POPULATIONS AGAINST A GIVEN STAN TE ON THE PROPORTION OF OBSERVATIONS ABOVE SAMPLE MEANS IN A BIVARIATE NORMAL DISTRIBUTION NOTE ON MULTIPLE COMPARISONS FOR ADJUSTED MEANS IN THE ANALYSIS OF COVARIANCE TESTINC EQUALITY OF MEANS IN THE PRESENCE OF CORRELATION JASA $62 \quad 61$ AMS $69 \quad 1374$ JASA $68 \quad 174$ AMS $61 \quad 406$ TECH $68 \quad 605$ AMS 6B 1350 BIOKA58 256 BI0KA69 119 TEST FOR THE SIGNIFICANCE OF THE DIFFERENCE BETWEEN MEANS IN TWO NORMAL POPULATIONS HAVING UNEQUAL VARIAN BIOKA51 252 ANALYSIS BAYESIAN COMPARISON OF MEANS OF A MIXED MODEL WITH APPLICATION TO RECRESSION BIOKA66 CONFTDENCE TNTERVALS FOR THE MEANS OF DEPENDENT NORMALLY DTSTRIBUTED VARIABLES JASA 59613 A TWO-STACE SUBSAMPLINC PROCEDURE FOR RANKING MEANS OF FINITE POPULATIONS WITH AN APPLICATION TO BU NOTES. ON ESTIMATING THE ARITHMETIC MEANS OF LOGNORMALL-DISTRIBUTED POPULATIONS

RECTANGULAR CONFIDENCE REGIONS FOR THE MEANS OF MULTIVARIATE NORMAL DISTRIBUTIONS

SEQUENTIAL INTERVAL ESTIMATION FOR THE MEANS OF NORMAL POPULATIONS

NOTES. SAMPLE SIZE FOR THE ESTIMATION OF MEANS OF NORMAL POPULATIONS

EXTENSIONS OF SOMERVILLE'S PROCEDURE FOR RANKING MEANS OF NORMAL POPULATIONS ESTIMATION OF MEANS OF NORMAL POPULATIONS FROM OBSERVED MINIMA SOME BIOKA6B BIOCS65 235 JASA $67 \quad 626$ AMS 69509 BIOCS67 B46 A TWO-SAMPLE MULTIPLE DECISION PROCEDURE FOR RANKING MEANS OF NORMAL POPULATIONS WITH A COMMON UNKNOWN VAR BIOKA54 170 NDENT STOCHASTIC SERIES THE COMPARISON OF MEANS OF SETS OF OBSERVATIONS FROM SECTIONS OF INDEPE JRSSB55 2OE

ANALYSIS OF EFFECTS OF ANTIBIOTICS ON BACTERIA BY MEANS OF STOCHASTIC MODELS BOCS66 76 ATION OF POPULATION PARAMETERS FROM DATA OBTAINED BY MEANS OF THE CAPTURE-RECAPTURE METHOD. I. THE MAXIMUM BIOKA5I 269 ATION OF POPULATION PARAMETERS FROM DATA OBTAINED BY MEANS OF THE CAPTURE-RECAPTURE METHOD. III.AN EXAMPLE BIOKA53 I37 VARIANCES RANKING MEANS OF TWO NORMAL POPULATIONS WITH UNKNOWN LCH STATISTIC FOR TESTINC THE DIFFERENCE BETWEEN THE MEANS OF TWO NORMAL POPULATIONS WITH UNKNOWN VARIANCE JRSSB6I 377 THE TWO MEANS PROBLEM A SECONDARILY BAYES APPROACH A TEST OF HOMOCENEITY OF MEANS UNDER RESTRICTED ALTERNATIVES (WITH DISCUSSION) JRSSB6I 239 EHAVIOUR OF CERTAIN TESTS OF THE HYPOTHESIS OF EQUAL MEANS UNDER VARIANCE HETEROGENEITY SMALL SAMPLE B BIOKA6O 345 EHAVTOUR OF CERTATN TESTS OF THE HYPOTHESIS OF FQUAL A TEST FOR EQUALITY OF MEANS WHEN COVARIANCE MATRICES ARE UNEQUAL AMS 63
671 ON POOLING MEANS WHEN VARIANCE IS UNKNOWN JASA 68 1333 TESTING OF MEANS WITH DIFFERENT ALTERNATIVES

THE DISTRIBUTION OF NONCENTRAL MEANS WITH KNOWN COVARIANCE

ON THE COMPARISON OF TWO MEANS, FURTHER DISCUSSION OF ITERATIVE METHODS FOR TECH $6 \mathrm{~B}$ 195 AMS $61 \quad 874$ BIOKA54 361 BIOKA59 317 BIOKA56 15 THE COMPLETE AMALGAMATION INTO BLOCKS, BY WEIGHTED MEANS, OF A FINITE SET OF REAL NUMBERS

ON ESTIMATING THE LATENT AND INFECTIOUS PERIODS OF MEASLES, I. FAMILIES WITH TWO SUSCEPTIBLES ONLY.

ON ESTIMATING THE LATENT AND INFECTIOUS PERIODS OF MEASLES, II. FAMILIES WITH THREE OR MORE SUSCEPTIBLES BIOKA56 322 A PERFECT MEASURABLE SPACE THAT IS NOT A LUSIN SPACE ON ESTIMATING A DENSITY WHICH IS MEASURABLE WITH RESPECT TO A SICMA-LATTICE ON MEASURABLE, NONLEAVABLE GAMBLING HOUSES WITH A GOAL ON MEASURES EQUIVALENT TO WIENER MEASURE FOR THE EXISTENCE OF A FINITELY ADDITIVE PROBABILITY MEASURE EXISTENCE OF AN INVARIANT MEASURE AND AN ORNSTEIN'S FRGODTC THEOREM RIGHT HAAR MEASURE FOR CONVERCENCE IN PROBABILITY TO QUASI NOTES. A MEASURE OF 'OVERALL VARIABILITY' IN POPULATIONS ON A MEASURE OF ASSOCIATION

POSTERIOR DISTRIBUTIONS

DISTRIBUTION OF THE SAMPLE VERSION OF THE MEASURE OF ASSOCIATION, GAMMA

A NOTE ON AVERAGE TAU AS A MEASURE OF CONCORDANCE

THE DISTRIBUTION OF HOTELLING'S GENERALIZED MEASURE OF MULTIVARIATE DISPERSION SAMPLINC FOR PROBABILITY PROPORTIONATE TO SOME MEASURE OF SIZE ESTIMATION IMPROVED BOUNDS ON A MEASURE OF SKEWNESS

ON A MEASURE OF TEST EFFICIENCY PROPOSED BY R. R. BAHADUR

PROPERTIES OF THE STATIONARY MEASURE OF THE CRITICAL CASE SIMPLE BRANCHING PROCESS AMS $67 \quad 482$ AMS 6966 AMS 67261 AMS $67 \quad 780$ AMS $69^{\circ} 79$ AMS $65 \quad 440$ BI0CS68 189 AMS 641157 JASA $66 \quad 440$ JASA $60 \quad 331$ AMS $66 \quad 215$ AMS $64 \quad 900$ AMS 621192 AMS $64 \quad 1537$ AMS $67 \quad 977$ GIVEN ROOT (BETA-1) AND BETA-2, EXPRESSED IN STANDARD MEASURE' /PERCENTAGE POINTS OF PEARSON CURVES, FOR BIOKA65 669 CORRELATION COEFFICIENTS MEASURED ON THE SAME INDIVIDUALS 
QUALITY CONTROL SYSTEMS BASED ON INACCURATELY MEASURED VARIABLES APPLICATIONS OF A NEW CRAPHIC METHOD IN STATISTICAL MEASUREMENT APPROACHES TO NATIONAL OUTPUT MEASUREMENT REGRESSION FOR TIME SERIES WITH ERRORS OF MEASUREMENT

IN MENTAL TEST THEORY ARISINC FROM ERRORS OF MEASUREMENT TATISTICAL EVALUATION OF SPLITTINC LIMIT CRITERIA IN MEASUREMENT DISPUTES CTOR FUEL ELEMENT QUALITY

A CHARACTERIZATION OF THE WEAK CONVERCENCE OF MEASURES
RADON-NIKODYM DERIVATIVES OF STATIONARY GAUSSIAN MEASURES

IDENTIFIABILITY OF MIXTURES OF PRODUCT MEASURES

INVARIANT SETS FOR TRANSLATION-PARAMETER FAMILIES OF MEASURES

DISTINGUISHABILITY OF PROBABILITY MEASURES

ON DISTINCUISHING TRANSLATES OF MEASURES

RANKS AND MEASURES

THE CLIVENKO-CANTELLI THEOREM FOR INFINITE INVARIANT MEASURES

SINGULAR RECURRENT MARKOV PROCESSES HAVE STATIONARY MEASURES

SETS AND CONVEX HULLS OF SAMPLES FROM PRODUCT MEASURES

DISTANCES OF PROBABILITY MEASURES AND RANDOM VARIABLES

PERFECT PROBABILITY MEASURES AND REGULAR CONDITIONAL PROBABILITIES

ON MEASURES EQUIVALENT TO WIENER MEASURE

INTECRAL KERNELS AND INVARIANT MEASURES FOR MARKOFF TRANSITION FUNCTIONS

THE EXISTENCE AND UNIQUENESS OF STATIONARY MEASURES FOR MARKOV RENEWAL PROCESSES

ORDINAL MEASURES OF ASSOCIATION

MEASURES OF ASSOCIATION FOR CROSS CLASSIFICATIONS,

MEASURES OF ASSOCIATION FOR CROSS CLASSIFICATIONS,

II. FURTHER DISCUSSION AND REFERENCES

11. APPROXIMATE SAMPLING THEORY

THE EFFECT OF NON-SAMPLINC ERRORS ON MEASURES OF ASSOCIATION IN 2-BY-2 CONTINGENCY TABLES

AN EXAMPLE OF LARGE DISCREPANCY BETWEEN MEASURES OF ASYMPTOTIC EFFICIENCY OF TESTS

MEASURES OF CONCENTRATION

ON MEASURES OF CORRELATION IN TIME SERIES OF EVENTS

MUTUAL INFORMATTON AND MAXIMAL CORRELATION AS MEASURES OF DEPENDENCE

APPROXIMATIONS TO THE DISTRIBUTIONS OF SOME MEASURES OF DISPERSION BASED ON SUCCESSIVE DIFFERENCE

APPROXIMATING TO THE DISTRIBUTIONS OF MEASURES OF DISPERSION BY A POWER OF CHI-SQUARE

BI0CS66 BIO

AMS 61 101

AMS $64 \quad 517$

AMS $66 \quad 321$

AMS $66 \quad 686$

AMS $66 \quad 729$

AMS 671300

AMS $69 \quad 162$

AMS 69381

AMS 691773

BIOKA62 133

ON . AMS 671273

NON- AMS 64 B69

LIMITING AMS 691824

AMS 6B 1563

AMS $66 \quad 1273$

AMS 67261

AMS $65 \quad 517$

AMS $66 \quad 1439$

JASA $58 \quad 814$

JASA 59123

JASA $63 \quad 310$

JASA 69852

AMS 6B 179

JASA $67 \quad 162$

BIOCS69 73

AMS $62 \quad 587$

NTERVALS FOR THE RATIO OF TWO PROBABILITIES AND SOME MEASURES OF EFFECTIVENESS

A UNIQUENESS THEOREM FOR STATIONARY MEASURES OF ERGODIC MARKOV PROCESSES ON SOME MEASURES OF FOOD MARKETING SERVICES

CONFIDENCE INTERVALS FOR MEASURES OF HERITABILITY

ON BEALE'S MEASURES OF NON-LINEARITY

THE MEDIAN SIGNIFICANCE LEVEL AND OTHER SMALL SAMPLE MEASURES OF TEST EFFICIENCY THE EPSILON ENTROPY ON CERTAIN MEASURES ON $(0.1)$

SOME STRUCTURE THEOREMS FOR STATIONARY PROBABILITY MEASURES ON FINITE STATE SEQUENCES PROBABILITY MEASURES ON PRODUCT SPACES

DERIVATIVE EQUIVALENT GAUSSIAN MEASURES WITH A PARTICULARLY SIMPLE RADON-NIKODYM

RELATIONS BETWEEN WEAK AND UNIFORM CONVERGENCE OF MEASURES WITH APPLICATIONS THE EXISTENCE OF PROBABILITY MEASURES WITH GIVEN MARCINALS

SION OF A RADON-NIKODYM DERIVATIVE TO THE PROBLEM OF MEASURINC ASSOCIATION /THE RELEVANCE OF THE DISPER J PROBLEMS IN MEASURING LONC TERM CROWTH IN INCOME AND WEALTH THE MEASURING PROCESS

MEASURING RECESSIONS

THE USE OF AN ITERATED MOVING AVERACE IN MEASURING SEASONAL VARIATIONS

$\begin{array}{ll}\text { BIOKA57 } & 349 \\ \text { BIOKA53 } & 336\end{array}$

$\begin{array}{lrr} & 36 \\ \text { AMS } & 64 & 1781\end{array}$

JASA $61 \quad 65$

BIOCS69 424

TECH $65 \quad 623$

JASA 69971

AMS $68 \quad 1310$

AMS $64 \quad 550$

SASJ 67

AMS $67 \quad 1027$

AMS $62 \quad 659$

AMS $65 \quad 423$

JRSSB 65108

JASA $57 \quad 450$

TECH 59251

JASA $58 \quad 259$

JASA $62 \quad 149$

ION OF THE CASE OF MARKET ORIENTATION OF PRODUCTI/ MEASURING SPATIAL ASSOCIATION WITH SPECIAL CONSIDERAT JASA 56 597 THE RATIONAL ORIGIN FOR MEASURING SUBJECTIVE VALUES

ON MEASURING THE EXTREME ACED IN THE POPULATION

A COEFFICIENT MEASURING THE COODNESS OF FIT

ERRATA, 'A COEFFICIENT MEASURING THE GOODNESS OF FIT'

MEASURING THE LENGTH OF A CURVE

ON THE USE OF PARTIALLY ORDERED OBSERVATIONS IN MEASURING THE SUPPORT FOR A COMPLETE ORDER

PER COUPLE

A CHANCE MECHANISM OF THE VARIATION IN THE NUMBER OF BIRTHS

THE EXPERTMENTAL STUDY OF PHYSICAL MECHANISMS

DISCRIMINATION AMONG MECHANISTIC MODELS

EXPERIMENTAL DEVELOPMENT OF NUTRITIVE MEDIA FOR MICRO-ORGANISMS

JASA $57 \quad 45 B$

JASA $68 \quad 29$

TECH $66 \quad 327$

TECH $67 \quad 195$

BIOKA66 359

JASA $61 \quad 299$

JASA $6 B \quad 209$

TECH $65 \quad 23$

BIOKA67 316

BIOKA68 43

AMS $62 \quad 157$

TECH $67 \quad 682$

QUERY, COMPLETED RUNS OF LENGTH K ABOVE AND BELOW MEDIAN

AND DISTRIBUTION-FREE CONFIDENCE INTERVALS FOR A MEDIAN

I. ITS CURVE-SHAPE CHARACTERISTICS II. THE SAMPLE MEDIAN

JOINT ASYMPTOTIC DISTRIBUTION OF THE MEDIAN AND A U-STATISTIC

PROPERTIES OF THE MEDIAN AND OTHER STATISTICS OF LOGISTIC VARIATES

THE 'INEFFICIENCY' OF THE SAMPLE MEDIAN FOR MANY FAMILIAR SYMMETRIC DISTRIBUTIONS

$\begin{array}{rrr}\text { STRATIFIED SAMPLING JASA } & 65 & 772 \\ \text { ON A GENERAL SYSTEM OF DISTRIBUTIONS, JASA } 68 & 627\end{array}$

JRSSB57 144

AMS 651779 BIOKA55 520 
HURWITZ WASHINGTON STATISTICAL SOCIETY MEMORIAL MEETING FOR WILLIAM N. HURWITZ. JASA 69 NO. 4

STATISTICS

APPLICATIONS

THE ESTIMATION RDER OF SIZE

SOME APPLICATIONS OF MEIJER-G FUNCTIONS TO DIS HURWITZ. THE DEVELOPMENT OF HO J
ON THE GENERALIZED MELLIN
F POPULATION PARAMETERS FROM MARKED MEMBERS THE DIFFERENCE BETWEEN CONSECUTIVE MEMBERS OF A SERIES OF RANDOM VARIABLES ARRANGED IN 0 BIOKA57 211
SECOND REVOLU CENSUS METHODS

HURWITZ

LLIAM N. HURWITZ

RINCIPLES OF STATI/

ENT OF HOUSEHOLD S/
ITHE FIRST FTSHER MEMORTAL LECTURE) WASHINGTON STATISTICAL SOCIETY MEMORIAL MEETINC FOR WILLIAM N HURWITZ COMPUTERS. THE WASHINGTON STATISTICAL SOCIETY MEMORIAL MEETING FOR WILLIAM N. HURWITZ, WASHINGTON STATISTICAL SOCIETY MEMORIAL MEETING FOR WILLIAM N. HURWITZ. WASHINGTON STATISTICAL SOCIETY MEMORIAL MEETING FOR WILLIAM N HURWITZ, WASHINGTON STATISTICAL SOCIETY MEMORIAL MEETING FOR WILLIAM N. HURWITZ. WASHINGTON STATISTICAL SOCIETY MEMORIAL MEETING FOR WILLIAM N. HURWITZ. MEMORIAL TO SIR RONALD AYLMER FISHER, 1890-1962 HYPOTHESIS TESTING WITH FINITE MEMORY ROBBINS-ISBELL TWO-ARMED-BANDIT PROBLEM WITH FINITE MEMORY RULES FOR THE TWO-ARMED BANDIT WITH FINITE MEMORY

BOUNDS ON THE PROBABILITY OF ERROR FOR A DISCRETE MEMORYLESS CHANNEL PROCESSES PROGRAMMINC

PROXIMATION TO PROBABILITIES TOPICS, CORR, 651249 A NOTE ON MEMORYLESS RULES FOR CONTROLLING SEQUENTIAL CONTROL MEMORYLESS STRATEGIES IN FINITE-STAGE DYNAMIC

CHASA 69233 COMMENTS JASA 69 NO. 4 ON WILLIAM JASA 69 NO. 4 PROFESSOR WI JASA 69 NO. 4 SOME BASIC P JASA 69 NO. 4 THE DEVELOPM JASA 69 NO 4 AMS $69 \quad 828$ THE AMS $65 \quad 1375$ RANDOMIZED AMS 682103 XMS 61577 AMS $66 \quad 276$ AMS $64 \quad 863$ NORMAL AP JRSSB57 334 A MENDELIAN MARKOV PROCESS WITH BINOMIAL TRANSITION BIOKAG6 37 A SUPPLEMENT TO MENDENHALL'S BIBLIOGRAPHY ON LIFE TESTINC AND RELATED JASA 641231 PROBLEMS IN MENTAL TEST THEORY ARISING FROM ERRORS OF MEASUREMENT JASA 59472 MERGING OF OPINIONS WITH INCREASINC INFORMATION AMS 62882

SELECTION INDICES FOR QUADRATIC MODELS OF TOTAL MERIT

THE ROLE OF SICNIFICANCE TESTINC, SOME DATA WITH A MESSACE A NOTE ON MATRIX INVERSION BY THE SQUARE ROOT METHOD A STUDY OF THE GROUP SCREENING METHOD MATRIX INVERSION WITH THE SQUARE ROOT METHOD

A DYNAMIC STOCHASTIC APPROXIMATION METHOD SEQUENTIAL ANALYSIS, DIRECT METHOD MODIFICATIONS TO THE VARIATE-DIFFERENCE METHOD THE ANGLE-COUNT METHOD

ON THE CONSISTENCY OF THE FIDUCTAL METHOD OF SURVIVORSHIP IN CHRONIC DISEASE, THE 'ACTUARIAL' METHOD STUDY OF ESTIMATORS FOR THE LINE TRANSECT SAMPLING METHOD MULTIVARIATE REGRESSION, EFFICIENCY OF A FIRST ORDER METHOD OLVED IN ESTIMATING BACTERIAL NUMBERS BY THE PLATING METHOD OGISTIC FUNCTION, USING THE MINIMUM LOGIT CHI-SQUARE METHOD IAL FREQUENCY FUNCTIONS IN CURVE FITTING BY AITKEN'S METHOD ONS TO SOME AVAILABLE DATA BY THE MAXIMUM LIKELIHOOD METHOD ON ESTIMATION BY THE SWEEP-OUT METHOD (CORR. 69 229) $/ \mathrm{N}$ THE ESTIMATION OF THE PARAMETERS OF THE L BIOKA62 250 /YNOMIALS OF THE POSITIVE AND NEGATIVE BINOM BIOKA6I 115 ON THE MULTIVARIATE SADDLE POINT METHOD AND CHI-SQUARED BIOKA68 305 THE FIDUCIAL METHOD AND INVARIANCE

TESTS THE AVERAGE CRITICAL VALUE METHOD AND THE ASYMPTOTIC RELATIVE EFFICIENCY OF
THE DOOLITTLE METHOD AND THE FITTING OF POLYNOMIALS TO WEIGHTED
A WIENER-HOPF TYPE METHOD FOR A GENERAL RANDOM WALK WITH A TWO-SIDED

DATA

BOUNDARY BIOKA61 261 BIOKA67 308 BIOKA53 229 AMS $63 \quad 1168$ AL TESTS IN TIME SERIE/ THE AVERAGE CRITICAL VALUE METHOD FOR ADJUDGING RELATIVE EFFICIENCY OF STATISTIC BIOKA66 IO9 A GENERAL METHOD FOR APPROXTMATING TO THE DISTRIBUTION OF PRODUCTS BAYES' METHOD FOR BOOKIES

DATA

NOTE ON A METHOD FOR CALCULATING CORRECTED SUMS OF SQUARES AND A COMPUTER METHOD FOR CALCULATING KENDALL'S TAU WITH UNGROUPED

A QUICK METHOD FOR CHOOSING A TRANSFORMATION A METHOD FOR CLUSTER ANALYSIS

ON THE TWO SAMPLE PROBLEM, A HEURISTIC METHOD FOR CONSTRUCTING TESTS

A NONPARAMETRIC STATISTICAL METHOD FOR CULLING RECRUITS FROM A MARK-RECAPTURE $\begin{array}{rr}\text { BIOKA56 } & 295 \\ \text { AMS } 69 & 1177\end{array}$ TECH $62 \quad 419$ JASA $66 \quad 436$ TECH $63 \quad 317$ BIOCS65 362 AMS 611091 BIOCS65 936

EXPERIMENT A METHOD FOR DISCRIMINATING BETWEEN FAILURE DENSITY FUN TECH 65 CTIONS USED IN RELIABILITY PREDICTIONS $M$ THE RANCE OF THE DEVIATIONS ABOUT THE R/ A RAPID METHOD FOR ESTIMATING THE CORRELATION COEFFICIENT FRO BIOKA53 QUANTAL DATA, AND ITS RELA/ ADAPTATION OF KARBER'S METHOD FOR ESTIMATING THE EXPONENTIAL PARAMETER FROM BIOCS67
THE ROBBINS-MONRO METHOD FOR ESTIMATING THE MEDIAN LETHAL DOSE AN INVESTICATION OF HARTLEY'S METHOD FOR FITTING AN EXPONENTIAL CURVE JRSSB 65 - 28 BIOKA59 281 BIOKA60 177 OF POINTS ACCORDING TO THE C/ A SHORT-CUT GRAPHIC METHOD FOR FITTING THE BEST STRAIGHT LINE TO A SERIES JASA 57 13 VARIANCE (CORR. 69 229) (CORR. 69 229) 
ICS

FORMULAE
A USEFUL METHOD FOR MODEL BUILDINC

SOME RULES FOR A COMBINATORIAL METHOD FOR MULTIPLE PRODUCTS OF GENERALIZED K-STATIST TECH 62301

A DEFORMATION METHOD FOR QUADRATIC PROCRAMMTNC

SUPPLEMENT TO'A DEFORMATION METHOD FOR QUADRATIC PROCRAMMINC

A RECRESSION METHOD FOR REAL ESTATE PRICE INDEX CONSTRUCTION

A SEQUENTIAL METHOD FOR SCREENINC EXPERIMENTAL VARIABLES

MULTIVARIATE-COVARIANCE AND CANONTCAL ANALYSIS, A METHOD FOR SELECTINC THE MOST EFFECTIVE DISCRIMINATOR BI THE UP-AND-DOWN METHOD FOR SMALL SAMPLES

ONS

AN A POSTERIORI PROBABILITY METHOD FOR SOLVINC AN OVERDETERMINED SYSTEM OF EQUATI

A SEMI-CRAPHICAL METHOD FOR THE ANALYSIS OF COMPLEX PROBLEMS

A NOTE ON A METHOD FOR THE ANALYSTS OF STCNIFTCANCE EN MASSE

A CRAPHICAL METHOD FOR THE ANALYSIS OF STATISTICAL DISTRIBUTIONS

A METHOD FOR THE CONSTRUCTION OF SECOND ORDER ROTATABLE

INTO TWO NORMAL COMPONENTS

DESICNS IN K DIMENSIONS

IONS BY LEAST SQUUARES

VARIOUS PREVENTIVE MAINTENANCE POLICIES

H SPECIAL REFERENCE TO EQUILIBRIA

ASYMPTOTIC PROPERTIES OF THE BLOCK UP-AND-DOHN METHOD IN BIO-ASSAY

THE MULTIPLE SAMPLE UP-AND-DOWN METHOD IN BIOASSAY

APPLICATIONS OF A NEW CRAPHIC METHOD IN STATISTICAL MEASUREMENT

SOME REMARKS ON A METHOD OF A MAXIMUM-LIKELIHOOD ESTIMATION PROPOSED BY JP

A METHOD OF ADJUSTMENT FOR DEFECTIVE DATA

A DISTRIBUTION-FREE METHOD OF ANALYZING A 2 TO THE M FACTORIAL EXPERIMENT SASJ 68

IVE BINOMIAL AND OTHER CONTACIOUS DISTRIBUTIONS A METHOD OF ANALYSINC UNTRANSFORMED DATA FROM THE NECAT BIOKA6B

AN APPROXIMATE METHOD OF ANALYSIS FOR A TWO-WAY LAYOUT

A SUCCESTED METHOD OF ANALYSTS OF A CERTAIN CLASS OF EXPERTUENTS

A METHOD OF ANALYZINC LOC-NORMALLY DISTRIBUTED SURVIVAL JASA 60

A METHOD OF ASSICNINC CONFIDENCE LIMITS TO LINEAR BIOKA55

IN CARCINOCENESIS

DATA WITH INCOMPLETE FOLLOW-UP

COMBINATIONS OF VARIANCES

A NOTE ON THE APPLICATION OF QUENOUTLLE'S METHOD OF BIAS REDUCTION TO THE ESTTMATION OF RATIOS

CONTINCENCY TABLES WITH SMALL MARCINAL/

A SIMPLE METHOD OF CALCULATINC THE EXACT PROBABILITY IN 2-BY-2

ON A NEW METHOD OF CAPACITY ESTIMATION

471

BIOKA55 522

JASA 64529

$\begin{array}{rrr}\text { PROCRAMMINC FISHER'S EXACT METHOD OF COMPARINC TWO PERCENTACES } & \text { TECH } 60103 \\ \text { A METHOD OF CONSTRUCTINC BALANCED INCOMPLETE DESICNS. } & \text { BIOKA65 }\end{array}$

HE SINGLE POPULATION BASED ON TWO SUCCESSIVE CENS/ METHOD OF CONSTRUCTION OF ATTRITION LIFE TABLES FOR T JASA 67 I433 WITH. TWO ASSOCIATE CLASSES

ON A CEOMETRICAL METHOD OF CONSTRUCTION OF PARTIALLY BALANCED DESICNS AMS 611177

A REPRODUCTBLE METHOD OF COUNTTNC PERSONS OF SPANTSH SURNAME

A SIMPLE METHOD OF DERIVINC BEST CRITICAL RECIONS SIMILAR TO T BIOKA53 231

A CENERAL METHOD OF DETERMININC FIXED-WIDTH CONFIDENCE

AMS 69704

INTERVALS

ETE TIME MARKOV PROCESS

OF NONPARAMETRIC TESTS FIELD

ON THE ITERATIVE METHOD OF DYNAMIC PROCRAMMINC ON A FINITE SPACE DISCR ON A DISTRIBUTION-FREE METHOD OF ESTIMATING ASYMPTOTIC EFFICIENCY OF A CLASS ON A METHOD OF ESTIMATINC BIOLOCICAL POPULATIONS IN THE

LINE TRANSECT METHOD OF ESTIMATINC CROUSE POPULATION DENSITIES

LINE TRANSECT METHOD OF ESTIMATINC CROUSE POPULATI

A NOTE ON THE CENSUS SURVIVAL RAT A SIMPLE METHOD OF ESTIMATINC RELATIVE POTENCY FROM TWO

PARABOLAS

COUNTIES

POPULATIONS

AN EFFICIENT METHOD OF ESTIMATINC SEEMINGLY UNRELATED RECRESSIONS

A METHOD OF ESTIMATINC THE INTERCENSAL POPULATION OF

SOME PROPERTIES OF A METHOD OF ESTIMATINC THE SIZE OF MOBILE ANIMAL

A QUICK METHOD OF ESTIMATINC THE STANDARD DEVIATION

ON THE CHOICE OF A STRATECY FOR A RATIO METHOD OF ESTIMATION

BIOKA66 559

JRSSB67 392

ESTTMATTON OF QUANTALRESPONSE CURVES A NEW METHOD OF EST IMATTON

E DATA SUITABLE FOR USE WITH AN ELECTRONIC COMP/A METHOD OF ESTIMATION OF MISSING VALUES IN MULTIVARIAT JR

A SIMPLE APPROACH TO THE BAYES CHOICE CRITERION. THE METHOD OF EXTREME PROBABILITIES

A SYSTEMATIC METHOD OF FINDINC DEFININC CONTRASTS

NOTE. A METHOD OF FITTING A NON-LINEAR CURVE CONTAINING A

SINGLE NON-LINEARITY

NOTE. A METHOD OF FITTING A NON-LIN
BY THE METHOD OF FITTING CONSTANTS

NOTE ON THE EST

TO-X

A METHOD OF FITTING EMPIRICAL SURFACES TO PHYSICAL AND

A METHOD OF FITTING THE RECRESSION CURVE $E(Y)=A+D X+B C-$

A CENERAL CLASS OF SERVICE-TIME DISTRIBUTIONS BY THE METHOD OF CENERATINC FUNCTIONS /CHANNEL QUEUE WITH J

EXACT (PI)PS SAMPLING SCHEME. A GENERALIZATION OF A METHOD OF HANURAV

ON THE METHOD OF INCLUSION AND EXCLUSION

AN JRSSB68 556

JASA $67 \quad 102$

ALYSIS OF N/ APPLICATION OF GREENBERG AND SARHAN'S METHOD OF INVERSTON OF PARTITIONED MATRTCES IN THE AN JASA G5 I2

THE INVESTICATION OF LINEAR RELATIONS FITTED BY THE METHOD OF LEAST SQUARES (WITH DISCUSSION) TOPICS IN JR MODIFIED SQUARE ROOT METHOD OF MATRIX INVERSION

ERRATA, MODIFIED SOUARE ROOT METHOD OF MATRIX INVERSION

BREEOING COEFFICIENT FROM PHENOTYPE FREQUENCIES BY A METHOD OF MAXIMUM LIKELIHOOD SCORING /ION OF THE IN BIOCS68 915 A METHOD OF MAXIMUM-LIKELIHOOD ESTIMATION JRSSB61 469

DISTRIBUTION

EXPONENTIAL DISTRIBUTIONS

EFFICIENCY OF THE METHOD OF MOMENTS AND THE CRAM-CHARLIER TYPE A

THE METHOD OF MOMENTS APPLIED TO A MIXTURE OF TWO

TRUNCATED BINOMIAL AN/ THE ASYMPTOTIC VARIANCES OF METHOD OF MOMENTS ESTIMATES OF THE PARAMETERS OF THE

NOTES. EQUIVALENCE OF MAXIMUM LIKELIHOOD AND THE METHOD OF MOMENTS IN PROBIT ANALYSIS ASYMPTOTICALLY EFFICIENT TESTS BY THE METHOD OF N RANKINGS

58

AMS $61 \quad 143$

JASA 61990

BI0CS67 154

JRSSB68 312

ABILITY OF MISCLASSIFICATION I/ AN ALMOST UNBIASED METHOD OF OBTAINING CONFIDENCE INTERVALS FOR THE PROB BIOCS67 639

RS IN EXPONENTIAL CURVE FITTINC

POWER OF RANK TESTS

A METHOD OF OBTAINING INITIAL ESTIMATES OF THE PARAMETE BIOCS69 580

AN ELEMENTARY METHOD OF OBTAINING LOWER BOUNDS ON THE ASYMPTOTIC AMS 682128

BIOKA52 211

ON A CORRECTION TERM IN THE METHOD OF PAIRED COMPARISONS

OMPLETE BLOCK DESIGNS. II. ADDITIONAL TABLES FOR THE METHOD OF PAIRED COMPARISONS E LARCE-SAMPLE RESULTS ON ESTIMATION AND PONER FOR A METHOD OF PAIRED COMPARISONS

RANK ANALYSIS OF INCOMPLETE BLOCK DESICNS. I. THE METHOD OF PAIRED COMPARISONS. OMPLETE BLOCK DESIGNS. II ADDITIONAL TABLES FOR THE METHOD OF PAIRED COMPARISONS.

RANK ANALYSIS OF INC BIOKA54 502 /OCK DESICNS. III, SOM BIOKA55 450 BIOKA52 324 COMPONENTS

PROPORTIONAL TO SIZE

/ANK ANALYSIS OF INC BIOKA54 288 ERCEOMETRIC, BINOMIAL, POISSON, AND EXPONENTIAL/ A METHOD OF SEQUENTIAL ESTIMATION APPLICABLE TO THE HYP AMS 65 I494 CLE SERVER AND CONSTANT PARAMETERS AN ELEMENTARY METHOD OF SOLUTION OF THE QUEUEINC PROBLEM WITH A SIN JRSSB56 125 PROPERTIES
AMS $64 \quad 435$

BIOKA53 452 
SURVEYS A SIMPLE METHOD OF TREND CONSTRUCTION JRSSB61 91

ON A METHOD OF USTNG MULTI-AUXILIARY INFORMATION IN SAMPLE J

SYSTEMS REPORTS

AETHOD OF WEATHER FORECAST EVALUATION

THE TRENTILE DEVIATION METHOD TO DETERMINE THE RELIABILITY OF TELEMETRY
A METHOD

APPLICATION OF A MODIFICATION OF DAVIDON'S METHOD TO NONLINEAR REGRESSION PROBLEMS

1) THE LOGNORMAL DISTRIBUTION AND THE TRANSLATION METHOD I. THE MAXIMUM LIKELIHOOD EQUATIONS FOR ESTIM BIOKA5I 269 II. THE ESTIMATION OF TOTAL NUMBERS /ETERS BIOKA52 363 III. AN EXAMPLE OF THE PRACTICAL APPLICATIONS BIOKA53 137 LOCATION OPTIMAL ROBUSTNESS. A GENERAL METHOD DESCRIPTION AND ESTIMATION PROBLEMS, CORR. 63 JASA 63231 G.S. WATSON'S PAPER 'A STUDY OF THE GROUP SCREENING METHOD IAL FREQUENCY FUNCTTONS IN CURVE FITTING BY AITKEN'S METHOD JASA 671230 SOME METHODOLOGICAL NOTES ON THE DEFLATION OF CONSTRUCTION JASA 59535 THE QUANTIFICATION OF JUDGMENT SOME METHODOLOGICAL SUGGESTIONS

R. A. FISHER AND THE LAST FIFTY YEARS OF STATISTICAL METHODOLOGY A REVIEW OF RESPONSE SURFACE METHODOLOGY. A LITERATURE SURVEY

SEASONAL ADJUSTMENTS BY ELECTRONIC COMPUTER METHODS RECENT ADVANCES IN SAMPLE SURVEY THEORY AND METHODS MULTIVARIATE THEORY FOR GENERAL STEPWISE METHODS A REMARK ON MULTIPLE COMPARISON METHODS COMPARISONS OF SOME TWO STAGE SAMPLING METHODS ON THE CHOICE OF DESIGN IN STOCHASTIC APPROXIMATION METHODS ASYMPTOTIC NORMALITY IN NONPARAMETRIC METHODS A COMPARISON OF TWO LIFE TABLE METHODS JASA $65 \quad 395$ TECH $66 \quad 571$ JASA $57 \quad 415$ AMS $62 \quad 325$ AMS $63 \quad 873$ TECH $65 \quad 223$ AMS $66 \quad 891$ AMS $6 B \quad 457$ AMS $6 B \quad 905$ BIOCS67 51

OXIMATIONS TO THE CENSUS AND BLS SEASONAL ADJUSTMENT METHODS EXPONENTIALLY WEIGHTED MOVING AVERAGES AND RELATED METHODS BABILITY DENSITIES AND CUMULATIVES BY FOURIER SERIES METHODS STIMATING THE DISTRIBUTION OF A RATIO BY MONTE CARLO METHODS ROPERTIES OF CERTATN BIOLOGICAL SYSTEMS BY NUMERICAL METHODS MEETING FOR WILLIAM $N$. HURWITZ. CHANGES IN CENSUS METHODS STATISTICAL METHODS AND SCIENTIFIC INDUCTION

RANKING METHODS AND THE MEASUREMENT OF ATTITUDES

LINEAR APPR JASA $6 B \quad 445$

PREDICTION BY JRSSB6I 414 THE ESTIMATION OF PRO JASA $68 \quad 925$ SOME CONTRIBUTTONS TO THE GRAPHIC METHODS BASED UPON PROPERTIES OF ADVANCING CENTROIDS JASA 59668

DISCUSSION

E DATA

ARISON OF TWO MEANS, FURT

COMPONENT LIQUID MIXTURE

MEAN OF A NORMAL DISTRIBUTION

EXPERIMENTS

BASED ON SAMPLE DATA
CONTINGENCY TABLES

TORIAL EXPERIMENTS WITH APPLICATIONS

SOME STATISTICAL METHODS CONNECTED WITH SERIES OF EVENTS (WITH SIMPLE METHODS FOR ANALYZING THREE-FACTOR INTERACTION IN YSTEMATC METHODS FOR ANALYZTNG 2-T0-THE-N-TIMES-3-T0-THE-M FAC TECH 67 INDUCTIVE METHODS FOR BALANCED INCOMPLETE BLOCK DESIGNS AMS $66 \quad 1348$ RANK METHODS FOR COMBINATION OF INDEPENDENT EXPERIMENTS IN AMS 62482 RAPID METHODS FOR ESTIMATING CORRELATION COEFFICIENTS BIOKA5I 464 METHODS FOR ESTIMATING THE COMPOSTTION OF A THREE TECH $64 \quad 343$ JASA $65 \quad 492$ FOURIER METHODS FOR EVOLVING SEASONAL PATTERNS

DIRECT METHODS FOR EXACT TRUNCATED SEQUENTIAL TESTS OF THE TECH 69 NO.4 THE DERIVATION OF METHODS FOR FITTING EXPONENTIAL REGRESSION CURVES BIOKA64 504 GRAPHICAL METHODS FOR INTERNAL COMPARISONS IN MULTIRESPONSE AMS 64613 QUICK ANALYSIS METHODS FOR RANDOM BALANCE SCREENING EXPERIMENTS $\quad$ TECH 59195 ON MULTIPLE DECISION METHODS FOR RANKING POPULATION MEANS NEW METHODS FOR REASONING TOWARDS POSTERIOR DISTRIBUTIONS AMS $66 \quad 355$ TECH $59 \quad 359$ BIOKA68 JASA 61 B41 AMS 61619 TECH $69 \quad 1 \mathrm{~B} 9$ BIOCS65 799 BIOKA64 439 AMS $61 \quad 12$ AMS 631588 SOME FURTHER APPLICATIONS OF NON-PARAMETRIC METHODS IN DILUTION (-DIRECT) ASSAYS SIMULTANEOUS TESTS BY SEQUENTIAL METHODS IN HIERARCHICAL CLASSIFICATIONS STATISTICAL METHODS IN MARKOV CHAINS, CORR, 611343

APPLICATION OF METHODS IN SEQUENTIAL ANALYSIS TO DAM THEORY LL-SAMPLE PROPERTIES OF SEVERAL TWO-STAGE REGRESSION METHODS IN THE CONTEXT OF AUTOCORRELATED ERRORS SMA JASA 69 253 / GRAPHICAL PROCEDURES FOR USING DISTRIBUTION-FREE METHODS IN THE ESTIMATION OF RELATIVE POTENCY IN DILU BIOCS66 6IO SPACED OBSERVATIONS SPACED OBSERVATIONS SERIES ANALYSIS GROUPING METHODS IN THE FITTING OF POLYNOMIALS TO EQUALLY BIOKA54 GROUPING METHODS IN THE FITTING OF POLYNOMIALS TO UNEQUALLY BIOKA56 FOURIER METHODS IN THE STUDY OF VARIANCE FLUCTUATIONS IN TIME TECH 69 DISTRIBUTIONS, POISSON LIMITING FORMS AND DERIVED METHODS OF APPROXIMATION

ON METHODS OF ASYMPTOTTO APPROXTMATTON FOR ON TWO METHODS OF BIAS REDUCTION IN THE ESTIMATION OF RATIOS BIOKA6 6 TECH $67 \quad 425$ TECH 69605 BIOCS67 623 CLASSICAL AND INVERSE REGRESSION METHODS OF CALIBRATION IN EXTRAPOLATION A COMPARISON OF SOME METHODS OF CLUSTER ANALYSIS

ENT FOR CLUSTERS OF UNEQUAL SIZES METHODS OF CLUSTER SAMPLING WITH AND WITHOUT REPLACEM BIOKA62 BIOKA54 344 BIOCS67, 345 TS NOTOR IN STATISTICS. II. METHODS OF COMPUTATION SOME METHODS OF CONSTRUCTING EXACT TESTS BIOKA6I 41 BIOKA66 629 TECH $60 \quad 507$ TECH 61 111 ON METHODS OF CONSTRUCTING SETS OF MUTUALLY ORTHOGONAL ON METHODS OF CONSTRUCTING SETS OF MUTUALLY ORTHOGONAL METHODS OF CONSTRUCTION AND ANALYSIS OF SERIALLY JRSSB57 2 B6 LATIN SQUARES USING A COMPUTER
LATIN SQUARES USING A COMPUTER. II BALANCED SEQUENCES ATION OF HETEROGENEITY, I 
ARTIAL DIALLEL TEST CROSSING 2. AN EVALUATION OF TWO MET

DATA A NOTE ON THE EQUIVALENCE OF TWO METHODS OF FITTINC A STRAICHT LINE THROUGH CUMULATIVE JA BIOCS67 325

SMALL SAMPLES SOME COMPARISONS OF METHODS OF FITTING THE DOSACE RESPONSE CURVE FOR

JASA 64 863

DISTRIBUTION

FOR SYSTEM RELIABILITY

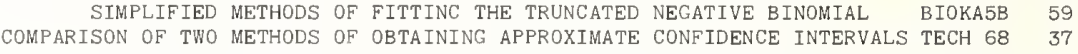
SOME METHODS OF PROBABILITY NON-REPLACEMENT SAMPLINC $\quad$ JASA $69 \quad 175$

ILITIES PROPORTIONAL TO SIZE WHEN THE SIZ/ SEVERAL METHODS OF RE-DESIGNINC AREA SAMPLES UTILIZINC PROBAB JASA 68 I2BO INBREEDING COEFFICIENT AND RATE OF CENE LOSS OF FOUR METHODS OF REPRODUCING FINITE DIPLOID POPULATIONS / BIOCS65 447

ON TWO METHODS ON UNBIASED ESTIMATION WITH AUXILIARY

SOME DISTANCE PROPERTIES OF LATENT ROOT AND VECTOR METHODS USED IN MULTIVARIATE ANALYSIS TESTS OF RANDOMNESS BASED ON DISTANCE METHODS.

THE SERVICE LIFE OF HOUSEHOLD GOODS BY ACTUARIAL METHODS. CORR. 57578

TESTS AND CONFIDENCE INTERVALS BASED ON THE METRIC D2

THE DIFFERENCE BETWEEN THE LEVY AND LEVY-PROKHOROV METRICS

STANDARD METROPOLITAN AREAS THE METROPOLITAN AREA CONCEPT. AN EVALUATION OF THE 1950 THE MIGRATION OF EMPLOYED PERSONS TO AND FROM METROPOLITAN AREAS OF THE UNITED STATES RESEARCH ON METROPOLITAN POPULATION, EVALUATION OF DATA

THE PRECISION OF MICHEY'S UNBIASED RATIO ESTIMATOR

EXPERIMENTAL DEVELOPMENT OF NUTRITIVE MEDIA FOR MICRO-ORCANISMS

THE BASIC BIRTH-DEATH MODEL FOR MICROBIAL INFECTIONS

DU MAXIMUM DE VRAISEMBLANCE DES COURBES DE SURVIE DE MICROORGANISMES IRRADIES

THE ASYMPTOTIC VARIANCE OF THE SAMPLE QUANTILES AND MID-RANGES

A NOTE ON MIDRANGE

POPULATION MIDRANGE THE MIDRANGE

THE CENSUS SURVIVAL RATIO METHOD OF ESTIMATINC NET MICRATION

TIMATION OF NET MICRATION IN THE STUDIES OF INTERNAL MICRATION

SURVIVAL RATES IN ESTIMATINC INTERCENSAL STATE NET MTCRATION

AND GAINS AND LOSSES IN HUMAN CAPITAL THROUGH MICRATION

\section{A MODEL FOR MIGRATION ANALYSIS}

MICRATION EXPECTANCY IN THE UNITED STATES

ERRORS IN THE ESTIMATION OF NET MICRATION IN THE STUDIES OF INTERNAL MIGRATION NOTES. A MICRATION MODEL

JASA $62 \quad 1 B 4$ BIOKA66 325 BIOKA65 345 $\begin{array}{lrrr}\text { ESTIMATING JASA } & 57 & 175 \\ & \text { AMS } & 63 & 618 \\ \text { EXAMPLE OF } & \text { AMS } & 69 & 322\end{array}$ OF THE 1950 IASA 65617 $\begin{array}{rrr}\text { JASA } & 65 & 617 \\ \text { JASA } & 67 & 141 B\end{array}$ JASA 56591 BIOKA67 321 BIOKA68 43 JRSSB65 338 ESTIMATION PAR LA METHODE BIOCS6 6673 ON SOME PROPERTIES OF JRSSB6I 453 AMS 651052 JASA $57 \quad 537$ A NOTE ON JASA $62 \quad 175$ ERRORS IN THE ES JASA 69 NO.4 EVALUATION OF CENSUS JASA $62 \quad 841$ SCOOLING, EXPERIENCE, JASA 67875 JASA $61 \quad 675$ JASA $63 \quad 444$ JASA 69 NO. 4 BIOCS66 409

N AREAS OF THE UNITED STATES THE MICRATION OF EMPLOYED PERSONS TO AND FROM METROPOLITA JASA 671418 IONS

STOCHASTIC BIRTH, DEATH AND MICRATION PROCESSES FOR SPATIALLY DISTRIBUTED POPULAT $\begin{array}{llll} & \text { INTERNAL MICRATION STATISTICS FOR THE UNITED STATES } & \text { JASA } 60 \\ \text { THE EXTENT OF REPEATED MICRATION, AND ANALYSIS BASED ON THE DANISH POPULATIO JASA } 64121\end{array}$

189

N REGISTER THE EXTENT OF REPEATED MICRATION, AND ANALYSIS BASED ON THE DANISH POPULATIO JASA 641121 NVIRONME/ EFFECTS OF PARTIAL ISOLATION (DISTANCE), MICRATION, AND DIFFERENT FITNESS REQUIREMENTS AMONG E BIOCS66 453 CURRENT WEIGHT-HEIGHT RELATIONSHIPS OF YOUTHS OF MILITARY AGE OPTIMIZATION OF A HOT ROLLINC MILL

JASA $62 \quad 895$ JRSSB $67 \quad 300$

EXPANSION FOR THE NORMAL PROBABILITY INTECRAL AND MILL'S RATIO A NEW ASYMPTOTIC JRSSB62 177 $N$ TYPE IV DISTRIBUTION.

THE MILLS RATIO AND THE PROBABILITY INTECRAL FOR A PEARSO BIOKA65 119 CHEBYSHEV POLYNOMIAL AND OTHER NEW APPROXIMATIONS TO MILLS' RATIO NEW CHEBYSHEV POLYNOMIAL APPROXIMATIONS TO MILLS' RATIO IRRATIONAL FRACTION APPROXIMATIONS TO MILLS' RATIO

TAIL AREAS OF THE T-DISTRIBUTION FROM A MILLS' RATIO-LIKE EXPANSION A TEST FOR RANDOM MINCLING OF THE PHASES OF A MOSAIC AMS $63 \quad 892$ JASA 69647 BIOKA64 339 AMS $63 \quad 335$ BIOCS67 657 OF MEANS OF NORMAL POPULATIONS FROM OBSERVED MINIMA ESTIMATION BIOKA57 2B2 OCESS BY MONTE/ ESTIMATING FINTTE-TIME MAXIMA AND MTNTMA OF A STATTONARY GAUSSIAN ORNSTEIN-UHLENBECK PR JASA 6B 15I7 A LIMIT THEOREM FOR SUMS OF MINIMA OF STOCHASTIC VARIABLES STOCHASTIC APPROXIMATION OF MINIMA WITH IMPROVED ASYMPTOTIC SPEED MULTIVARIATE MAXIMA AND MINIMA WITH MATRIX DERIVATIVES NON-LINEAR RECRESSION WITH MINIMAL ASSUMPTIONS AMS 651041 AMS $67 \quad 191$ JASA 69 N0. 4 JASA $62 \quad 572$ AMS $66 \quad 435$

ICATION MIXED MODEL DESIGN

THE SIMPLEST CASE

SIMPLEST CASE
ON A MINIMAL ESSENTIALLY COMPLETE CLASS OF EXPERIMENTS MINIMAL SUFFICIENT STATISTICS FOR THE TWO-WAY CLASSIF

RANDOM MINIMAL TREES

MINIMAX CHARACTER OF HOTELLING'S T-SQUARED TEST IN MINIMAX CHARACTER OF THE R-SQUARED-TEST IN THE BOUNDS IN A MINIMAX CLASSIFICATION PROCEDURE

NOTE ON A MINIMAX DESIGN FOR CLUSTER SAMPLINC MINIMAX DESIGNS IN TWO DIMENSIONAL REGRESSION ASYMPTOTICALLY MINIMAX DISTRIBUTION-FREE PROCEDURES

ADMISSIBLE AND MINIMAX ESTIMATES OF PARAMETERS IN TRUNCATED SPACES MINIMAX ESTIMATION OF A RANDOM PROBABILITY WHOSE

FIRST N MOMENTS ARE KNOWN UNIFORM APPROXIMATION OF MINIMAX POINT ESTIMATES

S USINC SEQUENTIAL SAMPLING

A MINIMAX PROCEDURE FOR CHOOSING BETWEEN TWO POPULATION J

OF A POPULATION WITH TWO-STAGE SAMPLING BAYES AND MINIMAX PROCEDURES FOR ESTIMATINC THE ARITHMETIC MEAN ASMPTOTICALLY OPTIMAL BAYES AND MINIMAX PROCEDURES IN SEQUENTIAL ESTIMATION LOCAL AND ASYMPTOTIC MINIMAX PROPERTIES OF MULTIVARIATE TESTS MINIMAX RESULTS FOR IFRA SCALE ALTERNATIVES MINIMAX RISK AND UNBIASEDNESS FOR MULTIPLE DECISION

PROBLEMS OF TYPE I ITERATION MINIMAX SOLUTION OF STATISTICAL DECISION PROBLEMS BY LOCALLY MINIMAX TESTS

LOCALLY AND ASYMPTOTICALLY MINIMAX TESTS OF A MULTIVARIATE PROBLEM MINIMAX THEOREMS ON CONDITIONALLY COMPACT SETS

SPACING OF OBSERVATIONS IN POLYNOMIAL REGRESSION FOR MINIMAX VARIANCE OF THE FITTED VALUES /NESS OF THE A PROBLEM IN MINIMAX VARIANCE POLYNOMIAL EXTRAPOLATION

A MINIMAX-REGRET PROCEDURE FOR CHOOSING BETWEEN TWO POPULATIONS USINC SEQUENTIAL SAMPLING CONTROL CHARTS AND THE MINIMIZATION OF COSTS (WITH DISCUSSION) MINIMIZATION OF EIGENVALUES OF A MATRIX AND OPTIMALIT Y OF PRINCIPAL COMPONENTS INTEREST DESIGNS WHICH MINIMIZE MODEL INADEQUACIES, CUBOIDAL RECIONS OF IN A GALTON-WATSON PROCESS AND IN SOME REL/ HOW TO MINIMIZE OR MAXIMIZE THE PROBABILITIES OF EXTINCTION
JASA $65 \quad 182$ BIOKA68 255 AMS 631524 AMS 641475 BIOKA65 653 AMS $6 \mathrm{~B} \quad 27 \mathrm{~B}$ AMS $65 \quad 1097$ AMS $66 \quad 619$ AMS $61 \quad 136$ AMS $6 B \quad 492$ AMS 641031 AMSB 57255 AMS $68 \quad 422$ AMS $64 \quad 21$ AMS 691778 AMS 691684 AMS $66 \quad 1643$ AMS $67 \quad 340$ AMS $68 \quad 171$ AMS 631536 AMS $62 \quad 810$ AMS $66 \quad 898$ JRSSB63 297 JRSSB $63 \quad 49$ AMS $68 \quad 859$ BIOKA65 111 AMS $68 \quad 1700$ 
LITIES (WITH DISCUSSION)

POSSIBILITIES

RESPONSE SURFACES

STATISTICS

PROBLEMS

917
ON MINIMIZING A CONVEX FUNCTION SUBJECT TO LINEAR INEQUA MINIMIZING RESPONSE ERRORS IN FINANCIAL DATA. THE MINIMUM BIAS ESTIMATION AND EXPERIMENTAL DESIGN FOR MINIMUM CHI-SQUARED ESTIMATION USING INDEPENDENT

A MINIMUM COST MODEL OF SPARE PARTS INVENTORY CONTROL LOWER BOUNDS FOR MINIMUM COVARIANCE MATRICES IN TIME SERIES REGRESSION A NOTE ON CURVE FITTING WITH MINIMUM DEVIATIONS BY LINEAR PROGRAMMING, CORR. 62

A NOTE ON MINIMUM DISCRIMINATION INFORMATION

NOTES. MINIMUM DISCRIMINATION INFORMATION

BETWEEN MULTIVARIATE POPULATIONS, THE PROBLEM OF MINIMUM DISTANCES

ESTIMATION ZZLE WITH A NOTATION ON THE PROBLE/ APPLICATION OF MINIMUM LOGIT CHI-SQUARE ESTIMATE TO A PROBLEM OF GRI BIOCS68 F THE PARAMETERS OF THE LOGISTIC FUNCTION, USING THE MINIMUM LOGIT CHI-SQUARE METHOD /N THE ESTIMATION O BIOKAG PTION AND USE OF TABLES. PART II. COMPARISON BETWEEN MINIMUM NORMIT CHI-SQUARE ESTIMATE AND THE MAXIMUM LI BIOKA5? A NOTE ON CRAIG'S PAPER ON THE MINIMUM OF BINOMIAL VARIATES

ON THE DISTRIBUTION OF THE MAXIMUM AND MINIMUM OF RATIOS OF ORDER STATISTICS MINIMUM RISK SPECIFICATION LIMITS

N COEFFICIENTS

COMPARISON OF THE VARIANCE OF MINIMUM VARIANCE AND WEIGHTED LEAST SQUARES REGRESSIO

(ACKNOWLEDGEMENT)

COMPARISON OF LEAST SQUARES AND MINIMUM VARIANCE ESTIMATES OF REGRESSION PARAMETERS,

THE MAXIMUM-LIKELIHOOD ESTIMATOR IS UNBIASED AND OF

MATORS OF RELIABILITY FUNCTIONS FOR SYSTEMS IN SE/ PROBLEMS OF ADDITIVE NUMBER THEORY

FOR THE TRUNCATED EXPONENTIAL DISTRIBUTION PROBABILITIES

T OF ECONOMIC TIME SERIES, CORR. 651250 MINIMUM VARIANCE STRATIFICATION CORR 63 - 161 MINIMUM VARIANCE UNBIASED AND MAXIMUM LIKELIHOOD ESTI MINIMUM VARIANCE UNBIASED ESTIMATION AND CERTAIN

ON MINIMUM VARIANCE UNBIASED ESTIMATION OF RELIABILITY MINIMUM VARIANCE UNBIASED ESTIMATION OF RELIABILITY MINIMUM VARIANCE UNBIASED ESTIMATORS FOR POISSON MINIMUM VARIANCE, LINEAR, UNBIASED SEASONAL ADJUST

411 BIOKA66 614 AMS 69918 JASA 59260 AMS $63 \quad 984$ AMS $62 \quad 462$ 200 JASA $59 \quad 88$ JASA $66 \quad 1052$ AMS 631050 AMS 69710 TECH 69609 TECH $62 \quad 409$ JASA 64681 JASA $65 \quad 1005$ POPULATIONS WITH CONSTRAINTS ON THE PROBABILITIES OF MISCLASSIFICATION J DISCRIMINATION BETWEEN K JRSSB 9 BTAINING CONFIDENCE INTERVALS FOR THE PROBABILITY OF MISCLASSIFICATION IN DISCRIMINANT ANALYSIS /OD OF O BIOCS67 SAMPLE SIZE, AND A/ ON EXPECTED PROBABILITIES OF MISCLASSIFICATION IN DISCRIMINANT ANALYSIS, NECESSARY BIOCS68 TS IN THE ANALY/ AN INVESTIGATION OF THE EFFECT OF MISCLASSIFICATION ON THE PROPERTIES OF CHI-SQUARE-TES BI DISCRIMINANT ANALYSIS WHEN THE INITIAL SAMPLES ARE MISCLASSIFIED

ESTIMATING FROM MISCLASSIFIED DATA

ERRATA. 'MISCLASSIFIED DATA FROM A BINOHIAL POPULATION' MISCLASSIFIED DATA FROM A BINOMINAL POPULATION MISCLASSIFIED DATA FROM CURTAILED SAMPLING PLANS

TESTS FOR THE VON MISES DISTRIBUTION

SOME RELATIONSHIPS BETWEEN THE NORMAL AND VON MISES DISTRIBUTIONS

SOME RELATIONSHIPS AMONG THE VON MISES DISTRIBUTIONS OF DIFFERENT DIMENSIONS

PERCENTAGE POINTS FOR W-SQUARE-SUB-N + (CRAMER-VON MISES GOODNESS-OF-FIT STATISTIC)

BIAS OF THE ONE-SAMPLE CRAMER-VON MISES TEST

BOUNDS FOR THE FREQUENCY OF MISLEADING BAYES INFERENCE

SPECTRAL ANALYSIS WITH REGULARLY MISSED OBSERVATIONS

SPECTRAL ANALYSIS WITH RANDOMLY MISSED OBSERVATIONS, THE BINOMIAL CASE

BIOKA65 95

TECH $66 \quad 657$

JASA $68 \quad 123$

TECH $66 \quad 215$

TECH 60109

TECH $68 \quad 489$

BIOKA69 149

BIOKA67 684 BIOKA66 269

FURTHER BIOKA68 428

JASA $66 \quad 246$

AMS $63 \quad 1109$

AMS $62 \quad 455$

AMS $65 \quad 971$

NOTES THE ANALYSIS OF BTOCS65 216

A DIALLEL CROSSING EXPERIMENT WITH CERTAIN CROSSES MISSING

POISSON DISTRIBUTION WHEN ZEROS AND SOME ONES ARE MISSING

RIATE NORMAL DISTRIBUTION WHEN SOME OBSERVATIONS ARE MISSING

ESTIMATION IN THE TRUNCATED JASA 60

MAXIMUM LIKELIHOOD ESTIMATES FOR A MULTIVA JASA 57 NTAL DESIGNS

THE ESTIMATION O MISSING AND MIXED-UP OBSERVATIONS IN

JRSSB68 67

D INTERACTIONS IN CONTINGENCY TABLES WITH OR WITHOUT MISSING ENTRIES /DEPENDENCE, QUASI-INDEPENDENCE. AN JASA 68 1091 RRORS OF TREATMENT COMPARISONS WHEN OBSERVATIONS ARE MISSING FROM A RANDOMISED BLOCK EXPERIMENT WITH ADDIT BIOCS66 632 AMETERS IN THE MULTIVARIATE NORMAL DISTRTBUTTON WTTH MISSING OBSERVATIONS MULT LINEAR REGRESSION ANALYSIS WITH MISSING OBSERVATIONS AMONG THE INDEPENDENT VARIABLES EFFICIENCY OF A FIRST ORDER METHOD

POINT ESTIMATION IN SIMPLE LINEAR REGRESSION ISSING OBSERVATIONS IN MULTIVARIATE REGRESSION MISSING OBSERVATIONS IN MULTIVARIATE STATISTICS II. MISSING OBSERVATIONS IN MULTIVARIATE STATISTICS, III MISSING OBSERVATIONS IN MULTIVARIATE STATISTICS, IV

159 JASA $56 \quad 122$ JASA $59 \quad 834$ JASA 69 NO. 4 JASA $67 \quad 10$ JASA $69 \quad 337$ JASA $69 \quad 359$ WHOLE-PLOTS ARE MISSING OR MIXED UP ESTIMATION OF MISSING OBSERVATIONS IN SPLIT-PLOT EXPERIMENTS WHERE NOTE ON THE MISSING PLOT PROCEDURE IN A RANDOMIZED BLOCK DESIGN QUERY, BIVARIATE SAMPLES WITH MISSING VALUES

THE FITTING OF POLYNOMIALS TO EQUIDISTANT DATA WITH MISSING VALUES

QUERY, MISSING VALUES IN FACTORIAL EXPERIMENTS MISSING VALUES IN LINEAR MULTIPLE DISCRIMINANT ANALYSIS WITH AN ELECTRONIC COMP/ OF THE LITERATURE

A METHOD OF ESTIMATION OF MISSING VALUES IN MULTIVARIATE DATA SUITABLE FOR USE MISSING VALUES IN MULTIVARIATE STATISTICS, I. REVIEU MISSING VALUES IN PARTIAL DIALLEL CROSS EXPERIMENTS MISSING VALUES IN RESPONSE SURFACE DESIGNS

QUERY, BIVARIATE SAMPLES WITH MISSING VALUES, II

PTIVE EXPECTATIONS' MODE/ SMALL SAMPLE BIAS DUE TO MISSPECIFICATION IN THE 'PARTIAL ADJUSTMENT' AND 'ADA J

TECHNIQUES FOR ESTIMATION OF INCIDENCE OF RED SPIDER MITE ON TEA CROP IN NORTH-EAST INDIA PROCEDURES AND TABLES FOR EVALUATING DEPENDENT MIXED ACCEPTANCE SAMPLING PLANS MAXIMUM-LIKELIHOOD ESTIMATION FOR THE MIXED ANALYSIS OF VARIANCE MODEL

THE IDENTIFICATION OF VECTOR MIXED AUTOREGRESSIVE-MOVING AVERAGE SYSTEMS

BIOKA6I BIOKA6I 468 JASA 61933 TECH $67 \quad 679$ BIOKA5I 410 TECH $65 \quad 649$ BIOCS68 835 JRSSB60 302 JASA $66 \quad 595$ BI0C\$68 903 TECH $61 \quad 389$ TECH $68 \quad 867$ JASA $66 \quad 1130$ BIOCS66 385 TECH 69341 BIOKA67 93 BIOKA69 223 UTION OF P FOR A CONTINUOUS PRIOR DISTRIBUTION THE MIXED BINOMIAL DISTRIBUTION AND THE POSTERIOR DISTRIB JRSSB68 359 THE PROCESS CURVE AND THE EQUIVALENT MIXED BINOMIAL WITH TWO COMPONENTS JRSSB59 63 MULTIVARIATE CORRELATION MODELS WITH MIXED DISCRETE AND CONTINUOUS VARIABLES, CORR, 65343 AMS 61.448 A NOTE ON CERTAIN DISCRETE MIXED DISTRIBUTIONS BIOCS66 566 IONS FROM CENSORED L/ ESTIMATION OF PARAMETERS OF MIXED EXPONENTIALLY DISTRIBUTED FAILURE TIME DISTRIBU BIOKA58 504 CONSTRUCTION OF CONFOUNDING PLANS FOR MIXED FACTORIAL DESIGNS

COMBINING ELEMENTS FROM DISTINCT FINITE FIELDS IN MIXED FACTORIALS

THE HYPOTHESIS OF NO FIXED MAIN-EFFECTS IN SCHEFFE'S MIXED MODEL 
XED FACTOR IN AN UNBALANCED HIERARCHAL DESIGN WITH A MIXED MODEL /E. THE QUASI-F TEST FOR AN UNNESTED FI BIOCS66 A DISCONTINUITY IN MIXED MODEL ANALYSIS SUFFICIENT STATISTICS FOR THE TWO-WAY CLASSIFICATION MIXED MODEL DESIGN BIOCS69 573

A MIXED MODEL OF REGRESSIONS

MINIMAL JASA 65

BIOKA69 327 ESTIMATING FIXED EFFECTS AND VARIANCE COMPONENTS IN MIXED MODEL SITUATIONS AN ITERATIVE PROCEDURE FOR BIOCS68 BAYESIAN COMPARISON OF MEANS OF A MIXED MODEL WITH APPLICATION TO REGRESSION ANALYSIS BIOKA66

SEQUENTIAL ANALYSIS OF VARIANCE UNDER RANDOM AND MIXED MODELS

THE ESTIMATION OF MIXED MOVING-AVERAGE AUTOREGRESSIVE SYSTEMS

BIOCS68 27

JASA 671401

DISTRIBUTION FREE TESTS FOR MIXED PROBABILITY DISTRIBUTIONS

BIOKA69 NO.3

ON THEIL'S MIXED REGRESSION ESTIMATOR

SPECIES

MIXED SELF- AND CROSS-FERTILIZATION IN A TETRASOMIC

THE ANALYSIS OF STATIONARY PROCESSES WITH MIXED SPECTRA,

BIOKA69 N0.3

JASA $69 \quad 273$

BIOCS6B 4B5

JRSSB62 215

JRSSB62 511

IT-PLOT EXPERIMENTS WHERE WHOLE-PLOTS ARE MISSING OR MIXED UP ESTIMATION OF MISSING OBSERVATIONS IN SPL BIOKA6I 468 RELATION COEFFICIENTS UNDER ASSUMPTIONS OF FIXED AND MIXED VARIATES THE SAMPLING VARIANCE OF COR BIOKA58 471

TUBES A GRAPHICAL ESTIMATION OF MIXED WEIBULL PARAMETERS IN LIFE TESTING ELECTRON ESTIMATING A MIXED-EXPONENTIAL RESPONSE LAW

THE ESTIMATION OF MISSING AND MIXED-UP OBSERVATIONS IN SEVERAL EXPERIMENTAL DESIGNS BIOKA59 91

CONSTRUCTION OF SEQUENCES ESTIMATING THE MIXING DISTRIBUTION

ON THE ESTIMATION OF MIXING DISTRIBUTIONS

BAYESIAN ESTIMATION OF MIXING DISTRIBUTIONS

THE WILCOXON TWO-SAMPLE STATISTIC ON STRONGLY MIXING PROCESSES

ON A THEOREM OF RENYI CONCERNING MIXING SEQUENCES OF SETS

EXTREME VALUES IN UNIFORMLY MIXING STATIONARY STOCHASTIC PROCESSES

THE REMAINDER IN THE CENTRAL LIMIT THEOREM FOR MIXING STOCHASTIC PROCESSES

THE LAW OF THE ITERATED LOGARITHM FOR MIXING STOCHASTIC PROCESSES

BERS FOR THE LINEAR COMBINATIONS OF EXCHANGEABLE AND MIXING STOCHASTIC PROCESSES /R THE LAW OF LARGE. NUM A

INVARIANTS UNDER MIXING WHICH GENERALIZE DE FINETTI'S THEOREM

INVARIANTS UNDER MIXING WHICH GENERALIZE DE FINETTI'S THEOREM.

OUS TIMES PARAMETER

THE RESPONSE OF A MIXTURE

MODELS FOR THE RESPONSE OF A MIXTURE
THE COMPOSITION OF A THREE COMPONENT LIQUID MIXTURE
MIXTURE DESIGNS FOR FOUR FACTORS JRSSB68 349

AMS $68 \quad 286$

AMS $66 \quad 177$

AMS $68 \quad 1289$

AMS 681202

AMS $61 \quad 257$

AMS 65993

AMS 69601

AMS 69 N0.6

AMS $651 B 40$ AMS $62 \quad 916$ AMS 631194 TOR FORE FACTORS

EXTREME VERTICES DESIGN OF MIXTURE EXPERIMENTS TECH $66 \quad 447$

DISCUSSION OF 'EXTREME VERTICES DESIGN OF MIXTURE EXPERIMENTS' BY R.A. MCLEAN AND V.L. ANDERSON TECH 66 455 ESTIMATION OF PARAMETERS OF A FINITE MIXTURE OF DISTRIBUTIONS

MODELS FOR QUANTAL RESPONSE TO THE JOINT ACTION OF A MIXTURE OF DRUGS

SUFFICIENT CONDITION FOR THE MIXTURE OF EXPONENTIALS TO BE A PROBABILITY DENSITY JRSSB $68 \quad 472$ FUNCTION

ESTIMATING THE COMPONENTS OF A MIXTURE OF NORMAL DISTRIBUTIONS

KA64 413

AMS 69 NO.6 BIOKA69 NO.3

DISCUSSION OF 'ESTIMATION OF PARAMETERS FOR A MIXTURE OF NORMAL DISTRIBUTIONS' BY VICTOR HASSELBLAD TECH 66 445

MODELS FOR THE NON-INTERACTIVE JOINT ACTION OF A MIXTURE OF STIMULI IN BIOLOGICAL ASSAY MOMENT ESTIMATORS FOR THE PARAMETERS OF A MIXTURE OF TWO BINOMIAL DISTRIBUTIONS THE METHOD OF MOMENTS APPLIED TO A MIXTURE OF TWO EXPONENTIAL DISTRIBUTIONS

RECURRENT

A MIXTURE OF TWO RECURRENT RANDOM WALKS NEED NOT BE

ESTIMATION OF PARAMETERS FOR A MIXTURE OR NORMAL DISTRIBUTIONS

RESPONSE SURFACE DESIGNS FOR MIXTURE PROBLEMS

IDENTIFIABILITY OF MIXTURES

IDENTIFIABILITY OF FINITE MIXTURES

NOTE ON THE INFINITE DIVISIVILITY OF EXPONENTIAL MIXTURES

ON THE IDENTIFIABILITY OF FINITE MIXTURES

A CLASS OF INFINITELY DIVISIBLE MIXTURES

DESIGN AND ANALYSIS OF EXPERIMENTS WITH MIXTURES

EXPERIMENTS WITH MIXTURES

REPLY TO MR QUENOUILLE'S COMMENTS ABOUT MY PAPER ON MIXTURES

EXPERIMENTS WITH P-COMPONENT MIXTURES

MEASUREMENT OF THE POTENCIES OF DRUG MIXTURES

ESTIMATOR FOR THE IDENTIFICATION OF FINITE MIXTURES

TO THE SIMPLEX-LATTICE DESIGN FOR EXPERIMENTS WITH MIXTURES

OF EXTREME VERTICES DESIGNS FOR FOUR COMPONENT MIXTURES

EXPERIMENTS WITH MIXTURES (CORR, 59 238)

THE SIMPLEX-CENTROID DESIGN FOR EXPERIMENTS WITH MIXTURES (WITH DISCUSSION)

ESTIMATING THE PARAMETERS OF MIXTURES OF BINOMIAL DISTRIBUTIONS

ON MIXTURES OF DISTRIBUTIONS

BIOKAG6 49 AMS $62 \quad 444$

AMS $61 \quad 143$

AMS 6B 1753

TECH $66 \quad 431$

TECH $68 \quad 739$

AMS 61244

AMS 631265

AMS 671303

AMS $68 \quad 209$

AMS 681153

AMS $68 \quad 1517$

JRSSB59 201

JRSSB6I 171

JRSSB6B 137

BIOCS69 477

A CONSISTENT AMS 691728

AN ALTERNATIVE JRSSB 69 NO. 2 THREE DIMENSIONAL MODELS TECH 67472

JRSSB5B 344

JRSSB 63235

JASA $64 \quad 510$

AMS $66 \quad 2 B I$

JRSSB68 444

AN ESTIMATION PROCEDURE FOR MIXTURES OF DISTRIBUTIONS

ESTIMATION OF FINITE MIXTURES OF DISTRIBUTIONS FROM THE EXPONENTIAL FAMILY JASA 69 NO 4

THE CONSTRUCTION OF MODELS FOR QUANTAL RESPONSES TO MIXTURES OF DRUGS A COMPARISON OF TWO APPROACHES TO BIOCS67 27

TION OF MATHEMATICAL MODELS FOR QUANTAL RESPONSES TO MIXTURES OF DRUGS IN BIOLOGICAL ASSAY /E CLASSIFICA BIOCS65 I81

INFORMATION FOR ESTIMATING THE PROPORTIONS IN MIXTURES OF EXPONENTIAL AND NORMAL DISTRIBUTIONS

MIXTURES OF GEOMETRIC DISTRIBUTIONS JRSSB61 409 MIXTURES OF MARKOV PROCESSES

RENEWAL THEORY

SAMPLING MIXTURES OF MULTI-SIZED PARTICLES, AN APPLICATION OF SAMPLING MIXTURES OF PARTICLES

R ACTION, THE ANALYSIS OF UN/ QUANTAL RESPONSES TO MIXTURES OF POISONS UNDER CONDITIONS OF SIMPLE SIMILA BI IDENTIFIABILITY OF MIXTURES OF PRODUCT MEASURES

ON STREAMS OF EVENTS AND MIXTURES OF STREAMS

ESTIMATION IN MIXTURES OF TWO NORMAL DISTRIBUTIONS

DESIGN

EXPERIMENTS WITH MIXTURES, A GENERALIZATION OF THE SIMPLEX-LATTICE

PROPERTIES OF A METHOD OF ESTIMATING THE SIZE OF MOBILE ANIMAL POPULATIONS

ON ESTIMATING THE SIZE OF MOBILE POPULATIONS FROM RECAPTURE DATA

TESTS FOR THE DISPERSION AND FOR THE MODAL VECTOR OF A DISTRIBUTION ON A SPHERE

ON ESTIMATION OF A PROBABILITY DENSITY FUNCTION AND MODE

SOME DIRECT ESTIMATES OF THE MODE

ON ESTIMATION OF THE MODE

THE MODE OF A MULTINOMIAL DISTRIBUTION

AMS $62 \quad 114$

TECH 69285

TECH $67 \quad 365$

BI0KA58 74

AMS 671300

JRSSB66 218

TECH $67 \quad 15$ JRSSB68 123

SOME BIOKA69 407

BIOKA51 293

BI0KA 67211

AMS 621065

AMS $65 \quad 131$

AMS 671446

BIOKA64 513 
TO CICARETTE SMOKINC AND A STOCHASTIC MODEL FOR THE MODE OF ACTION OF CARCINOCENS STATISTICAL METHODS FOR THE MOVER-STAYER MODEL SOME TESTS FOR THE INTRACLASS CORRELATION MODEL ESTIMATION FOR A ONE-PARAMETER EXPONENTIAL MODEL

INFERENCE ABOUT VARIANCE COMPONENTS IN THE ONE-WAY MODEL A NOTE ON AN 'ERRORS IN VARIABLES' MODEL DATA TRANSFORMATIONS AND THE LINEAR MODEL A MULTI-PROPORTIONS RANDOMIZED RESPONSE MODEL CORRELATED ERRORS IN THE RANDOM MODEL

RELIABILITY ESTIMATION OF THE TRUNCATED EXPONENTIAL MODEL LIMIT THEOREMS FOR THE MULTI-URN EHREFEST MODEL

BAYESIAN ESTIMATION OF MEANS FOR THE RANDOM EFFECT MODEL ESTIMATION IN A HETEROSCEDASTIC RECRESSION MODEL A BLACK BOX OR A COMPREHENSIVE MODEL

TESTINC AND ESTIMATION FOR A CIRCULAR STATIONARY MODEL A ROBUST POINT ESTIMATOR IN A CENERALIZED RECRESSION MODEL COMPARISON OF FOUR RATIO-TYPE ESTIMATES UNDER A MODEL SPEARMAN SIMULTANEOUS ESTIMATION FOR A COMPARTMENTAL MODEL THE CHOICE OF THE DECREE OF A POLYNOMIAL MODEL

SPEARMAN ESTIMATION FOR A SIMPLE EXPONENTIAL MODEL NOTES. A MICRATION MODEL ESTIMATION FOR A SIMPLE EXPONENTIAL MODEL MAMMALIAN REPRODUCTIVE DATA FITTED TO A MATHEMATICAL MODEL HALF-TABLE RATIO ESTIMATOR FOR A SIMPLE EXPONENTIAL MODEL TESTINC HYPOTHESES IN AN UNBALANCED RANDOM EFFECTS MODEL ANALYSIS OF A THREE-COMPONENT HIERARCHICAL DESIGN MODEL OF EMPIRICAL BAYES ESTIMATORS IN A LINEAR REGRESSION MODEL BAYES ESTIMATORS IN A MULTIPLE LINEAR RECRESSION MODEL PROBABILITY AND PREDICTION FOR THE MULTIVARIATE MODEL LIKELIHOOD ESTIMATE IN INTRACLASS CORRELATION MODEL ESTIMATION FOR THE MIXED ANALYSIS OF VARIANCE MODEL PREDICTION IN THE GENERALIZED LINEAR REGRESSION MODEL OF NO FIXED MAIN-EFFECTS IN SCHEFFE'S MIXED MODEL A GENERALIZATION OF THE MACHINE INTERFERENCE MODEL SQUARES ESTIMATORS OF VARIANCE IN A GENERAL LINEAR MODEL GOVARIANCE MATRICES UNDER THE INTRACLASS CORRELATION MODEL ANSIENT MARKOV CHAIN ARISING IN A RELIABILITY GROWTH MODEL ADULT FLOUR BEETLES, AN EXPERIMENT AND A STOCHASTIC MODEL OF THE ECONOMIC DESIGN OF X-CHARTS BASED ON DUNCAN'S MODEL DIGHOTOMOUS AND CONTINUOUS VARIABLES I. THE LOCATION MODEL CTOR IN AN UNBALANCED HIERARCHAL DESICN WITH A MIXED MODEL XV. THE HISTORICAL DEVELOPMENT OF THE GAUSS LINEAR MODEL ED BALANCED INCOMPLETE BLOCK DESIGN UNDER THE NEYMAN MODEL TURE DATA WITH BOTH DEATH AND DILUTION-DETERMINISTIC MODEL

F THE REDUCED ITH ORDER STATISTIC OF THE EXPONENTIAL MODEL

EXPERIMENTS. A GENERALIZATION OF THE BRADLEY-TERRY MODEL

PATTERNS IN RESIDUALS A TEST FOR REGRESSION MODEL ADEOUACY IN RAD A DISCONTINUITY IN MIXED MODEL ANALYSIS

TE PAIRED COMPARISONS. THE EXTENSION OF A UNIVARIATE MODEL AND ASSOCIATED ESTIMATION AND TEST PROCEDURES A PRODUCTION MODEL AND CONTINUOUS SAMPLING PLAN

/UNC CANCER INCIDENCE BIOCS65 839 JASA 61 841 AMS 651802 JASA $65 \quad 560$ JASA $65 \quad 806$ JASA $66 \quad 128$ AMS 671456 JASA $67 \quad 990$ JASA $67 \quad 1387$ TECH $67 \quad 332$ AMS $68 \quad 864$ JASA $68 \quad 174$ JASA $68 \quad 552$ TECH $68 \quad 219$ AMS 691358 AMS 691784 JASA $69 \quad 574$ TECH 69551 JRSSB68 469 BIOCS65 858 BIOCS66 409 BIOCS67 717 BIOCS69 529

THE BIOCS69 420 NOTE ON BIOKA67 659 BAYESIAN BIOKA67 109 THE USE BIOKA68 525 EMPIRICAL BIOKA69 367 STRUCTURAL JRSSB69 NO.2 QUERY, MAXIMUM TECH 69 NO. 4 MAXIMUM-LIKELIHOOD BIOKA67 93 BEST LINEAR UNBIASED JASA $62 \quad 369$ TESTINC THE HYPOTHESIS AMS 621085 CLOSED QUEUEING SYSTEMS, JRSSB61 385 ON THE BIAS OF SONE LEAST- BIOKA68 313 TESTS FOR THE EQUALITY OF AMS 671286 ESTIMATION OF PARAMETERS IN A TR AMS 691542 CANNIBALISM OF THE PUPAL STAGE BY BIOCS68 247 AN ALCORITHM FOR THE DETERMINATION JASA 68304 MULTIVARIATE TWO SAMPLE TESTS WITH AMS 69290 /E. THE QUASI-F TEST FOR AN UNNESTED FIXED FA BIOCS66 937 /IN THE HISTORY OF PROBABILITY AND STATISTICS BIOKA67 1 ISTRIBUTION OF THE F-STATISTIC IN A RANDOMIZ AMS 631558 /OF POPULATION PARAMETERS FROM MULTIPLE RECAP BIOKA63 113 /UTION OF ORDER STATISTICS AND DISTRIBUTION O AMS 63652 $\begin{array}{llllll}7 \text { TION OF ORDER STATISTICS AND DISTRIBUTION O AMS } & 63 & 652 \\ \text { CORR. } 68 \text { 1550) } & \text { TIES IN PAIRED-COMPARISON JASA } 67 & 194\end{array}$ TECH 65603 BIOCS69 573 BIOKA69 81 JASA 59231

OF THE GASOLINE OGTANE NUMBER REQUIREMENT OF NEW MODEL AUTOMOBILES STATISTICAL ESTIMATION TECH 60 TECH $62 \quad 301$ A USEFUL METHOD FOR MODEL BUILDING SEQUENTIAL MODEL BUILDINC FOR PREDICTION IN REGRESSION ANALYSIS, AMS 63462 I MODEL BUILDING WITH THE AID OF STOCHASTIC PROCESSES TECH $64 \quad 133$

STATISTICS FOR THE TWO-WAY CLASSIFICATION MIXED MODEL D MINIMAL SUFFTCIENT J

A JOINT DESIGN CRITERION FOR THE DUAL PROBLEM OF MODEL DISCRIMINATION AND PARAMETER ESTIMATION A NOTE ON DESIGNS FOR MODEL DISCRIMINATION, VARIANCE UNKNOWN CASE

A NON-NULL RANKING MODEL FOR A SEQUENCE OF M ALTERNATIVES

A MULTIPLICATIVE MODEL FOR ANALYZING VARIANCES WHICH ARE AFFECTED BY A TWO-STATE MARKOV MODEL FOR BEHAVIORAL CHANCE

SEVERAL FACTORS

$$
\text { A MODEL FOR CHEMICAL MUTACENESIS IN BACTERIOPHAGE }
$$

A SIMPLIFIED MODEL FOR DELAYS IN OVERTAKING ON A TWO-LANE ROAD THE GONSISTENCY AND ADEQUACY OF THE POISSON-MARKOFF MODEL FOR DENSITY FLUCTUATIONS

A STOCHASTIC MODEL FOR DISTRIBUTIONS OF BIOLOGICAL RESPONCE TIMES

RATES

A DEMOGRAPHIC MODEL FOR ESTTMATINC ACE-ORDER SPECIFIC FERTILITY

A MATRIX MODEL FOR FOREST MANACEMENT

A GENERAL MODEL FOR GENETIC EFFECTS

A STATISTICAL MODEL FOR LIFE-LENGTH OF MATERIALS

THE BASIC BIRTH-DEATH MODEL FOR MICROBIAL INFECTIONS

A MODEL FOR MIGRATION ANALYSIS

A MODEL FOR OPTIMUM LINKAGE OF RECORDS

ON A RELATIONSHIP BETWEEN TWO REPRESENTATIONS OF A MODEL FOR PAIRED COMPARISONS ESTIMATION OF THE PARAMETER IN THE STOCHASTIC MODEL FOR PHAGE ATTACHMENT TO BACTERIA SOME STOCHASTIC VERSIONS OF THE MATRIX MODEL FOR POPULATION DYNAMICS

A LEARNING MODEL FOR PROCESSES WITH TOOL WEAR

A MODEL FOR RAINFALL OCCURRENCE

A MODIFIED MODEL FOR RAINFALL OCCURRENCE

A QUEUEINC MODEL FOR ROAD TRAFFIC FLOW (WITH DISCUSSION)

A MODEL FOR SELECTING ONE OF TWO MEDICAL TREATMENTS

TECH 68 145

TECH $69 \quad 396$

BIOKA61 44]

JASA $60 \quad 245$

JASA $68 \quad 993$

BIOKA58 562

BI0CS65 875

JRSSB58 408

BIOKA57 43

BI0CS65 562

JASA $63 \quad 774$

BIOCS69 309

BIOCS66 864

JASA $58 \quad 151$

JRSSB $65 \quad 338$

JASA $61 \quad 675$

$\begin{array}{lll}\text { JASA } & 68 & 1321\end{array}$

BIOCS69 597

AMS $68 \quad 183$

JASA $69 \quad 111$

TECH $68 \quad 379$

JRSSB $64 \quad 345$

JRSSB67 151

JRSSB61 64

JASA $63 \quad 388$

BIOCS65 169

A TWO-STAGE MODEL FOR SELECTING ONE OR TWO TREATMENTS $\begin{array}{lll}\text { AL SYSTEMS BY NUMERICAL METHODS } & \text { A STOCHASTIC MODEL FOR STUDYINC THE PROPERTIES OF CERTAIN BIOLOGIC BIOKA58 } 16 \\ \text { (WITH DISCUSSION) } & \text { A BRANCHING POISSON PROCESS MODEL FOR THE ANALYSIS OF COMPUTER FAILURE PATTERNS JRSSB64 398 }\end{array}$ TESTING ON SYSTEM RELIABILITY

CORRECTION TO REFERENCE 681025

A MARKOVIAN MODEL FOR THE ANALYSIS OF THE EFFECTS OF MARGINAL AMS 62

A MATHEMATICAL MODEL FOR THE ESTIMATION OF INTER-PLANT COMPETITION BIOCS67 NCER INCIDENCE TO CICARETTE SMOKING AND A STOCHASTIC MODEL FOR THE MODE OF ACTION OF CARCINOGENS /UNG GA BIOCS65 839 
NOTES. ESTIMATION AFTER PRELIMINARY TESTING IN ANOVA MODEL I

RAMETRIC TESTING AGAINST ORDERED ALTERNATIVES IN MODEL I ANALYSIS OF VARIANCE. NORMAL THEORY AND NONPA

THEOREMS CONCERNING ETSENHART'S MODEL II

SOME MODEL I PROBLEMS OF SELECTION

ON THE BAYES CHARACTER OF A STANDARD MODEL II ANALYSIS OF VARIANCE TEST

THE SPECTRUM OF A MODEL II NESTED ANOVA AND ITS APPLICATIONS A K-SAMPLE MODEL IN ORDER STATISTICS

A NOTE ON 'A K-SAMPLE MODEL IN ORDER STATISTICS' BY W. J. CONOVER

ATE LOGARITHMIC SERIES DISTRIBUTION AS A PROBABILITY MODEL IN POPULATION AND COMMUNITY ECOLOGY AND SOME OF J DESIGNS WHICH MINIMIZE MODEL INADEQUACIES. CUBOIDAL REGIONS OF INTEREST IMITING BEHAVIOR OF POSTERIOR DISTRIBUTIONS WHEN THE MODEL IS INCORRECT, CORR. 66745

作 AMS 61990 AMS 61261 AMS 691094 TECH 6991 AMS 651223 AMS $66 \quad 287$ GROSS STATE PRODUCT AND AN ECONOMETRIC MODEL OF A STATE A STOCHASTIC MODEL OF ACHE TRANSPORTATION IN THE PERIPHERAL NERVE TRUNKS A STATISTICAL MODEL OF BOOK USE AND ITS APPLICATION TO THE BOOK A STOCHASTIG MODEL OF CREDIT SALES DEBT

EXPERIENCE

BAYESIAN MODEL OF DECISION-MAKING AS A RESULT OF LEARNING FROM
FOR PLANTS MANUFACTURING HAZARDOUS/ A STATISTICAL MODEL OF EVALUATING THE RELIABILITY OF SAFETY SYSTEMS A FORECASTING MODEL OF FEDERAL PURCHASES OF GOODS AND SERVICES ON THE STOCHASTIC MATRIX IN A GENETIG MODEL OF MORAN A MIXED MODEL OF REGRESSIONS A MINIMUM COST MODEL OF SPARE PARTS INVENTORY CONTROL

INFERENCE ON A GENETIC MODEL OF THE MARKOV CHAIN TYPE

A COMPUTER SIMULATION MODEL OF THE TEXTILE INDUSTRY

A QUARTERLY ECONOMETRIC MODEL OF THE UNITED STATES

TURE DATA WITH BOTH DEATH AND TMMIGRATION-STOCHASTIC MODEL

TESTS OF HYPOTHESES IN THE LINEAR AUTO-REGRESSIVE MODEL. II. NULL DISTRIBUTIONS FOR HIGHER ORDER SCHEME BIOKA56 I86

TESTS OF HYPOTHESES IN THE LINEAR AUTOREGRESSIVE MODEL. PART I

THE UNRELATED QUESTION RANDOMIZED RESPONSE MODEL, THEORETICAL FRAMEWORK

ASPECTS OF THE STATISTICAL ANALYSIS OF THE 'MIXED MODEL' APPLICATIONS OF THE PSEUDOINVERSE TO MODELING

ON THE ESTIMATION OF CONTRASTS IN LINEAR MODELS

DESIGNS FOR DISCRIMTNATING BETWEEN TWO RIVAL MODELS CONDITIONAL-NORMAL REGRESSION MODELS

LINEAR SEGMENT CONFIDENCE BANDS FOR SIMPLE LINEAR MODELS STRAIGHT LINE CONFIDENCE REGIONS OF LINEAR MODELS

ABOUT SENSITIVITY ANALYSIS IN LINEAR PROGRAMMING MODELS DISCRIMINATION AMONG MECHANISTIC MODELS

NON-DISCOUNTED DENUMERABLE MARKOVIAN DECISION MODELS

ON SOME BILHARZIA INFECTION AND IMMUNISATION MODELS CONFIDENCE REGIONS FOR VARIANCE RATIOS OF RANDOM MODELS EFFICIENT ESTIMATION OF PARAMETERS IN MOVING-AVERAGE MODELS

DISCRIMINATION BETWEEN ALTERNATIVE BINARY RESPONSE MODELS THE PROBABILITIES OF SOME EPIDEMIC MODELS A TEST FOR DISCRIMINATING BETWEEN MODELS ESTIMATION OF PARAMETERS IN TIME-SERIES REGRESSION MODELS ANALYSIS OF CATEGORICAL DATA BY LINEAR MODELS EQUILIBRIUM COVARIANCE MATRIX OF DYNAMIC ECONOMETRIC MODELS SAMPLE ESTIMATION OF PARAMETERS FOR MOVING-AVERAGE MODELS A UNIQUENESS RELATION IN CERTAIN ACCIDENT PRONENESS MODELS

INVARIANT TESTS IN UNBALANCED VARIANCE COMPONENTS MODELS BANDS OF UNIFORM AND PROPORTIONAL WIDTH FOR LINEAR MODELS OF SOME NONPARAMETRIC PROCEDURES IN LINEAR MODELS ANALYSIS OF VARIANCE UNDER RANDOM AND MIXED MODELS

TO ESTIMATE THE POPULATION MEAN IN RANDOM EFFECTS MODELS

TRIBUTIONS FOR SOME RANDOM WALKS ARISING IN LEARNING MODELS ESTIMATION BY PARTIAL TOTALS FOR COMPARTMENTAL MODELS

DETERMINANTS OF MOVING-AVERAGE AND AUTOREGRESSIVE MODELS

OF ANTIBIOTICS ON BACTERIA BY MEANS OF STOCHASTIC MODELS

BY REGRESSION FOR CERTAIN INCOMPLETELY SPECIFIED MODELS AMETRIC INFERENCE. AN ALTERNATIVE APPROACH TO LINEAR MODELS ASSOCIATED WITH CERTAIN STOCHASTIC LEARNING MODELS DUCTION TO ESSENTIALS I THE PURPOSE AND UNDERLYING MODELS VARIANCE POWER FUNCTION IN THE PARAMETRIC AND RANDOM MODELS AND EMPIRICAL RESULTS FOR SOME STOCHASTIC POPULATION MODELS

PRODUCT IN ANALYSING CERTAIN STOCHASTIC POPULATION MODELS IONS ESTIMATORS TO THE STOCHASTIC ASSUMPTIONS OF THE MODELS ON THE USE OF THE DIRECT MATRIX BIOKA66 ON THE SENSITIVITY OF SIMULTANEOUS-EQUAT JASA 66
JASA 69520

SOME BIOCS68 27 TECH $66 \quad 351$ AMS 65 19B

TECH 65307 JASA $66 \quad 477$ JASA $67 \quad 403$ JASA $67 \quad 1365$ SASJ $67 \quad 33$ TECH $67 \quad 57$ AMS $68 \quad 412$ SASJ 6861 JASA 69660 BIOKA59 306 BIOKA67 573 BIOKA69 197 BIOKA69 337 JRSSB 60139 BIOCS69 489

THE JASA $69 \quad 277$ LARGE- BIOKA61 343 NOTE ON JASA $67 \quad 2 B B$ OPTIMUM AMS $67 \quad 422$ CONFIDENCE JASA $66 \quad 182$ ROBUSTNESS AMS 6B 1913 SEQUENTIAL JASA $67 \quad 1401$ A PROCEDURE TECH $67 \quad 577$ LIMITING DIS AMS $66 \quad 393$ SIMULTANEOUS JASA $68 \quad 573$ ON THE COVARIANCE BIOKA6O 194 ANALYSIS OF EFFECTS BIOCS66 76I BIASES IN PREDICTION BIOKA63 39I ASYMPTOTICALLY NONPAR AMS 631494 LIMITING DISTRIBUTIONS AMS 621281 FACTOR ANALYSIS, AN INTRO BIOCS65 190 COMPARISNN 397 136 
AND SIMPLE LEAST SQUARES LINEAR ESTIMATORS IN LINEAR MODELS THE 'PARTIAL ADJUSTMENT' AND 'ADAPTIVE EXPECTATIONS' MODELS OF EXPERIMENTS TO ESTIMATE PARAMETERS IN NON-LINEAR MODELS CAUSAL CHAINS' ACAINST THE CLASS OF 'INTERDEPENDENT' MODELS ON MODELS
/NON-NECATIVE COVARIANCE MATRICES AND BEST /ALL SAMPLE BIAS DUE TO MISSPECIFICATION IN /CURRENCE OF REPLICATIONS IN OPTIMAL DESICNS J /N THE STATISTICAL TESTABILITY OF 'EXPLICIT ND HYPOTHESES WITH RESTRICTED ALTERNATIVES

STATISTICAL MODELS AND INVARIANCE

BIOLOCICAL BACKCROUND PROBABILISTIC AND STATISTICAL MODELS AND PROBLEMS (INVITED PAPER) /ILITY TESTINC. SOME QUANTITATIVE TESTS FOR STOCK PRICE GENERATING MODELS AND TRADING FOLKLORE THE SOLUTION OF QUEUEING AND INVENTORY MODELS BY SEMI-MARKOV PROCESSES

ORRECTION TO 'THE SOLUTION OF QUEUEINC AND INVENTORY MODELS BY SEMI-MARKOV PROCESSES' OMBINABILITY OF INFORMATION FROM UNCORRELATED LINEAR MODELS BY SIMPLE WEIGHTINC MODELS FOR A BACTERIAL CROWTH PROCESS WITH REMOVALS JRSSB63 140 IMATIONS TO THE VARIANCE IN DISCRETE-TIME STOCHASTIC MODELS FOR BIOLOGICAL SYSTEMS A NOTE ON SOME APPROX BIOKA60 I96 MODELS FOR CATALOGUING PROBLEMS

SYSTEMS

US DOSAGE RESPONSE CURVES

ON THEORETICAL MODELS FOR COMPETITIVE AND PREDATORY BIOLOCICAL

AMS 671255 MODELS FOR COMPETITIVE AND PREDATORY BIOLOCICAL_ BIOKA57 27 MODELS FOR COMPLEX CONTINGENCY TABLES AND POLYCHOTOMO BIOCS66 83 CONTAGION IN STOCHASTIC MODELS FOR EPIDEMICS AMS 68 1B63 FURTHER MODELS FOR ESTIMATING CORRELATION IN DISCRETE DATA JRSSB64 82 MIXTURE OF DRUGS GENERAL MODELS FOR QUANTAL RESPONSE TO THE JOINT ACTION OF A BIOKA64 413 COMPARISON OF TWO APPROACHES TO THE CONSTRUCTION OF MODELS FOR QUANTAL RESPONSES TO MIXTURES OF DRUGS A BIOCS67 27 NATIVE SYSTEM FOR THE CLASSIFICATION OF MATHEMATICAL MODELS FOR QUANTAL RESPONSES TO MIXTURES OF DRUGS IN BIOCS65 181 GROUPED DATA

JASA $60 \quad 503$ MODELS FOR THE ESTIMATION OF COMPETING RISKS FROM BIOCS69 329 OUS SAMPLING INSPECTION PLANS MARKOVIAN DECISION MODELS FOR THE EVALUATION OF A LARCE CLASS OF CONTINU AMS 65 1408 MIXTURE OF STIMULI IN BIOLOGICAL ASSAY A SYSTEM OF MODELS FOR THE LIFE CYCLE OF A BIOLOGICAL ORGANISM MODELS FOR THE NON-INTERACTIVE JOINT ACTION OF A STOCHASTIC MODELS FOR THE POPULATION GROWTH OF THE SEXES MODELS FOR THE RESPONSE OF A MIXTURE

COUPLE

PROBABILITY MODELS FOR THE VARIATION IN THE NUMBER OF BIRTHS PER BIOKA68 211 BIOKA66 49 BIOKA 6 B 469 JRSSB68 349 PER JASA $63 \quad 721$ PROCESSES MODELS FOR TWO-DIMENSIONAL STATIONARY STOCHASTIC

BIOKA55 170 N) MODELS FROM THE BAYESIAN POINT OF VIEN 1 CORR. 68 1551 JASA 65 608 MODELS IN THE ANALYSIS OF VARIANCE (WITH DISCUSSION) JRSSB60 195
RIBUTION OF VA/ BAYESIAN ANALYSIS OF RANDOM-EFFECT MODELS IN THE ANALYSIS OF VARIANCE. I. POSTERIOR DIST BIOKA65 37 OCORRELATED ER/ BAYESIAN ANALYSIS OF RANDOM-EFFECT MODELS IN THE ANALYSIS OF VARIANCE. II. EFFECT OF AUT BIOKA66 477 CONSTRAINED ESTIMATION AND INFERENCE FOR LINEAR MODELS IN WHICH SUBSETS OF THE DEPENDENT VARIABLE ARE JASA 68 1201 TA INFERENCE FOR SOME INCOMPLETELY SPECIFIED MODELS INVOLVING NORMAL APPROXIMATIONS TO DISCRETE DA BIOCS67 335 MIXTURES $\begin{array}{llllrr}\text { STOCHASTIC MODELS OF CAPITAL INVESTMENT (WITH DISCUSSION) } & \text { JRSSB69 } & 1 \\ \text { THREE DIMENSIONAL MODELS OF EXTREME VERTICES DESICNS FOR FOUR COMPONENT TECH } & 67 & 472\end{array}$ STEREOSCOPIC MODELS OF MULTIVARIATE STATISTICAL DATA B BIOCS66 MODELS OF THE SECOND KIND IN RECRESSION ANALYSIS

SELECTION INDICES FOR QUADRATIC MODELS OF TOTAL MERIT

SOME STOCHASTIC MODELS RELATING TIME AND DOSAGE IN RESPONSE CURVES ASYMPTOTICALLY OPTIMAL STATISTICS IN SOME MODELS WITH INCREASING FAILURE RATE AVERAGE VARIANCE COMPONENTS IN TWO-WAY CLASSIFICATION MODELS WITH INTERACTION CORR. 65343 MULTIVARIATE CORRELATION MODELS WITH MIXED DISCRETE AND CONTINUOUS VARIABLES, ROBUST PROCEDURES FOR SOME LINEAR MODELS WITH ONE OBSERVATION PER CELL SYMPTOTICALLY NONPARAMETRIC INFERENCE IN SOME LINEAR MODELS WITH ONE OBSERVATION PER CELI PAIRED COMPARISON MODELS WITH TESTS FOR INTERACTION 358 JRSSB67 266 BIOCS68 937 BIOCS65 583 AMS $67 \quad 1731$ BIOKA63 327 AMS $61 \quad 448$ AMS $67 \quad 878$ AMS $64 \quad 726$ BIOCS65 651 NCE TO THE BALANCED I/ BAYESIAN ANALYSIS OF LINEAR MODELS WITH TWO RANDOM COMPONENTS WITH SPECIAL REFERE BIOKA68 IOI NON-NULL RANKING MODELS. I MODELS, INFERENCE, AND STRATEGY BIOKA57 114 BIOCS69 457 AMS 682016 AMS 621160 CONVERGENCE RATES FOR PROBABILITIES OF MODERATE DEVIATIONS

THE SAMPLE MEAN AMONG THE MODERATE ORDER STATISTICS PERCENTACE POINTS AND MODES OF ORDER STATISTICS FROM THE NORMAL DISTRIBUTIO AMS 61888 KOLMOGOROV-SMIRNOV TESTS AND RENYI'S MODIFICATION

ON A MODIFICATION OF CERTAIN RANK TESTS BI0CS68 1019 AMS 631101

ION PROBLEMS

RY TIES IN BOTH RANKINGS

ASSAYS

UT/ COMPARA COMPOUNDING

CORRELATION AND REGRESSION

APPLICATION OF A MODIFICATION OF DAVIDON'S METHOD TO NONLINEAR REGRESS PERCENTILE MODIFICATIONS OF TWO-SAMPLE RANK TESTS MODIFICATIONS TO THE VARIATE-DIFFERENCE METHOD

A COMPARISON OF A MODIFIED 'HANNAN' AND THE BUREAU OF LABOR STATISTICS

ON THE EFFICIENCY OF MODIFIED BALANCED INCOMPLETE BLOCK DESIGNS FOR BIO-

A MODIFIED BAYES STOPPINC RULE

TECH $68 \quad 843$

33

BIOKA53 383

JASA $65 \quad 442$

BIOCS69 591 AMS $63 \quad 1404$

TWO MODIFIED CHI-SQUARE GOODNESS-OF-FIT TESTS FOR SMALL B

A MODIFIED COMPOUND POISSON PROCESS WITH NORMAL

A MODIFIED CONTROL CHART WITH WARNING LINES

A MODIFIED DOOLITTLE APPROACH FOR MULTIPLE AND PARTIAL ETWEEN HYPOTHETICAL DISTRIBUTION FUNCTION AND PYKE'S MODIFIED EMPIRICAL DISTRIBUTION FUNCTION /FERENCE B

INEAR REGRESSION FUNCTIONS BY LEAST SQUARES INEAR REGRESSION FUNCTIONS BY L
HYPOTHESES AND THEIR PROPERTIES A NOTH

A MODIFIED EXPONENTIALLY WEIGHTED PREDICTOR

THE MODIFIED GAUSS-NEWTON METHOD FOR THE FITTING OF NON-L SOME MODIFIED KOLMOGOROV-SMIRNOV TESTS OF APPROXIMATE THE MODIFIED LATIN SQUARE

TIME SERIES ANALYSIS BY MODIFIED LEAST-SQUARES TECHNIQUES

A MODIFIED MODEL FOR RAINFALL OCCURRENCE

EST IMATING THE PARAMETERS OF A MODIFIED POISSON DISTRIBUTION MODIFIED SAMPLING, BINOMIAL AND HYPERGEOMETRIC CASES MODIFIED SQUARE ROOT METHOD OF MATRIX INVERSION

ERRATA, 'MODIFIED SQUARE ROOT METHOD OF MATRIX INVERSION '

ON MODIFIED SYSTEMATIC SAMPLING

A MODIFIED TECHNIQUE FOR IMPROVING AN ESTIMATE OF THE

MEAN

SEQUENTIAL RANK TESTS II MODIFIED TWO-SAMPLE PROCEDURES

FUNCTION OF A SEQUENCE UNIFORMLY DISTRIBUTED MODULO I THE SEPARATION OF MOLECULAR

STOCHASTIC PROCESS

FROM A FINITE POPULATION
JASA $68 \quad 637$

BI0KA62 171

JASA $58 \quad 133$ AMS $62 \quad 525$ JRSSB $68 \quad 318$ TECH 61269 $\begin{array}{rr}\text { AMS } 62 & 513 \\ \text { JRSSB } 57 & 305\end{array}$ JASA $66 \quad 152$ JRSSB 67 151 JASA $60 \quad 139$ TECH 69 NO. 4 TECH $62 \quad 282$ TECH $62 \quad 622$ BIOKA68 541 BIOCS69 588 TECH $66 \quad 615$ AMS $63 \quad 1243$ BIOKA60 69 AMS $67 \quad 751$ BIOKA52 I
MOMENT COEFFICIENTS OF THE K-STATISTICS IN SAMPLES 
MOMENT CONSTANTS FOR THE DISTRIBUTION OF RANCE IN MOMENT CONVERCENCE OF SAMPLE EXTREMES

MOMENT CROSSINCS AS RELATED TO DENSITY CROSSINCS

A UNIQUENESS THEOREM CONCERNINC MOMENT DISTRIBUTIONS THE DISTRIBUTION OF MOMENT ESTIMATORS

MOMENT ESTIMATORS AND MAXIMUM LIKELIHOOD

CORRICENDA

CORRIGENDA, 'MOMENT ESTIMATORS AND MAXIMUM LIKELIHOOD'

MOMENT ESTIMATORS FOR THE PARAMETERS OF A MIXTURE OF

TWO BINOMIAL DISTRIBUTIONS ANCED R-WAY CLASSIFICATION

TH SPECIAL REFERENCE TO TYPE II CENSORE/ BINOMIAL DISTRIBUTION

CRITERION

NORMAL DISTRIBUTION

THE LAW OF LARGE NUMBERS

VARIANCES OF MOMENT ESTIMATORS OF VARIANCE COMPONENTS IN THE UNBAL

THE BIAS OF MOMENT ESTIMATORS WITH AN APPLICATION TO THE NEGATIVE BIOKA62 SOME DISTRIBUTION AND MOMENT FORMULAE FOR THE MARKOV CHAIN

ON THE MOMENT GENERATING FUNCTION OF PILLAI'S V-SUPER-S

THE MOMENT GENERATING FUNCTION OF THE TRUNCATED MULTI-

SOME RESULTS RELATING MOMENT GENERATING FUNCTIONS AND CONVERGENCE RATES IN

ON MOMENT GENERATING FUNCTIONS AND RENEWAL THEORY

Q) THE DETERMINATION OF SAMPLING DISTRIBUTIONS AND MOMENT GENERATING FUNCTIONS BY SOLVING DIFFERENTIAL E SERIALLY CORRELATED NORMAL VARIABLES MOMENT GENERATING FUNCTIONS OF QUADRATIC FORMS IN NOTE ON AN APPLICATION OF FOUR MOMENT INEQUALITIES TO A PROBLEM IN QUEUES

RENEWAL THEOREMS WHEN THE FIRST OR THE SECOND MOMENT IS INFINITE

INADMISSIBILITY OF THE BEST INVARIANT TEST WHEN THE MOMENT IS INFINITE UNDER ONE OF THE HYPOTHESES QUAL TO R. R LES/ INEQUALITIES OF THE RTH ABSOLUTE MOMENT OF A SUM OF RANDOM VARIABLES. 1 LESS THAN OR E THE THIRD MOMENT OF CINI'S MEAN DIFFERENCE

THE THIRD MOMENT OF KENDALL'S TAU IN NORMAL SAMPLES

THE CENERAL MOMENT PROBLEM, A CEOMETRIC APPROACH

JRSSB55 235

AMS $68 \quad$ B77

JRSSB61 223

AMS $67 \quad 742$

AMS $65 \quad 129 B$

JRSSB $65 \quad$ B6

BIOKA58 198

TECH $65 \quad 435$

AMS $6 \mathrm{~B} 1210$ AMS 691483 AMS $65 \quad 299$ BIOKA53 451 BIOKA62 177 AMS $6 B \quad 93$

BOTH TERMINALS ARE KNOWN

NOTE ON THE MOMENT-PROBLEM FOR UNIMODAL DISTRIBUTIONS WHEN ONE OR BIOKA56

BUTIONS FOR WHICH THE HARTLEY-KHAMIS SOLUTION OF THE MOMENT-PROBLEM IS EXACT

MACHINE COMPUTATION OF HIGHER MOMENTS

JOINT DISTRIBUTIONS WITH PRESCRIBED MOMENTS

SOME STRIKING PROPERTIES OF BINOMIAL AND BETA MOMENTS

TRUNCATED LOGNORMAL DISTRIBUTIONS. I. SOLUTION BY MOMENTS TABLES OF POISSON POWER MOMENTS

ON SERIES EXPANSIONS FOR THE RENEWAL MOMENTS

ARACTERIZATIONS OF SOME DISTRIBUTIONS BY CONDITIONAL MOMENTS

IN APPROXIMATING TO PROBABILITY DISTRIBUTIONS USING MOMENTS TRIBUTION TWO METHODS OF ESTIMATING PARAMETERS FROM MOMENTS SON FREQUENCY DISTRIBUTIONS WITHOUT RESORT TO HIGHER MOMENTS ON EXACT GROUPING CORRECTIONS TO MOMENTS AND CUMULANTS

CORRECTIONS TO 'A THEOREM ON FACTORIAL MOMENTS AND ITS APPLICATIONS' 50206

CH AMS $65 \quad 703$

PROBLEMS ARISING BIOKA63 95 THE FOLDED NORMAL DIS TECH 61551 JASA $56 \quad 4 B 9$ AMS $65 \quad 2 B 6$ AMS 691753 BIOKA5I 414 BIOKA56 489 BIOKA63 75 BIOKA52 429 AMS 61620 AND THE DISTRIBUTION OF THE RANGE FROM THE/ EXACT MOMENTS AND PERCENTAGE POINTS OF THE ORDER STATISTICS AMS 65 907 NDEPENDENT. BOUNDED RANDOM VA/ UPPER BOUNDS ON THE MOMENTS AND PROBABILITY INEQUALITIES FOR THE SUM OF I BIOKA65 559 FROM THE TRUNCATED LOGISTIC DISTRIBUTION EXACT MOMENTS AND PRODUCT MOMENTS OF THE ORDER STATISTICS JASA 66 5I4 EFFICIENCY OF THE METHOD OF MOMENTS AND THE GRAM-CHARLIER TYPE A DISTRIBUTION
BIOKA5I 58 DISTRIBUTIONS THE METHOD OF MOMENTS APPLIED TO A MIXTURE OF TWO EXPONENTIAL AMS $61 \quad 143$

OF THE PROBABILITY INTECRAL WHEN THE FIRST FOUR MOMENTS ARE GIVEN

ESTIMATION OF A RANDOM PROBABILITY WHOSE FIRST N MOMENTS ARE KNOWN C A SUEU DENSTTY UHOSE LEPT TERMINAL AND FIRST THREE MOMENTS ARE K BINOMIAL AN/ THE ASYMPTOTIC VARIANCES OF METHOD OF MOMENTS ESTIMATES OF THE PARAMETERS OF THE TRUNCATED JASA 6I 990 NENTIAL DISTRIBUTION THE USE OF FRACTIONAL MOMENTS FOR ESTIMATING THE PARAMETERS OF A MIXED EXPO ON PRODUCT MOMENTS FROM A FINITE UNIVERSE MORE RESULTS ON PRODUCT MOMENTS FROM A FINITE UNIVERSE MONOTONE CONVERGENCE OF MOMENTS IN AGE DEPENDENT BRANCHING PROCESSES

ASYMPTOTIC VALUES OF THE FIRST TWO MOMENTS IN MARKOV RENEWAL PROCESSES EQUIVALENCE OF MAXIMUM LIKELIHOOD AND THE METHOD OF MOMENTS IN PROBIT ANALYSIS ON THE CONVERGENCE OF MOMENTS IN THE CENTRAL LIMIT THEOREM THE MOMENTS OF A DOUBLY NONCENTRAL T-DISTRIBUTION HIGHER MOMENTS OF A MAXIMUM-LIKELIHOOD ESTIMATE MOMENTS OF A SERIAL CORRELATION COEFFICIENT MOMENTS OF A STOPPING RULE RELATED TO THE CENTRAL MOMENTS OF A TRUNCATED BIVARIATE NORMAL DISTRIBUTION LIMIT THEOREM MOMENTS OF A TRUNCATED BIVARIATE NORMAL
MOMENTS OF A TRUNCATED POISSON VARIATE A NOTE ON THE NEGATIVE MOMENTS OF A TRUNCATED POISSON VARIATE
THE MOMENTS OF A VARIATE RELATED TO THE NON-CENTRAL T

ON MCMENTS OF CUMULATIVE SUMS

ROOTS OF TWO MATRICES $S$ OF A MATRIX IN MULTIVARIATE ANALYSIS
S OF TWO MATRICES AND APPROXIMATIONS TO A DIST/ ON MOMENTS OF ELEMENTARY SYMMETRIC FUNCTIONS OF THE ROOT EXACT FIRST AND SECOND ORDER MOMENTS OF ESTIMATES OF COMPONENTS OF COVARIANCE ON THE MOMENTS OF THE RANGE AND PRODUCT MOMENTS OF EXTREME ORDER STATISTICS IN NORMAL SAMPLES B ON ASYMPTOTIC MOMENTS OF EXTREME STATISTICS

A NOTE ON MOMENTS OF GAMMA ORDER STATISTICS

THE MOMENTS OF LOG-WEIBULL ORDER STATISTICS

BOUNDS ON MOMENTS OF MARTINGALES

SAMPLING MOMENTS OF MEANS FROM FINITE MULTIVARIATE POPULATIONS MOMENTS OF NEGATIVE ORDER AND RATIO-STATISTICS BOUNDS AND APPROXIMATIONS FOR THE MOMENTS OF ORDER STATISTICS

ON MOMENTS OF ORDER STATISTICS AND QUASI-RANGES FROM RECURRENCE RELATIONS BETWEEN MOMENTS OF ORDER STATISTICS FOR EXCHANCEABLE VARIATES ON THE BIVARIATE MOMENTS OF ORDER STATISTICS FROM A LOGISTIC DISTRIBUT MOMENTS OF ORDER STATISTICS FROM A NORMAL POPULATION MOMENTS OF ORDER STATISTICS FROM THE EQUICORRELATED

ON THE MOMENTS OF ORDER STATISTICS IN SAMPLES FROM NORMAL POPULATIONS POPULATIONS DISTRIBUTION, ONE DEGREE OF FREEDOM RELATED POPULATIONS
CORRIGENDA, 'ON THE MOMENTS OF ORDER STATISTICS IN SAMPLES FROM NORMAL EXACT LOWER MOMENTS OF ORDER STATISTICS IN SAMPLES FROM THE CHIRELATIONS AMONC MOMENTS OF ORDER STATISTICS IN SAMPLES FROM TWO
TECH $68 \quad 161$

JASA $6 B \quad 535$ JASA $69 \quad 864$ AMS $66 \quad 1 B 06$ BIOKA67 597 BIOCS67 154 AMS 65 BOB JASA $67 \quad 278$ JRSSB63 305 JRSSB65 308 AMS 691236 JRSSB6I 405 JASA 641220 AMS $64 \quad 298$ AMS 661803 AMS $64 \quad 1704$ AMS 611152 AMS $6 B \quad 1274$ BIOKA69 NO. 3 BIOKA56 458 AMS $64 \quad 1738$ TECH $67 \quad 315$ TECH $69 \quad 373$ AMS $68 \quad 1719$ AMS 61406 JRSSB55 122 JASA 69 NO. 4 AMS $63 \quad 633$ AMS $68 \quad 272$ AMS $66 \quad 1002$ BIOKA59 433 AMS $62 \quad 12 B 6$ BIOKA54 200 BIOKA54 568 AMS 621292 TECH $63 \quad 514$ 
NORMAL POPULATION

NORMAL POPULATION

MOMENTS OF SAMPLE MOMENTS OF CENSORED SAMPLES FROM A BIOKA58 211 CORRICENDA TO 'MOMENTS OF SAMPLE MOMENTS OF CENSORED SAMPLES FROM A BIOKA58 587 ON THE DISTRIBUTION OF THE FIRST SAMPLE MOMENTS OF SHOT NOISE

ON THE MOMENTS OF SOME ONE-SIDED STOPPING RULES

ON SECOND MOMENTS OF STOPPING RULES

BOUNDS ON MOMENTS OF SUMS OF RANDOM VARIABLES

TECH $642 \mathrm{~B} 7$

AMS $66 \quad 382$

AMS $66 \quad 3 \mathrm{BB}$

AMS 691506

ASYMPTOTIC EXPANSIONS FOR THE MOMENTS OF THE DISTRIBUTION OF CORRELATION COEFFICIEN

SEGMENTS

THE FACTORIAL MOMENTS OF THE DISTRIBUTION OF JOINS BETWEEN LINE

THE MOMENTS OF THE LEIPNIK DISTRIBUTION

ON MOMENTS OF THE MAXIMUM OF NORMED PARTIAL SUMS

NUMBER OF INDEPENDENT NORMAL VARIATES

ON THE MOMENTS OF THE MAXIMUM OF PARTIAL SUMS OF A FINITE MOMENTS OF THE MEAN DEVIATION

JASA 69 N0.4

BIOKA57 270

AMS 69527

BIOKA56 79

BIOKA54 541

INOMIAL DISTRIBUTION

A NOTE ON THE FIRST TWO MOMENTS OF THE MEAN DEVIATION OF THE SYMMETRICAL MULT BIOKA67

ON (ATY'S FORMULAE AND MADOW/ THE CENTRAL SAMPLINC MOMENTS OF THE MEAN IN SAMPLES FROM A FINITE POPULATI BIOKA6I ABSOLUTE AND INCOMPLETE MOMENTS OF THE MULTIVARIATE NORMAL DISTRIBUTION

SOME APPLICATIONS

THE MOMENTS OF THE NON-CENTRAL T-DISTRIBUTION

BIOKA53 20

STATIONARI NORMAL PROCESS

THE MOMENTS OF THE NUMBER OF CROSSINCS OF A LEVEL BY A BIOKA6I 465

AN APPROXIMATION OF THE NEGATIVE MOMENTS OF THE POSITIVE BINOMIAL USEFUL IN LIFE TESTI RECURRENCE RELATIONS FOR THE INVERSE MOMENTS OF THE POSITIVE BINOMIAL VARIABLE

MOMENTS OF THE RADIAL ERROR, CORR. 651251

PBIB DESIGNS

ORDER STATISTICS IN NORMAL SAMPLES

THE GENERAL CASE

FIRST AND SECOND MOMENTS OF THE RANDOMIZATION TEST IN TWO ASSOCIATE

ON THE MOMENTS OF THE RANGE AND PRODUCT MOMENTS OF EXTREME

MOMENTS OF THE RANK CORRELATION COEFFICIENT TAU IN

TO THE MOMENTS OF THE SAMPLE MEDIAN

TO ITS NON-CENTRAL DISTRIBUTION

\author{
APPROXIMATIONS
}

ON THE MOMENTS OF THE TRACE OF A MATRIX AND APPROXIMATIONS

N THE NON-CENTRAL MULTIVARIATE BETA DISTRIBUTION AND MOMENTS OF TRACES OF TWO MATRICES SOME RESULTS

RANDOM VARIABLES

MANUFACTURERS' INVENTORY CYCLES AND MONETARY POLICY

FUNCTIONAL FORM IN THE DEMAND FOR MONEY

INCOME, WEALTH, AND THE DEMAND FOR MONEY, SOME EVIDENCE FROM CROSS-SECTION DATA

OF HYPOTHESES CONCERNING THE DECREE OF DOMINANCE IN MONOFACTORIAL INHERITANCE NOTES. STATISTICAL TESTS B

GENERALIZATION OF RAMANUJAN'S EQUATION

AN APPLICATION TO MAXIMUM LIKELIHOOD ESTIMATION

BRANCHING PROCESSES
MONOMIAL-MONOMIAL SYMMETRIC FUNCTION TABLES

MONOTONE CONVERGENCE OF BINOMIAL PROBABILITIES AND A

MONOTONE CONVERCENCE OF BINOMIAL PROBABILITIES WITH

MONOTONE CONVERGENCE OF MOMENTS IN ACE DEPENDENT

NOTE ON COMPLETELY MONOTONE DENSITIES

OBABILITY INFERENCES FOR FAMILIES OF HYPOTHESES WITH MONOTONE DENSITY RATIOS

MAXIMUM LIKELIHOOD ESTIMATTON FOR DISTRIBUTIONS WITH MONOTONE FAILURE RATE

LIFE TEST PROCEDURES WHEN THE DISTRIBUTION HAS MONOTONE FAILURE RATE

A NOTE ON TESTS FOR MONOTONE FAILURE RATE BASED ON INCOMPLETE DATA

UPPER AND LOWER PR

EXPONENTIAL

TEST FOR MONOTONE FAILURE RATE BASED ON NORMALIZED SPACING

TESTS FOR MONOTONE FAILURE RATE, II

PROPERTIES OF PROBABILITY DISTRIBUTIONS WITH MONOTONE HAZARD RATE

TABLES OF BOUNDS FOR DISTRIBUTIONS WITH MONOTONE HAZARD RATE

BOUNDS FOR DISTRIBUTIONS WITH MONOTONE HAZARD RATE, I

BOUNDS FOR DISTRIBUTIONS WITH MONOTONE HAZARD RATE, II

DISTRIBUTIONS POSSESSING A MONOTONE LIKELIHOOD RATIO

A TECHNICAL LEMMA FOR MONOTONE LIKELIHOOD RATIO FAMILIES

SOME APPLICATIONS OF MONOTONE OPERATORS IN MARKOV PROCESSES

ON ESTIMATING MONOTONE PARAMETERS

IATE STATISTICAL ANALYSIS

A CLASS OF TESTS WITH MONOTONE POWER FUNCTIONS FOR TWO PROBLEMS IN MULTIVAR ANALYSIS OF FACTORIAL EXPERIMENTS BY ESTIMATING MONOTONE TRANSFORMATIONS OF THE DATA

MULTIVARIATE TESTS

ON THE MONOTONIC CHARACTER OF THE POWER FUNCTIC

ON THE MONOTONICITY OF E-SUB-P(S-SUB-T-OVER-T)

EXISTENCE, UNIQUENESS AND MONOTONICITY OF SEQUENTIAL PROBABILITY RATIO TESTS

THE MULTIVARIATE LINEAR HYPOTHESIS

INDEPENDENCE BETWEEN TWO SETS OF VARIATES

VARIATIONS OF HENSEN'S INEQUALITY

TESTS OF THE EQUALITY OF TWO COVARIA MONOTONICITY OF THE POWER FUNCTIONS OF SOME TESTS OF MONOTONICITY OF THE POWER FUNCTIONS OF SOME TESTS OF MONOTONICITY OF THE VARIANCE UNDER TRUNCATION AND MONOTONICITY OF THE VARIANCE UNDER TRUNCATION AND
MONOTONICITY PROPERTY OF THE POWER FUNCTIONS OF SOME

MULTIVARIATE ANALYSIS OF VARIANCE

N THE MONOTONICITY PROPERTY OF THE THREE MAIN TESTS FOR

AN EXTENSION OF THE ROBBINS-MONRO PROCEDURE

A POOR MAN'S MONTE CARLO (WITH DISCUSSION)
STS EMPLOYING SATTERTHWAITE'S SYNTHETIC MEAN SQ/ A MONTE CARLO INVESTICATION OF THE SIZE AND POWER OF TE BIOKA68 43 THEORY IN ESTIMATING THE DISTRIBUTION OF A RATIO BY MONTE CARLO METHODS

LTERNATIVE TESTS FOR HETEROGENEITY OF VARIANCE, SOME MONTE CARLO RESULTS SOM D/ SOME MONTE CARLO RESULTS ON THE POWER OF THE
A SIMPLIFIED MONTE CARLO SIGNIFICANCE TEST PROCEDURE

A STATIONARY GAUSSIAN ORNSTEIN-UHLENBECK PROCESS BY MONTE CARLO SIMULATION /E-TIME MAXIMA AND MINIMA OF J D CLUSTER PROBLEM

A MONTE CARLO SOLUTION OF A TWO-DIMENSIONAL UNSTRUCTURE SEQUENTIAL RANK TESTS I. MONTE CARLO STUDIES OF THE TWD-SAMPLE PROCEDURE
FINITE SAMPLE MONTE CARLO STUDIES. AND AUTOREGRESSIVE ILLUSTRATION JASA

A MONTE CARLO STUDY COMPARING VARIOUS TWO-SAMPLE TESTS TECH
A MONTE CARLO STUDY OF THE ADEQUACY OF THE ASYMPTOTIC A BIOC

FOR DIFFERENCES IN MEAN

-PARAMETRIC ANALYSIS OF VARIANCE IN SMALL SAMPLES, A MONTE CARLO STUDY OF THE ADEQUACY OF THE ASYMPTOTIC A BIOCS69 593

GRESSION TECHNIQUE TD PRODUCE AREA BREAKDOWNS OF THE MONTHLY NATIONAL ESTIMATES OF RETAIL TRADE $/ O F$ A RE JASA 66 496

THE USE OF ROTATTNC SAMPLES TN THE CENSUS BUREAU'S MONTHLY SURVEYS

AMETRIC ALTERNA/ ASYMPTOTIC RELATIVE EFFICIENCY OF MOOD'S AND MASSEY'S TWO SAMPLE TESTS AGAINST SOME PAR AMS 62 I375 $N$ AND ITS NORMAL APPROX/ EXACT CRITICAL VALUES FOR MOOD'S DISTRIBUTION-FREE TEST STATISTIC FOR DISPERSID TECH 68 497 NOTE ON MOOD'S TEST

ESTIMATES OF MORALITY AND POPULATION FROM SURVEY-REMOVAL RECORDS

ON THE STOCHASTIC MATRIX IN A CENETIC MODEL OF MORAN

AMS 691130

AMS 681030

JRSSB 65
JASA $62 \quad 187$

458

AMS $62 \quad 157$

AMS 63101

JASA 58680

JASA $68 \quad 502$

JASA $64 \quad 746$

BIOKA59 205

1583

AMS $69 \quad 953$

SA $67 \quad 548$

AMS 691250

AMS $63 \quad 375$

JASA $65 \quad 872$

AMS 641234

AMS 641258

AMS 6761

AMS $65 \quad 1421$

AMS $61 \quad 1145$

AMS 681755

AMS 631541

AMS 64206

AMS 691106

AMS 641059

RSSB64 77

JRSSB $65 \quad 28$

23

MS 621194

BIOKA66 229

BIOKA66 199

SA $6 B \quad 1517$

ECH $68 \quad 497$

BIOCS65 921

BIOKA6I 203 
THE HISTORY OF PROBABILITY AND STATISTICS. VIII DE MORGAN AND THE STATISTICAL STUDY OF LITERARY STYLE LATENT CLASS ANALYSIS AND DIFFERENTIAL MORTALITY

PANEL MORTALITY AND PANEL BIAS

EXPERIMENT

THE ESTIMATION OF MORTALITY AND RECRUITMENT FROM A SINCLE TACCINC

OF A PATIENT POPULATION WITH RESPECT TO DIFFERENT MORTALITY RISKS

PARTITIONING

A TEST FOR RANDOM MINGLING OF THE PHASES OF A MOSAIC

THE CONCEPT OF RANDOMNESS IN THE PATTERNS OF MOSAICS

99

JASA $63 \quad 701$

BIOCS67 657

BI0CS65 90B

TEST

THE MOST ECONOMICAL BINOMIAL SEQUENTIAL PROBABILITY RATIO BIOKAGO 103

E AND CANONICAL ANALYSIS, A METHOD FOR SELECTING THE MOST EFFECTIVE DISCRIMINATORS IN A MULTIVARIATE SITUA BIOCS68 845

E INDEPENDENCE OF TWO POISSON VARIAB/ ON A LOCALLY MOST POWERFUL BOUNDARY RANDOMIZED SIMILAR TEST FOR TH AMS 61 809

EXISTENCE AND UNTOUENESS OF A UNIFORMLY MOST POWERFUL RANDOMIZED UNBIASED TEST FOR THE BINOMI BIOKA56 465 ASYMPTOTICALLY MOST POWERFUL RANK ORDER TESTS FOR GROUPED DATA

WITH CENSORED DATA ASYMPTOTIC EFFICIENCY OF CERTAIN LOCALLY MOST POWERFUL RANK TESTS ASYMPTOTICALLY MOST POWERFUL RANK TESTS FOR THE TWO-SAMPLE PROBLEM ASYMPTOTICALLY MOST POWERFUL RANK-ORDER TESTS

THE MOST STRINGENT AND THE MOST STRINCENT SOMEWHERE MOST POWERFUL TEST FOR CERTAIN PROBLEMS WITH RESTRICT MOST POWERFUL TESTS FOR SOME NON-EXPONENTIAL FAMILIES ASYMPTOTICALLY MOST POWERFUL TESTS IN MARKOV PROCESSES

POMERFUL TEST FOR CERTAIN PRO/ A COMPARISON OF THE MOST STRINGENT AND THE MOST STRINGENT SOMEWHERE MOST IN PRO/ A COMPARISON OF THE MOST STRINGENT AND THE MOST STRINGENT SOMEWHERE MOST POWERFUL TEST FOR CERTA ALTERNATIVE RESTRICTED BY A NUMBER OF LINEAR INEQ/ MOST STRINGENT SOMEWHERE MOST POWERFUL TESTS AGAINST OF LINEAR HYPOTHESES

LCALLY ASYMPTOTICALLY MOST STRINGENT TESTS AND LAGRANGIAN MULTIPLIER TESTS THE CONVEX HULL OF PLANE BROWNIAN MOTION

THE EXISTENCE OF CERTAIN STOPPING TIMES ON BROWNIAN MOTION SUBORDINATION OF DIFFERENTIAL PROCESSES TO BROWNIAN MOTION THEOREM FOR THE ANGULAR COMPONENT OF PLANE BROWNIAN MOTION ATION OF THE EQUTVALENCE CONDTTIONS FOR THE BROWNIAN MOTION TO THE EQUIVALENCE CONDITIONS FOR CERTAIN STAT OF THE ABSOLUTE MAXIMUM FOR CERTAIN BROWNIAN MOTIONS DISTRIBUTION
AL. WANDERINC AND VARIATION OF THE LONG-TAILED FIELD MOUSE, APODEMUS SYLVATICUS. III WANDERING PONER AND

AMS 671229 AMS $61 \quad$ BB AMS 651243

AMS 621124 AMS $68 \quad 531$ AMS $68 \quad 772$ AMS 691207 AMS $6 B \quad 531$ AMS $68 \quad 531$ AMS $66 \quad 1161$ BI0KA65 459 AMS $63 \quad 327$ AMS $69 \quad 715$ AMS 691603 A NOTE ON FOLLOW-UP FOR SURVIVAL IN THE PRESENCE OF MOVEMENT STATISTICAL METHODS FOR THE MOVER-STAYER MODEL

INVERSE OF THE COVARIANCE MATRIX OF A FIRST ORDER MOVING AVERAGE THE USE OF AN ITERATED MOVTNG AVERAGE IN MEASURING SEASONAL VARTATIONS VARIANCE STATIONARY ON A FINITE TIME INTERVAL A MOVING AVERAGE REPRESENTATION FOR RANDOM VARIABLES CO BIOKA65 295 CONTROL CHART TESTS BASED ON GEOMETRIC MOVING AVERAGES A LIMIT LAW CONCERNING MOVING AVERAGES

PREDICTION BY EXPONENTIALLY NEIGHTED MOVING AVERACES AND RELATED METHODS A NOTE ON MOVING RANGES

DISCRETE SAMPLES AND MOVING SUMS IN STATIONARY STOCHASTIC PROCESSES

ON THE COVARTANCE DETERMTNANTS OF MOVING-AVERAGE AND AUTOREGRESSIVE MODELS THE ESTIMATION OF MIXED MOVING-AVERAGE AUTOREGRESSIVE SYSTEMS EFFICIENT ESTIMATION OF PARAMETERS IN MOVING-AVERAGE MODELS LARGE-SAMPLE ESTIMATION OF PARAMETERS FOR MOVING-AVERAGE MODELS IANCE OF A SAMPLE OF CONSECUTIVE OBSERVATIONS FROM A MOVING-AVERAGE PROCESS IANCE OF A SAMPLE OF CONSECUTIVE OBSERVATIONS FROM A MOVING-AVERAGE PROCESS ' TION OF PARAMETERS FOR AUTORECRESSIVE PROCESSES WITH MOVING-AVERAGE RESIDUALS FOR STOCHASTIC PROCESSES OF THE AUTOREGRESSIVE AND MOVING-AVERAGE TYPE /HE LIMITING CENERALIZED VAR BIOKA6I 197 /E LIMITING GENERALIZED VAR BIOKA6I 476 LARGE-SAMPLE ESTIMA BIOKA62 117 1025) EQUILIBRIUM UNDER SELECTION AT A MULTI-ALLELIC SEX-LINKED LOCUS (ACKNOWLEDGEMENT 6B ON A METHOD OF USING MULTI-AUXILIARY INFORMATION IN SAMPLE SURVEYS

RELIABILITY MULTI-COMPONENT SYSTEMS AND STRUCTURES AND THEIR

HYPOTHESES OF 'NO INTERACTION' IN MULTI-DIMENSTONAL CONTINGENCY TABLES

A LOCAL LIMIT THEOREM FOR NONLATTICE MULTI-DIMENSIONAL DISTRIBUTION FUNCTIONS COMBINATORIAL RESULTS IN MULTI-DIMENSIONAL FLUCTUATION THEORY. CORR. 64924 SOME EXAMPLES OF MULTI-DIMENSTONAL INCOMPLETE BLOCK DESIGNS

PROCESS

A MULTI-DIMENSIONAL LINEAR GROWTH BIRTH AND DEATH

ONS TO THE WEAK CONVERGENCE OF RANDOM PROCESSES WITH MULTI-DIMENSIONAL TIME PARAMETERS /S WITH APPLICATI DESIGNING SOME MULTI-FACTOR ANALYTICAL STUDIES INTERACTIONS IN MULTI-FACTOR CONTINGENCY TABLES MULTI-FACTOR DESIGNS OF FIRST ORDER

INVERSE POLYNOMIALS, A USEFUL GROUP OF MULTI-FACTOR RESPONSE FUNCTIONS THE MOMENT GENERATING FUNCTION OF THE TRUNCATED MULTI-NORMAL DISTRIBUTION

A MULTI-PROPORTIONS RANDOMIZED RESPONSE MODEL MULTI-SAMPLE ANALOGUES OF SOME ONE-SAMPLE TESTS

THE MULTI-SAMPLE SINCLE RECAPTURE CENSUS MULTI-SAMPLE TESTS FOR THE FISHER DISTRTBUTION FOR

DIRECTIONS MULTT STZED PART TCLS AN APPLICATT

THEORY

SAMPLING MIXTURES OF MULTI-SIZED PARTICLE
IVE SAMPLING USING A MULTI-STAGE DESIGN ESTIMATES IN

A MULTI-STAGE PROCEDURE FOR THE SELECTION OF THE BEST

A MULTI-STAGE RENEWAL PROCESS

ON VARIANCES OF RATIOS AND THEIR DIFFERENCES IN MULTI-STAGE SAMPLES, CORR. 631162 ESTIMATION IN MULTI-STAGE SURVEYS

A MULTI-STAGE TEST FOR A NORMAL MEAN

AMS $67 \quad 25$ AMS 69 NO.6 AMS $65 \quad 311$ BIOKA52 389 BIOKA69 N0.3 $\begin{array}{ll}\text { BIOKA65 } & 295 \\ \text { TECH } 59 & 239\end{array}$ AMS $64 \quad 424$ JRSSB $61 \quad 414$ BIOKA55 512 JASA $67 \quad 484$ BIOKA60 194 BIOKA69 N0 3 BIOKA59 306 OF SEVERAL POPULATIONS

Y TIME SERIES POLYNOMIAL PROJECTING PROPERTIES OF MULTI-TERM PREDICTORS OR CONTROLLERS IN NON-STATIONAR JR CONTEXT ING PROBABILITIES

THE MULTI-TYPE GALTON-WATSON PROCESS IN A GENETICAL

BIOKA56 215

BIOCS68 187 JASA $65 \quad 270$ TECH 6155 TECH $68 \quad 107$ AMS $65 \quad 546$ AMS $63 \quad 402$ AMS 681577 AMS $68 \quad 727$ AMS $69 \quad 681$ JASA $67 \quad 1121$ JRSSB62 251 BIOKA52 49 BI0C566 128 JRSSB61 223 JASA $67 \quad 990$ AMS $67 \quad 523$ BIOKA62 339 BIOKA69 169 TECH 69285 JASA $68 \quad 99$ JASA 62785 JRSSB $63 \quad 150$ JASA $59 \quad 416$ JASA $69 \quad 830$ JRSSB68 461 JRSSB $65 \quad 144$ BIOCS68 147 A NOTE ON MULTI-TYPE GALTON-WATSON PROCESSES WITH RANDOM BRANCH BIOKA68 589 LIMIT THEOREMS FOR THE MULTI-URN EHREFEST MODEL INTERACTIONS IN MULTIDIMENSIONAL CONTINGENCY TABLES A NOTE ON THE GRAPHICAL ANALYSIS OF MULTIDIMENSIONAL CONTINGENCY TABLES AMS $68 \quad 864$ AMS 64632 TECH $67 \quad 481$ ENTROPY FOR HYPOTHESIS FORMULATION ESPECIALLY FOR MULTIDIMENSIONAL CONTINGENCY TABLES A LIMIT THEOREM FOR MULTIDIMENSIONAL GALTON-WATSON PROCESSES MAXIMUM AMS $63 \quad 911$ AMS 661211 ADDITIONAL LIMIT THEOREMS FOR INDECOMPOSABLE MULTIDIMENSIONAL GALTON-WATSON PROCESSES 
TOWR BOUNDS FOR AVERACE SAMPLE NUMRER OF SEQUENTIAL MULTIHYPOTHESIS TESTS

INTECRAL EXPRESSIONS FOR TAIL PROBABILITIES OF THE MULTINOMIAL AND NECATIVE MULTINOMIAL DISTRIBUTIONS. SMOOTHED ESTIMATES FOR MULTINOMIAL CELL PROBABILITIES

BIAS IN MULTINOMIAL CLASSIFICATION

A BAYESIAN STUDY OF THE MULTINOMTAL DISTRTBUTION

SOME APPLICATIONS OF TWO APPROXIMATIONS TO THE MULTINOMIAL DISTRIBUTION

THE MODE OF A MULTINOMIAL DISTRIBUTION

AMS 681615

BIOCS66 525

AMS 671343

BIOKA65 167

AMS $68 \quad 56$

JASA $68 \quad 298$

AMS 671423

BIOKA6O 463

BIOKA64 513

BIOKA68 377

PERCENTAGE POINTS OF THE RANGE FROM A SYMMETRIC MULTINOMIAL DISTRIBUTION

A S JASA $62 \quad 769$ EQUENTIAL TEST OF THE EQUALTTY OF PROBABILTTIES IN A MULTINOMIAL DISTRIBUTION IVARIATE SADDLE POINT METHOD AND CHI-SQUARED FOR THE MULTINOMIAL DISTRIBUTION TWO MOMENTS OF THE MEAN DEVIATION OF THE SYMMETRICAL MULTINOMIAL DISTRIBUTION THE MULT AMS $61 \quad 535$ SELY SAMPLED POLLEN COUN/ ON THE COMPOUND NEGATIVE MULTINOMIAL DISTRIBUTION AND CORRELATIONS AMONG INVER BIOKAG3 47 APPROPRIATE SCORES A PROPERTY OF THE MULTINOMIAL DISTRIBUTION AND THE DETERMINATION OF PPROXIMATION AND AN IMPPOVEMENT TO IT A COMPLETE MULTINOMIAL DISTRIBUTION COMPARED WITH THE X-SQUARE A BIOKA64 277 THE USE OF A GENERALIZED MULTINOMTAL DISTRIBUTION TN THE ESTTMATION OF CORRELA JRSSB62 530 AN APPROXTMATION TO THE MULTINOMIAL DISTRTBUTION INOME PROPERTIES AND APPLICA BIOKA6O IBUTION. AND CORRELATIONS AMONG P/ ON THE COMPOUND MULTINOMIAL DISTRIBUTION, THE MULTIVARIATE BETA-DISTR BIOKA62 ASYMPTOTICALLY OPTIMUM TESTS FOR MULTINOMIAL DISTRIBUTIONS

TESTING FOR HOMOGENEITY I THE BINOMIAL AND MULTINOMIAL DISTRIBUTIONS A BAYESIAN SIGNIFICANCE TEST FOR MULTINOMIAL DISTRIBUTIONS (WITH DISCUSSION) CORRECTIONS TO 'SADDLE POINT METHODS FOR THE MULTINOMIAL DISTRIBUTIONS' 57861 ON EFFICIENT MULTINOMIAL ESTIMATION

LAMP TESTS OF LINEAR AND LOGLINEAR HYPOTHESES IN MULTINOMIAL EXPERIMENTS, CORR, 661246 IMULTANEOUS CONFIDENCE INTERVALS FOR CONTRASTS AMONG MULTINOMIAL POPULATIONS AN INEQUALITY INVOLVING MULTINOMIAL PROBABILITIES MULTINOMIAL PROBABILITIES AND THE CHI-SQUARE AND X-

SQUARE DISTRIBUTIONS SQUARE DISTRIBUTIONS

CORRIGENDA, 'MULTINOMIAL PROBABILITIES AND THE CHI-SQUARE AND $X$

LARGE SAMPLE SIMULTANEOUS CONFIDENCE INTERVALS FOR MULTINOMIAL PROPORTIONS ON SIMULTANEOUS CONFIDENCE INTERVALS FOR MULTINOMIAL PROPORTIONS

MULTINOMIAL SAMPLING WITH PARTIALLY CATEGORIZED DATA CUMULANTS OF TRUNCATED MULTINORMAL DISTRIBUTIONS EQUALLY CORRELATED VARIATES AND THE MULTINORMAL INTEGRAL

DISCUSSION) MULTIPARAMETER BAYESIAN INDIFFERENCE PROCEDURES (WIT MULTIPARAMETER PROBLEMS FROM A BAYESIAN POINT OF VIEW OF LIKELIHOOD EQUATIONS BY ITERATION PROCESSES MULTIPARAMETRIC CASE

A MODIFIED DOOLTTL APPROACH FOR MULTIPLE AND PARTIAL CORRELATION AND REGRESSION CONVERGENCE THEOREMS FOR MULTIPLE CHANNEL LOSS PROBABILITIES THE SCORING OF MULTIPLE CHOICE QUESTIONNARES

MULTIPLE CLASSIFICATION ANALYSIS FOR ARBITRARY

ONS

RANK SUM MULTIPLE COMPARISIONS IN ONE AND TWO-WAY CLASSIFICATI MULTIPLE COMPARISIONS USING RANK SUMS MULTIPLE COMPARISIONS WITH A CONTROL IN BALANCED

INCOMPLETE BLOCK DESIGNS

A REMARK ON MULTIPLE COMPARISON METHODS

OL AN ASYMP
ANCE ANALYSIS OF VARIANCE CONTROL

AMS $65 \quad 369$

BIOKA66 167

JRSSB67 399

AMS $61 \quad 619$

JRSSB $66 \quad 45$

JASA $66 \quad 236$

5 AMS $64 \quad 716$

BIOKA68 422

BIOKA63 145

BIOKA63 546

TECH $64 \quad 191$

TECH $65 \quad 247$

JASA $68 \quad 542$

JRSSB62 535

JRSSB58 373

JRSSB 6929

AMS 651468

BIOKA62 479

JASA $58 \quad 133$

AMS $63 \quad 260$

AMS $62 \quad 375$

TECH $68 \quad 13$

BIOKA67 487

TECH 64241

TECH $61 \quad 103$

TECH 65223

AMS $66 \quad 735$

SASJ $69 \quad 35$

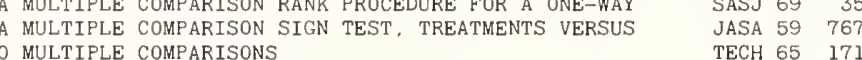

$\begin{array}{lllr}\text { A MULTIPLE COMPARISON RANK PROCEDURE FOR A ONE-WAY } & \text { SASJ } 69 & 35 \\ \text { A MULTIPLE COMPARISON SIGN TEST, TREATMENTS VERSUS } & \text { JASA } 59 & 767 \\ & & \text { TECH } 65 & 171\end{array}$

A BAYESIAN APPROACH TO MULTIPLE COMPARISONS

SIMULTANEOUS TEST PROCEDURES, SOME THEORY OF MULTIPLE COMPARISONS

A GENERALIZATION OF THE T-METHOD OF MULTIPLE COMPARISONS

MULTIPLE COMPARISONS AMONG MEANS

ANALYSIS OF COVARIANCE

NOTE ON MULTTPLE COMPARISONS FOR ADJUSTED MEANS IN THE

JASA $69 \quad 290$

JASA $61 \quad 52$

BIOKA58 256

$\begin{array}{llllr}\text { SHORT-CUT MULTIPLE COMPARISONS FOR BALANCED SINGLE AND DOUBLE } & \text { TECH } 65 & 95 \\ \text { SHORT-CUT MULTIPLE COMPARISONS FOR BALANCED SINGLE AND DOUBLE C BIOKA65 } & 485\end{array}$

CLASSIFICATIONS. PART 1, RESULTS

SHORT-CUT MULTIPLE COMPARISONS FOR BALANCED SINGLE AND DOUBLE LINEAR AND NON-LINEAR MULTIPLE COMPARISONS IN LOGIT ANALYSIS

CORRIGENDA, 'LINEAR AND NON-LINEAR MULTIPLE COMPARISONS IN LOGIT ANALYSIS'

A GRAPHICAL METHOD FOR MAKING MULTIPLE COMPARISONS OF FREQUENCIES

SIMULTANEOUS TEST PROCEDURES FOR MULTIPLE COMPARISONS ON CATEGORICAL DATA

A BAYES RULE FOR THE SYMMETRIC MULTIPLE COMPARISONS PROBLEM

PROBLEMS

BAYES RULES FOR A COMMON MULTIPLE COMPARISONS PROBLEM AND RELATED STUDENT-T

BIOKA61 359

BIOKA62 284

TECH $69 \quad 321$

JASA $66 \quad 1081$

JASA 69 NO. 4

AMS 611013

TECH $65 \quad 293$

BIOCS67 539

TECH $65 \quad 255$

A. MULTIPLE COMPARISONS SIGN TEST, ALL PAIRS OF

A NOTE ON MULTIPLE COMPARISONS USING RANK SUMS

MULTIPLE COMPARISONS WITH A CONTROL FOR MULTIPLY-CLAS TECH 68715

SIFIED VARIANCES OF NORMAL POPULATIONS

ESTIMATION OF MULTIPLE CONTRASTS USING T-DISTRIBUTIONS JASA $65 \quad 573$ INDIVIDUAL MATCHINC WITH MULTIPLE CONTROLS IN THE CASE OF ALL-OR-NONE RESPONSE

TABLES FOR CONSTRUCTING CONFIDENCE LIMITS ON THE MULTIPLE CORRELATION COEFFICIENT

A RELATIVELY SIMPLE FORM OF THE DISTRIBUTION OF THE MULTIPLE CORRELATION COEFFICIENT

YSIS, NECESSARY SAMPLE SIZE, AND A RELATION WITH THE MULTIPLE CORRELATION COEFFICIENT

THE GENERALIZED MULTIPLE CORRELATION MATRIX

JASA 631082 JRSSB $68 \quad 276$ DISTRIBUTION OF THE

BETA DISTRIBUTIONS ON THE DISTRIBUTION OF A MULTIPLE CORRELATION MATRIX, NON-CENTRAL MULTIVARIATE THE ASYMPTOTIC POWERS OF CERTAIN TESTS BASED ON MULTIPLE CORRELATTONS

MULTIPLE COVARIATE ANALYSIS (CORR, 66 962)

ERS A MULTIVARIATE IMMIGRATION WITH MULTIPLE DEATH PROCESS AND APPLICATIONS TO LUNAR CRAT ON SOME MULTIPLE DECISION (SELECTION AND RANKING) RULES ON MULTIPLE DECISION METHODS FOR RANKING POPULATION

MEANS ON MULTIPLE DECISION METHODS

CHOICE OF THE DEGREE OF A POLYNOMIAL REGRESSION AS A MULTIPLE DECISION PROBLEM
MINIMAX RISK AND UNBIASEDNESS FOR MULTIPLE DECISION PROBLEMS OF TYPE I

$$
\text { MINIMAX RISK AND UNBIASEDNESS FOR MULTIPLE DECISION PROBLEMS OF TYPE I }
$$


REGRESSION

MATRIX AND MULTIPLE DECREMENT IN POPULATION ANALYSIS MISSINC VALUES IN LINEAR MULTIPLE DISCRIMINANT ANALYSIS

SINCLE AND MULTIPLE DISCRIMINATION RECIONS IN MULTIPLE LINEAR

BI0CS67

SASJ $68 \quad 67$

BIOKA64 405

BIOKA62 351

THE ANALYSIS OF PERSISTENCE IN A CHATN OF MULTIPLE EVENTS

PERSISTENCE IN A CHAIN OF MULTIPLE EVENTS WHEN THERE IS SIMPLE DEPENDENCE

AMS $65 \quad 1873$

OFTIMUM ALLOCATION ARISINC IN CHEMICAL ANALYSES BY MULTIPLE ISOTOPE DILUTION

COMPUTATTON WTTH MULTIPLE K-STATISTICS

BEHAVIOR OF WILCOXON TYPE CONFIDENCE RECIONS IN MULTIPLE LINEAR RECRESSION

A PROBLEM OF TECH $61 \quad 509$

JASA $63 \quad 120$

FOR CLASS DIFFERENCES MULTIPLE LINEAR RECRESSION ANALYSIS WITH ADJUSTMENT

EMPIRTCAL BAYES ESTIMATORS IN A MULTTPLE LINEAR RECRESSION MODEL

ON THE ERCODICITY FOR NON-STATIONARY MULTIPLE MARKOV PROCESSES

A TABLE FOR RANK SUM MULTIPLE PAIRED COMPARISONS

SOME RULES FOR A COMBINATORIAL METHOD FOR MULTIPLE PRODUCTS OF GENERALIZED K-STATISTICS SOME MULTIPLE PRODUCTS OF POLYKAYS

APPROXIMATIONS TO THE CRITICAL VALUES FOR DUNCAN'S MULTIPLE RANGE TEST

PARTIAL AND MULTIPLE RANK CORRELATION

$\begin{array}{lr}\text { AMS } 68 & 9 B 3 \\ \text { AMS } 69 & 1297\end{array}$

$\begin{array}{rr}\text { AMS } 69 & \text { N0.6 } \\ \text { JASA } 61 & 729\end{array}$

BIOKAE9 367

AMS 681448

TECH $67 \quad 561$

BIOCS66 179

BIOKA51 26

DETERMINI/ ESTIMATES OF POPULATION PARAMETERS FROM MULTIPLE RECAPTURE DATA WITH BOTH DEATH AND DILUTION- BIOKAG3 133 ERRORS OF PREDICTION IN MULTIPLE REGRESSION

AUGMENTING EXISTING DATA IN MULTIPLE REGRESSION

THE CHOICE OF VARIABLES IN MULTIPLE REGRESSION (WITH DISCUSSION)

TECH 67309

TECH $68 \quad 73$

JRSSB $68 \quad 31$

JASA $63 \quad 993$

SEASONAL ADJUSTMENT OF ECONOMIC TTME SERIES AND MULTTPLE RECRESSION ANALYSIS

IS FORMULAE FOR ADDITION OR OMISSION OF A VARIATE IN MULTIPLE REGRESSION ANALYSIS

EXTENSION OF COCHRAN JASA $63 \quad 527$ MULTIPLE REGRESSION ANALYSIS OF A POISSON PROCESS JASA $61 \quad 235$

ATIONS OF JORDAN'S PROCEDURE FOR MATRIX INVERSION IN MULTIPLE REGRESSION AND MULTIVARIATE DISTANCE ANALYSI JRSSB63 352

UNBIASED MULTIPLE REGRESSION COEFFICIENTS ESTIMATED FROM ONE-W JASA 6672 PLOT INFORMATION MULTIPLE REGRESSION COMBINING WITHIN- AND BETWEEN- BIOCS66 26

ON THE ANALYSIS OF MULTIPLE REGRESSION IN K CATEGORIES

MULTIPLE REGRESSION IN PROCESS DEVELOPMENT

TECH 68 257

MULTIPLE REGRESSION WITH MISSING OBSERVATIONS AMONG JASA 56122

MULTIPLE REGRESSION WITH STATIONARY ERRORS JASA 66917

BIOKA57 131

THE GENERALIZATION OF PROBIT ANALYSIS TO THE CASE OF MULTIPLE RESPONSES

KELIHOOD ESTIMATOR WHERE THE LIKELIHOOD EQUATION HAS MULTIPLE ROOTS

EVALUATION OF THE MAXIMUM-LI BIOKA66 I5I MULTIPLE RUNS

A COMPOUNDED MULTIPLE RUNS DISTRIBUTION

CORRIGENDA TO 'MULTIPLE RUNS'

THE MULTIPLE SAMPLE UP-AND-DOWN METHOD IN BIOASSAY

SPECTRAL FACTORIZATION OF MULTIPLE TIME SERIES

BIOKA57 168

JASA 69 N0.4

BIOKA57 534

JASA 69147

BIOKA66 264

JASA $63 \quad 216$

RANKS

ORDERED HYPOTHESES FOR MULTIPLE TREATMENTS, A SIGNIFICANCE TEST FOR LINEAR

TION OF THE Q-SUB-1 TO Q-SUB-N BY M-SUB-1 TO M-SUB-N MULTIPLE-LATTICE DESIGN ESTIMATED REGRESSION FUNC J

IS IMMIGRATION OR DEATH

THE MULTIPLE-RECAPTURE CENSUS II. ESTIMATION WHEN THERE

POPULATION

A NOTE ON THE MULTIPLE-RECAPTURE CENSUS

JRSSB69 N0.2

BIOKA59 336

BIOKA65 249

THE MULTIPLE-RECAPTURE CENSUS. I ESTIMATION OF A CLOSED BIOKA58 343

GENETICS

SOME APPLICATIONS OF MULTIPLE-TYPE BRANCHING PROCESSES IN POPULATION MULTIPLEX SAMPLING

APPLIED MULTIPLEX SAMPLING

ARE AFFECTED BY SEVERAL FACTORS

THE RELIABILITY OF MULTIPLEX SYSTEMS WITH REPAIR

A MULTIPLICATIVE MODEL FOR ANALYZING VARIANCES WHICH

JRSSB68 164

AMS 631322

TECH $63 \quad 341$

JRSSB66 459

JASA $60 \quad 245$

CTION IN A GALTON-WATSON PROCESS AND IN SOME RELATED MULTIPLICATIVE POPULATION PROCESSES /ITIES OF EXTIN AMS 68 17OO RANDOMIZED ROUNDED-OFF MULTIPLIERS IN SAMPLINC THEORY

THE USE OF LAGRANGE MULTIPLIERS WITH RESPONSE SURFACES

SINGLE-STAGE PROCEDURES FOR RANKING MULTIPLY-CLASSIFIED VARIANCES OF NORMAL POPULATIONS

JASA $61 \quad 328$

TECH 59289

TECH $68 \quad 693$

MULTIPLE COMPARISONS WITH A CONTROL FOR MULTIPLY-CLASSIFIED VARIANCES OF NORMAL POPULATIONS TECH 68 7I5

IONS

A NOTE ON THE MULTIPLYINC FACTORS FOR VARIOUS CHI-SQUARE APPROXIMAT J

TS FOR PARAMETER ESTIMATION IN NON-LINEAR SITUATIONS MULTIRESPONSE CASE /IONS IN THE DESIGN OF EXPERIMEN B

GRAPHICAL METHODS FOR INTERNAL COMPARISONS IN MULTIRESPONSE EXPERIMENTS

ON A GENERAL CLASS OF DESIGNS FOR MULTIRESPONSE EXPERIMENTS

DESICN OF EXPERIMENTS FOR PARAMETER ESTIMATION IN MULTIRESPONSE SITUATIONS

CHARACTERIZATION OF MULTISAMPLE DISTRIBUTION-FREE STATISTICS

STATISTICS

ON SOME MULTISAMPLE PERMUTATION TESTS BASED ON A CLASS OF U-

SOME NONPARAMETRIC TESTS FOR MULT ISAMPLE PROBLEMS

ON MULTISTAGE ESTIMATION

OPTIMAL ALLOCATION IN STRATIFIED AND MULTISTAGE SAMPLES USING PRIOR INFORMATION

DISTRIBUTIONS AND COSTS

MULTISTAGE SAMPLING PROCEDURES BASED ON PRIOR

NS OF A LIMIT THEOREM OF EVERETT, ULAM AND HARRIS ON MULTITYPE BRANCHING PROCESSES TO A BRANCHING PROCESS

SOME RESULTS ON MULTITYPE CONTINUOUS TIME MARKOV BRANCHING PROCESSES

UPPER AND LOWER PROBABILITIES INDUCED BY A MULTIVALUED MAPPING

GENERAL SPECIFICATION ELLIPSOIDS

MULTIVARIATE ACCEPTANCE SAMPLING PROCEDURES FOR

SOME CONSIDERATIONS IN MULTIVARIATE ALLOMETRY

BABILITY INTEGRAL AND CERTAIN PERCENTAGE POINTS OF A MULTIVARIATE ANALOGUE OF STUDENT'S T-DISTRIBUTION

A MULTIVARIATE ANALOCUE OF THE ONE-SIDED TEST

SOME NON-CENTRAL DISTRIBUTION PROBLEMS IN MULTIVARTATE ANALYSIS

BAYESIAN ESTIMATION IN MULTIVARIATE ANALYSIS

SOME APPLICATIONS OF MATRIX DERIVATIVES IN MULTIVARIATE ANALYSIS

ONE SIDED PROBLEMS IN MULTIVARIATE ANALYSIS

SOME EXACT TESTS IN MULTIVARIATE ANALYSIS

SOME PROBLEMS INVOLVING LINEAR HYPOTHESES IN MULTIVARIATE ANALYSIS

THE DISCARDING OF VARIABLES IN MULTIVARIATE ANALYSIS

ADDING A POINT TO VECTOR DIAGRAMS IN MULTIVARIATE ANALYSIS

ON THE EXACT DISTRIBUTION OF A TEST IN MULTIVARIATE ANALYSIS

THE DISTRIBUTION OF THE LARGEST ROOT OF A MATRIX IN MULTIVARIATE ANALYSIS

PERCENTAGE POINTS OF THE LARGEST ROOT OF A MATRIX IN MULTIVARIATE ANALYSIS

TRIBUTION OF THE LARCEST OF SIX ROOTS OF A MATRIX IN MULTIVARIATE ANALYSIS

IBUTION OF THE LARGEST OF SEVEN ROOTS OF A MATRIX IN MULTIVARIATE ANALYSIS

PROPERTIES OF LATENT ROOT AND VECTOR METHODS USED IN MULTIVARIATE ANALYSIS

IHOOD-RATIO TEST OF THE CENERAL LINEAR HYPOTHESIS IN MULTIVARIATE ANALYSIS

AMS 681825

BIOKA66 525

AMS $64 \quad 735$

JASA $67 \quad 1201$

TECH $68 \quad 578$

AMS 631452

$\begin{array}{lrr}\text { JASA } & 68 \quad 964\end{array}$

AMS $67 \quad 464$

AMS $67 \quad 992$

AMS $68 \quad 347$

AMS $67 \quad 325$

JASA $65 \quad 905$

BIOCS66 747

/ BIOKA55 258

BIOKA63 403

AMS $63 \quad 1270$

AMS $65 \quad 150$

JASA $67 \quad 607$

AMS $69 \quad 549$

BIOKA52 17

BIOKA59 49

BIOKA67 357

BIOKA6B 582

JRSSB58 108

ON AMS $67 \quad 616$

UPPER BIOKA67 189

ON THE DIS BIOKA59 237

ON THE DISTR BIOKA64 270

SOME DISTANCE BIOKA66 325

POWER OF THE LIKEL BIOKA64 467 
OF THE LARGEST OR THE SMALLEST ROOT OF A MATRIX IN MULTIVARIATE ANALYSIS A MATRIX USED IN DERIVING TESTS OF SIGNIFICANCE IN MULTIVARIATE ANALYSIS TARY SYMMETRIC FUNCTIONS OF THE ROOTS OF A MATRIX IN MULTIVARIATE ANALYSIS THE ZERO OF A FUNCTION OF THE DISPERSION MATRIX IN MULTIVARIATE ANALYSIS FOR THE DETERMINANT OF A NON-CENTRAL B STATISTIC IN MULTIVARIATE ANALYSIS RAMETRIC GENERALIZATIONS OF ANALYSIS OF VARIANCE AND MULTIVARIATE ANALYSIS THE GENERALIZED B STATISTIC AND F STATISTICS AND IN MULTIVARIATE ANALYSIS PROGRAMMING UNIVARIATE AND MULTIVARIATE ANALYSIS ADMISSIBLE TESTS IN MULTIVARIATE ANALYSIS OF VARIANC

SIMULTANIOUS TEST PROCEDURES IN MULTIVARIATE ANALYSIS OF VARIANCE HOTELLING'S GENERALIZED T SQUARE IN THE MULTIVARIATE ANALYSIS OF VARIANCE

NON-CENTRAL DISTRIBUTIONS OF TWO TEST CRITERIA IN MULTIVARIATE ANALYSIS OF VARIANCE

MONOTONICITY PROPERTY OF THE THREE MAIN TESTS FOR MULTIVARIATE ANALYSIS OF VARIANCE BETWEEN TWO/ ON CONFIDENCE BOUNDS ASSOCIATED WITH MULTIVARIATE ANALYSIS OF VARIANCE COVARIANCE CASE, CORR. 641296 IALLY FOR GROWTH CURVE PROBLEMS MULTIVARIATE ANALYSIS OF

ON THE DISTRIBUTION BIOKA56 122 THE CONSTRUCTION OF BIOKA64 503 THE MOMENTS OF ELEMEN AMS 611152 AN ALGORITHM FOR OBTAINING JASA $67 \quad 114$ AN ASYMPTOTIC DISTRIBUTION SASJ $68 \quad 77$ /INTRODUCTION TO SOME NON-PA BIOKA56 361 ITHE SMALLEST LATENT ROOT OF AMS 671152 TECH 6395 AMS $6769 \mathrm{~B}$ BIOKA68 4B9 JRSSB $63 \quad 358$ ON THE AMS $68 \quad 215$ ON THE JRSSB64 77 A COMPARISON OF THE POWERS OF TWO MULTIVARIATE ANALYSIS OF VARIANCE TESTS $\begin{array}{llll} & \text { A COMPARISON OF THE POWERS OF TWO MULTIVARIATE ANALYSIS OF VARIANCE TESTS } \\ \text { CORRIGENDA, 'A COMPARISON OF THE POWERS OF TWO MULTIVARIATE ANALYSIS OF VARIANCE TESTS. ' } & \text { B TIOKA62 } 455 \\ \text { BIOKA63 546 }\end{array}$ MENTS EXPERIMENTS APPLICATION OF MULTIVARIATE ANALYSIS OF VARIANCE TO REPEATED MEASURE BIOCS66 8IO I/ ON THE ROBUSTNESS OF THE T-SQUARE-SUB-O TEST IN MULTIVARIATE ANALYSIS OF VARIANCE WHEN VARIANCE-COVAR BIOKA64 7I PROCESSES ON THE MULTIVARIATE ANALYSIS OF WEAKLY STATIONARY STOCHASTIC AMS 64 1765 ON V/ TESTS OF LINEAR HYPOTHESES IN UNIVARIATE AND MULTIVARIATE ANALYSIS WHEN THE RATIOS OF THE POPULATI BIOKA54 19 OMPARISON OF TESTS OF THE WILKS-LAWLEY HYPOTHESIS IN MULTIVARIATE ANALYSIS. SYMMETRIC FUNCTIONS OF THE ROOTS OF TWO MATRICES IN MULTIVARIATE ANALYSIS.

OF THE LARGEST CHARACTERISTIC ROOT OF A MATRIX IN MULTIVARIATE ANALYSIS. ACOBIANS OF CERTAIN MATRIX TRANSFORMATIONS USEFUL IN MULTIVARIATE ANALYSIS. ACOBIANS OF CERTAIN MATRIX TRANSFORMATION USEFULL IN MULTIVARIATE ANALYSIS BASED ON LECTURES BY P.L. HSU BIOKA5I 345 NOTE ON ITHE \& BIOKA53 43 DISTRIBUTIONS NOTE ON THE MULTIVARIATE AND THE GENERALIZED MULTIVARIATE BETA JASA 69 ONICAL FACTORIZATION OF A SPECT/ON THE FITTING OF MULTIVARIATE AUTOREGRESSIONS. AND THE APPROXIMATE CAN BIOKA63

AN APPROXIMATE DEGREES OF FREEDOM SOLUTION TO THE MULTIVARIATE BEHRENS-FISHER PROBLEM

MULTIVARIATE NORMALITY THE NON-CENTRAL MULTIVARIATE BETA DISTRIBUTION MULTIVARIATE BETA DISTRIBUTION AND A TEST FOR BIOKAG5 AMS $61 \quad 104$ $\begin{array}{rr}\text { AMS } 61 & 104 \\ \text { JRSSB } 68 & 511\end{array}$ OF TWO MATRICES SOME RESULTS ON THE NON-CENTRAL MULTIVARIATE BETA DISTRIBUTION AND MOMENTS OF TRACES NOTE ON THE UULTIVARTATE AND THE GENER BUTION OF A MULTIPLE CORRELATION MATRIX, NON-CENTRAL MULTIVARIATE BETA DISTRIBUTIONS ERTIES OF THE WISHART DISTRIBUTIONS, CORR, 66297 MULTIVARIATE BETA DISTRIBUTIONS AND INDEPENDENCE PROP THE NONCENTRAL MULTIVARIATE BETA TYPE TWO DISTRIBUTION

G P/ ON THE COMPOUND MULTINOMIAL DISTRIBUTION, THE MULTIVARIATE BETA-DISTRIBUTION, AND CORRELATIONS AMON BIOKAG2 65 VECTOR FORMS

TO CONTINUOUS PARAMETER PROCESSES

A MULTIVARIATE CENTRAL LIMIT THEOREM FOR RANDOM LINEAR

SOME MULTIVARIATE CHEBYSHEV INEQUALITIES WTTH- EXTENSIONS

\section{SOME DISTRIBUTION-FREE MULTIVARIATE COMPARISON PROCEDURES
MULTIVARIATE COMPETITION PROCESSES \\ SOME DISTRIBUTION-FREE MULTIVARIATE COMPARISON PROCEDURES
MULTIVARIATE COMPETITION PROCESSES}

CLASSICAL STATISTICAL ANALYSIS BASED ON A CERTAIN MULTIVARIATE COMPLEX GAUSSIAN DISTRIBUTION UCTION STATISTICAL ANALYSIS BASED ON A CERTAIN FURTHER CONTRIBUTIONS TO MULTIVARIATE CONFIDENCE BOUNDS

A NOTE ON 'FURTHER CONTRIBUTIONS TO MULTIVARIATE CONFIDENCE BOUNDS

CORRIGENDA, 'FURTHER CONTRIBUTIONS TO MULTIVARIATE CONFIDENCE BOUNDS'

AND CONTINUOUS VARIABLES, CORR. 65343

MULTIVARIATE CORRELATION MODELS WITH MIXED DISCRETE

ONE-WAY LAYOUT

MAXIMUM LIKELIHOOD ESTIMATION OF MULTIVARIATE COVARI YAXTMUM LIKELIHOOD ESTIMATION WITH INCOMPLETE MULTIVARIATE DATA

COMP/ A METHOD OF ESTIMATION OF MISSING VALUES IN MULTIVARIATE DATA SUITABLE FOR USE WITH AN ELECTRONIC J GAUSSIAN VARIATES A NONPARAMETRIC ESTIMATE OF A MULTIVARIATE DENSITY FUNCTION SOME MULTIVARIATE DENSITY FUNCTIONS OF PRODUCTS OF NONCENTRAL MULTIVARIATE DIRICHLET DISTRIBUTIONS

DISTRIBUTION OF HOTELLING'S GENERALIZED MEASURE OF MULTIVARIATE DISPERSION

A NOTE ON THE CIRCULAR MULTIVARIATE DISTRIBUTION
MBINATIONS OF THE PARAMETERS IN THE MEAN VECTOR OF A MULTIVARIATE DISTRIBUTION LIZATION OF SVERDRUP'S LEMMA AND ITS APPLICATIONS TO MULTIVARIATE DISTRIBUTION THEORY ON METHODS OF ASYMPTOTIC APPROXIMATION FOR MULTIVARIATE DISTRIBUTIONS DISTRIBUTION OF LINEAR SYSTEMATIC STATISTICS FROM MULTIVARIATE DISTRIBUTIONS OF INDEPENDENCE IN CERTAIN FAMILIES OF BIVARIATE AND MULTIVARIATE DISTRIBUTIONS ASYMPTOTIC JOINT JASA 69300 CHARACTERIZATIONS AMS 68433 A NOTE ON MULTIVARIATE DISTRIBUTIONS WITH SPECIFIED MARGINALS JASA 671460 A SOLUTION TO THE PROBLEM OF LINKING MULTIVARIATE DOCUMENTS

POPULATIONS GENERALIZED MULTIVARIATE ESTIMATOR FOR THE MEAN OF FINITE A MULTIVARIATE EXPONENTIAL DISTRIBUTION PARAMETER ESTIMATION FOR A MULTIVARIATE EXPONENTIAL DISTRIBUTION TESTS OF COMPOSITE HYPOTHESES FOR THE MULTIVARIATE EXPONENTIAL FAMILY, CORR. 671928 MULTIVARIATE EXPONENTIAL-TYPE DISTRIBUTIONS

R-TEST

A MULTIVARIATE EXTENSION OF FRIEDMAN'S CHI-SQUARE-SUBA COUNTER-EXAMPLE RELATING TO CERTAIN MULTIVARIATE GENERALIZATIONS OF T AND $F$ NOTE ON MULTIVARIATE GOODNESS-OF-FIT TESTS

PONER COMPARISONS OF TESTS OF TWO MULTTUARIATE HYPOTHESES BASED ON FOUR CRITERIA

A MULTIVARIATE IMMIGRATION WITH MULTIPLE DEATH PROCESS AND APPLICATIONS TO LUNAR CRATERS A REDUCTION FORMULA FOR NORMAL MULTIVARIATE INTEGRALS

DISTRIBUTION OF THE LIKELIHOOD RATIO FOR TESTING MULTIVARIATE LINEAR HYPOTHESES TONICITY OF THE POWER FUNCTIONS OF SOME TESTS OF THE MULTIVARIATE LINEAR HYPOTHESIS L DISTRIBUTIONS OF THE LIKELIHOOD RATIO CRITERIA FOR MULTIVARIATE LINEAR HYPOTHESIS AND INDEPENDENCE /UL
RESTRICTIONS
MULTIVARIATE LINEAR HYPOTHESIS WITH LINEAR MULTIVARIATE LINEAR HYPOTHESIS WITH LINEAR

STEPWISE MULTIVARIATE LINEAR REGRESSION A THEOREM ON LEAST SQUARES AND VECTOR CORRELATION IN MULTIVARIATE LINEAR REGRESSION A THEOREM ON LEAST SQUARES IN MULTIVARIATE LINEAR REGRESSION MULTIVARIATE LINEAR STRUCTURAL RELATIONS ASYMPTOTICALLY NEARLY EFFICIENT ESTIMATORS OF MULTIVARIATE LOCATION PARAMETERS NONPARAMETRIC CONFIDENCE REGIONS FOR SOME MULTIVARIATE LOCATION PROBLEMS

JASA $69 \quad 163$ JASA 671009 JASA $67 \quad 30$ JASA $6 B \quad 84 B$ AMS $67 \quad 681$ AMS $68 \quad 1316$ JASA 69 N0. 4 AMS $67 \quad 613$ AMS $62 \quad 807$ BIOKA67 195 BIOKA67 251 BIOKA54 351 AMS $61 \quad 333$ AMS 64200 AMS 69942 JRSSB $63 \quad 348$ JASA $63 \quad 770$ JASA $66 \quad 413$ JASA $67 \quad 1494$ BIOKA58 136 AMS 691809 JASA $68 \quad 1373$ BABILITY MODEL IN POPULATION AND COMMUNITY ECOLOG/ MULTIVARIATE LOGARITHMIC SERIES DISTRIBUTION AS A PRO JASA 67 655 
ON ELEMENTARY SYMMETRIC FUNCTIONS OF THE ROOTS OF A MULTIVARIATE MATRIX DISTRIBUTIONS DERIVATIVES

NOTE ON COMBINING CORRELATED ESTIMATES OF A RATIO OF MULTIVARIATE MEAN, CONFIDENCE SETS FOR MULTIVARIATE MEDIANS

STRUCTURAL PROBABILITY AND PREDICTION FOR THE MULTIVARIATE MODEL MULTIVARIATE NONPARAMETRIC SEVERAL-SAMPLE TESTS

ON CONSERVATIVE CONFIDENCE REGIONS FOR THE MEAN OF A MULTIVARIATE NORMAL PROBABILITY INTEGRALS OF MULTIVARIATE NORMAL AND MULTIVARIATE T

SOME RESULTS ON THE ORDER STATISTICS OF THE MULTIVARIATE NORMAL AND PARETD TYPE 1 POPULATIONS A NOTE

N OF PROBABILITIES OF CONVEX POLYHEDRA UNDER MULTIVARIATE NORMAL AND T-DISTRIBUTIDNS POSTERIOR ODDS FOR MULTIVARIATE NORMAL CLASSIFICATION

A CHARACTERIZATION OF THE MULTIVARIATE NORMAL DISTRIBUTION MOMENTS OF ORDER STATISTICS FROM THE EQUICORRELATED MULTIVARIATE NORMAL DISTRIBUTION A CHARACTERISTIC PROPERTY OF THE MULTIVARIATE NORMAL DISTRIBUTION ABSOLUTE AND INCOMPLETE MOMENTS OF THE MULTIVARIATE NORMAL DISTRIBUTION A NOTE ON THE EQUICORRELATED MULTIVARIATE NORMAL DISTRIBUTION ORTHANT PROBABILITIES FOR THE EQUICORRELATED MULTIVARIATE NORMAL DISTRIBUTION BAYESIAN ESTIMATION OF PARAMETERS OF A MULTIVARIATE NORMAL DISTRIBUTION A CENTRAL TOLERANCE REGION FOR THE MULTIVARIATE NORMAL DISTRIBUTION ONFIDENCE, PREDICTION, AND TOLERANCE REGIDNS FOR THE MULTIVARIATE NORMAL DISTRIBUTION CONFIDENCE SETS FOR THE MEAN OF A MULTIVARIATE NORMAL DISTRIBUTION (WITH DISCUSSION) $\begin{array}{lrr}\text { IONS } & \text { AMS } 64 & 1815 \\ \text { ON THE E JRSSB66 } & 366\end{array}$ JRSSB $64 \quad 69$ AMS $62 \quad 533$ AMS $6212 \mathrm{~B} 6$ AMS $661 \mathrm{~B} 29$ BIOKA6I 77 BIOKA62 269 BIOKA62 433 JRSSB $65 \quad 279$ JRSSB6B 599

C JASA $66 \quad 605$ JRSSB62 265 DICHOTOMISED. ESTIMATION OF THE PARAMETERS FOR A MULTIVARIATE NORMAL DISTRIBUTION WHEN ONE VARIABLE IS BIOKA65 664 MAXIMUM LIKELIHOOD ESTIMATES FOR A MULTIVARIATE NORMAL DISTRIBUTION WHEN SOME OBSERVATIO JASA 57 200 ESTIMATION OF PARAMETERS IN THE MULTIVARIATE NORMAL DISTRIBUTION WITH MISSING OBSERVA JASA 6B 159 NS ARE MISSINC TIONS NS INCOMPLETE AND ABSOLUTE MOMENTS OF THE MULTIVARIATE NORMAL DISTRIBUTION WITH SOME APPLICATIO BIDKA53 20 ASYMPTOTICALLY OPTIMAL TESTS FOR MULTIVARIATE NORMAL DISTRIBUTIONS

RECTANGULAR CONFTDENCE REGIONS FOR THE MEANS OF MULTIVARIATE NORMAL DISTRIBUTIONS THE MEANS OF MULTIVARIATE NORMAL DISTRIBUTIONS JASA 67626 ANCE MATRICES CLASSIFICATION INTO TWO MULTIVARIATE, NORMAL DISTRIBUTIONS WITH DIFFERENT COVA IONS OF SOME TESTS CONCERNING DISPERSION MATRICES OF MULTIVARIATE NORMAL DISTRIBUTIONS. /OF PDWER FUNCT A NOTE ON THE EVALUATION OF THE MULTIVARIATE NORMAL INTEGRAL REDUCTION OF THE MULTIVARIATE NORMAL INTECRAL TO CHARACTERISTIC FORM THE NUMERICAL EVALUATION OF CERTAIN MULTIVARIATE NORMAL INTEGRALS BIBLIOGRAPHY ON THE MULTIVARIATE NORMAL INTECRALS AND RELATED TOPICS NVARIANT SEQUENTIAL PROBABILITY RATIO TESTS BASED ON MULTIVARIATE NORMAL OBSERVATIONS /BABILITY ONE OF I APPROXIMATIONS TO MULTIVARIATE NORMAL ORTHANT PROBABILITIES

POSTERIOR DISTRIBUTIONS FOR MULTIVARIATE NORMAL PARAMETERS ILITY OF THE USUAL CONFIDENCE SETS FOR THE MEAN OF A MULTIVARIATE NORMAL POPULATION SORED SAMPLES

LDSS FUNCTION

ESTIMATIDN OF PARAMETERS OF A MULTIVARIATE NORMAL POPULATION $\begin{array}{rr}\text { AMS } 63 & 191 \\ \text { JRSSB } 63 & 368\end{array}$ AMS $62 \quad 420$ AMS 69697 BIOKA53 45B BIOKA67 293 AMS $62 \quad 571$ AMS $63 \quad 829$ AMS 678 CLASSIFICATION RULES FOR CLASSIFICATION INTO TWD MULTIVARIATE NORMAL POPULATIONS RISTIC ROOT UNDER NULL HYPOTHESIS CONCERNING COMPLEX MULTIVARIATE NORMAL POPULATIONS DN MULTIVARTATE NORMAL PROBABILITIES DF RECTANCLES QUARED AND OTHER FULLY INVARIANT TESTS FOR CLASSICAL MULTIVARIATE NORMAL PROBLEMS /TER DF T-SQUARED, R-S ASYMPTDTIC EFFICIENCY OF MULTIVARIATE NORMAL SCORE TEST

MULTIVARIATE BETA DISTRIBUTION AND A TEST FOR MULTIVARIATE NORMALITY ASSESSING THE ACCURACY OF MULTIVARIATE DBSERVATIONS

THE THEORY OF RANK ORDER TESTS FOR LDCATION IN THE MULTIVARIATE ONE SAMPLE PROBLEM RANK ORDER TESTS FOR MULTIVARIATE PAIRED COMPARISONS NIVARIATE MODEL AND ASSOCIATED ESTIMATION AND TES/ MULTIVARIATE PALEONTOLOGICAL CROWTH PROBLEM MULTIVARIATE PARETD DISTRIBUTIONS, CORR. 631603

A NDTE ON REGRESSION IN THE MULTIVARIATE POISSON DISTRIBUTION APPLTCATTONS OF MULTIVARTATE POIYKAYS TD THE THEORY OF UNBIASED RATIO J

-TYPE ESTIMATION APPLICATIONS OF MULTIVARIATE POLYKAYS TD
EANS FROM FINITE MULTIVARIATE POPULATIONS SAMPLING MOMENTS OF MEANS FROM FINITE MULTIVARIATE POPULATIONS

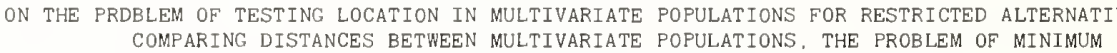

DISTANCES DN MULTIVARIATE PREDICTION INTERVALS FOR SAMPLE MEAN AND J COVARIANCE BASED ON PARTIAL OBSERVATIONS UNBIASED ESTIMATION OF SOME MULTIVARIATE PROBABILITY DENSITIES

CUBICAL AND SPHERICAL ESTIMATION OF MULTIVARIATE PROBABILITY DENSITY LOCALLY AND ASYMPTOTICALLY MINIMAX TESTS OF A MULTIVARIATE PROBLEM AN APPLICATION OF MULTIVARIATE QUALITY CONTROL TO PHOTOGRAPHIC PROCESSI J MULTIVARIATE QUANTAL ANALYSIS

ON MULTIVARIATE RATIO AND PRODUCT ESTIMATORS MULTIVARIATE RATIO ESTIMATION FOR FINITE POPULATIONS CONFIDENCE LIMITS FOR MULTIVARIATE RATIOS ON THE BAYESIAN ESTIMATION OF MULTIVARIATE RECRESSION MULTIVARIATE RECRESSION OF DUMMY VARIATES UNDER

NORMALITY ASSUMPTIONS MULTIVARIATE RECRESSION OF DUMMY

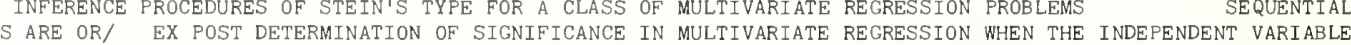
METHOD MISSING OBSERVATIONS IN MULTIVARIATE RECRESSION, EFFICIENCY OF A FIRST ORDER POISSON LIMITS OF MULTIVARIATE RUN DISTRIBUTIONS
THE MULTIVARIATE SADDLE POINT METHOD THE MULTIVARIATE SADDLE POINT METHOD AND CHI-SQUARED FOR

THE MULTINOMIAL DISTRIBUTION ESTIMATION OF PARAMETERS FROM INCOMPLETE MULTIVARIATE SAMPLES AN EMPIRICAL EVALUATION FOR THE MULTIVARIATE SIGN TEST NOTE ON A CHI-SQUARE APPROXIMATION FOR THE MULTIVARIATE SIGN TEST
ON MULTIVARIATE SICN TESTS

FOR SELECTING THE MOST EFFECTIVE DISCRIMINATORS IN A MULTIVARIATE SITUATION /NONICAL ANALYSIS, A METHOD BEST LINEAR UNBIASED ESTIMATION FOR MULTIVARIATE STATIONARY PROCESSES TS WITH MONOTONE POWER FUNCTIONS FOR TWO PROBLEMS IN MULTIVARIATE STATISTICAL ANALYSIS STEREOSCOPIC MODELS OF MULTIVARIATE STATISTICAL DATA TECH $68 \quad 523$ A CLASS OF TES AMS 651794 BI0CS66 35B

E LINEAR REGRESSION MISSING OBSERVATIONS IN MULTIVARIATE STATISTICS II. POINT ESTIMATION IN SIMPL J J MISSINC VALUES IN MULTIVARIATE STATISTICS, I. REVIEW OF THE LITERATURE MISSING OBSERVATIONS IN MULTIVARIATE STATISTICS, III MISSING OBSERVATIONS IN MULTIVARIATE STATISTICS, IV 10 $\begin{array}{lll}\text { JASA } & 66 & 595 \\ \text { JASA } & 69 & 337\end{array}$ JASA $69 \quad 359$ CENTRAL WISHART DISTRIBUTION AND CERTAIN PROBLEMS OF MULTIVARIATE STATISTICS', 46409 /ECTION. 'THE NON- AMS 64 923 COEFFICIENTS MULTIVARIATE STOCHASTIC PROCESSES WITH PERIODIC 
AMS $63 \quad 873$

EXPONENTIAL SMOOTHING FOR MULTIVARIATE TIME SERIES

CONTINUOUS VARIABLES I. THE LOCATION MODEL MULTIVARIATE TWO SAMPLE TESTS WITH DICHOTOMOUS AND

PREDIGTION THEORY

HOD FOR SELECTING THE MOST EFFECTIVE DISCRIMINATO/ MULTIVARIATE WIDE-SENSE MARKOV PROCESSES AND MULTIVARIATE-COVARIANCE AND CANONICAL ANALYSIS. A ME MULTIVARIATE-NORMAL CLASSIFICATION WITH COVARIANCE NOTE ON A 'MULTIVARIATE' FORM OF BONFERRONI'S INEQUALITIES A MODEL FOR CHEMICAL MUTAGENESIS IN BACTERIOPHAGE

QUERY + (ON FORMULA FOR DETERMINING THE INCIDENCE OF MUTANT GENES) SIMPLEX LATTICE DESIGNS FOR MUTICOMPONENT SYSTEMS CORREGTION TO 'ON THE MUTUAL INDEPENDENCE OF CERTAIN STATISTICS' 591258
MUTUAL INFORMATION AND MAXIMAL CORRELATION AS MEASURES OF DEPENDENCE A NOTE ON MUTUAL SINGULARITY OF PRIORS

ON METHODS OF CONSTRUCTING SETS OF MUTUALLY ORTHOGONAL LATIN SQUARES USING A COMPUTER ON METHODS OF CONSTRUCTING SETS OF MUTUALLY ORTHOGONAL LATIN SQUARES USING A COMPUTER HE MAIN EFFECTS AND INTERACTIONS IN A 2 TO THE POWER N FACTORIAL EXPERIMENT AS CALGULATED BY YATES'S ALGOR BIOCS67 571 LASS OF NON-ORTHOGONAL MAIN EFFECT PLANS IN K TO THE N FACTORIALS/APPROACH FOR CONSTRUCTING A USEFUL C JRSSBGB 37 I ESTIMATION OF THE PARAMETER N IN THE BINOMIAL DISTRIBUTION JASA 68 150 $R$ WHEN WALKING TIME AND REPAIR/ THE EFFICIENGY OF N MAGHINES UNI-DIRECTIONALLY PATROLLED BY ONE OPERATO JRSSB57 166 $R$ WHEN WALKING TIME IS CONSTANT/ THE EFFICIENCY OF N MACHINES UNI-DIRECTIONALLY PATROLLED BY ONE OPERATO JRSSB57 173 'N BENADERING VIR ' $N$ MAGREEKS WAARSKYNLIKHEIDSVERDELING SASJ 69 NO.2 ESTIMATION OF A RANDOM PROBABILITY WHOSE FIRST N MOMENTS ARE KNOWN ASYMPTOTICALLY EFFICIENT TESTS BY THE METHOD OF N RANKINGS THE ROBUSTNESS OF HOMOGENETTY TESTS IN 2 BY N TABLES

ON IDENTITY RELATIONSHIPS FOR TWO TO THE POWER OF N-R DESIGNS HAVING WORDS OF EQUAL LENGTHS

A NOTE ON THE DETERMINATION OF CONNECTEDNESS IN AN N-WAY CROSS CLASSIFICATION

A NOTE ON THE DETERMINATION OF CONNECTEDNESS IN AN N-WAY CROSS CLASSIFICATION' ASYMPTOTIC EXPANSIONS ASSOCIATED WITH THE N'TH POWER OF A DENSITY

TEXTS

DENSITY JRSSB 312 AMS 661842 TECH $64 \quad 319$ 2B1 65 BIOKA54 116 BIOKA5B 567 STATISTICAL DISCREPANCY IN THE REVISED UNITED STATES NATIONAL AGCOUNTS

TECHNIQUE TO PRODUCE AREA BREAKDOWNS OF THE MONTHLY NATIONAL ESTIMATES OF RETAIL TRADE /OF A REGRESSION JASA 66 496 PROBLEMS OF THE HOUSEHOLD INTERVIEW DESIGN FOR THE NATIONAL HEALTH SURVEY COUNTRIES NATIONAL INCOME STATISTICS OF UNDERDEVELOPED SOME JASA $59 \quad 69$ JASA $57 \quad 162$ JASA 58948 ATISTICAL ANALYSIS OF PROVISIONAL ESTIMATES OF GROSS NATIONAL PRODUCT AND ITS COMPONENTS, OF SELECTED NATI JASA 58 54 ERRORS IN THE 1960 CENSUS ENUMERATION OF NATIVE WHITES

ASYMPTOTIC RENEWAL RESULTS FOR A NATURAL GENERALIZATION OF CLASSICAL RENEWAL THEORY THE POLYKAYS OF THE NATURAL NUMBERS

MATHEMATICAL PROBABILITY IN THE NATURAL SCIENCES

DISTRIBUTION-FREE TOLERANCE INTERVALS OF A GENERAL NATURE

DESIGN OF EXPERIMENTS FOR INFINITELY MANY STATES OF NATURE FRACTIONAL FACTORIAL PLANS

OOD RATIO TEST STATISTIC WHEN THE TRUE PARAMETER IS JRSSB $67 \quad 141$ BIOKA60 53 TECH 5921 THE SEQUENTIAL AMS 61771 AMS 691840 'NEAR' THE BOUNDARIES OF THE HYPOTHESIS REGIONS/LIH AMS 6B 2044 NEAREST NEIGHBOURS IN A POISSON ENSEMBLE

THE DISTANCE FROM A RANDOM POINT TO THE NEAREST POINT OF A COSELY PACKED LATTICE.

BIOKA69 401 BIOKA65 261 JOINT PROBABILITY APPROACHES IN THE SPECIFICATION OF NEAREST-NEIGHBOUR SYSTEMS /NAL PROBABILITY AND THE BIOKA64 481 PARAMETERS ASYMPTOTICALLY NEARLY EFFICIENT ESTIMATORS OF MULTIVARIATE LOCATION AMS 69 I8O9 IBUTION THE DISTRIBUTION OF EXTREMAL AND NEARLY EXTREMAL VALUES IN SAMPLES FROM A NORMAL DISTR BIOKA63 89 OF ESTIMATORS WHEN STRICTLY CONVEX LOSS IS U/ ON A NECESSARY AND SUFFICIENT CONDITION FOR ADMISSIBILITY AMS 68 23 A RANDOM VARIABLE TO BE GAMMA

T-SQUARES ESTIMATORS BE BEST LINEAR UNBIASED PROBLEM TO BE INVARIANT UNDER A LIE GROUP

A NECESSARY AND SUFFIGIENT CONDITION FOR THE SQUARE OF BIOKA66 275 A NECESSARY AND SUFFICIENT CONDITION THAT ORDINARY LEAS JASA 671302 NECESSARY AND SUFFICIENT CONDITIONS FOR A STATISTICAL AMS 63492 A NOTE ON THE 'NECESSARY BEST ESTIMATOR' BRANCHING PROCESS WITH RANDOM ENVIRONMENT NECESSARY CONDITIONS FOR ALMOST SURE EXTINCTION OF AMS 6B 2136

JASA 69 NO 4 RICAL AND UNSYMMETRICAL TRIANGULAR PARTIALLY B/ ON NECESSARY CONDITIONS FOR THE EXISTENCE OF SOME SYMMET AMS 63 $34 B$

ITIES OF MISCL NECESSARY RESTRICTIONS FOR DISTRIBUTIONS A POSTERIORI JRSSB60 312 A MIXTURE OF TWO RECURRENT RANDOM WALKS NEED NOT BE RECURRENT
AMS 681753 
THE OUTER NEEDLE OF SOME BAYES SEQUENTIAL CONTINUATION RECIONS APPROXIMATINC THE NECATIVE BINOMIAL

EFFICIENCY OF CERTAIN METHODS OF ESTIMATION FOR THE NECATIVE BINOMIAL AND NEYMAN TYPE A DISTRIBUTIONS

A METHOD OF ANALYSINC UNTRANSFORMED DATA FROM THE NECATIVE BINOMIAL AND OTHER CONTACIOUS DISTRIBUTIONS A NOTE ON THE NECATIVE BINOMIAL DISTRIBUTION THE TRUNCATED NECATIVE BINOMIAL DISTRIBUTION

SIMPLIFIED METHODS OF FITTING THE TRUNCATED NEGATIVE BINOMIAL DISTRIBUTION A NOTE ON THE NEGATIVE BINOMIAL DISTRIBUTION

BIAS OF MOMENT ESTIMATORS WITH AN APPLICATION TO THE NEGATIVE BINOMIAL DISTRIBUTION S OF THE RECIPROCAL OF A VARIABLE FROM A DECAPITATED NEGATIVE BINOMIAL DISTRIBUTION ON THE EVALUATION OF THE NEGATIVE BINOMIAL DISTRIBUTION WITH EXAMPLES IMATING THE PARAMETERS OF THE LOCARITHMIC SERIES AND NEGATIVE BINOMIAL DISTRIBUTIONS ATES OF THE PARAMETERS OF THE TRUNCATED BINOMIAL AND NEGATIVE BINOMIAL DISTRIBUTIONS NEGATIVE BINOMIAL DISTRIBUTIONS WITH A COMMON K

BIOKA66 455 TECH $66 \quad 345$ BIOKA62 215 BIOKA68 163 TECH 62609 BIOKA55 58 BIOKA58 59 BIOKA64 264 THE BIOKA62 193 IATION JASA $62 \quad 439$ TECH $60 \quad 501$ ON EST BIOKA69 411 'THE USE OF ORTHOGONAL POLYNOMIALS OF POSITIVE AND NECATIVE BINOMIAL FREQUENCY FUNCTIONS IN CURVE FITTIN BIOKA61 476 HE USE OF ORTHOGONAL POLYNOMIALS OF THE POSITIVE AND NEGATIVE BINOMIAL FREQUENCY FUNCTIONS IN CURVE FITTIN BIOKA6I 115 THE RECIPROCAL OF THE DECAPITATED NEGATIVE BINOMIAL VARIABLE. CORR. 631162 ON STABILIZING THE BINOMIAL AND NEGATIVE BINOMIAL VARIANCES

ON TESTING FOR GOODNESS-OF-FIT OF THE NEGATIVE BINOMIAL WHEN EXPECTATIONS ARE SMALL JASA 62906 JASA $61 \quad 143$ BIOCS69 143 NSANSFORMATIONS OF THE BINOMIAL, NEGATIVE BINOMIAL, POISSON AND CHI-SQUARE DISTRIBUTIO
N/ CORRIGENDA TO TRANSFORMATIONS OF THE BINOMIAL, NEGATIVE BINOMIAL, POISSON AND CHI-SQUARE DISTRIBUTIO TRANSFORMATIONS OF THE BINOMIAL, NEGATIVE BINOMIAL, POISSON AND CHI-SQUARE DISTRIBUTIO BIOKA54 ERRATA, 'APPROXIMATINC THE NEGATIVE BINOMIAL'

THE INTERPRETATION OF NEGATIVE COMPONENTS OF VARIANCE

THE EFFECTIVE USE OF BOTH POSITIVE AND NEGATIVE GONTROLS IN SCREENING EXPERIMENTS NECATIVE DYNAMIC PROGRAMMINC

PROBABILITY OF OBTAININC NECATIVE ESTIMATES OF HERITABILITY

THE PROBLEM OF NEGATIVE ESTIMATES OF VARIANCE COMPONENTS

STATIONARY DISTRIBUTIONS OF THE NECATIVE EXPERIMENTAL TYPE FOR THE INFINITE DAN 235 TECH $6749 \mathrm{~B}$ BIOKA54 544 BIOCS67 285 AMS $66 \quad 871$ BIOCS68 517 AMS $62 \quad 273$ JRSSB57 342 UANTILES FOR THE ESTIMATION OF THE PARAMETERS OF THE NEGATIVE EXPONENTIAL DISTRIBUTION /PTOTIC OPTIMUM $Q$ AMS 66 143 DER STATI/ OPTIMUM ESTIMATORS OF THE PARAMETERS OF NEGATIVE EXPONENTIAL DISTRIBUTIONS FROM ONE OR TWO OR AMS 63 II7 ORDER STATISTIC FOR THE PARAMETER OF A ONE-PARAMETER NEGATIVE EXPONENTIAL POPULATION' /DS. BASED ON ONE TECH 64 4B3 R STATISTICS CORR I ESTIMATTNG THE PARAMETERS OF NEGATIVE EXPONENTTAL POPULATIONS FROM ONE OR TWO ORDE AMS 61 107 THE NEGATIVE EXPONENTIAL WITH CUMULATIVE ERROR

EIGENVALUES OF NON-NEGATIVE MATRICES

A NOTE ON THE NEGATIVE MOMENTS OF A TRUNCATED POISSON VARTATE

BIOCS6B 363

AMS 641797

JASA 641220 AN APPROXIMATION OF THE NEGATIVE MOMENTS OF THE POSITIVE BINOMIAL USEFUL IN TECH 60227

LIFE TESTING ONC INVERSELY SAMPLED POLLEN COUN/ ON THE COMPOUND NEGATIVE MULTINOMIAL DISTRIBUTION AND CORRELATIONS AM BIOKA63 47 SSIONS FOR TAIL PROBABILITIES OF THE MULTINOMIAL AND NEGATIVE MULTINOMIAL DISTRIBUTIONS. INTEGRAL EXPRE BIOKA65 167 MOMENTS OF NECATIVE ORDER AND RATIO-STATISTICS JRSSB55 122 TECH 65 r 75

E IN NESTED SAMPLING QUERY. NEGATIVE VARIANCE ESTIMATES NEGATIVE VARIANCE ESTIMATES AND STATISTICAL DEPENDENC JASA 681000 AGE PATTERNS OF MORTALITY OF AMERICAN NEGROES, 1900-02 TO 1959-61 NEAREST NEIGHBOURS IN A POISSON ENSEMBLE

MODEL OF ACHE TRANSPORTATION IN THE PERIPHERAL NERVE TRUNKS

JASA 69433 BIOKA69 401

A STOCHASTIC BIOKA62 447 THE SPECTRUM OF A MODEL II NESTED ANOVA AND ITS APPLICATIONS NESTED BALANCED INCOMPLETE BLOCK DESIGNS

VARIANCE COMPONENTS IN THE UNBALANCED TWO-WAY NESTED GLASSIFICATION $S$ OF VARIANCE COMPONENTS IN THE UNBALANCED THREE-WAY NESTED CLASSIFICATION EXPECTED MEAN SQUARES FOR NESTED CLASSIFICATIONS

VARIANCE COMPONENTS I EMPIRICAL STUDIES OF BALANCED NESTED DESIGN IANCE COMPONENTS II. EMPIRICAL STUDIES OF UNBALANCED NESTED DESIGNS ESTIMATION OF VARIANCE COMPONENTS IN TWO-STAGE NESTED DESIGNS

PROCEDURES FOR ESTIMATING PARAMETERS IN A TWO-STAGE NESTED PROCESS

VARIANCE ESTIMATES AND STATISTICAL DEPENDENCE IN NESTED SAMPLING

ON THE CENSUS SURVIVAL RATIO METHOD OF ESTIMATING NET MIGRATION SURVIVAL RATES IN ESTIMATING INTERCENSAL STATE NET MIGRATION ERRORS IN THE ESTIMATION OF NET MICRATION IN THE STUDIES OF INTERNAL MIGRATION A FAVORABLE SIDE BET IN NEVADA BACCARAT

ON THE RELATIONSHIP BETWEEN EARNING EXPECTATIONS AND NEW CAR PURGHASES /NC VARIANCES OF THE ESTIMATE AMS $63 \quad 521$ BIOCS69 427

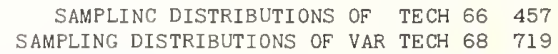
ITH COMPOSITE SAMPLES TECH $67 \quad 373$ /MPARISONS OF DESIGNS AND ESTIMATION TECH $67 \quad 499$ NECATIVE JASA 681000 EVALUATION OF CENSUS JASA 62 B41 JASA 69 NO. 4 JASA $66 \quad 313$ A NOTE JASA 59575 JASA $58 \quad 336$ OMETRIC PARAMETER THE THE RELATIONSHIP BETWEEN NEYMAN AND BAYES CONFIDENCE INTERVALS FOR THE HYPERGE TECH 68 I99 ANDOMIZED BALANCED INCOMPLETE BLOCK DESIGN UNDER THE NEYMAN MODEL /ISTRIBUTION OF THE F-STATISTIC IN A R AMS 63 1558 ON SLIPPAGE TESTS I. A GENERALIZATION OF NEYMAN PEARSON'S LEMMA

METHODS OF ESTIMATION FOR THE NEGATIVE BINOMIAL AND NEYMAN TYPE A DISTRIBUTIONS EFFICIENCY OF CERTAIN BIOKA62 215 BINOMIAL PARAMETER POISSON PARAMETER No. 2. 1956)

TABLE OF NEYMAN-SHORTEST UNBIASED CONFIDENCE INTERVALS FOR THE BIOKA6O TABLES OF NEYMAN-SHORTEST UNBIASED CONFIDENCE INTERVALS FOR THE BIOKA6I COMMENT ON THE NOTES BY NEYMAN. BARTLETT AND WELCH IN THIS JOURNAL (VOL. IB, ON THE DERIVATION AND APPLICABILITY OF NEYMAN'S TYPE A DISTRIBUTION BIVARIATE GENERALIZATIONS OF NEYMAN'S TYPE A DISTRIBUTION GAUSSIAN MEASURES WITH A PARTICULARLY SIMPLE RADON-NIKODYM DERIVATIVE TWEEN RANDOM VARIABLES AND THE DISPERSION OF A RADON-NIKODYM DERIVATIVE (CORR. 65533 ) BIOKA66 241 JRSSB57 179 EQUIVALENT AMS $67 \quad 1027$ RESULT ON THE RELFVANCE OF THE DISPERSION ON RADON-NIKODYM DERIVATIVES OF GAUSSIAN MEASURES RADON-NIKODYM DERIVATIVES OF STATIONARY GAUSSIAN MEASURES

LEADING AMERICAN STATISTICIANS IN THE NINETEENTH CENTURY

LEADING BRITISH STATISTICIANS OF THE NINETEENTH CENTURY

LEADING AMERICAN STATISTICIANS OF THE NINETEENTH CENTURY II

SOME EXTENSIONS OF THE WALD-WOLFOWITZ-NOETHER THEOREM REGRESSION WITH SYSTEMATIC NOISE

THE DISTRIBUTION OF THE FIRST SAMPLE MOMENTS OF SHOT NOISE ETE WAVEFORM WHICH IS RANDOMLY REPEATING IN GAUSSIAN NOISE YSTEMS, ARBITRARY SYSTEM PROCESS WITH ADDITIVE WHITE NOISE OBSERVATIONS ERROR FREQUENCY RESPONSE FROM STATIONARY NOISE, TWO CASE HISTORIES ON THE CODINC THEOREM FOR NOISELESS CHANNEL 
MAXIMUM LIKELIHOOD NTS, CORR, 62917 INTECRAL
A NOMOCRAM FOR THE 'STUDENT' "FISHER T TEST NOMOCRAMS FOR FITTING THE LOGISTIC FUNCTION BY THE NON-ABSOLUTE CONVERCENCE OF CIL-PELAEZ' INUERSION AMS 6133 NON-ADDITIVITIES IN A LATIN SQUARE DESIGN JASA 57218 POWER OF TUKEY'S TEST FOR NON-ADDITIVITY

THE INTERPRETATION OF THE EFFECTS OF NON-ADDITIVITY IN THE LATIN SQUARE NON-ADDITIVITY IN TWO-WAY ANALYSIS OF VARIANCE

NOTES. ESTIMATION OF NON-LINEAR PARAMETERS FOR A NON-ASYMPTOTIC FUNCTION

ABILITY OF CONSUMER ATTITUDES, STOCK PRICES, AND NON-ATTITUDINAL VARIABLES A CROSS-SECTION ANALYSIS OF NON-BUSINESS AIR TRAVEL THE PREDICTIVE JASA 64987 JASA 58928 AN ASYMPTOTIC DISTRIBUTION FOR THE DETERMINANT OF A NON-CENTRAL B STATISTIC IN MULTIVARIATE ANALYSIS
BUTIONS OF QUADRATIC FORMS IN NORMAL VARIABLES, II, NON-CENTRAL CASE 68 T7
SERIES REPRESENTATIONS OF DISTR AMS 67 B38 TABLE OF PERCENTACE POINTS OF NON-CENTRAL CHI BIOKA69 255 BIOKA59 364 NOTE ON AN APPROXIMATION TO THE DISTRIBUTION OF NON-CENTRAL CHI-SQUARE

PPER 5 PERCENT POINTS OF FISHER'S B DISTRIBUTION AND NON-CENTRAL CHI-SQUARE APPROXIMATIONS TO THE U B

A CONTOUR-INTECRAL DERIVATION OF THE NON-CENTRAL CHI-SQUARE DISTRIBUTION ANOTHER DERIVATION OF THE NON-CENTRAL CHI-SQUARE DISTRIBUTION

ON THE NON-CENTRAL CHI-SQUARE DISTRIBUTTON

APPROXIMATIONS TO THE NON-CENTRAL CHI-SQUARE DISTRIBUTION ERCENTAGE POINTS AND THE PROBABILITY INTEGRAL OF THE NON-CENTRAL CHI-SQUARE DISTRIBUTION A NOTE ON THE MAXIMIZATION OF A NON-CENTRAL CHI-SQUARE PROBABILITY THE DISTRIBUTION OF THE PRODUCT OF TWO CENTRAL OR NON-CENTRAL CHI-SQUARE VARIATES LINEAR COMBINATIONS OF NON-CENTRAL CHI-SQUARE VARIATES

THE NON-CENTRAL CHI-SQUARED AND BETA DISTRIBUTIONS

OF THE TRACE OF A MATRIX AND APPROXIMATIONS TO ITS NON-CENTRAL DISTRIBUTION

ON THE NON-CENTRAL DISTRIBUTION OF THE SECOND ELEMENTARY SYM SOME NON-CENTRAL DISTRIBUTION PROBLEMS IN MULTIVARIATE

METRIC FUNCTION OF THE ROOTS OF A MATRIX ANALYSIS

SOME INEQUALIT AND NON-CENTRAL DISTRTBUTIONS

MULTIVARIATE ANALYSIS OF VARIANCE PROPERTIES OF THE DISTRIBUTION OF THE LOGARITHM OF NON-CENTRAL F

A NOTE ON APPROXTMATING TO THE NON-CENTRAL F DISTRIBUTION

NORMAL APPROXIMATION TO THE CHI-SQUARE AND NON-CENTRAL F PROBABILITY FUNCTIONS

BIOKAG3 2309

/ULAE FOR THE P BIOKA54 538

AMS $64 \quad 441$

AMS 621016

AMS $66 \quad 480$

BIOKA63 542

AMS 661312

AMS $68 \quad 833$

AMS 631270

AMS 651521 AMS $68 \quad 215$

SOME BIOKA60 417

BIOKA66 606 BIOKA60 411 ION FOR ANALYSIS OF VARIANCE TESTS, DERIVED FROM THE NON-CENTRAL F-DISTRIBUTION/ARTS OF THE POWER FUNCT BIOKA5I II2 SOME NON-CENTRAL F-DISTRIBUTIONS EXPRESSED IN CLOSED FORM BIOKA64 107 THE NON-CENTRAL MULTIVARIATE BETA DISTRIBUTION

$S$ OF TRACES OF TWO MATRICES SOME RESULTS ON THE NON-CENTRAL MULTIVARIATE BETA DISTRIBUTION AND MOMENT

THE DISTRIBUTION OF A MULTIPLE CORRELATION MATRIX, NON-CENTRAL MULTIVARIATE BETA DISTRIBUTIONS

OF DEFINITE AND OF INDEFINITE QUADRATIC FORMS FROM A NON-CENTRAL NORMAL DISTRIBUTION DISTRIBUTION

DISTRIBUTION OF A DEFINITE QUADRATIC FORM FOR NON-CENTRAL NORMAL VARIATES, CORR, 63673

THE MOMENTS OF A VARIATE RELATED TO THE NON-CENTRAL T

AN APPROXIMATION TO THE DISTRIBUTION OF NON-CENTRAL T

TO THE DISTRIBUTION OF Q. A VARIATE RELATED TO THE NON-CENTRAL T

VARIATIONS OF THE NON-CENTRAL T AND BETA DISTRIBUTIONS AN APPROXIMATION AMS $64 \quad 315$

AMS $61 \quad 104$

AMS 651511

AMS $68 \quad 227$

AMS $63 \quad 186$ AMS $61 \quad 8 \mathrm{~B} 3$ AMS 64298 AMS 641583

CIENT

RELATION BETWEEN THE DISTRIBUTIONS OF NON-CENTRAL T AND OF A TRANSFORMED CORRELATION COEFFI A NOTE CN REPRESENTATIONS OF THE DOUBLY NON-CENTRAL T DISTRIBUTION

REPRESENTATIONS OF THE CENTRAL AND NON-CENTRAL T DISTRIBUTIONS

THE MOMENTS OF THE NON-CENTRAL T-DISTRIBUTION

A SPECIAL CASE OF A BIVARIATE NON-CENTRAL T-DISTRIBUTION

CILITATE THE COMPUTATION OF PERCENTAGE POINTS OF THE NON-CENTRAL T-DISTRIBUTION

SOME PERCENTAGE POINTS OF THE NON-CENTRAL T-DISTRIBUTION CORR APPROXIMATIONS TO THE NON-CENTRAL T, WITH APPLICATIONS

ERRATA, 'APPROXIMATIONS TO THE NON-CENTRAL T, WITH APPLICATIONS

219

JASA 681013

BIOKA64 451

BIOKA61 465

BIOKA65 437

AMS 62580

JASA $63 \quad 176$

TECH 63295 TECH $64 \quad 482$ OF MULTIVARIATE STATISTICS', 46/ CORRECTION. 'THE NON-CENTRAL WISHART DISTRIBUTION AND CERTAIN PROBLEMS AMS 64 923 VARIATE THE MAXIMUM LIKELIHOOD ESTIMATE OF THE NON-CENTRALITY PARAMETER OF A NONCENTRAL CHI-SQUARE JASA 67 1258 IMENTS WITH LEAST SQUARES, / LINEAR REGRESSION WITH NON-CONSTANT, UNKNOWN ERROR VARIANCES, SAMPLING EXPER BIOCS68 607 A POLYNOMIAL CONSTRAINED TO BE EITHER NON-NEGATIVE, NON-DECREASING OR CONVEX LEAST-SQUARES FITTING OF JRSSB69 113 A DELICATE LAW OF THE ITERATED LOGARITHM FOR NON-DECREASING STABLE PROCESSES (ADDENDUM, 69 $1 B 55$ ) USE OF CYCLIC BALANCED INCOMPLETE BLOCK DESICNS FOR NON DIRECTIONAL SEED ORCHARDS NON-DISCOUNTED DENUMERABLE MARKOVIAN DECISION MODELS AMS 68412 SOME FURTHER RESULTS IN THE NON-EQUILIBRIUM THEORY OF A SIMPLE QUEUE TREATMENT OF THE NON-EOUILTBRIUM THEORY OF SIMPLE QUEUES BY MEANS OF SE FOR EXPERIMENTS INVOLVING LOCATION PARAMETERS NON-EQUIVALENT COMPARISONS OF EXPERIMENTS AND THEIR U AMS 61326 OF A LOG-NORMAL DISTRIBUTION HAVING A PRE/ ON THE NON-EXISTENCE OF A FIXED SAMPLE ESTIMATOR OF THE MEAN DISTRIBUTIONS NON-EXISTENCE OF EVERYWHERE PROPER CONDITTONAL

THE APPLICATION OF GROUP THEORY TO THE EXISTENCE AND NON-EXISTENCE OF ORTHOGONAL LATIN SQUARES MOST POWERFUL TESTS FOR SOME NON-EXPONENTIAL FAMILIES

APPROXIMATION TO BAYES RISK IN SEQUENCES OF NON-FINITE GAMES

THE DISTRIBUTION OF INANIMATE MARKS OVER A NON-HOMOGENEOUS BIRTH-DEATH PROCESS NON-HOMOGENEOUS BRANCHING POISSON PROCESSES AMS 63223 BIOKA69 NO. 3 AMS $68 \quad 772$ AMS 69467 BIOKA69 225 JRSSB $67 \quad 343$

LE FOR DIFFERENT CLASSIFICATIONS WITH CORRELATED AND NON-HOMOGENEOUS ERRORS /AN ANALYSIS OF VARIANCE TAB JRSSB59 I14 7. IS A REALTZATION OF A NON-HOMOGENEOUS FINITE-STATE MARKOV CHAIN /-SUB-T), BIOKAG5 277 SOME LIMIT THEOREMS FOR NON-HOMOGENEOUS MARKOV CHAINS

OREMS CONCERNING THE STRONG LAW OF LARGE NUMBERS FOR NON-HOMOGENEOUS MARKOV CHAINS THE STATISTICS OF A PARTICULAR NON-HOMOGENEOUS POISSON PROCESS AMS $66 \quad 1224$ AMS 64566 BIOKA64 399 STRIBUTIONS, IV, THE DISTRIBUTION OF HOMOCENEOUS AND NON-HOMOGENEOUS QUADRATIC FUNCTIONS OF NORMAL VARIABL AMS 62 542 ROBUSTNESS OF NON-IDEAL DECISION PROCEDURES

COHERENT STRUCTURES OF NON-IDENTICAL COMPONENTS

JASA $63 \quad 480$ TECH 63191 A RENEWAL AMS $63 \quad 390$ A RENEWAL AMS $63 \quad 390$ THEOREM FOR RANDOM VARIABLES WHICH ARE DEPENDENT OR NON-IDENTICALLY DISTRIBUTED AN EXTENSION OF ROSEN'S THEOREM TO NON-IDENTICALLY DISTRIBUTED RANDOM VARIABLES IC VARIANCES OF EQUAL MAGN/ CENETIC COMPONENTS FOR NON-INBRED DIPLOID SPECIES HAVING ALL DIGENIC EPISTAT BIOCS69 545 OF THE SENSITIVITIES OF SIMTLAR INDEPENDENT AND NON-INDEPENDENT EXPERIMENTS

AN EXAMPLE OF DISCREPANCIES IN INFERENCES UNDER NON-INFORMATIVE STOPPING RULES COMPARTSON BIOKA69 17 BIOKA67 329 IN BIOLOGICAL ASSAY MODELS FOR THE NON-INTERACTIVE JOINT ACTION OF A MIXTURE OF STIMULI THE GOODNESS-OF-FIT OF A SINGLE (NON-ISOTROPIC) HYPOTHETICAL PRINCIPAL COMPONENT 

NOTE ON INTERVAL ESTIMATION IN NON-LINEAR REGRESSION WHEN RESPONSES ARE CORRELATED NON-LINEAR REGRESSION WITH MINIMAL ASSUMPTIONS

ON THE LEAST SQUARES ESTIMATION OF NON-LINEAR RELATIONS DESICN OF EXPERIMENTS IN NON-LINEAR SITUATIONS HE DESIGN OF EXPERIMENTS FOR PARAMETER ESTIMATION IN NON-LINEAR SITUATIONS HE DESIGN OF EXPERIMENTS FOR PARAMETER ESTIMATION IN NON-LINEAR SITUATIONS MULTIRESPONSE CASE

ON BEALE'S MEASURES OF NON-LINEARITY

OF FITTING A NON-LINEAR CURVE CONTAINING A SINGLE NON-LINEARITY TECH $65 \quad 623$ LEAST SQUARES LINEAR ESTIMATO/ ON CANONICAL FORMS, NON-NEGATIVE COVARIANCE MATRICES AND BEST AND SIMPLE AMS 67 IO92 NON-NEGATIVE ESTIMATES OF VARIANCE COMPONENTS

EIGENVALUES OF NON-NEGATIVE MATRICES

INFINITELY DIVISIBLE LAWS AND A RENEWAL THEOREM FOR NON-NEGATIVE RANDOM VARIABLES TESTINC FOR CORRELATION BETWEEN NON-NECATIVE VARIATES

RES FITTING OF A POLYNONIAL CONSTRAINED TO BE EITHER NON-NEGATIVE, NON-DECREASING OR CONVEX ORDER STATISTICS FROM A CLASS OF NON-NORMAL DISTRIBUTIONS PRODUCER AND CONSUMER RISKS IN NON-NORMAL POPULATION

OF THE REGRESSION COEFFICIENT IN SAMPLES FROM A NON-NORMAL POPULATION THE DISTRIBUTION OF RANGE IN CERTAIN NON-NORMAL POPULATIONS

ON THE EXTREME VALUES AND RANGE OF SAMPLES FROM NON-NORMAL POPULATIONS FFICIENT OF VARIATION OF RANGE IN SMALL SAMPLES FROM NON-NORMAL POPULATIONS SAMPLING DISTRIBUTIONS OF THE MEAN FOR SAMPLES FROM NON-NORMAL POPULATIONS THE DISTRIBUTION OF THE F-RATIO IN SAMPLES FROM TWO NON-NORMAL POPULATIONS OF RECRESSION COEFFICIENTS IN SAMPLES FROM BIVARIATE NON-NORMAL POPULATIONS.

CORRIGENDA, 'THE DISTRIBUTION OF RANGE IN CERTAIN NON-NORMAL POPULATIONS'

FFICIENT OF VARIATION OF RANGE IN SMALL SAMPLES FROM NON-NORMAL POPULATIONS '

SAMPLE POWER FOR THE ONE SAMPLE WILCOXON TEST FOR NON-NORMAL SHIFT ALTERNATI DISTRIBUTIONS OF ANY SIZE DRAMN FROM NON-NORMAL UNIVERSES

NON-NORMALITY AND TESTS ON VARIANCES. NON-NORMALITY IN TWO-SAMPLE T-TESTS

ROBUSTNESS TO NON-NORMALITY OF REGRESSION TESTS

CORRIGENDA 'ROBUSTNESS TO NON-NORMALITY OF REGRESSION TESTS

EFFECT OF NON-NORMALITY ON A SEQUENTIAL TEST FOR MEAN EFFECT OF NON-NORMALITY ON STEIN S TWO SAMPLE TEST

VARIANCE

ON THE EFFECT OF NON-NORMALITY ON THE ESTIMATION OF COMPONENTS OF EFFECT OF NON-NORMALITY ON THE PONER FUNCTION OF T-TEST

THE ANALYSIS OF VARIANCE

VARIANCE TEST

COMPONENTS ANALYSIS

EL. II NULL DISTRIBUTIC

IA FOR MULTIVARIATE/

ALTERNATIVES

ENERAL THEORY AND THE CA/ ASYMPTOT EXPANSIONS OF THE THE WILCOXON TEST AND NON-NULL RANKING MODEL FOR A SEQUENCE OF $M$

THE EFFECT OF NON-NORMALITY ON THE POWER FUNCTION OF THE F-TEST IN EFFECT OF NON-NORMALITY ON THE PONER FUNCTION OF THE SIGN TEST EFFECT OF NON-NORMALITY ON THE PONER OF THE ANALYSIS OF THE NON-NULL DISTRIBUTION OF A STATISTIC IN PRINCIPAL

\section{ITERATIVE ESTIMATION OF VARIANCE COMPONENTS FOR NON-ORTHOGONAL DATA}

INVERSION OF PARTITIONED MATRICES IN THE ANALYSIS OF NON-ORTHOGONAL DATA /ENBERG AND SARHAN'S METHOD OF ON DEPENDENT TESTS FROM A NON-ORTHOGONAL DESIGN NON-ORTHOGONAL DESICNS OF EVEN RESOLUTION

THE ANALYSIS OF VARIANCE OF SOME NON-ORTHOGONAL DESIGNS WITH SPLIT PLOTS

TION OF MEANS AND STANDARD ERRORS IN THE ANALYSIS OF NON-ORTHOGONAL EXPERIMENTS BY ELECTRONIC COMPUTER / JRSSB62 435 MAIN-EFFECT ANALYSIS OF THE GENERAL NON-ORTHOGONAL LAYOUT WITH ANY NUMBER OF FACTORS UNIFIED APPROACH FOR CONSTRUCTING A USEFUL CLASS OF NON-ORTHOGONAL MAIN EFFECT PLANS IN K TO THE N FACTOR JRSSB68 371 SQUARES SOME NON-ORTHOGONAL PARTITTONS OF $4 \times 4,5 \times 5$, AND $6 \times 6$ LATIN AMS 66 66 IANCES OF ESTIMATES OF COMPONENTS OF VARIANCE FROM A NON-ORTHOGONAL TWO-WAY CLASSIFICATION SAMPLING VAR BIOKA64 491 A MONTE CARLO STUDY OF THE ADEQUACY OF THE ASYMP/ NON-PARAMETRIC ANALYSIS OF VARIANCE IN SMALL SAMPLES. BIOCS69 593 DESIGN

IS CENSORED

STICAL DECISION PROBLEMS

E AND MULTIVARIATE ANALYS/
A NOTE ON

NON-PARAMETRIC APPROACH TO THE 2-CUBE FACTORIAL TECH 69 A NON-PARAMETRIC COMPARISON OF TWO SAMPLES ONE OF WHICH BIOKA66 599 A SUPPLEMENTARY SAMPLE NON-PARAMETRIC EMPIRICAL BAYES APPROACH TO SOME STATI BIOKA67 451 ON TWO-STAGE NON-PARAMETRIC ESTIMATION

AMS 641099 AN INTRODUCTION TO SOME NON-PARAMETRIC GENERALIZATIONS OF ANALYSIS OF VARIANC BIOKA56 361 
LOCATION PROBLEM PROBLEM

\section{SOME}

-

NON-PARAMETRIC METHODS IN DILUTION (-DIRECT) ASSAYS

A NON-PARAMETRIC TEST FOR THE BIVARIATE TWO-SAMPLE

TION PROBLEM IN THE NORMA/ SMALL SAMPLE POWER OF A NON-PARAMETRIC TEST FOR THE BIVARIATE TWO-SAMPLE LOCA J LATIONSHIP BETWEEN HODCES' BIVARIATE SICN TEST AND A NON-PARAMETRIC TEST OF DANIELS' 60 II9O/S TO 'A RE EXACT AND APPROXIMATE POWER FUNCTION OF THE NON-PARAMETRIC TEST OF TENDENCY

RECURSIVE CENERATION OF THE DISTRIBUTION OF SEVERAL NON-PARAMETRIC TEST STATISTICS UNDER CENSORINC POWER OF SOME TWO-SAMPLE NON-PARAMETRIC TESTS

SOME NON-PARAMETRIC TESTS FOR M-DEPENDENT TIME SERIES

ASYMPTOTIC EFFICIENCY OF A CLASS OF NON-PARAMETRIC TESTS FOR RECRESSION PARAMETERS NON-PARAMETRIC TESTS FOR SCALE

ON SOME TWO-SAMPLE NON-PARAMETRIC TESTS, CORR. 661249

PARAMETER-FREE AND NON-PARAMETRIC TOLERANCE LIMITS, THE EXPONENTIAL CASE

A POWER COMPARISON OF TWO TESTS OF NON-RANDOM CLUSTERINC

ON NON-RANDOMIZED FRACTIONAL WEICHINC DESICNS

WILCOXON'S AND ALLIED TEST STATISTICS RUNS TEST

TORS OF LOCATION PARAMETERS NON RANDOS IN A SEQUENCE OF

ON NON-REGULAR ESTIMATION, I. VARIANCE BOUNDS FOR ESTIMA JASA 691056 SOME METHODS OF PROBABILITY NON-REPLACEMENT SAMPLINC

PROBABILITIES WITHOUT REPLACEMENT, ROTATINC AND NON-ROTATINC SAMPLES BY-2 CONTINCENCY TABLES THE EFFECT OF NON-SAMPLINC ERRORS ON MEASURES IN WHICH A SEQUENTIAL ESTIMATION PROCEDURE IS NON-SEQUENTIAL NON-SINGULAR RECURRENT MARKOV PROCESSES HAVE JASA $69 \quad 175$ STATIONARY MEASURES

A TEST FOR NON-STATIONARITY OF TIME-SERIES

ON THE ERGODICITY FOR NON-STATIONARY MULTIPLE MARKOV PROCESSES

ON THE MEAN NUMBER OF CURVE CROSSINGS BY NON-STATIONARY NORMAL PROCESSES RECURSIVE RELATIONS FOR PREDICTORS OF NON-STATIONARY PROCESSES DESIGN RELATIONS FOR NON-STATIONARY PROCESSES ON THE PREDICTION OF NON-STATIONARY PROCESSES

EVOLUTIONARY SPECTRAL AND NON-STATIONARY PROCESSES (WITH DISCUSSION) ON THE CONCEPT OF THE SPECTRUM FOR NON-STATIONARY PROCESSES (WITH DISCUSSION) FILTERING NON-STATIONARY SIGNALS

A CHANGE IN LEVEL OF A NON-STATIONARY TIME SERIES

E EQUATIONS ROPERTIES OF MULTI-TERM PREDICTORS OR CONTROLLERS IN NON-STATIONARY TIME SERIES ESTIMATION OF NON-UNIQUE QUANTILES

WEIGHTED PROBITS ALLOWING FOR A NON-ZERO RESPONSE IN THE CONTROLS LIHOOD ESTIMATE OF THE NON-CENTRALITY PARAMETER OF A NONCENTRAL CHI-SQUARE VARIATE ENT ESTIMATORS AS LINEAR COMBINATIONS OF INDEPENDENT NONCENTRAL CHI-SQUARE VARIATES CORRELATION GOEFFICIENT

BIOC\$65 799

JRSSB $67 \quad 320$ JRSSB 6998 ASA $68 \quad 353$ BIOKA60 355 AMA 65 68 134 AMS $62 \quad 498$ JASA 651118 TECH $62 \quad 75$ TECH $66 \quad 493$ AMS 661836 SAMPLINC WITH VARYINC JASA 63 IB3 BIOKA67 229 AMS $64 \quad 869$ JRSSB $69 \quad 140$ AMS 681448 AMS $65 \quad 509$ JRSSB $65 \quad 523$ JRSSB $66 \quad 228$ JRSSB $67 \quad 570$ JRSSB 65204 JRSSB 68 JRSSB69 150 JASA 69581 BIOKA65 1BI AMS $66 \quad 451$ BIOKA56 207 THE MAXIMUM LIKE JAS $67 \quad 1258$ IOF VARIANCE-COMPON AMS 69 NO. 6 TONT ON OF NONCENTRAL MEANS WITH KNOWN COVARIANCE

THE NONCENTRAL MULTIVARIATE BETA TYPE TWO DISTRIBUTION NONCENTRAL MULTIVARIATE DIRICHLET DISTRIBUTIONS

THE MOMENTS OF A DOUBLY NONCENTRAL T-DISTRIBUTION

SERIES REPRESENTATIONS OF THE DOUBLY NONCENTRAL T-DISTRIBUTION A SURVEY OF PROPERTIES AND APPLICATIONS OF THE NONCENTRAL T-DISTRIBUTION ITH NONCONTROLLED PREDICTOR VARIABLES
ON NONCOVERACE OF SAMPLE DWELLINGS /PTIMAL TESTS OF JASA $65 \quad 699$ JASA 5 B 509 LITY A PROCRAM TO ESTIMATE MEASUREMENT ERROR IN NONDESTRUGTIVE EVALUATION OF REACTOR FUEL ELEMENT QUA TECH 64 293 PARTIALLY BALANCED INCOMPLETE BLOCK DESIGNS AND SOME NONEXISTENCE THEOREMS A PRICE AND PRODUCTIVITY INDEX FOR A NONHOMOGENEOUS PRODUCT DUALS OF AMS 661048 JASA $64 \quad 469$ SSOCIATED WITH MULTIVARIATE ANALYSIS OF VARIANCE AND NONINDEPENDENCE BETWEEN TWO SETS OF VARIATES /NDS A AMS 66 I736 A LOCAL LIMIT THEOREM FOR NONLATTICE MULTI-DIMENSIONAL DISTRIBUTION FUNCTIONS AMS 65546 ON MEASURABLE, NONLEAVABLE GAMBLING HOUSES WITH A COAL AMS $69 \quad 66$ STABILITY OF SOLUTIONS TO GERTAIN NONLINEAR DIFFERENCE EQUATIONS OF POPULATION GENETICS BIOCS69 27 SIMULTANEOUS NONLINEAR ESTIMATION ERRATA 'SIMULTANEOUS NONLINEAR ESTIMATION' SPECTRAL ESTIMATES USINC NONLINEAR FUNCTIONS AND REPARAMETERIZATION OF SOME SIGMOID OR OTHER NONLINEAR FUNCTIONS NONLINEAR LEAST SQUARES ESTIMATION TECH 66 - 319 TECH $67 \quad 353$ AMS 661237 AMS 65638 TECH $68 \quad 843$ APPLICATION OF A MODIFICATION OF DAVIDON'S METHOD TO NONLINEAR RECRESSION PROBLEMS TION OF SEVERAL ONE-DIMENSIONAL SEARCH PROGEDURES IN NONLINEAR REGRESSION PROBLEMS THE CONDITIONAL WISHART, NORMAL AND NONNORMAL

OR BLOCKS ARE OF UNEQUAL S/ NOTES. APPLICATIONS OF NONORTHOCONAL DESIGNS TO SITUATIONS WHERE TREATMENTS SOME NONORTHOGONAL FRACTIONS OF 2-TO THE-N DESICNS

BIVARIATE SYMMETRY TESTS, PARAMETRIC AND NONPARAMETRIC

$S$ IN MODEL I ANALYSIS OF VARIANCE, NORMAL THEORY AND NONPARAMETRIC ADAPTIVE NONPARAMETRIC CLASSIFICATION

TEST

PARAMETER

E LOCATION PROBLEMS

FUNCTION

FISHER SITUATION

ON FUNCTION OF A MARKOV PROCESS ONE OBSERVATION PER CELL

LINEAR MODELS

CAMMA DISTRIBUTION
CORR. $6515 \mathrm{~B} 3$

ON SOME ASYMPTOTICALLY NONPARAMETRIC COMPETITORS OF HOTELLINC'S T-SQUARE,

ASYMPTOTIC EFFICIENCY OF TWO NONPARAMETRIC COMPETITORS OF WILCOXON'S TWO SAMPLE NONPARAMETRIC CONFIDENCE INTERVALS FOR A SHIFT DONFIDENCE REGIONS FOR SOME MULTIVARIAT JASA 681373 NONPARAMETRIC DISGRIMINATION USING TOLERANGE REGIONS AMS 68664

A UNIFIED DERIVATION OF SOME NONPARAMETRIG DISTRIBUTIONS

A NONPARAMETRIC ESTIMATE OF A MULTIVARIATE DENSITY

ON SOME NONPARAMETRIG ESTIMATES FOR SHIFT IN THE BEHRENSNONPARAMETRIC ESTIMATION OF THE TRANSITION DISTRIBUTI AMS 691386 ASYMPTOTICALLY NONPARAMETRIC INFERENCE IN SOME LINEAR MODELS WITH AMS 64726 ASYMPTOTICALLY NONPARAMETRIC INFERENCE, AN ALTERNATIVE APPROACH TO AMS 631494 ASYMPTOTIG EFFICIENCIES OF A NONPARAMETRIC LIFE TEST FOR SMALLER PERCENTILES OF A SOME NONPARAMETRIC MEDIAN PROCEDURES

ASYMPTOTIC NORMALITY IN NONPARAMETRIC METHODS

THE NONPARAMETRIC ORDERINC, 1001 TO 0110

INING THE POPULATION WITH THE LARCEST ALPHA-QUANT/ ON WITH THE LARCEST ALPHA-QUANTILE
NONPARAMETRIC PROCEDURES FOR SELECTING A SUBSET CONTA NONPARAMETRIC PROCEDURES FOR SELECTINC THE T POPULATI BIOCS66 629 AMS $69 \quad 259$ AMS $67 \quad 1740$ TECH 69 NO. 4 AMS $65 \quad 160$ JASA $64 \quad 1042$ AMS 651049 JASA $56 \quad 467$ AMS $61 \quad 846$ AMS 6B 905 AMS 61101 AMS $67 \quad 1788$ AMS 671804 
AMS 681913 AMS $63 \quad 22$ ON SOME OPTIMUM NONPARAMETRIC PROCEDURES IN TWO-WAY LAYOUTS NONPARAMETRIC RANKINC PROCEDURES FOR COMPARISON WITH MULTIVARIATE NONPARAMETRIC SEVERAL-SAMPLE TESTS A NONPARAMETRIC STATISTICAL METHOD FOR CULLING RECRUITS BIOCS65 936 NONPARAMETRIC STATISTICS JASA 57331

A NONPARAMETRIC SUM OF RANKS PROCEDURE FOR RELATIVE SPR JASA $60 \quad 429$ $\begin{array}{ll}\text { NONPARAMETRIC SYMMETRY TESTS FOR CIRCULAR } & \text { BIOKA69 NO.3 }\end{array}$ A NONPARAMETRIC TEST FOR THE PROBLEM OF SEVERAL SAMPLES AMS 611108 EAD IN UNPAIRED SAMPLES, CORR. 611005 DISTRIBUTIONS A NONPARAMETRIC TEST FOR THE PROB
CERTAIN UNCORRELATED NONPARAMETRIC TEST STATISTICS

OF ESTIMATING ASYMPTOTIC EFFICIENCY OF A CLASS OF NONPARAMETRIC TESTS ON A DISTRIBUTION-FREE METHOD SERIES POPULATIONS SOME NONPARAMETRIC TESTS FOR COMOVEMENTS BETWEEN TIME

A CLASS OF NONPARAMETRIC TESTS FOR INDEPENDENCE IN BIVARIATE SOME NONPARAMETRIC TESTS FOR MULTISAMPLE PROBLEMS

A NOTE ON NONPARAMETRIC TESTS FOR SCALE NONPARAMETRIC TESTS FOR SHIFT AT UNKNOWN TIME POINT

ASYMPTOTICALLY NONPARAMETRIC TESTS OF SYMMETRY

IONS A CIRCULAR DISTRIBUTION THE DERIVATION OF NONPARAMETRIC TWO-SAMPLE TESTS FROM TESTS FOR UNIFORM BIOKA69 NO.3 MAXIMUM ASYMPTOTIC ERROR PROBABILITY SEOUNTIAL NONPARAMETRIC TWO-MAY CLASSIFTCATION WITH PRESCRIBED B AMS GO LIMITS. FOR THE PROBABILITY THAT Y IS LESS THAN/ NONPARAMETRIC UPPER CONFIDENCE BOUNDS. AND CONFIDENCE JAS OPTIMAL SAMPLE DESICN WITH NONRESPONSE

A NOTE ON THE EFFECTS OF NONRESPONSE ON SURVEYS

AND UNKNOWN AMOUNT OF DUPLICATION SOME NONRESPONSE SAMPLING THEORY WHEN THE FRAME CONTAINS APPROXIMATE DISTRIBUTION OF EXTREMES FOR NONSAMPLE CASES

TEST FOR SERIAL CORRELATTON SUITABLE FOR USE WITH NONSTATIONARY TIME SERIES TISTICAL TECHNIQUES IN THE DIFFERENTIAL DIAGNOSIS OF NONTOXIC GOITRE JASA $64 \quad 429$ JASA $68 \quad 707$ AMS $66 \quad 1759$ JASA $61 \quad 11$ TECH $6 B \quad 57 B$ AMS $67 \quad 274$ AMS $68 \quad 1731$ AMS $67 \quad B 49$ AMS 69445 JASA 64906 JASA $67 \quad 63$ JASA $57 \quad 29$ JASA $68 \quad 87$ A COMPARISON OF STA BIOCS6B 103 RATES BIAS IN ESTIMATES OF THE UNITED STATES NONWHITE POPULATION AS INDICATED BY TRENDS IN DEATH JASA 61 44 STIRLING BEHAVIOR IS ASYMPTOTICALLY NORMAL

CONFIDENCE REGIONS FOR THE MEAN OF A MULTIVARIATE NORMAL PROBABILITY THAT $Y$ IS LESS THAN $X$, WHEN $X$ AND $Y$ ARE NORMAL CIENCY OF ONE-SIDED KOLMOGOROV AND SMIRNOV TESTS FOR NORMAL ALTERNATIONS

OF CATEGORICAL DATA CHI-SQUARE TESTS ANALOGOUS TO NORMAL ANALYSIS OF VARIANCE $\begin{array}{rlrrr}\text { A NOTE ON CONSERV IVE AMS } & 67 & 278 \\ \text { AFIDENCE LIMITS, FOR THE JASA } 64 & 906\end{array}$ $\begin{array}{lllll}\text { A NOTE ON CONSERV IVE AMS } & 67 & 278 \\ \text { IFIDENCE LIMITS, FOR THE JASA } 64 & 906\end{array}$ QUERY, THE SUM OF VALUES FROM A NORMAL AND A TRUNCATED NORMAL DISTRIBUTION TECH 64 IO4 QUERY, THE SUM OF VALUES FROM A NORMAL AND A TRUNCATED NORMAL DISTRIBUTION (CONTD) TECH 64 469 QUERY, COMBINATION OF A NORMAL AND A UNIFORM DISTRIBUTION CHARACTERIZATION OF NORMAL AND GENERALIZED TRUNCATED NORMAL DISTRIBUTIONS AMS 661011

USING ORDER STATISTICS COMPUTER EVALATION

INTERVALS FOR THE COEFFICIENT OF VARIATION FOR THE NORMAL AND LOG NORMAL DISTRIBUTIONS LIFE TEST SAMPLING PLANS FOR NORMAL AND LOGNORMAL DISTRIBUTIONS

PROBABILITY INTEGRALS OF MULTIVARIATE NORMAL AND MULTIVARIATE T THE CONDITIONAL WISHART NORMAL AND NONNORMAL

RESULTS ON THE ORDER STATISTICS OF THE MULTIVARIATE NORMAL AND PARETO TYPE 1 POPULATIONS TECH 69 NO. 4 BIOKA64 25 TECH $62 \quad 151$ AMS $63 \quad 792$ AMS 6B 593 SOME AMS 641815 PROBABILITIES OF CONVEX POLYHEDRA UNDER MULTIVARIATE NORMAL AND T-DISTRIBUTIONS J ON THE EVALUATION OF JRSSB66 366 SOME RELATIONSHIPS BETWEEN THE NORMAL AND VON MISES DISTRIBUTIONS TRIBUTION-FREE TEST STATISTIC FOR DISPERSION AND ITS NORMAL APPROXIMATION /RITICAL VALUES FOR MOOD'S DIS TECH 68 497 COMMON, RELATED TAIL PROBABILITIES, I COMMON, RELATED TAIL PROBABILITIES, II A NORMAL APPROXIMATION FOR BINOMIAL, F, BETA, AND OTHER JASA 681416 PROCESSES

MANY REPAIR MEN

CENTRAL F PROBABILITY FUNCTIONS

ENDENT BINOMIALS, CONDITIONAL ON FIXED SUM RIBUTION WHEN ZERO DIFFERENCES ARE PRESENT

A NORMAL APPROXIMATION FOR BINOMIAL, F, BETA, AND OTHER JASA 681457 ON THE USE OF THE NORMAL APPROXIMATION IN THE TREATMENT OF STOCHASTIC JRSSB57 268 NORMAL APPROXIMATION TO MACHINE INTERFERENCE WITH JRSSB57 334 NORMAL APPROXIMATION TO THE CHI-SQUARE AND NON- $\quad$ BIOKA60 411 NORMAL APPROXIMATION TO THE DISTRIBUTION OF TWO INDEP AMS 631593 THE NORMAL APPROXIMATION TO THE SIGNED-RANK SAMPLING DIST JASA 671068 NCE FOR SOME INCOMPLETELY SPECIFIED MODELS INVOLVINC NORMAL APPROXIMATIONS TO DISCRETE DATA RIBUTION OF KENDALL'S TAU FOR SAMPLES OF FOUR FROM A NORMAL BIVARIATE POPULATION WITH CORRELATION RHO /T BIOKA63 538 FOR THE BIVARIATE TWO-SAMPLE LOCATION PROBLEM IN THE NORMAL CASE/SAMPLE POWER OF A NON-PARAMETRIC TEST JRSSB68 83 POSTERIOR ODDS FOR MULTIVARIATE NORMAL CLASSIFICATION MULTIV RTATE-NORMAL CLASSTFTCATTON UTTH COVARTANCE KNOWN THE ANALYSIS OF STATISTICAL DISTRIBUTIONS INTO TWO NORMAL COMPONENTS A GRAPHICAL METHOD FOR BIOKA53 460 A MODIFIED COMPOUND POISSON PROCESS WITH NORMAL COMPOUNDING

CONFIDENCE INTERVALS AND EXPERIMENTAL DESIGN WITH NORMAL CORRELATION DEPENDENT WITH SPECIAL REFERENCE TO TYPE II CENSORED NORMAL DATA /ENT ESTIMATORS WHEN THE VARIABLES ARE BI J TATA CHANGE CONSTRAINTS AND NORMAL DEVIATES

NO: 26 CORRIGENDA TO 'CORRELATED RANDOM NORMAL DEVIATES' PUBLISHED IN TRACTS FOR COMPUTERS.

I/ ON A PROPERTY OF A TEST FOR THE EQUALITY OF TWO NORMAL DISPERSION MATRICES AGAINST ONE-SIDED ALTERNAT OPTIMAL CONFIDENCE INTERVALS FOR THE VARIANCE OF A NORMAL DISTRIBUTION THE FOLDED NORMAL DISTRIBUTION

A CHARACTERIZATION OF THE MULTIVARIATE NORMAL DISTRIBUTION

ESTIMATION OF PARAMETERS OF A TRUNCATED BIVARIATE NORMAL DISTRIBUTION CUMULATIVE SUM CHARTS FOR THE FOLDED NORMAL DISTRIBUTION

ON TWO-SIDED TOLERANCE INTERVALS FOR A NORMAL DISTRIBUTION ORTHANT PROBABILITIES FOR THE QUADRIVARIATE NORMAL DISTRIBUTION GENERATING A VARIABLE FROM THE TAIL OF THE NORMAL DISTRIBUTION CONTROL OF PERCENTAGES IN BOTH TAILS OF THE NORMAL DISTRIBUTION A CHARACTERISTIC PROPERTY OF THE MULTIVARIATE NORMAL DISTRIBUTION VARIABLES SAMPLING PLANS BASED ON THE NORMAL DISTRIBUTION

ON THE ROBUSTNESS OF SOME CHARACTERIZATIONS OF THE NORMAL DISTRIBUTION THE COVERING CIRCLE OF A SAMPLE FROM A CIRCULAR NORMAL DISTRIBUTION EXACT LINEAR SEQUENTIAL TESTS FOR THE MEAN OF A NORMAL DISTRIBUTION TABLES FOR WALD TESTS FOR THE MEAN OF A NORMAL DISTRIBUTION TABLES FOR MAKINC INFERENCES ABOUT THE VARIANCE OF A NORMAL DISTRIBUTION ABSOLUTE AND INCOMPLETE MOMENTS OF THE MULTIVARIATE NORMAL DISTRIBUTION A NOTE ON THE EQUICORRELATED MULTIVARIATE NORMAL DISTRIBUTION ON GUPTA'S ESTIMATES OF THE PARAMETERS OF THE NORMAL DISTRIBUTION MOMENTS OF A TRUNCATED BIVARIATE NORMAL DISTRIBUTION 
BAYESIAN ESTIMATION OF THE VARIANCE OF A NORMAL DISTRIBUTION BAYESIAN ESTIMATION OF PARAMETERS OF A MULTIVARIATE NORMAL DISTRIBUTION A CENTRAL TOLERANCE RECION FOR THE MULTIVARIATE NORMAL DISTRIBUTION RTHOGONAL AND DUAL CONFIGURATIONS AND THE RECIPROCAL NORMAL DISTRIBUTION MOMENT CENERATINC FUNCTION OF THE TRUNCATED MULTI-NORMAL DISTRIBUTION THE SUM OF VALUES FROM A NORMAL AND A TRUNCATED NORMAL DISTRIBUTION PROBABILITIES FOR THE EQUICORRELATED MULTIVARIATE NORMAL DISTRIBUTION POINTS AND MODES OF ORDER STATISTICS FROM THE NORMAL DISTRIBUTION OF RADICAL ERROR IN THE BIVARIATE ELLIPTICAL NORMAL DISTRIBUTION EDICTION, AND TOLERANCE REGIONS FOR THE MULTIVARIATE NORMAL DISTRIBUTION STATISTICS FROM THE EQUICORRELATED MULTIVARIATE NORMAL DISTRIBUTION OF OBSERVATIONS ABOVE SAMPLE MEANS IN A BIVARIATE NORMAL DISTRIBUTION EXACT TRUNCATED SEQUENTIAL TESTS OF THE MEAN OF A NORMAL DISTRIBUTION TWEEN VARIATE-VALUES AND RANKS IN A DOUBLY TRUNCATED NORMAL DISTRIBUTION THE SAMPLE VARIANCES IN A SINGLY TRUNCATED BIVARIATE NORMAL DISTRIBUTION OF THE RANGE AND MEAN RANGE FOR SAMPLES FROM A NORMAL DISTRIBUTION XTREMAL AND NEARLY EXTREMAL VALUES IN SAMPLES FROM A NORMAL DISTRIBUTION TWO-SIDED PREDICTION INTERVALS FOR SAMPLES FROM A NORMAL DISTRIBUTION TUTE INTERVAL ESTIMATORS, WITH AN APPLICATION TO THE NORMAL DISTRIBUTION AND OF INDEFINITE QUADRATIC FORMS FROM A NON-CENTRAL NORMAL DISTRIBUTION RESULTING FROM CERTAIN SIMPLE TRANSFORMATIONS OF THE NORMAL DISTRIBUTION ONE OF $K$ HYPOTHESES CONCERNING THE UNKNOWN MEAN OF A NORMAL DISTRIBUTION AND VECTORS WITH SPECIAL REFERENCE TO THE BIVARIATE NORMAL DISTRIBUTION HE CRITERION W FOR TESTING SPHERICITY IN A P-VARIATE NORMAL DISTRIBUTION THE SUM OF VALUES FROM A NORMAL AND A TRUNCATED NORMAL DISTRIBUTION CONFIDENCE SETS FOR THE MEAN OF A MULTIVARIATE NORMAL DISTRIBUTION ON CHARACTERIZING THE NORMAL DISTRIBUTION BY STUDENT'S LAW

NGENCY TABLE SOME PROPERTIES OF THE BIVARIATE NORMAL DISTRIBUTION I. DESCRIPTION TABLES FOR USE IN ESTIMATING THE NORMAL DISTRIBUTION A USEFUL APPROXIMATION TO THE NORMAL DISTRIBUTION FUNCTION, WITH APPLICATION TO COMPUTER EVALUATION OF THE NORMAL AND INVERSE NORMAL DISTRIBUTION FUNCTIONS

NCE OF A FIXED SAMPLE ESTIMATOR OF THE MEAN OF A LOG-NORMAL DISTRIBUTION HAVING A PRESCRIBED PROPORTIONAL SEQUENTIAL TESTS FOR THE MEAN OF A NORMAL DISTRIBUTION II. LARGE T SEQUENTIAL TEST FOR THE MEAN OF A NORMAL DISTRIBUTION III, SMALL T MATION OF THE SLOPE OF THE MAJOR AXIS OF A BIVARIATE NORMAL DISTRIBUTION IN THE CASE OF A SMALL SAMPLE / BIOCS68 ORREL/CORRELATION IN A SINGLY TRUNCATED BIVARIATE NORMAL DISTRIBUTION IV. EMPIRICAL VARIANCES OF RANK C BIOKA68 SEQUENTIAL TESTS FOR THE MEAN OF A NORMAL DISTRIBUTION IV, DISCRETE CASE ANALOGUES OF THE NORMAL DISTRIBUTION ON THE CIRCLE AND THE SPHERE INTEGRAL OF THE BIVARIATE NORMAL DISTRIBUTION OVER AN OFFSET CIRCLE A TABLE OF THE INTEGRAL OF THE BIVARIATE NORMAL DISTRIBUTION OVER AN OFSET CIRCLE IN RELIABILITY ANAL/APPLICATIONS OF THE BIVARIATE NORMAL DISTRIBUTION TO A STRESS VS. STRENGTH PROBLEM BEST INVARIATE ESTIMATOR OF EXTREME QUANTILES OF THE NORMAL DISTRIBUTION UNDER SQUARED ERROR LOSS FROM SINGLY AND DOUBLY CENSORED SAMPLES, PART I. THE NORMAL DISTRIBUTION UP TO SAMPLES OF SIZE 10' /ICS TESTING THE MEAN AND STANDARD DEVIATION OF A NORMAL DISTRIBUTION USING QUANTILES

ESTIMATION OF THE PARAMETERS FOR A MULTIVARIATE NORMAL DISTRIBUTION WHEN ONE VARIABLE IS DICHOTOMISED BIOKA65 OR TRUNCATED SIMPLIFIED ESTIMATORS FOR THE NORMAL DISTRIBUTION WHEN SAMPLES ARE SINGLY CENSORED TECH 59 TIME ESTIMATING THE CURRENT MEAN OF A NORMAL DISTRIBUTION WHICH IS SUBJECTED TO CHANGES IN AMS 64 SAMPLING TWO THEOREMS FOR INFERENCES ABOUT THE NORMAL DISTRIBUTION WITH APPLICATIONS IN ACCEPTANCE

MS OF ONE WITH COVARIANCE MATRIX A EXPRESSING THE NORMAL DISTRIBUTION WITH COVARIANCE MATRIX A+B IN TER ON A NOTE ON ESTIMATING THE MEAN OF A NORMAL DISTRIBUTION

SHORTER CONFIDENCE INTERVALS FOR THE MEAN OF A NORMAL DISTRIBUTION

WITH MISSING OBSERVATIONS

INCOMPLETE AND ABSOLUTE MOMENTS OF THE MULTIVARIATE NORMAL DISTRIBUTION WITH SOME APPLICATIONS CORRELATION IN A SINGLY TRUNCATED BIVARIATE NORMAL DISTRIBUTION. II. RANK CORRELATION

ND VA/ CORRELATION IN A SINGLY TRUNCATED BIVARIATE NORMAL DISTRIBUTION. I TERS FROM MOMENTS THE FOLDED NORMAL DISTRIBUTION.
TABLES FOR MAKING INFERENCES ABOUT THE VARIANCE OF A NORMAL DISTRIBUTION. MAXIMUM LIKELIHOOD ANKS A BIOKA66 WO METHODS OF ESTTMATINC PARAME TECH 61 CORRIGENDA, ' BIOKA6I FOR DEALINC WITH OUTLIERS IN SMALL SAMPLES FROM THE NORMAL DISTRIBUTION, RESULTING FROM CERTAIN SIMPLE TRANSFORMATIONS OF THE NORMAL DISTRIBUTION' TISTICS FOR SAMPLES OF SIZE TWENTY AND LESS FROM THE NORMAL DISTRIBUTION" TABLES OF TOLERANCE-LIMIT FACTORS FOR NORMAL DISTRIBUTIONS ESTIMATION OF PARAMETERS FOR A MIXTURE OR NORMAL DISTRIBUTIONS ASYMPTOTICALLY OPTIMAL TESTS FOR MULTIVARIATE NORMAL DISTRIBUTIONS ESTIMATION IN MIXTURES OF TWO NORMAL DISTRIBUTIONS CENSORED SAMPLES FROM TRUNCATED NORMAL DISTRIBUTIONS THE CHI-SQUARE GOODNESS-OF-FIT TEST FOR NORMAL DISTRIBUTIONS ORDER STATISTICS FROM A CLASS OF NON-NORMAL DISTRIBUTIONS ESTIMATING THE COMPONENTS OF A MIXTURE OF NORMAL DISTRIBUTIONS FITTING OF GROUPED TRUNCATED AND GROUPED CENSORED NORMAL DISTRIBUTIONS ON TABLES FOR THE COMPARISION OF THE SPREAD OF TWO NORMAL DISTRIBUTIONS ROBABILITIES OF RANK ORDERS FOR TWO WIDELY SEPARATED NORMAL DISTRIBUTIONS

CONFIDENCE REGIONS FOR THE MEANS OF MULTIVARIATE NORMAL DISTRIBUTIONS OF PEARSON-LEE-FISHER FUNCTIONS OF SINGLY TRUNCATED NORMAL DISTRIBUTIONS BOUNDED RELATIVE ERROR FOR THE RATIO OF VARIANCES OF NORMAL DISTRIBUTIONS BIVARIATE NON-NORMAL UNIVERSES BY MEANS OF COMPOUND NORMAL DISTRIBUTIONS ATING THE PROPORTIONS IN MIXTURES OF EXPONENTIAL AND NORMAL DISTRIBUTIONS OF A TEST OF HOMOGENEITY FOR POPULATIONS COMPOSED OF NORMAL DISTRIBUTIONS ANEOUS CONFIDENCE BOU/ ON CERTAIN INEQUALITIES FOR NORMAL DISTRIBUTIONS OF THE COMMON MEAN OF TWO NORMAL DISTRIBUTIONS BASED ON SMALL SAMPLES OF EQUAL JA TESTS CONCERNING DISPERSION MATRICES OF MULTIVARIATE NORMAL DISTRIBUTIONS. READ 'PROBABILITY CONTENT OF REGIONS UNDER SPHERICAL NORMAL DISTRIBUTIONS, RAL PROBABILITY CONTENT OF REGIONS UNDER SPHERICAL NORMAL DISTRIBUTIONS II. THE DISTRIBUTION OF THE RAN /OF POWER FUNCTIONS OF SOME II. ACCURACY OF ESTIMATION BY TECH 62 ESTIMATION OF THE MEAN /LES TECH 69 $/$ 'PROPERTIES OF DISTRIBUTIONS BIOKA53 236 56410 /PRODUCTS OF ORDER STA AMS 611345 TECH $60 \quad 483$ TECH $66 \quad 431$ AHS 671829 TECH $67 \quad 15$ BIOKA55 516 BIOKA57 336 BIOKA69 415 BIOKA69 NO.3 THE BIOKA52 252 A NOTE BIOKA67 683 ON EXACT P AMS $67 \quad 1491$ RECTANGULAR JASA $67 \quad 626$ NOTES. TABLES BIOCS65 219 ESTIMATES OF JASA 56481 SAMPLING FROM BIOKA52 238 INFORMATION FOR ESTIM JASA $63 \quad 918$ EMPIRIC INVESTICATION JASA 58 55I ASA $66 \quad 467$ AMS $62 \quad 420$ AMS 69697 AMS $61 \quad 620$ AMS $61 \quad 171$ 
EOU/ PROBABILITY CONTENT OF REGIONS UNDER SPERICAL NORMAL DISTRIBUTIONS, IV, THE DISTRIBUTION OF HOMOGEN ERRATA. 'TABLES OF TOLERANCE-LIMIT FACTORS FOR NORMAL DISTRIBUTIONS' ERRATA, 'CONTROL OF PERCENTAGES IN BOTH TAILS OF THE NORMAL DISTRIBUTIONS'

USSION OF 'ESTIMATION OF PARAMETERS FOR A MIXTURE OF NORMAL DISTRIBUTIONS' BY VICTOR HASSELBLAD ON A FACTOR AUTOMORPHISM OF A NORMAL DYNAMICAL SYSTEM

DIMENSIONAL CHAINS INYOLVINC RECTANGULAR AND NORMAL ERROR-DISTRIBUTIONS

ON THE ASYMPTOTIC EFFICIENCY OF AN ASYMPTOTICALLY NORMAL ESTIMATOR SEQUENCE (CORR. 67 196) THE BIVARIATE NORMAL INTEGRAL

A NOTE ON THE EVALUATION OF THE MULTIVARIATE NORMAL INTEGRAL ON BOUNDS FOR THE NORMAL INTEGRAL

AN APPROXIMATION FOR THE SYMMETRIC, QUADRIVARIATE NORMAL INTEGRAL TWO EXPANSIONS FOR THE QUADRIVARIATE NORMAL INTEGRAL A NOTE ON THE QUADRIVARIATE NORMAL INTEGRAL QUALITIES FOR THE INCOMPLETE GAMMA FUNCTIONS AND THE NORMAL INTEGRAL

REDUCTION OF THE MULTIVARIATE NORMAL INTEGRAL TO CHARACTERISTIC FORM

THE NUMERICAL EVALUATION OF CERTAIN MULTIVARIATE NORMAL INTEGRALS

BIBLIOGRAPHY ON THE MULTIVARIATE NORMAL INTECRALS AND RELATED TOPICS

OF RANDOM VARIABLES WHICH ARE NOT ATTRACTED TO THE NORMAL LAW A MULTI-STAGE TEST FOR A NORMAL MEAN ON LARGE DEVIATION PROBLEMS FOR SUMS AMS $62 \quad 542$ TECH 61576 TECH $66 \quad 570$ ISC TECH $66 \quad 445$ AMS $66 \quad 1528$ TECH $63 \quad 404$ BIOKA5I 475 BIOKA53 458 BIOKA55 263 BIOKA56 206 BIOKA60 325 BIOKA61 201 EST IMATION OF THE LARGEST OF TWO NORMAL MEANS A REDUCTION FORMULA FOR NORMAL MULTIVARIATE INTEGRALS AMS $65 \quad 139$ BIOKA54 177 BIOKA67 293 AMS $62 \quad 571$ AMS $63 \quad$ B29 AMS 671575 RSSB 6 B 461 JASA $6 B \quad 861$ BIOKA54 351

E FOR TESTS OF SIGNIFICANCE THE DIMENSIONALITY OF NORMAL MULTIVARIATE SYSTEMS /F THE COMPUTING ROUTIN JRSSB56 70 ON THE LIKELIHOOD RATIO TEST OF A NORMAL MULTIVARIATE TESTING PROBLEM II AMS 106 ON THE LIKELIHOOD RATIO TEST OF A NORMAL MULTIVARIATE TESTING PROBLEM, CORR. $641388 \quad$ AMS 64 IBI QUERY. PSEUDO RANDOM NORMAL NUMBERS TECH $6 B \quad 401$

ENTIAL PROBABILITY RATIO TESTS BASED ON MULTIVARIATE NORMAL OBSERVATIONS /BABILITY ONE OF INVARIANT SEQU AMS 67 B THE SAMPLE MEAN AMONG THE EXTREME NORMAL ORDER STATISTICS EXPECTED VALUES OF NORMAL ORDER STATISTICS

THE DAVID-JOHNSON SERIES FOR THE EXPECTED VALUES OF NORMAL ORDER STATISTICS CORRIGENDA, 'EXPECTED VALUES OF NORMAL ORDER STATISTICS'

APPROXIMATIONS TO MULTIVARIATE NORMAL ORTHANT PROBABILITIES POSTERIOR DISTRIBUTIONS FOR MULTIVARIATE NORMAL PARAMETERS

TABLES FOR UNBIASED TESTS ON THE VARIANCE OF A NORMAL POPULATION AMS $63 \quad 33$ BIOKA61 151

/AFTER A NUMBER OF TERMS OF BIOKA60 79 BIOKA61 476 AMS 63191 JRSSB 63368 AMS $61 \quad 84$ BIOKA58 211 BIOKA59 433 JRSSB54 131 MOMENTS OF ORDER STATISTICS FROM A NORMAL POPULATION CONTROL CHARTS FOR THE MEAN OF A NORMAL POPULATION USUAL CONFIDENCE SETS FOR THE MEAN OF A MULTIVARIATE NORMAL POPULATION DENCE SETS FOR THE MEAN OF A UNIVARIATE OR BIVARIATE NORMAL POPULATION INADMISSIBILITY OF THE

AMS 671868 MEAN RANGE TABLES FOR TOLERANCE LIMITS FOR A NORMAL POPULATION ADMISSIBILITY OF THE USUAL CONFI AMS $69 \begin{array}{ll}1042 \\ \text { AMS }\end{array}$ ESTIMATION OF THE WEAN ESTIMATION OF PARAMETERS OF A MULTIVARIATE NORMAL POPULATION FROM TRUNCATED AND CENSORED SAMPLES J JASA 57 BB BIOKA52 260 JRSSB60 307 JRSSB $60 \quad 1$ ENTS OF VARIATION ON SELECTING THE LARCEST OF K NORMAL POPULATION MEANS (WITH DISCUSSION) A TEST OF EQUALITY OF TWO NORMAL POPULATION MEANS ASSUMING HOMOCENEOUS COEFFICI AMS 691374 SAMPLE SAMPLE $\begin{array}{lllll}\text { ESTIMATION OF THE NORMAL POPULATION PARAMETERS GIVEN A SINGLY CENSORED } & \text { BIOKA59 } & 150 \\ \text { ESTIMATION OF THE NORMAL POPULATION PARAMETERS GIVEN A TYPE I CENSORED } & \text { BIOKA61 } 367\end{array}$

SEQUENTIAL CONFIDENCE INTERVALS FOR THE MEAN OF A NORMAL POPULATION WITH UNKNOWN VARIANCE MOMENTS OF SAMPLE MOMENTS OF CENSORED SAMPLES FROM A NORMAL POPULATION' THE RANKING OF VARIANCES IN NORMAL POPULATIONS JOINT ESTIMATION OF THE PARAMETERS OF TWO NORMAL POPULATIONS ON MOMENTS OF ORDER STATISTICS AND QUASI-RANGES FROM NORMAL POPULATIONS ELLIPTICAL AND RADIAL TRUNCATION IN NORMAL POPULATIONS THE EFFECT OF TRUNCATION ON TESTS OF HYPOTHESES FOR NORMAL POPULATIONS AN APPROXIMATION TO TWO-SIDED TOLERANCE LIMITS FOR NORMAL POPULATIONS SEQUENTIAL INTERVAL ESTIMATION FCR THE MEANS OF NORMAL POPULATIONS ON THE MOMENTS OF ORDER STATISTICS IN SAMPLES FROM NORMAL POPULATIONS PLANE TRUNCATION IN NORMAL POPULATIONS

NOTES. SAMPLE SIZE FOR THE ESTIMATION OF MEANS OF NORMAL POPULATIONS

OF SOMERVILLE'S PROCEDURE FOR RANKING MEANS OF NORMAL POPULATIONS CEDURES FOR RANKING MULTIPLY-CLASSIFIED VARIANCES OF NORMAL POPULATIONS ATION RULES FOR CLASSIFICATION INTO TWO MULTIVARIATE NORMAL POPULATIONS WITH A CONTROL FOR MULTIPLY-CLASSIFIED VARIANCES OF NORMAL POPULATIONS PLING DISTRIBUTIONS OF THE MEAN FOR SAMPLES FROM NON-NORMAL POPULATIONS ELECTING THE POPULATION WITH THE LARGEST MEAN FROM K NORMAL POPULATIONS EQUATIONS FOR TRUNCATED AND CENSORED SAMPLES FROM NORMAL POPULATIONS NDER NULL HYPOTHESIS CONCERNING COMPLEX MULTIVARIATE NORMAL POPULATIONS THE DISTRIBUTION OF THE RANGE IN SMALL SAMPLES FROM NORMAL POPULATIONS OBSERVATIONS IN THE ESTIMATION OF THE PARAMETERS OF NORMAL POPULATIONS INT EFFICIENCY OF THE ESTIMATES OF THE PARAMETERS OF NORMAL POPULATIONS THE EFFICIENCY OF BAN ESTIMATES OF THE PARAMETERS OF NORMAL POPULATIONS B
A CONTROL ON PARTITIONING A SET OF NORMAL POPULATIONS BY THEIR LOCATIONS WITH RESPECT TO SEQUENTAL AMS 671365 JRSSB57 133 BIOKA5B $5 B 7$ JASA $56 \quad 621$ JASA $62 \quad 446$ AMS $63 \quad 633$ AMS $63 \quad 940$ AMS $65 \quad 1504$ TECH $66 \quad 115$ AMS 69509 BIOKA54 200 JRSSB65 301 BIOCS67 846 MME EXTENSIONS BIOKA6B 411 SINGLE-STAGE PRO TECH 68693 OPTIMUM CLASSIFIC AMS $65 \quad 1174$ MULTIPLE COMPARISONS TECH $68 \quad 715$ ON APPROXIMATTONS TO SAM AMS 631308 A SEQUENTIAL PROCEDURE FOR S AMS $64 \quad 174$ ON THE SOLUTION OF ESTIMATING BIOKA57 225

/SMALLEST CHARACTERISTIC ROOT U AMS 641807 /ARISON OF TWO APPROXIMATIONS TO BIOKA52 130 /BY TRUNCATED SAMPLES OF GROUPED BIOKA63 207 ASED ON SINGLY AND DOUBLY TRUNCAT JASA $62 \quad 46$ BY THEIR LOCATIONS WITH RESPECT TO AMS 691300 ESTIMATION OF MEANS OF NORMAL POPULATIONS FROM OBSERVED MINIMA BIOKA57 282

E MAXIMUM-LIKELIHOOD ESTIMATION OF THE PARAMETERS OF NORMAL POPULATIONS FROM SINGLY AND DOUBLY CENSORED SA BIOKA66 205 SIGNIFICANCE OF THE DIFFERENCE BETWEEN MEANS IN TWO NORMAL POPULATIONS HAVING UNEQUAL VARIANCES $/ O R$ THE BIOKA5 1252

PLE MULTIPLE DECISION PROCEDURE FOR RANKING MEANS OF NORMAL POPULATIONS WITH A COMMON UNKNOWN VARIANCE / BIOKA54 I7O INTERVAL ESTIMATION OF THE LARGEST MEAN OF K NORMAL POPULATIONS WITH KNOWN VARIANCES ON THE CHOICE OF THE BEST AMONGST THREE NORMAL POPULATIONS WITH KNOWN VARIANCES DETECTION OF BEST AND OUTLYING NORMAL POPULATIONS WITH KNOWN VARIANCES RANKING MEANS OF TWO NORMAL POPULATIONS WITH UNKNOWN VARIANCES

FOR TESTING THE DIFFERENCE BETWEEN THE MEANS OF TWO NORMAL POPULATIONS WITH UNKNOWN VARIANCES TWO-SIDED TOLERANCE LIMITS FOR NORMAL POPULATIONS, SOME IMPROVEMENTS

'ON THE MOMENTS OF ORDER STATISTICS IN SAMPLES FROM NORMAL POPULATIONS'

LARGE BATCHES OF ITEMS WHERE THE MEAN QUALITY HAS A NORMAL PRIOR DISTRIBUTION 
ON MULTIVARIATE NORMAL PROBABILITIES OF RECTANCLES

ORDINATE RATIOS AND OF THEIR RECIPROCALS THE NORMAL PROBABILITY FUNCTION, TABLES OF CERTAIN AREA-

A NEW ASYMPTOTIC EXPANSION FOR THE NORMAL PROBABILITY INTECRAL AND MILL'S RATIO HER FULLY INVARIANT TESTS FOR CLASSICAL MULTIVARIATE NORMAL PROBLEMS

THE NUMBER OF CROSSINCS OF A LEVEL BY A STATIONARY NORMAL PROCESS

THE MEAN NUMBER OF CURVE CROSSINCS BY NON-STATIONARY NORMAL PROCESSES

TIAL SCHEMES FOR ESTIMATING THE MEAN OF A CUMULATIVE NORMAL QUANTAL RESPONSE CURVE

THE DISTRIBUTION OF A QUADRATIC FORM OF NORMAL RANDOM VARIABLES

ON LINEAR FUNCTIONS OF ORDERED CORRELATED NORMAL RANDOM VARIABLES

ON THE RATIO OF TWO CORRELATED NORMAL RANDOM VARIABLES AND RATIOS OF LINEAR FUNCTIONS OF ORDERED CORRELATED NORMAL RANDOM VARIABLES WITH EMPHASIS ON RANGE /NS BIOKA64 I43 ECISION PROBLEMS WITH LINEAR LOSSES FOR BINOMIAL AND NORMAL RANDOM VARIABLES. SEQUENTIAL SAMPLING, TWO D BIOKA65 507 ON THE GENERATION OF NORMAL RANDOM VECTORS

INTERPOLATIONS AND APPROXIMATIONS RELATED TO THE NORMAL RANCE

THE EFFICIENCIES OF TESTS OF RANDOMNESS AGAINST NORMAL REGRESSION

THE EFFICIENCY OF THE RECORDS TEST FOR TREND IN NORMAL RECRESSION

CONDITIONAL-NORMAL RECRESSION MODELS

ISTRIBUTION FUNCTIONS OF STATIONARY TIME SERIES WITH NORMAL RESIDUALS THE RATIO OF RANGE TO STANDARD DEVIATION IN THE SAME NORMAL SAMPLE INTERVALS BASED ON THE MEAN ABSOLUTE DEVIATION OF A NORMAL SAMPLE THE MEAN AND STANDARD DEVIATION FROM A CENSORED NORMAL SAMPLE CATION AND SCALE PARAMETERS GIVEN A TYPE II CENSORED NORMAL SAMPLE THE DISTRIBUTION OF THE RATIO, IN A SINGLE NORMAL SAMPLE,

MOMENT CONSTANTS FOR THE DISTRIBUTION OF RANGE IN NORMAL SAMPLES THE VARIANCE OF SPEARMAN'S RHO IN NORMAL SAMPLES THE THIRD MOMENT OF KENDALL'S TAU IN NORMAL SAMPLES /ODNESS OF FIT TEST FOR SPECTRAL D BIOKA56 257 BIOKA64 4B4 CONFIDENCE JASA $65-257$ ESTIMATING BIOKA67 155 /XIMUM LIKELIHOOD ESTIMATES OF THE LO BIOKA6I 448 OF RANGE TO STANDARD DEVIATION BIOKA54 482 BIOKA51 463 BIOKA6I 19 BIOKA62 177 BIOKA68 595 A NOTE ON THE CORRELATION OF RANGES IN CORRELATED NORMAL SAMPLES OF MATRIX VARIATES AND LATENT ROOTS DERIVED FROM NORMAL SAMPLES AND PRODUCT MOMENTS OF EXTREME ORDER STATISTICS IN NORMAL SAMPLES THE DISTRTBUTION OF RANGE IN NORMAL SAMPLES WITH N=200

TABLES OF PERCENTAGE POINTS OF ROOT'BI' AND B2 IN NORMAL SAMPLES, A ROUNDING OFF ECONOMICS TWO-STAGE NORMAL SAMPLING IN TWO-ACTION PROBLEMS WITH LINEAR ASYMPTOTIC EFFICIENCY OF MULTIVARIATE NORMAL SCORE TEST ON THE SUM OF SQUARES OF NORMAL SCORES VALUES OF ORDERED VARIATES AND THE SUM OF SQUARES OF NORMAL SCORES DISTRIBUTION AND POWER OF THE ABSOLUTE NORMAL SCORES TEST EMENT AND EXACT BAHADUR EFFICIENCY OF THE TWO-SAMPLE NORMAL SCORES TEST THE CURVE THROUGH THE EXPECTED DISTRIBUTIONS AMS $64 \quad 475$ ON THE MOMENTS OF THE RANGE BIOKA56 458 BIOKA57 257 BIOKA65 282 JASA 69 NO. 4 AMS 671753 BIOKA56 456 BIOKA66 252 JASA $67 \quad 966$ ON THE EFFICIENCY OF THE NORMAL SCORES TEST RELATIVE TO THE F-TEST POWER AND EFFICIENCY FOR THE ONE SAMPLE WILCOXON AND NORMAL SCORES TESTS

ON THE NORMAL SCORES TWO-SAMPLE RANK TEST

CORRIGENDA, 'ON THE SUM OF SQUARES OF NORMAL SCORES

POWER FOR THE ONE SAMPLE WILCOXON TEST FOR NON-NORMAL SHIFT ALTERNATIVES

ON THE NORMAL STATIONARY PROCESS , AREAS OUTSTDE Q

ON THE LINEAR CONTROL OF A LINEAR SYSTEM HAVING A NORMAL STATIONARY STOCHASTIC INPUT

DINATE TRANSFORMATIONS TO NORMALITY AND THE POWER OF NORMAL TESTS FOR INDEPENDENCE

RDERED ALTERNATIVES IN MODEL I ANALYSIS OF VARIANCE, NORMAL THEORY AND NONPARAMETRIC

THE MULTIVARIATE DISTRIBUTION OF COMPLEX NORMAL VARIABLES

COMPUTING THE DISTRIBUTION OF QUADRATIC FORMS IN NORMAL VARIABLES

TRACES AND CUMULANTS OF QUADRATIC FORMS IN NORMAL VARIABLES

TRANSFORMATION TO A SET OF STOCHASTICALLY DEPENDENT NORMAL VARIABLES

FUNCTIONS OF QUADRATIC FORMS IN SERIALLY CORRELATED NORMAL VARIABLES

FUNCTION OF HERMITIAN QUADRATIC FORMS IN COMPLEX NORMAL VARIABLES

VARIABLES

RATTOS OF NORMAL VARIABLES

CONDITIONAL MEANS AND COVARIANCES OF NORMAL VARIABLES WITH SINGULAR COVARIANCE MATRIX

JRSSB68 381

CO-OR BIOKA69 139

TESTINC AGAINST O AMS 671740

BIOKA56 212

BIOKA61 419

JRSSB54 247

LINEAR JASA $57 \quad 247$

MOMENT GENERATING BIOKA5B 19B THE CHARACTERISTIC BIOKA60 199 JASA 641203 N DIFFERENTIAL FOR POSITIVE DIRECTIONAL SELECTION ON NORMAL VARIABLES WITHIN SETS OF FINITE SUBPOPULATIONS BIOCS67 842 PRESENTATIONS OF DISTRIBUTIONS OF QUADRATIC FORMS IN NORMAL VARIABLES, I CENTRAL CASE PRESENTATIONS OF DISTRIBUTIONS OF QUADRATIC FORMS IN NORMAL VARIABLES, II, NON-CENTRAL CASE

'COMPUTING THE DISTRIBUTION OF QUADRATIC FORMS IN NORMAL VARIABLES'

EAN ABSOLUTE DEVIATION IN CONFIDENCE INTERVALS FOR A NORMAL VARIATE ON DETECTINC CHANGES IN THE MEAN OF NORMAL VARIATES

SERIES RE AMS $67 \quad 838$ CORRIGENDA, BIOKA62 284 THE CORRECT USE OF THE SAMPLE M TECH $66 \quad 663$ AMS 69116 JRSSB62 148 ON THE DISTRIBUTION OF CERTAIN QUADRATIC FORMS IN NORMAL VARIATES INEQUALITY FOR THE RATIO OF TWO QUADRATIC FORMS IN NORMAL VARIATES OF PARTIAL SUMS OF A FINITE NUMBER OF INDEPENDENT NORMAL VARIATES OF PARTIAL SUMS OF A FINITE NUMBER OF INDEPENDENT NORMAL VARIATES OF PARTIAL SUMS OF A FINITE NUMBER OF INDEPENDENT NORMAL VARIATES ISTRIBUTION OF SUMS OF SQUARES AND CROSS PRODUCTS OF NORMAL VARIATES IN ORDER ON CERTAIN FUNCTIONS OF NORMAL VARIATES THE STATISTICAL INDEPENDENCE OF QUADRATIC FORMS IN NORMAT VARIATES

IBUTION OF A DEFINITE QUADRATIC FORM FOR NON-CENTRAL NORMAL VARIATES,

AND INDEPENDENCE OF SECOND DEGREE POLYNOMIALS IN NORMAL VECTOR

BASED ON POSITIVE DEFINITE QUADRATIC FUNCTIONS IN NORMAL VECTORS A CHARACTERTZATION OF NORMALITY

A COMPARATIVE STUDY OF VARIOUS TESTS FOR NORMALITY A COMPARISON OF CERTAIN TESTS OF NORMALITY

BETA DISTRIBUTION AND A TEST FOR MULTIVARIATE NORMALITY

VARIABLES ACCEPTANCE SAMPLING WITH EMPHASIS ON NON-NORMALITY AN ANALYSIS OF VARIANCE TEST FOR NORMALITY (COMPLETE SAMPLES AN AMS $68 \quad 1762$

ON THE RANCE BTOKA53 35

THE VARIANCE OF THE MAXIMUM BIOKA55 96 ON THE MOMENTS OF THE MAXIMUM BIOKA56 79 N THE PRESENCE OF INTRA-CLASS CORREL AMS 621461 HICH ARE UNCORRELATED OF A HICHER BIOKA60 175 CORRIGENDA, 'ON BIOKA59 279 DISTR AMS 61 8 B3 $\begin{array}{llr}\text { CONDITIONS FOR WISHARTNESS AMS } & 62 & 1002 \\ \text { TAIN DISTRIBUTION PROBLEMS } & \text { AMS } 66 & 468\end{array}$ ON CERTAIN DISTRIBUTION PROBLEMS AMS $66 \quad 468$ JASA $68 \quad 1343$ SASJ 69 N0.2 MULTIVARIATE JRSSB 68 5II

SUMMARY OF RECENT WORK ON TECH 69 NO. 4 BIOKA65 591 TORS FOR FAMILIES OF LINEAR REGRESSIONS ASYMPTOTIC NORMALITY AND CONSISTENCY OF THE LEAST SQUARES ESTIMA AMS 63 447 NCE CO-ORDINATE TRANSFORMATIONS TO NORMALITY AND THE POWER OF NORMAL TESTS FOR INDEPENDE BIOKA69 I39 OF ERROR SPACES AND THEIR USE FOR TNVESTI TATIN THE NORMALITY AND VARIANCES OF RESIDUALS MULTIVARIATE REGRESSION OF DUMMY VARIATES UNDER NORMALITY ASSUMPTIONS

VARIANCES FOR DUMMY YARIATE REGRESSION UNDER NORMALITY ASSUMPTIONS JASA $63 \quad 1054$ RECRESION OF IUNEAR EXAMPLE OF ERRORS INCURRED BY ERRONEOUSLY ASSUMING NORMALITY FOR CUSUM SCHEMES ASYMPTOTIC NORMALITY IN NONPARAMETRIC METHODS ON ASYMPTOTIC NORMALITY IN STOCHASTIC APPROXIMATION
AN TECH $67 \quad 457$ AMS 68905 AMS 681327 

ALTERNATIVES, II

TO DOSE-RESPONSE CURVES
HODGES BIVARIATE SIGN TEST BIVARIATE TWO-SAMPLE PROBLEM COMPONENTS ANALYSIS COEFFICIENT C NORMALITY HYPOTHESES I I

HESIS N THE NULL DISTRIBUTION AND BAHADUR EFFICIENCY OF THE THE NON NULL DISTRIBUTION OF A NON-PARAMETRIC TEST FOR THE NULL DISTRIBUTION OF THE FIRST SERIAL CORRELATION THE WILCOXON TEST AND NON-NULL HYPOTHESES ORDER STATISTICS
PROCESSES

ALTERNATIVES

TWO-SAMPLE PROBLEM
ASYMPTOTIC NORMALITY OF BISPECTRAL ESTIMATES ASYMPTOTIC NORMALITY OF CERTAIN TEST ASYMPTOTIC NORMALITY OF LINEAR COMBINATIONS OF FUNCTIONS OF AN ELEMENTARY PROOF OF ASYMPTOTIC NORMALITY OF LINEAR FUNCTIONS OF ORDER STATISTICS ON THE ASYMPTOTIC NORMALITY OF ONE-SIDED STOPPING RULES ASYMPTOTIC NORMALITY OF SAMPLE QUANTILES FOR M-DEPENDENT THE JOINT ASSESSMENT OF NORMALITY OF SEVERAL INDEPENDENT SAMPLES ASYMPTOTIC NORMALITY OF SIMPLE LINEAR RANK STATISTICS UNDER ASYMPTOTIC NORMALITY OF SIMPLE LINEAR RANK STATISTICS UNDER A NOTE ON THE ASYMPTOTIC NORMALITY OF THE MANN-WHITNEY-WILCOXON STATISTIC THE ASYMPTOTIC NORMALITY OF TWO TEST STATISTICS ASSOCIATED WITH THE EFFECT OF NON-NORMALITY ON STEIN'S TWO SAMPLE TEST

TRANSFORMATIONS TO NORMALITY USING FRACTIONAL POWERS OF THE VARIABLE

ON THE KOLMOGOROV-SMIRNOV TEST FOR NORMALITY WITH MEAN AND VARIANCE UNKNOWN APPROXIMATIONS FOR

THE NULL DISTRIBUTION OF THE W-STATISTIC +(TEST FOR NORMALITY)

ON CONVERGENCE IN R-MEAN OF NORMALIZED PARTIAL SUMS

TEST FOR MONOTONE FAILURE RATE BASED ON NORMALIZED SPACINC

ON NORMALIZING THE INCOMPLETE BETA-FUNCTION FOR FITTING

CONFIDENCE INTERVALS FOR THE MEANS OF DEPENDENT NORMALLY DISTRIBUTED VARIABLES

ON MOMENTS OF THE MAXIMUM OF NORMED PARTIAL SUMS

A CHARACTERIZATION OF CERTAIN SEQUENCES OF NORMING CONSTANTS ATION OF INCIDENCE OF RED SPIDER MITE ON TEA CROP IN NORTH-EAST INDIA PART I. DESCRIPTION AND USE OF TABLE BI TENSOR NOTATION AND THE SAMPLINC CUMULANTS OF K-STATISTICS SAMPLINC CUMULANTS OF K-STATTSTICS BIOKA52 319 T CHI-SQUARE ESTIMATE TO A PROBLEM OF CRIZZLE WITH A NOTATION ON THE PROBLEM OF NO INTERACTION /MUM LOGI BIOCS68 75 THE LIMIT OF THE NTH POWER OF A DENSITY

INTERFERENCE IN THE MANUFACTURE OF NUCLEPORE FILTERS

AMS 661257 AMS 69 NO. 6 AMS 68263 AMS $68 \quad 1493$ AMS $6 B \quad 1724$ TECH $68 \quad 825$ AMS $6 \mathrm{~B} \quad 325$ AMS 69 N0.6 JASA $61 \quad 687$ AMS 631513 AMS $65 \quad 651$ $\begin{array}{ll}\text { JASA } & 57 \quad 237\end{array}$ JASA $67 \quad 399$ TECH 6B B61 AMS 691216 IOKA60 173 JASA $59 \quad 613$ AMS 69527 AMS 68391 385 AMS $65 \quad 1 B 7 B$ TECH $67 \quad 319$ AMS $62 \quad 803$ JRSSB69 98 BIOKA66 590 BIOKA66 623 BIOKA67 629 $\begin{array}{lllll}\text { APPROXIMATIONS FOR THE NULL DISTRIBUTION OF THE W-STATISTIC + ITEST FOR } & \text { TECH } 6 B \\ \text { B-REGRESSIVE MODEL. II. NULL DISTRIBUTIONS FOR HIGHER ORDER SCHEMES, NON-NULL BIOKA56 } & 186\end{array}$ JRSSB $60 \quad 402$ A SEQUENTIAL PROCEDURE FOR TESTING A NULL HYPOTHESIS ACAINST A TWO SIDED ALTERNATIVE HYPOT JRSSB69 NO.2 OET BALANCED INCOMPLETE BLOCK DESICN UNDER THE/ ON THE NULL-DISTRIBUTION OF THE F-STATISTIC IN A RANDOMIZED AMS 63 I558 THE NUMBER AND WIDTH OF CLASSES IN THE CHI-SQUARE TEST JASA $6367 \mathrm{~B}$

EPTANCE SAMPLING PLANS SAMPLES WITH THE SAME NUMBER IN EACH STRATUM

A NOTE ON THE VARIANCE OF THE DISTRIBUTION OF SAMPLE NUMBER IN SEQUENTIAL PROBABILITY RATIO TESTS MAJORANTS OF THE CHROMATIC NUMBER OF A RANDOM CRAPH

PROBABILITY MODELS FOR THE VARIATION IN THE NUMBER OF BIRTHS PER COUPLE

A CHANCE MECHANISM OF THE VARIATION IN THE NUMBER OF BIRTHS PER COUPLE

A NOTE ON INCOMPLETE BLOCK DESIGNS WITH THE NUMBER OF BLOCKS EQUAL TO THE NUMBER OF TREATMENTS THE DISTRIBUTION OF THE NUMBER OF CIRCULAR TRIADS IN PAIRED COMPARISONS

TECH $6 \mathrm{~B} \quad 685$ TECH $66 \quad 700$ JRSSB 69 NO. 2 JASA $63 \quad 721$ JASA $68 \quad 209$ AMS 651877 BIOKA62 265 AMS $6 \mathrm{~B} \quad 379$ BIOKA52 414 SSICAL OCCUPANCY PROBLEM. UNBIASED ESTIMATION OF THE NUMBER OF CLASSES STATISTICAL INFERENCE IN THE CLA JASA 6B B37 CERTAIN PARTIALLY BALANCED INCOMP/ BOUNDS FOR THE NUMBER OF COMMON TREATMENTS BETWEEN ANY TWO BLOCKS OF AMS 65 337 PARTIALLY BALANC/ COMPARISON OF THE BOUNDS OF THE NUMBER OF COMMON TREATMENTS BETWEEN BLOCKS OF CERTAIN AMS 66 739 GULAR CROUP DIVISIBLE DESICNS ON THE BOUNDS OF THE NUMBER OF COMMON TREATMENTS BETWEEN BLOCKS OF SEMI-RE JASA 64 B67 DURING VIRAL INFECTION OF BACT/ ESTIMATION OF THE NUMBER OF CRITICAL SITES IN LIMITED GENOME EXPRESSION BIOCS69 537 PROCESS PROCESSES THE MOMENTS OF THE NUMBER OF CROSSINGS OF A LEVEL BY A STATIONARY NORMAL ON THE MEAN NUMBER OF CURVE CROSSINGS BY NON-STATIONARY NORMAL

AMS 651656 AMS $65 \quad 509$ ED INCOMPLETE BLOCK DESIGNS AN UPPER BOUND FOR THE NUMBER OF DISJOINT BLOCKS IN CERTAIN PARTIALLY BALANC AMS 64 398 PHS (CORR. 69 151/A CENTRAL LIMIT THEOREM FOR THE NUMBER OF EDGES IN THE RANDOM INTERSECTION OF TWO GRA AMS 69 144 ALYSIS OF THE GENERAL NON-ORTHOCONAL LAYOUT WITH ANY NUMBER OF FACTORS HOW TO SURVIVE A FIXED NUMBER OF FAIR BETS

ON THE RANGE OF PARTIAL SUMS OF A FINITE NUMBER OF INDEPENDENT NORMAL VARIATES VARIANCE OF THE MAXIMUM OF PARTIAL SUMS OF A FINITE NUMBER OF INDEPENDENT NORMAL VARIATES MOMENTS OF THE MAXIMUM OF PARTIAL SUMS OF A FINITE NUMBER OF INDEPENDENT NORMAL VARIATES ON LIMITINC DISTRIBUTIONS FOR SUMS OF A RANDOM NUMBER OF INDEPENDENT RANDOM VECTORS THE ENUMERATION OF ELECTION RETURNS BY NUMBER OF LEAD POSITIONS MAIN-EFFECT AN AMS 65 BB

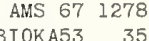
THE BIOKA55 96 ON THE BIOKA56 79 AMS 69935 AMS $64 \quad 369$ COVERAGE. WHEN A SAMPLE IS INCREASED THE NUMBER OF NEW SPECIES. AND THE INCREASE IN POPULATION BIOKA56 45 SPACINGS DETERMINED BY/ TESTS OF FIT BASED ON THE NUMBER OF OBSERVATIONS FALLING IN THE SHORTEST SAMPLE AMS 61 B3B ON THE SIZE OF AN EPIDEMIC AND THE NUMBER OF PEOPLE HEARING A RUMOUR STATISTICAL PROPERTIES OF THE NUMBER OF POSITIVE SUMS

A STATISTICAL TEST INVOLVING A RANDOM NUMBER OF RANDOM VARIABLES

ON THE NUMBER OF RENEWALS IN A RANDOM INTERVAL

JRSSB $66 \quad 4 B 7$ AMS 661295 AMS 661305

BIOKA60 449

ED SERIES PROBABILITY TABLE FOR NUMBER OF RUNS OF SIGNS OF FIRST DIFFERENCES IN ORDER JASA 61 156 LOWER BOUNDS FOR AVERAGE SAMPLE NUMBER OF SEQUENTIAL MULTIHYPOTHESIS TESTS AMS 67 1343 THE OPERATTNC CHARACTERISTIC AND THE AVERAGE SAMPLE NUMBER OF SOME SEQUENTIAL TESTS /AE FOR CALCULATING JRSSB58 379 THE DISPERSION OF A NUMBER OF SPECIES RIBUTION THEORY FOR MARKOV CHAINS WITH A DENUMERABLE NUMBER OF STATES JRSSB59 190 THETSTI ON THE DISTRIBUTION OF THE NUMBER OF SUCCESSES IN INDEPENDENT TRIALS ON THE NUMBER OF SUCCESSES IN INDEPENDENT TRIALS AMS 641317 AMS 651272

XPECTED VALUES OF NOR/A NOTE ON THE ERROR AFTER A NUMBER OF TERMS OF THE DAVID-JOHNSON SERIES FOR THE E BIOKA6O 79 THE EXPECTED NUMBER OF ZEROS OF A STATIONARY CAUSSIAN PROCESS AMS 651043 STATISTICAL ESTIMATION OF THE CASOLINE OCTANE NUMBER REQUIREMENT OF NEW MODEL AUTOMOBILES UNBIASED ESTIMATION AND CERTAIN PROBLEMS OF ADDITIVE NUMBER THEORY A COMBINATORIAL LEMMA FOR COMPLEX NUMBERS BIAS IN PSEUDO-RANDOM NUMBERS A MARKOV PROCESS ON BINARY NUMBERS

A NOTE ON THE WEAK LAW OF LARGE NUMBERS QUERY, PSEUDO RANDOM NORMAL NUMBERS TECH $60 \quad 5$ AMS 631050 AMS 61901 JASA $61 \quad 610$ AMS $63 \quad 416$ AMS 681348 TECH $6 \mathrm{~B} \quad 401$ 
ON THE RATE OF CONVERCENCE FOR THE LAW OF LARCE NUMBERS A PROBLEM IN THE SICNIFICANCE OF SMALL NUMBERS THE POLYKAYS OF THE NATURAL NUMBERS

CONVERCENCE OF MARTINCALES AND THE LAW OF LARCE NUMBERS

BETWEEN SUCCESSIVE MAXIMA IN A SERIES OF RANDOM NUMBERS

BLOCKS, BY WEIGHTED MEANS, OF A FINITE SET OF REAL NUMBERS

LOCAL AMS $65 \quad 552$ RANSFORMED PERCENTACE SIB DATA WITH UNEQUAL SUBCLASS NUMBERS FUNCTIONS AND CONVERCENCE RATES IN THE LAW OF LARCE NUMBERS APTURE-RECAPTURE METHOD. II. THE ESTIMATION OF TOTAL NUMBERS ISTICS, XXI ON THE EARLY HISTORY OF THE LAW OF LARCE NUMBERS THE DILUTION ERRORS INVOLVED IN ESTIMATINC BACTERIAL NUMBERS

THE DISTRIBUTION OF INTERVALS BIOKA57 524 THE COMPLETE AMALGAMATION INTO BIOKA59 317 ESTIMATES OF HERITABILITY FROM T BIOCS65 1001 SOME RESULTS RELATINC MOMENT GENERATINC AMS $67 \quad 742$ /ETERS FROM DATA OBTAINED BY MEANS OF THE C BIOKA52 363 /IES IN THE HISTORY OF PROBABILITY AND STAT BIOKA68 459 A BOUND FOR THE LAW OF LARCE NUMBERS FOR DISCRETE MARKOV PROCESSES TH A SPECIAL KIND OF IRRECULAR FRACTIONAL P/ INDEX NUMBERS FOR FACTORIAL EFFECTS AND THEIR CONNECTION WI JASA 63 497 VARI/ ON THE CONVERGENCE RATE OF THE LAW OF LARGE NUMBERS FOR LINEAR COMBINATIONS OF INDEPENDENT RANDOM AMS 65 559 CONVERGENCE RATES FOR THE LAW OF LARCE NUMBERS FOR LINEAR COMBINATIONS OF MARKOV PROCESSES AMS 66 7II L/ AN EXPONENTIAL BOUND ON THE STRONC LAW OF LARGE NUMBERS FOR LINEAR STOCHASTIC PROCESSES WITH ABSOLUTE AMS 61 5B3 ON THE STRONG LAM OF LARCE NUMBERS FOR MARTINGALES

SOME THEOREMS CONCERNING THE STRONG LAW OF LARGE NUMBERS FOR NON-HOMOGENEOUS MARKOV CHAINS ND MIXING/ CONVERGENCE RATES FOR THE LAW OF LARGE NUMBERS FOR THE LINEAR COMBINATIONS OF EXCHANGEABLE A AMS 65 1840 SEQUENCE A LAW OF LARGE NUMBERS FOR THE MAXIMUM IN A STATIONARY GAUSSIAN CHI-SQUARE PROBABILITIES FOR LARGE NUMBERS OF DEGREES OF FREEDOM BIOKA56 92 ANALYSIS OF MULTIFACTOR CLASSIFICATIONS WITH UNEQUAL NUMBERS OF OBSERVATIONS TATISTICAL DEPENDENCE BETWEEN SUBCLASS MEANS AND THE NUMBERS OF OBSERVATIONS IN THE SUBCLASSES FOR THE TWO JASA 68 1484 TATISTICAL DEPENDENCE BETWEEN RANDOM EFFECTS AND THE NUMBERS OF OBSERVATIONS ON THE EFFECTS FOR THE UNBALA JASA 67 1375 MPLING ERRORS IN AN ORCHARD SURVEY INVOLVING UNEQUAL NUMBERS OF ORCHARDS OF DISTINCT TYPE BALANCED DESIGNS WITH UNEQUAL NUMBERS OF REPLICATES SAMPLE HOW MANY OF A GROUP OF RANDOM NUMBERS WILL BE USABLE IN SELECTING A PARTICULAR ON CONVERGENCE TO INFINITY IN THE LAW OF LARGE NUMBERS, (AGKNOWLEDGEMENT OF PRIORITY 631111 ) COVARIANCE ANALYSIS WITH UNEQUAL SUBCLASS NUMBERS, COMPONENT ESTIMATION IN CORRELATION STUDIES BIOCS68 49 ERRORS OF BOTH KINDS AND THE GORRELATION BETWEEN THE NUMERATOR AND DENOMINATOR OF THE F-RATIO /-TEST TO JASA 68 660 RECRESSION ANALYSIS STATISTICS THE BINOMIAL DISTRIBUTION SOME EXPERIMENTS IN THE NUMERICAL ANALYSIS OF ARCHAEOLOCICAL DATA

JASA 68 660 A NUMERICAL ANALYSIS PROBLEM IN CONSTRAINED QUADRATIC TECH 62426 SOME NUMERICAL ASPECTS OF THE USE OF TRANSFORMS IN JASA $63 \quad 879$ SOME NUMERICAL COMPARISONS OF SEVERAL APPROXIMATIONS TO JASA 69 NO. NUMERICAL CONSTRUCTION OF ORTHOGONAL POLYNOMIALS FROM BIOCS6B 695

INTEGRALS

THE DEVELOPMENT OF NUMERICAL CREDIT EVALUATION SYSTEMS THE NUMERICAL EVALUATION OF CERTAIN MULTIVARIATE NORMAL AMS $62 \quad 571$ TOLERANCING $\begin{array}{llrrr}\text { UTILIZATION OF NON-NUMERICAL INFORMATION IN QUANTITATIVE ANALYSIS. GENER AMS } & 63 & 1347 \\ \text { AN APPLICATION OF NUMERICAL INTEGRATION TECHNIQUES TO STATISTICAL } & \text { TECH } 67 & 44\end{array}$ A NUMERICAL INVESTIGATION OF LEAST SQUARES REGRESSION JRSSB55 I05 YING THE PROPERTIES OF CERTAIN BIOLOGICAL SYSTEMS BY NUMERICAL METHODS VARIABILITY. THE SINGLE FACTOR CASE MATRIX, CORR. 661248 NUMERICAL OPTIMIZATION IN THE PRESENCE OF RANDOM BIOKA69 A NUMERICAL PROCEDURE TO GENERATE A SAMPLE COVARIANCE JASA 66

BODE'S LAW AND AN 'OBJECTIVE' TEST FOR APPROXIMATE NUMERICAL RATIONALITY A SUBJECTIVE EVALUATION OF JASA 69 $F$ BODE'S LAW AND AN 'OBJECTIVE' TEST FOR APPROXIMATE NUMERICAL RATIONALITY' /'A SUBJECTIVE EVALUATION O JASA 69 PROBABILITY GENETIC PROCESS

SUB-K-M-1

SUB-K-M-1.'

UL IN THE DESIGN OF EXPERIMENTS BINOMIAL PARAMETER

ON THE NUMERICAL REPRESENTATION OF QUALITATIVE CONDITION NUMERIGAL RESULTS AND DIFFUSION APPROXIMATIONS IN A SOME NUMERIGAL RESULTS FOR WAITING TIMES IN THE QUEUE ECORRIGENDA, 'SOME NUMERICAL RESULTS FOR WAITING TIMES IN THE QUEUE E-

THE NUMERICAL SOLUTION OF SOME NON-LINEAR EQUATIONS, USEF AMS $68 \quad 481$ BIOKA63 241 BIOKA60 202 BIOKA60 484 EXPERIMENTAL DEVELOPMENT OF NUTRITTVE MEDIA FOR MICRO-ORGANISMS SAMPLING IN A NUTSHELL ANCED INCOMPLETE BLOCK DESIGNS WITH PARAMETERS V=28, N1=12, N2=15 AND P2(1,1)=4/CTION OF PARTIALLY BAL AMS 66 1783 NCOMPLETE BLOCK DESIGNS WITH PARAMETERS V=2B, N1=12, N2=15 AND P2 $(1, I)=4$ /GTION OF PARTIALLY BALANCED I AMS 66 1783 SOME FURTHER DESIGNS OF TYPE O-PP OBITUARY, ADOLPHE FRANCESCHETTI OBITUARY, C. G. FRAGA, JR OBITUARY, FRANK WILCOXON OBITUARY, GORDON M. L. HASKELL OBITUARY, O. HEINISCH OBITUARY, SULLY LEDERMANN

AMS 611186 BIOCS6B 726 BIOCS66 634 BI0CS66 192 BI0CS67 B50 BI0CS66 413 BI0CS67 366 JASA $63 \quad 236$

HIERARCHICAL GROUPING TO OPTIMIZE AN OBJECTIVE FUNCTION A SUBJECTIVE EVALUATION OF BODE'S LAW AND AN 'OBJECTIVE' TEST FOR APPROXIMATE NUMERICAL RATIONALITY JASA 69 23 ON OF 'A SUBJECTIVE EVALUATION OF BODE'S LAW AND AN 'OBJECTIVE' TEST FOR APPROXIMATE NUMERICAL RATIONALITY JASA 69 50 RANDOM HYDRODYNAMIC FORCES ON OBJECTS AMS $67 \quad 37$ L BEHAVIOUR OF TWO MORPHOLOGICALLY INDISTINGUISHABLE OBJECTS STATISTICAL TESTING OF DIFFERENCES IN CASUA BIOCS67 RESULTS BASED ON A FEW HETEROGENEOUS LOGNORMAL OBSERVATIONS QUERY DISTRIBUTION OF A RANKED OBSERVATION LIFE-TESTING JASA 67 BIOCS67 65 RANKING PROCEDURES FOR ARBITRARILY RESTRICTED OBSERVATION INTERVAL FOR STANDARD DEVIATION FROM A SINGLE OBSERVATION

RIABLE SUBJECT BOTH TO DISTURBANCES AND TO ERRORS OF OBSERVATION THE USE OF THE CONCEPT OF A FUTURE OBSERVATION IN GOODNESS-OF-FIT PROBLEMS

QUERY CONFIDENCE TECH 66 PREDICTION OF AN AUTOREGRESSIVE VA JASA 65 JRSSB 67 JASA 62 TECH 69 BI0CS66

DISTRIBUTION OF TOTAL SERVICE TIME FOR A FIXED OBSERVATION INTERVAL
ESTIMATION OF A MEAN WHEN ONE OBSERVATION MAY BE SPURIOUS

NOTES. CORRECTED CORRELATION COEFFICIENTS WHEN OBSERVATION ON ONE VARIABLE IS RESTRICTED

ROBUST PROCEDURES FOR SOME LINEAR MODELS WITH ONE OBSERVATION PER CELL NPARAMETRIC INFERENCE IN SOME LINEAR MODELS WITH ONE OBSERVATION PER CELL

ASYMPTOTICALLY NO AMS 64 IN A SPECTFTED ADJUSTMENT BY SUBCLASSIFICATION IN REMOVING BIAS IN OBSERVATIONAL STUDIES NONPARAMETRIC ESTIMATION FROM INCOMPLETE OBSERVATIONS SOME REMARKS ON WILD OBSERVATIONS SPECTRAL ANALYSIS WITH REGULARLY MISSED OBSERVATIONS
PROCEDURES FOR A PROBLEM WITH CHOICE OF OBSERVATIONS $\begin{array}{ll}\text { JASA } & 64 \\ 225\end{array}$ 
ON THE RISK OF SOME STRATEGIES FOR OUTLYING OBSERVATIONS SEQUENTIAL ANALYSIS WITH DELAYED OBSERVATIONS ASSESSING THE ACCURACY OF MULTIVARIATE OBSERVATIONS

QUERY, JOINT CONFIDENCE LIMITS FOR RANKED OBSERVATIONS SHORTER CONFIDENCE INTERVALS USING PRIOR OBSERVATIONS

EXPERIMENTAL DESIGNS FOR SERIALLY CORRELATED OBSERVATIONS A NOTE ON THE LOSS OF INFORMATION DUE TO GROUPING OF OBSERVATIONS EXPONENTIAL REGRESSION WITH CORRELATED OBSERVATIONS NOTE ON DISCORDANT OBSERVATIONS

REMARKS ON EXPONENTIAL REGRESSION WITH CORRELATED OBSERVATIONS MULTIFACTOR CLASSIFICATIONS WITH UNEQUAL NUMBERS OF OBSERVATIONS STATISTIC BASED ON THE POOLED FREQUENCIES OF SEVERAL OBSERVATIONS OF SEQUENTIAL DECISION PROBLEM FOR MARKOV DEPENDENT OBSERVATIONS

FREE TEST OF INDEPENDENCE WITH A SAMPLE OF PAIRED OBSERVATIONS TO THE MEAN AND STANDARD DEVIATION OF RECIPROCALS OF OBSERVATIONS

IN THE FITTING OF POLYNOMIALS TO EQUALLY SPACED OBSERVATIONS

IN THE FITTING OF POLYNOMIALS TO UNEQUALLY SPACED OBSERVATIONS

FOR EXPERIMENTAL DESIGNS WITH SERIALLY CORRELATED OBSERVATIONS PULATION MEAN WHICH REDUCES THE EFFECT OF LARGE TRUE OBSERVATIONS

OF-FIT TEST FOR A CLASS OF CASES OF DEPENDENT OBSERVATIONS FOR LARGEST AND FOR SMALLEST OF A SET OF INDEPENDENT OBSERVATIONS IN THE MULTIVARIATE NORMAL DISTRIBUTION WITH MISSING OBSERVATIONS VALS FOR SAMPLE MEAN AND COVARIANCE BASED ON PARTIAL OBSERVATIONS PROBABILITY RATIO TESTS BASED ON MULTIVARIATE NORMAL OBSERVATIONS EXPERIMENT AS ORTHOGONAL LINEAR COMBINATIONS OF THE OBSERVATIONS FFERENCES, FOR SERIAL CORRELATION BETWEEN SUCCESSIVE OBSERVATIONS DISTRIBUTION

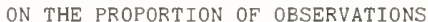

AMS 641524 JASA 641006 JASA $66 \quad 403$ TECH $66 \quad 36 \mathrm{~B}$ JASA 69378 BIOKA52 151 BIOKA64 495 BIOK A68 149 JRSSB 6B 545 FURTHER BIOKA68 575 ANALYSIS OF BIOCS66 525 CHI-SQUARE BIOKA63 524 BAYES SOLUTION AMS 641656 A DISTRIBUTION- JASA $62 \quad 116$ APPROXIMATIONS TECH $63 \quad 522$ GROUPING METHODS BIOKA54 62 GROUPING METHODS BIOKA56 149 TREATMENT VARIANCES BIOKA56 20B AN ESTIMATOR FOR A PO JASA 661200 THE CHI-SQUARE GOODNESS- BIOKA64 250 APPROXIMATE DISTRIBUTION SASJ 69 NO.2 ESTIMATION OF PARAMETERS JASA $68 \quad 159$

ON MULTIVARIATE PREDICTION INTER JASA $67 \quad 634$ /BABILITY ONE OF INVARIANT SEQUENTIAL AMS 678 /FOR FRACTIONS OF A COMPLETE FACTORIAL AMS 631068 /RITERIA, BASED ON FIRST AND SECOND DI AMS 62186 BOVE SAMPLE MEANS IN A BIVARIATE NORMAL AMS 681350 JASA $56 \quad 122$ JASA 59834 TABLES FOR THE SIGN TEST WHEN OBSERVATIONS ARE ESTIMATES OF BINOMIAL PARAMETERS
JASA 59 784 L SAMPLE SIZE IN TWO-ACTION PROBLEMS WHEN THE SAMPLE OBSERVATIONS ARE LOGNORMAL AND THE PRECISION H IS KNO JASA 68 653
TES FOR A MULTIVARIATE NORMAL DISTRIBUTION WHEN SOME OBSERVATIONS ARE MISSING MAXIMUM LIKELIHOOD ESTIMA JASA 57 200 RIMEN/ NOTES ERRORS OF TREATMENT COMPARISONS WHEN OBSERVATIONS ARE MISSING FROM A RANDOMISED BLOCK EXPE BIOCS66 632 DESIGNS THE USE OF CONTROL OBSERVATIONS AS AN ALTERNATIVE TO INCOMPLETE BLOCK JRSSB62 464 ARBITRARY SYSTEM PROCESS WITH ADDITIVE WHITE NOISE OBSERVATIONS ERROR ESTIMATION OF STOCHASTIC SYSTEMS AMS 68 7B5 DETERMINED BY/ TESTS OF FIT BASED ON THE NUMBER OF OBSERVATIONS FALLING IN THE SHORTEST SAMPLE SPACINGS AMS 61 B38 TING GENERALIZED VARIANCE OF A SAMPLE OF CONSECUTIVE OBSERVATIONS FROM A MOVING-AVERAGE PROCESS /HE LIMI BIOKA61 197 TING GENERALIZED VARIANCE OF A SAMPLE OF CONSECUTIVE OBSERVATIONS FROM A MOVING-AVERAGE PROCESS' /E LIMI BIOKA61 476 SERIES THE COMPARISON OF MEANS OF SETS OF OBSERVATIONS FROM SECTIONS OF INDEPENDENT STOCHASTIC JRSSB55 20B TABLES OF RANDOM OBSERVATIONS FROM STANDARD DISTRIBUTIONS LONGEST RUN OF CONSECUTIVE OBSERVATIONS HAVING A SPECIFIED ATTRIBUTE BIOKA6I 461 TECH $68 \quad 850$ $\begin{array}{llll}\text { ORDER } & \text { ON THE USE OF PARTIALLY ORDERED OBSERVATIONS IN MEASURING THE SUPPORT FOR A COMPLETE JASA 61 299 } \\ \text { OF A FIRST ORDER METHOD } & \text { MISSING OBSERVATIONS IN MULTIVARIATE REGRESSION, EFFICIENCY JASA 69 NO.4 }\end{array}$ $\begin{array}{llll}\text { ORDER } & \text { ON THE USE OF PARTIALLY ORDERED OBSERVATIONS IN MEASURING THE SUPPORT FOR A COMPLETE JASA 6I 299 } \\ \text { OF A FIRST ORDER METHOD } & \text { MISSING OBSERVATIONS IN MULTIVARIATE REGRESSION, EFFICIENCY JASA 69 NO.4 }\end{array}$ IMATION IN SIMPLE LINEAR REGRESSION MISSING OBSERVATIONS IN MULTIVARIATE STATISTICS II. POINT EST JASA 67 10 $\begin{array}{lllll}\text { MISSING OBSERVATIONS IN MULTIVARIATE STATISTICS, III } & \text { JASA } 69 & 337 \\ \text { MISSING OBSERVATIONS IN MULTIVARIATE STATISTICS, IV } & \text { JASA } 69 & 359\end{array}$ IANCE OF THE FIT/ THE UNIQUENESS OF THE SPACING OF OBSERVATIONS IN POLYNOMIAL REGRESSION FOR MINIMAX VAR AMS 62 BIO CENSORED OBSERVATIONS IN RANDOMIZED BLOCK EXPERIMENTS JRSSB59 214 PROCEDURES FOR DETECTING OUTLYING OBSERVATIONS IN SAMPLES

THE ESTIMATION OF MISSING AND MIXED-UP OBSERVATIONS IN SEVERAL EXPERIMENTAL DESIGNS OTS ARE MISSING OR MIXED UP ESTIMATION OF MISSING OBSERVATIONS IN SPLIT-PLOT EXPERIMENTS WHERE WHOLE-PL BIOKA6I 468 INFORMATION SUPPLIED BY CENSORED SAMPLES OF GROUPED OBSERVATIONS IN THE ESTIMATION OF STATISTICAL PARAMET BIOKA62 245 INFORMATION SUPPLIED BY TRUNCATED SAMPLES OF GROUPED OBSERVATIONS IN THE ESTIMATION OF THE PARAMETERS OF N BIOKA63 207 DEPENDENCE BETWEEN SUBCLASS MEANS AND THE NUMBERS OF OBSERVATIONS IN THE SUBCLASSES FOR THE TWO-WAY COMPLE JASA 68 1484 SOME OBSERVATIONS ON CHANGE-OVER TRIALS

ANALYSIS OF DISPERSION WITH INCOMPLETE OBSERVATIONS ON ONE OF THE CHARACTERS BIOCS69 413 JRSSB56 259 JASA 671179 SOME OBSERVATIONS ON ROBUST ESTIMATION

DEPENDENCE BETWEEN RANDOM EFFECTS AND THE NUMBERS OF OBSERVATIONS ON THE EFFECTS FOR THE UNBALANCED ONE-WA JASA 67 1375 DESIGNS CONSULTING SOME OBSERVATIONS ON THE TEACHING OF STATISTICAL

BIOKA51 248 BIOCS68 789

JASA $5 B \quad 2 B$ $\begin{array}{lllr}\text { USING THE OBSERVATIONS TO ESTIMATE THE PRIOR DISTRIBUTION } & 17 \\ \text { GROUPS OF OBSERVATIONS WHEN THE RATIOS OF THE POPULATION VARIAN BIOKA5I } & 324\end{array}$ CES ARE UNKNO/ THE COMPARISON OF SEVERAL GROUPS OF OBSERVATIONS WHEN THE RATIOS OF THE POPULATION VARIAN BIOKA5I 324
APPLICATIONS OF THE JIRINA SEQUENTIAL PROCEDURE TO OBSERVATIONS WITH TREND

THE TWO-WAY CLASSIFICATION FIXED EFFECTS MODEL WITH OBSERVATIONS WITHIN A ROW SERIALLY CORRELATED FITTING A POLYNOMIAL TO CORRELATED EQUALLY SPACED OBSERVATIONS SEQUENTIAL ANALYSIS OF DEPENDENT OBSERVATIONS. I

ON LEAST SQUARES WITH INSUFFICIENT OBSERVATIONS, CORR. 651249 SPECTRAL ANALYSIS WITH RANDOMLY MISSED OBSERVATIONS, THE BINOMIAL CASE

AGAINST A GIVEN/A A CHART FOR SEQUENTIALLY TESTING OBSERVED ARITHMETIC MEANS FROM LOGNORMAL POPULATIONS QUERY, COMBINING VALUES OF OBSERVED CHI-SQUARE'S THEORETICAL EXPLANATION OF OBSERVED DECREASE FAILURE RATE

ESTIMATION OF MEANS OF NORMAL POPULATIONS FROM OBSERVED MINTMA PRICING POLICIES CONTINGENT ON OBSERVED PRODUCT QUALITY

ESTIMATION OF PARTICLE SIZE DISTRIBUTION BASED ON OBSERVED WEIGHTS OF GROUPS OF PARTICLES /FOR BIOKA69 N0.3 BIOKA65 275 BIOKA65 157 JASA 64 107B AMS 65971 TECH $68 \quad 605$ TECH $66 \quad 709$ TECH $63 \quad 375$ BIOKA57 2B2 TECH $66 \quad 123$ TECH 65505 THE ESTIMATION OF POPULATION PARAMETERS FROM DATA OBTAINED BY MEANS OF THE CAPTURE-RECAPTURE METHOD. I. BIOKA5I 269 THE ESTIMATION OF POPULATION PARAMETERS FROM DATA OBTAINED BY MEANS OF THE CAPTURE-RECAPTURE METHOD. II BIOKA53 137 THE GOODNESS OF FIT OF FREQUENCY DISTRIBUTIONS OBTAINED FROM STOCHASTIC PROCESSES 'COEFFICIENTS OF VARIATION OF HERITABILITY ESTIMATES OBTAINED FROM VARIANCE ANALYSES' BIOKA54 450 RELIABILITY COMPARISON OF TIO METHODS OF OBTAINTNC APPROXIMATE CONFIDENCE INTERVAL EXPONENTIAL CURVE FITTINC RANK TESTS A METHOD OF OBTAINING INITIAL ESTIMATES OF THE PARAMETERS IN TRIX IN MULTIVARIATE ANALYSIS

$$
\begin{array}{r}
\text { A METHOD OF OBTAINING INITIAL ESTIMATES OF THE PARAMETERS IN } \\
\text { AN ELEMENTARY METHOD OF OBTAINING LOWER BOUNDS ON THE ASYMPTOTIC POWER OF }
\end{array}
$$
PROBABILITY OF OBTAINING NEGATIVE ESTIMATES OF HERTTABILITY AN ALGORITHM FOR OBTAINING THE ZERO OF A FUNCTION OF THE DISPERSION MA JASA $67 \quad 114$ 
THE PROBABILITY THAT A RANDOM TRIANGLE IS OBTUSE

ROTATION DESIGNS FOR SAMPLING ON REPEATED OCCASIONS

DOUBLE SAMPLING FOR STRATIFICATION ON SUCCESSIVE OCCASIONS

ON SAMPLING OVER TWO OCCASIONS WITH PROBABILITY PROPORTIONATE TO SIZE SEQUENTIAL OCCUPANCY

CONTAGIOUS OCCUPANCY

OCCUPANCY PROBABILITY DISTRIBUTION CRITICAL POINTS

ESTIMATION OF A PARAMETER IN THE CLASSICAL OCCUPANCY PROBLEM

A NOTE ON A SEQUENTIAL OCCUPANCY PROBLEM

AN ASYMPTOTIC DISTRIBUTION FOR AN OCCUPANCY PROBLEM WITH STATISTICAL APPLICATIONS

OF CLASSES STATISTICAL INFERENCE IN THE CLASSICAL OCCUPANCY PROBLEM, UNBIASED ESTIMATION OF THE NUMBER SEQUENTIAL OCCUPANCY WITH CLASSIFICATION

\section{PLANE BROWNIAN MOTION}

AN OCCUPATION TIME THEOREM FOR THE ANGULAR COMPONENT OF

INCOME

OCCUPATIONAL COMPONENTS OF EDUCATIONAL DIFFERENCES IN J

E PROBABILITY THAT TWO SPECIFIED SAMPLING UNITS WILL OCCUR IN A SAMPLE DRAWN WITH UNEQUAL PROBABILITIES AN

UTION SHAPE PARAMETER WHEN NO MORE THAN TWO FAILURES OCCUR PER LOT

A RANDOM WALK IN WHICH THE STEPS OCCUR RANDOMLY IN TIME

A MODEL FOR RAINFALL OCCURRENCE

A MODIFIED MODEL FOR RAINFALL OCCURRENCE

BIOKA69 NO.3

JASA $64 \quad 492$

JASA $65 \quad 784$

AMS $65 \quad 327$

BIOKA59 218

JRSSB59 120

BIOKA61 175

BIOKA 60180

BIOKA68 591

TECH $61 \quad 79$

JASA $68 \quad 837$

BIOKA68 229

AMS $67 \quad 25$

JASA 61783

JASA $66 \quad 384$

TECH $64 \quad 415$

BIOKA59 30

JRSSB $64 \quad 345$

JRSSB67 151

RELATION BETWEEN THE DICTIONARY DISTRIBUTION AND THE OCCURRENCE DISTRIBUTION OF WORD LENGTH AND ITS IMPORT BIOKA58 222

THE EQUIVALENCE OF TWO TESTS OF EQUALITY OF RATE OF OCCURRENCE IN TWO SERIES OF EVENTS OCCURRING RANDOMLY BIOKA58 267

RIMENTS TO ESTIMATE PARAMETERS IN NON-LINEAR/ THE OCCURRENCE OF REPLICATIONS IN OPTIMAL DESIGNS OF EXPE JRSSB68 290

TERISTICS OF A RATIO USED TO ESTIMATE FAILURE RATES, OCCURRENCES PER PERSON YEAR OF EXPOSURE

A TEST FOR A CHANGE IN A PARAMETER OCCURRING AT AN UNKNOWN POINT BIOKA55 523

A SEQUENTIAL TEST OF RANDOMNESS FOR EVENTS OCCURRING IN TIME OR SPACE

RATE OF OCCURRENCE IN TWO SERIES OF EVENTS OCCURRING RANDOMLY IN TIME /ENCE OF TWO TESTS OF EQ BIOKA58 267

ON PROBLEMS IN WHICH A CHANGE IN A PARAMETER OCCURS AT AN UNKNOWN POINT

STATISTICAL ESTIMATION OF THE GASOLINE OCTANE NUMBER REQUIREMENT OF NEN MODEL AUTOMOBILES TECH 60 5 WEIGHING DESIGNS WHEN N IS ODD

THE STATISTICAL SIGNIFICANCE OF ODD BITS OF INFORMATION

OF THE BIVARIATE NORMAL DISTRIBUTION OVER AN OFFSET CIRCLE SOME EFFECTS OF FLUCTUATING OFFSPRTNG DISTRIBUTIONS ON THE SURVIVAL OF A GENE BIOKA66 391

NTEGRAL OF THE BIVARIATE NORMAL DISTRIBUTION OVER AN OFFSET CIRCLE

A TABLE OF THE

JRSSB60 177

JASA $68 \quad 1269$

PERMUTATION WITHOUT RISING OR FALLING OMEGA-SEQUENCES

AMS 671245

EXTENSION OF COCHRAN'S FORMULAE FOR ADDITION OR OMTSSION OF A VARIATE IN MULTIPLE REGRESSION ANALYSIS TASA 63 527

CAL HYPOTHESES

LIMIT THEOREMS FOR QUEUES WITH TRAFFIC INTENSITY ONE

GALTON-WATSON BRANCHING PROCESS WITH MEAN LESS THAN ONE

PROPERTIES OF CONVERGENCE WITH PROBABILITY ONE

RANK SUM MULTIPLE COMPARISIONS IN ONE AND TWO-WAY CLASSIFICATIONS

AMS 651437

CONVERGENCE AMS $66 \quad 1800$ BIOKA67 487

DER STATISTICS IN SAMPLES FROM THE CHI-DISTRTBUTTON ONE DEGREE OF FREEDOU

FXACT LOWER MOMENTS OF OR AMS 621292

ZEL PROCEDURE CHI-SQUARE TESTS WITH ONE DEGREE OF FREEDOM, EXTENSIONS OF THE MANTEL-HAENS PARTITIONS IN MORE THAN ONE DIMENSION

ON THE SUPERCRITICAL ONE DIMENSIONAL AGE DEPENDENT BRANCHING PROCESSES

ONE DIMENSIONAL RANDOM WALK WITH A PARTIALLY

REFLECTING BARRIER

ONE DIMENSION

LATIN SQUARE DESIGNS WITH INDIVIDUAL CURVATURES IN ONE DIRECTION ON TESTING MORE THAN ONE HYPOTHESIS

OF CORRELATION BETWEEN TWO CONTINUOUS VARIABLES WHEN ONE IS DICHOTOMIZED ESTIMATION OF A MEAN WHEN ONE OBSERVATION MAY BE SPURIOUS

ROBUST PROCEDURES FOR SOME LINEAR MODELS WITH ONE OBSERVATION PER CELL

NONPARAMETRIC INFERENCE IN SOME LINEAR MODELS WITH ONE OBSERVATION PER CELL

ARIANT SEQUENTIAL PROBABILITY RATIO TESTS

TES CONCERNING THE LNKNOWN DRIFT PARA

SEQUENTIAL PROCEDURES FOR SELECTION OF THE BEST ONE OF SEVERAL BINOMIAL POPULATIONS

OF DISPERSION WITH INCOMPLETE OBSERVATIONS ON ONE OF THE CHARACTERS

EST INVARIANT TEST RHEN THE MOMENT IS INFINITE UNDER ONE OF THE HYPOTHESES

RODUCTION FROM A GROUP OF MACHINES UNDER THE CARE OF ONE OPERATIVE

AMS 67 137

ANALYSIS JRSSB56 259

INADMISSIBILITY OF THE B AMS $6914 \mathrm{~B} 3$

A TABLE FOR PREDICTING THE P JRSSB54 285

ICIENCY OF N MACHINES UNI-DIRECTIONALLY PATROLLED BY ONE OPERATOR WHEN WALKING TIME AND REPAIR TIMES ARE C JRSSB57 166

ICIENCY OF N MACHINES UNI-DIRECTIONALLY PATROLLED BY ONE OPERATOR WHEN WALKING TIME IS CONSTANT AND REPAIR JRSSB57 I73

THE MOMENT-PROBLEM FOR UNIMODAL DISTRIBUTIONS WHEN ONE OR BOTH TERMINALS ARE KNOWN

IMPLE STOCHASTIC EPIDEMIC FOR SMALL POPULATIONS WITH ONE OR MORE INITIAL INFECTIVES

CONCERNING A POPULATION CORRELATION COEFFICIENT FROM ONE OR POSSIBLY TWO SAMPLES SUBSEQUENT TO A PRELIMINA JRSSB67 282

BIASEDNESS OF SOME TEXT CRITERIA FOR THE EQUALITY OF ONE OR TWO COVARIANCE MATRICES A TWO-STAGE MODEL FOR SELECTING ONE OR TWO TREATMENTS

CHOICE OF LEVELS OF POLYNOMIAL REGRESSION WITH ONE OR TWO VARIABLES

BIOCS65 169

TECH $65 \quad 325$

TER NE/ ERRATA, 'EXACT CONFIDENCE BOUNDS, BASED ON ONE ORDER STATISTIC FOR THE PARAMETER OF A ONE-PARAME TECH 64 4B3 AL POPULATION EXACT CONFIDENCE BOUNDS, BASED ON ONE ORDER STATISTIC FOR THE PARAMETER OF AN EXPONENTI TECH 64 301

MEAN SQUARES IN GENETIC EXPERIMENTS WHEN ONLY ONE PARENT IS IDENTIFIED THE EXPECTED BIOCS65 436 ONE SAMPLE LIMITS OF SOME TWO-SAMPLE RANK TESTS JASA 64645

ALTERNATIVE ESTIMATES FOR SHIFT IN THE P-VARIATE ONE SAMPLE PROBLEM OF RANK ORDER TESTS FOR LOCATION IN THE MULTIVARIATE ONE SAMPLE PROBLEM SMALL SAMPLE POWER AND EFFICIENCY FOR THE ONE SAMPLE WILCOXON AND NORMAL SCORES TESTS

ON $S 0 M E$ A ON THE THEORY AMS 671216 AMS $63 \quad 624$ AMS 651767 SMALL SAMPLE POWER FOR THE ONE SAMPLE WILCOXON TEST FOR NON-NORMAL SHIFT ALTERNA AMS 65 I767
OR POISSON INPUT, GENERAL SERVICE TIME DISTRIBUTION, ONE SERVER
UT/ THE OUTPUT PROCESS OF THE QUEUEING SYSTEM WITH ONE SERVER AND WHICH INTERARRIVAL AND SERVING DISTRIB JRSSB59 375 UT/ THE OUTPUT PROCESS OF THE QUEUEING SYSTEM WITH ONE SERVER AND WHICH INTERARRIVAL AND SERVING DISTRIB JRSSB59 375
SOME NUMERICAL RESULTS FOR THE QUEUEING SYSTEM WITH ONE SERVER, WHILE THE INTERARRIVAL AND SERVING DISTRI JRSSB63 477 STRUCTURE OF THE DEPARTURE PROCESS OF THE QUEUE WITH ONE SERVER. WHILE THE INTERARRIVAL AND SERVING DISTRI JRSSB66 336 SOME EXPERIMENTAL DESIGNS OF USE IN CHANGING FROM ONE SET OF TREATMENTS TO ANOTHER. PART 1 SOME EXPERIMENTAL DESIGNS OF USE IN CHANGING FROM ONE SET OF TREATMENTS TO ANOTHER. PART 2 . EXISTENCE O JRSSB57 163 ONE SIDED PROBIFMS IN MULTIVARIATE ANALYSIS AMS 69549 OPTIMAL SEQUENTIAL PROCEDURES WHEN MORE THAN ONE STOP IS REQUIRED VARIANCE ESTIMATION WITH ONE UNIT PER STRATUM

APPROXIMATE CONFIDENCE INTERVALS. II. MORE THAN ONE UNKNOWN PARAMETER APPROXIMATE CONFIDENCE INTERVALS. II. MORE THAN ONE UNKNOWN PARAMETER
RAMETERS FOR A MULTIVARIATE NORMAL DISTRIBUTION WHEN ONE VARIABLE IS DICHOTOMISED. 
RRECTED CORRELATION COEFFICIENTS WHEN OBSERVATION ON ONE VARIABLE IS RESTRICTED A RANDOMIZED SYMMETRICAL DESICN FOR THE PROBLEM OF A ONE WAY CLASSIFICATION

NOTES. CO BIOCS66 182 DISTRIBUTION WITH COVARIANCE MATRIX A+B IN TERMS OF ONE WITH COVARIANCE MATRIX A EXPRESSING THE NORMAL BIOKA63 535 SION PROBLEMS A NUMERICAL INVESTIGATION OF SEVERAL ONE-DIMENSIONAL SEARCH PROCEDURES IN NONLINEAR RECRES TECH 69 265 TRANSFORMATION GROUPS SMOOTH EMPIRICAL BAYES ESTIMATION FOR ONE-PARAMETER DISCRETE DISTRIBUTIONS ONE-PARAMETER EXPONENTIAL FAMILIES GENERATED BY ESTIMATION FOR A ONE-PARAMETER EXPONENTIAL MODEL

BASED ON ONE ORDER STATISTIC FOR THE PARAMETER OF A ONE-PARAMETER NEGATIVE EXPONENTIAL POPULATION

A LOWER BOUND FOR THE CRITICAL PROBABILITY IN THE ONE-QUADRANT ORIENTED-ATOM PERCOLATION PROCESS R EFFICIENCIES FOR THE KOLMOGOROV-SMIRNOV AND KUIPER ONE-SAMPLE AND TWO-SAMPLE STATISTICS BIAS OF THE ONE-SAMPLE CRAMER-VON MISES TEST 'OPTIMAL' ONE-SAMPLE DISTRIBUTION-FREE TESTS AND THEIR TWO-

SAMPLE EXTENSIONS ER OF THE ONE-SAMPLE KOLMOGOROV-SMIRNOV TESTS

ON THE ASYMPTOTIC POWER OF THE ONE-SAMPLE KOLMO

E EQUALITY OF TWO NORMAL DISPERSION MATRICES ACAINST ONE-SIDED ALTERNATIVES /A PROPERTY OF A TEST FOR TH INDICES OF A COMPLEX ITEM V TYPE ONE-SIDED CONFIDENCE INTERVALS FOR THE QUALITY $\begin{array}{ll}\text { TECH } & 69 \\ \text { BIOKA66 } & 417\end{array}$ AMS 65261 JASA 65560 /DS, TECH $64 \quad 4 \mathrm{~B} 3$ JRSSB $63 \quad 401$ CORRECTION. 'A COMPARATIVE STUDY OF SEVERAL ONE-SIDED GOODNESS-OF-FIT TESTS'

ALTERNATIONS ENDENT. BOUNDED RANDOM VARIABLES TESTS FOR NORMAL AMS 671475 JASA $66 \quad 246$ AMS $66 \quad 120$ AMS 651000 AMS $67 \quad 523$ AMS $62 \quad 1463$ TECH $63 \quad 400$ AMS $61 \quad 499$ AMS 651583 AMS 66940 ON THE MOMENTS OF SOME ONE-SIDED STOPPINC RULES SOME ONE-SIDED STOPPING RULES IOKA6B 565 AMS $66 \quad 382$ AMS 671641 AMS 681493 ON THE ASYMPTOTIG NORMALITY OF ONE-SIDED STOPPING RULES THE VARIANCE OF THE ONE-SIDED STOPPINC RULES

A MULTIVARIATE ANALOGUE OF THE ONE-SIDED TEST

A SHORT-CUT RULE FOR A ONE-SIDED TEST OF HYPOTHESIS FOR QUALITATIVE DATA BEHAVIOR OF EXPECTED SAMPLE SIZE IN CERTAIN ONE-SIDED TESTS

A K-SAMPLE EXTENSION OF THE ONE-SIDED TWO-SAMPLE SMIRNOV TESTS STATISTIC

A MULTIPLE COMPARISON RANK PROCEDURE FOR A ONE-WAY ANALYSIS OF VARIANCE

UNEQUAL GROUP VARIANCES IN THE FIXED-EFFECTS ONE-WAY ANALYSIS OF VARIANCE, A BAYESIAN SIDELIGHT THE ROBUSTNESS OF THE COVARIANCE ANALYSIS OF A ONE-WAY CLASSIFICATION UNBIASED ESTIMATION OF VARIANCE COMPONENTS OF THE ONE-WAY CLASSIFICATION

THE CONSTRUCTION OF OPTIMAL DESIGNS FOR THE ONE-WAY CLASSIFICATION ANALYSIS OF VARIANCE A NOTE ON OPTIMUM ALLOCATION FOR A ONE-WAY LAYOUT MLLTIVARIATE COVARIANCE COMPONENTS FOR THE BALANCED ONE-WAY LAYOUT INFERENCE ABOUT VARIANCE COMPONENTS IN THE ONE-WAY MODEL RS OF OBSERVATIONS ON THE EFFECTS FOR THE UNBALANCED ONE-WAY RANDOM CLASSIFICATION /FFECTS AND THE NUMBE JASA 67 1375 ONE-WAY VARTANCES IN A TWO-WAY GLASSIFIGATION BIOKA58 11 ASED MULTIPLE RECRESSION COEFFICIENTS ESTIMATED FROM ONE-WAY-CLASSIFICATION TABLES WHEN THE GROSS CLASSIFI JASA 66 720 TRUNCATED POISSON DISTRIBUTION WHEN ZEROS AND SOME ONES ARE MISSING WITH THE LARGEST MEAN WHEN COMPARISONS CAN BE MADE ONLY IN PAIRS

EXPECTED MEAN SQUARES IN GENETIC EXPERIMENTS WHEN ONLY ONE PARENT IS IDENTIFIED STIMATINC PARAMETERS IN HUMAN GENETICS IF THE AGE OF ONSET IS RANDOM AN EXAMPLE OF THE ESTIMATION OF LINEAR OPEN LOOP TRANSFER FUNCTION ON CERTAIN REDUNDANT SYSTEMS WHICH OPERATE AT DISCRETE TIMES $\begin{array}{rl}\text { ESTIMATION IN THE JASA } 60 & 342 \\ \text { SELECTION OF THE POPULATION BIOKA58 } & 581\end{array}$ THE BIOCS65 436 TESTINC HYPOTHESES AND E BIOKA63 265 TECH $63 \quad 227$ TECH $62 \quad 69$ SIONS WHICH CAN BE USED FOR THE DETERMINATION OF THE OPERATING CHARACTERISTIC AND AVERAGE SAMPLE NUMBER OF JRSSB67 248 $R$ OF SOME SEQUENTIAL/ FORMULAE FOR CALCULATING THE OPERATING CHARACTERISTIC AND THE AVERAGE SAMPLE NUMBE JRSSBSB 379 $G$ BY VARIABLES WHEN THE PRODUCER'S AND CONSUM/ THE OPERATINC CHARACTERISTIC CURVE FOR SEQUENTIAL SAMPLIN JASA 56 IO8 L PROBABILITY RATIO TEST OPTIMALITY AND THE OPERATING CHARACTERISTIC CURVE FOR THE WALD SEQUENTIA JASA 64 464 HARTS OF THE 10 PERCENT AND 50 PERCENT POINTS OF THE OPERATING CHARACTERISTIC CURVES FOR FIXED EFFECTS ANA JASA 57 345 LIFE TESTS IN THE EXPONENTIAL CASE EXACT OPERATING CHARACTERISTIC FOR TRUNCATED SEQUENTIAL RULES OPERATINC CHARACTERISTICS OF SOME SEQUENTIAL DESICN AMS 68 1176 AMS 661704 LIKELIHOOD RATIO COMPUTATIONS OF OPERATING COMPUTATIONS

SEQUENTIAL APPLICATION TECH $62 \quad 441$ DESICN AND OPERATION OF A DOUBLE-LIMIT VARIABLES SAMPLINC PLAN JASA 58543 CONDENSED CALCULATIONS FOR EVOLUTIONARY OPERATION PROCRAMS
A SIMPLE SYSTEM OF EVOLUTIONARY OPERATION SUBJECT TO EMPIRICAL FEEDBACK EVOLUTIONARY OPERATION. A REVIEN THE THEORY OF EXPERIMENT, OPERATIONAL DEFINITION OF THE PROBABILITY SPACE $r \begin{array}{rr}67 & 401\end{array}$ STATISTICAL EVALUATION OF CLOUD SEEDINC OPERATIONS

CTION FROM A CROUP OF MACHINES UNDER THE CARE OF ONE OPERATIVE COEFFICIENTS BY THE USE OF THE LAPLACE-BELTRAMI OPERATOR A UNIFORM OPERATOR ERGODIC THEOREM

A TABLE FOR PREDICTING THE PRODU JRSSE 285 CALCULATION OF ZONAL POLYNOMIAL AMS 681711 ON AN OPERATOR LTMTT THEOREM OF ROTA AMS 691126 AMS 651 B64 NCY OF N MACHINES UNI-DIRECTIONALLY PATROLLED BY ONE OPERATOR WHEN WALKING TIME AND REPAIR TIMES ARE CONST JRSSB57 166 NCY OF N MACHINES UNI-DIRECTIONALLY PATROLLED BY ONE OPERATOR WHEN WALKINC TIME IS CONSTANT AND REPAIR TIM JRSSB57 I73 GONDITIONAL PROBABILITY OPERATORS SOME OPERATORS FOR ANALYSIS OF VARIANCE CALCULATIONS

AMS $62 \quad 634$ TECH 69511 ROXIMATE STABILIZATION/ THE INVERSION OF CUMULANT OPERATORS FOR POWER-SERIES DISTRIBUTIONS, AND THE APP JASA 6B 321 SOME APPLIGATIONS OF MONOTONE OPERATORS IN MARKOV PROCESSES THE OPINION POOL

MERGING OF OPINIONS WITH INCREASINC INFORMATION OPSOMMING VAN LESINGS. (SUMMARY OF PAPERS)

TIMID PLAY IS OPTIMAL OPTIMAL ACCELERATED LIFE DESIGNS FOR ESTIMATION AMS 651421 AMS 611339 AMS $62 \quad 882$ SASJ $68 \quad 55$ AMS $67 \quad 1281$ TECH 62 3B1 OLATION IN S-/ A NOTE ON THE CAIN IN PRECISION FOR OPTIMAL ALLOCATION IN REGRESSION AS APPLIED TO EXTRAP TECH 69 389 SAMPLES USING PRIOR INFORMATION

HYPOTHESES

ESTIMATION

NORMAL DISTRIBUTION IS OF VARIANCE CONVEX LOSS FUNCTION

IN NON-LINEAR/ THE OCCURRENCE OF REPLICATIONS IN OPTTMAL ALLOCATION IN STRATIFIED AND MULTISTACE OPTIMAL AND EFFICIENT DESIGNS OF EXPERIMENTS

ON OPTIMAL ASYMPTOTIC TESTS OF COMPOSITE STATISTICAL

ASYMPTOTICALLY OPTTMAL BAYES AND MINIMAX PROCEDURES IN SEQUENTIAL A SIMPLE SOLUTION FOR OPTIMAL CHEBYSHEV REGRESSION EXTRAPOLATION OPTIMAL CONFIDENCE INTERVALS FOR THE VARIANCE OF A

JASA $6 B \quad 964$ AMS 691570 AMS 671 B 45 AMS $68 \quad 422$ AMS $66 \quad 720$ JASA 59674 THE CONSTRUCTION OF OPTIMAL DESICNS FOR THE ONE-WAY CLASSIFICATION ANALYS JRSSB61 352 OPTIMAL DESICNS IN REGRESSION PROBLEMS WITH A CENERAL BIOKA68 53 OPTIMAL DESIGNS OF EXPERIMENTS TO ESTIMATE PARAMETERS JRSSB68 290 OPTIMAL DESIGNS ON TCHEBYSCHEFF POINTS 
INDEPENDENT VARIABLE IN RECRESSION ERAL EXPERIMENTAL CATECORIES WI/

NO DISCOUNTINC

ON THE EFFI

DISCUSSION

FORECASTS, CORR. 62919

OPTIMAL EXPERIMENTAL DESICNS

AMS $66 \quad 783$

OPTIMAL EXPERIMENTAL DESICNS FOR ESTIMATINC THE

TECH $68 \quad 811$

OPTIMAL FIXED SAMPLE SIZE PROCEDURE FOR COMPARINC SEV AMS 641571

OPTIMAL INVARIANT RANK TESTS FOR THE K-SAMPLE PROBLEM AMS 651207

$\begin{array}{lrr}\text { AMS } & 63 & 22 \\ \text { AMS } & 66 & 1284\end{array}$ ON FINDINC OPTIMAL POLICIES IN DISCRETE DYNAMIC PROCRAMMINC WITH AMS 661284 DESICN FOR OPTIMAL PREDICTION IN SIMPLE LINEAR RECRESSION JASA 65205 OPTIMAL PROGRAMMERS FOR VARIETAL SELECTION (WITH JRSSB61 282 OPTIMAL PROPERTIES OF EXPONENTIALLY WEICHTED $\quad$ JASA $60 \quad 299$

AN OPTIMAL PROPERTY OF PRINCIPAL COMPONENTS OPTIMAL REPLICATION IN SEQUENTIAL DRUG SCREENINC COMPUTATION AND STRUCTURE OF OPTIMAL RESET POLICIES NS TO LINEAR ESTIMATORS OF LOCATION OPTIMAL ROBUSTNESS. A GENERAL METHOD, WITH APPLICATIO OPTIMAL SAMPLE DESIGN WITH NONRESPONSE JASA 671462 AMPLE OBSERVATIONS ARE LOGNORMAL AND THE PRECISTO/ OPTIMAL SAMPLING FOR QUOTA FULFILMENT $\quad$ BIOKA57 518 A SECOND-ORDER APPROXIMATION TO OPTIMAL SAMPLING REGIONS

DESICN OF AN OPTIMAL SEQUENCE OF INTERRELATED SAMPLING PLANS AN OPTTMAL SEQUENTTAL ACCELERATED LIFE TEST.

AMS 69313 JASA $64 \quad 96$ TECH $62 \quad 367$ IMENTAL CATEGORIES WITH A CONTR/ AN ASYMPTOTICALLY OPTIMAL SEQUENTIAL DESIGN FOR COMPARING SEVERAL EXPER AR IS REQUIRED A CUMULATIVE NORMAL QUANTAL RESPONSE CURVE PREDICTION FAILURE RATE AVERAGE OPTIMAL SEQUENTIAL PROCEDURES WHEN MORE THAN ONE STOP

SOME OPTIMAL SEQUENTIAL SCHEMES FOR ESTIMATING THE MEAN OF OPTIMAL SPACINC AND WEIGHTING IN POLYNOMIAL

ASYMPTOTICALLY OPTIMAL STATISTICS IN SOME MODELS WITH INCREASING ON OPTIMAL STOPPING

EXPLICIT SOLUTIONS TO SOME PROBLEMS OF OPTIMAL STOPPING SOME PROBLEMS OF OPTIMAL STOPPING OPTIMAL STOPPINC AND EXPERIMENTAL DESIGN OPTIMAL STOPPING FOR FUNCTIONS OF MARKOV CHAINS OPTIMAL STOPPING IN A MARKOV PROCESS

N-OVER-N SOME PROBLEMS IN THE THEORY OF OPTIMAL STOPPING RULES

EXISTENCE OF OPTIMAL STOPPING RULES FOR REWARDS RELATED TO S-SUBAN OPTIMAL STOPPING THEOREM OPTIMAL STOPPING WHEN THE FUTURE IS DISCOUNTED OPTIMAL STRATEGIES IN FACTORIAL EXPERIMENTS APPROXIMATELY OPTIMAL STRATIFICATION

ASYMPTOTICALLY OPTIMAL TESTS FOR MULTIVARIATE NORMAL DISTRIBUTIONS EXPERIMENTS WITH NONCONTROLLED PRE/ ASYMPTOTICALLY OPTIMAL TESTS OPTIMAL TWO-STAGE STRATIFIED SAMPLING

TIMID PLAY IS OPTIMAL, II OPTIMAL; ONE-SAMPLE DISTRI8UTION-FREE TESTS AND THETR AMS 66 120 TWO-SAMPLE EXTENSIONS THE WALD SEQUENTIAL PROBABILITY RATIO TEST THEORY

WITH NO DISCOUNTING $\begin{array}{ll}\text { TEST } & \text { OPTIMALITY AND THE OPERATING CHARACTERISTIC CURV } \\ \text { CONDITIONS FOR OPTIMALITY AND VALIDITY AND SIMPLE LEAST SQUARES }\end{array}$ AN OPTIMALITY CONDITION FOR DISCRETE DYNAMIC PROGRAMMING DISCRETE DYNAMIC PROGRAMMING WITH SENSITIVE DISCOUNT OPTIMALITY CRITERIA TWO MORE CRITERIA EQUIVALENT TO D-OPTIMALITY OF DESIGNS EPSILON ASYMPTOTIC OPTIMALITY OF EMPIRICAL BAYES ESTIMATORS MINIMIZATION OF EICENVALUES OF A MATRIX AND OPTIMALITY OF PRINCIPAL COMPONENTS ON THE OPTIMALITY OF SEQUENTIAL PROBABILITY RATIO TESTS DOMAINS OF OPTIMALITY OF TESTS IN SIMPLE RANDOM SAMPLING SEQUENTIAL APPLICATION OF STMPLEX DESIGNS IN OPTIMISATION AND EVOLUTIONARY OPERATION A STATISTICAL BASIS FOR APPROXIMATION AND OPTIMIZATION REGULATION AND OPTIMIZATION SOME STATISTICAL ASPECTS OF ADAPTIVE OPTIMIZATION AND CONTROL (WITH DISCUSSION) THE SINGLE FACTOR CASE NUMERICAL OPTIMIZATION IN THE PRESENCE OF RANDOM VARIABILITY. OPTIMIZATION OF A HOT ROLLING MILL OPTIMIZATION OF QUALITY CONTROL IN THE CHEMICAL

LABORATORY OPTIMIZE AN OBJECTIVE FUNCTION

HIERARCHICAL GROUPING TO OPTIMIZE AN OBJECTIVE FUNC ECONOMICALLY OPTIMUM ACCEPTANCE TESTS PROBLEM OF OPTIMUM ALLOCATION ARISING IN CHEMICAL
A NOTE ON OPTIMUM ALLOCATION FOR A ONE-WAY LAYOUT OPTIMUM ALLOCATION IN MULTIVARIATE SURVEYS, AN OPTIMUM ALLOCATION OF SAMPLING UNITS TO STRATA WHEN THE OPTIMUM ALLOCATION OF SPARE COMPONENTS IN SYSTEMS

ANALYTICAL SOLUTION
THERE ARE R RESPONSES OF INTEREST TEST REMARK ON THE OPTIMUM CHARACTER OF THE SEQUENTIAL PROBABILITY RATIO OPTIMUM CHOICE OF CLASSES FOR CONTINGENCY TABLES OPTIMUM CLASSIFICATION RULES FOR CLASSIFICATION INTO

TWO MULTIVARIATE NORMAL POPULATIONS

EQUATIONS

PARAMETER

ALMOST LINEARLY-OPTIMUM COMBINATION OF UNBIASED ESTIMATES SOME OPTIMUM CONFIDENCE BOUNDS FOR ROOTS OF DETERMINANTAL OPTIMUM DECISION PROCEDURES FOR A POISSON PROCESS OPTIMUM DESIGNS FOR POLYNOMIAL EXTRAPOLATION OPTIMUM DESIGNS IN REGRESSION PROBLEMS, II OPTIMUM ESTIMATORS FOR LINEAR FUNCTIONS OF LOCATION

AND SCALE PARAMETERS

HYPER-ADMISSIBILITY AND OPTIMUM ESTIMATORS FOR SAMPLING FINITE POPULATIONS
NE OR TWO ORDER STATI/ OPTIMUM ESTIMATORS OF THE PARAMETERS OF NEGATIVE EXPO NENTIAL DISTRIBUTIONS FROM ONE OR TWO ORDER STATI/ OPTIMUM EXPERIMENTAL DESIGNS (WITH DISCUSSION) AMS $63 \quad 14 \mathrm{~B} 6$ AMS 671618 RSSB62 393 AMS 641553 AMS 671731 AMS $66 \quad 30$ AMS 69993 JRSSB68 108 AMS $66 \quad 7$ AMS $68 \quad 1905$ AMS 681333 AMS $67 \quad 1627$ AMS $68 \quad 1228$ AMS $69 \quad 677$ AMS 67601 AMS $63 \quad 780$ JASA $68 \quad 129 B$ AMS 67 1B29 JASA $65 \quad 699$ AMS $69 \quad 575$ JASA $64 \quad 464$ AMS 691617 AMS 681220 AMS 691635 AMS 62792 BIOKA69 220 AMS $68 \quad 859$ AMS $63 \quad 18$ AMS 69308 TECH $62 \quad 441$ AMS $66 \quad 59$ JRSSB69 160 JRSSB62 297 BIOKA69 65 JRSSB $67 \quad 300$ TECH $66 \quad 519$ JASA $63 \quad 236$ JASA $56 \quad 243$ TECH 61509 BIOKA62 563 JRSSB67 115 JASA $65 \quad 225$ TECH $61 \quad 399$ AMS $66 \quad 726$ JASA $68 \quad 291$ AMS $65 \quad 1174$ JASA $61 \quad 36$ AMS $65 \quad 468$ AMS 62 13B4 AMS 65 14B3 AMS 61298 AMS 69 N0.6 AMS 6B 621 AMS $63 \quad 117$ JRSSB59 272 Y ESTIMATES NOTES, OPTIMUM EXPERIMENTAL DESIGNS FOR REALIZED HERITABILIT BIOCS67 361 SELECTION FOR AN OPTIMUM GROWTH CURVE

DISCUSSION) COMPONENTS MODELS EFFICIENT ESTIMATES AND OPTIMUM INFERENCE PROCEDURES IN LARGE SAMPLES (WITH OPTIMUM INVARIANT TESTS IN UNBALANCED VARIANCE

A MODEL FOR OPTIMUM LINKAGE OF RECORDS PARAMETERS DETERMINATION OF THE EXACT OPTIMUM ORDER STATISTICS FOR ESTIMATING THE PARAMETER TECH 67 279 BINOMIAL PARAMETER

TIMUM ORDER STATISTICS IN CENSORED SAMPLES/F THE SEQUENTIAL OPTIMUM PROCEDURES FOR UNBIASED ESTIMATION OF A

BI0CS68 169 JRSSB $62 \quad 46$ AMS $67 \quad 422$ \begin{tabular}{lrr} 
JASA & 67 & 1214 \\
\hline
\end{tabular} AMS $66 \quad 1717$ TECH 64259 
OPTIMUM PROPERTIES AND ADMISSIBILITY OF SEQUENTIAL

ASYMPTOTIC OPTIMUM PROPERTIES OF CERTAIN SEQUENTIAL TESTS

SOME OPTIMUM PROPERTIES OF RANKINC PROCEDURES

PAIRWISE COMPARISON AND RANKING, OPTIMUM PROPERTIES OF THE ROW SUM PROCEDURE

1208 ACKNOWLEDCEMENT OF PRIORITY FOR 'AN OPTIMUM PROPERTY OF MAXIMUM LIKELIHOOD ESTIMATION' 6O

AN OPTIMUM PROPERTY OF THE HORVITZ-THOMSON ESTIMATE

$S$ OF THE NECATIVE EXPONENTIAL DISTRIBU/ ASYMPTOTIC OPTIMUM QUANTILES FOR THE ESTIMATION OF THE PARAMETER ON THE OPTIMUM RATE OF TRANSMITTINC INFORMATION SOME PROBLEMS OF OPTIMUM SAMPLINC OPTIMUM SAMPLINC IN BINOMIAL POPULATIONS

A SIMPLE PRESENTATION OF OPTIMUM SAMPLINC RESULTS ASYMPTOTICALLY OPTIMUM SEQUENTIAL INFERENCE AND DESIGN

THE OPTIMUM STRATEGY IN BLACKJACK, CORR, 59810 OPTIMUM STRATIFICATION WITH TWO CHARACTERS OPTIMUM STRATIFIED SAMPLINC USING PRIOR INFORMATION

ASYMPTOTICALLY OPTIMUM TESTS FOR MULTINOMIAL DISTRIBUTIONS

SAMPLING OF TWO UNITS FROM A STRATUM (ADDENDUM 6/ OPTIMUM UTILIZATION OF AUXILIARY INFORMATION. (PI)PS VARIANCE ESTIMATES IN 'OPTIMUM' SAMPLE DESIGNS

$\begin{aligned} & \text { OF DISTINCT TYPE } \text { SAMPLING ERRORS IN AN ORCHARD } \\ & \text { INCOMPLETE BLOCK DESIGNS FOR DIRECTIONAL SEED ORCHARDS }\end{aligned}$

INCOMPLETE BLOCK DESIGNS FOR NON-DIRECTIONAL SEED ORCHARDS

MULTI-FACTOR DESIGNS OF FIRST ORDER

PROPERTIES OF SPECTRAL ESTIMATES OF SECOND ORDER

NORMAL VARIATES WHICH ARE UNCORRELATED OF A HIGHER ORDER

INDEPENDENCE OF INTERMEDIATE STATES AND RESTRICTED ORDER

TIVE ANALYSIS. GENERAL THEORY AND THE CASE OF SIMPLE ORDER MOMENTS OF NECATIVE ORDER AND

ON THE ORDER AND THE TYPE OF ENTIRE

TESTING A MARKOV HYPOTHESIS WITH
$\angle I O N$ OF NON-NUMERICAL INFORMATION IN QUANTITA

TEQUAL NUMBERS OF ORCHARDS
THE USE OF CYCLIC BALANCED THE USE OF CYCLIC BALANCED

\author{
BIOKA52
}

ASYMPTOTIC BIOKA69

ON CERTAIN FUNCTIONS OF BIOKA6O 375

AMS $\begin{array}{lr}68 & 1244\end{array}$

AMS $67 \quad 124$

AMS $63 \quad 511$

AMS 611343 JASA $67 \quad 1013$

AMS $66 \quad 143$

AMS 69 NO.6

JASA $57 \quad 494$

JRSSB 4239

AMS $63 \quad 705$

JASA $56 \quad 429$

AMS $63 \quad 866$

JASA $65 \quad 750$

AMS $65 \quad 369$

JRSSB $67 \quad 374$

JASA $61 \quad 135$

BIOC\$65 55

BI0CS67 76I

561

175

605

AMS 631347

JRSSB55 122

AMS 621238

IN MULTIVARIATE RECRESSION, EFFICIENCY OF A FIRST ORDER METHOD

E EXACT FIRST AND SECOND ORDER MOMENTS OF ESTIMATES OF COMPONENTS OF COVARIANC BIOKAG9 NO.3 ON THE INVERSE OF THE COVARIANCE MATRIX OF A FIRST ORDER MOVING AVERAGE MEMBERS OF A SERIES OF RANDOM VARIABLES ARRANGED IN ORDER OF SIZE

TWO SERVERS WITH LIMITED WAITING ROOMS AND CERTAIN ORDER OF VISITS

IMATION OF A REGRESSION PARAMETER FOR CERTAIN SECOND ORDER PROCESSES A METHOD OF SYSTEMATIC SAMPLING BASED ON ORDER PROPERTIES ON INFERRING ORDER RELATIONS IN ANALYSIS OF VARIANCE THE CHOICE OF A SECOND ORDER ROTATABLE DESICN

CORRICENDA, 'THE CHOICE OF A SECOND ORDER ROTATABLE DESICN' FURTHER SECOND ORDER ROTATABLE DESIGNS

TWO THIRD ORDER ROTATABLE DESIGNS IN FOUR DIMENSIONS

A METHOD FOR THE CONSTRUCTION OF SECOND ORDER ROTATABLE DESIGNS IN K DIMENSIONS SPECIFIC DESIGNS THIRD ORDER ROTATABLE DESIGNS IN THREE DIMENSIONS, SOME THIRD ORDER ROTATABLE DESIGNS IN THREE FACTORS ANALYSIS BIOKA69 NO.3 THE DIFFERENCE BETWEEN CONSECUTIVE BIOKA57 211 A SYSTEM OF BIOKA68 223 EFFICIENT EST AMS $61 \quad 1299$ BIOKA53 452 BIOCS65 337 BIOKA63 335 BIOKA65 305 AMS 681995 AMS $64 \quad 445$ AMS $67 \quad 177$ AMS 61910 TECH $62 \quad 219$ -RECRESSIVE MODEL. II. NULL DISTRIBUTIONS FOR HIGHER ORDER SCHEMES, NON-NULL DISTRIBUTIONS /LINEAR AUTO BIOKA56 IB6 R A WEIBULL MODEL WITH PROGRESSIVE C/ EXACT THREE, ORDER STATISTIC CONFIDENCE BOUNDS ON RELIABLE LIFE FO JASA 69 306 THE EXPECTED COVERACE TO THE LEFT OF THE I'TH ORDER STATISTIC FOR ARBITRARY DISTRIBUTIONS NE/ ERRATA $: E X A C T$ CONFTDENCE BOUNDS BASED ON ONE ORDER ST ATISTIC FOR THE PARAMETER OF A ONE PARAMETER TECH 64 483 OPULATION EXACT CONFIDENCE BOUNDS, BASED ON ONE ORDER STATISTIC FOR THE PARAMETER OF AN EXPONENTIAL P TECH 64 3OI THE SAMPLE MEAN AMONG THE MODERATE ORDER STATISTICS

ON THE LIMIT BEHAVIOUR OF EXTREME ORDER STATISTICS THE SAMPLE MEAN AMONG THE EXTREME NORMAL ORDER STATISTICS LOGISTIC ORDER STATISTICS

ON UNCORRELATED LINEAR FUNCTIONS OF ORDER STATISTICS AN APPLICATION OF A BALLOT THEOREM IN ORDER STATISTICS ON EXTREME ORDER STATISTICS

SOME BOUNDS FOR EXPECTED VALUES OF ORDER STATISTICS A K-SAMPLE MODEL IN ORDER STATISTICS SIMPLE RANDOM WALK AND RANK ORDER STATISTICS A NOTE ON MOMENTS OF GAMMA ORDER STATISTICS LINEAR FUNCTIONS OF ORDER STATISTICS BOUNDS AND APPROXIMATIONS FOR THE MOMENTS OF ORDER STATISTICS THE MOMENTS OF LOG-WEIBULL ORDER STATISTICS EXPECTED VALUES OF NORMAL ORDER STATISTICS

ON THE ASYMPTOTIC SUFFICIENCY OF CERTAIN ORDER STATISTICS APPLICATIONS OF A BALLOT THEOREM IN PHYSICS AND IN ORDER STATISTICS DISTRIBUTION OF THE MAXIMUM AND MINIMUM OF RATIOS OF ORDER STATISTICS NORMALITY OF LINEAR COMBINATIONS OF FUNCTIONS OF ORDER STATISTICS OF PARAMETERS OF THE CAMMA DISTRIBUTION USING ORDER STATISTICS ESTIMATION OF LOCATION AND SCALE PARAMETERS USING ORDER STATISTICS PROOF OF ASYMPTOTIC NORMALITY OF LINEAR FUNCTIONS OF ORDER STATISTICS

RELATIONS BETWEEN EXPECTED VALUES OF FUNCTIONS OF ORDER STATISTICS AND CENERALIZED TRUNCATED NORMAL DISTRIBUTIONS USING ORDER STATISTICS OF THE PARAMETERS OF THE LOGISTIC DISTRIBUTION USING ORDER STATISTICS HE EXTREME VALUE DISTRIBUTION BY USE OF TWO OR THREE ORDER STATISTICS VID-JOHNSON SERIES FOR THE EXPECTED VALUES OF NORMAL ORDER STATISTICS NENTIAL DISTRIBUTION ON THE BASIS OF SUITABLY CHOSEN ORDER STATISTICS F NEGATIVE EXPONENTIAL DISTRIBUTIONS FROM ONE OR TWO ORDER STATISTICS OR SHAPE PARAMETERS OF THE GAMMA DISTRIBUTION USING ORDER STATISTICS HE PARAMETERS OF THE BETA DISTRIBUTION FROM SMALLEST ORDER STATISTICS ORDER STATISTIC OF TH/ CONDITIONAL DISTRIBUTION OF ORDER STATISTICS AND DISTRIBUTION OF THE REDUCED ITH
SAMP/ CORRECTION TO 'TABLES OF EXPECTED VALUES OF ORDER STATISTICS AND PRODUCTS OF ORDER STATISTICS FOR POPULATIONS

ON MOMENTS OF ORDER STATISTICS AND STATISTICS OF STRUCTURE

OM THE/ EXACT MOMENTS AND PERCENTAGE POINTS OF THE ORDER STATISTICS AND THE DISTRIBUTION OF THE RANGE FR CAUCHY DISTRIBUTION

GROUPED SAMPLES
ORDER STATISTICS ESTIMATORS OF THE LOCATION OF THE ORDER STATISTICS FOR DISCRETE POPULATIONS AND FOR
AMS 621160

AMS 63992

AMS $63 \quad 33$

JASA $63 \quad 245$

AMS 641356 AMS 641726 AMS 651055

AMS 651223 AMS $67 \quad 1042$ TECH $67 \quad 315$ AMS 69770 JASA 69 NO. 4 BIOKA61 151 JRSSB62 167 ON THE AMS 69918 ASYMPTOTIC AMS 69 NO.6 ESTIMATION BIOKA62 525 LEAST SQUARES BIOKA52 B8 AN ELEMENTARY AMS $68 \quad 263$ TION OF THE PARAMETERS OF T BIOKA69 429 /AFTER A NUMBER OF TERMS OF THE DA BIOKA60 79 /ONE OF TWO PARAMETERS OF THE EXPO AMS 631419 /UM ESTIMATORS OF THE PARAMETERS 0 AMS 630117 /UM-LIKELIHOOD ESTIMATION OF SCALE BIOKA63 217 T TECH $67 \quad 607$ AMS $63 \quad 652$ AMS 611345 AMS $63 \quad 633$ AMS $65 \quad 897$ AMS 65907 JASA $66 \quad 1205$ JASA 681390
AMS 63658 TECH $69 \quad 373$ JRSSB65 130 A NOTE ON RECURRENCE AMS 66733 
ONENTIAL DISTR/ DETERMINATION OF THE EXACT OPTIMUM ORDER STATISTICS FOR ESTIMATING THE PARAMETERS OF EXP TECH 67 279 DISTRIBUTIONS RECURRENCE RELATIONS BETWEEN MOMENTS OF ORDER STATISTICS FOR EXCHANGEABLE VARIATES ORDER STAT ISTICS FROM A CLASS OF NON-NORMAL ON THE BIVARIATE MOMENTS OF ORDER STATISTICS FROM A LOGISTIC DISTRIBUTION LINEAR FORMS IN THE ORDER STATISTICS FROM AN EXPONENTIAL DISTRIBUTION A RECURRENCE RELATION FOR DISTRIBUTION FUNCTIONS OF ORDER STATISTICS FROM BIVARIATE DISTRIBUTIONS ASYMPTOTIC DISTRIBUTION OF DISTANCES BETWEEN ORDER STATISTICS FROM BIVARIATE POPULATIONS INEQUALITIES FOR LINEAR COMBINATIONS OF ORDER STATISTICS FROM RESTRICTED FAMILIES 427 'ESTIMATION OF LOCATION AND SCALE PARAMETERS BY ORDER STATISTICS FROM SINGLY AND DOUBLY CENSORED SAMP NORMAL DISTRIBUTION MOMENTS OF ORDER STATISTICS FROM THE EQUICORRELATED MULTIVARIATE ORDER STATISTICS FROM THE GAMMA DISTRIBUTION

ERRATA, ORDER STATTSTICS FROM THE GAMMA DISTRTBUTTON PERCENTAGE POINTS AND MODES OF ORDER STATISTICS FROM THE NORMAL DISTRIBUTION AMS $68 \quad 272$ BIOKA69 415 AMS 661002 BIOKA59 433 AMS 64270 JASA 69600 AMS $64 \quad 748$ AMS $66 \quad 1574$ AMS $39 \quad 325$ AMS $62 \quad 1286$ TECH $60 \quad 243$ TECH $60 \quad 523$ AMS 61 B8B TION EXACT MOMENTS AND PRODUCT MOMENTS OF THE ORDER STATISTICS FROM THE TRUNCATED LOGISTIC DISTRIBU JASA 66 5I4 ERS OF THE EXPONENTIAL DISTRIBUTION BASED ON OPTIMUM ORDER STATISTICS IN CENSORED SAMPLES /F THE PARAMET AMS 66 I7I7 MOMENTS OF THE RANGE AND PRODUCT MOMENTS OF EXTREME ORDER STATTSTTCS TN NORMAL SAMPLES

ON THE BIOKA56 $45 \mathrm{~B}$ ON THE MOMENTS OF ORDER STATISTICS IN SAMPLES FROM NORMAL POPULATIONS BIOKA54 200 CORRIGENDA, 'ON THE MOMENTS OF CRDER STATISTICS IN SAMPLES FROM NORMAL POPULATIONS' BIOKA54 568 - ONE DEGREE OF FREEDOM EXACT LOWER MOMENTS OF ORDER STATISTICS IN SAMPLES FROM THE CHI-DISTRIBUTION RELATIONS AMONG MOMENTS OF ORDER STATISTICS IN SAMPLES FROM TWO RELATED POPULATI AMS 621292 RELATIONS AMONG MOMENTS OF ORDER STATISTICS IN SAMPLES FROM TWO RELATED POPULATI
SOME RELATIONS BETWEEN EXPECTATIONS OF ORDER STATISTICS IN SAMPLES OF DIFFERENT SIZES CTION OF A CONTINUOUS UNTVARIATE POPULATTON FROM THE ORDER STATISTICS OF A SAMPLE /ERSE DISTRIBUTION FUN BIOKA69 NO 3 LICA/ RECURRENCE RELATIONS BETWEEN THE P.D.F.'S OF ORDER STATISTICS OF DEPENDENT VARIABLES, AND SOME APP BIOKA67 283 EIR RELATION TO INVERSE SAMP/ EXACT MOMENTS OF THE ORDER STATISTICS OF THE GEOMETRIC DISTRIBUTION AND TH JASA 67 915 0 TYPE I POPULATTONS IAL DISTRIBUT/ TABLES FOR BEST LINEAR ESTIMATES BY ORDER STATISTICS OF THE PARAMETERS OF SINGLE EXPONENT JASA 57 58 SCALE PARAMETER ESTIMATION FROM THE ORDER STATISTICS OF UNEQUAL GAMMA COMPONENTS AMS 66 152 DISTRIBUTION OF LINEAR COMBINATIONS OF FUNCTIONS OF ORDER STATISTICS WITH APPLICATIONS TO ESTIMATION /C AMS 67 52 MATION OF PARAMETERS OF THE GAMMA DISTRIBUTION USING ORDER STATISTICS. CORRIGENDA, 'ESTI BIOKA63 546 LATIONS BETWEEN THE PROBABILITY DENSITY FUNCTIONS OF ORDER STATISTICS, AND SOME APPLICATIONS /URRENCE RE AMS 62 I69 OF NEGATIVE EXPONENTIAL POPULATIONS FROM ONE OR TWO ORDER STATISTICS, CORR. TO THIS PAPER PRINTED IN 63 I AMS 61 107B POTNT AND INTERUAL ESTTMATORS, BASED ON M ORDER STATISTICS, FOR THE SCALE PARAMETER OF A WEIBUL TECH 65 CORRIGENDA, 'EXPECTED VALUES OF NORMAL ORDER STATISTICS' ' A NOTE ON 'A K-SAMPLE MODEL IN ORDER STATISTICS' BY W. J. CONOVER ON THE ORDER STRUCTURE OF THE SET OF SUFFICIENT SUBFIELDS A CLASS OF RANK ORDER TESTS FOR A GENERAL LINEAR HYPOTHESIS

SAMPLE PROBLEM ASYMPTOTICALLY MOST POWERFUL RANK ORDER TESTS FOR GROUPED DATA

ON THE THEORY OF RANK ORDER TESTS FOR LOCATION IN THE MULTIVARIATE ONE RANK ORDER TESTS FOR MULTIVARIATE PAIRED COMPARISONS LINES ON A CLASS OF RANK ORDER TESTS FOR THE PARALLELISM OF SEVERAL REGRESSION A CLASS OF ALIGNED RANK ORDER TESTS IN TWO-WAY LAYOUTS RANK ORDER TESTS OF LINEAR HYPOTHESES

IN MARKOV-CHAIN FREQUENCIES, AND THE BINARY CHAIN OF ORDER 2 TESTING HOMOGENEITY AGAINST ORDERED ALTERNATIVES A DISTRIBUTION-FREE K-SAMPLE TEST AGAINST ORDERED ALTERNATIVES A TEST OF HOMOGENEITY FOR ORDERED ALTERNATIVES NORMAL THEORY AND NONPARAMETRIC TESTING AGAINST ORDERED ALTERNATIVES IN MODEL I ANALYSIS OF VARIANCE, ON CHERNOFF-SAVAGE TESTS FOR ORDERED ALTERNATIVES IN RANDOMIZED BLOCKS A TEST OF HOMOGENEITY FOR ORDERED ALTERNATIVES. II

LATION AND REGRESSION. WITH APPLICATION TO MANIFOLD, ORDERED CONTINGENCY TABLES /CT-MOMENT PARTIAL CORRE ESTIMATION OF ERROR VARIANCE FROM SMALLEST ORDERED CONTRASTS

ON LINEAR FUNCTIONS OF ORDERED CORRELATED NORMAL RANDOM VARIABLES $\begin{array}{ll}\text { JRSSB } 6 B & 4 B 3 \\ \text { JRSSB } 63 & 383\end{array}$ AMS 63945 BI0KA54 133 BIOKA59 36 AMS $67 \quad 1740$ AMS 68967 BIOKA59 328 BIOKA59 241 JASA $63 \quad 152$ BIOKA65 367 F LINEAR FUNCTIONS AND RATIOS OF LINEAR FUNCTIONS OF ORDERED CORRELATED NORMAL RANDOM VARIABLES WITH EMPHA BIOKA64 I43 FURTHER REMARKS ON TOPOLOGY AND CONVERGENCE IN SOME ORDERED FAMILIES OF DISTRIBUTION ON THE TOPOLOGICAL STRUCTURE OF SOME ORDERED FAMILIES OF DISTRIBUTIONS CANCE TEST FOR LINEAR RANKS ORDERED HYPOTHESES FOR MULTIPLE TREATMENTS, A SIGNIFI A NOTE ON ORDERED LEAST-SQUARES ESTIMATION

COMPLETE ORDER ON THE USE OF PARTIALLY ORDERED OBSERVATIONS IN MEASURING THE SUPPORT FOR A NOTE ON ESTIMATING ORDERED PARAMETERS ESTIMATING ORDERED PROBABILITIES

SOME NOTES ON ORDERED RANDOM INTERVALS

STIMATION OF THE DISTRIBUTIONS OF TWO STOCHASTICALLY ORDERED RANDOM VARIABLES SOME APPLICATIONS OF EXPONENTIAL ORDERED SCORES

FOR NUMBER OF RUNS OF SIGNS OF FIRST DIFFERENCES IN ORDERED SERIES ANTE-DEPENDENCE ANALYSIS OF AN ORDERED SET OF VARIABLES DISTRIBUTIONS OF KENDALL'S TAU BASED ON PARTIALLY ORDERED SYSTEMS ORDERED TESTS IN THE ANALYSIS OF VARIANCE ESTIMATION OF TWO ORDERED TRANSLATION PARAMETERS SOME TESTS OF SIGNIFICANCE WITH ORDERED VARIABLES OF THE MEAN OF A CENSORED NORMAL DISTRIBUTION BY ORDERED VARIABLES A TEST OF HOMOGENEITY FOR ORDERED VARIANCES THE CURVE THROUGH THE EXPECTED VALUES OF ORDERED VAR BLOCKS WHEN THE ALTERNATIVES HAVE AN 'A PRIORI' ORDERING

A RENEWAL PROBLEM WITH BULK ORDERING OF COMPONENTS

SAMPLE CASE

FINE STRUCTURE OF THE ORDERING OF PROBABILITIE THE NONPARAMETRIC ORDERING, 1001 TO 0110

SIGNIFICANCE PROBABILITY BOUNDS FOR RANK ORDERINGS

STATISTICAL REPRODUCTION OF ORDERINGS AND TRANSLATION SUBFAMILIES A THEOREM ON RANK ORDERS FOR TWO CENSORED SAMPLES

ON EXACT PROBABILITIES OF RANK ORDERS FOR TWO WIDELY SEPARATED NORMAL DISTRIBUTIONS ORDINAL MEASURES OF ASSOCIATION

ON THE CONVERGENCE OF ORDINARY INTEGRALS TO STOCHASTIC INTEGRALS AMS 6951 AMS 641216 JASA $63 \quad 216$ BIOKA53 457 JASA 61299 AMS 65698 AMS $63 \quad 967$ JRSSB56 79 MAXIMUM LIKELIHOOD E JASA 661067 JRSSB 64103 ASA $61 \quad 156$ AMS 62201 BIOKA55 417 BIOKA61 325 AMS $68 \quad 517$ JRSSB56 I $\begin{array}{rrr}\text { THE ESTIMATION } & \text { BIOKA56 } & 482 \\ & \text { JRSSB61 } & 195 \\ & & \\ \text { OF NORMAL SCO } & \text { BIOKA66 } & 252\end{array}$ $\begin{array}{rrr}\text { THE ESTIMATION } & \text { BIOKA56 } & 482 \\ & \text { JRSSB61 } & 195 \\ & & \\ \text { OF NORMAL SCO } & \text { BIOKA66 } & 252\end{array}$ OF SQUARES OF NORMAL SCO BIOKA66
RANK TESTS FOR RANDOMIZED AMS 67
B 67 JRSSB59 $1 \mathrm{BO}$ AMS $66 \quad 98$ AMS $61 \quad 101$ AMS 64 B91 AMS $66 \quad 196$ AMS $65 \quad 316$ AMS $67 \quad 1491$ J ASA $58 \quad 814$ AMS 651560

TIMATORS

ASED

THE EXACT SAMPLING DISTRIBUTION OF ORDINARY LEAST SQUARES AND TWO-STAGE LEAST SQUARES ES JASA 69 923 NORMAL PROBABILITY FUNCTION, TABLES OF CERTAIN AREA-ORDINATE RATIOS AND OF THEIR RECIPROCALS 
TAIL SICMA-FIELD OF A MARKOV CHAIN AND A THEOREM OF OREY THE DISTRIBUTION OF ORGANISMS

EXPERIMENTING WITH ORCANISMS AS BLOCKS
SYSTEM OF MODELS FOR THE LIFE CYCLE OF A BIOLOCICAL ORCANISM

THE STUDY OF POPULATION CROWTH IN ORCANISMS CROUPED BY STACES

ION WITH SPECIAL CONSIDERATION OF THE CASE OF MARKET ORIENTATION OF PRODUCTION /ASURINC SPATIAL ASSOCIAT J EXPERIMENTS

UND FOR THE CRITICAL PROBABILITY IN THE ONE-QUADRANT ORIENTED-ATOM PERCOLATION PROCESS THE RATIONAL ORIGIN FOR MEASURING SUBJECTIVE VALUES

AFRICAN STATISTICAL ASSOCIATION A SKETCH OF ITS ORIGINS AND GROWTH

NITE-TIME MAXIMA AND MINIMA OF A STATIONARY GAUSSIAN ORNSTEIN-UHLENBECK PROCESS BY MONTE CARLO SIMULATION JA A EXISTENCE OF AN INVARIANT MEASURE AND AN ORNSTEIN'S ERGODIC THEOREM

APPROXIMATIONS TO MULTIVARIATE NORMAL ORTHANT PROBABILITIES
IATE NORMAL DISTRIBUTION

DISTRIBUTION
ORTHANT PROBABILITIES FOR THE EQUICORRELATED MULTIVAR ORTHANT PROBABILITIES FOR THE QUADRIVARIATE NORMAL

THE ORTHANT PROBABILITIES OF FOUR GAUSSIAN VARIATES

ARE ORTHOGONAL /DETERMINATION OF SIGNIFICANCE IN MULTIV

ON ORTHOGONAL ARRAYS

SOME MAIN-EFFECT PLANS AND ORTHOGONAL ARRAYS OF STRENCTH TWO

ITERATIVE ESTIMATION OF VARIANCE COMPONENTS FOR NON-ORTHOGONAL DATA

GROUP THEORY TO THE EXISTENCE AND NON-EXISTENCE OF ORTHOGONAL LATIN SQUARES

ON METHODS OF CONSTRUCTING SETS OF MUTUALLY ORTHOGONAL LATIN SQUARES USING A COMPUTER

ON METHODS OF CONSTRUCTING SETS OF MUTUALLY ORTHOGONAL LATIN SQUARES USINC A COMPUTER. II MAIN-EFFECT ANALYSIS OF THE GENERAL NON-ORTHOGONAL LAYOUT WITH ANY NUMBER OF FAGTORS FOR FRACTIONS OF A COM. LETE FACTORIAL EXPERIMENT AS ORTHOGONAL LINEAR COMBINATIONS OF THE OBSERVATIONS A NOTE ON SMALL ORTHOGONAL MAIN EFFECT PLANS FOR FACTORIAL EXPERIMENT ORTHOGONAL MAIN-EFFECT PLANS FOR ASYMMETRICAL
FACTORIAL EXPERIMENTS

AL EXPERIMENTS

ALL TWO-FACTOR INTERACTIONS FOR THE 2-TO-THE-N T/

DESICNS AND TWO-FACTOR INTERACTION ALIASING SQUARES
'ORTHOGONAL MAIN-EFFECT PLANS FOR ASYMMETRICAL FACTORI ORTHOGONAL MAIN-EFFECT PLANS PERMITTING ESTIMATION OF ORTHOGONAL MAIN-EFFECT 2-TO-THE-N-TIMES-3-TO-THE-M -ORTHOGONAL PARTITIONS OF $4 \times 4,5 \times 5$, AND $6 \times 6$ LATIN ORTHOGONAL POLYNOMIAL FITTING

A CONGISE DERIVATION OF GENERAL ORTHOCONAL POLYNOMIALS
THE AMS 64129 I

A BIOKA68 $2 I 1$

BIOCS65 543

BIOKA57 $14 I$ BIOCS65 I JASA $56 \quad 597$ BIOCS67 269 JRSSB 63401 JASA $57 \quad 458$ 1 ASA $6 B \quad 1517$ AMS $69 \quad 79$ AMS $63 \quad 19 I$ BIOKA62 433 AMS 64 I 685 AMS 69 I52 JRSSB 67 I54 AMS 661355 AMS 6I 1167 BIOCS69 N0. 4 BIOKA69 NO. 3 TECH $60 \quad 507$ TECH $6 I$ III AMS $65 \quad 88$ AMS 63 I068 TECH 64220 TECH 62 2I TECH $62 \quad 440$ TECH 69 NO. 4 TECH $68 \quad 559$ AMS $66 \quad 666$ BIOKA53 36I JRSSB58 406 BIOCS68 695

FORMULA NUMERICAL CONSTRUCTION OF ORTHOGONAL POLYNOMIALS FROM A GENERAL RECURRENCE TRIALS WITH DAIRY COWS
IAL FREQUENCY FUNCTIONS I/ CORRICENDA, 'THE USE OF ORTHOGONAL POLYNOMIALS OF POSITIVE AND NECATIVE BINOM BIOKA61 476 $\begin{array}{lll}\text { DISTRIBUTIONS AND THEIR USES } & \text { THE ORTHOGONAL POLYNOMIALS OF POWER SERIES PROBABILITY } \\ \text { PROBABILITY DISTRIBUTTONS } & \text { THE ORTHOGONAL,POLYNOMIALS OF THE FACTORIAL POWER SERIES SASJ 67 }\end{array}$ PROBABILITY DISTRIBUTIONS THE ORTHOGONAL,POLYNOMIALS OF THE FACTORIAL POWER SERIES SASJ $67 \quad 49$ INOMIAL FREQUENCY FUNCTIONS IN CURVE F/ THE USE OF ORTHOGONAL POLYNOMIALS OF THE POSITIVE AND NEGATIVE B BIOKA6I II5 COMPLETE SET OF LEADING COEFFICIENTS FOR ORTHOGONAL POLYNOMIALS UP TO N $=26 \quad 644$ ESTIMATION OF PROBABILITY DENSITY BY AN ORTHOGONAL SERIES DENSITY ESTIMATION OF ORTHOGONAL SERIES ASYMMETRICAL ROTATABLE DESIGNS AND ORTHOGONAL TRANSFORMATIONS ORTHOGONALITY IN ANALYSIS OF VARIANCE THE ORTHOGONALIZATION OF UNDESIGNED EXPERIMENTS

ERRATA, 'THE ORTHOGONALIZATION OF UNDESIGNED EXPERIMENTS '

AMS 67 I26I

AMS 69 I 496

TECH $68 \quad 313$

AMS 64705

TECH $66 \quad 279$ TECH $66 \quad 731$

NVESTIGATING THE NORMALITY AND VARIANCES OF RESID/ ORTHONORMAL BASES OF ERROR SPACES AND THEIR USE FOR I JASA 67 IO22 AN OSCILLATING SEMIGROUP

A REVISED TEST FOR SYSTEMATIC OSCILLATION

AMS $67 \quad 924$ JRSSB54 292 BIOKA57 314 BIOKA66 455 JASA 59689 SASJ $69 \quad 9$ BIOKA68 1 I9 TECH $60 \quad 123$ BIOKA6I 379 BIOKA63 375 BIOKA65 429

ON AN EXTREME RANK SUM TEST FOR OUTLIERS

THE PERFORMANCE OF SEVERAL TESTS FOR OUTLIERS S RELATING TO THE EXPONENTIAL DISTRIBUTION WHEN SOME OUTLIERS ARE PRESENT, CORR. 65 1249 15 OF HYPOTHESE JASA 65 548
LOCATING OUTLIERS IN FACTORIAL EXPERIMENTS OUTLIERS IN PATTERNED EXPERIMENTS A STRATEGIC APPRAISAL N. $2 \mathrm{EST} /$ INVESTIGATION OF RULES FOR DEALING WITH OUTLIERS IN SMALL SAMPLES FROM THE NORMAL DISTRIBUTIO TE ANALYSIS OF OUTLIERS WITH ADJUSTED RESIDUALS

AN OUTLINE OF LINEAR PROGRAMMING AN OUTLINE OF LINEAR PROGRAMMING (WITH DISCUSSION) PROGRAMMING (WITH DISCUSSION) AN OUTLINE OF LINEAR PROGRAMMING AN OUTLINE OF LINEAR THE BAYESIAN OUTLOOK AND ITS APPLICATIONS (WITH DISCUSSION) AN OUTLOOK REPORT

DETECTION OF BEST AND OUTLYING NORMAL POPULATIONS WITH KNOWN VARIANCES

ON THE RISK OF SOME STRATEGIES FOR OUTLYING OBSERVATIONS

PROCEDURES FOR DETECTING OUTLYING OBSERVATIONS IN SAMPLES QUERY, REJECTION OF OUTLYINC VALUES

WAGE, PRICE, AND TAX ELASTICITIES OF OUTPUT AND DISTRIBUTIVE SHARES GRADING WITH A GAUGE SUBJECT TO RANDOM OUTPUT FLUCTUATIONS APPROACHES TO NATIONAL OUTPUT MEASUREMENT

THE OUTPUT PROCESS OF A STATIONARY M/M/S QUEUEING SYSTEM

THE CORRELATION STRUCTURE OF THE OUTPUT PROCESS OF SOME SINGLE SERVER SYSTEMS TECH 6191 $\begin{array}{lll}\text { TECH } & 69 & 527 \\ \text { TECH } & 67 & 54 I\end{array}$ JRSSB55 165 JRSSB55 165 BIOCS69 NO. 4 JASA 58 I BIOKAGI 457 AMS 64 I524 TECH 69 I TECH $64 \quad 22 \mathrm{~B}$ JASA 62607 JRSSB54 IIB JASA 58948 AMS $68 \quad 1 I 44$ AMS 6B 1007 AND WHICH INTERARRIVAL ABILITY GENERATING FUNCTIONALS TO THE STUDY OF INPUT-OUTPUT STREAMS SOF APPLICATIONS OF PROB JRSSB6B 32I ONCENTRATION OF DOMESTIC MANUFACTURING ESTABLISHMENT OUTPUT I939-1958

RECTIFYING INSPECTION OF A CONTINUOUS OUTPUT, CORR, 59 BIO

NOTES. A MEASURE OF 'OVERALL VARIABILITY' IN POPULATIONS

AN A POSTERIORI PROBABILITY METHOD FOR SOLVING AN OVERDETERMINED SYSTEM OF EQUATIONS OVERFLOW AT A TRAFFIC LICHT

THE BOKA59 420

A SIMPLIFIED MODEL FOR DELAYS IN OVERTAKING ON A TWO-LANE ROAD VARIATION, COMMENT ON A CRITICISM MADE BY KOOPMANS, OWEN AND ROSENBLATT. /IBUTION OF THE COEFFICIENT OF BIOKA65 303 
OMIAL DISTRIBUTION AND THE POSTERIOR DISTRIBUTION OF P FOR A CONTINUOUS PRIOR DISTRIBUTION THE MIXED BIN JRSSB68 359 RECURRENCE RELATTONS BETWEEN THE P.D. F IS OF ORDER STATTSTICS OF DEPEV

EXPERIMENTS WITH P-COMPONENT MIXTURES JRSSB68 137

STUART'S TESTS FOR TESTINC TREND IN DISPERSION OF A P-DEPENDENT TIME SERIES (CORR. 69 457) $10 F$ COX AND BIOKA68 381 BOUNDED LENCTH CONFIDENCE INTERVALS FOR THE P-POINT OF A DISTRIBUTION FUNCTION, II BOUNDED LENCTH CONFIDENCE INTERVALS FOR THE P-POINT OF A DISTRIBUTION FUNCTION, III

FREE VERSION OF THE SMIRNOV TWO SAMPLE TEST IN THE P-VARIATE CASE

ON SOME ALTERNATIVE ESTIMATES FOR SHIFT IN THE P-VARIATE ONE SAMPLE PROBLEM

FROM A RANDOM POINT TO THE NEAREST POINT OF A COSELY PACKED LATTICE

THE DISTRIBUTION OF KENDALL'S SCORE S FOR A PAIR OF TIED RANKINCS

EXTENDED TABLES OF THE WILCOXON MATCHED PAIR SIGNED RANK STATISTIC

PAIRED COMPARISONS FOR PAIRED CHARACTERISTICS

REDUCED GROUP DIVISIBLE PAIRED COMPARISON DESIGNS

BETWEEN JUDGES

PAIRED COMPARISON DESICNS FOR TESTING CONCORDANCE

OF INCOMPLETE BLOCK DESICNS. I THE METHOD OF PAIRED COMPARISONS EL AND ASSOCIATED ESTIMATION AND TES/ MULTIVARIATE PAIRED COMPARISONS. OCK DESICNS. II, ADDITIONAL TABLES FOR THE METHOD OF PAIRED COMPARISONS. TRIBUTION-FREE TEST OF INDEPENDENCE WITH A SAMPLE OF PAIRED OBSERVATIONS

SELECTION OF THE BEST TREATMENT IN A PAIRED-COMPARISON EXPERIMENT DAVID ENTITLED 'SELECTION OF THE BEST TREATMENT IN A PAIRED-COMPARISON EXPERIMENT'

\section{TREATMENTS} SIGNIFICANCE TESTS FOR PAIRED-COMPARISON EXPERIMENTS CORRICENDA, 'SIGNIFICANT TESTS FOR PAIRED-COMPARISON EXPERIMENTS'

NDERATION DES VALEURS GENOTYPIQUES DANS LA SELECTION PAR INDEX SUR PLUSIEURS CARACTERES METHOD OF ESTIMATING RELATIVE POTENCY FROM TWO PARABOLAS

ITIES FOR WISHART'S AND RELATED DISTRIBUTIONS, AND A PARADOX IN FIDUCIAL THEORY

A PARADOX IN STATISTICAL ESTIMATION PIVOTAL QUANT JRSSB55 79

A PARADOX INVOLVINC QUASI PRIOR DISTRTBUTIONS BIOKA55 527

FIRST EMPTINESS OF TWO DAMS IN PARALLEL

IOKA65 623 $\begin{array}{lrr}\text { AMS } & 61 & 219 \\ \text { AMS } & 61 & 1314\end{array}$ TWO SIMILAR QUEUES IN PARALLEL

F RELIABILITY FUNCTIONS FOR SYSTEMS IN SERIES AND IN PARALLEL SIGNIFICANCE TESTS IN PARALLEL AND IN SERIES

USE OF PRTOR INFORMATION TO DESTCN A ROUT INE PARALLEL LINE ASSAY THE SAMPLE DISTRIBUTION FUNCTION LIES BETWEEN TWO PARALLEL STRAIGHT LINES CONFIDENCE LIMITS FOR THE RELIABILITY OF SERIES AND PARALLEL SYSTEMS

ON A CLASS OF RANK ORDER TESTS FOR THE PARALLELISM OF SEVERAL RECRESSION LINES ARRIED OUT BY GAUSE WITH POPULATIONS OF THE PROTOZOA PARAMECIUM AURELIA AND PARAMECIUM CAUDATUM OPTIMUM DECISION PROCEDURES FOR A POISSON PROCESS PARAMETER JASA $58 \quad 799$ TECH 60263 BIOCS67 257 THE PROBABILITY THAT AMS 68 39B APPROXIMATE TECH $65 \quad 495$ AMS 691668 BIOKA57 314 AMS $62 \quad 1384$ 
NONPARAMETRIC CONFIDENCE INTERVALS FOR A SHIFT PARAMETER ROBUST ESTIMATION OF A LOCATION PARAMETER INVARIANT INTERVAL ESTIMATION OF A LOCATION PARAMETER ESTIMATION OF THE LARGER TRANSLATION PARAMETER A CLASS OF SEQUENTIAL TESTS FOR AN EXPONENTIAL PARAMETER LINEAR ESTIMATES OF A POPULATION SCALE PARAMETER CLOSED SEQUENTIAL TESTS FOR AN EXPONENTIAL PARAMETER STUDIES IN THE SEQUENTIAL ESTIMATION OF A BINOMIAL PARAMETER LINEARITY OF A RANK STATISTIC IN REGRESSION PARAMETER LIFE FOR THE EXPONENTIAL DISTRIBUTION WITH CHANCINC PARAMETER CONFIDENCE INTERVALS II. MORE THAN ONE UNKNOWN PARAMETER OF QUANTILE ESTIMATES OF A SINGLE LOCATION PARAMETER PROCEDURES FOR UNBIASED ESTIMATION OF A BINOMIAL PARAMETER DIRECT AND FIDUCIAL ARGUMENTS IN THE ESTIMATION OF A PARAMETER CONFIDENCE POINT PROCEDURES IN THE CASE OF A SINGLE PARAMETER

UNBIASED CONFIDENCE INTERVALS FOR THE BINOMIAL PARAMETER UNBIASED CONFIDENCE INTERVALS FOR THE POISSON PARAMETER PARAMETER IN THE PRESENCE OF AN INCIDENTAL SCALE PARAMETER

BAYES CONFIDENCE INTERVALS FOR THE HYPERGEOMETRIC PARAMETER OF ANY CONTINUOUS FORM AND KNOWN APART FROM A SCALE PARAMETER E PARAMETER OF A WEIBULL POPULATION WITH KNOWN SHAPE PARAMETER A SUFFICIENT STATISTIC WHEN THE RANGE DEPENDS ON THE PARAMETER ITERIA FOR THE CONTINUITY OF PROCESSES WITH A VECTOR PARAMETER DENT GENERALIZED GAMMA VARIABLES WITH THE SAME SHAPE PARAMETER RMATION IN THE ESTIMATION OF AN EXPONENTIAL SURVIVAL PARAMETER THE GAMMA DISTRIBUTION FOR SMALL VALUES OF THE SHAPE PARAMETER ACTERIZATIONS OF THE LINEAR EXPONENTIAL FAMILTY IN A PARAMETER 812 SMOOTH EMPIRICAL BAYES ESTIMATION FOR ONE-PARAMETER THE DESICN OF EXPERIMENTS FOR PARAMETER

FOR THE DUAL PROBLEM OF MODEL DISCRIMINATION AND PARAMETER ESTIMATTON DISTRIBUTION PARAMETER ESTIMATION FOR A CENERALIZED GAMMA DISTRIBUTION ON GROWTH PARAMETER ESTIMATION FOR EARLY LIFE STAGES

SCALE PARAMETER ESTIMATION FROM THE ORDER STATISTICS OF UNEQUAL CAMMA COMPONENTS DESICN OF EXPERIMENTS FOR PARAMETER ESTIMATION IN MULTIRESPONSE SITUATIONS PRIOR DISTRIBUTIONS IN THE DESIGN OF EXPERIMENTS FOR PARAMETER ESTIMATION IN NON-LINEAR SITUATIONS PRIOR DISTRIBUTIONS IN THE DESIGN OF EXPERIMENTS FOR PARAMETER ESTIMATION IN NON-LINEAR SITUATIONS MULTIRE B LIFE TESTING AND RELIABILITY ESTIMATION FOR THE TWO PARAMETER EXPONENTIAL DISTRIBUTION ESTIMATION OF THE PARAMETERS OF TWO PARAMETER EXPONENTIAL DISTRIBL
ESTIMATION FOR A ONE-PARAMETER EXPONENTIAL MODEL

\section{A TWO-PARAMETER FAMILY OF HYPER-POISSON DISTRIBUTIONS}

EFFICIENT ESTIMATION OF A REGRESSION PARAMETER FOR CERTAIN SECOND ORDER PROCESSES

THE ESTIMATION OF THE POISSON PARAMETER FROM A TRUNCATED DISTRIBUTION EFFICIENT ESTIMATION OF A SHIFT PARAMETER FROM GROUPED DATA

ON OF KARBER'S METHOD FOR ESTIMATING THE EXPONENTIAL PARAMETER FROM QUANTAL DATA, AND ITS RELATIONSHIP TO BI RIGHT ESTIMATING THE POISSON PARAMETER FROM SAMPLES THAT ARE TRUNCATED ON THE GENERALIZE DE FINETTI'S THEOREM. CONTINUOUS TIMES PARAMETER

AMS 631507 AMS $64 \quad 73$ AMS $68 \quad 193$ AMS $68 \quad 502$ JASA 69 NO. 4 BIOKA67 551 BIOKA6B 3B? NUMERICAL BIOKA58 ASYMPTOTIC AMS 69 N0.6 SEQUENTIAL TECH $66 \quad 217$ APPROXIMATE BIOKA53 306 ADMISSIBILITY AMS 641019 A COMPARISON OPTIMUM TECH 64259 ON COMPARISONS BETWEEN JRSSB65 I TABLE OF NEYMAN-SHORTEST BIOKA6O 3BI TABLES OF NEYMAN-SHORTEST BIOKA6I 191 CONSISTENT ESTIMATION OF A LOCATION AMS 691353 ON M ORDER STATISTICS, FOR THE SCAL TECH 65405 OF THE PRODUCT OF INDEPEN AMS 681751 T VARIABLES AND INCOMPLETE SURVIVAL INFO BIOCS66 665 /XIMATION TO THE PROBABILITY INTEGRAL OF BIOKA62 276 Y RECURRENCE RELATIONS FOR FUNCTIONS OF CU AMS 691721 BIOKA66 417 JASA $59 \quad 389$ TECH $68 \quad 271$ TECH 68,145 TECH $65 \quad 349$ JASA $68 \quad 848$ BIOCS66 162 AMS $66 \quad 152$ BIOKA66 525 BIOKA67 147 BIOKA67 662 JASA 69621 TECH $60 \quad 403$ JASA $65 \quad 560$ JASA $64 \quad 133$ AMS 611299 BIOKA52 247 AMS $67 \quad 1770$ BIOCS67 739 TECH $61 \quad 433$ TECH $67 \quad 159$ S FOR THE MAXIMUM-LIKELIHOOD ESTIMATOR OF AN UNKNOWN PARAMETER IN A SIMPLE MARKOV CHAIN /IENCY CONDITION BIOKA55 342 S FOR THE MAXIMUM-LIKELTHOOD ESTTMATOR OF AN UNKNOWN PARAMETER IN A SIMPLE MARKOV CHAIN' /ENCY CONDITION BIOKA56 497 THE ESTIMATION OF A FUNDAMENTAL INTERACTION PARAMETER IN AN EMIGRATION-IMMIGRATION PROCESS ESTIMATORS OF A LOCATION PARAMETER IN THE ABSOLUTELY CONTINUOUS CASE ESTIMATION OF A PARAMETER IN THE CLASSICAL OCCUPANCY PROBLEM B B BKAGO 180 $\begin{array}{ll}\text { T TO BACTERIA } & \text { ESTIMATION OF THE PARAMETER IN THE STOCHASTIC MODEL FOR PHAGE ATTACHMEN AMS 68 183 } \\ \text { E TRUE VALUE } & \text { SAMPLE SIZE REQUIRED TO ESTIMATE THE PARAMETER IN THE UNIFORM DENSITY WITHIN D UNITS OF TH JASA 64 550 }\end{array}$ HE LOC LIKELIHOOD RATIO TEST STATISTIC WHEN THE TRUE PARAMETER IS 'NEAR' THE BOUNDARTES OF THE HYPOTHESTS AMS 68 2044 $S$ OF A POINT-SOURCE EPIDEMIC THE THREE-PARAMETER LOGNORMAL DISTRIBUTION AND BAYESIAN ANALYSI J A NOTE ON SEQUENCES OF CONTINUOUS PARAMETER MARKOV CHAINS

A TWO-PARAMETER MODEL FOR THE SURVIVAL CURVE OF TREATED

CANCER PATIENTS

A TWO-PARAMETER MODEL FOR THE SURVIVAL CURVE OF
OF THE PARAMETER N IN THE BINOMIAL DISTRIBUTION ESTIMATION OF THE PARAMETER N IN THE BIN AM AN UNKNOWN POINT A TEST FOR A GHANGE IN A PARAMETER OCCURRINC AT AN UNKNOWN POIN
IN WHICH A CHANCE IN A PARAMETER OCCURS AT AN UNKNOWN POINT

ON PROBLEMS IN WHICH A CHANCE IN A PARAMETER OCCURS AT AN UNKNOWN POINT

AMS $68 \quad 2044$ $\begin{array}{rrr}\text { JASA } & 63 & 72 \\ \text { AMS } & 69 & 1078\end{array}$ JASA $65 \quad 16$ JASA $68 \quad 150$ BIOKA55 523 BIOKA57 248 BIOKA5B 275 ATISTIC WHEN THE RAN/ CONFIDENCE INTERVALS FOR THE PARAMETER OF A DISTRIBUTION ADMITTING A SUFFICIENT ST JRSSB55 86
ON ESTIMATING THE PARAMETER OF A DOUBLY TRUNCATED BINOMIAL DISTRIBUTION JASA 66 259 SEPARATE REGIMES THE ESTIMATION OF THE PARAMETER OF A LINEAR REGRESSION SYSTEM OBEYING TWO JASA 58 873 MAXIMUM LIKELIHOOD ESTIMATE OF THE NON-CENTRALITY PARAMETER OF A NONCENTRAL CHI-SQUARE VARIATE FIDENCE BOUNDS. BASED ON ONE ORDER STATISTIG FOR THE PARAMETER OF A ONE-PARAMETER NEGATIVE EXPONENTIAL POP TECH 64 483 TIMATORS, BASED ON M ORDER STATISTICS, FOR THE SCALE PARAMETER OF A WEIBULL POPULATION WITH KNOWN SHAPE PA TECH 65 405 A NOTE ON THE TEST FOR THE LOCATION PARAMETER OF AN EXPONENTIAL DISTRIBUTION ESTIMATION OF THE PARAMETER OF AN EXPONENTIAL DISTRIBUTION FIDENCE BOUNDS, BASED ON ONE ORDER STATISTIC FOR THE PARAMETER OF AN EXPONENTIAL POPULATION SHORTER INTERVALS FOR THE PARAMETER OF THE BINOMLAL AND POISSON DISTRIBUTIONS BIOKA57 436 A NOTE ON THE ESTIMATION OF THE LOCATION PARAMETER OF THE GAUCHY DISTRIBUTION EFFECT OF TRUNCATION ON A TEST FOR THE SCALE PARAMETER OF THE EXPONENTIAL DISTRIBUTION

JASA $66 \quad 852$ AMS $64 \quad 209$ ONS ON SOME PERMISSIBLE ESTIMATORS OF THE LOCATION PARAMETER OF THE WEIBULL AND GERTAIN OTHER DISTRIBUTI TECH 67 293 ING ONE OF $\mathrm{K}$ HYPOTHESES CONCERNING THE UNKNOWN DRIFT PARAMETER OF THE WIENER PROCESS /OCEDURES FOR CHOOS AMS 67 1376 HEBYSHEV INEOUALTTTES WITH - EXTENSIONS TO CONTTNUOUS PARAMETER PROCESSES

SOME MULTIVARIATE C LOT ESTIMATION OF WEIBULL DISTRIBUTION SHAPE PARAMETER WHEN NO MORE THAN TWO FAILURES OCCUR PER THE EXPONENTIAL CASE CONFIDENCE INTERVALS FOR THE PRODUCT OF TWO BINOMIAL PARAMETERS ON ESTTMATING SGALE AND LOGATION PARAMETERS NOTE ON ESTIMATING ORDERED PARAMETERS GAUSSIAN PROCESSES ON SEVERAL PARAMETERS
AMS $61 \quad 687$ TECH $64 \quad 415$ TECH $62 \quad 75$ JASA $57 \quad 482$ JASA $63 \quad 658$ AMS $65 \quad 771$ AMS 65698 
UNBIASED ESTIMATION OF LOCATION AND SCALE PARAMETERS SOME PERCENTILE ESTIMATORS FOR WEIBULL PARAMETERS ESTTMATION OF TWO ORDERED TRANSLATION PARAMETERS ON ESTIMATING MONOTONE PARAMETERS USING FACTOR ANALYSIS TO ESTIMATE PARAMETERS DISTRIBUTIONS OF RANDOM VARIABLES WITH RANDOM PARAMETERS FIDUCIAL INFERENCE FOR LOCATION AND SCALE PARAMETERS POSTERIOR DISTRIBUTIONS FOR MULTIVARIATE NORMAL PARAMETERS ESTIMATION BY RANKING PARAMETERS MAXIMUM LIKELIHOOD ESTIMATION OF SURVIVAL CURVE PARAMETERS SIZE CONFIDENCE ELLIPSOIDS FOR LINEAR REGRESSION PARAMETERS SAVINGS IN TEST TIME WHEN COMPARING WEIBULL SCALE PARAMETERS FOR REGRESSION PROBLEMS WITH CORRELATED ERRORS MANY PARAMETERS LOSS INTERVAL ESTIMATION OF LOCATION AND SCALE PARAMETERS CONFIDENCE LIMITS FOR THE PRODUCT OF N BINOMIAL PARAMETERS STIMATORS FOR LINEAR FUNCTIONS OF LOCATION AND SCALE PARAMETERS REGRESSION WITH INEQUALITY RESTRAINTS ON THE PARAMETERS PROPERTIES OF SEVERAL ESTIMATORS OF WEIBULL PARAMETERS SHAPES FOR SEQUENTIAL TESTING OF TRUNCATION PARAMETERS NEARLY EFFICIENT ESTIMATORS OF MULTIVARIATE LOCATION PARAMETERS OF FIELLER'S THEOREM TO THE RATIO OF COMPLEX PARAMETERS QUENCIES OF SPECIES AND THE ESTIMATION OF POPULATION PARAMETERS TEST WHEN OBSERVATIONS ARE ESTIMATES OF BINOMIAL PARAMETERS OF INVARIANT ESTIMATORS OF ONE OR MORE LOCATION PARAMETERS OF A CLASS OF NON-PARAMETRIC TESTS FOR REGRESSION PARAMETERS BAYESIAN PROBABILITY POINTS IN THE CASE OF SEVERAL PARAMETERS

I. VARIANCE BOUNDS FOR ESTIMATORS OF LOCATION PARAMETERS E SEQUENTIAL CONFIDENCE BOUNDS FOR LINEAR REGRESSION PARAMETERS E QUEUEING PROBLEM WITH A SINGLE SERVER AND CONSTANT PARAMETERS NTS AND THEIR USE FOR EXPERIMENTS INVOLVING LOCATION PARAMETERS ROUPED OBSERVATIONS IN THE ESTIMATION OF STATISTICAL PARAMETERS NTS FOR THE ESTIMATION OF A SUBGROUP OF PRE-ASSIGNED PARAMETERS RAMETERS IN PROBLEMS WITH UNKNOWN LOCATION AND SCALE PARAMETERS ENCE OF RANDOM PROCESSES WITH MULTI-DIMENSIONAL TIME PARAMETERS INCOMPLETE BLOCK DESIGNS

$$
\text { ON THE PARAMETERS }
$$

ON FIXED-WIDTH CONFIDENCE BOUNDS FOR REGRESSION PARAMETERS

ANALYSIS OF/ THE THEORY OF LEAST SOUARES WHEN THE PARAMETERS ARE STOCHASTIC AND ITS APPLICATION TO THE BI ESTIMATES OF REGRESSION PARAMETERS BASED ON RANK TESTS

TION TO AMS 56427 'ESTIMATION OF LOCATION AND SCALE PARAMETERS BY ORDER STATISTICS FROM SINGLY AND DOUBLY AMS 39 325 VICTOR HASSELBLAD DISCUSSION OF 'ESTIMATION OF PARAMETERS FOR A MIXTURE OF NORMAL DISTRIBUTIONS' BY TECH 66 445 ESTIMATION OF PARAMETERS FOR A MIXTURE OR NORMAL DISTRIBUTIONS TECH 66 431 $\mathrm{N}$ ONE VARIABLE IS DICHOTOMISED. ESTIMATION OF THE PARAMETERS FOR A MULTIVARIATE NORMAL DISTRIBUTION WHE BIOKA65 664 AVERAGE RESIDUALS NOTES. ESTIMATION OF NON-LINEAR PARAMETERS FOR A NON-ASYMPTOTIC FUNCTION 2 BIOCS6B 439 LARGE-SAMPLE ESTIMATION OF PARAMETERS FOR AUTOREGRESSIVE PROCESSES WITE MOVING- BIOKA62 117 ED SAMPLES -RECAPTURE METHOD. I/ THE ESTIMATION OF POPULATION PARAMETERS FROM DATA OBTAINED BY MEANS OF THE CAPTURE BIOKA5 ANSFORMATIONS OF SCALE AND THE ESTIMATION OF GENETIC PARAMETERS FROM DAUGHTER-DAM REGRESSION THE ESTIMATION OF LOCATION AND SCALE PARAMETERS FROM GROUPED DATA BIOKA54 296 BIOKA64 511 JASA $57 \quad 523$ ESTIMATION OF PARAMETERS FROM INCOMPLETE MULTIVARIATE SAMPLES

ON THE ESTIMATION OF POPULATION PARAMETERS FROM MARKED MEMBERS BIOKA55 269 NORMAL DISTRIBUTION. TWO METHODS OF ESTIMATING PARAMETERS FROM MOMENTS TH AND DILUTION DETERMINT/ THE BAYESIAN ESTIMATION OF COMMON PARAMETERS FROM SEVERAL RESPONSES
BIOKA65 355 G HOUSEHOLDS OF TWO THE ESTIMATION OF PARAMETERS FROM THE SPREAD OF A DISEASE BY CONSIDERIN BIOKAG ESTIMATION OF THE NORMAL POPULATION PARAMETERS GIVEN A SINGLY CENSORED SAMPLE BIOKA59 XIMUM LIKELIHOOD ESTIMATES OF THE LOCATION AND SCALE PARAMETERS GIVEN A TYPE II CENSORED NORMAL SAMPLE / BIOKA6I 44B RELIABILITY GROWTH MODEL ESTIMATION OF PARAMETERS IN A TRANSIENT MARKOV CHAIN ARISING IN A AMS 69 I542 UTION ESTIMATION OF LOCATION AND SCALE PARAMETERS IN A TRUNCATED GROUPED SECH SQUARE DISTRIB JASA 6I 692 OF DESIGNS AND ESTIMATION PROCEDURES FOR ESTIMATING PARAMETERS IN A TWO-STAGE NESTED PROCESS /MPARISONS TECH 67 499 CONSISTENCY AND LIMIT DISTRIBUTIONS OF ESTIMATORS OF PARAMETERS IN EXPLOSIVE STOCHASTIC DIFFERENCE EQUATIO AMS 6I I95 A METHOD OF OBTAINING INITIAL ESTIMATES OF THE PARAMETERS IN EXPONENTIAL CURVE FITTING CORR. 631603 LOCATION AND SCALE PARAMETERS IN EXPONENTIAL FAMILIES OF DISTRIBUTIONS. RANDOM TESTING HYPOTHESES AND ESTIMATING PARAMETERS IN HUMAN GENETICS IF THE AGE OF ONSET IS ON TESTING THE EQUALITY OF PARAMETERS IN K RECTANGULAR POPULATIONS

A GRAPHICAL ESTIMATION OF MIXED WEIBULL PARAMETERS IN LIFE TESTING ELECTRON TUBES

COMPARATIVE EFFICIENCIES OF METHODS OF ESTIMATING PARAMETERS IN LINEAR AUTOREGRESSIVE SCHEMES DISCUSSION) CONFIDENCE INTERVALS FOR PARAMETERS IN MARKOV AUTOREGRESSIVE SCHEMES (WITH EFFICIENT ESTIMATION OF PARAMETERS IN MOVING-AVERAGE MODELS

INADMISSIBILITY OF THE USUAL ESTIMATORS OF SCALE PARAMETERS IN PROBLEMS WITH UNKNOWN LOCATION AND SCAL AMS 68 29 NERALIZED LEAST-SQUARES ESTIMATION OF A SUBVECTOR OF PARAMETERS IN RANDOMIZED FRACTIONAL FACTORIAL EXPERIM AMS 69 I344 ESTIMATION OF THE PARAMETERS IN SHORT MARKOV SEQUENCES EQUATIONS THE ESTIMATION OF PARAMETERS IN SYSTEMS OF STOCHASTIC DIFFERENTIAL WILCOXON CONFIDENCE INTERVALS FOR LOCATION PARAMETERS IN THE DISCRETE CASE 
ST LINEAR ESTIMATES UNDER SYMMETRIC CENSORING OF THE PARAMETERS OF A DOUBLE EXPONENTIAL POPULATION

ULATION FROM/ MAXIMUM-LIKELIHOOD ESTIMATION OF THE PARAMETERS OF A FOUR- PARAMETER GENERALIZED GAMMA POP TECH 67 159 ESTIMATION OF THE PARAMETERS OF A LINEAR FUNCTIONAL RELATION $\quad$ JRSSB61 160

CONSISTENT ESTTMATES OF THE PARAMETERS OF A LTNEAR SYSTEM

CENSORED SAMPLES OF THE PARAMETERS OF A LOGTSTIC DISTRIBUTION

MOMENT ESTIMATORS FOR THE PARAMETERS OF A MIXTURE OF TWO BINOMIAL DISTRIBUTIONS ESTIMATING THE PARAMETERS OF A MODIFIED POISSON DISTRIBUTION

AMS 69 N0.6

JASA $67 \quad 675$ TECH $6 \mathrm{~B} \quad 161$ LETE AND FRO/ MAXIMUM LIKELIHOOD ESTIMATION OF THE PARAMETERS OF GAMMA AND WEIBULL POPULATIONS FROM COMP TECH 65 639 LET/ ERRATA, 'MAXIMUM-LIKELIHOOD ESTIMATION OF THE PARAMETERS OF GAMMA AND WEIBULL POPULATIONS FROM COMP TECH 67 195 ESTIMATING THE PARAMETERS OF LOG-NORMAL DISTRIBUTION FROM CENSORED JASA 68 134 TIME DISTRIBUTIONS FROM CENSORED L/ ESTIMATION OF PARAMETERS OF MIXED EXPONENTIALLY DISTRIBUTED FAILURE BIOKA58 504 ESTIMATING THE PARAMETERS OF MIXTURES OF BINOMIAL DISTRIBUTIONS JASA 64510

ONE OR TWO ORDER STATI/ OPTIMUM ESTIMATORS OF THE PARAMETERS OF NECATIVE EXPONENTIAL DISTRIBUTIONS FROM AMS 63 117 NE OR TWO ORDER STATISTICS, CORR./ ESTIMATING THE PARAMETERS OF NEGATIVE EXPONENTIAL POPULATIONS FROM O AMS 6I 1078 LES OF GROUPED OBSERVATIONS IN THE ESTIMATION OF THE PARAMETERS OF NORMAL POPULATIONS /BY TRUNCATED SAMP BIOKA63 207 D/ ON THE JOINT EFFICIENCY OF THE ESTIMATES OF THE PARAMETERS OF NORMAL POPULATIONS BASED ON SINGLY AND JASA 62 46 ORED SA/ ON THE EFFICIENCY OF BAN ESTIMATES OF THE PARAMETERS OF NORMAL POPULATIONS BASED ON SINGLY CENS BIOKA62 570 LY/ ITERATIVE MAXIMUM-LIKELIHOOD ESTIMATION OF THE PARAMETERS OF NORMAL POPULATIONS FROM SINCLY AND DOUB BIOKA66 205 ASSOCIATION SCHEMES A NOTE ON THE PARAMETERS OF PARTIALLY BALANCED INCOMPLETE BLOCK AMS 65 331 ON RANKING PARAMETERS OF SCALE IN TYPE III POPULATIONS JASA 58164 FOR BEST LINEAR ESTIMATES BY ORDER STATISTICS OF THE PARAMETERS OF SINGLE EXPONENTIAL DISTRIBUTIONS FROM S JASA 57 58 SIMPLIFIED TECHNIQUES FOR ESTIMATING PARAMETERS OF SOME GENERALIZED POISSON DISTRIBUTIONS BIOKA67 555 NKNOWN TI/ TEST PROCEDURES FOR POSSIBLE CHANGES IN PARAMETERS OF STATISTICAL DISTRIBUTIONS OCCURING AT U AMS 66 1196 ER STATISTICS MAXIMUM LIKELIHOOD ESTTMATION OF THE PARAMETERS OF THE BETA DISTRIBUTION FROM SMALLEST ORD TECE: 67 607 PTIMUM ORDER STATISTICS IN CENS/ ESTIMATION OF THE PARAMETERS OF THE EXPONENTIAL DISTRIBUTION BASED ON O AMS 66 I7I7 IS OF SUITABLY CHOSEN OR/ ESTIMATION OF ONE OF TWO PARAMETERS OF THE EXPONENTIAL DISTRIBUTION ON THE BAS AMS 63 I4I9 F TWO OR THREE ORDER STATISTICS ESTIMATION OF THE PARAMETERS OF THE EXTREME VALUE DISTRIBUTION BY USE O BIOKA69 429 OOD ESTIUATION. FROM DOUBLY CENSORED SAUPLES OF THE PARAMETERS OF THE FTRST ASYMPTOTIC DTSTRTBUTION OF EX JASA 6B B89

QUANTILES

STATISTICS MAXIMUM LIKELIHOOD ESTIMATION OF THE PARAMETERS OF THE GAMMA DISTRIBUTION AND THEIR BIAS ESTIMATION OF THE PARAMETERS OF THE GAMMA DISTRIBUTION BY SAMPLE ESTIMATION OF PARAMETERS OF THE GAMMA DISTRIBUTION USINC ORDER ISTICS.'

BINOMIAL DISTRIBUTIONS

QUANTILES

TATISTICS

\section{SCALE OR SHAPE PARAMETERS OF} 'ESTIMATION OF PARAMETERS OF OF PARAMETERS OF THE GAMMA DISTRIBUTION USING ORDER STAT ESTIMATION OF THE PARAMETERS OF THE LOGISTIC DISTRIBUTION ESTIMATION OF THE PARAMETERS OF THE LOGISTIC DISTRIBUTION BY SAMPLE $\begin{array}{lrr}\text { JASA } & 68 & 889 \\ \text { TECH } & 69 & \text { N0. } 4\end{array}$ TECH $64 \quad 405$ BIOKA62 525 M LOGIT CHI-SQUAR/ A NOTE ON THE ESTHES ABOUT THE PARAMETERS OF THE LOGISTIC FUNCTION YMPTOTIC OPTIMUM QUANTILES FOR THE ESTIMATION OF THE PARAMETERS OF THE NEGATIVE EXPONENTIAL DISTRIBUTION ON GUPTA'S ESTIMATES OF THE PARAMETERS OF THE NORMAL DISTRIBUTION OTIC VARIANCES OF METHOD OF MOMENTS ESTIMATES OF THE PARAMETERS OF THE TRUNCATED BINOMIAL AND NECATIVE BIN JASA 61 990 ESTIMATION OF THE SHAPE AND SCALE PARAMETERS OF THE WEIBULL DISTRIBUTION INFERENCES ON THE PARAMETERS OF THE WEIBULL DISTRIBUTION FOR OBTAININC THE BEST LINEAR INVARIANT ESTIMATES OF PARAMETERS OF THE WEIBULL DISTRIBUTION ROM CO/ LOCAL-MAXIMUM-LIKELIHOOD ESTIMATION OF THE PARAMETERS OF THREE-PARAMETER LOCNORMAL POPULATIONS F JA A NOTE ON 'THE ESTIMATION OF THE PARAMETERS OF TOLERANCE DISTRIBUTIONS' JOINT ESTIMATION OF THE PARAMETERS OF TWO NORMAL POPULATIONS $\begin{array}{llll}\text { ESTIMATION OF THE PARAMETERS OF TWO NORMAL POPULATIONS } & \text { JASA } 62 \\ \text { ESTIMATION OF THE PARAMETERS OF TWO PARAMETER EXPONENTIAL DISTRIBUTIONS TECH } 60\end{array}$

FROM CENSORED SAMPLES TIMATION, FROM SINGLY CENSORED SAMPLES, OF THE SCALE PARAMETERS OF TYPE II EXTREME-VALUE DISTRIBUTIONS / TECH 68 349 LIKELIHOOD ESTIMATORS. FROM CENSORED SAMPLES, OF THE PARAMETERS OF WEIBULL AND GAMMA POPULATIONS /XIMUM- AMS 67 557 LEAST SQUARES ESTIMATION OF LOCATION AND SCALE PARAMETERS USING ORDER STATISTICS

OF PARTIALLY BALANCED INCOMPLETE BLOCK DESICNS WITH PARAMETERS V=28. N $1=12, \quad N 2=15$ AND P2(1, 1$)=4 \quad / C T I O N$ AMS 66 1783 INFERENCE PROBLEMS ABOUT PARAMETERS WHICH ARE SUBJECTED TO CHANGES OVER TIME AMS 68 840 PROBLEM SOME INFERENCES ABOUT GAMMA PARAMETERS WITH AN APPLICATION TO A RELIABILITY POBLEM IS/ THE / AMS 62 462 OF MOOD'S AND MASSEY'S TWO SAMPLE TESTS AGAINST SOME PARAMETRIC ALTERNATIVES /TOTIC RELATIVE EFFICIENCY AMS 62 1375 BIVARIATE SYMMETRY TESTS. PARAMETRIC AND NONPARAMETRIC ARISON OF ANALYSIS OF VARIANCE POWER FUNCTION IN THE PARAMETRIC AND RANDOM MODELS AMS 69259 HICH CERTAIN SIMPLE LEAST SQUARES AND ANALYSIS OF/ PARAMETRIC AUGMENTATIONS AND ERROR STRUCTURES UNDER W JASA 69 NO.4 SURVIVAL RATE, CORR. 631161 A PARAMETRIC ESTIMATE OF THE STANDARD ERROR OF THE INTERVAL ESTIMATION OF NON-LINEAR PARAMETRIC FUNCTIONS INTERVAL ESTIMATION OF NON-LINEAR PARAMETRIC FUNCTIONS. II INTERVAL ESTIMATION OF NON-LINEAR PARAMETRIC FUNCTIONS, 11 JASA $61 \quad 111$ JASA 63611 JASA $64 \quad 168$ JASA 651191 IBUTIONS TO SAMPLE SPACINGS THEORY. II. TESTS OF THE PARAMETRIC GOODNESS OF FIT AND TWO-SAMPLE PROBLEMS
EMPIRICAL BAYES APPROACH TO THE TESTINC OF CERTAIN PARAMETRIC HYPOTHESES EMPIRICAL BAYES APPROACH TO THE TESTINC OF CERTAIN PARAMETRIC HYPOTHESES A NON-PARAMETRIC TEST FOR THE BIVARIATE TWO-SAMPLE LOCATION JRSSB67 320 EXACT AND APPROXIMATE POWER FUNCTION OF THE NON-PARAMETRIC TEST OF TENDENCY LARGE-SAMPLE RESTRICTED PARAMETRIC TESTS ASYMPTOTIC EFFICIENCY OF A CLASS OF NON-PARAMETRIC TESTS FOR REGRESSION PARAMETERS NON-PARAMETRIC TESTS FOR SCALE 
MEAN SQUARES IN CENETIC EXPERIMENTS WHEN ONLY ONE PARENT IS IDENTIFIED

THE EXPECTED BIOCS65 436 N BREEDINC PROCRAMMES WHEN ALL DAUCHTERS OF SELECTED PARENTS ARE RETAINED MULTIVARIATE PARETO DISTRIBUTIONS, CORR. 631603

THE ORDER STATISTICS OF THE MULTIVARIATE NORMAL AND PARETO TYPE 1 POPULATIONS

ON PARTIAL 'A PRIORI' INFORMATION IN STATISTICAL

SELECTION I BIOCS69 553 AMS 621008 INFERENCE

SMALL SAMPLE BIAS DUE TO MISSPECIFICATION IN THE 'PARTIAL ADJUSTMENT' AND 'ADA

AMS 641815

THE DETECTION OF PARTIAL ASSOCIATION, 2. THE GENERAL CASE

BIOKA51 26

JRSSB 64313

JRSSB 65 111

A PARTIAL COEFFICIENT FOR GOODMAN AND KRUSKAL'S GAMMA

PARTIAL CONFOUNDING IN FRACTIONAL REPLICATION

A MODIFIED DOOLITTLE APPROACH FOR MULTIPLE AND PARTIAL CORRELATION AND REGRESSION

TECH $61 \quad 353$

JASA $58 \quad 133$

TO MANIFOLD, THE RANK ANALOGUE OF PRODUCT-MOMENT PARTIAL CORRELATION AND REGRESSION, WITH APPLICATION BIOKA59 241 I THE

ON THE SIGNS OF GROSS CORRELATION COEFFICIENTS AND PARTIAL CORRELATION COEFFTCTENTS

A NOMOGRAPH FOR COMPUTING PARTIAL CORRELATION COEFFICIENTS, CORR. 62917

PARTIAL CORRELATIONS IN REGRESSION COMPUTATIONS

MISSING VALUES IN PARTIAL DIALLEL CROSS EXPERIMENTS

JASA $61 \quad 995$

JASA $61 \quad 363$

BIOCS68 903

BIOKA63 281

TWO CLASSES OF GROUP DIVISIBLE PARTIAL DIALLEL CROSSES

METHODS OF ESTIMATION O/ SIMULTANEOUS SELFING AND PARTIAL DIALLEL TEST CROSSING 2 . AN EVALUATION OF TWO BIOCS67 325

ON A PARTIAL DIFFERENTIAL EQUATION OF EPIDEMIC THEORY. I. BIOKA65 617 PARTIAL DUPLICATION OF FACTORIAL EXPERIMENTS TECH 5963 PARTIAL DUPLICATION OF RESPONSE SURFACE DESICNS TECH $60 \quad 185$

GOODMAN AND KRUSKAL'S TAU AND KENDALL'S TAU, WITH A PARTIAL INTERPRETATION OF THE LATTER /ARITY BETWEEN JASA 62 804 T FITNESS REQUIREMENTS AMONG ENVIRONME/ EFFECTS OF PARTIAL ISOLATION (DISTANCE), MIGRATION, AND DIFFEREN BIOCS66 453

INTERVALS FOR SAMPLE MEAN AND COVARIANCE BASED ON PARTIAL OBSERVATTONS A NOTE ON PREDICTION INTERVALS BASED ON PARTIAL OBSERVATIONS IN CERTAIN LIFE TEST EXPERIMENTS TECH 6B SIMULATED DISTRIBUTIONS FOR SMALL $N$ OF KENDALL'S PARTIAL RANK CORRELATION COEFFICIENT

LIMIT THEOREMS FOR RANDOMLY SELECTED PARTIAL SUMS

COMBINATORIAL THEOREM FOR PARTIAL SUMS

ON CONVERGENCE IN R-MEAN OF NORMALIZED PARTIAL SUMS ON MOMENTS OF THE MAXIMUM OF NORMED PARTIAL SUMS

BIOKA63 520

AMS 62 B5

AMS 631600

AMS $68 \quad 379$

AMS $69 \quad 527$

VARIATES

ON THE RANGE OF PARTIAL SUMS OF

VARIATES

VARIATES

THE VARIANCE OF THE MAXIMUM OF PARTIAL SUMS OF A FINTTE NUMBER OF INDEPENDENT NORMAL BTOKA55

ON THE MOMENTS OF THE MAXIMUM OF PARTIAL SUMS OF A FINITE NUMBER OF INDEPENDENT NORMAL BIOKA56 PARTIAL TESTS FOR PARTIAL TAUS

SIMULTANEOUS ESTTMATION BY PARTTAL TOTALS FOR COMPARTMENTAL MODELS

ON SOME METHODS OF CONSTRUCTION OF PARTIALLY BALANCED ARRAYS

ON OBTAINING BALANCED INCOMPLETE BLOCK DESIGNS FROM PARTIALLY BALANCED ASSOCIATION SCHEMES

BIOKA59 425

JASA $68 \quad 573$

AMS 611181

AMS $67 \quad 61 \mathrm{~B}$

AND RELATED DESIGNS

SOME NEW FAMILIES OF PARTIALLY BALANCED DESIGNS OF THE LATIN SQUARE TYPE

SCHEMES

ON A CEOMETRICAL METHOD OF CONSTRUCTION OF PARTIALIY BALANCED DESTCNS WITH TWO ASSOCIATE CLASSES A NOTE ON THE PARAMETERS OF PARTIALLY BALANCED INCOMPLETE BLOCK ASSOCIATION

LATIONSHIP ALGEBRA AND THE ANALYSIS OF VARIANCE OF A PARTIALLY BALANCED INCOMPLETE BLOCK DESICN EXTENDED GROUP DIVISIBLE PARTIALLY BALANCED INCOMPLETE BLOCK DESIGNS ON A CLASS OF PARTIALLY BALANCED INCOMPLETE BLOCK DESIGNS

COMMON TREATMENTS BETWEEN BLOCKS OF CERTAIN PARTIALLY BALANCED INCOMPLETE BLOCK DESIGNS GROUP SCREENING UTILIZING BALANCED AND PARTIALLY BALANCED INCOMPLETE BLOCK DESIGNS ICATION OF THE GEOMETRY OF QUADRICS FOR CONSTRUCTING PARTIALLY BALANCED INCOMPLETE BLOCK DESIGNS UMBER OF COMMON TREATMENTS BETWEEN BLOCKS OF CERTAIN PARTIALLY BALANCED INCOMPLETE BLOCK DESIGNS COMMON TREATMENTS BETWEEN ANY TWO BLOCKS OF CERTAIN PARTIALLY BALANCED INCOMPLETE BLOCK DESIGNS THE INTRABLOCK ANALYSIS OF A CLASS OF TWO ASSOCIATE PARTIALLY BALANCED INCOMPLETE BLOCK DESIGNS $R$ BOUND FOR THE NUMBER OF DISJOINT BLOCKS IN CERTAIN PARTIALLY BALANCED INCOMPLETE BLOCK DESIGNS NCE OF SOME SYMUETRICAL AND UNSY NONEXISTENCE THEOREMS

DUALS OF PARTIALLY BALANCED INCOMPLETE BLOCK DESICNS AND SOME THAN TWO ASSOCIATE CLASSES ANALYSIS OF A CLASS OF PARTIALLY BALANCED INCOMPLETE BLOCK DESIGNS WITH MORE METERS $V=28, N 1=12, N 2=/ \quad A$ NOTE ON CONSTRUCTION OF PARTIALLY BALANCED INCOMPLETE BLOCK DESIGNS WITH PARA LATIN SQUARE DESIGN PROPERTIES WAY CLASSIFICATION OF TREATMENTS A NEW FAMILY OF PARTIALLY BALANCED INCOMPLETE BLOCK DESICNS WITH SOME PARTIALLY BALANCED INCOMPLETE BLOCK DESIGNS WITH TWO624 ON THE BLOCK STRUCTURES OF CERTAIN PARTIALLY BALANCED INCOMPLETE BLOCK DESIGNS, CORR. 67 MULTINOMIAL SAMPLINC WITH PARTIALLY CATEGORIZED DATA ALIASING IN PARTIALLY CONFOUNDED FACTORIAL EXPERIMENTS

QUERY. ANALYSIS OF FACTORIAL EXPERIMENT (PARTIALLY CONFOUNDED 2-CUBE)

QUERY, ANALYSIS OF FACTORIAL EXPERIMENT (PARTIALLY CONFOUNDED 2-CUBE)

PARTIALLY DUPLICATED FRACTIONAL FACTORIAL DESIGNS

TECH 67229

AMS $61 \quad 1177$ AMS $65 \quad 331$ AMS 651815 AMS 64681 AMS 651807 AMS $68 \quad 999$ BIOCS65 865

AMS $63 \quad 348$ AMS $66 \quad 104 \mathrm{~B}$ AMS $61 \quad 800$ AMS $66 \quad 1783$ AMS $67 \quad 571$ AMS $69 \quad 175$ JASA $68 \quad 542$ BIOKA6I 218 TECH $67 \quad 170$ TECH $67 \quad 490$ TECH 6371 AMS 661401 ON THE USE OF PARTIALLY ORDERED OBSERVATIONS IN MEASURING THE SUPPO JASA 61299 RT FOR A COMPLETE ORDER ON THE USE OF PARTIALLY ORDERED OBSERV ONE DIMENSIONAL RANDOM WALK WITH A PARTIALLY REFLECTING BARRIER ON THE DUALS OF SYMMETRIC PARTIALLY-BALANCED INCOMPLETE BLOCK DESIGNS

OF GROUPS OF PARTICLES ON A COINCIDENCE PROBLEM CONCERNING PARTICLE COUNTERS

BIOKA55 417 AMS $63 \quad 405$ AMS $63 \quad 528$ AMS $61 \quad 739$ TECH $65 \quad 505$ TECH 69 NO.4 SAMPLING MIXTURES OF PARTICLES TECH $67 \quad 365$ DISTRIBUTION BASED ON OBSERVED WEIGHTS OF GROUPS OF PARTICLES SAMPLING MIXTURES OF MULTI-SIZED PARTICLES. AN APPLICATION OF RENEWAL THEORY
STICS INCLUDING A TABLE OF SIGNIFICANCE POINTS FOR A PARTICULAR CASE /S OF KOLMOGOROV-SMIRNOV TYPE STATI AMS 68 233 ESTIMATION OF PARTICLE SIZE TECH 65505 THE STATISTICS OF A PARTICULAR NON-HOMOCENEOUS POISSON PROCESS BIOKA64 399 OF RANDOM NUMBERS WILL BE USABLE IN SELECTING A PARTICULAR SAMPLE

THE LIMITING FREQUENCIES OF INTEGERS WITH A GIVEN PARTITIONAL CHARACTERISTIC HOW MANY OF A GROUP JASA 59102 JRSSB59 134 ION OF GREENBERG AND SARHAN'S METHOD OF INVERSION OF PARTITIONED MATRICES IN THE ANALYSIS OF NON-ORTHOGONA JASA 65 I2OO LOCATIONS WITH RESPECT TO A CONTROL ON PARTITIONING A SET OF NORMAL POPULATIONS BY THEIR AMS 69 I3OO DIFFERENT MORTALITY RISKS PARTITIONING OF A PATIENT POPULATION WITH RESPECT TO PARTITIONS PARTITIONS IN MORE THAN ONE DIMENSION

SOME NON-ORTHOGONAL PARTITIONS OF 4X4, 5X5. AND 6 X6 LATIN SQUARES

A CENTRAL LIMTT THEOREM FOR PARTLY DEPENDENT VARTABLES

JASA $63 \quad 701$

AMS $66 \quad 189$ JRSSB56 104

AMS $66 \quad 666$ AMS 61677 STATISTICIAN AND POLICY MAKER, A PARTNERSHIP IN THE MAKING

JASA $56 \quad 12$ 
FORMATION EVALUATION IN DECISIONS UNDER UNCERTAINTY, PARTS I, II, AND III TABLES OF SYMMETRIC FUNCTIONS PARTS II AND III.

A MINIMUM COST MODEL OF SPARE PARTS INVENTORY CONTROL

ON CASH EQUIVALENTS AND IN JASA $6 B \quad 252$ SOME PROPERTIES OF PASCAL DISTRIBUTION FOR FINITE POPULATION, CORR. 62 A STUDY OF THE VARIABILITY DUE TO COINCIDENT PASSACE IN AN ELECTRO
FIRST-PASSACE PERCOLATION

SOME RENEWAL THEOREMS WITH APPLICATION TO A FIRST PASSAGE PROBLEM

THE MEAN DURATION OF A BALL AND CELL GAME, A FIRST PASSAGE PROBLEM

A FIRST PASSAGE PROBLEM FOR THE WIENER PROCESS

ON THE CONTINUUM

SOME FIRST PASSAGE PROBLEMS FOR S-SUB-N-OVER-ROOT-N

THE FIRST PASSAGE TIME DENSITY FOR HOMOGENEOUS SKIP-FREE WALKS A TECHNIQUE FOR DISCUSSING THE PASSAGE TIME DISTRIBUTION FOR STABLE SYSTEMS FIRST PASSAGE TIME FOR A PARTICULAR CAUSSIAN PROCESS PROPERTIES OF GAUSSIAN PROCESSES AND THEIR FIRST PASSACE TIMES A LIMIT THEOREM FOR PASSAGE TIMES IN ERGODIC REGENERATIVE PROCESSES ACKNOWLEDGEMENT OF PRIORITY 611345 FIRST PASSAGE TIMES OF A GENERALIZED RANDOM WALK, CORR. FISHER, WRIGHT, AND PATH COEFFICIENTS SAMPLE PATH VARIATIONS OF HOMOGENEOUS PROCESSES

SAMPLE PA'TH VARIATIONS OF HOMOGENEOUS PROCESSES
NS WITH AN APPLICATION IN STUDYING THE DENTAL C/ A PATH-F $O$ OABILITY APPROACH TO IRREVERSIBLE MARKOV CHAI BIOCS66 791

$\begin{array}{rr}\text { AMS } 61 & 235 \\ \text { BIOCS6B } & 471\end{array}$ NOTE ON THE ABSENCE OF TANGENCIES IN GAUSSIAN SAMPLE PATHS PATHS AND CHAINS OF RANDOM STRAIGHT-LINE SECMENTS A TAMS 68 TECH $66 \quad 303$

Y RISKS

PARTITIONING OF A PATIENT

MODEL FOR THE SURVIVAL CURVE OF TREATED CANCER PATIENTS

SIGNIFICANCE TESTS

TREATED CANCER PATIENTS A TWO-PARA
ON THE USE OF PATNAIK TYPE CHI APPROXIMATIONS TO THE RANGE IN

A TWO-PARAMETER JASA 63

JASA 65 BIOKA66

R/ THE EFFICIENCY OF N MACHINES UNI-DIRECTIONALLY PATROLLED BY ONE OPERATOR WHEN WALKING TIME AND REPAI JRSSB57

NT/ THE EFFICIENCY OF N MACHINES UNI-DIRECTIONALLY PATROLLED BY ONE OPERATOR WHEN WALKING TIME IS CONSTA JRSSB57

OF AUTOMATIC WINDING MACHINES WITH CONSTANT PATROLLING TIME

STUDIES IN STATISTIGAL ECOLOGY. I. SPATIAL PATTERN

FOUR-LETTER WORDS. THE DISTRIBUTION OF PATTERN FREQUENCIES IN RING PERMUTATIONS

A MATHEMATICAL THEORY OF PATTERN RECOGNITION

THE ESTIMATION OF A CHANCING SEASONAL PATTERN, CORR. 661247

OUTLIERS IN PATTERNED EXPERIMENTS. A STRATEGIC APPRAISAL

ON INVERTING A CLASS OF PATTERNED MATRICES

RACTERISTIC EQUATIONS AND THEIR ROOTS FOR A CLASS OF PATTERNED MATRICES

FOURIER METHODS FOR EVOLVING SEASONAL PATTERNS

POINTS IN A CIRCLE AND THE ANALYSIS OF CHROMOSOME PATTERNS

PROCESS MODEL FOR TH ANALYSIS OF COMPUTER FAILURE PATTERNS (WITH DISCUSSION)

RECONSTRUCTING PATTERNS FROM SAMPLE DATA

MORTALITY PATTERNS IN EICHT STRAINS OF FLOUR BEETLE

PATTERNS IN RESIDUALS. A TEST FOR RECRESSION MODEL

$\begin{array}{r}1959-61 \\ \hline\end{array}$ ACE PATTERNS OF MORTALITY

THE CONCEPT OF RANDOMNESS IN THE PATTERNS OF MOSAICS
AN EXTENSION OF PAULSON'S SELECTION PROCEDURE

AN EXTENSION OF PAULSON'S SELEC

MOMENTS OF THE RANDOMIZATION TEST IN INO ASSOCIAE PDENIFICATION OF ANNUAL PEAK PERIODS FOR A DISEASE
THE IDENTER

THE IDENTIFICATION OF ANNUAL PEAK PERIODS FOR A DISEA
SOME STATISTICAL CHARACTERISTICS OF A PEAK TO AVERAGE RATIO

THE CONTRIBUTIONS OF KARL PEARSON

TIME INTERVALS BETWEEN ACCIDENTS, A NOTE ON MAGUIRE, PEARSON AND WYNN'S PAPER HE EFFICIENCY JRSSB59

346

JRSSB 67550

AMS 63 2B4

JASA 641063

TECH 6191

BIOKA56 227

JRSSB60 34B

JASA $65 \quad 492$

RANDOM BIOKA63 23

JRSSB64 39B AMS $67 \quad 13 B$ BIOCS65 99 TECH 65603 JASA $69 \quad 433$ BIOCS65 90B AMS 6B 2067

FIRST AND SECOND JASA 69 NO.4 BIOCS65 645 TECH $65 \quad 379$ AMS 651703 JASA 5B 11 BIOKA53 212 TS WITH RESPECT TO VALIDITY,/ A COMPARISON OF THE PEARSON CHI-SQUARE AND KOLMOGOROV GOODNESS-OF-FIT TES JASA 65 85

TABLES OF THE 5 PERCENT AND 0.5 PERCENT POINTS OF PEARSON CURVES (WITH ARCUMENT BETA-1 AND BETA-2) EXPR BIOKA5I RESSED IN STANDARD/ TABLE OF PERCENTACE POINTS OF PEARSON CURVES, FOR GIVEN ROOT(BETA-1) AND BETA-2 EXP BIOKA63 2 PRESSE/ CORRIGENDA, 'TABLE OF PERCENTAGE POINTS OF PEARSON CURVES. FOR GIVEN ROOT(BETA-1) AND BETA-2, EX BIOKA65 669 OSE LEFT TERMINAL AND FIRST THREE MOME/ USE OF THE PEARSON DENSITIES FOR APPROXIMATING A SKEW DENSITY WH BIOKA68 559 HER MOMENTS ESTIMATING PARAMETERS IN TRUNCATED PEARSON FREQUENCY DISTRIBUTIONS WITHOUT RESORT TO HIG BIOKA53 A PROPERTY OF THE MEAN DEVIATION FOR THE PEARSON TYPE DISTRIBUTIONS PRIORITY), 'A PROPERTY OF THE MEAN DEVIATION FOR THE PEARSON TYPE DISTRIBUTIONS' A NEW TABLE OF PERCENTAGE POINTS OF THE PEARSON TYPE III DISTRIBUTION DEVIATION, WITH SPECIAL REFERENCE TO SAMPLES FROM A PEARSON TYPE III POPULATION THE MILLS RATIO AND THE PROBABILITY INTEGRAL FOR A PEARSON TYPE IV DISTRIBUTION $65344)$

NORMAL DISTRIBUTIONS

OF HIS BIRTH

KARL PEARSON, AN APPRECIATION ON THE HUNDREDTH ANNIVERSARY JA
SPONDENCE BETWEEN W.S. COSSETT, R.A. FISHER AND KARL PEARSON, WITH NOTES AND COMMENTS /.SOME EARLY CORRE BIS CENTENARY LECTURE, KARL PEARSON, 1857-1957

ON A TEST OF SIGNIFICANCE IN PEARSON'S BIOMETRIKA TABLES (NO, 11 )

RONALD FISHER'S PAPER, 'ON A TEST OF SIGNIFICANCE IN PEARSON'S BIOMETRIKA TABLES (NO. 11 )

ON SLIPPACE TESTS I. A GENERALIZATION OF NEYMAN PEARSON'S LEMMA SOME FURTHER RESULTS IN THE THEORY OF PEDESTRIANS AND ROAD TRAFFIC

CORRIGENDA TO 'SOME FURTHER RESULTS IN THE THEORY OF PEDESTRIANS AND ROAD TRAFFIC'

THE DELAY TO PEDESTRIANS CROSSENG A ROAD

NOTE ON THE CONFIDENCE-PRIOR OF WELCH AND PEERS

THE NON-ABSOLUTE CONVERGENCE OF GIL-PELAEZ' INVERSION INTECRAL

ON THE SIZE OF AN EPIDEMIC AND THE NUMBER OF PEOPLE HEARING A RUMOUR LABOR FORCE ENTRY AND ATTACHMENT OF YOUNC PEOPLE, CORR. 66 124B DISTRIBUTION

99.9 PERCENT AND 0.1 PERCENT POINTS OF THE CHI-SQUARE

$\begin{array}{lr}\text { BIOKA53 } & 50 \\ \text { BIOKA66 } & 2 B 7\end{array}$ BIOKA67 333 TECH $69 \quad 177$ BIOKA58 478 BIOKA65 119 AMS $64 \quad 817$ BIOCS65 219 JASA 5B BIOKA6B BIOKA57 303 JRSSB56 56 JRSSB56 295 AMS 6B 1693 BIOKA54 375 BIOKA5B 29] BIOKA51 3B3 JRSSB66 55 AMS $61 \quad 33 B$ JRSSB66 4B? JASA $66 \quad 117$ JASA 66 117 TERISTIC CURVES FOR FIXED EFFECT/ CHARTS OF THE 10 PERCENT AND 50 PERCENT POINTS OF THE OPERATING CHARAC JASA 57 345 TRAL CHI-SQUARE APPROXTMATIONS TO THE UPPER 5 PERCENT POTNTS OF FTSHER'S B DISTRIBUTTON AND NON-CEN BIOKA57 1 AND BETA-2) EXP/ TABLES OF THE 5 PERCENT AND 0.5 PERCENT POINTS OF PEARSON CURVES (WITH ARGUMENT BETA- BIOKA51 TABLE OF THE UPPER 10 PERCENT POINTS OF THE 'STUDENTIZED' RANCE

99.9 PERCENT AND 0.1 PERCENT POINTS OF THE CHI-SQUARE DISTRIBUTION UPPER 5 AND 1 PERCENT POINTS OF THE MAXIMUM F-RATIO

TABLES OF INVERSE GAUSSIAN PERCENTAGE POINTS COEFFICIENTS FOR INTERPOLATION BETWEEN TABLED PERCENTACE POINTS BIOKA59 461 BIOKA53 421 BIOKA52 422 TECH 69591 LAGRANGIAN BIOKA68 19 STATISTICS CONNECTED WITH THE UNIFORM DISTRIBUTION, PERCENTACE POINTS AND APPLICATION TO TESTING FOR RAND BIOKA66 235 THE NORMAL DISTRIBUTION PERCENTAGE POINTS AND MODES OF ORDER STATISTICS FROM AMS 61 BB8 
NON-CENTRAL CHI-SQU/ APPROXIMATE FORMULAE FOR THE PERCENTACE POINTS AND THE PROBABILITY INTEGRAL OF THE BIOKA54 T'S CRITERION FOR TESTINC/ LARCE SAMPLE TABLES OF PERCENTACE POINTS FOR HARTLEY'S CORRECTION TO BARTLET BIOKAG2 QUALITY

$\mathrm{N}$ ADDITIONAL PERCENTACE POINTS FOR THE INCOMPLETE BETA DISTRIBUTIO BIOKA63 FURTHER PERCENTACE POINTS FOR W-SQUARE-SUB-N + (CRAMER-VON BIOKA68 GOODNESS-OF-FIT STATISTIC) CERTHER PERCENTACE POINTS FOR W-SQUARE-SUB-N + (CRAMER-VON BIOKA68 428 PROXIMATTONS TO THE PROBABTLITY I I UPPER PERCENTACE POINTS OF A SUBSTITUTE F-RATIO USINC 258 RANCES PERCENTACE POINTS OF A TEST FOR CLUSTERS

ON THE COMPUTATION AND USE OF A TABLE OF PERCENTACE POINTS OF BARTLETT'S M TABLE OF 0 I PERCENTACE POINTS OF BEHRENS'S D BIOKA61 195 JASA 69 NO. 4 BIOKA69 273 BIOKA66 267 S AND STANDARD DEVIATIONS BASED ON DISTANCES BETWEEN PERCENTACE POINTS OF FREQUENCY CURVES. /XIMATE MEAN BIOKA65 533 TABLE OF PERCENTAGE POINTS OF KOLMOGOROV STATISTICS JASA $56 \quad 111$ TABLE OF PERCENTAGE POINTS OF NON-CENTRAL CHI $\quad$ BIOKA69 255 ETA-1' AND BETA-2 EXPRESSED IN STANDARD/ TARLE OF PERCENTAGE POTNTS OF PEARSON CURVES, FOR GIVEN ROOT'B BTOKA63 A59 ETA-1' AND BETA-2 EXPRESSED IN STANDARD/, TABLE OF PERCENTAGE POINTS OF PEARSON CURVES, FOR GIVEN ROOT'B BIOKA63 45
ETA-1' AND BETA-2, EXPRESSE/ CORRIGENDA, 'TABLE OF PERCENTAGE POINTS OF PEARSON CURVES, FOR GIVEN ROOT'B BIOKA65 669

S, A ROUNDING OFF USE OF TABLES OF PERCENTAGE POINTS OF RANCE AND STUDENTIZED RANGE TECH 61407 TABLES OF PERCENTAGE POINTS OF ROOT'BI' AND B2 IN NORMAL SAMPLE BIOKA65 282

E FROM THE SAMPLE MEAN EXTENDED TABLES OF THE PERCENTAGE POINTS OF STUDENT'S T-DISTRIBUTION JASA 59683 TABLES OF PERCENTAGE POINTS OF THE 'STUDENTIZED' EXTREME DEVIAT BIOKA52 1 B9 EXTENDED AND CORRECTED TABLES OF THE UPPER PERCENTAGE POINTS OF THE 'STUDENTIZED' RANCE CORRTCENDA 'TABLES OF PERCENTAGE POINTS OF THE 'STUDENTIZED' RANCE' BAYESIAN ANALYSIS OF BERNOULLI PROCESSES PERCENTAGE POINTS OF THE BETA DISTRIBUTION FOR USE IN TECH 66 6B A NEW TABLE OF PERCENTAGE POINTS OF THE CHI-SQUARE DISTRIBUTION BIOKA64 231 $\begin{array}{rllll}\text { CORRICENDA, 'A NEW TABLE OF PERCENTAGE POINTS OF THE CHI-SQUARE DISTRIBUTIONS' } & \text { BIOKA65 } \\ \text { PERCENTACE POINTS OF THE EXTREME ROOTS OF A WISHART } & \text { BIOKA68 } & 505\end{array}$

MATRIX

FROM THE SAMPLE MEAN REVISED UPPER PERCENTAGE POINTS OF THE EXTREME STUDENTIZED DEVIATE BIOKA56 UPPER PERCENTAGE POINTS OF THE EXTREME STUDENTIZED DEVIATE BIOKA59 473 UPPER PERCENTACE POINTS OF THE GENERALIZED BETA DISTRIBUTIO BIOKA57 237 N. I

N. II

N. III

MULTIVARIATE ANALYSIS UPPER PERCENTAGE POINTS OF THE GENERALIZED BETA DISTRIBUTIO BIOKA58 UPPER PERCENTAGE POINTS OF THE LARGEST ROOT OF A MATRIX IN BIOKA67

ARE-MAX-OVER-S-SQUARE-SUB-0 EXTENSION OF TABLES OF PERCENTAGE POINTS OF THE LARGEST VARIANCE RATIO S-SQU BIOKA67 TABLES TO FACILITATE THE COMPUTATION OF PERCENTAGE POINTS OF THE NON-CENTRAL T-DISTRIBUTION AMS 6? CORR. $63 \quad 1163$ SOME PERCENTAGE POINTS OF THE NON-CENTRAL T-DISTRIBUTION, JASA 63 TRIBUTION OF THE RANGE FROM THE/ $\mathrm{N}$ MULTINOMIAL DISTRIBUTION POWER OF THE ASSOCIATED TEST VARIATION ONTIMATES OF HER PERCENTAGE POINTS OF THE SAMPLE COEFFICIENT OF TORTENTE POINTS OF THE ORDER STATISTICS AND THE DIS AMS 65907 A NEW TABLE OF PERCENTAGE POINTS OF THE PEARSON TYPE III DISTRIBUTIO TECH $69 \quad 177$ PERCENTACE POINTS OF THE RANGE FROM A SYMMETRIC $\quad$ BIOKA68 377 PERCENTAGE POINTS OF THE RATIO OF TWO RANGES AND $\quad$ BIOKA63 1 B7 BIOKA68 580 BIOCS65 1001 TECH 60103 PROGRAMMING FISHER'S EXACT METHOD OF COMPARING TWO PERCENTAGES

CONTROL OF PERCENTAGES IN BOTH TAILS OF THE NORMAL DISTRIBUTION TECH 64 377

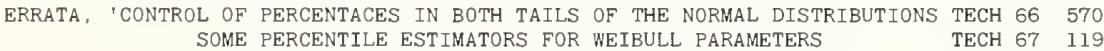
PERCENTILE MODIFICATIONS OF TWO-SAMPLE RANK TESTS JASA 651127

CUMULANTS THE PERCENTILE POINTS OF DISTRIBUTTONS HAVING KNOWN

CUMULANTS ITHE PERCENTILE POINTS OF TECH $60 \quad 209$ TECH $60 \quad 523$ EXTREME-VALUE DISTRIBUTION IN ESTIMATING EXTREME PERCENTILES DISCRIMINATION INTERVALS FOR PERCENTILES IN REGRESSION FFICIENCIES OF A NONPARAMETRIC LIFE TEST FOR SMALLER PERCENTILES OF A GAMMA DISTRIBUTION ASYMPTOTIC E JASA 56 467 ATION POSTERIOR DISTRIBUTION OF PERCENTILES. BAYES' THEOREM FOR SAMPLING FROM A POPUL JASA 6B 677 FIRST-PASSAGE PERCOLATION

ITICAL PROBABILITY IN THE ONE-QUADRANT ORIENTED-ATOM PERCOLATION PROCESS A LOWER BOUND FOR THE CR JRSSB63 401

PROBABILITIES

WIDTH INTERVAL ESTIMATION OF THE MEAN

GENERAL BIVARIATE DISTRIBUTION RANKING PROBLEM ENCY-TYPE BIVARIATE DISTRIBUTIONS WITH AND WITHOUT CENSORING

RATIO TEST, CORR. 661247

A PERFECT MEASURABLE SPACE THAT IS NOT A LUSTN SPACE PERFECT PROBABILITY MEASURES AND REGULAR CONDITIONAL THE PERFORMANCE OF A SEQUENTIAL PROCEDURE FOR THE FIXEDTHE PERFORMANCE OF SEVERAL TESTS FOR OUTLIERS

THE PERFORMANCE OF SOME CORRELATION COEFFICIENTS FOR A THE PERFORMANCE OF SOME SEQUENTIAL PROCEDURES FOR A THE PERFORMANCE OF SOME TESTS OF INDEPENDENCE FOR CONTING BIOKA69 449 THE PERFORMANCE OF SOME TWO-SAMPLE TESTS IN SMALL SAMPLES BIOKA69 127 ON THE PERFORMANCE OF THE LINEAR DISCRIMINANT FUNCTION

ON THE PERFORMANCE OF THE TRUNCATED SEQUENTIAL PROBABILITY JASA 65979 A TWO-PERIOD DESIGN WITH T-SQUARE EXPERIMENTAL UNITS THE BUSY PERIOD IN RELATION TO THE QUEUEING PROCESS GI-M-1 $\quad$ BIOKA59 246 EM WITH GENERAL INDEPENDENT ARRIVALS AND/ THE BUSY PERIOD IN RELATION TO THE SINGLE-SERVER QUEUEINC SYST JRSSB60 BO
SEVERAL TYPES
ON THE BUSY PERIOD OF A FACILITY WHICH SERVES CUSTOMERS OF SEVERAL TYPES STATISTICAL PROPERTIES OF A CERTAIN PERIODIC BINARY PROCESS MULTIVARIATE STOCHASTIC PROCESSES WITH PERIODIC COEFFICIENTS THE SUPERPOSITION OF SEVERAL STRICTLY PERIODIC SEQUENCES OF EVENTS TIME SERIES WITH PERIODIC STRUCTURE ALMOST PERIODIC VARTANCES PERIODOGRAM ANALYSIS AND VARIANCE FLUCTUATIONS

A REAPPRAISAL OF THE PERIODOGRAM IN SPECTRAL ANALYSIS ON THE CROSS PERIODOGRAM OF A STATIONARY GAUSSIAN VECTOR PROCESS RIAL CORRELATION IN REGRESSION ANALYSIS BASED ON THE PERIODOGRAM OF LEAST-SQUARES RESIDUALS TESTS FOR SE A NOTE ON THE PERIODOGRAM OF THE BEVERIDGE WHEAT PRICE INDEX CURVE AND PERIODOGRAM SMOOTHING (WITH DISCUSSION)
ON THE EFFICIENCY OF PROCEDURES FOR SMOOTHING PERIODOGRAMS FROM TIME SERIES WITH CONTINUOUS SPECTRA TECH $66 \quad 247$ JRSSB69 171 BIOKA53 3 BIOKA67 403 AMS $63 \quad 1549$ JRSSB63 442 TECH 65531 AMS $67 \quad 593$ TESTS FOR SE BIOKA69 THE IDENTIFICATION OF ANNUAL PEAK PERIODS FOR A DISEASE ONLY SCEPTIBL/ ON ESTIMATING THE LATENT AND INFECTIOUS PERIODS OF MEASLES, II. FAMILIES WITH THREE OR MORE S BIOKA56 A STOCHASTIC MODEL OF ACHE TRANSPORTATION IN THE PERIPHERAL NERVE TRUNKS HE WEIBULL AND CERTAIN OTHER DISTRIBUTIONS ON SOME PERMISSIBLE ESTIMATORS OF THE LOCATION PARAMETER OF T TECH 67 447 FOR THE 2-TO-THE-N T/ ORTHOGONAL FOR THE 2-TO-THE-N T/ ORTHOGONAL MAIN-EFFECT PLANS PERMITTING ESTIMATION
PROCESSES GENERATING PERMUTATION EXPANSIONS
JRSSB55 228 JRSSB57 38 BIOKA55 143 645 645
15 322 447 67293 TECH 69 NO. 4 BIOKA62 139 
IRICAL STUDY INTO FACTORS AFFECTINC THE F-TEST UNDER PERMUTATION FOR THE RANDOMIZED BLOCK DESICN AN EMP JASA 68 902 SOME EMPIRICAL RESULTS ON VARIANCE RATIOS UNDER PERMUTATION IN THE COMPLETELY RANDOMIZED DESICN MONTE CARLO RESULTS ON THE POWER OF THE F-TEST UNDER PERMUTATION IN THE SIMPLE RANDOMIZED BLOCK DESICN ERCODIC PROPERTIES OF SOME PERMUTATION PROCESSES

PERMUTATION SUPPORT FOR MULTIVARIATE TECHNIQUES JASA $66 \quad 813$

ON SOME MULTISAMPLE P PERMUTATTON TESTS BASED ON BIOKA66 199 BIOKA62 151 BIOKA64 65

IA AND THE STUDY OF DEPARTURES FROM ASSUMPTION (W) PERMUTATION THEORY IN THE DERIVATION OF ROBUST CRITER JRSSB55 RANDOM PERMUTATTONS

THE DISTRIBUTION OF PATTERN FREQUENCIES IN RING PERMUTATIONS

IS SIMPLE DEPENDENCE

PERSTSTENCE PROBLEU IN RENENAL THEORY ROBERT THE

BIOKA66 255

BRUCE'S SPIDER

ATIO USED TO ESTIMATE FAILURE RATES, OCCURRENCES PER PERSON YEAR OF EXPOSURE CHARACTERISTICS OF A R IOCS66 310

ENTS, OF SELECTED NATIONAL INCOME COMPONENTS, AND OF PERSONAL SAVING/SS NATIONAL PRODUCT AND ITS COMPON J

STATES A REPRODUCIBLE METHOD OF COUNTINC PERSONS OF SPANISH SURNAME

JASA $61-88$

THE MIGRATION OF EMPLOYED PERSONS TO AND FROM METROPOLITAN AREAS OF THE UNITED

NE POPULATION

ON THE EFFECT OF REMOVING PERSONS WITH N OR MORE ACCIDENTS FROM AN ACCIDENT PRO

JASA 6188

EPIDEMIC IN A LARGE POPULATION A PERTURBATION APPROXIMATION OF THE SIMPLE STOCHASTIC

RECURRENT GAMES AND THE PETERSBURC PARADOX

A REMARK ON THE KOLMOCOROFF-PETROVSKII CRITERION

STOCHASTIC PHAGE ATTACHMENT TO BACTERIA

IMATION OF THE PARAMETER IN THE STOCHASTIC MODEL FOR PHAGE ATTACHMENT TO BACTERIA

ASA 671418

BIOKA68 199

AMS $61 \quad 1 B 7$

AMS $6910 \mathrm{~B} 6$

BIOCS65 134 PHASE FREE ESTIMATION OF COHERENCE AMS 69540

BIRTH-AND-DEATH PROCESSES THAT ARE ACE-DEPENDENT OR PHASE-DEPENDENT THE PROBABILITIES OF EXTINCTION FOR BIOKA67 579 RANDOM QUEUEINC PROCESSES WITH PHASE-TYPE SERVICE

A TEST FOR RANDOM MINGLING OF THE PHASES OF A MOSAIC

JRSSB56 129

BI0CS67 657

BIOCS67 835

BACTERIAL EXTINCTION TIME AS AN EXTREME VALUE PHENOMENON

OD/ ESTIMATION OF THE INBREEDINC COEFFICIENT FROM PHENOTYPE FREQUENCIES BY A METHOD OF MAXIMUM LIKELIHO BIOCS68 915

PROBLEM IN THE DOCTRINE OF CHANCES (REPRODUCED FROM PHTL TRANS ROY SOC, $1763,53,370-41 B .120$ SURVEY OF HOUSEHOLDS

STATISTICAL THEORY OF A HIGH-SPEED PHOTOELECTRIC PLANIMETER

AN APPLICATION OF MULTIVARIATE QUALITY CONTROL TO PHOTOGRAPHIC PROCESSINC

A METHOD OF FITTING EMPIRICAL SURFACES TO PHYSICAL AND CHEMICAL DATA

SYSTEMATIC ERRORS IN PHYSICAL CONSTANTS

MATHEMATICAL REPRESENTATION OF THE BIOLOGICAL AND PHYSICAL DECAY OF CHAMBER AEROSOLS

THE EXPERTMENTAL STUDY OF PHYSICAL MECHANTSMS

APPLICATIONS OF A BALLOT THEOREM IN PHYSICS AND IN ORDER STATISTICS

6/ OPTIMUM UTILIZATION OF AUXILIARY INFORMATION. (PI)PS SAMPLING OF TWO UNITS FROM A STRATUM (ADDENDUM JRSSB67 374

OF HANURAV SAMPLING SCHEME. A GENERALIZATION OF A METHOD

ON THE MOMENT GENERATTNG FUNCTTON OF PILLAI'S V-SUPER-S CRITERION SOME NOTES ON PISTIMETRIC INFERENCE

ON PREDICTION FROM AN AUTOREGRESSIVE PROCESS USING PISTIMETRIC PROBABILITY

NOTE ON A PAPER BY RAY AND PITMAN + (FISHER-BEHRENS-STATISTIC

TESTS FOR NORMAL ALTERNATIONS

JASA $5 B \quad 78$

BIOKA68 419

JASA $57 \quad 186$

TECH $69 \quad 411$

TECH $62 \quad 11$

BI0CS65 55:

JRSSB68 556

JRSSB 60

A NOTE JRSSB6O 97

JRSSB $62 \quad 537$

AND THE CORRELATION COEFFICI/ THE RELATION BETWEEN PITMAN'S ASYMPTOTIC RELATIVE EFFICIENCY OF TWO TESTS AMS 63 I442

TIONS, AND A PARADOX IN FIDUCIAL THEORY PIVOTAL QUANTITIES FOR WISHART'S AND RELATED DISTRIBU J

CORRIGENDA, 'THE USE OF RANCE IN PLACE OF STANDARD DEVIATION IN THE T-TEST.

A REMARK ON HITTING PLACES FOR TRANSIENT STABLE PROCESS

ON PLACKETT'S TEST FOR CONTINGENCY TABLE INTERACTIONS JRSSB63 179

A PRODUCTION MODEL AND CONTINUOUS SAMPLING PLAN

DESIGN AND EVALUATION OF A REPETITIVE GROUP SAMPLINC PLAN

ON ADDELMAN'S 2-TO-THE- (17-9) RESOLUTION V PLAN A RECTIFYING INSPECTION PLAN

AND OPERATION OF A DOUBLE-LIMIT VARIABLES SAMPLINC PLAN ASPECTS OF THE LOT PLOT SAMPLING INSPECTION PLAN

SOME THEORET
A SINCLE SAMPLING PLAN FOR CORRELATED VARIABLES WITH A SINGLE-SID

SPECIFICATIS

CONSTRUCTION OF A 2-TO-THE-(17-9) RESOLUTION V PLAN IN EICHT BLOCKS OF 32 RENEWAL THEORY IN THE PLANE

ON STATIONARY PROCESSES IN THE PLANE

THE CONVEX HULL OF PLANE BROWNIAN MOTION

OCCUPATION TIME THEOREM FOR THE ANGULAR COMPONENT OF PLANE BROWNIAN MOTION

PIANE TRUNCATION IN NORMAL POPULATIONS

A RANDOM SET PROCESS IN THE PLANE WITH A MARKOVIAN PROPERTY

CORRICENDA, 'ON STATIONARY PROCESSES IN THE PLANE'

STATISTICAL THEORY OF A HIGH-SPEED PHOTOELECTRIC PLANIMETER

PLANNING A QUANTAL ASSAY OF POTENCY

PRODUCT TEST PLANNING FOR REPAIRABLE SYSTEMS

PLANNING SOME TWO-FACTOR COMPARATIVE SURVEYS

A NOTE ON SIMPLE BINOMIAL SAMPLING PLANS

SYMMETRICAL AND ASYMMETRICAL FRACTIONAL FACTORIAL PLANS

TECHNIQUES FOR CONSTRUCTING FRACTIONAL REPLICATE PLANS

NEW CRITERIA FOR SELECTING CONTINUOUS SAMPLING PLANS

DISTRIBUTION-FREE LIFE TEST SAMPLING PLANS

MISCLASSIFIED DATA FROM CURTAILED SAMPLING PLANS

RELATIVE COSTS OF COMPUTERIZED ERROR INSPECTION PLANS

SEQUENCES OF TWO-LEVEL FRACTIONAL FACTORIAL PLANS OPTIMAL DRUG SCREENINC PLANS

BOUNDARIES FOR CLOSED (WEDGE) SEQUENTIAL T TEST PLANS

OF AN OPTIMAL SEQUENCE OF INTERRELATED SAMPLING PLANS

NTATIONS FOR SOME RESOLUTION VI FRACTIONAL FACTORIAL PLANS

FOR THE DODGE-ROMTG LTPD SINCLE SAMPI ING INSPECTION PLANS

FOR EVALUATING DEPENDENT MIXED ACCEPTANCE SAMPLING PLANS

SINGLE AND DOUBLE ATTRIBUTES ACCEPTANCE SAMPLING PLANS

PROCEDURES AND TABLES TECH $69 \quad 34$ 
N OF A LARCE CLASS OF CONTINUOUS SAMPLINC INSPECTION PLANS OF BINOMIAL AND INVERSE BINOMIAL

TRIBUTION AND A SYSTEM OF SINCLE SAMF

CCEPTANCE SAMPLINC PLANS AND AN ACKNOWLEDCEMENT ON THE EQ
SOME MAIN-EFFECT PLANS AND ORTHOCONAL ARRAYS OF STRENCTH TWO
MMLINC INSPECTION PLANS BASED ON PRIOR DISTRIBUTIONS AND COST

VARIABLES SAMPLINC PLANS BASED ON THE NORMAL DISTRIBUTION

SOME ACCEPTANCE SAMPLING PLANS BASED ON THE THEORY OF RUNS

CENSORED SAMPLING IN CURTAILED SAMPLING PLANS BY ATTRIBUTES

OF FRACTION DEFECTIVE IN CURTAILED SAMPLINC PLANS BY ATTRIBUTES

CHNIQUES AND DIGITAL COMP/ DEVELOPMENT OF SAMPLING PLANS BY USINC SEQUENTIAL, ITEM BY ITEM, SELECTION TE J

ORTHOGONAL MAIN-EFFECT PLANS FOR ASYMMETRICAL FACTORIAL EXPERIMENTS

ERRATA. 'ORTHOCONAL MAIN-EFFECT PLANS FOR ASYMMETRICAL FACTORIAL EXPERIMENTS'

BAYESIAN SINGLE SAMPLING ATTRIBUTE PLANS FOR CONTINUOUS PRIOR DISTRIBUTIONS

SAMPLINC INSPECTION PLANS FOR DISCRIMINATING BETWEEN TWO WEIBULL PROCESSE

S A NOTE ON SMALL ORTHOCONAL MAIN EFFECT PLANS FOR FACTORIAL EXPERIMENTS LIFE TEST SAMPLINC PLANS FOR NORMAL AND LOCNORMAL DISTRIBUTIONS

ALUATIO AMS 651408 TENCE TECH $63 \quad 119$ AMS $61 \quad 1167$ TECH $60 \quad 275$ TECH $67 \quad 417$ TECH $62 \quad 177$ TECH $6 B \quad 854$ $\begin{array}{ll}67 & 219\end{array}$

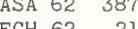
TECH $62 \quad 21$ TECH $62 \quad 440$ TECH 68667 TECH $65 \quad 5 B 9$ TECH 64220 AMS $65 \quad 1256$ TECH $62 \quad 151$ RUCTINC A USEFUL CLASS OF NON-ORTHOCONAL MAIN EFFECT PLANS IN K TO THE N FACTORIALS /APPROACH FOR CONST JRSSB68 37I NNECTION WITH A SPECIAL KIND OF IRREGULAR FRACTIONAL PLANS OF FACTORIAL EXPERIMENTS /FFECTS AND THEIR CO JASA 63 497 TIONS FOR THE 2-TO-THE-N T/ ORTHOGONAL MAIN-EFFECT PLANS PERMITTING ESTIMATION OF ALL TWO-FACTOR INTERAC TECH 69 NO.4

FACTORIAL 2-TO-THE-(P-Q) PLANS ROBUST AGAINST LINEAR AND OUADRATIC TRENDS TECH 66 CONTINUOUS SAMPLING PLANS UNDER DESTRUCTIVE TESTINC

THE EVALUATION OF H 106 CONTINUOUS SAMPLING PLANS UNDER THE ASSUMPTION OF WORST CONDITIONS SAMPLING PLANS WHERE THE ACCEPTANCE CRITERION IS THE VARI
SAMPLINC PLANS WHICH APPROXIMATELY MINIMIZE THE MAXIMUM

EXPECTED SAMPLE SIZE THE DETERMINATION OF SINGLE SAMPLING ATTRIBUTE PLANS WITH CIVEN PRODUCER'S AND CONSUMER'S RISK SOME TWO-LEVEL FACTORIAL PLANS WITH SPLIT PLOT CONFOUNDINC ADDITIVE COMBINING ABILITIES FITTED TO PLANT BREEDING DATA

\section{ANALYSIS OF PLANT COMPETITION EXPERIMENTS FOR DIFFERENT RATIOS OF} PLANT COMPETITION, THREE SPECIES PER POT

SOME TESTS FOR RANDOMNESS IN PLANT POPULATIONS

MATHEMATICAL MODEL RELATING PLANT YIELD WITH ARRANCEMENT FOR RECULARLY SPACED

CROPS SPREAD OF DISEASES IN A RECTANGULAR PLANTATION WITH VACANCIES

PROGRAMME FOR MATERIAL FLOW IN BATCH CHEMICAL PLANTS ACER EXPERIMENT TO DETERMINE ROOT ACTIVITY IN POTATO PLANTS OF EVALUATING THE RELIABILITY OF SAFETY SYSTEMS FOR PLANTS MANUFACTURINC HAZARDOUS PRODUCTS /ICAL MODEL TECH 59 RORS INVOLVED IN ESTIMATING BACTERIAL NUMBERS BY THE PLATING METHOD A DISCRIMINATORY PROBLEM CONNECTED WITH THE WORKS OF PLATO DISTRIBUTIONS

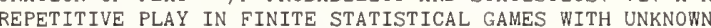

JASA $64 \quad 376$ JASA $66 \quad$ B33 JASA $64 \quad 67$ TECH $67 \quad 401$ TECH 64253 BIOCS67 45 BIOKA67 471 JRSSB $68 \quad 93$ BIOKA5I 102 BIOCS67 505 BIOKA53 2 B7 A GENERAL SIMULATION TECH $61 \quad 497$ /E STATISTICAL ANALYSIS OF A RADIO-ACTIVE TR BIOCS68 717 N JRSSB59 195 BIOKA57 515 AMS $66 \quad 976$ AMS 67 12BI AMS 671284 JASA 69131

TRIAL PLAY TNC CARDS

HISTORY OF PROBABILITY AND STATISTICS, V. A NOTE ON PLAYINC CARDS SOME TWO-LEVEL FACTORIAL PLANS WITH SPLIT PLOT CONFOUNDI
INCOMPLETE SPLIT PLOT DESIGNS

MULTIPLE REGRESSION COMBININC WITHIN- AND BETWEEN-PLOT INFORMATION

NOTE ON THE MISSING PLOT PROCEDURE IN A RANDOMIZED BLOCK DESIGN

SOME THEORETICAL ASPECTS OF THE LOT PLOT SAMPLING INSPECTION PLAN ON THE VARIATION OF YIELD VARIANCE WITH PLOT SIZE

SOME ASPECTS OF THE STATISTICAL ANALYSIS OF 'SPLIT PLOT' EXPERIMENTS IN COMPLETELY RANDOMIZED LAYOUTS VARIANCE OF SOME NON-ORTHOGONAL DESICNS WITH SPLIT PLOTS PROBABILITY PLOTS FOR THE GAMMA DISTRIBUTION JASA 69485 260 TECH 64253 BIOCS67 793 BIOCS66 26 JASA $61 \quad 933$ JASA $56 \quad 84$ BIOKA56 337 $\begin{array}{lr}\text { TECH } 62 & 1\end{array}$ USE OF HALF-NORMAL PLOTS IN INTERPRETING FACTORIAL TWO LEVEL EXPERIMENTS TECH 59311 PROBABILITY PLOTTINC METHODS FOR THE ANALYSIS OF DATA

ON THE CHOICE OF PLOTTINC POSITIONS ON PROBABILITY PAPER

VALEURS GENOTYPIQUES DANS LA SELECTION PAR INDEX SUR PLUSIEURS CARACTERES BIOKA68 I JASA $60 \quad 546$ D DIFFERENT FITNESS REQUIREMENTS AMONG ENVIRONMENTAL POCKETS UPON STEADY STATE CENE FREQUENCIES /ION, AN BIOCS66 453 NONPARAMETRIC TESTS FOR SHIFT AT UNKNOWN TIME POINT ESTIMATION OF A TRUNCATION POINT FOR A CHANGE IN A PARAMETER OCCURRINC AT AN UNKNOWN POINT WHICH A CHANGE IN A PARAMETER OCCURS AT AN UNKNOWN POINT GRESSION WITH RESTRICTED LOCATION FOR THE STATIONARY POINT LEAST SQUAR
A SURVEY OF COVERACE PROBLEMS ASSOCIATED WITH POINT AND AREA TARGETS

AMS $68 \quad 1731$ BIOKA64 33 A TEST BIOKA55 523 ON PROBLEMS IN BIOKA57 248 PARAMETER WEIBULL AND EXTREME-VALUE DISTRIBUTIONS STICS, FOR THE SCALE PARAMETER OF A WEIBULL POPUL/ POINT AND INTERVAL ESTIMATORS. BASED ON M ORDER STATI TECH 65 405 ON APPROXIMATING THE POINT BINOMIAL, CORR, 56 65l JASA $56 \quad 293$ UNIFORM APPROXIMATION OF MINIMAX POINT ESTIMATES

EXAMPLES OF LIKELIHOODS AND COMPARISON WITH POINT ESTIMATES AND LARGE SAMPLE APPROXIMATIONS SOME EMPIRICAL BAYES TECHNIQUES IN POINT ESTIMATION

MISSING OBSERVATIONS IN MULTIVARIATE STATISTICS II POINT ESTIMATION IN SIMPLE LINEAR RECRESSION

OF K ELEMENTS FROM THE SAME EXPONENTIAL DISTRIBU/ POINT ESTIMATION OF RELIABILITY OF A SYSTEM COMPRISED J J A ROBUST POINT ESTIMATOR IN A GENERALIZED REGRESSION MODEL

DISTRIBUTION

861 THE MULTIVARIATE SADDLE POINT METHOD AND CHI-SQUARED FOR THE MULTINOMIAL CORRECTIONS TO 'SADDLE POINT METHODS FOR THE MULTINOMIAL DISTRIBUTIONS' 57

BOUNDED LENGTH CONFIDENCE INTERVALS FOR THE P-POINT OF A DISTRIBUTION FUNCTION, II

BOUNDED LENGTH CONFIDENCE INTERVALS FOR THE P-POINT OF A DISTRIBUTION FUNCTION, III

QUARES PROCRAMS FOR THE ELECTRONIC COMPUTER FROM THE POINT OF VIEW OF THE USER AN APPRAISAL OF LEAST S J TRANSITION MATRICES

ON THE FIXED POINT PROBABILITY VECTOR OF RECULAR OR ERGODIC ON COMPARISONS BETWEEN CONFIDENCE POINT PROCEDURES IN THE CASE OF A SINGLE PARAMETER HIGHER-ORDER PROPERTIES OF A STATIONARY POINT PROCESS

PROPERTIES OF COUNTS OF EVENTS FOR CERTAIN TYPES OF POINT PROCESS ESTIMATION OF THE INTENSITY FUNCTION OF A STATIONARY POINT PROCESS

ON THE LENGTHS OF INTERVALS IN A STATIONARY POINT PROCESS (CORR. 63 500)

THE SPECTRAL ANALYSIS OF TWO-DIMENSIONAL POINT PROCESSES

ON THE SUPERPOSITION OF POINT PROCESSES

THE SPECTRAL ANALYSIS OF POINT PROCESSES (WITH DISCUSSION) $\begin{array}{rrr}\text { JASA } & 56 & 293 \\ \text { AMS } & 64 & 1031\end{array}$

JASA $69 \quad 468$

BIOKA69 133

JASA $67 \quad 10$

JASA $66 \quad 1029$

AMS 691784

AMS 61535

AMS $61 \quad 619$

AMS $66 \quad 581$

AMS $66 \quad 586$

JASA $67 \quad 819$

JASA $67 \quad 600$

JRSSB $65 \quad 1$

JRSSB $63 \quad 413$

SOME JRSSB6 4325

ON THE JRSSB65 332

JRSSB62 364

BIOKA64 299

JRSSB68 576

JRSSB $63 \quad 264$ 
STOCHASTIC POINT PROCESSES, LIMIT THEOREMS

SPATIAL POINT PROCESSES, WITH APPLICATIONS TO ECOLOGY

ORRIGENDA, 'THE SPECTRAL ANALYSIS OF TWO-DIMENSIONAL POINT PROCESSES'

THE DISTANCE FROM A RANDOM POINT TO THE NEAREST POINT OF A COSELY PACKED LATT ADDING A POINT TO VECTOR DIAGRAMS IN MULTIVARIATE ANALYSIS BIOKAGB 582

LOGNORMAL DISTRIBUTION AND BAYESIAN ANALYSIS OF A POINT-SOURCE EPIDEMIC THE THREE-PARAMETER JASA $63 \quad 72$ EXTENSTON OF THE WILCOXON-MAN JASA 60 , 25 OPTIMAL DESIGNS ON TCHEBYSCHEFF POINTS

TABLES OF INVERSE GAUSSIAN PERCENTACE POINTS AMS $6 \mathrm{~B} 1435$

CY PROBABILITY DISTRIBUTION CRITICAL POINTS

THE CONVEX HULL OF A RANDOM SET OF POINTS

PROCEDURE FOR FITTING THE BEST LINE TO A SET OF POINTS

FIT STATISTIC $V-S U B-N$, DISTRIBUTION AND SICNIFICANCE POINTS

FOR INTERPOLATION BETWEEN TABLED PERCENTAGE POINTS

F STATISTICAL DISTRIBUTIONS OCCURING AT UNKNOWN TIME POINTS

TECH 69591

BIOKA61 175 BIOKA65 331

GRAPHICAL TECH $60 \quad 477$

THE GOODNESS OF BIOKA65 309

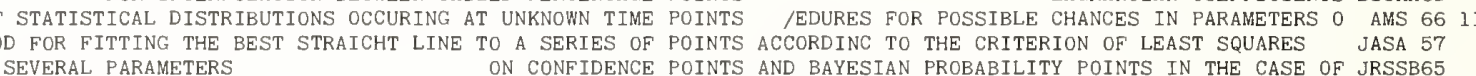

ON CONFIDENCE POINTS AND BAYESIAN PROBABILITY POINTS IN THE CASE OF JRSSB65

PERCENTAGE POINTS AND MODES OF ORDER STATISTICS FROM THE NORMAL AMS 61

DISTRIBUTION

OV TYPE STATISTICS INCLUDING A TABLE OF SIGNIFICANCE POINTS FOR A PARTICULAR CASE/S OF KOLMOGOROV-SMIRN AMS 6B PERCENTACE POINTS FOR THE DISTRIBUTION OF OUTGOING QUALITY JASA 59

SIGNIFICANCE POINTS FOR THE TWO-SAMPLE STATISTIC U-SQUARE-SUB-M, N BIOKA65

-OF-FIT STATISTIC) FURTHER PERCENTACE POINTS FOR W-SQUARE-SUB-N + (CRAMER-VON MISES GOODNESS BIOKA68 BIOKA68 428 PATTERNS FITTINC SECMENTED CURVES WHOSE JOIN POINTS HAVE TO BE ESTIMATED

RANDOM POINTS IN A CIRCLE AND THE ANALYSIS OF CHROMOSOME

BIOKA63

23 THE DISTANCES BETWEEN RANDOM POINTS IN TWO CONCENTRIC CIRCLES CLUSTERING OF RANDOM POINTS IN TWO DIMENSIONS PERCENTAGE POINTS OF A TEST FOR CLUSTERS

ON THE COMPUTATION AND USE OF A TABLE OF PERCENTACE POINTS OF BARTLETT'S

THE PERCENTILE POINTS OF DISTRIBUTIONS HAVINC KNOWN CUMULANTS

ERRATA, 'THE PERCENTILE POINTS OF DISTRIBUTIONS HAVING KNOWN CUMULANTS' ESTIMATES FOR THE POINTS OF INTERSECTION OF TWO POLYNOMIAL REGRESSIONS TABLE OF PERCENTAGE POINTS OF KOLMOCOROV STATISTICS

TABLE OF PERCENTACE POINTS OF NON-CENTRAL CHI

BETA-2, EXPRESSE/ CORRICENDA, 'TABLE OF PERCENTAGE POINTS OF PEARSON CURVES, FOR GIVEN ROOT(BETA-1) AND USE OF TABLES OF PERCENTACE POINTS OF RANGE AND STUDENTIZED RANCE

EXTENDED TABLES OF THE PERCENTACE POINTS OF STUDENT'S T-DISTRIBUTION

CORRICENDA, 'TABLES OF PERCENTACE POINTS OF THE 'STUDENTIZED' RANGE'

ANALYSIS OF BERNOULLI PROCESSES PERCENTAGE POINTS OF THE BETA DISTRIBUTION FOR USE IN BAYESIAN

CORRIGENDA, 'A NEW TABLE OF PERCENTACE POINTS OF THE CHI-SQUARE DISTRIBUTIONS'

PERCFNTACE POINTS OF THE EXTREME ROOTS OF A IUTSHART MATRTX

BIOKA65 263

JASA 69 NO. 4

BIOKA69 273

TECH 60209

TECH $60 \quad 523$

JASA $64 \quad 214$

JASA $56 \quad 111$ BIOKA69 255 BIOKA65 669 TECH 6l 407 JASA 59683 BIUKA53 236 TECH $66 \quad 6 B 7$ BIOKA65 305 BIOKA6B 505

E ANALYSIS UPPER PERCENTAGE POINTS OF THE LARCEST ROOT OF A MATRIX IN MULTIVARIAT BIOKA67

R-S-SQUARE-SUB-O EXTENSION OF TABLES OF PERCENTAGE POINTS OF THE LARGEST VARIANCE RATIO S-SQUARE-MAX-OVE BIOKAG 7 TABLES TO FACILITATE THE COMPUTATION OF PERCENTAGE POINTS OF THE NON-CENTRAL T-DISTRIBUTION 1163 SOME PERCENTAGE POINTS OF THE NON-CENTRAL T-DISTRIBUTION, CORR. 63 JASA 63 ED EFFECT/ CHARTS OF THE 10 PERCENT AND 50 PERCENT POINTS OF THE OPERATING CHARACTERISTIC CURVES FOR FIX JASA 57 F THE RANCE FROM THE/ EXACT MOMENTS AND PERCENTAGE POINTS OF THE ORDER STATISTICS AND THE DISTRIBUTION O AMS 65

A NEW TABLE OF PERCENTAGE POINTS OF THE PEARSON TYPE III DISTRIBUTION A NEW TABLE OF PERCENTAGE POINTS OF THE PEARSON TYPE II I DISTRIBUTION
PERCENTAGE POINTS OF THE RANGE FROM A SYMMETRIC MULTINOMIAL ON THE PERCENTAGE POINTS OF THE SAMPLE COEFFICIENT OF VARIATION DISTRIBUTION ON THE PERCENTAGE POINTS OF THE SAMPLE COEF

GEOMETRICAL PROBABILIY AND RANDOM POINTS ON A POINTS ON A LATTICE' 58256

TO 'THE THEORY OF PROBABILITY DISTRIBUTIONS OF POINTS ON A LATTI
PROBABILITY DISTRIBUTIONS ARISING FROM POINTS ON A LINE TESTS FOR RANDOMNESS OF POINTS ON A LINE

E ANALYSIS OF UN/ QUANTAL RESPONSES TO MIXTURES OF POISONS UNDER CONDITIONS OF SIMPLE SIMILAR ACTION, TH BIOKA5B 74 A NOTE ON ESTIMATION IN THE TRUNCATED POISSON

MAXIMUM LIKELIHOOD ESTIMATION FOR THE TRUNCATED POISSON

POISSON AND BINOMIAL FREQUENCY SURFACES

BIOKA65 279

NOTES. BIOCS66 620

BIOKA66 617

BIOKA54 302

ON AN EXTENSION OF THE CONNEXION BETWEEN POISSON AND CHI-SQUARE DISTRIBUTIONS

'TRANSFORMATIONS OF THE BINOMIAL, NEGATIVE BINOMIAL, POISSON AND CHI-SQUARE DISTRIBUTIONS'

CATION TO BACTERTAL ENDOCARD/ A TO SOME RESULTS FOR THE QUEUE WITH POISSON ARRIVALS

ON A CENERALIZED QUEUEING SYSTEM WITH POISSON ARRIVALS POISSON COUNTS FOR RANDOM SEQUENCES OF EVENTS

ESTIMATINC THE PARAMETERS OF A MODIFIED POISSON DISTRIBUTION

A NOTE ON RECRESSION IN THE MULTIVARIATE POISSON DISTRIBUTION

THE MEAN DEVIATION OF THE POISSON DISTRIBUTION

ESTIMATION FOR THE BIVARIATE POISSON DISTRIBUTION

TESTING FOR HOMOGENEITY II THE POISSON DISTRIBUTION

EMPIRICAL BAYES ESTIMATION FOR THE POISSON DISTRIBUTION

A RAPID TEST FOR THE POISSON DISTRIBUTION USING THE RANGE

MISSING

ESTIMATION IN THE TRUNCATED POISSON DISTRIBUTION WHEN ZEROS AND SOME ONES ARE THE DISPLACED POISSON DISTRIBUTION-RECION B

A TWO-PARAMETER FAMILY OF HYPER-POISSON DISTRIBUTIONS THE GENERALIZED MEAN DIFFERENCES OF THE BINOMIAL AND POISSON DISTRIBUTIONS

INTERVALS FOR THE PARAMETER OF THE BINOMIAL AND POISSON DISTRIBUTIONS ULTANEOUS CONFIDENCE LIMITS FOR THE BINOMIAL AND AND POISSON DISTRIBUTIONS

FREEMAN-TUKEY TRANSFORMATIONS FOR THE BINOMIAL AND POISSON DISTRIBUTIONS NIQUES FOR ESTIMATINC PARAMETERS OF SOME GENERALIZED POISSON DISTRIBUTIONS

THE VARIANCE FOR THE PARAMETERS IN THE BINOMIAL AND POISSON DISTRIBUT NEAREST NEIGHBOURS IN A POISSON ENSEMBLE 
THE TIME DEPENDENCE OF A SINCLE-SERVER QUEUE WITH POISSON INPUT AND CENERAL SERVICE TIMES

BIOKA57 286

AMS $67 \quad 759$

JRSSB66 329

AMS 621340

JRSSB66 448 THE ALMOST FULL DAM WITH POISSON INPUT, FURTHER RESULTS

SERVER

MATION

\section{ON THE QUEUETNC PROCESS MARKOV OR POISSON INPUT, CENERAL SERVICE}

QUEUEINC PROCESS, MARKOV OR POISSON INPUT, CENERAL SERVICE TIME DISTRIBUTION, ONE POISSON LIMITS OF MULTIVARIATE RUN DISTRIBUTIONS

TSTRIBUTTONS

SHORTEST UNBIASED CONFIDENCE INTERVALS FOR THE POISSON PARAMETER
THE ESTIMATION OF THE POISSON PARAMETER FROM A TRUNCATED DISTRIBUTION THE ESTIMATION OF THE POISSON PARAMETER FROM A TRUNCATED DISTRIBUTION 247 ESTIMATING THE POISSON PARAMETER FROM SAMPLES THAT ARE TRUNCATED ON TECH 61
TABLES OF POISSON POWER MOMENTS

THE RIGHT

MINIMUM VARIANCE UNBIASED ESTIMATORS FOR POISSON PROBABILITIES MULTIPLE REGRESSION ANALYSIS OF A POISSON PROCESS

THE STATISTICS OF A PARTICULAR NON-HOMOGENEOUS POISSON PROCESS

ILURE PATTERNS (WITH DISCUSSION) A BRANCHING POISSON PROCESS MODEL FOR THE ANALYSIS OF COMPUTER FA OPTIMUM DECISION PROCEDURES FOR A POISSON PROCESS PARAMETER

A MODIFIED COMPOUND POISSON PROCESS WITH NORMAL COMPOUNDING NON-HOMOGENEOUS BRANCHING POISSON PROCESSES

SOME PROCEDURES FOR COMPARING POISSON PROCESSES OR POPULATIONS

POISSON PROCESSES WITH RANDOM ARRIVAL RATE

SOME RESULTS ON TESTS FOR POISSON PROCESSES

THE ANALYSIS OF POISSON REGRESSION WITH AN APPLICATION IN VIROLOGY

RIAL DERIVATION OF THE DISTRIBUTION OF THE TRUNCATED POISSON SUFFICIENT STATISTIC THE POISSON TENDENCY IN TRAFFIC DISTRIBUTION

A NOTE ON THE POISSON TENDENCY IN TRAFFIC DISTRIBUTION

AND TESTING TREND IN A STOCHASTIC PROCESS OF POISSON TYPE

CONFIDENCE INTERVALS FOR THE EXPECTATION OF A POISSON VARIABLE

RANDOMIZED SIMILAR TEST FOR THE INDEPENDENCE OF TWO POISSON VARIABLES

A NOTE ON THE NEGATIVE MOMENTS OF A TRUNCATED POISSON VARIATE

OF THE SAMPLE MEAN AND SAMPLE VARIANCE OF A POISSON VARIATE SOME SIMPLE APPROXIMATE TESTS FOR POISSON VARIATES ON EXPECTATIONS OF SOME FUNCTIONS OF POISSON VARIATES

THE CONSISTENCY AND ADEQUACY OF THE POISSON-MARKOFF

CARIABLES ON FINITE PRODUCTS OF POISSON-TYPE CHARACTERISTIC FUNCTIONS OF SEVERAL

TIMATION APPLICABLE TO THE HYPERGEOMETRIC, BINOMIAL, POISSON, AND EXPONENTIAL DISTRIBUTIONS /QUENTIAL ES ESTIMATION OF PARAMETERS OF A TRUNCATED POISSONIAN BINOMIAL

COMPUTATION AND STRUCTURE OF OPTIMAL RESET POLICIES

YSIS OF SYSTEMS UNDER VARIOUS PREVENTIVE MAINTENANCE POLICIES A GENERAL METHOD FOR THE RELIABILITY ANAL DISCOUNTING PRICING POLIGIES CONTINGENT ON OBSERVED PRODUCT QUALITY ON FINDING OPTIMAL POLICIES IN DISCRETE DYNAMIC PROGRAMMING WITH NO COMPARISON OF REPLACEMENT POLICIES, AND RENEWAL THEORY IMPLICATIONS TINBERGEN ON ECONOMIC POLICY

MANUFACTURERS' INVENTORY CYCLES AND MONETARY POLICY A COMMUNICATIONS SATELLITE REPLENISHMENT POLICY

STATISTICIAN AND POLICY MAKER, A PARTNERSHIP IN THE MAKING DIVIDEND POLICY, AN EMPIRICAL ANALYSIS

TECH $62 \quad 409$

JASA $61 \quad 235$

BIOKA64 399

JRSSB64 398 AMS $62 \quad 1384$ JASA $68 \quad 637$ JRSSB67 343 BIOKA53 447 AMS 62924 BIOKA65 67 BIOKA64 517 AMS 61904 AMS $63 \quad 308$ AMS $64 \quad 1823$ $\begin{array}{lll}\text { AMS } & 64 & 1823 \\ \text { AMS } & 66 & 1564\end{array}$ BIOKA59 441 AMS 61 B09 JASA 641220 BIOCS69 171 BIOKA53 354 BIOCS6B 97 BIOKA57 43 AMS $69 \quad 434$ AMS 651494 BIOCS68 377 JASA 671462 AMS $62 \quad 137$ TECH $66 \quad 123$ AMS $66 \quad 1284$ AMS $64 \quad 577$ JASA $58 \quad 89$ JASA 58680 TECH $66 \quad 399$ JASA $56 \quad 12$ $\begin{array}{lll}\text { JASA } & 68 & 1132\end{array}$ ISTRIBUTION AND CORRELATIONS AMONG INVERSELY SAMPLED POLLEN COUNTS/THE COMPOUND NEGATIVE MULTINOMIAL D BIOKA63 47 INCREASING PROPERTIES OF POLYA FREQUENCY FUNCTIONS SOME RESULTS ON POLYA TYPE 2 DISTRIBUTIONS

MODELS FOR COMPLEX GONTINGENCY TABLES AND POLYCHOTOMOUS DOSAGE RESPONSE CURVES POLYCHOTOMY SAMPLING AMS $65 \quad 272$ AMS $68 \quad 1759$ BIOCS66 83 AMS $66 \quad 657$

NS

ON THE EVALUATION OF PROBABILITIES OF CONVEX POLYHEDRA UNDER MULTIVARIATE NORMAL AND T-DISTRIBUTIO J SOME MULTIPLE PRODUCTS OF POLYKAYS

PROPERTIES OF POLYKAYS OF DEVIATES THE POLYKAYS OF THE NATURAL NUMBERS

1069

ION

ON THE EQUIVALENCE OF POLYKAYS OF THE SECOND NOGBES

FINITE POPULATIONS A COMBINAT APPLICATIONS OF MULTIVARIATE POLYKAYS TO THE THEORY OF UNBIASED RATIO-TYPE ESTIMA RELATIONSHIP OF GENERALIZED POLYKAYS TO UNRESTRICTED SUMS FOR BALANCED COMPLETE AYS, GORR. 66746 COCTS OF TWO POLYKAYS WITH SOME GENERAL FORMULAE

GENERALIZED POLYKAYS, AN EXTENTION OF SIMPLE POLYKAYS AND BIPOLYK RATIO ON TESTING FOR THE DEGREE OF A POLYNOMIAL

CHEBYSHEV POLYNOMIAL AND OTHER NEW APPROXIMATIONS TO MILLS'

NEW CHEBYSHEV POLYNOMIAL APPROXIMATIONS TO MILLS' RATIO

LINEAR ESTIMATES WITH POLYNOMIAL COEFFICIENTS

CALCULATION OF ZONAL POLYNOMIAL COEFFICIENTS BY THE USE OF THE LAPLACE-

BELTRAMI OPERATOR -DECREASING OR CONVEX

LEAST-SQUARES FITTING OF A POLYNOMIAL CONSTRAINED TO BE EITHER NON-NEGATIVE, NON ASYMPTOTIC EFFICIENCY IN POLYNOMIAL ESTIMATION POLYNOMIAL EXPANSIONS OF BIVARIATE DISTRIBUTIONS

OPTIMUM DESIGNS FOR POLYNOMIAL EXTRAPOLATION

A PROBLEM IN MINIMAX VARIANCE POLYNOMIAL EXTRAPOLATION ORTHOGONAL POLYNOMIAL FITTING

THE CHOICE OF THE DECREE OF A POLYNOMIAL MODEL OPTIMAL SPACING AND WEIGHTING IN POLYNOMIAL PREDICTION

TORS OR CONTROLLERS IN NON-STATIONARY TIME SERIES POLYNOMIAL PROJECTING PROTECTION AGAINST ASSUMING THE WRONG DEGREE IN POLYNOMIAL REGRESSION AN APPROXIMATE TEST FOR SERIAL GORRELATION IN POLYNOMIAL REGRESSION ADJOINT MATRICES FOR POLYNOMIAL RECRESSION (CORRECTIONS 68 1025)

THE CHOICE OF THE DEGREE OF A POLYNOMIAL RECRESSION AS A MULTIPLE DECISTON PROBLEM CN A POINT ARISING IN POLYNOMIAL REGRESSION FITTING

/ THE UNIQUENESS OF THE SPACING OF OBSERVATIONS IN POLYNOMIAL REGRESSION FOR MINIMAX VARIANCE OF THE FIT CHOICE OF LEVELS OF POLYNOMIAL REGRESSION WITH ONE OR TWO VARIABLES ESTIMATES FOR THE POINTS OF INTERSECTION OF TWO POLYNOMIAL REGRESSIONS ADMISSIBLE DESIGNS FOR POLYNOMIAL SPLINE REGRESSION FITTING A POLYNOMIAL TO CORRELATED EQUALLY SPACED OBSERVATIONS

A CONCISE DERIVATION OF GENERAL ORTHOGONAL POLYNOMIALS
RSSB66 366 AMS 691297 AMS 641167 BIOKA60 53 AMS 641663 JASA $57 \quad 511$ AMS $68 \quad 643$ AMS 641174 AMS $66 \quad 226$ TECH $68 \quad 757$ AMS $63 \quad 892$ JASA 69647 BIOKA66 129 AMS $68 \quad 1711$ AMS $61 \quad 1042$ AMS $64120 B$ AMS $65 \quad 14 \mathrm{~B} 3$ AMS $66 \quad$ B9B BIOKA53 361 JRSSB6B 469 AMS 641553 JRSSB65 144 TECH 69 NO. 4 BIOKA6O 111 BIOCS68 401 AMS $62 \quad 255$ BIOKA64 501 AMS $62 \quad 810$ TECH $65 \quad 325$ JASA $64 \quad 214$ AMS 691557 BIOKA65 275 JRSSB58 406 JRSSB $69 \quad 113$ 
CORRIGENDA, 'THE USE OF ORTHOGONAL POLYNOMIALS OF POSITIVE AND NECATIVE BINOMIAL FREQUEN BIOKAGI THE ORTHOGONAL POLYNOMIALS OF POWER SERIES PROBABILITY DISTRIBUTIONS BIOKA 66 THE ORTHOGONAL POLYNOMIALS OF THE FACTORIAL POWER SERIES PROBABILITY SASJ 67

MISCLASSIFIED DATA FROM A BINOMINAL POPULATION SAMPLINC FROM A TRIANGULAR POPULATION ERRORS OF CLASSIFICATION IN A BINOMIAL POPULATION PRODUCER AND CONSUMER RISKS IN NON-NORMAL POPULATION CONFIDENCE INTERVALS FOR THE MEAN OF A FINITE POPULATION FINDING THE SIZE OF A FINITE POPULATION

ON MEASURING THE EXTREME AGED IN THE POPULATION MOMENT-STATISTICS IN SAMPLES FROM A FINITE POPULATION MOMENTS OF ORDER STATISTICS FROM A NORMAL POPULATION USE OF DOUBLE SAMPLING FOR SELECTING BEST POPULATION CONTROL CHARTS FOR THE MEAN OF A NORMAL POPULATION FITTING A STRAIGHT LINE TO DATA FROM A TRUNCATED POPULATION THF SPREAD OF AN EPIDEMIC TO FIXED CROUPS WITHIN THE POPULATION MULTIPLE-RECAPTURE CENSUS. I. ESTIMATION OF A CLOSED POPULATION FOR UNBIASED TESTS ON THE VARIANCE OF A NORMAL POPULATION OF SAMPLE MOMENTS OF CENSORED SAMPLES FROM A NORMAL POPULATION OF SEQUENTIAL RULES FOR ESTIMATION OF THE SIZE OF A POPULATION MAXIMUM LIKELIHOOD ESTIMATION OF THE SIZE OF A POPULATION SOME RELAY FAILURE DATA FROM A COMPOSITE EXPONENTIAL POPULATION THE SAMPLE MEAN AS ESTIMATE OF THE MEAN OF A FINITE POPULATION OF THE K-STATISTICS IN SAMPLES FROM A FINITE POPULATION AND EXPOSURE RESIDENCES FOR THE UNITED STATES POPULATION IMATION OF THE SIMPLE STOCHASTIC EPIDEMIC IN A LARGE POPULATION OF PERCENTILES. BAYES' THEOREM FOR SAMPLING FROM A POPULATION REGRESSION COEFFICIENT IN SAMPLES FROM A NON-NORMAL POPULATION OF THE SMALLER OF TWO DRAWINGS FROM A BINOMIAL POPULATION SPECIAL REFERENCE TO SAMPLES FROM A PEARSON TYPE III POPULATION NFERENCES BASED ON A SAMPLE FROM A FINITE UNIVARIATE POPULATION

SAMPLINC WITH VARYING PROBABILITIES FROM A FINITE POPULATION ONFIDENCE SETS FOR THE MEAN OF A MULTIVARIATE NORMAL POPULATION CENSORING OF THE PARAMETERS OF A DOUBLE EXPONENTIAL POPULATION ORDER STATISTIC FOR THE PARAMETER OF AN EXPONENTIAL POPULATION T OF MAXIMUM VALUES IN SAMPLES FROM A POWER-FUNCTION POPULATION SYSTEMATIC STATISTICS OF SAMPLES FROM ANY CONTINUOUS POPULATION ETS FOR THE MEAN OF A UNIVARIATE OR BIVARIATE NORMAL POPULATION E BOUNDS FOR THE STANDARD DEVIATION OF A RECTANGULAR POPULATION IN SAMPLING WITH VARYING PROBABILITIES FROM A FINITE POPULATION AMPLING MOMENTS OF THE MEAN IN SAMPLES FROM A FINITE POPULATION MATRIX AND MULTIPLE DECREMENT IN POPULATION ANALYSIS ITHMIC SERIES DISTRIBUTION AS A PROBABILITY MODEL IN POPULATION AND COMMUNITY ECOLOGY AND SOME OF ITS STAT JASA 67

BIAS IN ESTIMATES OF THE UNITED STATES NONWHITE POPULATION AS INDICATED BY TRENDS IN DEATH RATES JASA $61 \quad 44$ GE TABLES FOR TOLERANCE LIMITS FOR A NORMAL POPULATION BASED ON SAMPLE MEAN AND RANGE OR MEAN RAN JASA 57 B8 CONSTRUCTION OF ATTRITION LIFE TABLES FOR THE SINGLE POPULATION BASED ON TWO SUCCESSIVE CENSUSES (CORR. 68 JASA 67 1433 RIES OF ZERO, ERRORS IN RECORDING CHILDLESS CASES IN POPULATION CENSUSES/URE OF ENUMERATORS TO MAKE ENT JASA 61 909 LY TWO SAMPLES SUBSEQUENT/ INFERENCES CONCERNING A POPULATION CORRELATION COEFFICIENT FROM ONE OR POSSIB JRSSB67 2B2 THE NUMBER OF NEW SPECIES, AND THE INCREASE IN POPULATION COVERACE, WHEN A SAMPLE IS INCREASED LINE TRANSECT METHOD OF ESTIMATING GROUSE POPULATION DENSITIES ING TO SIMPLE BIRTH AND DEATH PROCESSES POPULATION DIFFERENCES BETWEEN SPECIES GROWINC ACCORD BIOKA53 370

SOME STOCHASTIC VERSIONS OF THE MATRIX MODEL FOR POPULATION DYNAMICS CAUSED BY A SELECTIVE REMOVAL POPULATION ESTIMATION BASED ON CHANCE OF COMPOSITION BIOKA55 279 ATION OF THE MEAN AND STANDARD DEVIATION OF A NORMAL POPULATION FROM A CENSORED SAMPLE OF LOCATION AND SCALE PARAMETERS FOR THE RECTANGULAR POPULATION FROM CENSORED SAMPLES J HE PARAMETERS OF A FOUR- PARAMETER GENERALIZED GAMMA POPULATION FROM COMPLETE AND CENSORED SAMPLES /OF T TECH 67 159 ESTIMATES OF MORALITY AND POPULATION FROM SURVEY-REMOVAL RECORDS RSE DISTRIBUTION FUNCTION OF A CONTINUOUS UNIVARIATE POPULATION FROM THE ORDER STATISTICS OF A SAMPLE /E BIOKAG9 NO. 3 ESTIMATION OF PARAMETERS OF A MULTIVARIATE NORMAL POPULATION FROM TRUNCATED AND CENSORED SAMPLES APPLICATIONS OF MULTIPLE-TYPE BRANCHING PROCESSES IN POPULATION GENETICS LUTIONS TO CERTAIN NONLINEAR DIFFERENCE EQUATIONS OF POPULATION GENETICS DISCRETE STOCHASTIC PROCESSES IN POPULATION GENETICS (WITH DISCUSSION)

SOME THEORETICAL ASPECTS OF DIFFUSION THEORY IN POPULATION GENETICS, CORR, 63352 $\begin{array}{rrrr} & \\ \text { PR IN POPULATION GENETICS, CORR, } 63 \quad 352 & \text { AMS } 62 & 939\end{array}$ THE STUDY OF POPULATION GROWTH IN ORGANISMS GROUPED BY STAGES BIOCS65 1 STOCHASTIC MODELS FOR THE POPULATION GRONTH OF THE SEXES BIOKA68 469 
PROBABILITY GENERATING FUNCTIONAL FOR THE CUMULATIVE POPULATION IN A SIMPLE BIRTH-AND-DEATH PROCESS /HE BIOKA64 245 THE EXPECTED FREQUENCIES IN A SAMPLE OF AN ANIMAL POPULATION IN WHICH THE ABUNDANCES OF SPECIES ARE LOG BIOKA5I 427 A NOTE ON THE POSTERIOR MEAN OF A POPULATION MEAN

A PROCEDURE TO ESTIMATE THE POPULATION MEAN IN RANDOM EFFECTS MODELS

DIFFICULTIES INVOLVED IN THE ESTIMATION OF A POPULATION MEAN USING TRANSFORMED SAMPLE DATA JRSSB69 NO.2 TECH $67 \quad 577$ TECH $66 \quad 535$ JASA $66 \quad 1200$ AMS $62 \quad 248$ ON MULTIPLE DECISION METHODS FOR RANKING POPULATION MEANS

ON SELECTING THE LARGEST OF K NORMAL POPULATION MEANS (WITH DISCUSSION)

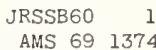
AN ESTIMATOR FOR A POPULATION MEAN WHICH REDUCES THE EFFECT OF LARGE

VARIATION A TEST OF EQUALITY OF TWO NORMAL POPULATION MEANS ASSU HEORETICAL AND EMPIRICAL RESULTS FOR SOME STOCHASTIC POPULATION MODELS IRECT MATRIX PRODUCT IN ANALYSING CERTAIN STOCHASTIC POPULATION MODELS A METHOD OF ESTIMATING THE INTERCENSAL POPULATION OF COUNTIES ON SAMPLING FROM A POPULATION OF RANKERS JASA $57 \quad 537$ A COMPARISON OF T BIOKA60 I ON THE USE OF THE D BIOKA6G 397 JASA $56 \quad 5 B 7$ BIOKA52 B2 ULATION FREQUENCIES OF SPECIES AND THE ESTIMATION OF POPULATION PARAMETERS THE POP BIOKA53 237 THE CAPTURE-RECAPTURE METHOD. I/ THE ESTIMATION OF POPULATION PARAMETERS FROM DATA OBTAINED BY MEANS OF BIOKA5I 269 THE CAPTURE-RECAPTURE METHOD. I/ THE ESTIMATION OF POPULATION PARAMETERS FROM DATA OBTAINED BY MEANS OF BIOKA52 363 THE CAPTURE-RECAPTURE METHOD. I/ THE ESTIMATION OF POPULATION PARAMETERS FROM DATA OBTAINED BY MEANS OF BIOKA53 ON THE ESTIMATION OF POPULATION PARAMETERS FROM MARKED MEMBERS

BIOKA55 TH BOTH DEATH AND DILUTION-DETERMINI/ ESTIMATES OF POPULATION PARAMETERS FROM MULTIPLE RECAPTURE DATA WI BIOKA63 II3 ESTIMATION OF THE NORMAL POPULATION PARAMETERS GIVEN A SINGLY CENSORED SAMPLE BIOKA59 150 ESTIMATION OF THE NORMAL POPULATION PARAMETERS GIVEN A TYPE I CENSORED SAMPLE BIOKA6I 367 A BAYESIAN APPROACH TO SOME BEST POPULATION PROBLEMS ON-WATSON PROCESS AND IN SOME RELATED MULTIPLICATIVE POPULATION PROCESSES /ITIES OF EXTINCTION IN A GALT AMS 68 ITOO REPEATED MIGRATION, AND ANALYSIS BASED ON THE DANISH POPULATION REGISTER AN OLD APPROACH TO FINITE POPULATION SAMPLING THEORY

LINEAR ESTIMATES OF A POPULATION SCALE PARAMETER

INFORMATIVE STOPPING RULES AND INFERENCES ABOUT POPULATION SIZE

QUASI-RANGES IN SETTING CONFIDENCE INTERVALS FOR THE POPULATION STANDARD DEVIATION ON DISCRETE STABLE POPULATION THEORY

CONVERGENCE OF A HUMAN POPULATION TO A STA8LE FORM THE EXTENT OF JASA $68 \quad 1269$ BIOKA67 551 JASA $67 \quad 763$ JASA $61 \quad 260$ BIOCS69 285 JASA $68 \quad 395$ CORR. 60755 SOME FINITE POPULATION UNBAISED RATIO AND REGRESSION ESTTMATORS JASA 59 EVERAL GROUPS OF OBSERVATIONS WHEN THE RATIOS OF THE POPULATION VARIANCES ARE UNKNOWN ATE AND MULTIVARIATE ANALYSIS WHEN THE RATIOS OF THE POPULATION VARIANCES ARE UNKNOWN /THESES IN UNIVARI BIOKA54 ION/ A TEST PROCEDURE WITH A SAMPLE FROM A NORMAL POPULATION WHEN AN UPPER BOUND TO THE STANDARD DEVIAT JASA 6O LL'S TAU FOR SAMPLES OF FOUR FROM A NORMAL BIVARIATE POPULATION WITH CORRELATION RHO /TRIBUTION OF KENDA BIOKA63 ESTIMATING THE MEAN OF A MULTIVARIATE NORMAL POPULATION WITH GENERAL QUADRATIC LOSS FUNCTION DER STATISTICS, FOR THE SCALE PARAMETER OF A WEIBULL POPULATION WITH KNOWN SHAPE PARAMETER /ASED ON M OR TECH 65 405 HYPOTHESIS TEST FOR DETERMINING THE MEAN OF A NORMAL POPULATION WITH KNOWN VARIANCE A SEQUENTIAL THREE AMS 67 1365 PARTITIONING OF A PATIENT POPULATION WITH RESPECT TO DIFFERENT MORTALITY RISKS JASA 63701 NONPARAMETRIC PROCEDURES FOR SELECTING THE T POPULATION WITH THE LARGEST ALPHA-QUANTILE AMS $67 \quad 1804$ RIC PROCEDURES FOR SELECTING A SUBSET CONTAINING THE POPULATION WITH THE LARGEST ALPHA-QUANTILE /PARAMET AMS 67 17B8 TIONS A SEQUENTIAL PROCEDURE FOR SELECTING THE POPULATION WITH THE LARGEST MEAN FROM K NORMAL POPULA AMS 64 I74 BE MADE ONLY IN PAIRS SELECTION OF THE POPULATION WITH THE LARGEST MEAN WHEN COMPARISONS CAN BIOKA5B 58 ON SELECTING A SUBSET CONTAINING THE POPULATION WITH THE SMALLEST VARIANCE $X$ PROCEDURES FOR ESTIMATING THE ARITHMETIC MEAN OF A POPULATION WITH TWO-STAGE SAMPLING BAYES AND MINIMA AMS 66 IIB6 SONS WITH N OR MORE ACCIDENTS FROM AN ACCIDENT PRONE POPULATION

SOME PROPERTIES OF PASCAL DISTRIBUTION FOR FINITE POPULATION

ERRATA, 'MISCLASSIFTED DATA FROM A BTNOMTAL POPULATION' OF SAMPLE MOMENTS OF CENSORED SAMPLES FROM A NORMAL POPULATION' XACT SAMPLING DISTRIBUTION OF RANGES FROM A DISCRETE POPULATION HE PARAMETER OF A ONE-PARAMETER NEGATIVE EXPONENTIAL POPULATION THE RANKING OF VARIANCES IN NORMAL POPULATIONS OPTIMUM SAMPLING IN BINOMIAL POPULATIONS ON RANKING PARAMETERS OF SCALE IN TYPE III POPULATIONS CORR. 62919 ON THE EFFECT OF REMOVING PER BIOKA65 29B EVALUATION OF DATA

JASA $62 \quad 172$ JASA $56 \quad 591$ TECH $66 \quad 215$ CORRIGENDA TO 'MOMENTS BIOKA58 5B7 CORRECTION, 'CALCULATION OF E AMS 67280 /DS, BASED ON ONE ORDER STATISTIC FOR T TECH 64 4B3 JASA $56 \quad 621$ JASA $57 \quad 494$ JASA $58 \quad 164$ AMS 61406 JASA $62 \quad 446$ AMS $63 \quad 940$ BIOKA5 102 BIOKA51 196 BIOKA53 447 BIOKA54 252 BI0KA54 463 BIOKA58 154 BIOKA68 438 BIOKA69 391 JRSSB55 269 JRSSB59 203 JRSSB $65 \quad 301$ JRSSB68 551 BIOCS68 189 BIOCS68 501 ON A THREE-DECISION TEST FOR COMPARING TWO BINOMIAL POPULATIONS PROXIMATION TO TWO-SIDED TOLERANCE LIMITS FOR NORMAL POPULATIONS SEQUENTIAL DESIGNS OF FIXED SIZE SAMPLES FROM FINITE POPULATIONS AN AP TECH $66 \quad 115$ BAYES JASA 69 NO. 4 NOTES. BIOCS67 846 ON THE BIOKA54 200

SAMPLE SIZE FOR THE ESTIMATION OF MEANS OF NORMAL POPULATIONS MOMENTS OF ORDER STATISTICS IN SAMPLES FROM NORMAL POPULATIONS EXTREME VALUES AND RANGE OF SAMPLES FROM NON-NORMAL POPULATIONS OF NONPARAMETRIC TESTS FOR INDEPENDENCE IN BIVARIATE POPULATIONS OF THE MEDIAN OF SMALL SAMPLES FROM SEVERAL SPECIAL POPULATIONS SSIBILITY AND OPTIMUM ESTIMATORS FOR SAMPLING FINITE POPULATIONS OF ORDER - STATISTICS AND QUASI-RANGES FROM NORMAL POPULATIONS INTERVAL ESTIMATION FOR THE MEANS OF NORMAL POPULATIONS 
OF TRUNCATION ON TESTS OF HYPOTHESES FOR NORMAL POPULATIONS MULTIVARIATE ESTIMATOR FOR THE MEAN OF FINITE POPULATIONS PROCEDURE FOR THE SELECTION OF THE BEST OF SEVERAL POPULATIONS FREE TOLERANCE INTERVALS FOR CONTINUOUS SYMMETRICAL POPULATIONS CONFIDENCE INTERVALS FOR CONTRASTS AMONG MULTINOMIAL POPULATIONS APPROXIMATION FOR USE IN SAMPLING FROM FINITE POPULATIONS ESTIMATING THE PARAMETERS OF DISCRETE HETEROGENEOUS POPULATIONS OF A METHOD OF ESTIMATING THE SIZE OF MOBILE ANIMAL POPULATIONS ERPRETATION OF THE VARIETY CROSS DIALLEL AND RELATED POPULATIONS

AND THE CHOICE OF ESTIMATOR IN TWO-WAY STRATIFIED POPULATIONS OF TWO-SAMPLE MANN-WHITNEY TEST FOR DISCRETE POPULATIONS SOMERVILLE'S PROCEDURE FOR RANKING MEANS OF NORMAL POPULATIONS THE ARITHMETIC MEANS OF LOGNORMALLY-DISTRIBUTED POPULATIONS FOR SELECTION OF THE BEST ONE OF SEVERAL BINOMIAL POPULATIONS REGARDING ADMISSIBLE ESTIMATES FOR EXPONENTIAL POPULATIONS OF ORDER STATISTICS IN SAMPLES FROM TWO RELATED POPULATIONS FOR RANKING MULTIPLY-CLASSIFIED VARIANCES OF NORMAL POPULATIONS AND MIGRATION PROCESSES FOR SPATIALLY DISTRIBUTED POPULATIONS OF DISTANCES BETWEEN ORDER STATISTICS FROM BIVARIATE POPULATIONS STICS IN SAMPLES FROM EXPONENTIAL AND POWER-FUNCTION POPULATIONS CONTROL FOR MULTIPLY-CLASSIFIED VARIANCES OF NORMAL POPULATIONS VARIATION OF RANGE IN SMALL SAMPLES FROM NON-NORMAL POPULATIONS FOR CLASSIFICATION INTO TWO MULTIVARIATE NORMAL POPULATIONS TISTICS OF THE MULTIVARIATE NORMAL AND PARETO TYPE I POPULATIONS ISTRIBUTIONS OF THE MEAN FOR SAMPLES FROM NON-NORMAL POPULATIONS ADMISSIBILITY OF LINEAR ESTIMATES IN EXPONENTIAL POPULATIONS TIONS FOR TRUNCATED AND CENSORED SAMPLES FROM NORMAL POPULATIONS TO UNRESTRICTED SUMS FOR BALANCED COMPLETE FINITE POPULATIONS TIONS OF PRODUCT STATISTICS ARISING FROM RECTANGULAR POPULATIONS LIKELIHOOD ESTIMATORS WHEN SAMPLING FROM ASSOCIATED POPULATIONS LL HYPOTHESIS CONCERNING COMPLEX MULTIVARIATE NORMAL POPULATIONS STRIBUTION OF THE RANGE IN SMALL SAMPLES FROM NORMAL POPULATIONS ATIONS IN THE ESTIMATION OF THE PARAMETERS OF NORMAL POPULATIONS D BAYESIAN ANALYSIS OF CATERGORICAL DATA FROM FINITE POPULATIONS E LOSS OF FOUR METHODS OF REPRODUCING FINITE DIPLOID POPULATIONS BUTION OF THE F-RATIO IN SAMPLES FROM TWO NON-NORMAL POPULATIONS ORED SAMPLES, OF THE PARAMETERS OF WEIBULL AND GAMMA POPULATIONS BETWEEN TWO BINARY CHARACTERISTICS IN TWO DIFFERENT POPULATIONS SUBJECTIVE BAYESIAN MODELS IN SAMPLING FINITE POPULATIONS LLY TESTING OBSERVED ARITHMETIC MEANS FROM LOGNORMAL POPULATIONS STRIBUTION OF THE RANGE FROM DISCRETE UNIFORM FINITE POPULATIONS AND ORDER STATISTICS FOR DISCRETE POPULATIONS AND ICIENCY OF THE ESTIMATES OF THE PARAMETERS OF NORMAL POPULATIONS BASE ICIENCY OF THE ESTIMATES OF THE PARAMETERS OF NORMAL POPULATIONS BASED ON SINLN ROL

EMPIRIC INVESTIGATION OF A TEST OF HOMOGENEITY FOR POPULATIONS COMPOSED OF NORMAL DISTRIBUTIONS ON SELECTING A SUBSET OF $K$ POPULATIONS CONTAINING THE BEST REFERENCE POPULATIONS FOR DIALLEL EXPERIMENTS

ON THE PROBLEM OF TESTING LOCATION IN MULTIVARIATE POPULATIONS FOR RESTRICTED ALTERNATIVES ATION OF THE PARAMETERS OF THREE-PARAMETER LOGNORMAL POPULATIONS FROM COMPLETE AND CENSORED SAMPLES, ICORR JASA 66 B42 OD FSTTMATION OF THE PARAMETERS OF GAMMA AND WEIBULL POPULATIONS FROM COMPLETE AND FROM CENSORED SAMPLES OD ESTIMATION OF THE PARAMETERS OF GAMMA AND WEIBULL POPULATIONS FROM COMPLETE AND FROM CENSORED SAMPLES' TECH 67 I95

ESTIMATION OF MEANS OF NORMAL POPULATIONS FROM OBSERVED MINIMA
ESTIMATING THE PARAMETERS OF NEGATIVE EXPONENTIAL POPULATIONS FROM ONE OR TWO ORDER STATISTICS, CORR. T AMS 61 1078 BIOKA57 282 ON ESTIMATING THE SIZE OF MOBILE POPULATIONS FROM RECAPTURE DATA

UM-LIKELIHOOD ESTIMATION OF THE PARAMETERS OF NORMAL POPULATIONS FROM SINGLY AND DOUBLY CENSORED SAMPLES ( BIOKA66 205 ICANCE OF THE DIFFERENCE BETWEEN MEANS IN TWO NORMAL POPULATIONS HAVING UNEQUAL VARIANCES /OR THE SIGNIF BIOKA51 252 ON A METHOD OF FSTIMATING BIOLOGICAL POPULATIONS IN THE FIELD

AL ANALYSIS FOR GENETIC CLINES IN BODY DIMENSIONS IN POPULATIONS OF 'DROSOPHILA SUBOBSCURA' COLL. AND A C BIOCS66 469 ON THE UTILIZATION OF MARKED SPECIMENS IN ESTIMATING POPULATIONS OF FLYING INSECTS THE SIMPLE STOCHASTIC EPIDEMIC CURVE FOR LARGE POPULATIONS OF SUSCEPTIBLES ESTIMATION OF MEANS AND TOTALS FROM FINITE POPULATIONS OF UNKNOWN SIZE, CORR. 641297 DISTANCE BETWEEN POPULATIONS ON THE BASIS OF ATTRIBUTE DATA

A MINIMAX PROCEDURE FOR GHOOSING BETWEEN TWO POPULATIONS USING SEQUENTIAL SAMPLING A MINIMAX-REGRET PROCEDURE FOR GHOOSING BETWEEN TWO POPULATIONS USING SEQUENTIAL SAMPLING TIPLE DECISION PROCEDURE FOR RANKING MEANS OF NORMAL POPULATIONS WITH A COMMON UNKNOWN VARIANGE /PLE MUL BIOKA54 170 GE SUBSAMPLING PROCEDURE FOR RANKING MEANS OF FINITE POPULATIONS WITH AN APPLIGATION TO BULK SAMPLING PROB TECH 67 355 MISCLASSIFIGATION

ON THE CHOIGE OF THE BEST AMONGST THREE NORMAL POPULATIONS WTTH KNOWN VARTANGES DETECTION OF BEST AND OUTLYING NORMAL POPULATIONS WITH KNOWN VARIANGES

THE SIMPLE STOGHASTIC EPIDEMIC FOR SMALL POPULATIONS WITH ONE OR MORE INITIAL INFEGTIVES

OF FINITE ABSORBENT MARKOV GHAINS TO SIB MATING POPULATIONS WITH SELECTION APPLI AN EMPIRICAL COMPARISON OF DISTANGE STATISTICS FOR POPULATIONS WITH UNEQUAL GOVARIANG
RANKING MEANS OF TWO NORMAL POPULATIONS WITH UNKNOWN VARIANGES A NEW APPROACH TO SAMPLING FROM FINITE POPULATIONS. I ON GOEFFICIENTS IN SAMPLES FROM BIVARIATE NON-NORMAL POPULATIONS. A NEW APPROACH TO SAMPLING FROM FINITE POPULATIONS. II DMISSIBILITY AND BAYES ESTIMATION IN SAMPLING FINITE POPULATIONS, I DMISSIBILITY AND BAYES ESTIMATION IN SAMPLING FINITE POPULATIONS. II DMISSIBILITY AND BAYES ESTIMATION IN SAMPLING FINITE POPULATIONS. III DMISSIBILITY AND BAYES ESTIMATION IN SAMPLING FINITE POPULATIONS, IV TWO-SIDED TOLERANGE LIMITS FOR NORMAL POPULATIONS, SOME IMPROVEMENTS BIOKA60 61 JRSSB $66 \quad 320$ A AMS 651707 A AMS 651723 A AMS 651730

A AMS 661658 JASA 69610

\author{
JRSSB66 310
}


COMPARINC DISTANCES BETWEEN MULTIVARIATE POPULATIONS, THE PROBLEM OF MINIMUM DISTANCES

DMISSIBILITY AND BAYES ESTIMATION IN SAMPLINC FINITE POPULATIONS, V

'THE DISTRIBUTION OF RANCE IN CERTAIN NON-NORMAL POPULATIONS'

A AMS 69 MOMENTS OF ORDER STATISTICS IN SAMPLES FROM NORMAL POPULATIONS

VARTATTON OF RANCE IN SMALL SAMPLES FROM NON-NORMAL POPULATIONS' ENUMERATION OF ELECTION RETURNS BY NUMBER OF LEAD POSITIONS

ON THE CHOICE OF PLOTTING POSITIONS ON PROBABILITY PAPER

RICENDA, 'THE MEAN AND COEFFICIENT OF BIOKA55 277

THE AMS $64 \quad 369$

JASA $60 \quad 546$

CURVE F/ THE USE OF ORTHOGONAL POLYNOMIALS OF THE POSITIVE AND NEGATIVE BINOMIAL FREQUENCY FUNCTIONS IN BIOKA61 115 CORRICENDA, THE USE OF ORTHOCONAL POLYNOMTALS OF POSITTVE AND NECATTVE BTNOMTAL FREQUENCY FUNCTIONS TN BTOKAGI TS THE EFFECTIVE USE OF BOTH POSITIVE AND NEGATIVE CONTROLS IN SCREENING EXPERIMEN BIOCS67

AN APPROXIMATION OF THE NEGATIVE MOMENTS OF THE POSITIVE BINOMIAL USEFUL IN LIFE TESTING

RECURRENCE RELATIONS FOR THE INVERSE MOMENTS OF THE POSITIVE BINOMIAL VARIABLE

UNDER WHICH GRAM-CHARLIER AND EDGEWORTH CURVES ARE POSITIVE DEFINITE AND UNIMODAL
INFINITELY DIFFERENTIABLE POSITIVE DEFINITE FUNCTIONS

227

JASA $63 \quad 46 B$

IOKA52 425

AMS $66 \quad 504$

RS

ON CERTAIN DISTRIBUTION PROBLEMS BASED ON POSITIVE DEFINITE QUADRATIC FUNCTTONS IN NORMAL VECTO AMS 66

THIN S/ NOTES. EXPECTED SELECTION DIFFERENTIAL FOR POSITIVE DIRECTIONAL SELECTION ON NORMAL VARIABLES WI BTOCS67 A NOTE ON POSITIVE DYNAMIC PROGRAMMING

A RELATIONSHIP BETWEEN ARBITRARY POSITIVE MATRICES AND DOUBLY STOCHASTIC MATRICES

THE RECIPROCAL OF THE CONDITIONAL EXPECTATION OF A POSITIVE RANDOM VARIABLE

A NOTE ON AMS 651302 STATISTICAL PROPERTIES OF THE NUMBER OF POSITIVE SUMS

AMS $66 \quad 1295$

LIER SERIES THE REGIONS OF UNIMODALITY AND POSITIVITY IN THE ABBREVIATED EDGEWORTH AND GRAM-CHAR JASA 57 253 RROR FREE COMMUNICATION' COMMENTS TO. EDWARD C. POSNER, 'THE APPLICATION OF EXTREME VALUE THEORY TO E TECH 66 363 DISTRIBUTIONS POSSESSING A MONOTONE LIKELIHOOD RATIO JASA $56 \quad 637$

THREE SOURCES OF DATA ON COMMUTING, PROBLEMS AND POSSIBILITIES

$\begin{array}{lll}\text { JASA } & 56 & 637 \\ \text { JASA } & 60 & \text { B }\end{array}$

$\begin{array}{lrr}\text { JASA } & 60 & \text { B } \\ \text { JASA } & 68 & 217\end{array}$

MINIMIZING RESPONSE ERRORS IN FINANCIAL DATA. THE POSSIBILITIES

TECH $612 \mathrm{BI}$

ON THE POSSIBILITY OF IMPROVING THE MEAN USEFUL LIFE OF ITEU UTIONS OCCURING AT UNKNOWN TT/ TEST PROCEDURES FOR POSSIBLE CHANCES IN PARAMETERS OF STATTSTICAL DISTRIB AND A P A BEST POSSIBLE KOLMOGOROFF-TYPE INEQUALITY FOR MARTINGALES AMS 69764 EFFICIENT CALCULATION OF ALL POSSIBLE REGRESSIONS POST CLUSTER SAMPLINC

EX ANTE AND EX POST DATA IN INVENTORY INVESTMENT ESTIMATION EMPLOYING POST STRATA

THE VARIANCE OF AN ESTIMATOR WITH POST-STRATIFIED WEIGHTING

COMMENTS ON A POSTERIOR DISTRIBUTION OF GEISSER AND CORNFIELD

STRIBUTION THE MIXED BINOMIAL DISTRIBUTION AND THE POSTERIOR DISTRIBUTION OF P FOR A CONTINUOUS PRIOR DI JRSSB68 359 FOR SAMPLING FROM A POPULATTON POSTERIOR DISTRIBUTION OF PERCENTILES BAYES' THEOREM JASA 68677 RANDOM-EFFECT MODELS IN THE ANALYSIS OF VARIANCE. I, POSTERIOR DISTRIBUTION OF VARIANCE-COMPONENTS /OF BIOKA65 37 AN ASYMPTOTIC EXPANSION FOR POSTERIOR DISTRIBUTIONS

ON THE ASYMPTOTIC BEHAVIOUR OF POSTERIOR DISTRIBUTIONS HAAR MEASURE FOR CONVERGENCE IN PROBABILITY TO QUASI POSTERIOR DISTRIBUTIONS
PARAMETERS

CORR. 66745
NEW METHODS FOR REASONING TOWARDS

\section{POSTERIOR DISTRIBUTIONS}

POSTERIOR DISTRIBUTIONS FOR MULTIVARIATE NORNAL

LIMITING BEHAVIOR OF POSTERIOR DISTRIBUTIONS WHEN THE MODEL IS INCORRECT,

A NOTE ON THE POSTERIOR MEAN OF A POPULATION MEAN

POSTERIOR ODDS FOR MULTIVARIATE NORMAL CLASSIFICATION

THE EMPIRICAL BAYES APPROACH ESTIMATING POSTERIOR QUANTILES

THE POSTERIOR T DISTRIBUTION

NECESSARY RESTRICTIONS FOR DISTRIBUTIONS A POSTERIORI

BETWEEN LIKELIHOODS AND ASSOCIATED DISTRIBUTIONS A POSTERIORI

AMS 671899

JRSSB69 80

AMS $65 \quad 440$

AMS $66 \quad 355$

JRSSB63 368

AMS $66 \quad 51$

JRSSB69 NO. 2

JRSSB64 69

BIOKA67 672

AMS $6356 \mathrm{~B}$

JRSSB60 312

MINED SYSTEM OF EQUATIONS

AN A POSTER

PLANT COMPETITION, THREE SPECIES PER POT

TIVE TRACER EXPERIMENT TO DETERMINE ROOT ACTIVITY IN POTATO PLANTS /E STATISTICAL ANALYSIS OF A RADIO-AC MEASUREMENT OF THE POTENCIES OF DRUG MIXTURES

PLANNING A OUANTAL ASSAY OF POTENCY

A SIMPLE METHOD OF ESTIMATING RELATIVE POTENCY FROM TWO PARABOLAS

SIMILARITIES JRSSB6I 460

TECH $66 \quad 675$

JRSSB68 93

BIOCS68 717

BIOCS69 477

BIOCS66 322

BIOCS65 140

TRIBUTION-FREE METHODS IN THE ESTIMATION OF RELATIVE POTENCY IN DILUTION (-DIRECT) ASSAYS /FOR USING DIS BIOCS66 6IO VEINOTT

A POTENTIAL THEORETIC PROOF OF A THEOREM OF DERMAN AND

A POTENTIAL THEORY FOR SUPERMARTIGALES

ON MARKOV CHAIN POTENTIALS

SMALL SAMPLE POWER AND EFFICIENCY FOR THE ONE SAMPLE WILCOXON AND

NORMAL SCORES TESTS

TYPE

LOCAL ASYMPTOTTC POWER AND FFFICIENCY OF TESTS OF KOLMOGOROV-SMIRNOV

ANCE MATRICES BASED ON FOUR CRITERIA

CLUSTERING

ESES BASED ON FOUR CRITERIA

POWER COMPARISIONS OF TESTS OF EQUALITY OF TWO COVARI B

A POWER COMPARISON OF TWO TESTS OF NON-RANDOM

NS. III. SOME LARGE-SAMPLE RESULTS ON ESTIMATION AND POWER FOR A METHOD OF PAIRED COMPARISONS /OCK DESIG BIOKA55 450

SHIFT ALTERNATIVES

D FROM THE NON-CENTRAL F-DISTRIBUTI/ CHARTS OF THE POWER FUNCTION FOR ANALYSIS OF VARIANCE TESTS, DERIVE COMPARTSON OF ANALYSTS OF VARTANCE POHER FUNCTION IN THE PARAUETRTC AND RANDOM MODELS

THE POWER FUNCTION OF SOME TESTS BASED ON RANGE

NOTE ON MR SRIVASTAVA'S PAPER ON THE POWER FUNCTION OF STUDENT'S TEST

EFFECT OF NON-NORMALITY ON THE POWER FUNCTION OF T-TEST

ON THE POWER FUNCTION OF THE EXACT TEST FOR THE 2-BY-2
NGENCY TABLE

CONTINGENCY TABLE

NCE
CONTINGENCY TABLE
CORRIGENDA, THE POWER FUNCTION OF THE EXACT TEST FOR THE 2-BY-3

THE EFFECT OF NON-NORMALITY ON THE POWER FUNCTION OF THE F-TEST IN THE ANALYSIS OF VARIA

EXACT AND APPROXIMATE POWER FUNCTION OF THE NON-PARAMETRIC TEST OF TENDENCY EFFECT OF NON-NORMALITY ON THE POWER FUNCTION OF THE SIGN TEST

TWO PROPORTIONS IN A 2-BY-2 TAB/ CORRIGENDA, 'THE POWER FUNCTION OF THE TEST FOR THE DIFFERENCE BETWEEN TREND CONTINGENCY TABLES ISTICAL ANALYSIS A CLASS OF TESTS WITH MONOTONE POWER FUNCTIONS FOR TWO PROBLEMS IN MULTIVARIATE STAT PONER FUNCTIONS FOR COX'S TEST OF RA COMPARISON OF THE POWER FUNCTIONS FOR THE TEST OF INDEPENDENCE IN 2 X2 TWO SETS OF VARIATES COVARIANCE MATRICES./ 
K ON THE MAIN EFFECTS AND INTERACTIONS IN A 2 TO THE POWER N FACTORIAL EXPERIMENT AS CALCULATED BY YATES'S BIOCS67 57 THE LIMIT OF THE NTH POWER OF A DENSITY

ASYMPTOTIC EXPANSIONS ASSOCIATED WITH THE N'TH POWER OF A DENSITY ON THE DISTRIBUTION AND POWER OF A TEST FOR A SINGLE OUTLIER

THE POWER OF A TEST IN COVARIANCE ANALYSIS

$\begin{array}{rr}\text { AMS } 67 & 1266 \\ \text { JRSSB } 6 \text { B } & 83\end{array}$

SASJ 69 BIOCS69 NO.4

TO NORMAL ANALYSIS OF VARIANCE THE LIMITING POWER OF CATEGORICAL DATA CHI-SQUARE TESTS ANALOGOUS AMS $63 \quad 1432$ COND DIFFERENCES, FOR SERIAL CORRELATI/ ASYMPTOTIC POWER OF CERTAIN TEST CRITERIA. BASED ON FIRST AND SE PROPORTIONS THE POWER OF CHI SQUARE TESTS FOR CONTINGENCY TABLES AMS $62 \quad 1$ B6 JASA $66 \quad 965$ ASYMPTOTIC POWER OF CHI SQUARE TESTS FOR LINEAR TRENDS IN $\quad$ BIOCS68 315 TO THE DISTRIBUTIONS OF MEASURES OF DISPERSION BY A POWER OF CHI-SQUARE APPROXIMA
RECTANGULAR ALTERNATIVES
EXACT POWER OF MANN-WHITNEY TEST FOR EXPONENTIAL AND EXACT POWER OF MANN-WHITNEY TEST FOR EXPONEN
AND THE POWER OF NORMAL TESTS FOR INDEPENDENCE

CO-ORDINATE TRANSFORMATIONS TO NORMALITY AND THE POWER OF NORMAL TESTS FOR INDEPENDENCE 2 TO THE POWER OF P FACTORIAL EXPERIMENTS WITH THE FACTORS ON THE POWER OF PRECEDENCE LIFE TESTS

STARSHAPED TRANSFORMATIONS AND THE POWER OF RANK TESTS

METHOD OF OBTAINING LOWER BOUNDS ON THE ASYMPTOTIC POWER OF RANK TESTS

THE POWER OF STUDENTIS T-TEST, CORR, 651251

THE RELATION BETWEEN ESTIMATING EFFICIENCY AND THE POWER OF TESTS AN SQ/ A MONTE CARLO INVESTIGATION OF THE SIZE AND POWER OF TESTS EMPLOYING SATTERTHWAITE'S SYNTHETIC ME BIOKA68 43 AND LOGIT TRANSFORMATIONS, CORR. $64 \mathrm{l2} /$ ASYMPTOTIC POWER OF TESTS OF LINEAR HYPOTHESES USING THE PROBIT JASA 62 877 DISTRIBUTION AND POWER OF THE ABSOLUTE NORMAL SCORES TEST

EFFECT OF NON-NORMALITY ON THE POWER OF THE ANALYSIS OF VARIANCE TEST

PERCENTAGE POINTS OF THE RATIO OF TWO RANGES AND POWER OF THE ASSOCIATEO TEST

JASA $67 \quad 966$ BIOKA59 114 BIOKA63 187

SMALL SAMPLE POWER OF THE BIVARIATE SIGN TEST OF BLUMEN AND HODGES AMS 641576 ON THE POWER OF THE BLUS PROCEDURE

BETWEEN THE POWER OF THE DURBIN-WATSON TEST AND THE POWER OF THE BLUS TEST JASA $68 \quad 1227$ BLUS TEST A COMPARISON BETWEEN THE POWER OF THE DURBIN-WATSON TEST AND THE POWER OF THE TABLES OF THE POWER OF THE F-TEST (CORR. 6B 1551) ANDOMIZED BLOCK D/ SOME MONTE CARLO RESULTS ON THE POWER OF THE F-TEST UNDER PERMUTATION IN THE SIMPLE R BIO ASA $67 \quad 525$ EAR HYPOTHESIS IN MULTIVARIATE ANALYSIS THE POWER OF THE LIKELIHOOD RATIO TEST AMS $67 \quad 802$ ON THE ASYMPTOTIC POWER OF THE ONE-SAMPLE KOLMOGOROV-SMIRNOV TESTS THE PONER OF THE POISSON INDEX OF DISPERSION

A COMPACT TABLE FOR POWER OF THE T-TEST

ON THE RANDOMIZATION DISTRIBUTION AND POWER OF THE VARIANCE RATIO TEST

BIOKA64 467 AMS 651000 BIOKA57 286 AMS 681629 JRSSB $63 \quad 334$ DISTRIBUTION FUNCTIONS ON THE POWER OF TWO-SAMPLE RANK TESTS ON THE EQUALITY OF TWO JRSSB64 293

RUN/ MAXIMUM LIKELIHOOD ESTTMATION FOR GENERALIZED POWER SERIES DISTRIBUTIONS AND ITS APPLICATION TO A T BIOKA62 227 THE ORTHOGONAL POLYNOMIALS OF THE FACTORIAL POWER SERIES PROBABILITY DISTRIBUTIONS SASJ $67-49$ THE ORTHOGONAL POLYNOMIALS OF POWER SERIES PROBABILITY DISTRIBUTIONS AND THEIR USES BIOKA66 12 ESTIMATION OF POWER SPECTRA BY A WAVE ANALYZER TECH $65 \quad 553$

DISTRIBUTION OF PRODUCT JASA $64-877$

OF SOME STATISTICS IN SAMPLES FROM EXPONENTIAL AND POWER-FUNCTION POPULATIONS TOPOGRAPHIC CORRELATION, POWER-LAW COVARIANCE FUNCTIONS, AND DIFFUSION TABLES FOR POWER-LAW TRANSFORMATIONS ON CERTAIN PROPERTIES OF POWER-SERIES DISTRIBUTIONS DISTRIBUTION JASA $67 \quad 259$ BIOKA62 305 BIOKA62 557 BIOKA59 486 LIZATION/ THE INVERSION OF CUMULANT OPERATORS FOR POWER-SERIES DISTRIBUTIONS, AND THE APPROXIMATE STABI JASA 6B 321 RR/ WEIGHT OF EVIDENCE. CORROBORATION, EXPLANATORY POWER, INFORMATION AND THE UTILITY OF EXPERIMENTS /CO JRSSB60 3I9 BALANCED L-RESTRICTIONAL PRIME PONERED LATTICE DESIGNS

EPENDENCE OF TWO POISSON VARIAB/ ON A LOCALLY MOST POWERFUL BOUNDARY RANDOMIZED SIMILAR TEST FOR THE IND EXISTENCE AND UNIQUENESS OF A UNIFORMLY MOST POWERFUL RANDOMIZED UNBIASED TEST FOR THE BINOMIAL ASYMPTOTICALLY MOST POWERFUL RANK ORDER TESTS FOR GROUPED DATA

ASYMPTOTIC EFFTCIENCY OF CERTAIN LOCALLY MOST POWERFUL RANK TESTS

\section{CENSORED DAT}

ASYMPTOTICALLY MOST POWERFUL RANK TESTS FOR THE TWO-SAMPLE PROBLEM WITH ASYMPTOTICALLY MOST POWERFUL RANK-ORDER TESTS

MOST STRINGENT AND THE MOST STRTNGENT SOMEWHERE MOST POWERFUL TEST FOR CERTAIN PROBLEMS WITH RESTRICTED AL MBER OF LINEAR INEQ/ MOST STRINGENT SOMEWHERE MOST POWERFUL TESTS AGAINST ALTERNATIVE RESTRICTED BY A NU MOST POWERFUL TESTS FOR SOME NON-EXPONENTIAL FAMILIES

ASYMPTOTICALLY MOST POWERFUL TESTS IN MARKOV PROCESSES QUICK POWERFUL TESTS WITH GROUPED DATA

A REMARK ON SOLVING EQUATIONS IN SUMS OF POWERS

AN ASYMPTOTIC FORMULA FOR THE DIFFERENCES OF THE POWERS AT ZERO

$$
\text { ON FRACTIONAL POWERS OF A MATRIX }
$$

SERIES

THE ASYMPTOTIC POWERS OF CERTAIN TESTS BASED ON MULTIPLE CORRELATION THE ASYMPTOTIC POWERS OF CERTAIN TESTS OF GOODNESS OF FIT FOR TIME THE ASYMPTOTIC POWERS OF MULTIVARIATE TESTS WTTH GROUPED DATA AN UNBIASED ESTIMATOR FOR POWERS OF THE ARITHMETIC MEAN

SERIES TRANSFORMATIONS TO NORMALITY USING FRACTIONAL POWERS OF THE VARIABLE CORRIGENDA A COMPARISON OF THE POWERS OF TWO MULTIVARIATE ANALYSIS OF VARIANCE TESTS THE CAPTURE-RECAPTURE METHOD. III. AN EXAMPLE OF THE PRACTICAL APPLICATIONS OF THE METHOD /D BY MEANS OF SOME OBSERVATIONS ON THE PRACTICAL ASPECTS OF WEIGHTING DESIGNS

THE INTERACTION ALGORITHM AND PRACTICAL FOURIER ANALYSIS STRATIFICATION, A PRACTICAL INVESTIGATION PRACTICAL VALUE OF INTERNATIONAL EDUCATIONAI

STATISTICS PRACTICE

PAPER, PRINCIPIES OF PROFESSTONAL STATISI

RIAL EXPERIMENTS FOR THE ESTIMATION OF A SUBGROUP OF PRE-ASSIGNED PARAMETERS /DESIGN OF FRACTIONAL FACTO ON PRE-EMPTIVE RESUME PRIORITY QUEUES
AMS 671127 AMS 61809 BIOKA56 465 AMS 671229 AMS $61 \quad 88$ AMS 651243 AMS 621124 AMS $68 \quad 531$ AMS $66 \quad 1161$ AMS $68 \quad 772$ AMS 691207 BIOKA6B 264 JRSSB6B 567 AMS 61249 JASA $67 \quad 1018$ JRSSB56 227 JRSSB58 143 JRSSB $68 \quad 338$ JRSSB 151 JRSSB55 115 JASA $57 \quad 237$ BIOKA62 455 IOKA63 546 IOKA53 137 JRSSB5B 361 JASA $66 \quad 74$ JASA $56 \quad 605$ AMS 651883 AMS $6 \mathrm{~B} \quad 973$ AMS 64600 
CONFIDENCE INTERVAL OF PREASSIGNED LENGTH FOR THE BEHRENS-FISHER PROBLEM TABLES FOR A PRECEDENCE LIFE TEST

ON PRECEDENCE LIFE TESTING

ON THE POWER OF PRECEDENCE LIFE TESTS

AMS 671175

TECH $63 \quad 491$

TECH $65 \quad 359$

TECH $67 \quad 154$

BIOCS69 174 AMS 691021

LIED TO EXTRAPOLATION IN S-/ A NOTE ON THE GAIN IN PRECISION FOR OPTIMAL ALLOCATION IN REGRESSION AS APP TECH 69 S WHEN THE SAMPLE O8SERVATIONS ARE LOGNORMAL AND THE PRECISION H IS KNOWN /LE SIZE IN TWO-ACTION PROBLEM JASA 68 653 BAYESIAN ANALYSIS OF THE J J THE PRECISION OF MICHEY'S UNBIASED RATIO ESTIMATOR $\begin{array}{llrlr}\text { PRECISION OF SIMULTANEOUS MEASUREMENT PROCEDURES } & \text { JASA } & 63 & 474 \\ \text { THE PRECISION OF UNBIASED RATIO-TYPE ESTIMATORS, CORR. } 63 & \text { JASA } 58 & 491\end{array}$ BIOKA 67 321

1162

THE PROPERTIES OF A STOCHASTIC MODEL FOR THE PREDATOR-PREY TYPE OF INTERACTION BETWEEN TWO SPECIES ON THEORETICAL MODELS FOR COMPETITIVE AND PREDATORY BIOLOGICAL SYSTEMS

AITKEN ESTIMATORS AS A TOOL IN ALLOCATING PREDETERMINED AGGREGATES

UNDER THE CARE OF ONE OPERATIVE OPTIMAL SPACING AND WEIGHTING IN POLYNOMIAL PREDICTION PROBABILISTIC PREDICTION

QUASI-LINEARLY INVARIANT PREDICTION FIDUCIAL THEORY AND INVARIANT PREDICTION SOME PROBLEMS OF STATISTICAL PREDICTION FROM THE BAYESIAN POINT OF VIEW (CORR. 6B 1551) AND RELATED METHODS

PREDICTION AND DECISION PROBLEMS IN REGRESSION MODELS PREDICTION BY EXPONENTIALLY WEIGHTED MOVING AVERAGES PREDICTION BY PROGRESSIVE CORRECTION

SPECIFIED MODELS BIASES IN PREDICTION BY REGRESSION FOR CERTAIN INCOMPLETELY

PISTIMETRIC PR08ABILITY STRUCTURAL PROBABILITY AND PREDICTION FOR THE MULTIVARIATE MODEL

A NOTE ON PREDICTION FROM AN AUTOREGRESSIVE PROCESS USING ERRORS OF PREDICTION IN MULTIPLE REGRESSION

SEQUENTIAL MODEL BUILDING FOR PREDICTION IN REGRESSION ANALYSIS, I DESICN FOR OPTIMAL PREDICTION IN SIMPLE LINEAR REGRESSION

BEST LINEAR UNBIASED PREDICTION IN THE GENERALIZED LINEAR REGRESSION MODEL SIMULTANEOUS PREDICTION INTERVALS

A NOTE ON PREDICTION INTERVALS BASED ON PARTIAL OBSERVATIONS IN TECH 68
CERTAIN LIFE TEST EXPERIMENTS BASED ON PARTIAL OBSERVATIONS BUTION ON MULTIVARIATE
FACTORS FOR CALCULATING TWO-SIDED TO DISTURBANCES AND TO ERRORS OF OBSERVATION $\begin{array}{llllllll} & \end{array}$ PREDICTION INTERVALS FOR SAMPLES FROM A NORMAL DISTRI JASA $6987 \mathrm{~B}$ PREDICTION OF AN AUTOREGRESSIVE VARIABLE SUBJECT BOTH JASA 65164 ON THE PREDICTION OF NON-STATIONARY PROCESSES $\quad$ JRSSB67 570 AMMES WHEN ALL DAUGHTERS OF SELECTED PARENTS/ THE PREDICTION OF RESPONSE TO SELECTION IN BREEDING PROGR BIOCS69 553 SOME EXPERIMENTS ON THE PREDICTION OF SUNSPOT NUMBERS ANCILLARY STATISTICS AND PREDICTION OF THE LOSS IN ESTIMATION PROBLEMS JRSSB54 112 AMS $68 \quad 1756$ TECH 6121 AMS $63 \quad 424$ AMS 651554 MULTIVARIATE WIDE-SENSE MARKOV PROCESSES AND PREDICTION THEORY ON A PROBLEM IN NON-LINEAR PREDICTION THEORY FITTING OF STRAIGHT LINES AND PREDICTION WHEN 80TH VARIABLES ARE SUBJECT TO ERROR JASA 61657

E NORMAL DISTRIBUTION ETHEEN FAILURE DENSITY FUNCTTONS USED IN RELIABILITY PREDICTION, A METHOD FOR DISCRIMINATING B TECH 65 r TIONSHIPS BETWEEN BAYESIAN AND CONFIDENCE LIMITS FOR PREDICTIONS (WITH DISCUSSION) JRSSB64 176 PREDICTION REGIONS FOR SEVERAL PREDICTIONS FROM A SINGLE REGRESSION LINE

S, AND NON-ATTITUDINAL VARIABLES THE PREDICTIVE ABILITY OF CONSUMER ATTITUDES, STOCK PRICE PREDICTIVE ZERO-MEAN UNIFORM DISCRII

A NOTE ON A MODIFIED EXPONENTIALLY WEIGHTED PREDICTOR JASA 64 9B7 BIOKA68 519 JRSSB 68318

THESES FOR RANDOMIZED EXPERIMENTS WITH NONCONTROLLED PREDICTOR VARIABLES /PTIMAL TESTS OF COMPOSITE HYPO JASA 65 699 REGRESSION PROBLFMS WHEN THE PREDTCTOR VARTABLES ARE PROPORTIONS SQUARES ESTIMATOR IN REGRESSION ANALYSIS WHEN THE 'PREDICTOR' VARIABLES ARE STOCHASTIC TEST FOR THE DIFFERENCE IN EFFICIENCY BETWEEN TWO PREDICTORS

RECURSIVE RELATIONS FOR PREDICTORS OF NON-STATIONARY PROCESSES
ES POLYNOMIAL PROJECTING PROPERTIES OF MULTI-TERM PREDICTORS OR CONTROLLERS IN NON-STATIONARY TIME SERI J PREEMPTIVE PRIORITY QUEUEING JRSSB69 107 QUERY, PREFERENCE SCORES (REVISITED) PREFERENCE-BASED DEFINITIONS OF SUBJECTIVE

PROBABILITY

ESTIMATION PROBLEM THE USE OF CORRELATED VARIABLES FOR PRELIMINARY CULLING PEIMINARY REGIONAL FORECASTS FOR THE OUTCOME OF AN JRSSB 55266 JRSSB65 523 JRSSB65 144 BIOKA61 57 TECH $68 \quad 612$ AMS 671605 BIOCS67 551
JASA $63 \quad 1104$ BIOKA62 403 ENT FROM ONE OR POSSIBLY TWO SAMPLES SUBSEQUENT TO A PRELIMINARY TEST OF SIGNIFICANCE /RELATION COEFFICI JRSSB67 282 NOTES. ESTIMATION AFTER PRELIMINARY TESTING IN ANOVA MODEL I N THE 8INOMIAL AND POISSON DISTRI/ ESTIMATORS WITH PRESCRIBED BOUND ON THE VARIANCE FOR THE PARAMETERS I JASA 66 220 SEQUENTIAL NONPARAMETRIC TWO-WAY CLASSIFICATION WITH PRESCRIBED MAXIMUM ASYMPTOTIC ERROR PROBABILITY JOINT DISTRIBUTIONS WITH PRESCRIBED MOMENTS OR OF THE MEAN OF A LOG-NORMAL DISTRIBUTION HAVING A PRESCRIBED PROPORTIONAL CLOSENESS /D SAMPLE ESTIMAT AMS 67 949 ON OF THE MEAN OF A LOG-NORMAL DISTRIBUTION HAVING A PRESCRIBED PROPORTIONAL CLOSENESS /UENTIAL ESTIMATI CONSISTENT ESTIMATION OF A LOCATION PARAMETER IN THE PRESENCE OF AN INCIDENTAL SCALE PARAMETER COMPUTATION OF INDIRECT-ADJUSTED RATES IN THE PRESENCE OF CONFOUNDING TESTING EQUALITY OF MEANS IN THE PRESENCE OF CORRELATION

ESTIMATION OF THE SPECTRAL DENSITY FUNCTION IN THE PRESENCE OF HARMONIC COMPONENTS A NOTE ON FOLLOW-UP FOR SURVIVAL IN THE PRESENCE OF MOVEMENT

CASE NUMERICAL OPTIMIZATION IN THE PRESENCE OF RANDOM VARIABILITY. THE SINGLE FACTOR SPECTRAL ANALYSIS IN THE PRESENCE OF VARIANCE FLUCTUATIONS

SPECTRAL ANALYSIS OF GAUSSIAN VECTOR PROCESS IN THE PRESENCE OF VARIANCE FLUCTUATIONS

TISTICS. III. A NOTE ON THE HISTORY OF THE GRAPHICAL PRESENTATION OF DATA /ISTORY OF PROBABILITY AND STA BI A SIMPLE PRESENTATION OF OPTIMUM SAMPLING RESULTS

THE PRESIDENT'S ECONOMIC REPORT

THE ECONOMICS OF THE PRESIDENT'S ECONOMIC REPORTS

OR THE RELIABILITY ANALYSIS OF SYSTEMS UNDER VARIOUS PREVENTIVE MAINTENANCE POLICIES PRODUCT PRESERVATION OF WEAK CONVERGENCE UNDER MAPPINGS PRESIDENTIAL ADDRESS

AMS 661688

AMS $69 \quad 1353$ BIOCS68 997 BIOKA69 119 JRSSB64 123 JASA $61 \quad 119$ BI0KA69 65 JRSSB6 4354 AMS $68 \quad 1507$ IOKA56 241 AMS 67,239 JASA $57 \quad 257$ JASA $66 \quad 1$ AMS $62 \quad 137$ A PRICE AND PRODUCTIVITY INDEX FOR A NONHOMOGENEOUS JASA 64469 JASA $56 \quad 454$ 
THE MEASUREMENT OF PRICE CHANCES IN CONSTRUCTION INCENTIVE CONTRACTS AND PRICE DIFFERENTIAL ACCEPTANCE TESTS SOME QUANTITATIVE TESTS FOR STOCK PRICE GENERATINC MODELS AND TRADINC FOLKLORE

SOME ASPECTS OF SEASONALITY IN THE CONSUMER PRICE INDEX CONSTANTS AND COMPROMISE IN THE CONSUMER PRICE INDEX SAMPLING ERROR IN THE CONSUMER PRICE INDEX

A NOTE ON THE PERIODOCRAM OF THE BEVERIDCE WHEAT PRICE INDEX

IN APPLYINC LINEAR PROCRAMMINC TO THE CONSUMER PRICE INDEX

USE OF VARYINC SEASONAL WEICHTS IN PRICE INDEX CONSTRUCTION

A RECRESSION METHOD FOR REAL ESTATE PRICE INDEX CONSTRUCTION WAGE, PRICE, AND TAX ELASTICITIES OF OUTPUT AND DISTRIBUTIV

E SHARES WAGE, PRICE, AND TAX ELASTICITIES OF OUTPUT
STOCK PRICES, AND NON-ATTITUDINAL VARIABLES

THE PREDI PRICING POLICIES CONTINGENT ON

BALANCED L-RESTRICTIONAL PRIME POWERED LATTICE DESIGNS GENERAL THEORY OF PRIME-POWER LATTICE DESIGNS

IONS FOR OBTAINING A BALANCED SET OF L-RESTRICTIONAL PRIME-POWERED LATTICE DESIGNS OF-FIT OF A STNGLE (NON-ISOTROPIC) HYPOTHETICAL PRINCIPAL COMPONENT

LATENT ROOT AND THE CORRESPONDING LATENT VECTOR FOR PRINCIPAL COMPONENT ANALYSIS ASYMPTOTIC THEORY FOR PRINCIPAL COMPONENT ANALYSIS

AN OPTIMAL PROPERTY OF PRINCIPAL COMPONENTS

OF EICENVALUES OF A MATRIX AND OPTIMALITY OF PRINCIPAL COMPONENTS

ON THE DISTRIBUTION OF THE LATENT VECTORS FOR PRINCIPAL COMPONENTS ANALYSIS

THE NON-NULL DISTRIBUTION OF A STATISTIC IN PRINCIPAL COMPONENTS ANALYSIS STAT ISTICAL RESEARCH

THE COLLINEAT AMS 671293

AMS $66 \quad 995$

AMS $63 \quad 122$

AMS 651579

MINIMIZATION AMS $68 \quad 859$

AMS $65 \quad 1 B 75$

BIOKA66 590

JASA $65 \quad 234$

ESTIMATION OF GENETIC CONTRIBUTION OF PRINCIPAL COMPONENTS TO INDIVIDUAL VARIATES CONCERNED BIOCS69 9

ORTS AVEC L'ANALYSE DISC/ L'ANALYSE EN COMPOSANTES PRINCIPALES, SON UTILISATION EN GENETIQUE ET SES RAPP BIOCS66 343

SONS ENTRE LES ESPECES ET LES VARIABLES ECOLOGIQUES, PRINCIPES FONDAMENTAUX /NALYSE STATISTIQUE DES LIAI BIOCS65 345

RATE OF CONVERCENCE RESULTS FOR THE INVARIANCE PRINCIPLE

THE INVARIANCE PRINCIPLE FOR A LATTICE OF RANDOM VARIABLES

AN INVARIANCE PRINCIPLE IN RENEWAL THEORY

THE HISTORY OF PROBABILITY AND STATISTICS. VII. THE PRINCIPLE OF THE ARITHMETIC MEAN

ON EXTENDED AMS 69 NO.6

AMS $68 \quad 382$

AMS 62685

ON THE SUFFICIENCY AND LIKELIHOOD PRINCIPLES

THE LIKELIHOOD AND INVARIANCE PRINCIPLES

SOME INVARIANCE PRINCIPLES FOR FUNCTIONALS OF A MARKOV CHAIN

SPECIAL PAPER. PRINCIPLES OF PROFESSIONAL STATISTICAL PRACTICE

JASA 63641

JRSSB67 533

AMS $67 \quad 1$

AMS $6518 B 3$

MEMORIAL MEETING FOR WILLIAM N HURWITZ. SOME BASIC PRINCIPLES OF STATISTICAL SURVEYS /TISTICAL SOCIETY JASA 69 NO. 4

THE ASYMPTOTICALLY UNBIASED PRIOR DISTRIBUTION

THE EMPIRICAL BAYES APPROACH, ESTIMATING THE PRIOR DISTRIBUTION

USINC THE OBSERVATIONS TO ESTIMATE THE PRIOR DISTRIBUTION

BATCHES OF ITEMS WHERE THE MEAN QUALITY HAS A NORMAL PRIOR DISTRIBUTION

AND THE POSTERIOR DISTRIBUTION OF P FOR A CONTINUOUS PRIOR DISTRIBUTION

INVARIANT PRIOR DISTRIBUTIONS

A PARADOX INVOLVING QUASI PRIOR DISTRIBUTIONS

$\begin{array}{rr}\text { BIOKA67 } & 326 \\ \text { JRSSB } 65 & 17\end{array}$

/G ACCEPTANCE SCHEMES FOR LARGE BIOKA68 393

THE MIXED BINOMIAL DISTRIBUTION JRSSB68 359

AMS $64 \quad 836$

BIOKA65 623

SINGLE SAMPLINC ATTRIBUTE PLANS FOR CONTINUOUS PRIOR DISTRIBUTIONS

SAMPLING PROCEDURES BASED ON PRIOR DISTRIBUTIONS AND COSTS

MULTISTAGE SAMPLING PROCEDURES BASED ON PRIOR DISTRIBUTIONS AND COSTS

SYSTEM OF SINGLE SAMPLINC INSPECTION PLANS BASED ON PRIOR DISTRIBUTIONS AND COSTS

THE ASSESSMENT OF PRIOR DISTRIBUTIONS IN BAYESIAN ANALYSIS

THE USE OF INCOMPLETE BETA FUNCTIONS FOR PRIOR DISTRIBUTIONS IN BINOMIAL SAMPLING

BAYESIAN TECH 6 B 667

TECH $63 \quad 47$

AMS $67 \quad 464$

TECH $65 \quad 335$

PARAMETER ESTIMATION IN NON-LINEAR SIT/ THE USE OF PRIOR DISTRIBUTIONS IN THE DESIGN OF EXPERIMENTS FOR BIOKA67 I47

PARAMETER ESTIMATION IN NON-LINEAR SIT/ THE USE OF PRIOR DISTRIBUTIONS IN THE DESIGN OF EXPERIMENTS FOR BIOKA67 662

ANNOT BE ASSOCIATED WI/ FUDUCTAL OPTIMUM STRATIFIED SAMPLINC USING PRIOR INFORMATION

LLOCATION IN STRATIFIED AND MULTISTAGE SAMPLES USING PRIOR INFORMATION

BILITY OF SOME STANDARD ESTIMATES IN THE PRESENCE OF PRIOR INFORMATION

REGRESSION ANALYSIS WHEN THERE IS PRIOR INFORMATION ABOUT SUPPLEMENTARY VARIABLES

ON THE USE OF INCOMPLETE PRIOR INFORMATION IN REGRESSION ANALYSIS

JASA $65 \quad 750$

OPTIMAL A JASA $6 B \quad 964$

ASSAY

USE OF PRIOR INFORMATION TO DESIGN A ROUTINE PAF

BAYES'S THEOREM AND THE USE OF PRIOR KNOWLEDGE IN REGRESSION ANALYSIS

SHORTER CONFIDENCE INTERVALS USING PRIOR OBSERVATIONS

NOTE ON THE CONFIDENCE-PRIOR OF WELCH AND PEERS

SIMULATION, C/ A HISTORY OF DISTRIBUTION SAMPLING PRIOR TO THE ERA OF THE COMPUTER AND ITS RELEVANCE TO JA

OF THE EXPERIMENTAL DETERMINATION OF PROBABILITIES A PRIORI SOME EXAMPLES OF BAYES' METHOD

ON THE A PRIORI DISTRIBUTION OF THE COVARIANCE MATRIX

ON PARTTAL 'A PRIORI' INFORMATTON IN STATISTTCAL INFERENCE

RANDOMIZED BLOCKS WHEN THE ALTERNATIVES HAVE AN 'A PRIORI' ORDERING

RANK TESTS FOR

THE ERGODICITY OF SERIES OF QUEUES WITH GENERAL PRIORITIES

A WAITING LINE WITH INTERRUPTED SERVICE, INCLUDING PRIORITIES

COMPETITIVE QUEUEING. IDLENESS PROBABILITIES UNDER PRIORITY DISCIPLINES

TIME-DEPENDENT SOLUTION OF THE 'HEAD-OF-THE-LINE' PRIORITY QUEUE

PREEMPTIVE PRIORITY QUEUEING

ON PRE-EMPTIVE RESUME PRIORITY QUEUES

A NOTE ON MUTUAL SINGULARITY OF PRIORS

OF HISTOCOMPATIBILITY TESTING, BIOLOCICAL BACKGROUND PROBABILISTIC AND STATISTICAL MODELS AND PROBLEMS (IN B PROBABILISTIC COMPLETION OF A KNOCKOUT TOURNAMENT

A DERIVATION OF THE PROBABILISTIC EXPLICATION OF INFORMATION

OV CHAINS ADMISSIBILITY AND DISTRIBUTION OF SOME PROBABILISTIC FUNCTIONS OF DISCRETE FINITE STATE MARK STATISTICAL INFERENCE FOR PROBABILISTIC FUNCTIONS OF FINITE STATE MARKOV CHAINS PROBABILISTIC FUNCTIONS OF FINITE STATE MARKOV CHAINS PROBABILISTIC INTERPRETATIONS FOR THE MEAN SQUARE PROBABILISTIC PREDICTION

CONTINGENCY, CORR, 5B 1030

RENEWAL THEOREM

A SIMPLE PROBABILISTIC PROOF OF THE DISCRETE GENERALIZED PROBABILISTIC SOLUTION OF THE SIMPLE BIRTH PROCESS

MAPS BASED ON PROBABILITIES

CIRCULAR ERROR PROBABILITIES

MINIMUM VARIANCE UNBIASED ESTIMATORS FOR POISSON PROBABILITIES $\begin{array}{ll}\text { JRSSB60 } & 172 \\ \text { JASA } 63 & 401\end{array}$

BIOCS67 257

BIOKA64 219

JASA $69 \quad 37 \mathrm{~B}$

JRSSB $66 \quad 55$

JASA $65 \quad 27$

JRSSB62 118

AMS 69 109B

AMS $67 \quad 867$

AMS $65 \quad 1664$

JRSSB62 73

JRSSB63 489

JRSSB62 91

BIOKA61 57

AMS $64 \quad 600$

AMS $66 \quad 375$

BIOCS69 207

AMS $66 \quad 495$

JRSSB 66 57B

AMS 6B 1646

AMS $69 \quad 97$

JASA $58 \quad 102$

JASA $65 \quad 50$

AMS 651294

BIOKA64 258

JASA $59 \quad 385$

JASA $60 \quad 723$

TECH $62 \quad 409$
AMS $67 \quad 1671$

AMS $66 \quad 1554$ 
APPROXIMATIONS TO MULTIVARIATE NORMAL ORTHANT PROBABILITIES CONVERGENCE THEOREMS FOR MULTIPLE CHANNEL LOSS PROBABILITIES ESTIMATING ORDERED PROBABILITIES LIMITING DISTRIBUTIONS OF RESPONSE PROBABILITIES ON THE LOCAL BEHAVIOR OF MARKOV TRANSITION PROBABILITIES REPRESENTING FINITELY ADDITIVE INVARIANT PROBABILITIES SMOOTHED ESTIMATES FOR MULTINOMIAL CELL PROBABILITIES UNBIASED ESTIMATION OF A SET OF PROBABILITIES ON INVERSE SAMPLING WITH UNEQUAL PROBABILITIES A MENDELIAN MARKOV PROCESS WITH BINOMIAL TRANSITION PROBABILITIES CLOSED SEQUENTIAL TESTS FOR BINOMIAL PROBABILITIES AN INEQUALITY INVOLVING MULTINOMIAL PROBABILITIES THE ASYMPTOTIC VALUES OF CERTAIN COVERAGE PROBABILITIES ON DIRECT PROBABILITIES QUERY, THE COMBINATION OF PROBABILITIES RIBUTION ESTIMATORS FROM THE RECURRENCE EQUATION FOR PROBABILITIES TYPE GALTON-WATSON PROCESSES WITH RANDOM BRANCHING PROBABILITIES TO THE BAYES CHOICE CRITERION, THE METHOD OF EXTREME PROBABILITIES BRIUM THEORY OF SIMPLE QUEUES BY MEANS OF CUMULATIVE PROBABILITIES

BAYES' METHOD OF THE EXPERIMENTAL DETERMINATION OF PROBABILITIES A PRIORI EQUATION A GENERAL THEORY OF SUBJECTIVE PROBABILITIES AND EXPECTED UTILITIES INFERENCE CONCERNING PROBABILITIES AND QUANTILES

TWO CONFIDENCE INTERVALS FOR THE RATIO OF TWO PROBABILITIES AND SOME MEASURES OF EFFECTIVENESS DISTRIBUTIONS MULTINOMIAL PROBABILITIES AND THE CHI-SQUARE AND X-SQUARE CORRIGENDA, "MULTINOMIAL PROBABILITIES AND THE CHI-SQUARE AND X-SQUARE DISTRIB SAMPLING WITH UNEQUAL PROBABILITIES AND WITHOUT REPLACEMENT UTIONS. NS OF SAMPLING DESIGN THROUGH REPLICATION WITH EQUAL PROBABILITIES AND WITHOUT STACES LOPMENT OF RANDOMIZED LOAD SEQUENCES WITH TRANSITION PROBABILITIES BASED ON A MARKOV PROCESS COMPLETE INVARIANT INFORMATION

INVARIANT PROBABILITIES FOR CERTAIN MARKOV PROCESSES ZERO CROSSING PROBABILITIES FOR GAUSSIAN STATIONARY PROCESSES

ACT BAHADUR EFFICIENCY OF THE TWO-SA/ NORMAL DISTRIBUTION SAMPLE WILCOXON STATISTIC DISTRIBUTION EXTREME TAIL PROBABILITIES FOR SAMPLING WITHOUT REPLACEMENT AND EX ORTHANT PROBABILITIES FOR THE EQUICORRELATED MULTIVARIATE EXTREME TAIL PROBABILITIES FOR THE NULL DISTRIBUTION OF THE TWOORTHANT PROBABILITIES FOR THE QUADRIVARIATE NORMAL

NOTES. RAPTD CALCULLATION OF EXACT PROBA8ILITIES FOR 2-BY-3 CONTINGENCY TABLES ASYMPTOTIC THEORY OF REJECTIVE SAMPLING WITH VARYING PROBABILITIES FROM A FINITE POPULATION OR-VARIANCE OF AN ESTIMATOR IN SAMPLING WITH VARYING PROBABILITIES FROM A FINITE POPULATION NOTES. F-RATIO PROBABILITIES FROM BINOMIAL TABLES

A SEQUENTIAL TEST OF THE EQUALITY OF PROBABILITIES IN A MULTINOMIAL DISTRIBUTION PROBABILITIES IN THE VOTING PARADOX

UPPER AND LOWER PROBABILITIES INDUCED $8 Y$ A MULTIVALUED MAPPING IABLE GENERATING FUNCTION FOR COMPUTING THE SAMPLING PROBABILITIES OF A CLASS OF WIDELY USED STATISTICS INEQUALITIES FOR FIRST EMPTINESS PROBABILITIES OF A DAM WITH ORDERED INPUTS

AMS $63 \quad 191$ AMS 63260 AMS 63967 AMS $65 \quad 706$ AMS $6 \mathrm{~B} 2123$ AMS E8 2131 AMS $68 \quad 561$ BIOKA6I 227 BIOKA64 185 BIOKA66 37 BIOKA66 73 BIOKA68 422 BIOKA69 NO. 3 JRSSB63 100 BI0CS67 840 DISCRETE DIST JASA 69602 A NOTE ON MULTT- BIOKA68 589 SIMPLE APPROACH JASA 641227 OF THE NON-EQUILI JRSSB63 457 JRSSB62 11B AMS 681191 AMS 691419 JRSSB69 N0.2 JASA $57 \quad 36$ BIOKA63 145 BIOKA63 546 AMS $62 \quad 350$ JASA $56 \quad 24$ TECH $66 \quad 107$ JASA $67 \quad 454$ AMS $66 \quad$ B37 AMS 621306 BI0KA56 92 BIOKA68 371 BIOKA62 433 BIOKA67 629 AMS 641685 BI0CS68 714 AMS $64 \quad 1491$ JASA 6B 91 BIOCS66 404 AMS $68 \quad 957$ JASA $62 \quad 769$ AMS $64 \quad 857$ AMS $67 \quad 325$ JASA $64 \quad 487$ JRSSB62 102 INEQUALITIES FOR FIRST EMPTINESS PROBABILITIES OF A DAM WITH ORDERED INPUTS
NOTES. ON ESTIMATING THE EQUILIBRIUM AND TRANSITION PROBABILITIES OF A FINITE-STATE MARKOV CHAIN FROM THE BIOCS6B IBS NORMAL AND T-DISTRIBUTIONS ON THE EVALUATION OF PROBABILITIES OF CONVEX POLYHEDRA UNDER MULTIVARIATE JRSSB66 NT ANALYSIS PROBABILITIES OF CORRECT CLASSIFICATION IN DISCRIMINA BIOCS66 SSES THAT ARE AGE-DEPENDENT OR PHASE-DEPENDENT THE PROBABILITIES OF EXTINCTION FOR BIRTH-AND-DEATH PROCE BIOKA67 $S$ AND IN SOME REL/ HOW TO MINIMIZE OR MAXIMIZE THE PROBABILITIES OF EXTINCTION IN A GALTON-WATSON PROCES AMS 68 I700 THE ORTHANT PROBABILITIES OF FOUR GAUSSIAN VARIATES AMS $69 \quad 152$ NATION BETWEEN K POPULATIONS WITH CONSTRAINTS ON THE PROBABILITIES OF MISCLASSIFICATION ALYSIS, NECESSARY SAMPLE SIZE, AND A/ ON EXPECTED PROBABILITIES OF MISCLASSIFICATION IN DISCRIMINANT AN BIOCS68 823 CONVERGENCE RATES FOR PROBABILITIES OF MODERATE DEVIATIONS

AMS 682016 SURVIVAL PROBABILITIES OF NEW INVERSIONS IN LARGE POPULATIONS BIOCS68 501 ON EXACT PROBABILITIES OF RANK ORDERS FOR TWO WIDELY SEPARATED AMS 671491 NORMAL DISTRIBUTIONS DERING OF PROBABILITIES OF RANK ORDERS IN THE TWO SAMPLE CASE AMS 6698 AMS $6 \mathrm{~B} \quad 1425$ BIOKA67 499 BIOKA69 197 ON SAMPLING WITHOUT REPLACEMENT WITH UNEQUAL PROBABILITIES OF SELECTION

THE PROBABILITIES OF SOME EPIDEMIC MODELS

MIAL DISTRIBUTIONS INTEGRAL EXPRESSIONS FOR TAIL PROBABILITIES OF THE MULTINOMIAL AND NEGATIVE MULTINO BIOKA65 167 VERAL METHODS OF RE-DESIGNING AREA SAMPLES UTILIZING PROBABILITIES PROPORTIONAL TO SIZE WHEN THE SIZES CHA JASA 6B I2BO A NOTE ON THE APPLICATION OF THE COMBINATION OF PROBABILITIES TEST TO A SET OF 2-BY-2 TABLES COMPETITIVE QUEUEING, IDLENESS PROBABILITIES UNDER PRIORITY DISCIPLINES 4B9 MONOTONE CONVERGENCE OF BINOMIAL PROBABILITIES WITH AN APPLICATION TO MAXIMUM LIKELIHO AMS 67 15B3
ESTIMATION OF EXPONENTIAL SURVIVAL PROBABILITIES WITH CONCOMITANT INFORMATION MONOTONE CONVERGENCE OF BINOMIAL PROBABILITIES WITH AN APPLICATION TO MAXIMUM LIKELIHO AMS 67 15B3
ESTIMATION OF EXPONENTIAL SURVIVAL PROBABILITIES WITH CONCOMITANT INFORMATION SOME ESTIMATORS IN SAMPLING WITH VARYING PROBABILITIES WITHOUT REPLACEMENT
CLASS OF LINEAR ESTIMATORS IN SAMPLING WITH VARYING PROBABILITIES WITHOUT REPLACEMENT ROTATING SAMPLES

SAMPLING WITH VARYING PROBABILITIES WITHOUT REPLACEMENT, ROTATING AND NON- JASA 63183 LIKELIHOOD AND BAYESIAN ESTIMATION OF TRANSITION PROBABILITIES.

CONSENSUS OF SUBJECTIVE PROBABILITIES. A CONVERGENCE THEOREM

CONVERGENT FXPANSION FOR CUMULATIVE HYPERGEOMETRIC PROBABILITIES, DIRECT AND INVERSE

Y CONVERGENT EXPANSION FOR CUMULATIVE HYPERGEOMETRIC PROBABILITIES, DIRECT AND INVERSE MAXIMUM JASA 68 1162 AMS $67 \quad 221$ E OF LARGEST CLUSTERS AND SMALLEST INTERVALS SOME PROBABILITIES, EXPECTATIONS AND VARIANCES FOR THE SIZ JASA 66 1191 BINOMIAL, F, BETA, AND OTHER COMMON, RELATED TAIL PROBABILITIES, I BINOMTAL, F, BETA, AND OTHER COMMON, RELATED TAIL PROBABILITIES. I KHINCHIN'S WORK IN MATHEMATICAL PROBABILITY A DEFINITION OF SUBJECTIVE PROBABILITY AMS 621227 AMS 63199 AMS 651113 AMS 671605 BIOKA66 365 BI0CS66 8B2 SOME INTEGRAL EQUATIONS IN GEOMETRICAL PROBABILITY A NEW SIMILARITY INDEX BASED ON PROBABILITY

NOTE ON THE MAXIMIZATION OF A NON-CENTRAL CHI-SQUARE PROBABILITY NUMERICAL REPRESENTATION OF QUALITATIVE CONDITION PROBABILITY
A AMS 64 44]

ON THE AMS $6 B$ B 
PPLICATION TO STATISTICS OF AN ELEMENTARY THEOREM IN PROBABILITY PROBLEM AND SOME APPROXIMATIONS TO THE REQUIRED PROBABILITY

FROM AN AUTORECRESSIVE PROCESS USING PISTIMETRIC PROBABILITY SSIFICATION WITH PRESCRIBED MAXIMUM ASYMPTOTIC ERROR PROBABILITY AC TODHUNTER'S HISTORY OF THE MATHEMATICAL THEORY OF PROBABILITY STRUCTURAL PROBABILITY AND A GENERALIZATION

ON THE A BIOKA56 THE HAUSA BIOKA63 A NOTE ON PREDICTION JRSSB 60 SEQUENTIAL NONPARAMETRIC TWO-WAY CLA AMS 69445 PRROBABILITY AND STATISTICS. XIII. ISA BIOKA63 204 JASA $63 \quad 628$ STRUCTURAL PROBABILITY AND PREDICTION FOR THE MULTIVARIATE MODEL JRSSB69 NO.2 CEOMETRICAL PROBABILITY AND RANDOM POINTS ON A HYPERSPHERE AMS 67213

SMS IN TALMUDIC LITERAT/ ORTH (1B45-1926) PMENT OF THE GAUSS LINE/ CONTINUITY IN THE DEVEL/ COINCIDENCES TALMUD HE SPE/ N THE DISTIN

STUDIES IN THE HISTORY OF PROBABILITY AND STATISTICS XVI RANDOM RANDOM MECHANI 8IOKA67 STUDIES IN THE HISTORY OF PROBABILITY AND STATISTICS. XIX. FRANCIS YSIDRO EDGEW BIOKA68 STUDIES IN THE HISTORY OF PROBABILITY AND STATISTICS. XV. THE HISTORICAL DEVELO BIOKA67 STUDIES IN THE HISTORY OF PROBABILITY AND STATISTICS XVII, SOME REFLEXIONS ON BIOKA67 STUDIES IN THE HISTORY OF PROBABILITY AND STATISTICS XVIII THOMAS YOUNG ON BIOKA68 STUDIES IN THE HISTORY OF PROBABILITY AND STATISTICS. XXII. PROBABILITY IN THE BIOKA69 SYSTEMATIC SAMPLING WITH UNEQUAL PROBABILITY AND WITHOUT REPLACEMENT

JASA $66 \quad 739$ TH AN APPLICATION IN STUDYING THE DENTAL C/ A PATH-PROBABILITY APPROACH TO IRREVERSIBLE MARKOV CHAINS WI BIOCS66 79I CONES SCORING RULES AND THE EVALUATION OF PROBABILITY ASSESSORS

PROBABILITY BOUNDS FOR A UNION OF HYPERSPHERICALSIGNIFICANCE PROBABILITY BOUNDS FOR RANK ORDERINGS AMS $64 \quad 891$

PROBABILITY AND STATISTICS. II. THE BEGINNINGS OF A PROBABILITY CALCULUS A SAMPLING TEST OF THE CHI-SQUARE THEORY FOR PROBABILITY CHAINS STUDIES IN THE HISTORY OF BIOKA56 BIOKA52 118 PROBABILITY CONTENT OF RECIONS UNDER SPHERICAL NORMAL AMS 62 542 DISTRIBUTIONS, III. THE BIVARIATE NORMAL INTEGRAL PROBABILITY CONTENT OF REGIONS UNDER SPHERICAL NORMAL A DISTRIBUTIONS/ CORRECTION. THE TITLE SHOULD READ 'PROBABILITY CONTENT OF RECIONS UNDER SPHERICAL NORMAL UNBIASED ESTIMATION OF SOME MULTIVARIATE PROBABILITY DENSITIES

\section{SERIES METHODS \\ THE ESTTMATION OF \\ ESTIMATION OF PROBABILITY DENSITY}

CUBICAL AND SPHERICAL ESTIMATION OF MULTIVARIATE PROBABILITY DENSITY NOTE ON A DISCONTINUOUS PROBABILITY DENSITY ESTIMATION OF PROBABILITY DENSITY BY AN ORTHOGONAL SERIES EFFICIENT ESTIMATION OF A PROBABILITY DENSITY FUNCTION CONDITION FOR THE MIXTURE OF EXPONENTIALS TO BE A PROBABILITY DENSITY FUNCTION ESTIMATION OF A PROBABILITY DENSITY FUNCTION AND ITS DERIVATIVES

ON ESTIMATION OF A PROBABILITY DENSITY FUNCTION AND MODE

ON THE SMOOTHING OF PROBABILITY DENSITY FUNCTIONS

AMS $62 \quad 542$ $\begin{array}{ll}\text { AMS } 61 & 171 \\ \text { AMS } 61 & 620\end{array}$ AMS $69 \quad 1261$ JASA $68 \quad 925$ AMS $68 \quad 1236$ AMS 651027 JASA $68 \quad 1495$ BIOKA58 270 AMS 671261 AMS $69 \quad 854$ AMS 69 NO. 6 AMS 691187 AMS 621065 JRSSB5B 334 D SOME APPLICATI/ RECURRENCE RELATIONS BETWEEN THE PROBABILITY DENSITY FUNCTIONS OF ORDER STATISTICS, AN A ON THE ESTIMATION OF THE PROBABILITY DENSITY. I OCCUPANCY PROBABILITY DISTRIBUTION CRITICAL POINTS

ON THE PROBABILITY DISTRIBUTION OF A FILTERED RANDOM

TELEGRAPH SIGNAL

COMPARISONS

AN EXACT PROBABILITY DISTRIBUTION OVER SAMPLE SPACES OF

LIKELIHOOD RATIO TESTS FOR RESTRICTED FAMILITES OF PROBABILITY DISTRIBUTIONS CONSTRUCTION OF JOINT PROBABILITY DISTRIBUTIONS

SELECTION PROCEDURES FOR RESTRICTED FAMILIES OF PROBABILITY DISTRIBUTIONS DETERMINATION OF PARAMETERS IN THE JOHNSON SYSTEM OF PROBABILITY DISTRIBUTIONS DISTRIBUTION FREE TESTS FOR MIXED PROBABILITY DISTRIBUTIONS CHARACTERIZATION THEOREMS FOR SOME UNIVARIATE PROBABILITY DISTRIBUTIONS CHARACTERIZATION THEOREMS FOR SOME UNIVARIATE PROBABILITY DISTRIBUTIONS ORTHOGONAL POLYNOMIALS OF THE FACTORIAL POWER SERIES PROBABILITY DISTRIBUTIONS OF SPECIAL FUNCTIONS IN THE CHARACTERIZATION OF PROBABILITY DISTRIBUTIONS THE ORTHOGONAL POLYNOMIALS OF POWER SERIES PROBABILITY DISTRIBUTIONS AND THEIR USES PROBABILITY DISTRIBUTIONS ARISING FROM POINTS ON A LINE PROBABILITY DISTRIBUTIONS OF POINTS ON A LATTICE' 58 CORRECTIONS TO 'THE THEORY OF PROBABILITY DISTRIBUTIONS OF POINTS ON
MS ARISING IN APPROXIMATING TO PROBABILITY DISTRIBUTIONS USING MOMENTS SOME PROBLEMS ARISING IN APPROXIMATING TO PROBABILITY DISTRIBUTIONS USING MOMENTS
PROPERTIES OF PROBABILITY DISTRIBUTIONS WITH MONOTONE

A METHOD OF SAMPLING WITH PROBABILITY EXACTLY PROPORTIONAL TO SIZE ESCAPE PROBABILITY FOR A HALF LINE

RATIOS AND OF THEIR RECIPROCALS THE NORMAL PROBABILITY FUNCTION, AMS $62 \quad 169$ AMS $63 \quad 480$ BIOKA61 175 AMS $68 \quad 890$ BI0CS65 $9 B 6$ AMS 6B 547 AMS $6 B \quad 1354$ AMS $69 \quad 905$ BIOKA59 229 BIOKA69 NO.3 JRSSB64 286 JRSSB66 143

THE SASJ $67 \quad 49$ SASJ $69 \quad 27$ 8I0KA66 121 BIOKA54 553 AMS $61 \quad 619$ BIOKA63 95 AMS $63 \quad 375$ 236 AMS 641351 APPROXIMATION TO THE CHI-SQUARE AND NON-CENTRAL F PROBABILITY FUNCTIONS INPUT-OUTPUT STREAMS SOME APPLICATONS SOME APPLICATIONS OF PROBABILITY GENERATING FUNCTION
TIMATORS WITH UNEQUAL PROBABILITY IN SAMPLE SURVEYS

$$
\text { USE OF DOMAIN ESTIMATORS WITH UNEQUAL PROBABILITY IN SAMPLE SURVEYS }
$$
PROBABILITY INEQUALITIES FOR SUMS OF BOUNDED RANDOM PROBABILITY INEQUALITIES FOR THE SUM OF INDEPENDENT BOUNDED RANDOM VA/ UPPER BOUNDS ON THE MOMENTS AND PROBABILITY INEQUALITIES FOR THE SUM OF INDEPENDENT, BOUNDED RANDOM VARIABLES E UNIVARIATE POPULATION

H MONOTONE DENSITY RATIOS

A MULTIVARIATE ANALOGUE OF/ A NEW ASYMPTOTIC

A ONE-SIDED PROBABILITY INEQUALITY FOR THE SUM OF INDEPENDENT, UPPER AND LOWER PROBABILITY INFERENCES BASED ON A SAMPLE FROM A FINIT BIOKAG7 UPPER AND LOWER PROBABILITY INFERENCES FOR FAMILIES OF HYPOTHESES WIT AMS 69 APPROXIMATIONS TO THE PROBABILITY INTEGRAL AND CERTAIN PERCENTAGE POINTS OF BIOKA55 JRSSB 62 EXPANSION FOR THE NORMAL PROBABILITY INTEGRAL AND MILL'S RATIO THE MILLS RATIO AND THE PROBABILITY INTEGRAL FOR A PEARSON TYPE IV DISTRIBUTI A NOTE ON THE PROBABILITY INTEGRAL OF THE CORRELATION COEFFICIENT APPROXIMATIONS TO THE PROBABILITY INTEGRAL OF THE DISTRIBUTION OF RANGE BIOKA54 278 BIOKA52 417 ALL VALUES OF THE SHAPE P/ AN APPROXIMATION TO THE PROBABILITY INTEGRAL OF THE GAMMA DISTRIBUTION FOR SM BIOKA62 276 ON ON THE EVALUATTON OF THE PROBABILITY INTEGRAL OF THE MULTIVARIATE T DISTRIBUTI BIOKAGI PROXIMATE FORMULAE FOR THE PERCENTAGE POINTS AND THE PROBABILITY INTEGRAL OF THE NON-CENTRAL CHI-SQUARE DI B ON THE PROBABILITY INTEGRAL TRANSFORMATION BIOKA54 538 GIVEN MULTIVARIATE T
TABLE OF THE BOUNDS OF THE PROBABILITY INTEGRAL WHEN THE FIRST FOUR MOMENTS ARE PROBABILITY INTEGRALS OF MULTIVARIATE NORMAL AND BIOKA59 48I 
VE DISTRIBUTION FOR SAMPL/ COMPACT TABLE OF TWELVE PROBABILITY LEVELS OF THE SYMMETRIC BINOMIAL CUMULATI JASA 59 I64 $1549)$ BLE OF TWELVE PROBABILITY LEVELS OF THE SYMMETRIC BINOMIAL CUMUL
SMALL SAMPLE PROBABILITY LIMITS FOR THE RANGE CHART (CORR. 68 $\begin{array}{rrr}\text { JASA } & 59 & 164 \\ \text { JASA } & 67 & 1488\end{array}$ CONDIT $\begin{array}{rrr}\text { JASA } & 67 & 1488 \\ \text { AMS } & 67 & 780\end{array}$ $\begin{array}{llll}\text { SUFFICIENT } & \text { AMS } & 67 & 780 \\ & \text { AMS } & 69 & 381\end{array}$ DISTINGUISHABILITY OF PROBABILITY MEASURES DISTANCES OF PROBABILITY MEASURES AND RANDOM VARIABLES

PROBABILITIES PERFECT PROBABILITY MEASURES AND REGULAR CONDITIONAL AMS 6B 1563 AMS $66 \quad 1273$ AMS 64550 SOME STRUCTURE THEOREMS FOR STATIONARY PROBABILITY MEASURES ON FINITE STATE SEQUENCES PROBABILITY MEASURES ON PRODUCT SPACES

THE EXISTENCE OF PROBABILITY MEASURES WITH GIVEN MARGINALS

SASJ $67 \quad 3$

AMS $65 \quad 423$

SYSTEM OF EQUATIONS

AN A POSTERIORI PROBABILITY METHOD FOR SOLVING AN OVERDETERMINED TECH $66 \quad 675$

MULTIVARIATE LOGARITHMIC SERIES DISTRIBUTION AS A PROBABILITY MODEL IN POPULATION AND COMMUNITY ECOLOGY JASA 67 655 BIRTHS PER COUPLE PROBABILITY MODELS FOR THE VARIATION IN THE NUMBER OF

SOME METHODS OF PROBABILITY NON-REPLACEMENT SAMPLING

BIOKA67 167

BIOKA65 323

VARIABLES

CAPS.

TESTS THE PROBABILITY OF COVERTNG A SPHERE WITH N CIRCULAR

ESTIMATION OF THE PROBABILITY OF DEFECTIVE FAILURE FROM DESTRUCTIVE TECH $63 \quad 459$

FOR SUMS OF BOUNDED, INDEPENDENT RANDOM VA/ MEANS ON THE PROBABILITY OF LARGE DEVIATIONS AND EXACT SLOPES

AMS $61 \quad 577$ ON THE PROBABILITY OF LARGE DEVIATIONS FROM THE EXPECTATION B BOKA ON THE PROBABILITY OF LARGE DEVIATIONS OF FAMILIES OF SAMPLE AMS 641304 ON THE PROBABILITY OF LARGE DEVIATIONS OF FUNCTIONS OF SEVER AMS $67 \quad 360$ AL EMPIRICAL CUMULATIVE DISTRIBUTION FUNCT/ $M$ VARIABLES IN AN INTERVAL OF LENGTH ONE ON THE PROBABILITY OF LARGE DEVIATIONS OF THE MEAN FOR RANDO AMS 65 2BO SED METHOD OF OBTAINING CONFIDENCE INTERVALS FOR THE PROBABILITY OF MISCLASSIFICATION IN DISCRIMINANT ANAL BIOCS67 639 TED RANDOMLY EXCEPT FOR 'EXOGAM/A FORMULA FOR THE PROBABILITY OF OBTAINING A TREE FROM A GRAPH CONSTRUC A HERITABILITY URE, WHEN DATA ARE INCOMPLETE NT PROBABILITY OF OBTAINING NEGATIVE ESTIMATES OF PROCEDURES TOTAL PROBABILITY OF THE UNOBSERVED OUTCOMES OF AN EXPERIME AMS $68 \quad 256$ $\begin{array}{lllllr} & \text { ON THE PROBABILITY OF WINNING WITH DIFFERENT TOURNAMENT } & \text { JASA } & 63 & 1064 \\ \text { ESTIMATION } & \text { OF THE PROBABILITY OF ZERO FAILURES IN M BINOMIAL TRIALS } & \text { JASA } & 67 & 272\end{array}$ WEAK QUALITATIVE PROBABILITY ON FINITE SETS CONDITIONAL PROBABILITY ON SIGMA-COMPLETE BOOLEAN ALGEBRAS AMS 69970 CONVERGENCE PROPERTIES OF CONVERGENCE WITH PROBABILITY ONE TIO TESTS BASE/ GENERAL PROOF OF TERMINATION WITH PROBABILITY ONE OF INVARIANT SEQUENTIAL PROBABILITY R CONDITIONAL PROBABILITY OPERATORS

AMS 66 1B00 AMS $67 \quad 8$ AMS $62 \quad 634$ ON THE CHOICE OF PLOTTING POSITIONS ON PROBABILITY PAPER PROBABILITY PLOTS FOR THE GAMMA DISTRIBUTION TECH 62 PROBABILITY PLOTTING METHODS FOR THE ANALYSIS OF DATA BIOKA68 ON CONFIDENCE POINTS AND BAYESIAN PROBABILITY POINTS IN THE CASE OF SEVERAL PARAMETERS JRSSB65 SAMPLING WITHOUT REPLACEMENT WITH PROBABILITY PROPORTIONAL TO SIZE ELLEGI'S METHOD OF SAMPLING WITHOUT REPLACEMENT WITH PROBABILITY PROPORTIONAL TO SIZE A NOTE ON A BIASED ESTIMATOR IN SAMPLING WITH PROBABILITY PROPORTIONAL TO SIZE WITH REPLACEMENT ON SAMPLING OVER TWO OCCASIONS WITH PROBABILITY PROPORTIONATE TO SIZE

ESTIMATION IN RANDOMTZED SYSTEMATIC SAMPLING WITH PROBABILITY PROPORTIONATE TO SIZE SURVEY ESTIMATION THE USE OF SYSTEMATIC SAMPLING WITH PROBABIT VARIANCE $J$ JRSSB58 393 ASA $67 \quad 79$ AMS 661045 AMS $65 \quad 327$ JASA $65 \quad 278$ JASA $64 \quad 251$ AMS 64900 JASA $58 \quad 1 B 7$ AMS 651753 AMS $66 \quad 726$ BIOKA60 103 JRSSB $60 \quad 360$

REMARK ON THE OPTIMUM CHARACTER OF THE SEQUENTIAL PROBABILITY RATIO TEST THE MOST ECONOMICAL BINOMIAL SEQUENTIAL PROBABILITY RATIO TEST BOUNDS FOR THE EXPECTED SAMPLE SIZE IN A SEQUENTIAL PROBABILITY RATIO TEST LIMITING RELATIVE EFFICIENCY OF THE WALD SEQUENTIAL PROBABILITY RATIO TEST ERATING CHARACTERISTIC CURVE FOR THE WALD SEQUENTIAL PROBABILITY RATIO TEST 671309 STOPPING TIME OF A RANK-ORDER SEQUENTIAL PROBABILITY RATIO TEST ON LEHMANN ALTERNATIVES, CORR. ON THE PERFORMANCE OF THE TRUNCATED SEQUENTIAL PROBABILITY RATIO TEST, CORR. 661247 EXISTENCE, UNIQUENESS AND MONOTONICITY OF SEQUENTIAL PROBABILITY RATIO TESTS ON THE OPTIMALITY OF SEQUENTIAL PROBABILITY RATIO TESTS

SIZE AND SIMPLIFICATION OF A CLASS OF SEQUENTIAL PROBABILITY RATIO TESTS COMPLETENESS OF THE CLASS OF GENERALIZED SEQUENTIAL PROBABILITY RATIO TESTS OF THE DISTRIBUTION OF SAMPLE NUMBER IN SEQUENTIAL PROBABILITY RATIO TESTS IZE DISTRIBUTION FOR A CLASS OF INVARIANT SEQUENTIAL PROBABILITY RATIO TESTS IES OF ESTIMATORS AND VARIANCE ESTIMATORS IN UNEQUAL PROBABILITY SAMPLING OF TWO UNITS PROBABILITY SAMPLING WITH QUOTAS

ON THREE PROCEDURES OF UNEQUAL PROBABILITY SAMPLING WITHOUT REPLACEMENT ON A SIMPLE PROCEDURE OF UNEQUAL PROBABILITY SAMPLING WITHOUT REPLACEMENT ON QUALITATIVE PROBABILITY SIGMA-ALGEBRAS

THEORY OF EXPERIMENT, OPERATIONAL DEFINITION OF THE PROBABILITY SPACE

A PROBABILITY STRUCTURE FOR GROWTH CURVES

PROBABILITY TABLE FOR NUMBER OF RUNS OF SIGNS OF PROBABILITY TABLES FOR THE EXTREMAL QUOTIENT

FIRST DIFFERENCES IN ORDERED SERIES

THE EQUAL PROBABILITY TEST AND ITS APPLICATIONS TO
THE PROBABILITY THAT A RANDOM GAME IS UNFAIR THE PROBABILITY THAT A RANDOM TRIANGLE IS OBTUSE

AMS $63 \quad 18$ $\begin{array}{rrrr}\text { THE ESSENTIAL AMS } & 61 & 602 \\ \text { A NOTE ON THE VARIANCE TECH } & 66 & 700\end{array}$ $\begin{array}{llrr}\text { NOTE ON THE VARIANCE TECH } & 66 & 700 \\ \text { BOUNDS ON THE SAMPLE S AMS } 6 B & 1048\end{array}$ NEOUS INFERENCE PROBLEMS /ILIT JASA 69540 JASA $66 \quad 749$ JASA $63 \quad 202$ JRSSB $62 \quad 4 B 2$ AMS 64 17B7 THE AMS $67 \quad 401$ BI0CS67 217 JASA $61 \quad 156$ AMS $67 \quad 1541$ IED CLASS S BETWEEN TWO PARALLEL STRAIGHT LINES ESTIMATION OF THE PROBABILITY THAT AN OBSERVATION WILL FALL IN A SPECIF JASA 64225 THE PROBABILITY THAT THE SAMPLE DISTRIBUTION FUNCTION LIE AMS 68 39B ER CONFIDENCE BOUNDS. AND CONFIDENCE LIMTTS, FOR THE PROBABILITY THAT Y IS LESS THAN $X$, WHEN $X$ AND Y ARE N JASA G4 APPLICATIONS OF PROBABILITY THEORY IN CRIMINALISTICS APPLICATIONS OF PROBABILITY THEORY IN CRIMINALISTICS, II JASA 651028

N) PROBLEMS IN THE PROBABILITY THEORY OF STORAGE SYSTEMS (WITH DISCUSSIO JRSSB57 181 MATRICES RIGHT HAAR MEASURE FOR CONVERGENCE IN PROBABILITY TO QUASI POSTERIOR DISTRIBUTIONS ON THE FIXED POINT PROBABILITY VECTOR OF REGULAR OR ERGODIC TRANSITION JASA $67 \quad 600$ MINIMAX ESTIMATION OF A RANDOM PROBABILITY WHOSE FIRST N MOMENTS ARE KNOWN EXAMPLES BEARING ON THE DEFINITION OF FIDUCIAL PROBABILITY WITH A BIBLIOGRAPHY AMS $68 \quad 492$ AMS 621349 TICS. I. DICING AND GAMING (A NOTE ON THE HISTORY OF PROBABILITY)/THE HISTORY OF PROBABILITY AND STATIS BIOKA55 CONSUMER BUYING INTENTIONS AND PURCHASE PROBABILITY, AN EXPERIMENT IN SURVEY DESIGN 
EFFECTS OF BIAS ON ESTIMATES OF THE CIRCULAR PROBABLE ERROR SOME MORE ESTIMATES OF CIRCULAR PROBABLE ERROR COMPARISON OF ESTIMATES OF CIRCULAR PROBABLE ERROR, CORR. 60755 OF MAXIMUM LIKELIHOOD AND THE METHOD OF MOMENTS IN PROBIT ANALYSIS RELIABILITY OF A SIMPLE SYSTEM THE CENERALIZATION OF PROBIT ANALYSIS TO THE CASE OF MULTIPLE RESPONSES PTOTIC POWER OF TESTS OF LINEAR HYPOTHESES USINC THE PROBIT AND LOCIT TRANSFORMATIONS, CORR. 64 1297 CONTROLS WEICHTED PROBITS ALLOWINC FOR A NON-ZERO RESPONSE IN THE

RANDOMIZATION TESTS FOR A MULTIVARIATE TWO-SAMPLE PROBLEM A RANDOM INTERVAL FILLINC PROBLEM CONTRIBUTIONS TO THE 'TWO-ARMED BANDIT' PROBLEM NOTE ON A SEQUENTIAL CLASSIFICATION PROBLEM INFERENCE IN AN AUTHORSHIP PROBLEM OPTIMAL INVARIANT RANK TESTS FOR THE K-SAMPLE PROBLEM ASYMPTOTIC DISTRIBUTORS FOR THE COUPON COLLECTOR'S PROBLEM ON ANALYSIS OF VARIANGE FOR THE K-SAMPLE PROBLEM AN INVESTICATION OF THE BURN-IN PROBLEM

A SEQUENTIAL ANALOQUE OF THE BEHRENS-FISHER PROBLEM ON A QUICKEST DETECTION PROBLEM THE CENERALIZED VARIANCE, TESTINC AND RANKINC PROBLEM THE AGE REPLACEMENT PROBLEM A TREE COUNTINC PROBLEM ON AN EXTENDED COMPOUND DECISION PROBLEM A BAYES RULE FOR THE SYMMETRIC MULTIPLE COMPARISONS PROBLEM A NOTE ON THE DESIGN PROBLEM

FURTHER CRITICAL VALUES FOR THE TWO-MEANS PROBLEM ESTIMATION OF A PARAMETER IN THE GLASSICAL OCCUPANCY PROBLEM MULTIVARIATE T AND THE RANKING PROBLEM

A NOTE ON A SEQUENTIAL OCCUPANCY PROBLEM A THREE-DIMENSIONAL CLUSTER PROBLEM A FIYED SUBSET-SIZE APPROACH TO THE SELECTION PROBLEM NOTE ON A CALIBRATION PROBLEM

THE LINDISFARNE SCRIBES' PROBLEM THE TWO-PACK MATCHING PROBLEM

ON SIMPLE RULES FOR THE COMPOUND DECISION PROBLEM A NOTE ON AN ALLOCATION PROBLEM A MULTIVARIATE PALEONTOLOGICAL CROWTH PROBLEM REMARKS ON SCHEFFE'S SOLUTION TO THE BEHRENS-FISHER PROBLEM SAMPLE POWER CURVES FOR THE TWO SAMPLE LOCATION PROBLEM RENEWAL THEOREMS WITH APPLICATION TO A FIRST PASSAGE PROBLEM AND ASYMPTOTICALLY MINIMAX TESTS OF A MULTIVARIATE PROBLEM HODGES AND LEHMANN SHIFT ESTIMATOR IN THE TWO SAMPLE PROBLEM SOLUTIONS OF THE SEQUENTIAL COMPOUND DECISION PROBLEM

DISTRIBUTION FOR A GENERALIZED BANACH MATCH BOX PROBLEM

OF SOME PROCEDURES FOR THE TWO-SAMPLE LOCATION PROBLEM

WILCOXON STATISTIC FOR A GENERALIZED BEHRENS-FISHER PROBLEM STATISTICAL AND TIME AVERAGES IN A REGULATION PROBLEM

DURATION OF A BALL AND CELL GAME, A FIRST PASSAGE PROBLEM RECIONAL FORECASTS FOR THE OUTCOME OF AN ESTIMATION PROBLEM

SOLUTION OF A TWO-DIMENSIONAL UNSTRUCTURED CLUSTER PROBLEM OF SOME SEQUENTIAL PROCEDURES FOR A RANKING PROBLEM TEST FOR THE BIVARIATE TWO-SAMPLE LOCATION PROBLEM

OF BOOK USE AND ITS APPLICATION TO THE BOOK STORAGE PROBLEM OF PREASSICNED LENGTH FOR THE BEHRENS-FISHER PROBLEM

ESTIMATES FOR SHIFT IN THE P-VARIATE ONE SAMPLE PROBLEM OF A POLYNOMIAL RECRESSION AS A MULTIPLE DECISION PROBLEM FREEDOM SOLUTION TO THE MULTIVARIATE BEHRENS-FISHER PROBLEM A NON-PARAMETRIC TEST FOR THE BIVARIATE TWO-SAMPLE PROBLEM

PARAMETERS WITH AN APPLICATION TO A RELIABILITY PROBLEM

TWO TEST STATISTICS ASSOCIATED WITH THE TWO-SAMPLE PROBLEM TWO TEST PROCEDURES PROPOSED FOR THE BEHRENS-FISHER PROBLEM DECISION RULES FOR THE SEQUENTIAL COMPOUND DECISION PROBLEM ESTS AND THEIR APPLICATION TO AN ACCEPTANCE SAMPLINC PROBLEM

TO TESTING OF HYPOTHESES AND THE COMPOUND DECISION PROBLEM AMPLE SIZES OF TWO SEQUENTIAL PROCEDURES FOR RANKINC PROBLEM THE GENERAL BULK QUEUE AS A HILBERT PROBLEM

A CONTRT BUTION

THE TWO MEANS PROBLDU A S PROBABILITY

A CENERALIZATION OF THE BALLOT PROBLEM AND ITS APPLICATION IN THE THEORY OF QUEUES BAYES RULES FOR A COMMON MULTIPLE COMPARISONS PROBLEM AND RELATED STUDENT-T PROBLEMS A CONFIDENCE INTERVAL COMPARISON OF JASA $66 \quad 454$ SEOUENTTAL CHI-SQUARE AND T-SQUARE T TECH 61906

ON THE SMOOTH EMPIRICAL BAYES APPROACH BIOKA68 83 A COMPARISON OF THE ASYMPTOTIC EXPECTED S AMS 69 NO.6 A STATISTICAL MODEL JASA 69 NO CONFIDENCE INTERVAL AMS $67 \quad 1175$ ON SOME ALTERNATIVE AMS 641079 THE CHOICE OF THE DEGREE AMS 62255 AN APPROXIMATE DEGREES OF BIOKA65 139 ON THE NULL DISTRIBUTION OF JRSSB69 98 SOME INFERENCES ABOUT CAMMA JASA 63670 THE ASYMPTOTTC NORMALTTY OF AMS SMALL TECH 69299 SOME AMS $66 \quad 699$ LOCALLY AMS $68 \quad 171$ $\begin{array}{lll}0 M & 1814\end{array}$ ASYMPTOTIC JASA $67 \quad 1252$ USE OF THE AMS 63 1596 CONSIDERING JRSSB67 475 ON THE MEAN AMS $66 \quad 517$ PRELIMINARY JASA 631104 A MONTE CARLO BIOKA67 625 THE PERFORMANCE AMS $68 \quad 1040$ A NON-PARAMETRIC JRSSB67 320 THE HAUSA PROBLEM AND SOME APPROXIMATIONS TO THE REQUIRED A PROBLEM CONCERNED WITH WEIGHTINC OF DISTRIBUTIONS ON A COINCIDENCE PROBLEM CONCERNING PARTICLE COUNTERS

ON A PROBLEM CONNECTED WITH QUADRATIC REGRESSION

ON A DISCRIMINATORY PROBLEM CONNECTED WITH THE WORKS OF PLATO BAYES SOLUTION OF SEQUENTIAL DECISION PROBLEM FOR MARKOV DEPENDENT OBSERVATIONS A FIRST PASSAGE PROBLEM FOR THE WIENER PROCESS

RATES OF CONVERCENCE IN THE COMPOUND DECISION PROBLEM FOR TWO COMPLETELY SPECIFIED DISTRIBUTIONS ON THE LIKELIHOOD
GRESSION ANALYSIS RATIO TEST OF A NORMAL MULTIVARIATE TESTING PROBLEM II A NOTE ON A SERIES SOLUTION OF A PROBLEM IN ESTIMATION A NOTE ON A PROBLEM IN ESTIMATION A PROBLEM IN LIFE TESTING A PROBLEM IN MINIMAX VARIANCE POLYNOMIAL EXTRAPOLATION AN ESTTMATTON PROBLEM IN QUANTITATIVE ASSAY ON AN APPLICATION OF FOUR MOMENT INEQUALITIES TO A PROBLEM IN QUEUES JRSSB62 344 JRSSB55 185 BIOKA67 B5 JASA $62 \quad 327$ AMS $61 \quad 1013$ BIOKA63 514 JASA 61281 AMS $61 \quad 739$ BIOKA60 335 JRSSB59 195 AMS 641656 AMS 671912 AMS 651743 AMS 651061 TECH $62 \quad 426$ BIOKA58 565 BIOKA62 553 JASA $57 \quad 350$ $\begin{array}{rrr}\text { JASA } & 57 & 350 \\ \text { AMS } & 66 & 898\end{array}$

BIOKA54 338 NOTE TECH $65 \quad 435$ 
VARIATE NORMAL DISTRIBUTION TO A STRESS VS. STRENCTH PROBLEM IN RELIABILITY ANALYSIS /ICATIONS OF THE BI TECH 64 325 A PERSISTENCE PROBLEM IN RENEWAL THEORY, ROBERT THE BRUCE'S SPIDER BIOKA66 255 AN ENUMERATION PROBLEM IN SELF-STERILITY $\quad$ BIOCS69 39 A PROBLEM IN SURVIVAL AMS 61605 $\begin{array}{llrl}\text { A PROBLEM IN THE COMBINATION OF ACCIDENT FREQUENCIES RIOKA58 } & 331\end{array}$ CRAPHICAL NOTE FOR T. BAYES' ESSAY TOWARDS SOLVINC A PROBLEM IN THE DOCTRINE OF CHANCES. /STICS. IX. BIO BIOKA58 293 PHIL. TRANS. ROY. SOC. 17/ ESSAY TOWARDS SOLVING A PROBLEM IN THE DOCTRINE OF CHANCES. (REPRODUCED FROM BIOKA58 296 ARAMETRIC TEST FOR THE BIVARIATE TWO-SAMPLE LOCATION PROBLEM IN THE NORMAL CASE /SAMPLE POWER OF A NON-P JRSSB68 83 BUTIONS IS BASED ON SAMPLES A CLASSIFICATION PROBLEM IN WHICH INFORMATION ABOUT ALTERNATIVE DISTRI AMS 62 213 ARE SCHEDULED Q QUEUEINC PROBLEM IN WHICH THE ARRIVAL TIMES OF
SSIBILITY OF A RANDOMIZED SYMMETRICAL DESICN FOR THE PROBLEM OF A ONE WAY CLASSIFICATION CUSTOMERS JRSSB 60 10B CN FOR THE PROBLEM OF A ONE WAY CLASSIFICATION ON THE ADMI ON THE RUIN PROBLEM OF COLLECTIVE RISK THEORY A PROBLEM OF DELAYED SERVICE, I A PROBLEM OF DELAYED SERVICE, THE MAXIMUM LIKELIHOOD SOLUTION TO THE PROBLEM OF ESTIMATINC A LINEAR FUNCTIONAL RELATIONSHI JR NOTE ON A PROBLEM OF ESTIMATION DISTRIBUTION ON THE PROBLEM OF ESTIMATION FOR THE BIVARIATE LOGNORMAL SIMULATION EXPERIMENTS WITH ECONOMIC SYSTEMS. THE PROBLEM OF EXPERIMENTAL DESIGN COMPUTER PPLICATION OF MINIMUM LOGIT CHI-SQUARE ESTIMATE TO A PROBLEM OF GRIZZLE WITH A NOTATION ON THE PROBLEM OF
A PROBLEM OF INTERFERENCE BETWEEN TWO QUEUES A PROBLEM OF INTERFERENCE BETWEEN TWO QUEUES

A SOLUTION TO THE PROBLEM OF LINKING MULTIVARIATE DOCUMENTS ON THE PROBLEM OF MATCHINC LISTS BY SAMPLES AMS $69 \quad 356$ AMS $61 \quad 757$ JRSSB $60 \quad 270$ RSSB69 NO.2 BIOKA64 522 ASA 671315 BIOCS6B 75 BIOKA53 58 JASA $69 \quad 163$ JASA 59403 THE PROBLEM OF NEGATIVE ESTIMATES OF VARIANCE COMPONENTS AMS $62 \quad 273$ ANALYSES BY MULTIPLE ISOTOPE DILUTION A PROBLEM OF OPTIMUM ALLOCATION ARISING IN CHEMICAL ON A PROBLEM OF REGRESSION ON THE PROBLEM OF SELF-INCOMPATABILITY ALLELES

A NONPARAMETRIC TEST FOR THE PROBLEM OF SEVERAL SAMPLES THE RANDOMIZATION BASES OF THE PROBLEM OF THE AMALGAMATION OF WEICHTED MEANS STATISTICS, VI. A NOTE ON THE EARLY SOLUTIONS OF THE PROBLEM OF THE DURATION OF PLAY/F PROBABILITY AND A HYBRID PROBLEM ON THE EXPONENTIAL FAMILY

TECH 61509 SASJ $67 \quad 43$ BIOCS66 111 AMS 611108 JRSSB61 423 BIOKA57 515 AMS 651185

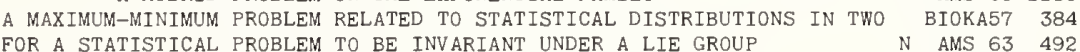
DIMENSIONS ECESSARY AND SUFFICIENT CONDITIONS FOR A STATISTICAL PROBLEM TO BE INVARIANT UNDER A LIE GROUP THE TWO-SAMPLE SCALE PROBLEM WHEN LOCATIONS ARE UNKNOWN AMS 651236

AN ELEMENTARY METHOD OF SOLUTION OF THE QUEUEING PROBLEM WITH A SINCLE SERVER AND CONSTANT PARAMETERS A RENEWAL PROBLEM WITH BULK ORDERING OF COMPONENTS

OTICALLY MOST POWERFUL RANK TESTS FOR THE TWO-SAMPLE PROBLEM WITH CENSORED DATA

ON BAYES PROCEDURES FOR A PROBLEM WITH CHOICE OF OBSERVATIONS THE GAMBLER'S RUIN PROBLEM WITH CORRELATION

THE ROBBINS-ISBELL TWO-ARMED-BANDIT PROBLEM WITH FINITE MEMORY

THE COMPOUND DECISION PROBLEM WITH M-BY-N FINITE LOSS MATRIX

AN ASYMPTOTIC DISTRIBUTION FOR AN OCCUPANCY PROBLEM WITH STATISTICAL APPLICATIONS

A BULK-SERVICE QUEUEING PROBLEM WITH VARIABLE CAPACITY THE GENERAL MOMENT PROBLEM, A CEOMETRIC APPROACH

ON THE TWO SAMPLE PROBLEM, A HEURISTIC METHOD FOR CONSTRUCTINC TESTS

CONTRIBUTIONS TO THE K-SAMPLE PROBLEM, A SYMMETRIC STATISTIC

KELIHOOD RATIO TEST OF A NORMAL MULTIVARIATE TESTING PROBLEM, CORR. 641388

\author{
ON THE LI
}

STATISTICAL INFERENCE IN THE CLASSICAL OCCUPANCY PROBLEM, UNBIASED EST IMATION OF THE NUMBER OF CLASSES JA A SEMI-GRAPHICAL METHOD FOR THE ANALYSIS OF COMPLEX PROBLEMS TEAM DECISION PROBLEMS

GENERALIZED BAYES SOLUTIONS IN ESTIMATION PROBLEMS

RANDOM HAZARD IN RELIABILITY PROBLEMS THE EMPIRICAL BAYES APPROACH TO STATISTICAL DECISION PROBLEMS

A REVIEW OF THE LITERATURE ON A CLASS OF COVERAGE PROBLEMS A BAYESIAN APPROACH TO SOME BEST POPULATION PROBLEMS BOUNDS ON INTECRALS WITH APPLICATIONS TO RELIABILITY PROBLEMS AN ESTIMATION PROCEDURE FOR RANGE COMPOSITION PROBLEMS MODELS FOR CATALOGUING PROBLEMS

STRINGENT SOLUTIONS TO STATISTICAL DECISION PROBLEMS WEAK CONVERGENCE OF A SEQUENCE OF QUICKEST DETECTION PROBLEMS SOME NONPARAMETRIC TESTS FOR MULTISAMPLE PROBLEMS RESPONSE SURFACE DESIGNS FOR MIXTURE PROBLEMS AN APPROXIMATION TO THE SAMPLE SIZE IN SELECTION PROBLEMS ON THE CLASSICAL RUIN PROBLEMS SOME CIRCULAR COVERAGE PROBLEMS A BAYESIAN APPROACH TO SOME OUTLIER PROBLEMS ELIMINATION OF VARIATES IN LINEAR DISCRIMINATION PROBLEMS THE DISTRIBUTION OF SOLUTIONS IN LINEAR PROCRAMMING PROBLEMS STATISTICS AND PREDICTION OF THE LOSS IN ESTIMATION PROBLEMS FUNCTION BETWEEN COMPOSITE HYPOTHESES AND RELATED PROBLEMS

CONFIDENCE REGIONS FOR SOME MULTIVARIATE LOCATION PROBLEMS TYPE TESTS FOR SOME BEHRENS-FISHER-TYPE REGRESSION PROBLEMS CONCEPT OF A FUTURE OBSERVATION IN GOODNESS-OF-FIT PROBLEMS FICATION OF DAVIDON'S METHOD TO NONLINEAR REGRESSION PROBLEMS COVARIANCE MATRTCES IN TIME SERIES REGRESSION PROBLEMS REGULAR GENERALIZED SUBMARTINGALES IN STOPPING PROBLEMS AND ITS APPLICATIONS TO SOME SIMULTANEOUS INFERENCE PROBLEMS CONCURRENCE OF SEVERAL REGRESSION LINES AND RELATED PROBLEMS STEIN'S TYPE FOR A CLASS OF MULTIVARIATE RECRESSION PROBLEMS VARIANCE MODEL USEFULL ESPECIALLY FOR GROWTH CURVE PROBLEMS MPIRICAL BAYES APPROACH TO SOME STATISTICAL DECISION PROBLEMS STS OF THE PARAMETRIC GOODNESS OF FIT AND TWO-SAMPLE PROBLEMS ITE POPULATIONS WITH AN APPLICATION TO BULK SAMPLING PROBLEMS LY INVARIANT TESTS FOR CLASSICAL MULTIVARIATE NORMAL PROBLEMS IMENSIONAL SEARCH PROCEDURES IN NONLINEAR REGRESSION PROBLEMS 
FARM LEVEL. SOME EMPIRICAL MEASUREMENTS AND RELATED PROBLEMS DEMAND FOR FARM PRODUCTS AT RETAIL AND THE JASA 5B BACKCROUND PROBABILISTIC AND STATISTICAL MODELS AND PROBLEMS (INVITED PAPER) /ILITY TESTINC, BIOLOCICAL BIOCS69 SOME RESULTS ON INVENTORY PROBLEMS (WITH DISCUSSION) JRSSB62

APPROACH TO SOME SCREENINC AND CLASSIFTCATION PROBLEMS (WITH DISCUSSION) INFERENCE PROBLEMS ABOUT PARAMETERS WHICH ARE SUBJECTED T
SAMPLINC. PROBLEMS AND LINES OF ATTACK CHANCES OVER TIME

NS IN NORMAL VECTORS MINIMAX SOLUTION OF STATISTICAL DECISION PROBLEMS BY ITERATION

DISCUSSION) SOME STATISTICAL PROBLEMS CONNECTED WITH CRYSTAL LATTICES (WITH JRSSB64 36 HE PRODUCT OF A WISHART VARIATE/ SOME DISTRIBUTION PROBLEMS CONNECTED WITH THE CHARACTERISTIC ROOTS OF T AMS $66 \quad 1643$ SOME FIRST PASSAGE PROBLEMS FOR S-SUB-N-OVER-ROOT-N MULTIPARAMETER PROBLEMS FROM A BAYESIAN POINT OF VIEW

TIPLE DECISION PROCEDURES BASED ON RANKS FOR CERTAIN PROBLEMS IN ANALYSIS OF VARIANCES SOME EXPERTMENTAL DESICN PROBLEMS IN ATTRIBUTE LIFE TESTING, CORR 63 116

EXPENDITURES PROBLEMS IN ESTIMATINC FEDERAL COVERNMENT

$$
\text { SOME STATISTICAL PROBLEMS IN EXPERIMENTAL PSYCHOLOCY (WITH DISCUSSION) }
$$

SOME PROBLEMS IN INTERVAL ESTIMATION (WITH DISCUSSION) JRSSB56 177 CENERALIZED INVERSE OF A MATRIX WITH APPLICATIONS TO PROBLEMS IN MATHEMATICAL STATISTICS WEALTH PROBLEMS IN MEASURING LONC TERM GROWTH IN INCOME AND JASA 57450 MEASUREMENT PROBLEMS IN MENTAL TEST THEORY ARISING FROM ERRORS OF JASA $59 \quad 472$ AMS 631270 SONE NON-CENTRAL DISTRIBUTION PROBLEMS IN MULTTVARTATE ANALYSTS AMS 69549 OF VIEW (CORR. 68 1551) HYPOTHESIS ONE SIDED PROBLEMS IN MULTIVARIATE ANALYSIS STATISTICA PROBLEMS IN SCIENCE. THE SYMMETRIC TEST OF A COMPLETE JASA 69 NO. TWO PROBLEMS IN SETS OF MEASUREMENTS

APPLICATIONS OF MEIJER-C FUNCTIONS TO DISTRIBUTION PROBLEMS IN STATISTICS BI0KA54 PROPOSAL

INTER-INDUSTRY TABLES, CORR 641299

(WITH DISCUSSION)

(WITH DISCUSSION

PROBLEMS IN THE ANALYSIS OF SURVEY DATA, AND A JASA $63 \quad 415$ POME PROBLEMS IN THE STATISTICAL ANALXSIS OF EPIDEMIC DATA JRSSB55 SOME PROBLEMS IN THE THEORY OF DAMS (WITH DISCUSSION) SOME PROBLEMS IN THE THEORY OF OPTIMAL STOPPING RULES SOME PROBLEMS IN THE THEORY OF PROVISIONINC AND OF DAMS

ON PROBLEMS IN WHICH A CHANGE IN A PARAMETER OCCURS AT

AN UNKNOWN POINT ANALYSIS MINIMUM VARIANCE UNBIASED ESTIMATION AND CERTAIN PROBLEMS OF ADDITIVE NUMBER THEORY STATISTICAL APPROAGH TO PROBLEMS OF COSMOLOGY (WITH DISCUSSION) ON SOME PROBLEMS OF MACHTNE INTERFERENCE

N. ITHE NON-CENTRAL WISHART DISTRIBUTION AND CERTAIN PROBLEMS OF MULTIVARTATE STATISTICS ' 46 409 EXPLICIT SOLUTIONS TO SOME PROBLEMS OF OPTIMAL STOPPINC

SOME PROBLEMS OF OPTIMAL STOPPING

SOME PROBLEMS OF OPTIMUM SAMPLING PROBLEMS OF SAMPLE ALLOCATION AND ESTIMATION IN AN

ACRICULTURAL SURVEY SOME MODEL I PROBLEMS OF SELECTION PROBLEMS OF SELECTION WITH RESTRICTIONS TREATMENT OF CONTINCENCY, GOODNESS OF FIT AND OTHER PROBLEMS OF SICNIFICANCE CHAINS SOME PROBLEMS OF STATISTIGAL INFERENCE IN ABSORBING MARKOV IAL REFERENCE TO THE CIGARETTE SMOKINC AND LUNC C/ PROBLEMS OF STATISTICAL INFERENCE IN HEALTH WITH SPEC JA NATIONAL HEALTH SURVEY SOME PROBLEMS OF STATISTICAL PREDICTION SOME PROBLEMS OF THE HOUSEHOLD INTERVIEW DESIGN FOR THE MINIMAX RISK AND UNBIASEDNESS FOR MULTIPLE DECISION PROBLEMS OF TYPE I ON LINEAR ESTIMATION FOR REGRESSION PROBLEMS ON TIME SERIES

L' 53239 CORRECTION TO 'ON A CLASS OF PROBLEMS RELATED TO THE RANDOM DIVISION OF AN INTERVA DECISION PROCEDURES FOR FINITE DECISION PROBLEMS UNDER COMPLETE ICNORANCE

NOTE ON DECISION PROCEDURES FOR FINITE DECISION PROBLEMS UNDER GOMPLETE ICNORANCE PRESENT IN THE SAMPLE ESTIMATION PROBLEMS WHEN A SIMPLE TYPE OF HETEROGENEITY IS JRSSB57 207 AMS 671627 BIOKA55 179 BIOKA57 248 BIOKA59 49 AMS 631050 JRSSB58 I JRSSB59 106 AMS 64923 AMS $69 \quad 993$ JRSSB68 108 BIOKA54 420 JRSSB54 223 AMS 61990 JRSSB 62401 BIOKA65 127 JASA $69 \quad 739$ BIOKA65 469 JASA $59 \quad 69$ AMS 691684 AMS $62 \quad 1077$ AMS $62 \quad 812$ AMS 641644 AMS $65 \quad 691$ BIOKA51 90 REGRESSION PROBLEMS WHEN THE PREDICTOR VARIABLES ARE PROPORTIONS JRSSB69 107 ND THE PRECISIO/ OPTIMAL SAMPLE SIZE IN TWO-ACTION PROBLEMS WHEN THE SAMPLE OBSERVATIONS ARE LOGNORMAL A JASA 68 653 OPTIMAL DESIGNS IN REGRESSION PROBLEMS WITH A GENERAL CONVEX LOSS FUNCTION DESIGNS FOR RECRESSION PROBLEMS WITH CORRELATED ERRORS DESIGNS FOR REGRESSION PROBLEMS WITH CORRELATED ERRORS MANY PARAMETERS AMS 66 (66 AMS 68 68 BIOKA67 668 JASA 69 NO 4 ON THE CHOICE OF VARIABLES IN CLASSIFICATION PROBLEMS WITH DICHOTOMOUS VARIABLES TWO-STACE NORMAL SAMPLINC IN TWO-ACTION PROBLEMS WITH LINEAR ECONOMICS ANDOM VARIABLES. SEQUENTIAL SAMPLINC, TWO DECISION PROBLEMS WITH LINEAR LOSSES FOR BINOMIAL AND NORMAL R BIOKA65 507 THE SEQUENTIAL COMPOUND DECISION PROBLEMS WITH M-BY-N FINITE LOSS MATRIX AMS 66 954 T STRINGENT SOMEWHERE MOST POWERFUL TEST FOR CERTAIN PROBLEMS WITH RESTRICTED ALTERNATIVE /T AND THE MOS AMS 68 53I ILITY OF THE USUAL ESTIMATORS OF SCALE PARAMETERS IN PROBLEMS WITH UNKNOWN LOCATION AND SCALE PARAMETERS AMS 68 29 D THE TRANSLATION METHOD, DESCRIPTION AND ESTIMATION PROBLEMS, CORR. 63 II63/LOCNORMAL DISTRIBUTION AN JASA 63 231 OPTIMUM DESIGNS IN REGRESSION PROBLEMS. II A BAYESIAN INDIFFERENCE PROCEDURE

ON CONVERGENCE OF THE KIEFER-WOLFOWITZ APPROXIMATION PROCEDURE AN EXTENSION OF THE ROBBINS-MONRO PROCEDURE A SEQUENTIAL SEARCH PROCEDURE AN EXTENSION OF PAULSON'S SELECTION PROCEDURE ON THE POWER OF THE BLUS PROCEDURE

BOUNDS IN A MINIMAX CLASSIFICATION PROCEDURE A SIMPLE RANDOMIZATION PROCEDURE

A SIMPLIFIED MONTE CARLO SICNIFICANCE TEST PROCEDURE

NOTES. A DEFICIENCY IN THE SUMMATION OF CHI PROCEDURE ON THE MAXIMUM SAMPLE SIZE OF A BAYES SEQUENTTAL PROCEDURE SAMPLE SIZE AND COVERAGE FOR THE JIRINA SEQUENTIAL PROCEDURE ON ZEROS AND TIES IN THE WILCOXON SIGNED RANK PROCEDURE AMS 61298 JASA $65 \quad 1104$ AMS 671031 AMS $67 \quad 181$ AMS $67 \quad 494$ AMS 682067 JASA $68 \quad 1227$ BIOKA65 653 JRSSB62 472 JRSSB68 582 BIOC\$66 407 BOUNDS AMS $65 \quad 859$ ON THE AMS $63 \quad 847$ REMARKS JASA 59655 
RANK TESTS I. MONTE CARLO STUDIES OF THE TWO-SAMPLE PROCEDURE

A KNOWN COEFFICIENT OF VARIATION IN THE ESTIMATION PROCEDURE AND RANKINC, OPTIMUM PROPERTIES OF THE ROW SUM PROCEDURE DEGREE OF FREEDOM, EXTENSIONS OF THE MANTEL-HAENSZEL PROCEOURE A MULTIPLE COMPARISON RANK PROCEOURE A ONE-WAY ANALYSIS OF VARIANCE A SIMPLIFICATION OF THE BLUS PROCEDURE FOR ANALYZINC RECRESSION OISTURBANCES A PROCEDURE FOR AUTOMATIC OATA EDITING

SEQUENTIAL SAMPLINC

SEQUENTIAL SAMPLING

A MINIMAX PROCEDURE FOR CHOOSING BETWEEN TWO POPULATIONS USINC A MINIMAX-RECRET PROCEDURE FOR CHOOSINC BETWEEN TWO POPULATIONS USING

THE UNKNOWN MEAN OF A NORM/ ES WITH A STANDARD OR CONTROL SEQUENTIAL DECISION PROCEDURE FOR CHOOSINC ONE OF K HYPOTHESES CONCERNING A SEQUENTIAL PROCEOURE FOR COMPARING SEVERAL EXPERIMENTAL CATECORI ES WI/ AN ASYMPTOTICALLY OPTIMAL FIXED SAMPLE SIZE PROCEDURE FOR COMPARING SEVERAL EXPERIMENTAL CATECORI CORR. 59811

A PROCEDURE FOR COMPUTING REGRESSION COEFFICIENTS

A PROCEOURE FOR CONSTRUCTINC INCOMPLETE BLOCK DESICNS

THE AVERACE SAMPLE RUN LENCTH OF A CUMUL/A SIMPLE PROCEDURE FOR DETERMINING UPPER AND LOWER LIMITS FOR J OMPONENTS IN MIXED MODEL SITUATIONS

IN MIXED MODEL SITUATIONS AN ITERATIVE PROCEDURE FOR ESTIMATING FIXED EF
ON THE ASYMPTOTIC EFFICIENCY OF A SEQUENTIAL PROCEDURE FOR ESTIMATING THE MEAN

POINTS

GRAPHICAL PROCEDURE FOR FITTING THE BEST LINE TO A SET OF

A SEQUENTIAL SEARCH PROCEDURE FOR LOCATING A RESPONSE JUMP A SAMPLING PROCEDURE FOR MAILED QUESTIONNAIRES

AN ESTIMATION PROCEDURE FOR MIXTURES OF DISTRIBUTIONS

A CONTINUOUS KIEFER-WOLFOWITZ PROCEDURE FOR RANDOM PROCESSES, CORR 66745

AN ESTIMATION PROCEDURE FOR RANGE COMPOSITION PROBLEMS

H AN APPLICATION TO BULK/ A TWO-STAGE SUBSAMPLING PROCEDURE FOR RANKING MEANS OF FINITE POPULATIONS WIT SOME EXTENSIONS OF SOMERVILLE'S PROCEDURE FOR RANKING MEANS OF NORMAL POPULATIONS

$\begin{array}{ll}\mathrm{H} \text { A COMMON UNKNOWN/ A TWO-SAMPLE MULTIPLE DECISION PROCEDURE FOR RANKING MEANS OF NORMAL POPULATIONS WIT } \\ \text { CORR. } 611005 & \text { A NONPARAMETRIC SUM OF RANKS PROCEDURE FOR RELATIVE SPREAD IN UNPAIRED SAMPLES, }\end{array}$ CORR. 611005 A SEQUENTIAL PROCEDURE FOR SELECTINC THE LARGEST OF K MEANS

A SEQUENTIAL PROCEDURE FOR SELECTING THE POPULATION WITH THE LARGE AN ADAPTIVE PROCEDURE FOR SEQUENTIAL CLINICAL TRIALS

ST MEAN FROM K NORMAL POPULATIONS

SIDED ALTERNATIVE HYPOTHESIS A SEQUENTIAL PROCEDURE FOR TESTING A NULL HYPOTHESIS AGAINST A TWO J

AN EMPIRICAL EVALUATION OF MULTIVARIATE SEQUENTIAL PROCEDURE FOR TESTING MEANS

TIAL DISTRIBUTIONS

THE MEAN

POPULATIONS

AN ITERATED PROCEDURE FOR TESTING THE EQUALITY OF SEVERAL EXPONEN JA

THE PERFORMANCE OF A SEQUENTIAL PROCEDURE FOR THE FIXED-WIDTH INTERVAL ESTIMATION OF A MULTI-STAGE PROCEDURE FOR THE SELECTION OF THE BEST OF SEVERAL NOTE ON THE MISSING PLOT PROCEDURE IN A RANDOMIZED BLOCK DESIGN

CLASS OF SITUATIONS IN WHICH A SEQUENTIAL ESTIMATION PROCEDURE IS NON-SEQUENTIAL ON RANDOMIZED RANK SCORE PROCEDURE OF BELL AND DOKSUM

SOME REMARKS ON A SIMPLE PROCEDURE OF SAMPLING WITHOUT REPLACEMENT

ON A SIMPLE PROCEDURE OF UNEQUAL PROBABILITY SAMPLING WITHOUT

A PROCEDURE TO ESTIMATE THE POPULATION MEAN IN RANDOM
A NUMERICAL PROCEDURE TO GENERATE A SAMPLE COVARIANCE MATRIX,

REPLACEMENT

CORR. 66 124B

SOME APPLICATIONS OF THE JIRINA SEQUENTIAL PROCEDURE TO OBSERVATIONS WITH TREND

AN UPPER BOUND TO THE STANDARD DEVIATION/ A TEST PROCEDURE WITH A SAMPLE FROM A NORMAL POPULATION WHEN JA A

THE PROBABILITY OF REVERSAL ASSOCIATED WITH A TEST PROCEDURE, WHEN DATA ARE INCOMPLETE

STATISTICAL LIFE TEST ACCEPTANCE PROCEDURES

SOME NONPARAMETRIC MEDIAN PROCEDURES

COMPARATIVE COST OF TWO LIFE TEST PROCEDURES

THE EFFICIENCY OF STATISTICAL SIMULATION PROCEDURES

PRECISION OF SIMULTANEOUS MEASUREMENT PROCEDURES ROBUSTNESS OF NON-IDEAL DECISION PROCEDURES

A PROPERTY OF SOME SYMMETRIC TWO-STAGE SEQUENTIAL PROCEDURES SEQUENTIAL ESTIMATION AND CLOSED SEQUENTIAL DECISION PROCEDURES ASYMPTOTICALLY MINIMAX DISTRIBUTION-FREE PROCEDURES AN INTRODUCTION TO RANKING AND SELECTION PROCEDURES ON ROBUST PROCEDURES

A COMPARISON OF SOME CONTROL CHART PROCEDURES

RANK TESTS II. MODIFIED TWO-SAMPLE PROCEDURES SOME OPTIMUM PROPERTIES OF RANKINC PROCEDURES STEP-WISE CLUSTERING PROCEDURES

RECENT RESEARCH IN REINTERVIEW PROCEDURES

A NOTE ON SEQUENTIAL MULTIPLE DECISION PROCEDURES SOME DISTRIBUTION-FREE MULTIVARIATE COMPARISON PROCEDURES RESTRICTED SEQUENTIAL PROCEDURES

SOME PROPERTIES OF RUNS IN QUALITY CONTROL PROCEDURES THE PROBABILITY OF WINNING WITH DIFFERENT TOURNAMENT PROCEDURES OF BLS AND CENSUS REVISED SEASONAL ADJUSTMENT PROCEDURES

UNIVARIATE MODEL AND ASSOCIATED ESTIMATION AND TEST PROCEDURES A FAMILY OF CLOSED SEQUENTIAL PROCEDURES MULTIPARAMETER BAYESIAN INDIFFERENCE PROCEDURES (WITH DISCUSSION)

MAXIMUM-LIKELIHOOD ESTIMATION PROCEDURES AND ASSOCIATED TESTS OF SIGNIFICANCE

CCCEPTANCE SAMPLINC PLANS

PROCEDURES AND TABLES FOR EVALUATING DEPENDENT MIXED

ERTAIN SIMPLE LEAST SQUARES AND ANALYSIS OF VARIANCE PROCEDURES ARE ALSO BEST /STRUCTURES UNDER WHICH C JA

SAMPLING PROCEDURES BASED ON PRIOR DISTRIBUTIONS AND COSTS

MULTISTAGE SAMPLING PROCEDURES BASED ON PRIOR DISTRIBUTIONS AND COSTS

MULTIPLE DECISION PROCEDURES BASED ON RANKS FOR CERTAIN PROBLEMS IN

ANALYSIS OF VARIANCES

THE ROBUSTNESS OF LIFE TESTING PROCEDURES DERIVED FROM THE EXPONENTIAL DISTRIBUTION OPTIMUM DECISION PROCEDURES FOR A POISSON PROCESS PARAMETER

ON BAYES PROCEDURES FOR A PROBLEM WITH CHOICE OF OBSERVATIONS

THE PERFORMANCE OF SOME SEQUENTIAL PROCEDURES FOR A RANKING PROBLEM

RANKING PROCEDURES FOR ARBITRARILY RESTRICTED OBSERVATION

G THE UNKNOWN DRIFT PARAMET/ A CLASS OF SEQUENTIAL PROCEDURES FOR CHOOSINC ONE OF K HYPOTHESES CONCERNIN POPULATIONS

SOME PROCEDURES FOR COMPARINC POISSON PROCESSES OR

TECH 65463 JASA 641225 AMS 63 511 JASA $63 \quad 690$ SASJ $69 \quad 35$ JASA $68 \quad 242$ JASA $67 \quad 341$ JRSSB57 255 JRSSB63 297 AMS $63 \quad 549$ AMS $62 \quad 438$ AMS 64 157I JASA $58 \quad 144$ TECH 64 3B9 JRSSB67 263 BIOC568 13 AMS $66 \quad 1173$ TECH $60 \quad 477$ TECH $62 \quad 610$ JASA 56209 JRSSB68 444 AMS $64 \quad 590$ JASA $65 \quad 308$ TECH $67 \quad 355$ 8IOKA68 411 IOKA54 170 JASA $60 \quad 429$ AMS $68 \quad 88$ AMS $64 \quad 174$ JASA 69759 RSSB69 NO. 2 AMS 621413 ASA $63 \quad 435$ JASA $62 \quad 785$ JASA $61 \quad 933$ BIOKA67 229 AMS $66 \quad 1697$ JASA $66 \quad 391$ JRSSB62 482 TECH $67 \quad 577$ JASA $66 \quad 199$ AMS $63 \quad 857$ JASA $60 \quad 94$ JASA $61 \quad 125$ TECH $60 \quad 435$ AMS $61 \quad 846$ TECH $62 \quad 140$ TECH $62 \quad 257$ JASA $63 \quad 474$ JASA $63 \quad 480$ AMS $64 \quad 755$ AMS 641048 AMS $66 \quad 619$ JASA $66 \quad 640$ JASA $66 \quad 929$ TECH $66 \quad 411$ TECH $66 \quad 615$ AMS $67 \quad 124$ JASA $67 \quad 86$ JASA $68 \quad 41$ AMS $69 \quad 653$ AMS $69 \quad 1486$ BIOKA57 9 BIOKA5B 89 ON JASA $63 \quad 1064$ SAMPLES ESTED PROCE/
NONPARAMETRIC RANKINC PROCEDURES FOR COMPARISON WITH A CONTROL

$\begin{aligned} \text { NONPARAMETRIC RANKINC PROCEDURES FOR COMPARISON WITH A CONTROL } & \text { PROCEDURES FOR DETECTING OUTLYING OBSERVATIONS IN } \\ \text { COMPARISONS OF DESIGNS AND ESTIMATION PROCEDURES FOR ESTIMATING PARAMETERS IN A TWO-STAGE N TECH 67 499 } & \end{aligned}$ 
PULATION WITH TWO-STAGE SAMPLINC BAYES AND MINIMAX PROCEDURES FOR ESTIMATINC THE ARITHMETIC MEAN OF A PO MEANS TWO-STACE PROCEDURES FOR ESTIMATINC THE DIFFERENCE BETWEEN

AMS 661186

COMPLETE IGNORANCE E ICNORANCE

\section{DATA}

ISTICAL DISTRIBUTIONS OF NORMAL POPULATIONS

A COMPARISON OF THREE DIFFFRENT PROCEDURES FOR FSTTMATTNC VARIANCE COMPONENTS DECISION PROCEDURES FOR FINITE DECISION PROBLEMS UNDER NOTE ON DECISION PROCEDURES FOR FINITE DECISION PROBLEMS UNDER COMPLET MULTIVARIATE ACCEPTANCE SAMPLINC PROCEDURES FOR CENERAL SPECIFICATION ELLIPSOIDS

SIMULTANEOUS TEST PROCEDURES FOR MULTIPLE COMPARISONS ON CATECORICAL
BIOKA54 146

TECH $63 \quad 421$ AMS 641644 AMS $65 \quad 691$ JASA $65 \quad 905$ JASA $66 \quad 1081$ AMS $66 \quad 1196$ SINCLE-STAGE PROCEDURES FOR RANKING MULTIPLY-CLASSIFIED VARIANCES TECH 68693 DISTRIBUTIONS

LATION WITH THE LARCEST ALPHA-QUANT/ LARGEST ALPHA-QUANTILE

BINOMIAL POPULATIONS

$S$ WITH CONTINUOUS SPECTRA

$\mathrm{N}$ PER CELL SELECTION PROCEDURES FOR RESTRICTED FAMILIES OF PROBABILITY

NONPARAMETRIC PROCEDURES FOR SELECTING A SUBSET CONTAINING THE POPU NONPARAMETRIC PROCEDURES FOR SELECTING THE T POPULATION WITH THE $\begin{array}{rrr}\text { AMS } & 69 & 905 \\ \text { AMS } & 67 & 1788\end{array}$ AMS $67 \quad 1 B 04$ $\begin{array}{llll}\text { SEQUENTIAL PROCEDURES FOR SELECTION OF THE BEST ONE OF SEVERAL AMS } 67 & 117 \\ \text { ICIENCY OF PROCEDURES FOR SMOOTHING PERIODOGRAMS FROM TIME SERIE BIOKA55 } & 143\end{array}$ ON THE EFFICIENCY OF PROCEDURES FOR SMOOTHING PERIODOGRAMS FROM TIME SERIE BIOKA55 143
ROBUST PROCEDURES FOR SOME LINEAR MODELS WITH ONE OBSERVATIO AMS 67 878 STATISTICAL ESTIMATION PROCEDURES FOR THE 'BURN-IN' PROCESS VALUE DISTRIBUTIONS POINT AND INTERVAL ESTIMATION PROCEDURES FOR THE TWO-PARAMETER WEIBULL AND EXTREME- TEGH 68 231 PARAMETER SEQUENTAL OF SOME PROCEDURES FOR THE TWO-SAMPLE LOCATION PROBLEM JASA $64 \quad 665$ TECH 64259 AMS 641136 SOME STOCHASTIC APPROXIMATION PROCEDURES FOR USE IN PROCESS CONTROL

ESTIMATION OF RELATIVE POTENCY IN DILU/ GRAPHICAL PROCEDURES FOR USING DISTRIBUTION-FREE METHODS IN THE EFFICIENT ESTIMATES AND OPTIMUM INFERENCE PROCEDURES IN LARGE SAMPLES (WITH DISCUSSION) ROBUSTNESS OF SOME NONPARAMETRIC PROCEDURES IN LINEAR MODELS

SIMULTANIOUS TEST PROCEDURES IN MULTIVARIATE ANALYSIS OF VARIANCE

ICAL INVESTIGATION OF SEVERAL ONE-DIMENSIONAL SEARCH PROCEDURES IN NONLINEAR REGRESSION PROBLEMS A NUMER IE ASYMPTOTICALLY OPTIMAL BAYES AND MINIMAX PROCEDURES IN SEQUENTIAL ESTIMATION ON THE EFFICIENCY OF OPTIMAL NONPARAMETRIC PROCEDURES IN THE TWO

ON SOME OPTIMUM NONPARAMETRIC PROCEDURES IN TWO-WAY LAYOUTS ON THREE PROCEDURES OF SAMPLING FROM FINITE POPULATIONS

E RECRESSION PROBLEMS REPLACEMENT SEQUENTIAL INFERENCE PROCEDURES OF STEIN'S TYPE FOR A CLASS OF MULTIVARIAT ON THREE PROCEDURES OF UNEQUAL PROBABILITY SAMPLING WITHOUT A CONFIDENCE INTERVAL COMPARISON OF TWO TEST PROCEDURES PROPOSED FOR THE BEHRENS-FISHER PROBLEM OPTIMAL SEQUENTIAL PROCEDURES WHEN MORE THAN ONE STOP IS REQUIRED

RATE EXPONENTIAL LIFE TEST PROCEDURES WHEN THE DISTRIBUTION HAS MONOTONE FAILURE JA

BUTION OF TWO RANDOM MATRICES USED IN CLASSIFICATION PROCEDURES, CORR, 64924 SOME RESULTS ON THE DISTRI SIMULTANEOUS TEST PROCEDURES, SOME THEORY OF MULTIPLE COMPARISONS

'SOME PROPERTIES OF RUNS IN QUALITY CONTROL PROCEDURES' THE MEASURING PROCESS

FIRST PASSAGE TIME FOR A PARTICULAR GAUSSIAN PROCESS MULTIPLE RECRESSION ANALYSIS OF A POISSON PROCESS GAMES ASSOCIATED WITH A RENEWAL PROCESS SOME ASPECTS OF THE EMIGRATION-IMMIGRATION PROCESS LIMITING DISTRIBUTION OF THE MAXIMUM OF A DIFFUSION PROCESS LIMIT DISTRIBUTIONS OF A BRANCHING STOCHASTIC PROCESS PRESENT VALUE OF A RENEWAL PROCESS ON RANDOM SAMPLING FROM A STOCHASTIC PROCESS ASYMPTOTIC PROPERTIES OF AN AGE DEPENDENT BRANCHING PROCESS A THEOREM ON. THE GALTON-WATSON PROCESS STATISTICAL PROPERTIES OF A CERTAIN PERIODIC BINARY PROCESS A FIRST PASSAGE PROBLEM FOR THE WIENER PROCESS STATISTICAL GONTROL OF A GAUSSIAN PROGESS A REMARK ON HITTING PLACES FOR TRANSIENT STABLE PROCESS A MULTI-DIMENSIONAL LINEAR GROWTH BIRTH AND DEATH PROCESS

THE DISTRIBUTION OF THE MAXIMUM OF A SEMI-MARKOV PROCESS OPTIMAL STOPPING IN A MARKOV PROCESS STATISTICAL ESTIMATION PROCEDURES FOR THE 'BURN-IN' PROCESS

AN AGE-DEPENDENT BIRTH AND DEATH PROCESS ESTIMATION FROM A LINEAR MARKOV PROCESS PROBABILISTIC SOLUTION OF THE SIMPLE BIRTH PROCESS THE DISTRIBUTION OF RESPONSE TIMES IN A BIRTH-DEATH PROCESS A NOTE ON THE WEIBULL RENEWAL PROCESS THE VARIANCE OF THE MEAN OF A STATIONARY PROCESS THE INSPECTION OF A MARKOV PROCESS A MULTI-STAGE RENEWAL PROCESS

A TWO-DIMENSIONAL POISSON GROWTH PROCESS EXPECTED NUMBER OF ZEROS OF A STATIONARY GAUSSIAN PROCESS STATISTICS OF A PARTICULAR NON-HOMOGENEOUS POISSON PROCESS CROSS PERIODOGRAM OF A STATIONARY GAUSSIAN VECTOR PROCESS THEOREM FOR RANDOM INTERVAL SAMPLINC OF A STOCHASTIC PROCESS RESULTS AND DIFFUSION APPROXIMATIONS IN A GENETIC PROCESS

THEOREMS CONCERNING THE SUPERCRITICAL GALTON-WATSON PROCESS

OF AN ESTIMATOR FOR A SIMPLE BIRTH AND DEATH PROCESS

OF COUNTS OF EVENTS FOR CERTAIN TYPES OF POINT PROCESS DISTRIBUTION OF A CERTAIN FUNCTIONAL OF THE WIENER PROCESS

OF THE INTENSITY FUNCTION OF A STATIONARY POINT PROCESS INANIMATE MARKS OVER A NON-HOMOGENEOUS BIRTH-DEATH PROCESS OF MEAN CHARTS USED TO MAINTAIN CURRENT CONTROL OF A PROCESS OF HIGH LEVEL CROSSINGS OF A STATIONARY GAUSSIAN PROCESS OF THE TRANSITION DISTRIBUTION FUNCTION OF A MARKOV PROCESS OF CROSSINGS OF A LEVEL BY A STATIONARY NORMAL PROCESS COMPOUNDS BY COUNTERCURRENT DIALYSIS. A STOCHASTIC PROCESS GENERATOR OF A CONTINUOUS TIME. FINITE STATE MARKOV PROCESS MEASURE OF THE CRITICAL CASE SIMPLE BRANCHING PROCESS INTERACTION PARAMETER IN AN EMIGRATION-IMMIGRATION PROCESS RESIDUALS FOLLOW A FIRST-ORDER STATIONARY MARKOFF PROCESS
CORRIGENDA, AMS 61610 JASA $61 \quad 235$ AMS $62 \quad 697$ AMS $64 \quad 319$ AMS $64 \quad 557$ AMS 641326 AMS 641713 AMS 651565 AMS $66 \quad 695$ TECH $66 \quad 247$ AMS 671912 TECH $67 \quad 29$ AMS $68 \quad 365$ AMS $6 B \quad 727$ AMS $6 \mathrm{~B} \quad 947$ AMS 6B 1333 TECH 68 51 BIOKA55 291 BIOKA60 482 BIOKA64 258 BIOKA65 581 BIOKA66 375 JRSSB57 282 JRSSB58 111 JRSSB63 150 JRSSB65 497 THE AMS 651043 THE BIOKA64 399 ON THE AMS $67 \quad 593$ A LIMIT AMS 64866 NUMERICAL BIOKA63 24I ON RECENT AMS 682098 THE BEHAVIOUR BIOKA56 23 SOME PROPERTIES JRSSB64 325 ON THE ASYMPTOTIC AMS 691409 ON THE ESTIMATION JRSSB65 332 THE DISTRIBUTION OF BIOKA69 225 THE ECONOMIC DESIGN JASA $56 \quad 228$ ON A LIMIT DISTRIBUTION AMS $6 B 210 B$ NONPARAMETRIC ESTIMATION AMS 691386 THE MOMENTS OF THE NUMBER AMS 651656 THE SEPARATION OF MOLECULAR BIOKA60 69 ESTIMATING THE INFINITESIMAL AMS $62 \quad 727$ PROPERTIES OF THE STATIONARY AMS 67977

THE ESTIMATION OF A FUNDAMENTAL AMS 63238 EFFICIENCY OF THE SAMPLE MEAN WHEN JASA 681237 AMS $62 \quad 119$ 
PROGRAMMING ON A FINITE SPACE DISCRETE TIME MARKOV PROCESS NCES WITH TRANSITION PROBABILITIES BASED ON A MARKOV PROCESS UTOCORRELATIONS OF A SAMPLE FROM A LINEAR STOCHASTIC PROCESS LE OF CONSECUTIVE OBSERVATIONS FROM A MOVING-AVERAGE PROCESS HE CUMULATIVE POPULATION IN A SIMPLE BIRTH-AND-DEATH PROCESS NS WITH AN APPLICATION IN STUDYING THE DENTAL CARIES PROCESS URES FOR ESTIMATING PARAMETERS IN A TWO-STAGE NESTED PROCESS CONCERNING THE UNKNOWN DRIFT PARAMETER OF THE WIENER PROCESS

ON THE LENGTHS OF INTERVALS IN A STATIONARY POINT PROCESS MATING THE SPECTRAL DENSITY FUNCTION OF A STOCHASTIC PROCESS

WITH DISCUSSION)

ON THE ITERATIVE METHOD OF DYNAMIC AMS 651279 DEVELOPMENT OF RANDOMIZED LOAD SEQUE TECH 66107 ON THE ASYMPTOTIC DISTRIBUTION OF THE A AMS 641296 /HE LIMITING GENERALIZED VARIANCE OF A SAMP BIOKA6I 197 /HE PROBABILITY GENERATING FUNCTIONAL FOR T BIOKA64 245 /ILITY APPROACH TO IRREVERSIBLE MARKOV CHAI BIOCS66 791 MMPARISONS OF DESIGNS AND ESTIMATION PROCED TECH $67 \quad 499$ /OCEDURES FOR CHOOSING ONE OF K HYPOTHESES AMS 671376 CORR. 63500

ON ESTI JRSSB57 13 JRSSB65 138

L CASE THE STATIONARY DISTRIBUTION OF A BRANCHING PROCESS ALLOWING IMMIGRATION, A REMARK ON THE CRITICA JRSSB68 I76 CORRECTIONS AND COMMENTS ON THE PAPER 'A BRANCHING PROCESS ALLOWING IMMIGRATION' WEAK CONVERGENCE OF A TWO-SAMPLE EMPIRTCAL PROCESS AND A NEW APPROACH TO CHERNOFF-SAVAGE THEOREM AMS 68 755 A MULTIVARIATE IMMIGRATION WITH MULTIPLE DEATH PROCESS AND APPLICATIONS TO LUNAR CRATERS E THE PROBABILITIES OF EXTINCTION IN A GALTON-WATSON PROCESS AND IN SOME RELATED MULTIPLICATIVE POPULATION AMS 6B I7OO ON THE HOMOGENEOUS BIRTH-AND-DEATH PROCESS AND ITS INTEGRAL

MINIMA OF A STATIONARY GAUSSIAN ORNSTEIN-UHLENBECK PROCESS BY MONTE CARLO SIMULATION /E-TIME MAXIMA AN JASA 6B I5I7 SOME STOCHASTIC APPROXIMATION PROCEDURES FOR USE IN PROCESS CONTROL APPLICATION OF STOCHASTIC APPROXIMATION TO PROCESS CONTROI

PROCESS CONTROL AND THE IMPACT OF AUTOMATIC PROCESS CONTROI STATISTTCAL PROCESS CONTROL AND THE IMPACT OF AUTOMAT THE PROCESS CURVE AND THE EQUIVALENT MIXED BINOMIAL WITH

CONTROL

TWO COMPONENTS UOUS PROCESS DERIVED FROM A DISCRETE PROCESS

THE SPECTRUM OF A CONTINUOUS PROCESS DERIVED FROM MULTIPLE REGRESSION IN PROCESS DEVELOPMENT SOME EQUILIBRIUM RESULTS FOR THE QUEUEING PROCESS E-SUB-K-M-1
PECTRUM OF A STATIONARY BIVARIATE GAUSSIAN PROCESS FROM ITS ZEROS

CROSS-SPECTRUM OF A STATIONARY BIVARIATE GAUSSIAN PROCESS FROM I THE MULTI-TYPE GALTON-WATSON PROCESS IN A GENETICAL CONTEXT A RANDOM SET PROCESS IN THE PLANE WITH A MARKOVIAN PROPERTY $\begin{array}{ll}\text { TECH } 68 & 257 \\ \text { JRSSB56 } & 275\end{array}$ AMS 641136 JRSSB65 321 TECH $65 \quad 2 B 3$ TECH $65 \quad 2 B 3$ JRSSB59 63 BIOKA63 517 $\begin{array}{ll}\text { JRSSB56 } & 275 \\ \text { JRSSB68 } & 145\end{array}$ BIOKA59 246 BIOCS6B 147 AMS 651859 AMS 681507 BIOKA64 262 AMS 6B 1069 CROSS SPECTRAL ANALYSIS OF GAUSSIAN VECTOR PROCESS IN THE PRESENCE OF VARIANCE FLUCTUATIONS A BRANCHING PROCESS IN WHICH INDIVIDUALS HAVE VARIABLE LIFETIMES SPLITTING A SINGLE STATE OF A STATIONARY PROCESS INTO MARKOVIAN STATES TTERNS (WITH DISCUSSION) A BRANCHING POISSON PROCESS MODEL FOR THE ANALYSIS OF COMPUTER FAILURE PA THE OUTPUT PROCESS OF A STATIONARY M/M/S QUEUEING SYSTEM ESTIMATING AND TESTING TREND IN A STOCHASTIC PROCESS OF POISSON TYPE THE CORRELATION STRUCTURE OF THE OUTPUT PROCESS OF SOME SINGLE SERVER SYSTEMS 398 AMS 681144 AMS $66 \quad 1564$ AMS 681007 ARR/ ON THE CORRELATION STRUCTURE OF THE DEPARTURE PROCESS OF THE QUEUE WITH ONE SERVER, WHILE THE INTER JRSSB66 336 ICH INTERARRIVAL AND SERVING DISTRIBUT/ THE OUTPUT PROCESS OF THE QUEUEING SYSTEM WITH ONE SERVER AND WH JRSSB59 375 EXPECTED ARC LENGTH OF A GAUSSIAN PROCESS ON A FINITE INTERVAL A MARKOV PROCESS ON BINARY NUMBERS

OPTIMUM DECISION PROCEDURES FOR A POISSON PROCESS PARAMETER

APPLICATIONS OF TRUNCATED DISTRIBUTIONS IN PROCESS START-UPS AND INVENTORY CONTROL SUFFICIENT CONDITIONS FOR A STATIONARY PROCESS TO BE A FUNCTION OF A FINITE MARKOV CHAIN ISN'T MY PROCESS TOO VARIABLE FOR EVOP

A NOTE ON PREDICTION FROM AN AUTOREGRESSIVE PROCESS USING PISTIMETRIC PROBABILITY

ESTIMATION OF STOCHASTIC SYSTEMS, ARBITRARY SYSTEM PROCESS WITH ADDITIVE WHITE NOISE OBSERVATIONS ERROR A MENDELIAN MARKOV PROCESS WITH BINOMIAL TRANSITION PROBABILITIES

OUTCOME PROBABILITIES FOR A RECORD MATCHING PROCESS WITH COMPLETE INVARIANT INFORMATION

INCTION OF A BACTERIAL COLONY BY PHAGES, A BRANCHING PROCESS WITH DETERMINISTIC REMOVALS

ON THE GALTON-WATSON BRANCHING PROCESS WITH MEAN LESS THAN ONE A MODIFIED COMPOUND POISSON PROCESS WITH NORMAL COMPOUNDING

CONDITIONS FOR ALMOST SURE EXTINCTION OF BRANCHING PROCESS WITH RANDOM ENVIRONMENT THE TRANSIENT BEHAVIOR OF A SINGLE SERVER QUEUING PROCESS WITH RECURRENT INPUT AND GAMMA SERVICE TIME MODELS FOR A BACTERIAL GROWTH PROCESS WITH REMOVALS A BRANCHING PROCESS WITHOUT REBRANCHING

EN THE MEAN AND VARIANCE OF A STATIONARY BIRTH-DEATH PROCESS, E DISTRIBUTION, ONE SERVER ON THE NORMAL STATIONARY PROCESS ON THE QUEUEING PROCESS,

BAYESIAN ANALYSIS OF THE INDEPENDENT MULTINORMAL PROCESS, APPLICATIONS THE LOGTSTIC PROCESS LE OF CONSECUTIVE OBSERVATIONS FROM A MOVING-AVERAGE PROCESS REMARK CONCERNING TWO-STATE SEMI-MARKOV PROCESSES MAXTMAL INDEPENDENT STOCHASTIC PROCESSES AND ITS ECONOMIC APPI APRLICATION MARKOV OR POISSON INPUT, GENERAL SERVICE TIM NEITHER MEAN NOR PRECISION KNOWN TABLES OF THE STOCHASTIC EPIDEMIC CURVE AND $/ E$ LIMITING GENERALIZED VARIANCE OF A SAMP JRSSB56 257 AMS $63 \quad 416$ AMS $62 \quad 1384$ TECH $61 \quad 429$ AMS $63 \quad 1033$ TECH $68 \quad 439$ JRSSB $60 \quad 97$ AMS 6B 7 B5 BIOKA66 37 JASA $67 \quad 454$ BIOKA62 272 AMS $67 \quad 264$ JASA $68 \quad 637$ AMS 6B 2136 AMS $61 \quad 12 B 6$ JRSSB63 140 AMS 691850 BIOKA62 253 JRSSB $63 \quad 1 B 9$ AMS $61 \quad 770$ JASA $65 \quad 347$ JRSSB $60 \quad 332$ BIOKA61 476 AMS 61615 AMS $61 \quad 704$ AMS $62 \quad 98$ AMS $62 \quad 114$ AMS 621306 AMS $63 \quad 206$ AMS $63 \quad 274$ AMS 64341 AMS $64 \quad 350$ AMS $64 \quad 431$ AMS $64 \quad 872$ AMS 641718 AMS 641746 TECH $64 \quad 57$ TECH $64 \quad 133$ AMS 651421 AMS 651569 AMS $65 \quad 1677$ AMS $65 \quad 304$ AMS $65 \quad 978$ AMS $66 \quad 837$ AMS $\begin{array}{ll}66 & 1211\end{array}$ TECH $66 \quad 91$ AMS $67 \quad 588$ 
SLOWLY BRANCHING PROCESSES

EPSILON ENTROPY OF STOCHASTIC PROCESSES ON HITTING FOR STABLE PROCESSES A RANDOM TIME CHANGE RELATING SEMI-MARKOV AND MARKOV PROCESSES TRANSFORMS OF STOCHASTIC PROCESSES ON RECURRENT DENUMBEABLE DECISION PROCESSES AN EXAMPLE IN DUNUMERABLE DECISION PROCESSES ARBITRARY STATE MARKOVIAN DECISION PROCESSES THE WILCOXON TWO-SAMPLE STATISTIC ON STRONGLY MIXING PROCESSES ON THE ERGODICITY FOR NON-STATIONARY MULTIPLE MARKOV PROCESSES EQUIVALENCE OF GAUSSIAN STATIONARY PROCESSES SAMPLE PATH VARIATIONS OF HOMOGENEOUS PROCESSES

ON THE MATRIX RENEWAL FUNCTION FOR MARKOV RENEWAL PROCESSES ASYMPTOTICALLY MOST POWERFUL TESTS IN MARKOV PROCESSES EPSILON ENTROPY OF GAUSSIAN PROCESSES

ON THE SUPERPOSITON OF RENEWAL PROCESSES MODELS FOR TWO-DIMENSIONAL STATIONARY STOCHASTIC PROCESSES CONDITIONED MARKOV PROCESSES ON THE CUMULANTS OF RENEWAL PROCESSES ERGODIC PROPERTIES OF SOME PERMUTATION PROCESSES THE SPECTRAL ANALYSIS OF TWO-DIMENSIONAL POINT PROCESSES INTEGRALS OF BRANCHING PROCESSES TRANSPOSED BRANCHING PROCESSES SOME APPLICATIONS OF ZERO-ONE PROCESSES SOME SIMPLE DURATION-DEPENDENT STOCHASTIC PROCESSES SOME SIMPLE WEAR-DEPENDENT RENEWAL PROCESSES RECURSIVE RELATIONS FOR PREDICTORS OF NON-STATIONARY PROCESSES AN EXPERIMENTAL STUDY OF CERTAIN SCREENING PROCESSES DESIGN RELATIONS FOR NON-STATIONARY PROCESSES NON-HOMOGENEOUS BRANCHING POISSON PROCESSES ON THE PREDICTION OF NON-STATIONARY PROCESSES ON A DISTRIBUTION ASSOCIATED WITH CERTAIN STOCHASTIC PROCESSES THE ERGODIC THEORY OF SUBADDITIVE STOCHASTIC PROCESSES ON THE SUPERPOSITION OF POINT PROCESSES THE SOLUTION OF THE LIKELIHOOD EQUATION BY ITERATION PROCESSES LAW OF THE ITERATED LOGARITHM FOR MIXING STOCHASTIC PROCESSES STRONG RATIO LIMIT PROPERTY FOR SOME GENERAL MARKOV PROCESSES

ON EXTREME VALUES, COMPETING RISKS AND SEMI-MARKOV PROCESSES FOR THE LAW OF LARGE NUMBERS FOR DISCRETE MARKOV PROCESSES

SAMPLE TEST FOR THE INDEPENDENCE OF TWO RENEWAL PROCESSES THEOREM FOR PASSAGE TIMES IN ERGODIC REGENERATIVE PROCESSES VALUES IN UNIFORMLY MIXING STATIONARY STOCHASTIC PROCESSES SAMPLES AND MOVING SUMS IN STATIONARY STOCHASTIC PROCESSES CONVERGENCE OF MOMENTS IN AGE DEPENDENT BRANCHING PROCESSES ULTIVARIATE ANALYSIS OF WEAKLY STATIONARY STOCHASTIC PROCESSES UPERCRITICAL ONE DIMENSIONAL AGE DEPENDENT BRANCHING PROCESSES MEMORYLESS RULES FOR CONTROLLING SEQUENTIAL CONTROL PROCESSES OF FINITE MARKOV CHAINS AND EXPONENTIAL TYPE PROCESSES NORMALITY OF SAMPLE QUANTILES FOR M-DEPENDENT PROCESSES

VALUES OF THE FIRST TWO MOMENTS IN MARKOV RENEWAL PROCESSES OF SPECTRA AFTER HARD CLIPPING OF GAUSSIAN TTME PROCESSES SOLUTIONS OF GREEN'S TYPE FOR UNIVARIATE STOCHASTIC PROCESSES UNBIASED ESTIMATION FOR MULTIVARIATE STATIONARY PROCESSES NUMBER OF CURVE CROSSINGS BY NON-STATIONARY NORMAL PROCESSES THEOREM FOR STATIONARY MEASURES OF ERGODIC MARKOV PROCESSES OF LEVELS AND CURVES BY A WIDE CLASS OF STOCHASTIC PROCESSES ON MULTITYPE CONTINUOUS TIME MARKOV BRANCHING PROCESSES OF QUEUEING AND INVENTORY MODELS BY SEMI-MARKOV PROCESSES

OF A FUNCTIONAL ON INFINITELY DIVISIBLE STOCHASTIC PROCESSES

IN THE CENTRAL LIMIT THEOREM FOR MIXING STOCHASTIC PROCESSES OF BIORTHONORMAL EXPANSIONS IN THEORY OF STOCHASTIC PROCESSES OF AN ALGEBRAIC REPRESENTATION OF STOCHASTIC PROCESSES NORMAL APPROXIMATION IN THE TREATMENT OF STOCHASTIC PROCESSES OF COHERENCE FOR WEAKLY STATIONARY STOCHASTIC PROCESSES UNIQUENESS OF STATIONARY MEASURES FOR MARKOV RENEWAL PROCESSES PLANS FOR DISCRIMINATING BETWEEN TWO WEIBULL PROCESSES OF FREQUENCY DISTRIBUTIONS OBTAINED FROM STOCHASTIC PROCESSES

OF A REGRESSION PARAMETER FOR CERTAIN SECOND ORDER PROCESSES SAMPLE EXCURSIONS OF STOCHASTIC APPROXIMATION PROCESSES TESTS FOR THE R-DEPENDENT MARGINALLY STATIONARY PROCESSES

SYSTEM OF EQUALITIES ARISING IN MARKOVIAN DECISION PROCESSES

FOR INDECOMPOSABLE MULTIDIMENSIONAL GALTON-WATSON PROCESSES OF LARGE NUMBERS FOR LINEAR COMBINATIONS OF MARKOV PROCESSES NEQUALITIES WITH- EXTENSIONS TO CONTINUOUS PARAMETER PROCESSES SPECIES GROWING ACCORDING TO SIMPLE BIRTH AND DEATH PROCESSES STRIBUTION FOR USE IN BAYESIAN ANALYSIS OF BERNOULLI PROCESSES TO THE EQUIVALENCE CONDITIONS FOR CERTAIN STATIONARY PROCESSES AND ITS RELATIONSHIP TO BIRTH, DEATH, AND BRANCHING PROCESSES ROCESS AND IN SONE RELATED MULTIPLICATIVE POPULATION PROCESSES $R$ COMBINATIONS OF EXCHANGEABLE AND MIXING STOCHASTIC PROCESSES

OF THE ITERATED LOGARITHM FOR NON-DECREASING STABLE PROCESSES CONTROL CHARTS AND STOCHASTIC PROCESSES THE SPECTRAL ANALYSIS OF POINT PROCESSES

EVOLUTIONARY SPECTRAL AND NON-STATIONARY PROCESSES AN APPROACH TO THE STUDY OF MARKOV PROCESSES

ON THE CONCEPT OF THE SPECTRUM FOR NON-STATIONARY PROCESSES $\begin{array}{llll}1 & \text { AMS } & 67 & 919\end{array}$

AMS 671000

AMS 671021

AMS $68 \quad 358$

AMS $68 \quad 372$

AMS $68 \quad 424$

AMS $68 \quad 674$

AMS $68 \quad 2118$

AMS $68 \quad 1202$

AMS 681448

AMS $69 \quad 197$

AMS 69399

AMS 69 No.6

AMS 691207

AMS $69 \quad 1272$

BIOKA54 91

BIOKA55 170

BIOKA58 241

BIOKA59 1

BIOKA62 15I

BIOKA64 299

BIOKA67 263

JRSSB54 76

JRSSB55 243

JRSSB59 144

JRSSB $61 \quad 368$

JRSSB $65 \quad 523$

JRSSB $66 \quad 88$

JRSSB $66 \quad 228$

JRSSB $67 \quad 343$

JRSSB67 570

JRSSB $68 \quad 160$

JRSSB $68 \quad 499$

JRSSB $68 \quad 576$

ON BIOKA61 452

THE AMS 69 NO. 6

THE AMS 69

NOTE AMS $63 \quad 1104$

A BOUND AMS $61 \quad 336$

A LARGE AMS $67 \quad 1037$

A LIMIT AMS $66 \quad 866$

EXTREME AMS 65993

DISCRETE JASA $67 \quad 484$

MONOTONE AMS $66 \quad 1806$

ON THE M AMS 641765

ON THE $S$ AMS $69 \quad 743$

A NOTE ON AMS $66 \quad 276$

FUNCTIONS AMS 681020

ASYMPTOTIC AMS 681724

ASYMPTOTIC BIOKA67 597

ESTIMATION TECH $67 \quad 391$

APPROXIMATE JRSSB6O 376

BEST LINEAR TECH 68523

ON THE MEAN AMS 65509

A UNIQUENESS AMS 641781

ON CROSSINGS AMS $66 \quad 260$

SOME RESULTS AMS $68 \quad 347$

THE SOLUTION JRSSB61 113

AN EVALUATION AMS $64 \quad 336$

THE REMAINDER AMS 69601

AN APPLICATION JRSSB68 334

SOME PROPERTIES AMS $68 \quad 164$

ON THE USE OF THE JRSSB57 268

ON THE COEFFICIENT AMS 64532

THE EXISTENCE AND AMS 661439

SAMPLING INSPECTION TECH $65 \quad 589$

THE GOODNESS OF FIT BIOKA54 450

EFFTCIENT ESTIMATION AMS 611299

A NOTE ON THE MAXIMUM AMS $66 \quad 513$

SEQUENTIAL HYPOTHESIS AMS $66 \quad 90$

A SOLUTION TO A COUNTABLE AMS 67582

ADDITIONAL LIMIT THEOREMS AMS 661463

CONVERGENCE RATES FOR THE LAW AMS $66 \quad 711$

SOME MULTIVARIATE CHEBYSHEV I AMS $61 \quad 687$

POPULATION DIFFERENCES BETWEEN BIOKA53 370

PERCENTAGE POINTS OF THE BETA DI TECH $66 \quad 687$ /ENCE CONDITIONS FOR THE BROWNIAN MOTION AMS 69 NO.6 EXPONENTIAL PARAMETER FROM QUANTAL DATA, BIOCS67 739 /ITIES OF EXTINCTION IN A GALTON-WATSON P AMS 681700 $/ R$ THE LAW OF LARGE NUMBERS FOR THE LINEA AMS 651840 (ADDENDUM, 69 1855)

(WITH DISCUSSION)

(WITH DISCUSSION)

WITH DISCUSSION

WITH DISCUSSION

(WITH DISCUSSION)
A DELICATE

AMS 681818

JRSSB59 239

JRSSB 63264

JRSSB $65 \quad 204$

JRSSB $66 \quad 417$

JRSSB68 
MULTIVARIATE WIDE-SENSE MARKOV PROCESSES AND PREDICTION THEORY

OF URN SCHEMES INTO CONTINUOUS TIME MARKOV BRANCHINC PROCESSES AND RELATED LIMIT THEOREMS

CERTAIN PROPERTIES OF GAUSSIAN PROCESSES AND THEIR FIRST PASSAGE TIMES

ON STOCHASTIC PROCESSES DERIVED FROM MARKOV CHAINS

INF INITE

STOCHASTIC BIRTH, DEATH AND MIGRATION PROCESSES FOR SPATIALLY DISTRIBUTED

NON-SINGULAR RECURRENT MARKOV PROCESSES HAVE STATIONARY MEASURES

SOME APPLICATIONS OF MULTIPLE-TYPE BRANCHINC PROCESSES IN POPULATION GENETICS

DISCRETE STOCHASTIC PROCESSES IN POPULATION GENETICS (WITH DISCUSSION)

ON BRANCHINC PROCESSES IN RANDOM ENVIRONMENTS

ON STATIONARY PROCESSES IN THE PLANE

CORRIGENDA, 'ON STATIONARY PROCESSES IN THE PLANE'

TYPE STATIONARITY CONDITIONS FOR STOCHASTIC PROCESSES OF THE AUTOREGRESSIVE AND MOVING-AVERACE STOCHASTIC PROCESSES ON A SPHERE

CONCERNINC CERTAIN EQUIVALENCE CLASSES OF GAUSSIAN PROCESSES ON AN INTERVAL GAUSSIAN PROCESSES ON SEVERAL PARAMETERS

THE ASYMMETRIC CAUCHY PROCESSES ON THE LINE

SOME PROCEDURES FOR COMPARINC POISSON PROCESSES OR POPULATIONS

THE BEHAVIOR OF LIKELIHOOD RATIOS OF STOCHASTIC PROCESSES RELATED BY CROUPS OF TRANSFORMATIONS THE PROBABILITIES OF EXTINCTION FOR BIRTH-AND-DEATH PROCESSES THAT ARE ACE-DEPENDENT OR PHASE-DEPENDENT

$M$ OF EVERETT, ULAM AND HARRIS ON MULTITYPE BRANCHING PROCESSES TO A BRANCHING PROCESS WITH COUNTABLY MANY THE LOOSE SUBORDINATION OF DIFFERENTIAL PROCESSES TO BROWNIAN MOTION

AGE-DEPENDENT BRANCHING PROCESSES UNDER A CONDITION OF ULTIMATE EXTINCTION

CHAINS EXCHANGEABLE PROCESSES WHICH ARE FUNCTIONS OF STATIONARY MARKOV

ON THE SAMPLE FUNCTIONS OF PROCESSES WHICH CAN BE ADDED TO A CAUSSIAN PROCESS

IMBEDDING THEOREMS TO CRITERIA FOR THE CONTINUITY OF PROCESSES WITH A VECTOR PARAMETER/FOR THE SOBOLEV HE STRONG LAW OF LARGE NUMBERS FOR LINEAR STOCHASTIC PROCESSES WITH ABSOLUTELY CONVERGENT COEFFICIENTS SOME STOCHASTIC PROCESSES WITH ABSORBING BARRIERS ON QUEUEING PROCESSES WITH BULK SERVICE

TRIBUTION OF THE SUPREMUM FUNCTIONAL FOR SEMI-MARKOV PROCESSES WITH CONTINUOUS STATE SPACES THE ANALYSIS OF TWO-DIMENSIONAL STATIONARY PROCESSES WITH DISCONTINUOUS SPECTRA ON A CHARACTERIZATION OF SYMMETRIC STABLE PROCESSES WITH FINITE MEAN

MARKOV RENEWAL PROCESSES WITH FINITELY MANY STATES

ON A FLUCTUATION THEOREM FOR PROCESSES WITH INDEPENDENT INCREMENTS. II FUNCTIONS OF PROCESSES WITH MARKOVIAN STATES

FUNCTIONS OF PROCESSES WITH MARKOVIAN STATES, II
THE ANALYSIS OF STATIONARY PROCESSES WITH MIXED SPECTRA, I ANALYSIS OF STATIONARY PROCESSES WITH MIXED SPECTRA, 2

SAMPLE ESTIMATION OF PARAMETERS FOR AUTOREGRESSIVE PROCESSES WITH MOVING-AVERAGE RESIDUALS WITH APPLICATIONS TO THE WEAK CONVERGENCE OF RANDOM PROCESSES WITH MULTI-DIMENSIONAL TIME PARAMETERS RESULTS SAMPLING INSPECTION OF CONTINUOUS PROCESSES WITH NO AUTOCORRELATION BETWEEN SUCCESSIVE BI MULTIVARIATE STOCHASTIC PROCESSES WITH PERIODIC COEFFICIENTS RANDOM QUEUEING PROCESSES WITH PHASE-TYPE SERVICE

THE ESTIMATION OF AMPLITUDE SPECTRA FOR STOCHASTIC PROCESSES WITH QUASI-LINEAR RESIDUALS POISSON PROCESSES WITH RANDOM ARRIVAL RATE

A NOTE ON MULTI-TYPE GALTON-WATSON PROCESSES WITH RANDOM BRANCHING PROBABILITIES A NOTE ON EXCHANGEABLE PROCESSES WITH STATES OF FINITE RANK A LEARNINC MODEL FOR PROCESSES WITH TOOL WEAR

COUNTING DISTRIBUTIONS FOR RENEWAL PROCESSES

SOME RESULTS ON TESTS FOR POISSON PROCESSES

HIERARCHICAL BIRTH AND DEATH PROCESSES. I. THEORY

HIERARCHICAL BIRTH AND DEATH PROCESSES. II. APPLICATIONS

CORRICENDA, 'ON THE CUMULANTS OF RENEWAL PROCESSES.' CORRIGENDA, 'CONDITIONED MARKOFF PROCESSES.'

BIRTH-AND -DEATH PROCESSES, AND THE THEORY OF CARCINOGENESIS

DENUMERABLE STATE MARKOVIAN DECISION PROCESSES, AVERAGE COST CRITERION

A CONTINUOUS KIEFER-WOLFOWITZ PROCEDURE FOR RANDOM PROCESSES, CORR. 66745

MARKOV RENEWAL PROCESSES, DEFINITIONS AND PRELIMINARY PROPERTIES

STOCHASTIC POINT PROCESSES, LIMIT THEOREMS

SPATIAL POINT PROCESSES, WITH APPLICATIONS TO ECOLOGY

ERRATA, 'THE DISCRIMINATION BETWEEN TWO WEIBULL PROCESSES'

'THE SPECTRAL ANALYSIS OF TWO-DIMENSIONAL POINT PROCESSES'

THE SOLUTION OF THE LIKELIHOOD EQUATION BY ITERATION PROCESSES'

OF QUEUEINC AND INVENTORY MODELS BY SEMI-MARKOV PROCESSES '

INSPECTION AND CORRECTION ERROR IN DATA PROCESSINC

OF MULTIVARIATE QUALITY CONTROL TO PHOTOGRAPHIC PROCESSINC AREA
AND SPECIFICATION LIMITS PROCESSING UNDERDEVELOPED DATA FROM AN UNDERDEVELOPED JASA $60 \quad 23$ PRODUCER AND CONSUMER RISKS FOR ASYMMETRICAL TESTS JASA 66505 PRODUCER AND CONSUMER RISKS IN NON-NORMAL POPULATION TECH $66 \quad 335$

NATION OF SINGLE SAMPLING ATTRIBUTE PLANS WITH GIVEN PRODUCER'S AND CONSUMER'S RISK THE DETERMI TECH 67401

CURVE FOR SEQUENTIAL SAMPLING BY VARIABLES WHEN THE PRODUCER'S AND CONSUMER'S RISKS ARE EQUAL /TERISTIC JASA 56 IOB A PRICE AND PRODUCTIVITY INDEX FOR A NONHOMOCENEOUS PRODUCT

ESTIMATING THE FRACTION OF ACCEPTABLE PRODUCT

GROSS STATE PRODUCT AND AN ECONOMETRIC MODEL OF A STATE

JASA $64 \quad 469$

TECH $65 \quad 43$ JASA 69 7B7

ANALYSIS OF PROVISIONAL ESTIMATES OF GROSS NATIONAL PRODUCT AND ITS COMPONENTS, OF SELECTED NATIONAL INCO JASA 58 54 FROM A POWER-FUNCTION POPULATION DISTRIBUTION OF PRODUCT AND OF QUOTIENT OF MAXIMUM VALUES IN SAMPLES JA DISTRIBUTION OF A PRODUCT AND THE STRUCTURAL SETUP OF DENSITIES

MARKET CROWTH, COMPANY DIVERSIFICATION AND PRODUCT CONCENTRATION 1947-1954

JASA $64 \quad$ B77 AMS 691439 JASA $60 \quad 640$ CULUS OF FACTORIAL ARRANCEMENTS I BLOCK AND DIRECT PRODUCT DESTCN COMMENT 641296 PRODUCT DIVERSIFICATION AND LIVING COSTS, A FURTHER PRODUCT DIVERSIFICATION AND THE COST OF LIVINC, CORR. PRODUCT ENTROPY TO CAUSSIAN DISTRIBUTIONS

ON MULTIVARIATE RATIO AND PRODUCT ESTIMATORS

ON PAIRS OF INDEPENDENT RANDOM VARIABLES WHOSE PRODUCT FOLLOWS THE GAMMA DISTRIBUTION MODELS
63 JASA $66 \quad 7 B 8$ JASA $63 \quad 807$ AMS $69 \quad 870$ BIOKA69 NO 3 BIOKA65 2B9 BIOKA66 397 
CATED

BLEMS CONNECTED WITH THE CHARACTERISTIC ROOTS OF THE PRODUCT OF A WISHART VARIATE WITH THE INVERSE OF ANOT ESTIMATORS FOR THE PRODUCT OF ARITHMETIC MEANS

ASSOCIATION MATRICES AND THE KRONECKER PRODUCT OF DESIGNS

TH THE SAME SHAPE PARAM/ EXACT DISTRIBUTION OF THE PRODUCT OF INDEPENDENT GENERALIZED GAMMA VARIABLES WI THE VARIANCE OF THE PRODUCT OF K RANDOM VARIABLES

BAYESIAN CONFIDENCE LIMITS FOR THE PRODUCT OF N BINOMIAL PARAMETERS

CONFIDENCE INTERVALS FOR THE PRODUCT OF TWO BINOMIAL PARAMETERS

THE DISTRIBUTION OF THE PRODUCT OF TWO CENTRAL OR NON-CENTRAL CHI-SQUARE

VARIATES THE DISTRIBUTION OF THE PRODUCT OF TWO
PRICINC POLICIES CONTINCENT ON OBSERVED PRODUCT QUALITY

E, REJECTION SAMPLING UPON SAMPLE ASSURANCE OF TOTAL PRODUCT QUALITY

CE-REJECTION SAMPLING UPON SAMPLE ASSURANCE OF TOTAL PRODUCT QUALITY' PROBABILITY MEASURES ON PRODUCT SPACES

/SEQUENTIAL BATCHING FOR ACCEPTANC TECH 60 /SEQUENTIAL BATCHING FOR ACCEPTAN TECH 61 131 SASJ 67

OF SEASONAL VARIATION WITH AN APPIICATION TO HOG PRODUCTION L CONSIDERATION OF THE CASE OF MARKET ORIENTATION OF PRODUCTION DEVELOPMENTS

ONE OPERATIVE

$$
\text { THE PRESENT STATUS OF AUTOMATIC PRODUCTION AND }
$$
AND CONTROL DEVICES AND EXPECTED FUTURE AN INDEX OF MANUFACTURING PRODUCTION IN NEW ENGLAND

A TEST OF THE ACCURACY OF A PRODUCTION INDEX

A DYNAMIC PROCRAMMING APPLICATION IN PRODUCTION LINE INSPECTION

A PRODUCTION MODEL AND CONTINUOUS SAMPLING PLAN

THE FACTORIAL ANALYSIS OF CROP PRODUCTIVITY

METHOD FOR CALCULATING CORRECTED SUMS OF SQUARES AND PRODUCTS ENTIATION WITH SPECIAL REFERENCE TO KRONECKER MATRIX PRODUCTS OF SAFETY SYSTEMS FOR PLANTS MANUFACTURING HAZARDOUS PRODUCTS DEMAND FOR MANUFACTURERS' SERVICES FOR BAKERY PRODUCTS AND FRUITS AND VECETABLES SOME THEOREMS ON MATRIX DIFFER
ICAL MODEL OF EVALUATING THE RELIABILITY IECH 66,73 JRSS854 285 JASA 5 B 336 JASA $56 \quad 17$ TECH $67 \quad 73$ JASA 59231 JASA $64 \quad 469$ TECH $62 \quad 419$ JASA 69953 TECH 59293 JASA $65 \quad 740$ LOCNORMAL APPROXIMATION TO PRODUCTS AND QUOTIENTS MEASUREMENTS AND RELATED PROBLEMS DEMAND FOR FARM PRODUCTS AT RETAIL AND THE FARM LEVEL. SOME EMPIRICAL JA SOME MULTIVARIATE DENSITY FUNCTIONS OF PRODUCTS OF GAUSSIAN VARIATES

SOME RULES FOR A COMBINATORIAL METHOD FOR MULTIPLE PRODUCTS OF CENERALIZED K-STATISTICS GAMMA-DISTRIBUTED PRODUCTS OF INDEPENDENT RANDOM VARIABLES DISTRIBUTIONS OF PRODUCTS OF INDEPENDENT VARIABLES BIOKA56 404 JASA 58656 BIOKA65 645 AMS 6B 9B3 BIOKA62 564 TECH $62 \quad 277$ ON THE DISTRIBUTION OF SUMS OF SQUARES AND CROSS PRODUCTS OF NORMAL VARIATES IN THE PRESENCE OF INTRA'TABLES OF EXPECTED VALUES OF ORDER STATISTICS AND PRODUCTS OF ORDER STATISTICS FOR SAMPLES OF SIZE TWEN SEVERAL CARIABLES ON FINITE PRODUCTS OF POISSON-TYPE CHARACTERISTIC FUNCTIONS OF SOME MULTIPLE PRODUCTS OF POLYKAYS ON THE DISTRIBUTION OF PRODUCTS OF RANDOM VARIABLES

DISTRIBUTIONS AND INDEPENDENT GAMMA-DISTRIBUTED PRODUCTS OF RANDOM VARIABLES ON SUMS AND PRODUCTS OF RECTANGULAR VARIATES

A COMBINATORIAL METHOD FOR PRODUCTS OF TWO POLYKAYS WITH SOME GENERAL FORMULAE ON THE EXACT VARIANCE OF PRODUCTS, CORR. 61917

SPECIAL PAPER, PRINCIPLES OF PROFESSIONAL STATISTICAL PRACTICE CAL SOCIETY MEMORIAL MEETING FOR WILLIAM N. HURWITZ. PROFESSOR WILLIAM N. HURWITZ WASHINGTON STATISTI J THE VARIABILITY OF PROFITIBILATY WITH SIZE OF FIRM, 1947-1958

RELIABILITY GROWTH DURING A DEVELOPMENT TESTING PROCRAM PHILIPPINE STATISTICAL PROCRAM DEVELOPMENT AND THE SURVEY OF HOUSEHOLDS A COMPUTER PROCRAM FOR FITTING THE RICHARDS FUNCTION JRSSB $67 \quad 513$ DISCRETE DYNAMIC PROCRAMMINC

MEMORYLESS STRATEGIES IN FINITE-STAGE DYNAMIC PROCRAMMINC

DISCOUNTED DYNAMIC PROCRAMMINC NECATIVE DYNAMIC PROCRAMMINC

A NOTE ON UNDISCOUNTED DYNAMIC PROCRAMMINC

A NOTE ON POSITIVE DYNAMIC PROCRAMMINC

A DEFORMATION METHOD FOR QUADRATIC PROGRAMMINC

LIKELIHOOD PAIRED COMPARISON RANKING BY LINEAR PROGRAMMING

LEAST SQUARES REGRESSION AND CONVEX QUADRATIC PROGRAMMING

OUTLINE OF LINEAR PROGRAMMING AN OUTLINE OF LINEAR PROGRAMMING (WITH DISCUSSION) DISCUSSION) AN OUTLINE OF LINEAR PROGRAMMING AN OUTLINE OF LINEAR PROGRAMMING (WITH INTEGER PROGRAMMING AND THE THEORY OF GROUPINC AMS $62 \quad 719$ AMS $64 \quad 863$ AMS $65 \quad 226$ AMS $66 \quad 871$ AMS 661042 AMS 69316 JRSSB 64 141 MAXIMUM BIOKA 69 N0.3 RESTRICTED TECH 69 N0.4 N JRSSB55 165 JRSSB55 165

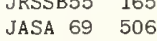
A DYNAMIC PROGRAMMING APPLICATION IN PRODUCTION LINE INSPECTION TECH 6773 PROGRAMMING FISHER'S EXACT METHOD OF COMPARING TWO TECH 60103 PERCENTAGES AUTOMATIC PROGRAMMING FOR AUTOMATIC COMPUTERS ABOUT SENSITIVITY ANALYSIS IN LINEAR PROGRAMMING MODELS JASA 59744 SASJ $67 \quad 33$ AMS 651279 
LINEAR PROGRAMMINC TECHNIQUES FOR RECRESSION ANALYSIS

JASA 59206 POTENTIALS IN APPLYINC LINEAR PROCRAMMINC TO THE CONSUMER PRICE INDEX

JASA $66 \quad 982$ PROCRAMMINC UNIVARIATE AND MULTTVARIATE ANALYSIS OF TECH 6395

ON FINDINC OPTIMAL POLICIES IN DISCRETE DYNAMIC PROCRAMMING WITH NO DISCOUNTINC

F VIEN OF THE USER I AN APPRAISAL OF LEAST SQUARES PROCRAMS FOR THE ELECTRONIC COMPUTER FROM THE POINT O JASA 67 B19 THE PROGRESS OF THE SCORE DURING A BASEBALL GAME JASA 61703

NCE BOUNDS ON RELIABLE LIFE FOR A WEIBULL MODEL WITH PROCRESSIVE CENSORINC /REE ORDER STATISTIC CONFTDE JASA G9 30 PREDTCTION BY PROCRESSIVE CORRECTTON

\section{LOCISTIC DISTRIBUTIONS}

\section{PROGRESSIVELY CENSORED SAMPLES FROM LOG-NORMAL AND} PROGRESSIVELY CENSORED SAMPLES IN LIFE TESTINC

JRSSB64 113 TECH 69 NO. 4 TECH $63 \quad 327$

TROLLERS IN NON-STATIONARY TIME SERIES POLYNOMIAL PROJECTING PROPERTIES OF MULTI-TERM PREDICTORS OR CON EXAMPLE OF THE DIFFERENCE BETWEEN THE LEVY AND LEVY-PROKHOROV METRICS

PERSONS WITH N OR MORE ACGIDENTS FROM AN ACCIDENT PRONE POPULATION.

UNIQUENESS OF A RESULT IN THE THEORY OF ACCIDENT PRONENESS

A RESULT ON ACCIDENT PRONENESS

WITH SPECIAL REFERENCE TO THE THEORY OF ACCIDENT PRONENESS

NOTE ON A UNIQUENESS RELATION IN CERTAIN ACCIDENT PRONENESS MODELS

RANDOM VARIABLES WITH INFINITE EXPECTATI/ A SHORT PROOF OF A KNOWN LIMIT THEOREM FOR SUM OF INDEPENDENT A POTENTIAL THEORETIC PROOF OF A THEOREM OF DERMAN AND VEINOTT

AN ELEMENTARY PROOF OF ASYMPTOTIC NORMALITY OF LINEAR FUNCTIONS OF SHORT PROOF OF DR HARLEY'S THEOREM ON THE CORRELATION

ORDER STATISTICS

COEFFICIENT

A SIMPLER PROOF OF SMITH'S ROULETTE THEOREM

GENERAL PROOF OF TERMTNATTON WITH PROBABILITY ONE OF INVARIAN

T SEQUENTIAL PROBABILITY RATIO TESTS BASE/ GEN

OF PRIORITY, 65344

AN AMS 69322

BIOKA65 298

BIOKA57 530

BIOKA67 324

A NEW PROOF OF THE PEARSON-FISHER THEOREM, (ACKNOWLEDGEMEN

JRSSB $66 \quad 180$

JASA $67 \quad 288$

AMS $69 \quad 1114$

AMS $67 \quad 5 B 5$

AMS 6B 263

BIOKA5B 57 I

AMS $6 B \quad 390$

AMS $67 \quad B$

AMS 651294

AMS $64 \quad 817$
INTRINSIC CORRELATION' IN THE THEORY OF ACCIDENT PRONENESS (ACKNOWLEDGEMENT 66 5B5)

GORRECTION TO 'A PROOF OF WALD'S THEOREM ON CUMULATIVE SUMS' 591245

ALTERNATIVE PROOFS FOR CERTAIN UPCROSSING INEQUALITIES

CONSUMERS ' PROPENSITIES TO HOLD LIQUID ASSETS

INVARIANT PROPER BAYES TESTS FOR EXPONENTIAL FAMILIES

NON-EXISTENCE OF EVERYWHERE PROPER CONDITIONAL DISTRIBUTIONS

A METHOD OF SYSTEMATTC SAMPLING BASED ON ORDER PROPERTIES

PROPOSED TWO-SAMPLE RANK TEST, THE PSI TEST AND ITS PROPERTIES

RENEWAL PROCESSES, DEFINITIONS AND PRELIMINARY PROPERTIES

SMIRNOV. TESTS OF APPROXIMATE HYPOTHESES AND THEIR PROPERTIES COMPLETE BLOCK DESIGNS WITH SOME LATIN SQUARE DESIGN PROPERTIES ON AND COMMUNITY EGOLOGY AND SOME OF ITS STATISTICAL PROPERTIES

IN TESTINC CORRELATION

TMM PROPERTIES AND ADMISSIBILITY OF SEQUENTIAL TESTS

SOME PROPERTIES AND AN APPLICATION OF A STATISTIC ARISING

DISTRIBUTION

CUMULANTS

CUMULANTS

STATISTIG

A SURVEY OF PROPERTIES AND APPLICATIONS OF THE NONCENTRAL T-

STATISTICAL PROPERTIES OF A CERTAIN PERIODIC BINARY PROCESS

SOME PROPERTIES OF A DISTRIBUTION SPECIFIED BY ITS

ERRATA, 'SOME PROPERTIES OF A DISTRIBUTION SPECIFIED BY ITS

ON THE LARGE SAMPLE PROPERTIES OF A GENERALIZED WILCOXON-MANN-WHITNEY

SOME STATISTICAL PROPERTIES OF A CENETIC SELECTION INDEX

CONVERGENCE PROPERTIES OF A LEARNING ALCORITHM

SOME PROPERTIES OF A METHOD OF ESTIMATING THE SIZE OF

MOBILE ANIMAL POPULATIONS

SQUARE

DIMENSIONAL PROPERTIES OF A RANDOM DISTRIBUTION FUNCTION ON THE

SUBSAMPLE MEANS

INVESTIGATING THE PROPERTIES OF A SAMPLE MEAN BY EMPLOYING RANDOM HIGHER-ORDER PROPERTIES OF A STATIONARY POINT PROCESS

Y TYPE OF INTERACTION BETWEEN TWO SPECIES THE PROPERTIES OF A STOCHASTIC MODEL FOR THE PREDATOR-PRE SPECIES

THE PROPERTIES OF A STOCHASTIC MODEL FOR TWO COMPETTNG

SPECIES.

CORRIGENDA. 'THE PROPERTIES OF A STOGHASTIC MODEL FOR TWO COMPETINC

AN INVESTIGATION INTO THE SMALL SAMPLE PROPERTIES OF A TWO SAMPLE TEST OF LEHMANN'S

GRAPHIG METHODS BASED UPON PROPERTIES OF ADVANCING CENTROIDS
UNRELATED REGRESSIONS

STOCHASTIC PROCESSES

CORRELATION COEFFICIENT

CORRELATION COEFFICIENT
SMALL SAMPLE PROPERTIES OF ALTERNATIVE ESTIMATORS OF SEEMINGLY

ASYMPTOTIC PROPERTIES OF AN AGE DEPENDENT BRANCHING PROCESS SOME PROPERTIES OF AN ALGEBRAIC REPRESENTATION OF SOME PROPERTIES OF AN ANGULAR TRANSFORMATION FOR THE

FURTHER PROPERTIES OF AN ANGULAR TRANSFORMATION OF THE

CONFIDENCE PROPERTIES OF BAYESIAN INTERVAL ESTIMATES

SOME STRIKINC PROPERTIES OF BINOMIAL AND BETA MOMENTS

SOME ANALYTTCAL PROPERTIES OF BIVARIATE EXTREMAL DISTRIBUTTONS
AMS 611344

AMS $67 \quad 735$

JASA $60 \quad 469$

AMS 69270

AMS $63 \quad 223$

BIOKA53 452

A JRSSB64 305

MARKOV AMS 611231

AMS 62

AMS $67 \quad 571$

JASA $67 \quad 655$

AMS $63 \quad 1$

AMS 691736

AN BIOKAGO 93

TECH $6 B \quad 445$

TECH $66 \quad 247$

TECH $63 \quad 63$

TECH $63 \quad 417$

AMS $67 \quad 905$

BIOKA62 325

AMS 64 1B19

BIOKA69 407

AMS $66 \quad B 49$

JASA $56 \quad 54$

JRSSB63 413

BIOKA60 219

BIOKA5B 316

BIOKA59 279

JASA 6B 345

JASA 59668

JASA 6B 1180

AMS 651565

AMS $6 B \quad 164$

BIOKA56 219

BIOKA57 273

JRSSB68 535

AMS 691753

JASA $67 \quad 569$

METHODS

ASYMPTOTIC OPTIMUM PROPERTIES OF CERTAIN SEQUENTIAL TESTS AMS 681244

ESTIGATION OF THE EFFECT OF MISCLASSIFICATION ON THE PROPERTIES OF CHI-SQUARE-TESTS IN THE ANALYSIS OF CAT BIOKA65 95 POINT PROCESS CONVERGENCE PROPERTIES OF CONVERGENCE WITH PROBABILITY ONE

AMS $66 \quad 1800$

POINT PROCESS

SOME PROPERTIES OF COUNTS OF EVENTS FOR CERTAIN TYPES OF JRSSB64 325

62919

PASSAGE TIMES

CORRIGENDA, 'PROPERTTES OF DISTRIBUTIONS RESULTING FROM CERTAIN SI

CERTAIN PROPERTIES OF GAUSSIAN PROCESSES AND THEIR FIRST JRSSB65 505 PROPERTIES OF GENERALIZED RAYLEIGH DISTRIBUTIONS

FUNCTIONS

MULTIVARIATE ANALYSIS

STOCHASTIC SERIES

LING FROM ASSOCIATED POPULATIONS

NON-STATIONARY TIME SERIES
ON CONTINUITY PROPERTIES OF INFTNITELY DIVISIBLE DISTRIBUTION

AMS 68936

SOME DISTANCE PROPERTIES OF LATENT ROOT AND VECTOR METHODS USED IN BIOKA66 325 SAMPLING PROPERTIES OF LOCAL STATISTICS IN STATIONARY $\quad$ BIOKA55 160

THE ASYMPTOTIC PROPERTIES OF MAXIMUM LIKELIHOOD ESTIMATORS WHEN SAMP BIOKA62 205 POLYNOMIAL PROJECTING PROPERTIES OF MULTI-TERM PREDICTORS OR CONTROLLERS IN JRSSB65 144 
STIC DIFFERENCE EQUATIONS

ON. CORR. 62919

C DISPERSION MATRICES OF MULTIVARIATE NORMAL DIST/

OROPRTIES OF PASCAL DISTRIBUTION FOR FINITE POPULATT JASA 62

INCREASINC PROPERTIES OF POLYA FREQUENCY FUNCTIONS PROPERTIES OF POLYKAYS OF DEVIATES AMS 641167

PROPERTIES OF POWER FUNCTIONS OF SOME TESTS CONCERNIN AMS 69697

ON CERTAIN PROPERTIES OF POWER-SERIES DISTRIBUTIONS B B PROPERTIES OF PROBABILITY DISTRIBUTIONS WITH MONOTONE AMS $63 \quad 375$ HAZARD RATE

SOME PROPERTIES OF RECULAR MARKOV CHAINS
SOME PROPERTIES OF RUNS IN QUALITY CONTROL PROCEDURES AMS BIOKA5B B

$\begin{array}{llllr}\text { SOME PROPERTIES OF RUNS IN QUALITY CONTROL PROCEDURES } & \text { BIOKA5B } & \text { B9 } \\ \text { SOME PROPERTIES OF RUNS IN QUALITY CONTROL PROCEDURES' } & \text { BIOKA59 } & 279\end{array}$

$\begin{array}{lllll}\text { CORRIGENDA. 'SOME PROPERTIES OF RUNS IN QUALITY CONTROL PROCEDURES' } & \text { BIOKA59 } & 279 \\ & \text { SOME PROPERTIES OF RUNS IN SMOOTHED RANDOM SERIES } & \text { BIOKA52 } & 19 B\end{array}$

JRSSB54 136

JRSSB $65 \quad 74$

TECH $65 \quad 423$

AN IMPROVEMENT TO WALD'S APPROXIMATION FOR SOME PROPERTIES OF SEQUENTIAL TESTS
FORMULAE TO IMPROVE WALD'S APPROXIMATION FOR SOME PROPERTIES OF SEQUENTIAL TESTS

PARAMETERS

ASYMPTOTIC PROPERTIES OF SEVERAL ESTIMATORS OF WEIBULL

JASA 69253

THE CONTEXT OF AUTOCORRELATED ERRORS SMALL-SAMPLE PROPERTIES OF SEVERAL TWO-STAGE RECRESSION METHODS IN J

CIRCULAR ERROR

STATISTICAL ANALYSIS U

USINC LOCAL PROPERTIES OF SMOOTHLY HETEROMORPHIC STOCHASTIC SERIE

ASYMPTOTIC PROPERTIES OF SOME ESTIMATORS OF QUANTILES OF

DIVERCENCE PROPERTIES OF SOME MARTINCALE TRANSFORMS

ERGODIC PROPERTIES OF SOME PERMUTATION PROCESSES

ASYMPTOTIC PROPERTIES OF SPECTRAL ESTIMATES OF SECOND ORDER

SOME PROPERTIES OF STATISTICAL RELIABILITY FUNCTIONS

SOME PROPERTIES OF SYMMETRIC STABLE DISTRIBUTIONS

AUTOREGRESSIVE SCHEMES

QUANTILES AND MID-RANCES

DERED IN THE FORM OF A CONTINCENCY TABLE ASSAY

NON-CENTRAL F

DISTRIBUTION

CORR. 651584

ON ANALYSIS WHEN THE 'PREDICTOR' VARIABLES

LOCISTIC VARIATES

SAMPLING PROPERTIES OF TESTS OF GOODNESS-OF-FIT FOR LINEAR SOME PROPERTIES OF THE 'HERMITE' DISTRIBUTION

ON SOME PROPERTIES OF THE ASYMPTOTIC VARIANCE OF THE SAMPLE SOME PROPERTIES OF THE BIVARIATE NORMAL DISTRIBUTION CONSI

ASYMPTOTIC PROPERTIES OF THE BLOCK UP-AND-DOWN METHOD IN BIOSOME PROPERTIES OF THE DISTRIBUTION OF THE LOCARITHM OF

ON CERTAIN PROPERTIES OF THE EXPONENTIAL-TYPE FAMILIES PROPERTIES OF THE EXTENDED HYPERCEOMETRIC

SOME BASIC PROPERTIES OF THE INCOMPLETE GAMMA FUNCTION RATIO. A NOTE ON SOME ASYMPTOTIC PROPERTIES OF THE LOCARITHMIC SERIES DISTRIBUTION PROPERTIES OF THE MEDIAN AND OTHER STATISTICS OF

STATISTTCAL PROPERTIES OF THE NUMBER OF POSITIVE SUMS

PAIRWISE COMPARISON AND RANKING, OPTIMUM PROPERTIES OF THE ROW SUM PROCEDURE

SOME PROPERTIES OF THE SPEARMAN ESTIMATOR IN BIOASSAY PROPERTIES OF THE STATIONARY MEASURE OF THE CRITICAL

CASE SIMPLE BRANCHING PROCESS

MULTIVARIATE BETA DISTRIBUTIONS AND INDEPENDENCE PROPERTIES OF, THE WISHART DISTRIBUTIONS, CORR. 66 297

A RANDOM SET PROCESS IN THE PLANE WITH A MARKOVIAN PROPERTY INDEPENDENT SEQUENCES WITH THE STEIN PROPERTY

TYPE INEQUALITY FOR MARTINGALES AND A CHARACTERISTIC PROPERTY

THE STRONC RATIO LIMIT PROPERTY FOR SOME CENERAL MARKOV PROCESSES

A FINITE MARKOV CHAIN

DESIGNS

PERSION MATRICES AGAINST ONE-SIDED ALTERNATI/ ONON PROPERTY OF A CLASS OF BALANCED INCOMPLETE BLOCK ON A PROPERTY OF A TEST FOR THE EQUA
ON A PROPERTY OF BALANCED DESIGNS CORRECTION TO 'A CONSERVATIVE PROPERTY OF BINOMIAL TESTS' 601205 ON A PROPERTY OF INCOMPLETE BLOCKS

A SAMPLE FUNCTION PROPERTY OF MARTINGALES

ACKNOWLEDCEMENT OF PRIORITY FOR 'AN OPTIMUM PROPERTY OF MAXIMUM LIKELIHOOD ESTIMATION' 60 1208 AN OPTIMAL PROPERTY OF PRINCIPAL COMPONENTS

A PROPERTY OF SOME SYMMETRIC TWO-STAGE SEQUENTIAL

PROCEDURES

NOTE ON A CONDITIONAL PROPERTY OF STUDENT'S T

ANOTHER CHARACTERISTIC PROPERTY OF THE CAUCHY DISTRIBUTION

AN EXTREMAL PROPERTY OF THE CONDITIONAL EXPECTATION

AN OPTIMUM PROPERTY OF THE HORVITZ-THOMSON ESTIMATE

ON A PROPERTY OF THE LOGNORMAL DISTRIBUTION

A PROPERTY OF THE MEAN DEVIATION FOR A CLASS OF

CONTINUOUS DISTRIBUTIONS

E DISTRIBUTIONS

DISTRIBUTIONS

ISTRIBUTIONS

CENERALIZATION OF JOHNSON

'S PROPERTY OF THE MEAN DEVIATION FOR A CLASS OF DISCRET

A PROPERTY OF THE MEAN DEVIATION FOR THE PEARSON TYPE

(ACKNOWLEDCEMENT OF PRIORITY).

A PROPERTY OF THE METHOD OF STEEPEST ASCENT

A PROPERTY OF THE MULTINOMIAL DISTRIBUTION AND THE

DETERMINATION OF APPROPRIATE SCORES

A CHARACTERISTIC PROPERTY OF THE MULTIVARIATE NORMAL DISTRIBUTION A PROPERTY OF THE MULTIVARIATE T DISTRIBUTION

EQUALITY OF TWO COVARIANCE MATRICES, / MONOTONICITY PROPERTY OF THE POWER FUNCTIONS OF SOME TESTS OF THE

AND DAMS

S SIGNED RANK STATISTIC

FUNCTIONS

ON A FURTHER ROBUSTNESS PROPERTY OF THE TEST AND ESTIMATOR BASED ON WILCOXON'

ON THE LIFTING PROPERTY, $V$

ON THE PROPERTY, W, OF THE CLASS OF STATISTICAL DECISION

CONFIDENCE INTERVALS FOR A PROPORTION

CONTROLLINE THE PROPORTION DEFECTIVE FROM CLASSIFICATION DATA

BINOMIAL CROUP-TESTINC WITH AN UNKNOWN PROPORTION OF DEFECTIVES

ON THE PROPORTION OF OBSERVATIONS ABOVE SAMPLE MEANS IN A

BIVARIATE NORMAL DISTRIBUTION CORRICENDA TO 'CONFIDENCE INTERVALS FOR A PROPORTION'

DISCRIMINANT FUNCTION WHEN COVARIANCE MATRICES ARE PROPORTIONAL

EAN OF A LOC-NORMAL DISTRIBUTION HAVING A PRESCRIBED PROPORTIONAL CLOSENESS

EAN OF A LOC-NORMAL DISTRIBUTION HAVING A PRESCRIBED PROPORTIONAL CLOSENESS

EQUAL AND PROPORTIONAL FREQUENCY SQUARES

PROPORTIONAL SAMPLING IN LIFE LENGTH STUDIES

USE OF A STRATIFICATION VARIABLE IN ESTIMATION BY PROPORTIONAL STRATIFIED SAMPLING

A METHOD OF SAMPLING WITH PROBABILITY EXACTLY PROPORTIONAL TO SIZE
DISTRIBUTION OF AMS 69979 D SAMPLE ESTIMATOR OF THE M AMS 67949 $\begin{array}{llllr}\text { /D SAMPLE ESTIMATOR OF THE M } & \text { AMS } & 67 & 949 \\ \text { /UENTIAL ESTIMATION OF } & \text { THE M } & \text { AMS } & 66 & 1688\end{array}$ JASA $67 \quad 226$ TECH 67205 THE JASA $6 B \quad 1310$ JRSSB54 236 
ON A BIASED ESTIMATOR IN SAMPLING WITH PROBABILITY PROPORTIONAL TO SIZE WITH REPLACEMENT A A CONFIDENCE BANDS OF UNIFORM AND PROPORTIONAL WIDTH FOR LINEAR MODELS JASA 66

ON SAMPLING OVER TWO OCCASIONS WITH PROBABILITY PROPORTIONATE TO SIZE

IN RANDOMIZED SYSTEMATIC SAMPLINC WITH PROBABILITY PROPORTIONATE TO SIZE AMS $65 \quad 327$

ON SIMULTANEOUS CONFIDENCE INTERVALS FOR MULTINOMIAL PROPORTIONS

LINEAR REGRESSION ON PROPORTIONS

JRSSB69 107

POWER OF CHI SQUARE TESTS FOR LINEAR TRENDS IN PROPORTIONS

PULTANEOUS CONFIDENCE INTERVALS FOR MULTINOMIAL PROPORTIONS LTIVARIATE BETA-DISTRIBUTION, AND CORRELATIONS AMONG PROPORTIONS

ASYMPTOTIC BIOCS68 315

NDUM 67/ THE CHI-SQUARE TEST FOR HETEROGENEITY OF PROPORTIONS AFTER ADJUSTMENT FOR STRATIFICATION (ADDE JRSSB66 150

FUNCTION OF THE TEST FOR THE DIFFERENCE BETWEEN TWO PROPORTIONS IN A 2-BY-2 TABLE. ' /ICENDA, 'THE POWER BIOKA59 502

AN EXACT TEST FOR COMPARING MATCHED PROPORTIONS IN CROSSOVER DESIGNS

INFORMATION

DISTRIBUTION CONCEPTS OF INDEPENDENCE FOR PROPORTIONS WITH A A GENERALIZATION OF THE DIRICHLET JASA 69 194 ANALYSIS OF VARIANCE OF PROPORTIONS WITH UNEQUAL FREQUENCIES

PROBLEMS IN THE ANALYSIS OF SURVEY DATA, AND A PROPOSAL

FOR A CALIBRATION LINE, CONSIDERATION OF A RECENT PROPOSAL

ASA 631133

JASA $63 \quad 415$ PROPERTIES

POLYNOMIAL REGRESSION

AROPOSED TWO-SAMPLE RANK TEST, THE PSI TEST ANDCTION

TECH 69 NO.

PROTECTION AGAINST ASSUMINC THE WRONG DEGREE IN

RIMENTS CARRIED OUT BY GAUSE WITH POPULATIONS OF THE PROTOZOA PARAMECIUM AURELIA AND PARAMECIUM CAUDATUM BIOKA57 314

$S$ TO LEAST SQUARES TYPE QUADRA/ A USEFUL LEMMA FOR PROVING THE EQUALITY OF TWO MATRICES WITH APPLICATION JASA 69 969 TS COMPONENTS, OF SELEC/ A STATISTICAL ANALYSIS OF PROVISIONAL ESTIMATES OF GROSS NATIONAL PRODUCT AND I JASA 58 54 SOME PROBLEMS IN THE THEORY OF PROVISIONING AND OF DAMS

OPTIMUM UTILIZATION OF AUXTLIARY INFORMATTON (PI)PS SAMPLING OF TWO UNTTS FROM A STRATUM (ADDENDUM G9 ANA QUERY, PSEUDO RANDOM NORMAL NUMBERS

THE DIFFUSION EQUATION AND A PSEUDO-DISTRIBUTION IN GENETICS

ON PSEUDO-GAMES

PSEUDO-INVERSES IN THE ANALYSIS OF VARIANCE

BIAS IN PSEUDO-RANDOM NUMBERS

APPLICATIONS OF THE PSEUDOINVERSE TO MODELING

A PROPOSED TWO-SAMPLE RANK TEST, THE PSI TEST AND ITS PROPERTIES

COMMENT

SOME STATISTICAL PROBLEMS IN EXPERTMENTAL PSYCHOLOGY (WTTH DISCUSSION)

JRSSB67 374

ECH 68401

JRSSB 63405

AMS 681932

AMS $64 \quad 895$

JASA 61

TECH $66 \quad 351$

AMS 61

JRSSB56 177

PUBLICATION DECISIONS AND TESTS OF SIGNIFICANCE, A JASA 59593

NFERENCES DRAWN FROM TESTS OF SIGNIFICANCE, OR VI/ PUBLICATION DECISIONS AND THEIR POSSIBLE EFFECTS ON I JASA 59 30

PUBLICATIONS OF FRANK WILCOXON (1892-1965) BIOCS67

PUBLICATIONS OF S. S. WILKS

AMS $65 \quad 24$

CORRIGENDA TO 'CORRELATED RANDOM NORMAL DEVIATES' PUBLISHED IN TRACTS FOR COMPUTERS, NO. 26.
LINEAR ESTIMATION AND THE ANALYSIS OF GAMMA RAY PULSE-HEIGHT SPECTRA

CORRIGENDA TO 'CORRELATED RANDOM NORMAL DEVIATES' PUBLISHED IN TRACTS FOR COMPUTERS, NO. 26.
LINEAR ESTIMATION AND THE ANALYSIS OF GAMMA RAY PULSE-HEIGHT SPECTRA

ANALYSIS OF FACTORIAL EXPERIMENTS AND THE USE OF PUNCH CARDS, CORR 56650

TABULAR JASA $56 \quad 149$

A STOCHASTIC MODEL

CANNIBALISM OF THE PUPAL STAGE BY ADULT FLOUR BEETLES, AN EXPERIMENT AND BIOCS68 247

ANIONS AND PURCHASE PROBABILITY, AN EXPERIMENT IN SURVEY DESIGN JASA 66

A FORECASTING MODEL OF FEDERAL PURCHASES OF GOODS AND SERVICES

JASA 62633

ANALYSIS, AN INTRODUCTION TO ESSENTIALS. 1. THE PURPOSE AND UNDERLYING MODELS

FACTOR BIOCS65 190

RENCE BETWEEN HYPOTHETICAL DISTRIBUTION FUNCTION AND PYKE'S MODIFIED EMPIRICAL DISTRIBUTION FUNCTION /FE AMS 62 525 BLOCK DESIGNS WITH PARAMETERS $V=28, N 1=12, N 2=15$ AND P2(1 1$)=4$ /CTION OF PARTTALLY BALANCED INCOMPLETE AMS 66 1783 NOTES. A NOTE ON COCHRAN'S $Q$ TEST

AMS 661783

A Q-TECHNIQUE FOR THE CALCULATION OF CANONICAL VARIATES BIOKA66 588

AN APPROXIMATION TO THE DISTRIBUTION OF $Q$, A VARIATE RELATED TO THE NON-CENTRAL T

MS 64315

LOWER BOUND FOR THE CRITICAL PROBABILITY IN THE ONE-QUADRANT ORIENTED-ATOM PERCOLATION PROCESS

UNBALANCED DESIGNS

ON QUADRATIC ESTIMATES OF THE INTERCLASS VARIANCE FOR

JRSSB $63 \quad 401$

JRSSB61 493

ON THE INDEPENDENCE OF QUADRATIC EXPRESSIONS (CORR, 66584 )

QUADRATIC EXTRAPOLATION AND A RELATED TEST OF

63673

DISTRIBUTION OF A DEFINITE QUADRATIC FORM FOR NON-CENTRAL NORMAL VARIATES, CORR

THE DISTRIBUTION OF A QUADRATIC FORM OF NORMAL RANDOM VARIABLES

CONDITIONS FOR A QUADRATIC FORM TO HAVE A CHI-SQUARED DISTRIBUTION

A NEW RESULT ON THE DISTRIBUTION OF QUADRATIC FORMS

APPROXIMATIONS TO THE DISTRIBUTION OF QUADRATIC FORMS

STATISTICAL CLASSIFICATION WITH QUADRATIC FORMS

SOME REMARKS CONCERNING KHATRI'S RESULT ON QUADRATIC FORMS

ON THE INDEPENDENCE OF QUADRATIC FORMS

MPOSITION OF SYMMETRIC MATRICES AND DISTRIBUTIONS OF QUADRATIC FORMS TWO MATRICES WITH APPLICATIONS TO LEAST SQUARES TYPE QUADRATIC FORMS ELEMENTS

$\mathrm{N}$

QUADRATIC FORMS

JASA 56

AMS 61883

AMS $67 \quad 1700$

BIOKA69 215

AMS $63 \quad 1582$

AMS $65 \quad 677$

BIOKA63 439

BIOKA68 593

JRSSB66 582

DEC0 AMS $65 \quad 683$

/LEMMA FOR PROVING THE EQUALITY OF JASA 69969 AMS 691430 AMS $63 \quad 186$ BIOKA60 199 AMS $66 \quad 567$ AMS 681502 BIOKA6I 419 JRSSB54 247 AMS $67 \quad 823$ AMS $67 \quad 838$ BIOKA62 284 AMS 681762 JRSSB62 148 BIOKA59 279 ON THE DISTRIBUTION OF CERTAIN QUADRATIC FORMS IN NORMAL VARIATES 
CORRICENDA, 'EXTREMA OF QUADRATIC FORMS WITH APPLICATIONS TO STATISTICS' BIOKA61 474

TO 'DISTRIBUTION OF DEFINITE AND OF INDEFINITE QUADRATIC FORMS' 55122

AIN DISTRIBUTION PROBLEMS BASED ON POSITIVE DEFINITE QUADRATIC FUNCTIONS IN NORMAL VECTORS

THE DISTRIBUTION OF HOMOGENEOUS AND NON-HOMOGENEOUS QUADRATIC FUNCTIONS OF NORMAL VARIABLES

ON AN A.P.O. RULE IN SEQUENTIAL ESTTMATION WITH QUADRATIC LOSS

OF A MULTIVARIATE NORMAL POPULATION WITH GENERAL QUADRATIC LOSS FUNCTION

SELECTION INDICES FOR QUADRATIC MODELS OF TOTAL MERIT

RESTRICTED LEAST SQUARES REGRESSION AND CONVEX QUADRATIC PROGRAMMING

A DEFORMATION METHOD FOR QUADRATIC PROGRAMMINC

SUPPLEMENT TO'A DEFORMATION METHOD FOR QUADRATIC PROGRAMMING'

ON A PROBLEM CONNECTED WITH QUADRATIC REGRESSION

A NUMERICAL ANALYSIS PROBLEM IN CONSTRAINED QUADRATIC REGRESSTON ANALYSIS

THE PARAMETERS

QUADRATIC REGRESSION WITH INEQUALITY RESTRAINTS ON

THE ESTIMATION OF 'TRANSFER FUNCTIONS' OF QUADRATIC SYSTEMS

2-TO-THE-(P-Q) PLANS ROBUST AGAINST LINEAR AND QUADRATIC SYSTEMS

CORRECTION AMS $62 \quad$ B13 ON CERT AMS $66 \quad 468$

/TIONS, IV, AMS 62542

AMS $69 \quad 417$ ESTIMATING THE MEAN AMS 661819 BIOCS6B 937 TECH 69 NO.4 JRSSB 64 141 JRSSB65 166 BIOKA60 335 TECH $62 \quad 426$ JASA 655914 TECH $61 \quad 563$

OF THE ONE-WAY CLASSIFICATION

QUADRATIC UNBTASED ESTIMATTON OP VARIANCE

ROBUSTNES/ THE ESTIMATION OF RESIDUAL VARIANCE IN QUADRATICALLY BALANCED LEAST-SQUARES PROBLEMS AND THE BIOKA62 83 BINARY CHAIN OF ORDER 2 QUADRATICS IN MARKOV-CHAIN FREQUENCIES, AND THE

VARIATION QUADRATIQUE DES MARTINGALES CONTINUES A DROITE

JRSSB63 383

AMS 69284 TE BLOCK DESIGNS APPLICATION OF THE GEOMETRY OF QUADRICS FOR CONSTRUCTINC PARTIALLY BALANCED INCOMPLE ORTHANT PROBABILITIES FOR THE QUADRIVARIATE NORMAL DISTRIBUTION

AN APPROXIMATION FOR THE SYMMETRIC, QUADRIVARIATE NORMAL INTEGRAL TWO EXPANSIONS FOR THE QUADRIVARIATE NORMAL INTEGRAL A NOTE ON THE QUADRIVARIATE NORMAL INTEGRAL

ON THE NUMERICAL REPRESENTATION OF QUALITATIVE CONDITION PROBABILITY

CUT RULE FOR A ONE-SIDED TEST OF HYPOTHESIS FOR QUALITATIVE DATA

WEAK QUALITATIVE PROBABILITY ON FINITE SETS

ON QUALITATIVE PROBABILITY SICMA-ALGEBRAS

ON DISCRIMINATION USTNC QUALITATIVE VARTABLES

PERCENTAGE POINTS FOR THE DISTRIBUTION OF OUTCOINC QUALITY

PRICING POLICIES CONTINCENT ON OBSERVED PRODUCT QUALITY

IN NONDESTRUCTIVE EVALUATION OF REACTOR FUEL ELEMENT QUALITY

TION SAMPLINC UPON SAMPLE ASSURANCE OF TOTAL PRODUCT QUALITY QUALITY /SEQUENTIAL BATCHINC FOR ACCE
QUALITY AND QUANTITY IN HIGHER EDUCATION

ON AN INDEX OF QUALITY CHANGE

ON AN INDEX OF QUALITY CONTROL AND EXPERIMENTATION

SERIAL DESICNS FOR ROUTNOF QUALITY CONTROL IN THE CHEMICAL LABORATORY
OPTIMIZATION OF QUAITY QUALITY CONTROL METHODS FOR SEVERAL RELATED VARIABLES

SOME PROPERTIES OF RUNS IN QUALTTY CONTROL PROCEDURES

CORRIGENDA, 'SOME PROPERTIES OF RUNS IN QUALITY CONTROL PROCEDURES'

AVERACE RUN LENCTHS IN CUMULATIVE CHART QUALITY CONTROL SCHEMES

MEASURED VARIABLES

QUALITY CONTROL SYSTEMS BASED ON INACCURATELY

AN APPLICATION OF MULTIVARIATE QUALITY CONTROL TO PHOTOGRAPHIC PROCESSINC

CE SCHEMES FOR LARCE BATCHES OF ITEMS WHERE THE MEAN QUALITY HAS A NORMAL PRIOR DISTRIBUTION/G ACCEPTAN ONE-SIDED CONFIDENCE INTERVALS FOR THE QUALITY INDICES OF A COMPLEX ITEM CONTROL OF QUALITY OF CODING IN THE 1960 CENSUSES THE VARYINC QUALITY OF INVESTMENT TRUST MANACEMENT THE QUALITY OF STATISTICAL INFORMATION AND STATISTICAL
/SEQUENTIAL BATCHING FOR ACCEPTANCE-REJEC

INFERENCE IN A RAPIDLY CHANCING WORLD

TION SAMPLINC UPON SAMPLE ASSURANCE OF TOTAL PRODUCT QUALTTY /SEQ

A SICNIFICANCE TEST FOR SIMULTANEOUS QUANTAL AND QUANTITATIVE RESPONSES

PLANNING A QUANTAL ASSAY OF POTENCY

RS OF THE LOCIT AND ITS VARIANCE WITH APPLICATION TO QUANTAL BIOASSAY

BIOCS66 322

A SIMPLE EXAMPLE OF A COMPARISON INVOLVINC QUANTAL DATA

$\begin{array}{cc}\text { BIOKA6I } & 201 \\ \text { AMS } 68 & 481\end{array}$

AMS $6416 B 5$

BIOKA56 206

BIOKA60 325

A SHORT- TECH 69197

AMS 69 NO. 6

AMS $64 \quad 17 B 7$

JASA $6 B \quad 1399$

JASA $59 \quad 6 B 9$

TECH $66 \quad 123$

TECH 64293

TECH 6019

JASA $65 \quad 1$

JASA $61 \quad 535$

TECH $64 \quad 77$

TEC4 $66 \quad 519$

TECH 59359

BI0KA5B B9

BIOKA59 279

TECH 61 11

BIOKA51 472

JASA 57 1B6

BIOKA6B 393

TECH 63400

JASA $64 \quad 120$

JASA 631011

JASA 67

TECH 61 131

JRSSB58 39B

BI0KA67 1BI BIOKA66 215

METHOD FOR ESTIMATING THE EXPONENTIAL PARAMETER FROM QUANTAL DATA, AND ITS RELATIONSHIP TO BIRTH, DEATH, A BIOCS67 739 FORMATIONS AND MAXTMUM LIKELTHOOD IN THE ANALYSIS OF QUANTAL EXPERIMENTS INVOLVINC TWO TREATMENTS /TRANS BTOKA55 $3 B 2$ ASSAYS ON THE SAME SUBJECTS THE QUANTAL RESPONSE ANALYSIS OF A SERIES OF BIOLOGICAL ANALYSIS OF QUANTAL RESPONSE ASSAYS WITH DOSACE ERRORS

SEQUENTTAL ESTTMATTON OF QUANTAL RESPONSE CURVES (WITH DISCUSSION)

SEQUENTIAL ESTIMATION OF QUANTAL RESPONSE CURVES, A NEW METHOD OF ESTIMATION

A NOTE ON ESTIMATION FOR QUANTAL RESPONSE DATA

REGRESSION METHODS FOR ANALYSINC SENSITIVITY AND QUANTAL RESPONSE DATA

THE USE OF NON-LINEAR

BIOKA60 23

BIOCS67 747

JRSSB63 1

BIOKA66 439

BIOKA68 578

PONSE IS SUBJECT TO ERROR

AN ANALYSIS OF QUANTAL RESPONSE DATA IN WHICH THE MEASUREMENT OF RES

WEIGHTED RECRESSION, QUANTAL RESPONSE DATA, AND INVERSE POLYNOMIALS

CS67 563

BIOCS65 811

DRUGS

CENERAL MODELS FOR QUANTAL RESPONSE TO THE JOINT ACTION OF A MIXTURE OF

THE WITHIN-ANIMAL BIOASSAY WITH QUANTAL RESPONSES

OF TWO APPROACHES EM FOR THE CLASSIFICATION OF MATHEMATICAL MODELS FOR QUANTAL RESPONSES TO MIXTURES OF DRUCS IN BIOLOCICAL BIOCS65 181 IONS OF SIMPLE SIMILAR ACTION, THE ANALYSIS OF UN/ QUANTAL RESPONSES TO MIXTURES OF POISONS UNDER CONDIT BIOKA5B 74 THE QUANTIFICATION OF JUDCMENT. SOME METHODOLOCTCAL NONPARAMETRIC PROCEDURES FOR AMS 671804

SELECTINC THE T POPULATION WITH THE LARCEST ALPHA-QUANTILE NONPARAMETRIC PROCEDURES FOR

SET CONTAINING THE POPULATION WITH THE LARGEST ALPHA-QUANTILE /PARAMETRIC PROCEDURES FOR SELECTING A

ESTIMATION OF NON-UNIQUE QUANTILES

ON BAHADUR'S REPRESENTATION OF SAMPLE QUANTILES

AN INEQUALITY FOR EXPECTED VALUES OF SAMPLE QUANTILES

THE EMPIRICAL BAYES APPROACH ESTIMATING POSTERIOR QUANTILES

SOME ASPECTS OF THE ESTIMATION OF QUANTILES

A NOTE ON THE ASYMPTOTIC DISTRIBUTION OF SAMPLE QUANTILES INFERENCE CONCERNINC PROBABILITIES AND QUANTILES

THE PARAMETERS OF THE GAMMA DISTRIBUTION BY SAMPLE QUANTILES

PARAMETERS OF THE LOGISTIC DISTRIBUTION BY SAMPLE QUANTILES

STANDARD DEVIATION OF A NORMAL DISTRIBUTION USING QUANTILES

PROPERTIES OF THE ASYMPTOTIC VARIANCE OF THE SAMPLE QUANTILES AND MID-RANGES

ASYMPTOTIC NORMALITY OF SAMPLE QUANTILES FOR M-DEPENDENT PROCESSES

ESTIMATION OF TECH $64 \quad 405$ ESTIMATION OF THE BIOKA69 NO.3 TESTING THE MEAN AND TECH 68 7B1 AMS $65 \quad 921$ ON SOME JRSSB61 453 AMS $68 \quad 1724$ 
NECATIVE EXPONENTIAL DISTRIBU/ ASYMPTOTIC OPTIMUM QUANTILES FOR THE ESTIMATION OF THE PARAMETERS OF THE ANALYSIS OF EXTREME-VALUE DATA BY SAMPLE QUANTILES FOR VERY LARCE SAMPLES ESTIMATION FROM QUANTILES IN DESTRUCTIVE TESTING A NOTE ON QUANTILES IN LARCE SAMPLES

ASYMPTOTIC PROPERTIES OF SOME ESTIMATORS OF QUANTILES OF CIRCULAR ERROR CONFIDENCE LIMITS FOR QUANTILES OF MORTALITY DISTRIBUTIONS THE DISTRIBUTION OF QUANTILES OF SMALL SAMPLES

AMS $66 \quad 143$ JASA $6 B \quad B 77$ JRSSB $61 \quad 434$ AMS $66 \quad 577$ JASA $66 \quad 61 \mathrm{~B}$ BIOCS69 176 BIOKA52 207 SSIBILITY OF THE BEST INVARIATE ESTIMATOR OF EXTREME QUANTILES OF THE NORMAL DISTRIBUTION UNDER SQUARED ER AMS 69 IBO ERPRETATION DU DETERMINISME CENETIQUE DES CARACTERES QUANTITATIFS ET RECHERCHE DE 'CENES MAJEURS' FFICIENT UTILIZATION OF NON-NUMERICAL INFORMATION IN QUANTITATIVE ANALYSIS. CENERAL THEORY AND THE CASE OF AMS 63 1347 AN ESTIMATION PROBLEM IN QUANTITATIVE ASSAY BIOKA54 33B NC AS A DEFENCE ACAINST BLADDER INFECTION A QUANTITATIVE DISCUSSION OF THE EFFECTIVENESS OF VOIDI BIOCS66 53 N OF WORD LENCTH AND ITS IMPORTANCE FOR THE STUDY OF QUANTITATIVE LINCUISTICS /HE OCCURRENCE DISTRIBUTIO BIOKA58 22 ON THE ANALYSIS OF CONTINCENCY TABLES WITH A QUANTITATIVE RESPONSE BIOCS6B

A SICNIFICANCE TEST FOR SIMULTANEOUS QUANTAL AND QUANTITATIVE RESPONSES AND TRADINC FOLKLORE SOME QUANTITATIVE TESTS FOR STOCK PRICE CENERATINC MODELS SOME NEW THREE LEVEL DESIGNS FOR THE STUDY OF QUANTITATIVE VARIABLES

'SOME NEW THREE LEVEL DESIGNS FOR THE STUDY OF QUANTITATIVE VARIABLES' TECH $64 \quad 273$ JASA $67 \quad 321$ TECH $60 \quad 455$ AND A PARADOX IN FIDUCIAL THEORY

PIVOTAL QUANTITIES FOR WTSHART'S AND RELATED DISTRTBUTTONS,

QUALITY AND QUANTITY IN HICHER EDUCATION QUANTUM HYPOTHESES

EXAMINATION OF A QUANTUM HYPOTHESIS BASED ON A SINCLE SET OF DATA

A QUARTERLY ECONOMETRIC MODEL OF THE UNITED STATES RIGHT HAAR MEASURE FOR CONVERGENCE IN PROBABILITY TO QUASI POSTERIOR DISTRIBUTIONS A PARADOX INVOLVINC QUASI PRIOR DISTRIBUTIONS TECH $61 \quad 576$ JRSSB $55 \quad 79$ JASA 65 BIOKA55 45 BIOKA56 32 JASA $61 \quad 379$ AMS $65 \quad 440$ BIOKA65 623 ANCED HIERARCHAL DESICN WITH A MIXED MO/ NOTE. THE QUASI-F TEST FOR AN UNNESTED FIXED FACTOR IN AN UNBAL BIOCS66 937 OF AMPLITUDE SPECTRA FOR STOCHASTIC PROCESSES WITH QUASI-LINEAR RESIDUALS A NOTE ON THE ESTIMATION JA ESTIMATION OF QUASI-LINEAR TREND AND SEASONAL VARIATION
QUASI-LINEARLY INVARIANT PREDICTION

ON MEDIANS AND QUASI-MEDIANS

A QUASI-MULTINOMIAL TYPE OF CONTINGENCY TABLE

ON MOMENTS OF ORDER STATISTTCS AND QUASI-RANGES FROM NORMAL POPULATIONS POPULATION STANDARD DEVIATION RANDOM WALK GENETICS (WITH DISCUSSION)

THE USE OF SAMPLE QUASI-RANGES IN SETTING CONFIDENCE INTERVALS FOR THE QUASI-STATIONARY BEHAVIOUR OF A LEFT-CONTINUOUS QUASI-STATIONARY DISTRIBUTIONS AND TIME-REVERSION IN

REPLY TO MR OUENOUILLE'S COMMENTS ABOUT MY PAPER ON MIXTURES NOTE ON MR QUENOUILLE'S EDGEWORTH TYPE A TRANSFORMATION ON OF RATIOS A NOTE ON THE APPLICATION OF QUENOUILLE'S METHOD OF BIAS REDUCTION TO THE ESTIMATI A NOTE ON ESTIMATION OF RATIOS BY QUENOUILLE'S METHOD.

N STRUCTURES IN TIME SERIES MUTANT GENES)

CONFOUNDED 2-CUBE)

CONFOUNDED 2-CUBE)

SOIL CONTENT)

THE RANGE

DISTRIBUTION

SAMPLING

MEDIAN

FROM A SINGLE OBSERVATION

AN EXTENSION OF QUENOUILLE'S TEST FOR THE COMPATIBILITY OF CORRELATIO QUERY + (ON FORMULA FOR DETERMINING THE INCIDENCE OF QUERY, ANALYSIS OF FACTORIAL EXPERIMENT (PARTIALLY QUERY, ANALYSIS OF FACTORIAL EXPERIMENT (PARTIALLY QUERY, BAULE'S EQUATION + (LEAST SQUARES ESTIMATE OF QUERY, BIVARIATE SAMPLES WITH MISSINC VALUES QUERY, BIVARIATE SAMPLES WITH MISSING VALUES, II QUERY, CALCULATION OF THE SAMPLING DISTRIBUTION OF QUERY, COMBINATION OF A NORMAL AND A UNIFORM QUERY, COMBINING VALUES OF OBSERVED CHI-SQUARE'S QUERY, COMPARISON OF SAMPLE SIZES IN INVERSE BINOMIAL QUERY, COMPLETED RUNS OF LENGTH K ABOVE AND BELOW QUERY, CONFIDENCE INTERVAL FOR STANDARD DEVIATION QUERY, CONFIDENCE LIMITS FROM RANK TESTS

QUERY, DEGREES OF FREEDOM OF CHI-SQUARE

QUERY, DISTRIBUTION OF A RANKED OBSERVATION QUERY, ERROR RATE BASES

QUERY, INADMISSIBLE RANDOM ASSIGNMENTS

QUERY, JOINT CONFIDENCE LIMITS FOR RANKED QUERY, LIFE TESTING AND EARLY FAILURE

QUERY, MAXIMUM LIKELIHOOD ESTIMATE IN INTRACLASS QUERY, MISSING VALUES IN FACTORIAL EXPERIMENTS QUERY, NEGATIVE VARIANCE ESTIMATES QUERY, PREFERENCE SCORES (REVISITED)

QUERY, PSEUDO RANDOM NORMAL NUMBERS

QUERY, RECRESSION ANALYSIS OF CUMULATIVE DATA

QUERY, REJECTION OF OUTLYING VALUES

QUERY, RESIDUAL ANALYSIS

QUERY, SAVINGS IN TEST TIME WHEN COMPARING WEIBULL

QUERY, SMALL TRIMMED SAMPLES

QUERY, TESTING TWO CORRELATED VARIANCES

QUERY, THE COMBINATION OF PROBABILITIES

QUERY, THE MEAN OF THE TAIL OF A DISTRIBUTION QUERY. THE SUM OF VALUES FROM A NORMAL AND A TRUNCATE TECH 64469 QUERY. THE SUM OF VALUES FROM A NORMAL AND A TRUNCATE TECH 64104 QUERY, TOLERANCE INTERVAL IN REGRESSION

QUERY, TOLERANCE LIMITS FOR A BINOMIAL DISTRIBUTION

D NORMAL DISTRIBUTION

ON THE QUESTION OF WHETHER A DISEASE IS FAMILIAL

FRAMEWORK

THE UNRELATED QUESTION RANDOMIZED RESPONSE MODEL, THEORETICAL A SAMPLING PROCEDURE FOR MAILED QUESTIONNAIRES THE SCORING OF MULTIPLE CHOICE QUESTIONNARES

SOME QUESTIONS OF DISTRIBUTION IN THE THEORY OF RANK

CORRELATION

CORRIGENDA, 'ON QUESTIC

ON THE TRAFFIC LIGHT QUEUE

ON THE TRANSIENT BEHAVIOUR OF A SIMPLE QUEUE

DIFFERENCE EQUATION TECHNIQUE APPLIED TO THE SIMPLE QUEUE
JASA $63 \quad 1033$

AMS $6616 B 4$

JASA $67 \quad 926$

SASJ $67 \quad 59$

AMS $63 \quad 633$

JASA 61260

AMS $69 \quad 53$

JRSSB6 171 BIOKA59 203 BIOKA65 477 JRSSB $68 \quad 180$ BIOC\$65 750 TECH $67 \quad 490$ BI0CS69 159 TECH $67 \quad 679$ TECH $6 \mathrm{~B} \quad \mathrm{~B} 67$ TECH $65 \quad 73$ TECH $65 \quad 449$ TECH $66 \quad 709$ TECH $67 \quad 337$ TECH $67 \quad 682$ TECH $66 \quad 367$ TECH $65 \quad 257$ TECH $67 \quad 489$ TECH $64 \quad 329$ TECH $65 \quad 260$

TECH $64 \quad 103$ TECH $66 \quad 368$ TECH $66 \quad 539$ TECH 69 NO. 4 TECH $65 \quad 649$ TECH $65 \quad 75$ TECH 6B 612 TECH 6B 401 TECH $64 \quad 225$ TECH 64 22B TECH $67 \quad 339$ TECH $64 \quad 471$ TECH $66 \quad 193$ TECH $65 \quad 447$ BIOCS67 TECH 69201 JASA $67 \quad 409$ JASA $69 \quad 520$ JASA $56 \quad 209$ AMS $62 \quad 375$ BIOKA5I 131 BIOKA5I 265 AMS $64 \quad 380$ JRSSB $60 \quad 277$ A JRSSB5B 165 
EFFECT OF THE SIZE OF THE WAITINC ROOM ON A SIMPLE QUEUE

RESULTS IN THE NON-EQUILIBRIUM THEORY OF A SIMPLE QUEUE SOLUTION OF THE 'HEAD-OF-THE-LINE' PRIORITY QUEUE WAITINC TIMES OF SUCCESSIVE CUSTOMERS IN A FINITE QUEUE

SOME NUMERICAL RESULTS FOR

'SOME NUMERICAL RESULTS FOR WAITINC TIMES IN THE QUEUE E-SUB-K-M-1. SOME INEQUALITIES FOR THE QUEUE GI/GI

FINITE CAPACITY THE ERCODIC QUEUE LENGTH DISTRIBUTION FOR QUEUEINC SYSTEMS WITH A CONTINUOUS TIME TREATMENT OF A SIMPLE QUEUE USINC GENERATINC FUNCTIONS

TIME SOLUTION OF THE EQUATIONS OF THE SINCLE CHANNEL QUEUE WITH A CENERAL CLASS OF SERVICE-TIME DISTRIBUTI JR ON THE CENERAL TIME DEPENDENT QUEUE WITH A SINCLE SERVER

DIFFERENCE EQUATION TECHNIQUE APPLIED TO THE SIMPLE QUEUE WITH ARBITRARY ARRIVAL INTERVAL DISTRIBUTION A CENERALIZED SINCLE-SERVER QUEUE WITH ERLANC INPUT A TRANSIENT DISCRETE TIME QUEUE WITH FINITE STORACE

ORRELATION STRUCTURE OF THE DEPARTURE PROCESS OF THE QUEUE WITH ONE SERVER, WHILE THE INTERARRIVAL AND SER JR

ORRELATION STRUCTURE OF THE DEPARTURE PROCESS OF THE QUEUE WITH ONE SERVER, WHILE THE INTERARRIVAL AND SER
SOME RESULTS FOR THE QUEUE WITH POISSON ARRIVALS
THE TIME DEPENDENCE OF A SINCLE-SERVER QUEUE WITH POISSON INPUT AND CENERAL SERVICE TIMES

DEPARTURES

A QUEUE WITH RANDOM ARRIVALS AND SCHEDULED BULK PREEMPTIVE PRIORITY QUEUEINC

THE SOLUTION OF QUEUEING AND INVENTORY MODELS BY SEMI-MARKOV

SOME FURTHER JRSSB57 326 TIME-DEPENDENT JRSSB62 91

PROCESSES

$S^{\prime}$

A CORRECTION TO 'THE SOLUTION OF QUEUEINC AND INVENTORY MODELS BY SEMI-MARKOV PROCESSE J QUEUEINC AT A SINGLE SERVINC POINT WITH GROUP ARRIVAL QUEUEINC FOR CAPS IN TRAFFIC.

DISCUSSION )

CUSTOMERS ARE SCHEDULED

A QUEUEINC MODEL FOR ROAD TRAFFIC FLOW (WITH

A QUEUEING PROBLEM IN WHICH THE ARRIVAL TIMES OF THE

RAMETERS AN ELEMENTARY METHOD OF SOLUTION OF THE QUEUEINC PROBLEM WITH A SINGLE SERVER AND CONSTANT PA A BULK-SERVIGE QUEUEING PROBLEM WITH VARIABLE CAPACITY

SOME EQUILIBRIUM RESULTS FOR THE QUEUEING PROCESS E-SUB-K-M-

THE BUSY PERIOD IN RELATION TO THE QUEUEING PROCESS GI-M-I

SERVICE TIME DISTRIBUTION, ONE SERVER ON THE QUEUEING PROCESS, MARKOV OR POISSON INPUT, GENERAL

ON QUEUEING PROCESSES WITH BULK SERVICE

RANDOM QUEUEING PROCESSES WITH PHASE-TYPE SERVICE

THE OUTPUT PROCESS OF A STATIONARY M/M/S QUEUEING SYSTEM

DETERMINISTIC CUSTOMER IMPATIENCE IN THE QUEUEINC SYSTEM GI-M-1

DETERMINISTIC CUSTOMER IMPATIENCE IN THE QUEUEING SYSTEM GI-M-1, A CORRECTION

A NOTE ON THE QUEUEING SYSTEM M-M-1 WITH BALKING.

ON THE TRANSIENT BEHAVIOR OF A QUEUEINC SYSTEM WITH BULK SERVICE AND FINITE CAPACITY AMS 62 973

THE BUSY PERIOD IN RELATION TO THE SINGLE-SERVER QUEUEING SYSTEM WITH GENERAL INDEPENDENT ARRIVALS AND JRSSB60 89

L AND SERVINC DISTRIBUT/ THE OUTPUT PROCESS OF THE QUEUEING SYSTEM WITH ONE SERVER AND WHICH INTERARRIVA JRSSB59 375

AL AND SERVING DIS/ SOME NUMERICAL RESULTS FOR THE QUEUEING SYSTEM WITH ONE SERVER, WHILE THE INTERARRIV JRSSB63 477

DISTRIBUTIONS

INTERFERENCE MODEL

DISCIPLINES ON A GENERALIZED QUEUEING SYSTEM WITH POISSON ARRIVALS

A NOTE ON QUEUEINC SYSTEMS WITH ERLANCIAN SERVICE TIME

CLOSED QUEUEINC SYSTEMS, A CENERALIZATION OF THE MACHINE QUEUEINC WITH BALKINC

QUEUEINC WITH BALKINC. II

COMPETITIVE QUEUEINC. IDLENESS PROBABILITIES UNDER PRIORITY

ON PRE-EMPTIVE RESUME PRIORITY QUEUES

THE DEPENDENCE OF DELAYS IN TANDEM QUEUES

A PROBLEM OF INTERFERENCE BETWEEN TWO QUEUES

A BIBLIOGRAPHY ON THE THEORY OF QUEUES

WAITING TIME IN BULK SERVICE QUEUES

ON LIMITINC DISTRIBUTIONS ARISING IN BULK SERVICE QUEUES

A CONTRIBUTION TO THE THEORY OF BULK QUEUES

ON THE ASYMPTOTIC BEHAVIOUR OF QUEUES

WAITING-TIME DISTRIBUTIONS FOR SINGLE-SERVER QUEUES

ONTINUOUS TIME) AND ITS APPLIGATION TO THE THEORY OF QUEUES

OF FOUR MOMENT INEQUALITIES TO A PROBLEM IN QUEUES

BALLOT PROBLEM AND ITS APPLICATION IN THE THEORY OF QUEUES

GEOMETRIC DISTRIBUTIONS IN THE THEORY OF QUEUES (WITH DISCUSSION)

ON A PROPERTY OF THE RANDOM WALKS DESCRIBING SIMPLE QUEUES AND DAMS

TREATMENT OF THE NON-EQUILIBRIUM THEORY OF SIMPLE QUEUES BY MEANS OF CUMULATIVE PROBABILITIES

ON QUEUES IN HEAVY TRAFFIC

TWO SIMILAR QUEUES IN PARALLEL

TWO QUEUES IN PARALLEL

ON TWO QUEUES IN PARALLEL

QUEUES IN SERIES

ON THE WAITING-TIME DISTRIBUTION FOR QUEUES IN SERIES

ON QUEUES IN TANDEM

NOTES ON QUEUES IN TANDEM

UTILITY

EXPECTED UTILITY FOR QUEUES SERVICINC MESSACES WITH EXPONENTIALLY DECAYING QUEUES SUBJECT TO SERVICE INTERRUPTION

QUEUES WITH BATCH DEPARTURES I

QUEUES WITH BATCH DEPARTURES II

CYCLIC QUEUES WITH FEEDBACK

THE ERGODICITY OF SERIES OF QUEUES WITH GENERAL PRIORITIES

A GENERAL CLASS OF BULK QUEUES WITH POISSON INPUT

LIMIT THEOREMS FOR QUEUES WITH TRAFFIC INTENSITY ONE

E TIME THE TRANSIENT BEHAVIOR OF A SINGLE SERVER QUEUING PROCESS WITH RECURRENT INPUT AND GAMMA SERVIC EXPERIMENTS

SPECIFICATIONS
QUICK ANALYSIS METHODS FOR RANDOM BALANCE SCREENING

A QUICK COMPACT TWO SAMPLE TEST TO DUCKWORTH'S

A QUICK ESTIMATE OF THE REGRESSION GOEFFICIENT

A QUICK METHOD FOR CHOOSING A TRANSFORMATION

A QUICK METHOD OF ESTIMATING THE STANDARD DEVIATION

$\begin{array}{ll}\text { QUICK POWERFUL TESTS WITH CROUPED DATA } & \text { BIOKA6B } \\ \text { SOME QUICK SICN TESTS FOR TREND IN LOCATION AND DISPERSION BIOKA55 }\end{array}$
JRSSB $66 \quad 456$

AMS 651574

JRSSB 61 3B5

BIOKA57 360

BIOKA60 2B5

JRSSB63 4B9

AMS 64600

AMS $64 \quad 874$

BIOKA53 5B

BIOKA57 490

JRSSB55 256

JRSSB $56 \quad 265$

JRSSB59 320

JRSSB $63 \quad 464$

STATIONARY AMS $62 \quad 1323$

THE RANDOM WALK (IN C BIOKA59 400

NOTE ON AN APPLICATION TECH 65435

JASA $62 \quad 327$

JRSSB59 1

JRSSB65 125

JRSSB $63 \quad 457$

JRSSB $62 \quad 3 B 3$

AMS $61 \quad 1314$

BIOKA5B 401

BIOKA60 198

JRSSB62 359

JRSSB 65491

AMS $63 \quad 300$

AMS $63 \quad 338$

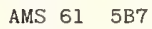

AMS $62 \quad 1314$

AMS $61 \quad 1324$

AMS $64 \quad 1147$

\begin{tabular}{lr} 
JRSSB $59 \quad 153$ \\
\hline
\end{tabular}

AMS 651664

AMS $67 \quad 759$

AMS $65 \quad 1437$

AMS $61 \quad 1286$

TECH 59195

TECH 5931

BIOKA58 431

TECH $63 \quad 317$ 
A QUICKLY CONVERCENT EXPANSION FOR CUMULATIVE HYPERCEOM BIOKA54 317 ETRIC PROBABILITIES, DIRECT AND IN/ CORRICENDA, A QUICKLY CONVERCENT EXPANSION FOR CUMULATIVE HYPERGEOM BIOKA55 277 OPTIMAL SAMPLINC FOR QUOTA FULFILMENT

BIOKA57 518 QUOTA FULFILMENT USINC UNRESTRICTED RANDOM SAMPLINC BIOKA6I 333 PROBABILITY SAMPLINC WITH QUOTAS PROBABILITY TABLES FOR THE EXTREMAL QUOTIENT

JASA $66 \quad 749$ AMS $67 \quad 1541$

VARIATE

THE QUOTIENT OF A RECTANCULAR OR TRIANCULAR AND A CENERAL BIOKA54 330 NCTION POPULATION DISTRIBUTION OF PRODUCT AND OF OUOTIENT OF MAXIMUM VALUES IN SAMPLES FROM A POWER-FU JASA 64 B77 RIBUTION ON BIVARIATE RANDOM VARIABLES WHERE THE QUOTIENT OF THEIR COORDINATES FOLLOWS SOME KNOWN DIST AMS 64 I673 CONCENTRATION OF RANDOM QUOTIENTS

LOCNORMAL APPROXIMATION TO PRODUCTS AND QUOTIENTS

THE CEOMETRY OF A R-BY-C CONTINCENCY TABLE

SYMMETRY AND MARCINAL HOMOCENEITY OF AN R-BY-R CONTINCENCY TABLE

ON RANDOM ROTATIONS IN R-CUBE

SEQUENTIAL HYPOTHESIS TESTS FOR THE R-DEPENDENT MARCINALLY STATIONARY PROCESSES

ON CONVERCENCE IN R-MEAN OF NORMALIZED PARTIAL SUMS ON THE COMPLEX ANALOCUES OF T-SQUARED AND R-SQUARED TESTS

MINIMAX CHARACTER OF THE R-SQUARED-TEST IN THE SIMPLEST CASE

AMS $6 B \quad 466$

BIOKA56 404

AMS 68 11B6

JASA 69 N0.4

AMS $66 \quad 90$

AMS $65 \quad 747$

AMS $65 \quad 664$

AMS 641475

ESTIMATORS OF VARIANCE COMPONENTS IN THE UNBALANCED R-WAY CLASSIFICATION MOMENTS OF THE RADIAL ERROR, CORR, 651251

VARIANCES OF MOMENT BIOCS68 527

ELLIPTICAL AND RADIAL TRUNCATION IN NORMAL POPULATTONS

DISTRIBUTION

JASA $62 \quad 1 B 7$

AMS $63 \quad 940$ 1 IN POTA/ NOTES. THE STATISTICAL ANALYSIS OF A RADIO-ACTIVE TRACER EXPERIMENT TO DETERMINE ROOT ACTI BIOCS6B 7I7

RESIDUALS, A TEST FOR REGRESSION MODEL ADEQUACY IN RADIONUCLIDE ASSAY

IVALENT CAUSSIAN MEASURES WITH A PARTICULARLY SIMPLE RADON-NIKODYM DERIVATIVE

MEASURES

RADON-NIKODYM DERIVATIVES OF GAUSSIAN MEASURES

ASURINC JRSSB65 108

AMS $66 \quad 321$

AMS $64 \quad 517$

JRSSB64 345

A MODEL FOR RAINFALL OCCURRENCE

A MODIFIED MODEL FOR RAINFALL OCCURRENCE

DISTRIBUTION OF STATISTICS SUITABLE FOR EVALUATING RAINFALL STIMULATION EXPERIMENTS

JRSSB67 151

UOUS DISTRIBUTIONS.

OF BINOMIAL PROBABILITIES AND A GENERALIZATION OF RAMANUJAN'S EQUATION RENEWAL THEORY AND ITS RAMIFICATIONS (WITH DISCUSSION)

AMS 681191

JRSSB58 243

PARAMETERS IN HUMAN GENETICS IF THE AGE OF ONSET IS RANDOM T265

SIMPLE RANDOM ALLOCATION RANDOM ALLOCATION DESIGNS II, APPROXIMATE THEORY FOR AMS 61 3B7

THE USE OF RANDOM ALLOCATION FOR THE CONTROL OF SELECTION BIAS BIOKA69 NO.3 SEQUENTIAL ANALYSIS OF VARIANCE UNDER RANDOM AND MIXED MODELS POISSON PROCESSES WITH RANDOM ARRIVAL RATE

A QUEUE WITH RANDOM ARRIVALS AND SCHEDULED BULK DEPARTURES EXTREMES IN A RANDOM ASSEMBLY

QUERY, INADMISSIBLE RANDOM ASSIGNMENTS

THE APPLICATION OF RANDOM BALANCE DESIGNS

ERRATA, 'THE APPLICATION OF RANDOM BALANCE DESIGNS'

RANDOM BALANCE EXPERIMENTATION

QUICK ANALYSIS METHODS FOR RANDOM BALANCE SCREENING EXPERIMENTS

A NOTE ON MULTI-TYPE CALTON-WATSON PROCESSES WITH RANDOM BRANCHINC PROBABILITIES INTERSECTIONS OF RANDOM CHORDS OF A CIRCLE RANDOM CIRCLES ON A SPHERE

JASA $67 \quad 1401$

AMS $62 \quad 924$

JRSSB6B 185

BIOKA67 273

TECH 64103

TECH 59139

TECH 59419

TECH $59 \quad 111$

TECH 59195

BIOKA6B 589

BIOKA64 373

BIOKA62 389

SERVATIONS ON THE EFFECTS FOR THE UNBALANCED ONE-WAY RANDOM CLASSIFICATION /FFECTS AND THE NUMBERS OF OB JASA 67 1375

UPPER AND LOWER PROBABILITIES CENERATED BY A RANDOM CLOSED INTERVAL

SOME ESTTMATORS FOR A LTNEAR MODEL WITH RANDOM COEFFICIENTS

JASA $6 B \quad 584$

CED I/ BAYESIAN ANALYSIS OF LINEAR MODELS WITH TWO RANDOM COMPONENTS WITH SPECIAL REFERENCE TO THE BALAN BIOKA6B IOI WEEN REGULAR EVENTS DISPLACED IN TIME BY INDEPENDENT RANDOM DEVIATIONS OF LARGE DISPERSION /NTERVALS BET JRSSB61 476 SECOND PAPER ON STATISTICS ASSOCIATED WITH THE RANDOM DISOREINTATION OF CUBES SOME STATISTICS ASSOCIATED WITH THE RANDOM DISORIENTATION OF CUBES RANDOM DISPERSAL IN THEORETICAL POPULATIONS

DIMENSIONAL PROPERTIES OF A RANDOM DISTRIBUTION FUNCTION ON THE SQUARE

CORRECTION TO 'ON A CLASS OF PROBLEMS RELATED TO THE RANDOM DIVISION OF AN INTERVAL' 53239

A LARGE-SAMPLE BIOASSAY DESIGN WITH RANDOM DOSES AND UNCERTAIN CONCENTRATION

BAYESIAN ESTIMATION OF MEANS FOR THE RANDOM EFFECT MODEL NOTE ON TESTING HYPOTHESES IN AN UNBALANCED RANDOM EFFECTS MODEL

A PROCEDURE TO ESTIMATE THE POPULATION MEAN IN RANDOM EFFECTS MODELS

QUADRATIC FORMS AND IDEMPOTENT MATRICES WITH RANDOM ELEMENTS

FOR ALMOST SURE EXTINCTION OF BRANCHING PROCESS WITH RANDOM ENVIRONMENT

ON BRANCHING PROCESSES IN RANDOM ENVIRONMENTS

NECESSARY CONDITIONS REGRESSION ON A RANDOM FIELD

THE CENTRAL LIMIT THEOREM FOR GENERALIZED RANDOM FIELDS

HOMOGENEOUS GAUSS-MARKOV RANDOM FIELDS

INTERPOLATION OF HOMOGENEOUS RANDOM FIELDS ON DISCRETE GROUPS

THE PROBABILITY THAT A RANDOM GAME IS UNFAIR

MAJORANTS OF THE CHROMATIC NUMBER OF A RANDOM GRAPH

RANDOM HAZARD IN RELIABILITY PROBLEMS

VERY IRRECULAR

(CORR. 69 NO.6)
SAMPLE FUNCTIONS OF GAUSSIAN RANDOM HOMOGENEOUS FIELDS ARE EITHER CONTINUOUS OR SAMPLING ENTROPY FOR RANDOM HOMOGENEOUS SYSTEMS WITH COMPLETE CONNECTIONS

$\begin{array}{rl}\text { CENTRAL LIMIT THEOREM FOR THE NUMBER OF EDCES IN THE RANDOM INTERSECTION OF TWO GRAPHS (CORR. } 69 \text { 15I0) } & \text { AMS } 67 \\ \text { AMS } 69 & 374\end{array}$ ON THE NUMBER OF RENEWALS IN A RANDOM INTERVAL

5B 229 BIOKA57 205 BIOKA5I 196 AMS $66 \quad 849$ AMS $62 \quad 812$ BIOKA55 307 JASA $67 \quad 1375$ BIOKA67 659 TECH $67 \quad 577$ AMS 691430 AMS 682136 AMS $69 \quad 814$ JASA 69 NO.4 AMS 69203 AMS 691625 AMS $69 \quad 251$ AMS 661796 JRSSB69 NO. TECH 63211 AMS $67 \quad 1579$ AMS $67 \quad 37$ BIOKA60 449 
A RANDOM INTERVAL FILLING PROBLEM

A LIMIT THEOREM FOR RANDOM INTERVAL SAMPLING OF A STOCHASTIC PROCESS SOME NOTES ON ORDERED RANDOM INTERVALS

A MULTIVARIATE CENTRAL LIMIT THEOREM FOR RANDOM LINEAR VECTOR FORMS

RR. 64924 SOME RESULTS ON THE DISTRIBUTION OF TWO RANDOM MATRICES USED IN CLASSIFICATION PROCEDURES THE BIAS OF FUNCTIONS OF CHARACTERISTIC ROOTS OF A RANDOM MATRIX

THE DISTRIBUTION OF THE LATENT ROOTS OF A SYMMETRIC RANDOM MATRTX UNDER CENERAL CONDITIONS

HE HISTORY OF PROBABILITY AND STATISTICS XVI. RANDOM RANDOM MECHANISMS IN TALMUDIC LITERATURE

A TEST FOR RANDOM MINGLING OF THE PHASES OF A MOSAIC RANDOM MINIMAL TREES

CORRELATED ERRORS IN THE RANDOM MODEL

CONFIDENCE RECIONS FOR VARIANCE RATIOS OF RANDOM MODELS

OF VARIANCE POWER FUNCTTON IN THE PARAMETRIC AND RANDOM MODELS

TERS, NO. 26.

QUERY, PSEUDO RANDOM NORMAL NUMBERS

ON LIMITINC DISTRIBUTIONS FOR SUMS OF A RANDOM NUMBER OF INDEPENDENT RANDOM VECTORS

A STATISTICAL TEST INVOLVING A RANDOM NUMBER OF RANDOM VARIABLES BIAS IN PSEUDO-RANDOM NUMBERS

INTERVALS BETWEEN SUCCESSIVE MAXIMA IN A SERIES OF RANDOM NUMBERS

AR SAMPLE

HOW MANY OF A CROUP OF RANDOM NUMBERS WILL BE USABLE IN SELECTINC A PARTICUL

TABLES OF RANDOM OBSERVATIONS FROM STANDARD DISTRIBUTIONS

CRADING WITH A GAUGE SUBJECT TO RANDOM OUTPUT FLUCTUATIONS

DISTRIBUTIONS OF RANDOM VARIABLES WITH RANDOM PARAMETERS

RANDOM PERMUTATIONS

LATTICE

CHROMOSOME PATTERNS

THE DISTANCE FROM A RANDOM POINT TO THE NEAREST POINT OF A CLOSELY PACKED

RANDOM POINTS IN A CIRCLE AND THE ANALYSIS OF

THE DISTANCES BETWEEN RANDOM POINTS IN TWO CONCENTRIC CIRCLES

CLUSTERING OF RANDOM POINTS IN TWO DIMENSIONS

GEOMETRICAL PROBABILITY AND RANDOM POINTS ON A HYPERSPHERE

MINIMAX ESTIMATION OF A RANDOM PROBABILITY WHOSE FIRST N MOMENTS ARE KNOWN

ALITIES WITH APPLICATIONS TO THE WEAK CONVERGENCE OF RANDOM PROCESSES WITH MULTI-DIMENSIONAL TIME PARAMETE A CONTINUOUS KIEFER-WOLFOWITZ PROCEDURE FOR RANDOM PROCESSES, CORR, 66745

RANDOM QUEUEINC PROCESSES WITH PHASE-TYPE SERVICE

CONCENTRATION OF RANDOM QUOTIENTS

ES IN THE HISTORY OF PROBABILITY AND STATISTICS XVI. RANDOM RANDOM MECHANISMS IN TALMUDIC LITERATURE

ON RANDOM ROTATIONS IN R-CUBE.

WEAK CONVERCENCE AND A CHERNOFF-SAVAGE THEOREM FOR RANDOM SAMPLE SIZES

REDUCINC A RANDOM SAMPLE TO A SMALLER SET, WITH APPLICATIONS

GENERATION OF RANDOM SAMPLES FROM THE BETA AND F DISTRIBUTIONS

ION OF THE PRODUCT-MOMENT CORRELATION COEFFICIENT IN RANDOM SAMPLES OF ANY SIZE DRAWN FROM NON-NORMAL UNIV BI

DOMAINS OF OPTIMALITY OF TESTS IN SIMPLE RANDOM SAMPLING QUOTA FULFILMENT USING UNRESTRICTED RANDOM SAMPLING

ON RANDOM SAMPLING FROM A STOCHASTIC PROCESS

SOME ASPECTS OF THE RANDOM SEQUENCE

CONSTRUCTING AN UNBIASED RANDOM SEQUENCE

TRIBUTION OF ASCENDINC PAIRS AND ASCENDING RUNS IN A RANDOM SEQUENCE

THE CAP TEST FOR RANDOM SEQUENCES

POISSON COUNTS FOR RANDOM SEQUENCES OF EVENTS

THE SUPERPOSITION OF RANDOM SEQUENCES OF EVENTS

SOME PROPERTIES OF RUNS IN SMOOTHED RANDOM SERIES

STATIONARY AMPLITUDE FLUCTUATIONS IN A RANDOM SERIES

THE CONVEX HULL OF A RANDOM SET OF POINTS

A RANDOM SET PROCESS IN THE PLANE WITH A MARKOVIAN

PROPERTY

PATHS AND CHAINS OF RANDOM STRAIGHT-LINE SECMENTS

RANDOM SUBDIVISIONS OF SPACE INTO CRYSTALS

IGATING THE PROPERTIES OF A SAMPLE MEAN BY EMPLOYING RANDOM SUBSAMPLE MEANS

ON RANDOM SUMS OF RANDOM VECTORS

LATENT VECTORS OF RANDOM SYMMETRIC MATRICES

ON THE PROBABILITY DISTRIBUTION OF A FILTERED RANDOM TELEGRAPH SICNAL

PROCESSES

A RANDOM TIME CHANCE RELATING

THE PROBABILITY THAT A RANDOM TRIANGLE IS OBTUSE

NUMERICAL OPTIMIZATION IN THE PRESENCE OF RANDOM VARIABILITY. THE SINCLE FACTOR CASE

IPROCAL OF THE CONDITIONAL EXPECTATION OF A POSITIVE RANDOM VARIABLE

OTHESIS TESTINC WHEN THE SAMPLE SIZE IS TREATED AS A RANDOM VARIABLE (WITH DISCUSSION)

ON THE CENERALIZED MELLIN TRANSFORM OF A COMPLEX RANDOM VARIABLE AND ITS APPLICATIONS

\begin{tabular}{lr} 
BIOKA69 & 65 \\
\hline
\end{tabular}

JASA $6 B \quad 1526$

AMS $61 \quad 524$

AMS 631217

BI0KA66 3B3

BIOKA52 19B

JRSSB64 36I

BIOKA65 331

AMS 651 B59

TECH $66 \quad 303$

AMS $62 \quad 958$

INVEST JASA $56 \quad 54$

AMS $65 \quad 1450$

BIOKA6I 133

AMS 6B B90

AMS $68 \quad 358$

BIOKA69 NO. 3

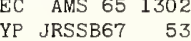
AMS 651459 EXPRESSING A RANDOM VARIABLE IN TERMS OF UNIFORM RANDOM VARIABLES AMS 61 B94

CESSARY AND SUFFICIENT CONDITION FOR THE SQUARE OF A RANDOM VARIABLE TO BE GAMMA

GENERATING EXPONENTIAL RANDOM VARIABLES

A FLUCTUATION THEOREM FOR CYCLIC RANDOM VARIABLES

PROBABILITY INEQUALITIES FOR THE SUM OF INDEPENDENT RANDOM VARIABLES

THE VARIANCE OF THE PRODUCT OF K RANDOM VARIABLES

CENTRAL LIMIT THEOREMS FOR FAMILIES OF SEQUENCES OF RANDOM VARIABLES

CORRELATTON AND COMPLETE DEPENDENCE OF RANDOM VARIABLES

PROBABILITY INEQUALITIES FOR SUMS OF BOUNDED RANDOM VARIABLES

ASYMPTOTIC EXTREMES FOR M-DEPENDENT RANDOM VARIABLES

SUFFICIENT STATISTICS IN THE CASE OF INDEPENDENT RANDOM VARIABLES

SOME CONVERGENCE THEOREMS FOR INDEPENDENT RANDOM VARIABLES

CONVERGENCE OF QUADRATIC FORMS IN INDEPENDENT RANDOM VARIABLES

INFINITE DIVISIVILITY OF INTECER-VALUED RANDOM VARIABLES

THE DTSTRIBUTION OF A QUADRATIC FORM OF NORMAL RANDOM VARIABLES

THE INVARIANCE PRINCIPLE FOR A LATTICE OF RANDOM VARIABLES

AN INEQUALITY IN CONSTRAINED RANDOM VARIABLES

DISTANCES OF PROBABILITY MEASURES AND RANDOM VARIABLES

BOUNDS ON MOMENTS OF SUMS OF RANDOM VARIABLES

THE MARKOV INEQUALITY FOR SUMS OF INDEPENDENT RANDOM VARIABLES

ON THE EXACT COVARIANCE OF PRODUCTS OF RANDOM VARIABLES $\begin{array}{rr}\text { A NE BIOKA66 } & 275 \\ \text { AMS } 61 & 899\end{array}$

AMS $62 \quad 1450$

JASA $62 \quad 33$

JASA $62 \quad 54$

AMS $63 \quad 439$

AMS $63 \quad 1315$

JASA $63 \quad 13$

AMS 641322

AMS 641456

AMS $66 \quad 1482$

AMS $66 \quad 567$

AMS 671306

AMS 671700

AMS $68 \quad 382$

AMS 681080

AMS $68 \cdot 1563$

AMS $69 \quad 1506$

AMS 69 NO. 6

JASA 69 NO. 4 
THE Z-TEST AND SYMMETRICALLY DISTRIBUTED RANDOM VARIABLES GAMMA-DISTRIBUTED PRODUCTS OF INDEPENDENT RANDOM VARIABLES ON LINEAR FUNCTIONS OF ORDERED CORRELATED NORMAL RANDOM VARIABLES ON BAYES SEQUENTIAL DESICN WITH TWO RANDOM VARIABLES SOME KOLMOCOROFF-TYPE INEQUALITIES FOR BOUNDED RANDOM VARIABLES ON THE RATIO OF TWO CORRELATED NORMAL RANDOM VARIABLES

ON AN IDENTITY FOR THE VARIANCE OF A RATIO OF TWO RANDOM VARIABLES ASYMPTOTIC SEQUENTIAL DESICN OF EXPERTMENTS WITH TWO RANDOM VARIABLES ON THE DISTRIBUTION OF PRODUCTS OF RANDOM VARIABLES NOTE ON MAXIMUM-LIKELIHOOD IN THE CASE OF DEPENDENT RANDOM VARIABLES A CHEBYSHEV-TYPE INEQUALITY FOR SUMS OF INDEPENDENT RANDOM VARIABLES SURE CONVERGENCE OF QUADRATIC FORMS IN INDEPENDENT RANDOM VARIABLES

OF ROSEN'S THEOREM TO NON-IDENTICALLY DISTRIBUTED RANDOM VARIABLES UTIONS AND INDEPENDENT GAMMA-DISTRIBUTED PRODUCTS OF RANDOM VARIABLES BUTION OF THE MAXIMUM TERM IN SEQUENCES OF DEPENDENT RANDOM VARIABLES IVISIBLE LAWS AND A RENEWAL THEOREM FOR NON-NEGATIVE RANDOM VARIABLES RITERION AND THE UNIFORM DISTRIBUTION OF INDEPENDENT RANDOM VARIABLES OF MOMENTS ON THE ASYMPTOTIC DISTRIBUTION OF SUMS OF RANDOM VARIABLES

INEQUALTTY FOR THE SUM OF INDEPENDENT, BOUNDED RANDOM VARIABLES OF THE DISTRIBUTIONS OF TWO STOCHASTICALLY ORDERED RANDOM VARIABLES LARGE NUMBERS FOR LINEAR COMBINATIONS OF INDEPENDENT RANDOM VARIABLES ROM THE EXPECTATION FOR SUMS OF BOUNDED, INDEPENDENT RANDOM VARIABLES ONVERCENCE OF LINEAR COMBINATIONS OF INDEPENDENT AND RANDOM VARIABLES M DERIVATIVE (CORR. 65533 ) ASSOCIATION BETWEEN RANDOM VARIABLES IFFERENCE BETWEEN CONSECUTIVE MEMBERS OF A SERIES OF RANDOM VARIABLES ME INTERVAL A MOVING AVERACE REPRESENTATION FOR RANDOM VARIABLES A CONVEXITY PROPERTY IN THE THEORY OF RANDOM VARIABLES DISTINGUISHINC A SEQUENCE OF RANDOM VARIABLES

THE PROBABILITY OF LARGE DEVIATIONS OF THE MEAN FOR RANDOM VARIABLES TES FOLLOWS SOME KNOWN DISTRIBUTION ON BIVARIATE RANDOM VARIABLES LY DISTRIBUTED A RENEWAL THEOREM FOR RANDOM VARIABLES L LAW ON LARGE DEVIATION PROBLEMS FOR SUMS OF RANDOM VARIABLES ON PAIRS OF INDEPENDENT RANDOM VARIABLES
IOS OF LINEAR FUNCTIONS OF ORDERED CORRELATED NORMAL RANDOM VARIABLES IOS OF LINEAR FUNCTIONS OF ORDERED CORRELATED NORMAL RANDOM VARIABLES
ROOF OF A KNOWN LIMIT THEOREM FOR SUM OF INDEPENDENT RANDOM VARIABLES A NOTE ON SUMS OF INDEPENDENT RANDOM VARIABLES DISTRIBUTIONS OF RANDOM VARIABLES

CONDITIONAL EXPECTATIONS OF RANDOM VARIABLES ITY INEQUALITIES FOR THE SUM OF INDEPENDENT, BOUNDED RANDOM VARIABLES. PROBLEMS WITH LINEAR LOSSES FOR BINOMIAL AND NORMAL RANDOM VARIABLESI SUM OF INDEPENDENT IDENTICALLY DISTRIBUTED DISCRETE RANDOM VARIABLES, ASSOCIATION RANDOM VARIABLES,

INEQUALITIES OF THE RTH ABSOLUTE MOMENT OF A SUM OF RANDOM VARIABLES, ON THE GENERATION OF NORMAL RANDOM VECTORS RIBUTIONS FOR SUMS OF A RANDOM NUMBER OF INDEPENDENT RANDOM VECTORS THE GROWTH OF A RECURRENT RANDOM WALK

QUASI-STATIONARY BEHAVIOUR OF A LEFT-CONTINUOUS RANDOM WALK THE GROWTH OF A RANDOM WALK THE CORRELATED UNRESTRICTED RANDOM WALK TO THE THEORY OF QUEUES IMPLE RANDOM WALK AND RANK ORDER STATISTICS DISTRIBUTIONS ASSOCIATED WITH RANDOM WALK AND RECURRENT EVENTS (WITH DISCUSSION) THE RANDOM WALK BETWEEN A REFLECTING AND AN ABSORBING RANDOM WALK DESIGN IN BIO-ASSAY

A RANDOM WALK IN WHICH THE STEPS OCCUR RANDOMLY IN TIME RANDOM WALK ON A CIRCLE

ONE DIMENSIONAL RANDOM WALK WITH A PARTIALLY REFLECTING BARRIER

1345 A. WIENER-HOPF TYPE METHOD FOR A CENERAL RANDOM WALK WITH A TWO-SIDED BOUNDARY FIRST PASSAGE TIMES OF A CENERALIZED RANDOM WALK, CORR. AND ACKNOWLEDGEMENT OF PRIORITY 61 ON A CLASS OF SIMPLE RANDOM WALKS

TMIT THEOREMS FOR STOPPED RANDOM WALKS

A LOCAL LIMIT THEOREM FOR A CERTAIN CLASS OF RANDOM WALKS

THE ERGODIC BEHAVIOUR OF RANDOM WALKS

NERALIZATION OF WALD'S IDENTITY WITH APPLICATIONS TO RANDOM WALKS CONDITIONS IN REGULAR MARKOV CHATNS AND CERTATN RANDOM WALKS

LIMITING DISTRIBUTIONS FOR SOME RANDOM WALKS ARISING IN LEARNING MODELS

ON A PROPERTY OF THE RANDOM WALKS DESCRIBING SIMPLE QUEUES AND DAMS

A MIXTURE OF TWO RECURRENT RANDOM WALKS NEED NOT BE RECURRENT

LIMIT THEOREMS FOR STOPPED RANDOM WALKS, II

LIMIT THEOREMS FOR STOPPED RANDOM WALKS, III

THE USE OF RANDOM WORK SAMPLING FOR COST ANALYSIS AND CONTROL

CORR. 58 1031

POSTERIOR DISTRIBUTION OF VA/

BAYESIAN ANALYSIS OF RANDOM-EFFECT MODELS IN THE ANALYSIS OF VARIANCE. I.
BAYESIAN ANALYSIS OF RANDOM-EFFECT MODELS IN THE ANALYSIS OF VARIANCE. II.

EFFECT OF AUTOCORRELATED ER/

THE INCLUSION OF VARIABLES IN LINEAR REGRESSION BY A RANDOMISATION TECHNIQUE (ERRATA. 69 627) /TINC FOR

ENT COMPARISONS WHEN OBSERVATIONS ARE MISSING FROM A RANDOMISED BLOCK EXPERIMENT WITH ADDITIONAL REPLICATI B SOME ASPECTS OF RANDOMIZATION

OF SOME SIGNIFICANCE TESTS UNDER EXPERIMENTAL RANDOMIZATION BLOCK DESIGN

BLOCK DESICN

CORRICENDA,

THE RANDOMIZATION ANALYSIS OF A GENERALIZED RANDOMIZED

RANDOMIZATION ANALYSIS OF A GENERALIZED

N OF WEIGHTED MEANS

RATIO TEST

PLOT DESIGN, AN EMPIRICAL INVESTIGATION THE RANDOMIZATION BASES OF THE PROBLEM OF THE AMALGAMATIO JRSSB6I 42

ON THE RANDOMIZATION DISTRIBUTION AND POWER OF THE VARIANCE JRSSB63 334 THE RANDOMTZATION DISTRIBUTION OF F-RATIOS FOR THE SPLIT- BIOKA63 43 $L$ CONSIDERATIONS REGARDING H. R. B. HACK'S SYSTEM OF RANDOMIZATION FOR CROSS-CLASSIFICATIONS THEORETICA BIOKA58 265 OMPLETE BLOCK DESICN SOME CONSEQUENCES OF RANDOMIZATION IN A CENERALIZATION OF THE BALANCED INC AMS 631569 AND TWO BAYESIANS

BIOKA59 123

BIOKA62 564

BI0KA66 369

BIOKA67 641

BIOKA69 NO. 3

JRSSB $64 \quad 484$

JRSSB67 513

A JRSSB61 444

ON AMS $66 \quad 248$

LMOST AMS $68 \quad 1502$

AN EXTENSION AMS 6B 897

ISTRIB BIOKA63 505

AMS $62 \quad 894$

AMS $68 \quad 139$

AMS 631042

BIOKA68 565

E CONVERGENCE RATE OF THE LAW OF AMS 65559

BIOKA63 528

295

AMS 1107

AMS 641673

AMS $63 \quad 390$

AMS 671575

BIOKA64 143

AMS 691114

ASJ 69

AMS $65 \quad 1556$

559

ASA $65 \quad 837$ AMS 671466

AMS $65 \quad 299$ AMS $69 \quad 935$ AMS $69 \quad 532$ JRSSB63 394 KA59 400 RSSB57 64 AMS $61 \quad 765$ ASA $67 \quad$ B42 IOKA63 385 AMS $63 \quad 405$ AMS 631168 AMS $61 \quad 235$ AMS $63 \quad 413$ AMS $66 \quad 855$ BIOKA6I 391 CE AMS 61549 IOKA56 276 JRSSB65 125 AMS 6B 1753 AMS $66 \quad$ B60 AMS 661510 ASA 58 3B2 BI0KA65 37 T) 66 JRSSB66 543 BIOKA69 231 BIOKA55 70 AMS 61 
ON THE NUIL-DISTRIBUTION OF THE F-STATISTIC IN A RANDOMIZED BALANCED INCOMPLETE BLOCK DESIGN UNDER THE AMS 63 1558 JASA 69 NO.4 RANDOMIZATION TESTS FOR A MULTIVARIATE TWO-SAMPLE NOTE ON THE MISSING PLOT PROCEDURE IN A RANDOMIZED BLOCK DESIGN

THE RANDOMIZATION ANALYSIS OF A GENERALIZED RANDOMIZED BLOCK DESIGN HETEROGENEITY OF ERROR VARIANCES IN A RANDOMIZED BLOCK DESIGN

CTORS AFFECTING THE F-TEST UNDER PERMUTATION FOR THE RANDOMTZED BLOCK DESTGN

POWER OF THE F-TEST UNDER PERMUTATION IN THE SIMPLE RANDOMIZED BLOCK DESIGN

IGENDA. 'THE RANDOMIZATION ANALYSIS OF A GENERALIZED RANDOMIZED BLOCK DESIGN'

CENSORED OBSERVATIONS IN RANDOMIZED BLOCK EXPERIMENTS

JASA 61933

BIOKA55 70

BIOKA57 275

AN EMPIRICAL STUDY INTO FA JASA 68902 /MONTE CARLO RESULTS ON THE BIOKA66 199

CORR BIOKA56 235

JRSSB59 214

JASA $63 \quad 894$

EFFICIENCY OF THE WILCOXON TWO-SAMPLE STATISTIC FOR RANDOMIZED BLOCKS

ON CHERNOFF-SAVAGE TESTS FOR ORDERED ALTERNATIVES IN RANDOMIZED BLOCKS PRIORI' ORDERING

RANK TESTS FOR RANDOMIZED BLOCKS

AMS 68967

VARIANCE RATIOS UNDER PERMUTATION IN THE COMPLETELY RANDOMIZED DESIGN

ALTERNATIVES HAVE AN 'A

AMS $67 \quad 867$

OPIMA AT INPINITY, WITHIN THE CLASS OF RANDOMIZED DESIGNS, OF BALANCED DESIGNS

OPTIMAL TESTS OF COMPOSITE HYPOTHESES FOR RANDOMIZED EXPERIMENTS WITH NONCONTROLLED PREDICTOR V JASA 65 699

A COMPLETE CLASS OF LINEAR UNBIASED ESTIMATORS FOR RANDOMTZED FACTORIAL EXPERIMENT TESTING HYPOTHESES IN RANDOMIZED FACTORIAL EXPERIMENTS

T-SQUARES ESTIMATION OF A SUBVECTOR OF PARAMETERS IN RANDOMIZED FRACTIONAL FACTORIAL EXPERIMENTS /D LEAS AMS 69 1344

GENERALIZED LEAST SQUARES ESTIMATORS FOR RANDOMIZED FRACTIONAL REPLICATION DESIGNS

AMS 64696 RANDOMIZED FRACTIONAL WEIGHING DESIGNS

ON NON-RANDOMIZED FRACTIONAL WEIGHING DESIGNS

AMS 661382 AMS 661836

L ANALYSIS OF 'SPLIT PLOT' EXPERIMENTS IN COMPLETELY RANDOMIZED LAYOUTS SOME ASPECTS OF THE STATISTICA JASA 69 485 ES BASED ON A MARKOV PROCESS DEVELOPMENT OF RANDOMIZED LOAD SEQUENCES WITH TRANSITION PROBABILITT ON RANDOMIZED RANK SCORE PROCEDURE OF BELL AND DOKSUM A MULTI-PROPORTIONS RANDOMIZED RESPONSE MODEL AMS $66 \quad 1697$ THE UNRELATED QUESTION RANDOMIZED RESPONSE MODEL, THEORETICAL FRAMEWORK JASA $69 \quad 520$

\section{NG EVASIVE ANSWER BIAS}

MEMORY OISSON VARIAB/ ON A LOCALLY MOST PONNFFU BOUNDARY RANDOMIZED STMTLAR TEST FOR THE INDEPENDENCE OF TWO P AMS 6I 809 E WAY CLASSIFICATION ON THE ADMISSIBILITY OF A RANDOMIZED SYMMETRICAL DESIGN FOR THE PROBLEM OF A ON AMS 69 35 RTIONATE TO SIZE VARIANCE ESTIMATION IN RANDOMIZED SYSTEMATIC SAMPLING WITH PROBABILITY PROPO JASA 65 XISTENCE AND UNIQUENESS OF A UNIFORMLY MOST POWERFUL RANDOMIZED UNBIASED TEST FOR THE BINOMIAL A RANDOM WALK IN WHICH THE STEPS OCCUR RANDOMLY IN TIME RATE OF OCCURRENCE IN TWO SERIES OF EVENTS OCCURRING RANDOMLY IN TIME /ENCE OF TWO TESTS OF EQUALITY OF B SPECTRAL ANALYSIS WITH RANDOMLY MISSED OBSERVATIONS, THE BINOMIAL CASE ESTIMATION OF AN UNKNOWN DISCRETE WAVEFORM WHICH IS RANDOMLY REPEATING IN GAUSSIAN NOISE LARGE SAMPLE LIMIT THEOREMS FOR RANDOMLY SELECTED PARTIAL SUMS MOMENTS OF RANDOMLY STOPPED SUMS

THE TESTING OF UNIT VECTORS FOR RANDOMNESS A SEQUENTIAL TEST FOR RANDOMNESS

NOTE ON THE USE OF SHERMAN'S STATISTIC AS A TEST OF RANDOMNESS

THE EFFICIENCIES OF TESTS OF RANDOMNESS AGAINST NORMAL REGRESSION

POWER FUNCTIONS FOR COX'S TEST OF RANDOMNESS AGAINST TREND

ON THE INDEPENDENCE OF TESTS OF RANDOMNESS AND OTHER HYPOTHESES

TESTS OF RANDOMNESS BASED ON DISTANCE METHODS.

IS A TREND

BIOKA56

AMS 67 BIOKA59 BIOKA58 267 ABILITY OF OBTAINING A TREE FROM A GRAPH CONSTRUCTED RANDOMLY EXCEPT FOR 'EXOGAMOUS BIAST /FOR THE PROB AMS $65 \quad 971$ AMS $65 \quad 489$ AMS $62 \quad 85$ AMS $65 \quad 789$ JASA $64 \quad 160$ BIOKA53 111 BIOKA54 556 JASA $56 \quad 285$ TECH $62 \quad 430$ JASA $57 \quad 53$ BIOKA65 345 $\begin{aligned} \text { A SEQUENTIAL TEST OF RANDOMNESS FOR EVENTS OCCURRING IN TIME OR SPACE } & \text { BIOKA56 } \\ \text { TESTS FOR RANDOMNESS IN A SERIES OF EVENTS WHEN THE ALTERNATIVE JRSSB56 } & 234\end{aligned}$ THE DEGREE OF RANDOMNESS IN A STATTONARY TTME SERTES SOME TESTS FOR RANDOMNESS IN PLANT POPULATIONS THE CONCEPT OF RANDOMNESS IN THE PATTERNS OF MOSIICS

AMS 631253 BIOKA51 102 BIOCS65 908 ON. PERCENTAGE POINTS AND APPLICATION TO TESTING FOR RANDOMNESS OF DIRECTIONS /TH THE UNIFORM DISTRIBUTI BIOKA66 235 ALTERNATIVES TESTS FOR RANDOMNESS OF DIRECTIONS AGAINST TWO CIRCULAR A SEQUENTIAL TEST FOR RANDOMNESS OF INTERVALS TESTS FOR RANDOMNESS OF POINTS ON A LINE COMPARISON OF TESTS FOR RANDOMNESS OF POINTS ON A LINE ON THE DISTRIBUTION OF THE BIVARIATE RANGE ON THE DISTRIBUTION OF 'STUDENTIZED' RANGE THE POWER FUNCTION OF SOME TESTS BASED ON RANGE

A REJECTION CRITERION BASED UPON THE RANGE THE TWO-SAMPLE T-TEST BASED ON RANGE

ON SEQUENTIAL TESTS OF RATIO OF VARIANCES BASED ON RANGE SOME SEQUENTIAL TEST USING RANGE A RAPID TEST FOR THE POISSON DISTRIBUTION USING THE RANGE A GENERAL SYSTEM OF DISTRIBUTIONS, III. THE SAMPLE RANGE ANALOGUE OF TCHEBYCHEFF'S INEQUALITY IN TERMS OF THE RANGE OF THE UPPER 10 PERCENT POINTS OF THE 'STUDENTIZED' RANGE CALCULATION OF THE SAMPLING DISTRIBUTION OF THE RANGE TABLES OF PERCENTAGE POINTS OF RANGE AND STUDENTIZED RANGE CONFIDENCE BANDS FOR A REGRESSION LINE OVER A FINITE RANGE

TO THE PROBABILITY INTEGRAL OF THE DISTRIBUTION OF RANGE AND APPROXIMATIONS RELATED TO THE NORMAL RANGE OF THE UPPER PERCENTAGE POINTS OF THE 'STUDENTIZED' RANGE FOR SMALL SAMPLE SIZES FOR CHI APPROXIMATION TO THE RANGE CORRELATED NORMAL RANDOM VARIABLES WITH EMPHASIS ON RANGE BUTION

IN NORMAL SAMPLES ON THE DISTRIBUTIONS OF. THE RANGE A DEAN RANGE FOR SAMPLES FROM A NORMAL DISTRI BIOKA66 /NS AND RATTOS OF LTNEAR FUNCTTONS OF ORDERFD BIOKA64 143 $\begin{array}{lll}\text { APPROXIMATIONS BIOKA52 } & 417 \\ \text { INTERPOLATIONS BIOKA55 } & 480\end{array}$ CORRECTED TABLES BIOKA52 192 SCALE FACTORS AND DEGREFS OF FREEDOM BIOKA53 449 AN TECH $62 \quad 133$ TABLE BIOKA59 461 QUERY, TECH $65 \quad 73$ USE OF TECH $61 \quad 407$ JASA 69280 BTOKA56 104 BIOKA63 315 TECH $67 \quad 476$ 194 BIOKA57 482 BIOKA63 419 JRSSB61 335 BIOCS67 685 N JASA 68 TECH $61 \quad 407$ JASA $67 \quad 1488$ JASA $65 \quad 308$ SMALL SAMPLE PROBABTLITY LTMTTS FOR THE RANGE CHART (CORR. 68 1549) AN TSTTMATION PROCEDURE FOR RANGE COMPOSTTION PROBLEMS

STRIBUTION ADMITTING A SUFFICIENT STATISTIC WHEN THE RANGE DEPENDS ON THE PARAMETER /E PARAMETER OF A DI JRSSB55 86 PERCENTAGE POINTS OF THE RANGE FROM A SYMMETRIC MULTINOMIAL DISTRIBUTION 377 
RANCE TEST FOR H/ THE SAMPLINC DISTRIBUTION OF THE RANCE FROM DISCRETE UNIFORM FINITE POPULATIONS AND A JASA 69 NO.4 OF THE ORDER STATISTICS AND THE DISTRIBUTION OF THE RANCE FROM DHS LOCISTIC DISTRIBUTION THE DISTRIBUTION OF RANCE IN CERTAIN NON-NORMAL POPULATIONS $\quad$ BIOKA54 463 CORRICENDA. 'THE DISTRIBUTION OF RANCE IN CERTAIN NON-NORMAL POPULATIONS' $\begin{array}{ll}\text { BIOKA54 } & 463 \\ \text { BIOKA55 } & 277\end{array}$

CONSTANTS FOR THE DISTRIBUTION OF RANCE IN NORMAL SAMPLES

BIOKA51 463 THE DISTRIBUTION OF RANCE IN NORMAL SAMPLES WITH N=200

BIOKA57 257

AL NORMAL DISTRIBUTIONS. II. THE DISTRIBUTION OF THE RANCE IN NORMAL SAMPLES' 601113 /ONS UNDER SPHERIC AMS 61 620

THE USE OF THE RANCE IN PLACE OF THE STAND
ON THE USE OF PATNAIK TYPE CHI APPROXIMATIONS TO THE RANCE IN SICNIFICANCE TESTS CORRICENDA, 'THE USE OF RANCE IN PLACE OF STANDARD DEVIATION IN THE T-TEST.' BIOKA52 442 THE USE OF THE RANCE IN PLACE OF THE STANDARD DEVIATION IN STEIN'S AMS $63 \quad 346$

THE MEAN AND COEFFICIENT OF VARIATION OF RANCE IN SMALL SAMPLES FROM NON-NORMAL POPULATIONS BIOKA54 469

ORRICENDA, 'THE MEAN AND COEFFICIENT OF VARIATION OF RANCE IN SMALL SAMPLES FROM NON-NORMAL POPULATIONS'SON OF TWO APPROXIMATIONS TO THE DISTRIBUTION OF THE RANCE IN SMALL SAMPLES FROM NORMAL POPULATIONS/ARI BIOKA52 130

$\begin{array}{lll} & \text { USE OF RANGE IN TESTING HETEROGENEITY OF VARIANCE } \\ \text { NT NORMAL VARIATES } & \text { ON THE RANGE OF PARTIAL SUMS OF A FINITE NUMBER OF INDEPENDE BIOKA53 }\end{array}$ BIOKA66 221 ON THE EXTREME VALUES AND RANCE OF SAMPLES FROM NON-NORMAL POPULATTONS

BIOKA67 FOR ESTIMATING THE CORRELATION COEFFICIENT FROM THE RANCE OF THE DEVIATIONS ABOUT THE REDUCED MAJOR AXIS BIOKA53 $21 B$ TION FUNCTION AND PYKE'S MODIFIED EMPIRICA/ ON THE RANGE OF THE DIFFERENCE BETWEEN HYPOTHETICAL DISTRIBU AMS 62 525

ITS FOR A NORMAL POPULATION BASED ON SAMPLE MEAN AND RANGE OR MEAN RANGE TO THE CRITICAL VALUES FOR DUNCAN'S MULTIPLE RANCE TEST

TABLES FOR TOLERANCE LIM JASA 57 88 NOTES. APPROXIMATIONS BIOCS66 179 RANGE FROM DISCRETE UNIFORM FINITE POPULATIONS AND A RANCE TEST FOR HOMOCENEITY /NC DISTRIBUTION OF THE JASA 69 NO.4 SEQUENTIAL RANCE TESTS FOR COMPONENTS OF VARIANCE, CORR. 651249 JASA 65 B26 BOUNDS FOR THE RATIO OF RANGE TO STANDARD DEVIATION RIBUTION OF THE RATIO, IN A SINGLE NORMAL SAMPLE, OF RANCE TO STANDARD DEVIATION BI0KA55 268 IN THE SAME NORMAL SAMPLE BIOKA64 4B 4 THE RATIO OF RANCE TO STANDARD DEVIATION IN THE SAME 'TABLES OF PERCENTAGE POINTS OF THE 'STUDENTIZED' RANCE' CORRELATION BETWEEN SAMPLE MEANS AND SAMPLE RANGES A NOTE ON MOVING RANCES PERCENTACE POINTS OF A SUBSTITUTE F -RATIO USING RANGES PERCENTACE POINTS OF THE RATIO OF TWO RANCES AND POWER OF THE ASSOCIATED TEST
(CALCULATION OF EXACT SAMPLING DISTRIBUTION OF RANGES FROM A DISCRETE POPULATION' CORRIGENDA, BIOKA.53 236 JASA $59 \quad 465$ BIOKA55 512 ON MOMENTS OF ORDER STATISTICS AND QUASI-RANCES FROM NORMAL POPULATIONS A NOTE ON THE CORRELATION OF RANCES IN CORRELATED NORMAL SAMPLES UPPER BIOKA6I 195 BIOKA63 1B7 ON MOMENTS OF

CORREC AMS 67 2BO AMS $63 \quad 633$ BIOKA6B 595 TION STANDARD DEVIATION THE USE OF SAMPLE QUASI-RANGES IN SETTING CONFIDENCE INTERVALS FOR THE POPULA JASA 61 260 NDARD DEVIATION OF A RECTANCULA/THE USE OF SAMPLE RANCES IN SETTING EXACT CONFIDENCE BOUNDS F0R THE STA JASA 61 601 CORRELATION OF RANGES OF CORRELATED DEVIATES CORRELATION OF THE RANGES OF CORRELATED SAMPLES

NOTE ON EXCHANCEABLE PROCESSES WITH STATES OF FINITE RANK BIOKA66 191 BIOKA67 529 NOTE ON EXCHANCEABLE PROCESSES WITH STATES OF FINTE RANK

A AMS 69 NO 6 ND REGRESSION, WITH APPLICATION TO MANIFOLD,/ THE RANK ANALOGUE OF PRODUCT-MOMENT PARTIAL CORRELATION A BIOKA59 241 METHOD OF PAIRED COMPARISONS. ONAL TABLES FOR THE METHOD OF PAIRED COMPARISONS ONAL TABLES FOR THE METHOD OF PAIRED COMPARISONS RANK ANALYSIS OF INCOMPLETE BLOCK DESIGNS. II. ADDITI BIOKA54 502
ONAL TABLES FOR THE METHOD OF PA/ CORRICENDA, THE RANK ANALYSIS OF INCOMPLETE BLOCK DESICNS. II. ADDITI BIOKA64 RANK ANALYSIS OP INCOMPLETE BLOCK DESICNS I THE BIOKA52 324 PARTIAL AND MULTIPLE RANK CORRELATION

SOME QUESTIONS OF DISTRIBUTION IN THE THEORY OF RANK CORRELATION SINCLY TRUNCATED BIVARIATE NORMAL DISTRIBUTION. II. RANK CORRELATION A REMARK ON SPEARMAN'S RANK CORRELATION COEFFICIENT DISTRIBUTIONS FOR SMALL N OF KENDALL'S PARTIAL RANK CORRELATION COEFFICIENT CORRECTING THE AVERAGE RANK CORRELATION COEFFICIENT FOR $\begin{array}{llll} & \\ & \end{array}$ BIOKA51 131 BIOKA65 639 BIOKA5B 273 RIATE NORMAL DISTRIBUTION IV. EMPIRICAL VARIANCES OF RANK CORRELATION COEFFICIENTS/INCLY TRUNCATED BIVA BIOKA68 437 THE TRANSFORMED KENDALL COEFFICIENT $\quad$ TESTS FOR RANK CORRELATION COEFFICIENTS. I TESTS FOR RANK CORRELATION COEFFICIENTS. III. DISTRIBUTION OF BIOKA57 470 TESTS FOR RANK CORRELATION COEFFICIENTS. II NDENCE CRITICAL VALUES OF THE COEFFICIENT OF RANK CORRELATION FOR TESTING THE HYPOTHESIS OF INDEPE BIOKA61 444 HE AVERAGE RANK/ SOME CONTRIBUTIONS TO THE AVERAGE RANK CORRELATION METHODS AND TO THE DISTRIBUTION OF T JASA 63 756 BOUNDS FOR THE VARIANCE OF KENDALL'S RANK CORRELATION STATISTIC THE EFFECT OF TIES ON THE MOMENTS OF RANK CRITERIA TS IN THE ANALYSIS OF VARIANCE RANK METHODS FOR COMBINATION OF INDEPENDENT EXPERIMEN BIOKA56 474 BIOKA57 526 SIMPLE RANDOM WALK AND RANK ORDER STATISTICS

A CLASS OF RANK ORDER TESTS FOR A CENERAL LINEAR HYPOTHESIS

SAMPLE PROBLEM ASYMPTOTICALLY MOST POWERFUL RANK ORDER TESTS FOR GROUPED DATA

ON THE THEORY OF RANK ORDER TESTS FOR LOCATION IN THE MULTIVARIATE ONE RANK ORDER TESTS FOR MULTIVARIATE PAIRED COMPARISONS

REGRESSION LINES ON A CLASS OF RANK ORDER TESTS FOR THE PARALLELISM OF SEVERAL ON A CLASS OF ALICNED RANK ORDER TESTS IN TWO-WAY LAYOUTS RANK ORDER TESTS OF LINEAR HYPOTHESES

SIGNIFICANCE PROBABILITY BOUNDS FOR RANK ORDERINCS

A THEOREM ON RANK ORDERS FOR TWO CENSORED SAMPLES ON EXACT PROBABILITIES OF RANK ORDERS FOR TWO WIDELY SEPARATED

FINE STRUCTURE OF THE ORDERING OF PROBABILITIES OF RANK ORDERS IN THE TWO SAMPLE CASE REMARKS ON ZEROS AND TIES IN THE WILCOXON SIGNED RANK PROCEDURE

A MULTIPLE COMPARISON RANK PROCEDURE FOR A ONE-WAY ANALYSIS OF VARIANCE ON RANDOMIZED RANK SCORE PROCEDURE OF BELL AND DOKSUM

ANALYSIS OF COVARIANCE BASED ON CENERAL RANK SCORES

EXTENDED TABLES OF THE WILCOXON MATCHED PAIR SICNED RANK STATISTIC

OF THE TEST AND ESTIMATOR BASED ON WILCOXON'S SIGNED RANK STATISTIC ASYMPTOTIC LINEARITY OF A RANK STATISTIC IN RECRESSION PARAMETER ASYMPTOTIC NORMALITY OF SIMPLE LINEAR RANK STATISTICS UNDER ALTERNATIVES ASYMPTOTIC NORMALITY OF SIMPLE LINEAR RANK STATISTICS UNDER ALTERNATIVES, II RANK SUM MULTIPLE COMPARISIONS IN ONE AND TWO-WAY A TABLE.FOR RANK SUM MULTIPLE PAIRED COMPARISONS A RANK SUM TEST FOR COMPARINC ALL PAIRS OF TREATMENTS AB 62 (B) AMS 671042 AMS 691325 AMS 671229 AMS $67 \quad 1216$ AMS 69 N0.6 AMS 69 166B AMS $68 \quad 1115$ JRSSB $68 \quad 4 B 3$ AMS $64 \quad$ B91 AMS $65 \quad 316$ AMS $67 \quad 1491$ AMS $66 \quad 98$ JASA $59 \quad 655$ SASJ $69 \quad 35$ AMS 661697 AMS $69 \quad 610$ JASA $65 \quad 864$ AMS $68 \quad 282$ AMS 69 NO. 6 AMS $68 \quad 325$ AMS 69 No.6 BIOKA67 487 TECH $67 \quad 561$ TECH $60 \quad 197$ 
ON AN EXTREME RANK SUM TEST FOR OUTLIERS

ON AN EXTREME RANK SUM TEST WITH EARLY DECISION

MULTIPLE COMPARISIONS USING RANK SUMS

A NOTE ON MULTIPLE COMPARISONS USINC RANK SUMS

ON THE NORMAL SCORES TWO-SAMPLE RANK TEST

A BIVARIATE SICNED RANK TEST

LIMITS FOR A RATIO USINC WILCOXON'S SICNED RANK TEST A PROPOSED TWO-SAMPLE RANK TEST,

ESTIMATES OF LOCATION BASED ON RANK TESTS

ON A MODIFICATION OF CERTAIN RANK TESTS

ONE SAMPLE LIMITS OF SOME TWO-SAMPLE RANK TESTS

ALTERNATIVE EFFICIENCIES FOR SICNED RANK TESTS

PERCENTILE MODIFICATIONS OF TWO-SAMPLE RANK TESTS

QUERY, CONFIDENCE LIMITS FROM RANK TESTS

ESTIMATES OF REGRESSION PARAMETERS BASED ON RANK TESTS

EFFICIENCY ROBUST TWO-SAMPLE RANK TESTS

STARSHAPED TRANSFORMATIONS AND THE POWER OF RANK TESTS

THE SMIRNOV TWO SAMPLE TESTS AS RANK TESTS

EFFICIENCY OF CERTAIN LOCALLY MOST POWERFUL RANK TESTS

OF OBTAINING LOWER BOUNDS ON THE ASYMPTOTIC POWER OF RANK TESTS

ON TWO K-SAMPLE RANK TESTS FOR CENSORED DATA

AN ELEMENTA

SYMPTOTIC EFFICIENCY OF CERTAIN RANK TESTS FOR COMPARATIVE EXPERIMENT

G SEVERAL TREATMENTS

S HAVE AN 'A PRIORI' ORDERING

RANK TESTS FOR PAIRED-COMPARISON EXPERIMENTS INVOLVIN RANK TESTS FOR RANDOMIZED BLOCKS WHEN THE ALTERNATIVE

OPTIMAL INVARIANT RANK TESTS FOR THE K-SAMPLE PROBLEM

DATA
PROCEDURE

ASYMPTOTTCALLY MOST POWERFUL RANK TESTS FOR THE TWO-SAMPLE PROBLEM WITH CENSORED SEQUENTIAL RANK TESTS I. MONTE CARLO STUDIES OF THE TWO-SAMPLE SEQUENTIAL RANK TESTS II. MODIFIED TWO-SAMPLE PROCEDURES RANK TESTS OF DISPERSION

ONS

ON THE POWER OF TWO-SAMPLE RANK TESTS ON THE EQUALITY OF TWO DISTRIBUTION FUNCT NOTE ON SOME SQUARED RANK TESTS WITH EXISTINC TIES

COMMENTS ON 'THE SIMPLEST SIGNED-RANK TESTS' OF SOME NON-LINEAR FUNCTIONS OF THE TWO-SAMPLE RANK VECTOR

THE ASYMPTOTIC DISTRIBUTION SPRT'S THE INFORMATION IN A RANK-ORDER AND THE STOPPING TIME OF SONE ASSOCIATED NN ALTERNATIVES, CORR. 671309 STOPPING TIME OF A RANK-ORDER SEQUENTIAL PROBABILITY RATIO TEST ON LEHMA CALTON'S RANK-ORDER TEST

ASYMPTOTICALLY MOST POWERFUL RANK-ORDER TESTS

QUERY, DISTRIBUTION OF A RANKED OBSERVATION

QUERY, JOINT CONFIDENCE LIMITS FOR RANKED OBSERVATIONS

ON SAMPLINC FROM A POPULATION OF RANKERS

AMPLINC DISTRIBUTION OF AVERAGE TAU WITH A CRITERION RANKINC

SOME FIXED-SAMPLE RANKING AND SELECTION PROBLEMS

AN INTRODUCTION TO RANKINC AND SELECTION PROCEDURES

ASYMPTOTICALLY EXTINCT SEQUENTIAL PROCEDURES FOR RANKING AND SLIPPAGE PROBLEMS

MAXIMUM LIKELIHOOD PAIRED COMPARISON RANKING BY LINEAR PROGRAMMING

AN APPLICATION OF THE DISTRIBUTION OF THE RANKING CONCORDANCE COEFFICIENT

MATHEMATICAL MODELS FOR RANKING FROM PAIRED COMPARISONS

PAIRWISE COMPARISON AND RANKING IN TOURNAMENTS

ON TO BULK/A TWO-STAGE SUBSAMPLING PROCEDURE FOR RANKING MEANS OF FINITE POPULATIONS WITH AN APPLICATI T

SOME EXTENSIONS OF SOMERVILLE'S PROCEDURE FOR RANKINC MEANS OF NORMAL POPULATIONS

BI0KA63 375

JASA $65 \quad 859$

TECH 64 241

TECH 65255

JASA $64 \quad 652$

JRSSB64 457

BI0CS65 231

JRSSB64 305

AMS $63 \quad 598$

AMS 631101

JASA $64 \quad 645$

AMS 651759

JASA $65 \quad 1127$

TECH $65 \quad 25^{\prime}$

AMS 67 B94

JASA $67 \quad 1241$

AMS 691167

AMS 691449

AMS $61 \quad 88$

AMS $68 \quad 2128$

AMS 671520

AMS $67 \quad 90$

AMS $64 \quad 122$

AMS $67 \quad 867$

AMS 651207

AMS $65 \quad 1243$

TECH $65 \quad 463$

TECH $66 \quad 615$

AMS $63 \quad 973$

JRSSB6 4293

TECH $67 \quad 312$

JASA 59213

AMS $69 \quad 1011$

AMS $6 B$ 1661

AMS 661154

BIOKA55 261

AMS $62 \quad 1124$

TECH $64 \quad 329$

TECH $66 \quad 36 \mathrm{~B}$

BIOKA52 82

AMS $67 \quad 1079$ JASA $66 \quad 640$

SOME JRSSB66 370

BIOKA69 N0.3

BIOKA5I 33

JASA $60 \quad 503$

AMS $63 \quad 501$

TECH $67 \quad 355$

BIOKA68 411

NOWN/ A TWO-SAMPLE MULTIPLE DECISION PROCEDURE FOR RANKING MEANS OF NORMAL POPULATIONS WITH A COMMON UNK BIOKA54 170 VARIANCES

RANKTNG MEANS OF TWO NORMAL POPULATIONS WITH UNKNOWN

RANKING METHODS AND THE MEASUREMENT OF ATTITUDES

A NON-NULL RANKING MODEL FOR A SEQUENCE OF M ALTERNATIVES

NON-NULL RANKINC MODELS I

ATIONS

SINCLE-STACE PROCEDURES FOR RANKINC MULTIPLY-CLASSIFIED VARIANCES OF NORMAL POPUL THE RANKING OF VARIANCES IN NORMAL POPULATIONS

ESTIMATION BY RANKING PARAMETERS

ON RANKINC PARAMETERS OF SCALE IN TYPE III POPULATIONS

ON MULTIPLE DECISION METHODS FOR RANKING POPULATION MEANS

THE GENERALIZED VARIANCE, TESTING AND RANKING PROBLEM

THE PERFORMANCE OF SOME SEQUENTIAL PROCEDURES FOR A RANKING PROBLEM MULTIVARIATE T AND THE RANKING PROBLEM

PECTED SAMPLE SIZES OF TWO SEQUENTIAL PROCEDURES FOR RANKINC PROBLEM

SOME OPTIMUM PROPERTIES OF RANKING PROCEDURES

RANKING PROCEDURES FOR ARBITRARILY RESTRICTED

OBSERVATION

ON SOME MULTIPLE DECISION (SETECTTON AND RANKTNG) RULES

NONPARAMETRIG RANKING PROCEDURES FOR COMPARISON WITH A CONTROL

PAIRWISE COMPARISON AND RANKINC, OPTIMUM PROPERTIES OF THE ROW SUM PROCEDURE APPROXIMATE TESTS FOR M RANKINCS

MAXIMUM-LIKELIHOOD PAIRED COMPARISON RANKINCS

ASYMPTOTICALLY EFFICIENT TESTS BY THE METHOD OF N RANKINCS

DISTRIBUTION OF KENDALL'S SCORE S FOR A PAIR OF TIED RANKINCS

KENDALL'S TAU FOR THE CASE OF ARBITRARY TIES IN BOTH RANKINGS

RANKINCS FROM PAIRED COMPARISONS

THE DISTRIBUTION OF THE MAXIMUM SUM OF RANKS

MULTIPLE TREATMENTS, A SIGNIFICANCE TEST FOR LINEAR RANKS

RANKS AND MEASURES

IOKA58 250

JASA 5B 720

BIOKA6I 441

BIOKA57 114

TECH $6 \mathrm{~B} \quad 693$

JASA $56 \quad 621$

JRSSB 66

AMS $62 \quad 24 \mathrm{~B}$

AMS $67 \quad 941$

AMS $68 \quad 1040$

BIOKA67 305

AMS 69 NO.6

AMS $67 \quad 124$

BIOCS67 65

AMS $6 B \quad 2075$

TECH $65 \quad 225$

AMS $63 \quad 511$

BIOKA60 476

BIOKA66 143

JRSSB6B 312

THE BIOKA60 151

A MODIFICATION OF JASA $57 \quad 33$

AMS $64 \quad 739$

TECH $67 \quad 271$

ORDERED HYPOTHESES FOR JASA $63 \quad 216$

BIOKA62 133

BIOKA66 278

MULTIPLE DECISION PROCEDURES BASED ON RANKS FOR CERTAIN PROBLEMS IN ANALYSIS OF VARIANCES
CORRELATION BETWEEN VARIATE-VALUES AND RANKS IN A DOUBLY TRUNCATED NORMAL DISTRIBUTION

MULTIPLE DECISION PROCEDURES BASED ON RANKS FOR CERTAIN PROBLEMS IN ANALYSIS OF VARIANCES
CORRELATION BETWEEN VARIATE-VALUES AND RANKS IN A DOUBLY TRUNCATED NORMAL DISTRIBUTION 69 6I9
BIOKA66 2BI

THE CORRELATION BETHEEN VARIATE-VALUES AND RANKS IN A DOUBLY TRUNCATED NORMAL DISTRIBUTION

ES, CORR, $611005 \quad$ ROBUSTNESS OF SUM OF SQUARED RANKS TEST

SIGNIFICANCE

RAO'S PARADOX CONCERNING MULTIVARIATE TESTS OF

RAPID ANALYSIS OF $2 X 2$ TABLES

JASA $68 \quad 33 \mathrm{~B}$

BI0CS69 411

JASA $57 \quad 18$

THE RAPID CALCULATION OF CHI-SQUARE AS A TEST OF HOMOGENE BIOKA55 519 
TES PRINCIPALES, SON UTILISATION EN CENETIQUE ET SES RAPPORTS AVEC L'ANALYSE DISCRIMINATOIRE /N COMPOSAN BIOCS66 POISSON PROCESSES WITH RANDOM ARRIVAL RATE

THEORETICAL EXPLANATION OF OBSERVED DECREASE FAILURE RATE

ESTIMATION OF JUMPS, RELIABILITY AND HAZARD RATE

DISCRETE DYNAMIC PROCRAMMINC WITH A SMALL INTEREST RATE

OF BOUNDS FOR DISTRIBUTIONS WITH MONOTONE HAZARD RATE

OF PROBABILITY DISTRIBUTIONS WITH MONOTONE HAZARD RATE

ESTIMATION FOR DISTRIBUTIONS WITH MONOTONE FAILURE RATE

THE CLASS OF DISTRIBUTIONS WITH INCREASING HAZARD RATE

ROGEDURES WHEN THE DISTRIBUTION HAS MONOTONE FAILURE RATE

FOR CLASSES OF DISTRIBUTIONS CLASSIFIED BY FAILURE RATE RELATIONSHIP BETWEEN SYSTEM FAILURE RATE AND COMPONENT FAILURE RATES

CHANGES IN THE RATE AND COMPONENTS OF HOUSEHOLD FORMATION

STATISTICS IN SOME MODELS WITH INCREASINC FAILURE RATE AVERAGE

A NOTE ON TESTS FOR MONOTONE FAILURE RATE BASED ON INCOMPLETE DATA

TEST FOR MONOTONE FAILURE RATE BASED ON NORMALIZED SPACINC QUERY, ERROR RATE BASES

ON THE RATE OF CONYERCENCE FOR THE LAW OF LARCE NUMBERS

A NOTE ON THE RATE OF CONVERGENCE OF A MEAN

PRINCIPLE

ON EXTENDED RATE OF CONVERGENCE RESULTS FOR THE INVARIANCE

ON A GLASS OF GAUSSIAN PROCESSES FOR WHICH THE MEAN RATE OF CROSSINGS IS INFINITE

THE CORRELATION BETWEEN FEED EFFICIENCY AND RATE OF GAIN, A RATIO AND ITS DENOMINATOR

PROPERTIES AMS $63 \quad 375$

TOLERANCE LIMITS FOR AMS 641561

EXPECTED EFFECTS ON THE INBREEDING COEFFICIENT AND RATE OF GENE LOSS OF FOUR METHODS OF REPRODUCING FINI BIOCS65 447

RA/ ON THE EQUIVALENCE OF TWO TESTS OF EQUALITY OF RATE OF OCCURRENCE IN TWO SERIES OF EVENTS OCCURRING BIOKA58 267

ONS OF INDEPENDENT RANDOM VARI/ ON THE CONVERGENCE RATE OF THE LAW OF LARGE NUMBERS FOR LINEAR COMBINATI AMS 65 559 ON THE OPTIMUM RATE OF TRANSMITTING INFORMATION

ESTIMATE OF THE STANDARD ERROR OF THE SURVIVAL RATE, CORR, 631161

LIMITS FOR CLASSES OF DISTRIBUTIONS BASED ON FAILURE RATE, CORR, 67950 BOUNDS FOR DISTRIBUTIONS WITH MONOTONE HAZARD RATE, I BOUNDS FOR DISTRIBUTIONS WITH MONOTONE HAZARD RATE, II TESTS FOR MONOTONE FAILURE RATE, II ANALYTICAL GRADUATION OF FERTILITY RATES AVERAGE RENEWAL LOSS RATES

BETWEEN SYSTEM FAILURE RATE AND COMPONENT FAILURE RATES $\begin{array}{rrr}\text { AMS } & 69 & \text { NO. } 6 \\ \text { A PARAMETRIC JASA } 61 & 111\end{array}$ $\begin{array}{rrr}\text { A PARAMETRIC JASA } & 61 & 111 \\ \text { TOLERANCE AND CONFTDENCE } & \text { AMS } 66 & 1593\end{array}$ AMS $64 \quad 1234$ AMS 641258 AMS 691250 JASA $56 \quad 461$ AMS $63 \quad 396$ MODEL FOR ESTTMATING AGE-ORDER SPECIFIC FERTILITY RATES THE UPPER AND LOWER CLASSES IN TERMS OF CONVERGENCE RATES NONWHITE POPULATION AS INDICATED BY TRENDS IN DEATH RATES ALLOCATION RULES AND THEIR ERROR RATES (WITH DISGUSSION)

SAMPL JRSSB66 I

ALYSIS OF POPULATION GROWTH WHEN THE BIRTH AND DEATH RATES DEPEND UPON SEVERAL FACTORS CONVERGENCE RATES FOR PROBABILITIES OF MODERATE DEVIATIONS $\quad$ AMS 682016

TIONS OF MARKOV PROGESSES BINATIONS OF EXCHANGEABLE AND MIXING/

CONVERGENCE RATES FOR THE LAW OF LARGE NUMBERS FOR LINEAR COMBINA CONVERGENCE RATES FOR THE LAW OF LARGE NUMBERS FOR THE LINEAR COM CONVERGENCE RATES FOR THE LAW OF THE ITERATED LOGARITHM

ESTIMATION OF ERROR RATES IN DISCRIMINANT ANALYSIS

COMMENTARY ON 'ESTIMATION OF ERROR RATES IN DISCRIMINANT ANALYSIS'

EVALUATION OF CENSUS SURVIVAL RATES IN ESTIMATING INTERCENSAL STATE NET MICRATION ON GONVERGENCE RATES IN THE CENTRAL LIMIT THEOREM

RELATING MOMENT GENERATING FUNCTIONS AND CONVERGENCE RATES IN THE LAW OF LARCE NUMBERS COMPUTATION OF INDIRECT-ADJUSTED RATES IN THE PRESENCE OF CONFOUNDING

SOME RESULTS

RATES OF CONVERCENCE IN THE COMPOUND DECISION PROBLEM RATES OF CONVERGENCE OF ESTIMATES AND TEST STATISTICS FOR TWO COMPLETELY SPECIFIED DISTRIBUTIONS

DISTRIBUTIONS POSSESSING A MONOTONE LIKELIHOOD RATIO
A CONFIDENCE INTERVAL FOR THE AVAILABILITY RATIO

A CONFIDENCE INTERVAL FOR THE AVAILABILITY RATIO

NEW CHEBYSHEV POLYNOMIAL APPROXIMATIONS TO MILLS' RATIO IRRATIONAL FRACTION APPROXIMATIONS TO MILLS' RATIO STATISTICAL CHARACTERISTICS OF A PEAK TO AVERAGE RATIO POLYNOMIAL AND OTHER NEW APPROXIMATIONS TO MILLS' RATIO FOR THE NORMAL PROBABILITY INTEGRAL AND MILL'S RATIO

LIKELIHOOD RATIO AND CONFIDENCE-RECION TESTS ON MULTIVARIATE RATIO AND PRODUCT ESTIMATORS

IV DISTRIBUTION

SOME FINITE POPULATION UNBAISED RATIO AND REGRESSION ESTIMATORS THE RATIO BIAS IN SURVEYS

OXON TEST THEORY IN ESTIMATING THE DISTRIBUTION OF A RATIO BY MONTE CARLO METHODS

LIKELIHOOD RATIO COMPUTATIONS OF OPERATING COMPUTATIONS

FOR APPROXIMATING TO THE DISTRIBUTION OF LIKELIHOOD RATIO CRITERIA

EXPANSIONS OF THE DISTRIBUTIONS OF THE LIKELIHOOD RATIO CRITERIA FOR COVARIANCE MATRIX A GENERAL METHOD ASYMPTOTIC

IONS OF THE NON-NULL DISTRIBUTIONS OF THE LIKELIHOOD RATIO CRITERIA FOR MULTIVARIATE LINEAR HYPOTHESIS AND RIATES U/ ON THE EXACT DISTRIBUTIONS OF LIKELIHOOD RATIO CRITERIA FOR TESTINC INDEPENDENCE OF SETS OF VA GRES/ ON THE EXACT DISTRIBUTIONS OF THE LIKELIHOOD RATIO CRITERIA FOR TESTING LINEAR HYPOTHESES ABOUT RE EXACT DISTRIBUTIONS OF WILKS'S LIKELIHOOD RATIO CRITERION

A NOTE ON THE VARIANCE OF THE RATIO ESTIMATE

MULTIVARIATE RATIO ESTIMATION FOR FINITE POPULATIONS

UNBIASED COMPONENTWISE RATIO ESTIMATION, CORR. 631163

THE -PRECISION OF MICHEY'S UNBIASED RATIO ESTIMATOR

THE HALF-TABLE RATIO ESTIMATOR FOR A SIMPLE EXPONENTIAL MODEL

ON SAMPLING SCHEMES PROVIDING UNBIASED RATIO ESTIMATORS

COMPARISON OF SOME RATIO ESTIMATORS

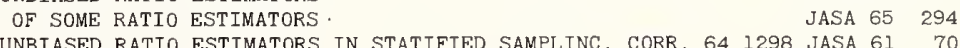

A TECHNICAL LEMMA FOR MONOTONE LIKELIHOOD RATIO FAMILIES
AMS $66 \quad 711$

AMS 651840

AMS $68 \quad 1479$

TECH $68 \quad 1$

TECH $68 \quad 204$

JASA $62 \quad 841$

AMS $69 \quad 475$

AMS $67 \quad 742$ BIOCS68 997 AMS $65 \quad 1743$ AMS $67 \quad 303$ TECH $67 \quad 465$ JASA $69 \quad 647$ BIOKA64 339 SOME TECH $65 \quad 379$ CHEBYSHEV AMS $63 \quad 892$ JRSSB $62 \quad 177$ JRSSB65 245 BIOKA69 NO. 3 JASA 59594 BIOKA65 119 JASA $62 \quad 863$ AMS $62 \quad 1194$ AMS $66 \quad 1704$ IOKA56 295 AMS 69 N0.6 942 $\begin{array}{ll}67 & 1160\end{array}$ AMS $66 \quad 1319$ BIOKA66 347 JASA $64 \quad 895$ BIOKA58 154 JASA $61 \quad 350$ BIOKAG7 321 BIOCS69 420 AMS $64 \quad 222$ AMS $67 \quad 611$ 
DISTRIBUTION OF THE LIKELIHOOD RATIO FOR TESTING MULTIVARIATE LINEAR HYPOTHESES DISTRIBUTION OF LIKELIHOOD RATIO IN TESTING AGAINST TREND

THE STRONG RATIO LIMIT PROPERTY FOR SOME GENERAL MARKOV

A NOTE ON THE CENSUS SURVIVAL RATIO METHOD OF ESTIMATING NET MIGRATION

ON THE CHOICE OF A STRATEGY FOR A RATIO METHOD OF ESTIMATION

A GENERALIZATION OF FIELLER'S THEOREM TO THE RATIO OF COMPLEX PARAMETERS THE LIMIT OF A RATIO OF CONVOLUTIONS

ON COMBINING ESTIMATES OF A RATIO OF MEANS LIMITS FOR THE RATIO OF MEANS (WITH DISCUSSION)

A NOTE ON COMBINING CORRELATED ESTIMATES OF A RATIO OF MULTIVARIATE MEANS BOUNDS FOR THE RATIO OF RANGE TO STANDARD DEVIATION

THE RATIO OF RANGE TO STANDARD DEVIATION IN THE SAME
NORMAL SAMPLE

TIVENESS
ON THE RATIO OF TWO CORRELATED NORMAL RANDOM VARIABLES TWO CONFIDENCE INTERVALS FOR THE RATIO OF TWO PROBABILITIES AND SOME MEASURES OF
AN INEQUALITY FOR THE RATIO OF TWO QUADRATIC FORMS IN NORMAL VARIATES
AN IDENTITY FOR THE VARIANCE OF A RATIO OF TWO RANDOM VARIABLES

PERCENTAGE POINTS OF THE RATIO OF TWO RANGES AND POWER OF THE ASSOCIATED TEST ON SEQUENTIAL TESTS OF RATIO OF VARIANCES BASED ON RANGE

ESTIMATES OF BOUNDED RELATIVE ERROR FOR THE RATIO OF VARIANCES OF NORMAL DISTRIBUTIONS SAMPLE SIZE REQUIRED TO ESTIMATE THE RATIO OF VARIANCES WITH BOUNDED RELATIVE ERROR TABLES OF PERCENTAGE POINTS OF THE LARGEST VARIANCE RATIO S-SQUARE-MAX-OVER-S-SQUARE-SUB-O EXTENSION OF A ROBUST VERSION OF THE PROBABILITY RATIO TEST THE POWER OF THE LIKELIHOOD RATIO TEST

THE MOST ECONOMICAL BINOMIAL SEQUENTIAL PROBABILITY RATIO TEST

ASPECTS OF THE USE OF THE SEQUENTIAL PROBABILITY RATIO TEST

ON THE RISKS OF ERROR INVOLVED IN THE SEQUENTIAL RATIO TEST RANDOMIZATION DISTRIBUTION AND POWER OF THE VARIANCE RATIO TEST THE OPTIMUM CHARACTER OF THE SEQUENTIAL PROBABILITY RATIO TEST THE EXPECTED SAMPLE SIZE IN A SEQUENTIAL PROBABILITY RATIO TEST LATIVE EFFICIENCY OF THE WALD SEQUENTIAL PROBABILITY RATIO TEST ACTERISTIC CURVE FOR THE WALD SEQUENTIAL PROBABILITY RATIO TEST THE LIKELIHOOD RATIO TEST

THE LIKELIHOOD RATIO TEST FOR MARKOFF CHAINS
CORRIGENDA TO 'THE LIKELIHOOD RATIO TEST FOR MARKOFF CHAINS

ON THE LIKELIHOOD RATIO TEST OF A NORMAL MULTIVARIATE TESTING PROBLEM

II ON THE LIKELIHOOD RATIO TEST OF A NORMAL MULTIVARIATE TESTING PROBLEM,

CORR. 641388

STOPPING TIME OF A RANK-ORDER SEQUENTIAL PROBABILITY RATIO TEST ON LEHMANN ALTERNATIVES, CORR. 67 1309

THE B/ ON THE DISTRIBUTION OF THE LOG LIKELIHOOD RATIO TEST STATISTIC WHEN THE TRUE PARAMETER IS 'NEAR PERFORMANCE OF THE TRUNCATED SEQUENTIAL PROBABILITY RATIO TEST, CORR. 661247 ON THE OPTIMALITY OF SEQUENTIAL PROBABILITY RATIO TESTS

NIQUENESS AND MONOTONICITY OF SEQUENTIAL PROBABILITY RATIO TESTS SIMPLIFICATION OF A CLASS OF SEQUENTIAL PROBABILITY RATIO TESTS

OF THE CLASS OF GENERALIZED SEQUENTIAL PROBABILITY RATIO TESTS TRIBUTION OF SAMPLE NUMBER IN SEQUENTIAL PROBABILITY RATIO TESTS TION FOR A CLASS OF INVARIANT SEQUENTIAL PROBABILITY RATIO TESTS SIMPLIFIED RUNS TESTS AND LIKELIHOOD RATIO TESTS FOR MARKOFF CHAINS

ON THE MEAN SUCCESSIVE DIFFERENCE AND ITS RATIO TO THE ROOT MEAN SQUARE

IGENDA TO 'ON THE MEAN SUCCESSIVE DIFFERENCE AND ITS RATIO TO THE ROOT MEAN SQUARE

ON THE JASA $65 \quad 979$ AMS 63 1B

EXISTENCE, U AMS 631541 ON THE SAMPLE SIZE AND AMS $66 \quad 425$ THE ESSENTIAL COMPLETENESS AMS 61602 A NOTE ON THE VARIANCE OF THE DIS TECH $66 \quad 700$ BOUNDS ON THE SAMPLE SIZE DISTRIBU AMS 681048

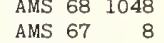
BIOKA5B 1B 1 AMS $68 \quad 547$ BIOKA53 116 NOTES.CONFIDENCE LIMITS FOR A RATIO USING WILCOXON'S SIGNED RANK TEST

TAIL AREAS OF THE T-DISTRIBUTION FROM A MILLS' RATIO-LIKE EXPANSION MOMENTS OF NEGATIVE ORDER AND RATIO-STATISTICS

COMPARISON OF FOUR RATIO-TYPE ESTIMATES UNDER A MODEL

OF MULTIVARIATE POLYKAYS TO THE THEORY OF UNBIASED RATIO-TYPE ESTIMATION

SOME RATIO-TYPE ESTIMATORS IN TWO-PHASE SAMPLING

THE PRECISION OF UNBIASED RATIO-TYPE ESTIMATORS, CORR. 631162

BASIC PROPERTIES OF THE INCOMPLETE GAMMA FUNCTION RATIO, CORR. $6515 B 4$

D DEVIATION

THE DISTRIBUTION OF THE RATIO, IN A SINGLE NORMAL SAMPLE, OF RANGE TO STANDAR THE RATIONAL ORIGIN FOR MEASURING SUBJECTIVE VALUES

AND AN 'OBJECTIVE' TEST FOR APPROXIMATE NUMERICAL RATIONALITY AW AND AN 'OBJECTIVE' TEST FOR APPROXIMATE NUMERICAL RATIONALITY'

ON THE ACCURACY OF WEIGHTED MEANS AND RATIOS 'A SUBJECTIVE EVALUATION OF BODE'S L JASA 69 BIOCS6 AMS $63 \quad 335$ JRSSB55 122 JASA $69 \quad 574$ APPLICATIONS JASA 57511 JASA $6262 B$ JASA $58 \quad 491$ SOME AMS $65 \quad 926$ CONFIDENCE LIMITS FOR MULTIVARIATE RATIOS

TWO METHODS OF BIAS REDUCTION IN THE ESTIMATION OF RATIOS ILLE'S METHOD OF BIAS REDUCTION TO THE ESTIMATION OF RATIOS

FOR FAMILIES OF HYPOTHESES WITH MONOTONE DENSITY RATIOS ROBABILITY FUNCTION, TABLES OF CERTAIN AREA-ORDINATE RATIOS AND OF THEIR RECIPROCALS
CORR. 631162
ON VARIANCES OF RATIOS AND THEIR DIFFERENCES IN ON VARIANCES OF RATIOS AND THEIR DIFFERENCES IN A NOTE ON ESTIMATION OF RATIOS BY QUENOUILLE 'M METHOD AL RA/ ON THE DISTRIBUTION OF LINEAR FUNCTIONS AND RATIOS OF LINEAR FUNCTIONS OF ORDERED CORRELATED NORM BIOKA64 UNIFORM VARIABLES RATIOS OF NORMAL VARIABLES AND RATIOS OF SUMS OF

ON THE DISTRIBUTION OF THE MAXIMUM AND MINIMUM OF RATIOS OF ORDER STATISTICS CONFIDENCE REGIONS FOR VARIANCE RATIOS OF RANDOM MODELS

SPACINGS THEORY, I. LIMIT DISTRIBUTIONS OF SUMS OF RATIOS OF SPACINGS OF PLANT COMPETITION EXPERIMENTS FOR DIFFERENT RATIOS OF SPECIES

JASA 69 JASA $65 \quad 193$ AMS 69918 ASA 69660 TRANSFORMATIONS THE BEHAVIOR OF LIKELIHOOD RATIOS OF STOCHASTIC PROCESSES RELATED BY GROUPS OF AMS 65 OMPARISON OF SEVERAL GROUPS OF OBSERVATIONS WHEN THE RATIOS OF THE POPULATION VARIANCES ARE UNKNOWN /E C BIOKA5I SES IN UNIVARIATE AND MULTIVARIATE ANALYSIS WHEN THE RATIOS OF THE POPULATION VARIANCES ARE UNKNOWN /THE BIOKA54 CRITERION FOR TESTS/ ON THE DISTRIBUTIONS OF THE RATIOS OF THE ROOTS OF A COVARIANCE MATRIX AND WILKS' DESIGN SOME EMPIRICAL RESULTS ON VARIANCE RATIOS UNDER PERMUTATION IN THE COMPLETELY RANDOMIZED J NOTE ON A PAPER BY RAY AND PITMAN + (FISHER-BEHRENS-STATISTIC)

LINEAR ESTIMATION AND THE ANALYSIS OF GAMMA RAY PULSE-HEIGHT SPECTRA ING RESULTS FOR REGRESSION ANALYSIS APPLIED TO GAMMA RAY SPECTROMETER DATA, I LING RESULTS FOR REGRESSION ANALYSIS APPLIED TO GAMMA RAY SPECTROMETER DATA, 2

SOME EXPERIMENTA SOME EXPERIMENTAL SAMP BIOC 68 353
333
371

86 175
392

B

5


PORTIONAL TO SIZE WHEN THE SIZ SEVERAL A NOTE ON THE RE-USE OF SAMPLES

TE MEASUREMENT ERROR IN NONDESTRUCTIVE EVALUATION OF REACTOR FUEL ELEMENT QUALITY A PROCRAM TO ESTIMA TE

AMS $63 \quad 341$ A NOTE ON MEASUREMENT ERRORS AND DETECTING REAL DIFFERENCES

A RECRESSION METHOD FOR REAL ESTATE PRICE INDEX CONSTRUCTION

JASA $61 \quad 314$

JASA 63

INTO BLOCKS, BY WEICHTED MEANS, OF A FINITE SET OF REAL NUMBERS THE COMPLETE AMALGAMATION BI ACCELERATION THE REAL STABLE CHARACTERISTIC FUNCTIONS AND CHAOTIC

ON FINDINC LOCAL MAXIMA OF FUNCTIONS OF A REAL VARIABLE STATISTICAL CONCEPTS IN THEIR RELATION TO REALITY

CAUSSIAN DISTRIBUTION A TEST FOR REALITY OF A COVARIANCE MATRIX IN A CERTAIN COMPLEX

-M OF $\mathrm{F}(\mathrm{Y}-\mathrm{SUB}-\mathrm{T})$, WHERE (Y-SUB-0, Y-SUB-1,...) IS A REALIZATION OF A NON-HOMOCENEOUS FINITE-STATE MARKOV REALIZATION OF STOCHASTIC SYSTEMS

NOTE ON THE COMPARISON OF SEVERAL REALIZATIONS OF A MARKOFF CHAIN

A REAPPRAISAL OF THE PERIODOGRAM IN SPECTRAL ANALYSIS

SAMPLE DATA

NEW METHODS FOR REASONING TOWARDS POSTERIOR DISTRIBUTTONS BASED ON

A BRANCHING PROCESS WITHOUT REBRANCHING THE MULTI-SAMPLE SINGLE RECAPTURE CENSUS

THE MULTIPLE-RECAPTURE CENSUS II ESTIMATION WHEN THERE IS IMMIGRA

TION OR DEATH

A NOTE ON THE MULTTPLE-RECAPTURE CENSUS

ON ESTIMATING THE SIZE OF MOBILE POPULATIONS FROM RECAPTURE DATA

BIOKA59 317

JRSSB6 180

BIOKA67 310

JRSSB55 204

AMS $65 \quad 115$

BIOKA65 277

AMS $67 \quad 927$

BIOKA59 412

TECH $65 \quad 531$

AMS $66 \quad 355$

AMS 691 1B50

BIOKA62 33

BIOKA5I 293

/ ESTIMATES OF POPULATION PARAMETERS FROM MULTIPLE RECAPTURE DATA WITH BOTH DEATH AND DILUTION-DETERMINI BIOKA63 II3 SOME RECENT ADVANCES IN SAMPLINC THEORY RECENT RESEARCH IN REINTERVIEW PROCEDURES JASA 68 4I

INFINITELY DIVISIBLE DISTRIBUTIONS, RECENT RESULTS AND APPLICATIONS

ON RECENT THEOREMS CONCERNING THE SUPERCRITICAL GALTON-

EMPHASIS ON NON-NORMALITY

SUMMARY OF RECENT WORK ON VARIABLES ACCEPTANCE SAMPLING WITH

MEASURING RECESSIONS

AMS 6B 209B

TECH 69 NO. 4

JASA 5B 259

BI0CS67 356

ETERMINISME CENETIQUE DES CARACTERES QUANTITATIFS ET RECHERCHE DE 'GENES MAJEURS' /. INTERPRETATION DU D BIOCS6B 277

BIORTHOGONAL AND DUAL CONFIGURATIONS AND THE RECIPROCAL NORMAL DISTRIBUTION

BI/ EXPECTED VALUES AND STANDARD DEVIATIONS OF THE RECIPROCAL OF A VARIABLE FROM A DECAPITATED NEGATIVE JASA 62 439

VE RANDOM VARIABLE A NOTE ON THE RECIPROCAL OF THE CONDITIONAL EXPECTATION OF A POSITI

VARIABLE, CORR. 631162 THE RECIPROCAL OF THE DECAPITATED NECATIVE BINOMIAL

ON A SIMPLE ESTIMATE OF THE RECIPROCAL OF THE DENSITY FUNCTION

AMS 651302

JASA 62906 AMS $6 \mathrm{~B} \quad 10 \mathrm{~B} 3$

TABLES OF CERTAIN AREA-ORDINATE RATIOS AND OF THEIR RECIPROCALS

APPROXIMATIONS TO THE MEAN AND STANDARD DEVIATION OF RECIPROCALS OF OBSERVATIONS

A MATHEMATICAL THEORY OF PATTERN RECOCNITION

RECONSTRUCTING PATTERNS FROM SAMPLE DATA

OF CONSUMER ATTITUDE SURVEYS, THEIR FORECASTINC RECORD

A THEORY FOR RECORD LINKACE

BIOKA55 217

TECH 63522

AMS $63 \quad 284$

AMS $67 \quad 13 \mathrm{~B}$

TEN YEARS JASA $63 \quad$ B99 JASA 69 NO. 4

MATION

OUTCOME PROBABILITIES FOR A RECORD MATCHING PROCESS WITH COMPLETE INVARIANT INFOR JU

A MODEL FOR OPTIMUM LINKAGE OF RECORDS

OF MORALITY AND POPULATION FROM SURVEY-REMOVAL RECORDS

TRANSFORMATION IN THE ANALYSIS OF FRUIT RETENTTON RECORDS

FREE TESTS IN TIME-SERIES BASED ON THE BREAKING OF RECORDS (WITH DISCUSSION)

THE EFFICIENCY OF THE RECORDS TEST FOR TREND IN NORMAL REGRESSION

A SAMPLING EXPERIMENT ON THE POWERS OF THE RECORDS TESTS FOR TREND IN A TIME SERIES

JASA $6 B \quad 1321$

ESTIMATES BIOCS65 921

DISTRIBUTION- JRSSB54

JRSSB57 149

JRSSB55 115

AVAILABLE FOR ECONOMIC RESEARCH ON CERTAIN TYPES OF RECREATION

THE ESTIMATION OF MORTALITY AND RECRUITMENT FROM A SINGLE TACCING EXPERIMENT

281

BIOCS65 529

A NONPARAMETRIC STATISTICAL METHOD FOR CULLING RECRUITS FROM A MARK-RECAPTURE EXPERIMENT

ON MULTIVARIATE NORMAL PROBABILITIES OF RECTANGLES

CLASSIFYINC YOUDEN RECTANGLES

EXACT POWER OF MANN-WHITNEY TEST FOR EXPONENTIAL AND RECTANGULAR ALTERNATIVES

DIMENSIONAL CHAINS INVOLVING RECTANGULAR AND NORMAL ERROR-DISTRIBUTIONS

MULTIVARIATE NORMAL DISTRIBUT IONS

RECTANGULAR CONFIDENCE REGIONS FOR THE MEANS OF

EACH MEMBER OF THE SAMPLE IS DRAWN FROM A DIFFERENT RECTANGULAR DISTRIBUTION/OF THE SAMPLE MEAN WHERE BI FITTING THE RECTANGULAR HYPERBOLA

FACTORIAL TREATMENTS IN RECTANGULAR LATTICE DESIGNS

THE QUOTIENT OF A RECTANGULAR OR TRIANGULAR AND A GENERAL VARIATE

SPREAD OF DISEASES IN A RECTANGULAR PLANTATION WITH VACANCIES

OCS65 936

AMS $68 \quad 1425$

JRSSB66 118

AMS $66 \quad 945$

TECH $63 \quad 404$

JASA $67 \quad 626$

BIOKA63 508

BIOCS66 573

JASA $61 \quad 368$

BIOKA54 330 BIOKA53 2B?

CT CONFIDENCE BOUNDS FOR THE STANDARD DEVIATION OF A RECTANGULAR POPULATION /AMPLE RANGES IN SETTING EXA JASA 6I 60I

ESTIMATION OF LOCATION AND SCALE PARAMETERS FOR THE RECTANGULAR POPULATION FROM CENSORED SAMPLFS ON TESTING THE EQUALITY OF PARAMETERS IN K RECTANGULAR POPULATIONS

THE DISTRIBUTIONS OF PRODUCT STATISTICS ARISING FROM RECTANGULAR POPULATIONS

SOME CENERALIZATIONS OF

59810

ON SUMS AND PRODUCTS OF RECTANGULAR VARIATES

RECTIFYING INSPECTION OF A CONTINUOUS OUTPUT, CORR RECTIFYINC INSPECTION OF LOTS

A RECTIFYING INSPECTION PLAN

DISCRETE DISTRIBUTION ESTIMATORS FROM THF RECURRENCE EQUATION FOR PROBABTL ITIES

JRSSB59 356

JASA $60 \quad 144$

JASA 64557

BIOKA66 615

JASA 5B 702

JASA 61 B07

JRSSB55 124

JASA 69602

A RECURRENCE FOR PERMUTATIONS WITHOUT RISING OR FALLING AMS 65708

SUCCESSIONS NUMERICAL C BIOCS6B

ONSTRUCTION OF ORTHOGONAL POLYNOMIALS FROM A GENERAL RECURRENCE FORMULA

A RECURRENCE RELATION FOR DISTRIBUTTON FUNCTIONS OF ORD JASA 6960

ER STATISTICS FROM BIVARIATE DISTRIBUTIONS

IONS OF ORDER STATISTICS

ICS FOR EXCHANGEABLE VARIATES

ATISTICS OF DEPENDENT VARIABLES, AND SOME APPLICA/

FUNCTIONS OF ORDER STATISTICS, AND SOME APPLICATI/

OF THE LINEAR EXPONENTIAL FAMILTY IN A PARAMETER BY

POSITIVE BINOMIAL VARIABLE

A MIXTURE OF TWO RECURRENT RANDOM WALKS NEED NOT BE RECURRENT RECURRENCE RELATIONS BETWEEN MOMENTS OF ORDER STATIST AMS $68 \quad 272$ RECURRENCE RELATIONS BETWEEN THE P.D.F.'S OF ORDER ST BIOKA67 283 RECURRENCE RELATIONS BETWEEN THE PROBABILITY DENSITY AMS 62169 RECURRENCE RELATIONS FOR FUNCTIONS OF CUMULANTS /NS AMS 691721 RECURRENCE RELATIONS FOR THE INVERSE MOMENTS OF THE JASA 63468 ON RECURRENT DENUMBEABLE DECISION PROCESSES

ON A SPECIAL CLASS OF RECURRENT EVENTS

ON EXTREMAL FACTORIZATION AND RECURRENT EVENTS

DISTRIBUTIONS ASSOCIATED WITH RANDOM WALK AND RECURRENT EVENTS (WITH DISCUSSION)

AMS $6 \mathrm{~B} \quad 1753$

AMS $6 \mathrm{~B} \quad 424$

AMS 611201

JRSSB $69 \quad 72$

JRSSB57 
TIONS WITH AN APPLICATION TO EXPERIM/ UNITED STATES, 1914-1953, CORR. 60755

INDIA

PROBLEM

A.SYM

ASYMPTOTIC SHAPES OF BAYES SEQUENTIAL TESTING REGIONS REGIONAL CYCLES OF MANUFACTURING EMPLOYMENT IN THE REGIONAL DISPARITIES IN HOUSEHOLD COMSUMPTION IN PRELIMINARY REGIONAL FORECASTS FOR THE OUTCOME OF AN ESTIMATION

A SECOND-ORDER APPROXIMATION TO OPTIMAL SAMPLING REGIONS OUTER NEEDLE OF SOME BAYES SEQUENTIAL CONTINUATION REGIONS 'SPHERICAL' AND 'CUBOIDAL' DESICNS IN THE WRONC REGIONS PARAMETER IS 'NEAR' THE BOUNDARIES OF THE HYPOTHESIS RECIONS BAYESIAN TOLERANCE REGIONS

SUFFICIENT STATISTICS, SIMILAR REGIONS AND DISTRIBUTION-FREE TESTS PREDICTION REGIONS FOR SEVERAL PREDICTIONS FROM A SINGLE

REGRESSION LINE

VARIANCE NONPARAMETRIC CONFIDENCE REGIONS FOR SOME MULTIVARIATE LOCATION PROBLEMS CRITICAL REGIONS FOR TESTS OF INTERVAL HYPOTHESES ABOUT THE A NOTE ON RECIONS FOR TESTS OF KURTOSIS

TIONS A NOTE ON CONSERVATIVE CONFIDENCE REGIONS FOR THE MEAN OF A MULTIVARIATE NORMAL RECTANGULAR CONFIDENCE REGIONS FOR THE MEANS OF MULTIVARIATE NORMAL DISTRIBU J LAWS CONFIDENCE, PREDICTION, AND TOLERANCE REGIONS FOR THE MULTIVARIATE NORMAL DISTRIBUTION EXACT CONFIDENCE RECIONS FOR THE PARAMETERS IN NON-LINEAR REGRESSION CONFIDENCE REGIONS FOR VARIANCE RATIOS OF RANDOM MODELS

SINGLE AND MULTIPLE DISCRIMINATION REGIONS IN MULTIPLE LINEAR RECRESSION ASYMPTOTIC BEHAVIOR OF WILCOXON TYPE CONFIDENCE RECIONS IN MULTIPLE LINEAR RECRESSION CONFIDENCE REGIONS IN NON-LINEAR ESTIMATION (WITH DISCUSSION) DESIGNS WHICH MINIMIZE MODEL INADEQUACIES, CUBOIDAL REGIONS OF INTEREST

$$
\text { STRAIGHT LINE CONFIDENCE REGIONS OF LINEAR MODELS }
$$
TED EDCEWORTH AND CRAM-CHARLIER SERIES THE RECIONS OF UNIMODALITY AND POSITIVITY IN THE ABBREVIA JASA 57 253 PORTANT/ A SIMPLE METHOD OF DERIVING BEST CRITICAL RECIONS SIMILAR TO THE SAMPLE SPACE IN TESTS OF AN IM BIOKA53 231 DISTRIBUTION OF HOMOGENEOU/ PROBABILITY CONTENT OF REGIONS UNDER SPERICAL NORMAL DISTRIBUTIONS, IV, THE AMS 62 542 CTION. THE TITLE SHOULD READ 'PROBABILITY CONTENT OF REGIONS UNDER SPHERICAL NORMAL DISTRIBUTIONS, IV, THE AMS 6I 620 E BIVARIATE NORMAL INTEGRAL PROBABILITY CONTENT OF REGIONS UNDER SPHERICAL NORMAL DISTRIBUTIONS. III. TH AMS 6I I7I GRATION, AND ANALYSIS BASED ON THE DANISH POPULATION REGISTER STEPWISE MULTIVARIATE LINEAR REGRESSION CONVERCENCE IN NON-LINEAR REGRESSION

CONFIDENCE BANDS IN STRAICHT LINE RECRESSION THE EXTENT OF REPEATED MI JASA 641121 JASA $63 \quad 770$ TECH $63 \quad 513$ JASA $64 \quad 1 B 2$ AMS 651097 JASA $65 \quad 205$ TECH $66 \quad 625$ AMS 671536 AMS $67 \quad 1679$ JASA 671050 $\begin{array}{lll}\text { JASA } & 67 & 1494\end{array}$ SASJ $67 \quad 43$ TECH $67 \quad 309$ JASA $6 B \quad 596$ JASA $6 B \quad 1034$ TECH 6B 73 TECH 6B 207 AMS $69 \quad 1557$ 
DISCRIMINATION INTERVALS FOR PERCENTILES IN RECRESSION TESTINC FOR SERIAL CORRELATION IN LEAST SQUARES RECRESSION TWO FURTHER APPLICATIONS OF A MODEL FOR BINARY RECRESSION

ON A PROBLEM CONNECTED WITH QUADRATIC RECRESSION SIMULTANEOUS TOLERANCE INTERVALS IN RECRESSION UNLIMITED SIMUTANEOUS DISCRIMINATION INTERVALS IN RECRESSION INFERENCE ABOUT THE INTERSECTION IN TWO-PHASE RECRESSION CONFIDENCE INTERVAL ESTIMATION IN NON-LINEAR REGRESSION ON THE BAYESIAN ESTIMATION OF MULTIVARIATE RECRESSION EFFICIENCIES OF TESTS OF RANDOMNESS AGAINST NORMAL REGRESSION EFFICIENCY OF THE RECORDS TEST FOR TREND IN NORMAL REGRESSION

DIFFERENCE EQUATION ESTIMATORS IN EXPONENTIAL RECRESSION

AGAINST ASSUMING THE WRONG DECREE IN POLYNOMIAL REGRESSION MULTIPLE DISCRIMINATION REGIONS IN MULTIPLE LINEAR REGRESSION OF VARIABLES IN THE DESIGN OF EXPERIMENTS FOR LINEAR REGRESSION TEST FOR SERIAL CORRELATION IN POLYNOMIAL REGRESSION SQUARE ERROR CRITERION FOR RESTRICTIONS IN LINEAR RECRESSION SQUARE ERROR TEST FOR EXACT LINEAR RESTRICTIONS IN REGRESSION APPROACH FOR MULTIPLE AND PARTIAL CORRELATION AND REGRESSION DESIGNS FOR ESTIMATING THE INDEPENDENT VARIABLE IN REGRESSION WILCOXON TYPE CONFIDENCE REGIONS IN MULTIPLE LINEAR RECRESSION AND VECTOR CORRELATION IN MULTIVARIATE LINEAR RECRESSION ATE STATISTICS II. POINT ESTIMATION IN SIMPLE LINEAR REGRESSION ESTIMATION OF GENETIC PARAMETERS FROM DAUGHTER-DAM REGRESSION THE CHOICE OF VARIABLES IN MULTIPLE REGRESSION

LINEAR PROGRAMMING TECHNIQUES FOR REGRESSION ANALYSIS ON AN ANALOC OF REGRESSION ANALYSIS

ON THE USE OF INCOMPLETE PRIOR INFORMATION IN REGRESSION ANALYSIS THE ANALYSIS OF DISTURBANCES IN REGRESSION ANALYSIS INEQUALITY RESTRICTIONS IN REGRESSION ANALYSIS

SOME FURTHER NOTES ON DISTURBANCE ESTIMATES IN REGRESSION ANALYSIS SELECTION OF THE BEST SUBSET IN REGRESSION ANALYSIS

BAYES'S THEOREM AND THE USE OF PRIOR KNOWLEDGE IN REGRESSION ANALYSIS MODELS OF THE SECOND KIND IN REGRESSION ANALYSIS MISSING DATA IN REGRESSION ANALYSIS NUMERICAL ANALYSIS PROBLEM IN CONSTRAINED QUADRATIC REGRESSION ANALYSIS ADJUSTMENT OF ECONOMIC TIME SERIES AND MULTIPLE REGRESSION ANALYSIS ECIFICATION ERRORS IN CLASSICAL LINEAR LEAST-SQUARES REGRESSION ANALYSIS ARISON OF MEANS OF A MIXED MODEL WITH APPLICATION TO REGRESSION ANALYSIS AE FOR ADDITION OR OMISSION OF A VARIATE IN MULTIPLE REGRESSION ANALYSIS ATIVE EFFICIENCY OF STATISTICAL TESTS IN TIME SERIES REGRESSION ANALYSIS DATA, 2 SOME EXPERIMENTAL SAMPLINC RESULTS FOR REGRESSION ANALYSIS

DATA, 1 SOME EXPERIMENTAL SAMPLING RESULTS FOR REGRESSION ANALYSIS APPLIED TO CAMMA RAY SPECTROMETER BIOCS67 -SQUARES RESIDUALS TESTS FOR SERIAL CORRELATION IN REGRESSION ANALYSIS BASED ON THE PERIODOGRAM OF LEAST BIOKA69 LEAST SQUARES REGRESSTON ANALYSTS FOR TREND-REDUCED TIME SERTES RECRESSION ANALYSIS IN SAMPLE SURVEYS, CORR. 631162 JASA 62 MULTIPLE REGRESSION ANALYSIS OF A POISSON PROCESS

THASA 61 QUERY, REGRESSION ANALYSIS OF CUMULATIVE DATA REGRESSION ANALYSIS OF RELATIONSHIPS BETWEEN REGRESSION ANALYSIS OF SEASONAL DATA

ION) (CORR. 59238 )

AUTOCORRELATED TIME SERIES

SOME PROPERTIES OF THE LEAST SQUARES ESTIMATOR IN REGRESSION ANALYSIS WHEN THE 'PREDICTOR' VARIABLES AR ABOUT SUPPLEMENTARY VARIABLES DIFFERENCES RECRESSION ANALYSIS WHEN THERE IS PRIOR INFORMATION REGRESSION ANALYSIS WITH DEPENDENT VARIABLE CENSORED THE INDEPENDENT VARIABLES MULTIPLE LINEAR RECRESSION ANALYSIS WITH ADJUSTMENT FOR CLASS LINEAR REGRESSION ANALYSIS WITH MISSING OBSERVATIONS AMONG SERIAL CORRELATION IN RECRESSION ANALYSIS. I. SERIAL CORRELATION IN RECRESSION ANALYSIS. II SEQUENTIAL MODEL BUILDING FOR PREDICTION IN REGRESSION ANALYSIS, I ESTIMATION OF WEIGHTING FACTORS IN LINEAR REGRESSION AND ANALYSIS OF VARIANCE RESTRICTED LEAST SQUARES RECRESSION AND CONVEX QUADRATIC PROGRAMMINC EFFICIENT GROUPINC, REGRESSION AND CORRELATION IN ENGEL CURVE ANALYSIS ON THE THEORY OF CLASSICAL REGRESSION AND DOUBLE SAMPLING ESTIMATION DISTRIBUTION OF THE ERRORS IS/ THE ESTIMATION OF REGRESSION AND ERROR-SCALE PARAMETERS, WHEN THE JOINT BIOKA61 I25 JORDAN'S PROCEDURE FOR MATRIX INVEPSION IN MULTIPLE REGRESSION AND MULTIVARIATE DISTANCE ANALYSIS /S OF JRSSB63 352

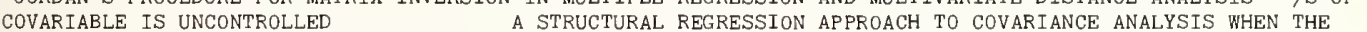
THE CHOICE OF THE DEGREE OF A POLYNOMIAL RECRESSION AS A MULTIPLE DECISION PROBLEM
E ON THE GAIN IN PRECISION FOR OPTIMAL ALLOCATION IN REGRESSION AS APPLIED TO EXTRAPOLATION IN S-N FATIGUE TECH 69 3B9 JASA $67 \quad 1037$ THE CHOICE OF THE DEGREE OF A POLYNOMIAL RECRESSION AS A MULTIPLE DECISION PROBLEM
E ON THE GAIN IN PRECISION FOR OPTIMAL ALLOCATION IN REGRESSION AS APPLIED TO EXTRAPOLATION IN S-N FATIGUE TECH 69 3B9 TESTTNG FOR THE INCLUSTON OF VARTABLES IN A QUICK ESTIMATE OF THE REGRESSION COEFFICIENT ESTIMATES OF THE REGRESSION COEFFICIENT BASED ON KENDALL'S TAU POPULATION THE DISTRIUTION OF THE REGRESSION COEFFICIENT IN SAMPLES FROM A NON-NORMAL THE JOINT DISTRIBUTION OF THE STUDENTIZED REGRESSION COEFFICIENTS IANCE OF MINIMUM VARIANCE AND WEIGHTED LEAST SQUARES REGRESSION COEFFICIENTS D RATIO CRITERIA FOR TESTING LINEAR HYPOTHESES ABOUT REGRESSTON COEFFICIENTS FICATION TABLES WHEN THE CROSS/ T SQUARES REGRESSION COEFFICIENTS
COMPARISON OF THE VAR
SES ABOUT REGRESSION COEFFICIENTS BIOKA58 431 JASA 6 B 1379 BIOKA54 548 BIOKA68 424 AMS $63 \quad 9 B 4$ -NORMAL POPULATIONS. I. THEOR/ THE DISTRIBUTION OF REGRESSION COEFFICIENTS IN SAMPLES FROM BIVARIATE NON BIOKA6O INFORMATTON A PROCEDURE FOR COMPUTING REGRESSION COEFFICIENTS, CORR. 59 BII PARTIAL CORRELATIONS IN REGRESSION COMPUTATIONS

A TEST OF LINEARITY VERSUS CONVEXTTY OF A MEDIAN REGRESSION CURVE

A METHOD OF FITTING THE REGRESSION CURVE $E(Y)=A+D X+B C-T O-X$

THE DERIVATION OF METHODS FOR FITTINC EXPONENTIAL REGRESSION CURVES THE FITTINC OF REGRESSION CURVES WITH AUTOCORRELATED DATA
JASA $5 B$ B 61 BIOCS66 26 JASA $61 \quad 363$ AMS 621096 TECH 6559 BIOKA64 504 BIOKA56 46B 

REGRESSION FOR TIME SERIES WITH ERRORS OF MEASUREMENT BIOKA63 293

LENGTH CONFIDENCE INTERVALS FOR THE ZERO OF A REGRESSION FUNCTTON

BOUNDED AMS $62 \quad 237$ B-1 TO M-SUB-N MULTIPLE-LATTICE DESICN ESTIMATED REGRESSION FUNCTION OF THE Q-SUB-1 TO Q-SUB-N BY M-SU JRSSB69 NO.2 ED CAUSS-NEWTON METHOD FOR THE FITTINC OF NON-LINEAR REGRESSION FUNCTIONS BY LEAST SQUARES THE MODIFI TECH 61 269 PRINCIPAL COMPONENTS RECRESSION IN EXPLORATORY STATISTICAL RESEARCH $\quad$ JASA $65 \quad 234$ ON THE ANALYSIS OF MULTIPLE RECRESSION IN K CATECORIES MULTIPLE RECRESSION IN PROCESS DEVELOPMENT

A NOTE ON REGRESSION IN THE MULTIVARIATE POISSON DISTRIBUTION A NOTE ON LINEAR RECRESSION IN TRIVARIATE DISTRIBUTIONS BIOKA57 67 TECH $6 \mathrm{~B} \quad 257$ JASA $67 \quad 251$ JASA $6 B \quad 1042$ A NUMERICAL INVESTICATION OF LEAST SQUARES RECRESSION INVOLVINC TREND-REDUCED MARKOFF SERIES JRSSB55 105 CONFIDENCE REGIONS FOR THE PARAMETERS IN NON-LINEAR RECRESSION LAWS RECIONS FOR SEVERAL PREDICTIONS FROM A SINGLE RECRESSION LINE
A NOTE ON CONFIDENCE BANDS FOR A RECRESSION LINE

A NOTE ON CONFIDENCE BANDS FOR A RECRESSION LINE OVER A FINITE RANCE ON COMPARING TWO SIMPLE LINEAR REGRESSION LINES

TESTS OF SIGNIFICANCE FOR CONCURRENT RECRESSION LINES OF RANK ORDER TESTS FOR THE PARALLELISM OF SEVERAL RECRESSION LINES

A CONSERVATIVE TEST FOR THE CONCURRENCE OF SEVERAL RECRESSION LINES AND RELATED PROBLEMS PREDICTION TECH $61 \quad 21$ JASA $6 B \quad 102 \mathrm{~B}$ SASJ $6 B \quad 33$ BIOKA53 297 AMS 691668 BIOKA66 272 BIOKA52 109 JASA $63 \quad 933$

CONSTRUCTION ON THE CONCURRENCE OF A SET OF REGRESSION LINES.

A REGRESSION METHOD FOR REAL ESTATE PRICE INDEX

ON A CLASS

TAL RESPONSE DATA THE USE OF NON-LINEAR REGRESSION METHODS FOR ANALYSING SENSITIVITY AND QUAN A NOTE ON REGRESSION METHODS IN CALIBRATION RRORS SMALL-SAMPLE PROPERTIES OF SEVERAL TWO-STAGE REGRESSION METHODS IN THE CONTEXT OF AUTOCORRELATED E JASA 69253 CLASSICAL AND INVERSE RECRESSION METHODS OF CALIBRATION CLASSICAL AND INVERSE REGRESSION METHODS OF CALIBRATION IN EXTRAPOLATION ESTIMATION IN A HETEROSCEDASTIC REGRESSION MODEL A ROBUST POINT ESTIMATOR IN A CENERALIZED REGRESSION MODEL THE USE OF EMPIRICAL BAYES ESTIMATORS IN A LINEAR REGRESSION MODEL EMPIRICAL BAYES ESTIMATORS IN A MULTIPLE LINEAR REGRESSION MODEL LINEAR UNBIASED PREDICTION IN THE CENERALIZED LINEAR REGRESSION MODEL PATTERNS IN RESIDUALS, A TEST FOR RECRESSION MODEL ADEQUACY IN RADIONUCLIDE ASSAY BAYESIAN ANALYSIS OF THE REGRESSION MODEL WITH AUTO-CORRELATED ERRORS CONDITIONAL-NORMAL RECRESSION MODELS

ESTIMATION OF PARAMETERS IN TIME-SERIES RECRESSION MODELS TECH $67 \quad 425$ TECH 69605 JASA $6 B \quad 552$ AMS 69 17B4 BIOKA6B 525 BIOKA69 367 BEST JASA $62 \quad 369$ TECH 65603 JASA $64 \quad 763$ JASA $66 \quad 477$ JRSSB60 139 RR. 68 1551) PREDICTION AND DECISION PROBLEMS IN REGRESSION MODELS FROM THE BAYESIAN POINT OF VIEW (CO JASA 65 608 ASSUMPTIONS MULTIVARIATE RECRESSTON OF DUMMY VARIATES UNDER NORMALITY JY 631054 TISTIC CHARACTERIZATIONS OF NORMALITY BY CONSTANT REGRESSION OF LINEAR STATISTICS ON ANOTHER LINEAR STA AMS 67 1894 THE REGRESSION OF TRUE VALUE ON ESTIMATED VALUE REGRESSION ON A RANDOM FIELD

LINEAR REGRESSION ON PROPORTIONS

ASYMPTOTIC LINEARITY OF A RANK STATISTIC IN RECRESSION PARAMETER EFFICIENT ESTIMATION OF A REGRESSION PARAMETER FOR CERTAIN SECOND ORDER PROCESS

ES EFFICIENT ESTIMATION OF A REGRESSION PARAMETER FIXED SIZE CONFIDENCE ELLIPSOIDS FOR LINEAR REGRESSION PARAMETERS EFFICIENCY OF A CLASS OF NON-PARAMETRIC TESTS FOR REGRESSION PARAMETERS ON FIXED-WIDTH CONFIDENCE BOUNDS FOR REGRESSION PARAMETERS AND MEAN VECTOR

ASYMPTOTIC JASA 69 N0.4 BIOCS69 5B5 AMS 69 No.6 AMS $61 \quad 1299$ AMS 661602 F FIXED-SIZE SEQUENTIAL CONFIDENCE BOUNDS FOR LINEAR RECRESSION PARAMETERS ON THE ASYMPTOTIC THEORY O ESTIMATES OF RECRESSION PARAMETERS BASED ON RANK TESTS

N OF LEAST SQUARES AND MINIMUM VARIANCE ESTIMATES OF RECRESSION PARAMETERS, (ACKNOWLEDCEMENT OF PRIORITY 6 SOME SCHEFFE-TYPE TESTS FOR SOME BEHRENS-FISHER-TYPE RECRESSION PROBLEMS

OF A MODIFICATION OF DAVIDON'S METHOD TO NONLINEAR RECRESSION PROBLEMS FOR MINIMUM COVARIANCE MATRICES IN TIME SERIES RECRESSION PROBLEMS OCEDURES OF STEIN'S TYPE FOR A CLASS OF MULTIVARIATE RECRESSION PROBLEMS VERAL ONE-DIMENSIONAL SEARCH PROCEDURES IN NONLINEAR RECRESSION PROBLEMS ON LINEAR ESTIMATION FOR RECRESSION PROBLEMS ON TIME SERIES PROPORTIONS FUNCTION OPTIMAL DESIGNS IN REGRESSTON PROBLEMS WTTH A GENERAL CONVEX LOSS DESIGNS FOR REGRESSION PROBLEMS WITH CORRELATED ERRORS

PARAMETERS DESIGNS FOR REGRESSION PROBLEMS WITH CORRELATED ERRORS MANY AMS 621077 JRSSB69 107 BIOKA6B 53 AMS $66 \quad 66$ AMS $68 \quad 49$

THE ESTIMATION OF A LAGCED REGRESSION RELATION

THE ESTIMATION OF THE PARAMETER OF A LINEAR RECRESSION SYSTEM OBEYING TWO SEPARATE REGIMES TESTS OF THE HYPOTHESIS THAT A LINEAR RECRESSION SYSTEM OBEYS TWO SEPARATE REGIMES 
AN APPLICATION OF STEPWISE REGRESSION TO NON-LINEAR ESTIMATION

A NOTE ON REGRESSION TRANSFORMATION FOR SMALLER ROUNDOFF ERROR

ASYMPTOTIC VARIANCES FOR DUMMY VARIATE REGRESSION UNDER NORMALITY ASSUMPTIONS

THE COMPARISON OF REGRESSION VARIABLES

INTERVAL ESTIMATION IN LINEAR REGRESSION WHEN BOTH VARIABLES ARE SUBJECT TO ERROR

NOTE ON INTERVAL ESTIMATION IN NON-LINEAR REGRESSION WHEN RESPONSES ARE CORRELATED

$X$ POST DETERMINATION OF SIGNIFICANCE IN MULTIVARIATE REGRESSION WHEN THE INDEPENDENT VARIABLES ARE ORTHOGO J

LES

THE ANALYSIS OF POISSON REGRESSION WITH AN APPLICATION IN VIROLOGY

CONFIDENCE BANDS IN LINEAR REGRESSION WITH CONSTRAINTS ON THE INDEPENDENT VARIAB JA EXPONENTIAL REGRESSION WITH CORRELATED OBSERVATIONS

FURTHER REMARKS ON EXPONENTIAL REGRESSION WITH CORRELATED OBSERVATIONS

QUADRATIC REGRESSION WITH INEQUALITY RESTRAINTS ON THE

NON-LINEAR REGRESSION WITH MINIMAL ASSUMPTIONS

MULTIPLE REGRESSION WITH MISSING OBSERVATIONS AMONG THE

INDEPENDENT VARIABLES

- SAMPLING EXPERIMENTS WITH LEAST SQUARES./ LINEAR REGRESSION WITH NON-CONSTANT, UNKNOWN ERROR VARIANCES CHOICE OF LEVELS OF POLYNOMIAL REGRESSION WITH ONE OR TWO VARIABLES

Y POINT LEAST SQUARES ESTIMATES AND PARABOLIC REGRESSION WITH RESTRICTED LOCATION MULTIPLE REGRESSION WITH STATIONARY ERRORS REGRESSION WITH SYSTEMATIC NOISE

TESTING FOR SERIAL CORRELATION IN LEAST SQUARES REGRESSION. II. UISSING OBSERVATIONS IN MUTTVARTATE RECRESSION EFFTCIENCY OF A FIRST ORDER METHOD

POLYNOMIALS WEIGHTED

\section{REGRESSION, QUANTAL RESPONSE DATA, AND INVERSE} REGRESSION, STRUCTURE AND FUNCTIONAL RELATIONSHIP

REGRESSION, STRUCTURE AND FUNCTIONAL RELATIONSHIPS. II

K ANALOGUE OF PRODUCT-MOMENT PARTIAL CORRELATION AND REGRESSION, WITH APPLICATION TO MANIFOLD, ORDERED CON BI EFFICIENCIES FOR STEPWISE REGRESSIONS

EFFICIENT CALCULATION OF ALL POSSIBLE REGRESSIONS

A MIXED MODEL OF REGRESSIONS

FOR THE POINTS OF INTERSECTION OF TWO POLYNOMIAL REGRESSIONS

OF ALTERNATIVE ESTIMATORS OF SEEMINGLY UNRELATED REGRESSIONS THE LEAST SQUARES ESTIMATORS FOR FAMILIES OF LINEAR REGRESSIONS EFFICIENT METHOD OF ESTIMATING SEEMINGLY UNRELATED REGRESSIONS AND TESTS FOR AGGREGATION BIAS
PERFECT PROBABILITY MEASURES AND REGULAR CONDITIONAL PROBABILITIES

OF LOCATION PARAMETERS MS

A NOTE ON RISK AND MAXIMAL REGULAR GENERALIZED SUBMARTINGALES IN STOPPING PROBLE SOME PROPERTIES OF REGULAR MARKOV CHAINS

A NOTE ON SUFFICIENCY IN REGULAR MARKOV CHAINS

SUFFICIENCY CONDITIONS IN REGULAR MARKOV CHAINS AND CERTAIN RANDOM WALKS

ON THE FIXED POINT PROBABILITY VECTOR OF REGULAR OR ERGODIC TRANSITION MATRICES SPECTRAL ANALYSTS WTTH REGULARLY MISSED OBSERVATTONS

MODEL RELATING PLANT YIELD WITH ARRANGEMENT FOR REGULARLY SPACED CROPS REGULATION AND OPTIMIZATION

CONSIDERING STATISTICAL AND TIME AVERAGES IN A REGULATION PROBLEM RECENT RESEARCH IN REINTERVIEW PROCEDURES

A REJECTION CRITERION BASED UPON THE RANGE REJECTION OF OUTLIERS

QUERY, REJECTION OF OUTLYING VALUES

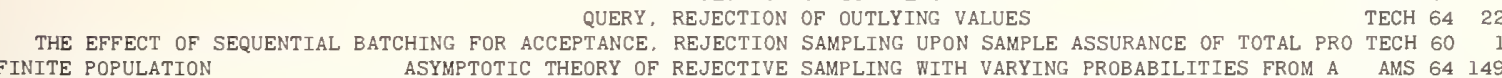
ASYMPTOTIC THEORY OF REJECTIVE SAMPLING WITH VARYING PROBABILITIES FROM A

ESTIMATION OF HERITABILITY FROM EXPERIMENTS WITH RELATED DAMS

TIALLY BALANCED DESIGNS OF THE LATIN SQUARE TYPE AND RELATED DESIGNS

ON TESTING THE EQUALITY OF UNIFORM AND RELATED DISTRIBUTIONS

PIVOTAL QUANTITIES FOR WISHART'S AND RELATED DISTRIBUTIONS,

RY

TIME MARKOV BRANCHING PROCESSES AND RELATED LIMIT THEOREMS BY EXPONENTIALLY WEIGHTED MOVING AVERAGES AND RELATED METHODS

OF EXTINCTION IN A GALTON-WATSON PROCESS AND IN SOME RELATED MULTIPLICATI

MOMENTS OF ORDER STATISTICS IN SAMPLES FROM TWO RELATED POPULATIONS

THE INTERPOLATION OF TIME SERIES BY RELATED SERIES

ATISTICS OF RELIGIOUS AFFILIATION WITH REFERENCES TO RELATED SOCIAL STUDIES, CORR, 59 BII

PROXIMATION FOR BINOMIAL, F, BETA, AND OTHER COMMON, RELATED TAIL PROBABILITIES, I

PROXIMATION FOR BINOMIAL, F, BETA, AND OTHER COMMON, RELATED TAIL PROBABILITIES, II QUADRATIC EXTRAPOLATION AND A RELATED TEST OF HYPOTHESES

THE ESTIMATION OF SECOND-ORDER TENSORS, WITH RELATED TESTS AND DESIGNS

BIOCS69 NO.

TECH 67229 JASA $66 \quad 856$

AND A PARADOX IN FIDUCIAL THEO JRSSB55 79 EMBEDDING OF URN SCHEMES AMS 6B 1801 PREDICTION JRSSB61 414 $\begin{array}{rrr}\text { PREDICTION JRSSB6I } & 414 \\ & \text { /ITIES AMS } 6 B & 1700\end{array}$ RELATIONS AMONG TECH $63 \quad 514$ JASA $62 \quad 729$ /ERATURE ON ST JASA 59335 A NORMAL AP JASA $6 B 1416$ A NORMAL AP JASA 681457 JASA $56 \quad 644$ BIOKA63 353 AMS 6B 1228 EXISTENCE OF OPTIMAL STOPPING RULES FOR RETARDS RELATED TO S-SUB-N-OVER-N

A SOME INVARIANT LAWS RELATED TO THE ARC SINE LAW

MOMENTS OF A STOPPING RULE RELATED TO THE CENTRAL LIMIT THEOREM

NTERPOLATIONS AND APPROXIMATIONS RELATED TO THE NORMAL RANGE

A BIBLIOGRAPHY ON LIFE TESTING AND RELATED TOPICS

QUALITY CONTROL METHODS FOR SEVERAL RELATED VARIABLES

TESTS OF RELATEDNESS

FUNCTION

A RANDOM TIME CHANGE RELATING SEMI-MARKOV AND MARKOV PROCESSES

AN INEQUALITY RELATING THE SPECTRAL DENSITY AND AUTOCORRELATION

CONFIDENCE REGION FOR A LINEAR RELATION

BIVARIATE STRUCTURAL RELATION

THE ESTIMATION OF A LAGGED REGRESSION RELATION

A TEST OF SIGNIFICANCE FOR AN UNIDENTIFIABLE RELATION

ESTIMATION OF THE PARAMETERS OF A LINEAR FUNCTIONAL RELATION OF TESTS

ON THE RELATION BETWEEN ESTIMATING EFFICIENCY AND THE POWER

TWO EARLY PAPERS ON THE RELATION BETWEEN EXTREME VALUES AND TENSILE STRENGTH

RSITY AND YULE'S CHARACTERTSTIC THE MATHEMATICAL RELATION BETWEEN GREENBERG'S INDEX OF LINGUISTIC DIVE NCY OF TWO TESTS AND THE CORRELATION COEFFICI/

THE RELATION BETWEEN PITMAN'S ASYMPTOTIC RELATIVE EFFICIE OCCURRENCE DISTRIBUTION OF WORD LENGTH AND IT/ AND OF A TRANSFORMED CORRELATION COEFFICIENT THE RELATION BETWEEN THE DICTIONARY DISTRIBUTION AND THE BIOKA58 222 RELATION BETWEEN THE DISTRIBUTIONS OF NON-CENTRAL T BIOKA57 219
A RELATION BETWEEN T AND F-DISTRIBUTIONS, CORR. 651249 JASA $6552 B$ 
SMIRNOV TYPE

CS FROM 8IVARIATE DISTRIBUTIONS
AMS 69 1B33 JASA 69600 NOTE ON A UNIQUENESS RELATION IN CERTAIN ACCIDENT PRONENESS MODELS $2 B B$ AN MOTION TO THE EQUIVALENCE CONDITIONS FOR C/ THE RELATION OF THE EQUIVALENCE CONDITIONS FOR THE BROWNI AMS 69 NO. 6 R STATISTICS OF THE CEOMETRIC DISTRIBUTION AND THEIR RELATION TO INVERSE SAMPLINC AND RELIABILITY OF REDUN JASA 67 915 STATISTICAL CONCEPTS IN THEIR RELATION TO REALITY

THE BUSY PERIOD IN RELATION TO THE QUEUEING PROCESS GI-M-1

INHALATION IN RELATION TO TYPE AND AMOUNT OF SMOKINC $\begin{array}{lr}\text { JASA } 59 & 35 \\ \text { BIOCS68 } & \text { B23 }\end{array}$

AMS 69462 BIOKA56 46I BIOKA58 136 JRSSB $69 \quad 65$

S FROM TWO RELATED POPULATIONS

ON ESTIMATING BINOMIAL RESPONSE RELATIONS

TINEAR STRUCTURAL RELATIONS

SAMPLES OF DIFFERENT SIZES

ORDER STATISTICS

RELATIONS AMONG MOMENTS OF ORDER STATISTICS IN SAMPLE TECH 63514

SOME RELATIONS BETWEEN EXPECTATIONS OF ORDER STATISTICS IN BIOKA64 259

A NOTE ON RECURRENCE RELATIONS BETWEEN EXPECTED VALUES OF FUNCTIONS OF

ON TWO EQUIVALENCE RELATIONS BETWEEN MEASURES RECURRENCE RELATIONS BETWEEN MOMENTS OF ORDER STATISTICS FOR AMS $6 B \quad 272$ RECURRENCE RELATIONS BETWEEN THE P.D.F.'S OF ORDER STATISTICS OF BIOKA67 2 B3 DEPENDENT VARIABLES, AND SOME APPLICA/, RECURRENCE RELATIONS BETWEEN THE P.D.F. S OF ORDER STATISTICS OF BIOKA67 2B3
F ORDER STATISTICS, AND SOME APPLICATI/ RECURRENCE RELATIONS BETWEEN THE PROBABILITY DENSITY FUNCTIONS O AMS 62 169
MEASURES WITH APPLICATIONS DEPENDENT VARIABLES, AND SOME APPLICA/, RECURRENCE RELATIONS BETWEEN THE P.D.F. S OF ORDER STATISTICS OF BIOKA67 2B3
F ORDER STATISTICS, AND SOME APPLICATI/ RECURRENCE RELATIONS BETWEEN THE PROBABILITY DENSITY FUNCTIONS O AMS 62 169
MEASURES WITH APPLICATIONS $\begin{array}{lll}\text { MEASURES WITH APPLICATIONS } & \text { RELATIONS BETWEEN WEAK AND UNIFORM CONVERGENCE OF } \\ \text { DISCUSSION) TOPICS IN THE INVESTIGATION OF LINEAR RELATIONS FITTED BY THE METHOD OF LEAST SQUARES (WITH JRSSB67 }\end{array}$ AR EXPONENTIAL FAMILTY IN A PARAMETER BY RECURRENCE RELATIONS FOR FUNCTIONS OF CUMULANTS /NS OF THE LIN AMS 69 I72I BINOMIAL VARIABLE RECURSIVE RELATIONS FOR PREDICTORS OF NON-STATIONARY PROCESSES RECURRENCE RELATIONS FOR THE INVERSE MOMENTS OF THE POSITIVE ON INFERRING ORDER RELATIONS IN ANALYSIS OF VARIANCE

OF INSTRUMENTAL VARIABLE ESTIMATION OF STRAICHT-LINE RELATIONS WHEN BOTH VARIABLES ARE SUBJECT TO ERROR MAXIMUM LIKELIHOOD ESTIMATION OF A LINEAR FUNCTIONAL RELATIONSHIP RECRESSION, STRUCTURE AND FUNCTIONAL RELATIONSHIP ESTIMATION OF A FUNCTIONAL RELATIONSHIP

THE BAYESIAN ESTIMATION OF A LINEAR FUNCTIONAL RELATIONSHIP

LIMITS FOR THE GRADIENT IN THE LINEAR FUNCTIONAL RELATIONSHIP MAXIMUM LIKELIHOOD ESTIMATION OF A LINEAR STRUCTURAL RELATIONSHIP

TO THE PROBLEM OF ESTIMATING A LINEAR FUNCTIONAL RELATIONSHIP A PARTIALLY BALANCED INCOMPLETE BLOCK DESICN THE RELATIONSHIP IZING INFORMATION FROM A DIALLEL MATING D/ SPATIAL RELATIONSHIP AMONG EIGHT POPULATIONS ZEA MAYS L. UTIL BI

A SIMPLE MATHEMATICAL RELATIONSHIP AMONC K-CLASS ESTIMATORS

A RELATIONSHIP BETWEEN ARBITRARY POSITIVE MATRICES AND AMS 64 B76

DOUBLY STOCHASTIC MATRICES

PURCHASES A NOTE ON THE RELATIONSHIP BETWEEN EARNING EXPECTATIONS AND NEW CAR JASA 59575 CORRECTIONS TO 'A RELATIONSHIP BETWEEN HODGES' BIVARIATE SIGN TEST AND AMS 6l 6I9 RVALS FOR THE HYPERGEOMETRIC PARAMETER THE RELATIONSHIP BETWEEN NEYMAN AND BAYES CONFIDENCE INTE TECH 6B 199 APPLICATIONS IN SEQUENTIAL ANALYSIS COMPONENT FAILURE RATES ONARY BIRTH-DEATH PROCESS, AND ITS ECONOMIC A/ FOR PAIRED COMPARISONS SUMS FOR BALANCED COMPLETE FINITE POPULATIONS EMPERICAL RELATIONSHIP SOME ANALYSES OF INCOME-FOOD RELATIONSHIPS
ON CIRCULAR FUNCTIONAL RELATIONSHIPS

THE RELATIONSHIP BETWEEN SUFFICIENCY AND INVARIANCE WITH AMS 65575 RELATTONSHTP BETWEEN SYSTEM FAILURE RATE AND TECH 63 IB3 THE RELATIONSHIP BETWEEN THE MEAN AND VARIANCE OF A STATI BIOKA62 253 ON A RELATIONSHIP BETWEEN TWO REPRESENTATIONS OF A MODEL BIOCS69 597 RELATIONSHIP OF GENERALIZED POLYKAYS TO UNRESTRICTED AMS 68643

SIMULTANEOUS PATRWISE LINEAR STRUCTURAL RELATIONSHIPS

NOTE ON TESTS OF SIGNIFICANCE FOR LINEAR FUNCTIONAL RELATIONSHIPS

FOR DISCRIMINANT FUNCTIONS AND LINEAR FUNCTIONAL RELATIONSHIPS

ERALIZED LEAST-SQUARES APPROACH TO LINEAR FUNCTIONAL RELATIONSHIPS (WITH DISCUSSION)

SOME RELATIONSHIPS AMONG THE VON MISES DISTRIBUTIONS OF DIFFERENT DIMENSIONS

RECRESSION ANALYSIS OF RELATIONSHIPS BETWEEN AUTOCORRELATED TIME SERIES

RELATIONSHIPS BETWEEN BAYESIAN AND CONFIDENCE LIMITS

FOR PREDICTIONS (WITH DISCUSSION)

DISTRIBUTIONS

SOME RELATIONSHIPS BETWEEN THE NORMAL AND VON MISES

LINEAR RELATIONSHIPS BETWEEN VARIABLES AFFECTED BY ERRORS

HAVING WORDS OF EQUAL LENGTHS

ON IDENTITY RELATIONSHIPS FOR TWO TO THE POWER OF N-R DESIGNS

LINEAR RELATIONSHIPS IN GROWTH AND SIZE STUDIES

A NOTE ON THE MEASUREMENT OF COST-QUANTITY RELATIONSHIPS IN THE AIRCRAFT INDUSTRY

CURRENT WEICHT-HEIGHT RELATIONSHIPS OF YOUTHS OF MILITARY AGE

A NOTE ON LTNEAR STRUCTURA RELATTONSHIPS WHEN

E OF INSTRUMENTAL VARIABLES

THE ESTIMATION OF RELATIONSHIPS WITH RECRESSION, STRUCTURE AND FUNCTIONAL RELATIONSHIPS. II

ON THE RELATIVE ACCURACY OF SOME SAMPLING TECHNIQUES

RELATIVE COSTS OF COMPUTERIZED ERROR INSPECTION PLANS J

THE RELATIVE EFFICACY OF INVESTMENT ANTICIPATIONS

ESTING TREND IN DISPERSI/ SCALAR ALTERNATIVES

A NOTE ON THE ASYMPTOTIC RELATIVE EFFICIENCIES OF COX AND STUART'S TESTS FOR T

THE ASYMPTOTIC RELATIVE EFFICIENCY OF GOODNESS-OF-FIT TESTS AGAINST

TESTS AGAINST SOME PARAMETRIC ALTERNA SCHEMES

ASYMPTOTIC RELATIVE EFFICIENCY OF MOOD'S AND MASSEY'S TWO SAMPLE

THE RELATIVE EFFICIENCY OF SOME TWO-PHASE SAMPLING

BIOCS65 B39

JASA $5 B \quad 905$

JRSSB $65 \quad 45$

BIOCS69 129

A BIOKA57 26B

BIOKA55 360

BIOKA66 269

JRSSB56 240

JRSSB64 176

BIOKA67 684

BI0CS66 252

AMS $66 \quad 1 B 42$

BIOCS6B

IOKA67 670

$\begin{array}{ll}\text { JRSSB59 } & 91 \\ \text { BIOKA52 } & 96\end{array}$ JASA $58 \quad 98$

JASA 69 NO. 4 JASA $66 \quad 104$

THE AVERAGE CRITICAL VALUE METHOD FOR ADJUDGING RELATIVE EFFICIENCY OF STATISTICAL TESTS IN TIME SERI B. THE AVERACE CRITICAL VALUE METHOD AND THE ASYMPTOTIC RELATIVE EFFICIENCY OF TESTS A NOTE ON THE LIMITING RELATIVE EFFICIENCY OF THE WALD SEQUENTIAL PROBABILIT JASA 60 660 $Y$ RATIO TEST COEFFICI/ THE RELATION BETWEEN PITMAN'S ASYMPTOTIC RELATIVE EFFICIENCY OF TWO TESTS AND THE CORRELATION AMS 63 I442 TO ESTIMATE THE RATIO OF VARIANCES WITH BOUNDED RELATIVE ERROR

DISTRIBUTION

DISTRIBUTIONS ESTIMATES OF BOUNDED RELATIVE ERROR FOR THE MEAN LIFE OF AN EXPONENTIAL ESTIMATES OF BOUNDED RELATIVE ERROR FOR THE RATIO OF VARIANCES OF NORMAL

A SIMPLE METHOD OF ESTIMATING RELATIVE POTENCY FROM TWO PARABOLAS

USING DISTRIBUTION-FREE METHODS IN THE ESTIMATION OF RELATIVE POTENCY IN DILUTION (-DIRECT) ASSAYS /FOR B APPROXIMATE CONFIDENCE LIMITS FOR THE RELATIVE RISK (CORR. 63 234)

DIFFERENT K-CLASS ESTIMATORS

THE RELATIVE SENSITIVITY TO SPECIFICATION ERROR OF

A NONPARAMETRIC SUM OF RANKS PROCEDURE FOR RELATIVE SPREAD IN UNPAIRED SAMPLES, CORR. 61 IO05 MULTIPLE CORRELATION COEFFICIENT

A RELATIVELY SIMPLE FORM OF THE DISTRIBUTION OF THE

JASA 631044 TECH $61 \quad 107$ JASA $56 \quad 4 B 1$ BIOCS65 140 BIOCS66 610 JRSSB $62 \quad 454$ JASA $66 \quad 345$

JASA $60 \quad 429$ JRSSB6B 276 HREN ZUR ERZEUGUNG VON SYMBOLFOLGEN MIT VORGECEBENER RELATIVER DYADENKONTEXTREDUNDANZ /N EINFACHES VERFA BIOCS68 703 
POPULATION

SOLIDS

TIVE TO THE PROBLEM OF ME/

NOTES. DISTRIBUTION AMONG RELATIVES OF GENOTYPES FOR TWINNING AN ANALYSIS OF SOME RELAY FAILURE DATA FROM A COMPOSITE EXPONENTIAL

FILL WEIGHT VARIATION RELEASE AND CONTROL OF CAPSULES, TABLETS, AND STERILE A FURTHER RESULT ON THE RELEVANCE OF THE DISPERSION OF A RADON-NIKODYM DERIVA SYSTEM EFFICIENCY AND RELIABILITY

MULTI-COMPONENT SYSTEMS AND STRUCTURES AND THEIR RELIABILITY ON MINIMUM VARIANCE UNBIASED ESTIMATION OF RELIABILITY

NALYSIS OF THE EFFECTS OF MARGINAL TESTING ON SYSTEM RELIABILITY BTAINING APPROXIMATE CONFIDENCE INTERVALS FOR SYSTEM RELIABILITY MAL DISTRIBUTION TO A STRESS VS. STRENGTH PROBLEM IN RELIABILITY ANALYSIS /ICATIONS OF THE BIVARIATE NOR TECH 64 325 IVE MAINTENANCE POLICIES A GENERAL METHOD FOR THE RELIABILITY ANALYSIS OF SYSTEMS UNDER VARIOUS PREVENT AH ESTIMATION OF JUMPS, RELIABILITY AND HAZARD RATE SEQUENTIAL RELIABILITY ASSURANCE IN FINITE LOTS

IAL DISTRIBUTION BAYESIAN APPROACH TO LIFE TESTING AND RELIABILITY ESTIMATION

LIFE TESTING AND RELIABILITY ESTIMATION FOR THE TWO PARAMETER EXPONENT J RELIABILITY ESTIMATION OF THE TRUNCATED EXPONENTIAL

ESTIMATES OF RELIABILITY FOR SOME DISTRIBUTIONS USEFUL IN LIFE

BIOCS6B 179

TECH $61 \quad 423$

TECH $69 \quad 161$

JRSSB $65 \quad 108$

TECH $60 \quad 43$

TECH $61 \quad 55$

AMS $69 \quad 710$

MODEL

TEST ING

MINIMUM VARIANCE UNBIASED ESTIMATION OF RELIABILITY FOR THE TR SOME PROPERTIES OF STATISTICAL RELIABILITY FUNCTION E MAXIMUM LIKELIHOOD AND BEST UNEIASED ESTIMATORS OF RELIABILITY FUNCTIONS /NCIES IN SMALL SAMPLES OF TH JASA 66 1033 RIANCE UNBIASED AND MAXIMUM LIKELIHOOD ESTIMATORS OF RELIABILITY FUNCTIONS FOR SYSTEMS IN SERIES AND IN PA JASA 66 IO52 PROGRAM

RELTABILITY GROWTH DURING A DEVELOPMENT TESTING

TECH $66 \quad 53$

PARAMETERS IN A TRANSIENT MARKOV CHAIN ARISING IN A RELIABILITY GROWTH MODEL ESTIMATION OF AMS 69 1542

EXACT ASYMPTOTICALLY EFFICIENT CONFIDENCE BOUND FOR RELIABILITY IN THE CASE OF THE WEIBULL DISTRIBUTION TECH 66 135

PROBIT ANALYSIS AS A TECHNIQUE FOR ESTIMATING THE RELIABILITY OF A SIMPLE SYSTEM

THE SAME EXPONENTIAL DISTRIBU/ POINT ESTIMATION OF RELIABILITY OF A SYSTEM COMPRISED OF $K$ ELEMENTS FROM JASA 66 IO29 DAMAGE EFFECTS

TIME-DEPOSITS

THE RELIABILITY OF COMPONENTS EXHIBITHO CUMULATIVE

TECH $61 \quad 413$

THE RELIABILITY OF CONSUMER SURVEYS OF FINANCIAL HOLDINGS JASA 65 I4B

THE RELIABILITY OF MULTIPLEX SYSTEMS WITH REPAIR JRSSB66 459

TRIBUTION AND THEIR RELATION TO INVERSE SAMPLING AND RELIABILITY OF REDUNDANT SYSTEMS /THE GEOMETRIC DIS JASA 67 915

NATED AT FIRST FAI/ BAYESIAN CONFIDENCE LIMITS FOR RELIABILITY OF REDUNDANT SYSTEMS WHEN TESTS ARE TERMI TECH 68 29

G HAZARDOUS/ A STATISTICAL MODEL OF EVALUATING THE RELIABILITY OF SAFETY SYSTEMS FOR PLANTS MANUFACTURIN TECH 59 293 APPROXIMATE CONFIDENCE LIMITS FOR THE RELIABILITY OF SERIES AND PARALLEL SYSTEMS 495 CONFIDENCE LIMITS FOR THE RELIABILITY OF SERIES SYSTEMS

ON CONFIDENCE LIMITS FOR THE RELIABILITY OF SYSTEMS

A METHOD TO DETERMINE THE RELIABILITY OF TELEMETRY SYSTEMS REPORTS

RIMINATING BETWEEN FAILURE DENSITY FUNCTIONS USED IN RELIABILITY PREDICTIONS ABOUT GAMMA PARAMETERS WITH AN APPLICATION TO A RELIABILITY PROBLEM RANDOM HAZARD IN RELIABILITY PROBLEMS

\author{
JASA 62 6B6
}

A METHOD FOR DISC TECH 65 SOME INFERENCES JASA $63 \quad 670$ TECH 63211

AMS $65 \quad 565$ BOUNDS ON INTEGRALS WITH APPLICATIONS TO RELIABILITY PROBLEMS

EXACT THREE, ORDER STATISTIC CONFIDENCE BOUNDS ON RELIABLE LIFE FOR A WEIBULL MODEL WITH PROGRESSIVE CE JASA 69 306 AL STU/ A GUIDE TO THE LITERATURE ON STATISTICS OF RELIGIOUS AFFILIATION WITH REFERENCES TO RELATED SOCI JASA 59 335 A COMPARISON OF MAJOR UNITED STATES RELIGIOUS GROUPS JASA 1 $56 B$ $\begin{array}{lllll}\text { THE REMAINDER IN THE CENTRAL LIMIT THEOREM FOR MIXING } & \text { AMS } 69 & 601 \\ \text { A REMARK ON HITTING PLACES FOR TRANSIENT STABLE PROCESS } & \text { AMS } 68 & 365\end{array}$ A REMARK ON MULTIPLE COMPARISON METHODS A REMARK ON SOLVING EQUATIONS IN SUMS OF POWERS JRSSB6B 567 $\begin{array}{llll}\text { A REMARK ON SOLVING EQUATIONS IN SUMS OF POWERS } & \text { JRSSB6B } & 567 \\ \text { A REMARK ON SPEARMAN'S RANK CORRELATION COEFFICIENT } & \text { BIOKA5B } & 273\end{array}$ A REMARK ON THE COIN TOSSING GAME AMS 641345 UTION OF A BRANCHING PROCESS ALLOWING IMMIGRATION, A REMARK ON THE CRITICAL CASE THE STATIONARY DISTRIB JRSSB68 IT6 $\begin{array}{rlrr}\text { A REMARK ON THE KOLMOGOROFF-PETROVSKII CRITERION } & \text { AMS } & 69 & 1086 \\ \text { SOME FURTHER REMARKS CONCERNING 'A GENERAL APPROACH TO THE ESTIMAT TECH } & 68 & 551\end{array}$ ION OF VARIANCE COMPONENTS' SOME REMARKS CONCERNING KHATRI'S RESULT ON QUADRATIC FORMS BIOKA68 593 MPLE DISTRIBUTION FUNCTIONS OF GENERALIZED CLASSI/ REMARKS CONCERNING THE APPLICATION OF EXACT FINITE SA JASA 63 943 REPLACEMENT SOME REMARKS ON A SIMPLE PROCEDURE OF SAMPLING WITHOUT JASA $66 \quad 391$ SOME REMARKS ON CONFIDENCE OF FIDUCIAL LIMITS $\quad$ BIOKA54 275 SOME GENERAL REMARKS ON CONSULTING IN STATISTICS SOME REMARKS ON DOUBLE SAMPLING FOR STRATIFICATION
OBSERVATIONS

DISTRIBUTIONS

PROBLEM

SAMPLING INSPECTION SCHEME

FAMILIES OF DISTRIBUTION
FURTHER REMARKS ON EXPONENTIAL REGRESSION WITH CORRELATED REMARKS ON LARGE SAMPLE ESTTMATORS FOR SOME DISCRETE SOME REMARKS ON SCHEFFE'S SOLUTION TO THE BEHRENS-FISHER SOME REMARKS ON THE ANALYSIS OF TIME-SERIES

SOME REMARKS ON THE BAYESIAN SOLUTION OF THE SINGLE

FURTHER REMARKS ON TOPOLOGY AND CONVERGENCE IN SOME ORDERED SOME REMARKS ON WILD OBSERVATIONS

A STATISTICAL THEORY OF REMNANTS

THE ESTIMATION OF THE SPECTRAL DENSITY AFTER TREND REMOVAL BASED ON CHANGE OF COMPOSITION CAUSED BY A SELECTIVE REMOVAL MODELS FOR A BACTERIAL GROWTH PROCESS WITH REMOVALS

BY PHAGES, A BRANCHING PROCESS WITH DETERMINISTIC REMOVALS OF THE UNRESTRICTED AOQL WHEN DEFECTIVE MATERIAL IS REMOVED BUT NOT REPLACED EFFECTIVENESS OF ADJUSTMENT BY SUBCLASSIFICATION IN REMOVING BIAS IN OBSERVATIONAL STUDIES THE BIOCS68 295 TECH 69241 BIOKA65 5 SB7 BIOKAGB 575 TECH $67 \quad 5 B 7$ JASA 69 NO. 4 BIOKA67 25 TECH $60 \quad 341$ AMS 6951 TECH $60 \quad 1$ JRSSB59 15B JRSSB $5 B \quad 323$

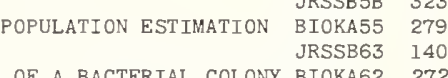
POPULATION ESTIMATION BIOKA55 279 THE EXTINCTION OF A BACTERIAL COLONY BIOKA62 272 THE COMPUTATION JASA 69665 IDENT PRONE POPULATION

ON THE EFFECT OF REMOVING PERSONS WITH N OR MORE ACCIDENTS FROM AN ACC BIOKA65 298 INFINITELY DIVISIBLE RENEWAL DISTRIBUTIONS

ON THE ERROR IN THE LINEAR APPROXIMATION TO THE RENEWAL FUNCTION

ON THE MATRIX RENEWAL FUNCTION FOR MARKOV RENEWAL PROCESSES ON THE RENEWAL FUNCTION FOR THE WEIBULL DISTRIBUTION

A NOTE ON THE RENEWAL FUNCTION WHEN THE MEAN RENEWAL LIFETIME IS AVERAGE RENEWAL LOSS RATES

ON SERIES EXPANSIONS FOR THE RENEWAL MOMENTS

A RENEWAL PROBLEM WITH BULK ORDERING OF COMPONENTS

GAMES ASSOCIATED WITH A RENEWAL PROCESS PRESENT VALUE OF A RENEWAL PROCESS

A NOTE ON THE WEIBULL RENEWAL PROCESS

A MULTI-STAGE RENEWAL PROCESS

LIMIT THEOREMS FOR MARKOV RENEWAL PROCESSES
AMS 691109 BOUNDS BIOKA64 355 AMS 69 NO.6 TECH $63 \quad 393$ JRSSB61 230 AMS $63 \quad 396$ BIOKA63 75 JRSSB59 1 BO AMS $62 \quad 697$ AMS 641326 BIOKA66 375 JRSSB63 150 AMS $64 \quad 1746$ 
PROPERTIES MARKOV RENEWAL PROCESSES.

PROBABILISTIC PROOF OF THE DISCRETE GENERALIZED RENEWAL THEOREM

SAMPLING

COMPARISON OF REPLACEMENT POLICIES, AND RENEWAL THEORY IMPLICATIONS RENEWAL THEORY IN THE PLANE

PROCESSES A PERSISTENCE PROBLEM IN RENEWAL THEORY, ROBERT THE BRUCE'S SPIDER A 'RENEWAL' LIMIT THEOREM FOR GENERAL STOCHASTIC

AMS $63 \quad 390$ AMS $68 \quad 155$ AMS $68 \quad 1210$ AMS $66 \quad 699$

AMS $62 \quad 685$ AMS 651298 AMS $66 \quad 271$ JRSSB $63 \quad 432$ TECH $692 \mathrm{~B} 5$ JRSSB58 243 AMS $64 \quad 577$ AMS 65946 BIOKA66 255 AMS $62 \quad 9 B$ BIOKA60 449 ON THE NUMBER OF RENEWALS IN A RANDOM INTERVAL INCREASE IN RENT OF DWELLING UNITS FROM 1940 TO 1950

FUNCTIONS, CORR, 651069 ON A THEOREM OF RENYI CONCERNING MIXING SEQUENCES OF SETS JASA $59 \quad 358$ AMS $61 \quad 257$ $\begin{array}{llrlrl}\text { SOME RENYI TYPE LIMIT THEOREMS FOR EMPIRICAL DISTRIBUTION } & \text { AMS } & 65 & 322 \\ \text { SOME RENYI TYPE STATISTICS FOR FINITE SAMPLE SIZES } & \text { JASA } 69 & 870\end{array}$ TABLES OF CRITICAL VALUES OF SOME RENYI TYPE STATISTICS FOR FINITE SAMPLE SIZES $\begin{array}{lr}\text { JASA } & 69 \\ \text { BIOCS68 } & 1019\end{array}$ KOLMOGOROV-SMIRNOV TESTS AND RENYI'S MODIFICATION

TIME DISTRIBUTIONS FOR REDUNDANT SYSTEMS WITH REPAIR APPROXIMATION TO MACHINE INTERFERENCE WITH MANY REPAIR MEN ALLY PATROLLED BY ONE OPERATOR WHEN WALKING TIME AND REPAIR TIMES ARE CONSTANTS ED BY ONE OPERATOR WHEN WALKING TIME IS CONSTANT AND REPAIR TIMES ARE VARIABLE PRODUCT TEST PLANNING FOR REPATRABLE SYSTEMS

SOME WAITING TECH $64 \quad 27$ NORMAL JRSSB $57 \quad 334$ $\begin{array}{ccc}\text { /MACHINES UNI-DIRECTION } & \text { JRSSB57 } & 166 \\ \text { /NI-DIRECTIONALLY PATROLL JRSSB57 } & 173\end{array}$ TECH $65 \quad 485$

FUNCTIONS GENERALIZATION AND REPARAMETERIZATION OF SOME SIGMOID OR OTHER NONLINEAR BIOCS65 GENETIC TRENDS BIOCS66

APPLICATION OF MULTIVARIATE ANALYSIS OF VARIANCE TO REPEATED MEASUREMENTS EXPERIMENTS POPULATION REGISTER THE EXTENT OF REPEATED MTGRATION AND ANALYSTS BASED ON THE DANISH $J$ IOCS66 810

JASA 641121 ROTATION DESIGNS FOR SAMPLING ON REPEATED OCCASIONS TICAL MODEL WITH APPLICATIONS TO A STUDY OF ACCIDENT REPEATEDNESS AMONG CHILDREN ON OF AN UNKNOWN DISCRETE WAVEFORM WHICH IS RANDOMLY REPEATING IN GAUSSIAN NOISE OF PAIRED COMPARISON DESIGNS WITH INCOMPLETE REPETITIONS DESIGN AND EVALUATION OF A REPETITIVE GROUP SAMPLING PLAN REPETITIV

CTED AOQL WHEN DEFECTTVE MATERIAL IS REMOVED BUT NOT REPLACED SAMPLING WITH UNEQUAL PROBABILITIES AND WITHOUT REPLACEMENT REMARKS ON A SIMPLE PROCEDURE OF SAMPLING WITHOUT REPLACEMENT PROCEDURES OF UNEQUAL PROBABILITY SAMPLING WITHOUT REPLACEMENT SAMPLING WITH UNEQUAL PROBABILITY AND WITHOUT REPLACEMENT PROCEDURE OF UNEQUAL PROBABILITY SAMPLING WITHOUT REPLACEMENT IN SAMPLING WITH VARYING PROBABILITIES WITHOUT REPLACEMENT ATORS IN SAMPLING WITH VARYING PROBABILITIES WITHOUT REPLACEMENT SAMPLING WITH PROBABILITY PROPORTIONAL TO SIZE WITH REPLACEMENT SAMPLE DRAWN WITH UNEQUAL PROBABILITIES AND WITHOUT REPLACEMENT

A/ EXTREME TAIL PROBABILITIES FOR SAMPLING WITHOUT REPLACEMENT METHODS OF CLUSTER SAMPLING WITH AND WITHOUT REPLACEMENT FOR CLUSTERS OF UNEQUAL SIZES NITE STATISTICAL GAMES WITH AMS $66 \quad 976$ A MATHEMA JASA 651046 LARGE SAMPLE ESTTMATI AMS $65 \quad 489$ AN ANALYSIS BIOKA57 97 JASA $69 \quad 665$ AMS $62 \quad 350$ SOME JASA $66 \quad 391$ ON THREE JASA $63 \quad 202$ SYSTEMATIC JASA $66 \quad 739$ ON A SIMPLE JRSSB 62 4B2 SOME ESTIMATORS JASA $56 \quad 269$ ON A CLASS OF LINEAR ESTIM JASA 65637 A NOTE ON A BIASED ESTIMATOR IN AMS 661045 THE AGE REPLACEMENT PROBLEM MARKOVIAN SEQUENTIAL REPLACEMENT PROCESSES

A NOTE ON FELLEGI'S METHOD OF SAMPLING WITHOUT REPLACEMENT WITH PROBABILITY PROPORTIONAL TO SIZE SAMPLING WITHOUT REPLACEMENT WITH PROBABILITY PROPORTIONAL TO SIZE ON SAMPLING WITHOUT REPLACEMENT WITH UNEQUAL PROBABILITIES OF SELECTION SAMPLING WITH VARYING PROBABILITIES WITHOUT REPLACEMENT, ROTATING AND NON-ROTATING SAMPLES A COMMUNICATIONS SATELLITE REPLENISHMENT POLICY

ON A SPECIAL SUBSET GIVING AN IRREGULAR FRACTIONAL REPLICATE OF A 2 TO THE POWER N FACTORIAL EXPERIMENT TECHNIQUES FOR CONSTRUCTING FRACTIONAL REPLICATE PLANS (WITH DISCUSSION) SIZES ROUTINE ANALYSIS OF REPLICATED EXPERIMENTS ON AN ELECTRONIC COMPUTER PARALLEL FRACTTONAL REPLICATES REPLICATED, OR INTERPENETRATING, SAMPLES OF UNEQUAL BALANCED DESIGNS WITH UNEQUAL NUMBERS OF REPLICATES ESTIMATES OF EFFECTS FOR FRACTIONAL REPLICATES ON THE STRUCTURE AND ANALYSIS OF SINGULAR FRACTIONAL REPLICATES SEOUFNCES OF FRACTTONAL REPLICATES IN THE 2-TO-THE-(P-0) SERIES, CORR 62919 JASA 62 BLOCKS ON CONSTRUCTING THE FACTORIAL REPLICATES OF THE TWO TO THE POWER OF M DESIGNS WITH ON THE ANALYSIS OF FACTORIAL EXPERIMENTS WITHOUT REPLICATION PARTIAL CONFOUNDING IN FRACTIONAL REPLICATION ON ESTIMATION AND CONSTRUCTION IN FRACTIONAL REPLICATION LEAST SQUARES ESTIMATORS FOR RANDOMIZED FRACTIONAL REPLICATION DESIGNS OPTIMAL REPLICATION IN SEQUENTIAL DRUG SCREENING 
ON SIMPLIFICATIONS OF SAMPLING DESIGN THROUGH REPLICATION WITH EQUAL PROBABILITIES AND WITHOUT STAG JASA 56 24 POOLING ANALYSIS OF VARIANCE FOR TWO-LEVEL FACTORIAL REPLICATION-FREE EXPERIMENTS BLOCK DESIGNS WITH DOUBLE GROUPING OF BL KS INTO REPLICATIONS

IMATE PARAMETERS IN NON-LINEAR/ THE OCCURRENCE OF REPLICATIONS IN OPTIMAL DESIGNS OF EXPERIMENTS TO EST JRSSB68 290

$\begin{array}{rrr}\text { AUTHOR'S REPLY TO ANSCOMBE'S COMMENTS } & \text { TECH } 65 & 169 \\ \text { THE PRESIDENT'S ECONOMIC REPORT } & \text { JASA } 57 \quad 257\end{array}$ AN OU/LOOK REPORT THE JASA 58

ASSISTANCE DURING 1959 THE VALIDITY OF INCOME REPORTED BY A SAMPLE OF FAMILIES WHO RECEIVED WELFARE JA THE VALIDITY OF INCOME REPORTED BY A SAMPLE OF FAMILIES WHO
FISCAL-YEAR REPORTING FOR CORPORATE INCOME TAX

INDIVIDUAL INCOME TAX

\section{ON THE NUMERICAL REPRESENTATION OF QUALITATIVE CONDITION PROBABIL
REPRESENTATION OF SIMILARITY MATRICES BY TREES}

OF CHAMBER AEROSOLS

DISTRIBUTION

FACTORIAL PLANS
IN NORMAL VARIABL S, I. CENTRAL CASE N NORMAL VARIABLES, II, NON-CENTRAL CASE DISTRIBUTIONS

DISTRIBUTION

DISTRIBUTION GNS

PROBABILITIES

SURNAME

SOME GENERALIZATIONS OF DISTINCT REPRESENTATIVES WITH APPLICATIONS TO STATISTICAL DESI REPRESENTING FINITELY ADDITIVE INVARIANT

A REPRODUCIBLE METHOD OF COUNTING PERSONS OF SPANISH

COEFFICIENT AND RATE OF GENE LOSS OF FOUR METHODS OF REPRODUCING FINITE DIPLOID POPULATIONS /INBREEDING

\section{STATISTICAL REPRODUCTION OF ORDERINGS AND TRANSLATION SUBFAMILIES} MAMMALIAN REPRODUCTIVE DATA FITTED TO A MATHEMATICAL MODEL

STATISTICAL ESTIMATION OF THE GASOLINE OCTANE NUMBER REQUIREMENT OF NEW MODEL AUTOMOBILES

DISTRIBUTION FREE TOLERANCE LIMITS. ELIMINATION OF REQUIREMENT THAT CUMULATIVE FUNCTIONS BE CONTINUOUS OLATION (DISTANCE), MIGRATION, AND DIFFERENT FITNESS REQUIREMENTS AMONG ENVIRONMENTAL POCKETS UPON STEADY SYSTEMS CCURACY REQUIREMENTS FOR ACCEPTANCE TESTING OF COMPLEX TRUNCATION TO MEET REQUIREMENTS ON MEANS

N OF FACTORIAL EXPERIMENTS, A SURVEY OF SOME SCHEMES REQUIRING NOT MORE THAN 256 TREATMENT COMBINATIONS COMPONENTS REGRESSION IN EXPLORATORY STATISTICAL RESEARCH

TO ESSENTIALS 2 THE ROLE OF FACTOR ANALYSIS IN RESEARCH RECENT RESEARCH FACTOR ANALYSIS

STATISTICAL DATA AVAILABLE FOR ECONOMIC RESEARCH ON CERTAIN TYPES OF RECREATION

DATA RESEARCH ON CERTAIN TYPES OF RECREATION
RESEARCH ON METROPOLITAN POPULATION, EVALU,

PRINCIPAL

THE EPOCHS OF EMPTINESS OF A SEMI-INFINITE DISCRETE RESERVOIR

DIMENSION IN CENTERLESS-GRINDING WITH AUTOMATIC RESET DEVICE

COMPUTATION AND STRUCTURE OF OPTIMAL RESET POLICIES

MACHINING ERRORS IN SET-UPS WITH AUTOMATIC RESETTING

UNITED STATES POPULATION

A NOTE ON RESIDUAL ANALYSIS

QUERY, RESIDUAL ANALYSIS

STEPWISE LEAST SQUARES, RESIDUAL ANALYSIS AND SPECIFICATION ERROR RESIDUAL ANALYSIS, CORR. 611005

SEQUENCES BALANCED FOR PAIRS OF RESIDUAL EFFECTS DESIGNS BALANCED FOR THE LINEAR COMPONENT OF FIRST RESIDUAL EFFECTS CHANGEOVER DESIGNS WITH COMPLETE BALANCE FOR FIRST RESIDUAL EFFECTS AMS 661279 295 AMS $68 \quad 481$ JASA 671140 BIOCS65 551 AMS 621256 AMS $691 B 40$ BIOCS69 597 AMS $67 \quad 823$ AMS $67 \quad 838$ BIOKA64 45I JASA $68 \quad 1013$ JASA $68 \quad 1004$ AMS $66 \quad 525$ AMS $68 \quad 2131$ JASA $61 \quad B 8$ BIOCS65 447 AMS 66196 BIOCS69 529 TECH $60 \quad 5$ TECH $63 \quad 518$ BIOCS66 453 JASA $59 \quad 447$ JASA $57 \quad 527$ BIOKA59 251 234 JASA $6 B \quad 41$ JASA 59 2BI JASA $56 \quad 591$ JRSSB 63 131 TECH $63 \quad 85$ TECH 69115 JASA 671462 TECH $64 \quad 423$ JASA $61 \quad 824$ JASA 631125 TECH $67 \quad 339$ JASA 61998 JASA 6198 BIOKA68 297

DISTRIBUTION OF THE RESIDUAL SUM OF SQUARES IN FITTING INEQUALITIES
BIOKA67 A NOTE ON LINEAR STRUCTURAL RELATIONSHIPS WHEN BOTH RESIDUAL VARIANCES ARE KNOWN TECH $63 \quad 141$ TECH 67541 THE EXAMINATION AND ANALYSIS OF RESIDUALS

ANALYSIS OF OUTLIERS WITH ADJUSTED RESIDUALS

ON COX AND SNELL'S DEFINITION OF RESIDUALS ERS FOR AUTOREGRESSIVE PROCESSES WITH MOVING-AVERAGE RESIDUALS GRESSION COEFFICIENTS FOR THE CASE OF AUTOCORRELATED RESIDUALS

SPECTRA FOR STOCHASTIC PROCESSES WITH QUASI-LINEAR RESIDUALS TION FUNCTIONS OF STATIONARY TIME SERIES WITH NORMAL RESIDUALS USE FOR INVESTIGATING THE NORMALITY AND VARIANCES OF RESIDUALS N ANALYSIS BASED ON THE PERIODOGRAM OF LEAST-SQUARES RESIDUALS A GENERAL DEFINITION OF RESIDUALS ( THE USE OF RESIDUALS AS A CONCOMITANT

LARGE-SAMPLE ESTTMATION OF PARAMET BI MAXIMUM LIKELIHOOD ESTIMATORS OF RE TECH 65 A NOTE ON THE ESTIMATION OF AMPLITUDE JASA $66 \quad 397$ /ODNESS OF FIT TEST FOR SPECTRAL DISTRIBU BIOKA56 257 /ONORMAL BASES OF ERROR SPACES AND THEIR JASA 671022 TESTS FOR SERIAL CORRELATION IN REGRESSIO BIOKA69 I WITH DISCUSSION

JRSSB 68248 BIOKA69 33 THE ESTIMATION OF RELATIONSHIPS WITH AUTOCORRELATED RESIDUALS BY THE USE OF INSTRUMENTAL VARIABLES
CESS EFFICIENCY OF THE SAMPLE MEAN WHEN RESIDUALS FOLLOW A FIRST-ORDER STATIONARY MARKOFF PRO JASA 68 1237 CESS

FOR VARIANCE RADIONUCLIDE ASSAY PATTERNS IN RESIDUALS, A TEST FOR REGRESSION MODEL ADEQUACY IN NON-ORTHOGONAL DESIGNS OF EVEN RESOLUTION REDUCED DESIGNS OF RESOLUTION FIVE

EVE/ CONSTRUCTION OF THE SET OF 256-RUN DESTGNS OF RESOLUTION GREATER THEN OR EQUAL TO 5 AND THE SET OF OR EQUAL TO 5 AND THE SET OF EVEN 512-RUN DESIGNS OF RESOLUTION GREATER THEN OR EQUAL TO 6 WITH SPECIAL RE 3-TO-THE-M SERIES RESULTS ON FACTORIAL DESIGNS OF RESOLUTION IV FOR THE 2-TO-THE-N AND 2-TO-THE-N TIMES Th A SIMPLE METHOD OF RESOLUTION OF A DISTRIBUTION INTO GAUSSIAN COMPONENTS ON THE RESOLUTION OF STATISTICAL HYPOTHESES

JRSSB 63451 TECH 65603 TECH $68 \quad 291$ TECH $61 \quad 459$ AMS 6B 246 AMS $68 \quad 246$ TECH 69431 BIOCS67 115 JASA 61978 ON ADDELMAN'S 2-TO-THE- (17-9) RESOLUTION V PLAN 
CONSTRUCTION OF A 2-TO-THE-(\#7-9) RESOLUTION V PLAN IN EICHT BLOCKS OF 32

EAR-CYCLIC REPRESENTATIONS FOR SOME RESOLUTION VI FRACTIONAL FACTORIAL PLANS BANDWIDTH AND RESOLVABILITY IN STATISTICAL SPECTRAL ANALYSIS

IN TRUNCATED PEARSON FREQUENCY DISTRIBUTIONS WITHOUT RESORT TO HICHER MOMENTS

A SET OF NORMAL POPULATIONS BY THEIR LOCATIONS WITH RESPECT TO A CONTROL

PARTITIONINC OF A PATIENT POPULATION WITH RESPECT TO DIFFERENT MORTALITYRISKS

ON PARTITIONINC AMS 691300

JASA 63701

BI0CS65 562

JASA $56 \quad 576$

THE EFFECT OF RESPONDENT ICNORANCE ON SURVEY RESULTS

ANALYSIS OF CONTINCENCY TABLES WITH A QUANTITATIVE RESPONSE

ON THE BIOCS68 329

THE SAME SUBJECTS

THE QUANTAL RESPONSE ANALYSIS OF A SERIES OF BIOLOGICAL ASSAYS ON

ANALYSIS OF QUANTAL RESPONSE ASSAYS WITH DOSAGE ERRORS

RESPONSE CRITERIA FOR THE BIOASSAY DF VITAMIN $K$

R ESTIMATING THE MBN OF A CUMULATTVE. NORMAL QUANTAL RESPONSE CURVE SOME COMPARISONS OF METHODS OF FITTING THE DOSAGE RESPONSE CURVE F SMALL SAMPLES JASA 64 779

SOME STOCHASTIC MODELS RELATING TIME AND DOSAGE IN RESPONSE CURVES ANALYSIS OF GROWTH AND DDSE RESPONSE CURVES

COMPLEX CONTINGENCY TABLES AND POLYCHOTOMOUS DOSAGE RESPONSE CURVES

SEQUENTIAL ESTIMATION DF QUANTAL RESPONSE CURVES (WITH DISCUSSION)

IOCS65 $5 \mathrm{~B} 3$

SEQUENTIAL ESTIMATION OF QUANTAL RESPONSE CURVES, A NEW METHOD OF

A NOTE ON ESTIMATION FOR OUANTAL RESPONSE DATA

ESSION METHODS FOR ANALYSING SENSITIVITY AND QUANTAL RESPONSE DATA

BIOKA66 439

BIOKA68 578

SUBJECT TO ERROR

AN ANALYSIS OF QUANTAL RESPONSE DATA IN WHICH THE MEASUREMENT OF RESPONSE IS

WEIGHTED REGRESSION QUANTAL RESPONSE DATA AND INVERSE POLYNOMTALS

RESPONSE ERROR IN SURVEY REPORTS OF EARNINGS

INFORMATION

RESPONSE ERROR
RESPONSE ERRORS

THE EFFEC

A STUDY OF RESPONSE ERRORS IN EXPENDITURES DATA FROM HOUSEHOLD MINIMIZING RESPONSE ERRORS IN FINANCIAL DATA. THE POSSIBILITIES

FREQUENCY RESPONSEFROM STATIONARY NOISE, TWO CASE HISTORIES

INVERSE POLYNOMIALS, A USEFUL GROUP OF MULTI-FACTOR RESPONSE FUNCTIONS

AN ANALYSIS OF CONSISTENCY OF RESPONSE IN HOUSEHOLD SURVEYS

WEIGHTED PROBITS ALLOWING FOR A NON-ZERO RESPONSE IN THE CONTROLS

ANALYSIS OF DATA WHEN THE RESPONSE IS A CURVE

A SEQUENTIAL SEARCH PROCEDURE FOR LOCATING A RESPONSE JUMP

ESTIMATING A MIXED-EXPONENTIAL RESPONSE LAW

A MULTI-PRDPORTIONS RANDOMIZED RESPONSE MODEL

THE UNRELATED QUESTION RANDOMIZED RESPONSE MODEL, THEORETICAL FRAMEWORK

DISCRIMINATION BETWEEN ALTERNATIVE BINARY RESPONSE MODELS

MODELS FOR THE RESPONSE OF A MIXTURE

LIMITING DISTRIBUTIONS OF RESPONSE PROBABILITIES

ON ESTIMATING BINOMIAL RESPONSE RELATIONS

A BASIS FOR THE SELECTTON DF A RESPONSE SURFACE DESIGN

PARTIAL DUPLICATION OF RESPONSE SURFACE DESIGNS MISSINC VALUES IN RESPONSE SURFACE DESIGNS

LEVELS PONSE SURFACE DESIGNS FOR FACTORS AT TWO AND THREE RESPONSE SURFACE DESIGNS FOR MIXTURE PROBLEMS

LEVELS RESPONSE SURFACE DESIGNS FOR THREE FACTORS AT THREE

A REVIEW OF RESPONSE SURFACE METHODOLOCY. A LITERATURE SURVEY

THE USE OF LAGRANGE MULTIPLIERS WITH RESPONSE SURFACES

'RIDGE ANALYSIS' OF RESPONSE SURFACES

MINIMUM BIAS ESTIMATION AND EXPERIMENTAL DESIGN FOR RESPONSE SURFACES

A NEW RESPONSE TIME DISTRIBUTION

THE DISTRIBUTTON OF RESPONSE TIMES IN A BTRTH-DEATH PROCESS

BI0CS65 811

BIOCS68 979

JASA $66 \quad 729$

JASA 651005

JASA $64 \quad 18$

JASA $68 \quad 217$

TECH $61 \quad 245$

BIOCS66 128

JASA $61 \quad 320$

BIOKA56 207

TECH $66 \quad 229$

TECH $62 \quad 610$

JASA $61 \quad 493$

JASA $67 \quad 990$

JASA $69 \quad 520$

BIOH.A67 573

JRSSB $68 \quad 349$

AMS $65 \quad 706$

BIOKA56 461

JASA 59622

TECH $60 \quad 185$

TECH 61389

739

TECH 59

TECH $66 \quad 571$

TECH 59289

TECH $63 \quad 469$

TECH 69461

BIOCS67 227

BIOKA65 581

DAUGHTERS OF SELECTED PARENTS/ THE PREDICTION OF RESPONSE TO SELECTION IN BREEDING PROGRAMMES WHEN ALL BIOCS69 553

GENERAL MODELS FOR QUANTAL RESPONSE TO THE JOINT ACTION OF A MIXTURE OF DRUGS BIOKA64 413 RESPONSE VARIANCE AND ITS ESTIMATION

JASA 641016

JASA $65 \quad 63$

JASA $65 \quad 437$

JRSSB56 133

BIOCS68 339

A CDMBINATDRIAL TEST FOR INDEPENDENCE OF DICHOTOMOUS RESPONSES
THE WITHIN-ANIMAL BIOASSAY WITH QUANTAL RESPONSES

ESTIMATION OF COMMON PARAMETERS FROM SEVERAL RESPONSES

TEST FOR SIMULTANEOUS QUANTAL AND QUANTITATIVE RESPONSES

OF PROBIT ANALYSIS TO THE CASE OF MULTIPLE RESPONSES

WITH MULTIPLE CONTROLS IN THE CASE OF ALL-OR-NONE RESPONSES

FUNCTION OF THE DIFFERENCE BETWEEN TWO ESTIMATED RESPONSES

ON INTERVAL ESTIMATION IN NON-LINEAR REGRESSION WHEN RESPONSES ARE CORRELATED

A SEQUENTIAL METHOD OF TESTINC THE LINEAR TRENDS OF RESPONSES IN DOSE TRIALS OCATION OF SAMPLING UNITS TO STRATA WHEN THERE ARE R RESPONSES OF INTEREST

APPROACHES TO THE CONSTRUCTION OF MODELS FOR QUANTAL RESPONSES TO MIXTURES OF DRUGS A COMPARISON OF TWO HE CLASSIFICATION OF MATHEMATICAL MODELS FOR QUANTAL RESPONSES TO MIXTURES OF DRUGS IN BIOLOCICAL ASSAY

SIMPLE SIMILAR ACTION, THE ANALYSIS DF UN/ QUANTAL RESPONSES TO MIXTURES OF POISONS UNDER CONDITIONS OF QUADRATIC REGRESSION WITH INEQUALITY RESTRAINTS ON THE PARAMETERS

MEWHERE MOST POWERFUL TEST FOR CERTAIN PROBLEMS WITH RESTRICTED ALTERNATIVE/T AND THE MOST STRINGENT SO ON MODELS AND HYPOTHESES WITH RESTRICTED ALTERNATIVES

OF TESTING LOCATION IN MULTIVARIATE POPULATIONS FOR RESTRICTED ALTERNATIVES

A TEST OF HOMOGENEITY OF MEANS UNDER RESTRICTED ALTERNATIVES (WITH DISCUSSION)
NT

$\begin{array}{lll}\text { THE BAYESIAN } & \text { BIOKA65 } & 355 \\ \text { SIGNIFICANCE TECH } & 64 & 273\end{array}$

THE CENERALIZATION BIOKA57 131

INDTVIDUAL MATCHING BIOCS69 339 THE BEHAVIOUR OF THE VARIANCE JRSSB67 174

NOTE JRSSB64 267

BIOCS68 663

JASA $65 \quad 225$

BI0CS67 27

BIOCS65 181

BIOKA5B 74

JASA $65 \quad 914$

JASA 651153

FOR LINEAR COMBINATIONS OF ORDER STATISTICS FROM RESTRICTED FAMTLIES

SELECTTON PROCEDURES FOR RESTRTCTED FAMILTES OF PROBABILITY DTSTRIBUTI

LIKELIHOOD RATIO TESTS FOR RESTRICTED FAMILITES OF PROBABILITY DISTRIBUTIONS

ON A RESTRICTED LEAST SQUARES ESTIMATOR

RESTRICTED LEAST SQUARES REGRESSION AND CONVEX

QUADRATIC PROGRAMMINC

EAST SQUARES ESTIMATES AND PARABOLIC RECRESSION WITH RESTRICTED LOCATION FOR
RANKING PROCEDURES FOR ARBITRARILY RESTRICTED OBSERVATION

OTHESIS WITH INDEPENDENCE OF INTERMEDIATE STATES AND RESTRICTED ORDER

LARGE-SAMPLE RESTRICTED PARAMETRIC TESTS

TESTING A MARKOV HYP BIOKA67 605

AMS 661161

AMS 661574

AMS 69905

AMS $68 \quad 547$

JASA 69964

TECH 69 NO. 4

JASA $64 \quad 564$

BIOCS67 65

RESTRICTED SEQUENTIAL PROCEDURES

JRSSB62 234

BIOKA57 
THE MAXIMUM VARIANCE OF RESTRICTED UNIMODAL DISTRIBUTIONS

AMS 691746 ANALYZINC A SET OF TIME SERIES SUBJECT TO A LINEAR RESTRICTION BALANCED L-RESTRICTIONAL PRIME POWERED LATTICE DESICNS
CLIC COLLINEATIONS FOR OBTAININC A BALANCED SET OF L-RESTRICTIONAL PRIME-POWERED LATTICE DESICNS

ASA 63513 PROBLEMS OF SELECTION WITH RESTRICTIONS INDEX SELECTION WITH RESTRICTIONS NECESSARY RESTRICTIONS FOR DISTRIBUTIONS A POSTERIORI A TEST OF THE MEAN SQUARE ERROR CRITERION FOR RESTRICTIONS IN LINEAR RECRESSION FOR THE MEAN SQUARE ERROR TEST FOR EXACT LINEAR RESTRICTIONS IN RECRESSION INEQUALITY RESTRICTIONS IN REGRESSION ANALYSIS UNIQUENESS OF A RESULT IN THE THEORY OF ACCIDENT PRONENESS BAYESIAN MODEL OF DECISION-MAKINC AS A RESULT OF LEARNINC FROM EXPERIENCE A RESULT ON ACCIDENT PRONENESS SOME REMARKS CONCERNINC KHATRI'S RESULT ON QUADRATIC FORMS

\section{PROCESS}

OBSERVAITONS

D INVERSE MATRICES

RENEWAL THEORY

KOLMOGOROV-SMIRNOV TYPE

SPECTROMETER DATA, 2

SPECTROMETER DATA, I

\section{A COMPAR} SAMPLING INSPECTION OF CONTINUOUS BIOKA6O 363 SHORT-CUT MULTIPLE COMPARISONS FOR TECH $65 \quad 95$ LIFE-TESTING RESULTS BASED ON A FEW HETEROGENEOUS LOGNORMAL 147 ADDITIONAL RESULTS CONCERNING ESTTMABLE FUNCTIONS AND CENERALIZE JRSSB65 486 ASYMPTOTIC RENEWAL RESULTS FOR A NATURAL GENERALIZATION OF CLASSICAL JRSSB67 141 SOME RESULTS FOR FIXED-TIME TRAFFIC SIGNALS

MINIMAX RESULTS FOR IFRA SCALE ALTERNATIVES

AMS 691778 SOME EXACT RESULTS FOR ONE-SIDED DISTRIBUTION TESTS OF THE $\quad$ AMS 61499 SOME EXPERIMENTAL SAMPLING RESULTS FOR REGRESSION ANALYSIS APPLIED TO GAMMA RAY BIOCS68 353 SOME EXPERIMENTAL SAMPLING RESULTS FOR REGRESSION ANALYSIS APPLIED TO GAMMA RAY BIOCS67 11 ON OF THEORETICAL AND EMPIRICAL RESULTS FOR SOME STOCHASTIC POPULATION MODELS ON EXTENDED RATE OF CONVERGENCE RESULTS FOR THE INVARIANCE PRINCIPLE SOME RESULTS FOR THE QUEUE WITH POISSON ARRIVALS

SOME EQUTI TRTUM RESULTS FOR THE QUEUEING PROCESS E-SUB-K-M-1 BIOKA60 I AMS 69 NO. 6 JRSSB60 104 JRSSB56 275 E THE INTERARRIVAL AND SERVING DIS/ SOME NUMERICAL RESULTS FOR THE QUEUEING SYSTEM WITH ONE SERVER, WHIL JRSSB63 477 SOME NUMERICAL RESULTS FOR WAITING TIMES IN THE QUEUE E-SUB-K-M-1 BIOKA60 202 CORRIGENDA, 'SOME NUMERICAL RESULTS FOR WAITING TIMES IN THE QUEUE E-SUB-K-M-1.' BIOKA60 484 ON COMBINING THE RESULTS FROM CLINICAL TRIALS OF A VACCINE COMBINATION OF RESULTS FROM SEVERAL 2 BY 2 CONTINGENCY TABLES THE KOLOMOGOROV-SMIRNOV TYPE RESULTS FROM THE RELATION BETWEEN TWO STATISTICS OF COMBINATORIAL RESULTS IN FLUCTUATION THEORY

CORR. 64924 COMBINATORIAL RESULTS IN MULTI-DIMENSIONAL FLUCTUATION THEORY, SOME GENERAL RESULTS IN SEQUENTIAL ANALYSIS

SOME CENERAL RESULTS IN SEQUENTIAL DESIGN (WITH DISCUSSION)

QUEUE

SOME FURTHER RESULTS IN THE NON-EQUILIBRIUM THEORY OF A SIMPLE SOME RESULTS IN THE THEORY OF INVENTORY

BIOCS65 616 BIOCS65 B6 AMS 691833 AMS $63 \quad 1233$ AMS $63 \quad 402$ BIOKA64 123 JRSSB65 371 JRSSB57 326 BIOKA64 4B7 SOME FURTHER RESULTS IN THE THEORY OF PEDESTRIANS AND ROAD TRAFFIC BIOKA54 375 CORRIGENDA TO 'SOME FURTHER RESULTS IN THE THEORY OF PEDESTRIANS AND ROAD TRAFFIC BIOKA58 291 ON SOME RESULTS OF N. V. SMIRNOV CONCERNINC LIMIT DISTRIBUTIO AMS 69 4BO NS FOR VARIATIONAL SERIES VALIDATING RESULTS OF SAMPLING INSPECTION BY ATTRIBUTES $\quad$ TECH 63 OF INCOMPLETE BLOCK DESIGNS. III SOME LARGE-SAMPLE RESULTS ON ESTTMATION AND POWER FOR A METHOD OF PAIRE BTOKA55 45O 2-TO-THE-N AND 2-TO-THE-N TIMES 3-TO-THE-M SERIES RESULTS ON FACTORIAL DESIGNS OF RESOLUTION IV FOR THE TECH 69 43 $\begin{array}{ll} & \text { SOME RESULTS ON INVENTORY PROBLEMS (WITH DISCUSSION) } \\ \text { PROCESSES } & \text { SOME RESULTS ON MULTITYPE CONTINUOUS TIME MARKOV BRANCHING AMS 6B 347 }\end{array}$ AMS $6 B \quad 347$ MORE RESULTS ON PRODUCT MOMENTS FROM A FINITE UNIVERSE $\quad$ JASA 69 B 64 SOME RESULTS ON TESTS FOR POISSON PROCESSES SOME RESULTS ON TESTS OF SEPARATE FAMILIES OF HYPOTHESES BIOKA6B 355 FURTHER RESULTS ON TESTS OF SEPARATE FAMILIES OF HYPOTHESES JRSSB62 406 F LINEAR COMBINATIONS OF INDEPENDENT AND RAN/ SOME RESULTS ON THE COMPLETE AND ALMOST SURE CONVERGENCE O AMS 6B 1549 COEFFICIENT NORMAL AND PARETO TYPE I POPULATIONS

SOME NEW RESULTS ON THE DISTRIBUTION OF THE SAMPLE CORRELATION JRSSB66 513 SOME RESULTS ON THE ORDER STATISTICS OF THE MULTIVARIATE AMS 641815 IN THE SIMPLE RANDOMIZED BLOCK D/ SOME MONTE CARLO RESULTS ON THE POWER OF THE F-TEST UNDER PERMUTATION BIOKA66 199

ERGENCE RATES IN THE LAW OF LARCE NUMBERS BAYESIAN STRATIFIED TWO-PHASE SAMPLING RESULTS, K CHARACTERISTICS ON PRE-EMPTIVE RESUME PRIORITY QUEUES JASA $66 \quad 813$ AMS $67 \quad 742$ BIOKA68 $5 B 7$ AMS 64600 S AND RELATED PROBLEMS DEMAND FOR FARM PRODUCTS AT RETAIL AND THE FARM LEVEL SOME EMPIRTCAL MEASUREMENT JASA 5B 656 A STOCHASTIC ANALYSIS OF THE SPATIAL CLUSTERING OF RETAIL ESTABLISHMENTS AREA BREAKDOWNS OF THE MONTHLY NATIONAL ESTIMATES OF RETAIL TRADE /OF A REGRESSION TECHNIQUE TO PRODUCE JASA 66 496 ROGRAMMES WHEN ALL DAUGHTERS OF SELECTED PARENTS ARE RETAINED /ON OF RESPONSE TO SELECTION IN BREEDING P BIOCS69 553

LOG (-LOG) TRANSFORMATION IN THE ANALYSIS OF FRUIT RETENTION RECORDS THE LAST RETURN TO EQUILIBRIUM IN A COIN TOSSING GAME

THE BIOCS6B 627 AMS 641344 AMS $64 \quad 369$ ARE INCOMPLETE THE ENUMERATION OF ELECTION RETURNS BY NUMBER OF LEAD POSITIONS JASA $61 \quad 125$ JASA $66 \quad 897$ TECH $66 \quad 3 B 9$ JASA $65 \quad 722$ EVOLUTTONARY MAKING AND REVERSAL OF THE STOCK EXCHANGE

THE PROBABILITY OF REVERSAL ASSOCTATED WITH A TEST PROCEDURE, WHEN DATA MARKET MAKING AND REVERSAL OF THE STOCK EXCHANGE

A REVIEW OF 'SMOKING AND HEALTH'

SURVEY

A REVIEW OF RESPONSE SURFACE METHODOLOGY. A LITERATURE $\begin{array}{lll}\text { JECH } & 66 & 571 \\ \text { JASA } & 66 & 595\end{array}$ 
WORDS. THE DISTRIBUTION OF PATTERN FREQUENCIES IN RING PERMUTATIONS

NOTE ON TWO BINOMIAL COEFFICIENT SUMS FOUND BY RIORDAN

PERMUTATION WITHOUT RISING OR FALLING OMEGA-SEQUENCES

A RECURRENCE FOR PERMUTATIONS WITHOUT RISING OR FALLING SUCCESSIONS

IN STOPPING PROBLEMS

OF TYPE I
THE THEORY OF RISK (WITH DISCUSSION)

A NOTE ON RISK AND MAXIMAL REGULAR GENERALIZED SUBMARTINGALES MINIMAX RISK AND UNBIASEDNESS FOR MULTIPLE DECISION PROBLEMS

APPROXIMATION TO BAYES RISK IN SEQUENCES OF NON-FINITE GAMES INTEGRATED RISK OF ASYMPTOTICALLY BAYES SEQUENTIAL TESTS

ON THE EFFECT OF STRAGGLERS ON THE RISK OF SOME MEAN ESTIMATORS IN SMALL SAMPLES ON THE RISK OF SOME STRATEGIES FOR OUTLYING O8SERVATIONS MINIMUM RISK SPECIFICATION LIMITS

ON THE RUIN PROBLEM OF COLLECTIVE RISK THEORY

POPULATION WITH RESPECT TO DIFFERENT MORTALITY RISKS

NOTE ON EXTREME VALUES, COMPETING RISKS AND SEMI-MARKOV PROCESSES PARTITIONING OF A PATIENT JASA 63 701 LING BY VARIABLES WHEN THE PRODUCER'S AND CONSUMER'S RISKS ARE EQUAL /TERISTIC CURVE FOR SEQUENTIAL SAMP JASA 56 IO8 PRODUCER AND CONSUMER RISKS FOR ASYMMETRICAL TESTS AND SPECIFICATION LIMITS JASA 66505 MODELS FFOR THE ESTIMATION OF COMPETINC RISKS FROM GROUPED DATA PRODUCER AND CONSUMER RISKS IN NON-NORMAL POPULATION BIOCS69 329 TECH $66 \quad 335$ A NOTE ON THE RISKS OF ERROR INVOLVED IN THE SEQUENTIAL RATIO TEST BIOKA56 231

ING AND LUNG CANCER, CORR./ COMPETING EXPONENTIAL RISKS, WITH PARTICULAR REFERENCE TO THE STUDY OF SMOK JASA 60 4I5 DESIGNS FOR DISCRIMINATING BETWEEN TWO RIVAL MODELS THE DELAY TO PEDESTRIANS CROSSING A ROAD 383 TRAFFIC DELAYS ON A TWO-LANE ROAD BIOKA51 383 MODEL FOR DELAYS IN OVERTAKING ON A TWO-LANE ROAD DELAYS ON A TWO-LANE ROAD (WITH DISCUSSION) FURTHER RESULTS IN THE THEORY OF PEDESTRIANS AND ROAD TRAFFIC A QUEUEING MODEL FOR ROAD TRAFFIC FLOW (WITH DISCUSSION) A SIMPLIFIED JRSSB5B 40B JRSSB61 38 SOME BIOKA54 375 JRSSB61 64 FURTHER RESULTS IN THE THEORY OF PEDESTRTANS AND ROAD TRAFFIC' MEAN AN EXTENSION OF A THEOREM OF CHOW AND ROBBINS ON SEQUENTIAL CONFIDENCE INTERVALS FOR THE AMS 69 667 DORY THE ROBBINS-ISBELL TWO-ARMED-BANDIT PROBLEM WITH FINITE AMS 651375 DOSE DIT PROBLEM WITH FINITE AN EXTENSION OF THE ROBBINS-MONRO PROCEDURE A PERSISTENCE PROBLEM IN RENEWAL THEORY. ROBERT THE BRUCE'S SPIDER THE ROUND ROBIN (ERRATA, 69627 )

NOTES CYCLIC GENERATION OF ROBINSON'S BALANCED INCOMPLETE BLOCK DESIGNS FACTORIAL 2-TO-THE-'P-Q' PLANS ROBUST AGAINST LINEAR AND QUADRATIC TRENDS FACTORIAL 2-TO-THE- P-Q PLANS ROBUST AGAINST LINEAR AND QUADRATIC TRENDS
MPTION (W/ PERMUTATION THEORY IN THE DERIVATI N OF ROBUST CRITERIA AND THE STUDY OF DEPARTURES FROM ASSU JRSSB55 1 ON SOME ROBUST ESTIMATES OF LOCATION SOME OBSERVATIONS ON ROBUST ESTIMATION ROBUST ESTIMATION IN ANALYSIS OF VARIANCE

A NOTE ON ROBUST ESTIMATION IN ANALYSIS OF VARIANCE ROBUST ESTIMATION IN INCOMPLETE BLOCK DESIGNS

ON ROBUST ESTIMATION IN INCOMPLETE BLOCK DESIGNS ROBUST ESTIMATION OF A LOCATION PARAMETER ROBUST ESTIMATION OF LOCATION

A STUDY OF ROBUST ESTIMATORS

ASYMPTOTICALLY ROBUST ESTIMATORS OF LOCATION

ON ROBUST LINEAR ESTIMATORS

MODEL

A ROBUST POINT ESTIMATOR IN A GENERALIZED REGRESSION

ON ROBUST PROCEDURES ROBUST PROCEDURES FOR SOME LINEAR MODELS WITH ONE

OBSERVATION PER CELL

EFFICIENCY ROBUST TWO-SAMPLE RANK TESTS
A ROBUST VERSION OF THE PROBABILITY RATIO TEST SUBOBSCURA' COLL. AND A COMPARISON WITH THOSE OF 'D. ROBUSTA' STURT /ONS IN POPULATIONS OF 'DROSOPHILA A NOTE ON CRITERION ROBUSTNESS AND INFERENCE ROBUSTNESS THE ROBUSTNESS OF HOMOGENEITY TESTS IN 2 BY N TABLES THE ROBUSTNESS OF HOTELLING'S T-SQUARE

THE ROBUSTNESS OF LIFE TESTING PROCEDURES DERIVED FROM ROBUSTNESS OF NON-IDEAL DECISION PROCEDURES

THE EXPONENTIAL DISTRIBUTION

DISTRIBUTION MODELS
ON THE ROBUSTNESS OF SOME CHARACTERIZATIONS OF THE NORMAL ROBUSTNESS OF SOME NONPARAMETRIC PROCEDURES IN LINEAR
$2 B$

AMS 67 1BI BIOKA66 255 TECH 6B 84I BIOCS67 AMS $65 \quad 847$ JASA $67 \quad 1179$ AMS $63 \quad 957$ AMS 681486 AMS 661331 AMS 671587 AMS $64 \quad 73$ JASA $67 \quad 353$ TECH $67 \quad 652$ JASA $67 \quad 950$ AMS $69 \quad 24$

AMS $69 \quad 1784$ JASA $66 \quad 929$ AMS $67 \quad 878$

JASA $67 \quad 1241$ AMS $65 \quad 1753$ 8I0C\$66 469 8IOKA64 169 BIOCS65 19 JASA $67 \quad 124$ TECH $61 \quad 29$

JASA $63 \quad 480$ AMS $\begin{array}{ll}68 & 1747\end{array}$ 
ANALYSIS OF VARIANCE WHEN VARIANCE-COVARI/ AGAINST A CERTAIN DEPENDENCE ROBUSTNESS OF THE T-SQUARE-SUB-O TEST IN MULTIVARIATE ROBUSTNESS OF THE WILCOXON ESTIMATE OF LOCATION ROBUSTNESS OF UNIFORM BAYESIAN ENCODING

N WILCOXON'S SIGNED RANK STATISTIC
ON A FURTHER ROBUSTNESS PROPERTY OF THE TEST AND ESTIMATOR BASED O ROBUSTNESS TO NON-NORMALITY OF REGRESSION TESTS

CORRIGENDA, 'ROBUSTNESS TO NON-NORMALITY OF REGRESSION TESTS'

A FURTHER LOOK AT ROBUSTNESS VIA BAYES'S THEOREM

\section{LINEAR ESTIMATORS OF LOCATION}

CORRIGENDA, 'A FURTHER LOOK AT ROBUSTNESS VIA BAYES'S THEOREM.'

EVALUATION OF CHEMICAL ANALYSES ON TWO ROCKS

RABLE GOODS EXPENDITURES, TITH

TICS, FINITE SAMPLING AND TWO BAYESIANS ANALYSIS. AN INTRODUCTION TO ESSENTIALS. MESSAGE

CS

THE ROLE OF EXPERIMENTAL RANDOMIZATION IN BAYESIA

2. THE ROLE OF FACTOR ANALYSIS IN RESEARCH

THE ROLE OF STCNIFICANCE TESTING SOME DATA WITH A

ROL ASSETS, CREDIT AND INTENTIONS CONSUMER DU JASA 63 648 THE ROLE OF SUFFICIENCY AND OF ESTIMATION IN THERMODYNAMI AMS 621021 OPTIMIZATION OF A HOT ROLLING MILL

THE EFFECT OF THE SIZE OF THE WAITING ROOM ON A SIMPLE QUEUE CONSTRUCTION OF ROOM SQUARES

A SYSTEM OF TWO SERVERS WITH LIMITED WAITING ROOMS AND CERTAIN ORDER OF VISITS JRSSB $67 \quad 300$ JRSSB58 182 AMS $6 B \quad 1540$ BIOKA68 223 SIS OF A RADIO-ACTTVE TRACER EXPERIMENT TO DETERMINE R00T ACTIVITY IN P0TATO PLANTS /E STATISTICAL ANALY BIOCS68 717 COMPON/ ON THE DISTRIBUTION OF THE LARGEST LATENT ROOT AND THE CORRESPONDING LATENT VECTOR FOR PRINCIPAL AMS 66 995 B STATISTIC AN/ DISTRIBUTION OF THE LARGEST LATENT ROOT AND THE SMALLEST LATENT ROOT OF THE GENERALIZED AMS 67 1152 SOME DISTANCE PROPERTIES OF LATENT ROOT AND VECTOR METHODS USED IN MULTIVARIATE ANALYSIS BIOKA66 325 THE MEAN SUCCESSIVE DIFFERENCE AND ITS RATIO TO THE ROOT MEAN SQUARE THE MEAN SUCCESSIVE DIFFERENCE AND ITS RATIO TO THE ROOT MEAN SQUARE' A NOTE ON MATRIX INVERSION BY THE SQUARE ROOT METHOD MATRIX INVERSION WITH THE SQUARE ROOT METHOD MODIFIED SQUARE ROOT METHOD OF MATRIX INVERSION ERRATA, 'MODIFIED SQUARE ROOT METHOD OF MATRIX INVERSION

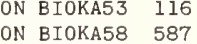
JASA $56 \quad 288$ TECH $64 \quad 197$ TECH $62 \quad 2 \mathrm{~B} 2$ TECH $62 \quad 622$ AMS $67-616$ BI0KA56 122 BIOKA67 IB9 BIOKA65 405

AMS $67 \quad 114 \mathrm{~B}$ ON THE DISTRIBUTION OF THE LARGEST OR THE SMALLEST ROOT OF A MATRIX IN MULTIVARIATE ANALYSIS UPPER PERCENTAGE POINTS OF THE LARGEST ROOT OF A MATRIX IN MULTIVARIATE ANALYSIS

ON THE DISTRIBUTION OF THE LARGEST CHARACTERISTIC ROOT OF A MATRIX IN MULTIVARIATE ANALYSIS. ON THE DISTRIBUTION OF THE LARGEST LATENT ROOT OF THE COVARIANCE MATRIX BUTION OF THE LARGEST OR THE SMALLEST CHARACTERISTIC ROOT UNDER NULL HYPOTHESIS CONCERNING COMPLEX MULTIVA AMS 64 1807 LE OF PERCENTAGE POINTS OF PEARSON CURVES, FOR GIVEN ROOT (BETA-1) AND BETA-2 EXPRESSED IN STANDARD MEASURE BIOKA63 459 LE OF PERCENTAGE POINTS OF PEARSON CURVES, FOR GIVEN RO0T(BETA-1) AND BETA-2, EXPRESSED IN STANDARD MEASUR BIOKA65 669 TABLES OF PERCENTAGE POINTS OF ROOT'BI' AND B2 IN NORMAL SAMPLES, A ROUNDING OFF BIOKA65 282 ESTIMATOR WHERE THE LIKELIHOOD EQUATION HAS MULTIPLE ROOTS $\quad$ EVALUATION OF THE MAXIMUM-LIKELIHOOD BIOKA66 151 IATE NORMAL DISTRIB/ BAYESIAN ESTIMATION OF LATENT ROOTS AND VECTORS WITH SPECIAL REFERENCE TO THE BIVAR BIOKA69 97 DISTRIBUTIONS OF MATRIX VARIATES AND LATENT ROOTS DERIVED FROM NORMAL SAMPLES OF DETERMINANTS, CHARACTERISTIC EQUATIONS AND THEIR ROOTS FOR A CLASS OF PATTERNED MATRICES EVALUATION JRSSB60 348 TESTS/ ON THE DISTRIBUTIONS OF THE RATIOS OF THE ROOTS OF A COVARIANCE MATRIX AND WILKS' CRITERION FOR AMS 69 NO.6 N OF THE SECOND ELEMENTARY SYMMETRIC FUNCTION OF THE ROOTS OF A MATRIX ON THE NON-CENTRAL DISTRIBUTIO THE MOMENTS OF ELEMENTARY SYMMETRIC FUNCTIONS OF THE ROOTS OF A MATRIX IN MULTIVARIATE ANALYSIS ON THE DISTRIBUTION OF THE LARGEST OF SIX ROOTS OF A MATRIX IN MULTIVARIATE ANALYSIS ON THE DISTRIBUTION OF THE LARGEST OF SEVEN ROOTS OF A MATRIX IN MULTIVARIATE ANALYSIS ON ELEMENTARY SYMMETRIC FUNCTIONS OF THE ROOTS OF A MULTIVARIATE MATRIX. DISTRIBUTIONS ON THE BIAS OF FUNCTIONS OF CHARACTERISTIC ROOTS OF A RANDOM MATRIX PERCENTAGE POINTS OF THE EXTREME ROOTS OF A WISHART MATRIX THE LATENT ROOTS OF CERTAIN STOCHASTIC MATRICES

TESTS OF SIGNIFICANCE FOR THE LATENT ROOTS OF COVARIANCE AND CORRELATION MATRICES SOME OPTIMUM CONFIDENCE BOUNDS FOR ROOTS OF DETERMINANAL EQUATIONS

A NOTE ON THE CONSISTENCY AND MAXIMA OF THE ROOTS OF LIKELIHOOD EQUATIONS SOME INEQUALITIES ON CHARACTERISTIC ROOTS OF MATRICES CORRIGENDA. 'SOME INEQUALITIES ON CHARACTERISTIC ROOTS OF MATRICES'

MPTOTIC EXPANSION FOR THE DISTRIBUTION OF THE LATENT ROOTS OF THE ESTIMATED COVARIANCE MATRIX THE MOMENTS OF ELEMENTARY SYMMETRIC FUNCTIONS OF THE ROOTS OF TWO MATRICES

ON MOMENTS OF ELEMENTARY SYMMETRIC FUNCTIONS OF THE ROOTS OF TWO MATRICES AND APPROXIMATIONS TO A DISTRIB ON ELEMENTARY SYMMETRIC FUNCTIONS OF THE ROOTS OF TWO MATRICES IN MULTIVARIATE ANALYSIS VARIABLES AN EXTENSION OF ROSEN'S THEOREM TO NON-IDENTICALLY DISTRIBUTED RANDOM $N$, COMMENT ON A CRITICISM MADE BY KOOPMANS, OWEN AND ROSE ON AN OPERATOR LIMIT THEOREM OF ROTA

THE CHOICE OF A SECOND ORDER ROTATABLE DESIGN CORRIGENDA, 'THE CHOICE OF A SECOND ORDER ROTATABLE DESIGN' CYLINDRICALLY ROTATABLE DESIGNS FURTHER SECOND ORDER ROTATABLE DESIGNS ASYMMETRICAL ROTATABLE DESIGNS AND ORTHOGONAL TRANSFORMATIONS TWO THIRD ORDER ROTATABLE DESIGNS IN FOUR DIMENSIONS DESIGNS

A METHOD FOR THE CONSTRUCTION OF SECOND ORDER ROTATABLE DESIGNS IN K DIMENSIONS

THIRD ORDER ROTATABLE DESICNS IN THREE DTMENSIONS, SOME SPECIFTC THIRD ORDER ROTATABLE DESIGNS IN THREE FACTORS. ANALYSIS

CYLINDRICALLY ROTATABLE DESIGNS OF TYPES 1 , 2, AND 3

DESIGNS

CONSTRUCTION OF ROTATABLE DESTGNS THROUGH BALANCED INCOMPLETE BLOCK

WITH VARYING PRO8A8ILITIES WITHOUT REPLACEMENT, ROTATING AND NON-ROTATING SAMPLES $\begin{array}{lll}\text { BLOCK AMS } 62 & 1421\end{array}$ SURVEYS THE USE OF ROTATING SAMPLES IN THE CENSUS 8UREAU'S MONTHLY ROTATION DESIGNS FOR SAMPLING ON REPEATED OCCASIONS THEORY OF CYCLIC ROTATION EXPERIMENTS (WITH DISCUSSION) AMS 611152 BIOKA59 237 BIOKA64 270 AMS $61 \quad 864$ BIOKA6B 505 BIOKA62 264 BI0KA56 128 AMS $65 \quad 468$ BIOKA54 56 BIOKA63 522 BIOKA65 669 AMS 651153 AMS $67 \quad 944$ AMS $64 \quad 1704$ AMS $68 \quad 1274$ $\begin{array}{ll}\text { AMS } 68 & 897\end{array}$ BIOKA65 303 AMS 65 1B64 BIOKA63 335 BIOKA 65305 AMS $66 \quad 242$ AMS 6B 1995 TECH 6B 313 AMS $64 \quad 445$ AMS $67 \quad 177$ AMS $61 \quad 910$ TECH $62 \quad 219$ AMS $67 \quad 167$ JASA $63 \quad 454$ JASA $64 \quad 492$ JRSS864 
ON RANDOM ROTATIONS IN R-CUBE.

ON SOME MULTIPLE DECISION (SELECTION AND RANKINC) 'RULES ON THE MOMENTS OF SOME ONE-SIDED STOPPING RULES ON SECOND MOMENTS OF STOPPING RULES

JASA 69 NO. 4 AMS $69 \quad 417$ AMS 691236 TECH $65 \quad 225$ AMS $66 \quad 382$ AMS $66 \quad 3 \mathrm{BB}$ AMS 671627

SOME PROBLEMS IN THE THEORY OF OPTIMAL STOPPING RULES SOME ONE-SIDED STOPPING RULES OPERATING CHARACTERISTICS OF SOME SEQUENTIAL DESIGN RULES

ON THE ASYMPTOTIC NORMALITY OF ONE-SIDED STOPPING RULES THE VARIANCE OF THE ONE-SIDED STOPPING RULES

IN INFERENCES UNDER NON-INFORMATIVE STOPPINC RULES INFORMATIVE STOPPING RULES AND INFERENCES ABOUT POPULATION SIZE SCORING RULES AND THE EVALUATION OF PROBABILITY ASSESSORS ALLOCATION RULES AND THEIR ERROR RATES (WITH DISCUSSION)

SOME RULES FOR A COMBINATORIAL METHOD FOR MULTIPLE PRODUCT

S OF GENERALIZED K-STATISTICS RELATED STUDENT-T PROBLEMS

BAYES RULES FOR A COMMON MULTIPLE COMPARISONS PROBLEM AND POPULATIONS OPTIMUM CLASSIFICATION RULES FOR CLASSIFICATION INTO TWO MULTIVARIATE NORMAL A NOTE ON MEMORYLESS RULES FOR CONTROLLING SEQUENTIAL CONTROL PROCESSES

THE NORMAL DISTRIBUTION, 2. EST/ INVESTIGATION OF RULES FOR DEALING WITH OUTLIERS IN SMALL SAMPLES FROM I COMPARISON OF SEQUENTIAL RULES FOR ESTIMATION OF THE SIZE OF A POPULATION EXISTENCE OF OPTIMAL STOPPINC RULES FOR REWARDS RELATED TO S-SUB-N-OVER-N ON SIMPLE RULES FOR THE COMPOUND DECISION PROBLEM SEQUENTIAL COMPOUND RULES FOR THE FINITE DECISION PROBLFM CONVERCENCE OF THE LOSSES OF CERTAIN DECISION RULES FOR THE SEQUENTIAL COMPOUND DECISION PROBLEM RANDOMIZED RULES FOR THE TWO-ARMED BANDIT WITH FINITE MEMORY

OF AN EPIDEMIC AND THE NUMBER OF PEOPLE HEARING A RUMOUR POISSON LIMITS OF MULTIVARIATE RUN DISTRIBUTIONS AMS 671641 AMS 6B 1176 AMS $6 B \quad 1493$ AMS $69 \quad 1074$ BIOKA67 329 JASA $67 \quad 763$ JASA $69 \quad 1073$ JRSSB 66 I AMS $68 \quad 9 B 3$ AMS $61 \quad 1013$ AMS $65 \quad 1174$ AMS $66 \quad 276$ ECH 69527 BIOCS69 517 AMS $68 \quad 1228$ JRSSB65 23B JRSSB 66 AMS 641606 AMS 682103 JRSSB 66 4B7 AMS $65 \quad 215$ MININC UPPER AND LOWER LIMITS FOR THE AVERAGE SAMPLE RUN LENGTH OF A CUMULATIVE SUM SCHEME /RE FOR DETER JRSSB67 263 IS USED SCHEMES ATTRIBUTE THE AVERACE RUN LENCTH OF THE CUMULATIVE SUM CHART WHEN A V-MASK AVERACE RUN LENGTHS IN CUMULATIVE CHART QUALITY CONTROL LONCEST RUN OF CONSECUTIVE OBSERVATIONS HAVING A SPECIFIED MULTIPLE RUNS

ACCEPTANCE SAMPLING PLANS BASED ON THE THEORY OF RUNS A COMPOUNDED MULTIPLE RUNS DISTRIBUTION JOINT DISTRIBUTION OF ASCENDING PAIRS AND ASCENDING RUNS IN A RANDOM SEQUENCE RUNS IN A RING

SOME PROPERTIES OF RUNS IN QUALITY CONTROL PROCEDURES

CORRICENDA, 'SOME PROPERTIES OF RUNS IN QUALITY CONTROL PROCEDURES' SOME PROPERTIES OF RUNS IN SMOOTHED RANDOM SERIES QUERY, COMPLETED RUNS OF LENGTH K ABOVE AND BELOW MEDIAN

PROBABILITY TABLE FOR NUMBER OF RUNS OF SICNS OF FIRST DIFFERENCES IN ORDERED SERIES JASA 61 I56 RANDOMNESS IN A SEQUENCE OF TWO ALTERNATIVES. II. RUNS TEST CHAINS SIMPLIFIED RUNS TESTS AND LIKELIHOOD RATIO TESTS FOR MARKOFF S OF PERCENTAGE POINTS OF THE LARGEST VARIANCE RATIO S- SQUARE-MAX-OVER-S-SQUARE-SUB-O OF OPTIMAL STOPPING RULES FOR REWARDS RELATED TO S-SUB-N-OVER-N EXISTENCE AMS $68 \quad 122$ AMS $6964 \mathrm{~B}$ SOME FIRST PASSACE PROBLEMS FOR S-SUB-N-OVER-ROOT-N TABLES TO FACILITATE FITTING S-SUB-U FREQUENCY CURVES.

BIOKA65 547

AL DISTRIBUTION

S' 57861 THE MULTIVARIATE SADDLE POINT METHOD AND CHI-SQUARED FOR THE MULTINOMI AMS 61535 CORRECTIONS TO 'SADDLE POINT METHODS FOR THE MULTINOMIAL DISTRIBUTION AMS 61619 FAILURE RATE ON THE DETERMTNATION OF A SAFE IIFE FOR CLASSES OF DISTRIBUTTONS CLASSIFIED BY TECH 68 36 A STATISTICAL MODEL OF EVALUATINC THE RELIABILITY OF SAFETY SYSTEMS FOR PLANTS MANUFACTURING HAZARDOUS PRO TECH 59 293 A STOCHASTIC MODEL OF CREDIT SALES DEBT

A NOTE ON ESTIMATION FROM A CAUCHY SAMPLE INDEX SELECTION AND ESTIMATION FROM A SINGLE SAMPLE OF RANGE TO STANDARD DEVIATION IN THE SAME NORMAL SAMPLE MEAN AND STANDARD DEVIATION FROM A CENSORED NORMAL SAMPLE NORMAL POPULATION PARAMETERS GIVEN A SINGLY CENSORED SAMPLE NORMAL POPULATION PARAMETERS CIVEN A TYPE I CENSORED SAMPLE BASED ON THE MEAN ABSOLUTE DEVIATION OF A NORMAL SAMPLE
JASA $66 \quad 1010$ JASA $64 \quad 460$ BIOKA63 195 THE RATIO BIOKA64 484 ESTIMATING THE BIOKA67 155 ESTIMATION OF THE BIOKA59 150 ESTIMATION OF THE BIOKA6I 367 CONFIDENCE INTERVALS JASA $65 \quad 257$ 
A SIMPLE TYPE OF HETEROCENEITY IS PRESENT IN THE SAMPLE NUMBERS WILL BE USABLE IN SELECTING A PARTICULAR SAMPLE DEVIATION OF A NORMAL POPULATION FROM A CENSORED SAMPLE UNIVARIATE POPULATION FROM THE ORDER STATISTICS OF A SAMPLE BIVARIATE NORMAL DISTRIBUTION IN THE CASE OF A SMALL SAMPLE AND SCALE PARAMETERS CIVEN A TYPE II CENSORED NORMAL SAMPLE SURVEY

PROBLEMS OF SAMPLE

ESTIMATION PROBLEMS WHEN BIOKA5I HOW MANY OF A CROUP OF RANDOM JASA $59 \quad 102$ ESTTMATION OF THE MEAN AND STANDARD BIOKA52 260 /ERSE DISTRIBUTION FUNCTION OF A CONTINUOUS BIOKA69 NO.3 /MATION OF THE SLOPE OF THE MAJOR AXIS OF A BIOCS68 679 /XIMUM LIKELIHOOD ESTIMATES OF THE LOCATION BIOKA6I 448 LLOCATION AND ESTIMATION IN AN ACRICULTURAL JRSSB54 223 IHOODS AND COMPARISON WITH POINT ESTIMATES AND LARCE SAMPLE APPROXIMATIONS EXAMPLES OF LIKEL JASA 69468 THE MIDRANGE OF A SAMPLE AS AN ESTIMATOR OF THE POPULATION MIDRANGE JASA 57537

IAL BATCHING FOR ACCEPTANCE, REJECTION SAMPLING UPON SAMPLE ASSURANCE OF TOTAL PRODUCT QUALITY /SEQUENT TECH 60 19 TIAL BATCHING FOR ACCEPTANCE-REJECTION SAMPLING UPON SAMPLE ASSURANCE OF TOTAL PRODUCT QUALITY' /SEQUEN TECH 61 I3. F EQUAL MEANS UNDER VARIANCE HETEROGENEITY SMALL SAMPLE BEHAVIOUR OF CERTAIN TESTS OF THE HYPOTHESIS O BIOKAGO 345 F EQUAL MEANS UNDER VARIANCE H/ CORRIGENDA, 'SMALL SAMPLE BEHAVIOUR OF CERTAIN TESTS OF THE HYPOTHESIS O BIOKA6I 230 DJUSTMENT' AND 'ADAPTIVE EXPECTATIONS' MODE/ SMALL SAMPLE BIAS DUE TO MISSPECIFICATION IN THE 'PARTIAL A JASA 66 1130 ORDERING OF PROBABILITIES OF RANK ORDERS IN THE TWO SAMPLE CASE ON THE PERCENTAGE POINTS OF THE SAMPLE COEFFICIENT OF VARIATION

VARIABLES SAMPLING AN INEQUALITY FOR THE SAMPLE COEFFICIENT OF VARTATION AND AN APPLICATION OF TECH 58 SBO NOTES. SMALL SAMPLE CONSIDERATIONS IN COMBINING 2 BY 2 TABLES SOME NEW RESULTS ON THE DISTRIBUTION OF THE SAMPLE CORRELATION COEFFICIENT

IS FALLIBLE

LARGE-SAMPLE COVARIANCE ANALYSIS WHEN THE CONTROL VARIABLE A NUMERICAL PROCEDURE TO GENERATE A SAMPLE COVARIANCE MATRIX, CORR. 66 1248 ON THE DISTRIBUTION OF THE TWO SAMPLE CRAMER-VON MISES CRITERION BIAS OF THE ONE-SAMPLE CRAMER-VON MISES TEST

RECONSTRUCTING PATTERNS FROM SAMPLE DATA REASONING TOWARDS POSTERIOR DISTRIBUTIONS BASED ON SAMPLE DATA ESTIMATION OF A POPULATION MEAN USING TRANSFORMED SAMPLE DATA ON THE MAXIMUM DEVIATION OF THE SAMPLE DENSITY OPTIMAL SAMPLE DESIGN WITH NONRESPONSE

VARIANCE ESTIMATES IN 'OPTIMUM' SAMPLE DESICNS

DISTRIBUTION FREE TESTS OF INDEPENDENCE BASED ON THE SAMPLE DISTRIBUTION FUNCTION A TEST FOR SYMMETRY USING THE SAMPLE DISTRIBUTION FUNCTION DISTRIBUTION FREE TESTS BASED ON THE SAMPLE DISTRIBUTION FUNCTION L STRAICHT LINES THE PROBABILITY THAT THE SAMPLE DISTRIBUTION FUNCTION

REMARKS CONCERNING THE APPLICATION OF EXACT FINITE SAMPLE DISTRIBUTION FUNCTIONS OF GENERALIZED CLASSICA JASA 63 IDENTIFIABILITY TEST STATISTICS ON FINITE SAMPLE DISTRIBUTIONS OF CENERALIZED CLASSICAL LINEAR JASA 60 AMS 67 138 NEW METHODS FOR AMS $66 \quad 355$ DIFFICULTIES INVOLVED IN THE TECH $66 \quad 535$ AMS $67 \quad 475$ JASA $67 \quad 63$ JASA $61 \quad 135$ AMS 61485 AMS 69 N0.6 BIOKA66 99 AMS $68 \quad 398$ BIOKA60 203 JASA 58509 ON NONCOVERAGE OF SAMPLE DWELLINGS CH IS RANDOMLY REPEATING IN GAUSSIAN NOISE LARGE SAMPLE ESTIMATION OF AN UNKNOWN DISCRETE WAVEFORM WHI AMS 65
TION HAVING A PRE/ ON THE NON-EXISTENCE OF A FIXED SAMPLE ESTIMATOR OF THE MEAN OF A LOG-NORMAL DISTRIBU AMS 67 TION HAVING A PRE/ ON THE NON-EXISTENCE OF A FIXED SAMPLE ESTIMATOR OF THE MEAN OF A LOG-NORMAL DISTRIBU REMARKS ON LARGE SAMPLE ESTIMATORS FOR SOME DISCRETE DISTRIBUTIONS

\section{ES TESTS STATISTIC}

INEAR ESTIMATORS IN TW/ INEAR ESTIMATORS IN A/
A K-SAMPLE EXTENSION OF THE ONE-SIDED TWO-SAMPLE SMIRNOV A K-SAMPLE EXTENSION
MOMENT CONVERCENCE OF SAMPLE EXTREMES

A NOTE ON THE EXACT FINITE SAMPLE FREQUENCY FUNCTIONS OF GENERALIZED CLASSICAL L

A NOTE ON THE EXACT FINITE SAMPLE FREQUENCY FUNCTIONS OF GENERALIZED CLASSICAL L THE COVERING CIRCLE OF A SAMPLE FROM A CIRCULAR NORMAL DISTRIBUTION

UPPER AND LOWER PROBABILITY INFERENCES BASED ON A SAMPLE FROM A FINITE UNIVARIATE POPULATION ASYMPTOTIC DISTRIBUTION OF THE AUTOCORRELATIONS OF A SAMPLE FROM A LINEAR STOCHASTIC PROCESS

0 THE STANDARD DEVIATION/ A TEST PROCEDURE WITH A SAMPLE FROM A NORMAL POPULATION WHEN AN UPPER BOUND T A SAMPLE FUNCTION PROPERTY OF MARTINGALES

SAMPLE FUNCTIONS OF CAUSSIAN RANDOM HOMOGENEOUS FIELD

S ARE EITHER CONTINUOUS OR VERY IRRECULAR

GAUSSIAN PROCESS

AN EMPIRICAL STUDY OF THE DISTRIBUTION OF THE SAMPLE GENETIC CORRELATION COEFFICIENT ON UTILIZINC INFORMATTON FROM A SECOND SAMPLE IN ESTTMATING VARIANCE

RIBUTION OF THE SAMPLE MEAN WHERE EACH MEMBER OF THE SAMPLE IS DRAWN FROM A DIFFERENT RECTANGULAR DISTRIBU BIOKA63 $50 B$ IES, AND THE INCREASE IN POPULATION COVERACE, WHEN A SAMPLE IS INCREASED THE NUMBER OF NEW SPEC BIOKA56 45 ACT AND APPROXIMATE SAMPLING DISTRIBUTION OF THE TWO SAMPLE KOLMOGOROV-SMIRNOV CRITERION D-SUB-MN, M LESS JASA 69 NO. 4 ASYMPTOTIC EFFICIENCY OF THE TWO SAMPLE KOLMOGOROV-SMIRNOV TEST ONE SAMPLE LIMITS OF SOME TWO-SAMPLE RANK TESTS

SMALL SAMPLE POWER CURVES FOR THE TWO SAMPLE LOCATION PROBLEM

POINTS OF THE EXTREME STUDENTIZED DEVIATE FROM THE SAMPLE MEAN OF THE EXTREME STUDENTIZED DEVIATE FROM THE SAMPLE MEAN POINTS OF THE 'STUDENTIZED' EXTREME DEVIATE FROM THE SAMPLE MEAN

POINTS OF THE EXTREME STUDENTIZED DEVIATE FROM THE SAMPLE MEAN $S$ FOR A NORMAL VARIATE THE CORRECT USE OF THE SAMPLE MEAN AI THE SAMPLE MEAN AMONG THE EXTREME NORMAL ORDER STATISTICS AMS 63 THE SAMPLE MEAN AMONG THE MODERATE ORDER STATISTICS AMS 62 ONS ON MULTIVARIATE PREDICTION INTERVALS FOR SAMPLE MEAN AND COVARIANCE BASED ON
TOLERANCE LIMITS FOR A NORMAL POPULATION BASED ON SAMPLE MEAN AND RANGE OR MEAN RANGE JASA $64 \quad 645$ TECH 69299 ON THE DISTRIBUTION BIOKA59 46" TABLES OF PERCENTAGE BIOKA52 189 REVISED UPPER PERCENTACE BIOKA56 449 663
33 160 634 POPULATION FUNCTIONS OF THE SAMPLE MEAN AND SAMPLE VARIANCE OF A POISSON VARIATE BIOCS69 ADMISSIBILITY OF THE SAMPLE MEAN AS ESTIMATE OF THE MEAN OF A FINITE AMS 6B 606 JASA $56 \quad 54$ ONARY MARKOFF PROCESS INVESTIGATINC THE PROPERTIES OF A SAMPLE MEAN BY EMPLOYING RANDOM SUBSAMPLE MEANS EFFICIENCY OF THE SAMPLE MEAN WHEN RESIDUALS FOLLOW A FIRST-ORDER STATI JASA 6B 1237 THE PROBABILITY OF LARGE DEVIATIONS OF FAMILIES OF SAMPLE MEANS

CORRELATION BETWEEN SAMPLE MEANS AND SAMPLE RANGES

ON THE PROPORTION OF OBSERVATIONS ABOVE SAMPLE MEANS IN A BIVARIATE NORMAL DISTRIBUTION ON AMS $64 \quad 1304$ JASA $59 \quad 465$ AMS 681350 JASA 69971 AMS $62 \quad 157$ THE MEDIAN SIGNIFICANCE LEVEL AND OTHER SMALL SAMPLE MEASURES OF TEST EFFICIENCY APPROXIMATIONS TO THE MOMENTS OF THE SAMPLE MEDIAN

TBUTIONS, I ITS CURVE-SHAPE CHARACTERTSTICS IT THE SAMPLE MEDIAN NS THE 'INEFFICIENCY' OF THE SAMPLE MEDIAN FOR MANY FAMILIAR SYMMETRIC DISTRIBUTIO ON THE DISTRIBUTION OF THE FIRST SAMPLE MOMENTS OF SHOT NOISE FINITE SAMPLE MONTE CARLO STUDIES. AND AUTOREGRESSIVE
JASA 67
ENTARY SAMPLE NON-PARAMETRIC EMPIRICAL BAYES APPROACH TO SOM BIOKA67 $\begin{array}{ll}\text { BIOKA55 } & 520 \\ \text { TECH } 64 & 2 B 7\end{array}$ JASA $67 \quad \mathrm{BO}$

ILLUSTRATION E STATISTICAL DECISION PROBLEMS TES ACCEPTANCE SAMPLING PLANS A SUPPLEMENTARY SAMPLE NON-PARAMETRIC EMPIRICAL BAYES APPROACH TO SOM BIOKA67 451 THE AVERAGE SAMPLE NUMBER FOR TRUNCATED SINCLE AND DOUBLE ATTRIBU TECH 68685 A NOTE ON THE VARIANCE OF THE DISTRIBUTION OF SAMPLE NUMBER IN SEQUENTIAL PROBABILITY RATIO TESTS TECH 66 700 
MINATION OF THE OPERATINC CHARACTERISTIC AND AVERACE SAMPLE NUMBER OF A SIMPLE SEQUENTIAL TEST /HE DETER JRSSB67 248 LOWER BOUNDS FOR AVERACE SAMPLE NUMBER OF SEQUENTIAL MULTIHYPOTHESIS TESTS 1343 ULATINC THE OPERATINC CHARACTERISTIC AND THE AVERAGE SAMPLE NUMBER OF SOME SEQUENTIAL TESTS /AE FOR CALC JRSSB58 379 OPTIMAL SAMPLE SIZE IN TWO-ACTION PROBLEMS WHEN THE SAMPLE OBSERVATIONS ARE LOCNORMAL AND THE PRECISION H JASA 68 653 $S$ OF SPECIES ARE LO/ THE EXPECTED FREQUENCIES IN A SAMPLE OF AN ANIMAL POPULATION IN WHICH THE ABUNDANCE BIOKA51 427 S FORMULA FOR THE LIMITINC CENERALIZED VARIANCE OF A SAMPLE OF CONSECUTIVE OBSERVATIONS FROM A MOVING-AVER BIOKA61 197 S FORMULA FOR THE LIMITING CENERALIZED VARIANCE OF A SAMPLE OF CONSECUTIVE OBSERVATIONS FROM A MOVINC-AVER BIOKA61 476 A DISTRIBUTION-FREE TEST OF INDEPENDENCE WITH A SAMPLE OF PAIRED OBSERVATIONS

A NOTE ON THE ABSENCE OF TANGENCIES IN GAUSSIAN SAMPLE PATHS

ON AND NORMAL SCORES TESTS

PROBLEM

NON-NORMAL SHIFT ALTERNATIVES

TE TWO-SAMPLE LOCATION PROBLEM IN THE NORMA/ HODGES

$6 B$ 1549) ON THE HODCES AND LEHMANN SHIFT ESTIMATOR IN THE TWO SAMPLE PROBLEM
ALTERNATIVE ESTIMATES FOR SHIFT IN THE P-VARIATE ONE SAMPLE PROBLEM OF TWO TEST STATISTICS ASSOCIATED WITH THE TWO-SAMPLE PROBLEM TESTS WHITNEY STATISTIC ON THE TWO SAMPLE PROBLEM A HEURISTIC METHOD FOR CONSTRUCTINC ON THE LARGE SAMPLE PROPERTIES OF A GENERALIZED WILCOXON-MANN-

AN INVESTIGATION INTO THE SMALL SAMPLE PROPERTIES OF A TWO SAMPLE TEST OF LEHMANN'S SMALL SAMPLE PROPERTIES OF ALTERNATIVE ESTIMATORS OF SEEMIN ON BAHADUR'S REPRESENTATION OF SAMPLE QUANTILES

AN INEQUALITY FOR EXPECTED VALUES OF SAMPLE QUANTILES

A NOTE ON THE ASYMPTOTIC DISTRIBUTION OF SAMPLE QUANTILES

OF THE PARAMETERS OF THE GAMMA DISTRIBUTION BY SAMPLE QUANTILES

OF THE PARAMETERS OF THE LOCISTIC DISTRIBUTION BY SAMPLE QUANTILES

ON SOME PROPERTIES OF THE ASYMPTOTIC VARIANCE OF THE SAMPLE QUANTILES AND MID-RANGES ASYMPTOTIC NORMALITY OF SAMPLE QUANTILES FOR M-DEPENDENT PROCESSES

ANALYSIS OF EXTREME-VALUE DATA BY SAMPLE QUANTILES FOR VERY LARCE SAMPLES

OR THE POPULATION STANDARD DEVIATION THE USE OF SAMPLE QUASI-RANGES IN SETTING CONFIDENCE

ON A GENERAL SYSTEM OF DISTRIBUTIONS. III. THE SAMPLE RANGE

THE STANDARD DEVIATION OF A RECTANGULA/ THE USE OF SAMPLE RANGES IN SETTING EXACT CONFIDENCE BOUNDS FOR ON TWO K-SAMPLE RANK TESTS FOR CENSORED DATA

UNRELATED REGRESSION EQUATIONS, SOME EXACT FINITE SAMPLE RESULTS WAY STRATIFIED POPULATIONS

FOR DISCRIMINATION BETWEEN TWO COMPOSITE/ IAL PROPORTIONS

UENTIAL PROBABILITY RATIO TESTS SAMPLE SIZE DETERMINATION FOR TOLERANCE LIMITS TE HYPOT/ APPROXIMATION TO THE DISTRIBUTION OF THE SAMPLE SIZE FOR SEQUENTIAL TEST. II. TESTS OF COMPOSI BIOKA6O 190 HYPOTHESES APPROXIMATION TO THE DISTRIBUTION OF SAMPLE SIZE FOR SEQUENTIAL TESTS. I. TESTS FOR SIMPLE BIOKA59 130 NOTES, SAMPLE SIZE FOR THE ESTIMATION OF MEANS OF NORMAL BOUNDS FOR THE EXPECTED SAMPLE SIZE IN A SEQUENTIAL PROBABILITY RATIO TEST BIOCS67 846 JRSSB $60 \quad 360$ JASA 69 NO. 4 AMS $64 \quad 36$ MOMENTS OF THE DISTRI8UTION OF SAMPLE SIZE IN A SPRT

ASYMPTOTIC BEHAVIOR OF EXPECTED SAMPLE SIZE IN CERTAIN ONE-SIDED TESTS AN APPROXIMATION TO THE SAMPLE SIZE IN SELECTION PROBLEMS BOUNDS ON THE MAXIMUM SAMPLE SIZE OF A BAYES SEQUENTIAL PROCEDURE TAL CATEGORIES WI/ AN ASYMPTOTICALLY OPTIMAL FIXED SAMPLE SIZE PROCEDURE FOR COMPARINC SEVERAL EXPERIMEN AMS 64 1571 WITIN D UNITS OF THE TRUE VALUE

UNIFORM DENSITY WITHIN D UNITS OF THE TRUE VALUE ES .WITH BOUNDED RELATIVE ERROR

SAMPLE SIZE REQUIRED TO ESTIMATE THE PARAMETER IN THE JASA 64550 SAMPLE SIZE REQUIRED TO ESTIMATE THE RATIO OF VARIANC JASA 631044 ISCLASSIFICATION IN DISCRIMINANT ANALYSIS, NECESSARY SAMPLE SIZE, AND A RELATION WITH THE MULTIPLE CORRELA BIOCS68 823 CONVERGENCE AND A CHERNOFF-SAVACE THEOREM FOR RANDOM SAMPLE SIZES

VALUES OF SOME RENYI TYPE STATISTICS FOR FINITE SAMPLE SIZES STIMATOR IS UNBIASED AND OF MINIMUM VARIANCE FOR ALL SAMPLE SIZES SCALE FACTORS AND DEGREES OF FREEDOM FOR SMALL SAMPLE SIZES FOR CHI APPROXIMATION TO THE RANGE

WEAK AMS 681675 QUERY COMPARISON OF SAMPLE SIZES IN INVERSE BINOMIAL SAMPLING

TABLES OF CRITICAL JASA 69 B70 PROBLEM A COMPARTSON OF THE ASYMPTOTIC EXPECTED SAMPLE SIZES OF TWO SEQUENTIAL PROCEDURES FOR RANKING AMS 69 NO.6 RIBUTION-FREE CONFIDENCE INTERVALS OF THE MEDIAN FOR SAMPLE SIZES TO 1,000/BOTH THE SIGN TEST AND DIST JASA 64935 $F$ THE SYMMETRIC BINOMIAL CUMULATIVE DISTRIBUTION FOR SAMPLE SIZES T0 1,000, CORR, 59811 AN EXACT PROBABILITY DISTRIBUTION OVER SAMPLE SPACES OF PAIRED COMPARISONS

N THE NUMBER OF OBSERVATIONS FALLING IN THE SHORTEST SAMPLE SPACINCS DETERMINED BY EARLIER OBSERVATIONS $S$ OF RATIOS OF SPACINGS OODNESS OF FIT AND TWO-SAMPLE PR/ CONTRIBUTIONS TO SAMPLE SPACINGS THEORY, II. TESTS OF THE PARAMETRIC G THE MAXIMUM DEVIATION OF SAMPLE SPECTRAL DENSITIES AN UPPER BOUND FOR THE SAMPLE STANDARD DEVIATTON ERRATA, ' AN UPPER BOUND FOR THE SAMPLE STANDARD DEVIATION ERRATA, 'AN UPPER BOUND FOR THE SAMPLE STANDARD DEVIATION' RECENT ADVANCES IN SAMPLE SURVEY THEORY AND METHODS

ON A METHOD OF USING MULTI-AUXILIARY INFORMATION IN SAMPLE SURVEYS USE OF DOMAIN ESTIMATORS WITH UNEQUAL PROBABILITY IN SAMPLE SURVEYS A NEW ESTIMATION THEORY FOR SAMPLE SURVEYS BIOCS65 986 AMS $61 \quad 838$ AMS $66 \quad 904$ AMS $66 \quad 925$ AMS 671558 TECH $62 \quad 134$ TECH $62 \quad 440$ TECH $63 \quad 417$ AMS $62 \quad 325$ JASA $65 \quad 270$ JASA $68 \quad 984$ 8IOKA68 547 
FOR WILLIAM N. HURWITZ. THE DEVELOPMENT OF HOUSEHOLD SAMPLE SURVEYS /ATISTICAL SOCIETY MEMORIAL MEETING JASA 69 NO. 4 REGRESSION ANALYSIS IN SAMPLE SURVEYS, CORR. $631162 \quad$ JASA 62590 ECTION TO BARTLETT'S CRITERION FOR TESTINC/ LARCE SAMPLE TABLES OF PERCENTACE POINTS FOR HARTLEY'S CORR BIOKA62 487 EFFECT OF NON-NORMALITY ON STEIN S TWO SAMPLE TEST A NOTE ON A DOUBLE SAMPLE TEST

OF TWO NONPARAMETRIC COMPETITORS OF WILCOXON'S TWO SAMPLE TEST

AMS $65 \quad 651$ JASA 69 NO. 4 ASYMPTOTIC EFFICIENCY JASA 67939

ONS PROCESSES A LARCE SAMPLE TEST FOR THE INDEPENDENCE OF TWO RENEWAL

A DISTRIBUTION FREE VERSION OF THE SMIRNOV TWO SAMPLE TEST IN THE P-VARIATE CASE

ESTIGATION INTO THE SMALL SAMPLE PROPERTIES OF A TWO SAMPLE TEST OF LEHMANN'S

A QUICK COMPACT TWO SAMPLE TEST TO DUCKWORTH'S SPECIFICATIONS

TOTIC RELATIVE EFFICIENCY OF MOOD'S AND MASSEY'S TWO SAMPLE TESTS AGAINST SOME PARAMETRIC ALTERNATIVES THE SMIRNOV TWO SAMPLE TESTS AS RANK TESTS NOV TAMPLE TESTS AS RANK TESTS
TWO SAMPLE TESTS IN THE WEIBULL DISTRIBUTION MULTIVARIATE TWO SAMPLE TESTS WITH DICHOTOMOUS AND CONTINUOUS VARIABLE AMS 69290

S I. THE LOCATION MODEL 'STUDENT' AND SMALL SAMPLE THEORY

THE LINEAR HYPOTHESIS AND LARGE SAMPLE THEORY

REDUCINC A RANDOM SAMPLE TO A SMALLER SET, WITH APPLICATIONS

THE MULTIPLE SAMPLE UP-AND-DOWN METHOD IN BIOASSAY

AL DISTRIBUTION FUNCTIONS OF THE SAMPLE MEAN AND SAMPLE VARIANCE OF A POISSON VARIATE

CORRELATION BETWEEN THE SAMPLE VARIANCES IN A SINGLY TRUNCATED BIVARIATE NORM DISTRIBUTION OF THE SAMPLE VERSION OF THE MEASURE OF ASSOCIATION, CAMMA

SMALL SAMPLE POWER AND EFFICIENCY FOR THE ONE SAMPLE WILCOXON AND NORMAL SCORES TESTS

THE DISTRIBUTION OF THE RATIO, IN A SINCLE NORMAL SAMPLE, OF RANCE TO STANDARD DEVIATION

NOMIAL DISTRIBUTION AND CORRELATIONS AMONC INVERSELY SAMPLED POLLEN COUNTS /THE COMPOUND NECATIVE MULTI ON THE PROBLEM OF MATCHINC LISTS BY SAMPLES

A NONPARAMETRIC TEST FOR THE PROBLEM OF SEVERAL SAMPLES CONFIDENCE INTERVALS FROM CENSORED SAMPLES ON MATCHING LISTS BY SAMPLES A NOTE ON THE RE-USE OF SAMPLES TESTS OF HOMOGENEITY FOR CORRELATED SAMPLES A THEOREM ON RANK ORDERS FOR TWO CENSORED SAMPLES THE UP-AND-DOWN METHOD FOR SMALL SAMPLES A NOTE ON QUANTILES IN LARGE SAMPLES QUERY, SMALL TRIMMED SAMPLES STANDARD ERRORS FOR INDEXES FROM COMPLEX SAMPLES PROCEDURES FOR DETECTING OUTLYING OBSERVATIONS IN SAMPLES THE DISTRIBUTION OF QUANTILES OF SMALL SAMPLES THE VARIANCE OF THE MEAN OF SYSTEMATIC SAMPLES

LIKELIHOOD FUNCTION FOR CAPTURE-RECAPTURE SAMPLES THE VARIANCE OF SPEARMAN'S RHO IN NORMAL SAMPLES THE THIRD MOMENT OF KENDALL'S TAU IN NORMAL SAMPLES CORRELATION OF THE RANGES OF CORRELATED SAMPLES NOTE ON CHI SQUARE TESTS FOR MATCHED SAMPLES THE EFFICIENCY OF MATCHED SAMPLES JOINT ASSESSMENT OF NORMALITY OF SEVERAL INDEPENDENT SAMPLES STATISTICS FOR DISCRETE POPULATIONS AND FOR GROUPED SAMPLES ON THE CORRELATION OF RANGES IN CORRELATED NORMAL SAMPLES CONSTANTS FOR THE DISTRIBUTION OF RANGE IN NORMAL SAMPLES ON ESTIMATINC RECESSIVE FREQUENCIES FROM TRUNCATED SAMPLES OF PARAMETERS FROM INCOMPLETE MULTIVARIATE SAMPLES PARAMETERS OF LOG-NORMAL DISTRIBUTION FROM CENSORED SAMPLES MATRIX VARIATES AND LATENT ROOTS DERIVED FROM NORMAL SAMPLES VALUE DATA BY SAMPLE QUANTILES FOR VERY LARGE SAMPLES AGCLERS ON THE RISK OF SOME MEAN ESTIMATORS IN SMALL SAMPLES FOR ESTIMATING AND TESTING HYPOTHESES FROM GROUPED SAMPLES TEST FOR COMPARING ARBITRARILY SINGLY-CENSORED SAMPLES

SAMPLE CRAMER-VON MISES CRITERION FOR SMALL EQUAL SAMPLES OMPONENTS IN TWO-STAGE NESTED DESIGNS WITH COMPOSITE SAMPLES OF FITTING THE DOSAGE RESPONSE CURVE FOR SMALL SAMPLES

ESTIMATES. SINGLY TRUNCATED AND SINCLY CENSORED SAMPLES ITIES WITHOUT REPLACEMENT, ROTATING AND NON-ROTATING SAMPLES RODUCT MOMENTS OF EXTREME ORDER STATISTICS IN NORMAL SAMPLES

PARAMETER EXPONENTIAL DISTRIBUTIONS FROM CENSORED SAMPLES ARIATE NORMAL POPULATION FROM TRUNCATED AND CENSORED SAMPLES ORMATION ABOUT ALTERNATIVE DISTRIBUTIONS IS BASED ON SAMPLES IBULL DISTRIBUTION BASED ON COMPLETE AND ON CENSORED SAMPLES WEIBULL POPULATIONS FROM COMPLETE AND FROM CENSORED SAMPLES MAL POPULATIONS BASED ON SINGLY AND DOUBLY TRUNCATED SAMPLES ENTIAL DISTRIBUTIONS FROM SINGLY AND DOUBLY CENSORED SAMPLES ETERS OF NORMAL POPULATIONS BASED ON SINGLY CENSORED SAMPLES BUTION BASED ON OPTIMUM ORDER STATISTICS IN CENSORED SAMPLES ERALIZED GAMMA POPULATION FROM COMPLETE AND CENSORED SAMPLES E PARAMETERS OF EXPONENTIAL DISTRIBUTION IN CENSORED SAMPLES TESTS OF HYPOTHESES CONCERNING MATCHED SAMPLES F NORMAL POPULATIONS FROM SINGLY AND DOUBLY CENSORED SAMPLES (CORR, 69 229) ESTIMATES AND OPTIMUM INFERENCE PROCEDURES IN LARGE SAMPLES (WITH DISCUSSION) INADMISSIBLE SAMPLES AND CONFTDENCE LIMITS DISCRETE SAMPLES AND MOVINC SUMS IN STATIONARY STOCHASTIC

PROCESSES DISCRIMINANT ANALYSIS WHEN THE INITIAL SAMPLES ARE MISCLASSIFIED MPLIFIED ESTIMATORS FOR THE NORMAL DISTRIBUTION WHEN SAMPLES ARE SINGLY CENSORED OR TRUNCATED OF AN ANCILLARY STATISTIC AND THE COMBINATION OF TWO SAMPLES BY BAYES' THEOREM EXTENSION OF THE WILCOXON-MANN-WHITNEY TEST TO SAMPLES CENSORED AT THE SAME FIXED POINT, CORR. 60 75 J VARIANCE OF THE MEDIAN OF SAMPLES FROM A CAUCHY DISTRIBUTION MOMENT COEFFICIENTS OF THE K-STATISTICS IN SAMPLES FROM A FINITE POPULATION
TABLES COMPARISONS OF METHODS JASA $64 \quad 779$ SAMPLING WITH VARYING PROBABIL JASA 63 1B3 ON THE MOMENTS OF THE RANGE AND P BIOKA56 458 ESTIMATION OF THE PARAMETERS OF TWO TECH 60403 ESTIMATION OF PARAMETERS OF A MULTIV JRSSB60 307 A CLASSIFICATION PROBLEM IN WHICH INF AMS $62 \quad 213$ /ESTIMATION OF THE PARAMETERS OF GAMMA AND TECH 65639 /OF THE ESTIMATES OF THE PARAMETERS OF NOR JASA 6246 E EFFICIENCY OF BAN ESTIMATES OF THE PARAM BIOKA62 570 /F THE PARAMETERS OF THE EXPONENTIAL DISTRI AMS 661717 /OF THE PARAMETERS OF A FOUR- PARAMETER CEN TECH $67 \quad 159$ /OPTIMUM ORDER STATISTICS FOR ESTIMATINC TH TECH 67279 JRSSB67 468 268 46 46 $\begin{array}{lll}\text { JASA } & 67 & 484 \\ \text { TECH } & 66 & 657\end{array}$ SI TECH 59217 AMS $61 \quad 616$ JASA $60 \quad 322$ BIOKA52 I 
MOMENT-STATISTICS IN SAMPLES FROM A FINITE POPULATION

BIOKA52

MADOW/ THE CENTRAL SAMPLING MOMENTS OF THE MEAN IN SAMPLES FROM A FINITE POPULATION (ATY'S FORMULAE AND BIOKA6I

THE DISTRIBUTION OF THE REGRESSION COEFFICIENT IN SAMPLES FROM A NON-NORMAL POPULATION

ON THE DISTRIBUTIONS OF THE RANCE AND MEAN RANGE FOR SAMPLES FROM A NORMAL DISTRIBUTION

STRIBUTION OF EXTREMAL AND NEARLY EXTREMAL VALUES IN SAMPLES FROM A NORMAL DISTRIBUTION

FOR CALCULATING TWO-SIDED PREDICTION INTERVALS FOR SAMPLES FROM A NORMAL DISTRIBUTION MOMENTS OF SAMPLE MOMENTS OF CENSORED SAMPLES FROM A NORMAL POPULATION

CORRIGENDA TO 'MOMENTS OF SAMPLE MOMENTS OF CENSORED SAMPLES FROM A NORMAL POPULATION'

THE MEAN DEVIATION. WITH SPECIAL REFERENCE TO SAMPLES FROM A PEARSON TYPE III POPULATION

TION OF PRODUCT AND OF QUOTIENT OF MAXIMUM VALUES IN SAMPLES FROM A POWER-FUNCTION POPULATION

IONS BETWEEN CERTAIN LINEAR SYSTEMATIC STATISTICS OF SAMPLES FROM ANY CONTINUOUS POPULATION

BIOKA54

BIOKA66 245

NS

DISTRIBUTTON OF SOME STATTSTICS IN SAMPLES FROM EXPONENTTAL AND POWER-FUNCTTON POPULATIO J BAYES SEQUENTIAL DESIGNS OF FIXED SIZE SAMPLES FROM FINITE POPULATIONS

PROGRESSIVELY CENSORED SAMPLES FROM LOG-NORMAL AND LOGISTIC DISTRIBUTIONS

THE DI BIOKA63 B9

FACTORS JASA 69 87B

BIOKA5B 211

BIOKA5B 5B7

BIOKA5B $47 \mathrm{~B}$

DISTRIBU JASA $64 \quad$ B77

INTERRELAT BIOKA5I 377

JASA 69 NO. 4

TECH 69 NO. 4

ON THE EXTREME VALUES AND RANCE OF SAMPLES FROM NON-NORMAL POPULATIONS

MEAN AND COEFFICIENT OF VARIATION OF RANGE IN SMALL SAMPLES FROM NON - NORMAL POPULATIONS

MEAN AND COEFFICIENT OF VARIATION OF RANGE IN SMALL SAMPLES FROM NON-NORMAL POPULATIONS' ON THE MOMENTS OF ORDER STATISTICS IN SAMPLES FROM NORMAL POPULATIONS

OF ESTIMATING EQUATIONS FOR TRUNCATED AND CENSORED SAMPLES FROM NORMAL POPULATIONS

OXIMATIONS TO THE DISTRIBUTION OF THE RANGE IN SMALL SAMPLES FROM NORMAL POPULATIONS

CORRICENDA, 'ON THE MOMENTS OF ORDER STATISTICS IN SAMPLES FROM NORMAL POPULATIONS'

BIOKA67 541

LIMITING SETS AND CONVEX HULLS OF SAMPLES FROM PRODUCT MEASURES

VARIANCE OF THE MEDIAN OF SMALL SAMPLES FROM SEVERAL SPECIAL POPULATIONS

CENERATION OF RANDOM SAMPLES FROM THE BETA AND F DISTRIBUTIONS

/RIGENDA, 'THE BIOKA55 277

BIOKA54 200

ON THE SOLUTION BIOKA57 225

/ARISON OF TWO APPR BIOKA52 130

BI0KA54 568

AMS 691824

JASA $60 \quad 148$

TECH $63 \quad 269$

DOM EXACT LOWER MOMENTS OF ORDER STATISTICS IN SAMPLES FROM THE CHI-DISTRIBUTION, ONE DECREE OF FREE AMS 621292

TIGATION OF RULES FOR DEALING WITH OUTLIERS IN SMALL SAMPLES FROM THE NORMAL DISTRIBUTION, 2 . ESTIMATION 0 TECH 69527 CENSORED SAMPLES FROM TRUNCATED NORMAL DISTRIBUTIONS BIOKA55 516

NVESTIGATION INTO THE DISTRIBUTION OF THE F-RATIO IN SAMPLES FROM TWO NON-NORMAL POPULATIONS /MPIRICAL I BIOKA58 260

RELATIONS AMONG MOMENTS OF ORDER STATISTICS. IN SAMPLES FROM TWO RELATED POPULATIONS

PROCRESSIVELY CENSORED SAMPLES IN LIFE TESTINC

THE USE OF ROTATING SAMPLES IN THE CENSUS BUREAU'S MONTHLY SURVEYS

TECH 63 327

JASA $63 \quad 454$

THE PRODUCT-MOMENT CORRELATION COEFFICIENT IN RANDOM SAMPLES OF ANY SIZE DRAWN FROM NON-NORMAL UNIVERSES BIOKA51 219
ELATIONS BETWEEN EXPECTATIONS OF ORDER STATISTICS IN SAMPLES OF DIFFERENT SIZES
SOME R BIOKA64 259

MMON MEAN OF TWO NORMAL DISTRIBUTIONS BASED ON SMALL SAMPLES OF EQUAL SIZE UNBAISED ESTIMATION OF THE CO JASA 664667

TH CORRELAT/ THE DISTRIBUTION OF KENDALL'S TAU FOR SAMPLES OF FOUR FROM A NORMAL BIVARIATE POPULATION WI BIOKA63 538

ON THE AMOUNT OF INFORMATION SUPPLIED BY CENSORED SAMPLES OF GROUPED OBSERVATIONS IN THE ESTIMATION OF BIOKA62 245

ON THE AMOUNT OF INFORMATION SUPPLIED BY TRUNCATED SAMPLES OF CROUPED OBSERVATIONS IN THE ESTIMATION OF BIOKA63 207 ON NAHORDNUNC AND FERNORDNUNG IN SAMPLES OF LITERARY TEXTS

BIOKA54 116

RDER STATISTICS AND PRODUCTS OF ORDER STATISTICS FOR SAMPLES OF SIZE TWENTY AND LESS FROM THE NORMAL DISTR AMS 61 1345 SORED SAMPLES, PART I. THE NORMAL DISTRIBUTION UP TO SAMPLES OF SIZE $10^{\prime}$ /ICS FROM SINGLY AND DOUBLY CEN AMS 39325 STIMATORS OF RELIABILIT/ THE EFFICIENCIES IN SMALL SAMPLES OF THE MAXIMUM LIKELIHOOD AND BEST UNBIASED E JASA 66 1033 REPLICATED, OR INTERPENETRATINC, SAMPLES OF UNEQUAL SIZES

A NON-PARAMETRIC COMPARISON OF TWO SAMPLES ONE OF WHICH IS CENSORED

AMS 671142

BIOKA66 599

ION CORRELATION COEFFICIENT FROM ONE OR POSSIBLY TWO SAMPLES SUBSEQUENT TO A PRELIMINARY TEST OF SIGNIFICA JRSSB67 $2 B 2$ ESTIMATINC THE POISSON PARAMETER FROM SAMPLES THAT ARE TRUNCATED ON THE RICHT

OPTIMAL ALLOCATION IN STRATIFIED AND MULTISTAGE SAMPLES USING PRIOR INFORMATION

WHEN THE SIZ/ SEVERAL METHODS OF RE-DESIGNINC AREA SAMPLES UTILIZING PROBABILITIES PROPORTIONAL TO SIZE JA

THE PERFORMANCE OF SOME TWO-SAMPLE TESTS IN SMALL SAMPLES WITH AND WITHOUT CENSORING

QUERY, BIVARIATE SAMPLES WITH MISSINC VALUES

QUERY, BIVARIATE SAMPLES WITH MISSING VALUES, II

THE DISTRIBUTION OF RANGE IN NORMAL SAMPLES WITH N=200

SAMPLES WITH THE SAME NUMBER IN EACH STRATUM

JASA $6 B \quad 964$

JASA $6 B \quad 12 B 0$

BIOKA69 127

TECH $67 \quad 679$

TECH 68 B 67

BIOKA57 257

BIOKA52 414

TER LOGNORMAL POPULATIONS FROM COMPLETE AND CENSORED SAMPLES, (CORR. 66 1247, CORR. 6B 1549) /REE-PARAME JASA 66 842

SYMP/ NON-PARAMETRIC ANALYSIS OF VARIANCE IN SMALL SAMPLES. A MONTE CARLO STUDY OF THE ADEQUACY OF THE A BIOCS69 593

OF PERCENTAGE POINTS OF ROOT'BI' AND B2 IN NORMAL SAMPLES, A ROUNDING OFF

OF RANYS PROCEDURE FOR RELATIVE SPREAD IN UNPAIRED SAMPLES, CORR. 611005

OF RATIOS AND THEIR DIFFERENCES IN MULTI-STAGE SAMPLES, CORR. 631162

CONFIDENCE INTERVALS FROM CENSORED SAMPLES, II

TABLES BIOKA65 2B2

A NONPARAMETRIC SUM JASA $60 \quad 420$

ON VARIANCES JASA 59416

TECH $66 \quad 291$

MAXIMUM-LTKEI MAXIMUM-LIKELIHOOD ESTIMATION, FROM DOUBLY CENSORED SAMPLES, OF THE PARAMETERS OF THE FIRST ASYMPTOTIC DI JASA 6B 8B9 NCES OF MAXIMUM-LIKELIHOOD ESTIMATORS, FROM CENSORED SAMPLES, OF THE PARAMETERS OF WEIBULL AND GAMMA POPUL AMS 67557 MAXTMUM-LIKEL THOOD ESTIMATTON FROM SINGLY CENSORED SAMPLES, OF THE SCALE PARAMETERS OF TYPE II EXTREME-V TECH 6B 349 BY ORDER STATISTICS FROM SINGLY AND DOUBLY CENORDD IBULL DISTRIBUTION BASED ON COMPLETE AND ON CENSORED SAMPLES WEIBULL POPULATIONS FROM COMPLETE AND FROM CENSORED SAMPLES' BUTIONS, II, THE DISTRIBUTION OF THE RANGE IN NORMAL SAMPLES'

/'MAXIMUM LIKELIHOOD ESTIMATION IN THE WE TECH $66 \quad 57$ /ESTIMATION OF THE PARAMETERS OF GAMMA AND TECH 67195 601113 LONS UNDER SPHERICAL NORMAL DISTRI AMS 61 620 SNOWBALL SAMPLINC AMS $61 \quad 148$ JASA $62 \quad 628$ AMS $63 \quad 5 B 7$ AMS 631322

SOME RATIO-TYPE ESTIMATORS IN TWO-PHASE SAMPLINC POST CLUSTER SAMPLING MULTIPLEX SAMPLINC

APPLIED MULTIPLEX SAMPLINC POLYCHOTOMY SAMPLINC

TECH $63 \quad 341$

AMS $66 \quad 657$

AMS $6 \mathrm{~B} \quad 27 \mathrm{~B}$

AMS $69 \quad 575$

AMS $6930 \mathrm{~B}$

JASA $69 \quad 175$

BIOKA52 217

BI0KA54 420

BIOKA61 333

BIOKA62 2BI

BIOKA63 544

BIOKA68 541

JRSSB54 140

JRSSB65 264

ANALYTICAL SURVEYS WITH CLUSTER SAMPLINC

JRSSB69 NO. 2 

QUERY, CALCULATION OF THE SAMPLING DISTRIBUTION OF THE RANGE

ORM FINITE POPULATIONS AND A RANGE TEST FOR H/ THE SAMPLING DISTRIBUTION OF THE RANGE FROM DISCRETE UNIF JASA 69 NO. 4 IRNOV CRITERION D-SU/ ON THE EXACT AND APPROXIMATE SAMPLING DISTRIBUTION OF THE TWC SAMPLE KOLMOGOROV-SM JASA 69 NO. 4 NT THE NORMAL A PROXIMATION TO THE SIGNED-RANK SAMPLING DISTRIBUTION WHEN ZERO DIFFERENCES ARE PRESE JASA 67 106B APPROXIMATING THE GENERAL NON-NORMAL VARIANCE-RATIO SAMPLING DISTRIBUTIONS

S BY SOLVING DIFFERENTIAL EQ/ THE DETERMINATION OF SAMPLING DISTRIBUTIONS AND MOMENT GENERATING FUNCTION JRSSB65 86 NON-NORMAL POPULATIONS ON APPROXIMATIONS TO SAMPLING DISTRIBUTIONS OF THE MEAN FOR SAMPLES FROM AMS 63 13OB RICAL STUDIES OF BALANCED NESTED DESIGN

IRICAL STUDIES OF UNBALANCED NESTED DESIGNS COMPLETE CONNECTIONS (CORR. 69 NO.6) SAMPLING DISTRIBUTIONS OF VARIANCE COMPONENTS I. EMPI TECH 66457 SAMPLING DISTRIBUTIONS OF VARIANCE COMPONENTS II. EMP TECH $6 B$ 719 SAMPLING ENTROPY FOR RANDOM HOMOGENEOUS SYSTEMS WITH AMS 651433 SAMPLING ERROR IN THE CONSUMER PRICE INDEX

JASA $67 \quad$ B99 JASA 69 N0.4

VARIANCE OF WEIGHTED REGRESSION ESTIMATORS WHEN SAMPLING ERRORS ARE INDEPENDENT AND HETEROSCEDASTIC L NUMBERS OF ORCHARDS OF DISTINCT TYPE

SAMPLING ERRORS IN AN ORCHARD SURVEY INVOLVING UNEQUA CONTINGENCY TABLES THE EFFECT OF NON-SAMPLING ERRORS ON MEASURES OF ASSOCIATION IN 2-BY-2 ON THE THEORY OF CLASSICAL REGRESSION AND DOUBLE SAMPLING ESTIMATION

TESTS FOR TREND IN A TIME SERIES A SAMPLING EXPERIMENT ON THE POWERS OF THE RECORDS THE APPLICATION OF AUTOMATIC COMPUTERS TO SAMPLING EXPERIMENTS (WITH DISCUSSION)

GRESSION WITH NON-CONSTANT, UNKNOWN ERROR VARIANCES, SAMPLING EXPERIMENTS WITH LEAST SQUARES, WEIGHTED LEA BI HYPER-ADMISSIBILITY AND OPTIMUM ESTIMATORS FOR SAMPLING FINITE POPULATIONS DISTRIBUTION-FREE SUFFICIENCY IN SAMPLING FINITE POPULATIONS SUBJECTIVE BAYESIAN MODELS IN SAMPLINC FINITE POPULATIONS (WITH DISCUSSION) ADMISSIBILITY AND BAYES ESTIMATION IN SAMPLING FINITE POPULATIONS. I ADMISSIBILITY AND BAYES ESTIMATION IN SAMPLING FINITE POPULATIONS, II ADMISSIBILITY AND BAYES ESTIMATION IN SAMPLING FINITE POPULATIONS, III ADMISSIBILITY AND BAYES ESTIMATION IN SAMPLING FINITE POPULATIONS, IV ADMISSIBILITY AND BAYES ESTIMATION IN SAMPLING FINITE POPULATIONS, V SAMPLING FOR CONFIDENCE BIOCS65 55 JASA $69 \quad 852$ JRSSB $60 \quad 131$ JRSSB55 115 JRSSB54 39 AMS 6B 621 JRSSB 6 B 551 JRSSB69 NO. 2 AMS 651707 AMS 651723 AMS 651730 AMS $66 \quad 165 \mathrm{~B}$ AMS $69 \quad 672$ JASA $67 \quad 540$ E OF SIZE ESTIMATION THE USE OF RANDOM WORK SAMPLING FOR COST ANALYSIS AND CONTROL, CORR. $5 B$ 1031 ON DOUBLE SAMPLING FOR PROBABILITY PROPORTIONATE TO SOME MEASUR JASA 5B 3B2 OPTIMAL SAMPLING FOR QUOTA FULFILMENT

USE OF DOUBLE SAMPLING FOR SELECTING BEST POPULATION DOUBLE SAMPLING FOR STRATIFICATION ON SUCCESSIVE OCCASIONS

SOME REMARKS ON DOUBLE SAMPLING FOR STRATIFICATION CURTAILED SAMPLING FOR VARIABLES

DISTRIBUTION OF PERCENTILES. BAYES' THEOREM FOR SAMPLING FROM A POPULATION ON SAMPLING FROM A POPULATION OF RANKERS

ON RANDOM SAMPLING FROM A STOCHASTIC PROCESS SAMPLING FROM A TRIANGULAR POPULATION TIC PROPERTIES OF MAXIMUM LIKELIHOOD ESTIMATORS WHEN SAMPLING FROM ASSOCIATED POPULATIONS OF COMPOUND NORMAL DISTRIBUTIONS SAMPLING FROM BIVARIATE NON-NORMAL UNIVERSES BY MEANS B A NEW BINOMIAL APPROXIMATION FOR USE IN SAMPLING FROM FINITE POPULATIONS ON THREE PROCEDURES OF SAMPLING FROM FINITE POPULATIONS A UNIFIED THEORY OF SAMPLING FROM FINITE POPULATIONS A NEW APPROACH TO SAMPLING FROM FINITE POPULATIONS. I

A NEW APPROACH TO SAMPLING FROM FINITE POPULATIONS. II INFORMATION AND SAMPLING FROM THE EXPONENTIAL DISTRIBUTION SAMPLING IN A NUTSHELL

OPTIMUM SAMPLING IN BINOMIAL POPULATIONS CENSORED SAMPLING IN CURTAILED SAMPLING PLANS BY ATTRIBUTES PROPORTIONAL SAMPLING IN LIFE LENGTH STUDIES A BAYES SEQUENTIAL SAMPLING INSPECTION 
SOME REMARKS ON THE BAYESIAN SOLUTION OF THE SINGLE SAMPLING INSPECTION SCHEME

SIMULATION STUDY OF ESTIMATORS FOR THE LINE TRANSECT SAMPLING METHOD COMPARISONS OF SOME TWO STAGE SAMPLING METHODS

APPLICATION OF RENEWAL THEORY

POPULATIONS

POPULATION A LIMIT THEOREM FOR RANDOM INTERVAL SAMPLING OF A STOCHASTIC PROCESS

SAMPLING MIXTURES OF MULTI-SIZED PARTICLES, AN

SAMPLING MIXTURES OF PARTICLES

SAMPLING MOMENTS OF MEANS FROM FINITE MULTIVARIATE

ECH 65589

TECH $60 \quad 341$

BI0CS69 317

AMS 66 B91

TECH 69 2B5

TECH $67 \quad 365$

AMS 61406

BIOKA61 199

AMS $64 \quad 866$

(PI) PS SAMPLN OF TWO UNTTS FROM A STRATUM (ADDENDUM $69192 \quad$ JRSSB67 374

ATORS AND VARIANCE ESTIMATORS IN UNEQUAL PROBABILITY SAMPLING OF TWO UNITS PER STRATUM /ILITIES OF ESTIM JASA 69 540 ROTATION DESIGNS FOR SAMPLING ON REPEATED OCCASIONS

PROPORTIONATE TO SIZE ON SAMPLING OVER TWO OCCASIONS WITH PROBABILITY

DESIGN AND OPERATION OF A DOUBLE-LIMIT VARIABLES SAMPLING PLAN A PRODUCTION MODEL AND CONTINUOUS SAMPLING PLAN

DESIGN AND EVALUATTON OF A REPETTTTVE GROUP SAMPLING PLAN

SIDED SPECIFICATION LIMIT

A SINGLE SAMPLING PLAN

A NOTE ON SIMPLE BINOMIAL SAMPLING PLANS

DESIGN OF AN OPTTMAL SEQUENCE OF INTERRELATED SAMPLING PLANS

NEW CRITERIA FOR SELECTING CONTINUOUS SAMPLING PLANS DISTRIBUTION-FREE LIFE TEST SAMPLING PLANS

MISCLASSIFIED DATA FROM CURTAILED SAMPLING PLANS

AND TABLES FOR EVALUATING DEPENDENT MIXED ACCEPTANCE SAMPLING PLANS

TRUNCATED SINGLE AND DOUBLE ATTRIBUTES ACCEPTANCE SAMPLING PLANS ASYMPTOTIC PROPERTIES OF BAYESIAN SINGLE SAMPLING PLANS

VARIABLES SAMPLING PLANS BASED ON THE NORMAL DISTRIBUTION $\quad$ TECH $67 \quad 417$

SOME ACCEPTANCE SAMPLING PLANS BASED ON THE THEORY OF RUNS $\quad$ TECH $62 \quad 177$

ESTIMATION OF FRACTION DEFECTIVE IN CURTAILED SAMPLING PLANS BY ATTRIBUTES

CENSORED SAMPLING IN CURTAILED SAMPLING PLANS BY ATTRIBUTES

TECH $67 \quad 219$

TECH $68 \quad 854$

DEVELOPMENT OF SAMPLING PIANS BY USING SEQUENTIAL. ITEM BY TTEM SEL JASA 62 387 LIFE TEST SAMPLING PLANS FOR NORMAL AND LOGNORMAL DISTRIBUTIONS TECH $62 \quad 151$ CONTINUOUS SAMPLING PLANS UNDER DESTRUCTIVE TESTING JASA 64376

VARIANCE

DOUBLE SAMPLING PLANS WHERE THE ACCEPTANCE CRITERION IS THE

JASA 66

TECH 68

JASA 64

EVANCE TO STMUUTION A TWO-VARIABLE GENERATING FUNCTION FOR COMPUTING THE SAMPLING PROBABILITIES OF A CLASS OF WIDELY USED STAT JASA 64 SQUARE TESTS AND THEIR APPLICATION TO AN ACCEPTANCE SAMPLING PROBLEM SEQUENTIAL CHI-SQUARE AND T- TECH 61 NS OF FINITE POPULATIONS ITTH AN

A SAMPLING PROCEDURE FOR MAILED QUESTIONNAIRES

COSTS SAMPLING PROCEDURES BASED ON PRIOR DISTRIBUTIONS AND TECH 63

COSTS

IDS

MULTTSTAGE SAMPLTNG PROCEDURES BASED ON PRIOR DTSTRIBUTIONS AND AMS $67 \quad 464$

STOCHASTIC SERIES

INEAR AUTOREGRESSIVE SCHEMES

PROCESSES

A SECOND-ORDER APPROXIMATION TO OPTIMAL SAMPLING REGIONS SAMPLING PROPERTIES OF LOCAL STATISTICS IN STATIONARY BIOKA55 160 SAMPLING PROPERTIES OF TESTS OF GOODNESS-OF-FIT FOR JRSSB62 492 SAMPLING RATES AND APPEARANCE OF STATIONARY GAUSSIAN TECH 66 91 AMS $69 \quad 313$ BIOKA68 131 JRSSB54 239 A SIMPLE PRESENTATION OF OPTIMUM SAMPLING RESULTS

BI0CS68 353 GAMMA RAY SPECTROMETER DATA, 2 SOME EXPERIMENTAL SAMPLING RESULTS FOR REGRESSION ANALYSIS APPLIED TO BIOCS68 AMMA RAY SPECTROMETER DATA, I

SOME EXPERTMENTAL SAMPLING RESULTS FOR REGRESSION ANALYSIS BAYESIAN STRATIFIED TWO-PHASE SAMPLING RESULTS, K CHARACTERISTICS DEPENDENCE OF THE FIDUCIAL ARGUMENT ON THE SAMPLING RULE

A DOUBLE SAMPLING SCHEME FOR ANALYTICAL SURVEYS

THE MOST ECONOMICAL SEQUENTIAL SAMPLING SCHEME FOR INSPECTION BY VARIABLES AN EXACT (PI)PS SAMPLING SCHEME, A GENERALIZATION OF A METHOD OF

HANURAV OF SOME TWO-PHASE SAMPLING SCHEMES BINOMIAL SAMPLING SCHEMES AND THE CONCEPT OF INFORMATION ON SAMPLING SCHEMES PROVIDING UNBIASED RATIO ESTIMATORS THE RELATIVE EFFICIENCY OF SINOMIAL SAMPLING SCHEMES AND
ON SAMPLING SCHEMES PRO

ON THE RELATIVE ACCURACY OF SOME SAMPLING TECHNIQUES

BIOKA68 587

BIOKA57 464

JASA $65 \quad 985$

JRSSB59 400

JRSSB 68556

AMS $67 \quad 937$

BIOKA57 179

AMS 64222

JASA $5 B \quad 9 B$ SAMPLING TECHNIQUES FOR ESTIMATION OF INCIDENCE OF RE BIOCS66 3B5

A SAMPLING TEST OF THE CHI-SQUARE THEORY FOR

D SPIDER MITE ON T

RANDOMIZED ROUNDED-OFF MULTIPLIERS IN SAMPLING THEORY
SOME RECENT ADVANCES IN SAMPLING THEORY SUFFICIENCY IN SAMPLING THEORY

AN OLD APPROACH TO FINITE POPULATION SAMPLING THEORY OCIATION FOR CROSS CLASSIFICATIONS, 111 . APPROXIMATE SAMPLING THEORY

HALF-RECTIFIED TRUNCATED DISTRIBUTIONS. SAMPLING THEORY AND HYPOTHESIS TESTING AMOUNT OF DUPLICATION

BIOKA52 118

JASA $61 \quad 32 B$

JASA $63 \quad 737$

AMS 64795

JASA 681269

JASA $63 \quad 310$ TECH $69 \quad 47$

JASA $68 \quad$ B7 BIOKA66 85 OPTIMUM ALLOCATION OF SAMPLING UNITS TO STRATA WHEN THERE ARE R RESPONSES JASA $65 \quad 225$ AN APPLICATION OF SEQUENTIAL SAMPLING TO ANALYTICAL SURVEYS EXACT FORMULA FOR THE PROBABILITY THAT TWO SPECIFIED SAMPLING UNITS WILL OCCUR IN A SAMPLE DRAWN WITH UNEQ JASA 66 384 ECT OF SEQUENTIAL BATCHING FOR ACCEPTANCE, REJECTION SAMPLING UPON SAMPLE ASSURANCE OF TOTAL PRODUCT QUALI TECH 60 19
FECT OF SEQUENTIAL BATCHING FOR ACCEPTANCE-REJECTION SAMPLING UPON SAMPLE ASSURANCE OF TOTAL PRODUCT QUALI TECH 61 131 FECT OF SEQUENTIAL BATCHING FOR ACCEPTANCE-REJECTION SAMPLING UPON SAMPLE ASSURANCE OF TOTAL PRODUCT QUALI TECH 61 131 OPTIMUM STRATIFIED SAMPLING USING PRIOR INFORMATION JASA $65 \quad 750$ 
ESTIMATED IN GENETIC EXPERIMENTS EACH STRATUM

THE SAMPLING VARIANCE OF THE CORRELATION COEFFICIENTS

BI0CS66 ESTIMATES OF SAMPLING VARIANCE WHERE TWO UNITS ARE SELECTED FROM JASA 57 ANCE FROM A NON-ORTHOGONAL TWO-WAY CLASSIFICATTON SAMPLING VARIANCES OF ESTIMATES OF COMPONENTS OF VARI BIOKA6 SAMPLING VARIANCES OF THE ESTIMATES OF VARIANCE COMPO AMS 63 NENTS IN THE UNBALANCED THREE- MAY NESTED CLASSIFI/ SOME THEORY OF SAMPLING WHEN THE STRATIFICATION IS SUBJECT TO ERROR UNEQUAL SIZES METHODS OF CLUSTER SAMPLING WITH AND WITHOUT REPLACEMENT FOR CLUSTERS OF SAMPLING WITH CONTROL VARIABLES

SUMMARY OF RECENT WORK ON VARIABLES ACCEPTANCE SAMPLING WITH EMPHASIS ON NON-NORMALITY MULTINOMIAL SAMPLING WITH PARTIALLY CATEGORIZED DATA

A METHOD OF SAMPLING WITH PROBABILITY EXACTLY PROPORTIONAL TO

SIZE

REPLACEMENT A NOTE ON A BIASED ESTIMATOR IN SAMPLING WITH PROBABILITY PROPORTIONAL TO SIZE WITH VARIANCE ESTIMATION IN RANDOMIZED SYSTEMATIC SAMPLING WITH PROBABILITY PROPORTIONATE TO SIZE

LARGE SCALE SURVEY THE USE OF SYSTEMATIC SAMPLING WITH PROBABILITY PROPORTIONATE TO SIZE IN A PROBABILITY SAMPLING WITH QUOTAS

ON INVERSE SAMPLING WITH UNEQUAL PROBABILITIES SAMPLING WITH UNEQUAL PROBABILITIES AND WITHOUT

REPLACEMENT REPLACEMENT POPULATION SYSTEMATIC SAMPLN ASYMPTOTIC THEORY OF REJECTIVE SAMPLING WITH VARYING PROBABILITIES FROM A FINITE TECH 67 BIOKA62 BIOKA54 494 TECH 69 NO. 4 JASA $68 \quad 542$ JRSSB54 236 AMS $66 \quad 1045$ JASA $65 \quad 27 B$ JASA $64 \quad 251$ JASA $66 \quad 749$ BIOKA64 IB5 AMS $62 \quad 350$ JASA $66 \quad 739$ AMS $64 \quad 1491$ NT NT SOME ESTIMATORS IN SAMPLING WITH VARYING PROBABILITIES WITHOUT REPLACEME JASA 56269 ON A CLASS OF LINEAR ESTIMATORS IN SAMPLING WITH VARYING PROBABILITIES WITHOUT REPLACEME ISA 65637 JASA $63 \quad 202$ SOME REMARKS ON A SIMPLE PROCEDURE OF SAMPLING WITHOUT REPLACEMENT
JASA 66
J91 SOME REMARKS ON A SIMPLE PROCEDURE OF SAMPLING WITHOUT REPLACEMENT
JASA 66
J91 ENCY OF THE TWO-SA/ EXTREME TAIL PROBABILITIES FOR SAMPLING WITHOUT REPLACEMENT AND EXACT BAHADUR EFFICI BIOKAG8 371 PROPORTIONAL TO SIZE IONAL TO SIZE ES OF SELECTION SAMPLING WITHOUT REPLACEMENT WITH PROB JRSSB58 393 A NOTE ON FELLEGI'S METHOD OF SAMPLING WITHOUT REPLACEMENT WITH PROBABILITY PROPORT JASA 67 ON SAMPLING WITHOUT REPLACEMENT WITH UNEQUAL PROBABILITI BIOKA67 499 BULK SAMPLING. PROBLEMS AND LINES OF ATTACK $\quad$ TECH $62 \quad 319$ MODIFIED SAMPLING, BINOMIAL AND HYPERGEOMETRIC CASES TECH 69 NO.4 UNBIASED RATTO ESTIMATORS IN STATIFIED SAMPLING, CORR, 641298 JASA $61 \quad 70$ SEQUENTIAL SAMPLING, TWO DECISION PROBLEMS WITH LINEAR LOSSES FO BIOKA65 507 $R$ BINOMIAL AND NORMAL RANDOM VARIA8LES. SEQUENTIAL SAMPLING;
SOME DEVELOPEMENTS IN 'DISTANCE SAMPLING'

IN THE ANALYSIS OF N/ APPLICATION OF GREENBERG AND SARHAN'S METHOD OF INVERSION OF PARTITIONED MATRICES JASA 65 I2OO A COMMUNICATIONS SATELLITE REPLENISHMENT POLICY DISCUSSION OF THE PAPERS OF MESSRS. SATTERTHWAITE AND BUDNE TECH $66 \quad 399$ TECH $59 \quad 157$ VESTIGATION OF THE SIZE AND POWER OF TESTS EMPLOYING SATTERTHWAITE'S SYNTHETIC MEAN SQUARES /TE CARLO IN BIOKAG8 431 F FREEDOU FOR LINEAR COUBINATIONS OF MEAN SQUARES BY SATTERTHWAITE'S FORMULA N OR EQUAL TO 6 WITH SPECIAL REFERENCE TO THE UNIQUE SATURATED DESIGNS /ESIGNS OF RESOLUTION GREATER THE AMS 6B 246 FACTORIAL DESIGNS SATURATED FRACTIONS OF 2-TO-THE-N AND 3-TO-THE-N SATURATED SEQUENTTAL FACTORIAL DESTCNS

THE CONSTRUCTION OF SATURATED TWO TO THE POWER OF K-P DESIGNS

ON A GENERALIZED SAVAGE STATISTIC WITH APPLICATIONS TO LIFE TESTING

A NOTE ON CHERNOFF-SAVAGE THEOREMS

THE USE OF WEALTH TO COMPARE HOUSEHOLDS' AVERAGE SAVING SELECTED NATIONAL INCOME COMPONENTS:- AND OF PERSONAL SAVING /SS NATIONAL PRODUCT AND ITS COMPONENTS, OF ECONOMETRIC EXPLORATION OF INDIAN SAVING BEHAVIOR

PARAMETERS

QUERY, SAVINGS IN TEST TIME WHEN COMPARING WEIBULL SCALE RELATIVE EFFICIENCY OF GOODNESS-OF-FIT TESTS AGAINST SCALAR ALTERNATIVES NON-PARAMETRIC TESTS FOR SCALE

A NOTE ON NONPARAMETRIC TESTS FOR SCALE MINIMAX RESULTS FOR IFRA SCALE ALTERNATIVES

ON ESTIMATING SCALE AND LOCATION PARAMETERS

DAUGHTER-DAM REGRESSION SOME TRANSFORMATIONS OF SCALE AND THE ESTIMATION OF

SIZES FOR CHI APPROXIMATION TO THE RANGE ON RANKING PARAMETERS OF SCALE IN TYPE III POPULATIONS THE ASYMPTOTIC

CH 67569

TECH $6 \mathrm{~B} \quad 535$ AMS 671110 AMS 681591 AMS 691116 JASA $64 \quad 737$ JASA $5 B \quad 54$ JASA $69 \quad 90$ TECH $64 \quad 471$ JASA $65 \quad 410$ AMS $62 \quad 498$ AMS $67 \quad 274$ AMS $69177 \mathrm{~B}$ JASA $63 \quad 658$ BIOCS67 823 BIOKA53 449 JASA $58 \quad 164$ SING OR/ SEPARATE MAXIMUM-LIKELIHOOD ESTIMATION OF SCALE OR SHAPE PARAMETERS OF THE GAMMA DISTRIBUTION U BIOKA63 217 LINEAR ESTIMATES OF A POPULATION SCALE PARAMETER LOCATION PARAMETER IN THE PRESENCE OF AN INCIDENTAL SCALE PARAMETER ORS IS OF ANY CONTINUOUS FORM AND KNOWN APART FROM A SCALE PARAMETER OF UNEQUAL GAMMA COMPONENTS THE JOTNT DISTRIBUTION OF THE ERR BIOHA6I 1353

VAL ESTIMATORS, BASED ON M ORDER STATISTICS, FOR THE SCALE PARANETER OF A TETBULL POPULATTON WITH KNOMN SH TECH G5 EFFECT OF TRUNCATION ON A TEST FOR THE SCALE PARAMETER OF THE EXPONENTIAL DISTRIBUTION

QUERY, SAVINGS IN TEST TIME WHEN COMPARING WEIBULL SCALE PARAMETERS UNBIASED ESTIMATION OF LOCATION AND SCALE PARAMETERS FIDUCIAL INFERENCE FOR LOCATION AND SCALE PARAMETERS

LINEAR-LOSS INTERVAL ESTIMATION OF LOCATION AND SCALE PARAMETERS ESTIMATORS FOR LINEAR FUNCTIONS OF LOCATION AND SCALE PARAMETERS ALE PARAMETERS IN PROBLEMS WITH UNKNOWN LOCATION AND SCALE PARAMETERS CORRECTION TO AMS 56427 IESTTUATTON OF LOCATTON AND SCALE PARAMETERS BY OR CENSORED SAMPLES ESTIMATION OF LOCATION AND SCALE PARAMETERS BY ORDER STATISTICS FROM SINGLY AND ESTIMATION OF LOCATION AND SCALE PARAMETERS FOR THE RECTANGULAR POPULATION FROM THE ESTIMATION OF LOCATION AND SCALE PARAMETERS FROM GROUPED DATA THE MAXTMUM ITELIHOOD ESTIMATES OF THE LOCATION AND SCALE PARANETERS GIVEN A TYPE IT CENSORED NORMAL SAUP DISTRIBUTION ESTIMATION OF LOCATION AND SCALE PARAMETERS IN A TRUNCATED GROUPED SECH SQUARE JASA 61 692 IONS. CORR. 631603 LOCATION AND SCALE PARAMETERS IN EXPONENTIAL FAMILIES OF DISTRIBUT AMS 62 9B6 D SCAL/ INADMISSIBILITY OF THE USUAL ESTIMATORS OF SCALE PARAMETERS IN PROBLEMS WITH UNKNOWN LOCATION AN AMS 6B 29 ESTIMATION OF THE SHAPE AND SCALE PARAMETERS OF THE WEIBULL DISTRIBUTION TECH $63 \quad 175$ OOD ESTIMATION, FROM SINGLY CENSORED SAMPLES, OF THE SCALE PARAMETERS OF TYPE II EXTREME-VALUE DISTRIBUTIO TECH 68 349 LEAST SQUARES ESTIMATION OF LOCATION AND SCALE PARAMETERS USING ORDER STATISTICS BIOKA52 BB TESTING AND ESTIMATING OF SCALE PARAMETERS THE TWO-SAMPLE SCALE PROBLEM WHEN LOCATIONS ARE UNKNOWN AMS 651236

WITH PROBABILITY PROPORTIONATE TO SIZE IN A LARGE SCALE SURVEY THE USE OF SYSTEMATIC SAMPLING JASA 64 25I A NOTE ON TIKS' INTERNAL SCATTER INCONSISTENCIES IN A SCHEDULE OF PAIRED COMPARISONS

IN WHICH THE ARRIVAL TIMES OF THE CUSTOMERS ARE SCHEDULED A QUEUE WITH RANDOM ARRIVALS AND SCHEDULED BULK DEPARTURES
AMS 651308 BIOKA6I 303 A QUEUEING PROBLEM JRSSB60 108 JRSSB 68 1B5 

FACTORIAL EXPERIMENTATION IN SCHEFFE'S ANALYSIS OF
OF NO FIXED MAIN-EFFECTS IN SCHEFFE'S MIXED MODEL

JASA $65 \quad 1163$

TESTINC THE HYPOTHESIS OF NO FIXED MAIN-EFFECTS IN SCHEFFE'S MIXED MODEL

SOME REMARKS ON SCHEFFE'S SOLUTION TO THE BEHRENS-FTSHER PROBLEM

BAYESIAN SOLUTION OF THE SINCLE SAMPLINC INSPECTION SCHEME

OR THE AVERACE SAMPLE RUN LENCTH OF A CUMULATIVE SUM SCHEME A DOUBLE SAMPLINC SCHEME FOR ANALYTICAL SURVEYS

AN EXTENSION OF THE TRIANCULAR ASSOCIATION SCHEME TO THREE ASSOCIATE CLASSES

$\begin{array}{rrr}\text { AMS } & 62 & 10 B 5 \\ \text { JASA } & 69 & \text { N0.4 } \\ \text { TECH } & 60 & 341\end{array}$

AN EXACT (PI)PS SAMPLING SCHEME, A GENERALIZATION OF A METHOD OF HANURAV

THE RELATIVE EFFICIENCY OF SOME TWO-PHASE SAMPLING SCHEMES

CONTINUOUS INSPECTION SCHEMES

RUN LENGTHS IN CUMULATIVE CHART QUALITY CONTROL SCHEMES

INCURRED BY ERRONEOUSLY ASSUMING NORMALITY FOR CUSUM SCHEMES

TESTS OF GOODNESS-OF-FIT FOR LINEAR AUTOREGRESSIVE SCHEMES

OF PARTIALLY BALANCED INCOMPLETE BLOCK ASSOCIATION SCHEMES

BLOCK DESIGNS FROM PARTIALLY BALANCED ASSOCIATION SCHEMES

OF ESTIMATINC PARAMETERS IN LINEAR AUTORECRESSIVE SCHEMES

INTERVALS FOR PARAMETERS IN MARKOV AUTOREGRESSIVE SCHEMES

SERIAL SAMPLING ACCEPTANCE SCHEMES DERIVED FROM BAYES'S THEOREM

SOME OPT

L QUANTAL RESPONSE CURVE

SOME OPTIMAL SEQUENTIAL SCHEMES FOR ESTIMATINC THE MEAN OF A CUMULATIVE NORMA
SERIAL SAMPLINC ACCEPTANCE SCHEMES FOR LARGE BATCHES OF ITEMS WHERE THE MEAN QUA

LITY HAS A NORMAL PRIO/ COMPARAT

ES AND RELATED LIMIT THEOREMS MPLINC ACCEPTANCE SCHEMES IN TESTING ANTICENICITY OF VACCINES
EMBEDDING OF URN SCHEMES INTO CONTINUOUS TIME MARKOV BRANCHING PROCESS ON SAMPLINC SCHEMES PROVIDING UNBIASED RATIO ESTIMATORS

HE DESIGN OF FACTORIAL EXPERIMENTS, A SURVEY OF SOME SCHEMES REQUIRING NOT MORE THAN 256 TREATMENT COMBINA CUMULATIVE SUM SCHEMES USING GAUGING

SSIVE MODEL. II NULL DISTRIBUTIONS FOR HICHER ORDER SCHEMES, NON-NULL DISTRIBUTIONS

ILLUSTRATIVE TABLES OF SCHOOL LIFE, CORR. 641299 STATISTICS AND SCIENCE

INDETERMINISM IN SCIENCE AND NEW DEMANDS ON STATISTICIANS

STATISTICAL PROBLEMS IN SCIENCE. THE SYMMETRIC TEST OF A COMPLETE HYPOTHESIS MATHEMATICAL PROBABILITY IN THE NATURAL SCIENCES

STATISTICAL METHODS AND SCIENTIFIC INDUCTION

THE STATISTICAL CONSULTANT IN A SCIENTIFIC LABORATORY

CAPITAL THROUGH MICRATION SCOOLING, EXPERIENCE, AND GAINS AND LOSSES IN HUMAN

THE PROGRESS OF THE SCORE DURING A BASEBALL CAME

ON RANDOMIZED RANK SCORE PROCEDURE OF BELL AND DOKSUM

THE DISTRIBUTION OF KENDALL'S SCORE S FOR A PAIR OF TIED RANKINGS ASYMPTOTIC EFFICIENCY OF MULTIVARIATE NORMAL SCORE TEST

ANALYSIS OF COVARIANCE BASED ON GENERAL RANK SCORES

ON THE SUM OF SQUARES OF NORMAL SCORES ROUND-ROBIN TOURNAMENT SCORES

SOME APPLICATIONS OF EXPONENTIAL ORDERED SCORES DISTRIBUTION AND THE DETERMINATION OF APPROPRIATE SCORES OF ORDERED VARIATES AND THE SUM OF SQUARES OF NORMAL SCORES

TABLES QUERY, PREFERENCE SCORES (REVISTTED)

TECH 6B $\begin{array}{lll} & \text { JRSSB64 } & 103 \\ & & \end{array}$ BIOKA6B 393 BI0CS66 6B 4 AMS 681801 AMS $64 \quad 222$ IOKA59 251 BIOKA56 186 JASA $63 \quad 1113$ JASA $57 \quad 322$ JASA $60 \quad 625$ JASA 69 NO. 4 TECH $59 \quad 21$ JRSSB55 69 TECH $69 \quad 247$ JASA 67 B75 JASA $61 \quad 703$ AMS 661697 BIOKA60 15I AMS $67 \quad 1753$ AMS 69610 BIOKA56 456 BIOKA69 295

CORRIGENDA, 'ON THE SUM OF SQUARES OF NORMAL SCORES'

N) ICAL TAXONOMY OPTIMAL REPLICATION IN SEQUENTIAL DRUG SCREENING

A GENERAL APPROACH TO SOME SCREENING AND CLASSIFICATION PROBLEMS (WITH DISCUSSIO JRSSB6B 407

A COMPARISON OF SUCCESSIVE SCREENINC AND DISCRIMINANT FUNCTION TECHNIQUES IN MED BIOCS69 NO 4 A NOTE ON 'A STUDY OF THE GROUP SCREENING EXPERIMENT' A SEQUENTIAL METHOD FOR SCREENING EXPERIMENTAL VARIABLES

QUICK ANALYSIS METHODS FOR RANDOM BALANCE SCREENING EXPERIMENTS

USE OF BOTH POSITIVE AND NEGATIVE CONTROLS IN SCREENING EXPERIMENTS ON THE THEORY OF SCREENING FOR CHRONIC DISEASES A STUDY OF THE GROUP SCREENING METHOD

A NOTE ON C.S. WATSON'S PAPER 'A STUDY OF THE CROUP SCREENING METHOD' OPTIMAL DRUG SCREENINC PLANS AN EXPERIMENTAL STUDY OF CERTAIN SCREENING PROCESSES

THERAPEUTIC INDEX A SCREENING SYSTEM P
THE DESIGN OF SCREENING TESTS GROUP SCREENING UTILIZING BALANCED AND PARTIALLY BALANCED INCOMPLETE BLOCK DESICNS CROUP SCREENING WITH MORE THAN TWO STAGES

THE LINDISFARNE SCRIBES' PROBLEM

A SEQUENTIAL SEARCH PROCEDURE

A SEQUENTIAL SEARCH PROCEDURE FOR LOCATINC A RESPONSE JUMP

A NUMERICAL INVESTIGATION OF SEVERAL ONE-DIMENSIONAL SEARCH PROCEDURES IN NONLINEAR REGRESSION PROBLEMS ALTERNATIVE AXIOMATIZATIONS OF SEASONAL ADJUSTMENT

LINEAR APPROXIMATIONS TO THE CENSUS AND BLS SEASONAL ADJUSTMENT METHODS SEASONAL ADJUSTMENT OF DATA FOR ECONOMETRIC ANALYSIS

MULTIPLE REGRESSION ANALYSIS SEASONAL ADJUSTMENT OF ECONOMTC TIME SERIES AND 
1162

$1951-1960$

ION
THE ESTIMATION OF SEASONAL VARIATION

IN ECONOMIC TIME SERIES, CORR. 63

HARMONIC ANALYSIS OF SEASONAL VARIATION WITH AN APPLICATION TO HOC PRODUC

USE OF VARYINC SEASONAL WEICHTS IN PRICE INDEX CONSTRUCTION

SOME ASPECTS OF SEASONALITY IN THE CONSUMER PRICE INDEX

CENERALIZED HYPERBOLIC SECANT DISTRIBUTIONS

LOCATION AND SCALE PARAMETERS IN A TRUNCATED GROUPED SECH SQUARE DISTRIBUTION

ON THE EQUIVALENCE OF POLYKAYS OF THE SECOND DEGREE AND SIGMA'S, CORR. 651069

GONDITIONS FOR WISHARTNESS AND INDEPENDENCE OF SECOND DEGREE POLYNOMIALS IN NORMAL VECTOR

C POWER OF CERTAIN TEST CRITERIA, BASED ON FIRST AND SECOND DIFFERENCES, FOR SERIAL CORRELATION BETWEEN SU

N MATRIX ON THE NON-CENTRAL DISTRIBUTION OF THE SECOND ELEMENTARY SYMMETRIC FUNCTION OF THE ROOTS OF MODELS OF THE SECOND KIND IN RECRESSION ANALYSIS

RENETAL THEOREMS WHEN THE FIRST OR THE SECOND MOMENT IS INFINITE

ON SECOND MOMENTS OF STOPPING RULES

ASSOCIATE PBIB DESIGNS

FIRST AND SECOND MOMENTS OF THE RANDOMIZATION TEST IN TWO ASYMPTOTIC PROPERTIES OF SPECTRAL ESTIMATES OF SECOND ORDER

COVARIANCE

EXACT FIRST AND SECOND ORDER MOMENTS OF ESTIMATES OF COMPONENTS OF

ESTIMATION OF A RECRESSION PARAMETER FOR CERTAIN SECOND ORDER PROCESSES

THE CHOICE OF A SECOND ORDER ROTATABLE DESIGN

CORRICENDA, 'THE CHOICE OF A SECOND ORDER ROTATABLE DESIGN

FURTHER SECOND ORDER ROTATABLE DESIGNS

A METHOD FOR THE CONSTRUCTION OF SECOND ORDER ROTATABLE DESIGNS IN $K$ DIMENSIONS

COMPUTERS. THE SECOND REVOLUTION IN STATISTICS (THE FIRST FISHER

MEMORIAL LECTURE) COMPUTERS. THE SECOND REVOLUTION IN STATISTICS (THE

OF TWO ESTIMATES THE WRONG REGIONS

REGIONS

DISTRIBUTION THEORY
JASA $56 \quad 615$

JASA $64 \quad 402$

JASA 641063

JASA $65 \quad 492$

JASA 631033

JASA $63 \quad 31$

JASA $66 \quad 706$

JASA $62 \quad 655$

JASA $62 \quad 149$

JASA $58 \quad 66$

JASA $61 \quad 27$

JASA $68 \quad 329$

JASA 61692

AMS 641663

AMS 621002

AMS $62 \quad 186$

AMS 6B B33

JRSSB67 266

AMS 6B 1210

AMS $66 \quad 3 B B$

JASA 69 NO. 4

BIOKA69 375

BIOKA69 NO.3

AMS 611299

BIOKA63 335

BIOKA65 305

NMS 6B 1995

AMS $67 \quad 177$

BIOCS66 233

BIOKA69 N0.3

BIOKA54 1

BIOKA66 596

A SECOND-ORDER APPROXIMATION TO OPTIMAL SAMPLING AMS 69313

THE ESTIMATION OF SECOND-ORDER TENSORS, WITH RELATED TESTS AND DESIGNS BIOKA63 353

THE TWO MEANS PROBLEM A SECONDARILY BAYES APPROACH

BALANCED TNCOMPLETE BLOCK DESIGNS FOR DTRECTIONAL SEED ORCHARDS

ALANCED INCOMPLETE BLOGK DESIGNS FOR NON-DIRECTIONAL SEED ORCHARDS

STATISTICAL EVALUATION OF CLOUD SEEDINC OPERATIONS

$\begin{array}{rr}\text { BIOKA67 } & 85 \\ \text { JRSSB55 } & 20 \mathrm{~B}\end{array}$

BIOCS67 761

THE USE OF CYCLIC B BIOCS69 561

JASA $60 \quad 446$

JASA $67 \quad 141$

JASA $63 \quad 977$ JASA 68 11BO

FINITE SAMPLE RESULTS

SMALL SAMPLE PROPERTIES OF ALTERNATIVE ESTIMATORS OF SEEMINCLY UNRELATED RECRESSIONS

TION BIAS

AN EFFICIENT METHOD OF ESTIMATING SEEMINGLY UNRELATED REGRESSIONS AND TESTS FOR AGGREG JJ LINEAR SEGMENT CONFIDENCE BANDS FOR SIMPLE LINEAR MODELS

EST IMATED FITTING SECMENTED CURVES WHOSE JOIN POINTS HAVE TO BE GURVE FITTING BY SEGMENTED STRAICHT LINES

PATHS AND CHAINS OF RANDOM STRAIGHT-LINE SEGMENTS

MOMENTS OF THE DISTRIBUTION OF JOINS BETWEEN LINE SEGMENTS

SELECTED ECONOMIC DATA, ACCURACY VS, REPORTING SPEED JA

ESTIMATES OF SAMPLING VARIANCE WHERE TWO UNITS ARE SELECTED FROM EACH STRATUM

TES OF GROSS NATIONAL PRODUCT AND ITS COMPONENTS, OF SELECTED NATIONAL INCOME COMPONENTS, AND OF PERSONAL JA

LECTION IN BREEDING PROGRAMMES WHEN ALL DAUGHTERS OF SELECTED PARENTS ARE RETAINED /ON OF RESPONSE TO SE LIMIT THEOREMS FOR RANDOMLY SELECTED PARTIAL SUMS

ASYMPTOTIC APPROXIMATION TO THE EXPECTED SIZE OF A SELEGTED SUBSET

MANY OF A GROUP OF RANDOM NUMBERS WILL BE USABLE IN SELECTING A PARTICULAR SAMPLE

JASA $62 \quad 34 \mathrm{~B}$

JASA $67 \quad 403$

JASA 661097

JASA 691079

TECH $66 \quad 303$

BIOKA54 555

JASA $68 \quad 436$

JASA $57 \quad 503$

JASA $5 B$

BIOGS69 553

AMS $62 \quad 85$

BIOKA69 207 HOW JASA $59 \quad 102$

LARGEST ALPHA-QUANT/ NONPARAMETRIC PROCEDURES FOR SELEGTING A SUBSET CONTAINING THE POPULATION WITH THE AMS 67 17BB

ON SELECTING A SUBSET CONTATNING THE POPULATION WITH THE BIOKA62 495

ON SELECTING A SUBSET OF K POPULATIONS CONTAININC THE AMS 671072

THE USE OF A GONCOMITANT VARIABLE IN SELECTING AN EXPERIMENTAL DESIGN

CORRIGENDA TO 'THE USE OF A CONCOMITANT VARIABLE IN SELECTING AN EXPERIMENTAL DESIGN'

USE OF DOUBLE SAMPLING FOR SELECTING BEST POPULATION

NEW CRITERIA FOR SELECTING CONTINUOUS SAMPLING PLANS

A MODEL FOR SELECTING ONE OF TWO MEDICAL TREATMENTS

A TWO-STAGE MODEL FOR SELECTING ONE OR TWO TREATMENTS

A SEQUENTIAL PROCEDURE FOR SELECTING THE LARGEST OF $K$ MEANS

BIOKA57 150

BIOKA57 534

BIOKA64 49

TECH 64 16]

JASA 63 3BE

BIOCS65 169

AMS 6B BB

JRSSB 60 I

"WITH DISCUSSION)

ON SELECTING THE LARGEST OF $K$ NORMAL POPULATION MEANS

NORMAL POPULATTONS

QUANTILE

A SEOUENTTAL PROCEDURE FOR SELECTTNG THE POPULATION

NONPARAMETRIC PROCEDURES FOR SELECTING THE T POPULATION WITH THE LARGEST ALPHA-

SOME MODEL I PROBLEMS OF SELECTION

AMS 671804

AMS $61 \quad 990$

BIOCS65 291

BIOCS65 $6 \mathrm{~B} 2$

BIOCS66 B 43

THE VALUE OF INDIRECT SELECTTON, 1 MASS SELECTTON

THE EFFECT OF FIELD BLOCKING ON GAIN FROM SELECTION

ON SAMPLING BIOKA67 499

WITHOUT REPLACEMENT WITH UNEQUAL PROBABILITIES OF SELECTION

SORBENT MARKOV CHAINS TO SIB MATING POPULATIONS WITH SELECTION

GENETIG EQUILIBRIUM UNDER SELECTION (INVITED PAPER)

APPLICATION OF FINITE AB BIOCS69 17

BIOCS67 397

JRSSB $61 \quad 282$

BIOCS69 49

BIOKAG3 195

TECH $65 \quad 225$

JASA 641054

INDEX SELECTION AND ESTTMATION FROM A SINCLE SAMPLE

STRATIFIED POPULATIONS

ON SOME MULTIPLE DECISION (SELECTION AND RANKING) RULES

SAMPLE SELECTION AND THE CHOICE OF ESTIMATOR IN TWO-WAY

EQUILIBRIUM UNDER SELECTION AT A MULTI-ALLELIC SEX-LINKED LOCUS (ACKNOW BIOCS68
SELECTION BASIS IN ESTIMATION OF THE GENETIC SELECTION BASIS IN ESTIMATION OF THE GENETIC

BIOKA69 NO.3

THE USE OF RANDOM ALLOCATION FOR THE CONTROL OF SELECTION BIAS

BIOCS67 842 SELECTION FOR AN OPTIMUM GROWTH CURVE 
BIOCS66 121

F SELECTED PARENTS/ THE PREDICTION OF RESPONSE TO SELECTION IN BREEDING PROGRAMMES WHEN ALL DAUGHTERS 0 BIOCS69 553 SOME STATISTICAL PROPERTIES OF A GENETIC SELECTION INDEX

SELECTION INDICES FOR QUADRATIC MODELS OF TOTAL MERIT BIOCS68 937

A BASIS FOR THE SELECTION OF A RESPONSE SURFACE DESIGN JASA 59622 SEQUENTIAL SELECTION OF EXPERIMENTS

A MULTI-STAGE PROCEDURE FOR THE SELECTION OF THE BEST OF SEVERAL POPULATIONS

AMS 681953

JASA $62 \quad 785$

IONS SEQUENTIAL PROCEDURES FOR SE SELECTION OF THE BEST ONE OF SEVERAL BINOMIAL POPULAT AMS $67 \quad 117$ SELECTION OF THE BEST SUBSET IN REGRESSION ANALYSIS TECH $67 \quad 63$

COMPARISON EXPERIMENT SELECTION OF THE BEST TREATMENT IN A PAIRED-

AMS $63 \quad 75$

A REMARK ON A PAPER OF TRAWINSKI AND DAVID ENTITLED 'SELECTION OF THE BEST TREATMENT IN A PAIRED-COMPARISO AMS 63 92

N COMPARISONS CAN BE MADE ONLY IN PAIRS SELECTION OF THE POPULATION WITH THE LARGEST MEAN WHE BIOKA58 581 SELECTION OF VARIABLES FOR FITTING EQUATIONS TO DATA TECH $66 \quad 27$ PONDERATION DES VALEURS GENOTYPIQUES DANS LA SELECTION PAR INDEX SUR PLUSIEURS CARACTERES 295 A FIXED SUBSET-SIZE APPROACH TO THE SELECTION PROBLEM SOME FIXED-SAMPLE RANKING AND SELECTION PROBLEMS AN APPROXIMATION TO THE SAMPLE SIZE IN SELECTION PROBLEMS AN EXTENSION OF PAULSON'S SELECTION PROCEDURE

AN INTRODUCTION TO RANKING AND SELECTION PROCEDURES

PROBABILITY DISTRIBUTIONS

SELECTION PROCEDURES FOR RESTRICTED FAMILIES OF OF SAMPLING PLANS BY USING SEQUENTIAL, ITEM BY ITEM. SELECTION TECHNIQUES AND DIGITAL COMPUTERS /OPMENT PROBLEMS OF SELECTION WITH RESTRICTIONS INDEX SELECTION WITH RESTRICTIONS

THE VALUE OF INDIRECT SELECTION, 1. MASS SELECTION

STIMATION BASED ON CHANGE OF COMPOSITION CAUSED BY A SELECTIVE REMOVAL BIOKA68 401 AMS 671079 AMS $69 \quad 492$ AMS 682067 JASA $66 \quad 640$ AMS $69 \quad 905$ JASA 62 3B7 JASA 62 3BSS 362 BIOCS68 1015 BIOCS65 682

A ON THE PROBLEM OF SELF-INCOMPATABILITY ALLELES

BIOCS66 111 AN ENUMERATION PROBLEM IN SELF-STERILITY BI0C569 39 ATION OF TWO METHODS OF ESTIMATION O/ SIMULTANEOUS SELFING AND PARTIAL DIALLEL TEST CROSSING 2 . AN EVALU BIOCS67 325 PROBLEMS A SEMI-GRAPHICAL METHOD FOR THE ANALYSIS OF COMPLEX.

THE EPOCHS OF EMPTINESS OF A SEMI-INFINITE DISCRETE RESERVOIR

A RANDOM TIME CHANGE RELATING SEMI-MARKOV AND MARKOV PROCESSES

BEHAVIOUR SEQUENCES AS SEMI-MARKOV CHAINS (WITH DISCUSSION)

THE DISTRIBUTION OF THE MAXIMUM OF A SEMI-MARKOV PROCESS

REMARK CONCERNING TWO-STATE SEMI-MARKOV PROCESSES

NOTE ON EXTREME VALUES, COMPETING RISKS AND SEMI-MARKOV PROCESSES

THE SOLUTION OF QUEUEING AND INVENTORY MODELS BY SEMI-MARKOV PROCESSES

ON THE DISTRIBUTION OF THE SUPREMUM FUNCTIONAL FOR SEMI-MARKOV PROCESSES WITH CONTINUOUS STATE SPACES TO THE SOLUTION OF QUEUEING AND INVENTORY MODELS BY SEMI-MARKOV PROCESSES

OF THE NUMBER OF COMMON TREATMENTS BETWEEN BLOCKS OF SEMI-REGULAR GROUP DIVISIBLE DESIGNS

A CORRECTION AN OSCILLATING SEMIGROUP

A THEOREM OF LEVY AND A PECULIAR SEMIGROUP

ON THE BOUNDS

ON THE SEMTMART INGALE CONYERGENCE THEOREM

A NOTE ON UPCROSSINGS OF SEMIMARTINGALES

DISCRETE DYNAMIC PROGRAMMING WITH SENSITIVE DISCOUNT OPTIMALITY CRITERIA

ON THE COMPARISON OF THE SENSITIVITIES OF EXPERIMENTS

COMPARISON OF THE SENSITIVITIES OF SIMILAR INDEPENDENT AND NON-INDEPEND ABOUT SENSITIVITY ANALYSIS IN LINEAR PROGRAMMING MODELS

ENT EXPERIMENTS

YSING SENSITIVITY AND QUANTAL RESPONSE DATA

USE OF NON-LINEAR REGRESSION METHODS FOR ANALYSI LINEAR HYPOTHESIS CANNOT BE CONTROLLED, CORR. 56650 ANALYSIS OF SENSITIVITY EXPERIMENTS WHEN THE LEVELS OF STIMULUS EXPECTED SIGNIFICANCE LEVEL AS A SENSITIVITY INDEX FOR TEST STATISTICS

THE STOCHASTIC ASSUMPTIONS OF THE MODELS ON THE SENSITIVITY OF SIMULTANEOUS-EQUATIONS ESTIMATORS TO CLASS ESTIMATORS THE RELATIVE SENSITIVITY TO SPECIFICATION ERROR OF DIFFERENT KSOME RESULTS ON TESTS OF SEPARATE FAMILIES OF HYPOTHESES FURTHER RESULTS ON TESTS OF SEPARATE FAMILIES OF HYPOTHESES

ANALYSIS SOME TESTS OF SEPARATE FAMILIES OF HYPOTHESES IN TIME SERIES

TECH $60 \quad 387$ JRSSB $63 \quad 13$ AMS $68 \quad 35 B$ JRSSB59 36 AMS $68 \quad 947$ AMS 61615 AMS 631104 JRSSB61 113 AMS $69 \quad 844$ JRSSB63 455 JASA $64 \quad$ B 67 AMS $67 \quad 924$ AMS $67 \quad 1552$ AMS $66 \quad 690$ AMS $66 \quad 728$ AMS $69 \quad 1635$ JRSSB62 447

BIOKA69 17 SASJ $67 \quad 33$

THE SEPARATION OF MOLECULAR COMPOUNDS BY COUNTERCURRENT

69 AMS $65 \quad 236$ SOME ASPECTS OF THE RANDOM SEQUENCE RECOGNIZING THE MAXIMUM OF A SEQUENCE

CONSTRUCTING AN UNBIASED RANDOM SEQUENCE

JASA 681526 AMS $69 \quad 456$

ON THE EXPECTED VALUE OF A STOPPED STOCHASTIC SEQUENCE

NUMBERS FOR THE MAXIMUM IN A STATIONARY GAUSSIAN SEQUENCE

OF ASCENDING PAIRS AND ASCENDING RUNS IN A RANDOM SEQUENCE

TIC EFFICIENCY OF AN ASYMPTOTICALLY NORMAL ESTIMATOR SEQUENCE (CORR. 67 196)

THE DISTRIBUTION OF THE NUMBER OF SUCCESSES IN A SEQUENCE OF DEPENDENT TRIALS

A LAW OF LARGE AMS $62 \quad 93$ THE JOINT DISTRIBUTION BIOKA67 330 A NOTE ON THE ASYMPTO JRSSB63 395 BIOKA59 454

IN CASES ON THE LACK OF A UNIFORMLY CONSISTENT SEQUENCE OF ESTIMATORS OF A DENSITY FUNCTION IN CERTA AMS 67 47 DESIGN OF AN OPTIMAL SEQUENCE OF INTERRELATED SAMPLING PLANS A NON-NULL RANKING MODEL FOR A SEQUENCE OF M ALTERNATIVES WEAK CONVERGENCE OF A SEQUENCE OF QUICKEST DETECTION PROBLEMS BIOKA61 441 $\begin{array}{rr}\text { BIOKA61 } & 441 \\ \text { AMS } 6 B & 2149\end{array}$

AMS 651107 DISTINGUISHING A SEQUENCE OF RANDOM VARIABLES FROM A TRANSLATE ITSELF AMS 651107 $\begin{array}{lllll}\text { NON-RANDOMNESS IN A SEQUENCE OF TWO ALTERNATIVES. I. WILCOXON'S AND ALLIE BIOKA58 } & 166 \\ \text { NON-RANDOMNESS IN A SEQUENCE OF TWO ALTERNATIVES. II. RUNS TEST } & \text { BIOKA5B }\end{array}$

D TEST STATISTICS

THE AUTOCORRELATION FUNCTION OF A SEQUENCE UNIFORMLY DISTRIBUTED MODULO

AMS $63 \quad 1243$ THE GAP TEST FOR RANDOM SEQUENCES

LIMIT THEOREMS FOR THE MAXIMUM TERM IN STATIONARY SEQUENCES PERMUTATION WITHOUT RISING OR FALLING OMEGA-SEQUENCES

AMS $61 \quad 524$ AMS $64 \quad 502$ AMS 671245

JRSSB63 206 ESTIMATION OF THE PARAMETERS IN SHORT MARKOV SEQUENCES METHODS JRSSB57 286

OF CONSTRUCTION AND ANALYSIS OF SERIALLY BALANCED SEQUENCES FOR STATIONARY PROBA8ILITY MEASURES ON FINITE STATE SEQUENCES RIAL CORRELATION COEFFICIENT IN SHORT AUTOREGRESSIVE SEQUENCES OODNESS OF FIT CRITERIA FOR MARKOV CHAINS AND MARKOV SEQUENCES THE REGRESSION ANALYSIS OF 8INARY SEQUENCES 8EHAVIOUR SEQUENCES AS SEMI-MARKOV CHAINS (WITH DISCUSSION) 
SEQUENCES BALANCED FOR PAIRS OF RESIDUAL EFFECTS CONSTRUCTION OF SEQUENCES ESTTMATINC THE MIXINC DISTRIBUTION SUBSIDIARY SEQUENCES FOR SOLVINC LESER'S LEAST-SQUARES GRADUATIO JRSSB62 112 A NOTE ON SEQUENCES OF CONTINUOUS PARAMETER MARKOV CHAINS

N EQUATIONS

TERM IN SEQUENCES OF DEPENDENT RANDOM VARIABLES

LIMITING DISTRIBUTION OF THE MAXIMUM TERM IN SEQUENCES OF DEPENDEN

THE SUPERPOSITION OF SEVERAL STRICTLY PERIODIC SEQUENCES OF EVENTS

THE SUPERPOSITION OF RANDOM SEQUENCES OF EVENTS

(P-Q) SERIES, CORR. 62919

SEQUENCES OF FRACTIONA

SAMPLE SEQUENCES OF MAXIMA

APPROXIMATION TO BAYES RISK IN SEQUENCES OF NON-FINITE CAMES

A CHARACTERIZATION OF CERTAIN SEQUENCES OF NORMINC CONSTANTS

CENTRAL LIMIT THEOREMS FOR FAMILIES OF SEQUENCES OF RANDOM VARIABLES

ON A THEOREM OF RENYI CONCERNINC MIXINC SEQUENCES OF SETS

UCTION OF BALANCED DESIGNS FOR EXPERIMENTS INVOLVINC SEQUENCES OF TREATMENTS

DESICNS FOR SEQUENCES OF TREATMENTS WITH CARRY-OVER EFFECTS

SEQUENCES OF TWO-LEVEL FRACTIONAL FACTORIAL PLANS

INDEPENDENT SEQUENCES WITH THE STEIN PROPERTY

RKOV PROCESS

DEVELOPMENT OF RANDOMTZED LOAD SEQUENCES WITH TRANSITION PROBABILITIES BASED ON A MA AN OPTIMAL SEQUENTIAL ACCELERATED LIFE TEST.

SOME SEQUENTIAL ANALOGS OF STEIN'S TWO-STAGE TEST

A SEQUENTIAL ANALOQUE OF THE BEHRENS-FISHER PROBLEM

BIBLIOGRAPHY ON SEQUENTIAL ANALYSIS

HYPERGEOMETRIC FUNCTIONS IN SEQUENTIAL ANALYSIS

DEPARTURES FROM ASSUMPTION IN SEQUENTIAL ANALYSIS

BAYESIAN SEQUENTIAL ANALYSIS

SOME GENERAL RESULTS IN SEQUENTIAL ANALYSIS

SYMPTOTIC BEHAVIOR OF DENSITIES WITH APPLICATIONS TO SEQUENTIAL ANALYSIS

WEEN SUFFICIENCY AND INVARIANCE WITH APPLICATIONS IN SEQUENTIAL ANALYSIS

DESIGNS IN THE ANALYSIS OF VARIANCE

MIXED MODELS

SEQUENT SEQUENTIAL ANALYSIS OF DEPENDENT OBSERVATIONS. I SEQUENTIAL ANALYSIS OF VARIANCE UNDER RANDOM AND

APPLICATION OF METHODS IN SEQUENTIAL ANALYSIS TO DAM THEORY

SEQUENTIAL ANALYSIS WITH DELAYED OBSERVATIONS SEQUENTIAL ANALYSIS, DIRECT METHOD

A MEDIAN TEST WITH SEQUENTIAL APPLICATION

DESIGNS FOR THE SEQUENTIAL APPLICATION OF FACTORS

TION AND EVOLUTIONARY OPERATION TIAL APPLICATION OF SIMPLEX DESIGNS IN OPTIMISA TECH $62 \quad 441$

UPON SAMPLE ASSURANCE OF/

ERRATA, 'THE EFFECT OF SEQUENTIAL BATCHING FOR ACCEPTANCE-REJECTION SAMPLING

G UPON SAMPLE ASSURANCE OF TOTAL PR/ THE EFFECT OF

PLICATION TO AN ACCEPTANCE SAMPLING PROBLEM 作

SEQUENTIAL CHI-SQUARE AND T-SQUARE TESTS AND THEIR AP TECH 61519 SEQUENTIAL CHI-SQUARED AND T-SQUARED TESTS

NOTE ON A SEQUENTIAL CLASSIFICATION PROBLEM

AN ADAPTIVE PROCEDURE FOR SEQUENTIAL CLINICAL TRIALS

OF SOME CLASSICAL HYPOTHESES, WITH APPLICATIONS TO SEQUENTIAL CLINICAL TRIALS

ASYMPTOTIC SOLUTIONS OF THE

ENCE OF THE LOSSES OF CERTAIN DECISION RULES FOR THE SEQUENTIAL COMPOUND DECISION PROBLEM

FINITE LOSS MATRIX

THE

SEQUENTIAL COMPOUND DECISION PROE

SEQUENTIAL COMPOUND ESTIMATORS

PROBLEM

RAMETERS

ON THE ASYMPTOTIC THEORY OF FIXED-SIZE ON THE ASYMPTOTIC THEORY OF FIXED-WIDTH

AN EXTENSION OF A THEOREM OF CHOW AND ROBBINS ON SEQUENTIAL CONFIDENCE INTERVALS FOR THE MEAN NORMAL POPULATION WITH UNKNOWN VARIANCE

THE OUTER NEEDLE SEQUENTIAL CONFIDENCE INTERVALS FOR THE MEAN OF A

ES SEQUENTIAL CONTINUATION REGIONS

ON SEQUENTIAL CONTROL PROCESSES

A NOTE ON MEMORYLESS RULES FOR CONTROLLING SEQUENTIAL CONTROL PROCESSES

SEQUENTIAL COUNTERBALANCING IN LATIN SQUARES

OBSERVATIONS

BAYES SOLUTION OF SEQUENTIAL DECISION PROBLEM FOR MARKOV DEPENDENT

YPOTHESES CONCERNING THE UNKNOWN MEAN OF A NORM/ A SEQUENTIAL DECISION PROCEDURE FOR CHOOSING ONE OF K H SOME GENERAL RESULTS IN SEQUENTIAL DESIGN (WITH DISCUSSION)

CATEGORIES WITH A CONTR

STATES OF NATURE

VARIABLES

AN ASYMPTOTICALLY OPTIMAL SEOUENTIAL DESIGN FOR COMPARINC SEVERAL EXPERIMENTAL

THE SEQUENTIAL DESIGN OF EXPERIMENTS FOR INFINITELY MANY

FOR THE ESTIMATION OF A SUBCROUP OF PRE-AS/ BAYES SEQUENTIAL DESIGN OF FRACTIONAL FACTORIAL EXPERIMENTS OPERATING CHARACTERISTICS OF SOME SEQUENTIAL DESIGN RULES ON BAYES SEQUENTIAL DESIGN WITH TWO RANDOM VARIABLES

MARKOV CHAINS

A COMPARISON OF SOME SEQUENTIAL DESIGNS

TRUNCATED SEQUENTIAL DESIGNS FOR CLINICAL TRIALS BASED ON

SEQUENTIAL DESICNS FOR SPHERICAL WEIGHT FUNCTIONS

POPULATIONS

BAYES SEQUENTIAL DESICNS OF FIXED SIZE SAMPLES FROM FINIT

A REMARK ON SEQUENTIAL DISCRIMINATION

OPTIMAL REPLICATION IN SEQUENTIAL DRUG SCREENING

1030

OPTIMAL REPLICATION IN SEQUENTIAL DRUG SCREEN

YMPTOTICALLY OPTIMAL BAYES AND MINIMAX PROCEDURES IN SEQUENTIAL ESTIMATION

PROCEDURES

SEQUENTIAL ESTIMATION AND CLOSED SEQUENTIAL DECISION

C. BINOMIAL, POISSON, AND EXPONENTIAL/ A METHOD OF SEQUENTIAL ESTIMATION APPLICABLE TO THE HYPERGEOMETRI NUMERICAL STUDIES IN THE SEQUENTIAL ESTIMATION OF A BINOMIAL PARAMETER

SEQUENTIAL ESTIMATION OF QUANTAL RESPONSE CURVES

SEQUENTIAL ESTIMATION OF QUANTAL RESPONSE CURVES, A
SEQUENTIAL ESTIMATION OF THE MEAN OF A LOG-NORMAL DIS

NEW METHOD OF ESTIMATION

TRIBUTION HAVING A PRESCRIBED PROPORTIONAL CLOSEN/ SEQUENTIAL ESTIMATION OF THE MEAN OF A LOG-NORMAL

ON AN A.P. O. RULE IN SEQUENTIAL ESTIMATION WITH QUADRATIC LOSS

THE CONSISTENCY OF CERTAIN SEQUENTIAL ESTIMATORS
AMS $62 \quad$ B94

AMS 631217

BIOKA53

BIOKA66 3B

JASA $62 \quad 403$

AMS 671570

AMS $69 \quad 46^{\prime}$

AMS $68 \quad 391$

AMS $63 \quad 439$

AMS $61 \quad 257$

BI0KA52 32

BIOCS66 292

TECH $69 \quad 477$

AMS 6B 1282

ECH $66 \quad 107$

TECH $62 \quad 367$

BIOKA62 367

AMS 67 13B4

JASA $60 \quad 561$

AMS 651870

BI0KA61 206

BIOKA61 281

BIOKA64 123

AMS $65 \quad 615$

AMS $65 \quad 575$

BIOKA65 15 '

JASA $67 \quad 1401$

AMS $63 \quad 1588$

JASA $64 \quad 1006$

TECH $6 B \quad 125$

BIOKA63 55

TECH $64 \quad 365$

AMS 631095

JASA $69 \quad 759$

JASA $66 \quad 577$

BIOCS66 730

AMS $63 \quad 1079$

AMS 641606

AMS $66 \quad 954$

AMS 681890

AMS $65 \quad 879$

JRSSB $66 \quad 63$

AMS $65 \quad 463$

AMS $65 \quad 457$

AMS 69667

JRSSB57 133

BIOKA66 455

AMS $64 \quad 341$

AMS $66 \quad 276$

AMS $66 \quad 741$

AMS $64 \quad 1656$

AMS $63 \quad 549$

JRSSB $65 \quad 371$

AMS 63 14B6

AMS 61771

JRSSB $66 \quad 73$

AMS $68 \quad 973$

AMS 6B 1176

BIOKA66 469

BIOKA69 301

BIOCS6B 159 TECH 67517 JASA 69 NO.4

AMS 671666 BIOKA64 B JASA 5B 525 AMS 6B 422

AMS 641048 AMS 651494 JRSSB63 1 BIOKA66 439 AMS $66168 \mathrm{~B}$ BIOKA67 229 AMS 69417 AMS $69 \quad 568$ BIOKA58 
AMS 691492 SATURATED SEQUENTIAL FACTORIAL DESICNS SEQUENTIAL FACTORIAL ESTIMATION

ERRATA, 'SEQUENTIAL FACTORIAL ESTIMATION' SEQUENTIAL HYPOTHESIS TESTS FOR THE R-DEPENDENT

MARC INALLY STATIONARY PROCESSES ASYMPTOTICALLY OPTIMUM SEQUENTIAL INFERENCE AND DESICN CLASS OF MULTIVARIATE REGRESSION PROBLEMS NORMAL POPULATIONS

CHANCINC PARAMETER SEQUENTAL INFERENCE PROCEDURES OF STEIN'S TYPE FOR A SEQUENTIAL INTERVAL ESTIMATION FOR THE MEANS OF SEQUENTIAL LIFE FOR THE EXPONENTIAL DISTRIBUTION WITH TECH $66 \quad 217$ EXACT OPERATINC CHARACTERISTIC FOR TRUNCATED SEQUENTIAL LIFE TESTS IN THE EXPONENTIAL CASE OF A POPULATION SEQUENTIAL MAXIMUM LIKELIHOOD ESTIMATION OF THE SIZE SEQUENTIAL MEDICAL TRIALS SEQUENTIAL MEDICAL TRIALS, SOME COMMENTS ON F. J.

ANSCOMBE'S PAPER

VARIABLES

RESPONSES IN DOSE TRIALS

A SEQUENTIAL METHOD FOR SCREENING EXPERIMENTAL

A SEQUENTIAL METHOD OF TESTINC THE LINEAR TRENDS OF

REGRESSION ANALYSIS, I SIMULTANEOUS TESTS BY SEQUENTIAL METHODS IN HIERARCHICAL CLASSIFICATIONS LOWER BOUNDS FOR AVERACE SAMPLE NUMBER OF SEOUENTTAL MULTIHYPOTHESIS TESTS

A NOTE ON SEQUENTIAL MULTIPLE DECISION PROCEDURES

PRESCRIBED MAXIMUM ASYMPTOTIC ERROR PROBABILITY SEQUENTIAL NONPARAMETRIC TWO-WAY CLASSIFICATION WITH SEQUENTIAL OCCUPANCY

A NOTE ON A SEQUENTIAL OCCUPANCY PROBLEM

SEQUENTIAL OCCUPANCY WITH CLASSIFICATION

AMS $62 \quad 404$

TECH $68 \quad 535$

TECH $64 \quad 41$

TECH 6593

AMS $66 \quad 90$ AMS $63 \quad 705$

AMS 621039 AMS 621403

AMS $6 \mathrm{~B} 1057$ JASA $63 \quad 365$ JASA $63 \quad 3 B 4$ JASA $62 \quad 455$ BIOCS68 663 BIOKA64 439 AMS $63 \quad 462$

AMS $67 \quad 1343$ AMS $69 \quad 653$ AMS 69445 BIOKA59 21B BIOKA6B 591 BIOKA6B 229

OF A BINOMIAL PARAMETER SEQUENTIAL OPTIMUM PROCEDURES FOR U

SOME ASPECTS OF THE USE OF THE SEQUENTIAL PROBABILITY RATIO TEST REMARK ON THE OPTIMUM CHARACTER OF THE SEQUENTIAL PROBABILITY RATIO TEST THE MOST ECONOMICAL BINOMIAL SEQUENTIAL PROBABILITY RATIO TEST BOUNDS FOR THE EXPECTED SAMPLE SIZE IN A SEQUENTIAL PROBABILITY RATIO TEST NOTE ON THE LIMITINC RELATIVE EFFICIENCY OF THE WALD SEQUENTIAL PROBABILITY RATIO TEST AND THE OPERATING CHARACTERISTIC CURVE FOR THE WALD SEQUENTIAL PROBABILITY RATIO TEST IVES, CORR. 671309 STOPPING TIME OF A RANK-ORDER SEQUENTIAL PROBABILITY RATIO TEST ON LEHMANN ALTERNAT ON THE PERFORMANCE OF THE TRUNCATED SEQUENTIAL PROBABILITY RATIO TEST, CORR. 661247 ON THE PERFORMANCE OF THE TRUNCATED SEQUENTIAL PROBABILITY RATIO TEST,
ON THE OPTIMALITY OF SEQUENTIAL PROBABILITY RATIO TESTS ON THE PERFORMANCE OF THE TRUNCATED SEQUENTIAL PROBABILITY RATIO TEST,
ON THE OPTIMALITY OF SEQUENTIAL PROBABILITY RATIO TESTS
EXISTENCE, UNIQUENESS AND MONOTONICITY OF SEQUENTIAL PROBABILITY RATIO TESTS UNBIASED ESTIMATION TECH $64 \quad 259$ JASA $5 \mathrm{~B} \quad 1 \mathrm{~B} 7$ AMS $66 \quad 726$ BIOKA60 103 JRSSB $60 \quad 360$ A JASA 60660 ON THE SAMPLE SIZE AND SIMPLIFICATION OF A CLASS OF SEQUENTIAL PROBABILITY RATIO TESTS

ESSENTIAL COMPLETENESS OF THE CLASS OF CENERALIZED SEQUENTIAL PROBABILITY RATIO TESTS THE VARIANCE OF THE DISTRIBUTION OF SAMPLE NUMBER IN SEQUENTIAL PROBABILITY RATIO TESTS

SAMPLE SIZE DISTRIBUTION FOR A CLASS OF INVARIANT SEQUENTIAL PROBABILITY RATIO TESTS ON THE SAMPLE SIZE AND COVERAGE FOR THE JIRINA SEQUENTIAL PROCEDURE BOUNDS ON THE MAXIMUM SAMPLE SIZE OF A BAYES SEOUENTIAL PROCEDURE AL CATEGORIES WITH A STANDARD OR CONTROL A SEQUENTIAL PROCEDURE FOR COMPARINC SEVERAL EXPERIMENT MEANS ON THE ASYMPTOTIC EFFICIENCY OF A SEQUENTIAL PROCEDURE FOR ESTIMATINC THE MEAN A SEQUENTIAL PROCEDURE FOR SELECTINC THE LARGEST OF $K$

H THE LARGEST MEAN FROM K NORMAL POPULATIONS AGAINST A TWO SIDED ALTERNATIVE HYPOTHESIS A SEQUENTTAL PROCEDURE FOR SELECTINC THE POPULATION WIT A SEQUENTIAL PROCEDURE FOR TESTINC A NULL HYPOTHESIS AN EMPIRICAL EVALUATION OF MULTIVARIATE SEQUENTIAL PROCEDURE FOR TESTING MEANS

IMATION OF THE MEAN THE PERFORMANCE OF A SEQUENT IAL PROCEDURE FOR THE FIXED-WIDTH INTERVAL EST SOME APPLICATIONS OF THE JIRINA SEQUENTIAL PROCEDURE TO OBSERVATIONS WITH TREND A PROPERTY OF SOME SYMMETRIC TWO-STAGE SEQUENTIAL PROCEDURES RESTRICTED SEQUENTIAL PROCEDURES A FAMILY OF CLOSED SEQUENTIAL PROCEDURES (CORR, 69457 ) THE PERFORMANCE OF SOME SEQUENTIAL PROCEDURES FOR A RANKING PROBLEM S CONCERNING THE UNKNOWN DRIFT PARAMET/ A CLASS OF SEQUENTIAL PROCEDURES FOR CHOOSING ONE OF K HYPOTHESE MS SOME ASYMPTOTICALLY EXTINCT SEQUENTIAL PROCEDURES FOR RANKINC AND SLIPPAGE PROBLE JR RISON OF THE ASYMPTOTIC EXPECTED SAMPLE SIZES OF TWO SEQUENTIAL PROCEDURES FOR RANKING PROBLEM A COMPA A OF SEVERAL BINOMIAL POPULATIONS REQUIRED

CORR. $65 \quad 1249$

TWO-SAMPLE PROCEDURE

PROCEDURES

A NOTE ON THE RISKS OF ERROR INVOLVED IN THE SEQUENTIAL RATIO TEST SEQUENTIAL PROCEDURES FOR SELECTION OF THE BEST ONE

OPTIMAL SEQUENTIAL PROCEDURES WHEN MORE THAN ONE STOP IS SEQUENTIAL RANGE TESTS FOR COMPONENTS OF VARIANCE, SEQUENTIAL RANK TESTS I. MONTE CARLO STUDIES OF THE SEQUENTIAL RANK TESTS II MODIFIED TWO-SAMPLE SEQUENTIAL RELIABILITY ASSURANCE IN FINITE LOTS

MARKOVIAN SEQUENTIAL REPLACEMENT PROCESSES

POPULATION COMPARISON OF SEQUENTIAL RULES FOR ESTIMATION OF THE SIZE OF A A NOTE ON TESTS OF HOMOCENEITY APPLIED AFTER SEQUENTIAL SAMPLING PROCEDURE FOR CHOOSING BETWEEN TWO POPULATIONS USING SEQUENTIAL SAMPLING PROCEDURE FOR CHOOSINC BETWEEN TWO POPULATIONS USING SEQUENTIAL SAMPLING AND CONSUM/THE OPERATING CHARACTERISTIC CURVE FOR SEQUENTIAL SAMPLING BY VARIABLES WHEN THE PRODUCER'S A BAYES SEQUENTIAL SAMPLING INSPECTION

THE MOST ECONOMTCAL SEQUENTIAL SAMPLING SCHEME FOR INSPECTION BY VARIABLE J AN APPLICATION OF SEQUENTIAL SAMPLING TO ANALYTICAL SURVEYS $\begin{array}{lll}R \text { LOSSES FOR BINOMIAL AND NORMAL RANDOM VARIABLES. } & \text { SEQUENTIAL SAMPLING, TWO DECISION PROBLEMS WITH LINEA } \\ \text { ATIVE NORMAL QUANTAL RESPONSE CURVE } & \text { SOME OPTIMAL SEQUENTIAL SCHEMES FOR ESTIMATING THE MEAN OF A CUMUL }\end{array}$ A SEQUENTIAL SEARCH PROCEDURE

A SEQUENTIAL SEARCH PROCEDURE FOR LOCATING A RESPONSE SEQUENTIAL SELECTION OF EXPERIMENTS

JUMP

BOUNDARIES FOR CLOSED (WEDGE) SEQUENTTAL T TEST PLANS

A NOTE ON THE SEQUENTIAL T-TEST

ON A TWO-SIDED SEQUENTIAL T-TEST

A TWO-SAMPLE SEQUENTIAL T-TEST

ON CERTAIN SUCGESTED FORMULAE APPLIED TO THE SEQUENTIAL T-TEST

CORRICENDA, 'ON A TWO-SIDED SEQUENTIAL T-TEST'

CLOSED SEQUENTIAL T-TESTS

CHARACTERISTIC AND AVERAGE SAMPLE NUMBER OF A SIMPLE SEQUENTIAL TEST /HE DETERMINATION OF THE OPERATING
JASA $64 \quad 464$

AMS 661154 JASA $65 \quad 979$ AMS $63 \quad 18$ AMS 631541 AMS $66 \quad 425$ IE AMS 61602 TECH 66700 AMS 6B 104B AMS $67 \quad B$ AMS $63 \quad 847$ AMS $65 \quad$ B59 AMS $62 \quad 43 \mathrm{~B}$ AMS $66 \quad 1173$ AMS 6B BB AMS $64 \quad 174$ JRSSB69 NO. AMS $62 \quad 1413$ AMS $66 \quad 36$ AMS $63 \quad 857$ AMS $64 \quad 755$ BIOKA57 9 BIOKA62 4 AMS 6B 1040

AMS 671376 JRSSB $66 \quad 370$ AMS 69 NO. 6 AMS $67 \quad 117$ AMS 671618 JASA $65 \quad 826$ TECH 65463 TECH $66 \quad 615$ BIOKA56 231 TECH 6961 AMS 651677 BIOCS69 517 JRSSB60 36B JRSSB57 255 JRSSB63 297 JASA $56 \quad 108$ AMS 65 13B?

JRSSB59 400 BIOKA66 85 JRSSB62 393 AMS $67 \quad 494$ TECH $62 \quad 610$ AMS 681953 BIOKA66 43I AMS 651867 BIOKA52 302 BIOKA6I 65 BIOKA64 97 BIOKA54 568 BIOKA62 359 JRSSB67 248 
POPULATIONS

N II, LARGE T

$\mathrm{N}$ IV, DISCRETE CASE

N SEQUENTIAL TESTS FOR BINOMIAL AND EXPONENTIAL CTIONAL REPLICATION OF 2-TO- JASA $68 \quad 644$ SEQUENTIALLY DETERMINED CONFIDENCE INTERVALS $\quad$ BIOKA57 279 $X$ STATIONARY TIME/ EXPECTATIONS AND COVARIANCES OF SERIAL AND CROSS-CORRELATION COEFFICIENTS IN A COMPLE BIOKA63 2I3 ON SERIAL CORRELATION AMS 69 1B8 EXACT TESTS FOR SERIAL CORRELATION

CRITERIA, BASED ON FIRST AND SECOND DIFFERENCES, FOR SERIAL CORRELATION BETWEEN SUCCESSIVE OBSERVATIONS AN ANGULAR TRANSFORMATION FOR THE SERIAL CORRELATION COEFFICIENT THE NULL DISTRIBUTION OF THE FIRST SERIAL CORRELATION COEFFICIENT MOMENTS OF A SERIAL CORRELATION COEFFICIENT

YMPTOTIC EXPANSIONS FOR THE MEAN AND VARIANCE OF THE SERIAL CORRELATION COEFFICIENT

AS BIOKAGI 85

E SEQUENCES ALTERNATIVE DEFINITIONS OF THE SERIAL CORRELATION COEFFICIENT IN SHORT AUTOREGRESSIV ON THE JOINT DISTRIBUTION OF THE CIRCULAR SERIAL CORRELATION COEFFICIENTS THE APPROXIMATE DISTRIBUTION OF SERIAL CORRELATION COEFFICIENTS

TESTING FOR SERIAL CORRELATION IN LEAST SQUARES REGRESSION TESTING FOR SERIAL CORRELATION IN LEAST SQUARES REGRESSION. II BIOKA56 161 BIOKA56 169 BIOKA57 57 BIOKA51 159 AN APPROXIMATE TEST FOR SERTAL CORRELATION IN POLYNOMIAL REGRESSION

E PERIODOGRAM OF LEAST-SQUARES RESIDUALS TESTS FOR SERIAL CORRELATION IN REGRESSION ANALYSIS BASED ON TH SERIAL CORRELATION IN REGRESSION ANALYSIS. I.

BIOKA60 111 SERIAL CORRELATION IN REGRESSION ANALYSIS. II

ION EQUATIONS Y TIME SERIES VARIATES

EXPERIMENTATION

BAYES'S THEOREM

OF ITEMS WHERE THE MEAN QUALITY HAS A NORMAL PRIO/ THE FITTING OF MARKOFF SERIAL VARIATION CURVES NOTE ON THE CHARACTERISTIC FUNCTION OF A SERIAL-CORRELATION DISTRIBUTION TESTING FOR SERIAL CORRELATION IN SYSTEMS OF SIMULTANEOUS REGRESS BIOKA57 370 A QUICK TEST FOR SERIAL CORRELATION SUITABLE FOR USE WITH NONSTATIONAR JASA $6372 B$ TESTING FOR SERIAL CORRELATION WITH EXPONENTIALLY DISTRIBUTED BIOKA67 395 ON BOUNDS OF SERIAL CORRELATIONS

SERIAL DESIGNS FOR ROUTINE QUALITY CONTROL AND SERIAL FACTORIAL DESIGN SERIAL SAMPLING ACCEPTANCE SCHEMES DERIVED FROM AMS 621457 TECH $64 \quad 77$ $\begin{array}{ll}\text { TECH } 64 & 77 \\ \text { BIOKA6B } & 67\end{array}$ TECH $60 \quad 353$ BIOKA6B 393 JRSSB58 120 BIOKA5B 559

$M$ OF REGRESSION EQUATIONS WHEN DISTURBANCES ARE BOTH SERIALLY AND CONTEMPORANEOUSLY CORRELATED
METHODS OF CONSTRUCTION AND ANALYSIS OF SERIALLY BALANCED SEQUENCES SYSTE JASA 67 500

$M$ OF REGRESSION EQUATIONS WHEN DISTURBANCES ARE BOTH SERIALLY AND CONTEMPORANEOUSLY CORRELATED
METHODS OF CONSTRUCTION AND ANALYSIS OF SERIALLY BALANCED SEQUENCES SYSTE JASA 67 500 N FIXED EFFECTS MODEL WITH OBSERVATIONS WITHIN A ROW SERIALLY CORRELATED /FOR THE TWO-WAY CLASSIFICATIO BIOKA69 NO. 3 RESERVOIRS WITH SERIALLY CORRELATED INPUTS

MOMENT GENERATING FUNCTIONS OF QUADRATIC FORMS IN SERIALLY CORRELATED NORMAL VARIABLES EXPERIMENTAL DESIGNS FOR SERIALLY CORRELATED OBSERVATIONS

TREATMENT VARIANCES FOR EXPERIMENTAL DESIGNS WITH SERIALLY CORRELATED OBSERVATIONS SIGNIFICANCE TESTS IN PARALLEL AND IN SERIES SOME COMMENTS ON SPECTRAL ANALYSIS OF TIME SERIES ON LINEAR ESTIMATION FOR REGRESSION PROBLEMS ON TIME SERIES THE DEGREE OF RANDOMNESS IN A STATIONARY TIME SERIES SOME NON-PARAMETRIC TESTS FOR M-DEPENDENT TIME SERIES ESTIMATION OF PROBABILITY DENSITY BY AN ORTHOGONAL SERIES ON FIXED PRECISION ESTIMATION IN TIME SERIES DENSITY ESTIMATION OF ORTHOGONAL SERIES NOTE ON THE VARIATE DIFFERENCES OF AUTOREGRESSIVE SERIES SOME PROPERTIES OF RUNS IN SMOOTHED RANDOM SERIES TESTS OF FIT IN TIME SERIES AN EXACT TEST FOR CORRELATION BETWEEN TIME SERIES TECH $63 \quad 85$ BIOKA58 198 BIOKA52 151 BIOKA56 208 JASA $5 B \quad 799$ TECH $61 \quad 221$ AMS 621077 AMS 631253 JASA $65 \quad 134$ AMS 671261 AMS 691021 AMS 691496 BIOKA5I 479 BIOKA52 198 BIOKA52 309 BIOKA55 316 
A CHANCE IN LEVEL OF A NON-STATIONARY TIME SERIES SPECTRAL FACTORIZATION OF MULTIPLE TIME SERIES ON THE STRUCTURE OF THE TETRACHORIC SERIES TESTINC FOR HOMOCENEITY OF A BINOMIAL SERIES QUEUES IN SERIES

STATIONARY AMPLITUDE FLUCTUATIONS IN A RANDOM SERIES

ON THE WAITINC-TIME DISTRIBUTION FOR QUEUES IN SERIES

EXPONENTIAL SMOOTHINC FOR MULTIVARIATE TIME SERIES

LEAST-SQUARES EFFICIENCY FOR VECTOR TIME SERIES

NONPARAMETRIC TESTS FOR COMOVEMENTS BETWEEN TIME SERIES SQUARES REGRESSION ANALYSIS FOR TREND-REDUCED TIME SERIES EXTRAPOLATION OF A SPECIAL CLASS OF STATIONARY TIME SERIES

OF THE INNOVATION VARIANCE OF A STATIONARY TIME SERIES

OF CORRELATION COEFFICIENTS IN ECONOMIC TIME SERIES TO DISTRIBUTION FUNCTIONS WHICH ARE HYPERCEOMETRIC SERIES POWERS OF CERTAIN TESTS OF COODNESS OF FIT FOR TIME SERIES

OF RELATIONSHIPS BETWEEN AUTOCORRELATED TIME SERIES

OF LOCAL STATISTICS IN STATIONARY STOCHASTIC SERIES CORRELATION SUITABLE FOR USE WITH NONSTATIONARY TIME SERIES THE POWERS OF THE RECORDS TESTS FOR TREND IN A TIME SERIES

OF RUNS OF SIGNS OF FIRST DIFFERENCES IN ORDERED SERIES

CONCERNING LIMIT DISTRIBUTIONS FOR VARIATIONAL SERIES

PROPERTIES OF SMOOTHLY HETEROMORPHIC STOCHASTIC SERIES THE CORRELATION BETWEEN TWO STATIONARY LINEAR MARKOV SERIES SQUARES REGRESSION INVOLVINC TREND-REDUCED MARKOFF SERIES OBSERVATIONS FROM SECTIONS OF INDEPENDENT STOCHASTIC SERIES IVITY IN THE ABBREVIATED EDGEWORTH AND GRAM-CHARLIER SERIES THE COMPATIBILITY OF CORRELATION STRUCTURES IN TIME SERIES

DENSITY FUNCTIONS FROM A CLIPPED STATIONARY TIME SERIES

USEFUL IN THE ANALYSIS OF JOINTLY STATIONARY TIME SERIES ERM PREDICTORS OR CONTROLLERS IN NON-STATIONARY TIME SERIES F THE SPECTRAL DENSITY FUNCTION OF A STATIONARY TIME SERIES ORRELATION COEFFICIENTS IN A COMPLEX STATIONARY TIME SERIES $\checkmark$ FOR THE 2-TO-THE-N AND 2-TO-THE-N TIMES 3-TO-THE-M SERIES OR TESTING TREND IN DISPERSION OF A P-DEPENDENT TIME SERIES THE SPECTRAL ANALYSIS OF TIME SERIES ( AN APPROACH TO TIME SERIES ANALYSIS

SOME CONSEQUENCES OF SUPERIMPOSED ERROR IN TIME SERIES ANALYSIS

TESTS OF SEPARATE FAMILIES OF HYPOTHESES IN TIME SERIES ANALYSIS

IN THE STUDY OF VARIANCE FLUCTUATIONS IN TIME SERIES ANALYSIS

POLYNOMIAL PROJECTINC PROPERTIES OF MULTI-T JRSSB65 144 /PTOTICALLY EFFICIENT CONSISTENT ESTIMATES O JRSSB58 303 TIONS AND COVARIANCES OF SERIAL AND CROSS-C BIOKA63 213 RESULTS ON FACTORIAL DESICNS OF RESOLUTION I TECH 69431 $\begin{array}{lllll}\text { RESULTS ON FACTORIAL DESICNS OF RESOLUTION I TECH } 69 & 431 \\ \text { ORR. } 69457 \text { ) /OF COX AND STUART'S TESTS F } & \text { BIOKA68 } & 381\end{array}$ N SOME RESULTS OF N. V. SMIRNOV AMS 69480 STATISTICAL ANALYSIS USING LOCAL BIOKA57 454 THE APPROXIMATE DISTRIBUTION OF BIOKA62 379 A NUMERICAL INVESTICATION OF LEAST JRSSB55 105 THE REGIONS OF UNIMODALITY AND POSIT JASA $57 \quad 253$ AN EXTENSION OF QUENOUILLE'S TEST FOR JRSSB6B $1 B 0$ ESTIMATTNC THE COVARIANCE AND SPECTRAL JRSSB67 180 DISTRIBUTIONS JASA $61 \quad 637$ APPROXIMATIONS BIOKA6B 243 REGRESSION ANALYSIS JRSSB56 240 SAMPLING PROPERTIES BIOKA55 160 A QUICK TEST FOR SERIAL JASA $63 \quad 728$ ANALISIS BY MODIFI $\begin{array}{lll}\text { FOURIER METHODS TECH } & 69 & 103 \\ \text { ARES TECHNIQUES JASA } 66 & 152\end{array}$

D ESTIMATORS OF RELIABILITY FUNCTIONS FOR SYSTEMS IN SERIES AND IN PARALLEL/IASED AND MAXIMUM LIKELIHOO JASA 66 IO52 SEASONAL ADJUSTMENT OF ECONOMIC TIME SERIES AND MULTIPLE REGRESSION ANALYSIS

ON ESTIMATING THE PARAMETERS OF THE LOGARITHMIC SERIES AND NECATIVE BINOMIAL DISTRIBUTIONS

JASA 63993 BIOKA69 411 TECH 65495 JASA $62 \quad 729$ FHE TNTERPOLATTON OF TTME SERIES BY RELATED SERIES

TABLES OF THE LOCARITHMIC SERIES DISTRIBUTION

ON SOME ASYMPTOTIC PROPERTIES OF THE LOGARITHMIC SERIES DISTRIBUTION AMS $64 \quad 2 B 4$ ON CERTAIN PROPERTIES OF POWER-SERIES DISTRIBUTIONS BIOKA59 486 MAXIMUM LIKELIHOOD ESTIMATION FOR CENERALIZED POWER SERIES DISTRIBUTIONS AND ITS APPLICATION TO A TRUNCAT BIOKA62 227 ON SERIES EXPANSIONS FOR THE RENEWAL MOMENTS
E ERROR AFTER A NUMBER OF TERMS OF THE DAVID-JOHNSON SERIES FOR THE EXPECTED VALUES OF NORMAL ORDER STATIS BIOKA6O LAGUERRE SERIES FORMS OF
OF PROBABILITY DENSITIES AND CUMULATIVES BY FOURIER SERIES METHODS LAGUERRE SERIES FORMS OF NON-CENTRAL CHI-SQUARE AND F BIOKA THE ESTIMATION JASA 68

A SERIES OF BALANCED INCOMPLETE BLOCK DESICNS

THE QUANTAL RESPONSE ANALYSTS OF A SERIES OF BIOLOGICAL ASSAYS ON THE SAME SUBJ CONSTRUCTION AND ANALYSIS OF SOME NEW SERIES OF CONFOUNDED ASYMMETRICAL FACTORIAL DESICNS BIOCS67 BI3 CTIONS FOR THE 2-TO-THE-N TIMES 3-TO-THE-N FACTORIAL SERIES OF DESIGNS /IMATION OF ALL TWO-FACTOR INTERA TECH 69 NO.4 HE TYPE A S/ A STUDY OF THE MATRIX OF FITTINC OF A SERIES OF DISCRETE FREQUENCY FUNCTIONS ANALOCOUS TO T SASJ 67 55 ON MEASURES OF CORRELATION IN TIME SERIES OF EVENTS

SOME STATISTICAL METHODS CONNECTED WITH SERIES OF EVENTS (WITH DISCUSSION) BIOCS69 73 JRSSB55 129

F TWO TESTS OF EQUALITY OF RATE OF OCCURRENCE IN TWO SERIES OF EVENTS OCCURRING RANDOMLY IN TIME /ENCE O BIOKA5B 267 TESTS FOR RANDOMNESS IN A SERIES OF EVENTS WHEN THE ALTERNATIVE IS A TREND JRSSB $56 \quad 234$ APHIC METHOD FOR FITTING THE BEST STRAIGHT LINE TO A SERIES OF POINTS ACCORDINC TO THE CRITERION OF LEAST JASA 57 13 THE ERGODICITY OF SERTES OF QUEUES WITH CENERAL PRIORITIES

RIBUTION OF INTERVALS BETWEEN SUCCESSIVE MAXIMA IN A SERIES OF RANDOM NUMBERS

DIFFERENCE BETWEEN CONSECUTIVE MEMBERS OF A SERIES OF RANDOM VARIABLES ARRANGED IN ORDER OF SIZE B BIOKA5' SASJ 67 BIOKA66 121 THE ORTHOGONAL POLYNOMTALS OF POWER SERIES PROBABILITY DISTRIBUTIONS AND THEIR USES ING RELATIVE EFFICIENCY OF STATISTICAL TESTS IN TIME SERIES RECRESSION ANALYSIS/VALUE METHOD FOR ADJUDC BIOKA66 IO LOWER BOUNDS FOR MINIMUM COVARIANCE MATRICES IN TIME SERIES REGRESSION PROBLEMS

FORMS IN NORMAL VARIABLES, I, CENTRAL CASE FORMS IN NORMAL VARIABLES, II, NON-CENTRAL CASE DISTRIBUTION A NOTE ON A SERIES SOLUTION OF A PROBLEM IN ESTIMATION

SERIES REPRESENTATIONS OF DISTRIBUTIONS OF QUADRATIC SERIES REPRESENTATIONS OF DISTRIBUTIONS OF QUADRATIC SERIES REPRESENTATTONS OF THE DOUBLY NONCENTRAL TAMS $64 \quad 362$ AMS $67 \quad$ B23 AMS 67 B3B JASA 681004 BIOKA5B 565 JASA $63 \quad 513$ JASA $67 \quad 1452$ AMS 691844 SOME TECHNIQUES FOR ANALYZING A SET OF TIME SERIES SUBJECT
CONFIDENCE LIMITS FOR THE RELIABILITY OF SERIES SYSTEMS NOTE ON THE THREE SERIES THEOREM

OF PROCEDURES FOR SMOOTHING PERIODOGRAMS FROM TIME SERIES WITH CONTINUOUS SPECTRA RECRESSION FOR TIME SERIES WITH ERRORS OF MEASUREMENT

CTENCY BIOKA 143 BIOKA63 293 R SPECTRAL DISTRIBUTION FUNCTIONS OF STATIONARY TIME SERIES WITH NORMAL RESIDUALS /ODNESS OF FIT TEST FO BIOKA56 257 TIME SERIES WITH PERTODIC STRUCTURE

BIOKA67 403 THE CORRELATION BETWEEN TWO STATIONARY LINEAR MARKOV SERIES. II. AT THE APPROXIMATE DISTRIBUTION OF BIOKA65 301
238)
DILUTION SERIES, A STATISTICAL TEST OF TECHNIQUE (CORR. 59 THE CORRELATION BETWEEN TWO STATIONARY LINEAR MARKOV SERIES. II. THE APPROXIMATE DISTRIBUTION OF BIOKA65 301
238)
DILUTION SERIES, A STATISTICAL TEST OF TECHNIQUE (CORR. 59 OF FRACTIONAL REPLICATES IN THE 2-TO-THE-(P-Q) SERIES, CORR, 62919 
ESTIMATION OF SEASONAL VARIATION IN ECONOMIC TIME SERIES, CORR. 631162 INEAR, UNBIASED SEASONAL ADJUSTMENT OF ECONOMIC TIME SERIES, CORR. 651250 SOME DESICNS OF USE IN SEROLOCY

ON THE GENERAL TIME DEPENDENT QUEUE WITH A SINCLE SERVER OISSON INPUT, CENERAL SERVICE TIME DISTRIBUTION, ONE SERVER OD OF SOLUTION OF THE QUEUEING PROBLEM WTTH A SINCLE SERVER AH ALS AND/ THE BUSY PERIOD IN RELATION TO THE SINGLE-SERVER QUEUEING SYSTEM WITH GENERAL INDEPENDENT ARRIV JRSSB60 89

STATIONARY WAITINC-TIME DISTRIBUTIONS FOR SINCLE-SERVER QUEUES

SERVICE TIME THE TRANSIENT BEHAVIOR OF A SINCLE SERVER QUEUINC PROCESS WITH RECURRENT INPUT AND CAMMA AMS 61 1286 STRUCTURE OF THE OUTPUT PROCESS OF SOME SINGLE SERVER SYSTEMS THE CORRELATION AMS 681007 E NUMERICAL RESULTS FOR THE QUEUEINC SYSTEM WITH ONE SERVER, WHILE THE INTERARRIVAL AND SERVINC DISTRIBUTI JRSSB63 477 CTURE OF THE DEPARTURE PROCESS OF THE QUEUE WITH ONE SERVER, WHTLE THE INTERARRIVAL AND SERV OF VISITS A SYSTEM OF TWO SERVERS WITH LIMITED WAITINC ROOMS AND CERTAIN ORDER ON THE BUSY PERIOD OF A FACILITY WHICH SERVES CUSTOMERS OF SEVERAL TYPES ON QUEUEINC PROCESSES WITH BULK SERVICE RANDOM QUEUEINC PROCESSES WITH PHASE-TYPE SERVICE A SIMPLE CONCESTION SYSTEM WITH INCOMPLETE SERVICE CONGESTION SYSTEMS WITH INCOMPLETE SERVICE (CORR, 64 365)

TRANSIENT BEHAVIOR OF A QUEUEING SYSTEM WITH BULK SERVICE AND FINITE CAPACITY QUEUES SUBJECT TO SERVICE INTERRUPTION

CORR. 57578 ESTIMATING THE SERVICE LIFE OF HOUSEHOLD GOODS BY ACTUARIAL METHODS, WAITING TIME IN BULK SERVICE QUEUES

ON LIMITING DISTRIBUTIONS ARISING IN BULK SERVICE QUEUES EFFECTS OF SLOW-DOWNS AND FAILURE ON STOCHASTIC SERVICE SYSTEMS ERVER QUEUING PROCESS WITH RECURRENT INPUT AND GAMMA SERVICE TIME A NOTE ON QUEUEING SYSTEMS WITH ERLANGIAN SERVICE TIME DISTRIBUTIONS
DISTRIBUTION OF TOTAL SERVICE TIME FOR A FIXED OBSE A NOTE ON QUEUEING SYSTEMS WITH ERLANGIAN SERVICE TIME DISTRIBUTIONS
DISTRIBUTION OF TOTAL SERVICE TIME FOR A FIXED OBSERVATION INTERVAL

BIOKA68 223 JRSSB65 361 JRSSB54 80 JRSSB56 129 JRSSB $61 \quad 215$ JRSSB62 107 AMS $62 \quad 973$ AMS $62 \quad 1314$ JASA $57 \quad 175$ JRSSB $55 \quad 256$ JRSSB5 6265 TECH 63 3B5 THE TRANSIENT BEHAVIOR OF A SINCLE S AMS 611286 THE TIME DEPENDENCE OF AMS $61 \quad 770$ AMS 651574 JASA $62 \quad 376$ AMS 621340 A SINGLE-SERVER QUEUE WITH POISSON INPUT AND CENERAL SERVICE TIMES /TION TO THE SINGLE-SERVER QUEUEING SY JRSS OF THE SINGLE CHANNEL QUEUE WITH A GENERAL CLASS OF SERVICE-TIME DISTRIBUTIONS BY THE METHOD OF GENERATIN JRSSBSB I76 A WAITING LINE WITH INTERRUPTED SERVICE, INCLUDINC PRIORITIES ON SOME MEASURES OF FOOD MARKETING SERVICES

JASA $61 \quad 65$ $\begin{aligned} \text { FORECASTING MODEL OF FEDERAL PURCHASES OF GOODS AND SERVICES } & \text { A JASA 62 633 } \\ \text { S } & \text { DEMAND FOR MANUFACTURERS' SERVICES FOR BAKERY PRODUCTS AND FRUITS AND VEGETABLE JASA 65 } 740\end{aligned}$

DXPECTED UTILITY FOR QUEUES SERVICINC MESSAGES WTTH EXPONENTTALLY DECAYTNG UTTLIT AMS 61587 QUEUEING AT A SINGLE SERVING POINT WITH GROUP ARRIVAL A BOREL SET NOT CONTAINING A GRAPH

TESTING THE HOMOCENEITY OF A SET OF CORRELATED VARIANCES ON TESTING A SET OF CORRELATION COEFFICIENTS FOR EQUALITY $\quad$ AMS 63149 ON TESTING A SET OF CORRELATION COFFFICIENTS FOR EQUALITY. SOME BIOKAGB 513 ASYMPTOTIC RESULTS OF A QUANTUM HYPOTHESIS BASED ON A SINGLE SET OF DATA EXAMINATION BIOKA56 32 GNS OF RESOLUTION CREATER THEN OR FOUAL TO 5 AND THE SET OF EVEN 512-RUN DESIGNS OF RESOLUTION GREATER THE AMS 6B 246 IMATE DISTRIBUTION FOR LARCEST AND FOR SMALLEST OF A SET OF INDEPENDENT OBSERVATIONS ION OF CYCLIC COLLINEATIONS FOR OBTAINING A BALANCED SET OF L-RESTRICTIONAL PRIME-POWERED LATTICE DESIGNS AMS 67 1293 S UP TO $\mathrm{N}=26$ COMPLETE SET OF LEADING COEFFTCIENTS FOR ORTHOGONAL POLYNOMTAL TECH 65 644 RESPECT TO A CONTROL ITERATIVE ESTIMATION OF A SET OF LINEAR REGRESSION EQUATIONS ON PARTITIONING A SET OF NORMAL POPULATIONS BY THEIR LOCATIONS WITH AMS 691300 GRAPHICAL PROCEDURE FOR FITTING THE BEST LINE TO A SET OF POINTS THE CONVEX HULL OF A RANDOM SET OF POINTS UN8IASED ESTIMATION OF A SET OF PROBABILITIES

GAMATION INTO BLOCKS, BY WEIGHTED MEANS, OF A FINITE SET OF REAL NUMBERS ON THE CONCURRENCE OF A SET OF REGRESSION LINES.

EXPERIM/ A CONFIDENCE REGION FOR THE SOLUTION OF A SET OF SIMULTANEOUS EQUATIONS WITH AN APPLICATION TO BI LINEAR TRANSFORMATION TO A SET OF STOCHASTICALLY DEPENDENT NORMAL VARIABLES SOME TECHNIQUES FOR ANALYZING A SET OF TIME SERIES SUBJECT TO A LINEAR RESTRICTION JASA 63 513 EXPERIMENTAL DESIGNS OF USE IN CHANGING FROM ONE SET OF TREATMENTS TO ANOTHER, PART 1 , OME EXPERIMENTAL DESIGNS OF USE IN CHANGING FROM ONE SET OF TREATMENTS TO ANOTHER, PART 2 , EXISTENCE OF TH JRSSB57 163 ANTE-DEPENDENCE ANALYSIS OF AN ORDERED SET OF VARIABLES AMS $62 \quad 201$ ARTLETT'S CRITERION FOR TESTING THE HOMOGENEITY OF A SET OF VARIANCES /NTS FOR HARTLEY'S CORRECTION TO B BIOKA62 4B7 CATION OF THE COMBINATION OF PROBABILITIES TEST TO A SET OF 2-BY-2 TABLES A NOTE ON THE APPLI BIOKA55 404 EQUAL TO 5 AND THE SET OF EVE/ CONSTRUCTION OF THE SET OF 256-RUN DESIGNS OF RESOLUTION GREATER THEN OR AMS 6B 246 A RANDOM SET PROCESS IN THE PLANE WITH A MARKOVIAN PROPERTY AMS 651859 ESTIMATING MACHINING ERRORS IN SET-UPS WITH AUTOMATIC RESETTING

REDUCING A RANDOM SAMPLE TO A SMALLER SET, WITH APPLICATIONS

ON A THEOREM OF RENYI CONCERNING MIXING SEQUENCES OF SETS

ENUMERATION OF LINEAR GRAPHS FOR MAPPINCS OF FINITE SETS

MINIMAX THEOREMS ON CONDITIONALLY COMPACT SETS CONSISTENT ESTIMATES AND ZERO-ONE SETS RECURRENT SETS

NOTE ON SHIFT-INVARIANT SETS

MEASURES

WEAK QUALITATIVE PROBABILITY ON FINITE SETS

LIMITING SETS AND CONVEX HULLS OF SAMPLES FROM PRODUCT CONFIDENCE SETS FOR MULTIVARIATE MEDIANS

CONFIDENCE SETS FOR THE MEAN OF A MULTIVARIATE NORMAL DISTRIBUTI JH

ON (WITH DISCUSSION)

INADMISSIBILITY OF THE USUAL CONFIDENCE SETS FOR THE MEAN OF A MULTIVARIATE NORMAL POPULATION

POPULATION ADMISSIBILITY OF THE USUAL CONFIDENCE SETS FOR THE MEAN OF A UNIVARIATE OR BIVARIATE NORMAL

SIZE THREE INVARIANT SETS FOR TRANSLATION-PARAMETER FAMILIES OF MEASURES BALANCED SETS OF BALANCED INCOMPLETE BLOCK DESIGNS OF BLOCK

IVE DIRECTIONAL SELECTION ON NORMAL VARIABLES WITHIN SETS OF FINITE SUBPOPULATIONS/FFERENTIAL FOR POSIT BALANCED INCOMPLETE BLOCK DESIGNS WITH SETS OF IDENTICAL BLOCKS

TWO PROBLEMS IN SETS OF MEASUREMENTS

COMPUTER

COMPUTER, II
CORRELATIONS BETWEEN SIMILAR SETS OF MEASUREMENTS

ON METHODS OF CONSTRUCTING SETS OF MUTUALLY ORTHOGONAL LATIN SQUARES USINC A

ON METHODS OF CONSTRUCTING SETS OF MUTUALLY ORTHOGONAL LATIN SQUARES USING A
TECH $64 \quad 423$

JASA $67 \quad 510$

AMS $61 \quad 257$

AMS $62 \quad 178$

AMS $63 \quad 1536$

AMS $64 \quad 157$

AMS $65 \quad 535$

AMS 69694

AMS 69 N0.6

AMS 691824

AMS $61 \quad 477$

JRSSB 62265 AMS $67 \quad 1 \mathrm{~B} 68$ AMS 691042 AMS $69 \quad 162$ TECH 65561 BIOCS67 842 TECH 69613 BIOKA54 560 8I0CS66 7BI TECH $60 \quad 507$ TECH 61 111 
STRATEGIES AND MARTINGALES IN A FINITELY ADDITIVE SETTING WILLIAM D. SUDDERTH
DISTRIBUTION OF A PRODUCT AND THE STRUCTURAL SETUP OF DENSITIES

ON THE DISTRIBUTION OF THE LARGEST OF SEVEN ROOTS OF A MATRIX IN MULTIVARIATE ANALYSIS

EQUILIBRIUM UNDER SELECTION AT A MULTI-ALLELIC SEX-LINKED LOCUS (ACKNOWLEDGEMENT 6B 1025)

STOCHASTIC MODELS FOR THE POPULATION CROWTH OF THE SEXES

THE DETECTION OF A CORRELATION BETWEEN THE SEXES OF ADJACENT SIBS IN HUMAN FAMILIES

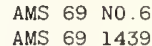

BIOKA64 270

$810 C 568 \quad 187$

BIOKA 6 B 469

JASA $65 \quad 1035$

N ESTIMATION OF THE SHAPE AND SCALE PARAMETERS OF THE WEIBULL DISTRIBUTIO TECH 63175 E SCALE PARAMETER OF A WEIBULL POPULATION WITH KNOWN SHAPE PARAMETER /ASED ON M ORDER STATISTICS, FOR TH TECH 65 405 NDEPENDENT GENERALIZED CAMMA VARIABLES WITH THE SAME SHAPE PARAMETER /T DISTRIBUTION OF THE PRODUCT OF I AMS 6B I75I AL OF THE GAMMA DISTRIBUTION FOR SMALL VALUES OF THE SHAPE PARAMETER /XIMATION TO THE PROBABILITY INTECR BIOKA62 276 PER LOT ESTIMATION OF WEIBULL DISTRIBUTION SHAPE PARAMETER WHEN NO MORE THAN TWO FAILURES OCCUR TECH 64 415

SEPARATE MAXIMUM-LIKELIHOOD ESTIMATION OF SCALE OR SHAPE PARAMETERS OF THE GAMMA DISTRIBUTION USING ORDE BIOKA63 217 ASYMPTOTIC SHAPES FOR SEQUENTIAL TESTTNG OF TRUNCATTON ASYMPTOTIC SHAPES OF BAYES SEQUENTIAL TESTINC RECIONS $\begin{array}{rrr}\text { AMS } & 68 & 2038 \\ \text { AMS } & 62 & 224\end{array}$ AND TAX ELASTICITIES OF OUTPUT AND DISTRIBUTIVE SHARES SOME SHARP MULTIVARIATE TCHEBYCHEFF INEQUALITIES ON SHARPENING SCHEFFE BOUNDS

NOTE ON THE USE OF SHERMAN'S STATISTIC AS A TEST OF RANDOMNESS ACE, PRICE, JASA $62 \quad 607$ AMS $67 \quad 393$ JRSSB67 110 BIOKA54 556 ROBUSTNESS OF THE HODGES-LEHMANN ESTIMATES FOR SHIFT FOR THE ONE SAMPLE WILCOXON TEST FOR NON-NORMAL SHIFT ALTERNATIVES

A DENSITY WHICH IS MEASURABLE WITH RESPECT TO A SICMA-LATTICE CONDITIONAL EXPECTATION GIVEN A SICMA-LATTICE AND APPLICATIONS

A REPRESENTATION FOR CONDITIONAL EXPECTATIONS CIVEN SICMA-LATTICES

AMS $66 \quad 1279$ MPLETE BLOCK DESIC/ ON USING AN INCORRECT VALUE OF SICMA-SQUARE-SUB-B-OVER-SICMA-SQUARE IN BALANCED INCO BIOKA6B 254 THE EQUIVALENCE OF POLYKAYS OF THE SECOND DEGREE AND SICMA'S, CORR. 651069

GENERALIZATION AND REPARAMETERIZATION OF SOME SICMOID OR OTHER NONLINEAR FUNCTIONS SICN AND WILCOXON TESTS FOR LINEARITY

$$
\text { A NEW BIVARIATE SICN TEST }
$$

EFFECT OF NON-NORMALITY ON THE POWER FUNCTION OF THE SIGN TEST

ON A CHI-SQUARE APPROXIMATION FOR THE MULTIVARIATE SICN TEST ON THE ASYMPTOTIC EFFICIENCY OF BENNETT'S BIVARIATE SICN TEST FOR A TREATMENTS VERSUS CONTROL MULTIPLE COMPARISONS SIGN TEST AND BAHADUR EFFICIENCY OF THE HODGES BIVARIATE SIGN TEST NULL DISTRIBUTION AMS 62 B03 ECTIONS TO 'A RELATIONSHIP BETWEEN HODGES' BIVARIATE SICN TEST AND A NON-PARAMETRIC TEST OF DANIELS' 60 II AMS 61 619 DISTRIBUTION $\quad$ ON HODCES'S BIVARIATE SICN TEST AND A TEST FOR UNIFORMITY OF A CIRCULAR BIOKA69 446 OF THE MEDIAN FOR SAMPLE SIZES/ TABLE FOR BOTH THE SIGN TEST AND DISTRIBUTION-FREE CONFIDENCE INTERVALS JASA 64 935 A BIVARIATE SIGN TEST FOR LOCATION 
CORRELATION MATRICES

OF FINNEY'S TABLE
A NOTE ON TESTS OF SIGNIFICANCE FOR LINEAR FUNCTIONAL RELATIONSHIP TESTS DF SIGNIFICANCE FOR THE LATENT ROOTS OF COVARIANCE AND TESTS OF SIGNIFICANCE IN A 2-BY-2 CONTINGENCY TABLE, EXTENSION

TABLES FOR TESTING SIGNIFICANCE IN A 2-BY-3 CONTINGENCY TABLE

TESTS OF SIGNIFICANCE IN CANONICAL ANALYSIS

TESTS DF SIGNIFICANCE IN CANONICAL ANALYSIS

EXACT TESTS OF SIGNIFICANCE IN CONTINGENCY TABLES

CDNSTRUCTION DF A MATRIX USED IN DERIVING TESTS OF SIGNIFICANCE IN MULTIVARIATE ANALYSIS

PENDENT VARIABLES ARE DR/ EX POST DETERMINATION OF SIGNIFICANCE IN MULTIVARIATE REGRESSION WHEN THE INDE JRSSB67 154 ON A TEST OF SIGNIFICANCE IN PEARSON'S BIOMETRIKA TABLES (NO. 11) JRSSB56 56 COMMENT DN SIR RONALD FISHER'S PAPER, 'DN A TEST DF SIGNIFICANCE IN PEARSON'S BIOMETRIKA TABLES (NO. 11 )' JRSSB56 295 TEST EFFICIENCY

STATISTICS

THE MEDIAN SIGNIFICANCE LEVEL AND OTHER SMALL SAMPLE MEASURES OF JASA 69 EXPECTED SIGNIFICANCE LEVEL AS A SENSITIVITY INDEX FOR TEST JASA 65 CED NESTED ANALYSIS OF VARIANCE/ NOTES. ON TESTING SIGNIFICANCE DF COMPONENTS OF VARIANCE IN THE UNBALAN

THE STATISTICAL SIGNIFICANCE OF ODD BITS OF INFORMATION JASA $65 \quad 420$

A PROBLEM IN THE SIGNIFICANCE OF SMALL NUMBERS

ORMAL POPULATIONS HAVING UNEQUAL VAR/ TEST FOR THE SIGNIFICANCE OF THE DIFFERENCE BETWEEN MEANS IN TWO N BIOKA5I 252 GEBRAIC THEORY OF THE COMPUTING RDUTINE FOR TESTS OF SIGNIFICANCE ON THE DIMENSIONALITY OF NORMAL MULTIVAR JRSSB56 70 GOODNESS OF FIT STATISTIC V-SUB-N, DISTRIBUTION AND SIGNIFICANCE POINTS THE BIDKA65 3D9 MOGOROV-SMIRNOV TYPE STATISTICS INCLUDING A TABLE OF SIGNIFICANCE PDINTS FOR A PARTICULAR CASE /S OF KOL AMS 68 233 SQUARE-SUB-M, N SIGNIFICANCE POINTS FOR THE TWO-SAMPLE STATISTIC U- BIOKA65 661 SIGNIFICANCE PROBABILITY BOUNDS FOR RANK ORDERINGS AMS 64891 A TWO-BY-TWO CONTINGENCY TABLE, AND FISHER'S 'EXACT' SIGNIFICANCE TEST J J EXACT BAYESIAN ANALYSIS DF JRSB 9 NO. ORDERED HYPOTHESES FOR MULTTPLE TREATMENTS A SIGNIFICANCE TEST FOR LINEAR RANKS DISCUSSION)

QUANTITATIVE RESPONSES

BETWEEN TWO PREDICTORS

\section{A BAYESIAN SIGNIFICANCE TEST FOR MULTINOMIAL DISTRIBUTIONS (WITH}

A SIGNIFICANCE TEST FOR SIMULTANEOUS QUANTAL AND

A SIGNIFICANCE TEST FOR THE DIFFERENCE IN EFFICIENCY

A SIMPLIFIED MONTE CARLO SIGNIFICANCE TEST PROCEDURE

THE ROLE OF SIGNIFICANCE TESTING, SOME DATA WITH A MESSAGE
ON THE WEIGHTED COMBINATION OF SIGNIFICANCE TESTS

OF PATNAIK TYPE CHI APPROXIMATIONS TO THE RANCE IN SIGNIFICANCE TESTS

IN CHAIN-BINOMIAL THEORY

LINEAR FUNCTIONAL RELATIONSHIPS

62919
SIGNIFICANCE TESTS FOR A VARIABLE CHANCE ON THE USE BIOKA66 248

SIGNIFICANCE TESTS FOR DISCRIMINANT FUNGTIONS AND BIOKA55 360

SIGNIFICANCE TESTS FOR PAIRED-GOMPARISON EXPERIMENTS BIOKA61 95

SIGNIFICANCE TESTS IN DISCRETE DISTRIBUTIDNS, CORR. JASA $61 \quad 223$

JASA $58 \quad 799$

BIOKA55 494

BIOKA56 344

BIOKA60 87

BIOKA69 231

JRSSB56 I

JASA 59593

JASA 5930 AMS $61 \quad 1223$ BIOKA61 475 JASA 61 JASA $61 \quad 156$ BIOKA56 480 BIOKA58 74 JASA $67 \quad 241$ BIOKA69 17 JRSSB57 262 $\begin{array}{cr}\text { CORRELATIONS BETWEEN SIMILAR SETS OF MEASUREMENTS } & \text { BIOCS66 } \\ \text { ON SLIPPAGE TEST (II) SIMILAR SLIPPAGE TESTS } & \text { AMS } 68 \text { 2029 }\end{array}$

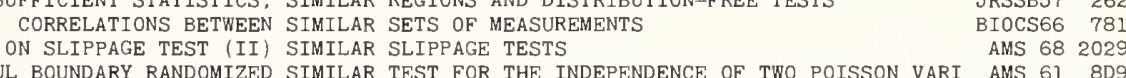
AB/ ON A LOCALLY MOST POWERFUL BOUNDARY RANDOMIZED SIMILAR TEST FOR THE INDEPENDENCE OF TWO POISSON VARI AMS 6I 8D9
A SIMPLE METHDD OF DERIVING BEST CRITICAL REGIDNS SIMILAR TO THE SAMPLE SPACE IN TESTS OF AN IMPORTANT BIOKA53 231 A SIMPLE METHDD OF DERIVING BEST CRITICAL REGIDNS SIMILAR TO THE SAMPLE SPACE IN TESTS OF AN IMPORTANT BIOKA53 231
SSTRIBUTIONS A POSTERIORI ALL'S TAU, WITH A PARTIAL INTERPRETATION OF THE/ A SIMILARITY BETWEEN GOODMAN AND KRUSKAL'S TAU AND KEND JASA 62 8D4 A NEW SIMILARITY INDEX BASED ON PROBABILITY BIOCS66 882 REPRESENTATION OF SIMILARITY MATRICES BY TREES A SIMPLE APPRDACH TD THE BAYES CHOICE CRITERION, THE JASA 641227 METHOD OF EXTREME PROBABILITIES SOME SIMPLE APPRDXIMATE TESTS FOR POISSON VARIATES 
RATINC FUNCTIONAL FOR THE CUMULATUE POPULATION IN A SIMPLE BIRTH-AND-DEATH PROCESS OF THE STATIONARY MEASURE OF THE CRITICAL CASE SIMPLE BRANCHING PROCESS

IN A CHAIN OF MULTTPLE EVENTS WHEN THERE IS STMPLE DEPENDENCE

SPEARMAN ESTIMATION FOR A SIMPLE EXPONENTIAL MODEL

BIOCS65 858 ESTIMATION FOR A SIMPLE EXPONENTIAL MODEL

THE HALF-TABLE RATIO ESTIMATOR FOR A SIMPLE EXPONENTIAL MODEL

LATION COEFFICIE

A RELATIVELY SIMPLE FORM OF THE DISTRIBUTION OF THE MULTIPLE CORRE JRSSB68 276 BIOCS69 420 ON OF SAMPLE SIZE FOR SEQUENTIAL TESTS. I. TESTS FOR SIMPLE HYPOTHESES APPROXIMATION TO THE DISTRIBUTI BIOKA59 I3O GMENTATIONS AND ERROR STRUCTURES UNDER WHICH CERTAIN SIMPLE LEAST SQUARES AND ANALYSIS OF VARIANCE PROGEDU JASA 69 NO. 4 CONDITIONS FOR OPTIMALITY AND VALIDITY AND SIMPLE LEAST SQUARES THEORY

LINEAR SEGMENT CONFIDENCE BANDS FOR SIMPLE LINEAR MODELS

AMS $6916 \mathrm{IT}$

JASA $67 \quad 403$

ASYMPTOTIC NORMALITY OF SIMPLE LINEAR RANK STATISTICS UNDER ALTERNATIVES $\quad$ AMS 68325

ASYMPTOTIC NORMALITY OF SIMPLE LINEAR RANK STATISTICS UNDER ALTERNATIVES, II AMS 69 NO.6

DESIGN FOR OPTIMAL PREDICTION TN SIMPLE IINEAR RECRESSION

IN MULTIVARIATE STATISTICS II. POINT ESTIMATION IN SIMPLE LINEAR REGRESSION

ON COMPARING TWO SIMPLE LINEAR REGRESSION LINES

JASA $65 \quad 205$

UM-LTKELTHOOD ESTTMATOR OF AN UNKNOWN PARAMETER IN A STMPLE MARKOV CHATN /TENCY CONDITIONS FOR THE MAXTM BIOKA55 3 UM-LIKELIHOOD ESTIMATOR OF AN UNKNOWN PARAMETER IN A SIMPLE MARKOV CHAIN' /ENCY CONDITIONS FOR THE MAXIM BIOKA56 497 A FURTHER NOTE ON A SIMPLE METHOD FOR FITTING AN EXPONENTIAL CURVE BIOKA60 I77 2-BY-2 CONTINGENCY TABLES WITH SMALL MARGINAL/ A SIMPLE METHOD OF CALCULATING THE EXACT PROBABILITY IN BIOKA55 522 AR TO THE SAMPIE SPACE TN TESTS OF AN TMPORTANT/ A SIMPLE METHOD OF DERIVING BEST CRTTTCAL REGIONS SIMIL BIOKA53 A SIMPLE METHOD OF ESTIMATING RELATIVE POTENCY FROM TWO BIOCS65 140 A SIMPLE METHOD OF RESOLUTION OF A DISTRIBUTION INTO BIOCS67 II5 A SIMPLE METHOD OF TREND CONSTRUCTION JRSSB6I

GAUSSIAN COMPONENTS

SIMPLE METHODS FOR ANALYZING THREE-FACTOR INTERACTION JASA 64319

IN CONTINGENCY TABLES

UANTITATIVE ANALYSIS. GENERAL THEORY AND THE CASE OF SIMPLE ORDER/ION OF NON-NUMERICAL INFORMATION IN Q AMS 63 I347 CENERALIZED POLYKAYS, AN EXTENTION OF SIMPLE POLYKAYS AND BIPOLYKAYS, CORR. $66746 \quad 226$

A SIMPLE PRESENTATION OF OPTIMUM SAMPLING RESULTS JRSSB54 239

TS FOR TUE AVERAGE SAMPLE RUN LENGTH OF A CUMUL/

SOME REMARKS ON A SIMPLE PROCEDURE OF SAMPLING WITHOUT REPLACEMENT ON A SIMPLE PROCEDURE OF UNEQUAL PROBABILITY SAMPLINC

WITHOUT REPLACEMENT THE SIMPIE QUEUE

A DIFFERENCE EQUATION TECHNIQUE APPLIED TO THE SIMPLE QUEUE

THE EFFECT OF THE SIZE OF THE WAITING ROOM ON A SIMPLE QUEUE
ON THE TRANSIENT BEHAVIOUR OF A SIMPLE QUEUE

FURTHER RESULTS IN THE NON-EQUILIBRIUM THEORY OF A SIMPLE QUEUE

A CONTINUOUS TIME TREATMENT OF A SIMPLE QUEUE USING GENERATING FUNCTIONS

JASA $66 \quad 391$ JKSSB62 4B2

JRSSB5B I65

JRSSB58 I82

JRSS860 277

SOME JRSSB57 326

JRSSB54 2B8

TI/ A DIFFERENCE EQUATION TECHNIQUE APPLIED TO THE SIMPLE QUEUE WITH ARBITRARY ARRIVAL INTERVAL DISTRIBU JRSSB5B 16B ON A PROPERTY OF THE RANDOM WALKS DESCRIBING SIMPLE QUEUES AND DAMS

TREATMENT OF THE NON-EQUILIBRIUM THEORY OF SIMPLE QUEUES BY MEANS OF CUMULATIVE PROBABILITIES DOMAINS OF OPTIMALITY OF TESTS IN SIMPLE RANDOM SAMPLING

\section{ON A CLASS OF SIMPLE RANDOM WALKS}

A SIMPLE RANDOMIZATION PROGEDURE

ON STMPLE RULES FOR THE COMPOUND DECISION PROBLEM JRSSB65 I25 JRSSB63 457

AMS $69 \quad 308$ AMS $63 \quad 4 I 3$ JRSSB62 472 JRSSB 65238

RATING CHARACTERISTIC AND AVERAGE SAMPLE NUMBER OF A SIMPLE SEQUENTIAL TEST /HE DETERMINATION OF THE OPE JRSSB67 24 ON A CLASS OF SIMPLE SEQUENTIAL TESTS ON MEANS TECH $62 \quad 345$ RESPONSES TO MIXTURES OF POISONS UNDER CONDITIONS OF SIMPLE SIMILAR ACTION, THE ANALYSIS OF UNCONTROLLED D BIOKA5B 74

A SIMPLE SOLUTION FOR OPTIMAL CHEBYSHEV REGRESSION AMS $66 \quad 720$ S OF SUSCEPTIBLES A GENERAL EXPRESSION FOR THE MEAN IN A SIMPLE STOCHASTIC EPIDEMIC BIOKA54 272 THE SIMPLE STOCHASTIC EPIDEMIC CURVE FOR LARGE POPULATION BIOKA65 57 ONE OR MORE INITIAL INFECTIVES THE SIMPLE STOCHASTIC EPIDEMIC FOR SMALL POPULATIONS WITH BIOKA69 I83 A PERTURBATION APPROXIMATION OF THE SIMPLE STOCHASTIC EPIDEMIC IN A LARGE POPULATION BIOKAG8 THE SIMPLE STOCHASTIC EPIDEMIC, A COMPLETE SOLUTION IN BIOKA63 235 TERMS OF KNOWM FUNCTIONS

AS A TECHNIQUE FOR ESTIMATING THE RELIABILITY OF A SIMPLE SYSTEM PROBIT ANALYSIS TECH 67 I97 EMPIRICAL FEEDBACK

A SIMPLE SYSTEM OF EVOLUTIONARY OPERATION SUBJECT TO TECH 66

A SIMPLE TEST FOR UNIFORMITY OF A CIRCULAR DISTRIBUTION BIOKA6B

A SIMPLE THEORETICAL APPROACH TO CUMULATIVE SUM CONTROL JASA $6 I$

CHARTS 'PROPERTIES OF DISTRIBUTIONS RESULTING FROM CERTAIN SIMPLE TRANSFORMATIONS OF THE NORMAL DISTRIBUTION' BI0KA53 236 SOME SIMPLE WEAR-DEPENDENT RENEWAL PROCESSES A SIMPLER PROOF OF SMITH'S ROULETTE THEOREM BIOKA5I 90 JRSSB61 368 AMS $68 \quad 390$

CHARAGTER OF HOTELLING'S T-SQUARED TEST IN THE SIMPLEST CASE GOMMENTS ON 'THE SIMPLEST SIGNED-RANK TESTS'

OPERATION SIMPLEX DESIGNS IN OPTIMISATION AND EVOLUTIONARY SIMPLEX LATTICE DESICNS FOR MUTICOMPONENT SYSTEMS AMS 63 I524 JASA 59213 TECH 62441 TECH $62 \quad 463$ AMS $68 \quad 1473$ DISTRIBUTIONS DETERMINED BY CUTTING SIMPIEX WITH HYPERPLANES THE SIMPLEX-CENTROID DESIGN FOR EXPERTMENTS WTTH MIXTURES JRSSB63 235 (WITH DISCUSSION THE SIMPLEX-CENTROID DESIGN
THE SIMPLEX-LATTICE DESIGN EXPERIMENTS WITH MIXTURES

\section{A GENERALIZATION OF THE SIMPLEX-LATTICE DESIGN} AN ALTERNATIVE TO THE SIMPLEX-LATTICE DESIGN FOR EXPERIMENTS WITH MIXTURES

RATIO TESTS

REGRESSION DISTURBANCES

$\mathrm{N}$ WITH EQUAL PROBABILITIES AND WITHOUT STAGES H TEST

N SAMPLES ARE SINGLY CENSORED OR TRUNCATED SQUARE FUNCTION ON A CONTINGENCY TABLE BINOMIAL DISTRIBUTION LANE ROAD

MARKOFF CHAINS
A SIMPLIFICATION OF THE BLUS PROCEDURE FOR ANALYZING

ON SIMPLIFICATIONS OF SAMPLING DESIGN THROUGH REPLICATIO SIMPLIFIED BETA-APPROXIMATIONS TO THE KRUSKAL-WALLIS SIMPLIFIED DECISION FUNCTIONS SIMPLIFIED ESTIMATES FOR THE EXPONENTIAL DISTRIBUTION SIMPLIFIED ESTIMATORS FOR THE NORMAL DISTRIBUTION WHE

A SIMPLIFIED EXPRESSION FOR THE VARIANCE OF THE CHISIMPLIFIED METHODS OF FITTING THE TRUNCATED NEGATIVE A SIMPLIFIED MODEL FOR DELAYS IN OVERTAKING ON A TWOA SIMPLIFIED MONTE CARLO SIGNIFICANCE TEST PROCEDURE SIMPLIFIED RUNS TESTS AND LIKELIHOOD RATIO TESTS FOR
JRSSB68 I23 JRSSB69 NO.2 AMS $66 \quad 425$ JASA $68 \quad 242$ JASA $56 \quad 24$ JASA 59225 BIOKA54 241 AMS 63 IO2 BIOKA54 280 BIOKA58 59 JRSSB58 408 JRSSB6B 582 BI0KA58 I8I 
SOME GENERALIZED POISSON DISTRIBUTIONS PARTIAL RANK CORRELATION COEFFICIENT DITIONAL DISTRIBUTION OF SETS OF TESTS ON A SYSTEM

SIMPLIFIED TECHNIQUES FOR ESTIMATING PARAMETERS OF SIMULATED DISTRIBUTIONS FOR SMALL N OF KENDALL'S

BIOKA67 555 $\checkmark$ GAUSSIAN ORNSTEIN-UHLENBECK PROCESS BY MONTE CARLO SIMULATION PROBLEM OF EXPERIMENTAL DESIGN

\section{COMPUTER SIMULATION EX}

ITS COMP A USEFUL APPROXIMATION TO THE TECH $67 \quad 647$ /E-TIME MAXIMA AND MINIMA OF A STATIONAR JASA $68 \quad 1517$

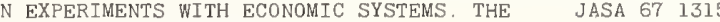
SIMULATION MODEL OF THE TEXTILE INDUSTRY SIMULATION OF AN AQUATIC ECOSYSTEM

THE EFFICIENCY OF STATISTICAL SIMULATION PROCEDURES

CHEMICAL PLANTS

A GENERAL SIMULATION PROGRAMME FOR MATERIAL FLOW IN BATCH

TWO-SAMPLE TESTS WHEN THE VARIANCES ARE UNEQUAL. A SIMULATION STUDY SAMPLING METHOD SOME BTOKA67 679 RIOR TO THE ERA OF THE COMPUTER AND ITS RELEVANCE TO STMULATION, CORR. 65 1251/25ISTRIBUTION SAMPLING P JASA 65 27 ALLIED TOPICS BIBLIOGRAPHY ON SIMULATION, GAMING, ARTIFICIAL INTELLIGENCE AND S FOR NORMAL DISTRIBUTIONS AND THEIR APPLICATIONS TO SIMULTANEOUS CONFIDENCE BOUNDS /CERTAIN INEQUALITIE AMS 67 IB53 DESIGN WITH NORMAL CORRELATION NOTES. SIMULTANEOUS CONFIDENCE INTERVALS AND EXPERIMENTAL BIOCS68 434. MULTINOMIAL POPULATIONS PROPORTIONS PROPORTIONS SIMULTANEOUS CONFIDENCE INTERVALS FOR CONTRASTS AMONG AMS $64 \quad 716$ LARGE SAMPLE SIMULTANEOUS CONFIDENCE INTERVALS FOR MULTINOMIAL TECH $64 \quad 191$ ON SIMULTANEOUS CONFIDENCE INTERVALS FOR MULTINOMIAL $\quad$ TECH $65 \quad 247$ SIMULTANEOUS CONFIDENCE INTERVALS FOR VARIANCES JASA $69 \quad 324$ SIMULTANEOUS CONFIDENCE LIMITS FOR CROSS-PRODUCT $\quad$ JRSSB64 86

RATIOS IN CONTINGENCY TABLES AND POISSON DISTRIBUTIONS

TABLES OF SIMULTANEOUS CONFIDENCE LIMITS FOR THE BINOMIAL AND BIOKA69 452 A CONFIDENCE REGION FOR THE SOLUTION OF A SET OF SIMULTANEOUS EQUATIONS WITH AN APPLICATION TO EXPERIM BIOKA54 ISO COMPARTMENTAL MODELS SIMULTANEOUS ESTIMATION BY PARTIAL TOTALS FOR SPEARMAN SIMULTANEOUS ESTIMATION FOR A COMPARTMENTAL MODEL EQUAL PROBABILITY TEST AND ITS APPLICATIONS TO SOME SIMULTANEOUS INFERENCE PROBLEMS THE WISHART DISTRIBUTION DERIVED BY SOLVING SIMULTANEOUS LINEAR DIFFERENTIAL EQUATIONS

PRECISION OF SIMULTANEOUS MEASUREMENT PROCEDURES SIMULTANEOUS NONLINEAR ESTIMATION

ERRATA 'SIMULTANEOUS NONLINEAR ESTIMATION'

SIMULTANEOUS PAIRWISE LINEAR STRUCTURAL RELATIONSHTPS SIMULTANEOUS PREDICTION INTERVALS

A SIGNIFICANCE TEST FOR SIMULTANEOUS QUANTAL AND QUANTITATIVE RESPONSES JASA $68 \quad 573$ TECH 69551 HE JASA 69986 BIOKA5I 470 JASA $63 \quad 474$ TECH $66 \quad 319$ TECH $67 \quad 353$ BIOCS69 129 TECH $68 \quad 323$ TECH 64273 BIOKA57 370 TESTING FOR SERIAL CORRELATION IN SYSTEMS OF SIMULTANEOUS REGRESSION EQUATIONS SIMULTANEOUS REGRESSION EQUATIONS IN EXPERIMENTATION BIOKA5B 96 SIMULTANEOUS SELFING AND PARTIAL DIALLEL TEST CROSSIN BIOCS67 325 SIMULTANEOUS TEST PROCEDURES FOR MULTIPLE COMPARISONS JASA 66 IOBI SIMULTANEOUS TEST PROCEDURES, SOME THEORY OF MULTIPLE AMS 69224 SIMULTANEOUS TESTS BY SEQUENTIAL METHODS IN HIERARCHI BIOKA64 439 SIMULTANEOUS TESTS FOR THE EQUALITY OF COVARIANCE AMS 681303 SIMULTANEOUS TESTS OF LINEAR HYPOTHESES

AN APPROACH TO SIMULTANEOUS TOLERANCE INTERVALS IN REGRESSION SIMULTANEOUS TOLERANCE INTERVALS IN REGRESSION

ASSUMPTIONS OF THE MODELS OF VARIANCE
ON THE SENSITIVITY OF BIOKA55 441 AMS 671536 BIOKA63 155 JASA $66 \quad 136$ SIMULTANEOUS TEST PROCEDURES IN MULTIVARIATE ANALYSIS BIOKA68 4B9 UNLIMITED SIMULTANEOUS DISCRIMINATION INTERVALS IN REGRESSION BIOKA67 133 NENTS FROM TWO-WAY CROSSED CLASSI/ DESIGNS FOR THE SIMULTANEOUS ESTIMATION OF FUNCTIONS OF VARIANCE COMPO BIOKA67 I27 AN EXTENSION OF THE ARC SINE LAW

NT SOME INVARIANT LAWS RELATED TO THE ARC SINE LAW THE GOODNESS-OF-FIT OF A SINGLE (NON-ISOTROPIC) HYPOTHETICAL PRINCIPAL COMPONE BIOKA6I 397 THE AVERAGE SAMPLE NUMBER FOR TRUNCATED SINGLE AND DOUBLE ATTRIBUTES ACCEPTANCE SAMPLING PLAN TECH 6B GB5 SHORT-CUT MULTIPLE COMPARISONS FOR BALANCED SINGLE AND DOUBLE CLASSIFICATIONS. PART 1 , RESULTS TECH 65 95 SHORT-CUT MULTIPLE COMPARISONS FOR BALANCED SINGLE AND DOUBLE CLASSIFICATIONS. PART 2. DERIVATION BI SINGLE AND MULTIPLE DISCRIMINATION REGIONS IN

THE CONTINUOUS TIME SOLUTION OF THE EQUATIONS OF THE SINGLE CHANNEL QUEUE WITH A GENERAL CLASS OF SERVICE- JRSSB58 $R$ ESTIMATES BY ORDER STATISTICS OF THE PARAMETERS OF SINGLE EXPONENTIAL DISTRIBUTIONS FROM SINGLY AND DOUB JASA 57 IMIZATION IN THE PRESENCE OF RANDOM VARIABILITY. THE SINGLE FACTOR CASE

ADMISSIBILITY OF QUANTILE ESTIMATES OF A SINGLE LOCATION PARAMETER

A METHOD OF FITTING A NON-LINEAR CURVE CONTAINING A SINGLE NON-LINEARITY AMS 641019 THE DISTRIBUTION OF THE RATIO, IN A SINGLE NORMAL SAMPLE, OF RANGE TO STANDARD DEVIATION BIOKA54 482
CONFIDENCE INTERVAL FOR STANDARD DEVIATION FROM A SINGLE OBSERVATION ON THE DISTRIBUTION AND POWER OF A TEST FOR A SINGLE OUTLIER

BETWEEN CONFIDENCE POINT PROCEDURES IN THE CASE OF A SINGLE PARAMETER

ON COMPARISONS JRSSB 65 HOD OF CONSTRUCTION OF ATTRITION LIFE TABLES FOR THE SINGLE POPULATION BASED ON TWO SUCCESSIVE CENSUSES (C JASA 67 I433 THE MULTI-SAMPLE SINGLE RECAPTURE CENSUS

PREDICTION REGIONS FOR SEVERAL PREDICTIONS FROM A SINGLE REGRESSION LINE INDEX SELECTION AND ESTIMATION FROM A SINGLE SAMPLE DISTRIBUTIONS BAYESIAN SINGLE SAMPLING ATTRIBUTE PLANS FOR CONTINUOUS PRIOR TECH 6$]$ BIOKA63 195 AND CONSUMER'S RISK THE DETERMINATION OF SINGLE SAMPLING ATTRIBUTE PLANS WITH GIVEN PRODUCER'S SOME LTMTT THEOREMS FOR THE DODGE-ROMIG LTPD SINGLE SAMPLING INSPECTION PLANS

COMPOUND HYPERGEOMETRIC DISTRIBUTION AND A SYSTEM OF SINGLE SAMPLING INSPECTION PLANS BASED ON PRIOR DISTR TE SOME REMARKS ON THE BAYESIAN SOLUTION OF THE SINGLE SAMPLING INSPECTION SCHEME SINGLE-SIDED SPECIFICATION LIMIT

ASYMPTOTIC PROPERTIES OF BAYESIAN SINGLE SAMPLING PLANS (CORR, 67586 ) ON THE GENERAL TIME DEPENDENT QUEUE WITH A SINGLE SERVER

RY METHOD OF SOLUTION OF THE QUEUEING PROBLEM WITH A SINGLE SERVER AND CONSTANT PARAMETERS AMS 62767

D GAMA SERVICE TIME THE TRANSIENT BEHAVIOR OF A SINGLE SERVER QUEUING PROCESS WITH RECURRENT INPUT AN CORRELATION STRUCTURE OF THE OUTPUT PROCESS OF SOME SINGLE SERVER SYSTEMS QUEUEING AT A SINGLE SERVING POINT WITH GROUP ARRIVAL STATES EXAMINATION OF A QUANTUM HYPOTHESIS BASED ON A SINGLE SET OF DATA

THE ESTIMATION OF MORTALITY AND RECRUITMENT FROM A SINGLE TAGGING EXPERIMENT A GENERALIZED SINGLE-SERVER QUEUE WITH ERLANG INPUT JRSSB $60 \quad 285$ BIOKA56 32 AMS 681069 BI0CS65 529 BIOKA62 242 SERVICE TIMES THE TIME DEPENDENCE OF A SINGLE-SERVER QUEUE WITH POISSON INPUT AND GENERAL AMS 621340 T ARRIVALS AND/ THE BUSY PERIOD IN RELATION TO THE SINGLE-SERVER QUEUEING SYSTEM WITH GENERAL INDEPENDEN JRSSBGO 89 STATIONARY WAITING-TIME DISTRIBUTIONS FOR SINGLE-SERVER QUEUES 
ED VARIANCES OF NORMAL POPULATIONS

SINCLE-STACE PROCEDURES FOR RANKINC MULTIPLY-CLASSIFI TECH $6 B$ CATION AND SCALE PARAMETERS BY ORDER STATISTICS FROM SINCLY AND DOUBLY CENSORED SAMPLES, PART I. THE NORMA AMS 39 TES OF THE PARAMETERS OF NORMAL POPULATIONS BASED ON SINCLY AND DOU8LY TRUNCATED SAMPLES /OF THE ESTIMA JASA 62 IMATORS FOR THE NORMAL DISTRIBUTION THEN SAMPLES ARE SINCLY CENSORED OR TRUNCATED

TIMATION OF THE NORMAL POPULATION PARAMETERS CIVEN A SINCLY CENSORED SAMPLE SIMPLIFIED EST TECH 59 ES BIOKA59

MAXIMUM LIKELIHOOD ESTIMATES. SINCLY TRUNCATED AND SINCLY CENSORED SAMPLES TES OF THE PARAMETERS OF NORMAL POPULATIONS BASED ON SINGLY CENSORED SAMPLES /E EFFICIENCY OF BAN ESTIMA BIOKA62

Y/ CONDITIONAL MAXIMUM-LIKELIHOOD ESTIMATION, FROM SINCLY CENSORED SAMPLES, OF THE SCALE PARAMETERS OF T TECH 68 TABLES FOR MAXIMUM LIKELIHOOD ESTIMATES. SINCLY TRUNCATED AND SINCLY CENSORED SAMPLES

CORRELATION BETWEEN THE SAMPLE VARIANCES IN A SINCLY TRUNCATED BIVARIATE NORMAL DISTRIBUTION

TECH $61-535$ BIOKA68 433 PIRICAL VARIANCES OF RANK CORREL/ CORRELATION IN A SINGLY TRUNCATED BIVARIATE NORMAL DISTRIBUTION IV. EM BIOKA68 437 RANK CORRELATION CORRELATION IN A SINCLY TRUNCATED BIVARIATE NORMAL DISTRIBUTION. II. BIOKA65 NOTES TABLES OF PEARSON-LEE-FISHER FUNCTIONS OF SINCLY TRUNCATED NORMAL DISTRI8UTIONS

GENERALIZED WILCOXON TEST FOR COMPARING ARBITRARILY SINGLY-CENSORED SAMPLES MEANS AND COVARIANCES OF NORMAL VARIABLES WITH SINGULAR COVARIANGE MATRIX SOME APPLICATIONS OF THE SINGULAR DECOMPOSITION OF A MATRIX ON THE STRUGTURE AND ANALYSIS OF SINGULAR FRACTIONAL REPLICATES
ON THE BLOCK STRUCTURE OF SINGULAR GROUP DIVISIBLE DESIGNS ON THE STRUGTURE AND ANALYSIS OF SINGULAR FRACTIONAL REPLICATES
ON THE BLOCK STRUCTURE OF SINGULAR GROUP DIVISIBLE DESIGNS

BIOCS65 219 A BIOKA65 203

CONDITIONAL JASA 641203 TECH 69 NO. 4 AMS $68 \quad 657$ AMS $66 \quad 1398$ AMS $64 \quad 330$ MEASURES SINGULAR TEIGHING DESIGNS

CENERALIZED INVERSE (CORR. 69 719) EQUIVALENCE AND SINGULARITY FOR FRIEDMAN URNS

SINGULARITY IN HOTELLING'S WEICHING DESICNS AND A A SINGULARITY IN THE ESTIMATION OF BINOMIAL VARIANCE A NOTE ON MUTUAL SINGULARITY OF PRIORS

AMS $64 \quad$ B69 AMS $64 \quad 673$ AMS $66 \quad 268$ AMS $66 \quad 1021$ BIOKA57 262 AMS $66 \quad 375$

TION OF BACT/ ESTIMATION OF THE NUMBER OF CRITICAL SITES IN LIMITED GENOME EXPRESSION DURING VIRAL INFEC BIOCS69 537 ON THE DISTRIBUTION OF THE LARGEST OF SIX ROOTS OF A MATRIX IN MULTIVARIATE ANALYSIS ESTIMATION OF SAMPLE SIZE

ON FORMING STRATA OF EQUAL AGGREGATE SIZE TECH $62 \quad 59$ JASA $64 \quad 481$ SEQUENTIAL TESTING OF SAMPLE SIZE ON THE VARIATION OF YIELD VARIANCE WITH PLOT SIZE OF SAMPLING WITH PROBABILITY EXACTLY PROPORTIONAL TO SIZE TITHOUT REPLACEMENT WITH PROBABILITY PROPORTIONAL TO SIZE STOPPINC RULES AND INFERENCES ABOUT POPULATION SIZE OVER TWO OCCASIONS TITH PROBA8ILITY PROPORTIONATE TO SIZE

TESTS WHIGH MINIMIZE THE MAXIMUM EXPECTED SAMPLE SIZE APPROXIMATELY MINIMIZE THE MAXIMUM EXPECTED SAMPLE SIZE YSTEMATIC SAMPLING WITH PROBABILITY PROPORTIONATE TO SIZE WITHOUT REPLACEMENT WITH PROBABILITY PROPORTIONAL TO SIZE OF A SERIES OF RANDOM VARIABLES ARRANCED IN ORDER OF SIZE WHERE TREATMENTS OR BLOCKS ARE OF UNEQUAL STATUS OR SIZE FROM THE BEST LINEAR ESTIMATES FOR A SMALLER SAMPLE SIZE NORMAL DISTRIBUTIONS BASED ON SMALL SAMPLES OF EQUAL SIZE NORMAL DISTRIBUTIONS BASED ON SMALL SAMPLES OF EQUAL SIZE UNBAISED ESTIMATION OF THE COMMON MEAN OF TWO JASA 66
ON THE SAMPLE SIZE AND COVERAGE FOR THE JIRINA SEQUENTIAL PROCEDURE AMS 63 TECH $68 \quad 331$ BIOKA56 337 THETIC MEAN SQ/ A MONTE CARLO INVESTIGATION OF THE SIZE AND POWER OF TESTS EMPLOYING SATTERTHWAITE'S SYN BIOKA6B PROBABILITY RATIO TESTS PARAMETERS ON THE SAMPLE SIZE AND SIMPLIFICATION OF A CLASS OF SEQUENT IAL FIXED SIZE CONFIDENCE ELLIPSOIDS FOR LINEAR REGRESSION SAMPLE SIZE DETERMINATION FOR TOLERANCE LIMITS

ENT CORRELATION COEFFIGIENT IN RANDOM SAMPLES OF ANY SIZE DRAWN FROM NON-NORMAL UNIVERSES /E PRODUCT-MOM BIOKA5I 219 FOR PROBABILITY PROPORTIONATE TO SOME MEASURE OF SIZE ESTIMATION ON DOUBLE SAMPLING AMS 64900 T/ APPROXIMATION TO THE DISTRIBUTION OF THE SAMPLE SIZE FOR SEQUENTIAL TEST. II. TESTS OF COMPOSITE HYPO BIOKA6O 190 ESES APPROXIMATION TO THE DISTRIBUTION OF SAMPLE SIZE FOR SEQUENTIAL TESTS. I. TESTS FOR SIMPLE HYPOTH BIOKA59 I3O YSTEMATIC SAMPLINC WITH PROBABILITY PROPORTIONATE TO SIZE IN A LARGE SCALE SURVEY THE USE OF S JASA 64 25 I BOUNDS FOR THE EXPECTED SAMPLE SIZE IN A SEOUENTIAL PROBABILITY RATIO TEST J JRSBGO 360 MOMENTS OF THE DISTRIBUTION OF SAMPLE SIZE IN A SPRT JASA 69 NO. 4 ASYMPTOTIC BEHAVIOR OF EXPECTED SAMPLE SIZE IN CERTAIN ONE-SIDED TESTS 36 AN APPROXIMATION TO THE SAMPLE SIZE IN SELECTION PRO8LEMS AMS 69492 ONS ARE LOGNORMAL AND THE PRECISIO/ OPTIMAL SAMPLE SIZE IN TWO-ACTION PROBLEMS WHEN THE SAMPLE OBSERVATI JASA 68 653 ) HYPOTHESIS TESTING WHEN THE SAMPLE SIZE IS TREATED AS A RANDOM VARIABLE (WITH DISCUSSION JRSSB67 53 BOUNDS ON THE MAXIMUM SAMPLE SIZE OF A BAYES SEQUENTIAL PROCEDURE AMS 65 B59 FINDING THE SIZE OF A FINITE POPULATION THE TOTAL SIZE OF A GENERAL STOCHASTIC EPIDEMIC A NOTE ON THE ULTIMATE SIZE OF A GENERAL STOCHASTIG EPIDEMIC

SEQUENTIAL MAXIMUM LIKELIHOOD ESTIMATION OF THE SIZE OF A POPULATION COMPARISON OF SEQUENTIAL RULES FOR ESTIMATION OF THE SIZE OF A POPULATION

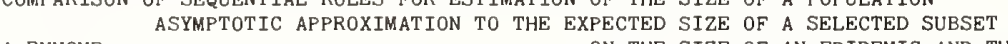

ON THE SIZE OF AN EPIDEMIC AND THE NUMBER OF PEOPLE HEARING THE ULTIMATE SIZE OF CARRIER-BORNE EPIDEMICS

THE VARIABILITY OF PROFITIBILATY WITH SIZE OF FIRM, 1947-195B

ME PROBABILITIES, EXPEGTATIONS AND VARIANCES FOR THE SIZE OF LARGEST CLUSTERS AND SMALLEST INTERVALS SOME PROPERTIES OF A METHOD OF ESTIMATING THE SIZE OF MOBILE ANIMAL POPULATIONS ON ESTIMATING THE SIZE OF MOBILE POPULATIONS FROM RECAPTURE DATA

THE DISTRIBUTION OF THE SIZE OF THE MAXIMUM CLUSTER OF POINTS ON A LINE THE EFFECT OF THE SIZE OF THE WAITING ROOM ON A SIMPLE QUEUE AMS 671392 BIOKA53 177 BIOKA67 314 AMS $6 B 1057$ BIOCS69 517 BIOKA69 207 JRSSB66 4B7 BIOKA68 277 JASA 641183

SO JASA 661191 BIOKA69 407 BIOKA5I 293 JASA $65 \quad 532$ JRSSB58 182 EGORIES WI/ AN ASYMPTOTICALLY OPTIMAL FIXED SAMPLE SIZE PROCEDURE FOR COMPARING SEVERAL EXPERIMENTAL CAT AMS 64 1571 THE CONDITION FOR LOT SIZE PRODUCTION

UNITS OF THE TRUE VALUE M DENSITY WITHIN D UNITS OF THE TRUE VALUE BOUNDED RELATIVE ERROR
SAMPLE SIZE REQUIRED FOR ESTIMATINC THE VARIANCE WITIN D

$\begin{array}{llll} & \end{array}$ SAMPLE SIZE REQUIRED TO ESTIMATE THE PARAMETER IN THE UNIFOR JASA 64550 SAMPLE SIZE REQUIRED TO ESTIMATE THE RATIO OF VARIANCES WITH JASA 631044 JASA 69 NO. 
TICS AND PRODUCTS OF ORDER STATISTICS FOR SAMPLES OF SIZE TWENTY AND LESS FROM THE NORMAL DISTRIBUTION' 56 AMS 61 1345 AREA SAMPLES UTILIZINC PROBABILITIES PROPORTIONAL TO SIZE WHEN THE SIZES CHANCE SICNIFICANTLY /ESIGNING JASA 68 I280 TIMATOR IN SAMPLING WITH PROBABILITY PROPORTIONAL TO SIZE WITH REPLACEMENT A NOTE ON A BIASED ES AMS 66 1045 ES, PART I. THE NORMAL DISTRIBUTION UP TO SAMPLES OF SIZE 10' /ICS FROM SINGLY AND DOUBLY CENSORED SAMPL AMS 39 325 IFICATION IN DISCRIMINANT ANALYSIS, NECESSARY SAMPLE SIZE, AND A RELATION WITH THE MULTIPLE CORRELATION CO BIOCS6B 823 MEANS AND TOTALS FROM FINITE POPULATIONS OF UNKNOWN SIZE, CORR, $641297 \quad 67$ REPLICATED, OR INTERPENETRATING, SAMPLES OF UNEQUAL SIZES

AMS 671142

UNEQUAL BLOCK ARRANGEMENTS WITH TWO UNEQUAL BLOCK SIZES

AND A CHERNOFF-SAVAGE THEOREM FOR RANDOM SAMPLE SIZES

OF SOME RENYI TYPE STATISTICS FOR FINITE SAMPLE SIZES

SYMMETRICAL AMS $62 \quad 620$ WEAK CONVERGENCE AMS 681675 CTATIONS OF ORDER STATISTICS IN SAMPLES OF DIFFERENT SIZES WITH AND WITHOUT REPLACEMENT FOR CLUSTERS OF UNEQUAL SIZES $R$ IS UNBIASED AND OF MINIMUM VARIANCE FOR ALL SAMPLE SIZES FOR WHICH THE MAXIMUM-LIKELIHOOD ESTIMATO BIOKA56 200 作 ons

ON THE ECONOMIC CHOICE OF EXPERIMENT SIZES FOR DECISION REGARDING CERTAIN LINEA

S BIOKA53 449 QUERY. COMPARISON OF SAMPLE SIZES IN INVERSE BINOMIAL SAMPLING TECH $67 \quad 337$

A COMPARISON OF THE ASYMPTOTIC EXPECTED SAMPLE SIZES OF TWO SEQUENTIAL PROCEDURES FOR RANKING PROBLE AMS 69 NO .6 N-FREE CONFIDENCE INTERVALS OF THE MEDIAN FOR SAMPLE SIZES TO 1,000 /B0TH THE SIGN TEST AND DISTRIBUTIO JASA 64 935 YMMETRIC BINOMIAL CUMULATIVE DISTRIBUTION FOR SAMPLE SIZES TO 1,000, CORR, 59811 /ILITY LEVELS OF THE S JASA 59 I64 THE SOUTH AFRICAN STATISTICAL ASSOCIATION, A SKETCH OF ITS ORIGINS AND GROWTH

SASJ 67

USE OF THE PEARSON DENSITIES FOR APPROXIMATING A SKEW DENSITY WHOSE LEFT TERMINAL AND FIRST THREE MOME BIOKA68 559 ON A CLASS OF SKEW DISTRIBUTION FUNCTIONS IMPROVED BOUNDS ON A MEASURE OF SKEWNESS

THE FIRST PASSAGE TIME DENSITY FOR HOMOGENEOUS SKIP-FREE WALKS ON THE CONTINUUM BIOKA55 425 AMS 621192 AMS 631003 ON A THEOREM OF SKOROHOD

GRAPHICAL VERSION OF TUKEY'S CONFIDENCE INTERVAL FOR SLIPPAGE EXTINCT SEQUENTIAL PROCEDURES FOR RANKINC AND SLIPPAGE PROBLEMS

AMS 682094 A TECH $68 \quad 193$ ON SLIPPAGE TEST TWO K-SAMPLE SLIPPAGE TESTS ON SLIPPAGE TESTS I. A GENERALIZATION OF NEYMAN

PEARSON'S LEMMA

UTION IN THE CASE OF A/ INTERVAL ESTIMATION OF THE SLOPE OF THE MAJOR AXIS OF A BIVARIATE NOR THE ESTIMATION OF SLOPE WHEN THE ERRORS ARE AUTOCORRELATED

ON THE PROBABILITY OF LARGE DEVIATIONS AND EXACT SLOPES

EFFECTS OF SLOW-DOWNS AND FAILURE ON STOCHASTIC SERVICE SYSTEMS SLOWLY BRANCHING PROCESSES

FIT OF THE NEGATIVE BINOMIAL WHEN EXPECTATIONS ARE SMALL ESTIMATION OF CROP YIELDS FOR SMALL AREAS AMS 682029 AMS 682029 JASA $68 \quad 614$ AMS 681693 IOCS68 679 JRSSB62 199 AMS 69 NO. 6 ECH $63 \quad 385$ AMS $67 \quad 919$ BIOCS66 374 ND TWO MODIFIED CHI-SOUARE GOODNESS-OF-FIT TESTS FOR SMALL BUT EQUAL EXPECTED FREQUENCIES HE POWER OF THE CHI-SQUARE GOODNESS OF FIT TEST WITH SMALL BUT EQUAL EXPECTED FREQUENCIES OF THE TWO-SAMPLE CRAMER-VON MISES CRITERION FOR SMALL EQUAL SAMPLES DISTRIBUTION AMS $63 \quad 95$ L REFERENCE TO ACCIDENTS/ THE CHI-SQUARE TEST FOR SMALL EXPECTATIONS IN CONTINGENCY TABLES, WITH SPECIA BIOKA59 365 BIOLOGICAL EXAMPLES OF SMALL EXPECTED FREQUENCIES

ON THE ESTIMATION OF SMALL FREQUENCIES IN CONTINGENCY TABLES JRSSB56 IOCS65 AMS $69 \quad 366$ DISCRETE DYNAMIC PROGRAMMING WITH A SMALL INTEREST RATE EXACT PROBABILITY IN 2-BY-2 CONTINGENCY TABLES WTTH SMALL MARGINAL TOTALS /LE METHOD OF CALCULATING THE BIOKA55 IENT SIMULATED DISTRIBUTIONS FOR SMALL $N$ OF KENDALL'S PARTIAL RANK CORRELATION COEFFIC BIOKAG.

EXPERIMENTS A PROBLEM IN THE SIGNIFICANCE OF SMALL NUMBERS A NOTE ON SMALL ORTHOGONAL MAIN EFFECT PLANS FOR FACTORIAL TECH 64 220
THE SIMPLE STOCHASTIC EPIDEMIC FOR SMALL POPULATIONS WITH ONE OR MORE INITIAL INFECTIVES BIOKA69 183 OF A BIVARIATE NORMAL DISTRIBUTION IN THE CASE OF A SMALL SAMPLE/MATION OF THE SLOPE OF THE MAJOR AXIS BIOCS68 G79 ESIS OF EQUAL MEANS UNDER VARIANCE HETEROGENEITY SMALL SAMPLE BEHAVIOUR OF CERTAIN TESTS OF THE HYPOTH BIOKA6O 345 ESIS OF EOUAL MEANS UNDER VARIANCE H/ CORRIGENDA,

TTAL ADJUSTMENT' AND 'ADAPTIVE EXPECTATIONS' MODE/

SMALL SAMPLE BEHAVIOUR OF CERTAIN TESTS OF THE HYPOTH BIOKA6I 230 SMALL SAMPLE BIAS DUE TO MISSPECIFICATION IN THE 'PAR JASA 66,1130 NOTES. SMALL SAMPLE CONSIDERATIONS IN COMBINING 2 BY $2 \quad$ BIOCS67 349 TABLES

THE MEDIAN SIGNIFICANCE LEVEL AND OTHER JASA 69971 WILCOXON AND NORMAL SCORES TESTS PROBLEM

FOR NON-NORMAL SHIFT ALTERNATIVES

IVARIATE TWO-SAMPLE LOCATION PROBLEM IN THE NORMA/ BLUMEN AND HODGES

(CORR. 68 1549)

LEHMANN'S

SEEMINGLY UNRELATED REGRESSIONS

AN INVESTIGATION INTO THE

SMALU SAMPLE PONER AND EFFTCIENCY FOR THE ONE SAMPLE AMS 6362 SMALL SAMPLE POWER CURVES FOR THE TWO SAMPLE LOCATION TECH 69299 SMALL SAMPLE POWER FOR THE ONE SAMPLE WILCOXON TEST AMS 651767 SMALL SAMPLE POWER OF A NON-PARAMETRIC TEST FOR THE B JRSSB68 83 SMALL SAMPLE POWER OF THE BIVARIATE SIGN TEST OF AMS 641576 SMALL SAMPLE PROBABILITY LIMITS FOR THE RANGE CHART JASA 671488 SMALL SAMPLE PROPERTIES OF A TWO SAMPLE TEST OF JASA 68345 SMALL SAMPLE PROPERTIED OF A TWO SAMPLE TEST OF SCALF FACTORS AND DEGREES OF FREEDOM FOR SMALL SAMPLE SIZES FOR CHI APPROXIMATION TO THE RANGE 'STUDENT' AND SMALL SAMPLE THEORY

THE UP-AND-DOWN METHOD FOR SMALL SAMPLES

THE DISTRTBUTION OF QUANTTLES OF SMALL SAMPLFS

OF STRAGGLERS ON THE RISK OF SOME MEAN ESTIMATORS IN SMALL SAMPLES

OF METHODS OF FITTING THE DOSAGE RESPONSE CURVE FOR SMALL SAMPLES

THE MEAN AND COEFFICIENT OF VARIATION OF RANGE IN SMALL SAMPLES FROM NON-NORMAL POPULATIONS

THE MEAN AND COEFFICIENT OF VARIATION OF RANGE IN SMALL SAMPLES FROM NON-NORMAL POPULATIONS
'THE MEAN AND COEFFICIENT OF VARIATION OF RANGE IN SMALL SAMPLES FROM NON-NORMAL POPULATIONS 1 /RIGENDA BIOKA55 277

BIOKA52 207

0 APPROXIMATIONS TO THE DISTRIBUTION OF THE RANGE IN SMALL SAMPLES FROM NORMAL POPULATIONS /ARISON OF TW BIOKA52 I3O VARIANCE OF THE MEDIAN OF SMALL SAMPLES FROM SEVERAL SPECIAL POPULATIONS JASA 60148

INVESTIGATION OF RULES FOR DEALING WITH OUTLIERS IN SMALL SAMPLES FROM THE NORMAL DISTRIBUTION, 2. ESTIMA TECH 69 527 THE COMMN ASED ESTIMATORS OF RELIABILIT/ THE EFFICIENCIES IN SMALL SAMPLES OF THE MAXIMUM LIKELIHOOD AND BEST UNBI JASA 66 1033 THE PERFORMANCE OF SOME TWO-SAMPLE TESTS IN SMALL SAMPLES WITH AND WITHOUT CENSORING

THE ASYMP/ PON TEST FOR THE MEAN OF A NORMAL DISTRIBUTION III, SMALL T
QUERY, SMALL TRIMMED SAMPLES E PROBABILITY INTEGRAL OF THE GAMMA DISTRIBUTION FOR SMALL VALUES OF THE SHAPE PARAMETER /XIMATION TO TH BIOKA62 276 VON MTSES' SMALL-SAMPLE DISTRTBUTIONS OF THE AMS 641091 
ON METHODS IN THE CONTEXT OF AUTOCORRELATED ERRORS SMALL-SAMPLE PROPERTIES OF SEVERAL TWO-STAGE REGRESSI JASA 69 253 ON THE MEAN AND VARIANCE OF THE SMALLER OF TWO DRAWINGS FROM A BINOMIAL POPULATION BIOKA62 566 PTOTIC EFFICIENCIES OF A NONPARAMETRIC LIFE TEST FOR SMALLER PERCENTILES OF A GAMMA DISTRIBUTION A NOTE ON REGRESSION TRANSFORMATION FOR SMALLER ROUNDOFF ERROR

IASED ESTIMATES FROM THE BEST LINEAR ESTIMATES FOR A SMALLER SAMPLE SIZE /ONSTRUCTION OF GOOD LINEAR UNB TECH 65 543 REDUCING A RANDOM SAMPLE TO A SMALLER SET, WITH APPLICATIONS JASA 67 510 NCERNING COMPL/ DISTRIBUTION OF THE LARGEST OR THE SMALLEST CHARACTERISTIC ROOT UNDER NULL HYPOTHESIS CO AMS 64 1807 ON THE STUDENTIZED SMALLEST CHI-SQUARE, CORR, 59812 JASA 58 868

$S$ AND VARIANCES FOR THE SIZE OF LARGEST CLUSTERS AND SMALLEST INTERVALS SOME PROBABILITIES, EXPECTATION JASA 66 II9I

N/ DISTRIBUTION OF THE LARGEST LATENT ROOT AND THE SMALLEST LATENT ROOT OF THE GENERALIZED B STATISTIC A AMS G7 1152 APPROXIMATE DISTRIBUTION FOR LARGEST AND FOR SMALLEST OF A SET OF INDEPENDENT OBSERVATIONS ON THE SMALLEST OF SEVERAL CORRELATED F STATISTICS 8IOKAG2 509 TION OF THE PARAMETERS OF THE BETA DISTRIBUTION FROM SMALLEST ORDER STATISTICS MAXIMUM LIKELIHOOD ESTIMA TECH 67 607 ESTIMATION OF ERROR VARIANCE FROM SMALLEST ORDERED CONTRASTS I52

ON THE DISTRIBUTION OF THE LARGEST OR THE SMALLEST ROOT OF A MATRIX IN MULTIVARIATE ANALYSIS BIOKA56 122 A SUBSET CONTAINING THE POPULATION WITH THE SMALLEST VARIANCE CS EXACT BAHADUR EFFICIENCIES FOR THE KOLMOGOROV-SMIRNOV AND KUIPER ONE-SAMPLE AND TWO-SAMPLE STATISTI AMS 67 1475 L SERIES ON SOME RESULTS OF N. V. SMIRNOV CONCERNING LIMIT DISTRIBUTIONS FOR VARIATIONA AMS 69 4BO E SAMPLING DISTRIBUTION OF THE TWO SAMPLE KOLMOGOROV-SMIRNOV CRITERION D-SUB-MN, M LESS THAN OR EQUAL TO N JASA 69 NO. 4 THE DISTRIBUTION FUNCTIONS OF TSAO'S TRUNCATED SMIRNOV STATISTICS ON THE ASYMPTOTIC EFFICIENCY OF THE KOLMOGOROV-SMIRNOV TEST

ON THE ASYMPTOTIC POWER OF THE ONE-SAMPLE KOLMOGOROV-SMIRNOV TESTS

ON THE PITMAN EFFICIENCY OF ONE-SIDED KOLMOGOROV AND SMIRNOV TESTS FOR NORMAL ALTERNATIONS

PROPERTIES SOME MODIFIED KOLMOGOROV-SMIRNOV TESTS OF APPROXIMATE HYPOTHESES AND THEIR JASA $65 \quad 843$ AMS 651000 AMS $66 \quad 940$ AMS $62 \quad 513$ AMS 671726 AMS 69 AMS 691449 INEQUALITY CONCERNING TESTS OF FIT OF THE KOLMOGOROV-SMIRNOV TYPE THE SMIRNOV TWO SAMPLE TEST IN THE P-VARIATE CASE POWER AND EFFICIENCY OF TESTS OF KOLMOCOROV-SMIRNOV TYPE RELATION BETWEEN TWO STATISTICS OF THE KOLOMOGOROV-SMIRNOV TYPE FOR ONE-SIDED DISTRIBUTION TESTS OF THE KOLMOGOROV-SMIRNOV TYPE SOME SMIRNOV TYPE THEOREMS OF PROBABILITY

SEVERAL K-SAMPLE KOLMOGOROV-SMIRNOV TESTS

VARIATIONS ON A RENEWAL THEOREM OF SMITH

$$
\text { A SIMPLER PROOF OF SMITH'S ROULETTE THEOREM }
$$

INHALATION IN RELATION TO TYPE AND AMOUNT OF SMOKING

L RELATIONSHIP OF LUNG CANCER INCIDENCE TO CIGARETTE SMOKING AND A STOCHASTIC MODEL FOR THE MODE OF ACTION BI A REVIEW OF 'SMOKING AND HEALTH'

AMS 671705 AMS 691833 AMS $61 \quad 499$ AMS 651113 AMS 651019 AMS $68 \quad 155$ AMS $68 \quad 390$ JASA $59 \quad 35$ BIOCS65 839 JASA $65 \quad 722$ CE IN HEALTH WTTH SPECIAL REFERENCE TO THE CICARETWE SUOKING AND LUNG CANCER CONTROVERSY /STICAL INFEREN JASA G9 IAL RISKS, WITH PARTICULAR REFERENCE TO THE STUDY OF SMOKING AND LUNG CANCER, CORR. 60 754 /ING EXPONENT JASA 60 415 RECENT REPORTS

SES AND THE COMPOUND DECISION PROBLEM DISTRIBUTIONS (CORR. 6B 597) DISCRETE DISTRIBUTIONS

\section{STOCHAST:} SMOKING AND LUNG CANCEER, SOME OBSERVATIONS ON TWO JASA $58 \quad 2 B$

ON THE SMOOTH EMPIRTCAL BAYES APPROACH TO TESTING OF HYPOTHE BIOKA68 B3 SMOOTH EMPIRICAL BAYES ESTIMATION FOR CONTINUOUS $\quad$ BIOKA67 435 SMOOTH EMPIRICAL BAYES ESTIMATION FOR ONE-PARAMETER BIOKA66 417 AMS 69299 SMOOTHED ESTIMATES FOR MULTINOMIAL CELL PROBABILITIES AMS 68561

SOME PROPERTIES OF RUNS IN SMOOTHED RANDOM SERIES CURVE AND PERIODOGRAM SMOOTHING (WITH DISCUSSION) SMOOTHING BY CHEATING

EXPONENTIAL SMOOTHING FOR MULTIVARIATE TIME SERIES

ON THE SMOOTHING OF PROBABILITY DENSITY FUNCTIONS BIOKA52 198 JRSSB57 3B AMS 691477 JRSSB 66241 JRSSB58 334

US SPECTRA ON THE EFFICIENCY OF PROCEDURES FOR SMOOTHING PERIODOGRAM

STATISTICAL ANALYSIS USING LOCAL PROPERTIES OF SMOOTHLY HETEROMORPHIC STOCHASTIC SERIES ON COX AND SNELL'S DEFINITION OF RESIDUALS

MARK TWAIN AND THE QUINTUS CURTIUS SNODGRASS LETTERS, A STATISTICAL TEST OF AUTHORSHIP SNOWBALL SAMPLING

BIOKA55 143 BIOKA69 361 BIOKA57 454 JRSSB 69 JASA $63 \quad 85$ AMS $61 \quad 148$ UITY OF PROCESSES WITH A V/ AN APPLICATION FOR THE SOBOLEV IMBEDDING THEOREMS TO CRITERIA FOR THE CONTIN AMS 69 517 OF STATISTICS IN THE FORMULATION AND EVALUATTON OF SOCIAL PROGRAMMES

THE USE JASA $60 \quad 454$ OF RELIGIOUS AFFILIATION WITH REFERENCES TO RELATED SOCIAL STUDIES, CORR. 59 BII /ERATURE ON STATISTICS JASA 59 335 COOPERATION AMONG STATISTICAL AND OTHER SOCIETIES

STATTSTICS AND SOCTETY

COMMENTS

GES IN CENSUS METHODS

WILLIAM HURWITZ

ESSOR WILLIAM N. HURWITZ

BASIC PRINCIPLES OF STATI/

DEVELOPMENT OF HOUSEHOLD $S /$
WASHINGTON STATISTICAL SOCIETY MEMORIAL MEETING FOR WILLIAM N. HURWITZ

WASHINGTON STATISTICAL SOCIETY MEMORIAL MEETING FOR WILLIAM N. HURWITZ.

WASHINGTON STATISTICAL SOCIETY MEMORTAL MEETTNG FOR WILLIAM N HURWITZ

WASHINGTON STATISTICAL SOCIETY MEMORIAL MEETING FOR WILLIAM N. HURWITZ.

WASHINGTON STATISTICAL SOCIETY MEMORIAL MEETING FOR WILLIAM N. HURWITZ. SOME

AST SQUARES ESTIMATE OF SOIL CONTENT

AND CONTROL OF CAPSULES, TABLETS, AND STERILE SOLIDS

ALLOCATION IN MULTIVARIATE SURVEYS, AN ANALYTICAL SOLUTION TRUNCATED LOGNORMAL DISTRIBUTIONS. I. SOLUTION BY MOMENTS FILL WEIGHT VARIATION RELEASE TECH 69 16I OPT IMUM JRSSB67 115 BIOKA51 414 JRSSB $61 \quad 173$ INPUTS THE TIME-DEPENDENT SOLUTION FOR AN INFINITE DAM WITH DISCRETE ADDITIVE A SIMPLE SOLUTION FOR OPTIMAL CHEBYSHEV REGRESSION EXTRAPOLATI THE SIMPLE STOCHASTIC EPIDEMIC, A COMPLETE SOLUTION IN TERMS OF KNOWM FUNCTIONS A NOTE ON A SERIES SOLUTION OF A PROBLEM IN ESTIMATION AMS 66 BIOKA63 235 BIOKA58 565 PPLICATION TO EXPERIM/ A CONFIDENCE REGION FOR THE SOLUTION OF A SET OF SIMULTANEOUS EQUATIONS WITH AN A PROBLEM A MONTE CARLO SOLUTION OF A TWO-DIMENSIONAL UNSTRUCTURED CLUSTER A NOTE ON THE SOLUTION OF DAM EQUATIONS ON THE SOLUTION OF ESTIMATING EQUATIONS FOR TRUNCATED AND CE BIOKA57 225 ON THE SOLUTION OF LIKELIHOOD EQUATIONS BY ITERATION PROCESS BIOKA62 479 THE SOLUTION OF QUEUEING AND INVENTORY MODELS BY SEMI- JRSSB6I 113 NSORED SAMPLES FROM NORMAL POPULATIONS ES MULTIPARAMETRIC CASE MARKOV PROCESSES MARKOV PROCESSES DEPENDENT OBSERVATIONS DESIGN OF EXPERIMENTS ITERATION JRSSB $63 \quad 455$ $\begin{array}{rlrr}\text { 8AYES SOLUTION OF SEQUENTIAL DECISION PROBLEM FOR MARKOV } & \text { AMS } 64 & 1656 \\ \end{array}$ THE NUMERICAL SOLUTION OF SOME NON-LINEAR EQUATIONS, USEPUL IN THE JRSSB65 466 
WITH A GENERAL CLASS OF SERV/

PROCESSES

PROCESSES
TIME-DEPENDENT SOLUTION OF THE 'HEAD-OF-THE-LINE' PRIORITY QUEUE JRSSB 62 TO SOLUTION OF THE EQUATIONS OF THE SINGLE CHANNEL QUEUE JRSSB5B

TABLE FOR THE SOLUTION OF THE EXPONENTIAL EQUATION EXP(B) -B/(1-P)=l BIOKA63

TABLES FOR THE SOLUTION OF THE EXPONENTIAL EQUATION, EXP $(-A)+K A=1$ A SOLUTION OF THE GENERAL STOCHASTIC EPIDEMIC.

AN APPROXIMATE SOLUTION OF THE INTEGRAL EQUATION OF RENEWAL THEORY ON THE SOLUTION OF THE LIKELIHOOD EQUATION BY ITERATION CORRIGENDA, 'ON THE SOLUTION OF THE LIKELIHOOD EQUATION BY ITERATION AN ELEMENTARY METHOD OF SOLUTION OF THE QUEUEING PROBLEH WITH A SINGLE SERVER PROBABILISTIC SOLUTION OF THE SIMPLE BIRTH PROCESS

SOME REMARKS ON THE BAYESIAN SOLUTION OF THE SINGLE SAMPLING INSPECTION SCHEME IN MARKOVIAN DECISION PROCESSES A SOLUTION TO A COUNTABLE SYSTEM OF EQUALITIES ARISING SOME REMARKS ON SCHEFFE'S SOLUTION TO THE BEHRENS-FISHER PROBLEM

AN APPROXIMATE DEGREES OF FREEDOM SOLUTION TO THE MULTIVARIATE BEHRENS-FISHER PROBLEM

ONAL RELATIONSHIP

THE MAXIMUM LIKELIHOOD SOLUTION TO THE PROBLEM OF ESTIMATING A LINEAR FUNCTI

DOCUMENTS A SOLUTION TO THE PROBLEM OF LINKING MULTIVARIATE

GENERALIZED BAYES SOLUTIONS IN ESTIMATION PROBLEMS

ON THE DISTRIBUTION OF SOLUTIONS IN LINEAR PROGRAMMING PROBLEMS APPROXIMATE SOLUTIONS OF GREEN'S TYPE FOR UNIVARIATE STOCHASTIC

PROCESSES

BIOKA60 BIOKA65 613 JRSSB $63 \quad 432$ BIOKA61 452 BI0KA62 284 8 IOKA51 74 JRSSB56 125 BIOKA64 25B TECH $60 \quad 341$ AMS $67 \quad 582$ JASA 69 N0. 4 BIOKA65 139 JRSSB 69 N0.2 JASA $69 \quad 163$ ASA 58 161 JRSSB60 376 PROBABILITY AND STATISTICS. VI. A NOTE ON THE EARLY SOLUTIONS OF THE PROBLEM OF THE DURATION OF PLAY /F BIOKA57 515 OF POPULATION GENETICS ATA EXPLICIT SOLUTIONS TO SOME PROBLEMS OF OPTIMAL STOPPING STRINGENT SOLUTIONS TO STATISTICAL DECISION PROBLEMS

631079 27 AMS 69993 AMS $67 \quad 447$ S. IX, BIOGRAPHICAL NOTE FOR T. BAYES' ESSAY TOWARDS SOLVING A PR08LEM IN THE DOCTRINE OF CHANCES. UCED FROY PHIL TRANS. ROY SOC I7/ ESSAY TOWARDS SOLVING A PROBLEM IN THE DOCTRINE OF CHANCES. AN A POSTERIORI PROBABILITY METHOD FOR SOLVING AN OVERDETERMINED SYSTEM OF EQUATIONS A REMARK ON SOLVING EQUATIONS IN SUMS OF POWERS

SUBSIDIARY SEQUENCES FOR SOLVING LESER'S LEAST-SOUARES GRADUATION EQUATIONS THE WISHART DISTRIBUTION DERIVED BY SOLVING SIMULTANEOUS LINEAR DIFFERENTIAL EQUATIONS

POPULATIONS SOME EXTENSIONS OF SOMERVILLE'S PROCEDURE FOR RANKING MEANS OF NORMAL TECH $66 \quad 675$ JRSSB $68 \quad 567$ JRSSB62 112 8I0KA5I 470 BI0KA68 411 PARISON OF THE MOST STRINGENT AND THE MOST STRINGENT SOMEWHERE MOST POWERFUL TEST FOR CERTAIN PROBLEMS WIT AMS 68 531 TRUNCATED DATA A COMPARISON OF TWO SORTS OF TEST FOR A CHANGE OF LOCATION APPLICABLE TO JR NORMAL DISTRIBUTION AND BAYESIAN ANALYSIS OF A POINT-SOURCE EPIDEMIC THE THREE-PARAMETER LOG JA POSSIBILITIES

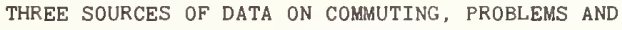

ITS ORIGINS AND GROWTH

FEMALE THAN MALE MORTALITY IN SOME COUNTRIES OF SOUTH ASIA, A DIGEST
ACCURACY OF INTERNATIONAL TRADE DATA, THE CASE OF SOUTHEAST ASIAN COUNTRIES SOME SOVIET STATISTICAL BOOKS OF 1957

TEST OF RANDOMNESS FOR EVENTS OCCURRING IN TIME OR SPACE XPERIMENT, OPERATIONAL DEFINITION OF THE PROBABILITY SPACE

ITERATIVE METHOD OF DYNAMIC PROGRAMMING ON A FINITE SPACE DISCRETE TIME MARKOV PROCESS RANDOM SUBDIVISIONS OF SPACE INTO CRYSTALS

RANDOM SUBDIVISIONS OF SPACE INTO CRYSTAL

SYSTEMATIC STATISTICS USED FOR DATA COMPRESSION IN SPACE TELEMETRY

A PERFECT MEASURABLE SPACE THAT IS NOT A LUSIN SPACE

ENERALIZATION OF KNOX'S APPROACH TO THE DETECTION OF SPACE-TIME INTERACTIONS

RELATING PLANT YIELD WITH ARRANGEMENT FOR REGULARLY SPACED CROPS

METHODS IN THE FITTING OF POLYNOMIALS TO EQUALLY SPACED OBSERVATIONS

METHODS IN THE FITTING OF POLYNOMIALS TO UNEQUALLY SPACED OBSERVATIONS FITTING A POLYNOMIAL TO CORRELATED EQUALLY SPACED OBSERVATIONS. PROBABILITY MEASURES ON PRODUCT SPACES

AND MINIMAX ESTIMATES OF PARAMETERS IN TRUNCATED SPACES ONAL FOR SEMI-MARKOV PROCESSES MITH CONTINUOUS STATE SPACES

\section{AN EXACT PROBABILITY DISTRIBUTION OVER SAMPLE SPACES OF PAIRED COMPARISONS} ON THE DISTRIBUTION OF THE SUPREMUM FUNCTI AMS $69 \quad 844$ A SEQUENTIAL BTOKA56 64 THE THEORY OF E AMS $67 \quad 401$ ON THE AMS 651279 IOKA53 231 JASA $65 \quad 97$ AMS 671918 DISEASE CLUSTERING, A G BIOCS6B 541 A MATHEMATICAL MODEL 8IOCS67 505 $\begin{array}{lrr}\text { GROUPING } & \text { 8IOKA54 } & 62 \\ \text { GROUPING } & \text { BIOKA56 } & 149\end{array}$ BIOKA65 \begin{tabular}{rr} 
JASA & 67 \\
\hline BIOCS65 & 986
\end{tabular} AMS 691216 AMS 641553

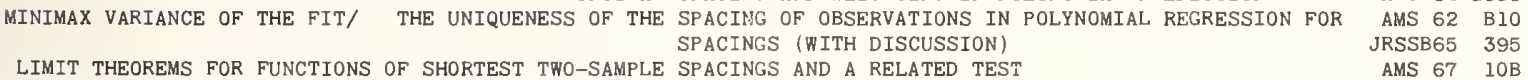

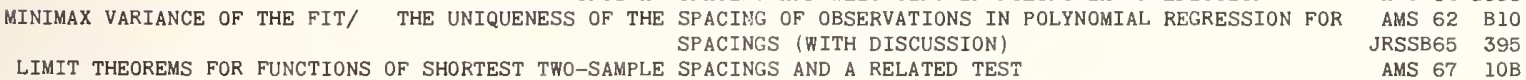

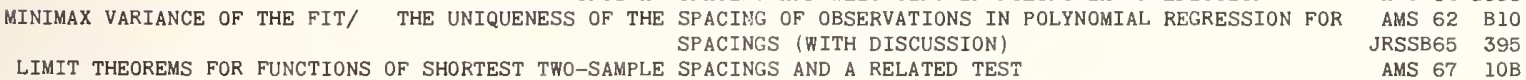
UMBER OF OBSERVATIONS FALLING IN THE SHORTEST SAMPLE SPACINGS DETERHINED BY EARLIER OBSERVATIONS /THE N AMS 61 B38 OF FIT AND TWO-SAMPLE PR/ CONTRIBUTIONS TO SAMPLE SPACINGS THEORY, II. TESTS OF THE PARAMETRIC GOODNESS AMS 66 925 A REPRODUCIBLE METHOD OF COUNTING PERSONS OF SPANISH SURNAME THE OPTIMUM ALLOCATION OF SPARE COMPONENTS IN SYSTEMS A MINIMUM COST MODEL OF SPARE PARTS INVENTORY CONTROL

CASE OF MARKET ORIENTATION OF PRODUCTI/ MEASURING SPATIAL ASSOCIATION WITH SPECIAL CONSIDERATION OF THE JASA 56 597 A STOCHASTIC ANALYSIS OF THE SPATIAL CLUSTERING OF RETAIL ESTABLISHMENTS STUDIES IN STATISTICAL ECOLOGY. I. SPATIAL PATTERN

JASA 651094 BIOKA52 346 SPATIAL POINT PROCESSES, WITH APPLICATIONS TO ECOLOGY BIOKA55 102 $\begin{array}{lrr}\text { SPATIAL RELATIONSHIP AMONG EIGHT POPULATIONS ZEA MAYS BIOCS6B } & \text { B67 } \\ \text { SPATIALLY DISTRIBUTED POPULATIONS } & \text { BIOKA68 } & 189\end{array}$

L. UTILIZING INFORMATION FROM A DIALLEL MATING D/ SPEARMAN ESTIMATION FOR A SIMPLE EXPONENTIAL MODEL BIOCS65 B58 STOCHASTIC BIRTH, DEATH AND MIGRATION PROCESSES FOR

SOME PROPERTIES OF THE SPEARMAN ESTIMATOR IN BIOASSAY SPEARMAN SIMULTANEOUS ESTIMATION FOR A COMPARTMENTAL

MODEL A REMARK ON SPEARMAN'S RANK CORRELATION COEFFICIENT

THE VARIANCE OF SPEARMAN'S RHO IN NORMAL SAMPLES

THE DISPERSION OF A NUMBER OF SPECIES

MIXED SELF- AND CROSS-FERTILIZATION IN A TETRASOMIC SPECIES PROPERTIES OF A STOCHASTIC MODEL FOR TWO COMPETING SPECIES COMPETITION EXPERIMENTS FOR DIFFERENT RATIOS OF SPECIES THE PREDATOR-PREY TYPE OF INTERACTION BETWEEN TWO SPECIES
BIOKA6I 293

TECH 69551 BIOKA6I 19 JRSSB59 190 BI0CS68 485 THE BIOKA58 316 ANALYSIS OF PLANT BIOKA67 471 THE PROPERTIES OF A STOCHASTIC MODEL FOR BIOKA60 219 BIOKA5B 273 
THE POPULATION FREQUENCIES OF SPECIES AND THE ESTIMATION OF POPULATION PARAMETERS

BIOKA53 237 $E$ OF AN ANIMAL POPULATION IN WHICH THE ABUNDANCES OF SPECIES ARE LOC-NORMALLY DISTRIBUTED /ES IN A SAMPL BIOKA5I 427 SPECIES FREQUENCY DISTRIBUTIONS

RIMENTAL DATA A STOCHASTIC MODEL FOR TWO COMPETINC SPECIES OF TRIBOLIUM AND ITS APPLICATION TO SOME EXPE BIOKA62 PLANT COMPETITION, THREE SPECIES PER POT

PROPERTIES OF A STOCHASTIC MODEL FOR TWO COMPETINC SPECIES.

CORRICENDA, ITHE JRSS868

$\mathrm{N}$ A SAMPLE IS INCREASED THE NUMBER OF NEW SPECIES, AND THE INCREASE IN POPULATION COVERACE, WHE BIS A DEMOGRAPHIC MODEL FOR ESTIMATING ACE-ORDER SPECIFIC FERTILITY RATES

BIOKA59 279

TIVARIATE ACCEPTANCE SAMPLING PROCEDURES FOR GENERAL SPECIFICATION ELLIPSOIDS STEPWISE LEAST SQUARES, RESIDUAL ANALYSIS AND SPECIFICATION ERROR

JASA 61998

THE RELATIVE SENSITIVITY TO SPEGIFICATION ERROR OF DIFFERENT K-CLASS ESTIMATORS JASA 66345

S REGRESSION ANALYSIS TESTS FOR SPEGIFICATION ERRORS IN CLASSICAL LINEAR LEAST-SQUARE JRSSB69 NO.2

PLAN FOR CORRELATED VARIABLES WITH A SINGLE-SIDED SPECIFICATION LIMIT A SINGLE SAMPLING JASA 59 24B MINIMUM RISK SPEGIFICATION LIMITS

JASA 59260

AND CONSUMER RISKS FOR ASYMMETRICAL TESTS AND SPECIFICATION LIMITS

PRODUCER JASA $66 \quad 505$

BABILITY AND THE JOINT PROBABILITY APPROACHES IN THE SPECIFICATION OF NEAREST-NEIGHBOUR SYSTEMS /NAL PRO BIOKA64 4B A QUICK COMPACT TWO SAMPLE TEST TO DUCKWORTH'S SPEGIFICATIONS

DISPERSION MATRICES FOR ALTERNATIVES OF INTERMEDIATE SPECIFICITY

LONGEST RUN OF CONSECUTIVE OBSERVATIONS HAVING A SPECIFIED ATTRIBUTE

SOME PROPERTIES OF A DISTRIBUTION SPEGIFIED BY ITS CUMULANTS

ERRATA, 'SOME PROPERTIES OF A DISTRIBUTION SPECIFIED BY ITS CUMULANTS'

THE PROBABILITY THAT AN OBSERVATION WILL FALL IN A SPECIFIED .GLASS

IN THE COMPOUND DECISION PROBLEM FOR TWO COMPLETELY SPECIFIED DISTRIBUTIONS

A NOTE ON MULTIVARIATE DISTRIBUTIONS WITH SPEGIFIED MARCINALS

IN PREDIGTION BY REGRESSION FOR CERTAIN INCOMPLETELY SPECIFIED MODELS

TWO-SAMPLE COMPARISONS OF

AMS $62 \quad 432$

BIOKA6I 46I

TECH 6363

TEGH $63 \quad 417$

ESTIMATION OF JASA $64 \quad 225$

RATES OF CONVERGENCE AMS 651743

JASA 671460

BIASES BIOKA63 391

WI/ AN EXACT FORMULA FOR THE PROBABILITY THAT TWO SPECIFIED SAMPLING UNITS WILL OCCUR IN A SAMPLE DRAWN JASA 66 3B4 ON THE UTILIZATION OF MARKED SPECIMENS IN ESTIMATINC POPULATIONS OF FLYING INSEGTS BIOKA53 170

GENERAL CONSIDERATIONS IN THE ANALYSIS OF SPECTRA

MATHEMATICAL CONSIDERATIONS IN THE ESTIMATION OF SPECTRA

BASIC CONSIDERATIONS IN THE ESTIMATION OF SPECTRA

AND THE ANALYSIS OF GAMMA RAY PULSE-HEIGHT SPECTRA

DIMENSIONAL STATIONARY PROCESSES WITH DISCONTINUOUS SPECTRA

OTHING PERIODOGRAMS FROM TIME SERIES WITH GONTINUOUS SPECTRA

TECH 61

TECH $61 \quad 167$

TECH $62 \quad 551$

LINEAR ESTIMATION TECH $62 \quad 565$

THE ANALYSIS OF TWO- BIOKA64 195

PROCESSES

ESTIMATION OF POWER SPECTRA BY A RAVE ANALYZER

SIDUALS A NOTE ON THE ESTIMATION OF AMPLITUDE SPECTRA FOR STOCHASTIC PROCESSES WITH QUASI-LINEAR RE JA

THE ANALYSIS OF STATIONARY PROCESSES WITH MIXED SPECTRA, 1

ANALYSIS OF STATIONARY PROCESSES WITH MIXED SPECTRA,

A REAPPRAISAL OF THE PERIODOGRAM IN SPECTRAL ANALYSIS

BANDWIDTH AND RESOLVABILITY IN STATISTICAL SPECTRAL ANALYSIS

ASSOCIATED INNER WINDOW

FLUCTUATIONS

PRESENCE OF VARIANCE FLUCTUATIONS

DISCUSSION)

THE BINOMIAL CASE

N)

\section{THE MAXIMUM DEVIATION OF SAMPLE SPECTRAL DENSITIES
THE ESTIMATION OF SPECTRAL DENSITIES}

SPECTRAL ANALYSIS COMBININC A BARTLETT WINDOW WITH AN

CROSS SPECTRAL ANALYSIS OF GAUSSIAN VECTOR PROCESS IN THE

THE SPECTRAL ANALYSIS OF POINT PROCESSES (WITH

SOME COMMENTS ON SPECTRAL ANALYSIS OF TIME SERIES

THE SPECTRAL ANALYSIS OF TIME SERIES (WITH DISCUSSION)

THE SPECTRAL ANALYSIS OF TWO-DIMENSIONAL POINT PROCESSES

CORRIGENDA, 'THE SPECTRAL ANALYSIS OF TWO-DIMENSIONAL POINT PROCESSES' SPECTRAL ANALYSIS WITH RANDOMLY MISSED OBSERVATIONS,

SPECTRAL ANALYSIS WITH RECULARLY MISSED OBSERVATIONS
EVOLUTIONARY SPECTRAL AND NON-STATIONARY PROCESSES (WITH DISCUSSIO

THE ESTIMATION OF THE SPECTRAL DENSITY AFTER TREND REMOVAL

AN INEQUALITY RELATING THE SPECTRAL DENSITY AND AUTOCORRELATION FUNCTION

THE AUTOCORRELATION FUNCTION AND THE SPECTRAL DENSITY FUNCTION

COMPONENTS

ESTIMATION OF THE SPECTRAL DENSITY FUNCTION IN THE PRESENCE OF HARMONIC

ASYMPTOTICALLY EFFICIENT CONSISTENT ESTIMATES OF THE SPECTRAL DENSITY FUNCTION OF A STATIONARY TIME SERIES J

(WITH DISCUSSION)

FIME SERIES

ON ESTIMATING THE SPECTRAL DENSITY FUNCTION OF A STOCHASTIG PROCESS

RIES WITH NORMAL RESID/A COODNESS OF FIT TEST FOR SPECTRAL DISTRIBUTION FUNCTIONS OF STATIONARY TIME SE ASYMPTOTIG PROPERTIES OF SPECTRAL ESTIMATES OF SECOND ORDER

SPECTRAL ESTIMATES USING NONLINEAR FUNCTIONS

SPECTRAL EVALUATION OF BLS AND CENSUS REVISED SEASONA $J$

L ADJUSTMENT PROCEDURES

SPECTRAL FACTORIZATION OF MULTIPLE TIME SERIES

TESTING FOR A JUMP IN THE SPECTRAL FUNCTION

SPECTRAL PROPERTIES OF NON-STATIONARY SYSTEMS OF

THE SPECTRAL THEOREM FOR FINITE MATRICES AND COCHRAN'S

LINEAR

THEOREM
RESULTS FOR REGRESSION ANALYSIS APPLIED TO GAMMA RAY SPECTROMETER DATA, 1

RESULTS FOR REGRESSION ANALYSIS APPLIED TO GAMMA RAY SPECTROMETER DATA, 2 ESTIMATION OF THE SPECTRUM

ESTIMATION OF THE CROSS-SPECTRUM

BANDWIDTH AND VARIANCE IN ESTIMATION OF THE SPECTRUN

THE CONNECTION BETWEEN ANALYSIS OF VARIANCE AND SPECTRUM ANALYSIS

SOME EXPERIMENTAL SAMPLING

SOME EXPERIMENTAL SAMPLING

ON THE CONCEPT OF
OHH

THE SPECTRUM FOR NON-STATIONARY PROCESSES (WITH DISCUSSIO

THE SPECTRUM OF A CONTINUOUS PROCESS DERIVED FROM A

THE SPECTRUM OF A MODEL II NESTED ANOVA AND ITS

DISCRETE PROCESS

APPLICATIONS

FROM ITS ZEROS

SELECTED ECONOMIC DATA, ACCURACY VS. REPORTINC SPEED

APPROXIMATION OF MINIMA WITH IMPROVED ASYMPTOTIC SPEED

THE SPEED OF GLIVENKO-CANTELLI CONYERGENCE

STOCHASTIC

F HOMOGENEOU/ PROBA8ILITY CONTENT OF REGIONS UNDER SPHERICAL NORMAL DISTRIBUTIONS, IV. THE DISTRIBUTION O
TECH $65 \quad 553$ RSS862 511 TECH 65 531 JRSSB59 169

CH 61235 RSSB64 354 AMS 681507 JRSSB63 264 TECH 61221 RSSB57 IOKA64 KA65 305 204 AMS 671558 JRSSB62 185 323 BIOKA62 262 BIOKA55 151 RSS864 123 IOKA56 257 BIOKA69 375 AMS $66 \quad 1237$ JASA $68 \quad 472$ BIOKA66 264 JRSSB61 394 JASA 69 AMS $64 \quad 443$ BI0CS67 11 353 AMS $61 \quad 730$ AMS 631012 JRSSB58 152 TECH $61 \quad 191$ JRSSB68 8IOKA63 517 TECH 6991 JRSS868 145 JASA $68 \quad 436$ AMS $67 \quad 191$ AMS $69 \quad 40$ AMS $62 \quad 542$ 
DENSITY

LE SHOULD READ 'PROBABILITY CONTENT OF REGIONS UNDER SPHERICAL NORMAL DISTRIBUTIONS, II. THE DISTRIBUTION AMS 6I 620 RMAL INTEGRAL PROBABILITY CONTENT OF REGIONS UNDER SPHERICAL NORMAL DISTRIBUTIONS, III. THE BIVARIATE NO AMS 61 171 SEQUENTIAL DESIGNS FOR SPHERICAL WEIGHT FUNCTIONS

REGIONS

THE USE OF SECOND-ORDER 'SPHERICAL' AND 'CUBOIDAL' DESIGNS IN THE WRONG

TECH $67 \quad 517$ BIOKA66 596

E EXACT DISTRIBUTIONS OF THE CRITTERION $\mathbb{T}$ FOR TESTING SPHERICITY IN A P-VARIATE NORMAL DISTRIBUTION A NOTE ON THE SPHERICITY TEST

PROBLEM IN RENEWAL THEORY, ROBERT THE BRUCE'S SPIDER AMS $66 \quad 464$ MPLING TECHNIQUES FOR ESTIMATION OF INCIDENCE OF RED SPIDER MITE ON TEA CROP IN NORTH-EAST INDIA ADMISSIBLE DESIGNS FOR POLYNOMIAL SPLINE REGRESSION

FULL CONTINGENCY TABLES, LOGITS, AND SPLIT CONTINGENCY TABLES

SOME THO-LEVEL FACTORIAL PLANS WITH SPLIT PLOT CONFOUNDING

AMS 691557

BIOCS69 3B3

TECH 64253

INCOMPLETE SPLIT PLOT DESIGNS

BIOCS67 793

UTS SOME ASPECTS OF THE STATISTICAL ANALYSIS OF 'SPLIT PLOT' EXPERIMENTS IN COMPLETELY RANDOMIZED LAYO JASA 69 485 OF VARIANCE OF SOME NON-ORTHOGONAL DESIGNS MITH SPLIT PLOTS

THE RANDOMIZATION DISTRIBUTION OF F-RATIOS FOR THE SPLIT-PLOT DESIGN, AN EMPIRICAL INVESTIGATION HETEROGENEOUS ERROR VARIANCES IN SPLIT-PLOT EXPERIMENTS OR MIXED UP ESTIMATION OF MISSING OBSERVATIONS IN SPLIT-PLOT EXPERIMENTS WHERE WHOLE-PLOTS ARE MISSING BIOKA6I 468 MARKOVIAN STATES $\begin{array}{rlrl} & \text { SPLITTING A SINGLE STATE OF A STATIONARY PROCESS INTO AMS } 6 B & 1069 \\ \text { STATISTICAL EVALUATION OF SPLITTING LIMIT CRITERIA IN MEASUREMENT DISPUTES } & \text { TECH } 63 & 263\end{array}$

A NONPARAMETRIC SUM OF RANKS PROCEDURE FOR RELATIVE SPREAD IN UNPAIRED SAMPLES, CORR 61 1005 THE ESTIMATION OF PARAMETERS FROM THE SPREAD OF A DISEASE BY CONSIDERING HOUSEHOLDS OF TWO. BIOKA65 271

POPULATION THE SPREAD OF AN EPIDEMIC TO FIXED GROUPS TITHIN THE

VACANCIES

A MATHEMATICAL ANALYSIS OF THE GRONTH AND SPREAD OF BREAST CANCER

SPREAD OPIOCS69 95

BIOKA53 287 BIOCS65 481 A MODEL FOR THE SPREAD OF EPIDEMICS BY CARRIERS

A NOTE ON TABLES FOR THE COMPARISION OF THE SPREAD OF TWO NORMAL DISTRIBUTIONS MOMENTS OF THE DISTRIBUTION OF SAMPLE SIZE IN A SPRT

RANK-ORDER AND THE STOPPING TIME OF SOME ASSOCIATED SPRT'S

ESTIMATION OF A MEAN WHEN ONE OBSERVATION MAY BE SPURIOUS

JASA 69 NO. 4 THE MODIFIED LATIN SQUARE THE INFORMATION IN A AMS $6 B 1661$ TECH $69 \quad 331$ JRSSB57 305 ALTERNATIVES TO A LATIN SQUARE BIOCS68 $65^{7}$ FACTOR ADDITIVE DESIGNS MORE GENERAL THAN THE LATIN SQUARE PROPERTIES OF A RANDOM DISTRIBUTION FUNCTION ON THE SQUARE

ADDITIVE DESIGNS MORE GENERAL THAN THE GRECO-LATIN SQUARE SUCCESSIVE DIFFERENCE AND ITS RATIO TO THE ROOT MEAN SQUARE OF THE EFFECTS OF NON-ADDITIVITY IN THE LATIN SQUARE LISTING EXPECTED MEAN SQUARE COMPONENTS

PROBABILISTIC INTERPRETATIONS FOR THE MEAN SQUARE CONTINGENCY, CORR. 581030 GENERALIZED LATTICE SQUARE DESIGN
DIRECTION COMPONENTS REGRESSION REGRESSION
THE ANALYSIS OF LATIN SQUARE DESIGNS WITH INDIVIDUAL CURVATURES IN ONE MEAN SQUARE EFFICIENCY OF ESTIMATORS OF VARIANCE

A TEST OF THE MEAN SQUARE ERROR CRITERION FOR RESTRICTIONS IN LINEAR

TABLES FOR THE MEAN SQUARE ERROR TEST FOR EXACT LINEAR RESTRICTIONS IN HOTELLING'S GENERALIZED T SQUARE IN THE MULTIVARIATE ANALYSIS OF VARIANCE A NECESSARY AND SUFFICIENT CONDITION FOR THE SQUARE OF A RANDOM VARIABLETO BE GAMMA A NOTE ON MATRIX INVERSION BY THE SQUARE ROOT METHOD MATRIX INVERSION WITH THE SQUARE ROOT METHOD MODIFIED SQUARE ROOT METHOD OF MATRIX INVERSION

ERRATA, 'MODIFIED SQUARE ROOT METHOD OF MATRIX INVERSION APPROXIMATIONS FOR MEAN SQUARE SUCCESSIVE DIFFERENCE CRITICAL VALUES A NOTE ON MEAN SQUARE SUCCESSIVE DIFFERENCES

ASYMPTOTIC POWER OF CHI SQUARE TESTS FOR LINEAR TRENDS IN PROPORTIONS NOTE ON CHI SQUARE TESTS FOR MATCHED SAMPLES

FAMILIES OF PARTIALLY BALANCED DESIGNS OF THE LATIN SQUARE TYPE AND RELATED DESIGNS THREE TECH $62 \quad 187$ DIMENSIONAL AMS $66 \quad 849$ FOUR FACTOR TECH $62 \quad 361$ ON THE MEAN BIOKA53 116 THE INTERPRETATION BIOKA58 69 BIOCS65 459 JASA $58 \quad 102$ JASA 66 B21 JRSSB5B 193 JASA 69 N0.4 JASA $68 \quad 558$ JASA 69 NO. 4 JRSSB $63 \quad 358$ BI0KA66 275 JASA $56 \quad 2 B 8$ TECH $64 \quad 197$ TECH $62 \quad 282$ TECH $62 \quad 622$ TECH $68 \quad 397$ JASA 59801 BIOCS68 315 JRSSB $6 B$ B $36 B$ NOTES.THE SQUARE-SUMMING CHECK ON THE MAIN EFFECTS AND INTERACT BIOCSG7 57 SUCCESSIVE DIFFERENCE AND ITS RATIO TO THE ROOT MEAN SQUARE' F EXTREME QUANTILES OF THE NORMAL DISTRIBUTION UNDER SQUARED ERROR LOSS NOTE ON SOME SQUARED RANK TESTS CORRIGENDA TO 'ON THE MEAN BIOKA58 587 /THE BEST INVARIATE ESTIMATOR 0 AMS 69 1BOI EQUAL AND PROPORTIONAL FREQUENCY SQUARES CONSTRUCTION OF ROOM SQUARES THE LOGIC OF LEAST SQUARES FOUNDATIONS FOR THE THEORY OF LEAST SQUARES THE EXISTENCE AND NON-EXISTENCE OF ORTHOGONAL LATIN SQUARES FITTING OF NON-LINEAR REGRESSION FUNCTIONS BY LEAST SQUARES ER OF TESTS EMPLOYING SATTERTHWAITE'S SYNTHETIC MEAN SQUARES ON OF LINEAR RELATIONS FITTED $8 Y$ THE METHOD OF LEAST SQUARES RUCTURES UNDER WHICH CERTAIN SIMPLE LEAST SQUARES AND ANALYSIS OF VARIANCE PROCEDURES ARE ALSO JASA 69 NO. 4 NOTE ON A ON THE DISTRIBUTION OF SUMS OF SQUARES AND CROSS PROD

THE EXACT SAMPLING DISTRIBUTION OF ORDINARY LEAST SQUARES AND TWO-STAGE LEAST SQUARES ESTIMATORS ECTATIONS, VARIANCES AND COVARIANCES OF 'ANOVA' MEAN SQUARES BY 'SYNTHESIS' ECTATIONS, VARIANCES, AND CONVARIANCES OF ANOVA MEAN SQUARES BY 'SYNTHESIS' E DEGREES OF FREEDOM FOR LINEAR COMBINATIONS OF MEAN SQUARES BY SATTERTHWAITE'S FORMULA QUERY, BAULE'S EQUATION + (LEAST SQUARES ESTIMATE OF SOIL CONTENT)
TECH $67 \quad 312$ JASA $68 \quad 33 \mathrm{~B}$ JASA $67 \quad 226$ AMS 681540 JRSS863 124 JRSS869 89

ON THE APPLICATION OF GROUP THEORY TO BIOKA69 NO.3 THE MODIFIED GAUSS-NERTON METHOD FOR THE TECH 61269 AMS 621461 TECH $62 \quad 419$ JASA 69923 EXP BIOCS67 105 ON EXP BIOCS6B 963 ESTIMATING TH TECH 69 NO.4 BIOCS69 159 
TI7 63 TECH 330 TAGE POINTS OF FREQUENCY CU/ APPROXIMATE MEANS AND STANDARD DEVIATIONS BASED ON DISTANCES BETWEEN PERCEN BIOKA65 533
ROM A DECAPITATED NEGATIVE BI/ EXPECTED VALUES AND STANDARD DEVIATIONS OF THE RECIPROCAL OF A VARIABLE F JASA 62 439 TABLES OF RANDOM OBSERVATIONS FROM STANDARD DISTRIBUTIONS

$$
\text { A PARAMETRIC ESTIMATE OF THE STANDARD ERROR OF THE SURVIVAL RATE, CORR. } 631161
$$
STANDARD ERRORS FOR INDEXES FROM COMPLEX SAMPLES BAYESIAN INTERPRETATION OF STANDARD INFERENCE STATEMENTS (WITH DISCUSSION) JRSB65 169 NOTE ON DYNKIN'S 'ALPHA, XI' SUBPROCESS OF STANDARD MARKOV PROCESS AMS 671647 RVES, FOR GIVEN ROOT(BETA-1) AND BETA-2 EXPRESSED IN STANDARD MEASURE /F PERCENTAGE POINTS OF PEARSON CU BIOKA63 459 VES, FOR GIVEN ROOT(BETA-1) AND BETA-2, EXPRESSED IN STANDARD MEASURE' /PERCENTAGE POINTS OF PEARSON CUR BIOKA65 669 METROPOLITAN AREA CONCEPT, AN EVALUATION OF THE 1950 STANDARD METROPOLITAN AREAS THE JASA 65 6I7 ON THE BAYES CHARACTER OF A STANDARD MODEL II ANALYSIS OF VARIANCE TEST 
FOR COMPARINC SEVERAL EXPERIMENTAL CATECORIES WITH A STANDARD OR CONTROL 1299 ANALYSIS

TESTS STARSHAPED TRANSFORMATIONS AND THE POWER OF RANK

APPLICATIONS OF TRUNCATED DISTRIBUTIONS IN PROCESS START-UPS AND INVENTORY CONTROL

CROSS STATE PRODUCT AND AN ECONOMETRIC MODEL OF A STATE

REOUIREMENTS AMONC ENVIRONMENTAL POCKETS UPON STEADY STATE GENE FREQUENCIES /ION, AND DIFFERENT FITNESS PROBABILISTIC FUNCTIONS OF FINITE STATE MARKOV CHAINS INFERENCE FOR PROBABILISTIC FUNCTIONS OF FINITE STATE MARKOV CHAINS

$N$ OF SOME PROBABILISTIC FUNCTIONS OF DISCRETE FINITE STATE MARKOV CHAINS INFINITESIMAL CENERATOR OF A CONTINUOUS TIME, FINITE STATE MARKOV PROCESS ARBITRARY STATE MARKOVIAN DECISION PROCESSES

CRITERION ARUITRARY STATE MARKOVIANDECISION PROCESSES

OF CENSUS SURVIVAL RATES IN ESTIMATINC. INTERCENSAL STATE NET MIGRATION SPLITTING A SINGLE STATE OF A STATIONARY PROCESS INTO MARKOVIAN STATES

CROSS STATE PRODUCT AND AN ECONOMETRIC MODEL OF A STATE

JASA $62 \quad 841$ AMS 6B 1069 JASA $697 \mathrm{~B} 7$

EOREMS FOR STATIONARY PROBABILITY MEASURES ON FINITE STATE SEQUENCES

FUNCTIONAL FOR SEMI-MARKOV PROCESSES TITH CONTINUOUS STATE SPACES SOME STRUCTURE TH AMS $64 \quad 550$ THE DEMAND FOR FERTILIZER IN 1954, AN INTER-STATE STUDY ON THE DISTRIBUTION OF THE SUPREMUM IDENTIFICATION OF STATE-CALCULABLE FUNCTIONS OF FINITE MARKOV CHAINS

BAYESIAN INTERPRETATION OF STANDARD INFERENCE STATEMENTS (WITH DISCUSSION) MARKOV RENEWAL PROCESSES MITH FINITELY MANY STATES FUNCTIONS OF PROCESSES WITH MARKOVIAN STATES

AMS 69844 $\begin{array}{rrr}\text { AMS } & 69 & 844 \\ \text { JASA } & 59 & 377\end{array}$ AMS $67 \quad 201$

SINCLE STATE OF A STATIONARY PROCESS INTO MARKOVIAN STATES

SPLITTINC A AMS $68 \quad 1069$ PERSONS TO AND FROM METROPOLITAN AREAS OF THE UNITED STATES HEORY FOR MARKOV CHAINS WITH A DENUMERABLE NUMBER OF STATES MARKOV HYPOTHESIS WITH INDEPENDENCE OF INTERMEDIATE STATES AND RESTRICTED ORDER A NOTE ON EXCHANGEABLE PROCESSES WITH STATES OF FINITE RANK SEQUENTIAL DESIGN OF EXPERIMENTS FOR INFINITELY MANY STATES OF NATURE
MARKOV CHAINS WITH ABSORBING STATES, A GENETIC EXAMPLE SEQUENTIAL DESIGN OF EXPERIMENTS FOR INFINITELY MANY STATES OF NATURE
MARKOV CHAINS WITH ABSORBING STATES, A GENETIC EXAMPLE

THE MIGRATION OF EMPLOYED JASA $67 \quad 1418$ FUNCTIONS OF PRO UNBIASED RATIO ESTIMATORS IN STATIFIED SAMPLING, CORR. 641298 THE AUTOREGRESSIVE AND MOVING-AVERAGE TYPE STATIONARY AMPLITUDE FLUCTUATIONS IN A RANDOM SERIES JR ESTIMATION OF THE CROSS-SPECTRUM OF A STATIONARY BIVARIATE CAUSSIAN PROCESS FROM ITS ZEROS JPF TESTINC A BIOKA67 605 AMS 69 N0.6 AMS 61771 AMS $61 \quad 716$ AMS 69865 $\begin{array}{lr}\text { JASA } 61 & 70 \\ \text { BIOKA56 } & 215\end{array}$ BIOKA56 215 BIOKA $62 \quad 253$ JRSSB $68 \quad 145$ NG IMMIGRATION, A REMARK ON THE CRITICAL CASE THE STATIONARY DISTRIBUTION OF A BRANCHING PROCESS ALLOWI GENETICS (TITH DISCUSSION) TYPE FOR THE INFINITE DAM

QUASI-STATIONARY DISTRIBUTIONS AND TIME-REVERSION IN 253 MULTIPLE REGRESSION WITH STATIONARY ERRORS

RADON-NI KODYM DERIVATIVES OF STATIONARY GAUSSIAN MEASURES THE EXPECTED NUMBER OF ZEROS OF A STATIONARY GAUSSIAN PROCESS

ON A LIMIT DISTRIBUTION OF HIGH LEVEL CROSSINGS OF A STATIONARY GAUSSIAN PROCESS SAMPLING RATES AND APPEARANCE OF STATIONARY GAUSSIAN PROCESSES

A LAW OF LARGE NUMBERS FOR THE MAXIMUM IN A STATIONARY GAUSSIAN SEQUENCE ON THE CROSS PERIODOGRAM OF A STATIONARY GAUSSIAN VECTOR PROCESS ROXIMATE DISTRIBUTION OF THE CORRELATION BETWEEN TWO STATIONARY LINEAR MARKOV SERIES ROXIMATE DISTRIBUTION OF THE CORRELATION BETWEEN TWO STATIONARY LINEAR MARKOV SERIES. II. THE OUTPUT PROCESS OF A STATIONARY M/M/S QUEUEINC SYSTEM

THE SAMPLE MEAN WHEN RESIDUALS FOLLOW A FIRST-ORDER STATIONARY MARKOFF PROCESS

EXCHANGEABLE PROCESSES WHICH ARE FUNCTIONS OF STATIONARY MARKOV CHAINS

ON STATIONARY MARKOV PROCESSES

AMS 651043 AMS 6B 2108 TECH $66 \quad 91$ AMS $62 \quad 93$ AMS $67 \quad 593$ HE APP BIOKA62 379 THE APP BIOKA65 301 AMS 6B 1144 ING PROCESS PROPERTIES OF THE STATIONARY MEASURE OF THE CRITICAL CASE SIMPLE BRANCH NON-SINGULAR RECURRENT MARKOV PROCESSES HAVE STATIONARY MEASURES

THE EXISTENCE AND UNIQUENESS OF STATIONARY MEASURES FOR MARKOV RENETAL PROCESSES A UNIQUENESS THEOREM FOR STATIONARY MEASURES OF ERGODIC MARKOV PROCESSES TESTING AND ESTIMATION FOR A CIRCULAR STATIONARY MODEL FREOUENCY RESPONSE FROM STATIONARY NOISE, TWO CASE HISTORIES

MOMENTS OF THE NUઃBER OF CROSSINGS OF A LEVEL BY A STATIONARY NORMAL PROCESS ON THE MEAN NUMBER OF CURVE CROSSINGS BY NON-STATIONARY NORMAL PROCESSES ERACE REPRESENTATION FOR RANDOM VARIABLES COVARIANCE STATIONARY ON A FINITE TIME INTERVAL ARABOLIC REGRESSION WITH RESTRICTED LOCATION FOR THE STATIONARY POINT HIGHER-ORDER PROPERTIES OF A STATIONARY POINT PROCESS A MOVING AV BIOKA65 295 AMS 64 (23) AMS $67 \quad 588$ AMS $67 \quad 977$ AMS $64 \quad 869$ AMS 661439 AMS 641781 AMS $69 \quad 1358$ TECH 61245 HE AMS 651656 AMS $65 \quad 509$

ON THE ESTIMATION OF THE INTENSITY FUNCTION OF A STATIONARY POINT PROCESS JRSSB $63 \quad 413$ JRSSB 65332 JRSSB62 364 ON THE LENGTHS OF INTERVALS IN A STATIONARY POINT PROCESS (CORR. 63 500) SOME STRUCTURE THEOREMS FOR STATIONARY PROBABILITY MEASURES ON FINITE STATE SEQUE AMS 64 550
THE VARIANCE OF THE MEAN OF A STATIONARY PROCESS THE VARIANCE OF THE MEAN OF A STATIONARY PROCESS SPLITTING A SINGLE STATE OF A STATIONARY PROCESS INTO MARKOVIAN STATES AMS 681069

V CHAIN SUFFICIENT CONDITIONS FOR A STATIONARY PROCESS TO BE A FUNCTION OF A FINITE MARKO ON THE NORMAL STATIONARY PROCESS, AREAS OUTSIDE GIVEN LEVELS ZERO CROSSING PROBABILITIES FOR CAUSSIAN STATIONARY PROCESSES

BEST LINEAR UNBIASED ESTIMATION FOR MULTIVARIATE STATIONARY PROCESSES EQUIVALENCE OF GAUSSIAN STATIONARY PROCESSES DESIGN RELATIONS FOR NON-STATIONARY PROCESSES ON THE PREDICTION OF NON-STATIONARY PROCESSES

HYPOTHESIS TESTS FOR THE R-DEPENDENT MARGINALLY STATIONARY PROCESSES IAN MOTION TO THE EQUIVALENCE CONDITIONS FOR CERTAIN STATIONARY PROCESSES ON STATIONARY PROCESSES IN THE PLANE CORRIGENDA, 'ON STATIONARY PROCESSES IN THE PLANE'

THE ANALYSIS OF TWO-DIMENSIONAL STATIONARY PROCESSES WITH DISCONTINUOUS SPECTRA THE ANALYSIS OF STATIONARY PROCESSES WITH MIXED SPECTRA, I ANALYSIS OF STATIONARY PROCESSES WITH MIXED SPECTRA, LIMIT THEOREMS FOR THE MAXIMUM TERM IN STATIONARY SEOUENCES 
LINEAR CONTROL OF A LINEAR SYSTEM HAVING A NORMAL STATIONARY STOCHASTIC INPUT ON THE COEFFICIENT OF COHERENCE FOR WEAKLY STATIONARY STOCHASTIC PROCESSES

ON THE JRSSB6B 381 AMS $64 \quad 532$ AMS $64 \quad 1765$ AMS 65993 JASA $67 \quad 484$ BIOKA55 170 BIOKA55 160 EXTREME VALUES IN UNIFORMLY MIXING STATIONARY STOCHASTIC PROCESSES MODELS FOR TWO-DIMENSTONAL STATIONARY STOCHASTIC PROCESSES SAMPLING PROPERTIES OF LÓCAL STATISTIGS IN STATIONARY STOGHASTIC SERIES THE DISTRIBUTIONS OF THE TIMES BETWEEN EVENTS IN A STATIONARY STREAM OF EVENTS THE DEGREE OF RANDOMNESS IN A STATIONARY TIME SERIES

ON THE EXTRAPOLATION OF A SPECIAL GLASS OF STATIONARY TIME SERIES

ESTIMATION OF THE INNOVATION VARIANCE OF A STATIONARY TIME SERIES RIANCE AND SPECTRAL DENSITY FUNCTIONS FROM A CLIPPED STATIONARY TIME SERIES OF SOME STATISTICS USEFUL IN THE ANALYSIS OF JOINTLY STATIONARY TIME SERIES TENT ESTIMATES OF THE SPECTRAL DENSITY FUNCTION OF A STATIONARY TIME SERIES RIAL AND CROSS-CORRELATION COEFFICIENTS IN A COMPLEX STATIONARY TIME SERIFS SERVER QUEUES

DISTRIBUTION OF THE ANDERSON-DARLING STATISTIC STATIONAR
STATISTIC NOTE ON THE WILCOXON-MANN-WHITNEY STATISTIC
DISTRIBUTIONS OF A M. KAC STATISTIC ON THE TRIMMED MANN-WHITNEY STATISTIC CONTRIBUTIONS TO THE K-SAMPLE PROBLEM, A SYMMETRIC STATISTIC ADDENDUM, THE LIMITING DISTRIBUTION OF KAMAT'S TEST STATISTIC A K-SAMPLE ANALOGUE OF WATSON'S U-SQUARE STATISTIC ON THE DISTRIBUTION FUNCTIONS OF THE BEHRENS-FISHER STATISTIC FOR THE VARIANCE OF KENDALL'S RANK CORRELATION STATISTIC TABLES OF THE WILCOXON MATCHED PAIR SIGNED RANK STATISTIC TABLE OF CRITIGAL VALUES FOR WILCOXON'S TEST STATISTIC EXTENSION OF THE ONE-SIDED TWO-SAMPLE SMIRNOV TESTS STATISTIC ASYMPTOTIC NORMALITY OF THE MANN-WHITNEY-WILCOXON STATISTIC PROPERTIES OF A GENERALIZED WILCOXON-MANN-WHITNEY STATISTIC FOR THE NULL DISTRIBUTION OF THE TWO-SAMPLE WILCOXON STATISTIC VALUES FOR THE MANN-WHITNEY-WILCOXON TWO-SAMPLE STATISTIC THE DISTRIBUTION OF THE TRUNCATED POISSON SUFFICIENT STATISTIC E TEST AND ESTIMATOR BASED ON WILCOXON'S SIGNED RANK STATISTIC OT AND THE SMALLEST LATENT ROOT OF THE GENERALIZED B STATISTIC THEOREM AN EXAMPLE OF AN ANCILLARY STATISTIC AND THE COMBINATION OF TWO SAMPLES BY BAYES SOME PROPERTIES AND AN APPLICATION OF A STATISTIC ARISING INTESTING CORRELATION NOTE ON THE USE OF SHERMAN'S STATISTIC AS A TEST OF RANDOMNESS OBSERVATIONS IBULL MODEL WITH PROCRESSIVE C/ THRE ORDER STATISTIG CONFIDENCE BOUNDS ON RELIABLE LIFE FOR A THE EXPECTED COVERACE TO THE LEFT OF THE I'TH ORDER STATISTIC FOR ARBITRARY DISTRIBUTIONS EXTREME TATL PROBABILTTIES BIOKAG7 AN EXTENDED TABLE OF CRITICAL JASA $64 \quad 925$ A COMBINATORIAL DERTVATION OF AMS 61904 ON A FURTHER ROBUSTNESS PROPERTY OF TH AMS 68282

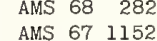
AMS 61616 AMS 691736 BIOKA54 556 BIOKA63 524 JASA 69306 AMS 631596 AMS $69 \quad 644$ APPROXIMATION TECH 68 497 EFFICIENCY OF THE WILCOXON TWO-SAMPLE STATISTIC FOR RANDOMIZED BLOCKS JASA $63 \quad$ B94

AN EXACT DISTRIBUTION OF THE BEHRENS-FISHER-WELCH STATISTIC FOR TESTING THE DIFFERENCE BETWEEN THE MEAN JRSSB61 377 A GOODNESS-OF-FIT STATISTIC FOR THE CIRCLE, WITH SOME COMPARISONS BIOKA69 161 ERRATA, 'EXACT GONFIDENCE BOUNDS, BASED ON ONE ORDER STATISTIC FOR THE PARAMETER OF A ONE-PARAMETER NEGATI TECH 64 4B3 ION EXACT CONFIDENCE BOUNDS, BASED ON ONE ORDER STATISTIC FOR THE PARAMETER OF AN EXPONENTIAL POPULAT TECH. 64301 DISTRIBUTION FOR THE DETERMINANT OF A NON-CENTRAL B STATISTIC IN MULTIVARIATE ANALYSIS AN ASYMPTOTIC SASJ 68 THE NON-NULL DISTRIBUTION OF A STATISTIC IN PRINCIPAL COMPONENTS ANALYSIS $\quad$ BIOKA66 590 ASYMPTOTIC LINEARITY OF A RANK STATISTIC IN REGRESSION PARAMETER APPROXIMATION TO THE DISTRIBUTION OF WILCOXON'S STATISTIC IN THE GENERAL CASE THE WILCOXON TWO-SAMPLE STATISTIC ON STRONCLY MIXING PROCESSES SIGNIFICANCE POINTS FOR THE TWO-SAMPLE STATISTIC U-SQUARE-SUB-M, N THE DISTRIBUTION OF THE GOODNESS-OF-FIT STATISTIC U-SQUARE-SUB-N. II ON THE DISTRIBUTION OF A STATISTIC USED FOR TESTING A GOVARIANCE MATRIX THE GOODNESS OF FIT STATISTIC V-SUB-N, DISTRIBUTION AND SIGNIFICANCE

POINTS ITTING A SUFFICIENT STATISTIG WHEN THE RANGE DEPENDS ON THE PARAMETER ON THE DISTRIBUTION OF THE LOG LIKELIHOOD RATIO TEST STATISTIC WHEN THE TRUE PARAMETER IS INEAR' THE BOUND ON A GENERALIZED SAVACE STATISTIC WITH APPLICATIONS TO LIFE TESTING EXACT AND APPROXIMATE DISTRIBUTIONS FOR THE WILCOXON STATISTIC WITH TIES THE INDEX OF DISPERSION AS A TEST STATISTIC. TABLES OF CRITICAL VALUES FOR WILCOXON'S TEST STATISTIC.' NOTE ON A PAPER BY RAY AND PITMAN +(FISHER-BEHRENS-STATISTIC) W-SQUARE-SUB-N + (CRAMER-VON MISES GOODNESS-OF-FIT STATISTIC) THE WILCOXON TWO-SAMPLE STATISTIC, TABLES AND BIBLIOGRAPHY

THE DISTRIBUTION OF THE GOODNESS-OF-FIT STATISTIC, U-SQUARE-SUB-N. I JRSSB62 537 JASA $63 \quad 10 B 6$ ONE POWER FUNCTIONS FOR TWO PROBLEMS IN MULTIVARIATE STATISTICAL ANALYSIS A CLASS OF TESTS WITH MONOT COMPLBX GAUSSIAN DISTRIBUTION, AN INTRODUCTION COMPLEX GAUSSIAN DISTRIBUTION STATISTICAL ANALYS IS BASED ON A CERTAIN MULTIVARIATE CLASSICAL STATSTIS ANALIS BASED ON A CERTAIN MULTIVARIATE AMS $63 \quad 152$ AMS $65 \quad 98$ OMPLETELY RANDOMIZED LAYOUTS ENT TO DETERMINE ROOT ACTIVITY N) ATION TO FOOD INDUSTRIES

\section{IN POIE} SOME ASPECTS OF THE STATISTICAL ANALYSIS OF ISPLIT PLOT' EXPERIMENTS IN C JASA 69 IN POTA/ NOTES. THE STATISTICAL ANALYSIS OF A RADIO-ACTIVE TRACER EXPERIM BIOCS68 SOME PROBLEMS IN THE STATISTICAL ANALYSIS OF EPIDEMIC DATA (WITH DISCUSSIO JRSSB55 THE STATISTICAL ANALYSIS OF INDUSTRY STRUCTURE, AN APPLIC JASA 61 STATISTICAL ANALYSIS OF INTROGRESSION S NATIONAL PRODUCT AND ITS COMPONENTS, OF SELEC/ A STATISTICAL ANALYSIS OF PROVISIONAL ESTIMATES OF CROS JASA 58 LY HETEROMORPHIC STOCHASTIC SERIES SOME ASPECTS OF THE STATISTICAL ANALYSIS OF THE 'MIXED MODEL' STATSTCAL ANLYSIS OPSTHE 'MTXL DROPERT' BIOKA57 JASA 61 COOPERATION AMONG STATISTICAL AND OTHER SOCIETIES

CONSIDFRING STATISTICAL AND TIME AVERAGES IN A REGULATION PROBLEM JRSSBG7 SYMPTOTIC DISTRIBUTION FOR AN OCCUPANCY PROBLEM WITH STATISTICAL APPLICATIONS DISCUSSION : CONTROL (WITH DISCUSSION) TEST ING STATISTICAL APPROACH TO PROBLEMS OF COSMOLOGY (WITH SOME STATISTICAL ASPECTS OF ADAPTIVE OPTIMIZATION AND SOME STATISTICAL ASPECTS OF THE ECONOMICS OF ANALYTICAL THE AMERICAN STATISTICAL ASSOCIATION AND FEDERAL STATISTICS

475
TECH $61 \quad 79$ JRSSB58 I JRSSB62 297 TECH $59 \quad 49$ JASA 64 

STATISTICAL CLASSIFICATION WITH QUADRATIC FORMS STATISTICAL CONCEPTS IN THEIR RELATION TO REALITY

THE STATISTICAL CONSULTANT IN A SCIENTIFIC LABORATORY

ERRORS OF THE THIRD KIND IN STATISTICAL CONSULTING

SOME OBSERVATIONS ON THE TEACHING OF STATISTICAL CONSULTING

STATISTICAL CONTROL OF A GAUSSIAN PROCESS

STATISTICAL CONTROL OF COUNTING EXPERIMENTS

STEREOSCOPIC MODELS OF MULTIVARIATE STATISTICAL DATA

CERTAIN TYPES OF RECREATION STATISTICAL DATA AVAILABLE FOR ECONOMIC RESEARCH ON

ON THE PROPERTY, W, OF THE CLASS OF STATISTICAL DECISION FUNCTIONS

THE EMPIRTCAL BAYES APPROACH TO STATISTICAL DECISION PROBLEMS STRINGENT SOLUTIONS TO STATISTICAL DECISION PROBLEMS MPLE NON-PARAMETRIC EMPIRICAL BAYES APPROACH TO SOME STATISTICAL DECISION PROBLEMS MTNTMAX SOLUTION OF STATISTICAL DECISION PROBLEMS BY ITERATTON SAMPLING INSPECTION AND STATISTICAL DECISIONS (WITH DISCUSSION)

NUMBERS OF OBSERVATIONS ON THE EFFECTS FOR THE U/ NUMBERS OF OBSERVATIONS IN THE SUBCLASSES FOR TH/ NEGATIVE VARIANCE ESTIMATES AND STATISTICAL DEPENDENCE IN NESTED SAMPLING SAL DEPENDENCE BETWEEN RANDOM EFFECTS AND THE JASA 671375 STATISTICAL DEPENDENCE BETWEEN SUBCLASS MEANS AND THE JASA 6B 1484 SOME GENERALIZATIONS AMS $66 \quad 525$ NATIONAL ACCOUNTS RVISED UNITED STATES ON THE STATISTICAL DISCREPANCY IN THE REVISED UNI A MAXIMUM-MTNTMUM PROBLEM RELATED TO STATISTICAL DISTRIBUTIONS IN TWO DIMENSIONS

A GRAPHICAL METHOD FOR THE ANALYSIS OF STATISTICAL DISTRIBUTIONS INTO TWO NORMAL COMPONENTS EST PROCEDURES FOR POSSIBLE CHANGES IN PARAMETERS OF STATISTICAL DISTRIBUTIONS OCCURING AT UNKNOWN TIME PO APPROXIMATE FORMULAE FOR THE STATISTICAL DISTRIBUTIONS OF EXTREME VALUES STUDIES IN STATISTICAL ECOLOGY. I. SPATIAL PATTERN A NOTE ON STATISTICAL EQUIVALENCE

REQUIREMENT OF NEW MODEL AUTOMOBILES PROCESS

A PARADOX IN STATISTICAL ESTIMATION

STATISTICAL ESTIMATION OF THE GASOLINE OCTANE NUMBER STATISTICAL ESTIMATION PROCEDURES FOR THE 'BURN-IN' STATISTICAL EVALUATION OF CLOUD SEEDING OPERATIONS STATISTICAL EVALUATION OF SPLITTING LIMIT CRITERIA IN

MEASUREMENT DISPUTES

THE STATISTICAL FOURIER ANALYSIS OF VARIANCES STATISTICAL FRONTIERS

REPETITIVE PLAY IN FINITE STATISTICAL GAMES WITH UNKNOWN DISTRIBUTIONS ON THE RESOLUTION OF STATISTICAL HYPOTHESES ON OPTIMAL ASYMPTOTIC TESTS OF COMPOSITE STATISTICAL HYPOTHESES TESTING THE APPROXIMATE VALIDITY OF STATISTICAL HYPOTHESES CONFIRMING STATISTICAL HYPOTHESES AN OMNIBUS TECHNIQUE FOR ESTIMATION AND TESTING STATISTICAL HYPOTHESES PAIRWISE STATISTICAL INDEPENDENCE CONFIDENCE CURVES, JASA 61246 AMS 651313 VARIATES." ANALYSIS OF VARIANCE

CORRIGENDA, ION THE STATISTICAL INDEPENDENCE OF QUADRATIC FORMS IN THE

ON THE FOUNDATIONS OF STATISTICAL TNFERENCE

SOME GRAPHS USEFUL FOR STATISTICAL INFERENCE

ON PARTIAL 'A PRIORI' INFORMATION IN STATISTICAL INFERENCE

(CORR, 66252

FINITE STATE MARKOV CHAINS

CONSISTENCY IN STATISTICAL INFERENCE AND DECISION (WITH DISCUSSION) STATISTICAL INFERENCE FOR PROBABILISTIC FUNCTIONS OF THE QUALITY OF STATISTICAL INFORMATION AND STATISTICAL INFERENCE IN A RAPIDLY CHANGING WORLD SOME PROBLEMS OF STATISTICAL INFERENCE IN ABSORBING MARKOV CHAINS.

BIOKA59 279 BIOKA51 482 AMS $62 \quad 294$ JASA $62 \quad 269$ JASA $65 \quad 334$ AMS 671671 JRSSB 61 AMS $66 \quad 1554$ JASA 67 BIOKA65 127 E TO THE CIGARETTE SMOKING AND LUNG C/ PROBLEMS OF STATISTICAL INFERENCE IN HEALTH WITH SPECIAL REFERENC JASA 69 739 LEM, UNBIASED ESTIMATION OF THE NUMBER OF CLASSES STATISTICAL INFERENCE IN THE CLASSICAL OCCUPANCY PROB JASA 68 B37 DISTRIBUTIONS BIOKA69 NO.3 AMS $61 \quad 414$ NERALIZED CLASSICAL LINEAR ESTIMATORS IN ECONOMETRIC STATISTICAL INFERENCE, CORR. 641296 /NCTIONS OF GE JASA 63 943 DISCUSSION OF 'ON THE FOUNDATIONS OF STATISTICAL INFERENCE' A RAPIDLY CHANGING WORLD CONTROVERSY

THE QUALITY OF STATISTICAL INFORMATION AND STATISTICAL INFERENCE IN A STATISTICAL INVESTIGATION OF THE INDUSTRIALIZATION STATISTICAL ISOMORPHISM

STATISTICAL LIFE TEST ACCEPTANCE PROCEDURES

APPLICATIONS OF A NEW GRAPHIC METHOD IN STATISTICAL MEASUREMENT

RECAPTURE EXPERIMENT NONPARAMETRIC STATISTICAL METHOD FOR CULLING RECRUITS FROM A MARK

$R$ A FISHER AND THE LAST FIFTY YEARS OF STATISTICAL METHODOLOGY STATISTICAL METHODS AND SCIENTIFIC INDUCTION

(WITH DISCUSSION) SOME STATISTICAL METHODS CONNECTED WITH SERIES OF EVENTS STATISTICAL METHODS FOR THE MOVER-STAYER MODEL STATISTICAL METHODS IN MARKOV CHAINS, CORR, $61 \quad 1343$

A STATISTICAL MODEL FOR LIFE-LENGTH OF MATERIALS JASA $67 \quad 1$ JASA $60 \quad 284$ AMS $66 \quad 203$ TECH $60 \quad 435$ JASA $57 \quad 472$ BIOCS65 936 JASA $65 \quad 395$ JRSSB55 69 JRSSB $55 \quad 129$ JASA 61 B4I AMS $61 \quad 12$ JASA $58 \quad 151$

THE BOOK STORAGE PROBLEM

A STATISTICAL MODEL OF BOOK USE AND ITS APPLICATION TO JASA 69 NO.4

A STATISTICAL MODEL OF EVALUATING THE RELIABILITY OF SA TECH 59293 STATISTICAL MODELS AND INVARIANCE

ITY TESTING, BIOLOGICAL BACKGROUND PROBABILISTIC AND STATISTICAL MODELS AND PROBLEMS (INVITED PAPER) /IL BIOCS69 207 A COMMENT ON D.V. LINDLEY'S STATISTICAL PARADOX

A STATISTICAL PARADOX SAMPLES OF GROUPED OBSERVATIONS IN THE ESTIMATION OF STATISTICAL PARAMETERS /ATION SUPPLIED BY CENSORED BIOKA62 245 SPECIAL PAPER, PRINCIPLES OF PROFESSIONAL STATISTICAL PRACTICE SOME PROBLEMS OF STATISTICAL PREDICTION

AMS 651883 BIOKA65 469 NECESSARY AND SUFFICIENT CONDITIONS FOR A STATISTICAL PROBLEM TO BE INVARIANT UNDER A LIE GROUP AMS 63 492 (WITH DISCUSSION) DISCUSSION )

OF A COMPLETE HYPOTHESIS SOME STATISTICAL PROBLEMS CONNECTED WITH CRYSTAL LATTICES JRSSB64 367 SOME STATISTICAL PROBLEMS IN EXPERIMENTAL PSYCHOLOGY (WITH JRSSB56 177 STATISTICAL PROBLEMS IN SCIENCE. THE SYMMETRIC TEST JASA 69 NO.4 STATISTICAL PROCESS CONTROL AND THE IMPACT OF 

$\begin{array}{llllll}\text { STATISTICAL PROPERTIES OF A CERTAIN PERIODIC BINARY } & \text { TECH } 66 & 247 \\ \text { STATISTICAL PROPERTIES OF A CENETIC SELECTION INDEX } & \text { BIOKA62 } & 325\end{array}$ STATISTICAL PROPERTIES OF THE NUMBER OF POSITIVE SUMS AMS 661295

HURWITZ CHANCES TN CENSUS METHODS

HURWITZ, ON WILLIAM HURWITZ

HURWITZ. COMMENTS

URWITZ. PROFESSOR WILLIAM N. HURWITZ

URWITZ. SOME BASIC PRINCIPLES OF STATI/

URWITZ. THE DEVELOPMENT OF HOUSEHOLD S/
THE EFFICIENCY OF STATISTICAL SIMULATION PROCEDURE

WASHTNCTON STATTSTICAL SOCIETY MEMORTAL MEETINC FOR WTLLIAM N. WASHINCTON STATISTICAL SOCIETY MEMORIAL MEETINC FOR WILLIAM N. WASHINGTON STATISTICAL SOCIETY MEMORIAL MEETING FOR WILLIAM $N$. WASHTNCTON STATISTICAL SOCIETY MEMORIAL MEETING FOR WILLIAM N H WASHINCTON STATISTICAL SOCIETY MEMORIAL MEETINC FOR WILLIAM N WASHINCTON STATISTICAL SOCIETY MEMORIAL MEETINC FOR WILLIAM N. BANDWIDTH AND RESOLVABILITY IN STATTSTICAL SPECTRAL ANALYSIS

F PROBABTLTTY AND STATISTICS. IV A NOTE ON AN EARLY STATTSTICAL STUDY OF LITERAR

ING FOR WILLIAM N. HURWITZ. SOME BASIC PRINCIPLES OF STATISTICAL SURVEYS /TISTICAL SOCIETY MEMORIAL MEET JASA 69 NO. 4 CHOICES FOR THE FUTURE DEVELOPMENT OF THE FEDERAL STATISTICAL SYSTEM B BOI OF NONTOXIC COITRE A COMPARISON OF STATISTICAL TECHNIQUES IN THE DIFFERENTIAL DIAGNOSIS BIOCS68 103 A STATISTICAL TEST FOR EQUALITY OF TWO AVAILABILITIES TECH $6 B \quad 594$

VARIABLES

A STATISTICAL TEST INVOUVTNC A RANDOM NUMBER OF RANDOM

AMS 661305

TWAIN AND THE QUINTUS CURTIUS SNODCRASS LETTERS, A STATISTICAL TEST OF AUTHORSHIP MARK JASA $63 \quad 85$ JRSSB $5 B \quad 205$ DILUTION SERIES, A STATISTICAL TEST OF TECHNIQUE (CORR, 59 238)

JASA 65 10B0

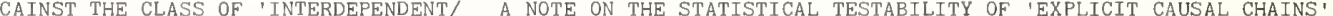
AL VALUE METHOD FOR ADJUDGINC RELATIVE EFFICIENCY OF STATISTICAL TESTS IN TIME SERIES RECRESSION ANALYSIS BIOKA6G IO OF DOMINANCE IN MONOFACTORIAL INHERITANCE NOTES. STATISTICAL TESTS OF HYPOTHESES CONCERNINC THE DECREE BIOCS68 429 PLANTMETER STATISTICAL THEORY OF A HICH-SPEED PHOTOELECTRIC A STATISTICAL THEORY OF REMNANTS

APPLICATION OF NUMERIC

FUNDAMENTAL FORMULAE STATISTICAL TREATMENT OF CENSORED DATA. PART I THE STATISTICAL TREATMENT OF MEAN DEVIATION

THE STATISTICAL WORK OF OSKAR ANDERSON STATISTICIAN AND POLICY MAKER. A PARTNERSHIP IN THE

MAKINC INDETERMINISM IN SCIENCE AND NEW DEMANDS ON STATISTICIANS LEADING AMERICAN STATISTICIANS IN THE NINETEENTH CENTURY EADINC BRITISH STATISTICIANS OF THE NINETEENTH CENTURY LEADINC AMERICAN STATISTICIANS OF THE NINETEENTH CENTURY II STATISTICIANS, TODAY AND TOMORROW

TABLE OF PERCENTACE POINTS OF KOLMOCOROV STATISTICS PRACTICAL VALUE OF INTERNATIONAL EDUCATIONAL STATISTICS NONPARAMETRIC STATISTICS THE DUAL FUNCTION OF STATISTICS CERTAIN UNCORRELATED STATISTICS ON CONDITIONAL EXPECTATIONS OF LOCATION STATISTICS THE SAMPLE MEAN AMONC THE MODERATE ORDER STATISTICS DECIMAL CORRECTION ERROR, AN EXAMPLE IN STATISTICS THE SAMPLE MEAN AMONC THE EXTREME NORMAL ORDER STATISTICS LOCISTIC ORDER STATISTICS

ON THE LIMIT BEHAVIOUR OF EXTREME ORDER STATISTICS COMPUTATION WITH MULTIPLE K-STATISTICS

ON UNCORRELATED LINEAR FUNCTIONS OF ORDER STATISTICS SOME NUMERICAL ASPECTS OF THE USE OF TRANSFORMS IN STATISTICS

SOME BASIC THEOREMS OF DISTRIBUTION-FREE STATISTICS CHARACTERIZATION OF MULTISAMPLE DISTRIBUTION-FREE STATISTICS ON CONTINUOUS SUFFICIENT STATISTICS AN APPLICATION OF A BALLOT THEOREM IN ORDER STATISTICS ON EXTREME ORDER STATISTICS ON ASYMPTOTIC MOMENTS OF EXTREME STATISTICS SOME BOUNDS FOR EXPECTED VALUES OF ORDER STATISTICS A K-SAMPLE MODEL IN ORDER STATISTICS ON INFORMATION IN STATISTICS MINIMUM CHI-SQUARED ESTIMATION USINC INDEPENDENT STATISTICS RATES OF CONVERCENCE OF ESTIMATES AND TEST STATISTICS ON THE COMBINATION OF INDEPENDENT TEST STATISTICS SIMPLE RANDOM WALK AND RANK ORDER STATISTICS

A NOTE ON MOMENTS OF CAMMA ORDER STATISTICS THE DISTRIBUTION OF CALTON'S STATISTICS CERTAIN UNCORRELATED NONPARAMETRIC TEST STATISTICS ERRORS OF MEASUREMENT IN STATISTICS LINEAR FUNCTIONS OF ORDER STATISTICS BOUNDS AND APPROXIMATIONS FOR THE MOMENTS OF ORDER STATISTICS SOME CENERAL REMARKS ON CONSULTINC IN STATISTICS THE MOMENTS OF LOC-WEIBULL ORDER STATISTICS XXTREMA OF QUADRATIC FORMS WITH APPLICATIONS TO STATISTICS ON THE SMALLEST OF SEVERAL CORRELATED F STATISTICS ON THE ASYMPTOTIC SUFFICIENCY OF CERTAIN ORDER STATISTICS DISTRIBUTION FUNCTIONS OF TSAO'S TRUNCATED SMIRNOV STATISTICS A THEOREM OF DYNKIN ON THE DIMENSION OF SUFFICIENT STATISTICS SICNIFICANCE LEVEL AS A SENSITIVITY INDEX FOR TEST STATISTICS

OF A MODIFIED 'HANNAN' AND THE BUREAU OF LABOR STATISTICS OF A BALLOT THEOREM IN PHYSICS AND IN ORDER STATISTICS OF MEIJER-G FUNCTIONS TO DISTRIBUTION PROBLEMS IN STATISTICS
BIOKAGB 419 JRSSB59 158

AN TECH $67 \quad 44$

BIOKA54 228 BIOKA54 12 JASA $61 \quad 273$ JASA $56 \quad 12$ JASA $60 \quad 625$ JASA $57 \quad 301$ JASA $60 \quad 38$ JASA $58 \quad 689$ JASA 59

JASA $56 \quad 111$ JASA $56 \quad 605$ JASA $57 \quad 331$ JASA 60 JASA $60 \quad 265$ JASA $60 \quad 714$ AMS 621160 TECH $62 \quad 421$ AMS $63 \quad 33$ AMS $63 \quad 658$ AMS $63 \quad 992$ JASA $63 \quad 120$ JASA $63 \quad 245$ JASA $63 \quad 879$ AMS $64 \quad 150$ AMS $64 \quad 735$ AMS 641229 AMS 641356 AMS 641726

AMS 64 173B AMS $65 \quad 1055$ AMS $65 \quad 1223$ AMS $65 \quad 890$ AMS $67 \quad 267$ AMS $67 \quad 303$ AMS $67 \quad 659$ AMS 671042 TECH $67 \quad 315$ AMS $68 \quad 2114$ JASA $6 B \quad 707$ TECH $68 \quad 637$ AMS $69 \quad 770$ JASA 69 NO. 4 TECH 69241 TECH $69 \quad 373$

BIOKA59 4B3 BIOKA62 509 JRSSB $62 \quad 167$

THE AMS 671208 NOTE ON AMS $69 \quad 1474$ EXPECTED JASA $65 \quad 420$ A COMPARISON JASA $65 \quad 442$ APPLICATIONS JRSSB65 130 SOME APPLICATIONS BIOKA58 578 
INVARIANTS FOR DISTRIBUTIONS ADMITTING SUFFICIENT STATISTICS OF THE MAXIMUM AND MINIMUM OF RATIOS OF ORDER STATISTICS OF ASYMPTOTIC NORMALITY OF LINEAR FUNCTIONS OF ORDER STATISTICS OF LINEAR COMBINATIONS OF FUNCTIONS OF ORDER STATISTICS

A CASE STUDY IN THE INTERPRETATION OF HISTORICAL STATISTICS ATIONS BETWEEN EXPECTED VALUES OF FUNCTIONS OF ORDER STATISTICS OF TWO ALTERNATIVES. I. WILCOXON'S AND ALLIED TEST STATISTICS OF GENERALIZED CLASSICAL LINEAR IDENTIFIABILITY TEST STATISTICS NERALIZED TRUNCATED NORMAL DISTRIBUTIONS USING ORDER STATISTICS MATRIX WITH APPLICATIONS TO PROBLEMS IN MATHEMATICAL STATISTICS PARAMETERS OF THE LOGISTIC DISTRIBUTION USING ORDER STATISTICS MOGOROV-SMIRNOV AND KUIPER ONE-SAMPLE AND TWO-SAMPLE STATISTICS REME VALUE DISTRIBUTION BY USE OF TWO OR THREE ORDER STATISTICS THE SAMPLING PROBABILITIES OF A CLASS OF WIDELY USED STATISTICS $S$ AND THE CORRELATION COEFFICIENT BETWEEN THEIR TEST STATISTICS L DISTRIBUTION ON THE BASIS OF SUITABLY CHOSEN ORDER STATISTICS TIVE EXPONENTIAL DISTRIBUTIONS FROM ONE OR TWO ORDER STATISTICS AMPLE DRAWN FROM A DISTRIBUTION ADMITTING SUFFICIENT STATISTICS AMETERS OF THE BETA DISTRIBUTION FROM SMALLEST ORDER STATISTICS COMPUTERS, THE SECOND REVOLUTION IN STATISTICS

NOTES ASSUMPTTON-FREE ESTTMATORS USING U STATTSTTCS

STATISTIC OF TH/ CONDITIONAL DISTRIBUTION OF ORDER STATISTICS AND A RELATIONSHIP TO THE JACKKNIFE METHOD PROBLEMS

CORRECTION TO 'TABLES OF EXPECTED VALUES OF ORDER STATISTICS ON MOMENTS OF ORDER STATISTICS AND STCS AND QUASI-RANGES FROM NORMAL POPULATIONS STATISTICS AND SCIENCE STATISTICS AND SOCIETY

ORDER STATISTICS AND STATISTICS OF STRUCTURE

/ EXACT MOMENTS AND PERCENTAGE POINTS OF THE ORDER STATISTICS AND THE DISTRIBUTION OF THE RANGE FROM THE SOME GENERALIZATIONS OF THE DISTRIBUTIONS OF PRODUCT STATISTICS ARISING FROM RECTANGULAR POPULATIONS OF CUBES OF CUBES

OFACT SOME ON THE DISTRIBUTION AN ELEMENTARY PROO SOME STATISTICS ASSOCIATED WITH THE RANDOM DISORIENTATION NO 69 NO.6 DOMNESS IN A SEQUENCE BIOKA5B 166 SAMPLE DISTRIBUTIONS JASA $60 \quad 650$ A CENERALIZED INVERSE OF A JRSSB62 152 $\begin{array}{llll} & \end{array}$ BXACT BAHADUR EFFICIENCIES FOR THE KOL AMS 671475 OF THE PARAMETERS OF THE EXT BIOKA69 429 ABLE GENERATING FUNCTION FOR COMPUTING JASA 64487 MPTOTIC RELATTVE EFFICIENCY OF TWO TEST AMS 631442 /ONE OF TWO PARAMETERS OF THE EXPONENTIA AMS 631419 VATURE OF THE LTKELTHOOD SURFACE OF A S BIOKA6O 203 MAXIMUM LIKELIHOOD ESTIMATION OF THE PAR TECH $67 \quad 607$ BIOCS66 233 BIOCS67 567 AMS $63 \quad 652$ AMS 6B 1756 AMS 611345 AMS $63 \quad 633$ JASA $57 \quad 322$ JASA $63 \quad 1$ AMS $65 \quad 897$ AMS $65 \quad 907$ JASA $64 \quad 557$ BIOKA58 229 BIOKA57 205 AMS 631513 JASA $59 \quad 730$ THE ASYMPTOTIC NORMALITY OF TWO TEST STATISTICS ASSOCIATED WITH THE TWO-SAMPLE PROBLEM ANALYSIS OF VITAL STATISTICS BY CENSUS TRACI ERCENTAGE POINTS AND APPLICATION TO TESTING FOR R/ STATISTICS CONNECTED WITH THE UNIFORM DISTRIBUTION, P BIOKA66 235 APPLICATIONS OF TIME-SHARED COMPUTERS IN A STATISTICS CURRICULUM
DISTRIBUTION

SAMPLES

GROUPED SAMPLES

ORDER STATISTICS ESTIMATORS OF THE LOCATION OF THE CAUCHY ORDER STATISTICS FOR DISCRETE POPULATIONS AND FOR GROUPED
JASA $6 B \quad 192$

JASA $66 \quad 1205$

JASA $68 \quad 1390$ CONSISTENT STATISTICS FOR ESTIMATING AND TESTING HYPOTHESES FROM BIOKA66 545 RECURRENCE RELATTONS BETWIEN MOMENTS OF ORDER STATISTICS FOR EXCHANGEABLE VART ATES TABLES OF CRITICAL VALUES OF SOME RENYI TYPE STATISTICS FOR FINITE SAMPLE SIZES MATRICES AN EMPIRICAL COMPARISON OF DISTANCE STATISTICS FOR POPULATIONS WITH UNEQUAL COVARIANCE BIOCS6B 6B3 DESICN MINIMAL SUFFICIENT STATISTICS FOR THE TWO-WAY CLASSIFICATION MIXED MODEL J INTERNAL MIGRATION STATISTICS FOR THE UNITED STATES ORDER STATTSTICS FROM BIOKA69 415

ON THE BIVARIATE MOMENTS OF ORDER STATI LINEAR FORMS IN THE ORDER STATISTICS FROM AN EXPONENTIAL DISTRIBUTION URRENCE RELATION FOR DISTRIBUTION FUNCTIONS OF ORDER STATISTICS FROM BIVARIATE DISTRIBUTIONS ASYMPTOTIC DISTRIBUTION OF DISTANCES BETWEEN ORDER STATISTICS FROM BIVARIATE POPULATIONS ASYMPTOTIC JOINT DISTRIBUTION OF LINEAR SYSTEMATIC STATISTICS FROM MULTIVARIATE DISTRIBUTIONS INEQUALITIES FOR LINEAR COMBINATIONS OF ORDER STATISTICS FROM RESTRICTED FAMILIES AMS 64270 A REC JASA 69600 AMS 64748 JASA 69300 AMS 661574 ESTIMATION OF LOCATION AND SCALE PARAMETERS BY ORDER STATISTICS FROM SINGLY AND DOUBLY CENSORED SAMPLES, P AMS 39 325 L DISTRIBUTION MOMENTS OF ORDER STATISTICS FROM THE EQUICORRELATED MULTIVARIATE NORMA ORDER STATISTICS FROM THE GAMMA DISTRIBUTION ERRATA, 'ORDER STATISTICS FROM THE GAMMA DISTRIBUTION'

PERCENTAGE POINTS AND MODES OF ORDER STATISTICS FROM THE NORMAL DISTRIBUTION

AMS 621286 TECH $60 \quad 243$ TECH $60 \quad 523$ AMS 61888 EXACT MOMENTS AND PRODUCT MOMENTS OF THE ORDER STATISTICS FROM THE TRUNCATED LOGISTIC DISTRIBUTION JASA 66 5I4 ESSION MISSING OBSERVATIONS IN MULTIVARIATE STATISTICS II. POINT ESTIMATION IN SIMPLE LINEAR REGR JASA 67 IO THE EXPONENTIAL DISTRIBUTION BASED ON OPTIMUM ORDER STATISTICS IN CENSORED SAMPLES /F THE PARAMETERS OF AMS 66 I7I7 THE ACCURACY OF CENSUS LITERACY STATISTICS IN IRAN OF THE RANGE AND PRODUCT MOMENTS OF EXTREME ORDER STATISTICS IN NORMAL SAMPLES JASA 59578 ON THE MOMENTS BIOKA56 458 TION POPULATIONS

DISTRIBUTION OF SOME STATISTICS IN SAMPLES FROM EXPONENTIAL AND POWER-FUNC CORRIGENDA, 'ON THE MOMENTS OF ORDER STATISTICS IN SAMPLES FROM NORMAL POPULATIONS' EXACT LOWER MOMENTS OF ORDER STATISTICS IN SAMPLES FROM THE CHI-DISTRIBUTION, ONE

RATE AVERAGE

RELATIONS AMONG MOMENTS OF ORDER STATISTICS IN SAMPLES FROM TWO RELATED POPULATIONS ASYMPTOTICALLY OPTIMAL STATISTICS IN SOME MODELS WITH INCREASING FAILURE STATISTICS IN SOUTH AFRICA

SAMPLING PROPERTIES OF LOCAL STATISTICS IN STATIONARY STOCHASTIC SERIES

VARIABLES

ON THE DISTRIBUTION OF THE F-TYPE STATISTICS IN THE ANALYSIS OF A GROUP OF EXPERIMENTS

SOCIAL PROGRAMMES SUFFICIENT STATISTICS IN THE CASE OF INDEPENDENT RANDOM THE USE OF STATISTICS IN THE FORMULATION AND EVALUATION OF 67259 BIOKA54 568 AMS 621292 TECH $63 \quad 514$ AMS 671731 SASJ $68 \quad 109$ BIOKA55 160 JRSSB66 526 AMS 641456 JASA $60 \quad 454$ CULATION OF DISTRIBUTIONS OF KOLMOGOROV-SMIRNOV TYPE STATISTICS INCLUDING A TABLE OF SIGNIFICANCE POINTS F ANS 68 233 PROCESS THE STATISTICS OF A PARTICULAR NON-HOMOGENEOUS POISSON OF A CONTINUOUS UNIVARIATE POPULATION FROM THE ORDER STATISTICS OF A SAMPLE /ERSE DISTRIBUTION FUNCTION B ON THE APPLICATION TO STATISTICS OF AN ELEMENTARY THEOREM IN PROBABILITY

BIOKA64 399 BIOKA69 NO. 3 BIOKA56 85 BIOKA64 253 AMS 651779 ASYMPTOTIC NORMALTTY OF CERTATN TEST STATISTICS OF EXPONENTIALITY PROPERTIES OF THE MEDIAN AND OTHER STATISTICS OF LOGISTIC VARIATES

0 RELATED SOCIAL STU/ A GUIDE TO THE LITERATURE ON STATISTICS OF RELICIOUS AFFILIATION WITH REFERENCES T JASA 59 335 INTERRELATIONS BETWEEN CERTAIN LINEAR SYSTEMATIC STATISTICS OF SAMPLES FROM ANY CONTINUOUS POPULATION BIOKA5I 377 LATION TO INVERSE SAMP/ EXACT MOMENTS OF THE ORDER STATISTICS OF THE GEOMETRIC DISTRIBUTION AND THEIR RE JASA 67 915 1 POPULATIONS RESULTS FROM THE RELATION BETWEEN TWO STATISTICS OF THE KOLOMOGOROV-SMIRNOV TYPE AMS 691833 SOME RESULTS ON THE ORDER STATISTICS OF THE MULTIVARIATE NORMAL AND PARETO TYPE AMS 64 1815 NOTES ON IMMICRATION STATISTICS OF THE UNITED STATES NATIONAL INCONE STATISTICS OF UNDERDEVELOPED COUNTRIES 
SCALE PARAMETER ESTIMATION FROM THE ORDER STATISTICS OF UNEQUAL CAMMA COMPONENTS ATIONS OF NORMALITY BY CONSTANT RECRESSION OF LINEAR STATISTICS ON ANOTHER LINEAR STATISTIC SOURCES OF STATISTICS ON CRIME AND CORRECTION

AMS $66 \quad 152$ CHARACTERIZ AMS 671894 JASA 59582

ON EXPERIMENTS

ON THE DISTRIBUTION OF STATISTICS SUITABLE FOR EVALUAT

ASYMPTOTIC NORMALITY OF SIMPLE LINEAR RANK STATISTICS UNDER ALTERNATIVES

ASYMPTOTIC NORMALITY OF SIMPLE LINEAR RANK STATISTICS UNDER ALTERNATIVES, II

69 AMS $68 \quad 325$ AMS 69 NO. 6

OF THE DISTRIBUTTON OF SEVERAL NON-PARAMETRIC TEST STATTSTICS UNDER CENSORINC TEL TMETRY SYSTEMATIC STATISTICS USED FOR DATA COMPRESSION IN SPACE JASA $65 \quad 97$ RY TIME SERIES ON THE DISTRIBUTION OF SOME STATISTICS USEFUL IN THE ANALYSIS OF JOINTLY STATIONA STATISTICS WE LIVE BY LITERAT/ STUDIES IN THE HISTORY OF PROBABILITY AND STATISTICS XVI. RANDOM RANDOM MECHANISMS IN TALMUDIC THE USE OF THE HANKEL TRANSFORM IN STATISTICS. I. GENERAL THEORY AND EXAMPLES THE USE OF THE HANKEL TRANSFORM IN STATISTICS. II. METHODS OF COMPUTATION STUDIES IN THE HISTORY OF PROBABILITY AND STATISTICS. XIX. FRANCIS YSIDRO EDGEWORTH (1845-1926) BIOKA68 269 SS LINE/ STUDIES IN THE HISTORY OF PROBABILITY AND STATISTICS. XV. THE HISTORICAL DEVELOPMENT OF THE GAU BIOKA67 E DEVEL/ STUDIES IN THE HISTORY OF PROBABILITY AND STATISTICS. XVII. SOME REFLEXIONS ON CONTINUITY IN TH BIOKA67 341 STUDIES IN THE HISTORY OF PROBABILITY AND STATISTICS. XVIII. THOMAS YOUNG ON COINCIDENCES STUDIES IN THE HISTORY OF PROBABILITY AND STATISTICS. XXII. PROBABILITY IN THE TALMUD SOME NEW DISTRTBUTTON-FREE STATISTTCS, (ACKNOWLEDCEMENT OF PRIORITY 65 1901) AMS 65203 S BETWEEN THE PROBABILITY DENSITY FUNCTIONS OF ORDER STATISTICS, AND SOME APPLICATIONS /URRENCE RELATION AMS 62 169 CATIVE EXPONENTIAL POPULATIONS FROM ONE OR TWO ORDER STATISTICS, CORR. TO THIS PAPER PRINTED IN 63 1421 AN AMS 61 $107 B$ LIGHT BULB STATISTICS, CORR, $66 \quad 1248$

THE ROLE OF EXPERIMENTAL RANDOMTZATTON IN BAYESTAN STATISTICS FINTTE SAMPLING AND TWO BAYESTANS

JASA $66 \quad 633$ BIOKA69 NO.3 L/ POINT AND INTERVAL ESTIMATORS, BASED ON M ORDER STATISTICS, FOR THE SCALE PARAMETER OF A WEIBULL POPU TECH 65 4O5 MISSING VALUES IN MULTIVARIATE STATISTICS I REVIEW OF THE ITTERATURE MISSING OBSERVATIONS IN MULTIVARIATE STATISTICS, II MISSINC OBSERVATIONS IN MULTIVARIATE STATISTICS, IV

TESTS SUFFICIENT STATISTICS,

SIMILAR REGIONS AND DISTRIBUTICN-FREE JASA $69 \quad 337$ JASA $69 \quad 359$ JRSSB 57262 ROXIMATIONS FOR THE DISTRIBUTIONS OF GOODNESS-OF-FIT STATISTICS, U-SQUARE-SUB-N AND W-SQUARE-SUB-N /APP BIOKA65 630 ONS ON CONTINUITY IN THE DEVELOPMENT OF MATHEMATICAL STATISTICS, 1885-1920 /ATISTICS. XVII. SOME REFLEXI BIOKA67 34I 'EXTREMA OF OUADRATIC FORMS WITH APPLICATIONS TO STATISTICS'

A NOTE ON 'A K-SAMPLE MODEL IN ORDER STATISTICS' BY W. J. CONOVER CORRTGENDA , BIOKA6I 474 AMS $66 \quad 287$ CORRECTION TO 'ON THE MUTUAL INDEPENDENCE OF CERTAIN STATISTICS' 591258 / 1394 RT DISTRIBUTION AND CERTAIN PROBLEMS OF MULTIVARIATE STATISTICS' 46409 /ECTION. 'THE NON-CENTRAL WISHA AMS 64 923 I/ LTUDE DES COMMUNAUTES VECETALES PAR L'ANALYSE STATISTIQUE DES LIAISONS ENTRE LES ESPECES ET LES VAR BIOCS65 345
I/ L'ETUDE DES COMMUNAUTES VECETALES PAR L'ANAEYSE STATISTIQUE DES LIAISONS ENTRE LES ESPECES ET LES VAR BIOCS65 890 AND EXPECTED FUTURE DEVELOPMENTS THE PRESENT STATUS OF AUTOMATIC PRODUCTION AND CONTROL DEVICES TECH 66 73 SITUATIONS WHERE TREATMENTS OR BLOCKS ARE OF UNEQUAL STATUS OR SIZE STATISTICAL METHODS FOR THE MOVER-STAYER MODEL

OF THE TIME-TO-EMPTINESS OF A DISCRETE DAM UNDER STEADY DEMAND THE FIRST 1,945 BRITISH STEAMSHIPS A PROPERTY OF THE METHOD OF STEEPEST ASCENT ON A FIDUCIAL EXAMPLE OF C. STEIN

INDEPENDENT SEQUENCES WITH THE STEIN PROPERTY EFFECT OF NON-NORMALITY ON STEIN'S TWO SAMPLE TEST

OF THE RANCE IN PLACE OF THE STANDARD DEVIATION IN STEIN'S TEST SOME SEQUENTTAL ANALOGS OF STEIN'S TWO-STACE TEST

PROBLEMS SEQUENTIAL INFERENCE PROCEDURES OF TEIN'S TYPE FOR A CLASS OF MULTIVARIATE RECRESSION STEP-WISE CLUSTERING PROCEDURES

A RANDOM WAEK IN WHICH THE STEPS OCCUR RANDOMLY IN TIME

NOTE ON STEPWISE LEAST SQUARES STEPWISE LEAST SQUARES, RESIDUAL ANALYSIS AND

SPECIFICATION ERROR MULTIVARIATE THEORY FOR GENERAL STEPWISE METHODS STEPWISE MULTIVARIATE LINEAR RECRESSION

A STEPWISE MULTIVARIATE T-DISTRIBUTION

AN APPLICATION OF STEPWISE RECRESSION TO NON-LINEAR ESTIMATION

EFFICIENCIES FOR STEPWISE REGRESSIONS STEREOSCOPIC MODELS OF MULTIVARIATE STATISTICAL DATA BIOCS66 358

RELEASE AND CONTROL OF CAPSULES, TABLETS, AND STERILE SOLIDS UTION OF STATISTICS SUITABLE FOR EVALUATING RAINFALL STIMULATION EXPERIMENTS FOR THE NON-INTERACTIVE JOINT ACTION OF A MIXTURE OF STIMULI IN BIOLOGICAL ASSAY ALYSIS OF SENSITIVITY EXPERIMENTS WHEN THE LEVELS OF STIMULUS CANNOT BE CONTROLLED, CORR. 56 65O STIRLING BEHAVIOR IS ASYMPTOTICALLY NORMAL

THE DISTRIBUTION JRSSB $63 \quad 137$

JASA 5B 360 AMS $64 \quad 435$ JRSSB $66 \quad 53$ AMS 681282 AMS $65 \quad 651$ THE USE AMS $63 \quad 346$ BIOKA62 367 AMS 621039 JASA $67 \quad 86$ BIOKA59 30 JASA $61 \quad 105$ JASA 61998 AMS $63 \quad 873$ JASA $63 \quad 770$ SASJ $69 \quad 17$ TECH $68 \quad 63$ FILL WEICHT VARIATION TECH 69161 ON THE DISTRIB TECH $69 \quad 149$ MODELS BIOKA66 49 AN JASA $56 \quad 257$ AMS $67 \quad 410$ GRESSION ANALYSIS WHEN THE 'PREDICTOR' VARIABLES ARE STOCHASTIC /ES OF THE LEAST SQUARES ESTIMATOR IN RE AMS 62 1365 FIRMS, CORR. 59810 RETAIL ESTABLISHMENTS

A STOCHASTIC ANALYSIS OF THE SIZE DISTRIBUTION OF

A STOCHASTIC ANALYSIS OF THE SPATIAL CLUSTERINC OF

THE THEORY OF LEAST SQUARES WHEN THE PARAMETERS ARE STOCHASTIC AND ITS APPLICATION TO THE ANALYSIS OF CRO BIO ON ASYMPTOTIC NORMALITY IN STOCHASTIC APPROXIMATION STOCHASTIC APPROXIMATION FOR SMOOTH FUNCTIONS A DYNAMIC STOCHASTIC APPROXIMATION METHOD

ON THE CHOICE OF DESIGN IN STOCHASTIC APPROXIMATION METHODS STOCHASTIC APPROXIMATION OF MINIMA WITH IMPROVED

ASYMPTOTIC SPEED

SOME STOCHASTIC APPROXIMATION PROCEDURES FOR USE IN

PROCESS CONTROL

A NOTE ON THE MAXIMUM SAMPLE EXCURSIONS OF STOCHASTIC APPROXIMATION PROCESSES ON DVORETZKY STOCHASTIC APPROXIMATION THEOREMS

APPLICATION OF STOCHASTIC APPROXIMATION TO PROCESS CONTROL

ON STOCHASTIC APPROXIMATIONS

JASA 58 B93

JASA $65 \quad 1094$

IOKA65 447

AMS 681327

AMS 69299

AMS 651695

AMS $68 \quad 457$

AMS $67 \quad 191$

AMS 641136

AMS $66 \quad 513$

AMS 661534

JRSSB $65 \quad 321$

AMS $63 \quad 343$ SPATIALLY DISTRIBUTED POPULATIONS $S$ AND SYSTEMS STOCHASTIC BTRTH, DEATH AND MIGRATION PROCESSES FOR A STOCHASTIC CHARACTERIZATION OF WEAR-OUT FOR COMPONENT STOCHASTIC COALESCENCE

ISOLATED GROUPS

PROPERTIES OF NON-STATIONARY SYSTEMS OF LINEAR STOCHASTIC DIFFERENCE EQUATIONS STRIBUTIONS OF ESTIMATORS OF PARAMETERS IN EXPLOSIVE STOCHASTIC DIFFERENCE EQUATIONS
STOCHASTIC CROSS-INFECTION BETWEEN TWO OTHERWISE
A NOTE ON STOCHASTIC DIFFERENCE EQUATIONS

/TENCY AND LIMIT DI AMS 61 195 
THE ESTIMATION OF PARAMETERS IN SYSTEMS OF STOCHASTIC DIFFERENTIAL EQUATIONS

ON BATLEY'S AND WHITTLE'S TREATMENT OF A CENERAL STOCHASTIC EPIDEMIC

SUSCEPTIBLES THE LOCISTIC PROCESS, TABLES OF THE STOCHASTIC EPIDEMIC

A NOTE BIOKA55 123 JRSSB60 332 THE SIMPLE STOCHASTIC EPIDEMIC CURVE FOR LARCE POPULATIONS OF EIOKA65 571 MORE INITIAL INFECTIVES

THE SIMPLE STOCHASTIC EPIDEMIC FOR SMALL POPULATIONS WITH ONE OR A PERTURBATION APPROXIMATION OF THE SIMPLE STOCHASTIC EPIDEMIC IN A LARCE POPULATION BIOKA6B 199 BIOKA65 613

KNOWM FUNCTIONS A SOLUTION OF THE CENERAL STOCHASTIC EPIDEMIC.

THE SIMPLE STOCHASTIC EPIDEMIC A COMPLETE SOLUTION IN TERMS OF BIOKA63 235 THE OUTCOME OF A STOCHASTIC EPIDEMIC, A NOTE ON BAILEY'S PAPER ONTROL OF A LINEAR SYSTEM HAVINC A NORMAL STATIONARY STOCHASTIC INPUT ON THE CONVERCENCE OF ORDINARY INTECRALS TO STOCHASTIC INTECRALS

STOCHASTIC INTEGRALS AND DERIVATIVES ON THE LINEAR C JRSSB 6838 AMS 651560 AMS 691610 AMS 62 12B1 LIMITING DISTRIBUTIONS ASSOCIATED WITH CERTAIN STOCHASTIC LEARNING MODELS THE LATENT ROOTS OF CERTAIN STOCHASTIC MATRICES BETWEEN ARBITRARY POSITIVE MATRICES AND DOUBLY STOCHASTIC MATRICES BETWEEN ARBITRARY POSITIVE MATRICES AND DOUBLY STOCHASTIC MATRICES
ON THE STOCHASTIC MATRIX IN BIOKA62 264 RESPONCE TIMES

A STOCHASTIC MODEL FOR DISTRIBUTIONS OF BIOLOGICAL BI0CS6B 247

ESTIMATION OF THE PARAMETER IN THE STOCHASTIC MODEL FOR PHACE ATTACHMENT TO BACTERIA BIOCS65 562 AMS $68 \quad 183$ IN BIOLOGICAL SYSTEMS BY NUMERICAL METHODS

A STOCHASTIC MODEL FOR STUDYING THE PROPERTIES OF CERTA BIOKA58

OF LUNG CANCER INCIDENCE TO CIGARETTE SMOKING AND A STOCHASTIC MODEL FOR THE MODE OF ACTION OF CARCINOGEN BIOCS65 CTION BETWEEN TWO SPECIES

THE PROPERTIES OF A STOCHASTIC MODEL FOR THE PREDATOR-PREY TYPE OF INTERA THE PROPERTIES OF A STOCHASTIC MODEL FOR TWO COMPETING SPECIES IOKA60 219 UM AND ITS APPLICATION TO SOME EXPERIMENTAL DATA A STOCHASTIC MODEL FOR TWO COMPETING SPECIES OF TRIBOLI BIOKAG2 CORRIGENDA, 'THE PROPERTIES OF A STOCHASTIC MODEL FOR TWO COMPETING SPECIES

A STOCHASTIC MODEL OF ACHE TRANSPORTATION IN THE $\quad$ BIOKAG2 447 A STOCHASTIC MODEL OF CREDIT SALES DEBT JASA 661010 PTURE-RECAPTURE DATA WITH BOTH DEATH AND IMMICRATION-STOCHASTTC MODEI

OF EFFECTS OF ANTIBIOTICS ON BACTERIA BY MEANS OF STOCHASTIC MODELS EXPLTCTT ESTIMATES FROM CA BTOKA65 225 ANALYSIS BIOCS66 761 SOME APPROXIMATIONS TO THE VARIANCE IN DISCRETE-TIME STOCHASTIC MODELS FOR BIOLOGICAL SYSTEMS A NOTE ON BIOKA6O I96

SEXES

RESPONSE CURVES
DISCUSSION)

\section{CONTAGION IN STOCHASTIC MODELS FOR EPIDEMTCS}

STOCHASTIC MODELS FOR THE POPULATION GROWTH OF THE STOCHASTIC MODELS OF CAPITAL INVESTMENT (WITH

SOME STOCHASTIC MODELS RELATING TIME AND DOSAGE IN STOCHASTIC PHAGE ATTACHMENT TO BACTERIA STOCHASTIC POINT PROCESSES, LIMIT THEOREMS

ARISON OF THEORETTCAL AND EMPIRTCAL RESULTS FOR SOME STOCHASTIC POPULATION MODELS

OF THE DIRECT MATRIX PRODUCT IN ANALYSING CERTAIN STOCHASTIC POPULATION MODELS LIMIT DISTRIBUTIONS OF A BRANCHING STOCHASTIC PROCESS

A LIMIT THEOREM FOR RANDOM INTERVAL SAMPLING OF A STOCHASTIC PROCESS ON RANDOM SAMPLINC FROM A STOCHASTIC PROCESS OF MOLECULAR COMPOUNDS BY COUNTERCURRENT DIALYSIS, A STOCHASTIC PROCESS OF THE AUTOCORRELATIONS OF A SAMPLE FROM A LINEAR STOCHASTIC PROCESS ESTIMATING AND TESTING TREND IN A STOCHASTIC PROCESS OF POISSON TYPE MAXIMAL INDEPENDENT STOCHASTIC PROCESSES

A 'RENEWAL' LIMIT THEOREM FOR GENERAL STOCHASTIC PROCESSES ON A CLASS OF STOCHASTIC PROCESSES DYNAMIC STOCHASTIC PROCESSES

ON ADDING INDEPENDENT STOCHASTIC PROCESSES

ON THE MULTIVARIATE ANALYSIS OF WEAKLY STATIONARY STOCHASTIC PROCESSES MODEL BUILDING WITH THE AID OF STOCHASTIC PROCESSES EXTREME VALUES IN UNIFORMLY MIXING STATIONARY STOCHASTIC PROCESSES

ON CROSSINGS OF LEVELS AND CURVES BY A WIDE CLASS OF STOCHASTIC PROCESSES EPSILON ENTROPY OF STOCHASTIC PROCESSES DISCRETE SAMPLES AND MOVING SUMS IN STATIONARY STOCHASTIC PROCESSES SOME PROPERTIES OF AN ALGEBRAIC REPRESENTATION OF STOCHASTIC PROCESSES TRANSFORMS OF STOCHASTIC PROCESSES

THE LAW OF THE ITERATED LOGARITHM FOR MIXING STOCHASTIC PROCESSES MODELS FOR TWO-DIMENSIONAL STATIONARY STOCHASTIC PROCESSES SOME SIMPLE DURATION-DEPENDENT STOCHASTIC PROCESSES APPROXIMATE SOLUTIONS OF GREEN'S TYPE FOR UNIVARIATE STOCHASTIC PROCESSES THE ERGODIC THEORY OF SUBADDITIVE STOCHASTIC PROCESSES ON A DISTRIBUTION ASSOCIATED WITH CERTAIN STOCHASTIC PROCESSES EVALUATION OF A FUNCTIONAL ON INFINITELY DIVISIBLE STOCHASTIC PROCESSES THE COEFFICIENT OF COHERENCE FOR WEAKLY STATIONARY STOCHASTIC PROCESSES APPLICATION OF BIORTHONORMAL EXPANSIONS IN THEORY OF STOCHASTIC PROCESSES

REMAINDER IN THE CENTRAL LIMIT THEOREM FOR MIXING STOCHASTIC PROCESSES USE OF THE NORMAL APPROXIMATION IN THE TREATMENT OF STOCHASTIC PROCESSES

OF FIT OF FREQUENCY DISTRIBUTIONS OBTAINED FROM STOCHASTIC PROCESSES $R$ THE LINEAR COMBINATIONS OF EXCHANGEABLE AND MIXING STOCHASTIC PROCESSES CONTROL CHARTS AND STOCHASTIC PROCESSES

$/ R$ THE LAW OF LARCE NUMBERS FO AMS 651840 WITH DISCUSSION)

DERIVED FROM MARKOV CHAINS

DISCRETE STOCHASTIC PROCESSES IN POPULATION GENETICS (WITH

DISCUSSION )

-AVERAGE TYPE

STATIONARTTY CONDITIONS FOR STOCHA STOCHASTIC PROCESSES ON A SPHERE

IONS THE BEHAVIOR OF LIKELTHOOD RATIOS OF STOCHASTIC PROCESSES RELATED BY GROUPS OF TRANSFORMAT

BOUND ON THE STRONG LAW OF LARGE NUMBERS FOR LINEAR STOCHASTIC PROCESSES WITH ABSOLUTELY CONVERGENT COEFF SOME STOCHASTIC PROCESSES WITH ABSORBING BARRIERS

MULTIVARIATE STOCHASTIC PROCESSES WITH PERIODIC COEFFICIENTS

A NOTE ON THE ESTIMATION OF AMPLITUDE SPECTRA FOR STOCHASTTC PROCESSES WITH QUASI-LINEAR RESIDUALS ON THE EXPECTED VALUE OF A STOPPED STOCHASTIC SEQUENCE

PROPERTIES OF LOCAL STATISTICS IN STATIONARY STOCHASTIC SERIES
AMS $6 \mathrm{~B} 1 \mathrm{~B} 63$

BIOKA6B 469

JRSSB 69

BIOCS65 583

BI0CS65 134

AMS $67 \quad 771$

A COMP BIOKA6O AMS $64 \quad 55^{\prime}$ AMS $64 \quad 866$

AMS 641713

BIOKA60 69

AMS 641296

JRSSB57 13

AMS $66 \quad 1564$

AMS $61 \quad 704$

AMS $62 \quad 98$

AMS $63 \quad 206$

AMS $63 \quad 274$

AMS $64 \quad 872$

AMS 641765

TECH $64 \quad 133$

AMS 65993

AMS $66 \quad 260$

AMS 671000

JASA $67 \quad 484$

AMS $68 \quad 164$

AMS $6 \mathrm{~B} \quad 372$

AMS 69 NO. 6

BIOKA55 170

JRSSB59 144

JRSSB $60 \quad 376$

JRSSB6B 499

JRSSB68 160

AN AMS $64 \quad 336$

ON AMS $64 \quad 532$

AN JRSSB68 334

THE AMS 69601

ON THE JRSSB57 268

JRSSB59 239

AMS 651286

JRSSB $60 \quad 21 \mathrm{~B}$

BIOKA56 215

AMS $63 \quad 213$

AMS $65 \quad 529$

AMS 61583

JRSSB61 319

JRSSB69 171

JASA $66 \quad 397$

AMS $69 \quad 456$ ON THE USE BIOKA66 397

SAMPLING BIOKA55 160 
USING LOCAL PROPERTIES OF SMOOTHLY HETEROMORPHIC STOCHASTIC SERIES OF SETS OF OBSERVATIONS FROM SECTIONS OF INDEPENDENT STOCHASTIC SERIES EFFECTS OF SLOW-DOWNS AND FAILURE ON STOCHASTIC SERVICE SYSTEMS

STATISTICAL ANALYSIS BIOKA57 454 THE COMPARISON OF MEANS JRSSB55 208

TECH $63 \quad 385$ AMS $67 \quad 927$ REALIZATION OF STOCHASTIC SYSTEMS

ITIVE WHITE NOISE OBSERVATIONS ERROR ESTIMATION OF STOCHASTIC SYSTEMS, ARBITRARY SYSTEM PROCESS WITH ADD A LIMIT THEOREM FOR SUMS OF MINIMA OF STOCHASTIC VARIABLES

AMS $68 \quad 785$

AMS 651041

N DYNAMICS

LINEAR TRANSFORMATION TO A SET OF STOCHASTICALLY DEPENDENT NORMAL VARIABLES

LIKELIHOOD ESTIMATION OF THE DISTRIBUTIONS OF TWO STOCHASTICALLY ORDERED RANDOM VARIABLES OF CONSUMER FINANCIAL CHARACTERISTICS, COMMON STOCK

INITIAL STOCK AND CONSUMER INVESTMENT IN AUTOMOBILES

MARKET MAKING AND REVERSAL OF THE STOCK EXCHANGE

SOME QUANTITATIVE TESTS FOR STOCK PRICE GENERATING MODELS AND TRADING FOLKLORE

THE PREDICTIVE ABILITY OF CONSUMER ATTITUDES, STOCK PRICES, AND NON-ATTITUDINAL VARIABLES

OPTIMAL SEQUENTIAL PROCEDURES WHEN MORE THAN ONE STOP IS REQUIRED

ON THE EXPECTED VALUE OF A STOPPED MARTINGALE

LIMIT THEOREMS FOR STOPPED RANDOM WALKS

LIMIT THEOREMS FOR STOPPED RANDOM WALKS, II

LIMIT THEOREMS FOR STOPPED RANDOM WALKS. III

ON THE EXPECTED VALUE OF A STOPPED STOCHASTIC SEQUENCE

ON THE EXPECTED VALUE OF A STOPPED SUBMARTINGALE

MOMENTS OF RANDOMLY STOPPED SUMS

ON OPTIMAL STOPPING

EXPLICIT SOLUTIONS TO SOME PROBLEMS OF OPTIMAL STOPPING

SOME PROBLEMS OF OPTIMAL STOPPING

OPTIMAL STOPPING AND EXPERIMENTAL DESIGN

OPTIMAL STOPPING FOR FUNCTIONS OF MARKOV CHAINS

OPTIMAL STOPPING IN A MARKOV PROCESS

AND MAXIMAL REGULAR GENERALIZED SUBMARTINGALES IN STOPPING PROBLEMS

A MODIFIED BAYES STOPPING RULE

ON A STOPPING RULE AND THE CENTRAL LIMIT THEOREM

MOMENTS OF A STOPPING RULE RELATED TO THE CENTRAL LIMTT THEOREM

ON THE MOMENTS OF SOME ONE-SIDED STOPPING RULES

ON SECOND MOMENTS OF STOPPING RULES

SOME PROBLEMS IN THE THEORY OF OPTIMAL STOPPING RULES

SOME ONE-SIDED STOPPING RULES

ON THE ASYMPTOTIC NORMALITY OF ONE-SIDED STOPPING RULES

THE VARIANCE OF THE ONE-SIDED STOPPING RULES

OF DISCREPANCIES IN INFERENCES UNDER NON-INFORMATIVE STOPPING RULES

INFORMATIVE STOPPING RULES AND INFERENCES ABOUT POPULATION SIZE

EXISTENCE OF OPTIMAL STOPPING RULES FOR REWARDS RELATED TO S-SUB-N-OVER-N AN OPTIMAL STOPPING THEOREM

FINITE STOPPING TIME AND FINITE EXPECTED STOPPING TIME

RATIO TEST ON LEHMANN ALTERNATIVES, CORR, 671309 STOPPING TIME OF A RANK-ORDER SEQUENTIAL PROBABILITY THE INFORMATION IN A RANK-ORDER AND THE STOPPING TIME OF SOME ASSOCIATED SPRT'S

A THEOREM ON STOPPING TIMES

THE EXISTENCE OF CERTAIN STOPPING TIMES ON BROWNIAN MOTION

OPTIMAL STOPPING WHEN THE FUTURE IS DISCOUNTED

A TRANSIENT DISCRETE TIME QUEUE WITH FINITE STORAGE

SURVEILLANCE PROGRAMS FOR LOTS IN STORAGE

INTER-PLANT STORAGE IN CONTINUOUS MANUFACTURING

MODEL OF BOOK USE AND ITS APPLICATION TO THE BOOK STORAGE PROBLEM

PROBLEMS IN THE PROBABILITY THEORY OF STORAGE SYSTEMS (WITH DISCUSSION)

SMALL SAMPLES

ON THE EFFECT OF STRAGGLERS ON THE RISK OF SOME MEAN ESTIMATORS IN STRAIGHT LINE CONFIDENCE REGIONS OF LINEAR MODELS

CONFIDENCE BANDS IN STRAIGHT LINE REGRESSION

NOTE ON THE EQUTVALENCE OF TWO METHODS OF FITTING A STRAIGHT LINE THROUGH CUMULATIVE DATA

C) A SHORT-CUT GRAPHIC METHOD FOR FITTING THE BEST STRAIGHT LINE TO A SERIES OF POINTS ACCORDING TO THE J FITTING A STRAIGHT LINE TO CERTAIN TYPES OF CUMULATIVE DATA FITTING A STRAIGHT LINE TO DATA FROM A TRUNCATED POPULATION

CURVE FITTING BY SEGMENTED STRAIGHT LINES

MPLE DISTRIBUTION FUNCTION LIES BETWEEN TWO PARALLEL STRAIGHT LINES
SUBJECT TO ERROR

ERROR, CORR 59 BI2

FITTING OF STRAIGHT LINES AND PREDICTION WHEN BOTH VARIABLES ARE J

THE FITTING OF STRAIGHT LINES WHEN BOTH VARIABLES ARE SUBJECT TO

FITTING STRAIGHT LINES WHEN ONE VARIABLE IS CONTROLLED

D APPLICATION OF INSTRUMENTAL VARIABLE ESTIMATION OF STRAIGHT-LINE RELATIONS WHEN BOTH VARIABLES ARE SUBJE PATHS AND CHAINS OF RANDOM STRAIGHT-LINE SEGMENTS

MORTALITY PATTERNS IN EIGHT STRAINS OF FLOUR BEETLE

ESTIMATION EMPLOYING POST STRATA

ON FORMING STRATA OF EQUAL AGGREGATE SIZE

OPTIMUM ALLOCATION OF SAMPLING UNITS TO STRATA WHEN THERE ARE R RESPONSES OF INTEREST OUTLIERS IN PATTERNED EXPERIMENTS. A STRATEGIC APPRAISAL

TING WILLIAM D SUDDERT
JASA $69 \quad 415$ JASA $63 \quad 789$ JASA $66 \quad 897$

JASA $67 \quad 321$

JASA $64 \quad 987$

AMS 671618

AMS 661505

AMS 641332

AMS $66 \quad 860$

AMS 661510

AMS $69 \quad 456$

AMS $67 \quad 608$

AMS $65 \quad 789$

AMS $66 \quad 30$

AMS 69993

JRSSB 68 10B

AMS $66 \quad 7$

AMS 681905

AMS 681333

AMS $67 \quad 606$

AMS $63 \quad 1404$

AMS 671915

AMS 691236

AMS $66 \quad 382$

AMS $66 \quad 388$

AMS $67 \quad 1627$

AMS $67 \quad 1641$

AMS 681493

AMS 691074

BIOKA67 329

JASA $67 \quad 763$

AMS 681228

AMS $69 \quad 677$

JRSSB $65 \quad 284$

AMS 661154

AMS $68 \quad 1661$

AMS 641348

AMS $69 \quad 715$

AMS 67601

AMS $62 \quad 130$

TECH $62 \quad 515$

TECH $60 \quad 393$

JASA 69 NO. JRSSB57 181

AMS $66 \quad 441$

JASA $67 \quad 1365$

JASA $64 \quad 1 B 2$

JASA 64863

JASA $57 \quad 13$

JASA $57 \quad 552$

BIOCS65 715

JASA 691079

JASA 61

JASA $59 \quad 173$ JASA $58 \quad 106$ TECH 69255 TECH $66 \quad 303$ BIOCS $65 \quad 99$ JASA $66 \quad 1172$

JASA 64 4BI JASA $65 \quad 225$ TECH 61 91

AMS 69 N0.6 AMS $64 \quad 1524$ AMS $63 \quad 780$ AMS $64 \quad 863$ JASA $67 \quad 976$ BIOCS69 457 JRSSB67 392 JASA $56 \quad 429$ JASA $60 \quad 105$ JASA $68 \quad 1298$ DESIGN AND ESTIMATION IN TWO-WAY STRATIFICATION APPROXIMATELY OPTIMAL STRATIFICATION

OR HETEROGENEITY OF PROPORTIONS AFTER ADJUSTMENT FOR STRATIFICATION (ADDENDUM 67 197) /CHI-SQUARE TEST F JRSSB66 150 SOME THEORY OF SAMPLING WHEN THE STRATIFICATION IS SUBJECT TO ERROR TECH 67 JASA $65 \quad 784$

JASA 68 I 
TRATIFICATION VARIABLE IN ESTIMATION BY PROPORTIONAL STRATIFIED SAMPLINC

THE USE OF A S JASA $6 B \quad 1310$ INTERVALS FOR A MEDIAN STRATIFIED SAMPLINC AND DISTRIBUTION-FREE CONFIDENCE

THE ANALYSIS OF VARIANCE OF DATA FROM STRATIFIED SUBSAMPLES OPTIMUM STRATIFIED SAMPLINC USING PRIOR INFORMATION

JASA $65 \quad 772$

JASA $65 \quad 750$ MULTTVARIATE STRATIFIED SURVEYS

SOME BAYESIAN STRATIFIED TWO-PHASE SAMPLINC RESULTS

JASA $6 \mathrm{~B} \quad 64$

JASA $68 \quad 530$

ICS

BAYESIAN STRATIFIED TWO-PHASE SAMPLINC RESULTS, $K$ CHARACTERIST BIOKA68 5B7

THE VARIANCE OF AN ESTIMATOR WITH POST-STRATIFIED WEICHTINC

VARIANCE ESTIMATION WITH ONE UNIT PER STRATUM

SAMPLES WITH THE SAME NUMBER IN EACH STRATUM

JASA $62 \quad 622$

JASA 69841

BIOKA52 414

VARIANCE WHERE TWO UNITS ARE SELECTED FROM EACH STRATUM ORS IN UNEQUAL PROBABILITY SAMPLINC OF TWO UNITS PER STRATUM RY INFORMATION, (PI)PS SAMPLINC OF TWO UNITS FROM A STRATUM (ADDENDUM 69 192) /M UTILIZATION OF AUXILIA JRSSB67 374 IBUTIONS OF THE TIMES BETWEEN EVENTS IN A STATIONARY STREAM OF EVENTS CENERATINC FUNCTIONALS TO THE STUDY OF INPUT-OUTPUT STREAMS ON STREAMS OF ON THE DISTR JRSSB 69 NO 2 SOME APPLICATIONS OF PROBABTLITY JRSSB68 321

EVENTS AND MIXTURES OF STREAMS OF THE BIVARIATE NORMAL DISTRIBUTTON TO A STRESS VS. STRENGTH PROBLEM IN RELIABILITY ANALYSIS /ICATTONS TECH 64 325 SOME MAIN-EFFEGT PLANS AND ORTHOGONAL ARRAYS OF STRENCTH TWO THE ESTIMATION AND COMPARISON OF STRENGTHS OF ASSOCIATION IN CONTINCENCY TABLES AMS 611167 BIOKA53 105 PLICATIONS OF THE BIVARIATE NORMAL DISTRIBUTION TO A STRESS VS. STRENGTH PROBLEM IN RELIABILITY ANALYSIS CIENT CONDITION FOR ADMISSIBILITY OF ESTIMATORS WHEN STRICTLY CONVEX LOSS IS USED /A NECESSARY AND SUFF THE SUPERPOSITION OF SEVERAL STRICTLY PERIODIC SEQUENCES OF EVENTS

SOME STRIKING PROPERTIES OF BINOMIAL AND BETA MOMENTS

FUL TEST FOR CERTAIN PRO/ A COMPARISON OF THE MOST STRINGENT AND THE MOST STRINCENT SOMEWHERE MOST POWER STRINGENT SOLUTIONS TO STATISTICAL DECISION PROBLEMS

O/ A COMPARISON OF THE MOST STRINGENT AND THE MOST STRINGENT SOMEWHERE MOST POWERFUL TEST FOR CERTAIN PR NATIVE RESTRICTED BY A NUMBER OF LINEAR INEQ/ MOST STRINGENT SOMEWHERE MOST POWERFUL TESTS AGAINST ALTER NEAR HYPOTHESES LOCALLY ASYMPTOTICALLY MOST STRINGENT SOMEWHERE MOST POWERFUL TESTS AGAINST ALTER
MOST STRINGENT TESTS AND LAGRANGIAN MULTIPLIER TESTS OF LI STRONG CONSISTENCY OF CERTAIN SEQUENTIAL ESTIMATORS

ON STRONG CONSISTENCY OF DENSITY ESTIMATES

A SHARPER FORM OF THE BOREL-CANTELLI LEMMA AND THE STRONG LAN

CESSES WITH ABSOLUTEL/ AN EXPONENTIAL BOUND ON THE STRONG LAW OF LARGE NUMBERS FOR LINEAR STOCHASTIC PRO ON THE STRONG LAW OF LARGE NUMBERS FOR MARTINGALES

V CHAINS

PROGESSES SOME THEOREMS CONCERNING THE STRONG LAW OF LARGE NUMBERS FOR NON-HOMOGENEOUS MARKO THE STRONG RATIO LIMIT PROPERTY FOR SOME CENERAL MARKOV

THE NILCOXON TWO-SAMPLE STATISTIC ON STRONCLY MTXING PROCESSES THE EXACT DISTRIBUTION OF A STRUCTURAL COEFFIGIENT ESTIMATOR STRUCTURAL PROBABILITY AND A GENERALIZATION

MULTIVARIATE MODEL STRUCTURAL PROBABILITY AND PREDICTION FOR THE

WHEN THE GOVARIABLE IS UNCONTROLLED

TECH 64325 AMS $68 \quad 23$ BIOKA53 I AMS 691753 AMS $68 \quad 531$ AMS $67 \quad 447$ AMS $68 \quad 531$ AMS 661161 BIOKA65 459 AMS 691765 AMS $65 \quad 800$ AMS $61 \quad 583$ AMS $67 \quad 610$ AMS $64 \quad 566$ AMS 69986 AMS $6 \mathrm{~B} 1202$ JASA $68 \quad 1214$ BIOKA66 1 JRSSB 69 NO. 2

A STRUCTURAL REGRESSION APPROACH TO COVARIANCE ANALYSIS JASA 671037 BIVARIATE STRUCTURAL RELATION

MULTIVARTATE LINEAR STRUCTURAL RELATIONS

ON THE MAXIMUM LIKELIHOOD ESTIMATION OF A LINEAR STRUCTURAL RELATIONSHIP BIOKA57 84 BIOKA58 136

A NOTE JASA 641175 BIOCS69 129

ARE KNOWN A NOTE ON LINEAR STRUCTURAL RELATIONSHIPS WHEN BOTH RESIDUAL VARIANCES DISTRIBUTTON OF A PRODUCT AND THE STRUCTURAL SETUP OF DENSITIES ORDER STATISTICS AND STATISTICS OF STRUCTURE FIDUGIAL CONSISTENCY AND GROUP STRUCTURE TIME SERIES WITH PERIODIC STRUCTURE THEOREM FOR VECTOR VARIABLES WTTH A LINEAR STRUCTURE REPLICATES ON THE STRUCTURE AND ANALYSIS OF SINGULAR FRACTIONAL

A SPECIAL STRUCTURE AND EQUTVARIANT ESTIMATION REGRESSION STRUCTURE AND FUNCTIONAL RELATIONSHIP REGRESSION, STRUCTURE AND FUNCTIONAL RELATIONSHIPS. II SYSTEMS STRUCTURE AND THE EXISTENCE OF A SYSTEM LIFE A PROBABILITY STRUCTURE FOR GROWTH CURVES

SE OF INDIVIDUAL FIRMS

ONE SERVER, WHILE THE INTERARR/ ORDERS IN THE TWO SAMPLE CASE SYSTEMS

S ON FINITE STATE SEQUENCE CORRECTION. 'THE STRUCTURE OF BIVARIATE DISTRIBUTIONS', 58719 THE ACCURACY AND STRUCTURE OF INDUSTRY EXPECTATIONS IN RELATION TO THO GOMPUTATION AND STRUCTURE OF OPTIMAL RESET POLICIES

ON THE BLOCK STRUCTURE OF SINGULAR GROUP DIVISIBLE DESICNS ON THE TOPOLOGICAL STRUCTURE OF SOME ORDERED FAMILIES OF DISTRIBUTIONS ON THE CORRELATION STRUCTURE OF THE DEPARTURE PROCESS OF THE QUEUE WITH FINE STRUCTURE OF THE ORDERING OF PROBABILITIES OF RANK

THE CORRELATION STRUCTURE OF THE OUTPUT PROCESS OF SOME SINGLE SERVER ON 'IHE ORDER STRUCTURE OF THE SET OF SUFFICIENT SUBFTELDS ON THE STRUCTURE OF THE TETRACHORIC SERIES

SOME STRUCTURE THEOREMS FOR STATIONARY PROBABILITY MEASURE THE STATISTICAL ANALYSIS OF INDUSTRY STRUCTURE, AN APPLICATION TO FOOD INDUSTRIES MULTI-COMPONENT SYSTEMS AND STRUCTURES AND THEIR RELIABILITY ENOUILLE'S TEST FOR THE COMPATIBILITY OF CORRELATION STRUCTURES IN TIME SERIES ON THE BLOCK STRUCTURES OF CERTAIN PARTIALLY BALANCED INGOMPLETE

GOHERENT STRUCTURES OF NON-IDENTTCAL COMPONENTS $\begin{array}{rr}\text { TECH } & 61 \\ \text { JRSSB } 6 B & 180\end{array}$ BLOCK DESIGNS, CORR. 67624 ND ANALYSIS OF/ PARAMETRIC AUGMENTATIONS AND ERROR STRUCTURES UNDER WHICH CERTAIN SIMPLE LEAST SQUARES A JASA 69 NO. 4 E ON THE ASYMPTOTIC RELATIVE EFFICIENCIES OF COX AND STUART'S TESTS FOR TESTING TREND IN DISPERSION OF A P BIOKA68 381 ON CHARACTERIZING THE CHI SQUARE DISTRIBUTION BY THE STUDENT LAW GRITICAL VALUES FOR BIVARIATE STUDENT T-TESTS OF THE WEIGHTED DIFFERENCE OF TWO INDEPENDENT STUDENT VARIABLES
JASA $66 \quad 976$

JASA 69637

ON THE DISTRIBUTION JRSSB 60 IBB 
A COMMON MULTIPLE COMPARISONS PROBLEM AND RELATED STUDENT-T PROBLEMS

'STUDENT' AND SMALL SAMPLE THEORY

BAYES RULES FOR AMS 611013

A NOMOCRAM FOR THE 'STUDENT' *FISHER T TEST
ALITY ON A BIVARIATE STUDENT'S 'T' DISTRIBUTION

AN INEQUALITY ON A BIVARIATE STUDENT'S T' DISTRIBUTIO
THE DISCRETE STUDENT'S DISTRIBUTION

STUDENT'S DISTRIBUTION AND RIEMANN'S ELLIPTIC

CEOMETRY

ON CHARACTERIZINC THE NORMAL DISTRIBUTION BY STUDENT'S LAW
NOTE ON A CONDITIONAL PROPERTY OF STUDENT'S T NOTE ON A CONDITIONAL PROPERTY OF STUDENT'S T
AN APPROXIMATION OF STUDENT'S T

STUDENT'S T IN A TWO-WAY CLASSIFICATION WITH UNEQUAL

VARIANCES

THE CONDITIONAL LEVEL OF STUDENT'S T TEST

EXTENDED TABLES OF THE PERCENTAGE POINTS OF STUDENT'S T-DISTRIBUTION

AN APPROXIMATION FOR STUDENT'S T-DISTRIBUTION

TAIN PERCENTAGE POINTS OF A MULTIVARIATE ANALOGUE OF STUDENT'S T-DISTRIBUTION

CIAL CASES STUDENT'S T-DISTRIBUTION, WITH TABLES FOR CERTAIN SPE STUDENT'S T-TEST UNDER SYMMETRY CONDITIONS

THE POWER OF STUDENT'S T-TEST, CORR. 651251

ON MR SRIVASTAVA'S PAPER ON THE POWER FUNCTION OF STUDENT'S TEST

REVISED UPPER PERCENTACE POINTS OF THE EXTREME STUDENTIZED DEVIATE FROM THE SAMPLE MEAN

ON THE DISTRIBUTION OF THE EXTREME STUDENTIZED DEVIATE FROM THE SAMPLE MEAN

UPPER PERCENTAGE POINTS OF THE EXTREME STUDENTIZED DEVIATE FROM THE SAMPLE MEAN

USE OF TABLES OF PERCENTAGE POINTS OF RANGE AND STUDENTIZED RANCE

THE JOINT DISTRIBUTION OF THE STUDENTIZED REGRESSION COEFFICIENTS

ON THE STUDENTIZED SMALLEST CHI-SQUARE, CORR, $59 \mathrm{~B} 12$

TABLES OF PERCENTAGE POINTS OF THE 'STUDENTIZED' EXTREME DEVIATE FROM THE SAMPLE MEAN

ON THE DISTRIBUTION OF 'STUDENTIZED' RANGE

TABLE OF THE UPPER 10 PERCENT POINTS OF THE 'STUDENTIZED' RANGE

RECTED TABLES OF THE UPPER PERCENTAGE POINTS OF THE 'STUDENTIZED' RANGE

CORRICENDA, 'TABLES OF PERCENTAGE POINTS OF THE 'STUDENTIZED' RANGE'

DESIGNINC SOME MULTI-FACTOR ANALYTICAL STUDIES

PROPORTIONAL SAMPLING IN LIFE LENGTH STUDIES

LINEAR RELATIONSHIPS IN GROWTH AND SIZE STUDIES

UBCLASS NUMBERS, COMPONENT ESTIMATION IN CORRELATION STUDIES

SUBCLASSIFICATION IN REMOVING BIAS IN OBSERVATIONAL STUDIES

COVARIANCE ANALYSIS WTTH UNEQUAL S BIOCS68 49

STUDIES IN THE HISTORY OF PROBABILITY AND STATISTICS BIOKA67 316

STUDIES IN THE HISTORY OF PROBABILITY AND STATISTICS. BIOKA55 1

STUDIES IN THE HISTORY OF PROBABILITY AND STATISTICS. BIOKA56 I

I. DICING AND GAMING (A NOTE ON THE HISTORY OF P/

II. THE BEGINNINGS OF A PROBABILITY CALCULUS

III. A NOTE ON THE HISTORY OF THE CRAPHICAL PRES/

IV. A NOTE ON AN EARLY STATISTICAL STUDY OF LITE/

V. A NOTE ON PLAYING CARDS

VI. A NOTE ON THE EARLY SOLUTIONS OF THE PROBLEM/

VII. THE PRINCIPLE OF THE ARITHMETIC MEAN

VIII. DE MORGAN AND THE STATISTICAL STUDY OF LIT/

IX. BIOCRAPHICAL NOTE FOR T. BAYES' ESSAY TOWARD/

$X$. WHERE SHALL THE HISTORY OF STATISTICS BECIN

$X I$. DANIEL BERNOULLI ON MAXIMUM LIKELIHOOD

$X I I$. THE BOOK OF FATE

XIII. ISAAC TODHUNTER'S HISTORY OF THE MATHEMATI/

$X I V$. SOME INCIDENTS IN THE EARLY HISTORY OF BIOM/

XVII. SOME REFLEXIONS ON CONTINUITY IN THE DEVEL/

$X V$. THE HISTORICAL DEVELOPMENT OF THE GAUSS LINE/

XVIII. THOMAS YOUNC ON COINGIDENCES

XIX. FRANCIS YSIDRO EDCEWORTH (1845-1926)

XXII. PROBABILITY IN THE TALMUD

STUDIES IN THE HISTORY OF PROBABILITY AND STATISTICS.

STUDIES IN THE HISTORY OF PROBABILITY AND STATISTIGS.

STUDIES IN THE HISTORY OF PROBABILITY AND STATISTICS

STUDIES IN THE HISTORY OF PROBABILITY AND STATISTICS.

STUDIES IN THE HISTORY OF PROBABILITY AND STATISTICS.

STUDIES IN THE HISTORY OF PROBABILITY AND STATISTICS.

STUDIES IN THE HISTORY OF PROBABILITY AND STATISTICS.

STUDIES IN THE HISTORY OF PROBABILITY AND STATISTICS.

STUDIES IN THE HISTORY OF PROBABILITY AND STATISTICS.

STUDIES IN THE HISTORY OF PROBABILITY AND STATISTICS. BIOKA65

STUDIES IN THE HISTORY OF PROBABILITY AND STATISTICS. BIOKA67

STUDIES IN THE HISTORY OF PROBABILITY AND STATISTICS. BIOKA67

STUDIES IN THE HISTORY OF PROBABILITY AND STATISTICS. BIOKA68

STUDIES IN THE HISTORY OF PROBABILITY AND STATISTICS. BIOKA68

STUDIES IN THE HISTORY OF PROBABILITY AND STATISTICS. BIOKA69

NUMERICAL STUDIES IN THE SEQUENTIAL ESTIMATION OF A BINOMIAL BIOKA58

BIOKA58 1

DISTRIBUTIONS OF VARIANCE COMPONENTS I EMPIRICAL STUDIES OF BALANCED NESTED DESIGN

ERRORS IN THE ESTIMATION OF NET MICRATION IN THE STUDIES OF INTERNAL MIGRATION VARIABLES STUDIES OF INTERNAL MIGRATION
STUDIES OF INTERVIEWER VARIANCE FOR ATTITUDINAL

SAMPLING TECH 66

JASA 69 N0.4

JASA $62 \quad 92$

TECH $65 \quad 463$

DISTRIBUTIONS OF VARIANCE COMPONENTS II. EMPIRICAL STUDIES OF UNBALANCED NESTED DESICNS FINITE SAMPLE MONTE CARLO STUDIES. AND AUTOREGRESSIVE ILLUSTRATION

SAMPLING TECH 68 719 JASA $67 \quad 801$

IGIOUS AFFILIATION WITH REFERENCES TO RELATED SOCIAL STUDIES, CORR. 59811 /ERATURE ON STATISTICS OF REL JASA 59 335

THE DEMAND FOR FERTILIZER IN 1954, AN INTER-STATE STUDY

TESTS WHEN THE VARIANCES ARE UNEQUAL. A SIMULATION STUDY SOME TWO-SAMPLE BIOKA67 679 CES IN MEAN

A MONTE CARLO STUDY COMPARING VARIOUS TWO-SAMPLE TESTS FOR DIFFEREN TECH 68 509

THE FEMALE LABOR FORCE. A CASE STUDY IN THE INTERPRETATTON OF HTSTORICAL STATISTICS JASA 60 71

TION FOR THE RANDOMIZED BLOCK DESIGN AN EMPIRICAL STUDY INTO FACTORS AFFECTING THE F-TEST UNDER PERMUTA JASA 68 902

A MATHEMATICAL MODEL WITH APPLICATIONS TO A STUDY OF ACCIDENT REPEATEDNESS AMONG CHILDREN

ENCE TO EQUILIBRTA A GRAPHICAL METHOD FOR THE STUDY OF COMPLEX GENETICAL SYSTEMS WITH SPECIAL REFER BIOCS69 NO. 4

THEORY IN THE DERIVATION OF ROBUST CRITERIA AND THE STUDY OF DEPARTURES FROM ASSUMPTION (WITH DISCUSSION) JRSSB55 1 METHOD SIMULATION STUDY OF ESTIMATORS FOR THE LINE TRANSECT SAMPLING BI0CS69 317 BIOKA60 469 BIOKA6I 230 BIOKA54 266

CORRIGENDA, 'SOME DISTRIBUTIONS ARISING IN THE STUDY OF GENERALIZED MEAN DIFFERENCES' A DISTRIBUTION ARISING IN THE STUDY OF INFECTIOUS DISEASES

CATIONS OF PROBABILITY GENERATING FUNCTIONALS TO THE STUDY OF INPUT-OUTPUT STREAMS

AND STATISTICS. VIII. DE MORCAN AND THE STATISTICAL STUDY OF LITERARY STYLE /THE HISTORY OF PROBABILITY BIOKA58 282

STACES THE EXPERIMENTAL STUDY OF PHYSICAL MECHANTSMS

TECH $65 \quad 23$

STRIBUTION OF WORD LENCTH AND ITS IMPORTANCE FOR THE STUDY OF QUANTITATIVE LINCUISTICS /HE OCCURRENCE DI SOME NEW THREE LEVEL DESIGNS FOR THE STUDY OF QUANTITATIVE VARIABLES

ERRATA, 'SOME NEW THREE LEVEL DESTCNS FOR THE STUDY OF QUANTITATIVE VARIABLES' HOUSEHOLD INTERVIEWS

A STUDY OF RESPONSE ERRORS IN EXPENDITURES DATA FROM A STUDY OF ROBUST ESTIMATORS

CORRECTION. 'A COMPARATIVE STUDY OF SEVERAL ONE-SIDED COODNESS-OF-FIT TESTS' BIOKA58 222 TECH 60455 TECH $61 \quad 576$ JASA $64 \quad 18$ TECH $67 \quad 652$ AMS 651583 
EXPONENTIAL RISKS, WITH PARTICULAR REFERENCE TO THE STUDY OF SMOKINC AND LUNG CANCER, CORR. $60754 \quad /$ ING JASA 60 415 ANALYSIS OF VARIANCE IN SMALL SAMPLES, A MONTE CARLO STUDY OF THE ADEQUACY OF THE ASYMPTOTIC APPROXIMATION BIOCS69 593 AN EMPIRICAL STUDY OF THE DISTRIBUTION OF THE SAMPLE GENETIC CORRE BIOCS69 A NOTE ON 'A STUDY OF THE GROUP SCREENING EXPERIMENT' A STUDY OF THE GROUP SCREENINC METHOD

TECH $63 \quad 397$

A NOTE ON G.S. WATSON'S PAPER 'A STUDY OF THE CROUP SCREENING METHOD' TECH $61 \quad 371$ TECH $65 \quad 444$ A BAYESIAN STUDY OF THE MULTINOMIAL DISTRIBUTION AMS 671423 STIMATORS IN UNEQUAL PROBABILITY SAM/ AN EMPIRICAL STUDY OF THE STABILITIES OF ESTIMATORS AND VARIANCE E JASA 69 540 AN ELECTRONIC BLOOD CELL COUNTER A STUDY OF THE VARIABILITY DUE TO COINCIDENT PASSAGE IN BIOCS67 671 A CORRELATION MODEL USEFUL IN THE STUDY OF TWINS JASA 661184 FOURIER METHODS IN THE STUDY OF VARIANCE FLUCTUATIONS IN TIME
A COMPARATIVE STUDY OF VARIOUS TESTS FOR NORMALITY TECH 69103 A COMPARATIVE STUDY OF VARIOUS TESTS FOR NORMALITY TO IRREVERSIBLE MARKOV CHAINS WITH AN APPLICATION IN STUDYING THE DENTAL CARIES PROCESS /ILITY APPROACH BIOCS66 791 BY NUMERICAL METHODS A STOCHASTIC MODEL FOR STUDYING THE PROPERTIES OF CERTAIN BIOLOGICAL SYSTEMS BIOKA58 A' COLL. AND A COMPARISON WITH THOSE OF 'D. ROBUSTA' STURT ON MATHEMATICAL ANALYSIS OF STYLE

IV. A NOTE ON AN EARLY STATISTICAL STUDY OF LITERARY STYLE III. DE MORGAN AND THE STATISTICAL STUDY OF LITERARY STYLE INFORMATION AND SUFFICIENT SUB-FIELDS

A NOTE ON CONVERGENCE OF SUB-MARTINCALES

THE ERGODIC THEORY OF SUBADDITIVE STOCHASTIC PROCESSES

VARIANCE FOR THE MIXED MODEL WITH DISPROPORTIONATE SUBCLASS FREQUENCIES 16 BIOCS66 469 BIOKA52 122 ITHE HISTORY OF PROBABILITY AND STATISTICS. BIOKA56 248 THE HISTORY OF PROBABILITY AND STATISTICS. V BIOKA58 282 AMS 682056 AMS 641811 JRSSB68 499 FROM TRANSFORMED PERCENTAGE SIB DATA WITH UNEQUAL SUBCLASS NUMBERS ESTIMATES OF HERITABILITY BIOCSG5 IOOI STUDIES ESTIMATES OF HERITABILITY BIOCS65 1001

UBCLASS MEANS AND THE NUMBERS OF OBSERVATIONS IN THE SUBCLASSES FOR THE TWO-WAY COMPLETELY-RANDOM CLASSIFI JASA 68 1484 STUDIES THE NUMBERS OF OBSERVATIONS IN THE SUBCLASSES FOR THE TWO-WAY COMPLETELY-RANDOM CLASSIFI
THE EFFECTIVENESS OF ADJUSTMENT BY SUBCLASSIFICATION IN REMOVING BIAS IN OBSERVATIONAL BIOCS68 295 RANDOM SUBDIVISIONS OF SPACE INTO CRYSTALS

REPRODUCTION OF ORDERINGS AND TRANSLATION SUBFAMILIES AMS $6295 \mathrm{~B}$ ON THE ORDER STRUCTURE OF THE SET OF SUFFICIENT SUBFIELDS ADEQUATE SUBFIELDS AND SUFFICIENCY

TIONAL FACTORIAL EXPERIMENTS FOR THE ESTIMATION OF A SUBGROUP OF PRE-ASSIGNED PARAMETERS

A SIMPLE SYSTEM OF EVOLUTIONARY OPERATION SUBJECT TO EMPIRICAL FEEDBACK

SOME THEORY OF SAMPLING WHEN THE STRATIFICATION IS SUBJECT TO ERROR ESPONSE DATA IN WHICH THE MEASUREMENT OF RESPONSE IS SUBJECT TO ERROR

FOR ESTIMATING FUNCTIONS WHEN BOTH VARIABLES ARE SUBJECT TO ERROR $\mathrm{N}$ OF STRAIGHT-LINE RELATIONS WHEN BOTH VARIABLES ARE SUBJECT TO ERROR AMS $66 \quad 196$ AMS 62596 AMS $67 \quad 155$ AMS 6B 973 TECH $66 \quad 19$ TECH 67 TIKELTHOOD DISTRIBUTIONS TECH $67 \quad 261$ GRADING WITH A GAUGE SUBJECT TO RANDOM OUTPUT FLUCTUATIONS

INFERENCE PROBLEMS ABOUT PARAMETERS WHICH ARE SUBJECTED TO CHANGES OVER TIME POPULATIONS (WITH DISCUSSION)

SUBJECTIVE BAYESIAN MODELS IN SAMPLING FINITE JRSSB55 173 JRSSB54 11B AMS $68 \quad 840$ JRSSB 69 NO. 2 TEST FOR APPROXIMATE NUMERICAL RATIONALITY A SUBJECTIVE EVALUATION OF BODE'S LAW AND AN 'OBJECTIVE JASA 69 23 TEST FOR APPROXIMATE NUMERICAL/ DISCUSSION OF I A SUBJECTIVE EVALUATION OF BODE'S IAII AND AN IOBJECTIVE JASA GO A GENERAL THEORY OF SUBJECTIVE PROBABILITIES AND EXPECTED UTILITIES CONSENSUS OF SUBJECTIVE PROBABILITIES, A CONVERGENCE THEOREM

A DEFINITION OF SUBJECTIVE PROBABILITY PREFERENCE-BASED DEFINITIONS OF SUBJECTIVE PROBABILITY THE RATIONAL ORIGIN FOR MEASURING SUBJECTIVE VALUES

NALYSIS OF A SERIES OF BIOLOGICAL ASSAYS ON THE SAME SUBJECTS ON THE EXPECTED VALUE OF A STOPPED SUBMARTINGALE AMS 691419 AMS $67 \quad 221$ AMS 63199 AMS $67 \quad 1605$ JASA $57 \quad 458$

A NOTE ON RISK AND MAXIMAL REGULAR GENERALIZED SUBMARTINGALES IN STOPPING PROBLEMS AMS 6760 B AMS 67606 ES IN BODY DIMENSIONS IN POPULATIONS OF 'DROSOPHILA SUBOBSCURA' COLL. AND A COMPARISON WITH THOSE OF 'D. BIOCS66 469 THE IOOSE SUBORDINATION OF DIFFERENTIAL PROCESSES TO BROWNT DN SELECTION ON NORMAL VARIABLES WITHIN SETS OF FINITE SUBPOPULATIONS /FFERENTIAL FOR POSITIVE DIRECTIONAL BIOCS67 842 NOTE ON DYNKIN'S 'ALPHA, XI' SUBPROCESS OF STANDARD MARKOV PROCESS AMS 67 1647 THE PROPERTIES OF A SAMPLE MEAN BY EMPLOYING RANDOM SUBSAMPLE MEANS

USING SUBSAMPLE VALUES AS TYPICAL VALUES

THE ANALYSIS OF VARIANCE OF DATA FROM STRATIFIED SUBSAMPLES

INVESTIGATING JASA $56 \quad 54$ JASA 69 NO. 4 JASA $68 \quad 64$ ULATIONS WITH AN APPLICATION TO BULK/ A TWO-STACE SUBSAMPLING PROCEDURE FOR RANKING MEANS OF FINITE POP TECH 67 355 ELATION COEFFICIENT FROM ONE OR POSSIBLY TWO SAMPLES SUBSEQUENT TO A PRELIMINARY TEST OF SIGNIFICANCE /R JRSSB67 282 APPROXIMATION TO THE EXPECTED SIZE OF A SELECTED SUBSET 207 HA-QUANT/ NONPARAMETRIC PROCEDURES FOR SELECTING A SUBSET CONTAINING THE POPULATION WITH THE LARGEST ALP AMS 67 $178 B$ VARIANCE ON SELECTING A SUBSET CONTAINING THE POPULATION WITH THE SMALLEST BIOKA62 495 2 TO THE POWER N FACTORIAL EXPERIMENT ON A SPECIAL SUBSET CIVINC AN IRREGULAR FRACTIONAL REPLICATE OF A JRSSB67 292 SELECTION OF THE BEST SUBSET IN REGRESSION ANALYSIS ON SELECTING A SUBSET OF K POPULATIONS CONTAINING THE BEST A FIXED SUBSET-SIZE APPROACH TO THE SELECTION PROBLEM ESTIMATION AND INFERENCE FOR LINEAR MODELS IN WHICH SUBSETS OF THE DEPENDENT VARIABLE ARE CONSTRAINED SQUARES GRADUATION EQUATIONS SUBSIDIARY SEQUENCES FOR SOLVING LESER'S LEASTUPPER PERCENTAGE POINTS OF A SUBSTITUTE F-RATIO USINC RANGES TO THE NORMAL DISTRIBUTION CRITERIA FOR BEST SUBSTITUTE INTERVAL ESTIMATORS, WITH AN APPLICATION SUBSTITUTES FOR CHI-SQUARE SUBSTITUTION IN CONDITIONAL EXPECTATION

ORIAL E/ GENERALIZED LEAST-SQUARES ESTIMATION OF A SUBVECTOR OF PARAMETERS IN RANDOMIZED FRACTIONAL FACT THE DISTRIBUTION OF THE NUMBER OF SUCCESSES IN A SEQUENCE OF DEPENDENT TRIALS ON THE DISTRIBUTION OF THE NUMBER OF SUCCESSES IN INDEPENDENT TRIALS ON THE NUMBER OF SUCCESSES IN INDEPENDENT TRIALS

FOR PERMUTATIONS WITHOUT RISING OR FALLINC SUCCESSIONS TECH $67 \quad 531$ AMS 671072 BIOKA68 401 JASA $68 \quad 1201$ JRSSB 62112 BIOKA61 195 JASA 641133 BIOKA55 265 AMS $68 \quad 377$ AMS 691344 BIOKA59 454 AMS 641317 AMS 651272 A RECURRENCE AMS 65708 N LIFE TABLES FOR THE SINCLE POPULATION BASED ON TWO SUCCESSIVE CENSUSES (CORR. 6B 1550) /ON OF ATTRITIO JASA 67 1433 FUNCTION SUCCESSIVE CONDITIONAL EXPECTATIONS OF AN INTEGRABLE AMS 62 B87 A NOTE ON EQUALISING THE MEAN WAITING TIMES OF SUCCESSIVE CUSTOMERS IN A FINITE QUEUE THE DISTRIBUTION OF THE MEAN HALF-SQUARE SUCCESSIVE DIFFERENCE

SQUARE SQUARE'
BIOKA67

BIOKA67 419 BIOKA53 116 BIOKA58 587 TECH $68 \quad 397$ JASA 59801 
ISTRIBUTIONS OF SOME MEASURES OF DISPERSION BASED ON SUCCESSIVE DIFFERENCES THE DISTRIBUTION OF INTERVALS BETWEEN SUCCESSIVE MAXIMA IN A SE D SECOND DIFFERENCES, FOR SERIAL CORRELATION BETWEEN SUCCESSIVE OBSERVATIONS DOUBLE SAMPLING FOR STRATIFICATION ON SUCCESSIVE OCCASIONS CONTINUOUS PROCESSES WITH NO AUTOCORRELATION BETWEEN SUCCESSIVE RESULTS

ESTMATES IN SUCCESSIVE SAMPLINC

APPROXIMATIONS TO THE D BIOKA57 349 ERIES OF RANDOM NUMBERS BIOKA57 524 /RITERIA, BASED ON FIRST AN AMS $62 \quad 186$ JASA $65 \quad 784$ BIOKA60 363 JASA $68 \quad 99$

QUES IN MEDICAL TAXONOMY ART INGALES IN A FINITELY ADDITIVE SETTINC WILLIAM D. SUDDERTH ADEQUATE SUBFIELDS AND SUFFICIENCY

LOCAL CONDITIONAL SUFFICIENCY

TRANSFORMATIONS AND SUFFICIENCY

SUFFICIENCY AND APPROXIMATE SUFFICIENCY

THE RELATIONSHIP BETWEEN SUFFICIENCY AND INVARIANCE WITH APPLICATIONS IN SEQUE ON THE SUFFICIENCY AND LIKELIHOOD PRINCIPLES

THE ROLE OF SUFFICIENCY AND OF ESTIMATION IN THERMODYNAMICS

ON SUFFICIENCY AND THE EXPONENTIAL FAMILY OF AN UNKNOWN PARAMETER/ SOME THEOREMS AND SUFFICIENCY CONDITIONS FOR THE MAXIMUM-LIKELIHOOD EST BIOKA55 342 IMATOR OF AN UNK/ CORRICENDA TO 'SOME THEOREMS AND SUFFICIENCY CONDITIONS FOR THE MAXIMUM-LIKELIHOOD EST CERTAIN RANDOM WALKS SUFFICIENCY CONDITIONS IN RECULAR MARKOV CHAINS AND
A NOTE ON SUFFICIENCY IN REGULAR MARKOV CHAINS

DISTRIBUTION-FREE SUFFICIENCY IN SAMPLINC FINITE POPULATIONS SUFFICIENCY IN SAMPLINC THEORY

THE SUFFICIENCY IN THE UNDOMINATED CASE

ON THE ASYMPTOTIC SUFFICIENCY OF CERTAIN ORDER STATISTICS

WHEN STRICTLY CONVEX LOSS IS U/ ON A NECESSARY AND SUFFICIENT CONDITION FOR ADMISSIBILITY OF ESTIMATORS TO BE A PROBABILITY DENSITY FUNCTION BLE TO BE GAMMA

MATORS BE BEST LINEAR UNBIASED A FUNCTION OF A FINITE MARKOV CHAIN INVARIANT UNDER A LIE CROUP ADDITIVE PROBABILITY MEASURE SUFFICIENT CONDITION FOR THE MIXTURE OF EXPONENTIALS

A NECESSARY AND SUFFICIENT CONDITION FOR THE SOUARE OF A RANDOM VARIA

A NECESSARY AND SUFFICIENT CONDITION THAT ORDINARY LEAST-SQUARES ESTI JASA 671302 SUFFICIENT CONDITIONS FOR A STATIONARY PROCESS TO BE AMS 631033

NECESSARY AND SUFFICIENT CONDITIONS FOR A STATISTICAL PROBLEM TO BE AMS 63492 SUFFICIENT CONDITIONS FOR THE EXISTENCE OF A FINITELY AMS 67780 IVATION OF THE DISTRIBUTION OF THE TRUNCATED POISSON SUFFICIENT STATISTIC A VALS FOR THE PARAMETER OF A DISTRIBUTION ADMITTINC A SUFFICIENT STATISTIC WHEN THE RANCE DEPENDS ON THE PA JRSSB55 86 ON CONTINUOUS SUFFICIENT STATISTICS

NOTE ON A THEOREM OF DYNKIN ON THE DIMENSION OF SUFFICIENT STATISTICS FORMS OF SOME INVARIANTS FOR DISTRIBUTIONS ADMITTING SUFFICIENT STATISTICS FACE OF A SAMPLE DRAWN FROM A DISTRIBUTION ADMITTINC SUFFICIENT STATISTICS MIXED MODEL DESICN

RANDOM VARIABLES

MINIMAL SUFFICIENT STATISTICS SUFFICIENT STATISTICS IN THE CASE OF INDEPENDENT SUFFICIENT STATISTICS, SIMILAR RECIONS AND DISTRIBUTI JRS INFORMATION AND SUFFICIENT SUB-FIELDS

ON THE ORDER STRUCTURE OF THE SET OF SUFFICIENT SUBFIELDS

ON CERTAIN SUCCESTED FORMULAE APPLIED TO THE SEQUENTIAL T-TEST A SUCCESTED METHOD OF ANALYSIS OF A CERTAIN CLASS OF

EXPERIMENTS IN CARCINOCENESIS THE QUANTIFICATION OF JUDCMENT SOME METHODOLOCICAL SUCCESTIONS

NTS OF TWO INDEPENDENT BINOMIALS, CONDITIONAL ON FIXED SUM THE AVERACE RUN LENCTH OF THE CUMULATIVE SUM CHART WHEN A V-MASK IS USED CUMULATIVE SUM CHARTS CUMULATIVE SUM CHARTS FOR THE FOLDED NORMAL DISTRIBUTION

A SIMPLE THEORETICAL APPROACH TO CUMULATIVE SUM CONTROL CHARTS THE ECONOMIC DESICN OF CUMULATIVE SUM CONTROL CHARTS CUMULATIVE SUM CONTROL CHARTS AND THE WEIBULL DISTRIBUTION RANK SUM MULTIPLE COMPARISIONS IN ONE AND TWO-WAY

CLASSIFICATIONS A TABLE FOR RANK SUM MULTIPLE PAIRED COMPARISONS AMS 641229 AMS 691474 EXACT BIOKA55 533 BIOKA60 203 JASA $65 \quad 182$ AMS 641456 JRSSB57 262 AMS 682056 AMS $62 \quad 596$ BIOKA64 97 BIOCS66 142 JASA $67 \quad 1105$ TECH $69 \quad 149$ JRSSB60 302 AMS 631593 JRSSB $61 \quad 149$ TECH 61 TECH $63 \quad 451$ JASA $61 \quad 835$ TECH $68 \quad 479$ TECH 66 481 BIOKA67 487 TECH $67 \quad 561$ ED CAMMA-VARIABLES. (ACKNOWLEDCEM/ DISTRIBUTION OF SUM OF IDENTICALLY DISTRIBUTED EXPONENTIALLY CORRELAT AMS 64 277 ANDOM VARIABLES, CORR./ EXACT DISTRIBUTION OF THE SUM OF INDEPENDENT IDENTICALLY DISTRIBUTED DISCRETE R JASA 65 837 PROBABILITY INEQUALITIES FOR THE SUM OF INDEPENDENT RANDOM VARIABLES JASA $62 \quad 33$ ECTATI/ A SHORT PROOF OF A KNOWN LIMIT THEOREM FOR SUM OF INDEPENDENT RANDOM VARIABLES WITH INFINITE EXP AMS 69 1114 A ONE-SIDED PROBABILITY INEQUALITY FOR THE SUM OF INDEPENDENT, BOUNDED RANDOM VARIABLES ON THE MOMENTS AND PROBABILITY INEQUALITIES FOR THE SUM OF INDEPENDENT, BOUNDED RANDOM VARIABLES. /UNDS BIOKA65 559 LES/ INEQUALITIES OF THE RTH ABSOLUTE MOMENT OF A SUM OF RANDOM VARIABLES, 1 LESS THAN OR EQUAL TO R, R AMS 65 299 THE DISTRIBUTION OF THE MAXIMUM SUM OF RANKS

D SAMPLES, CORR. 611005 A NONPARAMETRIC SUM OF RANKS PROCEDURE FOR RELATIVE SPREAD IN UNPAIRE JA ROBUSTNESS OF SUM OF SQUARED RANKS TEST

DISTRIBUTION OF THE RESIDUAL SUM OF SQUARES IN FITTINC INEQUALITIES ON THE SUM OF SQUARES OF NORMAL SCORES

OUCH THE EXPECTED VALUES OF ORDERED VARIATES AND THE SUM OF SQUARES OF NORMAL SCORES CORRICENDA, 'ON THE SUM OF SQUARES OF NORMAL SCORES

THE DISTRIBUTION OF THE LOCARITHM OF THE SUM OF TWO LOC-NORMAL VARIATES FURTHER CRITICAL VALUES FOR THE SUM OF TWO VARIANCES

TECH 67271

JASA $60 \quad 429$ JASA $68 \quad 338$ BIOKA67 69 BIOKA56 456 THE CURVE THR BIOKA66 252 BIOKA65 669 JASA 69655 BIOKA58 279 TECH $64 \quad 104$ TECH $64 \quad 469$ DISTRIBUTION QUERY, THE SUM OF VALUES FROM A NORMAL AND A TRUNCATED NORMAL QUERY, THE SUM OF VALUES FROM A NORMAL AND A TRUNCATED NORMAL PAIRWISE C AMS 63511

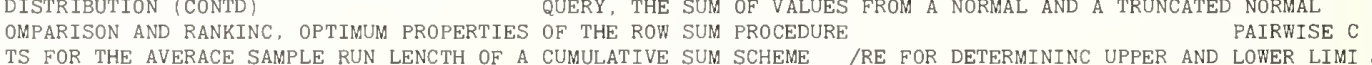
TS FOR THE AVERACE SAMPLE RUN LENCTH OF A CUMULATIVE SUM SCHEME /RE FOR DETER A RANK SUM TEST FOR COMPARINC ALL PAIRS OF TREATMENTS ON AN EXTREME RANK SUM TEST FOR OUTLIERS ON AN EXTREME RANK SUM TEST WITH EARLY DECISION

) IS A REALIZATION OF A NON-/ THE DISTRIBUTION OF SUM-0-T0-M OF F(Y-SUB-T), WHERE (Y-SUB-0, Y-SUB-1, FRENCH SUMMARIES OF PAPERS IN JUNE 1967 ISSUE OPSOMMING VAN LESINGS. (SUMMARY OF PAPERS)

NG WITH EMPHASIS ON NON-NORMALITY NOTES. A DEFICIENCY IN THE SUMMATION OF CHI PROCEDURE LIMIT THEOREMS FOR RANDOMLY SELECTED PARTIAL SUMS
TECH $62 \quad 97$ TECH $60 \quad 197$ BIOKA63 375 JASA $65 \quad 859$ BIOKA65 277 BIOCS67 581 SASJ $68 \quad 55$ TECH 69 N0.4 BIOCS66 407 AMS $62 \quad 85$ 
$S$

ON THE RANGE OF PARTIAL SUMS OF A FINITE NUMBER OF INDEPENDENT NORMAL VARIATE BIOKA53

THE VARIANCE OF THE MAXIMUM OF PARTIAL SUMS OF A FINITE NUMBER OF INDEPENDENT NORMAL VARIATE BIOKA55 96 ON THE MOMENTS OF THE MAXIMUM OF PARTIAL SUMS OF A FINITE NUMBER OF INDEPENDENT NORMAL VARIATE BIOKA56 79 ON LIMITING DISTRIBUTIONS FOR SURS OF A RANDOM NUMBER OF INDEPENDENT RANDOM VECTORS AWS 69935 PROBABILITY INEQUALITIES FOR SUMS OF BOUNDED RANDOM VARIABLES JASA $63 \quad 13$ ABILITY OF LARGE DEVIATIONS FROM THE EXPECTATION FOR SUNS OF BOUNDED INDEPENDENT RANDOM VARIABLES /PROB BIOKA63 528 ON A CHEBYSHEV-TYPE INEQUALITY FOR SUMS OF INDEPENDENT RANDOM VARIABLES AMS $66 \quad 248$ THE MARKOV INEQUALITY FOR SUWS OF INDEPENDENT RANDOM VARIABLES

A NOTE ON SUMS OF INDEPENDENT RANDOM VARIABLES WITH INEINITE

FIRST MOMENT A LIMIT THEOREM FOR SUMS OF MINIMA OF STOCHASTIC VARIABLES

AMS 69 NO. 6 Als $67 \quad 751$ AMS 651041 JRSSB $68 \quad 567$ AMS 691506 A REMARK ON SOLVING EQUATIONS IN SUMS OF POWERS BOUNDS ON MOMENTS OF SUMS OF RANDOM VARIABLES FLUENCE OF MOMENTS ON THE ASYMPTOTIC DISTRIBUTION OF SUMS OF RANDOM VARIABLES THE NORUAL LAT ON LARGE LEVIATION PROBLEMS FOR SUMS OF RANDOM VARIABLES ON THE IN AMS $63 \quad 1042$ ON RANDOM SUMS OF RANDOM VECTORS

TO SAMPLE SPACINGS THEORY. I. LIMIT DISTRIBUTIONS OF SUMS OF RATIOS OF SPACINGS IN THE PRESENCE OF INTRA-/ ON THE DISTRIBUTION OF SUMS OF SQUARES AND CROSS PRODUCTS OF NORMAL VARIATES NOTE ON A METHOD FOR CALCULATING CORRECTED SUMS OF SQUARES AND PRODUCTS

AMS 671575 AMS 651450 AMS $66 \quad 904$ AMS 621461 TECH $62 \quad 419$ CONVERGENCE OF SUMS OF SQUARES OF MARTINGALE DIFFERENCES $\quad$ AMS 68123 RATIOS OF NORMAL VARIABLES AND RATIOS OF SUMS OF UNIFORM VARIABLES $\begin{array}{lll}\text { AMS } & 68 & 123 \\ \text { JASA } & 65 & 193\end{array}$ TO 'A PROOF OF WALD'S THEOREM ON CUMULATIVE SUMS' 591245 SOME EXPERIMENTS ON THE PREDICTION OF SUNSPOT NUMBERS ON RECENT THEOREMS CONCERNING THE SUPERCRITICAL GALTON-TITSON PROCESS

CORRECTION AMS 611344 JRSSB 54112 AMS 682098 PROCESSES ON THE SUPERCRITICAL ONE DIMENSIONAL AGE DEPENDENT BRANCHING AMS 69743 SOME CONSEOUENCES OF SUPERIMPOSED ERROR IN TIME SERIES ANALYSIS A POTENTIAL THEORY FOR SUPERMARTINGALES

ON THE SUPERPOSITION OF POINT PROCESSES

$\begin{array}{llll}\text { THE SUPERPOSITION OF POINT PROCESSES } & \text { JRSSB } 68 & 576 \\ \text { THE SUPERPOSITION OF RANDOM SEQUENCES OF EVENTS } & \text { BIOKA66 } & 383\end{array}$

OF EVENTS

THE SUPERPOSITION OF SEVERAL STRICTLY PERIODIC SEQUENCES BIOKA53 ON THE SUPERPOSITON OF RENEMAL PROCESSES

SOME SYSTEMATIC SUPERSATURATED DESTGNS

NG AND RELATED TOPICS, CORR, 651249 ROGRAMMING

PPROACH TO SOME STATISTICAL DECISION PROBLEMS A SUPPLEMENT TO MENDENHALL'S BIBLIOGRAPHY ON LIFE TESTI SUPPLEMENT TO'A DEFORMATION METHOD FOR QUADRATIC

A SUPPLEMENTARY SAMPLE NON-PARAMETRIC EMPIRICAL BAYES A SUPPLEMENTARY VARIABLES SUPPLEMENTED BALANCE REGRESSION JRSSB60 172 BIOKA60 263 BIOKA6I 475 CORRIGENDA, 'SUPPLEMENTED BALANCE'

IN THE ESTIMATION OF/ ON THE AMOUNT OF TNFORYATION SUPPLIED BY CENSORED SAMPLES OF GROUPED OBSERVATIONS BIOKAG2 245 IN THE ESTIMATION O/ ON THE AMOUNT OF INFORMATION SUPPLIED BY TRUNCATED SAMPLES OF GROUPED OBSERVATIONS BIOKA63 207 THE EXCEEDANCE TEST FOR TRUNCATION OF A SUPPLIER'S DATA

OF PARTIALLY ORDERED OBSERVATIONS IN MEASURING THE SUPPORT FOR A COMPLETE ORDER

PERWUTATION SUPPORT FOR MULTIVARIATE TECHNIQUES
ON THE DISTRIBUTION OF THE SUPREUUM FUNCTIONAL FOR SEMI-MARKOV JASA 69823 NTINUOUS STATE SPACES ON THE DISTRIBUTION OF THE SUPREUUM FUNCTIONAL FOR
DES VALEURS GENOTYPIQUES DANS LA SELECTION PAR INDEX SUR PLUSIEURS CARACTERES AN INEQUALITY AND ALMOST SURE CONVERGENCE

$T$ AND RAN/ SOME RESULTS ON THE COMPLETE AND ALMOST SURE CONVERGENCE OF LINEAR COMBINATIONS OF INDEPENDEN RANDOM VARIABLES RONUENT

ALMOST SURE CONVERGENCE OF QUADRATIC FORMS IN INDEPENDENT

NECESSARY CONDITIONS FOR ALMOST SURE EXTINCTION OF BRANCHING PROCESS WITH RANDOM ENVI A BASIS FOR THE SELECTION OF A RESPONSE SURFACE DESIGN PARTIAL DUPLICATION OF RESPONSE SURFACE DESIGNS UISSING VALUES TN RESPONSE SURFACE DESICNS RESPONSE SURFACE DESIGNS FOR FACTORS AT TWO AND THREE LEVELS RESPONSE SURFACE DESIGNS FOR MIXTURE PROBLEMS RESPONSE SURFACE DESIGNS FOR THREE FACTORS AT THREE LEVELS

A REVIEW OF RESPONSE SURFACE METHODOLOGY. A LITERATURE SURVEY

NG/ A FORMULA FOR THE CURVATURE OF THE LIKELIHOOD SURFACE OF A SAMPLE DRAWN FROM A DISTRIBUTION ADMITTI THE USE OF LAGRANGE MULTIPLIERS TITH RESPONSE SURFACES 'RIDGE ANALYSIS' OF RESPONSE SURFACES POISSON AND BINOMIAL FREQUENCY SURFACES BIAS ESTIMATION AND EXPERIMENTAL DESIGN FOR RESPONSE SURFACES

A METHOD OF FITTING EMPIRICAL SURFACES TO PHYSICAL AND CHEMICAL DATA A REPRODUCIBLE METHOD OF COUNTING PERSONS OF SPANISH SURNAME SURVEILLANCE PROGRAMS FOR LOTS IN STORAGE THE NEW DESIGN OF THE CANADIAN LABOUR FORCE SURVEY

REVIET OF RESPONSE SURFACE METHODOLOGY A LITERATURE SURVEY SAMPLE ALLOCATION AND ESTIMATION IN AN AGRICULTURAL SURVEY HOUSEHOLD INTERVIET DESIGN FOR THE NATIONAL HEALTH SURVEY PROBABILITY PROPORTIONATE TO SIZE IN A LARGE SCALE SURVEY PROBLEMS IN THE ANALYSIS OF SURVEY DATA, AND A PROPOSAL BIOKA64 65 AHS 69844 BI0CS69 295 AMS 691091 AMS 681549 AMS 681502 AMS 682136 JASA 59622 TECH 60185 TECH $61 \quad 389$ TECH $68 \quad 177$ TECH $68 \quad 739$ TECH $59 \quad 1$ TECH $66 \quad 571$ BIOKA60 203 TECH 59289 TECH $63 \quad 469$ BIOKA66 617 MINIMUM TECH 69461 TECH 69411 JASA $61 \quad 88$ TECH $62 \quad 515$ JASA $67 \quad 421$ A TECH $66 \quad 573$ SURVEYS PROBLEMS OF JRSSBS4 223 COMPUTER EDITING OF SURVEY DATA, FIVE YEARS OF EXPERIENCE IN BLS MANPOWER JASA 66

IONS AND PURCHASE PROBABILITY, AN EXPERIMENT IN SURVEY DESIGN SAMPLING ERRORS IN AN ORCHARD SURVEY INVOLVING UNEQUAL NUMBERS OF ORCHARDS OF DISTI BIOCS65
A SURVEY OF COVERAGE PROBLEMS ASSOCIATED WITH POINT AND TECH 69 A SURVEY OF COVERAGE PROBLEMS ASSOCIATED WITH POINT AND TECH 69561 
PHILIPPINE STATISTICAL PROCRAM DEVELOPMENT AND THE SURVEY OF HOUSEHOLDS

207

AL T-DISTRIBUTION A SURVEY OF PROPERTIES AND APPLICATIONS OF THE NONCENTR TECH 68 EATMENT CO/ THE DESICN OF FACTORIAL EXPERIMENTS, A SURVEY OF SOME SCHEMES REQUIRING NOT MORE THAN 256 TR BIOKA59 251 RESPONSE ERROR IN SURVEY REPORTS OF EARNINCS INFORMATION THE EFFECT OF RESPONDENT ICNORANCE ON SURVEY RESULTS JT 56 5T6 INFLUENCE OF THE INTERVIEWER ON THE ACCURACY OF SURVEY RESULTS JASA 58 635 A FIDUCIAL ARCUMENT WITH APPLICATION TO SURVEY SAMPLINC JRSSB69 NO. 2 RANDOMIZED RESPONSE, A SURVEY TECHNIQUE FOR ELIMINATINC EVASIVE ANSWER BIAS JASA 6563 RECENT ADVANCES IN SAMPLE SURVEY THEORY AND METHODS AMS $62 \quad 325$ ESTIMATES OF MORALITY AND POPULATION FROM SURVEY-REMOVAL RECORDS BIOCS65 92I A NOTE ON THE EFFECTS OF NONRESPONSE ON SURVEYS JASA $57 \quad 29$ N ANALYSIS OF CONSISTENCY OF RESPONSE IN HOUSEHOLD SURVEYS THE RATIO BIAS IN SURVEYS

A DOUBLE SAMPLING SCHEME FOR ANALYTICAL SURVEYS MULTIVARIATE STRATIFIED SURVEYS

PLANNINC SOME TWO-FACTOR COMPARATIVE SURVEYS JASA $65 \quad 985$ JASA $6 B \quad 530$ ESTIMATION IN MULTI-STAGE SURVEYS

LIAM $N$. HURWITZ THE DEVELOPMENT OF HOUSEHOLD SAMPLE SURVEYS/ATISTICAL SOCIETY MEMORIAL MEETING FOR WIL JASA 69 NO 4 IAM N. HURWITZ. SOME BASIC PRINCIPLES OF STATISTICAL SURVEYS /TISTICAL SOCIETY MEMORIAL MEETING FOR WILL JASA 69 NO. 4 THE RELIABILITY OF CONSUMER SURVEYS OF FINANCIAL HOLDINGS. DEMAND DEPOSITS JASA 6691 THE RELIABILITY OF CONSUMER SURVEYS OF FINANCIAL HOLDINGS, TIME-DEPOSITS JASA 65 ANALYTICAL SURVEYS WITH CLUSTER SAMPLING

OPTIMUM ALLOCATION IN MULTIVARIATE SURVEYS, AN ANALYTICAL SOLUTION REGRESSION ANALYSIS IN SAMPLE SURVEYS, CORR. 631162

TEN YEARS OF CONSUMER ATTITUDE SURVEYS. THEIR FORECASTING RECORD A METHODE DU MAXIMUM DE VRAISEMBLANCE DES COURBES DE SURVIE DE MICROORGANISMES IRRADIES ESTIMATION PAR L BIOCS66 673 A PROBLEM IN SURVIVAL

A TWO-PARAMETER MODEL FOR THE SURVIVAL CURVE OF TREATED CANCER PATIENTS

MAXIMUM LIKELIHOOD ESTIMATION OF SURVIVAL CURVE PARAMETERS ANALYSIS OF SURVIVAL DATA BY REGRESSION TECHNIQUES

A METHOD OF ANALYZING LOG-NORMALLY DISTRIBUTED SURVIVAL DATA WITH INCOMPLETE FOLLOW-UP ESTIMATES OF SURVIVAL FROM THE SIGHTING OF MARKED ANIMALS

IAL S/ USE OF CONCOMITANT VARIABLES AND INCOMPLETE SURVIVAL INFORMATION IN THE ESTIMATION OF AN EXPONENT BIOCS66 665 OF FLUCTUATING OFFSPRING DISTRIBUTIONS ON THE SURVIVAL OF A GENE SOME EFFECTS BIOKA66 39I POPULATIONS SURVIVAL PROBABILITIES OF NEW INVERSIONS IN LARGE BIOCS68 501 BI0CS65 826 JASA $61 \quad 111$ JASA $62 \quad 841$ JASA $62 \quad 175$ JASA 67561 A PARAMETRIC ESTIMATE OF THE STANDARD ERROR OF THE SURVIVAL RATE, CORR. 631161 MIGRATION EVALUATION OF CENSUS SURVIVAL RATES IN ESTIMATING INTERCENSAL STATE NET A NOTE ON THE CENSUS SURVIVAL RATIO METHOD OF ESTIMATING NET MIGRATION FIELD MOUSE. APODEMUS SYLVATICUS. III/ THE GROWTH, SURVIVAL, WANDERING AND VARIATION OF THE LONG-TAILED BIOKA52 389 METHOD ESTIMATION OF SURVIVORSHIP IN CHRONIC DISEASE, THE 'ACTUARIAL' $\begin{array}{ll}\text { THE SIMPLE BIOKA65 } & 571 \\ \text { INFECTIOUS BIOKA56 } & 322\end{array}$ STOCHASTIC EPIDEMIC CURVE FOR LARGE POPULATIONS OF SUSCEPTIBLES PERIODS OF MEASLES. II. FAMILIES WITH THREE OR MORE SUSCEPTIBLES /ESTIMATING THE LATENT AND INFECTIOUS BIOKA56 322 INFECTIOUS PERIODS OF MEASLES, I. FAMILIES WITH TWO SUSCEPTIBLES ONLY. WITH TWO KINDS OF DISTRIBUTION THEORY SUSCEPTIBLES THE MATHEMATICAL ANALYSIS OF AN EPIDEMIC BIOCS6 GENERALIZATION OF SVERDRUP'S LEMMA AND ITS APPLICATIONS TO MULTIVARIATE AMS 65671 ON ESTIMATION BY THE SWEEP-OUT METHOD (CORR 69 229) BIOKA68 305 D VARIATION OF THE LONC-TAILED FIELD MOUSE. APODEMUS SYLVATICUS. III. WANDERING POWER AND DISTRIBUTION. BIOKA52 389

/ NOTES. EIN EINFACHES VERFAHREN ZUR ERZEUGUNG VON SYMBOLFOLGEN MIT VORGEGEBENER RELATIVER DYADENKONTEXT BIOCS68 703 COMPACT TABLE OF TWELVE PROBABILITY LEVELS OF THE SYMMETRIC BINOMIAL CUMULATIVE DISTRIBUTION FOR SAMPLE JASA 59 164 A REPRESENTATION OF THE SYMMETRIC BIVARIATE CAUCHY DISTRIBUTION AMS 621256 ONENTIAL POPULATION BEST LINEAR ESTIMATES UNDER SYMMETRIC CENSORINC OF THE PARAMETERS OF A DOUBLE EXP JASA 66248 INEFFICIENCY' OF THE SAMPLE MEDIAN FOR MANY FAMILIAR SYMMETRIC DISTRIBUTIONS HE NON-CENTRAL DISTRIBUTION OF THE SECOND ELEMENTARY SYMMETRIC FUNCTION OF THE ROOTS OF A MATRIX THE ' BIOKA55 520 ON T AMS $68 \quad 833$ MONOMIAL-MONOMIAL SYMMETRIC FUNCTION TABLES BIOKA59 205

VARIATE ANALYSIS MATRIX. DISTRIBUTIONS

THE MOMENTS OF ELEMENTARY SYMMETRIC FUNCTIONS OF THE ROOTS OF A MATRIX IN MULTI ON ELEMENTARY SYMMETRIC FUNCTIONS OF THE ROOTS OF A MULTIVARIATE ON THE MOMENTS OF ELEMENTARY SYMMETRIC FUNCTIONS OF THE ROOTS OF TWO MATRICES APPROXIMATIONS TO A DIST/ ON MOMENTS OF ELEMENTARY SYMMETRIC FUNCTIONS OF THE ROOTS OF TWO MATRICES AND MULTIVARIATE ANALYSIS.

ON ELEMENTARY SYMMETRIC FUNCTIONS OF THE ROOTS OF TWO MATRICES IN TABLES OF SYMMETRIC FUNCTIONS. PART IV TABLES OF SYMMETRIC FUNCTIONS. PART V

TABLES OF SYMMETRIC FUNCTIONS. PARTS II AND III.

ERRATA IN 'TABLES OF SYMMETRIC FUNCTIONS'

LATENT VECTORS OF RANDOM SYMMETRIC MATRICES

DECOMPOSITION OF SYMMETRIC MATRICES AND DISTRIBUTIONS OF QUADRATIC

FORMS COMPONENTS OF A SYMMETRIC MATRIX LEAST SQUARES ESTIMATION OF THE COMPONENTS OF A SYMMETRIC MATRIX
PERCENTACE POINTS OF THE RANGE FROM A SYMMETRIC MULTINOMIAL DISTRIBUTION

A BAYES RULE FOR THE SYMMETRIC MULTIPLE COMPARISONS PROBLEM ON THE DUALS OF SYMMETRIC PARTIALLY-BALANCED INCOMPLETE BLOCK DESIGNS RISTICS OF THE DISTRIBUTION OF THE LATENT ROOTS OF A SYMMETRIC RANDOM MATRIX UNDER GENERAL CONDITIONS SOME PROPERTIES OF SYMMETRIC STABLE DISTRIBUTIONS

ON A CHARACTERIZATION OF SYMMETRIC STABLE PROCESSES WITH FINITE MEAN CONTRIBUTIONS TO THE K-SAMPLE PROBLEM. A SYMMETRIC STATISTIC STATISTICAL PROBLEMS IN SCIENCE. THE SYMMETRIC TEST OF A COMPLETE HYPOTHESIS A PROPERTY OF SOME SYMMETRIC TWO-STACE SEQUENTIAL PROCEDURES AN APPROXIMATION FOR THE SYMMETRIC, QUADRIVARIATE NORMAL INTEGRAL SYMMETRICAL AND ASYMMETRICAL FRACTIONAL FACTORIAL
AMS 611152

AMS 641186 AMS 641704 AMS 681274 BIOKA65 499 BIOKA53 427 BIOKA55 223 BIOKA5I 435 BIOKA58 292 BIOKA6I 133 AMS $65 \quad 683$ TECH $66 \quad 360$ BIOKA68 377 JASA 69 NO. 4 AMS $63 \quad 528$ AMS 61864 JASA $68 \quad 817$ AMS 681498 AMS 69 No. 6 JASA 69 NO. 4 AMS $64 \quad 755$ BIOKA56 206 TECH $62 \quad 47$ 
ON NECESSARY CONDITIONS FOR THE EXISTENCE OF SOME SYMMETRICAL AND UNSYMMETRICAL TRIANGULAR PARTIALLY BA AMS 63 348 IFICATION ON THE ADMISSIBILITY OF A RANDOMIZED SYMMETRICAL DESIGN FOR THE PROBLEM OF A ONE WAY CLASS DISTRIBUTION-FREE TWO SAMPLE TEST FOR DISPERSION FOR SYMMETRICAL DISTRIBUTIONS

AN APPROXIMATION TO THE SYMMETRICAL INCOMPLETE BETA FUNCTION

THE FIRST TWO MOMENTS OF THE MEAN DEVIATION OF THE SYMMETRICAL MULTINOMIAL DISTRIBUTION DISTRIBUTION-FREE TOLERANCE INTERVALS FOR CONTINUOUS SYMMETRICAL POPULATIONS UNEQUAL BLOCK SIZES SYMMETRICAL UNEQUAL BLOCK ARRANGEMENTS WITH TWO $\begin{array}{lrr}\text { SASJ } & 69 & \text { NO.2 } \\ \text { BIOKA52 } & 204\end{array}$ THE Z-TEST AND SYMMETRICALLY DISTRIBUTED RANDOM VARIABLES

ASYMPTOTICALLY NONPARAMETRIC TESTS OF SYMMETRY FOR THE EXACT DISTRIBUTION OF THE WILCOXON TEST FOR SYMMETRY CONTINGENCY TABLE

STUDENT'S T-TEST UNDER SYMMETRY CONDITIONS STRIBUTIONS OF VOTAW'S CRITERIA FOR TESTING COMPOUND SYMMETRY OF A COVARIANCE MATRIX NONPARAMETRIC SYMMETRY TESTS FOR CIRCULAR DISTRIBUTIONS BIVARIATE SYMMETRY TESTS, PARAMETRIC AND NONPARAMETRIC A TEST FOR SYMMETRY USING THE SAMPLE DISTRIBUTION FUNCTION INDICES OF SYNCHRONY IN CELLULAR CULTURES

ARIANCES AND COVARIANCES OF 'ANOVA' MEAN SQUARES BY 'SYNTHESIS'

312 AMS 62620 BIOKA59 123 AMS 67849 JASA 69 NO. 4 JASA 69 NO. 4 AMS $69 \quad 836$ BIOKA69 N0.3 AMS 69259 AMS 69 N0.6 BIOCS67 693 ARIANCES, AND CONVARIANCES OF ANOVA MEAN SOUARES BY 'SYNTHESIS' HE SIZE AND POWER OF TESTS EMPLOYTNG SATTERTHWAITE'S SYNTHETTC MEAN SQUARES ON A FACTOR AUTOMORPHISM OF A NORMAL DYNAMICAL SYSTEM

THE OUTPUT PROCESS OF A STATIONARY M/M/S QUEUEING SYSTEM

CONSISTENT ESTIMATES OF THE PARAMETERS OF A LINEAR SYSTEM

THE FUTURE DEVELOPMENT OF THE FEDERAL STATISTICAL SYSTEM

TECHNIQUE FOR ESTIMATING THE RELIABILITY OF A SIMPLE SYSTEM

IAL DISTRIBU/ POINT ESTIMATION OF RELIABILITY OF A SYSTEM COMPRISED OF K ELEMENTS FROM THE SAME EXPONENT SYSTEM EFFICIENCY AND RELIABILITY
RELATIONSHIP BETWEEN SYSTEM FAILURE RATE AND COMPONENT

EXPECTATIONS、V BIOCS67 105 ON EXPECTATIONS V BIOCS68 963 /TE CARLO INVESTIGATION OF T BIOKA68 431 AMS 661528 AMS 681144 AMS 69 NO. 6 CROSSROAD CHOICES FOR JASA $68 \quad 801$ PROBIT ANALYSIS AS A TECH $67 \quad 197$

RELATIONSHIP BETWEEN SYSTEM FAILURE RATE AND COMPONENT FAILURE RATES

C INDEX A SCREENING SYSTEM FOR ANTI-CANCER AGENTS BASED ON THE THERAPEUTI
FOR QUANTAL RESPONSES TO MIXTURES/ AN ALTERNATIVE SYSTEM FOR THE CLASSIFICATION OF MATHEMATICAL MODELS DETERMINISTIC GUSTOMER IMPATIENCE IN THE QUEUEING SYSTEM GI-M-I

DETERMINISTIC CUSTOMER IMPATIENCE IN THE QUEUEING SYSTEM GI-M-1, A CORRECTION

ON THE LINEAR CONTROL OF A LINEAR SYSTEM HAVING A NORMAL STATIONARY STOCHASTIC INPUT SYSTEMS STRUCTURE AND THE EXISTENCE OF A SYSTEM LIFE A NOTE ON THE QUEUEING SYSTEM M-M-1 WITH BALKING.

ESTIMATION OF THE PARAMETER OF A LINEAR REGRESSION SYSTEM OBEYING TWO SEPARATE REGTMES TESTS OF THE HYPOTHESIS THAT A LINEAR REGRESSION SYSTEM OBEYS TWO SEPARATE REGIMES

A SYSTEM OF DENUMERABLY MANY TRANSIEN

ISTICS II. THE SAMPLE MEDIAN

$\begin{array}{rlrr}\text { A SYSTEM OF DENUMERABLY MANY TRANSIENT MARKOV CHAINS } & \text { AMS } 66 & 406 \\ \text { ON A SYSTEM OF DISCRETE DISTRIBUTIONS } & \text { BIOKA67 } & 649\end{array}$

ON A GENERAL SYSTEM OF DISTRIBUTIONS, I. ITS CURVE-SHAPE GHARACTER JASA 68627

ON A GENERAL SYSTEM OF DISTRIBUTIONS, III. THE SAMPLE RANGE JASA 68 636

A SOLUTTON TO A COUNTABLE SYSTEM OF EOUALTTIES ARTSTNG TN MARKOVIAN DECISION

PROBABILITY METHOD FOR SOLVING AN OVERDETERMINED SYSTEM OF EQUATIONS ATS A POSTERIORI TECH 66 675 FEEDBACK

FUNCTIONS AND THE NORMAL INTEGRAL A SYSTEM OF INEQUALITIES FOR THE INCOMPLETE GAMMA A

A SIMPLE SYSTEM OF EVOLUTIONARY OPERATION SUBJECT TO EMPIRICAL TEGH $66 \quad 19$

IBUTION OF HOTELLING'S GENERALIZED T-SQUARE-SUB/ A SYSTEM OF LINEAR DIFFERENTIAL EQUATIONS FOR THE DISTR AMS 68 815

ORGANISM

A SYSTEM OF MODELS FOR THE LIFE CYCLE OF A BIOLOGICAL BIOKA68 211

DETERMTNATION OF PARAMETERS IN THE JOHNSON SYSTEM OF PROBABTLTTY DTSTRTBUTTONS

THEORETICAL CONSIDERATIONS REGARDING H. R. B. HACK'S SYSTEM OF RANDOMIZATION FOR CROSS-CLASSIFICATIONS BOTH SERIALLY AND CONTE/ EFFICIENT ESTIMATION OF A SYSTEM OF REGRESSION EQUATIONS WHEN DISTURBANCES ARE JASA 67 500 RI/ THE COMPOUND HYPERGEOMETRIC DISTRIBUTION AND A SYSTEM OF SINGLE SAMPLING INSPECTION PLANS BASED ON P TECH 60 275 A SYSTEU OF TTO SERVERS IITTH LIMTTED WAITING ROOMS AND BTOKA68 ERROR ESTIMATION OF STOCHASTIC SYSTEMS, ARBITRARY SYSTEM PROCESS WITH ADDITIVE WHITE NOISE OBSERVATIONS AMS 68 785 THE ANALYSIS OF THE EFFECTS OF MARGINAL TESTING ON SYSTEM RELIABILITY

OF OBTAINING APPROXIMATE CONFIDENCE INTERVALS FOR SYSTEM RELIABILITY A MARKOVIAN MODEL FOR AMS $62 \quad 754$ ON THE TRANSIENT BEHAVIOR OF A QUEUEING SYSTEM WITH BULK SERVICE AND FINITE CAPACITY A SIMPLE CONGESTION SYSTEM WITH INCOMPLETE SERVICE VING DISTRIBUT/ THE OUTPUT PROCESS OF THE QUEUEING SYSTEM WITH ONE SERVER AND WHICH INTERARRIVAL AND SER JRSSB59 375 RVING DIS/ SOME NUMERIGAL RESULTS FOR THE QUEUEING SYSTEM WITH ONE SERVER. WHILE THE INTERARRIVAL AND SE JRSSB63 477 SYSTEMATIC ERRORS IN PHYSICAL CONSTANTS TECH 62111 SOME SYSTEMATIC EXPERIMENTAL DESIGNS

A SYSTEMATIC METHOD OF FINDING DEFINING CONTRASTS JASA $57 \quad 46$ O-THE-M FACTORIAL EXPERIMENTS WITH APPLICATIONS SYSTEMATIC METHODS FOR ANALYZING 2-TO-THE-N-TIMES-3-T TECH 67 245 REGRESSION WITH SYSTEMATIC NOISE A REVISED TEST FOR SYSTEMATIC OSCILLATION

THE VARIANCE OF THE MEAN OF SYSTEMATIC SAMPLES SYSTEMATIC SAMPLING

ON MODIFIED SYSTEMATIC SAMPLING

A METHOD OF SYSTEMATIC SAMPLING BASED ON ORDER PROPERTIES

JASA $64 \quad 422$ JRSSB54 292 BIOKA56 137 BIOKA62 $2 B 1$ BIOKA68 541 BIOKA53 452

SIZE IN A LARGE SCALE SURVEY

THE USE OF SYSTEMATTC SAMPLING WTTH PROBABILITY PROPOR $\begin{array}{ll}\text { CALE SURVEY } & \text { THE USE OF SYSTEMATIC SAMFLING WITH PROBABILITY PROPORTIONATE TO } \\ \text { VARIANCE ESTIMATION IN RANDOMIZED SYSTEMATIC SAMPLING WITH PROBABILITY PROPORTIONATE TO }\end{array}$ SIZE SYSTEMATIC SAMPLING WITH PROBABILITY PROPORTIONA
SYSTEMATIC SAMPLING WITH UNEQUAL PROBABILITY AND 251 WITHOUT REPLACEMENT SYSTEMATIC STATISTICS FROM MULTIVARIATE DISTRIBUTIONS

POPULATION INTERRELATIONS BETWEEN CERTAIN LINEAR SYSTEMATIG STATISTICS OF SAMPLES FROM ANY CONTINUOUS SPACE TELEMETRY

THE OPTIMUM ALLOCATION OF SPARE COMPONENTS IN SYSTEMS
THE ESTIMATION OF 'TRANSFER FUNCTIONS' OF QUADRATIC SYSTEMS SYSTEMATIC STATISTICS USED FOR DATA COMPRESSION IN SOME SYSTEMATIC SUPERSATURATED DESIGNS SIMPLEX LATTICE DESIGNS FOR MUTICOMPONENT SYSTEMS

THE DEVELOPMENT OF NUMERICAL CREDIT EVALUATION SYSTEMS PRODUCT TEST PLANNING FOR REPAIRABLE SYSTEMS REALIZATION OF STOCHASTIC SYSTEMS

CONFIDENCE LIMITS FOR THE RELIABILITY OF SERIES SYSTEMS ON GONFIDENCE LIMITS FOR THE RELIABILITY OF SYSTEMS ESTIMATION OF MIXED MOVING-AVERAGE AUTOREGRESSIVE SYSTEMS $\begin{array}{lll}\text { JASA } & 65 & 27 B \\ \text { JASA } & 66 & 739\end{array}$ JASA $69 \quad 300$ BIOK A51 377 JASA $65 \quad 97$ TECH $62 \quad 4 \mathrm{~B} 9$ TECH 61399 TECH $61 \quad 563$ TECH 62463 JASA $63 \quad 799$ TECH $65 \quad 485$ AMS $67 \quad 927$ 
OF SLOW-DOWNS AND FAILURE ON STOCHASTIC SERVICE SYSTEMS REQUIREMENTS FOR ACCEPTANCE TESTINC OF COMPLEX SYSTEMS CHARACTERIZATION OF WEAR-OUT FOR COMPONENTS AND SYSTEMS

OF KENDALL'S TAU BASED ON PARTIALLY ORDERED SYSTEMS

MODELS FOR COMPETITIVE AND PREDATORY BIOLOGICAL SYSTEMS DISCUSSINC THE PASSACE TIME DISTRIBUTION FOR STABLE SYSTEMS TRUCTURE OF THE OUTPUT PROCESS OF SOME SINCLE SERVER SYSTEMS OF VECTOR MIXED AUTOREGRESSIVE-MOVING AVERAGE SYSTEMS

LIMITS FOR THE RELIABILITY OF SERIES AND PARALLEL SYSTEMS FICANCE ON THE DIMENSIONALITY OF NORMAL MULTIVARIATE SYSTEMS APPROACHES IN THE SPECIFICATION OF NEAREST-NEIGHBOUR SYSTEMS ION TO INVERSE SAMPLING AND RELIABILITY OF REDUNDANT SYSTEMS CE IN DISCRETE-TIME STOCHASTIC MODELS FOR BIOLOGICAL SYSTEMS PROBLEMS IN THE PROBABILITY THEORY OF STORAGE SYSTEMS

\section{MULTI-COMPONENT SYSTEMS AND STRUCTURES AND THEIR RELIABILITY}

EFFECTS TECH $63 \quad 385$ ACCURACY JASA 59 A STOCHASTIC AMS $66 \quad 816$ DISTRIBUTIONS BIOKA55 417 ON THEORETICAL BIOKA57 27 A TECHNIQUE FOR JRSSB66 477 THE CORRELATION $S$ AMS 681007 THE IDENTIFICATION BIOKA69 223 APPROXIMATE CONFIDENCE TECH $65 \quad 495$

/F THE COMPUTTNC ROUTINE FOR TESTS OF SIGNI JRSSB56 70 /NAL PROBABILITY AND THE JOINT PROBABILITY BIOKA64 481 /THE CEOMETRIC DISTRIBUTION AND THEIR RELAT JASA 67915 A NOTE ON SOME APPROXIMATIONS TO THE VARIAN BIOKA60 196

FOR STUDYING THE PROPERTIES OF CERTAIN BIOLOGICAL SYSTEMS BY NUMERICAL METHODS A STOCHASTIC MODEL BIOKA58 I6 JRSSB57 IBI TECH 6155 BIOKA51 472 STICAL MODEL OF EVALUATING THE RELIABILITY OF SAFETY SYSTEMS FOR PLANTS MANUFACTURING HAZARDOUS PRODUCTS TECH 59 293 M LIKELIHOOD ESTIMATORS OF RELIABILITY FUNCTIONS FOR SYSTEMS IN SERIES AND IN PARALLEL /IASED AND MAXIMU JASA 66 IO52 SPECTRAL PROPERTIES OF NON-STATTONARY SYSTEMS OF IINEAR STOCHASTTC DIFFERENCE EQUATIONS TESTING FOR SERIAL CORRELATION IN SYSTEMS OF SIMULTANEOUS REGRESSION EQUATIONS THE ESTIMATION OF PARAMETERS IN SYSTEMS OF STOCHASTIC DIFFERENTIAL EQUATIONS

A METHOD TO DETERMTNE THE RELIABILITY OF TELEMETRY SYSTEMS REPORTS

JASA 62 6B6 SYSTEMS STRUCTURE AND THE EXISTENCE OF A SYSTEM LIFE TECH $64 \quad 459$

A GENERAL METHOD FOR THE RELIABILITY ANALYSIS OF SYSTEMS UNDER VARIOUS PREVENTIVE MAINTENANCE POLICIES AMS 62 137 ESIAN CONFIDENCE LIMITS FOR RELIABILITY OF REDUNDANT SYSTEMS WHEN TESTS ARE TERMINATED AT FIRST FAILURE ON CERTAIN REDUNDANT SYSTEMS WHICH OPERATE AT DISCRETE TIMES

SAMPLING ENTROPY FOR RANDOM HOMOCENEOUS SYSTEMS WITH COMPLETE CONNECTIONS (CORR. 69 NO.6) A NOTE ON OUEUEING SYSTEMS WITH ERLANGI AN SERVTCE TIME DISTRIBUTIONS THE ERCODIC QUEUE LENGTH DISTRIBUTION FOR QUEUEING SYSTEMS WITH FINITE CAPACITY CONGESTION SYSTEMS WITH INCOMPLETE SERVICE (CORR, 64 365)

SOME WAITING TIME DISTRIBUTIONS FOR REDUNDANT SYSTEMS WITH REPAIR THE RELIABILITY OF MULTIPLEX SYSTEMS WITH REPAIR

GRAPHICAL METHOD FOR THE STUDY OF COMPLEX GENETICAL SYSTEMS WITH SPECIAL REFERENCE TO EQUILIBRIA COMPUTER SIMULATION EXPERIMENTS WITH ECONOMIC SYSTEMS. THE PROBLEM OF EXPERIMENTAL DESIGN MODEL CLOSED QUEUEING SYSTEMS, A GENERALIZATION OF THE MACHINE INTERFERENCE

NOISE OBSERVATIONS ERROR ESTIMATION OF STOCHASTIC SYSTEMS, ARBITRARY SYSTEM PROCESS WITH ADDITIVE WHITE NOTE ON A CONDITIONAL PROPERTY OF STUDENT'S T THE MOMENTS OF A VARIATE RELATED TO THE NON-CENTRAL T AN APPROXIMATION OF STUDENT'S T AN APPROXIMATION TO THE DISTRIBUTION OF NON-CENTRAL T INTEGRALS OF MULTIVARIATE NORMAL AND MULTIVARIATE T FOR THE MEAN OF A NORMAL DISTRIBUTION III, SMALL T FOR THE MEAN OF A NORMAL DISTRIBUTION II, LARCE T TRIBUTION OF Q. A VARIATE RELATED TO THE NON-CENTRAL T PROXIMATE BEHAVIOR OF THE DISTRIBUTION OF WINSORIZED T (TRIMMING-WINSORIZATION 2 ) VARIATIONS OF THE NON-CENTRAL T AND BETA DISTRIBUTIONS

RELATINC TO CERTAIN MULTIVARIATE GENERALIZATIONS OF T AND F A RELATION BETWEEN T AND F-DISTRIBUTIONS, CORR. 651249

RELATTON RETWEEN THE DISTRIBUTIONS MULTIVARIATE T AND THE RANKING PROBLEM

EXPANSIONS OF T DENSITIES AND RELATED COMPLETE INTEGRALS THE POSTERIOR T DISTRIBUTION

A PROPERTY OF THE MULTIVARIATE T DISTRIBUTION

A NOTE ON REPRESENTATIONS OF THE DOUBLY NON-CENTRAL T DISTRIBUTION

OF THE PROBABILITY INTEGRAL OF THE MULTIVARIATE T DISTRIBUTION

MATRICVARIATE GENERALIZATIONS OF THE MULTIVARIATE T DISTRIBUTION AND THE INVERTED MULTIVARIATE T DISTRI

REPRESENTATIONS OF THE CENTRAL AND NON-CENTRAL T DISTRIBUTIONS A BIVARIATE T DISTRIBUTION, CORR. 671594

STUDENT'S T IN A TWO-WAY CLASSIFICATION WITH UNEQUAL VARIANCES

NONPARAMETRIC PROCEDURES FOR SELECTING THE T POPULATION WITH THE LARCEST ALPHA-QUANTILE HOTELLING'S CENERALIZED T SQUARE IN THE MULTIVARIATE ANALYSIS OF VARIANCE

THE CONDITIONAL LEVEL OF STUDENT'S T TEST

A NOMOGRAM FOR THE 'STUDENT'*FISHER T TEST

BOUNDARIES FOR CLOSED (WEDGE) SEQUENTIAL T TEST PLANS

APPROXIMATION TO THE CUMULATIVE T-DISTRIBUTION

THE MOMENTS OF A DOUBLY NONCENTRAL T-DISTRIBUTION

SERIES REPRESENTATIONS OF THE DOUBLY NONCENTRAL T-DISTRIBUTION A STEPWISE MULTIVARIATE T-DISTRIBUTION

THE MOMENTS OF THE NON-CENTRAL T-DISTRIBUTION

A SPECIAL CASE OF A BIVARIATE NON-CENTRAL T-DISTRIBUTION

AN APPROXIMATION FOR STUDENT'S T-DISTRIBUTION

OF PROPERTTES AND APPLICATIONS OF THE NONCENTRAL T-DISTRIBUTION

TABLES OF THE PERCENTAGE POINTS OF STUDENT'S T-DISTRIBUTION COMPUTATION OF PERCENTAGE POINTS OF THE NON-CENTRAL T-DISTRIBUTION NTACE POINTS OF A MULTIVARIATE ANALOGUE OF STUDENT'S T-DISTRIBUTION TAIL AREAS O1

SOME PERCENTAGE POINTS OF THE NON-CENTRAL T-DISTRIBUTION, CORR. 631163 ' RATIO-LIKE EXPANSION EXTENDED JASA 59 6B3 TABLES TO FACILITATE THE AMS $62 \quad 580$ ESTIMATION OF MULTIPLE CONTRASTS USING T-DISTRIBUTIONS SOME MULTIVARIATE T-DISTRIBUTIONS ES OF CONVEX POLYHEDRA UNDER MULTIVARIATE NORMAL AND T-DISTRIBUTIONS A GENERALIZATION OF THE T-METHOD OF MULTTPLE COMPARTSONS ON HOROVITZ AND THOMPSON'S T-ONE CLASS OF LINEAR ESTIMATION THE T-RATIO DISTRIBUTION

THE ROBUSTNESS OF HOTELLING'S T-SQUARE
TECH $68 \quad 29$

TECH $62 \quad 69$

AMS $65 \quad 1433$

AMS 651574 JRSSB $66 \quad 190$ JRSSB $62 \quad 107$ TECH $64 \quad 27$ JRSSB $66 \quad 459$ BIOCS69 NO. 4 JASA 671315 AMS $68 \quad 7 B 5$ AMS 64298 TECH $65 \quad 71$ BIOKA58 484 AMS $63 \quad 792$ AMS $65 \quad 28$ AMS $64 \quad 162$ AMS $64 \quad 315$ TECH $68 \quad 83$ AMS 64 15B3 AMS $67 \quad 613$ BIOKA57 219 305 AMS $67 \quad 503$ AMS $63 \quad 568$ AMS $65 \quad 712$ JASA 6B 1013 AMS 67 1 AMS $67 \quad 162$ BIOKA64 45I AMS 651248 AMS 67 1B04 JRSSB $63 \quad 358$ AMS 671068 JASA 69 N0.4 BIOKA66 43I TECH $66 \quad 358$ JASA $67 \quad 278$ JASA $68 \quad 1004$ SASJ 6917 BIOKAGI 465 BIOKA65 437 BIOKA65 437 BIOKA55 258 JASA $63 \quad 176$ BIOKA54 153 JASA $65 \quad 573$ AMS $68 \quad 1605$ JRSSB $66 \quad 366$ AMS 671882 JASA 69242 JASA $67 \quad 124$ AMS 63 109B JASA $65 \quad 528$ 
AL VARI/ SOME EMPIRICAL DISTRIBUTIONS OF BIVARIATE T-SQUARE AND HOMOSCEDASTICITY CRITERION M UNDER UNEQU JASA 63 IO48 A TWO-PERIOD DESIGN WITH T-SQUARE EXPERIMENTAL UNITS
SAMPLING PROBLEM SEQUENTIAL CHI-SQUARE AND T-SQUARE TESTS AND THEIR APPLICATION TO AN ACCEPTANCE TECH 61 5I9 IONS FOR THE DISTRIBUTION OF HOTELLING'S GENERALIZED T-SQUARE-SUB-ZERO /TEM OF LINEAR DIFFERENTIAL EQUAT AMS 6B 815 NCE WHEN VARIANCE-COVARI/ ON THE ROBUSTNESS OF THE T-SQUARE-SUB-0 TEST IN MULTIVARIATE ANALYSIS OF VARIA BIOKA64 71 MPTOTICALLY NONPARAMETRIC COMPETITORS OF HOTELLING'S T-SQUARE, CORR. 651583 ON THE COMPLEX ANALOGUES OF T-SQUARED AND R-SQUARED TESTS MINIMAX CHARACTER OF HOTELLING'S T-SQUARED TEST IN THE SIMPLEST CASE SEQUENTIAL CHI-SQUARED AND T-SQUARED TESTS

FOR CLASSICAL MULTI/ ADMISSIBLE BAYES CHARACTER OF T-SQUARED, R-SQUARED AND OTHER FULLY INVARIANT TESTS A NOTE ON THE SEQUENTIAL T-TEST

A COMPACT TABLE FOR POWER OF THE T-TEST ON A TWO-SIDED SEQUENTIAL T-TEST

EFFECT OF NON-NORMALITY ON THE POWER FUNCTION OF T-TEST A TWO-SAMPLE SEQUENTIAL T-TEST CERTAIN SUGGESTED FORMULAE APPLIED TO THE SEQUENTIAL T-TEST THE TWO-SAMPLE T-TEST BASED ON RANGE STUDENT'S T-TEST UNDER SYMMETRY CONDITIONS USE OF RANGE IN PLACE OF STANDARD DEVIATION IN THE T-TEST. THE POWER OF STUDENT'S T-TEST. CORR. 651251 CORRIGENDA, ION A TWO-SIDED SEQUENTIAL T-TEST CRITICAL VALUES FOR BIVARIATE STUDENT T-TESTS NON-NORMALITY IN TWO-SAMPLE T-TESTS CLOSED SEQUENTIAL T-TESTS

APPROXTMATTONS TO THE NON-CENTRAL T WITH APPLICATIONS ERRATA, 'APPROXIMATIONS TO THE NON-CENTRAL T. WITH APPLICATIONS' AN INEQUALITY ON A. BIVARIATE STUDENT'S 'T' DISTRIBUTION

A QUASI-MULTINOMIAL TYPE OF CONTINGENCY TABLE THE GEOMETRY OF A R-BY-C CONTINGENCY TABLE MEAN AND VARIANCE OF AN ENTRY IN A CONTINGENCY TABLE FOR TESTING SIGNIFICANCE IN A 2-BY-3 CONTINGENCY TABLE AND MARGINAL HOMOGENEITY OF AN R-BY-R CONTINGENCY TABLE

OF THE EXACT TEST FOR THE 2-BY-3 CONTINGENCY TABLE OF THE EXACT TEST FOR THE 2-BY-2 CONTINGENCY TABLE IN A 2-BY-2 CONTINGENCY TABLE, EXTENSION OF FINNEY'S TABLE OF CHI-SQUARE AS A TEST OF HOMOGENEITY FROM A 2-BY-N TABLE VARIANCE OF THE CHI-SQUARE FUNCTION ON A CONTINGENCY TABLE DISTRIBUTION CONSIDERED IN THE FORM OF A CONTINGENCY TABLE NFTDENCE INTERVALS OF TUE UEDTAN FOR SAMPLE STZES/ TABLE FOR BOT SOME PROPERTIES OF THE BIVARIATE NORMAL TABLES TECH $63 \quad 501$ SYMMETRY JASA 69 NO 4 ON THE POWER FUNCTION BIOKA6O 393 TESTS OF SIGNTFICANCE BIOKA53 74 THE RAPID CALCULATION BIOKA55 519 A TABLE FOR COMPUTING WORKING ANGLES BIOCS6B 4I
B F VARIOUS SUMS OF SQUARES IN AN ANALYSIS OF VARIANCE TABLE FOR DIFFERENT CLASSIFICATIONS WITH CORRELATED A JRSSB59 114 DISTRIBUTION

A TABLE FOR ESTIMATING THE MEAN OF A IOCNORMAL JASA 69632

$S$ IN ORDERED SERIES
MACHINES UNDER THE CARE OF ONE OPERATIVE $\operatorname{EXP}(B)-B /(1-P)=1$
PROBABILITY TABLE FOR NUMBER OF RUNS OF SIGNS OF FIRST DIFFERENCE A COMPACT TABLE FOR POWER OF THE T-TEST

A TABLE FOR PREDICTING THE PRODUCTION FROM A GROUP OF

A TABLE FOR RANK SUM MULTIPLE PAIRED COMPARISONS TABLE FOR THE SOLUTION OF THE EXPONENTIAL EQUATION

ON PIACKETTIS TEST FOR CONTTNGENCY TABLE TNTERACTIONS A COMPARISON OF TWO LIFE TABLE METHODS

AN EXTENDED TABLE OF CRITICAL VALUES FOR THE MANN-WHITNEY-WILCOXO TABLE OF CRITICAL VALUES FOR WILCOXON'S TEST TABLE OF NEYMAN-SHORTEST UNBIASED CONFIDENCE INTERVAL BIOKA6O STATISTIC

S FOR THE BINOMIAL PARAMETER ON THE COMPUTATION AND USE OF A TABLE OF PERCENTAGE POINTS OF BARTLETT'S $M$ TABLE OF PERCENTAGE POINTS OF KOLMOGOROV STATISTICS TABLE OF PERCENTAGE POINTS OF NON-CENTRAL CHI TABLE OF PERCENTAGE POINTS OF PEARSON CURVES, FOR GIV BIOKA63 EN ROOT (BETA-1) AND BETA-2 EXPRESSED IN STANDARD/ EN ROOT(BETA-1) AND BETA-2. EXPRESSE/ CORRIGEND DISTRIBUTION TIONS ' DISTRIBUTION A NEW TABLE OF PERCENTAGE POINTS OF THE CHI-SQUARE 'A NET TABLE OF PERCENTAGE POINTS OF THE CHI-SQUARE DISTRIBU BIOKA65 A NEW TABLE OF PERCENTAGE POINTS OF THE PEARSON TYPE III TECH 69 NS OF KOLMOGOROV-SMIRNOV TYPE STATISTICS INCLUDING A TABLE OF SIGNTFICANCE POINTS FOR A PARTTCULAR CASE THE FIRST FOUR MOMENTS ARE GIVEN UTION OVER AN OFSET CIRCLE 'STUDENTIZED' RANGE

INOMIAL CUMULATIVE DISTRIBUTION FOR SAMPL/ TABLE OF THE BOUNDS OF THE PROBABILITY INTEGRAL WHEN BIOKA60 399

A TABLE OF THE INTEGRAL OF THE BIVARIATE NORMAL DISTRIB JRSSB60 177 TABLE OF THE UPPER 10 PERCENT POINTS OF THE COMPACT TABLE OF TWELVE PROBABILITY LEVELS OF THE SYMMETRIC B JASA 59164

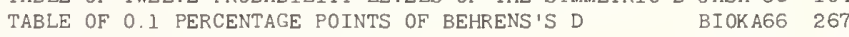
A LIFE TABLE THAT AGREES WITH THE DATA

A LIFE TABLE THAT AGREES WITH THE DATA. IT JASA $66 \quad 305$ JASA 681253

R THE DIFFERENCE BETWEEN TWO PROPORTIONS IN A 2-BY-2 TABLE.'//IGENDA, 'THE POWER FUNCTION OF THE TEST FO BIOKA59 502 EXACT BAYESIAN ANALYSIS OF A TWO-BY-TWO CONTINGENCY TABLE. AND FISHER'S 'EXACT' SIGNIFICANCE TEST TESTS OF STCNFTCANCE IN A 2-BY-2 CONTINCENCY TABLE, EXTENSTON OF FTNNEY IS TABLE UNCTION OF THE EXACT TEST FOR THE 2-BY-2 CONTINGENCY TABLE' LAGRANGIAN COEFFICIENTS FOR INTERPOLATION BETWEEN TABLED PERCENTAGE POINTS RAPID ANALYSIS OF $2 X_{2}$ TABLES CORRIGENDA, 'ON THE POWER F THE BAYESIAN ANALYSIS OF CONTINGENCY TABLES INTERACTIONS IN MULTIDIMENSIONAL CONTINGENCY TABLES THE POWER OF CHI SQUARE TESTS FOR CONTINGENCY TABLES ASSOCIATION AND ESTIMATION IN CONTINGENCY TABLES OPTIMUM CHOICE OF CLASSES FOR CONTINGENCY TABLES EXACT TESTS OF SIGNIFICANCE IN CONTINGENCY TABLES MONOMTAL-MONOMIAL SYMMETRIC FUNCTION TABLES

TESTS OF INDEPENDENCE IN INTRACLASS 2-BY-2 TABLES THE CONTINUITY CORRECTION IN 2-BY-2 TABLES

A NOTE ON INTERACTIONS IN CONTINGENCY TABLES INTERACTIONS IN MULTI-FACTOR CONTINGENCY TABLES IOK A61 475 BIOKA68 19 JASA $57 \quad 18$ AMS 641622 AMS $64 \quad 632$ JASA 66965 JASA $6 B \quad 1$ JASA $68 \quad 291$ TECH $69 \quad 393$ BIOKA59 205 BIOKA6I IBI BIOKA64 327 JRSSB $62 \quad 162$ JRSSB $62 \quad 251$ 
MAXIMUM LIKELIHOOD IN THREE-WAY CONTINCENCY TABLES ALTERNATIVE ANALYSIS OF CONTINCENCY TABLES

THE ROBUSTNESS OF HOMOCENEITY TESTS IN 2 BY N TABLES NOTES. F-RATIO PROBABILITIES FROM BINOMIAL TABLES

ON THE HYPOTHESES OF 'NO INTERACTION' IN CONTINCENCY TABLES INCOMPLETE TWO-DIMENSIONAL CONTINCENCY TABLES

THE ESTIMATION OF SMALL FREQUENCIES IN CONTINCENCY TABLES

CONTINGENCY TABLES, LOCITS, AND SPLIT CONTINCENCY TABLES

SMALL SAMPLE CONSIDERATIONS IN COMBININC 2 BY 2 TABLES

OF RESULTS FROM SEVERAL 2 BY 2 CONTINCENCY TABLES

OF 'NO INTERACTION' IN MULTI-DIMENSIONAL CONTINGENCY TABLES CRAPHICAL ANALYSIS OF MULTIDIMENSIONAL CONTINGENCY TABLES

FOR THE ANALYSIS OF ASSOCIATION IN CONTINGENCY TABLES

ANALYZING THREE-FACTOR INTERACTION IN CONTINCENCY TABLES

OMPARISON OF STRENCTHS OF ASSOCIATION IN CONTINGENCY TABLES

LIMITS FOR CROSS-PRODUCT RATIOS IN CONTINCENCY TABLES

OF NO THREE FACTOR INTERACTION IN CONTINCENCY TABLES

OF EXAGT PROBABILITIES FOR 2-BY-3 CONTINGENCY TABLES

COMBINATION OF PROBABILITIES TEST TO A SET OF 2-BY-2 TABLES

FOR THE TEST OF INDEPENDENCE IN $2 X 2$ CONTINGENCY TABLES

ON MEASURES OF ASSOCIATION IN 2-BY-2 CONTINCENCY TABLES

ULATION, ESPECIALLY FOR MULTIDIMENSIONAL CONTINCENCY TABLES

THER DISCUSSION OF ITERATIVE METHODS FOR CALCULATING TABLES

$\mathrm{N}$, WITH APPLICATION TO MANIFOLD, ORDERED CONTINCENCY TABLES

ON A TEST OF SIGNIFICANCE IN PEARSON'S BIOMETRIKA TABLES

THE WILCOXON TWO-SAMPLE STATISTIC TABLES AND BIBLIOGRAPHY TESTS FOR CONTINCENCY TABLES AND MARKOV CHAINS

EQUIPROBABLE ALTERNATIVES

MODELS FOR COMPLEX CONTINGENCY TABLES AND POLYCHOTOMOUS DOSACE RESPONSE CURVES

JRSSB63 220

JRSSB66 164

BIOCS65 19

BIOCS66 404

BI0CS6B 567

BIOCS69 119

ON JRSSB56 113

FULL BTOCS69 383

NOTES. BIOCS67 349

COMBINATION BIOCS65 86

HYPOTHESES TECH $68 \quad 107$

A NOTE ON THE TECH $67 \quad 4 \mathrm{BI}$

USE OF SCORES BIOKA52 274

SIMPLE METHODS FOR JASA 64319

THE ESTIMATION AND C BIOKA53 105

SIMULTANEOUS GONFIDENCE JRSSB64 86

LAMST AND THE HYPOTHESES JASA 69207

NOTES, RAPID CALCULATION BIOCS6B 714

A NOTE ON THE APPLICATION OF THE BIOKA55 404

COMPARISON OF THE POWER FUNCTIONS AMS 641115

THE EFFECT OF NON-SAMPLINC ERRORS JASA 69852

MAXIMUM ENTROPY FOR HYPOTHESIS FORM AMS 63911

ON THE COMPARISON OF TWO MEANS, FUR BIOKA54 361

/GT-MOMENT PARTTAL CORRELATTON AND REGRESSIO BIOKA59 24] JRSSB56 56 JRSSB56 295 JASA 631086 TECH $62 \quad 573$ BI0CS66 B3 BI0KA68 44I TECH $63 \quad 491$ TECH $65 \quad 293$

COMPARISONS SICN TEST TABLES FOR A PRECEDENCE LIFE TEST

$\begin{array}{llrrr}\text { TABLES FOR BEST LINEAR ESTIMATES BY ORDER STATISTICS } & \text { JASA } 57 & 58 \\ \text { TABLES FOR CERTAIN SPECIAL CASES } & \text { A BIVARIATE BIOKA54 } & 153\end{array}$

GENERALIZATION OF STUDENT'S T-DISTRIBUTION. WITH TABLES FOR CERTAIN SPECIAL CASES A BIVARIATE BI MUI.TIPLE CORRELATION COEFFICIENT

SAMPLINC PLANS

NORMAL DISTRIBUTION

NORMAL DISTRIBUTION, "

ATED AND SINGLY CENSORED SAMPLES

TABLES FOR ENSTRUCTINC CONFIDENCE LIMITS ON THE

PROCEDURES AND TABLES FOR EVALUATING DEPENDENT MIXED ACCEPTANCE R TECH 69341

TABLES FOR MAKING INFERENCES ABOUT THE VARIANCE OF A BIOKA60 433

CORRICENDA, 'TABLES FOR MAKING INFERENCES ABOUT THE VARIANCE OF A BIOKA61 230

WORKING LIFE TABLES FOR MALES IN GHANA $1960 \quad$ JASA 69102

TABLES FOR MAXIMUM LIKELIHOOD ESTIMATES. SINGLY TRUNC TECH 61535

TABLES FOR OBTAININC THE BEST LINEAR INVARIANT ESTIMA TECH 67629 TABLES FOR POWER-LAW TRANSFORMATIONS

TABLES FOR SIGNIFICANGE TESTS OF 2-BY-2 GONTINGENCY BIOKA55 494 TABLES FOR TESTINC SIGNIFICANCE IN A 2-BY-3

TABLES
CONTINGENCY TABLE

NORMAL DISTRIBUTIONS

LINEAR RESTRICTIONS IN REGRESSION

ANALYSIS OF INCOMPLETE BLOCK DESICNS

ANALYSIS OF INCOMPLETE BLOCK DESIGNS.

ESTIMATES OF BINOMIAL PARAMETERS

TABLES FOR THE COMPARISION OF THE

TABLES FOR THE MEAN SQUARE ERROR TEST FOR EXACT

I. ADDITIONAL TABLES FOR THE METHOD OF PAIRED COMPARISONS,

TABLES FOR THE SIGN TEST WHEN OBSERVATIONS ARE

TECH $63 \quad 501$

BIOKA67 6B3

AMS 671541

JASA 69 N0. 4

RANK BIOKA54 502

/ANK BIOKA64 2B8

JASA 59784

$\operatorname{EXP}(-\mathrm{A})+\mathrm{KA}=1$

BASED ON SAMPLE MEAN AND RANGE OR MEAN RANCE

POPULATION

FUNCTION BY NORMIT ANALYSIS. PART I. DESCRIPTION/

DISTRIBUTION

TABLES FOR WALD TESTS FOR THE MEAN OF A NORMAL
A NOTE ON CONTINCENCY TABLES INVOLVING ZERO FREQUENCIES AND THE 2 I TES

TABLES FOR THE SOLUTTON OF THE EXPONENTTAL EOUATTON BIOKA60 439

TABLES FOR TOLERANCE LIMITS FOR A NORMAL POPULATION JASA 5788

TABLES FOR UNBIASED TESTS ON THE VARIANCE OF A NORMAL AMS $61 \quad 84$

TABLES FOR USE IN ESTTMATING THE NORMAL DISTRIBUTION BIOKA57 4]

BIOKA59 169

TECH $63 \quad 39 B$

JRSSB56 212

JASA $65 \quad$ B72

TABLES OF BOUNDS FOR DISTRIBUTIONS WITH MONOTONE

RECIPROCALS

DISTRIBUTION

THE NORMAL PROBABILITY FUNCTION, TABLES OF CERTAIN AREA-ORDINATE RATIOS AND OF THEIR

TABLES OF CONFIDENCE LIMTTS FOR THE BINOMIAL

BIOKA55 217

JASA 60521

CORRICENDA, 'EXTENDED TABLES OF CRITTCAL VALUES FOR WILCOXON'S TEST STATIST BIOKA64 527 TABLES OF CRITICAL VALUES OF SOME RENYI TYPE STATISTI JASA 69 B70

TABLES OF DISTRIBUTION-FREE TOLERANGE LIMITS

AMS 641361

CS FOR FINITE SAMPLE SIZES

DUCTS OF ORDER STATISTICS FOR SAMP/

CORRECTION TO ITABLES OF EXPECTED VALUES OF ORDER STATISTICS AND PRO TABLES OF GENERALIZED K-STATISTICS

TABLES OF INVERSE GAUSSIAN PERCENTAGE POINTS

AMS 611345

LS FOR THE POISSON PARAMETER

TO BARTLETT'S CRITERION FOR TESTING/

RANGE

NORMAL SAMPLES, A ROUNDING OFF

EXTREME DEVIATE FROM THE SAMPLE MEAN RANGE'

ATIO S-SQUARE-MAX-OVER-S-SQUARE-SUB-O

DISTRIBUTIONS

BINOMIAL AND AND POISSON DISTRIBUTIONS

LARCE SAMPLE TABLES OF PERCENTAGE POINTS FOR HARTLEY'S CORRECTION

USE OF TABLES OF PERCENTAGE POINTS OF RANGE AND STUDENTIZED

TABLES OF PERCENTACE POINTS OF ROOT'B1' AND B2 IN

TABLES OF PERCENTACE POINTS OF THE 'STUDENTIZED'

CORRIGENDA, 'TABLES OF PERCENTAGE POINTS OF THE 'STUDENTIZED'

191

BIOKA62 4B7

TECH $61 \quad 407$

BI0KA65 282

BIOKA52 1 B9

BIOKA53 236

EXTENSION OF TABLES OF PERCENTAGE POTNTS OF THE LARGEST VARIANCE R BIOKA67 225 TABLES OF POISSON POWER MOMENTS

TABLES OF RANDOM OBSERVATIONS FROM STANDARD

ILLUSTRATIVE TABLES OF SCHOOL LIFE, CORR. 641299

TABLES OF SIMULTANEOUS CONFIDENCE LIMITS FOR THE

TABLES OF SYMMETRIC FUNCTIONS. PART IV.

TABLES OF SYMMETRIC FUNCTIONS. PART $V$.

TABLES OF SYMMETRIC FUNCTIONS. PARTS II AND III.

ERRATA IN 'TABLES OF SYMMETRIC FUNCTIONS'

TABLES OF THE ANGULAR TRANSFORMATION

BIOKA56 489

BIOKA59 17B

JASA 631113

BIOKA69 452

BIOKA53 427

BI0KA55 223

BIOKA51 435

BIOKA58 292

BI0KA53 70

TABLES OF THE DISTRTBUTTON OF THE MANN-WHITNEY-WILCOX TECH 67666

TABLES OF THE FREEMAN-TUKEY TRANSFORMATIONS FOR THE BIOKA61 433

TABLES OF THE LOGARITHMIC SERIES DISTRIBUTION 
ONS IZED' RANCE

STATISTIC

RSON CURVES (NTTH ARDED

DISTRIBUTIONS

DISTRIBUTIONS'

CURVES.

POINTS OF THE NON-CENTRAL T-DISTRIBUTION ON THE ANALYSIS OF CONTTNCENCY TABLES WHEN THE CROSS CLASSIFICATIONS

CONTINCENCY TABLES WITH CIVEN MARCINALS QUASI-INDEPENDENCE, AND INTERACTIONS IN CONTINCENCY TABLES WITH OR WITHOUT MISSINC ENTRIES /DEPENDENCE, JASA 68 1091 CULATINC THE EXACT PROBABILITY IN 2-BY-2 CONTINCENCY TABLES WITH SMALL MARCINAL TOTALS /LE METHOD OF CAL BIOKA55 522 THE INTERNATTONAL STANDARDTZATTON OF INTER-TNDUSTRY TABLES, GORR, G4 1299

FULL CONTINCENCY TABLES, LOCITS, AND SPLIT GONTINCENCY TABLES PROBLEMS IN JASA $64 \quad 256$ BIOCS69 383

HI-SQUARE TEST FOR SMALL EXPECTATIONS IN CONTINCENCY TABLES, WITH SPECIAL REFERENCE TO ACCIDENTS AND ABSEN BIOKA59 365 'TEST OF INDEPENDENCE IN INTRACLASS 2-BY-2 TABLES'

MEIGHT VARTATTON RELEASE AND CONTROL OF CAPSULES, TIBLETS, AND STERILE SOLIDS

OF PUNCH CARDS, GORR. 56650

TABULAR ANALYSIS OF FACTORIAL EXPERIMENTS AND THE USE JASA 56 149 THE TWO-SAMPLE CAPTURE-RECAPTURE CENSUS WHEN TAGGING AND SAMPLINC ARE STRATIFIED

STIMATION OF MORTALITY AND RECRUITMENT FROM A SINGLE TAGGINC EXPERIMENT LIKE EXPANSION
FIELD OF A MARKOV CHAIN

THE PROBABILITY IN THE TAIL OF A DISTRIBUTION

QUERY, THE MEAN OF THE TAIL OF A DISTRIBUTION

GENERATING A VARIABLE FROM THE TAIL OF THE NORMAL DISTRIBUTION

D EXAGT BAHADUR EFFICIENCY OF THE TWO-SA/ TWO-SAMPLE WILCOXON STATISTIC

EXPRESSI

EXTREME TAIL PROBABILITIES FOR SAMPLING WITHOUT REPLACEMENT A BIOKA68 371

EXTREME TAIL PROBABILITIES FOR THE NULL DISTRIBUTION OF THE BIOKA67 629 OREY

A NORMAL APPROXIMATION JASA 681416

A NORMAL APPROXIMATION JASA $6 \mathrm{~B} 1457$ THE TAIL SICMA-FTELD OF A MARKOV CHAIN AND A THEOREM OF AMS 641291 CONTROL OF PERCENTACES IN BOTH TAILS OF THE NORMAL DISTRIBUTION ERRATA, 'CONTROL OF PERGENTAGES IN BOTH TAILS OF THE NORMAL DISTRIBUTIONS'

TECH $66 \quad 570$ BIOKAG9 437 PROBABILITY AND STATISTICS, XXII, PROBABILITY IN THE TALMUD LITY AND STATISTICS XVI. RANDOM RANDOM MECHANISMS IN TALMUDIC LITERATURE /DIES IN THE HISTORY OF PROBABI BIC ON QUEUES IN TANDEM

NOTES ON QUEUES IN TANDEM

THE DEPENDENCE OF DELAYS IN TANDEM QUEUES

A NOTE ON THE ABSENCE OF TANCENCIES IN GAUSSIAN SAMPLE PATHS

A DISTRIBUTION ANALOGOUS TO THE BOREL-TANNER

THE BOREL-TANNER DISTRIBUTION

OF COVERAGE PROBLEMS ASSOCIATED WITH POINT AND AREA TARGETS

THE LADY TASTING TEA, AND ALLIED TOPICS

OF THE REGRESSTON COEFFICIENT BASED ON KENDALL'S TAU

OF AVERACE TAU WITH A GRITE/ A NOTE ON CALGULATING TAU AND AVERAGE TAU AND ON THE SAMPLING DISTRIBUTION JA A

OF THE/ A SIMILARITY BETWEEN GOODMAN AND KRUSKAL'S TAU AND KENDALL'S TAU, WITH A PARTIAL INTERPRETATION JA A GRAPHIG COMPUTATION OF TAU AS A COEFFICIENT OF DISARRAY

A NOTE ON GRIFFIN'S PAPER 'GRAPHIC COMPUTATION OF TAU AS A COEFFICIENT OF DISARRAY'

A NOTE ON AVERAGE TAU AS A MEASURE OF CONCORDANCE DISTRIBUTIONS OF KENDALL'S TAU BASED ON PARTIALLY ORDERED SYSTEMS

IOKA67 316

AMS $63 \quad 300$

AMS $63 \quad 338$

AMS $64 \quad 874$

AMS $68 \quad 261$

BIOKA61 167

BIOKA60 143

A SURVEY TECH 69561 JASA $59 \quad 776$

JASA $6 B \quad 1379$ JASA $62 \quad 567$ JASA $62 \quad 804$ JASA $58 \quad 441$ JASA $61 \quad 736$ JASA $60 \quad 331$ BIOKA55 417

A MODIFICATION OF KENDALL'S TAU FOR THE CASE OF ARBITRARY TIES IN BOTH RANKINCS JASA 5733 THE THIRD MOMENT OF KENDALL'S TAU IN NORMAL SAMPLES

MOMENTS OF THE RANK CORRELATION COEFFICIENT TAU IN THE CENERAL CASE

A COMPUTER METHOD FOR GALCULATING KENDALL'S TAU WITH UNCROUPED DATA

PARTIAL TESTS FOR PARTIAL TAUS

FISCAL-YEAR REPORTTNG FOR CORPORATE TNCOME TAX

INCOME UNDER THE WISCONSIN STATE INDIVIDUAL INCOME TAX

TAXPAYER COMPLTANCE JASA $56 \quad 304$ WAGE, PRICE, AND TAX ELASTICITIES OF OUTPUT AND DISTRIBUTIVE SHARES JASA 62607

NING AND DISCRIMINANT FUNCTION TECHNIQUES IN MEDICAL TAXONOMY

R THE WISCONSIN STATE INDIVIDUAL INCOME TAX

A COMPARISON OF SUCCESSIVE SCREE SOME SHARP MULTIVARIATE TCHEBYCHEFF INEQUALITIES

GENERALIZATIONS OF TCHEBYCHEFF'S INEQUALITIES (WITH DISCUSSION)

AN ANALOCUE OF TCHEBYCHEFF'S INEQUALITY IN TERMS OF THE RANCE OPTIMAL DESICNS ON TCHEBYCHEFF POINTS

FOR ESTIMATION OF INCIDENCE OF RED SPIDER MITE ON TEA CROP IN NORTH-EAST INDIA

THE LADY TASTINC TEA, AND ALLIED TOPICS

TEACHINC BIOMETRY IN THE UNIVERSITY

SOME OBSERVATIONS ON THE TEACHING OF STATISTICAL CONSULTINC

TEAM DECISION PROBLEMS

FAMILIES

A TECHNICAL LEMMA FOR MONOTONE LIKELIHOOD RATIO

SAMPLING TECHNIQUES BIOCS6 635

JASA 59776

BI0CS68 1

BIOCS6B 789

AMS $62 \quad 857$

AMS $67 \quad 611$

BIOKA69 361

JRSSB 58205

TECH $66 \quad 695$

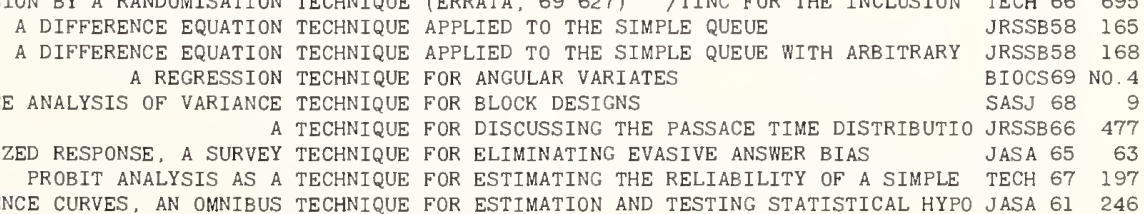

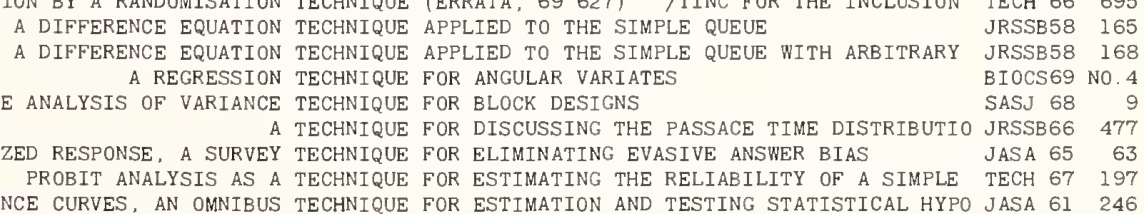

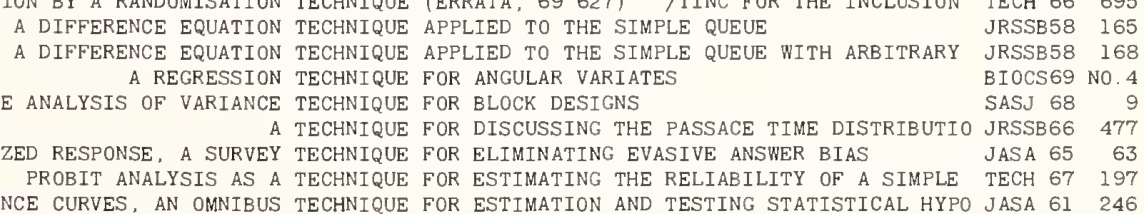

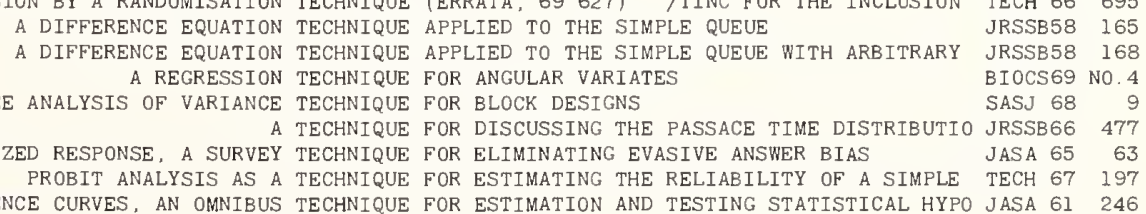

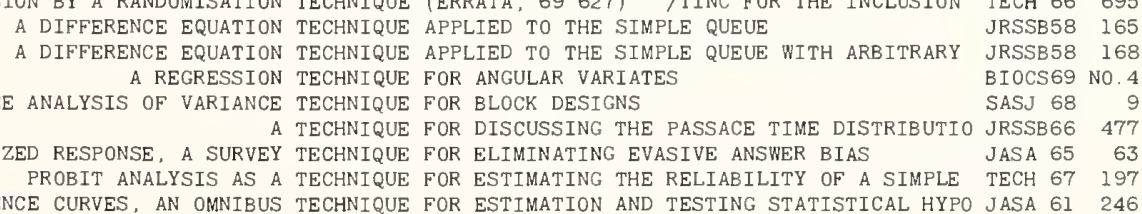

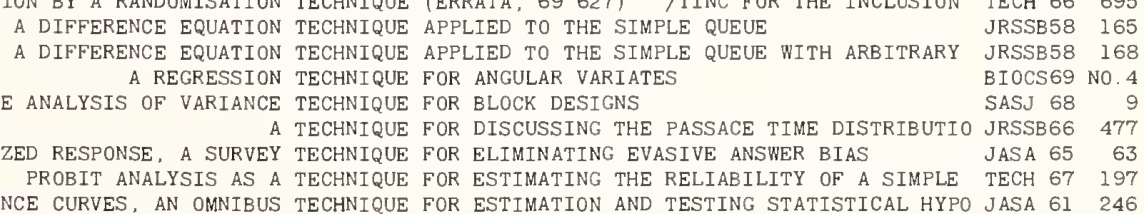
N FOR STABLE SYSTEMS

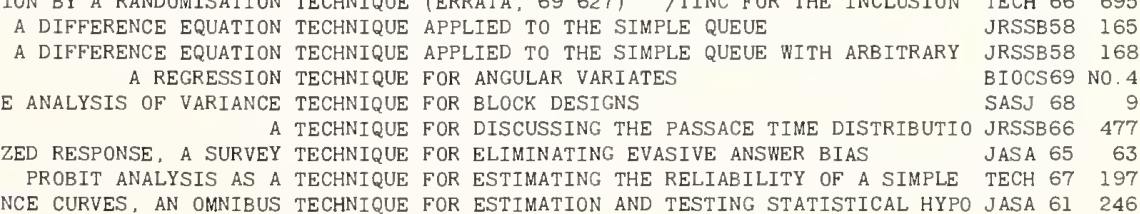

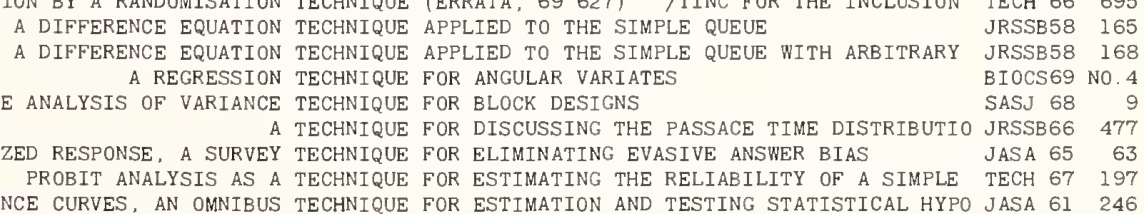

SYSTEM

THESES 
A MODIFIED TECHNIQUE FOR IMPROVINC AN ESTIMATE OF THE MEAN

ANALYTICAL TECHNIQUE FOR INCOMPLETE BLOCK EXPERIMENTS

ATIONAL ESTIMATES OF RETAIL T/ USE OF A RECRESSION TECHNIQUE TO PRODUCE AREA BREAKDOWNS OF THE MONTHLY N J ON THE RELATIVE ACCURACY OF SOME SAMPLING TECHNIQUES

ANALYSIS OF SURVIVAL DATA BY RECRESSION TECHNIQUES

TIME SERIES ANALYSIS BY MODIFIED LEAST-SQUARES TECHNIQUES PERMUTATION SUPPORT FOR MULTIVARIATE TECHNIQUES

C PLANS BY USINC SEQUENTIAL, ITEM BY ITEM, SELECTION TECHNIQUES AND DIGITAL COMPUTERS /OPMENT OF SAMPLIN JASA 62387 MENTS FOR CALENDAR SHIFTS

TO A LINEAR RESTRICTION PLANS

ZED POISSON DISTRIBUTIONS

MITE ON TEA CROP IN NORTH-EAST INDIA SOME TECHNIQUES FOR ANALYZINC A SET OF TIME SERIES SUBJECT J TECHNIQUES FOR CONSTRUCTING FRACTIONAL REPLICATE

SIMPLIFTED TECHNTOUES FOR ESTTMATING PARAMETERS OF SOME CENERALT BTOKAG7 SOME SHRINKACE TECHNIQUES FOR ESTIMATINC THE MEAN

LINEAR PROCRAMMINC TECHNIQUES FOR RECRESSION ANALYSIS

NEW TECHNIQUES FOR THE ANALYSIS OF ABSEY

OF SUCCESSIVE SCREENINC AND DISCRIMINANT FUNCTION TECHNIQUES IN MEDICAL TAXONOMY SOME EMPIRICAL BAYES TECHNIQUES IN POINT ESTIMATION

A COMPARISON OF STATISTICAL TECHNIQUES IN THE DIFFERENTIAL DIACNOSIS OF NONTOXIC

COITRE

AN APPLICATION OF NUMERICAL INTECRATION TECHNIQUES TO STATISTICAL TOLERANCINC

INDEX TO TECHNOMETRICS, VOLUMES I-7

ERRATA TO INDEX TO TECHNOMETRICS, VOLUMES I-?

THE CASE OF THE INDIANS AND THE TEEN-AGE WIDOWS

ON THE PROBABILITY DISTRIBUTTON OF A FILTERED RANDOM TELEGRAPH SIGNAL

STATISTICS USED FOR DATA COMPRESSION IN SPACE TELEMETRY

A METHOD TO DETERMINE THE RELIABILITY OF TELEMETRY SYSTEMS REPORTS

THE TRANSIENT BEHAVIOR OF A COINCIDENCE VARIATE IN TELEPHONE TRAFFIC

FORECASTING RECORD

TEN YEARS OF CONSUMER ATTITUDE SURVEYS THEIR

POWER FUNCTION OF THE NON-PARAMETRIC TEST OF TENDENCY THE POISSON TENDENCY IN TRAFFIC DISTRIBUTION

A NOTE ON THE POISSON TENDENCY IN TRAFFIC DISTRIBUTION

PAPERS ON THE RELATION BETWEEN EXTREME VALUES AND TENSILE STRENGTH

TENSOR NOTATION AND THE SAMPLINC CUMULANTS OF K-

STATISTICS

BIOCS69 588

BIOCS66 829

JASA $66 \quad 496$

JASA 5898

TECH 63161

615

513

45

555

BIOCS66 385

JASA 59206 BIOKA54 77

A COMPARISON BIOCS69 NO.4

BIOKA69 133

BIOCS68 103

TECH $67 \quad 441$

TECH $66 \quad 216$

TECH $66 \quad 387$

JASA $62 \quad 338$

AMS $68 \quad 890$

SYSTEMATTC JASA $65 \quad 97$

JASA $62 \quad 686$

AMS 61230

JASA $63 \quad 899$

AMS $62 \quad 471$

AMS $63 \quad 308$

AMS 64 1B23

WO EARLY BIOKA54 559

BIOKA52 319
SAMPLINC TECHNIQUES FOR ESTIMATION OF INCIDENCE OF RED SPIDER

JASA $68 \quad 113$

BIOKA63 353

JASA $57 \quad 450$

AMS $62 \quad 894$

AMS 64502

BIOKA52 211 ON A CORRECTION TERM IN THE METHOD OF PAIRED COMPARISONS

ENSITIES FOR APPROXIMATING A SKEW DENSITY WHOSE LEFT TERMINAL AND FIRST THREE MOMENTS ARE KNOWN /ARSON D BIOKA68 559 PROBLEM FOR UNIMODAL DISTRIBUTIONS WHEN ONE OR BOTH TERMINALS ARE KNOWN

NOTE ON THE MOMENT- BIOKA56 224

FOR RELIABILITY OF REDUNDANT SYSTEMS WHEN TESTS ARE TERMINATED AT FIRST FAILURE /SIAN CONFIDENCE LIMITS TECH 6829

IAL PROBABILITY RATIO TESTS BASE/ GENERAL PROOF OF TERMINATION WITH PROBABILITY ONE OF INVARIANT SEQUENT AMS 678

A CHARACTERIZATION OF THE UPPER AND LOWER CLASSES IN TERMS OF CONVERCENCE RATES

LUES OF NOR/ A NOTE ON THE FRROR AETER A NUMBER OF TERMS OF THE DAVTD- OOHNSON SERIRS FOR TUE EXPECTAD VA BIOK AN ANALOCUE OF TCHEBYCHEFF'S INEQUALITY IN TERMS OF THE RANGE

HISTORICAL NOTES ON THE WILCOXON UNPAIRED TWO-SAMPLE TEST

A NEW BIVARIATE SIGN TEST

ON THE EMPTY CELL TEST

THE NUMBER AND WIDTH OF CLASSES IN THE CHI-SQUARE TEST

EARLY DECISION IN THE WILCOXON TWO-SAMPLE TEST

TABLES FOR A PRECEDENCE LIFE TEST

FLUCTUATION THEOREM AND A DISTRIBUTION-FREE TEST NOTE ON MOOD'S TEST

ON THE NORMAL SCORES TWO-SAMPLE RANK TEST

A ROBUST VERSION OF THE PROBABILITY RATIO TEST

EFFECT OF NON-NORMALITY ON STEIN S TWO SAMPLE TEST A NOTE ON THE SPHERICITY TEST

BIAS OF THE ONE-SAMPLE CRAMER-VON MISES TEST

THE TREATMENT OF TIES IN THE WILCOXON TEST

THE POWER OF THE LIKELIHOOD RATIO TEST

THE CONDITIONAL LEVEL OF STUDENT'S T TEST

ASYMPTOTIC EFFICIENCY OF MULTIVARIATE NORMAL SCORE TEST

DISTRIBUTION AND POWER OF THE ABSOLUTE NORMAL SCORES TEST THE V-SUB-NM TWO-SAMPLE TEST

ROBUSTNESS OF SUM OF SQUARED RANKS TEST

A NOTE ON A DOUBLE SAMPLE TEST

A NOMOGRAM FOR THE 'STUDENT'*FISHER T TEST

ON A TWO-SIDED SEQUENTIAL T-TEST

GALTON'S RANK-ORDER TEST

A TWO-SAMPLE DISTRIBUTION-FREE TEST

EFFECT OF NON-NORMALITY ON THE POWER FUNCTION OF T-TEST

A TWO-SAMPLE SEQUENTIAL T-TEST

SOME SEQUENTIAL ANALOGS OF STEIN'S TWO-STACE TEST

A MULTIVARIATE ANALOGUE OF THE ONE-SIDED TEST

A BIVARIATE SIGNED RANK TEST

LOCALLY UNBIASED TYPE M TEST

NOTES. A NOTE ON COCHRAN'S Q TEST

THE ASYMPTOTIC EFFICIENCY OF THE KOLMOGOROV-SMIRNOV TEST

OF NON-NORMALITY ON THE POWER FUNCTION OF THE SIGN TEST

A CHI-SQUARE APPROXIMATION FOR THE MULTIVARIATE SIGN TEST

ECONOMICAL BINOMIAL SEQUENTIAL PROBABILITY RATIO TEST

THE RISKS OF ERROR INVOLVED IN THE SEQUENTIAL RATIO TEST

EFFICIENCY OF THE TWO SAMPLE KOLMOGOROV-SMIRNOV TEST

SUGGESTED FORMULAE APPLIED TO THE SEQUENTTAL T-TEST

BETA-APPROXIMATIONS TO THE KRUSKAL-WALLIS H TEST

RIVASTAVA'S PAPER ON THE POWER FUNCTION OF STUDENT'S TEST
AMS 691120

TECH $62 \quad 133$

JASA $57 \quad 356$

JASA $58 \quad 448$

TECH $62 \quad 235$

JASA 63678

JASA $63 \quad 713$

TECH $63 \quad 491$

AMS 641359

AMS 641825

JASA $64 \quad 652$

AMS $65 \quad 1753$

AMS $65 \quad 651$

AMS $66 \quad 464$

JASA $66 \quad 246$

AMS $67 \quad 519$

AMS $67 \quad 802$

AMS $67 \quad 1068$

AMS 671753

JASA $67 \quad 966$

AMS $68 \quad 923$

JASA 68 33B

JASA 69 N0.4

JASA 69 NO.4

BIOKA52 302

BIOKA55 261

BIOKA56 377

BIOKA5B 421

BIOKA61 65

BIOKA62 367

BIOKA63 403

JRSSB64 457

JRSSB $66 \quad 298$

BIOCS65 1008

ON JASA $65 \quad 843$

EFFECT JASA $64 \quad 142$

NOTE ON JRSSB65 82

THE MOST BIOKA6O 103

A NOTE ON BIOKA56 231

ASYMPTOTIC JASA $67 \quad 932$

ON CERTAIN BIOKA64 97

SIMPLIFIED JASA $59 \quad 225$

NOTE ON MR S BIOKA58 429 
OF THE USE OF THE SEQUENTIAL PROBABILITY RATIO TEST TREATMENTS VERSUS CONTROL MULTIPLE COMPARISONS SIGN TEST ASYMPTOTIC EFFICIENCY OF BENNETT'S BIVARIATE SIGN TEST ASYMPTOTIC EFFICIENCY OF FRIEDMAN'S CHI-SQUARE-SUB-R-TEST NORMALITY ON THE POWER OF THE ANALYSIS OF VARIANCE TEST IN A SEQUENCE OF TWO ALTERNATIVES. II. RUNS TEST RANGE IN PLACE OF THE STANDARD DEVIATION IN STEIN'S TEST LIMITS FOR A RATIO USING WILCOXON'S SIGNED RANK TEST TEST. A TWO-SIDED VERSION OF THE CONTROL MEDIAN TEST AND BAHADUR EFFICIENCY OF THE HODGES BIVARIATE SIGN TEST DISTRIBUTION AND POWER OF THE VARIANCE RATIO TEST THE RATIO OF TWO RANGES AND POWER OF THE ASSOCIATED TEST TABLES INVOLVING ZERO FREQUENCIES AND THE 2I TEST TO THE CRITICAL VALUES FOR DUNCAN'S MULTIPLE RANGE TEST CHARACTER OF THE SEQUENTIAL PROBABILITY RATIO TEST OF A STANDARD MODEL I I ANALYSIS OF VARIANCE TEST SAMPLE SIZE IN A SEQUENTIAL PROBABILITY RATIO TEST NONPARAMETRIC COMPETITORS OF WILCOXON'S TWO SAMPLE TEST OF THE DURBIN-WATSON TEST AND THE POWER OF THE BLUS TEST EFFICIENCY OF THE WALD SEQUENTIAL PROBABILITY RATIO TEST STIC CURVE FOR THE WALD SEQUENTIAL PROBABILITY RATIO TEST CONTINGENCY TABLE, AND FISHER'S 'EXACT' SIGNIFICANCE TEST TIC AND AVERAGE SAMPLE NUMBER OF A SIMPLE SEQUENTIAL TEST $T$ BAHADUR EFFICIENCY OF THE TWO-SAMPLE NORMAL SCORES TEST D LEAST-SQUARES PROBLEMS AND THE ROBUSTNESS OF THE F-TEST STATISTICAL LIFE TEST ACCEPTANCE PROCEDURES TESTS

A DISTRIBUTION-FREE K-SAMPLE TEST AGAINST ORDERED ALTERNATIVES A DISTRIBUTION-FREE K-SAMPLE TEST AGAINST ORDERED ALTERNATIVES
NS TO 'A RELATIONSHIP BETWEEN HODGES' BIVARIATE SIGN TEST AND A NON-PARAMETRIC TEST OF DANIELS' 60 1190 TION ON HODGES'S BIVARIATE SIGN TEST AND A TEST FOR UNIFORMITY OF A CIRCULAR DISTRIBU BIOKAG9 446 E MEDIAN FOR SAMPLE SIZES/ TABLE FOR BOTH THE SIGN TEST AND DISTRIBUTION-FREE CONFIDENCE INTERVALS OF TH JASA 64 935 ATISTIC ON A FURTHER ROBUSTNESS PROPERTY OF THE TEST AND ESTIMATOR BASED ON WILCOXON'S SIGNED RANK ST AMS 68 282 NGE PROBLEMS THE EQUAL PROBABILITY TEST AND ITS APPLICATIONS TO SOME SIMULTANEOUS INFERE JASA 69 9B6 ON BARTLETT'S TEST AND LEHMANN'S TEST FOR HOMOGENEITY OF VARIANCES AMS 69 NO.6 THE WILCOXON TEST AND NON-NULL HYPOTHESES

THE Z-TEST AND SYMMETRICALLY DISTRIBUTED RANDOM VARIABLES

A COMPARISON BETWEEN THE POWER OF THE DURBIN-WATSON TEST AND THE POWER OF THE BLUS TEST

THE TWO-SAMPLE T-TEST BASED ON RANCE

ON THE EXACT DISTRIBUTION OF A CLASS OF MULTIVARIATE TEST CRITERIA

A NOTE ON THE EQUIVALENCE OF TWO TEST CRITERIA FOR HYPOTHESES IN GATEGORIGAL DATA

JRSSB $60 \quad 402$

BIOKA59 123

JASA 69938

BIOKA57 482

AMS $62 \quad 1197$

JASA $66 \quad 228$

ON THE NON-CENTRAL DISTRIBUTIONS OF TWO TEST CRITERIA IN MULTIVARIATE ANALYSIS OF VARIANCE AMS 6B 215

FOR SERIAL GORRELATI/ASYMPTOTIC POWER OF CERTAIN TEST CRITERIA, BASED ON FIRST AND SEGOND DIFFERENGES, AMS 62 IB6

MATION O/ SIMULTANEOUS SELFING AND PARTIAL DIALLEL TEST CROSSING 2. AN EVALUATION OF TWO METHODS OF ESTI BIOCS67 325 THE ANALYSIS OF LIFE TEST DATA

ESTIMATION FROM LIFE TEST DATA IBUTED FAILURE TIME DISTRIBUTIONS FROM CENSORED LIFE TEST DATA /PARAMETERS OF MIXED EXPONENTIALLY DISTR BIOKA58 504 IGNIFIGANCE LEVEL AND OTHER SMALL SAMPLE MEASURES OF TEST EFFICIENCY ON A MEASURE OF TEST EFFICTENCY PROPOSED BY R. R. BAHADUR

ERVALS BASED ON PARTIAL OBSERVATIONS IN GERTAIN LIFE TEST EXPERIMENTS A NOTE ON PREDICTION INT TECH $68 \quad 850$ IDENT PRONENESS (AGKNOWLEDGEMENT 66 S85) A TEST FOR 'INTRINSIC CORRELATION' IN THE THEORY OF ACG JRSSB66

THE ASYMPTOTIG EFFIGIENCY OF THE CHI-SQUARE-SUB-R-TEST FOR A BALANCED INCOMPLETE BLOCK DESIGN UNKNOWN POINT

A TEST FOR A CHANGE IN A PARAMETER OCCURRING AT AN

BIOKA59 475 DATA THE CHI-SOUARE A MULTI-STAGE TEST FOR A NORMAL MEAN

ON THE DISTRIBUTION AND POWER OF A TEST FOR A SINGLE OUTLIER BIOKA64 250 JRSSB 68 461 SASJ $69 \quad 9$ ERARCHAL DESIGN WITH A MIXED MO/ NOTE. THE QUASI-F TEST FOR AN UNNESTED FIXED FACTOR IN AN UNBALANCED HI BIOCS66 9.37 BJECTIVE EVALUATION OF BODE'S LAW AND AN 'OBJECTIVE' TEST FOR APPROXIMATE NUMERICAL RATIONALITY BJECTIVE EVALUATION OF BODE'S LAW AND AN 'OBJEGTIVE' TEST FOR APPROXIMATE NUMERICAL RATIONALITY' /A SU JASA 69 50 NGENT AND THE MOST STRINGENT SOMEWHERE MOST POWERFUL TEST FOR CERTAIN PROBLEMS WITH RESTRICTED ALTERNATIVE AMS 68 531 PERCENTAGE POINTS OF A TEST FOR CLUSTERS

A RANK SUM TEST FOR COMPARING ALL PAIRS OF TREATMENTS

SAMPLES

A GENERALIZED WILCOXON TEST FOR COMPARING ARBITRARILY SINGLY-CENSORED

JASA 69 NO 4 TECH $60 \quad 197$ BIOKA65 203 BIOKA69 75 BIOKA59 106 BIOKA58 544 JRSSB63 179 BIOKA55 316 AN EXACT TEST FOR CORRELATION BETWEEN TIME SERIES

WITH KNOWN VARIANCE A SEQUENTIAL THREE HYPOTHESIS TEST FOR DETERMINING THE MEAN OF A NORMAL POPULATION ON THE EFFICIENCY OF TWO-SAMPLE MANN-WHITNEY TEST FOR DISCRETE POPULATIONS

A TEST FOR DISCRIMINATING BETWEEN MODELS

A DISTRIBUTION-FREE TWO SAMPLE TEST FOR DISPERSION FOR SYMMETRICAL DISTRIBUTIONS A GENERALIZED TWO-SAMPLE WILCOXON TEST FOR DOUBLY-GENSORED DATA.

A TEST FOR EQUAL CATCHABILITY

ARE UNEQUAL

A TEST FOR EQUALITY OF MEANS WHEN COVARIANCE MATRICES

A STATISTICAL TEST FOR EQUALITY OF TWO AVAILABILITIES

TABLES FOR THE MEAN SQUARE ERROR TEST FOR EXACT LINEAR RESTRTCTIONS IN REGRESSION EXACT POWER OF MANN-WHITNEY TEST FOR EXPONENTIAL AND RECTANGULAR ALTERNATIVES

T FOR STRATIFICATION (ADDENDUM 67) THE CHI-SQUARE TEST FOR HETEROGENEITY OF PROPORTIONS AFTER ADJUSTMEN FROM DISCRETE UNIFORM FINITE POPULATIONS AND A RANGE TEST FOR HOMOGENEITY /NG DISTRIBUTION OF THE RANGE AMS 671365 AMS $63 \quad 612$ BIOKA69 337 SASJ 69 NO.2 BIOKA65 650 BI0CS66 330 AMS $63 \quad 671$ TECH $68 \quad 594$ JASA 69 N0.4 AMS $66 \quad 945$ A TWO-WAY CLASSIFICATION $\begin{array}{lllll}\text { FOR HETEROSKEDASTICITY } & \text { JASA } & 69 & 316 \\ \text { FOR HOMOGENEITY/NG DISTRIBUTION OF THE RANGE JASA } & 69 & \text { NO } & 4\end{array}$ ON BARTLETT'S TEST AND LEHMANN'S TEST FOR HOMOGENEITY OF VARIANCES A COMBINATORTAL TEST FOR INDEPENDENCE OF DICHOTOMOUS RESPONSES HYPOTHESES FOR MULTIPLE TREATMENTS, A SIGNIFICANCE TEST FOR LINEAR RANKS AMS 69 N0.6 JASA $65 \quad 437$ 
A BIVARIATE SICN TEST FOR LOCATION

A TEST FOR MARKOFF CHAINS

THE LIKELIHOOD RATIO TEST FOR MARKOFF CHAINS

CORRICENDA TO 'THE LIKELIHOOD RATIO TEST FOR MARKOFF CHAINS'

A COMPARISON TEST FOR MARTINCALE INEQUALITIES

EFFECT OF NON-NORMALITY ON A SEQUENTIAL TEST FOR MEAN

TEST FOR MONOTONE FAILURE RATE BASED ON NORMALIZED

A BAYESIAN SICNIFICANCE TEST FOR MULTINOMIAL DISTRIBUTIONS (WITH DISCUSSION)

MULTIVARIATE BETA DISTRIBUTION AND A TEST FOR MULTIVARIATE NORMALITY

POWER OF TUKEY'S TEST FOR NON-ADDITIVITY

SMALL SAMPLE POWER FOR THE ONE SAMPLE WILCOXON TEST FOR NON-NORMAL SHIFT ALTERNATIVES

A TEST FOR NON-STATIONARITY OF TIME-SERIES

THE CHI-SQUARE GOODNESS-OF-FIT TEST FOR NORMAL DISTRIBUTIONS

AN ANALYSIS OF VARIANCE TEST FOR NORMALITY (COMPLETE SAMPLES)

ON THE KOLMOCOROV-SMIRNOV TEST FOR NORMALITY WITH MEAN AND VARIANCE UNKNOWN

FOR THE NULL DISTRIBUTION OF THE W-STATISTIC + (TEST FOR NORMALITY)

ON AN EXTREME RANK SUM TEST FOR OUTLIERS

A TEST FOR RANDOM MINGLINC OF THE PHASES OF A MOSAIC

THE GAP TEST FOR RANDOM SEQUENCES

A SEQUENTIAL TEST FOR RANDOMNESS

A SEQUENTIAL TEST FOR RANDOMNESS OF INTERVALS

A TEST FOR REALITY OF A COVARIANCE MATRIX IN A CERTAIN

COMPLEX GAUSSIAN DISTRIBUTION

ASSAY

PATTERNS IN RESIDUALS, A TEST FOR REGRESSION MODEL ADEQUACY IN RADIONUCLIDE

AN APPROXIMATE TEST FOR SERIAL CORRELATION IN POLYNOMIAL REGRESSION A QUICK TEST FOR SERIAL CORRELATION SUITABLE FOR USE WITH

ON A TEST FOR SEVERAL LINEAR RELATIONS

RESPONSES

A SIGNIFICANCE TEST FOR SIMULTANEOUS QUANTAL AND QUANTITATIVE

TH SPECIAL REFERENCE TO ACCIDENTS/ THE CHI-SQUARE TEST FOR SMALL EXPECTATIONS IN CONTINGENCY TABLES, WI
ASYMPTOTIC EFFICIENCIES OF A NONPARAMETRIC LIFE TEST FOR SMALLER PERCENTILES OF A GAMMA DISTRIBUTION

ASYMPTOTIC EFFICIENCIES OF A NONPARAMETRIC LIFE TEST FOR SMALLER PERCENTILES OF A GAMMA DISTRIBUTION
Y TIME SERIES WITH NORMAL RESID/A GOODNESS OF FIT TEST FOR SPECTRAL DISTRIBUTION FUNCTIONS OF STATIONAR
OXIMATION FOR THE EXACT DISTRIBUTION OF THE WILCOXON TEST FOR SYMMETRY A A A A

FUNCTION

A TEST FOR SYMMETRY USING THE SAMPLE DISTRIBUTION

A REVISED TEST FOR SYSTEMATIC OSCILLATION

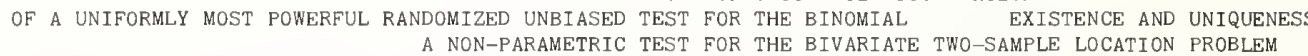

THE NORMA/ SMALL SAMPLE POWER OF A NON-PARAMETRIC TEST FOR THE BIVARIATE TWO-SAMPLE LOCATION PROBLEM IN J

ON THE NULL DISTRIBUTION OF A NON-PARAMETRIC TEST FOR THE BIVARIATE TWO-SAMPLE PROBLEM

IN TIME SERIES AN EXTENSION OF QUENOUILLE'S TEST FOR THE COMPATIBILITY OF CORRELATION STRUCTURES J

AND RELATED PROBLEMS A CONSERVATIVE TEST FOR THE CONCURRENCE OF SEVERAL REGRESSION LINES
$2-\mathrm{BY}-2 \mathrm{TAB} /$ CORRIGENDA, THE POWER FUNCTION OF THE TEST FOR THE DIFFERENCE BETWEEN TWO PROPORTIONS IN A

PREDICTORS A SIGNIFICANCE TEST FOR THE DIFFERENCE IN EFFICIENCY BETWEEN TWO

ES ACAINST ONE-SIDED ALTERNATI/ ON A PROPERTY OF A TEST FOR THE EQUALITY OF TWO NORMAL DISPERSION MATRIC UNKNOWN

ON THE KOLMOGOROV-SMIRNOV TEST FOR THE EXPONENTIAL DISTRIBUTION WITH MEAN

THE EFFECT OF UNEQUAL GROUP VARIANCES ON THE F-TEST FOR THE HOMOGENEITY OF GROUP MEANS

A LOCALLY MOST POWERFUL BOUNDARY RANDOMIZED SIMILAR TEST FOR THE INDEPENDENCE OF TWO POISSON VARIABLES

DISTRIBUTION

$\mathrm{T}$

A LARGE SAMPLE TEST FOR THE INDEPENDENCE OF TWO RENEWAL PROCESSES

A NOTE ON THE TEST FOR THE LOCATION PARAMETER OF AN EXPONENTIAL SEQUENTIAL TEST FOR THE MEAN OF A NORMAL DISTRIBUTION III, SMAL

A RAPID TEST FOR THE POISSON DISTRIBUTION USING THE RANCE

A NONPARAMETRIC TEST FOR THE PROBLEM OF SEVERAL SAMPLES

AMS 611108

IBUTION

EFFECT OF TRUNCATION ON A TEST FOR THE SCALE PARAMETER OF THE EXPONENTIAL DISTR
IONS HAVING UNEQUAL VAR/ TEST FOR THE SICNIFICANCE OF THE DIFFERENCE BETWEEN M BI ANOTHER TEST FOR THE UNIFORMITY OF A CIRCULAR DISTRIBUTION

ON THE POWER FUNCTION OF THE EXACT TEST FOR THE 2-BY-2 CONTINCENCY TA8LE

CORRICENDA, 'ON THE POWER FUNCTION OF THE EXACT TEST FOR THE 2-BY-2 CONTINGENCY TABLE'

THE POWER FUNCTION OF THE EXACT TEST FOR THE 2-BY-3 CONTINCENCY TABLE

THE EFFICIENCY OF THE RECORDS TEST FOR TREND IN NORMAL REGRESSION

THE EXCEEDANCE TEST FOR TRUNCATION OF A SUPPLIER'S DATA

A SIMPLE TEST FOR UNIFORMITY OF A CIRCULAR DISTRIBUTION

ON HODGES'S BIVARIATE SIGN TEST AND A TEST FOR UNIFORMITY OF A CIRCULAR DISTRIBUTION

GAUSSIAN MOVINC AVERAGE

A TEST FOR VARIANCE HETEROGENEIT
THE POWER OF A TEST IN COVARIANCE ANALYSIS

ON THE EXACT DISTRIBUTION OF A TEST IN MULTIVARIATE ANALYSIS

CE-COVARI/ ON THE ROBUSTNESS OF THE T-SQUARE-SUB-O TEST IN MULTIVARIATE ANALYSIS OF VARIANCE WHEN VARIAN BIOKA64 71

OF NON-NORMALITY ON THE POWER FUNCTION OF THE F-TEST IN THE ANALYSIS OF VARIANCE THE EFFECT BIOKA5I 43

OCIATE PARTIALLY BALANCED INCOMPLETE BLO/ ON THE F-TEST IN THE INTRABLOCK ANALYSIS OF A CLASS OF TWO ASS JASA 65 285

DISTRIBUTION FREE VERSION OF THE SMIRNOV TWO SAMPLE TEST IN THE P-VARIATE CASE

MINIMAX CHARACTER OF HOTELLINC'S T-SQUARED TEST IN THE SIMPLEST CASE

FIRST AND SECOND MOMENTS OF THE RANDOMIZATION TEST IN TWO ASSOCIATE PBI8 DESICNS

A STATISTICAL TEST INVOLVING A RANDOM NUMBER OF RANDOM VARIABLES

STATISTICAL PROBLEMS IN SCIENCE. THE SYMMETRIC TEST OF A COMPLETE HYPOTHESIS

ON THE LIKELIHOOD RATIO TEST OF A NORMAL MULTIVARIATE TESTING PROBLEM II

641388

ON THE LIKELIHOOD RATIO TEST OF A NORMAL MULTIVARIATE TESTINC PROBLEM, CORR.

THE QUINTUS CURTIUS SNODCRASS LETTERS, A STATISTICAL TEST OF AUTHORSHIP

SMALL SAMPLE POWER OF THE 8IVARIATE SIGN TEST OF BLUMEN AND HODCES

ING HOMOCENEOUS COEFFICIENTS OF VARIATION A TEST OF EQUALITY OF TWO NORMAL POPULATION MEANS ASSUM

A TEST OF HOMOGENEITY FOR ORDERED ALTERNATIVES

A TEST OF HOMOGENEITY FOR ORDERED ALTERNATIVES. II

A TEST OF HOMOGENEITY FOR ORDERED VARIANCES

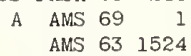

JASA 69 NO 4

AMS $66 \quad 1305$

JASA 69 NO. 4

AMS 651061

AMS $64 \quad 181$

JASA $63 \quad 85$ AMS $64 \quad 1576$

AMS $69 \quad 1374$ BIOKA59 36 BIOKA59 328 JRSS861 195

L DISTRIBUTIONS EMPIRIC INVESTIGATION OF A TEST OF HOMOGENEITY FOR POPULATIONS COMPOSED OF NORMA

THE RAPID CALCULATION OF CHI-SQUARE AS A TEST OF HOMOGENEITY FROM A 2-BY-N TABLE

JASA 58551

TIVES (WITH DISCUSSION)

A TEST OF HOMOGENEITY OF MEANS UNDER RESTRICTED ALTERNA QUADRATIC EXTRAPOLATION AND A RELATED TEST OF HYPOTHESES

A SHORT-CUT RULE FOR A ONE-SIDED TEST OF HYPOTHESIS FOR QUALITATIVE DATA

CORRIGENDA, 'TEST OF INDEPENDENCE IN INTRACLASS 2-8Y-2 TABLES '

COMPARISON OF THE POWER FUNCTIONS FOR THE TEST OF INDEPENDENCE IN 2 X2 CONTINGENCY TABLES
8IOKA55 519

JASA $56 \quad 644$

TECH $69 \quad 197$

BIOKA61 476

AMS 641115 
SPACE

L DISTRIBUTION

A SAMPLINC TEST OF THE CHI-SQUARE THEORY FOR PROBABILITY CHAINS BIOKA52

ANALYSIS LIKELIHOOD-RATIO TEST OF THE CENERAL LINEAR HYPOTHESIS IN MULTIVARIATE BIOKA6

ONS IN LINEAR RECRESSION TO THE STANDARD CHI-SQUARE-TEST OF THE HYPOTHESIS OF EQUAL CELL FREQUENCIES
A TEST OF THE MEAN SQUARE ERROR CRITERION FOR RESTRICTI J A TEST OF VARIANCES

A DISTRIBUTION-FREE TWO-SAMPLE TEST ON A CIRCLE

NC TIME OF A RANK-ORDER SEQUENTIAL PROBABILITY RATIO TEST ON LEHMANN ALTERNATIVES, CORR. 67 1309 PRODUGT TEST PLANNINC FOR REPAIRABLE SYSTEMS

BOUNDARIES FOR CLOSED (WEDGE) SEQUENTIAL T TEST PLANS

A SIMPLIFIED MONTE CARLO SICNIFICANCE TEST PROCEDURE

WHEN AN UPPER BOUND TO THE STANDARD DEVIATION/ A TEST PROCEDURE WITH A SAMPLE FROM A NORMAL POPULATION J THE PROBABILITY OF REVERSAL ASSOCIATED WITH A TEST PROCEDURE, WHEN DATA ARE INCOMPLETE

COMPARATIVE COST OF TWO LTFE TEST PROCEDURES

OF A UNIVARIATE MODEL AND ASSOCIATED ESTIMATION AND TEST PROCEDURES AL DATA SIMULTANEOUS TEST PROGEDURES FOR MULTIPLE COMPARISONS ON CATECORIC JASA 661081

STATISTIGAL DISTRIBUTIONS OCCURING AT UNKNOWN TI/ TEST PROCEDURES FOR POSSIBLE CHANGES IN PARAMETERS OF AMS 66 II96 SIMULTANIOUS TEST PROCEDURES IN MULTIVARIATE ANALYSIS OF VARIANCE BIOKA68 4B9 EM A CONFIDENCE INTERVAL COMPARISON OF TWO TEST PROCEDURES PROPOSED FOR THE BEHRENS-FISHER PROBL JASA 66 454 FAILURE RATE EXPONENTIAL LIFE TEST PROCEDURES WHEN THE DISTRIBUTION HAS MONOTONE JASA 67 548 SIMULTANEOUS TEST PROCEDURES, SOME THEORY OF MULTIPLE COMPARISONS AMS 69224 ON THE EFFICIENCY OF THE NORMAL SCORES TEST RELATIVE TO THE F-TEST DISTRIBUTION-FREE LIFE TEST SAMPLING PLANS

DISTRIBUTIONS LIFE TEST SAMPLING PLANS FOR NORMAL AND LOCNORMAL ADDENDUM, THE LIMITING DISTRIBUTION OF KAMAT'S TEST STATISTIC EXTENDED TABLE OF CRITIGAL VALUES FOR WILCOXON'S TEST STATISTIC B/ ON THE DISTRIBUTION OF THE LOG LIKELIHOOD RATIO TEST STATISTIG WHEN THE TRUE PARAMETER IS 'NEAR' THE AMS 6B 2044 THE INDEX OF DISPERSION AS A TEST STATISTIC

'EXTENDED TABLES OF CRITICAL VALUES FOR WILGOXON'S TEST STATISTIC.

RATES OF CONVERCENCE OF ESTIMATES AND TEST STATISTICS

ON THE COMBINATION OF INDEPENDENT TEST STATISTICS

CERTAIN UNCORRELATED NONPARAMETRIG TEST STATISTICS SIGNIFICANCE LEVEL AS A SENSITIVITY INDEX FOR TEST STATISTICS QUENCE OF TWO ALTERNATIVES. I. WILCOXON'S AND ALLIED TEST STATISTICS IONS OF CENERALIZED CLASSICAL LINEAR IDENTIFIABILITY TEST STATISTICS THE ASYMPTOTIC NORMALITY OF TWO TEST STATISTICS ASSOCIATED ASYMPTOTIC NORMALITY OF CERTAIN TEST STATISTICS OF EXPONENTIALITY RATION OF THE DISTRIBUTION OF SEVERAL NON-PARAMETRIC TEST STATISTICS UNDER CENSORING BY MONTE CARLO METHODS USE OF WILCOXON TEST THEORY IN ESTIMATINC THE DISTRIBUTION OF A RATIO AMS 621194 QUERY, SAVINGS IN TEST TIME WHEN COMPARINC WEIBULL SCALE PARAMETERS TECH 64 47I THE APPLICATION OF THE GOMBINATION OF PROBABILITIES TEST TO A SET OF 2-BY-2 TABLES

A NOTE ON BIOKA55 404 A QUICK COMPACT TWO SAMPLE TEST TO DUCKWORTH'S SPECIFICATIONS
R. 60755 EXTENSION OF THE WILCOXON-MANN-WHITNEY TEST TO SAMPLES CENSORED AT THE SAME FIXED POINT, COR JASA 60 125 D/ SOME MONTE CARLO RESULTS ON THE POWER OF THE F-TEST UNDER PERMUTATION IN THE SIMPLE RANDOMIZED BLOCK BIOKA66 I99 STUDENT'S T-TEST UNDER SYMMETRY CONDITIONS SOME SEQUENTIAL TEST USINC RANCE OTHESES
PARAMETERS

TABLES FOR THE SIGN TEST WHEN OBSERVATIONS ARE ESTIMATES OF BINOMIAL

INADMISSIBILITY OF THE BEST INVARIANT TEST WHEN THE MOMENT IS INFINITE UNDER ONE OF THE HYP ON AN EXTREME RANK SUM TEST WITH EARLY DECISION

$$
\text { A MEDIAN TEST WITH SEQUENTIAL APPLICATION }
$$

ATION TO THE POWER OF THE CHI-SQUARE GOODNESS OF FIT TEST WITH SMALL BUT EQUAL EXPECTED FREQUENCIES /XIM J AN OPTIMAL SEQUENTIAL ACCELERATED LIFE TEST THE FIRST-MEDIAN TEST

O THE DISTRIBUTION OF THE SAMPLE SIZE FOR SEQUENTIAL TEST USE OF RANGE IN PLACE OF STANDARD DEVIATION IN THE T-TEST

\section{A MULTIPLE COMPARISONS SIGN TEST, ALL PAIRS OF TREATMENTS} THE POWER OF STUDENT'S T-TEST, CORR. 651251

RMANCE OF THE TRUNCATED SEQUENTIAL PROBABILITY RATIO TEST, CORR, 661247

A PROPOSED TWO-SAMPLE RANK TEST, THE PSI TEST AND ITS PROPERTIES A MULTIPLE COMPARISON SIGN TEST, TREATMENTS VERSUS GONTROL JASA 69 NO. 4 JRSSB61 335 JASA 59784 AMS 691483 JASA $65 \quad 859$ BIOKA63 55 TECH $62 \quad 367$ JASA $68 \quad 692$

N BETWEEN TWO COMPOSITE/ A LARGE SAMPLE SEQUENTIAL TEST, USING CONCOMITANT INFORMATION FOR DISCRIMINATIO JASA 66 357 CORRICENDA. 'ON A TWO-SIDED SEQUENTIAL T-TEST' LASS OF 'INTERDEPENDENT/ A NOTE ON THE STATISTICAL TESTABILITY OF 'EXPLICIT CAUSAL GHAINS' AGAINST THE C J A PROBLEM IN LIFE TESTINC.

FACTORIAL EXPERIMENTS IN LIFE TESTINC EARLY FAILURES IN LIFE TESTING PROCRESSIVELY CENSORED SAMPLES IN LIFE TESTING CONTINUOUS SAMPLING PLANS UNDER DESTRUCTIVE TESTINC

\begin{tabular}{|c|c|c|c|c|}
\hline \multirow{4}{*}{\multicolumn{2}{|c|}{ CORRI GENDA }} & 'THE & BIOKA52 & 442 \\
\hline & & & BI0C\$67 & 539 \\
\hline & & & JASA 65 & 320 \\
\hline & & PERFO & JASA 65 & 979 \\
\hline 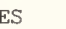 & & & JRSSB 64 & 305 \\
\hline & & & JASA 59 & 767 \\
\hline$D R$ & DISCRIMI & INATIO & JASA 66 & 357 \\
\hline & & & BIOKA54 & 56 \\
\hline IS & AGAINST & THE C & JASA 65 & 108 \\
\hline & & & JASA 57 & 350 \\
\hline & & & TECH 59 & 26 \\
\hline & & & J ASA 60 & 49 \\
\hline & & & $\mathrm{TECH} 63$ & \\
\hline & & & JASA & \\
\hline
\end{tabular}


ON PRECEDENCE LIFE TESTINC

ESTIMATION FROM QUANTILES IN DESTRUCTIVE TESTINC

STATISTICAL ASPECTS OF THE ECONOMICS OF ANALYTICAL TESTINC SAMPLINC DISTRIBUTION OF AN ESTIMATE ARISINC IN LIFE TESTINC OF RELIABILITY FOR SOME DISTRIBUTIONS USEFUL IN LIFE TESTINC SAVACE STATISTIC WITH APPLICATIONS TO LIFE TESTINC DISTRIBUTIONS, SAMPLINC THEORY AND HYPOTHESIS TESTINC

MOMENTS OF THE POSITIVE BINOMIAL USEFUL IN LIFE TESTINC ECRESSION AS APPLIED TO EXTRAPOLATION IN S-N FATICUE TESTINC ON THE DISTRIBUTION OF A STATISTIC USED FOR TESTINC A COVARIANCE MATRIX RMEDIATE STATES AND RESTRICTED ORDER TESTINC A MARKOV HYPOTHESIS WITH INDEPENDENCE OF INTE BIOKA67 605 TIVE HYPOTHESIS EQUALITY

A SEQUENTIAL PROCEDURE OR TESTINC A NULL HYPOTHESIS AGAINST A TWO SIDED ON TESTINC A SET OF CORRELATION COEFFICIENTS FOR JRSSB 69 NO.2 Y. SOME ASYMPTOTIC RESULTS ELS (CORR. 67 586)

ON TESTINC A SET OF CORRELATION COEFFICIENTS FOR EQUALIT BIOKA68 513 A CHANCE-OVER DESICN FOR TESTINC A TREATMENT FACTOR AT FOUR EQUALLY SPACED LEV JRSSB67 370 NORML THEORY AND NONPARAMETRIC TESTINC ACAINST ORDER QUERY, LIFE TESTINC AND EARLY FAILURE TESTINC AND ESTIMATINC OF SCALE PAREMENTERS

MODEL TESTINC AND ESTIMATION FOR A CIRCULAR STATIONARY TECH $66 \quad 539$ JASA 69999 AMS 691358 AMS $67 \quad 941$ THE CENERALIZED VARIANCE. TESTINC AND RANKINC PROBLEM

A BIBLIOCRAPHY ON LIFE TESTINC AND RELATED TOPICS

A SUPPLEMENT TO MENDENHALL'S BI8LIOCRAPHY ON LIFE TESTINC AND RELATED TOPIC, CORR. 65 1249 BAYESIAN APPROACH TO LIFE TESTINC AND RELIABILITY ESTIMATION 8IOKA58 521 JASA 641231 JASA $67 \quad 48$ TER EXPONENTIAL DISTRIBUTION LIFE TESTINC AND RELIABILITY ESTIMATION FOR THE TWO PARAME $\begin{array}{rrr}\text { JASA } & 69 & 621\end{array}$ COMPARATIVE SAMPLINC ACCEPTANCE SCHEMES IN TESTING ANTICENICITY OF VACCINES BIOCS66 684 CORR. 63 TESTINC APPROXIMATE HYPOTHESES IN THE COMPOSITE CASE. THE USE OF LEAST FAVORABLE DISTRIBUTIONS IN TESTINC COMPOSITE HYPOTHESES

ON THE EXACT DISTRIBUTIONS OF VOTAW'S CRITERIA FOR TESTINC COMPOUND SYMMETRY OF A COVARIANCE MATRIX PAIRED COMPARISON DESICNS FOR TESTINC CONCORDANCE BETWEEN JUDCES

PERTIES AND AN APPLICATION OF A STATISTIC ARISINC IN TESTINC CORRELATION ESTIMATION OF MIXED WEIBULL PARAMETERS IN LIFE TESTING ELECTRON TUBES AMS 69 B36 BIOKA56 113 EQUALITY OF VARIANCES CORRELATION TESTING EQUALITY OF MEANS AFTER A PRELIMTNARY TEST OF TESTING EQUALITY OF MEANS IN THE PRESENCE TESTING FOR A JUMP IN THE SPECTRAL FUNCTION TEING FOR CORRELATION BETWEEN NON-NECATIVE VARIATES BIOKA67 385

DISTRIBUTION WHEN EXPECTATIONS ARE SMALL TESTING FOR GOODNESS-OF-FIT OF THE NEGATIVE BINOMIAL TESTING FOR HOMOCENEITY OF A BINOMIAL SERIES TESTING FOR LINEAR CONTAGION, INVERSE SAMPLING JRSSB69 NO.2 M DISTRIBUTION, PERCENTAGE POINTS AND APPLICATION TO TESTING FOR RANDOMNESS OF DIRECTIONS /TH THE UNIFOR BIOKA66 235 REGRESSION. II RECRESSION EOUS REGRESSION EQUATIONS DISTRIBUTED VARIATES TESTING FOR SERTAL CORRELA BIOKA51 159 TESTINC FOR SERIAL CORRELATION IN LEAST SQUARES BIOKA57 57 TESTING FOR SERIAL CORRELATION IN SYSTEMS OF SIMULTAN BIOKA57 370 TESTING FOR SERIAL CORRELATION WITH EXPONENTIALLY BIOKA67 395

ON TESTINC FOR THE DECREE OF A POLYNOMIAL $\begin{array}{ll}\text { BIOKA } 67 & 395 \\ \text { TECH } 68 & 757\end{array}$ ESSION 8Y A RANDOMISATION TECHNIQUE (ERRATA, $696 /$ TESTINC FOR THE INCLUSION OF VARIABLES IN LINEAR REGR TECH 66 695 USE OF RANGE IN TESTING HETEROGENEITY OF VARIANCE TESTING HOMOGENEITY ACAINST ORDERED ALTERNATIVES AMS $63 \quad 945$ TESTING HYPOTHESES AND ESTIMATINC PARAMETERS IN HUMAN BIOKA63 265

GENETICS IF THE AGE OF ONSET IS RANDOM CONSISTENT STATISTICS FOR ESTIMATINC AND TESTING HYPOTHESES FROM CROUPED SAMPLES

MODEL EXPERIMENTS
NOTE ON TESTING HYPOTHESES IN AN UNBALANCED RANDOM EFFECTS TESTING HYPOTHESES IN RANDOMIZED FACTORIAL

NOTES. ESTIMATION AFTER PRELIMINARY TESTING IN ANOVA MODEL I

EXACT DISTRIBUTIONS OF LIKELIHOOD RATIO CRITERIA FOR TESTINC INDEPENDENCE OF SETS OF VARIATES UNDER THE HU RICTED ALTERNATIVES ON THE PROBLEM OF TESTING LOCATION IN MULTIVARIATE POPULATIONS FOR REST EVALUATION OF MULTIVARIATE SEQUENTIAL PROCEDURE FOR TESTING MEANS

ON TESTING MORE THAN ONE HYPOTHESIS AN EMPIRICAL AMS $66 \quad 113$ AMS 621413 AMS $63 \quad 555$ AMS $61 \quad 333$

DISTRIBUTION OF THE LIKELIHOOD RATIO FOR TESTING MULTIVARIATE LINEAR HYPOTHESES LATIONS ACAINST A GIVEN/ A CHART FOR SEQUENTIALLY TESTINC OBSERVED ARITHMETIC MEANS FROM LOCNORMAL POPU TEGH 6B 605
AN EMPIRICAL BAYES APPROACH TO THE TESTING OF CERTAIN PARAMETRIC HYPOTHESES JASA $59 \quad 447$ PHOLOGICALLY INDISTINGUISHABLE OBJECTS STATISTICAL TESTING OF DIFFERENCES IN CASUAL $8 E H A V I O U R$ OF TWO MOR BIOCS67 137 EM ON THE SMOOTH EMPIRICAL BAYES APPROACH TO TESTING OF HYPOTHESES AND THE COMPOUND DECISION PROBL BIOKA68 B3 TESTING OF MEANS WITH DIFFERENT ALTERNATIVES $\quad$ TECH $68 \quad 195$ SEQUENTIAL TESTING OF SAMPLE SIZE

ASYMPTOTIC SHAPES FOR SEQUENTIAL TESTING OF TRUNCATION PARAMETERS THE TESTING OF UNIT VECTORS FOR RANDOMNESS

MODEL FOR THE ANALYSIS OF THE EFFECTS OF MARCINAL TESTING ON SYSTEM RELIABILITY

THE LIKELIHOOD RATIO TEST OF A NORMAL MULTIVARIATE TESTING PROBLEM, CORR, 64 138B DISTRIBUTION

THE ROBUSTNESS OF LIFE TESTINC PROCEDURES DERIVED FROM THE EXPONENTIAL

RELIABILITY GROWTH DURING A DEVELOPMENT TESTING PROGRAM ASYMPTOTIC SHAPES OF BAYES SEQUENTIAL TESTING REGIONS TECH $68 \quad 331$ AMS 68 203B JASA $64 \quad 160$ A MARKOVIAN AMS $62 \quad 754$ ON AMS 64181 TECH $61 \quad 29$ TECH $66 \quad 53$ AMS $62 \quad 224$ TECH 63501 TABLES FOR TESTING SICNIFICANCE IN A 2-BY-3 GONTINGENCY TABLE TECH

UNBALANCED NESTED ANALYSIS OF VARIANCE/ NOTES ON TESTING SICNIFICANCE OF COMPONENTS OF VARIANCE IN THE B/ THE CURVES, AN OMNIBUS TECHNIQUE FOR ESTIMATION AND TESTING STATISTICAL HYPOTHESES CONFIDENCE JASA $61 \quad 246$ TESTING THE APPROXIMATE VALIDITY OF STATISTICAL JRSS854 261 STRIBUTION OF THE 8EHRENS-FISHER-WELCH STATISTIC FOR TESTING THE DIFFERENCE BETWEEN THE MEANS OF TWO NORMA JRSSB61 377 ON TESTINC THE EQUALITY OF $K$ COVARIANCE MATRICES $\quad$ BIOKA69 216 ON TESTING THE EQUALITY OF PARAMETERS IN K RECTANGULAR JASA $60 \quad 144$ POPULATIONS IONS DISTRIBUTIONS OR TESTING THE EQUALITY OF SEVERAL EXPONENTIAL DISTRIBUT $\begin{array}{lll}\text { JASA } & 60 & 144 \\ \text { JASA } & 63 & 435\end{array}$ ON TESTINC THE EQUALITY OF UNIFORM AND RELATED JASA $66 \quad 856$ BIOKA68 317 FOR HARTLEY'S CORRECTION TO BARTLETT'S CRITERION FOR TESTING THE, HOMOGENEITY OF A SET OF VARIANCES /NTS BIOKA62 4B? 
CLASSIFICATION

VALUES OF THE COEFFICIENT OF RANK CORRELATION FOR SCHEFFE'S MIXED MODEL

DISTRIBUTION USING QUANTILES

A SEQUENTIAL METHOD OF

TESTING THE HOMOGENETTY OF VARIANCES IN A TWO-WAY TESTING THE HYPOTHESIS OF INDEPENDENCE CRITICAL BIOKA6I 444 TESTING THE HYPOTHESIS OF NO FIXED MAIN-EFFECTS IN AMS 621085 TESTING THE INDEPENDENCE OF REGRESSION DISTURBANCES JASA $61 \quad 793$ TESTING THE LINEAR TRENDS OF RESPONSES IN DOSE TRIALS BIOCS6B 663 TESTING THE MEAN AND STANDARD DEVIATION OF A NORMAL TECH $6 B \quad 781$ ESTIMATING AND TESTING TREND IN A STOCHASTIC PROCESS OF POISSON TYPE AMS 661564 VARIABLE (WITH DISCUSSION) QUERY, TESTING TWO CORRELATED VARIANCES

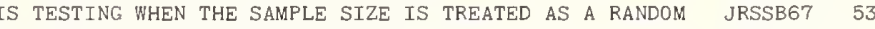
HYPOTHESIS TESTING WIZH FINITE MEMORY AMS $69 \quad 828$ ISTICAL MODELS AND P/ SURVEY OF HISTOCOMPATIBILITY TESTING, BIOLOGICAL BACKGROUND PROBABILISTIC AND STAT BIOCS69 207 SOME EXPERIMENTAL DESIGN PROBLEMS IN ATTRIBUTE LIFE TESTING, CORR. 631161 THE ROLE OF SIGNIFICANCE TESTING, SOME DATA WITH A MESSAGE ERRATA, 'FACTORIAL EXPERIMENTS IN LIFE TESTING' ECONOMICALLY OPTIMUM ACCEPTANCE TESTS SEQUENTIAL CHI-SQUARED AND T-SQUARED TESTS A NOTE ON UNBIASED TESTS NOTE ON MULTIVARIATE GOODNESS-OF-FIT TESTS ASYMPTOTICALLY MOST POWERFUL RANK-ORDER TESTS ON A MODIFICATION OF CERTAIN RANK TESTS OPTIMUM PROPERTIES AND ADMISSIBILITY OF SEQUENTIAL TESTS ON THE OPTIMALITY OF SEQUENTIAL PROBABILITY RATIO TESTS ESTIMATES OF LOCATION BASED ON RANK TESTS THE DESIGN OF SLREENING TESTS ASYMPTOTIC EFFICIENCY OF CLASS OF C-SAMPLE TESTS ONE SAMPLE LIMITS OF SOME TWO-SAMPLE RANK TESTS ALTERNATIVE EFFICIENCIES FOR SIGNED RANK TESTS ON THE COMPLEX ANALOGUES OF T-SQUARED AND R-SQUARED TESTS SEVERAL K-SAMPLE KOLMOGOROV-SMIROV TESTS

PERCENTILE MODIFICATIONS OF TWO-SAMPLE RANK TESTS QUERY, CONFIDENCE LIMITS FROM RANK TESTS

GOODNESS CRITERIA FOR TWO-SAMPLE DISTRIBUTION-FREE TESTS MULTIVARIATE NONPARAMETRIC SEVERAL-SAMPLE TESTS LOCALLY MINIMAX TESTS

MULTI-SAMPLE ANALOGUES OF SOME ONE-SAMPLE TESTS ESTTMATES OF REGRESSION PARAMETERS BASED ON RANK TESTS INTEGRATED RISK OF ASYMPTOTICALLY BAYES SEQUENTIAL TESTS EFFICIENCY LOSS DUE TO GROUPING IN DISTRIBUTION-FREE TESTS EFFICIENCY ROBUST TWO-SAMPLE RANK TESTS

A CLASS OF DISTRIBUTION-FREE ANALYSIS OF VARIANCE TESTS ON THE POWER OF PRECEDENCE LIFE TESTS

TOWARDS A THEORY OF GENERALIZED BAYES TESTS

ON SLIPPAGE TEST (II) SIMILAR SLIPPAGE TESTS ASYMPTOTIC OPTIMUM PROPERTIES OF CERTAIN SEQUENTIAL TESTS TWO K-SAMPLE SLIPPAGE TESTS

STARSHAPED TRANSFORMATIONS AND THE POWER OF RANK TESTS THE SMIRNOV TWO SAMPLE TESTS AS RANK TESTS A STABLE LIMIT THEOREM FOR MARKOV TESTS

THE FREQUENCY JUSTIFICATION OF CERTAIN SEQUENTIAL TESTS NON-NORMALITY IN TWO-SAMPLE.T-TESTS A NOTE ON THE THEORY OF QUICK TESTS

A NOTE ON WILCOXON'S AND ALLIED TESTS A NOTE ON THE DERIVATION OF SOME EXACT MULTIVARIATE TESTS POWER OF SOME TWO-SAMPLE NON-PARAMETRIC TESTS SOME METHODS OF CONSTRUGTING EXACT TESTS ROBUSTNESS TO NON-NORMALTTY OF REGRESSTON TESTS CLOSED SEQUENTIAL T-TESTS LINEAR HYPOTHESES AND INDUCED TESTS ON THE WEIGHTED COMBINATION OF SIGNIFICANCE TESTS ON MULTIVARIATE SIGN TESTS LARGE-SAMPLE RESTRICTED PARAMETRIC TESTS CONFTDENCE-REGION TESTS

LIKELIHOOD RATIO AND GONFIDENCE-REGION TESTS OF MEAN DEVIATION IN THE ANALYSIS OF INTERLABORATORY TESTS DISTRIBUTION IN ACCEPTANCE SAMPLING BASED ON LIFE TESTS AND ASYMPTOTIC MINIMAX PROPERTIES OF MULTIVARIATE TESTS CONTRACTS AND PRICE DIFFERENTIAL ACCEPTANCE TESTS EFFICIENCY OF CERTAIN LOCALLY MOST POWERFUL RANK TESTS

SAMPLE PROBLEM, A HEURISTIC METHOD FOR CONSTRUCTING TESTS STATISTICS, SIMILAR REGIONS AND DISTRIBUTION-FREE TESTS DEGENERACY AND THE EFFICIENCY OF SOME MULTIVARIATE TESTS TO THE CHARACTERTSTTCS OF SOME SEQUENTTAL TESTS THE POWERS OF TWO MULTIVARIATE ANALYSIS OF VARIANCE TESTS BETWEEN ESTIMATING EFFICIENCY AND THE POWER OF TESTS AVERAGE SAMPLE NUMBER OF SEQUENTIAL MULTIHYPOTHESIS TESTS PROBABILITY OF DEFECTIVE FAILURE FROM DESTRUCTIVE TESTS POWER OF THE ONE-SAMPLE KOLMOGOROV-SMIRNOV TESTS

CHARACTER OF THE POWER FUNCTIONS OF TWO MULTIVARIATE TESTS OF EXPECTED SAMPLE SIZE IN CERTAIN ONE-SIDED TESTS AND MONOTONICITY OF SEQUENTIAL PROBABILITY RATIO TESTS TYPE CHI APPROXIMATIONS TO THE RANGE IN SIGNIFICANCE TESTS REPANCY BETWEEN MEASURES OF ASYMPTOTIC EFFICIENCY OF TESTS APPROXIMATION FOR SOME PROPERTIES OF SEQUENTIAL TESTS

TAINING LOWER BOUNDS ON THE ASYMPTOTIC POWER OF RANK TESTS APPROXIMATION FOR SOME PROPERTIES OF SEQUENTIAL TESTS
JASA 62668

BIOKA69 NO. 3

TECH $60 \quad 121$

JASA $56 \quad 243$

AMS 611063

AMS $62 \quad 292$

AMS $62 \quad 807$

AMS $63 \quad 1101$

AMS 63

AMS $63 \quad 1 \mathrm{~B}$

AMS $63 \quad 598$

TECH 63481

AMS $64 \quad 102$

JASA $64 \quad 645$

AMS $65 \quad 1759$

AMS $65 \quad 664$

AMS 651019

JASA $65 \quad 1127$

TECH $65 \quad 257$

AMS $66 \quad 133$

AMS $66 \quad 611$

AMS $67 \quad 340$

AMS $67 \quad 523$

AMS $67 \quad 894$

AMS 671399

JASA $67 \quad 954$

JASA 67 124I

SASJ $67 \quad 75$

TECH $67 \quad 154$

AMS 681

AMS 682029

AMS 6B 1244

JASA $68 \quad 614$

AMS 691167

AMS 691449

AMS 691467

BIOK A52 144

BIOKA53 223

BIOKA56 478

BIOKA56 485

BIOKA60 4BO

BIOKA60 355

BIOKA6I 41

BIOKA62 93

BIOKA64 4I

JRSSB55 264

JRSSB62 159

JRSSB $62 \quad 234$

JRSSB $64 \quad 462$

JRSSB $65 \quad 245$

USE TECH $67 \quad 149$

GAMMA JASA 61942

LOCAL AMS 64 INCENTIVE JASA $64 \quad 149$ ASYMPTOTIC AMS 61 B8 ON THE TWO AMS 6l 1091 SUFFICIENT JRSSB57 262 APPROACH TO AMS $68 \quad 1654$ APPROXIMATIONS BIOKA69 203 A COMPARISON OF BIOKA62 455 ON THE RELATION BIOKA54 542 LOWER BOUNDS FOR AMS 671343 ESTIMATION OF THE TECH $63 \quad 459$ ON THE ASYMPTOTIC AMS 651000 ON THE MONOTONIC AMS 611145 ASYMPTOTIC BEHAVIOR AMS $64 \quad 36$ EXISTENCE, UNIQUENESS AMS 631541 ON THE USE OF PATNAIK BIOKA66 248 AN EXAMPLE OF LARGE DISC AMS $68 \quad 179$ AN IMPROVEMENT TO WALD'S JRSSB54 136 AN ELEMENTARY METHOD OF OB AMS $68212 \mathrm{~B}$ FORMULAE TO IMPROVE WALD'S JRSSB $65 \quad 74$
AMS 621124

BIOKA62 359 
METHOD AND THE ASYMPTOTIC RELATIVE EFFICIENCY OF TESTS CIENCY FOR THE ONE SAMPLE WILCOXON AND NORMAL SCORES TESTS IFICATION OF A CLASS OF SEQUENTIAL PROBABILITY RATIO TESTS CLASS OF GENERALIZED SEQUENTIAL PROBABILITY RATIO TESTS ION OF SAMPLE NUMBER IN SEQUENTIAL PROBABILITY RATIO TESTS A CLASS OF INVARIANT SEQUENTIAL PROBABILITY RATIO TESTS ASYMPTOTIC EFFICIENCY OF A GLASS OF NONPARAMETRIC TESTS TIC AND THE AVERAGE SAMPLE NUMBER OF SOME SEQUENTIAL TESTS INEAR INEQ/ MOST STRINCENT SOMEWHERE MOST POWERFUL TESTS ASYMPTOTIC RELATIVE EFFICIENCY OF GOODNESS-OF-FIT TESTS ELATIVE EFFICIENCY OF MOOD'S AND MASSEY'S TWO SAMPLE TESTS
TWO SEQUENTIAL TESTS

THE LIMITING POWER OF CATEGORICAL DATA CHI-SQUARE TESTS ANALOGOUS TO NORMAL ANALYSIS OF VARIANCE TESTS AND CONFIDENCE INTERVALS BASED ON THE METRIC D2 AMS $63 \quad 618$ THE ESTIMATION OF SECOND-ORDER TENSORS, WITH RELATED TESTS AND DESIGNS TERT SIMPLIFIED RUNS TESTS AND LIKELIHOOD RATIO TESTS FOR MARKOFF CHAINS BIOKA58 181 KOLMOGOROV-SMIRNOV TESTS AND RENYI'S MODIFICATION

PRODUCER AND CONSUMER RTSKS FOR ASYMMETRTCAL TESTS AND SPECTFTCATION LIMITS

THE AVERACE CRITICAL VALUE BIOKA67 308 SMALL SAMPLE POWER AND EFFI AMS $63 \quad 624$ ON THE SAMPLE SIZE AND SIMPL AMS $66 \quad 425$ THE ESSENTIAL COMPLETENESS OF THE AMS 61602 A NOTE ON THE VARIANCE OF THE DISTRIBUT TECH $66 \quad 700$ BOUNDS ON THE SAMPLE SIZE DISTRIBUTION FOR AMS $6 B 1048$ ON A DISTRIBUTION-FREE METHOD OF ESTIMATINC AMS 661759 /AE FOR CALCULATING THE OPERATINC CHARACTERIS JRSSB58 379 GAINST ALTERNATIVE RESTRIGTED BY A NUMBER OF L AMS 661161 THE JASA $65 \quad 410$ AMS 621375 JASA $56 \quad 440$ BIOKA63 353 BIOCS6B 1019 JASA $66 \quad 505$ TWEEN PITMAN'S ASYMPTOTIC RELATIVE EFFICIENCY OF TWO TESTS AND THE CORRELATION COEFFICIENT BETWEEN THEIR T AMS 63 1442 PROBLEM

SEQUENTIAL GHI-SQUARE AND T-SQUARE TESTS AND THEIR APPLICATION TO AN ACGEPTANCE SAMPLINC TECH 61 5I9 'OPTIMAL' ONE-SAMPLE DISTRIBUTION-FREE TESTS AND THEIR TWO-SAMPLE EXTENSTONS AMS $66 \quad 120$ CHAIN THE SMIRNOV TWO SAMPLE TESTS AS RANK TESTS ON SOME MULTISAMPLE PERMUTATION TESTS BASED ON A CLASS OF U-STATISTICS RRIGENDA, 'ON QUESTIONS RAISED BY THE COMBINATION OF TESTS BASED ON DISCONTINUOUS DISTRIBUTIONS.' THE COMBINATION OF TESTS BASED ON DISCRETE DISTRIBUTIONS CONTROL CHART TESTS BASED ON CEOMETRIC MOVING AVERAGES

THE ASYMPTOTIC POWERS OF CERTAIN TESTS BASED ON MULTIPLE CORRELATIONS BILITY ONE OF INVARIANT SEQUENTIAL PROBABILITY RATIO TESTS BASED ON MULTIVARIATE NORMAL OBSERVATIONS THE POWER FUNCTION OF SOME TESTS BASED ON RANCE

DISTRIBUTION FREE TESTS BASED ON THE SAMPLE DISTRIBUTION FUNCTION

CORRECTION, 'DISTRIBUTION FREE TESTS BASED ON THE SAMPLE DISTRIBUTION FUNCTION' THE GOODNESS-OF-FIT TESTS BASED ON W-SQUARE-SUB-N AND U-SQUARE-SUB-N. SIMULTANEOUS TESTS BY SEQUENTIAL METHODS IN HIERARCHICAL CLASSIFI A'TIONS ASYMPTOTICALLY EFFICIENT TESTS BY THE METHOD OF N RANKINGS $\begin{array}{rrr}\text { AMS } & 69 & 1449\end{array}$ AMS $63 \quad 56$ JASA $67 \quad 1201$ CO BIOKA5I 265 JASA $62 \quad 10$ TECH 59239 JRSSB56 227 /BA AMS $67 \quad 8$ BIOKA53 347 BIOKA66 99 BIOKA67 333 BIOKA62 397 BIOKA64 439 JRSSB68 312 NORMAL DIST/PROPERTTES OF PONER FUNCTIONS OF SOME TESTS CONCERNTNG DTSPERSTON MATRICES OF MULTIVARIATE AMS 69 697 A MONTE CARLO INVESTICATION OF THE SIZE AND POWER OF TESTS EMPLOYING SATTERTHWAITE'S SYNTHETIC MEAN SQUARE BIOKA6B 43I A CLASS OF RANK ORDER TESTS FOR A CENERAL LINEAR HYPOTHESIS RANDOMTZATION TESTS FOR A MULTTVARIATE TWO-SAMPLE PROBLEM SICNIFICANCE TESTS FOR A VARIABLE CHANCE OF INFECTION IN CHAINAMS 691325 JASA $58 \quad 729$ BINOMIAL THEORY BIOKA56 332 OF ESTIMATING SEEMINCLY UNRELATED REGRESSIONS AND TESTS FOR ACCREGATION BIAS A CLASS OF SEQUENTIAL TESTS FOR AN EXPONENTIAL PARAMETER SEQUENTIAL TESTS FOR BINOMIAL AND EXPONENTIAL POPULATIONS

CLOSED SEQUENTIAL TESTS FOR BINOMIAL PROBABILITIES SOME TESTS FOR CATEGORICAL DATA

ON TWO K-SAMPLE RANK TESTS FOR CENSORED DATA

ON A CLASS OF NONPARAMETRIC TWO-SAMPLE TESTS FOR CIRCULAR DISTRIBUTIONS

NONPARAMETRIC SYMMETRY TESTS FOR CIRCULAR DISTRIBUTIONS

ER OF T-SQUARED, R-SQUARED AND OTHER FULLY INVARIANT TESTS FOR CLASSICAL MULTIVARIATE NORMAL PROBLEMS

SOME NONPARAMETRIC TESTS FOR COMOVEMENTS BETWEEN TIME SERIES ASYMPTOTIC EFFICIENCY OF CERTAIN RANK TESTS FOR COMPARATIVE EXPERIMENT

SEQUENTIAL RANGE TESTS FOR COMPONENTS OF VARIANCE, CORR. 651249

THE POWER OF CHI SQUARE TESTS FOR CONTINGENCY TABLES TESTS FOR CONTINGENCY TABLES AND MARKOV CHAINS

ON GHI-SQUARE GOODNESS-OF-FIT TESTS FOR GONTINUOUS DISTRIBUTIONS (WITH DISCUSSION) TESTS FOR CORRELATION MATRICES

SOME TESTS FOR CORRELATION MATRICES

A MONTE GARLO STUDY COMPARING VARIOUS TWO-SAMPLE TESTS FOR DIFFERENCES IN MEAN EXACT AND APPROXIMATE TESTS FOR DIRECTIONS. I

EXACT AND APPROXIMATE TESTS FOR DIRECTIONS. II SIGNIFICANCE TESTS FOR DISCRIMINANT FUNCTIONS AND LINEAR FUNCTIONA
BI J

L RELATIONSHIPS

NOTE ON THE CONSISTENCY OF SOME DISTRIBUTION-FREE TESTS FOR DISPERSION

INVARIANT PROPER BAYES TESTS FOR EXPONENTIAL FAMILIES ASYMPTOTICALLY MOST POWERFUL RANK ORDER TESTS FOR CROUPED DATA

ALTERNATIVE TESTS FOR HETEROCENEITY OF VARIANCE, SOME MONTE CARLO SOME TESTS FOR HOMOSCEDASTICITY

GRAPHICALLY ORIENTED TESTS FOR HOST VARIABILITY IN DILUTION EXPERIMENTS CO-ORDINATE

TRANSFORMATIONS TO NORMALITY AND THE POWER OF NORMAL TESTS FOR INDEPENDENCE

A CLASS OF NONPARAMETRIC TESTS FOR INDEPENDENCE IN BIVARIATE POPULATIONS PAIRED COMPARISON MODELS WITH TESTS FOR INTERACTION

ON A CLASS OF CONDITIONALLY DISTRIBUTION-FREE TESTS FOR INTERACTIONS IN FACTORIAL EXPERIMENTS ASYMPTOTIC POWER OF CHI SQUARE TESTS FOR LINEAR TRENDS IN PROPORTIONS SIGN AND WILCOXON TESTS FOR LINEARITY

PROBLEM

ON THE THEORY OF RANK ORDER TESTS FOR LOCATION IN THE MULTIVARIATE ONE SAMPLE APPROXIMATE TESTS FOR M RANKINGS

SOME NON-PARAMETRIC TESTS FOR M-DEPENDENT TIME SERIES

SIMPLIFIED RUNS TESTS AND LIKELIHOOD RATIO TESTS FOR MARKOFF CHAINS

NOTE ON CHI SQUARE TESTS FOR MATCHED SAMPLES

DISTRIBUTION FREE TESTS FOR MIXED PROBABILITY DISTRIBUTIONS

A NOTE ON TESTS FOR MONOTONE FAILURE RATE BASED ON INCOMPLETE TESTS FOR MONOTONE FAILURE RATE, II

ASYMPTOTICALLY OPTIMUM TESTS FOR MULTINOMIAL DISTRIBUTIONS
BIOKA6B 387

BIOKA54 252

BIOKA66 73

AMS $61 \quad 72$

AMS 671520

AMS 691791

BIOKA69 NO. 3

/T AMS $65 \quad 747$

JASA $61 \quad 11$

AMS $67 \quad 90$

JASA $65 \quad 826$

JASA $66 \quad 965$

TECH $62 \quad 573$

JRSSB58 44

BIOKA6B 327

BIOKA69 443

TEGH 6B 509

BIOKA62 463

BIOKA62 547

BIOKA55 360

JASA $64 \quad 105$

BIOKA68 441

AMS 69270

AMS $67 \quad 1229$

BIOKA66 229

JASA $65 \quad 539$ BIOCS67 269

BIOKA69 139

AMS $64 \quad 138$ BI0CS65 651 AMS 69658 BIOCS68 315 AMS 671216 BIOKA60 476 JASA $65 \quad 134$ BIOKA58 181 JRSSB68 368 BIOKA69 NO.3 AMS $69 \quad 595$ AMS 691250 AMS $65 \quad 369$
JASA 69 NO AMS 671759 

RANK ORDER TESTS FOR MULTIVARIATE PAIRED COMPARISONS

ITMAN EFFICIENCY OF ONE-SIDED KOLMOCOROV AND SMIRNOV TESTS FOR NORMAL ALTERNATIONS

ON THE P AMS $66 \quad 940$

A COMPARATIVE STUDY OF VARIOUS TESTS FOR NORMALITY

JASA $6 B \quad 1343$

AMS 68967

SOME TESTS FOR OUTLIERS

THE PERFORMANCE OF SEVERAL TESTS FOR OUTLIERS

BIOKA61 379

BIOKA65 429

BIOKA61 95

AMS $64 \quad 122$

SEVERAL TREATMENTS

SICNIFICANCE TESTS FOR PAIRED-COMPARISON EXPERIMENTS

RANK TESTS FOR PAIRED-COMPARISON EXPERIMENTS INVOLVINC

CORRICENDA, 'SICNIFICANT TESTS FOR PAIRED-COMPARISON EXPERIMENTS'

PARTIAL TESTS FOR PARTIAL TAUS

SOME RESULTS ON TESTS FOR POISSON PROCESSES

$\begin{array}{ll}\text { BIOKA61 } & 475 \\ \text { BIOKA59 } & 425\end{array}$

BIOKA65 67

BIOKA53 354

AMS $67 \quad B 67$

JRSSB56 234

BIOKA51 102

JASA 69280

BIOKA56 104

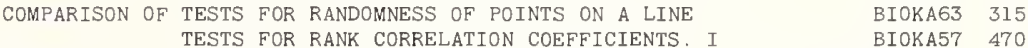

UTION OF THE TRANSFORMED KENDALL COEFFICIENT TESTS FOR RANK CORRELATION COEFFICIENTS. III. DISTRIB BIOKA62 1 B5 TESTS FOR RANK CORRELATION COEFFICIENTS. II

ASYMPTOTIG EFFTCIENCY OF A CLASS OF NON-PARAMETRIC TESTS FOR REGRESSION PARAMETERS UTIONS $\quad$ LIKELIHOOD RATIO TESTS FOR RESTRICTED FAMILITES OF PROBABILITY DISTRIB NON-PARAMETRIC TESTS FOR SCALE

A NOTE ON NONPARAMETRIC TESTS FOR SCALE

$\begin{array}{lll}\text { AMS } & 67 & \text { BB4 } \\ \text { AMS } & 68 & 547\end{array}$

AMS 62498

AMS $67 \quad 274$

EXACT TESTS FOR SERIAL CORRELATION

BIOKA55 133

ASED ON THE PERIODOGRAM OF LEAST-SQUARES RESIDUALS TESTS FOR SERIAL CORRELATION IN REGRESSION ANALYSIS B BIOKA69 1 NONPARAMETRIC TESTS FOR SHIFT AT UNKNOWN TIME POINT A AMS 68 1731 DISTRIBUTION OF SAMPLE SIZE FOR SEQUENTIAL TESTS. I. TESTS FOR SIMPLE HYPOTHESES APPROXIMATION TO THE BIOKA59 130 I-SQUARE AND TWO MODIFIED CHI-SQUARE GOODNESS-OF-FIT TESTS FOR SMALL BUT EQUAL EXPECTED FREQUENCIES /CH BIOKA66 6I9 PROBLEMS SOME SCHEFFE-TYPE TESTS FOR SOME BEHRENS-FISHER-TYPE REGRESSION

JASA 651163 MOST POWERFUL TESTS FOR SOME NON-EXPONENTIAL FAMILIES TESTS FOR SPECIFICATION ERRORS IN CLASSICAL LINEAR JRSSB69 NO.2

LEAST-SQUARES REGRESSION ANALYSIS FOLKLORE

SOME QUANTITATIVE TESTS FOR STOCK PRICE CENERATING MODELS AND TRADING ASYMPTOTIC RELATIVE EFFICIENCIES OF GOX AND STUART'S TESTS FOR TESTING TREND IN DISPERSION OF A P-DEPENDEN

A DISTRIBUTION ON A SPHERE CERTAIN ALTERNATIVES $\begin{array}{ll}\text { THE INTRACLASS CORRELATION MODEL } & \text { TESTS FOR THE EQUALITY OF COVARIANCE MATRICES UNDER } \\ \text { RELATION TO A BEST LINEAR DISCRIMINATOR ANALYSIS } & \text { TESTS FOR THE EQUALITY OF TWO COVARIANCE MATRICES IN }\end{array}$ MULTI-SAMPLE TESTS FOR THE FISHER DISTRIBUTION FOR DIRECTIONS SOME TESTS FOR THE INTRACLASS CORRELATION MODEL OPTIMAL INVARIANT RANK TESTS FOR THE K-SAMPLE PROBLEM

EXAGT LINEAR SEQUENTIAL TESTS FOR THE MEAN OF A NORMAL DISTRIBUTION TABLES FOR WALD TESTS FOR THE MEAN OF A NORMAL DISTRIBUTION SEQUENTIAL TESTS FOR THE MEAN OF A NORMAL DISTRIBUTION II, LARGE AMS 64162 SEQUENTIAL TESTS FOR THE MEAN OF A NORMAL DISTRIBUTION IV, $\mathrm{T}$

DISCRETE GASE

PROCESSES

ON A CLASS OF RANK ORDER TESTS FOR THE PARALLELISM OF SEVERAL REGRESSION LINES SEQUENTIAL HYPOTHESIS TESTS FOR THE R-DEPENDENT MARGINALLY STATIONARY

AMS 691668 AMS $66 \quad 90$ AMS 651243 ERLYING DISTRIBUTTON OF LIFE IS EXPONENTIAL, PART/ DERLYING DISTRIBUTION OF LIFE IS EXPONENTIAL, PAR/

TESTS FOR THE VALIDITY OF THE ASSUMPTTON THAT THE UND TECH TESTS FOR THE VALIDITY OF THE ASSUMPTIONS THAT THE UN TECH 60167 TESTS FOR THE VON MISES DISTRIBUTION $\quad$ BIOKA69 149

A SAMPLING EXPERIMENT ON THE POWERS OF THE RECORDS TESTS FOR TREND IN A TIME SERIES LARGE-SAMPLE SIGN TESTS FOR TREND IN DISPERSION

SOME QUICK SIGN TESTS FOR TREND IN LOCATION AND DISPERSION

ASYMPTOTIC THEORY OF A CLASS OF TESTS FOR UNIFORMITY OF A CIRCULAR DISTRIBUTION HE DERIVATION OF NONPARAMETRIC TWO-SAMPLE TESTS FROM TESTS FOR UNIFORMITY OF A CIRCULAR DISTRIBUTION ON DEPENDENT TESTS FROM A NON-ORTHOGONAL DESIGN

BIOKA66 289 BIOKA55 80 AMS 691196

T BIOKA69 N0.3 JASA $66 \quad 803$ UTION THE DERIVATION OF NONPARAMETRIC TWO-SAMPLE TESTS FROM TESTS FOR UNIFORMITY OF A CTRCULAR DISTRIB BIOKAG9 NO 3 PROCEDURE ON SLIPPAGE TESTS I A GENERALIZATION OF NEYMAN PEARSON'S LEMMA SEQUENTIAL RANK TESTS I. MONTE CARLO STUDIES OF THE TWO-SAMPLE SEQUENTIAL RANK TESTS II. MODIFIED TWO-SAMPLE PROCEDURES SIGNIFICANCE TESTS IN DISCRETE DISTRIBUTIONS, CORR. 62919 ASYMPTOTICALLY MOST POWERFUL TESTS IN MARKOV PROCESSES SOME EXACT TESTS IN MULTIVARIATE ANALYSIS ADMISSIBLE TESTS IN MULTIVARIATE ANALYSIS OF VARIANCE SIGNIFICANCE TESTS IN PARALLEL AND IN SERIES

DOMAINS OF OPTIMALITY OF TESTS IN SIMPLE RANDOM SAMPLING THE PERFORMANCE OF SOME TWO-SAMPLE TESTS IN SMALL SAMPLES WITH AND WITHOUT CENSORING BIOKA69 127 OF MISCLASSIFICATION ON THE PROPERTIES OF CHI-SQUARE-TESTS IN THE ANALYSIS OF CATEGORICAL DATA. /EFFECT BIOKA65 95 ORDERED TESTS IN THE ANALYSIS OF VARIANCE ERATING CHARACTERISTIC FOR TRUNCATED SEQUENTIAL LIFE TESTS IN THE EXPONENTIAL CASE TWO SAMPLE TESTS IN THE WEIBULL DISTRIBUTION AMS $62 \quad 1403$ TECH 69 NO. 4 HOD FOR ADJUDGING RELATIVE EFFICIENCY OF STATISTICAL TESTS IN TIME SERIES REGRESSION ANALYSIS /VALUE MET BIOKA66 IO9 (WITH DISGUSSION) DISTRIBUTION-FREE TESTS IN TIME-SERIES BASED ON THE BREAKINC OF RECORDS JRSSB54 AMS 681115 AMS $67 \quad 422$ OPTIMUM INVARIANT TESTS IN UNBALANCED VARIANCE COMPONENTS MODELS THE ROBUSTNESS OF HOMOGENEITY TESTS IN 2 BY N TABLES

LOCALLY AND ASYMPTOTICALLY MINIMAX TESTS OF A MULTIVARIATE PROBLEM BEST CRITICAL RECIONS SIMTLAR TO THE SAMPLE SPACE IN TESTS OF AN TMPORTANT CLASS OF COMPOSITE HY POTHESES BEST CRITICAL REGIONS SIMILAR TO THE SAMPLE SPACE IN TESTS OF AN IMPORTANT CLASS OF COMPOSITE HYPOTHESES
SOME MODIFIED KOLMOGOROV-SMIRNOV TESTS OF APPROXIMATE HYPOTHESES AND THEIR PROPERTIES AMS 62 513 RIBUTION OF THE SAMPLE SIZE FOR SEQUENTIAL TEST. II. TESTS OF COMPOSITE HYPOTHESES/XIMATION TO THE DIST BIOKA6O I9O 
NTS WITH NONCONTROLLED PRE/ ASYMPTOTICALLY OPTIMAL TESTS OF COMPOSITE HYPOTHESES FOR RANDOMIZED EXPERIME JASA 65 699 EXPONENTIAL FAMILY, CORR. 671928 TESTS OF COMPOSITE HYPOTHESES FOR THE MULTIVARIATE

OF EVENTS OCCURRING RA/ ON THE EQUIVALENCE OF TWO TESTS OF EQUALITY OF RATE OF OCCURRENCE IN TWO SERIES BIOKA58 267 FOUR CRITERIA

POWER COMPARISIONS OF TESTS OF EQUALITY OF TWO COVARIANCE MATRICES BASED ON BIOKA68 335 KOLMOCOROV-SMIRNOV TESTS OF FIT BASED ON SOME CENERAL BOUNDS JASA 68919 INC IN THE SHORTEST SAMPLE SPACINGS DETERMINED BY/ TESTS OF FIT BASED ON THE NUMBER OF OBSERVATIONS FALL AMS 61 838 TESTS OF FIT IN TIME SERIES

AN INEQUALITY CONCERNINC TESTS OF FIT OF THE KOLMOCOROV-SMIRNOV TYPE TESTS OF GOODNESS OF FIT

SCHËMES

ASYMPTOTIG EXPANSIONS FOR TESTS OF GOODNESS OF FIT FOR LINEAR AUTOREGRESSIVE BIOKA52 309 AMS 671240 $\begin{array}{rr}\text { JRSSB } 63 & 81\end{array}$ BIOKA64 459 JRSSB58 143

SCHEMES

SAMPLING THE ASYMPTOTIC POWERS OF CERTAIN TESTS OF GOODNESS OF FIT FOR TIME SERIES

SAMPLING PROPERTIES OF TESTS OF GOODNESS-OF-FIT FOR LINEAR AUTOREGRESSIVE

JRSSB $62 \quad 492$ JRSSB $60 \quad 368$ JASA $63 \quad 97$ TESTS OF HOMOCENEITY FOR CORRELATED SAMPLES

LOCISTIC FUNCTION

JASA $67 \quad 520$

ON ITERATED TESTS OF HYPOTHESES
TESTS OF HYPOTHESES ABOUT THE PARAMETERS OF THE 69 194) E IN"MONOFACTORIAL INHERITANCE TESTS OF HYPOTHESES CONCERNING MATCHED SAMPLES (CORR. WEIBULL DISTRIBUTION NOTES. STATISTICAL TESTS OF HYPOTHESES CONCERNING THE DEGREE OF DOMINANC SOME TESTS OF HYPOTHESES CONCERNING THE THREE-PARAMETER JASA $68 \quad 853$ THE EFFECT OF TRUNCATION ON TESTS OF HYPOTHESES FOR NORMAL POPULATIONS AMS 651504 TESTS OF HYPOTHESES IN THE LTNEAR AUTO-REGRESSIVE MOD BIOKA56 186 MODEL. PART I. TESTS OF HYPOTHESES IN THE LINEAR AUTOREGRESSIVE IBUTION WHEN SOME OUTLIERS ARE PRESENT, C/ ON SOME TESTS OF HYPOTHESES RELATING TO THE EXPONENTIAL DISTR JASA 65 548 DISTRIBUTION-FREE TESTS OF INDEPENDENCE N FUNCTION DISTRIBUTIONS MONOTONICITY OF THE POWER FUNCTIONS OF SOME TESTS OF INDEPENDENCE BETWEEN TWO SETS OF VARIATES AMS $64 \quad 206$ TESTS OF INDEPENDENCE IN INTRACLASS 2-BY-2 TABLES BIOKA69 449 BIOKA61 181 JASA $66 \quad 204$ AMS 671705 CRITICAL REGIONS FOR TESTS OF INTERVAL HYPOTHESES ABOUT THE VARIANCE LOCAL ASYMPTOTIC POWER AND EFFICIENCY OF TESTS OF KOLMOGOROV-SMIRNOV TYPE BIOKA53 465 A NOTE ON RECIONS FOR TESTS OF KURTOSIS

AL EXPERIMENTS. CORR. 661246 LAMP TESTS OF LINEAR AND LOGLINEAR HYPOTHESES IN MULTINOMI SIMULTANEOUS TESTS OF LINEAR HYPOTHESES RANK ORDER TESTS OF LINEAR HYPOTHESES BIOKA55 236 JRSSB68 IATE ANALYSIS WHEN THE RATIOS OF THE POPULATION V/ TESTS OF LINEAR HYPOTHESES IN UNIVARIATE AND MULTIVAR BIOKA54 19 TRANSFORMATIONS. CORR, $64 \mathrm{l2} /$ ASYMPTOTIC POWER OF TESTS OF LINEAR HYPOTHESES USING THE PROBIT AND LOGIT JASA 62 877 ON THE ADMISSIBILITY OF SOME TESTS OF MANOVA

A POWER COMPARISON OF TWO TESTS OF NON-RANDOM CLUSTERING

A COMPARISON OF CERTAIN TESTS OF NORMALITY

THE EFFICIENCIES OF TESTS OF RANDOMNESS AGAINST NORMAL REGRESSION

ON THE INDEPENDENCE OF TESTS OF RANDOMNESS AND OTHER HYPOTHESES TESTS OF RANDOMNESS BASED ON DISTANCE METHODS

ON SEQUENTIAL TESTS OF RATIO OF VARIANCES BASED ON RANGE TESTS OF RELATEDNESS

SOME RESULTS ON TESTS OF SEPARATE FAMILIES OF HYPOTHESES FURTHER RESULTS ON TESTS OF SEPARATE FAMILIES OF HYPOTHESES

SERIES ANALYSIS SOME TESTS OF SEPARATE FAMILIES OF HYPOTHESES IN TIME

AMS 64789 TECH $66 \quad 493$ SASJ 69 NO.2

JASA $56 \quad 285$ JASA $57 \quad 53$ BIOKA65 345 BIOKA63 419 BIOKA67 459 BIOKA68 355 JRSSB $62 \quad 406$ BIOKA67 39 BIOCS69 411 RAO'S PARADOX CONCERNING MULTIVARIATE TESTS OF SIGNIFICANCE

LIKELIHOOD ESTIMATION PROCEDURES AND ASSOCIATED TESTS OF SIGNIFICANCE

MAXIMUM - JRSSB $60 \quad 154$ TESTS OF SICNIFICANCE FOR CONCURRENT REGRESSION LINES BIOKA53 297

RELATIONSHIPS

NCE AND CORRELATION MATRICES

EXTENSION OF FINNEY'S TABLE
A NOTE ON TESTS OF SIGNIFICANCE FOR LINEAR FUNCTIONAL

TESTS OF SICNIFICANCE FOR THE LATENT ROOTS OF COVARTA BIOKA56

TESTS OF SICNIFICANCE IN A 2-BY-2 CONTINGENCY TABLE,

TESTS OF SICNIFICANCE IN CANONICAL ANALYSIS

TESTS OF SIGNIFICANCE IN CANONICAL ANALYSIS

EXACT TESTS OF SIGNIFICANCE IN CONTINGENCY TABLES

THE CONSTRUCTION OF A MATRIX USED IN DERIVING TESTS OF SIGNIFICANCE IN MULTIVARIATE ANALYSIS

MU/ ALCEBRAIC THEORY OF THE COMPUTING ROUTINE FOR TESTS OF SIGNIFICANCE ON THE DIMENSIONALITY OF NORMAL J SOME TESTS OF SIGNIFICANCE WITH ORDERED VARIABLES

PUBLICATION DECISIONS AND TESTS OF SICNIFICANCE, A COMMENT 128 BIOKA53 74 BIOKA52 58 BIOKA59 59 TECH $69 \quad 393$ BIOKA64 503 JRSSB56 70 JRSSB56 1 JASA 59593 AND THEIR POSSIBLE EFFECTS ON INFERENCES DRAWN FROM TESTS OF SIGNIFICANCE, OR VICE VERSA /ION DECISIONS JASA 59 30 ASYMPTOTICALLY NONPARAMETRIC TESTS OF SYMMETRY

ITERATED TESTS OF THE EQUALITY OF SEVERAL DISTRIBUTIONS ON TESTS OF THE EQUALITY OF TWO COVARIANCE MATRICES

MONOTONICITY PROPERTY OF THE POWER FUNCTIONS OF SOME TESTS OF THE EQUALITY OF TWO COVARIANCE MATRICES SENSITIVITY COMPARISONS AMONG TESTS OF THE GENERAL LINEAR HYPOTHESIS SOME NOTES ON VARIANCE-RATIO TESTS OF THE GENERAL LINEAR HYPOTHESIS H/ CORRIGENDA. 'SMALL SAMPLE BEHAVIOUR OF CERTAIN TESTS OF THE HYPOTHESIS OF EQUAL MEANS UNDER VARIANCE BIOKA61 230 SYSTEM OBEYS TWO SEPARATE REGIMES TESTS OF THE HYPOTHESIS THAT A LINEAR REGRESSION SOME EXACT RESULTS FOR ONE-SIDED DISTRIBUTION TESTS OF THE KOLMOGOROV-SMIRNOV TYPE DIRECT METHODS FOR EXACT TRUNCATED SEQUENTIAL TESTS OF THE MEAN OF A NORMAL DISTRIBUTION MONOTONICITY OF THE POWER FUNCTIONS OF SOME TESTS OF THE MULTIVARIATE LINEAR HYPOTHESIS

E PR/ CONTRIBUTIONS TO SAMPLE SPACINGS THEORY, II. TESTS OF THE PARAMETRIC GOODNESS OF FIT AND TWO-SAMPL ON COMPARING DIFFERENT TESTS OF THE SAME HYPOTHESIS A COMPARISON OF TESTS OF THE WILKS-LAWLEY HYPOTHESIS IN MULTIVARIATE BIOKA65 149 OOTS OF A COVARIANCE MATRIX AND WILKS CRITERION FOR TESTS OF THREE HYPOTHESES /S OF THE RATIOS OF THE
CRITERIA TABLES FOR SIGNIFICANCE TESTS OF 2-BY-2 CONTINGENCY TABLES GOODNESS-OF-FIT TESTS ON A CIRCLE GOODNESS-OF-FIT TESTS ON A CIRCLE. II JASA $60 \quad 324$ AMS $61 \quad 499$ TECH 69 NO. 4 AMS $64 \quad 200$ AMS $66 \quad 925$ BIOKA60 297 AMS 69 NO. 6 BIOKA67 195 BIOKA55 494 BIOKA6I 109 BIOKA62 57 THE CONDITIONAL DISTRIBUTION OF SETS OF TESTS ON A SYSTEM SIMULATED FROM TESTS ON ITS COMPONE ON A CLASS OF SIMPLE SEQUENTIAL TESTS ON MEANS ON THE CONSTRUCTION OF SIGNIFICANCE TESTS ON THE CIRCLE AND THE SPHERE 
ON THE POWER OF TWO-SAMPLE RANK TESTS ON THE EQUALITY OF TWO DISTRIBUTION FUNCTIONS

MORE SICNIFICANCE TESTS ON THE SPHERE

TABLES FOR UNBIASED TESTS ON THE VARIANCE OF A NORMAL POPULATION

NON-NORMALITY AND TESTS ON VARIANCES.

SAMPLE EXTENSION OF THE ONE-SIDED TWO-SAMPLE SMIRNOV TESTS STATISTIC

THE BEHAVIOUR OF SOME SICNIFICANCE TESTS UNDER EXPERIMENTAL RANDOMIZATION

JRSSB64 293

BIOKA60 87

AMS $61 \quad 84$

BIOKA53 318

A K- AMS $67 \quad 1726$

BIOKA69 231

BIOKA67 679

STUDY

SOME TWO-SAMPLE TESTS WHEN THE VARIANCES ARE UNEQUAL. A SIMULATION

THE LOCATION MODEL

ON SEQUENTIAL TESTS WHICH MINIMIZE THE MAXIMUM EXPECTED SAMPLE SIZE JASA 62 551 MULTIVARIATE TWO SAMPLE TESTS WITH DICHOTOMOUS AND CONTINUOUS VARIABLES I. AMS 69290 NOTE ON SOME SQUARED RANK TESTS WITH EXISTINC TIES

QUICK POWERFUL TESTS WITH CROUPED DATA

THE ASYMPTOTIC POWERS OF MULTIVARIATE TESTS WITH CROUPED DATA

TECH $67 \quad 312$

BIOKA68 264

JRSSB $68 \quad 338$

A CLASS OF TESTS WITH MONOTONE POWER FUNCTIONS FOR TWO PROBLEMS AMS 651794

IN MULTIVARIATE STATISTICAL ANALYSIS

MANTEL-HAENSZEL PROCEDURE

CHI-SQUARE TESTS WITH ONE DECREE OF FREEDOM EXTENSIONS OF THE

JASA $63 \quad 690$

HE PEARSON CHI-SQUARE AND KOLMOCOROV COODNESS-OF-FIT TESTS WITH RESPECT TO VALIDITY, CORR. 66 I249 /OF T JASA 65 B54

ON TO THE DISTRIBUTION OF SAMPLE SIZE FOR SEQUENTIAL TESTS. I. TESTS FOR SIMPLE HYPOTHESES APPROXIMATI BIOKA59 130

CORRECTION, 'SOME METHODS OF CONSTRUCTINC EXACT TESTS.'

THE POWERS OF TWO MULTIVARIATE ANALYSIS OF VARIANCE TESTS.'

THE FREQUENCY JUSTIFICATION OF SEQUENTIAL TESTS, ADDENDUM

CORRICENDA, 'A COMPARTSON OF

BIOKA63 546

BIOKA53 46B

STIC CURVES FOR FIXED EFFECTS ANALYSIS OF VARIANCE F TESTS, ALPHA EQUALS 0.01 AND $0.05 \quad / A T I N C$ CHARACTERI JASA 57345 ON SOME TWO-SAMPLE NON-PARAMETRIC TESTS CORR 661249

HARTS OF THE POWER FUNCTION FOR ANALYSIS OF VARIANCE TESTS, DERIVED FROM THE NON-CENTRAL F-DISTRIBUTION BIOKA5I II2

BIVARIATE SYMMETRY TESTS, PARAMETRIC AND NONPARAMETRIC $\quad$ AMS 69259

COMMENTS ON 'THE SIMPLEST SICNED-RANK TESTS

JASA 59213 'ROBUSTNESS TO NON-NORMALITY OF RECRESSION TESTS'

MPARATIVE STUDY OF SEVERAL ONE-SIDED COODNESS-OF-FIT TESTS *

CORRECTION TO 'A CONSERVATIVE PROPERTY OF BINOMIAL TESTS' 601205

ON THE STRUCTURE OF THE TETRACHORIC SERIES

CORRICENDA, BIOKA65 669

CORRECTION. 'A CO AMS $6515 \mathrm{~B} 3$

MIXED SELF - AND CROSS-FERTILIZATION IN A TETRASOMIC SPECIES

AMS 611343

BIOKA68 261 BIOCS68 485

CE MATRICES

UNBIASEDNESS OF SOME TEXT CRITERIA FOR

ON NAHORDNUNC AND FERNORDNUNG IN SAMPLES OF LITERARY TEXTS

ON THEIL'S MIXED RECRESSION ESTIMATOR

SOME EXTENSIONS OF THE WALD-WOLFOWITZ-NOETHER THEOREM

NOTE ON THE BERRY-ESSEN THEOREM

A LOCAL LIMIT THEOREM

CENERALIZATIONS OF THE MAXIMAL ERGODIC THEOREM

A UNIFORM ERCODIC THEOREM

ON THE CONVERGENCE OF MOMENTS IN THE CENTRAL LIMIT THEOREM

ON THE SEMIMARTINCALE CONVERCENCE THEOREM

A GENERALIZATION OF THE CAUSS-MARKOV THEOREM

CONSENSUS OF SUBJECTIVE PROBABILITIES, A CONVERGENCE THEOREM

ON A STOPPING RULE AND THE CENTRAL LIMIT THEOREM

A NOTE ON THE BIRKHOFF ERGODIC THEOREM

A SIMPLER PROOF OF SMITH'S ROULETTE THEOREM

ON CONVERCENCE RATES IN THE CENTRAL LIMIT THEOREM

AN OPTIMAL STOPPINC THEOREM

NOTE ON THE THREE SERIES THEOREM

AN L-TO-THE-P CONVERGENCE THEOREM

A UNIFORM OPERATOR ERCODIC THEOREM

NOTE ON THE INVERSION THEOREM

ON AN EXTENSION OF CEARY'S THEOREM

A FURTHER LOOK AT ROBUSTNESS VIA BAYES'S THEOREM

FIDUCIAL DISTRIBUTIONS AND BAYES' THEOREM

ON A MULTIVARIATE VERSION OF FIELLER'S THEOREM

SPECTRAL THEOREM FOR FINITE MATRICES AND COCHRAN'S THEOREM

SAMPLINC ACCEPTANCE SCHEMES DERIVED FROM BAYES'S THEOREM

OF A STOPPING RULE RELATED TO THE CENTRAL LIMIT THEOREM

OF AN INVARIANT MEASURE AND AN ORNSTEIN'S ERGODIC THEOREM

OF A CLASS OF FREQUENCY DISTRIBUTIONS VIA BAYES'S THEOREM

UNDER MIXINC WHICH GENERALIZE DE FINETTI'S THEOREM

BABILISTIC PROOF OF THE DISCRETE GENERALIZED RENEWAL THEOREM

OF ITO'S THEOREM CONCERNING THE POINTWISE ERCODIC THEOREM ATISTIC AND THE COMBINATION OF TWO SAMPLES BY BAYES' THEOREM IRICAL PROCESS AND A NEW APPROACH TO CHERNOFF-SAVACE THEOREM FLUCTUATION THEOREM AND A DISTRIBUTION-FREE TES'

FIELLER'S THEOREM AND A CENERALIZATION

BAYES'S THEOREM AND THE USE OF PRIOR KNOWLEDGE IN REGRESSION

ANALYSIS A UNIQUENESS THEOREM CONCERNINC MOMENT DISTRIBUTIONS

A CENERALIZATION OF ITO'S THEOREM CONCERNINC THE POINTWISE ERCODIC THEOREM

A LOCAL LIMIT THEOREM FOR A CERTAIN CLASS OF RANDOM WALKS

A FLUCTUATION THEOREM FOR CYCLIC RANDOM VARIABLES

THE SPECTRAL THEOREM FOR FINITE MATRICES AND COCHRAN'S THEOREM

A 'RENEWAL' LIMIT THEOREM FOR GENERAL STOCHASTIC PROCESSES

THE CENTRAL LIMIT THEOREM FOR GENERALIZED RANDOM FIELDS

ON THE GLIVENKO-CANTELLI THEOREM FOR INFINITE INVARIANT MEASURES

A STABLE LIMIT THEOREM FOR MARKOV TESTS

THE REMAINDER IN THE CENTRAL LIMIT THEOREM FOR MIXING STOCHASTIC PROCESSES

A LIMIT THEOREM FOR MULTIDIMENSIONAL GALTON-WATSON PROCESSES

ON THE CODINC THEOREM FOR NOISELESS CHANNEI

FUNCTIONS

ON INFINITELY DIVISIBLE LAWS AND A RENEWAL THEOREM FOR NON-NEGATIVE RANDOM VARIABLES

A LOCAL LIMIT THEOREM FOR NONLATTICE MULTI-DIMENSIONAL DISTRIBUTION

COMBINATORIAL THEOREM FOR PARTIAL SUMS

PROCESSES

A CENTRAL LIMIT THEOREM FOR PARTLY DEPENDENT VARIABLES

A LIMIT THEOREM FOR PASSAGE TIMES IN ERGODIC REGENERATIVE

AMS 681686

JASA $67 \quad 1338$

BIOKA54 116

JASA 69273

AMS 61506

AMS $63 \quad 1107$

AMS $64 \quad 419$

AMS 651292

AMS 651853

AMS $65 \quad 808$

AMS $66 \quad 690$

JASA $66 \quad 1063$

AMS $67 \quad 221$

AMS 671915

AMS $67 \quad 922$

AMS $68 \quad 390$

AMS $69 \quad 475$

AMS 69677

AMS 691844

AMS 691068

AMS 691126

BIOKA5I 48I

BIOKA53 228

BIOKA62 419

JRSSB58 102

JRSSB59 59

THE AMS $64 \quad 443$

SERIAL TECH $60 \quad 353$

MOMENTS AMS 691236

EXISTENCE AMS 6979

EXIVATION JRSSB65 290

$\begin{array}{llll} & \end{array}$

AMS 682145

AMS $61 \quad 616$

AMS $68 \quad 755$

AMS 641359

BIOKA67 567

BIOKA64 219

JASA $65 \quad 1203$

AMS 682145

AMS $66 \quad 855$

AMS $62 \quad 1450$

AMS $64 \quad 443$

AMS $62 \quad 98$

AMS 69203

AMS $67 \quad 1273$

AMS 691467

AMS 69601

AMS $66 \quad 1211$

AMS $61 \quad 594$

AMS $68 \quad 139$

AMS $65 \quad 546$

AMS 631600

AMS 61677

$\begin{array}{lll}\text { AMS } & 61 & 677 \\ \text { AMS } & 66 & 866\end{array}$

ON A FLUCTUATION THEOREM FOR PROCESSES WITH INDEPENDENT INCREMENTS, II AMS 69688 
A LIMIT THEOREM FOR RANDOM INTERVAL SAMPLINC OF A STOCHASTIC A MULTIVARIATE CENTRAL LIMIT THEOREM FOR RANDOM LINEAR VECTOR FORMS WEAK CONVERCENCE AND A CHERNOFF-SAVACE THEOREM FOR RANDOM SAMPLE SIZES

NON- IDENTICALLY DISTRIBUTED A RENEWAL THEOREM FOR RANDOM VARIABLES WHICH ARE DEPENDENT OR PROCFSSES POSTERIOR DISTRIBUTION OF PERCENTILES. BAYES' THEOREM FOR SAMPLINC FROM A POPULATION A UNIQUENESS THEOREM FOR STATIONARY MEASURES OF ERCODTC MARKOV A LIMIT THEOREM FOR SUMS OF MINIMA OF STOCHASTIC VARIABLES

MOTION

AN OCCUPATION TTME THEOREM FOR THE ANCULAR COMPONENT OF PLANE BROWNIAN CTION OF TWO GRAPHS (CORR. 69 151/ A CENTRAL LIMIT THEOREM FOR THE NUMBER OF EDCES IN THE RANDOM INTERSE A DECOMPOSITION THEOREM FOR VECTOR VARIABLES WITH A LINEAR STRUCTURE AN APPLICATION OF A BALLOT THEOREM IN ORDER STATISTICS APPLICATIONS OF A BALLOT THEOREM IN PHYSICS AND IN ORDER STATISTICS

ON THE APPLICATION TO STATISTICS OF AN ELEMENTARY THEOREM IN PROBABILITY A THEOREM IN TREND ANALYSIS

ON A THEOREM OF BAHADUR AND GOODMAN

INTERVALS FOR THE MEAN

A GENERALIZATION OF A THEOREM OF BALAKRISHNAN

AN EXTENSION OF A THEOREM OF CHOW AND RO88INS ON SEQUENTIAL CONFIDENCE ON A THEOREM OF CRAMER AND LEADBETTER

A POTENTIAL THEORETIC PROOF OF A THEOREM OF DERMAN AND VEINOTT ON A THEOREM OF DOBRUSHIN

STATISTICS

NOTE ON A THEOREM OF DYNKIN ON THE DIMENSION OF SUFFICIENT

CHING PROCESSES TO A BRANCH/ EXTENSIONS OF A LIMIT THEOREM OF EVERETT, ULAM AND HARRIS ON MULTITYPE 8RAN ON A THEOREM OF HOEL AND LEVINE ON EXTRAPOLATION

NOTE ON THE ERGODIC THEOREM OF INFORMATION THEORY

ESTIMATES IN EXPONENTIAL POPULATIONS EXPONENTIAL POPULATIONS

ON A THEOREM OF KARLIN REGARDING ADMISSIBILITY OF LINEAR

ON A THEOREM OF KARLIN REGARDING ADMISSIBLE ESTIMATES FOR INFINITE EXPECTATI/A SHORT PROOF OF A KNOWN LIMIT THEOREM FOR SUM OF INDEPENDENT RANDOM VARIABLES WITH

NOTE ON A THEOREM OF KINGMAN AND A THEOREM OF CHUNG

A THEOREM OF LEVY AND A PECULIAR SEMIGROUP

MARTINCALE EXTENSIONS OF A THEOREM OF MARCINKIEWICZ AND ZYGMUND

THE MARTINGALE VERSION OF A THEOREM OF MARCINKIEWICZ AND ZYGMUND

THE TAIL SICMA-FIELD OF A MARKOV CHAIN AND A THEOREM OF OREY

ON A THEOREM OF RENYI CONCERNING MIXING SEQUENCES OF SETS

ON AN OPERATOR LIMIT THEOREM OF ROTA

ON A THEOREM OF SKOROHOD

VARIATIONS ON A RENEWAL THEOREM OF SMITH

CORRECTION TO 'A PROOF OF WALD'S THEOREM ON CUMULATIVE SUMS' 591245

206
MULTIVARIATE LINEAR RECRESSION

REGRESSION

CORRECTIONS TO 'A THEOREM ON FACTORIAL MOMENTS AND ITS APPLICATIONS' 50

A THEOREM ON LEAST SQUARES AND VECTOR CORRELATION IN

A THEOREM ON LEAST SQUARES IN MULTIVARIATE LINEAR

A THEOREM ON RANK ORDERS FOR TWO CENSORED SAMPLES

A THEOREM ON STOPPING TIMES

SHORT PROOF OF DR HARLEY'S THEOREM ON THE CORRELATION COEFFICIENT

A THEOREM ON THE CALTON-WATSON PROCESS

ES

AN EXTENSION OF ROSEN'S THEOREM TO NON-IDENTICALLY DISTRIBUTED RANDOM VARIABL

A GENERALIZATION OF FIELLER'S THEOREM TO THE RATIO OF COMPLEX PARAMETERS

NVARIANTS UNDER MIXING WHICH GENERALIZE DE FINETTI'S THEOREM. CONTINUOUS TIMES PARAMETER

'A FURTHER LOOK AT ROBUSTNESS VIA BAYES'S THEOREM.'

A NEW PROOF OF THE PEARSON-FISHER THEOREM,

(A

CONDITIONED LIMIT THEOREMS

ON DVORETZKY STOCHASTIC APPROXIMATION THEOREMS

STOCHASTIC POINT PROCESSES, LIMIT THEOREMS

A. NOTE ON CHERNOFF-SAVAGE THEOREMS

INCOMPLETE 8LOCK DESIGNS AND SOME NONEXISTENCE THEOREMS

TIME MARKOV BRANCHINC PROCESSES AND RELATED LIMIT THEOREMS

ARKOV 8RANCHINC PROCESSES AND RELATED LIMIT THEOREMS EMBEDDING OF URN SCHEMES INTO CONTINUOUS
NEW CONDITIONS FOR CENTRAL LIMIT THEOREMS (CORR. 69 1855)

IKELIHOOD ESTIMATOR OF AN UNKNOWN PARAMETER/ SOME THEOREMS AND SUFFICIENCY CONDITIONS FOR THE MAXIMUM-L
IKELIHOOD ESTIMATOR OF AN UNK/ CORRIGENDA TO 'SOME THEOREMS AND SUFFICIENCY CONDITIONS FOR THE MAXIMUM-L

FOR NON-HOMOGENEOUS MARKOV CHAINS

PROCESS

651069

VARIABLES

$S$ AND A RELATED TEST THEOREMS CONCERNING EISENHART'S MODEL II

SOME THEOREMS CONCERNING THE STRONG LAW OF LARGE NUMBERS

ON RECENT THEOREMS CONCERNINC THE SUPERCRITICAL GALTON-WATSON

SOME RENYI TYPE LIMIT THEOREMS FOR EMPIRICAL DISTRIBUTION FUNCTIONS, CORR. CENTRAL LIMIT THEOREMS FOR FAMILIES OF SEQUENCES OF RANDOM

LIMIT THEOREMS FOR FUNCTIONS OF SHORTEST TWO-SAMPLE SPACING

ON LIMIT THEOREMS FOR GAUSSIAN PROCESSES

WATSON PROCESSES

ADDITIONAL LIMIT THEOREMS FOR INDECOMPOSABLE MULTIDIMENSIONAL GALTON-

SOME CONVERGENCE THEOREMS FOR INDEPENDENT RANDOM VARIABLES

WITH APPLICATIONS IN ACCEPTANCE SAMPLING

TWO THEOREMS FOR INFERENCES ABOUT THE NORMAL

CONVERGENCE THEOREMS FOR MULTIPLE CHANNEL LOSS PRO8A8ILITIES

SOME LIMIT THEOREMS FOR NON-HOMOGENEOUS MARKOV CHAINS

LIMIT THEOREMS FOR QUEUES WITH TRAFFIC INTENSITY ONE

LIMIT THEOREMS FOR RANDOMLY SELECTED PARTIAL SUMS

AMS $64 \quad 866$

AMS 661825

AMS 681675

AMS $63 \quad 390$

JASA $68 \quad 677$

AMS 641781

AMS 691114

AMS 651041

AMS $67 \quad 25$

AMS $69 \quad 144$

AMS 691845

AMS 641356

JRSSB $65 \quad 130$

BIOKA56 85

BIOKA61 224

AMS 66

AMS $61 \quad 1337$

AMS 69667

AMS $66 \quad 682$

AMS $67 \quad 585$

AMS $68 \quad 1391$

AMS 691474

AMS 67992

AMS $65 \quad 1627$

AMS $61 \quad 612$

AMS 661809

AMS $69 \quad 216$

AMS 661844

AMS 671552

AMS $69 \quad 427$

AMS $67 \quad 725$

AMS 641291

AMS $61 \quad 257$

AMS 651864

AMS 682094

AMS $68 \quad 155$

AMS 611344

AMS 61620

JASA $66 \quad 413$

JASA $67 \quad 1494$

AMS $65 \quad 316$

AMS 641348

BIOKA58 57]

AMS $66 \quad 695$

AMS $68 \quad 897$

JRSSB $67 \quad 126$

I AMS $63 \quad 1194$ 8IOKA63 546 AMS $64 \quad 817$

(8IOKA52 215 AMS $63 \quad 1147$ AMS $66 \quad 1534$ AMS $67 \quad 771$

AMS 691116

AMS 661048

AMS 681801

AMS $69 \quad 319$ BIOKA55 342 IOKA56 497 AMS $61 \quad 261$ AMS 64566 AMS 682098 AMS $65 \quad 322$ AMS $63 \quad 439$ AMS $67 \quad 108$

AMS $65 \quad 304$ AMS $66 \quad 1463$ AMS 661482 JASA $64 \quad 89$ AMS $64 \quad 1746$ AMS $63 \quad 260$ AMS 661224 AMS 651437 AMS $62 \quad 85$ CHARACTERTZATION THEOREMS FOR SOME UNIVARIATE PROBABILITY DISTRIBUTION JRSS864 286 CHARACTERIZATION THEOREMS FOR SOME UNIVARIATE PRO8ABILITY DISTRI8UTION JRSS866 143 SOME STRUCTURE THEOREMS FOR STATIONARY PROBABILITY MEASURES ON FINIT AMS 64550 LIMIT THEOREMS FOR STOPPED RANDOM WALKS LIMIT THEOREMS FOR STOPPED RANDOM WALKS, II LIMIT THEOREMS FOR STOPPED RANDOM WALKS, III

SOME LIMIT THEOREMS FOR THE DODGE-ROMIG LTPD SINCLE SAMPLING

INSPECTION PLANS

A NOTE ON LIMIT THEOREMS FOR THE ENTROPY OF MARKOV CHAINS

LIMIT THEOREMS FOR THE MAXIMUM TERM IN STATIONARY SEQUENCES

LIMIT THEOREMS FOR THE MULTI-URN EHREFEST MODEL

SOME BASIC THEOREMS OF DTSTRI8UTTON-FREE STATISTICS

SOME SMIRNOV TYPE THEOREMS OF PROBABILITY
AMS 641332

AMS $66 \quad 860$

AMS 661510

TECH $62 \quad 497$

AMS $66 \quad 522$

AMS 64502

AMS $68 \quad 864$

AMS $64 \quad 150$

AMS 651113 
MINIMAX THEOREMS ON CONDITIONALLY COMPACT SETS

SOME THEOREMS ON FUNCTIONALS OF MARKOV CHAINS

AMS $63 \quad 1536$

SOME THEOREMS ON MATRIX DIFFERENTIATION WITH SPE

ENCE TO KRONECKER MATRIX PRODUCTS WITH A V/ AN APPLICATION FOR THE SOBOLEV IMBE
INFINITE

INTERSECTION

POPULATION MODELS

GENETICS, CORR. 63352

INSPECTION PLAN

SYSTEM OF RANDOMIZATION FOR CROSS-CLASSIFICATIONS

RATE

THE UNRELATED QUESTION RANDOMIZED RESPONSE MODEL, THEORETICAL FRAMEWORK

IN SAMPLES FROM BIVARIATE NON-NORMAL POPULATIONS. I. THEORETTCAL INVESTIGATION /REGRESSION COEFFICIENTS BIOLOGICAL SYSTEMS

ON THEORETICAL MODELS FOR COMPETITIVE AND PREDATORY

RANDOM DISPERSAL IN THEORETICAL POPULATIONS

'STUDENT' AND SMALL SAMPLE THEORY

ON THE RUIN PROBLEM OF COLLECTIVE RISK THEORY

RANDOMIZED ROUNDED-OFF MULTIPLIERS IN SAMPLING THEORY

AN INVARIANCE PRINCIPLE IN RENEWAL THEORY

COMBINATORIAL RESULTS IN FLUCTUATION THEORY

APPLICATION OF METHODS IN SEQUENTIAL ANALYSIS TO DAM THEORY

SOME RECENT ADVANCES IN SAMPLING THEORY

ON THE AXIOMS OF INFORMATION THEORY

THE LINEAR HYPOTHESIS AND LARGE SAMPLE THEORY

SUFFICIENCY IN SAMPLING THEORY

ON MOMENT GENERATING FUNCTIONS AND RENEWAL THEORY

ON A PROBLEM IN NON-LINEAR PREDICTION THEORY

ON ABSOLUTELY CONTINUOUS COMPONENTS AND RENEWAL THEORY

AN OLD APPROACH TO FINITE POPULATION SAMPLING THEORY HIERARCHICAL BIRTH AND DEATH PROCESSES. I, THEORY A CONTRIBUTION TO COUNTER THEORY ON DISCRETE STABLE POPULATION THEORY

FOR OPTIMALITY AND VALIDITY AND SIMPLE LEAST SQUARES THEORY WIDE-SENSE MARKOV PROCESSES AND PREDICTION THEORY TO NON-OPTIMAL DESIGN IN BAYESIAN DECISION THEORY SOLUTION OF THE INTEGRAL EQUATION OF RENEWAL THEORY OF MULTI-SIZED PARTICLES, AN APPLICATION OF RENEWAL THEORY FOR A VARIABLE CHANCE OF INFECTION IN CHAIN-BINOMIAL THEORY FOR CROSS CLASSIFICATIONS, 111. APPROXIMATE SAMPLINC THEORY ESTIMATION AND CERTAIN PROBLEMS OF ADDITIVE NUMBER THEORY FOR A NATURAL CENERALIZATION OF CLASSICAL RENEWAL THEORY OF HICH EFFICIENCY IN BIVARIATE EXTREME VALUE THEORY AND RELATED DISTRIBUTIONS, AND A PARADOX IN FIDUCIAL THEORY AND ITS APPLICATIONS TO MULTIVARIATE DISTRIBUTION THEORY OF THE HANKEL TRANSFORM IN STATISTICS. I. GENERAL THEORY AND EXAMPLES

HALF-RECTIFIED TRUNCATED DISTRIBUTIONS, SAMPLING THEORY AND HYPOTHESIS TESTINC FIDUCIAL THEORY AND INVARIANT ESTIMATION FIDUCIAL THEORY AND INVARIANT PREDICTION RENEWAL THEORY AND ITS RAMIFICATIONS (WITH DISCUSSION)

RECENT ADVANCES IN SAMPLE SURVEY THEORY AND METHODS ALTERNATIVES IN MODEL I ANALYSIS OF VARIANCE, NORMAL THEORY AND NONPARAMETRIC ERICAL INFORMATION IN QUANTITATIVE ANALYSIS. GENERAL THEORY AND THE CASE OF SIMPLE ORDER /ION OF NON-NUM DISCUSSION) THE DECISION THEORY APPROACH TO SAMPLINC INSPECTION (WITH PROBLEMS IN MENTAL TEST THEORY ARISINC FROM ERRORS OF MEASUREMENT CONTRIBUTIONS TO CENTRAL LIMIT THEORY FOR DEPENDENT VARIABLES

MULTIVARIATE THEORY FOR CENERAL STEPWISE METHODS

STATES ISTRIBUTION THEORY FOR MARKOV CHAINS WITH A DENUMERAB

A SAMPLINC TEST OF THE CHI-SQUARE THEORY FOR PROBABILITY CHAINS A THEORY FOR RECORD LINKAGE

A NEW ESTIMATION THEORY FOR SAMPLE SURVEYS RANDOM ALLOCATION DESICNS II. APPROXIMATE THEORY FOR SIMPLE RANDOM ALLOCATION A POTENTIAL THEORY FOR SUPERMARTINGALES

COMPARISON OF REPLACEMENT POLICIES, AND RENEWAL THEORY IMPLICATIONS

APPLICATIONS OF PROBABILITY THEORY IN CRIMINALISTICS

APPLICATIONS OF PROBABILITY THEORY IN CRIMINALISTICS, II

MONTE CARLO METHODS

USE OF WILCOXON TEST THEORY IN ESTIMATINC THE DISTRIBUTION OF A RATIO BY

LARCE DEVIATIONS THEORY IN EXPONENTIAL FAMILIES
TUDY OF DEPARTURES FROM ASSUMPTION (W/ PERMUTATION THEORY IN THE DERIVATION OF ROBUST CRITERIA AND THE S JR RENEWAL THEORY IN THE PLANE

CIRCULAR DISTRIBUTION ASYMPTOTIC THEORY OF A CLASS OF TESTS FOR UNIFORMITY OF A STATISTICAL THEORY OF A HIGH-SPEED PHOTOELECTRIC PLANIMETER SOME FURTHER RESULTS IN THE NON-EQUILIBRIUM THEORY OF A SIMPLE QUEUE UNIQUENESS OF A RESULT IN THE THEORY OF ACCIDENT PRONENESS DISCRETE DISTRIBUTION WITH SPECIAL REFERENCE TO THE THEORY OF ACCIDENT PRONENESS A TEST FOR 'INTRINSIC CORRELATION' IN THE THEORY OF ACCIDENT PRONENESS
A MATHEMATICAL THEORY OF ANIMAL TRAPPINC
A CONTRIBUTION TO THE THEORY OF BULK QUEUES A CONTRIBUTION TO THE THEORY OF BULK QUEUES
ATH PROCESSES, AND THE THEORY OF CARCINOCENESIS

ON THE THEORY OF CLASSICAL REGRESSION AND DOUBLE SAMPLINC

ESTIMATION

$S$ WHEN ONE IS DICHOTOMIZED

DISCUSSION)

THE THEORY OF CORRELATION BETWEEN TWO CONTINUOUS VARIABLE LIMIT DISTRIBUTION IN THE THEORY OF COUNTERS, CORR. 621466 THEORY OF CYCLIC ROTATION EXPERIMENTS (WITH 
CODES

LINEAR RECRESSION PARAMETERS

FOR THE MEAN

OF LOCATION

ON A BOUND USEFUL IN THE THEORY OF FACTORIAL DESICNS AND ERROR CORRECTING

ON THE ASYMPTOTIC THEORY OF FIXED-SIZE SEQUENTIAL CONFIDENCE BOUNDS FOR

ON THE ASYMPTOTIC THEORY OF FIXED-WIDTH SEQUENTIAL CONFIDENCE INTERVALS

THE ASYMPTOTIC THEORY OF CALTON'S TEST AND A RELATED SIMPLE ESTIMATE TOWARDS A THEORY OF GENERALIZED BAYES TESTS

INTECER PROCRAMMINC AND THE THEORY OF CROUPINC

SOME RESULTS IN THE THEORY OF INVENTORY

FOUNDATIONS FOR THE THEORY OF LEAST SQUARES

ASTIC AND ITS APPLICATION TO THE ANALYSIS OF/ THE THEORY OF LEAST SQUARES WHEN THE PARAMETERS ARE STOCH BI

SOME CONTRIBUTIONS TO THE THEORY OF MACHINE INTERFERENCE

SIMULTANEOUS TEST PROCEDURES, SOME THEORY OF MULTIPLE COMPARISONS

SOME PROBLEMS IN THE THEORY OF OPTIMAL STOPPING RULES

A MATHEMATICAL THEORY OF PATTERN RECOGNITION

SOME FURTHER RESULTS IN THE THEORY OF PEDESTRIANS AND ROAD TRAFFIC

CORRIGENDA TO 'SOME FURTHER RESULTS IN THE THEORY OF PEDESTRIANS AND ROAD TRAFFIC'

GENERAL THEORY OF PRIME-POWER LATTICE DESICNS

XIII. ISAAC TODHUNTER'S HISTORY OF THE MATHEMATICAL THEORY OF PROBABILITY /PROBABILITY AND STATISTICS.

LATTICE' 58256 CORRECTIONS TO 'THE THEORY OF PROBABILITY DISTRIBUTIONS OF POINTS ON A

SOME PROBLEMS IN THE THEORY OF PROVISIONING AND OF DAMS

A BIBLIOGRAPHY ON THE THEORY OF QUEUES

WALK (IN CONTINUOUS TIME) AND ITS APPLICATION TO THE THEORY OF QUEUES

OF THE BALLOT PROBLEM AND ITS APPLICATION IN THE THEORY OF QUEUES

CEOMETRIC DISTRIBUTIONS IN THE THEORY OF QUEUES (WITH DISCUSSION)

A NOTE ON THE THEORY OF QUICK TESTS

CHAIN

A CONVEXITY PROPERTY IN THE THEORY OF RANDOM VARIABLES DEFINED ON A FINITE MARKOV SOME QUESTIONS OF DISTRIBUTION IN THE THEORY OF RANK CORRELATION

ARIATE ONE SAMPLE PROBLEM

ES FROM A FINITE POPULATION
ON THE THEORY OF RANK ORDER TESTS FOR LOCATION IN THE MULTIV ASYMPTOTIC THEORY OF REJECTIVE SAMPLING WITH VARYING PROBABILITI A STATISTICAL THEORY OF REMNANTS

THE THEORY OF RISK (WITH DISCUSSION)

SOME ACCEPTANCE SAMPLINC PLANS BASED ON THE THEORY OF RUNS

A UNIFIED THEORY OF SAMPLING FROM FINITE POPULATIONS

SOME THEORY OF SAMPLING WHEN THE STRATIFICATION ON THE THEORY OF SCREENING FOR CHRONIC DISEASES

TREATMENT OF THE NON-EQUILIBRIUM THEORY OF SIMPLE QUEUES BY MEANS OF CUMULATIVE PROBAB

ILITIES

AN APPLICATION OF BIORTHONORMAL EXPANSIONS IN THEORY OF STOCHASTIC PROCESSES

PROBLEMS IN THE PROBABILITY THEORY OF STORACE SYSTEMS (WITH DISCUSSION)

THE ERGODIC THEORY OF SUBADDITIVE STOCHASTIC PROCESSES

A GENERAL THEORY OF SUBJECTIVE PROBABILITIES AND EXPECTED

UT ILITIES

ANCE ON THE DIMENSIONALITY OF NORMAL MU/ ALGEBRAIC THEORY OF THE COMPUTING ROUTINE FOR TESTS OF SIGNIFIC JR
ON SECOND VARIATE DIFFERENCES DISTRIBUTION THEORY OF TWO ESTIMATES FOR STANDARD DEVIATION BASED BI APPLICATIONS OF MULTIVARIATE POLYKAYS TO THE THEORY OF UNBIASED RATIO-TYPE ESTIMATION

EDWARD C. POSNER, 'THE APPLICATION OF EXTREME VALUE THEORY TO ERROR FREE COMMUNICATION'

COMMENTS TO JASA $57 \quad 511$ THE APPLICATION OF EXTREME VALUE THEORY TO ERROR-FREE COMMUNICATION

AL LATIN SQUARES

DUPLICATION

ONTENCE OF ORTHOGON B ERCODIC THEORY WITH RECURRENT WEIGHTS

ON A PARTIAL DIFFERENTIAL EQUATION OF EPIDEMIC THEORY. I.

MBINATORIAL RESULTS IN MULTI-DIMENSIONAL FLUCTUATION THEORY, CORR. 64924

$\begin{array}{ll}\text { SPACINGS } & \text { CONTRIBUTIONS TO SAMPLE SPACINGS THEORY, I. LIMIT DISTRIBUTIONS OF SUMS OF RATIOS OF } \\ \text { ND TWO-SAMPLE PR/ CONTRIBUTIONS TO SAMPLE SPACINGS THEORY, II. TESTS OF THE PARAMETRIC GOODNESS OF FIT A }\end{array}$

CONTRIBUTIONS TO SAMPLE SPACINGS THEORY, II. TESTS OF THE PARAMETRIC
A PERSISTENCE PROBLEM IN RENEWAL THEORY, ROBERT THE BRUCE'S SPIDER

SCREENING SYSTEM FOR ANTI-CANCER AGENTS BASED ON THE THERAPEUTIC INDEX

LES MANQUANTS DANS L'ESSAI THERAPEUTIQUE

THE MULTTPLE-RECAPTURE CENSUS II, ESTIMATION WHEN THERE IS IMMIGRATION OR DEATH

PERSISTENCE IN A CHAIN OF MULTIPLE EVENTS WHEN THERE IS SIMPLE DEPENDENCE THE ROLE OF SUFFICIENCY AND OF ESTIMATION IN THERMODYNAMICS

ERRORS OF THE THIRD KIND IN STATISTICAL CONSULTING

THE THIRD MOMENT OF CINI'S MEAN DIFFERENCE

THE THIRD MOMENT OF KENDALL'S TAU IN NORMAL SAMPLES

TWO THIRD ORDER ROTATABLE DESIGNS IN FOUR DIMENSIONS THIRD ORDER ROTATABLE DESIGNS IN THREE DIMENSIONS.

SOME SPECIFIC DESICNS THIRD ORDER ROTATABLE DESIGNS IN THREE FACTORS.

ANALYSIS

THIS JOURNAL (VOL. 1B, NO. 2, 1956)

IN THE HISTORY OF PROBABILITY AND STATISTICS. XVIII. THOMAS YOUNG ON COINCIDENCES ON HOROVITZ AND THOMPSON'S T-ONE CLASS OF LINEAR ESTIMATION

STUDIES BIOKAGB 249 AMS $6718 \mathrm{~B} 2$ PROVINC THE MEAN USEFUL LIFE OF ITEMS BY ELIMINATING THOSE WITH SHORT LIVES OF BALANCED INCOMPLETE BLOCK DESIGNS OF BLOCK SIZE THREE

AN EXTENSION OF THE TRIANGULAR ASSOCIATION SCHEME TO THREE ASSOCIATE CLASSES ON THE POSSIBILITY OF IM TECH 61281 BALANCED SETS TECH 65561 JRSSB $66 \quad 361$ TECH $64 \quad 343$ TECH 63421 TECH $67 \quad 472$ TECH $62 \quad 187$ JASA 69207 JRSSB 65450 TECH $59 \quad 1$ TECH $62 \quad 219$ COMPONENTS FOR FOUR COM
LATIN SQUARE OMPOSITION OF A THREE COMPONENT LIQUTD MIXTURE

THREE DIFFERENT PROCEDURES FOR ESTTMATTNG VAR THRE DIMENSIONAL MODELS OF EXTREME VERTICES DESIGNS
THRE FACTOR ADDITIVE DESIGNS MORE CENERAL THAN THE

LAMST AND THE HYPOTHESES OF NO THREE FACTOR
MIXTURE DESICNS FOR THREE FACTORS

RESPONSE SURFACE DESICNS FOR THREE FACTORS AT THREE LEVELS

THIRD ORDER ROTATABLE DESICNS IN THREE FACTORS. ANALYSIS COVARIANCE MATRIX AND WILKS' CRITERION FOR TESTS OF THREE HYPOTHESES /S OF THE RATIOS OF THE ROOTS OF A AMS 69 NO. 6 ORMAL POPULATION WITH KNOWN VARIANCE A SEQUENTIAL THREE HYPOTHESIS TEST FOR DETERMINING THE MEAN OF A N VARIABLES

VARIABLES SOME NEW THREE LEVEL DESIGNS FOR THE STUDY OF QUANTITATIVE

ERRATA, 'SOME NEW THREE LEVEL DESIGNS FOR THE STUDY OF QUANTITATIVE RESPONSE SURFACE DESIGNS FOR THREE FACTORS AT THREE LEVELS
AMS 671365 TECH $61 \quad 576$ TECH 59 TECH $60 \quad 455$ 
RESPONSE SURFACE DESICNS FOR FACTORS AT TWO AND THREE LEVELS

TECH $68 \quad 177$

ON THE MONOTONICITY PROPERTY OF THE THREE MAIN TESTS FOR MULTIVARIATE ANALYSIS OF VARIANC JRSSB64 77 IMATINC A SKEW DENSITY WHOSE LEFT TERMINAL AND FIRST THREE MOMENTS ARE KNOWN /ARSON DENSITIES FOR APPROX BIOKAG8 559 BAYESIAN APPLICATIONS THREE MULTIDIMENSIONAL-INTECRAL IDENTITIES WITH

AMS 681615 ON THE CHOICE OF THE BEST AMONCST THREE NORMAL POPULATIONS WITH KNOWN VARIANCES

BIOKA58 436 AND INFECTIOUS PERIODS OF MEASLES, II. FAMILIES WITH THREE OR MORE SUSCEPTIBLES /ESTIMATINC THE LATENT BIOKA56 322 ON THREE PROCEDURES OF SAMPLING FROM FINITE POPULATIONS BIOKA68 438 NOTE ON THE THREE SERIES THEOREM

PLANT COMPETITION, THREE SPECIES PER POT A CRITICAL COMPARISON OF THREE STRATECIES OF COLLECTINC DATA FROM HOUSEHOLDS JASA 67976 CENERALIZED BEHRENS-FISHER DISTRIBUTION INVOLVING THREE VARIATES BAYESIAN ANALYSIS OF A THREE-COMPONENT HIERARCHICAL DESTCN MODEL

POPULATIONS NOTE ON A THREE-DECISION TEST FOR COMPARING TWO BINOMIAL A THREE-DIMENSIONAL CLUSTER PROBLEM APPROXIMATION TO THE BIOKAG9 NO.3 BI0KA67 109 BIOKA59 106 BIOKA68 258

GENERALIZED CLASSICAL LINEAR ESTIMATORS IN A LEADINC THREE-EQUATION CASE /HE EXACT DISTRIBUTIONS OF THE JASA 64 881 GENERALIZED CLASSICAL LINEAR ESTIMATORS IN A LEADINC THREE-EQUATION CASE /SAMPLE FREQUENCY FUNCTIONS OF JASA 63 I6I SIMPLE METHODS FOR ANALYZING THREE-FACTOR INTERACTION IN CONTINGENCY TABLES JASA 64319

ANALYSIS OF A POINT-SOURCE EPIDEMIC THE THREE-PARAMETER LOGNORMAL DISTRIBUTION AND BAYESIAN JASA 6372 SOME TESTS OF HYPOTHESES CONCERNINC THE THREE-PARAMETER WEIBULL DISTRIBUTION

VARIANCES OF ESTIMATES OF VARIANCE COMPONENTS IN A THREE-WAY CLASSIFICATION MAXIMUM LIKELIHOOD IN THREE-WAY CONTINGENCY TABLES

JASA $68 \quad 853$ BIOCS66 553 JRSSB 63220

E ESTIMATES OF VARIANCE COMPONENTS IN THE UNBALANCED THREE-WAY NESTED CLASSIFICATION /NG VARIANCES OF TH AMS 63 52I LIFE FOR A WEIBULL MODEL WITH PROGRESSIVE C/ EXACT THREE, ORDER STATISTIC CONFIDENCE BOUNDS ON RELIABLE JASA 69 306 IVE SETTING WILLIAM D. SUDDERTH A NOTE ON THRIFTY STRATEGIES AND MARTINGALES IN A FINITELY ADDI AMS 69 NO. 6 EXPERIENCE, AND GAINS AND LOSSES IN HUMAN CAPITAL THROUGH MIGRATION THE SUM OF SQUARES OF NORMAL SCORES THE CURVE THROUGH THE EXPECTED VALUES OF ORDERED VARIATES AND THE DISTRIBUTION OF KENDALL'S SCORE S FOR A PAIR OF TIED RANKINGS NOTE ON SOME SQUARED RANK TESTS WITH EXISTING TIES DISTRIBUTIONS FOR THE WILCOXON STATISTIC WITH TIES IFICATION OF KENDALL'S TAU FOR THE CASE OF ARBITRARY TIES IN BOTH RANKINGS
A TREATMENT OF TIES IN PAIRED COMPARISONS IFICATION OF KENDALL'S TAU FOR THE CASE OF ARBITRARY TIES IN BOTH RANKINGS
A TREATMENT OF TIES IN PAIRED COMPARISONS

JASA $67 \quad 875$ BIOKA66 252 BIOKA60 151 TECH $67 \quad 312$ EXACT AND APPROXIMATE JASA 61293 ON OF THE BRADLEY-TERRY MODEL (CORR. 68 1550)
THE AVERAGE RANK CORRELATION COEFFICIENT FOR TIES IN RANKINCS REMARKS ON ZEROS AND TIES IN THE WILCOXON SIGNED RANK PROCEDURE THE TREATMENT OF TIES IN THE WILCOXON TEST

THE EFFECT OF TIES ON THE MOMENTS OF RANK CRITERIA THE WILCOXON, TIES, AND THE COMPUTER

A RANDOM WALK IN WHICH THE STEPS OCCUR RANDOMLY IN TIME AUTOMATIC WINDING MACHINES WITH CONSTANT PATROLLINC TIME ABOUT PARAMETERS WHICH ARE SUBJECTED TO CHANGES OVER TIME

OF A MARKOV CHAIN AND THE TRANSITION TO CONTINUOUS TIME NORMAL DISTRIBUTION WHICH IS SUBJECTED TO CHANGES IN TIME EUING PROCESS WITH RECURRENT INPUT AND GAMMA SERVICE TIME RRENCE IN TWO SERTES OF EVENTS OCCURRING RANDOMLY IN TIME SOME STOCHASTTC MODELS RELATING TIME SOME STOCHASTIC MODELS RELATING TIME AND DOSAGE IN RESPONSE CURVES
FINITE STOPPING TIME AND FINITE EXPECTED STOPPING TIME THE EFFICIENCY OF JRSSB59 381 INFERENCE PROBLEMS AMS 68840 THE FREQUENCY COUNT AMS 6141 $\begin{array}{lllll}\text { ESTIMATING THE CURRENT MEAN OF A AMS } & 64 & 999 \\ \end{array}$ $\begin{array}{rlrrr}\text { THE TRANSIENT BEHAVIOR OF A SINGLE SERVER QU AMS } 61 & 1286 \\ \text { /ENCE OF TWO TESTS OF EQUALITY OF RATE OF UCCU BIOKA58 } & 267\end{array}$ BIOCS65 583 JRSSB65 284 DIRECTIONALLY PATROLLED BY ONE OPERATOR WHEN WALKINC TIME AND REPAIR TIMES ARE CONSTANTS /MACHINES UNI- JRSSB57 I66 BACTERIAL EXTINCTION TIME AS AN EXTREME VALUE PHENOMENON CONSIDERING STATISTICAL AND TIME AVERAGES IN A REGULATION PROBLEM BI0CS67 835 JRSSB $67 \quad 475$ THE INTERVALS BETWEEN REGULAR EVENTS DISPLACED IN TIME BY INDEPENDENT RANDOM DEVIATIONS OF LARGE DISPER JRSSB6I 476 CONTINUUM A RANDOM TTME CHANGE RELATING SEMI-MARKOV AND MARKOV PROCESSES INPUT AND GENERAL SERVICE TIMES THE FIRST PASSAGE TIME DENSITY FOR HOMOGENEOUS SKIP-FREE WALKS ON THE

AMS $68 \quad 358$ AMS 631003 AMS 621340 AMS 62767 BIOCS67 227 JRSSB $66 \quad 477$

ON THE GENERAL TIME DEPENDENT QUEUE WTTH A SINGLE SERVER A NEW RESPONSE TIME DISTRIBUTION

A TECHNIQUE FOR DISCUSSING THE PASSAGE TIME DISTRIBUTION FOR STABLE SYSTEMS

PROCESS, MARKOV OR POISSON INPUT, GENERAL SERVICE TIME DISTRIBUTION, ONE SERVER

A NOTE ON QUEUEING SYSTEMS WITH ERLANGIAN SERVICE TIME DISTRIBUTIONS ARAMETERS OF MIXED EXPONENTIALLY DISTRIBUTED FAILURE TIME DISTRIBUTIONS FROM CENSORED LIFE TEST DATA /P BIOKA58 504 DISTRIBUTION OF TOTAL SERVICE TIME FOR A FIXED OBSERVATION INTERVAL FIRST PASSAGE TIME FOR A PARTICULAR GAUSSIAN PROCESS WAITING TIME IN BULK SERVICE QUEUES

JASA $62 \quad 376$ AMS 61610 JRSSB55 256 R RANDOM VARIABLES COVARIANCE STATIONARY ON A FINITE TIME INTERVAL PEARSON AND WYNN'S PAPER TIME INTERVALS BETWEEN ACCIDENTS, A NOTE ON MAGUIRE, THE TIME INTERVALS BETWEEN INDUSTRIAL ACCIDENTS BIOKA53 212 BIOKA52 168 DIRECTIONALLY PATROLLED BY ONE OPERATOR WHEN WALKING TIME IS CONSTANT AND REPAIR TIMES ARE VARIABLE /NI- JRSSB57 I73 SOME RESULTS ON MULTITYPE CONTINUOUS TIME MARKOV BRANCHING PROCESSES

OREMS EMBEDDING OF URN SCHEMES INTO CONTINUOUS TIME MARKOV BRANCHING PROCESSES AND RELATED LIMIT THE OF DYNAMIC PROGRAMMINC ON A FINITE SPACE DISCRETE TIME MARKOV PROCESS ON THE ITERATIVE METHOD T ON LEHMANN ALTERNATIVES, CORR. 671309 STOPPING TIME OF A RANK-ORDER SEQUENTIAL PROBABILITY RATIO TES THE INFORMATION IN A RANK-ORDER AND THE STOPPING TIME OF SOME ASSOCIATED SPRT'S TEST OF RANDOMNESS FOR EVENTS OCCURRING IN TIME OR SPACE $\begin{array}{lrr}\text { AMS } & 68 & 347 \\ \text { AMS } & 68 & 1801\end{array}$ AMS 651279 AMS 661154 AMS 681661

A SEQUENTIAL BIOKA56 64 NONPARAMETRIC TESTS FOR SHIFT AT UNKNOWN TIME POINT ERS OF STATISTICAL DISTRIBUTIONS OCCURING AT UNKNOWN TIME POINTS OF SPECTRA AFTER HARD CLIPPING OF GAUSSIAN TIME PROCESSES A TRANSIENT DISCRETE TIME QUEUE WITH FINITE STORAGE

SOME NONPARAMETRIC TESTS FOR COMOVEMENTS BETWEEN TIME SERIES SOME COMMENTS ON SPECTRAL ANALYSIS OF TIME SERIES ON LINEAR ESTIMATION FOR REGRESSION PROBLEMS ON TIME SERIES THE: DEGREE OF RANDOMNESS IN A STATIONARY TIME SERIES SOME NON-PARAMETRIC TESTS FOR M-DEPENDENT TIME SERIES ON FIXED PRECISION ESTIMATION IN TIME SERTES TESTS OF FIT IN TIME SERIES JASA $61 \quad 11$ TECH 61221 AMS 621077 AMS 631253 JASA $65 \quad 134$ AMS 691021 BIOKA52 309 
AN EXACT TEST FOR CORRELATION BETWEEN TIME SERIES

A CHANGE IN LEVEL OF A NON-STATIONARY TIME SERIES

SPECTRAL FACTORIZATION OF MULTIPLE TIME SERIES

LEAST SQUARES RECRESSION ANALYSIS FOR TREND-REDUCED TIME SERIES

EXPONENTIAL SMOOTHING FOR MULTIVARIATE TIME SERIES

LEAST-SQUARES EFFICIENCY FOR VECTOR TIME SERIES

ISTRIBUTIONS OF CORRELATION COEFFICIENTS IN ECONOMIC TIME SERIES

THE EXTRAPOLATION OF A SPECIAL CLASS OF STATIONARY TIME SERIES

OF THE INNOVATION VARIANCE OF A STATIONARY TIME SERIES

ANALYSIS OF RELATIONSHIPS BETWEEN AUTOCORRELATED TIME SERIES

POWERS OF CERTAIN TESTS OF GOODNESS OF FIT FOR TIME SERIES

ON THE POWERS OF THE RECORDS TESTS FOR TREND IN A TIME SERIES

CORRELATION SUITABLE FOR USE WITH NONSTATIONARY TIME SERIES

TISTICS USEFUL IN THE ANALYSIS OF JOINTLY STATIONARY TIME SERIES

FOR THE COMPATIBILITY OF CORRELATION STRUCTURES IN TIME SERIES

LTI-TERM PREDICTORS OR CONTROLLERS IN NON-STATIONARY TIME SERIES

TES OF THE SPECTRAL DENSITY FUNCTION OF A STATIONARY TIME SERIES

OSS-CORRELATION COEFFICIENTS IN A COMPLEX STATIONARY TIME SERIES

STS FOR TESTING TREND IN DISPERSION OF A P-DEPENDENT TIME SERIES THE SPECTRAL ANALYSIS OF TIME SERIES

BIOKA55

BIOKA65

BIOKA66 264

JRSSB55 91

JRSSB66 241

JRSSB68 490

D JASA 61637

ON AMS $65 \quad 1426$

ESTIMATION JASA $68 \quad 141$

REGRESSION JRSSB56 240

THE ASYMPTOTIC JRSSB58 143

A SAMPLINC EXPERIMENT JRSSB55 115

A QUICK TEST FOR SERIAL JASA $63 \quad 728$

ON THE DISTRIBUTION OF SOME STA AMS $68 \quad 1849$

AN EXTENSION OF QUENOUILLE'S TEST JRSSB68 180

POLYNOMIAL PROJECTING PROPERTIES OF MU JRSSB65 144

/PTOTICALLY EFFICIENT CONSISTENT ESTIMA JRSSB58 303

/TIONS AND COVARIANCES OF SERIAL AND CR BIOKA63 213 CORR. 69 457/ /OF COX AND STUART'S TE BIOKA68 381 (NITH DISCUSSION) JRSSB57 ANALYSIS

SOME CONSEQUENCES OF SUPERIMPOSED ERROR IN TIME SERIES ANALYSIS

SOME TESTS OF SEPARATE FAMILIES OF HYPOTHESES IN TIME SERIES ANALYSIS

METHODS IN THE STUDY OF VARIANCE FLUCTUATIONS IN TIME SERIES ANALYSIS TECHNIQUES

AMS $61 \quad 951$

BIOKA60 33

BIOKA67 39

JASA $66 \quad 152$

JASA 63993

JASA 62729

BI0CS69 73

THE INTERPOLATION OF TIME SERIES BY RELATED SERIES

ON MEASURES OF CORRELATION IN TIME SERIES OF EVENTS

DJUDGING RELATIVE EFFICIFNCY OF STATISTICAL TESTS IN TIME SERIES REGRESSION ANALYSIS

LOWER BOUNDS FOR MINIMUM COVARIANCE MATRICES IN TIME SERIES REGRESSION PROBLEMS

SOME TECHNIQUES FOR ANALYZINC A SET OF TIME SERIES SUBJECT TO A LINEAR RES

CIENCY OF PROCEDURES FOR SMOOTHING PERIODOGRAMS FROM TIME SERIES WITH CONTINUOUS SPECTRA REGRESSION FOR TIME SERIES WITH ERRORS OF MEASUREMENT

VALUE METHOD FOR A BIOKA66 109 AMS $64 \quad 362$ JASA $63 \quad 513$

ST FOR SPECTRAL DISTRIBUTION FUNCTIONS OF STATIONARY TIME SERIES WITH NORMAL RESIDUALS TIME SERIES WITH PERIODIC STRUCTURE

THE ESTIMATION OF SEASONAL VARIATION IN ECONOMIC TIME SERIES, CORR. 631162

LINEAR, UNBIASED SEASONAL ADJUSTMENT OF ECONOMIC TIME SERIES, CORR. 651250

BIOKA55 143 $\begin{array}{lll}\text { BIOKA63 } & 293 \\ \text { /ODNESS OF FIT TE BIOKA56 } & 257\end{array}$ BIOKA67 403 JASA $63 \quad 31$ THE CONTINUOUS TIME SOLUTION OF THE EQUATIONS OF THE SINGLE CHANNEL J BROWNIAN MOTION FUNCTIONS AN OCCUPATION TIME THEOREM FOR THE ANGULAR COMPONENT OF PLANE

A CONTINUOUS TIME TREATMENT OF A SIMPLE QUEUE USING CENERATING

EXPERIMENTAL DESIGNS TO ADJUST FOR TIME TRENDS QUERY, SAVINCS IN TEST TIME WHEN COMPARING WEIBULL SCALE PARAMETERS

THE RANDOM WALK (IN CONTINUOUS TIME) AND ITS APPLICATION TO THE THEORY OF QUEUES DISCRETE ADDITIVE INPUTS $\begin{array}{ll}\text { PRIORITY QUEUE } & \text { TIME-DEPENDENT } \\ \text { LIABILITY OF CONSUMER SURVEYS OF FINANCIAL HOLDINGS, TIME-DEPOSITS }\end{array}$ THE TIME-DEPENDENT SOLUTION FOR AN INFINITE DAM WITH

QUASI-STATIONARY DISTRIBUTIONS AND TIME-REVERSION IN GENETICS (WITH DISCUSSION) SOME REMARKS ON THE ANALYSIS OF TIME-SERIES

THE COMPARISON OF CORRELATIONS IN TIME-SERIES

A TEST FOR NON-STATIONARITY OF TIME-SERIES

MATRIX OF A CONTINUOUS AUTOREGRESSIVE VECTOR TIME-SERIES DISCRIMINATION IN TIME-SERIES ANALYSIS

DISCUSSION DISTRIBUTION-FREE TESTS IN TIME-SERIES BASED ON ESTIMATION OF PARAMETERS IN TIME-SERIES REGRESSION MODELS APPLICATIONS OF TIME-SHARED COMPUTERS IN A STATISTICS CURRICULUM

DEMAND THE DISTRIBUTION OF THE TIME-TO-EMPTINESS OF A DISCRETE DAM UNDER STEADY TIMATING THE INFINITESIMAL GENERATOR OF A CONTINUOUS TIME, FINITE STATE MARKOV PROCESS

A THEOREM ON STOPPING TIMES

CERTAIN REDUNDANT SYSTEMS WHICH OPERATE AT DISCRETE TIMES MODEL FOR DISTRIBUTIONS OF BIOLOGICAL RESPONCE TIMES OF GAUSSIAN PROCESSES AND THEIR FIRST PASSAGE TIMES TROLLED BY ONE OPERATOR IHEN AHALKNG TIME AND REPAIR TIMES ARE CONSTANTS NE OPERATOR WHEN WALKING TIME IS CONSTANT AND REPAIR TIMES ARE VARIABLE /NI-DIRECTIONALLY PATROLLED BY O JRSSB57 I73 ON THE DISTRIBUTIONS OF THE TIMES BETWEEN EVENTS IN A STATIONARY STREAM OF EVENTS JRSSB69 NO.2 THE DISTRIBUTION OF RESPONSE TIMES IN A BIRTH-DEATH PROCESS

A LIMIT THEOREM FOR PASSACE TIMES IN ERGODIC REGENERATIVE PROCESSES

SOME NUMERICAL RESULTS FOR WAITING TIMES IN THE QUEUE E-SUB-K-M-1

CORRIGENDA, 'SOME NUMERICAL RESULTS FOR WAITING TIMES IN THE QUEUE E-SUB-K-M-1.' BIOKA65 581 AMS $66 \quad$ B66

BIOKA60 202 BIOKA60 484 EDCEMENT OF PRIORITY 611345 FIRST PASSACE TIMES OF A GENERALIZED RANDOM SOME FEATURES OF THE GENERATION TIMES OF INDIVIDUAL BACTERI

A NOTE ON EQUALISING THE MEAN WAITING TIMES OF SUCCESSIVE CUSTOMERS IN A FINITE QUEUE

A QUEUEING PROBLEM IN WHICH THE ARRIVAL TIMES OF THE CUSTOMERS ARE SCHEDULED THE EXISTENCE OF CERTAIN STOPPING TIMES ON BROWNIAN MOTION

WHICH CENERALIZE DE FINETTI'S THEOREM. CONTINUOUS TIMES PARAMETER

S OF RESOLUTION IV FOR THE 2-TO-THE-N AND 2-TO-THE-N TIMES 3-TO-THE-M SERIES TIMID PLAY IS OPTIMAL TIMID PLAY IS OPTIMAL, II TINBERGEN ON ECONOMIC POLICY BIOK A55 $\quad 16$ JRSSB55 262 JRSSB60 108 AMS $69 \quad 715$

INVARIANTS UNDER MIXING AMS 631194 RESULTS ON FACTORIAL DESIGN TEGH 69431 AMS $67 \quad 1281$ AMS $67 \quad 1284$ $\begin{array}{lll}\text { JASA } & 5 B \quad 89\end{array}$ JASA $59 \quad 1$ STATISTICIANS, TODAY AND TOMORROW

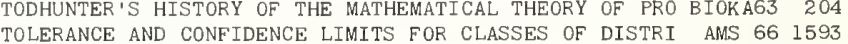
$\begin{aligned} \text { BUTIONS BASED ON FAILURE RATE, CORR. } 67950 & \text { TOLERANCE AND CONFIDENCE LIMITS FOR CLASSES OF DISTRI AMS 66 1593 } \\ \text { A NOTE ON 'THE ESTIMATION OF THE PARAMETERS OF TOLERANCE DISTRIBUTIONS ' } & \text { BIOKA52 } 439\end{aligned}$

QUERY, TOLERANCE INTERVAL IN REGRESSION

EXPECTED-COVER AND LINEAR-UTILITY TOLERANCE INTERVALS

ON TWO-SIDED TOLERANCE INTERVALS FOR A NORMAL DISTRIBUTION

TECH $6 B \quad 207$

JRSSB $66 \quad 57$

AMS $64 \quad 762$

AMS $62 \quad 1167$ 
AN APPROACH TO SIMULTANEOUS TOLERANCE INTERVALS IN RECRESSION

AMS 671536 SIMULTANEOUS TOLERANCE INTERVALS IN RECRESSION

SOME TWO-SIDED DISTRIBUTION-FREE TOLERANCE INTERVALS OF A CENERAL NATURE

BIOKA63 155

JASA $62 \quad 775$

TABLES OF DISTRIBUTION-FREE TOLERANCE LIMITS

SAMPLE SIZE DETERMINATION FOR TOLERANCE LIMITS

QUERY, TOLERANCE LIMITS FOR A BINOMIAL DISTRIBUTION

AMS 641361

TECH $6 \mathrm{~B} \quad 343$

TECH 69201

PLE MEAN AND RANCE OR MEAN RANCE

TABLES FOR TOLERANCE LIMTTS FOR A NORMAL POPULATION BASED ON SAM JASA 5788

AN APPROXIMATION TO TWO-SIDED TOLERANCE LIMITS FOR NORMAL POPULATIONS

TECH $66 \quad 115$

TWO-SIDED TOLERANCE LIMITS FOR NORMAL POPULATIONS, SOME

JASA 69610 TOLERANCE LIMITS FOR THE CLASS OF DISTRIBUTIONS WITH AMS 641561

INCREASING HAZARD RATE

TOLERANCE LIMITS FOR THE CENERALIZED CAMMA

A NOTE ON TOLERANCE LIMITS WITH TYPE I CENSORINC

ULATIVE FUNCTIONS BE CONTINUOUS DISTRIBUTION FREE TOLERANCE LIMITS. ELIMINATION OF REQUIREMENT THAT CUM Th

JASA 651142 TECH $6 \mathrm{~B} \quad 392$ ULATIVE FUNCTIONS BE CONTINUOUS DISTRIBUTION FREE TOLERANCE LIMITS, ELIMINATION OF REQUIR
PARAMETER-FREE AND NON-PARAMETRIC TOLERANCE LIMITS, THE EXPONENTIAL CASE PARAMETER-FREE AND NON-PARAMETRIC TOLERANCE LIMITS, THE EXPONENTIAL CASE
A CENTRAL TOLERANCE RECION FOR THE MULTIVARIATE NORMAL TEĆH 63 51B DISTRIBUTION TECH 6275 JRSSB 68599 AMS $68 \quad 664$ BAYESIAN TOLERANCE RECIONS (WITH DISCUSSION)

UTION CONFIDENCE, PREDICTION, AND TOLERANCE RECIONS FOR THE MULTIVARIATE NORMAL DISTRIB
TABLES OF TOLERANCE-LIMIT FACTORS FOR NORMAL DISTRIBUTIONS CONFIDENCE, PREDICTION, AND TOLERANCE RECIONS FOR THE MULTIVARIATE NORMAL DIS
TABLES OF TOLERANCE-LIMIT FACTORS FOR NORMAL DISTRIBUTIONS
ERRATA, "TABLES OF TOLERANCE-LIMIT FACTORS FOR NORMAL DISTRIBUTIONS. JRSSB64 161 ANCH 61576 OF NUMERICAL INTECRATION TECHNIQUES TO STATISTICAL TOLERANCINC STATISTICIANS, TODAY AND TOMORROW ISN'T MY PROCESS TOO VARIABLE FOR EVOP

AITKEN ESTIMATORS AS A TOOL IN ALLOCATING PREDETERMINED AGGRECATES

A LEARNING MODEL FOR PROCESSES WITH TOOL WEAR THE LADY TASTINC TEA, AND ALLIED TOPICS A BIBLIOCRAPHY ON LIFE TESTING AND RELATED TOPICS MULATION, CAMINC, ARTIFICIAL INTELLIGENCE AND ALLIED TOPIGS ENDENHALL'S BIBLIOGRAPHY ON LIFE TESTING AND RELATED TOPICS, GORR. 651249 FUNCTIONS, AND DIFFUSION TOPOCRAPHIC CORRELATION, POWER-LAW COVARIANCE

DENSITY ESTIMATION IN A TOPOLOGICAL CROUP CTERIZATION OF THE UNIFORM DISTRIBUTION ON A COMPACT TOPOLOGICAL GROUP ON THE TOPOLOGICAL STRUCTURE OF SOME ORDERED FAMILIES OF DISTRIBUTIONS ARKS ON TOPOLOGY AND CONVERGENCE IN SOME ORDERED FAMTLIES FURTHER REMARKS ON TOPOLOGY AND
THE LAST RETURN TO EQUILIBRIUM IN A COIN TOSSING CAME
A REMARK ON THE COIN TOSSINC CAME

A REMARK ON THE COIN TOSSINC CAME

LINEAR APPROXIMATION USING THE CRTERT SELECTION INDICES FOR QUADRATIC MODELS OF TOTAL MERIT ETERS FROM DATA OBTAINED BY MEANS OF BIOKA52 363 ESTIMATING THE TOTAL PROBABILITY OF THE UNOBSERVED OUTCOMES OF AN AMS 68 256 EPTANCE, REJECTION SAMPLING UPON SAMPLE ASSURANCE OF TOTAL PRODUCT QUALITY /SEQUENTIAL BATCHING FOR ACC TECH 6O I9 GEPTANCE-REJECTION SAMPLING UPON SAMPLE ASSURANCE OF TOTAL PRODUCT QUALITY' /SEQUENTIAL BATCHING FOR AC TECH 6I I3I DISTRIBUTION OF TOTAL SERVICE TIME FOR A FIXED OBSERVATION INTERVAL JASA $62 \quad 376$ ITY IN 2-BY-2 CONTINGENCY TABLES WITH SMALL MARGINAL TOTALS/LE METHOD OF CALCULATING THE EXACT PROBABIL BIOKA55 522 SIMULTANEOUS ESTIMATION BY PARTIAL TOTALS FOR COMPARTMENTAL MODELS 641297 ESTIMATION OF MEANS AND TOTALS FROM FINITE POPULATIONS OF UNKNOWN SIZE, CORR. JASA 6261 PROBABILISTTC COMPLETION OF A KNOCKOUT TOURNAMENT INFERENCE FROM A KNOCKOUT TOURNAMENT

ON THE PROBABILITY OF WINNINC WITH DIFFERENT TOURNAMENT PROCEDURES ROUND-ROBIN TOURNAMENT SCORES

PAIRWISE COMPARISON AND RANKING IN TOURNAMENTS

A GOMPARISON OF THE EFFECTIVENESS OF TOURNAMENTS

TOURNAMENTS AND PAIRED COMPARISONS

TOWARDS A THEORY OF GENERALIZED BAYES TESTS

AMS $66 \quad 495$

AMS $68 \quad 583$

JASA $63 \quad 1064$

BIOKA69 295

AMS $63 \quad 501$

BIOKA60 253

BIOKA59 139

AMS 681

TATISTICS. IX. BIOCRAPHICAL NOTE FOR T. BAYES' ESSAY TOWARDS SOLVINC A PROBLEM IN THE DOCTRINE OF CHANCES. BIOKA58 293 (REPRODUCED FROM PHIL. TRANS. ROY, SOC 17/ ESSAY TOWARDS SOLVINC A PROBLEM IN THE DOGTRINE OF CHANCES. BIOKA58 296

NOTES. THE STATISTICAL ANALYSIS OF A RADIO-ACTIVE TRACER EXPERIMENT TO DETERMINE ROOT ACTIVITY IN POTAT BIOCS68 717 VARIABLES TRACES AND CUMULANTS OF QUADRATIC FORMS IN NORMAL JRSSB54 247

ENTRAL MULTIVARIATE BETA DISTRIBUTION AND MOMENTS OF TRACES OF TWO MATRICES SOME RESULTS ON THE NON-C AMS 65 I5II ANALYSIS OF VITAL STATISTICS BY CENSUS TRACT

TO 'CORRELATED RANDOM NORMAL DEVIATES' PUBLISHED IN TRACTS FOR COMPUTERS, NO. 26 JASA $59 \quad 730$

CORRIGENDA BIOKA56 496 TITATIVE TESTS FOR STOCK PRICE CENERATINC MODELS AND TRADING FOLKLORE SOME QUAN JASA 67 321 ON QUEUES IN HEAVY TRAFFIC

RESULTS IN THE THEORY OF PEDESTRIANS AND ROAD TRAFFIC BEHAVIOR OF A COINCIDENCE VARIATE IN TELEPHONE TRAFFIC

TRAFFIC DELAYS ON A TWO-LANE ROAD

THE POISSON TENDENCY IN TRAFFIC DISTRIBUTION

A NOTE ON THE POISSON TENDENCY IN TRAFFIC DISTRIBUTION

A QUEUEINC MODEL FOR ROAD TRAFFIC FLOW (WITH DISCUSSION)

LIMIT THEOREMS FOR QUEUES WITH TRAFFIC INTENSITY ONE

DELAY AT TRAFFIC INTERSECTIONS

OVERFLOW AT A TRAFFIC LIGHT

ON THE TRAFFIC LICHT QUEUE

SOME RESULTS FOR FIXED-TIME TRAFFIC SIGNALS QUEUEING FOR GAPS IN TRAFFIC.

RESULTS IN THE THEORY OF PEDESTRIANS AND ROAD TRAFFIC

PERIOD CHANGE-OVER DESICN AND ITS USE IN CLINICAL TRAILS

SOME FURTHER

BIOKA54 375 THE TRANSIENT AMS 61230

BIOKA64 11

AMS $63 \quad 308$

AMS 641823

JRSSB61 64

AMS 651437

JRSSB $66 \quad 202$

BIOKA59 420

AMS $64 \quad 380$

JRSSB $64 \quad 133$

BIOKA65 79

CORRICENDA TO 'SOME FURTHER BIOKA58 291 LINE TRANSECT METHOD OF ESTIMATING GROUSE POPULATION

SIMULATION STUDY OF ESTIMATORS FOR THE LINE TRANSECT SAMPLINC METHOD

AN EXAMPLE OF THE ESTIMATION OF LINEAR OPEN LOOP TRANSFER FUNCTION

THE ESTIMATION OF 'TRANSFER FUNCTIONS' OF QUADRATIC SYSTEMS

EXAMPLES

THE USE OF THE HANKEL TRANSFORM IN STATISTICS. I. CENERAL THEORY AND THE TWO- BIOCS65 467 BIOCS68 135 BIOCS69 317 TECH $63 \quad 227$ TECH 61563 BIOKA54 44 BIOKA54 344 
ON THE CENERALIZED MELLIN TRANSFORM OF A COMPLEX RANDOM VARIABLE AND ITS APPLIC AMS 651459 A. QUICK METHOD FOR CHOOSINC A TRANSFORMATION

TABLES OF THE ANCULAR TRANSFORMATION

NOTE ON MR QUENOUILLE'S EDCEWORTH TYPE A TRANSFORMATION

ON THE PROBABILITY INTECRAL TRANSFORMATION

INTERVAL ANALYSIS AND THE LOGARITHMIC TRANSFORMATION

ESTIMATION OF VARIANCES AFTER USINC A CAUSSIANATINC TRANSFORMATION

A NOTE ON REGRESSION TRANSFORMATION FOR SMALLER ROUNDOFF ERROR

SOME PROPERTIES OF AN ANCULAR TRANSFORMATION FOR THE CORRELATION COEFFICIENT

AN ANCULAR TRANSFORMATION FOR THE SERIAL CORRELATION COEFFICIENT RECORDS

ONE-PARAMETER EXPONENTIAL FAMILIES CENERATED BY TRANSFORMATION CROUPS

FURTHER PROPERTIES OF AN ANCULAR TRANSFORMATION OF THE CORRELATION COEFFICIENT

ON NAIR'S TRANSFORMATION OF THE CORRELATION COEFFICIENT

NOTE ON FISHER'S TRANSFORMATION OF THE CORRELATION COEFFICIENT

TRANSFORMATION OF THE INDEPENDENT VARIABLES

NORMAL VARIABLES LINEAR TRANSFORMATION TO A SET OF STOCHASTIGALLY DEPENDENT

NOTE ON 'THE JACOBIANS OF CERTAIN MATRIX TRANSFORMATION USEFULL IN MULTIVARIATE ANALYSIS'

ASYMMETRICAL ROTATABLE DESIGNS AND ORTHOGONAL TRANSFORMATIONS

TABLES FOR POWER-LAW TRANSFORMATIONS

RATIOS OF STOCHASTIC PROCESSES RELATED BY GROUPS OF TRANSFORMATIONS

NS, AND THE APPROXIMATE STABILIZATION OF VARIANCE BY TRANSFORMATIONS

S OF QUANTAL EXPERIMENTS INVOLVINC TWO/ THE USE OF TRANSFORMATIONS AND MAXIMUM LIKEL

THE BEHAVIOR OF LIKELIHOOD AMS 65529

МतH 317

70

BIOKA59 203

BTOKA59 481

THE $1 B 7$

TECH 6B 393

BIOKA56 219

AMS $65 \quad 261$

BIOCS68 627

BIOKA57 273

BIOKA58 567

JRSSB59 409

TECH $62 \quad 531$

JASA $57 \quad 247$

BIOKA53 43

/ATORS FOR POWER-SERIES DISTRIBUTIO JASA $68 \quad 321$

JRSSB64 211 $S$ OF QUANTAL EXPERIMENTS INVOLVINC TWO/ THE USE OF TRANSFORMATIONS AND MAXIMUM LIKELIHOOD IN THE ANALYSI BIOKA55 382
JRSSB65
479

DATA TRANSFORMATIONS AND THE LINEAR MODEL

TIONS

STARSHAPED TRANSFORMATIONS AND THE POWER OF RANK TESTS

AMS 671456

AMS 691167 C PARAMETERS FROM DAUGHTER-DAM RECRESSION SOME TRANSFORMATIONS OF SCALE AND THE ESTIMATION OF GENETI BIOCS67 823 POISSON AND CHI-SQUARE DISTRIBUTIONS TRANSFORMATIONS OF THE BINOMIAL, NEGATIVE BINOMIAL, BIOKA54 302

OISSON AND GHI-SQUARE DISTRIBUTION/ GORRIGENDA TO 'TRANSFORMATIONS OF THE BINOMIAL, NECATIVE BINOMIAL, P BIOKA56 235 OF FACTORIAL EXPERIMENTS BY ESTIMATINC MONOTONE TRANSFORMATIONS OF THE DATA

RTIES OF DISTRIBUTIONS RESULTING FROM CERTAIN SIMPLE TRANSFORMATIONS OF THE NORMAL DISTRIBUTION

RTIES OF DISTRIBUTIONS RESULTINC FROM CERTAIN SIMPLE TRANSFORMATIONS OF THE NORMAL DISTRIBUTION' / PROPE BIOKA53 236

COEFFICIENTS THE EFFECT OF TRANSFORMATIONS OF VARIABLES UPON THEIR CORRELATION BIOKA57 272

TESTS FOR INDEPENDENCE CO-ORDINATE TRANSFORMATIONS TO NORMALITY AND THE POWER OF NORMAL BIOKA69 139

OF THE VARIABLE

TRANSFORMATIONS TO NORMALITY USING FRACTIONAL POWERS JASA $57 \quad 237$

D ON LECTURES BY/ THE JACOBTANS OF CERTAIN MATRIX TRANSFORMATIONS USEFUL IN MULTIVARTATE ANALYSTS BASE BIOKA5I

ESTS OF LINEAR HYPOTHESES USINC THE PROBIT AND LOGIT TRANSFORMATIONS, CORR. 64 1297/ /YMPTOTIG POWER OF T JASA 62 877 TRANSFORMATIONS, SOME EXAMPLES REVISITED TECH $69 \quad 23$

BETWEEN THE DISTRIBUTTONS OF NON-CENTRAL T AND OF A TRANSFORMED CORRELATTON COEFFICIENT

CORRELATION COEFFICIENTS. III. DISTRIBUTION OF THE TRANSFORMED KENDALL COEFFICIENT TESTS FOR RANK BIOKA62 I85 NUMBERS ESTIMATES OF HERITABILITY FROM TRANSFORMED PERCENTAGE SIB DATA WITH UNEQUAL SUBCLASS BIOCS65 IOOI NVOLVED IN THE ESTIMATION OF A POPULATION MEAN USING TRANSFORMED SAMPLE DATA TACH 66 . 535 CUMULANTS OF A TRANSFORUED VARTATE MARTINGALE TRANSFORMS

DIVERGENCE PROPERTIES OF SOME MARTINCALE TRANSFORMS SOME NUMERICAL ASPECTS OF THE USE OF TRANSFORMS IN STATISTICS SOME INTEGRAL TRANSFORMS OF CHARACTERISTIC FUNCTIONS TRANSFORMS OF STOCHASTIC PROCESSES

FUNCTIONS

TELEPHONE TRAFFIC

SERVICE AND FINITE CAPACITY

WITH RECURRENT INPUT AND GAMMA SERVICE TIME

THE USE OF INTEGRAL TRANSFORMS TO DETERMINE EXPANSIONS OF DISTRIBUTION THE TRANSIENT BEHAVIOR OF A COINCIDENCE VARIATE IN

ON THE TRANSIENT BEHAVIOR OF A QUEUEINC SYSTEM WITH BULK THE TRANSIENT BEHAVIOR OF A SINGLE SERVER QUEUING PROCESS

ON THE TRANSIENT BEHAVIOUR OF A SIMPLE QUEUE

A TRANSIENT DISCRETE TIME QUEUE WITH FINITE STORACE

H MODEL

ESTIMATION OF PARAMETERS IN A TRANSIENT MARKOV CHAIN ARISING IN A RELIABILITY GROWT

A SYSTEM OF DENUMERABLY MANY TRANSIENT MARKOV CHAINS

A REMARK ON HITTINC PLACES FOR TRANSIENT STABLE PROCESS

NONPARAMETRIC ESTIMATION OF THE TRANSITION DISTRIBUTION FUNCTION OF A MARKOV PROCESS

INTEGRAL KERNELS AND INVARIANT MEASURES FOR MARKOFF TRANSITION FUNCTIONS

FIXED POINT PROBABILITY VECTOR OF REGULAR OR ERGODIC TRANSITION MATRICES

ON THE LOCAL BEHAVIOR OF MARKOV TRANSITION PROBABILITIES

A MENDELIAN MARKOV PROCESS WITH BINOMIAL TRANSITION PROBABILITIES

N FROM NOTES ON ESTTMATING THE EQUTLIBRIUM AND TRANSITION PROBABILIT MAXIMUM LIKELIHOOD AND BAYESIAN ESTIMATION OF TRANSITION PROBABILITIES.

THE FREQUENCY COUNT OF A MARKOV CHAIN AND THE TRANSITION TO CONTINUOUS TIME

DISTINGUISHING A SEQUENCE OF RANDOM VARIABLES FROM A TRANSLATE ITSELF

ON DISTINGUISHING TRANSLATES OF MEASURES

BIOKA55 529

AMS 661494

AMS 691852

JASA $63 \quad 879$

AMS $68 \quad 1923$

BIOKA60 460

AMS $61 \quad 230$

AMS $62 \quad 973$

AMS 611286

JRSSB $60 \quad 277$

AMS $62 \quad 130$

AMS 691542

AMS $66 \quad 406$

AMS $68 \quad 365$

AMS 691386

AMS $65 \quad 517$

JASA $67 \quad 600$

TECH $66 \quad 107$

JASA $68 \quad 1162$

$\begin{array}{rr}\text { AMS } 61 & 41\end{array}$

AMS $65 \quad 1107$ AMS 691773

MS, CORR. 63 l/ THE LOCNORMAL DISTRIBUTION AND THE TRANSLATION METHOD, DESCRIPTION AND ESTIMATION PROBLE JASA 63 23I ESTIMATION OF THE LARGER TRANSLATION PARAMETER

ESTIMATION OF TWO ORDERED TRANSLATION PARAMETERS

STATISTICAL REPRODUCTION OF ORDERINGS AND TRANSLATION SUBFAMILIES

INVARIANT SETS FOR TRANSLATION-PARAMETER FAMILIES OF MEASURES

ON THE OPTIMUM RATE OF TRANSMITTING INFORMATION

A. STOCHASTIC MODEL OF ACHE TRANSPORTATION IN THE PERIPHERAL NERVE TRUNKS TRANSPOSED BRANCHING PROCESSES

A MATHEMATICAL THEORY OF ANIMAL TRAPPING

CONTRIBUTIONS TO THE MATHEMATICS OF ANIMAL TRAPPING

A CROSS-SECTION ANALYSIS OF NON-BUSINESS AIR TRAVEL

A CONTRIBUTION TO THE 'TRAVELLING-SALESMAN' PROBLEM (WITH DISCUSSION)

AMS 68502

AMS $68 \quad 517$

AMS $66 \quad 196$

AMS $69 \quad 162$

AMS 69 NO. 6

BIOKA62 447

JRSSB54 76

BIOKA5I 307

BIOCS66 925

JASA 58928

JRSSB55 185

REATMENT IN A PAIRED-COMPA/ A REMARK ON A PAPER OF TRAWINSKI AND DAVID ENTITLED 'SELECTION OF THE BEST T AMS 63 92
A TWO-PARAMETER MODEL FOR THE SURVIVAL CURVE OF TREATED CANCER PATIENTS

THE DESIGN OF AN EXPERIMENT IN WHICH CERTAIN TREATMENT ARRANGEMENTS ARE INADMISSIBLE

BIOKA54 287 
A SURVEY OF SOME SCHEMES REQUIRINC NOT MORE THAN 256 TREATMENT COMBINATIONS /OF FAGTORIAL EXPERIMENTS, BIOKA59 25I ROM A RANDOMISED BLOCK EXPERIMEN/ NOTES ERRORS OF TREATMENT COMPARISONS WHEN OBSERVATIONS ARE MISSING F BIOCS66 63 $675 B 6\}$ A GHANCE-OVER DESIGN FOR TESTING A TREATMENT FACTOR AT FOUR EQUALLY SPACED LEVELS (GORR. SELECTION OF THE BEST TREATMENT IN A PAIRED-COMPARISON EXPERIMENT TRAWINSKI AND DAVID ENTITLED ISELECTION OF THE BEST TREATMENT IN A PAIRED-COMPARISON EXPERIMENT I- /ER OF AMS 63 3 A NOTE ON BAILEY'S AND WHITTLE'S TREATMENT OF A GENERAL STOGHASTIG EPIDEMIG A CONTINUOUS TIME TREATMENT OF A SIMPLE QUEUE USINC CENERATINC FUNCTION JRSSB54 288 FORMULAE PROBLEMS OF SICNIFIGANCE STATISTICAL TREATMENT OF CENSORED DATA PART I FUNDAMENTAL

BIOKA54 228 NOTE ON AN EXACT TREATMENT OF GONTINCENGY, COODNESS OF FIT AND OTHER BIOKA5I 141 THE STATISTICAL TREATMENT OF MEAN DEVIATION

ON THE USE OF THE NORMAL APPROXIMATION IN THE TREATMENT OF STOCHASTIC PROCESSES

BIOKA54 12 JRSSB57 $26 \mathrm{~B}$ UES BY MEANS OF GUMULATIVE PROBABILITIES

TREATMENT OF THE NON-EQUILIBRIUM THEORY OF SIMPLE QUE A TREATMENT OF TIES IN PAIRED GOMPARISONS 457 THE TREATMENT OF TIES IN THE WILCOXON TEST AMS 682002

SERIALLY CORRELATED OBSERVATIONS TREATMENT VARTANGES FOR DISTRIBUTION-FREE MULTIPLE GOMPARISON PROCEDURE, TREATMENT VERSUS CONTROL

A RANK SUM TEST FOR COMPARINC ALL PAIRS OF TREATMENTS

A MODEL FOR SELECTINC ONE OF TWO MEDICAL TREATMENTS

A TWO-STACE MODEL FOR SELEGTING ONE OR TWO TREATMENTS

SOME ROW AND GOLUMN DESIGNS FOR TWO SETS OF TREATMENTS

A MULTIPLE COMPARISONS SICN TEST, ALL PAIRS OF TREATMENTS BALANCED INGOMPLETE BLOCK DESIGNS FOR TWO SETS OF TREATMENTS

FOR PAIRED-COMPARISON EXPERIMENTS INVOLVINC SEVERAL TREATMENTS DESIGNS BASED ON YOUDEN SQUARES WITH 5,6 , OR 7 TREATMENTS OMPLETE BLOCK DESIGNS WITH TWO-WAY CLASSIFICATION OF TREATMENTS

DESIGNS FOR EXPERIMENTS INVOLVING SEQUENCES OF TREATMENTS

WITH THE NUMBER OF BLOCKS EQUAL TO THE NUMBER OF TREATMENTS IN THE ANALYSIS OF QUANTAL EXPERIMENTS INVOLVING TWO TREATMENTS / COMPARISON OF THE BOUNDS OF THE NUMBER OF COMMON TREATMENTS BETWEEN BLOCKS OF CERTAIN PARTIALLY BALANC AMS 66 739 ED INGOMPLETE BLOGK DESIGNS IBLE DESIGNS ON THE BOUNDS OF THE NUMBER OF GOMMON TREATMENTS BETWEEN BLOCKS OF SEMI-REGULAR GROUP DIVIS JASA 64 86'7 GED BLOGK EXPERIMENTS HAVING ERROR VARIANGE AND SOME TREATMENTS IN GOMMON ANALYSIS OF A GROUP OF BALAN BIOGS68 389 FACTORIAL TREATMENTS IN REGTANGULAR LATTICE DESTGNS

GATTONS OF NONORTHOGONAL DESTGNS TO STTUATTONS ERIMENTAL DESIGNS OF USE IN CHANGING FROM ONE SET OF TREATMENTS TO ANOTHER, PART 1 SOME EXP JRSSB57 154 ERIMENTAL DESIGNS OF USE IN GHANGING FROM ONE SET OF TREATMENTS TO ANOTHER, PART 2 , EXISTENGE OF THE DESIG JRSSB57 163 TEST A MULTIPLE GOMPARISON SIGN TEST, TREATMENTS VERSUS GONTROL TABLES FOR A TREATMENTS VERSUS CONTROL MULTIPLE COMPARISONS SIGN DESIGNS FOR SEQUENCES OF TREATMENTS WITH GARRY-OVER EFFECTS ORDERED HYPOTHESES FOR MULTIPLE TREATMENTS, A SIGNIFIGANGE TEST FOR LINEAR RANKS JASA 59767 TEGH $65 \quad 293$ BIOGS66 292 JASA $63 \quad 216$ A TREE GOUNTING PROBLEM AMS 6 B 242

OGAM/ A FORMULA FOR THE PROBABILITY OF OBTAINING A TREE FROM A GRAPH CONSTRUGTED RANDOMLY EXGEPT FOR 'EX AMS 67 226 REPRESENTATION OF SIMILARITY MATRICES BY TREES RANDOM MINIMAL TREES

TWO SEQUENTIAL TESTS AGAINST TREND

JASA 671140 BIOKA6B 255 JASA $56 \quad 440$ TECH $62 \quad 430$ AMS 69371 BIOKA68 535

POWER FUNCTIONS FOR COX'S TEST OF RANDOMNESS AGAINST TREND DISTRIBUTION OF LIKELIHOOD RATIO IN TESTING AGAINST TREND A DESIGN BALANCED FOR TREND

IN A SERIES OF EVENTS WHEN THE ALTERNATIVE IS A TREND THE JIRINA SEQUENTIAL PROGEDURE TO OBSERVATIONS WITH TREND A THEOREM IN TREND ANALYSIS

ESTIMATION OF QUASI-LINEAR TREND AND SEASONAL VARIATION A SIMPLE METHOD OF TREND CONSTRUGTION

ESTIMATING AND TESTING TREND IN A STOCHASTIC PROCESS OF POISSON TYPE

EXPERIMENT ON THE POWERS OF THE REGORDS TESTS FOR TREND IN A TIME SERIES LARGE-SAMPLE SIGN TESTS FOR TREND IN DISPERSION

TESTS FOR RANDOMNESS JRSSB56 234 SOME APPLIGATIONS OF AMS $63 \quad 857$ BIOKA6I 224 JASA 631033 JRSSB 6191 AMS 661564 E EFFICIENCIES OF COX AND STUART'S TESTS FOR TESTING TREND IN DISPERSION OF A P-DEPENDENT TIME SERIES (GOR BIOKAG8 38 . SOME QUICK SIGN TESTS FOR TREND IN LOGATION AND DISPERSION THE EFFIGIENGY OF THE REGORDS TEST FOR TREND IN NORMAL RECRESSION THE ESTIMATION OF THE SPECTRAL DENSITY AFTER TREND REMOVAL

INVESTIGATION OF LEAST SQUARES REGRESSION INVOLVING TREND-REDUCED MARKOFF SERIES LEAST SQUARES REGRESSION ANALYSIS FOR TREND-REDUGED TIME SERIES EXPER IMENTAL DESIGNS TO ADJUST FOR TIME TRENDS THE- $(\mathrm{P}-\mathrm{Q})$ PLANS ROBUST AGAINST LINEAR AND QUADRATIC TRENDS DESIGN FOR ESTIMATING ENVIRONMENTAL AND GENETIC TRENDS

UNITED STATES NONWHITE POPULATION AS INDICATED BY TRENDS IN DEATH RATES FAGTOR GHANGES AND LINEAR TRENDS IN EIGHT-RUN T

ASYMPTOTIG POWER OF CHI SQUARE TESTS FOR LINEAR TRENDS IN PROPORTIONS

A SEQUENTIAL METHOD OF TESTING THE LINEAR TRENDS OF RESPONSES IN DOSE TRIALS

EVALUATION THE TRENTILE DEVIATION METHOD OF WEATHER FORECAST THE DISTRIBUTION OF THE NUMBER OF CIRCULAR TRIADS IN PAIRED GOMPARISONS

PLAY THE WINNER RULE AND THE GONTROLLED CLINICAL TRIAL

JASA $69 \quad 131$

JASA $63 \quad 365$ SEQUENTIAL MEDICAL TRIALS

ON THE NUMBER OF SUCCESSES IN INDEPENDENT TRIALS AMS $65 \quad 1272$ JASA 69759 BIOKA68 365 BIOGS69 111 ON THE EFFIGIENCY OF MATGHED PAIRS IN BERNOULLI TRIALS TWO-STAGE DESIGNS FOR CLINICAL TRIALS SOME OBSERVATIONS ON GHANGE-OVER TRIALS BIOGS69 413

STRIBUTION OF THE NUMBER OF SUGGESSES IN INDEPENDENT TRIALS APPROACH TO THE ANALYSIS OF DATA FROM GLINICAL TRIALS OF THE PROBABILITY OF ZERO FAILURES IN M BINOMIAL TRIALS

OF TESTING THE LINEAR TRENDS OF RESPONSES IN DOSE TRIALS THE NUMBER OF SUGGESSES IN A SEQUENCE OF DEPENDENT TRIALS HYPOTHESES, WITH APPLICATIONS TO SEQUENTIAL GLINIGAL TRIALS TRUNGATED SEQUENTIAL DESIGNS FOR CLINICAL TRIALS BASED ON MARKOV CHAINS 
ON COMBININC THE RESULTS FROM CLINICAL TRIALS OF A VACCINE

RTHOCONAL POLYNOMIALS IN THE ANALYSIS OF CHANCE-OVER TRIALS WITH DAIRY COWS

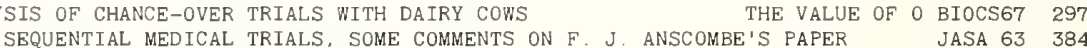
THE PROBABILITY THAT A RANDOM TRIANCLE IS OBTUSE

THE QUOTIENT OF A RECTANCULAR OR TRIANCULAR AND A CENERAL VARIATE AN EXTENSION OF THE TRIANCULAR ASSOCIATION SCHEME TO THREE ASSOCIATE

BIOKA69 N0.3 BIOKA54 330 JRSSB66 361

CLASSES

AMS $63 \quad 348$ SAMPLINC FROM A TRIANCULAR POPULATION

JASA $63 \quad 509$

TA A STOCHASTIG MODEL FOR TWO COMPETING SPECIES OF TRIBOLIUM AND ITS APPLICATION TO SOME EXPERIMENTAL DA BIOKA62 2 ON THE DISTRIBUTION OF TRIBOLIUM CONFUSUM IN A CONTAINER 32 A TRIBUTE TO FRANK WILCOXON

ON THE TRIMMED MANN-WHITNEY STATISTIC QUERY, SMALL TRIMMED SAMPLES

BEHAVIOR OF THE DISTRIBUTION OF WINSORIZED T (TRIMMINC-WINSORIZATION 2)

A NOTE ON LINEAR REGRESSION IN TRIVARIATE DISTRIBUTIONS

A POPULATION MEAN WHICH REDUCES THE EFFECT OF LARCE TRUE OBSERVATIONS

TECH $66 \quad 195$

AMS $6 B \quad 1610$

TECH $66 \quad 193$

APPROXIMATE TECH $6 \mathrm{~B} \quad 83$ JASA $68 \quad 1042$

AN ESTIMATOR FOR JASA $66 \quad 1200$

F THE LOC LIKELIHOOD RATIO TEST STATISTIC WHEN THE TRUE PARAMETER IS 'NEAR' THE BOUNDARIES OF THE HYPOTH AMS 68 2044

FOR ESTIMATING THE VARIANCE WITHIN D UNITS OF THE TRUE VALUE SAB

RAMETER IN THE UNIFORM DENSITY WITHIN D UNITS OF THE TRUE VALUE SAMPLE SIZE REQUIRED TO ESTIMATE THE PA JASA 64 550 THE REGRESSION OF TRUE VALUE ON ESTIMATED VALUE $\quad$ BIOKA60 457

DISTRIBUTION WHEN SAMPLES ARE SINGLY CENSORED OR TRUNCATED SIMPLIFIED ESTIMATORS FOR THE NORMAL TECH 59 217 PARAMETERS OF A MULTIVARIATE NORMAL POPULATION FROM TRUNCATED AND CENSORED SAMPLES S ON THE SOLUTION OF ESTIMATING EQUATIONS FOR TRUNCATED AND CENSORED SAMPLES FROM NORMAL POPULATION BIOKA57 225 THE FITTING OF GROUPED TRUNCATED AND GROUPED CENSORED NORMAL DISTRIBUTIONS BIOKA52 252

TABLES FOR MAXIMUM LIKELIHOOD ESTIMATES. SINCLY TRUNCATED AND SINGLY CENSORED SAMPLES METHOD OF MOMENTS ESTIMATES OF THE PARAMETERS OF THE TRUNCATED BINOMIAL AND NEGATIVE BINOMIAL DISTRIBUTION JASA 61 990 ON ESTIMATING THE PARAMETER OF A DOUBLY TRUNCATED BINOMIAL DISTRIBUTION JASA $66 \quad 259$ POWER SERIES DISTRIBUTIONS AND ITS APPLICATION TO A TRUNCATED BINOMIAL DISTRIBUTION /ON FOR GENERALIZED BIOKA62 227 CORRELATION BETWEEN THE SAMPLE VARIANCES IN A SINCLY TRUNCATED BIVARIATE NORMAL DISTRIBUTION MOMENTS OF A TRUNCATED BIVARIATE NORMAL DISTRIBUTION $\quad$ JRSSB61 405

VARIANCES OF RANK CORREL/ GORRELATTON IN A SINGLY TRUNCATED BIVARTATE NORMAL DISTRIBUTION, IV EMPIRICAL BIOKAGB 43ク CORRELATION CORRELATION IN A SINGLY TRUNCATED BIVARIATE NORMAL DISTRIBUTION. II. RANK BIOKA65 639 TION BETWEEN RANKS AND VA/ CORRELATION IN A SINGLY TRUNCATED BIVARIATE NORMAL DISTRIBUTION. III. CORRELA BIOKA66 27B SORTS OF TEST FOR A CHANCE OF LOCATION APPLICABLE TO TRUNCATED DATA THE ESTIMATION OF THE POISSON PARAMETER FROM A TRUNCATED DISTRIBUTION 247 INVENTORY CONTROL APPLICATIONS OF TRUNCATED DISTRIBUTIONS IN PROCESS START-UPS AND TECH 61 429 HALF-RECTIFIED TRUNCATED DISTRIBUTTONS, SAMPLING THEORY AND HYPOTHES TECH 69 A NOTE ON THE TRUNCATED EXPONENTIAL DISTRIBUTION AMS 641366

VARIANCE UNBIASED ESTIMATION OF RELIABILITY FOR THE TRUNCATED EXPONENTIAL DISTRIBUTION UTION OF AN ESTIMATOR ARISING IN CONNECTTON WITH THE TRUNCATED EXPONENTIAL DISTRIBUTTON RELIABILITY ESTIMATION OF THE TRUNCATED EXPONENTIAL MODEL ESTIMATION OF LOCATION AND SCALE PARAMETERS IN A TRUNCATED GROUPED SECH SQUARE DISTRIBUTION MINIMUM TECH 69609 AND PRODUCT MOMENTS OF THE ORDER STATISTICS FROM THE TRUNCATED LOGISTIC DISTRIBUTION MOMENTS TRUNCATED LOGNORMAL DISTRIBUTIONS.

\section{THE MOMENT GENERATING FUNCTION OF THE TRUNCATED MULTI-NORMAL DISTRIBUTION
CUMULANTS OF TRUNCATED MULTINORMAL DISTRIBUTIONS} THE TRUNCATED NEGATIVE BINOMIAL DISTRIBUTION

SIMPLIFIED METHODS OF FITTING THE TRUNCATED NEGATIVE BINOMIAL DISTRIBUTION QUERY, THE SUM OF VALUES FROM A NORMAL AND A TRUNCATED NORMAL DISTRIBUTION BETWEEN VARIATE-VALUES AND RANKS IN A DOUBLY TRUNCATED NORMAL DISTRIBUTION ELATION BETWEEN VARIATE-VALUES AND RANKS IN A DOUBLY TRUNCATED NORMAL DISTRIBUTION
QUERY. THE SUM OF VALUES FROM A NORMAL AND A TRUNCATED NORMAL DISTRIBUTION (CONTD)
CENSORED SAMPLES FROM TRUNCATED NORMAL DISTRIBUTIONS ELATION BETWEEN VARIATE-VALUES AND RANKS IN A DOUBLY TRUNCATED NORMAL DISTRIBUTION
QUERY. THE SUM OF VALUES FROM A NORMAL AND A TRUNCATED NORMAL DISTRIBUTION
CENSORED SAMPLES FROM TRUNCATED NORMAL DISTRIBUTIONS AMPLING DISTRIB AMS 69702 TECH $67 \quad 332$ JASA 61692 JASA $66 \quad 514$ BIOKA51 414 JRSSB $61 \quad 223$ JRSSB $62 \quad 535$ BIOKA55 5B BIOKA58 59 TECH $64 \quad 104$ THE CORR BIOKA66 281 TECH $64 \quad 469$ BIOKA55 516 TES TABLES OF PEARSON-LEE-FISHER FUNGTIONS OF SINGLY TRUNCATED NORMAL DISTRIBUTIONS NO BIOCS65 219 CHARACTERIZATION OF NORMAL AND GENERALIZED TRUNGATED NORMAL DISTRIBUTIONS USING ORDER STATISTIGS AMS 66 IOII TIMATING THE POISSON PARAMETER FROM SAMPLES THAT ARE TRUNCATED ON THE RIGHT ORT TO HIGHER MOMENTS ESTIMATINC PARAMETERS IN TRUNCATED PEARSON FREQUENCY DISTRIBUTIONS WITHOUT RES BTOKA53 50 $\begin{array}{ll}\text { A NOTE ON ESTIMATION IN THE TRUNCATED POISSON } & \text { BIOKA65 } 279\end{array}$

NOTES. MAXIMUM LIKELIHOOD ESTIMATION FOR THE TRUNCATED POISSON ONES ARE MISSTNG ESTIMATION IN THE TRUNCATED POISSON DISTRIBUTION WHEN ZEROS AND SOME COMBINATORIAL DERIVATION OF THE DISTRIBUTION OF THE TRUNCATED POISSON SUFFICIENT STATISTIC A NOTE ON THE NEGATIVE MOMENTS OF A TRUNCATED POISSON VARIATE ESTIMATION OF PARAMETERS OF A TRUNCATED POISSONIAN BINOMIAL BIOCS66 620 JASA $60 \quad 342$ A AMS $61 \quad 904$ JASA 641220 BI0CS68 377 BI0CS65 715 BIOCS67 356 NOTES. ON ESTIMATING RECESSIVE FREQUENCIES FROM TRUNCATED SAMPLES ERS OF NORMAL POPULATIONS BASED ON SINGLY AND DOUBLY TRUNCATED SAMPLES /OF THE ESTIMATES OF THE PARAMET JASA 62 46 MATION O/ ON THE AMOUNT OF INFORMATION SUPPLIED BY TRUNCATED SAMPLES OF GROUPED OBSERVATIONS IN THE ESTI BIOKA63 207 BASED ON MARKOV CHAINS TRUNCATED SEQUENTIAL DESIGNS FOR CLINICAL TRIALS CASE EXACT OPERATING CHARACTERISTIC FOR TRUNCATED SEQUENTIAL LIFE TESTS IN THE EXPONENTIAL AMS 62 1403

1247 ON THE PERFORMANCE OF THE TRUNCATED SEQUENTTAL PROBABTLTTY RATTO TEST CORR. DIRECT METHODS FOR EXACT TRUNCATED SEQUENTIAL TESTS OF THE MEAN OF A NORMAL DISTRIBUTION PLINC PLANS THE AVERAGE SAMPLE NUMBER FOR TRUNCATED SINGLE AND DOUBLE ATTRIBUTES ACCEPTANCE SAM THE DISTRIBUTION FUNCTIONS OF TSAO'S TRUNCATED SMIRNOV STATISTICS ADMISSIBLE AND MINIMAX ESTIMATES OF PARAMETERS IN TRUNCATED SPACES MONOTONICITY OF THE VARIANCE UNDER TRUNCATION AND VARIATIONS OF HENSEN'S INEQUALITY ELLIPTICAL AND RADIAL TRUNCATION IN NORMAL POPULATIONS PLANE TRUNCATION IN NORMAL POPULATIONS THE EXCEEDANCE TEST FOR TRUNCATION OF A SUPPLIER'S DATA

EFFECT OF TRUNCATION ON A TEST FOR THE SCALE PARAMETER OF THE EXPONENTIAL DISTRIBUTION POPULATIONS ASYMPTOTIC SHAPES FOR SEQUENTIAL TESTING OF TRUNCATION PARAMETERS ESTIMATION OF A TRUNCATION POINT TRUNCATION TO MEET REQUIREMENTS ON MEANS THE VARYING QUALITY OF INVESTMENT TRUST MANAGEMENT A TRUSTWORTHY JACKKNIFE

THE DISTRIBUTION FUNCTIONS OF TSAO'S TRUNCATED SMIRNOV STATISTICS
JASA 65979 TECH 69 NO. 4 AMS 671208 AMS $61 \quad 136$ AMS 691106 AMS $63 \quad 940$ JRSSB $65 \quad 301$ JASA 69823 AMS 64209 AMS 651504 AMS 682038 BIOKA64 33 JASA $57 \quad 527$ JASA 631011 AMS $64 \quad 1594$ AMS 671208 
OF MIXED WEIBULL PARAMETERS IN LIFE TESTINC ELECTRON TUBES COMMENTS ON THE DISCUSSIONS OF MESSRS. TUKEY AND COODMAN

DISTRIBUTIONS

TABLES OF THE FREEMAN-TUKEY TRANSFORMATIONS FOR THE BINOMIAL AND POISSON

A CRAPHICAL VERSION OF TUKEY'S CONFIDENCE INTERVAL FOR SLIPPACE

TECH 65163

BIOKA6I 433

A DEVELOPMENT OF TUKEY'S QUICK TEST OF LOCATION

POWER OF TUKEY'S TEST FOR NON-ADDITIVITY

TECH $68 \quad 193$

JASA $66 \quad 949$

JRSSB 63213

MARK TWAIN AND THE QUTNTUS CURTIUS SNODCRASS LETTERS, A JASA $63 \quad 85$

STATISTICAL, TEST OF AUTHORSHIP

UMULATIVE DISTRIBUTION FOR SAMPL/ COMPACT TABLE OF TWELVE PROBABILITY LEVELS OF THE SYMMETRIC BINOMIAL C JASA 59 I64
AND PRODUCTS OF ORDER STATISTICS FOR SAMPLES OF SIZE TWENTY AND LESS FROM THE NORMAL DISTRIBUTION' 56410
AMS 61 1345 THE TWENTY-SEVEN PER CENT RULE

NOTES. DISTRIBUTION AMONC RELATIVES OF CENOTYPES FOR TWINNING

MS 64214

BI0CS68 179 A CORRELATION MODEL USEFUL IN THE STUDY OF TWINS

MAIN-EFFECT PLANS AND ORTHOCONAL ARRAYS OF STRENCTH TWO

JASA $66 \quad 1184$

SOME AMS $61 \quad 1167$

STICS

OF OPTIMAL NONPARAMETRIC PROCEDURES IN THE TWO

ON THE FFFTCIENCY AMS 63

NON-RANDOMNESS IN A SEQUENCE OF TWO ALTERNATIVES. I. WILCOXON'S AND ALLIED TEST STATI BIOKA58 166 NON-RANDOMNESS IN A SEQUENCE OF TWO ALTERNATIVES. II. RUNS TEST

RESPONSE SURFACE DESICNS FOR FACTORS AT TWO AND THREE LEVELS

TAL RESPONSES TO

OF CONSTRUCTION OF PARTIALLY 8ALANCED DESIGNS WITH TWO ASSOCIATE CLASSES ON A GEOMETRICAL METHOD AMS 61 1IT7

LLY BALANCED INCOMPLETE BLOCK DESICNS WITH MORE THAN TWO ASSOCIATE CLASSES ANALYSIS OF A CLASS OF PARTIA AMS 6I 800 AND SECOND MOMENTS OF THE RANDOMIZATION TEST IN TWO ASSOCIATE PBIB DESIGNS A STATISTICAL TEST FOR EQUALITY OF TWO AVAILABILITIES TECH $68 \quad 594$ MIZATION IN BAYESIAN STATISTICS, FINITE SAMPLING AND TWO 8AYESIANS THE ROLE OF EXPERIMENTAL RANDO BIOKA69 NO. 3 NS ON COMPARING INTENSITIES OF ASSOCIATION BETWEEN TWO BINARY CHARACTERISTICS IN TWO DIFFERENT POPULATIO JASA 6I 889 NOTE ON TWO 8INOMIAL COEFFICIENT SUMS FOUND BY RIORDAN AMS $63 \quad 333$ CONFIDENCE INTERVALS FOR THE PRODUCT OF TWO 8INOMIAL PARAMETERS NOTE ON A THREE-DECISTON TEST FOR COMPARING TWO BTNOMTAL POPULATTONS NDS FOR THE NUMBER OF COMMON TREATMENTS BETWEEN ANY TWO BLOCKS OF CERTAIN PARTIALLY BALANCED INCOMPLETE B AMS 65 337 FREQUENCX RESPONSE FROM STATIONARY NOISE, TWO CASE HISTORIES

A THEOREM ON RANK ORDERS FOR TWO CENSORED SAMPLES

THE DISTRIBUTION OF THE PRODUCT OF TWO CENTRAL OR NON-CENTRAL CHI-SQUARE VARIATES OPTIMUM STRATIFICATION WITH TWO CHARACTERS

TESTS FOR RANDOMNESS OF DIRECTIONS AGAINST TWO CIRCULAR ALTERNATIVES

THE PROPERTIES OF A STOCHASTIC MODEL FOR TWO COMPETING SPECIES

ORRIGENDA, 'THE PROPERTIES OF A STOCHASTIC MODEL FOR TWO COMPETING SPECIES. '

OF CONVERGENCE IN THE COMPOUND DECISION PROBLEM FOR TWO COMPLETELY SPECIFIED DISTRIBUTIONS

PROCESS CURVE AND THE EQUIVALENT MIXED BINOMIAL WITH TWO COMPONENTS

THE DISTANCES BETWEEN RANDOM POINTS IN TWO CONCENTRIC CIRCLES

THE TWO CONCEPTS OF INFORMATION

THE THEORY OF CORRELATION BETWEEN TWO CONTINUOUS VARIABLES WHEN ONE IS DICHOTOMIZED ON THE RATIO OF TWO CORRELATED NORMAL RANDOM VARIABLES

QUERY, TESTING TWO CORRELATED VARIANCES

ON TESTS OF THE EQUALITY OF TWO COVARIANCE MATRICES

OF SOME TEXT CRITERIA FOR THE EQUALITY OF ONE OR TWO COVARIANCE MATRICES

TECH 61245

AMS $65 \quad 316$

AMS 621016

AMS $63 \quad$ B 66

JASA 69280

BIOKA58 316

BIOKA59 279

RATES AMS 651743

THE JRSSB59 63

BIOKA64 275

JASA $67 \quad 685$

BIOKA55 205

BIOKA69 NO. 3

TECH $65 \quad 447$ AMS $68 \quad 275$

POWER COMPARISIONS OF TESTS OF EQUALITY OF TWO COVARIANCE MATRICES BASED ON FOUR CRITERIA DISCRIMINATOR ANALYSIS TESTS FOR THE EQUALITY OF TWO COVARIANCE MATRICES IN RELATION TO A BEST LINEAR AMS 64 191 FIRST EMPTINESS OF TWO DAMS IN PARALLEL

AMS 64 AMS 61 219

AND NORMAL RANDOM VARIABLES SEQUENTIAL SAMPLING, TWO DECISION PROBLEMS WITH LINEAR LOSSES FOR BINOMIAL BIOKA65 507 MINIMAX DESIGNS IN TWO DIMENSIONAL REGRESSION

PROBLEM RELATED TO STATISTICAL DISTRIBUTIONS IN TWO DIMENSIONS CLUSTERING OF RANDOM POINTS IN TWO DIMENSIONS. AMS 651097 THE NONCENTRAL MULTTVARTATE BETA TYPE TWO DISTRIBUTION

POWER OF TWO-SAMPLE RANK TESTS ON THE EQUALITY OF TWO DISTRIBUTION FUNCTIONS

ON THE MEAN AND VARIANCE OF THE SMALLER OF TWO DRAWINCS FROM A BINOMIAL POPULATION

A MAXIMUM-MINIMUM BIOKA57 384 BIOKA65 263

SASJ 69 NO. 2

ON TWO EQUTVALENCE RELATIONS BETWEEN MEASURES

OF THE VARIANCE FUNCTION OF THE DIFFERENCE BETWEEN TWO ESTIMATED RESPONSES

ON THE JRSSB 64293 BIOKA62 566 AMS $66 \quad 686$

EQUIVALENCE OF TWO ESTIMATES OF PRODUCT VARIANCE THE BEHAVIOUR JRSSB $67 \quad 174$ JASA $56 \quad 451$

182) TWO ESTIMATES OF THE BINOMIAL DISTRIBUTION, (CORR. 64 AMS $64 \quad 809$

THE METHOD OF MOMENTS APPLIED TO A MIXTURE OF TWO EXPONENTIAL DISTRIBUTIONS

IBULL DISTRIBUTION SHAPE PARAMETER WHEN NO MORE THAN TWO FAILURES OCCUR PER LOT

OR THE NUMBER OF EDGES IN THE RANDOM INTERSECTION OF TWO GRAPHS (CORR. 69 1510)

ON THE DISTRIBUTION OF THE WEIGHTED DIFFERENCE OF TWO INDEPENDENT STUDENT VARIABLES

THE MATHEMATICAL ANALYSIS OF AN EPIDEMIC WTTH TWO KINDS OF

TWO K-SAMPLE SLIPPAGE TESTS

USE OF HALF-NORMAL PLOTS IN INTERPRETING FACTORIAL TWO LEVEL EXPERIMENTS

FACTOR CHANGES AND LINEAR TRENDS IN EIGHT-RUN TWO LEVEL FACTORIAL DESIGNS A COMPARISON OF TWO LIFE TABLE METHODS COMPARATIVE COST OF TWO LIFE TEST PROCEDURES

THE DISTRIBUTION OF THE LOGARITHM OF THE SUM OF TWO LOG-NORMAL VARIATES

OF ELEMENTARY SYMMETRIC FUNCTIONS OF THE ROOTS OF TWO MATRICES TIVARIATE BETA DISTRIBUTION AND MOMENTS OF TRACES OF TWO MATRICES

ON ELEMENTARY SYMMETRIC FUNCTIONS OF THE ROOTS OF TWO MATRICES IN MULTIVARIATE ANALYSIS.

QUADRA/ A USEFUL LEMMA FOR PROVING THE EQUALITY OF TWO MATRICES WITH APPLICATIONS TO LEAST SQUARES TYPE THE TWO MEANS PROBLEM A SECONDARILY BAYES APPROACH AMS $61 \quad 143$

FOR CALCULATING TABLES CIENTS 
STICAL TESTING OF DIFFERENCES IN CASUAL BEHAVIOUR OF TWO MORPHOLOGICALLY INDISTINGUISHABLE 0BJECTS STATI BIOCS67 377

COVARIANCE MATRICES POWER COMPARISONS OF TESTS OF TWO MULTIVARIATE HYPOTHESES BASED ON FOUR CRITERIA
CLASSIFICATION INTO TWO MULTIVARIATE NORMAL DISTRIBUTIONS WITH DIFFERENT

BIOKA67 195

AMS $62 \quad 420$

AMS 651174 OPTIMUM CLASSIFICATION RULES FOR CLASSIFICATION INTO TWO MULTIVARIATE NORMAL POPULATIONS

AMS 611145

ON THE MONOTONIC CHARACTER OF THE POWER FUNCTIONS OF TWO MULTIVARIATE TESTS

ASYMPTOTIC EFFICIENCY OF TWO NONPARAMETRIC COMPETITORS OF WILCOXON'S TWO SAMPL JASA 67939

A GRAPHICAL METHOD BIOKA53 460

RNATI/ ON A PROPERTY OF A TEST FOR THE EQUALITY OF TWO NORMAL DISPERSION MATRICES AGAINST ONE-SIDED ALTE AMS 62 I463 ESTIMATION IN MIXTURES OF TWO NORMAL DISTRIBUTIONS

NOTE ON TABLES FOR THE COMPARISION OF THE SPREAD OF TWO NORMAL DISTRIBUTIONS

TECH $67 \quad 15$

UAL SIZE UNBAISED ESTIMATION OF THE GOMMON MEAN OF TWO NORMAL DISTRIBUTIONS BASED ON SMALL SAMPLES OF EQ JASA $66 \quad 467$

ESTIMATION OF THE LARGEST OF TWO NORMAL MEANS

JOINT ESTIMATION OF THE PARAMETERS OF TWO NORMAL POPULATIONS

BIOKA58 250

STIC FOR TESTING THE DIFFERENCE BETWEEN THE ON SAMPLING OVER TWO OCCASIONS WITH PROBABILITY PROPORTIONATE TO SIZE AMS $65 \quad 327$ RAMETERS OF THE EXTREME VALUE DISTRIBUTION BY USE OF TWO OR THREE ORDER STATISTICS ESTIMATION OF THE PA BIOKA69 429 ESTIMATION OF TWO ORDERED TRANSLATION PARAMETERS

ON COMPARING THE CORRELATIONS WITHIN TWO PAIRS OF VARIABLES

A SIMPLE METHOD OF ESTIMATING RELATIVE POTENCY FROM TWO PARABOLAS

THAT THE SAMPLE DISTRIBUTION FUNGTION LIES BETWEEN TWO PARALLEL STRAIGHT LINES

LIFE TESTING AND RELIABILITY ESTIMATION FOR THE TWO PARAMETER EXPONENTIAL DISTRIBUTION

$\begin{array}{ll}\text { BIOCS68 } & 987 \\ \text { BIOCS65 } & 140\end{array}$

SAMPLES ESTIMATION OF THE PARAMETERS OF TWO PARAMETER EXPONENTIAL DISTRIBUTIONS FROM CENSORED TECH 60 403

PROGRAMMING FISHER'S EXACT METHOD OF COMPARING TWO PERCENTAGES

A COMBINATORIAL METHOD FOR PRODUCTS OF TWO POLYKAYS WITH SOME GENERAL FORMULAE

ESTIMATES FOR THE POINTS OF INTERSECTION OF TWO POLYNOMIAL REGRESSIONS

A DIFFERENT LOSS FUNCTION FOR THE CHOICE BETWEEN TWO POPULATIONS

A MINIMAX PROCEDURE FOR CHOOSING BETWEEN TWO POPULATIONS USING SEQUENTIAL SAMPLING

A MINIMAX-REGRET PROCEDURE FOR CHOOSING BETWEEN TWO POPULATIONS USING SEQUENTIAL SAMPLING

TEST FOR THE DIFFERENCE IN EFFICIENCY BETWEEN TWO PREDICTORS

TECH $60 \quad 103$

AMS 641174

JASA $64 \quad 214$

JRSSB59 203

JRSSB57 255

JRSSB 63297

OWER FUNCTTON OF THE TEST FOR THE DTFFERENCE BETMEEN TWO PROPORTIONS IN A 2-BY-2 TABLE, AN INEQUALITY FOR THE RATIO OF TWO QUADRATIC FORMS IN NORMAL VARIATES AMS 6B 1762 A PROBLEM OF INTERFERENCE BETWEEN TWO QUEUES

TWO QUEUES IN PARALLEL

ON TWO QUEUES IN PARALLEL

BIOKA53 5 B

BIOKA58 401

BIOKA60 198

ALANCED I/ BAYESIAN ANALYSIS OF LINEAR MODELS WITH TWO RANDOM COMPONENTS WITH SPECIAL REFERENCE TO THE B BIOKA68 101

CORR 64924 SOME RESULTS ON THE DISTRIBUTION OF TWO RANDOM MATRICES USED IN CLASSIFICATION PROCEDURES AMS 63 181 ON BAYES SEQUENTIAL DESIGN WITH TWO RANDOM VARIABLES

ON AN IDENTITY FOR THE VARIANCE OF A RATIO OF TWO RANDOM VARIABLES

ASYMPTOTIC SEQUENTIAL DESIGN OF EXPERIMENTS WITH TWO RANDOM VARIABLES

PERCENTAGE POINTS OF THE RATIO OF TWO RANGES AND POWER OF THE ASSOCIATED TEST

BIOKA66 469

JRSSB $64 \quad 484$

JRSSB $66 \quad 73$

BIOK A63 IB?

A MIXTURE OF TWO RECURRENT RANDOM WALKS NEED NOT BE REGURRENT AMS $6 B$ B 1753

AMONG MOMENTS OF ORDER STATISTICS IN SAMPLES FROM TWO RELATED POPULATIONS

A LARGE SAMPLE TEST FOR THE INDEPENDENCE OF TWO RENEWAL PROCESSES

RELATIONS TECH $63 \quad 514$

AMS $67 \quad 1037$

ON A RELATIONSHIP BETWEEN TWO REPRESENTATIONS OF A MODEL FOR PAIRED COMPARISONS BIOCS69 597 DESIGNS FOR DISCRIMINATING BETWEEN TWO RIVAL MODELS

EVALUATION OF CHEMICAL ANALYSES ON TWO ROCKS

THE ORDERING OF PROBABILITIES OF RANK ORDERS IN THE TWO SAMPLE CASE

ON THE DISTRIBUTION OF THE TWO SAMPLE CRAMER-VON MISES CRITERION

TECH 65307

TECH 59409

E EXACT AND APPROXIMATE SAMPLING DISTRIBUTION OF THE TWO SAMPLE KOLMOGOROV-SMIRNOV CRITERION D-SUB-MN, M L JASA 69 NO.4

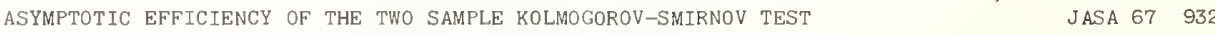

SMALL SAMPLE POWER CURVES FOR THE TWO SAMPLE LOCATION PROBLEM $\quad$ TEGH 69299

AMS 661814

ON THE HODGES AND LEHMANN SHTFT ESTIMATOR IN THE TWO SAMPLE PROBLEM NG TESTS ON THE TWO SAMPLE PROBLEM, A HEURISTIC METHOD FOR CONSTRUCTI AMS 611091 EFFECT OF NON-NORMALITY ON STEIN S TWO SAMPLE TEST AMS $65 \quad 651$

OF TWO NONPARAMETRTC COMPETTTORS OF WTLCOXON'S TWO SAMPLE TEST

ASYMPTOTIC EFFICIENCY JASA $67 \quad 939$ BUTIONS A DISTRIBUTION-FREE TWO SAMPLE TEST FOR DISPERSION FOR SYMMETRICAL DISTRI SASJ 69 NO.2 A DISTRIBUTION FREE VERSION OF THE SMIRNOV TWO SAMPLE TEST IN THE P-VARIATE CASE AMS 69 INVESTIGATION INTO THE SMALL SAMPLE PROPERTIES OF A TWO SAMPLE TEST OF LEHMANN'S A QUICK COMPACT TWO SAMPLE TEST TO DUCKWORTH'S SPECIFICATIONS

AN JASA $6 B \quad 345$ TECH $59 \quad 31$ SYMPTOTIC RELATIVE EFFICIENCY OF MOOD'S AND MASSEY'S TWO SAMPLE TESTS AGAINST SOME PARAMETRIC ALTERNATIVES AMS 621375 THE SMIRNOV TWO SAMPLE TESTS AS RANK TESTS

TWO SAMPLE TESTS IN THE WEIBULL DISTRIBUTION

AMS 691449

TECH 69 NO. 4

ABLES I. THE LOCATION MODEL MULTIVARIATE TWO SAMPLE TESTS WITH DICHOTOMOUS AND CONTINUOUS VARI AMS 69290

OF AN ANCILLARY STATISTIC AND THE COMBINATION OF TWO SAMPLES BY BAYES' THEOREM AN EXAMPLE AMS 61616

A NON-PARAMETRTC COMPARISON OF TWO SAMPLES ONE OF WHTCH IS CENSORED $\quad$ BIOKA66 599

ULATION CORRELATION COEFFICIENT FROM ONE OR POSSIBLY TWO SAMPLES SUBSEQUENT TO A PRELIMINARY TEST OF SIGNI JRSSB67 $2 B 2$ THE HYPOTHESIS THAT A LINEAR REGRESSION SYSTEM OBEYS TWO SEPARATE REGIMES

THE PARAMETER OF A LINEAR REGRESSION SYSTEM OBEYING TWO SEPARATE REGIMES TESTS OF JASA $60 \quad 324$ CE OF TWO TESTS OF EQUALITY OF RATE OF OCCURRENCE IN TWO SERIES OF EVENTS OCCURRING RANDOMLY IN TIME /EN BIOKA58 267 ORDER OF VISITS SOME BALANCED INCOMPLETE BLOCK DESIGNS FOR TWO SETS OF TREATMENTS

SOME ROW AND COLUMN DESIGNS FOR TWO SETS OF TREATMENTS

BIOKA66 497 BIOCS66 I

OWER FUNCTIONS OF SOME TESTS OF INDEPENDENCE BETWEEN TWO SETS OF VARIATES ATE ANALYSIS OF VARIANCE AND NONINDEPENDENCE BETWEEN TWO SETS OF VARIATES

MONOTONICITY OF THE P AMS $64 \quad 206$

PROCEDURE FOR TESTING A NULL HYPOTHESIS AGAINST A TWO SIDED ALTERNATIVE HYPOTHESIS TWO SIMILAR QUEUES IN PARALLEL

TO TRUNCATED DATA

ON COMPARING TWO SIMPLE LINEAR REGRESSION LINES A SEQUENTIAL JRSSB69 NO.2 AMS $61 \quad 1314$ SASJ $68 \quad 33$ A COMPARISON OF TWO SORTS OF TEST FOR A CHANGE OF LOCATION APPLICABLE JRSSB57 119 COMPARISONS OF SOME TWO STAGE SAMPLING METHODS

GROUP SCREENTNG WTTH MORE THAN TWO STAGES

APPROXIMATE DISTRIBUTION OF THE CORRELATION BETWEEN TWO STATIONARY LINEAR MARKOV SERIES

APPROXIMATE DISTRIBUTION OF THE CORRELATION BETWEEN TWO STATIONARY LINEAR MARKOV SERIES. II RESULTS FROM THE RELATION BETWEEN TWO STATISTICS OF THE KOLOMOGOROV-SMIRNOV TYPE

6689

TECH 62209

THE BIOKA62 379

THE BIOKA65 301

AMS 691833 
ITION LIFE TABLES FOR THE SINCLE POPULATION BASED ON TWO SUCCESSIVE CENSUSES (CORR. 68 1550) $/ O N$ OF ATTR JASA 67 I433 AND INFECTIOUS PERIODS OF MEASLES, I. FAMILIES WITH TWO SUSCEPTIBLES ONLY. ON ESTIMATINC THE LATENT BIOKA56 15 EQUIPROBABLE ALTERNATIVES TWO TABLES CONNECTED WITH COODNESS-0F-FIT TESTS FOR BIOKA68 441 E ON THE NON-CENTRAL DISTRIBUTIONS OF TWO TEST CRITERIA IN MULTIVARIATE ANALYSIS OF VARIANC AMS 68 215 THE ASYMPTOTIC NORMALITY OF TWO TEST STATISTICS ASSOCIATED WITH THE TWO-SAMPLE AMS 631513 N BETWEEN PITMAN'S ASYMPTOTIC RELATIVE EFFICIENCY OF TWO TESTS AND THE CORRELATION COEFFICIENT BETWEEN THE AMS 63 I442 A POWER COMPARISON OF TWO TESTS OF NON-RANDOM CLUSTERINC THE CONSTRUCTION OF SATURATED TWO TO THE POWER OF K-P DESICNS

ON CONSTRUCTINC THE FACTORIAL REPLICATES OF THE TWO TO THE POWER OF M DESICNS WITH BLOCKS TECH $66 \quad 493$ AMS 671110 AMS 621440 LENCTHS

ON IDENTITY RELATIONSHIPS FOR TWO TO THE POWER OF N-R DESICNS HAVINC WORDS OF EQUAL AMS 661842 - A TWO-STACE MODEL FOR SELECTINC ONE OR TWO TREATMENTS BIOCS65 169 OOD IN THE :ANALYSIS OF QUANTAL EXPERIMENTS INVOLVINC TWO TREATMENTS /TRANSFORMATIONS AND MAXIMUM LIKELIH BIOKA55 38 OF EXPONENTIALLY DISTRIBUTED LIFE-TIMES WITH TWO TYPES OF FAILURE THE ANALYSIS JRSSB59 4II SYMMETRICAL UNEQUAL BLOCK ARRANGEMENTS WITH TWO UNEQUAL BLOCK SIZES ZATION OF AUXILIARY INFORMATION, (PI)PS SAMPLINC OF TWO UNITS FROM A STRATUM (ADDENDUM 69 192) /M UTILI JRSSB67 374 RIANCE ESTIMATORS IN UNEQUAL PROBABILITY SAMPLINC OF TWO UNITS PER STRATUM /ILITIES OF ESTIMATORS AND VA JASA 69 540 OF LEVELS OF POLYNOMIAL REGRESSION WITH ONE OR TWO VARIABLES FURTHER CRITICAL VALUES FOR THE SUM OF TWO VARIANCES

TIONS OF THE CALCULUS FOR FACTORIAL ARRANGEMENTS II. TWO WAY ELIMINATION OF HETEROGENEITY THE DISCRIMINATION BETWEEN TWO WEIBULL PROCESSES SAMPLING INSPECTION PLANS FOR DISCRIMINATING BETWEEN TWO WEIBULL PROCESSES ERRATA, 'THE DISCRIMINATION BETWEEN TWO WEIBULL PROCESSES

THE SPREAD OF A DISEASE BY CONSIDERTNC HOUSEHOLDS OF TWO.

THE ESTIMATION OF PARAMETERS FROM LOGNORMAL AND THE PRECISIO/ OPTIMAL SAMPLE SIZE IN TWO-ACTION PROBLEMS WHEN THE SAMPLE OBSERVATIONS ARE TWO-STAGE NORMAL SAMPLINC IN TWO-ACTION PROBLEMS WITH LINEAR ECONOMICS RANDOMIZED RULES FOR THE TWO-ARMED BANDIT WITH FINITE MEMORY CONTRIBUTIONS TO THE 'TWO-ARMED BANDIT' PROBLEM THE ROBBINS-ISBELL TWO-ARMED-BANDIT PROBLEM WITH FINITE MEMORY

GNIFICANCE TEST ANALYSTS OF A TWO-BY -TWO CONTINGENCY TABLE AND CHOICE TECH $65 \quad 325$ BIOKA58 279 APPLICA AMS $64 \quad 658$ TECH $64 \quad 57$ TECH $65 \quad 589$ TECH 64240 BIOKA65 271 JASA $68 \quad 653$ JASA 69 NO. 4 AMS 682103 AMS $62 \quad 847$ AMS 651375 INCOMPLETE TWO-DIMENSIONAL CONTINGENCY TABLES THE SPECTRAL ANALYSIS OF TWO-DIMENSIONAL POINT PROCESSES CORRICENDA, 'THE SPECTRAL ANALYSIS OF TWO-DIMENSIONAL POINT PROCESSES'

A TWO-DIMENSIONAL POISSON CROWTH PROCESS

US SPECTRA

THE ANALYSIS OF TWO-DIMENSIONAL STATIONARY PROCESSES WITH DISCONTINUO MODELS FOR TWO-DIMENSIONAL STATIONARY STOCHASTIC PROCESSES

A MONTE CARLO SOLUTION OF A TWO-DIMENSIONAL UNSTRUCTURED CLUSTER PROBLEM PLANNINC SOME TWO-FACTOR COMPARATIVE SURVEYS

MAIN-EFFECT 2-TO-THE-N-TIMES-3-TO-THE-M DESICNS AND TWO-FACTOR INTERACTION ALIASINC TRAFFIC DELAYS ON A TWO-LANE ROAD

A SIMPLIFIED MODEL FOR DELAYS IN OVERTAKING ON A TWO-LANE ROAD

DELAYS ON A TWO-LANE ROAD (WITH DISCUSSION)

SOME TWO-LEVEL FACTORIAL PLANS WITH SPLIT PLOT CONFOUNDINC

CHAIN-POOLINC ANALYSIS OF VARIANCE FOR TWO-LEVEL FACTORIAL REPLICATION-FREE EXPERIMENTS SEQUENCES OF TWO-LEVEL FRACTIONAL FACTORIAL PLANS FURTHER CRITICAL VALUES FOR THE TWO-MEANS PROBLEM

THE TWO-PACK MATCHINC PROBLEM

A TWO-PARAMETER FAMILY OF HYPER-POISSON DISTRIBUTIONS BIOCS69 119 BIOKA64 299 BIOKA65 305 JRSSB $65 \quad 497$ BIOKA64 195 BIOKA55 170 BIOKA67 625 JASA 69560 ORTHOGONAL TECH $68 \quad 559$

CANCER PATIENTS RA ILS

POINT AND INTERVAL ESTIMATION PROCEDURES FOR THE TWO-PARAMETER WEIBULL AND EXTREME-VALUE DISTRIBUTIONS TECH 68 23

THE TWO-PERIOD CHANGE-OVER DESICN AND ITS USE IN CLINICAL BIOCS65 467

A TWO-PERTOD DESIGN WITH T-SQUARE EXPERIMENTAL UNITS BIOCS68 61 WEAK APPROACHABILITY IN A TWO-PERSON GAME INFERENCE ABOUT THE INTERSECTION IN TWO-PHASE RECRESSION SOME RATIO-TYPE ESTIMATORS IN TWO-PHASE SAMPLINC SOME BAYESIAN STRATIFIED TWO-PHASE SAMPLINC RESULTS BAYESIAN STRATIFIED TWO-PHASE SAMPLINC RESULTS, K CHARACTERISTICS THE RELATIVE EFFICIENCY OF SOME TWO-PHASE SAMPIING SCHEMES AMS $69 \quad 789$ BIOKA69 NO. 3 JASA $62 \quad 628$ BIOKA68 131 BIOKA68 587 AMS $67 \quad 937$ SAMPLINC ARE STRATIFIED ALTERNATIVES OF INTERMEDIATE SPECIFICITY

THE TWO-SAMPLE CAPTURE-RECAPTURE CENSUS WHEN TAGGING AND TWO-SAMPLE COMPARISONS OF DISPERSION MATRICES FOR

OKA61 241 SAMPLES

DISTRIBUTTON OF THE TWO-SAMPLE CRAMER-VON MISES CRITERTON FOR SMALL EQUAL U-SQUARED SMALL-SAMPLE DISTRIBUTIONS OF THE TWO-SAMPLE CRAMER-VON MISES' W-SOUARED AND WATSON'S VARIANCES

A TWO-SAMPLE DISTRIBUTION FREE TEST FOR COMPARINC AMS 6395 AMS 641091 A TWO-SAMPLE DISTRIBUTION-FREE TEST

ERNOFF-SAVACE THEOREM GOODNESS CRITERIA FOR TMO-SAMPIE DISTRTBUTION-FREE TESTS BIOKA58 544 BIOKA56 377 AMS $66 \quad 133$ WEAK CONVERCENCE OF A TWO-SAMPLE EMPIRICAL PROCESS AND A NEW APPROACH TO CH AMS 68 755 ONE-SAMPLE DISTRIBUTION-FREE TESTS AND THEIR TWO-SAMPLE EXTENSIONS ROBUSTNESS OF SOME PROCEDURES FOR THE TWO-SAMPLE LOCATION PROBLE

A NON-PARAMETRIC TEST FOR THE BIVARIATE TWO-SAMPLE LOCATION PROBLEM 'OPTIMAL' AMS $66 \quad 120$

JASA $64 \quad 665$ JRSSB $67 \quad 320$ PLE POWER OF A NON-PARAMETRIC TEST FOR THE BIVARIATE TWO-SAMPLE LOCATION PROBLEM IN THE NORMAL CASE /SAM JRSSB68 83

ON THE EFFICIENCY OF TWO-SAMPLE MANN-WHITNEY TEST FOR DISCRETE POPULATIONS AMS 63612 ANS OF NORMAL POPULATIONS WITH A COMMON UNKNOWN/ A TWO-SAMPLE MULTIPLE DECISION PROCEDURE FOR RANKING ME BIOKA54 I7O POWER OF SOME TWO-SAMPLE NON-PARAMETRIC TESTS ON SOME TWO-SAMPLE NON-PARAMETRIC TESTS, CORR, 661249

HOUT REPLACEMENT AND EXACT BAHADUR EFFTCIENCY OF THE TWO SAMPLE NORMAL SCORES TEST RANDOMIZATION TESTS FOR A MULTIVARIATE TWO-SAMPLE PROBLEM TRIBUTION OF A NON-PARAMETRIC TEST FOR THE BIVARIATE TWO-SAMPLE PROBLEM ASYMPTOTICALLY MOST POWERFUL RANK TESTS FOR THE TWO-SAMPLE PROBLEM WIT ORY, II. TESTS OF THE PARAMETRIC GOODNESS OF FIT AND TWO-SAMPLE PROBLEMS SEQUENTIAL RANK TESTS I. MONTE CARLO STUDIES OF THE TWO-SAMPLE PROCEDURE SEQUENTIAL RANK TESTS II MODIFIED TWO-SAMPLE PROCEDURES ON THE NORMAL SCORES TWO-SAMPLE RANK TEST

A PROPOSED TWO-SAMPLE RANK TEST,

ONE SAMPLE LIMITS OF SOME TWO-SAMPLE RANK TESTS PERCENTILE MODIFTCATIONS OF TWO-SAMPLE RANK TESTS EFFICIENCY ROBUST TWO-SAMPLE RANK TESTS 
THE TWO-SAMPLE SCALE PROBLFM WHEN LOCATIONS ARE UNKNOWN A TWO-SAMPLE SEQUENTIAL T-TEST

A K-SAMPLE EXTENSION OF THE ONE-SIDED TWO-SAMPLE SMIRNOV TESTS STATISTIC

LIMIT THEOREMS FOR FUNCTIONS OF SHORTEST TWO-SAMPLE SPACINCS AND A RELATED TEST

OF CRITICAL VALUES FOR THE MANN-WHITNEY-WILCOXON TWO-SAMPLE STATISTIC

SICNIFICANCE POINTS FOR THE TWO-SAMPLE STATISTIC U-SQUARE-SUB-M, N THE WILCOXON TWO-SAMPLE STATISTIC, TABLES AND BIBLIOGRAPHY

FOR THE KOLMOGOROV-SMIRNOV AND KUIPER ONE-SAMPLE AND TWO-SAMPLE STATISTICS EXACT BAHADUR EFFICIENCIES THE TWO-SAMPLE T-TEST BASED ON RANGE

NON-NORMALITY IN TWO-SAMPLE T-TESTS

HISTORICAL NOTES ON THE WILCOXON UNPAIRED TWO-SAMPLE TEST

EARLY DECISION IN THE WILCOXON TWO-SAMPLE TEST

THE V-SUB-NM TWO-SAMPLE TEST

A DISTRIBUTION-FREE TWO-SAMPLE TEST ON A CIRCLE

ON A CLASS OF NONPARAMETRIC TWO-SAMPLE TESTS FOR CIRCULAR DISTRIBUTIONS

A MONTE CARLO STUDY COMPARINC VARIOUS TWO-SAMPLE TESTS FOR DIFFERENCES IN MEAN

LAR DISTRIBUTION THE DERIVATION OF NONPARAMETRIC TWO-SAMPLE TESTS FROM TESTS FOR UNIFORMITY OF A CIRCU BI

CENSORING

THE PERFORMANCE OF SOME TWO-SAMPLE TESTS IN SMALL SAMPLES WITH AND WITHOUT

SOME TWO-SAMPLE TESTS WHEN THE VARIANCES ARE UNEQUAL. A JASA $64 \quad 925$ JASA $63 \quad 894$

AMS 681202 BIOKA65 661 JASA $63 \quad 10 B 6$ AMS 671475 BIOKA57 482 BIOKA53 223 JASA $57 \quad 356$ JASA $63 \quad 713$ AMS $68 \quad 923$ BIOKA64 256 AMS 691791 TECH $68 \quad 509$ SIMULATION STUDY

TAIL PROBABILITIES FOR THE NULL DISTRIBUTION OF THE TWO-SAMPLE WILCOXON STATISTIC

CENERALIZED TWO-SAMPLE WILCOXON TEST FOR DOUBLY-CENSORED DATA BIOKA697 1279

BIOKA65 650

HOPF TYPE METHOD FOR A GENERAL RANDOM WALK WITH A TWO-SIDED BOUNDARY A WIENER- AMS 63 1I68 GENERAL NATURE MAL DISTRIBUTION SOME TWO-SIDED DISTRIBUTION-FREE TOLERANCE INTERVALS OF A JASA 62775

FACTORS FOR CALCULATING TWO-SIDED PREDICTION INTERVALS FOR SAMPLES FROM A NOR J ON A TWO-SIDED SEQUENTIAL T-TEST

DISTRIBUTION CORRIGENDA, 'ON A TWO-SIDED SEQUENTIAL T-TEST'

ON TWO-SIDED TOLERANCE INTERVALS FOR A NORMAL

SOME IMPROVEMENTS

AN APPROXIMATION TO TWO-SIDED TOLERANCE LIMITS FOR NORMAL POPULATIONS TWO-SIDED TOLERANCE LIMITS FOR NORMAL POPULATIONS.

878 BIOKA52 302 BIOKA54 568 AMS $64 \quad 762$ TECH $66 \quad 115$ JASA 69610 JASA 68692 TWO-STAGE DESIGNS FOR CLINICAL TRIALS

SAMPLING DISTRIBUTION OF ORDINARY LEAST SQUARES AND TWO-STAGE LEAST SQUARES ESTIMATORS BIOCS69 111

TWO-STAGE MODEL FOR SELECTING ONE OR TWO TREATMENTS BIOCS65 169 ESTIMATTON OF VARIANCE COMPONENTS IN TWO-STAGE NESTED DESIGNS WITH COMPOSITE SAMPLES ESTIMATION PROCEDURES FOR ESTIMATING PARAMETERS IN A TWO-STAGE NESTED PROCESS /MPARISONS OF DESIGNS AND TECH 67 499 ON TWO-STAGE NON-PARAMETRIC ESTIMATION

AMS 641099

LINEAR ECONOMICS

BETWEEN MEANS TWO-STAGE NORMAL SAMPLING IN TWO-ACTION PROBLEMS WITH JASA 69 NO.4 TO-STACE PROCEDURES FOR ESTIMATING THE DIFFERENCE BIOKA54 146 SMALL-SAMPLE PROPERTIES OF SEVERAL TWO-STAGE RECRESSION METHODS IN THE CONTEXT OF AUTOCO JASA 69 253

THE VAR ESTIMATING THE ARITHMETIC MEAN OF A POPULATION WITH TWO-STAGE SAMPLING BAYES AND MINIMAX PROCEDURES FOR A PROPERTY OF SOME SYMMETRIC TWO-STACE SEQUENTIAL PROCEDURES

OPTIMAL TWO-STAGE STRATIFIED SAMPLING

FINITE POPULATIONS WITH AN APPLICATION TO BULK/ A TWO-STACE SUBSAMPLING PROCEDURE FOR RANKING MEANS OF SOME SEQUENTIAL ANALOGS OF STEIN'S TWO-STACE TEST

A TWO-STATE MARKOV MODEL FOR BEHAVIORAL CHANGE

REMARK CONCERNING TWO-STATE SEMI-MARKOV PROCESSES

ASA $66 \quad 220$

AMS $64 \quad 755$

AMS $69 \quad 575$

TECH $67 \quad 355$

BIOKA62 367

JASA 68993

AMS $61 \quad 615$

MPLING PROBABILITIES OF A CLASS OF WIDELY USED/ A TWO-VARIABLE GENERATING FUNCTION FOR COMPUTING THE SA JASA 64 487 NON-ADDITIVITY IN TWO-WAY ANALYSIS OF VARIANCE

DISPROPORTIONATE SUBCLASS FREOUENCIES DISTRIBUTION-FREE ANALYSIS OF VARIANCE FOR THE TWO-WAY CLASSIFICATION ONE-WAY VARIANCES IN A TWO-WAY CLASSIFICATION

BIOCS65 308 SASJ $67 \quad 67$ BIOKA5B 111 BIOCS69 153

TESTING THE HOMOGENEITY OF VARIANCES IN A TWO-WAY CLASSIFICATION A TEST BIOKA55 412

FOR HOMOGENEITY OF THE MARGINAL DISTRIBUTIONS IN A TWO-WAY CLASSIFICATION ATES OF COMPONENTS OF VARIANCE FROM A NON-ORTHOCONAL TWO-WAY CLASSIFICATION VATTONS WTTHTN A/ THE ANALYSTS OF VARTANCE FOR THE TWO WAY CLASSTFTCATION MINIMAL SUFFICIENT STATISTICS FOR THE TWO-WAY CLASSIFICATION MIXED MODEL DESIGN VARIANCE COMPONENTS IN TWO-WAY CLASSIFICATION MODELS WITH INTERACTION

PARTIALLY BALANCED INCOMPLETE BLOCK DESIGNS WITH TWO-WAY CLASSIFICATION OF TREATMENTS ESTIMABILITY OF VARIANCE COMPONENTS FOR THE TWO-WAY CLASSIFICATION WITH ITERATION

OTIC ERROR PROBABILITY SEQUENTIAL NONPARAMETRIC TWO-WAY CLASSIFICATION WITH PRESCRIBED MAXIMUM ASYMPT STUDENT'S T IN A TWO-WAY CLASSIFICATION WITH UNEQUAL VARTANCES

RANK SUM MULTIPLE COMPARISIONS IN ONE AND TWO-WAY CLASSIFICATIONS

AMS $69 \quad 175$ AMS 671508 AMS 69445

AMS 651248 BIOKA67 487 HE NUMBERS OF OBSERVATIONS IN THE SUBCLASSES FOR THE TWO-WAY COMPLETELY-RANDOM CLASSIFICATION /ANS AND T JASA 6B 1484 OF VARIANCE-COMPONENT ESTIMATORS FOR THE UNBALANCED TWO-WAY CROSS CLASSIFICATION WITH APPLICATION TO BALA AMS 69 408 ESTIMATION OF FUNCTIONS OF VARIANCE COMPONENTS FROM TWO-WAY CROSSED CLASSIFICATIONS /OR THE SIMULTANEOUS BIOKA67 I27 SOME METHODS OF CONSTRUCTION OF DESIGNS FOR TWO-WAY ELIMINATION OF HETEROGENEITY, I AN APPROXTMATE METHOD OF ANALYSIS FOR A TWO-WAY LAYOUT ON SOME OPTIMUM NONPARAMETRIC PROCEDURES IN TWO-WAY LAYOUTS ON A CLASS OF ALICNED RANK ORDER TESTS IN TWO-WAY LAYOUTS VARIANCE COMPONENTS IN THE UNBALANCED TWO-WAY NESTED CLASSIFICATION DESIGN AND ESTIMATION IN TWO-WAY STRATIFICATION

SAMPLE SELECTION AND THE CHOICE OF ESTIMATOR IN TWO-WAY STRATIFIED POPULATIONS JASA $66 \quad 1153$ BIOCS65 376 JASA $67 \quad 1214$ AMS 681115 AMS 611161 JASA $60 \quad 105$ JASA 641054 AMS 681264 GENERALIZED ASYMPTOTIC EXPANSIONS OF CORNISH-FISHER TYPE

AND TESTING TREND IN A STOCHASTIC PROCESS OF POISSON TYPE CONCERNING TESTS OF FIT OF THE KOLMOGOROV-SMIRNOV TYPE

BETWEEN TWO STATISTICS OF THE KOLMOGOROV-SMIRNOV TYPE SIDED DISTRIBUTION TESTS OF THE KOLMOGOROV-SMIRNOV TYPE VOLUTION, WHEN THE OTHER COMPONENT IS OF EXPONENTIAL TYPE PROCESSES OF THE AUTOREGRESSIVE AND MOVINC-AVERAGE TYPE ON THE DERIVATION AND APPLICABILITY OF NEYMAN'S TYPE A DISTRIBUTION ESTIMATING AMS 661564 AN INEQUALITY AMS 671240 RESULTS FROM THE RELATION AMS 691833 SOME EXACT RESULTS FOR ONE- AMS 61499 ESTIMATION OF A COMPONENT OF A CON TECH 64222 STATIONARITY CONDITIONS FOR STOCHASTIC BIOKA56 215 BIVARIATE GENERALIZATIONS OF NEYMAN'S TYPE A DISTRIBUTION 
OF THE METHOD OF MOMENTS AND THE GRAM-CHARLIER TYPE A DISTRIBUTION $S$ OF ESTIMATION FOR THE NEGATIVE BINOMIAL AND NEYMAN TYPE A DISTRIBUTIONS

INHALATION IN RELATION TO TYPE AND AMOUNT OF SMOKING
OF PARTIALLY BALANCED DESIGNS OF THE LATIN SQUARE TYPE AND RELATED DESIGNS BIOKA59 203

OF PARTIALLY BALANCED DESIGNS OF THE LATIN SQUARE TYPE AND RELATED DESIGNS $\begin{array}{rrr} & \text { JASA } & 59 \\ \text { SOME NEW FAMILIES TECH } & 67 & 229\end{array}$

A PROPERTY OF THE MEAN DEVIATION FOR THE PEARSON TYPE DISTRIBUTIONS

'A PROPERTY OF THE MEAN DEVIATION FOR THE PEARSON TYPE DISTRIBUTIONS CF MULTIVARIATE REGRESSION PROBLEMS AMS 621039 TATIONARY DISTRIBUTIONS OF THE NEGATIVE EXPERIMENTAL TYPE FOR THE INFINITE DAM AND UNBIASEDNESS FOR MULTIPLE DECISION PROBLEMS OF TYPE I

TIMATION OF THE NORMAL POPULATION PARAMETERS GIVEN A TYPE I CENSORED SAMPLE A NOTE ON TOLERANCE LIMITS WITH TYPE I CENSORING A NOTE ON ESTIMATION FROM A TYPE I EXTREME-VALUE DISTRIBUTION N MULTIPLE LINEAR REGRESSION AMS 69 NO. 6

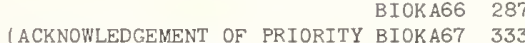
S JRSSB57 342 ES BIOKA6I 367 TECH $68 \quad 392$ $\mathrm{TECH} 67 \quad 325$ HE VARIABLES ARE DEPENDENT WITH SPECIAL REFERENCE TO TYPE II CENSORED NORMAL DATA /ENT ESTIMATORS WHEN T BIOKA62 155 TIMATES OF THE LOCATION AND SCALE PARAMETERS GIVEN A TYPE II CENSORED NORMAL SAMPLE /XIMUM LIKELIHOOD ES BIOKAGI 448 SINGLY CENSORED SAMPLES, OF THE SCALE PARAMETERS OF TYPE II EXTREME-VALUE DISTRIBUTIONS /TIMATION, FROM TECH 68 349 A NEW TABLE OF PERCENTAGE POINTS OF THE PEARSON TYPE III DISTRIBUTION WITH SPECIAL REFERENCE TO SAMPLES FROM A PEARSON TYPE III POPULATION WITH SPECIAL REFERENCE TO SAMPLES FROM A PEARSON TYPE III POPULATION
ON RANKING PARAMETERS OF SCALE IN TYPE III POPULATIONS TECH $69 \quad 177$

RATIO AND THE PROBABILITY INTEGRAL FOR A PEARSON TYPE IV DISTRIBUTION. THE MEAN DEVIATION, BIOKA5B 47B JASA $58 \quad 164$

ONS, CORR. 651069 SIDED BOUNDARY

SOME RENYI TYEE THE MILLS BIOKA65 119 AMS 631168 AMS $61 \quad 1186$ AMS 621238 BIOKA5I 90 SOME FURTHER DESICNS OF TYPE O-PP

ON THE ORDER AND THE TYPE OF ENTIRE CHARACTERISTIC FUNCTIONS ESTIMATION PROBLEMS WHEN A SIMPLE TYPE OF HETEROGENEITY IS PRESENT IN THE SAMPLE

OPERTIES OF A STOCHASTIC MODEL FOR THE PREDATOR-PREY TYPE OF INTERACTION BETWEEN TWO SPECIES ANALYSIS OF LATIN SQUARES WITHIN A CERTAIN TYPE OF ROW-COLUMN INTERACTION FUNCTIONS OF FINITE MARKOV CHAINS AND EXPONENTIAL TYPE PROCESSES THE PR BIOKA6O 219 TECH $59 \quad 379$ AMS $68 \quad 1020$ Y OF TWO MATRICES WITH APPLICATIONS TO LEAST SQUARES TYPE QUADRATIC FORMS /LEMMA FOR PROVING THE EQUALIT JASA 69 969 TABLES OF CRITICAL VALUES OF SOME RENYI TYPE STATISTICS FOR FINITE SAMPLE SIZES

JASA $69 \quad 870$ E CALCULATION OF DISTRIBUTIONS OF KOLMOGOROV-SMIRNOV TYPE STATISTICS INCLUDING A TABLE OF SIGNIFICANCE POI AMS 68 233 SOME SMIRNOV TYPE THEOREMS OF PROBABILITY AMS 65 1113

THE NONCENTRAL MULTIVARIATE BETA TYPE TWO DISTRIBUTION SOME RESULTS ON POLYA TYPE 2 DISTRIBUTIONS

SASJ 69 NO'.2 AMS 681759 VOLUTION, WHEN THE OTHER COMPONENT IS OF EXPONENTIAL TYPE' ERRATA, 'ESTIMATION OF A COMPONENT OF A CON TECH 65 462 OF EXPONENTIALLY DISTRIBUTED LIFE-TIMES WITH TWO TYPES OF FATLURE SOME PROPERTIES OF COUNTS OF EVENTS FOR CERTAIN TYPES OF POINT PROCESS DATA AVAILABLE FOR ECONOMIC RESEARCH ON CERTAIN TYPES OF RECREATION CYLINDRICALLY ROTATABLE DESIGNS OF TYPES 1, 2, AND 3 USING SUBSAMPLE VALUES AS TYPICAL VALUES

OD A K-SAMPLE ANALOGUE OF WATSON'S U-SQUARE STATTSTIC SIGNIFICANCE POINTS FOR THE TWO-SAMPLE STATISTIC U-SQUARE-SUB-M, N GOODNESS-OF-FIT TESTS BASED ON $W-S Q U A R E-S U B-N$ AND U-SQUARE-SUB-N

FOR THE DISTRIBUTIONS OF GOODNESS-OF-FIT STATISTICS, U-SQUARE-SUB-N AND W-SQUARE-SUB THE DISTRIBUTION OF THE GOODNESS-OF-FIT STATISTIC, U-SQUARE-SUB-N. I . THE DISTRIBUTION OF THE GOODNESS-OF-FIT STATISTIC U-SQUARE-SUB-N.II TWO-SAMPLE CRAMER-VON MISES' W-SQUARED AND WATSON'S U-SQUARED JOINT ASYMPTOTIC DISTRIBUTION OF THE MEDIAN AND A U-STATISTIC OF THE DISTRIBUTION OF THE MANN-WHITNEY-WILCOXON U-STATISTIC UNDER LEHMANN ALTERNATIVES JACKKNIFING U-STATISTICS

MULTISAMPLE PERMUTATION TESTS BASED ON A CLASS OF U-STATISTICS

E GENERATION OF THE DISTRIBUTION OF THE MANN-WHITNEY U-STATISTICS UNDER LEHMANN ALTERNATIVES THE ANALYSIS JRSSB59 411 JRSSB $64 \quad 325$ STATISTICAL JASA 59281 AMS $67 \quad 167$ JASA 69 NO. 4 BIOKA66 579 BIOKA65 661 THE BIOKA62 397 BIOKA65 630 BIOKA63 303 BIOKA64 393 SMALL-SAMPLE DISTRIBUTIONS OF THE AMS 641091 JRSSB57 144 TABLES TECH $67 \quad 666$ AMS 69 NO. 6 BRANCH/ EXTENSIONS OF A LIMIT THEOREM OF EVERETT, ULAM AND HARRIS ON MULTITYPE BRANCHING PROCESSES TO A AMS 67 992 DEPENDENT BRANCHING PROCESSES UNDER A CONDITION OF ULTIMATE EXTINCTION A NOTE ON THE ULTIMATE SIZE OF A GENERAL STOCHASTIC EPIDEMIC THE ULTIMATE SIZE OF CARRIER-BORNE EPIDEMICS
DISTRIBUTIONS BASED ON SMALL SAMPLES OF EQUAL SIZE UNBAISED ESTIMATION OF THE COMMON MEAN OF TWO NORMAL JASA 66 467 755 SOME FINITE POPULATION UNBAISED RATIO AND REGRESSION ESTIMATORS, CORR. 60 JASA 59 594 QUADRATIC ESTIMATES OF THE INTERCLASS VARIANCE FOR UNBALANCED DESIGNS THE QUASI-F TEST FOR AN UNNESTED FIXED FACTOR IN AN UNBALANCED HIERARCHAL DESIGN WITH A MIXED MODEL /E. BIOCS66 937 ESTING SIGNIFICANCE OF COMPONENTS OF VARIANCE IN THE UNBALANCED NESTED ANALYSIS OF VARIANCE (CORRECTION 68 BIOCS68 423 IONS OF VARIANCE COMPONENTS II. EMPIRICAL STUDIES OF UNBALANCED NESTED DESIGNS SAMPLING DISTRIBUT TECH 68 719 D THE NUMBERS OF OBSERVATIONS ON THE EFFECTS FOR THE UNBALANCED ONE-WAY RANDOM CLASSIFICATION /FFECTS AN JASA 67 1375 OF MOMENT ESTIMATORS OF VARIANCE COMPONENTS IN THE UNBALANCED R-WAY CLASSIFICATION NOTE ON TESTING HYPOTHESES IN AN UNBALANCED RANDOM EFFECTS MODEL ANCES OF THE ESTIMATES OF VARIANCE COMPONENTS IN THE UNBALANCED THREE-WAY NESTED CLASSIFICATION /NG VARI AMS 63 521 VARIANCES OF VARIANCE-COMPONENT ESTIMATORS FOR THE UNBALANCED TWO-WAY CROSS CLASSIFICATION WITH APPLICAT AMS 69 408 VARIANCE COMPONENTS IN THE UNBALANCED TWO-WAY NESTED CLASSIFICATION AMS 61 1161 OPTIMUM INVARIANT TESTS IN UNBALANCED VARIANCE COMPONENTS MODELS 422 HAT ORDINARY LEAST-SQUARES ESTIMATORS BE BEST LINEAR UNBIASED A NECESSARY AND SUFFICIENT CONDITION T JASA 67 I3O2 LITY FUNCTIONS FOR SYSTEMS IN SE/. MINIMUM VARIANCE UNBIASED AND MAXIMUM LIKELIHOOD ESTIMATORS OF RELIABI JASA 66 1052 UTIONS FOR WHICH THE MAXIMUM-LIKELIHOOD ESTIMATOR IS UNBIASED AND OF MINIMUM VARIANCE FOR ALL SAMPLE SIZES BIOKA56 200 1163 TER UNBIASED COMPONENTWISE RATIO ESTIMATION, CORR. 63 JASA 61350 TR

TABLE OF NEYMAN-SHORTEST UNBIASED CONFIDENCE INTERVALS FOR THE BINOMIAL PARAME BIOKA60 381 TABLES OF NEYMAN-SHORTEST UNBIASED CONFIDENCE INTERVALS FOR THE POISSON PARAMET BIOKAGI 191 ALMOST LINEARLY-OPTIMUM COMBINATION OF UNBIASED ESTIMATES 36 LEAST SQUARES AND BEST UNBIASED ESTIMATES AMS $62 \quad 266$ A SMALLER SAMPLE/ THE CONSTRUCTION OF GOOD LINEAR UNBIASED ESTIMATES FROM THE BEST LINEAR ESTIMATES FOR TECH 65 543 ON LOCAL UNBIASED ESTIMATION

NUMBER THEORY PROCESSES
MINIMUM VARIANCE UNBIASED ESTIMATION AND CERTAIN PROBLEMS OF ADDITIVE BEST LINEAR UNBIASED ESTIMATION FOR MULTIVARIATE STATIONARY UNBIASED ESTIMATION IN CONVEX FAMILIES $\begin{array}{rr}\text { TECH } & 65 \\ \text { JRSSB } 64 & 46\end{array}$ AMS 631050 TECH $68 \quad 523$ AMS 691523 
ON MINIMUM VARIANCE UNBIASED ESTIMATION OF RELIABILITY

AMS 69710

EXPONENTIAL DISTRIBUTION DENSITIES

MINIMUM VARIANCE UNBIASED ESTIMATION OF SOME MULTIVARIATE PROBABILITY STICAL INEERENCE IN THE CLASSICAL OCCUPANCY PROBLEM, UNBIASED ESTIMATION OF THE NUMBER OF CLASSES
ONTADRATIC UNBIASED ESTIMATION OF VARIANCE COMPONENTS OF THE

ON TWO METHODS ON UNBIASED ESTIMATION WITH AUXILIARY VARIATES

AN UNBIASED ESTIMATOR FOR POWERS OF THE ARITHMETIC MEAN

MINIMUM VARIANCE UNBIASED ESTIMATORS FOR POISSON PROBABILITIES

ON A COMPLETE CLASS OF LINEAR UNBIASED ESTIMATORS FOR RANDOMIZED FACTORIAL EXPERIME

A NOTE ON UNIFORMLY BEST UNBIASED ESTIMATORS FOR VARIANCE COMPONENTS

69609

AMS 691261

JASA $68 \quad 837$

BIOKA69 313

JASA $62 \quad 184$

JRSSB $61 \quad 154$

TECH $62 \quad 409$ IN SMALL SAMPLES OF THE MAXIMUM LIKELIHOOD AND BEST UNBIASED ESTIMATORS OF RELIABILITY FUNCTIONS /NCIES JASA 66 1033 LITY OF UNKNOWN VARIANCES

COMBINATIONS OF UNBIASED ESTIMATORS OF THE MEAN WHICH CONSIDER INEQUA JASA 691042 BEST LINEAR UNBIASED ESTIMATORS OF THE PARAMETERS OP THE LOGISTIC TECH 67 THE PROBABILITY OF MISCLASSIFICATION I/ AN ALMOST UNBIASED METHOD OF OBTAINING CONFIDENCE INTERVALS FOR BIOCS67 639 ROM ONE-WAY-CLASSIFICATION TABLES WHEN THE CROSS/ UNBIASED MULTIPLE RECRESSION COEFEICIENTS ESTIMATED F JASA 66 720 REGRESSION MODEL

\section{THE ASYMPTOTICALLY UNBIASED PRIOR DISTRIBUTION}

CONSTRUCTING AN UNBIASED RANDOM SEQUENCE

THE PRECISION OF MICHEY'S UNBIASED RATIO ESTIMATOR

ON SAMPLING SCHEMES PROVIDING UNBIASED RATIO ESTIMATORS

UNBIASED RATIO ESTIMATORS IN STATIFIED SAMPLING,

CORR. 641298

UNBIASED RATIO-TYPE ESTIMATION

PLICATIONS OF MULTIVARIATE POLYKAYS TO THE THEORY OF UNBIASED RATIO-TYPE ESTIMATION THE PRECISION OF UNBIASED RATIO-TYPE ESTIMATORS, CORR. 63 1162

JASA $62 \quad 369$

AMS 651137

JASA 681526

BIOKA67 321

AMS $64 \quad 222$

JASA $61 \quad 70$

AP JASA 57511

JASA $58 \quad 491$

MINIMUM VARIANCE, LINEAR, UNBIASED SEASONAL ADJUSTMENT O

UNIQUENESS OF A UNIFORMLY MOST POWERFUL RANDOMIZED UNBIASED TEST FOR THE BINOMIAL

A NOTE ON UNBIASED TESTS

EXISTENCE AND BIOKA56 465

TABLES FOR UNBIASED TESTS ON THE VARIANCE OF A NORMAL POPULATION

LOCALLY UNBIASED TYPE M TEST

OF ONE OR TWO COVARIANCE MATRICES

ION EQUATIONS ESTIMATORS

MINIMAX RISK AND UNBIASEDNESS FOR MULTIPLE DECISION PROBLEMS OF TYPE I UNBIASEDNESS OF SOME TEXT CRITERIA FOR THE EQUALITY

THE UNBIASEDNESS OF ZELLNER'S SEEMINGLY UNRELATED REGRESS J

A LARCE-SAMPLE BIOASSAY DESIGN WITH RANDOM DOSES AND UNCERTAIN CONCENTRATION

THE FOUNDATIONS OF DECISION UNDER UNCERTAINTY, AN ELEMENTARY EXPOSITION

UNCERTAINTY, INFORMATION, AND SEQUENTIAL EXPERIMENTS

AMS $62 \quad 292$

AMS $61 \quad 84$

JRSSB 66298

AMS 691684

AMS 681686

JASA $67 \quad 141$

BIOKA55 307

JASA $64 \quad 353$

AMS $62 \quad 404$

ALENTS AND INFORMATION EVALUATION IN DECISIONS UNDER UNCERTAINTY PARTS I II. AND III PROACH TO COVARIANCE ANALYSIS WHEN THE COVARIABLE IS UNCONTROLLED A STRUCTURAL REGRESSION AP JASA 67 I037 CONDITIONS OF SIMPLE SIMILAR ACTION, THE ANALYSIS OF UNCONTROLLED DATA /ES TO MIXTURES OF POISONS UNDER BIOKA58 74

A THEORETICAL ANALYSIS OF DELAYS AT AN UNCONTROLLED INTERSECTION THE CAPACITY OF AN UNCONTROLLED INTERSECTION

ON UNCORRELATED LINEAR FUNCTIONS OF ORDER STATISTICS

ON COMBINABILITY OF INFORMATION FROM UNCORRELATED LINEAR MODELS BY SIMPLE WEIGHTING CERTAIN UNCORRELATED NONPARAMETRIC TEST STATISTICS

ON CERTAIN FUNCTIONS OF NORMAL VARIATES WHICH ARE UNCORRELATED OF A HIGHER ORDER CERTATN UNCORRELATED STATISTICS

NATIONAL INCOME STATISTICS OF UNDERDEVELOPED COUNTRIES

INVESTMENT ESTIMATES OF UNDERDEVELOPED COUNTRIES, AN APPRAISAL

PROCESSINC UNDERDEVELOPED DATA FROM AN UNDERDEVELOPED AREA

TESTS FOR THE VALIDITY OF THE ASSUMPTION THAT THE UNDERLYING DISTRIBUTION OF LIFE IS EXPONENTIAL, PART

TESTS FOR THE VALIDITY OF THE ASSUMPTIONS THAT THE UNDERLYING DISTRIBUTION OF LIFE IS EXPONENTIAL, PART

AN INTRODUCTION TO ESSENTIALS, 1. THE PURPOSE AND UNDERLYINC MODELS

THE ORTHOGONALIZATION OF UNDESIGNED EXPERIMENTS

ERRATA, 'THE ORTHOGONALIZATION OF UNDESIGNED EXPERIMENTS

A NOTE ON UNDISCOUNTED DYNAMIC PROCRAMMING

FACTOR ANALYSIS

A NOTE ON UNDISCOUNTED DYNAM UNDOMTNATED CASE

THE SUFFICIENCY TN THE UNDOMINAT

FOR SIZES

SYMMETRICAL UNEQUAL BLOCK ARRANCEMENTS WITH TWO UNEQUAL BLOCK

ON BALANCED UNEQUAL BLOCK DESIGNS

A NOTE ON DISCRIMINATION IN THE CASE OF UNEQUAL COVARIANCE MATRICES

MPARISON OF DISTANCE STATISTICS FOR POPULATIONS WITH UNEQUAL COVARIANCE MATRICES

GENERALISED COVARIANCE ANALYSIS WITH UNEQUAL ERROR

ANALYSIS OF VARIANCE OF PROPORTIONS WITH UNEQUAL FREQUENCIES

PARAMETER ESTIMATION FROM THE ORDER STATISTICS OF UNEQUAL CAMMA COMPONENTS

BIOKA62 163

BIOKA67 657

JASA $63 \quad 245$

AMS 661338

JASA $68 \quad 707$

BIOKA60 175

JASA $60 \quad 265$

JASA $57 \quad 162$

JASA 58669

JASA 6023

TECH $60 \quad 83$

TECH $60 \quad 167$

BIOCS65 190

TECH $66 \quad 279$

$\mathrm{TECH} 66 \quad 731$

AMS 661042

AMS $61 \quad 1191$

AMS $63 \quad 671$

AMS $62 \quad 620$

BIOKA62 561

BIOKA68 586

AN EMPIRICAL CO BIOCS68 683

BIOCS69 NO. 4

JASA $63 \quad 1133$

SCALE AMS $66 \quad 152$

ANALYSIS OF VARIANCE, A BAYESIAN SIDELICHT

EITY OF GROUP

ONA TANCES IN THE FIXED-EFFECTS ONE-WAY BIOKA66

27

EQUENCY DISTRIBUTION. WITH ESPECIAL REFERENCE TO THE UNEQUAL INTERVAL CASE /CLASS MARKS OF A GROUPED FR TECH 68 793

ANALYSIS OF MULTIFACTOR CLASSIFICATIONS WITH UNEQUAL NUMBERS OF OBSERVATIONS

SAMPLING ERRORS IN AN ORCHARD SURVEY INVOLVINC UNEQUAL NUMBERS OF ORCHARDS OF DISTINCT TYPE

BALANCED DESIGNS WITH UNEQUAL NUMBERS OF REPLICATES

ON INVERSE SAMPLING WITH UNEQUAL PROBABILITIES

SAMPLINC WITH UNEQUAL PROBABILITIES AND WITHOUT REPLACEMENT

IED SAMPLING UNITS WILL OCCUR IN A SAMPLE DRAWN WITH UNEQUAL PROBABILITIES AND WITHOUT REPLACEMENT

ON SAMPLINC WITHOUT REPLACEMENT WITH UNEQUAL PROBABILITIES OF SELECTION

SYSTEMATTC SAMPLINC WTTH UNEQUAL PROBABILITY AND WITHOUT REPLACEMENT

USE OF DOMAIN ESTIMATORS WITH UNEQUAL PROBABILITY IN SAMPLE SURVEYS

BI0CS66 525

BIOCS65 55

AMS $64 \quad 897$

BIOKA64 185

AMS $62 \quad 350$

/ECIF JASA $66 \quad 384$

BIOKA67 499

JASA $66 \quad 739$

JASA $68 \quad 984$

STABILITIES OF ESTIMATORS AND VARIANCE ESTIMATORS IN UNEQUAL PROBABILITY SAMPLING OF TWO UNITS PER STRATUM JASA 69 540

ON THREE PROCEDURES OF UNEQUAL PROBABILITY SAMPLING WITHOUT REPLACEMENT 202

ON A SIMPLE PROCEDURE OF UNEQUAL PROBABILITY SAMPLING WITHOUT REPLACEMENT 4 JRSSB62 482

REPLICATED, OR INTERPENETRATING, SAMPLES OF UNEQUAL SIZES

AMS $67 \quad 1142$

AMPLTNG WTTH AND WITHOI

IGNS TO SITUATIONS WHERE TREATMENTS OR BLOCKS ARE OF UNEQUAL STATUS OR SIZE

RITABILITY FROM TRANSFORMED PERCENTAGE SIB DATA WITH UNEQUAL SUBCLASS NUMBERS

METHODS OF CLUSTER S BIOKA62 27 IATE T-SQUARE AND HOMOSCEDASTICITY CRITERION M UNDER UNEQUAL VARIANCE AND LEPTOKURTOSIS /UTIONS OF BIVAR JASA 63 IO48 
/OR THE SICNTFTCANCE OF THE DTFFE BTOKA51 252 SOME TWO-SAMPLE TESTS WHEN THE VARIANCES ARE UNEQUAL. A SIMULATION STUDY

GROUPING METHODS IN THE FITTING OF POLYNOMIALS TO UNEQUALLY SPACED OBSERVATIONS NOTES ORTHOCONAL POLYNOMIALS FOR UNEQUALLY WEIGHED MEANS THE PROBABILITY THAT A RANDOM GAME IS UNFAIR UNFOLDING PARTICLE SIZE DISTRIBUTIONS BIOKA67 679 BIOKA56 149 BI0CS65 226 AMS 661796 TECH 69 NO. 4 JASA $66 \quad 436$

A COMPUTER METHOD FOR CALCULATING KENDALL'S TAU WITH UNGROUPED DATA ING TIME AND REPAIR/ THE EFFICIENCY OF N MACHINES UNI-DIRECTIONALLY PATROLLED BY ONE OPERATOR WHEN WALK JRSSB57 I66 ING TIME IS CONSTANT/ THE EFFICIENCY OF N MACHINES UNI-DIRECTIONALLY PATROLLED BY ONE OPERATOR WHEN WALK JRSSB57 I73 A TEST OF SICNIFICANCE FOR AN UNIDENTIFIABLE RELATION JRSSB56 61 A UNTFIED APPROACH FOR CONSTRUCTING A USEFUL CLASS OF N JRSSBG8 37 $\mathrm{S}$

A UNIFIED DERIVATION OF SOME NONPARAMETRIC DISTRIBUTION UNIFIED LEAST SQUARES ANALYSIS

A UNIFIED THEORY OF ESTIMATION. I

A UNIFIED THEORY OF SAMPLINC FROM FINITE POPULATIONS

CONFIDENCE BANDS OF UNIFORM AND PROPORTIONAL WIDTH FOR LINEAR MODELS

ON TESTING THE EQUALITY OF UNIFORM AND RELATED DISTRIBUTIONS UNIFORM APPROXIMATION OF MINIMAX POINT ESTIMATES

FUNCTION ROBUSTNESS OF UNIFORM BAYESIAN ENCODING

UNIFORM GONSISTENCY OF SOME ESTIMATES OF A DENSITY UNIFORM CONVERGENCE OF FAMILIES OF MARTINGALES

RELATIONS BETWEEN WEAK AND UNIFORM CONVERCENCE OF MEASURES WITH APPLICATIONS ESTIMATION IN THE UNIFORM COVARIANCE CASE

AMPLE SIZE REQUIRED TO ESTIMATE THE PARAMETER IN THE UNIFORM DENSITY WITHIN D UNITS OF THE TRUE VALUE PREDICTIVE ZERO-MEAN UNIFORM DISCRIMINATION

QUERY, GOMBINATION OF A NORMAL AND A UNIFORM DISTRIBUTION

NOTE ON WEYL'S CRITERION AND THE UNIFORM DISTRIBUTION OF INDEPENDENT RANDOM VARTABLES

A CHARACTERIZATION OF THE UNIFORM DISTRIBUTION ON A COMPACT TOPOLOGICAL GROUP JASA 641042 JASA $65 \quad 523$ AMS $61 \quad 112$ JRSSB55 269 JASA $66 \quad 182$ JASA $66 \quad 856$ AMS 641031 TECH $63 \quad 121$ AMS 691499 AMS 691071 AMS $62 \quad 659$ JRSSB $64 \quad 477$

S JASA $64 \quad 550$ BIOKA68 519 TECH 65449 AMS 691124 AMS $63 \quad 319$ ON TO TESTING FOR R/ STATISTICS CONNECTED WITH THE UNIFORM DISTRIBUTION. PERCENTAGE POINTS AND APPLICATI BIOKA66 235 A UNIFORM ERGODIC THEOREM

THE SAMPL TNC DISTRTBUTTON OF TE A UNIFORM OPERATOR ERGODIC THEOREM AMS 691126

EXPRESSING A RANDOM VARIABLE IN TERMS OF UNIFORM RANDOM VARIABLES

RATIOS OF NORMAL VARIABLES AND RATIOS OF SUMS OF UNIFORM VARIABLES ASYMPTOTIC THEORY OF A CLASS OF TESTS FOR UNIFORMITY OF A CIRCULAR DISTRIBUTION ANOTHER TEST FOR THE UNIFORMITY OF A CIRCULAR DISTRIBUTION A SIMPLE TEST FOR UNIFORMITY OF A CIRCULAR DISTRIBUTION

ON HODGES'S BIVARIATE SICN TEST AND A TEST FOR UNIFORMITY OF A CIRCULAR DISTRIBUTION ION OF NONPARAMETRIG TWO-SAMPLE TESTS FROM TESTS FOR UNIFORMITY OF A CIRCULAR DISTRIBUTION COMPONENTS ARRANCEMENTS WITH CONFOUNDING

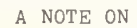

USE OF TNTER-BLOGK INFORMATION TO ORTATN UNTFORMLY BETTER ESTIMATORS

ITY FUNCTION IN CERTAIN CASES

ON THE LACK OF A UNIFORMLY CONSISTENT SEQUENCE OF ESTIMATORS OF A DENS THE AUTOGORRELATION FUNCTION OF A SEQUENCE UNIFORMLY DISTRIBUTED MODULO 1

THE BINOMIAL

EXISTENCE AND UNIQUENESS OF A UNIFORMLY MOST PONERFUL RANDOMIZED UNBIASED TEST FOR RLIER AND EDGEWORTH GURVES ARE POSITIVE DEFINITE AND UNIMODAL

A NOTE ON ESTIMATING A UNIMODAL DENSITY

THE MAXIMUM VARIANCE OF RESTRTCTED UNIMODAL DISTRIBUTTONS BIOKA56 465 KNOWN TH AND GRAM-CHARLIER SERIES NOTE ON THE MOMENT-PROBLEM FOR UNIMODAL DISTRIBUTIONS WHEN ONE OR BOTH TERMINALS ARE BIOKA56 224 THE REGIONS OF UNIMODALITY AND POSITIVITY IN THE ABBREVIATED EDGEWOR A NOTE ON THE UNIMODALITY OF DISTRIBUTION FUNCTIONS OF CLASS

BOUNDS OF THE PROBABILITY OF A UNION OF EVENTS, WITH APPLICATIONS PROBABILITY BOUNDS FOR A UNION OF HYPERSPHERICAL CONES ESTIMATION OF NON-UNIQUE QUANTTLFS

TER THEN OR EQUAL TO 6 WITH SPECIAL REFERENCE TO THE UNIQUE SATURATED DESIGNS /ESIGNS OF RESOLUTION GREA RATIO TESTS PRONENESS UNBIASED TEST FOR THE BINOMIAL PROCESSES EXISTENCE, UNIQUENESS AND MONOTONICITY OF SEQUENTIAL PROBABILITY UNIQUENESS OF A RESULT IN THE THEORY OF ACCIDENT

EXISTENCE AND UNIQUENESS OF A UNIFORMLY MOST POWERFUL RANDOMIZED MODELS

OF THE FIT/ THE UNIQUENESS OF THE SPACING OF OBSERVATIONS IN POLYNOMI AMS $61 \quad 894$ JASA $65 \quad 193$ AMS 691196 BIOKA67 675 BIOKA68 343 BIOKA69 446 HOKA69 NO.3 JASA $67 \quad 638$ JASA $63 \quad 172$ AMS 641064 AMS $67 \quad 471$ $\begin{array}{lrr}\text { AMS } & 67 & 471 \\ \text { AMS } & 1243\end{array}$ AMS $63 \quad 1243$ BIOKA52 425 AMS 691661 AMS 67,253 AMS 682154 JRSSB $65 \quad 57$ AMS $66 \quad 451$ AMS $68 \quad 246$ AMS $63 \quad 1541$ BIOKA57 530

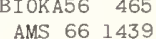
AMS $62 \quad 810$ JASA $67 \quad 288$ A UNIQUENESS THEOREM GONCERNING MOMENT DISTRIBUTIONS JASA 651203
A UNIQUENESS THEOREM FOR STATIONARY MEASURES OF ERCODIC AMS 641781 MARKOV PROCESSES

A UNIQUENESS THEOREM FOR STATIONARY MEASURES OF ERCODIC JASA 69841 JASA $64 \quad 160$ JASA $58 \quad 963$ JASA $60 \quad 664$ JASA $61 \quad 379$ OTES ON IMMICRATION STATISTICS OF THE UNITED STATES $\begin{array}{lll}\text { JASA } & 61 & 379 \\ \text { JASA } & 63 & 444\end{array}$ A QUARTERLY ECONOMETRIC MODEL OF THE UNITED STATES MIGRATION EXPECTANCY IN THE UNITED STATES PLOYED PERSONS TO AND FROM METROPOLITAN AREAS OF THE UNITED STATES AN ECONOMETRIC MODEL FOR UNITED STATES AGRICULTURE

THE MIGRATION OF EM JASA 671418 JASA 59556 ANTICIPATIONS AND INVESTMENT BEHAVIOR IN UNITED STATES MANUFACTURING 1947-1960 JASA $69 \quad 67$ ON THE STATISTICAL DISCREPANCY IN THE REVISED UNITED STATES NATIONAL ACCOUNTS JASA $66 \quad 1219$ NDS IN DEATH RATES BIAS IN ESTIMATES OF THE UNITED STATES NONWHITE POP RESIDENCE HISTORIES AND EXPOSURE RESIDENCES FOR THE UNITED STATES POPULATION A COMPARISON OF MAJOR UNITED STATES RELIGIOUS GROUPS

REGIONAL CYCLES OF MANUFACTURINC EMPLOYMENT IN THE UNITED STATES, 1914-1953, CORR, 60755 SEASONAL VARIATION OF DEATHS IN THE UNITED STATES, 1951-1960

A.TWO-PERIOD DESIGN WITH T-SQUARE EXPERIMENTAL UNITS

ESTIMATES OF SAMPLING VARIANCE WHERE TWO UNITS ARE SELECTED FROM EACH STRATUM INCREASE IN RENT OF DWELLING UNITS FROM 1940 TO 1950 SIZE REQUIRED FOR ESTIMATING THE VARIANCE WITHIN D UNITS OF THE TRUE VALUE JASA $61 \quad 44$ JASA $61 \quad 824$ JASA 61568 JASA $60 \quad 151$ JASA $66 \quad 706$ BIOCS68 61 JASA $57 \quad 503$ JASA $59 \quad 358$ SELECTED STATISTICAL JOURNALS SAMPLE AMS $64 \quad 438$ 
TIMATE THE PARAMETER IN THE UNIFORM DENSITY WITHIN D UNITS OF THE TRUE VALUE SAMPLE SIZE REQUIRED TO ES JASA 64 CE ESTIMATORS IN UNEQUAL PROBABILITY SAMPLINC OF TWO UNITS PER STRATUM /ILITIES OF ESTIMATORS AND VARIAN JASA 69 540 T OPTIMUM ALLOCATION OF SAMPLINC UNITS TO STRATA WHEN THERE ARE R RESPONSES OF INTERES JASA 65 MULA FOR THE PROBABILITY THAT TWO SPECIFIED SAMPLINC UNITS WILL OCCUR IN A SAMPLE DRAWN WITH UNEQUAL PROBA JASA 66 3 PROCRAMMINC UNTVARIATE AND MULTIVARIATE ANALYSTS OF VARIANCE TECH 63 OF THE POPULATION V/ TESTS OF LINEAR HYPOTHESES IN UNIVARIATE AND MULTIVARIATE ANALYSIS WHEN THE RATIOS BIOKA54 MULTIVARIATE PAIRED COMPARISONS. THE EXTENSION OF A UNIVARIATE MODEL AND ASSOCIATED ESTIMATION AND TEST P BIOKA69 ILITY OF THE USUAL CONFIDENCE SETS FOR THE MEAN OF A UNIVARIATE OR BIVARIATE NORMAL POPULATION ADMISSIB AMS 69 IO42 OBABILITY TNFERENCES BASED ON A SAMPLE FROM A FINITE UNIVARIATE POPULATION TO THE INVERSE DISTRIBUTION FUNCTION OF A CONTINUOUS UNIVARIATE POPULATION FROM THE ORDER STATISTICS OF A BIOKAG9 NO. 3 CHARACTERIZATION THEOREMS FOR SOME UNIVARIATE PROBABILITY DISTRIBUTIONS CHARACTERIZATION THEOREMS FOR SOME UNIVARIATE PROBABILITY DISTRIBUTIONS JRSSB64 286 IMATE SOLUTIONS OF GREEN'S TYPE FOR UNIVARIATE STOCHASTIC PROCESSES

APPROXIMATE SOLUTIONS OF GREEN'S TYPE FOR UNIVARIA
ON PRODUCT MOMENTS FROM A FINITE UNIVERSE

MORE RESULTS ON PRODUCT MOMENTS FROM A FINITE UNIVERSE
IN RANDOM SAMPLES OF ANY SIZE DRAWN FROM NON-NORMAL UNIVERSES /E PRODUCT-MOMENT CORRELATION COEFFICIENT SAMPLING FROM BIVARIATE NON-NORMAL UNIVERSES BY MEANS OF COMPOUND NORMAL DISTRIBUTIONS TEACHINC BIOMETRY IN THE UNIVERSITY

REGRESSION UNLIMITED SIMUTANEOUS DISCRIMINATION INTERVALS IN JRSSB $66 \quad 143$ JRSSB $60 \quad 376$ JASA $6 B \quad 535$ JASA $69 \quad 864$

IGN WITH A MIXED MO/ NOTE THE QUASI-F TEST FOR AN UNNESTED FIXED FACTOR IN AN UNBALANCED HIERARCHAL DES ESTIMATING THE TOTAL PROBABILITY OF THE UNOBSERVED OUTCOMES OF AN EXPERIMENT

METRIC SUM OF RANKS PROCEDURE FOR RELATIVE SPREAD IN UNPAIRED SAMPLES, CORR. 611005 HISTORICAL NOTES ON THE WILCOXON UNPAIRED TWO-SAMPLE TEST

THEORETICAL FRAMEWORK

THE UNRELATED QUESTION RANDOMIZED RESPONSE MODEL

A NONPARA JASA 60

JASA $57 \quad 356$

JASA $69 \quad 520$

JASA $67 \quad 141$ $\begin{array}{lll}\text { JASA } & 67 & 141 \\ \text { JASA } & 63 & 977\end{array}$ ESTIMATORS FOR SEEMINGLY UNRELATED RECRESSION EQUATIONS, SOME EXACT

SAMPLE RESULTS E ESTIMATORS OF SEEMINGLY UNRELATED REGRESSIONS

AN BUT NOT REPLACED THE COMPUTATION OF THE UNRESTRICTED AOQL WHEN DEFECTIVE MATERIAL IS REMOVED

JASA $6 B \quad 1180$ JASA $62 \quad 34 B$ JASA 69665 QUOTA FULFILMENT USING UNRESTRICTED RANDOM SAMPLING THE CORRELATED UNRESTRICTED RANDOM WALK

TIONS

RELATIONSHIP OF CENERALIZED POLYKAYS TO UNRESTRICTED SUMS FOR BALANCED COMPLETE FINITE POPULA A MONTE CARLO SOLUTION OF A TWO-DIMENSIONAL UNSTRUCTURED CLUSTER PROBLEM ER CONTAGIOUS DISTRIBUTIONS A METHOD OF ANALYSING UNTRANSFORMED DATA FROM THE NEGATIVE BINOMIAL AND OTH UNUSUAL FREQUENCY DISTRIBUTIONS

OF LEADING COEFFICIENTS FOR ORTHOCONAL POLYNOMIALS UP TO $\mathrm{N}=26$ LY CENSORED SAMPLES, PART I. THE NORMAL DISTRIBUTION UP TO SAMPLES OF SIZE IO'/ICS FROM SINGLY AND DOUB THE UP-AND-DOWN METHOD FOR SMALL SAMPLES

ASYMPTOTIC PROPERTIES OF THE BLOCK UP-AND-DOWN METHOD IN BIO-ASSAY THE MULTIPLE SAMPLE UP-AND-DOWN METHOD IN BIOASSAY ALTERNATIVE PROOFS FOR CERTAIN UPCROSSINC INEQUALITIES A NOTE ON UPCROSSINGS OF SEMIMARTINGALES

A CHARACTERIZATION OF THE UPPER AND LOWER CLASSES IN TERMS OF CONVERCENCE RATES A CTH OF A CUMUL/ A SIMPLE PROCEDURE FOR DETERMININC UPPER AND LOWER LIMITS FOR THE AVERACE SAMPLE RUN LEN JR CLOSED INTERVAL MULTIVALUED MAPPING PLE FROM A FINITE UNIVARIATE POPULATION OF HYPOTHESES WITH MONOTONE DENSITY RATIOS AIN PARTIALLY BALANCED INCOMPLETE BLOCK DESIGNS UPPER AND LOWER PROBABILITIES GENERATED BY A RANDOM UPPER AND LOWER PROBABILITIES INDUCED BY A BIOKA61 333 JRSSB63 394 AMS 6B 643 AMS $63 \quad 348$ $\begin{array}{ll}\text { BIOKA68 } & 163 \\ \text { BIOCS65 } & 159\end{array}$ TECH 65644 AMS $39 \quad 325$ JASA 65967 AMS 671822 JASA $69 \quad 147$ AMS $67 \quad 735$ AMS $66 \quad 72 \mathrm{~B}$ AMS 691120 EDURE WITH A SAMPLE FROM A NORMAL POPULATION WHEN AN UPPER BOUND TO THE STANDARD DEVIATION IS KNOWN /ROC JASA 60 94 IES FOR THE SUM OF INDEPENDENT, BOUNDED RANDOM VA/ UPPER BOUNDS ON THE MOMENTS AND PROBABILITY INEQUALIT BIOKA65 559 HE PROBABILITY THAT Y IS LESS THAN/ NONPARAMETRIC UPPER CONFIDENCE BOUNDS, AND CONFIDENCE LIMITS, FOR T JASA 64 906 MATRIX IN MULTIVARIATE ANALYSIS UPPER PERCENTAGE POINTS OF THE LARGEST ROOT OF A BIOKA67 189 UPPER 5 AND 1 PERCENT POINTS OF THE MAXIMUM F-RATIO BIOKA52 422

BERNARD FRTEDMAN'S URN

CESSES AND RELATED LIMIT THEOREMS EMBEDDING OF URN SCHEMES INTO CONTINUOUS TIME MARKOV BRANCHING PRO EQUIVALENCE AND SINGULARITY FOR FRIEDMAN URNS

HOW MANY OF A GROUP OF RANDOM NUMBERS WILL BE USABLE IN SELECTING A PARTICULAR SAMPLE RECENT EFFORTS TO IMPROVE LAND USE INFORMATION

GENERALIZED MULTIVARIATE ANALYSIS OF VARIANCE MODEL USEFUL ESPECIALLY FOR GROWTH CURVE PROBLEMS

ON 'THE JACOBIANS OF CERTAIN MATRIX TRANSFORMATION USEFUL IN MULTIVARIATE ANALYSIS'

$\begin{array}{lrr}\text { AMS } & 65 & 956 \\ \text { AMS } & 6 B & 1 B 01\end{array}$

AMS $66 \quad 268$

JASA 59102

JASA $66 \quad 647$

A BIOKA64 313

BIVARTATE UNKNOWN LOCATION AND SCAL/ INADMISSIBILITY OF THE USUAL ESTIMATORS OF SCALE PARAMETERS IN PROBLEMS WITH AMS 68 29 SE DISC/ L'ANALYSE EN COMPOSANTES PRINCIPALES, SON UTILISATION EN GENETIQUE ET SES RAPPORTS AVEC L'ANALY BIOCS66 343 THEORY OF SUBJECTIVE PROBABILITIES AND EXPECTED UTILITIES BOUNDED EXPECTED UTILITY AMS 671054 LLY DECAYING UTILITY EXPECTED UTILITY FOR QUEUES SERVICING MESSAGES WITH EXPONENTIA AMS 615 B7 ORROBORATION, EXPLANATORY POWER, INFORMATION AND THE UTILITY OF EXPERIMENTS (CORR. 68 203) /EVIDENCE, G JRSSB60 319 THE ESTIMATION PROCEDURE C OF TWO UNITS FROM A STRATUM (ADDENDUM 6/ OPTIMUM UTILIZATION OF AUXILIARY INFORMATION, (PI)PS SAMPLIN JRSSB67 374
(P) ON THE UTTILIZATION OF MARKED SPECTMENS IN ESTIMATING POPULAT BIOKA53 170 IVE ANALYSIS. GENERAL THEORY AND THE CA/ EFFICIENT UTILIZATION OF NON-NUMERICAL INFORMATION IN QUANTITAT AMS 63 I347 BLOCK DESICNS CROUP SCREENINC UTILIZINC BALANCED AND PARTIALLY BALANCED INCOMPLETE BIOCS65 865 IAL RELATIONSHIP AMONG EICHT POPULATIONS ZEA MAYS L. UTILIZING INFORMATION FROM A DIALLEL MATING DESIGN BIOGS68 867 ESTIMATING VARIANCE ON UTILIZING INFORMATION FROM A SECOND SAMPLE IN

SIZ/ SEVERAL METHODS OF RE-DESICNING AREA SAMPLES UTILIZING PROBABILITIES PROPORTIONAL TO SIZE WHEN THE JASA 6B I2BO ON ADDELMAN'S 2-TO-THE-(17-9) RESOLUTION V PLAN CONSTRUCTION OF A 2-TO-THE-(17-9) RESOLUTION V PLAN IN EIGHT BLOCKS OF 32 RUN LENCTH OF THE CUMULATIVE SUM CHART WHEN A V-MASK IS USED THE GOODNESS OF FIT STATISTIC V-SUB-N, DISTRIBUTION AND SICNIFICANCE POINTS THE V-SUB-NM TWO-SAMPLE TEST

ON THE MOMENT GENERATING FUNCTION OF PILLAI'S V-SUPER-S CRITERION 
LY BALANCED INCOMPLETE BLOCK DESIGNS WITH PARAMETERS V=28, N1=12, N2=15 AND P2 $(1,1)=4$ SPREAD OF DISEASES IN A RECTANGULAR PLANTATION WITH VACANCIES

THE DISTRIBUTION OF VACANCIES ON A LINE A NOTE ON VACANCIES ON A LINE

ON COMBINING THE RESULTS FROM CLINICAL TRIALS OF A VACCINE ACCEPTANCE SCHEMES IN TESTING ANTIGENICITY OF VACCINES

PLUSIEURS CARACTERES

ATTRIBUTES

COMMON STOCK

VALEURS GENOTYPIQUES DANS LA SELETTION PAR INDEX SUR

VALIDATING RESULTS OF SAMPLING INSPECTION BY

VALIDATION OF CONSUMER FINANCIAL CHARACTERISTICS,

CONDITIONS FOR OPTIMALITY AND VALIDITY AND SIMPLE LEAST SQUARES THEORY

WHO RECEIVED WELFARE ASSISTANCE DURING 1959

THE VALIDITY OF INCOME REPORTED BY A SAMPLE OF FAMILIES
TESTING THE APPROXIMATE VALIDITY OF STATISTICAL HYPOTHESES

/CTION OF PARTIAL AMS 661783 BIOKA53 287 JRSSB59 364 JRSSB61 207 BI0CS65 616 BIOCS66 684 BIOCS69 295 TECH $63 \quad 23$ JASA 69415 AMS 691617 JASA 62680 JRSSB 54261 BUTION OF LIFE IS EXPONENTIAL, PART/ TESTS FOR THE VALIDITY OF THE ASSUMPTION THAT THE UNDERLYING DISTRI TECH 60 B3 IBUTION OF LIFE IS EXPONENTIAL, PAR/ TESTS FOR THE VALIDITY OF THE ASSUMPTIONS THAT THE UNDERLYING DISTR TECH 60 167 E GOODNESS-OF-FIT TESS FOR SMALL BUT/ COMPARATIVE VALIDITY OF THE CHI-SQUARE AND TWO MODIFIED CHI-SQUAR BIOKA66 6I9 AND KOLMOGOROV GOODNESS-OF-FIT TESTS WITH RESPECT TO VALIDITY, CORR. 66 1249 /OF THE PEARSON CHI-SQUARE JASA 65 854 THE REGRESSION OF TRUE VALUE ON ESTIMATED VALUE

ESTIMATING THE VARIANCE WITHIN D UNITS OF THE TRUE VALUE ER IN THE UNIFORM DENSITY WITHIN D UNITS OF THE TRUE VALUE LINEAR ESTIMATES OF PARAMETERS IN THE EXTREME VALUE DISTRIBUTION

STICS ESTIMATION OF THE PARAMETERS OF THE EXTREME VALUE DISTRIBUTTON GAME VALUE DISTRIBUTIONS I

GAME VALUE DISTRIBUTIONS II

OF TESTS

TISTICAL TESTS IN TIME SERIE/ GALUE METHOD AND THE ASYMPTOTIC RELATIVE EFFICTENCY THE AVERAGE CRITICAL VALUE METHOD AND THE ASYMPTOTIC RELATIVE EFFICIENCY
THE AVERAGE CRITICAL VALUE METHOD FOR ADJUDGING RELATIVE EFFICIENCY OF STA PRESENT VALUE OF A RENEWAL PROCESS

ON THE EXPECTED VALUE OF A STOPPED MARTINGALE

ON THE EXPECTED VALUE OF A STOPPED STOCHASTIC SEQUENCE

ON THE EXPECTED VALUE OF A STOPPED SUBMARTINGALE

A NOTE ON THE EXPECTED VALUE OF AN INVERSE MATRIX

THE VALUE OF INDIRECT SELECTION, 1. MASS SELECTION

PRACTICAL VALUE OF INTERNATIONAL EDUCATIONAL STATISTICS

THE VALUE OF ORTHOGONAL POLYNOMTALS IN THE ANALYSIS OF

CHANGE-OVER TRIALS WITH DAIRY COWS

NCED INCOMPLETE BLOCK DESIG/ ON USING AN INCORRECT VALUE OF SIGMA-SQUARE-SUB-B-OVER-SIGMA-SQUARE IN BALA B THE REGRESSION OF TRUE VALUE ON ESTIMATED VALUE

BACTERIAL EXTINCTION TIME AS AN EXTREME VALUE PHENOMENON

AN ESTIMATOR OF HIGH EFFICIENCY IN BIVARIATE EXTREME VALUE THEORY

TS TO, EDWARD C. POSNER, 'THE APPLICATION OF EXTREME VALUE THEORY TO ERROR FREE COMMUNICATION' THE APPLICATION OF EXTREME VALUE THEORY TO ERROR-FREE COMMUNICATION

THE RATIONAL ORIGIN FOR MEASURING SU8JECTIVE VALUES

ELEMENTS OF THE THEORY OF EXTREME VALUES QUERY, REJECTION OF OUTLYING VALUES

QUERY, BIVARIATE SAMPLES WITH MISSING VALUES USING SUBSAMPLE VALUES AS TYPICAL VALUES

OF POLYNOMIALS TO EQUIDISTANT DATA WITH MISSING VALUES

FOR MEAN SQUARE SUCCESSIVE DIFFERENCE CRITICAL VALUES

FOR THE STATISTICAL DISTRIBUTIONS OF EXTREME VALUES TERS OF THE FIRST ASYMPTOTIC DISTRIBUTION OF EXTREME VALUES NOMIAL REGRESSION FOR MINIMAX VARIANCE OF THE FITTED VALUES NS ON THE EXTREME VALUES A ON THE EXTREME VALUES AND RANGE OF SAMPLES FROM NON-NORMAL POPULATIO $8 I O K A 67$ 54I
VARIABLE FROM A DECAPITATED NEGATIVE BI/ EXPECTED VALUES AND STANDARD DEVIATIONS OF THE RECIPROCAL OF A JASA 62 439 TWO EARLY PAPERS ON THE RELATION BETWEEN EXTREME VALUES AND TENSILE STRENGTH USING SUBSAMPLE VALUES AS TYPICAL VALUES CRITICAL VALUES FOR BIVARIATE STUDENT T-TESTS

NOTES. APPROXIMATIONS TO THE CRITICAL VALUES FOR DUNCAN'S MULTIPLE RANGE TEST

ASA 65 BIOKA60 457 JASA $64 \quad 550$ TECH $66 \quad 3$ BIOKA69 429 AMS 67242 AMS 67251 BIOKA67 308 BIOKA66 109 AMS 641326 AMS 661505 AMS 69456 AMS $6760 \mathrm{~B}$ 8IOKA69 NO. 3 BIOCS65 682 JASA $56 \quad 605$ BIOCS67 297 BIOKA68 254 BIOKA60 457 BI0CS67 B35 JASA 69 NO. 4 TECH $65 \quad 517$ JASA $57 \quad 458$ TECH $60 \quad 27$ TECH 64228 TECH $67 \quad 679$ JASA 69 NO. 4 THE FITTING BIOKA5I 410 APPROXIMATIONS TECH 6 B 397 APPROXIMATE FORMULAE BIOKA58 447 /FROM DOUBLY CENSORED SAMPLES, OF THE PARAME JASA $6 \mathrm{~B}$ 8B9 $\begin{array}{lllll}\text { FROM DOUBLY CENSORED SAMPLES, OF THE PARAME JASA } 6 \mathrm{~B} & 8 B \\ \text { NESS OF THE SPACING OF OBSERVATIONS IN POLY AMS } 62 & 810\end{array}$ JASA $62 \quad 439$ BIOKA54 559 JASA 69 N0. 4 JASA $69 \quad 637$ BIOCS66 179 R DISPERSION AND ITS NORMAL APPROX/ EXACT CRTTICAL VALUES FOR MOODIS DISTRTBUTTON-FREE TEST STATTSTIC FO TECH 68 497 STIC AN EXTENDED TABLE OF CRITICAL VALUES FOR THE MANN-WHITNEY-WILCOXON TWO-SAMPLE STATI JASA 64 925 FURTHER CRITICAL VALUES FOR THE SUM OF TWO VARIANCES FURTHER CRITICAL VALUES FOR THE TWO-MEANS PROBLEM BIOKA63 177 BIOKA64 527 QUERY, THE SUM OF VALUES FROM A NORMAL AND A TRUNCATED NORMAL DISTRIBUT TECH 64 104 ION (CONTD)
QUERY, THE SUM OF VALUES FROM A NORMAL AND A TRUNCATED NORMAL DISTRIBUT TECH 64 469
QUERY. MISSING VALUES IN FACTORIAL EXPERIMENTS
MISSING VALUES IN LINEAR MULTIPLE DISCRIMINANT ANALYSIS ION (CONTD)
QUERY, THE SUM OF VALUES FROM A NORMAL AND A TRUNCATED NORMAL DISTRIBUT TECH 64 469
QUERY. MISSING VALUES IN FACTORIAL EXPERIMENTS
MISSING VALUES IN LINEAR MULTIPLE DISCRIMINANT ANALYSIS ION (CONTD)
QUERY, THE SUM OF VALUES FROM A NORMAL AND A TRUNCATED NORMAL DISTRIBUT TECH 64 469
QUERY. MISSING VALUES IN FACTORIAL EXPERIMENTS
MISSING VALUES IN LINEAR MULTIPLE DISCRIMINANT ANALYSIS ELECTRONIC COMP/A METHOD OF ESTIMATION OF MISSING VALUES IN MULTIVARIATE DATA SUITABLE FOR USE WITH AN JRSSB6O 302 LITERATURE MISSING VALUES IN MULTIVARIATE STATISTICS, I. REVIEN OF THE MISSING VALUES IN PARTIAL DIALLEL CROSS EXPERIMENTS MISSING VALUES IN RESPONSE SURFACE DESIGNS

THE DISTRIBUTION OF EXTREMAL AND NEARLY EXTREMAL VALUES IN SAMPLES FROM A NORMAL DISTRIBUTION

DISTRIBUTION OF PRODUCT AND OF QUOTIENT OF MAXIMUM VALUES IN SAMPLES FROM A POWER-FUNCTION POPULATION PROCESSES EXTREME VALUES TN UNIFORMLY MIXING STATIONARY STOCHASTIC

THE ASYMPTOTIC VALUES OF CERTAIN COVERAGE PROBABILITIES

DETERMINING BOUNDS ON EXPECTED VALUES OF CERTAIN FUNCTIONS

A NOTE ON RECURRENCE RELATIONS BETWEEN EXPECTED VALUES OF FUNCTIONS OF ORDER STATISTICS EXPECTED VALUES OF NORMAL ORDER STATISTICS F TERMS OF THE DAVID-JOHNSON SERIES FOR THE EXPECTED VALUES OF NORMAL ORDER STATISTICS CORRIGENDA, 'EXPECTED VALUES OF NORMAL ORDER STATISTICS' QUERY, COMBINING VALUES OF OBSERVED CHI-SQUARE'S SOME BOUNDS FOR EXPECTED VALUES OF ORDER STATISTICS

ISTICS FOR SAMP/ CORRECTION TO 'TABLES OF EXPECTED VALUES OF ORDER STATISTICS AND PRODUCTS OF ORDER STAT AN INEQUALITY FOR EXPECTED VALUES OF SAMPLE QUANTILES TABLES OF CRITICAL VALUES OF SOME RENYI TYPE STATISTICS FOR FINITE

SAMPLE STZES CRITICAL VALUES OF THE COEFFICIENT OF RANK CORRELATION FOR TES TING THE HYPOTHESIS OF INDEPENDENCE PROCESSES SYMPTOTIC VALUES OF THE FIRST TWO MOMENTS IN MARKOV RENEWAL JASA $66 \quad 595$ BI0CS68 903 TECH 61389 BIOKA63 89 JASA $64 \quad 877$ AMS 65993 BIOKA69 N0.3 AMS 621454 AMS $66 \quad 733$ BIOKA61 151 BIOKA60 79 BIOKA61 476 TECH $66 \quad 709$ AMS $65 \quad 1055$ AMS 611345 AMS 671817 JASA $69 \quad 870$ BIOKA61 444 BIOKA67 597 ABILITY INTEGRAL OF THE GAMMA DISTRIBUTION FOR SMALL VALUES OF THE SHAPE PARAMETER /XIMATION TO THE PROB BIOKAG2 276 
作 SIGNIFICANCE TESTS FOR A VARIABLE CHANCE OF INFECTION IN CHAIN-BINOMIAL THEORY BIOKA56 332

OTH VAR/ A GENERALIZED APPLICATION OF INSTRUMENTAL VARIABLE ESTIMATION OF STRAIGHT-LINE RELATIONS WHEN B TECH 69 255 ISN'T MY PROCESS TOO VARIABLE FOR EVOP TECH $6 \mathrm{~B} \quad 439$

ALUES AN STANDARD DEVIATIONS OF THE RECIPROCAL OF A VARIABLE FROM A DECAPITATED NEGATIVE BINOMIAL DISTRIB JASA 62 439 GENERATING A VARIABLE FROM THE TAIL OF THE NORMAL DISTRIBUTION TECH 64101 NG PROBABILITIES OF A CLASS OF WIDELY USED/ A TWO-VARIABLE GENERATING FUNCTION FOR COMPUTING THE SAMPLI JASA 64 487 SAMPLING THE USE OF A STRATIFICATION VARIABLE IN ESTIMATION BY PROPORTIONAL STRATIFIED JASA 681310 EXPERIMENTAL DESIGNS FOR ESTIMATING THE INDEPENDENT VARIABLE IN REGRESSION THE USE OF A CONCOMITANT VARIABLE IN SELECTING AN EXPERIMENTAL DESIGN

CORRIGENDA TO 'THE USE OF A CONCOMITANT VARIABLE IN SELECTING AN EXPERIMENTAL DESIGN OPTIMAL TECH 68 811 EXPRESSING A RANDOM VARIABLE IN TERMS OF UNIFORM RANDOM VARIABLES

FITTING STRAICHT LINES WHEN ONE VARIABLE IS CONTROLLED

TERS FOR A MULTIVARIATE NORMAL DISTRIBUTION WHEN ONE VARIABLE IS DICHOTOMISED. LARGE-SAMPLE COVARIANCE ANALYSIS WHEN THE CONTROL VARIABLE IS FALLIBLE

CORRELATION COEFFICIENTS WHEN OBSERVATION ON ONE VARIABLE IS RESTRICTED BIOKA57 150 BIOKA57 534 AMS $61 \quad 894$ JASA $58 \quad 106$ A BRANCHING PROCESS IN WHICH INDIVIDUALS HAVE VARIABLE LIFETIMES

PAIRWISE INDEPENDENCE OF JOINTLY DEPENDENT VARIABLES

A FLUCTUATION THEOREM FOR CYCLIC RANDOM VARIABLES

THE VARIANCE OF THE PRODUCT OF K RANDOM VARIABLES

STUDIES OF INTERVIEWER VARIANCE FOR ATTITUDINAL VARIABLES

A SEQUENTIAL METHOD FOR SCREENING EXPERIMENTAL VARIABLES TRANSFORMATION OF THE INDEPENDENT VARIABLES

DISTRIBUTIONS OF PRODUCTS OF INDEPENDENT VARIABLES

ON THE INDEPENDENCE OF CERTAIN WISHART VARIABLES CORRELATION AND COMPLETE DEPENDENCE OF RANDOM VARIABLES PROBABILITY INEQUALITIES FOR SUMS OF BOUNDED RANDOM VARIABLES ASYMPTOTIC EXTREMES FOR M-DEPENDENT RANDOM VARIABLES

A LIMIT THEOREM FOR SUMS OF MINIMA OF STOCHASTIC VARIABLES CONVERGENCE OF QUADRATIC FORMS IN INDEPENDENT RANDOM VARIABLES SOME CONVERGENCE THEOREMS FOR INDEPENDENT RANDOM VARIABLES

INFINITE DIVISIVILITY OF INTEGER-VALUED RANDOM VARIABLES

THE INVARIANCE PRINCIPLE FOR A LATTICE OF RANDOM VARIABLES AN INEQUALITY IN CONSTRAINED RANDOM VARIABLES

CONTRIBUTIONS TO CENTRAL LIMIT THEORY FOR DEPENDENT VARIABLES

DISTANCES OF PROBABILITY MEASURES AND RANDOM VARIABLES ON DISCRIMINATION USING QUALITATIVE VARIABLES

THE MARKOV INEQUALITY FOR SUMS OF INDEPENDENT RANDOM VARIABLES BOUNDS ON MOMENTS OF SUMS OF RANDOM VARIABLES

ON THE EXACT COVARIANCE OF PRODUCTS OF RANDOM VARIABLES SAMPLING WITH CONTROL VARIABLES

THE MULTIVARIATE DISTRIBUTION OF COMPLEX NORMAL VARIABLES

THE Z-TEST AND SYMMETRICALLY DISTRIBUTED RANDOM VARIABLES

GAMMA-DISTRIBUTED PRODUCTS OF INDEPENDENT RANDOM VARIABLES

ON BAYES SEQUENTIAL DESICN WITH TWO RANDOM VARIABLES

ON THE RATIO OF TWO CORRELATED NORMAL RANDOM VARIABLES TRACES AND CUMULANTS OF QUADRATIC FORMS IN NORMAL VARIABLES SOME TESTS OF SIGNIFICANCE WITH ORDERED VARIABLES THE COMPARISON OF REGRESSION VARIABLES

ON THE DISTRTBUTION OF PRODUCTS OF RANDOM VARIABLES ON COMPARING THE CORRELATIONS WITHIN TWO PAIRS OF VARIABLES SELECTION AMONG DIALLEL CLASSIFIED VARIABLES 
IDENTITY FOR THE VARIANCE OF A RATIO OF TWO RANDOM VARIABLES OF LEVELS OF POLYNOMIAL REGRESSION WITH ONE OR TWO VARIABLES LIMIT THEOREMS FOR FAMILIES OF SEQUENCES OF RANDOM VARIABLES CONTROL SYSTEMS BASED ON INACCURATELY MEASURED VARIABLES THREE LEVEL DESIGNS FOR THE STUDY OF QUANTITATIVE VARIABLES MAXIMUM-LIKELIHOOD IN THE CASE OF DEPENDENT RANDOM VARIABLES THE DISTRIBUTION OF QUADRATIC FORMS IN NORMAL VARIABLES

SEQUENTIAL DESIGN OF EXPERIMENTS WITH TWO RANDOM VARIABLES STATISTICS IN THE CASE OF INDEPENDENT RANDOM VARIABLES INEQUALITIES FOR THE SUM OF INDEPENDENT RANDOM VARIABLES CONVERGENCE OF QUADRATIC FORMS IN INDEPENDENT RANDOM VARIABLES THE PROBABILITY OF AN EVENT AS A FUNCTION OF SEVERAL VARIABLES TYPE INEQUALITY FOR SUMS OF INDEPENDENT RANDOM VARIABLES ARIABLES IN CLASSIFICATION PROBLEMS WITH DICHOTOMOUS VARIABLES WITH MISSING OBSERVATIONS AMONG THE INDEPENDENT VARIABLES WHEN THERE IS PRIOR INFORMATION ABOUT SUPPLEMENTARY VARIABLES SEQUENTIAL SAMPLING SCHEME FOR INSPECTION BY VARIABLES

FOR THE MEANS OF DEPENDENT NORMALLY DISTRIBUTED VARIABLES TO A SET OF STOCHASTICALLY DEPENDENT NORMAL VARIABLES

MEAN OF A CENSORED NORMAL DISTRIBUTION BY ORDERED VARIABLES AND INDEPENDENT GAMMA-DISTRIBUTED PRODUCTS OF RANDOM VARIABLES OF THE MAXIMUM TERM IN SEQUENCES OF DEPENDENT RANDOM VARIABLES

THE WEIGHTED DIFFERENCE OF TWO INDEPENDENT STUDENT VARIABLES THEOREM TO NON-IDENTICALLY DISTRIBUTED RANDOM VARIABLES

LAWS AND A RENEWAL THEOREM FOR NON-NEGATIVE RANDOM VARIABLES AND THE UNIFORM DISTRIBUTION OF INDEPENDENT RANDOM VARIABLES NEQUALITY FOR THE SUM OF INDEPENDENT, BOUNDED RANDOM VARIABLES REGRESSION WITH CONSTRAINTS ON THE INDEPENDENT VARIABLES WITH MISSING OBSERVATIONS AMONG THE INDEPENDENT VARIABLES OF QUADRATIC FORMS IN SERIALLY CORRELATED NORMAL VARIABLES ON THE ASYMPTOTIC DISTRIBUTION OF SUMS OF RANDOM VARIABLES OF HERMITIAN QUADRATIC FORMS IN COMPLEX NORMAL VARIABLES ONSUMER ATTITUDES, STOCK PRICES, AND NON-ATTITUDINAL VARIABLES

DISTRIBUTIONS OF TWO STOCHASTICALLY ORDERED RANDOM VARIABLES AUTOCORRELATED RESIDUALS BY THE USE OF INSTRUMENTAL VARIABLES ZED SIMILAR TEST FOR THE INDEPENDENCE OF TWO POISSON VARIABLES UMBERS FOR LINEAR GOMBINATIONS OF INDEPENDENT RANDOM VARIABLES EXPECTATION FOR SUMS OF BOUNDED. INDEPENDENT RANDOM VARIABLES RANDOMIZED EXPERIMENTS WITH NONCONTROLLED PREDICTOR VARIABLES US AND NON-HOMOGENEOUS QUADRATIC FUNCTIONS OF NORMAL VARIABLES NORMALITY THE ANALYSIS OF ASSOGIATION AMONG MANY VARIABLES SUMMARY OF RECENT WORK ON VARIABLES LINEAR RELATIONSHIPS BETWEEN VARIABLES A ESTIMATION OF AN EXPONENTIAL S/ USE OF CONCOMITANT VARIABLES NCE OF LINEAR GOMBINATIONS OF INDEPENDENT AND RANDOM VARIABLES RATIOS OF NORMAL VARIABLES A

ATIVE (CORR 65 533) ASSOGIATION BETWEEN RANDOM VARIABLES A ANCE IN EFFICIENT MOMENT ESTIMATORS WHEN THE VARIABLES ARE DEPENDENT WITH SPECIAL REFERENCE TO TYP BIOKA62 155 ULTIVARIATE REGRESSION WHEN THE INDEPENDENT VARIABLES ARE ORTHOGONAL /DETERMINATION OF SIGNIFIC JRSSB67 I54 REGRESSION PROBLEMS WHEN THE PREDICTOR VARIABLES ARE PROPORTIONS STIMATOR IN REGRESSION ANALYSIS WHEN THE 'PREDICTOR' VARIABLES ARE STOCHASTIC /ES OF THE LEAST SQUARES E AMS 62 1365 FITTING OF STRAIGHT LINES AND PREDICTION WHEN BOTH VARIABLES ARE SUBJECT TO ERROR

INTERVAL ESTIMATION IN LINEAR REGRESSION WHEN BOTH VARIABLES ARE SUBJECT TO ERROR

DISTRIBUTIONS FOR ESTIMATING FUNCTIONS WHEN BOTH VARIABLES ARE SUBJECT TO ERROR ABLE ESTIMATION OF STRAIGHT-LINE RELATIONS WHEN BOTH VARIABLES ARE SUBJECT TO ERROR THE FITTING OF STRAIGHT LINES WHEN BOTH VARIABLES ARE SUBJECT TO ERROR, CE BETWEEN CONSECUTIVE MEMBERS OF A SERIES OF RANDOM VARIABLES ARRANGED IN ORDER OF SIZE RVAL

$$
\text { A MOVING AVERAGE REPRESENTATION FOR RANDOM VARIABLES COVARIANCE STATIONARY ON }
$$

CONVEXITY PROPERTY IN THE THEORY OF RANDOM VARIABLES DEFINED ON A FINITE MARKOV CHAIN

ON AN JRSSB64 484 CHOICE TECH $65 \quad 325$ CENTRAL AMS $63 \quad 439$ QUALITY BIOKA51 472 SOME NEW TECH $60 \quad 455$ A NOTE ON JRSSB61 444 COMPUTING BIOKA61 419 ASYMPTOTIC JRSSB $66 \quad 73$ SUFFICIENT AMS 641456 PROBABILITY JASA $62 \quad 33$ ALMOST SURE AMS 681502 ESTIMATION OF BIOKA67 167 ON A CHEBYSHEV - AMS 66248 ON THE CHOICE OF V BIOKA67 668 MULTIPLE REGRESSION JASA $56 \quad 122$ REGRESSION ANALYSIS JRSSB60 172 THE MOST ECONOMICAL JRSSB59 400 CONFIDENCE INTERVALS JASA 59613 LINEAR TRANSFORMATION JASA $57 \quad 247$ THE ESTIMATION OF THE BIOKA.56 482 INVERSE DISTRIBUTIONS BIOKA63 505 LIMITING DISTRIBUTION AMS 62894 AN EXTENSION OF ROSEN'S AMS 6B 897 ON INFINITELY DIVISIBLE AMS $68 \quad 139$ NOTE ON WEYL'S CRITERION AMS 691124 TENERATING FUNCTIONS BIOKA58 198 ON THE INFLUENCE OF MOMENTS AMS 631042 THE CHARACTERISTIC FUNCTION BIOKA60 199 THE PREDICTIVE ABILITY OF C JASA 64987

MAXIMUM LIKELIHOOD ESTIMATION OF THE JASA 661067 IV THE DISTRIBUTION OF HOMOGENEO AMS $62 \quad 542$ JRSS867 199 TECH 69 N0. 4 BIOCS66 252 BIOCS66 665 $\begin{array}{rr}\text { BIOCS66 } & 665 \\ \text { AMS } 68 & 1549\end{array}$ AMS 681549

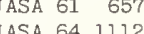
JASA 641112 LIKELIHOOD TECH 67261 /F INSTRUMENTAL VARI TECH $69 \quad 255$ $\begin{array}{llll}59 & 812 & \text { JASA } 59 & 173\end{array}$ THE DIFFEREN BIOKA57 211 SE STATISTIQUE DES LIAISONS ENTRE LES ESPECES ET LES VARIABLES ECOLOGIQUES, PRINCIPES FONDAMENTAUX /NALY BIOCS65 345 SE STATISTIQUE DES LIAISONS ENTRE LES ESPECES ET LES VARIABLES ECOLOGIQUES, UN EXEMPLE /ALES PAR L'ANALY BIOCS65 B9O SELEGTION OF VARIABLES FOR FITTING EQUATIONS TO DATA $\quad$ TECH $66 \quad 27$ THE USE OF CORRELATED VARIABLES FOR PRELIMINARY GULLING DISTINGUISHING A SEQUENCE OF RANDOM VARIABLES FROM A TRANSLATE ITSELF TWO SAMPLE TESTS WITH DICHOTOMOUS AND CONTINUOUS VARIABLES I. THE LOCATION MODEL OTH HNIQUE (ERRATA, 69 6/ TESTING FOR THE INCLUSION OF VARIABLES IN LINEAR REGRESSION BY A RANDOMISATION TEC TECH 66 THE CHOICE OF VARIABLES IN MULTIPLF REGRESSION (WITH DISCUSSION) HE DISCARDING OF VARIABLES IN MULTIVARIATE ANALYSIS USE OF DUMMY VARIABLES IN REGRESSION EQUATIONS JASA $57 \quad 548$ BIOKA69 55 REGRESSION THE CHOICE OF VARIABLES IN THE DES. AMPLE COEFFICIENT OF VARIATION AND AN APPLICATION OF VARIABLES SAMPLING
DESIGN AND OPERATION OF A DOUBLE-LIMIT VARIABLES SAMPLING PLAN DISTRIBUTION VARIABLES SAMPLING PLANS BASED ON THE NORMAL

THE EFFECT OF TRANSFORMATTONS OF VARTABLES UPON THETR CORREIATTON COEFFICIENTS

THE THEORY OF CORRELATION BETWEEN TWO CONTINUOUS VARIABLES WHEN ONE IS DICHOTOMIZED TING CHARACTERISTIC CURVE FOR SEQUENTIAL SAMPLING BY VARIABLES WHEN THE PRODUCER'S AND CONSUMER'S RISKS AR JASA 56 IO8 LOWS SOME KNOWN DISTRIBUTION ON BIVARIATE RANDOM VARIABLES WHERE THE QUOTIENT OF THEIR COORDINATES FOL AMS 64 1673 RIBUTED

A RENEWAL THEOREM FOR RANDOM VARIABLES WHICH ARE DEPENDENT OR NON-IDENTI ON LARGE DEVIATION PROBLEMS FOR SUMS OF RANDOM VARIABLES WHICH ARE NOT ATTRACTED TO THE NORMAL LAW AMS $63 \quad 390$ N ON PAIRS OF INDEPENDENT RANDOM VARIABLES WHOSE PRODUCT FOLLOWS THE A DECOMPOSITION THEOREM FOR VECTOR VARIABLES WITH A LINEAR STRUCTURE

A SINGLE SAMPLING PLAN FOR CORRELATED VARIABLES WITH A SINGLE-SIDED SPECIFICATION LIMIT JASA 59 248 LINEAR FUNCTIONS OF ORDERED CORRELATED NORMAL RANDOM VARIABLES WITH EMPHASIS ON RANGE /NS AND RATIOS OF BIOKA64 I43 A KNOWN LIMIT THEOREM FOR SUM OF INDEPENDENT RANDOM VARIABLES WITH INFINITE EXPECTATIONS /HORT PROOF OF AMS 69 11 I 4 

TION OF THE PRODUCT OF INDEPENDENT CENERALIZED CAMMA VARIABLES WITH THE SAME SHAPE PARAMETER /T DISTRIBU AMS 68 1751 RENTIAL FOR POSITIVE DIRECTIONAL SELECTION ON NORMAL VARIABLES WITHIN SETS OF FINITE SUBPOPULATIONS /FFE BIOCS67 842 CONDITIONAL EXPECTATIONS OF RANDOM VARIABLES WITHOUT EXPECTATIONS

AMS 651556 QUALITIES FOR THE SUM OF INDEPENDENT, BOUNDED RANDOM VARIABLES. MS WITH LINEAR LOSSES FOR BINOMIAL AND NORMAL RANDOM VARIABLES ETWEEN THE P.D.F.'S OF ORDER STATISTICS OF DEPENDENT VARIABLES, ORRELATION MODELS WITH MIXED DISCRETE AND CONTINUOUS VARIABLES INDEPENDENT IDENTICALLY DISTRIBUTED DISCRETE RANDOM VARIABLES, ATIONS OF DISTRIBUTIONS OF QUADRATIC FORMS IN NORMAL VARIABLES.

/UNDS ON THE MOMENTS AND PROBABILITY INE BIOKA65 559 SEQUENTIAL SAMPLING. TWO DECISION PROBLE BIOKA65 507 AND SOME APPLICATIONS /RENCE RELATIONS B BIOKA67 $2 B 3$ CORR. $65343 \quad$ MULTIVARIATE C AMS $61 \quad 44 \mathrm{~B}$ $\begin{array}{llll}\text { CORR, } 66 & 1246 \text { /ISTRIBUTION OF THE SUM OF JASA } 65 & 837\end{array}$ I, CENTRAL CASE SERIES REPRESENT AMS $67 \quad$ B23 II, NON-CENTRAL CASE SERIES REPRESENT AMS $67 \quad 838$ ASSOCIATION RANDOM VARIABLES, WITH APPLICATIONS

LITIES OF THE RTH ABSOLUTE MOMENT OF A SUM OF RANDOM VARIABLES, I LESS THAN OR EQUAL TO R, R LESS THAN OR AMS 65 299 THREE LEVEL DESIGNS FOR THE STUDY OF QUANTITATIVE VARIABLES ' THE DISTRIBUTION OF QUADRATIC FORMS IN NORMAL VARIABLES A NOTE ON AN 'ERRORS IN VARIABLES' MODEL EQUIVALENCE OF TWO ESTIMATES OF PRODUCT VARIANCE NON-ADDITIVITY IN TWO-WAY ANALYSIS OF VARIANCE ROBUST ESTIMATION IN ANALYSIS OF VARIANCE

PROCRAMMING UNIVARIATE AND MULTIVARIATE ANALYSIS OF VARIANCE ORTHOGONALITY IN ANALYSIS OF VARIANCE PSEUDO-INVERSES IN THE ANALYSIS OF VARIANCE THE DISTRIBUTION OF THE GENERALIZED VARIANCE ADMISSIBLE TESTS IN MULTIVARIATE ANALYSIS OF VARIANCE A NOTE ON ROBUST ESTIMATION IN ANALYSIS OF VARIANCE COMPARISON OF ANOVA AND HARMONIC COMPONENTS OF VARIANCE FURTHER APPLICATIONS OF RANGE TO THE ANALYSIS OF VARIANCE

THE INTERPRETATION OF NEGATIVE COMPONENTS OF VARIANCE

A SINGULARITY IN THE ESTIMATION OF BINOMIAL VARIANCE APPROXIMATE CONFIDENCE LIMITS FOR COMPONENTS OF VARIANCE CONFIDENCE INTERVALS FOR DISTANCE IN THE ANALYSIS OF VARIANCE ORDERED TESTS IN THE ANALYSIS OF VARIANCE

USE OF RANGE IN TESTING HETEROCENEITY OF VARIANCE

ON INFERRINC ORDER RELATIONS IN ANALYSIS OF VARIANCE ON THE ADMISSIBILITY OF POOLING IN THE ANALYSIS OF VARIANCE SAMPLING PLANS WHERE THE ACCEPTANCE CRITERION IS THE VARIANCE REGIONS FOR TESTS OF INTERVAL HYPOTHESES ABOUT THE VARIANCE COMPARISON RANK PROCEDURE FOR A ONE-WAY ANALYSIS OF VARIANCE GENERALIZED T SQUARE IN THE MULTIVARIATE ANALYSIS OF VARIANCE INFORMATION FROM A SECOND SAMPLE IN ESTIMATING VARIANCE TEST PROCEDURES IN MULTIVARIATE ANALYSIS OF VARIANCE A SUBSET CONTAINING THE POPULATION WITH THE SMALLEST VARIANCE OF NON-NORMALITY ON THE ESTIMATION OF COMPONENTS OF VARIANCE FACTORS IN LINEAR REGRESSION AND ANALYSIS OF VARIANCE INDEPENDENCE OF QUADRATIC FORMS IN THE ANALYSIS OF VARIANCE TO CERTAIN EXPERIMENTAL DESIGNS IN THE ANALYSIS OF VARIANCE DESICNS FOR THE ONE-WAY CLASSIFICATION ANALYSIS OF VARIANCE OF INDEPENDENT EXPERIMENTS IN THE ANALYSIS OF VARIANCE

FOR THE MEAN OF A NORMAL DISTRIBUTION WITH KNOWN VARIANCE OF THE THREE MAIN TESTS FOR MULTIVARIATE ANALYSIS OF VARIANCE

THE POWER FUNCTION OF THE F-TEST IN THE ANALYSIS OF VARIANCE

FOR THE MEAN OF A NORMAL POPULATION WITH UNKNOWN VARIANCE

OF TWO TEST CRITERIA IN MULTIVARIATE ANALYSIS OF VARIANCE ATA CHI-SQUARE TESTS ANALOGOUS TO NORMAL ANALYSIS OF VARIANCE TERMININC THE MEAN OF A NORMAL POPULATION WITH KNOWN VARIANCE O METHODS OF ESTIMATION OF CENETIC AND ENVIRONMENTAL VARIANCE NG MEANS OF NORMAL POPULATIONS WITH A COMMON UNKNOWN VARIANCE

METHOD FOR JUDGINC ALL CONTRASTS IN THE ANALYSIS OF VARIANCE MODELS IN THE ANALYSIS OF VARIANCE OF VARIATION OF HERITABILITY ESTIMATES OBTAINED FROM VARIANCE ANALYSES RESPONSE VARIANCE AND ITS ESTIMATION ERRATA, SOME NEW TECH 6I 576 CORRIGENDA, 'COMPUTING BIOKA62 284 JASA $66 \quad 128$ JASA $56 \quad 451$ JASA $61 \quad$ B78 AMS $63 \quad 957$ TECH $63 \quad 95$ AMS $64 \quad 705$ AMS 64895 AMS $65 \quad 120$ AMS $67 \quad 698$ AMS $6 B \quad 1486$ TECH $69 \quad 75$ BIOKA5I 393 BIOKA54 544 BIOKA57 262 BIOKA57 159 BIOKA58 360 BI OKA61 325 BIOKA66 221 BIOCS65 337 A NOTE AMS $68 \quad 1744$ DOUBLE TECH $6 B \quad 99$ CRITICAL JASA $66 \quad 204$ A MULTIPLE SASJ $69 \quad 35$ HOTELLING'S JRSSB 63358 ON UTILIZING BIOKA69 NO.3 SIMULTANIOUS BIOKA6B 489 ON SELECTING BIOKA62 495 ON THE EFFECT JRSSB62 140 ESTIMATION OF WEIGHTING TECH 641 A NOTE ON THE STATISTICAL BIOKA51 482 SEQUENTIAL ANALYSIS APPLIED BIOKA56 3BB THE CONSTRUCTION OF OPTIMAL JRSSB6I 352 RANK METHODS FOR COMBINATION AMS $62 \quad 482$ SHORTER CONFIDENCE INTERVALS AMS $63 \quad 574$ ON THE MONOTONICITY PROPERTY JRSSB64 77 THE EFFECT OF NON-NORMALITY ON BIOKA51 43 SEQUENTIAL CONFIDENCE INTERVALS JRSSB57 133 ON THE NON-CENTRAL DISTRIBUTIONS AMS 68215 THE LIMITING POWER OF CATEGORICAL D AMS 631432 A SEQUENTIAL THREE HYPOTHESIS TEST FOR DE AMS 671365 /LLEL TEST CROSSING 2. AN EVALUATION OF TW BIOCS67 325 /PLE MULTIPLE DECISION PROCEDURE FOR RANKI BIOKA54 170 CORR, 69 229) (CORR. 69 229) A BIOKA53 B7 ITH DISCUSSION JRSSB $60 \quad 195$ CORRETION TO 'COEFFICIENTS BIOCS65 265 ENCE BOUNDS ASSOCIATED WITH MULTIVARIATE ANALYSIS OF VARIANCE AND NONINDEPENDENCE BETWEEN TWO SETS OF VARI AMS 66 IT36 $F$ A GROUP OF BALANCED BLOCK EXPERIMENTS HAVING ERROR VARIANCE AND SOME TREATMENTS IN COMMON ANALYSIS 0 BIOCS68 389 SION, EMPHASIZING THE CONNECTION BETWEEN ANALYSIS OF VARIANCE AND SPECTRUM ANALYSIS ANALYSIS OF VARIANCE AS AN ALTERNATIVE TO FACTOR ANALYSIS DISCUS TECH $61 \quad 191$ JRSSB57 318 ON NON-REGUTAR ESTTMATION. I VARIANCE BOUNDS FOR ESTIMATORS OF LOCATTON PARAMETERS JASA 691056 DISTRIBUTIONS, AND THE APPROXIMATE STABILIZATION OF VARIANCE BY TRANSFORMATIONS /ATORS FOR POWER-SERIES JASA 68 321 SOME OPERATORS FOR ANALYSIS OF VARIANCE CALCULATIONS FIDUCIAL LIMITS FOR A VARIANCE COMPONENT A COMPARISON OF SEVERAL VARIANCE COMPONENT ESTIMATORS TECH 69511 JRSSB $63 \quad 128$ BIOKA67 301 LIMITS FOR A VARIANCE COMPONENT WITH AN EXACT CONFIDENCE COEFFICIE AMS 61466

A NOTE ON UNIFORMLY BEST UNBIASED ESTIMATORS FOR VARIANCE COMPONENTS THE PROBLEM OF NEGATIVE ESTIMATES OF VARIANCE COMPONENTS NON-NEGATIVE ESTIMATES OF VARIANCE COMPONENTS JASA $56 \quad 266$ AMS $62 \quad 273$ TECH $63 \quad 441$ TECH $67 \quad 93$ A GENERAL APPROACH TO THE ESTIMATION OF VARIANCE COMPONENTS MEAN SQUARE EFFICIENCY OF ESTIMATORS OF VARIANCE COMPONENTS A CONFIDENCE INTERVAL FOR VARIANCE COMPONENTS JASA 69 NO. 4 BIOKA62 278 BIOCS65 395

FURTHER EVIDENCE ON THE CONSISTENCY OF ESTIMATES OF VARIANCE COMPONENTS OF THREE DIFFERENT PROCEDURES FOR ESTIMATING VARIANCE COMPONENTS ANOTHER LOOK AT HENDERSON'S METHODS OF ESTIMATINC VARIANCE COMPONENTS (WITH DISCUSSION)

A COMPARISON TECH $63 \quad 421$ BI0CS68 749 ITERATIVE ESTIMATION OF VARIANCE COMPONENTS FOR NON-ORTHOCONAL DATA 
SIGNS FOR THE SIMUTANEOUS ESTIMATION OF FUNCTIONS OF VARIANCE COMPONENTS FROM TWO-WAY CROSSED CLASSIFICATI BIOKAG7 I27 NESTED DESICN SAMPLINC DISTRIBUTIONS OF VARIANCE COMPONENTS I. EMPIRICAL STUDIES OF BALANCED TECH 66457

ED NESTED DESICNS

SAMPLINC DISTRIBUTIONS OF VARIANCE COMPONENTS II. EMPIRICAL STUDIES OF UNBALANC TECH 68 7I9 ITERATIVE PROCEDRE FOR ESTIMATTNG FIXED EFFECTS AND VARTANCE COMPONENTS IN MTXED MODEL SITUATIONS ESTIMATORS OF VARIANCE COMPONENTS IN THE BALANCED INCOMPLETE BLOCK JASA 691014 INFERENCE ABOUT VARIANCE COMPONENTS IN THE ONE-WAY MODEL

CLASSIFICATION COMPOSITE SAMPLES WITH INTERACTION VARIANCE COMPONENTS IN THE UNBALANCED TWO-WAY NESTED ESTIMATION OF VARIANCE COMPONENTS IN TWO-STACE NESTED DESICNS WITH
VARIANCE COMPONENTS IN TWO-WAY CLASSIFICATION MODELS VARIANCE COMPONENTS MODELS

OPTIMUM INVARIANT TESTS IN UNBALANCED VARIANCE COMPONENTS MODELS
QUADRATIC UNBIASED ESTIMATION OF VARIANCE COMPONENTS OF THE ONE-WAY CLASSIFICATION AMS 611161 TECH $67 \quad 373$ BIOKA63 327 AMS $67 \quad 422$ BIOKA69 313 CONCERNING 'A GENERAL APPROACH TO THE ESTIMATION OF VARIANCE COMPONENTS' SOME FURTHER REMARKS TH A CHECK ON GROSS ERRORS IN CERTAIN VARIANCE COMPUTATIONS QUERY, NEGATIVE VARIANCE ESTIMATES

NESTED SAMPLING NEGATIVE VARIANCE ESTIMATES AND STATISTICAL DEPENDENCE IN VARIANCE ESTIMATES IN 'OPTIMUM' SAMPLE DESICNS

EDGEMENT/ COMPARISON OF LEAST SQUARES AND MINIMUM

WITH PROBABILITY PROPORTIONATE TO SIZE VARIANCE ESTIMATION IN RANDOMIZED SYSTEMATIC SAMPLING VARIANCE ESTIMATION WITH ONE UNIT PER STRATUM

EMPIRICAL STUDY OF THE STABILITIES OF ESTIMATORS AND VARIANCE ESTIMATORS IN UNEQUAL PROBABILITY SAMPLING O JA CHARACTERISTIC CURVES FOR FIXED EFFECTS ANALYSIS OF VARIANCE F TESTS, ALPHA EQUALS 0.01 AND 0.05 /ATING JA PERIODOGRAM ANALYSIS AND VARIANCE FLUCTUATIONS

SPECTRAL ANALYSIS IN THE PRESENCE OF VARIANCE FLUCTUATIONS

ALYSIS OF GAUSSIAN VECTOR PROCESS IN THE PRESENCE OF VARIANCE FLUCTUATIONS

CROSS SPECTRAL AN TRSS FOURIER METHODS IN THE STUDY OF VARIANCE FLUCTUATIONS IN TIME SERIES ANALYSIS IMUM-LIKELIHOOD ESTIMATOR IS UNBIASED AND OF MINIMUM VARIANCE FOR ALL SAMPLE SIZES/NS FOR WHICH THE MAX BIOKA56 200 STUDIES OF INTERVIEWER VARIANCE FOR ATTITUDINAL VARIABLES

FACTORIAL EXPERIMENTATION IN SCHEFFE'S ANALYSIS OF VARIANCE FOR PAIRED COMPARISONS ON ANALYSIS OF VARIANCE FOR THE K-SAMPLE PROBLEM

JASA 5 B 529 AMS $66 \quad 1747$ BIOCS65 308

SUBCLASS FREQUENCIES TWO-WAY ANALYSIS OF VARIANCE FOR THE MIXED MODEL WITH DISPROPORTIONATE JASA $66 \quad 220$ SASJ $67 \quad 67$ DISTRIBUTION-FREE ANALYSIS OF VARIANCE FOR THE TWO-WAY CLASSIFICATION

$\begin{array}{lr}\text { SASJ } & 67 \\ \text { BIOKA69 } & \text { NO. } 3\end{array}$ TECH 69 NO. 4 JRSSB $61 \quad 493$ JASA 62648 MODEL WITH OBSERVATIONS WITHIN A/ THE ANALYSIS OF VARIANCE FOR THE TWO-WAY CLASSIFICATION FIXED EFFECTS EXPERIMENTS CHAIN-POOLING ANALYSIS OF VARIANCE FOR TWO-LEVEL FACTORIAL REPLICATION-FREE ON QUADRATIC ESTIMATES OF THE INTERCLASS VARIANCE FOR UNBALANCED DESIGNS

COEFFICIENT OF CONCENTRATION VARIANCE FORMULAS FOR THE MEAN DIFFERENCE AND

SAMPLING VARIANCES OF ESTIMATES OF COMPONENTS OF VARIANCE FROM A NON-ORTHOGONAL TWO-WAY CLASSIFICATION BI ESTIMATION OF ERROR VARIANCE FROM SMALLEST ORDERED CONTRASTS

ATED RESPONSES THE BEHAVIOUR OF THE VARIANCE FUNCTION OF THE DIFFERENCE BETWEEN TWO ESTIM JRSSB67 CERTAIN TESTS OP MOVING AVERAGE A TEST FOR VARIANCE HETEROGENEITY IN THE RESIDUALS OF A GAUSSIAN JRSSB 63 SMALL SAMPLE BEHAVIOUR OF BIOKA60 ON THE BIAS OF SOME LEAST-SQUARES ESTIMATORS OF VARIANCE IN A GENERAL LINEAR MODEL

ICAL SYSTEMS A NOTE ON SOME APPROXIMATIONS TO THE VARTANCE IN DISCRETE-TIME STOCHASTIC MODELS FOR BTOLO BIOKAG8 BANDWIDTH AND VARIANCE IN ESTIMATION OF THE SPECTRUM

LEMS AND THE ROBUSTNES/ THE ESTIMATION OF RESIDUAL VARIANCE IN QUADRATICALLY BALANCED LEAST-SQUARES PROB BIOKA62 ADEQUACY OF THE ASYMP/ NON-PARAMETRIC ANALYSIS OF VARIANCE IN SMALL SAMPLES A MONTE CARLO STUDY OF THE BIOCSEO

E/ NOTES. ON TESTING SIGNIFICANCE OF COMPONENTS OF VARIANCE IN THE UNBALANCED NESTED ANALYSIS OF VARIANC BIOCS68 4 ON POOLING MEANS WHEN VARIANCE IS UNKNOWN LIKELIHOOD ESTIMATION FOR THE MIXED ANALYSIS OF VARIANCE MODEL MAXIMUM- BIOKA67

OBLEMS A GENERALIZED MULTIVARIATE ANALYSIS OF VARIANCE MODEL USEFULL ESPECIALLY FOR GROWTH CURVE PR BIOKA64. OPTIMAL CONFIDENCE INTERVALS FOR THE VARIANCE OF A NORMAL DISTRIBUTION TABLES FOR MAKING INFERENCES ABOUT THE VARIANCE OF A NORMAL DISTRIBUTION JASA $59 \quad 674$ BIOKA60 433 JRSSB $64 \quad 63$ BAYESIAN ESTIMATION OF THE VARIANCE OF A NORMAL DISTRIBUTION BIOKA6I 230 CORRIGENDA, 'TABLES FOR MAKING INFERENCES ABOUT THE VARIANCE OF A NORMAL DISTRIBUTION. AMS $61 \quad 84$ TABLES FOR UNBIASED TESTS ON THE VARIANCE OF A NORMAL POPULATION

IGN THE RELATIONSHIP ALGEBRA AND THE ANALYSIS OF VARIANCE OF A PARTIALLY BALANCED INCOMPLETE BLOCK DES FUNCTIONS OF THE SAMPLE MEAN AND SAMPLE VARIANCE OF A POISSON VARIATE

ON AN IDENTITY FOR THE VARIANCE OF A RATIO OF TWO RANDOM VARIABLES

AMS 651815 BIOCS69 171 JRSSB $64 \quad 484$

/ ON DURBIN'S FORMULA FOR THE LIMITING GENERALIZED VARIANCE OF A SAMPLE OF CONSECUTIVE OBSERVATIONS FROM BIOKAGI 197 A. ION DURBTNIS FORMULA FOR THE IIMITING GENERALIZED VARIANCE OF A SAMPLE OF CONSECUTIVE OBSERVATIONS FROM BIOKAGI ECONOMIC A/ THE RELATIONSHIP BETWEEN THE MEAN AND VARIANCE OF A STATIONARY BIRTH-DEATH PROCESS, AND ITS BIOKA62 253 ESTIMATION OF THE INNOVATION VARIANCE OF A STATIONARY TIME SERIES

MEAN AND VARTANCE OF AN ENTRY IN A CONTTNGENCY TABLE THE VARIANCE OF AN ESTIMATOR WITH POST-STRATIFIED

BIOKA5] JASA $62 \quad 622$

WEIGHTING

$S$ OF FIXED AND MIXED VARIATES THE SAMPLING VARIANCE OF CORRELATION COEFFICIENTS UNDER ASSUMPTION BIOKA58 THE ANALYSIS OF VARIANCE OF DATA FROM STRATIFIED SUBSAMPLES JASA 68

CATIONS

PRESENT

ES REGRESSION COEFFICIENTS

PLOTS

TABLE

GENETIC EXPERIMENTS

ENTIAL PROBABILITY RATIO TESTS THE VARIANCE OF SPEARMAN'S RHO IN NORMAL SAMPLES BOUNDS FOR THE VARIANCE OF KENDALL'S RANK CORRELATION STATISTIC COMPARISON OF THE VARTANCE OF MINIMUM VARIANCE AND UEICHTED IEAST SQUAR AKS G3 ON THE EXACT VARIANCE OF PRODUCTS, CORR. 61917 ANALYSIS OF VARIANCE OF PROPORTIONS WITH UNEQUAL FREQUENCIES THE MAXIMUM VARIANCE OF RESTRICTED UNIMODAL DISTRIBUTIONS

THE ANALYSIS OF VARIANCE OF DESIGNS WITH MANY NON-ORTHOGONAL CLASSIFI JRSSB66 ANALYSIS OF VARIANCE OF DISPROPORTIONATE DATA WHEN INTERACTION IS BIOCS65 AMS 691746 BIOKA69 43 BIOKA61 19 $\begin{array}{lllll}\text { THE SAMPLING VARIANCE OF THE CORRELATION COEFFICIENTS ESTIMATED IN BIOCS66 } & 187\end{array}$ A NOTE ON THE VARIANCE OF THE DISTRIBUTION OF SAMPLE NUMBER IN SEQU TECH $66 \quad 700$ OF OBSERVATIONS IN POLYNOMIAL REGRESSION FOR MINIMAX VARIANCE OF THE FITTED VALUES /NESS OF THE SPACING AMS 62 8IO NUMBER OF INDEPENDENT NORMAL VARIATES THE VARIANCE OF THE MAXIMUM OF PARTIAL SUMS OF A FINITE THE VARIANCE OF THE MEAN OF A STATIONARY PROCESS THE VARIANCE OF THE MEAN OF SYSTEMATIC SAMPLES VARIANCE OF THE MEDIAN OF SAMPLES FROM A CAUCHY 
VARIANCE OF THE MEDIAN OF SMALL SAMPLES FROM SEVERAL JASA $6014 \mathrm{~B}$ THE VARIANCE OF THE ONE-SIDED STOPPINC RULES THE VARIANCE OF THE PRODUCT OF K RANDOM VARIABLES

A NOTE ON THE VARIANCE OF THE RATIO ESTIMATE

ON SOME PROPERTIES OF THE ASYMPTOTIC VARIANCE OF THE SAMPLE QUANTILES AND MID-RANGES ASYMPTOTIC EXPANSIONS FOR THE MEAN AND VARIANCE OF THE SERIAL CORRELATION COEFFICIENT

AL POPULATION

ON THE MEAN AND VARIANCE OF THE SMALLER OF TWO DRAWINGS FROM A

THE VARIANCE OF WEIGHTED REGRESSION ESTIMATORS

ING ERRORS ARE INDEPENDENT AND HETEROSCEDASTIC A PROBLEM IN MINIMAX VARIANCE POLYNOMIAL EXTRAPOLATION

MODELS $R$ WHICH CERTAIN SIMPLE LEAST SQUARES AND ANALYSIS OF VARIANCE PROCEDURES ARE ALSO BEST /STRUCTURES UNDE JASA 69 NO. 4 ENSION OF TABLES OF PERCENTAGE POINTS OF THE LARGEST VARIANCE RATIO S-SQUARE-MAX-OVER-S-SQUARE-SUB-0 EXT BIOKA67 225 ON THE RANDOMIZATION DISTRIBUTION AND PONER OF THE VARIANCE RATIO TEST CONFIDENCE REGIONS FOR VARIANCE RATIOS OF RANDOM MODELS

RANDOMIZED DESICN MINIMUM VARIANCE STRATIFICATION, CORR. 631161 JRSSB $63 \quad 334$ JASA 69660 JASA $66 \quad 813$ JASA 5988 IBUTION OF VARIOUS SUMS OF SQUARES IN AN ANALYSIS OF VARIANCE TABLE FOR DIFFERENT CLASSIFICATIONS WITH COR JRSSB59 II4 A DISTRIBUTION-FREE ANALYSIS OF VARIANCE TECHNIQUE FOR BLOCK DESICNS OF NON-NORMALITY ON THE POWER OF THE ANALYSIS OF VARIANCE TEST BAYES CHARACTER OF A STANDARD MODEL II ANALYSIS OF VARIANCE TEST AN ANALYSIS OF VARIANCE TEST FOR NORMALITY (COMPLETE SAMPLES)

A CLASS OF DISTRIBUTION-FREE ANALYSIS OF VARIANCE TESTS OF THE POWERS OF TWO MULTIVARIATE ANALYSIS OF VARIANCE TESTS ARISON OF THE POWERS OF TWO MULTIVARIATE ANALYSIS OF VARIANCE TESTS.' CORRIGENDA, 'A COMP BIOKA63 546 BUTI/CHARTS OF THE PONER FUNCI APPLICATION OF MULTIVARIATE ANALYSIS OF VARIANCE TO REPEATED MEASUREMENTS EXPERIMENTS SASJ $6 B$ B BIOKA59 114 ON THE AMS 691094 BIOKA65 591 SASJ $67 \quad 75$ A COMPARISON BIOKA62 455 F RELIABILITY FUNCTIONS FOR SYSTEMS IN SE/ MINIMUM VARIANCE UNBIASED AND MAXIMUM LIKELIHOOD ESTIMATORS O JASA 66 1052 ADDITIVE NUMBER THEORY

TRUNCATED EXPONENTIAL DISTRIBUTION MINIMUM VARIANCE UNBIASED ESTIMATION AND CERTATN PROBLEMS OF MINIMUM VARIANCE UNBIASED ESTIMATION OF RELIABILITY FOR THE TECH 69609 MINIMUM VARIANCE UNBIASED ESTIMATORS FOR POISSON PROBABILITIE TECH 62409

SEQUENTIAL ANALYSIS OF VARIANCE UNDER RANDOM AND MIXED MODELS

JASA 671401

INEQUALITY MONOTONICITY OF THE VARIANCE UNDER TRUNCATION AND VARIATIONS OF HENSEN'S AMS 691106 KOLMOGOROV-SMIRNOV TEST FOR NORMALITY WITH MEAN AND VARIANCE UNKNOWN A NOTE ON DESIGNS FOR MODEL DISCRIMINATION, VARIANCE UNKNOWN CASE

ON THE JASA $67 \quad 399$ TECH 69396 ON THE COST OF NOT KNOWING THE VARIANCE WHEN MAKINC A FIXED WIDTH CONFIDENCE INTERVA L FOR THE MEAN THE ESTIMATES OF SAMPLINC VARIANCE WHERE TWO UNITS ARE SELECTED FROM EACH

THE BIAS OF VARIOUS ESTIMATORS OF THE LOGIT AND ITS VARIANCE WITH APPLICATION TO QUANTAL BIOASSAY ON THE VARIATION OF YIELD VARIANCE WITH PLOT SIZE

SAMPLE SIZE REQUIRED FOR ESTIMATING THE VARIANCE WITIN D UNITS OF THE TRUE VALUE ANALYSIS OF RANDOM-EFFECT MODELS IN THE ANALYSIS OF VARIANCE. II. EFFECT OF AUTOCORRELATED ERRORS /SIAN BIOKA66 477 OF INDEPENDENT NONCENTRAL CHI-SQUAR/ EXPRESSION OF VARIANCE-COMPONENT ESTIMATORS AS LINEAR COMBINATIONS AMS 69 NO. 6 WAY CROSS CLASSIFICATION WITH APPLIC/ VARIANCES OF VARIANCE-COMPONENT ESTIMATORS FOR THE UNBALANCED TWO- AMS 69 408 E ANALYSIS OF VARIANCE. I POSTERIOR DISTRIBUTION OF VARIANCE-COMPONENTS/OF RANDOM-EFFECT MODELS IN TH BIOKA65 37 SUB-0 TEST IN MULTIVARTATE ANALYSIS OF VARIANCE WHEN VARIANCE-COVARIANCE MATRICES ARE NOT EQUAL /SQUARE- BIOKAG4 71 IMINANT FUNCTION THE EFFECT OF UNEQUAL VARIANCE-COVARIANCE MATRICES ON FISHER'S LINEAR DISCR BIOCS69 BIOKA64 B3 APPROXIMATING THE GENERAL NON-NORMAL VARIANCE-RATIO SAMPLING DISTRIBUTIONS SOME NOTES ON VARIANCE-RATIO TESTS OF THE GENERAL LINEAR HYPOTHESIS BIOKA64 508

VARIANCES IN THE FIXED-EFFECTS ONE-WAY ANALYSIS OF VARIANCE, A BAYESIAN SIDELICHT UNEQUAL GROUP BIOKA66 27 SEQUENTIAL RANCE TESTS FOR COMPONENTS OF VARIANCE, CORR. 651249 JASA 65 826 NOMIC TIME SERIES, CORR 651250 MINIMUM VARIANCE, LINEAR, UNBIASED SEASONAL ADJUSTMENT OF ECO JASA 64 6BI AGAINST ORDERED ALTERNATIVES IN MODEL I ANALYSIS OF VARIANCE, NORMAL THEORY AND NONPARAMETRIC TESTING AMS 67 I740 ALTERNATIVE TESTS FOR HETEROGENEITY OF VARIANCE. SOME MONTE CARLO RESULTS THE GENERALIZED VARIANCE, TESTING AND RANKING PROBLEM

ON LINEAR COMBINATIONS OF SEVERAL VARIANCES A TEST OF VARIANCES

ON STABILIZINC THE BINOMIAL AND NEGATIVE BINOMIAL VARIANCES ALMOST PERIODIC VARIANCES ON FISHER'S BOUND FOR ASYMPTOTIC VARIANCES STUDENT'S T IN A TWO-WAY CLASSIFICATION WITH UNEQUAL VARIANCES QUERY, TESTING TWO CORRELATED VARIANCES JACKNIFING VARIANCES SIMULTANEOUS CONFIDENCE INTERVALS FOR VARIANCES RANKING MEANS OF TWO NORMAL POPULATIONS WITH UNKNOWN VARIANCES FURTHER CRITICAL VALUES FOR THE SUM OF TWO VARIANCES

A TWO-SAMPLE DISTRIBUTION FREE TEST FOR COMPARING VARIANCES TESTINC THE HOMOGENEITY OF A SET OF CORRELATED VARIANCES A TEST OF HOMOCENEITY FOR ORDERED VARIANCES

THE STATISTICAL FOURIER ANALYSIS OF VARIANCES

OF BEST AND OUTLYING NORMAL POPULATIONS WITH KNOWN VARIANCES TEST AND LEHMANN'S TEST FOR HOMOGENEITY OF VARIANCES

OF MEANS AFTER A PRELIMINARY TEST OF EQUALITY OF VARIANCES THE BEST AMONGST THREE NORMAL POPULATIONS WITH KNOWN VARIANCES CONFIDENCE LIMITS TO LINEAR COMBINATIONS OF VARIANCES THE LARGEST MEAN OF K NORMAL POPULATIONS WITH KNOWN VARIANCES

BASED ON RANKS FOR CERTAIN PROBLEMS IN ANALYSIS OF VARIANCES PORTANCE OF ASSUMPTIONS APPLIED TO THE COMPARISON OF VARIANCES

OF THE MEAN WHICH CONSIDER INEQUALITY OF UNKNOWN VARIANCES 'S CRITERION FOR TESTING THE HOMOGENEITY OF A SET OF VARIANCES TWEEN MEANS IN TWO NORMAL POPULATIONS HAVING UNEQUAL VARIANCES EEN THE MEANS OF TWO NORMAL POPULATIONS WITH UNKNOWN VARIANCES THE ESTIMATION OF VARIANCES ON ESTIMATORS FOR VARIANCES AND COVARIANCES
BIOKA66 229 JASA $56 \quad 132$ JASA $58 \quad 741$ $\begin{array}{lll}\text { JASA } & 61 \quad 143\end{array}$ AMS 631549 AMS 641545 AMS 651248 TECH $65 \quad 447$ AMS $68 \quad 567$ JASA $69 \quad 324$ BIOKA58 250 BIOKA58 279 BIOKA58 544 BIOKA6B 317 JRSSB61 195 JRSSB65 159 DETECTION BIOKA6I 457 ON BARTLETT'S AMS 69 NO. 6 TESTING EQUALITY BIOKA62 403 ON THE CHOICE OF BIOKA58 436 A METHOD OF ASSICNING BIOKA55 471 INTERVAL ESTIMATION OF JASA 69296 MULTIPLE DECISION PROCEDURES AMS 69619 A BAYESIAN APPROACH TO THE IM BIOKA64 153 COMBINATIONS OF UNBIASED ESTIMATORS JASA 691042 /NTS FOR HARTLEY'S CORRECTION TO BARTLETT BIOKA62 4B7 /OR THE SIGNIFICANCE OF THE DIFFERENCE BE BIOKA51 252 /TATISTIC FOR TESTINC THE DIFFERENCE BETW JRSSB61 377 TER USINC A GAUSSIANATINC TRANSFORMATION AMS 6B 1125 BIOKA62 259 AMS 67941 
ATORS, FROM CENSORED SAMPLES, OF THE P/ ASYMPTOTIC VARIANCES AND COVARIANCES OF MAXIMUM-LIKELIHOOD ESTIM AMS 67

LINEAR STRUCTURAL RELATIONSHIPS WHEN BOTH RESIDUAL VARIANCES ARE KNOWN

PS OF OBSERVATIONS WHEN THE RATIOS OF THE POPULATION VARIANCES ARE UNKNOWN /E COMPARISON OF SEVERAL CROU BIOKA5I 324

TIVARIATE ANALYSIS WHEN THE RATIOS OF THE POPULATION VARIANCES ARE UNKNOWN /THESES IN UNIVARIATE AND MUL BIOKA5A IS ON SEQUENTIAL TESTS OF RATIO OF VARIANCES BASED ON RANGE BIOKA63 419

Y ASSUMPTIONS CORRELATED OBSERVATIONS ST INTERVALS
ASYMPTOTIC VARIANCES FOR DUMMY VARIATE RECRESSION UNDER NORM

TREATMENT VARIANCES FOR EXPERIMENTAL DESICNS WITH SERIALLY

RIBUTION

$$
\begin{array}{r}
\text { SOME PROBABILITIES, EXPECTATIONS AND VARIANCES FOR THE SIZE OF LARCEST CLUST } \\
\text { HETEROGENEITY OF ERROR VARIANCES IN A RANDOMIZED BLOCK DESIGN }
\end{array}
$$

TESTINC THE HOMOCENEITY OF VARIANCES IN A TWO-WAY CLASSIFICATION BIOCS69 153

THE RANKINC OF VARIANCES IN NORMAL POPULATIONS

VARIANCE, A BAYESIAN SIDELICHT HETEROCENEOUS ERROR VARIANCES IN SPLIT-PLOT EXPERIMENTS JASA $56 \quad 621$ UNEQUAL CROUP VARIANCES IN THE FIXED-EFFECTS ONE-WAY ANALYSIS OF BIOKA66 27 A NON-ORTHOCONAL TWO-WAY CLASSIFICATION SAMPLINC VARIANCES OF ESTIMATES OF COMPONENTS OF VARIANCE FROM BIOKA64 491 THREE-WAY CLASSIFICATION VARIANCES OF ESTIMATES OF VARIANCE COMPONENTS IN A BIOCS66 553

TERS OF THE TRUNCATED BINOMIAL AN/ THE ASYMPTOTIC VARIANCES OF METHOD OF MOMENTS ESTIMATES OF THE PARAM JASA 6I 99O TN THE UNBALANCED R- TAY CLASSIFICATION

VARIANCES OF MOMENT ESTIMATORS OF VARIANCE COMPONENTS BIOCS6B ESTIMATES OF BOUNDED RELATIVE ERROR FOR THE RATIO OF VARIANCES OF NORMAL DISTRIBUTIONS

STACE PROCEDURES FOR RANKINC MULTIPLY-CLASSIFTED VARIANCES OF NORMAL POPULATIONS COMPARISONS WITH A CONTROL FOR MULTIPLY-CLASSIFIED VARIANCES OF NORMAL, POPULATIONS RUNCATED BIVARIATE NORMAL DISTRIBUTION IV. EMPIRICAL VARIANCES OF RANK CORRELATION COEFFICIENTS /INCLY T BIOKAGB 437 STACE SAMPLES, CORR, 631162

ON VARIANCES OF RATIOS AND THEIR DIFFERENCES IN MULTI- JASA 59416 ES AND THEIR USE FOR INVESTIGATINC THE NORMALITY AND VARIANCES OF RESIDUALS /ONORMAL BASES OF ERROR SPAC JASA 67 IO22 THE UNBALANCED THREE-WAY NESTED CLASSIFI/ SAMPLINC VARIANCES OF THE ESTIMATES OF VARIANCE COMPONENTS IN AMS 63 52I BALANCED TWO-WAY CROSS CLASSIFICATION WITH APPLIC/ VARIANCES OF VARIANCE-COMPONENT ESTIMATORS FOR THE UN AMS 69 408 A MULTIPLICATIVE MODEL FOR ANALYZINC VARIANCES WHICH ARE AFFECTED BY SEVERAL FACTORS SAMPLE SIZE REQUIRED TO ESTIMATE THE RATIO OF VARIANCES WITH BOUNDED RELATIVE ERROR NON-NORMALITY AND TESTS ON VARIANCES.

'SYNTHESIS ' ON EXPECT

LINEAR RECRESSION WITH NON-CONSTANT, UNKNOWN ERROR VARIANCE CUMULANTS OF A TRANSFORMED VARIATE

NOTE ON THE NECATIVE MOMENTS OF A TRUNCATED POISSON VARTATE

OF THE SAMPLE MEAN AND SAMPLE VARIANCE OF A POISSON VARIATE OF A RECTANCULAR OR TRIANCULAR AND A CENERAL VARIATE OLUTE DEVIATION IN CONGIDENCE INTERVALS FOR A NORMAL VARIATE NON-CENTRALITY PARAMETER OF A NONCENTRAL CHI-SQUARE VARIATE TWO ESTIMATES FOR STANDARD DEVIATION BASED ON SECOND VARTAT

AND CONVARIANCES OF ANOVA MEAN SQUARES BY BIOCS68 963 , AND CONVARIANCES OF ANOVA MEAN SQUARES BY BIOCS68
963
SAMPLING EXPERIMENTS WITH LEAST SQUARES, W BIOCS68 BIOKA55 529

THE CORRECT USE OF THE SAMPLE MEAN ABS TECH $66 \quad 663$ THE MAXIMUM LIKELIHOOD ESTIMATE OF THE JASA 671258

OF COCHRAN'S FORMULAE FOR ADDITTON OR OMISS THE TRANSIENT BEHAVIOR OF A COINCIDENCE VARIATE IN TELEPHONE TRAFFIC

ONS OF THE CRITERION W FOR TESTING SPHERICITY IN A P-VARIATE NORMAL DISTRIBUTION ON THE EXACT DISTRIBUTI AMS 67 1170 ASYMPTOTIC VARIANCES FOR DUMMY VARIATE RECRESSION UNDER NORMALITY ASSUMPTIONS JASA 67 1305 THE MOMENTS OF A VARIATE RELATED TO THE NON-CENTRAL T AMS 64298 AN APPROXIMATION TO THE DISTRIBUTION OF Q. A VARIATE RELATED TO THE NON-CENTRAL T THE CHARACTERISTIC ROOTS OF THE PRODUCT OF A WISHART VARIATE WITH THE INVERSE OF ANOTHER INDEPENDENT WISHA AMS 67 944 MODIFICATIONS TO THE VARIATE-DIFFERENCE METHOD BIOKA53 383 MAL DISTRIBUTION, III. CORRELATION BETWEEN RANKS AND VARIATE-VALUES /IN A SINCLY TRUNCATED BIVARIATE NOR BIOKA66 278 DISTRIBUTION THE CORRELATION BETWEEN VARIATE-VALUES AND RANKS IN A DOUBLY TRUNCATED NORMAL BIOKA66 281 ON TWO METHODS ON UNBIASED ESTIMATION WITH AUXILIARY VARIATES LINEAR COMBINATIONS OF NON-CENTRAL CHI-SQUARE VARIATES CAUCHY-DISTRIBUTED FUNCTTONS OF CAUCHY VARIATES ON DETECTINC CHANCES IN THE MEAN OF NORMAL VARIATES THE ORTHANT PROBABILITIES OF FOUR GAUSSIAN VARIATES SOME SIMPLE APPROXIMATE TESTS FOR POISSON VARIATES A Q-TECHNIQUE FOR THE CALCULATION OF CANONICAL VARIATES A NOTE ON CRAIC'S PAPER ON THE MINIMUM OF BINOMIAL VARIATES ON SUMS AND PRODUCTS OF RECTANCULAR VARIATES

TESTINC FOR CORRELATION BETWEEN NON-NEGATIVE VARIATES ON EXPECTATIONS OF SOME FUNCTIONS OF POISSON VARIATES A RECRESSION TECHNIQUE FOR ANGULAR VARIATES

DISTRIBUTION OF CERTAIN QUADRATIC FORMS IN NORMAL VARIATES OF THE MEDIAN AND OTHER STATISTICS OF LOCISTIC VARIATES

SERIAL CORRELATION WITH EXPONENTIALLY DISTRIBUTED VARIATES

FOR THE RATIO OF TWO QUADRATIC FORMS IN NORMAL VARIATES OF THE LOCARITHM OF THE SUM OF TWO LOC-NORMAL VARIATES THE PRODUCT OF TWO CENTRAL OR NON-CENTRAL CHI-SQUARE VARIATES BETWEEN MOMENTS OF ORDER STATISTICS FOR EXCHANCEABLE VARIATES

SUMS OF A FINITE NUMBER OF INDEPENDENT NORMAL VARIATES ERALIZED BEHRENS-FISHER DISTRIBUTION INVOLVINC THREE VARIATES ARTIAL SUMS OF A FINITE NUMBER OF INDEPENDENT NORMAL VARIATES ARTIAL SUMS OF A FINITE NUMBER OF INDEPENDENT NORMAL VARIATES

OF SOME TESTS OF INDEPENDENCE BETWEEN TWO SETS OF VARIATES

COEFFICIENTS UNDER ASSUMPTIONS OF FIXED AND MIXED VARIATES AR COMBINATIONS OF INDEPENDENT NONCENTRAL CHI-SQUARE VARIATES OF VARIANCE AND NONINDEPENDENCE BETWEEN TWO SETS OF VARIATES DISTRIBUTIONS OF MATRIX VARIATES EQUALLY CORRELATED VARIATES

CONTRIBUTION OF PRINCIPAL COMPONENTS TO INDIVIDUAL VARIATES

TOF VARIANCE-COMPONENT ESTIMATORS AS LINE

ND LATENT ROOTS DERIVED FROM NORMAL SAMPLES

APPROXIMATION TO THE CEN BIOKA69 NO.3 THE VARIANCE OF THE MAXIMUM OF P BIOKA55 96 ON THE MOMENTS OF THE MAXIMUM OF P BIOKA56 79 MONOTONICITY OF THE POWER FUNCTIONS AMS 64206

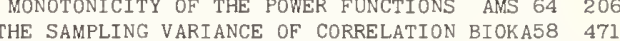
AMS $66 \quad 480$ AMS $67 \quad 916$ AMS $69 \quad 116$ AMS $69 \quad 152$ BIOKA53 354 BIOKA66 588 BI0KA66 615 BIOKA67 385 BI OCS68 97 BIOCS69 No. 4 TESTING FOR BIOKA67 395 AN INEQUALITY AMS 681762 THE DISTRIBUTION JASA 69655 THE DISTRIBUTION OF AMS 621016 THE DISTRIBUTION OF AMS 621016 ELIMINATION OF VARIATES IN LINEAR DISCRIMINATION PROBLEMS TION OF SUMS OF SQUARES AND CROSS PRODUCTS OF NORMAL VARIATES IN THE PRESENCE OF INTRA-CLASS CORRELATION 
MULTIVARIATE REGRESSION OF DUMMY VARIATES UNDER NORMALITY ASSUMPTIONS

D RATIO CRITERIA FOR TESTINC INDEPENDENCE OF SETS OF VARIATES UNDER THE HULL HYPOTHESIS

JASA 631054

ON CERTAIN FUNCTIONS OF NORMAL VARIATES WHICH ARE UNCORRELATED OF A HICHER ORDER BIOKA60 I75

LTIVARIATE DENSITY FUNCTIONS OF PRODUCTS OF GAUSSIAN VARIATES

TATISTICAL INDEPENDENCE OF QUADRATIC FORMS IN NORMAL VARIATES

OF A DEFINITE QUADRATIC FORM FOR NON-CENTRAL NORMAL VARIATES, CORR. 63673

ESTIMATION OF QUASI-LINEAR TREND AND SEASONAL VARIATION

CORRIGENDA, SOME MU BIOKA65 645 DISTRIBUTION AMS 61883

JASA $63 \quad 1033$

THE PERCENTAGE POINTS OF THE SAMPLE COEFFICIENT OF VARIATION

OF A NORMAL DISTRIBUTION WITH KNOWN COEFFICIENT OF VARIATION

SIMILAR EXPERIMENTS, ALLOWING FOR INTER-EXPERIMENT VARIATION

OPULATION MEANS ASSUMING HOMOGENEOUS COEFFTCIENTS OF VARIATTON

AN INEQUALITY FOR THE SAMPLE COEFFICIENT OF VARIATION AND AN

THE FITTING OF MARKOFF SERIAL VARIATION CURVES
CONFIDENCE INTERVALS FOR THE COEFFICIENT OF VARIATION FOR THE NORMAL AND LOG NORMAL DISTRIBUTIONS

ON BIOKA68 580

A NOTE ON ESTIMATING THE MEAN JASA $68 \quad 1039$

THE COMBINATION OF ESTIMATES FROM JASA $67 \quad 241$

A TEST OF EQUALITY OF TWO NORMAL P AMS 691374

TECH $65 \quad 67$

JRSSB58 120

THE ESTIMATION OF SEASONAL VARIATION IN ECONOMIC TIME SERIES, CORR. 63 1I62 JASA 63 31

$\begin{array}{rr}\text { BIOCS65 } & 733\end{array}$

JASA 641225

JASA $63 \quad 721$

JASA $68 \quad 209$ PROBABILITY MODELS FOR THE VARIATION IN THE NUMBER OF BIRTHS PER COUPLE A CHANCE MECHANISM OF THE VARIATION IN THE NUMBER OF BIRTHS PER COUPLE

SEASONAL VARIATION OF DEATHS IN THE UNITED STATES, 1951-1960 JASA 66706

A BOUND FOR THE VARIATION OF GAUSSIAN DENSITIES

AMS 69 NO.6

IANCE ANALYSES'

POPULATIONS

CORRECTION TO 'COEFFICIENTS OF VARIATION OF HERITABILITY ESTIMATES OBTAINED FROM VAR BIOCS65 265

THE MEAN AND COEFFICIENT OF VARIATION OF RANGE IN SMALL SAMPLES FROM NON-NORMAL BIOKA54 469

CORRIGENDA. 'THE MEAN AND COEFFICIENT OF VARIATION OF RANGE IN SMALL SAMPLES FROM NON-NORMAL P BIOKA55 277

LVATICUS. III/ THE GROWTH, SURVIVAL, WANDERING AND VARIATION OF THE LONG-TAILED FIELD MOUSE, APODEMUS SY BIOKA52 389

DROITE

ON THE VARIATION OF YIELD VARIANCE WITH PLOT SIZE

BIOKA56 337

AND STERILE SOLIDS

VARIATION QUADRATIQUE DES MARTINCALES CONTINUES A

AMS 69 - 33

TECH $69 \quad 161$

JASA $62 \quad 655$

WEN AND RO/ THE DISTRIBUTION OF THE COEFFICIENT OF VARIATTON COMMENT ON A CRITICISM MADE BY KOOPMANS, O BIOKA65 303

OF N. V. SMIRNOV CONCERNING LIMIT DISTRIBUTIONS FOR VARIATIONAL SERIES

OF AN ITERATED MOVINC AVERACE IN MEASURING SEASONAL VARIATIONS

VARIATIONS FLOW ANALYSIS

MONOTONICITY OF THE VARIANCE UNDER TRUNCATION AND VARIATIONS OF HENSEN'S INEQUALITY

DISTRIBUTIONS

SAMPLE PATH VARIATIONS OF HOMOGENEOUS PROCESSES

VARIATIONS OF THE NON-CENTRAL T AND BETA

VARIATIONS ON A RENEWAL THEOREM OF SMITH

ON SOME RESULTS AMS 69480

THE USE JASA $62 \quad 149$

TECH $60 \quad 373$

AMS 691106

AMS $69 \quad 399$

AMS 641583

AMS $68 \quad 155$

OPTIMAL PROGRAMMERS FOR VARIETAL SELECTION (WITH DISCUSSION)

ANALYSIS AND INTERPRETATION OF THE VARIETY CROSS DIALLEL AND RELATED POPULATIONS

A NOTE ON THE MULTIPLYING FACTORS FOR VARIOUS CHI-SQUARE APPROXIMATIONS

JRSSB61 282

BIOCS66 439

JRSSB54 296

APPLICATION TO QUANTAL BIOASSAY ON THE BIAS OF VARIOUS ESTIMATORS OF THE LOGIT AND ITS VARIANCE WITH

A COMPARATIVE STUDY OF VARIOUS TESTS FOR NORMALITY

CITY OF EXPENDITURES

A MONTE CARLO STUDY COMPARING VARIOUS TWO-SAMPLE TESTS FOR DIFFERENCES IN MEAN

JASA 681343

TECH $68 \quad 509$

EFFECT OF VARYING DEGREES OF TRANSITORY INCOME ON INCOME ELASTI JASA 58 348 IN SAMPLING WITH VARYING PROBABILITIES FROM A FINITE POPULATION /FOR JASA 6891 SOME ESTIMATORS IN SAMPLING WITH VARYING PROBABILITIES WITHOUT REPLACEMENT

ON A CLASS OF LINEAR ESTIMATORS IN SAMPLING WITH VARYING PROBABILITIES WITHOUT REPLACEMENT AND NON-ROTATING SAMPLES SAMPLING WITH VARYINC PROBABILITIES WITHOUT REPLACEMENT, ROTATING JASA 63 183 THE VARYING QUALITY OF INVESTMENT TRUST MANACEMENT JASA 631011 USE OF VARYING SEASONAL WEIGHTS IN PRICE INDEX CONSTRUCTION JASA 5866

ALL ADMISSIBLE LINEAR ESTIMATES OF THE MEAN VECTOR AMS $66 \quad 458$ CONFTDENCE BOUNDS FOR REGRESSION PARAMETERS AND MEAN VECTOR OF SOME NON-LINEAR FUNCTIONS OF THE TWO-SAMPLE RANK VECTOR INDEPENDENCE OF SECOND DEGREE POLYNOMIALS IN NORMAL VECTOR

ON FIXED-WTDTH JRSSB $67 \quad 132$ A THEOREM ON LEAST SQUARES AND VECTOR CORRELATION IN MULTIVARIATE LINEAR REGRESSION JASA 66 413 ADDING A POINT TO VECTOR DIAGRAMS IN MULTIVARIATE ANALYSIS

THE LARGEST LATENT ROOT AND THE CORRESPONDING LATENT VECTOR FOR PRINCIPAL COMPONENT ANALYSIS /IBUTION OF AMS 66 995 MULTIVARIATE CENTRAL LIMIT THEOREM FOR RANDOM LINEAR VECTOR FORMS

SOME DTSTANCE PROPERTIES OF

THE IDENTIFICATION OF VECTOR MIXED AUTOREGRESSIVE-MOVINC AVERAGE SYSTEMS

TESTS FOR THE DISPERSION AND FOR THE MODAL VECTOR OF A DISTRIBUTION ON A SPHERE

OF LINEAR COMBINATIONS OF THE PARAMETERS IN THE MEAN VECTOR OF A MULTIVARIATE DISTRIBUTION

ON THE FIXED POINT PROBABILITY VECTOR OF REGULAR OR ERGODIC TRANSITION MATRICES

S TO CRITERIA FOR THE CONTINUITY OF PROCESSES WITH A VECTOR PARAMETER /FOR THE SOBOLEV IMBEDDING THEOREM

ON THE CROSS PERTODOGRAM OF A STATTONARY GAUSSIAN VECTOR PROCESS NS

CROSS SPECTRAL ANALYSIS OF GAUSSIAN VECTOR PROCESS IN THE PRESENCE OF VARIANCE FLUCTUATIO

LEAST-SQUARES EFFICIENCY FOR VECTOR TIME SERIES

THE COVARIANCE MATRIX OF A CONTINUOUS AUTOREGRESSIVE VECTOR TIME-SERIES

A DECOMPOSITION THEOREM FOR VECTOR VARIABLES WITH A LINEAR STRUCTURE

ONS IN POPULATIONS OF 'DROSOPHILA SUBOBSCURA' CO/ VECTORIAL ANALYSIS FOR CENETIC GLINES IN BODY DIMENSI ON THE GENERATION OF NORMAL RANDOM VECTORS

ON RANDOM SUMS OF RANDOM VECTORS

AN AVERACE ASSOCIATED WITH DEPENDENT GAUSSIAN VECTORS

FOR SUMS OF A RANDOM NUMBER OF INDEPENDENT RANDOM VECTORS

ON POSITIVE DEFINITE QUADRATIC FUNCTIONS IN NORMAL VECTORS

$$
\text { ON THE DISTRIBUTION OF THE LATENT VECTORS FOR PRINCIPAL COMPONENTS ANALYSIS }
$$
THE TESTING OF UNIT VECTORS FOR RANDOMNESS

LATENT VECTORS OF RANDOM SYMMETRIC MATRICES

AMS $65 \quad 1450$

ON DOMINATING AMS 681844 ON LIMITING DISTRIBUTIONS AMS 69935

AMS 661825

BTOKA66 325

BIOKA69 223

IOKA67 211

AMS $65 \quad 78$ 600 AMS $67-593$ AMS $68 \quad 1507$ 490 AMS 691845 BI0CS66 469 TECH $62 \quad 278$ AMS $66 \quad 468$ AMS 651875 JASA $64 \quad 160$ BIOKA61 133 L DISTRIB/ BAYESIAN ESTIMATION OF LATENT ROOTS AND VECTORS WITH SPECIAL REFERENCE TO THE BIVARIATE NORMA BIOKA69 97 CTURERS' SERVICES FOR BAKERY PRODUCTS AND FRUITS AND VEGETABLES DEMAND FOR MANUFA JASA $65 \quad 740$

E LES ESPECES ET LES VARI/ L'ETUDE DES COMMUNAUTES VECETALES PAR L'ANALYSE STATISTIQUE DES LIAISONS ENTR BIOCS65 345 E LES ESPECES ET LES VARI/ L'ETUDE DES COMMUNAUTES VEGETALES PAR L'ANALYSE STATISTIQUE DES LIAISONS ENTR BIOCS65 890 POTENTIAL THEORETIC PROOF OF A THEOREM OF DERMAN AND VEINOTT ENER RELATIVER DYADENKONTEXT/ NOTES. EIN EINFACHES VERFAHREN ZUR ERZEUGUNG VON SYMBOLFOLGEN MIT VORGEGEB BIOCS68 703 SOME STOCHASTIC VERSIONS OF THE MATRIX MODEL FOR POPULATION DYNAMICS JASA 69111 TABLES FOR A TREATMENTS VERSUS CONTROL MULTIPLE COMPARISONS SIGN TEST 293 
CORRICENDA, 'A FURTHER LOOK AT ROBUSTNESS VIA BAYES'S THEOREM.' PARAMETERS FOR A MIXTURE OF NORMAL DISTRIBUTIONS' BY VICTOR HASSELBLAD OGRAMS FOR THE ELECTRONIC COMPUTER FROM THE POINT OF VIEW OF THE USER ' $N$ BENADERINC VIR ' $N$ MACREEKS WAARSKYNLIKHEIDSVERDELINC F CRITICAL SITES IN LIMITED CENOME EXPRESSION DURINC VIRAL INFECTION OF BACTERIA /MATION OF THE NUMBER O BIOCS69 537 OF POISSON RECRESSION WITH AN APPLICATION IN VIROLOCY THE ANALYSIS BIOKA64 THE ESTIMATION OF CONCENTRATION OF VIRUSES AND BACTERIA FROM DILUTION COUNTS WITH LIMITED WAITING ROOMS AND CERTAIN ORDER OF VISITS A SYSTEM OF TWO SERVERS BIOKA68 223 ANALYSIS OF VITAL STATISTICS BY CENSUS TRACT

RESPONSE CRITERIA FOR THE BIOASSAY OF VITAMIN $K$

A QUANTITATIVE DISCUSSION OF THE EFFECTIVENESS OF VOIDINC AS A DEFENCE ACAINST BLADDER INFECTION INDEX TO TECHNOMETRICS, VOLUMES 1-7 ERRATA TO INDEX TO TECHNOMETRICS, VOLUMES $1-7$

ON THE DISTRIBUTTON OF THE TWO SAMPLE CRAMER-VON MISES CRITERION DISTRIBUTION OF THE TWO-SAMPLE CRAMER-VON MISES CRITERION FOR SMALL EQUAL SAMPLES TESTS FOR THE VON MISES DISTRIBUTION

SOME RELATIONSHIPS BETWEEN THE NORMAL AND VON MISES DISTRIBUTIONS SOME RELATIONSHIPS AMONG THE VON MISES DISTRIBUTIONS OF DIFFERENT DIMENSIONS BIAS OF THE ONE-SAMPLE CRAMER-VON MISES TEST

SMALL-SAMPLE DISTRIBUTIONS OF THE TWO-SAMPLE CRAMER-VON MISES' W-SQUARED AND WATSON'S U-SQUARED NFACHES VERFAHREN ZUR ERZEUGUNG VON SYMBOLFOLGEN MIT VORGEGEBENER RELATIVER DYADENKONTEXTREDUNDANZ COVARIANCE MATRIX ON THE EXACT DISTRIBUTIONS OF VOTAW'S CRITERIA FOR TESTING COMPOUND SYMMETRY OF A PROBABILITIES IN THE VOTING PARADOX JASA 59730 BIOCS69 NO. 4 BI0CS66 53 TECH $66 \quad 216$ TECH $66 \quad 387$ AMS 621148 AMS $63 \quad 95$ BIOKA69 149 BIOKA67 684 BIOKA66 269 JASA $66 \quad 246$ AMS 641091 S IRRADIES ESTIMATION PAR LA METHODE DU MAXIMUM DE VRATSEMBLANCE DES COURBES DE SURVIE DE MICROORGANISME BIOCS66 673 BUTION ON THE EXACT DISTRIBUTIONS OF THE CRITERION W FOR TESTING SPHERICITY IN A P-VARIATE NORMAL DISTRI AMS 67 II7O NS OF GOODNESS-OF-FIT STATISTICS, U-SQUARE-SUB-N AND W-SQUARE-SUB-N /APPROXIMATIONS FOR THE DISTRIBUTIO BIOKA65 630 FURTHER PERCENTAGE POINTS FOR W-SQUARE-SUB-N + (CRAMER-VON MISES GOODNESS-OF-FTT THE GOODNESS-OF-FIT TESTS BASED ON W-SQUARE-SUB-N AND U-SQUARE-SUB-N

DISTRIBUTIONS OF THE TWO-SAMPLE CRAMER-VON MISES' W-SQUARED AND WATSON'S U-SQUARED

APPROXIMATIONS FOR THE NULL DISTRIBUTION OF THE W-STATISTIC +(TEST FOR NORMALITY) ON THE PROPERTY, W, OF THE CLASS OF STATISTICAL DECISION FUNCTIONS BIOKA62 397 SMALL-SAMPLE AMS 641091 TECH $68 \quad 861$ AMS 661631 ' $N$ BENADERING VIR 'N MAGREEKS WAARSKYNLIKHEIDSVERDELING SASJ 69 NO.2

RENSIAALVERGELYKINGE DISTRIBUTIVE SHARES EIENSKAPPE VAN WAARSKYNLIKHEIDSVERDELINGS DEUR DIE GEBRUIK VAN WAGE, PRICE, AND TAX ELASTICITIES OF OUTPUT AND A WAITING LINE WITH INTERRUPTED SERVICE, INCLUDING THE EFFECT OF THE SIZE OF THE WAITING ROOM ON A SIMPLE QUEUE

A SYSTEM OF TWO SERVERS WITH LIMITED WAITING ROOMS AND CERTAIN ORDER OF VISITS

REPAIR SOME WAITING TIME DISTRIBUTIONS FOR REDUNDANT SYSTEMS WITH WAITING TIME IN BULK SERVICE QUEUES

SOME NUMERICAL RESULTS FOR WAITING TIMES IN THE QUEUE E-SUB-K-M-1

CORRICENDA, 'SOME NUMERICAL RESULTS FOR WAITING TIMES IN THE QUEUE E-SUB-K-M-1.'
QUEUE A NOTE ON EQUALISING THE MEAN WAITING TIMES OF SUCCESSIVE CUSTOMERS IN A FINITE ON THE WAITING-TIME DISTRIBUTION FOR QUEUES IN SERIES STATIONARY WAITING-TIME DISTRIBUTIONS FOR SINGLE-SERVER QUEUES

A NOTE ON THE LIMITING RELATIVE EFFICIENCY OF THE WALD SEQUENTIAL PROBABILITY RATIO TEST ALITY AND THE OPERATING CHARACTERISTIC CURVE FOR THE WALD SEQUENTIAL PROBABILITY RATIO TEST TABLES FOR WALD TESTS FOR THE MEAN OF A NORMAL DISTRIBUTION SOME EXTENSIONS OF THE WALD-WOLFOWITZ-NOETHER THEOREM

L TESTS

L TESTS AN IMPROVEMENT TO WALD'S APPROXIMATION FOR SOME PROPERTIES OF SEQUENTIA JRSSB54 136 FORMULAE TO IMPROVE WALD'S APPROXIMATION FOR SOME PROPERTIES OF SEQUENTIA JRSSB65 74 A GENERALIZATION OF WALD'S IDENTITY WITH APPLICATIONS TO RANDOM WALKS AMS 61549 CORRECTION TO 'A PROOF OF WALD'S THEOREM ON CUMULATIVE SUMS' $591245 \quad 1344$ THE GROWTH OF A RECURRENT RANDOM WALK THE GROWTH OF A RANDOM WALK STATIONARY BEHAVIOUR OF A LEFT-CONTINUOUS RANDOM WALK THEORY OF QUEUES

THE RANDOM WALK (IN CONTINUOUS TIME) AND ITS APPLICATION TO THE SIMPLE RANDOM WALK AND RANK ORDER STATISTICS

DISTRIBUTIONS ASSOCIATED WITH RANDOM WALK AND RECURRENT EVENTS (WITH DISCUSSION) THE RANDOM WALK BETWEEN A REFLECTING AND AN ABSORBINC BARRIER RANDOM WALK DESIGN IN BIO-ASSAY

A RANDOM WALK IN WHICH THE STEPS OCCUR RANDOMLY IN TIME RANDOM WALK ON A CIRCLE

ONE DIMENSTONAL RANDOM WALK WTTH A PARTIALLY REFLECTING BARRIER

A WIENER-HOPF TYPE METHOD FOR A GENERAL RANDOM WALK WITH A TWO-SIDED BOUNDARY

FIRST PASSAGE TIMES OF A GENERALIZED RANDOM WALK, CORR. AND ACKNOWLEDGEMENT OF PRIORITY 611345 NES UNI-DIRECTIONALLY PATROLLED BY ONE OPERATOR WHEN WALKING TIME AND REPAIR TIMES ARE CONSTANTS /MACHI JRSSB57 I66 NES UNT-DIRECTIONALIY PATROLLED BY ONE OPERATOR WHEN WALKING TIME IS CONSTANT AND REPATR TTMES ARE VART ABL JRSSB57 73 ON A CLASS OF SIMPLE RANDOM WALKS LIMIT THEOREMS FOR STOPPED RANDOM WALKS

A LOCAL LIMIT THEOREM FOR A CERTAIN CLASS OF RANDOM WALKS THE ERGODIC BEHAVIOUR OF RANDOM WALKS

OF WALD'S IDENTITY WITH APPLICATIONS TO RANDOM WALKS IN REGULAR MARKOV CHAINS AND CERTAIN RANDOM WALKS

LIMITING DISTRIBUTIONS FOR SOME RANDOM WALKS ARISING IN LEARNING MODELS A MIXTURE OF TWO RECURRENT RANDOM WALKS NEED NOT BE RECURRENT

FIRST PASSAGE TIME DENSITY FOR HOMOGENEOUS SKIP-FREE WALKS ON THE CONTINUUM LIMIT THEOREMS FOR STOPPED RANDOM WALKS, II LIMIT THEOREMS FOR STOPPED RANDOM WALKS, III COMMENTS ON PAPER BY KURTZ, LINK, TUKEY AND WALLACE

SIMPLIFIED BETA-APPROXIMATIONS TO THE KRUSKAL-WALIIS H TEST E, APODEMUS SYLVATICUS. III/ THE GROWTH, SURVIVAL, WANDERINC AND VARIATION OF THE LONG-TAILED FIELD MOUS BIOKA52 389 


\section{ON EVALUATION OF}

WILLIAM $N$. HURWITZ CHANCES IN CENSUS METHODS

WILLIAM N. HURWITZ, ON WILLIAM HURWITZ

WILLIAM N HURWITZ, COMMENTS

ILLIAM N HURWITZ. PROFESSOR WILLIAM N, HURWITZ

ILLIAM $N$ HURWITZ SOME BASIC PRINCIPLES OF STATI/

ILLIAM N . HURWITZ. THE DEVELOPMENT OF HOUSEHOLD S/

\section{ON THE CALTON}

WARRANTY ASSURANCE WHEN LIFE HAS A WEIBULL DISTRIBUTI WASHINCTON STATISTICAL SOCIETY MEMORIAL MEETINC FOR WASHINCTON STATISTICAL SOCIETY MEMORIAL MEETINC FOR WASHINCTON STATISTICAL SOCIETY MEMORIAL MEETINC FOR W JASA 69 NO.4 WASHINGTON STATISTICAL SOCIETY MEMORIAL MEETINC FOR W JASA 69 NO.4 WASHINCTON STATISTICAL SOCIETY MEMORIAL MEETINC FOR W JASA 69 N0.4

ON THE GALTON-WATSON PROCESS

THE MULTI-TYPE CALTON-WATSON PROCESS IN A CENETICAL CONTEXT

A LIMIT THEOREM FOR MULTIDIMENSIONAL GALTON-WATSON PROCESSES

THEOREMS FOR INDECOMPOSABLE MULTIDIMENSIONAL GALTON-WATSON PROCESSES

A NOTE ON MULTI-TYPE CALTON-WATSON PROCESSES WTTH RANDOM BRANC

A COMPARISON BETWEEN THE POWER OF THE DURBIN-WATSON TEST AND THE POWER OF THE BLUS TEST METHOD' A NOTE ON G S WATSON'S PAPER 'A STUDY OF THE GROUP SCREENING

K-SAMPLE ANALOCUE OF WATSON'S U-SQUARE STATISTIC

OF THE TWO-SAMPLE CRAMER-VON MISES' W-SQUARED AND WATSON'S U-SQUARED

SMALL-SAMPLE DISTRIBUTIONS ESTIMATION OF POWER SPECTRA BY A WAVE ANALYZER

AMS $67 \quad 264$

AMS $66 \quad 695$

BIOCS6B 147

AMS 661211

AMS 66.1463

BIOKA68 5B9 JASA 69938 TECH $65 \quad 444$ BIOKA66 579 AMS 641091 TECH $65 \quad 553$

E LARCE SAMPLE ESTTMATION OF AN UNKNOWN DISCRETE WAVEFORM WHICH IS RANDOMLY REPEATING IN GAUSSIAN NOIS AMS 65 489 NDOMIZED SYMMETRICAL DESIGN FOR THE PROBLEM OF A ONE WAY CLASSIFIGATION AN THE ADMISSIBILITY OF A RA TIONS WHERE DO WE GO FROM HERE

RELATIONS BETWEEN WEAK AND UNIFORM CONVERGENCE OF MEASURES WITH APPLICA

RANDOM SAMPLE SIZES

PROBLEMS

WEAK APPROACHABILITY IN A TWO-PERSON GAME

WEAK CONVERGENCE AND A CHERNOFF-SAVAGE THEOFEM FOR

WEAK CONVERGENCE OF A SEQUENCE OF QUICKEST DETECTION

D A NEW APPROACH TO CHERNOFF-SAVAGE THEOREM

WEAK CONVERGENCE OF A TWO-SAMPLE EMPIRICAL PROCESS AN A CHARACTERIZATION OF THE WEAK CONVERGENCE OF MEASURES

SIONAL TIME/ INEQUALITIES WITH AFPLICATTONS TO THE WEAK CONVERGENCE OF RANDOM PROCESSES WITH MULTI-DIMEN PRESERVATION OF WEAK CONVERGENCE UNDER MAPPINGS

A NOTE ON THE WEAK LAW

A NOTE ON THE WEAK LAW OF LARGE NUMBERS

WEAK QUALITATIVE PROBABILITY ON FINITE SETS

ON THE MULTIVARIATE ANALYSIS OF WEAKLY STATIONARY STOCHASTIC PROCESSES

ON THE COEFFICIENT OF COHERENCE FOR WEAKLY STATIONARY STOCHASTIC PROCESSES

PROBLEMS IN MEASURING LONG TERM CROWTH IN INCOME AND WEALTH

THE USE OF WEALTH TO COMPARE HOUSEHOLDS' AVERAGE SAVING

INCOME, WEALTH, AND THE DEMAND FOR MONEY, SOME EVIDENCE FROM

CROSS-SECTION DATA

A LEARNING MODEL FOR PROCESSES WTTH TOOL WEAR

SOME SIMPLE WEAR-DEPENDENT RENEWAL PROCESSES

A STOCHASTIC CHARACTERIZATION OF WEAR-OUT FOR COMPONENTS AND SYSTEMS

ON THE "FTNAL REPORT OF THE ADVISORY GOMMITTEE ON WEATHER CONTROL"

THE TRENTILE DEVIATION METHOD OF WEATHER FORECAST EVALUATION

BOUNDARIES FOR CLOSED (WEDGE) SEQUENTIAL T TEST PLANS

MISSIBLE ESTTMATORS OF THE LOCATION PARAMETER OF THE WEIBULL AND CERTAIN OTHER DISTRIBUTIONS

INTERVAL ESTIMATION PROCEDURES FOR THE TWO-PARAMETER WEIBULL AND EXTREME-VALUE DISTRIBUTIONS

IMATORS, FROM CENSORED SAMPLES. OF THE PARAMETERS OF WEIBULL AND GAMMA POPULATIONS /XIMUM-LIKELIHOOD EST

ESTIMATION OF THE SHAPE AND SCALE PARAMETERS OF THE WEIBULL DISTRIBUTION

ON THE RENEWAL FUNCTION FOR THE WEIBULL DISTRIBUTION

CUMULATIVE SUM CONTROL CHARTS AND THE WEIBULL DISTRIBUTION

ESTIMATION OF PARAMETERS IN THE WEIBULL DISTRIBUTION

INFERENCES ON THE PARAMETERS OF THE WEIBULL DISTRIBUTION

TWO SAMPLE TESTS IN THE WEIBULL DISTRIBUTION

ON EVALUATION OF WARRANTY ASSURANCE WHEN LIFE HAS A WEIBULL DISTRIBUTION

TESTS OF HYPOTHESES CONCERNING THE THREE-PARAMETER WEIBULL DISTRIBUTION

BEST LINEAR INVARIANT ESTIMATES OF PARAMETERS OF THE WEIBULL DISTRIBUTION

CONFIDENCE BOUND FOR RELIABILITY IN THE CASE OF THE WEIBULL DISTRIBUTION

D SAMPLES MAXTMUM LIKELIHOOD ESTIMATION IN THE WEIBULL DISTRIBUTION BASED

D S/ ERRATA, 'MAXIMUM LIKELIHOOD ESTIMATION IN THE WEIBULL DISTRIBUTION BASED ON COMPLETE AND ON CENSORE TECH 66 570

$\mathrm{N}$ TWO FAILURES OCCUR PER LOT ESTIMATION OF WEIBULL DISTRIBUTION SHAPE PARAMETER WHEN NO MORE THA TECH 64 4I

R STATISTIC CONFIDENCE BOUNDS ON RELIABLE LIFE FOR A WEIBULL MODEL WITH PROGRESSIVE CENSORINC /REE, ORDE JASA 69 306 THE MOMENTS OF LOC-WEIBULL ORDER STATISTICS

ASYMPTOTIC PROPERTIES OF SEVERAL ESTIMATORS OF WEIBULL PARAMETERS

SOME PERCENTILE ESTIMATORS FOR WEIBULL PARAMETERS

A GRAPHTCAL ESTIMATION OF MIXED WETBULL PARAMETERS IN LIFE TESTING ELECTRON TUBES TECH 59 389

ON M ORDER STATISTICS. FOR THE SCALE PARAMETER OF A WEIBULL POPULATION WITH KNOWN SHAPE PARAMETER /ASED TECH 65 405

LIKELIHOOD ESTIMATION OF THE PARAMETERS OF CAMMA AND WEIBULL POPULATIONS FROM COMPLETE AND FROM CENSORED S TECH 65 639

LIKELIHOOD ESTIMATION OF THE PARAMETERS OF GAMMA AND WEIBULL POPULATIONS FROM COMPLETE AND FROM GENSORED S TECH 67 195 THE DISCRIMINATION BETWEEN TWO WEIBULL PROCESSES

INSPECTION PLANS FOR DISCRIMINATING BETWEEN TWO WEIBULL PROCESSES

ERRATA, THE DISCRIMTNATTON BETWEEN TWIO WTETBULL PROCESSES '

A NOTE ON THE WEIBULL RENEWAL PROCESS

QUERY, SAVINGS IN TEST TIME WHEN COMPARING WEIBULL SCALE PARAMETERS

NOTES. ORTHOGONAL POLYNOMIALS FOR UNEQUALLY WEIGHED MEANS

SINGULAR WEIGHING DESIGNS

ON NON-RANDOMIZED FRACTIONAL WEICHING DESIGNS

RANDOMIZED FRACTIONAL WEICHING DESIGNS

719)

SINGULARITY IN HOTELLINC'S WEICHING DESIGNS AND A GENERALIZED INVERSE (CORR. 69

ON HOTELLING'S WEIGHING DESIGNS UNDER AUTO-CORRELATION OF ERRORS WEICHING DESIGNS WHEN N IS ODD

AN APPLICATION OF VARIABLE WEICHT DISTRIBUTED LAGS

TECH $64 \quad 57$

SAMPLING TECH 65589

TECH $64 \quad 240$

BIOKA66 375

TECH $64 \quad 471$

BI0CS65 226

AMS $64 \quad 673$

AMS 661 B36

AMS $66 \quad 13$ B2

AMS 661021

AMS 651 B29

AMS 661371

JASA 671277

SEQUENTIAL DESIGNS FOR SPHERICAL WEIGHT FUNCTIONS 
INFORMATION AND THE UTILITY OF EXPERIMENTS (CORR/ WEICHT OF EVIDENCE, CORROBORATION, EXPLANATORY POWER, JRSSB6O 319 TABLETS, AND STERILE SOLIDS

FILL WEICHT VARIATTON RELEASE AND CONTROL OF CAPSULES,

EXPERIENCE

CURRENT WEICHT-HETCHT RELATIONSHIPS OF YOUTHS OF MILTTARY ACE JASA 62895 WEICHT-HEIGHT STANDARDS BASED ON WORLD WAR II JASA 58408

ON THE WEICHTED COMBINATION OF SIGNIFICANCE TESTS JRSSB55 264

DOOLITTLE METHOD AND THE FITTTNG OF POLYNOMTALS TO WEICHTED DATA LES

ON THE UISTRIBUTION OF THE WEICHTED DIFFERENCE OF TWO INDEPENDENT STUDENT VARIAB JRSSB60 188 OPTIMAL PROPERTIES OF EXPONENTIALLY WEICHTED FORECASTS, CORR. 62919

AN EXPERTMENT WTTH WETCHTED INDEXES OF CYCLTCAL DIFFUSTON

JASA $60 \quad 299$

JASA $58 \quad 39$

VARIANCES, SAMPLINC EXPERIMENTS WITH LEAST SQUARES, WEICHTED LEAST SQUARES AND MAXIMUM LIKELIHOOD ESTIMAT BIOCS68 607

COMPARISON OF THE VARIANCE OF MINIMUM VARIANCE AND WEICHTED LEAST SQUARES REGRESSION COEFFICIENTS

FORMULAE FOR CONFIDENCE POINTS BASED ON INTECRALS OF WEICHTED LIKELIHOODS

THE BEHRENS-FISHER DISTRIBUTION AND WEICHTED MEANS

MIZATION BASES OF THE PROBLEM OF THE AMALCAMATION OF WEICHTED MEANS

ON THE ACCURACY OF WEICHTED MEANS AND RATIOS

THE COMPLETE AMALGAMATION INTO BLOCKS, BY WEICHTED MEANS, OF A FINITE SET OF REAL NUMBERS

PREDICTION BY EXPONENTIALLY WEICHTED MOVINC AVERACES AND RELATED METHODS

THE CONTROLS

A NOTE ON A MODIFIED EXPONENTIALLY WEIGHTED PREDIGTOR

ON JRSSB63 318

JRSSB59 73

THE RANDO JRSSB61 423

BIOKA56 304

BIOKA59 317

JRSSB61 414

JRSSB 68318

PROBTS ALLOWING FOR A NON-ZERO RESPONSE IN BIOKA56 207

THE VARIANCE OF WEIGHTED REGRESSION ESTIMATORS

VARIANCE OF WEIGHTED REGRESSION ESTIMATORS WHEN SAMPLING ERRORS

JASA 671290

JASA 69 NO. 4

BIOCS68 979

JASA $62 \quad 622$

THE VARTANCE

NFORMATION FROM UNCORRELATED LINEAR MODELS BY SIMPLE WEIGHTING

SOME OBSERVATIONS ON THE PRACTICAL ASPECTS OF WEIGHTING DESIGNS

OF VARIANCE

ESTIMATION OF WEIGHTING FACTORS IN LINEAR REGRESSION AND ANALYSIS

BIOKA5I 248

TECH $64 \quad 1$

AMS 641553

JASA $61 \quad 281$

AMS 681107

JASA $58 \quad 66$

ERGODIC THEORY WITH RECURRENT WEIGHTS
USE OF VARYING SEASONAL WEIGHTS IN PRICE INDEX CONSTRUCTION

OF PARTICLE SIZE DISTRIBUTION BASED ON OBSERVED WEIGHTS OF GROUPS OF PARTICLES

NOTE ON THE CONFIDENCE-PRIOR OF WELCH AND PEERS

COMMENT ON THE NOTES BY NEYMAN BARTLETT AND WELCH IN THTS JOURNAL (VOL 18, NO. 1956$)$

TECH 65505

JRSSB 6655

JRSSB57 179

E MEA/ AN EXACT DISTRIBUTION OF THE BEHRENS-FISHER-WELCH STATISTIC FOR TESTING THE DIFFERENCE BETWEEN TH JRSSB61 377 INCOME REPORTED BY A SAMPLE OF FAMILIES WHO RECEIVED WELFARE ASSISTANCE DURING 1959 THE VALIDITY OF JASA 62 680 DISCUSSION OF THE PAPERS OF MESSRS. HALD, WETHERILL AND COX

INDEPENDENT RANDOM VARIABLES NOTE ON WEYL'S CRITERION AND THE UNIFORM DISTRIBUTION OF

A NOTE ON THE PERIODOGRAM OF THE BEVERIDCE WHEAT PRICE INDEX

ON THE QUESTION OF WHETHER A DISEASE IS FAMILIAL

STIC SYSTEMS, ARBITRARY SYSTEM PROCESS WITH ADDITIVE WHITE NOISE OBSERVATIONS ERROR

ERRORS IN THE 1960 CENSUS ENUMERATION OF NATIVE WHITES

AN APPROXIMATION TO THE WILCOXON-MANN-WHITNEY DISTRIBUTION

NOTE ON THE WILCOXON-MANN-WHITNEY STATISTIC

SAMPLE PROPERTIES OF A GENERALIZED WILCOXON-MANN-WHITNEY STATISTIC

ON THE EFFTCIENCY OF TWO-SAMPLE MANN-WHITNEY TEST FOR DISCRETE POPULATIONS

JASA $67 \quad 409$

TECH $60 \quad 361$

AMS 691124

JASA $64 \quad 437$

JASA $69 \quad 591$

AMS 651058

ON THE LARGE AMS 67905

AMS 63612

IVES

EXACT POWER OF MANN-WHITNEY TEST FOR EXPONENTIAL AND RECTANGULAR ALTERNAT

INT, GORR. 60755 EXTENSION OF THE WILCOXON-MANN-WHITNEY TEST TO SAMPLES CENSORED AT THE SAME FIXED PO JA A

RECURSIVE GENERATION OF THE DISTRIBUTION OF THE MANN-WHITNEY U-STATISTICS UNDER LEHMANN ALTERNATIVES

A NOTE ON THE ASYMPTOTIC NORMALITY OF THE MANN-WHITNEY-WILGOXON STATISTIC

AN EXTENDED TABLE OF CRITIGAL VALUES FOR THE MANN-WHITNEY-WILCOXON TWO-SAMPLE STATISTIC

A NOTE ON BAILEY'S AND WHITTLE'S TREATMENT OF A GENERAL STOCHASTIC EPIDEMIC BIOKA55 123

MISSING OBSERVATIONS IN SPLIT-PLOT EXPERTMENTS WHERE WHOLE-PLOTS ARE MISSTNG OR MIXED UP FSTIMATION OF BIOKA6I 468 MINIMAX ESTIMATION OF A RANDOM PROBABILITY WHOSE FIRST N MOMENTS ARE KNOWN

E PEARSON DENSITIES FOR APPROXIMATING A SKEW DENSITY WHOSE LEFT TERMINAL AND FIRST THREE MOMENTS ARE KNOWN BIOKA68 559

ON PAIRS OF INDEPENDENT RANDOM VARIABLES WHOSE PRODUCT FOLLOWS THE GAMMA DISTRIBUTION

ON CROSSINGS OF LEVELS AND CURVES BY A WIDE CLASS OF STOCHASTIC PROCESSES

MULTIVARIATE WIDE-SENSE MARKOV PROCESSES AND PREDICTION THEORY

THE CASE OF THE INDIANS AND THE TEEN-AGE WIDOWS

COST OF NOT KNOWING THE VARIANCE WHEN MAKING A FIXED WIDTH CONFIDENGE INTERVAL FOR THE MEAN

CONFIDENCE BANDS OF UNIFORM AND PROPORTIONAL WIDTH FOR LINEAR MODELS

PERFORMANCE OF A SEQUENTIAL PROCEDURE FOR THE FIXED-WIDTH INTERVAL ESTIMATION OF THE MEAN

THE NUMBER AND WIDTH OF CLASSES IN THE CHI-SQUARE TEST

ON MEASURES EQUIVALENT TO WIENER MEASURE

A FIRST PASSAGE PROBLEM FOR THE WIENER PROCESS

YMPTOTIC DISTRIBUTION OF A CERTAIN FUNCTIONAL OF THE WIENER PROCESS

THESES CONCERNING THE UNKNOWN DRIFT PARAMETER OF THE WIENER PROCESS

/OCEDURES FOR CHOOSING ONE OF $K$ HYPO

WITH A TWO-SIDED BOUNDARY

A TRIBUTE TO FRANK WTLCOXON

OBITUARY, FRANK WILCOXON

PUBLICATIONS OF FRANK WILGOXON (1892-1965)

SMALL SAMPLE POWER AND EFFICIENCY FOR THE ONE SAMPLE WILCOXON AND NORMAL SCORES TESTS

IN THE DISCRETE CASE

DEPENDENCE

WILCOXON CONFIDENCE INTERVALS FOR LOGATION PARAMETERS JA

ROBUSTNESS OF THE WILCOXON ESTIMATE OF LOCATION AGAINST A CERTAIN

EXTENDED TABLES OF THE WILCOXON MATCHED PAIR SIGNED RANK STATISTIC

REMARKS ON ZEROS AND TIES IN THE WILCOXON SIGNED RANK PROCEDURE

NOTE ON THE ASYMPTOTIC NORMALITY OF THE MANN-WHITNEY-WILCOXON STATISTIC

BILITIES FOR THE NULL DISTRIBUTION OF THE TWO-SAMPLE WILCOXON STATISTIC

AMS $66 \quad 260$

AMS $63 \quad 424$

JASA $62 \quad 338$

ON THE AMS $68 \quad 1946$ JASA $66 \quad 182$

E AMS $66 \quad 36$

JASA $63 \quad 678$

AMS $67 \quad 261$

AMS 671912

AMS 691409

AMS 671376

AMS 631168

TECH $66 \quad 195$

BIOGS66 192

BI0GS67

AMS $63 \quad 624$

$\begin{array}{rrr}\text { JASA } & 67 & 184 \\ \text { AMS } & 68 & 1196\end{array}$

JASA $65 \quad 864$

JASA 59655

A JASA 61687 PROBLEM

USE OF THE WTLGOXON STATISTIC FOR A GENERALTZED BEHRENS-FISHER

EXACT AND APPROXIMATE DISTRIBUTIONS FOR THE WILCOXON STATISTIC WITH TIES THE TREATMENT OF TIES IN THE WILCOXON TEST

THE WILCOXON TEST AND NON-NULL HYPOTHESES

CENSORED SAMPLES

A GENERALIZED WILCOXON TEST FOR COMPARING ARBITRARILY SINGLY-

A GENERALIZED TWO-SAMPLE WILCOXON TEST FOR DOUBLY-CENSORED DATA

SMALL SAMPLE POWER FOR THE ONE SAMPLE WILCOXON TEST FOR NON-NORMAL SHIFT ALTERNATIVES

AN APPROXIMATION FOR THE EXACT DISTRIBUTION OF THE WILCOXON TEST FOR SYMMETRY

OF A RATIO BY MONTE CARLO METHODS

USE OF WILCOXON TEST THEORY IN ESTIMATING THE DISTRIBUTION

AMS 631596

JASA $61 \quad 293$

AMS $67 \quad 519$

JRSSB $60 \quad 402$

BIOKA65 203

BIOKA65 650

AMS 651767

JASA $64 \quad 899$ AMS 621194 
PROCESSES

BIBLIOCRAPHY

RECRESSION
EFFICIENCY OF THE WILCOXON TWO-SAMPLE STATISTIC FOR RANDOMIZED BLOCKS

THE WILCOXON TWO-SAMPLE STATISTIC ON STRONCLY MIXINC

THE WILCOXON TWO-SAMPLE STATISTIC, TABLES AND

EARLY DECISION IN THE WILCOXON TWO-SAMPLE TEST

ASYMPTOTIC BEHAVIOR OF WILCOXON TYPE CONFIDENCE RECIONS IN MULTIPLE LINEAR HISTORICAL NOTES ON THE WILCOXON UNPAIRED TWO-SAMPLE TEST

AN APPROXIMATION TO THE WILCOXON-MANN-WHITNEY DISTRIBUTION NOTE ON THE WILCOXON-MANN-WHITNEY STATISTTC

ON THE LARCE SAMPLE PROPERTIES OF A CENERALIZED WILCOXON-MANN-WHITNEY STATISTIC

SAME FIXED POINT, CORR. 60755 EXTENSION OF THE WILCOXON-MANN-WHITNEY TEST TO SAMPLES CENSORED AT THE JA THE WILCOXON, TIES, AND THE COMPUTER

NON-RANDOMNESS IN A SEQUENCE OF TWO ALTERNATIVES. I. WILCOXON'S AND ALLIED TEST STATISTICS A NOTE ON WILCOXON'S AND ALLIED TESTS

BUSTNESS PROPERTY OF THE TEST AND ESTIMATOR BASED ON WILCOXON'S SICNED RANK STATISTIC NOTES. CONFIDENCE LIMITS FOR A RATIO USING WILCOXON'S SIGNED RANK TEST

A FURTHER APPROXIMATION TO THE DISTRIBUTION OF WILCOXON'S STATISTIC IN THE CENERAL CASE EXTENDED TABLE OF CRITICAL VALUES FOR WILCOXON'S TEST STATISTIC

CORRIGENDA, 'EXTENDED TABLES OF CRITICAL VALUES FOR WILCOXON'S TEST STATISTIC.

EFFICIENCY OF TWO NONPARAMETRIC COMPETITORS OF WILCOXON'S TWO SAMPLE TEST

SOME REMARKS ON WILD OBSERVATIONS

PUBLICATIONS OF S. S. WILKS

SAMUEL S. WILKS

SAMUEL STANLEY WILKS 1906-1964

A COMPARISON OF TESTS OF THE WILKS-LAWLEY HYPOTHESIS IN MULTIVARIATE ANALYSIS.

F THE RATIOS OF THE ROOTS OF A COVARIANCE MATRIX AND WILKS' CRITERION FOR TESTS OF THREE HYPOTHESES /S O A NOTE ON WILKS' INTERNAL SCATTER

ON THE EXACT DISTRIBUTION OF WILKS'S CRITERION

EXACT DISTRIBUTIONS OF WILKS'S LIKELIHOOD RATIO CRITERION

$\begin{array}{lrr}\text { BIOKA66 } & 347 \\ \text { A NOTE ON THRIFTY STRAT AMS } & 69 & \text { NO. } 6\end{array}$

ECIES AND MARTINGALES IN A FINITELY ADDITIVE SETTING WILLIAM D. SUDDERTH

SOCIETY MEMORIAL MEETING FOR WILLIAM N. HURWITZ. ON WILLIAM HURWITZ

THE EFFICIENCY OF AUTOMATIG WINDINC MACHINES WITH GONSTANT PATROLLINC TIME

COMBININC A BARTLETT WINDOW WITH AN ASSOCIATED INNER WINDOW

SPECTRAL ANALYSIS COMBINING A BARTLETT WINDOW WITH AN ASSOCIATED INNER WINDOM

PLAY THE WINNER RULE AND THE CONTROLLED CLINICAL TRIAL

ON THE PROBABILITY OF WINNING WITH DIFFERENT TOURNAMENT PROCEDURES

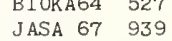

TECH $60 \quad 1$

AMS $65 \quad 24$

JASA $65 \quad 939$

AMS $65 \quad 1$

BIOKA65 149

AMS 69 NO. 6

AMS $65 \quad 1308$

BI0KA69 109

STRAT AMS 69 N0.6 JRSSB59 381 TECH 61235 TECH $61 \quad 235$

JASA $69 \quad 131$ JASA $63 \quad 1064$

OF THE DISTRIBUTION OF WINSORIZED T (TRIMMINC-WINSORIZATION 2) APPROXIMATE BEHAVIOR TECH 68 B3

APPROXIMATE BEHAVIOR OF THE DISTRIBUTION OF WINSORIZED T (TRIMMING-WINSORIZATION 2)

COMPLIANCE IN REPORTING INTEREST INCOME UNDER THE WISCONSIN STATE INDIVIDUAL INCOME TAX

THE DISTRIBUTION OF THE DETERMINANT OF A GOMPLEX WISHART DISTRIBUTED MATRIX

A CHARACTERIZATION OF THE WISHART DISTRIBUTION

ON THE COMPLEX WISHART DISTRIBUTION

DECOMPOSITION OF WISHART DISTRIBUTION

TECH $6 B \quad 83$

$\begin{array}{lll}\text { TAXPAYER JASA } 63 \quad 487 & 03\end{array}$

AMS $63 \quad 178$

AMS 621272

AMS $65 \quad 313$

BIOKA64 267

IATE STATISTICS' 46/ CORRECTION. 'THE NON-CENTRAL WISHART DISTRTBUTION AND CERTAIN PROBLEMS OF MULTIVAR AMS 64 923 LINEAR DIFFERENTIAL EQUATIONS THE WISHART DISTRIBUTION DERIVED BY SOLVING SIMULTANEOUS BIOKA5I 470 CORRECTION. 'SOME EXTENSIONS OF THE WISHART DISTRIBUTION', $44345 \quad 923$

ETA DISTRIBUTIONS AND INDEPENDENCE PROPERTIES OF THE WISHART DISTRIBUTIONS, CORR. $66297 \quad$ MULTIVARIATE B AMS 64 261

PERCENTAGE POINTS OF THE EXTREME ROOTS OF A. WISHART MATRIX

A NOTE ON THE BARTLETT DECOMPOSITION OF A WISHART MATRIX

ON THE INDEPENDENCE OF CERTAIN WISHART VARIABLES 促TSHRT VARIATE WITH THE INVERSE OF ANOTHER INDEPENDE AMS 67944 THE CONDITIONAL WISHART, NORMAL AND NONNORMAL $\quad$ AMS $68 \quad 593$ EDITORIAL, JOHN WISHART, 1898-1956

BIOKA57 I

FIDUCIAL THEORY

IALS IN NORMAL VECTOR

PIVOTAL QUANTITIES FOR WISHART'S AND RELATED DISTRIBUTIONS, AND A PARADOX IN JRSSB55 79 CONDITIONS FOR WISHARTNESS AND INDEPENDENCE OF SECOND DEGREE POLYNOM AMS 621002 ANALYSIS OF LATIN SQUARES WITHIN A CERTAIN TYPE OF ROW-COLUMN INTERACTION TECH 59379 CLASSIFICATION FIXED EFFEGTS MODEL WITH OBSERVATIONS WITHIN A ROW SERIALLY CORRELATED /FOR THE TWO-WAY BIOKA69 NO.3 RED TO ESTIMATE THE PARAMETER IN THE UNIFORM DENSITY WITHIN D UNITS OF THE TRUE VALUE SAMPLE SIZE REQUI JASA 64 550 DESIGNS

ON THE ADMISSIBILITY AT INFINITY, WITHIN THE CLASS OF RANDOMIZED DESICNS, OF BALANCED

THE SPREAD OF AN EPIDEMIC TO FIXED GROUPS WITHIN THE POPULATION

ON COMPARING THE CORRELATIONS WITHIN TWO PAIRS OF VARIABLES

MULTIPLE REGRESSION COMBINING WITHIN- AND BETWEEN-PLOT INFORMATION

THE WITHIN-ANIMAL BIOASSAY WITH QUANTAL RESPONSES

NOTES.COMPUTING A DISCRIMINANT FUNCTION FROM WITHIN-SAMPLE DISPERSIONS

ON CONVERGENCE OF THE KIEFER-WOLFOWITZ APPROXIMATION PROCEDURE

A CONTINUOUS KIEFER-WOLFOWITZ PROCEDURE FOR RANDOM PROCESSES, CORR. 66

SOME EXTENSIONS OF THE WALD-WOLFOWITZ-NOETHER THEOREM

745

NARY DISTRIBUTION AND THE OCGURRENCE DISTRIBUTION OF WORD LENGTH AND ITS IMPORTANCE FOR THE STUDY OF QUANT BIOKA5B 222 TIONSHIPS FOR TWO TO THE POWER OF N-R DESICNS HAVINC WORDS OF EQUAL LENCTHS

RING PERMUTATIONS

FOUR-LETTER WORDS. THE DISTRIBUTION

ON IDENTITY RELA AMS 661842 THE STATISTICAL WORK OF OSKAR ANDERSON

JRSSB $67 \quad 550$ JASA $61 \quad 273$

ON NON-NORMALITY

1031

SUMMARY OF RECENT WORK ON VARIABLES ACCEPTANCE SAMPLINC WITH EMPHASIS TECH 69 NO.4 THE USE OF RANDOM WORK SAMPLING FOR COST ANALYSIS AND CONTROL, CORR. 58 JASA 58382 A TABLE FOR COMPUTING WORKING ANCLES WORKING LIFE TABLES FOR MALES IN GHANA 1960 BIOCS6B 413 JASA 69102 JRSSB59 195

ON A DISCRIMINATORY PROBLEM CONNECTED WITH THE WORKS OF PLATO TION AND STATISTICAL INFERENCE IN A RAPIDLY CHANGINC WORLD WEICHT-HEICHT STANDARDS BASED ON WORLD WAR II EXPERIENCE

CONTINUOUS SAMPLINC PLANS UNDER THE ASSUMPTION OF WORST CONDITIONS FISHER, WRICHT, AND PATH COEFFICIENTS

PROTECTION AGAINST ASSUMING THE WRONC DECREE IN POLYNOMIAL RECRESSION JASA 58408 JASA $66 \quad$ B33 BIOCS68 471 TECH 69 NO. 4

ORDER 'SPHERICAL' AND 'CUBOIDAL' DESIGNS IN THE WRONG RECIONS

BETWEEN ACCIDENTS, A NOTE ON MAGUIRE, PEARSON AND WYNN'S PAPER

ITHM FOR THE DETERMINATION OF THE ECONOMIC DESICN OF X-CHARTS BASED ON DUNCAN'S MODEL

THE USE OF SECOND- BIOKA66 596 TIME INTERVALS BIOKA53 212 AN ALGOR JASA $68 \quad 304$ 
TUDIES IN THE HISTORY OF PROBABILITY AND STATISTICS. XVII. SOME REFLEXIONS ON CONTINUITY IN THE DEVELOPMEN BIOKA67 341 TUDIES IN THE HISTORY OF PROBABILITY AND STATISTICS. XVIII. THOMAS YOUNG ON COINCIDENCES NDS, AND CONFTDENCE LTMITS FOR THE PROBABITY THAT Y IS LESS THAN X WHEN X AND Y ARE NORMAL /ENCE BOU JASA 64 $X$ ION OF A NON-/ THE DISTRIBUTION OF SUM-O-T0-M OF F(Y-SUB-T), WHERE (Y-SUB-0, Y-SUB-1,...) IS A REALIZAT BIOKA65 277 $\begin{array}{llll}\text { THE INVERSE YATES ALGORITHM } & \text { TECH } 66 & 177\end{array}$ EXPERIMENT THE EXTENSION OF YATES' 2-TO-THE-N ALGORITHM TO ANY COMPLETE FACTORIAL TECH 68 575 NOTES. CHECKS ON YATES'S ALGORITHM BIOCS67 573 TO THE POWER N FACTORIAL EXPERIMENT AS CALCULATED BY YATES'S ALGORITHM /EFFECTS AND INTERACTIONS IN A 2 BIOCS67 57I RECORD TEN YEARS OF CONSUMER ATTITUDE SURVEYS, THEIR FORECASTING JASA 63899

R. A. FISHER AND THE LAST FIFTY YEARS OF STATISTICAL METHODOLOGY ON THE VARIATION OF YIELD VARIANCE WITH PLOT SIZE

A MATHEMATICAL MODEL RELATING PLANT YIELD WITH ARRANGEMENT FOR REGULARLY SPACED CROPS ESTIMATION OF CROP YIELDS FOR SMALL AREAS HOW DEVIANT CAN YOU BE. CLASSIFYING YOUDEN RECTANGLES

FOUR-WAY BALANCED DESIGNS BASED ON YOUDEN SQUARES WITH 5, 6 , OR 7 TREATMENTS HISTORY OF PROBABILITY AND STATISTIGS. XVIII. THOMAS YOUNG ON COINCIDENCES

LABOR FORCE ENTRY AND ATTACHMENT OF YOUNG PEOPLE. CORR. 661248 CURRENT WEIGHT-HEIGHT RELATIONSHIPS OF YOUTHS OF MILITARY AGE HISTORY OF PROBABILITY AND STATISTICS. XIX. FRANCIS YSIDRO EDGEWORTH (1845-1926)
ETWEEN GREENBERG'S INDEX OF LINGUISTIC DIVERSITY AND YULE'S GHARACTERISTIC THE STUDIES IN THE JASA $65 \quad 395$ BIOKA56 337 BIOCS67 505 BI0CS66 374 JASA 681522 JRSSB 66118 BT0CS67 803 BIOKA68 249 JASA $66 \quad 117$ JASA $62 \quad 895$ AND YULE'S GHARACTERISTIC THE MATHEMATIGAL RELATION B BIOKA58 THE Z-TEST AND SYMMETRICALLVDISTRIBUTED RANDOM VARIABLES BIOKA59 I23 NG D/ SPATIAL RELATIONSHIP AMONG EIGHT POPULATIONS ZEA MAYS L. UTILIZING INFORMATION FROM A DIALLEL MATI BIOCS68 867 ESTIMATORS THE UNBIASEDNESS OF ZELLNER'S SEEMINGLY UNRELATED REGRESSION EQUATIONS JASA 67 I4I FORMULA FOR THE DIFFERENGES OF THE POWERS AT ZERO AN ASYMPTOTIC AMS 6I 249 PROCESSES ZERO CROSSING PROBABILITIES FOR GAUSSIAN STATIONARY AMS $62 \quad 1306$ MATION TO THE SIGNED-RANK SAMPLING DISTRIBUTION WHEN ZERO DIFFERENCES ARE PRESENT THE NORMAL APPROXI JA ESTIMATION OF THE PROBABILITY OF ZERO FAILURES IN M BINOMIAL TRIALS

A NOTE ON CONTINGENCY TABLES INVOLVING ZERO FREQUENCIES AND THE 2 I TEST DISCRIMINATION IN THE CASE OF ZERO MEAN DIFFERENGES AN ALGORITHM FOR OBTAINING THE ZERO OF A FUNCTION OF THE DISFERSION MATRIX IN MULTIV JASA 67 I BOUNDED LENGTH CONFIDENCE INTERVALS FOR THE ZERO OF A REGRESSION FUNCTION PREDICTIVE ZERO-MEAN UNIFORM DISCRIMINATION SOME APPLICATIONS OF ZERO-ONE PROGESSES AMS $62 \quad 237$ BIOKA6B 519 JRSSB55 243 CONSISTENT ESTIMATES AND ZERO-ONE SETS AMS $64 \quad 157$

ON CENS/ FAILURE OF ENUMERATORS TO MAKE ENTRIES OF ZERO, ERRORS IN RECORDING CHILDLESS GASES IN POPULATI JASA 61 909 OF A STATIONARY BIVARIATE GAUSSIAN PROCESS FROM ITS ZEROS OF INFINITELY DIVISIBLE DENSITIES
ESTIMATION OF THE GROSS-SPECTRUM JRSSB6B I45 ESTIMATION OF THE GROSS-SPECTRUM JRSSB6B 145 STIMATION IN THE TRUNGATED POISSON DISTRIBUTION WHEN ZEROS AND SOME ONES ARE MISSING REMARKS ON ZEROS AND TIES IN THE WILCOXON SIGNED RANK PROCEDURE JASA 59655 THE EXPECTED NUMBER OF ZEROS OF A STATIONARY GAUSSIAN PROCESS

CE-BELTRAMI OPERATOR E TF THE LAPLA EXTENSIONS OF A THEOREM OF MARCINKIEWICZ AND ZYGMUND MARTINGALE VERSION OF A THEOREM OF MARCINKIEWICZ AND ZYGNUND THE EPSILON ENTROPY ON CERTAIN MEASURES ON $(0,1)$

INDEX TO TECHNOMETRICS. VOLUMES $1-7$

ERRATA TO INDEX TO TECHNOMETRICS, VOLUMES $1-7$ NFIDENCE INTERVALS OF THE MEDIAN FOR SAMPLE SIZES TO 1,000 BINOMIAL CUMULATIVE DISTRIBUTION FOR SAMPLE SIZES TO 1,000, K DESIGNS WITH PARAMETERS V=28, N1=12, N2=15 AND P2 $(1,1)=4$ THE FIRST 1,945 BRITISH STEAMSHIPS /BOTH THE SIGN TEST AND DISTRIBUTION-FREE CO JASA 64935 AMS $68 \quad 1711$

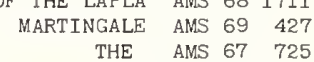
AMS 681310 TECH $66 \quad 216$ RACTERISTTC CURVES FOR FTXED EFFECT/ CHARTS OF THE 10 PERCENT JAS 58 360 ART I. THE NORMAL DISTRIBUTION UP TO SAMPLES OF SIZE 10 , /ICS FROM SINGLY AND DOUBLY CENSORED SAMPLES, P AMS 39 325 WORST CONDITIONS THE EVALUATION OF H 106 CONTINUOUS SAMPLING PLANS UNDER THE ASSUMPTION OF JASA 66 833 ED INCOMPLETE BLOCK DESIGNS WITH PARAMETERS V=28, N1=12, N2=15 AND P2 $(1,1)=4$ /CTION OF PARTIALLY BALANC AMS 66 1783 MPLETE BLOCK DESIGNS WITH PARAMETERS V=28, N1=12, N2=15 AND P2 $(1,1)=4$ /CTION OF PARTIALLY BALANCED INCO AMS 66 1783 OF GHANCES. (REPRODUCED FROM PHIL. TRANS. ROY. SOC. 1763, 53, 370-4IB.) /VING A PROBLEM IN THE DOCTRINE BIOKA58 296 ILITY AND STATISTICS. XIX. FRANCIS YSIDRO EDGEWORTH (1845-1926) STUDIES IN THE HISTORY OF PROBAB BIOKA68 269 CENTENARY LECTURE, KARL PEARSON, 1857-1957 WILLIAM PALIN ELDERTON, $1877-1962$ MAJOR GREENWOOD, 1B80-1949

NUITY IN THE DEVELOPMENT OF MATHEMATICAL STATISTICS, 1885-1920 NTS IN THE EARLY HISTORY OF BIOMETRY AND STATISTICS, 1890-1894 MEMORIAL TO SIR RONALD AYLMER FISHER, 1890-1962 RONALD AYLMER FISHER, 1B90-1962 PUBLICATIONS OF FRANK WILCOXON (1892-1965) EDITORIAL, JOHN WISHART, 1898-1956 BIOKA57 303 BIOKA62 297 BIOKA5I 1

/ATISTIGS. XVII. SOME REFLEXIONS ON CONTI BIOKA67 341 /ABILITY AND STATISTICS. XIV. SOME INCIDE BIOKA65 3 JASA $62 \quad 727$ BIOKA63 BIOCS67 BI OKA57 JASA $69 \quad 433$ AGE PATTERNS OF MORTALITY OF AMERICAN NEGROES, 1900-02 TO 1959-6I BIOMETRIKA, 1901-1951

OF MANUFACTURING EMPLOYMENT IN THE UNITED STATES, 1914-1953, CORR. 60755 OF DOMESTIG MANUFACTURING ESTABLISHMENT OUTPUT 1939-195B INCREASE IN RENT OF DWELLING UNITS FROM 1940 TO 1950

COMPANY DIVERSIFICATION AND PRODUCT CONCENTRATION 1947-1954

THE VARIABILITY OF PROFITIBILATY WITH SIZE OF FIRM, 1947-1958

INVESTMENT BEHAVIOR IN UNITED STATES MANUFACTURING 1947-1960

INCREASE IN RENT OF DWELLING UNITS FROM 1940 TO 1950

THE METROPOLITAN AREA CONCEPT, AN EVALUATION OF THE 1950 STANDARD METROPOLITAN AREAS BIOMETRIKA , 1901-1951

SEASONAL VARIATION OF DEATHS IN THE UNITED STATES, 1951-1960

MANUFACTURING EMPLOYMENT IN THE UNITED STATES, 1914-1953, GORR. 60755 BIOKA51 267 DIVERSIFICATION AND PRODUCT CONCENTRATION 1947-1954 
THE DEMAND FOR FERTILIZER IN 1954, AN INTER-STATE STUDY

JASA $59 \quad 377$

CONFESSION OF FAITH, 1955

SOME SOVIET STATISTTCAL BOOKS OF 1957

OF FAMILIES WHO RECEIVED WELFARE ASSISTANCE DURINC 1959

BOOK REVIEWS, 10 YEAR INDEX (1959-1968)

JASA $59 \quad 12$

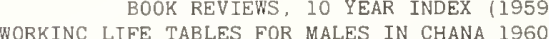

THE VALIDITY OF INCOME REPORTED BY A SAMPLE

ERRORS IN THE 1960 CENSUS ENUMERATION OF NATIVE WHITES

CONTROL OF QUALITY OF CODING IN THE 1960 CENSUSES

JASA $62 \quad 6 B 0$

TECH 69223

JASA $69 \quad 102$

JASA $64 \quad 437$

JASA $64 \quad 120$

BIOCS67 349

NOTES. SMALL SAMPLE CONSIDERATIONS IN COMBININC 2 BY 2 TABLES

MINC CHECK ON THE MAIN EFFECTS AND INTERACTIONS IN A 2 TO THE POWER N FACTORIAL EXPERIMENT AS CALCULATED B BIOCS67 571

OF CHI-SQUARE AS A TEST OF HOMOCENEITY FROM A 2-BY-N TABLE

THE RAPID CALCULATION BIOKA55 519

ON THE POWER FUNCTION OF THE EXACT TEST FOR THE 2-BY-2 CONTINCENCY TABLE

BIOKA60 393

TESTS OF SICNIFICANCE IN A 2-BY-2 CONTINCENCY TABLE, EXTENSION OF FINNEY'S TABLE BIOKA53

'ON THE POWER FUNCTION OF THE EXACT TEST FOR THE 2-BY-2 CONTINCENCY TABLE'

TABLES FOR SIGNIFICANCE TESTS OF 2-BY-2 CONTINCENCY TABLES

CORRIGENDA, BIOKA61 475

BIOKA55 494

THE EFFECT JASA $69 \quad 852$

OF NON-SAMPLINC ERRORS ON MEASURES OF ASSOCIATION IN 2-BY-2 CONTINGENCY TABLES

IMPLE METHOD OF CALCULATINC THE EXACT PROBABILITY IN 2-BY-2 CONTINCENCY TABLES WITH SMALL MARCINAL TOTALS BIOKA55 522
TEST FOR THE DIFFERENCE BETWEEN TWO PROPORTIONS IN A 2-BY-2 TABLE.' /IGENDA, 'THE POWER FUNCTION OF THE BIOKA59 502

TEEN TWO PROPORTIONS IN A 2-BY-2 TABLY

/IGENDA, 'THE POWER FUNCTION OF THE

BIOKA6I 181

THE CONTINUITY CORRECTION IN 2-BY-2 TABLES

OF THE COMBINATION OF PROBABILITIES TEST TO A SET OF 2-BY-2 TABLES

BIOKA64 327

CORRIGENDA, 'TEST OF INDEPENDENCE IN INTRACLASS 2-BY-2 TABLES

A NOTE ON THE APPLICATION BIOKA55 404

BIOKA6I 476

TABLES FOR TESTINC SIGNIFICANCE IN A 2-BY-3 GONTINGENGY TABLE

TECH 63501

TECH $64 \quad 439$

THE POWER FUNCTION OF THE EXACT TEST FOR THE 2-BY-3 CONTINGENCY TABLE

BIOCS68 714

NOTES RAPID CALCULATION OF EXACT PROBABILITIES FOR 2-BY-3 CONTINGENCY TABLES

TECH $69 \quad 193$

A NOTE ON A NON-PARAMETRIC APPROACH TO THE 2-CUBE FACTORIAL DESIGN

OF FACTORIAL EXPERIMENT (PARTIALLY CONFOUNDED 2-CUBE)

OF FACTORIAL EXPERIMENT (PARTIALLY CONFOUNDED 2-CUBE)

QUERY, ANALYSIS TECH $67 \quad 170$

THE 2-TO-THE-(K-P) FRACTIONAL FACTORIAL DESIGNS

TECH 61311

TECH $61 \quad 449$

TECH $63 \quad 417$

ERRATA, THE 2-T0-THE-(K-P) FRACTIONAL FACTORI AL DESIGNS AUGMENTING 2-TO-THE-(N-1) DESIGNS

QUADRATIC TRENDS

FACTORIAL 2-TO-THE-(P-Q) PLANS ROBUST AGAINST LINEAR AND

TECH $66 \quad 469$

TECH $66 \quad 259$

JASA $62 \quad 403$

SEQUENCES OF FRACTIONAL REPLICATES IN THE 2-TO-THE-(P-Q) SERIES, CORR, 62919

TECH $66 \quad 705$

32

MENT

ON ADDELMAN'S 2-TO-THE- $(17-9)$ RESOLUTION V PLAN

CONSTRUCTION OF A 2-TO-THE-(17-9) RESOLUTION $V$ PLAN IN EIGHT BLOCKS OF TECH 65

THE EXTENSION OF YATES' 2-TO-THE-N ALGORITHM TO ANY COMPLETE FACTORIAL EXPERI TECH 68

ESULTS ON FAGTORIAL DESIGNS OF RESOLUTION IV FOR THE 2-TO-THE-N AND 2-TO-THE-N TIMES 3-TO-THF-M SERIES

SATURATED FRACTIONS OF 2-TO-THE-N AND 3-TO-THE-N FACTORIAL DESIGNS

SOME NONORTHOGONAL FRACTIONS OF 2-TO-THE-N DESIGNS

IRREGULAR FRACTIONS OF THE 2-TO-THE-N FACTORIAL EXPERIMENTS

RIAL DESIGNS OF RESOLUTION IV FOR THE 2-TO-THE-N AND 2-TO-THE-N TIMES 3-TO-THE-M SERIES

NG ESTIMATION OF ALL TWO-FACTOR INTERACTIONS FOR THE 2-TO-THE-N TIMES 3-TO-THE-N FACTORIAL SERIES OF DESIC TE

INTERACTION ALIASINC

H APPLICATIONS

LIED SEQUENTIALLY

ORTHOCONAL MAIN-EFFECT 2-TO-THE-N-TIMES-3-TO-THE-M DESICNS AND TWO-FACTOR

575

CH 6931

TECH 67569

JRSSB 69 NO.2

$\mathrm{TECH} 61 \quad 479$

ONTINGENCY TABLES INVOLVINC ZERO FREQUENCIES AND THE 2 I TEST

THE POWER FUNCTIONS FOR THE TEST OF INDEPENDENCE IN 2 X2 CONTINCENCY TABLES

RAPID ANALYSIS OF $2 X 2$ TABLES

THE DISTRIBUTION OF RANGE IN NORMAL SAMPLES WITH $\mathrm{N}=200$

CONSTRUCTION OF THE SET OF 256-RUN DESIGNS OF RESOLUTION

5 AND THE SET OF EVE/ CONSTRUCTION OF THE SET OF $256-\mathrm{R}$
COEFFICIENTS FOR ORTHOGONAL POLYNOMIALS UP TO $\mathrm{N}=26$

BALANCED INCOMPLETE BLOCK DESIGNS WITH PARAMETERS V=28, N1=12, N2=15 AND P2 $(1,1)=4$

BLOCKINC OF 3-TIMES-2-TO-THE-(N-K)

A NOTE ON FRACTIONS OF $3-T 0-T H E-(4 N+1)$ DESIGNS

REATER THEN OR EQUAL T AMS $68 \quad 246$

COMPETE SET OF LEADING TECH 65644

/CTION OF PARTIALLY AMS 661783

TECH $64 \quad 371$

TECH $65 \quad 69$

ESOLUTION IV FOR THE 2-TO-THE-N AND 2-T0-THE-N TIMES 3-TO-THE-M SERIES RESULTS ON FACTORIAL DESIGNS OF R TECH 69 431

SATURATED FRACTIONS OF 2-TO-THE-N AND 3-TO-THE-N FACTORIAL DESIGNS

ALL TWO-FACTOR INTERACTIONS FOR THE 2-TO-THE-N TIMES 3-TO-THE-N FACTORIAL SERIES OF DESIGNS /IMATION OF TECH 69 NO. 4 2-TO-THE-(17-9) RESOLUTION V PLAN IN EIGHT BLOCKS OF 32

IGNS WITH PARAMETERS $V=28, N 1=12, N 2=15$ AND P2 $(1,1)=4$

SOME NON-ORTHOGONAL PARTITIONS OF 4 X4, $5 \times 5$, AND 6 X 6 LATIN SQUARES

CONSTRUCTION OF A TECH 65439

CONSTRUCTION OF A TECH 65439

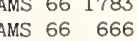

6-RUN DESICNS OF RESOLUTION GREATER THEN OR EQUAL TO 5 AND THE SET OF EVEN $512-$ RUN DESICNS OF RESOLUTION G AMS 68 246

WAY BALANCED DESICNS BASED ON YOUDEN SQUARES WITH 5,6 , OR 7 TREATMENTS

SOME NON-ORTHOCONAL PARTITIONS OF 4X4, 5X5, AND 6X6 LATIN SQUARES

FOUR- BIOCS67 803

AMS $66 \quad 666$

VES FOR FIXED EFFECT/ CHARTS OF THE 10 PERCENT AND 50 PERCENT POINTS OF THE OPERATING CHARACTERISTIC CUR JASA 57 345 UTION CREATER THEN OR EQUAL TO 5 AND THE SET OF EVEN 5I2-RUN DESICNS OF RESOLUTION GREATER THEN OR EQUAL T AMS 68 246 2-RUN DESIGNS OF RESOLUTION GREATER THEN OR EQUAL TO 6 WITH SPECIAL REFERENCE TO THE UNIQUE SATURATED DESI AMS 68 246 WAY BALANCED DESIGNS BASED ON YOUDEN SQUARES WITH 5,6, OR 7 TREATMENTS

SOME NON-ORTHOGONAL PARTITIONS OF 4 X4, 5X5, AND 6 X6 LATIN SQUARES

DESIGNS BASED ON YOUDEN SQUARES WITH 5,6 , OR 7 TREATMENTS
FOUR- BIOC\$67 803

AMS $66 \quad 666$

FOUR-WAY BALANCED BIOCS67 803 


\section{AUTHOR INDEX}

ABBOTT, J. H. ON A THEOREM OF RENYI CONCERNING MIXING SEQUENCES OF SETS, AMS 61, 257

ABDEL ATY, S. H. APPROXIMATE FORMULAE FOR THE PERCENTAGE POINTS AND THE PROBABILITY INTEGRAL OF THE NON-C, BIOKA 54, 53B

ABDEL ATY, S. H. TABLES OF GENERALIZED K-STATIST ICS, BIOKA 54, 253 ABDRABBO, N A A FILTERING NON-STATIONARY SIGNALS, JRSSB 69,150 ABDRABBO, N. A. ON THE PREDICTION OF NON-STATIONARY PROCESSES, JRSSB 67,570

ABE, O. A CENTRAL LIMIT THEOREM FOR THE NUMBER OF EDGES IN THE RANDOM INTERSECTION OF TWO GRAPHS I CORR, 6 , AMS 69,144

ABEL, MARTIN E. HARMONIC ANALYSIS OF SEASONAL VARIATION WITH AN APPLICATION TO HOG PRODUCTION, JASA 62, 655

ABEL, MARTIN E. ON FRACT IONAL POWERS OF A MATRIX, JASA 67, 1018

ABELSON, ROBERT $P$. EFFICIENT UTILIZATION OF NON-NUMERICAL INFORMATION IN QUANT ITATIVE ANALYSIS, GENERAL T, AMS 63, 1347

ABRAHAM, WILLIAM I. INVESTMENT ESTIMATES OF UNDERDEVELOPED COUNTRIES, AN APPRA ISAL, JASA 58,669

ABRAHAMSE, A. P. J. A COMPARISON BETWEEN THE POWER OF THE DURBINWATSON TEST AND THE POWER OF THE BLUS TE, JASA 69, 938

ABRAHAMSE, A.P. J. ON THE POWER OF THE BLUS PROCEDURE, JASA 68, 1227 ABRAHAMSE, ALLAN $F$. THE TAIL FIELD OF A MARKOV CHAIN, AMS 69, 127

ABRAHAMSON, I. G. ORTHANT PROBABILIT IES FOR THE QUADR IVARIATE NORMAL DISTRIBUTION, AMS 64,1685

ABRAHAMSON, INNIS G. EXACT BAHADUR EFFICIENCIES FOR THE KOLMOGOROV-SMIRNOV AND KUIPER ONE-SAMPLE AND TWO-, AMS 67, 1475

ABRAMSON, L. R. ASYMPTOTIC SEQUENTIAL DESIGN OF EXPERIMENTS WITH TWO RANDOM VARIABLES, JRSSB 66,73

ABRAMSON, MORTON PERMUTATION WITHOUT RISING OR FALLING OMEGASEQUENCES, AMS 67, 1245

ABUL-ELA, ABDEL-LATIF A. A MULTI-PROPORTIONS RANDOMIZED RESPONSE MODEL, JASA 67, 990

ABUL-ELA, ABDEL-LATIF A. THE UNRELATED QUESTION RANDOMIZED RESPONSE MODEL, THEORET ICAL FRAMEWORK, JASA 69,520

ADAMS, A. COMPARATIVE SAMPLING ACCEPTANCE SCHEMES IN TESTING ANTIGENICITY OF VACCINES, BIOCS $66,6 \mathrm{~B} 4$

ADAMS, F. GERARD ON THE STATISTICAL DISCREPANCY IN THE REVISED UNITED STATES NATIONAL ACCOUNTS, JASA 66, 1219

ADAMS, F. GERARD THE PREDICTIVE ABILITY OF CONSUMER ATTITUDES STOCK PRICES, AND NON-ATTITUDINAL VARIABLE, JASA 64,987

ADAMS, JOHN W. DISTRIBUTION OF SUM OF IDENT ICALLY DISTRIBUTED EX PONENTIALLY CORRELATED GAMMA-VARIABLES, AMS 64,277

ADDELMAN, S. SEQUENCES OF TWO-LEVEL FRACTIONAL FACTORIAL PLANS TECH 69,477

ADDELMAN, S. SEQUENTIAL COMBINATION CHEMOTHERAPY EXPERIMENTS BIOCS 66,730

ADDELMAN, SIDNEY A PROCEDURE FOR CONSTRUCTING INCOMPLETE BLOCK DESIGNS, TECH 64.389

ADDELMAN, SIDNEY CONSTRUCTION OF A 2-T0-THE-(17-9) RESOLUTION V PLAN IN EIGHT BLOCKS OF 32, TECH 65,439

ADDELMAN, SIDNEY DESIGNS FOR THE SEQUENTIAL APPLICATION OF FACTORS, TECH 64,365

ADDELMAN, SIDNEY EQUAL AND PROPORTIONAL FREQUENCY SQUARES, JASA 67,226

ADDELMAN, SIDNEY ERRATA, 'ORTHOGONAL MAIN-EFFECT PLANS FOR ASYMMETRICAL FACTORIAL EXPER IMENTS' ' TECH 62, 440

ADDELMAN, SIDNEY IRREGULAR FRACTIONS OF THE 2-TO-THE-N FACTORIAL EXPERIMENTS, TECH 61,479

ADDELMAN, SIDNEY ORTHOGONAL MAIN-EFFECT PLANS FOR ASYMMETRICAL FACTORI AL EXPERIMENTS, TECH 62,21

ADDELMAN, SIDNEY SOME MAIN-EFFECT PLANS AND ORTHOGONAL ARRAYS OF STRENGTH TWO, AMS 61,1167

ADDELMAN, SIDNEY SOME TWO-LEVEL FACTORIAL PLANS WITH SPLIT PLOT CONFOUNDING, TECH 64,253

ADDELMAN, SIDNEY SYMMETRICAL AND ASYMMETRICAL FRACTIONAL FACTORIAL PLANS, TECH 62,47

ADDELMAN, SIDNEY TECHNIQUES FOR CONSTRUCTING FRACTIONAL REPLICATE PLANS, JASA 63,45

ADELMAN, IRMA ON AN INDEX OF QUALITY CHANGE, JASA 61,535

ADELMAN, IRMA G. A STOCHASTIC ANALYSIS OF THE SIZE DISTRIBUTION OF FIRMS, CORR. 59810 , JASA 58,893

ADICHIE, J. N. ASYMPTOTIC EFFICIENCY OF A CLASS OF NON-PARAMETRIC TESTS FOR REGRESSION PARAMETERS, AMS 67, B84

ADICHIE, J. N. ESTIMATES OF REGRESSION PARAMETERS BASED ON RANK TESTS, AMS 67,894

ADLER, LETA MACKINNEY A MODIFICATION OF KENDALL'S TAU FOR THE CASE OF ARBITRARY TIES IN BOTH RANKINGS, JASA 57.33

ADLER, NORMAN TAXPAYER COMPLIANCE IN REPORTING INTEREST INCOME UNDER THE WISCONSIN STATE INDIVIDUAL INCOM, JASA 63; 487

AFIFI, A. MISSING VALUES IN MULTIVARIATE STATISTICS, I, REVIEW OF THE LITERATURE. JASA 66, 595

AFIFI, A. A. AN INVESTTGATION INTO THE SMALL SAMPLE PROPERTIES OF A TWO SAMPLE TEST OF LEHMANN' $S$, JASA 68, 345

AFIH'I, A. A. MISSING OBSERVATIONS IN MULTIVARIATE STATISTICS II POINT ESTIMATION IN SIMPLE LINEAR REGRES, JASA 67,10
AFIFI, A. A. MISSING OBSERVATIONS IN MULTIVARIATE STATISTICS, III JASA 69,337

AFIFI, A. A. MISSING OBSERVATIONS IN MULTIVARIATE STATISTICS, IV JASA 69,359

AFIFI, A. A. MULTIVARIATE TWO SAMPLE TESTS WITH DICHOTOMOUS AND CONTINUOUS VARIABLES I. THE LOCATION MODE, AMS 69,290

AFONJA, B. ANALYSIS OF A GROUP OF BALANCED BLOCK EXPERIMENTS HAVING ERROR VARIANCE AND SOME TREATMENTS IN, BIOCS 6B, 389

AGGARWAL, OM $P$. BAYES AND MINIMAX PROCEDURES FOR ESTIMATING THE ARI THMETIC MEAN OF A POPULATION WITH TWO-, AMS 66, 1186

AGNEW. R. A. ON THE SUPERPOSITION OF POINT PROCESSES, JRSS8 68,576

AGRAWAL. HIRALAL COMPARISON OF THE BOUNDS OF THE NUMBER OF COMMON TREATMENTS BETWEEN BLOCKS OF CERTAIN P, AMS 66, 739

AGRAWAL, HIRALAL ON THE BOUNDS OF THE NUMBER OF COMMON TREATMENTS BETWEEN BLOCKS OF SEMI-REGULAR GROUP DI, JASA 64,867

AGRAWAL, HIRALAL SOME GENERALIZATIONS OF DISTINCT REPRESENTATIVES WITH APPLICATIONS TO STATISTICAL DESIGN, AMS 66,525

AGRAWAL, HIRALAL SOME METHODS OF CONSTRUCTION OF DESIGNS FOR TWOWAY ELIMINATI ON OF HETEROGENEITY, I , JASA 66, 1153

AHMED, MOHAMAD SALAHUDDIN ON A LOCALLY MOST POWERFUL BOUNDARY RANDOMIZED SIMILAR TEST FOR THE INDEPENDENC, AMS 61,809

AIGAONKAR, S. G. PRABHU BOUNDS FOR THE ERROR-VARI ANCE OF AN EST IMATOR IN SAMPLING WITH VARYING PROBABILIT, JASA 6B, 91

AIGNER, DENNIS J. A LINEAR APPROXIMATOR FOR THE CLASS MARKS OF A GROUPED FREQUENCY DISTRIBUTI ON, WITH ESP, TECH 68,793

AIGNER, DENNIS J, AN ESTIMATION PROCEDURE FOR RANGE COMPOSITION PROBLEMS, JASA 65,308

AITCHISON, J. A STATISTICAL THEORY OF REMNANTS, JRSSB 59, 158

AITCHISON, J. AN ESTIMATION PROBLEM IN QUANTITATIVE ASSAY, BIOKA $54,33 \mathrm{~B}$

AITCHISON, J. BAYESIAN TOLERANCE REGIONS (WITH DISCUSSION), JRSSB 64,161

AITCHISON, J . CONFIDENCE-REGION TESTS, JRSSB 64,462

AITCHISON, J, EXPECTED-COVER AND LINEAR-UTILITY TOLERANCE INTERVALS, JRSSB 66,57

AITCHISON, J. INVERSE DISTRIBUTIONS AND INDEPENDENT GAMMA-DISTRIBUTED PRODUCTS OF RANDOM VARIABLES, BIOKA 63,505

AITCHISON, J, LIKELIHOOD RATIO AND CONFIDENCE-REGION TESTS, JSSB 65,245

AITCHISON, J. LINEAR-LOSS INTERVAL ESTIMATION OF LOCATION AND SCALE PARAMETERS, 8IOKA 68, 141

AITCHISON. J. MAXIMUM-LIKELIHOOD ESTIMATION PROCEDURES AND ASSOCIATED TESTS OF SIGNIFICANCE, JRSSB 60,154

AITCHISON, J. SOME PROBLEMS OF STATISTICAL PREDICTION, BIOKA 65 469

AITCHISON, J. THE CONSTRUCTION OF OPTIMAL DESIGNS FOR THE ONE-WAY CLASSIFICATION ANALYSIS OF VARIANCE, JRSSB 61,352

AITCHISON, J. THE GENERALIZATION OF PROBIT ANALYSIS TO THE CASE OF MULTIPLE RESPONSES, BIOKA 57,131

AITCHISON, JOHN LARGE-SAMPLE RESTRICTED PARAMETRIC TESTS, JRSSB 62,234

AITKEN, A. C. CORRIGENDA, 'ON THE STATISTICAL INDEPENDENCE OF QUADRAT IC FORMS IN NORMAL VARI ATES. ' , BIOKA 59, 279

AITKIN, M. A. CORRELATION IN A SINGLY TRUNCATED 8IVARIATE NORMAL DISTRIBUTION. II. RANK CORRELATION, BIOKA 65,639

AITKIN, M. A. CORRELATION IN A SINGLY TRUNCATED BIVARIATE NORMAL DISTRIBUTION. III, CORRELATION BETWEEN R, BIOKA 66, $27 \mathrm{~B}$

AITKIN, M. A. CORRELATION IN A SINGLY TRUNCATED BIVARIATE NORMAL DISTRIBUTION IV. EMP IRICAL VARIANCES OF, BIOKA $6 B, 437$

AITKIN, M. A, SOME TESTS FOR CORRELATION MATRICES, BIOKA 69, 443

AITKIN, M. A. TESTS FOR CORRELATION MATRICES, BI A 68, 327

AITKIN, M. A. THE CORRELATION BETWEEN VARIATE-VALUES AND RANKS IN A DOUBLY TRUNCATED NORMAL DISI'RIBUTION. BIOKA 66281

AIYAR, $K, R$. ON UNCORRELATED LINEAR FUNCTIONS OF ORDER STATISTICS, JASA 63,245

AJGAONKAR, S. G. PRABHU ON A CLASS OF LINEAR ESTTMATORS IN SAMPLING WITH VARYING PROBABILITIES WITHOUT RE, JASA 65,637

AJGAONKAR, S. G. PRABHU ON HOROVITZ AND THOMPSON'S T-ONE CLASS OF LINEAR ESTIMATI ON, AMS 67,1882

AJNE, B. A SIMPLE TEST FOR UNIFORMITY OF A CIRCULAR DISTRIBUTION, 8IOKA 68,343

AL-ANI, S. ON THE DISTRIBUTIONS OF THE RATIOS OF THE ROOTS OF COVARIANCE MATRIX AND WILKS' CRITERION FO, AMS 69, NO 0.6

ALAM, KHURSHEED SOME RESULTS ON POLYA TYPE 2 DISTRIBUTIONS, AMS 6B, 1759

ALANEN, J. D. ASYMPTOTIC RELATIVE EFFICIENCY OF MOOD 'S AND MASSEY 'S TWO SAMPLE TESTS AGAINST SOME PARAMET, AMS 62,1375

ALANEN, J. D. SAMPLING INSPECTION PLANS FOR DISCR IMINATING BETWEEN TWO WEIBULL PROCESSES, TECH 65, 5B9

AL8ASINY, E. L. THE NUMERICAL SOLUTION OF SOME NON-LINEAR EQUATIONS, USEFUL IN THE DESIGN OF EXPERIMENTS, JRSSB 65,466

ALBERT, ARTHUR A MATHEMATICAL THEORY OF PATTERN RECOGNITION, AMS 63,284

ALBERT, ARTHUR ESTIMATING THE INFINITESIMAL GENERATOR OF A CONTINUOUS TIME, FINITE STATE MARKOV PROCESS, AMS 62,727 
ALBERT, ARTHUR FIXED SIZE CONFIDENCE ELLIPSOIDS FOR LINEAR RECRESSION PARAMETERS, AMS 66,1602

ALBERT, ARTHUR E. THE SEQUENTIAL DESICN OF EXPERIMENTS FOR INFINITELY MANY STATES OF NATURE, AMS 61, 771

ALI, MIR M, ASYMPTOTIC OPTIMUM QUANTILES FOR THE ESTIMATION OF THE PARAMETERS OF THE NECATIVE EXPONENTIAL, AMS 66, 143

ALI, MIR M. ON GUPTA 'S EST IMATES OF THE PARAMETERS OF THE NORMAL DISTRIBUTION, BIOKA 64,498

ALI, MIR M. SOME BOUNDS FOR EXPECTED VALUES OF ORDER STATISTICS, AMS 65. 1055

ALI. S. M. A FURTHER RESULT ON THE RELEVANCE OF THE DISPERSION OF A RADON-NIKODYM DERIVATIVE TO THE PROBL, JRSSB 65, 108

ALI , S. M. A GENERAL CLASS OF COEFFICIENTS OF DIVERGENCE OF ONE DISTRIBUTION FROM ANOTHER, JRSSB 66.131

ALI, S. M. ASSOCIATION BETWEEN RANDOM VARIA8LES AND THE DISPERSION OF A RADON-NHODYM DERIVATIVE (CORR, 6, JRSSB 65,100

ALLAIRE, F . R. NOTES. EXPEGTED SELEGTION DIFFERENTIAL FOR POSITIVE DIRECTIONAL SELECTION ON NORMAL VARIAB, 8IOCS 67,842

ALLEN, D. M. ANALYSIS OF CROWTH AND DOSE RESPONSE CURVES, BIOCS 69. 357

ALLEN, J . L. A STATISTICAL TEST INVOLVING A RANDOM NUMBER OF RANDOM VARIABLES. AMS 66,1305

ALLEN, J, L, DISTRIBUTIONS OF A M. KAC STATISTIC, AMS 67, 1919

ALLING. D. W CLOSED SEQUENTIAL TESTS FOR BINOMIAL PROBABILITIES, BIOKA 66,73

ALLING, D. T. TESTS OF RELATEDNESS, 8IOKA 67, 459

ALLING, DAVID $W$. EARLY DECISION IN THE WILCOXON TWO-SAMPLE TEST, JASA 63,713

ALTHAM, PATRICIA M. E. EXAGT 8AYESIAN ANALYSIS OF A TWO-BY-TWO CONTINGENCY TABLE, AND FISHER'S 'EXACT' SI, JRSSB 69, NO.2

ALWAY. G. G. THE DISTRIBUTION OF THE NUMBER OF CIRCULAR TRIADS IN PAIRED COMPARISONS, BIOKA 62, 265

AMES, EDWARD DISTRIBUTIONS OF CORRELATION COEFFIC IENTS IN ECONOM IC TIME SERIES. JASA 61.637

AMOS, D. E. A NOTE ON A DOU BLE SAMPLE TEST, JASA 69, NO 4

AMOS, D. E. A NOTE ON REPRESENTATIONS OF THE DOUBLY NON-CENTRAL T DISTRIBUTION, JASA 6B, 1013

AMOS, D. E. ADDITIONAL PERCENTAGE POINTS FOR THE INCOMPLETE BETA DISTRIBUTION, BIOKA 63,449

AMOS, D. E. CORRICENDA, 'TABLE OF PERCENTAGE POINTS OF PEARSON CURVES, FOR GIVEN ROOT (BETA-1) AND BETA-2, . BIOKA 65, 669

AMOS, D. E. REPRESENTATIONS OF THE CENTRAL AND NON-CENTRAL T DISTRIBUTIONS, BIOKA 64, 45I

AMOS, D. E. TABLE OF PERCENTAGE POINTS OF PEARSON CURVES, FOR CIVEN ROOT (8ETA-1) AND BETA-2 EXPRESSED IN, 8IOKA 63, 459

AMOS, D. E . THE EXCEEDANCE TEST FOR TRUNCATION OF A SUPPLIER'S DATA. JASA 69,823

AMSTER, SIGMUND $J$. A MODIFIED BAYES STOPPING RULE, AMS 63, 1404

ANDEL, JIRI LOCAL ASYMPTOTIC POWER AND FEFICIENCY OF TESTS OF KOLMOGOROV-SMIRNOV TYPE, AMS 67, 1705

ANDERSEN, G. SOME INTECRAL TRANSFORMS OF CHARACTERISTIC FUNCTIONS, AMS $62^{2}, 1923$

ANDERSEN, S. L. PERMUTATION THEORY IN THE DERIVATION OF ROBUST CRITERIA AND THE STUDY OF DEPARTURES FROM. JRSSB 55 . I

ANDERSON JR, WILLIAM N. CONSISTENT ESTIMATES OF THE PARAMETERS OF A LINEAR SYSTEM, AMS 69, NO 6

ANDERSON, A. J.B. A GENERAL COMPUTER PROGRAMME FOR THE ANALYSIS OF FACT ORIAL EXPERIMENTS, BIOCS 66.503

ANDERSON, E. A SEMI-GRAPHICAL METHOD FOR THE ANALYSIS OF COMPLEX PROBLEMS, TECH 60,387

ANDERSON, GEORGE A. AN ASYMPTOTIC EXPANSION FOR THE DISTRIBUTION OF THE LATENT ROOTS OF THE ESTIMATED COV, AMS 65, 1153

ANDERSON, HENRY PRODUCT DIVERSIFICATION AND LIVING COSTS, A FURTHER COMMENT, JASA 66,788

ANDERSON, HENRY PRODUCT DIVERSIFICATION AND THE COST OF LIVING, CORR, 64 1296, JASA 63, B07

ANDERSON, J, A, A COMPARISON OF STATISTICAL TECHNIQUES IN THE DIFFERENTIAL DIAGNOSIS OF NONTOXIC GOITRE, BIOCS 6B, 103

ANDERSON, J. A. DISCRIMINATION BETWEEN K POPULATIONS WITH CONSTRAINTS ON THE PROBABILITIES OF MISCLASSIFI, JRSSB 69, 123

ANDERSON, R. L. A COMPARISON OF THREE DIFFERENT PROCEDURES FOR ESTIMATING VARIANCE COMPONENTS, TECH 63,421

ANDERSON, R. L. AN INVESTIGATION OF THE EFFECT OF MISCLASSIFICATION ON THE PROPERTIES OF CHI-SQUARE-TESTS, 8IOKA 65, 95

ANDERSON, R. L. COMPARISONS OF DESIGNS AND EST IMATION PROCEDURES FOR EST IMAT ING PARAMETERS IN A TWO-STAGE, TECH 67,499

ANDERSON, R. L DISCUSSION OF 'A SUBJECT IVE EVALUATION OF BODE 'S LAK AND AN 'OBJECTIVE' TEST FOR APPROXIM. JASA 69,50

ANDERSON, R. L. ESTIMATION OF VARIANCE COMPONENTS IN TWO-STACE NESTED DESIGNS WITH COMPOSITE SAMPLES, TECH 67,373

ANDERSON, R, L QUERY, NEGATIVE VARIANCE ESTIMATES, TECH 65, 75

ANDERSON, R, L, THE DISTRIBUTION OF THE PRODUCT OF TWO CENTRAL OR NON-CENTRAL CHI-SQUARE VARIATES, AMS 62, 1016

ANDERSON, T. W. A TEST FOR EQUALITY OF MEANS WHEN COVARIANCE MATRICES ARE UNEQUAL, AMS 63, 671

ANDERSON, T. W. APPROXIMATING THE LOWER BINOMIAL CONFIDENCE LIMIT (CORR, 69660), JASA 68, 1413

ANDERSON, T. W. ASYMPTOTIC THEORY FOR PRINCIPAL COMPONENT ANALYSIS, AMS 63, 122
ANDERSON, T . W. CLASSIFICATION INTO TWO MULTIVARIATE NORMAL DISTRIBUTIONS WITH DIFFERENT COVARIANCE MATRI, AMS 62, 420

ANDERSON, T, W, CORRECTION 'SOME EXTENSIONS OF THE WISHART DISTRIBUTION', 44345, AMS 64, 923

ANDERSON, T . W. CORRECTION. 'THE NON-CENTRAL WISHART DISTRIBUTION AND CERTAIN PROBLEMS OF MULTIVARIATE ST, AMS 64,923

ANDERSON, T. $W$. CORRICENDA, 'SOME INEQUALITIES ON CHARACTERISTIC ROOTS OF MATRICES' , BIOKA 65, 669

ANDERSON. T. W. LEAST SQUARES AND BEST UNBIASED ESTIMATES, AMS 62 , 266

ANDERSON, T. W. MAXIMUMLIKEL IHOOD ESTIMATESS FOR A MULTIVARIATE NORMAL DISTRIBUTION WHEN SOME OBSERVATION, JASA 57, 200

ANDERSON, T. W. MONOTONICITY OF THE POWER FUNCTIONS OF SOME TESTS OF THE MULTIVARIATE LINEAR HYPOTHESIS, AMS 64, 200

ANDERSON, T. W. MONOTONICITY OF THE POWER FUNCTIONS OF SOME TESTS OF INDEPENDENCE BETWEEN TWO SETS OF VAR, AMS 64, 206

ANDERSON, T. W. MONOTONICITY PROPERTY OF THE POWER FUNCTIONS OF SOME TESTS OF THE EQUALITY OF TWO COVARIA, AMS 64, 1059

ANDERSON, T. W. ON BAYES PROCEDURES FOR A PROBLEM WITH CHOICE OF OBSERVATIONS, AM S64, 1128

ANDERSON, T. W. ON THE ASYMPTOTIC DISTRIBUTION OF THE AUTOCORRELATIONS OF A SAMPLE FROM A LINEAR STOCHAST, AMS 64, 1296

ANDERSON, T. W. ON THE DISTRIBUTION OF THE TWO SAMPLE CRAMER-VON MISES CRITERION, AMS 62, 1148

ANDERSON, T. W. PUBLICATIONS OF S. S. WILKS, AMS 65, 24

ANDERSON, T. W. SAMUEL STANLEY WILKS 1906-1964, AMS 65, I

ANDERSON, T. $W$. SEQUENTIAL ANALYSIS WITH DELAYED OBSERVATIONS. JASA 64, 1006

ANDERSON, T. W. SOME INEQUALITIES ON CHARACTERISTIC ROOTS OF MATRICES, BIOKA 63, 522

ANDERSON. T. W. SOME OPTIMUM CONFIDENCE BOUNDS FOR ROOTS OF DETERMINANTAL EQUATIONS, AMS 65,468

ANDERSON, T, $W$, THE CHOICE OF THE DEGREE OF A POLYNOMIAL REGRESSION AS A MULTIPLE DECISION PROBLEM. AMS 62,255

ANDERSON, V . L. A STATISTICAL MODEL OF BOOK USE AND ITS APPLICATION TO THE $800 K$ STORAGE PROBLEM, JASA 69 , NO. 4

ANDERSON, V. L. EXTREME VERTIGES DESIGN OF MIXTURE EXPERIMENTS, TECH 66,447

ANDO. AL8ERT BAYESIAN ANALYSIS OF THE INDEPENDENT MULTINORMAL PROCESS, NEI THER MEAN NOR PRECISION KNOWN, JASA 65,347

ANDREWS, F. C . A LARGE-SAMPLE BIOASSAY DESIGN WITH RANDOM DOSES AND UNCERTAIN CONCENTRATION, BIOKA 55,307

ANIS. A. A . ON THE MOMENTS OF THE MAXIMUM OF PARTIAL SUMS OF A FINITE NUMBER OF INDEPENDENT NORMAL VARIAT, BIOKA 56,79

ANIS, A. A. ON THE RANGE OF PARTIAL SUMS OF A FINITE NUMBER OF INDEPENDENT NORMAL VARIATES, BIOKA 53,35

ANIS, A. A. THE VARIANCE OF THE MAXIMUM OF PARTIAL SUMS OF A FINITE NUMBER OF INDEPENDENT NORMAL VARIATES, BIOKA 55, 96

ANSCOMBE, F J A DEFINITION OF SUB.JEGTIVE PROBABILITY, AMS 63, 199 ANSCOMBE, F. J. DEPENDENCE OF THE FIDUCIAL ARGUMENT ON THE SAMPLING RULE, BIOKA 57,464

ANSCOMBE, $F, J, D I S C U S S I O N$ OF THE PAPERS OF MESSRS. HALD, WETHERILL AND COX, TECH 60,361

ANSCOMBE, F. J. ESTIMATING A MIXED-EXPONENT IAL RESPONSE LAW, JASA 61.493

ANSCOMBE, F, J. ON ESTIMATINC BINOMIAL RESPONSE RELATIONS, BIOKA 56,461

ANSCOMBE, F. J, QUICK ANALYSIS METHODS FOR RANDOM BALANCE SCREENING EXPERIMENTS, TECH 59,195

ANSCOMBE, F. J. RECTIFYING INSPECTION OF A CONTINUOUS OUTPUT, CORR 59 B 10 . JASA $5 B, 702$

ANSCOMBE, F. J . RECT IFYING INSPECTION OF LOTS, JASA 61, 807

ANSCOMBE, F, J, REJECTION OF OUTLIERS, TECH 60,123

ANSCOMBE, F. J . SEQUENT IAL MEDICAL TRIALS, JASA 63, 365

ANSCOMBE, $F, J$, SEQUENT I AL TESTS FOR 8INOMI AL AND EXPONENT IAL POPULATIONS, BIOKA 54,252

ANSCOMBE, F.J, TESTS OF GOODNESS OF FIT, JRSSB 63,81

ANSCOMBE, F.J. THE EXAMINATION AND ANALYSIS OF RESIDUALS, TECH 63 141

ANSCOMBE, F.J. TOPICS IN THE INVESTICATION OF LINEAR RELATIONS FITTED BY THE METHOD OF LEAST SQUARES (WI, JRSSB 67, I

ANSCOMBE, FRANCIS J. COMMENTS ON PAPER BY KURTZ, LINK, TUKEY AND WALLACE, TECH 65,163

ANSCOMBE, FRANCIS $\mathrm{J}$. DISCUSSION OF 'A SUBJECTIVE EVALUATION OF BODE'S LAW AND AN 'OBJECTIVE' TEST FOR APP. JASA 69, 50

ANTELMAN, GORDON R. INSENSITIVITY TO NON-OPTIMAL DESIGN IN BAYESIAN DECISION THEORY, JASA 65, 5B4

ANTLE, C. THE CHOICE OF THE DEGREE OF A POLYNOMIAL MODEL, JRSSB 68 , 469

ANTLE, C E. ESTIMATION OF PARAMETERS IN THE WEIBULL DISTRIBUTION, TECH 67,621

ANTLE, C. E. INFERENCES ON THE PARAMETERS OF THE WE IBULL DISTRIBUTION. TECH 69,445

ANTLE, CHARLES E. OPTIMUM ALLOCATION OF SAMPLINC UNITS TO STRATA WHEN THERE ARE R RESPONSES OF INTEREST , JASA 65, 225

ANTLE, CHARLES E. STRAIGHT LINE CONFIDENCE REGIONS OF LINEAR MODELS, JASA $67 \quad 1365$ 
ANTLE, CHARLES E. THE UNIQUENESS OF THE SPACING OF OBSERVATIONS IN POLYNOMIAL REGRESSION FOR M INIMAX VARI, AMS 62,810

APPLEBY, R. $H$. AN EMPIRICAL EVALUATION OF MULT IVARIATE SEQUENTIAL PROCEDURE FOR TEST ING MEANS, AMS 62, 1413

ARBOUS: A. G. NEK TECHNIQUES FOR THE ANALYSIS OF ABSENTEEISM DATA, BIOKA 54, 77

ARMITAGE, P. BOUNDARIES FOR CLOSED (TEDGE) SEQUFNTIAL T TEST PLANS, BIOKA 66,431

ARMITAGE, P. CLOSED SEQUENT IAL T-TESTS, BIOKA 62, 359

ARMITAGE, P. NUMERICAL STUDIES IN THE SEQUENTIAL ESTIMATION OF A BINOMIAL PARAMETER, BIOKA 58,1

ARMIT AGE, P. RESTRICTED SEQUENT IAL PROCEDURES, BIOKA 57, 9

ARMITAGE, P. SEQUENTIAL MEDICAL TRIALS, SOME COMMENTS ON F. J. ANSCOMBE'S PAPER, JASA $63,3 B 4$

ARMITAGE, $P$. THE CHI-SQUARE TEST FOR HETEROGENEITY OF PROPORTIONS AFTER AD JUSTMENT FOR STRATIFICATION (AD, JRSSB 66,150

ARMITAGE, $P$. USE OF CONCOMITANT VARIABLES AND INCOMPLETE SURVIVAL INFORMATION IN THE ESTIMATION OF AN EXP, 8IOCS 66,665

ARMITAGE, P. A . A FAMILY OF CLOSED SEQUENTIAL PROCEDURES (CORR. 69 457), BIOKA 62, 41

ARMSEN, P. TABLES FOR SIGNIFICANCE TESTS OF 2-BY-2 CONTINGENCY TABLES, BIOKA 55,494

ARMSEN, P. E. R. ABOUT SENSITIVITY ANALYSIS IN LINEAR PROGRAMMING MODELS, SASJ 67,33

ARNOLD, BARRY C. A NOTE ON MULTIVARIATE DISTRIBUTIONS WITH SPECIF IED MARG INALS, JASA 67,1460

ARNOLD, BARRY C. PARAMETER ESTIMATION FOR A MULTIVARIATE EXPONENTIAL DISTRIBUTION, JASA 68,848

ARNOLD, $H . J$. PERMUTATION SUPPORT FOR MULTIVARIATE TECHNIQUES,

BIOKA 64,65

ARNOLD, HARVEY J. SMALL SAMPLE POWER FOR THE ONE SAMPLE WILCOXON TEST FOR NON-NORMAL SHIFT ALTERNATIVES, AMS 65,1767

ARNOLD, J. C. A MODIFIED TECHNIQUE FOR IMPROVING AN ESTIMATE OF THE MEAN, BIOCS $69,5 B B$

AROIAN, L. A. DIRECT METHODS FOR EXACT TRUNCATED SEQUENT IAL TESTS OF THE MEAN OF A NORMAL DISTRIBUTION, TECH 69, NO. 4

AROIAN, LEOA . SEQUENTIAL ANALYSIS, DIRECT METHOD, TECH 6B, 125

AROIAN, LEO A. SEQUENTIAL LIFE FOR THE EXPONENTIAL DISTRIBUTION WITH CHANG ING PARAMETER, TECH 66,217

ARROW, KENNETH J. TINBERGEN ON ECONOMIC POLICY, JASA 5B, B9

ARVESEN, JAMESN. JACKKNIFING U-STATISTICS, AMS 69, NO.6

ASHFORD, J. R. A SYSTEM OF MODELS FOR THE LIFE CYCLE OF A BIOLOGICAL ORGANISM. BIOKA 6B, 211

ASHFORD, J. R. AN ALTERNATIVE SYSTEM FOR THE CLASSIFICATION OF MATHEMATICAL MODELS FOR QUANTAL RESPONSES, BIOCS $65,1 B 1$

ASHFORD, J. R. AN ANALYSIS OF QUANTAL RESPONSE DATA IN WHICH THE MEASUREMENT OF RESPONSE IS SUBJECT TO ER, 8IOCS 65,811

ASHFORD, J. R. GENERAL MODELS FOR QUANTAL RESPONSE TO THE JOINT ACTION OF A MIXTURE OF DRUGS, BIOKA 64,413

ASHFORD, J. R. GENERALISED COVARIANCE ANALYSIS WITH UNEQUAL ERROR, BIOCS 69 , NO. 4

ASHFORD, J. R. MODELS FOR THE NON-INTERACTIVE JOINT ACTION OF A MIXTURE OF STIMULI IN BIOLOGICAL ASSAY, 8IOKA 66, 49

ASHFORD, J. R. QUANTAL RESPONSES TO MIXTURES OF POISONS UNDER CONDITIONS OF SIMPLE SIMILAR ACTION, THE AN, BIOKA 5B, 74

ASHFORD, J.R. THE QUANTAL RESPONSE ANALYSIS OF A SERIES OF BIOLOGICAL ASSAYS ON THE SAME SUBJECTS, BIOKA 60,23

ASHLOCK, JOHN C. APPLICATION OF AN ESTIMATOR OF HIGH EFFICIENCY IN BIVARIATE EXTREME VALUE THEORY, JASA 69 , NO 4

ASKOVITZ, S. I. A SHORT-CUT GRAPHIC METHOD FOR FITTING THE BEST STRA IGHT LINE TO A SERIES OF POINTS ACCOR, JASA 57, 13

ASKOVITZ, S. I. GRAPHIC METHODS BASED UPON PROPERTIES OF ADVANCING CENTROIDS, JASA 59,668

ATHREYA, KRISHNA B, EMBEDDING OF URN SCHEMES INTO CONTINUOUS TIME MARKOV BRANCHING PROCESSES AND RELATED, AMS 68, 1B01

ATHREYA, KRISHNA B, ON THE SUPERCRITICAL ONE DIMENSIONAL AGE DEPENDENT BRANCHING PROCESSES, AMS 69,743

ATHREYA, KRISHNA BALASUNDARAM SOME RESULTS ON MULTITYPE CONTINUOUS TIME MARKOV BRANCHING PROCESSES, AMS 6B, 347

ATIQULLAH, M. ON A PROPERTY OF BALANCED DESIGNS, BIOKA 61,215

ATIQULLAH, M. ON A RESTRICTED LEAST SQUARES ESTIMATOR, JASA 69, 964

ATIQUALLAH, M. ON ESTTMATION BY THE SWEEP-OUT METHOD (CORR, 69 229), 8IOKA 6B, 305

ATIQULLAH, M. ON THE EFFECT OF NON-NORMALITY ON THE ESTIMATION OF COMPONENTS OF VARIANCE, JRSSB 62,140

ATIQULLAH, $M$. ON THE RANDOMIZATION DISTRIBUTION AND POWER OF THE VARIANCE RATIO TEST, JRSSB 63,334

ATIQULLAH, M. THE ESTIMATION OF RESIDUAL VARIANCE IN QUADRATICALLY BALANCED LEAST-SQUARES PROBLEMS AND TH, BIOKA 62, B3

ATIQULLAH, M. THE ROBUSTNESS OF THE COVARIANCE ANALYSIS OF A ONE-WAY CLASSIFICATION, BIOKA 64,365

ATIQULLAH, $M$. THE USE OF CONTROL OBSERVATIONS AS AN ALTERNATIVE TO INCOMPLETE BLOCK DESIGNS, JRSSB 62,464

ATKINSON, A , C . A TEST FOR DISCRIMINATING BETWEEN MODELS, BIOKA 69 , 337

ATKINSON, A. C. CONSTRA INED MAXIMISATION AND THE DESIGN OF EXPERIMENTS, TECH 69,616

ATKINSON, A. C. THE USE OF RESIDUALS AS A CONCOMITANT VARIABLE, 8IOKA 69,33
ATKINSON, ANTHONY C. THE DESIGN OF EXPERIMENTS FOR PARAMETER ESTIMATION, TECH 68,271

ATKINSON, F, V. DECISION PROCEDURES FOR FINITE DECISION PROBLEMS UNDER COMPLETE IGNORANCE, AMS 64, 1644

ATKINSON, G. F. DESIGNS FOR SEQUENCES OF TREATMENTS WITH CARRY-OVER EFFECTS, BIOCS 66,292

ATWOOD, CORWIN L. OPTIMAL AND EFFICIENT DESIGNS OF EXPERIMENTS, AMS 69. 1570

AUMANN, R.J. A DEFINITION OF SUBJECTIVE PROBABILITY, AMS 63, 199

AUST IN, D. G. A NOTE ON THE BIRKHOFF ERGODIC THEOREM, AMS 67, 922

AUSTIN, D. G. A SAMPLE FUNCTION PROPERTY OF MARTINGALES, AMS 66, 1396

AVRAHAMI, RAM QUERY, ANALYSIS OF FACTORIAL EXPERIMENT (PARTIALLY CONFOUNDED 2-CUBE\}, TECH 67,490

AXTELL, LILLIAN M. PARTITIONING OF A PATIENT POPULATION WITH RESPECT TO DIFFERENT MORTALITY RISKS, JASA 63,701

BABIAK, HARVEY DIVIDEND POLICY, AN EMPIRICAL ANALYSIS, JASA 68. 1132

BACON, RALPH HOYT APPROXIMATIONS TO MULT IVARIATE NORMAL ORTHANT PROBABILITIES, AMS 63,191

BAGAI, O.P. THE DISTRIBUTION OF THE GENERALIZED VARIANCE, AMS 65 120

BAHADUR, $R$ R A A NOTE ON QUANTILES IN LARGE SAMPLES, AMS 66, 577

BAHADUR, $R, R$. CLASSIF ICATION INTO TWO MULTIVARIATE NORMAL DISTRIBUTIONS WITH D IFFERENT COVARIANCE MA TR IC, AMS 62, 420

BAHADUR, R, R. ONF ISHER'S BOUND FOR ASYMPTOTIC VARIANCES, AMS 64 , 1545

BAHADUR, $R$. R. RATES OF CONVERGENCE OF ESTIMATES AND TEST STATISTICS, AMS 67,303

BAHADUR, R, R. SUBST ITUT ION IN CONDITIONAL EXPECTATION, AMS 68, 377 BAILAR, BARBARA A RECENT RESEARCH IN REINTERVIEN PROCEDURES, JASA 68. 41

BAILEY, MARTIN J. A REGRESSION METHOD FOR REAL ESTATE PRICE INDEX CONSTRUCT ION, JASA 63,933

BAILEY, MART IN J. PREDICT ION OF AN AUTOREGRESSI VE VARIABLE SUBJECT 8OTH TOD ISTURBANCES AND TO ERRORS OF, JASA 65, 164

BAILEY, N. T. STOCHAST IC BIRTH, DEATH AND MIGRAT ION PROCESSES FOR SPATIALLY DISTRIBUTED ? OPULATIONS, BIOKA 68 , 1B9

BA ILEY. N.T. J. A CONT INUOUS T IME TREA TMENT OF A S IMPLE QUEUE US ING GENERAT ING FUNCT IONS, JRSSB 54,288

BAILEY, N. T. J. A PERTURBATION APPROXIMATION OF THE SIMPLE STOCHASTICEPIDEMIC IN A LARGE POPULATION, BIOKA 6B, 199

BAILEY, N. T. J. ON ESTIMATING THE LATENT AND INFECTIOUS PERIODS OF MEASLES, I, FAMILIES WITH TWO SUSCEPT, BIOKA 56, 15

BAILEY, N. T. J. ON ESTIMATING THE LATENT AND INFECT IOUS PERIODS OF MEASLES, II. FAMILIES WITH THREE ORM, BIOKA 56,322

BAILEY, N. T, J. ON QUEUEING PROCESSES WITH BULK SERVICE, JRSSB 54 80

BAILEY, N. T. J. SIGNIFICANCE TESTS FOR A VARI ABLE CHANCE OF INFECT ION IN CHA IN-B INOM IAL THEORY, BIOKA 56,332

BAILEY, N. T. J. SOME FURTHER RESULTS IN THE NON-EQU ILIBRIUM THEORY OF A SIMPLE QUEUE, JRSSB 57,326

BAILEY, NORMAN T J A NOTE ON EQUALISING THE MEAN WAITING TIMES OF SUCCESS IVE CUSTOMERS IN A F INITEQUEU, JRSSB 55, 262

BAILEY, NORMAN T.J. ON ESTIMATING THE SIZE OF MOBILE POPULATIONS FROM RECAPTURE DATA, B IOKA 51, 293

BAILEY, NORMAN T. J. SOME PROBLEMS IN THE STATISTICAL ANALYSIS OF EPIDEMIC DATA (WITH DISCUSSION), JRSSB 55, 35

BAILEY, NORMAN T. J. THE SIMPLE STOCHAST IC EPIDEMIC, A COMPLETE SOLUT ION IN TERMS OF KNOWN FUNCTIONS, BIOKA 63,235

BAILEY, NORMAN T. J. THE TOTAL SIZE OF A GENERAL STOCHASTIC EPIDEMIC, BIOKA 53,177

BAILEY, NORMAN T, J THE USE OF CHAIN-BINOMIALS WITH A VARIABLE CHANCE OF INFEC TION FOR THE ANAL YS IS OF I, BIOKA 53, 279

BAIN. L. J. ESTIMATION OF PARAMETERS IN THE WEIBULL DISTRIBUTION, TECH 67,621

BAIN, L. J. INFERENCES ON THE PARAMETERS OF THE WEIBULL DISTRIBUTION, TECH 69,445

BAIN, L. J. TWO SAMPLE TESTS IN THE WEIBULL DISTRIBUTION, TECH 69. NO. 4

BAIN, LEE J. A NOTE ON THE TRUNCATED EXPONENT IAL DISTRIBUTION, AMS 64,1366

BAIN, LEE J REDUCING A RANDOM SAMPLE TO A SMALLER SET, WITH APPLICATIONS, JASA 67,510

BAIN, LEE J. SOME TESTS OF HYPOTHESES CONCERNING THE THREE-PARAMETER WEIBULL DISTR IBUT ION, JASA 68,853

BAIN, LEE J. TOLERANCE LIMITS FOR THE GENERALIZED GAMMA DISTRIBUTION, JASA 65,1142

BAINBRIDGE, J.R. TABULAR ANALYS IS OFFACTORI AL EXPERIMENTS AND THE USE OF PUNCH CARDS, CORR, 56 650, JASA 56, 149

BAKER, F. B. SOME MONTE CARLO RESULT S ON THE POWER OF THE F-TEST UNDER PERMUTATION IN THE SIMPLE RANDOMIZ, BIOKA 66, 199

BAKER, FRANK B. AN EMPIRICAL STUDY INTO FACTORS AFFECTING THE F-TEST UNDER PERMUTAT ION FOR THE RANDOMIZED, JASA 68, 902

BAKER, FRANK B. SOME EMPIRICAL RESULTS ON VARIANCE RA TIOS UNDER PERMUTATION IN THE COMPLETELY RANDOM IZED , JASA 66, 813

BAKER, FRANK B, THE RANDOMIZATION DISTRIBUTION OF F-RAT IOS FOR THE SPLIT-PLOT DESIGN, AN EMPIRICAL INVEST, BIOKA 63, 431 
BAKER, G. A. EMPIRIC INVESTIGATION OF A TEST OF HOMOGENEITY FOR POPULAT IONS COMP OSED OF NORMAL DISTRIBUTI, JASA 58, 551

BALAAM . L. N. A TWO-PERIOD DESIGN WITH T-SQUARE EXPER IMENTAL UNITS BIOCS 6B, 6I

BALAAM, L. N QUERY, ERRORRATEBASES, TECH 65,260

BALAKRISHNAN, T. R. STRATIFICATION, A PRACTICAL INVESTIGATION JASA 66.74

BALAKRISHNAN. $V$. DISTANCE BETWEEN POPULATIONS ON THE BASIS OF ATTRIBUTE DATA, BIOCS 6B. B 59

BALDESSARI, BRUNO THE DISTRIBUTION OF A QUADRATIC FORM OF NORMAL RANDOMVARIABLES, AMS 67,1700

BALDWIN, ROGER R. THE OPT IMUM STRATECY IN BLACKJACK, CORR, 59810 JASA 56,429

BALLAS, JOE A. ONDEPENDENT TESTSFROMA NON-ORTHOGONAL DESIGN, JASA 66. B03

BANCROFT, T. A BIASES IN PREDICTION BY REGRESSION FOR CERTAIN IN COMPLETELY SPECIFIED MODELS, BIOKA 63, 391

BANCROFT, T. A. INFERENCE FOR SOME INCOMPLETELY SPECIFIED MODELS INVOLVING NORMAL APPROXIMATIONS TO DISCR, BIOCS 67,335

BANCROFT, T, A. INFERENCES CONCERNING A POPULATION CORRELATION COEFF ICIENT FROM ONE OR POSSIBLY TWO SAMPL. JRSSB 67.282

BANCROFT. T. A. ON POOLINC MEANS WHEN VARIANCE IS UNKNOWN. JASA 6B 1333

BANCROFT. T. A. SEQUENT IAL MODEL BUILDINC FOR PREDICTION IN REGRESSION ANALYSIS. I. AMS 63,462

BANERJEE, D.P. ON THE EXACT DISTR IBUTION OF A TEST IN MULTIVARIATE ANALYSIS, JRSSB 5B, IOB

BANERJEE, K. S. A NOTE ON IDEMPOTENT MATRICES, AMS 64,880

BANERJEE, K. S. BOUNDS IN A MINIMAX CLASS IFICATION PROCEDURE, 8IOKA 65,653

BANERJEE, K. S. ESTIMATES OF EFFECTS FOR FRACTIONAL REPLICATES, AMS 64.711

BANERJEE, $K, S$. INDEX NUMBERS FOR FACTORIAL EFFECTS AND THEIR CONNECTION WITH A SPECIAL KIND OF IRREGULAR, JASA 63, 497

BANERJEE. K. S. ON A SPECIAL SUBSET GIVING AN IRREGULAR FRACTIONAL REPLICATE OF A 2 TO THE POWER N FACTOR, JRSSB 67,292

BANERJEE, K. S. ON ESTIMATES FOR FRACTIONS OF A COMPLETE FACTORIAL EXPERIMENT AS ORTHOGONAL LINEAR COMBIN, AMS 63, 1068

BANERJEE, K. S. ON ESTIMATION AND CONSTRUCTION IN FRACTIONAL REPLICATION, AMS 66, 1033

BANERJEE, K. S, ON HOTELLING'S WEICHING DESIGNS UNDER AUTO-CORRELATION OF ERRORS, AMS 65, 1829

BANERJEE, K. S. ON NON-RANDOMIZED FRACTIONAL WEICHING DESIGNS, AMS 66. 1836

BANERJEE, K. S. ON THE STRUCTURE AND ANALYSIS OF SINGULAR FRACTIONAL REPLICATES, AMS 68,657

BANERJEE, K. S. SINGULARITY IN HOTELLING'S WEIGHING DESICNS AND A GENERAL IZED INVERSE (CORR. 69 719). AMS 66, 1021

BANERJEE, $K$. S. SOME ORSERVATIONS ON THE PRACTICAL ASPECTS OF WEIGHTING DESIGNS, BIOKA $51,24 \mathrm{~B}$

BANERJEE. SAIBAL CONFIDENCE INTERVAL OF PREASSIGNED LENGTH FOR THE BEHRENS-FISHER PROBLEM, AMS 67, 1175

BANKS, CHARLOTTE THE FACTORIAL ANALYSIS OF CROP PRODUCTIVITY. JRSSB 54, 100

BANOS, ALFREDO ON PSEUDO-CAMES, AMS 68, 1932

BANTEGUI, CELIA C. ON THE DISTRIBUTION OF THE LARGEST OF SIX ROOTS OF A MATRIX IN MULTIVARIATE ANALYSIS, BIOKA 59, 237

BARDWELL, C. E. ON CERTAIN CHARACTERISTICS OF SOME DISCRETE DISTRIBUTIONS, BIOKA 60, 473

BARDWELL, GEORGE E. A TWO-PARAMETER FAMILY OF HYPER-POISSON DISTRIBUTIONS. JASA 64,133

BARCMANN, R. E. MAXIMUM LIKELIHOOD EST IMATION WITH INCOMPLETE MULTIVARIATEDATA, AMS 64,647

BARGMANN, R. E. POWER OF THE LIKELIHOOD-RATIO TEST OF THE CENERAL LINEAR HYPOTHESIS IN MULT IVARIATE ANALY, BIOKA 64,467

BARGMANN. ROLF E. DISCUSSION OF 'A SU8JECTIVE EVALUATION OF BODE'S LAW AND AN 'OBJECT IVE' TEST FOR APPROX, JASA 69, 50

BARLOW, R. E. A NOTE ON TESTS FOR MONOTONE FAILURE RATE BASED ON INCOMPLETE DATA, AMS 69, 595

BARLOW, R. E. ON THE DISTRIBUTION OF THE MAXIMUM AND MINIMUM OF RATIOS OF ORDER STATISTICS, AMS 69, 918

BARLOW, R. E. SYSTEM EFFICIENCY AND RELIABILITY, TECH 60, 43

BARLOW, RICHARD E. BOUNDS FOR DISTRIBUTTONS WITH MONOTONE HAZARD RATE, I, AMS 64, 1234

BARLOW, RICHARD E. BOUNDS FOR DISTRIBUTIONS WITH MONOTONE HAZARD RATE, II, AMS 64, 1258

BARLOW, RICHARD E, BOUNDS ON INTEGRALS WITH APPLICATIONS TO RELIABILITY PRO8LEMS, AMS 65, 565

BARLOW, RICHARD E. COMPARISON OF REPLACEMENT POLICIES. AND RENEWAL THEORY IMPLICATIONS, AMS 64,577

BARLOW. RICHARD E. DISTRIBUTION-FREE LIFE TEST SAMPLING PLANS TECH 66. 591

BARLOW, RICHARD E. EXPONENTIAL LIFE TEST PROCEDURES WHEN THE DISTRIBUTION HAS MONOTONE FAILURE RATE, JASA 67,548

BARLOW, RICHARD E. INEQUALITIES FOR LINEAR COMBINATIONS OF ORDER STATISTICS FROM RESTRICTED FAMILIES, AMS 66, 1574

BARLOW, RICHARD E. LIKELIHOOD RATIO TESTS FOR RESTRICTED FAMILIES OF PROBABILITY DISTRIBUTIONS, AMS 68,547
BARLOW, RICHARD E. PROPERTIES OF PROBABILITY DISTRIBUTIONS WITH MONOTONE HAZARD RATE, AMS 63, 375

BARLOW, RICHARD E . RELIABILITY GROWTH DURING A DEVELOPMENT TESTING PKOCRAM, TECH 66, 53

BARLOW. RICHARD E. SELECTION PROCEDURES FOR RESTRICTED FAMILIES OF PROBABILITYDISTRIBUTIONS, AMS 69, 905

BARLOW, RICHARD E. STATISTICAL ESTIMATION PROCEDURES FOR THE 'BURN-IN' PROCESS, TECH 68.51

BARLOW, RICHARDE. TABLES OF BOUNDS FOR DISTR IBUTIONS WITH MONOTONE HAZARD RATE, JASA 65,872

BARLOW, RICHARD E. TOLERANCE AND CONFIDENCE LIMITS FOR CLASSES OF DISTRIBUTIONS BASED ONFA ILURE RATE, CO, AMS 66, 1593

BARNARD, G. A. AN ANALOGUE OF TCHEBYCHEFF'S INEQUALITY IN TERMS OF THE RANGE, TECH 62,133

BARNARD, G. A. CONTROL CHARTS AND STOCHASTIC PROCESSES (WITH DISCUSSION), JRSSB 59, 239

BARNARD, G. A. DISCUSSION OF THE PAPERS OF MESSRS. HALD, WETHERILL AND COX, TECH 60,361

BARNARD, C. A. DISTRIBUTIONS OF PRODUCTS OF INDEPENDENT VARIABLES, TECH 62,277

BARNARD, G. A. SAMPLING INSPECTION AND STATISTICAL DECISIONS (WITH DISCUSSION). JRSSB 54, 151

BARNARD, G. A. SIMPLIFIED DECISION FUNCTIONS, BIOKA 54,241

BARNARD, G. A. SOME LOGICAL ASPECTS OF THE FIDUCIAL ARGUMENT, JRSSB 63. 111

BARNARD, G. A. STUDIES IN THE HISTORY OF PROBABILITY AND STATISTICS IX. BIOGRAPHICAL NOTE FOR T. BAYES'. BIOKA 58, 293

BARNARD, G. A THE FREQUENCY JUSTIFICATION OF CERTAIN SEQUENTIAL TESTS, BIOKA 52, 144

BARNARD, G A. THE FREQUENCY JUSTIFICATION OF SEQUENT IAL TESTS, ADDENDUM, BIOKA 53,468

BARNARD, G. A THE LOGIC OF LEAST SQUARES; JRSSB 63, 124

BARNARD, G A TIME TNTERVALS BETWEEN ACCIDENTS, A NOTE ON MAGUIRE PEARSON AND WYNN' S PAPER, BIOKA 53,212

BARNARD, GEORGE DISCUSSION OF 'ON THE FOUNDATIONS OF STATISTICAL INFERENCE', JASA 62,307

BARNDOFF-NIELSEN, OLE ON THE LIMIT BEHAVIOUR OF EXTREME ORDER STATISTICS. AMS 63, 992

BARNETT, B $N$ SEQUENTIAL SAMPLING, TWO DECISION PROBLEMS WITH LINEAR LOSSES FOR BINOMIAL AND NORMAL RAND. BIOKA 65.507

BARNETT. F. C. LINEAR ESTIMATES OF A POPULATION SCALE PARAMETER BIOKA 67. 551

BARNETT. V.D A NOTE ON LINEAR STRUCTURAL RELATIONSHIPS WHEN BOTH RESIDUAL VARIANCES ARE KNOWN, BIOKA 67,670

BARNETT, V. D. EVALUATION OF THE MAXIMUM-LIKELIHOOD ESTIMATOR WHERE THE LTKELIHOOD EQUAT ION HAS MULT IPLE, BIOKA 66,151

BARNETT, V. D. LARGE SAMPLE TABLES OF PERCENTAGE POINTS FOR HARTLEY'S CORRECTION TO BARTLETT' S CRITERION, BIOKA 62, 4B7

BARNETT, $V, D$ ORDER STATISTICS ESTIMATORS OF THE LOCATION OF THE CAUCHY DISTRIBUTION, JASA 66, 1205

BARNETT. V. D. SIMULTANEOUS PAIRWISE LINEAR STRUCTURAL RELATIONSHIPS, BIOCS 69,129

BARR, DAVID R. AN INTRODUCTION TO RANKING AND SELECTION PROCEDURES JASA 66,640

BARR, DAVID R. ON TESTING THE EQUALITY OF UNIFORM AND RELATED DISTRIBUTIONS, JASA 66, B56

BARRACLOUGH. ELIZABETH D. TABLES FOR WALD TESTS FOR THE MEAN OF A NORMAL DISTRIBUTION. BIOKA 59, 169

BARTHOLOMEW. D. J. A COMPARISON OF SOME BAYESIAN AND FREQUENTIST INFERENCES . BIOKA 65, 19

BARTHOLOMEW. D. J . A COMPARISON OF SOME BAYES IAN AND FREQUENT IST INFERENCES. II, BIOKA 66,262

BARTHOLOMEW, D. J . A MULTI-STAGE RENEWAL PROCESS, JRSSB 63, 150

BARTHOLOMEW. D. J. A PROBLEM IN LIFE TESTING, JASA 57,350

BARTHOLOMEW. D. J. A SEQUENTIAL TEST FOR RANDOMNESS OF INTERVALS JRSSB 56,95

BARTHOLOMEW, D. J. A SEQUENTIAL TEST OF RANDOMNESS FOR EVENTS OCCURRING IN TIME OR SPACE, BIOKA 56,64

BARTHOLOMEW,D.J. A TEST OF HOMOGENEITY FOR ORDERED ALTERNATIVES BIOKA 59,36

BARTHOLOMEW. D. J. A TEST OF HOMOGENEITY FOR ORDERED ALTERNATIVES II, BIOKA 59,328

BARTHOLOMEW. D. J. A TEST OF HOMOGENEITY OF MEANS UNDER RESTRICTED ALTERNATIVES (WITHDISCUSSION), JRSSB 61,239

BARTHOLOMEW, D. J AN APPROXIMATE SOLUTION OF THE INTEGRAL EQUATION OF RENEWAL THEORY, JRSSB 63,432

BARTHOLOMEW, D J. HYPOTHESIS TESTINC WHEN THE SAMPLE SIZE IS TREATED AS A RANDOM VARIABLE (WITHDISCUSSION), JRSSB 67,53

BARTHOLOMEW, D. J ORDERED TESTS IN THE ANALYSIS OF VARIANCE, BIOKA 61,325

BARTHOLOMEW. D. J SUFFICIENT CONDITION FOR THE MIXTURE OF EXPONENTIALS TO BE A PROBABILITY DENSITY FUNCT, AMS 69, NO. 6

BARTHOLOMEW. D. J. TESTING FOR DEPARTURE FROM THE EXPONENTIAL DISTRIBUTION. BIOKA 57,253

BARTHOLOMEW, D. J TESTS FOR RANDOMNESS IN A SERIES OF EVENTS WHEN THE ALTERNATIVE IS A TREND, JRSSB 56.234

BARTHOLOMEW, D. J. THE SAMPLING DISTRIBUTION OF AN EST IMATE ARISINC IN LIFE TESTING, TECH 63,361 
BARTHOLOMEW, D. J. NOTE ON THE USE OF SHERMAN'S STATISTIC AS A TEST OF RANDOMNESS, BIOKA 54,556

BARTKO, J. J. ON EXPECTATIONS OF SOME FUNCTIONS OF POISSON VARIATES. BIOCS 6 B, 97

BARTKO, J. J. SOME PROBLEMS OF STATISTICAL INFERENCE IN ABSORBING MARKOV CHAINS., BIOKA 65,127

BARTKO, JOHN J INFERENCE ON A GENETIC MODEL OF THE MARKOV CHAIN TYPE BIOKA 63, 251

BARTKO, JOHN J. A NOTE ON THE NEGATIVE BINOMIAL DISTRIBUTION, TECH 62,609

BARTKO, JOHN J. APPROXIMATING THE NEGATIVE BINOMIAL, TECH 66,345

BARTKO, JOHN J. ERRATA. 'APPROXIMATING THE NEGATIVE BINOMIAL

TECH 67,498

BARTLETT, M. S. A COMMENT ON D.V. LINDLEY'S STATISTICAL PARADOX, BIOKA 57,533

BARTLETT, M. S. A COMPARISON OF THEORETICAL AND EMPIRICAL RESULTS FOR SOME STOCHASTIC POPULATION MODELS, BIOKA 60 ,

BARTLETT, M. S. A NOTE ON TESTS OF SIGNIFICANCE FOR LINEAR FUNCTIONAL RELATIONSHIPS, BIOKA 57,268

BARTLETT, M. S. A NOTE ON THE MULTIPLYING FACTORS FOR VARIOUS CHISQUARE APPROXIMATIONS, JRSSB 54, 296

BARTLETT, M.S. A SAMPLING TEST OF THE CHI-SQUARE THEORY FOR PROBABILITY CHAINS, BIOKA 52,118

BARTLETT. M.S. APPROXIMATE CONF IDENCE INTERVALS, BIOKA 53, 12

BARTLETT, M. S. APPROXIMATE CONFIDENCE INTERVALS III. A BIAS CORRECTION, BIOKA 55, 201

BARTLETT, M.S. APPROXIMATE CONFIDENCE INTERVALS. II. MORE THAN ONE UNKNOWN PARAMETER, BIOKA 53, 306

BARTLETT, M. S. COMMENT ON SIR RONALD FISHER'S PAPER, 'ON A TEST OF SIGNIF ICANCE IN PEARSON' S BIOMETR IKA, JRSSB 56, 295

BARTLETT, $M$. S. CORRIGENDA, 'THE SPECTRAL ANALYSIS OF TWO-DIMENSIONAL POINT PROCESSES', BIOKA 65,305

BARTLETT, M. S. DISCRIMINATION IN THE CASE OF ZERO MEAN DIFFERENCES, BIOKA 63,17

BARTLETT, M. S. DISTRIBUTIONS ASSOCIATED WITH CELL POPULATIONS. BIOKA 69,391

BARTLETT. M. S. ON THE EFFICIENCY OF PROCEDURES FOR SMOOTHINO PER IOD OGRAMS FROM TIME SERIES WITH CONT INUO. BIOKA 55, 143

BARTLETT, M. S. ON THEORETICAL MODELS FOR COMPETITIVE AND PREDATORY BIOLOGICAL SYSTEMS, BIOKA 57,27

8ARTLETT, M. S. R. A. FISHER AND THE LAST FIFTY YEARS OF STATISTICAL METHODOLOGY, JASA 65,395

BARTLETT, M. S. SOME REMARKS ON THE ANALYSIS OF TIME-SERIES, BIOKA 67,25

BARTLETT. M. S. THE EFFECT OF STANDARDIZATION ON AN APPROXIMATION IN FACTOR ANALYSIS, BIOKA 51,337

BARTLETT, M. S. THE SPECTRAL ANALYSIS OF POINT PROCESSES (WITH DISCUSSION), JRSSB 63,264

BARTLETT, M. S. THE SPECTRAL ANALYSIS OF TWO-DIMENSIONAL POINT PROCESSES, 8IOKA 64, 299

BARTLETT, M. S. THE STATISTICAL SIGNIFI CANCE OF ODD BITS OF INFORMATION, BIOKA $52,22 B$

BARTON, D. E. A CLASS OF DISTRIBUTIONS FOR WHICH THE MAXIMUMLIKELIHOOD ESTIMATOR IS UNBIASED AND OF MINI, BIOKA 56, 200

BARTON, D, E. A COMPARISON OF TWO SORTS OF TEST FOR A CHANGE OF LOCATION APPLICABLE TO TRUNCATED DATA. JRSSB 57. 119

BARTON, D. E. A PERSISTENCE PROBLEM IN RENEWAL THEORY, ROBERT THE BRUCE'S SPIDER, BIOKA 66,255

BARTON, D, E. A QUICK ESTIMATE OF THE REGRESSION COEFFICIENT, BIOKA 58,431

BARTON, D. E. ADDENDUM, THE LIMITING DISTRIBUTION OF KAMAT'S TEST STATISTIC. BIOKA 56,386

BARTON, D. E. CONTAGIOUS OCCUPANCY, JRSSB 59, 120

BARTON, D. E. CORRIGENDA TO 'MULTIPLE RUNS', BIOKA 57,534

BARTON, D. E. FOUR-LETTER WORDS. THE DISTRIBUTION OF PATTERN FREQUENCIES IN RING PERMUTATIONS, JRSSB 67, 550

BARTON, D. E. MULTIPLE RUNS, BIOKA 57,168

BARTON, D. E. NON-RANDOMNESS IN A SEQUENCE OF TWO ALTERNATIVES. I WILCOXON'S AND ALLIED TEST STATISTICS. BIOKA 5B, 166

BARTON, D. E. NON-RANDOMNESS IN A SEQUENCE OF TWO ALTERNATIVES. II. RUNS TEST , BIOKA 58,253

BARTON, D. E. ON THE EQUIVALENCE OF TWO TESTS OF EQUALITY OF RATE OF OCCURRENCE IN TWO SERIES OF EVENTS 0, BIOKA 58,267

BARTON, D. E. PERSISTENCE IN A CHAIN OF MULTIPLE EVENTS WHEN THERE IS SIMPLE DEPENDENCE, BIOKA 62,351

BARTON, D. E. QUERY, COMPARISON OF SAMPLE SIZES IN INVERSE BINOMIAL SAMPLING, TECH 67,337

BARTON, D. E. QUERY, COMPLETED RUNS OF LENGTH K ABOVE AND BELOW MEDIAN, TECH 67,682

BARTON, D. E. RANDOM POINTS IN A CIRCLE AND THE ANALYSIS OF CHROMOSOME PATTERNS, BIOKA 63,23

BARTON, D. E. RUNS INA RING, BIOKA 58,572

BARTON, D. E. SEQUENTIAL OCCUPANCY, BIOKA 59,218

BARTON, D. E. SEQUENTI IAL OCCUPANCY WITH CLASSIFICATION, BIOKA 68 , 229

BARTON, D. E. SOME ASPECTS OF THE RANDOM SEQUENCE, AMS 65,236

BARTON, D. E. SOME NOTES ON ORDERED RANDOM INTERVALS, JRSSB 56,79

BARTON, D. E. SOME PROPERTIES OF THE DISTRIBUTION OF THE LOGARITHM OF NON-CENTRAL F, BIOKA 60,417
BARTON, D. E. TABLE FOR THE SOLUTION OF THE EXPONENTIAL EQUATION $\operatorname{EXP}(B)-B(1-P)=1$, BIOKA 63,177

BARTON, D. E. TABLES FOR THE SOLUTION OF THE EXPONENT IAL EQUATION $\operatorname{EXP}(-A)+K A=1, B I O K A 60,439$

BARTON, D. E. TESTS FOR RANDOMNESS OF POINTS ON A LINE, BIOKA 56, 104 BARTON, D. E. THE CENTRAL SAMPLING MOMENTS OF THE MEAN IN SAMPLES FROM A FINITE POPULATION (ATY 'S FORMULA, BIOKA 61,199

BARTON, D. E. THE CONDITIONS UNDER WHICH GRAM-CHARLIER AND EDGEWORTH CURVES ARE POSITIVE DEF INITE AND UNI, BIOKA 52, 425

BARTON, D. E. THE DISPERSION OF A NUMBER OF SPECIES, JRSS8 59, 190

BARTON. D. E. THE MATCHING DISTRIBUTIONS, POISSON LIMITING FORMS AND DERIVED METHODS OF APPROXIMATION, JRSSB 58,73

BARTON, D. E. THE POLYKAYS OF THE NATURAL NUMBERS, BIOKA 60,53

8ARTON, D. E. THE RANDOMIZATION BASES OF THE PROBLEM OF THE AMALGAMATION OF WEIGHTED MEANS, JRSSB 61,423

BARTON, D. E. UNBIASED ESTIMATION OF A SET OF PROBABILITIES, BIOKA 61,227

BARTOO. J. B. ASYMPTOTIC DISTRIBUTION OF DISTANCES BETWEEN ORDER STATISTICS FROM BIVARI ATE POPULATIONS, AMS 64,748

BART00. JAMES B. ON OPTIMAL ASYMPTOTIC TESTS OF COMPOSITE STATISTICAL HYPOTHESES, AMS 67,1845

BARTOSZYNSKI, R. A STOCHASTIC MODEL OF ACHE TRANSPORTATION IN THE PERIPHERAL NERVE TRUNKS, BIOKA 62. 447

BARTOSZYNSKI, ROBERT A CHARACTERIZATION OF THE WEAK CONVERGENCE OF MEASURES. AMS 61,561

BASMANN, R. L. A NOTE ON THE EXACT FINITE SAMPLE FREQUENCY FUNCTIONS OF GENERALIZED CLASSICAL LINEAR ESTI , JASA 61,619

BASMANN, R. L. A NOTE ON THE EXACT FINITE SAMPLE FREQUENCY FUNCTIONS OF GENERALIZED CLASSICAL LINEAR ESTI. JASA 63, 161

BASMANN, R. L. A NOTE ON THE STATISTICAL TESTABILITY OF 'EXPLICIT CAUSAL CHAINS ' AGAINST THE CLASS OF ' IN, JASA 65,1080

BASMANN, R. L. ON FINITE SAMPLE DISTRIBUTIONS OF GENERALIZED CLASSICAL LINEAR IDENTIFIABILITY TEST STATIS, JASA 60, 650

BASMANN, R. L. REMARKS CONCERNING THE APPLICATION OF EXACT FINITE SAMPLE DISTRIBUTION FUNCTIONS OF GENERA, JASA 63,943

BASSETT, E. E. A COMPARISON OF SOME BAYESIAN AND FREQUENTIST INFERENCES, II, BIOKA 66,262

BASU, A , 0. ON A TEST FOR SEVERAL LINEAR RELATIONS, JRSSB 69,65

BASU, A. P. A NOTE ON NONPARAMETRIC TESTS FOR SCALE, AMS 67, 274

BASU A.P. EFFECT OF TRUNCATION ON A TEST FOR THE SCALE PARAMETER OF THE EXPONENTI AL DISTRIBUTION, AMS 64, 209

BASU. A. P. ESTIMATES OF RELIABILITY FOR SOME DISTRIBUTIONS USEFUL IN LIFE TESTING, TECH 64,215

BASU, A.P. ON A GENERALIZED SAVAGE STATISTIC WITH APPLICATIONS TO LIFE TESTING, AMS 6B, 1591

BASU, A. P. ON SOME TESTS OF HYPOTHESES RELATING TO THE EXPONENTIAL DISTR IBUTION WHEN SOME OUTLIERS ARE P, JASA 65, 548

BASU, A. P. ON THE LARGE SAMPLE PROPERTIES OF A GENERALIZED WILCOXON-MANN-WHITNEY STATISTIC, AMS 67,905

BASU, A.P. ON TWO K-SAMPLE RANK TESTS FOR CENSORED DATA, AMS 67, 1520 BASU, D. INVARIANT SETS FOR TRANSLATION-PARAMETER FAMILIES OF MEASURES, AMS 69,162

BATHER, J A CONTROL CHARTS AND THE MINIMIZATION OF COSTS (WITH DISCUSSION) , JRSSB 63,49

BATHER. J. A. INVARIANT CONDITIONAL DISTRIBUTIONS, AMS 65,829 BATHER, J. A. ON A QUICKEST DETECTION PROBLEM, AMS 67.711

BATSCHELET, EDWARD TEST ING HYPOTHESES AND ESTIMATING PARAMETERS IN HUMAN GENETICS IF THE AGE OF ONSET IS, BIOKA 63,265

BAUM, LEONARD E. ASYMPTOTIC DISTRIBUTORS FOR THE COUPON COLLECTOR'S PROBLEM AMS 65,1835

BAUM, LEONARD E. ON CONVERGENCE TO INFINITY IN THE LAW OF LARGE NUMBERS, (ACKNOWLEDGEMENT OF PRIORITY 63, AMS 63, 219

BAUM, LEONARD E. ON THE INFLUENCE OF MOMENTS ON THE ASYMPTOTIC DISTRIBUTION OF SUMS OF RANDOM VARIABLES. AMS 63.1042

BAUM, LEONARD E. STATIST ICAL INFERENCE FOR PROBABILISTIC FUNCTIONS OF FINITE STATE MARKOV CHAINS, AMS 66,1554

BAXTER, GLEN A COMBINATOR IAL LEMMA FOR COMPLEX NUMBERS, AMS 61, 901 BAXTER, GLEN GENERALIZATIONS OF THE MAXIMAL ERGODIC THEOREM, AMS 65.1292

BAXTER, GLEN ON A GENERALIZATION OF THE FINITE ARC-SINE LAW, AMS 62. 909

BAYES. THOMAS ESSAY TOWARDS SOLVING A PROBLEM IN THE DOCTRINE OF CHANCES, REPRODUCED FROM PHIL. TRANS. R, BIOKA 58, 296

BAYLESS, D L AN EMPIRICAL STUDY OF THE STABILITIES OF ESTIMATORS AND VARI ANCE EST IMATORS IN UNEQUAL PRO. JASA 69.540

BEALE. E. M. L. CONFIDENCE REGIONS IN NON-LINEAR ESTIMATION (WITH DISCUSSION , JRSSB 60,41

BEALE, E. M. L. ONMINIMIZING A CONVEX FUNCTION SUBJECT TO LINEAR INEQUALITIES (WITHDISCUSSION), JRSSB 55, 173

BEALE. E. M. L. THE DISCARDING OF VARIABLES IN MULTIVARIATE ANALYSIS, BIOKA 67,357

BEATTIE, RONALD H. SOURCES OF STATISTICS ON CRIME AND CORRECTION, JASA 59,582

BEATTY. GLENN H. ERRATA, 'TABLES OF TOLERANCE-LIMIT FACTORS FOR NORMAL DISTRIBUTIONS ${ }^{\prime}$, TECH 61,576

BEATTY, GLENN H. TABLES OF TOLERANCE-LIMIT FACTORS FOR NORMAL DISTRIBUTIONS, TECH 60,483 
BEAUCHAMP. J. J. MAXIMUM LIKELIHOOD ESTIMATION OF SURVIVAL CURVE PARAMETERS, BIOGS $6 B .595$

BEAUCHAMP, J, J. SPEARMAN SIMULTANEOUS ESTIMATION FOR A COMPARTMENTAL MODEL, TEGH 69, 551

BEAUCHAMP, JOHN J. ERRATA 'SIMULTANEOUS NONLINEAR ESTIMATION' TECH 67,353

BEAUGHAMP, JOHN J. SIMULTANEOUS ESTIMATION BY PARTIAL TOTALS FOR COMPARTMENTAL MODELS. JASA 68.573

BEAUCHAMP, JOHN J. SIMULTANEOUS NONLINEAR ESTIMATION, TECH 66, 319 BECHHOFER, R, E. A TWO-SAMPLE MULT IPLE DEC ISION PROGEDURE FOR RANKING MEANS OF NORMAL POPULATIONS WITH A. BIOKA 54, 170

BECHHOFER. R. E. A TWO-STAGE SUBSAMPLING PROGEDURE FOR RANKING MEANS OF FINITE POPULATIONS WITH AN APPLIC, TECH 67,355

BECHHOFER. ROBERT E. A MULTIPLICATIVE MODEL FOR ANALYZING VARIANCES WHIGH ARE AFFECTED BY SEVERAL FACTORS, JASA 60.245

BECHHOFER, ROBERT E. A NOTE ON THE LIMITING RELATIVE EFFIGIENCY OF THE WALD SEQUENTIAL PROBABILITY RATIO, JASA 60,660

BEGHHOFER. ROBERT E. MULTIPLE COMPARISONS WITH A CONTROL FOR MULTIPLY-CLASSIFIED VARIANCES OF NORMAL POPU, TEGH 6B, 715

BECHHOFER, ROBERT E. SINGLE-STAGE PROGEDURES FOR RANKING MULTIPL.YCLASSIFIED VARIANCES OF NORMAL POPULATI, TECH 6B, 693

BECKER, N. G. MODELS FOR THE RESPONSE OF A MIXTURE, JRSSB 6B. 349

BECKER. N. G. REGRESSION PROBLEMS WHEN THE PREDICTOR VARIABLES ARE PROPORTIONS, JRSSB 69, 107

BEGKER, N. G. THE SPREAD OF AN EPIDEMIC TO FIXED GROUPS WITHIN THE POPULATION, BIOGS 68,1007

BECKER, W. A. ESTIMATES OF HERITABILITY FROM TRANSFORMED PERCENTAGE SIB DATA WITH UNEQUAL SUBGLASS NUMBER, BIOCS 65, 1001

BEEKMAN, J. A. A STATISTIGAL TEST INVOLVING A RANDOM NUMBER OF RANDOM VARIABLES, AMS 66, 1305

BEEKMAN, J. A. DISTRIBUTIONS OF A M. KAC STATISTIG, AMS 67, 1919

BEHNKEN, D. W. ERRATA, 'SOME NEW THREE LEVEL DESIGNS FOR THE STUDY OF QUANT ITATIVE VARIABLES ', TEGH 61, 576

BEHNKEN, D. $\mathbb{\text { W }}$. SAMPLING MOMENTS OF MEANS FROM FINITE MULTIVARIATE POPULATIONS, AMS 61,406

BEHNKEN, D. W. SOME NEW THREE LEVEL DESIGNS FOR THE STUDY OF QUANTITATIVE VARIABLES, TECH 60,455

BEIGHTLER, C, S. DESIGN OF AN OPT IMAL SEQUENGE OF INTERRELATED SAMPLING PLANS, JASA 64, 96

BELL, G. B. 'OPTIMAL' ONE-SAMPLE DISTRIBUTION-FREE TESTS AND THEIR TWO-SAMPLE EXTENSIONS, AMS 66. 120

BELL, G. B. BIVARIATE SYMMETRY TESTS, PARAMETRIG AND NONPARAMETRIC, AMS 69, 259

BELL, G. B. CHARACTERIZATION OF MULTISAMPLE DISTRIBUTION-FREE STATISTICS, AMS 64,735

BELL, C . B. DISTRIBUTION-FREE TESTS OF INDEPENDENCE, AMS 67,429

BELL, G. B. GOODNESS GRITERIA FOR TWO-SAMPLE DISTRIBUTION-FREE TESTS, AMS 66, 133

BELL, C. B. MAXIMAL INDEPENDENT STOGHASTIG PROGESSES, AMS 61,704

BELL, C. B. MUTUAL INFORMATION AND MAXIMAL GORRELATION AS MEASURES OF DEPENDENCE, AMS $62,5 \mathrm{~B} 7$

BELL, G. B. SOME BASIG THEOREMS OF DISTRIBUTION-FREE STATISTIGS, AMS 64,150

BELL, G. B. SOME NEW DISTRIBUTION-FREE STATISTIGS, (ACKNOWLEDGEMENT OF PRIORITY 65 1901), AMS 65, 203

BELL, EARL J. THE STAT IST IGAL ANALYSIS OF INDUSTRY STRUGTURE, AN APPLIGATION TOFOOD INDUSTRIES, JASA 61,925

BELLMAN, RIGHARD GURVE FITTING BY SEGMENTED STRAIGHT LINES, JASA 69,1079

BEMENT, T, R. VARIANGE OF WEIGHTED REGRESSION ESTIMATORS WHEN SAMPLING ERRORS ARE INDEPENDENT AND HETEROS, JASA 69, NO. 4

BEN-ISRAEL, A. A PROBLEM OF DELAYED SERVIGE, 1, JRSSB 60, 245

BEN-ISRAEL, A. A PROBLEM OF DELAYED SERVIGE, 2, JRSSB 60,270

BEN-TUVIA, S. THE EFFIGIENCY OF STATISTICAL SIMULATION PROCEDURES, TEGH 62,257

BENES, V. E. A 'RENEWAL' LIMIT THEOREM FOR GENERAL STOGHASTIG PROCESSES, AMS 62, 9B

BENISHAY, HASKEL A STOGHASTIC MODEL OF GREDIT SALES DEBT, JASA 66 , 1010

BENNETT, B. M. A BIVARIATE SIGNED RANK TEST, JRSSB 64, 457

BENNETT, B. M. A NOTE ON COMBINING GORRELATED EST IMATES OF A RATIO OF MULTIVARIATE MEANS, TEGH 64,463

BENNETT, B. M. GONFIDENGE LIMITS FOR MULT IVARIATE RATIOS, JRSSB 61 , 108

BENNETT, B. M. GORRIGENDA, 'ON THE POWER FUNGTION OF THE EXAGT TEST FOR THE 2-BY-2 GONT INGENGY TABLE', BIOKA 61, 475

BENNETT, B. M. NOTE ON A CHI-SQUARE APPROXIMATION FOR THE MULTIVARIATE SIGN TEST, JRSSB $65, \mathrm{~B} 2$

BENNETT, B. M. NOTE ON CHI SQUARE TESTS FOR MATCHED SAMPLES, JRSSB

BENNETT, B. M. NOTES. GONFIDENCE LIMITS FOR A RATIO USING WILCOXON'S SIGNED RANK TEST, BIOGS 65, 231

BENNETT. B. M. ON A MULTIVAR IATE VERSION OF FIELLER'S THEOREM, JRSSB 59,59

BENNETT, B. M. ON COMBINING ESTIMATES OF A RATIO OF MEANS, JRSSB 63 , 201

BENNETT, B. M. ON MULTIVARIATE SIGN TESTS, JRSSB 62, 159

BENNETT, B. M. ON THE POWER FUNGTION OF THE EXACT TEST FOR THE 2-BY-2 GONTINGENGY TABLE, BIOKA 60,393
BENNETT, B. M. PERCENTAGE POINTS OF THE RANGE FROM A SYMMETRIC MULTINOMIAL DISTRIBUTION, BIOKA 6B, 377

BENNETT , B. M. RANK ORDER TESTS OF LINEAR HYPOTHESES, JRSSB 6B, 4B3

BENNETT, B. M. TABLES FOR TESTING SIGNIFIGANGE IN A 2-BY-3 GONTINGENCY TABLE, TECH 63, 501

BENNETT, B. M. TESTS OF HYPOTHESES CONCERNING MATCHED SAMPLES (CORR. 69 194), JRSSB 67, 46B

BENNETT, B. M. THE POWER FUNGTION OF THE EXACT TEST FOR THE 2-BY-3 CONTINGENCY TABLE, TEGH 64,439

BENNETT, D. THE USE OF LAMBDA AS AN INDEX OF PRECISION, BIOGS 69, 174 BENNETT, G. A ONE-SIDED PROBABILITY INEQUALITY FOR THE SUM OF INDEPENDENT, BOUNDED RANDOM VARIABLES, BIOKA 68, 565

BENNETT, G. ON THE PROBABILITY OF LARGE DEVIATIONS FROM THE EXPEGTATION FOR SUMS OF BOUNDED, INDEPENDENT, BIOKA 63, 52B

BENNETT, G. UPPER BOUNDS ON THE MOMENTS AND PROBABILITY INEQUALITIES FOR THE SUM OF INDEPENDENT, BOUNDED, BIOKA 65, 559

BENNETT, GEORGE PROBABILITY INEQUALITIES FOR THE SUM OF INDEPENDENT RANDOM VARIABLES, JASA 62,33

BENNETT, J. H. A GENERAL GLASS OF ENUMERATIONS ARISING IN GENETICS, BIOCS 67,517

BENNET T, J. H. MIXED SELF- AND CROSS-FERTILIZATION IN A TETRASOMIC SPECIES, BIOCS 68,485

BENNETT, J . H. PARTITIONS IN MORE THAN ONE DIMENSION, JRSSB 56, 104 BENNETT, J. H. THE DISTRIBUTION OF HETEROGENEITY UPON INBREEDING, JRSSB 54, BB

BENSON, $F$. CLOSED QUEUEING SYSTEMS, A GENERALIZATION OF THE MAGHINE INTERFERENCE MODEL, JRSSB 61, 385

BENTLEY, D. L. A CONTRIBUTION TO COUNTER THEORY, JRSSB 63.169

BERAN, R. J. ASYMPTOTIC THEORY OF A CLASS OF TESTS FOR UNIFORMITY OF A GIRGULAR DISTRIBUTION AMS 69, 1196

BERAN. R. J. THE DERIVATION OF NONPARAMETRIG TWO-SAMPLE TESTS FROM TESTS FOR UNIFORMITY OF A GIRGULAR DIS, BIOKA 69, NO.3

BERENBLUT, I I A GHANGE-OVER DESIGN FOR TESTING A TREATMENT FACTOR AT FOUR EQUALLY SPACED LEVELS, CORR. , JRSSB 67,370

BERENBLUT. I. I. GHANGEOVER DESIGNS BALANCED FOR THE LINEAR COM PONENT OF FIRST RESIDUAL EFFECTS, BIOKA 6B, 297

BERENBLUT, I. I. THE ANALYSIS OF CHANGEOVER DESIGNS WITH GOMPLETE BALANCE FOR FIRST RESIDUAL EFFEGTS, BIOCS 67, 578

BERGER. A. NOTES. ON ESTIMATING REGESSIVE FREQUENGIES FROM TRUNCATED SAMPLES, BIOCS 67,356

BERGER, A. ON THE QUESTION OF WHETHER A DISEASE IS FAMILIAL, JASA 67 , 409

BERGER, AGNES ON COMPARING INTENSITIES OF ASSOCIATION BETWEEN TWO BINARY GHARACTERISTICS IN TWO DIFFERENT, JASA 61, 889

BERGSTROM, H. A REMARK ON SPEARMAN'S RANK GORRELATION GOEFFIGIENT BIOKA 5B, 273

BERK, KENNETH AN EVALUATION OF A FUNCTIONAL ON INF INITELY DIVISIBLE STOCHASTIC PROCESSES, AMS 64, 336

BERK, KENNETH N, ERGOD IG THEORY WITH RECURRENT WEIGHTS, AMS 6B, 1107 BERK, ROBERT H. A SPEGIAL STRUGTURE AND EQU IVARIANT ESTIMATION, AMS 67,1436

BERK, ROBERT H. BIORTHOGONAL AND DUAL CONFIGURATIONS AND THE REGIPROCAL NORMAL DISTRIBUTION, AMS 69, 393

BERK, ROBERT H. LIMITING BEHAVIOR OF POSTERIOR DISTRIBUTIONS WHEN THE MODEL IS INGORREGT, CORR. 66745, AMS 66, 5I

BERK, ROBERT H. ON INVARIANCE AND ALMOST INVARIANCE, AMS 6B, 1573

BERK, ROBERT H. STRONG CONSISTENCY OF CERTAIN SEQUENTIAL ESTIMATORS, AMS 69. 1492

BERK, ROBERT H THE INFORMATION IN A RANK-ORDER AND THE STOPPING TIME OF SOME ASSOCIATED SPRT 'S, AMS 68, 1661

BERKSON, J, APPLICATION OF MINIMUM LOGIT GHI-SQUARE ESTIMATE TO A PROBLEM OF GRIZZLE WITH A NOTATION ON T, BIOCS 68,75

BERKSON, J, ESTIMATION OF A LINEAR FUNGTION FOR A CALIBRATION LINE, CONSIDERATION OF A RECENT PROPOSAL, TEGH 69, NO. 4

BERKSON, J. NOMOGRAMS FOR FITTING THE LOGISTIC FUNCTION BY MAXIMUM LIKELIHOOD, BIOKA 60, 121

BERKSON, J. TABLES FOR USE IN ESTIMATING THE NORMAL DISTRIBUTION FUNCTION BY NORMIT ANALYSIS. PART I. DES, BIOKA 57, 411

BERKSON, JOSEPH GOMPETING EXPONENTIAL RISKS, WITH PARTICULAR REFERENGE TO THE STUDY OF SMOKING AND LUNG C, JASA 60,415

BERKSON, JOSEPH SMOKING AND LUNG CANGER, SOME OBSERVATIONS ON TWO RECENT REPORTS, JASA 5B, 2B

BERKSON, JOSEPH THE OTHER SIDE OF THE LOWER BOUND. A NOTE WITHA GORREGTION, JASA 61, 670

BERMAN, S.M. ON THE QUESTION OF WHETHER A DISEASE IS FAMILIAL, JASA 67,409

BERMAN, SIMEON M. A LAW OF LARGE NUMBERS FOR THE MAXIMUM IN A STA TIONARY GAUSSIAN SEQUENCE, AMS 62.93

BERMAN, SIMEONM. A MARKOV PROCESS ON BINARY NUMBERS, AMS 63,416

BERMAN, SIMEONM. AN EXTENSION OF THEARC SINE LAW, AMS 62, 681 BERMAN, SIMEON M. AN OCCUPATION TIME THEOREM FOR THE ANGULAR COMPONENT OF PLANE BROWNIAN MOTION, AMS 67,25

BERMAN, SIMEON M. LIMIT THEOREMS FOR THE MAXIMUM TERM IN STATIONARY SEQUENGES, AMS 64, 502

BERMAN, SIMEON M. LIMITING DISTRIBUTION OF THE MAXIMUM OF A DIFFUSION PROCESS, AMS 64,319

BERMAN, SIMEON M. LIMITING DISTRIBUTION OF THE MAXIMUM TERM IN SEQUENGES OF DEPENDENT RANDOM VARIABLES, AMS 62, B94 
BERMAN, SIMEONM. NOTE ON EXTREME VALUES, COMPETINC RISKS ANO SEMIMARKOV PROCESSES, AMS 63. 1104

BERNDT, CERALD D. THE REGIONS OF UNIMOOALITY ANO POSITIVITY IN THE ABBREVIATEO EOGEWORTH AND GRAM-CHARLIE, JASA 57, 253

BERRETTONI, J. N. CHAIN-POOLING ANALYSIS OF VARIANCE FOR TWO-LEVEL FACTORIAL REPLICATION-FREE EXPERIMENTS, TECH 69, NO 4

BERRY, G. A MATHEMATICAL MODEL RELATINC PLANT YIELD WITH ARRANCEMENT FOR REGULARLY SPACED CROPS, BIOCS 67.505

BERSHAD, MAX A. WASHINCTON STATISTICAL SOCIETY MEMORIAL MEETINC FOR WILLIAM N. HURWITZ. THE OEVELOPMENT 0, JASA 69, NO 4

BERZ, F. ON THE CUMULATIVE EFFECT OF CHANCE OEVIATIONS, JRSSB 54 269

BESSLER. S. AN OPTIMAL SEQUENT IAL ACCELERATEO LIFE TEST., TECH 62 . 367

BEUTLER, FREDERICK J. MULTIVARIATE WIDE-SENSE MARKOV PROCESSES AND PREDICTION THEORY, AMS 63, 424

BHAPKAR, V. P. A NONPARAMETRIC TEST FOR THE PROBLEM OF SEVERAL SAMPLES, AMS 61, 1108

BHAPKAR, V. P. A NOTE ON THE EQUIVALENCE OF TWO TEST CRITERIA FOR HYPOTHESES IN CATEGORICAL DATA, JASA $66,22 B$

BHAPKAR, V. P. HYPOTHESES OF 'NO INTERACTION' IN MULTI-DIMENSIONAL CONTINGENCY TABLES. TECH GB. 107

BHAPKAR, V. P. ON THE ANALYSIS OF CONTINGENCY TABLES WITH A QUANTITATIVE RESPONSE. BIOCS 68,329

BHAPKAR, V. P. ON THE HYPOTHESES OF 'NO INTERACTION' IN CONTINGENCY TABLES, BIOCS $6 B, 567$

BHAPKAR, V, P. SOME NONPARAMETRIC MEDIAN PROCEDURES, AMS 61, B46

BHAPKAR, $V$. P. SOME NONPARAMETRIC TESTS FOR MULTISAMPLE PROBLEMS

TECH $6 B, 57 B$

BHAPKAR, V.P. SOME TESTS FOR CATEGORICALDATA, AMS 61,72

BHAT. B. R. A NOTE ON SUFFICIENCY IN REGULAR MARKOV CHAINS, B KA 60 452

BHAT, B. R. LAMP TESTS OF LINEAR AND LOGL INEAR HYPOTHESES IN MULTINOMIAL EXPERIMENTS, CORR. 661246 , JASA 66,236

BHAT. B. R. LOCALLY ASYMPTOTICALLY MOST STRINGENT TESTS AND LAGRANGIAN MULTIPLIER TESTS OF LINEAR HYPOTHE, BIOKA 65,459

BHAT, B. R. ON EFFICIENT MULTINOMIAL ESTIMATION, JRSSB 66, 45

BHAT, B. R. ON THE ASYMPTOTIC DISTRIBUTION OF THE 'PSI-SQUARED'

GOODNESS OF FIT CRITERIA FOR MARKOV CHAIN, AMS 61,49

BHAT , B. R. ON THE DISTRIBUTION OF CERTAIN QUADRATIC FORMS IN NORMAL VARIATES, JRSSB $62,14 \mathrm{~B}$

BHAT, B. R. ON THE DISTRIBUTION OF VARIOUS SUMS OF SQUARES IN AN ANAL-

YSIS OF VARI ANCE TABLE FOR DIFFERENT, JRSSB 59, 114

BHAT, B. R. SOME PROPERTIES OF REGULAR MARKOV CHAINS, AMS 61,59

BHAT, R. R. BAYES SOLUTION OF SEQUENTIAL DECISION PROBLEM FOR MARKOV DEPENDENT OBSERVATIONS, AMS 64, 1656

BHATE, D. H. APPROXIMATION TO THE DISTRIBUTION OF SAMPLE SIZE FOR SEQUENTIAL TESTS. I. TESTS FOR SIMPLE H, BIOKA 59, 130

BHATE, D. H. APPROXIMATION TO THE DISTRIBUTION OF THE SAMPLE SIZE FOR SEQUENTIAL TEST. II . TESTS OF COMPO, BIOKA 60, 190

BHATT, N. M. ESTIMATION OF FRACTION DEFEGTIVE IN CURTA ILED SAMPLINC PLANS BY ATTRIBUTES, TEGH 67,219

BHATTACHARJEE, G.P. DIMENSIONAL CHAINS INVOLVING RECTANCULAR AND NORMAL ERROR-DISTRIBUTIONS, TECH 63,404

BHATTACHARJEE, G. P. EFFECT OF NON-NORMALITY ON A SEQUENTIAL TEST FOR MEAN, BIOKA 64, 2BI

BHATTACHARJEE, G. P. EFFECT OF NON-NORMALITY ON STEIN'S TWO SAMPLE TEST, AMS 65, 65I

BHATTACHARYA, C. G. A SIMPLE METHOD OF RESOLUTION OF A DISTRIBUTION INTO GAUSSIAN COMPONENTS, BIOCS 67,115

BHATTACHARYA, N. REGIONAL DISPARITIES IN HOUSEHOLD CONSUMPTION IN INDIA, JASA 67,143

BHATTACHARYA, P. K. EFFICIENT ESTIMATION OF A SHIFT PARAMETER FRON GROUPED DATA, AMS 67,1770

BHATTACHARYA, P. K. ESTIMATING THE MEAN OF A MULTIVARIATE NORMAL POPULATION WITH GENERAL QUADRATIC LOSS F, AMS 66, 1 B 19

BHATTACHARYA, P. K. ON AN ANALOG OF REGRESSION ANALYSIS, AMS 63 , 1459

BHATTACHARYA, P. K. SOME PROPERTIES OF THE LEAST SQUARES ESTIMATOR IN REGRESSION ANALYSIS WHEN THE 'PREDI, AMS 62, 1365

BHATTACHARYA, S. K. A RESULT ON ACCIDENT PRONENESS, BIOKA 67, 324

BHATTACHARYA, S. K. ON A DISCRETE DISTRIBUTION WITH SPECIAL

REFERENCE TO THE THEORY OF ACCIDENT PRONENESS, JASA 65, 1060

BHATTACHARYA, SAMIR KUMAR BAYESIAN APPROACH TO LIFE TESTING AND RELIABILITYESTIMATION, JASA 67,48

BHATTACHARYYA, A. K. ESTIMATING MACHINING ERRORS IN SET-UPS WITH AUTOMATIC RESETTING, TECH 64, 423

BHATTACHARYYA, G. K. A NOTE ON THE ASYMPTOTIC EFFICIENCY OF BENNETT'S BIVARIATE SIGN TEST, JRSSB 66, 146

BHATTACHARYYA, G. K. APPROACH TO DEGENERACY AND THE EFFICIENCY OF SOME MULTIVARIATE TESTS, AMS 6B, 1654

BHATTACHARYYA, G. K. ASYMPTOTIC EFFICIENCY OF MULTIVARIATE NORMAL SCORE TEST, AMS 67,1753

BHATTACHARYYA, G. K. NONPARAMETRIC TESTS FOR SHIFT AT UNKNOWN TIME POINT, AMS 6B, 1731

BHATTACHARYYA, G. K. ON HODGES 'S BIVARIATE SIGN TEST AND A TEST FOR UNIFORMITY OF A CIRCULARDISTRIBUTION, BIOKA 69, 446
BHUCHONGKUL, S. A CLASS OF NONPARAMETRIC TESTS FOR INDEPENOENCE IN BIVARIATE POPULATIONS, AMS 64, 138

BHUCHONCKUL, SUBHA ON THE ESTIMATION OF CONTRASTS IN LINEAR MOOELS, AMS 65, 19B

BICKEL, P. J. A DISTRIBUTION FREE VERSION OF THE SMIRNOV TWO SAMPLE TEST IN THE P-VARIATE CASE, AMS 69, I

BICKEL, P. J . A REMARK ON THE KOLMOGOROFF-PETROVSKII CRITERION, AMS $69,10 B 6$

BICKEL, P. J . ON INVARIANCE ANO ALMOST INVARIANCE, AMS 6B, 1573

BICKEL, P. $J$, SUBSTITUTION IN CONDITIONAL EXPECTATION, AMS 6B, 377

BICKEL, P. J . TESTS FOR MONOTONE FA ILURE RATE, II, AMS 69, 1250

BICKEL, P. J. THE ASYMPTOTIC THEORY OF CALTON'S TEST AND A RELATEO

SIMPLE ESTIMATE OF LOCATION, AMS 67,73

BICKEL. P. J . UNBIASED EST IMAT ION IN CONVEX FAMILIES, AMS 69, 1523

BICKEL, PETER TEST FOR MONOTONE FAILURE RATE BASED ON NORMALIZED

SPACINC, AMS 69, 1216

BICKEL, PETER J. A NOTE ON BAYES ESTIMATES, AMS 67, 1907

BICKEL, PETER J. ASYMPTOTICALLY OPTIMAL BAYES AND MINIMAX

PROCEDURES IN SEQUENT IAL ESTIMATION, AMS 68,422

BICKEL, PETER J. ON AN A.P.O. RULE IN SEQUENTIAL ESTIMATION WITH QUADRATIC LOSS, AMS 69,417

BICKEL, PETER $J$. ON SOME ALTERNATIVE ESTIMATES FOR SHIFT IN THE PVARIATE ONE SAMPLE PROBLEM, AMS 64, 1079

BICKEL, PETER J. ON SOME ASYMPTOTICALLY NONPARAMETRIC COMPETITORS

OF HOTELLING 'S T-SQUARE, CORR . 65 15B3, AMS 65, 160

BIGKEL, PETER J. ON SOME ROBUST ESTIMATES OF LOCATION, AMS 65, B47

BICKEL, PETER J . RENEWAL THEORY IN THE PLANE , AMS 65, 946

BIELENSTEIN, U.M. THE APPROXIMATE DISTRIBUTION OF THE CORRELATION BETWEEN TWO ST ATIONARY LINEAR MARKOV S, BIOKA 65, 301

BIGGERS, J . D. ESTIMATION OF MISSING OBSERVATIONS IN SPLIT-PLOT EXPERIMENTS WHERE WHOLE-PLOTS ARE MISSING, BIOKA $61,46 B$

BIGGERS, J D. THE EST IMATION OF MISSING AND MIXED-UP OBSERVATIONS IN SEVERAL EXPERIMENTAL DESIGNS, BIOKA 59, 91

BIKLE. A. THE COMBINATION OF ESTIMATES FROM SIMILAR EXPERIMENTS ALLOWINC FOR INTER-EXPERIMENT VARIATION, JASA 67, 241

BILDIKAR, S. MULTIVARIATE LOGARITHMIC SERIES DISTRIBUTION AS A PROBABILITY MODEL IN POPULATION AND COMMUN, JASA 67, 655

BILDIKAR, SHEELA MULTIVARIATE EXPONENTIAL-TYPE DISTRIBUTIONS, AMS 68,1316

BILLARD, L. A SEQUENTIAL PROCEDURE FOR TESTING A NULL HYPOTHESIS AGAINST A TWO SIDED ALTERNATIVE HYPOTHES, JRSSB 69, N0.2

BILLEWICZ, W. Z. THE EFFIGIENCY OF MATCHED SAMPLES, BIOCS 65,623

BILLINCSLEY, PATRICK ASYMPTOTIC DISTRIBUTORS FOR THE COUPON COLLECTOR'S PROBLEM, AMS 65, $2 B 35$

BILLINGSLEY, PATRICK LIMIT THEOREMS FOR RANDOMLY SELECTED PARTIAL SUMS, AMS 62,85

BILLINGSLEY, PATRICK ON THE CODING THEOREM FOR NOISELESS CHANNEL, AMS 61,594

BILLINGSLEY, PATRICK STATISTICAL METHODS IN MARKOV CHAINS, CORR 611343 , AMS 61,12

BINET, F. E. ALCEBRAIC THEORY OF THE GOMPUTING ROUTINE FOR TESTS OF SICNIFICANCE ON THE DIMENSIONALITY OF, JRSSB 56, 70

BINET, F. E. ON THE CONSTRUCTION OF AN INDEX FOR INDIRECT SELECTION, BIOCS 65,291

BINGHAM JR, R. S. APPROXIMATIONS FOR MEAN SQUARE SUCCESSIVE DIFFERENCE CRITICAL VALUES, TECH 6B, 397

BINMORE, K. G. A NOTE ON CHARACTERISTIC FUNCTIONS, AMS 69, 303

BIRCH, JOHN J SMALL SAMPLE POWER CURVES FOR THE TWO SAMPLE LOCATION PROBLEM, TECH 69,299

BIRCH, JOHN J. APPROXIMATIONS FOR THE ENTROPY FOR FUNCTIONS OF MARKOV CHAINS, AMS 62,930

BIRCH, M. W. A NEW PROOF OF THE PEARSON-FISHER THEOREM, (ACKNOWLEDGEMENT OF PRIORITY, 63 344), AMS 64, B17

BIRCH, M. W. A NOTE ON THE MAXIMUM LIKELIHOOD ESTIMATION OF A LINEAR STRUGTURAL RELATIONSHIP, JASA 64, 1175

BIRCH, M. W. MAXIMUM LIKELIHOOD IN THREE-WAY CONTINCENCY TABLES, JRSSB 63, 220

BIRCH, M. W. THE DETECTION OF PARTIAL ASSOCIAI'ION, I, THE 2 BY 2 CASE JRSSB 64, 313

BIRCH, $M$. W. THE DETECTION OF PARTIAL ASSOCIATION, 2. THE GENERAL CASE, JRSSB 65,111

BIRNBAUM. ALLAN A UNIFIED THEORY OF ESTIMATION, I, AMS 61,112

BIRNBAUM, ALLAN CONFIDENCE CURVES, AN OMNIBUS TECHNIQUE FOR ESTIMATION AND TESTING STATISTI CAL HYPOTHESES, JASA 61,246

BIRNBAUM, ALLAN DISCUSSION OF ' ON THE FOUNDATIONS OF STATISTICAL INFERENCE' , JASA 62.307

BIRNBAUM, ALLAN EFFICIENCY ROBUST TWO-SAMPLE RANK TESTS, JASA 67 1241

BIRNBAUM, ALLAN LOGISTIC ORDER STATISTICS, AMS 63, 658

BIRNBAUM, ALLAN ON THE ANALYSIS OF FACTORIAL EXPERIMENTS WITHOUT REPLICATION, TECH 59,343

BIRNBAUM, ALLAN ON THE FOUNDATIONS OF STATISTICAL INFERENCE, JASA 62,269

BIRNBAUM, ALLAN ON THE FOUNDATIONS OF STATISTICAL INFERENCE, BINARY EXPERIMENTS, AMS 61, 414

BIRNBAUM, ALLAN OPTIMAL ROBUSTNESS. A GENERAL METHOD, WITH APPLICATIONS TO LINEAR EST IMATORS OF LOCATION, JASA 67, 1230 
BIRNBAUM, ALLAN SOME PROCEDURES FOR COMPARINC POISSON PROCESSES OR POPULATIONS, BIOKA 53, 447

BIRNBAUM, Z W. A STATISTICAL MODEL FOR LIFE-LENCTH OF MATERIALS. JASA 58, 151

8IRNBAUM, Z. W. A STOCHASTIC CHARACTERIZATION OF WEAR-OUT FOR COMPONENTS AND SYSTEMS, AMS 66, 816

BIRNBAUM. $Z$. W MULTI-COMPONENT SYSTEMS AND STRUCTURES AND THEIR RELIABILITY, TECH 61,55

BIRNBAUM, $z$. W. SOME MULTIVARIATE CHEBYSHEV INEQUALITIES WITH EXTENSIONS TO CONT INUOUS PARAMETER PROCESS, AMS 61, 6B7

BIRNBAUM, $Z$. W. TABLES OF CRITICAL VALUES OF SOME RENYI TYPE STATISTICS FOR FINITE SAMPLE SIZES, JASA 69, 870

BISHIR, J. A LOWER BOUND FOR THE CRITICAL PROBABILITY IN THE ONEQUADRANT ORIENTED-ATOM PERCOLATION PROCE, JRSSB 63, 401

BISHOP, Y. M. M. INCOMPLETE TWO-DIMENSIONAL CONTINGENCY TABLES, BIOCS 69,119

BISHOP, YVONNE M. M. FULL CONTINCENCY TABLES, LOGITS, AND SPLIT CONTINCENCY TA8LES, BIOCS 69, 3B3

BIZLEY, M. T. L, THE TWO-PACK MATCHING PROBLEM, JRSSB 60,114

BLACKWELL, D. NON-EXISTENCE OF EVERYWHERE PROPER CONDITIONAL DISTRIBUTIONS, AMS 63, 223

BLACKWELL, D. THE LAST RETURN TO EQUILIBRIUM IN A COIN TOSSING CAME, AMS 64,1344

BLACKWELL, DAVID MEMORYLESS STRATECIES IN FINITE-STAGE DYNAMIC PROGRAMMINC, AMS 64, 863

BLACKWELL, DAVID A BOREL SET NOT CONTAINING A GRAPH, AMS 6B, 1345

BLACKWELL, DAVID A NOTE ON BAYES ESTIMATES, AMS 67, 1907

BLACKWELL, DAVID A REMARK ON THE GOIN TOSSING GAME, AMS 64, 1345

BLACKWELL, DAVID DISCOUNTED DYNAMIC PROGRAMMING, AMS 65, 226

BLACKWELL, DAVID DISCRETE DYNAMIC PROCRAMMING, AMS 62, 719

BLACKWELL, DAVID MERGING OF OPINIONS WITH INCREASINC INFORMATION AMS 62,882

BLACKWELL. DAVID ON THE LOCAL BEHAVIOR OF MARKOV TRANSITION PROBABILITIES, AMS 68,2123

BLACKWELL, DAVID THE BIG MATCH, AMS 6B, 159

BLACKWELL, DAVID THE TAIL SIGMA-FIELD OF A MARKOV CHAIN AND A THEOREM OF OREY, AMS 64, 1291

BLALOCK JR, H. M. PROBABILISTIC INTERPRET ATIONS FOR THE MEAN SQUARE GONTINCENCY, CORR. 5B 1030, JASA 5B, 102

BLAND, R. P. ON THE DISTRIBUTIONS OF THE RANGE AND MEAN RANCE FOR SAMPLES FROM A NORMAL DISTRIBUTION. BIOKA 66,245

BLANK, A. A. EXISTENCE AND UNIQUENESS OF A UNIFORMLY MOST POWERFUL RANDOMIZED UN8IASED TEST FOR THE BINOM, BIOKA 56, 465

BLIGHT, B. J.N A NOTE ON A MODIFIED EXPONENT IALLY WEIGHTED PREDICTOR, JRSSB 6B, 318

BLISCHKE, W. R. ESTIMATING THE PARAMETERS OF MIXTURES OF BINOMIAL DISTRIBUTIONS, JASA 64,510

BLISCHKE, W. R. MOMENT ESTIMATORS FOR THE PARAMETERS OF A MIXTURE OF TWO BINOMIAL DISTRIBUTIONS, AMS 62, 444

BLISCHKE, W. R. ON NON-RECULAR ESTIMATION, I. VARIANCE BOUNDS FOR EST IMATORS OF LOGATION PARAMETERS, JASA 69, 1056

BLISCHKE, W. R. VARIANCES OF ESTIMATES OF VARIANCE COMPONENTS IN A THREE-WAY CLASSIFICATION, BIOCS 66,553

BLISCHKE, W. R. VARIANCES OF MOMENT ESTIMATORS OF VARIANCE COM

PONENTS IN THE UNBALANCED R-WAY CLASSIFICAT, BIOCS 6B, 527

BLISCHKE, WALLACE R. ASYMPTOTIC PROPERTIES OF SOME ESTIMATORS OF QUANTILES OF CIRCULAR ERROR, JASA 66, 618

BLISS, C. I. A REJECTION CRITERION BASED UPON THE RANCE, BIOKA 56 , 418

BLISS, C. I. A TABLE FOR COMPUTING WORKING ANGLES, BIOCS 6B, 413

BLISS, C. I. FITTINC THE RECTANGULAR HYPERBOLA, BIOCS 66, 573

BLISS, C. I. NECATIVE BINOMIAL DISTRIBUTIONS WITH A COMMON K, BIOKA 58,37

BLISS, C. I. RESPONSE CRITERIA FOR THE BIOASSAY OF VITAMIN K, BIOCS 69, NO. 4

BLOCH, DANIEL A NOTE ON THE ESTIMATION OF THE LOCATION PARAMETER OF THE CAUCHY DISTRIBUTION, JASA 66, B52

BLOCH. DANIEL A. A BAYESIAN STUDY OF THE MULTINOMIAL DISTRIBUTION, AMS 67,1423

BLOCH, DANIEL A. ON A SIMPLE ESTIMATE OF THE RECIPROCAL OF THE DENSITY FUNCTION. AMS 6B, 1083

BLOM, G. CORRIGENDA TO 'TRANSFORMATIONS OF THE BINOMIAL, NECATIVE BINOMIAL, POISSON AND CHI-SOUAREDISTRI, BIOKA 56, 235

BLOM, G. HIERARCHICAL BIRTH AND DEATH PROCESSES. I. THEORY, BIOKA 60,235

BLOM, G. HIERARCHICAL BIRTH AND DEATH PROCESSES. II APPLICATIONS, BIOKA 60,245

BLOM, G. TRANSFORMATIONS OF THE BINOMIAL, NEGATIVE BINOMIAL, POISSON AND CHI-SOUARE DISTRIBUTIONS, BIOKA 54, 302

BLOM, GUNNAR SOME CONTRIBUTIONS TO THE THEORY OF MACHINE INTERFERENCE , BIOKA 63, 135

BLOOD, DWIGHT M. A CROSS-SECTION ANALYSIS OF NON-BUSINESS AIR TRAVEL, JASA $58,92 B$

BLUM, J.R. DISTRIBUTION FREE TESTS OF INDEPENDENCE BASED ON THE SAMPLE DISTRIBUTION FUNCTION, AMS 61, 4B5

BLUM, J.R. ON A CLASS OF SIMPLE RANDOM WALKS, AMS 63, 413

BLUM, J.R. ON A THEOREM OF RENYI CONCERNING MIXINC SEQUENCES OF SETS, AMS 61,257
BLUM. J, R. ON FIXED PRECISION ESTIMATION IN TIME SERIES, AMS 69 1021

BLUM, J R. ON MULTISTACE ESTIMATION, AMS 63, 1452

BLUM, J. R. ON PARTIAL 'A PRIORI' INFORMATION IN STATISTICAL INFERENCE, AMS 67, 1671

BLUM, J.R. ON RANDOM SAMPLINC FROM A STOCHASTIC PROCESS, AMS 64 1713

BLUMEN, ISADORE A NEW BIVARIATE SICN TEST, JASA 5B, 44B

BLUMENSON, L. E. A MATHEMATICAL ANALYSIS OF THE GROWTH AND SPREAD OF BREAST CANCER, BIOCS 69,95

BLUMENSON, L. E. PROPERTIES OF GENERALIZED RAYLEIGH DISTRIBUTIONS AMS 63, 903

BLUMENSTEIN, B. A. A GENERALIZATION OF THE LOCISTIC LAW OF CROWTH, BIOCS 69,577

BLUMENTHAL, R, M. A THEOREM ON STOPP ING TIMES, AMS 64, 1348

BLUMENTHAL, S. PROPORTIONAL SAMPLINC IN LIFE LENGTH STUDIES, TECH 67,205

BLUMENTHAL, SAUL CONTRIBUTIONS TO SAMPLE SPACINGS THEORY, II. TESTS OF THE PARAMETRIC GOODNESS OF FIT AND, AMS 66, 925

BLUMENTHAL, SAUL CONTRIBUTIONS TO SAMPLE SPACINGS THEORY, I. LIMIT DISTRIBUTIONS OF SUMS OF RATIOS OF SPA, AMS 66,904

BLUMENTHAL, SAUL ESTIMATION OF THE LARGER TRANSLATION PARAMETER, AMS 6B, 502

BLUMENTHAL, SAUL ESTIMATION OF THE LARGEST OF TWO NORMAL MEANS, JASA $6 B, 861$

BLUMENTHAL, SAUL ESTIMATION OF TWO ORDERED TRANSLATION PARAMETERS, AMS $6 B, 517$

BLUMENTHAL, SAUL LIMIT THEOREMS FOR FUNCTIONS OF SHORTEST TWO-SAMPLE SPACINGS AND A RELATED TEST, AMS 67, 108

BLUMENTHAL, SAUL MULTINOMIAL SAMPLING WITH PARTIALLY CATEGORIZED DATA, JASA $6 B, 542$

BLUMENTHAL, SAUL THE ASYMPTOTIC NORMALITY OF TWO TEST STATISTICS ASSOCIATED WITH THE TWO-SAMPLE PROBLEM, AMS 63, 1513

BLYTH, C. R. ESTIMATION OF A PARAMETER IN THE CLASSICAL OCCUPANCY PR08LEM, BIOKA 60, IBO

BLYTH, C. R. TABLE OF NEYMAN-SHORTEST UNBIASED CONFIDENCE INTERVALS FOR THE BINOMI AL PARAMETER, BIOKA 60,381

BLYTH, G. R. TABLES OF NEYMAN-SHORTEST UNBIASED CONF IDENCE INTERVALS FOR THE POISSON PARAMETER, BIOKA 61, 191

BOAS, R. P. LIPSCHITZ BEHAVIOR AND INTEGRABILITY OF CHARACTERISTIC FUNCTIONS, AMS 67, 32

BOCK, R. DARRELL PROGRAMMING UNIVARIATE AND MULTIVARIATE ANALYSIS OF VARIANCE, TECH 63,95

BODMER, W. F. DISCRETE STOCHASTIC PROCESSES IN POPULATION GENETICS (WITHDISCUSSION) , JRSSB 60, 21B

BODMER, W. F. THE LIMITINC FREQUENCIES OF INTEGERS WITH A CIVEN PARTITIONAL CHARACTERISTIC, JRSSB 59, 134

$B O E N, J . R$. A QUANT ITATIVE DISGUSSION OF THE EFFECTIVENESS OF VOIDING AS A DEFENCE ACAINST BLADDER INFECT, BIOCS 66,53

$B O E N, J, R$. USE OF PRIOR INFORMATION TO DESIGN A ROUTINE PARALLEL LINE ASSAY, 8IOCS 67,257

BOES, ARDEL $J$. CONDITIONAL PROBABILITY ON SIGMA-COMPLETE 800LEAN ALGEBRAS, AMS 69,970

BOES, D. C. ON THE ESTIMATION OF MIXING DISTRIBUTIONS, AMS 66, 177

BOFINGER, EVE THE GAP TEST FOR RANDOM SEQUENCES, AMS 61, 524

BOFINGER, V. J THE GAP TEST FOR RANDOM SEQUENCES, AMS 61, 524

BOGOROV, V. G. EXPERIMENTAL DEVELOPMENT OF NUTRITIVE MEDIA FOR MICRO-ORGANISMS, BIOKA 68,43

BOGYO, T. P. EST IMATES OF HERITABILITY FROM TRANSFORMED PERCENTAGE SIB DATA WITH UNEQUAL SUBGLASS NUMBERS, BIOCS 65, 1001

BOGYO. THOMAS $P$. GORRECTION TO 'GOEFFICIENTS OF VARIATION OF HERITABILITY ESTIMATES OBTAINED FROM VARIANC, BIOCS 65,265

BOHREN , 8. B. THE EXPECTED MEAN SQUARES IN GENETIC EXPERIMENTS WHEN ONLY ONE PARENT IS IDENTIFIED, BIOCS 65,436

BOHRER, $R$. ON BAYES SRQUENTIAL DESIGN WITH TWO RANDOM VARIABLES, BIOKA 66,469

BOHRER, R. ON SHARPENINC SCHEFFE BOUNDS, JRSSB 67, 110

BOHRER, R. E. SEQUENTIAL COMBINATION CHEMOTHERAPY EXPERIMENTS BIOCS 66, 730

BOHRER, ROBERT A NOTE ON TOLERANCE LIMITS WITH TYPE I CENSORING, TECH 68,392

BOHRER, ROBERT OPERAT INC CHARACTERIST ICS OF SOME SEQUENT IAL DESICN RULES, AMS 68, 1176

BOHRNSTEDT, GEORCE W. ON THE EXACT COVARIANCE OF PRODUCTS OF RANDOM VARIABLES, JASA 69 , N0. 4

BOLGER, E. M. CHARACTERIZATIONS OF SOME DISTRIBUTIONS BY CONDITIONAL MOMENTS, AMS 65, 703

BOMBAY, BARBARA $F$. AN APPROXIMATION OF STUDENT'S T, TECH 65,71

BOOKER, AARON NONLINEAR LEAST SQUARES ESTIMATION, AMS 65, 638

BOOTH, GORDON PLANNING SOME TWO-FACTOR COMPARATIVE SURVEYS, JASA 69,560

BOOTH, KATHLEEN H. V. SOME SYSTEMATIC SUPERSATURATED DESIGNS, TECH 62,489

BORARRAIN, 0. M. APPLICATION OF FINITE ABSORBENT MARKOV CHAINS TO SIB MATING POPULATIONS WITH SELECTION, BIOCS 69, 17

BORCH, K. THE THEORY OF RISK (WITH DISCUSSION), JRSSB 67, 432

BORGES, R. ONE-PARAMETER EXPONENTIAL FAMILIES GENERATED BY TRANSFORMATION CROUPS, AMS 65, 261 
BORGMAN, LEONE. RANDOM HYDRODYNAMIC FORCES ON OBJECTS, AMS 67, 37 BORTS, GEORGE H. REGIONAL CYCLES OF MANUFACTURING EMPLOYMENT IN THE UNITED STATES, 1914-1953, CORR. 60 75, JASA 60, 151

BORUS, MICHAEL E. RESPONSE ERROR IN SURVEY REPORTS OF EARNINGS INFORMATION, JASA 66,729

BOSE, R. C. MOMENTS OF ORDER STATISTICS FROM A NORMAL POPULATION, BIOKA 59,433

BOSE, R. C. ON A BOUND USEFUL IN THE THEORY OF FACTORIAL DESIGNS AND ERROR CORRECT ING CODES, AMS $64,40 B$

BOSE, R. C. ON METHODS OF CONSTRUCTING SETS OF MUTUALLY ORTHOGONAL LATIN SQUARES USING A COMPUTER, TECH 60,507

BOSE, R. C. ON METHODS OF CONSTRUCT ING SETS OF MUTUALLY ORTHOGONAL LATIN SQUARES USING A COMPUTER. II, TECH 61, 111

BOSE. R. C. PAIRED COMPARISON DESIGNS FOR TESTING CONCORDANCE BETWEEN JUDGES, 8IOKA 56. 113

BOSSO. J. A. APPLICATION OF FINITE ABSORBENT MARKOV CHAINS TO STB MATING POPULATIONS WITH SELECTION, 8IOCS 69,17

BOSWELL, $M$. T. DISTRIBUTION OF LIKELIHOOD RATIO IN TESTING AGAINST TREND, AMS 69,371

BOSKELL. M. T. ESTIMATING AND TESTING TREND IN A STOCHASTIC PROCESS OF POISSON TYPE, AMS 66,1564

BOUDREAU. PAUL E FUNCTIONS OF FINITE MARKOV CHAINS AND EXPONENTIAL TYPE PROCESSES, AMS 68,1020

BOKDEN, D. C. LINEAR SEGMENT CONFIDENCE BANDS FOR SIMPLE LINEAR MODELS, JASA 67,403

8OWDEN, DAVID C. CONFIDENCE BANDS OF UNIFORM AND PROPORTIONAL WIDTH FOR LINEAR MODELS, JASA 66, IB2

BOTDEN, DAVID C. QUERY, TOLERANCE INTERVAL IN REGRESSION, TECH 6B 207

BONERS, DAVID A. ESTIMATION IN A HETEROSCEDASTIC REGRESSION MODEL JASA 68,552

BOTKER, ALBERT H. QUALITY AND QUANTITY IN HIGHER EDUCATION, JASA 65

BOTMAN, K. HIGHER MOMENTS OF A MAXIMUM-LIKELIHOOD EST IMATE, JRSSB 63,305

BOTMAN, MARY JEAN SCHOOLING, EXPERIENCE, AND GAINS AND LOSSES IN HUMAN CAPITAL THROUGH MIGRATION, JASA 67,875

BOKMAN, RAYMOND T. CROSSROAD CHOICES FOR THE FUTURE DEVELOPMENT OF THE FEDERAL STATISTICAL SYSTEM, JASA 68, 801

BOMMAN, RAYWOND T. THE AMERICAN STATISTICAL ASSOCIATION AND FEDERAL STATISTICS, JASA 64 , I

BOX, G. E. P. A BASIS FOR THE SELECTION OF A RESPONSE SURFACE DESIGN JASA 59,622

BOX, G. E. P. A BAYESI AN APPROACH TO SOME OUTLIER PROBLEMS, BIOKA 68 119

BOX. G. E. P. A BAYESIAN APPROACH TO THE IUPORTANCE OF ASSUMPTIONS APPLIED TO THE COMPARISON OF VARIANCES, BIOKA 64,153

BOX, G. E. P. A CHANGE IN LEVEL OF A NON-STATIONARY TIME SERIES, BIOKA 65,181

BOX, G. E. P. A CONFIDENCE REGION FOR THE SOLUTION OF A SET OF SIMULTANEOUS EQUATIONS WITH AN APPLICATION, BIOKA 54,190

BOX, G. E. P. A FURTHER LOOK AT ROBUSTNESS VIA BAYES'S THEOREM, BIOKA 62,419

BOX, G. E. P. A NOTE ON CRITERION ROBUSTNESS AND INFERENCE ROBUSTNESS, BIOKA 64,169

BOX, G. E. P. A NOTE ON REGIONS FOR TESTS OF KURTOSIS. BIOKA 53, 465

BOX, G. E. P. AN ANALYSIS OF TRANSFORMATIONS (WITH DISCUSSION) JRSSB 64,211

BOX, G. E. P. BAYESIAN ANALYSIS OF A THREE-COMPONENT HIERARCHICAL DESIGN MODEL, 8IOKA 67, 109

BOX, G. E. P. BAYESIAN ESTIMATION OF MEANS FOR THE RANDOM EFFECT MODEL, JASA 68,174

BOX. G. E. P. CONDENSED CALCULATIONS FOR EVOLUTIONARY OPERATION PROGRAMS. TECH 59,77

BOX, G. E. P CORRIGENDA, 'A FURTHER LOOK AT ROBUSTNESS VIA BAYES'S THEOREM. ', BIOKA 63, 546

BOX, G. E. P. CORRIGENDA. 'ROBUSTNESS TO NON-NORMALITY OF REGRESSION TESTS', BIOKA 65, 669

BOX, G. E. P. CORRIGENDA, 'THE CHOICE OF A SECOND ORDER ROTATABLE DESIGN , BIOKA 65, 305

BOX, G. E. P. DESIGN OF EXPERIMENTS IN NON-LINEAR SITUATIONS, BIOKA 59,77

BOX, G. E. P. DISCRIMINATION AMONG MECHANISTIC MODELS, TECH 67,57

BOX, G. E. P. DISCUSSION OF 'ON THE FOUNDATIONS OF STATISTICAL INFERENCE', JASA 62, 307

BOX, G. E. P. DISCUSSION OF THE PAPERS OF MESSRS. SATTERTHWAITE AND BUDNE, TECH 59,157

BOX, G. E. P. ERRATA, 'SOME NEW THREE LEVEL DESIGNS FOR THE STUDY OF QUANTITATIVE VARIABLES', TECH 61,576

BOX, G. E. P. ERRATA. 'THE 2-TO-THE-(K-P) FRACTIONAL FACTORIAL DESIGNS', TECH 63,417

BOX, G. E. P. ISN 'T MY PROCESS TOO VARIABLE FOR EVOP, TECH $6 B, 439$

BOX, G. E. P. MULTI-FACTOR DESIGNS OF FIRST ORDER, BIOKA 52,49

BOX, G. E. P. MULTIPARAMETER PROBLEMS FROM A BAYESIAN POINT OF VIEW, AMS 65,1468

BOX, G. E. P. NON-NORMALITY AND TESTS ON VARIANCES , BIOKA 53, 318

BOX, G. E. P. PERMUTATION THEORY IN THE DERIVATION OF ROBUST CRITERIA AND THE STUDY OF DEPARTURES FROM AS, JRSSB 55,1
BOX, G. E. P. ROBUSTNESS TO NON-NORMALITY OF REGRESSION TESTS, BIOKA 62,93

BOX, G. E. P, SOME ASPECTS OF RANDOMIZATION, JRSSB 66,543

BOX, G. E. P. SOME NEW THREE LEVEL DESIGNS FOR THE STUDY OF QUANTITATIVE VARIABLES, TECH 60,455

BOX, G. E. P. SOME STATISTICAL ASPECTS OF ADAPTIVE OPTIMIZATION AND CONTROL (WITH DISCUSSION), JRSSB 62, 297

BOX, G. E. P. THE BAYESIAN ESTIMATION OF COMMON PARAMETERS FROM SEVERAL RESPONSES, BIOKA 65,355

BOX, G. E. P. THE EFFECTS OF ERRORS IN THE FACTOR LEVELS AND EXPERIMENT AL DESIGN, TECH 63,247

BOX, G. E. P. THE EXPERIMENTAL STUDY OF PHYSICAL MECHANISMS, TECH 65,23

BOX. G. E. P. THE 2-TO-THE-(K-P) FRACTIONAL FACTORIAL DESIGNS, TECH 61,311

BOX, G. E.P. THE 2-TO-THE- ( $K-P)$ FRACTTONAL FACT ORIAL DESIGNS, II. TECH 61,449

BOX. G. E. P. TRANSFORMATION OF THE INDEPENDENT VARIABLES, TECH 62 . 531

BOX, GEORGE E. P. A NOTE ON AUGMENTED DESIGNS, TECH 66, IB4

BOX, GEORGE E. P. A SIMPLE SYSTEM OF EVOLUTIONARY OPERATION SUBJECT TO EMPIRICAL FEEDBACK, TECH 66, 19

BOX. GEORGE E. P. A USEFUL METHOD FOR MODEL BUILDING, TECH 62, 301

BOX. GEORGE E. P. THE CHOICE OF A SECOND ORDER ROTATABLE DESIGN, BIOKA 63, 335

BOX. GEORGE E. P. USE AND A8USE OF REGRESSION, TECH 66,625

BOX.M. J. THE OCCURRENCE OF REPLICATIONS IN OPTIMAL DESIGNS OF EXPERIMENTS TO ESTIMATE PARAMETERS IN NON, JRSSB 6B, 290

BOYCE, RAY DISTRIBUTION OF RADICAL ERROR IN THE BIVARIATE ELLIPTICAL NORMAL DISTRIBUTION, TECH 62, 13B

BOYD, D. W. SERIES REPRESENTATIONS OF DISTRIBUTIONS OF QUADRATIC FORMS IN NORH'AL VARIABLES, I, CENTRAL CA, AMS 67. B23

BOYD, D. T. SERIES REPRESENTATIONS OF DISTRIBUTIONS OF QUADRATIC FORMS IN NORMAL YARIABLES, II, NON-CENTR, AMS 67,838

BOYD, WILLIAM C. A NOMOGRAM FOR CHI-SQUARE, CORR. 66 1246, JASA 65 344

BOYD, WILLIAM C. A NOMOGRAM FOR THE 'STUDENT' *FISHER T TEST, JASA 69, N0.4

BOYLE, J. A. A COMPARISON OF STATISTICAL TECHNIQUES IN THE DIFFERENT IAL DIAGNOSIS OF NONTOXIC GOITRE, 8IOCS 68,103

BRACKEN, JEROME PERCENTAGE POINTS OF THE 8ETA DISTRIBUTION FOR USE IN BAYESIAN ANALYSIS OF BERNOULLI PROC, TECH 66, 6B7

BRADLEY, HUGH E. MULTIPLE CLASSIFICATION ANALYSIS FOR ARBITRARY EXPERTMENTAL DESIGN, TECH $6 \mathrm{~B}, 13$

BRADLEY, JAMES $V$. COMPLETE COUNTERBALANCING OF IMMEDIATE SEQUENTIAL EFFECTS IN A LATIN SQUARE DESIGN, COR, JASA 5B, 525

BRADLEY, $R$, A CORRIGENDA. 'THE RANK ANALYSIS OF INCOMPLETE'BLOCK DESIGNS. II. ADDITIONAL TABLES FOR THE, BIOKA 64,288

BRADLEY. R. A. MULTIVARIATE PAIRED COMPARISONS. THE EXTENSION OF A UNIVARIATE MODEL AND ASSOCIATED ESTIMA, BIOKA 69, B]

BRADLEY, R, A, ONE-WAY VARIANCES IN A TWO-WAY CLASSIFICATION, BIOKA 58,111

BRADLEY, R. A. RANK ANALYSIS OF INCOMPLETE BLOCK DESIGNS. II. ADDITIONAL TABLES FOR THE METHOD OF PAIRED, BIOKA 54. 502

BRADLEY, $R$. A. RANK ANALYSIS OF INCOMPLETE BLOCK DESIGNS. III. SOME LARGE-SAMPLE RESULTS ON ESTIMATION AN, 8IOKA 55, 450

BRADLEY, RALPH SEQUENTIAL CHI-SQUARE AND T-SQUARE TESTS AND THEIR APPLICATION TO AN ACCEPTANCE SAMPLING P, TECH 61, 519

BRADLEY, RALPH A. SEQUENTIAL CHI-SQUARED AND T-SQUARED TESTS, AMS 61,1063

BRADLEY, RALPH A SEQUENTIAL RANK TESTS I. MONTE CARLO STUDIES OF THE TWO-SAMPLE PROCEDURE, TECH 65,463

BRADLEY, RALPH A. SEQUENTIAL RANK TESTS II. MODIFIED TWO-SAMPLE PROCEDURES, TECH 66,615

BRADLEY, RALPH A THE ASYMPTOTIC PROPERTIES OF MAXIMUM LIKELIHOOD ESTIMATORS WHEN SAMPLING FROW ASSOCIATE, BIOKA 62, 205

BRADLEY, RALPH ALLAN RANK ANALYSIS OF INCOMPLETE BLOCK DESIGNS. I. THE METHOD OF PAIRED COMPARISONS., BIOKA 52,324

BRADU, DAN MAIN-EFFECT ANALYSIS OF THE GENERAL NON-ORTHOGONAL LAYOUT WITH ANY NUMBER OF FACTORS. AMS 65.88

BRAGA-ILLA, ALVISE A SIMPLE APPROACH TO THE BAYES CHOICE CRITERION, THE METHOD OF EXTREME PROBABILITIES, JASA 64,1227

BRAINERD, B. A NOTE ON SIMPLE BINOUI AL SAMPLING PLANS, AMS 61,906

BRANDWOOD, L. ON A DISCRIMINAT ORY PROBLEM CONNECTED WITH THE WORKS OF PLATO, JRSSB 59, 195

BRASS, W. SIMPLIFIED METHODS OF FITTING THE TRUNCATED NEGATIVE BINOMIAL DISTRIBUTION, 8IOKA 58,59

BRAY. D. F. EXPECTED EFFECTS ON THE INBREEDING COEFFICIENT AND RATE OF GENE LOSS OF FOUR METHODS OF REPRO, BIOCS 65,447

BREAKWELL, JOHN SEQUENTIAL TESTS FOR THE MEAN OF A NORMAL DISTRIBUTION II, LARGE T. AMS 64,162

BREAKTELL, JOHN V. ECONOMICALLY OPTIMUM ACCEPTANCE TESTS, JASA 56 , 243

BREIMAN, LEO A DELICATE LAW OF THE ITERATED LOGARITHM FOR NONDECREASING STABLE PROCESSES (ADDENDUM, 69 1, AMS 68, 1818

BREIMAN, LEO CONSISTENT EST IMATES AND ZERO-ONE SETS, AMS 64, 157

BREIMAN, LEO CONVERGENCE PROPERTIES OF A LEARNING ALGORITHM, AMS 64.1819 
BREIMAN, LEO THE POISSON TENDENCY IN TRAFF IC DISTRIBUTION, AMS 63 308

BREITENBERCER, ERNEST ANALOCUES OF THE NORMAL DISTRIBUTION ON THE CIRCLE AND THE SPHERE, 8IOKA 63, 81

BRELSFORD, W. M. TIME SERIES WITH PERIODIC STRUCTURE, BIOKA 67, 403 BREMS, HANS WACE, PRICE, AND TAX ELASTICITIES OF OUTPUT AND DISTRIBUTIVE SHARES, JASA 62, 607

BRENNA, LEROY STANLEY FACTORIAL TREATMENTS IN RECTANCULAR LATTICE DESICNS, JASA 61, 36B

BRETHERTON, M. H. TABLES OF THE LOCARITHMIC SERIES DISTRIBUTION, AMS 64, 284

BREUER, M. A . THE BOREL-TANNER DISTRIBUTION, BIOKA 60, 143

BREWER, K. R. W. A NOTE ON FELLECI'S METHOD OF SAMPLINC WITHOUT REPLACEMENT WITH PROBABILITY PROPORTIONAL, JASA 67, 79

BRILLINCER, D. R. A MOVING AVERAGE REPRESENTAT ION FOR RANDOM VARIABLES COVARIANCE STAT IONARY ON A FINITE, BIOKA 65, 295

BRILLINCER, D. R. AN EXTREMAL PROPERTY OF THE CONDITIONAL EXPECTATION, BIOKA 66,594

BRILLINCER, D. R. ASYMPTOTIC PROPERTIES OF SPECTRAL ESTIMATES OF SECOND ORDER, BIOKA 69,375

BRILLINCER, D. R. EST IMATION OF THE GROSS-SPECTRUM OF A STATIONARY BIVARIATE GAUSSIAN PROCESS FROM ITS ZE, JRSSB 68, 145

BRILLINCER, DAVID AN INTRODUCTION TO POLYSPECTRA, AMS 65, 1351

8RILLINCER, DAVID R. A NOTE ON THE RATE OF CONVERGENCE OF A MEAN, BIOKA 62,574

BRILLINCER, DAVID R. A NOTE ON THE RE-USE OF SAMPLES, AMS 63, 341

BRILLINCER, DAVID R. EXAMPLES BEARING ON THE DEFINITION OF FIDUCIAL PROBABILITY WITH A BIBLIOCRAPHY, AMS 62,1349

BRILLINCER, DAVID R. NECESSARY AND SUFFICIENT CONDITIONS FOR A STATISTICAL PROBLEM TO 8E INVARIANT UNDER, AMS 63, 492

BRINEGAR, C. S. STATISTICAL ESTIMATION OF THE GASOLINE OCTANE NUMBER REQUIREMENT OF NEW MODEL AUTOMOBILES, TECH 60, 5

BRINEGAR, CLAUDE S. MARK TWAIN AND THE OUINTUS CURTIUS SNODCRASS LETTERS. A STATISTICAL TEST OF AUTHORSHI, JASA 63.85

BROADBENT, S. R, EXAMINATION OF A QUANTUM HYPOTHESIS BASED ON A SINGLE SET OF DATA, BIOKA 56,32

BROADBENT, S. R, LOGNORMAL APPROXIMATION TO PRODUCTS AND QUOTIENTS, BIOKA 56,404

BROADBENT, S. R, QUANTUM HYPOTHESES, BIOKA 55, 45

BROADBENT, S.R. THE INSPECTION OF A MARKOV PROCESS, JRSSB 58, 111

BROADBENT. S. R. THE QUOTIENT OF A RECTANGULAR OR TRIANGULAR AND A CENERAL VARIATE, BIOKA 54,330

BROCK, N A SCREENINC SYSTEM FOR ANTI-CANCER AGENTS BASED ON THE THERAPEUTIC INDEX, BIOCS 65,150

BROEMELINC, L. D. CONF IDENCE INTERVALS FOR MEASURES OF HER ITABILITY, BIOCS 69,424

BROEMELINC，L. D. GONF IDENCE REGIONS FOR VARIANCE RATIOS OF RANDON MODELS, JASA 69,660

BRONS, H. K. GENERALIZED MEANS AND ASSOCIATED FAMILIES OF DISTRIBUTIONS, AMS 69,339

BROOK, D. ON THE DISTINCTION BETWEEN THE GONDITIONAL PROBABILITY AND THE JOINT PROBABILITY APPROACHES IN. BIOKA 64, 4B I

BROOKHOUSE, J . K. SOME ACCEPTANCE SAMPLING PLANS BASED ON THE THEORY OF RUNS, TECH 62,177

BROSS, I. D. J. A MATHEMATICAL ANALYSIS OF THE GROWTH AND SPREAD OF BREAST CANCER, BIOCS 69,95

BROSS, IRWIN D. J. DISCUSSION OF 'A SUB.JECTIVE EVALUATION OF 8ODE' LAW AND AN 'OBJEGT IVE' TEST FOR APPRO, JASA 69, 50

BROSS, IRWIN D. J. DISCUSSION OF 'ON THE FOUNDATIONS OF STATISTICAL INFERENCE', JASA 62, 307

BROSS, IRWIN D. J. OUTLIERS IN PATTERNED EXPERIMENTS. A STRATECIC APPRAISAL, TEGH 61,91

BROSS, IRWIND, J. RAPID ANALYSIS OF $2 X 2$ TABLES, JASA 57,1

BROSS, IRWIND. J. TAKINC A COVARIABLE INTO ACCOUNT, JASA 64, 725

BROWN JR, 8. W. PLANNING A QUANTAL ASSAY OF POTENCY, 8IOGS 66, 322

BROWN JR, B. W, USE OF PRIOR INFORMATION TO DESIGN A ROUTINE PARALLEL

LINE ASSAY, BIOCS 67,257

BROWN JR, B. WM. SOME PROPERT IES OF THE SPEARMAN EST IMATOR IN BIOASSAY, BIOKA 61, 293

BROWN, B. M. USE OF RANCE IN TESTING HETEROCENEITY OF VARIANCE BIOKA 66,221

BROWN, BARRY $W$, ON THE ITERATIVE METHOD OF DYNAMIC PROGRAMMING ON A FINITE SPACE DISCRETE TIME MARKOV PRO, AMS 65,1279

BROWN, BRUCE M. MOMENTS OF A STOPPING RULE RELATED TO THE CENTRAL LIMIT THEOREM, AMS 69, 1236

BROWN, G, H. AN EMPIRICAL STUDY OF THE DISTRIBUTION OF THE SAMPLE GENETIC CORRELATION COEFFICIENT. BIOCS 69.63

BROWN, G. H. THE USE OF CORRELATED VARIABLES FOR PRELIMINARY CULLINC, BIOCS 67,551

BROWN, J.A. C. AN ESTIMATION PROBLEM IN QUANTITATIVE ASSAY, BIOKA $54.33 \mathrm{~B}$

BROWN, L. INADMISSIBILITY OF THE USUAL EST IMATORS OF SCALE PARAMETERS IN PROBLEMS WITH UNKNOWN LOCATION A, AMS 6B, 29

BROWN, L. SUFFICIENT STATISTICS IN THE CASE OF INDEPENDENT RANDOM VARIABLES, AMS 64, 1456

BROWN, L. THE CONDITIONAL LEVEL OF STUDENT'S T TEST, AMS 67, 1068

BROWN, LAWRENCE DAVID ON THE ADMISSIBILITY OF INVARIANT ESTIMATORS OF ONE OR MORE LOCATION PARAMETERS, AMS 66, 1087
BROWN, M. 8. THE TWO MEANS PROBLEM A SECONDARILY BAYES APPROACH BIOKA 67,85

BROWN, MORTON B BOUNDS ON THE DISTRIBUTION FUNCTIONS OF THE BEHRENS-FISHER STATISTIC, AMS 66, 639

BROWN, MURRAY A FORECASTINC MODEL OF FEDERAL PURCHASES OF COODS AND SERVICES, JASA 62,633

BROWN, MURRAY EX ANTE AND EX POST DATA IN INVENTORY INVESTMENT, JASA 61,518

BROWN, R. L . 8IVARIATE STRUCTURAL RELATION, BIOKA 57, 84

BROWN, R . L. MULTIVARIATE LINEAR STRUCTURAL' RELATIONS, BIOKA 58 . 136

BROWN, SUSANNAH CENERALISED COVARIANCE ANALYSIS WITH UNEQUAL ERROR, BIOCS 69 , NO 4

BROWN, SUSANNAH THE QUANTAL RESPONSE ANALYSIS OF A SERIES OF BIOLOGICAL ASSAYS ON THE SAME SUB JEGTS, BIOKA 60,23

BROWN, THOMAS A. ENTROPY AND CONJUGACY, AMS 63,226

BROWNLEE, K, A. A NOTE ON THE EFFECTS OF NONRESPONSE ON SURVEYS, JASA 57,29

8ROWNLEE, K. A, A REVIEW OF 'SMOKING AND HEALTH' , JASA 65, 722

BROWNLEE, $K$. A. STATISTICAL EVALUATION OF CLOUD SEEDING OPERA TIONS, JASA 60,446

BRUCKNER, L. INTERPOLATION OF HOMOGENEOUS RANDOM FIELDS ON DISCRETE GROUPS, AMS 69,251

BRUNK, H. D. CONDITIONAL EXPECTATION GIVEN A SICMA-LATTICE AND APPLICATIONS, AMS 65, 1339

BRUNK, H, D. DISTRIBUTION OF LIKELIHOOD RATIO IN TESTING AGAINST TREND, AMS 69,371

BRUNK, H. D. CENERALIZED MEANS AND ASSOCIATED FAM ILIES OF DISTRIBUTIONS, AMS 69,339

BRUNK, H. D. MATHEMATICAL MODELS FOR RANKINC FROM PAIRED COMPARISONS, JASA 60, 503

BRUNK, H. D. MAXIMUM LIKELIHOOD ESTIMATION OF THE DISTRIBUTIONS OF TWO STOCHAST I CALLY ORDERED RANDOM V ARI, JASA 66, 1067

BRUNK, H, D, ON THE RANGE OF THE DIFFERENCE BETWEEN HYPOTHETICAL DISTRIBUTION FUNCTION AND PYKE' S MODIF IE, AMS 62, 525

BRYAN-JONES, J, A DESICN BALANCED FOR TREND, BIOKA 6B, 535

BRYANT, EDWARD C. DESIGN AND EST IMATION IN TWO-WAY STRATIFICATION, JASA 60, 105

BRYSON, MARION R ERRORS OF CLASSIFICATION IN A BINOMIAL POPULATION, JASA 65,217

BRYSON, MAURICE G. SOME CRITERIA FOR AGINC, JASA 69, NO 4

BUCK, S. F . A METHOD OF ESTIMATION OF MISSING VALUES IN MULT IVARIATE DATA SUITABLE FOR USE WITH AN ELECTR, JRSSB 60, 302

BUCKLE. N. AN APPROXIMATION TO THE WILCOXON-MANN-WHITNEY DISTRIBUTION, JASA 69, 591

BUCKLEY, D. J, SOME RESULTS FOR FIXED-TIME TRAFFIC SIGNALS, JRSSB 64. 133

BUCY, R. S. REGURRENT SETS, AMS 65, 535

BUDNE, T A A ERRATA, 'THE APPLICATION OF RANDOM BALANCE DESIGNS' TECH 59, 419

BUDNE, T. A. THE APPLICATION OF RANDOM BALANCE DESICNS, TECH 59, 139 BUECHLEY, ROBERT W. A REPRODUCIBLE METHOD OF COUNTINC PERSONS OF SPANISH SURNAME, JASA 61,88

BUEHLER, R J. CONFIDENCE LIMITS FOR THE RELIABILITY OF SERIES SYSTEMS, JASA 67,1452

BUEHLER, R. J. FIDUCIAL THEORY AND INVARI ANT EST IMATION, AMS 66, 643 BUEHLER, R. J FIDUCIAL THEORY AND INVARIANT PREDICTION, AMS 67, 795 BUEHLER, R. J. NOTE ON A GONDIT IONAL PROPERTY OF STUDENT' $S T$, AMS 63 . 1098

BUEHLER, R. J. SOME INFERENCES ABOUT CAMMA PARAMETERS WITH AN APPLICATION TO A RELIABILITY PROBLEM，JASA 63, 670

BUEHLER, ROBERT J GONFIDENCE INTERVALS FOR THE PRODUCT OF TWO BINOMIAL PARAMETERS, JASA 57, 4B2

BUEHLER, ROBERT J. THE LIMIT OF THE NTH POWER OF A DENSITY, AMS 65. 1B7B

BUENAVENTURA. ANGELES R. UPPER PERCENTAGE POINTS OF A SUBSTITUTE FRATIOUSING RANCES, BIOKA 61, 195

BUHLER, WOLFCANG J, SLOWLY BRANCHINC PROCESSES, AMS 67, 919

BUHLER, WOLFCANC J. THE TREATMENT OF TIES IN THE WILCOXON TEST, AMS 67,519

BUHLMANN, HANS PAIRWISE COMPARISON AND RANKING IN TOURNAMENTS, AMS 63,501

BULGREN. W. C. A NOTE ON REPRESENTATIONS OF THE DOUBLY NON-CENTRAL T DISTRIBUTION, JASA 6B, 1013

BULCREN, W. C. AN ESTIMATION PROCEDURE FOR MIXTURES OF DISTRIBUTIONS, JRSSB 68,444

BULCREN, WILLIAM G. A NOTE ON A DOUBLE SAMPLE TEST, JASA 69, N0, 4 BULMER, M. G. APPROXIMATE CONF IDENCE LIMITS FOR COMPONENTS OF VARIANCE, BIOKA 57,159

BULMER, M. G. CONFIDENCE INTERVALS FOR DISTANCE IN THE ANALYSIS OF VARIANCE, BIOKA 58,360

BULMER, M . C . CONFIRMING STATIST ICAL HYPOTHESES, JRSSB 57, 125

BURCH, S. W. THE FORECASTING ACCURACY OF CONSUMER ATTITUDE DATA, JASA 69 , N0. 4

BURCH, SUSAN W. SELECTED ECONOMIC DATA, ACCURACY VS. REPORTING SPEED, JASA 6B, 436

BURDICK, DONALD S. COMPUTER SIMULATION EXPERIMENTS WITH ECONOMIC SYSTEMS THE PROBLEM OF EXPERIMENTAL DES, JASA 67, 1315 
BURK, MARCUERITE C. SOME ANALYSES OF INCOME-FOOD RELATIONSHIPS, JASA 58,905

BURKE, CEORCE A UNIFORM ERCODIC THEOREM, AMS $65,1 B 53$

BURKE, P. J. THE DEPENDENCE OF DELAYS IN TANDEM QUEUES, AMS 64,874

BURKE, P. J. THE OUTPUT PROCESS OF A STATIONARY M-MS QUEUEINC SYSTEM, AMS 68, 1144

BURKHOLDER, D. L. INDEPENDENT SEQUENCES WITH THE STEIN PROPERTY, AMS $68,12 B 2$

BURKHOLDER, D. L. MART INCALE TRANSFORMS, AMS 66, 1494

BURKHOLDER, D. L : ON THE ORDER STRUCTURE OF THE SET OF SUFFICIENT SUBF IELDS. AMS 62,596

BURKHOLDER, D. L. OPTIMUM PROPERT IES AND ADMISSIBILITY OF SEQUENTIAL TESTS, AMS 63,1

BURKHOLDER, D. L. SUCCESSIVE CONDITIONAL EXPECTATIONS OF AN INTECRABLE FUNCTION, AMS 62,887

BURKHOLDER, D. L. THE SUFFICIENCY IN THE UNDOMINATED CASE, AMS 61 , 1191

BURNABY. T. P. GROWTH-INVARIANT DISCRIMINANT FUNCTIONS AND GENERALIZED DISTANCES, BIOCS 66,96

BURNETT-HALL, D. G. INDICES OF SYNCHRONY IN CELLULAR CULTURES, 8IOCS 67.693

BURR, E. J. DISTRIBUTION OF THE TWO-SAMPLE CRAMER-VON MISES CRITERION FOR SMALL EQUAL SAMPLES, AMS 63, 95

BURR, E. J. LONGEST RUN OF CONSECUTIVE OBSERVATIONS HAVINC A SPECIFIED ATTRIBUTE, BIOKA 61, 461

BURR, E. J. SMALL-SAMPLE DISTRIBUTIONS OF THE TWO-SAMPLE CRAMERVON MISES' W-SQUARED AND WATSON' S U-SQUAR, AMS 64. 1091

BURR, E. J. THE DISTRIBUTION OF KENDALL'S SCORE S FOR A PAIR OF TIED RANKINGS, BIOKA 60, 151

BURR, IRVINC $W$. A USEFUL APPROXIMATION TO THE NORMAL DISTRIBUTION FUNCTION, WITH APPLICATION TO SIMULATIO. TECH 67,647

BURR. IRVINC W. CORRECTION, 'CALCULATION OF EXACT SAMPLINC DISTRIBUT ION OF RANGES FROM A DISCRETE POPULAT, AMS 67, 280

BURR, IRVING $\mathbb{W}$. ON A CENERAL SYSTEM OF DISTRIBUTIONS. I. ITS CURVESHAPE CHARACTERISTICS II. THE SAMPLE M, JASA 68,627

BURR, IRVING W. ON A GENERAL SYSTEM OF DISTRIBUTIONS, III. THE SAMPLERANGE, JASA 68,636

BURR, IRVING $W$. QUERY, CALCULATION OF THE SAMPLINC DISTRIBUTION OF THE RANCE, TECH 65,73

BURROWS, C. CORRICENDA, 'SOME NUMERICAL RESULTS FOR WA ITING TIMES IN THE QUEUE E-SU8-K-M-1, ', BIOKA 60,484

BURROWS. C. SOME NUMERICAL RESULTS FOR WAITING TIMES IN THE QUEUE ESUB-K-M-1. BIOKA 60,202

BURROWS, G. L. AN ASYMPTOTIC DISTRIBUTION FOR AN OCCUPANCY PROBLEM WITH STATISTICAL APPLICATIONS, TECH 61,79

BURROWS, C. L. ERRATA. 'THE EFFECT OF SEQUENTIAL BATCHING FOR ACCEPTANCE-REJECTION SAMPLINC UPON SAMPLE A, TECH 61,131

BURROWS, G. L. THE EFFECT OF SEQUENT IAL BATCHING FOR ACCEPT ANCE, REJECT ION SAMPLING UPON SAMPLE ASSURANCE, TECH 60,19

BURSTEIN, HERMAN APPROXIMATINC THE LONER BINOMIAL CONFIDENCE LIMIT (CORR. 69 669), JASA 68, 1413

BUSH, K. A. CORRIGENDA, 'EXTREMA OF QUADRATIC FORMS WITH APPLICATIONS TOSTATISTICS', BIOKA 61, 474

BUSH, K. A. EXTREMA OF QUADRATIC FORMS WITH APPLICATIONS TO STATISTICS. BIOKA $59,4 B 3$

BUSH, NORMAN A COMPARISON OF THREE DIFFERENT PROCEDURES FOR ESTIMATING VARIANCE COMPONENTS, TECH 63,421

BUSH, SEYMOUR A PROCEDURE FOR CONSTRUCTINC INCOMPLETE BLOCK DESIGNS, TECH 64,389

BUTCHER, J. C. TREATMENT VARIANCES FOR EXPERIMENTAL DESIGNS WITH SERIALLY CORRELATED OBSERVATIONS, 8IOKA 56, 208

BUTLER, CALVIN ASYMPTOTIC JOINT DISTRIBUTION OF LINEAR SYSTEMATIC STATISTICS FROM MULT IVARIATE DISTRIBUTI, JASA 69, 300

BUTLER, CALVIN C. A TEST FOR SYMMETRY USINC THE SAMPLE DISTRIBUTION FUNCTION, AMS 69, N0.6

CABELLO, OCTAVIO THE USE OF STATISTICS IN THE FORMULATION AND EVALUATION OF SOCIAL PROCRAMMES, JASA 60,454

CACOULLOS, T . ASYMPTOTIC DISTRIBUTION FOR A GENERALIZED BANACH MATCH BOX PROBLEM, JASA 67,1252

CACOULLOS, T. ON A CLASS OF ADMISSIBLE PARTITIONS. AMS 66, 189

CACOULLOS, T. ON THE 8IAS OF FUNCTIONS OF CHARACTERISTIC ROOTS OF A RANDOM MATRIX, 8IOKA 65.87

CACOULLOS, T. ON THE DISTRIBUTION OF THE BIVARIATE RANGE, TECH 67 476

CACOULLOS, T. A. A COMBINATORIAL DERIVATION OF THE DISTRIBUTION OF THE TRUNCATED POISSON SUFFICIENT STATI, AMS 61,904

CACOULLOS. THEOPHILOS A RELATION BETWEEN T AND F-DISTRIBUTIONS, CORR. 651249, JASA 65,528

CACOULLOS. THEOPHILOS CHARACTERIZATIONS OF NORMALITY BY CONSTANT RECRESSION OF LINEAR STATISTICS ON ANOTH, AMS 67, 1 B9 4

CADWELL. J. H. AN APPROXIMATION TO THE SYMMETRICAL INCOMPLETE BETA FUNCTION, BIOKA 52,204

CADWELL, J. H. APPROXIMATING TO THE DISTRIBUTIONS OF MEASURES OF DISPERSION BY A POWER OF CHI-SQUARE, BIOKA 53, 336

CADHELL, J. H. THE BIVARIATE NORMAL INTEGRAL, BIOKA 51, 475

CADHELL, J $\mathrm{H}$. THE DISTRIBUTION OF QUANTILES OF SMALL SAMPLES, BIOKA 52,207
CADWELL, J, H. THE STATISTICAL TREATMENT OF MEAN DEVIATION, BIOKA 54,12

CACAN, PHILLIP THE USE OF WEALTH TO COMPARE HOUSEHOLDS ' AVERACE SAVINC. JASA 64,737

CALINSKI, T. ON THE DISTRIBUTION OF THE F-TYPE STATISTICS IN THE ANALYSIS OF A CROUP OF EXPERIMENTS, JRSSB 66,526

CAMERON, J. M. THE STATIST ICAL CONSULTANT IN A SCIENTIFIC LABORATO. RY, TECH 69, 247

CAMPBELL, R. C. THE CHICK ASSAY OF LYSINE, BIOCS 66,58

CAMPBELL, VINCENT N. A NOTE ON CALCULAT INC TAU AND AVERACE TAU AND ON THE SAMPLINC DISTR IBUT ION OF AVERAC, JASA 62,567

CAMPLINC, C. E. C. SERIAL SAMPLINC ACCEPTANCE SCHEMES FOR LARCE BATCHES OF ITEMS WHERE THE MEAN QUALITY H, BIOKA 68,393

CAMPLINC, C. E. C. THE DECISION THEORY APPROACH TO SAMPLINC INSPECTION (WITH DISCUSSION), JRSSB 66, 381

CANE, CWENDA LONCEST RUN OF CONSECUTIVE OBSERVATIONS HAVINC A SPECIFIED ATTRIBUTE, BIOKA 61,461

CANE, VIOLET R. BEHAVIOUR SEQUENCES AS SEMI-MARKOV CHAINS (WITH DISCUSSION , JRSSB 59, 36

CANE, VIOLET R. ON THE SIZE OF AN EPIDEMIC AND THE NUMBER OF PEOPLE HEARING A RUMOUR. JRSSB 66,487

CANE, VIOLET R. SOME STATISTICAL PROBLEMS IN EXPERIMENTAL PSYCHOLOCY (WITHDISCUSSION), JRSSB 56, 177

CANNINGS, C. A GRAPHICAL METHOD FOR THE STUDY OF COMPLEX GENETICAL SYSTEMS WITH SPECIAL REFERENCE TO EQUI, BIOCS 69, NO.4

CANNINGS. C. EQUILIBRIUM UNDER SELECTION AT A MULTI-ALLELIC SEXLINKED LOCUS (ACKNOWLEDCEMENT 68 1025), BIOCS 68,187

CANTEY, WILBERT E. THE OPTIMUM STRATECY IN BLACKJACK, CORR. 59810. JASA 56, 429

CAPON. JACK A NOTE ON THE ASYMPTOTIC NORMALITY OF THE MANN-WHITNEYWILCOXON STATISTIC. JASA 61,687

CAPON. JACK ASYMPTOTIC EFFICIENCY OF CERTAIN LOCALLY MOST POWERFUL RANK TESTS, AMS 61,88

CAPON. JACK ON THE ASYMPTOTIC EFFICIENCY OF THE KOLMOCOROV-SMIRNOV TEST, JASA 65,843

CAPON, JACK RADON-NIKODYM DERIVATIVES OF STATIONARY GAUSSIAN MEASURES, AMS 64,517

CARLSON, F. D. LINEAR RELATIONSHIPS BETWEEN VARIABLES AFFECTED BY ERRORS, 8IOCS 66,252

CARLSON. P. G. A NOTE ON MIDRANGE. AMS 65, 1052

CARLSSON. SIV SOME PROPERTIES OF STATISTICAL RELIABILITY FUNCTIONS. AMS 66, B26

CARLYLE, J. $W$. IDENTIFICATION OF STATE-CALCULABLE FUNCTIONS OF FINITE MARKOV CHAINS. AMS 67,201

CARNEY, EDWARD J. RELATIONSHIP OF GENERALIZED POLYKAYS TO UNRESTR ICTED SUMS FOR BALANCED COMPLETE FINITE, AMS 6B, 643

CARPENTER, J. A. THE MILLS RATIO AND THE PROBABILITY INTEGRAL FOR A PEARSON TYPE IV DISTRIBUT ION., BIOKA 65, 119

CARTER, CHARLES F. A TEST OF THE ACCURACY OF A PRODUCTION INDEX. JASA 56,17

CASAS, EDUARDO SPATIAL RELATIONSHIP AMONG EICHT POPULATIONS ZEA MAYS L. UTILIZINC INFORMATION FROM A DIAL, BIOCS $68, B 67$

CASLEY, D. J. A QUICK EST IMATE OF THE RECRESSION COEFFICIENT, BIOKA 58.431

CATTELL, R. B. FACTOR ANALYSIS. AN INTRODUCTION TO ESSENTIALS. 1. THE PURPOSE AND UNDERLY INC MODELS. BIOCS 65,190

CATTELL, RAYMOND B. FACTOR ANALYSIS, AN INTRODUCTION TO ESSENTIALS. 2. THE ROLE OF FACTOR ANALYSIS INRES, BIOCS 65,405

CAUSEY, B. D. SOME EXAMPLES OF MULTI-DIMENSIONAL INCOMPLETE BLOCK DESIGNS, AMS 68,1577

CAUSTON, D. R. A COMPUTER PROGRAM FORFITTING THE RICHARDS FUNCTION. BIOCS 69,401

CAUSTON, D. R. ADJOINT MATRICES FOR POLYNOMIAL REGRESSION (CORRECTIONS 68 1025), BIOCS 68,401

CAVALLI-SFORZA, L. L. A METHOD FOR CLUSTER ANALYSIS, BIOCS 65,362

CELL. JOHN W. THE DISTRIBUTION OF THE PRODUCT OF TWO CENTRAL OR NONCENTRAL CHI-SQUARE VARIATES, AMS 62, 1016

CHACKO, V. J. TESTING HOMOGENEITY AGAINST ORDERED ALTERNATIVES, AMS 63.945

CHADDHA, R. L. AN EMPIRICAL COMPARISON OF DISTANCE STATISTICS FOR POPULATIONS WITH UNEQUAL COVARIANCE MAT, BIOCS 6B, 683

CHAKRABARTY, R.P. SAMPL ING TECHNIQUES FOR EST IMATION OF INCIDENCE OF RED SP IDER MITE ON TEA CROP IN NORT, BIOCS 66,385

CHAKRAVARTI, I. M. ASYMPTOTIC RELATIVE EFFICIENCY OF MOOD'S AND MASSEY 'S TWO SAMPLE TESTS AGAINST SOME PA, AMS 62, 1375

CHAKRAVARTI, I. M. ON METHODS OF CONSTRUCTING SETS OF MUTUALLY ORTHOGONAL LAT IN SQUARES USING A COMPUTER, TECH 60,507

CHAKRAVARTI. I. M. ON METHODS OF CONSTRUCTING SETS OF MUTUALLY ORTHOGONAL LAT IN SQUARES USING A COMPUTER . . TECH 61, 111

CHAKRAVARTI, I. M. ON SOME METHODS OF CONSTRUCTION OF PARTIALLY BALANCED ARRAYS. AMS 61,1181

CHAKRAVARTI, I. M. QUERY, SMALL TR IMMED SAMPLES, TECH 66, 193

CHAMBERS, C. EXTENSION OF TABLES OF PERCENTAGE POINTS OF THE LARGEST VARIANCE RATIO S-SQUARE-MAX-OVER-S-S, 8IOKA 67, 225

CHAMBERS, ELIZABETH A. DISCRIMINATION BETWEEN ALTERNATIVE BINARY RESPONSE MODELS. BIOKA 67.573

CHAMBERS, J. M. ON METHODS OF ASYMPTOTIC APPROXIMATION FOR MULTIVARI ATE DISTRIBUTIONS, 8IOKA 67,367 
CHAMBERS, M. L. USE OF DOUBLE SAMPLING FOR SELECTINC BEST POPULATION, BIOKA 64,49

CHAMPERNOWNE. D. C. AN ELEMENTARY METHOD OF SOLUTION OF THE QUEUEINC PROBLEM WITH A SINGLE SERVER AND CON. JRSSB 56,125

CHAN. L. K. ON CUPTA 'S ESTIMATES OF THE PARAMETERS OF THE NORMAL DISTRIBUTION. BIOKA 64.498

CHAN. L. K. REMARK ON THE LINEARIZED MAXIMUM LIKELIHOOD ESTIMATE, AMS $67.1 \mathrm{~B} 76$

CHAN, LAI K. SOME BOUNDS FOR EXPECTED VALUES OF ORDER STATISTICS, AMS 65.1055

CHAN. NAI NG. ON CIRCULAR FUNCTIONAL RELATIONSHIPS, JRSSB 65,45

CHANDA, K. C. A NOTE ON THE CONSISTENCY AND MAXIMA OF THE ROOTS OF LIKELIHOOD EQUATIONS, BIOKA 54,56

CHANDA, K. C. ASYMPTOTIC EXPANSIONS FOR A CLASS OF DISTRIBUTION FUNCTIONS, AMS 63,1302

CHANDA, K. C. ASYMPTOTIC EXPANSIONS FOR TESTS OF GOODNESS OF FIT FOR LINEAR AUTOREGRESSIVE SCHEMES, BIOKA 64,459

CHANDA, K. C. COMPARATIVE EFFICIENCIES OF METHODS OF ESTIMATING PARAMETERS IN LINEAR AUTORECRESSIVE SCHEM, BIOKA 61,427

CHANDA, K. C. ON BOUNDS OF SERIAL CORRELATIONS, AMS 62,1457

CHANDA, K. C. ON THE EFFICIENCY OF TWO-SAMPLE MANN-WHITNEY TEST FOR DISCRETE POPULATIONS, AMS 63,612

CHANDA, K. C. SAMPLING PROPERTIES OF TESTS OF GOODNESS-OF-FIT FOR LINEAR AUTORECRESSIVE SCHEMES, JRSSB 62,492

CHANDRASEKHARARAO, $\mathrm{K}$. CUBIC DESICNS, AMS 64,389

CHANMUGAN. J. THE EST IMATION OF SLOPE WHEN THE ERRORS ARE AUTOCORRELATED, JRSSB 62,199

CHAPMAN, D. G, ASYMPTOTIC POWER OF CHI SQUARE TESTS FOR LINEAR TRENDS IN PROPORTIONS, BIOCS 68,315

CHAPMAN. D. G. CORRECTION. 'A COMPARATIVE STUdY OF SEVERAL ONESIDED GOODNESS-OF-FIT TESTS ' , AMS 65, 15B3

CHAPMAN, D. G. DISCUSSION OF HOEFFDINGS PAPER, AMS 65,401

CHAPMAN, D. G. ESTIMATES OF MORALITY AND POPULATION FROM SURVEYREMOVAL RECORDS, BIOCS 65,921

CHAPMAN, D. G. POPULATION ESTIMATION BASED ON CHANGE OF COMPOSITION CAUSED BY A SELECTIVE REMOVAL, BIOKA 55, 279

CHAPMAN. D. G. THE ESTIMATION OF MORTALITY AND RECRUITMENT FROM A SINCLE TAGGING EXPERIMENT, BIOCS 65,529

CHAPMAN. DOUGLAS G. THE POWER OF CHI SQUARE TESTS FOR CONTINCENCY TABLES, JASA 66, 965

CHARNES, A, CHANGE CONSTRAINTS AND NORMAL DEVIATES, JASA 62, 134

CHASE, G. R. ON THE EFFICIENCY OF MATCHED PAIRS IN BERNOULLI TRIALS, BIOKA 68,365

CHATFIELD, C. ON ESTIMATING THE PARAMETERS OF THE LOGARITHMIC SERIES AND NECATIVE BINOMIAL DISTRIBUTIONS, BIOKA 69, 411

CHATTERJEE. SAMPRIT MULTIVARIATE STRATIFIED SURVEYS, JASA 68,530

CHATTERJEE, SHOUTIR KISHORE A BIVARIATE SIGN TEST FOR LOCATION, AMS 66,1771

CHATTERJEE, SHOUTIR KISHORE SEQUENTIAL INFERENCE PROCEDURES OF STEIN 'S TYPE FOR A CLASS OF MULTIVARIATE R, AMS 62, 1039

CHATTERJI, S. D. AN L-TO-THE-P CONVERCENCE THEOREM, AMS 69, 106B

CHAZAN, DAN A NOTE ON CONVERGENCE OF SUB-MARTINGALES, AMS 64, IB11

CHEN, H. SEQUENTIAL ESTIMATION OF QUANTAL RESPONSE CURVES, A NEW METHOD OF ESTIMATION. BIOKA 66.439

CHEN, MRS. H. J. A COMPARATIVE STUDY OF VARIOUS TESTS FOR NORMALITY, JASA $6 B, 1343$

CHENG. M. C. THE ORTHANT PROBABILITIES OF FOUR GAUSSIAN VARIATES. AMS 69,152

CHERNOFF, H. A LARCE-SAMPLE BIOASSAY DESICN WITH RANDOM DOSES AND UNCERTAIN CONCENTRATION, BIOKA 55, 307

CHERNOFF, $H$. A NOTE ON RISK AND MAXIMAL REGULAR GENERALIZED SUBMART INGALES IN STOPPINC PROBLEMS, AMS 67,606

CHERNOFF. H. AN OPTIMAL SEQUENT I AL ACCELERATED LIFE TEST ., TECH 62. 367

CHERNOFF. H. ESTIMATING THE CURRENT MEAN OF A NORMAL DISTRIBUTION WHICH IS SUBJECTED TO CHANCES IN TIME, AMS 64,999

CHERNOFF, H. QUERY, DEGREES OF FREEDOM OF CHI-SQUARE. TECH 67, 4B9

CHERNOFF. HERMAN A BAYES SEQUENTIAL SAMPLING INSPECTION. AMS 65 , 13B7

CHERNOFF. HERMAN ASYMPTOTICDISTRIBUTION OF LINEAR COMBINATIONS OF FUNCTIONS OF ORDER STATISTICS WITH APP, AMS 67,52

CHERNOFF, HERMAN DISCUSSION OF HOEFFDINGS PAPER, AMS 65,401

CHERNOFF, HERMAN OPTIMAL ACCELERATED LIFE DESIGNS FOR ESTIMATION, TECH 62,381

CHERNOFF, HERMAN SEQUENT IAL TEST FOR THE MEAN OF A NORMAL DISTRIBUTION III, SMALL T, AMS 65,28

CHERNOFF, HERMAN SEQUENTIAL TESTS FOR THE MEAN OF A NORMAL DISTRIBU-

TION II, LARGE T, AMS 64.162

CHERNOFF, HERMAN SEQUENTIAL TESTS FOR THE MEAN OF A NORMAL DISTRIBUTION IV, DISCRETE CASE, AMS 65,55

CHERNOFF, HERMAN THE SCORING OF MULTIPLE CHOICE QUEST IONNARES, AMS 62,375

CHETTY, V. KARUPPAN PREDICTION AND DECISION PROBLEMS IN REGRESSION MODELS FROM THE BAYESIAN POINT OF VIEW, JASA 65,608

CHEW JR, MILTON C. A SEQUENTIAL SEARCH PROCEDURE, AMS 67, 494

CHEW, VECTOR SIMULTANEOUS PREDICTION INTERVALS, TECH 68,323

CHEW, VICTOR CONFIDENCE, PREDICTION, AND TOLERANCE REGIONS FOR THE MULTIVARIATE NORMAL DISTRIBUTION, JASA 66, 605
CHEW, VICTOR DISTRIBUTION OF RADICAL ERROR IN THE BIVARIATE ELLIPTICAL NORMAL DISTRIBUTION, TECH 62,13B

CHILDS, D. R. REDUCTION OF THE MULTIVARIATE NORMAL INTECRAL TO CHARACTERIST IC FORM, BIOKA 67,293

CHIPMAN, JOHN S. EFFICIENCY OF THE SAMPLE MEAN WHEN RESIDUALS FOLLOW A FIRST-ORDER STATIONARY MARKOFF PRO, JASA 6B, 1237

CHIPMAN, JOHN S. ON LEAST SQUARES WITH INSUFFICIENT OBSERVATIONS, CORR. 651249 , JASA 64,1078

CHITTY. DENNIS THE ESTIMATION OF POPULATION PARAMETERS FROM DATA OBTA INED BY MEANS OF THE CAPTURE-RECAPTU, BIOKA 51, 269

CHITTY, DENNIS THE ESTIMATION OF POPULATION PARAMETERS FROM DATA OBTAINED BY MEANS OF THE CAPTURE-RECAPTU, BIOKA 53, 137

CHITTY, HELEN THE ESTIMATION OF POPULATION PARAMETERS FROM DATA OBTAINED BY MEANS OF THE CAPTURE-RECAPTUR, BIOKA 53, 137

CHOI, K. AN ESTIMATION PROCEDURE FOR MIXTURES OF DISTRIBUTIONS, JRSSB 68,444

CHOI. KEEWHAN PROBABILITY BOUNDS FOR A UNION OF HYPERSPHERICAL CONES, JRSSB 65,57

CHOI, S. C. MAXIMUM LIKELIHOOD ESTIMATION OF THE PARAMETERS OF THE GAMMA DISTRIBUTION AND THEIR BIAS, TECH 69, NO.4

CHOI, S. C. TRUNCATED SEQUENTIAL DESIGNS FOR CLINICAL TRIALS BASED ON MARKOV CHAINS, BIOCS 6B, 159

CHOW, B. THE CURVE THROUGH THE EXPECTED VALUES OF ORDERED VARIATES AND THE SUM OF SQUARES OF NORMAL SCORE, BIOKA 66,252

CHOW, GREGORY C. A THEOREM ON LEAST SQUARES AND VECTOR CORRELATION IN MULTIVARIATE LINEAR REGRESSION, JASA 66, 413

CHOW, GREGORY C. SPECTRAL PROPERTIES OF NON-STATIONARY SYSTEMS OF LINEAR STOCHASTIC DIFFERENCE EQUATIONS, JASA 69, 581

CHOW, T. R. EQUIVALENCE OF GAUSSIAN STATIONARY PROCESSES, AMS 69 197

CHOW, WEN M. ON THE CALCULATION OF CERTAIN CONSTRAINED MAXIMA, TECH 62,135

CHOW, Y. S. A RENEWAL THEOREM FOR RANDOM VARIABLES WHICH ARE DEPENDENT OR NON-IDENTICALLY DISTRIBUTED, AMS 63,390

CHOW, $Y . S$. CONVERGENCE OF SUMS OF SQUARES OF MARTINCALE DIFFERENCES. AMS $6 B, 123$

CHOW, Y.S. LOCAL CONVERGENCE OF MARTINGALES AND THE LAW OF LARGE NUMBERS, AMS 65,552

CHOW, Y. S. MART INGALE EXTENSIONS OF A THEOREM OF MARCINKIEWICZ AND ZYGMUND, AMS 69,427

CHOW, Y. S. MOMENTS OF RANDOMLY STOPPED SUMS, AMS 65,789

CHOW, Y. S. MONOTONICITY OF THE VARIANCE UNDER TRUNCATION AND VARIATIONS OF HENSEN'S INEQUALITY, AMS 69, 1106

CHOW, Y. S. ON SECOND MOMENTS OF STOPPING RULES, AMS 66, 388

CHOW, Y S. ON THE ASYMPTOTIC THEORY OF FIXED-WIDTH SEQUENTIAL CONFIDENCE INTERVALS FOR THE MEAN, AMS 65,457

CHOW, Y. S. ON THE EXPECTED VALUE OF A STOPPED STOCHASTIC SEQUENCE AMS 69,456

CHOW, Y. S. ON THE EXPECTED VALUE OF A STOPPED SUBMARTINGALE, AMS 67 , $60 \mathrm{~B}$

CHOW, Y. S. ON THE MOMENTS OF SOME ONE-SIDED STOPPING RULES, AMS 66 . 3B2

CHOW, Y. S. ON THE MONOTONICITY OF E-SUB-P'S-SUB-T-OVER-T' ', AMS 6B, 1755

CHOW, Y.S. ON THE STRONC LAW OF LARGE NUMBERS FOR MARTINGALES, AMS 67,610

CHOW, Y. S, SOME CONVERGENCE THEOREMS FOR INDEPENDENT RANDOM VARIABLES, AMS $66,14 \mathrm{~B} 2$

CHOWN, L. N. RAPID METHODS FOR ESTIMATING CORRELATION COEFFICIENTS, BIOKA 51,464

CHOYNOWSKI, MIECZYSLAW MAPS BASED ON PROBABILITIES, JASA 59, 385

CHU, J, T. ON BOUNDS FOR THE NORMAL INTEGRAL, BIOKA 55, 263

CHU, J. T. THE 'INEFFICIENCY' OF THE SAMPLE MEDIAN FOR MANY FAMILIAR SYMMETRIC DISTRIBUTIONS, BIOKA 55,520

CHUN, D. A NOTE ON REGRESSION TRANSFORMATION FOR SMALLER ROUNDOFF ERROR, TECH 68,393

CHUN, D. ON AN EXTREME RANK SUM TEST WITH EARLY DECISION, JASA 65, B59 CHUNG, J. H. RANDOMIZATION TESTS FOR A MULTIVARIATE TWO-SAMPLE PROBLEM, JASA 58,729

CHUNG, K. L. NOTE ON THE ERGODIC THEOREM OF INFORMATION THEORY, AMS 61,612

CHURCH JR, ALONZO ANALYSIS OF DATA WHEN THE RESPONSE IS A CURVE, TECH 66,229

CHURCH, B. M. PROBLEMS OF SAMPLE ALLOCATION AND ESTIMATION IN AN AGRICULTURAL SURVEY, JRSSB 54,223

CHURCH, J. D, DECISION PROCEDURES FOR FINITE DECISION PROBLEMS UNDER COMPLETE ICNORANCE, AMS 64,1644

CICCHINELLI, A. L. NOTES. TABLES OF PEARSON-LEE-FISHER FUNCTIONS OF SINGLY TRUNCA TED NORMAL DISTRIBUTIONS, BIOCS 65,219

CINLAR, E. ON THE SUPERPOSITION OF POINT PROCESSES, JRSSB 68,576

CISLAK, PETER J. ON A GENERAL SYSTEM OF DISTRIBUTIONS, I I ITS CURVESHAPE CHARACTERISTICS II. THE SAMPLE, JASA 68,627

CLAERBOUT, J. F. SPECTRAL FACTORIZATION OF MULTIPLE TIME SERIES, BIOKA 66,264

CLARINCBOLD, P. J. MULT IVARIATE QUANTAL ANALYSIS, JRSDB 5B, 39B CLARINGBOLD, P. J. THE WITHIN-ANIMAL BIOASSAY WITH QUANTAL RESPONSES, JRSSB 56,133 
CLARK, DR. VIRCINIA CHOICE OF LEVELS OF POLYNOMIAL RECRESSION WITH ONE OR TWO VARIABLES, TECH 65,325

CLARK, F. EUGENE TRUNCATION TO MEET REQUIREMENTS ON MEANS, JASA 57 , 527

CLARK, VIRCINIA CORRELATION COEFFICIENTS MEASURED ON THE SAME INDIVIDUALS, JASA 69,366

CLARK, VIRCINIA PROPERTIES OF THE MEDIAN AND OTHER STATIST ICS OF LOCISTIC VARIATES, AMS 65, 1779

CLARKE, C. M. FOUR-WAY BALANCED DESICNS BASED ON Y OUDEN SQUARES WITH 5, 6, OR 7 TREATMENTS, BIOCS 67,803

CLARKE, R. T. NOTES. THE STATISTICAL ANALYSIS OF A RADIO-ACTIVE TRACER EXPERIMENT TO DETERMINE ROOT ACTIV, BIOCS 68, 717

CLATMORTHY, W. H. ON JOHN'S CYCLIC INCOMPLETE BLOCK DESICNS, JRSSB 67,243

CLATMORTHY, $W . H$. SOME NEW FAMILIES OF PARTIALLY BALANCED DESICNS OF THE LAT IN SQUARE TYPE AND RELATED DE, TECH 67, 229

CLAWSON, MARION RECENT EFFORTS TO IMPROVE LAND USE INFORMATION, JASA 66,647

CLAWSON, MARION STATISTICAL DATA AVAILABLE FOR ECONOMIC RESEARCH ON CERTAIN TYPES OF RECREATION, JASA 59, 281

CLAY, P.P.F. SOME EMPIRICAL DISTRIBUTIONS OF BIVARIATE T-SQUARE AND HOMOSCEDAST ICITY CRITERION M UNDER, JASA 63, 104B

CLEMANS, K. G. CONFIDENCE LIMITS IN THE CASE OF THE GEOMETRIC DISTRIBUTION, BIOKA 59, 260

CLEMMER, B. A. THE USE OF EMPIRICAL BAYES ESTIMATORS IN A LINEAR REGRESSION MODEL, BIOKA 6B, 525

CLEROUX, ROBERT FIRST AND SECOND MOMENTS OF THE RANDOMIZATION TEST IN TWO ASSOCIATE PBIB DESIGNS, JASA 69, NO 4

CLUNIES-ROSS, C. W. DISCUSSION OF 'ON THE FOUNDATIONS OF STATIST ICAL INFERENCE', JASA 62, 307

CLUNIES-ROSS, C. W. GEOMETRY AND LINEAR DISCRIMINATION, BIOKA 60 , 185

CLUNIES-ROSS, C. W. INTERVAL ESTIMATION FOR THE PARAMETER OF A BINOMIAL DISTRIBUTION, BIOKA 58,275

CLUNIES-ROSS, C. W. JOINT ESTIMATION OF THE PARAMETERS OF TWO NORMAL POPULAT'IONS, JASA 62,446

CLUNIES-ROSS, C. W. RESIDUAL ANALYSIS, CORR . 61 1005, JASA 61, 9B

CLUTTON-BROCK, M. LIKELIHOOD DISTRIBUTIONS FOR ESTIMATING FUNCTIONS WHEN BOTH VARIABLES ARE SUBJECT TO ER, TECH 67, 261

CLUTTON-BROCK, M. USING THE OBSERVATIONS TO ESTIMATE THE PRIORDISTRIBUTION, JRSSB 65,17

COALE, ANSLEY J . CONVERGENCE OF A HUMAN POPULATION TO A STABLE FORM, JASA 68,395

COALE, ANSLEY $\mathrm{J}$. THE CASE OF THE INDIANS AND THE TEEN-ACE WIDOWS, JASA 62,338

COCHRAN, W. G. A REJECTION CRITERION BASED UPON THE RANGE, BIOKA 56 418

COCHRAN, W. G. COMMENTARY ON 'EST IMATION OF ERROR RATES IN DISCRIMINANT ANALYSIS', TECH $6 \mathrm{~B}, 204$

COCHRAN, W. G. ON A SIMPLE PROCEDURE OF UNEQUAL PROBABILITY SAMPLINC WITHOUT REPLACEMENT, JRSSB 62,482

COCHRAN, W. G. THE EFFECTIVENESS OF ADJUSTMENT BY SUBCLASSIFICATION IN REMOVING BIAS IN OBSERVAT IONAL STU, BIOCS 68, 295

COCHRAN, W. C. THE ROBBINS-MONRO METHOD FOR ESTIMATING THE MEDIAN LETHAL DOSE, JRSSB $65,2 B$

COCHRAN, WILLIAM C, ERRORS OF MEASUREMENT IN STATISTICS, TECH 6B 637

COCHRAN, WILLIAM G. QUERY, TESTING TWO CORRELATED VARIANCES, TECH 65,447

COCHRAN, WM. G, ON THE PERFORMANCE OF THE LINEAR DISCRIMINANT FUNCTION, TECH 64, 179

COCKERHAM, C. C. SELECTION AMONG DIALLEL CLASSIFIED VARIABLES, BIOCS 69,49

COCKERHAM, C. C. SIMULTANEOUS SELFING AND PARTIAL DIALLEL TEST CROSSING 2. AN EVALUATION OF TWO METHODS 0, BIOCS 67,325

COCKERHAM, C. C. THE EFFECT OF FIELD BLOCKINC ON CAIN FROM SELECTION, BIOCS 66,843

COCKERHAM, C. CLARK REFERENCE POPULATIONS FOR DIALLEL EXPERIMENTS BIOCS 68,881

COCBURN, ROBERT CONDITIONAL PROBABILITY OPERATORS, AMS 62, 634

COGBURN, ROBERT STRINGENT SOLUTIONS TO STATISTICAL DECISION PROBLEMS, AMS 67,447

COHEN JR, A CLIFFORD ESTIMATING THE POISSON PARAMETER FROM SAMPLES THAT ARE TRUNCATED ON THE RIGHT, TECH 61,433

COHEN JR, A. C. A NOTE ON CERTAIN DISCRETE MIXED DISTRIBUTIONS BIOCS 66,566

COHEN JR, A. C . EST IMATING PARAMETERS IN TRUNCATED PEARSON FREQUENCY DISTRIBUTIONS WITHOUT RESORT TO HIGH, BIOKA 53, 50

COHEN JR, A. C. ESTIMATION IN MIXTURES OF TWO NORMAL DISTRIBUTIONS TECH 67,15

COHEN JR, A. CLIFFORD ERRATA, 'MISCLASSIFIED DATA FROM A BINOMIAL POPULATION ${ }^{*}$, TECH 66,215

COHEN JR, A. CLIFFORD ESTIMATING THE PARAMETERS OF A MODIF IED POISSON DISTRIBUTION, JASA 60, 139

COHEN JR, A. CLIFFORD ESTIMATION IN THE TRUNCATED POISSON DISTRIBUTION WHEN ZEROS AND SOME ONES ARE MISSI, JASA 60, 342

COHEN JR, A. CLIFFORD MAXIMUM LIKELIHOOD ESTIMATION IN THE WEIBULL DISTRIBUTION BASED ON COMPLETE AND ON, TECH 65,579
COHEN JR, A . CLIFFORD MISCLASSIFIED DATA FROM A BINOMINAL POPULATION, TECH 60,109

COHEN JR, A. CLIFFORD PROCRESSIVELY CENSORED SAMPLES IN LIFE TESTINC, TECH 63,327

COHEN JR, A. CLIFFORD SIMPLIFIED ESTIMATORS FOR THE NORMAL DISTRIBUTION WHEN SAMPLES ARE SINCLY CENSORED, TECH 59, 217

COHEN JR, A. CLIFFORD TABLES FOR MAXIMUM LIKELIHOOD ESTIMATES SINCLY TRUNCATED AND SINCLY CENSORED SAMPL, TECH 61,535

COHEN, A. C CENSORED SAMPLES FROM TRUNCA TED NORMAL DISTRIBUTIONS, BIOKA 55, 516

COHEN, A. C. ON THE SOLUTION OF ESTIMAT INC EQUATIONS FOR TRUNCATED AND CENSORED SAMPLES FROM NORMAL POPUL, BIOKA 57, 225

COHEN, A. CLIFFORD DISCUSSION OF 'ESTIMATION OF PARAMETERS FOR A MIXTURE OF NORMAL DISTRIBUT IONS ' BY VICT', TECH 66, 445

COHEN. A. CLIFFORD ERRATA, 'MAXIMUM LIKELIHOOD EST IMATION IN THE WEIBULL DISTRIBUT ION BASED ON COMPLETE A, TECH 66, 570

COHEN. A. CLIFFORD QUERY, LIFE TESTING AND EARLY FAILURE, TECH 66 , 539

COHEN. ARTHUR A HYBRID PROBLEM ON THE EXPONENTIAL FAMILY, AMS 65 11B5

COHEN, ARTHUR A NOTE ON THE ADMISSIBILITY OF POOLING IN THE ANALYSIS OF VARIANCE, AMS 68, 1744

COHEN, ARTHUR ALL ADMISSIBLE LINEAR ESTIMATES OF THE MEAN VECTOR, AMS 66,458

COHEN, ARTHUR EST IMATES OF LINEAR COMBINATIONS OF THE PARAMETERS IN THE MEAN VECTOR OF A MULTIVARIATE DIS, AMS 65,78

COHEN, ARTHUR ESTIMATION OF THE LARGER TRANSLATION PARAMETER, AMS $6 B, 502$

COHEN, ARTHUR ESTIMATION OF THE LARGEST OF TWO NORMAL MEANS, JASA 68,861

COHEN, ARTHUR ESTIMATION OF TWO ORDERED TRANSLATION PARAMETERS AMS 68,517

COHEN, ARTHUR TABLES FOR THE SICN TEST WHEN OBSERVATIONS ARE ESTIMATES OF BINOMIAL PARAMETERS, JASA 59,784

COHEN, AYALA REGRESSION ON A RANDOM FIELD, JASA 69, N0.4

COHEN, J. E. NOTES. ON ESTIMATING THE EQUILIBRIUM AND TRANSITION PROBABILITIES OF A FINITE-STATE MARKOV C, BIOCS 68, 185

COHN, SAMUEL M. PROBLEMS IN EST IMATING FEDERAL GOVERNMENT EXPENDITURES, JASA 59, 717

COLE, J W. L. APPLICATION OF MULT IVARIATE ANALYSIS OF VARIANCE TO REPEATED MEASUREMENTS EXPERIMENTS, BIOCS 66, BIO

COLLIER JR, R. 0. SOME MONTE CARLO RESULTS ON THE POWER OF THE F-TEST UNDER PERMUTATION IN THE SIMPLE RAN, BIOKA 66, 199

COLLIER JR, RAYMOND O. THE RANDOMIZATION DISTRIBUT ION OF F-RATIOS FOR THE SPLIT-PLOT DESIGN, AN EMPIRICAL, BIOKA 63, 431

COLLIER, RAYMOND O. AN EMPIRICAL STUDY INTO FACTORS AFFECT INC THE FTEST UNDER PERMUTATION FOR THE RANDOM, JASA 6B, 902

COLLIER, RAYMOND O. SOME EMPIRICAL RESULTS ON VARIANCE RATIOS UNDEF PERMUTATION IN THE COMPLETELY RANDOMI, JASA 66,813

COLTON, T A TWO-STACE MODEL FOR SELECT INC ONE OR TWO TREATMENTS BIOCS 65,169

COLTON, THEODORE A MODEL FOR SELECTING ONE OF TWO MEDICAL TREATMENTS, JASA 63, 3BB

COLTON, THEODORE A TEST PROCEDURE WITH A SAMPLE FROM A NORMAL POPULATION WHEN AN UPPER BOUND TO THE STAND, JASA 60,94

COLTON, THEODORE OPT IMAL DRUG SCREEN ING PLANS, BIOKA 63, 31

COMER JR, J.P. APPLICATION OF STOCHASTIC APPROXIMATION TO PROCESS CONTROL, JRSSB 65,321

COMER JR, JOHN P. SOME STOCHAST IC APPROXIMATION PROCEDURES FOR USE IN PROCESS CONTROL, AMS 64, 1136

COMPTON, W. A. FURTHER EVIDENCE ON THE CONSISTENCY OF ESTIMATES OF VARIANCE COMPONENTS, BIOCS 65, 395

CONKLINE, RANDALL M DECIMAL CORRECTION ERROR, AN EXAMPLE IN STATISTICS, TECH 62, 421

CONLISK, JOHN THE EQUILIBRIUM COVARIANCE MATRIX OF DYNAMIC ECONOMETRIC MODELS, JASA 69, 277

CONNELL, TERRENCE L. SAMPLE SIZE REQUIRED FOR ESTIMAT ING THE VARIANCE WITIND UNITS OF THE TRUE VALUE, AMS 64,438

CONNELL, TERRENCE L. SAMPLE SIZE REQUIRED TO ESTIMATE THE RATIO OF VARIANCES WITH BOUNDED RELAT IVE ERROR, JASA 63, 1044

CONNELL, TERRENCE L. SAMPLE SIZE REQUIRED TO EST IMATE THE PARAMETER IN THE UNIFORM DENSITY WITHIN D UNITS, JASA 64,550

CONNER, JAMES R. USE OF DOMAIN ESTIMATORS WITH UNEQUAL PROBABILITY IN SAMPLE SURVEYS, JASA 6B, 9BA

CONNOR, ROBERT J . CONCEPTS OF INDEPENDENCE FOR PROPORTIONS WITH A A GENERALIZATION OF THE DIRICHLET DISTR, JASA 69, 194

CONNOR, ROBERT J THE SAMPLING DISTRIBUTION OF THE RANGE FROM DISCRETE UNIFORM FINITE POPULATIONS AND A R, JASA 69, N0.4

CONNOR, W. S. AN EXACT FORMULA FOR THE PROBABILITY THAT TWO SPEC IF IED SAMPLING UNITS WILL OCCUR IN A SAMP, JASA 66, 384

CONNOR, $\mathrm{T}$. DISTRIBUTION OF TOTAL SERVICE TIME FOR A FIXED OBSERVATION INTERVAL, JASA 62,376

CONNOR, W. S. MEASUREMENTS MADE BY MATCHINC WITH KNOWN STANDARDS TECH 59, 101

CONNOR, W. S. STUDENT'S T IN A TWO-WAY CLASSIFICATION WITH UNEQUAL VARIANCES, AMS 65, 1248

CONNOR, $W . S$. THE CONDITIONAL DISTRIBUTION OF SETS OF TESTS ON A SYSTEM SIMULATED FROM TESTS DN ITS COMPO , AMS 63, 1585 
CONOLLY,B.W. A DIFFERENCE EQUATION TECHNIQUE APPLIED TO THE SIMPLE QUEUE WITH ARBITRARY ARRIVAL INTERVA, JRSSB 5B, 16B

CONOLLY, B. W. A DIFFERENCE EQUATION TECHNIQUE APPL IED TO THE SIMPLE QUEUE, JRSSB 5B, 165

CONOLLY, B. W. QUEUEING AT A SINGLE SERVINC POINT WITH GROUP ARRIVAL, JRSSB $60,2 B 5$

CONOLLY, B. W. THE BUSY PERIOD IN RELATION TO THE QUEUEING PROCESS GI-M-1, BIOKA 59,246

CONOLLY, B. W. THE BUSY PERIOD IN RELATION TO THE SINGLE-SERVER QUEUEING SYSTEM WITH CENERAL INDEPENDENT, JRSSB 60, B9

CONOVER, W. J. A K-SAMPLE EXTENSION OF THE ONE-SIDED TWO-SAMPLE SMIRNOV TESTS STATISTIC, AMS 67, 1726

CONOVER, W. J. A K-SAMPLE MODEL IN ORDER STATISTICS, AMS 65, 1223

CONOVER, W. J. SEVERAL K-SAMPLE KOLMOCOROV-SMIROV TESTS, AMS 65 1019

CONOVER, W J. THE DISTRIBUTION FUNCTIONS OF TSAO'S TRUNCATED SMIRNOV STATISTICS, AMS $67,120 \mathrm{~B}$

CONOVER. W. J. THE DISTRIBUTION OF SUM-O-TO-M OF F,Y-SUB-T), WHERE (Y-SUB-0, Y-SUB-1, . . .) IS A REALIZATI, BIOKA 65, 277

CONOVER, W. J. TWO K-SAMPLE SLIPPAGE TESTS, JASA 6B, 614

CONSTANTINE, A. G. SOME NON-CENTRAL DISTRIBUTION PROBLEMS IN MULTIVARIATE ANALYSIS, AMS 63, 1270

CONSTANTINE, A. G. THE DISTRIBUTION OF HOTELLINC'S GENERALIZED MEASURE OF MULTIVARIATE DISPERSION, AMS 66, 215

CONSUL, P. C. ON THE EXACT DISTRIBUTIONS OF LIKELIHOOD RATIO CRITERIA FOR TESTINC INDEPENDENCE OF SETS OF, AMS 67, 1160

CONSUL, P. C. ON THE EXACT DISTRIBUTIONS OF THE CRITERION W FOR TESTING SPHERICITY IN A P-VARIATE NORMAL, AMS 67, 1170

CONSUL, P. C. ON THE EXACT DISTRIBUTIONS OF THE LIKELIHOOD RATIO CRITERIA FOR TESTINC LINEAR HYPOTHESES A, AMS 66, 1319

CONSUL, $P, C$, ON THE EXACT DISTRIBUTIONS OF VOTAW'S CRITERIA FOR TESTINC COMPOUND SYMMETRY OF A COVARIANC, AMS 69, B36

COOK, M. B. BIVARIATE K-STATISTICS AND CUMULANTS OF THEIR JOINT SAMPLING DISTRIBUTION, BIOKA 51, 179

COOK, M B. TWO APPLICATIONS OF BIVARIATE K-STATISTICS, BIOKA 51 , $36 \mathrm{~B}$

COON, HELEN J. ON THE USE OF PATNAIK TYPE CHI APPROXIMATIONS TO THE RANCE IN SIGNIFICANCE TESTS, BIOKA 66, 24B

COOPER. B. E. THE EFFECT OF TIES ON THE MOMENTS OF RANK CRITERIA, BIOKA 57,526

COOPER, B. E. THE EXTENSION OF YATES' 2-TO-THE-N ALGORITHM TO ANY COMPLETE FACTORIAL EXPERIMENT, TECH 6B, 575

COOPER, PAUL $W$. STATISTICAL GLASSIFICATION WITH QUADRATIC FORMS, BIOKA 63,439

COOPER, $W$. W. CHANGE CONSTRA INTS AND NORMAL DEVIATES, JASA 62, 134

COOTE, G. G. THE EST IMATION OF CONCENTRATION OF VIRUSES AND BACTERI FROM DILUTION COUNTS, BIOCS 65,600

CORMACK, R. M. A TEST FOR EQUAL CATCHABILITY, BIOCS 66,330

CORMACK, R, M. ESTIMATES OF SURVIVAL FROM THE SIGHTINC OF MARKED ANIMALS, BIOKA 64,429

CORNELL, R. G. ESTIMATION FOR A SIMPLE EXPONENT IAL MODEL, BIOCS 67. 717

CORNELL, R. C. SPEARMAN ESTIMATION FOR A SIMPLE EXPONENTIAL MODEL, BIOCS 65, B5B

CORNELL, R. G. SPEARMAN SIMULTANEOUS EST IMATION FOR A COMPARTMENTAL MODEL, TEGH 69,551

CORNELL, RICHARD C. ERRATA 'SIMULTANEOUS NONLINEAR ESTIMATION' TECH 67,353

CORNELL, RICHARD C. ESTIMATION FOR A ONE-PARAMETER EXPONENTIAL MODEL, JASA 65,560

CORNELL, RICHARD G, SIMULTANEOUS ESTIMATION BY PARTIAL TOTALS FOR COMPARTMENTAL MODELS, JASA 6B, 573

CORNELL, RICHARD G. SIMULTANEOUS NONLINEAR ESTIMATION, TECH 66 . 319

CORNFIELD, $J$. THE BAYESIAN OUTLOOK AND ITS APPLICATIONS (WITH DISCUSSION), BIOCS 69, NO 4

CORNFIELD, JEROME A BAYESIAN TEST OF SOME CLASSICAL HYPOTHESES, WITH APPLICATI ONS TO SEQUENT IAL CLINICAL, JASA 66, 577

CORNFIELD, JEROME AN ADAPTIVE PROCEDURE FOR SEQUENTIAL CLINICAL TRI ALS, JASA 69,759

CORNFIELD, JEROME DISCUSSION OF 'ON THE FOUNDATIONS OF STATISTICAL INFERENCE' ', JASA 62, 307

CORNFIELD, JEROME POSTERIOR DISTRIBUTIONS FOR MULTIVARIATE NORMAL PARAMETERS, JRSSB $63,36 B$

CORNISH, E. A. ERRATA, 'THE PERCENTILE POINTS OF DISTRIBUTIONS HAVINC KNOWN CUMULANTS', TECH 60,523

CORNISH, E. A. THE PERCENTILE POINTS OF DISTRIBUTIONS HAVING KNOWN CUMULANTS, TECH 60,209

COTE, L. ON THE INADMISSIBILITY OF SOME STANDARD ESTIMATES IN THE PRESENCE OF PRIOR INFORMATION, AMS 63, 539

COULTER, ELIZABETH J. ANALYSIS OF VITAL STATISTICS BY CENSUS TRACT, JASA 59,730

COVER, THOMAS M. GEOMETRICAL PROBABILITY AND RANDOM POINTS ON A HYPERSPHERE, AMS 67, 213

COVER. THOMAS M. HYPOTHESIS TESTING WITH FINITE MEMORY, AMS 69, B2B COVER, THOMAS M. THE PROBABILITY THAT A RANDOM GAME IS UNFAIR, AMS 66, 1796
COWDEN, DUDLEY J A PROCEDURE FOR COMPUTINC RECRESSION COEFFICIENTS, CORR, 59 B 11, JASA 5B, 144

COX, C. P. A CONCISE DERIVATION OF GENERAL ORTHOCONAL POLYNOMIALS, JRSSB 5B, 406

COX, C. P. THE ANALYSIS OF LAT IN SQUARE DESIGNS WITH INDIVIDUAL CURVATURES IN ONE DIRECTION, JRSSB 5B, 193

COX. C. PHILIP A LARGE SAMPLE SEQUENTIAL TEST, USING CONCOMITANT INFORMATION FOR DISCRIMINAT ION BETWEEN T, JASA 66,357

COX, C. PHILIP A NOTE ON THE VARIANCE OF THE DISTRIBUTION OF SAMPLE NUMBER IN SEQUENT IAL PROBABILITY RATI, TECH 66, 700

COX,C. PHILIP SOME OBSERVAT IONS ON THE TEACHING OF STATIST ICAL CONSULTINC, BIOCS $6 B, 7 B 9$

COX, D. R. A GENERAL DEFINITION OF RESIDUALS (WITH DISCUSSION) JRSSB $6 B, 24 B$

COX, D. R. A NOTE ON TESTS OF HOMOGENEITY APPLIED AFTER SEQUENTIAL SAMPLINC, JRSSB $60,36 B$

COX, D. R. A NOTE ON THE EFFICIENCY OF LEAST-SQUARES ESTIMATES IRSSB $6 \mathrm{~B}, 2 \mathrm{~B} 4$

COX, D. R. A NOTE ON THE GRAPHICAL ANALYSIS OF MULT IDIMENSIONAL CONTINGENCY TABLES, TECH $67,4 B$

COX,D.R. A NOTE ON THE THEORY OF QUICK TESTS, BIOKA 56,47B

COX, D. R. A REMARK ON MULTIPLE COMPARISON METHODS, TECH 65,223

COX, D. R, A RENEWAL PROBLEM WITH BULK ORDERING OF COMPONENTS, JRSSB $59,1 \mathrm{BO}$

GOX, D. R. A SIMPLE CONGESTION SYSTEM WITH INCOMPLETE SERVICE, JRSSB 61, 215

COX, D. R. A SIMPLE EXAMPLE OF A COMPARISON INVOLVING QUANTAL DATA, BIOKA 66,215

COX, D. R. A TABLE FOR PREDICTING THE PRODUCTION FROM A CROUP OF MACHINES UNDER THE CARE OF ONE OPERATIVE, JRSSB 54, $2 B 5$

COX, D. R. AN ANALYSIS OF TRANSFORMATIONS (WITH DISCUSSION), JRSSB 64, 211

COX, D. R. CORRIGENDA TO 'THE USE OF A CONCOMITANT VARIABLE IN SELECT ING AN EXPERIMENTAL DESIGN' ${ }^{\prime}$, BIOKA 57,534

COX, D. R. CORRIGENDA, 'THE MEAN AND COEFFIGIENT OF VARIATION OF RANGE IN SMALL SAMPLES FROM NON-NORMAL P, BIOKA 55, 277

COX, D R DISCRIMINATION BETWEEN ALTERNATIVE BINARY RESPONSE MODELS, BIOKA 67,573

COX, D. R. ESTIMATION BY DOUBLE SAMPLING, BIOKA 52, 217

COX, D. R. FIELLER' S THEOREM AND A GENERALIZATION, BIOKA 67, 567

COX, D. R. FURTHER RESULTS ON TESTS OF SEPARATE FAMILIES OF HYPOTHESES, JRSSB 62,406

COX, D. R. NOTE ON GROUPING, JASA 57,543

COX, D. R. ON A DISCRIMINATORY PROBLEM CONNECTED WITH THE WORKS OF PLATO, JRSSB 59, 195

COX, D. R. ON THE DISTRIBUTION OF TRIBOLIUM CONFUSUM IN A CONTAINER, BIOKA $57,32 \mathrm{~B}$

COX, D. R. ON THE ESTIMATION OF THE INTENSITY FUNCTION OF A STATIONARY POINT PROCESS, JRSSB 65,332

COX, D. R. ON THE NUMBER OF RENEWALS IN A RANDOM INTERVAL, BIOKA 60 449

COX, D . R. ON THE SUPERPOSITON OF RENEWAL PROCESSES, BIOKA 54, 91

COX,D.R. PREDICTION BY EXPONENTIALLY WEICHTED MOVINC AVERACES AND RELATED METHODS, JRSSB 61,414

COX, D. R, QUERY, ANALYSIS OF FACTORIAL EXPERIMENT (PARTIALLY CONFOUNDED 2-CUBE), TECH 67,170

COX, D, R. REGRESSION ANALYSIS WHEN THERE IS PRIOR INFORMAT ION ABOUT SUPPLEMENTARY VARIABLES, JRSSB 60,172

COX, D. R. SERIAL SAMPLING ACCEPTANCE SCHEMES DERIVED FROM BAYES 'S THEOREM, TECH 60,353

COX, D. R. SOME APPLICATIONS OF EXPONENTIAL ORDERED SCORES, JRSSB 64. 103

COX, D. R. SOME QUICK SICN TESTS FOR TREND IN LOCATION AND DISPERSION, BIOKA 55, BO

COX, D. R. SOME SIMPLE APPROXIMATE TESTS FOR POISSON VARIATES, BIOKA 53,354

COX, D. R. SOME STAT ISTICAL METHODS CONNECTED WITH SERIES OF EVENTS (WITH DISCUSSION), JRSSB 55, 129

COX, D. R. SOME SYSTEMAT IC EXPERIMENTAL DESIGNS, BIOKA 51,312

COX, D. R. SOME SYSTEMAT IC SUPERSATURATED DESIGNS, TECH 62, 4B9

COX, D. R. THE ANALYSIS OF EXPONENTIALLY DISTRIBUTED LIFE-TIMES WITH TWO TYPES OF FAILURE, JRSSB 59, 411

COX, D. R. THE DESIGN OF AN EXPERIMENT IN WHICH CERTAIN TREATMENT ARRANCEMENTS ARE INADMISSIBLE, BIOKA 54, 2B7

COX, D. R. THE INTERPRETATION OF THE EFFECTS OF NON-ADDITIVITY IN THE LATIN SQUARE, BIOKA 5B, 69

COX, D. R. THE MEAN AND COEFFICIENT OF VARIATION OF RANGE IN SMALL SAMPLES FROM NON-NORMAL POPULATIONS, BIOKA 54, 469

COX. D. R. THE NULL DISTRIBUTION OF THE FIRST SERIAL CORRELATION COEFFICIENT, BIOKA 66, 623

COX. D. R. THE REGRESSION ANALYSIS OF BINARY SEQUENCES (WITHDISCUSSION) (CORR, 59 23B), JRSSB 5B, 215

COX.D.R. THE SUPERPOSITION OF SEVERAL STRICTLY PERIODIC SEQUENCES OF EVENTS, BIOKA 53,1

COX, D. R. THE USE OF A CONCOMITANT VARIABLE IN SELECTING AN EXPERIMENT AL DESIGN, BIOKA 57,150

COX, D. R. THE USE OF CONTROL OBSERVATIONS AS AN ALTERNATIVE TO INCOMPLETE BLOCK DESIGNS，JRSSB 62,464 
COX, D. R. TWO FURTHER APPLICATIONS OF A MODEL FOR BINARY RECRESSION, BIOKA $5 B, 562$

COX, EDWIN B. CHANCES IN THE SIZE DISTRIBUTION OF DIVIDEND INCOME JASA 61,250

COX, GERTRUDE M. STATISTICAL FRONTIERS, JASA 57,1

CRACG, J. G. ON THE SENSITIVITY OF SIMULTANEOUS-EQUATIONS ESTIMATORS TO THE STOCHASTIC ASSUMPTIONS OF THE, JASA 66, 136

CRAIG, C. C. ON A CLASS OF SIMPLE SEQUENTIAL TESTS ON MEANS, TECH 62. 345

CRAIG, C. C. ON A METHOD OF ESTIMATING BIOLOG ICAL POPULATIONS IN THE FIELD, BIOKA 53, 216

CRAIG, C. C. ON THE MEAN AND VARIANCE OF THE SMALLER OF TWO DRAWINGS FROM A BINOMIAL POPULATION, BIOKA 62.566

CRAIG, C. C. ON THE UTILIZATION OF MARKED SPECIMENS IN ESTIMATINC POPULATIONS OF FLYING INSECTS, BIOKA 53, 170

CRAIG, C. C. THE AVERAGE SAMPLE NUMBER FOR TRUNCATED SINCLE AND DOUBLE ATTRIBUTES ACCEPT ANCE SAMPLING PLA, TECH 68,685

CRAMER, E. M. NOTES. EQUIVALENCE OF TWO METHODS OF COMPUTING DISCRIMINANT FUNCTION COEFFICIENTS, 8IOCS 67,153

CRAMER, ELLIOT M. SOME COMPARISONS OF METHODS OF FITTING THE DOSAGE RESPONSE CURVE FOR SMALL SAMPLES, JASA 64,779

CRAMER, HARALD KHINCHIN'S WORK IN MATHEMATICAL PROBABILITY, AMS 62, 1227

CRAMER, HARALD MODEL BUILDING WITH THE AID OF STOCHASTIC PROCESSES, TECH 64, 133

CRAMER, HARALD THE MOMENTS OF THE NUMBER OF CROSSINGS OF A LEVEL BY A STATIONARY NORMAL PROCESS, AMS 65, 1656

CRAMER, J. S. EFFICIENT GROUPING, RECRESSION AND CORRELATION IN ENGEL CURVE ANALYSIS, JASA 64,233

CRASWELL, K. J. DENSITY ESTIMATION IN A TOPOLOGICAL GROUP, AMS 65. 1047

CRASWELL, $K, J$. NONPARAMETRIC UPPER CONFIDENCE BOUNDS, AND CONFIDENCE LIMITS, FOR THE PROBABILITY THAT Y, JASA 64, 906

CRAWFORD, C. R. LINEAR REGRESSION WITH NON-CONSTANT, UNKNOWN ERROR VARIANCES, SAMPLING EXPERIMENTS WITHL, BIOCS $6 B, 607$

CRAWFORD, GORDON B. CHARACTERIZATION OF GEOMETRIC AND EXPONENTIAL DISTRIBUTIONS, AMS 66, 1790

CREASY, M. A. ANALYSIS OF VARIANCE AS AN ALTERNATIVE TO FACTOR ANALYSIS, JRSSB 57,318

CREASY, MONICA A. CONFIDENCE LIMITS FOR THE CRADIENT IN THE LINEAR FUNCTIONAL RELATIONSHIP, JRSSB 56, 65

CREASY. MONICA A. LIMITS FOR THE RATIO OF MEANS (WITH DISCUSSION), JRSSB 54, 186

CROMARTY, WILLIAM A. AN ECONOMETRIC MODEL FOR UNITED STATES AGRICULTURE, JASA 59,556

CRONHOLM, J. N. TWO TABLES CONNECTED WITH GOODNESS-OF-FIT TESTS FOR EQUIPROBA8LE ALTERNATIVES, BIOKA 68, 441

CRONHOLM, JAMES N. A TWO-VARIABLE GENERATING FUNCTION FOR COMPUTING THE SAMPLING PROBABILIT IES OF A CLASS, JASA 64, 4B7

CROSETTI, ALBERT H. A METHOD OF ESTIMAT ING THE INTERCENSAL POPULATION OF COUNTIES, JASA 56,5B7

CROUSE, C. F, A CLASS OF DISTRIBUTION-FREE ANALYSIS OF VARIANCE TESTS, SASJ 67,75

CROUSE, C. F. A DISTRIBUTION-FREE METHOD OF ANALYZING A 2 TO THE $M$ FACTORIAL EXPERIMENT, SASJ 68,101

CROUSE, C. F. A DISTRIBUTION-FREE TWO SAMPLE TEST FOR DISPERSION FOR SYMMETRICAL DISTRIBUTIONS, SASJ 69, NO.2

CROUSE, C. $F$. A MULTIPLE COMPARISON RANK PROCEDURE FOR A ONE-WAY ANALYSIS OF VARIANCE, SASJ 69,35

CROUSE, C. F. A NON-NULL RANKING MODEL FOR A SEQUENCE OF M ALTERNATIVES, BIOKA 61,441

CROUSE, C. F . CORRECTION, 'DISTRIBUT ION FREE TESTS BASED ON THE SAMPLE DISTRIBUTION FUNCTION' , BIOKA 67,333

CROUSE, C. F. DISTRIBUTION FREE TESTS BASED ON THE SAMPLE DISTRIBUTION FUNCTION, BIOKA 66,99

CROUSE, C. F . NOTE ON MOOD'S TEST, AMS 64, 1 B 25

CROUSE, C. F. ON A POINT ARISING IN POLYNOMIAL REGRESSION FITTINC BIOKA 64, 50I

CROW, E. L. CONFIDENCE INTERVALS FOR A PROPORTION, BIOKA 56, 423

CROW, E. L. CONFIDENCE INTERVALS FOR THE EXPECTATION OF A POISSON VARIABLE, BIOKA 59, 44I

CROW, E. L. CORR IGENDA TO 'CONF IDENCE INTERVALS FOR A PROPORTION' 8IOKA 58, 29]

CROW, E. L. THE MEAN DEVIATION OF THE POISSON DISTRIBUTION, BIOKA $5 B, 556$

CROW, EDWIN L. A TWO-PARAMETER FAMILY OF HYPER-POISSON DISTRIBUTIONS, JASA 64.133

CROW. EDWIN L, ROBUST ESTIMATION OF LOCATION, JASA 67,353

CRUM. W. L. FISCAL-YEAR REPORT ING FOR CORPORATE INCOME TAX. JASA 56, 304

CRUMP, P. P. COMPARISONS OF DESIGNS AND ESTIMATION PROCEDURES FOR EST IMATING PARAMETERS IN A TWO-STAGE NE, TECH 67, 499

CRYER, J, D. ON THE MEAN NUMBER OF CURVE CROSSINGS BY NON-ST AT IONARY NORMAL PROCESSES, AMS 65, 509

CSORGO, M. ON THE EMPTY CELL TEST, TECH 62, 235

CSORGO, MIKLOS SOME RENYI TYPE LIMIT THEOREMS FOR EMPIRICAL DISTRIBUTION FUNCTIONS, CORR, 651069 , AMS 65, 322
CSORGO, MIKLOS SOME SMIRNOV TYPE THEOREMS OF PROBABILITY, AMS 65. 1113

CUNIA, T. LEAST SQUARES ESTIMATES AND PARABOLIC RECRESSION WITH RESTRICTED LOCAT ION FOR THE STAT IONARY PO. JASA 64, 564

CUNNINCHAM, E. P. A NOTE ON THE ESTIMATION OF VARIANCE COMPONENTS BY THE METHOD OF FITTING CONSTANTS, BIOKA 69, NO. 3

CUNNINGHAM, E. P. AN ITERATIVE PROCEDURE FOR ESTIMAT INC FIXED EFFECTS AND VARIANCE COMPONENTS IN MIXED MO, BIOCS 68,13

CUNNINCHAM, E. P. ANALYTICAL TECHNIQUE FOR INCOMPLETE BLOCK EXPERIMENTS, BIOCS 66,829

CUPPENS, ROGER ON FINITE PRODUCTS OF POISSON-TYPE CHARACTERISTIC FUNCTIONS OF SEVERAL VARIABLES, AMS 69,434

CURETON, EDWARD E. THE NORMAL APPROXIMATION TO THE SIGNED-RANK SAMPLING DISTRIBUT ION WHEN ZERO DIFFERENCE, JASA 67, 1068

CURME, G. L. ESTIMATION OF A PARAMETER IN THE CLASSICAL OCCUPANCY PROBLEM. BIOKA 60,180

CURNOW, R. N. A NOTE ON G.S. WATSON'S PAPER 'A STUDY OF THE GROUP SCREENING METHOD', TECH 65, 444

CURNOW, R. N. HETEROGENEOUS ERROR VARIANCES IN SPLIT-PLOT EXPERIMENTS, BIOKA 57,378

CURNOW, R. N. OPTIMAL PROCRAMMERS FOR VARIETAL SELECTION (WITH DISCUSSION), JRSS861, 2B2

CURNOW. R. N. THE NUMER ICAL EVALUATION OF CERTA IN MULT IVARIATE NORMAL INTEGRALS, AMS 62,571

CURNOW. R. N. THE REGRESSION OF TRUE VALUE ON ESTIMATED VALUE, BIOKA 60.457

CURTIS, E, COUNT A POTENT IAL THEORY FOR SUPERMARTINGALES, AMS 68, 802 CUTLER, SIDNEY J. PARTITIONING OF A PATIENT POPULATION WITH RESPECT TO DIFFERENT MORTALITY RISKS, JASA 63,701

DACY, DOUGLAS C. A PRICE AND PRODUCT IVITY INDEX FOR A NONHOMOCENEOUS PRODUCT, JASA 64, 469

DAGNELIE, P. L'ETUDE DES COMMUNAUTES VEGETALES PAR L'ANALYSE STAT IST IQUE DES LIAISONS ENTRE LES ESPECES E, BIOCS 65,345

DAGNELIE, $P$ L'ETUDE DES COMMUNAUTES VEGETALES PAR L'ANALYSE STAT IST IQUE DES LIAISONS ENTRE LES ESPECES E, BIOCS 65, B90

DAHIYA, R. C. FUNCTIONS OF THE SAMPLE MEAN AND SAMPLE VARIANCE OF A POISSON VARIATE, BIOCS 69, 171

DALENIUS, TORE MINIMUM VARIANCE STRATIFICATION, CORR, 631161 JASA 59,88

DALENIUS, TORE RECENT ADVANCES IN SAMPLE SURVEY THEORY AND METHODS AMS 62,325

DALENIUS, TORE SOME THEORY OF SAMPLING WHEN THE STRATIFICATION IS SUBJECT TOERROR, TECH 67,1

DALEY, D. J Q QUASI-STATIONARY BEHAVIOUR OF A LEFT-CONTINUOUS RANDOM WALK, AMS 69, 532

DALEY, D. J. THE CORRELATION STRUCTURE OF THE OUTPUT PROCESS OF SOME SINGLE SERVER SYSTEMS, AMS 68, 1007

DALL'ACLIO, GIORGIO PRESENT VALUE OF A RENEWAL PROCESS, AMS 64, 1326 DALY, JOSEPH F. WASHINCTON STATISTICAL SOCIETY MEMORIAL MEETING FOR WILLIAMN. HURWITZ. SOME BASIC PRINCI, JASA 69, NO.4

DALY, REX F. DEMAND FOR FARM PRODUCTS AT RETAIL AND THE FARM LEVEL SOME EMPIRICAL MEASUREMENTS AND RELAT, JASA 5B, 656

DANFORD, M. B. A COMPARISON OF CONTINUOUS DISTRIBUTIONS OF PARAMETERS OF EXPONENT IAL DECAY CURVES, BIOCS 6B, 117

DANFORD, M. B. THE NECATIVE EXPONENTIAL WITH CUMULATIVE ERROR BIOCS 6B, 363

DANIEL, C. LOCATING OUTLIERS IN FACTORIAL EXPERIMENTS, TECH 60, 149 DANIEL, C, PARALLEL FRACTIONAL REPLICATES, TECH 60,263

DANIEL, CUTHBERT FACTORIAL 2-TO-THE- $(P-Q)$ PLANTS ROBUST AGAINST LINEAR AND QUADRATIC TRENDS, TECH 66, 259

DANIEL CUTHBERT QUERY. ANALYSIS OF FACTORIAL EXPERIMENT (PARTIALLY CONFOUNDED 2-CUBE). TECH 67. 170

DANIEL, CUTHBERT SEQUENCES OF FRACTIONAL REPLICATES IN THE 2-TOTHE- $(P-Q)$ SERIES, CORR. 62919. JASA 62, 403

DANIEL, CUTHBERT SOME CENERAL REMARKS ON CONSULTING IN STATISTICS. TECH 69,241

DANIEL, CUTHBERT USE OF HALF-NORMAL PLOTS IN INTERPRETINC FACTORIAL TWO LEVEL EXPERIMENTS, TECH 59, 311

DANIELS. H. E. AN INEQUALITY RELATING THE SPECTRAL DENSITY AND AUTOCORRELATION FUNCTION. BIOKA 62,262

DANIELS, H. E. APPROXIMATE SOLUTIONS OF GREEN 'S TYPE FOR UNI VARIATE STOCHAST IC PROCESSES, JRSSB 60,376

DANIELS, H. E. MIXTURES OF GEOMETRIC DISTRIBUTIONS, JRSSB 61, 409

DANIELS, H. E. PROCESSES GENERATING PERMUTATION EXPANSIONS, BIOKA 62,139

DANIELS, H. E. ROUND-ROBIN TOURNAMENT SCORES, BIOKA 69, 295

DANIELS. H. E. SHORT PROOF OF DR HARLEY'S THEOREM ON THE CORRELATION COEFFICIENT, BIOKA 58,571

DANIELS, H. E. THE APPROXIMATE DISTRIBUTION OF SERIAL CORRELATION COEFFICIENTS, BIOKA 56, 169

DANIELS, H. E. THE COVERING CIRCLE OF A SAMPLE FROM A CIRCULAR NORMAL DISTRIBUTION, BIOKA 52,137

DANIELS, H. E. THE EST IMATION OF SPECTRAL DENSITIES, JRSSB 62, 185

DANIELS, H. E, THE HAUSA PROBLEM AND SOME APPROXIMATIONS TO THE REQUIRED PROBABILITY, BIOKA 63,514

DANNEMILLER, MARY C. THE ROBUSTNESS OF LIFE TESTING PROCEDURES DERIVED FROM THE EXPONENTIAL DISTR IBUT ION, TECH 61, 29 
DANZICER, L, TABLES OF DISTRIBUTION-FREE TOLERANCE LIMITS, AMS 64 1361

DAR, S. N. ON THE COMPARISON OF THE SENSITIVITIES OF EXPERIMENTS, JRSSB 62,447

DARLING, D. A. CORRECTION TO 'ON A CLASS OF PROBLEMS RELATED TO THE RANDOM DIVISION OF AN INTERVAL' 5323 . AMS 62, 812

DARLINC, D. A, FINDING THE SIZE OF A FINITE POPULATION, AMS 67, 1392

DARROCH, J. N. AN OPT IMAL PROPERTY OF PRINCIPAL COMPONENTS, AMS 65 1579

DARROCH, J. N. INTERAGTIONS IN MULTI-FACTOR CONTINGENCY TABLES JRSSB 62, 251

DARROCH, J. N. ON TEST ING MORE THAN ONE HYPOTHESIS, AMS 63, 555

DARROCH, J. N. ON THE DISTRIBUTION OF THE NUMBER OF SUCCESSES IN INDEPENDENT TRIALS, AMS 64,1317

DARROCH, J. N. ON THE TRAFFIC LIGHT QUEUE, AMS 64, 380

DARROCH, J. N. THE MULTIPLE-RECAPTURE CENSUS II. ESTIMATION WHEN THERE IS IMMIGRATION OR DEATH, BIOKA 59,336

DARROCH, J. N. THE MULTIPLE-RECAPTURE CENSUS. I. ESTIMATION OF A GLOSED POFULATION, BIOKA 5B, 343

DARROCH, J. N. THE TWO-SAMPLE CAPTURE-RECAPTURE CENSUS WHEN TAGG IN $G$ AND SAMPLING ARE STRATIFIED, BIOKA 61,241

DARST, R. 8. A PERFECT MEASURABLE SPACE THAT IS NOT A LUSIN SPACE, AMS 67. $191 \mathrm{~B}$

DARWIN, J. H. NOTE ON A THREE-DECISION TEST FOR COMPARING TWO BINOMIAL POPULATIONS, BIOKA 59, 106

DARWIN, J. H. NOTE ON THE COMPARISON OF SEVERAL REALIZATIONS OF A MARKOFF CHAIN, 8IOKA 59,412

DARWIN, J . H. ON CORRECT IONS TO THE GHI-SQUARED DISTRIBUTION, JRSSB 58,387

DARWIN, J. $H$. POPULATION DIFFERENCES BETWEEN SPECIES GROWING ACCORDINC TO SIMPLE BIRTH AND DEATH PROCESSE, 8IOKA 53, 370

DARWIN. J. H. THE BEHAVIOUR OF AN EST IMATOR FOR A SIMPLE BIRTH AND DEATH PROCESS, BIOKA 56, 23

DARWIN, J $H$. THE DIFFERENCE BETWEEN CONSECUT IVE MEMBERS OF A SER IES OF RANDOM VARIABLES ARRANGED IN ORDE. BIOKA 57,211

DARWIN, J. H. THE POWER OF THE POISSON INDEX OF DISPERSION, BIOKA 57 $2 B 6$

DAS GUPTA, S. MONOTONICITY OF THE POWER FUNCTIONS OF SOME TESTS OF THE MULTIVARIATE LINEAR HYPOTHESIS, AMS 64, 200

DAS GUPTA. S. MONOTONICITY OF THE POWER FUNCTIONS OF SOME TESTS OF INDEPENDENCE BETWEEN TWO SETS OF VARIA, AMS 64.206

DAS GUPTA. S. MONOTONICITY PROPERTY OF THE POWER FUNCTIONS OF SOME TESTS OF THE EQUALITY OF TWO COVARIANG. AMS 64, 1059

DAS CUPTA,S OPTIMUM CLASSIFICATION RULES FOR CLASSIFICATION INTO TWO MULT IVARIATE NORMAL POPULATIONS, AMS 65, 1174

DAS, M. N. ASYMMETRICAL ROTATABLE DESIGNS AND ORTHOGONAL 'TRANSFORMATIONS, TECH 6B, 313

DAS, M N CONSTRUGTION AND ANALYSIS OF SOME NEW SERIES OF CONFOUNDED ASYMMETRICAL FACTORIAL DESICNS, BIOCS 67, B 13

DAS. M. N. CONSTRUCTION OF ROTATABLE DESIGNS THROUCH BALANCED INCOMPLETE BLOCK DESIGNS. AMS 62, 1421

DAS. M. N. DESIGN AND ANALYSIS OF EXPER IMENTS WITHMIXTURES. AMS 6B 1517

DAS, M. N, INCOMPLETE BLOCKDESICNS FOR BIO-ASSAYS, BIOCS 66, 706

DAS, M. N. ON THE CONSTRUCTION AND ANALYSIS OF SOME CONFOUNDED ASYMMETRICAL FACTORIAL DESIGNS, BIOCS $65,94 \mathrm{~B}$

DAVES, HILDA M. THE FITTING OF MARKOFF SERIAL VARIATION CURVES, JRSSB $5 B, 120$

DAVID, F. N. A NOTE ON THE EVALUATION OF THE MULTIVARIATE NORMAL INTEGRAL, BIOKA $53,45 B$

DAVID, F.N. A NOTE ON WILCOXON'S AND ALLIED TESTS, BIOKA 56, 485

DAVID, F. N. A PERSISTENCE PROBLEM IN RENEWAL THEORY. ROBERT THE BRUCE'S SPIDER, BIOKA 66,255

DAVID, F. N. CONTACIOUS OCCUPANCY, JRSSB 59, 120

DAVID, F. N. CORR IGENDA TO 'MULTIPLE RUNS', BIOKA 57,534

DAVID, F, N . ERRATA IN 'TABLES OF SYMMETRIC FUNCTIONS', BIOKA 5B, 292

DAVID, F. N . FOUR-LETTER WORDS. THE DISTRIBUTION OF PATTERN FREQUENCIES IN RING PERMUTATIONS, JRSSB 67, 550

DAVID, F. N. INTERSECTIONS OF RANDOM CHORDS OF A CIRCLE, BIOKA 64 373

DAVID, F. N. MULTIPLERUNS, BIOKA 57,168

DAVID, F. N. NON-RANDOMNESS IN A SEQUENCE OF TWO ALTERNATIVES. I WILC\& ON'S AND ALLIED TEST STATISTICS, BIOKA 58, 166

DAVID. F. N. NON-RANDOMNESS IN A SEQUENCE OF TWO ALTERNATIVES. II RUNS TEST, BIOKA 58, 253

DAVID, F . N. PERSISTENCE IN A CHAIN OF MULT IPLE EVENTS WHEN THERE IS SIMPLE DEPENDENCE, BIOKA 62, 351

DAVID, F.N. RANDOM POINTS IN A CIRCLE AND THE ANALYSIS OF CHROMOSOME PATTERNS, BIOKA 63,23

DAVID, F. N. RUNS IN A RING, BIOKA 58, 572

DAVID, F. N. SEQUENT IAL OCCUPANCY, BIOKA 59, 218

DAVID, F. N. SEQUENTIAL OCCUPANCY WITH CLASSIFICATION, BIOKA 6B, 229

DAVID, F. N. SOME NOTES ON ORDERED RANDOM INTERVALS, JRSSB 56.79

DAVID, F. N. SOME PROPERTIES OF THE DISTRIBUTION OF THE LOGARITHM OF NON-CENTRALF, BIOKA 60,417
DAVID, F. N. SOME TESTS OF SIGNIFICANCE WITH ORDERED VARIABLES, JRSSB 56,1

DAVID, F. N. STATISTICAL TREATMENT OF CENSORED DATA . PART I. FUNDAMENTAL FORMULAE, BIOKA $54,22 B$

DAVID, F. N. STUDIES IN THE HISTORY OF PROBABILITY AND STATISTICS. I. DICINC AND GAMINC, A NOTE ON THE HI, 8IOKA 55, 1

DAVID, F. N. TABLE FOR THE SOLUTION OF THE EXPONENTIAL EQUATION $\operatorname{EXP}(B)-B(1-P)=1$, BIOKA 63,177

DAVID, F . N. TABLES FOR THE SOLUTION OF THE EXPONENTIAL EQUATION, $\operatorname{EXP}(-\mathrm{A})+\mathrm{KA}=1, \mathrm{BIOKA} 60,439$

DAVID, F. N, TABLES OF SYMMETRIG FUNCTIONS. PART IV., BIOKA 53,427

DAVID, F. N. TABLES OF SYMMETRIC FUNCTIONS. PART V , BIOKA 55, 223

DAVID, F, N, TABLES OF SYMMETRIC FUNCTIONS, PARTS II AND III, BIOKA 51,435

DAVID, F. N, TESTS FOR RANDOMNESS OF POINTS ON A LINE, BIOKA 56, 104 DAVID, F.N. THE CENTRAL SAMPLING MOMENTS OF THE MEAN IN SAMPLES FROM A FINITE POPULATION (ATY'S FORMULAE, BIOKA 61, 199

DAVID, F . N . THE DISPERSION OF A NUMBER OF SPECIES, JRSSB 59, 190

DAVID, F.N. THE EFFEGT OF NON-NORMALITY ON THE POWER FUNCTION OF THE F-TEST IN THE ANALYSIS OF VARIANCE, BIOKA 5 I , 43

DAVID, F.N. THE POLYKAYS OF THE NATURAL NUMBERS, BIOKA 60,53

DAVID, $F . N$. THE VARIANCE OF SPEARMAN'S RHO IN NORMAL SAMPLES, BIOKA 61,19

DAVID, F.N. THE Z-TEST AND SYMMETRICALLY DISTRIBUTED RANDOM VARIABLES, 8IOKA 59, 123

DAVID, H. A. A MULTI-STAGE PROCEDURE FOR THE SELECT ION OF THE BEST OF SEVERAL POPULATIONS, JASA $62,7 B 5$

DAVID, H. A. A NOTE ON 'A K-SAMPLE MODEL IN ORDER STATISTICS' BY $W . J$ CONOVER, AMS 66, $2 B 7$

DAVID, H. A, A NOTE ON MOVING RANGES, BIOKA 55, 512

DAVID, $H$. A . CORRECTION TO 'A CONSERVATIVE PROPERTY OF BINOMIAL TESTS' 601205 . AMS 61, 1343

DAVID, H. A . CORRIGENDA, 'SICNIFICANT TESTS FOR PAIRED-COMPARISON EXPERIMENTS', BIOKA 61, 475

DAVID, H. A. CORRICENDA, 'THEDISTRIBUTION OF RANGE IN CERTAIN NONNORMAL POPULATIONS' ' BIOKA 55, 277

DAVID, H. A . CYCLIC DESIGNS, AMS 65, 1526

DAVID, $H$. A. EST IMATION OF MEANS OF NORMAL POPULATIONS FROM OBSERVED MINIMA, BIOKA 57,282

DAVID, H. A. EXACT DISTRIBUTION OF THE SUM OF INDEPENDENT IDENTICALLY DISTR IBUTED DISGRETE RANDOM VARIABL, JASA 65, B37

DAVID. H. A. FUR'I'HER APPLICATIONS OF RANGE TO THE ANALYSIS OF VARIANCE, 8IOKA 51,393

DAVID, H. A. GINI 'S MEAN DIFFERENCE REDISCOVERED, 8IOKA 6B, 573

DAVID, H. A. MOMENTS OF NEGATIVE ORDER AND RATIO-S'TATISTICS, JRSSB 55,122

DAVID, H. A. ON COMPARING DIFFERENT TESTS OF THE SAME HYPOTHESIS, BIOKA 60,297

DAVID. H. A. ON THE APPLICATION TO STATISTICS OF AN ELEMENTARY THEOREM IN PROBABILITY, BIOKA 56, B 5

DAVID, H, A. ORDER STATISTICS FOR DISCRETE POPULATIONS AND FOR GROUPED SAMPLES, JASA 68,1390

DAVID, H. A. PAIRED COMPARISONS FOR PAIRED CHARACTERISTICS, AMS 68 , 200

DAVID, H. A. RECURRENCE RELATIONS BETWEEN MOMENTS OF ORDER STATISTICS FOR EXCHANGEABLE VARIATES, AMS 6B, 272

DAVID, $H$. A. REVISED UPPER PERGENTAGE POINTS OF THE EXTREME STUDENT IZED DEVIATE FROM THE SAMPLE MEAN, BIOKA 56, 449

DAVID, H. A. SELECTION OF THE BEST TREATMENT IN A PAIRED-COMPARISON EXPERIMENT, AMS 63,75

DAVID, H. A. SIGNIFICANCE TESTS FOR PAIRED-COMPARISON EXPERIMENTS, BIOKA 61,95

DAVID, H, A SOME TESTS FOR OUTLIERS, BIOKA 61,379

DAVID, H. A. THE DISTRIBUTION OF RANGE IN CERTAIN NON-NORMAL POPULATIONS, BIOKA 54, 463

DAVID, H. A. THE DISTRIBUTION OF THE RATIO, IN A SINGLE NORMAL SAMPLE, OF RANGE TO STANDARD DEVIATION, BIOKA 54, 4B2

DAVID, H. A. THE IDENTIFICATION OF ANNUAL PEAK PERIODS FOR A DISEASE. BIOCS 65,645

DAVID, H. A. THE PERFORMANCE OF SEVERAL TESTS FOR OUTLIERS, BIOKA 65, 429

DAVID. $H$. A. THE POWER FUNCTION OF SOME TESTS BASED ON RANGE, BIOKA 53.347

DAVID, H. A. THE RANKING OF VARIANCES IN NORMAL POPULATIONS, JASA 56,621

DAVID, $H$. A. TOURNAMENTS AND PAIRED COMPARISONS, BIOKA 59, 139

DAVID, H. A. UPPER 5 AND 1 PERCENT POINTS OF THE MAXIMUM F-RATIO, BIOKA 52,422

DAVID, H. T. GAME VALUE DISTRIBUTIONS I, AMS 67, 242

DAVID. H. T. LIKELIHOOD RATIO COMPUTATIONS OF OPERATING COMPUTATIONS, AMS 66, 1704

DAVID, $H$. T. POISSON LIMITS OF MULTIVARIATE RUN DISTRIBUTIONS. AMS 65, 215

DAVID, HERBERT ORDER STATISTICS AND STATISTICS OF STRUCTURE, AMS 65. 897

DAVID, HERBERT A. DISCUSSION OF 'A SUBJECTIVE EVALUATION OF BODE'S LAW AND AN 'OBJECTIVE' TEST FOR APPROX. JASA 69, 50 
DAVID, HERBERT T. THE SAMPLE MEAN AMONG THE EXTREME NORMAL ORDER STATISTICS, AMS 63, 33

DAVID, HERBERT T. THE SAMPLE MEAN AMONG THE MODERATE ORDER STATISTICS, AMS 62, 1160

DAVID, MARTIN THE VALIDITY OF INCOME REPORTED BY A SAMPLE OF FAMILIES WHO RECEI VED WELFARE ASSISTANCE DUR, JASA 62,680

DAVID, S. T. CONFIDENCE INTERVALS FOR PARAMETERS IN MARKOV AUTOREGRESSIVE SCHEMES (WITH DISCUSSION) , JRSSB 54, 195

DAVID, S. T. SOME QUESTIONS OF DISTRIBUTION IN THE THEORY OF RANK CORRELATION, BIOKA 51,131

DAVIDSON, R. R. MULTIVARIATE PAIRED COMPARISONS. THE EXTENSION OF A UNIVAR IATE MODEL AND ASSOCI ATED ESTIM, BIOKA 69, 81

DAVIDSON, R. R. ON A RELATIONSHIP BETWEEN TWO REPRESENTATIONS OF A MODEL FOR PAIRED COMPARISONS, BIOCS 69,597

DAVIES, $M$. LINEAR APPROXIMATION USING THE CRITERION OF LEAST TOTAL DEVIATIONS (ACKNOWLEDGEMENT 67587 ), JRSSB 67.101

DAVIES, M. MULTIPLE LINEAR REGRESSION ANALYSIS WITH ADJUSTMENT FOR CLASS DIEFERENCES, JASA 61,729

DAVIES, 0. L. SOME STATIST ICAL ASPECTS OF THE ECONOMICS OF ANALYTI CAL TESTING, TECH 59, 49

DAVIES, 0. L. THE DESIGN OF SCREENING TESTS, TEGH 63. 481

DAVIES, P. A SEQUENTIAL METHOD OF TESTING THE LINEAR TRENDS OF RESPONSES IN DOSE TRIALS, 8IOCS 68, 663

DAVIES, $P$. THE CHOICE OF VARIABLES IN THE DESIGN OF EXPERIMENTS FOR LINEAR REGRESSION, BIOKA 69, 55

DAVIES, R. B. CANNIBALISM OF THE PUPAL STAGE BY ADULT FLOUR BEETLES, AN EXPERIMENT AND A STOCHAST IC MODEL, BIOCS 68,247

DAVIS, A. W. A COUNTER-EXAMPLE RELATING TO CERTAIN MULTIVARIATE GENERALIZATIONS OF T AND F, AMS 67, 613

DAVIS, A. W. A SYSTEM OF LINEAR DIFFERENT IAL EQUATIONS FOR THE DISTRIBUTION OF HOTELLING 'S GENERALIZED T- , AMS 6B, B15

DAVIS, A, W. CYCLIG CHANGE-OVER DESIGNS, BIOKA 69, 283

DAVIS, A. W. GENERALIZED ASYMPTOTIC EXPANSIONS OF CORNISH-FISHER TYPE, AMS 68, 1264

DAVIS, A. W, ON THE PROBABILITY GENERAT ING FUNCTIONAL FOR THE CUMULAT IVE POPULATION IN A SIMPLE BIRTH-AND, BIOKA 64,245

DAVIS, BURGESS A COMPARISON TEST FOR MARTINGALE INEQUALITIES, AMS 69,505

DAVIS, BURGESS GOMPARISON TESTS FOR THE CONVERGENCE OF MARTINGALES, AMS 6B, 2141

DAVIS, BURGESS DIVERGENCE PROPERTIES OF SOME MARTINGALE TRANSFORMS, AMS 69,1852

DAVIS. C. E. ON COMPARING THE CORRELATIONS WITHIN TWO PAIRS OF VARIABLES, BIOCS 68, 987

DAVIS, HERBERT T. ESTIMATION OF THE INNOVATION VARIANCE OF A STATIONARY TIME SERIES, JASA 68, 141

DAVIS, JAMES A. A PART IAL COEFFICIENT FOR GOODMAN AND KRUSKAL 'S GAMMA, JASA $67,1 B 9$

DAVIS, JAMES AVERY A GHARACTERIZATION OF THE UPPER AND LOWER CLASSES IN TERMS OF CONVERGENCE RATES, AMS 69, 1120

DAVIS, JAMES AVERY CONVERGENCE RATES FOR PROBABILITIES OF MODERATE DEVIATIONS, AMS 6B, 2016

DAVIS, JAMES AVERY CONVERGENCE RATES FOR THE LAN OF THE ITERATED LOGARITHM, AMS 6B, 1479

DAVIS, M. THE ROBBINS-MONRO METHOD FOR EST IMATING THE MEDIAN LETHAL DOSE, JRSSB $65,2 B$

DAVIS, MILES DISCUSSION OF 'A SUBJECTIVE EVALUATION OF 8ODE'S LAN AND AN ' OBJECTIVE' TEST FOR APPROXIMATE, JASA 69, 50

DAVIS, S. A. TABLES OF DISTRIBUTION-FREE TOLERANCE LIMITS, AMS 64 , 1361

DAWSON, R. B. A SIMPLIFIED EXPRESSION FOR THE VARIANCE OF THE CHI SQUARE FUNCTION ON A CONTINGENCY TABLE, BIOKA 54,280

DAY, N. E. A GOMPARISON OF SOME SEQUENT I AL DESIGNS, BIOKA 69, 301

DAY. N. E. A GENERAL MAXIMUM LIKELIHOOD DISCRIMINANT, BIOCS 67, 313

DAY. N. E. ESTIMATING THE COMPONENTS OF A MIXTURE OF NORMAL DISTRIBUTIONS, BIOKA 69, NO.3

DAY. N. E. FITTING CURVES TO LONGITUDINAL DATA, BIOCS $€ 6,276$

DAY, N. E. TWO-STAGE DESIGNS FOR CLINICAL TRIALS, BIOCS69, 111

DAYHOFF, EUGENE GENERALIZED POLYKAYS, AN EXTENTION OF SIMPLE POLYKAYS AND BIPOLYKAYS, CORR. 66746 , AMS 66, 226

DAYHOFF, EUGENE ON THE EQUIVALENCE OF POLYKAYS OF THE SECOND DEGREE AND SIGMA'S, CORR. 651069 , AMS 64,1663

DE BRUYN, C. S. VAN DO8BEN PREDICTION BY PROGRESSIVE CORRECTION, JRSSB 64, 113

DE GANI. J. S. MAXIMUM LIKELIHOOD PAIRED COMPARISON RANKING BY LINEAR PROGRAMMING, 8IOKA 69, N0.3

DE GICCO, HENRY NOTE ON AN APPLICATION OF FOUR MOMENT INEQUALITIES TO A PROBLEM IN QUEUES, TECH 65,435

DE GROOT , M. H. OPTIMAL TWO-STAGE STRATIFIED SAMPLING, AMS 69, 575

DE GROOT, M. H. THE ESSENTIAL COMPLETENESS OF THE CLASS OF GENERALIZED SEQUENTIAL PROBA8ILITY RATIO TESTS, AMS 61, 602

DE JANOSI, PETER E. A NOTE ON THE RELATIONSHIP BETWEEN EARNING EXPECTATIONS AND NEW CAR PURCHASES, JASA 59,575

DE LA GARZA, A, QUADRATIC EXTRAPOLATION AiND A RELATED TEST OF HYPOTHESES, JASA 56,644

DE LEEUW, FRANK THE CONCEPT OF CAPACITY, JASA 62,826

DE OLIVEIRA, J. TIAGO QUASI-LINEARLY INVARIANT PREDICTION, AMS 66 , 1684
DE ST GROTH, S. FAZEKAS RANDOM CIRCLES ON A SPHERE, BIOKA 62, 389 DE WAAL, D. J. AN ASYMPTOTIC DISTRIBUTION FOR THE DETERMINANT OF A NON-CENTRAL B STATISTIC IN MULTIVARIAT, SASJ 6B, 77

DE WAAL, D. J. ON THE NONCENTRAL DISTRI8UTION OF THE LARGEST CANONICAL CORRELATION COEFFICIENT, SASJ 69, NO. 2

DE WAAL, D. J. THE NONCENTRAL MULTIVARIATE BETA TYPE TWO DISTRIBUTION, SASJ 69, NO.2

DEAN, WILLIAM BEST LINEAR UNBIASED ESTIMATION FOR MULTIVARIATE STATIONARY PROCESSES, TECH 6B, 523

DEBAUN, R. RESPONSE SURFACE DESIGNS FOR THREE FACTORS AT THREE LEVELS, TECH 59,1

DEBERGHES, HELENE ON THE ERGODICITY FOR NON-STATIONARY MULTIPLE MARKOV PROCESSES, AMS 68,1448

DECELL JR, HENRY P. ON THE FIXED POINT PROBABILITY VECTOR OF REGULAR OR ERGODIC TRANSITION MATRICES, JASA 67, 600

DECICCO, $\mathrm{H}$. ON THE DISTRIBUTION OF THE BIVARIATE RANGE, TECH 67, 476 DEELY, J. J , CONSTRUCTION OF SEQUENCES ESTIMATING THE MIXING DISTRIBUTION, AMS 6B, 286

DEELY, J. J. THE EXCEEDANCE TEST FOR TRUNCATION OF A SUPPLIER'S DATA, JASA 69,823

DEELY, JOHN SHORTER CONFIDENCE INTERV ALS USING PRIOR OBSERVATIONS, JASA $69,37 B$

DEEMER, WALTER L. THE JAGOBIANS OF CERTAIN MATRIX TRANSFORMATIONS USEFUL IN MULTIVARIATE ANALYSIS, BASED, BIOKA 51, 345

DEGRAY, DICK THE ROUND ROBIN (ERRATA, 69 627) , TECH 68, B4 1

DEGRAY, R. J. DESIGN FOR INTERACT IONS, TECH $6 B, 3 B 9$

DEGROOT, M. H. BAYES ESTIMATION WITH CONVEX LOSS, AMS 63,839

DEGROOT, M. H, CORRELATIONS BETWEEN SIMILAR SETS OF MEASUREMENTS, BIOCS 66,781

DEGROOT, M. H. SOME ASPECTS OF THE USE OF THE SEQUENT IAL PROBABILITY RATIO TEST, JASA 5B, 187

DEGROOT, M. H. SOME PROBLEMS OF OPTIMAL STOPPING, JRSSB 68, 108

DEGROOT, M. H. UNCERTAINTY, INFORMATION, AND SEQUENTIAL EXPERI MENTS, AMS 62, 404

DEJANOSI, PETER E. ON THE STATISTICAL DISCREPANCY IN THE REVISED UNITED STATES NATIONAL ACCOUNTS, JASA 66, 1219

DELANGE, E. M. EXACT CRITIGAL VALUES FOR MOOD 'S DISTRIBUTION-FREE TEST STAT ISTIC FOR DISPERSION AND ITS N, TECH 68, 497

DEMING. W. EDWARDS ON SIMPLIFICATIONS OF SAMPLING DESIGN THROUGH REPLICATION WITH EQUAL PROBABILIT IES AND, JASA 56,24

DEMING, W. EDWARDS ON THE PROBLEM OF MATCHING LISTS BY SAMPLES, JASA 59,403

DEMING, W. EDWARDS SPECIAL PAPER, PRINCIPLES OF PROFESSIONAL STATISTICAL PRACTICE, AMS 65, 1883

DEMING , W. EDWARDS WASHINGTON ST AT IST ICAL SOCIETY MEMORIAL MEET ING FOR KILLIAMN. HURWITZ. ON WILLIAM HUR, JASA 69, NO 4

DEMPSTER, A. P. A GENERALIZATION OF BAYESIAN INFERENCE (WITH DISCUSSION), JRSSB 6B, 205

DEMPSTER, A.P. DISCUSSION OF ' ON THE FOUNDATIONS OF STATISTICAL INFERENCE', JASA 62,307

DEMPSTER, A.P. DISTRIBUTIONS DETERMINED BY CUTTING SIMPLEX WITH HYPERPLANES, AMS 6B, 1473

DEMPSTER, A. P. EXPECTED SIGNIFICANCE LEVEL AS A SENSITIVITY INDEX FOR TEST STATISTICS. JASA 65,420

DEMPSTER, A.P. FURTHER EXAMPLES OF INCONSISTENCIES IN THE FIDUCIAL ARGUMENT, AMS 63, B44

DEMPSTER, A. P. MULTIVARIATE THEORY FOR GENERAL STEPWISE METHODS AMS 63,873

DEMPSTER, A, P. NEW METHODS FOR REASONING TOWARDS POSTERIOR DISTRIBUTIONS BASED ON SAMPLE DATA, AMS 66, 355

DEMPSTER, A.P. ON A PARADOX CONCERNING INFERENCE ABOUT A COVARIANCE MATRIX, AMS 63, 1414

DEMPSTER A P ONDIRECT PROBABILITIES, JRSSB 63, 100

DEMPSTER, A. P. ON THE DIFFICULTIES INHERENT IN FISHER'S FIDUCIAL ARGUMENT, JASA 64,56

DEMPSTER, A. P. RANDOM ALLOCATION DESIGNS II, APPROX IMATE THEORY FOR SIMPLE RANDOM ALLOCATION, AMS 61, 3B7

DEMPSTER, A.P. TESTS FCR THE EQUALITY OF TWO COVARIANCE MATRICES IN RELATION TO A BEST LINEAR DISCRIMINA, AMS 64, 191

DEMPSTER, A.P. UPPER AND LOWER PROBABILITIES GENERATED BY A RANDOM GLOSED INTERVAL, AMS 6B, 957

DEMPSTER, A. P. UPPER AND LOWER PROBABILITIES INDUCED BY A MULTIVALUED MAPPING, AMS 67,325

DEMPSTER, A. P. UPPER AND LOWER PROBABILITY INFERENCES BASED ON A SAMPLE FROM A FINITE UNIVARIATE POPULAT, BIOKA 67, 515

DEMPSTER, A.P. UPPER AND LOWER PROBABILITY INFERENCES FOR FAMILIES OF HYPOTHESES WITH MONOTONE DENSITY R, AMS 69, 953

DENARDO, E. V. AN OPTIMALITY CONDITION FOR DISCRETE DYNAMIC PROGRAMMING WITH NO DISCOUNTING, AMS 68, 1220

DENNIS, K. E. THE GONDITIONS UNDER WHICH GRAM-CHARLIER AND EDGEWORTH CURVES ARE POSITIVE DEFINITE AND UNI, 8IOKA 52, 425

DENNY, J . L. GONVERGENGE PROPERTIES OF CONVERGENCE WTH PROBABILITY ONE, AMS 66, 1800

DENNY, J, L. NOTE ON A THEOREM OF DYNKIN ON THE DIMENSION OF SUFFICIENT STATISTICS, AMS 69, 1474

DENNY; J , L. ON CONT INUOUS SUFFICIENT STATISTICS, AMS 64, 1229

DENTON, FRANK T. SOME TECHNIQUES FOR ANALYZING A SET OF TIME SERIES SUBJECT TO A LINEAR RESTRICTION, JASA 63, 513 
DEO, C. M. A NOTE ON THE WEAK LAW, AMS 6B, 2159

DERMAN, C. SOME ASYMPTOTIC DISTRIBUTION THEORY FOR MARKOV CHAINS WITH A DENUMERABLE NUMBER OF STATES, BIOKA 56, 2B5

DERMAN, CYRUS A NOTE ON MEMORYLESS RULES FOR CONTROLLING SEQUENTIAL CONTROL PROCESSES, AMS 66, 276

DERMAN, CYRUS A SOLUTION TO A COUNTABLE SYSTEM OF EQUALITIES ARISING IN MARKOVIAN DECISION PROCESSES, AMS 67, 5B2

DERMAN, CYRUS DENUMERABLE STATE MARKOVIAN DECISION PROCESSES, AVERAGE COST CRITERION, AMS 66, 1545

DERMAN, CYRUS ON SEQUENT IAL CONTROL PROCESSES, AMS 64, 341

DERMAN, CYRUS REMARK CONCERNING TWO-STATE SEMI-MARKOV PROCESSES, AMS 61, 615

DES RAJ, A NOTE ON THE VARIANEE OF THE RATIO ESTIMATE, JASA 64, B95

DES RAJ, ON A METHOD OF USING MULTI-AUXILIARY INFORMATION IN SAMPLE SURVEYS, JASA 65,270

DES RAJ, ON DOUBLE SAMPLING FOR PROBABILITY PROPORTIONATE TO SOME MEASURE OF SIZE ESTIMATION, AMS 64,900

DES RAJ, ON FORMING STRATA OF EQUAL AGGREGATE SIZE, JASA 64, 4BI

DES RAJ, ON MATCHING LISTS BY SAMPLES, JASA 61, 151

DES RAJ, ON SAMPLING OVER TWO OCCASIONS WITH PROBABILITY PROPORTIONATE TO SIZE. AMS 65,327

DES RAJ, ON THE RELATIVE ACCURACY OF SOME SAMPLING TECHNIQUES, JASA $5 B, 9 B$

DES RAJ, SOME ESTIMATORS IN SAMPLING WITH VARYING PROBABILITIES WITHOUT REPLACEMENT, JASA 56, 269

DES RAJ SOME REMARKS ON A SIMPLE PROCEDURE OF SAMPLING WITHOUT REPLACEMENT, JASA 66, 391

DES RAJ, THE USE OF SYSTEMATIC SAMPLING WITH PROBABILITY PROPORTIONATE TO SIZE IN A LARGE SCALE SURVEY, JASA 64,251

DES RAJ, VARIANCE ESTIMATION IN RANDOMIZED SYSTEMATIC SAMPLING WITH PROBABILITY PROPORTIONATE TO SIZE, JASA 65, 27B

DESHPANDE, J. V. SOME NONPARAMETRIC TESTS FOR MULTISAMPLE PROBLEMS, TECH $68,57 \mathrm{~B}$

DESU, M. M. A FIXED SUBSET-SIZE APPROACH TO THE SELECTION PROBLEM, BIOKA 68,401

DESU, M. M. PREDICTIVE ZERO-MEAN UNIFORM DISCRIMINATION, BIOKA 68, 519

DEUEL, P. THE LAST RETURN TO EQUILIBRIUM IN A COIN TOSSING GAME, AMS 64,1344

DHARMADHIKARI, $S$. W. A CHARACTERIZATION OF A CLASS OF FUNCTIONS OF FINITE MARKOV CHAINS, AMS 65, 524

DHARMADHIKARI, S. W. A NOTE ON EXCHANGEABLE PROCESSES WITH STATES OF FINITE RANK, AMS 69, N0.6

DHARMADHIKARI, S. W. BOUNDS ON MOMENTS OF MARTINGALES, AMS 6B, 1719

DHARMADHIKARI, S. W. BOUNDS ON MOMENTS OF SUMS OF RANDOM VARIABLES, AMS 69, 1506

DHARMADHIKARI, S. W. EXCHANGEABLE PROCESSES WHICH ARE FUNCTIONS OF STAT IONARY MARKOV CHAINS, AMS 64,429

DHARMADHIKARI, S. W. FUNCTIONS OF FINITE MARKOV CHAINS, AMS 63, 1022 DHARMADHIKARI. S. W. SPLITTING A SINGLE STATE OF A STATIONARY PROCESS INTO MARKOVIAN STATES, AMS 6B, 1069

DHARMADHIKARI, S. W. SUFFICIENT CONDITIONS FOR A STATIONARY PROCESS TO BE A FUNCTION OF A FINITE MARKOV C, AMS 63, 1033

DIAMOND, EARL L. THE LIMITING POWER OF CATEGORICAL DATA CHI-SQUARE TESTS ANALOGOUS TO NORMAL ANALYSIS OF, AMS 63, 1432

DIAMOND, W. J. THREE DIMENS IONAL MODELS OF EXTREME VERTICES DES IGNS FOR FOUR COMPONENT MIXTURES, TECH 67,472

DICKEY, JAMES $M$. EXPANSIONS OF T DENSITIES AND RELATED COMPLETE INTEGRALS, AMS 67, 503

DICKEY, JAMES M. MATRICVARIATE GENERALIZATIONS OF THE MULT IVARIATE TDISTRIBUTION AND THE INVERTED MULTIV, AMS 67, 511

DICKEY, JAMES $M$. SMOOTHED ESTIMATES FOR MULTINOMIAL CELL PROBABILITIES, AMS 6B, 561

DICKEY, JAMES M. SMOOTHING BY CHEATING, AMS 69, 1477

DICKEY, JAMES M. THREE MULTIDIMENSIONAL-INTEGRAL IDENTITIES WITH BAYESIAN APPLICATIONS, AMS 6B, 1615

DINGMAN, H. F. LATENT CLASS ANALYSIS AND DIFFERENTIAL MORTALITY, JASA 62,430

DISHON, MENACHEM A COMMUNICATIONS SATELLITE REPLENISHMENT POLICY, TECH 66,399

DIXON, W. J. APPROXIMATE BEHAVIOR OF THE DISTRIBUTION OF WINSORIZED T (TRIMMING-WINSORIZATION 2), TECH 6B, B3

DIXON, W. J , QUERY, REJECTION OF OUTLYING VALUES, TECH $64,22 B$

DIXON, W. J. SAMUEL S. WILKS, JASA 65, 939

DIXON, W. $J$. THE UP-AND-DOWN METHOD FOR SMALL SAMPLES, JASA 65, 967

DODGE, H. F. PROCEDURES AND TABLES FOR EVALUATING DEPENDENT MIXED ACCEPTANCE SAMPLING PLANS, TECH 69,341

DOEHLERT, DAVID $H$. BALANCED SETS OF BALANCED INCOMPLETE BLOCK DESIGNS OF BLOCK SIZE THREE, TECH 65, 561

DOERFLER, T. E. THE BEHAVIOUR OF SOME SIGNIFICANCE TESTS UNDER EXPERIMENTAL RANDOMIZATION, BIOKA 69, 231

DOIG, ALISON A BIBLIOGRAPHY ON THE THEORY OF QUEUES. BIOKA 57,490

DOKSUM, K. TEST FOR MONOTONE FA ILURE RATE BASED ON NORMALIZED SPACING. AMS 69. 1216

DOKSUM, K. A 'OPTIMAL' ONE-SAMPLE DISTRIBUTION-FREE TESTS AND THEIR TWO-SAMPLE EXTENSIONS, AMS 66, 120

DOKSUM. K. A DISTRIBUTION AND POWER OF THE ABSOLUTE NORMAL SCORES TEST, JASA 67,966
DOKSUM. K. A. DISTRIBUTION-FREE TESTS OF INDEPENDENCE, AMS 67, 429 DOKSUM, K. A SOME NEW D ISTR IBUTION-FREE STATISTICS , ACKNOWLEDGEMENT OF PRIORITY 65 1901). AMS65. 203

DOKSUM. KJELL ASYMPTOTICALLY MINIMAX DISTRIBUTION-FREE PROCEDURES, AMS 66,619

DOKSUM, KJELL ASYMPTOTICALLY OPTIMAL STATISTICS IN SOME MODELS WITH INCREAS ING FA ILURE RATE AVERAGE, AMS 67 . 1731

DOKSUM, KJELL MINIMAX RESULTS FOR IFRA SCALE ALTERNATIVES, AMS 69 $177 \mathrm{~B}$

DOKSUM. KJELL ROBUST PROCEDURES FOR SOME LINEAR MODELS WITH ONE OBSERVATION PER CELL, AMS67. B7B

DOKSUM, KJELL STARSHAPED TRANSFORMATIONS AND THE POWER OF RANK TESTS, AMS 69, 1167

DOLBY. J. L. GRAPHICAL PROCEDURE FOR FITTING THE BESTLINE TO A SET OF POINTS, TECH 60,477

DOLBY. JAMES L. A QUICK METHOD FOR CHOOSING A TRANSFORMATION, TECH 63. 317

DOLEANS, CATHERINE VARIATION QUADRATIQUE DES MARTINGALES CONTINUES A DROITE, AMS 69, 2B4

DOMB, C. SOME STATISTICAL PROBLEMS CONNECTED WITH CRYSTAL LATTICES (WITH DISCUSSION) , JRSSB 64, 367

DONALDSON, THEODORE S. ROBUSTNESS OF THE F-TEST TO ERRORS OF BOTH KINDS AND THE CORRELATION BETWEEN THEN, JASA 68,660

DOOLITTLE. D. P. MAMMALIAN REPRODUCTIVE DATA FITTED TO A MATHEMATICAL MODEL, BIOCS 69,529

DORAN, J. E. SOME EXPERIMENTS IN THE NUMERICAL ANALYSIS OF ARCHAEOLOGICAL DATA, BIOKA 66, 311

DORFF, M. ESTIMATION OF THE PARAMETERS OF A LINEAR FUNCTIONAL RELATION, JRSSB 61,160

DOSS, D. C. CHARACERTIZATICNS OF THE LINEAR EXPONENTIAL FAMILY IN A PARAMETER BY RECURRENCE RELATIONSFO, AMS 69, 1721

DOSS, S. A. D. C. ON THE EFFICIENCY OF BAN EST IMATES OF THE PARAMETERS OF NORMAL POPULATIONS BASED ON SIN, BIOKA 62,570

DOUGLAS, J.B TABLES OF POISSON POWER MOMENTS, BIOKA 56, 4B9

DOWNS, T. D. SOME RELATIONSHIPS AMONG THE VON MISES DISTRIBUTIONS OF DIFFERENT DIMENSIONS, BIOKA 66, 269

DOWNS, T. D. SOME RELATIONSHIPS BETWEEN THE NORMAL AND VON MISES DISTRIBUTIONS, BIOKA 67,684

DOWNTON, F. "A NOTE ON ORDERED LEAST-SQUARES ESTIMATION, BIOKA 53 457

DOWNTON, F A NOTE ON THE ULTIMATE SIZE OF A GENERAL STOCHASTIC EPIDEMIC, BIOKA 67,314

DOWNTON, F. A NOTE ON VACANCIES ON A LINE, JRSSB 61, 207

DOWNTON, F, CONGESTION SYSTEMS WITH INCOMPLETE SERVICE (CORR. 64 365), JRSSB 62, 107

DOWNTON, F. LINEAR ESTIMATES WITH POLYNOMIAL COEFFICIENTS, BIOKA 66, 129

DOWNTON, F. ON LIMITING DISTRIBUTIONS ARISING IN BULK SERVICE QUEUES. JRSSB 56. 265

DOWNTON, F. THE RELIABILITY OF MULTIPLEX SYSTEMS WITH REPAIR, JRSSB 66,459

DOWNTON, F. THE ULTIMATE SIZE OF CARRIER-BORNE EPIDEMICS, BIOKA 6B 277

DOWNTON, F. WAITING TIME IN BULK SERVICE QUEUES, JRSSB 55, 256

DOWNTON, FRANK LINEAR ESTIMATES OF PARAMETERS IN THE EXTREME VALUE DISTRIBUTION, TECH 66,3

DOWSON . D . C O ON THE LINEAR CONTROL OF A LINEAR SYSTEM HAVTNG A NORMAL STATIONARY STOCHASTIC INPUT, JRSSB 68,381

DOWSON, D. C. OPTIMIZATION OF A HOT ROLLING MILL, JRSSB 67.300

DRAPER, J CORRIGENDA, 'PROPERTIES OF DISTRIBUTIONS RESULT ING FROM CERTAIN SIMPLE TRANSFORMATIONS OF THE, BIOKA 53, 236

DRAPER, J. PROPERTIES OF DISTRIBUTIONS RESULTING FROM CERTAIN SIMPLE TRANSFORMATIONS OF THE NORMAL DISTRI. BIOKA 52, 290

DRAPER, N. R. BAYESIAN ANALYSIS OF LINEAR MODELS WITH TWO RANDOM COMPONENTS WITH SPECIAL REFERENCE TO THE, BIOKA 68, 101

DRAPER, N. R. BAYESIAN STRATIFIED TWO-PHASE SAMPLING RESULTS, K CHARACTERISTICS, BIOKA 6B, 5B7

DRAPER. N, R. CORRIGENDA, 'THE CHOICE OF A SECOND ORDER ROTATABLE DESIGN', BIOKA 65, 305

DRAPER, N. R. DESIGN OF EXPERIMENTS FOR PARAMETER ESTIMATION IN MULTIRESPONSE SITUATIONS, BIOKA 66,525

DRAPER, N.R. DESIGNS WHICH MINIMIZE MODEL INADEQUACIES. CUBOIDAL REGIONS OF INTEREST, BIOKA 65, 111

DRAPER, N. R. MIXTUREDESIGNS FOR THREE FACTORS, JRSSB 65, 450

DRAPER, N. R. SEQUENTIAL DESIGNS FOR SPHERICAL WEIGHT FUNCTIONS, TECH 67, 517

DRAPER, N R. SOME BAYESIAN STRATIFIED TWO-PHASE SAMPLING RESULTS, BIOKA 68, 131

DRAPER, N. R. THE BAYESIAN ESTIMATION OF COMMON PARAMETERS FROM SEVERAL RESPONSES, BIOKA 65,355

DRAPER, N. R. THE USE OF PRIOR D ISTRIBUTIONS IN THE DESIGN OF EXPERIMENTS FOR PARAMETER ESTIMATION IN NON, BIOKA 67, 147

DRAPER, N . R . THE USE OF PRIOR DISTRIBUTIONS IN THE DESIGN OF EXPERIMENTS FOR PARAMETER ESTIMATION IN NON, BIOKA 67,662

DRAPER, N. R. THE USE OF SECOND-ORDER 'SPHERICAL' AND 'CUBOIDAL' DESIGNS IN THE WRONG REGIONS, BIOKA 66, 596

DRAPER, $N$. R. UNEQUAL GROUP VARIANCES IN THE FIXED-EFFECTS ONE-WAY ANALYSIS OF VARIANCE, A BAYESIAN SIDEL, BIOKA 66, 27 
DRAPER, NORMAN 'RIDGE ANALYSIS' OF RESPONSE SURFACES, TECH 63, 469 DRAPER, NORMAN ISN'T MY PROCESS TOO VARIABLE FOR EVOP . , TECH 6B, 439

DRAPER, NORMAN R THE CHOICE OF A SECOND ORDER ROTATABLE DESIGN, 8IOKA 63, 335

DRAPER, NORMAN R. A BASIS FOR THE SELECTION OF A RESPONSE SURFACE DESIGN, JASA 59.622

DRAPER, NORMAN R. CONSTRUCTION OF THE SET OF 256-RUN DESIGNS OF RESOLUT ION GREATER THAN OR EQUAL TO 5 AND, AMS 6B, 246

DRAPER, NORMAN R. FACTOR CHANGES AND LINEAR TRENDS IN EIGHT-RUN TWO LEVEL FACTORIAL DESIGNS, TECH 68,301

DRAPER, NORMAN R. FURTHER SECOND ORDER ROTATABLE DESIGNS, AMS 6B, 1995

DRAPER, NORMAN R. MISSING VALUES IN RESPONSE SURFACE DESIGNS, TECH 61.389

DRAPER, NORMAN R. RESPONSE SURFACE DESIGNS FOR FACTORS AT TWO AND THREE LEVELS, TECH 68,177

DRAPER, NORMAN R. TESTING FOR THE INCLUSION OF VARIABLES IN LINEAR REGRESSION BY A RANDOMISATION TECHNIQU, TECH 66, 695

DRAPER, NORMAN R. THE CONSTRUCTION OF SATURATED TWO TO THE POWER OF K-P DESIGNS, AMS 67,1110

DRAPER, NORMAN R. THIRD ORDER ROTATABLE DESIGNS IN THREE DIMEN SIONS, SOME SPECIFIC DESIGNS, AMS 61, 910

DRAPER, NORMAN R. THIRD ORDER ROTATABLE DESIGNS IN THREE FACTORS, ANALYSIS, TECH 62,219

DRAPER, NORMAN R. TRANSFORMATIONS, SOME EXAMPLES REVISITED, TECH 69,23

DRONKERS, J. J. APPROXIMATE FORMULAE FOR THE STATISTICAL DISTRIBUTIONS OF EXTREME VALUES, BIOKA 58,447

DU BOIS, N. S. D'ANDREA A SOLUTION TO THE PROBLEM OF LINKING MULTIVARIATEDOCUMENTS, JASA 69, 163

DUBEY, S. D. ON SOME PERMISSIBLE ESTIMATORS OF THE LOCATION PARAMETER OF THE WEI8ULL AND CERTAIN OTHER DI, TECH 67,293

DUBEY, S. D. ON THE DETERMINATION OF CONFIDENCE LIMITS OF AN INDEX, BIOCS 66,603

DU8EY, SATYA D. ASYMPTOTIC PROPERTIES OF SEVERAL ESTIMATORS OF WEIBULL PARAMETERS, TECH 65,423

DU8EY, SATYA D. SOME PERCENTILE ESTIMATORS FOR WEIBULL PARAMETERS, TECH 67,119

DUBINS, LESTER MERGING OF OPINIONS WITH INCREASING INFORMATION, AMS 62, B82

DUBINS, LESTER E. A NOTE ON UPCROSSINGS OF SEMIMARTINGALES, AMS 66 , 728

DU8INS, LESTER E. A SHARPER FORM OF THE BOREL-CANTELL I LEMMA AND THE STRONG LAW, AMS 65,800

DU8INS, LESTER E. A SIMPLER PROOF OF SMITH'S ROULETTE THEOREM, AMS 68,390

DUBINS, LESTER E, INVARIANT PROBABILITIES FOR CERTAIN MARKOV PROCESSES, AMS 66,837

DUBINS, LESTER E. ON A THEOREM OF SKOROHOD, AMS 68, 2094

DU8INS, LESTERE. ON THE EXPECTED VALUE OF A STOPPED MART INGALE, AMS 66. 1505

DUBINS, LESTER E. OPTIMAL STOPPING WHEN THE FUTURE IS DISCOUNTED, AMS 67,601

DU8MAN, $M$. ESTIMATION OF PARAMETERS IN A TRANSIENT MARKOV CHAIN ARISING IN A RELIABILITY GRONTH MODEL, AMS 69, 1542

DUDEWICZ, EDWARD J. AN APPROXIMATION TO THE SAMPLE SIZE IN SELECT ION PROBLEMS, AMS 69, 492

DUDLEY, R. M. DISTANCES OF PROBABILITY MEASURES AND RANDOM VARIABLES, AMS 68,1563

DUDLEY, R. M. GAUSSIAN PROCESSES, ON SEVERAL PARAMETERS, AMS 65, 771 DUDLEY, R. M. THE SPEED OF GLIVENKO-CANTELLI CONVERGENCE, AMS 69, 40 DUDMAN, JACK LOGISTIC ORDER STATISTICS, AMS 63,658

DUDZINSKI, M. L. THE USE OF LAMBDA AS AN IGDEX OF PRECISION, BIOCS 69 , 174

DUGUE, D. GEORGES DARMOIS, 1888-1960, AMS 61, 357

DUNCAN, ACHESON J . BULK SAMPLING. PROBLEMS AND LINES OF ATTACK, TECH 62,319

DUNCAN, ACHESON 3. CHARTS OF THE 10 PERCENT AND 50 PERCENT POINTS OF THE OPERATING CHARACTERIST IC CURVES, JASA 57,345

DUNCAN, ACHESON J. DESIGN AND OPERATION OF A DOURLE-LIMIT VARIABLES SAMPLING PLAN, JASA 5B, 543

DUNCAN, ACHESON 3 . THE ECONOMIC DESIGN OF MEAN CHARTS USED TO MAINTAIN CURRENT CONTROL OF A PROCESS, JASA 56, 22B

DUNCAN, D. 8. ESTIMATION OF THE PROBABILITY OF AN EVENT AS A FUNCTION OF SEVERAL VARIABLES, BIOKA 67,167

DUNCAN, D. B. MULTIPLE REGRESSION COMBINING RITHIN- AND BETWEENPLOT INFORMATION, BIOCS 66,26

DUNCAN, DAVID B. A BAYES RULE FOR THE SYMMETRIC MULTIPLE COMPARISONS PROBLEM. JASA 69, NO. 4

DUNCAN, DAVID B. A BAYESIAN APPROACH TO MULTIPLE COMPARISONS, TECH 65,171

DUNCAN, DAVID B. 8AYES RULES FOR A COMMON MULTIPLE COMPARISONS PROBLEM AND RELATED STUDENT-T PROBLEMS, AMS 61, 1013

DUNCAN. DAVID 8. MULTIPLE REGRESSION WITH STATIONARY ERRORS, JASA 66,917

DUNCAN, OTIS DUDLEY OCCUPATIONAL COMPONENTS OF EDUCATIONAL DIFFERENCES IN INCOME, JASA 61, 7B3
DUNCAN, OTIS DUDLEY RESEARCH ON METROPOLITAN POPULATION, EVALUATION OF DATA, JASA 56,591

DUNN, JAMES E. A COMPOUNDED MULTIPLE RUNS DISTRIBUTION, JASA 69 , NO. 4

DUNN, 0. J. ELIMINATION OF VARIATES IN LINEAR DISCRIMINATION PROBLEMS, BIOCS 66,268

DUNN, $0 . \mathrm{J}$. PROBABILITIES OF CORRECT CLASSIFICATION IN DISCRIMINANT ANALYSIS, BIOCS 66,908

DUNN, OLIVE J. THE ROBUSTNESS OF HOTELLING'S T-SQUARE, JASA 67, 124

DUNN, OLIVE JEAN A NOTE ON CONFIDENCE BANDS FOR A REGRESSION LINE OVER A FINITE RANGE, JASA 68,1028

DUNN, OLIVE JEAN A PROPERTY OF THE MULTIVARIATE T DISTRIBUTION. AMS 65,712

DUNN, OLIVE JEAN CONFIDENCE INTERVALS FOR THE MEANS OF DEPENDENT NORMALLY DISTRIBUTED VARIABLES, JASA 59,613

DUNN, OLIVE JEAN CORRELATION COEFFICIENTS MEASURED ON THE SAME INDIVIDUALS, JASA 69,366

DUNN, OLIVE JEAN ESTIMATION OF MULTIPLE CONTRASTS USING T-DISTRIBUTIONS, JASA 65,573

DUNN, OLIVE JEAN MULTIPLE COMPARISIONS USING RANK SUMS, TECH 64, 241

DUNN, OLIVE JEAN MULT IPLE COMPARISONS AMONG MEANS, JASA 61, 52

DUNNETT, C. W. A BIVARIATE GENERALIZATION OF STUDENT'S T-DISTRIBUTION, WITH TA8LES FOR CERTAIN SPECIAL CA, BIOKA 54, 153

DUNNETT, C. W. A TWO-SAMPLE MULT IPLE DECISION PROCEDURE FOR RANKING MEANS OF NORMAL POPULAT IONS WITH A CO, BIOKA 54,170

DUNNETT, C. W. APPROXIMATIONS TO THE PROBA8ILITY INTEGRAL AND CERTA IN PERCENTAGE POINTS OF A MULTIVARIATE, BIOKA 55, 258

DUNNETT, C. W. ON SELECTING THE LARGEST OF K NORMAL POPULATION MEANS (WITHDISCUSSION), JRSSB 60,1

DUNNETT, C . W. THE NUMERICAL EVALUATION OF CERTAIN MULTIVARIATE NORMAL INTEGRALS, AMS 62,571

DUNNETT, CHARLES W. A TRIBUTE TO FRANK WILCOXON, TECH 66, 195

DUNSING, MARILYN EFFECT OF VARYING DEGREES OF TRANSITORY INCOME ON INCOME ELAST ICITY OF EXPENDITURES, JASA 5B, 34B

DUNSMORE, I. R. A BAYESIAN APPROACH TO CALIBRATION, JRSSB 68, 396

DUNSMORE, I. R. A BAYESIAN APPROACH TO CLASSIFICATION, JRSSB 66, 568

DUNSMORE, I. R. LINEAR-LOSS INTERVAL ESTIMATION OF LOCATION AND SCALE PARAMETERS, BIOKA 68,141

DUNSMORE, I . R. REGULATION AND OPTIMIZATION, JRSSB 69,160

DUPAC, VACLAV A DYNAMIC STOCHASTIC APPROXIMATION METHOD, AMS 65 1695

DUPAC, VACLAV ASYMPTOTIC NORMALITY OF SIMPLE LINEAR RANK STATISTICS UNDER ALTERNATIVES, II, AMS 69 , NO.6

DURAN, BENJAMIN S. ROBUSTNESS OF SUM OF SQUARED RANKS TEST, JASA 6B, 338

DURAND, D. AIDS FOR FITTING THE GAMMA DISTRIBUTION BY MAXIMUM LIKELIHOOD, TECH 60,55

DURAND, DAVID A NOTE ON MATRIX INVERSION $8 Y$ THE SQUARE ROOT METHOD JASA 56,288

DURBIN, EUGENE P. PRICING POLICIES CONTINGENT ON OBSERVED PRODUCT QUALITY, TECH 66,123

DURBIN, J, A NOTE ON THE APPLICATION OF QUENOUILLE'S METHOD OF BIAS REDUCTION TO THE ESTIMATION OF RATIOS, BIOKA 59,477

DURBIN, J CORRECTION, 'SOME METHODS OF CONSTRUCTING EXACT TESTS. ', BIOKA 66,629

DURBIN, J. EFFICIENT ESTIMATION OF PARAMETERS IN MOVING-AVERAGE MODELS, BIOKA 59,306

DURBIN, J. ESTIMATION OF PARAMETERS IN TIME-SERIES REGRESSION MODELS, JRSSB 60,139

DURBIN, J . SOME METHODS OF CONSTRUCT ING EXACT TESTS, BIOKA 61, 41

DURBIN, J . TESTING FOR SERIAL CORRELATION IN LEAST SQUARES REGRESSION. II. , BIOKA 51,159

DURBIN, J . TESTING FOR SERIAL CORRELATION IN SYSTEMS OF SIMULTANEOUS REGRESSION EQUATIONS, BIOKA 57,370

DURBIN, J. TESTS FOR SERIAL CORRELATION IN REGRESSION ANALYSIS BASED ON THE PERIODOGRAM OF LEAST-SQUARES, BIOKA 69, I

DURB IN, J . THE GEOMETRY OF ESTIMATION, BIOKA 51, 150

DURBIN, J, THE PROBABILITY THAT THE SAMPLE DISTRIBUTION FUNCTION LIES BETWEEN TWO PARALLEL STRA IGHT LINES, AMS 6B, 398

DUVALL, RICHARD M. TIME SERIES ANALYSIS BY MODIFIED LEAST-SQUARES TECHNIQUES, JASA 66, 152

DWASS, MEYER A FLUCTUATION THEOREM FOR CYCLIC RANDOM VARIABLES, AMS 62,1450

DWASS, MEYER CONDITIONED LIMIT THEOREMS, AMS 63, 1147

DWASS, MEYER EXTREMAL PROCESSES, AMS 64, 1718

DWASS, MEYER SIMPLE RANDOM WALK AND RANK ORDER STATISTICS. AMS 67 1042

DWYER, P, S, A COMBINATORIAL METHOD FOR PRODUCTS OF TWO POLYKAYS WITH SOME GENERAL FORMULAE, AMS 64, 1174

DWYER, P. S. PROPERT IES OF POLYKAYS OF DEVIATES, AMS 64, 1167

DWYER, PAUL S. COMPUTATION WITH MULTIPLE K-STATISTICS, JASA 63, 120

DWYER. PAUL $S$. MATRIX INVERSION WITH THE SQUARE ROOT METHOD, TECH 64,197

DWYER, PAUL S. MULTIVARIATE MAXIMA AND MINIMA WITH MATRIX DERIVATIVES, JASA 69, NO 4

DWYER, PAUL $S$. SOME APPLICATIONS OF MATRIX DERIVATIVES IN MULTIVARIATE ANALYSIS, JASA 67,607 
DYKSTRA JR, OTTO ERRATA, 'THE ORTHOCONALIZATION OF UNDESICNED EXPERIMENTS', TECH 66,73 '

DYKSTRA JR, OTTO FACTORIAL EXPERIMENTATION IN SCHEFFE'S ANALYSIS OF VARIANCE FOR PAIRED COMPARISONS, JASA 58,529

DYKSTRA JR. OTTO THE ORTHOCONALIZATION OF UNDESICNED EXPERIMENTS TECH 66,279

DYKSTRA. O. PART IAL DUPLICATION OF FACTORIAL EXPER IMENTS. TECH 59 63

DYKSTRA, O. PARTIAL DUPLICATION OF RESPONSE SURFACE DESICNS, TECH $60,1 B 5$

DYM, HARRY A NOTE ON LIMIT THEOREMS FOR THE ENTROPY OF MARKOV CHAINS, AMS 66,522

DYM, HARRY ON THE MEAN DURATION OF A BALL AND CELL GAME, A FIRST PASSAGE PROBLEM AMS 66, 517

DYSON, J. A GENERAL SIMULATION PROCRAMME FOR MATERIAL FLOW IN BATCH CHEMICAL PLANTS, TECH 61,497

EAGLESON, G. K. A NOTE ON LINEAR REGRESSION IN TR IVARIATE DISTR IBUTIONS, JASA 6B, 1042

EAGLESON, C. K. POLYNOMIAL EXPANSIONS OF BIVARIATE DISTRIBUTIONS AMS $64,120 \mathrm{~B}$

EAST. D. A . CORRIGENDA, 'TABLES FOR MAKINC INFERENCES ABOUT THE VARIANCE OF A NORMAL DISTRIBUTION. ' , BIOKA 61, 230

EAST, D. A. TABLES FOR MAKING INFERENCES ABOUT THE VARIANCE OF A NORMAL DISTRIBUTION, BIOKA 60,433

EASTERLING, ROBERT G. DISCRIMINATION INTERVALS FOR PERCENTILES IN RECRESSION, JASA 69, 1031

EATON, MORRIS L. SOME OPTIMUM PROPERTIES OF RANKING PROCEDURES, AMS 67.124

EATON, MORR IS L. SOME REMARKS ON SCHEFFE'S SOLUTION TO THE BEHRENSFISHER PROBLEM, JASA 69 , NO 4

EATON. MORRIS L. THE GENERALIZED VARIANCE, TESTING AND RANKING PROBLEM. AMS 67, 941

EAVES, D. M. SAMPLE FUNCTIONS OF CAUSSI AN RANDOM HOMOGENEOUS F IELDS ARE EITHER CONT INUOUS OR VERY IRREGUL, AMS 67,1579

EAVES. D. M. THE CENTRAL LIMIT THEOREM FOR GENERALIZED RANDOM FIELDS, AMS 69, 203

EBERHARDT, L . L. SOME DEVELOPEMENTS IN 'DISTANCE SAMPLING', BIOCS 67.207

EBERHART. S. A . A GENERAL MODEL FOR GENETIC EFFECTS, BIOCS 66. B64

EBERHART, S.A. ANALYSIS AND INTERPRETATION OF THE VARIETY CROSS DIALLEL AND RELATED POPULATIONS, BIOCS 66,439

ECKLER, A. R. A SURVEY OF COVERAGE PROBLEMS ASSOCIATED WITH POINT AND AREA TARGETS, TECH 69,561

EDERER, FRED A PARAMETRIC ESTIMATE OF THE STANDARD ERROR OF THE SURVIVALRATE, CORR. 631161 , JASA 61, 111

EDCETT, CEORGE L. MULTIPLE REGRESSION WITH MISSINC OBSERVATIONS AMONG THE INDEPENDENT VARIABLES, JASA 56, 122

EDGINGTON, EUGENE S. PROBABILITY TABLE FOR NUMBER OF RUNS OF SIGNS OF FIRST DIFFERENCES IN ORDERED SER IES, JASA 61, 156

EDITORIAL, THE NORMAL PROBABILITY FUNCTION, TABLES OF CERTAIN AREAORDINATE RATIOS AND OF THEIR RECIPROCAL, BIOKA 55, 217

EDWARDS, A.W. F. A METHOD FOR CLUSTER ANALYSIS, BIOCS 65,362

EDWARDS, A. W. F. ESTIMATION OF THE PARAMETERS IN SHORT MARKOV SEQUENCES, JRSSB 63,206

EDWARDS, CAROL B. A CLASS OF DISTRIBUTIONS APPLICABLE TO ACCIDENTS JASA 61,503

EFRON, B. THE CONVEX HULL OF A RANDOM SET OF POINTS, BIOKA 65, 331

EFRON, BRADLEY GEOMETRICAL PROBABILITY AND RANDOM POINTS ON A HYPERSPHERE, AMS 67,213

EFRON, BRADLEY INCREASINC PROPERTIES OF POLYA FREQUENCY FUNCTIONS, AMS 65, 272

EFRON, BRADLEY LARCE DEVIATIONS THEORY IN EXPONENTIAL FAMILIES, AMS 68,1402

EFRON BRADLEY NOTE ON DECISION PROCEDURES FOR FINITE DECISION PROBLEMS UNDER COMPLETE ICNORANCE, AMS 65, 691

EFRON, BRADLEY STUDENT'S T-TEST UNDER SYMMETRY CONDITIONS, JASA 69. NO. 4

EFRON, BRADLEY THE POWER OF THE LIKELIHOOD RATIO TEST, AMS 67, 802

EHRENBERG. A. S. C. ON SAMPLING FROM A POPULATION OF RANKERS. BIOKA 52. B2

EHRENFELD, S. OPTIMAL STRATEGIES IN FACTORIAL EXPERIMENTS, AMS 63 780

EHRENFELD, S. RANDOMIZATION AND FACTORIAL EXPERIMENTS, AMS 61, 270 EHRENFELD, S. TESTING HYPOTHESES IN RANDOMIZED FACTORIAL EXPERIMENTS, AMS 67, 1494

EHRENFELD, S. THE EFFICIENCY OF STATISTICAL SIMULATION PROCEDURES TECH 62,257

EHRENFELD. SYLVAIN ON A MINIMAL ESSENTIALLY COMPLETE CLASS OF EXPERIMENTS, AMS 66, 435

EHRENFELD, SYLVAIN SOME EXPERIMENTAL DESIGN PROBLEMS IN ATTRIBUTE LIFE TESTING, CORR. 631161 , JASA 62, 668

EHRENFELD, SYLVAIN SOME NUMERICAL ASPECTS OF THE USE OF TRANSFORMS IN STATISTICS, JASA 63, B79

EICKER, F. A MULTIVARIATE CENTRAL LIMIT THEOREM FOR RANDOM LINEAR VECTOR FORMS, AMS 66, 1825

EICKER, F. ASYMPTOTIC NORMALITY AND CONSISTENCY OF THE LEAST SQUARES ESTIMATORS FOR FAMILIES OF LINEAR RE, AMS 63, 447
EICKER, F. CENTRAL LIMIT THEOREMS FOR FAMILIES OF SEQUENCES OF RANDCM VARIABLES. AMS 63,439

EIDEMILLER, R. L. APPLICATIONS OF THE BIVARIATE NORMAL DISTRIBU TION TO A STRESS VS. STRENGTH PROBLEM IN R, TECH 64, 325

EILBOTT, JOAN ON PRECEDENCE LIFE TESTINC. TECH 65, 359

EINHORN, HENRY ADLER CHANGES IN CONCENTRATION OF DOMESTIC MANUFACTURINC ESTABLISHMENT OUTPUT 1939-195B, JASA 62, 797

EISEMANN, DORIS M. MANUFACTURERS' INVENTORY CYCLES AND MONETARY POLICY, JASA 5B, 6BO

EISEN, M. M. EFFECTS OF SLOW-DOWNS AND FA ILURE ON STOCHAST IC SERVICE SYSTEMS, TECH $63,3 B 5$

EISENBERG. BENNETT THE RELATION OF THE EQUIVALENCE CONDITIONS FOR THE BROWN IAN MOTION TO THE EQUIVALENCE, AMS 69, NO.6

EISENBERG, $H$. B. A CENERAL USE OF THE POISSON APPROXIMATION FOR BINOMIAL EVENTS, WITH APPLICATION TO BACT, BIOCS 66, 74

EISENBERGER, ISIDORE GENESIS OF BIMODAL DISTRIBUTIONS, TECH 64, 357

EISENBERGER, ISIDORE SYSTEMATIC STATISTICS USED FOR DATA COMPRESSION IN SPACE TELEMETRY, JASA 65,97

EISENBERGER, ISIDORE TESTING THE MEAN AND STANDARD DEVIATION OF A NORMAL DISTRIBUTION USING QUANTILES. TECH 6B, 7B 1

EISENPRESS, HARRY REGRESSION TECHNIQUES APPLIED TO SEASONAL CORRECT IONS AND ADJUSTMENTS FOR CALENDAR SHIF, JASA 56,615

EISENPRESS, HARRY SEASONAL ADJUSTMENTS BY ELECTRONIC COMPUTER METHODS, JASA 57,415

EISENSTAT, STAN SAMPLING DISTRIBUTIONS OF VARIANCE COMPONENTS II. EMPIR ICAL STUDIES OF UNBALANCED NESTED, TECH 6B, 719

EISENSTAT, STANLEY A STUDY OF ROBUST ESTIMATORS, TECH 67,652

EISSEN, E. J. NOTE. THE QUASI-F TEST FOR AN UNNESTED FIXED FACTOR IN AN UNBA LANCED HIERARCHAL DESIGN WITH, BIOCS 66, 937

EL-BADRY, M. A. A SAMPLINC PROCEDURE FOR MAILED QUESTIONNAIRES, JASA 56,209

EL-BADRY, M. A. FAILURE OF ENUMERATORS TO MAKE ENTRIES OF ZERO, ERRORS IN RECORDINC CHILDLESS CASES IN P0, JASA 61.909

EL-BADRY, M. A. HIGHER FEMALE THAN MALE MORTALITY IN SOME COUNTRIES OF SOUTH ASIA, A DIGEST, JASA 69 , N0.4

EL-SAYYAD, G, M. ESTIMATION OF THE PARAMETER OF AN EXPONENTIAL DISTRIBUTION, JRSSB 67,525

EL-SAYYAD, C. M. INFORMATION AND SAMPLINC FROM THE EXPONENTIAL DISTRIBUTION, TECH 69,41

EL-SAYYAD, G. M. THE BAYESIAN ESTIMATION OF A LINEAR FUNCTIONAL RELATIONSHIP, JRSSB 6B, 190

ELANDT-JOHNSON, REGINA SURVEY OF HISTOCOMPATIBILITY TESTING, BIOLOCICAL BACKGROUND PROBAB ILISTIC AND STAT, BIOCS 69, 207

ELANDT. REGINA C. EXACT AND APPROXIMATE POWER FUNCTION OF THE NONPARAMETRIC TEST OF TENDENCY, AMS 62, 47 I

ELANDT, RECINA C . THE FOLDED NORMAL DISTRIBUTION, TWO METHODS OF EST IMATING PARAMETERS FROM MOMENTS, TECH 61.551

ELASHOFF, JANET D. ON THE CHOICE OF VARIABLES IN CLASSIFICATION PROBLEMS WITH DICHOTOMOUS VARIABLES, BIOKA 67, 66B

ELASHOFF, R. M. AN INVESTIGATION INTO THE SMALL SAMPLE PROPERTIES OF A TWO SAMPLE TEST OF LEHMANN'S, JASA 68,345

ELASHOFF, R. M. MISSING OBSERVATIONS IN MULTIVARIATE STATISTICS II . POINT ESTIMATION IN SIMPLE LINEAR REG, JASA 67, 10

ELASHOFF, R. M. MULTIVARIATE TWO SAMPLE TESTS WITHDICHOTOMOUS AND CONT INUOUS VARIABLES I. THE LOCATION M, AMS 69, 290

ELASHOFF, R. M. ON THE CHOICE OF VARIABLES IN CLASSIFICATION PROBLEMS WITH DICHOTOMOUS VARIABLES, BIOKA 67,668

ELASHOFF, ROBERT M. MISSING OBSERVATIONS IN MULTIVARIATE STATISTICS, III, JASA 69, 337

ELASHOFF, ROBERT $M$. MISSINC OBSERVATIONS IN MULTIVARIATE STATISTICS, IV, JASA 69,359

ELASHOFF, ROBERT M. MISSING VALUES IN MULTIVARIATE STATISTICS, I REVIEW OF THE LITERATURE, JASA 66,595

ELDERTON, W.P. BIOMETRIKA, 1901-1951, BIOKA 51, 267

ELKINS. THOMAS A. CUBICAL AND SPHERICAL ESTIMATION OF MULT IVARIATE PROBABILITY DENSITY, JASA 68,1495

ELLISON, BOB E. A CLASSIFICATION PROBLEM IN WHICH INFORMATION ABOUT ALTERNATIVE DISTRIBUTIONS IS BASED ON, AMS 62, 213

ELLISON, BOB E. MULTIVARIATE-NORMAL CLASSIFICATION WITH COVARIANCE KNOWN, AMS 65, 17B7

ELLISON. BOB E. ON TWO-SIDED TOLERANCE INTERVALS FOR A NORMAL DISTRIBUTION, AMS 64,762

ELLISON, BOB E. TWO THEOREMS FOR INFERENCES ABOUT THE NORMAL DISTRIBUTION WITH APPLICATIONS IN ACCEPTANCE, JASA 64, B9

ELLNER. HENRY VALIDATING RESULTS OF SAMPLINC INSPECTION BY ATTRIBUTES. TECH 63, 23

ELSTON, R. C. A SIMPLE METHOD OF ESTIMATINC RELATIVE POTENCY FROM TWO PARABOLAS, BIOCS 65,140

ELVEBACK, LILA COMPETING EXPONENTIAL RISKS, WITH PARTICULAR REFERENCE TO THE STUDY OF SMOKING AND LUNG CA, JASA 60, 415

ELVEBACK, LILA ESTIMATION OF SURVIVORSHIP IN CHRONIC DISEASE. THE ACTUARIAL' METHOD, JASA 58, 420

EMERSON, P. L. NOTES. ORTHOGONAL POLYNOMIALS FOR UNEQUALLY WEIGHED MEANS, BIOCS 65,226

EMERSON, P. L. NUMERICAL CONSTRUCTION OF ORTHOGONAL POLYNOMIALS FROM A GENERAL RECURRENCE FORMULA, BIOCS 68,695 
ENDRES, ALLEN C. THE COMPUTATION OF THE UNRESTRICTED AOQL WHEN DEFECT IVE MATERI AL IS REMOVED BUT NOT REPL, JASA 69, 665

ENGELMAN, L. PERCENTAGE POINTS OF A TEST FOR CLUSTERS, JASA 69, N0.4 ENRICK. NORBERT L. VARIATIONS FLOW ANALYSIS, TECH 60,373

EPSTEIN, B. BACTERIAL EXTINCTION TIME AS AN EXTREME VALUE PHENOMENON, BIOCS 67,835

EPSTEIN, 8. ELEMENTS OF THE THEORY OF EXTREME VALUES, TECH 60, 27

EPS'IEIN, B. ESTIMATION OF THE PARAMETERS OF TWO PARAMETER EXPONENTIAL DISTRIBUTIONS FROM CENSORED SAMPLES, TECH 60, 403

EPSTEIN, B. TESTS FOR THE VALIDITY OF THE ASSUMPT ION THAT THE UNDERLYING DISTRIBUTION OF LIFE IS EXPONENT, TECH 60,83

EPSTEIN, B. TESTS FOR THE VALIDITY OF THE ASSUMPTIONS THAT THE UNDERLYING DISTRIBUTION OF LIFE IS EXPONEN, TECH 60, 167

EPSTEIN, BENJAMIN ESTIMATES OF BOUNDED RELATIVE ERROR FOR THE MEAN LIFE OF AN EXPONENT IAL DISTRIBUT ION, TECH 61, 107

EPSTEIN, BENJAMIN ESTIMATION FROM LIFE TEST DATA, TECH 60,447

EPSTEIN, BENJAMIN STATISTICAL LIFE TEST ACCEPTANCE PROCEDURES TECH 60,435

ERICSON, RAGNAR ON MOMENTS OF CUMULATIVE SUMS, AMS 66, IBO3

ERICSON, W. A. A NOTE ON THE POSTERIOR MEAN OF A POPULATION MEAN, JRSSB 69. NO.2

ERICSON. W. A. AN EXAMPLE OF DISCREPANCIES IN INFERENCES UNDER NONINFORMATIVE STOPP ING RULES, BIOKA 67, 329

ERICSON, W. A. ON THE ECONOMIC CHOICE OF EXPERIMENT SIZES FOR DECISION REGARDING CERTAIN LINEAR COMBINATI, JRSSB 67, 503

ERICSON, W. A . OPTIMAL SAMPLE DESIGN WITH NONRESPONSE, JASA 67, 63

ERICSON, W. A. OPTIMUM STRATIFIED SAMPLING USING PRIOR INFORMATION, JASA 65,750

ERICSON. W. A. SUBJECTIVE BAYESIAN MODELS IN SAMPLING FINITE POPULATIONS (WITHDISCUSSION), JRSSB 69, NO 2

ERICSON. WILLIAM A. OPTIMAL ALLOCATION IN STRATIFIED AND MULT ISTAGE SAMPLES USING PRIOR INFORMATION, JASA GB, 964

ERNST, HARRY BENJAMIN AN INDEX OF MANUFACTURING PRODUCTION IN NEW ENGLAND, JASA 5B, 336

ESARY, J. D. A STOCHASTIC CHARACTERIZATION OF WEAR-OUT FOR COMPONENTS AND SYSTEMS, AMS 66,816

ESARY, J D. ASSOCIATION RANDOM VARI ABLES, WITH APPLICATIONS, AMS 67,1466

ESARY, J. D. MULTI-COMPONENT SYSTEMS AND STRUCTURES AND THEIR RELIABILITY, TECH 61, 55

ESARY, J. D. SYSTEMS STRUCTURE AND THE EXISTENCE OF A SYSTEM LIFE。 TECH 64, 459

ESARY, JAMES D. COHERENT STRUCTURES OF NON-IDENTICAL COMPONENTS TECH 63,191

ESARY, JAMES D. RELATIONSHIP BETWEEN SYSTEM FAILURE RATE AND COMPONENT FAILURE RATES, TECH 63, 1B3

ESSEEN, CARL-GUSTAV INEQUALITIES OF THE RTH ABSOLUTE MOMENT OF A SUM OF RANDOM VARIABLES, 1 LESS THAN OR, AMS 65, 299

EVANS, D. A . EXPER IMENTAL EVIDENCE CONCERNING CONTAGIOUS DISTR IBUTIONS INECOLOGY, 8IOKA 53, 1 B6

EVANS, D. ANTHONY SELECTION INDICES FOR QUADRATIC MODELS OF TOTAL MERIT, BIOCS 6B, 937

EVANS, DAVID H. AN APPLICATION OF NUMERICAL INTEGRATION TECHNIQUES TO STATISTICAL TOLERANCING, TECH 67,441

EVANS, DAVIDH. APPLIED MULTIPLEX SAMPLING, TECH 63,341

EVANS, DAVIDH. MULTIPLEX SAMPLING, AMS 63,1322

EVANS, I. G. BAYESIAN ESTIMATION OF PARAMETERS OF A MULTIVARIATE NORMAL DISTRIBUTION, JRSSB 65,279

EVANS, I. G. 8AYESIAN ESTIMATION OF THE VARIANCE OF A NORMAL DISTRIBUTION, JRSSB 64,63

EVANS, MICHAEL $K$. THE RELATIVE EFFICACY OF INVESTMENT ANTICIPATIONS, JASA 66,104

EVEN, M. MINIMUM VARIANCE UNBIASED AND MAXIMUM LIKELIHOOD ESTIMATORS OF RELIABILITY FUNCT IONS FOR SYSTEMS, JASA 66, 1052

EVEN, M. THE EFFICIENCIES IN SMALL SAMPLES OF THE MAXIMUM LIKELIHOOD AND BEST UNBIASED ESTIMATORS OF RELI, JASA 66, 1033

EWAN, W. D. SAMPLING INSPECTION OF CONTINUOUS PROCESSES WITH NO AUTOCORRELATION 8ETWEEN SUCCESSIVE RESULT, BIOKA 60,363

EWAN, W. D. WHEN AND HOW TO USE CU-SUM CHARTS, TECH 63,1

EWENS, W. J. A GENERALIZED SINGLE-SERVER QUEUE WITH ERLANG INPUT BIOKA 62,242

EWENS, W. J. DEPARTURES FROM ASSUMPTION IN SEQUENTIAL ANALYSIS, BIOKA 61, 206

EWENS, W. J. NUMERICAL RESULTS AND DIFFUSION APPROXIMATIONS IN A GENETIC PROCESS, BIOKA 63,241

EWENS, W. J. SOME APPLICATIONS OF MULTIPLE-TYPE BRANCHING PROCESSES IN POPULATION GENET ICS, JRSS 868,164

EWENS, W. J. THE ADEQUACY OF THE DIFFUSION APPROXIMATION TO CERTAIN DISTRIBUTIONS IN GENETICS, 8IOCS $65,3 \mathrm{~B} 6$

EWENS, W. J. THE DIFFUSION EQUATION AND A PSEUDO-DISTRIBUTION IN GENETICS, JRSSB 63,405

FABENS, A. J A A CORRECTION TO 'THE SOLUTION OF QUEUEING AND INVENTORY MODELS BY SEMI-MARKOV PROCESSES' ', JRSSB 63,455

FABENS, A. J. THE SOLUTION OF QUEUEING AND INVENTORY MODELS BY SEMIMARKOV PROCESSES, JRSSB 61, 113

FABIAN, V. BOUNDS ON MOMENTS OF MART INGALES, AMS 68, 1719

FABIAN, VACLAV ON ASYMPTOTIC NORMALITY IN STOCHASTIC APPROXIMATION, AMS 6B, 1327
FABIAN, VACLAV ON MULT IPLE DECISION METHODS FOR RANKING POPULATION MEANS, AMS $62,24 B$

FABIAN, VACLAV ON THE CHOICE OF DESIGN IN STOCHASTIC APPROXIMATION METHODS, AMS 68, 457

FABIAN, VACLAV STOCHASTIC APPROXIMATION FOR SMOOTH FUNCTIONS, AMS 69,299

FABIAN, VACLAV STOCHASTIC APPROXIMATION OF MINIMA WITH IMPROVED ASYMPTOTIC SPEED, AMS 67, 191

FA8IUS, J . ASYMPTOTIC 8EHAVIOR OF BAYES' EST IMATES, AMS 64, 846

FAIRTHORNE, DAVID THE DISTANCES BETWEEN RANDOM POINTS IN TWO CONCENTRIC CIRCLES, BIOKA 64,275

FAIRWEATHER, W. R. SOME EXTENSIONS OF SOMERVILLE'S PROCEDURE FOR RANKING MEANS OF NORMAL POPULATIONS, BIOKA 68, 411

FALK, C.T STA8ILITY OF SOLUTIONS TO CEETAIN NONL INEAR DIFFERENCE EQUATIONS OF POPULATION GENETICS, BIOCS 69,27

FALK, H. STABILITY OF SOLUTIONS TO CERTAIN NONLINEAR DIFFERENCE EQUATIONS OF POPULATION GENETICS, BIOCS 69,27

FAMA, EUGENE F. DIVIDEND POLICY, AN EMPIRICAL ANALYSIS, JASA 68 1132

FAMA, EUGENE F . SOME PROPERTIES OF SYMMETRIC STABLE DISTRIBUTIONS, JASA $6 B, B 17$

FAN, C. T. DEVELOPMENT OF SAMPLING PLANS BY USING SEQUENTIAL, ITEM BY ITEM, SELECTION TECHNIQUES AND DIGI, JASA 62, 387

FARLEY, JOHN U, ESTIMATION AND INFERENCE FOR LINEAR MODELS IN WHICH SUBSETS OF THE DEPENDENT VARIABLE ARE, JASA 68,1201

FARLIE, D. J. G. THE ASYMPTOTIC EFFICIENCY OF DANIELS 'S GENERALIZED CORRELATION COEFFICIENTS, JRSSB 6I, 12B

FARLIE, D. J. G. THE ASYMPTOTIC EFFICIENCY OF DANIELS'S GENERALIZED CORRELATION COEFFICIENT, BIOKA 63, $499^{\circ}$

FARLIE, D. J.G. THE PERFORMANCE OF SOME CORRELATION COEFFICIENTS FOR A GENERAL BIVARIATE DISTRIBUTION, BIOKA 60,307

FARRELL, R. H. ASYMPTOTIC BEHAVIOR OF EXPECTED SAMPLE SIZE IN CERTAIN ONE-SIDED TESTS, AMS 64,36

FARRELL, $R$, H BOUNDED LENGTH CONFIDENCE INTERVALS FOR THE P-POINT OF A DISTRIBUTION FUNCTION, II, AMS 66, 581

FARRELL, R. H. BOUNDED LENGTH CONFIDENCE INTERVALS FOR THE P-POINT OF A DISTRIBUTION FUNCTION, III, AMS 66,5B6

FARRELL, R. H BOUNDED I.ENGTH CONFIDENCE INTERVALS FOR THE ZERO OF REGRESSION FUNCTION, AMS 62, 237

FARRELL, R, H, ESTIMATORS OF A LOCATION PARAMETER IN THE ABSOLUTELY CONT INUOUS CASE, AMS 64,949

FARRELL, R. H. LIMIT THEOREMS FOR STOPPED RANDOM WALKS, AMS 64, 1332

FARRELL, R. H. LIMIT THEOREMS FOR STOPPED RANDOM WALKS, II, AMS 66 B60

FARRELL, $R, H$, LIMIT THEOREMS FOR STOPPED RANDOM WALKS, II I, AMS 66 , 1510

FARRELL, R. H. ON A NECESSARY AND SUFFICIENT CONDITION FOR ADMISSIBILITY OF ESTIMATORS WHEN STR ICTLY CONV, AMS 68,23

FARRELL, R. H. ON THE ADMISSIBILITY AT INFINITY. WITHIN THE CLASS OF RANDOMIZED DESIGNS, OF BALANCED DESI, AMS 6B, 197B

FARRELL, $R, H$ ON THE ADMISSIBILITY OF A RANDOMIZED SYMMETRICAL DESIGN FOR THE PROBLEM OF A ONE WAY CLASS, AMS 69,356

FARRELL, R. H. ON THE BAYES CHARACTER OF A STANDARD MODEL II ANALYSIS OF VARIANCE TEST, AMS 69, 1094

FARRELL, R. H. ON THE LACK OF A UNIFORMLY CONSISTENT SEQUENCE OF ESTIMATORS OF A DENSITY FUNCTION IN CERT, AMS 67, 471

FARRELL, R. H. TOWARDS A THEORY OF GENERALIZED 8AYES TESTS, AMS GB

FASTEAU, HERMAN H. CONTROL OF QUALITY OF CODING IN THE 1960 CENSUSES, JASA 64,120

FAULKENBERRY, G. DAVID SAMPLE SIZE DETERMINATION FOR TOLERANCE LIMITS, TECH 68,343

FAVRET, E. E. A. APPLICATION OF FINITE ABSORBENT MARKOV CHAINS TO SIB MAT ING POPULATIONS WITH SELECTION, BIOCS 69, 17

FEAREY J P ACCURACY REQUTREMENTS FOR ACCEPT ANCE TESTING OF COMPLEX SYSTEMS, JASA 59, 447

FEDDERSEN, A. P. NOTE ON A CONDITIONAL PROPERTY OF STUDENT'S T, AMS 63.1098

FEDER, PAUL EXISTENCE OF OPTIMAL STOPP ING RULES FOR REWARDS RELATED TO S-SUB-N-OVER-N, AMS 68, 122B

FEDER, PAUL ON THE DISTRIBUTION OF STATISTICS SUITABLE FOR EVALUATING RAINFALL STIMULAT ION EXPER IMENTS, TECH 69,149

FEDER, PAUL I. ON THE DISTRIBUTION OF THE LOG LIKELIHOOD RATIO TEST STAT ISTIC WHEN THE TRUE PARAMETER IS, AMS 68, 2044

FEDERER, W. APPLICATIONS OF THE CALCULUS FOR FACTORIAL ARRANGEMENTS II. TWO WAY ELIMINAT ION OF HETEROGENE, AMS 64, 658

FEDERER, W. T. A UNIF IED APPROACH FOR CONSTRUCT ING A USEFUL CLASS OF NON-ORTHOGONAL MAIN EFFECT PLANS IN, JRSS8 68, 371

FEDERER W T ANALYSIS OF MULTIFACTOR CLASSIFICATIONS WITH UNEQUAL NUMBERS OF OBSERV AT IONS, BIOCS 66,525

FEDERER, W. T. ESTIMATES OF EFFECTS FOR FRACTIONAL REPLICATES, AMS 64,711

FEDERER, W. T. GENERAL THEORY OF PRIME-POWER LATTICE DESIGNS, JASA 65,891

FEDERER, W, T ON A SPECIAL SUBSET GIVING AN IRREGULAR FRACTIONAL REPLICATE OF A 2 TO THE POWER N FACTORI, JRSSB 67, 292

FEDERER, $W$. T. ON ESTIMATES FOR FRACTIONS OF A COMPLETE FACTORIAL EXPERIMENT AS ORTHOGONAL LINEAR COMBINA, AMS 63, 1068 
FEDERER, W. T. ON ESTIMATION AND CONSTRUCTION IN FRACTIONAL REPLI CATION, AMS 66, 1033

FEDERER, W. T. ON THE APPLICATION OF CROUP THEORY TO THE EXISTENCE AND NON-EXISTENCE OF ORTHOCONAL LATIN, BIOKA 69, NO.

FEDERER, W. T. ON THE STRUCTURE AND ANALYSIS OF SINCULAR FRACTIONAL REPLICATES, AMS 68,657

FEDERER, W. T . QUERY, ERROR RATE BASES, TECH 65, 260

FEDERER, WALTER T. GENERALIZED LATTICE SQUARE DESICN, JASA 66, 821

FEDERIGHI, ENRICO T. EXTENDED TABLES OF THE PERCENTAGE POINTS OF STUDENT'S T-DISTRIBUTION, JASA 59,683

FEDORV. V. D. EXPERIMENTAL DEVELOPMENT OF NUTRITIVE MEDIA FOR MICRO-ORCANISMS, BIOKA 6B, 43

FEICL, P. ESTIMATION OF EXPONENTIAL SURVIVAL PROBABILITIES WITH CONCOMITANT INFORMATION, BIOCS 65. B26

FEINBERG. S. EFFICIENT CALCULATION OF ALL POSSIBLE REGRESSIONS, TECH 68,769

FEINLEIB, F. ON THE THEORY OF SCREENING FOR CHRONIC DISEASES, BIOKA 69, NO. 3

FEINLEIB, MANNING A METHOD OF ANALYZING LOC-NORMALLY DISTRIBUTED SURVIVAL DATA WITH INCOMPLETE FOLLOW-UP, JASA 60,534

FEIVESON, A. H. A NUMERICAL PROCEDURE TO GENERATE A SAMPLE COVARIANCE MATRIX, CORR, $66124 \mathrm{~B}$, JASA 66,199

FELDMAN, DORIAN CONTRIBUTIONS TO THE 'TWO-ARMED BANDIT' PROBLEM. AMS 62,847

FELDMAN, DORIAN ESTIMATION OF NON-UNIQUE QUANTILES, AMS 66, 451

FELDMAN, DORIAN ESTIMATION OF THE PARAMETER N IN THE BINOMIAL DISTRIBUTION, JASA 6B, 150

FELDMAN, J A CLARIFICATION CONCERNING CERTAIN EQUIVALENCE CLASSES OF CAUSSI AN PROCESSES ON AN INTERVAL, AMS 6B, 107B

FELDMAN, J. INTECRAL KERNELS AND INVARIANT MEASURES FOR MARKOFF TRANSITION FUNCTIONS, AMS 65, 517

FELDMAN, S. A COMPARISON OF SUCCESSIVE SCREENING AND DISCRIMINANT FUNCTION TECHNIQUES IN MEDICAL TAXONOMY, BIOCS 69 , NO 4

FELDT, ALLAN G. THE METROPOLITAN AREA CONCEPT, AN EVALUATION OF THE 1950 STANDARD METROPOLITAN AREAS, JASA 65,617

FELLEGI. I. P. THE NEW DESIGN OF THE CANADIAN LABOUR FORCE SURVEY, JASA 67,421

FELLEGI, IVAN P. A THEORY FOR RECORD LINKAGE, JASA 69, NO. 4

FELLEGI, IVAN P. RESPONSE VARI ANCE AND ITS ESTIMATION, JASA 64, 1016 FELLEGI, IVAN P. SAMPLING WITH VARYINC PROBABILITIES WITHOUT REPLAGEMENT, ROTATING AND NON-ROTATING SAMPL, JASA 63,183

FELLINGHAM, S. A. AN APPROXIMATION FOR THE EXACT DISTRIBUTION OF THE WILCOXON TEST FOR SYMMETRY, JASA 64 , B99

FELS, EBERHARD M. SOME SOVIET STATISTICAL BOOKS OF 1957, JASA 59, 12

FELSENSTEIN, J. THE ROBUSTNESS OF HOMOGENEITY TESTS IN 2 BY N TABLES, BIOCS 65,19

FERBER, ROBERT THE ACCURACY AND STRUCTURE OF INDUSTRY EXPECTATIONS IN RELATION TO THOSE OF INDIVIDUAL FIR, JASA 5B, 317

FERBER, ROBERT THE EFFECT OF RESPONDENT IGNORANCE ON SURVEY RESULTS, JASA 56,576

FERBER, ROBERT THE RELIABILITY OF CONSUMER SURVEYS OF FINANCIAL HOLDINCS, TIME-DEPOSITS, JASA 65, 14B

FERBER, ROBERT THE RELIABILITY OF CONSUMER SURVEYS OF FINANCIAL HOLDINGS, DEMAND DEPOSITS, JASA 66, 91

FERBER, ROBERT VALIDATION OF CONSUMER FINANCIAL CHARACTERISTICS, COMMON STOCK, JASA 69,415

FEREDAY, F. MULTIVARIATE LINEAR STRUCTURAL RELATIONS, BIOKA 5B, 136

FERGUSON, T. $\$$. DISCUSSION OF THE PAPERS OF MESSRS. ANSCOMBE AND DANIEL, TECH 60,157

FERGUSON, T. S. THE BIG MATCH, AMS 68,159

FERGUSON, THOMAS S. A CHARACTERIZATION OF THE EXPONENTIAL DISTRIBUTION, AMS 64, 1199

FERGUSON, THOMAS S. A REPRESENTATION OF THE SYMMETRIC BIVARIATE CAUCHY DISTRIBUTION, AMS 62, 1256

FERGUSON, THOMAS S. LOCATION AND SCALE PARAMETERS IN EXPONENTIAL FAMILIES OF DISTRIBUTIONS, CORR. 631603 , AMS 62, 986

FIELDS, R. I. JOINT ESTIMATION OF THE PARAMETERS OF TWO NORMAL POPULATIONS, JASA 62,446

FIELLER, E. C C CORRIGENDA TO 'CORRELATED RANDOM NORMAL DEVIATES' PUBLISHED IN TRACTS FOR COMPUTERS, NO . 2, BIOKA 56, 496

FIELLER, E. C. SAMPLING WITH CONTROL VARIABLES, BIOKA 54, 494

FIELLER, E. C. SOME PROBLEMS IN INTERVAL ESTIMATION (WITH DISCUSSION ), JRSSB 54,175

FIELLER, E. C. TESTS FOR RANK CORRELATION COEFFICIENTS. I, BIOKA 57 , 470

FIELLER, E. C. TESTS FOR RANK CORRELATION COEFFICIENTS. II, BIOKA 61,29

FIENBERG, S. BAYESIAN ESTIMATION OF LATENT ROOTS AND VECTORS WITH SPECIAL REFERENCE TO THE BIVAR IATE NORM, BIOKA 69, 97

FIENBERG, S. INCOMPLETE TWO-DIMENSIONAL CONTINCENCY TABLES, BIOCS 69,119

FIENBERG, STEPHEN E, THE CEOMETRY OF A R-BY-C CONTINGENCY TABLE, AMS 68,1186

FIERING, MYRON B. ON THE USE OF CORRELATION TO AUCMENT DATA, JASA 62 , 20

FINCH, P. D. A GENERALIZED SINGLE-SERVER QUEUE WITH ERLANG INPUT . BIOKA 62, 242
FINCH, P. D. CYCLIC QUEUES WITH FEEDBACK, JRSSB 59, 153

FINCH, P. D. DETERMINISTIC CUSTOMER IMPATIENCE IN THE QUEUEINC SYSTEM CI-M-1, BIOKA 60,45

FINCH, P. D. DETERMINISTIC CUSTOMER IMPATIENCE IN THE QUEUEINC SYSTEM CI-M-1, A CORRECTION, BIOKA 61,472

FINCH, P. D. ON THE COVARIANCE DETERMINANTS OF MOVINC-AVERACE AND AUTORECRESSIVE MODELS, BIOKA 60,194

FINCH, P. D. ON THE TRANSIENT BEHAVIOR OF A QUEUEING SYSTEM WITH BULK SERVICE AND F INITE CAPACITY, AMS 62, 973

FINCH, P. D . ON THE TRANSIENT BEHAVIOUR OF A SIMPLE QUEUE, JRSSB 60 277

FINCH, P. D. THE EFFECT OF THE SIZE OF THE WAITING ROOM ON A SIMPLE QUEUE, JRSSB 5B, 182

FINCH, P. D. THE OUTPUT PROCESS OF THE QUEUEING SYSTEM WITH ONE SERVER AND WHI CH INTERARR IVAL AND SERVINC, JRSSB 59, 375

FINCH, P. D. THE TRANSIENT BEHAVIOR OF A COINCIDENCE VARIATE IN TELEPHONE TRAFFIC, AMS 61,230

FINE, TERRENCE ON THE HODGES AND LEHMANN SHIFT ESTIMATOR IN THE TWO SAMPLE PROBLEM, AMS 66,1814

FINNEY, D. J. A NOTE ON 'THE ESTIMATION OF THE PARAMETERS OF TOLERANCE DISTRIBUTIONS' ', AIOKA 52,439

FINNEY, D. J . AN EXPERIMENTAL STUDY OF GERTAIN SCREENING PROCESSES JRSSB 66, B8

FINNEY, D. J. GUMULANTS OF TRUNCATED MULTINORMAL DISTRIBUTIONS, JRSSB 62,535

FINNEY, D. J . ERRATA, 'SOME PROPERTIES OF A DISTRIBUTION SPECIFIED BY ITS CUMULANTS', TECH 63, 417

FINNEY, D. J. QUERY. ANALYSIS OF FACTORIAL EXPERIMENT (PARTIALLY CONFOUNDED 2-CUBE ) , TECH 67, 170

FINNEY, D. J , SOME PROPERTIES OF A DISTRIBUTION SPECIFIED BY ITS CUMULANTS, TECH 63,63

FINNEY, D. J . TEACHING BIOMETRY IN THE UNIVERSITY, BIOGS 6B， 1

FINNEY, D, J THE EFFICIENGIES OF ALTERNATIVE ESTIMATORS FOR AN ASYMPTOTIC REGRESSION EQUATION, BIOKA 58,370

FINNEY, D. J. THE MEANING OF BIOASSAY, BIOCS 65,785

FINUCAN, H. M. A NOTE ON KURTOSIS. JRSSB 64,111

FINUCAN, H. M. THE MODE OF A MULTINOMIAL DISTRIBUTION, BIOKA 64, 513

FISCHER, G. R. NOTES. MAXIMUM LIKELIHOOD ESTIMATION FOR THE TRUNCATED POISSON, BIOCS 66,620

FISHBURN, PETER C. A GENERAL THEORY OF SUBJECTIVE PROBABILITIES AND EXPECTED UTILITIES, AMS 69, 1419

FISHBURN, PETER C. BOUNDED EXPECTED UTILITY, AMS 67, 1054

FISHBURN, PETER C. PREFERENCE-BASED DEFINITIONS OF SUBJECTIVE PROBABILITY, AMS 67, 1605

FISHBURN, PETER C. WEAK QUALITATIVE PROBABILITY ON FINITE SETS, AMS 69. N0.6

FISHER, FRANKLIN M. A NOTE ON ESTIMATION FROM A CAUCHY SAMPLE, JASA 64,460

FISHER, FRANKLIN M, APPROXIMATE SPECIFICATION AND THE CHOICE OF A KCLASS ESTIMATOR, JASA 67,1265

FISHER, FRANKLIN $M$. THE RELATIVE SENSITIVITY TO SPECIFICATION ERROR OF DIFFERENT K-CLASS ESTIMATORS, JASA 66, 345

FISHER, JANET A. CONSUMER DURABLE COODS EXPENDITURES, WITH MAJOR EMPHASIS ON THE ROLE OF ASSETS, CREDIT A, JASA 63, 64B

FISHER, LLOYD AN EXAMPLE IN DUNUMERABLE DECISION PROCESSES, AMS 68 674

FISHER, LLOYD AN EXAMPLE OF THE DIFFERENCE BETWEEN THE LEVY AND LEVY-PROKHOROV METRICS, AMS 69, 322

FISHER, LLOYD DISTINGUISHABILITY OF PROBABILITY MEASURES, AMS 69 3BI

FISHER, LLOYD LIMITINC SETS AND CONVEX HULLS OF SAMPLES FROM PRODUCT MEASURES, AMS 69, 1824

FISHER, LLOYD ON RECURRENT DENUMERABLE DECISION PROCESSES, AMS 68 , 424

FISHER, R. A. ERRATA, 'THE PERCENTILE POINTS OF DISTRIBUTIONS HAVINC KNOWN CUMULANTS' ' TECH 60,523

FISHER, R. A. MATHEMATICAL PROBABILITY IN THE NATURAL SCIENCES, TECH 59,21

FISHER, R. A. NEW TABLES OF BEHREN'S TEST OF SIGNIFICANCE, JRSSB 56. 212

FISHER, R. A. ON SOME EXTENSIONS OF BAYESIAN INFERENCE PROPOSED BY MR LINDLEY, JRSSB 60, 299

FISHER, R. A. THE PERCENTILE POINTS OF DISTRIBUTIONS HAVING KNOWN CUMULANTS, TECH 60,209

FISHER, SIR ROLAND SOME EXAMPLES OF BAYES' METHOD OF THE EXPERIMENTAL DETERMINATION OF PROBABILITIES A PR, JRSSB 62, 118

FISHER, SIR RONALD COMMENT ON THE NOTES BY NEYMAN, BARTLETT AND WELCH IN THIS JOURNAL , VOL. 18, NO . 2, 19, JRSSB 57, 179

FISHER, SIR RONALD ON A TEST OF SIGNIFICANCE IN PEARSON'S BIOMETRIKA TABLES (NO. 11), JRSSB 56, 56

FISHER, SIR RONALD STATISTICAL METHODS AND SCIENTIFIC INDUCTION, JRSSB 55, 69

FISHER, WALTER D. A NOTE ON CURVE FITTINC WITH MINIMUM DEVIATIONS BY LINEAR PROGRAMMING, CORR. 62917, JASA 61,359

FISHER, WALTER D. ON GROUPING FOR MAXIMUM HOMOGENEITY', JASA 58, 789

FISK, P. R , ESTIMATION OF LOCATION AND SCALE PARAMETERS IN A TRUNCATED CROUPED SECH SQUARE DISTRIBUTION, JASA 61, 692 
FISK, P. R. MODELS OF THE SECOND KIND IN RECRESSION ANALYSIS, JRSSB 67,266

FISZ, MAREK INFINITELY DIVISIBLE DISTRIBUTIONS, RECENT RESULTS AND APPLICATIONS, AMS 62,68

FITCH, E. R. A CHART FOR THE INCOMPLETE BETA-FUNCTION AND THE CUMULATIVE BINOMIAL DISTRIBUTION, BIOKA 51,423

FITZPATRICK, PAUL J. LEADING AMERICAN STATISTICIANS IN THE NINETEENTH CENTURY, JASA 57, 301

FITZPATRICK, PAUL J. LEADINC AMERICAN STATISTICIANS OF THE NINETEENTH CENTURY II, JASA 58, 689

FITZPATRICK, PAUL $J$. LEADINC BRITISH STATISTICIANS OF THE NINETEENTH CENTURY, JASA 60,38

FIX. E. RANDOM POINTS IN A CIRCLE AND THE ANALYSIS OF CHROMOSOME PATTERNS, BIOKA 63, 23

FIX. EVELYN INTERSECTIONS OF RANDOM CHORDS OF A CIRCLE, BIOKA 64 373

FIX, EVELYN PERSISTENCE IN A CHAIN OF MULTIPLE EVENTS WHEN THERE IS SIMPLE DEPENDENCE, BIOKA.62, 351

FIX, EVELYN THE POLYKAYS OF THE NATURAL NUMBERS, BIOKA 60,53

FLANACAN. P. D. A NUMERICAL INVESTIGATION OF SEVERAL ONE-DIMENSIONAL SEARCH PROCEDURES IN NONLINEAR REGRE，TECH 69, 265

FLEHINGER, B. J. A CENERAL METHOD FOR THE RELIABILITY ANALYSIS OF SYSTEMS UNDER VARIOUS PREVENT IVE MA INTE, AMS 62, 137

FLEHINGER, BETTY J. A MARKOVIAN MODEL FOR THE ANALYSIS OF THE EFFECTS OF MARGINAL TESTING ON SYSTEM RELIA, AMS 62,754

FLEHINGER, BETTY J. INCENTIVE CONTRACTS AND PRICE DIFFERENTIAL ACCEPTANCE TESTS, JASA 64,149

FLEHINGER, BETTY J. PRODUCT TEST PLANNING FOR REPAIRABLE SYSTEMS TECH 65,4 B5

FLEISS, J. L. NOTES. A NOTE ON COCHRAN'S Q TEST, BIOCS $65,100 \mathrm{~B}$

FLEISS, JOSEPH L. ASSESSING THE ACCURACY OF MULTIVARIATE OBSERVATIONS, JASA 66,403

FLETCHER, N. T. ESTIMATION OF THE PROBABILITY OF DEFECTIVE FAILURE FROM DESTRUCTIVE TESTS, TECH 63, 459

FLICK, W A A NONPARAMETRIC STATISTICAL METHOD FOR CULLING RECRUITS FROM A MARK-RECAPTURE EXPERIMENT , BIOCS 65, 936

FOLKS, J. L. HETEROGENEITY OF ERROR VARIANCES IN A RANDOMIZED BLOCK DESIGN, BIOKA 57,275

FOLKS, J. L. THE EFF ICIENCY OF BLOCKING IN INCOMPLETE BLOCK DESIGNS . BIOKA 60,273

FOLKS, JOHN L. ESTIMATING THE FRACTION OF ACCEPTABLE PRODUCT, TECH 65,43

FOLKS, JOHN LEROY A PROPERTY OF THE METHOD OF STEEPEST ASCENT, AMS 64,435

FOLKS, JOHN LEROY NOTE ON THE MISSING PLOT PROCEDURE IN A RANDOMIZED BLOCKDESIGN, JASA 61,933

FOLKS, JOHN LEROY OPTIMUM ALLOCATION OF SAMPLING UNITS TO STRATA WHEN THERE ARE R RESPONSES OF INTEREST, JASA 65, 225

FOLKS, JOHN LEROY STRAIGHT LINE CONFIDENCE REGIONS OF LINEAR MODELS, JASA 67,1365

FONG, CHING SOME CONTRIBUTIONS TO THE AVERACE RANK CORRELATION METHODS AND TO THE DISTRIBUTION OF THE AVE, JASA 63,756

FOOTE, RICHARD J. A MODIFIED DOOLITTLE APPROACH FOR MULTIPLE AND PARTIAL CORRELATION AND REGRESSION, JASA 5B, 133

FORGY, EDWARD W. THE DEVELOPMENT OF NUMERICAL CREDIT EVALUATION SYSTEMS, JASA 63,799

FORSYTHE, JOHN VALIDATION OF CONSUMER FINANCIAL CHARACTERISTICS, COMMON STOCK, JASA 69,415

FOSS, S. D. A METHOD OF OBTAINING INITIAL ESTIMATES OF THE PARAMETERS IN EXPONENTI AL CURVE FITTING, BIOCS 69,580

FOSTER, F. G. A NOTE ON BAILEY'S AND WHITTLE'S TREATMENT OF A GENERAL STOCHASTIC EPIDEMIC, BIOKA 55, 123

FOSTER, F. G. A SAMPLING EXPERIMENT ON THE POWERS OF THE RECORDS TESTS FOR TREND IN A TIME SERIES, JRSSB 55,115

FOSTER, F. G. DISTRIBUTION-FREE TESTS IN TIME-SERIES BASED ON THE BREAKING OF RECORDS (WITHDISCUSSION) JRSSB 54,

FOSTER, F . G. QUEUES WITH BATCH DEPARTURES I, AMS 61, 1324

FOSTER, F. G. QUEUES WITH BATCH DEPARTURES II, AMS 64,1147

FOSTER, F. G. UPPER PERCENTACE POINTS OF THE GENERALIZED BETA DIS TRIBUTION. I, BIOKA 57,237

FOSTER, F. G. UPPER PERCENTAGE POINTS OF THE GENERALIZED BETA DISTRIBUTION. II, BIOKA 57, 441

FOSTER, F. G. UPPER PERCENTAGE POINTS OF THE GENERALIZED BETA DISTRIBUTION. III, BIOKA 5B, 492

FOULKES, H. O. NOTES. FURTHER ANALYSIS OF R. A. FISHER'S ENUMERATIONS IN CENETICS, BIOCS 65, 1012

FOWLKES, E. B. SOME OPERATORS FOR ANALYSIS OF VARIANCE CALCULATIONS, TECH 69,511

FOX, BENNETT L. GENERATION OF RANDOM SAMPLES FROM THE BETA AND F DISTRIBUTIONS, TECH 63, 269

FOX. KARL A. CRAPHIC COMPUTATION OF THE MULTIPLE CORRELATION COEFFICIENT, CORR. 581031 , JASA 57,479

FOX. MARTIN ADMISSIBILITY OF QUANTILE ESTIMATES OF A SINGLE LOCATION PARAMETER, AMS 64, 1019

FOX, MARTIN EST IMATION OF THE PARAMETER N IN THE BINOMIAL DISTRIBUTION, JASA 68,150

FOX, MARTIN FUNCTIONS OF PROCESSES WITH MARKOVIAN STATES, AMS 68 , 938
OX, MARTIN FUNCTIONS OF PROCESSES WITH MARKOVIAN STATES, II, AMS 69,865

FOX, MARTIN INADMISSIBILITY OF THE BEST INVARIANT TEST WHEN THE MOMENT IS INFINITE UNDER ONE OF THE HYPOT, AMS 69,1483

FRANCK, W. E. CENERALIZED MEANS AND ASSOCIATED FAMILIES OF DISTRIBUTIONS, AMS 69, 339

FRANCK, W. E. MAXIMUM LIKELIHOOD ESTIMATION OF THE DISTRIBUT IONS OF TWO STOCHASTICALLY ORDERED RANDOM VAR, JASA 66, 1067

FRANK, PETER THE ASYMPTOTIC ERROR OF ITERATIONS, AMS 68, 266

FRANKEL, LESTER R. WASHINGTON STATIST ICAL SOCIETY MEMORI AL MEET ING FOR WILLIAM N. HURWITZ. COMMENTS, JASA 69, NO 4

FRANKLIN, JOEL N. THE COVARIANCE MATRIX OF A CONTINUOUS AUTORECRESSIVE VECTOR TIME-SERIES, AMS 63, 1259

FRASER, A. R. STEREOSCOPIC MODELS OF MULTIVARIATE STATISTICAL DATA, BIOCS 66, 358

FRASER, D. A. S. A BLACK BOX OR A COMPREHENSIVE MODEL, TECH 68, 219

FRASER, D. A. S. DATA TRANSFORMATIONS AND THE LINEAR MODEL, AMS 67. 1456

FRASER, D. A. S, FIDUCIAL CONSISTENCY AND GROUP STRUCTURE, BIOKA 65 , 55

FRASER, D. A . S. FIDUCIAL INFERENCE FOR LOCATION AND SCALE PARAMETERS, BIOKA 64,17

FRASER, D. A. S. LOCAL CONDITIONAL SUFFICIENCY, JRSSB 64, 52

FRASER, D. A. S. ONFIDUCIAL INFERENCE, AMS 61, 66I

FRASER, D. A.S. ON INFORMATION IN STATISTICS, AMS 65, 890

FRASER, D. A. S. ON LOCAL INFERENCE AND INFORMATION, JRSSB 64, 253

FRASER, D. A. S. ON LOCAL UNBIASED ESTIMATION, JRSSB 64,46

FRASER, D. A.S. ON SUFFICIENCY AND THE EXPONENT IAL FAMILY, JRSSB 63,115

FRASER, D. A . S. ON THE CONS ISTENCY OF THE F IDUCIAL METHOD, JRSSB 62 425

RASER, D.A.S. ON THE SUFFICIENCY AND LIKELIHOOD PRINCIPLES, JASA 63. 641

FRASER, D. A. S. RANDOMIZATION TESTS FOR A MULTIVARIATE TWO-SAMPLE PROBLEM, JASA 58, 729

FRASER, D. A. S. STATIST ICAL MODELS AND INVARIANCE, AMS 67, 1061

FRASER, D. A. S. STRUCTURAL PROBABILITY AND A GENERALIZATION, BIOKA 66. 1

FRASER, D. A. S, THE CONDIT IONAL WISHART, NORMAL AND NONNORMAL, AMS 68,593

FRASER, D. A. S. THE FIDUCI AL METHOD AND INVARIANCE, BIOKA 61, 261

FREE, S. M. A SHORT-CUT RULE FOR A ONE-SIDED TEST OF HYPOTHESIS FOR QUALITATIVE DATA, TECH 69, 197

FREEDMAN, D. THE LAST RETURN TO EQUILIBRIUM IN A COIN TOSSING GAME. AMS 64,1344

FREEDMAN, DAVID A REMARK ON THE COIN TOSSINC GAME, AMS 64, 1345

FREEDMAN, DAVID ON THE LOCAL BEHAVIOR OF MARKOV TRANSITION PROBABILITIES, AMS 6B, 2123

FREEDMAN, DAVID THE TAIL SIGMA-FIELD OF A MARKOV CHAIN AND A THEORE OF OREY, AMS 64, 1291

FREEDMAN, DAVID TIMID PLAY IS OPTIMAL, AMS 67, 1281

FREEDMAN, DAVID TIMID PLAY IS OPTIMAL, II, AMS 67, 12B4

FREEDMAN, DAVID A. A NOTE ON MUTUAL SINGULARITY OF PRIORS, AMS 66 375

FREEDMAN, DAVID A. A REMARK ON SEQUENTIAL DISCRIMINATION, AMS 67 1666

FREEDMAN, DAVID A. A REMARK ON THE LAW OF THE ITERATED LOGARITHM, AMS 67,599

FREEDMAN, DAVTD A. A SHARPER FORM OF THE BOREL-CANTELLI LEMMA AND THE STRONG LAW, AMS 65,800

FREEDMAN, DAVID A. A THEOREM OF LEVY AND A PECULIAR SEMIGROUP, AMS 67,1552

FREEDMAN, DAVID A. AN OSCILLATING SEMICROUP, AMS 67, 924

FREEDMAN, DAVID A. BAYES 'METHOD FOR BOOKIES, AMS 69, 1177

FREEDMAN, DAVID A. BERNARD FRIEDMAN'S URN, AMS 65, 956

FREEDMAN, DAVID A EQUIVALENCE AND SINGULARITY FOR FRIEDMAN URNS, AMS 66, 268

FREEDMAN, DAVID A. INVARIANT PROBABILITIES FOR CERTAIN MARKOV PROCESSES, AMS 66, 837

FREEDMAN, DAVID A INVARIANTS UNDER MIXING WHICH GENERALIZE DE FINETTI'S THEOREM, AMS 62, 916

FREEDMAN, DAVID A. INVARIANTS UNDER MIXING WHICH GENERALIZE DE FINETTI 'S THEOREM . CONTINUOUS TIMES PARAME, AMS 63, 1194

FREEDMAN, DAVID A. MIXTURES OF MARKOV PROCESSES, AMS 62, 114

FREEDMAN, DAVID A. ON THE ASYMPTOTIC BEHAVIOR OF BAYES ESTIMATES IN THE DISCRETE CASE II, AMS 65, 454

FREEDMAN, DAVID A. ON THE ASYMPTOTIC BEHAVIOR OF BAYES ' ESTIMATES IN THE DISCRETE CASE, AMS 63, 1386

FREEDMAN, DAVID A. ON THE EXPECTED VALUE OF A STOPPED MARTINGALE AMS 66, 1505

FREEDMAN, DAVID A. ON TWO EQUIVALENCE RELATIONS BETWEEN MEASURES AMS 66,686

FREEDMAN, DAVID A. POISSON PROCESSES WITH RANDOM ARRIVAL RATE, AMS 62,924

FREEDMAN, DAVID A. SOME INVARIANCE PRINCIPLES FOR FUNCTIONALS OF A MARKOV CHAIN, AMS 67, I

FREEMAN, A. E. SOME TRANSFORMATIONS OF SCALE AND THE ESTIMATION OF GENETIC PARAMETERS FROM DAUGHTER-DAM R, BIOCS 67,823 
FREEMAN. DAVID SAMPLINC PLANS WHICH APPROXIMATELY MINIMIZE THE MAXIMUM EXPECTED SAMPLE SIZE. JASA 64.67

FREEMAN, G. H. ESTIMATION OF MEANS AND ST ANDARD ERRORS IN THE ANALYSIS OF NON-ORTHOCONAL EXPERIMENTS BY E, JRSSB 62, 435

FREEMAN, G. H. NOTE ON AN EXACT TREATMENT OF CONT INGENCY, GOODNESS OF FIT AND OTHER PROBLEMS OF SIGNIFICA, BIOKA 51,141

FREEMAN, G. H. SOME EXPER IMENTAL DESIGNS OF USE IN CHANG ING FROM ONE SET OF TREATMENTS TO ANOTHER, PART 2, JRSSB 57, 163

FREEMAN, C. H. SOME EXPER IMENTAL DESIGNS OF USE IN CHANGING FROM ONE SET OF TREATMENTS TO ANOTHER, PART 1, JRSSB 57, 154

FREEMAN, G. H. SOME FURTHER DESIGNS OF TYPE 0-PP. AMS 61.11B6

FREEMAN, G. H. SOME NON-ORTHOGONAL PARTITIONS OF 4X4, 5X5. AND 6 X6 LATIN SQUARES, AMS 66, 666

FREEMAN. G. H. SPREAD OF DISEASES IN A RECTANCULAR PLANTATION WITH VACANCIES, BIOKA $53,2 \mathrm{~B} 7$

FREEMAN, G. H. THE USE OF CYCLIC BALANCED INCOMPLETE BLOCK DESIGNS FOR DIRECT IONAL SEED ORCHARDS, BIOCS 67,761

FREEMAN, C. H. THE USE OF CYCLIC BALANCED INCOMPLETE BLOCK DESICNS FOR NON-DIRECT IONAL SEED ORCHARDS, BIOCS 69,561

FREEMAN, 4 . MULTIVARIATE T AND THE RANKINC PROBLEM, BIOKA 67,305

FREENY, ANNE E. ESTIMATION OF ERROR VARIANCE FROM SMALLEST ORDERED CONTRASTS, JASA 63, 152

FREUND, JOHN E. A BIVARIATE EXTENSION OF THE EXPONENTIAL DISTRIBUTION, JASA 61,971

FREUND, JOHN E. EXPECTED ARC LENCTH OF A GAUSSIAN PROCESS ON A FINITE INTERVAL, JRSSB 56, 257

FREUND, JOHN E. SOME METHODS OF ESTIMATING THE PARAMETERS OF DISCRETE HETEROCENEOUS POPULATIONS, JRSSB 56, 222

FREUND, R. J. A PROCEDURE FOR AUTOMATIC DATA EDITING, JASA 67, 341

FREUND, $R$. J AN EMPIRICAL EVALUATION OF MULTIVARIATE SEQUENTIAL PROCEDURE FOR TESTING MEANS. AMS 62. 1413

FREUND. RUDOLF J. RESIDUAL ANALYSIS, CORR, 61 1005, JASA 61, 98

FRIARS, G. W. THE EXPECTED MEAN SQUARES IN GENET IC EXPERIMENTS WHEN ONLY ONE PARENT IS IDENTIFIED, BIOCS 65,436

FRIEDMAN, H. P. ON SOME INVARIANT CRITERIA FOR CROUPINC DATA, JASA 67,1159

FRIEDMAN, MILTON THE INTERPOLATION OF TIME SERIES BY RELATED SERIES, JASA 62,729

FRIEDMAN, SHMUEL ON STOCHASTIC APPROXIMATIONS, AMS 63,343

FRIEND, IRW IN THE PREDICT IVE ABILITY OF CONSUMER ATTITUDES, STOCK PRICES, AND NON-ATTITUDINAL VARIABLES, JASA 64, 987

FRISTEDT, BERT A SHORT PROOF OF A KNOWN LIMIT THEOREM FOR SUM OF INDEPENDENT RANDOM VARIABLES WITH INFINI, AMS 69, 1114

FROME, E. L. MAXIMUM LIKELIHOOD ESTIMATION OF SURVIVAL CURVE PARAMETERS, BIOCS 68,595

FROMM, D. CROSS STATE PRODUCT AND AN ECONOMETRIC MODEL OF A STATE JASA 69, 7B7

FRY, R E. ERRATA, 'F INDING NEW FRACTIONS OF FACTORI AL EXPERIMENTAL DESICNS ', TECH 63, 134

FRY, R. E FINDING NEW FRACTIONS OF FACTORIAL EXPERIMENTAL DESIGNS TECH 61,359

FRY, THORNTON C. THE AUTOMATIC COMPUTER IN INDUSTRY, JASA 56, 565

FUCHS, CAROL F POISSON LIMITS OF MULTIVARIATE RUN DISTRIBUTIONS, AMS 65,215

FUCKS, W. ON NAHORDNUNG AND FERNORDNUNG IN SAMPLES OF LITERARY TEXTS, BIOKA 54, 116

FUCKS, WILHELM ON MATHEMATICAL ANALYSIS OF STYLE, BIOKA 52, 122

FUJIKOSHI, YASUNORI ASYMPTOTIC EXPANSIONS OF THE NON-NULL DISTRIBUT IONS OF THE LIKELIHOOD RATIO CRITERIA, AMS 69, 942

FULLER, WAYNE A, ESTIMATION EMPLOYING POST STRATA, JASA 66, 1172

GABRIEL. K. R. ANALYSIS OF VARIANCE OF PROPORTIONS WITH UNEQUAL FREQUENCIES, JASA 63,1133

CABRIEL, $K, R$, ANTE-DEPENDENCE ANALYSIS OF AN ORDERED SET OF VARIABLES, AMS 62, 201

CABRIEL, K. R. NON-PARAMETRIC ANALYSIS OF VARIANCE IN SMALL SAMPLES, A MONTE CARLO STUDY OF THE ADEQUACY, BIOCS 69,593

CABRIEL, K. R. ON THE DISTRIBUTION OF STATISTICS SUITABLE FOR EVALUATING RAINFALL STIMULATION EXPERIMENTS, TECH 69, 149

GABRIEL, K. R. SIMULTANEOUS TEST PROCEDURES FOR MULTIPLE COMPARISONS ON CATEGORICALDATA. JASA 66, 1081

GABRIEL. K. R. SIMULTANEOUS TEST PROCEDURES, SOME THEORY OF MULTIPLE COMPARISONS, AMS 69,224

GABRIEL, K.R. SIMULTANEOUS TEST PROCEDURES IN MULTIVARIATE ANALYSIS OF VARIANCE, BIOKA $68,4 B 9$

GABRIEL, K. R. THE DISTRIBUTION OF THE NUMBER OF SUCCESSES IN A SEQUENCE OF DEPENDENT TRIALS. BIOKA 59.454

GAFARIAN, A, V. CONFIDENCE BANDS IN STRAIGHT LINE REGRESSION, JASA 64,182

GAFFEY, WILLIAMR. A MATHEMATICAL MODEL WITH APPLICATIONS TO A STUDY OF ACCIDENT REPEATEDNESS AMONG CHILD, JASA 65, 1046

GAINSBRUGH, MARTINR. STATISTICS WE LIVE BY, JASA 62, I

GAJJAR, A. V. PROGRESSIVELY CENSORED SAMPLES FROM LOC-NORMAL AND LOGISTIC DISTRIBUTIONS, TECH 69, N0.4

CALL, G. A.E. COVARIANCE ANALYSIS WITH UNEQUAL SUBCLASS NUMBERS, COMPONENT ESTIMATION IN CORRELATION STU, BIOCS 68,49

GALLANT, A. R. A NOTE ON THE MEASUREMENT OF COST-QUANTITY RELATIONSHIPS IN THE AIRCRAFT INDUSTRY, JASA 68,1247
CALLAWAY, LOWELL E. A QUARTERLY ECONOMETRIC MODEL OF THE UNITED STATES, JASA 61,379

CANI, J. A NOTE ON SUFFICIENCY IN RECULAR MARKOV CHAINS, BIOKA 60 . 452

GANI, J, CORRICENDA TO 'SOME THEOREMS AND SUFFICIENCY CONDITIONS FOR THE MAXIMUM-LIKELIHOOD ESTIMATOR OF, BIOKA 56, 497

GANI, J , FIRST EMPT INESS OF TWO DAMS IN PARALLEL, AMS 61,219

GANI, J. INEQUALITIES FOR FIRST EMPTINESS PROBABILITIES OF A DAM WITH ORDERED INPUTS, JRSSB 62, 102

GANI, J. MODELS FOR A BACTERIAL GROWTH PROCESS WITH REMOVALS, JRSSB 63. 140

GANI, $J$. ON A PARTIAL DIFFERENTIAL EQUATION OF EPIDEMIC THEORY. I. BIOKA 65, 6I\%

GANI, J. ON THE STOCHASTIC MATRIX IN A CENETIC MODEL OF MORAN, BIOKA 61. 203

GANI, J, PROBLEMS IN THE PROBABILITY THEORY OF STORAGE SYSTEMS (WITH DISCUSSION , JRSSB 57, IBI

CANI. 3. SOME PROBLEMS IN THE THEORY OF PROVISIONING AND OF DAMS, BIOKA 55, 179

GANI, J. SOME THEOREMS AND SUFFICIENCY CONDITIONS FOR THE MAXIMUMLIKELIHOOD EST IMATOR OF AN UNKNOWN PARA, BIOKA 55, 342

CANI, J. STATIONARY DISTRIBUTIONS OF THE NECATIVE EXPERIMENTAL TYPE FOR THE INFINITE DAM, JRSSB 57,342

CANI, J. STOCHASTIC PHACE ATTACHMENT TO BACTERIA, BIOCS 65, 134

GANI, J. SUFFICIENCY CONDITIONS IN RECULAR MARKOV CHAINS AND CERTAIN RANDOM WALKS, BIOKA 56,276

GANI, J. THE EXTINCTION OF A BACTERIAL COLONY BY PHACES, A BRANCHINC PROCESS WITH DETERMINISTIC REMOVALS, BIOKA 62, 272

GANSER, C. C . INFINITELY DIFFERENTIABLE POSIT IVE DEFINITE FUNCTIONS, AMS 66,504

GARDINER, DONALD A. AN APPROXIMATION OF STUDENT'S T, TECH 65, 71

GARDINER, DONALD A. AN APPROXIMATION TO TWO-SIDED TOLERANCE LIMITS FOR NORMAL POPULATIONS, TECH 66, 115

CARDNER JR, L. A. ON DETECTING CHANGES IN THE MEAN OF NORMAL VARIATES, AMS 69, 116

GARDNER, C . 0. A CENERAL MODEL FOR GENETIC EFFECTS, BIOCS 66, B64

CARDNER, C . O. ANALYSIS AND INTERPRETATION OF THE VARIETY CROSS DIALLEL AND RELATED POPULATIONS. BIOCS 66,439

CARDNER, C. O. FURTHER EVIDENCE ON THE CONSISTENCY OF ESTIMATES OF VARIANCE COMPONENTS, BIOCS 65,395

CARDNER, R. S. CONFIDENCE INTERVALS FOR THE EXPECTATION OF A POISSON VARIABLE, BIOKA 59, 441

CARC, J . N . ON MODIFIED SYSTEMATIC SAMPLINC, BIOKA 6B, 54

CARC, M. L. CORRELATION BETWEEN THE SAMPLE VARIANCES IN A SINCLY TRUNCATED BIVARIATE NORMAL DISTRIBUT ION, BIOKA 68, 433

CARNER, NORMANR . CURTAILED SAMPLING FOR VARIABLES, JASA 5B, B62

GARNER, NORMAN R. THE OPERATING CHARACTERISTIC CURVE FOR SEQUENTIAL SAMPLING BY VARIABLES WHEN THE PRODUC, JASA 56, IOB

CART, J. J. ALTERNATIVE ANALYSIS OF CONTINGENCY TABLES, JRSSB 66 . 164

CART. J.J. AN EXACT TEST FOR COMPARINC MATCHED PROPORTIONS IN CROSSOVER DESIGNS. BIOKA 69,75

CART, J J APPROXIMATE CONFIDENCE LIMITS FOR THE RELATIVE RISK (CORR. 63234), JRSSB 62, 454

GART, J . J. CRAPHICALLY ORIENTED TESTS FOR HOST VARIABILITY IN DILUTION EXPERIMENTS, BIOCS 67,269

GART, $J, J$ ON THE BIAS OF VARIOUS ESTIMATORS OF THE LOCIT AND ITS VARIANCE WITH APPLICAT ION TO QUANT AL B, BIOKA 67, 181

CART, J. J. SOME STOCHASTIC MODELS RELATING TIME AND DOSACE IN RESPONSE CURVES, BIOCS 65,583

GART, J.J. SUSCEPTIBLES THE MATHEMATICAL ANALYSIS OF AN EPIDEMIC WITH TWO KINDS OF, BIOCS 6B, 557

GART, JOHN J. A MEDIAN TEST WITH SEQUENTIAL APPLICATION, BIOKA 63 , 55

GART, JOHN J, THE ANALYSIS OF POISSON RECRESSION WITH AN APPLICATION IN VIROLOGY, BIOKA 64,517

GART, JOHN J. THE ASYMPTOTIC PROPERT IES OF MAXIMUM LIKELIHOOD EST IMATORS WHEN SAMPLING FROM ASSOCIATED PO, BIOKA 62, 205

GASTWIRTH, J. L. THE FIRST-MEDIAN TEST. A TWO-SIDED VERSION OF THE CONTROL MEDIAN TEST, JASA 68,692

GASTWIRTH. JOSEPH L. AN ELEMENTARY METHOD OF OBTAININC LOWER BOUNDS ON THE ASYMPTOTIC POWER OF RANK TESTS, AMS 6B, 212B

GASTRIRTH JOSEPH L ASYMPTOTIC DISTRIBUTION OF LINEAR COMBINATIONS OF FUNCTIONS OF ORDER STATISTICS WITH, AMS 67, 52

GASTWIRTH, JOSEPH L. ASYMPTOTICALLY MOST POWERFUL RANK TESTS FOR THE TWO-SAMPLE PROBLEM WITH CENSORED DAT, AMS 65, 1243

CASTWIRTH, JOSEPH L. ON A SIMPLE ESTIMATE OF THE RECIPROCAL OF THE DENSITY FUNCTION, AMS 68, $10 B 3$

GASTWIRTH, JOSEPH L. ON ROBUST LINEAR EST IMATORS, AMS 69, 24

GASTWIRTH, JOSEPH L. ON ROBUST PROCEDURES, JASA 66, 929

CASTWIRTH, JOSEPH L. PERCENTILE MODIFICATIONS OF TWO-SAMPLE RANK TESTS, JASA 65,1127

CATES, C. E. LINE TRANSECT METHOD OF EST IMATINC GROUSE POPULATION DENSITIES, BIOCS 68,135

GATES. C. E. SIMULATION STUDY OF ESTIMATORS FOR THE LINE TRANSECT SAMPLINC METHOD, BIOCS 69, 317

GATES, C.R. ACCURACY REQUIREMENTS FOR ACCEPTANCE TESTING OF COMPLEX SYSTEMS, JASA 59,447 
CAVER JR, D. P. A WAITING LINE WITH INTERRUPTED SERVICE, INCLUDINC PRIORITIES, JRSS8 62.73

CAVER JR. D. P. RANDOM HAZARD IN RELIABILITY PROBLEMS, TECH 63, 211

GAVER JR, DONALD P. COMPETITIVE QUEUEINC, IDLENESS PROBABILITIES UNDER PRIORITY DISCIPLINES, JRSSB 63,489

CAYEN, A. K. THE FREQUENCY DISTRIBUTION OF THE PRODUCT-MOMENT CORRELATION COEFFICIENT IN RANDOM SAMPLES 0, BIOKA 51, 219

CAYLOR, D. W. AUCMENTINC EXISTING DATA IN MULTIPLE RECRESSION, TECH 68.73

CAYLOR, D. W. DESICN FOR OPTIMAL PREDICTION IN SIMPLE LINEAR RECRESSION, JASA 65, 205

GAYLOR, D. W. EQU IVALENCE OF TWO ESTIMATES OF PRODUCT VARIANCE. JASA 56,451

GAYLOR, D. W. ESTIMATING THE DEGREES OF FREEDOM FOR LINEAR COMBINATIONS OF MEAN SQUARES BY SATTERTHWAITHE, TECH 69, NO.4

GAYLOR, D. $W$. EXPECTED MEAN SQUARES FOR NESTED GLASSIFIGATIONS, BIOCS 69,427

GAYLOR, D. W. SEQUENTIAL COMBINATION CHEMOTHERAPY EXPERIMENTS, BIOCS 66,730

GEARY, R. C. EX POST DETERMINATION OF SICNIFIGANCE IN MULTIVARIATE REGRESSION WHEN THE INDEPENDENT VARIAB , JRSSB 67,154

GEARY. R. G. THE AVERAGE CRITICAL VALUE METHOD FOR ADJUDG ING RELATIVE EFFICIENCY OF ST ATISTICAL TESTS IN, BIOKA 66, 109

GEBHARD, RICHARD F. A LIMIT THEOREM FOR RANDOM INTERVAL SAMPLINC OF A STOGHASTIG PROCESS, AMS 64.866

GEBHARDT, F. NOTES. APPROXIMATIONS TO THE CRITICAL VALUES FOR DUNCAN'S MULTIPLE RANCE TEST, BIOCS 66, 179

GEBHARDT, FRIEDRICH ON THE EFFECT OF STRAGGLERS ON THE RISK OF SOME MEAN ESTIMATORS IN SMALL SAMPLES, AMS 66, 441

GEBHARDT, FRIEDRICH ON THE RISK OF SOME STRATEG IES FOR OUTLYINC OBSERVATIONS, AMS 64, 1524

GEBHARDT, FRIEDRICH SOME NUMERICAL COMPARISONS OF SEVERAL APPROXIMATIONS TO THE BINOMIAL DISTRIBUTION, JASA 69. NO. 4

GEHAN, E. A. A GENERALIZED TWO-SAMPLE WILCOXON TEST FOR DOUBLY-CENSORED DATA . BIOKA 65, 650

GEHAN, E. A. A GENERALIZED WILGOXON TEST FOR GOMPARING AR8ITRARILY SINGLY-CENSORED SAMPLES, BIOKA 65,203

GEHAN, E A. THE PERFORMANCE OF SOME TWO-SAMPLE TESTS IN SMALL SAMPLES WITH AND WITHOUT CENSORING, BIOKA 69, 127

GEISSER, S. A NECESSARY AND SUFFICIENT CONDITION FOR THE SQUARE OF A RANDOM VARIABLE TO BE GAMMA, BIOKA 66, 275

GEISSER, S. ESTIMATION IN THE UNIFORM COVARIANCE CASE, JRSSB 64, 477 CEISSER, S. POSTERIOR ODDS FOR MULTIVARIATE NORMAL CLASSIFICATION, JRSSB 64,69

GEISSER, S. PREDICTIVE ZERO-MEAN UNIFORM DISCRIMINATION, BIOKA 68 , 519

GEISSER, SEYMOUR A BAYES APPROAGH FOR COMBININC CORRELATED ESTIMATES, JASA 65,602

CEISSER, SEYMOUR BAYESIAN ESTIMATION IN MULTIVARIATE ANALYSIS, AMS 65. 150

GEISSER, SEYMOUR ESTIMATION ASSOCIATED WITH LINEAR DISCRIMINANTS, AMS 67,807

GEISSER, SEYMOUR MULTIVARIATE ANALYSIS OF VARIANCE FOR A SPECIAL COVARIANGE CASE, CORR, 641296 , JASA 63,660

GEISSER, SEYMOUR PAIRWISE INDEPENDENCE OF JOINTLY DEPENDENT VARIA8LES, AMS 62,290

GEISSER, SEYMOUR POSTERIOR DISTRIBUTIONS FOR MULTIVARIATE NORMAL PARAMETERS, JRSSB $63,36 \mathrm{~B}$

GELZER, JOSEPH THE ASYMPTOTIG RELATIVE EFFICIENCY OF GOODNESS-OFFIT TESTS AGAINST SCALAR ALTERNATIVES, JASA 65, 410

GENIZI. A NOTES. OPTIMUM EXPERIMENTAL DESIGNS FOR REALIZED HERITABILITY ESTIMATES, BIOCS 67,361

GENIZI, ABRAHAM ON THE PERFORMANCE OF THE TRUNCATED SEQUENTIAL PROBABILITY RATIO TEST, CORR. 661247, JASA 65,979

GENTLEMAN, $W$. M. AN APPROXIMATION FOR STUDENT'S T-DISTRIBUTION, BIOKA 68,571

GEOGHAGEN, R. R. M. A GENERAL USE OF THE POISSON APPROXIMATION FOR BINOMI AL EVENTS, WITH APPLICATION TO B, 8IOGS 66,74

GERIG, THOMAS M. A MULTIVARIATE EXTENSION OF FRIEDMAN'S CHISQUARE-SUB-R-TEST, JASA 69, NO. 4

GERSCHENKRON, ALEXANDER PROBLEMS IN MEASURING LONG TERM GROWTH IN INCOME AND WEALTH, JASA 57,450

GESSAMAN, M. P. NONPARAMETRIC DISCRIMINATION USING TOLERANCE REGIONS, AMS 68,664

GETOOR, R. K. A THEOREM ON STOPPING TIMES, AMS 64, 1348

CETOOR, R. K. ADDITIVE FUNCTIONALS AND EXCESSIVE FUNCTIONS, AMS 65 409

GETOOR, R. K. SOME REMARKS ON CONTINUOUS ADDITIVE FUNCTIONALS, AMS 67,1655

GHIRTIS, G. C. A SYSTEM OF TWO SERVERS WITH LIMITED WAITING ROOMS AND CERTAIN ORDER OF VISITS, BIOKA 68,223

GHOSAL, A. QUEUES IN SERIES, JRSSB 62,359

GHOSAL, A. SOME RESULTS IN THE THEORY OF INVENTORY, BIOKA 64, 487

GHOSH. B. K. ASYMPTOTIC EXPANSIONS FOR THE MOMENTS OF THE DISTRIBUTION OF CORRELATION COEFFICIENT, BIOKA 66,258

GHOSH, B. K. MOMENTS OF THE DISTRIBUTION OF SAMPLE SIZE IN A SPRT, JASA 69 , NO 4
CHOSH, B $K$ ON SEQUENTIAL TESTS OF RATIO OF VARIANCES BASED ON RANCE, BIOKA 63, 419

GHOSH, B. K. SEQUENTI AL ANALYSIS OF VARIANCE UNDER RANDOM AND MIXED MODELS, JASA 67,1401

CHOSH, B. K. SEQUENTIAL RANCE TESTS FOR COMPONENTS OF VARIANCE, CORR. 65 1249, JASA 65,826

CHOSH, B K. SIMULTANEOUS TESTS BY SEQUENT I AL METHODS IN HIERARCHICAL CLASSIFICATIONS, BIOKA 64, 439

CHOSH, J. K. INVARIANT SETS FOR TRANSLATION-PARAMETER FAMILIES OF MEASURES, AMS 69, 162

GHOSH, J. K. THE RELATIONSHIP BETWEEN SUFFICIENCY AND INVARIANCE WITH APPLICATIONS IN SEQUENTIAL ANALYSIS, AMS 65.575

GHOSH, J. K. UNBIASED ESTIMATION OF LOCATION AND SCALE PARAMETERS, AMS 66, 1671

GHOSH, M. N. BOUNDS FOR THE EXPECTED SAMPLE SIZE IN A SEQUENTIAL PROBABILITY RATIO TEST, JRSSB 60,360

GHOSH, M. N. HOTELLING'S GENERALIZED T SQUARE IN THE MULTIVARIATE ANALYSIS OF VARIANCE, JRSSB $63,35 B$

GHOSH, M. N. ON THE ADMISSIBILITY OF SOME TESTS OF MANOVA, AMS 64, 789 GHOSH, M. N. POWER OF TUKEY'S TEST FOR NON-ADDITIVITY, JRSSB 63, 213 GHOSH. M. N . SIMULTANEOUS TESTS OF LINEAR HYPOTHESES, BIOKA 55, 441 GHOSH. M. N. UNIFORM APPROXIMATION OF MINIMAX POINT ESTIMATES, AMS 64,1031

CHOSH, S. P. OPTIMUM STRATIFICAT ION WITH TWO CHARACTERS, AMS 63, 866 GHOSH, S. P SOME THEORY OF SAMPLINC WHEN THE STRATIFICATION IS SUBJECT TO ERROR, TECH 67,1

GHOSH, SAKTI P. POLYCHOTOMY SAMPLING, AMS 66, 657

GHOSH, SAKTI P, POST GLUSTER SAMPLING, AMS 63, 587

GHURYE, S. G. A CHARACTERIZATION OF THE MULTIVARIATE NORMAL DISTRIBUTION, AMS 62, 533

GHURYE, S. G. INFORMATION AND SUFFICIENT SUB-FIELDS, AMS 68, 2056

GHURYE. S. G. TWO-STAGE PROCEDURES FOR ESTIMATINC THE DIFFERENCE BETWEEN MEANS, BIOKA 54, 146

GHURYE. S. G. UNBIASED ESTIMATION OF SOME MULTIVARIATE PROBABILITY DENSITIES, AMS 69,1261

GIBBONS. JEAN D. A PROPOSED TWO-SAMPLE RANK TEST, THE PSI TEST AND ITS PROPERTIES, JRSSB 64, 305

ITBBONS JEAN D EFFECT OF NON-NORMALITY ON THE POWER FUNCTION OF THE SIGN TEST, JASA 64,142

SIBBONS, JEAN D. ESTIMATION OF THE NUMBER OF CRITICAL SITES IN LIMITED CENOME EXPRESSION DUR ING VIRAL INF , BIOCS 69, 537

GIBBONS, JEAND ON THE POWER OF TWO-SAMPLERANK TESTS ON THE EQUALITY OF TWO DISTRIBUTION FUNCTIONS, JRSSB 64,293

GIBSON, C. H. ESTIMATION OF POWER SPECTRA BY A WAVE ANALYZER, TECH 65.553

IESBRECHT , F . EXAMINATION OF A REPEAT MAT ING DESIGN FOR ESTIMATING ENVIRONMENTAL AND GENETIC TRENDS, BIOCS 65,63

GIL-PELAEZ, J (ACKNOWLEDGEMENT OF PRIORITY) 'NOTE ON THE INVERSION THEOREM ' . BIOKA 52. 215

GIL-PELAEZ, J. NOTE ON THE INVERSION THEOREM, BIOKA 51, 481

GILBERT, E.N. RANDOM SUBDIVISIONS OF SPACE INTO CRYSTALS, AMS 62 958

GILBERT . E. N. THE PROBABILITY OF COVERING A SPHERE WITH N CIRCULAR CAPS. . BIOKA 65,323

GILBERT, ETHEL S. ON DISCRIMINATION USING QUALITATIVE VARIABLES. JASA 68,1399

GILBERT, ETHEL S. THE EFFECT OF UNEQUAL VARIANCE-COVARIANCE MATRICES ON FISHER' S LINEAR DISCRIMINANT FUNC, BIOCS 69, 505

GILBERT, JOHN P. RECOCNIZING THE MAXIMUM OF A SEQUENCE. JASA 66, 35

GILBERT. N. ADDITIVE COMBINING ABILITIES FITTED TO PLANT BREEDINC DATA, BIOCS 67,45

GILBERT N EST IMATION FROM A LINEAR MARKOV PROCESS, BIOKA 60, 4B2

GILBERT. N. E. G. LIKELIHOOD FUNCTION FOR CAPTURE-RECAPTURE SAMPLES, BIOKA 56,488

GILBERT, R. D. ON THE DISTRIBUTIONS OF THE RANGE AND MEAN RANGE FOR SAMPLES FROM A NORMAL DISTRIBUTION, BIOKA 66.245

GILBERT. ROY F. SMALL SAMPLE PROPERTIES OF ALTERNATIVE ESTIMATORS OF SEEMINCLY UNRELATED REGRESSIONS, JASA 6B , 11BO

GILCHRIST, W. G METHODS OF ESTIMATION INVOLVING DISCOUNTING, JRSSB 67,355

GILCHRIST,$W$. G. SOME SEQUENTIAL TEST USING RANGE , JRSSB 61, 335

GILL, J L PROBABILITY OF OBTAINING NEGATIVE EST IMATES OF HER ITA-

BILITY, BIOCS 68,517

GILLILAND. DENNIS APPROXIMATION TO BAYES RISK IN SEQUENCES OF NONFINITE GAMES, AMS 69, 467

ILLILAND, DENNIS C. A NOTE ON THE MAXIMIZATION OF A NON-CENTRAL CHI-SQUARE PROBABILITY, AMS 64, 441

TILILAND, DENNIS C INTEGRAL OF THE BIVARIATE NORMAL DISTRIBUTION OVER AN OFFSET CIRCLE, JASA 62,758

GILLILAND, DENNIS C , ON AN EXTENDED COMPOUND DECISION PROBLEM. AMS 69. 1536

GILLILAND, DENNIS C. SEQUENTIAL COMPOUND ESTIMATION, AMS 68, 1890

GIRI. N. LOCAL AND ASYMPTOTIC MINIMAX PROPERTIES OF MULTIVARIATE TESTS, AMS 64, 21

GIRI, N LOCALLY AND ASYMPTOTICALLY MINIMAX TESTS OF A MULT IVARIATE PROBLEM, AMS 68, 171

GIRI, N. MINIMAX CHARACTER OF HOTELLING 'S T-SQUARED TEST IN THE SIMPLEST CASE, AMS 63, 1524 
GIRI, N. MINIMAX CHARACTER OF THE R-SQUARED-TEST IN THE SIMPLEST CASE, AMS 64.1475

GIRI, N. ON TESTS OF THE EQUALITY OF TWO COVARIANCE MATRICES, AMS 68 275

GIRI, N ON THE COMPLEX ANALOGUES OF T-SQUARED AND R-SQUARED TESTS AMS 65.664

GIRI. N. ON THE F-TEST IN THE INTRABLOCK ANALYSIS OF A CLASS OF TWO ASSOCIATE PARTIALLY BALANCED INCOMPLE, JASA 65, 285

GIRI. N. ON THE LIKELIHOOD RATIO TEST OF A NORMAL MULTIVARIATE TESTING PROBLEM, CORR. 641388 , AMS 64, 181

GIRI N. ON THE LIKELIHOOD RATIO TEST OF A NORMAL MULTIVARIATE TESTING PROBLEM II. AMS 65, 1061

GIRSHICK. M A. CORRECTION. 'SOME EXTENSIONS, OF THE WISHART DISTRIBUTION', 44345 , AMS 64, 923*

GLASSER, G, J AN UNBIASED ESTIMATOR FOR POWERS OF THE ARITHMETIC MEAN, JRSSB 61,154

GLASSER, G, J CRITICAL VALUES OF THE COEFFICIENT OF RANK CORRELATION FOR TESTING THE HYPOTHESIS OF INDEP, BIOKA 61, 444

GLASSER, G. J. EST IMATORS FOR THE PRODUCT OF ARITHMETIC MEANS, JRSSB 62,180

GLASSER, GERALD J. A DISTRIBUTION-FREE TEST OF INDEPENDENCE WITH A SAMPLE OF PAIRED OBSERVATIONS, JASA 62,116

GLASSER, GERALD J. MINIMUM VARIANCE UNBIASED ESTIMATORS FOR POISSON PROBABILITIES, TECH 62, 409

GLASSER, GERALD J, ON ESTIMATORS FOR VARIANCES AND COVARIANCES BIOKA 62.259

GLASSER, GERALD J. ON THE PROBLEM OF MATCHING LISTS BY SAMPLES, JASA 59.403

GLASSER, GERALD J. THE AGE REPLACEMENT PROBLEM, TECH 67.83

GLASSER, GERALD J. VARIANCE FORMULAS FOR THE MEAN DIFFERENCE AND COEFFICIENT OF CONCENTRATION, JASA 62, 648

GLASSER, M. LINEAR REGRESSION ANALYSIS WITH MISSING OBSERVATIONS AMONG THE INDEPENDENT VARIABLES, JASA 59, B34

CLASSER, M, REGRESSION ANALYSIS WITH DEPENDENT VARIABLE CENSORED BIOCS 65,300

GLASSER, MARVIN EXPONENTIAL SURVIVAL WITH COVARIANCE, JASA 67, 561

GLEJSER, H. A NEW TEST FOR HETEROSKEDAST ICITY, JASA 69, 316

CLENN, W. A. A COMPARISON OF THE EFFECTIVENESS OF TOURNAMENTS. BIOKA 60,253

GLESER, L. J. ON TESTING A SET OF CORRELATION COEFFICIENTS FOK EQUALITY. SOME ASYMPTOTIC RESULTS, BIOKA 6B, 513

GLESER, LEON J. A NOTE ON THE SPHERICITY TEST, AMS 66, 464

GLESER, LEON J. ON A MEASURE OF TEST EFFICIENCY PROPOSED BY $R$. $R$ BAHADUR, AMS 64, 1537

GLESER, LEON J. ON THE ASYMPTOTIC THEORY OF FIXED-SIZE SEQUENTIAL CONFIDENCE BOUNDS FOR LINEAR REGRESSION, AMS 65, 463

GLESER, LEON JAY ON LIMITINC DISTRIBUTIONS FOR SUMS OF A RANDOM NUMBER OF INDEPENDENT RANDOM VECTORS, AMS 69, 935

GNANADESIKAN, M. ESTIMATION OF THE PARAMETERS OF THE LOGISTIC DISTRIBUTION, BIOKA 66,565

GNANADESIKAN, R. A NOTE ON 'FURTHER CONTRIBUTIONS TO MULTIVARIATE CONFIDENCE BOUNDS' ', BIOKA 58,581

GNANADESIKAN, $R$, CORRIGENDA, 'ESTIMATION OF PARAMETERS OF THE GAMMA DISTRIBUTION USING ORDER STATISTICS ' ', BIOKA 63, 546

GNANADESIKAN, R. CORRIGENDA, 'FURTHER CONTRIBUTIONS TO MUL'TIVARIATE CONFIDENCE BOUNDS' ', BIOKA 61,474

GNANADESIKAN, R. ESTIMATION OF ERROR VARIANCE FROM SMALLEST ORDERED CONTRASTS, JASA 63, 152

GNANADESIKAN, R. ESTIMATION OF PARAMETERS OF THE GAMMA DISTRIBUTION USING ORDER STATIST ICS, BIOKA 62, 525

GNANADESIKAN, R. FURTHER CONTRIBUTIONS TO MULTIVARIATE CONFIDENCE BOUNDS, BIOKA 57,399

GNANADESIKAN, R, GRAPHICAL METHODS FOR INTERNAL COMPARISONS IN MULTIRESPONSE EXPERIMENTS, AMS 64,613

GNANADESIKAN, R. MAXIMUM LIKELIHOOD ESTIMATION OF THE PARAMETERS OF THE BETA DISTRIBUTION FROM SMALLEST 0 . TECH 67, 607

GNANADESIKAN, R PROBABILITY PLOTS FOR THE GAMMA DISTRIBUTION TECH 62,1

GNANADESIKAN, R, PROBABILITY PLOTTING METHODS FOR THE ANALYSIS OF DATA, BIOKA 68, 1

CNANADESIKAN, $R$. SCALE PARAMETER ESTIMATION FROM THE ORDER STATISTICS OF UNEQUAL GAMMA COMPONENTS, AMS 66,152

CNANADESIKAN, R. SEPARATE MAXIMUM-LIKELIHOOD ESTIMATION OF SCALE OR SHAPE PARAMETERS OF THE GAMMA DISTRIB, BIOKA 63,217

CNANADESIKAN, R. TWO-SAMPLE COMPARISONS OF DISPERSION MATRICES FOR ALTERNATIVES OF INTERMEDIATE SPECIFICI, AMS 62, 432

GODAMBE, $V$. P. A FIDUCIAL ARGUMENT WITH APPLICATION TO SURVEY SAMPLING, JRSSB 69, NO.2

CODAMBE, V. P. A NEW APPROACH TO SAMPLING FROM FINITE POPULATIONS II , JRSSB 66,320

GODAMBE, V. P. A NEW APPROACH TO SAMPLING FROM FINITE POPULATIONS I, JRSSB 66,310

GODAMBE, V. P. A UNIFIED THEORY OF SAMPLING FROM FINITE POPULATIONS, JRSSB 55, 269

GODAMBE, $V . P$. ACKNOWLEDGEMENT OF PRIORITY FOR 'AN OPTIMUM PROPERTY OF MAX IMUM LIKELIHOOD ESTIMAT ION' 60 , AMS 61,1343

GODAMBE, $V, P$. ADMISSIBILITY AND BAYES ESTIMATION IN SAMPLINC FINITE POPULATIONS, I, AMS 65, 1707
CODAMBE, $V$, P ADMISSIBILITY AND BAYES ESTIMATION IN SAMPLING FINITE POPULATIONS, V, AMS 69, 672

GODAMBE, V. P. ON THE TWO SAMPLE PROBLEM, A HEURIST IC METHOD FOR CONSTRUCTING TESTS, AMS 61, 1091

GODWIN, H. J. A CENTRAL LIMIT THEOREM FOR PARTLY DEPENDENT VARIABLES, AMS 61, 677

GOEL, A. L. AN ALGORITHM FOR THE DETERMINATION OF THE ECONOMIC DESIGN OF X-CHARTS BASED ON DUNCAN' SMODEL, JASA 68,304

GOLD, R. Z. NOTES. ON ESTIMATING RECESSIVE FREQUENCIES FROM TRUNCATED SAMPLES, BIOCS 67,356

GOLD, R. Z. ON THE QUESTION OF WHETHER A DISEASE IS FAMILIAL, JASA 67 409

GOLD, RUTH Z. TESTS AUXILIARY TO CHI-SQUARED TESTS IN A MARKOV CHAIN, AMS 63,56

GOLDBERGER. ARTHUR $S$. BEST LINEAR UNBIASED PREDICTION IN THE GENERALIZED LINEAR REGRESSION MODEL, JASA 62,369

GOLDBERGER, ARTHUR S. NOTE ON STEPWISE LEAST SQUARES, JASA 61, 105

GOLDBERGER, ARTHUR S. ON THE EXACT COVARIANCE OF PRODUCTS OF RANDOM VARI ABLES, JASA 69, NO. 4

GOLDBERGER, ARTHUR S. STEPWISE LEAST SQUARES, RESIDUAL ANALYSIS AND SPECIFICATION ERROR, JASA 61, 998

GOLDFELD, STEPHEN M. SOME TESTS FOR HOMOSCEDASTICITY, JASA 65, 539 GOLDMAN, AARON S. COMPARISONS OF SOME TWO STAGE SAMPLING METHODS, AMS 66, 891

GOLDMAN, G. E. ON THE CHOICE OF VARI ABLES IN CLASSIFICATION PROBLEMS WITH DICHOTOMOUS VARIABLES, BIOKA 67, 66B

GOLDMAN, JAYR. STOCHASTIC POINT PROCESSES, LIMIT THEOREMS, AMS 67, 771

GOLDMAN, THOMAS DISCUSSION OF 'ON THE FOUNDATIONS OF STATISTICAL INFERENCE' , JASA 62, 307

GOLDSMITH, P. L. A CENERAL SIMULATION PROGRAMME FOR MATERIAL FLOW IN BATCH CHEMICAL PLANTS, TECH 61,497

GOLDSMITH, P. L. AVERAGE RUN LENGTHS IN CUMULATIVE CHART QUALITY CONTROL SCHEMES, TECH 61,11

GOLDSTEIN, NEIL ANALYSIS OF EMPIRICAL BIVARIATE EXTREMAL DISTRIBUTIONS, JASA 64.794

GOLDSTEIN, SIDNEY THE EXTENT OF REPEATED MIGRATION, AND ANALYSIS BASED ON THE DANISH POPULATION REGISTER, JASA 64, 1121

GOLUB, ABRAHAM ANALYSIS OF SENSITIVITY EXPERIMENTS WHEN THE LEVELS OF STIMULUS CANNOT BE CONTROLLED, CORR, JASA 56, 257

GOLUB, GENE $H$. COMPARISON OF THE VARIANCE OF MINIMUM VARIANCE AND WEIGHTED LEAST SQUARES REGRESSION COEFF, AMS 63, 9B4

CONIN, H. T. A STUDY OF THE MATRIX OF FITTING OF A SERIES OF DISCRETE FREQUENCY FUNCTIONS ANALOGOUS TO TH, SASJ 67,55

GONIN, H. T . CORRIGENDA, 'THE USE OF ORTHOGONAL POLYNOMI ALS OF POSITIVE AND NEGATIVE BINOM IAL FREQUENCY F , BIOKA 61, 476

GONIN, H. T. POISSON AND BINOMIAL FREQUENCY SURFACES, BIOKA 66, 617 GONIN, H T T THE ORTHOGONAL POLYNOM IALS OF POWER SER IES PROBABILITY DISTRIBUTIONS AND THEIR USES, BIOKA 66, 121

GONIN, H. T. THE ORTHOGONAL POLYNOMIALS OF THE FACTORIAL POWER SERIES PROBABILITY DISTRIBUTIONS, SASJ 67,49

GONIN, H. T. THE USE OF ORTHOGONAL POLYNOMIALS OF THE POSITIVE AND NEGATIVE BINOMIAL FREQUENCY FUNCTIONS, BIOKA 61, 115

GOOD, I. J. A BAYESIAN SIGNIFICANCE TEST FOR MULTINOMIAL DISTRIBUTIONS (WITHDISCUSSION), JRSSB 67, 399

GOOD, I. J. A CLASSIFICATION OF FALLACIOUS ARCUMENTS AND INTERPRETATIONS, TECH 62,125

GOOD, I J A DERIVATION OF THE PROBABILISTIC EXPLICATION OF INFORMATION, JRSSB 66,578

GOOD, I. J, A SUB JECT IVE EVALUATION OF BODE' S LAW AND AN ' OBJECT IVE' TEST FOR APPROXIMATE NUMERI CAL RATIO, JASA 69, 23

GOOD, I. J. AN ASYMPTOTIC FORMULA FOR THE DIFFERENCES OF THE POWERS AT ZERO, AMS 61,249

GOOD, I. J . CONDITIONS FOR A QUADRATIC FORM TO HAVE A CHI-SQUARED DISTRIBUTION, BIOKA 69, 215

GOOD, I . J . CORRECTIONS TO 'SADDLE POINT METHODS FOR THE MULTINOMIAL DISTRIBUTIONS' 57861 , AMS 61,619

GOOD, I. J CORRIGENDA TO 'THE LIKELIHOOD RATIO TEST FOR MARKOFF CHAINS', BIOKA 57,301

GOOD, I. J. DISCUSSION OF 'ON THE FOUNDATIONS OF STATISTICAL INFERENCE', JASA 62,307

COOD, I. J. DISCUSSION OF THE PAPERS OF MESSRS. HALD, WETHERILL AND COX, TECH 60,361

GOOD, I J J MAXIMUM ENTROPY FOR HYPOTHESIS FORMULATION, ESPECIALLY FOR MULTIDIMENSIONAL CONTINGENCY TABLE, AMS 63, 911

GOOD, I. J. NOTES . CHECKS ON YATES 'S ALGORITHM, BIOCS 67, 573

GOOD, I. J . ON THE ESTIMATION OF SMALL FREQUENCIES IN CONTINGENCY TABLES, JRSSB 56, 113

GOOD. I. J. ON THE INDEPENDENCE OF QUADRATIC EXPRESSIONS (CORR. 66 584), JRSSB 63,377

GOOD, I , J ON THE WEIGHTED COMB INATION OF SIGNIFICANCE TESTS, JRSSB 55,264

GOOD, I. J QUADRATICS IN MARKOV-CHAIN FREQUENCIES, AND THE BINARY CHAIN OF ORDER 2, JRSSB 63,383

GOOD, I. J. SIGNIFICANCE TESTS IN PARALLEL AND IN SERIES, JASA 58, 799

GOOD, I. J. SOME APPLICATIONS OF THE SINGULAR DECOMPOSITION OF A MATRIX, TECH 69 , NO. 4 
GOOD, I. J. THE FREQUENCY COUNT OF A MARKOV CHAIN AND THE TRANSITION TO CONTINUOUS TIME, AMS 61,41

GOOD, I. J . THE INTERACTION ALGORITHM AND PRACT ICAL FOURIER ANALYSIS, AN ADDENDUM, JRSSB 60,372

GOOD, I. J , THE INTERACTION ALGORITHM AND PRACT ICAL FOURIER ANALYSIS, JRSSB 58,361

GOOD, I. J. THE LIKELIHOOD RATIO TEST FOR MARKOFF CHAINS, BIOKA 55. 531

GOOD, I. J. THE MULT IVARIATE SADDLE POINT METHOD AND CHI-SQUARED FOR THE MULTINOMIAL DISTRIBUTION, AMS 61, 535

GOOD, I. J. THE NUMBER OF NEW SPECIES, AND THE INCREASE IN POPULATION COVERAGE, WHEN A SAMPLE IS INCREASE, BIOKA 56,45

GOOD, I. J. THE POPULATION FREQUENC IES OF SPECIES AND THE ESTIMATION OF POPULATION PARAMETERS, BIOKA 53,237

GOOD, I . J. THE REAL STABLE CHARACTER IST IC FUNCTIONS AND GHAOTIC ACCELERATION, JRSSB $61,1 B O$

GOOD, I, J. WEIGHT OF EVIDENCE, CORROBORATION, EXPLANATORY POWER, INFORMATION AND THE UTILITY OF EXPERIME, JRSSB 60,319

GOODALL, D. W. A NEW SIMILARITY INDEX 8ASED ON PROBABILITY, BIOCS 66. BB2

GOODALL, D. W. THE DISTRIBUTION OF THE MATCHING COEFFICIENT, 8IOCS 67,647

GOODGHILD, N, A. NOTES. APPLICATIONS OF NONORTHOGONAL DESIGNS TO SITUATIONS WHERE TREATMENTS OR BLOCKS AR, BIOCS 66,629

GOODMAN, L. A. ON PLACKETT'S TEST FOR CONTINGENCY TA8LE INTERACTIONS, JRSS8 63, 179

GOODMAN, L. A. PART I AL TESTS FOR PART I AL TAUS, BIOKA 59, 425

GOODMAN, L. A. SIMPLIFIED RUNS TESTS AND LIKELIHOOD RATIO TESTS FOR MARKOFF GHAINS, BIOKA $5 B$, IBI

GOODMAN, L. A. SIMULTANEOUS CONFIDENCE LIMITS FOR CROSS-PRODUCT RATIOS IN CONTINGENCY TABLES, JRSSB 64,86

GOODMAN, L. A. STOCHASTIC MODELS FOR THE POPULATION GROWTH OF THE SEXES, BIOKA 6B, 469

GOODMAN, L. A. THE ANALYSIS OF POPULATION GROWTH WHEN THE BIRTH AND DEATH RATES DEPEND UPON SEVERAL FACTO, BIOCS 69 , NO 4

GOODMAN, L. A. THE PROBABILITIES OF EXTINCT ION FOR BIRTH-AND-DEATH PROGESSES THAT ARE AGE-DEPENDENT OR PH, BIOKA 67, 579

GOODMAN, LEO A. HOW TO MINIMIZE OR MAXIMIZE THE PROBA8ILITIES OF EXTINGTION IN A GALTON-WATSON PROCESS AN, AMS 68, 1700

GOODMAN, LEO A. INTERACTIONS IN MULTIDIMENSIONAL CONTINGENCY TABLES, AMS 64, 632

GOODMAN, LEO A. MEASURES OF ASSOCIATION FOR CROSS CLASSIFICATIONS, II . FURTHER DISCUSSION AND REFERENCES, JASA 59, 123

GOODMAN, LEO A. MEASURES OF ASSOCIATION FOR CROSS CLASSIFICATIONS,

111. APPROXIMATE SAMPLING THEORY, JASA 63,310

GOODMAN, LEO A. ON SIMULTANEOUS CONFIDENCE INTERVALS FOR MULTINOMIAL PROPORTIONS, TECH 65,247

GOODMAN, LEO A. ON THE EXACT VARIANGE OF PRODUCTS, CORR, 61917, JASA 60,708

GOODMAN, LEO A. PARAMETER-FREE AND NON-PARAMETRIC TOLERANCE LIMITS, THE EXPONENTIAL CASE, TECH 62, 75

GOODMAN, LEO A. SIMPLE METHODS FOR ANALYZING THREE-FACTOR INTERACTION IN CONTINGENCY TABLES, JASA 64,319

GOODMAN, LEO A. SIMULTANEOUS CONFIDENCE INTERVALS FOR GONTRASTS AMONG MULT INOMI AL POPULAT IONS, AMS 64, 716

GOODMAN, LEO A. SNOWBALL SAMPLING, AMS 61, 14B

GOODMAN, LEO A. SOME NONPARAMETRIC TESTS FOR COMOVEMENTS BETWEEN TIME SERIES, JASA 61,11

GOODMAN, LEO A. STATISTICAL METHODS FOR THE MOVER-STAYER MODEL. JASA 61, B 41

GOODMAN, LEO A. THE ANALYSIS OF CROSS-CLASSIFIED DATA, INDEPENDENCE, QUASI-INDEPENDENCE, AND INTERACTIONS, JASA 6B, 1091

GOODMAN, LEO A. THE ANALYSIS OF PERSISTENCE IN A CHAIN OF MULTIPLE EVENTS, 8IOKA 64, 405

GOODMAN, LEO A. THE PRECISION OF UNBIASED RATIO-TYPE ESTIMATORS, CORR, 631162, JASA 5B, 491

GOODMAN, LEO A. THE VARIANCE OF THE PRODUCT OF K RANDOM VARIABLES, JASA 62,54

GOODMAN, M. M. NOTES. A MEASURE OF 'OVERALL VARIABILITY' IN POPULATIONS, BIOCS $6 B, 1 B 9$

GOODMAN, N. R. FREQUENCY RESPONSE FROM STATIONARY NOISE, T-O CASE HISTORIES, TECH 61,245

GOODMAN, N. R. SOME COMMENTS ON SPECTRAL ANALYSIS OF TIME SERIES. TECH 61,221

GOODMAN, N. R. STATISTICAL ANALYSIS 8ASED ON A CERTAIN MULTIVARIATE COMPLEX GAUSSIANDISTRIBUTION, AN INT, AMS 63,152

GOODMAN, N. R. THE DISTRI8UTION OF THE DETERMINANT OF A COMPLEX WISHART DISTRI8UTED MATRIX, AMS 63, 178

GORDON, MYRON J . THE CONDITION FOR LOT SIZE PRODUCTION, JASA 56, 627 GORMAN, J.W. DISCUSSION OF 'EXTREME VERTICES DESIGN OF MIXTURE EXPERIMENTS' BY R. A. MCLEAN AND V . L. ANDE, TECH 66, 455

GORMAN, J.W. SELECTION OF VARIABLES FOR FITTING EQUATIONS TO DATA, TECH 66,27

GORMAN, J. W. SIMPLEX LATTICE DESIGNS FOR MUTICOMPONENT SYSTEMS, TECH 62,463

GOSSLEE, D. G. ANALYSIS OF VARIANCE OF DISPROPORTIONATE DATA WHEN INTERACTION IS PRESENT, 8IOCS 65,115
GOULD, A. L. A REGRESSION TECHNIQUE FOR ANGULAR VARIATES, BIOCS 69 , NO. 4

GOULD, A. L. SOME RELATIONSHIPS BETWEEN THE NORMAL AND VON MISES DISTRIBUTIONS, BIOKA $67,6 B 4$

GOULD, H. W. NOTE ON TWO BINOMIAL COEFFICIENT SUMS FOUND BY RIORDAN AMS 63,333

GOVIER, L. $J$. SOME PROPERTIES OF COUNTS OF EVENTS FOR CERTA IN TYPES OF POINT PROCESS, JRSSB 64,325

GOVINDARAJULU, $Z$. DISTRIBUTION AND POWER OF THE ABSOLUTE NORMAL SCORES TEST, JASA 67,966

GOVINDARAJULU, $Z$. RELATIONS AMONG MOMENTS OF ORDER STATISTICS IN SAMPLES FROM THO RELATED POPULAT IONS, TECH 63, 514

GOVINDARAJULU, ZAKKULA A SUPPLEMENT TO MENDENHALL'S BIBLIOGRAPHY ON LIFE TEST ING AND RELATED TOPICS, CORR, JASA 64, 1231

GOVINDARAJULU, ZAKKULA BEST LINEAR ESTIMATES UNDER SYMMETRIC CENSORING OF THE PARAMETERS OF A DOUBLE EXPO, JASA 66, 24B

GOVINDARAJULU, ZAKKULA CHARACTERIZATION OF NORMAL AND GENERALIZED TRUNCATED NORMAL DISTR IBUT IONS USING OR, AMS 66, 1011

GOVINDARAJULU, ZAKKULA EXACT LOWER MOMENTS OF ORDER STATISTICS IN SAMPLES FROM THE CHI-DISTRIBUTION, ONE, AMS 62, 1292

GOVINDARAJULU, ZAKKULA EXACT POWER OF MANN-WHITNEY TEST FOR EXPONENT IAL AND RECTANGULAR ALTERNATIVES, AMS 66,945

GOVINDARAJULU, ZAKKULA ON MOMENTS OF ORDER STATISTICS AND QUASIRANGES FROM NORMAL POPULAT IONS, AMS 63, 633

GOVINDARAJULU, ZAKKULA RECURRENCE RELATIONS FOR THE INVERSE MOMENTS OF THE POSITIVE BINOMI AL VARI ABLE, JASA 63,46B

GOVINDARAJULU, ZAKKULA THE RECIPROCAL OF THE DECAPITATED NEGATIVE BINOMI AL VAR I ABLE, CORR, 631162, JASA 62,906

GOWER, J. C. A COMPARISON OF SOME METHODS OF CLUSTER ANALYSIS, BIOCS 67,623

GOWER, J . C. A COMPARISON OF THEORETICAL AND EMPIRICAL RESULTS FOR SOME STOCHASTIC POPULATION MODELS, BIOKA 6O, I

GOWER, J . C. A NOTE ON SOME ASYMPTOT IC PROPERTIES OF THE LOGARITHMIC SERIES DISTRIBUTION, BIOKA 61, 212

GOWER, J . C. A NOTE ON THE PERIODOGRAM OF THE BEVERIDGE WHEAT PRICE INDEX, JRSSB 55, 228

GOWER, J, C. A Q-TECHNIQUE FOR THE CALCULATION OF CANONICAL VARIATES, BIOKA 66, 5B8

GOWER, J . C. ADDING A POINT TO VECTOR DIAGRAMS IN MULT IVARIATE ANAL YSIS, BIOKA 68, 5B2

GOWER, J. C. ALIASING IN PARTIALLY CONFOUNDED FACTORIAL EXPERIMENTS, BIOKA 61,21B

GOWER, J. C. CORRIGENDA, 'THE PROPERTIES OF A STOCHASTIC MODEL FOR TWO COMPETING SPECIES. ' , BIOKA 59, 279

GONER, J. G SOME DISTANCE PROPERTIES OF LATENT ROOT AND VECTOR METHODS USED IN MULT IVARI ATE ANALYSIS, BIOKA 66, 325

GONER, J. C. THE PROPERTIES OF A ST OCHAST IC MODEL FOR THE PREDATORPREY TYPE OF INTERACT ION BETWEEN TWO S, BIOKA 60, 219

GOWER, J . C. THE PROPERTIES OF A STOCHASTIC MODEL FOR TWO COMPETING SPECIES, BIOKA 5B, 316

GRACE, D. W. APPLICATIONS OF TRUNCATED DISTRIBUTIONS IN PROCESS START-UPS AND INVENTORY CONTROL, TECH 61,429

GRAHAM, JACK E. ROTATION DESIGNS FOR SAMPLING ON REPEATED OCCASIONS, JASA 64,492

GRAHAM, R . L. COMBINATORI AL THEOREM FOR PART IAL SUMS, AMS 63, 1600

GRANGER, C. W. J. A MONTE CARLO STUDY COMPARING VARIOUS TWO-SAMPLE TESTS FOR DIFFERENCES IN MEAN, TECH 6B, 509

GRANGER, C, W. J. A QUICK TEST FOR SERIAL CORRELATION SUITABLE FOR USE WITH NONST AT IONARY TIME SERIES, JASA 63,72B

GRANT, ALISON M. SOME PROPERTIES OF RUNS IN SMOOTHED RANDOM SERIES, BIOKA 52, $19 B$

GRANT, ALISONM. TABULAR ANALYSIS OF FACTORIAL EXPERIMENTS AND THE USE OF PUNCH CARDS, CORR, 56650 , JASA 56, 149

GRASER, D. A.S. STRUCTURAL PROBABILITY AND PREDICTION FOR THE MULTIVARIATE MODEL, JRSSB 69, NO. 2

GRAY JR, K. B, SEQUENT I AL SELECT ION OF EXPERIMENTS, AMS 6B, 1953

GRAY, G, B SEVERAL METHODS OF RE-DESIGNING AREA SAMPLES UTILIZING PROBABILITIES PROPORT IONAL TO SIZE WHE, JASA 6B, $12 B 0$

GRAY, G, B, THE NEW DESIGN OF THE CANADIAN LABOUR FORCE SURVEY, JASA 67,421

GRAY, H, L. A CONF IDENCE INTERVAL FOR THE AVAILABILITY RATIO, TECH 67,465

GRAY, H, L ON SUMS AND PRODUCTS OF RECTANGULAR VARIATES, BIOKA 66 615

GRAY, H. L. ON THE EVALUATION OF DISTRI8UTION FUNCTIONS, JASA 68 715

GRAY8ILL, F. A. HETEROGENEITY OF ERROR VARIANCES IN A RANDOMIZED 8LOCK DESIGN, BIOKA 57, 275

GRAYBILL, F. A. LINEAR SEGMENT CONFIDENCE 8ANDS FOR SIMPLE LINEAR MODELS, JASA 67,403

GRAY8ILL，F. A 、 QUADRATIC FORMS AND IDEMPOTENT MATRICES WITH RANDOM ELEMENTS, AMS 69, 1430

GRAY8ILL, FRANKLIN A. A NOTE ON UNIFORMLY BEST UN8IASED ESTIMATORS FOR VARI ANCE COMPONENTS, JASA 56, 266

GRAY8ILL, FRANKLINA. CONFIDENCE 8ANDS OF UNIFORM AND PROPORTIONAL WIDTH FOR LINEAR MODELS, JASA 66, 1B2

GRAY8ILL, FRANKLIN A. MINIMAL SUFFICIENT STATISTICS FOR THE TWOWAY CLASSIF ICATION M IXED MODEL DESIGN, JASA 65, 182 
CRAYBILL. FRANKLINA. SAMPLE SIZE REQUIRED FOR EST IMATINC THE VARIANCE WITHIN D UNITS OF THE TRUE VALUE. AMS 64.438

CRAYBILL. FRANKLIN A. SAMPLE SIZE REQUIRED TO ESTIMATE THE RATIO OF VARIANCES WITH BOUNDED RELAT IVE ERROR, JASA 63, 1044

CRAYBILL, FRANKLIN A. SAMPLE SIZE REQUIRED TO EST IMATE THE PARAMETER IN THE UNIFORM DENSITY WITHIN D UNIT, JASA 64, 550

CRAYBILL, FRANKLIN A. THEOREMS CONCERNINC EISENHART'S MODEL II AMS 61,261

CREEN, EDWARD W. THE RELATIVE EFFICACY OF INVESTMENT ANTICIPATIONS, JASA 66,104

CREEN, J.R. A MODEL FOR RAINFALL OCCURRENCE, JRSSB 64,345

CREEN, J.R. A MODIFIED MODEL FOR RAINFALL OCCURRENCE, JRSSB 67, 151

GREEN, J.R. INFERENCE CONCERNINC PROBABILITIES AND QUANTILES, JRSSB 69 , NO.2

CREENBERG. B. G. CORRECTION TO AMS 56427 'ESTIMATION OF LOCATION AND SCALE PARAMETERS BY ORDER STATISTIC, AMS 39, 325

GREENBERG , 8. G. ERRATA, 'MODIFIED SQUARE ROOT METHOD OF MATRIX INVERSION', TECH 62,622

GREENBERG. B. G. ESTIMATION OF LOCATION AND SCALE PARAMETERS FOR THE RECTANGULAR POPULATION FROM CENSORED, JRSSB 59, 356

CREENBERC, B. G. EVALUATION OF DETERMINANTS. CHARACTERISTIC EQUATIONS AND THEIR ROOTS FOR A CLASS OF PATT, JRSSB 60,348

GREENBERC, B. G. MATRIX INVERSION, ITS INTEREST AND APPLICATION IN ANALYSIS OF DATA, JASA 59,755

GREENBERC, 8. G. MODIFIED SQUARE ROOT METHOD OF MATRIX INVERSION, TECH 62,282

GREENBERG, B. G. PROBLEMS OF STATISTICAL INFERENCE IN HEALTH WITH SPECIAL REFERENCE TO THE CIGARETTE SMOK, JASA 69,739

GREENBERG. B. G. SIMPLIFIED ESTIMATES FOR THE EXPONENTIAL DISTRIBUTION, AMS 63, 102

GREENBERG, B. G. TABLES FOR BEST LINEAR ESTIMATES BY ORDER STATISTICS OF THE PARAMETERS OF SINGLE EXPONEN, JASA 57,58

CREENBERG, BERNARD G. A MULTI-PROPORTIONS RANDOMIZED RESPONSE MODEL, JASA 67,990

GREENBERG, BERNARD C. THE UNRELATED QUESTION RANDOMIZED RESPONSE MODEL, THEORET ICAL FRAMEWORK, JASA 69, 520

GREENBERG, EDWARD APPROXIMATIONS DATA AND THE INVESTMENT DECISION, JASA 65,503

GREENBERG, RICHARD A. THE DETECTION OF A CORRELATION BETWEEN THE SEXES OF ADJACENT SIBS IN HUMAN FAMILIES, JASA 65, 1035

CREENRERG, VIDA L. ROBUST ESTIMATION IN INCOMPLETE BLOCK DESIGNS AMS 66. 1331

GREENHOUSE, S. W. NOTE ON MULT I PLE COMPARISONS FOR ADJUSTED MEANS IN THE ANALYSIS OF COVARIANCE. BIOKA 5B, 256

GREENHOUSE, S. W. NOTES. EQUIVALENCE OF MAXIMUM LIKELIHOOD AND THE METHOD OF MOMENTS IN PROBIT ANALYSIS, BIOCS 67,154

CREENHOUSE, S. W. ON EXPECTATIONS OF SOME FUNCTIONS OF POISSON VARIATES, BIOCS 68,97

GREENHOUSE, SAMUEL $W$. AN ADAPTIVE PROCEDURE FOR SEQUENTIAL CLINICAL TRIALS, JASA 69,759

CREENWOOD, J. A. AIDS FOR FITTING THE GAMMA DISTRIBUT ION BY MAXIMUM LIKELIHOOD, TECH 60,55

GREGOR, J. AN ALCORITHM FOR THE DECOMPOSIT ION OF A DISTRIBUTION INTO CAUSSIAN COMPONENTS, BIOCS 69,79

GREGORY, G. A NOTE ON THE QUEUEING SYSTEM M-M-1 WITH BALKING. . BIOKA 65,643

CREGORY G CLOSED QUEUEING SYSTEMS, A GENERALIZATION OF THE MACHINE INTERFERENCE MODEL, JRSSB 61,385

CREIG, MARGARET EXTREMES IN A RANDOM ASSEMBLY, BIOKA 67, 273

GRENANDER, $U$. BANDWIDTH AND VARIANCE IN ESTIMATION OF THE SPECTRUM. JRSSB 5B, 152

GRENANDER, ULF A LIMIT THEOREM FOR SUMS OF MINIMA OF STOCHASTIC VARIABLES, AMS 65, 1041

GRENANDER, ULF SOME DIRECT ESTIMATES OF THE MODE, AMS 65, 131

GRENANDER, ULF SOME PROPERTIES OF STATISTICAL RELIABILITY FUNCTIONS, AMS 66, B26

GRIDGEMAN, N.T. THE LADY TASTING TEA, AND ALLIED TOPICS, JASA 59. 776

GRIFFIN, HAROLD D. GRAPHIC COMPUTATION OF TAU AS A COEFFICIENT OF DISARRAY, JASA 5B, 44]

CRIFFITHS, R. C. THE CANONICAL CORRELATION COEFFICIENTS OF BIVARIATE GAMMA DISTRIBUTIONS, AMS 69, 1401

GRILICHES, ZVI ON AN INDEX OF QUALITY CHANGE, JASA 61, 535

CRILICHES, ZVI SMALL-SAMPLE PROPERTIES OF SEVERAL TWO-STAGE REGRESSIDN METHDDS IN THE CONTEXT OF AUTOCDRR, JASA 69, 253

GRILICHES, ZVI THE DEMAND FOR FERTILIZER IN 1954. AN INTER-STATE STUDY, JASA 59,377

GRIMINGER, P. RESPONSE CRITERIA FOR THE BIOASSAY OF VITAMIN K, BIOCS 69. NO. 4

GRINCDRTEN, IRVINC I, ESTIMATING FINITE-TIME MAXIMA AND MINIMA OF A STATIDNARY GAUSSIAN ORNSTE IN-UHLENBEC, JASA 6B, 1517

GRIZZLE, J, E. ANALYSIS OF CATEGORICAL DATA BY LINEAR MODELS, BIDCS 69. 489

GRIZZLE, J. E. ANALYSIS OF GRDWTH AND DOSE RESPONSE CURVES, BIOCS 69.357

GRIZZLE, J, E. APPLICATION OF MULTIVARIATE ANALYSIS OF VARIANCE TO REPEATED MEASUREMENTS EXPERIMENTS, BIOCS $66, \mathrm{~B} 10$

CRIZZLE. J.E. THE TWO-PERIOD CHANCE-OVER DESIGN AND ITS USE IN CLINICAL TRAILS, BIOCS 65,467
CRIZZLE, JAMES E, A BAYESIAN APPROACH TO THE ANALYSIS OF DATA FROM CLINICAL TRIALS, JASA 65,81

CRIZZLE, JAMES E, ASYMPTOTIC POWER OF TESTS OF LINEAR HYPOTHESES USINC THE PROBIT AND LOCIT TRANSFORMATIO, JASA 62,877

CROLL. PHYLLIS A, BINOMIAL CROUP-TESTING WITH AN UNKNOWN PROPORTION OF DEFECTIVES. TECH 66, 631

CROLL. PHYLLIS A. CAMMA DISTRIBUTION IN ACCEPTANCE SAMPLINC BASED ON LIFE TESTS. JASA 61.942

CRONOW. D. G. C. NON-NORMALITY IN THO-SAMPLE T-TESTS, BIOKA 53, 223

CRONOW, D. G, C. TEST FOR THE SIGNIF ICANCE OF THE DIFFERENCE 8ETWEEN MEANS IN TWO NORMAL POPULATIONS HAVI, BIOKA 51,252

GROSENBAUCH, L. R. CENERALIZATION AND REPARAMETERIZATION OF SOME SIGMOID OR OTHER NONLINEAR FUNCTIONS, 8IOCS 65,708

CROSS. A. J THE EFFECTIVE USE OF BOTH POSITIVE AND NEGATIVE CONTROLS IN SCREENING EXPERIMENTS, BIOCS 67,285

GROSS, SHULAMTH THE DISTRIBUTION OF GALTON'S STATISTICS, AMS 6B 2114

GROSSMAN, M. COVARIANCE ANALYSIS WITH UNEQUAL SUBCLASS NUMBERS, COMPONENT ESTIMATION IN CORRELATION STUDI, BIOCS $6 B, 49$

GROVES, T. A NOTE ON THE EXPECTED VALUE OF AN INVERSE MATRIX, BIOKA 69. NO. 3

GRUBBS. F. E. ON THE USE OF PATNAIK TYPE CHI APPROXIMATIONS TO THE RANCE IN SIGNIFICANCE TESTS, BIOKA 66, 24B

GRUBBS, FRANK E. ANALYSIS OF SENSITIVITY EXPERIMENTS WHEN THE LEVELS OF STIMULUS CANNOT BE CONTROLLED, CO, JASA 56, 257

GRUBBS. FRANK E. PROCEDURES FOR DETECTING OUTLYING OBSERVATIONS IN SAMPLES, TECH 69 ,

GRUNDY, P. M. A METHOD OF SAMPLING WITH PROBABILITY EXACTLY PROPORTIONAL TO SIZE. JRSSB 54, 236

GRUNDY, $P . M$. ECONOMIC CHOICE OF THE AMOUNT OF EXPERIMENTATION. JRSSB 56,32

GRUNDY, P. M. FIDUCIAL DISTRIBUTIONS AND PRIOR DISTRIBUTIONS, AN EXAMPLE IN WHICH THE FORMER CANNOT BE AS, JRSSB 56, 217

GRUNDY , $P, M$. THE EXPECTED FREQUENCIES IN A SAMPLE OF AN ANIMAL POPULATION IN WHICH THE ABUNDANCES OF SPE. BIOKA 51.427

GRUNDY, $P, M$. THE FITTING OF CROUPED TRUNCATED AND CROUPED CENSORED NORMAL DISTRIBUTIONS, BIOKA 52,252

GRUNFELD, YEHUDA SOME NONPARAMETRIC TESTS FOR CGMOVEMENTS 8ETHEEN TIME SERIES, JASA 61,11

GUENTHER, $W . C$. MODIFIED SAMPLING, BINOMIAL AND HYPERGEOMETRIC CASES, TECH 69 , NO. 4

GUENTHER. WILLAIM C. A REVIEW OF THE LITERATURE ON A CLASS OF COVERAGE PRO8LEMS, AMS 64,232

GUENTHER, WILLIAM C ANOTHER DERIVATION OF THE NON-CENTRAL CHISQUARE DISTRIBUTION, JASA 64, 957

GUENTHER, WILLIAM C. CRITICAL REGIONS FOR TESTS OF INTERVAL HYPOTHESES ABOUT THE VARIANCE, JASA 66, 204

GUENTHER, WILLIAM C. SOME GRAPHS USEFUL FOR STATISTICAL INFERENCE, JASA 65,334

GUEST, P. G. GROUPINC METHODS IN THE FITTING OF POLYNOMIALS TO EQUALLY SPACED OBSERVATIONS, BIOKA 54,62

GUEST, P. G. GROUPINC METHODS IN THE FITTING OF POLYNOMIALS TO UNEQUALLY SPACED 08SERVATIONS, 8IOKA 56, 149

GUEST, P. G. THE DOOLITTLE METHOD AND THE FITTING OF POLYNOMIALS TO WEIGHTED DATA, BIOKA 53, 229

CULLAND, J.A, ON THE ESTIMATION OF POPULATION PARAMETERS FROM MARKED MEMBERS, BIOKA 55,269

GUMBEL, E. J. A NOTE ON MIDRANCE, AMS 65, 1052

CUMBEL, E. J. ANALYSIS OF EMPIRICAL BIVARIATE EXTREMAL DISTRIBUTIONS, JASA 64,794

GUMBEL, E, J . BIVARIATE EXPONENTIALDISTRIBUTIONS, JASA 60, 698

GUMBEL, E. J. BIVARIATE LOGISTIC DISTRIBUTIONS, JASA 61.335

GUMBEL, E. J . COMMENTS TO, EDWARD C. POSNER, 'THE APPLICATION OF EXTREME VALUE THEORY TO ERROR FREE COMMU, TECH 66,363

GUMBEL. E. J. DISCUSSION OF THE PAPERS OF MESSRS. ANSCOMBE AND DANIEL, TECH 60,157

GUMBEL, E. J. PRO8ABILITY TABLES FOR THE EXTREMAL QUOTIENT, AMS 67. 1541

GUMBEL, E . J . SOME ANALYT ICAL PROPERTIES OF 8IVARIATE EXTREMAL DISTRIBUTIONS, JASA 67,569

CUNDY, RICHARD ON A STOPPING RULE AND THE CENTRAL LIMIT THEOREM, AMS 67,1915

GUNDY, RICHARD F.' A DECOMPOSITION OF LI-BOUNDED MARTINGALES, AMS 68,134

GUNDY, RICHARD F, THE MARTINGALE VERSION DF A THEDREM DF MARCINKIEWICZ AND ZYGUMD, AMS 67,725

GUNTHER, PAUL QUERY, CDMBINATION OF A NORMAL AND A UNIFORM DISTRIBUTION, TECH 65,449

GUPTA, A. K. ESTIMATION OF THE MEAN AND STANDARD DEVIATION OF A NORMAL POPULA TIDN FROM A CENSDRED SAMPLE, BIOKA 52,260

GUPTA, A. K. DN THE EXACT DISTRIBUTION OF WILKS'S CRITERION, BIOKA 69. $1 \mathrm{D} 9$

GUPTA, ARJUN K. ON THE NON-CENTRAL DISTRIBUTIDN OF THE SECOND ELEMENTARY SYMMETRIC FUNCTION DF THE ROOTS, AMS 68,833

GUPTA, M. K. ASYMPTDTICALLY NONPARAMETRIC TESTS OF SYMMETRY, AMS 67,849

GUPTA, S. DAS CDRRICENDA, 'SOME INEQUALITIES ON CHARACTERISTIC RDDTS DF MATRICES' BIOKA 65, 669 
GUPTA, S. DAS SOME INEQUALITIES ON CHARACTERISTIC ROOTS OF MATRICES, BIOKA 63, 522

GUPTA. S. S, ERRATA, 'ORDER STATISTICS FROM THE GAMMA DISTRIBUTION', TECH 60,523

GUPTA, S. S. ESTIMATION OF THE PARAMETERS OF THE LOGISTIC DISTRIBUTION, BIOKA 66,565

GUPTA, S. S. MOMENTS OF ORDER STATISTICS FROM A NORMAL POPULATION, BIOKA 59. 433

GUPTA. S. S. ON LINEAR FUNCTIONS OF ORDERED CORRELATED NORMAL RANDOM VARIABLES. BIOKA 65,367

GUPTA. S. S. ON THE DISTRIBUTION OF THE MAXIMUM AND MIN IMUM OF RATIOS OF ORDER STATISTICS, AMS 69,918

GUPTA. S. S. ORDER STATISTICS FROM THE GAMMA DISTRIBUTION, TECH 60 , 243

GUPTA. SHANTI S. A SYSTEM OF INEQUALITIES FOR THE INCOMPLETE GAMMA FUNCTIONS AND THE NORMAL INTEGRAL, AMS 65,139

GUPTA. SHANTI S. BEST LINEAR UNBIASED EST IMATORS OF THE PARAMETERS OF THE LOGISTIG DISTRIBUTION USING ORD, TECH 67,43

GUPTA, SHANTI S. BIBLIOGRAPHY ON THE MULTIVARIATE NORMAL INTEGRALS AND RELATED TOPICS, AMS 63, B29

GUPTA, SHANTI S. DISTRIBUTION-FREE LIFE TEST SAMPLING PLANS, TECH 66,591

GUPTA, SHANTI S. EXACT MOMENTS AND PERCENTAGE POINTS OF THE ORDER STATISTICS AND THE DISTRIBUTION OF THE, AMS 65,907

GUPTA. SHANTI S. GAMMA DISTRIBUTION IN ACCEP TANCE SAMPLING BASED ON LIFE TESTS, JASA 61,942

GUPTA. SHANTI S. LIFE TEST SAMPLING PLANS FOR NORMAL AND LOGNORMAL DISTRIBUTIONS, TECH 62,151

GUPTA, SHANTI S. ON SELECTING A SUBSET CONTAINING THE POPULATION WITH THE SMALLEST VARIANCE, BIOKA 62,495

GUPTA. SHANTI S. ON SOME MULTIPLE DECISION (SELECTION AND RANKING RULES, TECH 65,225

GUPTA, SHANTI S. ON THE DISTRIBUTION OF LINEAR FUNCTIONS AND RATIOS OF LINEAR FUNCTIONS OF ORDERED CORREL, BIOKA 64, 143

GUPTA, SHANTI S. ON THE SMALLEST OF SEVERAL CORRELATED F STATISTICS, BIOKA 62,509

GUPTA. SHANTI S. PERCENTAGE POINTS AND MODES OF ORDER STATISTICS FROM THE NORMAL DISTRIBUTION, AMS 61,888

GUPTA, SHANTI S. PROBABILITY INTEGRALS OF MULTIVARIATE NORMAL AND MULTIVARIATE T, AMS 63,792

GUPTA, SHANTI $S$. SELECTION PROCEDURES FOR RESTRICTED FAMILIES OF PROBABILITY DISTRIBUTIONS, AMS 69,905

GUPTA, SOMESH DAS PROPERTIES OF POWER FUNCTIONS OF SOME TESTS GONCERNING DISPERSION MATRICES OF MULTIVARI, AMS 69, 697

GUPTA, V. P. NOTES. ESTIMATION AFTER PRELIMINARY TESTING IN ANOVA MODEL I, BIOCS 65,752

GUPTA, Y. P. ASYMPTOTIC VALUES OF THE FIRST TWO MOMENTS IN MARKOV RENEWAL PROGESSES, BIOKA 67,597

GURALNICK, LILLIAN ANALYSIS OF VITAL STATISTICS BY CENSUS TRACT, JASA 59,730

GURIAN, JOAN CONFIDENCE BANDS IN LINEAR REGRESSION WITH CONSTRAINTS ON THE INDEPENDENT VARIABLES, JASA 6B, 1020

GURLAND. J. A METHOD OF ANALYSING UNTRANSFORMED DATA FROM THE NEGATIVE BINOMIAL AND OTHER CONTAG IOUS DIST, BIOKA 68, 163

GURLAND, J, A RELATIVELY SIMPLE FORM OF THE DISTRIBUTION OF THE MULTIPLE CORRELATION COEFFICIENT, JRSSB 68,276

GURLAND, J. CORRIGENDA, 'SMALL SAMPLE BEHAVIOUR OF CERTAIN TESTS OF THE HYPOTHESIS OF EQUAL MEANS UNDER V, BIOKA 61,230

GURLAND, J. ESTIMATION OF THE PARAMETERS OF A LINEAR FUNCTIONAL RELATION, JRSSB 61,160

GURLAND, J. FUNCTIONS OF THE SAMPLE MEAN AND SAMPLE VARIANCE OF A POISSON VARIATE, BIOCS 69,171

GURLAND, J. NOTE ON A PAPER BY RAY AND PITMAN + (FISHER-BEHRENSSTATISTIC), JRSSB 62,537

GURLAND, J. ON UTILIZING INFORMATION FROM A SECOND SAMPLE IN ESTIMATING VARIANCE, BIOKA 69 , NO.3

GURLAND, J. SIMPLIFIED TECHNIQUES FOR ESTIMATING PARAMETERS OF SOME GENERALIZED POISSON DISTRIBUTIONS, BIOKA 67,555

GURLAND, J. SMALL SAMPLE BEHAVIOUR OF CERTAIN TESTS OF THE HYPOTHESIS OF EQUAL MEANS UNDER VARIANCE HETER, BIOKA 60,345

GURLAND, J. SOME INTERRELATIONS AMONG COMPOUND AND GENERALIZED DISTRIBUTIONS, BIOKA 57,265

GURLAND, J. TESTING EQUALITY OF MEANS IN THE PRESENCE OF CORRELATION, BIOKA 69, 119

GURLAND, JOHN A CLASS OF DISTRIBUTIONS APPLICABLE TO ACCIDENTS, JASA 61,503

GURLAND, JOHN COMBINATIONS OF UNBIASED ESTIMATORS OF THE MEAN WHICH CONSIDER INEQUALITY OF UNKNOWN VARIAN, JASA 69,1042

GURLAND, JOHN CORREGTION TO 'DISTRIBUTION OF DEFINITE AND OF INDEFINITE QUADRATIC FORMS' 55 122, AMS 62, 813

GURLAND, JOHN EFFICIENCY OF CERTAIN METHODS OF ESTIMATION FOR THE NEGATIVE BINOMIAL AND NEYMAN TYPE A DIS, BIOKA 62,215

GURLAND, JOHN SOME PROPERTIES AND AN APPLICATION OF A STATISTIC ARISING IN TESTING CORRELATION. AMS 69,1736

GURLAND, JOHN TESTING EQUALITY OF MEANS AFTER A PRELIMINARY TEST OF EQUALITY OF VARI ANCES, BIOKA 62,403

GUSTAFSON, ROBERT L. PARTIAL CORRELATIONS IN REGRESSION COMPUTATIONS, JASA 61,363
GUTERMAN, H. E. AN UPPER BOUND FOR THE SAMPLE STANDARD DEVIATION. TECH 62, 134

GUTERMAN, H. E. ERRATA, 'AN UPPER BOUND FOR THE SAMPLE STANDARD DEVIATION', TECH 63,417

GUTERMAN, H. E. THE USE OF RANDOM WORK SAMPLING FOR COST ANALYSIS AND CONTROL, CORR. 58 1031. JASA 58, 382

GUTHRIE, HAROLD W. CONSUMERS' PROPENSITIES TO HOLD LIQUID ASSETS, JASA 60,469

GUTHRIE, HAROLD $W$. VALIDATION OF CONSUMER FINANCIAL CHARACTERISTICS, COMMON STOCK, JASA 69, 415

GUTTMAN, I. A NOTE ON A SERIES SOLUTION OF A PROBLEM IN ESTIMATION, BIOKA 58,565

GUTTMAN, I. BAYESIAN STRATIFIED TWO-PHASE SAMPLING RESULTS, $K$ CHARACTERISTICS, BIOKA 68, 587

GUTTMAN, I. INVESTIGATION OF RULES FOR DEALING WITH OUTLIERS IN SMALL SAMPLES FROM THE NORMAL DISTRIBUT IO, TECH 69,527

GUTTMAN, I. SOME ASPECTS OF RANDOMIZATION, JRSSB 66, 543

GUTTMAN, I. SOME BAYESIAN STRATIFIED TWO-PHASE SAMPLING RESULTS, BIOKA 68,131

GUTTMAN, I. THE USE OF THE CONCEPT OF A FUTURE OBSERVATION IN GOODNESS-OF-FIT PROBLEMS, JRSSB 67,83

GUTTMAN, I. UNEQUAL GROUP VARIANCES IN THE FIXED-EFFECTS ONE-WAY ANALYSIS OF VARIANCE. A BAYESIAN SIDELIG, BIOKA 66,27

GUTTMAN, IRWIN A BAYESIAN APPROACH TO SOME BEST POPULATION PROBLEMS, AMS 64, B25

GUTTMAN, IRWIN ANALYSIS OF OUTLIERS WITH ADJUSTED RESIDUALS, TECH 67,541

GUTTMAN. IRWIN ON BEALE' 'S MEASURES OF NON-LINEARITY, TECH 65,623

GUTTMAN, IRWIN ON THE EMPTY CELL TEST, TECH 62,235

GUTTMAN, IRWIN THE INVERTED DIRICHLET DISTRIBUTION WITH APPLICATIONS, GORR, 651251 , JASA 65, 793

HABERMAN, S. DISTRIBUTIONS OF KENDALL'S TAU BASED ON PARTIALLY ORDERED SYSTEMS, BIOKA 55,417

HACHIGIAN. JACK COLLAPSED MARKOV CHAINS AND THE CHAPMAN-KOLMOGOROV EQUATION, AMS 63, 233

HACK. H. R. B. AN EMPIRICAL INVESTIGATION INTO THE DISTRIBUTION OF THE F-RATIO IN SAMPLES FROM TWO NON-NO, BIOKA 58, 260

HACKER, H. P. THE GROWTH, SURVIVAL, WANDERING AND VARIATION OF THE LONG-TAILED FIELD MOUSE. APODEMUS SYLV, BIOKA 52,389

HADER, R. J. ESTIMATION OF PARAMETERS OF MIXED EXPONENTIALLY DISTRIBUTED FA ILURE TIME DISTR IBUTIONS FROM. BIOKA 58, 504

HADER, R. J. MINIMUM BIAS ESTIMATION AND EXPERIMENTAL DESIGN FOR RESPONSE SURFACES, TECH 69,461

HAENSZEL. WILLIAM RESIDENCE HISTORIES AND EXPOSURE RESIDENCES FOR THE UNITED STATES POPULATION, JASA 61, B24

HAGER, $H$. THE CHOICE OF THE DEGREE OF A POLYNOMIAL MODEL, JRSSB 68 , 469

HAGGSTROM, GUS W. OPTIMAL SEQUENTIAL PROCEDURES WHEN MORE THAN ONE STOP IS REQUIRED, AMS 67, 1618

HAGGSTROM, GUS W. OPTIMAL STOPPING AND EXPERIMENTAL DESIGN, AMS 66 7

HAHN, GERALD H. FACTORS FOR CALGULATING TWO-SIDED PREDICTION INTERVALS FOR SAMPLES FROM A NORMAL DISTRIBU, JASA 69,878

HAIGH, J . AN ENUMERAT ION PROBLEM IN SELF-STERILITY, BIOCS 69, 39

HAIGHT, F. A. A DISTRIBUTION ANALOGOUS TO THE BOREL-TANNER, BIOKA 61,167

HAIGHT, F. A. COUNTING DISTRIBUTIONS FOR RENEWAL PROCESSES.. BIOKA 65.395

HAIGHT, F. A. NOTES. MAXIMUM LIKELIHOOD ESTIMATION FOR THE TRUNCATED POISSON, BIOCS 66,620

HAIGHT, F. A. ON THE EFFECT OF REMOVING PERSONS WITH N OR MORE ACCIDENTS FROM AN ACCIDENT PRONE POPULATIO, BIOKA 65,298

HAIGHT, F. A, OVERFLOW AT A TRAFFIC LIGHT, BIOKA 59,420

HAIGHT, F, A, QUEUEING WITH BALKING, BIOKA 57,360

HAIGHT, F. A. QUEUEING WITH BALKING. II ., BIOKA 60, 285

HAIGHT, F. A . THE BOREL-TANNER DISTRIBUTION, BIOKA 60, 143

HAIGHT, F A TWO QUEUES IN PARALLEL, BIOKA 58,401

HAIGHT, FRANK A. EXPECTED UTILITY FOR QUEUES SERVICING MESSAGES WITH EXPONENT IALLY DECAY ING UTILITY, AMS 61, 587

HAITOVSKY, Y. MISSING DATA IN REGRESSION ANALYSIS, JRSSB 6B, 67

HAITOVSKY, YOEL UNBIASED MULTIPLE REGRESSION COEFFICIENTS ESTIMATED FROM ONE-WAY-CLASSIFICATION TABLES WH, JASA 66, 720

HAJEK, JAROSLAV ASYMPTOTIC NORMALITY OF SIMPLE LINEAR RANK STATISTICS UNDER ALTERNATIVES, II, AMS 69 , NO 6

HAJEK, JAROSLAV ASYMPTOTIG NORMALITY OF SIMPLE LINEAR RANK STATISTICS UNDER ALTERNATIVES, AMS 6B, 325

HAJEK, JAROSLAV ASYMPTOTIC THEORY OF REJECTIVE SAMPLING WITH VARY ING PROBABILITIES FROM A FINITE POPULATI, AMS 64, 1491

HAJEK, JAROSLAV ASYMPTOTICALLY MOST PONERFUL RANK-ORDER TESTS, AMS 62,1124

HAJEK, JAROSLAV SOME EXTENSIONS OF THE WALD-WOLFOWITZ-NOETHER THEOREM, AMS 61.506

HAJNAL, J. A TWO-SAMPLE SEQUENTIAL T-TEST, BIOKA 61, 65

HALD, A. ASYMPTOTIC PROPERTIES OF BAYESIAN SINGLE SAMPLING PLANS (CORR. 67 586), JRSSB 67,162

HALD. A. THE COMPOUND HYPERGEOMETRIC DISTRIBUTION AND A SYSTEM OF SINGLE SAMPLING INSPECTION PLANS BASED, TECH 60, 275 
HALD. A. THE DETERMINATION OF SINCLE SAMPLINC ATTRIBUTE PLANS WITH CIVEN PRODUCER 'S AND CONSUMER ' S RISK, TECH 67, 401

HALD, A. THE MIXED BINOMIAL DISTRIBUTION AND THE POSTERIOR DISTRIBUTION OF P FOR A CONT INUOUS PRIOR DISTR. JRSSB 68,359

HALD. ANDERS BAYESIAN SINCLE SAMPLING ATTRIBUTE PLANS FOR CONTINUOUS PRIOR DISTRIBUTIONS, TECH 6B，667

HALD, ANDERS SOME LIMIT THEOREMS FOR THE DODCE-ROMIC LTPD SINGLE SAMPLINC INSPECTION PLANS, TECH 62, 497

HALDANE, J, B. S. A PROBLEM IN THE SICNIFICANCE OF SMALL NUMBERS, BIOKA 55, 266

HALDANE, J.B. S. CENTENARY LECTURE, KARL PEARSON, 1B57-1957, BIOKA 57,303

HALDANE, J, B S S. SUBSTITUTES FOR CHI-SQUARE, BIOKA 55, 265

HALDANE, J. B. S. THE DISTRIBUTION OF EXTREMAL AND NEARLY EXTREMAL VALUES IN SAMPLES FROM A NORMAL DISTRI, BIOKA 63, B9

HALDANE, J, B, S. THE RAPID CALCULATION OF CHI-SQUARE AS A TEST OF HOMOCENEITY FROM A 2-BY-N TABLE, BIOKA 55, 519

HALDANE, J.B. S. THE SAMPLINC DISTR IBUTION OF A MAXIMUM-LIKELIHOOD EST IMATE, BIOKA 56, 96

HALEY, K. D. C. ANALYSIS OF QUANTAL RESPONSE ASSAYS WITH DOSACE ERRORS, BIOCS 67,747

HALL, IRVINC $H$. ON SLIPPACE TESTS I, A CENERALIZATION OF NEYMAN PEARSON' S LEMMA, AMS 68, 1693

HALL, IRVINC $J$. ON SLIPPACE TEST (II) SIMILAR SLIPPACE TESTS, AMS 68. 2029

HALL, MARSHALL MEASURES OF CONCENTRATION, JASA 67, 162

HALL, W. B. CYCLIC CHANGE-OVER DESICNS, BIOKA 69, 283

HALL, W. J. A BAYESIAN INDIFFERENCE PROCEDURE. JASA 65, 1104

HALL. W. J. SOME SEQUENT IAL ANALOCS OF STEIN'S TWO-STACE TEST, BIOKA 62,367

HALL, W. J THE RELATIONSHIP BETWEEN SUFFICIENCY AND INVARIANCE WITH APPLICATIONS IN SEQUENTIAL ANALYSIS, AMS 65, 575

HALLER, $H$. SMITH BIVARIATE SYMMETRY TESTS, PARAMETRIC AND NONPARAMETRIC, AMS 69, 259

HALPERIN, M. A CENERALIZATION OF FIELLER'S THEOREM TO THE RATIO OF COMPLEX PARAMETERS, JRSSB 67,126

HALPERIN, M. AN ASYMPTOTIC DISTRIBUTION FOR AN OCCUPANCY PROBLEM WITH STATIST ICAL APPLICATIONS, TECH 61, 79

HALPERIN, M ERRATA, 'THE EFFECT OF SEQUENTIAL BATCHINC FOR ACCEPTANCE-REJECTION SAMPLINC UPON SAMPLE ASS, TECH 61,131

HALPERIN, M NOTE ON INTERVAL ESTIMATION IN NON-LINEAR RECRESSION WHEN RESPONSES ARE CORRELATED, JRSSB 64, 267

HALPERIN, M. NOTE ON MULT IPLE COMPARISONS FOR ADJUSTED MEANS IN THE ANALYSIS OF COVARIANCE, BIOKA 5B, 256

HALPERIN, M. THE EFFECT OF SEQUENTIAL BATCHINC FOR ACCEPTANCE, REJECT ION SAMPLINC UPON SAMPLE ASSURANCE 0, TECH 60, 19

HALPERIN, MAX ALMOST LINEARLY-OPTIMUM COMBINATION OF UNBIASED ESTIMATES, JASA 61, 36

HALPERIN, MAX AN ADAPTIVE PROCEDURE FOR SEQUENTIAL CLINICAL TRIALS, JASA 69,759

HALPERIN. MAX AN INEQUALITY ON A BIVARIATE STUDENT' S 'T' DISTRIBUTION. JASA 67,603

HALPERIN, MAX APPROXIMATIONS TO THE NON-CENTRAL T, WITH APPLICATIONS. TECH 63.295

HALPERIN, MAX CONFIDENCE BANDS IN LINEAR REGRESSION WITH CONSTRAINTS ON THE I NDEPENDENT VARIABLES, JASA 68, 1020

HALPERIN, MAX CONFIDENCE INTERVAL ESTIMATION IN NON-LINEAR RECRESSION, JRSSB 63,330

HALPER IN, MAX CONFIDENCE INTERVALS FROM CENSORED SAMPLES, AMS 61 828

HALPERIN, MAX CONFIDENCE INTERVALS FROM CENSORED SAMPLES. II, TECH 66, 291

HALPERIN, MAX ERRATA, 'APPROXIMATIONS TO THE NON-CENTRAL T, WITH APPLICATIONS' ' TECH 64,482

HALPERIN, MAX EXTENSION OF THE WILCOXON-MANN-WHITNEY TEST TO SAMPLES CENSORED AT THE SAME FIXED POINT, C0, JASA 60, 125

HALPERIN, MAX FITTING OF STRAIGHT LINES AND PREDICTION WHEN BOTH VARIABLES ARE SUBJECT TO ERROR, JASA 61.657

HALPERIN, MAX INTERVAL ESTIMATION IN LINEAR REGRESSION WHEN BOTH VARIABLES ARE SUBJECT TO ERROR, JASA 64,1112

HALPERIN, MAX INTERVAL ESTIMATION OF NON-LINEAR PARAMETRIC FUNCTIONS, JASA 63,611

HALPERIN, MAX INTERVAL ESTIMATION OF NON-LINEAR PARAMETRIC FUNCTIONS, II, JASA 64,168

HALPERIN, MAX INTERVAL ESTIMATION OF NON-LINEAR PARAMETRIC FUNCTIONS, 111, JASA 65, 1191

HALPERIN, MAX SHORTER CONFIDENCE BANDS IN LINEAR RECRESSION, JASA 67,1050

HALPERIN, MAX SOME WAITINC TIME DISTRIBUTIONS FOR REDUNDANT SYSTEMS WITH REPAIR, TECH 64, 27

HALPIN, ALAN ASYMPTOTIC PROPERTIES OF SOME ESTIMATORS OF QUANTILES OF C IRCULAR ERROR, JASA 66, 618

HALTON, J.H. NOTE ON AN EXACT TREATMENT OF CONTINGENCY, GOODNESS OF FIT AND OTHER PROBLEMS OF SICNIFICAN, BIOKA 51, 141

HAMDAN, M. A. ON THE STRUCTURE OF THE TETRACHOR IC SERIES, BIOKA 68 , 261

HAMDAN, M. A. OPTIMUM CHOICE OF CLASSES FOR CONT INCENCY TABLES, JASA 68.291
HAMDAN, M. A. THE NUMBER AND WIDTH OF CLASSES IN THE CHI-SQUARE TEST. JASA 63, 67B

HAMILTON, M. A UNLTMITED SIMUTANEOUS D ISCR IMINAT ION INTERVALS IN RECRESSION, BIOKA 67,133

HAMILTON, P. A. CORRICENDA, 'TABLES FOR MAKING INFERENCES ABOUT THE VARIANCE OF A NORMAL DISTR IBUTION, ' , BIOKA 61, 230

HAMILTON, P. A. TABLES FOR MAKINC INFERENCES ABOUT THE VARIANCE OF A NORMAL DISTRIBUTION, BIOKA 60,433

HAMMERSLEY, J.M A POOR MAN'S MONTE CARLO (WITH DISCUSSION), JRSSB 54,23

HAMMERSLEY, J. M. CAPTURE-RECAPTURE ANALYSIS, BIOKA 53, 265

HAMMERSLEY, J, M. FIRST-PASSACE PERCOLATION, JRSSB 66, 491

HAMMERSLEY J M THE ESTIMATION OF LOCATION AND SCALE PARAMETERS FROM CROUPED DATA, BIOKA 54, 296

HAMMERSLEY, J. M. TRANSPOSED BRANCHINC PROCESSES, JRSSB 54, 76

HAMMOND, E, CUYLER INHALATION IN RELATION TO TYPE AND AMOUNT OF SMOKINC, JASA 59,35

HAN, C. TESTINC THE HOMOGENEITY OF VARIANCES IN A TWO-WAY CLASSIFICATION, BIOCS 69,153

HAN, CHIEN-PAI A NOTE ON DISCRIMINATION IN THE CASE OF UNEQUAL COVARIANCE MATRICES, BIOKA 68,5B6

HAN, CHIEN-PAI DISTRIBUTION OF DISCRIMINANT FUNCTION WHEN COVARIANCE MATRICES ARE PROPORTIONAL, AMS 69, 979

HAN, CHIEN-PAI ON POOLING MEANS WHEN VARIANCE IS UNKNOWN, JASA 68 , 1333

HAN CHIEN-PAI QUERY, MAXIMUM LIKELIHOOD ESTIMATE IN INTRACLASS CORRELATION MODEL, TECH 69, NO. 4

HAN, CHIEN-PAI TESTINC THE HOMOCENEITY OF A SET OF CORRELATED VARIANCES, BIOKA 68,317

HANANI, HAIM A BALANCED INCOMPLETE BLOCK DESICN, AMS 65, 711

HANANI, HAIM THE EXISTENCE AND CONSTRUCTION OF BALANCED INCOMPLETE BLOCK DESICNS, AMS 61, 361

HANNAN, E. J. AN EXACT TEST FOR CORRELATION BETWEEN TIME SERIES, BIOKA 55, 316

HANNAN, E. J. EXACT TESTS FOR SERIAL CORRELATION, BIOKA 55, 133

HANNAN, E. J. LEAST-SQUARES EFFICIENCY FOR VECTOR TIME SERIES, JRSSB 68,490

HANNAN, E. J. RECRESSION FOR TIME SERIES WITHERRORS OF MEASUREMENT BIOKA 63,293

ANNAN E J SERIAL CORRELATTON IN RECRESSION ANALYSIS. II, BIOKA 56. 436

HANNAN, E. J. SYSTEMATIC SAMPLINC, BIOKA 62, 281

HANNAN, E, J TESTINC FOR A JUMP IN THE SPECTRAL FUNCTION, JRSSB 61 394

HANNAN, E. J. TESTINC FOR SERIAL CORRELATION IN LEAST SQUARES REGRESSION, BIOKA 57,57

HANNAN, E. J. THE ASYMPTOTIC POWERS OF CERTA IN TESTS BASED ON MULTI PLE CORRELATIONS. JRSSB 56,227

HANNAN, E J THE ASYMPTOTIC POWERS OF CERTAIN TESTS OF COODNESS OF FTT FOR TIME SERIES, JRSSB 58,143

HANNAN, E. J. THE ESTIMATION OF A CHANGINC SEASONAL PATTERN, CORR. 661247, JASA 64,1063

HANNAN, E, J, THE ESTIMATION OF A LAGCED REGRESSION RELATION, BIOKA 67,409

HANNAN, E. J. THE ESTIMATION OF MIXED MOVING-AVERAGE AUTOREGRES SIVE SYSTEMS BIOKA 69 , NO 3

HANNAN, E, J. THE ESTIMATION OF SEASONAL VARIATION IN ECONOMIC TIME SERIES. CORR, 631162, JASA 63, 31

HANNAN, E, J. THE ESTIMATION OF THE SPECTRAL DENSITY AFTER TREND REMOVAL, JRSSB 58,323

HANNAN, E J. THE IDENTIFICATION OF VECTOR MIXED AUTOREGRESSIVEMOVING AVERACE SYSTEMS, BIOKA 69, 223

HANNAN, E, J THE VARIANCE OF THE MEAN OF A STATIONARY PROCESS, JRSSB 57,282

HANNAN, J. NORMAL APPROXIMATION TO THE DISTRIBUTION OF TWO INDEPENDENT BINOMIALS, CONDITIONAL ON FIXED SU, AMS 63, 1593

HANNAN, J, F EST IMATION OF THE PARAMETERS FOR A MULT IVAR IA TE NORMAL DISTR IBUTION WHEN ONE VAR IABLE IS DI, BIOKA 65.664

HANNAN, J F RATES OF CONVERGENCE IN THE COMPOUND DECISION PROBLEM FOR TWO COMPLETELY SPEC IFIED DISTR IBU, AMS 65, 1743

HANNAN. JAMES F. ON AN EXTENDED COMPOUND DECISION PROBLEM. AMS 69 1536

HANSEN MORRIS H. COOPERATION AMONG STATISTICAL AND OTHER SOCIETIES, JASA 61,1

HANSEN, MORRISH. SAMUELS. WILKS, JASA 65, 939

HANSEN, MORRIS H. WASHINGTON STATISTICAL SOCIETY MEMORIAL MEETINO FOR WILLIAMN. HURWITZ, PROFESSOR WILLI, JASA 69, N0.4

HANSON. D. L. CONVERGENCE RATES FOR THE LAW OF LARGE NUMBERS FOR THE LINEAR COMBINATIONS OF EXCHANCEABLE, AMS 65, 1840

HANSON, D. L. DISTRIBUTION FREE TOLERANCE LIMITS, ELIMINATION OF REQUIREMENT THAT CUMULATIVE FUNCTIONS BE, TECH 63.518

HANSON, D L, GENERALIZED MEANS AND ASSOCIATED FAMILIES OF DISTRIBUTIONS. AMS 69, 339

HANSON. D. L NONPARAMETRIC UPPER CONFIDENCE BOUNDS, AND CONFIDENCE LIMITS, FOR THE PROBABILITY THATY IS, JASA 64, 906

HANSON, D. L. ONA CLASS OF SIMPLE RANDOM WALKS, AMS 63, 413

HANSON, D, L. ON THE CONVERGENCE RATE OF THE LAW OF LARGE NUMBERS FOR LINEAR COMBINATIONS OF INDEPENDENT, AMS 65, 559 
HANSON, D. L. SOME RESULTS RELATINC MOMENT GENERATINC FUNCTIONS AND CONVERCENCE RATES IN THE LAW OF LARCE, AMS 67.742

HANSON. D. L. TOLERANCE LIMITS FOR THE CLASS OF DISTRIBUTIONS WITH INCREASING HAZARD RATE, AMS 64,1561

HANSON, DAVID LEE MAXIMUM LIKELIHOOD ESTIMATION OF THE DISTRIBUTIONS OF TWO STOCHAST ICALLY ORDERED RANDOM, JASA 66, 1067

HANSON. ROBERT H. INFLUENCE OF THE INTERVIEWER ON THE ACCURACY OF SURVEY RESULTS, JASA 58,635

HANSON, W. D. EFFECTS OF PARTIAL ISOLATION (DISTANCE), MIGRATION AND DIFFERENT FITNESS REQUIREMENTS AMON, BIOCS 66,453

HANSON, W. D. SPATIAL RELATIONSHIP AMONG EIGHT POPULATIONS ZEA MAYS L. UTILIZING INFORMATION FROM A DIALL, BIOCS $6 B, B 67$

HANUMARA, R. C. PERCENTAGE POINTS OF THE EXTREME ROOTS OF A WISHART MATRIX, BIOKA $6 \mathrm{~B}, 505$

HANURAV, T V. HYPER-ADMISSIBILITY AND OPTIMUM ESTIMATORS FOR SAMPLING FINITE POPULATIONS, AMS 68,621

HANURAV. T. V. OPTIMUM UTILIZATION OF AUXILIARY INFORMATION. (PI) PS SAMPLING OF TWO UNITS FROM A STRATUM, JRSSB 67, 374

HAQ. M. S. STRUCTURAL PROBABILITY AND PREDICTION FOR THE MUL TIVARIATE MODEL, JRSSB 69 , NO 2

HARBERGER, ARNOLD C. THE ECONOMICS OF THE PRESIDENT'S ECONOMIC REPORTS, JASA 56.454

HARGOLIN, B. H. ORTHOGONAL MAIN-EFFECT 2-TO-THE-N-TIMES-3-TO-THE M DESIGNS AND TWO-FACTOR INTERACTION ALI . TECH 68, 559

HARKNESS, M. L. GENERALIZED HYPERBOLIC SECANT DISTRIBUTIONS, JASA 68, 329

HARKNESS, W. NORMAL APPROXIMATION TO THE DISTRIBUTION OF TWO INDEPENDENT BINOMIALS, CONDITIONAL ON FIXED, AMS 63, 1593

HARKNESS, W. L. ASYMPTOTIC DISTRIBUTION OF DISTANCES BETWEEN ORDER STATISTICS FROM BIVARIATE POPULATIONS. AMS $64,74 \mathrm{~B}$

HARKNESS, W. L. CHARACTERIZATIONS OF SOME DISTRIBUTIONS BY CONDITIONAL MOMENTS, AMS 65,703

HARKNESS, $W . L$. COMPARISON OF THE POWER FUNCTIONS FOR THE TEST OF IN DEPENDENCE IN 2X2 CONTINGENCY TABLES, AMS 64, 1115

HARKNESS, W. L. GENERALIZED HY PERBOLIC SECANT DISTRIBUTIONS, JASA $6 B, 329$

HARKNESS, W. L. PROPERTIES OF THE EXTENDED HYPERGEOMETRIC DISTRIBUTION, AMS 65, 938

HARLEY, B. I. A NOTE ON THE PROBABILITY INTEGRAL OF THE CORRELATION COEFFICIENT, BIOKA $54,27 \mathrm{~B}$

HARLEY, B. I. FURTHER PROPERTIES OF AN ANGULAR TRANSFORMATION OF THE CORRELATION COEFFICIENT, BIOKA 57, 273

HARLEY, B. I. RELATION BETWEEN THE DISTRIBUTIONS OF NON-CENTRAL T AND OF A TRANSFORMED CORRELATION COEFFI, BIOKA 57, 219

HARLEY, B, I. SOME PROPERTIES OF AN ANGULAR TRANSFORMATION FOR THE CORRELATION COEFFICIENT, BIOKA 56, 219

HARLEY, B. I. THE DISTRIBUTION OF RANGE IN NORMAL SAMPLES WITH $\mathrm{N}=200, \mathrm{BIOKA} 57,257$

HARPER, L. H. STIRLING BEHAVIOR IS ASYMPTOTICALLY NORMAL, AMS 67. 410

HARPER, LAWRENCE H. A FAMILY OF COMBINATORIAL IDENTITIES. AMS 66. 509

HARPER, W. M. THE DISTRIBUTION OF THE MEAN HALF-SQUARE SUCCESSIVE DIFFERENCE, BIOKA 67, 419

HARPER, W. M. THE USE OF INTECRAL TRANSFORMS TO DETERMINE EXPANSIONS OF DISTRIBUTION FUNCTIONS, BIOKA 60,460

HARR IS JR, W. A. APPLICATIONS OF THE PSEUDO INVERSE TO MODELING. TECH 66,351

HARRIS, A. J A MAXIMUM-MINIMUM PROBLEM RELATED TOSTATISTICALDISTRIBUTIONS IN TWO DIMENSIONS, BIOKA 57.384

HARRIS. B. DECISION PROCEDURES FOR FINITE DECISION PROBLEMS UNDER COMPLETE ICNORANCE, AMS 64,1644

HARRIS, BERNARD DETERMINING BOUNDS ON EXPECTED VALUES OF CERTAIN FUNCTIONS, AMS 62,1454

HARRIS. BERNARD STATISTICAL INFERENCE IN THE CLASSICAL OCCUPANCY PROBLEM, UNBIASED ESTIMATION OF THE NUMB, JASA 68,837

HARRISON, J.Y. TESTINC OF MEANS WITH DIFFERENT ALTERNATIVES, TECH $6 B, 195$

HARSAAE, E. ON THE COMPUTATION AND USE OF A TABLE OF PERCENTAGE POINTS OF BARTLET'T' S M, BIOKA 69, 273

HARTER, H. L. A NOTE ON ESTIMATION FROM A TYPE I EXTREME-VALUE DISTRIBUTION, TECH 67,325

HARTER, H. L. EXPECTED VALUES OF NORMAL ORDER STATISTICS, BIOKA 61 . 151

HARTER, H. L. ITERATIVE MAXIMUM-LIKELIHOOD ESTIMATION OF THE PARAMETERS OF NORMAL POPULAT IONS FROM SINGLY, BIOKA 66, 205

HARTER, H. LEON A NEW TABLE OF PERCENTAGE POINTS OF THE CHI-SQUARE DISTRIBUTION, BIOKA 64, 231

HARTER, H. LEON A NEW TABLE OF PERCENTAGE POINTS OF THE PEARSON TYPE III DISTRIBUTION, TECH 69, 177

HARTER, H. LEON ASYMPTOTIC VARIANCES AND COVARIANCES OF MAXIMUMLIKELIHOOD EST IMATORS, FROM CENSORED SAMP, AMS 67,557

HARTER, H. LEON CIRCULAR ERROR PROBABILITIES, JASA 60,723

HARTER, H. LEON CONDITIONAL MAXIMUM-LIKELIHOOD ESTIMATION, FROM SINGLY CENSORED SAMPLES, OF THE SCALE PAR, TECH 68,349

HARTER, H. LEON CORRIGENDA, 'A NEW TABLE OF PERCENTACE POINTS OF THE CHI-SQUARE DISTRIBUTIONS', BIOKA 65, 305
HARTER, H. LEON CORRICENDA STATISTICS', BIOKA 61,476

HARTER, H. LEON CRITERIA FOR BEST SUBSTITUTE INTERVAL ESTIMATORS WITH AN APPLICATION T0 THE NORMAL DISTR, JASA 64, 1133

HARTER, H. LEON ERRATA, 'EXACT CONFIDENCE BOUNDS, BASED ON ONE ORDER STATISTIC FOR THE PARAMETER OF A ONE, TECH 64,483

HARTER, H. LEON ERRATA, 'MAXIMUM-LIKELIHOOD ESTIMATION OF THE PARAMETERS OF GAMMA AND WEIBULL POPULATIONS, TECH 67,195

HARTER, H. LEON ESTIMATINC THE PARAMETERS OF NEGATIVE EXPONENTIAL POPULAT IONS FROM ONE OR TWO ORDER STATI, AMS 61, 107B

HARTER, H. LEON EXACT CONFIDENCE BOUNDS, BASED ON ONE ORDER STATIST IC FOR THE PARAMETER OF AN EXPONENTIAL, TECH 64,301

HARTER, H. LEON LOCAL-MAXIMUM-LIKELIHOOD ESTIMATION OF THE PARAMETERS OF THREE-PARAMETER LOGNORMAL POPULA, JASA 66, B42

HARTER, H. LEON MAXIMUM LIKELIHOOD ESTIMATION OF THE PARAMETERS OF GAMMA AND WEIBULL POPULATIONS FROM COM. TECH 65,639

HARTER, H. LEON MAXIMUM-LIKELIHOOD ESTIMATION OF THE PARAMETERS OF A FOUR- PARAMETER GENERALIZED GAMMA PO, TECH 67,159

ARTER, H. LEON MAXIMUM-LIKELIHOOD ESTIMATION, FROM CENSORED SAMPLES, OF THE PARAMETERS OF A LOGISTICDIS, JASA 67,675

HARTER, H. LEON MAXIMUM-LIKELIHOOD ESTIMATION, FROM DOUBLY CENSORED SAMPLES, OF THE PARAMETERS OF THE FIR, JASA $6 B, B B 9$

HARTER, $H$. LEON PERCENTAGE POINTS OF THE RATIO OF TWO RANCES AND POWER OF THE ASSOCIATED TEST, BIOKA 63, 187

HARTER, H. LEON POINT AND INTERVAL ESTIMATORS, BASED ON M ORDER STATISTICS, FOR THE SCALE PARAMETER OF A, TECH 65, 405

HARTER, H. LEON THE USE OF SAMPLE RANGES IN SETTTING EXACT CONFIDENCE BOUNDS FOR THE STANDARD DEVIATION OF, JASA 61,601

HARTER, H. LEON USE OF TABLES OF PERCENTAGE POINTS OF RANGE AND STUDENTIZED RANCE, TECH 61,407

HARTICAN.J. INVARIANT PRIOR DISTRIBUTIONS, AMS 64, 836

HARTIGAN, J. A. DISTRIBUTION OF THE RESIDUAL SUM OF SQUARES IN FITTINC INEQUALITIES, BIOKA 67,69

HARTIGAN, J A. EST IMATION BY RANKING PARAMETERS, JRSSB 66, 32

HART IGAN, J. A. INFERENCE FROM A KNOCKOUT TOURNAMENT, AMS 68,5B3

HARTIGAN, J.A. NOTE ON DISCORDANT OBSERVATIONS, JRSSB 68,545

HARTIGAN, J. A. NOTE ON THE CONFIDENCE-PRIOR OF WELCH AND PEERS, JRSSB 66,55

HARTIGAN, 'J. A. PERCEN'IAGE POINTS OF A TEST FOR CLUSTERS, JASA 69 NO. 4

HARTIGAN, J A. PROBABILISTIC COMPLETION OF A KNOCKOUT TOURNAMENT, AMS 66,495

HARTIGAN, J. A. JASA 67,1140

HARTIGAN, J. A . AMS 65,1137

HARTIGAN, J A THE LIKELIHOOD AND INVARIANCE PRINCIPLES, JRSSB 67 533

HARTIGAN, J. A. USING SUBSAMPLE VALUES AS TYPICAL VALUES, JASA 69 NO. 4

HARTLEY, H. O. A CHART FOR THE INCOMPLETE BETA-FUNCTION AND THE CUMULATIVE BINOMIALDISTRIBUTION, BIOKA 51,423

HARTLEY, H. O. A DISCONTINUITY IN MIXED MODEL ANALYSIS, BIOCS 69 573

HARTLEY, H . O A NEW ESTIMATION THEORY FOR SAMPLE SURVEYS, BIOKA 6B, 547

HARTLEY, H. O. A NOTE ON THE CORRELATION OF RANGES IN CORRELATED NORMAL SAMPLES, BIOKA 6B, 595

HARTLEY, H. O. A PROCEDURE FOR AUTOMATIC DATA EDITINC, JASA 67, 341

HARTLEY, H. O CHARTS OF THE POWER FUNCTION FOR ANALYSIS OF VARIANCE TESTS, DERIVED FROM THE NON-CENTRAL, BIOKA 51,112

HARTLEY, $H, O$, CORRICENDA. 'TABLES OF PERCENTAGE POINTS OF THE 'STUDENTIZED' RANCE' ', BIOKA 53, 236

HARTLEY, $H .0$. DESIGN AND ESTIMATION IN TWO-WAY STRATIFICATION, JASA 60,105

HARTLEY, H. O. DISCUSSION OF' 'A SUBJECTIVE EVALUATION OF BODE'S LAW AND AN 'OBJECTIVE' TEST FOR APPROXIMA, JASA 69,50

HARTLEY, $\mathrm{H}, \mathrm{O}$. EXACT CONFIDENCE REGIONS FOR THE PARAMETERS IN NONLINEAR RECRESSION LAWS, BIOKA 64,347

HARTLEY, $H .0$. EXPECTATIONS, VARIANCES AND COVARIANCES OF 'ANOVA' MEAN SQUARES BY 'SYNTHESIS', BIOCS 67, 105

HARTLEY, $H .0$. MAXIMUM-LIKELIHOOD ESTIMATION FOR THE MIXED ANALYSIS OF VARIANCE MODEL, BIOKA 67,93

HARTLEY, H. O. MOMENT CONSTANTS FOR THE DISTRIBUTION OF RANCE IN NORMAL SAMPLES, BIOKA 51,463

HARTLEY, H, 0 , NONLINEAR LEAST SQUARES ESTIMATION, AMS 65, 638

HARTLEY, H. O. ON A SIMPLE PROCEDURE OF UNEQUAL PROBABILITY SAMPLINO WITHOUT REPLACEMENT, JRSSB 62, 482

HARTLEY, $H .0$. QUERY, JOINT CONFIDENCE LIMITS FOR RANKED OBSERVATIONS, TECH 66,368

HARTLEY, H. 0. SAMPLINC WITH CONTROL VARIABLES, BIOKA 54. 494

HARTLEY, H. 0 . SAMPLING WITH UNEQUAL PROBABILITIES AND WITHOUT REPLACEMENT, AMS 62,350

HARTLEY, H. O. SYSTEMATIC SAMPLING WITH UNEQUAL PROBABILITY AND WITHOUT REPLACEMENT, JASA 66,739

HARTLEY, H. O. TESTS FOR RANK CORRELATION COEFF ICIENTS. I, BIOKA 57 , 470

HARTLEY, H. O. THE DISTRIBUTION OF THE RATIO. IN A SINCLE NORMAL SAMPLE, OF RANGE TO STANDARD DEVIATION, BIOKA 54, 4B2 
HARTLEY, H. O. THE EFFICIENCY OF INTERNAL RECRESSION FOR THE F ITTING OF THE EXPONENTIAL RECRESSION, BIOKA 59,293

HARTLEY, H. O. THE FITTING OF POLYNOMIALS TO EQUIDISTANT DATA WITH MISSINC VALUES, BIOKA 5I, 410

HARTLEY, $H$. O. THE MODIF IED GAUSS-NEWTON METHOD FOR THE FITTING OF NON-LINEAR REGRESSION FUNCT IONS BY LEA, TECH 61, 269

HARTLEY, $H . O$. THE PRECISION OF UNBIASED RATIO-TYPE ESTIMATORS, CORR. 631162 , JASA 5B, 491

HARTLEY, H. O. VARIANCE ESTIMATION WITH ONE UNIT PER STRATUM, JASA 69,841

HARTWELL, T. D. EXPECTED MEAN SQUARES FOR NESTED CLASSIFICATIONS, BIOCS 69,427

HARVEY, J R. R, UNIFIED LEAST SQUARES ANALYSIS, JASA 65, 523

HARVILLE, D. A. QUADRATIC UNBIASED ESTIMATION OF VARIANCE COMPONENTS OF THE ONE-WAY CLASSIFICATION, BIOKA 69,313

HARVILLE, DAVID A. ESTIMABILITY OF VARIANCE COMPONENTS FOR THE TWOWAY CLASSIFICATION WITH ITERATION, AMS $67,150 B$

HARVILLE, DAVIDA. EXPRESSION OF VARIANCE-COMPONENT ESTIMATORS AS LINEAR COMBINATIONS OF INDEPENDENT NONC, AMS 69, NO.6

HARVILLE, DAVID A. STATISTICAL DEPENDENCE BETWEEN RANDOM EFFECTS AND THE NUMBERS OF OBSERVATIONS ON THE E, JASA 67, 1375

HARVILLE. DAVID A. STATISTICAL DEPENDENCE BETWEEN SUBCLASS MEANS AND THE NUMBERS OF OBSERVATIONS IN THE S, JASA 6B, $14 \mathrm{~B} 4$

HARVILLE, DAVID A. VARIANCES OF VARIANCE-COMPONENT ESTIMATORS FOR THE UNBALANCED TWO-WAY CROSS CLASSIFICA, AMS 69, 40B

HASHIGUCHI, S. ESTIMATION OF GENETIC CONTRIBUTION OF PRINCIPAL COMPONENTS TO INDIVIDUAL VARIATES CONCERNE, BIOCS 69 ,

HASKEY, H. W. A GENERAL EXPRESSION FOR THE MEAN IN A SIMPLE STOCHASTIC EPIDEMIC, BIOKA 54, 272

HASKEY, H. W. STOCHASTIC CROSS-INFECTION BETWEEN TWO OTHERWISE ISOLATED CROUPS, BIOKA 57, 193

HASOFER, A. M ON THE INTEGRABILITY, CONTINUITY AND DIFFERENTIABILITY OF A FAMILY ON FUNCT IONS INTRODUCED, AMS 63, 1045

HASOFER, A. M. STUDIES IN THE HISTORY OF PROBABILITY AND STATISTICS XVI . RANDOM RANDOM MECHANISMS IN TALM, BIOKA 67,316

HASOFER, A. M. THE ALMOST FULL DAM WITH POISSON INPUT, JRSSB 66,320

HASOFER, A. M. THE ALMOST FULL DAM WITH POISSON INPUT, FURTHER RESULTS, JRSSB $66,44 B$

HASSANEIN, K. M. ESTIMATION OF THE PARAMETERS OF THE LOGISTIC DISTRIBUTION BY SAMPLE QUANTILES, BIOKA 69, NO 3

HASSANEIN, KHATAB M. ESTIMATION OF THE PARAMETERS OF THE EXTREME VALUE DISTRIBUTION BY USE OF TWO OR THRE, BIOKA 69,429

HASSELBLAD, VICTOR ESTIMATION OF FINITE MIXTURES OF DISTRIBUTIONS FROM THE EXPONENT I AL FAMILY, JASA 69, NO.4

HASSELBLAD, VICTOR ESTIMATION OF PARAMETERS FOR A MIXTURE OR NORMAL DISTRIBUTIONS, TECH 66,43

HASSINEIN. KHATABM. ANALYSIS OF EXTREME-VALUE DATA BY SAMPLE QUANTILES FOR VERY LARCE SAMPLES, JASA $6 B .877$

HAUSER, PHILIPM STATISTICS AND SOCIETY, JASA 63,

HAWKES, A, G, DELAY AT TRAFFIC INTERSECTIONS, JRSSB 66, 202

HAWKES. A. C. QUEUEINC FOR CAPS IN TRAFFIC. . BIOKA 65, 79

HAWKINS, D. M. ON THE DISTRIBUTION AND POWER OF A TEST FOR A SINGLE OUTLIER, SASJ 69,9

HAYBITTLE, J. L. A TWO-PARAMETER MODEL FOR THE SURVIVAL CURVE OF TREATED CANCER PATIENTS, JASA 65,16

HAYNAM, G.E ANALYSISOF CATEGORICALDATA, BIOKA 65.654

HAYNAM, GEORGE E, EXACT POWER OF MANN-WHITNEY TEST FOR EXPONENTIAL AND RECTANCULAR ALTERNATIVES, AMS 66, 945

HAYS, WILLIAM L. A NOTE ON AVERAGE TAU AS A MEASURE OF CONCORDANCE, JASA 60,331

HEALY JR, W. C LIMITS FOR A VARIANCE COMPONENT WITH AN EXACT CONFIDENCE COEFFICIENT, AMS 61,466

HEALY, M J.R. A PROPERTY OF THE MULTINOMIAL DISTRIBUTION AND THE DETERMINATION OF APPROPRIATE SCORES, BIOKA 64, 265

HEALY, M.J.R A SIGNIFICANCE TEST FOR THE DIFFERENCE IN EFFICIENCY BETWEEN TWO PREDICTORS, JRSSB 55, 266

HEALY, M J.R. ALIASING IN PART IALLY CONFOUNDED FACTORIAL EXPERIMENTS, BIOKA 61, 218

HEALY, M. J.R. ECONOMIC CHOICE OF THE AMOUNT OF EXPERIMENTATION JRSSB 56,32

HEALY, M J.R EXACT TESTS OF SIGNIFICANCE IN CONTINGENCY TABLES, TECH 69,393

HEALY, M J. R. FIDUCIAL LIMITS FOR A VARIANCE COMPONENT, JRSSB 63

HEALY, M J.R. NEW TABLES OF BEHREN'S TEST OF SIGNIFICANCE, JRSSB 56,212

HEALY, M J R NOTES. COMPUTING A DISCRIMINANT FUNCTION FROM WITHIN-SAMPLE DISPERSIONS, BIOCS 65,1011

HEALY. M J.R. RAO'S PARADOX CONCERNING MULTIVARIATE TESTS OF SIGNIFICANCE, BIOCS 69,411

HEALY, M J.R. ROUTINE ANALYSIS OF REPLICATED EXPERIMENTS ON AN ELECTRONIC COMPUTER (WITH DISCUSSION), JRSSB 57, 234

HEALY.M J.R. TABLES FOR POWER-LAW TRANSFORMATIONS, BIOKA 62, 557

HEALY, M. J.R. WEIGHTED PROBITS ALLOWING FOR A NON-ZERO RESPONSE IN THE CONTROLS, BIOKA 56,207

HEATHCOTE, C. R. A BRANCHING PROCESS ALLOWING IMMIGRATION, JRSSB $65,13 B$

HEATHCOTE, C. R. CORRECTIONS AND COMMENTS ON THE PAPER 'A BRANCHING PROCESS ALLOWING IMMIGRATION' ', JRSSB 66,213
HEATHCOTE, C. R. ON THE QUEUEING PROCESS, MARKOV OR POISSON INPUT, GENERAL SERVICE TIME DISTRIBUTION, ONE , AMS 61, 770

HEATHCOTE, C. R. PREEMPTIVE PRIORITY QUEUEING, BIOKA 61, 57

HEATHCOTE, C.R. THE RANDOM WALK (IN CONTINUOUS TIME) AND ITS APPLICATION TO THE THEORY OF QUEUES, BIOKA 59, 400

HEBERT, $C . N$. COMPARATIVE SAMPLING ACCEPTANCE SCHEMES IN TESTINC ANTIGENICITY OF VACCINES, BIOCS $66,6 B 4$

HEDAYAT, A. ON THE APPLICATION OF CROUP THEORY TO THE EXISTENCE AND NON-EXISTENCE OF ORTHOGONAL LATIN SQU, BIOKA 69, NO.3

HEDCES, A. J NOTES. ON THE DILUTION ERRORS INVOLVED IN ESTIMATINC BACTER I AL NUMBERS BY THE PLATING METHO, BIOCS 67, 15B

HEGE, VIJAYA S. AN OPTIMUM PROPERTY OF THE HORVITZ-THOMSON ESTIMATE, JASA 67,1013

HEIEN, DALE M. A NOTE ON LOG-LINEAR REGRESSION, JASA 68, 1034

HEINE, V MODELS FOR TWO-DIMENSIONAL STATIONARY STOCHASTIC PROCESSES, BIOKA 55, 170

HELLER, ALEX ON STOCHASTIC PROCESSES DERIVED FROM MARKOV CHAINS, AMS $65,12 B 6$

HELLER, R. A. DEVELOPNENT OF RANDOMIZED LOAD SEQUENCES WITH TRANSITION PROBABILITIES BASED ON A MARKOV PR, TECH 66, 107

HELVIG, T. N APPLICATIONS OF THE PSEUDOINVERSE TO MODELINC, TECH 66.351

HENDERSON, C. R AN ITERATIVE PROCEDURE FOR ESTIMATING FIXED EFFECTS AND VARIANCE COMPONENTS IN MIXED MOD, BIOCS 6B, 13

HENDERSON. C. R. ANALYTICAL TECHNIQUE FOR INCOMPLETE BLOCK EXPERIMENTS, BIOCS 66, B29

HENDRICKS. WALTER A ESTIMATION OF THE PROBABILITY THAT AN OBSERVATION WILL FALL IN A SPECIF IED CLASS, JASA 64, 225

HENRICHON, E. G. UNIFORM CONSISTENCY OF SOME ESTIMATES OF A DENSITY FUNCTION, AMS 69, 1499

HENSLEY, CARLTON THE LOGISTIC PROCESS, TABLES OF THE STOCHASTTC EPIDEMIC CURVE AND APPLICATIONS, JRSSB 60,332

HERBST, L. SPECTRAL ANALYSIS IN THE PRESENCE OF VARIANCE FLUCTUATIONS, JRSSB 64,354

HERBST, L. STATIONARY AMPLITUDE FLUCTUATIONS IN A. RANDOM SERIES JRSSB 64,361

HERBST, L J FOURIER METHODS IN THE STUDY OF VARIANCE FLUCTUATIONS IN TIME SERIES ANALYSIS, TECH 69, 103

HERBST. L. J. THE STATISTICAL FOURIER ANALYSIS OF VARIANCES, JRSSB 65. 159

HERBST LAURENCE ALMOST PERTODIC VARIANCES, AMS 63.1549

HERBST. LAURENCE J. PERIODOGRAM ANALYSIS AND VARIANCE FLUCTUA TIONS, JRSSB 63,442

HERBST, LAURENCE $N$ A TEST FOR VARIANCE HETEROGENEITY IN THE RESIDUALS OF A GAUSSIAN MOVING AVERAGE, JRSSB 63,451

HERDAN, G. THE MATHEMATICAL RELATION BETWEEN GREENBERG 'S INDEX OF LINGUIST IC DIVERS ITY AND YULE'S CHARACT, BIOKA 5B, 26B

HERDAN,C THE RELATION BETWEEN THE DICTIONARY DISTRIBUTION AND THE OCCURRENCE D ISTRIBUTION OF WORD LENGT, BIOKA 58, 222

HERR, DAVID G. ASYMPTOTICALLY OPTIMAL TESTS FOR MULTIVARIATE NORMAL DISTRIBUTIONS, AMS 67,1 B29

HERREY, ERNA M. J CONFIDENCE INTERVALS BASED ON THE MEAN ABSOLUTE DEVIATION OF A NORMAL SAMPLE, JASA 65,257

HERTZ, ELLEN S. ON CONVERGENCE RATES IN THE CENTRAL LIMIT THEOREM, AMS 69, 475

HERZBERG, AGNES M A METHOD FOR THE CONSTRUCTION OF SECOND ORDER ROTATABLEDESICNS IN KDIMENSIONS, AMS 67, 177

HERZBERG, AGNES $M$. CYLINDRICALLY ROTATABLE DESIGNS OF TYPES 1,2 AND 3, AMS 67,167

HERZBERC, A. THE BEHAVIOUR OF THE VARIANCE FUNGTION OF THE DIFFERENCE BETWEEN TWO EST IMATED RESPONSES, JRSSB 67, 174

HERZBERC AGNES QUERY, ANALYSIS OF FACTORIAL EXPERIMENT (PARTIALLY CONFOUNDED 2-CUBE) , TECH 67,170

HERZBERG, ACNESM. CYLINDRICALLY ROTATABLE DESIGNS, AMS 66, 242

HERZBERG, AGNES M. FURTHER SECOND ORDER ROTATABLE DESIGNS, AMS $6 B$ 1995

HERZBERG, AGNES M. TWO THIRD ORDER ROTATABLE DESIGNS IN FOUR DIMENSIONS, AMS 64,445

HESS, IRENE ON NONCOVERACE OF SAMPLE DWELLINCS, JASA 58,509

HESS, IRENE ON VARIANCES OF RATIOS AND THEIR DIFFERENCES IN MULTISTAGE SAMPLES, CORR, 631162, JASA 59, 416

HESS, IRENE STRATIFICATION, A PRACTICAL INVESTICATION, JASA 66,74 HETTMANSPERCER, THOMAS P. ON THE TRIMMED MANN-WHITNEY STATISTIC, AMS 68,1610

HEWETT, JOHNE. A NOTE ON A DOUBLE SAMPLE TEST, JASA 69, NO. 4

HEWETT, JOHN E. A NOTE ON PREDICTION INTERVALS BASED ON PARTIAL OBSERVATIONS IN CERTAIN LIFE TEST EXPERIM. TECH $6 B, B 50$

HEWLETT, P, S. A COMPARISON OF TWO APPROACHES TO THE CONSTRUCTION OF MODELS FOR QUANTAL RESPONSES TO MIXT, BIOCS 67, 27

HEWLETT, P. S. MEASUREMENT OF THE POTENCIES OF DRUG MIXTURES, BIOCS 69,477

HEXT, G. R. SEQUENTIAL APPLICATION OF SIMPLEX DESIGNS IN OPTIMISATION AND EVOLUTIONARY OPERATION, TECH 62,441

HEXT, GEORGE R, THE ESTIMATION OF SECOND-ORDER TENSORS, WITH RELATED TESTS AND DESIGNS, BIOKA 63, 353

HEYDE, G. C, ASYMPTOTIC RENEWAL RESULTS FOR A NATURAL GENERALIZATION OF CLASSICAL RENEWAL THEORY, JRSSB 67,141

HEYDE, C. C. ON A FLUCTUATION THEOREM FOR PROCESSES WITH INDEPENDENT INCREMENTS, II AMS 69,688 
HEYDE, C. C, ON A PROPERTY OF THE LOCNORMAL DISTRIBUTION, JRSSB 63, 392

HEYDE, C. C. ON EXTENDED RATE OF CONVERCENCE RESULTS FOR THE INVARIANCE PRINCIPLE, AMS 69, N0.6

HEYDE, C. C. ON EXTREMAL FACTORIZATION AND RECURRENT EVENTS, JRSSB 69.72

HEYDE, C. C. ON LARCE DEVIATION PROBLEMS FOR SUMS OF RANDOM VARIABLES WHICH ARE NOT ATTRACTED TO THE NORM, AMS 67, 1575

HEYDE, C. C. SOME RENEWAL THEOREMS WITH APPLICATION TO A FIRST PASSAGE PROBLEM, AMS 66,699

HEYDE, C, C. VARIATIONS ON A RENEWAL THEOREM OF SMITH, AMS 6B, 155

HICKMAN, BERT G. AN EXPERIMENT WITH WEIGHTED INDEXES OF CYCLICAL DIFFUSION, JASA 5B, 39

HICKMAN, BERT C. ON A NEW METHOD OF CAPACITY ESTIMATION, JASA 64,529

HICKMAN, JAMES C. PRELIMINARY REG IONAL FORECASTS FOR THE OUTCOME OF AN ESTIMATION PROBLEM, JASA 63,1104

HILDEBRAND, DAVID K. DOMAINS OF OPT IMALITY OF TESTS IN SIMPLE RANDOM SAMPLINC, AMS 69, 308

HILDRETH, CLIFFORD ASYMPTOTIC DISTRIBUTION OF MAXIMUM LIKELIHOOD ESTIMATORS IN A LINEAR MODEL WITH AUTORE, AMS 69, 583

HILDRETH, CLIFFORD SOME ESTIMATORS FOR A LINEAR MODEL WITH RANDOM COEFFICIENTS, JASA 6B, 5B4

HILL, B. DISCUSSION OF THE PAPERS OF MESSRS. HALD, WETHERILL AND COX, TECH 60,361

HILL, B. M. FOUNDATIONS FOR THE THEORY OF LEAST SQUARES, JRSSB 69, B9 HILL, BRUCE M. CORRECTIONS TO 'A RELATIONSHIP BETWEEN HODGES' BIVARIATE SIGN TEST AND A NON-PARAMETRIC TE, AMS 61,619

HILL, BRUCE M . CORRELATED ERRORS IN THE RANDOM MODEL, JASA 67, 13B7

HILL, BRUCE M. INFERENCE ABOUT VARIANCE COMPONENTS IN THE ONE-WAY MODEL, JASA 65, BO6

HILL, BRUCE M. INFORMATION FOR ESTIMATING THE PROPORTIONS IN MIXTURES OF EXPONENTIAL AND NORMAL DISTR IBUT, JASA $63,91 \mathrm{~B}$

HILL, BRUCE M. POSTERIOR DISTRIBUTION OF PERCENTILES. BAYES' THEOREM FOR SAMPLING FROM A POPULATION, JASA 68,677

HILL, BRUCE M. THE THREE-PARAMETER LOGNORMAL DISTRIBUTION AND BAYESIAN ANALYSIS OF A POINT-SOURCE EPIDEMI，JASA 63,72

HILL, BRUCE MARVIN A TEST OF LINEARITY VERSUS CONVEXITY OF A MEDIAN REGRESSION CURVE, AMS 62, 1096

HILL, G. W. GENERALIZED ASYMPTOTIC EXPANSIONS OF CORNISH-FISHER TYPE, AMS $6 B, 1264$

HILL, HUBERT M. EXPERIMENTAL DESIGNS TO ADJUST FOR TIME TRENDS, TECH 60,67

HILL, I. D. THE DISTRIBUTION OF THE REGRESSION COEFFICIENT IN SAMPLES FROM A NON-NORMAL POPULATION, BIOKA 54, 54B

HILL, R. T. THE SIMPLE STOCHASTIC EPIDEMIC FOR SMALL POPULATIONS WITH ONE OR MORE INITIAL INFECT IVES, BIOKA 69, 1B3

HILL, WILLIAM J. A JOINT DESIGN CRITERION FOR THE DUAL PROBLEM OF MODEL DISCRIMINATION AND PARAMETER ESTI, TECH 6B, 145

HILL, WILLIAM J. A NOTE ON DESIGNS FOR MODEL DISCRIMINATION, VARIANCE UNKNOWN CASE, TECH 69,396

HILL, WILLIAM J. A REVIEW OF RESPONSE SURFACE METHODOLOGY . A LITERATURE SURVEY, TECH 66,571

HILL, WILLIAM J . DISCR IMINATION AMONC MECHANISTIC MODELS, TECH 67 , 57

HILLIER, F. S. NEW CRITERIA FOR SELECTING CONTINUOUS SAMPLINC PLANS, TECH 64,161

HILLIER, FREDERICK S. CONTINUOUS SAMPLING PLANS UNDER DESTRUCTIVE TESTING, JASA 64,376

HILLIER, FREDERICK S. SMALL SAMPLE PROBABILITY LIMITS FOR THE RANGE CHART (CORR, 68 1549), JASA 67, 1488

HILLIER, FREDERICK S. SURVEILLANCE PROGRAMS FOR LOTS IN STORAGE. TECH 62, 515

HILLS, M. ALLOCATION RULES AND THEIR ERROR RATES (WITH DISCUSSION) JRSSB 66 , 1

HILLS, M. NOTES. A NOTE ON THE ANALYSIS OF CROWTH CURVES, BIOCS 6B 192

HILLS, M. ON LOOKING AT LARCE CORRELATION MATRICES, BIOKA 69, 249

HIMSWORTH, F. R. SEQUENTIAL APPLICATION OF SIMPLEX DESIGNS IN OPTIMISATION AND EVOLUTIONARY OPERATION, TECH 62, 441

HINCHEN, JOHN D. MULTIPLE REGRESISION IN PROCESS DEVELOPMENT, TECH $6 \mathrm{~B}, 257$

HINICH, MELVIN ESTIMATION OF SPECTRA AFTER HARD CLIPPING OF GAUSSIAN TIME PROCESSES, TECH 67,391

HINICH, MELVIN LARGE SAMPLE ESTIMATION OF AN UNKNOWN DISCRETE WAVEFORM WHICH IS RANDOMLY REPEATING IN GAU, AMS 65, 489

HINKELMANN, K. ESTIMATION OF HERITABILITY FROM EXPERIMENTS WITH RELATED DA.ต́S, BIOCS 69, NO . 4

HINKELMANN, K. TWO CLASSES OF CROUP DIVISIBLE PARTIAL DIALLEL CROSSES, BIOKA 63, 2B1

HINKELMANN, KLAUS EXTENDED GROUP DIVISIBLE PARTIALLY BALANCED INCOMPLETE BLOCK DESIGNS, AMS 64, 681

HINKELMANN, KLAUS MISSING VALUES IN PARTIAL DIALLEL CROSS EXPERIMENTS, BIOCS 68,903

HINKLEY, D , V. A NOTE ON THE EFFICIENCY OF LEAST-SQUARES ESTIMATES, JRSSB 68,284

HINKLEY, D. V. INFERENCE ABOUT THE INTERSECTION IN TWO-PHASE REGRESSION, BIOKA 69, NO.3
INKLEY D V ON THE RATIO OF TWO CORRELATED NORMAL RANDOM VARIABLES, BIOKA 69, NO. 3

HINMAN, J, E. SIMPLEX LATTICE DESICNS FOR MUTICOMPONENT SYSTEMS, TECH 62,463

HINZ, P. A METHOD OF ANALYSINC UNTRANSFORMED DATA FROM THE NEGATIVE BINOMIAL AND OTHER CONTACIOUS DISTRIB, BIOKA 68, 163

HINZ, P. SIMPLIFIED TECHNIQUES FOR ESTIMATINC PARAMETERS OF SOME GENERALIZED POISSON DISTRIBUTIONS, BIOKA 67, 555

HIRSCH, WERNER Z. STATISTICIAN AND POLICY MAKER, A PARTNERSHIP IN THE MAKING, JASA 56,12

HIST, BARTHOLOMEW P. THE MULTIPLE SAMPLE UP-AND-DOWN METHOD IN BIOASSAY, JASA 69,147

HITCHCOCK, SHIRLEY E. A NOTE ON THE ESTIMATION OF THE PARAMETERS OF THE LOGISTIC FUNCT ION, USING THE MINI, BIOKA 62,250

HITCHCOCK, SHIRLEY E, TESTS OF HYPOTHESES ABOUT THE PARAMETERS OF THE LOGISTIC FUNCTION, BIOKA 66, 535

HO, IRWIN SHORTER CONFIDENCE BANDS IN LINEAR REGRESSION, JASA 67 , 1050

HOADLEY JR, WALTER E. STATISTICIANS, TODAY AND TOMORROW, JASA 59, 1 HOADLEY, A. B. USE OF THE PEARSON DENSITIES FOR APPROXIMATING A SKEW DENSITY WHOSE LEFT TERMINAL AND FIRS, BIOKA 68,559

HOADLEY, A. BRUCE ON THE PRO8ABILITY OF LARGE DEVIATIONS OF FUNCTIONS OF SEVERAL EMPIRICAL CUMULATIVE DIS, AMS 67,360

HOADLEY, A. BRUCE THE COMPOUND MULTINOMIAL DISTRIBUTION AND BAYESIAN ANALYSIS OF CATERGORICAL DATA FROM F, JASA 69,216

HO8BY, CHARLES COMBINATORIAL RESULTS IN FLUÇTUATION THEORY, AMS 63,1233

HOBBY, CHARLES COMBINATORIAL RESULTS IN MULTI-DIMENSIONAL FLUCTUATION THEORY, CORR. 64924 , AMS 63,402

HOBBY, CHARLES SOME STRUCTURE THEOREMS FOR STATIONARY PROBABILITY MEASURES ON FINITE STATE SEQUENCES, AMS 64,550

HOCHSTIM, JOSEPH R. A CRITICAL COMPARISON OF THREE STRATECIES OF COLLECTING DATA FROM HOUSEHOLDS, JASA 67,976

HOCKING, R. R. ESTIMATION OF PARAMETERS IN THE MULTIVARIATE NORMAL DISTRIBUTION WITHMISSING OBSERVATIONS, JASA 6B, 159

HOCKING, R. R. QUADRATIC REGRESSION WITH INEQUALITY RESTRAINTS ON THE PARAMETERS, JASA 65,914

HOCKINC, R. R. SELECTION OF THE BEST SUBSET IN REGRESSION ANALYSIS, TECH 67,531

HODGES JR, J. L. A COMPACT TABLE FOR POWER OF THE T-TEST, AMS 68, 1629 HODGES JR, J. L. ESTIMATES OF LOCATION BASED ON RANK TESTS, AMS 63. $59 B$

HODCES JR, J L . ON MEDIANS AND QUASI-MEDIANS, JASA 67, 926

HODGES JR, J. L. RANK METHODS FOR COMBINATION OF INDEPENDENT EXPERI MENTS IN THE ANALYSIS OF VARIANCE, AMS 62, 4B2

HODCES JR, J. L. TESTING THE APPROXIMATE VALIDITY OF STATISTICAL HYPOTHESES, JRSS8 54,261

HODGES JR, J . L. THE ASYMPTOTIC THEORY OF GALTON 'S TEST AND A RELATED SIMPLE ESTIMATE OF LOCATION, AMS 67,73

HODGES JR, JOSEPH L. MINIMUM VARIANCE STRATIFICATION, CORR. 63 1161, JASA $59, \mathrm{BB}$

HODGES, J. L. CALTON'SRANK-ORDER TEST, BIOKA 55, 261

HODSON, F R SOME EXPERIMENTS IN THE NUMERICAL ANALYSIS OF ARCHAEOLOCICAL DATA, BIOKA 66, 311

HOEFFDING, WASSILY ASYMPTOTICALLY OPTIMUM TESTS FOR MULTINOMIAL DISTRIBUTIONS, AMS 65,369

HOEFFDING, WASSILY PROBABILITY INEQUALITIES FOR SUMS OF BOUNDED RANDOM VARIABLES, JASA 63.13

HOEL, D. G. A CLASS OF SEQUENTIAL TESTS FOR AN EXPONENTIAL PARAME TER, JASA 69 , NO. 4

HOEL, D. G. AN EXTENSION OF PAULSON'S SELECTION PROCEDURE, AMS 68 , 2067

HOEL, D. G CLOSED SEQUENTIAL TESTS FOR AN EXPONENTIAL PARAMETER, BIOKA 6B, 3B7

HOEL, DAVID C. SEQUENTIAL TESTING OF SAMPLE SIZE, TECH 68,331

HOEL, $P$, G , A TEST FORMARKOFF CHAINS, BIOKA 54,430

HOEL, P G CONFIDENCE SETS FOR MULT IVARIATE MEDIANS, AMS 61,477

HOEL, P. G. OPTIMAL SPACING AND WEIGHTING IN POLYNOM IAL PREDICTION AMS 64, 1553

HOEL. PAUL C ON TEST TNG FOR THE DEGREE OF A POLYNOMIAL, TECH 6B,757 HOEL, PAUL G. A SIMPLE SOLUT ION FOR OPTIMAL CHEBYSHEV REGRESSION EXTRAPOLATION, AMS 66,720

HOEL, PAUL G, ASYMPTOTIC EFFICIENCY IN POLYNOMIAL ESTIMATION, AMS 61,1042

HOEL, PAUL C. MINIMAX DESIGNS IN TWO DIMENSIONAL RECRESSION, AMS 65 1097

HOEL, PAUL G. OPT IMUM DESIGNS FOR POLYNOMIAL EXTRAPOLATION, AMS 65 1483

HOEM. JAN M. THE SAMPLING DISTRIBUTION OF AN ESTIMATOR ARISING IN CONNECTION WITH THE TRUNCATED EXPONENT I, AMS 69,702

HOFFMAN, A. J. ON THE DUALS OF SYMMETRIC PARTIALLY-BALANCED IN COMPLETE BLOCK DESIGNS, AMS 63, 52B

HOFFMAN, A . J . ON THE LINE GRAPH OF THE COMPLETE BIPARTITE GRAPH, AMS 64.883

HOFLUND, OLLE SIMULATED DISTRIBUTIONS FOR SMALL N OF KENDALL 'S PARTIAL RANK CORRELATION COEFFICIENT , BIOKA 63,520

HOCBEN, D. AN APPROXIMATION TO THE DISTRIBUTION OF Q. A VARIATE RELATED TO THE NON-CENTRAL T, AMS 64,315 
HOGBEN, D. THE MOMENTS OF A VARI ATE RELATED TO THE NON-CENTRAL T, AMS 64,298

HOGBEN, D. THE MOMENTS OF THE NON-CENTRAL T-DISTRIBUTION, BIOKA 61 , 465

HOGG. ROBERT V. AN ITERATED PROCEDURE FOR TESTING THE EQUALITY OF SEVERAL EXPONENTIAL DISTRIBUTIONS, JASA 63, 435

HOCC, ROBERT V. CERTAIN UNCORRELATED STATIST ICS. JASA 60.265

HOGG, ROBERT V. ITERATED TESTS OF THE EQUALITY OF SEVERAL DISTRIBUTIONS, JASA 62,579

HOGG, ROBERT V. MAXIMUM LIKELIHOOD ESTIMATION OF THE DISTRIBUTIONS OF TWO STOCHASTICALLY ORDERED RANDOM V, JASA 66, 1067

HOGG, ROBERT V. ON CONDITIONAL EXPECTATIONS OF LOCATION STATISTICS. JASA 60.714

HOCC. ROBERT $V$. ON MODELS AND HYPOTHESES WITH RESTRICTED ALTERNATIVES, JASA 65, 1153

HOGG, ROBERT $V$. ON THE INDEPENDENCE OF CERTAIN WISHART VARIABLES AMS 63,935

HOGG, ROBERT $V$, ON THE RESOLUTION OF STATISTICAL HYPOTHESES, JASA $61,97 B$

HOGG, ROBERT $V$ SOME OBSERVATIONS ON ROBUST ESTIMATION, JASA 67. 1179

HOLEWIJN, $P, J$. NOTE ON WEYL'S CRITERION AND THE UNIFORM DISTRIBUTION OF INDEPENDENT RANDOM VARIABLES, AMS 69, 1124

HOLGATE. P. BIVARIATE GENERALIZATIONS OF NEYMAN'S TYPE A DISTRIBUTION, BIOKA 66, 241

HOLCATE, $P$. CONTRIBUTIONS TO THE MATHEMATICS OF ANIMAL TRAPPING, BIOCS 66.925

HOLGATE. P. ESTIMATION FOR THE BIVARIATE POISSON DISTRIBUTION. B IOKA 64.241

HOLGATE, P. FITTING A STRAIGHT LINE TO DATA FROM A TRUNCATED POPULATION. BIOCS 65,715

HOLGATE, P. MAJORANTS OF THE CHROMATIC NUMBER OF A RANDOM GRAPH. JRSSB 69 , NO.2

HOLGATE. P. SPECIES FREQUENCY DISTRIBUTIONS, BIOKA 69, NO 3

HOLGATE, $P$ TESTS OF RANDOMNESS BASED ON DISTANCE METHODS, BIOKA 65,345

HOLCATE, P. THE ANCLE-COUNT METHOD, BIOKA 67,615

HOLGATE. P. THE DISTANCE FROM A RANDOM POINT TO THE NEAREST POINT OF A CLOSELY PACKED LATTICE., BIOKA 65. 261

HOLLA, M. S. ON A DISCRETE DISTRIBUTION WITH SPECIAL REFERENCE TO THE THEORY OF ACCIDENT PRONENESS, JASA 65,1060

HOLLA, M. S. RELIABILITY ESTIMATION OF THE TRUNCATED EXPONENTIAL MODEL, TECH 67,332

HOLLAND, D. A. SAMPLING ERRORS IN AN ORCHARD SURVEY INVOLVINC UNEQUAL NUMBERS OF ORCHARDS OF DISTINCT TYP. BIOCS 65,55

HOLLAND, PAUL $W$ SOME PROPERT IES OF AN ALGEBRAIC REPRESENTATION OF STOCHASTIC PROCESSES. AMS 68,164

HOLLAND, PAUL W. THE DISTRIBUTION OF GALTON'S STATISTICS, AMS 68 , 2114

HOLLANDER, MYLES AN ASYMPTOTICALLY DISTRIBUTION-FREE MULTIPLE COMPARISON PROCEDURE, TREATMENT VERSUS CONT, AMS 66,735

HOLLANDER, MYLES ASYMPTOTIC EFFICIENCY OF TWO NONPARAMETRIC COMPETITORS OF WILCOXON'S TWO SAMPLE TEST, JASA 67,939

HOLLANDER, MYLES CERTAIN UNCORRELATED NONPARAMETRIC TEST STATISTICS. JASA 68, 707

HOLLANDER, MYLES RANK TESTS FOR RANDOMIZED BLOCKS WHEN THE ALTERNATIVES HAVE AN 'A PRIORI' ORDERINC, AMS 67, 867

HOLLOWAY JR, CLARK A SYSTEMATIC METHOD OF FINDING DEFINING CONTRASTS, JASA 57,46

HOLLOWAY. LOIS N THE ROBUSTNESS OF HOTELLING'S T-SQUARE, JASA 67 124

HOLMS, A G. CHAIN-POOLING ANALYSIS OF VARIANCE FOR TWO-LEVEL FAC TORIAL REPLICATION-FREE EXPERIMENTS, TECH 69, NO 4

HONIGFELD, G. A COMPARISON OF SUCCESSIVE SCREENING AND DISCRIMINANT FUNCTION TECHNIQUES IN MEDICAL TAXONO, BIOCS 69, NO. 4

HOOKE, ROBERT USE OF RANDOMIZATION IN THE INVESTICATION OF UNKNOWN FUNCTIONS, JASA 5B, 176

HOOPEN, M. TEN ON MEASURES OF CORRELATION IN TIME SERIES OF EVENTS, BIOCS 69,73

HOOPER, J. W. THE SAMPLING VARIANCE OF CORRELATION COEFFICIENTS UNDER ASSUMPTIONS OF FIXED AND MIXED VARI, BIOKA 5B, 471

HOPE, ADERY C. A. A SIMPLIFIED MONTE CARLO SICNIFICANCE TEST PROCEDURE, JRSSB 68, 582

HOPKINS, J. W. SOME CONSIDERATIONS IN MULTIVARIATE ALLOMETRY, BIOCS 66,747

HOPKINS, J. W. SOME EMPIRICAL DISTRIBUTIONS OF BIVARIATE T-SQUARE AND HOMOSCEDASTICITY CRITERION M UNDER, JASA 63,104B

HOPPER, F. N. ESTIMAT ING THE DECREES OF FREEDOM FOR LINEAR COMBINATIONS OF MEAN SQUARES BY SATTERTHWAITHE, TECH 69, NO 4

HORA, R, B. FIDUCIAL THEORY AND INVARIANT ESTIMATION, AMS 66, 643

HORA, R. B, FIDUCIAL THEORY AND INVARIANT PREDICTION, AMS 67, 795

HORNER, T. W. MATHEMATICAL REPRESENTATION OF THE BIOLOGICAL AND PHYSICAL DECAY OF CHAMBER AEROSOLS, BIOCS 65, 551

HOROWITZ, IRA THE VARYINC QUALITY OF INVESTMENT TRUST MANAGEMENT, JASA 63, 1011

HORSNELL, G. DISCUSSION OF THE PAPERS OF MESSRS, HALD, WETHERILL AND COX. TECH 60,361
HORSNELL, C. THE EFFECT OF UNEQUAL GROUP VARIANCES ON THE F-TEST FOR THE HOMOCENE ITY OF GROUP MEANS, BIOKA 53, 12B

HORTON, I. F MULTIVARIATE-COVARI ANCE AND CANONICAL ANALYSIS, A METHOD FOR SELECT ING THE MOST EFFECTIVE D, BIOCS $6 B, 845$

HORVITZ, DANIEL G. A MULTI-PROPORTIONS RANDOMIZED RESPONSE MODEL. JASA 67,990

HORVITZ, DANIEL C. THE UNRELATED QUESTION RANDOMIZED RESPONSE MODEL, THEORETICAL FRAMEWORK, JASA 69,520

HOU, TEIN-FANG WEAK APPROACHABILITY IN A TWO-PERSON CAME, AMS 69 $7 B 9$

HOUCK, JAMES P. SOME ESTIMATORS FOR A LINEAR MODEL WITH RANDOM COEFFICIENTS, JASA $68,5 B 4$

HOUSTON, TOM R. SEQUENTIAL COUNTERBALANCINC IN LATIN SQUARES, AMS 66.741

HOWE, R. B. ON THE PERCENTAGE POINTS OF THE SAMPLE COEFFICIENT OF VARIATION, BIOKA 6B, 580

HOWE, W. G. TWO-SIDED TOLERANCE LIMITS FOR NORMAL POPULATIONS, SOME IMPROVEMENTS, JASA 69, 610

HOWIE, A . J . THE EFFICIENCY OF AUTOMAT IC WINDING MACHINES WITH CONSTANT PATROLLING TIME, JRSSB 59, 3 BI

HOYLAND, ARNLJOT ROBUSTNESS OF THE HODGES-LEHMANN ESTIMATES FOR SHIFT, AMS 65, 174

HOYLAND. ARNLJOT ROBUSTNESS OF THE WILCOXON ESTIMATE OF LOCATION AGAINST A CERTAIN DEPENDENCE, AMS 6B, 1196

HOYLE, M. H. THE ESTIMATION OF VARIANCES AFTER USING A GAUSSIANATING TRANSFORMATION, AMS 68, 1125

HSI, BARTHOLOMEW P. OPTIMIZATION OF QUALITY CONTROL IN THE CHEMICAL LABORATORY, TECH 66,519

HSU, P. CORRICENDA, 'ON THE POWER FUNCTION OF THE EXACT TEST FOR THE 2-BY-2 CONT INGENCY TABLE', BIOKA 61,475

HSU, P. ON THE POWER FUNCTION OF THE EXACT TEST FOR THE 2-BY-2 CONT INGENCY TABLE, BIOKA 60,393

HUANG, DAVID $S$. INITIAL STOCK AND CONSUMER INVESTMENT IN AUTOMOBILES, JASA $63,7 B 9$

HUBER, PETER PAIRWISE COMPARISON AND RANKING IN TOURNAMENTS, AMS 63,501

HUBER, PETER J. A REMARK ON A PAPER OF TRAWINSKI AND DAVID ENTITLED 'SELECTION OF THE BEST TREATMENT IN A, AMS 63, 92

HUBER, PETER J, A ROBUST VERSION OF THE PROBABILITY RATIO TEST, AMS 65,1753

HUBER, PETER J, PAIRWISE COMPARISON AND RANKING, OPTIMUM PROPERTIES OF THE ROW SUM PROCEDURE, AMS 63, 511

HUBER, PETER J. ROBUST ESTIMATION OF A LOCATION PARAMETER, AMS 64 , 73

HUDSON JR, J. D. A MONTE CARLO INVESTIGATION OF THE SIZE AND POWER OF TESTS EMPLOYING SATTERTHWAITE' S SYN, BIOKA 68, 431

HUDSON, D. J . LEAST-SQUARES FITTING OF A POLYNOMIAL CONSTRAINED TO BE EITHER NON-NEGATIVE, NON-DECREASING, JRSSB 69, 113

HUDSON, DEREK J. FITTINC SECMENTED CURVES WHOSE JOIN POINTS HAVE TO BE ESTIMATED, JASA 66, 1097

HUFF, BARTHEL $W$. THE LOOSE SUBORDINATION OF DIFFERENTIAL PROCESSES TO BROWNIAN MOTION, AMS 69, 1603

HUGHES, H. M. THE NEGATIVE EXPONENTIAL WITH CUMULAT IVE ERROR, BIOCS 68,363

HUGHES, J.R. T, THE FIRST 1,945 BRITISH STEAMSHIPS, JASA 58,360

HUCHES, L. P. MAXIMUM LIKELIHOOD ESTIMATION OF THE P ARAMETERS OF THE BETA DISTRIBUT ION FROM SMALLEST ORDE, TECH 67, 607

HUI, $Y$ LIMITINC DISTRIBUTIONS ASSOCIATED WITH CERTAIN STOCHASTIC LEARNINC MODELS, AMS 62, 12B1

HUITSON, A. A METHOD OF ASSIGNING CONFIDENCE LIMITS TO LINEAR COMBINATIONS OF VARIANCES, BIOKA 55,471

HUITSON, A. FURTHER CRITICAL VALUES FOR THE SUM OF TWO VARIANCES, BIOKA 5B, 279

HULL, NORMA C. AN APPROXIMATION TO TWO-SIDED TOLERANCE LIMITS FOR NORMAL POPULATIONS, TECH 66,115

HULTQUIST, R. A. A BIVARIATE WARNING-TIME, FAILURE-TIME DISTRIBUTION, JASA 67,589

HULTQUIST, ROBERT A. CONSTRUCTION OF CONFOUNDING PLANS FOR MIXED FACTORI AL DESIGNS, AMS 65, 1256

HULTQUIST, ROBERT A. MINIMAL SUFFICIENT STATISTICS FOR THE TWO-WAY CLASSIF ICATION MIXED MODEL DESIGN, JASA $65,1 B 2$

HULTQUIST, ROBERT A. THEOREMS CONCERNINC EISENHART 'S MODEL II, AMS 61,261

HUME, M. W. CORRELATION IN A SINGLY TRUNCATED BIVARIATE NORMAL DISTRIBUTION. II. RANK CORRELATION, BIOKA 65, 639

HUME, M. W. CORRELATION IN A SINGLY TRUNCATED BIVARIATE NORMAL DISTRIBUTION. III. CORRELATION BETWEEN RAN, BIOKA 66, $27 \mathrm{~B}$

HUME, M.W. CORRELATION IN A SINCLY TRUNCATED BIVARIATE NORMAL DISTRIBUTION IV, EMPIRICAL VARIANCES OF RA, BIOKA 68,437

HUNTER, J . S. A CONFIDENCE REGION FOR THE SOLUTION OF A SET OF SIMULTANEOUS EQUATIONS WITH AN APPLICATION, BIOKA 54, 190

HUNTER, J. S. CONDENSED CALCULATIONS FOR EVOLUTIONARY OPERATION PROGRAMS, TECH 59, 77

HUNTER, J, S. DISCUSSION OF THE PAPERS OF MESSRS, SATTERTHWA ITE AND BUDNE, TECH 59,157

HUNTER, J. S, ERRATA, 'SEQUENTIAL FACTORIAL ESTIMATION', TECH 65 , 93 
HUNTER, J. S. ERRATA. 'THE 2-TO-THE-(K-P) FACTIONAL FACTORIAL DESIGNS', TECH 63,417

HUNTER, J S . SEQUENTIAL FACTORIAL ESTIMATION, TECH 64, 41

HUNTER, J S S THE INVERSE YATES ALGORITHM. TECH 66, 177

HUNTER. J. S. THE 2-TO-THE-,(K-P) FRACTIONAL FACTORIAL DESIGNS TECH 61.311

HUNTER, J. S. THE 2-TO-THE-(K-P) FRACTIONAL FACTORIAL DESIGNS TECH 61, 449

HUNTER, L. C. SYSTEM EFFICIENCY AND RELIABILITY, TECH 60,43

HUNTER, T. G. DESIGN OF EXPER IMENTS FOR PARAMETER ESTIMATION IN MULTIRESPONSE SITUATIONS. BIOKA 66,525

HUNTER, W. G. THE USE OF PRIOR DISTRIBUT IONS IN THE DESIGN OF EXPERIMENTS FOR PARAMETER EST IMAT ION IN NON, BIOKA 67, 147

HUNTER, W. G. THE USE OF PRIOR DISTR IBUT IONS IN THE DES IGN OF EXPERIMENTS FOR PARAMETER EST IMATION IN NON, BIOKA 67, 662

HUNTER, W. G. TRANSFORMATIONS, SOME EXAMPLES REVISITED, TECH 69, 23

HUNTER, HILLIAM G. A JOINT DESIGN CRITERION FOR THE DUAL PROBLEM OF MODEL DISCRIMINATION AND PARAMETER ES, TECH 68, 145

HUNTER, WILLIAM G. A NOTE ON DESIGNS FOR MODEL DISCRIMINATION, VARIANCE UNKNOWN CASE, TECH 69, 396

HUNTER, WILLIAM G. A REVIEX OF RESPONSE SURFACE METHODOLOGY. A LITERATURE SURVEY, TECH 66. 571

HUNTER, WILLIAM G. A USEFUL METHOD FOR MODEL BUILDING, TECH 62,301

HUNTER, RILLIAM G. DESIGNS FOR DISCRIMINATING BETKEEN TWO RIVAL MODELS, TECH 65,307

HUNTER, WILLIAM G. EVOLUTIONARY OPERATION. A REVIEW, TECH 66,389

HUNTER, TILLIAMG. THE DESIGN OF EXPER IMENTS FOR PARAMETER ESTIMA-

TION, TECH 68,27

HUNTER, WILLIAM G. THE EXPERIMENTAL STUDY OF PHYSICAL MECHANISMS, TECH 65,23

HUNTER, WILLIAMG, WHICH PRODUCT IS BETTER, TECH 69,309

HUNTSBERGER, D. V. ESTIMATION OF A MEAN MHEN ONE OBSERVATION MAY BE SPURIOUS, TECH 69, 331

HURST, D. C. A PROBABILITY STRUCTURE FOR GRONTH CURVES, BIOCS 67 217

HURST, D. C. LARGE SAMPLE SIMULTANEOUS CONFIDENCE INTERVALS FOR MULT INOMIAL PROPORTIONS. TECH 64,191

HURWITZ, ABNER CONSTANTS AND COMPROMISE IN THE CONSUMER PRICE INDEX. JASA 62,813

HUSSIAN, A. A MIXED MODEL OF REGRESSIONS, BIOKA 69, 327

HUTCHINSON, D. $W$. TABLE OF NEYMAN-SHORTEST UNBIASED CONFIDENCE INTERVALS FOR THE BINOMIAL PARAMETER, BIOKA 60, 3BI

HUTCHINSON, D. $W$, TABLES OF NEYMAN-SHORTEST UNBIASED CONFIDENCE INTERVALS FOR THE POISSON PARAMETER, BIOKA 61, 191

HUTCHINSON, E, P, NOTES ON IMMIGRATION STATISTICS OF THE UNITED STATES, JASA 58,963

HUTTLY. N. A. THE FITTING OF REGRESSION CURVES WITH AUTOCORRELATED DATA, BIOKA 56,468

HUYETT, $M$. J. CORRIGENDA. 'ESTIMATION OF PARAMETERS OF THE GAMMA DISTRIBUTION USING ORDER STATISTICS. ' , BIOKA 63, 546

HUYETT. MARILYN J. ESTIMATION OF PARAMETERS OF THE GAMMA DISTRIBUTION USING ORDER STATISTICS, BIOKA 62, 525

HUYETT, MARILYN J. SEPARATE MAXIMUM-LIKELIHOOD EST IMATION OF SCALE OR SHAPE PARAMETERS OF THE GAMMA DISTR, BIOKA 63,217

HUYETT, MISS $M$. J . PROBABILITY PLOTS FOR THE GAMMA DISTRIBUTION, TECH 62,1

HUZURBAZAR, V. S. CONFIDENCE INTERVALS FOR THE PARAMETER OF A DISTRIBUTION ADMITT ING A SUFF ICIENT STATIST, JRSSB 55, 86

HUZURBAZAR, V. S. EXACT FORMS OF SOME INVAR IANTS FOR DISTRIBUTIONS ADMITTING SUFFICIENT STATISTICS, BIOKA 55, 533

HYRENIUS, HANNES SAMPLING FROM BIVARIATE NON-NORMAL UNIVERSES BY MEANS OF COMPOUND NORMAL DISTR IBUTIONS, BIOKA 52,238

IFRAM, ADNAN ON THE ASYMPTOTIC BEHAVIOR OF DENSITIES KITH APPLICATIONS TO SEQUENTIAL ANALYSIS, AMS 65, 615

IFRAM, ADNAN F. HYPERGEOMETRIC FUNCTIONS IN SEQUENTIAL ANALYSIS, AMS 65, $1 B 70$

IFRAM, ADNAN F. ON THE SAMPLE SIZE AND SIMPLIFICATION OF A CLASS OF SEQUENT IAL PROBAB ILITY RATIO TESTS, AMS 66, 425

IGLEHART, DONALD L. LIMIT THEOREMS FOR QUEUES WITH TRAFFIC INTENSITY ONE, AMS 65,1437

IGLEHART, DONALD L. LIMIT THEOREMS FOR THE MULTI-URN EHREFEST MODEL, AMS $68, \mathrm{~B} 64$

IGLEHART, DONALD L. WEAK CONVERGENCE OF A SEQUENCE OF QUICKEST DETECTION PROBLEMS, AMS 68, 2149

IGLEWICZ, B. ON THE PERCENTAGE POINTS OF THE SAMPLE COEFFICIENT OF VARIATION, BIOKA 68,580

IMHOF, J. P. COMPUTING THE DISTR IBUT ION OF QUADRATIC FORMS IN NORMAL VARIABLES, BIOKA 61,419

IMHOF, J. P. CORRIGENDA, 'COMPUTING THE DISTRIBUTION OF QUADRATIC FORMS IN NORMAL VARIABLES', BIOKA $62,2 \mathrm{~B} 4$

IMHOF, J. P. SOME INVARIANT LAWS RELATED TO THE ARC SINE LAW. AMS 68 258

IMHOF, J.P. TESTING THE HYPOTHESIS OF NO FIXED MAIN-EFFECTS IN SCHEFFE ' S MIXED MODEL, AMS 62, 1085

INGLEHART, DONALD L. MULTIVARIATE COMPETITION PROCESSES, AMS 64. 350

INGRAM. J. JACK CONTROL OF QUALITY OF CODING IN THE 1960 CENSUSES. JASA 64,120
IOSIFESCU, MARIUS SAMPLING ENTROPY FOR RANDOM HOMOGENEOUS SYSTEMS WITH COMPLETE CONNECTIONS ,CORR. 69 NO . AMS 65. 1433

IRELAND , C. T . CONTINGENCY TABLES WITH GIVEN MARGINALS, BIOKA 68 179

IRELAND. C. T. NOTES. MINIMUM DISCRIMINATION INFORMATION ESTIMA TION, BIOCS 68.707

IRELAND, C. T. SYMMETRY AND MARGINAL HOMOGENEITY OF AN R-BY-R CONTINGENCY TABLE. JASA 69 . NO. 4

IRWIN, J. O. A DISTR IBUTION ARISING IN THE STUDY OF INFECTIOUS DISEASES, BIOKA 54, 266

ISAAC, RICHARD A GENERAL VERS ION OF DOEBLIN'S CONDITION, AMS 63,668 ISAAC, RICHARD A UNIQUENESS THEOREM FOR STATIONARY MEASURES OF ERGODIC MARKOV PROCESSES, AMS 64, 1781

ISAAC, RICHARD NON-SINGULAR RECURRENT MARKOV PROCESSES HAVE STATIONARY MEASURES. AMS 64.869

ISAAC. RICHARD ON STATIONARY MARKOV PROCESSES, AMS 67,588

ISAACSON, DEAN NOTE ON THE THREE SERIES THEOREM, AMS 69, 1844

ISAACSON, DEAN STOCHASTIC INTEGRALS AND DERIVATIVES, AMS 69, 1610

ISHII. G. CORRIGENDA, 'TEST OF INDEPENDENCE IN INTRACLASS 2-BY-2 TABLES' , BIOKA 61,476

ISHII, G. TESTS OF INDEPENDENCE IN INTRACLASS 2-BY-2 TABLES, BIOKA 61,181

ISHII. GORO THE RELATIONSHIP ALGEBRA AND THE ANALYSIS OF VAR IANCE OF A PARTIALLY BALANCED INCOMPLETE BLOC, AMS 65, IBI5

ITO, KOICHI A COMPARISON OF THE POWERS OF TWO MULTIVARIATE ANALYSIS OF VARIANCE TESTS. BIOKA 62.455

ITO. KOICHI CORRIGENDA, 'A COMPARISON OF THE POWERS OF TWO MULTIVARIATE ANALYSIS OF VARIANCE TESTS, ' , BIOKA 63, 546

ITO, KOICHI ON THE ROBUSTNESS OF THE T-SQUARE-SUB-O TEST IN MUL TIVARIATE ANALYSIS OF VARIANCE WHEN VARIAN, BIOKA 64,7I

IYER, P. V. KRISHNA PROBABILITY DISTRIBUTIONS ARISING FROM POINTS ON A LINE, BIOKA 54,553

JACKSON, ESTHER C. MISSING VALUES IN LINEAR MULTIPLE DISCRIMINANT ANALYSIS, BIOCS 68.835

JACKSON, J. E. QUERY, RESIDUAL ANALYSIS, TECH 67, 339

JACKSON, J. E. SEQUENTIAL CHI-SQUARE AND T-SQUARE TESTS AND THEIR APPLICATION TO AN ACCEPTANCE SAMPLING P. TECH 61.519

JACKSON, J. EDWARD AN APPLICATION OF MULTIVARIATE QUALITY CONTROL TO PHOTOGRAPHIC PROCESSING, JASA 57,186

JACKSON, J. EDWARD BIBLIOGRAPHY ON SEQUENTIAL ANALYSIS, JASA 60 561

JACKSON, J. EDWARD COMMENTS ON PAPER BY KURTZ, LINK. TUKEY AND WALLACE, TECH 65,163

JACKSON. J. EDTARD COMPARISON OF ANOVA AND HARMONIC COMPONENTS OF VARIANCE. TECH 69,75

JACKSON, J, EDWARD QUALITY CONTROL METHODS FOR SEVERAL RELATED VARIABLES, TECH 59, 359

JACKSON, J . EDWARD SEQUENTIAL CHI-SQUARED AND T-SQUARED TESTS, AMS 61,1063

JACKSON, J. EDWARD THE SPECTRUM OF A MODEL II NESTED ANOVA AND ITS APPLICATIONS. TECH 69.91

JACKSON, J. T.R. A DYNAMIC PROGRAMMING APPLICATION IN PRODUCTION LINE INSPECTION, TECH 67,73

JACKSON, O. A. Y. AN ANALYSIS OF DEPARTURES FROM THE EXPONENTIAL DISTRIBUTION, JRSSB 67,540

JACKSON, O.A. Y. SOME RESULTS ON TESTS OF SEPARATE FAMILIES OF HYPOTHESES, BIOKA 68,355

JACKSON, R. R, P RANDOM QUEUEING PROCESSES NITH PHASE-TYPE SERVICE. JRSSB 56,129

JACKSON, R. R. P. SOME EQUILIBRIUM RESULTS FOR THE QUEUEING PROCESS E-SUB-K-M-1, JRSSB 56, 275

JACOBSON, HAROLD I. THE MAXIMUM VARIANCE OF RESTRICTED UNIMODAL DISTRIBUTIONS, AMS 69, 1746

JACOBSON, JAMES E. THE WILCOXON TWO-SAMPLE STATISTIC, TABLES AND BIBLIOGRAPHY, JASA $63,10 B 6$

JACQUEZ. J. A. LINEAR REGRESSION WITH NON-CONSTANT, UNKNOWN ERROR VARIANCES, SAMPLING EXPERIMENTS WITH LE, BIOCS 68,607

JAECH, J, L. A NOTE ON THE EQUIVALENCE OF TWO METHODS OF FITTING A STRA IGHT LINE THROUGH CUMULAT IVE DATA, JASA 64,863

JAECH, J. L. A PROGRAM TO ESTIMATE MEASUREMENT ERROR IN NONDESTRUCTIVE EVALUATION OF REACTOR FUEL ELEMENT, TECH 64, 293

JAECH, J . L. ESTIMATION OF PARTICLE SIZE DISTRIBUTION BASED ON OBSERVED WEIGHTS OF GROUPS OF PART ICLES, TECH 65, 505

JAECH, J. L. ESTIMATION OF WEIBULL DISTRIBUTION SHAPE PARAMETER THEN NO MORE THAN TWO FAILURES OCCUR PER, TECH 64,415

JAECH, J. L. INTERFERENCE IN THE MANUFACTURE OF NUCLEPORE FTLTERS, TECH 67,319

JAEGER, CAROL M. AN ANALYSIS OF CONSISTENCY OF RESPONSE IN HOUSEHOLD SURVEYS, JASA 61,320

JAEGER, CAROL M. ESTIMATING THE SERVICE LIFE OF HOUSEHOLD GOODS BY ACTUARIAL METHODS, CORR, 57578, JASA 57,175

JAGERMAN, DAVID L, THE AUTOCORRELATION FUNCTION OF A SEQUENCE UNIFORMLY DISTRIBUTED MODULO 1, AMS 63, 1243

JAGERS. P. INTEGRALS OF BRANCHING PROCESSES, BIOKA 67, 263

JAIN. A. K. A STATISTICAL MODEL OF BOOK USE AND ITS APPLICATION TO THE BOOK STORAGE PROBLEM, JASA 69, NO, 4

JAIN, N. C. A NOTE ON INVARIANT MEASURES, AMS 66, 729

JAIN, NARESH C. THE STRONG RATIO LIMIT PROPERTY FOR SOME GENERAL MARKOV PROCESSES, AMS 69, 986 
JAIN, S. C. AN ALGORITHM FOR THE DETERMINATION OF THE ECONOMIC DESIGN OF X-CHARTS BASED ON DUNCAN'S MODEL, JASA 68,304

JAISWAL, M. C. ESTIMATION OF PARAMETERS OF A TRUNCATED BIVARIATE NORMAL DISTRIBUTION, JASA 63,519

JAISWAL, N. K. A BULK-SERVICE QUEUEING PROBLEM WITH VARIABLE CAPACITY, JRSSB 61,143

JAISWAL, $N$. K. TIME-DEPENDENT SOLUTION OF THE 'HEAD-OF-THE-LINE' PRIORITY QUEUE, JRSSB 62,91

JAMES, A. T. CALCULATION OF ZONAL POLYNOMIAL COEFFICIENTS BY THE USE OF THE LAPLACE-BELTRAMI OPERATOR, AMS 68, 1711

JAMES, A. T, FITTING THE RECTANGULAR HYPERBOLA, BIOCS 66. 573

JAMES, ALAN T. DISTRIBUTIONS OF MATRIX VARIATES AND LATENT ROOTS DER I VED FROM NORMAL SAMPLES, AMS 64, 475

JAMES, ALAN T. THE DISTRIBUTION OF NONCENTRAL MEANS WITH KINOWN COVARIANCE, AMS 61, B74

JAMES. G. S. CUMULANTS OF A TRANSFORMED VAR IATE, BIOKA 55, 529

JAMES, G. S. FURTHER CRITICAL VALUES FOR THE TWO-MEANS PROBLEM, 8IOKA 56, 203

JAMES, G. S. ON THE ACCURACY OF WEIGHTED MEANS AND RATIOS, BIOKA 56. 304

JAMES, G. S. TESTS OF LINEAR HYPOTHESES IN UNIVARIATE AND MULTIVARIATE ANALYSIS WHEN THE RATIOS OF THE PO. BIOKA 54, 19

JAMES, C. S. THE BEHRENS-FISHER DISTRIBUTION AND WEIGHTED MEANS JRSSB 59,73

JAMES, G. S. THE COMPARISON OF SEVERAL GROUPS OF OBSERVATIONS WHEN THE RAT IOS OF' THE POPULAT ION VAR IANCES, BIOKA 51, 324

JAMES, J. W. INDEX SELECTION WITHRESTRICTIONS, BIOCS 68, 1015

JAMISON, BENTON AN OPTIMAL STOPPING THEOREM. AMS 69,677

JARDINE, R, RANKINC METHODS AND THE MEASUREMENT OF ATTITUDES, JASA 58. 720

JARRATT, P USE OF DOUBLE SAMPLING FOR SELECTING BEST POPULATION, 8IOKA 64,49

JASPEN, NATHAN MACHINE COMPUTATION OF HIGHER MOMENTS, JASA 56, 489

JAYACHANDRAN, $K$. POWER COMPARISIONS OF TESTS OF EQUALITY OF TWO COVAR I ANCE MATRICES BASED ON FOUR CRITERI, BIOKA 68,335

JAYACHANDRAN, $K$. POWER COMPARISONS OF TESTS OF TWO MULTIVARIATE HYPOTHESES BASED ON FOUR CRITERIA, BIOKA 67,195

JAYACHANDRAN, TOKE A STUDY OF ROBUST ESTIMATORS, TECH 67,652

JAYAKAR, S. D. THE DISTRIBUTION OF EXTREMAL AND NEARLY EXTREMAL VALUES IN SAMPLES FROM A NORMAL DISTR IBUT, BIOKA 63, B9

JEBE, EMIL H. A NOTE ON THE GAIN IN PRECISION FOR OPTIMAL ALLOCATION IN RECRESSION AS APPLIED TO EXTRAPOL, TECH 69, 389

JEFFERS, J. N. R. ESTIMATION OF MEANS AND STANDPRD ERRORS IN THE ANALYSIS OF NON-ORTHOGONAL EXPERIMENTS B, JRSSB 62, 435

JENKINS, G. M. AN ANGULAR TRANSFORMATION FOR THE SER IAL CORRELATION COEFFICIENT, BIOKA 54,261

JENKINS. G. M. AN EXAMPLE OF THE ESTIMATION OF LINEAR OPEN LOOP TRANSFER FUNCTION, TECH 63,227

JENKINS. G. M. COMMENTS ON THE DISCUSSIONS OF MESSRS. TUKEY AND GOODMAN, TECH 61,229

JENKINS, G. M. GENERAL CONSIDERATIONS IN THE ANALYSIS OF SPECTRA TECH 61,133

JENKINS, C. M. SOME STATISTICAL ASPECTS OF ADAPTIVE OPTIMIZATION AND CONTROL (WITH DISCUSSION), JRSSB 62,297

JENKINS, G. M. TESTS OF HYPOTHESES IN THE LINEAR AUTO-REGRESSIVE MODEL . II . NULL DISTR IBUTIONS FOR HIGHER, BIOKA 56, 186

JENKINS, G.M. TESTS OF HYPOTHESES IN THE LINEAR AUTOREGRESSIVE MODEL. PART I., BIOKA 54, 405

JENKINS, G.M THE ESTIMATION OF SLOPE WHEN THE ERRORS ARE AUTOCORRELATED, JRSSB 62, 199

JENKINS, G. M THE SPECTRAL ANALYSIS OF TIME SERIES (WITH DISCUSSION), JRSSB 57,1

JENKINS, J. H. ON THE CORRELATION STRUCTURE OF THE DEPARTURE PROCESS OF THE QUEUE WITH ONE SERVER, WHILE, JRSSB 66, 336

JENKINS, M. A. AN APPROXIMATION FOR STUDENT'S T-DISTRIBUTION, BIOKA 68,571

JENNRICH, ROBERT I. AN APPLICATION OF STEPWISE REGRESSION TO NONLINEAR ESTIMATION, TECH 68, 63

JENNRICH, ROBERT I. ASYMPTOTIC PROPERTIES OF NON-LINEAR LEAST SQUARES ESTIMATORS, AMS 69,633

ENSEN, DONALD R AN INEQUALTTY FOR A CLASS OF BIVAR TATE CHI-SQUARE DISTRIBUTIONS, JASA 69,333

JENSEN, DONALD R. SIMULTANEOUS CONFIDENCE INTERVALS FOR VARIANCES JASA 69,324

JENSEN, E L PROBABILITY OF OBTAINING NEGATIVE ESTIMATES OF HERITABILITY, BIOCS 68,517

JESSEN, R. J. DESICN AND ESTIMATION IN TWO-WAY STRATIFICATION, JASA 60. 105

JESSEN, RAYMOND J. SOME METHODS OF PROBABILITY NON-REPLACEMENT SAMPLING, JASA 69,175

JINDAL, K. K. ONMODIFIED SYSTEMAT IC SAMPLING, BIOKA 6B, 541

JOFFE, A CONVERGENCE THEOREMS FOR MULTIPLE CHANNEL LOSS PROBABILITIES, AMS 63, 260

JOFFE. A. NULL DISTRIBUTION AND BAHADUR EFFICIENCY OF THE HODGES BIVARIATE SIGN TEST, AMS 62, 803

JOFFE. A. ON THE GALTON-WATSON BRANCHING PROCESS WITHMEAN LESS THAN ONE, AMS 67,264
JOFFE, A. D A CHART FOR SEQUENTIALLY TESTING OBSERVED AR ITHMET IC MEANS FROM LOGNORMAL POPULATIONS AGA INS, TECH 6B, 605

JOFFE. A. D. MINIMUM CHI-SQUARED ESTIMATION USING INDEPENDENT STATISTICS, AMS 67,267

JOGDEO, K. BOUNDS ONMOMENTS OFMARTINGALES, AMS 68, 1719

JOGDEO, KUMAR ASYMPTOTIC NORMALITY IN NONPARAMETRIC METHODS, AMS 68,905

JOGDEO, KUMAR BOUNDS ON MOMENTS OF SUMS OF RANDOM VAR IABLES. AMS 69 1506

JOGDEO, KUMAR CHARACTERIZATIONS OF INDEPENDENCE IN CERTAIN FAMILIES OF BIVARIATE AND MULTIVARIATE DISTRIB, AMS 6B, 433

JOGDEO, KUMAR MONOTONE CONVERGENCE OF BINOMIAL PROBABILITIES WITH AN APPLICATION TO MAX IMUM LIKELIHOOD ES, AMS 67, 15B3

JOGDEO, KUMAR MONOTONE CONVERCENCE OF BINOMIAL PROBABILITIES AND A GENERALIZATION OF RAMANUJAN'S EQUATION, AMS 6B, 1191

JOGDEO . KUMAR ON RANDOMIZED RANK SCORE PROCEDURE OF BELL AND DOKSUM . AMS 66, 1697

JOHANSEN, S. ON THE SEM IMARTINGALE CONVERGENCE THEOREM, AMS 66,690

JOHN, J. A. A NOTE ON THE ANALYSIS OF INCOMPLETE BLOCK EXPERIMENTS

BIOKA 65.633

JOHN, J A. CYCLIC INCOMPLETE BLOCK DESIGNS, JRSSB 66, 345

JOHN, J.A. REDUCED GROUP DIVISIBLE PAIRED COMPARISON DESIGNS, AMS $67,1 B 87$

JOHN . P. W. M. AN EXTENSION OF THE TR IANGULAR ASSOCIATION SCHEME TO THREE ASSOCIATE CLASSES. JRSSB 66,361

JOHN, P. W. M. SOME NONORTHOGONAL FRACTIONS OF 2-TO-THE-N DESIGNS, JRSSB 69 , NO 2

JOHN, PETER W. M AN APPLICATION OF A BALANCED INCOMPLETE BLOCK DESICN, TECH 6I, 51

JOHN, PETER W M. AUGMENTING 2-TO-THE-(N-1) DESIGNS, TECH 66, 469

JOHN. PETER W $M$ BALANCED DESIGNS WITH UNEQUAL NUMBERS OF REPLICATES, AMS 64.897

JOHN, PETER W. M BLOCKING OF 3-TIMES-2-TO-THE- $(\mathrm{N}-\mathrm{K})$, TECH 64,371 JOHN, PETER W.M. ON IDENTITY RELATIONSHIPS FOR TWO TO THE POWER OF NR DESIGNS HAVING WORDS OF EQUAL LEN, AMS 66, 1842

JOHN. PETER W. M. ON OBTAINING BALANCED INCOMPLETE BLOCK DESICNS FROM PARTIALLY BALANCED ASSOCIATION SCHE. AMS 67, 61B

JOHN, PETER W. M. PSEUDO-INVERSES IN THE ANALYSIS OF VARIANCE, AMS 64,895

JOHN, S. A CENTRAL TOLERANCE REGION FOR THE MULT IVARIATE NORMAL DISTRIBUTION, JRSSB 6B, 599

JOHN, S. ERRORS INDISCR IMINATION, AMS 61, 1125

JOHN, S ON MULTIVARIATE RATIO AND PRODUCT ESTIMATORS, BIOKA 69 NO. 3

JOHN, S. ON THE EVALUATION OF PROBABILITIES OF CONVEX POLYHEDRA UNDER MULTIVARIATE NORMAL AND T-DISTRIBUT, JRSSB 66, 366

JOHN, S. ON THE EVALUATION OF THE PROBABILITY INTEGRAL OF THE MULTIVARIATE T DISTRIBUTION, BIOKA 6I, 409

JOHNS JR, $M$, V. AN EXACT ASYMPTOTICALLY EFFICIENT CONFIDENCE BOUND FOR RELIABILITY IN THE CASE OF THE WEI, TECH 66,135

JOHNS JR, M. V. AVERAGE RENEWAL LOSS RATES, AMS 63, 396

JOHNSON, ARTHUR F. QUERY, ANALYSIS OF FACTORIAL EXPERIMENT (PARTIALLY CONFOUNDED 2-CUBE), TECH 67, 490

JOHNSON. BRUCE MCK. THE ERGODICITY OF SERIES OF QUEUES WITH GENERAL PRIORITIES, AMS 65, 1664

JOHNSON, CHARLES HENRY A PROPERTY OF THE METHOD OF STEEPEST ASCENT, AMS 64,435

JOHNSON, ELLIS L. COMPUTATION AND STRUCTURE OF OPTIMAL RESET POLICIES, JASA 67,1462

JOHNSON, N. L. A M INIMAX-REGRET PROCEOURE FOR CHOOSING BETWEEN TWO POPULATIONS USING SEQUENTIAL SAMPLING, JRSSB 63, 297

JOHNSON, N L A NOTE ON THE MEAN DEVIATION OF THE BINOMIAL DISTRIBUTION, BIOKA 57,532

JOHNSON, N. L. A SIMPLE THEORETICAL APPROACH TO CUMULATIVE SUM CONTROL CHARTS, JASA 61,835

JOHNSON, N. L. AN APPROXIMATION TO THE MULTINOMIAL DISTRIBUTION SOME PROPERTIES AND APPLICATIONS, BIOKA 60,93

JOHNSON, N. L APPROXIMATIONS TO THE PROBABILITY INTEGRAL OF THE DISTRIBUTION OF RANGE, BIOKA 52,417

JOHNSON, N. L. COMPARISON OF ANALYSIS OF VARIANCE POWER FUNCTION IN THE PARAMETRIC AND RANDOM MODELS, BIOKA 52, 427

JOHNSON, N L CORRECTION TO 'A PROOF OF WALD'S THEOREM ON CUMULATIVE SUMS ' 59 1245. AMS 61,1344

JOHNSON, N, L CORRICENDA TO 'A NOTE ON THE MEAN DEVIATION OF THE BINOMIAL DISTRIBUTION', BIOKA 5B, 5B7

JOHNSON, $\mathrm{N}, \mathrm{L}$, CORRIGENDA, ITABLE OF PERCENTAGE POINTS OF PEARSON CURVES, FOR GIVEN ROOT (BETA-1) AND BETA, BIOKA 65, 669

JOHNSON, N. L. CUMULAT IVE SUM CHARTS FOR THE FOLDED NORMAL DISTR IBUTION, TECH 63,451

JOHNSON, N. L. CUMULATIVE SUM CONTROL CHARTS AND THE WEIBULL DISTRIBUTION, TECH $66,4 \mathrm{~B}$

JOHNSON, N, L. ESTIMATION OF SAMPLE SIZE, TECH 62, 59

JOHNSON, N. L. NOTE ON A UNIQUENESS RELATION IN CERTAIN ACCIDENT PRONENESSMODELS, JASA 67, 2B8

JOHNSON, N. L. ON AN EXTENSION OF THE CONNEXION BETWEEN POISSON AND CHI-SQUARE DISTRIBUTIONS, BIOKA 59, 352

JOHNSON, N. L . OPTIMAL SAMPLING FOR QUOTA FULFILMENT, BIOKA 57, 518 
JOHNSON, N, L, SAMPLING DISTRIBUTIONS OF VARIANCE COMPONENTS II. EMPIRICAL STUDIES OF UNBALANCED NESTED D, TECH 68, 719

JOHNSON, N. L. SEQUENT IALLY DETERMINED CONFIDENCE INTERVALS, 8IOKA 57,279

JOHNSON, N. L. SERIES REPRESENTATIONS OF DISTRIBUTIONS OF QUADRATIG FORMS IN NORMAL VARIABLES, I, CENTRAL, AMS 67, 823

JOHNSON, N. L. SERIES REPRESENTATIONS OF DISTRIBUTIONS OF QUADRATIC FORMS IN NORMAL VARI ABLES, II, NON-CE, AMS 67, B3B

JOHNSON, N. L. SOME APPLICATIONS OF TWO APPROXIMATIONS TO THE MULTINOMIAL DISTRIBUTION, BIOKA 60,463

JOHNSON, N. L. SOME TESTS OF SICNIFICANCE WITH ORDERED VARIABLES, JRSSB 56, 1

JOHNSON, N. L. STATISTICAL TREATMENT OF CENSORED DATA. PART I FUNDAMENTAL FORMULAE, BIOKA 54, 22B

JOHNSON, N. L. TABLE OF PERCENTAGE POINTS OF NON-CENTRAL CHI. BIOKA 69,255

JOHNSON, N. L. TABLE OF PERCENTACE POINTS OF PEARSON CURVES, FOR GIVEN ROOT (BETA-1) AND BETA-2 EXPRESSED, BIOKA 63,459

JOHNSON, N. L. TABLES TO FACILITATE FITTING S-SUB-U FREQUENCY CURVES. , BIOKA 65,547

JOHNSON, N. L. THE DISTRIBUTION OF THE COEFFICIENT OF VARIATION, COMMENT ON A CRITICISM MADE BY KOOPMANS, , BIOKA 65, 303

JOHNSON, N. L. THE EFFECT OF NON-NORMALITY ON THE POWER FUNCTION OF THE F-TEST IN THE ANALYSIS OF VARIANC, BIOKA 51,43

JOHNSON, N. L. THE FOLDED NORMAL DISTRIBUTION, III. ACCURACY OF EST IMATION BY MAXIMUM LI KELIHOOD, TECH 62,249

JOHNSON, N. L. THE MEAN DEVIATION, WITH SPECIAL REFERENCE TO SAMPLES FROM A PEARSON TY PE III POPULATION, BIOKA $58,47 \mathrm{~B}$

JOHNSON, N. L. THEORETICAL CONSIDERATIONS REGARDING H. R. B. HACK'S SYSTEM OF RANDOMIZATION FOR CROSS-CLA, BIOKA 5B, 265

JOHNSON, N. L. UNIQUENESS OF A RESULT IN THE THEORY OF ACCIDENT PRONENESS, BIOKA 57,530

JOHNSON, NORMAN L. PATHS AND CHAINS OF RANDOM STRAIGHT-LINE SEGMENTS, TECH 66, 303

JOHNSON, NORMAN L. QUERY, DISTRIBUTION OF A RANKED OBSERVATION, TECH 64, 329

JOHNSON, R. A. AN ASYMPTOTIC EXPANSION FOR POSTERIOR DISTRIBUTIONS, AMS 67,1899

JOHNSON, R. A. ASYMPTOTIC EXPANSIONS ASSOCIATED WITH THE N' TH POWER OF A DENSITY, AMS 67,1266

JOHNSON, $R$. A. ON HODCES'S BIVARIATE SICN TEST AND A TEST FOR UNIFORMITY OF A CIRCULAR DISTRIBUTION, BIOKA 69,446

JOHNSON, RICHARD A. APPROACH TO DEGENERACY AND THE EFFICIENCY OF SOME MULT IVARIATE TESTS, AMS 6B, 1654

JOHNSON, RICHARD A. ASYMPTOTICALLY MOST POWERFUL TESTS IN MARKOV PROCESSES, AMS 69, 1207

JOHNSON, RICHARD A. NONPARAMETRIG TESTS FOR SHIFT AT UNKNOWN TIME POINT, AMS 68,1731

JOHNSON, W. L. MOMENTS OF A SERIAL CORRELATION COEFFICIENT, JRSSB $65,30 B$

JOHNSTON, J. A REVISED TEST FOR SYSTEMATIC OSCILLATION, JRSSB 54 . 292

JOINER, BRIAN L. THE MEDIAN SIGNIFICANCE LEVEL AND OTHER SMALL SAMPLE MEASURES OF TEST EFFIGIENCY, JASA 69, 971

JOLICOEUR, $P$. INTERVAL ESTIMATION OF THE SLOPE OF THE MAJOR AXIS OF A BIVARIATE NORMAL DISTRIBUTION IN TH, 8IOCS 6B, 679

JOLLY, G. M. ESTIMATES OF POPULATION PARAMETERS FROM MULTIPLE RECAPTURE DATA WITH BOTH DEATH AND DILUTION, BIOKA 63, 113

JOLLY, G. M. EXPLICIT ESTIMATES FROM CAPTURE-RECAPTURE DATA WITH BOTH DEATH AND IMMIGRATION-ST OCHASTIC MO, BIOKA 65,225

JONCKHEERE, A. R. A DISTRIBUTION-FREE K-SAMPLE TEST AGAINST ORDERED ALTERNAT IVES, BIOKA 54,133

JONES. HOWARD L. HOW MANY OF A CROUP OF RANDOM NUMBERS WILL BE USABLE IN SELECTING A PARTICULAR SAMPLE, JASA 59, 102

JONES, HOWARD L. INADMISSIBLE SAMPLES AND CONFIDENCE LIMITS, JASA $5 B, 482$

JONES, HOWARD L. INVESTIGATINC THE PROPERTIES OF A SAMPLE MEAN BY EMPLOY ING RANDOM SUBSAMPLE MEANS, JASA 56,54

JONES, HOWARD L. THE ANALYSIS OF VARIANCE OF DATA FROM STRATIFIED SUBSAMPLES, JASA 68,64

JONES, LYLE V. THE RATIONAL ORICIN FOR MEASUR ING SUBJECTIVE VALUES, JASA 57,458

JONES, M. B. NOTES, ON THE EVALUATION OF VARIABILITY IN ISOCENIC HYBRIDS, BIOCS 66,623

JONES, $M . Q$. SIMULTANEOUS CONFIDENCE INTERVALS FOR VARIANCES, JASA 69,324

JONES, $M$. V. ASYMPTOTIC DISTRIBUTION OF LINEAR COMBINATIONS OF FUNCTIONS OF ORDER STATISTICS WITH APPLTCA. AMS 67, 52

JONES, R. H. EXPONENTIAL SMOOTHINC FOR MULTIVARIATE TIME SERIES, JRSSB 66,241

JONES, R. H. TIME SERIES WITH PERIODIC STRUCTURE, BIOKA 67,403

JONES, R. MORLEY ON A PROPERTY OF INCOMPLETE BLOCKS, JRSSB 59, 172

JONËS, RICHARD H. A REAPPRAISAL OF THE PERIODOCRAM IN SPECTRAL, ANALYSIS, TECH 65,531

JONES, RICHARD H. ESTIMATION OF THE INNOVATION VARIANCE OF A STATIONARY TIME SERIES, JASA 6B, 141

JONES, RIGHARD H. MULTIPLE REGRESSION WITH STATIONARY ERRORS, JASA 66,917
JONES, RICHARD H. PHASE FREE ESTIMATION OF COHERENCE, AMS 69, 540 JONES, RICHARD H. REGRESSION ON A RANDOM FIELD, JASA 69, NO 4

JONES, RICHARD H. SPECTRAL ANALYSIS WITH REGULARLY MISSED OBSERVATIONS, AMS 62,455

JONES, RICHARDH. STOCHASTIC PROCESSES ON A SPHERE, AMS 63, 213

JORGENSON, DALE W. ANTICIPATIONS AND INVESTMENT BEHAVIOR IN UNITED

STATES MANUFACTURING 1947-1960. JASA 69,67

JORGENSON, DALE W. MINIMUM VARIANCE, LINEAR, UNBIASED SEASONAL ADJUSTMENT OF ECONOMIC TIME SERIES, CORR , JASA 64, 6B]

JORCENSON, DALE W. MULTIPLE REGRESSION ANALYSIS OF A POISSON PROCESS, JASA 61,235

JORGENSON, DALE W. SEASONAL ADJUSTMENT OF DATA FOR ECONOMETRIC ANALYSIS, JASA 67,137

JOSEPH. A. W. SUBSIDIARY SEQUENCES FOR SOLVING LESER'S LEASTSQUARES GRADUATION EQUATIONS, JRSSB 62,112

JOSEPH, A.W. THE TWO-PACK MATCHING PROBLEM, JRSSB 60, 114

JOSHI, P. C. RECURRENCE RELATIONS BETWEEN MOMENTS OF ORDER STATISTICS FOR EXCHANGEABLE VARIATES, AMS 6B, 272

JOSHI, PRAKASH C. BOUNDS AND APPROXIMATIONS FOR THE MOMENTS OF ORDER STATISTICS, JASA 69 , NO 4

JOSHI, V. M. ADMISSIBILITY AND BAYES ESTIMATION IN SAMPLING FINITE POPULATIONS, I, AMS 65,1707

JOSHI, V. M. ADMISSIBILITY AND BAYES ESTIMATION IN SAMPLING FINITE POPULATIONS, II, AMS 65, 1723

JOSHI, V. M. ADMISS IBILITY AND BAYES ESTIMATION IN SAMPLING FINITE POPULATIONS, III, AMS 65,1730

JOSHI, V. M. ADMISSIBILITY AND BAYES ESTIMATION IN SAMPLINC FINITE POPULATIONS. IV. AMS 66,1658

JOSHI, V. M. ADMISSIBILITY OF CONFIDENCE INTERVALS, AMS 66, 629

JOSHI , V. M. ADMISSIBILITY OF THE SAMPLE MEAN AS EST IMATE OF THE MEAN OF A FINITE POPULATION, AMS 68,606

JOSHI, V. M. ADMISSIBILITY OF THE USUAL CONFIDENCE SETS FOR THE MEAN OF A UNIVARIATE OR BIVARIATE NORMAL, AMS 69, 1042

JOSHI, $V . M$. CONFIDENCE INTERVALS FOR THE MEAN OF A FINITE POPULATION, AMS $67,11 B O$

JOSHI, V. M. DISTRIBUTION-FREE SUFFICIENCY IN SAMPLING FINITE POPULATIONS, JRSSB 6B, 551

JOSHI, $V . M$. INADMISSIBILITY OF THE USUAL CONFIDENCE SETS FOR THE MEAN OF A MULTIVARIATE NORMAL POPULATIO. AMS $67,186 \mathrm{~B}$

JOSHI, V.M. NOTE ON A MINIMAX DESICN FOR CLUSTER SAMPLING, AMS 6B, $27 \mathrm{~B}$

JOSHI, $\vee . M$. ON A THEOREM OF KARL IN REGARDING ADMISSIBLE ESTIMATES FOR EXPONENTIAL POPULATIONS, AMS 69, 216

JOURIS, G. M. ON THE DISTRIBUTIONS OF THE RATIOS OF THE ROOTS OF A COVARIANCE MATRIX AND WILKS ' CRITERION, AMS 69, NO .6

JOWETT, G. H. APPLICATIONS OF JORDAN'S PROCEDURE FOR MATRIX INVERSION IN MULTIPLE REGRESSION AND MULTIVAR, JRSSB 63, 352

JOWETT, G. H. JUMP ANALYSIS, BIOKA 59, 3B6

JOWETT, G. H. LEAST SQUARES REGRESSION ANALYSIS FOR TREND-REDUCED TIME SERIES, JRSSB 55, 91

JOWETT, C. H. SAMPLING PROPERTIES OF LOCAL STATISTICS IN STATIONARY STOCHASTIC SERIES, BIOKA 55,160

JOWETT, G. H. STATISTICAL ANALYSIS USING LOCAL PROPERTIES OF SMOOTHLY HETEROMORPHIC STOCHASTIC SERIES, BIOKA 57,454

JOWETT, C. H. THE GOMPARISON OF MEANS OF SETS OF OBSERVATIONS FROM SECTIONS OF INDEPENDENT STOCHASTIC SER, JRSSB $55,20 \mathrm{~B}$

JOWETT, G. H. THE FITTING OF MARKOFF SERIAL VARIATION CURVES, JRSSB $5 B, 120$

JUDCE, G. G. INEQUALITY RESTRICTIONS IN REGRESSION ANALYSIS, JASA 66,166

JUDCE, C. G. MAXIMUM LIKELIHOOD AND BAYESIAN ESTIMATION OF TRANSITION PROBABILITIES, , JASA 6B, 1162

JURECKOVA, JANA ASYMPTOTIC LINEARITY OF A RANKSTATISTIC IN RECRESSION PARAMETER, AMS 69, NO 6

JUSTER, F. THOMAS CONSUMER BUYING INTENTIONS AND PURCHASE PROBABILITY, AN EXPERIMENT IN SURVEY DESICN, JASA 66, 658

KABE, D, G. A NOTE ON THE BARTLETT DECOMP OS ITION OF A WISHART MATRIX, JRSSB 64,270

KABE, D. C. A NOTE ON THE EXACT DISTRIBUTIONS OF THE GENERALIZED CLASS ICAL LINEAR EST IMATORS IN TWO LEADI, JASA 63, 535

KABE, D G DECOMPOSITION OF WISHART DISTRIBUTION, BIOKA 64,267

KABE, D. C. EXTENSION OF COCHRAN 'S FORMULAE FOR ADDITION OR OMISSION OF A VARIATE IN MULTIPLE REGRESSION, JASA 63,527

KABE, D. C. CENERALIZATION OF SVERDRUP' S LEMMA AND ITS APPLICATIONS TO MULT IVARIATE DISTRIBUT ION THEORY, AMS 65,671

KABE. D. G. MULTIVARIATE LINEAR HYPOTHESIS WITH LINEAR RESTRICTIONS, JRSSB 63,348

KABE, D. G. ON MULTIVARI ATE PREDICTION INTERVALS FOR SAMPLE MEAN AND COVARIANCE BASED ON PARTIAL OBSERVAT. JASA 67.634

KABE, D. G. ON THE DISTRIBUTIONS OF DIRECTION AND COLL INEARITY FACTORS IN DISCRIMINANT ANALYSIS, AMS 68, B55

KABE, D. G. ON THE EXACT DISTRIBUTION OF A CLASS OF MULTIVARIATE TEST CRITERIA, AMS 62, 1197

KABE, D. G. ON THE EXACT DISTRIBUTIONS OF THE GENERALIZED CLASSICAL LINEAR ESTIMATORS IN A LEADING THREE-, JASA 64 , BBI

KABE, D. G. SOME APPLICATIONS OF MEIJER-G FUNGTIONS TODISTRIBUTION PROBLEMS IN STATISTIGS, BIOKA 58, 57B 
KABE, D. C SOME RESULTS ON THE DISTRIBUTION OF TWO RANDOM MATRICES USED IN CLASSIFACATION PROCEDURES, C0. AMS 63. 181

KABE, D. C. STEPWISE MULTIVARIATE LINEAR RECRESSION, JASA 63, 770

KABIR. A. B. M. L. ESTIMATION OF PARAMETERS OF A FINITE MIXTURE OF DISTRIBUTIONS, JRSSB 6B, 472

KADANE, JOSEPH B. SOME EQUIVALENCE CLASSES IN PAIRED COMPARISONS, AMS 66,488

KADIYALA, KOTESWARA RAO AN INEQUALITY FOR THE RATIO OF TWO QUADRATIC FORMS IN NORMAL VARIATES, AMS 68, 1762

KADIYALA, KOTESWARA RAO EFFICIENCY OF THE SAMPLE MEAN WHEN RESIDUALS FOLLOW A FIRST-ORDER STATIONARY MARK. JASA 68,1237

KAHN, LOUIS B. A STATISTICAL MODEL OF EVALUATING THE RELIABILITY OF SAFETY SYSTEMS FOR PLANTS MANUFACTURI, TECH 59,293

KAILATH. THOMAS ON MEASURES EQUIVALENT TO WIENER MEASURE. AMS 67. 261

KAITZ. HYMAN B. A CHECK ON GROSS ERRORS IN CERTAIN VARIANCE COMPUTATIONS. JASA 59,741

KAKWANI, N. C. THE UNBIASEDNESS OF ZELLNER'S SEEMINCLY UNRELATED RECRESSION EQUATIONS ESTIMATORS, JASA 67, 141

KALBFLEISCH. JOHN D. EXAMPLES OF LIKELIHOODS AND COMPARISON WITH POINT ESTIMATES AND LARGE SAMPLE APPROXI, JASA 69,46B

KALE, B, K. A NOTE ON A PROBLEM IN ESTIMATION, BIOKA 62, 553

KALE, B. K. A NOTE ON THE LOSS OF INFORMATION DUE TO CROUPING OF OBSERVATIONS, BIOKA 64,495

KALE, B. K APPROXIMATIONS TO THE MAXIMUM-LIKELIHOOD ESTIMATOR USINC CROUPED DATA, BIOKA 66,282

KALE, B, K. CORRICENDA, 'ON THE SOLUTION OF THE LIKELIHOOD EQUATION BY ITERATION PROCESSES', BIOKA 62, 2B4

KALE, B. K. INFERENCE FOR SOME INCOMPLETELY SPECIFIED MODELS INVOLVINC NORMAL APPROXIMATIONS TO DISCRETE, BIOCS 67,335

KALE. B. K. ON THE SOLUTION OF LIKELIHOOD EQUATIONS BY ITERATION PROCESSES MULTIPARAMETRIC CASE, BIOKA 62,479

KALE, B. K. ON THE SOLUTION OF THE LIKELIHOOD EQUATION BY ITERATION PROCESSES, BIOKA 61,452

KALE, B . K. SOME REMARKS ON A METHOD OF A MAXIMUM-L IKELIHOOD EST IMATION PROPOSED BY RICHARDS, JRSSB 63, 209

KALLIANPUR, G. ESTIMATION OF STOCHASTIC SYSTEMS, ARBITRARY SYSTEM PROCESS WITH ADDITIVE WHITE NOISE OBSER, AMS 6B. 785

KAMAT, A.R. (ACKNOWLEDCEMENT OF PRIORITY). 'A PROPERTY OF THE MEAN DEV IATION FOR THE PEARSON TYPE DISTRI, BIOKA 67,333

KAMAT, A. R. A CENERALIZATION OF JOHNSON'S PROPERTY OF THE MEAN DEVIATION FOR A CLASS OF DISCRETE DISTRIB, BIOKA 66,2 B5

KAMAT, A R A PROPERTY OF THE MEAN DEVIATION FOR A CLASS OF CONTINUOUS DISTRIBUTIONS. , BIOKA 65.288

KAMAT, A. R. A PROPERTY OF THE MEAN DEVIATION FOR THE PEARSON TYPE DISTRIBUTIONS, BIOKA $66,2 B 7$

KAMAT, A. R. A TWO-SAMPLE DISTRIBUTION-FREE TEST, BIOKA 56, 377

KAMAT, A R. APPROXIMATIONS TO THE DISTRIBUTIONS OF SOME MEASURES OF DISPERSION BASED ON SUCCESSIVE DIFFE, BIOKA 57, 349

KAMAT, A R. ASYMPTOTIC POWER OF CERTAIN TEST CRITERIA, BASED ON FIRST AND SECOND DIFFERENCES, FOR SERIAL, AMS 62, IB6

KAMAT. A. R CORRIGENDA TO 'ON THE MEAN SUCCESSIVE DIFFERENCE AND ITS RATIO TO THE ROOT MEAN SQUARE' , BIOKA 5B, 587

KAMAT. A. R DISTRIBUTION THEORY OF TWO ESTIMATES FOR STANDARD DEV IATION BASED ON SECOND VAR IATE DIFFEREN, BIOKA 54 ,

KAMAT. A. R. INCOMPLETE AND ABSOLUTE MOMENTS OF THE MULTIVARIATE NORMAL DISTRIBUTION WITH SOME APPLICATIO. BIOKA 53, 20

KAMAT, A, R. MOMENTS OF THE MEAN DEV IATION, BIOKA 54,541

KAMAT, A. R. ON THE MEAN SUCCESSIVE DIFFERENCE AND ITS RATIO TO THE ROOT MEAN SQUARE, BIOKA 53, 116

KAMAT, A.R. SOME MORE ESTIMATES OF CIRCULAR PROBABLE ERROR, JASA 62,191

KAMAT, A, R. THE THIRD MOMENT OF GINI'S MEAN DIFFERENCE, BIOKA 53 451

KAMERSCHEN, DAVID R. MARKET GROWTH AND INDUSTRY CONCENTRATION JASA 68,228

KANAZAWA, MITSUYO MINIMIZATION OF EICENVALUES OF A MATRIX AND OPTIMALITY OF PRINCIPAL COMPONENTS, AMS 68,859

KANDER, Z. TEST PROCEDURES FOR POSSIBLE CHANCES IN PARAMETERS OF STATIST ICAL DISTRIBUTIONS OCCURING AT UN, AMS 66, 1196

KANTER, MAREK ON DISTINGUISHING TRANSLATES OF MEASURES. AMS 69 , 1773

KAO, EDWARD P. C. A NOTE ON A NON-PARAMETRIC APPROACH TO THE 2-CUBE FACTORIAL DESICN, TECH 69,193

KAO, JOHN H K. A GRAPHICAL ESTIMATION OF MIXED WEIBULL PARAMETERS IN LIFE TESTING ELECTRON TUBES, TECH 59, 3B9

KAO, JOHN H. K. QUERY. SAVINGS IN TEST TIME WHEN COMPARING WEIBULL SCALE PARAMETERS, TECH 64,471

KAPADAI, C. H. ON THE BLOCK STRUCTURE OF SINGULAR GROUP DIVISIBLE DESIGNS. AMS 66, 1398

KAPADIA, C. H COMBINING INTRA AND INTER BLOCK ANALYSIS OF GROUP DIVIS IBLE DESIGNS, TECH $66,18 B$

KAPADIA, C. H. ON THE ANALYSIS OF GROUP DIVISIBLE DESIGNS. JASA 64 , 1217

KAPADIA, C. H. ON THE DISTRIBUTIONS OF THE RANGE AND MEAN RANCE FOR SAMPLES FROM A NORMAL DISTRIBUTION, BIOKA 66,245
KAPADIA, C. H. VARIANCE COMPONENTS IN TWO-WAY CLASSIFICATION MODELS WITH INTERACTION, BIOKA 63,327

KAPLAN, E. L. NONPARAMETRIC ESTIMATION FROM INCOMPLETE OBSERVATIONS, JASA $5 B, 457$

KAPLAN. E. L. TENSOR NOTATION AND THE SAMPLINC CUMULANTS OF KSTATISTICS, BIOKA 52,319

KAPLAN, NORMANM SOMEMETHODOLOCICAL NOTES ON THEDEFLATION OF CONSTRUCTION, JASA 59,535

KAPUR, M. N . PROBABILITY DISTRIBUTIONS ARISINC FROM POINTS ON A LINE, BIOKA 54,553

KARAS, J. PUBLICATIONS OF FRANK WILCOXON (1892-1965), BIOCS 67, I KARLIN, SAMUEL CONDITIONED LIMIT THEOREMS, AMS 63, 1147

KARLIN, SAMUEL DISTRIBUTIONS POSSESSING A MONOTONE LIKELIHOOD RATIO. JASA 56.637

KARLIN, SAMUEL EMBEDDING OF URN SCHEMES INTO CONTINUOUS TIME MARKOV BRANCHINC PROCESSES AND RELATED LIMIT, AMS 68, 1801

KARLIN, SAMUEL OPTIMAL EXPERIMENTAL DESICNS, AMS 66, 783

KARLIN. SAMUEL PROPERTIES OF THE STATIONARY MEASURE OF THE CRITICAL CASE SIMPLE BRANCHINC PROCESS, AMS 67,977

KARPINOS. BERNARD D. CURRENT WEICHT-HEICHT RELATIONSHIPS OF YOUTHS OF MILITARY AGE, JASA 62, B95

KARPINOS, BERNARD D WEICHT-HEICHT STANDARDS BASED ON WORLD WAR II EXPERIENCE, JA\$ 58,408

KARSON, M.J. MINIMUM BIAS ESTIMATION AND EXPER IMENTAL DESICN FOR RESPONSE SURFACES, TECH 69, 461

KARST, OTTO J. LINEAR CURVE FITTINC USINC LEAST DEVIATIONS, JASA 5B 118

KARUSH. J. ON THE SEMIMAR TINCALE CONVERCENCE THEOREM. AMS 66, 690 KARUSH, JACK ON THE CHAPMAN-KOLMOCOROV EQUATION, AMS 61, 1333 KASTEMBAUM, M A. THE SEPARATION OF MOLECULAR COMPOUNDS BY COUNTERCURRENT DIALYSIS, A STOCHASTIC PROCESS, BIOKA 60,69

KASTEN, ETHEL L. RAPID ANALYSIS OF 2X2 TABLES, JASA 57,18

KATHIRGAMATAMBY, N NOTE ON THE POISSON INDEX OF DISPERSION, BIOKA 53.225

KATTI, S, K. BIOLOGICAL EXAMPLES OF SMALL EXPECTED FREQUENCIES", BIOCS 65.49

KATTI, S. K. DISTRIBUTION OF THE LIKELIHOOD RATIO FOR TESTING MULTIVARIATE LINEAR HYPOTHESES. AMS 61, 333

KATTI, S. K EFFICIENCY OF CERTAIN METHODS OF ESTIMATION FOR THE NECATIVE BINOMIAL AND NEYMAN TYPE A DIST, BIOKA 62, 215

KATTI, S. K. FITTINC OF SOME CONTACIOUS DISTRIBUTIONS TO SOME AVA ILABLE DATA BY THE MAXIMUM LIKELIHOOD ME, BIOCS 65,34

KATTI, $S, K$. INF INITE DIVISIVILITY OF INTECER-VALUED RANDOM VARIABLES, AMS 67,1306

KATTI, S. K. INTERRELATIONS AMONG GENERALIZED DISTRIBUTIONS AND THEIR COMPONENTS, BIOCS 66,44

KATTI, S. K. MULTIPLY COVARIATE ANALYSIS (CORR. 66 962), BIOCS 65 957

KATZ JR, MELVIN A BOUND FOR THE LAW OF LARGE NUMBERS FOR DISCRETE MARKOV PROCESSES. AMS 61,336

KATZ, L. COMPARISON OF THE POWER FUNCTIONS FOR THE TEST OF INDEPENDENCE IN 2 X2 CONTINGENCY TABLES, AMS 64, 1115

KATZ, MELVIN A NOTE ON THE WEAK LAW OF LARGE NUMBERS, AMS 6B, 1348

KATZ, MELVIN L. NOTE ON THE BERRY-ESSEN THEOREM, AMS 63, 1107

KATZ, MELVIN L. ON THE INFLUENCE OF MOMENTS ON THE ASYMPTOTIC DIS-

TRIBUTION OF SUMS OF RANDOM VARIABLES, AMS 63, 1042

KATZ, MELVIN L. THE PROBABILITY IN THE TAIL OF A DISTRIBUTION, AMS 63. 312

KATZ, MORRIS W ADMISSIBLE AND MINIMAX ESTIMATES OF PARAMETERS IN TRUNCATED SPACES, AMS 61,136

KATZ, MORRIS W. ESTIMATING ORDERED PROBABILITIES, AMS 63, 967

KATZ, S. FREQUENCY RESPONSE FROM STATIONARY NOISE, TWO CASE HISTO RIES, TECH 6I, 245

KAUFMAN, C.M BAYESIAN ANALYSIS OF THE INDEPENDENT MULTINORMAL PROCESS, NEITHER MEAN NOR PRECISION KNOWN, JASA 65, 347

KAUFMAN, CORDONM. OPTIMAL SAMPLE SIZE IN TWO-ACTION PROBLEMS WHEN THE SAMPLE OBSERVATIONS ARE LOCNORMAL, JASA 6B, 653

KAUFMAN, H. DISTRIBUTIONS OF RANDOM VARIABLES WITH RANDOM PARAMETERS, SASJ 69 . I

KAWATA, T SOME INTEGRAL TRANSFORMS OF CHARACTERISTIC FUNCTIONS. AMS 68,1923

KETFER, J OPTTMUM EXPERIMENTAL DESIGNS (WITH DISCUSSION), JRSSB 59. 272

KEILSON. J. A TECHNIQUE FOR DISCUSSING THE PASSAGE TIME DISTRIBUTION FOR STABLE SYSTEMS, JRSSB 66,477

KEILSON. J. ON THE ASYMPTOTIC BEHAVIOUR OF QUEUES, JRSSB 63, 464

KEILSON, J. ON THE GENERAL TIME DEPENDENT QUEUE WITH A SINGLE SERVER, AMS 62,767

KEILSON, J. ON THE MATRIX RENEWAL FUNCTION FOR MARKOV RENEWAL PROCESSES, AMS 69, NO.6

KEILSON, J. THE ERGODIC QUEUE LENGTH DISTRIBUTION FOR QUEUEINC SYSTEMS WITH FINITE CAPACITY, JRSSB 66, 190

KEILSON.J. THE GENERAL BULK QUEUE AS A HILBERT PROBLEM (CORR. 64 487), JRSSB 62,344

KEILSON, JULIAN A LIMIT THEOREM FOR PASSAGE TIMES IN ERGODIC RECENERATIVE PROCESSES, AMS 66, B66 
KEILSON. JULIAN QUEUES SUBJECT TO SERVICE INTERRUPTION, AMS 62 , 1314

KEILSON, JULIAN THE FIRST PASSAGE TIME DENSITY FOR HOMOGENEOUS SKIP-FREE WALKS ON THE CONTINUUM, AMS 63, 1003

KELEJIAN, H. H. MISSING OBSERVATIONS IN MULTIVARIATE REGRESSION, EFFICIENCY OF A FIRST ORDER METHOD, JASA 69, NO. 4

KELLER. JOSEPH B. FACTORIZATION OF MATRICES BY LEAST-SQUARES. BIOKA 62,239

KEMENY, JOHNG. ON MARKOV CHAIN POTENTI ALS, AMS 61, 709

KEMP JR, L. F . CONSTRUCTION OF JOINT PROBABILITY DISTRIBUTIONS, AMS $6 B, 1354$

KEMP, A. W. GENERALIZED HYPERGEOMETRIC DISTRIBUTIONS. JRSSB 56. 202

KEMP. A. W. ON A DISTRIBUTION ASSOCIATED WITH CERTAIN STOCHASTIC PROCESSES, JRSSB 68,160

KEMP, ADRIENNE SOME PROPERTIES OF THE 'HERMITE' DISTRIBUTION, BIOKA 65,381

KEMP. ADRIENNE W. AN ALTERNATIVE DERIVATION OF THE HERMITE DISTRIBUTION. BIOKA 66,627

KEMP. C. D. AN ALTERNATIVE DERIVATION OF THE HERMITE DISTRIBUTION BIOKA 66,627

KEMP, C. D. GENERALIZED HYPERGEOMETRIC DISTRIBUTIONS, JRSSB 56 202

KEMP. C. D. ON A CONTAGIOUS DISTRIBUTION SUGGESTED FOR ACCIDENT DATA, BIOCS 67, 241

KEMP, C. D. ON A DISTRIBUTION ASSOCIATED WITH CERTAIN STOCHASTIC PROCESSES, JRSSB 68, 160

KEMP, C. D. SOME PROPERTIES OF THE 'HERMITE' DISTRIBUTION, BIOKA 65 3B 1

KEMP, K. W. A SIMPLE PROCEDURE FOR DETERMINING UPPER AND LOWER LIMITS FOR THE AVERAGE SAMPLE RUN LENGTH 0, JRSSB 67, 263

KEMP, $K$. W. FORMAL EXPRESSIONS WHICH CAN BE USED FOR THE DETERMINATION OF THE OPERATING CHARACTERISTIC AN, JRSSB $67,24 \mathrm{~B}$

KEMP, K. W. FORMULAE FOR CALCULATING THHE OPERATING CHARACTERISTIC AND THE AVERAGE SAMPLE NUMBER OF SOME S, JRSSB 58, 379

KEMP, K. W. SAMPLING INSPECTION OF CONTINUOUS PROCESSES WITH NO AUTOCORRELATION BETWEEN SUCCESSIVE RESULT , BIOKA 60, 363

KEMP, K. W. THE AVERAGE RUN LENGTH OF THE CUMULATIVE SUM CHART WHEN A V-MASK IS USED, JRSSB 61,149

KEMP, KENNETH W. AN EXAMPLE OF ERRORS INCURRED BY ERRONEOUSLY ASSUMING NORMALITY FOR CUSUM SCHEMES. TECH 67,457

KEMPERMAN, J. H. B. A WIENER-HOPF TYPE METHOD FOR A GENERAL RANDOM WALK WITH A TWO-SIDED BOUNDARY, AMS 63, 116B

KEMPERMAN, J.H.B. ON THE OPTIMUM RATE OF TRANSMITT ING INFORMATION, AMS 69 . NO. 6

KEMPERMAN, J. H. B. THE GENERAL MOMENT PROBLEM, A GEOMETRIC APPROACH, AMS 68,93

KEMPTHORNE, O. EXAMINATION OF A REPEAT MATING DESIGN FOR EST IMATING ENVIRONMENTAL AND GENETIC TRENDS, BIOCS 65,63

KEMPTHORNE, O. THE BEHAVIOUR OF SOME SIGNIFICANCE TESTS UNDER EXPERIMENTAL RANDOMIZATION, BIOKA 69, 231

KEMPTHORNE, O. THE EFFICIENCY OF BLOCKING IN INCOMPLETE BLOCK DESIGNS, BIOKA 60,273

KEMPTHORNE. O. TWO CLASSES OF GROUP DIVISIBLE PARTIAL DIALLEL CROSSES, BIOKA 63, 281

KEMPTHORNE, OSCAR DISCUSSION OF 'ON THE FOUNDATIONS OF STATISTICAL INFERENCE' , JASA 62, 307

KEMPTHORNE, OSCAR DISCUSSION OF THE PAPERS OF MESSRS. SATTERTHWAITE AND BUDNE, TECH 59,157

KEMPTHORNE, OSCAR NON-ADDITIVITIES IN A LATIN SQUARE DESIGN, JASA 57,218

KEMPTHORNE, OSCAR SOME ASPECTS OF EXPERIMENTAL INFERENCE, JASA 66 11

KEMPTHORNE, OSCAR SOME MAIN-EFFECT PLANS AND ORTHOGONAL ARRAYS OF STRENGTH TWO, AMS 61, 1167

KENDALL. D. G. BIRTH-AND-DEATH PROCESSES, AND THE THEORY OF CARCINOGENESIS, BIOKA 60,13

KENDALL, D. G. SOME PROBLEMS IN THE THEORY OF DAMS (WITH DISCUSSION), JRSSB 57,207

KENDALL, M. G. A THEOREM IN TREND ANALYSIS, BIOKA 61, 224

KENDALL, M. G. ERRATA IN 'TABLES OF SYMMETRIC FUNCTIONS', BIOKA 58 292

KENDALL, M. G. MOMENT-STATISTICS IN SAMPLES FROM A FINITE POPULATION, BIOKA 52,14

KENDALL, M. G. NOTE ON BIAS IN THE ESTIMATION OF AUTOCORRELATION, BIOKA 54,403

KENDALL, M. G. RANKS AND MEASURES, BIOKA 62, 133

KENDALL, M. G. REGRESSION, STRUCTURE AND FUNCTIONAL RELATIONSHIP, BIOKA 51,11

KENDALL, M. G. REGRESSION, STRUCTURE AND FUNCTIONAL RELATIONSHIPS. II., BIOKA 52, 96

KENDALL, M. G. RONALD AYLMER FISHER, 1890-1962, BIOKA 63, I

KENDALL, M. G. SHORT PROOF OF DR HARLEY'S THEOREM ON THE CORRELATION COEFFICIENT, BIOKA 58, 571

KENDALL, M. G. SOME QUESTIONS OF DISTRIBUTION IN THE THEORY OF RANK CORRELATION, BIOKA 51,131
KENDALL, M, G STUDIES IN THE HISTORY OF PROBABILITY AND STATISTICS $X$. WHERE SHALL THE HISTORY OF STATIS, BIOKA 60, 447

KENDALL, M. G. STUDIES IN THE HISTORY OF PROBABILITY AND STATISTICS II, THE BEG INNINGS OF A PROBABILITY. BIOKA 56,1

KENDALL, M. G. STUDIES IN THE HISTORY OF PROBABILITY AND STATISTICS XI. DANIEL BERNOULLI ON MAXIMUM LIKE, BIOKA 61, I

KENDALL, M. G. STUDIES IN THE HISTORY OF PROBABILITY AND STATISTICS V.A NOTE ON PLAYING CARDS, BIOKA 57,260

KENDALL, M. G. STUDIES IN THE HISTORY OF PROBABILITY AND STATISTICS XII. THE BOOK OF FATE, BIOKA 61,220

KENDALL, M. G. STUDIES IN THE HISTORY OF PROBABILITY AND STATISTICS XIII, ISAAC TODHUNTER'S HISTORY OF T, BIOKA 63, 204

KENDALL, M. G. STUDIES IN THE HISTORY OF PROBABILITY AND STATISTICS XVIII. THOMAS YOUNG ON COINCIDENCES, BIOKA 6B, 249

KENDALL, M. G. STUDIES IN THE HISTORY OF PROBABILITY AND STATISTICS XIX. FRANCIS YSIDRO EDGEWORTH (1B45-, BIOKA 6B, 269

KENDALL, M. G. TABLES OF SYMMETRIC FUNCTIONS. PART IV., BIOKA 53. 427

KENDALL, M. G. TABLES OF SYMMETRIC FUNCTIONS. PART V., BIOKA 55, 223 KENDALL, M. G. TABLES OF SYMMETRIC FUNCTIONS. PARTS II AND III., BIOKA 51,435

KENDALL, M, G. THE DISCARDING OF VARIABLES IN MULTIVARI ATE ANALYSIS, BIOKA 67,357

KENDALL, M. G. THE GEOMETRY OF ESTIMATION, BIOKA 51, 150

KENDALL. M. G. THE MOMENTS OF THE LEIPNIK DISTRIBUTION, BIOKA 57 , 270

KENDALL. M. G. TWO PROBLEMS IN SETS OF MEASUREMENTS, BIOKA 54, 560 KENNARD, $R, W$, COMPUTER AIDED DESIGN OF EXPERIMENTS, TECH 69, 137

KERR, J. D. THE ESTIMATION OF THE 'SHORT' DISTRIBUTION, BIOCS 69 , 417

KERRICH. J. E. NOTE ON A DISCONTINUOUS PROBABILITY DENSITY, BIOKA 5B. 270

KERRICH, J E E STATISTICS IN SOUTH AFRICA, SASJ 68, 109

KERRICH, J. E. THE SOUTH AFRICAN STATISTICAL ASSOCIATION, A SKETCH OF ITS ORIGINS AND GROWTH, SASJ 67,1

KERRIDGE, D. BOUNDS FOR THE FREQUENCY OF MISLEADING BAYES INFERENCE, AMS 63, 1109

KERRIDGE, D. ERRORS OF PREDICTION IN MULTIPLE REGRESSION, TECH 67 . 309

KERRIDGE, D. PROBABILISTIC SOLUTION OF THE SIMPLE BIRTH PROCESS, BIOKA 64,258

KERRIDGE, D. F. A GENERAL MAXIMUM LIKELIHOOD DISCRIMINANT, BIOCS 67,313

KERRIDGE, D. F. INACCURACY AND INFERENCE, JRSSB 61, 184

KESTEN, H. A LIMIT THEOREM FOR MULTIDIMENSIONAL GALTON-WATSON PROCESSES, AMS 66,1211

KESTEN, H. ADDITIONAL LIMIT THEOREMS FOR INDECOMPOSABLE MULTIDIMENSIONAL GALTON-WATSON PROCESSES, AMS 66, 1463

KEYFITZ, N. MATRIX AND MULTIPLE DECREMENT IN POPULATION ANALYSIS, BIOCS $67,4 \mathrm{~B} 5$

KEYFITZ, NATHAN A LIFE TABLE THAT AGREES WITH THE DATA, JASA 66, 305 KEYFITZ, NATHAN A LIFE TABLE THAT AGREES WITH THE DATA. II, JASA GB. 1253

KEYFITZ, NATHAN ESTIMATES OF SAMPLING VARIANCE WHERE TWO UNITS ARE SELECTED FROM EACH STRATUM, JASA 57, 503

KEYFITZ. NATHAN ON THE INTERPRETATION OF AGE DISTRIBUTIONS, JASA 67,862

KHAIRAT, M. A. A NOTE ON MINIMUM DISCRIMINATION INFORMATION, AMS 66 , 279

KHAMIS, S. H. SOME BASIC PROPERT IES OF THE INCOMPLETE GAMMA FUNCTION RATIO, CORR, 65 15B4, AMS 65, 926

KHAN. RASUAL A. A GENERAL METHOD OF DETERMINING FIXED-WIDTH CONFIDENCE INTERVALS, AMS 69,704

KHAN, RASUL A. A NOTE ON ESTIMATING THE MEAN OF A NORMAL DISTRIBUTION WITH KNOWN COEFFICIENT OF VARIATION, JASA 68, 1039

KHAN. S. OPTIMUM ALLOCATION IN MULTIVARIATE SURVEYS, AN ANALYTICAL SOLUTION, JRSSB 67,115

KHATRI, C. G. A METHOD OF FITTING THE REGRESSION CURVE E $(\mathrm{Y})=\mathrm{A}+\mathrm{DX}+\mathrm{BC}-$ TO-X, TECH 65,59

KHATRI, C. G. A TEST FOR REALITY OF A COVARIANCE MATRIX IN A CERTAIN COMPLEXGAUSSIAN DISTRIBUTION, AMS 65, 115

KHATRI, C. G. A THEOREM ON LEAST SQUARES IN MULTIVARIATE LINEAR REGRESSION, JASA 67, 1494

KHATRI, C. G. CHARACTERIZATION OF THE INVERSE GAUSSIAN DISTRIBUTION, AMS 62, 800

KHATRI, C. G. CLASSICAL STATISTICAL ANALYSIS BASED ON A CERTAIN MULTIVARIATE COMPLEX GAUSSIAN DISTRIBUTIO, AMS 65.98

KHATRI, C. G. CONDITIONS FOR WISHARTNESS AND INDEPENDENCE OF SECOND DEGREE POLYNOMIALS IN NORMAL VECTOR, AMS 62, 1002

KHATRI, C. G. CORRECTION TO ' ON THE MUTUAL INDEPENDENCE OF CERTAIN STATISTICS' 591258 , AMS 61, 1344

KHATRI. C. G. DISTRIBUTION OF A DEFINITE QUADRATIC FORM FOR NON-CENTRAL NORMAL VARIATES, CORR. 63673, AMS 61, 883

KHATRI, C. G. DISTRIBUTION OF DEFINITE AND OF INDEFINITE QUADRATIC FORMS FROM A NON-CENTRAL NORMAL DISTRI, AMS 63, 186

KHATRI, C. G. DISTRIBUTION OF THE 'GENERALIZED' MULTIPLE CORRELATION MATRIX IN THE DUAL CASE, AMS 64, 1801

KHATRI, C. G. DISTRIBUTION OF THE LARGEST OR THE SMALLEST CHARACTERISTIC ROOT UNDER NULL HYPOTHESIS CONCE, AMS 64, 1807 
KHATRI, C. G. ESTIMATION OF PARAMETERS OF A TRUNCATED BIVARI ATE NORMAL DISTRIBUTION, JASA 63, 519

KHATRI, C. C . ON CERTAIN DISTRIBUTION PROBLEMS BASED ON POSITIVE DEFINITE QUADRATIC FUNCT IONS IN NORMAL V, AMS 66, 46B

KHATRI. C. G. ON CERTAIN INEQUALITIES FOR NORMAL DISTRIBUTIONS AND THEIR APPLICATIONS TO SIMULTANEOUS CON, AMS 67, IB53

KHATRI, C. C . ON CERTAIN PROPERTIES OF POWER-SERIES DISTRIBUTIONS, BIOKA 59, 486

KHATRI, C. C . ON MOMENTS OF ELEMENTARY SYMMETRIC FUNCTIONS OF THE ROOTS OF TWO MATRICES AND APPROXIMATION. AMS 6B, 1274

KHATRI, C . C . ON TESTINC THE EQUALITY OF PARAMETERS IN K RECTANCULAR POPULATIONS, JASA 60,144

KHATRI, C, C ON THE MOMENTS OF THE TRACE OF A MATRIX AND APPROXIMATIONS TO ITS NON-CENTRAL DISTRIBUTION, AMS 66, 1312

KHATRI, C. G. ON THE NON-CENTRAL DISTR IBUTIONS OF TWO TEST CRITERIA IN MULTIVARIATE ANALYSIS OF VARIANCE, AMS 6B, 215

KHATRI, $C$ C PROCRESSIVELY CENSORED SAMPLES FROM LOC-NORMAL AND LOC ISTIC DISTRIBUTIONS, TECH 69. NO. 4

KHATRI, C. C. SOME DISTRIBUTION PROBLEMS CONNECTED WITH THE CHARACTERISTIC ROOTS OF THE PRODUCT OF A WISH, AMS 67, 944

KHATRI, C. C. SOME RESULTS ON THE NON-CENTRAL MULT IVARIATE BETA DISTRIBUTION AND MOMENTS OF TRACES OF TWO, AMS 65, 1511

KHAZANIE, R, C. A MENDELIAN MARKOV PROCESS WITH BINOMIAL TRANSITION PROBABILITIES. BIOKA 66,37

KIEFER, CRACE VARIANCE ESTIMATION WITH ONE UNIT PER STRATUM, JASA 69.841

KIEFER, J. ADMISSIBLE BAYES CHARACTER OF T-SQUARED, R-SQUARED AND OTHER FULLY INVARIANT TESTS FOR CLASSIC, AMS 65,747

KIEFER, J. ASYMPTOTICALLY OPTIMUM SEQUENTIAL INFERENCE AND DESICN AMS 63. 705

KIEFER. J. DISTRIBUTION FREE TESTS OF INDEPENDENCE BASED ON THE SAMPLE DISTRIBUTION FUNCTION, AMS 61.485

KIEFER, J LOCAL AND ASYMPTOTIC MINIMAX PROPERTIES OF MULTIVARIATE TESTS, AMS 64,21

KIEFER, J. MINIMAX CHARACTER OF HOTELLINC'S T-SQUARED TEST IN THE SIMPLEST CASE, AMS 63, 1524

KIEFER, J. MINIMAX CHARACTER OF THE R-SQUARED-TEST IN THE SIMPLEST CASE, AMS 64. 1475

KIEFER, J ON A THEOREM OF HOEL AND LEVINE ON EXTRAPOLATION, AMS 65 1627

KIEFER, J ON BAHADUR'S REPRESENTATION OF SAMPLE QUANTILES, AMS 67. 1323

IEFER, J OPTIMUM DESICNS IN RECRESSION PROBLEMS, II, AMS 61, 298

KIEFER, J TWO MORE CRITERIA EQUIVALENT TOD-OPTIMALITY OF DESICNS, AMS 62.792

KIM. CHOO-WHAN A CENERALIZATION OF ITO'S THEOREM CONCERNING THE POINTWISE ERGODIC THEOREM, AMS 6B, 2145

KIM. P. J. ON THE EXACT AND APPROXIMATE SAMPLING DISTRIBUTION OF THE TWO SAMPLE KOLMOGOROV-SMIRNOV CRITER, JASA 69. NO 4

KIMBALL, A W A MODEL TOR CHEMICAL MUTAGENESIS IN BACTERIOPHAGE, BIOCS 65,875

KIMBALL, A. W APPROXIMATE LINEARIZATION OF THE INCOMPLETE BETAFUNCTION, BIOKA 59,214

KIMBALL. A. W ERRORS OF THE THIRD KIND IN STATISTICAL CONSULTING JASA 57,133

KIMBALL, A. W MODELS FOR THE ESTIMATION OF COMPETING RISKS FROM GROUPED DATA, BIOCS 69,329

KIMBALL, BRADFORD F. ON THE CHOICE OF PLOTTING POSITIONS ON PROBABILITY PAPER, JASA 60,546

KIMBLETON, STEPHEN R. A CHARACTERIZATION OF CERTAIN SEQUENCES OF NORMING CONSTANTS. AMS 68, 391

KIMBLETON, STEPHEN R. A STABLE LIMIT THEOREM FOR MARKOV TESTS, AMS 69,1467

KINCAID, W. M THE COMBINATION OF TESTS BASED ON DISCRETE DISTRIBUTIONS, JASA 62,10

KINDAHL, JAMES $K$ ESTIMATION OFMEANS AND TOTALS FROM FINITE POPULATIONS OF UNKNOWN SIZE, CORR, 641297 , JASA 62,61

KING. BENJAMIN STEP-WISE CLUSTERING PROCEDURES, JASA 67,86

KING, E. P. GROUP SCREENING UTILIZINC BALANCED AND PARTIALLY BALANCED INCOMPLETE BLOCK DESIGNS, BIOCS 65,865

KING. E. P. OPTIMAL REPLICATION IN SEQUENTIAL DRUG SCREENING, BIOKA 64. 1

KINGMAN I. F C AN APPROACH TO THE STUDY OF MARKOV PROCESSES (WITH DISCUSSION), JRSSB $66,4 \times 7$

KINGMAN, J, F, C, ON QUEUES IN HEAVY TRAFFIC, JRSSB 62,383

KINGMAN, J.F , C . POISSON COUNTS FOR RANDOM SEQUENCES OF EVENTS, AMS 63. 1217

KINGMAN. J. F. C. SOME INEQUALITIES FOR THE QUEUE GI/GI, BIOKA 62 315

KINGMAN, J. F. C. THE ERCODIC BEHAVIOUR OF RANDOM WALKS. BIOKA 61 391

KINGMAN, J. F, C. THE ERGODIC THEORY OF SUBADDITIVE STOCHASTIC PROCESSES, JRSSB 68,499

KINGMAN, J. F. C. TWOSIMILARQUEUES IN PARALLEL, AMS61. 1314

KINGSTON, CHARLES R. APPLICATIONS OF PROBABILITY THEORY IN CRIMINALISTICS, II. JASA 65, 1028

KINGSTON. CHARLES $R$. APPLICATIONS OF PROBABILITY THEORY IN CRIMINALISTICS, JASA 65,70
KINNEY. J, R. DIMENSIONAL PROPERTIES OF A RANDOM DISTRIBUTION FUNCTION ON THE SQUARE. AMS 66, B49

KINNEY, J.R. THE CONVEX HULL OF PLANE BROWNIAN MOTION, AMS 63, 327

KINNEY. JOHN R. A TRANSIENT DISCRETE TIME QUEUE WITH FINITE STORAGE AMS 62,130

KINNEY. JOHA R FIRST PASSACE TIMES OF A CENERALIZED RANDOM WALK, CORR. AND ACKNOWLEDCEMENT OF PRIORITY 6. AMS 61,235

KISH, LESLIE ON NONCOVERAGE OF SAMPLE DWELLINGS, JASA 5B. 509

KISH, LESLIE ON VARIANCES OF RATIOS AND THEIR DIFFERENCES IN MULTISTACE SAMPLES, CORR, 631162 , JASA 59,416

KISH, LESLIE STANDARD ERRORS FOR INDEXES FROM COMPLEX SAMPLES, JASA $6 B, 512$

KISH, LESLIE STUDIES OF INTERVIEWER VARIANCE FOR ATTITUDINAL VARIABLES, JASA 62,92

KISH. LESLIE THE RATIO BIAS IN SURVEYS, JASA 62, B63

KITTRELL, J.R. EVOLUTIONARY OPERATION, A REVIEW, TECH 66, 389

KLEIN, D. F A COMPARISON OF SUCCESSIVE SCREENINC AND DISCR IMINANT FUNCTION TECHNIQUES IN MEDICAL TAXONOM, BIOCS 69, NO. 4

KLEINDORFER. CEORGE B. CONSISTENT ESTIMATES OF THE PARAMETERS OF A LINEAR SYSTEM, AMS 69 , NO 6

KLEINDORFER, PAUL R. CONSISTENT ESTIMATES OF THE PARAMETERS OF A LINEAR SYSTEM, AMS 69, NO.6

KLETT, C. W OPTIMAL CONFIDENCE INTERVALS FOR THE VARIANCE OF A NORMAL DISTRIBUTION, JASA 59,674

KLEYLE, ROBERT $M$. DISTRIBUTIONS DETERMINED BY CUTTINC SIMPLEX WITH HYPERPLANES, AMS 68,1473

KLTMKO, E. M. A UNIFORM OPERATOR ERCODIC THEOREM, AMS 69, 1126

KL IMKO. EUCENE M. ON THE CLIVENKO-CANTELLI THEOREM FOR INFINITE INVARIANT MEASURES. AMS 67,1273

KLOTZ, J H MEAN SQUARE EFFICIENCY OF ESTIMATORS OF VARIANCE COMPONENTS, JASA 69, NO.4

KLOTZ. J. H. ON THE NORMAL SCORES TWO-SAMPLE RANK TEST, JASA 64, 652

KLOTZ, JEROME ALTERNATIVE EFFICIENCIES FOR SICNED RANK TESTS, AMS 65. 1759

KLOTZ. JEROME ASYMPTOTIC EFFICIENCY OF THE TWO SAMPLE KOLMOCOROVSMIRNOV TEST, JASA 67,932

KLOTZ, JEROME MAXIMUM LIKELIHOOD ESTIMATION OF MULTIVARIATE COVARIANCE COMPONENTS FOR THE BALANCED ONE-WA, AMS 69, 1100

KLOTZ, JEROME NON-PARAMETRIC TESTS FOR SCALE. AMS 62, 49B

KLOTZ, JEROME NULL DISTRIBUTION AND BAHADUR EFFICIENCY OF THE HODCES BIVARIATE SICN TEST, AMS 62, BO3

KLOTZ, JEROME SMALL SAMPLE POWER AND EFFICIENCY FOR THE ONE SAMPLE WILCOXON AND NORMAL SCORES TESTS, AMS 63. 624

KLTZ JEROME SMALL SAMPLE POWER OF THE BIVAR IATE SICN TEST OF BLUMEN AND HODGES, AMS 64, 1576

KLOTZ, JEROME THE WILCOXON, TIES, AND THE COMPUTER, JASA 66, 772

KMENTA, JAN SMALL SAMPLE PROPERTIES OF ALTERNATIVE ESTIMATORS OF SEEMINGLY UNRELATED REGRESSIONS, JASA 68, 1180

KNIGHT, FRANK B. DISTRIBUTION OF THE ABSOLUTE MAXIMUM FOR CERTAIN BROWNIAN MOTIONS, AMS 65,311

KNIGHT, WILLIAM A LEMMA FOR MULTIPLE INFERENCE, AMS 65, 1873

KNIGHT, WILLIAM A METHOD OF SEQUENTIAL ESTIMATION AP PLICABLE TO THE HYPERGEOMETRIC, BINOMIAL, POISSON, AN, AMS 65, 1494

KNTGHT, WILLIAM THE USE OF THE RANGE IN PLACE OF THE STANDARD DEVIATION IN STEIN'S TEST, AMS 63, 346

KNIGHT, WILLIAM R. A COMPUTER METHOD FOR CALCULATING KENDALL 'S TAU WITH UNGROUPED DATA, JASA 66,436

KNOTT, MARTIN MODELS FOR CATALOGUING PROBLEMS, AMS 67, 1255

KNOTT, MARTIN SAMPLING MIXTURES OF PARTICLES, TECH 67,365

KNUTH, D. E. ON METHODS OF CONSTRUCTING SETS OF MUTUALLY ORTHOGONAL LATIN SQUARES USING A COMPUTER, TECH 60,507

KNUTH, D. E. ON METHODS OF CONSTRUCTING SETS OF MUTUALLY ORTHOGONAL LATIN SQUARES USING A COMPUTER. II. TECH 51.111

KOCH , G. G. A PROCEDURE TO EST IMATE THE POPULATION MEAN IN RANDOM EFFECTS MODELS, TECH 67,577

$\mathrm{KOCH}, \mathrm{C}, \mathrm{C}$. ANALYSIS OF CATECORICAL DATA BY LINEAR MODELS, BIOCS 69 $4 \mathrm{~B} 9$

$K O C H, G, G$. ON THE HYPOTHESES OF 'NO INTERACTION' IN CONTINCENCY TABLES, BIOCS $6 B, 567$

KOCH, G. G. SOME ASPECTS OF THE STATISTICAL ANALYSIS OF THE 'MIXED MODEL', BIOCS $6 \mathrm{~B}, 27$

KOCH, GARY G. A GENERAL APPROACH TO THE ESTIMATION OF VARI ANCE COM PONENTS, TECH 67,93

KOCH, GARY G. A USEFUL LEMMA FOR PROVING THE EQUALITY OF TWO MATRICES WITH APPLICATIONS TO LEAST SQUARES, JASA 69,969

KOCH. GARY C. HYPOTHESES OF 'NO INTERACTION' IN MULTI-DIMENSIONAL CONTINCENCY TABLES, TECH 6B, 107

KOCH, CARY G. SOME ASPECTS OF THE STATISTICAL ANALYSIS OF 'SPLIT PLOT' EXPERIMENTS IN COMPLETELY RANDOMIZ, JASA 69, 4B5

KOCH, CARY G. SOME FURTHER REMARKS CONCERN ING 'A GENERAL APPROACH TO THE ESTIMATION OF VARIANCE COMPONENT, TECH 68551

$\mathrm{KOCH}$, CARY G. THE EFFECT OF NON-SAMPLING ERRORS ON MEASURES OF ASSOCIATION IN 2-BY-2 CONTINCENCY TABLES, JASA 69. B52

KODLIN, D. A NEW RESPONSE TIME DISTRIBUTION. BIOCS 67, 227

KODLIN, D. A NOTE ON FOLLOW-UP FOR SURVIVAL IN THE PRESENCE OF MOVEMENT, JASA 61,119

KOERTS. J. A COMPARISON BETWEEN THE POWER OF THE DURBIN-WATSON TEST AND THE POWER OF THE BLUS TEST, JASA 69, 938

KOERTS, J. ON THE POWER OF THE BLUS PROCEDURE, JASA 6B, 1227 
KOERTS, JOHAN SOME FURTHER NOTES ON DISTURBANCE ESTIMATES IN REGRESSION ANALYSIS, JASA 67, 169

KOJIMA, K. SURVIVAL PROBABILITIES OF NEW INVERSIONS IN LARGE POPULATIONS, BIOCS $6 B, 501$

KOKAN, A. R. OPTIMUM ALLOCATION IN MULTIVARIATE SURVEYS, AN ANALYTICAL SOLUTION, JRSSB 67,115

KONIJN, H.S. REGRESS ION ANALYSIS IN SAMPLE SURVEYS, CORR, 631162 , JASA 62, 590

KONIJN, $H$ S. STATISTICAL REPRODUCTION OF ORDERINGS AND TRANSLATION SUBFAMILIES, AMS 66, 196

KOOHARIAN, A. ON THE GENERAL TIME DEPENDENT QUEUE WITH A SINGLE SERVER, AMS 62,767

KOOP, J. C. ON AN IDENTITY FOR THE VARIANCE OF A RATIO OF TWO RANDOM VARIABLES, JRSSB $64,4 B 4$

KOOP, J. C. REPLICATED, OR INTERPENETRATING, SAMPLES OF UNEQUAL SIZES, AMS 67,1142

KOOPMANS, L. H. A NOTE ON THE ESTIMATION OF AMPLITUDE SPECTRA FOR STOCHASTIC PROCESSES WITH QUASI-LINEAR, JASA 66,397

KOOPMANS, L. H. AN EXPONENTIAL BOUND ON THE STRONG LAW OF LARGE NUMBERS FOR LINEAR STOCHASTIC PROCESSES W, AMS 61,583

KOOPMANS, L. H. AN EXTENSION OF ROSEN'S THEOREM TO NON-IDENTICALLY DISTRIBUTED RANDOM VARIABLES, AMS $6 B, B 97$

KOOPMANS, L. H. CONFIDENCE INTERVALS FOR THE COEFFICIENT OF VARIATION FOR THE NORMAL AND LOG NORMAL DISTR, BIOKA 64,25

KOOPMANS, L. H. CONVERGENCE RATES FOR THE LAW OF LARGE NUMBERS FOR THE LINEAR COMBINATIONS OF EXCHANGEABL, AMS 65,1 B 40

KOOPMANS, L. $\mathrm{H}$. CONVERGENCE RATES FOR THE LAW OF LARGE NUMBERS FOR LINEAR COMBINATIONS OF MARKOV PROCESSE, AMS 66,711

KOOPMANS, L. H. ON THE COEFFIC IENT OF COHERENCE FOR WEAKLY STATIONARY STOCHASTIC PROCESSES, AMS 64,532

KOOPMANS, L. H. ON THE CONVERGENCE RATE OF THE LAW OF LARGE NUMBERS FOR LINEAR COMBINAT IONS OF INDEPENDEN, AMS 65,559

KOOPMANS, L. H. ON THE MULTIVARIATE ANALYSIS OF WEAKLY STATIONARY STOCHASTIC PROCESSES, AMS 64,1765

KOOPMANS, L. H. TOLERANCE LIMITS FOR THE CLASS OF DISTRIBUTIONS WITH INCREASING HAZARD RATE, AMS 64,1561

KORBEL, JOHN LABOR FORCE ENTRY AND ATTACHMENT OF YOUNG PEOPLE, CORR 661248, JASA 66,117

KORIN, B. P. ON TEST ING THE EQUALITY OF K COVARIANCE MATRICES, BIOKA 69,216

KORIN, B. P. ON THE DISTRIBUTION OF A STATISTIC USED FOR TESTING A COVARIANCE MATRIX, BIOKA 68,171

KOTLARSKI, I. ON CHARACTERIZING THE NORMAL DISTRIBUTION BY STUDENT'S LAW, BIOKA 66, 603

KOTLARSKI, I. ON PAIRS OF INDEPENDENT RANDOM VARIABLES WHOSE PRODUCT FOLLOWS THE GAMMA DISTRIBUTION., BIOKA 65,289

KOTLARSKI, IGNACY ON BIVARIATE RANDOM VARIABLES WHERE THE QUOT IENT OF THEIR COORDINATES FOLLOWS SOME KNOW, AMS 64,1673

KOTLARSKI, IGNACY ON CHARACTERIZING THE CHI SQUARE DISTRIBUTION BY THE STUDENT LAW, JASA 66, 976

KOTLARSKI, IGNACY ON THE GENERALIZED MELLIN TRANSFORM OF A COMPLEX RANDOM VARI ABLE AND ITS APPLICATIONS, AMS 65,1459

KOTZ, SAMEUL SERIES REPRESENTATIONS OF DISTRIBUTIONS OF QUADRATIC FORMS IN NORMAL VARIABLES, I, CENTRAL C, AMS 67, B23

KOTZ, SAMEUL SERIES REPRESENTATIONS OF DISTRIBUTIONS OF QUADRATIC FORMS IN NORMAL VARI ABLES. II, NON-CENT, AMS 67, B3B

KOTZ, SAMUEL DISTRIBUTION OF SUM OF IDENTICALLY DISTRIBUTED EXPONENTIALLY CORRELATED GAMMA-VARTABLES, AC, AMS 64,277

KOTZ, SAMUEL EXPONENTIAL BOUNDS ON THE PROBABILITY OF ERROR FOR A DISCRETE MEMORYLESS CHANNEL, AMS 61,577

KOUL, HIRA LAL ASYMPTOTIC BEHAVIOR OF WILCOXON TYPE CONFIDENCE REGIONS IN MULTIPLE LINEAR REGRESSION, AMS 69, NO 6

KOUNIAS, E. CONSIDERING STATISTICAL AND TIME AVERAGES IN A REGULATION PROBLEM, JRSSB 67,475

KOUNIAS, EUSTRATIOS G. AN INEQUALITY AND ALMOST SURE CONVERGENCE, AMS 69,1091

KOUNIAS, EUSTRATIOS G. BOUNDS OF THE PROBABILITY OF A UNION OF EVENTS, WITH APPLICATIONS, AMS 68, 2154

KOVATS, M. STEREOSCOPIC MODELS OF MULTIVARIATE STATISTICAL DATA, BIOCS $66,35 \mathrm{~B}$

KOWALSKI, C. J. CO-ORDINATE TRANSFORMATIONS TO NORMALITY AND THE POWER OF NORMAL TESTS FOR INDEPENDENCE, BI OKA 69,139

KOWMAN, K. O. REMARKS ON LARGE SAMPLE ESTIMATORS FOR SOME DISCRETE DISTRIBUTIONS, TECH 67,587

KPEDEKPO, G. M. K. WORK ING LIFE TABLES FOR MALES IN GHANA 1960, JASA 69,102

KRAEMER, HELEN CHMURA ONE-SIDED CONFIDENCE INTERVALS FOR THE QUALITY IND ICES OF A COMPLEX ITEM, TECH 63,400

KRAFFT, O. A NOTE ON HOEFFDING'S INEQUALITY, JASA 69, 907

KRAFT, C. H. AN APPROXIMATION TO THE WILCOXON-MANN-WHITNEY DISTRIBUTION, JASA 69,591

KRAFT, CHARLESH. BAYESIANBIO-ASSAY, AMS $64,8 B 6$

KRAFT, CHARLES $H$. FLUCTUATION THEOREM AND A DISTRIBUTION-FREE TEST, AMS 64,1359

KRAMER, B. H. FREQUENCY RESPONSE FROM STATIONARY NOISE, TWO CASE HISTORIES, TECH 61,245
KRAMER, C. Y. JOINT ESTIMATION OF THE PARAMETERS OF TWO NORMAL POPULATIONS, JASA 62,446

KRAMER, CLYDE Y. APPROXIMATION TO THE CUMULATIVE T-DISTRIBUTION, TECH 66,358

KRAMER, CLYDE YOUNG FACTORIAL TREATMENTS IN RECTANGULAR LATTICE DESIGNS, JASA 61, 36B

KRAMER, $K . H$. TABLES FOR CONSTRUCT ING CONFIDENCE LIMITS ON THE MULTIPLE CORRELATION COEFPICIENT, JASA 63, 1082

KRAMER, KENNETH H. USE OF MEAN DEVIATION IN THE ANALYSIS OF INTERLABORATORY TESTS, TECH 67,149

KRANE, SCOTT A. ANALYSIS OF SURVIVAL DATA BY REGRESS ION TECHNIQUES, TECH 63,161

KRAUSE, G. F. A PROBABILITY STRUCTURE FOR GROWTH CURVES, BIOCS 67 217

KRENGEL, U. NOTE ON SHIFT-INVARIANT SETS, AMS 69,694

KREYBERG, H. J. A. EMPERICAL RELAT IONSHIP OF LUNG CANCER INCIDENCE TO CIGARETTE SMOKING AND A STOCHASTIC, BIOCS 65,839

KRICHNAJI, N. THE JOINT DISTRIBUTION OF ASCENDING PAIRS AND ASCENDING RUNS IN A RANDOM SEQUENCE, BIOKA 67,330

KRISHNA, IYER, P, V. CORRECTIONS TO 'A THEOREM ON FACTORIAL MOMENTS AND ITS APPLICATIONS' 50 206, AMS 61, 620

KRISHNA IYER, P. V. CORRECTIONS TO 'THE THEORY OF PROBABILITY DISTRIBUTIONS OF POINTS ON A LATTICE' 5825 , AMS 61,619

KRISHNAIAH, P. R. A NOTE ON MOMENTS OF GAMMA ORDER STATISTICS, TECH 67,315

KRISHNAIAH, P. R. A NOTE ON RECURRENCE RELATIONS BETWEEN EXPECTED VALUES OF FUNCTIONS OF ORDER STATISTICS, AMS 66,733

KRISHNAIAH, P. R. SIMULTANEOUS TESTS FOR THE EQUALITY OF COVARIANCE MATRICES AGA INST CERTAIN ALTERNATIVES, AMS 68,1303

KRISHNAIAH, P. R. TESTS FOR THE EQUALITY OF COVARIANCE MATRICES UNDER THE INTRACLASS CORRELATION MODEL, AMS 67,1286

KRISHNAN, M. LOCALLY UNBIASED TYPE M TEST, JRSSB 66,298

KRISHNAN, MARAKATHA SERIES REPRESENTATIONS OF THE DOUBLY NONCENTRAL T-DISTRIBUTION, JASA 6B, 1004

KRISHNAN, MARAKATHA THE MOMENTS OF A DOUBLY NONCENTRAL T-DISTRIBUTION, JASA 67,278

KRISHNASWAMI, P. BIAS IN MULT INOMI AL CLASS IF ICATION, JASA 6B, 298 KRONMAL, R. THE ESTIMATION OF PROBABILITY DENSITIES AND CUMULATIVES BY FOURIER SERIES METHODS, JASA 68, 925

KRUSE, R. L. CONSTRUCTION OF SEQUENCES ESTIMATINC THE MIXINC DISTRIBUTION, AMS $68,2 B 6$

KRUSKAL, J, B. ANALYSIS OF FACTORIAL EXPERIMENTS BY ESTIMATING MONOTONE TRANSFORMATIONS OF THE DATA, JRSSB 65,251

KRUSKAL, W. H. DISCUSSION OF THE PAPERS OF MESSRS. ANSCOMBE AND DANIEL, TECH 60,157

KRUSKAL, W. H. SOME REMARKS ON WILD OBSERVATIONS, TECH 60 ,

KRUSKAL, WILLIAM WHEN ARE GAUSS-MARKOV AND LEAST SQUARES ESTIMATORS IDENTICAL. A COORDINATE-FREE APPROACH, AMS 6B, 70

KRUSKAL, WILLIAM H. HISTORICAL NOTES ON THE WILCOXON UNPAIRED TWOSAMPLE TEST, JASA 57,356

KRUSKAL, WILLIAMH, MEASURES OF ASSOCTATION FOR CROSS CLASSTFTCATIONS, II . FURTHER DISCUSSION AND REFEREN, JASA 59, 123

KRUSKAL, WILLIAM H. MEASURES OF ASSOCIATION FOR CROSS CLASSIFICATIONS, 111. APPROXIMATE SAMPLING THEORY, JASA 63,310

KRUSKAL, WILLIAMH. ORDINAL MEASURES OF ASSOCIATION, JASA 58, B14

KRUTCHKOFF, R. G. A MONTE CARLO INVESTIGATION OF THE SIZE AND POWER OF TESTS EMPLOYING SATTERTHWAITE'S SY, BIOKA 68, 431

KRUTCHKOFF, R. G. A SUPPLEMENTARY SAMPLE NON-PARAMETRIC EMPIRICAL BAYES APPROACH TO SOME STATISTICALDECI, BIOKA 67,451

KRUTCHKOFF, R, G. AN EMPIRICAL BAYES SMOOTHING TECHNIQUE, BIOKA 69 361

KRUTCHKOFF, R. G. CLASSICAL AND INVERSE REGRESSION METHODS OF CALIBRATION IN EXTRAPOLATION, TECH 69,605

KRUTCHKOFF, R. G. EMPIRICAL BAYES ESTIMATORS IN A MULTIPLE LINEAR REGRESSION MODEL, BIOKA 69, 367

KRUTCHKOFF, R, G. EPSILON ASYMPTOTIC OPTIMALITY OF EMPIRICAL BAYES ESTIMATORS, BIOKA 69,220

KRUTCHKOFF, R. G. SOME EMPIRICAL BAYES TECHNIQUES IN POINT ESTIMATION, BIOKA 69,133

KRUTCHKOFF, R. G. THE EMPIRICAL BAYES APPROACH, ESTIMATING THE PRIOR DISTRIBUTION, BIOKA 67,326

KRUTCHKOFF, R. G. THE USE OF EMPIRICAL BAYES ESTIMATORS IN A LINEAR REGRESSION MODEL, BIOKA 68, 525

KRUTCHKOFF, RICHARD G. CLASSICAL AND INVERSE RECRESSION METHODS OF CALIBRATION, TECH 67,425

KRUTCHKOFF, RTCHARD G THE CORRECT USE OF THE SAMPLE MEAN ABSOLUTE DEVIATION IN CONF IDENCE INTERVALS FOR, TECH 66,663

KSHIRSAGAR, A. M. A NOTE ON DIRECTION AND COLLINEARITY FACTORS IN CANONICAL ANALYSIS, BIOKA 62, 255

KSHIRSAGAR, A. M. A NOTE ON THE DERIVATION OF SOME EXACT MULTIVARIATE TESTS, BIOKA $60,4 \mathrm{BO}$

KSHIRSAGAR, A, M. ASYMPTOTIC VALUES OF THE FIRST TWO MOMENTS IN MARKOV RENEWAL PROCESSES, BIOKA 67,597

KSHIRSACAR, A. M. BALANCED FACTORIAL DESICNS, JRSSB 66,559

KSHIRSAGAR, A. M. THE GOODNESS-OF-FIT OF A SINGLE (NON-ISOTROPIC) HYPOTHET ICAL PRINCIPAL COMPONENT , BIOKA 61,397 
KSHIRSACAR, A.M. THE NON-CENTRAL MULTIVARIATE BETA DISTRIBUTION, AMS 61, 104

KSHIRSACAR, A.M THE NON-NULL DISTRIBUTION OF A STATISTIC IN PRINCIPAL COMPONENTS ANALYSIS, BIOKA 66,590

$\mathrm{KU}, \mathrm{H} . \mathrm{H}$. A NOTE ON CONTINCENCY TABLES INVOLVING ZERO FREQUENCIES AND THE 2 I TEST, TECH 63,398

KU, H. H. SYMMETRY AND MARCINAL HOMOCENEITY OF AN R-BY-R CONT INGENCY TABLE, JASA 69 , NO 4

KU, $H, H$. TESTS FOR CONTINGENCY TABLES AND MARKOV CHAINS, TECH 62 573

KUDO, AKIO A MULTIVARIATE ANALOGUE OF THE ONE-SIDED TEST, BIOKA 63. 403

KUDO, AKIO ON SLIPPAGE TEST (II) SIMILAR SLIPPAGE TESTS, AMS 6B, 2029

KUDO, AKIO ON SLIPPAGE TESTS I. A GENERALIZATION OF NEYMAN PEARSON'S LEMMA, AMS 68, 1693

KUDO. HIROKICHI ON THE PROPERTY, W, OF THE CLASS OF STATISTICAL DECISION FUNCTIONS, AMS 66, 1631

KUEHL, R. O. REFERENCE POPULATIONS FOR DIALLEL EXPERIMENTS, BIOCS 68. BBI

KUELBS, J THE INVARIANCE PRINCIPLE FOR A LATTICE OF RANDOM VARIABLES, AMS 6B, 382

KULKARNI, G. A. INCOMPLETE BLOCK DESIGNS FOR 8IO-ASSAYS, BIOCS 66 . 706

KULKARNI, N , V. ON EFFICIENT MULT INOMIAL EST IMATION, JRSSB 66, 45 KULKARNI, S. R. LAMP TESTS OF LINEAR AND LOGLINEAR HYPOTHESES IN MULTINOMIAL EXPERIMENTS, CORR. 66 1246, JASA 66, 236

KULLBACK, S. A BOUND FOR THE VARIATION OF GAUSSIAN DENSITIES, AMS 69, N0.6

KULLBACK, S. A NOTE ON MINIMUM DISCRIMINATION INFORMATION, AMS 66. 279

KULLBACK, S. CONTINGENCY TABLES WITH GIVEN MARGINALS. BIOKA 68, 179 KULLBACK. S. NOTES. MINIMUM DISCRIMINATION INFORMATION ESTIMATION, 8IOCS 68,707

KULLBACK, S. ON THE ANALYSIS OF MULT IPLE REGRESSION IN K CATEGORIES BIOKA 57,67

KULLBACK. S. PROBABILITY DENSITIES WITH GIVEN MARCINALS, AMS 68. 1236

KULLBACK, S. SYMMETRY AND MARC INAL HOMOGENEITY OF AN R-BY-R CONT INGENCY TABLE, JASA 69 , NO. 4

KULLBACK, S. TESTS FOR CONTINCENCY TABLES AND MARKOV CHAINS, TECH 62.573

KULL8ACK, S. THE TWO CONCEPTS OF INFORMATION, JASA 67, 685

KULLDORFF, GUNNAR ESTIMATION OF ONE OF TWO PARAMETERS OF THE EXPONENT IAL DISTRIBUTION ON THE BASIS OF SUI. AMS 63, 1419

KULSHRESHTHA, A. C. ON THE EFFICIENCY OF MODIFIED BALANCED INCOMPLETE BLOCK DESIGNS FOR BIO-ASSAYS, BIOCS 69,591

KUMAR, JOCINDER METHOD OF CONSTRUCTION OF ATTRITION LIFE TABLES FOR THE SINGLE POPULATION BASED ON TWO SU, JASA 67,1433

KUMAR, PRANAB A CLASS OF RANK ORDER TESTS FOR A GENERAL LINEAR HYPOTHESIS, AMS 69,1325

KUMAR, PRANAB ON A CLASS OF ALIGNED RANK ORDER TESTS IN TWO-WAY LAYOUTS, AMS 68, 1115

KUNITA, HIROSHI NOTE ON DYNKIN'S 'ALPHA, XI ' SUBPROCESS OF STANDARD MARKOV PROCESS, AMS 67,1647

KUO, M. T. FREQUENCY RESPONSE FROM STATIONARY NOISE, TWO CASE HISTORIES, TECH 61,245

KUPPER, L . L. TIES IN PAIRED-COMPARISON EXPERIMENTS. A GENERALIZATION OF THE 8RADLEY-TERRY MODEL, CORR, 6, JASA 67, 194

KUPPERMAN, M. TESTS FOR CONTINGENCY TABLES AND MARKOV CHAINS, TECH 62,573

KUPPERMAN, MORTON ON EXACT GROUPING CORRECTIONS TO MOMENTS AND CUMULANTS, BIOKA 52, 429

KURKJIAN, B A CALCULUS FOR FACTORIAL ARRANGEMENTS, AMS 62,600

KURKJIAN, 8, APPLICATIONS OF THE CALCULUS OF FACTORIAL ARRANGEMENTS. I. BLOCK AND DIRECT PRODUCT DESIGN, BIOKA 63.63

KURKJIAN. BAKRIG $M$. EXACT OPERATING CHARACTERISTIC FOR TRUNCATED SEQUENTI AL LIFE TESTS IN THE EXPONENTIAL, AMS 62, 1403

KURTZ, T. E. AUTHOR' S REPLY TO ANSCOMBE 'S COMMENTS, TECH 65,169

KURTZ. T. E. CORRELATION OF RANGES OF CORRELATED DEVIATES, BIOKA 66. 191

KURTZ, T . E. SHORT-CUT MULTIPLE COMPARISONS FOR BALANCED SINCLE AND DOUBLE CLASSIFICATIONS. PART 2. DERIV, BIOKA 65, 4B5

KURTZ, T. E. SHORT-CUT MULTIPLE COMPARISONS FOR BALANCED SINCLE AND DOUBLE CLASSIFICATIONS. PART 1, RESUL, TECH 65, 95

KURTZ, THOMAS C. A NOTE ON SEQUENCES OF CONTINUOUS PARAMETER MARKOV CHAINS, AMS 69, 1078

KURZ, LUDWIK SEQUENTIAL NONPARAMETRIC TWO-WAY CLASSIFICATION WITH PRESCRIBED MAXIMUM ASYMPTOTIC ERROR PRO. AMS 69.445

KUSHNER, HAROLD J. A NOTE ON THE MAXIMUM SAMPLE EXCURSIONS OF STOCHASTIC APPROXIMATION PROCESSES, AMS 66, 513

KUSHNER, HAROLD J, AN APPLICATION FOR THE SOBOLEV IMBEDDINC THEOREMS TO CRITERIA FOR THE CONTINUITY OF PR, AMS 69.517

KUSSMAUL, $K$. PROTECTION ACAINST ASSUMING THE WRONC DEGREE IN POLYNOMIAL REGRESSION, TECH 69 , N0.4

KUSSMAUL, K. L. A STUDY OF THE VARIABILITY DUE TO COINCIDENT PASSAGE IN AN ELECTRONIC BLOOD CELL COUNTER, BIOCS 67,671
KUSSMAUL, KEITH ESTIMATION OF VARIANCE COMPONENTS IN TWO-STACE NESTED DESICNS WITH COMPOSITE SAMPLES, TECH 67,373

KUZMA. J. W. A COMPARISON OF TWO LIFE TABLE METHODS, BIOCS 67,51

KUZMACK, A. MULTIVARIATE T AND THE RANKINC PROBLEM, BIOKA 67, 305

L'ESPERANCE, W. L. CROSS STATE PRODUCT AND AN ECONOMETRIC MODEL OF A

STATE, JASA 69,787

LACHENBRUCH. P. A. AN ALMOST UNBIASED METHOD OF OBTAININC CONFIDENCE INTERVALS FOR THE PRO8ABILITY OF MIS, BIOCS 67,639

LACHENBRUCH, P. A . NON-PARAMETRIC ANALYSIS OF VARIANCE IN SMALL SAMPLES, A MONTE CARLO STUDY OF THE ADEQU, BIOCS 69,593

LACHENBRUCH, P. A. TABLES OF SIMULTANEOUS CONF IDENCE LIMITS FOR THE BINOMI AL AND AND POISSON DISTRIBUTION, BIOKA 69, 452

LACHENBRUCH, PETER A. DISCRIMINANT ANALYSIS WHEN THE INITIAL SAMPLES ARE MISCLASSIFIED, TECH 66,657

LACHENBRUCH, PETER A. ESTIMATION OF ERROR RATES IN DISCRIMINANT ANALYSIS, TECH $6 B, 1$

LACHENBRUCH, PETER A ON EXPECTED PROBABILITIES OF MISCLASSIFICA TION IN DISCRIMINANT ANALYSIS. NECESSARY, BIOCS 68,823

LADD, GEORGE W. ON SOME MEASURES OF FOOD MARKETING SERVICES, JASA 61. 65

LADD, GEORGE W. REGRESSION ANALYSIS OF SEASONAL DATA, JASA 64, 402

LAH. IVO ANALYTICAL GRADUATION OF FERT ILITY RATES, JASA 56, 46

LAHA, R. G. ON A PROBLEM CONNECTED WITH QUADRATIC REGRESSION. BIOKA 60.335

LAHA, R. G, ON AN EXTENSION OF GEARY 'S THEOREM, BIOKA 53, 22B

LAHA, R, G ON CERTAIN FUNCTIONS OF NORMAL VARIATES WHICH ARE UNCORRELATED OF A HIGHER ORDER, BIOKA 60, 175

LAMBRAKIS, D. P. AN ALTERNATIVE TO THE SIMPLEX-LATTICE DESIGN FOR EXPER IMENTS WITH MIXTURES, JRSSB 69 , NO.2

LAMBRAKIS, D. P. EST IMATED REGRESSION FUNCTION OF THE Q-SUB-1 TO Q SUB-N BY M-SUB-1 TOM-SUB-N MULT IPLE-L, JRSSB 69, NO .2

LAMBRAKIS, D . P EXPERIMENTS WITH MIXTURES, A GENERALIZATION OF THE SIMPLEX-LATTICE DESIGN, JRSSB 6B, 123

LAMBRAKIS, D. P. EXPERIMENTS WITH P-COMPONENT MIXTURES, JRSSB 68 , 137

LAMPERTI, JOHN AN INVARIANCE PRINCIPLE IN RENEWAL THEORY, AMS 62 , 685

LAMPERTI, JOHN ON A CLASS OF STOCHASTIC PROCESSES, AMS 63, 206

LAMPERTI, JOHN ON EXTREME ORDER STATIST ICS , AMS 64, 1726

LAMPERTI, JOHN ON LIMIT THEOREMS FOR GAUSSIAN PROCESSES, AMS 65, 304 LANCASTER, H, O. CORRECTION. 'THE STRUCTURE OF BIVARIATE DISTRIBUTIONS', 58719, AMS 64, 13BB

LANCASTER, H O CORRELATION AND COMPLETE DEPENDENCE OF RANDOM VARIABLES, AMS 63, 1315

LANCASTER, H. O. CORRELATIONS AND CANONICAL FORMS OF BIVARIATE DISTRIBUTIONS, AMS 63, 532

LANCASTER, H. O. KOLMOCOROV'S REMARK ON THE HOTELLING CANONICAL CORRELATIONS. BIOKA 66,585

LANCASTER, H . 0. PAIRWISE STATIST ICAL INDEPENDENCE, AMS 65, 1313 LANCASTER, H, O, QUERY, THE COM8INATION OF PROBABILITIES, BIOCS 67 840

LANCASTER, H. 0. SIGNIFICANCE TESTS IN DISCRETE DISTRIBUTIONS CORR. 62919, JASA 61,223

LANCASTER, H. O. SOME PROPERTIES OF THE BIVARIATE NORMAL DISTRIBUTION CONSIDERED IN THE FORM OF A CONTING, BIOKA 57, 289

LANCASTER, $H$. O. STATISTICAL CONTROL OF COUNTING EXPERIMENTS, BIOKA 52,419

LANCASTER, H. O. TRACES AND CUMULANTS OF QUADRATIC FORMS IN NORMAL VARIABLES. JRSSB 54,247

LANCASTER, TONY A NOTE ON AN 'ERRORS IN VARIABLES' MODEL, JASA 66. 128

LANCASTER, TONY GROUPING ESTIMATORS IN HETEROSCEDASTIC DATA (CORR 6B 1550), JASA 6B, 182

LAND, A. H. A CONTRIBUTION TO THE 'TRAVELLING-SALESMAN' PROBLEM. (WITH DISCUSSION) , JRSSB 55, 185

LAND, R. O. D. A CLASS OF SITUATIONS IN WHICH A SEQUENTIAL ESTIMATION PROCEDURE IS NON-SEQUENTIAL, BIOKA 67,229

LANDIS, BENSONY. A GUIDE TO THE LITERATURE ON STATISTICS OF RELIGIOUS AFFILIATION WITH REFERENCES TO REL, JASA 59, 335

LANCFORD, E. THE PROBABILITY THAT A RANDOM TRIANGLE IS OBTUSE, BIOKA 69. NO.3

LANGLEY,P. G. AN INVESTIGATION INTO THE SMALL SAMPLE PROPERTIES OF A TWO SAMPLE TEST OF LEHMANN' $S$, JA.SA 68,345

LANSING, JOHN B. A CROSS-SECTION ANALYSIS OF NON-BUSINESS AIR TRAVEL, JASA 5B, 928

LARSEN, W A THE ANALYSIS OF VARIANCE FOR THE TWO-WAY CLASSIFICATION FIXED EFFECTS MODEL WITH OBSERVATIO, BIOKA 69, NO .3

LARSON, HAROLD J. BIASES IN PREDICTION BY REGRESSION FOR CERTAIN INCOMPLETELY SPECIFIED MODELS, BIOKA 63, 391

LARSON, HAROLD J. LEAST SQUARES ESTIMATION OF THE COMPONENTS OF A SYMMETRIC MATRIX, TECH 66, 360

LARSON, HAROLD J. SEQUENTIAL MODEL BUILDING FOR PREDICTION IN REGRESSION ANALYSIS, I, AMS 63,462

LASKA, EUGENE EFFICIENCY ROBUST TWO-SAMPLE RANK TESTS, JASA 67. 1241 
LASKA, EUGENE OPTIMAL ROBUSTNESS. A GENERAL METHOD, WITH APPLICATIONS TO LINEAR ESTIMATORS OF LOCATION, JASA 67, 1230

LATSCHA, $R$. TESTS OF SIGNIFICANCE IN A 2-BY-2 CONTINGENCY TABLE, EXTENSION OF FINNEY 'S TABLE, BIOKA 53, 74

LAUBSCHER, N. F. EXACT CRITICAL VALUES FOR MOOD'S DISTRIBUTIONFREE TEST STATISTIC FOR DISPERSION AND ITS, TECH 68,497

LAUBSCHER, F. NOTE ON FISHER'S TRANSFORMATION OF THE CORRELATION COEFFICIENT, JRSSB 59,409

LAUBSCHER, N. F. SINGLE AND MULTIPLE DISCRIMINATION REGI ONS IN MUI TIPLELINEAR REGRESSION, SASJ 6B, 67

LAUBSCHER, NICO F. ON STABILIZING THE BINOMIAL AND NEGATIVE BINOMIAL VARIANCES, JASA 61,143

LAUH, ELIZABETH A NOTE ON THE GRAPHICAL ANALYSIS OF MULTIDIMENSI ONAL CONTINGENCY TABLES, TECH 67,481

LAUH. ELIZABETH SCALE PARAMETER ESTIMATION FROM THE ORDER STATISTICS OF UNEQUAL GAMMA COMPONENTS, AMS 66, 152

LAURENT. ANDRE G. CONDITIONAL DISTRIBUTION OF ORDER STATISTICS AND DISTRIBUTION OF THE REDUCED ITH ORDER, AMS 63,652

LAURENT, ANDRE G. THE LOGNORMAL DISTRIBUTION AND THE TRANSLATION METHOD, DESCRIPTION AND ESTIMATION PROBL, JASA 63, 231

LAVALLE, IRVING H. ON CASH EQUIVALENTS AND INFORMATION EVALUATION IN DECISIONS UNDER UNCERTAINTY, PARTS I, JASA 68,252

LAWING. WILLIAMD. LIKEL IHOOD RATIO COMPUTATIONS OF OPERATING COMPUTATIONS, AMS 66, 1704

LAWLEY, D. N . A GENERAL METHOD FOR APPROXIMATING TO THE DISTRIBUTION OF LI YELIHOOD RATIO CRITERIA, BIOKA 56, 295

LAWLEY, D. N. ON TESTING A SET OF CORRELATION COEFFICIENTS FOR EQUALITY, AMS 63, 149

LATLEY. D. N. TESTS OF SIGNIFICANCE FOR THE LATENT ROOTS OF COVARIANCE AND CORRELATION MATRICES, BIOKA 56, 12B

LANLEY, D. N. TESTS OF SIGNIFICANCE IN CANONICAL ANALYSIS; BIOKA 59 59

LAWRENCE, M. J. AN INVESTIGATION OF THE BURN-IN PROBLEM, TECH 66, 61 LARRENCE, N R R. DRAPER, W. MIXTURE DESIGNS FOR FOUR FACTORS, JRSSB 65.473

LATRENCE, W. MIXTURE DESIGNS FOR THREE FACTORS, JRSSB 65, 450

LAWRENCE. W. E. DESIGNS WHICH MINIMIZE MODEL INADEQUACIES. CUBOIDAL REGIONS OF INTEREST, BIOKA 65, III

LAWRENCE, W. E. SEQUENTI AL DESIGNS FOR SPHERICAL WEIGHT FUNCTIONS, TECH 67, 517

LAWRENCE. W. E. THE USE OF SECOND-ORDER 'SPHERICAL' AND 'CUBOIDAL' DESIGNS IN THE WRONG REGI ONS, BIOKA 66, 596

LANTON, W. H. COMPARISON OF ANOVA AND HARMONIC COMPONENTS OF VARIANCE, TECH 69,75

LAWTON, W. H. QUERY, RESIDUAL ANALYSIS, TECH 67,339

LAWTON, W. H. THE SPECTRUM OF A MODEL II NESTED ANOVA AND ITS APPLICATIONS, TECH 69,91

LAWTON, WILLIAMH. CONCENTRATION OF RANDOM QUOTIENTS, AMS 68, 466

LAWTON, WILLIAM H. SOME INEQUALITIES FOR CENTRAL AND NON-CENTRAL DISTRIBUTIONS, AMS 65,1521

LAYCOCK, P. J. OPT IMAL DESI GNS IN REGRESSION PROBLEMS WITH A GENERAL CONVEX LOSS FUNCTION, BIOKA 68, 53

LAZERWITZ, BERNARD A COMPARISON OF MAJOR UNITED STATES RELIGIOUS GROUPS, JASA 61,568

LEACH, E. APPROXIMATE LINEARIZATION OF THE INCOMPLETE BETA-FUNCTION, BIOKA 59,214

LEADBETTER, M. R. BOUNDS ON THE ERROR IN THE LINEAR APPROXIMATION TO THE RENEWAL FUNCTION, BIOKA 64,355

LEADBETTER, W. R. HAZARD ANALYSIS. I, BIOKA 64,175

LEADBETTER. M. R. ON CROSSINGS OF LEVELS AND CURVES BY A WIDE CLASS OF STOCHASTIC PROCESSES, ANS 66,260

LEADBETTER, M. R. ON SERIES EXPANSIONS FOR THE RENEWAL MOMENTS BIOKA 63,75

LEADBETTER, M. $R$. ON STREAMS OF EVENTS AND MIXTURES OF STREAMS JRSSB 66,218

LEADBETTER, M. R. ON THE ESTIMATION OF THE PROBABILITY DENSITY, I AMS 63, $4 B 0$

LEADBETTER, M.R. ON THE MEAN NUMBER OF CURVE CROSSINGS BY NON-STATIONARY NORMAL PROCESSES, AMS 65,509

LEADBETTER, M. R. ON THE NORMAL STATIONARY PROCESS, AREAS OUTSIDE GIVEN LEVELS, JRSSB 63 , IB9

LEADBETTER, M. R. ON THE RENEWAL FUNCTION FOR THE WEIBULL DISTRIBUTION, TECH 63,393

LEADBETTER, M. R. THE MOMENTS OF THE NUMBER OF CROSSINGS OF A LEVEL BY A STATIONARY NORMAL PROCESS, AMS 65,1656

LEADBETTER, $R$. ON THE DISTRIBUTIONS OF THE TIMES BETWEEN EVENTS IN A STATIONARY STREAM OF EVENTS, JRSSB 69, NO.2

LEAVERTON, PAUL SMALL SAMPLE POWER CURVES FOR THE TWO SAMPLE LOCATION PROBLEM, TECH 69,299

LECAM, L. SUFEICIENCY AND APPROXIMATE SUFFICIENCY, AMS 64, 1419 LECAM. LUCIEN CONSISTENT ESTIMATES AND ZERO-ONE SETS, AMS 64, 157 LECHNER, J. A . OPTIMUM DECISION PROCEDURES FOR A POISSON PROCESS PARAMETER, AMS 62,1384

LECHNER, JAMES A. OPTIMALITY AND THE OPERATING CHARACTERISTIC CURVE FOR THE TALD SEQUENTIAL PROBABILITY R, JASA 64, 464
LEE, ANNE S. INTERNAL MIGRATION STATISTICS FOR THE UNITED STATES JASA 60,664

LEE. EVERETT S. INTERNAL MIGRATION STATISTICS FOR THE UNITED STATES, JASA 60.664

LEE. MAW LIN INCOME. INCOME CHANGE, AND DURABLE GOODS DEMAND, JASA 64. 1194

LEE, P. M. ON THE AXIOMS OF INFORMATION THEORY, AMS 64,415

LEE. T. C. MAXIMUM LIKELIHOOD AND BAYESIAN ESTIMATION OF TRANSITION PROBABILITIES, , JASA 68,1162

LEE, TONG HUN INCOME. WEALTH, AND THE DEMAND FOR MONEY, SOME EVIDENCE FROM CROSS-SECTION DATA, JASA 64,746

LEES, RUTH W. A NOMOGRAPH FOR COMPUTING PARTIAL CORRELATION COEFFICIENTS, CORR. 62917, JASA 61, 995

LEFKOVITCH, L, P. THE STUDY OF POPULATION GROWTH IN ORGANISMS GROUPED BY STAGES, BIOCS 65 , I

LEHMAN JR, E. H. AN APPROXIMATION OF THE NEGATIVE MOMENTS OF THE POSITIVE BINOMIAL USEFUL IN LIFE TESTING, TECH 60, 227

LEHMAN, SHIRLEY YOUNG EXACT AND APPROXIMATE DISTRIBUTIONS FOR THE WILCOXON STATISTIC WITH TIES, JASA 61, 293

LEHMANN, E. L. A COMPACT TABLE FOR POWER OF THE T-TEST, AMS 6B, 1629

LEHMANN, E. L ASYMPTOTICALLY NONPARAMETRIC INFERENCE IN SOME LINEAR MODELS WITH ONE OBSERVATION PER CELL, AMS 64,726

LEHMANN, E. L. ASYMPTOTICALLY NONPARAMETRIC INFERENCE, AN ALTERNATIVE APPROACH TO LINEAR MODELS, AMS 63,1494

LEHMANN, E. L. EST IMATES OF LOCATION BASED ON RANK TESTS, AMS 63, 598

LEHMANN, E. L. NONPARAMETRIC CONFIDENCE INTERVALS FOR A SHIFT PARAMETER, AMS 63,1507

LEHMANN, E. L. ON A THEOREM OF BAHADUR AND GOODMAN, AMS 66, I

LEHMANN, E. L. ON MEDIANS AND QUASI-MEDI ANS. JASA 67, 926

LEHMANN, E, L, RANK METHODS FOR COMBINATION OF INDEPENDENT EXPERIMENTS IN THE ANALYSIS OF VARIANCE. AMS 62,482

EHMANN. E. L. ROBUST ESTIMATION IN ANALYSIS OF VARIANCE, AMS 63 957

EHMANN, E L L SOME CONCEPTS OF DEPENDENCE, AMS 66, 1137

LEHMANN, E. L. SOME MODEL I PROBLEMS OF SELECTION. AMS 61. 990

LEHMANN, E. L. TESTING THE APPROXIMATE VALIDITY OF STATISTICAL HYPOTHESES, JRSSB 54,261

LEHMANN, E. L, UNBIASED ESTIMATION IN CONVEX FAMILIES, AMS 69, 1523 LEHNER, G. ONE DIMENSIONAL RANDOM WALK WITH A PARTIALLY REFLECTING BARRIER. AMS 63, 405

LEIGH-DUGMORE, C. H. A RAPID METHOD FOR EST IMATING THE CORRELATION COEFFICIENT FROM THE RANGE OF THE DEVI. BIOKA 53,218

LEIMKUHLER, F. F. A STATISTICAL MODEL OF BOOK USE AND ITS APPLICATION TO THE BOOK STORAGE PROBLEM, JASA 69, NO. 4

LEIPNIK, R, MOMENT GENERATING FUNCTIONS OF QUADRATIC FORISS IN SERIALLY CORRELATED NORMAL VARIABLES. BIOKA $5 B, 19 B$

LEIPNIK, R. NOTE ON THE CHARACTERISTIC FUNCTION OF A SERIAL-CORPELATION DISTRIBUTION, BIOKA $5 B, 559$

LELLOUCH, J. ESTIMATION PAR LA METHODE DU MAXIMUM DE VRAISEMBLANCE DES COURBES DE SURVIE DE MICROORGANISM. BIOCS 66.673

LELLOUCH, J. LES MANQUANTS DANS L'ESSAI THERAPEUTIQUE. BIOCS 67. 145

LEMMER. H. H. A DISTRIBUTION-FREE ANALYSIS OF VARIANCE TECHNIQUE FOR BLOCKDESIGNS, SASJ 68,9

LEMMER, $\mathrm{H}$ H DISTRIBUTION-FREE ANALYSIS OF VARIANCE FOR THE TWOWAY CLASSIFICATION, SASJ 67,67

LEMON, G. H. AN EMPIRICAL BAYES SMOOTHING TECHNIQUE, BIOKA 69, 361

LENTNER, M. LISTING EXPECTED MEAN SQUARE COMPONENTS, BIOCS 65, 459

LENTNER, $M$ M. GENERALIZED LEAST-SQUARES ESTIMATION OF A SUBVECTOR OF PARAMETERS IN RANDOMIZED FRACTIONAL, AMS 69,1344

LENTNER, M. M. SONE INFERENCES ABOUT GAMMA PARAMETERS WITH AN APPLICATION TO A RELIABILITY PROBLEM, JASA 63, 670

LEONARD, WILLIAMR. AN OUTLOOKREPORT, JASA 5B,

LEONE, F. C. ANALYSIS OF CATEGORICAL DATA., BIOKA 65,654

LEONE, F. C . ASYMPTOTIC RELATIVE EFFICIENCY OF MOOD'S AND MASSEY'S TWO SAMPLE TESTS AGAINST SOME PARAMETR, AMS 62,1375

LEONE. F. C. THE FOLDED NORMAL DISTRIBUTION, TECH 61,543

LEONE, F. C. THE USE OF SAMPLE QUASI-RANGES IN SETTING CONFIDENCE INTERVALS FOR THE POPULATION STANDARD D. JASA 61,260

LEONE, FRED C. A STUDY OF ROBUST ESTIMATORS, TECH 67,652

LEONE, FRED C. EDITORIAL, TECH 66, 1

LEONE, FRED C. SAMPLING DISTRIBUTIONS OF VARIANCE COMPONENTS I. EMPIRICAL STUDIES OF BALANCED NESTED DESI, TECH 66,457

LEONE, FRED C. SAMPLING DISTRIBUTIONS OF VARIANCE COMPONENTS II EMPIRICAL STUDIES OF UNBALANCED NESTED D. TECH 68,719

LEONG, $Y . S$. THE USE OF AN ITERATED MOVING AVERAGE IN MEASURING SEASONAL VARIATIONS, JASA 62,149

LERWICK, TRYGVE R. MAXIMUM LIKELIHOOD ESTIMATORS OF REGRESSION COEFFICIENTS FOR THE CASE OF AUTOCORRELATE. TECH 65. 51

LESER, C. E.V. A SIMPLE METHOD OF TREND CONSTRUCTION, JRSSB 61, 91

LESER, C. E.V. EST IMATION OF QUASI-LINEAR TREND AND SEASONAL VARIATION, JASA 63, 1033

LESLIE, D. C. M. DETERMINATION OF PARAMETERS IN THE JOHNSON SYSTEM OF PROBABILITY DISTRIBUTIONS, BIOKA 59,229

LESLIE. P. H. A COMPARISON OF THEORETICAL AND EMPIRICAL RESULTS FOR SOME STOCHASTIC POPULATION MODELS. BIOKA 60,1

LESLIE. P. H. A NOTE ON SOME APPROXIMATIONS TO THE VARIANCE IN DISCRETE-TIME STOCHASTIC MODELS FOR BIOLOG, BIOKA 60, 196 
LESLIE, P. H. A SIMPLE METHOD OF CALCULATING THE EXACT PROBABILITY IN 2-BY-2 CONTINGENCY TABLES WITH SMAL, BIOKA 55, 522

LESLIE, P. H. A STOCHASTIC MODEL FOR STUDY ING THE PROPERTIES OF CERTA IN BIOLOG ICAL SYSTEMS BY NUMER I CAL M, BIOKA 5B, 16

LESLIE, $P$. H. A STOCHASTIC MODEL FOR TWO COMPETING SPECIES OF TRIBOLIUM AND ITS APPLICATION TO SOME EXPER, BIOKA 62, I

LESLIE, P. H. AN ANALYSIS OF THE DATA FOR SOME EXPERIMENTS CARRIED OUT BY GAUSE WITH POPULATIONS OF THE P, BIOKA 57,314

LESLIE, P. H. CORRIGENDA, 'THE PROPERTIES OF A STOCHASTIC MODEL FOR TWO COMPETING SPECIES. ' , BIOKA 59, 279

LESLIE. P. H. THE ESTIMATION OF POPULATION PARAMETERS FROM DATA OBTAINED BY MEANS OF THE CAPTURE-RECAPTUR, BTOKA 51,269

LESLIE, P. H. THE ESTIMATION OF POPULATION PARAMETERS FROM DATA OBTAINED BY MEANS OF THE CAPTURE-RECAPTUR, BIOKA 52, 363

LESLIE, P. H. THE ESTIMATION OF POPULATION PARAMETERS FROM DATA OBTA INED BY MEANS OF THE CAPTURE-RECAPTUR, BIOKA 53, 137

LESLIE. P. H. THE PROPERTIES OF A STOCHASTIC MODEL FOR THE PREDATORPREY TYPE OF INTERACTION BETWEEN TWO, BIOKA 60,219

LESLIE, P. H. THE PROPERTIES OF A STOCHASTIC MODEL FOR TWO COMPETING SPECIES, BIOKA 5B, 316

LESLIE. R. N. SELECTION OF THE BEST SUBSET IN REGRESSION ANALYSIS. TECH 67, 531

LESLIE, R. T. USE OF RANGE IN TESTING HETEROGENEITY OF VARIANCE, BIOKA 66, 221

LEVENE, HOWARD DISCUSSION OF 'ON THE FOUNDATIONS OF STATISTICAL INFERENCE', JASA 62, 307

LEVER, W. E. CONFIDENCE LIMITS FOR QUANTILES OF MORTALITY DISTRIBUTIONS, BIOCS 69,176

LEVINE, A. A PROBLEM IN MINIMAX VARIANCE POLYNOMIAL EXTRAPOLATION, AMS 66, B9B

LEVINE, A. OPTIMAL SPACING AND WEIGHTING IN POLYNOMIAL PREDICTION AMS 64,1553

LEVINE. J MONOMIAL-MONOMIAL SYMMETRIC FUNCTION TABLES, BIOKA 59 , 205

LEVITAN, RICHARDE. SPECTRAL PROPERTIES OF NON-STATIONARY SYSTEMS OF LINEAR STOCHASTIC DIFFERENCE EQUATIO, JASA 69, 581

LEWIS, P. A. W. A BRANCHING POISSON PROCESS MODEL FOR THE ANALYSIS OF COMPUTER FAILURE PATTERNS (WITH DIS) JRSSB 64, 398

LEWIS, P. A. W. NON-HOMOGENEOUS BRANCHING POISSON PROCESSES, JRSSB 67.343

LEWIS, P. A W. SOME RESULTS ON TESTS FOR POISSON PROCESSES. , BIOKA 65, 67

LEWIS, PETER A.W DISTRIBUTION OF THE ANDERSON-DARLING STATISTIC AMS 61, 1118

LEWIS, T. CORRIGENDA TO 'CORRELATED RANDOM NORMAL DEVIATES' PUBLISHED IN TRACTS FOR COMPUTERS. NO . 26, BIOKA 56, 496

LEWIS. T SOME PROPERTIES OF COUNTS OF EVENTS FOR CERTAIN TYPES OF POINT PROCESS, JRSSB 64, 325

LEWIS, T. THE INTERVALS BETWEEN REGULAR EVENTS DISPLACED IN TIME BY INDEPENDENT RANDOM DEVIATIONS OF LARG, JRSSB 61,476

LEWIS, T. 99.9 PERCENT AND 0.1 PERCENT POINTS OF THE CHI-SQUAREDISTRIBUTION. BIOKA 53,421

LEWIS. T. O. A GENERALIZATION OF THE GAUSS-MARKOV THEOREM, JASA 66 1063

LEWIS, TRUMAN A CONFIDENCE INTERVAL FOR THE AVAILABILITY RATIO TECH 67.465

LEWONTIN, R C. THE ROBUSTNESS OF HOMOGENEITY TESTS IN 2 BY N TABLES BIOCS 65,19

LEYSIEFFER, FREDERICKW. FUNCTIONS OF FINITEMARKOV CHAINS, AMS 67 206

LEYTON $M, K$ NOTES, RAPTD CALCULATION OF EXACT PROBABILITIES FOR 2BY-3 CONTINGENCY TABLES, BIOCS 68,714

LI, C C. CORRELATION BETWEEN THE SAMPLE VARIANCES IN A SINGLY TRUN CATED BIVARIATE NORMAL DISTRIBUTION, BIOKA 68,433

LI, C. C. CORRELATIONS BETWEEN SIMILAR SETS OF MEASUREMENTS, BIOCS 66,781

LI, C. C. FISHER, WRIGHT, AND PATH COEFFICIENTS, BIOCS 68,471

LI, C. C. GENETIC EQUILIBRIUM UNDER SELECTION (INVITED PAPER) BIOCS 67,397

LI, CHOU HSIUNG A SEQUENTIAL METHOD FOR SCREENING EXPERIMENTAL VARIABLES, JASA 62,455

LIEBERMAN, G. J. AN EXACT ASYMPTOTICALLY EFFICIENT CONFIDENCE BOUND FOR RELIABILITY IN THE CASE OF THE WE, TECH 66, 135

LIEBERMAN, G. J. UNLIMITED SIMULTANEOUS DISCRIMINATION INTERVALS IN REGRESSION, BIOKA 67, 133

LIEBERMAN. GERALD J. PREDICTION REGIONS FOR SEVERAL PREDICTIONS FROM A SINGLE REGRESSION LINE, TECH 61,21

LIEBERMAN, GERALD J SIMULTANEOUS TOLERANCE INTERVALS IN REGRESSION, BIOKA 63,155

LIEBERMAN, GERALD J. STATISTICAL PROCESS CONTROL AND THE IMPACT OF AUTOMATIC PROCESS CONTROL, TECH 65,283

LIEBERMAN, MILTON D. PHILIPPINE STATISTICAL PROGRAM DEVELOPMENT AND THE SURVEY OF HOUSEHOLDS, JASA 58,78

LIEBLEIN, J. TWO EARLY PAPERS ON THE RELATION BETWEEN EXTREME VALUES AND TENSILE STRENGTH, BIOKA 54,559

LIENTZ. B. P. TABLES OF CRITICAL VALUES OF SOME RENYI TYPE STATISTICS FOR FINTTE SAMPLE SIZES, JASA 69, 870

LIEU, BUI-TRONG ON THE ERGODICITY FOR NON-STATIONARY MULTIPLE MARKOV PROCESSES. AMS 68,1448
LIGHT, R. THE USE OF FRACTIONAL MOMENTS FOR ESTIMATING THE PARAMETERS OF A MIXED EXPONENTIAL DISTRIBUTION, TECH 68, 161

LIKERT, RENSIS THE DUAL FUNCTION OF STATISTICS, JASA 60,

LIKES, J. NOTES. SAMPLE SIZE FOR THE ESTIMATION OF MEANS OF NORMAL POPULATIONS, BIOCS 67,846

LIKES, JIRI DISTRIBUTION OF SOME STATISTICS IN SAMPLES FROM EXPONENTIAL AND POWER-FUNCTION POPULATIONS, JASA 67, 259

LILLIEFORS, H. W. ON THE KOLMOGOROV-SMIRNOV TEST FOR THE EXPONENTIAL DISTRIBUTION WITH MEAN UNKNOWN, JASA 69, 3B7

LILLIEFORS, HUBERT W. ON THE KOLMOGOROV-SMIRNOV TEST FOR NORMALITY WITHMEAN AND VARIANCE UNKNOWN, JASA 67,399

LINDLEY, D. V. A STATISTICAL PARADOX, BIOKA $57,1 \mathrm{~B} 7$

LINDLEY, D. V. BINOMIAL SAMPLING SCHEMES AND THE CONCEPT OF INFORMATTON, BIOKA 57,179

LINDLEY. D. V. CORRIGENDA, 'TABLES FOR MAKING INFERENCES ABOUT THE VARIANCE OF A NORMAL DISTR IBUTION, ' , BIOKA 61,230

LINDLEY, D. V. DISCUSSION OF 'ON THE FOUNDATIONS OF STATISTICAL INFERENCE' JASA 62, 307

LINDLEY, D. V. DISCUSSION OF THE PAPERS OF MESSRS. HALD, WETHERILL AND COX, TECH 60,361

LINDLEY, D . V. ESTIMATION OF A FUNCTIONAL RELATIONSHIP. BIOKA 53, 47

LINDLEY. D. V. FIDUCIAL DISTRIBUTIONS AND BAYES' THEOREM, JRSSB 5B, 102

LINDLEY, D. $V$. SEQUENTIAL SAMPLING, TWO DECISION PROBLEMS WTTH LINEAR LOSSES FOR BINOMIAL AND NORMAL RAND, BIOKA 65, 507

LINDLEY, D. V. TABLES FOR MAKING INFERENCES ABOUT THE VARIANCE OF A NORMAL DISTR IBUTION, BIOKA 60,433

LINDLEY, D. V. THE BAYESIAN ANALYSIS OF CONTINGENCY TABLES, AMS 64. 1622

LINDLEY, D. V. THE CHOICE OF VARIABLES IN MULTIPLE REGRESSION (WITH DISCUSSION \}, JRSSB 68,31

LINDSEY, G. R. THE PROGRESS OF THE SCORE DURING A BASEBALL GAME, JASA 61,703

LINHART, H, APPROXIMATE CONFIDENCE LIMITS FOR THE COEFFICIENT OF VARIATION IN GAMMA DISTRIBUTIONS, BIOCS 65.733

LINHART, H. APPROXIMATE TESTS FOR M RANKINGS. BIOKA 60,476

LINHART, $H$. ON SOME BILHARZIA INFECTION AND IMMUNISATION MODELS, SASJ $6 B, 61$

LINHART, H. ON THE DISTRIBUTION OF THE FIRST SAMPLE MOMENTS OF SHOT NOISE, TECH $64,2 B 7$

LINK, B. F. AUTHOR'S REPLY TO ANSCOMBE' S COMMENTS, TECH 65, 169

LINK, B. F. SHORT-CUT MULTIPLE COMPARISONS FOR BALANCED SINGLE AND DOUBLE CLASSIFICATIONS. PART 1 , RESULT, TECH 65,95

LINK, R. F. CORRELATION OF RANGES OF CORRELATED DEVIATES, BIOKA 66, 191

LINK, R. F. SHORT-CUT MULTIPLE COMPARISONS FOR BALANCED SINGLE AND DOUBLE CLASSIFICATIONS. PART 2. DERIVA, BIOKA 65, 4B5

LIPOW, M. APPLICATIONS OF THE BIVARIATE NORMAL DISTRIBUTION TO A STRESS VS. STRENGTH PROBLEM IN RELIABILI, TECH 64, 325

LIPOW, M. QUERY, THE SUM OF VALUES FROM A NORMAL AND A TRUNCATED NORMAL DISTRIBUTION (CONTD), TECH 64, 469

LIPTON. S. AN INVESTIGATION OF HARTLEY 'S METHOD FOR FITTING AN EXPONENTIAL CURVE, BIOKA 59, 2BI

LIPTON, S. ROUTINE ANALYSIS OF REPLICATED EXPERIMENTS ON AN ELECTRONIC COMPUTER (WITH DISCUSSION), JRSSB 57,234

LIPTON, S. THE DERIVATION OF METHODS FOR FITTING EXPONENTIAL REGRESSION CURVES, BIOKA 64, 504

LITTLE, R. E. A NOTE ON ESTIMATION FOR QUANTAL RESPONSE DATA, BIOKA 68,578

LITTLE, R, E. A NOTE ON THE GAIN IN PRECISION FOR OPTIMAL ALLOCATION IN REGRESSION AS APPLIED TO EXTRAPOL, TECH 69, 389

LITWIN, S. ESTIMATION OF THE NUMBER OF CRITICAL SITES IN LIMITED GENOME EXPRESSION DUR ING VIRAL INFECTION, BIOCS 69, 537

LIUZZI, A. SOME EXPERIMENTAL SAMPLING RESULTS FOR REGRESSION ANALYSIS APPLIED TO GAMA RAY SPECTROMETER DA, BIOCS 68,353

LIUZZI, A. SOME EXPERIMENTAL SAMPLING RESULTS FOR REGRESSION ANALYSIS APPLIED TO GAMMA RAY SPECTROMETER D, BIOCS 67,11

LIUZZI, ANTHONY PATTERNS IN RESIDUALS, A TEST FOR REGRESSION MODEL ADEQUACY IN RADIONUCLIDE ASSAY, TECH 65, 603

LLEWELYN, F.W.M. THE LOG (-LOG) TRANSFORMATION IN THE ANALYSIS OF FRUIT RETENTION RECORDS, BIOCS 68,627

LLOYD, D. E. NOTE ON A PROBLEM OF ESTIMATION, BIOKA 59, 231

LLOYD, E. H. A NOTE ON THE SOLUTION OF DAM EQUATIONS, JRSSB 64,338

LLOYD, E. H. LEAST SQUARES ESTIMATION OF LOCATION AND SCALE PARAMETERS USING ORDER STATISTICS, BIOKA 52,88

LLOYD, E. H. ON THE RANGE OF PARTIAL SUMS OF A FINITE NUMBER OF INDEPENDENT NORMAL VARIATES, BIOKA 53,35

LLOYD, E. H. RESERVOIRS WITH SER IALLY CORRELATED INPUTS, TECH 63.85

LLOYD, E. H. THE EPOCHS OF EMPTINESS OF A SEMI-INFINITE DISCRETE RESERVOIR, JRSSB 63, 131

LO YANG, GRACE CONTAGION IN STOCHASTIC MODELS FOR EPIDEMICS, AMS 68 , 1863

LOCHNER, R. H. A NOTE ON TABLES FOR THE COMPARISION OF THE SPREAD OF TWO NORMAL DISTRIBUTIONS, BIOKA 67,683

LOCKS. MITCHELL O. AUTOMATIC PROGRAMMING FOR AUTOMATIC COMPUTERS JASA 59,744

LOFTSGAARDEN, D. O. A NONPARAMETRIC ESTIMATE OF A MULTIVARIATE DENSITY FUNCTION, AMS 65, 1049 
LOHRD ING, R. K. A TEST OF EQUALITY OF TWO NORMAL POPULATION MEANS ASSUMING HOMOGENEOUS COEFFICIENTS OF VA, AMS 69, 1374

LOMNICKI, Z. A. A NOTE ON THE WEIBULL RENEWAL PROCESS, BIOKA 66, 375 LOMNICKI, Z. A. BANDWIDTH AND RESOLVABILITY IN STATISTICAL SPECTRAL ANALYSIS, JRSSB 59, 169

LOMNICKI, Z. A. ON ESTIMATING THE SPECTRAL DENSITY FUNCTION OF A STOCHASTRIC PROCESS (WITH DISCUSSION), JRSSB 57, 13

LOMNICKI, $Z$. A. ON THE DISTR IBUT ION OF PRODUCTS OF RANDOM VARIABLES JRSSB 67,513

LOMNICKI, Z. A. SOME APPLICATIONS OF ZERO-ONE PROCESSES, JRSSB 55 , 243

LONG, W. M. ESTIMATION PROBLEMS WHEN A SIMPLE TYPE OF HETEROGENEITY IS PRESENT IN THE SAMPLE, BIOKA 51,90

LONG, W. M. QUALITY CONTROL SYSTEMS BASED ON INACCURATELY MEASURED VARIABLES, BIOKA 51,472

LONGLEY, JAMES W. AN APPRAISAL OF LEAST SQUARES PROGRAMS FOR THE ELECTRONIC COMPUTER FROM THE POINT OF VI, JASA 67,819

LONNQUIST, J . H. FURTHER EVIDENCE ON THE CONSISTENCY OF ESTIMATES OF VARIANCE COMPONENTS, BIOCS 65, 395

LORD, E. CORRIGENDA, 'THE USE OF RANGE IN PLACE OF STANDARD DEVIATION IN THE T-TEST . ', BIOKA 52,442

LORD, FREDERIC $M$. A NOMOGRAPH FOR COMPUTING PARTIAL CORRELATION COEFFICIENTS, CORR, 62917, JASA 61,995

LORD. FREDERIC $M$. LARGE-SAMPLE COVARIANCE ANALYSIS WHEN THE CONTROL VARIABLE IS FALL IBLE, JASA 60,307

LORD, FREDERIC M. PROBLEMS IN MENTAL TEST THEORY ARISING FROM ERRORS OF MEASUREMENT, JASA 59, 472

LORD, R. D. STUDIES IN THE HISTORY OF PROBABILITY AND STATISTICS VIII. DE MORGAN AND THE STATISTICAL STU, BIOKA 5B, $2 B 2$

LORD, R. D. THE USE OF THE HANKEL TRANSFORM IN STATISTICS. I. GENERAL THEORY AND EXAMPLES, BIOKA 54,44

LORD, R. D. THE USE OF THE HANKEL TRANSFORM IN STATISTICS. II METHODS OF COMPUTATION, BIOKA 54,344

LORDEN, GARY INTEGRATED RISK OF ASYMPTOTICALLY BAYES SEQUENTIAL TESTS, AMS 67, 1399

LOVELL, MICHAEL C. ALTERNATIVE AXIOMATIZATIONS OF SEASONAL ADJUSTMENT, JASA 66, BOO

LOVELL, MICHAEL C. SEASONAL ADJUSTMENT OF ECONOMIC TIME SERIES AND MULT IPLE REGRESSION ANALYSIS, JASA 63,993

LOVNES, R. M. ON COX AND SNELL'S DEFINITION OF RESIDUALS, JRSSB 69 . 103

LOW, LEONE Y. ESTIMATORS OF VARIANCE COMPONENTS IN THE BALANCED INCOMPLETE BLOCK, JASA 69,1014

LOW, LEONE $Y$. SAMPLING VARIANCES OF ESTIMATES OF COMPONENTS OF VARIANCE FROM A NON-ORTHOGONAL TWO-WAY CLA, BIOKA 64, 491

LOWE, J. R. A TABLE OF THE INTEGRAL OF THE BIVARIATE NORMAL DISTRIBUTION OVER AN OFSET CIRCLE, JRSSB 60, 177

LOYNES, R. M. EXTREME VALUES IN UNIFORMLY MIXINC STATIONARY STOCHASTIC PROCESSES, AMS 65, 993

LOYNES, R. M. ON A PROPERTY OF THE RANDOM WALKS DESCRIBING SIMPLE QUEUES AND DAMS, JRSSB 65, 125

LOYNES, R. M. ON IDEMPOTENT MATRICES, AMS 66, 295

LOYNES, R. M. ON THE CONCEPT OF THE SPECTRUM FOR NON-STATIONARY PROCESSES (WITH DISCUSSION), JRSSB 6B, I

LOYNES, R. M. ON THE WAITING-TIME DISTRIBUT I ON FOR QUEUES IN SERIES. JRSSB 65,491

LOYNES, R, M. SOME ASPECTS OF THE ESTIMATION OF QUANTILES, JRSSB 66. 497

LOYNES, R. M. STATIONARY WAITING-TIME DISTRIBUTIONS FOR SINGLESERVER QUEUES, AMS 62,1323

LOYNES, R. M. THE CONSISTENCY OF CERTA IN SEQUENTIAL ESTIMATORS, AMS 69,568

LU, K. H. A PATH-PROBABILITY APPROACH TO IRREVERSIBLE MARKOV CHAINS WITH AN APPLICATION IN STUDY ING THE D, BIOCS 66, 791

LU, K. H. HARMONIC ANALYSIS OF THE HUMAN FACE, BIOCS 65, 491

LUBINSKA. L. A STOCHASTIC MODEL OF ACHE TRANSPORTATION IN THE PERIPHERAL NERVE TRUNKS, BIOKA 62,447

LUCAS JR, ROBERT E. ESTIMATION AND INFERENCE FOR LINEAR MODELS IN WHICH SUBSETS OF THE DEPENDENT VARIABLE, JASA 68, 1201

LUCAS, $H$. L. ANALYSIS OF VARIANCE OF DISPROPORT IONATE DATA WHEN INTERACTION IS PRESENT, BIOCS 65,115

LUCAS, H. L. DESIGN OF EXPERIMENTS IN NON-LINEAR SITUATIONS, BIOKA 59. 77

LUCE, $R$. DUNCAN ON THE NUMERICAL REPRESENTATION OF QUALITATIVE CONDITION PROBABILITY, AMS 6B, 4BI

LUCE, $R$. DUNCAN SUFFICIENT CONDITIONS FOR THE EXISTENCE OF A FINITELY ADDITIVE PROBABILITY MEASURE, AMS 67, 7BO

LUCHAK, G. THE CONTINUOUS TIME SOLUTION OF THE EQUATIONS OF THE SINGLE CHANNEL QUEUE WITH A GENERAL CLASS, JRSSB 5B, 176

LUKACS, E. ON A PROBLEM CONNECTED WITH QUADRATIC REGRESSION, BIOKA 60,335

LUKACS, E. ON CERTAIN FUNCTIONS OF NORMAL VARIATES WHICH ARE UNCORRELATED OF A HIGHER ORDER, BIOKA 60,175

LUKS, EUGENE $M$. ON THE MEAN DURATION OF A BALL AND CELL GAME, A FIRST PASSAGE PROBLEM, AMS 66, 517

LURIE, SANDRA APPLICATION OF AN ESTIMATOR OF HIGH EFFICIENCY IN BIVARIATE EXTREME VALUE THEORY, JASA 69 , NO.4

LUTHER, NORMAN Y. DECOMPOSITION OF SYMMETRIC MATRICES AND DISTR IBUTIONS OF QUADRATIC FORMS, AMS $65,6 \mathrm{~B} 3$
MAAG, U. R. A K-SAMPLE ANALOGUE OF WATSON'S U-SQUARE STATISTIC, BIOKA 66,579

MAAG, U. R, FURTHER PERCENTAGE POINTS FOR W-SQUARE-SUB-N+ (CRAMERVON MISES GOODNESS-OF-FIT STATISTIC), BIOKA 68, 42B

MAAG, URS. R. THE V-SUB-NM TWO-SAMPLE TEST, AMS 6B, 923

MACCALL JR, CHESTER H. A METHOD OF ADJUSTMENT FOR DEFECTIVE DATA, JASA 58,736

MACCARTHY, PHILIP J. STRATIFIED SAMPLINC AND DISTRIBUTION-FREE CONFIDENCE INTERVALS FOR A MEDIAN, JASA 65, 772

MACCORNACK, ROBERT L. EXTENDED TABLES OF THE WILCOXON MATCHED PAIR SIGNED RANK STATISTIC, JASA 65, B64

MACDERMOTT, JAMES P. THE OPTIMUM STRATEGY IN BLACKJACK, CORR. 59 B10, JASA 56,429

MACDONALD, J. A. THE USE OF INTEGRAL TRANSFORMS TO DETERMINE EXPANSIONS OF DISTRIBUTION FUNCTIONS, BIOKA 60,460

MACHIN, D. THE PREDICTION OF RESPONSE TO SELECTION IN BREEDING PROGRAMMES WHEN ALL DAUGHTERS OF SELECTED, BIOCS 69,553

MACIMOV, $V . N$. EXPERIMENTAL DEVELOPMENT OF NUTRITIVE MEDIA FOR MICRO-ORGANISMS, BIOKA $6 \mathrm{~B}, 43$

MACIVER, R. M. THE PREDICTION OF RESPONSE TO SELECTION IN BREEDING PROGRAMMES WHEN ALL DAUCHTERS OF SELEC, BIOCS 69,553

MACK, C. QUERY, TOLERANCE LIMITS FOR A BINOMIAL DISTRIBUTION, TECH 69,201

MACK, C. THE EFFECT OF OVERLAPP INC IN BACTERIAL COUNTS OF INCUBATED COLONIES, BIOKA 53,220

MACK, C. THE EFFICIENCY OF N MACHINES UNI-DIRECTIONALLY PATROLLED BY ONE OPERATOR WHEN WALKING TIME AND R, JRSSB 57, 166

MACK. C. THE EFFICIENCY OF N MACHINES UNI-DIRECTIONALLY PATROLLED BY ONE OPERATOR WHEN WALKING TIME IS CO, JRSSB 57,173

MACKENZIE, J.K. SECOND PAPER ON STATIST ICS ASSOCIATED WITH THE RANDOM DISOREINTATION OF CUBES, BIOKA 58,229

MACKENZIE, J. K. SOME STATISTICS AS JOCIATED WITH THE RANDOM DISORIENTATION OF CUBES, BIOKA 57,205

MACKEON, A. J. THE USE OF RANDOM WORK SAMPLING FOR COST ANALYSIS AND CONTROL, CORR. 5B 1031, JASA 5B, 3B2

MACKINNON, WILLIAM J . COMPACT TABLE OF TWELVE PROBABILITY LEVELS OF THE SYMMETRIC BINOMIAL CUMULATIVE DIS, JASA 59, 164

MACKINNON, WILLIAM J . TABLE FOR BOTH THE SIGN TEST AND DISTRIBUTI ONFREE CONFIDENCE INTERVALS OF THEMEDI, JASA 64,935

MACQUEEN, J AN INTRINSICALLY DETERMINED MARKOV CHAIN, AMS 67,934 MACQUEEN, J. SOME APPLICATIONS OF MONOTONE OPERATORS IN MARKOV PROCESSES, AMS 65, 1421

MACQUEEN, JAMES B A PROBLEM IN SURVIVAL, AMS 61,605

MADANSKY, ALBERT APPROXIMATE CONFIDENCE LIMITS FOR THE RELIABILITY OF SERIES AND PARALLEL SYSTEMS, TECH 65,495

MADANSKY, ALBERT EFFICIENCY OF THE SAMPLE MEAN WHEN RESIDUALS FOLLOW A FIRST-ORDER STATIONARY MARKOFF PRO, JASA 68, 1237

MADANSKY, ALBERT MORE ON LENGTH OF CONFIDENCE INTERVALS, JASA 62, $5 B 6$

MADANSKY, ALBERT PARAMETER-FREE AND NON-PARAMETRIC TOLERANCE LIMITS, THE EXPONENTIAL CASE, TECH 62,75

MADANSKY, ALBERT STATISTICAL ESTIMATION PROCEDURES FOR THE 'BURNIN' PROCESS, TECH $6 B, 51$

MADANSKY, ALBERT TESTS OF HOMOCENEITY FOR CORRELATED SAMPLES, JASA 63,97

MADANSKY, ALBERT THE FITTING OF STRAIGHT LINES WHEN BOTH VARIABLES ARE SUBJECT TO ERROR, CORR, 59812, JASA 59, 173

MAESHIRO, ASATOSHI A SIMPLE MATHEMATICAL RELATIONSHIP AMONG KCLASS ESTIMATORS, JASA 66,368

MAGNESS, T. A. COMPARISON OF LEAST SQUARES AND MINIMUM VARIANCE ESTIMATES OF RECRESSION PARAMETERS, (ACKN, AMS 62, 462

MAGUIRE, B. A. FURTHER NOTES ON THE ANALYSIS OF ACCIDENT DATA, BIOKA 53,214

MAGUIRE, B A THE TIME INTERVALS BETWEEN INDUSTRIAL ACCIDENTS BIOKA 52,168

MAHALANOBIS, B. REGIONAL DISPARITIES IN HOUSEHOLD COMSUMPTION IN INDIA, JASA 67,143

MAHAMUNULU, D. M. A NOTE ON REGRESSION IN THE MULTIVARIATE POISSON DISTRIBUTION, JASA 67,251

MAHAMUNULU, D. M. SAMPLING VARIANCES OF THE ESTIMATES OF VARIANCE COMPONENTS IN THE UNBALANCED THREE-WAY, AMS 63, 521

MAHAMUNULU, D. M SOME FIXED-SAMPLE RANKING AND SELECTION PROBLEMS, AMS 67, 1079

MAHMOUD, M. W. ON THE PROBLEM OF ESTIMATION FOR THE BIVARIATE LOGNORMAL DISTRIBUTION, BIOKA 64, 522

MAISEL, HERBERT BEST K OF 2K-1 COMPARISONS, JASA 66, 329

MAISEL, HERBERT THE OPTIMUM STRATEGY IN BLACKJACK, CORR. 59 BIO JASA 56,429

MAISEL, SHERMAN $J$. CHANGES IN THE RATE AND COMPONENTS OF HOUSEHOLD FORMATION, JASA 60,268

MAITRA, ASHOK A NOTE ON POSITIVE DYNAMIC PROGRAMMING, AMS 69, 316 MAITRA, ASHOK A NOTE ON UNDISCOUNTED DYNAMIC PROGRAMMING, AMS 66 1042

MAJINDAR, KULENDRA N. IMPROVED BOUNDS ON A MEASURE OF SKEWNESS, AMS 62, 1192

MAJINDAR, KULENDRA N. ON THE PARAMETERS AND INTERSECTION OF BLOCKS OF BALANCED INCOMPLETE BLOCK DESICNS, AMS 62,1200 
MALIK. HENRICK JOHN EXACT DISTRIBUTION OF THE PRODUCT OF INDEPENDENT CENERALIZED CAMMA VARIABLES WITH THE, AMS 6B, 1751

MALLIOS, WILLIAM S. A CENERALIZED APPLICATION OF INSTRUMENTAL VARIABLE ESTIMATION OF STRAICHT-LINE RELATI, TECH 69, 255

MALLIOS, WILLIAMS. A STRUCTURAL RECRESSION APPROACH TO COVARIANCE ANALYSIS WHEN THE COVARIABLE IS UNCONT, JASA 67, 1037

MALLOWS. C. L. AN INEQUALITY IN CONSTRAINED RANDOM VARIABLES. AMS 68,1080

MALLOWS, C, L. AN INEQUALITY INVOLVINC MULTINOMIAL PROBABILITIES BIOKA 68,422

MALLOWS, C. L. CENERALIZATIONS OF TCHEBYCHEFF'S INEQUALITIES (WITH DISCUSSION , JRSSB 56,139

MALLOWS, C. L. INEQUALITIES OF CHEBYSHEV TYPE INVOLVINC CONDITIONAL EXPECTATIONS, AMS 69, NO.6

MALLOWS. C. L. LATENT VECTORS OF RANDOM SYMMETRIC MATRICES, BIOKA 61,133

MALLOWS, C. L. NON-NULL RANKINC MODELS. I, BIOKA 57, 114

MALLOWS, C. L. NON-RANDOMNESS IN A SEQUENCE OF TWO ALTERNATIVES. I WILCOXON'S AND ALLIED TEST STATISTICS, BIOKA 58, 166

MALLOWS, C. L. NOTE ON THE MOMENT-PROBLEM FOR UNIMODAL DISTRIBUTIONS WHEN ONE OR BOTH TERMINALS ARE KNOWN, BIOKA 56, 224

MALLOWS, C. L. ON THE PROBABILITY INTECRAL TRANSFORMATION, BIOKA 59,481

MALLOWS, C . L. SOME A SPECTS OF THE RANDOM SEQUENCE, AMS 65, 236 MALLOWS, C. L THE INFORMATION IN AN EXPERIMENT, JRSSB 59, 67

MALLOWS, C. L. THE RANDOMIZATION BASES OF THE PROBLEM OF THE AMALCAMATION OF WEICHTED MEANS, JRSSB 61,423

MALLOWS, C. L. THE VARIANCE OF SPEARMAN'S RHO IN NORMAL SAMPLES, BIOKA 61,19

MANDEL, J. A METHOD OF FITTING EMPIRICAL SURFACES TO PHYSICAL AND CHEMICAL DATA. TECH 69,411

MANDEL, JOHN ANALYSIS OF LATIN SQUARES WITHIN A CERTAIN TYPE OF ROWCOLUMN INTERACTION, TECH 59, 379

MANDEL. JOHN ESTIMATION OF WEIGHTINC FACTORS IN LINEAR RECRESSION AND ANALYSIS OF VARIANCE, TECH 64

MANDEL, JOHN FITTING A STRAICHT LINE TO CERTAIN TYPES OF CUMULATIVE DATA, JASA 57,552

MANDEL, JOHN NON-ADDITIVITY IN TWO-WAY ANALYSIS OF VARIANCE, JASA 61,878

MANDEL, JOHN QUERY, RECRESSION ANALYSIS OF CUMULATIVE DATA, TECH 64,225

MANDEL, JOHN THE MEASURINC PROCESS, TECH 59, 251

MANDEL, L. CRADINC WITH A CAUCE SUBJECT TO RANDOM OUTPUT FLUCTUATIONS, JRSSB 54, 118

MANDELBROT, BENOIT THE ROLE OF SUFFICIENCY AND OF ESTIMATION IN THERMODYNAMTCS, AMS 62, 1021

MANHEIMER, DEAN I. A MATHEMAT ICAL MODEL WITH APPLICATIONS TO A STUDY OF ACCIDENT REPEATEDNESS AMONC CHILD, JASA 65, 1046

MANLY, B. F. J. APPROXIMATIONS TO THE CHARACTERISTICS OF SOME SEQUENTIAL TESTS, BIOKA 69,203

MANLY, B. F. J. SOME PROPERTIES OF A METHOD OF ESTIMATINC THE SIZE OF MOBILE ANIMAL POPULATIONS, BIOKA 69,407

MANN, D. W. THE DISCARDINC OF VARIABLES IN MULTIVARIATE ANALYSIS, BIOKA 67,357

MANN, HENRY B. A NOTE ON BALANCED INCOMPLETE BLOCK DESICNS, AMS 69 , 679

MANN, N. R. ON EVALUATION OF WARRANTY ASSURANCE WHEN LIFE HAS A WEIBULL DISTRIBUTION, BIOKA 69, NO.3

MANN, NANCY R, EXACT THREE, ORDER STATISTIC CONFIDENCE BOUNDS ON RELIABLE LIFE FOR A WEIBULL MODEL WITH P, JASA 69, 306

MANN, NANCY R. OPTIMUM ESTIMATORS FOR LINEAR FUNCTIONS OF LOCATION AND SCALE PARAMETERS, AMS 69, NO.6

MANN. NANCY R. POINT AND INTERVAL ESTIMATION PROCEDURES FOR THE TWOPARAMETER WEIBULL AND EXTREME-VALUE D, TECH 6B, 231

MANN, NANCY R. TABLES FOR OBTAINING THE BEST LINEAR INVARIANT ESTIMATES OF PARAMETERS OF THE WEIBULL DIST, TECH 67,629

MANSFIELD, EDWIN POWER FUNCTIONS FOR COX'S TEST OF RANDOMNESS AGAINST TREND, TECH 62,430

MANSFIELD, EDWIN THE LOCISTIC PROCESS, TABLES OF THE STOCHASTIC EP IDEMIC CURVE AND APPLICATIONS, JRSSB 60,332

MANSON, A.R. MINIMUM BIAS ESTIMATION AND EXPERIMENTAL DESICN FOR RESPONSE SURFACES, TECH 69.461

MANTEL, N. ADAPTATION OF KARBER'S METHOD FOR ESTIMATING THE EXPONENTIAL PARAMETER FROM QUANTAL DATA, AND, BIOCS 67,739

MANTEL, N. KOLMOGOROV-SMIRNOV TESTS AND RENYI'S MODIFICATION, BIOCS 6B, 1019

MANTEL, N. MODELS FOR COMPLEX CONTINGENCY TABLES AND POLYCHOTOMOUS DOSACE RESPONSE CURVES, BIOCS 66, B3

MANTEL, N. NOTES. A DEFICIENCY IN THE SUMMATION OF CHI PROCEDURE. BIOCS 66,407

MANTEL. N. NOTES. ASSUMPTION-FREE ESTIMATORS USING U STATISTICS AND A RELATIONSHIP TO THE JACKKNIFE METHO, BIOCS 67, 567

MANTEL, N. NOTES. CORRECTED CORRELATION COEFFICIENTS WHEN OBSERVATION ON ONE VARIABLE IS RESTRICTED, BIOCS $66,1 \mathrm{~B} 2$

MANTEL, N. NOTES. EQUIVALENCE OF MAXIMUM LIKELIHOOD AND THE METHOD OF MOMENTS IN PROBIT ANALYSIS, BIOCS 67,154
MANTEL, N. NOTES. F-RATIO PROBABILITIES FROM BINOMIAL TABLES BIOCS 66,404

MANTEL, N. NOTES. STMULTANEOUS CONFIDENCE INTERVALS AND EXPERIMEN TAL DESICN WITH NORMAL CORRELATION, BIOCS 68,434

MANTEL, N. QUERY, THE SUM OF VALUES FROM A NORMAL AND A TRUNCATED NORMALDISTRIBUTION (CONTD), TECH 64,469

MANTEL, $N$. RANKINC PROCEDURES FOR ARBITRARILY RESTRICTED OBSERVATION. BIOCS 67,65

MANTEL, N. RESTRICTED LEAST SQUARES REGRESSION AND CONVEX QUADRATIC PROCRAMMING, TECH 69 , NO. 4

MANTEL, N. THE EFFECTIVE USE OF BOTH POSITIVE AND NECATIVE CONTROLS IN SCREENINC EXPERIMENTS, BIOCS 67,285

MANTEL, NATHAN CHI-SQUARE TESTS WITH ONE DEGREE OF FREEDOM, EXTENSIONS OF THE MANTEL-HAENSZEL PROCEDURE, JASA 63, 690

MANTEL, NATHAN COMPUTATION OF INDIRECT-ADJUSTED RATES IN THE PRESENCE OF CONFOUNDINC, BIOCS 68,997

MANTEL. NATHAN INTERVAL ESTIMATION OF NON-LINEAR PARAMETRIC FUNCTIONS, JASA 63.611

MANTEL, NATHAN LICHT BULBSTATISTICS, CORR. 661248 , JASA 66, 633

MARCUS, A. H. A MULTIVARIATE IMMIGRATION WITH MULTIPLE DEATH PROCESS AND APPLICATIONS TO LUNAR CRATERS, BIOKA 67, 251

MARCUS, ALLENH. STOCHASTIC COALESCENCE, TECH 68, 133

MARCUS, L. F. AN EMPIRICAL COMPARISON OF DISTANCE STATISTICS FOR POPULATIONS WITH UNEQUAL COVARIANCE MATR, BIOCS 68,683

MARCUS, L. F. BOUNDS IN A MINIMAX CLASSIFICATION PROCEDURE, BIOKA 65,653

MARDIA, K. V. A NON-PARAMETRIC TEST FOR THE BIVARIATE TWO-SAMPLE LOCATION PROBLEM, JRSSB 67,320

MARDIA, $K, V$. CORRELATION OF THE RANCES OF CORRELATED SAMPLES, BIOKA 67,529

MARDIA. K, V. MULTIVARIATE PARETO DISTRIBUTIONS, CORR. 63 1603, AMS 62. 1008

MARDIA, K, V. ON THE NULL DISTRIBUTION OF A NON-PARAMETRIC TEST FOR THE BIVARIATE TWO-SAMPLE PROBLEM. JRSSB 69, 98

MARDIA, K. V. SMALL SAMPLE POWER OF A NON-PARAMETRIC TEST FOR THE, BIVARIATE TWO-SAMPLE LOCATION PROBLEM I, JRSSB 68, 83

MARDIA, K. V. SOME CONTRIBUTIONS TO CONTINCENCY-TYPE BIVARIATE DISTRIBUTIONS (CORR. 6B 597), BIOKA 67, 235

MARDIA, K. V. SOME RESULTS ON THE ORDER STATISTIUS OF THE MULTIVARIATE NORMAL AND PARETO TYPE 1 POPULAT IO, AMS 64,1815

MARDIA, K. V. THE PERFORMANCE OF SOME TESTS OF INDEPENDENCE FOR CONTINGENCY-TYPE BIVARIATE DISTRIBUTIONS, BIOKA 69, 449

MARCOLIN, B. H. ORTHOCONAL MAIN-EFFECT PLANS PERMITTINC ESTIMATION OF ALL TWO-FACTOR INTERACTIONS FOR THE, TECH 69, NO 4

MARCOLIN, B. H. RESULTS ON FACTORIAL DESIGNS OF RESOLUTION IV FOR THE 2-TO-THE-N AND 2-TO-THE-N TIMES 3-T, TECH 69, 431

MARCOLIN, B. H. SYSTEMATIC METHODS FOR ANALYZINC 2-TO-THE-N-TIMES3-TO-THE-M FACTORIAL EXPERIMENTS WITH A, TECH 67, 245

MARCOLIN, BARRY H. EXACT MOMENTS OF THE ORDER STATISTICS OF THE CEOMETRIC DISTRIBUTION AND THEIR RELATION, JASA 67,915

MARCOLIN, BARRY H. THE EXPECTED COVERACE TO THE LEFT OF THE I'TH ORDER STATISTIC FOR ARBITRARY DISTRIBUTI, AMS 69, 644

MARITZ. J. S. EMPIRICAL BAYES ESTIMATION FOR THE POISSON DISTRIBUTION, BIOKA 69,349

MARITZ, J.S. NOTE ON A CERTAIN FAMILY OF DISCRETE DISTRIBUTIONS, BIOKA 52, 196

MARITZ, J.S. ON THE SMOOTH EMPIRICAL BAYES APPROACH TO TESTING OF HYPOTHESES AND THE COMPOUND DECISIONP, BIOKA 68,83

MARITZ, J. S. ON THE USE OF THE GENERALIZED EXTREME-VALUE DISTRIBUTION IN ESTIMATING EXTREME PERCENTILES, BIOCS 67,79

MARITZ, J. S. SMOOTH EMPIRICAL BAYES ESTIMATION FOR CONT INUOUS DISTRIBUTIONS (CORR. 68597), BIOKA 67, 435

MARITZ, J. S. SMOOTH EMP IRICAL BAYES ESTIMATION FOR ONE-PARAMETER DISCRETE DISTRIBUTIONS, BIOKA 66,417

MARKS, B. L . SOME OPT IMAL SEQUENT I AL SCHEMES FOR EST IMATING THE MEAN OF A CUMULATIVE NORMAL QUANTAL RESPO, JRSSB 62,393

MARKS, ELI S. INFLUENCE OF THE INTERVIEWER ON THE ACCURACY OF SURVEY RESULTS, JASA 5B, 635

MARLOW, W. H. FACTORIAL DISTRIBUTIONS, AMS 65, 1066

MARRIOTT, F.H. C. ASSOCIATED DIRECTIONS, BIOCS 69, NO. 4

MARRIOTT, F, H C C BIAS IN THE ESTIMATION OF AUTOCORRELATIONS, BIOKA 54,390

MARRIOTT. F.H. C. TESTS OF SICNIFICANCE IN CANONICAL ANALYSIS, BIOKA 52, 5B

MARSAGLIA, G. EXPRESS INC A RANDOM VARIABLE IN TERMS OF UNIFORM RANDOM VARIABLES, AMS 61,894

MARSACLIA, G. GENERATING A VARIABLE FROM THE TAIL OF THE NORMALDISTRIBUTION, TECH 64,101

MARSAGLIA, G. GENERATING EXPONENTIAL RANDOM VARIABLES, AMS 61, B99 MARSAGLIA, G. MOMENT CROSSINGS AS RELATED TO DENSITY CROSSINGS, JRSSB 65,91

MARSAGLIA, GEORGE CONDITIONAL MEANS AND COVARIANCES OF NORMAL VARIABLES WITH SINGULAR COVARIANCE MATRIX, JASA 64, 1203 MARSAGLIA, GEORCE EXPRESSING THE NORMAL DISTRIBUTION WITH COVARIANCE MATRIX A+B IN TERMS OF ONE WITH COVA, BIOKA 63, 535

MARSAGLIA, GEORCE QUERY, PSEUDO RANDOM NORMAL NUMBERS, TECH 6B, 401 MARSAGLIA, GEORCE RATIOS OF NORMAL VARIABLES AND RATIOS OF SUMS OF UNIFORM VARIABLES, JASA 65, 193 
MARSHALL, A. W. A GENERAL APPROACH TO SOME SCREENING AND CLASSIFICATION PROBLEMS (WITH DISCUSSION), JRSSB 68, 407

MARSHALL, A. W. A STOCHASTIG CHARAGTERIZATION OF WEAR-OUT FOR COMPONENTS AND SYSTEMS, AMS 66,816

MARSHALL, A. W. AN OPTIMAL SEQUENTIAL ACGELERATED LIFE TEST . TECH 62,367

MARSHALL, A.W. MOMENT CROSSINGS AS RELATED TO DENSITY CROSSINGS, JRSSB 65,91

MARSHALL, A. W. SYSTEMS STRUCTURE AND THE EXISTENCE OF A SYSTEM LIFE, TEGH 64,459

MARSHALL, ALBERT W. A MULTIVARIATE EXPONENTIAL DISTRIBUTION, JASA 67,30

MARSHALL, ALBERT W. BOUNDS FOR DISTRIBUTIONS WITH MONOTONE HAZARD RATE, I, AMS 64, 1234

MARSHALL, ALBERT $W$. BOUNDS FOR DISTRIBUTIONS WITH MONOTONE HAZARD RATE, II, AMS 64, 125B

MARSHALL, ALBERT W. PROPERTIES OF PROBABILITY DISTRIBUTIONS WITH MONOTONE HAZARD RATE, AMS 63, 375

MARSHALL, ALBERT W. SOME MULTIVARI ATE CHEBYSHEV INEQUALITIES WITHEXTENSIONS TO CONTINUOUS PARAMETER PRO, AMS 61, 6B7

MARSHALL, ALBERT $W$. TABLES OF BOUNDS FOR DISTRIBUTIONS WITH MONOTONE HAZARD RATE, JASA 65, 872

MARSHALL, ALBERT. W. MAXIMUM LIKELIHOOD ESTIMATION FOR DISTRIBUTIONS WITHMONOTONE FAILURE RATE, AMS 65, 69

MARSHALL, W. H. LINE TRANSECT METHOD OF ESTIMATING GROUSE POPULATION DENSITIES, BIOCS 6B, 135

MARTIN, D. C. FITTING OF SOME CONTAGIOUS DISTRIBUTIONS TO SOME AVAILABLE DATA BY THE MAXIMUM LIKELIHOOD M, BIOCS 65,34

MARTIN, DONALD C. SEQUENTIAL RANK TESTS I. MONTE CARLO STUDIES OF THE TWO-SAMPLE PROCEDURE, TECH 65,463

MARTIN, FRANK B. ON COMBINABILITY OF INFORMATION FROM UNCORRELATED LINEAR MODELS BY SIMPLE WEIGHTING, AMS 66, 1338

MARTIN, N . F , G. UNIFORM CONVERGENCE OF FAMILIES OF MARTINGALES, AMS 69,1071

MARTINEZ, CHARLES A METHOD TO DETERMINE THE RELIABILITY OF TELEMETRY SYSTEMSREPORTS, JASA 62, 6B6

MARTZ, H. F. EMPIRICAL BAYES ESTIMATORS IN A MULTIPLE LINEAR REGRESSION MODEL, BIOKA 69, 367

MASSEY JR, FRANK J. ESTIMATION OF MULTIPLE GONTRASTS USING T-DISTRIBUTIONS, JASA 65.573

MASSY, WILLIAM F. PRINCIPAL GOMPONENTS REGRESSION IN EXPLORATORY STATISTICALRESEARCH, JASA 65,234

MASTERSON, GREGORYE. ON QUEUES IN TANDEM, AMS 63, 300

MATHAI, A. M. AN APPROXIMATE METHOD OF ANALYSIS FOR A TWO-WAY LAYOUT, BIOGS 65, 376

MATHAI, A. M. APPLICATION OF SPECIAL FUNCTIONS IN THE CHARACTERIZATION OF PROBABILITY DISTRIBUTIONS, SASJ 69,27

MATHAI, A.M. DISTRIBUTION OF A PRODUCT AND THE STRUCTURAL SETUP OF DENSITIES, AMS 69, 1439

MATHAI, A.M. DISTRIBUTIONS OF RANDOM VARIABLES WITH RANDOM PARAMETERS, SASJ 69,1

MATHAI, A.M. ON A PROBLEM OF REGRESSION, SASJ 67,43

MATHER, F. J. LINEAR REGRESSION WITH NON-CONSTANT, UNKNOWN ERROR VARIANCES, SAMPLING EXPERIMENTS WITHLEA, BIOCS 6B, 607

MATTHES, T. K. OPTIMAL INVARIANT RANK TESTS FOR THE K-SAMPLE PROBLEM, AMS 65, 1207

MATTHES, T.K. TESTS OF COMPOSITE HYPOTHESES FOR THE MULTIVARIATE EXPONENTIAL FAMILY, CORR. 67 192B, AMS 67,681

MATTHES, THEODORE K. ON THE OPTIMALITY OF SEQUENTIAL PROBABILITY RATIO TESTS, AMS 63, 18

MATUSZEWSKI, T. I. SOME PROPERTIES OF PASCAL DISTRIBUTION FOR FINITE POPULATION, CORR. 62919, JASA 62, 172

MATZINGER, D. F. SIMULTANEOUS SELFING AND PARTIAL DIALLEL TEST CROSSING 2. AN EVALUATION OF TWO METHODS O, BIOCS 67,325

MAULDON, J. G. PIVOTAL QUANTITIES FOR WISHART'S AND RELATED DISTRIBUTIONS, AND A PARADOX IN FIDUCIAL THEO, JRSSB 55,79

MAURICE, $R$. J A MINTMAX PROCEDURE FOR CHOOSING BETWEEN TWO POPULATIONS USING SEQUENTIAL SAMPLING, JRSSB 57,255

MAURICE, RITA MULTIVARIATE T AND THE RANKING PROBLEM, BIOKA 67, 305

MAURIGE, RITA RANKING MEANS OF TWO NORMAL POPULATIONS WITH UNKNOWN VARIANCES, BIOKA $5 B, 250$

MAURICE, RITA SELECTION OF THE POPULATION WITH THE LARGEST MEAN WHEN COMPARISONS CAN BE MADE ONLY IN PAIR, BIOKA $58,5 B 1$

MAURICE, RITA J. A DIFFERENT LOSS FUNCTION FOR THE CHOICE BETWEEN TWO POPULATIONS, JRSSB 59,203

MAURICE, RITA J. A MINIMAX-REGRET PROCEDURE FOR CHOOSING BETWEEN TWO POPULATIONS USING SEQUENTIAL SAMPLIN, JRSSB 63, 297

MAUTNER, A. J. THE DETERMINISTIC MODEL OF A SIMPLE EPIDEMIC FOR MORE THAN ONE COMMUNITY, BIOKA 55, 126

MAWAZINY, A. H. EL CONFIDENCE LIMITS FOR THE RELIABILITY OF SERIES SYSTEMS, JASA 67,1452

MAY, JOYCE M. EXTENDED AND CORRECTED TABLES OF THE UPPER PERCENTAGE POINTS OF THE 'STUDENTIZED' RANGE, BIOKA 52, 192

MAYNE, A. J. CORRIGENDA TO 'SOME FURTHER RESULTS IN THE THEORY OF PEDESTRI ANS AND ROAD TRAFFIC' ', BIOKA 58, 291

MAYNE, A. J. SOME FURTHER RESULTS IN THE THEORY OF PEDESTRIANS AND ROAD TRAFFIC, BIOKA 54, 375

MAYNES, E. SCOTT THE EFFECT OF MIS-MATCHING ON THE MEASUREMENT OF RESPONSE ERRORS, JASA 65, 1005
MAYNES, E. SCOTT VALIDATION OF CONSUMER FINANCIAL CHARACTERISTICS COMMON STOCK, JASA 69,415

MAYO, 0. ON THE PROBLEM OF SELF-INCOMPATABILITY ALLELES, BIOCS 66 111

MAZUMDAR, M. A CLASS OF SEQUENT IAL TESTS FOR AN EXPONENTIAL PARAMETER, JASA 69, NO. 4

MAZUMDAR, M. A STUDY OF THE VARIABILITY DUE TO COINCIDENT PASSAGE IN AN ELECTRONIC BLOOD CELL COUNTER, BIOCS 67,671

MAZUMDAR, M. AN EXTENSION OF PAULSON'S SELECTION PROCEDURE, AMS $6 B$ 2067

MAZUMDAR, SATI ON THE CONSTRUCTION OF CYCLIC COLLINEATIONS FOR OBTAINING A BALANCED SET OF L-RESTRICTIONA, AMS 67, 1293

MAZUR, D. PETER A DEMOGRAPHIC MODEL FOR ESTIMATING AGE-ORDER SPECIFIC FERTILITY RATES, JASA 63, 774

MAZUY, KAY KNIGHT STUDENT'S T IN A TWO-WAY CLASSIFICATION WITH UNEQUAL VARIANCES, AMS 65, 124B

MC COOL, JOHN I. THE CONSTRUCTION OF GOOD LINEAR UNBIASED ESTIMATES FROM THE BEST LINEAR ESTIMATES FOR A. TECH 65,543

MC LEAN, R. A. EXTREME VERTICES DESIGN OF MIXTURE EXPERIMENTS, TECH 66,447

MCCABE, B. J. THE ASYMPTOTIC BEHAVIOR OF A CERTAIN MARKOV CHAIN, AMS 69,665

MCCORD, JAMES R. ON ASYMPTOTIC MOMENTS OF EXTREME STATISTICS, AMS 64,1738

MCCREA, J. M. THE HALF-TABLE RATIO ESTIMATOR FOR A SIMPLE EXPONENTIAL MODEL. BIOCS 69,420

MCCULLOCH. A. J. LIFE-TESTING RESULTS BASED ON A FEW HETEROGENEOUS LOGNORMAL OBSERVAITONS, JASA 67,45

MCCULLOUGH, R. S. CORRIGENDA, 'SMALL SAMPLE BEHAVIOUR OF CERTAIN TESTS OF THE HYPOTHESIS OF EQUAL MEANSU, BIOKA 61,230

MCCULLOUGH, R. S. SMALL SAMPLE BEHAVIOUR OF CERTAIN TESTS OF THE HYPOTHESIS OF EQUAL MEANS UNDER VARIANCE, BIOKA 60,345

MCCULLOUGH, ROGER S. TESTING EQUALITY OF MEANS AFTER A PRELIMINARY TEST OF EQUALITY OF VARIANCES, BIOKA 62, 403

MCDONALD, B. J. RANK SUM MULTIPLE COMPARISIONS IN ONE AND TWO-WAY CLASSIFICATIONS, BIOKA $67,4 B 7$

MCFADDEN, J.A. AN APPROXIMATION FOR THE SYMMETRIC, QUADRIVARIATE NORMAL INTEGRAL, BIOKA 56, 206

MCFADDEN, J. A. CERTAIN PROPERTIES OF GAUSSIAN PROCESSES AND THEIR FIRST PASSAGE TIMES, JRSSB 65, 505

MCFADDEN, J. A. HIGHER-ORDER PROPERTIES OF A STATIONARY POINT PROCESS, JRSSB 63, 413

MCFADDEN, J.A. ON A CLASS OF GAUSSIAN PROCESSES FOR WHICH THE MEAN RATE OF CROSSINGS IS INFINITE, JRSSB 67, 4B9

MCFADDEN, J. A. ON THE LENGTHS OF INTERVALS IN A STATIONARY POINT PROCESS CORR. 63500), JRSSB 62, 364

MCFADDEN, J.A. TWO EXPANSIONS FOR THE QUADRIVARIATE NORMAL INTEGRAL, BIOKA 60,325

MCFLROY, F. W. A NECESSARY AND SUFFICIENT CONDITION THAT ORDINARY LEAST-SQUARES ESTIMATORS BE BEST LINEAR, JASA 67, 1302

MCGILCHRIST, C. ANALYSIS OF PLANT COMPETITION EXPERIMENTS FOR DIFFERENT RATIOS OF SPECIES, BIOKA 67, 471

MCGILCHRIST, C. A. ANALYSIS OF COMPETITION EXPERIMENTS, BIOCS 65 975

MCGILCHRIST, C. A. DISCRETE DISTRIBUTION ESTIMATORS FROM THE RECURRENCE EQUATION FOR PROBABILITIES, JASA 69,602

MCGILCHRIST , C. A . EFFICIENT DIFFERENCE EQUATION ESTIMATORS IN EXPONENTIAL REGRESSION, AMS 6B, 1638

MCGILCHRIST, C. A. PLANT COMPETITION, THREE SPECIES PER POT, JRSSB 68,93

MCGILCHRIST, C.A. TESTING OF MEANS WITH DIFFERENT ALTERNATIVES TECH 6B, 195

MCGILCHRIST, C. A. THE DERIVATION OF METHODS FOR FITTING EXPONENTIAL REGRESSION CURVES, BIOKA 64, 504

MCGREGOR, J. R. AN APPROXIMATE TEST FOR SERIAL CORRELATION IN POLYNOMIAL REGRESSION, BIOKA 60, 111

MCGREGOR, J R. LIMITING DISTRIBUTIONS ASSOCIATED WITH CERTAIN STOCHASTIC LEARNING MODELS, AMS 62, 12BI

MCGREGOR, J.R. LIMITING DISTRIBUTIONS OF RESPONSE PROBABILITIES AMS 65, 706

MCGREGOR, J.R. THE APPROXIMATE DISTRIBUTION OF THE CORRELATION BETWEEN TWO STATIONARY LINEAR MARKOV SERI, BIOKA 62,379

MCGREGOR, J.R. THE APPROXIMATE DISTRIBUTION OF THE CORRELATION BETWEEN TWO STATIONARY LINEAR MARKOV SERI, BIOKA 65, 301

MCGREGOR, JAMES PROPERTIES OF THE STATIONARY MEASURE OF THE CRITICAL CASE SIMPLE BRANCHING PROCESS, AMS 67, 977

MCGUIRE, J B COMPARISON OF LEAST SQUARES AND MINIMUM VARIANCE EST IMATES OF REGRESSION PARAMETERS, (ACKN, AMS 62, 462

MCGUIRE, TIMOTHY W. ESTIMATION AND INFERENCE FOR LINEAR MODELS IN WHICH SUBSETS OF THE DEPENDENT VARIABLE, JASA 68, 1201

MCHUGH, R. B. TWO-WAY ANALYSIS OF VARIANCE FOR THE MIXED MODEL WITH DISPROPORTIONATE SUBCLASS FREQUENCIES, BIOCS 65,308

MCHUGH, RICHARD B. NEGATIVE VARIANCE ESTIMATES AND STATISTICAL DEPENDENCE IN NESTED SAMPLING. JASA 68,1000

MCKEAN, H. E. A MENDELIAN MARKOV PROCESS WITH BINOMIAL TRANSITION PROBABILITIES, BIOKA 66,37

MCKEAN, H. E. THE EXPECTED MEAN SQUARES IN GENETIC EXPERIMENTS WHEN ONLY ONE PARENT IS IDENTIFIED, BIOCS 65,436 
MCKINLAY, P, L. MAJOR GREENWOOD, 1880-1949, BIOKA 51, I

MCNEIL, D. R. CONSISTENT STATISTICS FOR ESTIMATING AND TESTING HYPOTHESES FROM GROUPED SAMPLES, BIOKA 66,545

MCNEIL, D. R. EFFICIENCY LOSS DUE TO GROUPING IN DISTRIBUTION-FREE TESTS. JASA 67.954

MCNEIL. D. R. ESTIMATINC THE COVARIANCE AND SPECTRAL DENSITY FUNCTIONS FROM A CLIPPED STATIONARY TIME SER, JRSSB 67, 180

MCNEIL, D. R. QUICK POWERFUL TESTS WITH CROUPED DATA, BIOKA 68, 264

MCNEIL, D. R. THE ASYMPTOTIC POWERS OF MULTIVARIATE TESTS WITH GROUPED DATA, JRSSB 68,338

MCNOLTY, FRANK A CONTOUR-INTECRAL DERIVATION OF THE NON-CENTRAL CHI-SQUARE DISTRIBUTION, AMS 62, 796

MEAD, R. A GENERALISED LOGIT-NORMAL DISTRIBUTION, BIOCS 65,721

MEAD, R. A MATHEMATICAL MODEL FOR THE ESTIMATION OF INTER-PLANT COMPETITION (CORRECTION TOREFERENCE 681 1, BIOCS 67, 189

MEAD, R. A. A QUICK METHOD OF ESTIMATING THE STANDARD DEVIATION, BIOKA 66,559

MEDHI, J. A NOTE ON THE RISKS OF ERROR INVOLVED IN THE SEQUENTIAL RATIOTEST, BIOKA 56, 231

MEDHI, J. ON THE EFFICIENCY OF PROCEDURES FOR SMOOTHING PERIODOGRAMS FROM TIME SERIES WITH CONTINUOUS SPE, BIOKA 55, 143

MEETER, DUANE A ON BEALE'S MEASURES OF NON-LINEARITY, TECH 65, 623

MEHR, C. B. AN APPLICATION OF BIORTHONORMAL EXPANSIONS IN THEORY OF STOCHASTIC PROCESSES, JRSSB 68,334

MEHR. C. B. CERTAIN PROPERTIES OF CAUSSIAN PROCESSES AND THEIR FIRST PASSAGE TIMES, JRSSB 65,505

MEHRA. K. L. ASYMPTOTIC EFFICIENCY OF CERTAIN RANK TESTS FOR COMPARATIVE EXPERIMENT. AMS 67, 90

MEHRA, K. L. MULTI-SAMPLE ANALOGUES OF SOME ONE-SAMPLE TESTS, AMS 67,523

MEHRA, K, L. ON A CLASS OF CONDIT IONALLY DISTRIBUTION-FREE TESTS FOR INTERACTIONS IN FACTORIAL EXPERIMENT, AMS 69, 658

MEHRA, K. L. RANK TESTS FOR PAIRED-COMPARISON EXPERIMENTS INVOLVINC SEVERAL TREATMENTS. AMS 64, 122

MEHTA. J. A. COMBINATIONS OF UNBIASED ESTIMATORS OF THE MEAN WHICH CONSIDER INEQUALITY OF UNKNOWN VARIANC, JASA 69, 1042

MEHTA, J. S. ASYMMETRICAL ROTATABLE DES IGNS AND ORTHOCONAL TRANSFORMATIONS, TECH 68,313

MEHTA, J. S. ON THEIL 'S MIXED REGRESSION ESTIMATOR, JASA 69, 273

MEHTA, J. S. ON UTILIZING INFORMATION FROM A SECOND SAMPLE IN ESTIMATING VARIANCE, BIOKA 69, NO.3

MEHTA, J. S. SOME PROPERTIES AND AN APPLICATION OF A STATISTIC ARISING IN TESTING CORRELATION, AMS 69, 1736

MEHTA, J. S. TESTING EQUALITY OF MEANS IN THE PRESENCE OF CORRELATION, BIOKA 69, 119

MEIER, PAUL NONPARAMETRIC ESTIMATION FROM INCOMPLETE OBSERVATIONS, JASA 58,457

MEILIJSON, ISAAC A NOTE ON SEQUENTIAL MULTIPLE DECISION PROCEDURES, AMS 69, 653

MEJZLER, D ON SOME RESULTS OF N. V SMIRNOV CONCERNING LIMIT DISTRIBUTIONS FOR VARIATIONAL SERIES. AMS 69,480

MELLINGER. GLEN D. A MATHEMAT ICAL MODEL WITH APPLICATIONS TO A STUDY OF ACCIDENT REPEATEDNESS AMONG CHILD. JASA 65. 1046

MENDELSOHN. J A NUMERICAL INVESTIGATION OF SEVERAL ONE-DIMENSIONAL SEARCH PROCEDURES IN NONLINEAR RECRES, TECH 69, 265

MENDENHALL, W. A BIBLIOCRAPHY ON LIFE TESTING AND RELATED TOPICS BIOKA 58, 521

MENDENHALL, W. AN APPROXIMATION OF THE NEGATIVE MOMENTS OF THE POSITIVE BINOM IAL USEFUL IN LIFE TESTING, TECH 60,227

MENDENHALL, W. ESTIMATION OF PARAMETERS OF MIXED EXPONENTIALLY DISTR IBUTED FA ILURE TIME DISTR IBUTIONS FRO, BIOKA 58, 504

MENG, ROSA C THE POWER OF CHI SQUARE TESTS FOR CONTINGENCY TABLES JASA 66,965

MENON, M. V. A CHARACTERIZATION OF THE CAUCHY DISTRIBUTION, AMS 62 1267

MENON, M.V. ANOTHER CHARACTERISTIC PROPERTY OF THE CAUCHY DISTRIBUTION, AMS 66, 289

MENON. M. V. CHARACTERIZATION THEOREMS FOR SOME UNIVARIATE PROBABILITY DISTRIBUTIONS, JRSSB 66,143

MENON, M. V ESTIMATION OF THE SHAPE AND SCALE PARAMETERS OF THE WEIBULL DISTRIBUTION, TECH 63,175

MERAT. P DISTRIBUTIONS DE FREQUENCES, INTERPRETATION DU DETERMINISME CENETIQUE DES CARACTERES QUANTITATI, BIOCS 68, 277

MERCER, A A QUEUE WITH RANDOM ARRIVALS AND SCHEDULED BULK DEPARTURES, JRSSB 68,185

MERCER. A. A QUEUEINC PROBLEM IN WHICH THE ARRIVAL TIMES OF THE CUSTOMERS ARE SCHEDULED, JRSSB 60,108

MERCER, A. A RANDOM WALK IN WHICH THE STEPS OCCUR RANDOMLY IN TIME. BIOKA 59,30

MERCER, A. SOME SIMPLE DURATION-DEPENDENT STOCHASTIC PROCESSES. JRSSB 59, 144

MERCER, A SOME SIMPLE WEAR-DEPENDENT RENEWAL PROCESSES, JRSSB 61. 368

MERCHANT, SARLA D. SEQUENTIAL RANK TESTS II. MODIFIED TWO-SAMPLE PROCEDURES, TECH 66,615

MERCKX, K.R. UNFOLDING PARTICLE SIZE DISTRIBUTIONS, TECH 69, NO, 4 MERRILL, J. A. AUGMENTING EXISTING DATA IN MULTIPLE REGRESSION. TEC': 68,73
MERRILL. J. A MINIMUMRISKSPECIFICATIONLIMITS, JASA 59, 260 MERRINGTON, M. TABLE FOR THE SOLUTION OF THE EXPONENTIAL EQUATION EXP $(B)-B(1-P)=1$. BIOKA 63,177

MERRINGTON, $M$. TABLES FOR THE SOLUTION OF THE EXPONENTIAL EQUATION $\operatorname{EXP}(-\mathrm{A})+\mathrm{KA}=1, \mathrm{BIOKA} 60,439$

MERRINGTON, MAXINE AN APPROXIMATION TO THE DISTRIBUTION OF NONCENTRAL T, BIOKA 58,484

MERRINGTON. MAXINE TABLES OF THE 5 PERCENT AND 0.5 PERCENT POINTS OF PEARSON CURVES (WITH ARGUMENT BETA-1, BIOKA 51, 4

MERTZ, D. B. CANN IBALISM OF THE PUPAL STAGE BY ADULT FLOUR BEETLES, AN EXPERIMENT AND A STOCHASTICMODEL, BIOCS 68,247

MERTZ, D. B. MORTALITY PATTERNS IN EIGHT STRAINS OF FLOUR BEETLE. BIOCS 65,99

MESHALKIN, L.K. ON THE ROBUSTNESS OF SOME CHARACTERIZATIONS OF THE NORMAL DISTRIBUTION, AMS 68, 1747

MESNER, DALEM. A NEW FAMILY OF PART IALLY BALANCED INCOMPLETE BLOCK DESIGNS WITH SOME LATIN SQUARE DESIGN, AMS 67, 571

MESNER, DALE M A NOTE ON THE PARAMETERS OF PARTIALLY BALANCED INCOMPLETE BLOCK ASSOCIATION SCHEMES, AMS 65, 331

METAKIDES, THEOCHARIS ORTHOGONAL POLYNOMIAL FITTING, BIOKA 53, 361 METIVIER, MICHEL EXISTENCE OF AN INVARIANT MEASURE AND AN ORNSTEIN'S ERCODIC THEOREM, AMS 69,79

MEYER, DONALD L. ERRATA, ' AN UPPER BOUND FOR THE SAMPLE STANDARD DEVIATION', TECH 62,440

MEYER. PAUL L. THE MAXIMUM LIKEL IHOOD EST IMATE OF THE NON-CENTRALITY PARAMETER OF A NONCENTRAL CHI-SQUARE. JASA 67, 1258

MEYER, RICHARD M. NOTE ON A 'MULTIVARIATE' FORM OF BONFERRONI'S INEQUALITIES, AMS 69, 692

MICKEY, M. R. SOME FINITE POPULATION UNBA ISED RATIO AND REGRESSION ESTIMATORS, CORR. 60755 , JASA 59, 594

MICKEY. M. RAY BOUNDS ON THE DISTRIBUTION FUNCTIONS OF THE BEHRENSFISHER STATISTIC, AMS 66,639

MICKEY, M. RAY ESTIMATION OF ERROR RATES IN DISCRIMINANT ANALYSIS, TECH 68 , I

MIELKE JR, P. W. NOTE ON SOME SQUARED RANK TESTS WITH EXISTING TIES, TECH 67.312

MIELKE JR, PAUL $W$. A COMBINATORIAL TEST FOR INDEPENDENCE OF DICHOTOMOUS RESPONSES, JASA 65, 437

MIELKE JR, PAUL W. NEGATIVE VARIANCE ESTIMATES AND STATISTICAL DEPENDENCE IN NESTED SAMPLING, JASA 68,1000

MIELKE JR, PAUL W. ROBUSTNESS OF SUM OF SQUARED RANKS TEST, JASA 68 , 338

MIELKE, P. TWO-WAY ANALYSIS OF VARIANCE FOR THE MIXED MODEL WITH DISPROPORTIONATE SUBCLASS FREQUENCIES, BIOCS 65,308

MIETTINEN, 0.5 . INDIV IDUAL MATCHING WITH MULTIPLE CONTROLS IN THE CASE OF ALL-OR-NONE RESPONSES, BIOCS 69, 339

MIETTINEN , 0. S. THE MATCHED PAIRS DESICN IN THE CASE OF ALL-OR-NONE RESPONSES, BIOCS 68,339

MIHRAM, G. A. A BIVARIATE WARNING-TIME, FAILURE-TIME DISTRIBUTION JASA 67,589

MIHRAM, G. A. PARAMETER ESTIMATION FOR A GENERALIZED GAMMA DISTRIBUTION, TECH 65,349

MIJARES, TITOA. ON ELEMENTARY SYMMETRIC FUNCTIONS OF THE ROOTS OF A MULTIVARIATE MATRIX. DISTRIBUTIONS, AMS 64, 1186

MIJARES, TITO A. THE MOMENTS OF ELEMENTARY SYMMETRIC FUNCTIONS OF THE ROOTS OF A MATRIX IN MULT IVARIATE A, AMS 61, 1152

MIKHAIL, N. N, A COMPARISON OF TESTS OF THE WILKS-LAWLEY HYPOTHESIS IN MULT IVARIATE ANALYSIS., BIOKA 65,149

MIKHAIL, W. F. ON THE MONOTONIC CHARACTER OF THE POWER FUNCTIONS OF TWO MULTIVARIATE TESTS, AMS 61, 1145

MIKHAIL, WADIE F ON A PROPERTY OF A TEST FOR THE EQUALITY OF TWONORMALDISPERSION MATRICES ACAINST ONE-, AMS 62,1463

MIKULSKI, PIOTR WITOLD ON THE EFFICIENCY OF OPTIMAL NON-PARAMETRIC PROCEDURES IN THE TWO SAMPLE CASE, AMS 63, 22

MILCH, PAUL R. A MULTI-DIMENSIONAL LINEAR GROWTH BIRTH AND DEATH PROCESS, AMS 68, 727

MILDER, D. MICHAEL REGRESSION WITH SYSTEMATIC NOISE, JASA 64, 422

MILES, R. E. ON RANDOM ROTATIONS INR-CUBE, , BIOKA 65,636

MILES, R. E. THE ASYMPTOTIC VALUES OF CERTAIN COVERAGE PROBABILITIES, BIOKA 69 , NO.3

MILES, $R$, E THE COMPLETE AMALGAMATION INTO BLOCKS, BY WEIGHTED MEANS, OF A FINITE SET OF REAL NUMBERS, BIOKA 59, 317

MILLAR, P. WARWICK MARTINGALES WITH INDEPENDENT INCREMENTS, AMS 69, 1033

MILLAR, P. WARWICK TRANSFORMS OF STOCHASTIC PROCESSES, AMS 68, 372 MILLER JR, R. G. AVERAGERENEWAL LOSSRATES, AMS 63, 396

MILLER JR, R. G. UNLIMITED SIMUTANEOUS DISCRIMINATION INTERVALS IN REGRESSION, BIOKA 67, 133

MILLER JR, RUPERT G. A CONTRIBUTION TO THE THEORY OF BULK QUEUES, JRSSB 59,320

MILLER JR, RUPERT G. A TRUSTWORTHY JACKKNIFE, AMS 64, 1594

MILLER JR, RUPERT G. EARLY FA.ILURES IN LIFE TESTING, JASA 60, 491

MILLER JR, RUPERTG. JACKNIF ING VARIANCES, AMS 68, 567

MILLER JR, RUPERT G. SIMULTANEOUS TOLERANCE INTERVALS IN REGRESSION, BIOKA 63, 155

MILLER, A. J A A QUEUEING MODEL FOR ROAD TRAFFIC FLOW (WITH DISCUSSION , JRSSB 61,64 
MILLER, ANN R. THE MIGRATION OF EMPLOYED PERSONS TO AND FROM METROPOLITAN AREAS OF THE UNITED STATES, JASA 67,1418

MILLER, B. L. AN OPTIMALITY CONDITION FOR DISCRETE DYNAMIC PROGRAMMING WITH NO DISCOUNTING, AMS 68, 1220

MILLER, BRUCE L. DISCRETE DYNAMIC PROGRAMMING WITH A SMALL INTEREST RATE, AMS 69,366

MILLER, C. R. LATENT CLASS ANALYSIS AND DIFFERENTIAL MORTALITY JASA 62,430

MILLER, D. L. NOTES. ESTIMATION OF NON-LINEAR PARAMETERS FOR A NONASYMPTOTIC FUNCTION, BIOCS 68,439

MILLER, H. D. A CONVEXITY PROPERTY IN THE THEORY OF RANDOM VARIABLES DEFINED ON A FINITE MARKOV CHAIN, AMS 61,1260

MILLER, H. D. A GENERALIZATION OF WALD'S IDENTITY WITH APPLICATIONS TO RANDOM WALKS, AMS 61, 549

MILLER, H. D. A NOTE ON SUMS OF INDEPENDENT RANDOM VARIABLES WITH INFINITE FIRST MOMENT, AMS 67,751

MILLER, H. D. INTER-PLANT STORAGE IN CONTINUOUS MANUFACTURING TECH 60,393

MILLER, IRWIN EXPECTED ARC LENGTH OF A GAUSSIAN PROCESS ON A FINITE INTERVAL, JRSSB 56,257

MILLER, JAMES INCENTIVE CONTRACTS AND PRICE DIFFERENTIAL ACCEPTANCE TESTS, JASA 64,149

MILLER, K. S. A NOTE ON STOCHASTIC DIFFERENCE EQUATIONS, AMS 68, 270 MILLER, K. S. PROPERTIES OF GENERALIZED RAYLEIGH DISTRIBUTIONS

AMS 63,903

MILLER, K. S. SOME MULTIVARIATE DENSITY FUNCTIONS OF PRODUCTS OF GAUSSIAN VARIATES. . BIOKA 65, 645

MILLER, K. S. SOME MULTIVARIATE T-DISTR IBUTIONS, AMS 68, 1605

MILLER, LESLIE $H$. TABLE OF PERCENTAGE POINTS OF KOLMOGOROV STATISTICS, JASA 56,111

MILLER, R. R. STAT ISTICAL ESTIMATION OF THE GASOLINE OCTANE NUMBER REQUIREMENT OF NEW MODEL AUTOMOBILES, TECH 60,5

MILLIKEN, GEORGE QUADRATIC FORMS AND IDEMPOTENT MATRICES WITH RANDOM ELEMENTS, AMS 69, 1430

MILTON, R. C. COMPUTER EVALUATION OF THE NORMAL AND INVERSE NORMAL DISTRIBUTION FUNCTIONS, TECH 69 , NO 4

MILTON, R. C. MEAN SQUARE EFFICIENCY OF ESTIMATORS OF VARIANCE COMPONENTS, JASA 69, NO.4

MILTON, ROY C. AN EXTENDED TABLE OF CRITICAL VALUES FOR THE MANNWHITNEY-WILCOXON TWO-SAMPLE STATISTIC, JASA 64, 925

MILTON, ROY C. ON EXACT PROBABILITIES OF RANK ORDERS FOR TWO WIDELY SEPARATED NORMAL DISTRIBUTIONS, AMS 67, 1491

MINCER, JACOB APPLICATIONS OF A NEW GRAPHIC METHOD IN STATISTICAL MEASUREMENT, JASA 57,472

MINEKA, J. A MIXTURE OF TWO RECURRENT RANDOM WALKS NEED NOT BE RECURRENT , AMS 68, 1753

MINTON, GEORGE CONTROL OF QUALITY OF CODING IN THE 1960 CENSUSES, JASA 64,120

MINTON, GEORGE INSPECTION AND CORRECTION ERROR IN DATA PROCESS ING JASA 69 , NO 4

MISHRA, R. ESTIMATING MACHINING ERRORS IN SET-UPS WITH AUTOMATIC RESETTING, TECH 64,423

MISHRIKY, R, S. ORDER STATISTICS FOR DISCRETE POPULATIONS AND FOR GROUPED SAMPLES, JASA 68, 1390

MISRA, R. K. NOTES. STATISTICAL TESTS OF HYPOTHESES CONCERNING THE DEGREE OF DOMINANCE IN MONOFACTORIAL I, BIOCS 68,429

MISRA, R, K. VECTORIAL ANALYSIS FOR GENETIC CLINES IN BODY DIMENSIONS IN POPULATIONS OF 'DROSOPHILIA SUBO. BIOCS 66,469

MITCHELL, ANN F. S. EXPONENTIAL REGRESSION WITH CORRELATED OBSERVATIONS, BIOKA 68,149

MITCHELL. ANN F. S. FURTHER REMARKS ON EXPONENT IAL REGRESSION WITH CORRELATED OBSERVATIONS, BIOKA 68,575

MITCHELL, TOBY J CONSTRUCTION OF THE SET OF 256-RUN DESIGNS OF RESOLUTION GREATER THAN OR EQUAL TO 5 AND, AMS 68, 246

MITCHELL, TOBY J. THE CONSTRUCTION OF SATURATED TWO TO THE POWER OF K-P DESIGNS, AMS 67, 1110

MITRA, S. K. AN INTRODUCTION TO SOME NON-PARAMETRIC GENERALIZATIONS OF ANALYSIS OF VARIANCE AND MULTIVARI, BIOKA 56,36

MITRA, SUJIT KUMAR CONDITIONS FOR OPTIMALITY AND VALIDITY AND SIMPLE LEAST SQUARES THEORY, AMS 69, 1617

MITTEN, L. G. DESIGN OF AN OPTIMAL SEQUENCE OF INTERRELATED SAMPLING PLANS, JASA 64,96

MITTON, R. G THE DESIGN OF FACTORIAL EXPERIMENTS, A SURVEY OF SOME SCHEMES REQUIRING NOT MORE THAN $256 \mathrm{~T}$, BIOKA 59, 251

MODE. ELMER B. PROBABILITY AND CRIMINALIST ICS, JASA 63, 628 MODER, JOSEPH J. A SEQUENTIAL SEARCH PROCEDURE FOR LOCATING A RESPONSE JUMP, TECH 62,610

MOHAN, C. THE GAMBLER 'SRUIN PROBLEM WITH CORRELATION, BIOKA 55, 486 MOHAN, R. CONTROLLING DIMENSION IN CENTERLESS-GRINDING WITH AUTOMATIC RESET DEVICE, TECH 69, 115

MOHAN, R. DIMENSIONAL CHAINS INVOLVING RECTANGULAR AND NORMAL ERROR-DISTRIBUTIONS, TECH 63, 404

MOHAN, R. ESTIMATING MACHINING ERRORS IN SET-UPS WITH AUTOMATIC RESETTING, TECH 64, 423

MOHAN, RAMESH DIAMOND-PIN LOCATION, TECH 67, 131

MOHAN, RAMESH ERRATA, 'DIAMOND-PIN LOCATION' , TECH 67,498

MOHLER, W. C. A RAPID TEST FOR THE POISSON DISTRIBUTION USING THE RANGE, BIOCS 67,685
OHN E THE JOINT DISTRIBUTION OF THE STUDENTIZED REGRESSION COEFFICIENTS, BIOKA 68,424

MOLENAAR, W. HOW TO SURVIVE A FI XED NUMBER OF FAIR BETS, AMS 67, 1278 MOLENAAR, W ONMIXTURES OFDISTRIBUTIONS, AMS 66, 281

MOOD. ALEXM. SAMUELS. WILKS, JASA 65, 939

MOON, J.W. A TREE COUNTING PROBLEM, AMS 68,242

MOON, J.W. ON THE LINE, GRAPH OF THE COMPLETE BIGRAPH, AMS 63, 664

MOONAN, WILLIAM J. LINEAR TRANSFORMATION TO A SET OF STOCHASTICALLY DEPENDENT NORMAL VARIABLES, JASA 57,247

MOORE, A. H, A NOTE ON ESTIMATION FROM A TYPE I EXTREME-VALUE DISTRIBUTION, TECH 67,325

MOORE, A. H. ITERATIVE MAXIMUM-LIKELIHOOD ESTIMATION OF THE PARAMETERS OF NORMAL POPULATIONS FROM SINGLY, BIOKA 66, 205

MOORE. A. W MULTIVARIATE-COVARIANCE AND CANONICAL ANALYSIS, A METHOD FOR SELECTING THE MOST EFFECTIVE DI, BIOCS 68,845

MOORE, ALBERT H. ASYMPTOTIC VARIANCES AND COVARIANCES OF MAXIMUMLIKELIHOOD ESTIMATORS, FROM CENSORED SAM, AMS 67, 557

MOORE, ALBERT H. CONDITIONAL MAXIMUM-LIKELIHOOD ESTIMATION, FROM SINGLY CENSORED SAMPLES, OF THE SCALE PA, TECH 68,349

MOORE, ALBERT H. ERRATA, 'MAXIMUM-LIKELIHOOD ESTIMATION OF THE PARAMETERS OF GAMMA AND WEIBULL POPULATION, TECH 67,195

MOORE, ALBERT H, LOCAL-MAXIMUM-LIKELIHOOD ESTIMATION OF THE PARAMETERS OF THREE-PARAMETER LOGNORMAL POPUL, JASA 66,842

MOORE. ALBERT H. MAXIMUM LIKELI HOOD ESTIMATION OF THE PARAMETERS OF GAMMA AND WE IBULL POPULATIONS FROM CO, TECH 65,639

MOORE. ALBERT H. MAXIMUM-LIKELIHOOD ESTIMATION, FROM CENSORED SAMPLES, OF THE PARAMETERS OF A LOGISTIC DI, JASA 67, 675

MOORE, ALBERT H, MAXIMUM-LIKELIHOOD ESTTMATION, FROM DOUBLY CEN SORED SAMPLES, OF THE PARAMETERS OF THE FI, JASA 68.889

MOORE, ALBERT H. POINT AND INTERVAL ESTIMATORS, BASED ON M ORDER STATISTICS, FOR THE SCALE PARAMETER OF A, TECH 65,405

MOORE, CALVIN C. THE DEGREE OF RANDOMNESS IN A STATIONARY TIME SE RIES, AMS 63, 1253

MOORE, D. S. AN ELEMENTARY PROOF OF ASYMPTOTIC NORMALITY OF LINEAR FUNCT IONS OF ORDER STATISTICS, AMS 68,263

MOORE, D. S. ASYMPTOTICALLY NEARLY EFFICIENT ESTIMATORS OF MULTIVAR IATE LOCATION PARAMETERS, AMS 69, 1809

MOORE, DAVID S. UNIFORM CONSISTENCY OF SOME ESTIMATES OF A DENSITY FUNCTION, AMS 69, 1499

MOORE, GEOFFREY H. FORECASTING SHORT-TERM ECONOMIC CHANGE, JASA 69,1

MOORE, GEOFFREY H. MEASURING RECESSIONS, JASA 58, 259

MOORE, JAMES R. NON-NEGATIVE ESTIMATES OF VARIANCE COMPONENTS TECH 63,441

MOORE, P. G. A SEQUENTIAL TEST FOR RANDOMNESS, BIOKA 53, 11

MOORE. P. G . CORRIGENDA. 'SOME PROPERTIES OF RUNS IN QUALITY CONTROL PROCEDURES', BIOKA 59.279

MOORE, P G INTERVAL ANALYSIS AND THE LOGARITHMIC TRANSFORMATION JRSSB 58,187

MOORE, P. G. SOME PROPERTIES OF RUNS IN QUALITY CONTROL PROCEDURES BIOKA 58,89

MOORE, P. G. THE ESTIMATION OF THE MEAN OF A CENSORED NORMAL DISTRIBUTION BY ORDERED VARIABLES, BIOKA 56,482

MOORE, P. G THE ESTIMATION OF THE POISSON PARAMETER FROM A TRUNCATED DISTRIBUTION, BIOKA 52,247

MOORE, P. G. THE TWO-SAMPLE T-TEST BASED ON RANGE, BIOKA 57, 482

MOORE, P. G. TRANSFORMATIONS TO NORMALITY USING FRACTIONAL POWERS OF THE VARIABLE, JASA 57,237

MOORE, R. H. NOTES. ON TESTING SIGNIFICANCE OF COMPONENTS OF VARIANCE IN THE UNBALANCED NESTED ANALYSIS O, BIOCS 68,423

MOORE, R. H. THE USE OF NON-LINEAR REGRESSION METHODS FOR ANALYSING SENSITIVITY AND QUANTAL RESPONSE DATA, BIOCS 67,563

MORAN, P. A. P. A MATEMATICAL THEORY OF ANIMAL TRAPPING, BIOKA 51, 307 MORAN, P. A. P. A TEST OF SIGNIFICANCE FOR AN UNIDENTIFIABLE RELATION, JRSSB 56,61

MORAN, P. A. P. MEASURING THE LENGTH OF A CURVE, BIOKA 66,359

MORAN, P. A. P. PART IAL AND MULTIPLE RANK CORRELATION, BIOKA 51,26

MORAN, P. A, P. RANDOM CIRCLES ON A S PHERE, BIOKA 62, 389

MORAN, P. A. P. RAPID METHODS FOR ESTIMATING CORRELATION COEFFICIENTS, BIOKA 51,464

MORAN, P. A. P. SOME EXPERIMENTS ON THE PREDICTION OF SUNSPOT NUMBERS, JRSSB 54,112

MORAN, $P$. A. P. STATISTICAL INFERENCE WITH BIVARIATE GAMMA DISTRIBUTIONS, BIOKA 69, NO. 3

MORAN, $P$ A $P$ STATISTICAL THEORY OF A HIGH-SPEED PHOTOELECTRIC PLANIMETER, BIOKA 68,419

MORAN, P. A. P. TESTING FOR CORRELATION BETWEEN NON-NEGATIVE VARIATES, BIOKA 67,385

MORAN, P. A. P. TESTING FOR SERIAL CORRELATION WITH EXPONENTIALLY DISTRIBUTED VARIATES, BIOKA 67, 395

MORAN, P. A. P. THE ESTIMATION OF DEATH-RATES FROM CAPTURE-MARKRECAPTURE SAMPLING, BIOKA 52,181

MORANDA, P. B. COMPARISON OF ESTIMATES OF CIRCULAR PROBABLE ERROR CORR, 60755, JASA 59, 794

MORANDA, P. B. EFFECTS OF BIAS ON ESTIMATES OF THE CIRCULAR PROBABLE ERROR, JASA 60,732

MORBEY, G. K. REDUCED DESIGNS OF RESOLUTION FIVE, TECH 61,459 
MORGAN, F. R. THE DESIGN OF FACTORIAL EXPERIMENTS, A SURVEY OF SOME SCHEMES REQUIRING NOT MORE THAN 256 T. BIOKA 59, 251

MORGAN, JAMES N. PROBLEMS IN THE ANALYSIS OF SURVEY DATA, AND A PROPOSAL, JASA 63,415

MORGAN, R. W. A TWO-DIMENSIONAL POISSON GROWTH PROCESS, JRSSB 65 497

MORGAN, R. W. THE ESTIMATION OF PARAMETERS FROM THE SPREAD OF A DISEASE BY CONSIDER ING HOUSEHOLDS OF TWO ., BIOKA 65. 271

MORCAN, THEODORE THE ACCURACY OF INTERNATIONAL TRADE DATA, THE CASE OF SOUTHEAST ASIAN COUNTRIES, JASA 69.452

MORGENTHALER, G. W. SOME CIRCULAR COVERAGE PROBLEMS, BIOKA 61, 313 MORISHIMA . H. ESTIMATION OF GENETIC CONTRIBUTION OF PRINCIPAL COMPONENTS TO INDIVIDUAL VARIATES CONCERNED, BIOCS 69,9

MORRIS, $K$. W. A NOTE ON DIRECT AND INVERSE BINOMIAL SAMPLING, BIOKA 63.544

MORRIS, ROBERT H. AN APPLICATION OF MULTIVARIATE QUALITY CONTROL TO PHOTOGRAPHIC PROCESSINC, JASA 57,186

MORRISON. DONALD F. EXPECTATIONS AND COVARIANCES OF SERIAL AND CROSS-CORRELATION COEFFICIENTS IN A COMPLE, BIOKA 63, 213

MORRISON, DONALD F. ON THE DISTRIBUTION OF SUMS OF SQUARES AND CROSS PRODUCTS OF NORMAL VARIATES IN THE P, AMS 62, 1461

MORRISON, DONALD F. THE OPTIMUM ALLOCATION OF SPARE COMPONENTS IN SYSTEMS, TECH 61,399

MORRISON, MILTON SOME STATISTICAL CHARACTERISTICS OF A PEAK TO AVERACERATIO, TECH 65,379

MORSE, NORMAN STATISTICAL ISOMORPHISM, AMS 66, 203

MORSE, PAMELA M. THE COMBINATION OF ESTIMATES FROM SIMILAR EXPERIMENTS, ALLOWING FOR INTER-EXPERIMENT VAR, JASA 67, 241

MORTON, G. A CONTRIBUTION TO THE 'TRAVELLING-SALESMAN' PROBLEM (WITH DISCUSSION), JRSSB 55, 185

MORTON, K. W. A POOR MAN'S MONTE CARLO (WITH DISCUSSION), JRSSB 54 , 23

MORTON, K. W. THE ESTIMATION OF LOCATION AND SCALE PARAMETERS FROM GROUPED DATA, BIOKA 54,296

MORTON, K.W. TRANSPOSED BRANCHING PROCESSES, JRSSB 54,76

MORTON. RICHARD ON A THEOREM OF KARLIN REGARDINC ADMISSIBILITY OF LINEAR ESTIMATES IN EXPONENTIAL POPULAT, AMS 66, 1809

MOSER, J. M. GOODNESS CRITERIA FOR TWO-SAMPLE DISTRIBUTION-FREE TESTS, AMS 66, 133

MOSER, W. O J J PERMUTATION WITHOUT RISING OR FALLING OMEGASEQUENCES, AMS 67, 1245

MOSES. LINCOLN E. ONE SAMPLE LIMITS OF SOME TWO-SAMPLE RANK TESTS JASA 64,645

MOSES, LINCOLN E. QUERY, CONFIDENCE LIMITS FROM RANK TESTS, TECH 65 , 257

MOSES, LINCOLNE. RANK TESTS OF DISPERSION, AMS 63, 973

MOSES, LINCOLN E. SOME THEORETICAL ASPECTS OF THE LOT PLOT SAMPLING INSPECTION PLAN, JASA 56,84

MOSES, LINCOLN E. USE OF WILCOXON TEST THEORY IN ESTIMATING THE DISTRIBUTION OF A RATIO BY MONTE CARLO ME, AMS 62, 1194

MOSIMANN, JAMES E. CONCEPTS OF INDEPENDENCE FOR PROPORTIONS WITH A A GENERALIZATION OF THE DIRICHLET DIST, JASA 69, 194

MOSIMANN, JAMES E. ON THE COMPOUND MULTINOMIAL DISTRIBUTION, THE MULTIVARIATE BETA-DISTRIBUTION, AND CORR, BIOKA 62,65

MOSIMANN. JAMES E. ON THE COMPOUND NEGATIVE MULTINOMIAL DISTRIBUTION AND CORRELATIONS AMONG INVERSELY SAM, BIOKA 63, 47

MOSTAFA, M. D. ON THE PROBLEM OF ESTIMATION FOR THE BIVARIATE LOGNORMAL DISTRIBUTION BIOKA 64,522

MOSTAFA. M. G. DESIGNS FOR THE SIMULTANEOUS ESTIMATION OF FUNCTIONS OF VARIANCE COMPONENTS FROM TWO-WAY CR. BIOKA 67, 127

MOSTAFA, M G. NOTE ON TESTING HYPOTHESES IN AN UNBALANCED RANDOM EFFECTS MODEL, BIOKA 67,659

MOSTELLER. F. TABLES OF THE FREEMAN-TUKEY TRANSFORMATIONS FOR THE BINOMIAL AND POISSON DISTRIBUTIONS, BIOKA 61,433

MOSTELLER. FREDERICK ASSOCIATION AND ESTIMATION IN CONTINCENCY TABLES, JASA 68,1

MOSTELLER, FREDERICK INFERENCE IN AN AUTHORSHIP PROBLEM, JASA 63 , 275

MOSTELLER, FREDERICK RECOCNIZING THE MAXIMUM OF A SEQUENCE, JASA 66,35

MOSTELLER, FREDERICK SAMUELS. WILKS, JASA 65, 939

MOSTELLER, FREDERICK THE EXPECTED COVERACE TO THE LEFT OF THE I'TH ORDER STATISTIC FOR ARBITRARY DISTRIBU, AMS 69,644

MOTE, V. L. AN INVESTICATION OF THE EFFECT OF MISCLASSIFICATION ON THE PROPERTIES OF CHI-SQUARE-TESTS IN, BIOKA 65, 95

MOTT-SMITH, J. C. TWO ESTIMATES OF THE BINOMIAL DISTRIBUTION, (CORR. 64 IB2), AMS 64,809

MOTT, J. L. THE DISTRIBUTION OF THE TIME-TO-EMPTINESS OF A DISCRETE DAM UNDER STEADY DEMAND. JRSSB 63, 137

MOTT, J. L. THE LATENT ROOTS OF CERTAIN STOCHASTIC MATRICES, BIOKA 62,264

MOY, SHK-TEH C. EXTENSIONS OF A LIMIT THEOREM OF EVERETT, ULAM AND HARRIS ON MULTITYPE BRANCHING PROGESSE, AMS 67, 992

MOYAL, J. E. THE RANDOM WALK (IN CONTINUOUS TIME) AND ITS APPLICATION TO THE THEORY OF QUEUES, BIOKA 59,400

MUDHOLKAR, G. S. MONOTONIGITY OF THE POWER FUNGTIONS OF SOME TESTS OF THE MULTIVARIATE LINEAR HYPOTHESIS, AMS 64,200

MUDHOLKAR, GOVIND S. A CLASS OF TESTS WITH MONOTONE POWER FUNGTIONS FOR TWO PROBLEMS IN MULT IVAR IATE ST AT, AMS 65, 1794
MUDHOLKAR, GOVIND S. GENERALIZED MULTIVARIATE ESTIMATOR FOR THE MEAN OF FINITE POPULATIONS, JASA 67, 1009

MUDHOLKAR, GOVIND S. ON CONFIDENCE BOUNDS ASSOCIATED WITH MULTIVARIATE ANALYSIS OF VARIANCE AND NONINDEPE, AMS 66, 1736

MUDHOLKAR, GOVIND S. SOME SHARP MULTIVARI ATE TCHEBYCHEFF INEQUALITIES, AMS 67, 393

MUELLER, EVA TEN YEARS OF CONSUMER ATTITUDE SURVEXS, THEIR FORECASTING RECORD, JASA 63,899

MULHOLLAND, H. P. ON DISTRIBUTIONS FOR WHICH THE HARTLEY-KHAMIS SOLUTION OF THE MOMENT-PROBLEM IS EXACT, BIOKA 51, 74

MULLEN, K. LINEAR ESTIMATES OF A POPULATION SCALE PARAMETER, BIOKA 67,551

MULLER, E. R. A METHOD OF CONSTRUCTING BALANCED INCOMPLETE DESIGNS., BIOKA 65,285

MULLER, E. R. BALANCED CONFOUNDINC OF FACTORIAL EXPERIMENTS, BIOKA 66,507

MULLER, MERVIN E. DEVELOPMENT OF SAMPLING PLANS BY USINC SEQUENTIAL, ITEM BY ITEM, SELECTION TECHNIQUES A, JASA 62, 387

MULLIN, R. C. CONSTRUCTION OF ROOM SQUARES, AMS 68, 1540

MULLIN, $R$. C. INDUCTIVE METHODS FOR BALANCED INCOMPLETE BLOCK DESIGNS, AMS 66, 1348

MUNDLE, P. B. ON NON-REGULAR ESTIMATION, I. VARIANCE BOUNDS FOR ESTIMATORS OF LOCATION PARAMETERS, JASA 69, 1056

MUNRO, A. H. ON THE USE OF THE GENERALIZED EXTREME-VALUE DISTRIBUTION IN ESTIMATING EXTREME PERCENTILES, BIOCS 67,79

MURPHY, B. P. SOME TWO-SAMPLE TESTS WHEN THE VARIANCES ARE UNEQUAL. A SIMULATION STUDY, BIOKA 67,679

MURPHY, E. M. MATRIX AND MULTIPLE DECREMENT IN POPULATION ANALYSIS, BIOCS 67,485

MURPHY, G. I. ESTIMATES OF MORALITY AND POPULATION FROM SURVEYREMOVAL RECORDS, BIOCS 65,921

MURPHY, T. THE EFFICIENCY OF N MACHINES UNI-DIRECTIONALLY PATROLLED BY ONE OPERATOR WHEN WALKING TIME AND, JRSSB 57, 166

MURTEIRA, BENTO NOTE ON THE VARIATE DIFFERENCES OF AUTOREGRESSIVE SERIES, BIOKA 51,479

MURTHY, $M$. N. RANDOMIZED ROUNDED-OFF MULTIPLIERS IN SAMPLING THEORY, JASA 61,328

MURTHY, M. N. SOMERECENT ADVANCES IN SAMPLING THEORY, JASA 63, 737

MURTHY, V. K. ESTIMATION OF JUMPS, RELIABILITY AND HAZARD RATE, AMS 65,1032

MURTHY, V.K. ESTIMATION OF PROBABILITY DENSITY, AMS 65, 1027

MURTHY, V. K. ESTIMATION OF THE CROSS-SPECTRUM, AMS 63, 1012

MURTHY, V.K. ESTIMATION OF THE SPECTRUM, AMS 61,730

MURTY, J. S. DESIGN AND ANALYSIS OF EXPERIMENTS WITH MIXTURES, AMS 68,1517

MURTY, V. N. AN INEQUALITY FOR BALANCED INCOMPLETE BLOCK DESIGNS, AMS 61,908

MUSGRAVE, JOHN C. THE MEASUREMENT OF PRICE CHANGES IN CONSTRUCTION, JASA 69,771

MUSTAFI, C. K. ANOTE ON MIDRANGE, AMS 65, 1052

MUSTAFI, C. K. COMMENTS TO, EDWARD C. POSNER, 'THE APPLICATION OF EXTREME VALUE THEORY TO ERROR FREE COMM, TECH 66,363

MUSTAFI, C. K. SOME ANALYTICAL PROPERTIES OF BIVARIATE EXTREMAL DISTRIBUTIONS . JASA 67,569

MUSTAFI, CHANDAN INFERENCE PROBLEMS ABOUT PARAMETERS WHICH ARE SUBJECTED TO CHANCES OVER TIME, AMS 6B, 840

MUSTAFI, CHANDAN K. ON ITERATED TESTS OF HYPOTHESES, JASA 67, 520

MUSTAFI, CHANDAN $K$. ON THE PROPORTION OF OBSERVATIONS ABOVE SAMPLE MEANS IN A BIVARIATE NORMAL DISTRIBUTI, AMS 68, 1350

MUSTAFI, CHANDAN $K$. THE INVERSE OF A CERTAIN MATRIX, WITH APPLICATION, AMS 67,1289

MUSTAFI, CHANDAN KUMAR A RECURRENCE RELATION FOR DISTRIBUTION FUNCTIONS OF ORDER STATISTICS FROM BIVARIAT, JASA 69,600

MUTH, JOHN $F$. OPTIMAL PROPERTIES OF EXPONENTIALLY WEIGHTED FORECASTS, CORR. 62919, JASA 60, 299

MUTH, RICHARD F. A REGRESSION METHOD FOR REAL ESTATE PRICE INDEX CONSTRUCTION, JASA 63,933

MYERS, JAMES H. THE DEVELOPMENT OF NUMERICAL CREDIT EVALUATION SYSTEMS, JASA 63,799

MYERS, M. H BOUNDARIES FOR CLOSED (WEDGE) SEQUENTIAL T TEST PLANS BIOKA 66,431

MYERS, R. H. ON THE PERCENTAGE POINTS OF THE SAMPLE COEFFICIENT OF VARIATION, BIOKA 68,580

MYERS, RAYMOND H. METHODS FOR ESTIMATING THE COMPOSITION OF A THREE COMPONENT LIQUID MIXTURE, TECH 64,343

MYERS, RAYMOND H. OPT IMAL EXPERIMENTAL DESIGNS FOR ESTIMATING THE INDEPENDENT VARIABLE IN REGRESSION, TECH 68,811

MYERS, RAYMOND H. RESPONSE SURFACE DESICNS FOR MIXTURE PROBLEMS, TECH 68,739

MYERS, ROBERT G. SCHOOLING, EXPERIENCE, AND GAINS AND LOSSES IN HUMAN CAPITAL THROUGH MIGRATION, JASA 67,875

MYHRE, J. M. COMPARISON OF TWO METHODS OF OBTA IN ING APPROXIMATE CONFIDENGE INTERVALS FOR SYSTEM RELIABILI, TEGH 6B, 37

MYRE, JANET M. ON CONFIDENGE LIMITS FOR THE RELIABILITY OF SYSTEMS, AMS 68,1463

NA, HWA SUNG A FORMULA FOR THE PROBABILITY OF OBTAINING A TREE FROM A GRAPH GONSTRUCTED RANDOMLY EXCEPT F, AMS 67, 226

NABAVIAN, $K$. J. SAMPLING INSPEGTION PLANS FOR DISGRIMINATING BETWEEN TWO WEIBULL PROGESSES, TECH $65,5 B 9$ 
NABEYA, S. ABSOLUTE AND INCOMPLETE MOMENTS OF THE MULTIVARIATE NORMAL DISTRIBUTION, BIOKA 61,77

NADAS, ARTHUR A CONFIDENCE RECION FOR THE LOC-NORMAL HAZARD FUNCTION, TECH 69,387

NADAS, ARTHUR AN EXTENSION OF A THEOREM OF CHOW AND ROBBINS ON SEQUENT IAL CONF IDENCE INTERVALS FOR THE ME, AMS 69, 667

NADLER, JACK ON PRECEDENCE LIFE TESTINC, TECH 65, 359

NADLER, JACK QUERY, BIVARIATE SAMPLES WITH MISS INC VALUES, TECH 67 , 679

NADLER, JACK SOME ASPECTS OF THE USE OF THE SEQUENTIAL PROBABILITY RATI0 TEST, JASA 58,187

NACAO, HISAO ON BARTLET' ' S TEST AND LEHMANN'S TEST FOR HOMOCENEITY OF VARIANCES, AMS 69, N0.6

NACAO, HISAO UNBIASEDNESS OF SOME TEXT CRITERIA FOR THE EQUALITY OF ONE OR TWO COVARIANCE MATRICES, AMS 68, 1686

NAGAR, A. L. TESTING THE INDEPENDENCE OF REGRESSION DISTURBANCES, JASA 61,793

NAGENDRA, Y. EFFECT OF NON-NORMALITY ON A SEQUENTI IAL TEST FOR MEAN, BIOKA 64, 281

NAGNUR, B. N. LAMST AND THE HYPOTHESES OF NO THREE FACTOR INTERAGTION IN CONTINGENCY TABLES, JASA 69, 207

NAGNUR, B. N. LOCALLY ASYMPTOTICALLY MOST STRINGENT TESTS AND LAGRANGI AN MULT IPLIER TESTS OF LINEAR HYPOT, BIOKA 65, 459

NAGNUR, DHRUVA ON THE INTERPRETATION OF AGEDISTRIBUTIONS, JASA 67 , 862

NAIK, UMESH D. THE EQUAL PROBABILITY TEST AND ITS APPLICATIONS TO SOME SIMULTANEOUS INFERENCE PROBLEMS, JASA 69, 986

NAIR, C. RAMANKUTTY A NEW CLASS OF DESIGNS, CORR, 65 1250, JASA 64 , 817

NAIR, G. RAMANKUTTY ON PARTIALLY LINKED BLOCK DESIGNS, AMS 66, 1401

NAIR, C. RAMANKUTTY PARTIALLY BALANCED INCOMPLETE BLOCK DESIGNS WITH TWO-WAY CLASSIFICATION OF TREATMENTS, AMS 69,175

NAIR, C. RAMANKUTTY SEQUENCES BALANCED FOR PAIRS OF RESIDUAL EFFECTS, JASA 67,205

NAIR, $K$. R. TABLES OF PERCENTAGE POINTS OF THE 'STUDENTIZED ' EXTREME DEVIATE FROM THE SAMPLE MEAN, BIOKA 52, 189

NAKAMURA, E. PERCENTAGE POINTS OF THE RANGE FROM A SYMMETRIC MULTINOMIAL DISTRIBUTION, BIOKA 68, 377

NAKAMURA, E. TABLES FOR TESTING SICNIFICANCE IN A 2-BY-3 CONTINGENCY TABLE, TECH 63,501

NAKAMURA, E. THE POWER FUNCTION OF THE EXACT TEST FOR THE 2-BY-3 CONTINGENCY TABLE, TECH 64,439

NAM, CHARLES B. ILLUSTRATIVE TABLES OF SCHOOL LIFE, CORR, 641299 JASA 63, 1113

NAM, J. ASYMPTOTIC POWER OF CHI SQUARE TESTS FOR LINEAR TRENDS IN PROPORTIONS, BIOCS 68,315

NAMBOODIRI, N. KRISHNAN THE RATIO BIAS IN SURVEYS, JASA 62, 863

NAMKOONG, C. NOTES. ESTIMATION OF NON-LINEAR PARAMETERS FOR A NONASYMPTOTIC FUNCTION, BIOCS 68,439

NAMKOONG, G. STATISTICAL ANALYSIS OF INTROGRESSION, BIOCS 66, 488

NAOR, P. A PROBLEM OF DELA YED SERVICE, 1 , JRSSB 60,245

NAOR, P. A PROBLEM OF DELAYED SERVICE, 2 , JRSSB 60,270

NAOR, $P$. NORMAL APPROXIMATION TO MACHINE INTERFERENCE WITH MANY REPAIR MEN, JRSSB 57, 334

NAOR, P. ONMACHINE INTERFERENCE, JRSSB 56, 280

NARASIMHAM, V. L. CONSTRUCTION OF ROTATABLE DESIGNS THROUGH BALANCED INCOMPLETE BLOCK DESIGNS, AMS 62, 1421

NARAYANA, T. V. A NOTE ON SIMPLE BINOMIAL SAMPLING PLANS, AMS 61, 906 NASOETION, A. H. SIMULTANEOUS SELFING AND PARTIAL DIALLEL TEST CROSSING 2. AN EVALUATION OF TWO METHODS 0, BIOGS 67,325

NASR, S. K. ON SOME PROBLEMS OF MACHINE INTERFERENCE, JRSSB 59, 106

NASS, G. A. G. THE CHI-SQUARE TEST FOR SMALL EXPECTATIONS IN GONTINGENCY TABLES, WITH SPECIAL REFERENCE T, BIOKA 59,365

NATH, RE JESHWAR BIAS IN MULT INOMIAL CLASSIFICATION, JASA 68, 298

NATH, S. N. MORE RESULTS ON PRODUCT MOMENTS FROM A FINITE UNIVERSE, JASA 69,864

NATH, S. N. ON PRODUCT MOMENTS FROM A FINITE UNIVERSE, JASA 68, 535

NATHAN, GAD OUTCOME PROBABILITIES FOR A RECORD MATCHING PROCESS WITH COMPLETE INVARIANT INFORMATION, JASA 67,454

NATHAN, MANTEL PATRWISE INDEPENDENCE OF JOINTLY DEPENDENT VARIABLES, AMS 62,290

NAUS, J. I. GLUSTERING OF RANDOM POINTS IN TWO DIMENSIONS., BIOKA 65,263

NAUS, J. I. SOME PROBABILITIES, EXPEGTATIONS AND VARIANCES FOR THE SIZE OF LARGEST CLUSTERS AND SMALLEST, JASA 66, 1191

NAUS, J. I. THE DISTRIBUTION OF THE LOGARITHM OF THE SUM OF TWO LOGNORMAL VARIATES, JASA 69,655

NAUS, JOSEPH I. A POWER COMPARISON OF TWO TESTS OF NON-RANDON CLUSTERING, TECH 66,493

NAUS, JOSEPH I. THE DISTRIBUTION OF THE SIZE OF THE MAXIMUM CLUSTER OF POINTS ON ALINE, JASA 65, 532

NAYA, SEIJI THE ACCURACY OF INTERNATIONAL TRADE DATA, THE CASE OF SOUTHEAST ASIAN COUNTRIES, JASA 69, 452

NAYLOR, A. F. NOTES. SMALL SAMPLE CONSIDERATIONS IN COMBINING 2 BY 2 TABLES, BIOCS 67,349

NAYLOR, THOMAL H. COMPUTER SIMULATION EXPERIMENTS WITH ECONOMIC SYSTEMS. THE PROBLEM OF EXPERIMENTAL DESI, JASA 67, 1315
NAYLOR, THOMAS H. A COMPUTER SIMULATION MODEL OF THE TEXTILE INDUSTRY, JASA 67,1338

NEAVE, HENRY R. A DEVELOPMENT OF TUKEY'S QUICK TEST OF LOCATION, JASA 66,949

NEAVE, HENRY R, A MONTE CARLO STUDY COMPARINC VARIOUS TWO-SAMPLE TESTS FOR DIFFERENCES IN MEAN, TECH 68, 509

NEISWANCER, W. A. PARAMETER ESTIMATES AND AUTONOMOUS CROWTH, CORR 59812 , JASA 59,389

NELDER, J. A. A NOTE ON THE STATISTICAL INDEPENDENCE OF QUADRATIC FORMS IN THE ANALYSIS OF VARIANCE, BIOKA 51,482

NELDER, J. A. INVERSE POLYNOMIALS, A USEFUL CROUP OF MULTI-FACTOR RESPONSE FUNCTIONS, BIOCS 66,128

NELDER, J. A. THE COMBINATION OF INFORMATION IN CENERALLY BALANCED DESICNS, JRSSB 68,303

NELDER, J. A. THE INTERPRETATION OF NEGATIVE COMPONENTS OF VARIANCE, BIOKA 54,544

NELDER, J. A. WEIGHTED REGRESSION, QUANTAL RESPONSE DATA, AND INVERSE POL YNOMIALS, BIOCS 68,979

NELSON JR, A. C. ESTIMATION OF THE PROBABILITY OF DEFECTIVE FAILURE FROM DESTRUCTIVE TESTS, TECH 63,459

NELSON, A. C. QUERY + (ON FORMULA FOR DETERMINING THE INCIDENCE OF MUTANT GENES), BIOCS 65,750

NELSON, L. S. SAMPLING DISTRIBUTIONS OF VARIANCE COMPONENTS II. EMPIRICAL STUDIES OF UNBALANCED NESTED DE, TECH 68, 719

NELSON, L. S. THE FOLDED NORMAL DISTRIBUTION, TECH 61,543

NELSON, LLOYDS, QUERY, GOMBINING VALUES OF OBSERVED CHI-SQUARE'S, TECH 66. 709

NELSON, LLOYD S. SAMPLING DISTRIBUTIONS OF VARIANCE COMPONENTS I EMPIRICAL STUDIES OF BALANCED NESTED DE, TECH 66,457

NELSON, LLOYDS. TABLES FOR A PRECEDENCE LIFE TEST, TECH 63, 49]

NELSON, RALPH L. MARKET GROWTH, COMPANY DIVERSIFICATION AND PRODUCT CONCENTRATTON 1947-1954, JASA 60,640

NELSON, W. C. TESTS FOR CORRELATTON MATRICES, BIOKA 68, 327

NELSON, WAYNE MINIMAX SOLUTION OF STATISTICAL DECISION PROBLEMS BY ITERATION, AMS 66,1643

NELSON, WAYNE B, A STATISTICAL TEST FOR EQUALITY OF TWO AVAILABILITIES, TECH 68,594

NERLOVE, MARC A COMPARISON OF A MODIFIED 'HANNAN' AND THE BUREAU OF LABOR STATISTTCS, JASA 65,442

NESTEL, G. CROSS STATE PRODUC'T AND AN ECONOMETRIC MODEL OF A STATE, JASA 69,787

NETER, JOHN A STUDY OF RESPONSE ERRORS IN EXPENDITURES DATA FROM HOUSEHOLD INTERVIEWS, JASA 64,18

NETER, JOHN POTENTIALS IN APPLYING LINEAR PROGRAMMING TO THE CONSUMER PRICE INDEX, JASA 66, 982

NETER, JOHN THE EFFEGT OF MIS-MATCHING ON THE MEASUREMENT OF RESPONSE ERRORS, JASA 65, 1005

NETTHEIM, NIGEL F. FOURIER METHODS FOR EVOLVING SEASONAL PATTERNS JASA 65,492

NEUDECKER, H A NOTE ON BLUS ESTIMATTON, JASA 69, 949

NEUDECKER, H. SOME THEOREMS ON MATRIX DIFFERENTIATION WITH SPECIAL REFERENCE TO KRONECKER MATRIX PRODUCTS, JASA 69, 953

NEUTS, MARCEL $F$. A GENERAL CLASS OF BULK QUEUES WITH POISSON INPUT, AMS 67,759

NEUTS, MARCEL F. CENERATINC FUNCTIONS FOR MARKOV RENEWAL PROCESSES, AMS 64, 431

NEW, MARY L MAMMALIAN REPRODUCTIVE DATA FITTED TO A MATHEMATICAL MODEL, BIOGS 69,529

NEWELL, D. J. THE IDENTIFICATION OF ANNUAL PEAK PERIODS FOR A DISEASE, BIOCS 65,645

NEWELL, D. J. UNUSUAL FREQUENCY DISTRIBUT IONS, BIOCS 65, 159

NEWELL, G. F. ASYMPTOTIC EXTREMES FOR M-DEPENDENT RANDOM VARIABLES, AMS 64,1322

NEWELL, G. F. ZERO CROSSING PROBABILITIES FOR GAUSSIAN STATIONARY PROCESSES, AMS 62, 1306

NEWMAN, DAVID S. ON THE PROBABILITY DISTRIBUTION OF A FILTERED RANDOM TELEGRAPH STGNAL, AMS 68,890

NEWTON, D. ON A FACTOR AUTOMORPHISM OF A NORMAL DYNAMICAL SYSTEM, AMS 66,1528

NEY, P. E. A RANDOM INTERVAL FILL ING PROBLEM, AMS 62, 702

NEY, P. E. GONVERCENCE THEOREMS FOR MULTIPLE CHANNEL LOSS PROBABILITIES, AMS 63,260

NEY, P. E. THE LIMIT OF A RATIO OF CONVOLUTIONS, AMS 63, 457

NEYMAN, J STATISTICAL APPROACH TO PROBLEMS OF COSMOLOGY (WITH DISCUSSION ), JRSSB 58, 1

NEYMAN, JERZY ASYMPTOTICALLY OPTIMAL TESTS OF COMPOSITE HYPOTHESES FOR RANDOMIZED EXPERIMENTS WITH NONCON, JASA 65, 699 NEYMAN, JERZY DISCUSSION OF HOEFFDINGS PAPER, AMS 65, 401

NEYMAN, JERZY FURTHER COMMENTS ON THE ' FINAL REPORT OF THE ADVISORY COMMITTEE ON WEATHER CONTROL' ', JASA 61,580

NEYMAN, JERZY INDETERMINISM IN SCIENCE AND NEW DEMANDS ON STATISTICIANS, JASA 60,625

NEYMAN, JERZY NOTE ON AN ARTICLE BY SIR RONALD FISHER, JRSSB 56, 288 NEYMAN, JERZY STATITSTICAL PROBLEMS IN SCIENCE. THE SYMMETRIC TEST OF A COMPLE'TE HYPOTHESIS, JASA 69, NO 4

NICHOLSON JR, GEORGE E. ESTIMATION OF PARAMETERS FROM INCOMPLETE MULT IVARIATE SAMPLES. JASA 57.523 
NICHOLSON, W. L OCCUPANCY PROBABILITY DISTRIBUTION CRITICAL POINTS, BIOKA 61,175

NICHOLSON, W. L. UNFOLDINC PARTICLE SIZE DISTRIBUTIONS, TECH 69 NO. 4

NICKOLS, D. C. SOME EQUILIBRIUM RESULTS FOR THE QUEUEINC PROCESS ESUB-K-M-1, JRSSB 56, 275

NIEDERHOFFER, VICTOR MARKET MAKING AND REVERSAL OF THE STOCK EXCHANGE, JASA 66, B97

NIERMIERKO, S. A. A STOCHASTIC MODEL OF ACHE TRANSPORTATION IN THE PERIPHERAL NERVE TRUNKS, BIOKA 62, 447

NIETO DE PASCUAL, JOSE UNBIASED RATIO ESTIMATORS IN STATIFIED SAMPLING, CORR. 641298 , JASA 61,70

NISSELSON, HAROLD SOME PROBLEMS OF THE HOUSEHOLD INTERVIEW DESICN FOR THE NATIONAL HEALTH SURVEY, JASA 59,69

NISSEN-MEYER, S. ANALYSIS OF EFFECTS OF ANTIBIOTICS ON BACTERIA BY MEANS OF STOCHASTIC MODELS, BIOCS 66, 761

NITRA, SUJIT KUMAR TABLES FOR TOLERANCE LIMITS FOR A NORMAL POPULATION BASED ON SAMPLE MEAN AND RANGE OR, JASA 57, BB

NIXON, ERIC CORRIGENDA, 'TABLE OF PERCENTAGE POINTS OF PEARSON CURVES, FOR GIVEN ROOT (BETA-1) AND BETA-2 . BIOKA 65, 669

NIXON, ERIC TABLE OF PERCENTACE POINTS OF PEARSON CURVES, FOR GIVEN ROOT (BETA-1) AND BETA-2 EXPRESSED IN, BIOKA 63, 459

NOE, MARC AN INEQUALITY CONCERNING TESTS OF FIT OF THE KOLMOCOROVSMIRNOV TYPE, AMS 67,1240

NOE, MARC THE CALCULATION OF DISTRIBUTIONS OF KOLMOGOROV-SMIRNOV TYPE STATISTICS INCLUDING A TABLE OF SIG, AMS 6B, 233

NOETHER, G, E. THE ASYMPTOTIC EFFICIENCY OF THE CHI-SQUARE-SUB-RTEST FOR A BALANCED INCOMPLETE BLOCK DES, BIOKA 59, 475

NOETHER, GOTTFRIED E. EFFICIENCY OF THE WILCOXON TWO-SAMPLE STATISTIC FOR RANDOMIZED BLOCKS, JASA 63,894

NOETHER, COTTFRIED E. TWO CONFIDENCE INTERVALS FOR THE RATIO OF TWO PROBABILITIES AND SOME MEASURES OF EF, JASA 57,36

NOETHER, GOTTFRIED E. TWO SEQUENTIAL TESTS AGAINST TREND, JASA 56 , 440

NOETHER, GOTTFRIED E. WILCOXON CONFIDENCE INTERVALS FOR LOCATION PARAMETERS IN THEDISCRETE CASE, JASA 67,184

NORMAN JR, J. E. EXACT DISTRIBUTION OF THE SUM OF INDEPENDENT IDENTICALLY DISTRIBUTED DISCRETE RANDOM VAR, JASA 65, B37

NORMAN, M. FRANK LIMITING DISTRIBUTIONS FOR SOME RANDOM WALKS ARISINC IN LEARNING MODELS, AMS 66, 393

NORVIG, TORSTEN CONSENSUS OF SUBJECTIVE PROBABILITIES, A CONVERGENCE THEOREM, AMS 67, 221

NOTT INGHAM, R. B. THE FOLDED NORMAL DISTRIBUT ION, TECH 61,543

NOURSE, HUGH 0 . A REGRESSION METHOD FOR REAL ESTATE PRICE INDEX CONSTRUCTION, JASA 63,933

NOVICK, M. R. MULTIPARAMETER BAYESIAN INDIFFERENCE PROCEDURES (WITH DISCUSSION) , JRSSB 69, 29

NOVICK, MELVIN R. A BAYESIAN APPROACH TO THE ANALYSIS OF DATA FROM CLINICAL TRIALS, JASA $65, B 1$

NOVICK, MELVIN R. A BAYESIAN INDIFFERENCE PROCEDURE, JASA 65, 1104 NUESCH, PETER E. ON THE PROBLEM OF TESTING LOCATION IN MULTIVARIATE POPULATIONS FOR RESTRICTED ALTERNATIV, AMS 66, 113

NURI, WALID A. FOURIER METHODS IN THE STUDY OF VARIANCE FLUCTUATIONS IN TIME SERIES ANALYSIS, TECH 69, 103

NYUNT, K. M. QUEUES WITH BATCH DEPARTURES I, AMS 61, 1324

O'NEILL, ANNE F. SOME PROPERTIES OF THE DISTRIBUTION OF THE LOGARITHM OF NON-CENTRAL F, BIOKA 60,417

O'REAGAN, ROBERT T. RELATIVE COSTS OF COMPUTERIZED ERROR INSPECTION PLANS, JASA 69 , NO, 4

ODEH , R . E. THE DISTRIBUTION OF THE MAXIMUM SUM OF RANKS, TECH 67, 271

ODELL, P. L, A GENERALIZATION OF THE GAUSS-MARKOV THEOREM, JASA 66 , 1063

ODELL, P. L. A NUMERICAL PROCEDURE TO CENERATE A SAMPLE COVARIANCE MATRIX, CORR, 661248 , JASA 66, 199

ODELL, P. L. ON SUMS AND PRODUCTS OF RECTANCULAR VARIATES, BIOKA 66 . 615

ODELL, P. L. ON THE FIXED POINT PROBABILITY VECTOR OF REGULAR OR ERGODIC TRANSITION MATRICES, JASA 67, 600

ODOOM, S. A NOTE ON THE SOLUTION OF DAM EQUATIONS, JRSSB $64,33 B$

OGAWA, JUNJIRO ON THE NULL-DISTRIBUTION OF THE F-STATISTIC IN A RANDOMIZED BALANCED INCOMPLETE BLOCKDESI, AMS 63, 155B

OGAWA, JUNJIRO SIMPLIFIED ESTIMATES FOR THE EXPONENTIAL DISTRIBUTION, AMS 63, 102

OCAWA, JUNJIRO THE PROBABILITY OF REVERSAL ASSOCIATED WITH A TEST PROCEDURE, WHEN DATA ARE INCOMPLETE, JASA 61, 125

OGAWA, JUNJIRO THE RELATIONSHIP ALGEBRA AND THE ANALYSIS OF VARIANCE OF A PART IALLY BALANCED INCOMPLETE B, AMS 65, 1815

OGILIVIE, J, THE PERFORMANCE OF SOME SEQUENTIAL PROCEDURES FOR A RANKINC PROBLEM, AMS 68,1040

OCILVIE, J . C. PAIRED COMPARISON MODELS WITH TESTS FOR INTERACTION, BIOCS 65,651

OGUS, JACK L. A NOTE ON THE 'NECESSARY BEST ESTIMATOR', JASA 69, NO.4 OHLSEN, SALLY ON ESTIMATING EPIDEMIC PARAMETERS FROM HOUSEHOLD DATA, BIOKA 64, 511

OHTA, T'. SURVIVAL PROBABILITIES OF NEW INVERSIONS IN LARCE POPULATIONS, BIOCS 6B, 501

OKAMOTO. M. CORRIGENDA, 'TEST OF INDEPENDENCE IN INTRACLASS 2-BY-2 TABLES', BIOKA 61,476
OKAMOTO, M. TESTS OF INDEPENDENCE IN INTRACLASS 2-BY-2 TABLES, BIOKA 61,181

OKAMOTO, MASASHI AN ASYMPTOTIC EXPANSION FOR THE DISTRIBUTION OF THE LINEAR DISCRIMINANT FUNCTION, AMS 63, 1286

OKAMOTO, MASASHI CHI-SQUARE STATISTIC BASED ON THE POOLED FREQUENCIES OF SEVERAL OBSERVATIONS, BIOKA 63, 524

OKAMOTO, MASASHI MINIMIZATION OF EIGENVALUES OF A MATRIX AND OPTIMALITY OF PRINCIPAL COMPONENTS, AMS 68,859

OLDHAM. P. D. NOTES. ON ESTIMATING THE ARITHMETIC MEANS OF LOGNORMALLY-DISTRIBUTED POPULATIONS, BIOCS 65,235

OLIVER, $F$. R. ASPECTS OF MAXIMUM LIKELIHOOD ESTIMATION OF THE LOGISTIC GROWTH FUNCTION, JASA 66, 697

OLKIN, I. A GENERAL APPROACH TO SOME SCREENING AND CLASSIFICATION PROBLEMS , WITHDISCUSSION ), JRSSB 68, 407

OLKIN, I. CORRICENDA, 'EXTREMA OF QUADRATIC FORMS WITH APPLICATIONS TOSTATISTICS', BIOKA 61, 474

OLKIN, I. EXTREMA OF QUADRATIC FORMS WITH APPLICATIONS TO STATISTICS, BIOKA 59,483

OLKIN, I. INTEGRAL EXPRESSIONS FOR TAIL PROBABILITIES OF THE MULTINOMIAL AND NEGATIVE MULT INOMI AL DISTRIB, BIOKA 65, 167

OLKIN, I . MULTIVARIATE CORRELATION MODELS WITH MIXED DISCRETE AND CONTINUOUS VARIABLES, CORR. 65343, AMS 61, 44B

OLKIN, I. MULTIVARIATE RATIO ESTIMATION FOR FINITE POPULATIONS. BIOKA 58,154

OLKIN, I. ON THE BIAS OF FUNCTIONS OF CHARACTERISTIC ROOTS OF A RANDOMMATRIX, BIOKA 65,87

OLKTN, INGRAM A CHARACTERIZATION OF THE MULTIVARIATE NORMAL DISTRIBUTION, AMS 62. 533

OLKIN, INCRAM A CHARACTERIZATION OF THE WISHART DISTRIBUTION, AMS 62,1272

OLKIN, INCRAM A MULTIVARIATE EXPONENTIAL DISTRIBUTION, JASA 67, 30 OLKIN, INGRAM MULTIVARIATE BETA DISTRIBUTIONS AND INDEPENDENCE PROPERTIES OF THE WISHART DISTRIBUTIONS, C, AMS 64, 261

OLKIN, INGRAM NOTE ON 'THE JACOBIANS OF CERTAIN MATRIX TRANSFORMATION USEFULL IN MULTIVARIATE ANALYSIS', BIOKA 53,43

OLKIN, INGRAM TESTING AND ESTIMATION FOR A CIRCULAR STATIONARY MODEL, AMS 69, 1358

OLKIN, INGRAM THE JACOBIANS OF CERTAIN MATRIX TRANSFORMATIONS USEFUL IN MULTIVARIATE ANALYSIS, BASED ON L, BIOKA 51,345

OLKIN, INGRAM UNBI ASED EST IMATION OF SOME MULTIVARIATE PROBABILITY DENSITIES, AMS 69, 1261

OLSHEN, R. A. SOME FIRST PASSAGE PROBLEMS FOR S-SUB-N-OVER-ROOT-N, AMS 69, 64B

OLSHEN, RICHARD A. REPRESENT ING FINITELY ADDITIVE INVARIANT PROBABILITIES, AMS 68, 2131

OLSHEN, RICHARD A. SIGN AND WILCOXON TESTS FOR LINEARITY, AMS 67 , 1759

OLSON, D. P. LINE TRANSECT METHOD OF ESTIMATING GROUSE POPULATION DENSITIES, BIOCS 68, 135

OLSON, MILTON PHILIP THE THEORY OF EXPERIMENT, OPERATIONAL DEFINI TION OF THE PROBABILITY SPACE, AMS 67, 401

OOSTERHOFF, J. ON THE COMBINATION OF INDEPENDENT TEST STATISTICS AMS 67,659

ORD, J. K. APPROXIMATIONS TO DISTRIBUTION FUNCTIONS WHICH ARE HYPERCEOMETRIC SERIES, BIOKA 6B, 243

ORD, J . K, ON A SYSTEM OF DISCRETE DISTRIBUTIONS, BIOKA 67, 649

ORD, J , K, THE DISCRETE STUDENT' S DISTRIBUTION, AMS 6B, 1513

OREY, STEVEN AN OPTIMAL STOPPINC THEOREM, AMS 69, 677

OREY, STEVEN ON CONTINUITY PROPERTIES OF INFINITELY DIVISIBLE DISTRIBUTION FUNCTIONS, AMS 68,936

OSBORNE, M. F. M. MARKET MAKING AND REVERSAL OF THE STOCK EXCHANGE, JASA 66,897

OSBORNE, M.F.M. SOME QUANTITAT IVE TESTS FOR STOCK PRICE GENERATING MODELS AND TRADINC FOLKLORE, JASA 67,321

OSHIMA, HARRY T. NATIONAL INCOME STATISTICS OF UNDERDEVELOPED COUNTRIES, JASA 57,162

OSTLE, B. AN ANALYSIS OF SOME RELAY FAILURE DATA FROM A COMPOSITE EXPONENTIAL POPULATION, TECH 61,423

OSTLE, BERNARD CORRELATION BETWEEN SAMPLE MEANS AND SAMPLE RANGES JASA 59,465

OTT, R. L. A SHORT-CUT RULE FOR A ONE-SIDED TEST OF HYPOTHESIS FOR QUALITATIVE DATA. TECH 69,197

OTT, R. LYMAN OPT IMAL EXPERIMENTAL DESIGNS FOR ESTIMATING THE INDEPENDENT VARIABLE IN REGRESSION, TECH 68, 811

OWEN, A. R. G. NEGATIVE BINOMIAL DISTRIBUTIONS WITH A COMMON K, BIOKA 58,37

OWEN, D. B. A NOTE ON THE EQUICORRELATED MULTIVARIATE NORMAL DISTRIBUTION, BIOKA 62,269

OWEN, D. B. A SPECIAL CASE OF A BIVARIATE NON-CENTRAL T-DISTRIBUTION, BIOKA 65,437

OWEN, D. B. CONFIDENCE INTERVALS FOR THE COEFFICIENT OF VARIATION FOR THE NORMAL AND LOG NORMAL DISTRIBUT, BIOKA 64, 25

OWEN, D. B CONTROL OF PERCENTACES IN BOTH TAILS OF THE NORMAL DISTRIBUTION, TECH 64,377

OWEN, D. B. DISTRIBUTION FREE TOLERANCE LIMITS, ELIMINATION OF REQUIREMENT THAT CUMULAT IVE FUNCT IONS BE C, TECH $63,51 \mathrm{~B}$

OWEN, D, B, ERRATA, 'CONTROL OF PERCENTAGES IN BOTH TAILS OF THE NORMAL DISTRIBUTIONS' , TECH 66,570 
OWEN, D. B. MOMENTS OF ORDER STATISTICS FROM THE EQUICORRELATED MULTIVARIATE NORMAL DISTRIBUTION, AMS 62, 1286

OWEN, D. B. NONPARAMETRIC UPPER CONFIDENCE BOUNDS, AND CONFIDENCE LIMITS, FOR THE PROBABILITY THAT Y IS L, JASA 64,906

OWEN, D. B. ON THE DISTRIBUTIONS OF THE RANGE AND MEAN RANGE FOR SAMPLES FROM A NORMAL DISTRIBUTION, BIOKA 66, 245

OWEN, D. B. PERCENTAGE POINTS FOR THE DISTRIBUTION OF OUTCOINC QUALITY, JASA 59,689

OWEN, D. B. SUMMARY OF RECENT WORK ON VARIABLES ACCEPTANCE SAMPLINC WITH EMPHASIS ON NON-NORMALITY, TECH 69, NO .4

OWEN, D. B. THE POWER OF STUDENT'S T-TEST, CORR. 65 1251, JASA 65,320

OWEN, D. B. VARIABLES SAMPLING PLANS BASED ON THE NORMAL DISTRIBUTION, TECH 67,417

OWEN, DON B. A SURVEY OF PROPERTIES AND APPLICATIONS OF THE NONCENTRAL T-DISTRIBUTION, TECH 68,445

PAGHARES, J. TABLE OF THE UPPER 10 PERCENT POINTS OF THE 'STUDENTIZED ' RANGE, BIOKA 59,461

PACHARES, JAMES TABLES FOR UNBIASED TESTS ON THE VARIANCE OF A NORMAL POPULATION, AMS 61, B 4

PACHARES, JAMES TABLES OF CONFIDENCE LIMITS FOR THE BINOMIAL DISTRIBUTION, JASA 60,521

PAGE, E. S. A MODIF IED CONTROL CHART WITH WARNING LINES, BIOKA 62, 171

PACE, E. S. A TEST FOR A CHANCE IN A PARAMETER OCCURRINC AT ANUNKNOWN POINT, BIOKA 55, 523

PAGE, E. S. AN APPROACH TO THE SCHEDULING OF JOBS ON MACHINES, JRSSB 61,484

PAGE, E. S. AN IMPROVEMENT TO WALD'S APPROXIMATION FOR SOME PROPERTIES OF SEQUENTIAL TESTS, JRSSB 54, 136

PAGE, E. S. CONTINUOUS INSPECTION SCHEMES, BIOKA 54,100

PAGE, E. S. CONTROL CHARTS FOR THE MEAN OF A NORMAL POPULATION, JRSSB 54,131

PAGE, E. S . CONTROL CHARTS WITH WARNING LINES, BIOKA 55,243

PAGE, E. $S$. CONTROLLING THE ST ANDARD DEVIATION BY CUSUMS AND WARNING LINES, TECH 63,307

PAGE, E. S. CUMULATIVE SUM CHARTS, TECH 61,1

PACE, E. S. CUMULATIVE SUM SCHEMES USING GAUGING, TECH 62,97

PAGE, E. S. ON PROBLEMS IN WHICH A CHANGE IN A PARAMETER OCCURS AT AN UNKNOWN POINT, BIOKA 57,248

PAGE, E. S. SEQUENTIAL TESTS FOR BINOMIAL AND EXPONENTIAL POPULATIONS, BIOKA 54,252

PACE, E. S. TABLES FOR WALD TESTS FOR THE MEAN OF A NORMAL DISTRIBUTION, BIOKA 59,169

PAGE, E. S. THE DISTRIBUT ION OF VACANCIES ON A LINE, JRSSB 59, 364

PAGE, ELLIS BATTEN ORDERED HYPOTHESES FOR MULTIPLE TREATMENTS, A SIGNIFICANCE TEST FOR LINEAR RANKS, JASA 63, 216

PAHL, P. J. ON TEST ING FOR GOODNESS-OF-FIT OF THE NEGATIVE BINOMIAL WHEN EXPECTATIONS ARE SMALL, BIOCS 69,143

PALMER, D. S. THE DISTRIBUTION OF INTERVALS BETWEEN SUCCESSIVE MAXIMA IN A SERIES OF RANDOM NUMBERS, BIOKA 57,524

PANCHAPAKESAN, $S$. ON THE DISTRIBUTION OF THE MAXIMUM AND MINIMUM OF RATIOS OF ORDER STATISTICS, AMS 69, 918

PANDIT, S. N. N. DIMENSIONAL CHAINS INVOLVING RECTANGULAR AND NORMAL ERROR-DISTRIBUTIONS, TECH 63, 404

PANSE, V. P. ESTIMATION OF CROP YIELDS FOR SMALL AREAS, BIOCS 66,374 PANZONE, RAFAEL ALTERNATIVE PROOFS FOR CERTAIN UPCROSSINC INEQUALITIES, AMS 67,735

PARK JR, JOHN H. VARIATIONS OF THE NON-CENTRAL T AND BETA DISTRIBUTIONS, AMS $64,15 B 3$

PARK, T. MORTALITY PATTERNS IN EIGHT STRAINS OF FLOUR BEETLE, BIOCS 65,99

PARKER, RICHARD A. SIMULATION OF AN AQUATIC ECOSYSTEM, BIOCS 6B, B03

PARKS, RICHARD W. EFFICIENT ESTIMATION OF A SYSTEM OF RECRESSION EQUATI I ONS WHEN DISTURBANCES ARE BOTH SER, JASA 67,500

PARR, VAN B. A METHOD FOR DISCRIMINATING BETWEEN FAILURE DENSITY FUNCTIONS USED IN RELIABILITY PREDICTION, TECH 65,1

PARRY, W. ON A FACTOR AUTOMORPHISM OF A NORMAL DYNAMICAL SYSTEM, AMS 66,1528

PARRY, WILLIAM ERGODIC PROPERTIES OF SOME PERMUTATION PROCESSES, BIOKA 62, 151

PARTER, S. V. ON A CLASS OF SIMPLE RANDOM WALKS, AMS 63, 413

PARZEN, EMANUEL AN APPROACH TO TIME SERIES ANALYSIS, AMS 61,951

PARZEN, EMANUEL COMMENTS ON THE DISCUSSIONS OF MESSRS. TUKEY AND GOODMAN, TECH 61,229

PARZEN, EMANUEL MATHEMATICAL CONSIDERATIONS IN THE ESTIMATION OF SPECTRA, TECH 61, 167

PARZEN, EMANUEL ON ASYMPTOTICALLY EFFICIENT CONSISTENT ESTIMATES OF THE SPECTRAL DENSITY FUNCTION OF A ST, JRSSB 58,303

PARZEN, EMANUEL ON ESTIMATION OF A PROBABILITY DENSITY FUNCTION AND MODE, AMS 62, 1065

PASTERNACK, B. NOTES. A DEFICIENCY IN THE SUMMATION OF CHI PROCEDURE, BIOCS 66,407

PASTERNACK, B.S. SOME EXPERIMENTAL SAMPLING RESULTS FOR REGRESSION ANALYSIS APPLIED TO GAMMA RAY SPECTRO, BIOCS 67, 11

PASTERNACK, B. S. SOME EXPERIMENTAL SAMPLING RESULTS FOR REGRESSION ANALYSIS APPLIED TO GAMA RAY SPECTROM, BIOCS 68,353

PASTERNACK, BERNARD LIGHT BULB STATISTICS, CORR. 66 1248, JASA 66 , 633
PASTERNACK, BERNARD PATTERNS IN RESIDUALS, A TEST FOR RECRESSION MODEL ADEQUACY IN RADIONUCLIDE ASSAY, TECH 65, 603

PASTERNACK, BERNARD S. LINEAR ESTIMATION AND THE ANALYSIS OF GAMMA RAY PULSE-HEIGHT SPECTRA, TECH 62, 565

PASTERNACK, BERNARD S. THE PROBABILITY OF REVERSAL ASSOCIATED WITH A TEST PROCEDURE, WHEN DATA ARE INCOMP, JASA 61, 125

PATANKAR, $V, N$. THE GOODNESS OF FIT OF FREQUENCY DISTRIBUTIONS OBTAINED FROM STOCHASTIG PROCESSES, BIOKA 54,450

PATEL, M. S. A NOTE ON 'A STUDY OF THE CROUP SCREENINC EXPERIMENT' TECH 63, 397

PATEL, M. S. GROUP SCREENING WITH MORE THAN TWO ST AGES, TECH 62, 209

PATEL, M. S. ON CONSTRUCTING THE FACTORIAL REPLICATES OF THE TWO TO THE POWER OF M DESIGNS WITH BLOCKS, AMS 62,1440

PATEL, M. S. PARTIALLY DUPLICATED FRACTIONAL FACTORIAL DESIGNS TECH 63, 71

PATEL, R. M. SELECTION AMONG DIALLEL CLASSIFIED VARIABLES, BIOCS 69,49

PATHAK, P. K. ON INVERSE SAMPLING WITH UNEQUAL PROBABILITIES, BIOKA 64,185

PATHAK, P. K. ON SAMPLING SCHEMES PROVIDING UNBIASED RATIO EST IMATORS, AMS 64,222

PATHAK, P. K, SUFFICIENCY IN SAMPL ING THEORY, AMS 64,795

PATHAK, $P . K$. TESTS FOR THE EQUALITY OF COVARIANCE MATRICES UNDER THE INTRACLASS CORRELATION MODEL, AMS 67, 1286

PATIL, G. P. A CHARACTERIZATION OF THE EXPONENTIAL-TYPE DISTRIBUTION, BIOKA 63,205

PATIL, G. P. CHARACTERIZATION THEOREMS FOR SOME UNIVARIATE PROBABILITY DISTRIBUTIONS, JRSSB $64,2 B 6$

PATIL, G, P MAXIMUM LIKELIHOOD ESTIMATION FOR CENERALIZED POWER SERIES DISTRIBUTIONS AND ITS APPLICATION, BIOKA 62,227

PATIL, G. P. MINIMUM VARIANCE UNBIASED ESTIMATION AND CERTAIN PROBLEMS OF ADDITIVE NUMBER THEORY, AMS 63, 1050

PATIL, G. P. MULTIVARIATE EXPONENTIAL-TYPE DISTRIBUTIONS, AMS 68 , 1316

PATIL, G. P. MULTIVARIATE LOGARITHMIC SERIES DISTRIBUTION AS A PROBABILITY MODEL IN POPULATION AND COMMUN, JASA 67,655

PATIL, G. P. ON CERTAIN PROPERTIES OF THE EXPONENTIAL-TYPE FAMILIES, JRSSB 65,94

PATIL, G. P. ON THE EQUIVALENCE OF BINOMIAL AND INVERSE BINOMIAL ACCEPT ANCE SAMPLING PLANS AND AN ACKNOWL, TECH 63, 119

PATIL, G. P. ON THE EVALUATION OF THE NEGATIVE BINOMIAL DISTRIBUTION WITH EXAMPLES, TECH 60,501

PATIL, V. H. APPROXIMATION TO THE BEHRENS-FISHER DISTRIBUTIONS. BIOKA 65,267

PATIL, V. H. APPROXIMATION TO THE GENERALIZED BEHRENS-FISHER DISTRIBUTION INVOLVING THREE VARIATES, BIOKA 69, NO.3

PATIL, $V . T$. THE CONSISTENCY AND ADEQUACY OF THE POISSON-MARKOFF MODEL FOR DENSITY FLUGTUATIONS, BIOKA 57,43

PATLAK, C. S. ONEXPECTATIONS OF SOME FUNCTIONS OF POISSON VARIATES, BIOGS 68,97

PATNAIK, P. B. CORRIGENDA, 'THE POWER FUNCTION OF THE TEST FOR THE DIFFERENCE BETWEEN TWO PROPORTIONS IN, BIOKA 59, 502

PATTERSON, H.D. A FURTHER NOTE ON A SIMPLE METHOD FOR FITTING AN EXPONENTIAL CURVE, BIOKA 60,177

PATTERSON, H. D. AN INVEST IGATION OF HARTLEY'S METHOD FOR FITT INC AN EXPONENTI AL CURVE, BIOKA $59,2 B 1$

PATTERSON, H.D. QUERY, BAULE'S EQUATION+ (LEAST SQUARES ESTIMATE OF SOIL CONTENT I, BIOCS 69,159

PATTERSON, H. D. SERIAL FACTORIAL DESIGN, BIOKA 6B, 67

PATTERSON, H. D. THE CONSTRUCTION OF BALANCED DESIGNS FOR EXPERIMENTS INVOLVING SEQUENCES OF TREATMENTS, BIOKA 52,32

PATTERSON, H. D. THE ERRORS OF LATT ICE SAMPLINC, JRSSB 54,140

PATTERSON, H.D. THE USE OF AUTORECRESSION IN FITTI ING AN EXPONENT IAL CURVE, BTOKA 58,389

PATTERSON, H. D. THEORY OF CYCLIC ROTATION EXPERIMENTS (WITH DISCUSSION), JRSSB 64, I

PATTERSON, R. L. DIFFICULTIES INVOLVED IN THE ESTIMATION OF A POPULATION MEAN USING TRANSF ORMED SAMPLE DA, TECH 66, 535

PATWARY, K. M. ANALYSIS OF QUANTAL RESPONSE ASSAYS WITH DOSAGE ERRORS, BIOCS 67,747

PAULSON, A. S. THE PERFORMANCE OF SEVERAL TESTS FOR OUTLIERS, BIOKA 65,429

PAULSON, EDWARD A SEQUENTIAL DECISION PROCEDURE FOR CHOOSING ONE OF K HYPOTHESES CONCERNING THE UNKNOWN M, AMS 63, 549

PAULSON. EDWARD A SEQUENTIAL PROCEDURE FOR COMPARING SEVERAL EXPER IMENTAL CATEGORIES WITH A STANDARD OR C. AMS 62,438

PAULSON, EDWARD A SEQUENTIAL PROCEDURE FOR SELECTING THE POPULATION WITH THE LARGEST MEAN FROM K NORMAL P, AMS 64.174

PAULSON, EDWARD SEQUENTIAL ESTIMATION AND CLOSED SEQUENTIAL DECI SION PROCEDURES, AMS 64,1048

PAULSON, EDWARD SEQUENTIAL INTERVAL ESTIMATION FOR THE MEANS OF NORMAL POPULATIONS, AMS 69,509

PAULSON, EDWARD SEQUENT IAL PROCEDURES FOR SELECTION OF THE BEST ONE OF SEVERAL BINOMIAL POPULATIONS, AMS 67,117

PEACH, PAUL BIAS IN PSEUDO-RANDOM NUMBERS, JASA 61,610

PEARCE, S. C. ALTERNATIVES TO A LATIN SQUARE, BIOCS 68.657

PEARCE, S, C , CORRIGENDA, 'SUPPLEMENTED BALANCE' , BIOKA 61, 475

PEARCE, S. C. EXPERIMENTING WITH ORGANISMS AS BLOCKS, BIOKA 57, 141 
PEARCE, S. C. SUPPLEMENTED BALANCE, BIOKA 60, 263

PEARCE. S. C. THE MEAN EFF ICIENCY OF EQUI-REPLICATE DESIGNS, BIOKA 68.251

PEARSON, E. S. ALTERNATIVE TESTS FOR HETEROGENEITY OF VARIANCE SOME MONTE CARLORESULTS. BIOKA 66,229

PEARSON, E. S. AN APPROXIMATION TO THE DISTRIBUTION OF NON-CENTRAL T, BIOKA $5 B, 4 B 4$

PEARSON, E. S. APPROXIMATE MEANS AND STANDARD DEVIATIONS BASED ON DISTANCES BETWEEN PERCENTAGE POINTS OF, BIOKA 65,533

PEARSON. E.S CHARTS OF THE POWER FUNCTION FOR ANALYSIS OF VARI ANCE TESTS, DERIVED FROM THE NON-CENTRAL, BIOKA 51,112

PEARSON, E S, COMPARISON OF TESTS FOR RANDOMNESS OF POINTS ON A LINE, BIOKA 63,315

PEARSON, E. S. COMPARISON OF TWO APPROXIMATIONS TO THEDISTRIBUTION OF THE RANGE IN SMALL SAMPLES FROM NO, BIOKA 52,130

PEARSON, E. S. CORRIGENDA TO 'CORRELATED RANDOM NORMAL DEVIATES PUBLISHED IN TRACTS FOR COMPUTERS, NO. 2, BIOKA 56.496

PEARSON, E S CORRIGENDA, 'ON QUESTIONS RAISED BY THE COMBINATION OF TESTS BASED ON DISCONTINUOUSDISTRI, BIOKA 51,265

PEARSON, E. S. CORRIGENDA, TABLE OF PERCENTAGE POINTS OF PEARSON CURVES, FOR GIVEN ROOT (BETA-1) AND BETA, BIOKA 65, 669

PEARSON, E. S. EDITORIAL, JOHN WISHART, IB9B-1956, BIOKA 57, 1

PEARSON, E, S. FURTHER NOTES ON THE ANALYSIS OF ACCIDENT DATA, BIOKA 53. 214

PEARSON, E. S. LAGRANGIAN COEFFICIENTS FOR INTERPOLATION BETWEEN TABLED PERCENTAGE POINTS, BICKA 68, 19

PEARSON, E. S. MOMENT CONSTANTS FOR THE DISTRIBUTION OF RANGE IN NORMAL SAMPLES, BIOKA 51,463

PEARSON, E. S. NOTE ON AN APPROXIMATION TO THE DISTRIBUTION OF NONCENTRAL CHI-SQUARE, BIOKA 59,364

PEARSON, E. S. NOTE ON MR QUENOU ILLE'S EDGEWORTH TYPE A TRANSFORMATION. BIOKA 59,203

PEARSON, E. S. NOTE ON MR SRIVASTAVA 'S PAPER ON THE POWER FUNCTION OF STUDENT'S TEST, BIOKA 5B, 429

PEARSON, E. S. ON THE USE OF PATNAIK TYPE CHI APPROXIMATIONS TO THE RANGE IN SIGNIFICANCE TESTS, BIOKA 66,248

PEARSON. E. S. SOME COMMENTS ON THE ACCURACY OF BOX 'S APPROXIMATIONS TO THEDISTRIBUTION OF M, BIOKA 69, 219

PEARSON, E. S. SOME PROBLEMS ARISING IN APPROXIMATING TO PROBABILITY DISTRIBUTIONS USING MOMENTS, BIOKA 63, 95

PEARSON. E. S. SOME THOUGHTS ON STATISTICAL INFERENCE, AMS 62, 294

PEARSON, E. S. STATISTICAL CONCEPTS IN THEIR RELATION TO REALITY JRSSB 55, 204

PEARSON, E. S. STUDIES IN THE HISTORY OF PROBABILITY AND STATISTICS $X X$. SOME EARLY CORRESPONDENCE BETWEEN, BIOKA $6 B, 445$

PEARSON. E. S. STUDIES IN THE HISTORY OF PROBABILITY AND STATISTICS. XIV SOME INCIDENTS IN THE EARLY HIS, BIOKA 65, 3

PEARSON, E. S. STUDIES IN THE HISTORY OF PROBABILITY AND STATISTICS XVII. SOME REFLEXIONS ON CONTINUITY, BIOKA 67,341

PEARSON, E. S. TABLE OF PERCENTAGE POINTS OF NON-CENTRAL CHI. BIOKA 69. 255

PEARSON, E. S. TABLE OF PERCENTAGE POINTS OF PEARSON CURVES, FOR GIVEN ROOT, BETA-1) AND BETA-2 EXPRESSED, BIOKA 63, 459

PEARSON. E. S. TABLES OF PERCENTAGE POINTS OF ROOT'BI' AND B2 IN NORMAL SAMPLES. A ROUNDING OFF. BIOKA 65,282

PEARSON. E. S. TABLES OF THE 5 PERCENT AND 0 5 PERCENT POINTS OF PEARSON CURVES, WITH ARGUMENT BETA-I AND, BIOKA 51,4

PEARSON, E. S. TESTS FOR RANK CORRELATION COEFF I CIENTS. I, BIOKA 57 , 470

PEARSON, E S. TESTS FOR RANK CORRELATION COEFFICIENTS. III. DISTRIBUTION OF THE TRANSFORMED KENDALL COEF, BIOKA 62, IB5

PEARSON, E. S. TESTS FOR RANK CORRELATION COEFFICIENTS II, BIOKA 61,29

PEARSON, E. S. THE DISTRIBUTION OF RANGE IN NORMAL SAMPLES WITH $\mathrm{N}=200$, BIOKA 57,257

PEARSON, E. S. THE DISTRIBUTION OF THE RATIO, IN A SINGLE NORMAL SAMPLE , OF RANGE TO STANDARD DEVIATION, BIOKA 54,482

PEARSON, E. S. THE GOODNESS-OF-FIT TESTS BASED ON W-SQUARE-SUBNAAD-U-SQUARE-SUB-N, BIOKA 62,397

PEARSON, E. S. THE RATIO OF RANGE TO STANDARD DEVIATION IN THE SAME NORMAL SAMPLE, BIOKA $64,4 B 4$

PEARSON, E. S. THE TIME INTERVALS BETWEEN INDUSTRIAL ACCIDENTS BIOKA 52, 16B

PEARSON, E. S. WILLIAM PALIN ELDERTON, 1B77-1962, BIOKA 62, 297

PEARSON, H. S. THE GROWTH, SURVIVAL, WANDERING AND VARIATION OF THE LONG-TA ILED FIEI D MOUSE, APODEMUS SYL, BIOKA 52, 3B9

PEERS, $H, W$. CONF IDENCE PROPERTIES OF BAYESIAN INTERVAL EST IMATES, JRSSB 68,535

PEERS, $H . W$. ON CONFIDENCE POINTS AND BAYESIAN PROBABILITY POINTS IN THE CASE OF SEVERAL PARAMETERS, JRSSB 65,9

PEERS. H.W. ON FORMULAE FOR CONF IDENCE POINTS BASED ON INTEGRALS OF WEIGHTED LIKELIHOODS, JRSSB 63, $31 \mathrm{~B}$

PEIZER. DAVID B. A NORMAL APPROXIMATION FOR BINOMIAL, F, BETA, AND OTHER GOMMON, RELATED TAIL PROBABILITI, JASA 68, 1416

PELTO, C. R. ADAPTIVE NONPARAMETRIG GLASSIFIGATION, TEGH 69, NO.4
PENNOCK, JEAN L. AN ANALYSIS OF CONSISTENCY OF RESPONSE IN HOUSEHOLD SURVEYS, JASA 61,320

PENNOCK, JEAN L. ESTIMATING THE SERVICE LIFE OF HOUSEHOLD GOODS BY ACTUARIAL METHODS, CORR . 57578 , JASA 57, 175

PERERA, A F . A. D. QUEUES WITH BATCHDEPARTURES II. AMS 64, $114^{\prime 7}$

PERERA, A.G. A. D. A CORRECTION TO 'THE SOLUTION OF QUEUEING AND INVENTORY MODELS BY SEMI-MARKOV PROCESS, JRSSB 63,455

PEREZ, CARMEN A. ON COMPARING DIFFERENT TESTS OF THE SAME HYPOTHESIS, BIOKA 60,297

PERITZ, E. ON INFERRING ORDER RELATIONS IN ANALYSIS OF VARIANCE BIOCS 65,337

PERITZ, E. TESTING FOR LINEAR CONTAGION, INVERSE SAMPLING, JRSSB 69. NO. 2

PERLMAN, MICHAEL D. ONE SIDED PROBLEMS IN MULTIVARIATE ANALYSIS, AMS 69.549

PERNG, S. K. A COMPARISON OF THE ASYMPTOTIC EXPECTED SAMPLE SIZES OF TWO SEQUENT I AL PROCEDURES FOR RANKIN, AMS 69, NO. 6

PERNG, S. K. INADMISSIBILITY OF THE BEST INVARIANT TEST WHEN THE MOMENT IS INFINITE UNDER ONE OF THE HYPO, AMS 69, I4B3

PETRIE, T . PROBABILISTIC FUNCTIONS OF FINITE STATE MARKOV CHAINS, AMS 69.97

PETRIE. TED STATISTICAL INFERENCE FOR PROBABILISTIC FUNCTIONS OF FINITE STATE MARKOV CHAINS, AMS 66,1554

PETTIGREW. H.M A RAPID TEST FOR THE POISSONDISTRIBUTION USING THE RANGE, BIOCS $67,6 \mathrm{~B} 5$

PFANZAGL, J. A TECHNICAL LEMMA FOR MONOTONE LIKELIHOOD RATIO FAMILIES, AMS 67,611

PFANZAGL. J CHARACTERIZATIONS OF CONDITIONAL EXPECTATIONS, AMS 67.415

PFANZAGL , J FURTHER REMARKS ON TOPOLOGY AND CONVERGENCE IN SOME ORDERED FAMILIES OF DISTRIBUTION, AMS 69. 51

PFANZAGL. J. ON THE TOPOLOGICAL STRUCTURE OF SOME ORDERED FAMILIES OF DISTRIBUTIONS, AMS 64,1216

PFANZAGL. J, ONE-PARAMETER EXPONENTIAL FAMILIES GENERATED BY TRANSFORMATION GROUPS, AMS 65,261

PFANZAGL, J . SAMPLING PROCEDURES BASED ON PRIOR DISTRIBUTIONS AND COSTS, TECH 63,47

PFANZAGL, J. CONSISTENT ESTIMATION OF A LOCATION PARAMETER IN THE PRESENCE OF AN INCIDENT AL SCALE PARAMETE, AMS 69, 1353

PHATAK, A G CENSORED SAMPLING IN CURTAILED SAMPLING PLANS BY ATTRIBUTES, TECH $68, B 54$

PHATAK, A. G. ESTIMATION OF FRACTION DEFEGTIVE IN CURTAILED SAMPLING PLANS BY ATTRIBUTES, TECH 67,219

PHATAK. A. G MISGLASSIFIED DATA FROM CURTAILED SAMPLING PLANS TECH $68.4 B 9$

PHATARFOD, R.M. APPLICATION OF METHODS IN SEQUENTIAL ANALYSIS TO DAM THEORY, AMS 63. 1588

PHATARFOD, R. M. SEQUENTIAL ANALYSIS OF DEPENDENT OBSERVATIONS. I BIOKA 65,157

PHILIP, J. R. SOME INTEGRAL EQUATIONS IN GEOMETRICAL PROBABILITY BIOKA 66,365

PHILIPP, WALTER THE LAW OF THE ITERATED LOGARITHM FOR MIXING STOCHASTIC PROCESSES, AMS 69, NO 6

PHILIPP. WALTER THE REMAINDER IN THE CENTRAL LIMIT THEOREM FOR MIXING STOCHASTIG PROCESSES, AMS 69,601

PHILLIPS, $A$. W. THE ESTIMATION OF PARAMETERS IN SYSTEMS OF STOCHASTIC DIFFERENT I AL EQUATIONS, BIOKA 59,67

PICKANDS III, JAMES EFFICIENT ESTIMATION OF A PROBABILITY DENSITY FUNCTION, AMS 69, B54

PICKANDS III, JAMES MOMENT CONVERGENCE OF SAMPLE EXTREMES, AMS 6B, $\mathrm{BBI}$

PICKANDS III, JAMES PROBABILITY TABLES FOR THE EXTREMAL QUOTIENT AMS 67,1541

PICKANDS III. JAMES SAMPLE SEQUENCES OF MAXIMA, AMS 67, 1570

PIELOU, E. C. A TEST FOR RANDOM MINGLING OF THE PHASES OF A MOSAIC BIOCS 67,657

PIELOU, E. C. THE CONCEPT OF RANDOMNESS IN THE PATTERNS OF MOSAICS BIOCS 65.908

PIERCE, DONALD A. ESTIMATING THE FRACTION OF ACCEPTABLE PRODUGT, TECH 65,43

PIERRE, PERCY A. NEW CONDITIONS FOR CENTRAL LIMIT THEOREMS (CORR. 69 1B55), AMS 69, 319

PIKE, EUGENE W. A NOTE ON 'LEARNING CURVES', JASA 69, NO.4

PIKE, M. C. A SUGGESTED METHOD OF ANALYSIS OF A GERTAIN CLASS OF EXPERIMENTS IN CARCINOGENESIS, BIOCS 66, 142

PIKE, M. C. DISEASE CLUSTERING, A GENERALIZATION OF KNOX'S APPROACH TO THE DETECTION OF SPACE-TIME INTERA, BIOCS 68, 541

PIKE, M. C . SOME NUMERICAL RESULTS FOR THE QUEUE ING SYSTEM WITH ONE SERVER, WHILE THE INTERARR IVAL AND SE, JRSSB 63.477

PILLAI, K. C. S. ON THE EXACT DISTRIBUTION OF WILKS'S CRITERION, BIOKA 69, 109

PILLAI, K, C S S. UPPER PERCENTAGE POINTS OF THE LARGEST ROOT OF A MATRIX IN MULTIVARIATE ANALYSIS, BIOKA 67, IB9

PILLAI, K. C, S. ON ELEMENTARY SYMMETRIG FUNGTIONS OF THE ROOTS OF TWO MATRIGES IN MULTIVARIATE ANALYSIS. . BIOKA 65. 499

PILLAI, K. G. S. ON HOTELLING 'S GENERALIZATION T-SQUARE, BIOKA 59, 160 
PILLAI, K. C. S. ON LINEAR FUNCTIONS OF ORDERED CORRELATED NORMAL RANDOM VARIABLES, BIOKA 65,367

PILLAI, K. C. S. ON MOMENTS OF ELEMENTARY SYMMETRIC FUNCT IONS OF THE ROOTS OF TWO MATRICES AND APPROXIMAT, AMS 68, 1274

PILLAI, K. C. S. ON THE DISTRIBUTION OF 'STUDENTIZED' RANGE, BIOKA 52,194

PILLAI, K. C. S. ON THE DISTRIBUTION OF THE EXTREME STUDENTIZED DEVIATE FROM THE SAMPLE MEAN, BIOKA 59,467

PILLAI, K. C. S. ON THE DISTRIBUTION OF THE LARGEST CHARACTERISTIC ROOT OF A MATRIX IN MULTIVARIATE ANALY, BIOKA 65,405

PILLAI, K. C. S. ON THE DISTRIBUTION OF THE LARGEST OF SIX ROOTS OF A MATRIX IN MULTIVARIATE ANALYSIS, BIOKA 59, 237

PILLAI, K. C. S. ON THE DISTRIBUTION OF THE LARGEST OR THE SMALLEST ROOT OF A MATRIX IN MULTIVARIATE ANAL, BIOKA 56,122

PILLAI, K. C. S. ON THE DISTRIBUTIONS OF THE RATIOS OF THE ROOTS OF A COVARIANCE MATRIX AND WILKS' CRITER, AMS 69, N0.6

PILLAI, K. C. S. ON THE MOMENTS OF THE TRACE OF A MATRIX AND APPROXIMATI ONS TO ITS NON-CENTRAL DISTR IBUT I, AMS 66, 1312

PILLAI, K. C. S. ON THE NON-CENTRAL DISTRIBUTIONS OF TWO TEST CRITERIA IN MULTIVARIATE ANALYSIS OF VARIAN, AMS 68,215

PILLAI, K. C. S. POWER COMPARISIONS OF TESTS OF EQUALITY OF TWO COVARIANCE MATRICES BASED ON FOUR CRITERI, BIOKA 6B, 335

PILLAI, K. C. S. POWER COMPARISONS OF TESTS OF TWO MULTIVARIATE HYPOTHESES BASED ON FOUR CRITERIA, BIOKA 67, 195

PILLAI, K. C. S. SOME RESULTS ON THE NON-CENTRAL MULTIVARIATE BETA DISTRIBUTION AND MOMENTS OF TRACES OF, AMS 65,1511

PILLAI, K. C. S. UPPER PERCENTAGE POINTS OF A SUBSTITUTE F-RATIO USINC RANCES, BIOKA 61, 195

PILLAI, K. C. S. UPPER PERCENTAGE POINTS OF THE EXTREME STUDENTIZED DEVIATE FROM THE SAMPLE MEAN, BIOKA 59, 473

PILLAI, K. C. SREEDHARAN ON THE DISTRIBUT ION OF LINEAR FUNCTIONS AND RATIOS OF LINEAR FUNCTIONS OF ORDERE, BIOKA 64,143

PILLAI, $K$. C. SREEDHARAN ON THE DISTRIBUTION OF THE LARGEST OF SEVEN ROOTS OF A MATRIX IN MULTIVARIATE AN, BIOKA 64,270

PILLAI, K. C. SREEDHARAN ON THE DISTRIBUTION OF THE LARGEST ROOT OF A MATRIX IN MULTIVARIATE ANALYSIS, AMS 67, 616

PILLAI, K. C. SREEDHARAN ON THE MOMENT GENERATINC FUNCTION OF PILLAI'S V-SUPER-S CRITERION, AMS 68, 877

PILLAI, K. C. SREEDHARAN ON THE MOMENTS OF ELEMENTARY SYMMETRIC FUNCTIONS OF THE ROOTS OF TWO MATRICES, AMS 64,1704

PILLAI, K. C. SREEDHARAN ON THE NON-CENTRAL DISTRIBUTION OF THE SECOND ELEMENTARY SYMMETRIC FUNCTION OF T, AMS 68,833

PILLAI, R. KR ISHNA THE RATIO BIAS IN SURVEYS, JASA 62, B63

PILLAI, S. S. ESTIMATION OF CROP YIELDS FOR SMALL AREAS, BIOCS 66. 374

PINKHAM, R. S. AN APPROXIMATION TO THE DISTRIBUTION OF Q, A VARIATE RELATED TO THE NON-CENTRAL T, AMS 64,315

PINKHAM, R. S. AN APPROXIMATION TO THE PROBABILITY INTEGRAL OF THE GAMMA DISTRIBUTION FOR SMALL VALUES OF, BIOKA 62, 276

PINKHAM, R. S. MAXIMUM LIKELIHOOD ESTIMATION OF THE PARAMETERS OF THE BETA DISTRIBUT ION FROM SMALLEST ORD, TECH 67,607

PINKHAM, R. S. ON A FIDUCIAL EXAMPLE OF C. STEIN, JRSSB 66,53

PINKHAM, R. S. TAIL AREAS OF THE T-DISTRIBUTION FROM A MILLS ' RATIOLIKE EXPANSION, AMS 63, 335

PINKHAM, R. S. THE MOMENTS OF A VARIATE RELATED TO THE NON-CENTRAL T AMS 64,298

PINKHAM, R. S. THE MOMENTS OF THE NON-CENTRAL T-DISTRIBUTION, BIOKA 61,465

PINKHAM, ROGER S. ON THE DISTRIBUTION OF FIRST SIGNIFICANT DICITS AMS 61,1223

PITCHER, T. S. DIMENSIONAL PROPERTIES OF A RANDOM DISTRIBUTION FUNCTION ON THE SQUARE, AMS 66,849

PITCHER, T. S. ON THE SAMPLE FUNCTIONS OF PROCESSES WHICH CAN BE ADDED TO A CAUSSIAN PROCESS. AMS 63, 329

PITCHER, T. S. ON THE EPSILON ENTROPY ON CERTAIN MEASURES ON $(0.1)$ AMS 68,1310

PITCHER, TOM S. ON ADDING INDEPENDENT STOCHASTIC PROCESSES, AMS 64 872

PITCHER, TOM S. THE BEHAVIOR OF LIKELIHOOD RATIOS OF STOCHASTIC PROCESSES RELATED BY CROUPS OF TRANSFORMA, AMS 65, 529

PITMAN, A. E. N. T. AN EXACT DISTRIBUTION OF THE BEHRENS-FISHERWELCH STATISTIC FOR TESTING THE DIFFERENC, JRSSB 61, 377

PITMAN, A. E. N. T . CHEBYSHEV POLYNOMIAL AND OTHER NEW APPROXIMATIONS TO MILLS' RATIO, AMS 63,892

PITMAN. E. J. G. CAUCHY-DISTRIBUTED FUNCTIONS OF CAUCHY VARIATES AMS 67, 916

PITMAN, E. J. G. STATISTICS AND SCIENCE, JASA 57, 322

PLACKETT, R. L. A CLASS OF BIVARIATE DISTRIBUTIONS, JASA 65, 516

PLACKETT, R. L. A COMPARISON OF TWO APPROACHES TO THE CONSTRUCTION OF MODELS FOR QUANTAL RESPONSES TOMIX, BIOCS 67,27

PLACKETT, R. L. A NOTE ON INTERACTIONS IN CONTINGENCY TABLES, JRSSB 62,162

PLACKETT, R. L. A REDUCTION FORMULA FOR NORMAL MULTIVARIATE INTEGRALS, BIOKA 54,351

PLACKETT, R. L. MODELS IN THE ANALYSIS OF VARIANCE (WITHDISCUSSION). JRSSB 60. 195

PLACKETT, R. L. RANDOM PERMUTATIONS, JRSSB 68, 517
PLACKETT, $R$, L STOCHASTIC MODELS OF CAPITAL INVESTMENT (WITH DISCUSSION ), JRSSB 69,

PLACKETT, R. L. STUDIES IN THE HISTORY OF PROBABILITY AND STATISTICS. VII. THE PRINCIPLE OF THE ARITHMETI, BIOKA 58, 130

PLACKETT, $R, L$. THE ANALYSIS OF LIFE TEST DATA, TECH 59,9

PLACKETT, R. L. THE CONTINUITY CORRECTION IN 2-BY-2 TABLES, BIOKA 64,327

PLATEK, R. SEVERAL METHODS OF RE-DESIGNING AREA SAMPLES UTILIZING PROBABIL ITIES PROPORT IONAL TO SIZE WHEN, JASA 68, 1280

PLATEK, $R$. THE NEW DESIGN OF THE CANADIAN LABOUR FORCE SURVEY, JASA 67,421

PLEASE, N. W. DISCRIMINATION IN THE CASE OF ZERO MEAN DIFFERENCES, BIOKA 63, 17

POLLAK, E. SOME EFFECTS OF FLUCTUATING OFFSPRING DISTRIBUTIONS ON THE SURVIVAL OF A CENE, BIOKA 66, 391

POLLARD, J. H. A NOTE ON MULTI-TYPE GALTON-WATSON PROCESSES WITH RANDOM BRANCHING PROBABILITIES, BIOKA 6B, 5B9

POLLARD, J. H. ON THE USE OF THE DIRECT MATRIX PRODUCT IN ANALYSING CERTAIN STOCHAST IC POPULATION MODELS, BIOKA 66,397

POLLARD, J . H. THE MULTI-TYPE GALTON-WATSON PROCESS IN A GENET ICAL CONTEXT, BIOCS 68,147

POPE, J. A. BIAS IN THE ESTIMATION OF AUTOCORRELATIONS, BIOKA 54 , 390

PORT, S. C. A SYSTEM OF DENUMERABLY MANY TRANSIENT MARKOV CHAINS, AMS 66,406

PORT, S. C. THE ASYMMETRIC CAUCHY PROCESSES ON THE LINE, AMS 69, 137

PORT, SIDNEY C. A LARGE SAMPLE TEST FOR THE INDEPENDENCE OF TWO RENEWAL PROCESSES, AMS 67,1037

PORT, SIDNEY C. A REMARK ON HITTING PLACES FOR TRANSIENT STABLE PROCESS, AMS 68,365

PORT, SIDNEY C. A SIMPLE PROBABILISTIC PROOF OF THE DISCRETE GENERALIZED RENEWAL THEOREM, AMS 65, 1294

PORT, SIDNEY C. ESCAPE PROBABILITY FOR A HALF LINE, AMS 64, 135

PORT, SIDNEY C. ON HITTING FOR ST ABLE PROCESSES, AMS 67, 1021

PORT, SIDNEY C. SOME THEOREMS ON FUNCTIONALS OF MARKOV CHAINS, AMS 64,1275

POSNER, EDWARD C. APPLICATION OF AN ESTIMATOR OF HIGH EFFICIENCY IN BIVARIATE EXTREME VALUE THEORY, JASA 69, NO 4

POSNER, EDWARD C. EPSILON ENTROPY OF GAUSSIAN PROCESSES, AMS 69. 1272

POSNER, EDNARD C. EPSILON ENTROPY OF STOCHASTIC PROCESSES, AMS 67 1000

POSNER, EDWARD C. JOINT DISTRIBUTIONS WITH PRESCRIBED MOMENTS, AMS $65,2 \mathrm{~B} 6$

POSNER, EDWARD C. PRODUCT ENTROPY TO GAUSSIAN DISTRIBUTIONS, AMS $69, \mathrm{~B} 70$

POSNER, EDWARD C. SYSTEMATIC STATISTICS USED FOR DATA COMPRESSION IN SPACE TELEMETRY, JASA 65,97

POSNER, EDWARD C. THE APPLICATION OF EXTREME VALUE THEORY TO ERRORFREE COMMUNICATION, TECH 65,517

POSTEN, H. O. POWER OF THE LIKELIHOOD-RATIO TEST OF THE GENERAL LINEAR HYPOTHESIS IN MULT IVARIATE ANALYSI, BIOKA 64, 467

POSTEN, H O ROBUSTNESS OF UNTFORM BAYESIAN ENCODING, TECH 63, 121

POTTHOFF, R. F. TESTING FOR HOMOCENEITY. I. THE BINOMIAL AND MULTINOMIAL DISTRIBUTIONS, BIOKA 66, 167

POTTHOFF, R. F. TESTING FOR HOMOGENEITY. II THE POISSON DISTRIBUTION, BIOKA 66,183

POTTHOFF, RICHARD F. A CENERALIZED MULTIVARIATE ANALYSIS OF VARIANCE MODEL USEFULL ESPEC IALLY FOR GROWTH, BIOKA 64,313

POTTHOFF, RICHARD F. FOUR FACTOR ADDITIVE DESIGNS MORE GENERAL THAN THE CREC0-LATIN SQUARE, TECH 62,361

POTTHOFF, RICHARD F. SOME SCHEFFE-TYPE TESTS FOR SOME BEHRENSFISHER-TYPE REGRESSION PROBLEMS, JASA 65, 1163

POTTHOFF, RICHARD F. THREE FACTOR ADDITIVE DESIGNS MORE GENERAL THAN THE LAT IN SQUARE, TECH 62,187

POTTHOFF, RICHARD F. USE OF THE WILCOXON STATIST IC FOR A GENERALIZED BEHRENS-FISHER PROBLEM, AMS 63,1596

POWELL. ALAN AITKEN ESTIMATORS AS A TOOL IN ALLOCATING PREDETERMINED AGGREGATES, JASA 69,913

POWELL, E. O. SOME FEATURES OF THE GENERATION TIMES OF INDIVIDUAL BACTERIA, BIOKA 55, 16

PRABHU, N. U . ON THE RUIN PROBLEM OF COLLECTIVE RISK THEORY, AMS 61 757

PRABHU, N. U. SOME RESULTS FOR THE QUEUE WITH POISSON ARRIVALS, JRSSB 60,104

PRABHU, N. U. STATIONARY DISTRIBUTIONS OF THE NEGATIVE EXPERIMENTAL TYPE FOR THE INFINITE DAM, JRSSB 57, 342

PRAIRIE, R. R. AN ANALYSIS OF SOME RELAY FAILURE DATA FROM A COMPOSITE EXPONENTIAL POPULATION, TECH 61, 423

PRAIRIE, R. R. FRACTIONAL REPLICATION OF 2-TO-THE-P FACTORIAL EXPERIMENTS WITH THE FACTORS APPLIED SEQUEN, JASA 68,644

PRAIRIE, R. R. PROBIT ANALYSIS AS A TECHNIQUE FOR ESTIMATING THE RELIABILITY OF A SIMPLE SYSTEM, TECH 67, 197

PRAIRIE, R. R. SOME ACCEPTANCE SAMPLING PLANS BASED ON THE THEORY OF RUNS, TECH 62,177

PRAIRIE, R, R. 2 TO THE POWER OF P FACTORIAL EXPERIMENTS WITH THE FACTORS APPLIED SEQUENTIALLY, JASA 64, 1205 
PRAKASA, B. L, S. ESTIMATION OF THE LOCATION OF THE CUSP OF A CONTINUOUS DENSITY, AMS 68, 76

PRATT, J. W. THE OUTER NEEDLE OF SOME BAYES SEQUENTIAL CONTINUATION REGIONS, BIOKA 66, 455

PRATT, JOHN W. A NORMAL APPROXIMATION FOR BINOMIAL, F, BETA, AND OTHER COMMON, RELATED TAIL PROBABILITIES, JASA 68, 1416

PRATT, JOHN W. A NORMAL APPROXIMATION FOR BINOMIAL, F, BETA, AND OTHER COMMON, RELATED TAIL PROBABILITIES, JASA 6B, 1457

PRATT, JOHNW. A NOTE ON UNBIASED TESTS, AMS 62,292

PRATT, JOHN W. ACKNOWLEDCEMENT OF PRIORITY ON 'ON INTERCHANGING LIMITS AND INTEGRALS ' , 6074 , AMS 66, 1407

PRATT, JOHN $W$. BAYESIAN INTERPRETATION OF STANDARD INFERENCE STATEMENTS (WITH DISCUSSION), JRSSB 65,169

PRATT, JOHN W. DISCUSSION OF 'ON THE FOUNDATIONS OF STATISTICAL INFERENCE', JASA 62,307

PRATT, JOHN W. EFFICIENCY OF THE SAMPLE MEAN WHEN RESIDUALS FOLLOW A FIRST-ORDER STATIONARY MARKOFF PROCE, JASA 6B, 1237

PRATT, JOHNW LENCTH OF CONFIDENCE INTERVALS, JASA 61,549

PRATT, JOHN W. REMARKS ON ZEROS AND TIES IN THE WILCOXON SIGNED RANK PROCEDURE, JASA 59, 655

PRATT, JOHN W. ROBUSTNESS OF SOME PROCEDURES FOR THE TWO-SAMPLE LOCATION PROBLEM, JASA 64,665

PRATT, JOHN W. SHORTER CONFIDENCE INTERVALS FOR THE MEAN OF A NORMAL DISTRIBUTION WITH KNOWN VARIANCE, AMS 63, 574

PRATT, JOHN $W$. THE FOUNDATIONS OF DECISION UNDER UNCERTAINTY, AN ELEMENTARY EXPOSITION, JASA 64,353

PREECE, D. A. BALANCED INCOMPLETE BLOCK DESIGNS WITH SETS OF IDENTICAL BLOCKS, TECH 69,613

PREECE, D. A . CLASSIFYINC YOUDEN RECTANGLES, JRSSB 66,118

PREECE, D. A . NEAR-CYCLIC REPRESENTATIONS FOR SOME RESOLUTION VI FRACT IONAL FACTORIAL PLANS, AMS 69, 1B40

PREECE, D. A . NESTED BALANCED INCOMPLETE BLOCK DESICNS, BIOKA 67 479

PREECE. D. A. NOTES. CYCLIC GENERATION OF ROBINSON'S BALANCED INCOMPLETE BLOCK DESIGNS, BIOCS 67,574

PREECE, D. A. ON ADDELMAN'S 2-TO-THE-(17-9) RESOLUTION V PLAN, TECH 66,705

PREECE, D. A . SOME BALANCED INCOMPLETE BLOCK DESIGNS FOR TWO SETS OF TREATMENTS, BIOKA 66,497

PREECE, D. A . SOME ROW AND COLUMN DES IGNS FOR TWO SETS OF TREATMENTS, BIOCS 66,1

PRESS, S. J. TESTINC AND ESTIMATION FOR A CIRCULAR STATIONARY MODEL AMS 69,1358

PRESS, S. JAMES A CONFIDENCE INTERVAL COMPARISON OF TWO TEST PROCEDURES PROPOSED FOR THE BEHRENS-FISHER P, JASA 66,454

PRESS, S. JAMES A MODIFIED COMPOUND POISSON PROCESS WITH NORMAL COMPOUNDINC, JASA 6B, 637

PRESS, S, JAMES ESTIMATINC FROM MISCLASSTFIED DATA, JASA 6B, 123

PRESS, S. JAMES ON SERIAL CORRELATION. AMS 69, 18B

PRESS, S. JAMES THE T-RATIODISTRIBUTION, JASA 69, 242

PRESS, SHELDON JAMES LINEAR COMBINATIONS OF NON-CENTRAL CHI-SQUARE VARIATES, AMS $66,4 B 0$

PRESTON, ERIC J. A GRAPHICAL METHOD FOR THE ANALYSIS OF STATISTICAL DISTRIBUTIONS INTO TWO NORMAL COMPONE, BIOKA 53,460

PRESTON, LEE E. THE STATISTICAL ANALYSIS OF INDUSTRY STRUCTURE, AN APPLICATION TO FOOD INDUSTRIES, JASA 61,925

PRICE, ROBERT SOME NON-CENTRAL F-DISTRIBUTIONS EXPRESSED IN CLOSED FORM, BIOKA 64, 107

PRIESTLEY, M. B. A TEST FOR NON-STATIONARITY OF TIME-SERIES, JRSSB 69. 140

PRIESTLEY, M. B. ANALYSIS OF STATIONARY PROCESSES WITH MIXED SPECTRA, 2, JRSSB 62, 511

PRIESTLEY, M. B. BASIC CONSIDERATIONS IN THE ESTIMATION OF SPECTRA TECH 62,551

PRIESTLEY, M. B. DESIGN RELATIONS FOR NON-STATIONARY PROCESSES, JRSSB 66,228

PRIESTLEY, M. B. ESTIMATION OF THE SPECTRAL DENSITY FUNCTION IN THE PRESENCE OF HARMONIC COMPONENTS, JRSSB 64, 123

PRIESTLEY, M. B. EVOLUTIONARY SPECTRAL AND NON-STATIONARY PROCESSES (WITHDISCUSSION), JRSSB 65, 204

PRIESTLEY, M. B. FILTERING NON-STATIONARY SICNALS, JRSSB 69, 150

PRIESTLEY, M. B. ON THE PREDICTION OF NON-STATIONARY PROCESSES, JRSSB 67,570

PRIESTLEY, M. B. THE ANALYSIS OF STATIONARY PROCESSES WITH MIXED SPECTRA, 1, JRSSB 62, 215

PRIESTLEY, $M$. B. THE ANALYSIS OF TWO-DIMENSIONAL STATIONARY PROCESSES WITHDISCONT INUOUS SPECTRA, BIOKA 64, 195

PRIESTLEY, M. B. THE SPECTRAL ANALYSIS OF TIME SERIES (WITHDISCUSSION), JRSSB 57,1

PRIESTLEY, M. B. THE SPECTRUM OF A CONTINUOUS PROCESS DERIVED FROM A DISCRETE PROCESS, BIOKA 63, 517

PRIESTLEY, MAURICE ESTIMATION OF POWER SPECTRA BY A WAVE ANALYZER, TECH 65,553

PRINGLE, R. M. A NOTE ON CENERALIZED INVERSES IN THE LINEAR HYPOTHESIS NOT OF FULL RANK, AMS 67, 271

PRITZKER, LEON WASHINGTON STATISTICAL SC $\perp E$ IY MLMORIAL MEETING FOR WILLIAMN. HURWITZ. CHANCES IN CENSUS, JAS 69 , NO.4
PROSCHAN, F. A NOTE ON TESTS FOR MONOTONE FALLUKE KALE BASED ON INCOMPLETE DATA, AMS 69,595

PROSCHAN, F. ASSOCIATION RANDOM VARIABLES, WITH APPLICATIONS, AMS 67,1466

PROSCHAN, F JRSSB 65,91

PROSCHAN, FRANK ASYMPTOTIC NORMALITY OF CERTAIN TEST STATISTICS OF EXPONENTIALITY, BIOKA 64,253

PROSCHAN, FRANK COHERENT STRUCTURES OF NON-IDENTICAL COMPONENTS TECH 63, 191

PROSCHAN, FRANK COMPARISON OF REPLACEMENT POLICIES, AND RENEWAL THEORY IMPLICATIONS, AMS 64, 577

PROSCHAN, FRANK EXPONENTIAL LIFE TEST PROCEDURES WHEN THE DISTRIBUTION HAS MONOTONE FAILURE RATE, JASA 67, 54B

PROSCHAN, FRANK INEQUALITIES FOR LINEAR COMBINATIONS OF ORDER STATISTICS FROM RESTRICTED FAMILIES, AMS 66, 1574

PROSCHAN, FRANK MAXIMUM LIKELIHOOD ESTIMATION FOR DISTRIBUTIONS WITH MONOTONE FAILURE RATE, AMS 65,69

PROSCHAN, FRANK PEAKEDNESS OF DISTRIBUTIONS OF CONVEX COMBINATIONS, AMS 65, 1703

PROSCHAN, FRANK PROPERTIES OF PROBABILITY DISTRIBUTIONS WITH MONOTONE HAZARD RATE, AMS 63,375

PROSCHAN, FRANK RELATIONSHIP BETWEEN SYSTEM FAILURE RATE AND COMPONENT FA ILURE RATES, TECH 63, 183

PROSCHAN, FRANK STATISTICAL ESTIMATION PROCEDURES FOR THE 'BURNIN' ' PROCESS, TECH $6 B, 51$

PROSCHAN, FRANK THEORETICAL EXPLANATION OF OBSERVED DECREASE FAILURE RATE, TECH 63,375

PROSCHAN, FRANK TOLERANCE AND CONFIDENCE LIMITS FOR CLASSES OF DISTRIBUTIONS BASED ON FAILURE RATE, CORR . AMS 66, 1593

PRUITT, WILLIAM E. EIGENVALUES OF NON-NEGATIVE MATRICES, AMS 64 , 1797

PRUZAN, PETER M. A DYNAMIC PROGRAMMINC APPLICATION IN PRODUCTION LINE INSPECTION, TECH 67,73

PURI, M. L. MULTI-SAMPLE ANALOGUES OF SOME ONE-SAMPLE TESTS, AMS 67 , 523

PURI, MADAN L. MULTIPLE DECISION PROCEDURES BASED ON RANKS FOR CERTAIN PROBLEMS IN ANALYSIS OF VARIANCES, AMS 69,619

PURI, MADAN L. ON THE ESTIMATION OF CONTRASTS IN LINEAR MODELS, AMS 65,198

PURI, MADAN L. RANK ORDER TESTS FOR MULTIVARIATE PAIRED COMPARISONS, AMS 69, NO.6

PURI, MADAN LAL A CLASS OF RANK ORDER TESTS FOR A GENERAL LINEAR HYPOTHESIS, AMS 69, 1325

PURI, MADAN LAL ANALYSIS OF COVARIANCE BASED ON GENERAL RANK SCORES AMS 69,610

PURI, MADAN LAL ASYMPTOTIC EFFICIENCY OF CLASS OF C-SAMPLE TESTS, AMS 64, 102

PURI, MADAN LAL NONPARAMETRIC CONFIDENCE REGIONS FOR SOME MULTIVARIATE LOCATION PROBLEMS, JASA 6B, 1373

PURI, MADAN LAL ON CHERNOFF-SAVAGE TESTS FOR ORDERED ALTERNATIVES IN RANDOMIZED BLOCKS, AMS 6B, 967

PURI, MADAN LAL ON ROBUST ESTIMATION IN INCOMPLETE BLOCK DESIGNS AMS 67,1587

PURI, MADAN LAL ON SOME OPTIMUM NONPARAMETRIC PROCEDURES IN TWO-WAY LAYOUTS, JASA 67,1214

PURI, MADAN LAL ON THE THEORY OF RANK ORDER TESTS FOR LOCATION IN THE MULTIVARIATE ONE SAMPLE PROBLEM, AMS 67,1216

PURI, P. S. ON THE HOMOGENEOUS BIRTH-AND-DEATH PROCESS AND ITS INTEGRAL, BIOKA 66, 61

PURI, PREM S. MULTIPLE DECISION PROCEDURES BASED ON RANKS FOR CERTAIN PROBLEMS IN ANALYSIS OF VARIANCES, AMS 69,619

PURI, PREM S. ON OPT IMAL ASYMPTOTIC TESTS OF COMPOSITE STATISTICAL HYPOTHESES, AMS 67,1845

PURVES, ROCER TIMID PLAY IS OPTIMAL, II, AMS 67, 1284

PURVES, ROGER A. BAYES ' METHOD FOR BOOKIES, AMS 69, 1177

PUTTER, JOSEPH MAXIMUM LIKELIHOOD ESTIMATION OF MULTIVARIATE COVARIANCE COMPONENTS FOR THE BALANCED ONE-W, AMS 69, 1100

PUTTER, JOSEPH ORTHONORMAL BASES OF ERROR SPACES AND THEIR USE FOR INVESTIGATING THE NORMALITY AND VARIAN, JASA 67, 1022

PUTTER, JOSEPH THE CHI-SQUARE GOODNESS-OF-FIT TEST FOR A CLASS OF CASES OF DEPENDENT OBSERVATIONS, BIOKA 64, 250

PYKE, R. INEQUALITIES FOR FIRST EMPTINESS PROBABILITIES OF A DAM MITH ORDERED INPUTS, JRSSB 62, 102

PYKE, $R$ SPACINGS (WITH DISCUSSION), JRSSB 65, 395

PYKE, RONALD A NOTE ON CHERNOFF-SAVAGE THEOREMS, AMS 69, 1116

PYKE, RONALD ASYMPTOTIC NORMALITY OF CERTAIN TEST STATISTICS OF EXPONENTIALITY, BIOKA 64,253

PYKE, RONALD COMBINATORIAL RESULTS IN FLUCTUATION THEORY, AMS 63 1233

PYKE, RONALD COMBINATORIAL RESULTS IN MULTI-DIMENSIONAL FLUCTUATION THEORY, CORR. 64924, AMS 63, 402

PYKE, RONALD LIMIT THEOREMS FOR MARKOV RENEWAL PROCESSES, AMS 64 1746

PYKE, RONALD MARKOV RENEWAL PROCESSES WITH FINITELY MANY STATES AMS 61,1243

PYKE, RONALD MARKOV RENEWAL PROCESSES, DEFINITIONS AND PRELIMINARY PROPERTIES, AMS 61, 1231 
PYKE, RONALD ON CONVERGENCE IN R-MEAN OF NORMALIZED PARTIAL SUMS. AMS $6 B, 379$

PYKE, RONALD THE ASYMPTOTIC RELATIVE EFFICIENCY OF GOODNESS-OF-FIT TESTS AGAINST SCALAR ALTERNATIVES, JASA 65,410

PYKE. RONALD THE EXISTENCE AND UNIQUENESS OF STATIONARY MEASURES FOR MARKOV RENEWAL PROCESSES, AMS 66, 1439

PYKE. RONALD THE ROBBINS-ISBELL TWO-ARMED-BANDIT PROBLEM WITH FINITE MEMORY AMS 65, 1375

PYKE, RONALD WEAK CONVERGENCE AND A CHERNOFF-SAVAGE THEOREM FOR RANDOM SAMPLE SIZES, AMS 6B, 1675

PYKE, RONALD WEAK CONVERGENCE OF A TWO-SAMPLE EMPIRICAL PROCESS AND A NEW APPROACH TO CHERNOFF-SAVAGE THE, AMS 6B, 755

QUADE. DANA ON ANALYSIS OF VARIANCE FOR THE K-SAMPLE PROBLEM, AMS 66, 1747

QUADE. DANA ON COMPARING THE CORRELATIONS WITHIN TWO PAIRS OF VARIABLES, BIOCS $6 B, 9 B 7$

QUADE, DANA ON THE ASYMPTOTIC PONER OF THE ONE-SAMPLE KOLMOGOROVSMIRNOV TESTS, AMS 65, 1000

QUADE, DANA RANK ANALYSIS OF COVARIANCE, JASA 67, I1B7

QUALLS, CLIFFORD ON A LIMIT DISTRIBUTION OF HIGH LEVEL CROSSINGS OF A STATIONARY GAUSSIAN PROCESS, AMS 68, 210B

QUANDT, RICHARD E. SOME TESTS FOR HOMOSCEDASTICITY, JASA 65, 539

QUANDT, RICHARD E. TESTS OF THE HYPOTHESIS THAT A LINEAR REGRESSION SYSTEM OBEYS TWO SEPARATE REGIMES, JASA 60,324

QUANDT, RICHARD E. THE ESTIMATION OF THE PARAMETER OF A LINEAR REGRESSION SYSTEM OBEYING TWO SEPARATE REG, JASA 5B, B73

QUARTERMAIN. A. R. SOME TRANSFORMATIONS OF SCALE AND THE ESTIMATION OF GENETIC PARAMETERS FROM DAUGHTER-D, BIOCS 67, B23

QUENOUILLE, M. H. EXPERIMENTS WITHMIXTURES, JRSSB 59, 201

QUENOUILLE, $M$. H. MODIFICATIONS TO THE VARIATE-DIFFERENCE METHOD BIOKA 53, 3B3

QUENOUILLE, M. H. NOTES ON BIAS IN ESTIMATION, BIOKA 56. 353

QUENOUILLE, M. H. TABLES OF RANDOM OBSERVATIONS FROM STANDARD DISTRIBUTIONS, BIOKA 59, 178

QUENOUILLE, $M, H$. THE COMPARISON OF CORRELATIONS IN TIME-SERIES, JRSSB 58,158

QUENOUILLE, $M$. H. THE EFFECT OF TRANSFORMATIONS OF VARIABLES UPON THEIR CORRELATION COEFF ICIENTS, BIOKA 57,272

QUESENBERRY, C , P. A NONPARAMETRIC ESTIMATE OF A MULTIVARIATE DENSITY FUNCTION, AMS 65, 1049

QUESENBERRY, C. P. CONTROLLING THE PROPORT ION DEFECTIVE FROM CLASSIFICATION DATA, TECH 64, 99

QUESENBERRY, C. P. LARGE SAMPLE SIMULT TNEOUS CONF IDENCE INTERVALS FOR MULTINOMIAL PROPORTIONS. TECH 64, 191

QUESENBERRY，C. $P$. NONPARAMETRIC DISCRIMINATION USING TOLERANCE REGIONS, AMS 6B. 664

QUESENBERRY, C. P. SOME TESTS FOR OUTLIERS, BIOKA 61,379

QUREISHI. A. S. BEST LINEAR UNBIASED ESTIMATORS OF THE PARAMETERS OF THE LOGISTIC DISTRIBUT ION USING ORDE, TECH 67, 43

QUREISHI, A. S. ERRATA. 'THE DISCRIMINATION BETWEEN TWO WEIBULL PROCESSES', TECH 64, 240

QUREISHI, A. S. SAMPLING INSPECTION PLANS FOR DISCRIMINATING BETWEEN TWO WEIBULL PROCESSES, TECH 65, 5B9

QUREISHI, A. S. THE DISCRIMINATION BETWEEN TWO WEIBULL PROCESSES, TECH 64,57

RABINOVITCH, $\mathrm{N}$. L. STUDIES IN THE HISTORY OF PROBABILITY AND STATISTICS, XXII, PROBABILITY IN THE TALMUD, BIOKA 69.437

RABINOWITZ, PHILIP NEW CHEBYSHEV POLYNOMIAL APPROXIMATIONS TO MILLS' RATIO. JASA 69,647

RADCLIFFE, J. A NOTE ON AN APPROXIMATE FACTORIZATION IN DISCRIMINANT ANALYSIS, BIOKA 67,665

RADCLIFFE, J. THE CONSTRUCTION OF A MATRIX USED IN DERIVING TESTS OF SIGNIF ICANCE IN MULT IVARIATE ANALYSI, BIOKA 64,503

RADHAKRISHNA, S. COMBINATION OF RESULTS FROM SEVERAL 2 BY 2 CONTINGENCY TABLES, BIOCS 65, B6

RADNER, ROY TEAMDECISION PROBLEMS, AMS 62, B57

RADOK, U. TABULAR ANALYSIS OF FACTORIAL EXPERIMENTS AND THE USE OF PUNCH CARDS, CORR, 56650 , JASA 56, 149

RAFF, MORTON S. ON APPROXIMATING THE POINT BINOMIAL, CORR. 56651 , JASA 56, 293

RAGHAVACHARI. M. ON A THEOREM OF KARLIN REGARDING ADMISSIBILITY OF LINEAR ESTIMATES IN EXPONENTIAL POPULA, AMS 66, 1809

RAGHAVACHARI, $M$. ON THE EFFICIENCY OF THE NORMAL SCORES TEST RELATIVE TO THE F-TEST. AMS 65, 1306

RAGHAVACHARI. $M$. THE TWO-SAMPLE SCALE PROBLEM WHEN LOCATIONS ARE UNKNOWN. AMS 65, 1236

RAGHAVARAO, D. A NOTE ON FRALIIONS OF 3-TO-THE- (4N+1) DESIGNS. TECH 65. 69

RAGHAVARAO, D. CUBIC DESIGNS, AMS 64, 3B9

RAGHAVARAO, DAMARAJU DUALS OF PART IALLY BALANCED INCOMPLETE BLOCK DESIGNS AND SOME NONEXISTENCE THEOREMS, AMS 66, 104B

RAGHAVARA0. DAMARAJU ON BALANCED UNEQUAL BLOCK DESIGNS, BIOKA 62. 561

RAGHAVARAO, DAMARAJU SINGULAR WEIGHING DESIGNS, AMS 64,673

RAGHAVARAO, DAMARAJU SYMMETRICAL UNEQUAL BLOCK ARRANGEMENTS WITH TWO UNEQUAL BLOCK SIZES, AMS 62, 620

RAGHUNANDANAN, K. ASYMPTOTICALLY ROBUST ESTIMATORS OF LOCATION, JASA 67,950
RAHMAN, N. A. SOME GENERALIZATIONS OF THE DISTRIBUTIONS OF PRODUCT STATISTICS ARISING FROM RECT ANGULAR PO, JASA 64, 557

RAIFFA, HOWARD THE FOUNDATIONS OF DECISION UNDER UNCERTAINTY, AN ELEMENTARY EXPOSITION, JASA 64, 353

RAJAGOPALAN, M. ESTIMATION OF CROP YIELDS FOR SMALL AREAS, BIOCS 66 374

RAKTOE, B . L. A UNIFIED APPROACH FOR CONSTRUCTING A USEFUL CLASS OF NON-ORTHOGONAL MAIN EFFECT PLANS IN K. JRSSB 6B, 371

RAKTOE, B. L. APPLICATION OF CYCLIC COLLINEATIONS TO THE CONSTRUCTION OF BALANCED L-RESTRICTIONAL PRIME POWERED LATTICE DESIGNS. AMS 67, 1127

RAKTOE. B. L. COMBINING ELEMENTS FROM DISTINCT FINITE FIELDS IN MIXED FACTORIALS. AMS $69,49 B$

RAKTOE, B. L. GENERAL THEORY OF PRIME-POWER LATTICE DESIGNS, JASA 65. B91

RAKTOE, B. L. GENERALIZED LATT ICE SQUARE DESIGN, JASA 66, B2I

RAMACHANDRAMURTY, $P$. V. ERRATA TO INDEX TO TECHNOMETRICS, VOLUMES $1-7$, TECH $66,3 \mathrm{~B} 7$

RAMACHANDRAMURTY, P. V. INDEX TO TECHNOMETRICS, VOLUMES 1-7, TECH 66. 216

RAMACHANDRAMURTY, $P, V$. ON SOME NONPARAMETRIC ESTIMATES FOR SHIFT IN THE BEHRENS-FISHER SITUATION, AMS 66.593

RAMACHANDRAMURTY. P. V. ON THE PITMAN EFFICIENCY OF ONE-SIDED KOLMOGOROV AND SMIRNOV TESTS FOR NORMAL ALT, AMS 66, 940

RAMACHANDRAN, $K, V$. A TEST OF VARIANCES, JASA 5B, 741

RAMACHANDRAN, K. V. ON THE STUDENTIZED SMALLEST CHI-SQUARE, CORR $59 B 12$, JASA $5 B, B 6 B$

RAMACHANDRAW, B. ON THE ORDER AND THE TYPE OF ENT IRE CHARACTERIST IC FUNCTIONS, AMS $62,123 \mathrm{~B}$

RAMANATHAN, R. ECONOMETRIC EXPLORATION OF INDIAN SAVING BEHAVIOR JASA 69.90

RAMANATHAN, R. THE EFFECT OF MIS-MATCHING ON THE MEASUREMENT OF RESPONSE ERRORS, JASA 65, 1005

RAMASUBBAN, T. A. CORRIGENDA. 'SOME DISTRIBUTIONS ARISING IN THE STUDY OF GENERALIZED MEAN DIFFERENCES' ', BIOKA 61,230

RAMASUBBAN, T.A. SOME DISTRIBUTIONS ARISING IN THE STUDY OF GENERALIZED MEAN DIFFERENCES, BIOKA 60,469

RAMASUBBAN, T. A. THE GENERALIZED MEAN DIFFERENCES OF THE BINOMIAL AND POISSON DISTRIBUTIONS, BIOKA 59,223

RAMASUBBAN, T. A. THE MEAN DIFFERENCE AND THE MEAN DEVIATION OF SOME DISCONTINUOUS DISTRIBUTIONS, BIOKA 5B, 549

RAMSEY J. B. TESTS FOR SPECIFICATION ERRORS IN CLASSICAL LINEAR LEAST-SQUARES REGRESSION ANALYSIS, JRSSB 69, NO.2

RAO, B. L. S. PRAKASA ON A CHARACTERIZATION OF SYMMETRIC STABLE PROCESSES WITH FINITE MEAN, AMS 6B, 149B

RAO, B. R. A FORMULA FOR THE CURVATURE OF THE LIKELIHOOD SURFACE OF A SAMPLE DRAWN FROM A DISTRIBUTION AD, BIOKA 60, 203

RAO. B. R. CORRELATION BETWEEN THE SAMPLE VARIANCES IN A SINGLY TRUNCATED BIVARIATE NORMAL DISTRIBUTION, BIOKA 6B, 433

RAO. B. RAJA A FURTHER NOTE ON THE GEOMETRY OF LINEAR ESTIMATION BIOKA 63,540

RAO, B. RAJA A NOTE ON THE GEOMETRY OF LINEAR ESTIMATION, BIOKA 62 560

RAO, C. R. A NOTE ON A GENERALIZED INVERSE OF A MATRIX WITH APPLICATIONS TO PROBLEMS IN MATHEMATICAL STAT, JRSSB 62.152

RAO, C. R DISCRIMINANT FUNCTION BETWEEN COMPOSITE HYPOTHESES AND RELATED PROBLEMS, BIOKA 66,339

RAO. C. R. EFFICIENT ESTIMATES AND OPTIMUM INFERENCE PROCEDURES IN LARGE SAMPLES (WITH DISCUSSION), JRSSB 62, 46

RAO, C. R. PROBLEMS OF SELECTION WITH RESTRICTIONS, JRSSB 62, 401

RAO, C. R. SOME PROBLEMS INVOLVING LINEAR HYPOTHESES IN MULTIVARIATE ANALYSIS, BIOKA 59,49

RAO, C. R. THE THEORY OF LEAST SQUARES WHEN THE PARAMETERS ARE STOCHAST IC AND ITS APPLICATION TO THE ANAL, BIOKA 65, 447

RAO, C. RADHAKRISHNA A DECOMPOSITION THEOREM FOR VECTOR VARIABLES WITH A LINEAR STRUCTURE, AMS 69. IB45

RAO C. RADHAKRISHNA ANALYSIS OF DISPERSION WITH INCOMPLETE OBSERVATIONS ON ONE OF THE CHARACTERS, JRSSB 56,259

RAO, C. RADHAKRISHNA CONDITIONS FOR OPTIMALITY AND VALIDITY AND SIMPLE LEAST SQUARES THEORY, AMS 69, 1617

RAO, J. N. K. A NEW EST IMATION THEORY FOR SAMPLE SURVEYS, BIOKA 6B, 547

RAO $, J, N, K$. A NOTE ON EST IMATION OF RATIOS BY QUENOUILLE'S METHOD BIOKA 65,647

RAO. J. N, K. A NOTE ON MEAN SQUARE SUCCESSIVE DIFFERENCES, JASA 59. 801

RAO J $N . K$ AN EMPIRICAL STUDY OF THE STABILITIES OF ESTIMATORS AND VARIANCE ESTIMATORS IN UNEQUAL PROB, JASA 69,540

RAO, J. N. K. MAXIMUM-LIKELIHOOD ESTIMATION FOR THE MIXED ANALYSIS OF VARI ANCE MODEL, BIOKA 67,93

RAO $, \mathrm{J}, \mathrm{N}, \mathrm{K}$. ON A SIMPLE PROCEDURE OF UNEQUAL PROBABILITY SAMPLING WITHOUT REPLACEMENT, JRSSB 62, 482

RAO, J. N. K. ON EXPECT ATIONS, VARIANCES. AND CONVARIANCES OF ANOVA MEAN SQUARES BY 'SYNTHESIS' , BIOCS 6B, 963

RAO, J. N. K. ON THREE PROCEDURES OF UNEQUAL PROBABILITY SAMPLING WITHOUT REPLACEMENT, JASA 63,202

RAO, J. N. K. ON TWO METHODS OF BIAS REDUCTION IN THE ESTIMATION OF RATIOS, BIOKA 66, 571 
RAO, J. N. K. ROTATION DESIGNS FOR SAMPLING ON REPEATED OCCASIONS, JASA 64,492

RAO, J. N. K. SAMPLING WITH UNEQUAL PROBABILITIES AND WITHOUT REPLACEMENT, AMS 62, 350

RAO, J. N. K. SOME NONRESPONSE SAMPLING THEORY WHEN THE FRAME CONTAINS AN UNKNOWN AMOUNT OF DUPLICATION, JASA 6B, 87

RAO, J. N. K. THE PRECISION OF MICHEY'S UNBIASED RATIO ESTIMATOR, BIOKA 67,321

RAO, J . N . K. VARI ANCE ESTIMATION WITH ONE UNIT PER STRATUM, JASA 69 841

RAO, K. S. A SIMPLE METHOD OF DERIVINC BEST CRITICAL RECIONS SIMILAR TO THE SAMPLE SPACE IN TESTS OF AN I, BIOKA 53, 231

RAO, M. BHASKAR A NOTE ON INCOMPLETE BLOCK DESIGNS WITH THE NUMBER OF BLOCKS EQUAL TO THE NUMBER OF T'REAT, AMS 65, 1B77

RAO, M. BHASKAR APPLICATION OF GREENBERG AND SARHAN 'S METHOD OF INVERS ION OF PARTITIONED MATRICES IN THE, JASA 65, 1200

RAO, M. BHASKAR WEIGHING DES IGNS WHEN N IS ODD, AMS 66, 1371

RAO, M. M. BAYES ESTIMATION WITH CONVEX LOSS, AMS 63, 839

RAO M. M. CONSISTENCY AND LIMIT DISTRIBUTIONS OF ESTIMATORS OF PARAMETERS IN EXPLOSIVE STOCHASTICDIFFER, AMS 61, 195

RAO, P. S. CONSTRUCTION AND ANALYSIS OF SOME NEW SERIES OF CONFOUNDED ASYMMETRICAL FACTORIAL DESIGNS, BIOCS 67,813

RAO, P.S.R. S. ON THREE PROCEDURES OF SAMPLING FROM FINITE POPULATIONS, BIOKA 68,438

RAO, P. V. A ROBUST POINT ESTIMATOR IN A GENERALIZED REGRESSION MODEL, AMS 69, 1784

RAO, P. V. ANALYSIS OF A CLASS OF PARTIALLY BALANCED INCOMPLETE BLOCK DESIGNS WITH MORE THAN TWO ASSOCIAT, AMS 61, 800

RAO, P. V. TIES IN PAIRED-COMPARISON EXPERIMENTS . A GENERALIZATION OF THE BRADLEY-TERRY MODEL , CORR. 681 , JASA 67,194

RAO, PODURI S. R. S. COMPARISON OF FOUR RATIO-TYPE EST IMATES UNDER A MODEL, JASA 69,574

RAO, PODURI S. R. S. GENERALIZED MULT IVARIATE EST IMATOR FOR THE MEAN OF FINITE POPULATIONS, JASA 67,1009

RAO, PODURI S. R. S. SOME SHARP MULTIVAR IATE TCHEBYCHEFF INEQUALITIES, AMS 67,393

RAO, POTLURI SMALL-SAMPLE PROPERTIES OF SEVERAL TWO-STAGE RECRESSIGN METHODS IN THE CONTEXT OF AUTOCORREL, JASA 69,253

RAO, R. RANGA RELATIONS BETWEEN WEAK AND UNIFORM CONYERGENCE OF MEA SURES WITH APPLICATIONS, AMS 62,659

RAO, R. SUBBA A NOTE ON THE ASYMPTOTIC RELATIVE EFFICIENCIES OF COX AND STUART' $S$ TESTS FOR TES TING TREND, BIOKA 68,381

RAO, T. J. ON THE CHOICE OF A STRATECY FOR A RATIO METHOD OF ESTIMATION, JRSSB 67,392

RAO T . SUBBA A TEST FOR NON-STATIONARITY OF TIME-SERIES, JRSSB 69 140

RAO, T, SUBBA CROSS SPECTRAL ANALYSIS OF GAUSSIAN VECTOR PROCESS IN THE PRESENCE OF VARIANCE FLUCTUATIONS, AMS 68,1507

RAO, T. SUBBA ON THE CROSS PERIODOGRAM OF A STATIONARY GAUSS IAN VECTOR PROCESS, AMS 67,593

RAPOPORT, ANATOL A FORMULA FOR THE PROBABILITY OF OBTAINING A TREE FROM A GRAPH CONSTRUCTED RANDOMLY EXCE, AMS 67, 226

RASTOCI, SURESH C. SHORTER CONF IDENCE BANDS IN LINEAR RECRESSION JASA 67,1050

RAWLINGS, J 0 REFERENCE POPULATIONS FOR DIALLEL EXPERIMENTS, BIOCS $6 B, B 81$

RAWLINGS, J. 0. SELECTION AMONG DIALLE'L CLASSIFIED VARIABLES, BIOCS 69,49

RAY-CHAUDHURI, D. K. APPLICATION OF THE GEOMETRY OF QUADRICS FOR CONSTRUCTING PART I ALLY BALANCED INCOMPLE, AMS 62, 1175

RAY, S. N. A BAYES SEQUENTIAL SAMPLING INSPECTION, AMS 65, 1387

RAY, S. N. BOUNDS ON THE MAXIMUM SAMPLE SIZE OF A BAYES SEQUENTIA PROCEDURE, AMS 65, 859

RAY, W. D, AN EXACT DISTRIBUTION OF THE BEHRENS-FISHER-WELCH STATIST IC FOR TESTING THE DIFFERENCE BETWEEN, JRSSB 61, 377

RAY, W. D. CHEBYSHEV POLYNOMIAL AND OTHER NEW APPROXIMATIONS TO MILLS' RATIO, AMS 63, 892

RAY, W. D. POLYNOMIAL PROJECTING PROPERTIES OF MULT I-TERM PREDIC TORS OR CONTROLLERS IN NON-STATIONARY TIM, JRSSB 65,144

RAY, W. D. SEQUENTIAL ANALYSIS APPLIED TO CERTAIN EXPERIMENTAL DESIGNS IN THE ANALYS IS OF VARIANCE, BIOKA 56, 38

RAY, W. D. SEQUENTIAL CONFIDENCE INTERVALS FOR THE MEAN OF A NORMAL POPULATION WITH UNKNOWN VARI ANCE, JRSSB 57, 133

RAYNER, A. A. A NOTE ON GENERALIZED INVERSES IN THE LINEAR HYPOTHES IS NOT OF FULL RANK, AMS 67,271

RAYNER, A. A NOTES, THE SQUARE-SUMMINC CHECK ON THE MAIN EFFECTS AND INTERACTIONS IN A 2 TO THE POWER N, BIOCS 67,571

READ, K. L . Q. A SYSTEM OF MODELS FOR THE LIFE CYCLE OF A BIOLOGICAL ORGANISM, BIOKA GB, 211

READ, R. R. ON QUADRATIC ESTIMATES OF THE INTERCLASS VARIANCE FOR UNBALANCED DESICNS , JRSSB 61, 493

RECHTSCHAFFNER, R. L. SATURATED FRACTIONS OF 2-T0-THE-N AND 3-TOTHE-N FACTORIAL DESIGNS, TECH 67, 569

REDHEFFER, R. M. SOME APPLICATIONS OF MONOTONE OPERATORS IN MARKOV PROCESSES, AMS 65, 1421

REDMAN, C. E. GROUP SCREENING UTILIZING BALANCED AND PARTIALLY BALANCED INCOMPLETE BLOCK DES IGNS, BIOCS 65,865
REES, D. H. ECONOMIC CHOICE OF THE AMOUNT OF EXPERIMENTATION, JRSSB 56,32

REES, D. H, SOME DES IGNS OF USE IN SEROLOGY, BIOCS 67,779

REES, D. H. SOME OBSERVATIONS ON CHANGE-OVER TRIALS, BIOCS $69,4 \overline{1} 3$

REES, $D, H$ THE ANALYSIS OF VARIANCE OF DESIGNS WITH MANY NONORTHOGONAL CLASSIFICATIONS. JRSSB 66, 110

REES, D. H. THE ANALYSIS OF VARIANCE OF SOME NON-ORTHOGONAL DESIGNS WITH SPLIT PLOTS, BIOKA 69,43

REES, D. $H$. UPPER PERCENTAGE POINTS OF THE GENERALIZED BETA DISTRIBUTION. I, BIOKA 57,237

RECIER, MARY H. A TWO-STATE MARKOV MODEL FOR BEHAVIORAL CHANGE, JASA 68,993

REICH, EDGAR NOTES ON QUEUES IN TANDEM, AMS 63, 338

REID, MARCARET G. EFFECT OF VARYINC DEGREES OF TRANSITORY INCOME ON INCOME ELASTICITY OF EXPENDITURES, JASA 58, 348

REID, MARCARET G. INCREASE IN RENT OF DWELLING UNITS FROM 1940 TO 1950, JASA 59,358

REIERSOL, O. A NOTE ON THE SIGNS OF GROSS CORRELATION COEFFICIENTS AND PARTIAL CORRELATION COEFF ICIENTS, BIOKA 56, 480

REIERSOL, O. LINEAR AND NON-LINEAR MULTIPLE COMPARISONS IN LOGIT ANALYSIS, BIOKA 61, 359

RETERSOL, OLAV CORRIGENDA, 'LINEAR AND NON-LINEAR MULTIPLE COMPARISONS IN LOGIT ANALYSIS ' , BIOKA 62, 284

REINACH, S. G. A DISTRIBUTION-FREE ANALYSIS OF VARIANCE TECHNIQUE FOR BLOCK DESICNS, SASJ 68,9

REINER, ALBEY M. DESIGNS FOR DISCRIMINATING BETWEEN TWO RIVAL MODELS, TECH 65,307

REINFURT, KARENH. TESTS FOR CORRELATION MATRICES, BIOKA 68, 327

REINHARDT, H. E. NOTES. CHARACTERIZING THE EXPONENTIAL DISTRIBUTION, BIOCS 68,437

REINHARDT, $H$. E. THE USE OF LEAST FAVORABLE DISTRIBUTIONS IN TEST ING COMPOSITEHYPOTHESES, AMS 61, 1034

REISCH, JOANS. THE POWER OF A TEST IN COVARIANCE ANALYSIS, BIOCS 69 NO. 4

REITER, STANLEY DISTRIBUTIONS OF CORRELATION COEFFICIENTS IN ECONOMIC TIME SERIES, JASA 61,637

REITER, STANLEY ESTIMATES OF BOUNDED RELATIVE ERROR FOR THE RATIO OF VARIANCES OF NORMAL DISTRIBUTIONS, JASA 56, 481

REITER, STANLEY THE FIRST 1 945 BRITISH STEAMSHIPS, JASA 58, 360

REITSMA, A. ON APPROXIMATIONS TO SAMPLING DISTRIBUTIONS OF THE MEAN FOR SAMPLES FROM NON-NORMAL POPULATIO, AMS 63, 1308

REITSMA, A THE DETERMINATION OF SAMPLINC DISTRIBUTIONS AND MOMENT CENERATINC FUNCTIONS BY SOLVING DIFFER, JRSSB 65,86

REMAGE JR, R. MAXIMUM-LIKELIHOOD PAIRED COMPARISON RANKINGS, BIOKA 66,143

REMAGE JR, RUSSEL RANKINGS FROM PAIRED COMPARISONS, AMS 64, 739

RENNER, MAYNARD $S$. A CRAPHICAL METHOD FOR MAKING MULTIPLE COM PARISONS OF FREQUENCIES TECH 69,321

RESNIKOFF, GEORGE J TABLES TO FACILITATE THE COMPUTATION OF PERCENTAGE POINTS OF THE NON-CENTRAL T-DISTR, AMS 62, 580

REUVER, H. A. ON MEASURES OF CORRELATION IN TIME SERIES OF EVENTS, BIOCS 69.73

REUVER, H. A. THE SUPERPOSITION OF RANDOM SEQUENCES OF EVENTS, BIOKA $66,3 \mathrm{~B} 3$

REYMENT, R. A. A MULTIVARIATE PALEONTOLOGICAL GROWTH PROBLEM, BIOCS 69,1

REZUCHA, IVAN DEVELOPMENT OF SAMPLING PLANS BY USING SEQUENTIAL ITEM BY ITEM, SELECTION TECHNIQUES AND D, JASA 62,387

RHYNE, A. L A MULTIPLE COMPARISONS SICN TEST, ALL PAIRS OF TREATMENTS, BIOCS 67,539

RHYNE, A. L. TABLES FOR A TREATMENTS VERSUS CONTROL MULTIPLE COMPARISONS SIGN TEST, TECH 65,293

RICH, R. N. A STATISTICAL BASIS FOR APPROXIMATION AND OPTIMIZATION, AMS 66, 59

RICHARDS, F. S. G. A METHOD OF MAXIMUM-LIKELIHOOD ESTIMATION, JRSSB 61,469

RICHARDS, F. S. G. ON FINDINC LOCAL MAXIMA OF FUNCTIONS OF A REAL VARIABLE, BIOKA 67,310

RICHARDSON, DAVID H THE EXACT DISTRIBUTION OF A STRUCTURAL COEFFICIENT ESTIMATOR, JASA $6 B, 1214$

RICHTER, DONALD A TABLE FOR RANK SUM MULTIPLE PAIRED COMPARISONS TECH 67, 561

RICHTER, DONALD INEQUALITIES OF CHEBYSHEV TYPE INVOLVING CONDI TIONAL EXPECTATIONS. AMS 69, NO.6

RIDER, PAUL R. DISTRIBUTION OF PRODUCT AND OF QUOTIENT OF MAXIMUM VALUES IN SAMPLES FROM A POWER-FUNCTION, JASA 64, 877

RIDER, PAUL R. EXPECTED VALUES AND STANDARD DEVIATIONS OF THE RECIPROCAL OF A VARI ABLE FROM A DECAPITATED, JASA 62, 439

RIDER, PAULR SAMPLING FROM A TRIANGULAR POPULATION, JASA 63, 509

RIDER, PAUL R. THE METHOD OF MOMENTS APPLIED TO A MIXTURE OF TWO EX PONENTIAL DISTRIBUTIONS, AMS 61, 143

RIDER, PAUL R. THE MIDRANGE OF A SAMPLE AS AN ESTIMATOR OF THE POPULATION MIDRANGE, JASA 57,537

RIDER, PAUL R. VARIANCE OF THE MEDIAN OF SAMPLES FROM A CAUCHY DISTRIBUTION, JASA 60, 322

RIDER, PAUL R. VARIANCE OF THE MEDIAN OF SMALL SAMPLES FROM SEVERAL SPECIAL POPULATIONS, JASA 60, 14B

RIEDWYL, HANS GOODNESS OF FIT, JASA 67,390 
RIFFENBURGH, R. H. GEOMETRY AND LINEAR DISCRIMINATION, BIOKA 60 , $1 B 5$

RIFFENBURGH, R. H. ON GROWTH PARAMETER ESTIMATION FOR EARLY LIFE STAGES, BIOCS 66,162

RIFFENBURGH, ROBERT H. HALF-RECTIFIED TRUNCATED DISTRIBUTIONS SAMPLING THEORY AND HYPOTHESIS TESTING, TECH 69,47

RILEY, H. E. SOME ASPECTS OF SEASONALITY IN THE CONSUMER PRICE INDEX, JASA 61,27

RILEY, JAMES D. COMPARATIVE COST OF TWO LIFE TEST PROCEDURES, TECH 62,140

RING, L. WINSTON EST IMATION AND INFERENCE FOR LINEAR MODELS IN WHICH SUBSETS OF THE DEPENDENT VARIABLE AR, JASA 68,1201

RIORDAN, JOHN A RECURRENCE FOR PERMUTATIONS WITHOUT RISING OR FALLING SUCCESSIONS, AMS 65,70B

RIORDAN, JOHN ENUMERATION OF LINEAR GRAPHS FOR MAPPINGS OF FINITE SETS, AMS 62, 17B

RIORDAN, JOHN THE ENUMERATION OF ELECTION RETURNS BY NUMBER OF LEAD POSITIONS, AMS 64, 369

RIZVI, $M$. AN INTRODUCTION TO RANKING AND SELECTION PROCEDURES, JASA 66,640

RIZVI, M. H. A NOTE ON MOMENTS OF GAMMA ORDER STATISTICS, TECH 67, 315

RIZVI, M. HASEEB A NOTE ON RECURRENCE RELATIONS BETWEEN EXPECTED VALUES OF FUNCT IONS OF ORDER STATISTICS, AMS 66, 733

RIZVI, M. HASEEB NONPARAMETRIC PROCEDURES FOR SELECTING A SUBSET CONTAINING THE POPULATION WITH THE LARGE, AMS 67, 1788

RIZVI, M. HASEEB NONPARAMETRIC RANKING PROCEDURES FOR COMPARISON WITH A CONTROL, AMS 6B, 2075

ROACH, S. A. THE FREQUENCY DISTRIBUTION OF THE SAMPLE MEAN WHERE EACH MEMBER OF THE SAMPLE IS DRAWN FROM, BIOKA 63,50B

ROBB, MARGARET A. FURTHER REMARKS ON EXPONENTIAL REGRESSION WITH CORRELATED OBSERVATIONS, BIOKA $6 B, 575$

ROBBINS, H. A SEQUENTIAL ANALOGUE OF THE BEHRENS-FISHER PROBLEM, AMS 67,1384

ROBBINS, $H$. A SEQUENTIAL PROCEDURE FOR SELECTING THE LARGEST OF $K$ MEANS, AMS 68,88

ROBBINS, H. FINDING THE SIZE OF A FINITE POPULATION, AMS 67, 1392

ROBBINS, H. TWO-STAGE PROCEDURES FOR ESTIMATING THE DIFFERENCE BETWEEN MEANS, BIOKA 54,146

ROBBINS, HERBERT A RENEWAL THEOREM FOR RANDOM VARIABLES WHICH ARE DEPENDENT OR NON-IDENTICALLY DISTRIBUTE, AMS 63, 390

ROBBINS, HERBERT MOMENTS OF RANDOMLY STOPPED SUMS, AMS 65, 7B9

ROBBINS, HERBERT QN THE ASYMPTOTIC THEORY OF FIXED-WIDTH SEQUENTIAL CONF IDENCE INTERVALS FOR THE MEAN, AMS 65,457

ROBBINS, HERBERT RECURRENT GAMES AND THE PETERSBURG PARADOX, AMS 61,187

ROBBINS, HERBERT THE EMPIRICAL BAYES APPROACH TO STATISTICAL DECISION PROBLEMS, AMS 64,1

ROBBINS, HERBERT E. ESTIMATING THE TOTAL PROBABILITY OF THE UNOBSERVED OUTGOMES OF AN EXPERIMENT, AMS 68, 256

ROBERTS, C. A NECESSARY AND SUFFICIENT GONDITION FOR THE SQUARE OF A RANDOM VARIABLE TO BE GAMMA, BIOKA 66, 275

ROBERTS, C. FILL WEIGHT VARIATION RELEASE AND CONTROL OF CAPSULES. TABLETS. AND STERILE SOLIDS, TEGH 69,161

ROBERTS, CHARLES A. A CORRELATION MODEL USEFUL IN THE STUDY OF TWINS, JASA 66,1184

ROBERTS, CHARLES DEWITT AN ASYMPTOTICALLY OPTIMAL FIXED SAMPLE SIZE PROCEDURE FOR COMPARING SEVERAL EXPER, AMS 64, 1571

ROBERTS, CHARLES DEWITT AN ASYMPTOTICALLY OPTIMAL SEQUENTIAL DESIGN FOR GOMPARING SEVERAL EXPER IMENTAL CA. AMS 63.1486

ROBERTS, E. A. THE ESTIMATION OF CONCENTRATION OF VIRUSES AND BACTERIA FROM DILUTION COUNTS, BIOCS 65,600

ROBERTS, ELEANOR ERRATA. 'MODIFIED SQUARE ROOT METHOD OF MATRIX INVERSION ' , TECH 62,622

ROBERTS, ELEANOR MODIFIED SQUARE ROOT METHOD OF MATRIX INVERSION, TECH $62,2 \mathrm{~B} 2$

ROBERTS. F. D. K. A MONTE CARLO SOLUTION OF A TWO-DIMENSIONAL UNSTRUCTURED CLUSTER PROBLEM, BIOKA 67, 625

ROBERTS, F . D. K. A THREE-DIMENSIONAL CLUSTER PROBLEM, BIOKA 68, 258 ROBERTS, F. D. K. NEAREST NEIGHBOURS IN A POISSON ENSEMBLE, BIOKA 69,401

ROBERTS, F. D. K. RANDOM MINIMAL TREES, BIOKA 6B, 255

ROBERTS, HARRY $V$. INFORMATIVE STOPPING RULES AND INFERENCES ABOUT POPULATIONSIZE, JASA 67.763

ROBERTS, HARRY V. PROBABILISTIC PREDICTION, JASA 65, 50

ROBERTS, S. W. A COMPARISON OF SOME GONTROL CHART PROCEDURES, TECH 66,411

ROBERTS, S. W. CONTROL CHART TESTS BASED ON GEOMETRIC MOVING AVERAGES, TECH 59,239

ROBERTSON, H. H. APPROXIMATE DESIGN OF DIGITAL F ILTERS, TECH 65, 387 ROBERTSON, J. S. M. A GENERAL SIMULATION PROGRAMME FOR MATERIAL FLOW IN BATCH CHEMIGAL PLANTS, TECH 61,497

ROBERTSON, JAMES B. ON A PROBLEM IN NON-LINEAR PREDICTION THEORY, AMS 65,1554

ROBERTSON, TIM A NOTE ON THE RECIPROCAL OF THE GONDITIONAL EXPECTATION OF A POSITIVE RANDOM VARIABLE, AMS 65, 1302

ROBERTSON, TIM A REPRESENTATION FOR CONDITIONAL EXPECTATIONS GIVEN SIGMA-LATT ICES, AMS 66, 1279
ROBERTSON, TIM ON ESTIMATING A DENSITY WHICH IS MEASURABLE WITH RESPECT TO A SIGMA-LATTICE, AMS 67,482

ROBERTSON, TIM ON ESTIMATING MONOTONE PARAMETERS, AMS 6B, 1030

ROBERTSON, W. H. PROGRAMMING FISHER 'S EXACT METHOD OF COMPARING TWO PERCENTAGES, TECH 60,103

ROBINSON, J. BALANCED INCOMPLETE BLOCK DESIGNS WITH DOUBLE GROUPING OF BLOCKS INTO REPLICATIONS, BIOCS 66,368

ROBINSON, J. INCOMPLETE SPLIT PLOT DESIGNS, BIOCS 67,793

ROBINSON, $P$. EXPECTED EFFECTS ON THE INBREEDING COEFFICIENT AND RATE OF GENE LOSS OF FOUR METHODS OF REPR, BIOCS 65,447

ROBINSON, P. NOTES, THE ANALYSIS OF A DIALLEL CROSSING EXPERIMENT WITH CERTAIN CROSSES MISSING, BIOCS 65, 216

ROBISON. D. E, DIRECT METHODS FOR EXACT TRUNCATED SEQUENTIAL TESTS OF THE MEAN OF A NORMAL DISTRIBUTION, TECH 69, NO 4

ROBISON, D. E. ESTIMATES FOR THE POINTS OF INTERSECTION OF TWO POLYNOMIAL REGRESSIONS, JASA 64,214

ROBISON, D. E. SEQUENTIAL LIFE FOR THE EXPONENTIAL DISTRIBUTION WITH CHANGING PARAMETER, TECH 66,217

ROBSON, D. S. A NONPARAMETRIC STATISTICAL METHOD FOR CULLING RECRUITS FROM A MARK-RECAPTURE EXPERIMENT, BIOCS 65,936

ROBSON, D. S. APPLICATIONS OF MULTIVARIATE POLYKAYS TO THE THEORY OF UNBIASED RATIO-TYPE EST IMATION, JASA 57, 511

ROBSON, D. S. ESTIMATION OF A TRUNCATION POINT, BIOKA 64,33

ROBSON, D. S. MULTIPLE COMPARISIONS WITH A CONTROL IN BALANCED INCOMPLETE BLOCK DESIGNS, TECH 61, 103

ROBSON, D. S. UNBIASED COMPONENTWISE RATIO ESTIMATION, CORR. 63 1163, JASA 61,350

ROBSON, MARY A TEST OF THE ACCURACY OF A PRODUCTION INDEX, JASA 56, 17 RODEMICH, EUGENE R, APPLICATION OF AN ESTIMATOR OF HIGH EFFICIENCY IN BIVARIATE EXTREME VALUE THEORY, JASA 69, N0. 4

RODEMICH. EUGENE R. EPSILON ENTROPY OF GAUSSIAN PROCESSES. AMS 69 1272

RODEMICH, EUGENE R. EPSILON ENTROPY OF STOCHASTIC PROCESSES, AMS 67,1000

RODEMICH, EUGENE R. PRODUCT ENTROPY TO GAUSSIAN DISTRIBUTIONS, AMS $69, B 70$

RODEMICH, EUGENE R. SPECTRAL ESTIMATES USING NONLINEAR FUNCTIONS, AMS 66,1237

RODINE, ROBERT H. PERFECT PROBABILITY MEASURES AND REGULAR CONDITIONAL PROBABILITIES, AMS 66, 1273

ROGERS, ANDREI A STOGHASTIC ANALYSIS OF THE SPATIAL CLUSTERING OF RETAIL ESTABLISHMENTS, JASA 65, 1094

ROGERS, GERALD S. AN APPLICATION OF A GENERALIZED GAMMA DISTRIBUTION, AMS 64, 1368

ROGOT, EUGENE A NOTE ON MEASUREMENT ERRORS AND DETECTING REAL DIFFERENCES, JASA 61,314

ROHATGI, M. S. ON THE ASYMPTOTIC SUFFICIENCY OF CERTAIN ORDER STATISTICS, JRSSB 62,167

ROHDE, C. A. EXACT FIRST AND SECOND ORDER MOMENTS OF ESTIMATES OF COMPONENTS OF GOVARIANCE, BIOKA 69 , NO 3

ROHDE, C. A. UNIFIED LEAST SQUARES ANALYSIS, JASA 65,523

ROJAS, B. THE MODIFIED LATIN SQUARE, JRSSB 57,305

ROLL, RICHARD SOME PROPERTIES OF SYMMETRIC STABLE DISTRIBUTIONS JASA $6 B, 817$

ROLPH, JOHN E. BAYESIAN ESTIMATION OF MIXING DISTRIBUTIONS, AMS 68 $12 \mathrm{B9}$

ROOT, D. H. THE EXISTENCE OF CERTAIN STOPPING TIMES ON BROWNIAN MOTION, AMS 69, 715

ROOT, DAVID ON CONVERGENCE IN R-MEAN OF NORMALIZED PARTIAL SUMS, AMS $6 B, 379$

ROOT, W. L. ON DOMINATING AN AVERAGE ASSOCIATED WITH DEPENDENT GAUSSIAN VECTORS, AMS $68,1 B 44$

ROSANDER, A. G. THE USE OF RANDOM WORK SAMPLING FOR COST ANALYSIS AND CONTROL, CORR. 581031 , JASA 5B, 3B2

ROSE, GEORGE A TABLE FOR RANK SUM MULTIPLE PAIRED COMPARISONS, TECH 67,561

ROSEBERRY, THOMAS D. A LARGE SAMPLE SEQUENTIAL TEST, USING CONCOMITANT INFORMATION FOR DISCRIMINATION BET , JASA 66,357

ROSEBERRY, THOMAS D. A NOTE ON THE VARIANCE OF THE DISTRIBUTION OF SAMPLE NUMBER IN SEQUENTI AL PROBABILIT, TECH 66, 700

ROSEN, BENGT ON AN INEQUALITY OF HOEFFDING, AMS 67,3B2

ROSENBAUM, $S$. MOMENTS OF A TRUNCATED BIVARIATE NORMAL DISTRIBUTION, JRSSB 61,405

ROSENBAUM, S. ON SOME TWO-SAMPLE NON-PARAMETRIC TESTS, CORR. 66 1249, JASA 65,1118

ROSENBERG, L. CORRIGENDA, 'SMALL SAMPLE BEHAVIOUR OF CERTAIN TESTS OF THE HYPOTHESIS OF EQUAL MEANS UNDER, BIOKA 61, 230

ROSENBERG, L. SMALL SAMPLE BEHAVIOUR OF CERTAIN TESTS OF THE HYPOTHESIS OF EQUAL MEANS UNDER VARI ANCE HET, BIOKA 60,345

ROSENBLATT-ROTH, M. QUANTILES AND MEDI ANS, AMS 65, 921

ROSENBLATT-ROTH, M. SOME THEOREMS CONCERNING THE STRONG LAW OF LARGE NUMBERS FOR NON-HOMOGENEOUS MARKOV C , AMS 64, 566

ROSENBLATT-ROTH, MILLU SOME LIMIT THEOREMS FOR NON-HOMOGENEOUS MARKOV CHAINS, AMS 66, 1224

ROSENBLATT, H. M. ON THE ANALYSIS OF MULTIPLE REGRESSION IN $K$ CATEGORIES, BIOKA 57,67

ROSENBLATT, HARRY M. SPECTRAL EVALUATION OF BLS AND CENSUS REVISED SEASONAL ADJUSTMENT PROCEDURES, JASA 68,472 
ROSENBLATT, J, I. CONFIDENCE INTERVALS FOR THE COEFFICIENT OF VARIATION FOR THE NORMAL AND LOC NORMAL DIS, BIOKA 64,25

ROSENBLATT, JUDAH NOTE ON MULTIVARIATE COODNESS-OF-FIT TESTS, AMS 62,807

ROSENBLATT, JUDAH ON FIXED PRECISION ESTIMATION IN TIME SERIES, AMS 69, 1021

ROSENBLATT, JUDAH ONMULTISTACE ESTIMATION, AMS 63, 1452

ROSENBLATT, JUDAH ON PARTIAL 'A PRIORI' INFORMATION IN STATISTICAL INFERENCE, AMS 67, 1671

ROSENBLATT, JUDAH ON RANDOM SAMPLINC FROM A STOCHASTIC PROCESS, AMS 64,1713

ROSENBLATT, JUDAH QUERY, CONFIDENCE INTERVAL FOR STANDARD DEVIATION FROM A SINCLE OBSERVATION, TECH 66,367

ROSENBLATT, JUDAH SOME MODIFIED KOLMOGOROV-SMIRNOV TESTS OF APPROX IMATE HYPOTHESES AND THEIR PROPERTIES, AMS 62, 513

ROSENBLATT, JUDAH TESTING APPROXIMATE HYPOTHESES IN THE COMPOSITE CASE, CORR . 63. AMS 62, 1356

ROSENBLATT, JUDAH TESTS AND CONFIDENCE INTERVALS BASED ON THE METRIC D2, AMS 63, 61B

ROSENBLATT.M. DISTRIBUTION FREE TESTS OF INDEPENDENCE BASED ON THE SAMPLE DISTRIBUTION FUNCTION, AMS 61,4B5

ROSENBLATT, M. ESTIMATION OF THE BISPECTRUM, AMS 65, 1120

ROSENBLATT, M. ZERO GROSSING PROBABILIT IES FOR GAUSSIAN STATIONARY PROCESSES, AMS 62, 1306

ROSENHEAD, J AN EXTENSION OF QUENOUILLE'S TEST FOR THE COMPATIBILITY OF CORRELATION STRUCTURES IN TIME S, JRSSB 68,180

ROSENKRANTZ, WALTER A. A LOCAL LIMIT THEOREM FOR A CERTAIN CLASS OF RANDOM WALKS, AMS 66,855

ROSENTHAL, IRENE DISTRIBUTION OF THE SAMPLE VERSION OF THE MEASURE OF ASSOCIATION. GAMMA, JASA 66,440

ROSENWAIKE, IRA ON MEASURING THE EXTREME AGED IN THE POPULATION, JASA 68,29

ROSENWAIKE, IRA SEASONAL VARIATION OF DEATHS IN THE UNITED STATES, 1951-1960, JASA 66, 706

ROSS, A. S. G. THE HAUSA PROBLEM AND SOME APPROXIMATIONS TO THE REQUIRED PROBABILITY, BIOKA 63, 514

ROSS, ALAN VARIANCE ESTIMATES IN 'OPTIMUM' SAMPLEDESIGNS, JASA 61 . 135

ROSS, JOHN THE TWENTY-SEVEN PER CENT RULE, AMS 64, 214

ROSS, SHELDON NON-DISCOUNTED DENUMERABLE MARKOVIAN DECISION MODELS, AMS 68,412

ROSS, SHELDON M. AN EXAMPLE IN DUNUMERABLE DECISION PROCESSES, AMS 68,674

ROSS, SHELDON M ARBITRARY STATE MARIZOVIAN DECISION PROCESSES AMS 68,2118

ROSSINC, R. C. A COMPARISON OF CONTINUOUS DISTRIBUTIONS OF PARAMETERS OF EXPONENTIAL DECAY CURVES, BIOCS 68,117

ROTH, ROBERT CURVE FITTING BY SECMENTED STRAICHT LINES, JASA 69 1079

ROTHENBERG, T. A NOTE ON THE EXPECTED VALUE OF AN INVERSE MATRIX, 8IOKA 69, NO. 3

ROTHENBERG, THOMAS J. A NOTE ON ESTIMATION FROM A CAUCHY SAMPLE JASA 64,460

ROTHWELL, DORIS P. USE OF VARYING SEASONAL WEICHTS IN PRICE INDEX CONSTRUCTION, JASA 5B, 66

ROUSSAS, G. G. ASYMPTOTIC INFLRENCE INMARKOV PROCESSES, AMS 65, 978 ROUSSAS, GEORGE NONPARAMETRIG ESTIMATION OF THE TRANSITION DISTRIBUTION FUNCTION OF A MARKOV PROCESS, AMS 69, 13B6

ROUSSAS, GEORGE G. ASYMPTOTICALLY MOST POWERFUL TESTS IN MARKOV PROCESSES, AMS 69, 1207

ROUVIER, $R$. L'ANALYSE EN COMPOSANTES PRINCIPALES, SON UTILISATION EN GENETI QUE ET SES RAPPORTS AVEC L 'ANA, BIOCS 66,343

ROUVIER, R, PONDERATION DES VALEURS GENOTYPIQUES DANS LA SELECTION PAR INDEX SUR PLUSIEURS CARACTERES, BIOCS 69, 295

ROWELL, J.G. THE ANALYSIS OF A FACTORIAL EXPER IMENT (WITH CONFOUNDING) ON AN ELECTRONIC CALCULATOR, JRSSB 54,242

ROY, A. D. A NOTE ON PREDICTION FROM AN AUTOREGRESSIVE PROCESS USING PISTIMETRIC PROBABILITY, JRSSB 60,97

ROY, A. D. SOME NOTES ON PISTIMETRIC INFERENCE, JRSS $860,33 \mathrm{~B}$

ROY, L. K. TABLES OF INVERSE GAUSSIAN PERCENTAGE POINTS, TECH 69 591

ROY, S. N. A GENERALIZED MULTIVARIATE ANALYSIS OF VARIANCE MODEL USEFULL ESPECIALLY FOR GROWTH CURVE PROB, BIOKA 64, 313

ROY, S. N. A NOTE ON 'FURTHER CONTRIBUTIONS TO MULTIVARIATE CONFIDENCE BOUNDS', BIOKA 5B, 5B I

ROY. S. N. AN INTRODUCTION TO SOME NON-PARAMETRIC GENERALIZATIONS OF ANALYSIS OF VARIANCE AND MULTIVARIAT, BIOKA 56,361

ROY, S. N . CORRIGENDA, 'FURTHER CONTRIBUTIONS TO MULTIVARIATE CONFIDENCE BOUNDS ', BIOKA 61,474

ROY, S. N. EVALUATION OF DETERMINANTS, CHARACTERISTIC EQUATIONS AND THEIR ROOTS FOR A CLASS OF PATTERNED, JRSSB 60,348

ROY, S. N. FURTHER CONTRIBUTIONS TO MULTIVARIATE CONFIDENCE BOUNDS, BIOKA 57,399

ROY, S. N, ON INVERTING A CLASS OF PATTERNED MATRICES, 8IOKA 56, 227

ROY, S. N. ON THE MONOTONIC CHARACTER OF THE POWER FUNCTIONS OF TWO MULTIVARIATE TESTS, AMS 61, 1145

ROY,$S . N$. TWO-SAMPLE COMPARISONS OF DISPERSION MATRICES FOR ALTERNATIVES OF INTERMED IATE SPECIFICITY, AMS 62,432
ROYALL, RICHARD AN OLD APPROACH TO FINITE POPULATION SAMPLINC THEORY, JASA 68,1269

ROYSTON, ERICA STUDIES IN THE HISTORY OF PROBABILITY AND STATISTICS. III. A NOTE ON THE HISTORY OF THE CR, BIOKA 56, 241

RUBEN, $H$. A NEW ASYMPTOTIC EXPANSION FOR THE NORMAL PROBABILITY INTECRAL AND MILL ' S RATIO, JRSSB 62, 177

RUBEN, H. CORRICENDA, 'ON THE MOMENTS OF ORDER STATISTICS IN SAMPLES FROM NORMAL POPULATIONS ' , BIOKA $54,56 \mathrm{~B}^{\prime}$

RUBEN, H. CORRICENDA, 'ON THE SUM OF SQUARES OF NORMAL SCORES', BIOKA 65,669

RUBEN, $H$. ON THE DISTRIBUTION OF THE WEICHTED DIFFERENCE OF TWO INDEPENDENT STUDENT VARIABLES, JRSSB $60,1 B 8$

RUBEN, H. ON THE MOMENTS OF ORDER STATISTICS IN SAMPLES FROM NORMAL POPULATIONS, BIOKA 54, 200

RUREN, H. ON THE MOMENTS OF THE RANGE AND PRODUCT MOMENTS OF EXTREME ORDER STATIST ICS IN NORMAL SAMPLES, BIOKA 56, 45B

RUBEN, H. ON THE SUM OF SQUARES OF NORMAL SCORES, BIOKA 56, 456

RUBEN, $H$. SOME NEW RESULTS ON THE DISTRIBUTION OF THE SAMPLE CORRELATION COEFFICIENT, JRSSB 66,513

RUBEN, HAROLD A NEW RESULT ON THE DISTRIBUTION OF QUADRATIC FORMS, AMS 63, 15B2

RUBEN, HAROLD CORRECTION. THE TITLE SHOULD READ 'PROBABILITY CONTENT OF RECIONS UNDER SPHERICAL NORMAL DI, AMS 61,620

RUBEN, HAROLD IRRATIONAL FRACTION APPROXIMATIONS TO MILLS' RATIO, BIOKA 64,339

RU8EN, HAROLD PROBABILITY CONTENT OF REGIONS UNDER SPERICAL NORMAL DISTRIBUTIONS, IV, THE DISTRIBUTION OF, AMS 62, 542

RUBEN, HAROLD PROBABILITY CONTENT OF REGIONS UNDER SPHERICAL NORMAL DISTRIBUTIONS, III. THE BIVARIATE NOR, AMS 61, 171

RUBEN, HAROLD SOME ASPECTS OF THE EMIGRATION-IMMIGRATION PROCESS AMS 62,119

RUBEN, HAROLD THE ESTIMATION OF A FUNDAMENTAL INTERACTION PARAMETER IN AN EMIGRATION-IMMIGRATION PROCESS, AMS 63, 238

RUBIN, H. DISTRIBUTIONS POSSESSING A MONOTONE LIKELIHOOD RATIO, JASA 56, 637

RUBIN, HERMAN A CHARACTERIZATION OF THE WISHART DISTRIBUTION, AMS 62,1272

RUBIN, HERMAN ADMISSIBILITY OF QUANTILE EST IMATES OF A SINGLE LOCATION PARAMETER, AMS 64, 1019

RUBIN, HERMAN FUNCTIONS OF PROCESSES WITH MARKOVIAN STATES, II, AMS 69,865

RUBIN, HERMAN FUNCTIONS OF PROCESSES WITH MARKOVIAN STATES, AMS 68 , 938

RUBIN, HERMAN MULTIVARIATE BETA DISTRIBUTIONS AND INDEPENDENCE PROPERTIES OF THE WISHART DISTRIBUTIONS, C, AMS 64, 261

RUBIN, HERMAN ON ROBUST LINEAR ESTIMATORS, AMS 69, 24

RUBIN, J . ON SOME INVARIANT CRITERIA FOR GROUPING DATA, JASA 67 1159

RUDOLPH, G. J. A QUASI-MULTINOMIAL TYPE OF CONTINCENCY TABLE, SASJ 67,59

RUDOLPH, G J ON THE USE AND MISUSE OF GORRECTIONS FOR CONTINUITY SASJ $6 B, B 5$

RUDRA, A. DISCRIMINATION IN TIME-SERIES ANALYSIS, BIOKA 52, 434

RUIZ-MONCAYO, ALBERTO OPTIMAL STOPPING FOR FUNCTIONS OF MARKOV CHAINS, AMS 68, 1905

RUMSEY JR, HOWARD EPSILON ENTROPY OF GAUSSIAN PROCESSES, AMS 69 1272

RUMSEY JR, HOWARD JOINT DISTRIBUTIONS WITH PRESCRIBED MOMENTS, AMS $65,2 B 6$

RUMSEY JR, HOWARD PRODUCT ENTROPY TO GAUSSIAN DISTRIBUTIONS, AMS 69,870

RUMSEY JR, HOWARD J. EPSILON ENTROPY OF STOCHASTIC PROCESSES, AMS 67,1000

RUSHTON, S. CORRICENDA, 'ON A TWO-SIDED SEQUENTIAL T-TEST', BIOKA 54,568

RUSHTON, S. ON A TWO-SIDED SEQUENTIAL T-TEST, BIOKA 52, 302

RUSHTON, S. THE DETERMINISTIC MODEL OF A SIMPLE EPIDEMIC FOR MORE THAN ONE COMMUNITY, BIOKA 55, 126

RUSSELL, ARCH THE PRESIDENT' S ECONOMIC REPORT, JASA 57, 257

RUSSELL, J.S. MULTIVARIATE-COVARIANCE AND CANONICAL ANALYSIS, A METHOD FOR SELECTING THE MOST EFFECTIVE, BIOCS 6B, B45

RUSSELL, T. S. ONE-WAY VARI ANCES IN A TWO-WAY CLASSIFICATION, BIOKA 58,111

RUTEMILLER, HERBERT C. ESTIMATION IN A HETEROSCEDASTIC REGRESSION MODEL, JASA $6 B, 552$

RUTEMILLER, HERBERT C. ESTIMATION OF THE PROBABILITY OF ZERO FAILURES IN M BINOMIAL TRIALS, JASA 67,272

RUTEMILLER, HERBERT C . POINT ESTIMATION OF RELIABILITY OF A SYSTEM COMPRISED OF K ELEMENTS FROM THE SAME, JASA 66, 1029

RUTENBERG, $Y$. H. THE USE OF SAMPLE QUASI-RANGES IN SETTING CONFIDENCE INTERVALS FOR THE POPULATION STANDA, JASA 61, 260

RUTHERFORD, J . R. EPSILON ASYMPTOTIC OPTIMALITY OF EMPIRICAL BAYES ESTIMATORS, BIOKA 69,220

RUTHERFORD, J, R, SOME EMPIRICAL BAYES TECHNIQUES IN POINT ESTIMATION, BIOKA 69,133

RUTHERFORD, J . R. THE EMPIRICAL BAYES APPROACH ESTIMATING POSTERIOR QUANTILES, BIOKA 67,672 
RUTHERFORD, J. R. THE EMPIRICAL BAYES APPROACH, ESTIMATING THE PRIOR DISTRIBUTION, BIOKA 67, 326

RYLL-MARDZEWSKI, C. NON-EXISTENCE OF EVERYWHERE PROPER CONDITIONAL DISTRIBUT IONS, AMS 63, 223

SAATY, T. L. SOME STOCHASTIC PROCESSES WITH ABSORBINC BARRIERS, JRSSB 61,319

SABAGH, G. LATENT CLASS ANALYSIS AND DIFFERENTIAL MORTALITY, JASA 62,430

SACK, R. A. TREATMENT OF THE NON-EQUILIBRIUM THEORY OF S IMPLE QUEUES BY MEANS OF CUMULAT IVE PROBABILITIES, JRSSB 63,457

SACKS, J. ASYMPTOTICALLY OPT IMUM SEQUENT IAL INFERENCE AND DESIGN, AMS 63,705

SACKS, JEROME A NOTE ON THE SEQUENTI AL T-TEST, AMS 65, 1867

SACKS, ,TEROME DESIGNS FOR REGRESS ION PROBLEMS WITH CORRELATED ERRORS, AMS 66, 66

SACKS, JEROME DESIGNS FOR REGRESSION PROBLEMS WITH CORRELATED ERRORS MANY PARAMETERS, AMS $6 B, 49$

SACKS, JEROME GENERALIZED BAYES SOLUTIONS IN ESTIMATION PROBLEMS. AMS 63, 751

SACKSTEDER, RICHARD A NOTE ON STATISTICAL EQUIVALENCE, AMS 67,7B7 SACKSTEDER, RICHARD STATISTICAL ISOMORPHISM, AMS 66, 203

SAKRISON. DAVID J. A CONTINUOUS KIEFER-WOLFOWITZ PROCEDURE FOR RANDOM PROCESSES, CORR. 66745 , AMS 64,590

SALEH. A K K. DETERMINATION OF THE EXACT OPTIMUM ORDER STATISTICS FOR EST TMATING THE PARAMETERS OF EXPONEN, TECH 67,279

SALEH. A.K. MD. EHSANES ASYMPTOTIC OPTIMUM QUANTILES FOR THE ESTIMATION OF THE PARAMETERS OF THE NECATIV, AMS 66, 143

SALEH, A K. MD. EHSANES ESTIMATION OF THE PARAMETERS OF THE EXPONENTIAL DISTRIBUTION BASED ON OPT IMUM OR, AMS 66, 1717

SAMPFORD, M. R. CENSORED OBSERVATIONS IN RANDOMIZED BLOCK EXPERIMENTS, JRSSB 59,214

SAMPFORD, M. R. METHODS OF CLUSTER SAMPLING WITH AND WITHOUT REPLACEMENT FOR CLUSTERS OF UNEQUAL SIZES, BIOKA 62,27

SAMPFORD, M. R. METHODS OF CONSTRUCTION AND ANALYSIS OF SERIALLY BALANCED SEQUENCES, JRSSB 57, 286

SAMPFORD, $M . R$, ON SAMPLING WITHOUT REPLACEMENT WITH UNEQUAL PROBABILITIES OF SELECTION, BIOKA 67, 499

SAMPFORD, M. R. THE TRUNCATED NEGATIVE BINOMIAL DISTRIBUTION, BIOKA 55, 5B

SAMPSON JR, P. ON HOTELLING'S GENERALIZATION T-SQUARE, BIOKA 59 160

SAMPSON, P. F. AN APPLICATION OF STEPWISE REGRESSION TO NON-LINEAR ESTIMATION, TECH $6 B, 63$

SAMUEL. ESTER AN EMPIRICAL BAYES APPROACH TO THE TESTING OF CERTAIN PARAMETRIC HYPOTHESES, AMS 63,1370

SAMUEL. ESTER ASYMPTOTIC SOLUTIONS OF THE SEQUENTIAL COMPOUND DECISION PROBLEM, AMS 63, 1079

SAMUEL, ESTER COMPARISON OF SEQUENTIAL RULES FOR ESTIMATION OF THE SIZE OF A POPULATION. BIOCS 69,517

SAMUEL, ESTER CONVERGENCE OF THE LOSSES OF CERTAIN DECISION RULES FOR THE SEQUENT IAL COMPOUND DECISION PR, AMS 64, 1606

SAMUEL, ESTER ESTIMATORS WITH PRESCRIBED BOUND ON THE VARIANCE FOR THE PARAMETERS IN THE BINOMIAL AND POI, JASA 66, 220

SAMUEL, ESTER NOTE ON A SEQUENTIAL CLASSIFICATION PROBLEM, AMS 63, 1095

SAMUEL, ESTER NOTE ON ESTTMATING ORDERED PARAMETERS, AMS 65, 698

SAMUEL, ESTER ON SIMPLE RULES FOR THE COMPOUND DECISION PROBLEM JRSSB $65,23 B$

SAMUEL, ESTER SEQUENTIAL COMPOUND ESTIMATORS, AMS 65, 879

SAMUEL, ESTER SEQUENTIAL COMPOUND RULES FOR THE FINITE DECISION PROBLEM. JRSSB 66,63

SAMUEL, ESTER SEQUENTIAL MAXIMUM LIKELIHOOD ESTIMATION OF THE SIZE OF A POPULATION, AMS 68, 1057

SAMUELS. S. M. MONOTONE CONVERGENCE OF BINOMIAL PROBABILITIES AND A GENERALIZATION OF RAMANUJAN' S EQUATIO, AMS 68,1191

SAMUELS, S. M. ON A CHEBYSHEV-TYPE INEQUALITY FOR SUMS OF INDEPENDENT RANDOM VARIABLES, AMS 66,248

SAMUELS, S. M, RANDOMIZED RULES FOR THE TWO-ARMED BANDIT WITH FINITE MEMORY, AMS 68,2103

SAMUELS, S. M. THE MARKOV INEQUALITY FOR SUMS OF INDEPENDENT RANDOM VARIABLES, AMS 69 , NO.6

SAMUELS, STEPHEN M ON THE NUMBER OF SUCCESSES IN INDEPENDENT TRIALS, AMS 65, 1272

SAMUELSON. PAUL A. CONSTRUCTINC AN UNBIASED RANDOM SEQUENCE, JASA $6 \mathrm{~B}, 1526$

SAMUELSON, PAUL A . HOW DEVIANT CAN YOU BE. , JASA 68, 1522

SANDELIUS, M. A SIMPLE RANDOMIZATION PROCEDURE, JRSSB 62, 472

SANDELIUS, MARTIN A GRAPHICAL VERSION OF TUKEY'S CONFIDENCE INTERVAL FOR SLIPPAGE, TECH 68,193

SANDIFORD. PETER J. A NEW BINOMIAL APPROX IMATION FOR USE IN SAMPLING FROM FINITE POPULATIONS, JASA 60,718

SANDVED, ELSE ANCILLARY STATISTICS AND PREDICTION OF THE LOSS IN ESTIMATION PROBLEMS, AMS 68,1756

SANGHVI, L. D. DISTANCE BETWEEN POPULATIONS ON THE BASIS OF ATTRIBUTE DATA, BIOCS 68,859

SANKARAN, M. ON NAIR'S TRANSFORMATION OF THE CORRELATION COEFFICIENT, BIOKA 58,567
SANKARAN, M. ON THE NON-CENTRAL CHI-SQUARE DISTRIBUTION, BIOKA 59, 235

SANKARAN, MUNUSWAMY APPROXIMATIONS TO THE NON-CENTRAL CHI-SQUARE DISTRIBUTION, BIOKA 63, 199

SANKARAN, MUNUSWAMY ON AN ANALOGUE OF BHATTACHARYA BOUND, BIOKA 64 , 268

SANKARANARAYANAN, G. LIMIT DISTRIBUTION IN THE THEORY OF COUNTERS, CORR, 62 1466, AMS 61, 1271

SARANGI, J, ASYMPTOTIC EFFICIENCY OF CERTAIN RANK TESTS FOR COMPARATIVE EXPERIMENT, AMS 67,90

SARDANA, M. G. ON THE CONSTRUCTION AND ANALYSIS OF SOME CONFOUNDED ASYMMETRICAL FACTORIAL DESIGNS, BIOCS $65,94 \mathrm{~B}$

SARGAN, J. D. THE ESTIMATION OF RELATIONSHIPS WITH AUTOCORRELATED RESIDUALS BY THE USE OF INSTRUMENTAL VA , JRSSB 59, 91

SARHAN. A. E. CORRECTION TO AMS 56427 'ESTIMATION OF LOCATION AND SCALE PARAMETERS BY ORDER STATISTICS F. AMS 39, 325

SARHAN, A. E. ERRATA, 'MODIFIED SQUARE ROOT METHOD OF MATRIX INVERSION ', TECH 62, 622

SARHAN, A. E. ESTIMATION OF LOCATION AND SCALE PARAMETERS FOR THE RECTANGULAR POPULATION FROM CENSORED SA, JRSSB 59, 356

SARHAN, A. E. EVALUATION OF DETERMINANTS, CHARACTERISTIC EQUATIONS AND THEIR ROOTS FOR A CLASS OF PATTERN. JRSSB 60,348

SARHAN, A. E. MATRIX INVERSION, ITS INTEREST AND APPLICATION IN ANALYSIS OF DATA, JASA 59,755

SARHAN. A. E. MODIFIED SQUARE ROOT METHOD OF MATRIX INVERSION. TECH 62. $2 \mathrm{~B} 2$

SARHAN, A.E. ON INVERTING A CLASS OF PATTERNED MATRICES, BIOKA 56. 227

SARHAN, A, E. SIMPLIFIED ESTIMATES FOR THE EXPONENTIAL DISTRIBUTION, AMS 63, 102

SARHAN, A. E. TABLES FOR BEST LINEAR EST IMATES BY ORDER STATISTICS OF THE PARAMETERS OF SINGLE EXPONENTIA, JASA 57, 5B

SARKAR, A.R. SAMPLING TECHNIQUES FOR EST IMATION OF INCIDENCE OF RED SP IDER MITE ON TEA CROP IN NORTH-EAS, BIOCS 66, 3B5

SARNDAL, CARL ERIK ESTIMATION OF THE PARAMETERS OF THE GAMMA DISTRIBUTION BY SAMPLE QUANTILES, TECH 64,405

SARNDAL, CARL-ERIK A THEOREM ON RANK ORDERS FOR TWO CENSORED SAMPLES, AMS 65, 316

SARNDAL, CARL-ERIK A UNIF IED DERIVATION OF SOME NONPARAMETRIC DISTRIBUTIONS, JASA 64,1042

SARNDAL, CARL-ERIK DERIVATION OF A CLASS OF FREQUENCY DISTRIBUTIONS VIA BAYES 'S THEOREM, JRSSB 65,290

SARNDAL, CARL-ERIK THE USE OF A STRATIFICATION VARIABLE IN ESTIMATION BY PROPORTIONAL STRATIFIED SAMPLING, JASA 68,1310

SASSER, W. EARL A COMPUTER SIMULAT ION MODEL OF THE TEXT ILE INDUSTRY JASA 67, 133B

SASSER, W. EARL COMPUTER SIMULATION EXPERIMENTS WITH ECONOMIC SYSTEMS. THE PROBLEM OF EXPERIMENTAL DESIGN, JASA 67, 1315

SASTRY. A. N. BIOLOGICAL EXAMPLES OF SMALL EXPECTED FREQUENCIES BIOCS 65,49

SATHE, Y. S. APPROX IMATIONS TO THE DISTR IBUTIONS OF SOME MEASURES OF DISPERSION BASED ON SUCCESS IVE D IFFE, BIOKA 57,349

SATHE, Y S A ASYMPTOTIC POWER OF CERTAIN TEST CRITERIA, BASED ON FIRST AND SECOND DIFFERENCES, FOR SERIAL, AMS 62.186

SATHE, Y.S. MINIMUM VARIANCE UNBIASED ESTIMATION OF RELIABILITY FOR THE TRUNCATED EXPONENT IAL DISTRIBUTI I, TECH 69.609

SATHE, Y. S. ON MINIMUM VARIANCE UNBIASED ESTIMATION OF RELIABILITY, AMS 69,710

SATTERTHWAITE, F, E. QUERY, THE MEAN OF THE TAIL OF A DISTRIBUTION TECH 64,331

SATTERTHWAITE, F. E. RANDOM BALANCE EXPER IMENTATION, TECH 59, 111

SATYAMURTY, $P$. R. A NOTE ON THE QUEUE ING SYSTEM M-M-I WITH BALKING BIOKA 65,643

SAUNDERS, S. C. A STATISTICAL MODEL FOR LIFE-LENGTH OF MATERIALS JASA 5B, 151

SAUNDERS, S. C. MULTI-COMPONENT SYSTEMS AND STRUCTURES AND THEIR RELIABILITY, TECH 61,55

SAUNDERS, S. C. ON EVALUATION OF WARRANTY ASSURANCE WHEN LIFE HAS A WEIBULL DISTRIBUT ION, BIOKA 69, NO .3

SAUNDERS, SAM C, COMPARISON OF TWO METHODS OF OBTAINING APPROXIMATE CONFIDENCE INTERVALS FOR SYSTEM RELIA, TECH 68,37

SAUNDERS, SAM C. ON CONFIDENCE LIMITS FOR THE RELIABILITY OF SYSTEMS, AMS 68, 1463

SAUNDERS, SAM C. ON THE DETERMINATION OF A SAFE LIFE FOR CLASSES OF DISTRIBUT IONS CLASS IFIED BY FAILURE R, TECH 68,361

SAUNDERS, SAM C. ON THE SAMPLE SIZE AND COVERAGE FOR THE JIRINA SEQUENT IAL PROCEDURE, AMS 63,847

SAUNDERS, SAM C. SOME APPLICATIONS OF THE JIRINA SEQUENTIAL PROCEDURE TO OBSERVATIONS WITH TREND, AMS 63, B57

SAVACE, I $R$ A BRANCHING PROCESS WITHOUT REBRANCHING, AMS 69, 1 B50 SAVACE, I. R. FINE STRUCTURE OF THE ORDERING OF PROBABILITIES OF RANK ORDERS IN THE TWO SAMPLE CASE, AMS 66,98

SAVAGE, I. R. FINITE STOPPING TIME AND FINITE EXPECTED STOPPINC TIME, JRSSB 65,284

SAVAGE, I. R. PUBLICATIONS OF FRANK WILCOXON (1892-1965), BIOCS 67 SAVAGE, I. RICHARD A PRODUCTION MODEL AND CONT INUOUS SAMPLING PLAN. JASA 59.231 
SAVAGE. I. RICHARD NONPARAMETRIC STATISTICS. JASA 57,331

SAVAGE. I. RICHARD ON THE INDEPENDENCE OF TESTS OF RANDOMNESS AND OTHER HYPOTHESES, JASA 57,53

SAVAGE. I RICHARD STOPPING TIME OF A RANK-ORDER SEQUENTIAL PROBABILITY RATIO TEST ON LEHMANN ALTERNATIVE, AMS 66, 1154

SAVAGE. I RICHARD THE INFORMATION IN A RANK-ORDER AND THE STOPPING TIME OF SOME ASSOCI ATED SPRT'S. AMS 68,1661

SAVAGE, L. J. DISCUSSION OF 'ON THE FOUNDATIONS OF STATISTICAL INFERENCE' JASA 62,307

SAVAGE, L J. FINITE STOPPINC TIME AND FINITE EXPECTED STOPPINC TIME, JRSSB 65,284

SAW. J.G A CONSERVATIVE TEST FOR THE CONCURRENCE OF SEVERAL REGRESSION LINES AND RELATED PROBLEMS, BIOKA 66, 272

SAW, J,G. A NON-PARAMETRIC COMPARISON OF TWO SAMPLES ONE OF WHICH IS CENSORED, BIOKA 66,599

SAW. J. G. A NOTE ON THE ERROR AFTER A NUMBER OF TERMS OF THE DAVIDJOHNSON SERIES FOR THE EXPECTED VALUE. BIOKA 60.79

SAW. J. C. CORRIGENDA TO 'MOMENTS OF SAMPLE MOMENTS OF CENSORED SAM PLES FROM A NORMAL POPULATION' ', BIOKA 58, 587

SAW. J.G. EFFICIENT MOMENT EST IMATORS WHEN THE VARIABLES ARE DEPEN DENT WITH SPECIAL REFERENCE TO TYPE II , BIOKA 62, 155

SAW, J G ESTIMATION OF THE NORMAL POPULATION PARAMETERS GIVEN A TYPE I CENSORED SAMPLE, BIOKA 61, 367

SAW. J.G ESTIMATION OF THE NORMAL POPULATION PARAMETERS GIVEN A SINGLY CENSORED SAMPLE. BIOKA 59,150

SAW. J. C. LINEAR ESTIMATES OF A POPULATION SCALE PARAMETER, BIOKA 67,551

SAW, J.G. MOMENTS OF SAMPLE MOMENTS OF CENSORED SAMPLES FROM A NORMAL POPULATION, BIOKA 5B, 211

SAW, J. C. THE BIAS OF THE MAXIMUM LIKELIHOOD EST IMATES OF THE LOCATION AND SCALE PARAMETERS GIVEN A TYPE, BIOKA 61, 44B

SAW, J.G. THE CURVE THROUCH THE EXPECTED VALUES OF ORDERED VARIATES AND THE SUM OF SQUARES OF NORMAL SCO, BIOKA 66,252

SAW, JOHN G. SOME NOTES ON VARIANCE-RATIO TESTS OF THE GENERAL LINEAR HYPOTHESIS, BIOKA 64,508

SAWA. TAKAMITSU THE EXACT SAMPLINC DISTRIBUTION OF ORDINARY LEAST SQUARES AND TWO-STAGE LEAST SQUARES EST. JASA 69, 923

SAXENA. ASHOKK. A NOTE ON CLASSIFICATION, AMS 67, 1592

SAXENA, K. M LAL INTERVAL EST IMATION OF THE LARGEST MEAN OF K NORMAL POPULATIONS WITH KNOWN VARIANCES, JASA 69, 296

SAXENA, R. K. APPLICATION OF SPECIAL FUNCTIONS IN THE CHARACTERIZATION OF PROBABILITY DISTRIBUTIONS, SASJ 69, 27

SAXENA, R. K. DISTRIBUTION OF A PRODUCT AND THE STRUCTURAL SETUP OF DENSITIES, AMS 69, 1439

SAXENA, R. K. DISTRIBUT IONS OF RANDOM VARI ABLES WITH RANDOM PARAMETERS, SASJ 69 ,

SCEINBERG. E. THE SAMPLING VARIANCE OF THE CORRELATION COEFFICIENTS ESTIMATED IN GENET IC EXPERIMENTS, BIOCS 66, 1B7

SCHAAFSMA, W. A COMPARISON OF THE MOST STRINCENT AND THE MOST STRINGENT SOMEWHERE MOST POWERFUL TEST FOR, AMS 68, 531

SCHAAFSMA. W. MOST STRINCENT SOMEWHERE MOST POWERFUL TESTS AGAINST ALTERNATI VE RESTRICTED 8Y A NUMBER OF, AMS 66, 1161

SCHAAFSMA, WILLEM MINIMAX RISK AND UNBIASEDNESS FOR MULTIPLE DECISION PROBLEMS OF TYPE I. AMS 69, 1684

SCHACH. S. NONPARAMETRIC SYMMETRY TESTS FOR CIRCULAR DISTRIBUTIONS, 8IOKA 69, NO 3

SCHACH, SIEGFRIED ON A CLASS OF NONPARAMETRIC TWO-SAMPLE TESTS FOR CIRCULAR DISTRIBUTIONS, AMS 69, 1791

SCHACH, SIEGFRIED THE ASYMPTOTIC DISTRIBUTION OF SOME NON-LINEAR FUNCTIONS OF THE TWO-SAMPLE RANK VECTOR, AMS 69, 1011

SCHAEFFER, ESTHER COMPUTATION WITH MULTIPLE K-STATISTICS, JASA 63 120

SCHATZOFF, M EXACT DISTRI8UTIONS OF WILKS'S LIKELIHOOD RATIO CRITERION, 8IOKA 66, 347

SCHATZOFF, M. EXPECTED SIGNIFICANCE LEVEL AS A SENSITIVITY INDEX FOR TEST STATISTICS, JASA 65,420

SCHATZOFF, MARTIN APPLICATIONS OF TIME-SHARED COMPUTERS IN A STATISTICS CURRICULUM, JASA 68, 192

SCHATZOFF, MARTIN EFFICIENT CALCULATION OF ALL POSSIBLE REGRESSIONS, TECH 68,769

SCHATZOFF, MARTIN SENSITIVITY COMPARISONS AMONG TESTS OF THE GENERAL LINEAR HYPOTHESIS, JASA 66,415

SCHAUFELE, RONALD LIMIT THEOREMS FOR MARKOV RENEWAL PROCESSES, AMS 64,1746

SCHAUFELE, RONALD THE EXISTENCE AND UNIQUENESS OF STATIONARY MEASURES FOR MARKOV RENEWAL PROCESSES, AMS 66,1439

SCHAUFELE, RONALD A. A POTENTIAL THEORETIC PROOF OF A THEOREM OF DERMAN AND VEINOTT, AMS 67, 585

SCHEAFFER, RICHARD L. SAMPLING MIXTURES OF MULTI-SIZED PARTICLES, AN APPLICATION OF RENEWAL THEORY, TECH 69, 285

SCHEFFE, H. REPLY TO MR QUENOUILLE'S COMMENTS ABOUT MY PAPER ONMIXTURES, JRSSB 61, 171

SCHEFFE, HENRY A METHOD FOR JUDGINC ALL CONTRASTS IN THE ANALYSIS OF VARIANCE (CORR, 69 229) , CORR. 69 22, BIOKA 53,87

SCHEFFE, HENRY EXPERIMENTS WITH MIXTURES (CORR, 59 238), JRSS8 58 344

SCHEFFE, HENRY FITTING STRAIGHT LINES WHEN ONE VARIABLE IS CONTROLLED, JASA 58, 106
SCHEFFE, HENRY THE SIMPLEX-CENTROID DESICN FOR EXPERIMENTS WITH MIXTURES (WITH DISCUSSION), JRSSB 63, 235

SCHEINOK, $P$. ESTIMATION OF A COMPONENT OF A CONVOLUTION, WHEN THE OTHER COMPONENT IS OF EXPONENT IAL TYPE, TECH 64,222

SCHEINOK, PERRY A. ERRATA, 'ESTIMATION OF A COMPONENT OF A CONVOLUTION, WHEN THE OTHER COMPONENT IS OF EX, TECH 65,462

SCHEINOK, PERRYA. SPECTRAL ANALYSIS WITH RANDOMLY MISSED OBSERVATIONS, THE BINOMIAL CASE, AMS 65, 971

SCHEUER, E. M. CONF IDENCE SETS FOR MULT IVAR IATE MEDI ANS, AMS 61, 477

SCHEUER, E. M. ON THE GENERATION OF NORMAL RANDOM VECTORS, TECH 62 278

SCHEUER, E. M. STATISTICAL ESTIMATION PROCEDURES FOR THE 'BURN-IN' PROCESS, TECH $6 B, 51$

SCHEUER, ERNEST M. MOMENTS OF THE RADIAL ERROR, CORR. 65 1251, JASA 62,187

SCHEUER, ERNEST M. RELIABILITY CROWTH DURINC A DEVELOPMENT TEST ING PROCRAM, TECH 66,53

SCHEUER. ERNEST M. SOME PERCENTACE POINTS OF THE NON-CENTRAL T-DISTRIBUTION, CORR, 631163, JASA 63, 176

SCHILLING, E G PROCEDURES AND TABLES FOR EVALUATINC DEPENDENT MIXED ACCEPTANCE SAMPLINC PLANS, TECH 69,341

SCHLAIFER, ROBERT THE FOUNDATIONS OF DECISION UNDER UNCERTAINTY, AN ELEMENTARY EXPOSITION, JASA 64,353

SCHLEIFER JR, ARTHUR S. TWO-STACE NORMAL SAMPLING IN TWO-ACTION PROBLEMS WITH LINEAR ECONOMICS, JASA 69, NO 4

SCHMITT, ROBERT C. A METHOD OF ESTIMATING THE INTERCENSAL POPULATION OF COUNTIES, JASA 56,587

SCHMITZ, N. A NOTE ON HOEFFDING 'S INEQUALITY, JASA 69, 907

SCHNEIDER, B. A SCREENING SYSTEM FOR ANTI-CANCER ACENTS BASED ON THE THERAPEUT IC INDEX, BIOCS 65, 150

SCHNEIDERMAN, M. A A FAMILY OF CLOSED SEQUENTIAL PROCEDURES/CORR 69 457). BIOKA 62, 41

SCHNEIDERMAN, M. A. BOUNDARIES FOR CLOSED (WEDCE) SEQUENTIAL T TEST PLANS, BIOKA 66,431

SCHNEIDERMAN, M. A. CLOSED SEQUENTIAL T-TESTS, BIOKA 62, 359

SCHNORE, LEO F. THREE SOURCES OF DATA ON COMMUTINC, PROBLEMS AND POSSIBILITIES, JASA 60,8

SCHOEMAN, A COMPARISON OF THE SENSITIVITIES OF SIMILAR INDEPENDENT AND NON-INDEPENDENT EXPERIMENTS, BIOKA 69, 17

SCHUCANY, W. R. ON THE EVALUATION OF DISTRIBUTION FUNCTIONS, JASA $6 \mathrm{~B}, 715$

SCHULER, W. MULTISTAGE SAMPLINC PROCEDURES BASED ON PRIOR DISTRIBUTIONS AND COSTS, AMS 67, 464

CHULL. WILLIAM J. ON THE ROBUSTNESS OF THE T-SQUARE-SUB-O TEST IN MULT IVARIATE ANALYSIS OF VARIANCE WHEN, BIOKA 64, 71

SCHULZER, $M$. CONTRIBUTIONS TO THE K-SAMPLE PROBLEM, A SYMMETRIC STATISTIC, AMS 69, NO 6

SCHUMANN, D. E. W. COMPARISON OF THE SENSITIVITIES OF SIMILAR INDEPENDENT AND NON-INDEPENDENT EXPERIMENTS, BIOKA 69, 17

SCHUSTER, EUCENE F. ESTIMATION OF A PROBABILITY DENSITY FUNCTION AND ITS DERIVATIVES, AMS 69, 1187

SCHUTZ, W. M. THE EFFECT OF FIELD BLOCKING ON GAIN FROM SELECTION, BIOCS 66,843

SCHUTZENBERGER, M.P. ON A SPECIAL CLASS OF RECURRENT EVENTS, AMS 61,1201

SCHWARTZ, D. LES MANQUANTS DANS L'ESSAI THERAPEUTIQUE, BIOCS 67 ,

SCHWARTZ, GIDEON ASYMPTOTIC SHAPES OF BAYES SEQUENTIAL TESTING REGIONS. AMS 62, 224

SCHWARTZ, LORRAINE CONSISTENT ESTIMATES AND ZERO-ONE SETS, AMS 64. 157

SCHWARTZ, R. ADMISSI8LE BAYES CHARACTER OF T-SQUARED, R-SQUARED AND OTHER FULLY INVARIANT TESTS FOR CLASS, AMS 65, 747

CHWARTZ, RICHARD ADMISSI8LE TESTS IN MULTIVARIATE ANALYSIS OF VARIANCE, AMS 67, 698

SCHWARTZ, RICHARD E. INVARIANT PROPER BAYES TESTS FOR EXPONENTIAL FAMILIES, AMS 69,270

SCHWARTZ, RICHARD E. LOCALLY MINIMAX TESTS, AMS 67,340

SCHWARTZ, S. C. ON DOMINATING AN AVERAGE ASSOCIATED WITH DEPENDENT GAUSSIAN VECTORS, AMS 68,1844

SCHWARTZ, STUART C. ESTIMATION OF PROBABILITY DENSITY $8 Y$ AN ORTHOGONAL SERIES, AMS 67, 1261

SCHWARZ, GIDEON A SECOND-ORDER APPROXIMATION TO OPTIMAL SAMPLING REGIONS, AMS 69,313

SCHWARZ, GIDEON ASYMPTOTIC SHAPES FOR SEQUENTIAL TESTING OF TRUNCATION PARAMETERS, AMS 68,2038

SCLOVE, S. L. ESTIMATING THE PARAMETERS OF A CONVOLUTION, JRSSB 69 18

SCLOVE, STANLEY L. IMPROVED ESTIMATORS FOR COEFFICIENTS IN LINEAR REGRESSION, JASA 68, 596

SCOTT, A. A MULT I-STACE TEST FOR A NORMAL MEAN, JRSS8 68, 461

SCOTT, A. J. A NOTE ON AN ALLOCATION PROBLEM, JRSS8 69, 119

SCOTT, ALAST IR A NOTE ON CONSERVATIVE CONFIDENCE RECIONS FOR THE MEAN OF A MULT IVARI ATE NORMAL, AMS 67,278

SCOTT, ALASTAIR ESTIMATION IN MULTI-STAGE SURVEYS, JASA 69, 830

SCOTT, ELIZABETH L. ASYMPTOTICALLY OPTIMAL TESTS OF COMPOSITE HYPOTHESES FOR RANDOMIZED EXPERIMENTS WITH, JASA 65, 699

SCOTT, ELIZABETH L. FURTHER COMMENTS ON THE 'FINAL REPORT OF THE ADVISORY COMMITTEE ON WEATHER CONTROL', JASA 61,580 
SCOTT, ELIZABETH L. STATISTICAL APPROACH TO PROBLEMS OF COSMOLOCY (WITH DISCUSSION), JRSSB $5 B, I$

SCOTT, J. F. A NUMERICAL INVESTIGATION OF LEAST SQUARES REGRESSION INVOLV ING TREND-REDUCED MARKOFF SERIES, JRSSB 55, 105

SCOTTMAYNES, E. MINIMIZING RESPONSE ERRORS IN FINANCIAL DATA. THE POSSIBILITIES, JASA $6 B, 217$

SCULTHORPE, DIANE SOME PROBLEMS OF STATISTICAL PREDICTION, BIOKA 65,469

SEAL, H, L. STUDIES IN THE HISTORY OF PROBABILITY AND STATISTICS XV. THE HISTORICAL DEVELOPMENT OF THE C, BIOKA 67,

SEAL, K. C. A SINGLE SAMPLING PLAN FOR CORRELATED VARIABLES WITH A SINGLE-SIDED SPECIF ICATION LIMIT, JASA 59, 248

SEAL, K. C. ON RANKINC PARAMETERS OF SCALE IN TYPE III POPULATIONS, JASA 5B, 164

SEAL, K. E. SERIAL DESIGNS FOR ROUTINE QUALITY CONTROL AND EXPERIMENTATION, TECH 64,77

SEARLE, S. R A DISCONTINUITY IN MIXED MODEL ANALYSIS, BIOCS 69,573

SEARLE, S. R. A REMARK ON SOLVINC EQUATIONS IN SUMS OF POWERS, JRSSB $6 \mathrm{~B}, 567$

SEARLE, S. R. ADDITIONAL RESULTS CONCERNINC ESTIMABLE FUNCTIONS AND GENERALIZED INVERSE MATRICES, JRSSB 65,486

SEARLE, S. R. ANOTHER LOOK AT HENDERSON'S METHODS OF ESTIMATING VARIANCE COMPONENTS (WITH DISCUSSION), BIOCS 68,749

SEARLE, $S$. R. THE VALUE OF INDIRECT SELECTION, 1. MASS SELECTION BIOCS 65,682

SEARLE, S. R. VARIANCE COMPONENTS IN THE UNBALANCED TWO-WAY NESTED CLASSIFICATION, AMS 61,1161

SEARLS, DONALD T. AN ESTIMATOR FOR A POPULATION MEAN WHICH REDUCES THE EFFECT OF LARGE TRUE OBSERVATIONS, JASA 66,1200

SEARLS, DONALD T. ON THE PROBABILITY OF WINNING WITH DIFFERENT TOURNAMENT PROCEDURES, JASA 63, 1064

SEARLS, DONALD T. THE UTILIZATION OF A KNOWN COEFFICIENT OF VARIATION IN THE ESTIMATION PROCEDURE, JASA 64, 1225

SEBAUGH, JEANNE L. A GENERALIZATION OF THE LOGISTIC LAW OF CROWTH, BIOCS 69,577

SEBER, G. A. F. A NOTE ON THE MULTIPLE-RECAPTURE CENSUS. , BIOKA 65 249

SEBER, G. A. F. LINEAR HYPOTHESES AND INDUCED TESTS, BIOKA 64, 41

SEBER, G. A. F. ORTHOCONALITY IN ANALYSIS OF VARIANCE, AMS 64,705

SEBER, G. A. F. THE LINEAR HYPOTHESIS AND IDEMPOTENT MATRICES, JRSSB 64,261

SEBER, G. A. F. THE LINEAR HYPOTHESIS AND LARCE SAMPLE THEORY, AMS 64, 773

SEBER, G. A, F. THE MULTI-SAMPLE SINGLE RECAPTURE CENSUS, BIOKA 62 339

SEBER, G. A . F. THE NON-CENTRAL CHI-SQUARED AND BETA DISTRIBUTIONS, BIOKA 63, 542

SEDRANSK, J. A DOUBLE SAMPLING SCHEME FOR ANALYTICAL SURVEYS, JASA $65,9 B 5$

SEDRANSK, J. AN APPLICATION OF SEQUENTIAL SAMPLING TO ANALYTICAL SURVEYS, BIOKA $66, B 5$

SEDRANSK, J. ANALYTICAL SURVEYS WITH CLUSTER SAMPLING, JRSSB 65 264

SEDRANSK, J. DESICNING SOME MULTI-FACTOR ANALYTICAL STUDIES, JASA 67,1121

SEDRANSK, J. PLANNING SOME TWO-FACTOR COMPARATIVE SURVEYS, JASA 69,560

SEEGER, PAUL A NOTE ON A METHOD FOR THE ANALYSIS OF SIGNIFICANCE EN MASSE, TECH $68,5 B 6$

SEIDEN, ESTHER A NOTE ON CONSTRUCTION OF PARTIALLY BALANCED INCOMPLETE BLOCK DESIGNS WITH PARAMETERS V $=28$, AMS $66,17 \mathrm{~B} 3$

SEIDEN, ESTHER ON A CEOMETRICAL METHOD OF CONSTRUCTION OF PARTIALLY BALANCED DESIGNS WITH TWO ASSOCIATE C, AMS 61, 1177

SEIDEN, ESTHER ON NECESSARY CONDITIONS FOR THE EXISTENCE OF SOME SYMMETRICAL AND UNSYMMETRICAL TRI ANGULAR, AMS 63,34B

SEIDEN, ESTHER ON ORTHOGONAL ARRAYS, AMS 66, 1355

SEIGMUND, DAVID EXISTENCE OF OPTIMAL STOPPINC RULES FOR REWARDS RELATED TO S-SUB-N-OVER-N, AMS 6B, 1228

SELBY, B. GIRDLE DISTRIBUTIONS ON A SPHERE, BIOKA 64, 381

SELBY. B. THE INDEX OF DISPERSION AS A TEST STATISTIC . BIOKA 65, 627

SEN, A.R. SAMPLING TECHNIQUES FOR ESTIMATION OF INCIDENCE OF RED SPIDER MITE ON TEA CROP IN NORTH-EAST I, BIOCS 66, 3B5

SEN, P. K. A GENERALIZATION OF THE T-METHOD OF MULTIPLE COMPARISONS, JASA 69,290

SEN, P. K. A NOTE ON THE ASYMPTOTIC EFFICIENCY OF FRIEDMAN'S CHISQUARE-SUB-R-TEST, BIOKA 67, 677

SEN, P. K. ASYMPTOTICALLY EFFICIENT TESTS BY THE METHOD OF $N$ RANKINGS, JRSSB 68,312

SEN, P. K. ON A CLASS OF CONDITIONALLY DISTRIBUTION-FREE TESTS FOR INTERACT IONS IN FACTORI AL EXPERIMENTS, AMS 69, 658

SEN, $P$. K. ON SOME PROPERTIES OF THE ASYMPTOTIC VARIANCE OF THE SAMPLE QUANT ILES AND MID-RANGES, JRSSB 61, 453

SEN, P. K. PAIRED COMPARISONS FOR PAIRED CHARACTERISTICS, AMS 6B, 200

SEN, P. K. SOME ASPECTS OF THE STATISTICAL ANALYSIS OF THE 'MIXED MODEL', BIOCS 68,27

SEN, P. K. SOME FURTHER APPLICATIONS OF NON-PARAMETRIC METHODS IN DILUTION (-DIRECT) ASSAYS, BIOCS 65,799
SEN, PRANAB KUMAR ANALYSIS OF COVARIANCE BASED ON CENERAL RANK SCORES, AMS 69, 610

SEN, PRANAB KUMAR ASYMPTOTIC NORMALITY OF SAMPLE QUANTILES FOR MDEPENDENT PROCESSES, AMS 68, 1724

SEN. PRANAB KUMAR ASYMPTOTICALLY MOST POWERFUL RANK ORDER TESTS FOF CROUPED DATA, AMS 67, 1229

SEN, PRANAB KUMAR ESTIMATES OF THE RECRESSION COEFFICIENT BASED ON KENDALL'S TAU, JASA 68, 1379

SEN, PRANAB KUMAR NONPARAMETRIC CONFIDENCE REGIONS FOR SOME MULTIVARIATE LOCATION PROBLEMS, JASA 68, 1373

SEN, PRANAB KUMAR ON A CLASS OF RANK ORDER TESTS FOR THE PARALLELISM OF SEVERAL REGRESSION LINES, AMS $69,166 \mathrm{~B}$

SEN, PRANAB KUMAR ON A DISTRIBUTION-FREE METHOD OF ESTIMATINO ASYMPTOTIC EFFICIENCY OF A CLASS OF NONPARA, AMS 66, 1759

SEN. PRANAB KUMAR ON A FURTHER ROBUSTNESS PROPERTY OE THE TEST AND ESTIMATOR BASED ON WILCOXON'S SIGNED R, AMS $68,2 B 2$

SEN PRANAB KUMAR ON CHERNOFF-SAVACE TESTS FOR ORDERED ALTERNATIVES IN RANDOMIZED BLOCKS, AMS 68,967

SEN, PRANAB KUMAR ON ROBUST ESTIMATION IN INCOMPLETE BLOCK DESIGNS, AMS 67,1587

SEN, PRANAB KUMAR ON SOME OPTIMUM NONPARAMETRIC PROCEDURES IN TWOWAY LAYOUTS, JASA 67,1214

SEN, PRANAB KUMAR ON THE THEORY OF RANK ORDER TESTS FOR LOCATION IN THE MULTIVARIATE ONE SAMPLE PROBLEM. AMS 67, 1216

SEN, PRANAB KUMAR ROBUSTNESS OF SOME NONPARAMETRIC PROCEDURES IN LINEAR MODELS, AMS 68, 1913

SEN, PRANAB KUMAR SOME NON-PARAMETRIC TESTS FOR M-DEPENDENT TIME SERIES, JASA 65,134

SEN. PRANEA KUMAR ON SOME MULTISAMPLE PERMUTATION TESTS BASED ON A CLASS OF U-STATISTICS, JASA 67, 1201

SENETA, E. ON RECENT THEOREMS CONCERNING THE SUPERCRITICAL CALTONWATSON PROCESS, AMS 68, 209B

SENETA, E. QUASI-STATIONARY DISTRIBUTIONS AND TIME-REVERSION IN GENETICS (WITH DISCUSSION), JRSSB 66, 253

SENETA, E. THE STATIONARY DISTRIBUTION OF A BRANCHING PROCESS ALLOWING IMMIGRATION, A REMARK ON THE CRITI, JRSSB 6B, 176

SERFLING, R. J. APPROXIMATELY OPTIMAL STRATIFICATION, JASA 6B, $129 B$

SERFLING, R. J. CONTRIBUTIONS TO CENTRAL LIMIT THEORY FOR DEPENDENT VARIABLES, AMS 6B, $115 B$

SERFLING, R, J. THE WILCOXON TWO-SAMPLE STATISTIC ON STRONGLY MIXING PROCESSES, AMS 6B, 1202

SESHADRI, V. A CHARACTERISTIC PROPERTY OF THE MULTIVARIATE NORMAL DISTRIBUTION, AMS 66,1 B29

SESHADRI, $V$. CHARACTERIZATION THEOREMS FOR SOME UNIVARIATE PROBABILITY DISTRIBUTIONS, JRSSB $64,2 B 6$

SESHADRI, V. COMPARISON OF COMBINED ESTIMATORS IN BALANCED INCOMPLETE BLOCKS, AMS 66, 1832

SESHADRI, VANAMAMALAI CONSTRUCTING UNIFORMLY BETTER ESTIMATORS, JASA 63,172

SETH, ASHÁ THE CORRELATED UNRESTRICTED RANDOM WALK, JRSSB 63, 394

SETHI, $V . K$. RANDOMIZED ROUNDED-OFF MULTIPLIERS IN SAMPLING THEORY, JASA 61, 328

SETHI, V. K. STRATIFICATION, A PRACTICAL INVESTICATION, JASA 66, 74 SETHURAMAN, J. ON THE PROBABILITY OF LARGE DEVIATIONS OF FAMILIES OF SAMPLE MEANS, AMS 64,1304

SETHURAMAN, J, ON THE PROBABILITY OF LARGE DEVIATIONS OF THE MEAN FOR RANDOM VARIABLES IN AN INTERVAL OF, AMS $65,2 B 0$

SETHURAMAN, J. STOPPING TIME OF A RANK-ORDER SEQUENTIAL PROBABILITY RATIO TEST ON LEHMANN ALTERNATIVES, C, AMS 66,1154

SEVERO, N. C. MEASUREMENTS MADE BY MATCHING WITH KNOWN STANDARDS, TECH 59, 101

SEVERO, N. C. NORMAL APPROXIMATION TO THE CHI-SQUARE AND NON-CENTRAL F PROBABILITY FUNCTIONS, BIOKA 60,411

SEVERO, N. C. THE PROBABILITIES OF SOME EPIDEMIC MODELS, BIOKA 69 197

SEVERO, N. C. THE SIMPLE STOCHASTIC EPIDEMIC FOR SMALL POPULATIONS WITH ONE OR MORE INITIAL INFECTIVES, BIOKA 69, 183

SEVERO, NORMAN C. DISTRIBUTION OF TOTAL SERVICE TIME FOR A FIXED OBSERVATION INTERVAL, JASA 62.376

SHAH, B. DISTRIBUTION OF DEFINITE AND OF INDEF INITE QUADRAT IC FORMS FROM A NON-CENTRAL NORMAL DISTRIBUTIO, AMS 63, 1B6

SHAH, B. NOTE. A METHOD OF FITTINC A NON-LINEAR CURVE CONTAINING A SINGLE NON-LINEARITY, BIOCS 65,506

SHAH, B. K. A METHOD OF FITTING THE RECRESSION CURVE E $(Y)=A+D X+B C-$ TO-X, TECH 65,59

SHAH, B. K. A NOTE ON CRAIC'S PAPER ON THE MINIMUM OF BINOMIAL VARIATES, BIOKA 66,614

SHAH, B. K. BEST LINEAR UNBIASED EST IMATORS OF THE PARAMETERS OF THE LOGISTIC DISTRIBUTION USING ORDER ST, TECH 67,43

SHAH, B. K. DISTRIBUTION OF A DEFINITE QUADRATIC FORM FOR NON-CENTRAL NORMAL VARI ATES, CORR. 63 673, AMS 61, 883

SHAH, B. K. ON THE BIVARIATE MOMENTS OF ORDER STATISTICS FROM A LOGISTIC DISTRIBUTION, AMS 66, 1002

SHAH, BHUPENDRA K. EXACT MOMENTS AND PERCENTAGE POINTS OF THE ORDER STATISTICS AND THEDISTRIBUTION OF TH, AMS 65, 907

SHAH $K, R$, UNIFORMLY BETTER COMBINED ESTIMATORS IN FACTORIAL ARRANGEMENTS WITH CONFOUNDINC, JASA 67, 638 
SHAH, K. R. USE OF INTER-BLOCK INFORMATION TO OBTAIN UNIFORMLY BETTER ESTIMATORS, AMS 64, 1064

SHAH, S. M. A NOTE ON CRIFFIN'S PAPER 'GRAPHIC COMPUTATION OF TAU AS A COEFFIC IENT OF DISARRAY', JASA 61,736

SHAH, S. M. AN UPPER BOUND FOR THE NUMBER OF DISJOINT BLOCKS IN CERTA IN PART IALLY BALANCED INCOMPLETE BLO, AMS 64, 398

SHAH, S. M. BOUNDS FOR THE NUMBER OF COMMON TREATMENTS BETWEEN ANY TWO BLOCKS OF CERTAIN PART IALLY BALANC, AMS 65,337

SHAH, S. M. ON ESTIMATING THE PARAMETER OF A DOUBLY TRUNCATED BINOMIAL DISTRIBUTION, JASA 66, 259

SHAH, S. M. ON THE BLOCK STRUCTURES OF CERTAIN PARTIALLY BALANCED INCOMPLETE BLOCK DESIGNS, CORR. 67 624, AMS 66, 1016

SHAH, S. M. THE ASYMPTOTIC VARIANCES OF METHOD OF MOMENTS EST IMATES OF THE PARAMETERS OF THE TRUNCATED BI, JASA 61,990

SHAKKUN, MELVIN F . MULTIVARIATE ACCEPTANCE SAMPL ING PROCEDURES FOR GENERAL SPECIFICATION ELLIPSOIDS, JASA 65, 905

SHAMAN, P. ON THE INVERSE OF THE COVARIANCE MATRIX OF A FIRST ORDER MOVING AVERACE, BIOKA 69, NO. 3

SHAMAN, PAUL SAMPLING RATES AND APPEARANCE OF STATIONARY GAUSSIAN PROCESSES, TECH 66, 91

SHANBHAG, D. N. A NOTE ON QUEUEINC SYSTEMS WITH ERLANCIAN SERVICE TIME DISTRIBUTIONS, AMS 65, 1574

SHANBHAG, D. N. ON A CENERALIZED QUEUEING SYSTEM WITH POISSON ARRIVALS, JRSSB 66,456

SHANBHAG, D. N. ON THE INDEPENDENCE OF QUADRATIC FORMS, JRSSB 66. 582

SHANBHAC, D. N. SOME REMARKS CONCERNINC KHATRI'S RESULT ON QUADRATIC FORMS, BIOKA 68, 593

SHANE, HAROLD D. RANK ORDER TESTS FOR MULTIVARIATE PAIRED COMPARISONS, AMS 69, NO.6

SHAPIRO, S. S. A COMPARATIVE STUDY OF VARIOUS TESTS FOR NORMALITY, JASA 68,1343

SHAPIRO, S. S. AN ANALYSIS OF VARIANCE TEST FOR NORMALITY (COMPLETE SAMPLES), BIOKA 65, 591

SHAPIRO, S. S. APPROXIMATIONS FOR THE NULL DISTRIBUTION OF THE WSTATISTIC+(TEST FOR NORMALITY), TECH 68,861

SHAPIRO, S. S. THE JOINT ASSESSMENT OF NORMALITY OF SEVERAL INDEPENDENT SAMPLES, TECH 68,825

SHARMA, D POWER OF TUKEY'S TEST FOR NON-ADDITIVITY, JRSSB 63, 213

SHARMA, DIVAKAR ON THE INTERPRETATION OF ACE DISTRIBUTIONS, JASA 67,862

SHARPE, MICHAEL SAMPLE PATH VARIATIONS OF HOMOGENEOUS PROCESSES AMS 69, 399

SHARPE, MICHAEL J. ZEROES OF INFINITELY DIVISIBLE DENSITIES, AMS 69,1503

SHENTON L R CORRIGENDA, MOMENT ESTIMATORS AND MAXIMUM LIKELIHOOD. ', BIOKA 59, 502

SHENTON, L. R. CORRICENDA, 'MOMENT ESTIMATORS AND MAXIMUM LIKELIHOOD', 8IOKA 6I, 474

SHENTON $L$ DISTRIBUTIONS ASSOCI ATED WITH RANDOM WALK AND RECURRENTS EVENTS (WITH DISCUSSION), JRSSB 57,64

SHENTON, L. R. EFFICIENCY OF THE METHOD OF MOMENTS AND THE CRAMCHARLIER TYPE A DISTRIBUTION, 8IOKA 51,58

SHENTON, L. R. HICHER MOMENTS OF A MAXIMUM-LIKELIHOOD ESTIMATE, JRSSB 63, 305

SHENTON, $L . R$. INEQUALITIES FOR THE NORMAL INTEGRAL INCLUDING A NEW CONTINUED FRACTION, 8IOKA 54, 177

SHENTON, L. R. MOMENT ESTIMATORS AND MAXIMUM LIKELIHOOD, BIOKA 58 411

SHENTON, L. R. MOMENTS OF A SERIAL CORRELATION COEFFICIENT, JRSSB 65,308

SHENTON, L. R. REMARKS ON LARCE SAMPLE ESTIMATORS FOR SOME DISCRETE DISTRIBUTIONS, TECH 67,587

SHENTON, L. R. THE BIAS OF MOMENT ESTIMATORS WITH AN APPLICATION TO THE NECAT IVE BINOMI AL DISTRIBUT ION, BIOKA 62, 193

SHENTON, L. R. THE DISTRI8UTION OF MOMENT EST IMATORS, BIOKA 59, 296 SHENTON, L. R. THE EFFICIENCY OF AUTOMATIC WINDING MACHINES WITH CONSTANT PATROLLING TIME, JRSSB 59, 381

SHENTON, L. R. THE MILLS RATIO AND THE PROBABILITY INTEGRAL FOR A PEARSON TYPE IVDISTRIBUTION. 8IOKA 65, 119

SHEPP, L. A. A FIRST PASSAGE PRO8LEM FOR THE WIENER PROCESS, AMS 67 1912

SHEPP, L A A LIMIT LAW CONCERNINC MOVING AVERAGES, AMS 64, 424

SHEPP, L. A. A LOCAL LIMIT THEOREM. AMS 64,419

SHEPP, L. A. DISTINCUISHING A SEQUENCE OF RANDOM VARIABLES FROM A TRANSLATE ITSELF, AMS 65,1107

SHEPP, L. A EXPLICIT SOLUTIONS TO SOME PROBLEMS OF OPTIMAL STOPPING, AMS 69, 993

SHEPP, L. A. RADON-NIKODYM DERIVATIVES OF GAUSSIAN MEASURES, AMS 66,321

SHEPS, M. C. GHARAGTERISTIGS OF A RATIO USED TO ESTIMATE FAILURE RATES, OGGURRENCES PER PERSON YEAR OF EX, 8IOGS 66, 310

SHEPS, MINDEL C. MAMMALIAN REPRODUGTIVE DATA FITTED TO A MATHEMAT ICAL MODEL, 8IOGS 69.529

SHERMAN, 8. ESTIMATION OF PARAMETERS IN A TRANSIENT MARKOV GHAIN ARIS ING IN A RELIABILITY GROWTH MODEL, AMS 69, 1542

SHERMAN, ELLEN A NOTE ON MULTIPLE GOMPARISONS USING RANK SUMS, TEGH 65,255
SHERMAN, ROBERT E. DESICN AND EVALUATION OF A REPETITIVE CROUP SAMPLINC PLAN, TECH 65, 11

SHERMAN, SEYMOUR ON QUEUES IN TANDEM, AMS 63, 300

SHETH, JAGDISH N. USINC FACTOR ANALYSIS TO ESTIMATE PARAMETERS, JASA 69, BO8

SHEYNIN, $0 . B$. STUDIES IN THE HISTORY OF PROBABIL ITY AND ST ATISTICS. XXI . ON THE EARLY HISTORY OF THE LAW, BIOKA $6 B, 459$

SHIKATA, M. A CENERALIZATION OF THE INBREEDING COEFFICIENT, BIOCS 65,665

SHIMI, I, N. A BRANCHING PROCESS WITHOUT REBRANCHING, AMS 69, IB50

SHINOZUKA, MASANOBU DEVELOPMENT OF RANDOMIZED LOAD SEQUENCES WITH TRANSIT ION PROBABILITIES BASED ON A MAR, TECH 66, 107

SHISHIDO, SHUNTARO PROBLEMS IN THE INTERNATIONAL STANDARDIZATION OF INTER-INDUSTRY TABLES, CORR. 641299 , JASA 64, 256

SHISKIN, JULIUS SEASONAL ADJUSTMENTS BY ELECTRONIC COMPUTER METHODS, JASA 57,415

SHLOM, E. TESTINC FOR LINEAR CONTACION, INVERSE SAMPLING, JRSSB 69 NO.2

SHORACK, G. R. GRAPHICAL PROCEDURES FOR USINC DISTRIBUTION-FREE METHODS IN THE ESTIMATION OF RELATIVE POT, BIOCS 66,610

SHORACK, CALENR. A NOTE ON CHERNOFF-SAVAGE THEOREMS, AMS 69, 1116

SHORACK, GALEN R, ASYMPTOTIC NORMALITY OF LINEAR COMBINATIONS OF FUNCTIONS OF ORDER STATISTICS, AMS 69 , NO, 6

SHORACK, CALEN R. TESTINC ACAINST ORDERED ALTERNATIVES IN MODEL I ANALYSIS OF VARIANCE, NORMAL THEORY AND, AMS 67, 1740

SHORACK, GALEN R. TESTINC AND ESTIMATING OF SCALE PAREMENTERS, JASA 69. 999

SHORACK, GALEN R. WEAK CONVERGENCE AND A CHERNOFF-SAVAGE THEOREM FOR RANDOM SAMPLE SIZES, AMS 68, 1675

SHORACK, GALEN $R$. WEAK CONVERCENCE OF A TWO-SAMPLE EMPIRICAL PROCESS AND A NEW APPROACH TO CHERNOFF-SAVAC, AMS 68,755

SHORACK, ROCER A. ON THE POWER OF PRECEDENCE LIFE TESTS, TECH 67, 154

SHORACK, ROGER A. RECURSIVE GENERATION OF THE DISTRIBUTION OF SEVERAL NON-PARAMETRIC TEST STATISTICS UNDE, JASA 6B, 353

SHORACK, ROGER A RECURSIVE CENERATION OF THE DISTRIBUTION OF THE MANN-WHITNEY U-STAT ISTICS UNDER LEHMANN, AMS 66, 284

SHORACK, ROGER A. TABLES OF THE DISTRIBUTION OF THE MANN-WHITNEYWILCOXON U-STAT ISTIC UNDER LEHMANN ALTER, TECH 67.666

SHORROCK, $R$ ON CERTAIN PROPERTIES OF THE EXPONENT-AL-TYPE FAMILIES, JRSSB 65,94

SHORTLEY. G. A STOCHASTIC MODEL FOR DISTRIBUTIONS OF BIOLOGICAL RESPONCE TIMES, BIOCS 65,562

SHRTKHANDE, $S, S$. ON A CLASS OF PARTIALLY BALANCED INCOMPLETE BLOCK DESIGNS, AMS 65, 1807

SHRIVASTAVA, J, N. ON A GENERAL CLASS OF DESIGNS FOR MULT IRESPONSE EXPERTMENTS, AMS 68, 1B25

SHUBERT. BRUNO O. BAYESIAN MODEL OF DECISION-MAKINC AS A RESULT OF LEARNING FROM EXPERIENCE, AMS 69, NO.6

SHUBIK, MARTIN 8I8L IOGRAPHY ON SIMULATION, GAMING, ARTIFICIAL INTELLILENCE AND ALLIED TOPICS, JASA 60,736

SHUMWAY, ROBERT H. BEST LINEAR UNBIASED ESTIMATION FOR MULTIVARIATE STATIONARY PROCESSES, TECH 68, 523

SHUSTER. JONATHAN ON THE INVERSE CAUSSIAN DISTRIBUTION FUNCTION JASA 68,1514

SICHEL, H S A CHART FOR SEQUENTIALLY TEST ING OBSERVED ARITHMETIC MEANS FROM LOGNORMAL POPULAT IONS AGA IN, TECH 68,605

SICHEL, H. S. NEW TECHNIQUES FOR THE ANALYSIS OF ABSENTEEISM DATA 8IOKA 54.77

STDAK, ZBYNEK ON MULTIVARIATE NORMAL PROBABILITIES OF RECTANGLES AMS 68,1425

SIDAK, ZBYNEK RECTANCULAR CONFIDENCE REGIONS FOR THE MEANS OF MUL TIVARIATE NORMAL DISTRIBUTIONS, JASA 67,626

SIDDIOUI. M. M. A COMBINATORIAL TEST FOR INDEPENDENCE OF DICHOTOMOUS RESPONSES. JASA 65, 437

SIDDIQUI, M.M. A BIVARIATE T DISTRI8UTION, CORR. 67 15Y4, AMS 67 162

SIDDIQUI, M M APPROXIMATIONS TO THE DISTRIBUTION OF QUADRATIC FORMS, AMS 65, 67'

SIDDIQUI M.M APPROXIMATIONS TO THE MOMENTS OF THE SAMPLE MEDIAN AMS 62,157

SIDDIQUI, M M. ASYMPTOTIC JOINT DISTRIBUTION OF LINEAR SYSTEMATIC STATISTICS FROM MULTIVARI ATE D ISTRIBUT, JASA 69,300

SIDDIQUI, M M. ASYMPTOTICALLY ROBUST ESTIMATORS OF LOCATION. JASA 67,950

STDDIQUI M GAMES ASSOCIATED WITH A RENEWAL PROCESS, AMS 62, 697

SIDDIQUI. M.M. OPT IMUM EST IMATORS OF THE PARAMETERS OF NEGAT I VE EXPONENTIAL DISTRIBUTIONS FROM ONE OR TW, AMS 63, 117

SIDDIQUI, M M RO8UST ESTIMATION OF LOCATION, JASA 67, 353

SIDDIQUI, M. M. SOME CRITERIA FOR ACING, JASA 69. NO.4

SIEGEL, P. 8. A PRO8A8ILITY STRUCTURE FOR GROWTH CURVES, BIOCS 67 217

SIEGEL, SIDNEY A NONPARAMETRIG SUM OF RANKS PROGEDURE FOR RELATIVE SPREAD IN UNPAIRED SAMPLES, CORR. 61 1, JASA 60,429

SIEGMUND, D. ON THE ASYMPTOTIG NORMALITY OF ONE-SIDED STOPPING RULES, AMS 68, 1493

SIEGMUND, D O SOME FIRST PASSAGE PRO8LEMS FOR S-SUB-N-OVER-ROOTN. AMS 69,648 
SIEGMUND, DAVID ON A STOPPING RULE AND THE CENTRAL LIMIT THEOREM. AMS 67,1915

SIEGMUND, DAVID ON MOMENTS OF THE MAXIMUM OF NORMED PART IAL SUMS, AMS 69,527

SIEGMUND, DAVID THE VARIANCE OF THE ONE-SIDED STOPPINC RULES, AMS 69. 1074

SIEGMUND, DAVID OLIVER SOME ONE-SIDED STOPPING RULES, AMS 67, 1641

SIEGMUND, DAVID OLIVER SOME PROBLEMS IN THE THEORY OF OPTIMAL STOPPING RULES, AMS 67,1627

SIEVERS, GERALD L. ON THE PROBABILITY OF LARGE DEVIATIONS AND EXACT SLOPES, AMS 69 , NO.6

SILLITTO, C. P. AN EXTENSION PROPERTY OF A CLASS OF BALANCED INCOMPLETE BLOCK DESICNS, BIOKA 57,278

SILLITTO, G. P. DERIVATION OF APPROXIMANTS TO THE INVERSE DISTRIBUTION FUNCTION OF A CONT INUOUS UNIVARIAT, BIOKA 69 , NO 3

SILLITTO, G. P. INTERRELATIONS BETWEEN CERTAIN LINEAR SYSTEMATIC STATISTICS OF SAMPLES FROM ANY CONT INUOU, BIOKA 51, 377

SILLITTO, G. P. SOME RELATIONS BETWEEN EXPECTATIONS OF ORDER STATISTICS IN SAMPLES OF DIFFERENT SIZES, BIOKA 64, 259

SILVERSTONE, H. ESTIMATING THE LOGIST IC CURVE. JASA 57, 567

SILVEY, S. D. A FURTHER RESULT ON THE RELEVANCE OF THE DISPERSION OF

A RADON-NIKODYM DERIVATIVE TO THE PR, JRSSB $65,10 B$

SILVEY. S. D. A GENERAL CLASS OF COEFFICIENTS OF DIVERGENCE OF ONE

DISTRIBUTION FROM ANOTHER, JRSSB 66, 131

SILVEY, S. D. A NOTE ON MAXIMUM-LIKELIHOOD IN THE CASE OF DEPENDENT RANDOM VARIABLES. JRSSB 61,444

SILVEY. S. D. ASSOCIATION BETWEEN RANDOM VARIABLES AND THE DISPERSION OF A RADON-NIKODYM DERIVATIVE , CORR, JRSSB 65, 100

SILVEY, S. D. MAXIMUM-LIKELIHOOD ESTIMATION PROCEDURES AND ASSOCIATED TESTS OF SIGNIFICANCE, JRSSB 60,154

SILVEY, S. D. ON A MEASURE OF ASSOCIATION, AMS 64, 115'

SILVEY, S. D. ON TESTING MORE THAN ONE HYPOTHESIS, AMS 63,555

SILVEY. S. D. OPTIMAL DESIGNS IN REGRESSION PROBLEMS WITH A GENERAL GONVEX LOSS FUNCTION. BIOKA 6 B. 53

SILVEY, S. D. THE GENERALIZATION OF PROBIT ANALYSIS TO THE CASE OF MULTIPLE RESPONSES, BIOKA 57,13

SILVEY, S. D. THE LINDISFARNE SCRIBES ' PROBLEM, JRSSB 5B, 93

SIMMONS, WALT R. THE UNRELATED QUESTION RANDOMIZED RESPONSE MODEL

THEORETICAL FRAMEWORK, JASA 69,520

SIMON, H. A. ON A CLASS OF SKEW DISTRIBUTION FUNCTIONS, BIOKA 55, 425

SIMON, LESLIEE. SAMUEL S. WILKS, JASA 65,939

SIMONS, G. A SEQUENTIAL ANALOGUE OF THE BEHRENS-FISHER PROBLEM, AMS 67,1384

SIMONS, CORDON A CLASS OF SEQUENTIAL PROCEDURES FOR CHOOSING ONE OF K HYPOTHESES CONCERNINC THE UNKNOWN D, AMS 67, 1376

SIMONS, GORDON A SEQUENTIAL THREE HYPOTHESIS TEST FOR DETERMININC THE MEAN OF A NORMAL POPULATION WITH KN, AMS 67,1365

SIMONS, GORDON EXISTENCE OF OPTIMAL STOPPING RULES FOR REWARDS RELATED TO S-SUB-N-OVER-N, AMS 6B, 1228

SIMONS, CORDON LOWER BOUNDS FOR AVERAGE SAMPLE NUMBER OF SEQUENTIAL MULTIHYPOTHESIS TESTS, AMS 67, 1343

SIMONS, CORDON ON THE COST OF NOT KNOWING THE VARIANCE WHEN MAKINC A FIXED WIDTH CONF IDENCE INTERVAL FOR, AMS 6B, 1946

SIMPSON, J. A. TABLE OF THE BOUNDS OF THE PROBABILITY INTEGRAL WHEN THE FIRST FOUR MOMENTS ARE GIVEN, BIOKA 60,399

SIMPSON, PAUL B. APPROACHES TO NATIONAL OUTPUT MEASUREMENT, JASA 58,948

SINGH, B. D. DOUBLE SAMPLINC FOR STRAT IF ICATION ON SUCCESSIVE OCCASIONS, JASA 65,784

SINGH, B. D. SOME REMARKS ON DOUBLE SAMPLING FOR STRATIFICATION BIOKA 65,587

SINCH, G. ON THE EXTREME VALUES AND RANGE OF SAMPLES FROM NON-NORMAL POPULATIONS, BIOKA 67,541

SINCH, D. DOUBLE SAMPLING FOR STRATIFICATION ON SUCCESSIVE OCCASIONS, JASA 65,784

SINCH, D. ESTIMATES IN SUCCESSIVE SAMPLINC USING A MULTI-STAGE DESICN, JASA 68,99

SINGH，D. ON MODIFIED SYSTEMATIC SAMPLING, BIOKA 68,541

SINGH, D. SOME REMARKS ON DOUBLE SAMPLING FOR STRATIFICATION BIOKA 65,587

SINGH, H. R. PRODUCER AND CONSUMER RISKS FOR ASYMMETRICAL TESTS AND SPECIFICATION LIMITS, JASA 66, 505

SINGH, H. R. PRODUCER AND CONSUMER RISKS IN NON-NORMAL POPULATION TECH 66,335

SINGH, JAGBIR A TREATMENT OF TIES IN PAIRED COMPARISONS, AMS 6B, 2002

SINGH, M. P. THE RELATIVE EFFICIENCY OF SOME TWO-PHASE SAMPLING SCHEMES, AMS 67,937

SINGH, NAUNIHAL EST IMATION OF PARAMETERS OF A MULTIVARIATE NORMAL POPULATION FROM TRUNCA TED AND CENSORED, JRSSB 60,307

SINGH, RAJINDER EXISTENCE OF BOUNDED LENGTH CONFIDENCE INTERVALS, AMS 63,1474

SINCH, RAJINDER UNBIASED ESTIMATION OF LOCATION AND SCALE PARAMETERS, AMS 66,1671

SINCH, S. N. A CHANCE MECHANISM OF THE VARIATION IN THE NUMBER OF BIRTHS PER COUPLE, JASA 6B, 209

SINCH, S. N. PROBABILITY MODELS FOR THE VARIATION IN THE NUMBER OF BIRTHS PER COUPLE, JASA 63, 721
SINKHORN, RICHARD A RELATIONSHIP BETWEEN ARBITRARY POSITIVE MATRICES AND DOUBLY STOCHASTIC MATRICES, AMS 64, 876

SIOTANI, MINORU INTERVAL ESTIMATION FOR LINEAR COMBINATIONS OF MEANS, JASA 64, 1141

SIRKEN, MONROE G. RESIDENCE HISTORIES AND EXPOSURE RESIDENCES FOR THE UNITED STATES POPULATION, JASA 61, 824

SISKIND, $V$. A SOLUTION OF THE CENERAL STOCHASTIC EPIDEMIC, , BIOKA 65,613

SISKIND, V. MULTIVARIATE STOCHAST IC PROCESSES WITH PERIODIC COEFFICIENTS, JRSSB 69, 171

SISKIND, V. ON CERTAIN SUGGESTED FORMULAE APPLIED TO THE SEQUENT IAL T-TEST, BIOKA 64,97

SISKIND, V. ON USINC AN INCORRECT VALUE OF SIGMA-SQUARE-SUB-BOVER-SIGMA-SQUARE IN BALANCED INGOMPLETE BL, BIOKA 68, 254

SIVAMURTHY, M. ERRORS IN THE ESTIMATION OF NET MIGRATION IN THE STUDIES OF INTERNAL MICRATION, JASA 69 , NO 4

SKELLAM, J. G. DISTRIBUT IONS ASSOCI ATED WITH RANDOM WALK AND RECURRENT EVENTS (WITH DISCUSSION), JRSSB 57, 64

SKELLAM, J.G. MODELS, INFERENCE, AND STRATEGY, BIOCS 69,457

SKELLAM, J. G. ON THE DERIVATION AND APPLICABILITY OF NEYMAN'S TYPE A DISTRIBUTION, BIOKA 5B, 32

SKELLAM, J.G. RANDOM DISPERSAL IN THEORETICAL POPULATIONS, BIOKA 51.196

SKELLAM, J. G. STUDIES IN STATIST ICAL ECOLOCY. I. SPAT IAL PATTERN, BIOKA 52,346

SKIBINSKY, M. ON THE INADMISSIBILITY OF SOME STANDARD ESTIMATES IN THE PRESENCE OF PRIOR INFORMATION, AMS 63, 539

SKIBINSKY, MORRIS ADEQUATE SUBFIELDS AND SUFFICIENCY, AMS 67, 155

SKIBINSKY, MORRIS MINIMAX ESTIMATION OF A RANDOM PROBABILITY WHOSE FIRST N MOMENTS ARE KNOWN, AMS 68, 492

SKIBINSKY. MORRIS SOME STRIKING PROPERTIES OF BINOMI AL AND BETA MOMENTS, AMS 69, 1753

SLAKTER, $M$. J. COMPARATIVE VALIDITY OF THE CHI-SQUARE AND TWO MODIFIED CHI-SQUARE GOODNESS-OF-FIT TESTS F , BIOKA 66, 619

SLAKTER, MALCOLM J. A GOMPARISON OF THE PEARSON CHI-SQUARE AND KOLMOG OROV COODNESS-OF-FIT TESTS WITH RESP, JASA 65, 854

SLAKTER, MALCOLM J. ACCURACY OF AN APPROXIMATION TO THE POWER OF THE CHI-SQUARE GOODNESS OF FIT TEST WITH, JASA 6B, 912

SLATER, P. INCONSISTENCIES IN A SCHEDULE OF PAIRED COMPARISONS, BIOKA 61, 303

SLEPLAN, D. FIRST PASSACE TIME FOR A PARTICULAR GAUSSIAN PROCESS, AMS 61,610

SLONIM, MORRIS JAMES A METHOD OF ADJUSTMENT FOR DEFECTIVEDATA, JASA $5 B, 736$

SLONIM, MORRIS JAMES SAMPLING IN A NUTSHELL, JASA 57, 143

SLONIM, MORRIS JAMES THE TRENTILE DEVIATION METHOD OF WEATHER FORECAST EVALUATION, JASA 58, 398

SMALL, V. J. A NUMERICAL INVESTICATION OF LEAST SQUARES REGRESSION INVOLVINC TREND-REDUCED MARKOFF SERIES, JRSSB 55, 105

SMID, L. J . MOST STRINGENT SOMEWHERE MOST POWERFUL TESTS AGA INST ALTERNATIVE RESTRIGTED BY A NUMBER OF LI, AMS 66, 1161

SMILEY, M. F. THE SPECTRAL THEOREM FOR FINITE MATRIGES AND COCHRAN'S THEOREM, AMS 64,443

SMITH, BARNARD E. A LEARNING MODEL FOR PROCESSES WITH TOOL WEAR, TECH 6B, 379

SMITH, C. A. B. CONSISTENCY IN STATISTICAL INFERENCE AND DECISION (WITH DISCUSSION) (CORR, 66 252), JRSSB 61, I

SMITH, C. A. B. QUERY + (ON FORMULA FOR DETERMINING THE INCIDENCE OF MUTANT GENES) , BIOCS 65,750

SMITH, C. S. A RANDOM WALK IN WHICH THE STEPS OCGUR RANDOMLY IN TIME, BIOKA 59,30

SMITH, C. S. AN ALTERNATIVE SYSTEM FOR THE CLASSIFICATION OF MATHEMATI CAL MODELS FOR QUANTAL RESPONSES TO, BIOCS 65, IBI

SMITH, G. S. AN ANALYSIS OF QUANTAL RESPONSE DATA IN WHICH THE MEASUREMENT OF RESPONSE IS SUBJECT TO ERRO, BIOCS 65,811

SMITH, C. S. GENERAL MODELS FOR QUANT AL RESPONSE TO THE JOINT ACTION OF A MIXTURE OF DRUGS, BIOKA 64,413

SMITH, C. S. MODELS FOR THE NON-INTERACTIVE JOINT ACTION OF A MIXTURE OF ST IMULI IN BIOLOGICAL ASSAY, BIOKA 66, 49

SMITH, C. S. THE QUANTAL RESPONSE ANALYSIS OF A SERIES OF BIOLOG ICAL ASSAYS ON THE SAME SUBJECTS, BIOKA 60,23

SMITH, CARTER VINCENT THE ROBBINS-ISBELL TWO-ARMED-BANDIT PROBLEM WITH FINITE MEMORY, AMS 65, 1375

SMITH, D. E. INVESTIGATION OF RULES FOR DEALING WITH OUTLIERS IN SMALL SAMPLES FROM THE NORMAL DISTRIBUTI, TECH 69, 527

SMITH, H. APPLICATIONS OF TRUNCATED DISTRIBUTIONS IN PROCESS START-UPS AND INVENTORY CONTROL, TECH 61,429

SMITH, H. FAIRFIELD QUERY, PREFERENCE SCORES (REVISITED), TECH 6B, 612

SMITH, MARK A TABLE FOR RANK SUM MULTIPLE PAIRED COMPARISONS, TECH 67,561

SMITH, P. G. DISEASE CLUSTERINC, A CENERALIZATION OF KNOX'S APPROACH TO THE DETECTION OF SPACE-TIME INTER, BIOCS 68, 541

SMITH, PAUL E. A QUARTERLY ECONOMETRIC MODEL OF THE UNITED STATES, JASA 61,379

SMITH, SHEILAM. THE SAMPLING DISTRIBUTION OF A MAXIMUM-LIKELIHOOD EST IMATE, BIOKA 56,96

SMITH, T. M. F. ESTIMATION IN MULTI-STAGE SURVEYS, JASA 69, 830 
SMITH, W. B. A NOTE ON THE CORRELATION OF RANGES IN CORRELATED NORMAL SAMPLES, BIOKA 68,595

SMITH, W. L. A NOTE ON THE RENEWAL FUNCTION WHEN THE MEAN RENEWAL LIFETIME IS INFINITE, JRSSB 61,230

SMITH, W. L. CORRICENDA, 'ON THE CUMULANTS OF RENEWAL PROCESSES .' BIOKA 59,502

SMITH, W L. ON THE CUMULANTS OF RENEWAL PROCESSES, BIOKA 59, I

SMITH, W. L. ON THE DISTRIBUTION OF TRIBOLIUM CONFUSUM IN A CONTAINER, BIOKA 57,328

SMITH, W. L. ON THE RENEWAL FUNCTION FOR THE WEIBULL DISTRIBUTION, TECH 63,393

SMITH, W. L. ON THE SUPERPOSITON OF RENEWAL PROCESSES, BIOKA 54, 91

SMITH, W. L. THE SUPERPOBITION OF SEVERAL STRICTLY PERIODIC SEQUENCES OF EVENTS, BTOKA 53 , I

SMITH, W. N. THE USE OF LACRANCE MULTIPLIERS WITH RESPONSE SURFACES TECH 59,289

SMITH, WALTER L. NECESSARY CONDITIONS FOR ALMOST SURE EXTINCTION OF BRANCHING PROCESS WITH RANDOM ENVIRON, AMS 68, 2136

SMITH, WALTER L. ON BRANCHING PROCESSES IN RANDOM ENVIRONMENTS, AMS 69,814

SMITH, WALTER L. ON INFINITELY DIVISIBLE LAWS AND A RENEWAL THEOREM FOR NON-NEGATIVE RANDOM VARI ABLES, AMS 6B, 139

SMITH, WALTER L. RENEWAL THEORY AND ITS RAMIFICATIONS (WITH DISCUSSION), JRSSB 58, 243

SMITH. WAYNE E. AN A POSTERIORI PROBABILITY METHOD FOR SOLVING AN OVERDETERM INED SYSTEM OF EQUATIONS, TECH 66,675

SMITH, WILLIAM B. ESTIMATION OF PARAMETERS IN THE MULTIVARIATE NORMAL DISTRIBUTION WITHMISSING OBSERVATI, JASA 68, 159

SMITH, WILLIAM B. QUERY, BIVARIATE SAMPLES WITH MISSING VALUES, II TECH $6 B, B 67$

SMUTS, ROBERT W. THE FEMALE LABOR FORCE, A CASE STUDY IN THE INTERPRETATION OF HISTORICAL STATISTICS, JASA 60, 71

SNEATH, P. H. A. SOME EXPERIMENTS IN THE NUMERICAL ANALYSIS OF ARCHAEOLOGICAL DATA, BIOKA 66,311

SNELL, E. J. A DESICN BALANCED FOR TREND, BIOKA 68,535

SNELL. E. J. A GENERAL DEFINITION OF RESIDUALS (WITH DISCUSSION). JRSSB 6B, 248

SNELL, J . LAURIE ON MARKOV CHAIN POTENTIALS, AMS 61, 709

SNOW, BARBARA A S. THE THIRD MOMENT OF KENDALL 'S TAU IN NORMAL SAMPLES, BIOKA 62, 177

SNOW, BARBARA A. S. TESTS FOR RANK CORRELATION COEFFICIENTS. III DISTRIBUTION OF THE TRANSFORMED KENDALL, BIOKA 62, 1 B5

SNOW. BARBARA A. S. THE DISTRIBUTION OF KENDALL'S TAU FOR SAMPLES OF FOUR FROM A NORMAL BIVARIATE POPULAT, BIOKA 63,538

SOBEL, E. LINEAR RELATIONSHIPS BETWEEN VARIABLES AFFECTED BY ERRORS. BIOCS 66,252

SOBEL. M. A BIVARIATE CENERALIZATION OF STUDENT 'S T-DISTRIBUTION, WITH TABLES FOR CERTAIN SPECIAL CASES, BIOKA 54, 153

SOBEL, M. A FIXED SUBSET-SIZE APPROACH TO THE SELECTION PROBLEM. BIOKA $6 B, 401$

SOBEL, $M$. A SEQUENTIAL PROCEDURE FOR SELECTINC THE LARGEST OF $K$ MEANS, AMS 68,88

SOBEL, M. A TWO-SAMPLE MULTIPLE DECISION PROCEDURE FOR RANKING MEANS OF NORMAL POPULATIONS WITH A COMMON, BIOKA 54, 170

SOBEL, M. APPROXIMATIONS TO THE PROBABILITY INTEGRAL AND CERTAIN PERCENTACE POINTS OF A MULTIVARIATE ANAL, BIOKA 55, 258

SOBEL, M. INTEGRAL EXPRESSIONS FOR TAIL PROBABILITIES OF THE MULTINOMI AL AND NEGATIVE MULTINOMIAL DISTRIB, BIOKA 65, 167

SOBEL, MILTON BINOMIAL CROUP-TESTING WITH AN UNKNOWN PROPORTION OF DEFECTIVES, TECH 66,631

SOBEL, MILTON FINE STRUCTURE OF THE ORDERINC OF PROBABILITIES OF RANK ORDERS IN THE TWO SAMPLE CASE, AMS $66,9 B$

SOBEL, MILTON NONPARAMETRIC PROCEDURES FOR SELECTING A SUBSET CONTAINING THE POPULATION WITH THE LARGEST, AMS 67, 17BB

SOBEL, MILTON NONPARAMETRIC PROCEDURES FOR SELECTING THE T POPULATION WITH THE LARGEST ALPHA-QUANTILE, AMS 67, 1 BO 4

SOBEL, MILTON NONPARAMETRIC RANKING PROCEDURES FOR COMPARISON WITH A CONTROL. AMS 68, 2075

SOBEL, MILTON ON SELECTINC A SUBSET CONTAININC THE POPULATION WITH THE SMALLEST VARIANCE, BIOKA 62,495

SOBEL, MILTON ON THE SMALLEST OF SEVERAL CORRELATED F STATISTICS, BIOKA 62,509

SOBOL, MARION GROSS PANEL MORT ALITY AND PANEL BIAS, JASA 59, 52

SOLARI, MARY E. THE MAXIMUM LIKELIHOOD SOLUTION TO THE FROBLEM OF ESTIMATING A LINEAR FUNCT IONAL RELATION, JRSSB 69, NO.2

SOLLER, $M$. NOTES. OPTIMUM EXPERIMENTAL DESIGNS FOR REALIZED HERITABILITY ESTIMATES, BIOCS 67,361

SOMERS, R. H. THE RANK ANALOGUE OF PRODUCT-MOMENT PART IAL CORRELATION AND REGRESSION, WITH APPLICATION TO, BIOKA 59, 241

SOMERS, ROBERT H. A SIMILARITY BETWEEN GOODMAN AND KRUSKAL 'S TAU AND KEND ALL 'S TAU, WITH A PART IAL INTERP, JASA 62,304

SOMERVILLE, P. N. SOME PROBLEMS OF OPTIMUM SAMPLING, BIOKA 54, 420

SOMERVILLE, PAUL N OPTIMUM SAMPLING IN BINOMIAL POPULATIONS, JASA 57,494

SONDHI, M. M. A NOTE ON THE QUADRIVARIATE NORMAL INTEGRAL, BIOKA 61 , 201

SONQUIST, JOHN A. PROBLEMS IN THE ANALYSIS OF SURVEY DATA, AND A PROPOSAL, JASA 63,415
SPARGI

SPECKMAN, JANACE A

MODEL, JASA 65, 560

SPECKMAN, JANACE A.

BIOCS 67,717

SPENDLEY, W SEQUENTIAL APPLICATION OF SIMPLEX DESICNS IN OPTIMISATION AND EVOLUTIONARY OPERATION, TECH 62,441

SPIECELGLAS, STEPHEN A STATISTICAL INVESTIGATION OF THE INDUSTRIALIZATION CONTROVERSY, JASA $60,2 B 4$

SPJOTVOLL, EMIL A NOTE ON ROBUST ESTIMATION IN ANALYSIS OF VARIANCE AMS 68, 14B6

SPJOTVOLL, EMIL MOST POWERFUL TESTS FOR SOME NON-EXPONENTIAL FAMILIES, AMS 6B, 772

SPJOTVOLL, EMIL OPTIMUM INVARIANT TESTS IN UNBALANCED VARIANCE COMPONENTS MODELS, AMS 67, 422

SPRENT, P. A GENERALIZED LEAST-SQUARES APPROACH TO LINEAR FUNCTIONAL RELATIONSHIPS (WITH DISCUSSION), JRSSB 66,27B

SPRENT, P. FITTING A POLYNOMIAL TO CORRELATED EQUALLY SPACED OBSERVATIONS. , BIOKA 65,275

SPRENT, $P$. LINEAR RELATIONSHIPS IN GROWTH AND SIZE STUDIES, BIOCS 6B. 639

SPRINCER, B. G. F. A PARADOX INVOLVING QUASI PRIOR DISTRIBUTIONS, BIOKA 65, 623

SPRINGER, B . C . F. NUMERICAL OPTIMIZATION IN THE PRESENCE OF RANDOM VARIABILITY. THE SINCLE FACTOR CASE, BIOKA 69, 65

SPRINGER, M. D. BAYESIAN CONFIDENCE LIMITS FOR THE PRODUCT OF BINOMIAL PARAMETERS, BIOKA 66,611

SPRINGER, MELVIN D. BAYESIAN CONFIDENCE LIMITS FOR RELIABILITY OF REDUNDANT SYSTEMS WHEN TESTS ARE TERMIN, TECH 6B, 29

SPROTT, D. A. AN EXAMPLE OF AN ANCILLARY STATISTIC AND THE COMBINATION OF TWO SAMPLES BY BAYES' THEOREM, AMS 61, 616

SPROTT, D. A. EXAMPLES OF LIKELIHOODS AND COMPARISON WITH POINT ESTIMATES AND LARGE SAMPLE APPROXIMATIONS, JASA 69,46B

SPROTT, D. A. NECESSARY RESTRICTIONS FOR DISTRIBUTIONS A POSTERIORI, JRSSB 60,312

SPROTT, D. A. SIMILARITIES BETWEEN LIKELIHOODS AND ASSOCIATED DISTRIBUTIONS A POSTERIORI, JRSSB 61, 460

SPROTT, D. A. TRANSFORMATIONS AND SUFFICIENCY, JRSSB 65, 479

SPURCEON, ROBERT A. SOME PERCENTAGE POINTS OF THE NON-CENTRAL TDISTRIBUTION, CORR. 631163, JASA 63, 176

SRIKANTAN, K. S. RECURRENCE RELATIONS BETWEEN THE PROBABILITY DENSITY FUNCTIONS OF ORDER STATISTICS, AND, AMS 62, 169

SRIVASTAVA, A. B. L. EFFECT OF NON-NORMALITY ON THE POWER FUNCTION OF T-TEST, BIOKA 58,421

SRIVASTAVA, A. B. L. EFFECT OF NON-NORMALITY ON THE POWER OF THE ANALYSIS OF VARIANCE TEST, BIOKA 59,114

SRIVASTAVA, A.B. L. THE DISTRIBUTION OF RECRESSION COEFFICIENTS IN SAMPLES FROM BIVARIATE NON-NORMAL POP, BIOKA 60,6I

SRIVASTAVA. J. N. ON A BOUND USEFUL IN THE THEORY OF FACTORIAL DESIGNS AND ERROR CORRECTING CODES, AMS 64, 408

SRIVASTAVA, J. N. ON THE MONOTONICITY PROPERTY OF THE THREE MAIN TESTS FOR MULTIVARIATE ANALYSIS OF VARIA, JRSSB 64,77

SRIVASTAVA, $M, S$, COMPARINC DISTANCES BETWEEN MULTIVARIATE POPULATIONS, THE PROBLEM OF MINIMUM DISTANCES, AMS 67, 550

SRIVASTAVA. M. S. ON FIXED-WIDTH CONFIDENCE BOUNDS FOR REGRESSION PARAMETERS AND MEAN VECTOR, JRSSB 67, 132

SRIVASTAVA, M. S. ON THE COMPLEX WISHART DISTRIBUTION, AMS 65, 313

SRIVASTAVA, M. S. ON THE DISTRIBUTION OF A MULTIPLE CORRELATION MATRIX, NON-CENTRAL MULTIVARIATE BETADIS, AMS 68, 227

SRIVASTAVA, M $S$ SOME ASYMPTOTICALLY EXTINCT SEQUENTIAL PROCEDURES FOR RANKING AND SLIPPAGE PROBLEMS, JRSSB 66, 370

SRIVASTAVA. M. S. SOME TESTS FOR THE INTRACLASS CORRELATION MODEL AMS $65,1 B 02$

SRIVASTAVA, M.S. THE PERFORMANCE OF SOME SEQUENTIAL PROCEDURES FOF A RANKING PROBLEM. AMS 6B, 1040

SRIVASTAVA, O. P. ASYMPTOTIC DISTRIBUTION OF DISTANCES BETWEEN ORDER STATISTICS FROM BIVARIATE POPULATION, AMS 64,74B

SRIVASTAVA, R. C. ESTIMATION OF THE PARAMETER IN THE STOCHASTIC MODEL FOR PHACE ATTACHMENT TO BACTERIA, AMS 68, IB3

SRIVASTAVA, S. R. INFERENCES CONCERNING A POPULATION CORRELATION COEFFICIENT FROM ONE OR POSSIBLY TWO SAM, JRSSB 67, 282

SRIVASTAVA, S. R. NOTES. ESTIMATION AFTER PRELIMINARY TESTINC IN ANOVA MODEL I, BIOCS 65,752

ST-PIERRE, J ON THE CHOICE OF THE BEST AMONGST THREE NORMAL POPULATIONS WITH KNOWN VARIANCES, BIOKA 5B, 436

STACY, E. W. A GENERALIZATION OF THE GAMMA DISTRIBUTION, AMS 62. $11 \mathrm{~B} 7$

STACY, E.W. PARAMETER ESTIMATION FOR A GENERALIZED GAMMA DISTRIBUTION, TECH 65,349

STAFF, P. L. THE DISPLACED POISSON DISTRIBUTION-REGION B, JASA 67 . 643

STANTON, R. G. CONSTRUCTION OF ROOM SQUARES, AMS 6B, 1540

STANTON. R. G. INDUCTIVE METHODS FOR BALANCED INCOMPLETE BLOCK DESIGNS, AMS 66, 1348

STAPLETON, JAMES H. A CHARACTERIZATION OF THE UNIFORM DISTRIBUTION ON A COMPACT TOPOLOCICAL GROUP, AMS 63, 319 
STARK, CHARLES R. COMPUTATION OF INDIRECT-ADJUSTED RATES IN THE PRESENCE OF CONFOUNDINC, BIOCS 6B, 997

STARKS, T. H. CORRICENDA, 'SICNIF ICANT TESTS FOR PAIRED-COMPARISON EXPERIMENTS', BIOKA 61,475

STARKS, T. H. SIGNIFICANCE TESTS FOR PAIRED-COMPARISON EXPERIMENTS, BIOKA 61,95

STARKS, THOMAS H. A NOTE ON SMALL ORTHOCONAL MAIN EFFECT PLANS FOR FACTORIAL EXPERIMENTS, TECH 64,220

STARMER, C. F. ANALYSIS OF CATEGORICAL DATA BY LINEAR MODELS, BIOCS 69,489

STARR. N. A SEQUENTIAL PROCEDURE FOR SELEGTING THE LARGEST OF $\mathrm{K}$ MEANS, AMS $68,8 B$

STARR, N. OPTIMAL TWO-STAGE STRATIFIED SAMPLING, AMS 69,575

STARR, NORMAN ON THE ASYMPTOTIC EFFICIENCY OF A SEQUENTIAL PROCEDURE FOR ESTIMATINC THE MEAN, AMS 66, 1173

STARR, NORMAN THE PERFORMANCE OF A SEQUENTIAL PROCEDURE FOR THE FIXED-WIDTH INTERVAL EST IMATION OF THE ME, AMS 66,36

STARR, NORMANN A SEQUENTIAL ANALOQUE OF THE BEHRENS-FISHER PROBLEM, AMS $67,13 B 4$

STARR, NORTON ON AN OPERATOR LIMIT THEOREM OF ROTA, AMS 65, 1864

STECH, G. P. ON THE DISTRIBUTION OF LINEAR FUNCTIONS AND RATIOS OF LINEAR FUNCTIONS OF ORDERED CORRELATED, BIOKA 64,143

STECK, G. P. A NOTE ON CONTINGENCY-TYPE BIVARIATE DISTRIBUTIONS, BIOKA 68,262

STECK, G.P. A NOTE ON THE EQUICORRELATED MULTIVARIATE NORMAL DISTRIBUTION, BIOKA 62, 269

STECK, C. P. MOMENTS OF ORDER STATISTICS FROM THE EQUICORRELATED MULT IVARIATE NORMAL DISTRIBUTION, AMS 62, 1286

STECK, C. P. ORTHANT PROBABILITIES FOR THE EQUICORRELATED MULTIVARIATE NORMAL DISTRIBUTION, BIOKA 62, 433

STECK, G. P. PERCENTACE POINTS FOR THE DISTRIBUTION OF OUTGOINC QUALITY, JASA 59, 6B9

STECK. G. P. THE EXCEEDANCE TEST FOR TRUNCATION OF A SUPPLIER'S DATA, JASA 69, B23

STECK, G.P. THE RELATIONSHIP BETWEEN NEYMAN AND BAYES CONFIDENCE INTERVALS FOR THE HYPERGEOMETRIC PARAME, TECH 6B, 199

STECK, G. P. THE SMIRNOV TWO SAMPLE TESTS AS RANK TESTS, AMS 69,1449 STECK, GEORGE P. CORRELATION BETWEEN SAMPLE MEANS AND SAMPLE RANGES, JASA 59,465

STEEL, R. G. D. A MULTIPLE GOMPARISONS SIGN TEST, ALL PAIRS OF TREATMENTS. BIOCS 67.539

STEEL, R. G. D. A RANK SUM TEST FOR COMPARING ALL PAIRS OF TREATMENTS. TECH 60,197

STEEL, ROBERT G. D. A MULTIPLE COMPARISON SIGN TEST, TREATMENTS VERSUS GONTROL, JASA 59,767

STEEL, ROBERT G.D. TABLES FOR A TREATMENTS VERSUS CONTROL MULTIPLE GOMPARISONS SIGN TEST, TEGH 65, 293

STEFFENS, F.E. A DISTRIBUTION-FREE TWO SAMPLE TEST FOR DISPERSION FOR SYMMETRICAL DISTRIBUTIONS, SASJ 69 , NO .2

STEFFENS, F. E. A STEPWISE MULTIVARIATE T-DISTRIBUTION, SASJ 69, 17 STEFFENS, F. E. CRITICAL VALUES FOR BIVARIATE STUDENT T-TESTS, JASA 69,637

STEFFENS, F E EXACT CRITICAL VALUES FOR MOOD'S DISTRIBUTION-FREE TEST STATISTIC FOR DISPERSION AND ITS, TECH 6B, 497

STEFFENS. F. E. ON COMPARING TWO SIMPLE LINEAR REGRESSION LINES, SASJ 68,33

STEIGER, W. L. A BEST POSSIBLE KOLMOCOROFF-TYPE INEQUALITY FOR MART INGALES AND A CHARACTERISTIC PROPERTY, AMS 69,764

STEIGER, W. L. SOME KOLMOCOROFF-TYPE INEQUALITIES FOR BOUNDED RANDOMVARIABLES, BIOKA 67,641

STEIN, C. MINIMAX CHARACTER OF HOTELLING'S T-SQUARED TEST IN THE SIMPLEST CASE, AMS 63,1524

STEIN, C.M. CONFIDENCE SETS FOR THE MEAN OF A MULTIVARIATE NORMAL DISTRIBUTION (WITH DISCUSSION), JRSSB 62, 265

STEINKAMP, STANLEY $W$. THE IDENTIFICATION OF EFFECTIVE INTERVIEWERS, JASA 64, 1165

STEKLER, H. O. DATA REVISIONS AND ECONOMIG FORECASTING, JASA 67, 470 STEKLER, H. O. FORECASTINC INDUSTRIAL PRODUCTION, JASA 61, B 69

STEKLER. H. O. SELECTED ECONOMIC DATA, ACCURACY VS. REPORTING SPEED, JASA 68,436

STEKLER, H. O. THE FORECASTINC ACCURACY OF CONSUMER ATTITUDE DATA, JASA 69 , NO. 4

STEKLER, $\mathrm{H}, \mathrm{O}$. THE VARIABILITY OF PROFITIBILATY WITH SIZE OF FIRM. 1947-1958, JASA 64, 1183

STEPHAN, FREDERICK F. SAMUELS. WILKS, JASA 65, 939

STEPHAN, FREDERICK $F$. THE CASE OF THE INDIANS AND THE TEEN-AGE WIDOWS, JASA 62,338

STEPHAN, FREDERICK F. THE QUALITY OF STATISTICAL INFORMATION AND ST ATISTICAL INFERENCE IN A RAPIDLY CHANC, JASA 67, 1

STEPHENS, M. A. A GOODNESS-OF-FIT STATISTIC FOR THE CIRCLE, WITH SOME COMPARISONS, BIOKA 69,161

STEPHENS, M. A. APPENDIX TO 'EQUATORIAL DISTRIBUTIONS ON A SPHERE', BIOKA 65,200

STEPHENS, M. A. EXACT AND APPROXIMATE TESTS FOR DIRECTIONS. I, BIOKA 62,463

STEPHENS, M. A. EXACT AND APPROXIMATE TESTS FOR DIRECTIONS. II, BIOKA 62,547
STEPHENS, M. A. FURTHER PERCENTACE POINTS FOR W-SQUARE-SUB-N + (CRAMER-VON MISES COODNESS-OF-FIT STAT ISTIC, BIOKA 6B, 428 STEPHENS, M. A. MULTI-SAMPLE TESTS FOR THE F ISHER DISTRIBUTION FOR DIRECTIONS, BIOKA 69, 169

STEPHENS, M. A. RANDOM WALK ON A CIRCLE, BIOKA 63,385

STEPHENS, M. A. RESULTS FROM THE RELATION BETWEEN TWO STATISTICS OF THE KOLOMOCOROV-SMIRNOV TYPE, AMS 69, 1833

STEPHENS, M. A. SICNIF ICANCE POINTS FOR THE TWO-SAMPLE STATISTIC USQUARE-SUB-M, N. BIOKA 65, 661

STEPHENS, M. A. STATISTICS CONNECTED WITH THE UNIFORM DISTRIBUTION, PERCENT AGE POINTS AND APPLICATION TO, BIOKA 66, 235

STEPHENS, M. A. TESTS FOR THE DISPERSION AND FOR THE MODAL VECTOR OF A DISTRIBUTION ON A SPHERE, BIOKA 67, 211

STEPHENS, M. A. TESTS FOR THE VONMISES DISTRIBUTION, BIOKA 69, 149

STEPHENS, M. A. THE DISTRIBUTION OF THE GOODNESS-OF-FIT STATISTIC U-SQUARE-SUB-N. II, BIOKA 64,393

STEPHENS, M. A. THE DISTRIBUTION OF THE COODNESS-OF-FIT STATISTIC, U-SQUARE-SUB-N. I., BIOKA 63, 303

STEPHENS, M. A. THE COODNESS OF FIT STATISTIC V-SUB-N, DISTRIBUTION AND SIGNIFICANCE POINTS, BIOKA 65,309

STEPHENS, M A. THE COODNESS-OF-FIT TESTS BASED ON W-SQUARE-SUB-N AND U-SQUARE-SUB-N, BIOKA 62, 397

STEPHENS, M. A. THE RATIO OF RANCE TO STANDARD DEVIATION IN THE SAME NORMAL SAMPLE, BIOKA $64,4 B 4$

STEPHENS, M. A. THE TESTINC OF UNIT VECTORS FOR RANDOMNESS, JASA 64. 160

STEPHENS, M. A. THE V-SUB-NM TWO-SAMPLE TEST, AMS 68, 923

STEPHENS, MICHAEL A. TESTS FOR RANDOMNESS OF DIRECTIONS AGAINST TWO CIRCULAR ALTERNATIVES, JASA 69,280

STEPHENSON. JAMES A. ANTICIPATIONS AND INVESTMENT BEHAVIOR IN UNITED STATES MANUFACTURING 1947-1960, JASA 69,67

STERLING, THEODORED. PUBLICATION DECISIONS AND THEIR POSSIBLE EFFECTS ON INFERENCES DRAWN FROM TESTS OF, JASA 59,30

STERN, F. ESTIMATION FROM QUANTILES IN DESTRUCTIVE TESTING, JRSSB 61,434

STERNE. T. E. SOME REMARKS ON CONFIDENCE OF FIDUCIAL LIMITS, BIOKA 54,275

STEUTEL, F. W. A GLASS CF INFINITELY DIVISIBLE MIXTURES, AMS 6B, 1153

STEUTEL, F . W. INF INITELY DIV ISIBLE RENEWAL DISTRIBUTIONS, AMS 69 , 1109

STEUTEL, F. W. NOTE ON COMPLETELY MONOTONE DENSITIES. AMS 69,1130

STEUTEL, F. W. NOTE ON THE INF INITE DIV ISIVILITY OF EXPONENT IAL MIXTURES, AMS 67,1303

STEVENS, W. L. DILUTION SERIES, A STATISTICAL TEST OF TECHNIQUE (CORR, 59 238), JRSSB 5B, 205

STEVENS, W. L. MEAN AND VARIANGE OF AN ENTRY IN A CONTINGENCY TABLE, BIOKA $51,46 B$

STEVENS, W. L. SAMPLES WITH THE SAME NUMBER IN EACH STRATUM, BIOKA 52.414

STEVENS. W. L. SAMPLINC WITHOUT REPLACEMENT WITH PROBABILITY PROPORTIONAL TO SIZE, JRSSB 5B, 393

STEVENS, $W$. L. SHORTER INTERVALS FOR THE PARAMETER OF THE BINOMIAL AND POISSON DISTRIBUTIONS, BIOKA 57,436

STEVENS, W. L. TABLES OF THE ANGULAR TRANSFORMATION, BIOKA 53, 70

STEWART, CHARLES ESTIMATINC THE FRACTION OF ACCEPTABLE PRODUCT, TECH 65,43

STEYN, H. S. EIENSKAPPE VAN WAARSKYNLIKHEIDSVERDELINGS DEUR DIE CEBRUIK YAN DIFFERENSI AALVERGELYKINGE, SASJ $6 B$,

STEYN, H. S. THE WISHART DISTRIBUTION DERIVED BY SOLVING SIMULTANEOUS LINEAR DIFFERENTI AL EQUATIONS, BIOKA 51,470

STICLER, S. M. THE USE OF RANDOM ALLOCATION FOR THE CONTROL OF SELECTIONBIAS, BIOKA 69, NO 3

STICLER, STEPHEN MACK LINEAR FUNCTIONS OF ORDER STATISTICS, AMS 69 , 770

STIGUM, B P A A LIMIT THEOREM FOR MULTIDIMENSTONAL GALTON-WATSON PROCESSES, AMS 66,1211

STIGUM, B. P. ADDITIONAL LIMIT THEOREMS FOR INDECOMPOSABLE MULTIDIMENSIONAL GALTON-WATSON PROCESSES, AMS 66, 1463

STIGUM, BERNT P. A THEOREM ON THE GALTON-WATSON PROCESS, AMS 66.695 STIGUM, BERNT P. DYNAMIC STOCHASTIC PROCESSES, AMS 63,274

STILSON, DONALD W. A NOTE ON CALCULATING TAU AND AVERAGE TAU AND ON THE SAMPLINC DISTRIBUTION OF AVERAGE, JASA 62, 567

STOCKWELL, EDWARD C. ILLUSTRATIVE TABLES OF SCHOOL LIFE, CORR. 64 1299, JASA 63, 1113

STOKER, D.J. A DISTRIBUTION-FREE ANALYSIS OF VARIANCE TECHNIQUE FOR BLOCK DESIGNS, SASJ 68,9

STOKER, D. J. AN APPROXIMATION FOR THE EXACT DISTRIBUTION OF THE WILCOXON TEST FOR SYMMETRY, JASA 64,899

STOKER, D. J. DISTRIBUTION-FREE ANALYSIS OF VARIANCE FOR THE TWOWAY CLASSIFICATION, SASJ 67,67

STOLLER, D. S. ON THE GENERATION OF NORMAL RANDOM VECTORS. TECH 62. 278

STONE, C. J. THE ASYMMETRIC CAUCHY PROCESSES ON THE LINE, AMS 69, 137 STONE, CHARLES A LOCAL LIMIT THEOREM FOR NONLATTICE MULTI-DIMENSIONAL DISTRIBUTION FUNCTIONS, AMS 65, 546

STONE, CHARLES ON A THEOREM OF DOBRUSHIN, AMS 68,1391 
STONE. CHARLES ON ABSOLUTELY CONTINUOUS COMPONENTS AND RENEWAL THEORY, AMS 66, 271

STONE, CHARLES ON MOMENT GENERATING FUNCTIONS AND RENEWAL THEORY AMS 65, 1298

STONE, CHARLES THE GROWTH OF A RECURRENT RANDOM WALK, AMS 66, 1040 STONE, CHARLES J. A LARGE SAMPLE TEST FOR THE INDEPENDENCE OF TWO RENEWAL PROCESSES, AMS 67, 1037

STONE, CHARLES J. THE GROWTH OF A RANDOM WALK, AMS 69 , N0.6 STONE, L. A . COMPUTER AIDED DESIGN OF EXPERIMENTS, TECH 69, 137 STONE, LAWRENCE D. ON THE DISTRIBUTION OF THE SUPREMUM FUNCT IONAL FOR SEMI-MARKOV PROCESSES WITH CONTINUO, AMS 69,844

STONE. LAWRENCE D. THE DISTRIBUTION OF THE MAXIMUM OF A SEMI-MARKOV PROCESS, AMS 68,947

STONE, M. A PARADOX INVOLVING QUASI PRIOR DISTRIBUTIONS. BIOKA 65. 623

STONE, M. COMMENTS ON A POSTERIOR DISTRIBUTION OF GEISSER AND CORNFIELD, JRSSB 64,274

STONE, M. EXTREME TAIL PROBABILITIES FOR SAMPLING WITHOUT REPLACEMENT AND EXACT BAHADUR EFF ICIENCY OF THE, BIOKA 6B, 371

STONE. M. EXTREME TAIL PROBABILITIES FOR THE NULL DISTRIBUTION OF THE TWO-SAMPLE WILCOXON STATISTIC, BIOKA 67,629

STONE. M. GENERALIZED BAYES DECISION FUNCTIONS, ADMISSI8ILITY AND THE EXPONENTIAL FAMILY, AMS 67,818

STONE, M. NON-EQUIVALENT COMPARISONS OF EXPERIMENTS AND THEIR USE FOR EXPERIMENTS INVOLVING LOCATION PARA, AMS 61, 326

STONE, M. RIGHT HAAR MEASURE FOR CONVERGENCE IN PROBAB IL ITY TO QUAS I POSTERIOR DISTRIBUTIONS, AMS 65, 440

STONE, M. THE OPINION POOL, AMS 61,1339

STONE, M. THE POSTERIOR T DISTRIBUTION, AMS 63.56B

STONE, $M$ THE ROLE OF EXPERIMENTAL RANDOMIZATION IN BAYESIAN STATISTICS, FINITE SAMPLING AND TWO BAYESIAN, BIOKA 69, NO.3

STONE, M. THE ROLE OF SIGNIFICANCE TESTING, SOME DATA WITH A MESSAGE, BIOKA 69, NO.3

STONE, MERVYN ROBUSTNESS OF NON-IDEAL DECISION PROCEDURES, JASA $63,4 \mathrm{BO}$

STONEMAN, DAVID M. RESPONSE SURFACE DESIGNS FOR FACTORS AT TWO AND THREE LEVELS, TECH 68,177

STONEMAN, DAVID M. TESTING FOR THE INCLUSION OF VARIABLES IN LINEAR REGRESSION BY A RANDOMISATION TECHNIQ, TECH 66,695

STONEMAN DAVIDS FACTOR CHANGES AND LINEAR TRENDS IN EIGHT-RUN TWO LEVEL FACTORIAL DESIGNS. TECH 6B, 301

STOREY, S.H. A THREE-DIMENSIONAL CLUSTER PROBLEM, BIOKA 6B, 25B

STOUFFER, SAMUEL A. KARL PEARSON, AN APPRECIATION ON THE HUNDREDTH ANNIVERSARY OF HIS BIRTH, JASA 58,23

STOUT, H. P. ESTIMATION FROM QUANTILES IN DESTRUCTIVE TESTING JRSSB 61,434

STOUT, WILLIAM F, SOME RESULTS ON THE COMPLETE AND ALMOST SURE CONVERGENCE OF LINEAR COMBINATIONS OF INDE, AMS 68,1549

STRASSEN, V. THE EXISTENCE OF PROBABILITY MEASURES WITH GIVEN MARGINALS, AMS 65,423

STRATTON JR, HOWARD H. LIMIT DISTRIBUTIONS OF A BRANCHING STOCHASTIC PROCESS, AMS 64, 557

STRATTON, H. H. A NOTE ON CHARACTERISTIC FUNCTIONS, AMS 69, 303

STRAUCH, R. E. CONDITIONAL EXPECTATIONS OF RANDOM VARIABLES WITHOUT EXPECTATIONS. AMS 65, 1556

STRAUCH, RALPHE, A NOTE ON MEMORYLESS RULES FOR CONTROLLING SEQUENTIAL CONTROL PROCESSES, AMS 66, 276

STRAUCH, RALPHE. NEGATIVE DYNAMIC PROGRAMMING, AMS 66, 871

STRIEBEL, C. ESTIMATION OF STOCHASTIC SYSTEMS, ARBITRARY SYSTEM PROCESS WITH ADDITIVE WHITE NOISE OBSERVA, AMS 6B. 785

STRIEBEL, CHARLOTTE T. EFFICIENT ESTIMATION OF A REGRESSION PARAMETER FOR CERTAIN SECOND ORDER PROCESSES, AMS 61, 1299

STROUT, WILLIAM F. ON THE EXPECTED VALUE OF A STOPPED STOCHASTIC SEQUENCE, AMS 69, 456

STUART, A. A PARADOX IN STATISTICAL ESTIMATION, BIOKA 55,527

STUART, A. A SIMPLE PRESENT ATION OF OPTIMUM SAMPLING RESULTS, JRSSB 54.239

STUART, A. A SINGULARITY IN THE ESTIMATION OF BINOMIAL VARIANCE, BIOKA 57,262

STUART, A. A TEST FOR HOMOGENEITY OF THE MARG INAL DISTRIBUTIONS IN A TWO-WAY CLASSIF ICATION, BIOKA 55,412

STUART, A. AN APPLICATION OF THE DISTRIBUTION OF THE RANKING CONCORDANCE COEFFICIENT, BIOKA 51,33

STUART, A. BOUNDS FOR THE VARIANCE OF KENDALL'S RANK CORRELATION STATISTIC, BIOKA 56,474

STUART, A. DISTRIBUTION-FREE TESTS IN TIME-SERIES BASED ON THE BREAKING OF RECORDS (WITH DISCUSSION), JRSSB 54, 1

STUART, A. SOME QUESTIONS OF DISTRIBUTION IN THE THEORY OF RANK CORRELATION, BIOKA 51,131

STUART, A. SOME QUICK SIGN TESTS FOR TREND IN LOCATION AND DISPERSION, BIOKA 55,80

STUART, A. THE AVERAGE CRITICAL VALUE METHOD AND THE ASYMPTOTIC RELATIVE EFFICIENCY OF TESTS, BIOKA $67,30 \mathrm{~B}$

STUART, A. THE EFFICIENCY OF THE RECORDS TEST FOR TREND IN NORMAL REGRESSION, JRSSB 57,149

STUART, A. THE ESTIMATION AND COMPARISON OF STRENGTHS OF ASSOCIATION IN CONT INGENCY TABLES, BIOKA 53, 105
STUART, ALAN EQUALLY CORRELATED VARIATES AND THE MULTINORMAL INTEGRAL, JRSSB 58,373

STUART, ALAN GAMMA-DISTRIBUTED PRODUCTS OF INDEPENDENT RANDOM VARI ABLES, BIOKA 62,564

STUART, ALAN THE EFFICIENCIES OF TESTS OF RANDOMNESS AGAINST NORMAL REGRESSION, JASA 56. 285

STUART, WALTER $J$. COMPUTER EDITING OF SURVEY DATA. FIVE YEARS OF EXPERIENCE IN BLS MANPOWER SURVEYS, JASA 66,375

STUDDEN. W. J. MONOTONICITY OF THE VARIANCE UNDER TRUNCATION AND VARI ATIONS OF HENSEN'S INEQUALITY, AMS 69, 1106

STUDDEN, W. J. ON SELECTING A SUBSET OF K POPULATIONS CONTA INING THE BEST, AMS 67, 1072

STUDDEN, W. J, ON THE MONOTONICITY OF E-SUB-P'S-SUB-T-OVER-T', AMS 68,1755

STUDDEN, $\boldsymbol{W}, J$, OPTIMAL DESIGNS ON TCHEBYSCHEFF POINTS, AMS 68, 1435 STUDDEN, WILLIAM J. ADMISSIBLE DESIGNS FOR POLYNOMIAL SPLINE REGRESSION, AMS 69, 1557

STUDDEN, WILLIAM J . OPTIMAL EXPERIMENTAL DESIGNS, AMS 66, 7B3

SUBRAHAMANIAM, K, A, A NOTE ON ESTIMATION IN THE TRUNCATED POISSON, BIOKA 65,279

SUBRAHMANIAM, K. A TEST FOR 'INTRINSIC CORRELATION' IN THE THEORY OF ACCIDENT PRONENESS (ACKNOWLEDGEMENT, JRSSB 66, 180

SUBRAHMANIAM, K . ORDER STATISTICS FROM A CLASS OF NON-NORMAL DISTRIBUTIONS, BIOKA 69,415

SUBRAHMANYA, M. T. A NOTE ON A BIASED ESTIMATOR IN SAMPLING WITH PR08AB ILITY PROPORTIONAL TO SIZE WITH RE, AMS 66, 1045

SUCHESTON, L. NOTE ON SHIFT-INVARIANT SETS, AMS 69,694

SUDDERTH. WILLIAM D. A NOTE ON THRIFTY STRATEGIES AND MARTINGALES IN A F INITELY ADDITIVE SETTING WILLIAM, AMS 69, NO. 6

SUDDERTH, WILLIAM ON MEASURA8LE, NONLEAVABLE GAMBLING HOUSES WITH A GOAL. AMS 69,66

SUDMAN, SEYMOUR PROBABILITY SAMPLING WITH QUOTAS, JASA 66, 749

SUGIURA, NARIAKI ASYMPTOTIC EXPANSIONS OF THE DISTRIBUT IONS OF THE LIKELIHOOD RATIO CRITERI A FOR COVARIAN, AMS 69, N0.6

SUGIURA, NARIAKI ASYMPTOTIC EXPANSIONS OF THE NON-NULL DISTRIBUTIONS OF THE LIKELIHOOD RATIO CRITERIA FOR, AMS 69, 942

SUGIURA, NARIAKI ON BARTLETT'S TEST AND LEHMANN'S TEST FOR HOMOGENEITY OF VARIANCES, AMS 69 , NO. 6

SUG IURA. NARIAKI UNBIASEDNESS OF SOME TEXT CRITERIA FOR THE EQUALITY OF ONE OR TWO COVARIANCE MATRICES, AMS 68, 1686

SUGIYAMA, T, DISTRIBUTION OF THE LARGEST LATENT ROOT AND THE SMALLEST LATENT ROOT OF THE GENERALIZED B ST, AMS 67, 1152

SUGIYAMA, T ON THE DISTRIBUTION OF THE LARGEST LATENT ROOT AND THE CORRESPONDING LATENT VECTOR FOR PRINCI, AMS 66. 995

SUGIYAMA, T. ON THE DISTRIBUTION OF THE LARGEST LATENT ROOT OF THE COVARIANCE MATRIX, AMS 67,1148

SUG IYAMA，T , ON THE DISTRIBUTION OF THE LATENT VECTORS FOR PRINCIPAL COMPONENTS ANALYSIS, AMS 65, 1875

SUITS. DANIEL B. USE OF DUMMY VARIABLES IN REGRESSION EQUATIONS, JASA 57,548

SUKHATME, B. V. A TWO-SAMPLE DISTRIBUTION FREE TEST FOR COMPARING VARIANCES, BIOKA 58,544

SUKHATME, B. $V$. JOINT ASYMPTOTIC DISTRIBUTION OF THE MEDIAN AND A USTATISTIC, JRSSB 57, 144

SUKHATME, B. V. POWER OF SOME TWO-SAMPLE NON-PARAMETRIC TESTS, BIOKA 60,355

SUKHATME, BALKRISHNA V SOME RATIO-TYPE ESTIMATORS IN TWO-PHASE SAMPLING, JASA $62,62 B$

SUMMERS, ROBERT D. AN INEQUALITY FOR THE SAMPLE COEFFICIENT OF VARIATION AND AN APPLICATION OF VARIABLES, TECH 65,67

SUN. TZE-CHIEN A NOTE ON THE UNIMODALITY OF DISTRIBUTION FUNCTIONS OF CLASS L. AMS 67,1296

SUNDRUM, R. M. A FURTHER APPROXIMATION TO THE DISTRIBUTION OF WILCOXON' $S$ STATISTIC IN THE GENERAL CASE, JRSSB 54, 255

SUNDRUM. R. M. A METHOD OF SYSTEMATIC SAMPLING BASED ON ORDER PROPERTIES, BIOKA 53,452

SUNDRUM. R. M. MOMENTS OF THE RANK CORRELATION COEFFICIENT TAU IN THE GENERAL CASE, BIOKA 53,409

SUNDRUM. R.M. ON THE RELATION BETWEEN ESTIMATING EFFICIENCY AND THE POWER OF TESTS , BIOKA 54,542

SUNTER, ALAN B. A THEORY FOR RECORD LINKAGE, JASA 69, NO 4

SURENDRAN, P. U. ASSOCIATION MATRICES AND THE KRONECKER PRODUCT OF DESIGNS. AMS 68, 676

SURENDRAN, P. U. COMMON TREATMENTS BETWEEN BLOCKS OF CERTAIN PARTI ALLY BALANCED INCOMPLETE BLOCK DESIGNS, AMS 68, 999

SUTHERLAND, T, M. THE CORRELATION BETWEEN FEED EFFICIENCY AND RATE OF GAIN, A RATIO AND ITS DENOMINATOR, BIOCS 65,739

SUZUKI, GIITIRO KOLMOGOROV-SMIRNOV TESTS OF FIT BASED ON SOME GENERAL BOUNDS, JASA 6B, 919

SWAMY, $P, S$, ON THE AMOUNT OF INFORMATION SUPPLIED BY CENSORED SAMPLES OF GROUPED OBSERVATIONS IN THE EST, BIOKA 62, 245

SWAMY, P. S. ON THE AMOUNT OF INFORMATION SUPPLIED BY TRUNCATED SAMPLES OF GROUPED OBSERVATIONS IN THE ES, BIOKA 63, 207

SWAMY, P. S. ON THE JOINT EFFICIENCY OF THE ESTIMATES OF THE PARAMETERS OF NORMAL POPULATIONS BASED ON SI, JASA 62, 46

SWAMY, R. A. V. B. ON THEIL'S MIXED REGRESSION ESTIMATOR, JASA 69 , 273 
SWEENY, H. C. DESICN FOR OPT IMAL PREDICT ION IN S IMPLE LINEAR RECRESSION, JASA 65,205

SWINDEL, B. F. ON THE BIAS OF SOME LEAST-SQUARES EST IMATORS OF VARIANCE IN A GENERAL LINEAR MODEL, BIOKA 68,313

SWITZER, PAUL A RANDOM SET PROCESS IN THE PLANE WITH A MARKOVIAN PROPERTY. AMS 65. IB59

SWITZER, PAUL RECONSTRUCTING PATTERNS FROM SAMPLEDATA, AMS 67, 138

SWITZER, PAUL SIGNIFICANCE PROBABILITY BOUNDS FOR RANK ORDERINGS AMS 64,891

SYKES, Z. M. ON DISCRETE STABLE POPULATION THEORY, BIOCS 69.285

SYKES, Z. M. SOME STOCHASTIC VERSIONS OF THE MATRIX MODEL FOR POPULATION DYNAMICS. JASA 69, 111

SYLWESTER. D. A QUANTITATIVE DISCUSSION OF THE EFFECTIVENESS OF VOIDING AS A DEFENCE AGA INST BLADDER INFE, BIOCS 66,53

SYLWESTER, DAVID L. A MATHEMATICAL MODEL WITH APPLICATIONS TO A STUDY OF ACCIDENT REPEATEDNESS AMONG CHIL, JASA 65, 1046

TAEUBER, KARL E. RESIDENCE HISTORIES AND EXPOSURE RESIDENCES FOR THE UNITED STATES POPULATION. JASA 61, B24

TAINITER, $M$. SEQUENTIAL HYPOTHESIS TESTS FOR THE R-DEPENDENT MARGINALLY STATIONARY PROCESSES. AMS 66.90

TAKACS, L. APPLICATIONS OF A BALLOT THEOREM IN PHYSICS AND IN ORDER STATISTICS, JRSSB 65,130

TAKACS, L. CHARLES JORDAN, 1B71-1959, AMS 61, I

TAKACS. LAJOS A GENERALIZATION OF THE BALLOT PROBLEM AND ITS APPLICATION IN THE THEORY OF QUEUES, JASA 62, 327

TAKACS, LAJOS AN APPLICATION OF A BALLOT THEOREM IN ORDER STATISTICS, AMS 64, 1356

TAKACS. LAJOS ON A COINCIDENCE PROBLEM CONCERNING PARTICLE COUNTERS. AMS 61,739

TAKACS, LAJOS ON ERLANG 'S FORMULA, AMS 69,71

TAKACS. LAJOS ON THE CLASSICAL RUIN PROBLEMS, JASA 69, BB9

TAKACS, LAJOS ON THE METHOD OF INCLUSION AND EXCLUSION, JASA 67, 102

TAKACS, LAJOS THE TIME DEPENDENCE OF A SINGLE-SERVER QUEUE WITH POISSON INPUT AND GENERAL SERVICE TIMES, AMS 62, 1340

TAKACS, LAJOS THE TRANSIENT BEHAVIOR OF A SINGLE SERVER QUEUINC PROCESS WITH RECURRENT INPUT AND GAMMA SE, AMS 61,1286

TAKAYAMA, T. INEQUALITY RESTRICTIONS IN REGRESSION ANALYSIS, JASA 66. 166

TAKEUCHI, KEI A NOTE ON THE TEST FOR THE LOCATION PARAMETER OF AN EXPONENTIAL DISTRIBUTION, AMS 69, IB3B

TALLIS. G. M. APPROXIMATE MAXIMUM LIKELIHOOD ESTIMATES FROM GROUPED DATA, TECH 67,599

TALLIS, G. M. ELLIPTICAL AND RADIAL TRUNCATION IN NORMAL POPULATIONS, AMS 63, 940

TALLIS, G. M. EQUILIBRIA UNDER SELECTION FOR K ALLELES, BIOCS 66. 121

TALLIS, G M EXACT FIRST AND SECOND ORDER MOMENTS OF EST IMATES OF COMPONENTS OF COVARIANCE, BIOKA 69, NO.3

TALLIS, G. M. FORMULAE TO IMPROVE WALD'S APPROXIMAT ION FOR SOME PROPERTIES OF SEQUENTIAL TESTS, JRSSB 65,74

TALLIS, G. M. FURTHER MODELS FOR ESTIMAT ING CORRELATION IN DISCRETE DATA, JRSSB 64,82

TALLIS, G. M. NOTE ON A CALIBRATION PROBLEM, BIOKA 69, NO.3

TALLIS, G. M. NOTES. A MIGRATION MODEL, BIOCS 66.409

TALLIS, G. M. PLANE TRUNCATION IN NORMAL POPULATIONS, JRSSB 65, 301

TALLIS. G. M. SELECT ION FOR AN OPTIMUM GROWTH CURVE. BIOCS 6B, 169

TALLIS, G. M. THE MOMENT GENERAT ING FUNCT ION OF THE TRUNCATED MULTI NORMALDISTRIBUTION, JRSSB 61,223

TALLIS, G. M. THE USE OF A GENERALIZED MULTINOMIAL DISTRIBUTION IN THE ESTIMATION OF CORRELATION IN DISCR. JRSSB 62.530

TALLIS, G. $M$. THE USE OF FRACTIONAL MOMENTS FOR ESTIMATING THE PARAMETERS OF A MIXED EXPONENTIALDISTRIBU, TECH 68.161

TAMHANKAR, M. V. A CHARACTERIZATION OF NORMALITY, AMS 67. 1924

TAMURA, RYOJI MULTIVARIATE NONPARAMETRIC SEVERAL-SAMPLE TESTS AMS 66, 611

TAMURA, RYOJI ON A MODIFICATION OF CERTAIN RANK TESTS, AMS 63, 1101

TAMURA, RYOJI SOME DISTRIBUTION-FREE MULTIVARIATE COMPARISON PROCEDURES, AMS 69,1486

TAN, $W$. Y. BAYESIAN ANALYSIS OF RANDOM-EFFECT MODELS IN THE ANALYSIS OF VARIANCE. I. POSTERIOR DISTRIBUTI, BIOKA 65,37

TAN, W. Y. BAYESIAN ANALYSIS OF RANDOM-EFFECT MODELS IN THE ANALYSIS OF VARIANCE. II. EFFECT OF AUTOCORRE. BIOKA 66,477

TAN, WAI-YUAN NOTE ON THE MULTIVARIATE AND THE GENERALIZED MULTIVARIATE BETA DISTR IBUTIONS, JASA 69, 230

TANIS, ELLIOT A. AN ITERATED PROCEDURE FOR TESTING THE EQUALITY OF SEVERAL EXPONENTIAL DISTRIBUTIONS, JASA 63, 435

TANIS, ELLIOT A. LINEAR FORMS IN THE ORDER STATISTICS FROM AN EXPONENTIALDISTRIBUTION, AMS 64,270

TANNER, J . C. A DERIVATION OF THE BOREL DISTRIBUTION, BIOKA 61, 222

TANNER, J. C. A PROBLEM IN THE COMBINATION OF ACCIDENT FREQUENCIES, BIOKA 58, 331

TANNER, J, C. A PROBLEM OF INTERFERENCE BETWEEN TWO QUEUES, BIOKA 53. 58

TANNER, J. C. A SIMPLIFIED MODEL FOR DELAYS IN OVERTAKING ON A TWOLANE ROAD, JRSSB 58, 108

TANNER, J. C. A THEORETICAL ANALYSIS OF DELAYS AT AN UNCONTROLLED INTERSECTION, BIOKA 62, 163
TANNER, J C C DELAYS ON A TWO-LANE ROAD, WITH DISCUSSION ), JRSSB 61. 38

TANNER, J.C. THE CAPACITY OF AN UNCONTROLLED INTERSECTION, BIOKA 67,657

TANNER, J . C . THE DELAY TO PEDESTRIANS CROSSINC A ROAD, 8IOKA 51, 383 TARTER, M. THE ESTIMATION OF PROBABILITY DENS IT IES AND CUMULATIVES BY FOURIER SERIES METHODS, JASA 6B, 925

TARTER, M. E. CO-ORDINATE TRANSFORMATIONS TO NORMALITY AND THE POWER OF NORMAL TESTS FOR INDEPENDENCE, BIOKA 69, 139

TARTER, M. E. INVERSE CUMULATIVE APPROXIMATION AND APPLICATIONS, BIOKA 68,29

TARTER, MICHAEL E. EXACT MOMENTS AND PRODUCT MOMENTS OF THE ORDER STAT ISTICS FROM THE TRUNCATED LOGISTIC, JASA 66, 514

TARTER, MICHAEL E. PROPERTIES OF THE MEDIAN AND OTHER STATISTICS OF LOCISTIC VARIATES, AMS 65,1779

TARVER, JAMES D. EVALUATION OF CENSUS SURVIVAL RATES IN ESTIMATING INTERCENSAL STATE NET MIGRATION, JASA 62, B41

TATE, R. F. ESTIMATION OF THE PARAMETERS FOR A MULTIVARIATE NORMAL DISTRIBUTION WHEN ONE VARIABLE IS DICH, BIOKA 65,664

TATE, R. F. MULT IVARIATE CORRELATION MODELS WITH MIXED DISCRETE AND CONTINUOUS VARIABLES, CORR. 65343 . AMS 61.448

TATE, R. F. ON THE USE OF PARTIALLY ORDERED OBSERVATIONS IN MEASURING THE SUPPORT FOR A COMPLETE ORDER, JASA 61,299

TATE. R. F. OPTIMAL CONFIDENCE INTERVALS FOR THE VARIANCE OF A NORMAL DISTRIBUTION, JASA 59,674

TATE, R. F. THE THEORY OF CORRELATION BETWEEN TWO CONTINUOUS VAR IABLES WHEN ONE IS DICHOTOMIZED, BIOKA 55, 205

TATE, ROBERT F. CONDITIONAL-NORMAL REGRESSION MODELS, JASA 66, 477

TAUBMAN, PAUL A FORECASTING MODEL OF FEDERAL PURCHASES OF GOODS AND SERVICES, JASA 62, 633

TAYLOR III, HOWARD M. MARKOVIAN SEQUENTIAL REPLACEMENT PROCESSES, AMS 65, 1677

TAYLOR, G. APPLICATION OF A MODIF ICATION OF DAV IDON 'S METHOD TO NONLINEAR REGRESSION PROBLEMS, TECH 6B, 843

TAYLOR. HOWARD STATISTICAL CONTROL OF A CAUSSIAN PROCESS. TECH 67 . 29

TAYLOR, HOWARD THE ECONOMIC DESICN OF CUMULATIVE SUM CONTROL CHARTS. TECH 68,479

TAYLOR. HOWARD M. OPTIMAL STOPPING IN A MARKOV PROCESS, AMS 68, 1333

TAYLOR, HOWARD M. WEAK CONVERGENCE OF A SEQUENCE OF QUICKEST DETECTION PROBLEMS, AMS 68. 2149

TAYLOR, J . CENSORED OBSERVATIONS IN RANDOMIZED BLOCK EXPERIMENTS, JRSS8 59, 214

TAYLOR, J. EXACT LINEAR SEQUENTIAL TESTS FOR THE MEAN OF A NORMAL DISTRIBUTION, BIOKA 56,452

TAYLOR, J. THE VALUE OF ORTHOGONAL POLYNOMIALS IN THE ANALYSIS OF CHANGE-OVER TRIALS WITHDAIRY COWS, BIOCS 67,297

TAYLOR. L. R. TABLES FOR POWER-LAW TRANSFORMATIONS, BIOKA 62, 557

TAYLOR. R. J. A MULTI-STAGE PROCEDURE FOR THE SELECTION OF THE BEST OF SEVERAL POPULATIONS, JASA 62.7B5

TAYLOR, WILLIAM J. THE CONDITION FOR LOT SIZE PRODUCTION, JASA 56. 627

TAYLOR, WILSON L. CORRECTING THE AVERACE RANK CORRELATION COEFFICIENT FOR TIES IN RANKINGS, JASA 64, 872

TAYLOR. WILSON L. SOME CONTRIBUTIONS TO THE AVERAGE RANK CORRELATION METHODS AND TO THE DISTRIBUTION OF T, JASA 63.756

TEICHER, $\mathrm{H}$. ON SECOND MOMENTS OF STOPP INC RULES, AMS 66,388

TEICHER, HENRY IDENTIF I AB ILITY OF FINITE MIXTURES, AMS 63, 1265

TEICHER, HENRY IDENTIF I ABILITY OF MIXTURES, AMS 61, 244

TEICHER, HENRY IDENTIFIABILITY OF MIXTURES OF PRODUCT MEASURES, AMS 67,1300

TEICHER, HENRY MAXIMUM LIKELIHOOD CHARACTERIZATION OF DISTRIBUTIONS. AMS 61, 1214

TEICHER. HENRY MOMENTS OF RANDOMLY STOPPED SUMS, AMS 65, 789

TEICHER, HENRY ON RANDOM SUMS OF RANDOM VECTORS, AMS 65, 1450

TEICHER, HENRY OPTIMAL STOPPING WHEN THE FUTURE IS DISCOUNTED, AMS 67,601

TEICHROEW, D. A SAMPLING EXPERIMENT ON THE POWERS OF THE RECORDS TESTS FOR TREND IN A TIME SERIES, JRSSB 55, 115

TEICHROEW, D. CORRECTION TO 'TABLES OF EXPECTED VALUES OF ORDER STATISTICS AND PRODUCTS OF ORDER STATISTI, AMS 61, 1345

TEICHROEW, DANIEL A HISTORY OF DISTRIBUTION SAMPLINC PRIOR TO THE ERA OF THE COMPUTER AND ITS RELEVANCE T, JASA 65,27

TELSER, LESTER G. DISCRETE SAMPLES AND MOVING SUMS IN STATIONARY STOCHASTIC PROCESSES, JASA 67,484

TELSER, LESTER G. ITERATIVE ESTIMATION OF A SET OF LINEAR REGRESSION EQUATIONS, JASA 64,845

TEN HOOPEN, M. THE SUPERPOSITION OF RANDOM SEQUENCES OF EVENTS BIOKA 66,383

TEPPING, BENJAMIN J. A MODEL FOR OPTIMUM LINKAGE OF RECORDS, JASA 68, 1321

TEPPING, BENJAMIN J. WASHINGTON STATISTICAL SOCIETY MEMORIAL MEETING FOR WILLIAM N. HURWITZ. THE DEVELOPM. JASA 69, NO.4

TERRAGNO, PAUL J. A REVIEW OF THE LITERATURE ON A CLASS OF COVERAGE PROBLEMS, AMS 64, 232

TERRY, MILTON E. RANK ANALYSIS OF INCOMPLETE BLOCK DESIGNS. I. THE METHOD OF PAIRED COMPARISONS . . BIOKA 52,324 
TEUGELS, JOZEF L. RENEWAL THEOREMS WHEN THE FIRST OR THE SECOND MOMENT IS INFINITE, AMS 6B, 1210

THARTHARE. SURESH K. GENERALIZED RIGHT ANCULAR DESIGNS. AMS 65 , 1535

THARTHARE, SURESH K, RIGHT ANGULAR DESIGNS, AMS 63, 1057

THATCHER, A. R. RELATIONSHIPS BETWEEN BAYESIAN AND CONFIDENCE LIMITS FOR PREDICTIONS (WITH DISCUSSION), JRSSB 64, 176

THATCHER, A. R. SOME RESULTS ON INVENTORY PROBLEMS (WITH DISCUSSION), JRSSB 62,1

THATCHER, A. R. STUDIES IN THE HISTORY OF PROBABILITY AND STATISTICS. VI. A NOTE ON THE EARLY SOLUTIONS O, BIOKA 57, 515

THEDEEN, TORBJORN A NOTE ON THE POISSON TENDENCY IN TRAFFIC DISTRIBUTION, AMS 64, 1B23

THEIL, $H$. ON THE USE OF INCOMPLETE PRIOR INFORMATION IN REGRESSION ANALYSIS, JASA 63,401

THEIL, H. TESTINC THE INDEPENDENCE OF REGRESSION DISTURBANCES, JASA 61,793

THEIL, $H$. THE ANALYSIS OF DISTURBANCES IN REGRESSION ANALYSIS, JASA 65. 1067

THEIL. HENRI A SIMPLIFICATION OF THE BLUS PROCEDURE FOR ANALYZINC REGRESSION DISTURBANCES, JASA 68,242

THIEBAUX, J. TESTING A MARKOV HYPOTHESIS WITH INDEPENDENCE OF INTERMEDIATE ST ATES AND RESTR ICTED ORDER, BIOKA 67.605

THOMAN, D. R. INFERENCES ON THE PARAMETERS OF THE WEIBULL DISTRIBUTION, TECH 69,445

THOMAN, D. R. TWO SAMPLE TESTS IN THE WEIBULL DISTRIBUTION, TECH 69 . NO. 4

THOMAN, DARREL $R$. SOME TESTS OF HYPOTHESES CONCERNINC THE THREEPARAMETER WEIBULL DISTRIBUTION, JASA 68,853

THOMAS. D. G. THE PERFORMANCE OF SOME TWO-SAMPLE TESTS IN SMALL SAMPLES WITH AND WITHOUT CENSORING, BIOKA 69, 127

THOMAS, DAVIDR. GAME VALUE DISTRIBUTIONS I, AMS 67, 242

THOMAS, DAVIDR, GAME VALUE DISTRIBUTIONS II, AMS 67, 251

THOMAS, E. A. C. DISTRIBUTION FREE TESTS FOR MIXED PROBABILITY DISTRIBUTIONS, BIOKA 69 , NO 3

THOMAS, MARJORIE SOME TESTS FOR RANDOMNESS IN PLANT POPULATIONS. BIOKA 51,102

THOMAS, P. 0 . SOME GRAPHS USEFUL FOR STAT IST ICAL INFERENCE, JASA 65 , 334

THOMASIAN, A. J. A BOUND FOR THE LAW OF LARGE NUMBERS FOR DISCRETE MARKOV PROCESSES. AMS 61, 336

THOMASIAN, A, J A FINITE CRITERION FOR INDECOMPOSABLE CHANNELS, AMS 63.337

THOMLINSON. RALPH A MODEL FOR MICRATION ANALYSIS, JASA 61, 675

THOMPSON JR, W. A. A TREATMENT OF TIES IN PAIRED COMPARISONS, AMS 68 . 2002

THOMPSON JR, W. A. MAXIMUM-LIKELIHOOD PAIRED COMPARISON RANKINGS. BIOKA 66,143

THOMPSON JR, W. A. NON-NEGATIVE ESTIMATES OF VARIANCE COMPONENTS TECH 63,441

THOMPSON JR, W. A. ON AN EXTREME RANK SUM TEST FOR OUTLIERS, BIOKA 63. 375

THOMPSON JR, W. A. PRECISION OF SIMULTANEOUS MEASUREMENT PROCEDURES, JASA 63,474

THOMPSON JR, W. A RANKINCS FROM PAIRED COMPARISONS, AMS 64,739

THOMPSON JR, W. A. THE PROBLEM OF NEGATIVE ESTIMATES OF VARIANCE COMPONENTS, AMS 62,273

THOMPSON, D. J. A NOTE ON FOLLOW-UP FOR SURVIVAL IN THE PRESENCE OF MOVEMENT, JASA 61,119

THOMPSON, H. R. A NOTE ON CONTAGIOUS DISTRIBUTIONS, 8IOKA 54,268

THOMPSON, $H$. R. SERIAL DESICNS FOR ROUTINE QUALITY CONTROL AND EXPERIMENTATION, TECH 64,77

THOMPSON, H. R. SPATIAL POINT PROCESSES, WITH APPLICATIONS TO ECOLOCY. 8IOKA 55, 102

THOMPSON. H R. TRUNCATED LOCNORMAL DISTRIBUTIONS. I. SOLUTION BY MOMENTS, BIOKA 51, 414

THOMPSON. J. W. A PROPERTY OF SOME SYMMETRIC TWO-STAGE SEQUENTIAL PROCEDURES, AMS 64,755

THOMPSON, JAMES R. ACCURACY BORROWING IN THE ESTIMATION OF THE MEAN BY SHRINKACE TO AN INTERVAL, JASA 68,953

THOMPSON, JAMES $R$. SOME SHRINKACE TECHNIQUES FOR ESTIMATING THE MEAN, JASA 68,113

THOMPSON, $R$. ITERATIVE ESTIMATION OF VARIANCE COMPONENTS FOR NONORTHOGONAL DATA, BIOCS 69. NO. 4

THOMPSON, RORY BIAS OF THE ONE-SAMPLE CRAMER-VON MISES TEST, JASA 66,246

THOMPSON, RORY DISTRIBUTION AND POWER OF THE ABSOLUTE NORMAL SCORES TEST, JASA 67,966

THOMPSON, RORY GOODNESS CRITERIA FOR TWO-SAMPLE DISTRIBUTION-FREE TESTS, AMS 66, 133

THOMPSON, W. A. RANK SUM MULT IPLE COMPARISIONS IN ONE AND TWO-WAY CLASSIFICATIONS, 8IOKA, 67, 487

THOMPSON, W. E. 8AYESIAN CONFIDENCE LIMITS FOR RELIABILITY OF REDUNDANT SYSTEMS WHEN TESTS ARE TERMINATED. TECH 68,29

THOMPSON, W. E. BAYESIAN CONFIDENCE LIMITS FOR THE PRODUCT OF $N$ BINOMIAL PARAMETERS, 8IOKA 66, 611

THOMPSON, W. S. PERCENTAGE POINTS OF THE EXTREME ROOTS OF A WISHART MATRIX, 8IOKA 68,505
THOMPSON, WILLIAM 0 . RESPONSE SURFACE DESICNS FOR MIXTURE PROBLEMS, TECH 68,739

THOMSON, G. W. BOUNDS FOR THE RATIO OF RANGE TO STANDARD DEVIATION, BIOKA 55, 268

THOMSON, GEORGE WM. SCALE FACTORS AND DEGREES OF FREEDOM FOR SMALL SAMPLE SIZES FOR CHI APPROXIMATION TO, BIOKA 53, 449

THOMSON, M. J. SOME STATISTICS ASSOCIATED WITH THE RANDOM DISORIENTATION OF CUBES, BIOKA 57,205

THONI, HANSPETER A TABLE FOR ESTIMATING THE MEAN OF A LOGNORMALDISTRIBUTION, JASA 69,632

THORNBER, HODSON FINITE SAMPLE MONTE CARLO STUDIES. AND AUTOREGRESSIVE ILLUSTRATION, JASA 67, 801

THORNBY, J. I. A ROBUST POINT ESTIMATOR IN A GENERALIZED RECRESSION MODEL, AMS 69, 17B4

THORP, EDWARD 0, A FAVORABLE SIDE BET IN NEVADA BACCARAT, JASA 66 , 313

THURSTONE, L. L. THE RATIONAL ORIGIN FOR MEASURINC SUBJECTIVE VALUES, JASA 57,458

TIAO , G. C. A BAYESIAN APPROACH TO SOME OUTLIER PROBLEMS, BIOKA 68 , 119

TIAO, G. C. A CHANGE IN LEVEL OF A NON-STATIONARY TIME SERIES, BIOKA 65,181

TIAO, G. C. A FURTHER LOOK AT ROBUSTNESS VIA BAYES'S THEOREM, BIOKA 62, 419

TIAO, G. C. A NOTE ON TABLES FOR THE COMPARISION OF THE SPREAD OF TWO NORMAL DISTRIBUTIONS, BIOKA $67,6 \mathrm{~B} 3$

TIAO, G. C. ANALYSIS OF OUTLIERS WITH ADJUSTED RESIDUALS, TECH 67 . 541

TIAO, C. C. BAYESIAN ANALYSIS OF A THREE-COMPONENT HIERARCHICAL DESIGN MODEL, BIOKA 67,109

TIAO, G. C. BAYESIAN ANALYSIS OF LINEAR MODELS WITH TWO RANDOM COMPONENTS WITH SPECI AL REFERENCE TO THE B, BIOKA 68, 101

TIAO, G. C. BAYESIAN ANALYSIS OF RANDOM-EFFECT MODELS IN THE ANALYSIS OF VARIANCE. I. POSTERIOR DISTRIBUT, BIOKA 65, 37

TIAO, G, C. BAYESIAN ANALYSIS OF RANDOM-EFFECT MODELS IN THE ANALY SIS OF VARIANCE. II . EFFECT OF AUTOCORR, BIOKA 66,477

TIAO, G. C. BAYESIAN COMPARISON OF MEANS OF A MIXED MODEL WITH APPLICATION TORECRESSION ANALYSIS, BIOKA 66, II

TIAO, G. C. BAYESIAN ESTIMATION OF LATENT ROOTS AND VECTORS WITH SPECIAL REFERENCE TO THE BIVARIATE NORMA, BIOKA 69.97

TIAO. C. C. BAYESIAN ESTIMATION OF MEANS FOR THE RANDOM EFFECT MODEL, JASA GB, I74

TIAO. G. C. CORRIGENDA. 'A FURTHER LOOK AT ROBUSTNESS VIA BAYES'S THEOREM. ', BIOKA 63,546

TIAO, GEORCE C. A BAYESIAN APPROACH TO SOME BEST POPULATION PROBLEMS, AMS 64, B25

TIAO, CEORCE C. A BAYESIAN APPROACH TO THE IMPORTANCE OF ASSUMPTIONS APPLIED TO THE COMPARISON OF VARIANC, BIOKA 64, 153

TIAO, GEORCE C. A NOTE ON CRITERION ROBUST NESS AND INFERENCE ROBUSTNESS, BIOKA 64, 169

TIAO, GEORGE C. BAYES'S THEOREM AND THE USE OF PRIOR KNOWLEDGE IN REGRESSION ANALYSIS, BIOKA 64,219

TIAO, GEORGE C. BAYESIAN ANALYSIS OF THE REGRESSION MODEL WITH AUTOCORRELATED ERRORS, JASA 64,763

TIAO, CEORGE $C$. MULTIPARAMETER PROBLEMS FROM A BAYESIAN POINT OF VIEW, AMS 65, 1468

TIAO, CEORGE C. ON THE BAYESIAN ESTIMATION OF MULTIVARIATE REGRESSION, JRSSB 64,277

TIAO, CEORGE C. THE INVERTED DIRICHLET DISTRIBUTION WITH APPLICATIONS, CORR. 651251 , JASA 65,793

TICK, LEO J. THE ESTIMATION OF 'TRANSFER FUNCTIONS' OF QUADRATIC SYSTEMS, TECH 61,563

TICK, LEO JOSEPH SAMPLING RATES AND APPEARANCE OF STATIONARY GAUSSIAN PROCESSES, TECH 66,91

TIDEMAN, NICOLAUS MEASURES OF CONCENTRATION, JASA 67, 162

TIDWELL. PAUL $\mathbb{W}$. TRANSFORMATION OF THE INDEPENDENT VARIABLES, TECH 62,531

TIENZO B P ON THE DISTRI 8UTION OF THE EXTREME STUDENTIZED DEVIATE FROM THE SAMPLEMEAN, BIOKA 59, 467

TIERNEY, DAVIDE. WHICH PRODUCT IS BETTER, TECH 69, 309

TIETJEN, G. L. DOUBLE SAMPLING PLANS WHERE THE ACCEPTANCE CRITERION IS THE VARIANCE, TECH 68,99

TIETJEN, G. L. NOTES. ON TESTING SIGNIFICANCE OF COMPONENTS OF VARIANCE IN THE UNBALANCED NESTED ANALYSIS, BIOCS 68,423

TIKKIWAL, B. D. ON THE THEORY OF CLASSICAL REGRESSION AND DOUBLE SAMPLING ESTIMATION, JRSS8 60, 131

TIKU, M L. A NOTE ON APPROXIMATINC TO THE NON-CENTRAL F DISTRI8UTION, BIOKA 66,606

TIKU, M. L. A NOTE ON THE NEGATIVE MOMENTS OF A TRUNCATED POISSON VARIATE, JASA 64,1220

TIKU, M L APPROXIMATING THE CENERAL NON-NORMAL VARIANCE-RATIO SAMPLING DISTRIRUTIONS, BIOKA 64,83

TIKU, M. L. CHI-SQUARE APPROXIMATIONS FOR THE DISTRIBUTIONS OF GOODNESS-OF-FIT STATISTICS, U-SQUARE-SU8-N, 8IOKA 65, 630

TIKU, $M$. L. ESTIMATING THE MEAN AND STANDARD DEVIATION FROM A CENSORED NORMAL SAMPLE, BIOKA 67, 155

TIKU, M. L. ESTIMATING THE PARAMETERS OF LOG-NORMAL DISTRIBUTION 
TIKU, M. L, LACUERRE SERIES FORMS OF NON-CENTRAL CHI-SQUARE AND F DISTRIBUTIONS, BIOKA 65,415

TIKU, M. L. TABLES OF THE PONER OF THE F-TEST (CORR. 68 1551), JASA 67,525

TILANUS, C. B. A NOTE ON ESTIMATION FROM A CAUCHY SAMPLE, JASA 64, 460 TIMCEY, FREDH. STATISTICAL EVALUATION OF SPLITTINC LIMIT CRITERIA IN MEASUREMENT DISPUTES, TECH 63,263

TIN, MYINT COMPARISON OF SOME RATIO ESTIMATORS, JASA 65, 294

TINCEY, F, H. MINIMUM RISK SPECIFICATION LIMITS, JASA 59, 260

TINSLEY, P. A. AN APPLICATION OF VARIABLE WEICHT DISTRIBUTED LACS, JASA 67,1277

TINTNER, CERHARD THE STATISTICAL WORK OF OSKAR ANDERSON, JASA 61 , 273

TIPLITZ, C. APPROXIMATIONS TO THE MEAN AND STANDARD DEVIATION OF RECIPROCALS OF OBSERVATIONS, TECH 63, 522

TIPPETT, L. H. C. EDITORIAL ARRANCEMENTS, BIOKA 65, 1

TJOE-TIE, TEH MINIMAX THEOREMS ON CONDITIONALLY COMPACT SETS, AMS 63,1536

TOBACH, ETHEL A TABLE FOR RANK SUM MULTIPLE PAIRED COMPARISONS, TECH 67,561

TOBIAS, FILBERT SOME STATISTICAL CHARACTERISTICS OF A PEAK TO AVERACE RATIO, TECH 65, 379

TOCHER, K, D. A NOTE ON THE DESICN PROBLEM, BIOKA 52, IB9

TOCHER, K. D. ON THE CONCURRENCE OF A SET OF RECRESSION LINES., BIOKA 52,109

TOCHER, K. D. THE APPLICATION OF AUTOMATIC COMPUTERS TO SAMPLINC EXPERIMENTS (WITH DISCUSSION), JRSSB 54,39

TOMAN, R. J. SELECTION OF VARIABLES FOR FITTINC EQUATIONS TO DATA, TECH 66. 27

TOMASSON, RICHARD F. BIAS IN ESTIMATES OF THE UNITED STATES NONWHITE POPULATION AS INDICATED BY TRENDS IN, JASA 61.44

TONC, $Y . L$. INTERVAL ESTIMATION OF THE LARCEST MEAN OF K NORMAL POPULATIONS WITH KNOWN VARIANCES, JASA 69, 296

TONC, YUNC LIANC ON PARTITIONINC A SET OF NORMAL POPULATIONS BY THEIR LOCAT IONS WITH RESPECT TO A CONTROL, AMS 69, 1300

TOOTILL, J, P. R. COMPARATIVE SAMPLINC ACCEPTANCE SCHEMES IN TESTINC ANTICENICITY OF VACCINES, BIOCS $66,6 \mathrm{~B} 4$

TOOTILL, J . P. R. ON COMBININC THE RESULTS FROM CLINICAL TRIALS OF A VACCINE, BIOCS 65,616

TOPP, C. W. THE USE OF SAMPLE QUASI-RANCES IN SETTINC CONFIDENCE INTERVALS FOR THE POPULATION STANDARD DE, JASA 61,260

TOPSOE, FLEMMINC PRESERVATION OF WEAK CONVERGENCE UNDER MAPPINCS, AMS 67, 1661

TORNHEIM, TEONARD CONVERCENCE IN NON-LINEAR RECRESSION, TECH 63. 513

TORO-VIZCARRONDO, C. E. TABLES FOR THE MEAN SQUARE ERROR TEST FOR EXACT LINEAR RESTRICTIONS IN RECRESSION, JASA 69, N0.4

TORO-VIZCARRONDO, CARLOS A TEST OF THE MEAN SQUARE ERROR CRITERION FOR RESTRICTIONS IN LINEAR RECRESS ION, JASA 6B , 55B

TOULMIN, G. H. THE NUMBER OF NEW SPECIES, AND THE INCREASE IN POPULATION COVERACE, WHEN A SAMPLE IS INCRE, BIOKA 56,45

TRACY, D. S. A COMBINATORIAL METHOD FOR PRODUCTS OF TWO POLYKAYS WI TH SOME CENERAL F ORMULAE, AMS 64, 1174

TRACY, DERRICK $S$. MULTIVARIATE MAXIMA AND MINIMA WITH MATRIX DERIVATIVES, JASA 69 , NO 4

TRACY, DERRICKS. SOME MULTIPLE PRODUCTS OF POLYKAYS, AMS 69, 1297

TRACY, DERRICK S. SOME RULES FOR A COMBINATORIAL METHOD FOR MULTIPLE PRODUCTS OF GENERALIZED K-STATISTICS, AMS 68,983

TRAPPL, R. NOTES. EIN EINFACHES VERFAHREN ZUR ERZEUCUNG VON SYMBOLFOLGEN MIT VORCEGEBENER RELATIVER DYADE, BIOCS 68,703

TRAWINSKI, B. J. AN EXACT PROBABILITY DISTRIBUTION OVER SAMPLE SPACES OF PAIRED GOMPARISONS, BIOCS $65,9 B 6$

TRAWINSKI, B. J. ASYMPTOTIC APPROXIMATION TO THE EXPECTED SIZE OF A SELECTED SUBSET, BIOKA 69,207

TRAWINSKI, B. $J$. SELEGTION OF THE BEST TREATMENT IN A PAIRED-COMPARISON EXPERIMENT, AMS 63, 75

TRAWINSKI, IRENE M. AN ALGORITHM FOR OBTAININC THE ZERO OF A FUNCTION OF THE DISPERSION MATR IX IN MULTIVA, JASA 67, 114

TRAWINSKI, IRENE MONAHAN MAXIMUM LIKELIHOOD ESTIMATION WITH INCOMPLETE MULT IVARIATE DATA, AMS 64,647

TRENCH, WILLIAMF. ON THE EXTRAPOLATION OF A SPECIAL CLASS OF STATIONARY TIME SERIES, AMS 65, 1426

TRICKETT, W. H. FURTHER CRITICAL VALUES FOR THE TWO-MEANS PROBLEM, BIOKA 56,203

TRICKETT, W. H. ON THE COMPARISON OF TWO MEANS, FURTHER DISCUSSION OF ITERATIVE METHODS FOR CALCULATING T, BIOKA 54, 361

TROSKIE, C. G. NONCENTRAL MULTIVARIATE DIRICHLET DISTRIBUTIONS, SASJ 67,21

TROSKIE, C. C. THE GENERALIZED MULTIPLE CORRELATION MATRIX, SAS J 69, NO.2

TRUAX, D. R. A NOTE ON THE WEAK LAW, AMS 68, 2159

TRUAX, D. R. OPTIMAL INVARIANT RANK TESTS FOR THE K-SAMPLE PROBLEM, AMS 65,1207

TRUAX, D. R. TESTS OF COMPOS ITE HYPOTHESES FOR THE MULTIVARIATE EXPONENT IAL FAMILY, CORR. 67 1928, AMS 67, GB 1

TRUAX, DONALD LARGE DEVIATIONS THEORY IN EXPONENTIAL FAMILIES, AMS $6 B, 1402$
TRULOVE, A.J, ON NON-RECULAR ESTIMATION, I. VARIANCE BOUNDS FOR EST IMATORS OF LOCATION PARAMETERS, JASA 69, 1056

TSAO, CHIA KUEI ADMISSIBILITY AND DISTRIBUTION OF SOME PROBABILISTIC FUNCTIONS OF DISCRETE FINITE STATEM, AMS 6B, 1646

TSAO, R, EFFICIENT CALCULATION OF ALL POSSIBLE RECRESSIONS, TECH $6 \mathrm{~B}, 769$

TSUTAKAWA, $R . K$. AN EXAMPLE OF LARCE DISCREPANCY BETWEEN MEASURES OF ASYMPTOTIC EFFICIENCY OF TESTS, AMS 6B, 179

TSUTAKAWA, R. K. ASYMPTOTIC PROPERTIES OF THE BLOCK UP-AND-DOWN METHOD IN BIO-ASSAY. AMS 67, 1822

TSUTAKAWA, R. K. RANDOM WALK DESICN IN BIO-ASSAY. JASA 67,842

TUCKER, HOWARD C. CONVOLUTIONS OF DISTRIBUTIONS ATTRACTED TO STABLE LAWS, AMS 6B, 13B1

TUCKER, HOWARD C. ESTIMATION OF NON-UNIQUE QUANTILES, AMS 66, 45

TUCKER, HOWARD C. LIMIT DISTRIBUTIONS OF A BRANCHINC STOCHASTIC PROCESS, AMS 64, 557

TUCKER, HOWARD C. ON CONTINUOUS SINCULAR INFINITELY DIVISIBLE DISTRIBUTIONFUNCTIONS, AMS 64,330

TUKEY, J. W. A QUICK COMPACT TWO SAMPLE TEST TO DUCKWORTH 'S SPECIF ICATIONS, TECH 59,31

TUKEY, J. W. A REJECTION CRITERION BASED UPON THE RANCE, BIOKA 56, 418

TUKEY, J.W. APPROXIMATE MEANS AND STANDARD DEVIATIONS BASED ON DISTANCES BETWEEN PERCENTACE POINTS OF FR, BIOKA 65, 533

TUKEY, J. W. APPROXIMATIONS TO THE UPPER 5 PERCENT POINTS OF FISHER'S B DISTRIBUT ION AND NON-CENTRAL CHI-, BIOKA 57, 528

TUKEY, J. W. AUTHOR'S REPLY TO ANSCOMBE'S COMMENTS, TECH 65, 169

TUKEY, J. W. CONCLUSIONS VS DECISIONS, TECH 60,423

TUKEY, J. W. CORRELATION OF RANCES OF CORRELATED DEV IATES, BIOKA 66, 191

TUKEY, J. W. DISCUSSION OF THE PAPERS OF MESSRS. ANSCOMBE AND DANIEL, TECH 60,157

TUKEY, J. W. DISCUSSION OF THE PAPERS OF MESSRS. SATTERTHWAITE AND BUDNE, TECH 59,157

TUKEY, $J$. W. INTERPOLATIONS AND APPROXIMATIONS RELATED TO THE NORMALRANCE, BIOKA 55, 4BO

TUKEY, J. W. SHORT-CUT MULTIPLE COMPARISONS FOR BALANCED SINCLE AND DOUBLE CLASSIF ICATIONS. PART 2, DERIV, BIOKA 65, 485

TUKEY, J. W. SHORT-CUT MULT IPLE COMPARISONS FOR BALANCED SINCLE AND DOUBLE CLASSIFICATIONS. PART 1, RESUL, TECH 65, 95

TUKEY, JOHN W. A NONPARAMETRIC SUM OF RANKS PROCEDURE FOR RELATIVE SPREAD IN UNPA IRED SAMPLES, CORR. 611 , JASA 60,429

TUKEY, JOHN $W$. APPROXIMATE BEHAVIOR OF THE DISTRIBUTION OF WINSORIZED T (TRIMMINC-WINSORIZATION 2), TECH 6B, B3

TUKEY, JOHN W. DISCUSSION, EMPHASIZINC THE CONNECTION BETWEEN ANALYSIS OF VARIANCE AND SPECTRUM ANALYSIS, TECH 61,191

TUKEY, JOHN W. EFFICIENT UTILIZATION OF NON-NUMERICAL INFORMATION IN QUANTI TATIVE ANALYS IS. CENERAL THEOR, AMS 63, 1347

TUKEY, JOHN W. SAMUEL S. WILKS, JASA 65, 939

TUKEY, JOHN W. THE EXAMINATION AND ANALYSIS OF RESIDUALS, TECH 63 , 141

TUKEY, JOHN W. THE FUTURE OF DATA ANALYSIS, CORR, 62812, AMS 62, 1

TUKEY, JOHN W. WHERE DO WE GO FROM HERE, JASA 60 , BO

TULCEA, A. IONESCU ON THE LIFTING PROPERTY, V, AMS 65, 819

TULLOCK, CORDON PUBLICATION DECISIONS AND TESTS OF SIGNIFICANCE, A GOMMENT, JASA 59,593

TURIN, G. L. THE CHARACTERISTIC FUNCTION OF HERMITIAN QUADRATIC FORMS IN COMPLEX NORMAL VARIABLES, BIOKA 60,199

TURNER JR, M. E. A GENERALIZATION OF THE LOCISTIC LAW OF GROWTH, BIOCS 69,577

TWEEDIE, M C K A MEAN-SQUARE-ERROR CHARACTERIZATION OF BINOMIAL-TYPEDISTRIBUTIONS, AMS 67, 620

TWEEDIE, M. C. K. THE INVERSION OF CUMULANT OPERATORS FOR POWER-SERIES DISTRIBUTIONS, AND THE APPROXIMATE, JASA 6B, 321

UMLAND, A. W. THE USE OF LAGRANGE MULTIPLIERS WITH RESPONSE SURFACES, TECH 59,289

URBAKH, V. YU, STATISTICAL TESTINC OF DIFFERENCES IN CASUAL BEHAVIOUR OF TWO MORPHOLOG ICALLY INDIST INCUIS, BIOCS 67,137

URY, H. K. LARCE-SAMPLE SIGN TESTS FOR TREND IN DISPERSION, BIOKA 66, $2 \mathrm{~B} 9$

URY, HANS K. A NOTE ON TAKING A COVARIABLE INTO ACCOUNT, JASA 66, 490 USHER, M. B. A MATRIX MODEL FOR FOREST MANACEMENT, BIOCS 69,309 USISKIN, ZALMAN PROBABILITIES IN THE VOTING PARADOX, AMS 64,857

VAGHOLKAR, M. K. A SEQUENTIAL PROCEDURE FOR TESTING A NULL HYPOTHESIS ACAINST A TWO SIDED ALTERNATIVE HYP, JRSSB 69 , NO 2

VACHOLKAR, M. K. FORMULAE TO IMPROVE WALD'S APPROXIMATION FOR SOME PROPERTIES OF SEQUENTIAL TESTS, JRSSB 65, 74

VACHOLKAR, M. K. THE MOST ECONOMICAL BINOMIAL SEQUENTIAL PROBABILITY RATIO TEST, BIOKA 60, 103

VACHOLKAR, M. K. THE PROCESS CURVE AND THE EQUIVALENT MIXED BINOMIAL WITH TWO COMPONENTS, JRSSB 59,63

VAIL, RICHARD W. RESIDUAL ANALYSIS, CORR, 61 1005, JASA 61, 98

VAJDA, S. AN OUTLINE OF LINEAR PROCRAMMINC AN OUTLINE OF LINEAR PROGRAMMING (WITH DISCUSSION), JRSSB 55, 165

VALAND, $R$. S. INVARIANT INTERVAL ESTIMATION OF A LOCATION PARAMETER, AMS 6B, 193

VAN ARMAN, D. J. ADMISSIBLE DESIGNS FOR POLYNOMIAL SPLINE RECRESSION, AMS 69, 1557 
VAN DER HEIDEN, J. A . ON A CORRECTION TERM IN THE METHOD OF PAIRED COMPARISONS, BIOKA 52,211

VAN DER VAART, H. R. ON CERTAIN CHARACTERISTICS OF THE DISTRIBUTION OF THE LATENT ROOTS OF A SYMMETRIC RA, AMS 61, B 64

VAN DER VAART, H. R. SOME EXTENSIONS OF THE IDEA OF BIAS, AMS 61, 436

VAN DER VAART, H. ROBERT A NOTE ON WILKS' INTERNAL SCATTER, AMS 65. 1308

VAN DER VELDE, E. A. HOW TO SURVIVE A FIXED NUMBER OF FAIR BETS, AMS 67,1278

VAN DER WATT, P. A COMPARISON OF CERTA IN TESTS OF NORMALITY, SASJ 69. NO. 2

VAN EEDEN. C. AN APPROXIMATION TO THE WILCOXON-MANN-WHITNEY DISTRIBUTION, JASA 69.591

VAN EEDEN, CONSTANCE 8AYESIAN BIO-ASSAY, AMS 64.886

VAN EEDEN, CONSTANCE FLUCTUATION THEOREM AND A DISTRIBUTION-FREE TEST, AMS 64, 1359

VAN EEDEN, CONSTANCE NOTE ON THE CONSISTENCY OF SOME DISTRI8UTIONFREE TESTS FOR DISPERSION, JASA 64. 105

VAN EEDEN, CONSTANCE THE RELATION BETWEEN PITMAN'S ASYMPTOTIC RELATIVE EFFICIENCY OF TWO TESTS AND THE CO, AMS 63, 1442

VAN ELTEREN, PH. THE ASYMPTOTIC EFFICIENCY OF THE CHI-SQUARE-SU8R-TEST FOR A BALANCED INCOMPLETE 8LOCK D, 8IOKA 59, 475

VAN HEERDEN, D. F. I. THE ORTHOGONAL POLYNOMIALS OF THE FACTORIAL POWER SERIES PR08A8ILITY DISTRI8UTIONS, SASJ 67,49

VAN HERRDEN, D. F. I. THE ORTHOGONAL POLYNOMIALS OF POWER SERIES PR08A8ILITY DISTRI8UTIONS AND THEIR USES, 8IOKA 66, 121

VAN NESS, J S S. EST IMATION OF THE 8ISPECTRUM, AMS 65, 1120

VAN NESS, JOHN $W$ ASYMPTOTIC NORMALITY OF BISPECTRAL ESTIMATES, AMS 66. 1257

VAN NESS, JOHN W DISTINGUISHA8ILITY OF PRO8A8ILITY MEASURES, AMS 69,381

VAN NESS, JOHN W. THE MAXIMUM DEVIATION OF SAMPLE SPECTRAL DENSITIES, AMS 67,1558

VAN RENSBURG, G. J. J. 'N BENADERING VIR 'N MAGREEKS WAARSKYNLIKHEIDSVERDELING, SASJ 69 . NO. 2

VAN RYZIN, J. ESTIMATING THE PARAMETERS OF A CONVOLUTION, JRSS8 69. 181

VAN RYZIN, J. ON STRONG CONSISTENCY OF DENSITY ESTIMATES, AMS 69. 1765

VAN RYZIN, J REPETITIVE PLAY IN FINITE STATIST ICAL GAMES WITH UNKNOWN DISTRIBUTIONS. AMS 66.976

VAN RYZIN, J. THE SEQUENTIAL COMPOUND DECISION PROBLEMS WITH M-8Y-N FINITE LOSSMATRIX. AMS 66, 954

VAN RYZIN, J.R. RATES OF CONVERGENCE IN THE COMPOUND DECISION PROBLEM FOR TWO COMPLETELY SPECIFIED DISTR, AMS 65, 1743

VAN RYZIN, J.R. THE COMPOUND DECISION PROBLEM WITH M-8Y-N FINITE LOSS MATRIX, AMS 66, 412

VAN VLECK. L. D. SELECTION BASIS IN ESTIMATION OF THE GENETIC CORRELATION, BIOCS 68,951

VAN VLECK, L. D. SELECTION INDICES FOR QUADRATIC MODELS OF TOTAL MERIT, 8IOCS 68,937

VAN ZWET, W. R. AN INEQUALITY FOR EXPECTED VALUES OF SAMPLE QUANTILES, AMS 67,1817

VANZWET, W. R. ONMIXTURES OF DISTRIBUTIONS, AMS 66, 281

VAN ZWET, W. R. ON THE COMBINATION OF INDEPENDENT TEST STATISTICS. AMS 67,659

VANDEWIELE, GEORGES AN INEQUALITY CONCERNING TESTS OF FIT OF THE KOLMOGOROV-SMIRNOV TYPE, AMS 67, 1240

VANDEWIELE, GEORGES THE CALCULATION OF DISTRIBUTIONS OF KOLMOGOROV-SMIRNOV TYPE STAT ISTICS INCLUDING A TA, AMS 68, 233

VARADY, P. D. PROBABILITIES OF CORRECT CLASSIFICATION IN DISCRIMINANT ANALYSIS, 8IOCS 66,908

VAR8ERG, DALE E. ALMOST SURE CONVERGENCE OF QUADRATIC FORMS IN INDEPENDENT RANDOM VARIA8LES, AMS 68,1502

VARBERG. DALE E. CONVERGENCE OF QUADRATIC FORMS IN INDEPENDENT RANDOM VARIABLES, AMS 66,567

VARBERG, DALE E. EQUIVALENT GAUSSIAN MEASURES WITH A PARTICULARLY SIMPLE RADON-NIKODYM DERIVATIVE, AMS 67, 1027

VARDE, S. D. LIFE TESTING AND RELIABILITY ESTIMATION FOR THE TWO PARAMETER EXPONENT IAL DISTRIBUTION, JASA 69, 621

VARDE. S. D. MINIMUM VARIANCE UNBIASED ESTIMATION OF RELIABILITY FOR THE TRUNCATED EXPONENTIAL DISTRIBUTI, TECH 69, 609

VARDE, S. D. ON MINIMUM VARIANCE UNBIASED ESTIMATION OF RELIABILITY, AMS 69,710

VASUDEVA, R. B. SEQUENTIAL ESTIMATION OF QUANTAL RESPONSE CURVES. A NEW METHOD OF ESTIMATION, BIOKA 66,439

VEALE, JAMES R. EST IMATION OF A MEAN WHEN ONE OBSERVATION MAY BE SPURIOUS, TECH 69,331

VEEVERS. A. THE INVERSION OF CUMULANT OPERATORS FOR POWER-SERIES DISTRIBUTIONS. AND THE APPROXIMATE STABI, JASA 68, 321

VEINOTT JR, ARTHUR F. A SOLUTION TO A COUNTABLE SYSTEM OF EQUALITIES ARISING IN MARKOV IAN DECISION PROCES, AMS 67, 5B2

VEINOTT JR, ARTHUR F. DISCRETE DYNAMIC PROGRAMMING WITH A SMALL INTEREST RATE, AMS 69, 366

VEINOTT JR. ARTHUR F. DISCRETE DYNAMIC PROGRAMMING WITH SENSITIVE DISCOUNT OPTIMALITY CRITERIA, AMS 69, 1635

VEINOTT JR, ARTHUR F. ON FINDING OPTIMAL POLICIES IN DISCRETE DYNAMIC PROGRAMMING WITH NO DISCOUNTING. AMS 66, 12B4
VEMUGANTI, R. R. A LEARNING MODEL FOR PROCESSES WITH TOOL WEAR, TECH 68,379

VENTER, J.H. AN EXTENSION OF THE ROBBINS-MONRO PROCEDURE, AMS 67. 181

VENTER, J . H. ON CONVERGENCE OF THE KIEFER-WOLFOWITZ APPROXIMATION PROCEDURE, AMS 67, 1031

VENTER, J.H. ON DVORETZKY STOCHASTIC APFROXIMATION THEOREMS, AMS 66.1534

VENTER, J . H. ON ESTIMATION OF THE MODE, AMS 67, 1446

VENTER, J. H. PROBABILITY MEASURES ON PRODUCT SPACES, SASJ 67,3

VERDOOREN, L. R. CORRIGENDA, 'EXTENDED TABLES OF CRITICAL VALUES FOR WILCOXON'S TEST STATISTIC. ' , 8IOKA 64. 527

VERDOOREN, L. R. EXTENDED TABLE OF CRITICAL VALUES FOR WILCOXON'S TEST STATISTIC, 8IOKA 63, 177

VERE-JONES, D. NOTE ON A THEOREM OF KINGMAN AND A THEOREM OF CHUNG. AMS 66,1844

VERE-JONES, D. SOME APPLICATIONS OF PROBABILITY GENERATING FUNCTIONALS TO THE STUDY OF INPUT- OUTPUT STREA, JRSS8 68,321

VERHAGEN, A. M. W. THE ESTIMATION OF REGRESSION AND ERROR-SCALE PARAMETERS, WHEN THE JOINT DISTR IBUTION 0,8 IOKA 61,125

VIDWANS, SUDHAKAR M. A NOTE ON THE NEGATIVE BINOMIAL DISTRI8UTION, BIOKA 64,264

VIJAYAN, K. AN EXACT (PI)PS SAMPLING SCHEME, A GENERALIZATION OF A METHOD OF HANURAV, JRSS 868,556

VILLEGAS, C. CONFIDENCE REGION FOR A LINEAR RELATION, AMS 64,7BO

VILLEGAS. C. MAXIMUM LIKELIHOOD EST IMATION OF A LINEAR FUNCTIONAL RELATIONSHIP, AMS 61, 1048

VILLEGAS, C. ON QUALITATIVE PRO8A8ILITY SIGMA-ALGE8RAS. AMS 64. 1787

VILLEGAS, C. ON THE A PRIORI DISTRIBUTION OF THE COVARIANCE MATRIX. AMS 69, 1098

VILLEGAS, C. ON THE ASYMPTOTIC EFFICIENCCY OF LEAST SQUARES ESTIMATORS, AMS 66, 1676

VILLEGAS, C. ON THE LEAST SQUARES ESTIMATION OF NON-LINEAR RELATIONS, AMS 69, 462

VINCENT, S, E. A TEST OF HOMOGENEITY FOR ORDERED VARIANCES, JRSSB 61,195

VINOD. HRISHIKESH D. INTEGER PROGRAMMING AND THE THEORY OF GROUPING. JASA 69,506

VITALE, P. A. A NUMERICAL INVESTIGATION OF SEVERAL ONE-DIMENSIONAL SEARCH PROCEDURES IN NONLINEAR REGRESS, TECH 69.265

VITALE. PATRICK A. APPLICATION OF A MODIFICATION OF DAVIDON'S METHOD TO NONLINEAR REGRESSION PRO8LEMS. TECH 68.843

VITHAYASAI, C. UNBIASED COMPONENTWISE RATIO ESTIMATION, CORR, 63 1163. JASA 61,350

VON BAHR, BENGT INEQUALITIES OF THE RTH ABSOLUTE MOMENT OF A SUM OF RANDOM VARIA8LES, I LESS THAN OR EQUA, AMS 65, 299

VON BAHR, BENGT ON THE CONVERGENCE OF MOMENTS IN THE CENTRAL LIMIT THEOREM, AMS 65. 808

WAGLE, 8. MULTIVARIATE 8ETA DISTRIBUTION AND A TEST FOR MULTIVARIATE NORMALITY, JRSS8 68,511

TAGNER, HARVEY M. LINEAR PROGRAMMING TECHNIQUES FOR REGRESSION ANALYSIS, JASA 59, 206

WAGNER, HARVEY M. NON-LINEAR REGRESSION WITH MINIMAL ASSUMPTIONS, JASA 62,572

WAGNER, HARVEY M. ON THE DISTRIBUTION OF SOLUTIONS IN LINEAR PROGRAMMING PRO8LEMS, JASA 58, 161

WAGNER, TERRY J, ON THE RATE OF CONVERGENCE FOR THE LAW OF LARGE NUM8ERS, AMS 69, NO. 6

WAHBA, GRACE ON THE DISTRIBUTION OF SOME STATISTICS USEFUL IN THE ANALYSIS OF JOINTLY STATIONARY TIME SER, AMS 68,1849

WAKNIS, MRUDULLA N. A SYSTEM OF INEQUALITIES FOR THE INCOMPLETE GAMMA FUNCTIONS AND THE NORMAL INTEGRAL. AMS 65. 139

WAKSBERG, JOSEPH A STUDY OF RESPONSE ERRORS IN EXPENDITURES DATA FROM HOUSEHOLD INTERVIEWS, JASA 64,18

WAKSBERG, JOSEPH WASHINGTON STATISTICAL SOCIETY MEMORIAL MEETING FOR WILLIAMN. HURWITZ. CHANGES IN CENSU, JASA 69, NO.4

WALDEN, WILLIAME. A FAVORABLE SIDE BET IN NEVADA BACCARAT, JASA 66. 313

WALDORF, WILLIAM H. DEMAND FOR MANUFACTURERS' SERVICES FOR BAKERY PRODUCTS AND FRUITS AND VEGETABLES, JASA 65,740

WALES, TERENCE J. EST IMATION OF AN ACCELERATED DEPRECIATION LEARNING FUNCTION, JASA 66, 995

WALKER, A.M. A GOODNESS OF FIT TEST FOR SPECTRAL DISTRIBUTION FUNCTIONS OF STATIONARY TIME SERIES WITH N, BIOKA 56, 257

WALKER, A.M. A NOTE ON THE ASYMPTOTIC DISTRIBUTION OF SAMPLE QUANTILES, JRSSB 6B, 570

WALKER, A.M. A NOTE ON THE ASYMPTOTIC EFFICIENCY OF AN ASYMPTOTICALLY NORMAL EST IMATOR SEQUENCE , CORR . 6, JRSSB 63. 195

WALKER, A. M. CORRIGENDA, 'ON DURBIN'S FORMULA FOR THE LIMITING GENERALIZED VARIANCE OF A SAMPLE OF CONSE, BIOKA 61,476

WALKER, A. M. LARGE-SAMPLE ESTIMATION OF PARAMETERS FOR AUTOREGRESSIVE PROCESSES WITH MOVING-AVERAGE RESI. BIOKA 62, 117

WALKER, A. M. LARGE-SAMPLE ESTIMATION OF PARAMETERS FOR MOVINGAVERAGE MODELS, BIOKA 61,343

WALKER, A . M. ON DURBIN 'S FORMULA FOR THE LIMITING GENERALIZED VARIANCE OF A SAMPLE OF CONSECUTIVE OBSERV. BIOKA 61, 197

WALKER. A. M. ON THE ASYMPTOTIC BEHAVIOUR OF POSTERIOR DISTRIBUTIONS, JRSSB 69.80 
WALKER, A. M. ON THE ASYMPTOTIC DISTRIBUTION OF THE AUTOCORRELATIONS OF A SAMPLE FROM A LINEAR STOCHASTIC, AMS 64, 1296

WALKER, A. M. SOME CONSEQUENCES OF SUPERIMPOSED ERROR IN TIME SERIES ANALYSIS, BIOKA 60,33

WALKER, A. M. SOME TESTS OF SEPARATE FAMILIES OF HYPOTHESES IN TIME SERIES ANALYSIS, BIOKA 67,39

WALKER, HELEN M. THE CONTRIBUTIONS OF KARL PEARSON, JASA 58, 11

WALKER. S. H. ESTIMATION OF THE PROBABILITY OF AN EVENT AS A FUNCTION OF SEVERAL VARIABLES, BIOKA 67,167

WALKUP, D. W. AN EXAMPLE OF THE DIFFERENCE BETWEEN THE LEVY AND LEVYPROKHOROV METRICS, AMS 69,322

WALKUP. D. W. ASSOCIATION RANDOM VARIABLES, WITH APPLICATIONS, AMS 67,1466

WALLACE, D. L. AUTHOR 'S REPLY TO ANSCOMBE 'S COMMENTS, TECH 65, 169

WALLACE, D. L. CORRELATION OF RANCES OF CORRELATED DEVIATES. BIOKA 66, 191

TALLACE, D. L. SHORT-CUT MULTIPLE COMPARISONS FOR BALANCED SINCLE AND DOUBLE CLASSIFICATIONS. PART 2. DER, BIOKA $65,4 B 5$

MALLACE, D. L. SHORT-CUT MULTIPLE COMPARISONS FOR BALANCED SINGLE AND DOUBLE CLASSIFICATIONS. PART 1, RES, TECH 65,95

WALLACE, DAVIDL. INFERENCE IN AN AUTHORSHIP PROBLEM, JASA 63, 275

WALLACE, DAVID L. SIMPLIFIED BETA-APPROXIMATIONS TO THE KRUSKALMALLIS H TEST, JASA 59, 225

WALLACE, T. D. A TEST OF THE MEAN SQUARE ERROR CRITER ION FOR RESTRICTIONS IN LINEAR REGRESSION, JASA 6B, 558

WALLACE, T, D. EFFICIENCIES FOR STEPWISE REGRESSIONS, JASA 64, 1179

WALLAGE, T. D. TABLES FOR THE MEAN SQUARE ERROR TEST FOR EXACT LINEAR RESTRICTIONS IN REGRESSION, JASA 69, NO .4

WALLACE, WILLIAM H. A COMPUTER SIMULATION MODEL OF THE TEXTILE INDUSTRY, JASA 67,1338

TALLENIUS, $K$. T. SAMPLING FOR CONF IDENCE, JASA 67,540

WALLENIUS, K. T. SEQUENTIAL RELIABILITY ASSURANCE IN FINITE LOTS, TECH 69,61

WALLER, RAY A. A BAYES RULE FOR THE SYMMETRIG MULTIPLE COMPARISONS PROBLEM, JASA 69, NO .4

RALLINGTON, P. A. THE BIAS OF MOMENT ESTIMATORS WITH AN APPLICATION TO THE NEG ATIVE BINOMIAL DISTRIBUT ION, BIOKA 62, 193

TALLIS, $\mathbb{W}$. ALLEN PRESIDENTIAL ADDRESS, JASA 66, 1

TALSER, M. MULTIPLE REGRESSION COMBINING WITHIN-AND BETWEEN-PLOT INFORMATION, BIOCS 66,26

WALSH, J. E. A CENERAL USE OF THE POISSON APPROXIMATION FOR BINOMIAL EVENTS, WITH APPLICATION TO BACTERIA, BIOCS 66,74

WALSH, J. E. APPROXIMATE DISTRIBUTION FOR LARGEST AND FOR SMALLEST OF A SET OF INDEPENDENT OBSERVATIONS, SASJ 69 , NO.2

WALSH. JOHN E. APPROXIMATE DISTRIBUTION OF EXTREMES FOR NONSAMPLE GASES, JASA 64,429

WALSH, JOHNE. ASYMPTOTIC EFFICIENCIES OF A NONPARAMETRIC LIFE TEST FOR SMALLER PERCENT ILES OF A GAMMA DI, JASA 56,467

WALSH, JOHN E. COMMENTS ON 'THE SIMPLEST SIGNED-RANK TESTS', JASA 59,213

WALSH, JOHN E. DISTRIBUTION-FREE TOLERANCE INTERVALS FOR CONTINUOUS SYMMETRICAL POPULATIONS, AMS 62, 1167

WALSH, JOHN E. LIFE-TESTING RESULTS BASED ON A FEW HETEROGENEOUS LOGNORMAL OBSERVAITONS, JASA 67,45

WALSH, JOHN E. SOME TWO-SIDED DISTRIBUTION-FREE TOLERANCE INTERVALS OF A GENERAL NATURE, JASA 62, 775

WALTMAN, PAUL ON ESTIMATING MONOTONE PARAMETERS, AMS 6B, 1030

WAMBERSIE, A. ESTIMATION PAR LA METHODE DU MAXIMUM DE VRA ISEMBLANCE DES COURBES DE SURVIE DE MICROORGANIS, BIOCS 66,673

WANG, Y. Y. A COMPARISON OF SEVERAL VARIANCE COMPONENT ESTIMATORS, BIOKA 67, 301

WARD JR, JOE H. HIERARGHICAL GROUPINC TO OPTIMIZE AN OBJECTIVE FUNCTION, JASA 63,236

WARNER, STANLEY L. ASYMPTOTIC VARIANCES FOR DUMMY VARIATE RECRESSION UNDER NORMALITY ASSUMPTIONS, JASA 67, 1305

WARNER, STANLEY L. MULTIVARIATE REGRESSION OF DUMMY VARIATES UNDER NORMALITY ASSUMPTIONS. JASA 63, 1054

MARNER, STANLEY L. RANDOMIZED RESPONSE, A SURVEY TECHNIQUE FOR ELIMINATING EVASIVE ANSWER BIAS, JASA 65,63

WARNTZ, MILLIAM MEASURING SPATIAL ASSOCIATION WITH SPECIAL CONSIDERAT ION OF THE CASE OF MARKET ORIENTATIO, JASA 56, 597

WASAN, M. T. SEQUENTIAL OPTIMUM PROCEDURES FOR UNBIASED ESTIMATION OF A BINOMIAL PARAMETER, TEGH 64,259

WASAN, M. T. TABLES OF INVERSE GAUSSIAN PERCENTAGE POINTS, TECH 69 591

WASSERMAN. WILLIAM POTENTIALS IN APPLYING LINEAR PROGRAMMING TO THE CONSUMER PRICE INDEX, JASA 66, 982

WATKINS, R. GENETIC COMPONENTS FOR NON-INBRED DIPLOID SPECIES HAVINC ALL DIGENIC EPISTATIC VARIANCES OF E. BIOCS 69,545

WATKINS, RALPH J. CONFESSION OF FAITH, 1955, JASA 56, 1

WATSON, G.S. A DISTRIBUTION-FREE TWO-SAMPLE TEST ON A CIRCLE, BIOKA 64,256

WATSON, G. S. A NOTE ON THE CIRCULAR MULTIVARIATE DISTRIBUTION, BIOKA 56, 467

WATSON, G. S. A STUDY OF THE GROUP SCREENINC METHOD, TECH 61,371

WATSON, G.S. ALGEBRAIC THEORY OF THE COMPUTING ROUTINE FOR TESTS OF SIGNIFICANCE ON THE DIMENSIONALITY 0, JRSSB 56,70
WATSON, C. S. ANOTHER TEST FOR THE UNIFORMITY OF A CIRCULAR DISTRIBUTION, BIOKA 67,675

WATSON, C. S. CORRICENDA, 'ROBUSTNESS TO NON-NORMALITY OF RECRESSION TESTS', BIOKA 65,669

WATSON, C. S. EQUATORIAL DISTRIBUTIONS ON A SPHERE. , BIOKA 65, 193

WATSON, C. S. COODNESS-OF-FIT TESTS ON A CIRCLE, BIOKA 61, 109

WATSON, C . S . COODNESS-OF-FIT TESTS ON A CIRCLE, II, BIOKA 62,57

WATSON, G.S. HAZARD ANALYSIS. I, BIOKA 64, 175

WATSON, G. S. LINEAR RECRESSION ON PROPORTIONS, BIOCS 69, 5 B5

WATSON, G. S. LINEAR RELATIONSHIPS BETWEEN VARIABLES AFFECTED BY ERRORS, BIOCS 66,252

WATSON, C. S. MORE SICNIFICANCE TESTS ON THE SPHERE, BIOKA 60, 87

WATSON, C. S. ON CHI-SQUARE GOODNESS-OF-FIT TESTS FOR CONTINUOUS DISTRIBUTIONS (WITH DISCUSSION). JRSSB 58, 44

WATSON, G. S. ON THE CONSTRUCTION OF SICNIFICANCE TESTS ON THE CIRCLE AND THE SPHERE, BIOKA 56,344

WATSON, C.S. ON THE ESTIMATION OF THE PROBABILITY DENSITY, I, AMS 63,480

WATSON, C. S. ON THE JOINT DISTRIBUTION OF THE CIRCULAR SERIAL CORRELATION COEFFICIENTS, BIOKA 56, 161

WATSON, G. S. ON THE POSSIBILITY OF IMPROVING THE MEAN USEFUL LIFE OF ITEMS BY ELIMINATING THOSE WITH SHO, TECH 61, 281

WATSON, C. S. ROBUSTNESS TO NON-NORMALITY OF REGRESSION TESTS, BIOKA 62,93

WATSON. G. S. SERIAL CORRELATION IN RECRESSION ANALYSIS. I. BIOKA 55,327

WATSON, C. S. SERIAL CORRELATION IN RECRESSION ANALYSIS. II, BIOKA 56,436

WATSON, G. S. SUFFICIENT STATISTICS, SIMILAR REGIONS AND DISTRIBUTION-FREE TESTS, JRSSB 57, 262

WATSON, C. S. TESTING FOR SERIAL CORRELATION IN LEAST SQUARES REGRESSION. II . BIOKA 51, 159

WATSON, G. S. THE CHI-SQUARE GOODNESS-OF FIT TEST FOR NORMAL DISTRIBUTIONS, BIOKA 57,336

WATSON, G. S. THE DISTRIBUTION OF ORGANISMS, BIOCS 65,543

WATSON, GEOFFREY S. A BAYESIAN STUDY OF THE MULTINOMIAL DISTRIBUTION, AMS 67,1423

WATSON, GEOFFREY S. DENSITY ESTIMATION OF ORTHOCONAL SERIES, AMS 69. 1496

WATSON, GEOFFREYS. LINEAR LEAST SQUARES REGRESSION, AMS 67, 1679

WATTERSON, G. A. MARKOV CHAINS WITH ABSORBING STATES, A GENETIC EXAMPLE, AMS 61,716

WATTERSON, G. A. SOME PROBLEMS OF STATISTICAL INFERENCE IN ABSORBING MARKOV CHAINS. BIOKA 65,127

WATTERSON, G. A. SOME THEORETICAL ASPECTS OF DIFFUSION THEORY IN POPULATION CENETICS, CORR. 63352 , AMS 62,939

WATTERSON, GEOFFREY A INFERENCE ON A CENETIC MODEL OF THE MARKOV CHAIN TYPE, BIOKA 63, 251

WAUD, ROGER N. SMALL SAMPLE BIAS DUE TO MISSPECIFICATION IN THE 'PART IAL ADJUSTMENT' AND 'ADAPTIVE EXPECT, JASA 66, 1130

MAUGH, FREDERICK V CRAPHIC COMPUTATION OF THE MULTIPLE CORRELATION GOEFFICIENT, GORR. 58 1031. JASA 57. 479

WAUGH, FREDERICKV. ON FRACTIONAL POWERS OF A MATRIX, JASA 67, 1018

WAUGH, $\mathbb{W}$. A. O'N. AGE-DEPENDENT BRANCHINC PROCESSES UNDER A CONDITION OF ULT IMATE EXTINCTION, BIOKA 68, 291

WAUGH. W. A. O'N. AN AGE-DEPENDENT BIRTH AND DEATH PROCESS, BIOKA 55,291

WAUGH, W. A, O'N , CONDITIONED MARKOV PROCESSES, BIOKA 58,241

TAUGH, W. A. O'N. CORRIGENDA, 'CONDITIONED MARKOFF PROCESSES.' BIOKA 59,279

WAUGH, W. A. $0^{\prime} \mathrm{N}$. INDICES OF SYNCHRONY IN CELLULAR CULTURES, BIOCS 67,693

WEBB, N. L. THE EFFICIENCY OF N MACHINES UNI-DIRECTIONALLY PATROLLED BY ONE OPERATOR WHEN WALKINC TIME AN, JRSSB 57, 166

MEBB，S R R NON-ORTHOGONAL DESIGNS OF EVEN RESOLUTION, TECH 68, 291 WEBB , STEVE R, SATURA TED SEQUENT IAL FACTORI AL DESIGNS, TECH 6B, 535 WEBSTER, J. T. A METHOD FOR DISCRIMINATING BETWEEN FAILURE DENSITY FUNCT IONS USED IN REL IAB ILITY PREDICT I, TECH 65, I

WEBSTER, $\checkmark . T$. ON DEPENDENT TESTS FROM A NON-ORTHOGONAL DESIGN. JASA 66. BO3

WEBSTER, J. T. ON TWO METHODS OF BIAS REDUCTION IN THE ESTIMATION OF RATIOS, BIOKA 66, 57I

WEBSTER, J. T. THE POWER OF A TEST IN COVARIANCE ANALYSIS, BIOCS 69 NO. 4

WEEKS, D. L. ON THE ANALYSIS OF GROUP DIVISIBLE DESIGNS, JASA 64 , 1217

WEEKS, DAVID L. A NOTE ON THE DETERMINATION OF CONNECTEDNESS IN AN NWAY CROSS CLASSIFICATION, TECH 64,319

"WEEKS, DAVID L. A NOTE ON THE TRUNCATED EXPONENTIAL DISTRIBUTION, AMS 64, 1366

WEEKS, DAVID L, ERRATA, ' A NOTE ON THE DETERMINATION OF CONNECTEDNESS IN AN N-WAY CROSS CLASSIFICATION 1 ,TECH 65,281

WEEKS, DAVID L. SAMPLE SIZE DETERMINATION FOR TOLERANCE LIMITS TECH 68,343

WEEKS, DAVID L. TOLERANCE LIMITS FOR THE GENERALIZED GAMMA DISTRIBUTION, JASA 65, 1142

WEEKS, DAVID L. VARIANCE COMPONENTS IN TWO-WAY CLASSIFICATION MODELS WITH INTERACTION, BIOKA 63, 327 
WEESAKUL, B. FIRST EMPT INESS IN A F INITE DAM, JRSSB 61,343

作 BARRIER, AMS 61, 765

WECMAN, EDWARD J. A NOTE ON ESTIMATINC A UNIMODAL DENSITY, AMS 69. 1661

WEILER, $H$. A COEFFICIENT MEASURINC THE COODNESS OF FIT, TECH 66, 327

WEILER, $H$. A PROBLEM OF OPTIMUM ALLOCATION ARISINC IN CHEMICAL ANALYSES BY MULTIPLE ISOTOPE DILUTION, TECH 6I, 509

WEILER, $H$. A SICNIFICANCE TEST FOR SIMULTANEOUS QUANTAL AND QUANTITATIVE RESPONSES, TECH 64,273

WEILER, $H$. ERRATA, 'A COEFFICIENT MEASURING THE GOODNESS OF FIT' TECH 67,195 -

WEILER, H. THE USE OF INCOMPLETE BETA FUNCTIONS FOR PRIOR DISTRIBUTIONS IN BINOMIAL SAMPLING, PECH 65,335

NEINER, $H$. J. AN INTECRAL EQUATION IN AGE DEPENDENT BRANCHING PROCESSES, AMS 65,1569

WEINER, $H$. J. ASYMPTOTIC PROPERTIES OF AN AGE DEPENDENT BRANCHING PROCESS, AMS 65, 1565

WEINER, HOWARD J, MONOTONE CONVERGENCE OF MOMENTS IN AGE DEPENDENT BRANCHING PROCESSES, AMS 66, 1806

WEINER, J. M. ELIMINATION OF VARIATES IN LINEAR DISCRIMINATION PROBLEMS, BIOCS $66,26 \mathrm{~B}$

NEINSTEIN, ABBOTT S. ALTERNATIVE DEFINITIONS OF THE SERIAL CORRELATION COEFFICIENT IN SHORT AUTOREGRESSIV. JASA $58, \mathrm{BBI}$

WEINSTEIN, M. A. QUERY, THE SUM OF VALUES FROM A NORMAL AND A TRUNCATED NORMAL DISTRIBUTION, TECH 64, 104

WEIR, J. B. DE V. TABLE OF O. I PERCENTAGE POINTS OF BEHRENS 'S D, BIOKA 66, 267

WEISS, G. H. A MODEL FOR THE SPREAD OF EPIDEMICS BY CARRIERS, BIOCS 65,481

WEISS, G. H. GRAPHICALLY ORIENTED TESTS FOR HOST VARIABILITY IN DILUTION EXPER IMENTS, BIDCS 67,269

WEISS, GEORGE ON CERTAIN REDUNDANT SYSTEMS WHICH OPERATE AT DISCRETE TIMES, TECH 62,69

WEISS, GEORCE H. A COMMUNICATIONS SATELLITE REPLENISHMENT POLICY TECH 66, 399

WEISS, CEORGE H. THE RELIABILITY OF COMPONENTS EXHIBITING CUMULATIVE DAMAGE EFFECTS, TECH 61,413

WEISS, LIONEL A SEQUENTIAL TEST OF THE EQUALITY OF PROBABILITIES IN A MULTINOMIAL DISTRIBUTION, JASA 62, 769

WEISS, LIONEL ON ESTIMATING SCALE AND LOCATION PARAMETERS, JASA 63 $65 \mathrm{~B}$

WEISS, LIONEL ON SEQUENTIAL TESTS WHICH MINIMIZE THE MAXIMUM EXPECTED SAMPLE SIZE, JASA 62, 551

WEISS, LIONEL SAMPLING PLANS WHICH APPROXIMATELY MINTMIZE THE MAX IMUM EXPECTED SAMPLE SIZE, JASA 64,67

WEISS, LIONEL TESTS OF FIT BASED ON THE NUMBER OF OBSERVATIONS FALLING IN THE SHORTEST SAMPLE SPACINGS DE, AMS 61, B 3B

WEISSBERG, ALFRED ERRATA, 'TABLES OF TOLERANCE-LIMIT FACTORS FOR NORMAL DISTRIBUT IONS ' , TECH 61,576

NEISSBERG, ALFRED TABLES OF TOLERANCE-LIMIT FACTORS FOR NORMAL DISTRIBUTIONS, TECH $60,4 \mathrm{~B} 3$

WEISSBLUM, WALTER HIGHER-ORDER PROPERTIES OF A STATIONARY POINT PROCESS, JRSSB 63,413

WEISSMAN, I ON SOME RESULTS OF $N, V$. SMIRNOV CONCERNING LIMIT DISTRIBUTIONS FOR VARIATIONAL SERIES, AMS 69,480

WEITZMAN, R. A. THE TWENTY-SEVEN PER CENT RULE, AMS 64,214

WELCH, B , L. ' STUDENT' AND SMALL SAMPLE THEORY, JASA 58, 777

WELCH, B. L. FURTHER CRITICAL VALUES FOR THE TWO-MEANS PROBLEM BIOKA 56, 203

WELCH, B, L. NOTE ON SOME CRT ICISMS MADE BY SIR RONALD F ISHER, JRSSB 56,297

WELCH, B. L. ON COMPARISONS BETWEEN CONFIDENCE POINT PROCEDURES IN THE CASE OF A SINGLE PARAMETER, JRSSB 65 ,

WELCH, B. L. ON FORMULAE FOR CONFIDENCE POINTS BASED ON INTECRALS OF WEIGHTED LIKELIHOODS, JRSSB 63, 31B

WELCH, B. L. ON LINEAR COMBINATIONS OF SEVERAL VARIANCES, JASA 56 132

WELCH, B. L. ON THE COMPARISON OF SEVERAL MEAN VALUES, AN ALTERNATIVE APPROACH, BIOKA 51,330

WELCH, B. L. ON THE COMPARISON OF TWO MEANS, FURTHER DISCUSSION OF ITERAT IVE METHODS FOR CALCULATING TABL, BIOKA 54,361

WELCH, B. L. TABLE OF THE BOUNDS OF THE PROBAB ILITY INTECRAL WHEN THE FIRST FOUR MOMENTS ARE GIVEN, BIOKA 60,399

WELCH, B . L. THE DISTRIBUTION OF THE COEFFICIENT OF VARIATION, COMMENT ON A CRITICISM MADE BY KOOPMANS, O, BIOKA 65,303

WELCH, P. D. ON THE BUSY PERIOD OF A FACILITY WHICH SERVES CUSTOMERS OF SEVERAL TYPES, JRSSB 65,361

WELCH， PETER D . ON PRE-EMPTIVE RESUME PRIORITY QUEUES, AMS 64, 600

WELFORD, W. P. NOTE ON A METHOD FOR CALCULATINC CORRECTED SUMS OF SQUARES AND PRODUCTS, TECH 62, 419

WELLS, W. $R$ ON THE POSSIBILITY OF IMPROVING THE MEAN USEFUL LIFE OF ITEMS BY ELIMINAT ING THOSE WITH SHOR, TECH $61,2 \mathrm{~B} 1$

WELLS, W. T. THE DISTRIBUTION OF THE PRODUCT OF TWO CENTRAL OR NONCENTRAL CHI-SQUARE VARIATES, AMS 62, 1016

WELSCH, DELANE E. USE OF DOMAIN EST IMATORS WITH UNEQUAL PROBABILITY IN SAMPLE SURVEYS, JASA 6B, 9B4
WELSH, D. J. A. A TWO-DIMENSIONAL POISSON CROWTH PROCESS, JRSSB 65 497

WENDEL, J. G. THE NON-ABSOLUTE CONVERCENCE OF CIL-PELAEZ' INVERSION INTECRAL, AMS 61,338

WENC, TENC-SHAN AN INEQUALITY AND ALMOST SURE CONVERCENCE, AMS 69 , 1091

WEST, DEL LON NOTE ON THE MISSING PLOT PROCEDURE IN A RANDOMIZED BLOCK DESIGN, JASA 61,933

WESTLAKE, W. J A NUMERICAL ANALYSIS PROBLEM IN CONSTRAINED QUADRAT IC REGRESSION ANALYSIS, TECH 62, 426

WESTLAKE, W. J. COMPOSITE DESIGNS BASED ON IRREGULAR FRACTIONS OF FACTORIALS (CORR, 651036 ), BIOCS 65, 324

WETHER ILL, G. B. BAYESIAN SEQUENTIAL ANALYSIS, BIOKA 61, 2 BI

WETHERILL, G. B. SEQUENTIAL EST IMATION OF QUANTAL RESPONSE CURVES A NEW METHOD OF ESTIMATION, BIOKA 66,439

WETHERILL, G. B. SEQUENT IAL ESTIMATION OF QUANTAL RESPONSE CURVES (WITH DISCUSSION), JRSSB 63, 1

WETHERILL，G. B. SOME REMARKS ON THE BAYESIAN SOLUTION OF THE SINCLE SAMPLINC INSPECTION SCHEME, TECH 60, 341

WETHERILL, G. B. THE DECISION THEORY APPROACH TO SAMPLING INSPECTION (WITH DISCUSSION), JRSSB 66, 3B

WETHERILL, G. B. THE MOST ECONOMICAL BINOMIAL SEQUENTIAL PROBABILITY RATIO TEST, BIOKA 60, 103

WETHER ILL, C . B. THE MOST ECONOMICAL SEQUENT IAL SAMPL ING SCHEME FOR INSPECTION BY VARIABLES, JRSSB 59, 400

WETHERILL, G. B. THE WILCOXON TEST AND NON-NULL HYPOTHESES, JRSSB 60,402

WETTE, R. MAXIMUM LIKELIHOOD ESTIMATION OF THE PARAMETERS OF THE CAMMA DISTRIBUT ION AND THEIR BIAS, TECH 69, NO.4

WHARTON JR, CLIFTON R. PROCESSING UNDERDEVELOPED DATA FROM AN UNDERDEVELOPED AREA, JASA 60,23

WHEELER, R. C. SOME RESULTS FOR FIXED-TIME TRAFFIC SIGNALS, JRSSB 64. 133

WHEELER, STANLEY A DISTRIBUTION-FREE TWO-SAMPLE TEST ON A CIRCLE, BIOKA 64, 256

WHITCOMB, MARY G, CRITICAL REGIONS FOR TESTS OF INTERVAL HYPOTHESES ABOUT THE VARIANCE, JASA 66, 204

WHITE, C. ESTIMATION OF PARAMETERS OF A TRUNCATED POISSONIAN BINOMI AL, BIOCS 6B, 377

WHITE, COLIN THE DETECTION OF A CORRELATION BETWEEN THE SEXES OF ADJACENT SIBS IN HUMAN FAMILIES, JASA 65, 1035

WHITE, DAVID CONSTRUCTION OF CONFOUNDING PLANS FOR MIXED FACTORIAL DESIGNS, AMS 65, 1256

WHITE, J $S$ ASYMPTOTIC EXPANSIONS FOR THE MEAN AND VARIANCE OF THE SERI AL CORRELATION COEFFICIENT, BIOKA 61, B5

WHITE, JOHN S. THE MOMENTS OF LOG-WEIBULL ORDER STATISTICS, TECH 69 373

WHITE, JOHN S, THE NONPARAMETRIC ORDERING, 1001 TO 0110 , AMS 61, 101 WHITE, LEON S. MARKOVIAN DECISION MODELS FOR THE EVALUATION OF LARCE CLASS OF CONT INUOUS SAMPLING INSPE, AMS 65, 1408

WHITE, LEON S. THE EVALUATION OF H 106 CONTINUOUS SAMPLING PLANS UNDER THE ASSUMPTION OF WORST CONDITIONS, JASA 66,833

WHITE, R. F. THE MODIF IED LATIN SQUARE, JRSSB 57, 305

WHITFIELD, $H$. AVERAGE RUN LENCTHS IN CUMULATIVE CHART QUALITY CONTROL SCHEMES, TECH 61,11

WHITLOCK, J. H. ESTIMATION OF A TRUNCATION POINT, BIOKA 64,33 WHITMAN, S. S. A TABLE FOR COMPUT ING WORKING ANGLES, BIOCS 68, 413

WHITT INGHILL, M. TEST ING FOR HOMOGENEITY. I THE BINOMIAL AND MULTINOMIAL DISTRIBUTIONS, BIOKA 66,167

WHITTINGHILL, M. TESTING FOR HOMOCENEITY. II. THE POISSON DISTRIBUTION, BIOKA 66,183

WHITTLE, P. A BRANCHINC PROCESS IN WHICH INDIVIDUALS HAVE VARIABLE LIFET IMES, BIOKA 64,262

WHITTLE, $P$ A CLASS OF SITUATIONS IN WHICH A SEQUENTIAL ESTIMATION PROCEDURE IS NON-SEQUENTIAL, BIOKA 67,229

WHITTLE, $P$. CORRICENDA, 'ON STATIONARY PROCESSES IN THE PLANE' BIOKA 55,277

WHITTLE, P. CURVE AND PERIODOGRAM SMOOTHING (WITH DISCUSSION) JRSSB $57,3 \mathrm{~B}$

WHITTLE, P. ON STATIONARY PROCESSES IN THE PLANE, BIOKA 54, 434

WHITTLE, $P$. ON THE FITT INC OF MULTIVARIATE AUTOREGRESSIONS, AND THE APPROXIMATE CANONICAL FACTORIZATION O, BIOKA 63,129

WHITTLE, $P$. ON THE SMOOTHINC OF PROBABILITY DENSITY FUNCTIONS JRSSB 58,334

WHITTLE, $P$. ON THE USE OF THE NORMAL APPROXIMATION IN THE TREATMENT OF STOCHASTIC PROCESSES, JRSSB $57,26 \mathrm{~B}$

WHITTLE, P. ON THE VARIATION OF YIELD VARIANCE WITH PLOT SIZE, BIOKA

WHITTLE, $P$. RECURSIVE RELATIONS FOR PREDICTORS OF NON-STATIONARY PROCESSES, JRSSB 65,523

WHITTLE, $P$. SOME DISTRIBUTION AND MOMENT FORMULAE FOR THE MARKOV CHAIN, JRSSB 55, 235

WHITTLE. P. SOME EXACT RESULTS FOR ONE-SIDED DISTRIBUTION TESTS OF THE KOLMOGOROV-SMIRNOV TYPE, AMS 61, 499

WHITTLE, $P$. SOME GENERAL RESULTS IN SEQUENT IAL ANALYSIS, BIOKA 64 12

WHITTLE, P. SOME GENERAL RESULTS IN SEQUENT IAL DES IGN (WITH DISCUSSION), JRSSB 65,371 
WHITTLE, $P$, TESTS OF FIT IN TIME SERIES, BIOKA 52, 309

WHITTLE, P. THE OUTCOME OF A STOCHASTIC EPIDEMIC, A NOTE ON BAILEY'S PAPER, BIOKA 55, 116

WHITTLE, P. TOPOCRAPHIC CORRELATION, POWER-LAW COVARIANCE FUNCTIONS, AND DIFFUSION. BIOKA 62, 305

WHITWELL, JOHN C. REDUCED DESICNS OF RESOLUTION FIVE, TECH 61,459

WICHERN, DEAN W. A JOINT DESICN CRITERION FOR THE DUAL PROBLEM OF MODEL DISCRIMINATION AND PARAMETER ESTI, TECH 68,145

WICHURA, MICHAEL J. INEQUALIT IES WITH APPLICATIONS TO THE WEAK CONVERGENCE OF RAND OM PROCESSES WITH MULTI, AMS 69, 6B 1

WIGGINS, ALVIN D. A MINIMUM COST MODEL OF SPARE PARTS INVENTORY CONTROL, TECH 67,661

WI JSMAN, R. A. BOUNDS ON THE SAMPLE SIZE DISTRIBUT ION FOR A CLASS OF INVARI ANT SEQUENTI AL PROBABILITY RAT, AMS 6B, 104B

WIJSMAN, R. A. EXISTENCE, UNIQUENESS AND MONOTONICITY OF SEQUENTIAL PROBABILITY RATIO TESTS, AMS 63,1541

WIJSMAN, R. A. GENERAL PROOF OF TERMINATION WITH PROBABILITY ONE OF INVARI ANT SEQUENTIAL PROBABILITY RATI, AMS 67,8

WIJSMAN, R. A. OPTIMUM PROPERTIES AND ADMISSIBILITY OF SEQUENTIAL TESTS, AMS 63, 1

MIJSMAN, R. A. THE RELATIONSHIP BETWEEN SUFFICIENCY AND INVARI ANCE WITH APPLICATIONS IN SEQUENTIAL ANALYS, AMS 65, 575

WILBER, GEORGE L. MIGRATION EXPECTANCY IN THE UNITED STATES. JASA 63,444

WILCOXON, FRANK FACTORIAL 2-TO-THE-(P-Q) PLANS ROBUST AGAINST LINEAR AND QUADRATIC TRENDS, TECH 66, 259

WILCOXON, FRANK SEQUENTIAL RANK TESTS I. MONTE CARLO STUDIES OF THE TWO-SAMPLE PROCEDURE, TECH 65,463

WILCOXON, FRANK SEQUENTIAL RANK TESTS II. MODIFIED TWO-SAMPLE PROCEDURES, TECH 66,615

WILK, M. 8. A COMPARATIVE STUDY OF VARIOUS TESTS FOR NORMALITY, JASA $6 \mathrm{~B}, 1343$

WILK, M. B. AN ANALYSIS OF VARIANCE TEST FOR NORMALITY (COMPLETE SAMPLES), BIOKA 65,591

WILK, M. B. AN APPROXIMATION TO THE DISTRIBUTION OF Q, A VARIATE RELATED TO THE NON-CENTRAL T, AMS 64,315

WILK, M. B. APPROXIMATIONS FOR THE NULL DISTRIBUTION OF THE WSTATISTIC+ (TEST FOR NORMALITY), TECH 68,861

WILK, M. B. CORRIGENDA, 'ESTIMATION OF PARAMETERS OF THE GAMMA DISTRIBUTION USING ORDER STATISTICS. ' ' BIOKA 63, 546

WILK, M. B. CORRIGENDA, 'THE RANDOMIZATION ANALYSIS OF A GENERALIZED RANDOMIZED BLOCKDESIGN' ', BIOKA 56, 235

WILK, M. B. ESTIMATION OF ERROR VARIANCE FROM SMALLEST ORDERED CONTRASTS, JASA 63,152

WILK, M. B. ESTIMATION OF PARAMETERS OF THE GAMMA DISTRIBUTION USING ORDER STATISTICS, BIOKA 62,525

WILK, M. B. GRAPHICAL METHODS FOR INTERNAL COMPARISONS IN MULTIRESPONSE EXPERIMENTS, AMS 64,613

MILK, M. B NON-ADDITIVITIES IN A LATIN SQUARE DESIGN, JASA 57, 218 WILK, M. 8. PROBABILITY PLOTS FOR THE GAMMA DISTRIBUTION, TECH 62, 1

WILK, M. B. PROBABILITY PLOTTING METHODS FOR THE ANALYSIS OF DATA, BIOKA 6B, I

WILK, M. B. SCALE PARAMETER ESTIMATION FROM THE ORDER STATISTICS OF UNEQUAL GAMMA COMPONENTS, AMS 66, 152

WILK, M. B. SEPARATE MAXIMUM-LIKELIHOOD ESTIMATION OF SCALE OR SHAPE PARAMETERS OF THE GAMMA DISTRIBUT ION, BIOKA 63, 217

WILK, M. B. TAIL AREAS OF THE T-DISTRIBUTION FROM A MILLS' RATIOLIKE EXPANSION, AMS 63, 335

WILK, 'M. B. THE MOMENTS OF A VARIATE RELATED TO THE NON-CENTRAL T, AMS 64,298

WILK, M. B. THE MOMENTS OF THE NON-CENTRAL T-DISTRIBUTION, BIOKA 61 , 465

WILK, M. B. THE RANDOMIZATION ANALYSIS OF A GENERALIZED RANDOMIZED BLOCKDESIGN, BIOKA 55,70

WILK, MARTIN B. THE JOINT ASSESSMENT OF NORMALITY OF SEVERAL INDEPENDENT SAMPLES, TECH 68,825

WILKERSON, MARVIN SAMPLING ERROR IN THE CONSUMER PRICE INDEX. JASA 67,899

WILKIE, D. COMPLETE SET OF LEADING COEFFICIENTS FOR ORTHOCONAL POLYNOMI ALS UP TO N $=26$, TECH 65,644

WILKINS, C. A. ON TWO QUEUES IN PARALLEL, BIOKA 60, 198

WILKINS, COLERIDGE A. A PROBLEM CONCERNED WITH WEIGHTING OF DISTRIBUTIONS, JASA 61,281

WILKINSON, J. W. AN ANALYSIS OF PAIRED COMPARISON DESIGNS WITH INCOMPLETE REPETITIONS, BIOKA 57, 97

WILKINSON, $J$. W. QUERY, THE SUM OF VALUES FROM A NORMAL AND A TRUNCATED NORMAL DISTRIBUTION (CONTD), TECH 64, 469

WILKINSON, WILLIAM E. ON BRANCHING PROCESSES IN RANDOM ENVIRONMENTS, AMS 69,814

WILLIAMS, BRITAIN J. THE EFFECT OF TRUNCATION ON TESTS OF HYPOTHESES FOR NORMAL POPULATIONS, AMS 65, 1504

WILLIAMS, G. B. STUDIES IN THE HISTORY OF PROBABILITY AND STATISTICS. IV, A NOTE ON AN EARLY STATISTICAL, BIOKA 56, 248

WILLIAMS, D. A. NOTES. ERRORS OF TREATMENT COMPARISONS WHEN OBSERVATIONS ARE MISSING FROM A RANDOMISED BL, BIOCS 66,632

WILLIAMS, DONALD R. A NOTE ON THE DETERMINATION OF CONNECTEDNESS IN AN N-WAY CROSS CLASSIFICATION, TECH 64,319
WILLIAMS, DONALD R. ERRATA, ' A NOTE ON THE DETERMINATION OF CONNECTEDNESS IN AN N-WAY CROSS CLASSIFICATI, TECH 65,281

WILLIAMS, E. J. A COMPARISON OF THE DIRECT AND FIDUCIAL ARCUMENTS IN THE ESTIMATION OF A PARAMETER, JRSSB 63,95

WILLIAMS, E. J. A NOTE ON RECRESSION METHODS IN CALIBRATION, TECH 69,189

WILLIAMS, E. J. CAUCHY-DISTRIBUTED FUNCTIONS AND A CHARACTERIZATION OF THE CAUCHY DISTRIBUTION, AMS 69,1083

WILLIAMS, E. J. CAUCHY-DISTRIBUTED FUNCTIONS OF CAUCHY VARIATES, AMS 67,916

WILLIAMS, E J EXACT FIDUCIAL LIMITS IN NON-LINEAR ESTIMATION, JRSSB 62,125

WILLIAMS, E. J. ON THE CONSTRUCTION OF SICNIFICANCE TESTS ON THE CIRCLE AND THE SPHERE, BIOKA 56,344

WILLI AMS, E. J. SICNIFICANCE TESTS FOR DISCRIMINANT FUNCTIONS AND LINEAR FUNCTIONAL RELATIONSHIPS, BIOKA 55,360

WILLIAMS, E. J. SIMULTANEOUS REGRESSION EQUATIONS IN EXPERIMENTATION, BIOKA $5 B, 96$

WILLIAMS, E. J SOME EXACT TESTS IN MULTIVARIATE ANALYSIS, BIOKA 52 , 17

WILLIAMS, E. J. TESTS OF SIGNIFICANCE FOR CONCURRENT RECRESSION LINES, BIOKA 53,297

WILLIAMS, E. J. THE ANALYSIS OF ASSOCIATION AMONC MANY VARIABLES (WITH DISCUSSION), JRSSB 67,199

WLLIAMS, E J J THE COMPARISON OF RECRESSION VARIABLES, JRSSB 59 . 396

WILLI AMS, E. J. THE INTERPRETATION OF INTERACT IONS IN FACTORIAL EXPERIMENTS, BIOKA 52, 65

WILLIAMS, E, J USE OF SCORES FOR THE ANALYSIS OF ASSOCIATION IN CONTINCENCY TABLES, BIOKA 52, 274

WILLIAMS, J. S. A CONFIDENCE INTERVAL FOR VARIANCE COMPONENTS, BIOKA 62,278

WILLIAMS, J.S. ESTIMATION OF THE PROBABILITY OF DEFECTIVE FAILURE FROM DESTRUCTIVE TESTS, TECH 63,459

WILLIAMS, J S. INDEX SELECTION AND ESTIMATION FROM A SINGLE SAMPLE. BIOKA 63, 195

WILLIAMS, J.S. SOME STATISTICAL PROPERTIES OF A GENETIC SELECTION INDEX, BIOKA 62, 325

WILLIAMS, J. S. VARIANCE OF WEICHTED REGRESSION ESTIMATORS WHEN SAMPL ING ERRORS ARE INDEPENDENT AND HETER, JASA 69, NO.4

WILLIAMS, JAMES S. THE VARIANCE OF WEIGHTED REGRESSION ESTIMATORS JASA 67,1290

WILLIAMS, R. M. EXPERIMENTAL DESIGNS FOR SERIALLY CORRELATED OBSERVATIONS, BIOKA 52,151

WILLIAMS, R. M. THE VARIANCE OF THE MEAN OF SYSTEMATIC SAMPLES, BIOKA 56,137

WILLIAMS, T. THE BASIC BIRTH-DEATH MODEL FOR MICROBIAL INFECTIONS, JRSSB 65,338

WILLIAMS, T. THE DISTRIBUTION OF INANIMATE MARKS OVER A NONHOMOCENEOUS BIRTH-DEATH PROCESS, BIOKA 69, 225

WILLIAMS, T. THE DISTRIBUTION OF RESPONSE TIMES IN A BIRTH-DEATH PROCESS, BIOKA 65,581

WILLIAMS, T. THE SIMPLE STOCHASTIC EPIDEMIC CURVE FOR LARCE POPULATIONS OF SUSCEPTIBLES, BIOKA 65, 571

WILLIAMS, THEODORE J. THE PRESENT STATUS OF AUTOMATIC PRODUCTION AND CONTROL DEVICES AND EXPECTED FUTURE, TECH 66,73

WILLIAMS, W. H. ON TWO METHODS ON UNBIASED ESTIMATION WITH AUXILIARY VARIATES, JASA 62, 1B4

WILLIAMS, W. H. SAMPLE SELECTION AND THE CHOICE OF ESTIMATOR IN TWOWAY STRATIF IED POPULATIONS, JASA 64, 1054

WILLIAMS, $W . H$. THE VARIANCE OF AN ESTIMATOR WITH POST-STRATIFIED WEIGHTING, JASA 62,622

WILLIAMSON, E. TABLES OF THE LOCARITHMIC SERIES DISTRIBUTION, AMS 64,284

WILLIS. D. M. THE STATISTICS OF A PARTICULAR NON-HOMOCENEOUS POISSON PROCESS, BIOKA 64, 399

WILLIS, RICHARD H. LOWER BOUND FORMULAS FOR THE MEAN INTERCORRELATION COEFFICIENT, JASA 59, 275

WILLKE, T. A. ON AN EXTREME RANK SUM TEST FOR OUTLIERS, BIOKA 63, 375 WILSON, A. L AN APPROACH TO SIMULTANEOUS TOLERANCE INTERVALS IN RECRESSION, AMS 67, 1536

WILTON, J, W. SELECTION INDICES FOR QUADRATIC MODELS OF TOTAL MERIT BIOCS 68,937

WINDLE, CHARLES THE ACCURACY OF CENSUS LITERACY STATISTICS IN IRAN, JASA 59,578

WINKLER, ROBERT L. SCORING RULES AND THE EVALUATION OF PROBABILITY ASSESSORS, JASA 69, 1073

WINKLER, ROBERT L. THE ASSESSMENT OF PRIOR DISTRIBUTIONS IN BAYESIAN ANALYSIS, JASA 67, 776

WINKLER, ROBERT L. THE QUANTIFICATION OF JUDGMENT. SOME METHODOLOGICAL SUGGESTIONS, JASA 67, 1105

WINOKUR JR, HERBERT S. EXACT MOMENTS OF THE ORDER STATISTICS OF THE GEOMETRIC DISTRIBUTION AND THEIR RELA, JASA 67, 915

WINSTEN, G. B. GEOMETRIC DISTRIBUTIONS IN THE THEORY OF QUEUES \{WITH DISCUSSION), JRSS8 59,1

MINTER, R. F . CRITICAL VALUES OF THE COEFFIGIENT OF RANK CORRELATION FOR TESTING THE HYPOTHESIS OF INDEPE, BIOKA 61,444 
WINTNER, A. STUDENT'S DISTRIBUTION AND RIEMANN'S ELLIPTIC CEOMETRY, BIOKA 57,264

WISE, J. RECRESSION ANALYSIS OF RELATIONSHIPS BETWEEN AUTOCORRELATED TIME SERIES, JRSSB 56,240

WISE, J. STATIONARITY CONDITIONS FOR STOCHASTIC PROCESSES OF THE AUTOREGRESSIVE AND MOVINC-AVERACE TYPE, BIOKA 56, 215

WISE, J. THE AUTOCORRELATION FUNCTION AND THE SPECTRAL DENSITY FUNCTION, BIOKA 55, 151

WISE, J. THE RELATIONSHIP BETWEEN THE MEAN AND VARIANCE OF A STATIONARY BIRTH-DEATH PROCESS, AND ITS ECON, BIOKA 62, 253

WISE, M. E . A COMPLETE MULT INOMI AL DISTR IBUTION COMPARED WITH THE XSQUARE APPROXIMAT ION AND AN IMPROVEME, BIOKA 64, 277

WISE, M E. A QUICKLY CONVERGENT EXPANSION FOR CUMULATIVE HYPERGEOMETRIC PROBABILITIES, DIRECT AND INVERS, BIOKA 54,317

WISE, M. E . CORRIGENDA. 'A QUICKLY CONVERCENT EXPANSION FOR CUMULATIVE HYPERGEOMETRIC PROBABILIT IES, DIRE, BIOKA 55, 277

WISE, M. E. CORRICENDA. 'MULTINOMIAL PROBABILITIES AND THE CHISQUARE AND X-SQUARE DISTRIBUT IONS ' ' BIOKA 63, 546

WISE, M. E. MULTINOMIAL PROBABILITIES AND THE CHI-SQUARE AND XSQUARE DISTRIBUTIONS, BIOKA 63,145

WISE, M. E . ON NORMALIZING THE INCOMPLETE BETA-FUNCT ION FOR F ITT INC TODOSE-RESPONSE CURVES, BIOKA 60,173

WISHART, D. AN ALGORITHM FOR HIERARCHICAL CLASSIFICATIONS, BIOCS 69,165

WISHART, $J$. CHI-SQUARE PROBABILIT IES FOR LARCE NUMBERS OF DEGREES OF FREEDOM, BIOKA 56,92

WISHART, J. THE FACTORIAL MOMENTS OF THE DISTRIBUTION OF JOINS BETWEEN LINE SEGMENTS, 8IOKA 54,555

WISHART, JOHN MOMENT COEFFICIENTS OF THE K-STATISTICS IN SAMPLES FROM A FINITE POPULATION, BIOKA 52, I

WISHART, JOHN ORTHOGONAL POLYNOMIAL FITTING, BIOKA 53, 361

WISNIEWSKI, T. K. M. TESTING FOR HOMOGENEITY OF A BINOMIAL SERIES, BIOKA 68,426

WOINSKY, MELVIN N SEQUENTIAL NONPARAMETRIC TWO-WAY CLASSIFICATION WITH PRESCR IBED MAXIMUM ASYMPTOTIC ERR. AMS 69, 445

WOLD, HERMAN OSKAR ANDERSON, 1BB7-1960, AMS 61, 651

WOLFF, STEPHEN AN ELEMENT ARY METHOD OF OBTAINING LONER BOUNDS ON THE ASYMPTOTIC POWER OF RANK TESTS, AMS 68, $212 \mathrm{~B}$

WOLFOWITZ, J. ON A THEOREM OF HOEL AND LEVINE ON EXTRAPOLATION, AMS 65,1627

WOLFOWITZ, J. REMARK ON THE OPTIMUM CHARACTER OF THE SEQUENTIAL PROBABILITY RATIO TEST, AMS 66,726

WOLOCK, F.W. CYCLIC DESICNS, AMS 65, 1526

MONG, EUGENE HOMOGENEOUS GAUSS-MARKOV RANDOM FIELDS, AMS 69, 1625

WONG, EUGENE ON THE CONVERCENCE OF ORDINARY INTEGRALS TO STOCHASTIC INTEGRALS, AMS 65, 1560

WONG, SEOK PIN ASYMPTOTIC OPTIMUM PROPERTIES OF CERTAIN SEQUENTIAL TESTS, AMS 68, 1244

WONNACOTT. THOMAS A. SPECTRAL ANALYSIS COMBINING A BARTLETT WINDOW WITH AN ASSOCIATED INNER WINDOW, TECH 61, 235

WOODALL, ROSALIE C. EXACT OPERATING CHARACTERISTIC FOR TRUNCATED SEQUENTIAL LIFE TESTS IN THE EXPONENTIAL, AMS 62, 1403

WOODING, R. A. THE MULTIVARIATE DISTRIBUTION OF COMPLEX NORMAL VARIABLES, BIOKA 56,212

WOODROOFE, MICHAEL ON THE MAXIMUM DEVIATION OF THE SAMPLE DENSITY. AMS 67,475

WOODROOFE, MICHAEL STATISTICAL PROPERTIES OF THE NUMBER OF POSITIVE SUMS, AMS 66, 1295

WOODROOFE. MICHAEL B. CONSISTENT ESTIMATES OF THE PARAMETERS OF A LINEAR SYSTEM. AMS 69, NO. 6

WOODROOFE, MICHAEL B THE MAXIMUM DEVIAT ION OF SAMPLE SPECTRAL DENSITIES, AMS 67,1558

WOODRUFF, RALPH S. THE USE OF ROTATING SAMPLES IN THE CENSUS BUREAU 'S MONTHLY SURVEYS, JASA 63,454

WOODRUFF, RALPH S. USE OF A REGRESSION TECHNIQUE TO PRODUCE AREA BREAKDOWNS OF THE MONTHLY NATIONAL ESTIM, JASA 66, 496

WOODWORTH, GEORGE A NOTE ON NONPARAMETRIC TESTS FOR SCALE, AMS 67. 274

WOODWORTH, GEORGE FINE STRUCTURE OF THE ORDERING OF PROBABILITIES OF RANK ORDERS IN THE TWO SAMPLE CASE, AMS 66,98

WOODWORTH, GEORCE C NONPARAMETRIC RANKINC PROCEDURES FOR COMPARISON WITH A CONTROL, AMS 68, 2075

WOOLSEY, THEODORE D. SOME PROBLEMS OF THE HOUSEHOLD INTERVIEW DES IGN FOR THE NATIONAL HEALTH SURVEY, JASA 59,69

WORTHAM, A. W. A NOTE ON UNIFORMLY BEST UNBIASED ESTIMATORS FOR VARIANCE COMPONENTS, JASA 56, 266

WORTHAM. A. W. QUERY. JOINT CONFIDENCE LIMITS FOR RANKED OBSERVATIONS, TECH 66,368

WOUK, ARTHUR STATISTICAL PROPERTIES OF A CERTAIN PERIODIC BINARY PROCESS, TECH 66,247

WRICHT, WINDYM M JUMP ANALYSIS, BIOKA 59, 386

WU, S. M. AN ALGORITHM FOR THE DETERMINATION OF THE ECONOMIC DESIGN OF X-CHARTS BASED ON DUNCAN'S MODEL, JASA 68,304

WURTELE, ZIVIAS. A RECTIFYING INSPECTION PLAN, JRSSB 55.124

WURTELE, ZIVIAS. CONVERCENCE PROPERTIES OF A LEARNING ALGORITHM. AMS 64, 1819

WYLD, C. POLYNOMIAL PROJECTING PROPERT IES OF MULT I-TERM PREDICTORS OR CONTROLLERS IN NON-STATIONARY TIME, JRSSB 65, 144
WYNER, A D ON THE ASYMPTOT IC DISTRIBUT ION OF A CERTA IN FUNCT IONAL OF THE WIENER PROCESS, AMS 69, 1409

WYNN, A. H. A. FURTHER NOTES ON THE ANALYSIS OF ACCIDENT DATA, BIOKA 53,214

WYNN, A. H. A. THE TIME INTERVALS BETWEEN INDUSTRIAL ACCIDENTS, BIOKA 52, 16B

WYSHAK, C. ESTIMATION OF PARAMETERS OF A TRUNCATED POISSONIAN BINOMIAL, BIOCS 68,377

WYSHAK, CRACE NOTES, DISTRIBUTION AMONC RELATIVES OF GENOTYPES FOR TWINNING, BIOCS 6B, 179

YACKEL, JAMES A RANDOM TIME CHANCE RELAT ING SEMI-MARKOV AND MARKOV PROCESSES, AMS 68, 358

YAHAV, JOSEPH A. ASYMPTOTICALLY OPTIMAL BAYES AND MINIMAX PROCEDURES IN SEQUENTIAL EST IMATION, AMS 68,422

YAHAV, JOSEPH A. ON AN A.P.O. RULE IN SEQUENTIAL ESTIMATION WITH QUADRATIC LOSS, AMS 69, 417

YAHAV, JOSEPHA. ON OPTIMAL STOPPING, AMS 66,30

YAHAV, JOSEPH A . RENEWAL THEORY IN THE PLANE, AMS 65, 946

YAKOWITZ. S. A CONSISTENT ESTIMATOR FOR THE IDENTIFICATION OF FINITE MIXTURES, AMS 69, 1728

YAKOWITZ, SIDNEY J. ON THE IDENTIFIABILITY OF FINITE MIXTURES, AMS 68,209

YALAVIGI, C . C. A SERIES OF BALANCED INCOMPLETE BLOCK DESICNS, AMS $68,6 B 1$

YANCEY, T. A. PARAMETER ESTIMATES AND AUTONOMOUS GROWTH, CORR. 59 812, JASA 59,389

YANC, Y. Y. SHORTER CONFIDENCE BANDS IN LINEAR REGRESSION, JASA 67. 1050

YAO. YING AN APPROXIMATE DECREES OF FREEDOM SOLUTION TO THE MULT IVARIATE BEHRENS-F ISHER PROBLEM, BIOKA 65, 139

YASUDA, NORIKAZU ESTIMATION OF THE INBREEDING COEFFICIENT FROM PHENOTYPE FREQUENCIES BY A METHOD OF MAXIM, BIOCS 68,915

YATES, F. A GENERAL COMPUTER PROGRAMME FOR THE ANALYSIS OF FACTORIAL EXPERIMENTS, BIOCS 66,503

YATES, F. A NOTE ON THE APPLICATION OF THE COMBINATION OF PROBABILITIES TEST TO A SET OF 2-BY-2 TABLES, BIOKA 55, 404

YATES, F . COMPUTERS, THE SECOND REVOLUTION IN STATISTICS (THE FIRST FISHER MEMORIAL LECTURE), BIOCS 66, 233

YATES, F. ROUTINE ANALYSIS OF REPLICATED EXPERIMENTS ON AN ELECTRONIC COMPUTER (WITH DISCUSSION), JRSSB 57, 234

YATES, F. THE USE OF TRANSFORMATIONS AND MAXIMUM LIKELIHOOD IN THE ANALYSIS OF QUANTAL EXPER IMENTS INVOLV, BIOKA 55,382

YEH, NENG-CHE ON SLIPPAGE TEST (II) SIMILAR SLIPPACE TESTS, AMS 68 2029

YEN, E. H. ON TWO-STAGE NON-PARAMETRIC ESTIMATION, AMS 64, 1099

YEO , G. F. THE TIME-DEPENDENT SOLUTION FOR AN INFINITE DAM WITH DISCRETE ADDITIVE INPUTS, JRSSB 61, 173

YEO, G. F. TRAFFIC DELAYS ON A TWO-LANE ROAD, BIOKA 64, 11

YLVISAKER, DONALD A NOTE ON THE ABSENCE OF TANGENCIES IN CAUSSIAN SAMPLE PATHS, AMS 68,261

YLVISAKER. DONALD DESIGNS FOR REGRESSION PROBLEMS WITH CORRELATED ERRORS MANY PARAMETERS, AMS 6B, 49

YLVISAKER, DONALD DESIGNS

ON TIME SERIES, AMS 62, 1077

YLVISAKER, N. DONALD SOME STRUCTURE THEOREMS FOR STATIONARY PROBA8ILITY MEASURES ON FINITE STATE SEQUENCE, AMS 64, 550

YLVISAKER, $N$. DONALD THE EXPECTED NUMBER OF ZEROS OF A STATIONARY GAUSSIAN PROCESS, AMS 65, 1043

YOUDEN, W. J. DISCUSSION OF THE PAPERS OF MESSRS. SATTERTHWAITE AND BUDNE, TECH 59,157

YOUDEN, W. J. EVALUATION OF CHEMICAL ANALYSES ON TWO ROCKS, TECH 59 , 409

YOUDEN, W. J. MEASUREMENTS MADE BY MATCHING WITH KNOWN STANDARDS, TECH 59, 101

YOUDEN, W. J. MEMORIAL TO SIR RONALD AYLMER FISHER, 1890-1962, JASA 62,727

YOUDEN, W. J. MORTALITY PATTERNS IN EIGHT STRAINS OF FLOUR BEETLE BIOCS 65.99

YOUDEN, W. J. PARTIAL CONFOUNDING IN FRACTIONAL REPLICATION, TECH 61,353

YOUDEN. W. J . QUERY, INADMISSIBLE RANDOM ASSIGNMENTS, TECH 64, 103 YOUDEN, $\pi$. J. SYSTEMATIC ERRORS IN PHYSICAL CONST ANTS, TECH 62, 11 YOUNC, ALLAN H. LINEAR APPROXIMATIONS TO THE CENSUS AND BLS SEASONAL ADJUSTMENT METHODS, JASA 68,445

YOUNG. D. H. A NOTE ON A SEQUENT IAL OCCUPANCY PRO8LEM, BIOKA 68, 59

YOUNG, D. H. A NOTE ON THE FIRST TWO MOMENTS OF THE MEAN DEVIATION OF THE SYMMETR ICAL MULT INOMIAL DISTRIB, BIOKA 67,312

YOUNG. D. H. QUOTA FULFILMENT USING UNRESTRICTED RANDOM SAMPLINC. BIOKA 61,333

YOUNG, D. H. RECURRENCE RELATIONS BETWEEN THE P.D.F. 'S OF ORDER STATIST ICS OF DEPENDENT VARIABLES, AND SO, BIOKA 67, 283

YOUNG, D. H. SOME APPLICATIONS OF TWO APPROXIMATIONS TO THE MULTINOMIAL DISTRIBUTION, BIOKA 60,463

YOUNG, D. H. TWO ALTERNATIVES TO THE ST ANDARD CHI-SQUARE-TEST OF THE HYPOTHESIS OF EQUAL CELL FREQUENCIES, BIOKA 62, 107

YOUTZ, CLEO TABLES OF THE FREEMAN-TUKEY TRANSFORMATIONS FOR THE BINOMIAL AND POISSON DISTRIBUTIONS, BIOKA 61,433 
ZACHARIAH, K. C. A NOTE ON THE CENSUS SURVIVAL RATIO METHOD OF ESTIMATINC NET MICRATION, JASA 62, 175

ZACKS, S. BAYES SEQUENTIAL DESICN OF FRACTIONAL FACTORIAL EXPERIMENTS FOR THE EST IMATION OF A SUBCROUP OF, AMS 6B, 973

ZACKS, S. EST IMATINC THE CURRENT MEAN OF A NORMAL DISTR IBUTION WHICH IS SUB JECTED TO CHANCES IN TIME, AMS 64, 999

ZACKS. S. GENERALIZED LEAST SQUARES ESTIMATORS FOR RANDOMIZED FRACTIONAL REPLICATION DESICNS, AMS 64.696

ZACKS. S. MEAN SQUARE EFFICIENCY OF ESTIMATORS OF VARIANCE COMPONENTS, JASA 69, NO .4

ZACKS. S. MINIMUM VARIANCE UNBIASED AND MAX IMUM LIKELIHOOD ESTIMATORS OF RELIAB ILITY FUNCT IONS FOR SYSTEM. JASA 66, 1052

ZACKS. S. ON A COMPLETE CLASS OF LINEAR UNB IASED EST IMATORS FOR RANDOMIZED FACTORIAL EXPERIMENT, AMS 63,769

ZACKS, $S$. ON THE NON-EXISTENCE OF A FIXED SAMPLE ESTIMATOR OF THE MEAN OF A LOG-NORMAL DISTRIBUT ION HAVIN, AMS 67,949

ZACKS, S. OPT IMAL STRATEGIES IN FACTORIAL EXPERIMENTS, AMS 63, 7BO ZACKS, S. RANDOMIZATION AND FACTORIAL EXPERIMENTS, AMS 61,270

ZACKS, S. RANDOMIZED FRACTIONAL WEIGHING DESIGNS, AMS 66, 1382

ZACKS, $S$. SEQUENTIAL ESTIMATION OF THE MEAN OF A LOC-NORMAL DISTRIBUTION HAVINC A PRESCRIBED PROPORT IONAL, AMS 66, $16 B 8$

ZACKS, $S$. TEST PROCEDURES FOR POSSIBLE CHANGES IN PARAMETERS OF STATISTICAL DISTRIBUTIONS OCCURRING AT UNK, AMS 66, 1196

ZACKS, S. TESTING HYPOTHESES IN RANDOMIZED FACTORIAL EXPERIMENTS, AMS 67,1494

ZACKS, $S$. THE EFFICIENCIES IN SMALL SAMPLES OF THE MAXIMUM LIKELIHOOD AND BEST UN8IASED ESTIMATORS OF REL, JASA 66, 1033

ZACKS, S. UNBAISED ESTIMATION OF THE COMMON MEAN OF TWO NORMAL DISTRIBUTIONS BASED ON SMALL SAMPLES OF EQ. JASA 66,467

ZACKS. SHELLEY BAYES SEQUENTIAL DESIGNS OF FIXED SIZE SAMPLES FROM FINITE POPULATIONS, JASA 69 , NO, 4

ZAHL, S. A DEFORMATION METHOD FOR QUADRATIC PROGRAMMING, JRSSB 64. 141

ZAHL, S. SUPPLEMENT TO'A DEFORMATION METHOD FOR QUADRATIC PROCRAMMINC', JRSSB 65,166

ZAKAI, MOSHE ON THE CONVERGENCE OF ORDINARY INTECRALS TO STOCHASTIC INTEGRALS, AMS 65,1560

ZAKRZEWSKI, GUSTAVE PRACTICAL VALUE OF INTERNATIONAL EDUCATIONAL STATISTICS, JASA 56, 605

ZAREMBA, S. K. A CENTRAL LIMIT THEOREM FOR PARTLY DEPENDENT VARIABLES, AMS 61,677

ZAREMBA, S. K. BANDWIDTH AND RESOLVABILITY IN STATIST ICAL SPECTRAL ANALYSIS, JRSSB 59, 169

ZAREMBA, S. K. NOTE ON THE WILCOXON-MANN-WHITNEY STATISTIC, AMS 65 105B

ZAREMBA, S. K. ON ESTIMATING THE SPECTRAL DENSITY FUNCTION OF A STOCHASTIC PROCESS (WITH DISCUSSION), JRSSB 57,13

ZAREMBA.S. K. SOME APPLICATIONS OF ZERO-ONE PROCESSES, JRSSB 55. 243

ZAREMBKA, PAUL FUNCTIONAL FORM IN THE DEMAND FOR MONEY, JASA 6B, 502 ZEHNA, PETER $W$, INVARIANCE OF MAXIMUM LIKELIHOOD ESTIMATIONS, AMS 66. 744

ZEIGLER, R. K. A UNIQUENESS THEOREM CONCERNING MOMENT DISTRIBUTIONS, JASA 65,1203

ZEIGLER, R. K. COMPARISONS OF SOME TWO STACE SAMPLINC METHODS, AMS 66. B91

ZEICLER, R. K. DOUBLE SAMPLING PLANS WHERE THE ACCEPT ANCE CRITERION IS THE VARIANCE, TECH $6 B, 99$

ZEIGLER, R. K. THE USE OF NON-LINEAR RECRESSION METHODS FOR ANALYSING SENSITIVITY AND QUANTAL RESPONSE DA, BIOCS 67,563

ZELEN, M. A CALCULUS FOR FACTORIAL ARRANCEMENTS, AMS 62,600

ZELEN, M. ANALYSIS OF MULTIFACTOR CLASSIFICATIONS WITH UNEQUAL NUMBERS OF OBSERVATIONS, BIOCS 66,525

ZELEN, M. APPLICATIONS OF THE CALCULUS FOR FACTORIAL ARRANGEMENTS II. TWO WAY ELIMINATION OF HETEROGENEIT, AMS $64,65 B$

ZELEN, M. APPLICATIONS OF THE CALCULUS OF FACTORIAL ARRANGEMENTS. I. BLOCK AND DIRECT PRODUCT DESICN, BIOKA 63, 63

ZELEN. M. ESTIMATION OF EXPONENTIAL SURVIVAL PROBABILITIES WITH CONCOMITANT INFORMATION, BIOCS 65. B26

ZELEN, M. NORMAL APPROXIMATION TO THE CHI-SQUARE AND NON-CENTRAL F PROBABILITY FUNCTIONS, BIOKA 60,411
ZELEN, M. ON THE THEORY OF SCREENINC FOR CHRONIC DISEASES, BIOKA 69. No.3

ZELEN, MARVIN DISCUSSION OF 'A SUBJECTIVE EVALUATION OF BODE'S LAW AND AN '08JECTIVE' TEST FOR APPROXIMAT, JASA 69, 50

ZELEN. MARVIN ERRATA, 'FACTORIAL EXPERIMENTS IN LIFE TESTINC', TECH 60,121

ZELEN, MARVIN FACTORIAL EXPERIMENTS IN LIFE TESTINC, TECH 59, 269

ZELEN, MARVIN PLAY THE WINNER RULE AND THE CONTROLLED CLINICAL TRIAL, JASA 69, 131

ZELEN, MARVIN THE ANALYSIS OF INCOMPLETE BLOCK DESICNS, JASA 57, 204 ZELEN, MARVIN THE ROBUSTNESS OF LIFE TESTINC PROCEDURES DERIVED FROM THE EXPONENTIAL DISTRIBUTION, TECH 61,29

ZELLNER. A. MAXIMUM LIKELIHOOD AND BAYESIAN ESTIMATION OF TRANSITION PROBABILITIES., JASA 6B, 1162

ZELLNER, ARNOLD A STATISTICAL ANALYSIS OF PROVISIONAL ESTIMATES OF GROSS NATIONAL PRODUCT AND ITS COMPONE, JASA 5B, 54

ZELLNER, ARNOLD AN EFFICIENT METHOD OF EST IMATING SEEMINGLY UNRELATED RECRESSIONS AND TESTS FOR AGCREGATI, JASA 62, 348

ZELLNER, ARNOLD BAYES'S THEOREM AND THE USE OF PRIOR KNOWLEDGE IN RECRESSION ANALYSIS, BIOKA 64,219

ZELLNER, ARNOLD BAYESIAN ANALYSIS OF THE REGRESSION MODEL WITH AUTO-CORRELATED ERRORS, JASA 64,763

ZELLNER, ARNOLD ESTIMATORS FOR SEEMINGLY UNRELATED REGRESSION EQUATIONS, SOME EXACT FINITE SAMPLE RESULTS, JASA 63, 977

ZELLNER, ARNOLD ON THE BAYESIAN ESTIMATION OF MULTIVARIATE REGRESSION, JRSSB 64,277

ZELLNER, ARNOLD PREDICTION AND DECISION PROBLEMS IN RECRESSION MODELS FROM THE BAYESIAN POTNT OF VIEW, CO, JASA $65,60 \mathrm{~B}$

ZELNIK, MARVIN ACE PATTERNS OF MORTALITY OF AMERICAN NEGROES, 190002 T0 1959-61, JASA 69, 433

ZELNIK, MELVIN ERRORS IN THE 1960 CENSUS ENUMERATION OF NATIVE WHITES, JASA 64,437

ZEMACH, RITA ON ORTHOCONAL ARRAYS, AMS 66, 1355

ZIDEK. J. $\checkmark$. INADMISSIBILITY OF THE BEST INVARIATE ESTIMATOR OF EXTREME QUANTILES OF THE NORMAL DISTRIBUT, AMS 69, 1801

ZIDEK, J. V. LIMITINC DISTRIBUTIONS OF RESPONSE PROBABILITIES, AMS 65,706

ZTMMER, W J FRACTTONAL REPLICATION OF 2-T0-THE-P FACTORIAL EXPERIMENTS WITH THE FACTORS APPLIED SEQUENT, JASA 68,644

ZIMMER. W. J. SHORTER CONFIDENCE INTERVALS USINC PRIOR OBSERVATIONS, JASA 69,378

ZIMMER, W. J. SOME ACCEPTANCE SAMPLINC PLANS BASED ON THE THEORY OF RUNS, TECH 62,177

ZIMMER, W. J. THE RELATIONSHIP BETWEEN NEYMAN AND BAYES CONFIDENCE INTERVALS FOR THE HYPERGEOMETRIC PARAM, TECH 6B, 199

ZIMMER, W. J 2 TO THE POWER OF P FACTORIAL EXPERIMENTS WITH THE FACTORS APPLIED SEQUENTIALLY, JASA 64,1205

ZINGER, A. A NOTE ON OPTIMUM ALLOCATION FOR A ONE-WAY LAYOUT. BIOKA 62,563

ZINGER, A. DETECTION OF BEST AND OUTLY ING NORMAL POPULATIONS WITH KNOWN VARIANCES, BIOKA 61,457

ZINGER, A. ON THE CHOICE OF THE BEST AMONGST THREE NORMAL POPULATIONS WITH KNOWN VARIANCES, BIOKA 5B, 436

ZINK, R. E. A PERFECT MEASURABLE SPACE THAT IS NOT A LUSIN SPACE, AMS 67,1918

ZIPPEN, C. USE OF CONCOMITANT VARIABLES AND INCOMPLETE SURVIVAL INFORMATION IN THE ESTIMATION OF AN EXPON, BIOCS 66,665

ZOUTENDIJK, C. MAXIMIZING A FUNCTION IN A CONVEX REGION. JRSSB 59 , 338

ZWETFEL, J R R ON THE BIAS OF VARIOUS EST IMATORS OF THE LOGIT AND ITS VARIANCE WITH APPLICATION TO QUANTA, BIOKA 67, 181

ZYSKIND, CEORGE A NOTE ON RESIDUAL ANALYSIS, JASA 63, 1125

ZYSKIND, CEORGE ON CANONICAL FORMS, NON-NECATIVE COVARIANCE MATR ICES AND BEST AND SIMPLE LEAST SQUARES LI, AMS 67, 1092

ZYSKIND, GEORCE ON COMBINABILITY OF INFORMATION FROM UNCORRELATED LINEAR MODELS BY SIMPLE WEICHT ING, AMS 66, 133B

ZYSKIND CEORGE PARAMETRIC AUCMENTATIONS AND ERROR STRUCTURES UNDER WHICH CERTA IN SIMPLE LEAST SQUARES AN, JASA 69. NO . 4

ZYSKIND, GEORCE QUERY, MISSING VALUES IN FACTORIAL EXPERIMENTS, TECH 65,649

ZYSKIND, CEORGE SOME CONSEQUENCES OF RANDOMIZATION IN A CENERALIZATION OF THE BALANCED INCOMPLETE BLOCK D, AMS 63 , 


\section{BIBLIOGRAPHY}

ANNALS OF MATHEMATICAL STATISTICS VOLUME 32, 1961

AMS $61 \quad 1$ CHARLES JORDAN, 1871-1959* L. TAKACS

AMS 6112 STATISTICAL METHODS IN MARKOV CHAINS, CORR. 611343 * PATRICKBILL INCSLEY

AMS 61 4I THE FREQUENCY COUNT OF A MARKOV CHAIN AND THE TRANSITION TO CONTINUOUS TIME* I. J . GOOD

AMS 6149 ON THE ASYMPTOTIC DISTRIBUTION OF THE 'PSI-SQUARED' GOODNESS OF FIT CRITERIA FOR MARKOV CHAINS AND MARKOV SEQUENCES * B. R. BHAT

AMS 6159 SOME PROPERTIES OF RECULAR MARKOV CHAINS * B. R. BHAT

AMS 6172 SOME TESTS FOR CATECORICAL DATA *V.P. BHAPKAR

AMS $61 \quad 84$ TABLES FOR UNBIASED TESTS ON THE VARIANCE OF A NORMAL POPULATION * JAMES PACHARES

AMS 61 BB ASYMPTOTIC EFFICIENCY OF CERTAIN LOCALLY MOST POWERFUL RANK TESTS * JACK CAPON

AMS 61101 THE NONPARAMETRIC ORDERING, 1001 TO 0110 * JOHN S WHITE

AMS 61104 THE NON-CENTRAL MULTIVARIATE BETA DISTRIBUTION * A M. KSHIRSAGAR

AMS 61112 A UNIFIED THEORY OF ESTIMATION, I * ALLAN BIRNBAUM

AMS 61136 ADMISSIBLE AND MINIMAX ESTIMATES OF PARAMETERS IN TRUNCATED SPACES * MORRIS W. KATZ

AMS 61143 THE METHOD OF MOMENTS APPLIED TO A MIXTURE OF TWO EXPONENTI IAL DISTRIBUTIONS * PAUL R, RIDER

AMS 61148 SNOWBALL SAMPLINC * LEO A. GOODMAN

AMS 61171 PROBABILITY CONTENT OF REGIONS UNDER SPHERICAL NORMAL DISTRIBUTIONS, III. THE BIVARIATE NORMAL INTEGRAL * harold RUben

AMS 61 1B7 RECURRENT GAMES AND THE PETERSBURG PARADOX * HERBERT ROBBINS

AMS 61195 CONSISTENCY AND LIMIT DISTRIBUTIONS OF ESTIMATORS OF PARAMETERS IN EXPLOSIVE STOCHASTIC DIFFERENCE EQUATIONS * M. M. RAO

AMS 61219 FIRST EMPTINESS OF TWO DAMS IN PARALLEL * J.GANI

AMS 61230 THE TRANSIENT BEHAVIOR OF A COINCIDENCE VARIATE IN TELEPHONE TRAFFIC * P. D. FINCH

AMS 61235 FIRST PASSAGE TIMES OF A CENERALIZED RANDOM WALK, CORR. AND ACKNOWLEDGEMENT OF PRIORITY 611345 * JOHN R, KINNEY

AMS 61244 IDENTIFIABILITY OF MIXTURES * HENRY TEICHER

AMS 61249 AN ASYMPTOTIC FORMULA FOR THE DIFFERENCES OF THE POWERS AT ZERO * I, J GOOD

AMS 61257 ON A THEOREM OF RENYI CONCERNINC MIXING SEQUENCES OF SETS* J. H. ABBOTT, J. R. BLUM

AMS 61261 THEOREMS CONCERNING EISENHART'S MODEL II * FRANKLIN A. GRAYBILL, ROBERT A. HULTQUIST

AMS 61270 RANDOMIZATION AND FACTORIAL EXPERIMENTS * $S$ EHRENFELD, S, ZACKS

AMS 6I 29B OPTIMUM DESIGNS IN REGRESSION PROBLEMS, II * J, KIEFER

AMS 61326 NON-EQUIVALENT COMPARISONS OF EXPERIMENTS AND THEIR USE FOR EXPERIMENTS INVOLVING LOCATION PARAMETERS * M. STONE

AMS 61333 DISTRIBUTION OF THE LIKEL IHOOD RATIO FOR TEST ING MULTIVAR IATE LINEAR HYPOTHESES * $S$. K. KATT I

AMS 61336 A BOUND FOR THE LAW OF LARGE NUMBERS FOR DISCRETE MARKOV PROCESSES * MELVIN KATZ JR, A J . THOMASIAN

AMS 61 33B THE NON-ABSOLUTE CONVERGENCE OF GIL-PELAEZ' INVERSION INTEGRAL * J. G. WENDEL

AMS 61357 GEORGES DARMOIS, IBBB-1960* D. DUGUE

AMS 61361 THE EXISTENCE AND CONSTRUCTION OF BALANCED INCOMPLETE BLOCK DESIGNS * HAIM HANANI

AMS $613 B 7$ RANDOM ALLOCATION DESIGNS II, APPROXIMATE THEORY FOR SIMPLE RANDOM ALLOCATION * A. P. DEMPSTER

AMS 61406 SAMPLING MOMENTS OF MEANS FROM FINITE MULTIVARIATE POPULATIONS * D. W. BEHNKEN

AMS 61414 ON THE FOUNDATIONS OF STATISTICAL INFERENCE, BINARY EXPERIMENTS * ALLAN BIRNBAUM

4MS 61436 SOME EXTENSIONS OF THE IDEA OF BIAS * H. R. VAN DER VAART

AMS 61448 MULTIVARIATE CORRELATION MODELS WITH MIXED DISCRETE AND CONTINUOUS VARIABLES, CORR. $65343^{*} I$. OLKIN, R. F. TATE

IMS 61466 LIMITS FOR A VARIANCE COMPONENT WITH AN EXACT CONFIDENCE COEFFICIENT * W. C. HEALY JR

AMS 61477 CONFIDENCE SETS FOR MULTIVARIATE MEDIANS * P. G. HOEL, E. M. SCHEUER

AMS 61485 DISTRIBUTION FREE TESTS OF INDEPENDENCE BASED ON THE SAMPLE DISTRIBUTION FUNCTION * J. R. BLUM, J. KIEFER, M. ROSENBLATT

AMS 61499 SOME EXACT RESULTS FOR ONE-SIDED DISTRIBUTION TESTS OF THE KOLMOGOROV-SMIRNOV TYPE * P. WHITTLE

AMS 61506 SOME EXTENSIONS OF THE WALD-WOLFOWITZ-NOETHER THEOPEM * JAROSLAV HAJEK

AMS 61524 THE GAP TEST FOR RANDOM SEQUENCES * EVE BOFINGER, V. J BOFINGER
AMS 61535 THE MULT IVARIATE SADDLE POINT METHOD AND CHI-SQUARED FOR THE MULT INOMIAL DISTRIBUTION * I . J . GOOD

AMS 61549 A CENERALIZATION OF WALD'S IDENT ITY WITH APPLICATIONS TO RANDOM WALKS* H. D. MILLER

AMS 61561 A CHARACTERIZATION OF THE WEAK CONVERCENCE OF MEASURES * ROBERT BARTOSZYNSKI

AMS 61577 EXPONENTIAL BOUNDS ON THE PROBABILITY OF ERROR FOR A DISCRETE MEMORYLESS CHANNEL * SAMUEL KOTZ

AMS 61583 AN EXPONENTIAL BOUND ON THE STRONC LAW OF LARCE NUMBERS FOR LINEAR STOCHAST IC PROCESSES W ITH ABSOLUTELY CONVERCENT COEFFICIENTS * L. H. kOOPmans

AMS $615 B 7$ EXPECTED UTILITY FOR QUEUES SERVICING MESSAGES WITH EXPONENT I ALLY DECAY INC UT ILITY * FRANK A. HAIGHT

AMS 61594 ON THE GODING THEOREM FOR NOISELESS CHANNEL * PATRICK BILLINGSLEY

AMS 61602 THE ESSENTIAL COMPLETENESS OF THE CLASS OF GENERALIZED SEQUENTIAL PROBABILITY RATIO TESTS * $M$. H. DE GROOT

AMS 61605 A PROBLEM IN SURVIVAL* JAMES B MACQUEEN

AMS 61610 FIRST PASSAGE TIME FOR A PARTICULAR GAUSSIAN PROCESS * D. SLEPLAN

AMS 61612 NOTE ON THE ERCODIC THEOREM OF INFORMATION THEORY * $k$ L. CHUNG

AMS 61615 REMARK CONCERNING TWO-STATE SEMI-MARKOV PROCESSES * CYRUS DERMAN

AMS 61616 AN EXAMPLE OF AN ANCILLARY STATIST IC AND THE COMBINATION OF TWO SAMPLES BY BAYES' THEOREM* D A SPROTT

AMS 61619 CORRECTIONS TO 'SADDLE POINT METHODS FOR THE MULTINOMIAL DISTRIBUT IONS ' $57 \mathrm{~B} 61$ * I. J . GOOD

AMS 61619 CORRECTIONS TO 'A RELATIONSHIP BETWEEN HODCES' BIVARIATE SIGN TEST AND A NON-PARAMETRIC TEST OF DANIELS' 601190 * BRUCEM. HILL

AMS 61619 CORRECTIONS TO 'THE THEORY OF PROBABILITY DISTRIBUTIONS OF POINTS ON A LATTICE' 5B $256 * \mathrm{P}$, V. KRISHNA IYER

AMS 61620 CORRECTIONS TO 'A THEOREM ON FACTORIAL MOMENTS AND ITS APPLICATIONS' 50206 * P. V. KRISHNA IYER

AMS 61620 CORRECTION. THE TITLE SHOULD READ 'PROBABILITY CONTENT OF RECIONS UNDER SPHERICAL NORMAL DISTRIBUTIONS, II. THE DISTRIBUTION OF THE RANGE IN NORMAL SAMPLES' 601113 * HAROLD RUBEN

AMS 61651 OSKAR ANDERSON, 1887-1960 * HERMAN WOLD

AMS 61661 ONFIDUCIAL INFERENCE * D. A. S. FRASER

AMS 61677 A CENTRAL LIMIT THEOREM FOR PARTLY DEPENDENT VARIABLES * H. J. GODWIN, S. K. ZAREMBA

AMS $616 B 7$ SOME MULTIVARIATE CHEBYSHEV INEQUALITIES WITH EX TENSIONS TO CONTINUOUS PARAMETER PROCESSES * Z. W BIRNBAUM, ALBERT W. MARSHALL

AMS 61704 MAXIMAL INDEPENDENT STOCHASTIC PROCESSES * C. B. BELL AMS 61709 ON MARKOV CHAIN POTENTIALS * JOHN G. KEMENY, J. LAUR IE SNELL

AMS 61716 MARKOV CHAINS WITH ABSORBINC STATES, A GENETIC EXAMPLE * C. A. WATTERSON

AMS 61730 ESTIMATION OF THE SPECTRUM * V. K. MURTHY

AMS 61739 ON A COINCIDENCE PROBLEM CONCERNING PARTICLE COUNTERS * LAJOS TAKACS

AMS 61757 ON THE RUIN PROBLEM OF COLLECTIVE RISK THEORY * N. U PRABHU

AMS 61765 THE RANDOM WALK BETWEEN A REFLECTINC AND AN ABSORBINC BARR IER * B. WEESAKUL

AMS 61770 ON THE QUEUEINC PROCESS, MARKOV OR POISSON INPUT, GENERAL SERVICE TIME DISTRIBUTION, ONE SERVER * C $R$. HEATHCOTE

AMS 61771 THE SEQUENTIAL DESIGN OF EXPERIMENTS FOR INFINITELY MANY STATES OF NATURE* ARTHUR E. ALBERT

AMS 61 BOO ANALYSIS OF A CLASS OF PARTIALLY BALANCED INCOMPLETE BLOCK DESICNS WITH MORE THAN TWO ASSOCIATE CLASSES * P. V. RAO

AMS 61809 ON A LOCALLY MOST POWERFUL BOUNDARY RANDOMIZED SIMILAR TEST FOR THE INDEPENDENCE OF TWO POISSON VARIABLES * MOHAMAD SALAHUDDIN AHMED

AMS 61 82B CONFIDENCE INTERVALS FROM CENSORED SAMPLES * MAX HALPERIN

AMS 61838 TESTS OF FIT BASED ON THE NUMBER OF OBSERVATIONS FALLING IN THE SHORTEST SAMPLE SPACINGS DETERMINED BY EARLIER OBSERVAT IONS * LIONEL WEISS

AMS 61846 SOME NONPARAMETR IC MEDIAN PROCEDURES * V. P. BHAPKAR

AMS 61 B64 ON CERTAIN CHARACTERISTICS OF THE DISTRIBUTION OF THE LATENT ROOTS OF A SYMMETRIC RANDOM MATRIX UNDER GENERAL CONDITIONS *H. R. VANDER VAART

AMS 61 B74 THE DISTRIBUTION OF NONCENTRAL MEANS WITH KNOWN COVARIANCE * ALAN T. JAMES 
AMS 61 BB3 DISTRIBUTION OF A DEFINITE QUADRATIG FORM FOR NONGENTRAL NORMAL VARIATES, GORR. 63673 * B. K. SHAH G. G. KHATRI

AMS 61 88B PERGENTAGE POINTS AND MODES OF ORDER STATISTIGS FROM THE NORMAL DISTR IBUTION * SHANT I S. GUPTA

AMS 61 B94 EXPRESSING A RANDOM VARIABLE IN TERMS OF UNIFORM RANDOM VARIABLES * G. MARSAGLIA

AMS 61 B99 GENERATING EXPONENTIAL RANDOM VARIABLES * G. MAR-

AMS 61901 A GOMBINATORIAL LEMMA FOR GOMPLEX NUMBERS * GLEN BAXTER

AMS 61904 A GOMBINATORIAL DERIVATION OF THE DISTRIBUTION OF THE TRUNCATED POISSON SUFFIGIENT STATISTIG * T. A GAGOULLOS

AMS 61906 A NOTE ON SIMPLE BINOMIAL SAMPLING PLANS * B. BRAINERD, T. V. NARAYANA

AMS 61908 AN INEQUALITY FOR BALANGED INCOMPLETE BLOCK DESIGNS * V. N. MURTY

AMS 61910 THIRD ORDER ROTATABLE DESIGNS IN THREE DIMENSIONS. SOME SPECIFIC DESIGNS * NORMANR. DRAPER

AMS 61951 AN APPROAGH TO TIME SERIES ANALYSIS * EMANUEL PARZEN

AMS 61990 SOME MODEL I PROBLEMS OF SELEGTION * E. L. LEHMANN

AMS 611013 BAYES RULES FOR A GOMMON MULTIPLE GOMPARISONS PROBLEM AND RELATED STUDENT-T PROBLEMS * DAVID B. DUNGAN

AMS 611034 THE USE OF LEAST FAVORABLE DISTRIBUTIONS IN TESTING GOMPOSITE HYPOTHESES * H. E. REINHARDT

AMS 611042 ASYMPTOTIC EFFIGIENGY IN POLYNOMIAL ESTIMATION * PAUL G. HOEL

AMS 611048 MAXIMUM LIKELIHOOD ESTIMATION OF A LINEAR FUNGTIONAL RELATIONSHIP * G. VILLEGAS

AMS 611063 SEQUENTIAL CHI-SQUARED AND T-SQUARED TESTS * J. EDTARD JAGKSON, RALPH A. BRADLEY

AMS 611078 ESTIMATING THE PARAMETERS OF NEGATIVE EXPONENTIAL POPULATIONS FROM ONE OR TWO ORDER STATISTIGS. GORR. TO THIS PAPER PRINTED IN 631421 AND $1423^{*} \mathrm{H}$ LEON HARTER

AMS 611091 ON THE TWO SAMPLE PROBLEM, A HEURISTIG METHOD FOR GONSTRUCTING TESTS* V.P. GODAMBE

AMS $61110 B$ A NONPARAMETRIG TEST FOR THE PROBLEM OF SEVERAL SAMPLES * V.P. 8HAPKAR

AMS $61111 \mathrm{~B}$ DISTRIBUTION OF THE ANDERSON-DARLING STATISTIC * PETER A. W LEWIS

AMS 611125 ERRORS IN DISGRIMINATION * S. JOHN

AMS 611145 ON THE MONOTONIG GHARACTER OF THE POWER FUNGTIONS OF TWO MULTIVARIATE TESTS * S. N. ROY, W. F. MIKHAIL

AMS 611152 THE MOMENTS OF ELEMENTARY SYMMETRIG FUNCTIONS OF THE ROOTS OF A MATRIX IN MULTIVARIATE ANALYSIS * TITOA MIJARES

AMS 611161 VARIANGE GOMPONENTS IN THE UNBALANGED TWO-WAY NESTED GLASSIFIGATION * S. R. SEARLE
AMS 611167 SOME MAIN-EFFEGT PLANS AND ORTHOGONAL ARRAYS OF STRENGTH TWO* SIDNEY ADDELMAN. OSGAR KEMPTHORNE

AMS 611177 ON A GEOMETRIGAL METHOD OF GONSTRUGTION OF PARTIALLY BALANGED DESIGNS WITH TWO ASSOGIATE CLASSES * ESTHER SEIDEN

AMS $6111 \mathrm{BI}$ ON SOME METHODS OF CONSTRUGTION OF PARTIALLY BALANGED ARRAYS * I. M. GHAKRAVARTI

AMS 611186 SOME FURTHER DESIGNS OF TYPE 0-PP * G. H. FREEMAN

AMS 611191 THE SUFFIGIENGY IN THE UNDOMINATED GASE* D. L. BURKHOLDER

AMS 611201 ON A SPEGIAL CLASS OF REGURRENT EVENTS * M. P. SGHUTZENBERGER

AMS 611214 MAXIMUM LIKELIHOOD GHARAGTERIZATION OF DISTRIBUTIONS * HENRY TEIGHER

AMS 611223 ON THE DISTRIBUTION OF FIRST SIGNIFICANT DIGITS * ROGER S. PINKHAM

AMS 611231 MARKOV RENEWAL PROGESSES, DEFINITIONS AND PRELIMINARY PROPERTIES * RONALD PYKE

AMS 611243 MARKOV RENEWAL PROGESSES WITH FINITELY MANY STATES * RONALD PYKE

AMS 611260 A GONVEXITY PROPERTY IN THE THEORY OF RANDOM VARIABLES DEFINED ON A FINITE MARKOV CHAIN * H. D. MILLER

AMS 611271 LIMIT DISTRIBUTION IN THE THEORY OF GOUNTERS, GORR. 62 $1466^{*} \mathrm{G}$. SANKARANAKAYANAN

AMS 61 12B6 THE TRANSIENT BEHAVIOR OF A SINGLE SERVER QUEUING PROCESS WITH RECURRENT INPUT AND GAMMA SERVICE TIME * LAJOS TAKACS

AMS 611299 EFFICIENT ESTIMATION OF A REGRESSION PARAMETER FOR GERTAIN SEGOND ORDER PROGESSES * GHARLOTTE T STRIEBEL

AMS 611314 TWO SIMILAR QUEUES IN PARALLEL * J. F. G. KINGMAN

AMS 611324 QUEUES WITH BATGH DEPARTURES I * F. G. FOSTER, K. M. NYUNT

AMS 611333 ON THE CHAPMAN-KOLMOGOROV EQUATION * JAGK KARUSH

AMS 611337 A GENERALIZATION OF A THEOREM OF BALAKRISHNAN * N DONALD YLVISAKER

AMS 611339 THE OPINION POOL * M. STONE

AMS 611343 CORREGTION TO 'A GONSERVATIVE PROPERTY OF BINOMIAL TESTS' $601205^{*}$ H. A. DAVID

AMS 611343 ACKNOWLEDGEMENT OF PRIORITY FOR 'AN OPTIMUM PROPERTY OF MAXIMUM LIKELIHOOD ESTIMATION' $60120 \mathrm{~B}$ * V. P. GODAMBE

AMS 611344 GORREGTION TO 'A PROOF OF WALD'S THEOREM ON GUMULATIVE SUMS' $591245^{*} \mathrm{~N}$ L. JOHNSON

AMS 611344 CORRECTION TO 'ON THE MUTUAL INDEPENDENGE OF CERTAIN STATISTICS' $59125 B *$ *. G. KHATRI

AMS 611345 CORRECTION TO 'TABLES OF EXPEGTED VALUES OF ORDER STATISTICS AND PRODUGTS OF ORDER STATISTIGS FOR SAMPLES OF SIZE TWENTY AND LESS FROM THE NORMAL DISIRIBUTION' $56410^{*}$ D. TEIGHROEW

ANNALS OF MATHEMATICAL STATISTIGS VOLUME 33. 1962

AMS 621 THE FUTURE OF DATA ANALYSIS, GORR, 62812 * JOHN W. TUKEY

AMS 6268 INFINITELY DIVISIBLE DISTRIBUTIONS, REGENT RESULTS AND APPLIGATIONS * MAREK FISZ

AMS 6285 LIMIT THEOREMS FOR RANDOMLY SELECTED PARTIAL SUMS * PATRICK BILLINGSLEY

AMS 6293 A LAW OF LARGE NUMBERS FOR THE MAXIMUM IN A STATIONARY GAUSSIAN SEQUENGE * SIMEONM. BERMAN

AMS $629 B$ A 'RENEWAL' LIMIT THEOREM FOR GENERAL STOCHASTIG PROCESSES * V. E. BENES

AMS 62114 MIXTURES OF MARKOV PROCESSES * DAVID A. FREEDMAN

AMS 62119 SOME ASPEGTS OF THE EMIGRATION-IMMIGRATION PROCESS * HAROLD RUBEN

AMS 62130 A TRANSIENT DISCRETE TIME QUEUE WITH FINITE STORAGE * JOHN R. KINNEY

AMS 62137 A GENERAL METHOD FOR THE RELIABILITY ANALYSIS OF SYSTEMS UNDER VARIOUS PREVENTIVE MAINTENANGE POLIGIES * B . J. FLEHINGER

AMS 62157 APPROXIMATIONS TO THE MOMENTS OF THE SAMPLE MEDIAN * M. M. SIDDIQUI

AMS 62169 REGURRENGE RELATIONS BETWEEN THE PROBABILITY DENSITY FUNGTIONS OF ORDER STATISTIGS, AND SOME APPLIGATIONS * K. S. SRIKANTAN

AMS 62 17B ENUMERATION OF LINEAR GRAPHS FOR MAPPINGS OF FINITE SETS * JOHN RIORDAN

AMS 621 B6 ASYMPTOTIG POWER OF CERTAIN TEST GRITERIA. BASED ON FIRST AND SECOND DIFFERENGES, FOR SERIAL GORRELATION BETWEEN SUGGESSIVE OBSERVATIONS * A. R. KAMAT. Y. S. SATHE

AMS 62201 ANTE-DEPENDENGE ANALYSIS OF AN ORDERED SET OF VARIABLES * K. R. GABRIEL

AMS 62213 A GLASSIFIGATION PROBLEM IN WHICH INFORMATION ABOUT ALTERNATIVE DISTRIBUTIONS IS BASED ON SAMPLES * BOB E. ELLISON
AMS 62224 ASYMPTOTIG SHAPES OF BAYES SEQUENTIAL TESTING REGIONS * GIDEON SCHWARTZ

AMS 62237 BOUNDED LENGTH CONFIDENCE INTERVALS FOR THE ZERO OF A REGRESSION FUNGTION * R. H. FARRELL

AMS $6224 \mathrm{~B}$ ON MULTIPLE DECISION METHODS FOR RANKING POPULATION MEANS * VACLAV FABIAN

AMS 62255 THE GHOIGE OF THE DEGREE OF A POLYNOMIAL REGRESSION AS A MULTIPLE DEGISION PROBLEM * T. W. ANDERSON

AMS 62266 LEAST SQUARES AND BEST UNBIASED ESTIMATES * T. W. ANDERSON

AMS 62273 THE PROBLEM OF NEGATIVE ESTIMATES OF VARIANGE GOMPONENTS * W. A. THOMPSON JR

AMS 62290 PAIRTISE INDEPENDENGE OF JOINTLY DEPENDENT VARIABLES * SEYMOUR GEISSER, MANTEL NATHAN

AMS 62292 A NOTE ON UNBIASED TESTS * JOHN W. PRATT

AMS 62294 SOME THOUGHTS ON STATISTIGAL INFERENCE* E. S. PEARSON

AMS 62325 REGENT ADVANCES IN SAMPLE SURVEY THEORY AND METHODS * TORE DALENIUS

AMS 62350 SAMPLING WITH UNEQUAL PROBABILITIES AND WITHOUT REPLACEMENT * H. O. HARTLEY, J.N. K. RAO

AMS 62375 THE SGORING OF MULTIPLE CHOICE QUESTIONNARES * HERMAN CHERNOFF

AMS 62404 UNGERTAINTY, INFORMATION, AND SEQUENTIAL EXPERIMENTS * M. H. DEGROOT

AMS 62420 CLASSIFICATION INTO TWO MULTIVARIATE NORMAL DISTRIBUTIONS WITH DIFFERENT COVARIANGE MATRIGES * T. W. ANDERSON. R. R. BAHADUR

AMS 62432 TWO-SAMPLE GOMPARISONS OF DISPERSION MATRIGES FOR ALTERNATIVES OF INTERMEDIATE SPEGIFIGITY * S. N ROY R. GNANADESIKAN

AMS $62438^{\circ}$ A SEQUENTIAL PROCEDURE FOR COMPARING SEVERAL EXPERIMENTAL GATEGORIES WITH A STANDARD OR CONTROL * EDWARD PAULSON 
AMS 62444 MOMENT ESTIMATORS FOR THE PARAMETERS OF A MIXTURE OF TWO BINOMIAL DISTRIBUTIONS * W. R. BLISCHKE

AMS 62455 SPECTRAL ANALYSIS WITH REGULARLY MISSED OBSERVATIONS * RICHARD H. JONES

AMS 62462 COMPARISON OF LEAST SQUARES AND MINIMUM VARIANCE ESTIMATES OF REGRESSION PARAMETERS, (ACKNOWLEDGEMENT OF PRIORITY 633521 * T. A. MAGNESS, J. B. MCGUIRE

AMS 62471 EXACT AND APPROXIMATE PONER FUNCTION OF THE NONPARAMETRIC TEST OF TENDENCY * REGINA C. ELANDT

AMS 62482 RANK METHODS FOR COMBINATION OF INDEPENDENT EXPERIMENTS IN THE ANALYSIS OF VARIANCE * J. L. HODGES JR, E. L. LEHMANN

AMS 62498 NON-PARAMETRIC TESTS FOR SCALE * JEROME KLOTZ

AMS 62513 SOME MODIFIED KOLMOGOROV-SMIRNOV TESTS OF APPROXIMATE HYPOTHESES AND THEIR PROPERTIES * JUDAH ROSENBLATT

AMS 62525 ON THE RANGE OF THE DIFFERENCE BETWEEN HYPOTHETICAL DISTRIBUTION FUNCTION AND PYKE' 'S MODIFIED EMPIRICAL DISTRIBUTION FUNCTION * H. D. BRUNK

AMS 62533 A CHARACTERIZATION OF THE MULTIVARIATE NORMAL DISTRIBUTION* $S$. G. GHURYE. INGRAM OLKIN

AMS 62542 PROBABILITY CONTENT OF REGIONS UNDER SPERICAL NORMAL DISTRIBUTIONS, IV, THE DISTRIBUTION OF HOMOGENEOUS AND NON-HOMOGENEOUS QUADRATIG FUNCTIONS OF NORMAL VARIABLES * HAROLD RUBEN

AMS 62571 THE NUMER ICAL EVALUATION OF CERT A IN MULT IVAR I ATE NORMAL INTEGRALS * R. N. CURNOW, G. W. DUNNETT

AMS 62580 TABLES TO FACILITATE THE COMPUTATION OF PERCENTAGE POINTS OF THE NON-CENTRAL T-DISTRIBUTION * GEORGE J . RESNIKOFF

AMS 62587 MUTUAL INFORMATION AND MAXIMAL CORRELATION AS MEASURES OF DEPENDENCE * C. B. BELL

AMS 62596 ON THE ORDER STRUCTURE OF THE SET OF SUFFICIENT SUBFIELDS * D. L. BURKHOLDER

AMS 62600 A CALCULUS FOR FACTORIAL ARRANGEMENTS * B. KURKJIAN. M. ZELEN

AMS 62620 SYMMETRICAL UNEQUAL BLOCK ARRANGEMENTS WITH TWO UNEQUAL BLOCK SIZES * DAMARA JU RAGHAVARAO

AMS 62634 CONDITIONAL PROBABILITY OPERATORS * ROBERT COGBURN

AMS 62659 RELATIONS BETWEEN WEAK AND UNIFORM CONVERGENCE OF MEASURES WITH APPLICATIONS * R. RANGA RAO

AMS 62681 AN EXTENSION OF THE ARC SINE LAW * SIMEON M. BERMAN

AMS 62685 AN INVARIANCE PRINCIPLE IN RENETAL THEORY * JOHN LAMPERTI

AMS 62697 GAMES ASSOGIATED WITH A RENEWAL PROGESS * M. M. SIDDIQUI

AMS 62702 A RANDOM INTERVAL FILLING PROBLEM * P. E. NEY

AMS 62719 DISCRETE DYNAMIC PROGRAMMING * DAVID BLACKWELL

AMS 62727 ESTIMATING THE INFINITESIMAL GENERATOR OF A CONTINUOUS TIME, FINITE STATE MARKOV PROGESS * ARTHUR ALBERT

AMS 62754 A MARKOVIAN MODEL FOR THE ANALYSIS OF THE EFFECTS OF MARGINAL TESTING ON SYSTEM RELIABILITY * BETTY J FLEHINGER

AMS 62767 ON THE GENERAL TIME DEPENDENT QUEUE WITH A SINGLE SERVER * J. KEILSON, A, KOOHARIAN

AMS 62792 TWO MORE GRITERIA EQUIVALENT TO D-OPTIMALITY OF DESIGNS * J. KIEFER

AMS 62796 A CONTOUR-INTEGRAL DERIVATION OF THE NON-CENTRAL CHISQUARE DISTRIBUTION * FRANK MCNOLTY

AMS 62800 CHARACTERIZATION OF THE INVERSE GAUSSIAN DISTRIBUTION * C. G. KHATRI

AMS 62803 NULL DISTRIBUTION AND BAHADUR EFFICIENCY OF THE HODGES BIVARIATE SIGN TEST * A. JOFFE, JEROME KLOTZ

AMS 62807 NOTE ON MULTIVARIATE GOODNESS-OF-FIT TESTS * JUDAH ROSENBLATT

AMS 62810 THE UNIQUENESS OF THE SPACING OF OBSERVATIONS IN POLYNOMIAL REGRESSION FOR MINIMAX VARIANCE OF THE FITTED VALUES * CHARLES E. ANTLE

AMS 62 B12 CORREGTION TO ON A CLASS OF PROBLEMS RELATED TO THE RANDOM DIVISION OF AN INTERVAL' 53239 * D. A DARLING

AMS 62813 CORRECTION TO 'DISTRIBUTION OF DEFINITE AND OF INDEF INITE QUADRATIG FORMS ' 55122 * JOHN GURLAND

AMS 62847 CONTRIBUTIONS TO THE 'TWO-ARMED BANDIT' PROBLEM * DORIAN FELDMAN

AMS 62857 TEAMDECISION PROBLEMS * ROY RADNER

AMS 62882 MERGING OF OPINIONS WITH INCREASING INFORMATION * DAVID BLACKWELL, LESTER DUBINS

AMS 62887 SUCCESSIVE CONDITIONAL EXPECTATIONS OF AN INTEGRABLE FUNCTION * D. L. BURKHOLDER

AMS 62894 LIMITING DISTRIBUTION OF THE MAXIMUM TERM IN SEQUENCES OF DEPENDENT RANDOM VARIABLES * SIMEON M. BERMAN

AMS 62909 ON A GENERALIZATION OF THE FINITE ARC-SINE LAW * GLEN BAXTER

AMS 62916 INVAR IANTS UNDER MIX ING WHICH GENERALIZE DE F INETTI I'S THEOREM * DAVID A . FREEDMAN
AMS 62924 POISSON PROCESSES WITH RANDOM ARRIVAL RATE * DAVID A. FREEDMAN

AMS 62930 APPROXIMATIONS FOR THE ENTROPY FOR FUNCTIONS OFMARKOV CHAINS * JOHN J, BIRCH

AMS 62939 SOME THEORET ICAL ASPECTS OF DIFFUSION THEORY IN POPULATIONGENETICS, CORR. 63352 *G. A. WATTERSON

AMS 62 95B RANDOM SUBDIVISIONS OF SPACE INTO CRLSTALS * E. N. GILBERT

AMS 62973 ON THE TRANSIENT BEHAVIOR OF A QUEUEING SYSTEM WITH BULK SERVICE AND FINITE CAPACITY * P. D. FINCH

AMS 62986 LOCATION AND SCALE PARAMETERS IN EXPONENTIAL FAMILIES OF DISTRIBUTIONS, CORR. 631603 * THOMAS S. FERGUSON

AMS 621002 CONDITIONS FOR WISHARTNESS AND INDEPENDENCE OF SECOND DEGREE POLYNOMIALS IN NORMAL VECTOR * C. G. KHATRI

AMS $62100 \mathrm{~B}$ MULTIVARIATE PARETO DISTRIBUTIONS, CORR. $631603 * \mathrm{~K}$. V. MARDIA

AMS 621016 THE DISTRIBUTION OF THE PRODUCT OF TWO CENTRAL OR NONCENTRAL CHI-SQUARE VARIATES * W. T. WELLS, R. L. ANDERSON. JOHN W. CELL

AMS 621021 THE ROLE OF SUFFICIENCY AND OF ESTIMATION IN THERMODYNAMICS * BENOIT MANDELBROT

AMS 621039 SEQUENTIAL INFERENCE PROCEDURES OF STEIN'S TYPE FOR A GLASS OF MULTIVARIATE REGRESSION PROBLEMS * SHOUTIR KISHORE CHATTERJEE

AMS 621065 ON ESTIMATION OF A PROBABILITY DENSITY FUNCTION AND MODE * EMANUEL PARZEN

AMS 621077 ON LINEAR ESTIMATION FOR REGRESSION PROBLEMS ON TIME SERIES * N. DONALD YLVISAKER

AMS 621085 TESTING THE HYPOTHESIS OF NO FIXED MAIN-EFFECTS IN SCHEFFE' S MIXED MODEL * J, P. IMHOF

AMS 621096 A TEST OF LINEARITY VERSUS CONVEXITY OF A MEDIAN REGRESS ION CURVE * BRUCE MARVIN HILL

AMS 621124 ASYMPTOTICALLY MOST POWERFUL RANK-ORDER TESTS * JAROSLAV HA JEK

AMS 621148 ON THE DISTRIBUTION OF THE TWO SAMPLE CRAMER-VON MISES GRITERION * T. W. ANDERSON

AMS 621160 THE SAMPLE MEAN AMONG THE MODERATE ORDER STATISTICS * HERBERT T . DAVID

AMS 621167 DISTRIBUTION-FREE TOLERANCE INTERVALS FOR CONTINUOUS SYMMETRICAL POPULATIONS * JOHNE. WALSH

AMS 621175 APPLICATION OF THE GEOMETRY OF QUADRICS FOR CONSTRUCTING PARTIALLY BALANCED INCOMPLETE BLOCK DESIGNS * D. K. RAY-CHAUDHURI

AMS 621187 A GENERALIZATION OF THE GAMMA DISTRIBUTION* E. W. STACY

AMS 621192 IMPROVED BOUNDS ON A MEASURE OF SKEWNESS * KULENDRA N. MAJINDAR

AMS 621194 USE OF WILCOXON TEST THEORY IN ESTIMATING THE DISTRIBUTION OF A RATIO BY MONTE CARLO METHODS * LINCOLN E. MOSES

AMS 621197 ON THE EXACT DISTRIBUTION OF A CLASS OF MULTIVARIATE TEST GRITERIA * D. G. KABE

AMS 621200 ON THE PARAMETERS AND INTERSECTION OF BLOGKS OF BALANCED INCOMPLETE BLOCK DESIGNS * KULENDRA N MAJINDAR

AMS 621227 KHINCHIN'S WORK IN MATHEMATICAL PROBABILITY * HARALD CRAMER

AMS 62 123B ON THE ORDER AND THE TYPE OF ENTIRE CHARACTERISTIC FUNCTIONS * B. RAMACHANDRAW

AMS 621256 A REPRESENTATION OF THE SYMMETRIC BIVARIATE CAUCHY DISTRIBUTION * THOMAS S. FERGUSON

AMS 621267 A CHARACTERIZATION OF THE CAUCHY DISTRIBUTION * M. V MENON

AMS 621272 A CHARACTERIZATION OF THE WISHART DISTRIBUTION * INGRAM OLKIN, HERMANRUBIN

AMS 621281 LIMITING DISTRIBUTIONS ASSOCIATED WITH GERTAIN STOCHASTIC LEARNING MODELS * J. R. MCGREGOR, Y. Y . HUI

AMS 621286 MOMENTS OF ORDER STATISTICS FROM THE EQUIGORRELATED MULTIVARIATE NORMAL DISTRIBUTION* D. B. OWEN, G. P. STECK

AMS 621292 EXACT LOWER MOMENTS OF ORDER STATISTICS IN SAMPLES FROM THE CHI-DISTRIBUTION, ONE DEGREE OF FREEDOM * ZAKKULA GOVINDARAJULU

AMS 621306 ZERO CROSSING PROBABILITIES FOR GAUSSIAN STATIONARY PROCESSES * G. F. NEWELL, M. ROSENBLATT

AMS 621314 QUEUES SUBJECT TO SERVICE INTERRUPTION * JULIAN KEILSON

AMS 621323 STATIONARY WAITING-TIME DISTRIBUTIONS FOR SINGLESERVER QUEUES * R. M. LOYNES

AMS 621340 THE TIME DEPENDENCE OF A SINGLE-SERVER QUEUE WITH POISSON INPUT AND GENERAL SERVICE TIMES * LAJOS TAKACS

AMS 621349 EXAMPLES BEARING ON THE DEFINITION OF FIDUGIAL PROBABILITY WITH A BIBLIOGRAPHY * DAVID R. BRILLINGER

AMS 621356 TESTING APPROXIMATE HYPOTHESES IN THE COMPOSITE CASE. CORR. 63 * JUDAH ROSENBLATT 
AMS 621365 SOME PROPERTIES OF THE LEAST SQUARES ESTIMATOR IN RECRESSION ANALYSIS WHEN THE 'PREDICTOR' VARIABLES ARE STOCHASTIC * P. K. BHATTACHARYA

AMS 621375 ASYMPTOTIC RELATIVE EFFICIENCY OF MOOD 'S AND MASSEY'S TWO SAMPLE TESTS ACAINST SOME PARAMETRIC ALTERNATIVES* I M. CHAKRAVARTT, $F, C$, LEONE, J, D. ALANEN

AMS 621384 OPTIMUM DECISION PROCEDURES FOR A POISSON PROCESS PARAMETER * J. A. LECHNER

AMS 621403 EXACT OPERATINC CHARACTERISTIC FOR TRUNCATED SEQUENTIAL LIFE TESTS IN THE EXPONENTIAL CASE * ROSALIE C WOODALL, BAKRIG M. KURKJIAN

AMS 621413 AN EMPIRICAL EVALUATION OF MULTIVARIATE SEQUENTIAL PROCEDURE FOR TESTING MEANS * R. H. APPLEBY, $R, J$ FREUND
AMS 621421 CONSTRUCTION OF ROTATABLE DESICNS THROUCH BALANCED INCOMPLETE BLOCK DESICNS * M. N. DAS, V. L. NARASIMHAM

AMS 621440 ON CONSTRUCT INC THE FACTOR IAL REPLICATES OF THE TWO TO THE POWER OF M DESICNS WITH BLOCKS * M. S. PATEL

AMS 621450 A FLUCTUATION THEOREM FOR CYCLIC RANDOM VARIABLES * MEYER DWASS

AMS 621454 DETERMINING BOUNDS ON EXPECTED VALUES OF CERTAIN FUNCTIONS * BERNARD HARRIS

AMS 621457 ON BOUNDS OF SERIAL CORRELATIONS * K. C. CHANDA

AMS 621461 ON THE DISTRIBUTION OF SUMS OF SQUARES AND CROSS PRODUCTS OF NORMAL VARIATES IN THE PRESENCE OF INTRA-CLASS CORRELATION * DONALD F. MORRISON

AMS 621463 ON A PROPERTY OF A TEST FOR THE EQUALITY OF TWO NORMAL DISPERSION MATRICES AGAINST ONE-SIDED ALTERNATIVES * WADIE F. MIKHAIL

ANNALS OF MATHEMATICAL STATISTICS VOLUME 34, 1963

AMS $63 \quad 1$ OPTIMUM PROPERTIES AND ADMISSIBILITY OF SEQUENTIAL TESTS * D. L. BURKHOLDER, R. A. WI JSMAN

AMS 63 IB ON THE OPTIMALITY OF SEQUENTIAL PROBABILITY RATIO TESTS * THEODORE K. MATTHES

AMS 6322 ON THE EFFICIENCY OF OPTIMAL NONPARAMETRIC PROCEDURES IN THE TWO SAMPLE CASE* PIOTR WITOLD MIKULSKI

AMS 6333 THE SAMPLE MEAN AMONG THE EXTREME NORMAL ORDER STATISTICS * HERBERT T. DAVID

AMS 6356 TESTS AUXILIARY TO CHI-SQUARED TESTS IN A MARKOV CHAIN * RUTHZ, COLD

AMS 6375 SELECTION OF THE BEST TREATMENT IN A PAIRED-COMPARISON EXPERIMENT * B. J. TRAWINSKI, H. A. DAVID

AMS 6392 A REMARK ON A PAPER OF TRAWINSKI AND DAVID ENTITLED SELECTION OF THE BEST TREATMENT IN A PAIRED-COMPARISON EXPERIMENT ' * PETER J. HUBER

AMS 6395 DISTRIBUTION OF THE TWO-SAMPLE CRAMER-VON MISES CRITERION FOR SMALL EQUAL SAMPLES * E.J.BURR

AMS 63102 SIMPLIFIED ESTIMATES FOR THE EXPONENTIAL DISTRIBUTION*A. E. SARHAN, B. C. GREENBERG, JUNJIRO OCAWA

AMS 63117 OPTIMUM ESTIMATORS OF THE PARAMETERS OF NEGATIVE EXPONENTIAL DISTRIBUTIONS FROM ONE OR TWO ORDER STATISTICS * M.M. SIDDIQUI

AMS 63122 ASYMPTOTIC THEORY FOR PRINCIPAL COMPONENT ANALYSIS * T. W. ANDERSON

AMS 63149 ON TESTINC A SET OF CORRELATION COEFFICIENTS FOR EQUALITY* D. N. LAWLEY

AMS 63152 STATISTICAL ANALYSIS BASED ON A CERTAIN MULTIVARIATE COMPLEX CAUSSIAN DISTRIBUTION, AN INTRODUCTION*N R. GOODMAN

AMS 63178 THE DISTRIBUTION OF THE DETERMINANT OF A COMPLEX WISHART DISTRIBUTED MATRIX * N, R, COODMAN

AMS 63 IBI SOME RESULTS ON THE DISTRIBUTION OF TWO RANDOM MATRICES USED IN CLASSIFICATION PROCEDURES, CORR. $64924 * \mathrm{D} . \mathrm{G}, \mathrm{KABE}$

AMS 631 1B6 DISTRIBUTION OF DEFINITE AND OF INDEFINITE QUADRATIC FORMS FROM A NON-CENTRAL NORMAL DISTRIBUTION * B SHAH, C. G. KHATRI

AMS 63191 APPROXIMATIONS TOMULTIVARIATE NORMAL ORTHANT PROBABILITIES * RALPH HOYT BACON

AMS 63199 A DEFINITION OF SUBJECTIVE PROBABILITY * F. J. ANSCOMBE, R, J AUMANN

AMS 63206 ON A CLASS OF STOCHASTIC PROCESSES * JOHN LAMPERTI

AMS 63213 STOCHASTIC PROCESSES ON A SPHERE* RICHARD H. JONES

AMS 63219 ON CONVERGENCE TO INFINITY IN THE LAW OF LARCE NUMBERS, (ACKNOWLEDGEMENT OF PRIORITY 63 1111) * LEONARD E. BAUM

AMS 63223 NON-EXISTENCE OF EVERYWHERE PROPER CONDITIONAL DISTRIBUTIONS * D. BLACKWELL, C. RYLL-MARDZEWSKI

AMS 63226 ENTROPY AND CONJUGACY* THOMAS A BROWN

AMS 63233 COLLAPSED MARKOV CHAINS AND THE CHAPMAN-KOLMOCOROV EQUATION * JACK HACHIGIAN

AMS 63238 THE ESTIMATION OF A FUNDAMENTAL INTERACTION PARAMETER IN AN EMIGRATION-IMMICRATION PROCESS * HAROLD RUBEN

AMS 63260 CONVERGENCE THEOREMS FOR MULTIPLE CHANNEL LOSS PROBABILITIES* A. JOFFE, P. E . NEY

AMS 63274 DYNAMIC STOCHASTIC PROCESSES * BERNT P. STIGUM

AMS 63284 AMATHEMATICAL THEORY OF PATTERN RECOGNITION * ARTHUR ALBERT

AMS 63300 ON QUEUES IN TANDEM * GRECORY E. MASTERSON, SEYMOUR SHERMAN

AMS 63308 THE POISSON TENDENCY IN TRAFFIC DISTRIBUTION * LEO BREIMAN

AMS 63312 THE PROBABILITY IN THE TAIL OF A DISTRIBUTION * MELVIN L. KATZ

AMS 63319 A CHARACTERIZATION OF THE UNIFORM DISTRIBUTION ON A COMPACT TOPOLOG ICAL GROUP * JAMES H. STAPLETON

AMS 63327 THE CONVEX HULL OF PLANE BROWNIAN MOTION * J. R. KINNEY
AMS 63329 ON THE SAMPLE FUNCTIONS OF PROCESSES WHICH CAN BE ADDED TO A GAUSSI AN PROCESS * T. S. PITCHER

AMS 63333 NOTE ON TWO BINOMIAL COEFFICIENT SUMS FOUND BY RIORDAN * H. W. GOULD

AMS 63335 TAIL AREAS OF THE T-DISTRIBUTION FROM A MILLS ' RATIOLIKE EXPANSION * R. S. PINKHAM, M. B. WILK

AMS 63337 A FINITE CRITERION FOR INDECOMPOSABLE' CHANNELS * A.J THOMASIAN

AMS 63338 NOTES ON QUEUES IN TANDEM * EDGAR REICH

AMS 63341 A NOTE ON THE RE-USE OF SAMPLES * DAVIDR. BRILLINGER

AMS 63343 ON STOCHASTIC APPROXIMATIONS * SHMUEL FRIEDMAN

AMS 63346 THE USE OF THE RANGE IN PLACE OF THE STANDARD DEVIATION IN STEIN'S TEST * WILLIAM KNIGHT

AMS 63348 ON NECESSARY CONDITIONS FOR THE EXISTENCE OF SOME SYMMETRICAL AND UNSYMMETRICAL TRIANGULAR PARTIALLY BALANCED INCOMPLETE BLOCK DESIGNS AND BALANCED INCOMPLETE BLOCK DESICNS * ESTHER SEIDEN

AMS 63375 PROPERTIES OF PROBABILITY DISTRIBUTIONS WITH MONOTONE HAZARD RATE* RICHARD E. BARLOW, ALBERT W MARSHALL, FRANK PROSCHAN

AMS 63390 A RENEWAL THEOREM FOR RANDOM VARIABLES WHICH ARE DEPENDENT OR NON-IDENTICALLY DISTRIBUTED * Y . S. CHOW HERBERT ROBBINS

AMS 63396 AVERAGE RENEWAL LOSS RATES * M. V. JOHNS JR, R, G . MILLER JR

AMS 63402 COMBINATORIAL RESULTS IN MULTI-DIMENSIONAL FLUCTUATION THEORY, CORR. 64924 * CHARLES HOBBY, RONALD PYKE

AMS 63405 ONE DIMENSIONAL RANDOM WALK WITH A PARTIALLY REFLECTING BARRIER * G. LEHNER

AMS 63413 ON A CLASS OF SIMPLE RANDOM WALKS * J.R. BLUM, D. L HANSON, S. V. PARTER

AMS 63416 A MARKOV PROCESS ON BINARY NUMBERS * SIMEON M. BERMAN

AMS 63424 MULTIVARIATE WIDE-SENSE MARKOV PROCESSES AND PREDICTION THEORY* FREDERICK J. BEUTLER

AMS 63439 CENTRAL LIMIT THEOREMS FOR FAMILIES OF SEQUENCES OF RANDOM VARIABLES * F EICKER

AMS 63447 ASYMPTOTIC NORMALITY AND CONSISTENCY OF THE LEAST SQUARES ESTIMATORS FOR FAMILIES OF LINEAR REGRESSIONS * F . EICKER

AMS 63457 THE LIMIT OF A RATIOOF CONVOLUTIONS * P. E. NEY

AMS 63462 SEQUENTIAL MODEL BUILDING FOR PREDICTION IN REGRESSION ANALYSIS, I* HAROLD J. LARSON, T. A. BANCROFT

AMS 634 BO ON THE ESTIMATION OF THE PROBABILITY DENSITY, I * G S . WATSON, M. R. LEADBETTER

AMS 63492 NECESSARY AND SUFFICIENT CONDITIONS FOR A STATISTICAL PROBLEM TO BE INVARIANT UNDER A LIE GROUP * DAVID R. BRILLINGER

AMS 63501 PAIRWISE COMPARISON AND RANKING IN TOURNAMENTS * HANS BUHLMANN, PETER HUBER

AMS 63511 PAIRWISE COMPARISON AND RANKING, OPTIMUM PROPERTIES OF THE ROW SUM PROCEDURE * PETER J. HUBER

AMS 63521 SAMPLINC VARIANCES OF THE ESTIMATES OF VARIANCE COMPONENTS IN THE UNBALANCED THREE-WAY NESTED CLASSIFICATION * D. M MAHAMUNULU

AMS 63528 ON THE DUALS OF SYMMETRIC PARTIALLY-BALANCED INCOMPLETE BLOCK DESIGNS * A. J. HOFFMAN

AMS 63532 CORRELATIONS AND CANONICAL FORMS OF BIVARIATE DISTRIBUTIONS * H. O. LANCASTER

AMS 63539 ON THE INADMISSIBILITY OF SOME STANDARD ESTIMATES IN THE PRESENCE OF PRIOR INFORMATION * M. SKIBINSKY, L. COTE

AMS 63549 A SEQUENTIAL DECISION PROCEDURE FOR CHOOSING ONE OF K HYPOTHESES CONCERNING THE UNKNOWN MEAN OF A NORMAL DISTRIBUTION * EDWARD PAULSON

AMS 63555 ON TESTING MORE THAN ONE HYPOTHESIS * J. N. DARROCH, S D. SILVEY

AMS 63568 THEPOSTERIOR T DISTRIBUTION * M. STONE 
AMS 63574 SHORTER CONFIDENCE INTERVALS FOR THE MEAN OF A NORMAL DISTRIBUTION WITH KNOWN VARIANCE * JOHN W. PRATT

AMS 63 5B7 POST CLUSTER SAMPLINC * SAKTI P. CHOSH

AMS 63 59B ESTIMATES OF LOCATION BASED ON RANK TESTS * J. L. HODGES JR, E. L. LEHMANN

AMS 63612 ON THE EFFICIENCY OF TWO-SAMPLE MANN-WHITNEY TEST FOR DISCRETE POPULATIONS * K. C. CHANDA

AMS 63618 TESTS AND CONFIDENCE INTERVALS BASED ON THE METRIC D2 * JUDAH ROSENBLATT

AMS 63624 SMALL SAMPLE POWER AND EFFICIENCY FOR THE ONE SAMPLE WILGOXON AND NORMAL SCORES TESTS * JEROME KLOT2

AMS 63633 ON MOMENTS OF ORDER STATISTICS AND QUASI-RANCES FROM NORMAL POPULATIONS * ZAKKULA GOVINDARA JULU

AMS 63652 CONDITIONAL DISTRIBUTION OF ORDER STATISTICS ANDDISTRIBUTION OF THE REDUCED ITH ORDER STATISTIC OF THE EXPONENTIAL MODEL * ANDRE G. LAURENT

AMS 63658 LOGISTIC ORDER STATISTICS * ALLAN BIRNBAUM, JACK DUDMAN

AMS 63664 ON THE LINE, GRAPH OF THE COMPLETE BIGRAPH * J. W. MOON

AMS 63668 A GENERAL VERSION OF DOEBLIN'S CONDITION * RICHARD ISAAC

AMS 63671 A TEST FOR EQUALITY OF MEANS WHEN COVARIANCE MATRICES ARE UNEQUAL * T. W. ANDERSON

AMS 63705 ASYMPTOTICALLY OPTIMUM SEQUENTIAL INFERENCE AND DESIGN * J KIEFER, J SACKS

AMS 63751 GENERALIZED BAYES SOLUTIONS IN ESTIMATION PROBLEMS * JEROME SACKS

AMS 63769 ON A COMPLETE CLASS OF LINEAR UNBIASED ESTIMATORS FOR RANDOMIZED FACTORIAL EXPERIMENT * S ZACKS

AMS 63780 OPTIMAL STRATEGIES IN FACTORIAL EXPERIMENTS * S EHRENFELD, S. ZACKS

AMS 63792 PROBABILITY INTEGRALS OF MULTIVARIATE NORMAL AND MULTIVARIATE T * SHANTI S. GUPTA

AMS 63829 BIBLIOCRAPHY ON THE MULT IVARI ATE NORMAL INTEGRALS AND RELATED TOPICS * SHANTI S, GUPTA

AMS 63839 BAYES ESTIMATION WITH CONVEX LOSS* M. H. DEGROOT, M. M. RAO

AMS 63844 FURTHER EXAMPLES OF INCONSISTENCIES IN THE FIDUCIAL ARGUMENT * A.P. DEMPSTER

AMS 63 B47 ON THE SAMPLE SIZE AND COVERAGE FOR THE JIRINA SEQUENTIAL PROCEDURE * SAM C. SAUNDERS

AMS 63 B57 SOME APPLICATIONS OF THE JIRINA SEQUENT I AL PROCEDURE TO OBSERVATIONS WLTH TREND * SAM C . SAUNDERS

AMS 63 B66 OPTIMUM STRATIFICATION WITH TWO CHARACTERS * S. P GHOSH

AMS 63873 MULTIVARIATE THEORY FOR GENERAL STEPWISE METHODS * A P. DEMPSTER

AMS 63892 GHEBYSHEV POLYNOMIAL AND OTHER NEW APPROXIMATIONS TO MILLS' RATIO * W. D. RAY, A E. N, T. PITMAN

AMS 63903 PROPERTIES OF CENERALIZED RA YLEIGH DISTRIBUTIONS * L E. BLUMENSON, K. S. MILLER

AMS 63911 MAXIMUM ENTROPY FOR HYPOTHESIS FORMULATION, ESPECIALLY FOR MULTIDIMENSIONAL CONTINGENCY TABLES * I. J. GOOD

AMS 63935 ON THE INDEPENDENCE OF CERTAIN WISHART VARIABLES * ROBERT V , HOCG

AMS 63940 ELLIPTICAL AND RADIAL TRUNCATION IN NORMAL POPULATIONS* G. M. TALLIS

AMS 63945 TESTINC HOMOGENEITY AGAINST ORDERED ALTERNATIVES * V J. CHACKO

AMS 63957 ROBUST ESTIMATION IN ANALYSIS OF VARIANCE * E. L. LEHMANN

AMS 63967 ESTIMATING ORDERED PROBABILITIES * MORRIS W. KATZ

AMS 63973 RANK TESTS OF DISPERSION * LINCOLNE. MOSES

AMS 63984 COMPARISON OF THE VARIANCE OF MINIMUM VARIANCE AND WEIGHTED LEAST SQUARES REGRESSION COEFFICIENTS * GENEH. GOLUB

AMS 63992 ON THE LIMIT BEHAVIOUR OF EXTREME ORDER STATISTICS * OLEBARNDOFF-NIELSEN

AMS 631003 THE FIRST PASSAGE TIME DENSITY FOR HOMOCENEOUS SKIPFREE WALKS ON THE CONTINUUM * JULIAN KEILSON

AMS 631012 ESTIMATION OF THE CROSS-SPECTRUM *V. K. MURTHY

AMS 631022 FUNCTIONS OF FINITE MARKOV CHAINS * S. W. DHARMADHIKARI

AMS 631033 SUFFICIENT CONDITIONS FOR A STATIONARY PROCESS TO BE A FUNCTION OF A FINITE MARKOV HAIN* S. W. DHARMADHIKARI

AMS 631042 ON THE INFLUENCE OF MOMENTS ON THE ASYMPTOTIC DISTRIBUTION OF SUMS OF RANDOM VARIABLES * LEONARD E. BAUM, MELVINL, KATZ

AMS 631045 ON THE INTEGRABILITY, CONTINUITY AND DIFFERENTIABILITY OF A FAMILY ON FUNCTIONS INTRODUCED BY L TACAKS * A. M. HASOFER

AMS 631050 MINIMUM VARIANCE UNBIASED ESTIMATION AND CERTAIN PROBLEMS OF ADDITIVE NUMBER THEORY * G. P. PATIL

AMS 631057 RIGHT ANGULAR DESIGNS * SURESH K. THARTHARE
AMS 631068 ON ESTIMATES FOR FRACTIONS OF A COMPLETE FACTOKIAL EX PERIMENT AS ORTHOCONAL LINEAR COMBINATIONS OF THE OBSERVATIONS * K. S. BANERJEE, W. T. FEDERER

AMS 631079 ASYMPTOTIC SOLUTIONS OF THE SEQUENTIAL COMPOUND DECISION PROBLEM * ESTER SAMUEL

AMS 631095 NOTE ON A SEQUENTIAL CLASSIFICATION PROBLEM * ESTER SAMUEL

AMS 63 109B NOTE ON A CONDITIONAL PROPERTY OF STUDENT'S T * R J BUEHLER, A. P. FEDDERSEN

AMS 631101 ON A MODIFICATION OF CERTAIN RANK TESTS * RYOJI TAMURA AMS 631104 NOTE ON EXTREME VALUES, COMPETING RISKS AND SEMI-MARKOV PROCESSES * SIMEONM. BERMAN

AMS 631107 NOTE ON THE BERRY-ESSEN THEOREM * MELVINL. KAT2

AMS 631109 BOUNDS FOR THE FREQUENCY OF MISLEADING BAYES INFERENCE * D. KERRIDGE

AMS 631147 CONDITIONED LIMIT THEOREMS * MEYER DWASS, SAMUEL KARLIN

AMS 631168 A WIENER-HOPF TYPE METHOD FOR A GENERAL RANDOM WALK WITH A TWO-SIDED BOUNDARY * J,H, B, KEMPERMAN

AMS 631194 INVARIANTS UNDER MIXING WHICH GENERALIZE DE FINETTI 'S THEOREM. CONTINUOUS TIMES PARAMETER* DAVID A FREEDMAN

AMS 631217 POISSON COUNTS FOR RANDOM SEQUENCES OF EVENTS * J.F C. KINCMAN

AMS 631233 COMBINATORIAL RESULTS IN FLUCTUATION THEORY * CHARLES HOBBY, RONALD PYKE

AMS 631243 THE AUTOCORRELATION FUNCTION OF A SEQUENCE UNIFORMLY DISTRIBUTED MODULO 1 * DAVID L. JACERMAN

AMS 631253 THE DEGREE OF RANDOMNESS IN A STATIONARY TIME SERIES * CALVIN C. MOORE

AMS 631259 THE COVARIANCE MATRIX OF A CONTINUOUS AUTORECRESSIVE VECTOR TIME-SERIES * JOELN FRANKL IN

AMS 631265 IDENTIFIABILITY OF FINITE MIXTURES * HENRY TEICHER

AMS 631270 SOME NON-CENTRAL DISTRIBUTION PROBLEMS IN MULTIVARIATE ANALYSIS * A, G. CONSTANTINE

AMS 631286 AN ASYMPTOTIC EXPANSION FOR THE DISTRIBUTION OF THE LINEAR DISCRIMINANT FUNCTION * MASASHI OKAMOTO

AMS 631302 ASYMPTOTIC EXPANSIONS FOR A CLASS OF DISTRIBUTION FUNCTIONS * K. C. CHANDA

AMS $63130 \mathrm{~B}$ ON APPROXIMATIONS TO SAMPLING DISTRIBUTIONS OF THE MEAN FOR SAMPLES FROM NON-NORMAL POPULATIONS * A REITSMA

AMS 631315 CORRELATION AND COMPLETE DEPENDENCE OF RANDOM VARIABLES* H. D. LANCASTER

AMS 631322 MULTIPLEX SAMPLING * DAVIDH. EVANS

AMS 631347 EFFICIENT UTILIZATION OF NON-NUMERICAL INFORMATION IN QUANTITATIVE ANALYSIS, GENERAL THEORY AND TH CASE OF SIMPLE ORDER * ROBERT P. ABELSON, JOHN W TUKEY

AMS 631370 AN EMPIRICAL BAYES APPROACH TO THE TESTING OF CERTA IN PARAMETRIC HYPOTHESES * ESTER SAMUEL

AMS 631386 ON THE ASYMPTOTIC BEHAVIOR OF BAYES ' ESTIMATES IN THE DISCRETE CASE * DAVID A. FREEDMAN

AMS 631404 A MODIFIED BAYES STOPPING RULE * SIGMUND J AMSTER

AMS 631414 ON A PARADOX CONCERNING INFERENCE ABOUT A COVARIANCE MATRIX*A.P. DEMPSTER

AMS 631419 ESTIMATION OF ONE OF TWO PARAMETERS OF THE EXPONENTIAL DISTRIBUTION ON THE BASIS OF SUITABLY CHOSEN ORDER STATISTICS * GUNNAR KULLDORFF

AMS 631432 THE LIMITING POWER OF CATEGORIGAL DATA CHI-SQUARE TESTS ANALOCOUS TO NORMAL ANALYSIS OF VARIANCE * EARL L. DIAMOND

AMS 631442 THE RELATION BETWEEN PITMAN'S ASYMPTOTIC RELATIVE EFFICIENCY OF TWO TESTS AND THE CORRELATION COEFFTCIENT BETWEEN THEIR TEST STATISTICS * CONSTANCE VAN EEDEN

AMS 631452 ON MULTISTAGE ESTIMATION * J. R. BLUM, JUDAH ROSENBLATT

AMS 631459 ON AN ANALOG OF REGRESSION ANALYSIS * P. K. BHATTACHARYA

AMS 631474 EXISTENCE OF BOUNDED LENGTH CONFIDENCE INTERVALS * RAJINDER SINCH

AMS 631486 AN ASYMPTOTICALLY OPTIMAL SEQUENTIAL DESIGN FOR COMPARINC SEVERAL EXPERIMENTAL CATEGORIES WITH A CONTROL * CHARLES DEWITT ROBERTS

AMS 631494 ASYMPTOTICALLY NONPARAMETRIC INFERENCE. AN ALTERNATIVE APPROACH TO LINEAR MODELS * E. L. LEHMANN

AMS 631507 NONPARAMETRIC CONFIDENCE INTERVALS FOR A SHIFT PARAMETER * E. L. LEHMANN

AMS 631513 THE ASYMPTOTIC NORMALITY OF TWO TEST STATISTICS ASSOCIATED WITH THE TWO-SAMPLE PROBLEM * SAUL BLUMENTHAL

AMS 631524 MINIMAX CHARACTER OF HOTELLING'S T-SQUARED TEST IN THE SIMPLEST CASE* N. GIRI. J. KIEFER. C. STEIN

AMS 631536 MINIMAX THEOREMS ON CONDITIONALLY COMPACT SETS * TEH TJOE-TIE

AMS 631541 EXISTENCE, UNIQUENESS AND MONOTONICITY OF SEQUENTIAL PROBABILITY RATIO TESTS * R. A. WIJSMAN 
AMS 631549 ALMOST PERIODIC VARIANCES * LAURENCE HERBST

AMS 631558 ON THE NULL-DISTRIBUTION OF THE F-STATISTIC IN A RANDOMIZED BALANCED INCOMPLETE BLOCK DESICN UNDER THE NEYMAN MODEL * JUNJIRO OCAWA

AMS 631569 SOME CONSEQUENCES OF RANDOMIZATION IN A CENERALIZATION OF THE BALANCED INCOMPLETE BLOCK DESICN * CEORCE ZYSKIND

AMS 631582 A NEW RESULT ON THE DISTRIBUTION OF QUADRATIC FORMS * HAROLD RUBEN
AMS 631585 THE CONDITIONAL DISTRIBUTION OF SETS OF TESTS ON A SYSTEM SIMULATED FROM TESTS ON ITS COMPONENTS * W.S. CONNOR

AMS 631588 APPLICATION OF METHODS IN SEQUENTIAL ANALYSIS TO DAM THEORY * R. M. PHATARFOD

AMS 631593 NORMAL APPROXIMATION TO THE DISTRIBUTION OF TWO INDEPENDENT BINOMIALS, CONDITIONAL ON FIXED SUM * J. HANNAN, W. HARKNESS

AMS 631595 USE OF THE WILCOXON STATISTIC FOR A CENERALIZED BEHRENS-F ISHER PROBLEM * RICHARD F. POTTHOFF

AMS 631600 COMBINATORIAL THEOREM FOR PARTIAL SUMS * R. L. CRAHAM

ANNALS OF MATHEMATICAL STATISTICS VOLUME 35, 1964

AMS 641 THE EMPIRICAL BAYES APPROACH TO STATISTICAL DECISION PROBLEMS * HERBERT ROBBINS

AMS 6421 LOCAL AND ASYMPTOTIC MINIMAX PROPERTIES OF MULTIVARIATE TESTS * N. CIRI, J.KIEFER

AMS 6436 ASYMPTOTIC BEHAVIOR OF EXPECTED SAMPLE SIZE IN CERTAIN ONE-SIDED TESTS* R. H. FARRELL

AMS 6473 ROBUST ESTIMATION OF A LOCATION PARAMETER * PETER J. HUBER

AMS 64102 ASYMPTOTIC EFFICIENCY OF CLASS OF C-SAMPLE TESTS * MADAN LAL PURI

AMS 64122 RANK TESTS FOR PAIRED-COMPARISON EXPERIMENTS INVOLVINC SEVERAL TREATMENTS * K. L. MEHRA

AMS 64138 A CLASS OF NONPARAMETRIC TESTS FOR INDEPENDENCE IN BIVARIATE POPULATIONS* SI BHUCHONGKUL

AMS 64150 SOME BASIC THEOREMS OF DISTRIBUTION-FREE STATISTICS * C. B. BELL

AMS 64157 CONSISTENT ESTIMATES AND ZERO-ONE SETS * LEO BREIMAN, LUCIEN LECAM. LORRA INE SCHWARTZ

AMS 64162 SEQUENTIAL TESTS FOR THE MEAN OF A NORMAL DISTRIBUTION II, LARCE T * JOHN BREAKWELL. HERMAN CHERNOFF

AMS 64174 A SEQUENTIAL PROCEDURE FOR SELECTINC THE POPULATION WITH THE LARGEST MEAN FROM K NORMAL POPULATIONS * EDWARD PAULSON

AMS 64181 ON THE LIKELIHOOD RATIO TEST OF A NORMAL MULTIVARIATE TESTING PROBLEM, CORR . $44138 \mathrm{~B} * \mathrm{~N}$. GIRI

AMS 64191 TESTS FOR THE EQUALITY OF TWO COVARIANCE MATRICES IN RELATION TO A BEST LINEAR DISCRIMINATOR ANALYSIS * A. P. DEMPSTER

AMS 64200 MONOTONICITY OF THE PONER FUNCTIONS OF SOME TESTS OF THE MULTIVARIATE LINEAR HYPOTHESIS * S. DAS GUPTA, T. W. ANDERSON, G. S. MUDHOLKAR

AMS 64206 MONOTONICITY OF THE POWER FUNCTIONS OF SOME TESTS OF INDEP ENDENCE BETWEEN TWO SETS OF VARIATES * T. W. ANDERSON, S. DAS GUPTA

AMS 64209 EFFECT OF TRUNCATION ON A TEST FOR THE SCALE PARAMETER OF THE EXPONENTIAL DISTRIBUTION * A. P. BASU

AMS 64214 THE TWENTY-SEVEN PER CENT RULE * JOHN ROSS. R. A. WEITZMAN

AMS 64222 ON SAMPLINC SCHEMES PROVIDINC UNBIASED RATIO ESTIMATORS * P. K. PATHAK

AMS 64232 A REVIEW OF THE LITERATURE ON A CLASS OF COVERAGE PROBLEMS * WILLAIM C. GUENTHER, PAUL J. TERRAGNO

AMS 64261 MULTIVARIATE BETA DISTRIBUTIONS AND INDEPENDENCE PROPERTIES OF THE WISHART DISTRIBUTIONS. CORR. 66 297 * INGRAM OLKIN, HERMAN RUBIN

AMS 64270 LINEAR FORMS IN THE ORDER STATISTICS FROM AN EXPONENTIALDISTRIBUTION * ELLIOTA. TANIS

AMS 64277 DISTRIBUTION OF SUM OF IDENTICALLY DISTRIBUTED EXPONENTIALLY CORRELATED CAMMA-VARIABLES, (ACKNOWLEDGEMENT OF PRIORITY 64925 ) * SAMUEL KOTZ, JOHN W. ADAMS

AMS 64284 TABLES OF THE LOGARITHMIC SERIES DISTRIBUTION * E WILLIAMSON, M. H. BRETHERTON

AMS 64298 THE MOMENTS OF A VARIATE RELATED TO THE NON-CENTRAL T * D. HOGBEN, R. S. PINKHAM, M. B. WILK

AMS 64315 AN APPROXIMATION TO THE DISTRIBUTION OF Q, A VARIATE RELATED TO THE NON-CENTRAL T * D. HOCBEN, R. S. PINKHAM, M. B. WILK

AMS 64319 LIMITING DISTRIBUTION OF THE MAXIMUM OF A DIFFUSION PROCESS* SIMEON M. BERMAN

AMS 64330 ON CONTINUOUS SINGULAR INFINITELY DIVISIBLE DISTRIBUTION FUNCTIONS * HOWARD C. TUCKER

AMS 64336 AN EVALUATION OF A FUNCTIONAL ON INF INITELY DIVISIBLE STOCHASTIC PROCESSES * KENNETH 8ERK

AMS 64341 ON SEQUENTIAL CONTROL PROCESSES * CYRUS DERMAN

AMS 64350 MULTIVARIATE COMPETITION PROCESSES * DONALD L. INGLEHART

AMS 64362 LOWER 8OUNDS FOR MINIMUM COVARIANCE MATRICES IN TIME SER IES REGRESSION PROBLEMS * N . DONALD YLVISAKER

AMS 64369 THE ENUMERATION OF ELECTION RETURNS 8Y NUMBER OF LEAD POSITIONS * JOHN RIORDAN

AMS 64380 ON THE TRAFFIC LIGHT QUEUE * J. N. DARROCH
AMS 64389 CUBIC DESICNS * D. RACHAVARAO, K. CHANDRASEKHARARAO

AMS 64398 AN UPPER BOUND FOR THE NUMBER OF DISJOINT BLOCKS IN CERTAIN PARTIALLY BALANCED INCOMPLETE BLOCK DESICNS * S. M. SHAH

AMS 64408 ON A BOUND USEFUL IN THE THEORY OF FACTORIAL DESICNS AND ERROR CORRECTINC CODES * R. C. BOSE, J. N. SRIVASTAVA

AMS 64415 ON THE AXIOMS OF INFORMATION THEORY * P. M. LEE

AMS $64 \quad 419$ A LOCAL LIMIT THEOREM * L. A. SHEPP

AMS 64424 A LIMIT LAW CONCERNINC MOVINC AVERAGES* L. A. SHEPP

AMS 64429 EXCHANGEABLE PROCESSES WHICH ARE FUNCTIONS OF STATIONARY MARKOV CHAINS * S. W. DHARMADHIKARI

AMS 64431 GENERATING FUNCTIONS FOR MARKOV RENEWAL PROCESSES * MARCEL F. NEUTS

AMS 64435 A PROPERTY OF THE METHOD OF STEEPEST ASCENT * CHARLES HENRY JOHNSON, JOHN LEROY FOLKS

AMS 64 43B SAMPLE SIZE REQUIRED FOR ESTIMATING THE VARIANCE WITHIN D UNITS OF THE TRUE VALUE* FRANKLIN A. CRAYBILL, TERRENCE L CONNELL

AMS 64441 ANOTE ON THE MAXIMIZATION OF A NON-CENTRAL CHI-SQUARE PROBABILITY * DENNIS C, GILLILAND

AMS 64443 THE SPECTRAL THEOREM FOR FINITE MATRICES AND COCHRAN'S THEOREM * M. F. SMILEY

AMS 64445 TWO THIRD ORDER ROTATABLE DESICNS IN FOUR DIMENSIONS - AGNES M. HERZBERG

AMS 64475 DISTRIBUTIONS OF MATRIX VARIATES AND LATENT ROOTS DERI VED FROM NORMAL SAMPLES * ALAN T. JAMES

AMS 64502 LIMIT THEOREMS FOR THE MAXIMUM TERM IN STATIONARY SEQUENCES * SIMEONM. BERMAN

AMS 64517 RADON-NIKODYM DERIVATIVES OF STATIONARY GAUSSIAN MEASURES * JACK CAPON

AMS 64532 ON THE COEFFICIENT OF COHERENCE FOR WEAKLY STATIONARY STOCHASTIC PROCESSES* L. H. KOOPMANS

AMS 64550 SOME STRUCTURE THEOREMS FOR STATIONARY PROBABILITY MEASURES ON FINITE STATE SEQUENCES * CHARLES HOBBY. N. DONALD YLVISAKER

AMS 64557 LIMIT DISTRIBUTIONS OF A BRANCHINC STOCHASTIC PROCESS * hOWARD H. STRATTON JR, HOWARD C. TUCKER

AMS 64566 SOME THEOREMS CONCERNING THE STRONC LAW OF LARGE NUMBER FOR NON-HOMOGENEOUS MARKOV CHAINS* M. ROSENBLATT-ROTH

AMS 64577 COMPARISON OF REPLACEMENT POLICIES, AND RENEWAL THEORY IMPLICATIONS * RICHARD E. BARLOW, FRANK PROSCHAN

AMS 64590 A CONTINUOUS KIEFER-WOLFOWITZ PROCEDURE FOR RANDOM PROCESSES, CORR, $66745 *$ DAVID J SAKRISON

AMS 64600 ON PRE-EMPTIVE RESUME PRIORITY QUEUES * PETER D. WELCH

AMS 64613 CRAPHICAL METHODS FOR INTERNAL COMPARISONS IN MULTIRESPONSE EXPERIMENTS * M. B. WILK, R. CNANADESIKAN

AMS 64632 INTERACTIONS IN MULTIDIMENSIONAL CONTINCENCY TABLES * LEO A. GOODMAN

AMS 64647 MAXIMUM LIKELIHOOD ESTIMATION WITH INCOMPLETE MULTIVARIATE DATA * IRENE MONAHAN TRAWINSKI, R. E. BARGMANN

AMS 64658 APPLICATIONS OF THE CALCULUS FOR FACTORIAL ARRANGEMENTS II. TWO WAY ELIMINATION OF HETEROGENEITY * $M$. ZELEN. W. FEDERER

AMS 64673 SINGULAR WEIGHING DESIGNS * DAMARAJU RAGHAVARAO

AMS 64681 EXTENDED CROUP DIVISIBLE PARTIALLY BALANCED INCOMPLETE BLOCK DESICNS * KLAUS HINKELMANN

AMS 64696 GENERALIZED LEAST SQUARES ESTIMATORS FOR RANDOMIZED FRACTIONAL REPLICATION DESIGNS * S. ZACKS

AMS 64705 ORTHOGONALITY IN ANALYSIS OF VARIANCE * G. A , F . SEBER

AMS 64711 ESTIMATES OF EFFECTS FOR FRACTIONAL REPLICATES * K. S. BANERJEE, W. T. FEDERER

AMS 64716 SIMULTANEOUS CONFIDENCE INTERVALS FOR CONTRASTS AMONG MULTINOMIAL POPULATIONS * LEO A. GOODMAN

AMS 64726 ASYMPTOTICALLY NONPARAMETRIC INFERENCE IN SOME LINEAR MODELS WITH ONE OBSERVATION PER CELL * E. L. LEHMANN

AMS 64735 CHARACTERIZATION OF MULTISAMPLE DISTRI8UTION-FREE STATISTICS * C. 8. BELL 
AMS 64739 RANKINGS FROM PAIRED COMPARISONS * W. A. THOMPSON JR, RUSSEL REMAGE JR

AMS 64748 ASYMPTOTIC DISTRIBUTION OF DISTANCES BETWEEN ORDER STATISTICS FROM BIVARIATE POPULATIONS * $0 . P$ SRIVASTAVA, W. L. HARKNESS, J. B. BARTOO

AMS 64755 A PROPERTY OF SOME SYMMETRIC TWO-STAGE SEQUENTIAL PROCEDURES* J.W. THOMPSON

PROCEDURES* J. W. THOMPSON
AMS 64762 ON TWO-SIDED TOLERANCE INTERVALS FOR A NORMAL DISTRIBUTION * BOBE. ELLISON

AMS 64773 THE LINEAR HYPOTHESIS AND LARGE SAMPLE THEORY * G. A F. SEBER

AMS 647 7BO CONFIDENCE REGION FOR A LINEAR RELATION * C. VILLEGAS

AMS 647 B 9 ON THE ADMISSIBILITY OF SOME TESTS OF MANOVA * M. N GHOSH

AMS 64795 SUFFICIENCY IN SAMPLING THEORY* P. K. PATHAK

AMS 64809 TWO ESTIMATES OF THE BINOMIAL DISTRIBUTION, (CORR, 64 $182)$ * J. C. MOTT-SMITH

AMS $64817 \mathrm{~A}$ NEW PROOF OF THE PEARSON-FISHER THEOREM. (ACKNONLEDGEMENT OF PRIORITY, 65 344)* M. W. BIRCH

AMS 64825 A BAYESIAN APPROACH TO SOME BEST POPULATION PROBLEMS * IRTIN GUTTMAN, GEORGE C. TIAO

AMS 64 B36 INVARIANT PRIOR DISTRIBUTIONS* J. HARTIGAN

AMS 64846 ASYMPTOTIC BEHAVIOR OF BAYES ' ESTIMATES * J. FABIUS

AMS 64857 PROBABILITIES IN THE VOTING PARADOX * ZALMAN USISKIN

AMS 64863 MEMORYLESS STRATEGIES IN FINITE-STAGE DYNAMIC PROGRAMMING * DAVID BLACKNELL

AMS 64866 A LIMIT THEOREM FOR RANDOM INTERVAL SAMPLING OF A STOCHAST IG PROCESS * RICHARD F . GEBHARD

AMS 64869 NON-SINGULAR RECURRENT MARKOV PROCESSES HAVE STATIONARY MEASURES* RICHARD ISAAC

AMS 64872 ON ADDING INDEPENDENT STOCHASTIC PROCESSES * TOM S PITCHER

AMS 64874 THE DEPENDENCE OF DELAYS IN TANDEM QUEUES * P. J . BURKE

AMS 64876 A RELATIONSHIP BETWEEN ARBITRARY POSITIVE MATRICES AND DOUBLY STOCHASTIC MATRICES * RICHARD SINKHORN

AMS 648 BO ANOTE ON IDEMPOTENT MATRICES * K. S. BANERJEE

AMS 64883 ON THE LINE GRAPH OF THE COMPLETE BIPARTITE GRAPH * A J. HOFFMAN

AMS 64886 BAYESIAN BIO-ASSAY * CHARLES H. KRAFT, CONSTANCE VAN EEDEN

AMS 64891 SIGNIFICANCE PROBABILITY BOUNDS FOR RANK ORDERINGS * PAUL SWITZER

AMS 64895 PSEUDO-INVERSES IN THE ANALYSIS OF VARIANCE * PETER W M. JOHN

AMS 64897 BALANCED DESIGNS WITH UNEQUAL NUMBERS OF REPLICATES * PETER W. M. JOHN

AMS 64900 ON DOUBLE SAMPLING FOR PROBABILITY PROPORTIONATE TO SOME MEASURE OF SIZE ESTIMATION * DES RAJ

AMS 64923 CORRECTION. 'SOME EXTENSIONS OF THE WISHART DISTRIBUTION', $44345^{*}$ 'T. W. ANDERSON, M. A. GIRSHICK

AMS 64923 GORRECTION. 'THE NON-CENTRAL WISHART DISTRIBUTION AND CERTAIN PROBLEMS OF MULTIVARIATE STATISTICS', $46409 * T . W$. ANDERSON

AMS 64949 ESTIMATORS OF A LOCATION PARAMETER IN THE ABSOLUTELY CONTINUOUS CASE * R. H. FARRELL

AMS 64999 ESTIMATING THE GURRENT MEAN OF A NORMAL DISTRIBUTION WHICH IS SUBJECTED TO CHANGES IN TIME * H. CHERNOFF, S. ZACKS

AMS 641019 ADMISSIBILITY OF QUANT ILE EST IMATES OF A SINGLE LOCATION PARAMETER * MART IN FOX, HERMAN RUBIN

AMS 6410331 UNIFORM APPROXIMATION OF MINIMAX POINT ESTIMATES * $M$. N. GHOSH

AMS $64104 B$ SEQUENTIAL ESTIMATION AND CLOSED SEQUENTIAL DECISION PROCEDURES * EDWARD PAULSON

AMS 641059 MONOTONICITY PROPERTY OF THE POWER FUNCTIONS OF SOME TESTS OF THE EQUALITY OF TWO COVARIANCE MATRICES, CORR. $651318 *$ T. W. ANDERSON, S. DASGUPTA

AMS 641064 USE OF INTER-BLOCK INFORMATION TO OBTAIN UNIFORMLY BETTER EST TMATORS * K.R. SHAH

AMS 641079 ON SOME ALTERNATIVE ESTIMATES FOR SHIFT IN THE PVARIATE ONE SAMPLE PROBLEM * PETER J. BICKEL

AMS 641091 SMALL-SAMPLE DISTRIBUTIONS OF THE TWO-SAMPLE CRAMERVON MISES' $W$-SQUARED AND WATSON'S U-SQUARED * E. J . BURR

AMS 641099 ON TWO-STAGE NON-PARAMETRIG ESTIMATION * E. H. YEN

AMS 641115 COMPARISON OF THE POWER FUNCTIONS FOR THE TEST OF INDEPENDENCE IN $2 X 2$ CONTINGENCY TABLES * W. L. HARKNESS, L. KATZ

AMS 641128 ON BAYES PROCEDURES FOR A PROBLEM WITH CHOICE OF OBSERVATIONS * T. W. ANDERSON

AMS 641136 SOME STOCHASTIC APPROXIMATION PROCEDURES FOR USE IN PROCESS CONTROL * JOHN P. GOMER JR

AMS 641147 QUEUES WITH BATCHDEPARTURES II * F. G. FOSTER, A. F. A. D. PERERA

AMS 641157 ON A MEASURE OF ASSOCIATION * S. D. SILVEY

AMS 641167 PROPERTIES OF POLYKAYS OF DEVIATES * P. S. DWYER

AMS 641174 A COMBINATORIAL METHOD FOR PRODUCTS OF TWO POLYKAYS WITH SOME GENERAL FORMULAE * P. S. DWYER, D. S. TRACY
AMS 6411 B 6 ON ELEMENTARY SYMMETRIC FUNCTIONS OF THE ROOTS OF A MULTIVARIATE MATRIX. DISTRIBUTIONS * TITO A MIJARES

AMS 641199 A CHARACTERIZATION OF THE EXPONENTIAL DISTRIBUTION * THOMASS. FERGUSON

AMS 641208 POLYNOMIAL EXPANSIONSOF BIVARIATEDISTRIBUTIONS * G K. EAGLESON

AMS 641216 ON THE TOPOLOGICAL STRUCTURE OF SOME ORDERED FAMILIES OF DISTRIBUTIONS * J.PFANZAGL

AMS 641229 ON CONTINUOUS SUFFICIENT STATISTICS * J. L. DENNY

AMS 641234 BOUNDS FOR DISTRIBUTIONS WITH MONOTONE HAZARD RATE, I * RICHARD E. BARLOW, ALBERT W. MARSHALL

AMS 64 125B BOUNDS FOR DISTRIBUTIONS WITH MONOTONE HAZARD RATE II * RICHARDE. BARLOW, ALBERT W. MARSHALL

AMS 641275 SOME THEOREMS ON FUNCTIONALS OF MARKOV CHAINS * SIDNEY C. PORT

AMS 641291 THE TAIL SIGMA-FIELD OF A MARKOV CHAIN AND A THEOREM OF OREY* DAVID BLACKWELL, DAVID FREEDMAN

AMS 641296 ON THE ASYMPTOTIC DISTRIBUTION OF THE AUTOCORRELATIONS OF A SAMPLE FROM A LINEAR STOCHASTIC PROCESS * T. W. ANDERSON, A. M. WALKER

AMS 641304 ON THE PROBABILITY OF LARGE DEVIATIONS OF FAMILIES OF SAMPLE MEANS * J. SETHURAMAN

AMS 641317 ON THE DISTRIBUTION OF THE NUMBER OF SUCCESSES IN INDEPENDENT TRIALS J. N. DARROCH

AMS 641322 ASYMPTOTIC EXTREMES FOR M-DEPENDENT RANDOM VARIABLES * G. F. NEWELL

AMS 641326 PRESENT VALUE OF A RENEWAL PROCESS * GIORGIO DALL' AGLIO

AMS 641332 LIMIT THEOREMS FOR STOPPED RANDOM WALKS * R. H. FARRELL

AMS 641344 THE LAST RETURN TO EQUILIBRIUM IN A COIN TOSSING GAME * D. BLACKWELL, $P$. DEUEL, D. FREEDMAN

AMS 641345 A REMARK ON THE COIN TOSSING GAME * DAVID BLACKWELL, DAVID FREEDMAN

AMS 64 134B A THEOREM ON STOPPING TIMES * R. M. BLUMENTHAL, R. K GETOOR

AMS 641351 ESCAPE PROBABILITY FOR A HALF LINE * SIDNEY C. PORT

AMS 641356 AN APPLICATION OF A BALLOT THEOREM IN ORDER STATISTICS * LAJOS TAKACS

AMS 641359 FLUCTUATION THEOREM AND A DISTRIBUTION-FREE TEST * CHARLES H. KRAFT, CONSTANCE VAN EEDEN

AMS 641361 TABLES OF DISTRIBUTION-FREE TOLERANCE LIMITS * L DANZIGER, $S$, A, DAVIS

AMS 641366 A NOTE ON THE TRUNCATED EXPONENTIAL DISTRIBUTION * LEE J. BAIN, DAVID L. WEEKS

AMS 641368 AN APPLICATION OF A GENERALIZED GAMMA DISTRIBUTION * GERALD S. ROGERS

AMS 64 I3BB CORRECTION. 'THE STRUGTURE OF BIVARIATE DISTRIBUTIONS', $58719 *$ H. O. LANCASTER

AMS 641419 SUFFICIENCY AND APPROXIMATE SUFFICIENCY * L. LECAM

AMS 641456 SUFFICIENT STATISTICS IN THE CASE OF INDEPENDENT RANDOM VARI ABLES * L. BROWN

AMS 641475 MINIMAX CHARACTER OF THE R-SQUARED-TEST IN THE SIMPLEST CASE * N. GIRI, J KIEFER

AMS 641491 ASYMPTOTIC THEORY OF REJECTIVE SAMPLING WITH VARYING PROBABILITIES FROM A FINITE POPULATION * JAROSLAV HAJEK

AMS 641524 ON THE RISK OF SOME STRATEGIES FOR OUTLYING OBSERVATIONS * FRIEDRICH GEBHARDT

AMS 641537 ON A MEASURE OF TEST EFFICIENCY PROPOSED BY R. R 8AHADUR * LEON J. GLESER

AMS 641545 ON FISHER'S BOUND FOR ASYMPTOTIC VARIANCES * R. R BAHADUR

AMS 641553 OPTIMAL SPACING AND WEIGHTING IN POLYNOMIAL PREDICTION * P. G. HOEL, A. LEVINE

AMS 641561 TOLERANCE LIMITS FOR THE CLASS OF DISTRIBUTIONS WITH INCREASING HAZARD RATE *D. L. HANSON, L. H. KOOPMANS AMS 64 1571 AN ASYMPTOTICALLY OPT IMAL FIXED SAMPLE SIZE PROCEDURE FOR COMPARING SEVERAL EXPERIMENT AL GATEGORIES WITH A CONTROL * CHARLES DEWITT ROBERTS

AMS 641576 SMALL SAMPLE POWER OF THE BIVARIATE SIGN TEST OF BLUMEN AND HODGES * JEROME KLOTZ

AMS 641583 VARIATIONS OF THE NON-CENTRAL T AND BETA DISTRIBUTIONS * JOHN H. PARK JR

AMS 641594 A TRUSTWORTHY JACKKNIFE * RUPERT G. MILLER JR

AMS 641606 CONVERGENCE OF THE LOSSES OF CERTAIN DECISION RULES FOR THE SEQUENTIAL COMPOUND DECISION PROBLEM * ESTER SAMUEL

AMS 641622 THE BAYESIAN ANALYSIS OF CONTINGENCY TABLES* D. V. LINDLEY

AMS 641644 DECISION PROGEDURES FOR FINITE DECISION PROBLEMS UNDER COMPLETE IGNORANCE * F. V. ATKINSON, J. D CHURCH, B. HARRIS

AMS 641656 BAYES SOLUTION OF SEQUENTIAL DECISION PROBLEM FOR MARKOV DEPENDENT OBSERVATIONS * R. R. BHAT

AMS 641663 ON THE EQUIVALENCE OF POLYKAYS OF THE SECOND DEGREE AND SIGMA 'S, CORR. 651069 * EUGENE DAYHOFF 
AMS 641673 ON BIVARIATE RANDOM VARIABLES WHERE THE QUOTIENT OF THEIR COORDINATES FOLLOWS SOME KNOWN DISTRIBUTION * ICNACY KOTLARSKI

AMS 641685 ORTHANT PROBABILITIES FOR THE QUADRIVARIATE NORMAL DISTRIBUTION * I . C. ABRAHAMSON

AMS 641704 ON THE MOMENTS OF ELEMENTARY SYMMETRIC FUNCTIONS OF THE ROOTS OF TWO MATRI CES * K. C. SREEDHARAN PILLAI

AMS 641713 ON RANDOM SAMPLING FROM A STOCHASTIC PROCESS * J.R. BLUM, JUDAH ROSENBLATTT

AMS 64 171B EXTREMAL PROCESSES * MEYER DWASS

AMS 641726 ON EXTREME ORDER STATISTICS * JOHN LAMPERTI

AMS 64 173B ON ASYMPTOTIC MOMENTS OF EXTREME STATISTICS * JAMESR. MCCORD

AMS 641746 LIMIT THEOREMS FOR MARKOV RENEWAL PROCESSES * RONALD PYKE, RONALD SCHAUFELE

AMS 641765 ON THE MULTIVARIATE ANALYSIS OF WEAKLY STATIONARY STOCHASTIC PROCESSES * L. H. KOOPMANS

AMS 64 17BI A UNIQUENESS THEOREM FOR STATIONARY MEASURES OF ERGODIC MARKOV PROCESSES * RICHARD ISAAC
AMS 641787 ON QUALITATIVE PROBABILITY SICMA-ALCEBRAS * C. VILLECAS

AMS 641797 EICENVALUES OF NON-NECATIVE MATRICES * WILLIAM E PRUITT

AMS 641801 DISTRIBUTION OF THE 'CENERALIZED' MULTIPLE CORRELATION MATRIX IN THE DUAL CASE * C. G. KHATRI

AMS 641807 DISTRIBUTION OF THE LARGEST OR THE SMALLEST CHARACTERISTIC ROOT UNDER NULL HYPOTHESIS CONCERNING COMPLEX MULTIVARIATE NORMAL POPULATIONS * C. G. KHATRI

AMS 641811 A NOTE ON CONVERGENCE OF SUB-MARTINGALES * DAN CHAZAN AMS 64 IBI5 SOME RESULTS ON THE ORDER STATISTICS OF THE MULTIVARIATE NORMAL AND PARETO TYPE 1 POPULATIONS * $K$. V. MARDIA

AMS 641819 CONVERGENCE PROPERTIES OF A LEARNING ALGORITHM * LEO BREIMAN, ZIVIA S. WURTELE

AMS 641823 A NOTE ON THE POISSON TENDENCY IN TRAFFIC DISTRIBUTION * TORBJORN THEDEEN

AMS 641825 NOTE ON MOOD'S TEST * C. F. CROUSE

ANNALS OF MATHEMATICAL STATISTICS VOLUME 36, 1965

AMS 651 SAMUEL STANLEY WILKS 1906-1964*T.W. ANDERSON

AMS 6524 PUBLICATIONSOF S. S. WILKS * T. W. ANDERSON

AMS 65 2B SEQUENTIAL TEST FOR THE MEAN OF A NORMAL DISTRIBUTION III, SMALL T * HERMAN CHERNOFF

AMS 6555 SEQUENTIAL TESTS FOR THE MEAN OF A NORMAL DISTRIBUTION IV, DISCRETE CASE * HERMAN CHERNOFF

AMS 6569 MAXIMUM LIKELIHOOD ESTIMATION FOR DISTRIBUTIONS WITH MONOTONE FAILURE RATE * ALBERT.W. MARSHALL, FRANK PROSCHAN

AMS 6578 ESTIMATES OF LINEAR COMBINATIONS OF THE PARAMETERS IN THE MEAN VECTOR OF A MULTIVARIATE DISTRIBUTION * ARTHUR COHEN

AMS 65 8B MAIN-EFFECT ANALYSIS OF THE CENERAL NON-ORTHOCONAL LAYOUT WITH ANY NUMBER OF FACTORS * DAN BRADU

AMS 659 CLLASSICAL STATISTICAL ANALYSIS BASED ON A CERTAIN MULTIVARIATE COMPLEX GAUSSIAN DISTRIBUTION * C. G. KHATRI

AMS 65115 A TEST FOR REALITY OF A COVARIANCE MATRIX IN A CERTAIN COMPLEX GAUSSIAN DISTRIBUTION * C. G. KHATRI

AMS 65120 THE DISTRIBUTION OF THE GENERALIZED VARIANCE * $0 . P$ BAGAI

AMS 65131 SOME DIRECT ESTIMATES OF THE MODE * ULF CRENANDER

AMS 65139 A SYSTEM OF INEQUALITIES FOR THE INCOMPLETE CAMMA FUNCTIONS AND THE NORMAL INTEGRAL * SHANTI S. GUPTA, MRUDULLA N. WAKNIS

AMS 65150 BAYESIAN ESTIMATION IN MULTIVARIATE ANALYSIS * SEYMOUR GEISSER

AMS 65160 ON SOME ASYMPTOTICALLY NONPARAMETRIC COMPETITORS OF HOTELLINC'S T-SQUARE, CORR. $6515 B 3$ * PETER J. BICKEL

AMS $65 \quad 174$ ROBUSTNESS OF THE HODCES-LEHMANN EST IMATES FOR SHIFT * ARNLJOT HOYLAND

AMS $6519 B$ ON THE ESTIMATION OF CONTRASTS IN LINEAR MODELS * SUBHA BHUCHONGKUL, MADAN L, PURI

AMS 65203 SOME NEW DISTRIBUTION-FREE STATISTICS, (ACKNOWLEDCEMENT OF PRIORITY 65 1901) * C. B. BELL. K. A. DOKSUM

AMS 65215 POISSON LIMITS OF MULTIVARIATE RUN DISTRIBUTIONS * CAROL F. FUCHS. H. T. DAVID

AMS 65226 DISCOUNTED DYNAMIC PROCRAMM INC * DAVID BLACKWELL

AMS 65236 SOME ASPECTS OF THE RANDOM SEQUENCE * D. E. BARTON, C. L. MALLOWS

AMS 65261 ONE-PARAMETER EXPONENTIAL FAMILIES GENERATED BY TRANSFORMATION GROUPS* R, BORGES, J, PFANZAGL

AMS 65272 INCREASING PROPERTIES OF POLYA FREQUENCY FUNCTIONS * BRADLEY EFRON

AMS 65280 ON THE PROBABILITY OF LARGE DEVIATIONS OF THE MEAN FOR RANDOM VARIABLES IN AN INTERVAL OF LENCTH ONE * J. SETHURAMAN

AMS 65286 JOINT DISTRIBUTIONS WITH PRESCRIBED MOMENTS * HOWARD RUMSEY JR, EDWARD C. POSNER

AMS 65299 INEQUALITIES OF THE RTH ABSOLUTE MOMENT OF A SUM OF RANDOM VARIABLES, I LESS THAN OR EQUAL TO R, R LESS THAN OR EQUAL TO 2 * BENGT VON BAHR. CARL-GUSTAV ESSEEN

AMS 65304 ON LIMIT THEOREMS FOR CAUSSIAN PROCESSES * JOHN LAMPERTI

AMS 65311 DISTRIBUTION OF THE ABSOLUTE MAXIMUM FOR CERTAIN BROWNIAN MOTIONS * FRANK B. KNICHT

AMS 65313 ON THE COMPLEX WISHART DISTRIBUTION * M. S. SRIVASTAVA

AMS 65316 A THEOREM ON RANK ORDERS FOR TWO CENSORED SAMPLES * CARL-ERIK SARNDAL

AMS 65322 SOME RENYI TYPE LIMIT THEOREMS FOR EMPIRICAL DISTRIBUTION FUNCTIONS, CORR. 651069 * MIKLOS CSORGO
AMS 65327 ON SAMPLINC OVER TWO OCCASIONS WITH PROBABILITY PROPORTIONATE TO SIZE * DES RAJ

AMS 65331 A NOTE ON THE PARAMETERS OF PARTIALLY BALANCED INCOMPLETE BLOCK ASSOCIATION SCHEMES * DALE M MESNER

AMS 65337 BOUNDS FOR THE NUMBER OF COMMON TREATMENTS BETWEEN ANY TWO BLOCKS OF CERTAIN PARTIALLY BALANCED INCOMPLETE BLOCK DESIGNS * S. M. SHAH

AMS 65369 ASYMPTOTICALLY OPTIMUM TESTS FOR MULTINOMIAL DISTRIBUTIONS * WASSILY HOEFFDING

AMS 65401 DISCUSSION OF HOEFFDINGS PAPER * JERZY NEYMAN, HERMAN CHERNOFF, D. G. CHAPMAN

AMS 65409 ADDITIVE FUNCTIONALS AND EXCESSIVE FUNCTIONS* R. K GETOOR

AMS 65423 THE EXISTENCE OF PROBABILITY MEASURES WITH GIVEN MARGINALS* V. STRASSEN

AMS 65440 RIGHT HAAR MEASURE FOR CONVERGENCE IN PROBABILITY TO QUASI POSTERIOR DISTRIBUTIONS * M. STONE

AMS 65454 ON THE ASYMPTOTIC BEHAVIOR OF BAYES ESTIMATES IN THE DISCRETE CASE II * DAVIDA. FREEDMAN

AMS 65457 ON THE ASYMPTOTIC THEORY OF FIXED-WIDTH SEQUENTIAL CONFIDENCE INTERVALS FOR THE MEAN * Y. S. CHOW, HERBERT ROBBINS

AMS 65463 ON THE ASYMPTOTIC THEORY OF FIXED-SIZE SEQUENTIAL CONF IDENCE BOUNDS FOR LINEAR REGRESSION PARAMETERS * LEON J. CLESER

AMS 65468 SOME OPTIMUM CONFIDENCE BOUNDS FOR ROOTS OF DETERMINANTAL EQUATIONS * T. W. ANDERSON

AMS 654 49 LARGE SAMPLE ESTIMATION OF AN UNKNOWN DISCRETE WAVEFORM WHICH IS RANDOMLY REPEATINC IN GAUSSIAN NOISE * MELVIN HINICH

AMS 65509 ON THE MEAN NUMBER OF CURVE CROSSINGS BY NON-STATIONARY NORMAL PROCESSES * M. R. LEADBETTER, J. D. CRYER

AMS 65517 INTECRAL KERNELS AND INVARIANT MEASURES FOR MARKOFF TRANSITION FUNCTIONS * J FELDMAN

AMS 65524 A CHARACTERIZATION OF A CLASS OF FUNCTIONS OF FINITE MARKOV CHAINS * S. W. DHARMADHIKARI

AMS 65529 THE BEHAVIOR OF LIKELIHOOD RATIOS OF STOCHASTIC PROCESSES RELATED BY GROUPS OF TRANSFORMATIONS * TOM S. PITCHER

AMS 65535 RECURRENT SETS * R. S. BUCY

AMS 65546 A LOCAL LIMIT THEOREM FOR NONLATTICE MULTI-DIMENSIONAL DISTRIBUTION FUNCTIONS * CHARLES STONE

AMS 65552 LOCAL CONVERGENCE OF MARTINCALES AND THE LAW OF LARGE NUMBERS * Y S CHOW

AMS 65559 ON THE CONVERCENCE RATE OF THE LAW OF LARGE NUMBERS FOR LINEAR COMBINATIONS OF INDEPENDENT RANDOM VARIABLES * D. L. HANSON, L. H. KOOPMANS

AMS 65565 BOUNDS ON INTEGRALS WITH APPLICATIONS TO RELIABILITY PROBLEMS * RICHARDE. BARLOW

AMS 65575 THE RELATIONSHIP BETWEEN SUFFICIENCY AND INVARIANCE WITH APPLICATIONS IN SEQUENTIAL ANALYSIS * W. J HALL, R. A. WIJSMAN, J. K. GHOSH

AMS 65615 ON THE ASYMPTOTIC BEHAVIOR OF DENSITIES WITH APPLICA TIONS TO SEQUENTIAL ANALYSIS * ADNAN IFRAM

AMS 65638 NONLINEAR LEAST SQUARES ESTIMATION * H. O. HARTLEY AARON BOOKER

AMS 65651 EFFECT ON NON-NORMALITY ON STEIN'S TWO SAMPLE TEST* G P. BHATTACHARJEE

AMS 65664 ON THE COMPLEX ANALOGUES OF T-SQUARED AND R-SQUARED TESTS * N. GIRI

AMS 65671 GENERALIZATION OF SVERDRUP'S LEMMA AND ITS APPLICATIONS TO MULTIVARIATE DISTRIBUTION THEORY * D. G KABE

AMS 65677 APPROXIMATIONS TO THE DISTRIBUTION OF QUADRATIC FORMS * M. M. SIDDIQUI 
AMS 65683 DECOMPOSITION OF SYMMETRIC MATRICES AND DISTRIBUTIONS OF QUADRATIC FORMS * NORMAN Y. LUTHER

AMS 65691 NOTE ON DECISION PROCEDURES FOR FINITE DECISION PROBLEMS UNDER COMPLETE ICNORANCE * BRADLEY EFRON

AMS 65698 NOTE ON ESTIMATINC ORDERED PARAMETERS * ESTER SAMUEL

AMS 65703 CHARACTERIZATIONS OF SOME DISTRIBUTIONS BY CONDITIONAL MOMENTS * E. M. BOLGER, W. L. HARKNESS

AMS 65706 LIMITING DISTRIBUTIONS OF RESPONSE PROBABILITIES * J R. MCGREGOR, J.V. ZIDEK

AMS 65708 A RECURRENCE FOR PERMUTATIONS WITHOUT RISING OR FALLINC SUCCESSIONS * JOHN RIORDAN

AMS 65711 A BALANCED INCOMPLETE BLOCK DESIGN* HAIM HANANI

AMS 65712 A PROPERTY OF THE MULTIVARIATE T DISTRIBUTION * OLIVE JEAN DUNN

AMS 65747 ADMISSIBLE BAYES CHARACTER OF T-SQUARED, R-SQUARED AND OTHER FULLY INVARIANT TESTS FOR CLASSICAL MULTIVARIATE NORMAL PROBLEMS * J. KIEFER, R. SCHWARTZ

AMS 65771 GAUSSIAN PROCESSES ON SEVERAL PARAMETERS * $R$. M. DUDLEY

AMS 65789 MOMENTS OF RANDOMLY STOPPED SUMS * Y. S. CHOW, HERBERT ROBBINS, HENRY TEICHER

AMS 65800 A SHARPER FORM OF THE BOREL-CANTELLI LEMMA AND THE STRONG LAW * LESTERE. DUBINS, DAVIDA. FREEDMAN

AMS $6580 \mathrm{~B}$ ON THE CONVERGENCE OF MOMENTS IN THE CENTRAL LIMIT THEOREM * BENGT VON BAHR

AMS 65 B 19 ON THE LIFTING PROPERTY, $V * A$. IONESCU TULCEA

AMS 65 B29 INVARIANT CONDITIONAL DISTRIBUTIONS * J. A. BATHER

AMS 65 B47 ON SOME ROBUST ESTIMATES OF LOCATTON * PETER J BICKEL

AMS 65859 BOUNDS ON THE MAXIMUM SAMPLE SIZE OF A BAYES SEQUENTIAL PROCEDURE * S. N. RAY

AMS 65 B79 SEQUENTIAL COMPOUND ESTTMATORS * ESTER SAMUEL

AMS 65890 ON INFORMATION IN STATISTICS * D. A. S. FRASER

AMS 65897 ORDER STATISTICS AND STATISTICS OF STRUCTURE * HERBERT DAVID

AMS 65907 EXACT MOMENTS AND PERCENTACE POINTS OF THE ORDER STATISTICS AND THE DISTRIBUTION OF THE RANGE FROM THE LOGISTICDISTRIBUTION * SHANTI S. GUPTA . BHUPENDRA K. SHAH

AMS 65921 QUANTILES AND MEDIANS * M. ROSENBLATT-ROTH

AMS 65926 SOME BASIC PROPERTIES OF THE INCOMPLETE GAMMA FUNCTION RATIO, CORR, 65 15B4* S. H. KHAMIS

AMS 65 93B PROPERTIES OF THE EXTENDED HYPERGEOMETRIC DISTRIBUTION * T. L. HARKNESS

AMS 65946 RENEWAL THEORY IN THE PLANE * PETER J. BICKEL, JOSEPH A. YAHAV

AMS 65956 BERNARD FRIEDMAN'S URN * DAVID A. FREEDMAN

AMS 65971 SPECTRAL ANALYSIS WITH RANDOMLY MISSED OBSERVATIONS, THE BINOMIAL CASE* PERRY A, SCHEINOK

AMS 65978 ASYMPTOTIC INFERENCE IN MARKOV PROCESSES * G. C. ROUSSAS

AMS 65993 EXTREME VALUES IN UNIFORMLY MIXINC STATIONARY STOCHASTIC PROCESSES * R. M. LOYNES

AMS 651000 ON THE ASYMPTOTIC POWER OF THE ONE-SAMPLE KOLMOGOROVSMIRNOV TESTS * DANA QUADE

AMS 651019 SEVERAL K-SAMPLE KOLMOCOROV-SMIROV TESTS * W. J. CONOVER

AMS 651027 ESTIMATION OF PROBABILITY DENSITY* V. K. MURTHY

AMS 651032 ESTIMATION OF JUMPS, RELIABILITY AND HAZARD RATE * $v$ K. MURTHY

AMS 651041 A LIMIT THEOREM FOR SUMS OF MIN IMA OF STOCHASTIC VARIABLES * ULF GRENANDER

AMS 651043 THE EXPECTED NUMBER OF ZEROS OF A STATIONARY GAUSSIAN PROCESS * N. DONALD YLVISAKER

AMS 651047 DENSITY ESTIMATION IN A TOPOLOGICAL GROUP * K. J CRASWELL

AMS 651049 A NONPARAMETRIC ESTIMATE OF A MULTIVARIATE DENSITY FUNCTION * D. O. LOFTSGAARDEN, C. P. QUESENBERRY

AMS 651052 A NOTE ON MIDRANGE * E. J. GUMBEL, P. G. CARLSON, C. K MUSTAFI

AMS 651055 SOME BOUNDS FOR EXPECTED VALUES OF ORDER STATISTICS * MIR M. ALI, LAI K. CHAN

AMS 651058 NOTE ON THE WILCOXON-MANN-WHITNEY STATISTIC * S. K. ZAREMBA

AMS 651061 ON THE LIKELIHOOD RATIO TEST OF A NORMAL MULTIVARIATE TESTING PROBLEM II * N. GIRI

AMS 651066 FACTORIALDISTRIBUTIONS * W. H. MARLOW

AMS 651097 MINIMAX DESIGNS IN TWO DIMENSIONAL REGRESSION * PAUL G. HOEL

AMS 651107 DISTINGUISHING A SEQUENCE OF RANDOM VARIABLES FROM A TRANSLATE ITSELF* L. A. SHEPP

AMS 651113 SOME SMIRNOV TYPE THEOREMS OF PROBABILITY * MIKLOS CSORGO

AMS 651120 ESTIMATION OF THE BISPECTRUM * M. ROSENBLATT, J. S. VAN NESS

AMS 651137 THE ASYMPTOTICALLY UNBIASED PRIOR DISTRIBUTION * J A. HART IGAN
AMS 651153 AN ASYMPTOTIC EXPANSION FOR THE DISTRIBUTION OF THE LATENT ROOTS OF THE ESTIMATED COVARIANCE MATRIX * GEORCE A. ANDERSON

AMS 651174 OPTIMUM CLASSIFICATION RULES FOR CLASSIFICATION INTO TWO MULT IVARIATE NORMAL POPULAT IONS * S. DAS CUPTA

AMS 651185 A HYBRID PROBLEM ON THE EXPONENTIAL FAMILY * ARTHUR COHEN

AMS 651207 OPTIMAL INVARIANT RANK TESTS FOR THE K-SAMPLE PROBLEM * T. K. MATTHES, D. R. TRUAX

AMS 651223 A K-SAMPLE MODEL IN ORDER STATISTICS* W. J CONOVER

AMS 651236 THE TWO-SAMPLE SCALE PROBLEM WHEN LOCATIONS ARE UNKNOWN* M. RAGHAVACHARI

AMS 651243 ASYMPTOTICALLY MOST POWERFUL RANK TESTS FOR THE TWOSAMPLE PROBLEM WITH CENSORED DATA * JOSEPH L. GASTWIRTH

AMS 65 124B STUDENT'S T IN A TWO-WAY CLASSIFICATION WITH UNEQUAL VARIANCES * KAY KNIGHT MAZUY, W. S. CONNOR

AMS 651256 CONSTRUCTION OF CONFOUNDING PLANS FOR MIXED FACTORIAL DESIGNS * DAVID WHITE, ROBERT A. HULTQUIST

AMS 651272 ON THE NUMBER OF SUCCESSES IN INDEPENDENT TRIALS * STEPHEN M. SAMUELS

AMS 651279 ON THE ITERATIVE METHOD OF DYNAMIC PROGRAMMING ON A FINITE SPACE DISCRETE TIME MARKOV PROCESS * BARRY W BROWN

AMS 651286 ON STOCHASTIC PROCESSES DERIVED FROM MARKOV CHAINS * ALEX HELLER

AMS 651292 GENERALIZATIONS OF THE MAXIMAL ERGODIC THEOREM * CLEN BAXTER

AMS 651294 A SIMPLE PROBABILISTIC PROOF OF THE DISCRETE CENERALIZED RENEWAL THEOREM * SIDNEY C . PORT

AMS $65129 \mathrm{~B}$ ON MOMENT CENERATING FUNCTIONS AND RENEWAL THEORY * GHARLES STONE

AMS 651302 A NOTE ON THE RECIPROCAL OF THE CONDITIONAL EXPECTATION OF A POSITIVE RANDOM VARIABLE * TIM ROBERTSON

AMS 651306 ON THE EFFICIENCY OF THE NORMAL SCORES TEST RELATIVE TO THE F-TEST * M. RACHAVACHARI

AMS 65 13OB A NOTE ON WILKS' INTERNAL SCATTER * H. ROBERT VAN DER VAART

AMS 651313 PAIRWISE STATISTICAL INDEPENDENCE * H. O. LANCASTER

AMS 651339 CONDITIONAL EXPECTATION CIVENA SICMA-LATTICE AND APPLICATIONS * H. D. BRUNK

AMS 651351 AN INTRODUCT ION TO POLYSPECTRA * DAVID BRILLINGER

AMS 651375 THE ROBBINS-ISBELL TWO-ARMED-BANDIT PROBLEM WITH FINITE MEMORY * CARTER VINCENT SMITH, RONALD PYKE

AMS 651387 A BAYES SEQUENTIAL SAMPLINC INSPECTION * HERMAN CHERNOFF, S. N. RAY

AMS 65 140B MARKOVIAN DECISION MODELS FOR THE EVALUATION OF A LARCE CLASS OF CONTINUOUS SAMPLING INSPECTION PLANS * LEONS. WHITE

AMS 651421 SOME APPLICATIONS OF MONOTONE OPERATORS IN MARKOV PROCESSES * J. MACQUEEN, R. M. REDHEFFER

AMS 651426 ON THE EXTRAPOLATION OF A SPECIAL CLASS OF STATIONARY TIMF SERIES * WILLIAM F. TRENCH

AMS 651433 SAMPLING ENTROPY FOR RANDOM HOMOCENEOUS SYSTEMS WITH COMPLETE CONNECTIONS (CORR. 69 NO.6) * MARIUS IOSIFESCU

AMS 651437 LIMIT THEOREMS FOR QUEUES WITH TRAFFIC INTENSITY ONE * DONALD L, ICLEHART

AMS 651450 ON RANDOM SUMS OF RANDOM VECTORS * HENRY TEICHER

AMS 651459 ON THE GENERALIZED MELLIN TRANSFORM OF A COMPLEX RANDOM VARIABLE AND ITS APPLICATIONS * ICNACY KOTLARSKI

AMS 651468 MULTIPARAMETER PROBLEMS FROM A BAYESIAN POINT OF VIEW * G, E, P. BOX, CEORCE C. TIAO

AMS 651483 OPTIMUM DESIGNS FOR POLYNOMIAL EXTRAPOLATION * PAUL G. HOEL

AMS 651494 A METHOD OF SEQUENTIAL ESTIMATION APPLICABLE TO THE HYPERGEOMETRIC, BINOMIAL, POISSON, AND EXPONENTIAL DISTRIBUTIONS * WILLIAM KNIGHT

AMS 651504 THE EFFECT OF TRUNCATION ON TESTS OF HYPOTHESES FOR NORMAL POPULATIONS * BRITAIN J. WILLIAMS

AMS 651511 SOME RESULTS ON THE NON-CENTRAL MULTIVARIATE BETA DISTRIBUTION AND MOMENTS OF TRACES OF TWO MATRICES * C. G. KHATRI, K, C. S. PILLAI

AMS 651521 SOME INEQUALITIES FOR CENTRAL AND NON-CENTRAL DISTRIBUTIONS * WILLIAM H. LAWTON

AMS 651526 CYCLICDESIGNS * H. A. DAVID, F. W. WOLOCK

AMS 651535 GENERALIZED RICHT ANCULAR DESIGNS * SURESH K. THARTHARE

AMS 651554 ON A PROBLEM IN NON-LINEAR PREDICTION THEORY * JAMES B. ROBERTSON

AMS 651556 CONDITIONAL EXPECTATIONS OF RANDOM VARIABLES WITHOUT EXPECTATIONS *R. E. STRAUCH

AMS 651560 ON THE CONVERGENCE OF ORDINARY INTEGRALS TO STOCHASTIC INTEGRALS * EUGENE WONG, MOSHE ZAKAI

AMS 651565 ASYMPTOTIC PROPERTIES OF AN AGE DEPENDENT BRANCHING PROCESS * H. J. WEINER

AMS 651569 AN INTEGRAL EQUATION IN AGE DEPENDENT BRANCHING PROCESSES * H. J. WEINER 
AMS 651574 A NOTE ON QUEUEINC SYSTEMS WITH ERLANC IAN SERVICE TIME DISTRIBUTIONS * D. N. SHANBHAG

AMS 651579 AN OPTIMAL PROPERTY OF PRINCIPAL COMPONENTS * J.N. DARROCH

AMS 651583 CORRECTION. 'A COMPARATIVE STUDY OF SEVERAL ONE-SIDED COODNESS-OF-FIT TESTS' * D. G . CHAPMAN

AMS 651627 ON A THEOREM OF HOEL AND LEVINE ON EXTRAPOLATION * J KIEFER, J. WOLFOWITZ

AMS 651656 THE MOMENTS OF THE NUMBER OF CROSSINCS OF A LEVEL BY A STATIONARY NORMAL PROCESS * HARALD CRAMER, M. R. LEAD8ETTER

AMS 651664 THE ERGODICITY OF SERIES OF QUEUES WITH GENERAL PRIORITIES * BRUCE MCK, JOHNSON

AMS 651677 MARKOVIAN SEQUENTIAL REPLACEMENT PROCESSES * HOWARD M. TAYLOR III

AMS 651695 A DYNAMIC STOCHASTIC APPROXIMATION METHOD * VACLAV DUPAC

AMS 651703 PEAKEDNESS OF DISTRIBUTIONS OF CONVEX COM8INATIONS * FRANK PROSCHAN

AMS 651707 ADMISSIBILITY AND 8AYES ESTIMATION IN SAMPLING FINITE POPULATIONS. I* V. P. GODAMBE. V. M. JOSHI

AMS 651723 ADMISSI8ILITY AND BAYES EST IMATION IN SAMPLING FINITE POPULATIONS, II * V. M. JOSHI

AMS 651730 ADMISSIBILITY AND 8AYES ESTIMATION IN SAMPLINC FINITE POPULATIONS, III *V. M. JOSHI

AMS 651743 RATES OF CONVERGENCE IN THE COMPOUND DECISION PRO8LEM FOR TWO COMPLETELY SPECIFIED DISTRIBUTIONS * J. F HANNAN, J . R. VAN RYZIN

AMS 651753 A ROBUST VERSION OF THE PROBABILITY RATIO TEST * PETER $\mathrm{J}$. HU8ER

AMS 651759 ALTERNATIVE EFFICIENCIES FOR SIGNED RANK TESTS * JEROME KLOTZ

AMS 651767 SMALL SAMPLE POWER FOR THE ONE SAMPLE WILCOXON TEST FOR NON-NORMAL SHIFT ALTERNAT I VES * HARVEY J. ARNOLD

AMS 651779 PROPERTIES OF THE MEDIAN AND OTHER STATISTICS OF LOGISTIC VARIATES * MICHAEL E. TARTER, VIRGINIA CLARK
AMS 651787 MULTIVARIATE-NORMAL CLASSIFICATION WITH COVARIANCE KNOWN * BOBE, ELLISON

AMS 651794 A CLASS OF TESTS WITH MONOTONE POWER FUNCTIONS FOR TWO PROBLEMS IN MULTIVARIATE STATISTICAL ANALYSIS * COVINDS. MUDHOLKAR

AMS 65 IBO2 SOME TESTS FOR THE INTRACLASS CORRELATION MODEL * M S. SRIVASTAVA

AMS 651 BO7 ON A CLASS OF PARTIALLY BALANCED INCOMPLETE BLOCK DESICNS * S. S. SHRIKHANDE

AMS 651815 THE RELATIONSHIP ALGE8RA AND THE ANALYSIS OF VARIANCE OF A PARTIALLY 8ALANCED INCOMPLETE BLOCK DESIGN * JUNJIRO OGAWA, GORO ISHII

AMS 651829 ON HOTELLING'S WEIGHING DESIGNS UNDER AUTO-CORRELATION OF ERRORS * K. S. 8ANERJEE

AMS 651835 ASYMPTOTIC DISTRI8UTORS FOR THE COUPON COLLECTOR'S PR08LEM * LEONARD E. BAUM, PATRICK 8ILLINGSLEY

AMS 651840 CONVERGENCE RATES FOR THE LAW OF LARGE NUM8ERS FOR THE LINEAR COMBINATIONS OF EXCHANGEA8LE AND MIXING STOCHASTIC PROCESSES* D. L. HANSON, L. H. KOOPMANS AMS 651 1B53 A UNIFORM ERGODIC THEOREM * GEORCE 8URKE

AMS 651859 A RANDOM SET PROCESS IN THE PLANE WITH A MARKOVIAN PROPERTY * PAUL SWITZER

AMS 651864 ON AN OPERATOR LIMIT THEOREM OF ROTA * NORTON STARR

AMS 651867 A NOTE ON THE SEQUENTIAL T-TEST * JEROME SACKS

AMS 651870 HYPERCEOMETRIC FUNCTIONS IN SEQUENTIAL ANALYSIS * ADNAN F. IFRAM

AMS 651873 A LEMMA FOR MULTIPLE INFERENCE * WILLIAM KNIGHT

AMS $651 B 75$ ON THE DISTRIBUTION OF THE LATENT VECTORS FOR PRINCIPAL COMPONENTS ANALYSIS * T. SUCIYAMA

AMS 651877 A NOTE ON INCOMPLETE BLOCK DESIGNS WITH THE NUMBER OF BLOCKS EQUAL TO THE NUMBER OF TREATMENTS * M. BHASKAR RAO

AMS 651878 THE LIMIT OF THE NTH POWER OF A DENSITY* RO8ERT J. 8UEHLER

AMS 651883 SPECIAL PAPER. PRINCIPLES OF PROFESSIONAL STATISTICAL PRACTICE * W. EDWARDS DEMING

ANNALS OF MATHEMATICAL STATISTICS VOLUME 37.1966

AMS $66 \quad 1$ ON A THEOREM OF 8 AHADUR AND GOODMAN * E . L. LEHMANN

AMS 667 OPTIMAL STOPPING AND EXPERIMENTAL DESIGN * GUS W. HAGCSTROM

AMS $66 \quad 30$ ON OPTIMAL STOPPINC * JOSEPH A. YAHAV

AMS 6636 THE PERFORMANCE OF A SEQUENTIAL PROCEDURE FOR THE FIXED-WIDTH INTERVAL EST IMATION OF THE MEAN * NORMAN STARR

AMS 6651 LIMITINC 8EHAVIOR OF POSTERIOR DISTR I8UTIONS WHEN THE MODEL IS INCORRECT, CORR . 66745 * ROBERT H. BERK

AMS 6659 A STATISTICAL BASIS FOR APPROXIMATION AND OPTIMIZATION * R, N. RICH

AMS 6666 DESIGNS FOR RECRESSION PRO8LEMS WITH CORRELATED ERRORS * JEROME SACKS, DONALD YLVISAKER

AMS 6690 SEQUENTIAL HYPOTHESIS TESTS FOR THE R-DEPENDENT MARGINALLY STATIONARY PROCESSES * M. TAINITER

AMS 6698 FINE STRUCTURE OF THE ORDERING OF PROBABILITIES OF RANK ORDERS IN THE TWO SAMPLE CASE * I. R. SAVAGE. MILTON SO8EL, GEORGE WOODWORTH

AMS 66113 ON THE PRO8LEM OF TESTINC LOCATION IN MULTIVARIATE POPULATIONS FOR RESTRICTED ALTERNATIVES * PETER E NUESCH

AMS 66120 'OPTIMAL' ONE-SAMPLE DISTRIBUTION-FREE TESTS AND THEIR TWO-SAMPLE EXTENSIONS * C. 8, 8ELL, K. A. DOKSUM

AMS 66133 GOODNESS CRITERIA FOR TWO-SAMPLE DISTRIBUTION-FREE TESTS * C. 8. 8ELL, J . M. MOSER, RORY THOMPSON

AMS 66143 ASYMPTOTIC OPTIMUM QUANTILES FOR THE ESTIMATION OF THE PARAMETERS OF THE NEGATIVE EXPONENTIAL DISTRIBUTION* A. K. MD. EHSANES SALEH, MIR M. ALI

AMS 66152 SCALE PARAMETER ESTIMATION FROM THE ORDER STATISTICS OF UNEQUAL CAMMA COMPONENTS * M. B. WILK, R GNANADESIKAN, ELIZABETH LAUH

AMS 66177 ON THE ESTIMATION OF MIXINC DISTRIBUTIONS * D. C. BOES AMS 66189 ON A CLASS OF ADMISSIBLE PARTITIONS*T. CACOULLOS

AMS 66196 STATISTICAL REPRODUCTION OF ORDERINCS AND TRANSLATION SUBFAMILIES * H. S. KONI JN

AMS 66203 STATISTICAL ISOMORPHISM * NORMAN MORSE. RICHARD SACKSTEDER

AMS 66215 THE DISTRIBUTION OF HOTELLINC'S GENERALIZED MEASURE OF MULTIVARIATE DISPERSION * A. G. CONSTANTINE

AMS 66226 GENERALIZED POLYKAYS, AN EXTENTION OF SIMPLE POLYKAYS AND BIPOLYKAYS, CORR. 66746 * EUGENE DAYHOFF

AMS 66242 CYLINDRICALLY ROTATABLE DESICNS * AGNES M. HERZBERG

AMS $6624 B$ ON A CHEBYSHEV-TYPE INEQUALITY FOR SUMS OF INDEPENDENT RANDOM VARIABLES * S. M. SAMUELS

AMS 66260 ON CROSSINGS OF LEVELS AND CURVES BY A WIDE CLASS OF STOCHASTIC PROCESSES * M R. LEADBETTER
AMS 66268 EQUIVALENCE AND SINGULARITY FOR FRIEDMAN URNS * DAVID A. FREEDMAN

AMS 66271 ON A8SOLUTELY CONTINUOUS COMPONENTS AND RENEWAL THEORY * CHARLES STONE

AMS 66276 A NOTE ON MEMORYLESS RULES FOR CONTROLLING SEQUENTIAL CONTROL PROCESSES * CYRUS DERMAN, RALPHE. STRAUCH

AMS 66279 A NOTE ON MINIMUM DISCRIMINATION INFORMATION * $S$. KULLBACK, M A KHAIRAT

AMS 66281 ON MIXTURES OF DISTRI8UTIONS* W. MOLENAAR, W. R, VAN ZWET

AMS 66284 RECURSIVE GENERATION OF THE DISTRI8UTION OF THE MANNWHITNEY U-STATISTICS UNDER LEHMANN ALTERNATIVES * ROGER A. SHORACK

AMS 66287 A NOTE ON 'A K-SAMPLE MODEL IN ORDER ST ATISTICS' 8Y J. CONOVER * H. A. DAVID

AMS 66289 ANOTHER CHARACTERISTIC PROPERTY OF THE CAUCHY DISTRIBUTION * M. V. MENON

AMS 66295 ON IDEMPOTENT MATRICES * R. M. LOYNES

AMS 66321 RADON-NIKODYM DERIVATIVES OF GAUSSIAN MEASURES * L. A. SHEPP

AMS 66355 NEW METHODS FOR REASONING TOWARDS POSTERIOR DISTR IBUTIONS BASED ON SAMPLE DATA * A. P. DEMPSTER

AMS 66375 A NOTE ON MUTUAL SINGULARITY OF PRIORS * DAVID A. FREEDMAN

AMS 66382 ON THE MOMENTS OF SOME ONE-SIDED STOPPING RULES * Y.S. CHOW

AMS 66388 ON SECOND MOMENTS OF STOPPING RULES * Y. S. CHOW, H. TEICHER

AMS 66393 LIMITING DISTRI8UTIONS FOR SOME RANDOM WALKS ARISING IN LEARNING MODELS * M. FRANK NORMAN

AMS 66406 A SYSTEM OF DENUMERA8LY MANY TRANSIENT MARKOV CHAINS * S. C. PORT

AMS 66412 THE COMPOUND DECISION PROBLEM WITH M-BY-N FINITE LOSS MATRIX * J.R. VAN RYZIN

AMS 66425 ON THE SAMPLE SIZE AND SIMPLIFICATION OF A CLASS OF SEQUENTIAL PROBABILITY RATIO TESTS * ADNAN F. IFRAM

AMS 66435 ON A MINIMAL ESSENTIALLY COMPLETE CLASS OF EXPERIMENTS * SYLVAIN EHRENFELD

AMS 66441 ON THE EFFECT OF STRAGGLERS ON THE RISK OF SOME MEAN ESTIMATORS IN SMALL SAMPLES * FRIEDRICH GEBHARDT

AMS 66451 ESTIMATION OF NON-UNIQUE QUANTILES * DORIAN FELDMAN, HOWARD C. TUCKER

AMS 66 45B ALL ADMISSIBLE LINEAR ESTIMATES OF THE MEAN VECTOR * ARTHUR COHEN

AMS 66464 A NOTE ON THE SPHERICITY TEST * LEON J GLESER

AMS $6646 \mathrm{~B}$ ON CERTAIN DISTRIBUTION PROBLEMS BASED ON POSITIVE DEFINITE QUADRATIC FUNCTIONS IN NORMAL VECTORS * $\mathrm{C}$ 
AMS 66 4BO LINEAR COMBINATIONS OF NON-CENTRAL CHI-SQUARE VARIATES * SHELDON JAMES PRESS

AMS 66488 SOME EQUIVALENCE CLASSES IN PAIRED COMPARISONS * JOSEPHB. KADANE

AMS 66495 PROBABILISTIC COMPLETION OF A KNOCKOUT TOURNAMENT * J. A. HARTIGAN

AMS 66504 INFINITELY DIFFERENTIABLE POSITIVE DEFINITE FUNCTIONS * C. C. GANSER

AMS 66509 A FAMILY OF COMBINATORIAL IDENTITIES * LAWRENCE $\mathrm{H}$ HARPER

AMS 66513 A NOTE ON THE MAXIMUM SAMPLE EXCURSIONS OF STOCHASTIC APPROXIMATION PROCESSES * HAROLD J. KUSHNER

AMS 66517 ON THE MEAN DURATION OF A BALL AND CELL GAME, A FIRST PASSAGE PROBLEM * HARRY DYM, EUGENE $M$. LUKS

AMS 66522 A NOTE ON LIMIT THEOREMS FOR THE ENTROPY OF MARKOV CHAINS * HARRY DYM

AMS 66525 SOME GENERALIZATIONS OF DISTINCT REPRESENTATIVES WITH APPLICATIONS TO STATISTICAL DESIGNS * HIRALAL AGRATAL

AMS 66567 CONVERGENCE OF QUADRATIC FORMS IN INDEPENDENT RANDOM VARIABLES * DALE E. VARBERG

AMS 66577 A NOTE ON QUANTILES IN LARGE SAMPLES * R. R. BAHADUR

AMS 66581 BOUNDED LENGTH CONFIDENCE INTERVALS FOR THE P-POINT OF ADISTRIBUTION FUNCTION, II * R. H. FARRELL

AMS 665 B 6 BOUNDED LENGTH CONFIDENCE INTERVALS FOR THE P-POINT OF A DISTRIBUTION FUNCTION, III * R. H. FARRELL

AMS 66593 ON SOME NONPARAMETRIC ESTIMATES FOR SHIFT IN THE BEHRENS-FISHER SITUATION * P. V. RAMACHANDRAMURTY

AMS 66611 MULTIVARIATE NONPARAMETRIC SEVERAL-SAMPLE TESTS * RYOJI TAMURA

AMS 66619 ASYMPTOTICALLY MINIMAX DISTRIBUTION-FREE PROCEDURES * KJELL DOKSUM

AMS 66629 ADMISSIBILITY OF CONFIDENCE INTERVALS * V. M. JOSHI

AMS 66639 BOUNDS ON THE DISTRIBUTION FUNCTIONS OF THE BEHRENSFISHER STATISTIC * M RAY MICKEY, MORTON B, BROWN

AMS 66643 FIDUCIAL THEORY AND INVARIANT ESTIMATION * R. B. HORA R. J. BUEHLER

AMS 66657 POLYCHOTOMY SAMPLING * SAKTI P. GHOSH

AMS 66666 SOME NON-ORTHOGONAL PARTITIONS OF 4 X4, 5X5, AND 6 X6 LATIN SQUARES* G. H. FREEMAN

AMS 66682 ON A THEOREM OF CRAMER AND LEADBETTER * N. DONALD YLVISAKER

AMS 66686 ON TWO EQUIVALENCE RELATIONS BETWEEN MEASURES * DAVID A. FREEDMAN

AMS 66690 ON THE SEMIMART INGALE CONVERGENCE THEOREM * S. JOHANSEN, J. KARUSH

AMS 66695 A THEOREM ON THE GALTON-WATSON PROCESS * BERNT P. STIGUM

AMS 66699 SOME RENEWAL THEOREMS WITH APPLICATION TO A FIRST PASSAGE PROBLEM * C. C. HEYDE

AMS 66711 CONVERGENCE RATES FOR THE LAW OF LARGE NUMBERS FOR LINEAR COMBINATIONS OF MARKOV PROCESSES * L. H KOOPMANS

AMS 66720 A SIMPLE SOLUTION FOR OPTIMAL CHEBYSHEV REGRESSION EXTRAPOLATION * PAUL G . HOEL

AMS 66726 REMARK ON THE OPTIMUM CHARACTER OF THE SEQUENTIAL PROBABILITY RATIO TEST * 3 . WOLFOWITZ

AMS 66728 A NOTE ON UPCROSSINGS OF SEMIMARTINGALES * LESTER E DUBINS

AMS 66729 A NOTE ON INVARIANT MEASURES * N. C. JAIN

AMS 66733 A NOTE ON RECURRENCE RELATIONS BETWEEN EXPECTED VALUES OF FUNCTIONS OF ORDER STATISTICS * $P . R$ KRISHNAIAH, M. HASEEB RIZVI

AMS 66735 AN ASYMPTOTICALLY DISTRIBUTION-FREE MULTIPLE COMPARISON PROCEDURE, TREATMENT VERSUS CONTROL * MYLES HOLLANDER

AMS 66739 COMPARISON OF THE BOUNDS OF THE NUMBER OF COMMON TREATMENTS BETWEEN BLOCKS OF CERTAIN PARTIALLY BALANCED INCOMPLETE BLOCK DESIGNS* HIRALAL AGRAWAL

AMS 66741 SEQUENTIAL COUNTERBALANCING IN LATIN SQUARES * TOM R. HOUSTON

AMS 66744 INVARIANCE OF MAXIMUM LIKELIHOOD ESTIMATIONS * PETER W. ZEHNA

AMS 66783 OPTIMAL EXPERIMENTAL DESIGNS * SAMUEL KARLIN, WILLIAM J. STUDDEN

AMS 66816 A STOCHASTIC CHARACTERIZATION OF WEAR-OUT FOR COMPONENTS AND SYSTEMS * Z W. BIRNBAUM, J D. D. ESARY, A W. MARSHALL

AMS 66826 SOME PROPERTIES OF STATISTICAL RELIABILITY FUNCTIONS * SIV CARLSSON, ULF GRENANDER

AMS $66 \quad B 37$ INVARIANT PROBABILITIES FOR CERTAIN MARKOV PROCESSES * LESTER E. DUBINS, DAVID A. FREEDMAN

AMS 66849 DIMENSIONAL PROPERTIES OF A RANDOM DISTRIBUTION FUNCTION ON THE SQUARE * J. R. KINNEY, T. S. PITCHER

AMS 66 B55 A LOCAL LIMIT THEOREM FOR A CERTAIN CLASS OF RANDOM WALKS * WALTER A . ROSENKRANTZ

AMS 66860 LIMIT THEOREMS FOR STOPPED RANDOM WALKS, II * R. H FARRELL
AMS 66866 A LIMIT THEOREM FOR PASSAGE TIMES IN ERGODIC REGENERATIVE PROCESSES * JULIAN KEILSON

AMS 66871 NEGATIVE DYNAMIC PROGRAMMING * RALPHE. STRAUCH

AMS 66 B91 COMPARISONS OF SOME TWO STAGE SAMPLING METHODS * AARON S. GOLDMAN, R. K. ZEIGLER

AMS 66 B98 A PROBLEM IN MINIMAX VARIANCE POLYNOMIAL EXTRAPOLATION* A. LEVINE

AMS 66904 CONTRIBUTIONS TO SAMPLE SPACINGS THEORY, I. LIMIT DISTRIBUTIONS OF SUMS OF RATIOS OF SPACINGS * SAUL BLUMENTHAL

AMS 66925 CONTRIBUTIONS TO SAMPLE SPACINGS THEORY, II. TESTS OF THE PARAMETRIC GOODNESS OF FIT AND TWO-SAMPLE PROBLEMS * SAUL BLUMENTHAL

AMS 66940 ON THE PITMAN EFFICIENCY OF ONE-SIDED KOLMOGOROV AND SMIRNOV TESTS FOR NORMAL ALTERNATIONS * P. V. RAMACHANDRAMURTY

AMS 66945 EXACT POWER OF MANN-WHITNEY TEST FOR EXPONENTIAL AND RECTANGULAR ALTERNATIVES * GEORGE E. HAYNAM, ZAKKULA GOVINDARAJULU

AMS 66954 THE SEQUENT I AL COMPOUND DECISI ON PROBLEMS WITH M-BY-N FINITE LOSS MATRIX * J, VAN RYZIN

AMS 66976 REPETITIVE PLAY IN FINITE STATISTICAL GAMES WITH UNKNOWN DISTRIBUTIONS* J. VAN RYZIN

AMS 66995 ON THE DISTRIBUTION OF THE LARGEST LATENT ROOT AND THE CORRESPONDING LATENT VECTOR FOR PRINCIPAL COMPONENT ANALYSIS* T. SUGIYAMA

AMS 661002 ON THE BIVARIATE MOMENTS OF ORDER STATISTICS FROM A LOGISTIC DISTRIBUTION * B. K. SHAH

AMS 661011 CHARACTERIZATION OF NORMAL AND GENERALIZED TRUNCATED NORMAL DISTRIBUTIONS USING ORDER STATISTICS * ZAKKULA GOVINDARAJULU

AMS 661016 ON THE BLOCK STRUCTURES OF CERTAIN PARTIALLY BALANCED INCOMPLETE BLOCK DESIGNS, CORR. $67624 *$ S. M. shah

AMS 661021 SINGULARITY IN HOTELLING'S WEIGHING DESIGNS AND A GENERALIZED INVERSE (CORR, 69 719)* K. S. BANERJEE

AMS 661033 ON ESTIMATION AND CONSTRUCTION IN FRACTIONAL REPLICATION * K. S. BANERJEE, W. T. FEDERER

AMS 661040 THE GROWTH OF A RECURRENT RANDOM WALK * CHARLES STONE

AMS 661042 A NOTE ON UNDISCOUNTED DYNAMIC PROGRAMMING * ASHOK MAITRA

AMS 661045 A NOTE ON A BIASED ESTIMATOR IN SAMPLING WITH PROBABILITY PROPORT IONAL TO SIZE WITH REPLACEMENT * M. T . SUBRAHMANYA

AMS 661048 DUALS OF PARTIALLY BALANCED INCOMPLETE BLOCK DESIGNS AND SOME NONEXISTENCE THEOREMS * DAMARAJU RAGHAVARAO

AMS $6610 B 7$ ON THE ADMISSIBILITY OF INVARIANT ESTIMATORS OF ONE OR MORE LOCAT I ON PARAMETERS * LAWRENCE DAVID BROWN

AMS 661137 SOME CONCEPTS OF DEPENDENCE * E. L. LEHMANN

AMS 661154 STOPPING TIME OF A RANK-ORDER SEQUENTIAL PROBABILITY RATIO TEST ON LEHMANN ALTERNATIVES, CORR. 671309 * I. RICHARD SAVAGE, J, SETHURAMAN

AMS 661161 MOST STRINGENT SOMEWHERE MOST POWERFUL TESTS AGAINST ALTERNATIVE RESTRICTED BY A NUMBER OF LINEAR INEQUALITIES* $W$. SCHAAFSMA, L. J. SMID

AMS 661173 ON THE ASYMPTOTIC EFFICIENCY OF A SEQUENTIAL PROCEDURE FOR EST IMATING THE MEAN * NORMAN STARR

AMS 661186 BAYES AND MINIMAX PROCEDURES FOR ESTIMATING THE ARITHMETIC MEAN OF A POPULATION WITH TWO-ST AGE SAMPLING * OMP. AGG ARWAL

AMS 661196 TEST PROCEDURES FOR POSSIBLE CHANGES IN PARAMETERS OF STATISTICAL DISTRIBUTIONS OCCURRING AT UNKNOWN TIME POINTS* Z KANDER, S, ZACKS

AMS 661211 A LIMIT THEOREM FOR MULTIDIMENSIONAL GALTON-WATSON PROCESSES * H. KESTEN, B. P. STIGUM

AMS 661224 SOME LIMIT THEOREMS FOR NON-HOMOG ENEOUS MARKOV CHAINS * MILLU ROSENBLATT-ROTH

NMS 661237 SPECTRAL ESTIMATES USING NONLINEAR FUNCTIONS * EUGENE R. RODEMICH

AMS 661257 ASYMPTOTIC NORMALITY OF BISPECTRAL ESTIMATES * JOHN W. VAN NESS

AMS 661273 PERFECT PROBABILITY MEASURES AND REGULAR CONDITIONAL PROBABILITIES * ROBERT H. RODINE

AMS 661279 A REPRESENTATION FOR CONDITIONAL EXPECTATIONS GIVEN SIGMA-LATTICES * TIM ROBERTSON

AMS 661284 ON FINDING OPTIMAL POLICIES IN DISCRETE DYNAMIC PROGRAMMING WITH NODISCOUNTING * ARTHUR F. VEINOTT JR

AMS 661295 STATISTICAL PROPERTIES OF THE NUMBER OF POSITIVE SUMS * MICHAEL WOODROOFE

AMS 661305 A STAT ISTICAL TEST INVOLVING A RANDOM NUMBER OF RANDOM VARIABLES * J. L. ALLEN. J. A. BEEKMAN

AMS 661312 ON THE MOMENTS OF THE TRACE OF A MATRIX AND APPROXIMATIONS TO ITS NON-CENTRAL DISTRIBUTION * C. G. KHATRI, K. C. S. PILLAI

AMS 661319 ON THE EXACT DISTRIBUTIONS OF THE LIKELIHOOD RATIO CRITERIA FOR TESTING LINEAR HYPOTHESES ABOUT REGRESSION COEFFICIENTS * P. C . CONSUL 
AMS 661331 ROBUST ESTIMATION IN INCOMPLETE BLOCK DESICNS * VIDA L. CREENBERC

AMS 661338 ON COMBINABILITY OF INFORMATION FROM UNCORRELATED LINEAR MODELS BY SIMPLE WEIGHTING * FRANK B. MARTIN, CEORCE ZYSKIND

AMS 661348 INDUCTIVE METHODS FOR BALANCED INCOMPLETE BLOCK DESTGNS* $R$ G STANTON, $R$ C MULLIN

AMS 661355 ONORTHOGONAL ARRAYS * ESTHER SEIDEN, RITA ZEMACH

AMS 661371 WEIGHINC DESICNS WHEN N IS ODD * M. BHASKARRAO

AMS 66 13B2 RANDOMIZED FRACTIONAL WEIGHINC DESIGNS * S. ZACKS

AMS 661396 A SAMPLE FUNCTION PROPERTY OF MARTINGALES * D. G AUSTIN

AMS 66 139B ON THE BLOCK STRUCTURE OF SINGULAR GROUP DIVISIBLE DESIGNS * C, H. KAPADAI

AMS 661401 ON PART IALLY LINKED BLOCK DESICNS * C. RAMANKUTTY NAIR AMS 661407 ACKNOWLEDCEMENT OF PRIORITY ON 'ON INTERCHANGINC LIMITS AND INTEGRALS ', 6074 * JOHN $W$. PRATT

AMS 661439 THE EXISTENCE AND UNIQUENESS OF STATIONARY MEASURES FOR MARKOV RENEWAL PROCESSES * RONALD PYKE, RONALD SCHAUFELE

AMS 661463 ADDITIONAL LIMIT THEOREMS FOR INDECOMPOSABLE MULTIDIMENSIONAL GALTON-WATSON PROCESSES * H. KESTEN, B. P. STIGUM

AMS 661482 SOME CONVERCENCE THEOREMS FOR INDEPENDENT RANDOM VARIABLES * Y.S. CHOW

AMS 661494 MARTINGALE TRANSFORMS * D. L. BURKHOLDER

AMS 661505 ON THE EXPECTED VALUE OF A STOPPED MART INGALE * LESTER E. DUBINS. DAVID A. FREEDMAN

AMS 661510 LIMIT THEOREMS FOR STOPPED RANDOM WALKS. III * R. H. FARRELLL

AMS 661528 ON A FACTOR AUTOMORPHISM OF A NORMAL DYNAMICAL SYSTEM *D. NEWTON, W PARRY

AMS 661534 ON DVORETZKY STOCHASTIC APPROXIMATION THEOREMS * J. H. VENTER

AMS 661545 DENUMERABLE STATE MARKOVIAN DECISION PROCESSES, AVERAGE COST CRITERION * CYRUS DERMAN

AMS 661554 STATIST ICAL INFERENCE FOR PROBABILIST IC FUNCTIONS OF FINITE STATE MARKOV CHAINS * LEONARD E. BAUM, TED PETRIE

AMS 661564 ESTIMATINC AND TESTING TREND IN A STOCHASTIC PROCESS OF POISSON TYPE * M. T. BOSWELL

AMS 661574 INEQUALITIES FOR LINEAR COMBINATIONS OF ORDER STATISTICS FROM RESTRICTED FAMILIES * RICHARD E. BARLOW, FRANK PROSCHAN

AMS 661593 TOLERANCE AND CONFIDENCE LIMITS FOR CLASSES OF DISTRIBUTIONS BASED ON FAILURE RATE. CORR. 67950 * RICHARD E. BARLOW, FRANK PROSCHAN

AMS 661602 FIXED SIZE CONFIDENCE ELLIPSOIDS FOR LINEAR REGRESSION PARAMETERS * ARTHUR ALBERT

AMS 661631 ON THE PROPERTY. W, OF THE CLASS OF STATISTICAL DECISION FUNCTIONS * HIROKICHI KUDO

NMS 661643 MINIMAX SOLUTION OF STATISTICAL DECISION PROBLEMS BY ITERATION * WAYNE NELSON

AMS 661658 ADMISSIBILITY AND BAYES ESTIMATION IN SAMPLINC FINITE POPULATIONS, IV * V. M JOSHI

AMS 661671 UNBIASED ESTIMATION OF LOCATION AND SCALE PARAMETERS * J. K. GHOSH. RAJINDER SINGH
AMS 661676 ON THE ASYMPTOTIC EFFICIENCY OF LEAST SQUARES ESTIMATORS * C. VILLECAS

AMS 661684 QUASI-LINEARLY INVARIANT PREDICTION * J. TIACO DE OLIVEIRA

AMS 661688 SEQUENTIAL ESTIMATION OF THE MEAN OF A LOC-NORMALDISTRIBUTION HAVINC A PRESCRIBED PROPORTIONAL CLOSENESS * S. ZACKS

AMS 661697 ON RANDOMIZED RANK SCORE PROCEDURE OF BELL AND DOKSUM * KUMAR JOGDEO

AMS 661704 LIKELIHOOD RATIO COMPUTATIONS OF OPERATING COMPUTA TIONS * WILLIAMD. LAWING, H. T. DAVID

AMS 661717 ESTIMATION OF THE PARAMETERS OF THE EXPONENTIAL DISTRIBUT ION BASED ON OPTIMUM ORDER STATISTICS IN CENSORED SAMPLES * A. K. MD. EHSANES SALEH

AMS 661736 ON CONFIDENCE BOUNDS ASSOCIATED WITH MULTIVARIATE ANALYSIS OF VARIANCE AND NONINDEPENDENCE BETWEEN TWO SETS OF VARIATES * GOVINDS. MUDHOLKAR

AMS 661747 ON ANALYSIS OF VARIANCE FOR THE K-SAMPLE PROBLEM * DANA QUADE

AMS 661759 ON A DISTRIBUTION-FREE METHOD OF ESTIMATING ASYMPTOTIC EFFICIENCY OF A CLASS OF NONPARAMETRIC TESTS * PRANAB KUMAR SEN

AMS 661771 A BIVARIATE SICN TEST FOR LOCATION * SHOUTIR KISHORE CHATTERJEE

AMS 661783 A NOTE ON CONSTRUCTION OF PARTIALLY BALANCED INCOMPLETE BLOCK DESIGNS WITH PARAMETERS V $=2 \mathrm{~B}, \mathrm{~N} I=12$ N2 $=15$ AND P2 $(1,1)=4 *$ ESTHER SEIDEN

AMS 661790 CHARACTERIZATION OF GEOMETRIC AND EXPONENTIAL DISTRIBUTIONS * GORDON B. CRAWFORD

AMS 661796 THE PROBABILITY THAT A RANDOM GAME IS UNFAIR * THOMAS M. COVER

AMS 66 1BOO CONVERCENCE PROPERTIES OF CONVERGENCE WITH PROBABILITY ONE * J. L. DENNY

AMS 661 BO3 ONMOMENTS OF CUMULATIVE SUMS * RAGNAR ERICSON

AMS 66 1BO6 MONOTONE CONVERGENCE OF MOMENTS IN AGE DEPENDENT BRANCHING PROCESSES * HOWARD J. WEINER

AMS 661809 ON A THEOREM OF KARLIN REGARDING ADMISSIBILITY OF LINEAR ESTIMATES IN EXPONENTIAL POPULATIONS * RICHARD MORTON, M. RAGHAVACHARI

AMS 661814 ON THE HODGES AND LEHMANN SHIFT ESTIMATOR IN THE TWO SAMPLE PROBLEM * TERRENCE FINE

AMS 661819 ESTIMATING THE MEAN OF A MULTIVARIATE NORMAL POPULATION WITH GENERAL QUADRATIC LOSS FUNCTION * P. K BHATTACHARYA

AMS 661825 A MULTIVARIATE CENTRAL LIMIT THEOREM FOR RANDOM LINEAR VECTOR FORMS * F, EICKER

AMS 661 B29 A CHARACTERISTIC PROPERTY OF THE MULTIVARIATE NORMAL DISTRIBUTION * V. SESHADRI

AMS 661832 COMPARISON OF COMBINED ESTIMATORS IN BALANCED INCOMPLETE BLOCKS *V. SESHADRI

AMS 661836 ON NON-RANDOMIZED FRACTIONAL WEIGHING DESIGNS * K. S BANERJEE

AMS 661842 ON IDENTITY RELATIONSHIPS FOR TWO TO THE POWER OF N-R DESIGNS HAVING WORDS OF EQUAL LENGTHS * PETER W.M JOHN

AMS 661844 NOTE ON A THEOREM OF KINGMAN AND A THEOREM OF CHUNG * D VERE-JONES

ANNALS OF MATHEMATICAL STATISTICS VOLUME 3B, 1967

AMS 671 SOME INVARIANCE PRINCIPLES FOR FUNCTIONALS OF A MARKOV CHAIN* DAVID A FREEDMAN

AMS 67 B GENERAL PROOF OF TERMINATION WITH PROBABILITY ONE OF INVARIANT SEQUENTIAL PROBABILITY RATIO TESTS BASED ON MULTIVARIATE NORMAL OBSERVATIONS * R. A. WI JSMAN

AMS 6725 AN OCCUPATION TIME THEOREM FOR THE ANCULAR COMPONENT OF PLANE BROWNIAN MOTION * SIMEONM BERMAN

AMS 6732 LIPSCHITZ BEHAVIOR AND INTEGRABILITY OF CHARACTERISTIC FUNCTIONS* R. P. BOAS

AMS 6737 RANDOM HYDRODYNAMIC FORCES ON OBJECTS * LEON E. BORCMAN

AMS 6752 ASYMPTOTIC DISTRIBUTION OF LINEAR COMBINATIONS OF FUNCTIONS OF ORDER STATISTICS WITH APPLICATIONS TO ESTIMATION * HERMAN CHERNOFF, JOSEPH L. GASTWIRTH, M. V. JONES

AMS 6773 THE ASYMPTOTIC THEORY OF CALTON'S TEST AND A RELATED SIMPLE ESTIMATE OF LOCATION * P. J. BICKEL, J. L HODCES JR

AMS 6790 ASYMPTOTIC EFFICIENCY OF CERTAIN RANK TESTS FOR COMPARATIVE EXPERIMENT * K. L. MEHRA, J. SARANGI

AMS 67108 LIMIT THEOREMS FOR FUNCTIONS OF SHORTEST TWO-SAMPLE SPACINGS AND A RELATED TEST * SAUL BLUMENTHAL

AMS 67117 SEQUENTIAL PROCEDURES FOR SELECTION OF THE BEST ONE OF SEVERAL BINOMIAL POPULATIONS * EDWARD PAULSON

AMS 67124 SOME OPTIMUM PROPERTIES OF RANKING PROCEDURES * MORRIS L . EATON
AMS 67138 RECONSTRUCTING PATTERNS FROM SAMPLE DATA * PAUL SWITZER

AMS 67155 ADEQUATE SUBFIELDS AND SUFFICIENCY * MORRIS SKIBINSKY

AMS 67162 A BIVARIATE T DISTRIBUTION, CORR. 671594 * M. M. SIDDIQUI

AMS 67167 CYLINDRICALLY ROTATABLE DESIGNS OF TYPES 1, 2, AND 3 * AGNES M HERZBERC

AMS 67177 A METHOD FOR THE CONSTRUCTION OF SECOND ORDER ROTATABLE DESIGNS IN K DIMENSIONS * AGNES M. HERZERG

AMS 67181 AN EXTENSION OF THE ROBBINS-MONRO PROCEDURE * J. H. VENTER

AMS $67 \quad 191$ STOCHASTIC APPROXIMATION OF MINIMA WITH IMPROVED ASYMPTOTIC SPEED * VACLAV FABIAN

AMS 67201 IDENTIFICATION OF STATE-CALCULABLE FUNCTIONS OF FINITE MARKOV CHAINS* J. W CARLYLE

AMS 67206 FUNCTIONS OF FINITE MARKOV CHAINS * FREDERICK W. LEYSIEFFER

AMS 67213 GEOMETRICAL PROBABILITY AND RANDOM POINTS ON A HYPERSPHERE * THOMASM. COVER, BRADLEY EFRON

AMS 67221 CONSENSUS OF SUBJECTIVE PROBABILITIES, A CONVERGENCE THEOREM * TORSTEN NORVIC

AMS 67226 A FORMULA FOR THE PROBABILITY OF OBTAINING A TREE FROM A GRAPH CONSTRUCTED RANDOMLY EXCEPT FOR 'EXOCAMOUS BIAS' * HWA SUNG NA, ANATOL RAPOPORT

AMS 67242 GAME VALUE DISTRIBUTIONS I * DAVID R. THOMAS, H. T.

AMS 67251 GAME VALUEDISTRIBUTIONS II * DAVIDR. THOMAS 
AMS 67261 ON MEASURES EQUIVALENT TO WIENER MEASURE * THOMAS KAILATH

AMS 67264 ON THE GALTON-WATSON BRANCHING PROCESS WITH MEAN LESS THAN ONE* A. JOFFE

AMS 67267 MINIMUM CHI-SQUARED ESTIMATION USING INDEPENDENT STATISTICS * A. D. JOFFE

AMS 67271 A NOTE ON GENERALIZED INVERSES IN THE LINEAR HYPOTHESIS NOT OF FULL RANK * A. A. RAYNER, R. M. PRINGLE

AMS 67274 A NOTE ON NONPARAMETRIC TESTS FOR SCALE * A. P. BASU, GEORGE WOODWORTH

AMS 67278 A NOTE ON CONSERVATIVE CONFIDENCE REG IONS FOR THE MEAN OF A MULTIVARIATE NORMAL * ALASTAIR SCOTT

AMS 67280 CORRECTION, 'CALCULATION OF EXACT SAMPLING OISTRIBUTION OF RANGES.FROM A DISCRETE POPULATION' * IRVING W. BURR

AMS 67303 RATES OF CONVERGENCE OF ESTIMATES AND TEST STATISTICS * R. R. BAHAOUR

AMS 67325 UPPER AND LOWER PROBABILITIES INDUCEO BY A MULTIVALUED MAPPING * A. P. DEMPSTER

AMS 67340 LOCALLYMINIMAX TESTS * RICHARDE, SCHWARTZ

AMS 67360 ON THE PROBABILITY OF LARGE DEVI AT IONS OF FUNCTIONS OF SEVERAL EMPIRICAL CUMULATIVE DISTRIBUTION FUNCTIONS * A. BRUCE HOADLEY

AMS 67 3B2 ON AN INEQUALITY OF HOEFFDING * BENGT ROSEN

AMS 67393 SOME SHARP MULTIVARIATE TCHEBYCHEFF INEQUALITIES * GOVINDS. MUDHOLKAR, PODURI S. R. S. RAO

AMS 67401 THE THEORY OF EXPERIMENT, OPERATIONAL DEFINITION OF THE PROBABILITY SPACE * MILTON PHILIP OLSON

AMS 67410 STIRLING BEHAVIOR IS ASYMPTOTICALLY NORMAL * L. H HARPER

AMS 67415 CHARACTERIZATIONS OF CONDITIONAL EXPECTATIONS * J PFANZAGL

AMS 67422 OPTIMUM INVARIANT TESTS IN UNBALANCEO VARIANCE COMPONENTS MOOELS * EMIL SP JOTVOLL

AMS 67429 OISTRIBUTION-FREE TESTS OF INDEPENOENCE * C. B. BELL K. A. DOKSUM

AMS 67447 STRINGENT SOLUTIONS TO STATISTICAL DECISION PROBLEMS * ROBERT COGBURN

AMS 67464 MULTISTAGE SAMPLING PROCEDURES BASEO ON PRIOR OISTRIBUTIONS AND COSTS* $W$. SCHULER

AMS 67471 ON THE LACK OF A UNIFORMLY CONSISTENT SEQUENCE OF ESTIMATORS OF A DENSITY FUNCTION IN CERTAIN CASES * R. H. FARRELL

AMS 67475 ON THE MAXIMUM DEVIATION OF THE SAMPLE DENSITY * MICHAEL WOODROOFE

AMS 67482 ON ESTIMATING A DENSITY WHICH IS MEASURABLE WITH RESPECT TO A SIGMA-LATTICE * TIM ROBERTSON

AMS 67494 A SEQUENTI AL SEARCH PROCEOURE * MILTON C. CHEW JR

AMS 67503 EXPANSIONS OF T OENSITIES AND RELATED COMPLETE INTEGRALS * JAMESM. DICKEY

AMS 67511 MATRICVARIATE GENERALIZATIONS OF THE MULTIVARIATE T DISTRIBUTION AND THE INVERTEO MULTIVARIATE T DISTRIBUTION * JAMESM. DICKEY

AMS 67519 THE TREATMENT OF TIES IN THE WILCOXON TEST * WOLFGANG J. BUHLER

AMS 67523 MULTI-SAMPLE ANALOGUES OF SOME ONE-SAMPLE TESTS * $K$ L. MEHRA, M. L. PURI

AMS 67550 COMPARING DISTANCES BETWEEN MULTIVARIATE POPULATIONS, THE PROBLEM OF MINIMUM DISTANCES * M. S. SRIVASTAVA

AMS 67557 ASYMPTOTIC VARIANCES ANO COVARIANCES OF MAXIMUMLIKELIHOOD ESTIMATORS, FROM CENSOREO SAMPLES, OF THE PARAMETERS OF WEIBULL AND GAMMA POPULATIONS * $\mathrm{H}$ LEON HARTER, ALBERT H, MOORE

AMS 67571 A NEW FAMILY OF PARTIALLY BALANCED INCOMPLETE BLOCK DESIGNS WITH SOME LATIN SQUARE DESIGN PROPERTIES * DALE M. MESNER

AMS 67582 A SOLUTION TO A COUNTABLE SYSTEM OF EQUALITIES ARISING IN MARKOVIAN OECISION PROCESSES * CYRUS DERMAN, ARTHUR F. VEINOTT JR

AMS 67585 A POTENTIAL THEORETIC PROOF OF A THEOREM OF DERMAN AND VEINOTT * RONALD A. SCHAUFELE

AMS 67588 ON STATIONARY MARKOV PROCESSES * RICHARD ISAAC

AMS 67593 ON THE CROSS PERI ODOGRAM OF A STATIONARY GAUSSI AN VECTOR PROCESS * T. SUBBA RAO

AMS 67599 A REMARK ON THE LAW OF THE ITERATED LOGARITHM * DAVID A FREEDMAN

AMS 67601 OPTIMAL STOPPING WHEN THE FUTURE IS DISCOUNTED * LESTER E DUBINS, HENRY TEICHER

AMS 67606 A NOTE ON RISK AND MAXIMAL REGULAR GENERALIZED SUBMARTINGALES IN STOPP ING PROBLEMS * H. CHERNOFF

AMS 67608 ON THE EXPECTED VALUE OF A STOPPED SUBMARTINGALE * Y S. $\mathrm{CHOW}$

AMS 67610 ON THE STRONG LAW OF LARGE NUMBERS FOR MARTINGALES * Y S. CHOW

AMS 67611 A TECHNICAL LEMMA FOR MONOTONE LIKELIHOOD RATIO FAMILIES * J . PFANZAGL

AMS 67613 A COUNTER-EXAMPLE RELATING TO CERTAIN MULTIVARIATE GENERALIZATIONS OF T AND F* A. W. DAVIS
AMS 67616 ON THE DISTRIBUTION OF THE LARGEST ROOT OF A MATRIX IN MULTIVARIATE ANALYSIS * $K$. C. SREEDHARAN PILLAI

AMS 67618 ON OBTAINING BALANCED INCOMPLETE BLOCK DESIGNS FROM PARTI ALLY BALANCED ASSOCIATION SCHEMES * PETER W. M. JOHN

AMS 67620 A MEAN-SQUARE-ERROR CHARACTERIZATION OF BINOMIALTYPEDISTRIBUTIONS * M. C. K. TWEEDIE

AMS 67659 ON THE COMBINATION OF INDEPENDENT TEST STATISTICS * W R. VAN ZWET, J . OOSTERHOFF

AMS 67681 TESTS OF COMPOSITE HYPOTHESES FOR THE MULTIVARIATE EXPONENTIAL FAMILY, CORR. 671928 * T. K. MATTHES, D R. TRUAX

AMS 67698 AOMISSIBLE TESTS IN MULT IVAR I ATE ANALYSIS OF VARIANCE * RICHARD SCHWARTZ

AMS 67711 ONA QUICKEST DETECTION PROBLEM * J. A. BATHER

AMS 67725 THE MARTINGALE VERSION OF A THEOREM OF MARCINKIEWICZ AND ZYGUMD * RICHARD F. GUNOY

AMS 67735 ALTERNATIVE PROOFS FOR CERTAIN UPCROSSING INEQUALITIES * RAFAEL PANZONE

AMS 67742 SOME RESULTS RELATING MOMENT GENERATING FUNCTIONS ANO CONVERGENCE RATES IN THE LAW OF LARGE NUMBERS * $0 . \mathrm{L}$ HANSON

AMS 67751 A NOTE ON SUMS OF INOEPENDENT RANDOM VARIABLES WITH INF INITE F IRST MOMENT * H. O. MILLER

AMS 67759 A GENERAL CLASS OF BULK QUEUES WITH POISSON INPUT * MARCEL F. NEUTS

NMS 67771 STOCHASTIC POINT PROCESSES, LIMIT THEOREMS * JAY R, GOLDMAN

AMS 67780 SUFFICIENT CONOITIONS FOR THE EXISTENCE OF A FINITELY ADDIT IVE PROBABILITY MEASURE * R. DUNCAN LUCE

AMS 67787 A NOTE ON STATISTICAL EQUIVALENCE * RICHARD SACKSTEOER

AMS 67795 FIOUCIAL THEORY AND INVARIANT PREDICTION * R. B. HORA. R. J . BUEHLER

AMS 67802 THE POWER OF THE LIKELIHOOO RATIO TEST * BRAOLEY EFRON

AMS 67 BO7 ESTIMATION ASSOCIATEO WITH LINEAR DISCRIMINANTS * SEYMOUR GE ISSER

AMS 67 B18 GENERALIZED BAYES DECISION FUNCTIONS, ADMISSIBILITY ANO THE EXPONENT IAL FAMILY * M. STONE

AMS 67823 SERIES REPRESENTATIONS OF DISTRIBUTIONS OF QUADRATIC FORMS IN NORMAL VARIABLES, I, CENTRAL CASE * SAMEUL KOTZ, N. L. JOHNSON, D. W. BOYO

AMS 67 B3B SERIES REPRESENTATIONS OF DISTRIBUTIONS OF QUAORATIC FORMS IN NORMAL VARIABLES, II, NON-CENTRAL CASE * SAMEUL KOTZ, N. L, JOHNSON, O. W. BOYO

AMS 67 B49 ASYMPTOTICALLY NONPARAMETRIC TESTS OF SYMMETRY * $M$ K. GUPTA

AMS 67867 RANK TESTS FOR RANDOMIZEO BLOCKS WHEN THE ALTERNATIVES HAVE AN 'A PRIORI' OROERING * MYLES HOLLANDER

AMS 67878 ROBUST PROCEOURES FOR SOME LINEAR MODELS WITH ONE OBSERVATION PER CELL * KJELL OOKSUM

AMS 67 B84 ASYMPTOTIC EFFICIENCY OF A CLASS OF NON-PARAMETRIC TESTS FOR REGRESSION PARAMETERS * J. N. ADICHIE

AMS 67 B94 ESTIMATES OF REGRESSION PARAMETERS BASED ON RANK TESTS * J, N. ADICHIE

AMS 67905 ON THE LARGE SAMPLE PROPERTIES OF A GENERALIZED WILCOXON-MANN-WHITNEY STATISTIC * A. P. BASU

AMS 67916 CAUCHY-DISTRIBUTED FUNCTIONS OF CAUCHY VARIATES * E J. G. PITMAN, E. J. WILLIAMS

AMS 67919 SLOWLY BRANCHING PROCESSES * WOLFGANG J. BUHLER

AMS 67922 A NOTE ON THE BIRKHOFF ERGOOIC THEOREM *D. G. AUSTIN

AMS 67924 AN OSCILLATING SEMIGROUP * DAVID A. FREEOMAN

AMS 67927 REALIZATION OF STOCHASTIC SYSTEMS * MICHAEL ARBIB

AMS 67934 AN INTRINSICALLY DETERMINED MARKOV CHAIN * J. MACQUEEN

AMS 67937 THE RELATIVE EFFICIENCY OF SOME TWO-PHASE SAMPLING SCHEMES * M. P. SINGH

AMS 67941 THE GENERALIZED VARIANCE, TEST ING ANO RANKING PROBLEM * MORRIS L . EATON

AMS 67944 SOME DISTRIBUTION PROBLEMS CONNECTEO WITH THE CHARACTERISTIC ROOTS OF THE PRODUCT OF A WISHART VARIATE WITH THE INVERSE OF ANOTHER INDEPENDENT WISHART VARIATE * C.G. KHATRI

AMS 67949 ON THE NON-EXISTENCE OF A FIXED SAMPLE ESTIMATOR OF THE MEAN OF A LOG-NORMAL DISTRIBUTION HAVING A PRESCRIBED PROPORTIONAL CLOSENESS * S. ZACKS

AMS 67977 PROPERTIES OF THE STATIONARY MEASURE OF THE CRITICAL CASE SIMPLE BRANCHING PROCESS * SAMUEL KARLIN, JAMES MCGREGOR

AMS 67992 EXTENSIONS OF A LIMIT THEOREM OF EVERETT, ULAM AND HARRIS ON MULTITYPE BRANCHING PROCESSES TO A BRANCHING PROCESS WITH COUNTABLY MANY TYPES * SHKTEH C , MOY

AMS 671000 EPSILON ENTROPY OF STOCHASTIC PROCESSES * EDWARD C POSNER. EUGENE R. RODEMICH, HOWARD J. RUMSEY JR

AMS 671021 ONHITTING FOR STABLE PROCESSES * SIDNEY C. PORT

AMS 671027 EQUIVALENT GAUSSIAN MEASURES WITH A PART ICULARLY SIMPLERADON-NIKODYM DERIVATIVE * DALE E . VARBERG 
AMS 671031 ON CONVERCENCE OF THE KIEFER-WOLFOWITZ APPROXIMATION PROCEDURE * J. H. VENTER

AMS 671037 A LARCE SAMPLE TEST FOR THE INDEPENDENCE OF TWO RENEWAL PROCESSES * SIDNEY C. PORT, CHARLES J. STONE

AMS 671042 SIMPLE RANDOM WALK AND RANK ORDER STATISTICS * MEYER DWASS

AMS 671054 BOUNDED EXPECTED UTILITY * PETER C. FISHBURN

AMS 671061 STATISTICAL MODELS AND INVARIANCE* D. A. S. FRASER

AMS 671068 THE CONDITIONAL LEVEL OF STUDENT'S T TEST * L, BROWN

AMS 671072 ON SELECTING A SUBSET OF K POPULATIONS CONTAINING THE BEST * W. J. STUDDEN

AMS 671079 SOME FIXED-SAMPLE RANKINC AND SELECTION PROBLEMS * D M. MAHAMUNULU

AMS 671092 ON CANONICAL FORMS, NON-NEGATIVE COVARIANCE MATRICES AND BEST AND SIMPLE LEAST SQUARES LINEAR ESTIMATORS IN LINEAR MODELS * GEORGE ZYSKIND

AMS 671110 THE CONSTRUCTION OF SATURATED TWO TO THE POWER OF K-P DESICNS * NORMANR. DRAPER, TOBY J, MITCHELL

AMS 671127 APPLTCATION OF CYCLIC COLLINEATIONS TO THE CONSTRUCTION OF BALANCED L-RESTRICTIONAL PRIME POWERED LATTICE DESIGNS* B. L. RAKTOE

AMS 671142 REPLICATED, OR INTERPENETRATING, SAMPLES OF UNEQUAL SIZES * J, C. KOOP

AMS 671148 ON THE DISTRIBUTION OF THE LARGEST LATENT ROOT OF THE COVARIANCE MATRIX*T . SUGIYAMA

AMS 671152 DISTRIBUTION OF THE LARCEST LATENT ROOT AND THE SMALLEST LATENT ROOT OF THE GENERALIZED B STATISTIC AND F STATISTICS AND IN MULTIVARIATE ANALYSIS * T. SUGIYAMA

AMS 671160 ON THE EXACT DISTRIBUTIONS OF LIKELIHOOD RATIO CRITERIA FOR TESTING INDEPENDENCE OF SETS OF VARIATES UNDER THE HULL HYPOTHESIS * P. C. CONSUL

AMS 671170 ON THE EXACT DISTRIBUTIONS OF THE CRITERION W FOR TESTING SPHERICITY IN A P-VARIATE NORMAL DISTRIBUTION* P. C. CONSUL

AMS 671175 CONFIDENCE INTERVAL OF PREASSICNED LENGTH FOR THE BEHRENS-F ISHER PROBLEM * SAIBAL BANERJEE

AMS 671180 CONFIDENCE INTERVALS FOR THE MEAN OF A FINITE POPULATION* V.M. JOSHI

AMS 67 120B THE DISTRIBUTION FUNCTIONS OF TSAO'S TRUNCATED SMIRNOV STATISTICS * W. J. CONOVER

AMS 671216 ON THE THEORY OF RANK ORDER TESTS FOR LOCATION IN THE MULTIVARIATE ONE SAMPLE PROBLEM * PRANAB KUMAR SEN. MADAN LAL PURI

AMS 671229 ASYMPTOTICALLY MOST POWERFUL RANK ORDER TESTS FOR GROUPED DATA * PRANAB KUMAR SEN

AMS 671240 AN INEQUALITY CONCERNING TESTS OF FIT OF THE KOLMOCOROV-SMIRNOV TYPE * GEORCES VANDEWIELE, MARC NOE

AMS 671245 PERMUTATION WITHOUT RISING OR FALLINC OMECASEQUENCES * MORTON ABRAMSON, W. O.J. MOSER

AMS 671255 MODELS FOR CATALOGUING PROBLEMS * MARTIN KNOTT

AMS 671261 ESTIMATION OF PROBABILITY DENSITY BY AN ORTHOGONAL SERIES * STUART C. SCHWARTZ

AMS 671266 ASYMPTOTIC EXPANSIONS ASSOCIATED WITH THE N'TH POWER OF A DENSITY* R. A. JOHNSON

AMS 671273 ON THE GLIVENKO-CANTELLI THEOREM FOR INFINITE INVARIANT MEASURES * EUCENEM. KLIMKO

AMS 67 127B HOW TO SURVIVE A FIXED NUMBER OF FAIR BETS * W. MOLENAAR, E. A. VAN DER VELDE

AMS 671281 TIMID PLAY IS OPTIMAL * DAVID FREEDMAN

AMS 671284 TIMID PLAY IS OPTIMAL, II * DAVID FREEDMAN, ROGER PURVES

AMS 671286 TESTS FOR THE EQUALITY OF COVARIANCE MATRICES UNDER THE INTRACLASS CORRELATION MODEL * P. R. KRISHNAIAH. P. K. PATHAK

AMS 671289 THE INVERSE OF A CERTAIN MATRIX, WITH APPLICATION * CHANDAN K. MUSTAFI

AMS 671293 ON THE CONSTRUCTION OF CYCLIC COLLINEATIONS FOR OBTAINING A 8ALANCED SET OF L-RESTRICTIONAL PRIMEPOWERED LATT ICE DESIGNS * SAT I MAZUMDAR

AMS 671296 A NOTE ON THE UNIMODALITY OF DISTRIBUTION FUNCTIONS OF CLASS L * TZE-CHIEN SUN

AMS 671300 IDENTIFIA8ILITY OF MIXTURES OF PRODUCT MEASURES * HENRY TEICHER

AMS 671303 NOTE ON THE INFINITE DIVISIVILITY OF EXPONENTIAL MIX TURES * F W. STEUTEL

AMS 671306 INFINITEDIVISIVILITY OF INTEGER-VALUED RANDOM VARI ABLES * S. K. KATTI

AMS 671323 ON 8AHADUR'S REPRESENTATION OF SAMPLE QUANTILES * $\mathrm{J}$ KIEFER

AMS 671343 LOWER BOUNDS FOR AVERAGE SAMPLE NUMBER OF SEQUENTIAL MULT IHYPOTHESIS TESTS * GORDON SIMONS

AMS 671365 A SEQUENTIAL THREE HYPOTHESIS TEST FOR DETERMININC THE MEAN OF A NORMAL POPULATION WITH KNOWN VARIANCE * GORDON SIMONS

AMS 671376 A CLASS OF SEQUENTIAL PROCEDURES FOR CHOOSING ONE OF K HYPOTHESES CONCERNINC THE UNKNOWN DRIFT PARAMETER OF THE WIENER PROCESS * GORDON SIMONS
AMS 671384 A SEQUENTIAL ANALOGUE OF THE BEHRENS-FISHER PROBLEM* H. ROBBINS, C. SIMONS, NORMANN STARR

AMS 671392 FINDINC THE SIZE OF A FINITE POPULATION * D. A DARLINC, H. ROBBINS

AMS 671399 INTECRATED RISK OF ASYMPTOTICALLY BAYES SEQUENTIAL TESTS * GARY LORDEN

AMS 671423 A BAYESIAN STUDY OF THE MULTINOMIAL DISTRIBUTION * DANIEL A. BLOCH, GEOFFREY S. WATSON

AMS 671436 A SPECIAL STRUCTURE AND EQUIVARIANT ESTIMATION * ROBERT H. BERK

AMS 671446 ON ESTIMATION OF THE MODE * J. H. VENTER

AMS 671456 DATA TRANSFORMATIONS AND THE LINEAR MODEL * D. A. S. FRASER

AMS 671466 ASSOCIATION RANDOM VARIABLES, WITH APPLICATIONS * J. D. ESARY, F. PROSCHAN, D. W. WALKUP

AMS 671475 EXACT BAHADUR EFFICIENCIES FOR THE KOLMOGOROV-SMIRNOV AND KUIPER ONE-SAMPLE AND TWO-SAMPLE STATISTICS * INNIS G. ABRAHAMSON

AMS 671491 ON EXACT PROBABILITIES OF RANK ORDERS FOR TWO WIDELY SEPARATED NORMAL DISTRIBUTIONS * ROY C. MILTON

AMS 671494 TESTING HYPOTHESES IN RANDOMIZED FACTORIAL EXPERIMENTS * S. EHRENFELD, S. ZACKS

AMS 671508 ESTIMABILITY OF VARIANCE COMPONENTS FOR THE TWO-WAY CLASSIFICATION WITH ITERATION * DAVID A. HARVILLE

AMS 671520 ON TWO K-SAMPLE RANK TESTS FOR CENSORED DATA * A. P BASU

AMS 671536 AN APPROACH TO SIMULTANEOUS TOLERANCE INTERVALS IN REGRESSION *A. L. WILSON

AMS 671541 PROBABILITY TABLES FOR THE EXTREMAL QUOTIENT * E. J. GUMBEL, JAMES PI CKANDS III

AMS 671552 A THEOREM OF LEVY AND A PECULIAR SEMICROUP * DAVID A FREEDMAN

AMS 671558 THE MAXIMUM DEVIATION OF SAMPLE SPECTRAL DENSITIES * MICHAEL B. WOODROOFE, JOHN W. VAN NESS

AMS 671570 SAMPLE SEQUENCES OF MAXIMA * JAMES PICKANDS III

AMS 671575 ON LARGE DEVIATION PROBLEMS FOR SUMS OF RANDOM VARIABLES WHICH ARE NOT ATTRACTED TO THE NORMAL LAW* C. C. HEYDE

AMS 671579 SAMPLE FUNCTTONS OF CAUSSIAN RANDOM HOMOGENEOUS FIELDS ARE EITHER CONTINUOUS OR VERY IRREGULAR * D M. EAVES

AMS 67 15B3 MONOTONE CONVERGENCE OF BINOMIAL PROBABILITIES WITH AN APPLICATION TO MAXIMUM LIKELIHOOD ESTIMATION * KUMAR JOGDEO

AMS 671587 ON ROBUST ESTIMATION IN INCOMPLETE BLOCK DESIGNS * MADAN LAL PURI, PRANAB KUMAR SEN

AMS 671592 A NOTE ON CLASSIFICATION * ASHOK K. SAXENA

AMS 671605 PREFERENCE-BASED DEFINITIONS OF SU8JECTIVE PROBABILITY* PETER C. FISHBURN

AMS 671618 OPTIMAL SEQUENTIAL PROCEDURES WHEN MORE THAN ONE STOP IS REQUIRED * GUS W. HAGGSTROM

AMS 671627 SOME PRO8LEMS IN THE THEORY OF OPTIMAL STOPPINC RULES * DAV ID OLIVER SIEGMUND

AMS 671641 SOME ONE-SIDED STOPPING RULES * DAVID OLIVER SIECMUND AMS 671647 NOTE ON DYNKIN'S 'ALPHA, XI' SUBPROCESS OF STANDARD MARKOV PROCESS * HIROSHI KUNITA

AMS 671655 SOME REMARKS ON CONTINUOUS ADDITIVE FUNCTIONALS * R. K. GETOOR

AMS 671661 PRESERVATION OF WEAK CONVERGENCE UNDER MAPPINGS * FLEMMING TOPSOE

AMS 671666 A REMARK ON SEQUENTIAL DISCRIMINATION * DAVID A. FREEDMAN

AMS 671671 ON PARTIAL 'A PRIORI' INFORMATION IN STATISTICAL INFERENCE * J, R. 8LUM, JUDAH ROSENBLATT

AMS 671679 LINEAR LEAST SQUARES RECRESSION * GEOFFREY S. watson

AMS 671700 THE DISTRIBUTION OF A QUADRATIC FORM OF NORMAL RANDOM VARIA8LES * BRUNO BALDESSARI

AMS 671705 LOCAL ASYMPTOTIC POWER AND EFF ICIENCY OF TESTS OF KOLMOGOROV-SMIRNOV TYPE * JIRI ANDEL

AMS 671726 A K-SAMPLE EXTENSION OF THE ONE-SIDED TWO-SAMPLE SMIRNOV TESTS STATISTIC * W. J. CONOVER

AMS 671731 ASYMPTOTICALLY OPTIMAL STATISTICS IN SOME MODELS WITH INCREASING FAILURE RATE AVERAGE * KJELL DOKSUM

AMS 671740 TESTING AGAINST ORDERED ALTERNATIVES IN MODEL I ANALYSIS OF VARIANCE, NORMAL THEORY AND NONPARAMETRIC * GALEN R. SHORACK

AMS 671753 ASYMPTOTIC EFFICIENCY OF MULTIVARIATE NORMAL SCORE TEST* G. K. BHATTACHARYA

AMS 671759 SIGN AND WILCOXON TESTS FOR LINEARITY* RICHARD A. OLSHEN

AMS 671770 EFFICIENT ESTIMATION OF A SHIFT PARAMETER FROM CROUPED DATA * P. K. BHATTACHARYA

AMS 671788 NONPARAMETRTC PROCEDURES FOR SELECTING A SUBSET CONTA ININC THE POPULATION WITH THE LARGEST ALPHA-QUANTILE* M. HASEEB RIZVI, MILTON SOBEL

AMS 671804 NONPARAMETRIC PROCEDURES FOR SELECTING THE T POPULATION WITH THE LARGEST ALPHA-QUANTILE * MILTON SO8EL

AMS 671817 AN INEQUALITY FOR EXPECTED VALUES OF SAMPLE QUANT ILES * W. R. VAN ZWET 
AMS 671822 ASYMPTOTIC PROPERTIES OF THE BLOCK UP-AND-DOWN METHOD IN 8IO-ASSAY * R. K. TSUTAKAWA

AMS 671829 ASYMPTOTICALLY OPTIMAL TESTS FOR MULTIVARIATE NORMAL DISTRI8UTIONS * DAVID G. HERR

AMS 671845 ON OPTIMAL ASYMPTOTIC TESTS OF COMPOSITE STATISTICAL HYPOTHESES* JAMES 8. BARTOO, PREMS PURI

AMS 671853 ON CERTAIN INEQUALITIES FOR NORMAL DISTRI8UTIONS AND THEIR APPLICATIONS TO SIMULTANEOUS CONFIDENCE BOUNDS * C. G. KHATRI

AMS 671868 INADMISSI8ILITY OF THE USUAL CONFIDENCE SETS FOR THE MEAN OF A MULTIVARIATE NORMAL POPULATION * V. M. JOSHI

AMS 671876 REMARK ON THE LINEARIZED MAXIMUM LIKELIHOOD ESTIMATE * L. K. CHAN

AMS 671882 ON HOROVITZ AND THOMPSON 'S T-ONE CLASS OF LINEAR ESTIMATION * S. G. PRABHU AJGAONKAR

AMS 671887 REDUCED GROUP DIVISI8LE PAIRED COMPARISON DESIGNS * J. A. JOHN
AMS 671894 CHARACTERIZATIONS OF NORMALITY BY CONSTANT REGRESSION OF LINEAR STATISTICS ON ANOTHER LINEAR STATISTIC * THEOPHILOS CACOULLOS

AMS 671899 AN ASYMPTOTIC EXPANSION FOR POSTERIOR DISTRIBUTIONS * R. A. JOHNSON

AMS 671907 A NOTE ON BAYES ESTIMATES * PETER J. 8ICKEL, DAVID 8LACKWELL

AMS 671912 A FIRST PASSAGE PRO8LEM FOR THE WIENER PROCESS * L. A SHEPP

AMS 671915 ON A STOPPING RULE AND THE CENTRAL LIMIT THEOREM * RICHARD GUNDY. DAVID SIEGMUND

AMS 671918 A PERFECT MEASURA8LE SPACE THAT IS NOT A LUSIN SPACE * R. B. DARST, R. E. ZINK

AMS 671919 DISTRI8UTIONS OF A M. KAC STATISTIC * J. L. ALLEN, J. A BEEKMAN

AMS 671924 A CHARACTERIZATION OF NORMALITY * M. V. TAMHANKAR

ANNALS OF MATHEMATICAL STATISTICS VOLUME 39. 1968

AMS 68

AMS 68

AMS 68

AMS 68

AMS 68

AMS 68

AMS 68

AMS 68

AMS 68

AMS 68

AMS 68

AMS 68

AMS 68

AMS 68

AMS 68

AMS 68

AMS 68

AMS 68

$$
1 \text { TOWARDS A }
$$

FARRELL

23 ON A NECESSARY AND SUFFICIENT CONDITION FOR ADMISSIBILITY OF ESTIMATORS WHEN STRICTLY CONVEX LOSS IS USED * R. H. FARRELL

29 INADMISSI8ILITY OF THE USUAL ESTIMATORS OF SCALE PARAMETERS IN PROBLEMS WITH UNKNOWN LOCATION AND SCALE PARAMETERS * L . 8ROWN

49 DESIGNS FOR REGRESSION PRO8LEMS WITH CORRELATED ERRORS MANY PARAMETERS * JEROME SACKS, DONALD YLVISAKER

70 WHEN ARE GAUSS-MARKOV AND LEAST SQUARES ESTIMATORS IDENTICAL. A COORDINATE-FREE APPROACH * WILLIAM KRUSKAL

76 ESTIMATION OF THE LOCATION OF THE CUSP OF A CONTINUOUS DENSITY * 8. L. S. PRAKASA

88 A SEQUENTIAL PROCEDURE FOR SELECTING THE LARGEST OF $\mathrm{K}$ MEANS * H. R088INS, M. S08EL, N. STARR

93 THE GENERAL MOMENT PRO8LEM. A GEOMETRIC APPROACH * J. H. 8. KEMPERMAN

CONVERGENCE OF SUMS OF SQUARES OF MARTINGALE DIFFERENCES * Y. S. CHOW

DECOMPOSITION OF LI-BOUNDED MARTINGALES * RICHARD F. GUNDY

N INF INITELY DIVISI8LE LAWS AND A RENEWAL THEOREM FOR NON-NEGATIVE RANDOM VARIABLES * WALTER L. SMITH

155 VARIATIONS ON A RENEWAL THEOREM OF SMITH* C. C. HEYDE

159 THE 8IG MAT́CH * DAVID 8LACKWELL, T. S. FERGUSON

164 SOME PROPERTIES OF AN ALGE8RAIC REPRESENTATION OF STOCHASTIC PROCESSES * PAUL W. HOLLAND

193 INVARIANT INTERVAL ESTIMATION OF A LOCATION PARAMETER

AMS 68200 PAIRED COMPARISONS FOR PAIRED CHARACTERISTICS * P, K SEN, H. A. DAVID

AMS 68209 ON THE IDENTIFIABILITY OF FINITE MIXTURES * SIDNEY J YAKOWITZ. JOHND. SPARGINS

AMS 68215 ON THE NON-CENTRAL DISTRI8UTIONS OF TWO TEST CRITERIA IN MULTIVARIATE ANALYSIS OF VARIANCE * C. G. KHATRI. K. C. S. PILLAI

AMS 68227 ON THE DISTRIBUTION OF A MULTIPLE CORRELATION MATRIX, NON-CENTRAL MULTIVARIATE 8ETA DISTRIBUTIONS * M. S SRIVASTAVA

AMS 68233 THE CALCULATION OF DISTRI8UTIONS OF KOLMOGOROV-SMIRNOV TYPE STATISTICS INCLUDING A TA8LE OF SIGNIFICANCE POINTS FOR A PARTICULAR CASE * MARC NOE, GEORGES VANDEWIELE

AMS 68242 A TREE COUNTING PRO8LEM * J. W. MOON

AMS 68246 CONSTRUCTION OF THE SET OF 256-RUN DESIGNS OF RESOLUTION GREATER THAN OR EQUAL TO 5 AND THE SET OF EVEN 512-RUN DESIGNS OF RESOLUTION GREATER THAN OR EQUAL TO 6 WITH SPEC IAL REFERENCE TO THE UNIQUE SATURATED DESIGNS * NORMANR. DRAPER, TO8Y J. MITCHELL

AMS 68256 ESTIMATING THE TOTAL PRO8A8ILITY OF THE UNO8SERVED OUTCOMES OF AN EXPERIMENT * HER8ERT E. ROB8INS

AMS 68258 SOME INVARIANT LAWS RELATED TO THE ARC SINE LAW * J,P IMHOF

AMS 68261 A NOTE ON THE ABSENCE OF TANGENCIES IN GAUSSIAN SAMPLE PATHS * DONALD YLVISAKER
AMS 68263 AN ELEMENTARY PROOF OF ASYMPTOTIC NORMALITY OF LINEAR FUNCTIONS OF ORDER STATISTICS * D. S. MOORE

AMS 68266 THE ASYMPTOTIC ERROR OF ITERATIONS * PETER FRANK

AMS 68270 A NOTE ON STOCHASTIC DIFFERENCE EQUATIONS * K. S MILLER

AMS 68272 RECURRENCE RELATIONS 8ETWEEN MOMENTS OF ORDER STATISTICS FOR EXCHANGEA8LE VARIATES * H. A. DAVID, P. C. JOSHI

AMS 68275 ON TESTS OF THE EQUALITY OF TWO COVARIANCE MATRICES * N. GIRI

AMS 68278 NOTE ON A MINIMAX DESIGN FOR CLUSTER SAMPLING * V.M. JOSHI

AMS 68282 ON A FURTHER ROBUSTNESS PROPERTY OF THE TEST AND ESTIMATOR BASED ON WILCOXON'S SIGNED RANK STATISTIC * PRANA8 KUMAR SEN

AMS 68286 CONSTRUCTION OF SEQUENCES ESTIMATING THE MIXING DISTRIBUTION * J. J. DEELY, R. L. KRUSE

AMS 68325 ASYMPTOTIC NORMALITY OF SIMPLE LINEAR RANK STATISTICS UNDER ALTERNAT I VES * JAROSLAV HAJEK

AMS 68347 SOME RESULTS ON MULTITYPE CONTINUOUS TIME MARKOV 8RANCHING PROCESSES * KRISHNA 8ALASUNDARAM ATHREYA

AMS 68358 A RANDOM TIME CHANGE RELATING SEMI-MARKOV AND MARKOV PROCESSES * JAMES YACKEL

AMS 68365 A REMARK ON HITTING PLACES FOR TRANSIENT STA8LE PROCESS * SIDNEY C. PORT

AMS 68372 TRANSFORMS OF STOCHASTIC PROCESSES * P. WARWICK MILLAR

AMS 68377 SU8STITUTION IN CONDITIONAL EXPECTATION * $R$. $R$ 8AHADUR, P. J. BICKEL

AMS 68379 ON CONVERGENCE IN R-MEAN OF NORMALIZED PARTIAL SUMS * RONALD PYKE, DAVID ROOT

AMS 68382 THE INVARIANCE PRINCIPLE FOR A LATTICE OF RANDOM VARIABLES * J, KUEL8S

AMS 68390 A SIMPLER PROOF OF SMITH'S ROULETTE THEOREM * LESTER E. DU8INS

AMS 68391 A CHARACTERIZATION OF CERTAIN SEQUENCES OF NORMING CONSTANTS * STEPHENR, KIM8LETON

AMS 68398 THE PROBA8ILITY THAT THE SAMPLE DISTRIBUTION FUNCTION LIES 8ETWEEN TWO PARALLEL STRAIGHT LINES * J. DURBIN

AMS 68412 NON-DISCOUNTED DENUMERA8LE MARKOVIAN DECISION MODELS * SHELDON ROSS

AMS 68424 ON RECURRENT DENUMERA8LE DECISION PROCESSES* LLOYD FISHER

AMS 68433 CHARACTERIZATIONS OF INDEPENDENCE IN CERTAIN FAMILIES OF 8IVARIATE AND MULTIVARIATE DISTRIBUTIONS * KUMAR JOGDEO

AMS 68442 ASYMPTOTICALLY OPTIMAL 8AYES AND MINIMAX PROCEDURES IN SEQUENTIAL ESTIMATION* PETER J. 8ICKEL, JOSEPH A. YAHAV

AMS 68457 ON THE CHOICE OF DESIGN IN STOCHASTIC APPROXIMATION METHODS * VACLAV FA8IAN

AMS 68466 CONCENTRATION OF RANDOM QUOTIENTS * WILLIAM H. LAWTON

AMS 68481 ON THE NUMERICAL REPRESENTATION OF QUALITAT IVE CONDITION PR08A8ILITY * R. DUNCAN LUCE

AMS 68492 MINIMAX ESTIMATION OF A RANDOM PROBABILITY WHOSE FIRST N MOMENTS ARE KNOWN * MORRIS SKIBINSKY

AMS 68502 ESTIMATION OF THE LARGER TRANSLATION PARAMETER * SAUL BLUMENTHAL, ARTHUR COHEN

AMS 68517 ESTIMATION OF TWO ORDERED TRANSLATION PARAMETERS * SAUL BLUMENTHAL, ARTHUR COHEN

AMS 68531 A COMPARISON OF THE MOST STRINGENT AND THE MOST STRINGENT SOMEWHERE MOST POWERFUL TEST FOR CERTAIN PROBLEMS WITH RESTRICTED ALTERNATIVE* W. SCHAAFSMA

AMS 68547 LIKELIHOOD RATIO TESTS FOR RESTRICTED FAMILITES OF PROBABILITY DISTRIBUTIONS * RICHARDE. BARLOW 
AMS 68561 SMOOTHED ESTIMATES FOR MULTINOMIAL CELL PROBABILITIES * JAMES M. DICKEY

AMS 68567 JACKNIFING VARIANCES * RUPERT G. MILLER JR

AMS 68583 INFERENCE FROM A KNOCKOUT TOURNAMENT * J. A. HARTIGAN

AMS 68593 THE CONDITIONAL WISHART, NORMAL AND NONNORMAL * D. A . S. FRASER

AMS 68606 ADMISSIBILITY OF THE SAMPLE MEAN AS ESTIMATE OF THE MEAN OF A FINITE POPULATION * V. M. JOSHI

AMS 68621 HYPER-ADMISSIBILITY AND OPTIMUM ESTIMATORS FOR SAMPLING FINITE POPULATIONS * T. V. HANURAV

AMS 68643 RELATIONSHIP OF GENERALIZEO POLYKAYS TOUNRESTRICTED SUMS FOR BALANCED COMPLETE FINITE POPULATIONS * EDWARD J CARNEY

AMS 68657 ON THE STRUCTURE AND ANALYSIS OF SINGULAR FRACTIONAL REPLICATES * K.S. 8ANERJEE, W. T. FEOERER

AMS 68664 NONPARAMETRIC DISCRIMINATION USING TOLERANCE RECIONS * C. P. QUESENBERRY, M. P. GESSAMAN

AMS 68674 AN EXAMPLE IN DUNUMERA8LE OECISION PROCESSES * LLOYO FISHER, SHELDONM, ROSS

AMS 68676 ASSOCIATION MATRICES ANO THE KRONECKER PROOUCT OF OESIGNS* P.U. SURENDRAN

AMS 68681 A SERIES OF BALANCED INCOMPLETE BLOCK DESICNS * C. C . YALAVIGI

AMS 68727 A MULTI-OIMENSIONAL LINEAR GROWTH BIRTH ANO OEATH PROCESS * PAUL R. MILCH

AMS 68755 WEAK CONVERGENCE OF A TWO-SAMPLE EMPIRICAL PROCESS AND A NEW APPROACH TO CHERNOFF-SAVAGE THEOREM * RONALO PYKE, GALEN R. SHORACK

AMS 68772 MOST POWERFUL TESTS FOR SOME NON-EXPONENTIAL FAMILIES * EMIL SP JOTVOLL

AMS 68785 ESTIMATION OF STOCHASTIC SYSTEMS, AR8ITRARY SYSTEM PROCESS WITH AOOITIVE WHITE NOISE OBSERVATIONS ERROR * G. KALLIANPUR, C. STRIEBEL

AMS 68802 A POTENTIAL THEORY FOR SUPERMARTINCALES * E. COUNT CURTIS

AMS 68815 A SYSTEM OF LINEAR DIFFERENT IAL EQUATIONS FOR THEDISTRI8UTION OF HOTELLING 'S GENERALIZEO T-SQUARE-SUBZERO * A. W. DAVIS

AMS 68833 ON THE NON-CENTRAL OISTRI8UTION OF THE SECOND ELEMENTARY SYMMETRIC FUNCTION OF THE ROOTS OF A MATRIX * $\mathrm{K}$ C. SREEOHARAN PILLAI, ARJUNK. GUPTA

AMS 68840 INFERENCE PROBLEMS A8OUT PARAMETERS WHICH ARE SUBJECTEO TO CHANGES OVER TIME * CHANOAN MUSTAFI

AMS 68855 ON THE OISTRIBUTIONS OF DIRECTION AND COLLINEARITY FACTORS IN DISCRIMINANT ANALYSIS *D. G, KABE

AMS 68859 MINIMIZATION OF EIGENVALUES OF A MATRIX ANO OPTIMALITY OF PRINCIPAL COMPONENTS * MASASHI OKAMOTO. MITSUYO KANAZAWA

AMS 68864 LIMIT THEOREMS FOR THE MULTI-URN EHREFEST MODEL * DONALD L. IGLEHART

AMS 68877 ON THE MOMENT GENERATING FUNCTION OF PILLAI'S VSUPER-S CRITERION * K. C. SREEDHARAN PILLAI

AMS 68881 MOMENT CONVERGENCE OF SAMPLE EXTREMES * JAMES PICKANDS III

AMS 68890 ON THE PROBABILITY DISTRIBUTION OF A FILTERED RANDOM TELEGRAPH SIGNAL * DAVID S. NEWMAN

AMS 68897 AN EXTENSION OF ROSEN'S THEOREM TO NON-IDENTICALLY OISTRIBUTED RANDOM VARIABLES * L, H. KOOPMANS

AMS 68905 ASYMPTOTIC NORMALITY IN NONPARAMETRIC METHODS * KUMAR JOGDEO

AMS 68923 THE V-SUB-NM TWO-SAMPLE TEST * URS. R. MAAG. M. A STEPHENS

AMS 68936 ON CONTINUITY PROPERT IES OF INFINITELY DIVISIBLEDISTRIBUTION FUNCTIONS * STEVEN OREY

AMS 68938 FUNCTIONS OF PROCESSES WITH MARKOVIAN STATES * MARTIN FOX, HERMAN RUBIN

AMS 68947 THE DISTRIBUTION OF THE MAXIMUM OF A SEMI-MARKOV PROCESS * LAWRENCED. STONE

AMS 68957 UPPER AND LOWER PROBABILITIES GENERATED 8Y A RANDOM CLOSED INTERVAL * A.P. DEMPSTER

AMS 68967 ON CHERNOFF-SAVAGE TESTS FOR ORDERED ALTERNATIVES IN RANDOMIZED BLOCKS * MADAN LAL PURI, PRANAB KUMAR SEN

AMS 68973 BAYES SEQUENTIAL DESIGN OF FRACTIONAL FACTORIAL EXPERIMENTS FOR THE ESTIMATION OF A SUBGROUP OF PREASSIGNED PARAMETERS * S. ZACKS

AMS 68983 SOME RULES FOR A COMBINATORIAL METHOD FOR MULTIPLE PRODUCTS OF GENERALIZED K-STATISTICS * DERRICK S TRACY

AMS 68999 COMMON TREATMENTS BETWEEN BLOCKS OF CERTA IN PART IALLY BALANCED INCOMPLETE 8LOCK DESIGNS * P. U. SURENDRAN

AMS 681007 THE CORRELATION STRUCTURE OF THE OUTPUT PROCESS OF SOME S INGLE SERVER SYSTEMS * D. J. DALEY

AMS 681020 FUNCTIONS OF FINITE MARKOV CHAINS AND EXPONENTIAL TYPE PROCESSES * PAUL E. BOUDREAU

AMS 681030 ON ESTIMATING MONOTONE PARAMETERS * TIM ROBERTSON. PAUL WALTMAN

AMS 681040 THE PERFORMANCE OF SOME SEQUENTIAL PROCEDURES FOR A RANKING PROBLEM * M. S. SRIVASTAVA, J. OGILIVIE
AMS 681048 BOUNDS ON THE SAMPLE SIZE DISTRIBUTION FOR A CLASS OF INVARIANT SEQUENTI AL PROBABILITY RATIO TESTS * R. A WIJSMAN

AMS 681057 SEQUENTIAL MAXIMUM LIKELIHOOD ESTIMATION OF THE SIZE OF A POPULATION * ESTER SAMUEL

AMS 681069 SPLITTINC A SINGLE STATE OF A STATIONARY PROCESS INTO MARKOVIAN STATES * S. W. DHARMADHIKARI

AMS 681078 A CLARIFICATION CONCERNING CERTAIN EQUIVALENCE CLASSES OF GAUSSIAN PROCESSES ON AN INTERVAL * $J$ FELDMAN

AMS 681080 AN INEQUALITY IN CONSTRAINED RANDOM VARIABLES * C. L MALLOWS

AMS 681083 ON A SIMPLE ESTIMATE OF THE RECIPROCAL OF THE DENSITY FUNCTION * DANIEL A. BLOCH, JOSEPHL. GASTWIRTH

AMS 681107 ERGOOIC THEORY WITH RECURRENT WEIGHTS * KENNETH N BERK

AMS 681115 ON A CLASS OF ALIGNED RANK ORDER TESTS IN TWO-WAY LAYOUTS * PRANAB KUMAR

AMS 681125 THE ESTIMATION OF VARIANCES AFTER USING A GAUSSIANATING TRANSFORMATION *M. H. HOYLE

AMS 681144 THE OUTPUT PROCESS OF A STATIONARY M/M/S QUEUEING SYSTEM $* P, J, B U R K E$

AMS 681153 A CLASS OF INFINITELY DIVISI8LE MIXTURES * F. W. STEUTEL

AMS 681158 CONTRIBUTIONS TO CENTRAL LIMIT THEORY FOR DEPENOENT VARIABLES * R. J. SERFLING

AMS 681176 OPERATING CHARACTERISTICS OF SOME SEQUENTIAL DESIGN RULES * ROBERT BOHRER

AMS 681186 THE CEOMETRY OF A R-8Y-C CONTINGENCY TA8LE * STEPHEN E. FIEN8ERC

AMS 681191 MONOTONE CONVERGENCE OF 8INOMIAL PRO8A8ILITIES AND A GENERALIZATION OF RAMANUJAN' S EQUATION * KUMAR JOGOEO. S.M. SAMUELS

AMS 681196 ROBUSTNESS OF THE WILCOXON ESTIMATE OF LOCATION AGAINST A CERTAIN OEPENOENCE * ARNLJOT HOYLANO

AMS 681202 THE WILCOXON TWO-SAMPLE STATISTIC ON STRONGLY MIXING PROCESSES *R. J. SERFLING

AMS 681210 RENEWAL THEOREMS WHEN THE FIRST OR THE SECOND MOMENT IS INFINITE * JOZEF L. TEUGELS

AMS 681220 AN OPTIMALITY CONDITION FOR OISCRETE DYNAMIC PROGRAMMING WITH NO OISCOUNTING * E. V. DENARDO, B. L MILLER

AMS 681228 EXISTENCE OF OPTIMAL STOPPING RULES FOR REWARDS RELATEO TO S-SUB-N-OVER-N * DAVIO SEIGMUND, GOROON SIMONS, PAUL FEOER

AMS 681236 PROBABILITY OENSITIES WITH GIVEN MARGINALS * S. KULLBACK

AMS 681244 ASYMPTOTIC OPTIMUM PROPERTIES OF CERTAIN SEQUENTIAL TESTS * SEOK PIN WONG

AMS 681264 GENERALIZED ASYMPTOTIC EXPANSIONS OF CORNISH-FISHER TYPE* G. W. HILL, A. W. DAVIS

AMS 681274 ON MOMENTS OF ELEMENTARY SYMMETRIC FUNCTIONS OF THE ROOTS OF TWO MATRICES AND APPROXIMATIONS TO A DISTRIBUTION * C. C. KHATRI, K. C. S. PILLAI

AMS 681282 INDEPENOENT SEQUENCES WITH THE STEIN PROPERTY * D. L BURKHOLOER

AMS 681289 8AYESIAN ESTIMATION OF MIXING DISTRIBUTIONS * JOHN E. ROLPH

AMS 681303 SIMULTANEOUS TESTS FOR THE EQUALITY OF COVARIANCE MATRICES AGA INST CERTAIN ALTERNATIVES * P. R. KRISHNAIAH

AMS 681310 THE EPSILON ENTROPY ON CERTAIN MEASURES ON $(0.1)$ *T S. PITCHER

AMS 681316 MULTIVARIATE EXPONENTIAL-TYPE DISTRIBUTIONS * SHEELA BILOIKAR, G, P. PATIL

AMS 681327 ON ASYMPTOTIC NORMALITY IN STOCHASTIC APPROXIMATION * Vaclav fabian

AMS 681333 OPTIMAL STOPPING IN A MARKOV PROCESS * HOWARD M. TAYLOR

AMS 681345 A 8OREL SET NOT CONTAINING A GRAPH * DAVID 8LACKWELL AMS 681348 A NOTE ON THE WEAK LAW OF LARGE NUMBERS * MELVIN KATZ

AMS 681350 ON THE PROPORTION OF O8SERVATIONS ABOVE SAMPLE MEANS IN A 8IVARIATE NORMAL DISTRIBUTION * CHANDAN $K$ MUSTAFI

AMS 681354 CONSTRUCTION OF JOINT PROBABILITY DISTRIBUTIONS * L F. KEMP JR

AMS 681381 CONVOLUTIONS OF DISTRI8UTIONS ATTRACTED TO STA8LE LAWS * HOWARD G. TUCKER

AMS 681391 ON A THEOREM OF DOBRUSHIN * CHARLES STONE

AMS 681402 LARGE DEVIATIONS THEORY IN EXPONENTIAL FAMILIES * BRADLEY EFRON, DONALD TRUAX

AMS 681425 ON MULTIVARIATE NORMAL PROBA8ILITIES OF RECTANGLES * ZBYNEK SIDAK

AMS 681435 OPTIMAL DESIGNS ON TCHE8YSCHEFF POINTS * W. J. STUDDEN AMS 681448 ON THE ERCODICITY FOR NON-STATIONARY MULTIPLE MARKOV PROCESSES * BUI-TRONG LIEU, HELENE DE8ERGHES

AMS 681463 ON CONFIDENCE LIMITS FOR THE RELIABILITY OF SYSTEMS * JANET M. MYRE, SAM C. SAUNDERS 
AMS 681473 DISTRIBUTIONS DETERMINED BY CUTTING SIMPLEX WITH HYPERPLANES * A. P. DEMPSTER, ROBERT M. KLEYLE

AMS 681479 CONVERGENCE RATES FOR THE LAW OF THE ITERATED LOCARITHM * JAMES AVERY DAVIS

AMS 681486 A NOTE ON ROBUST ESTIMATION IN ANALYSIS OF VARIANCE * EMIL SPJOTVOLL

AMS 681493 ON THE ASYMPTOTIC NORMALITY OF ONE-SIDED STOPPINC RULES * D. SIECMUND

AMS $6 B 1498$ ON A CHARACTERIZATION OF SYMMETRIC STABLE PROCESSES WITH FINITE MEAN * B. L. S. PRAKASA RAO

AMS 681502 ALMOST SURE CONVERCENCE OF QUADRATIC FORMS IN INDE-

PENDENT RANDOM VARIABLES * DALE E. VARBERG
AMS $6 B \quad 1507$ CROSS SPECTRAL ANALYSIS OF CAUSSIAN VECTOR PROCESS IN THE PRESENCE OF VARIANCE FLUCTUATIONS * T . SUBBA RAO AMS 681513 THEDISCRETE STUDENT'S DISTRIBUTION * J. K. ORD

AMS 681517 DESIGN AND ANALYSIS OF EXPERIMENTS WITH MIXTURES * J. S. MURTY, M. N. DAS

AMS $6 B 1540$ CONSTRUCTION OF ROOM SQUARES * R. G. STANTON, R. C MULLIN

AMS 6B 1549 SOME RESULTS ON THE COMPLETE AND ALMOST SURE CONVERGENCE OF LINEAR COMBINATIONS OF INDEPENDENT AND RANDOM VARIABLES AND MARTINCALE DIFFERENCES * WILLIAM F. STOUT

AMS 681563 DISTANCES OF PROBABILITY MEASURES AND RANDOM VARIABLES * R. M. DUDLEY

AMS 6B 1573 ON INVARIANCE AND ALMOST INVARI ANCE * ROBERT H. BERK, P. J. BICKEL

AMS 681577 SOME EXAMPLES OF MULTI-DIMENSIONAL INCOMPLETE BLOCK DESIGNS * B. D. CAUSEY

AMS 681591 ON A GENERALIZED SAVAGE STATISTIC WITH APPLICATIONS TOLIFE TESTING * A. P. BASU

AMS 6B 1605 SOME MULTIVARIATE T-DISTRIBUTIONS * K. S. MILLER

AMS 681610 ON THE TRIMMED MANN-WHITNEY STATISTIC * THOMAS P. HETTMANSPERGER

AMS 681615 THREE MULTIDIMENSIONAL-INTEGRAL IDENTITIES WITH BAYESIAN APPLICATIONS * JAMES M. DICKEY

AMS 681629 A COMPACT TABLE FOR POWER OF THE T-TEST * J. L. HODGES JR, E. L. LEHMANN

AMS 681638 EFFICIENT DIFFERENCE EQUATION ESTIMATORS IN EXPONENTIAL REGRESSION * C. A. MCG ILCHRIST

AMS 681646 ADMISSIBILITY AND DISTRIBUTION OF SOME PROBABILISTIC FUNCTIONS OF DISCRETE FINITE STATE MARKOV CHAINS * CHIA KUEI TSAO

AMS 681654 APPROACH TO DEGENERACY AND THE EFFICIENCY OF SOME MULTIVARIATE TESTS * G. K. BHATTACHARYYA, RICHARD A. JOHNSON

AMS 6B 1661 THE INFORMATION IN A RANK-ORDER AND THE STOPPINC TIME OF SOME ASSOCIATED SPRT'S * ROBERT H. BERK, I. RICHARD SAVAGE

AMS 681675 WEAK GONVERGENCE AND A CHERNOFF-SAVACE THEOREM FOR RANDOM SAMPLE SIZES * RONALD PYKE, GALEN R. SHORACK

AMS 681686 UNBIASEDNESS OF SOME TEXT CRITERIA FOR THE EQUALITY OF ONE OR TWO COVARIANCE MATRICES * NARIAKI SUCIURA, HISAO NAGAO

AMS 681693 ON SLIPPAGE TESTS I. A GENERALIZATION OF NEYMAN PEARSON 'S LEMMA * IRVINC H. HALL, AKIO KUDO

AMS 681700 HOW TO MINIMIZE OR MAXIMIZE THE PROBABILITIES OF EXTINCTION IN A GALTON-WATSON PROCESS AND IN SOME RELATED MULTIPLIGATIVE POPULATION PROCESSES * LEO A. GOODMAN

AMS 681711 GALCULATION OF ZONAL POLYNOMIAL COEFFICIENTS BY THE USE OF THE LAPLACE-BELTRAMI OPERATOR * A. T. JAMES

AMS 6B 1719 BOUNDS ON MOMENTS OF MARTINGALES * S. W. DHARMADHIKARI, V. FABIAN, K. JOGDEO

AMS 681724 ASYMPTOTIC NORMALITY OF SAMPLE QUANTILES FOR M-DEPENDENT PROCESSES * PRANAB KUMAR SEN

AMS 681731 NONPARAMETRIC TESTS FOR SHIFT AT UNKNOWN TIME POINT * G. K. BHATTACHARYYA, RICHARD A. JOHNSON

AMS 681744 A NOTE ON THE ADMISSIBILITY OF POOLING IN THE ANALYSIS OF VARI ANCE * ARTHUR COHEN

AMS $6 B 1747$ ON THE ROBUSTNESS OF SOME CHARACTERIZATIONS OF THE NORMAL DISTRIBUTION * L. K. MESHALKIN

AMS 6B 1751 EXACT DISTRIBUTION OF THE PRODUCT OF INDEPENDENT GENERALIZED GAMMA VARIABLES WITH THE SAME SHAPE PARAMETER * HENRICK JOHN MALIK

AMS 681753 A MIXTURE OF TWO RECURRENT RANDOM WALKS NEED NOT BE RECURRENT * J. MINEKA

AMS 6B 1755 ON THE MONOTONICITY OF E-SUB-P (S-SUB-T-OVER-T) * Y. S. CHOW, W. J. STUDDEN

AMS 681756 ANCILLARY STATISTICS AND PREDICTION OF THE LOSS IN EST IMATION PROBLEMS * ELSE SANDVED

AMS 6B 1759 SOME RESULTS ON POLYA TYPE 2 DISTRIBUTIONS * KHURSHEED ALAM
AMS 681762 AN INEQUALITY FOR THE RATIO OF TWO QUADRATIC FORMS IN NORMAL VARIATES * KOTESWARA RAO KADIYALA

AMS 681801 EMBEDDINC OF URN SCHEMES INTO CONT INUOUS TIME MARKOV BRANCHING PROCESSES AND RELATED LIMIT THEOREMS * KRISHNA B. ATHREYA, SAMUEL KARLIN

AMS 681818 A DELICATE LAW OF THE ITERATED LOCARITHM FOR NONDECREASINC STABLE PROCESSES (ADDENDUM, 69 1855) * LEO BREIMAN

AMS 681825 ON A CENERAL CLASS OF DESICNS FOR MULTIRESPONSE EXPERIMENTS * $J$. N. SHRIVASTAVA

AMS 6B 1844 ON DOMINATINC AN AVERACE ASSOCIATED WITH DEPENDENT GAUSSIAN VECTORS * S. C. SCHWARTZ, W. L. ROOT

AMS 6B 1 B49 ON THE DISTRIBUTION OF SOME STATISTICS USEFUL IN THE ANALYSIS OF JOINTLY STATIONARY TIME SERIES * GRACE WAHBA

AMS 681863 CONTACION IN STOCHASTIC MODELS FOR EPIDEMICS * GRACE LOYANC

AMS 6B 1 B90 SEQUENTIAL COMPOUND ESTIMATION * DENNIS C. GILLILAND AMS $6 B 1905$ OPTIMAL STOPPINC FOR FUNCTIONS OF MARKOV CHAINS * ALBERTO RUIZ-MONCAYO

AMS 681913 ROBUSTNESS OF SOME NONPARAMETRIC PROCEDURES IN L INEAR MODELS * PRANAB KUMAR SEN

AMS 681923 SOME INTEGRAL TRANSFORMS OF CHARACTERISTIC FUNCTIONS * G. ANDERSEN, T. KAWATA

AMS 6B 1932 ON PSEUDO-GAMES * ALFREDO BANOS

AMS 6B 1946 ON THE COST OF NOT KNOWING THE VARIANCE WHEN MAKING A FIXED WIDTH CONFIDENCE INTERVAL FOR THE MEAN * GORDON SIMONS

AMS 6B 1953 SEQUENTIAL SELECTION OF EXPERIMENTS * K. B. GRAY JR

AMS 681978 ON THE ADMISSIBILITY AT INFINITY, WITHIN THE CLASS OF RANDOMIZED DESICNS, OF BALANCED DESIGNS * R. H. FARRELL

AMS 681995 FURTHER SECOND ORDER ROTATABLE DESICNS * NORMAN R. DRAPER, AGNESM. HERZBERC

AMS 6B 2002 A TREATMENT OF TIES IN PAIRED COMPARISONS * JAGBIR SINCH, W. A. THOMPSON JR

AMS 6B 2016 CONVERCENGE RATES FOR PROBABILITIES OF MODERATE DEVIATIONS * JAMES AVERY DAVIS

AMS 682029 ON SLIPPAGE TEST (II) SIMILAR SLIPPAGE TESTS * IRVING J. HALL, AKIO KUDO, NENG-CHE YEH

AMS 6B 2038 ASYMPTOTIC SHAPES FOR SEQUENTIAL TESTING OF TRUNCATION PARAMETERS * GIDEON SCHWARZ

AMS 682044 ON THE DISTRIBUTION OF THE LOG LIKELIHOOD RATIO TEST STATISTIC WHEN THE TRUE PARAMETER IS 'NEAR' THE BOUNDARIES OF THE HYPOTHESIS REGIONS * PAUL I, FEDER

AMS 6B 2056 INFORMATION AND SUFF ICIENT SUB-FIELDS * S. G. GHURYE

AMS 682067 AN EXTENSION OF PAULSON'S SELECTION PROCEDURE * D. G HOEL, M. MAZUMDAR

AMS 6B 2075 NONPARAMETRIC RANKINC PROCEDURES FOR COMPARISON WITH A CONTROL * M. HASEEB RIZVI, MILTON SOBEL, GEORGE G WOODWORTH

AMS $6 B 2094$ ON A THEOREM OF SKOROHOD * LESTER E. DUBINS

AMS $6 B 2098$ ON RECENT THEOREMS CONCERNINC THE SUPERCRITICAL GALTON-WATSON PROCESS *E. SENETA

AMS 6B 2103 RANDOMIZED RULES FOR THE TWO-ARMED BANDIT WITH FINITE MEMORY * S. M. SAMUELS

AMS $68210 B$ ON A LIMIT DISTRIBUTION OF HIGH LEVEL CROSSINCS OF A ST ATIONARY GAUSSIAN PROCESS * CLIFFORD QUALLS

AMS 6B 2114 THE DISTRIBUTION OF GALTON'S STATISTICS * SHULAMTH GROSS, PAUL W. HOLLAND

AMS 68 211B ARBITRARY STATE MARKOVIAN DECISION PROCESSES * SHELDONM. ROSS

AMS 682123 ON THE LOCAL BEHAVIOR OF MARKOV TRANSITION PROBABILITIES * DAVID BLACKWELL, DAVID FREEDMAN

AMS 68 212B AN ELEMENTARY METHOD OF OBTAINING LOWER BOUNDS ON THE ASYMPTOTIC POWER OF RANK TESTS * JOSEPH L. GASTWIRTH, STEPHEN WOLFE

AMS 682131 REPRESENTINC FINITELY ADDITIVE INVARIANT PROBABILITIES * RICHARD A. OLSHEN

AMS 682136 NECESSARY CONDITIONS FOR ALMOST SURE EXTINCTION OF BRANCHING PROCESS WITH RANDOM ENVIRONMENT * WALTER L. SMITH

AMS 6B 2141 COMPARISON TESTS FOR THE CONVERCENCE OF MARTINGALES * BURGESS DAVIS

AMS 682145 A GENERALIZATION OF ITO'S THEOREM CONCERNING THE POINTWISE ERGODIC THEOREM * CHOO-WHAN KIM

AMS 6B 2149 WEAK CONVERGENCE OF A SEQUENCE OF QUICKEST DETECTION PROBLEMS * DONALD L. IGLEHART, HOWARD M. TAYLOR

AMS $6 B 2154$ BOUNDS OF THE PROBABILITY OF A UNION OF EVENTS, WITH APPLICATIONS * EUSTRATIOS G. KOUNIAS

AMS 6B 2159 A NOTE ON THE WEAK LAW * C. M. DEO, D. R. TRUAX 
AMS 69 I A DISTRIBUTION FREE VERSION OF THE SMIRNOV TWO SAMPLE TEST IN THE P-VARIATE CASE * P. J. BICKEL

AMS 6924 ON ROBUST LINEAR ESTIMATORS * JOSEPH L. CASTWIRTH, HERMAN RUBIN

AMS 6940 THE SPEED OF CLIVENKO-CANTELLI CONVERCENCE * R. M. DUDLEY

AMS 6951 FURTHER REMARKS ON TOPOLOCY AND CONVERCENCE IN SOME ORDERED FAMILIES OF DISTRIBUTION * J. PFANZACL

AMS 6966 ON MEASURABLE, NONLEAVABLE CAMBLING HOUSES WITH A GOAL * WILLIAM D. SUDDERTH

AMS 6971 ONERLANG'S FORMULA * LAJOS TAKACS

AMS 6979 EXISTENCE OF AN INVARIANT MEASURE AND AN ORNSTEIN'S ERGODIC THEOREM * MICHEL METIVIER

AMS 6997 PROBABILISTIC FUNCTIONS OF FINITE STATE MARKOV CHAINS * T. PETRIE

AMS 69116 ON DETECTING CHANGES IN THE MEAN OF NORMAL VARIATES * L. A. GARDNER JR

AMS 69127 THE TAIL FIELD OF A MARKOV CHAIN * ALLAN F ABRAHAMSE

AMS 69137 THE ASYMMETRIC CAUCHY PROCESSES ON THE LINE * S. C. PORT, C. J. STONE

AMS 69144 A CENTRAL L IMIT THEOREM FOR THE NUMBER OF EDCES IN THE RANDOM INTERSECTION OF TWO GRAPHS (CORR. 69 1510) * $0 . A B E$

AMS 69152 THE ORTHANT PROBABILITIES OF FOUR GAUSSIAN VARIATES * M. C. CHENC

AMS 69162 INVARIANT SETS FOR TRANSLATION-PARAMETER FAMILIES OF MEASURES * D. BASU, J. K. GHOSH

AMS 69175 PARTIALLY BALANCED INGOMPLETE BLOCK DESIGNS WITH TWOWAY CLASSIFICATION OF TREATMENTS * C. RAMANKUTTY NAIR

AMS 69188 ON SERIAL CORRELATION * S. JAMES PRESS

AMS 69197 EQUIVALENCE OF GAUSSIAN STATIONARY PROCESSES * T. R. CHOW

AMS 69203 THE CENTRAL LIMIT THEOREM FOR CENERALIZED RANDOM FIELDS *D. M. EAVES

AMS 69216 ON A THEOREM OF KARLIN REGARDING ADMISSIBLE ESTIMATES FOR EXPONENTIAL POPULATIONS * V.M. JOSHI

AMS 69224 SIMULTANEOUS TEST PROCEDURES, SOME THEORY OF MULTIPLE GOMPARISONS * K.R.GABRIEL

AMS 69251 INTERPOLATION OF HOMOGENEOUS RANDOM FIELDS ON DISCRETE GROUPS * L . BRUCKNER

AMS 69259 BIVARIATE SYMMETRY TESTS, PARAMETRIC AND NONPARAMETRIC * C. B. BELL, H. SMITH HALLER

AMS 69270 INVARIANT PROPER BAYES TESTS FOR EXPONENTIAL FAMILIES * RICHARDE, SCHWARTZ

AMS 69 2B4 VARIATION QUADRATIQUE DES MARTINGALES CONTINUES A DROITE * CATHERINE DOLEANS

AMS 69290 MULTIVARIATE TWO SAMPLE TESTS WITH DICHOTOMOUS AND CONTINUOUS VARIABLES I. THE LOCATION MODEL * A A AFIFI, R. M ELASHOFF

AMS 69299 STOCHASTIC APPROXIMATION FOR SMOOTH FUNCTIONS * VACLAV FABIAN

AMS 69303 A NOTE ON CHARACTERISTIC FUNCTIONS * K. G. BINMORE, H H. STRATTON

AMS $6930 \mathrm{~B}$ DOMAINS OF OPTIMALITY OF TESTS IN SIMPLE RANDOM SAMPLINC * DAVID K. HILDEBRAND

AMS 69313 A SECOND-ORDER APPROXIMATION TO OPTIMAL SAMPLINC REGIONS * GIDEON SCHWARZ

AMS 69316 A NOTE ON POSITIVE DYNAMIC PROGRAMMING * ASHOK MAITRA AMS 69319 NEW CONDITIONS FOR CENTRAL LIMIT THEOREMS (CORR. 69 1855) * PERCY A. PIERRE

AMS 69322 AN EXAMPLE OF THE DIFFERENCE BETWEEN THE LEVY AND LEVY-PROKHOROV METRICS * LLOYD FISHER, D. W. WALKUP

AMS 39325 CORRECTION TO AMS 56427 'ESTIMATION OF LOCATION AND SCALE PARAMETERS BY ORDER STATISTICS FROM SINCLY AND DOUBLY CENSORED SAMPLES, PART I. THE NORMAL DISTRIBUTION UP TO SAMPLES OF SIZE $10^{\circ} *$ A. E. SARHAN, B. G. GREENBERG

AMS 69339 GENERALIZED MEANS AND ASSOCIATED FAMILIES OF DISTRIBUTIONS * H. K. BRONS. H. D. BRUNK, W. E. FRANCK, D. L. HANSON

AMS 69356 ON THE ADMISSI8ILITY OF A RANDOMIZED SYMMETRICAL DESICN FOR THE PROBLEM OF A ONE WAY CLASSIFICATION * R. H. FARRELL

AMS 69366 DISCRETE DYNAMIC PROCRAMMING WITH A SMALL INTEREST RATE * BRUCE L. MILLER, ARTHUR F. VEINOTT JR

AMS 69371 DISTRIBUTION OF LIKELIHOOD RATIO IN TESTINC AGAINST TREND * M T. BOSWELL, H. D. BRUNK

AMS 69381 DISTINGUISHABILITY OF PROBABILITY MEASURES * LLOYD FISHER, JOHN W VAN NESS

AMS 69393 BIORTHOCONAL AND DUAL CONFIGURATIONS AND THE RECIPROCAL NORMAL DISTRI8UTION * ROBERT H. BERK

AMS 69399 SAMPLE PATH VARIATIONS OF HOMOCENEOUS PROCESSES * MICHAEL SHARPE
AMS 69408 VARIANCES OF VARIANCE-COMPONENT ESTIMATORS FOR THE UNBALANCED TWO-WAY CROSS CLASSIFICATION WITH APPLICATION TO BALANCED INCOMPLETE BLOCK DESICNS * DAVID A. HARVILLE

AMS 69417 ON AN A.P.0. RULE IN SEQUENTIAL ESTIMATION WITH QUADRATIC LOSS * PETER J. BICKEL, JOSEPH A. YAHAV

AMS 69427 MARTINCALE EXTENSIONS OF A THEOREM OF MARCINKIEWICZ AND ZYCMUND * Y.S. CHOW

AMS 69434 ON FINITE PRODUCTS OF POISSON-TYPE CHARACTERISTIC FUNCTIONS OF SEVERAL VARIABLES * ROGER CUPPENS

AMS 69445 SEQUENTIAL NONPARAMETRIC TWO-WAY CLASSIFICATION WITH PRESCRIBED MAXIMUM ASYMPTOTIC ERROR PROBABILITY * MELVIN N. WOINSKY, LUDWIK KURZ

AMS 69456 ON THE EXPECTED VALUE OF A STOPPED STOCHAST IC SEQUENCE * WILLIAM F. STROUT, Y S, CHOW

AMS 69462 ON THE LEAST SQUARES ESTIMATION OF NON-LINEAR RELATIONS * C. VILLECAS

AMS 69467 APPROXIMATION TO BAYES RISK IN SEQUENCES OF NONFINTTE GAMES * DENNISGILLILAND

AMS 69475 ON CONVERGENCE RATES IN THE CENTRAL LIMIT THEOREM * ELLEN S. HERTZ

AMS 69 4BO ON SOME RESULTS OF N.V. SMIRNOV CONGERNING LIMIT DISTRIBUTIONS FOR VARIATIONAL SERIES * D. MEJZLER, I. WEISSMAN

AMS 69492 AN APPROXIMATION TO THE SAMPLE SIZE IN SELECTION PROBLEMS * EDWARD J, DUDEWICZ

AMS 69498 COMBININC ELEMENTS FROM DISTINCT FINITE FIELDS IN MIXED FACTORIALS * B. L. RAKTOE

AMS 69505 A COMPARISON TEST FOR MARTINGALE INEQUALITIES * BURCESS DAVIS

AMS 69509 SEQUENTIAL INTERVAL ESTIMATIION FOR THE MEANS OF NORMAL POPULATIONS * EDWARD PAULSON

AMS 69517 AN APPLICATION FOR THE SOBOLEV IMBEDDINC THEOREMS TO CRITERIA FOR THE CONTINUITY OF PROCESSES WITH A VECTOR PARAMETER * HAROLD J KUSHNER

AMS 69527 ON MOMENTS OF THE MAXIMUM OF NORMED PARTIAL SUMS * DAVID SIEGMUND

AMS 69532 QUASI-STATIONARY BEHAVIOUR OF A LEFT-CONTINUOUS RANDOM WALK*D, J. DALEY

AMS 69540 PHASE FREE ESTIMATION OF COHERENCE * RICHARD H. JONES

AMS 69549 ONE SIDED PROBLEMS IN MULTIVARIATE ANALYS IS * MICHAEL D. PERLMAN

AMS 6956 B THE CONSISTENCY OF CERTAIN SEQUENTIAL ESTIMATORS * $\mathrm{R}$ M. LOYNES

AMS 69575 OPTIMAL TWO-STAGE STRATIFIED SAMPLINC * M. H. DE CROOT, N. STARR

AMS 69583 ASYMPTOTIC DISTRIBUTION OF MAXIMUM LIKELIHOOD EST IMATORS IN A LINEAR MODEL WITH AUTOREGRESSIVE DISTURBANCES * GLIFFORD HILDRETH

AMS 69595 A NOTE ON TESTS FOR MONOTONE FAILURE RATE BASED ON INCOMPLETE DATA * R. E. BARLOW, F. PROSCHAN

AMS 69601 THE REMAINDER IN THE CENTRAL LIMIT THEOREM FOR MIXINC STOCHASTIC PROCESSES * WALTER PHILIPP

AMS 69610 ANALYSIS OF COVARIANCE BA.SED ON GENERAL RANK SCORES * MADAN LAL PURI, PRANAB KUMAR SEN

AMS 69619 MULTIPLE DECISION PROCEDURES BASED ON RANKS FOR CERTAIN PROBLEMS IN ANALYSIS OF VARIANCES * MADAN L PURI. PREM S. PURI

AMS 69633 ASYMPTOTIG PROPERTIES OF NON-LINEAR LEAST SQUARES ESTIMATORS * ROBERT I. JENNRICH

AMS 69644 THE EXPECTED COVERACE TO THE LEFT OF THE I'TH ORDER STATISTIC FOR ARBITRARY DISTRIBUTIONS * BARRY $\mathrm{H}$ MARGOLIN, FREDERICK MOSTELLER

AMS $6964 B$ SOME FIRST PASSAGE PROBLEMS FOR S-SU8-N-OVER-ROOT-N * R. A OLSHEN D O SIECMUND

AMS 69653 A NOTE ON SEQUENTIAL MULTIPLE DECISION PROCEDURES * ISAAC MEILIJSON

AMS 69658 ON A CLASS OF CONDITIONALLY DISTRIBUTION-FREE TESTS FOR INTERACTIONS IN FACTORIAL EXPERIMENTS * K. L MEHRA, P. K. SEN

AMS 69665 THE ASYMPTOTIC 8EHAVIOR OF A CERTAIN MARKOV CHAIN * 8 J. MCCABE

AMS 69667 AN EXTENSION OF A THEOREM OF CHOW AND ROB8INS ON SEQUENTIAL CONFIDENCE INTERVALS FOR THE MEAN * ARTHUR NADAS

AMS 69672 ADMISSI8ILITY AND BAYES ESTIMATION IN SAMPLING FINITE POPULATIONS, $V * V$. P. GODAMBE

AMS 69677 AN OPTIMAL STOPPING THEOREM * BENTON JAMISON, STEVEN OREY

AMS 69679 A NOTE ON 8ALANCED INCOMPLETE BLOCK DESIGNS * HENRY 8 MANN

AMS 69681 INEQUALITIES WITH APPLICATIONS TO THE WEAK CONVERGENCE OF RANDOM PROCESSES WITH MULTI-DIMENSIONAL TIME PARAMETERS * MICHAEL J. WICHURA

AMS 69688 ON A FLUCTUATION THEOREM FOR PROCESSES WITH INDEPENDENT INCREMENTS, II * C. C. HEYDE 
AMS 69692 NOTE ON A 'MULTIVARIATE' FORM OF BONFERRONI'S INEQUALITIES * RICHARDM. MEYER

AMS 69694 NOTE ON SHIFT-INVARIANT SETS * U. KRENCEL, L. SUCHESTON

AMS 69697 PROPERTIES OF POWER FUNCTIONS OF SOME TESTS CONCERNING DISPERSION MATRICES OF MULTIVARIATE NORMAL DISTRIBUTIONS * SOMESHDAS CUPTA

AMS 69702 THE SAMPLINC DISTRIBUTION OF AN ESTIMATOR ARISINC IN CONNECTION WITH THE TRUNCATED EXPONENTIAL DISTRIBUTION * JAN M. HOEM

AMS 69704 A CENERAL METHOD OF DETERMININC FIXED-WIDTH CONFIDENCE INTERVALS * RASUAL A. KHAN

AMS 69710 ON MINIMUM VARIANCE UNBIASED EST IMATION OF RELIABILI$T Y * Y, S . S A T H E, S, D, V A R D E$

AMS 69715 THE EXISTENCE OF CERTAIN STOPPINC TIMES ON BROWNIAN MOTION * D. H. ROOT

AMS 69743 ON THE SUPERCRITICAL ONE DIMENSIONAL ACE DEPENDENT BRANCHING PROCESSES * KRISHNA B. ATHREYA

AMS 69764 A BEST POSSIBLE KOLMOGOROFF-TYPE INEQUALITY FOR MARTINGALES AND A CHARACTERISTIC PROPERTY * W, L STEIGER

AMS 69770 LINEAR FUNCTIONS OF ORDER STATISTICS * STEPHEN MACK STIGLER

AMS 69789 WEAK APPROACHABILITY IN A TWO-PERSON GAME * TEIN-FANC HOU

AMS 69 B14 ON BRANCHING PROCESSES IN RANDOM ENVIRONMENTS * WALTER L. SMITH, WILLIAME. WILKINSONN

AMS 69823 HYPOTHESIS TESTING WITH FINITE MEMORY * THOMAS M. COVER

AMS 69 B36 ON THE EXACT DISTRIBUTIONS OF VOTAW'S CRITERIA FOP TESTINC COMPOUND SYMMETRY OF A COVARIANCE MATRIX * P. C. CONSUL

AMS 69 B44 ON THE DISTRIBUTION OF THE SUPREMUM FUNCTIONAL FOR SEMI-MARKOV PROCESSES WITH CONTINUOUS STATE SPACES * LAWRENCE D. STONE

AMS 69 B54 EFFICIENT ESTIMATION OF A PROBABILITY DENSITY FUNCTION * JAMES PICKANDS III

AMS 69 B65 FUNCTIONS OF PROCESSES WITH MARKOVIAN STATES, II * MARTIN FOX, HERMAN RUBIN

AMS 69870 PRODUCT ENTROPY TO GAUSSIAN DISTRIBUT IONS * EDWARD C POSNER, EUGENE R. RODEMICH, HOWARD RUMSEY JR

AMS 69905 SELECTION PROCEDURES FOR RESTRICTED FAMILIES OF PROBABILITY DISTRIBUTIONS * RICHARD E. BARLOW, SHANTI S. GUPTA

AMS 69918 ON THE DISTRIBUTION OF THE MAXIMUM AND MINIMUM OF RATIOS OF ORDER STATISTICS * R. E. BARLOW, S. S, GUPTA, S. PANCHAPAKESAN

AMS 69935 ON LIMITING DISTRIBUTIONS FOR SUMS OF A RANDOM NUMBER OF INDEPENDENT RANDOM VECTORS * LEON JAY GLESER

AMS 69942 ASYMPTOTIC EXPANSIONS OF THE NON-NULL DISTRIBUTIONS OF THE LIKELIHOOD RATIO CRITERIA FOR MULTIVARIATE LINEAR HYPOTHESIS AND INDEPENDENCE * NARIAKI SUCIURA, YASUNORI FUJIKOSHI

AMS 69953 UPPER AND LOWER PROBABILITY INFERENCES FOR FAMILIES OF HYPOTHESES WITH MONOTONE DENSITY RATIOS * A. P. DEMPSTER

AMS 69970 CONDITIONAL PROBABILITY ON SICMA-COMPLETE BOOLEAN ALGEBRAS * ARDEL J . BOES

AMS 69979 DISTRIBUTION OF DISCRIMINANT FUNCTION WHEN COVARIANCE MATRICES ARE PROPORTIONAL * CHIEN-PAI HAN

AMS 699 B6 THE STRONC RATIO LIMIT PROPERTY FOR SOME GENERAL MARKOV PROCESSES * NARESH C. JAIN

AMS 69993 EXPLICIT SOLUTIONS TO SOME PROBLEMS OF OPTIMAL STOPPINC * L. A. SHEPP

AMS 691011 THE ASYMPTOTIC DISTRIBUTION OF SOME NON-LINEAR FUNCTIONS OF THE TWO-SAMPLE RANK VECTOR * SIEGFRIED $\mathrm{SCHACH}$

AMS 691021 ON FIXED PRECISION ESTIMATION IN TIME SERIES * J.R BLUM, JUDAH ROSENBLATT

AMS 691033 MARTINGALES WITH INDEPENDENT INCREMENTS * P. WARWICK MILLAR

AMS 691042 ADMISSIBILITY OF THE USUAL CONFIDENCE SETS FOR THE MEAN OF A UNIVARIATE OR BIVARIATE NORMAL POPULATION * V. M. JOSHI

AMS 691068 ANL-TO-THE-P CONVERGENCE THEOREM * S. D. CHATTERJI

AMS 691071 UNIFORM CONVERGENCE OF FAMILIES OF MARTINGALES * N , F G. MARTIN

AMS 691074 THE VARIANCE OF THE ONE-SIDED STOPPINC RULES * DAVID SIEGMUND

AMS $69107 \mathrm{~B}$ A NOTE ON SEQUENCES OF CONTINUOUS PARAMETER MARKOV CHAINS * THOMASG. KURTZ

AMS 691083 CAUCHY-DISTRIBUTED FUNCTIONS AND A CHARACTERIZATION OF THE CAUCHY DISTRIBUTION * E J WILLIAMS

AMS 691086 A REMARK ON THE KOLMOGOROFF-PETROVSKII CRITERION * ? J. BICKEL

AMS 691091 AN INEQUALITY AND ALMOST SURE CONVERGENCE * EUSTRATIOS G. KOUNIAS, TENG-SHAN WENG
AMS 691094 ON THE BAYES CHARACTER OF A STANDARD MODEL II ANALYSIS OF VARIANCE TEST * R. H. FARRELL

AMS 69 109B ON THE A PRIORI DISTRIBUTION OF THE COVARIANCE MATRIX * C, VILLEGAS

AMS 691100 MAXIMUM LIKELIHOOD ESTIMATION OF MULTIVARIATE COVARIANCE COMPONENTS FOR THE BALANCED ONE-WAY LAYOUT * JEROME KLOTZ, JOSEPH PUTTER

AMS 691106 MONOTONICITY OF THE VARIANCE UNDER TRUNCATION AND VARIATIONS OF HENSEN'S INEQUALITY * Y. S. CHOW, W.J. STUDDEN

AMS 691109 INFINITELY DIVISIBLE RENEWAL DISTRIBUTIONS * F. W STEUTEL

AMS 691114 A SHORT PROOF OF A KNOWN LIMIT THEOREM FOR SUM OF INDEPENDENT RANDOM VARIABLES WITH INFINITE EXPECTATIONS * BERT FRISTEDT

AMS 691116 A NOTE ON CHERNOFF-SAVACE THEOREMS * RONALD PYKE, GALENR, SHORACK

AMS 691120 A CHARACTERIZATION OF THE UPPER AND LOWER CLASSES IN TERMS OF CONVERGENCE RATES * JAMES AVERY DAVIS

AMS 691124 NOTE ON WEYL'S CRITERION AND THE UNIFORM DISTRIBUTION OF INDEPENDENT RANDOM VARIABLES * $\mathrm{P}, \mathrm{J}$, HOLEWIJN

AMS 691126 A UNIFORM OPERATOR ERGODIC THEOREM * E. M. KLIMKO

AMS 691130 NOTE ON COMPLETELY MONOTONE DENSITIES * F. W. STEUTEL

AMS 691167 STARSHAPED TRANSFORMATIONS AND THE POWER OF RANK TESTS * KJELL DOKSUM

AMS 691177 BAYES ' METHOD FOR BOOKIES * ROGER A. PURVES, DAVID A. FREEDMAN

AMS 691187 ESTIMATION OF A PROBABILITY DENSITY FUNCTION AND ITS DERIVATIVES * EUGENE $F$, SCHUSTER

AMS 691196 ASYMPTOTIC THEORY OF A CLASS OF TESTS FOR UNIFORMITY OF A CIRCULAR DISTRIBUTION * R J BERAN

AMS 691207 ASYMPTOTICALLY MOST POWERFUL TESTS IN MARKOV PROCESSES * GEORGE C, ROUSSAS, RICHARD A. JOHNSON

AMS 691216 TEST FOR MONOTONE FAILURE RATE BASED ON NORMALIZED SPACINC * K. DOKSUM, PETER BICKEL

AMS 691236 MOMENTS OF A STOPPING RULE RELATED TO THE CENTRAL LIMIT THEOREM * BRUCE M. BROWN

AMS 691250 TESTS FOR MONOTONE FAILURE RATE, II * P. J . BICKEL

AMS 691261 UNBIASED ESTIMATION OF SOME MULTIVARIATE PROBABILITY DENSITIES * S. G. GHURYE, INGRAM OLKIN

AMS 691272 EPSILON ENTROPY OF GAUSSIAN PROCESSES * EDWARD C POSNER, EUGENE R. RODEMICH, HOWARD RUMSEY JR

AMS 691297 SOME MULTIPLE PRODUCTS OF POLYKAYS * DERRICK S. TRACY AMS 691300 ON PARTITIONING A SET OF NORMAL POPULATIONS BY THEIR LOCATIONS WITH RESPECT TO A CONTROL * YUNG LIANG TONG

AMS 691325 A CLASS OF RANK ORDER TESTS FOR A GENERAL LINEAR HYPOTHESIS * MADAN LAL PURI, PRANAB KUMAR

AMS 691344 GENERALIZED LEAST-SQUARES ESTIMATION OF A SUBVECTOR OF PARAMETERS IN RANDOMIZED FRACTTONAL FACTORIAL EXPERIMENTS * M.M. LENTNER

AMS 691353 CONSISTENT ESTIMATION OF A LOCATION PARAMETER IN THE PRESENCE OF AN INCIDENTAL SCALE PARAMETER * J. PFANZGL

AMS 69 135B TESTING AND ESTIMATION FOR A CIRCULAR STATIONARY MODEL * INCRAM OLKIN, S. J. PRESS

AMS 691374 A TEST OF EQUALITY OF TWO NORMAL POPULATION MEANS ASSUMING HOMOGENEOUS COEFFICIENTS OF VARIATION * R. K LOHRDING

AMS $6913 B 6$ NONPARAMETRIC EST IMATION OF THE TRANSITION DISTRIBUTION FUNCTION OF A MARKOV PROCESS * GEORGE ROUSSAS

AMS 691401 THE CANONICAL CORRELATION COEFFICIENTS OF BIVARIATE GAMMA DISTRIBUTIONS * R. C. GRIFFITH.

AMS 691409 ON THE ASYMPTOTIC DISTRIBUTION OF A CERTAIN FUNCTIONAL OF THE WIENER PROCESS *A, D. WYNER

AMS 691419 A GENERAL THEORY OF SUBJECTIVE PROBABILITIES AND EXPECTED UTILITIES * PETER C FISHBURN

AMS 691430 QUADRATIC FORMS AND IDEMPOTENT MATRICES WITH RANDOM ELEMENTS * F. A. GRAYBILL, GEORGE MILLI KEN

AMS 691439 DISTRIBUTION OF A PRODUCT AND THE STRUCTURAL SETUP OF DENSITIES * R. K. SAXENA, A.M. MATHAI

AMS 691449 THE SMIRNOV TWO SAMPLE TESTS AS RANK TESTS * C.P. STECK AMS 691467 A STABLE LIMIT THEOREM FOR MARKOV TESTS * STEPHEN R. KIMBLETON

AMS 691474 NOTE ON A THEOREM OF DYNKIN ON THE DIMENSION OF SUFFICIENT STATISTICS * J. L. DENNY

AMS 691477 SMOOTHING BY CHEATING * JAMESM. DICKEY

AMS $6914 B 3$ INADMISSIBILITY OF THE BEST INVARIANT TEST WHEN THE MOMENT IS INFINITE UNDER ONE OF THE HYPOTHESES * MARTIN FOX,$S$. K. PERNG

AMS $6914 B 6$ SOME DISTRIBUTION-FREE MULTIVARIATE COMPARISON PROCEDURES * RYOJI TAMURA

AMS 691492 STRONG CONSISTENCY OF CERTAIN SEQUENTIAL ESTIMATORS * ROBERT H. BERK

AMS 691496 DENSITY ESTIMATION OF ORTHOGONAL SERIES * GEOFFREY S WATSON

AMS 691499 UNIFORM CONSISTENCY OF SOME ESTIMATES OF A DENSITY FUNCTION * DAVIDS, MOORE, E. G, HENRICHON 
AMS 691503 ZEROES OF INFINITELY DIVISIBLE DENSITIES * MICHAEL J . SHARPE

AMS 691506 BOUNDS ON MOMENTS OF SUMS OF RANDOM VARIABLES * KUMAR JOCDEO, S. W. DHARMADHIKARI

AMS 691523 UNBIASED ESTIMATION IN CONVEX FAMILIES * P. J. BICKEL, E. L. LEHMANN

AMS 691536 ON AN EXTENDED COMPOUND DECISION PROBLEM * DENNIS C. GILLILAND, JAMES F, HANNAN

AMS 691542 ESTIMATION OF PARAMETERS IN A TRANSIENT MARKOV CHAIN ARISINC IN A RELIABILITY CROWTH MODEL * M. DUBMAN, B. SHERMAN

AMS 691557 ADMISSIBLE DESIGNS FOR POLYNOMIAL SPLINE REGRESSION * william J . STUdDEn, D. J. VAN ARMan

AMS 691570 OPTIMAL AND EFFICIENT DESICNS OF EXPERIMENTS * CORWIN L. ATWOOD

AMS 691603 THE LOOSE SUBORDINATION OF DIFFERENTIAL PROCESSES TO BROWNIAN MOTION * BARTHEL W. HUFF

AMS 691610 STOCHASTIC INTEGRALS AND DERIVATIVES * DEAN ISAACSON AMS 691617 CONDITIONS FOR OPTIMALITY AND VALIDITY AND SIMPLE LEAST SQUARES THEORY * SUJIT KUMAR MITRA, C. RADHAKRISHNA RAO

AMS 691625 HOMOCENEOUS GAUSS-MARKOV RANDOM FIELDS * EUGENE WONC

AMS 691635 DISCRETE DYNAMIC PROGRAMMINC WITH SENSITIVE DISCOUNT OPT IMALITY CRITERIA * ARTHUR F. VEINOTT JR

AMS 691661 A NOTE ON ESTIMATING A UNIMODAL DENSITY * EDWARD $J$. WECMAN

AMS 691668 ON A CLASS OF RANK ORDER TESTS FOR THE PARALLELISM OF SEVERAL RECRESSION LINES * PRANAB KUMAR SEN

AMS 691684 MINIMAX RISK AND UNBIASEDNESS FOR MULTIPLE DECISION PROBLEMS OF TYPE I * WILLEM SCHAAFSMA

AMS 691721 CHARACTERIZATIONS OF THE LINEAR EXPONENT IAL FAMILTY IN A PARAMETER BY RECURRENCE RELATIONS FOR FUNCT IONS OF CUMULANTS *D. C. DOSS

AMS 691728 A CONSISTENT ESTIMATOR FOR THE IDENTIFICATION OF FINITE MIXTURES * S. YAKOWITZ

AMS 691736 SOME PROPERTIES AND AN APPLICATION OF A STATISTIC ARISINC IN TESTING CORRELATION * J. S. MEHTA, JOHN GURLAND

AMS 691746 THE MAXIMUM VARIANCE OF RESTRICTED UNIMODAL DISTRIBUTIONS * HAROLD I. JACOBSON

AMS 691753 SOME STRIKING PROPERTIES OF BINOMIAL AND BETA MOMENTS * MORRIS SKIBINSKY

AMS 691765 ON STRONG CONSISTENCY OF DENSITY ESTIMATES * J. VAN RYZIN

AMS 691773 ON DISTINCUISHING TRANSLATES OF MEASURES * MAREK KANTER

AMS 691778 MINIMAX RESULTS FOR IFRA SCALE ALTERNATIVES * KJELL DOKSUM

AMS 691784 A ROBUST POINT ESTIMATOR IN A GENERALIZED REGRESSION MODEL *P.V.RAO, J. I. THORNBY

AMS 691791 ON A CLASS OF NONPARAMETRIC TWO-SAMPLE TESTS FOR CIRCULAR DISTRIBUTIONS * SIEGFRIED SCHACH

AMS 691801 INADMISSIBILITY OF THE BEST INVARIATE ESTIMATOR OF EXTREME QUANTILES OF THE NORMAL DISTRIBUTION UNDER SQUARED ERROR LOSS * J. V. ZIDEK

AMS 691809 ASYMPTOTICALLY NEARLY EFFICIENT ESTIMATORS OF MULTIVARIATE LOCATION PARAMETERS * D. S. MOORE

AMS 691824 LIMITINC SETS AND CONVEX HULLS OF SAMPLES FROM PRODUCT MEASURES * LLOYD FISHER

AMS 691833 RESULTS FROM THE RELATION BETWEEN TWO STATISTICS OF THE KOLOMOGOROV-SMIRNOV TYPE* $M$. A. STEPHENS

AMS 691838 A NOTE ON THE TEST FOR THE LOCATION PARAMETER OF AN EXPONENTIAL DISTRIBUTION * KEI TAKEUCHI

AMS 691840 NEAR-CYCLIC REPRESENTATIONS FOR SOME RESOLUTION VI FRACT IONAL FACTORIAL PLANS * D. A. PREECE

AMS 691844 NOTE ON THE THREE SERIES THEOREM * DEAN ISAACSON

AMS 691845 A DECOMPOSITION THEOREM FOR VECTOR VARIABLES WITH A LINEAR STRUCTURE * C. RADHAKRISHNA RAO

AMS 691850 A BRANCHING PROCESS WITHOUT REBRANCHING * I. R. SAVAGE, I. N. SHIMI
AMS 691852 DIVERCENCE PROPERTIES OF SOME MARTINCALE TRANSFORMS * BURCESS DAVIS

AMS 69 NO. 6 ASYMPTOTIC LINEARITY OF A RANK STATISTIC IN RECRESSION PARAMETER * JANA JURECKOVA

AMS 69 NO. 6 ON THE MATRIX RENEWAL FUNCTION FOR MARKOV RENEWAL PROCESSES * J, KEILSON

AMS 69 NO.6 ON THE PROBABILITY OF LARCE DEVIATIONS AND EXACT SLOPES * CERALD L. SIEVERS

AMS 69 NO. 6 INEQUALITIES OF CHEBYSHEV TYPE INVOLVINC CONDITIONAL EXPECTATIONS * C. L. MALLOWS. DONALD RICHTER

AMS 69 NO. 6 CONTRIBUTIONS TO THE K-SAMPLE PROBLEM, A SYMMETRIC STATISTIC * M. SCHULZER

AMS 69 NO. 6 ASYMPTOTIC BEHAVIOR OF WILCOXON TYPE CONFIDENCE RECIONS IN MULTIPLE LINEAR RECRESSION * HIRA LAL KOUL

AMS 69 NO. 6 THE MARKOV INEQUALITY FOR SUMS OF INDEPENDENT RANDOM VARTABLES * S. M. SAMUELS

AMS 69 NO.6 THE LAW OF THE ITERATED LOCARITHM FOR MIXINC STOCHASTIC PROCESSES * WALTER PHILIPP

AMS 69 NO. 6 ASYMPTOTIC NORMALITY OF SIMPLE LINEAR RANK STATISTICS UNDER ALTERNATIVES, II * VACLAV DUPAC, JAROSLAV HAJEK

AMS 69 NO. 6 ON BARTLETT'S TEST AND LEHMANN 'S TEST FOR HOMOCENEITY OF VARIANCES * NARIAKI SUG IURA, HISAO NACAO

AMS 69 NO. 6 ON THE DISTRIBUTIONS OF THE RATIOS OF THE ROOTS OF A COVARIANCE MATRIX AND WILKS ' CRITERION FOR TESTS OF THREE HYPOTHESES * K. C. S. PILLAI, S. AL-ANI, G. M. JOURIS

AMS 69 NO. 6 ASYMPTOTIC NORMALITY OF LINEAR COMBINATIONS OF FUNCTIONS OF ORDER STATISTICS * GALENR. SHORACK

AMS 69 NO. 6 ASYMPTOTIC EXPANSIONS OF THE DISTRIBUTIONS OF THE LIKELIHOOD RATIO CRITERIA FOR COVARIANCE MATRIX * NARIAKI SUGIURA

AMS 69 NO. 6 CONSISTENT ESTIMATES OF THE PARAMETERS OF A LINEAR SYSTEM * WILLIAM N. ANDERSON JR, GEORCE B. KLEINDORFER, PAULR. KLEINDORFER, MICHAEL B. WOODROOFE

AMS 69 NO.6 JACKKNIFING U-STATISTICS * JAMES N. ARVESEN

AMS 69 NO. 6 RANK ORDER TESTS FÓR MULTIVARIATE PAIRED COMPARISONS * HaROLD D. SHANE, MADAN L. PURI

AMS 69 NO. 6 WEAK QUALITATIVE PROBABILITY ON FINITE SETS * PETER C. FISHBURN

AMS 69 NO. 6 BAYESIAN MODEL OF DECISION-MAKING AS A RESULT OF LEARNING FROM EXPERIENCE * BRUNO O. SHUBERT

AMS 69 NO. 6 THE RELATION OF THE EQUIVALENCE CONDITIONS FOR THE BROWNIAN MOTION TO THE EQUIVALENCE CONDITIONS FOR CERTA IN STATIONARY PROCESSES * BENNETT EISENBERG

AMS 69 NO.6 OPTIMUM ESTIMATORS FOR LINEAR FUNCTIONS OF LOCATION AND SCALE PARAMETERS * NANCY R. MANN

AMS 69 NO.6 ON THE OPT IMUM RATE OF TRANSMITTING INFORMATION * $\mathrm{J}$ H. B. KEMPERMAN

AMS 69 NO. 6 ON EXTENDED RATE OF CONVERGENCE RESULTS FOR THE INVARIANCE PRINCIPLE * C. C. HEYDE

AMS 69 NO. 6 A BOUND FOR THE VARIATION OF GAUSSIAN DENSITIES * KULLBACK

AMS 69 NO. 6 SUFFICIENT CONDITION FOR THE MIXTURE OF EXPONENTIALS TO BE A PROBABILITY DENSITY FUNCTION * D. J. BARTHOLOMEW

AMS 69 NO. 6 EXPRESSION OF VARIANCE-COMPONENT ESTIMATORS AS LINEAR COMBINATIONS OF INDEPENDENT NONCENTRAL CHISQUARE VARIATES * DAVID A. HARVILLE

AMS 69 NO. 6 ON THE RATE OF CONVERCENCE FOR THE LAW OF LARGE NUMBERS * TERRY J. WACNER

AMS 69 NO. 6 A COMPARISON OF THE ASYMPTOTIC EXPECTED SAMPLE SIZES OF TWO SEQUENTIAL PROCEDURES FOR RANKING PROBLEM * S. K. PERNG

AMS 69 NO.6 THE GROWTH OF A RANDOM WALK * CHARLES J. STONE

AMS 69 NO. 6 A NOTE ON EXCHANCEABLE PROCESSES WITH STATES OF FINITE RANK * S. W. DHARMADHIKARI

AMS 69 NO. 6 A TEST FOR SYMMETRY USING THE SAMPLE DISTRIBUTION FUNCTION * CALVIN C BUTLER

AMS 69 NO. 6 A NOTE ON THRIFTY STRATEGIES AND MARTINGALES IN A FINITELY ADDITIVE SETT ING WILLIAMD. SUDDERTH * WILLIAM D. SUDDERTH 
BI0CS65

BI0CS65

BI0CS65

BIOCS65

BI0CS65

BIOCS65

BI0CS65

BI0CS65

BIOCS65

BI0CS65

BIOCS65

BI0CS65

BIOCS65

BIOCS65

BIOCS65

BIOCS65

BIOCS65

BI0CS65

BIOCS65

BI 0CS65

BIOCS65

BIOCS65

BIOCS65

BI0C\$65

BIOCS65

BIOCS65

BI0CS65

BI0CS65

BI0CS65

BI0CS65

BI0CS65

BIOGS65

BIOCS65

BI0CS65

BI0C\$65

BI0CS65

BIOCS65
1 THE STUDY OF POPULATION CROWTH IN ORCANISMS CROUPED BY STACES * L.P. LEFKOVITCH

19 THE ROBUSTNESS OF HOMOGENEITY TESTS IN 2 BY N TABLES * R. C. LEWONTIN, J. FELSENSTEIN

34 FITTING OF SOME CONTAGIOUS DISTRIBUTIONS TO SOME AVAILABLE DATA BY THE MAXIMUM LIKELIHOOD METHOD (CORR. 65514$) *$ D. C. MARTIN, S. K. KATTI

49 BIOLOGICAL EXAMPLES OF SMALL EXPECTED FREQUENCIES * S. K. KATTI, A. N. SASTRY

55 SAMPLINC ERRORS IN AN ORCHARD SURVEY INVOLVINC UNEQUAL NUMBERS OF ORCHARDS OF DISTINCT TYPE* D. A HOLLAND

63 EXAMINATION OF A REPEAT MATING DESIGN FOR ESTIMATINC ENVIRONMENTAL AND GENET IC TRENDS * F. GIESBRECHT , 0 KEMPTHORNE

B6 COMBINATION OF RESULTS FROM SEVERAL 2 BY 2 CONTINGENCY TABLES * S. RADHA KR ISHNA

99 MORTALITY PATTERNS IN EIGHT STRAINS OF FLOUR BEETLE * D. B. MERTZ, T. PARK, W. J. YOUDEN

115 ANALYSIS OF VARIANCE OF DISPROPORTIONATE DATA WHEN INTERACTION IS PRESENT * D. G. GOSSLEE, H. L. LUCAS

134 STOCHASTIC PHAGE ATTACHMENT TO BACTERIA * J. GANI

140 A SIMPLE METHOD OF ESTIMATINC RELATIVE POTENCY FROM TWO PARABOLAS * R. C. ELSTON

150 A SCREENING SYSTEM FOR ANTI-CANCER AGENTS BASED ON THE THERAPEUT IC INDEX * N. BROCK, B. SCHNEIDER

159 UNUSUAL FREQUENCY DISTR IBUTIONS * D. J. NEWELL

169 A TWO-STACE MODEL FOR SELECTING ONE OR TWO TREATMENTS * T. COLTON

IBI AN ALTERNATIVE SYSTEM FOR THE CLASSIFICATION OF MATHEMATICAL MODELS FOR QUANTAL RESPONSES TO MIXTURES OF DRUGS IN BIOLOCICAL ASSAY * J.R. ASHFORD, C. S. SMITH

FACTOR ANALYSIS, AN INTRODUCTION TO ESSENTIALS. THE PURPOSE AND UNDERLY ING MODELS * R. B. CATTELL

216 NOTES. THE ANALYSIS OF A DIALLEL CROSSING EXPERIMENT WITH CERTA IN CROSSES MISSING *P. ROBINSON

219 NOTES.TABLES OF PEARSON-LEE-FISHER FUNCTIONS OF SINGLY TRUNCATED NORMAL DISTRIBUTIONS * A. L CICCHINELLI

226 NOTES.ORTHOGONAL POLYNOMIALS FOR UNEQUALLY WEIGHED MEANS * P. L. EMERSON

231 NOTES. CONFIDENCE LIMITS FOR A RATIO USING WILCOXON'S SIGNED RANK TEST * B. M. BENNETT

235 NOTES. ON ESTIMATING THE ARITHMETIC MEANS OF LOGNORMALLY-DISTR IBUTED POPULATIONS * P. D. OLDHAM

265 CORRECTION TO 'COEFFICIENTS OF VARIATION OF HERITABILITY ESTIMATES OBTAINED FROM VARIANCE ANALYSES' * THOMAS P. BOGYO

291 ON THE CONSTRUCTION OF AN INDEX FOR INDIRECT SELECTION * F. E. BINET

300 REGRESSION ANALYSIS WITH DEPENDENT VARIABLE CENSORED * M. glasser

308 TWO-WAY ANALYSIS OF VARIANCE FOR THE MIXED MODEL WITH DISPROPORTIONATE SUBCLASS FREQUENCIES * P. MIELKE, R. B. MCHUGH

324 COMPOSITE DESIGNS BASED ON IRREGULAR FRACTIONS OF FACTORIALS (CORR, 651036$) * W$. J. WESTLAKE

337 ON INFERRING ORDER RELATIONS IN ANALYSIS OF VARIANCE * E. PERITZ

345 L'ETUDE DES COMMUNAUTES VEGETALES PAR L'ANALYSE STATISTIQUE DES LIAISONS ENTRE LES ESPECES ET LES VARIABLES ECOLOGIQUES, PRINCIPES FONDAMENTAUX * $\mathrm{P}$. DAGNELIE

2 A METHOD FOR CLUSTER ANALYSIS * A. W. F. EDWARDS, L. L. CAVALLI-SFORZA

376 AN APPROXIMATE METHOD OF ANALYSIS FOR A TWO-WAY LAYOUT * A. M. MATHAI

386 THE ADEQUACY OF THE DIFFUSION APPROXIMATION TO CERTAIN DISTR IBUT IONS IN GENETICS * W. J . EWENS

395 FURTHER EVIDENCE ON THE CONSISTENCY OF ESTIMATES OF VAR IANCE COMPONENTS * W. A. GOMPTON, G. 0. GARDNER. J. H. LONNQUIST

405 FACTOR ANALYSIS, AN INTRODUCTION TO ESSENTIALS. 2. THE ROLE OF FACTOR ANALYSIS IN RESEARCH * RAYMOND B. CATTELL

THE EXPECTED MEAN SQUARES IN GENETIC EXPER IMENTS WHEN ONLY ONE PARENT IS IDENTIFIED * B. B. BOHREN, H. E MCKEAN, G. W. FRIARS

EXPECTED EFFECTS ON THE INBREEDING COEFFICIENT AND RATE OF GENE LOSS OF FOUR METHODS OF REPRODUCING FINITE DIPLOID POPULATIONS * P. ROBINSON, D. F. BRAY

459 LISTING EXPECTED MEAN SQUARE COMPONENTS * M. LENTNER

467 THE TWO-PERIOD CHANGE-OVER DESIGN AND ITS USE IN CLINICAL TRA ILS * J. E. GRIZZLE
BI0CS65 481 A MODEL FOR THE SPREAD OF EPIDEMICS BY CARRIERS * G. H WEISS

BIOCS65 491 HARMONIC ANALYSIS OF THE HUMAN FACE * K. H. LU

BIOCS65 506 NOTE. A METHOD OF FITTING A NON-LINEAR CURVE CONTAININC A SINCLE NON-LINEAR ITY * B. SHAH

BIOCS65 529 THE ESTIMATION OF MORTALITY AND RECRUITMENT FROM A SINGLE TAGGINC EXPERIMENT * D. G. CHAPMAN

BIOCS65 543 THE DISTRIBUTION OF ORGANISMS * G.S. WATSON

BIOCS65 551 MATHEMATICAL REPRESENTATION OF THE BIOLOCICAL AND PHYSICAL DECAY OF CHAMBER AEROSOLS * T. W. HORNER

BIOCS65 562 A STOCHASTIC MODEL FOR DISTRIBUTIONS OF BIOLOGICAL RESPONCE TIMES * G. SHORTLEY

BIOCS65 583 SOME STOCHASTIC MODELS RELATINC TIME AND DOSACE IN RESPONSE CURVES * J.J. CART

BIOCS65 600 THE ESTIMATION OF CONCENTRATION OF VIRUSES AND BACTERIA FROM DILUTION COUNTS * E. A. ROBERTS, G. G. COOTE

BIOCS65 616 ON COMBINING THE RESULTS FROM CLINICAL TRIALS OF A VACCINE * J.P.R. TOOTILL

BIOCS65 623 THE EFFICIENCY OF MATCHED SAMPLES * W. Z. BILLEWICZ

BIOCS65 645 THE IDENTIFICATION OF ANNUAL PEAK PERIODS FOR A DISEASE * H. A. DAVID, D. J . NEWELL

BIOCS65 651 PAIRED COMPARISON MODELS WITH TESTS FOR INTERACTION * J. C. OCILVIE

BIOCS65 665 A GENERALIZATION OF THE INBREEDING COEFFICIENT * $M$ SHIKATA

BIOCS65 682 THE VALUE OF INDIRECT SELECTION, 1. MASS SELECTION * S. R. SEARLE

BIOCS65 70B GENERALIZATION AND REPARAMETERIZATION OF SOME SIGMOID OR OTHER NONLINEAR FUNCTIONS * L. R. CROSENBAUCH

BIOCS65 715 FITTINC A STRAIGHT LINE TO DATA FROM A TRUNCATED POPULATION * P. HOLGATE

BIOCS65 721 A GENERALISED LOGIT-NORMAL DISTRIBUTION * R. MEAD

BIOCS65 733 APPROXIMATE CONFIDENCE LIMITS FOR THE COEFFICIENT OF VARIATION IN CAMMA DISTRIBUTIONS * H. LINHART

BIOCS65 739 THE CORRELATION BETWEEN FEED EFFICIENCY AND RATE OF GAIN, A RATIO AND ITS DENOMINATOR * T.M. SUTHERLAND

BIOCS65 750 QUERY + (ON FORMULA FOR DETERMINING THE INCIDENCE OF MUTANT GENES) * A. C. NELSON, C. A. B. SMITH

BIOCS65 752 NOTES. ESTIMATION AFTER PRELIMINARY TESTING IN ANOVA MODEL I* S. R. SRIVASTAVA, V, P. GUPTA

BIOCS65 785 THE MEANING OF BIOASSAY * D. J. FINNEY

BIOCS65 799 SOME FURTHER APPLICATIONS OF NON-PARAMETRIC METHODS INDILUTION (-DIRECT) ASSAYS *P. K. SEN

BIOCS65 BII AN ANALYSIS OF QUANTAL RESPONSE DATA IN WHICH THE MEASUREMENT OF RESPONSE IS SUBJECT TO ERROR * J. R. ASHFORD, C. S. SMITH

BIOCS65 B26 ESTIMATION OF EXPONENTIAL SURVIVAL PROBABILITIES WITH CONCOMITANT INFORMATION * P. FEICL, M. ZELEN

BIOCS65 839 EMPERICAL RELATIONSHIP OF LUNG CANCER INCIDENCE TO CIGARETTE SMOKING AND A STOCHASTIC MODEL FOR THE MODE OF ACTION OF CARCINOGENS * H. J. A. KREYBERG

BIOCS65 858 SPEARMAN ESTIMATION FOR A SIMPLE EXPONENTIAL MODEL * R. G. CORNELL

BIOCS65 865 GROUP SCREENING UTILIZING BALANCED AND PARTIALLY BALANCED INCOMPLETE BLOCK DESIGNS * C. E. REDMAN, E P. KING

BIOCS65 875 A MODEL FOR CHEM ICAL MUTAGENESIS IN BACTER IOPHAGE * A W. KIMBALL

BIOCS65 890 L'ETUDE DES COMMUNAUTES VECETALES PAR L'ANALYSE STATISTIQUE DES LIAISONS ENTRE LES ESPECES ET LES VARIABLES ECOLOGIQUES, UN EXEMPLE * P. DAGNELIE

BIOCS65 908 THE CONCEPT OF RANDOMNESS IN THE PATTERNS OF MOSAICS * E. C. PIELOU

BIOCS65 921 ESTIMATES OF MORALITY AND POPULATION FROM SURVEYREMOVAL RECORDS * D. G. CHAPMAN, G. I. MURPHY

BIOCS65 936 A NONPARAMETRIC STATISTICAL METHOD FOR CULLING RECRUITS FROM A MARK-RECAPTURE EXPERIMENT * D. S. ROBSON, W. A. FLICK

BIOCS65 948 ON THE CONSTRUCTION AND ANALYSIS OF SOME CONFOUNDED ASYMMETRICAL FACTORIAL DESIGNS * M. C. SARDANA, $M$. N. DAS

BIOCS65 957 MULTIPLE COVARIATE ANALYSIS (CORR. 66 962) * S. K. KATTI

BIOCS65 975 ANALYSIS OF COMPETITION EXPERIMENTS * C. A. MCGILCHRIST

BIOGS65986 AN EXACT PROBABILITY DISTRIBUTION OVER SAMPLE SPACES OF PAIRED COMPARISONS * B. J. TRAWINSKI

BIOCS65 1001 ESTIMATES OF HERITABILITY FROM TRANSFORMED PERCENTACE SIB DATA WITH UNEQUAL SUBCLASS NUMBERS * T. P BOGYO. W. A. BECKER

BIOCS65 1008 NOTES. A NOTE ON COCHRAN'S Q TEST * J. L. FLEISS

BIOCS65 1011 NOTES. GOMPUTINC A DISCRIMINANT FUNCTION FROM WITHINSAMPLE DISPERSIONS*M. J.R. HEALY

BIOCS65 1012 NOTES. FURTHER ANALYSIS OF R. A. FISHER'S ENUMERATIONS IN CENETICS * H. O. FOULKES 
BIOCS66 I SOME ROW AND COLUMN DESICNS FOR TWO SETS OF TREATMENTS * D. A. PREECE

BIOCS66 26 MULTIPLE REGRESSION COMBININC WITHIN- AND BETWEENPLOT INFORMATION* D. B. DUNCAN, M. WALSER

BIOCS66 44 INTERRELATIONS AMONC CENERALIZED DISTRIBUTIONS AND THEIR COMPONENTS * S. K. KATTI

BIOCS66 53 A QUANTITATIVE DISCUSSION OF THE EFFECTIVENESS OF VOIDING AS A DEFENCE AGAINST BLADDER INFECTION * $\mathrm{J}$ R. BOEN, D, SYLWESTER

BIOCS66 BIOCS66

BIOCS66

8I0CS66

BIOCS66

BI0CS66

BI0CS66

BI0C566

BI0CS66

BI0CS66

BI0CS66

BIOCS66

BI0CS66

BIOCS66

BI0C\$66

BI0CS66

BIOCS66

BI0CS66

BI0CS66

BI0CS66

58 THE CHICK ASSAY OF LYSINE * R. C. CAMPBELL

74 A GENERAL USE OF THE POISSON APPROXIMATION FOR BINOMIAL EVENTS, WITH APPLICATION TO BACTERIAL ENDOCARDITIS DATA * H. B. EISENBERC, R. R. M. CEOCHAGEN, J. E. WALSH

83 MODELS FOR COMPLEX CONTINGENCY TABLES AND POLYCHOTOMOUS DOSAGE RESPONSE CURVES * N. MANTEL

96 GROWTH-INVARIANT DISCRIMINANT FUNCTIONS AND GENERALIZEDDISTANCES * T.P. BURNABY

111 ON THE PROBLEM OF SELF-INCOMPATABILITY ALLELES * 0 MAYO

121 EQUILIBRIA UNDER SELECTION FOR K ALLELES * G. M. TALLIS

28 INVERSE POLYNOMIALS, A USEFUL GROUP OF MULTI-FACTOR RESPONSE FUNCTIONS * J. A. NELDER

42 A SUGGESTED METHOD OF ANALYSIS OF A CERTAIN CLASS OF EXPERIMENTS IN CARCINOGENESIS * M. C. PIKE

162 ON GROWTH PARAMETER ESTIMATION FOR EARLY LIFE STAGES * R. H. RIFFENBURGH

179 NOTES. APPROXIMATIONS TO THE CRITICAL VALUES FOR DUNCAN'S MULTIPLE RANGE TEST * $F$. GEBHARDT

182 NOTES. CORRECTED CORRELATION COEFFICIENTS WHEN OBSERVATION ON ONE VARIABLE IS RESTRICTED * N. MANTEL

1BT THE SAMPLING VARIANCE OF THE CORRELATION COEFFICIENTS ESTIMATED IN GENETIC EXPER IMENTS * E. SCEINBERG

192 OBITUARY, FRANK WILCOXON

195 APPRECIATION, OTTOKAR HEINISCH (7OTH BIRTHDAY, 23RD APRIL, 1966)

33 COMPUTERS, THE SECOND REVOLUTION IN STATISTICS (THE FIRST FISHER MEMORIAL LECTURE) * F. YATES

52. LINEAR RELATIONSHIPS BETWEEN VARIABLES AFFECTED BY ERRORS * F. D. CARLSON, E. SOBEL, C. S. WATSON

$26 B$ ELIMINATION OF VARIATES IN LINEAR DISCRIMINATION PROBLEMS * J, M. WEINER, O J J DUNN

276 FITTING CURVES TO LONGITUDINAL DATA * N. E. DAY

292 DESIGNS FOR SEQUENCES OF TREATMENTS WITH CARRY-OVER EFFECTS * G. F. ATKINSON RATES, OCCURRENCES PER PERSON YEAR OF EXPOSURE * $M$.

BIOCS66 322 PLANNING A QUANTAL ASSAY OF POTENCY * B. W. BROWN JR

BIOCS66 330 A TEST FOR EQUAL CATCHABILITY * R. M. CORMACK

BIOCS66 343 L'ANALYSE EN COMPOSANTES PRINCIPALES, SON UTILISATION EN GENETIQUE ET SES RAPPORTS AVEC L'ANALYSE DISCR IMINATOIRE * R. ROUVIER

BIOCS66 358 STEREOSCOPIC MODELS OF MULTIVARIATE STATISTICAL DATA * A. R. FRASER, M. KOVATS

BIOCS66 36B BALANCED INCOMPLETE BLOCK DESIGNS WITH DOUBLE GROUPING OF BLOCKS INTO REPLICATIONS * J . ROBINSON

BIOCS66 374 ESTIMATION OF CROP YIELDS FOR SMALL AREAS * V. P PANSE, M. RAJAGOPALAN, S. S. PILLAI

BIOCS66 3B5 SAMPLING TECHNIQUES FOR ESTIMATION OF INCIDENCE OF RED SPIDER MITE ON TEA CROP IN NORTH-EAST INDIA * A $R$, SEN, R, P . CHAKRABARTY, A, R, SARKAR

BIOCS66 404 NOTES. F-RATIO PROBABILITIES FROM BINOMIAL TABLES * N. MANTEL

BIOCS66 407 NOTES. A DEFICIENCY IN THE SUMMATION OF CHI PROCEDURE * B. PASTERNACK, N. MANTEL

BIOCS66 409 NOTES. A MIGRATION MODEL * G. M. TALLIS

BIOCS66 413 OBITUARY, O. HEINISCH

BIOCS66 439 ANALYSIS AND INTERPRETATION OF THE VARIETY CROSS DIALLEL AND RELATED POPULATIONS * C . 0. GARDNER, S. A EBERHART

BIOCS66 453 EFFECTS OF PARTIAL ISOLATION (DISTANCE), MIGRATION, AND DIFFERENT FITNESS REQUIREMENTS AMONG ENVIRONMENTAL POCKETS UPON STEADY STATE GENE FREQUENCIES * W. D. HANSON

BIOMETRICS

VOLUME 23, 1967

BIOCS66 469 VECTORIAL ANALYSIS FOR CENETIC CLINES IN BODY DIMENSIONS IN POPULATIONS OF 'DROSOPHILIA SUBOBSCURA' COLL. AND A COMPARISON WITH THOSE OF 'D. ROBUSTA' STURT * R. K. MISRA

BIOCS66 488 STATISTICAL ANALYSIS OF INTROCRESSION * C. NAMKOONC

BIOCS66 503 A CENERAL COMPUTER PROGRAMME FOR THE ANALYSIS OF FACTORIAL EXPERIMENTS * F. YATES, A. J . B. ANDERSON

BIOCS66 525 ANALYSIS OF MULTIFACTOR CLASS IFICATIONS WITH UNEQUAL NUMBERS OF OBSERVATIONS * W. T . FEDERER, M. ZELEN

BIOCS66 553 VARIANCES OF ESTIMATES OF VARIANCE COMPONENTS IN A THREE-WAY CLASSIFICATION * W. R. BLISCHKE

BIOCS66 566 A NOTE ON CERTAIN DISCRETE MIXED DISTRIBUTIONS * A. C COHEN JR

BIOCS66 573 FITTINC THE RECTANCULAR HYPERBOLA * C. I. BLISS, A. T. JAMES

BIOCS66 603 ON THE DETERMINATION OF CONFIDENCE LIMITS OF AN INDEX * S. D. DUBEY

BIOCS66 610 CRAPHICAL PROCEDURES FOR USING DISTRIBUTION-FREE METHODS IN THE ESTIMATION OF RELATIVE POTENCY IN DILUTION (-DIRECT) ASSAYS * C . R. SHORACK

BIOCS66 620 NOTES. MAXIMUM LIKELIHOOD ESTIMATION FOR THE TRUNCATED POISSON * F. A. HAIGHT, G. R. FISCHER

BIOCS66 623 NOTES. ON THE EVALUATION OF VARIABILITY IN ISOCENIC HYBRIDS * M. B. JONES

BIOCS66 629 NOTES. APPLICATIONS OF NONORTHOGONAL DESIGNS TO SITUATIONS WHERE TREATMENTS OR BLOCKS ARE OF UNEQUAL STATUS OR SIZE* N. A. GOODCHILD

BIOCS66 632 NOTES. ERRORS OF TREATMENT COMPARISONS WHEN OBSERVATIONS ARE MISSING FROM A RANDOMISED BLOCK EXPER IMENT WITH ADDITIONAL REPLICATION OF A CONTROL TREATMENT * D. A. WILLIAMS

BIOCS66 634 OBITUARY, C. G. FRAGA, JR

BIOCS66 665 USE OF CONCOMITANT VARIABLES AND INCOMPLETE SURVIVAL INFORMATION IN THE ESTIMATION OF AN EXPONENTIAL SURVIVAL PARAMETER * C. ZIPPEN, P. ARMITACE

8IOCS66 673 ESTIMATION PAR LA METHODE DU MAXIMUM DE VRAISEMBLANCE DES COURBES DE SURVIE DE MICROORGANISMES IRRADIES * J. LELLOUCH, A. WAMBERSIE

BIOCS66 6B4 COMPARATIVE SAMPLINC ACCEPTANCE SCHEMES IN TESTING ANTIGENICITY OF VACCINES * J. P. R. TOOTILL, C. N HEBERT, A. ADAMS

BIOCS66 706 INCOMPLETE BLOCK DESIGNS FOR BIO-ASSAYS * M. N. DAS, G. A. KULKARNI

BIOCS66 730 SEQUENTIAL COMBINATION CHEMOTHERAPY EXPERIMENTS * $S$. ADDELMAN, D. W. GAYLOR, R. E. BOHRER

BIOCS66 747 SOME CONSIDERATIONS IN MULTIVARIATE ALLOMETRY * J. W HOPKINS

BIOCS66 761 ANALYSIS OF EFFECTS OF ANTIBIOTICS ON BACTERIA BY MEANS OF STOCHASTIC MODELS * S. NISSEN-MEYER

BIOCS66 781 CORRELATIONS BETWEEN SIMILAR SETS OF MEASUREMENTS * M. H. DEGROOT, C. C. LI

BIOCS66 791 A PATH-PROBABILITY APPROACH TO IRREVERSIBLE MARKOV CHAINS WITH AN APPLICATION IN STUDYING THE DENTAL CARIES PROCESS * K. H. LU

BIOCS66 810 APPLICATION OF MULTIVARIATE ANALYSIS OF VARIANCE TO REPEATED MEASUREMENTS EXPERIMENTS * J.W. L. COLE, J. E. GRIZZLE

BIOCS66 829 ANALYTICAL TECHNIQUE FOR INCOMPLETE BLOCK EXPERIMENTS * E.P. CUNNINCHAM, C. R. HENDERSONN

BIOCS66 843 THE EFFECT OF FIELD BLOCKING ON GAIN FROM SELECTION * W. M. SCHUTZ, C. C. COCKERHAM

BIOCS66 864 A GENERAL MODEL FOR GENETIC EFFECTS * S. A. EBERHART, C. O. GARDNER

BIOCS66 882 A NEW SIMILARITY INDEX BASED ON PROBABILITY * D. W GOODALL

BIOCS66 90B PROBABILITIES OF CORRECT CLASSIFICATION INDISCRIMINANT ANALYSIS * O. J. DUNN, P.D. VARADY

BIOCS66 925 CONTRIBUTIONS TO THE MATHEMATICS OF ANIMAL TRAPPING * P. HOLGATE

BIOCS66 937 NOTE. THE QUASI-F TEST FOR AN UNNESTED FIXED FACTOR IN AN UNBALANCED HIERARCHAL DESIGN WITH A MIXED MODEL * E. J. EISSEN

BIOCS67 KARAS, I. R. SAVAGE

BIOCS67 11 SOME EXPERIMENTAL SAMPLING RESULTS FOR REGRESSION ANALYSIS APPLIED TO GAMMA RAY SPECTROMETER DATA, 1 * B. S. PASTERNACK, A. LIUZZI

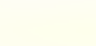

BIOCS67

BIOCS67
27 A COMPARISON OF TWO APPROACHES TO THE CONSTRUCTION OF MODELS FOR QUANTAL RESPONSES TO MIXTURES OF DRUGS * R. L. PLACKETT, P. S. HEWLETT

45 ADDITIVE COMBINING ABILITIES FITTED TO PLANT BREED ING DATA * N. GILBERT

51 A COMPARISON OF TWO LIFE TABLE METHODS * J. W. KUZMA 
BI0CS67

65 RANKINC PROCEDURES FUR ARBITRARILY RESTRICTED OBSERVATION * N. MANTEL

BIOCS67 79 ON THE USE OF THE CENERALIZED EXTREME-VALUE DISTRIBUTION IN ESTIMATINC EXTREME PERCENTILES * $\mathrm{J}$. S MARITZ, A. H. MUNRO

BIOCS67 105 EXPECTATIONS, VARIANCES AND COVARIANCES OF 'ANOVA' MEAN SQUARES BY 'SYNTHESIS' * $\mathrm{H}, 0$. HARTLEY

BIOCS67 115 A SIMPLE METHOD OF RESOLUTION OF A DISTRIBUTION INTO CAUSSIAN COMPONENTS * C. C. BHATTACHARYA

BIOCS67 137 STATISTICAL TESTINC OF DIFFERENCES IN CASUAL BEHAVIOUR OF TWO MORPHOLOCICALLY INDIST INCUISHABLE OBJECTS * V. YU. URBAKH

BIOCS67 145 LES MANQUANTS DANS L'ESSAI THERAPEUTIQUE * D. SCHWARTZ, J. LELLOUCH

BIOCS67 153 NOTES. EQUIVALENCE OF TWO METHODS OF COMPUTING DISCRIMINANT FUNCTION COEFFICIENTS * E. M. CRAMER

BIOCS67 154 NOTES. EQUIVALENCE OF MAXIMUM LIKELIHOOD AND THE METHOD OF MOMENTS IN PROBIT ANALYSIS * N. MANTEL, $S$. W. GREENHOUSE

BIOCS67 158 NOTES. ON THE DILUTION ERRORS INVOLVED IN ESTIMATING BACTERIAL NUMBERS BY THE PLATING METHOD * A.J. HEDGES

BIOCS67 189 A MATHEMATICAL MODEL FOR THE ESTIMATION OF INTERPLANT COMPETITION (CORRECTION TO REFERENCE 68 1025) * R. MEAD

BIOCS67 207 SOME DEVELOPEMENTS IN 'DISTANCE SAMPLING' * L. L EBERHARDT

BIOCS67 217 A PROBABILITY STRUCTURE FOR GROWTH CURVES * G. F. KRAUSE, P. B. SIEGEL, D. C. HURST

BIOCS67 227 A NEW RESPONSE TIME DISTRIBUTION * D. KODLIN

BIOCS67 241 ON A CONTAGIOUS DISTRIBUTION SUGGESTED FOR ACCIDENT DATA * C. D. KEMP

BIOCS67 257 USE OF PRIOR INFORMATION TO DESIGN A ROUT INE PARALLEL LINE ASSAY* J. R. BOEN, B. W. BROWN JR

BIOCS67 269 GRAPHICALLY ORIENTED TESTS FOR HOST VARIABILITY IN DILUTION EXPERIMENTS * J. J. GART, G. H. WEISS

BIOCS67 285 THE EFFECTIVE USE OF BOTH POSITIVE AND NEGATIVE CONTROLS IN SCREENING EXPERIMENTS * A. J. GROSS, N. MANTEL

BIOCS67 297 THE VALUE OF ORTHOG ONAL POLYNOMIALS IN THE ANALYSIS OF CHANGE-OVER TRIALS WITHDAIRY COWS * J. TAYLOR

BIOCS67 313 A GENERAL MAXIMUM LI KELIHOOD DISCRIMINANT * N. E. DAY, D. F. KERRIDGE

BIOCS67 325 SIMULTANEOUS SELFING AND PARTIAL DIALLEL TEST CROSSING 2. AN EVALUATION OF TWO METHODS OF ESTIMATION OF GENETIC AND ENVIRONMENTAL VARIANCE * A. H. NASOETION, C. C. COCKERHAM, D. F. MATZINGER

BIOCS67 335 INFERENCE FOR SOME INCOMPLETELY SPECIFIED MODELS INVOLVING NORMAL APPROXIMATIONS TO DISCRETE DATA * B. K. KALE, T. A. BANCROFT

BIOCS67 349 NOTES. SMALL SAMPLE CONSIDERATIONS IN COMBININC 2 BY 2 TABLES *A,F. NAYLOR

BIOCS67 356 NOTES. ON ESTIMAT ING RECESSIVE FREQUENCIES FROM TRUNCATED SAMPLES * A. BERGER, R. Z . GOLD

BIOCS67 361 NOTES. OPTIMUM EXPERIMENTAL DESIGNS FOR REALIZED HERITABILITY EST IMATES * M. SOLLER, A. GENIZI

BIOCS67 366 OBITUARY, SULLY LEDERMANN

BIOCS67 397 GENETIC EQUILIBRIUM UNDER SELECTION (INVITED PAPER ) * C. C. LI

BIOCS67 4B5 MATRIX AND MULTIPLE DECREMENT IN POPULATION ANALYSIS * N. KEYFITZ, E. M. MURPHY

BIOCS67 505 A MATHEMATICAL MODEL RELATINC PLANT YIELD WITH ARRANGEMENT FOR REGULARLY SPACED CROPS * G. BERRY

BIOCS67 517 A GENERAL CLASS OF ENUMERATIONS ARISING IN GENETICS * J. H. BENNETT

BIOMETRICS

BIOCS6B I TEACHING BIOMETRY IN THE UNIVERSITY * D. J. FINNEY

BIOCS6B

13 AN ITERATIVE PROCEDURE FOR ESTIMATING FIXED EFFECTS AND VARIANCE COMPONENTS IN MIXED MODEL SITUATIONS * E. P. CUNNINCHAM, C. R. HENDERSON

BIOCS68 27 SOME ASPECTS OF THE STATISTICAL ANALYSIS OF THE 'MIXED MODEL ${ }^{\prime *}$ G. G. KOCH, P. K. SEN

BIOCS68 49 COVARIANCE ANALYSIS WITH UNEQUAL SUBCLASS NUMBERS. COMPONENT ESTIMATION IN CORRELATION STUDIES * M. CROSSMAN, G. A. E. GALL

BIOCS6B 61 A TWO-PERIOD DESIGN WITH T-SQUARE EXPERIMENTAL UNITS * L. N. BALAAM

BIOCS68 75 APPLICATION OF MINIMUM LOGIT CHI-SQUARE ESTIMATE TO A PROBLEM OF GRIZZLE WITH A NOTATION ON THE PROBLEM OF NO INTERACTION * J. BERKSON

BIOCS68 97 ON EXPECTATIONS OF SOME FUNCTIONS OF POISSON VARIATES * J. J. BARTKO, S. W. GREENHOUSE, C. S. PATLAK

BIOCS6B 103 A COMPARISON OF STATISTICAL TECHNIQUES IN THE DIFFERENTIAL DIAGNOSIS OF NONTOXIC GOITRE * J. A. ANDERSON, J, A. BOYLE
BIOCS67 539 A MULTIPLE COMPARISONS SIGN TEST, ALL PAIRS OF TREATMENTS * A. L. RHYNE, R. C. D. STEEL

BIOCS67 551 THE USE OF CORRELATED VARIABLES FOR PRELIMINARY CULLINC $* \mathrm{C} . \mathrm{H}$. BROWN

BIOCS67 563 THE USE OF NON-LINEAR RECRESSION METHODS FOR ANALYSINC SENSITIVITY AND QUANTAL RESPONSE DATA* R. $H$ MOORE, R. K. ZEICLER

BIOCS67 567 NOTES. ASSUMPTION-FREE ESTIMATORS USINC U STATISTICS AND A RELATIONSHIP TO THE JACKKNIFE METHOD. * N. MANTEL

BIOCS67 571 NOTES. THE SQUARE-SUMMING CHECK ON THE MAIN EFFECTS AND INTERACTIONS IN A 2 TO THE POWER N FACTORIAL EXPERIMENT AS CALCULATED BY YATES'S ALGORITHM * A. A RAYNER

BIOCS67 573 NOTES. CHECKS ON YATES 'S ALGORITHM * I. J , COOD

BIOCS67 574 NOTES. CYCLIC GENERATION OF ROBINSON'S BALANCED INCOMPLETE BLOCK DESIGNS * D. A. PREECE

BIOCS67 578 THE ANALYSIS OF CHANGEOVER DESIGNS WITH COMPLETE BALANCE FOR FIRST RESIDUAL EFFECTS * I. I. BERENBLUT

BIOCS67 581 FRENCH SUMMARIES OF PAPERS IN JUNE 1967 ISSUE

BIOCS67 623 A COMPARISON OF SOME METHODS OF CLUSTER ANALYSIS * J C. GOWER

BIOCS67 639 AN ALMOST UNBIASED METHOD OF OBTAINING CONFIDENCE IN TERVALS FOR THE PROBABILITY OF MISCLASSIFICATION IN DISCRIMINANT ANALYSIS * P. A. LACHENBRUCH

BIOCS67 647 THE DISTRIBUTION OF THE MATCHING COEFFICIENT * D. W GOODALL

BIOCS67 657 A TEST FOR RANDOM MINCLING OF THE PHASES OF A MOSAIC * E. C. PIELOU

BIOCS67 67I A STUDY OF THE VARIABILITY DUE TO COINCIDENT PASSACE IN AN ELECTRONIC BLOOD CELL COUNTER * M. MAZUMDAR, K. L. KUSSMAUL

BIOCS67 685 A RAPID TEST FOR THE POISSON DISTRIBUTION USING THE RANGE * J M. PETTIGREW, W. C MOHLER

BIOCS67 693 INDICES OF SYNCHRONY IN CELLULAR CULTURES * D. G. BURNETT-HALL, W.A. O'N. WAUCH

BIOCS67 717 ESTIMATION FOR A S IMPLE EXPONENTIAL MODEL * R. G. CORNELL, JANACE A. SPECKMAN

BIOCS67 739 ADAPTATION OF KARBER'S METHOD FOR ESTIMATING THE EXPONENT I AL PARAMETER FROM QUANTAL DATA, AND ITS RELATIONSHIP TO BIRTH, DEATH, AND BRANCHING PROCESSES * N. MANTEL

BIOCS67 747 ANALYSIS OF QUANTAL RESPONSE ASSAYS WITH DOSAGE ERRORS * K, M. PATWARY, K. D. C. HALEY

BIOCS67 761 THE USE OF CYCLIC BALANCED INCOMPLETE BLOCK DESICNS FOR DIRECTIONAL SEED ORCHARDS * G. H. FREEMAN

EIOCS67 779 SOME DESIGNS OF USE IN SEROLOCY *D. H. REES

BIOCS67 793 INCOMPLETE SPLIT PLOT DESIGNS * J. ROBINSON

BIOCS67 803 FOUR-WAY BALANCED DESIGNS BASED ON YOUDEN SQUARES WITH 5, 6, OR 7 TREATMENTS * G. M. CLARKE

BIOCS67 B13 CONSTRUCTION AND ANALYSIS OF SOME NEW SERIES OF CONFOUNDED ASYMMETRICAL FACTORIAL DESIGNS * M. N. DAS, P. S. RAO

BIOCS67 823 SOME TRANSFORMATIONS OF SCALE AND THE ESTIMATION OF GENETIC PARAMETERS FROM DAUGHTER-DAM REGRESSION * A. R. QUARTERMAIN, A. E. FREEMAN

BIOCS67 835 BACTERIAL EXTINCTION TIME AS AN EXTREME VALUE PHENOMENON* B. EPSTEIN

BIOCS67 840 QUERY, THE COMBINATION OF PROBABILITIES * H. O. LANCASTER

BIOCS6T 842 NOTES. EXPECTED SELECTION DIFFERENTIAL FOR POSITIVE DIRECTIONAL SELECTION ON NORMAL VARIABLES WITHIN SETS OF FINITE SUBPOPULATIONS * F, R. ALLAIRE

BIOCS67 B46 NOTES. SAMPLE SIZE FOR THE ESTIMATION OF MEANS OF NORMAL POPULATIONS * J. LIKES

BIOCS67 850 OBITUARY, GORDON M. L. HASKELL

VOLUME $24,196 \mathrm{~B}$

BIOCS6B 117 A COMPARISON OF CONTINUOUS DISTRIBUTIONS OF PARAMETERS OF EXPONENTIAL DECAY CURVES * R. G. ROSSING, $M$ B. DANFORD

BIOCS6B 135 LINE TRANSECT METHOD OF ESTIMATING CROUSE POPULATION DENSITIES * C. E. GATES, W. H. MARSHALL, D. P. OLSON

BIOCS68 147 THE MULTI-TYPE GALTON-WATSON PROCESS IN A GENETICAL CONTEXT* J.H. POLLARD

BIOCS68 159 TRUNCATED SEQUENTIAL DESIGNS FOR CLINICAL TRIALS BASED ON MARKOV CHAINS * S. C. CHOI

BIOCS68 169 SELECTION FOR AN OPTIMUM GROWTH CURVE * C. M. TALLIS

BIOCS68 179 NOTES. DISTRIBUTION AMONG RELATIVES OF GENOTYPES FOR TWINNING * CRACE WYSHAK

BIOCS6B 185 NOTES. ON ESTIMATING THE EQUILIBRIUM AND TRANSITION PROBABILITIES OF A FINITE-STATE MARKOV CHAIN FROM THE SAME DATA * J, E, COHEN

BIOCS68 187 EQUILIBRIUM UNDER SELECTION AT A MULTI-ALLELIC SEXLINKED LOCUS (ACKNOWLEDGEMENT GB 1025) *C. CANNINGS

EIOCS68 $1 B 9$ NOTES. A MEASURE OF 'OVERALL VARIABILITY' IN POPULATIONS * M.M. GOODMAN 
BIOCS6B 192 NOTES. A NOTE ON THE ANALYSIS OF CROWTH CURVES * M. HILLS

BIOCS6B 247 CANNIBALISM OF THE PUPAL STACE BY ADULT FLOUR BEETLES, AN EXPERIMENT AND A STOCHASTIC MODEL * D. B. MERTZ, R. B. DAVIES

BIOCS6B 277 DISTRIBUTIONS DE FREQUENCES, INTERPRETATION DU DETERMINISME GENET IQUE DES CARACTERES QUANTITATIFS ET RECHERCHE DE 'GENES MAJEURS' * P. MERAT

BIOCS6B 295 THE EFFECTIVENESS OF AD JUSTMENT BY SUBCLASSIF ICATION IN REMOVING BIAS IN OBSERVATIONAL STUDIES * W. C COCHRAN

BIOCS6B 315 ASYMPTOTIC POWER OF CHI SQUARE TESTS FOR LINEAR TRENDS IN PROPORTIONS * D. G. CHAPMAN, J. NAM

$8 I O C S 68329$ ON THE ANALYSIS OF CONTINCENCY TABLES WITH A QUANTITATIVE RESPONSE * V. P. BHAPKAR

BIOCS68 339 THE MATCHED PAIRS DESICN IN THE CASE OF ALL-OR-NONE RESPONSES * 0 . S. MIETTINEN

BIOCS68 353 SOME EXPERIMENTAL SAMPLING RESULTS FOR REGRESSION ANALYSIS APPLIED TO GAMA RAY SPECTROMETER DATA, 2 * B. S. PASTERNACK, A LIUZZI

BIOCS68 363 THE NECATIVE EXPONENTIAL WITH CUMULATIVE ERROR * M. B DANFORD, H. M. HUGHES

BIOCS6B 377 ESTIMATION OF PARAMETERS OF A TRUNCATED POISSONIAN BINOMIAL * G. WYSHAK, C. WHITE

8IOCS68 3B9 ANALYSIS OF A GROUP OF BALANCED BLOCK EXPERIMENTS HAVING ERROR VARIANCE AND SOME TREATMENTS IN COMMON * B AFONJA

BIOCS68 401 ADJOINT MATRICES FOR POLYNOMIAL RECRESSION (CORRECTTONS 6B 1025) * D.R. CAUSTON

BIOCS68 413 A TABLE FOR COMPUTING WORKING ANGLES * C. I. BLISS, S S. WHITMAN

BIOCS68 423 NOTES. ON TESTING SIGNIFICANCE OF COMPONENTS OF VARIANCE IN THE UNBALANCED NESTED ANALYSIS OF VARIANCE (CORRECTION 681025 ) * C. L. TIET JEN, R, H. MOORE

BIOCS68 429 NOTES. STATISTICAL TESTS OF HYPOTHESES CONCERN ING THE DEGREE OF DOMINANCE IN MONOFACTORIAL INHERITANCE * R. K MISRA

BIOCS6B 434 NOTES. SIMULT ANEOUS CONF IDENCE INTERVALS AND EXPERIMENTAL DESIGN WITH NORMAL CORRELATION * N MANTEL

BIOCS6B 437 NOTES. CHARACTERIZINC THE EXPONENTIAL DISTRIBUTION * H. E. REINHARDT

8IOCS6B 439 NOTES. ESTIMATION OF NON-LINEAR PARAMETERS FOR A NONASYMPTOTIC FUNCT ION * G. NAMKOONG, D. L. MILLER

BIOCS6B 471 FISHER, WRIGHT, AND PATH COEFFICIENTS * C. C. LI

BIOCS6B 4B5 MIXED SELF- AND CROSS-FERTILIZATION IN A TETRASOMIC SPECIES * J, H. BENNETT

BIOCS6B 501 SURVIVAL PROBABILITIES OF NEW INVERSIONS IN LARGE POPULATIONS *T. OHTA, K. KOJIMA

BIOCS6B 517 PROBABILITY OF OBTAINING NEGATIVE ESTIMATES OF HERITABILITY * J, L, GILL, E. L. JENSEN

BIOCS68 527 VARIANCES OF MOMENT ESTIMATORS OF VARI ANCE COMPONENTS IN THE UNBALANCED R-WAY CLASSIFICATION * W. R BLISCHKE

BIOCS6B 541 DISEASE CLUSTERINC. A GENERALIZATION OF KNOX'S APPROACH TO THE DETECTION OF SPACE-TIME INTERACTIONS * M. C. PIKE, P. G. SMITH

BIOCS68 557 SUSCEPTIBLES THE MATHEMAT ICAL ANALYSIS OF ANEPIDEMIC WITH TWO KINDS OF* J. J. GART

BIOCS6B 567 ON THE HYPOTHESES OF 'NO INTERACTION' IN CONTINGENCY TABLES * V. P. BHAPKAR, G. G. KOCH

BIOCS6B 595 MAXIMUM LIKELIHOOD ESTIMATION OF SURVIVAL CURVE PARAMETERS * E. L. FROME. J. J. BEAUCHAMP

BIOCS68 607 LINEAR RECRESSION WITH NON-CONSTANT. UNKNOWN ERROR VARIANCES. SAMPLINC EXPERIMENTS WITH LEAST SQUARES. WEIGHTED LEAST SQUARES AND MAXIMUM LIKELIHOOD ESTIMATORS * J. A. JACQUEZ, F. J. MATHER, C. R. CRAWFORD

BIOCS6B 627 THE LOG (-LOG) TRANSFORMATION IN THE ANALYSIS OF FRUIT RETENTION RECORDS * F.W. M LLEWELYN
BIOCS6B 639 LINEAR RELATIONSHIPS IN CROWTH AND SIZE STUDIES * P. SPRENT

BIOCS6B 657 ALTERNATIVES TO A LATIN SQUARE * S. C. PEARCE

BIOCS6B 663 A SEQUENTIAL METHOD OF TESTING THE LINEAR TRENDS OF RESPONSES IN DOSE TRI ALS * P. DAVIES

BIOCS6B 679 INTERVAL ESTIMATION OF THE SLOPE OF THE MAJOR AXIS OF A BIVARIATE NORMAL DISTRIBUTION IN THE CASE OF A SMALL SAMPLE * P. JOLICOEUR

BIOCS6B $6 B 3$ AN EMPIRICAL COMPARISON OF DISTANCE STATISTICS FOR POPULATIONS WITH UNEQUAL COVARIANCE MATRICES * R. L CHADDHA. L. F. MARCUS

BIOCS6B 695 NUMERICAL CONSTRUCTION OF ORTHOGONAL POLYNOMIALS FROM A GENERAL RECURRENCE FORMULA * P. L. EMERSON

BIOCS68 70.3 NOTES. EIN EINFACHES VERFAHREN ZUR ERZEUGUNG VON SYMBOLFOLGEN MIT VORGECEBENER RELATIVER DYADENKONTEXTREDUNDANZ * R. TRAPPL

BIOCS6B 707 NOTES. MINIMUM DISCRIMINATION INFORMATION ESTIMATION * C. T. IRELAND, S. KULLBACK

BIOCS6B 714 NOTES. RAPID CALCULATION OF EXACT PROBABILITIES FOR 2-BY-3 CONTINGENCY TABLES * $M$. K. LEYTON

BIOCS6B 717 NOTES. THE STATISTICAL ANALYSIS OF A RADIO-ACTIVE TRACER EXPERIMENT TO DETERMINE ROOT ACTIVITY IN POTATO PLANTS * R. T. CLARKE

BIOCS68 726 OBITUARY, ADOLPHE FRANCESCHETTI

BIOCS6B 749 ANOTHER LOOK AT HENDERSON'S METHODS OF ESTIMATING VARIANCE COMPONENTS (WITH DISCUSSION) * S. R. SEARLE

BIOCS6B 789 SOME OBSERVATIONS ON THE TEACHING OF STATISTICAL CONSULTING * C. PHILIP COX

BIOCS6B 803 SIMULATION OF AN AQUATIC ECOSYSTEM * RICHARD A. PARKER BIOCS6B 823 ON EXPECTED PROBABILITIES OF MISCLASSIFICATION IN DISCRIMINANT ANALYSIS. NECESSARY SAMPLE SIZE, AND A RELATION WITH THE MULTIPLE CORRELATION COEFFICIENT * PETER A. LACHENBRUCH

BIOCS68 B35 MISSING VALUES IN LINEAR MULTIPLE DISCRIMINANT ANALYSIS * ESTHER C. JACKSON

BIOCS6B B45 MULTIVARIATE-COVARIANCE AND CANONICAL ANALYSIS, A METHOD FOR SELECT ING THE MOST EFFECTIVE DISCRIMINATORS IN A MULTIVARIATE SITUATION * I. F. HORTON, J. S. RUSSELL, A. W. MOORE

BIOCS68 B59 DISTANCE BETWEEN POPULATIONS ON THE BASIS OF ATTRIBUTE DATA * V. BALAKRISHNAN, L. D. SANCHV I

BIOCS6B B67 SPATIAL RELATIONSHIP AMONG EICHT POPULATIONS ZEA MAYS L. UTILIZING INFORMATION FROM A DIALLEL MATINC DESICN * W. D. HANSON, EDUARDO CASAS

BIOCS6B 881 REFERENCE POPULATIONS FOR DIALLEL EXPERIMENTS * R. 0 KUEHL. J. O. RAWLINCS, C. CLARK COCKERHAM

BIOCS68 903 MISSING VALUES IN PARTI AL DIALLEL CROSS EXPERIMENTS * KLAUS HINKELMANN

BIOCS6B 915 ESTIMATION OF THE INBREEDING COEFFICIENT FROM PHENOTYPE FREQUENCIES BY A METHOD OF MAXIMUM LIKELIHOOD SCORING * NORIKAZU YASUDA

BIOCS68 937 SELECTION INDICES FOR QUADRATIC MODELS OF TOTAL MERIT * J. W. WILTON, D. ANTHONY EVANS, L. D. VAN VLECK

BIOCS68 951 SELECTION BASIS IN ESTIMATION OF THE GENETIC CORRELATION* L. D. VAN VLECK

BIOCS68 963 ONEXPECTATIONS, VARIANCES. AND CONVARIANCES OF ANOVA MEAN SQUARES BY 'SYNTHESIS' * J. N. K. RAO

BIOCS6B 979 WEIGHTED REGRESSION, QUANTAL RESPONSE DATA, AND INVERSE POLYNOMIALS * J. A. NELDER

BIOCS6B 987 ON COMPARING THE CORRELATIONS WITHIN TWO PAIRS OF VARIABLES * C. E. DAVIS. DANA QUADE

BIOCS6B 997 COMPUTATION OF INDIRECT-ADJUSTED RATES IN THE PRESENCE OF CONFOUNDINC * NATHAN MANTEL, CHARLES R. STARK

BIOCS6B 1007 THE SPREAD OF AN EPIDEMIC TO FIXED GROUPS WITHIN THE POPULATION * N. G. BECKER

BIOCS6B 1015 INDEX SELECTION WITH RESTRICTIONS * J. W. JAMES

BIOCS6B 1019 KOLMOGOROV-SMIRNOV TESTS AND RENYI'S MODIFICATION * N. MANTEL

BIOMETRICS VOLUME 25, 1969

BIOCS69 I A MULTIVARIATE PALEONTOLOCICAL GROWTH PROBLEM * R. A REYMENT

BIOCS69 9 ESTIMATION OF CENETIC CONTRIBUTION OF PRINCIPAL COMPONENTS TO INDIVIDUAL VARIATES CONCERNED * $S$. HASHICUCHI, H. MORISHIMA

BIOCS69 17 APPLICATION OF FINITE ABSORBENT MARKOV CHAINS TO SIB MATINC POPULATIONS WITH SELECTION * J. A. BOSSO. 0. M. BORARRAIN, E. E. A. FAVRET

BIOCS69 27 STABILITY OF SOLUTIONS TO CERTAIN NONLINEAR DIFFERENCE EQUATIONS OF POPULATION GENETICS * H. FALK. C. T. FALK

BIOCS69

BIOCS69

39 AN ENUMERATION PROBLEM IN SELF-STERILITY * J. HAICH

49 SELECTION AMONC DIALLEL CLASSIFIED VARIABLES * R. M PATEL, C. C. COCKERHAM, J. O. RAWLINGS
BIOCS69 63 AN EMPIRICAL STUDY OF THE DISTRIBUTION OF THE SAMPLE CENETIC CORRELATION COEFFICIENT * G. H. BROWN

BIOCS69 73 ON MEASURES OF CORRELATION IN TIME SERIES OF EVENTS * M. TEN HOOPEN, H. A. REUVER

BIOCS69 79 AN ALGORITHM FOR THE DECOMPOSITION OF A DISTRIBUTION INTO GAUSSIAN COMPONENTS * J GREGOR

BIOCS69 95 A MATHEMATICAL ANALYSIS OF THE CROWTH AND SPREAD OF BREAST CANCER * L. E. BLUMENSON, I , D, J . BROSS

BIOCS69 111 TWO-STAGE DESIGNS FOR CLINICAL TRIALS * N. E. DAY

BIOCS69 119 INCOMPLETE TWO-DIMENSIONAL CONT INGENCY TABLES * Y. M M. BISHOP. S. FIENBERC

BIOCS69 129 SIMULTANEOUS PAIRWISE LINEAR STRUCTURAL RELATIONSHIPS * V. D. BARNETT 
43 ON TESTING FOR GOODNESS-OF-FIT OF THE NECATIVE BINOMIAL WHEN EXPECTATIONS ARE SMALL * P. J. PAHL

153 TESTINC THE HOMOCENEITY OF VARIANCES IN A TWO-WAY CLASSIFICATION * C. HAN

159 QUERY, BAULE'S EQUATION + (LEAST SQUARES ESTIMATE OF SOIL CONTENT) * H. D. PATTERSON

165 AN ALCORITHM FOR HIERARCHICAL CLASSIFICATIONS * D WISHART

171 FUNCTIONS OF THE SAMPLE MEAN AND SAMPLE VARIANCE OF A POISSON VARIATE * R. C. DAHIYA, J. CURLAND

174 THE USE OF LAMBDA AS AN INDEX OF PRECISION * M. L. DUDZINSKI, D. BENNETTT

176 CONFIDENCE LIMITS FOR QUANTILES OF MORTALITY DISTRIBUTIONS * W. E. LEVER

207 SURVEY OF HISTOCOMPATIBILITY TESTINC, BIOLOCICAL BACKCROUND PROBABILISTIC AND STATISTICAL MODELS AND PROBLEMS (INVITED PAPER) * RECINA ELANDT-JOHNSON

285 ON DISCRETE STABLE POPULATION THEORY * Z. M. SYKES

295 PONDERATION DES VALEURS CENOTYPIQUES DANS LA SELECTION PAR INDEX SUR PLUSIEURS CARACTERES * R. ROUVIER

309 A MATRIX MODEL FOR FOREST MANAGEMENT * M. B. USHER

317 SIMULATION STUDY OF EST IMATORS FOR THE LINE TRANSECT SAMPLING METHOD* C. E. CATES

329 MODELS FOR THE ESTIMATION OF COMPETINC RISKS FROM GROUPED DATA* A. W. KIMBALL

339 INDIVIDUAL MATCHING WITH MULTIPLE CONTROLS IN THE CASE OF ALL-OR-NONE RESPONSES * O. S. MIETTINEN

357 ANALYSIS OF GROWTH AND DOSE RESPONSE CURVES * J. E. GRIZZLE, D. M. ALLEN

3B3 FULL CONTINGENCY TABLES, LOGITS, AND SPLIT CONTINCENCY TABLES * YVONNE M. M. BISHOP

401 A COMPUTER PROGRAM FOR FITTING THE RICHARDS FUNCTION * D. R. CAUSTON

411 RAO'S PARADOX CONCERNING MULTIVARIATE TESTS OF SIGNIFICANCE * M. J.R. HEALY

413 SOME OBSERVATIONS ON CHANGE-OVER TRIALS * D. H. REES

417 THE ESTIMATION OF THE 'SHORT' DISTRIBUTION * J.D. KERR

420 THE HALF-TABLE RATIO ESTIMATOR FOR A SIMPLE EXPONENTIAL MODEL * J.M. MCCREA

424 CONFIDENCE INTERVALS FOR MEASURES OF HERITABILITY * L. D. BROEMELING

427 EXPECTED MEAN SQUARES FOR NESTED CLASSIFICATIONS * D W. GAYLOR, T. D. HARTWELL

457 MODELS, INFERENCE, AND STRATEGY * J. G. SKELLAM

477 MEASUREMENT OF THE POTENCIES OF DRUG MIXTURES * P. S. HEWLETT

489 ANALYSIS OF CATEGORICAL DATA BY LINEAR MODELS * J. E GRIZZLE, C. F. STARMER, G. C. KOCH

505 THE EFFECT OF UNEQUAL VARIANCE-COVARIANCE MATRICES ON FISHER'S LINEAR DISCRIMINANT FUNCTION * ETHEL S. GILBERT
BIOCS69 517 COMPARISON OF SEQUENTIAL RULES FOR ESTIMATION OF THE SIZE OF A POPULATION * ESTER SAMUEL

BIOCS69 529 MAMMALIAN REPRODUCTIVE DATA FITTED TO A MATHEMATICAL MODEL * MINDEL C. SHEPS, D. P. DOOLITTLE, MARY L. NE

BIOCS69 537 ESTIMATION OF THE NUMBER OF CRITICAL SITES IN LIMITED GENOME EXPRESSION DURINC VIRAL INFECTION OF BACTERIA * JEAND, GIBBONS, S. LITWIN

BIOCS69 545 CENETIC COMPONENTS FOR NON-INBRED DIPLOID SPECIES HAVINC ALL DICENIC EPISTATIC VARIANCES OF EQUAL MACNITUDE * R. WATKINS

BIOCS69 553 THE PREDICTION OF RESPONSE TO SELECTION IN BREEDINC PROCRAMMES WHEN ALL DAUCHTERS OF SELECTED PARENTS ARE RETAINED * D. MACHIN, R. M. MACIVER

BIOCS69 561 THE USE OF CYCLIC BALANCED INCOMPLETE BLOCK DESICNS FOR NON-DIRECTIONAL SEED ORCHARDS * C . H . FREEMAN

BIOCS69 573 A DISCONTINUITY IN MIXED MODEL ANALYSIS * H. O. HARTLEY, S. R. SEARLE

BIOCS69 577 A CENERALIZATION OF THE LOGISTIC LAW OF CROWTH * M. E TURNER JR, B. A. BLUMENSTEIN, JEANNE L. SEBAUGH

BIOCS69 580 A METHOD OF OBTAININC INITIAL EST IMATES OF THE PARAMETERS IN EXPONENTIAL CURVE FITTINC * S. D. FOSS

BIOCS69 585 LINEAR RECRESSION ON PROPORTIONS *G. S. WATSON

BIOCS69 588 A MODIFIED TECHNIQUE FOR IMPROVINC AN ESTIMATE OF THE MEAN * J.C. ARNOLD

BIOCS69 591 ON THE EFFICIENCY OF MODIFIED BALANCED INCOMPLETE BLOCK DESIGNS FOR BIO-ASSAYS * A. C. KULSHRESHTHA

BIOCS69 593 NON-PARAMETRIC ANALYSIS OF VARIANCE IN SMALL SAMPLES A MONTE CARLO STUDY OF THE ADEQUACY OF THE ASYMPTOTIC APPROXIMATION * K. R. GABRIEL, P. A. LACHENBRUCH

BIOCS69 597 ON A RELATIONSHIP BETWEEN TWO REPRESENTATIONS OF A MODEL FOR PAIRED COMPARISONS * R. R. DAVIDSON

BIOCS69 NO.4 THE BAYESIAN OUTLOOK AND ITS APPLICATIONS (WITH DISCUSSION) * J. CORNFIELD

BIOCS69 NO.4 THE ANALYSIS OF POPULATION GROWTH WHEN THE BIRTH AND DEATH RATES DEPEND UPON SEVERAL FACTORS * L. A. COODMAN

BIOCS69 NO. 4 A REGRESSION TECHNIQUE FOR ANCULAR VARIATES * A. L GOULD

BIOCS69 NO. 4 THE POWER OF A TEST IN COVARIANCE ANALYSIS * JOAN S REISCH, J.T. WEBSTER

BIOCS69 NO. 4 CENERALISED COVARIANCE ANALYSIS WITH UNEQUAL ERROR * J.R. ASHFORD, SUSANNAH BROWN

BIOCS69 NO. 4 A COMPARISON OF SUCCESSIVE SCREENING AND DISCRIMINANT FUNCTION TECHNIQUES IN MEDICAL TAXONOMY * S. FELDMAN, D. F. KLEIN, G. HONICFELD

BIOCS69 NO. 4 RESPONSE CRITERIA FOR THE BIOASSAY OF VITAMIN K * C. I BLISS, P. GRIMINGER

BIOCS69 NO. 4 A GRAPHICAL METHOD FOR THE STUDY OF COMPLEX GENETICAL SYSTEMS WITH SPECIAL REFERENCE TO EQUILIBRIA * C CANNINGS

BIOCS69 NO. 4 ESTIMATION OF HERITABILITY FROM EXPERIMENTS WITH RELATED DAMS * K. HINKELMANN

BIOCS69 NO. 4 ITERATIVE ESTIMATION OF VARIANCE COMPONENTS FOR NONORTHOGONAL DATA* $R$. thompson

BIOCS69 NO. 4 ASSOCIATED DIRECTIONS * F. H. C. MARRIOTT 
BIOKA5 1 1 MAJOR GREENWOOD, 1BB0-1949*P. L. MCKINLAY

BIOKA51

4 TABLES OF THE 5 PERCENT AND 0.5 PERCENT POINTS OF PEARSON CURVES (WITH ARGUMENT BETA-1 AND BETA-2) EXPRESSED IN STANDARD MEASURE * E. S, PEARSON, MAXINE MERRINGTON

BIOKA51 11 REGRESSION, STRUCTURE AND FUNCTIONAL RELATIONSHIP * M. G. KENDALL

BIOKA51 26 PARTIAL AND MULTIPLE RANK CORRELATION * P. A. P. MORAN

BIOKA51 33 AN APPLICATION OF THE DISTRIBUTION OF THE RANKING CONCORDANCE COEFFICIENT * A . STUART

BIOKA51 43 THE EFFECT OF NON-NORMALITY ON THE POWER FUNCTION OF THE F-TEST IN THE ANALYSIS OF VARIANCE * F. N. DAVID. N. L. JOHNSON

BIOKA51 5B EFFICIENCY OF THE METHOD OF MOMENTS AND THE GRAMCHAKLIER TYPE A DISTRIBUTION * L. R. SHENTON

BIOKA5I 74 ON DISTRIBUTIONS FOR WHICH THE HARTLEY-KHAMIS SOLUTION OF THE MOMENT-PROBLEM IS EXACT * H. P. MULHOLLAND

BIOKA5I 90 ESTIMATION PROBLEMS WHEN A SIMPLE TYPE OF HETEROGENEITY IS PRESENT IN THE SAMPLE * . M. LONG

BIOKA51 102 SOME TESTS FOR RANDOMNESS IN PLANT POPULATIONS * MARJORIE THOMAS

BIOKA5I 112 CHARTS OF THE PONER FUNCTION FOR ANALYSIS OF VARIANCE TESTS, DERIVED FROM THE NON-CENTRAL F-DISTRIBUT ION * E. S. PEARSON, H. O. HARTLEY

BIOKA51 131 SOME QUESTIONS OF DISTRIBUTION IN THE THEORY OF RANK CORRELATION * S.T DA'ID. M. G KENDALL. A. STUART

BIOKA51 141 NOTE ON AN EXACT TREATMENT OF CONTINGENCY, GOODNESS OF FIT AND OTHER PROBLEMS OF SIGNIFICANCE * G. H. FREEMAN, J.H. HALTON

BIOKA51 150 THE GEOMETRY OF ESTIMATION * J. DURBIN, M. G. KENDALL

BIOKA5I 159 TESTING FOR SERIAL CORRELATION IN LEAST SQUARES REGRESSION, I I * J DURBIN. G. S. WATSON

BIOKA51 179 8IVARIATE K-STATISTICS AND CUMULANTS OF THEIR JOINT SAMPLINGDISTRIBUTION*M. B. COOK

BIOKA51 196 RANDOM DISPERSAL IN THEORETICAL POPULATIONS * J.G. SKELLAM

BIOKA51 219 THE FREQUENCY DISTRIBUTION OF THE PRODUCT-MOMENT CORRELATION COEFFICIENT IN RANDOM SAMPLES OF ANY SIZE DRAWN FROM NON-NORMAL UNIVERSES * A. K. GAYEN

BIOKA5I 248 SOME OBSERVATIONS ON THE PRACTICAL ASPECTS OF WEIGHT ING DESIGNS * K. S. BANERJEE

BIOKA51 252 TEST FOR THE SIGNIFICANCE OF THE DIFFERENCE BETWEEN MEANS IN TWO NORMAL POPULATIONS HAVING UNEQUAL VARIANCES * D. G. C. GRONOW

BIOKA5 2265 CORRIGENDA, 'ON QUESTIONS RAISED BY THE COMBINATION OF TESTS BASED ON DISCONTINUOUS DISTRIBUTIONS. ' * E. S. PEARSON

BIOKA51 267 BIOMETRIKA, 1901-1951*W. P. ELDERTON

BIOKA51 269 THE ESTIMATION OF POPULATION PARAMETERS FROM DATA OBTAINED BY MEANS OF THE CAPTURE-RECAPTURE METHOD. I. THE MAXIMUM LIKELIHOOD EQUAT IONS FOR EST IMATING THE DEATH-RATE * P. H. LESLIE, DENNIS CHITTY
BTOKA51 293 ON ESTTMATING THE SIZE OF M08ILE POPULATIONS FROM RECAPTURE DATA * NORMAN T. J. BAILEY

BIOKA51 307 A MATHEMATICAL THEORY OF ANIMAL TRAPPING * P. A. P MORAN

BIOKA51 312 SOME SYSTEMATIC EXPERIMENTAL DESIGNS * D. R. COX

BIOKA51 324 THE COMPARISON OF SEVERAL GROUPS OF OBSERVATIONS WHEN THE RATIOS OF THE POPULATION VARIANCES ARE UNKNOWN * G. S. JAMES

8IOKA51 330 ON THE COMPARISON OF SEVERAL MEAN VALUES, AN ALTERNATIVE APPROACH * B. L. WELCH

BIOKA51 337 THE EFFECT OF STANDARDIZATION ON AN APPROXIMATION IN FACTOR ANALYSIS * M. S. BARTLETT

BIOKA51 345 THE JACOBIANS OF CERTAIN MATRIX TRANSFORMATIONS USEFUL IN MULTIVARIATE ANALYSIS, BASED ON LECTURES BY P. L. HSU * WALTER L. DEEMER, INGRAM OLKIN

BIOKA51 368 TWO APPLICATIONS OF BIVARIATE K-STATISTICS * M. B $\mathrm{COOK}$

BIOKA51 377 INTERRELATIONS BETWEEN CERTAIN LINEAR SYSTEMATIC STATISTICS OF SAMPLES FROM ANY CONTINUOUS POPULATION*G.P. SILLITTO

BIOKA51 3B3 THEDELAY TO PEDESTRIANS CROSSING A ROAD * J. C. TANNER BIOKA51 393 FURTHER APPLICATIONS OF RANGE TO THE ANALYSIS OF VARIANCE * H. A. DAVID

BIOKA51 410 THE FITTING OF POLYNOMIALS TO EQUIDISTANT DATA WITH MISSING VALUES * H. O. HARTLEY

BIOKA51 414 TRUNCATED LOGNORMAL DISTRIBUTIONS. I . SOLUTION BY MOMENTS *H. R. THOMPSON

BIOKA5I 423 A CHART FOR THE INCOMPLETE BETA-FUNCTION AND THE CUMULATIVE BINOMIAL DISTRIBUTION * H. O. HARTLEY, E. R FITCH

BIOKA51 427 THE EXPECTED FREQUENCIES IN A SAMPLE OF AN ANIMAL POPULATION IN WHICH THE ABUNDANCES OF SPECIES ARE LOG-NORMALLY DISTRIBUTED * P. M. GRUNDY

BIOKA5I 435 TABLES OF SYMMETRIC FUNCTIONS. PARTS II AND III. * F N. DAVID, M. G. KENDALL

BIOKA51 463 MOMENT CONSTANTS FOR THE DISTRIBUTION OF RANGE IN NORMAL SAMPLES * H. O. HARTLEY, E. S. PEARSON

BIOKA51 464 RAPID METHODS FOR ESTIMATING CORRELATION COEFFICIENTS* L. N. CHOWN, P. A. P. MORAN

BIOKA51 468 MEAN AND VARIANCE OF AN ENTRY IN A CONT INGENCY TABLE * W. L. STEVENS

BIOKA51 470 THE WISHART DISTRIBUTION DERIVED BY SOLVING SIMULTANEOUS LINEAR DIFFERENTIAL EQUATIONS * H. S. STEYN

BIOKA51 472 QUALITY CONTROL SYSTEMS BASED ON INACCURATELY MEASURED VARIABLES * W. M. LONG

BIOKA5 1475 THE BIVARIATE NORMAL INTEGRAL * J. H. CADWELL

BIOKA51 479 NOTE ON THE VARIATE DIFFERENCES OF AUTOREGRESSIVE SERIES * BENTO MURTEIRA

BIOKA51 4BI NOTE ON THE INVERSION THEOREM * J. GIL-PELAEZ

BIOKA51 4B2 A NOTE ON THE STATISTICAL INDEPENDENCE OF QUADRATIC FORMS IN THE ANALYSIS OF VARIANCE * J , A , NELDER

BIOMETRIKA VOLUME 39, 1952

BIOKA52 1 MOMENT COEFFICIENTS OF THE K-STATISTICS IN SAMPLES FROM A FINITE POPULATION * JOHN WISHART

BIOKA52 14 MOMENT-STATISTICS IN SAMPLES FROM A FINITE POPULATION * M. G. KENDALL

BIOKA52 17 SOME EXACT TESTS IN MULTIVARIATE ANALYSIS * E. J. WILLIAMS

BIOKA52 32 THE CONSTRUCTION OF BALANCED DESIGNS FOR EXPERIMENTS INVOLVING SEOUENCES OF TREATMENTS * H. D. PATTERSON

BIOKA52

BIOKA52

BIOKA52

BI0KA52

BIOKA52

BIOKA52

49 MULTI-FACTOR DESIGNS OF FIRST ORDER * G. E. P. BOX

$5 B$ TESTS OF SIGNIFICANCE IN CANONICAL ANALYSIS * F, H. C MARRIOTT

65 THE INTERPRETATION OF INTERACTIONS IN FACTORIAL EXPERIMENTS * E. J. WILLIAMS

82 ON SAMPLING FROM A POPULATION OF RANKERS * A. S. C EHRENBERG

SHIPS. II. * M. G. KENDALL
8IOKA52 109 ON THE CONCURRENCE OF A SET OF REGRESSION LINES. * K. D. TOCHER

BIOKA52 118 A SAMPLING TEST OF THE CHI-SQUARE THEORY FOR PROBABILITY CHAINS * M. S. BARTLETT

BIOKA52 122 ON MATHEMATICAL ANALYSIS OF STYLE* WILHELM FUCKS

BIOKA52 130 COMPARISON OF TWO APPROXIMATIONS TO THE DISTRIBUTION OF THE RANGE IN SMALL SAMPLES FROM NORMAL POPULATIONS* E. S. PEARSON
BIOKA52 137 THE COVERING CIRCLE OF A SAMPLE FROM A CIRCULAR NORMAL DISTRIBUTION * H. E. DANIELS

BIOKA52 144 THE FREQUENCY JUSTIFICATION OF CERTAIN SEQUENTIAL TESTS * G. A. BARNARD

BIOKA52 151 EXPERIMENTAL DESIGNS FOR SERIALLY CORRELATED OBSERVATIONS* R.M. WILLIAMS

BIOKA52 168 THE TIME INTERVALS 8ETWEEN INDUSTRIAL ACCIDENTS * $\mathrm{B}$ A. MAGUIRE, E. S. PEARSON. A. H. A. WYNN

BIOKA52 181 THE ESTIMATION OF DEATH-RATES FROM CAPTURE-MARKRECAPTURE SAMPLING * P. A. P. MORAN

BIOKA52 IB9 A NOTE ON THEDESIGN PROBLEM * K.D. TOCHER

BIOKA52 1B9 TABLES OF PERCENTAGE POINTS OF THE 'STUDENTIZED' EXTREME DEVIATE FROM THE SAMPLE MEAN * K. R. NAIR

BIOKA52 192 EXTENDED AND CORRECTED TABLES OF THE UPPER PERCENTAGE POINTS OF THE 'STUDENTIZED' RANGE * JOYCE M. MAY

BIOKA52 194 ON THE DISTRIBUTION OF 'STUDENTIZED' RANGE * K. C. S . PILLAI

BIOKA52 196 NOTE ON A CERTAIN FAMILY OF DISCRETE DISTRIBUTIONS * J. S. MARITZ

BICKA52 198 SOME PROPERTIES OF RUNS IN SMOOTHED RANDOM SERIES * ALISON M. GRANT

BIOKA52 204 AN APPROXIMATION TO THE SYMMETRICAL INCOMPLETE BETA FUNCTION * J. H. CADWELL

BIOKA52 207 THE DISTRIBUTION OF QUANTILES OF SMALL SAMPLES * J . H. CADWELLL

BIOKA52 211 ON A CORRECTION TERM IN THE METHOD OF PAIRED COMPARISONS * J . A. VAN DER HEIDEN 
BIOKA52 215 (ACKNOWLEDCEMENT OF PRIORITY), 'NOTE ON THE INVERSION THEOREM ' * $J$. CIL-PELAEZ

BIOKA52 217 ESTIMATION BY DOUBLE SAMPLINC * D. R. COX

BIOKA52 22B THE STATISTICAL SICNIFICANCE OF ODD BITS OF INFORMATION * M. S. BARTLETT

BIOKA52 238 SAMPLINC FROM BIVARIATE NON-NORMAL UNIVERSES BY MEANS OF COMPOUND NORMAL DISTRIBUTIONS * HANNES HYRENIUS

BIOKA52 247 THE ESTIMATION OF THE POISSON PARAMETER FROM A TRיNCATED DISTRIBUTION * P. G. MOORE

BIOKA52 252 THE FITTING OF GROUPED TRUNCATED AND CROUPED CENSORED NORMAL DISTRIBUTIONS * P. M. CRUNDY

BIOKA52 260 ESTIMATION OF THE MEAN AND STANDARD DEVIATION OF A NORMAL POPULATION FROM A CENSORED SAMPLE * A. K. GUPTA

BIOKA52 274 USE OF SCORES FOR THE ANALYSIS OF ASSOCIATION IN CONTINGENCY TABLES * E. J. WILLIAMS

BIOKA52 290 PROPERTIES OF DISTRIBUTIONS RESULTING FROM CERTAIN SIMPLE TRANSFORMATIONS OF THE NORMAL DISTRIBUTION * J. DRAPER

BIOKA52 302 ONA TWO-SIDED SEQUENTIAL T-TEST * S. RUSHTON

BIOKA52 309 TESTS OF FIT IN TIME SERIES * P. WHITTLE

BIOKA52 319 TENSOR NOTATION AND THE SAMPLING CUMULANTS OF $K-$ STATISTICS * E. L. KAPLAN

BIOKA52 324 RANK ANALYSIS OF INCOMPLETE BLOCK DESIGNS. I. THE METHOD OF PA IRED COMPARISONS. * RALPH ALLAN BRADLEY, MILTONE. TERRY

BIOKA52 346 STUDIES IN STATISTICAL ECOLOGY. I. SPATIAL PATTERN * J. G. SKELLAM
BIOKA52 363 THE EST IMATION OF POPULATION PARAMETERS FROM DATA OBTAINED BY MEANS OF THE CAPTURE-RECAPTURE METHOD. II THE EST IMAT ION OF TOT AL NUMBERS * P. H. LESLIE

BIOKA52 3B9 THE GROWTH, SURVIVAL, WANDERINC AND VARIATION OF THE LONG-TA ILED FIELD MOUSE, APODEMUS SYLVATICUS. III WANDERINC POWER AND DISTRIBUTION. * H. P. HACKER, H. S. PEARSON

BIOKA52 414 SAMPLES WITH THE SAME NUMBER IN EACH STRATUM * W. L STEVENS

BIOKA52 417 APPROXIMATIONS TO THE PROBABILITY INTECRAL OF THE DISTRIBUTION OF RANGE *N. L. JOHNSON

BIOKA52 419 STATISTICAL CONTROL OF COUNTING EXPERIMENTS * H. O LANCASTER

BIOKA52 422 UPPER 5 AND I PERCENT POINTS OF THE MAXIMUM F-RATIO * H. A. DAVID

BIOKA52 425 THE CONDITIONS UNDER WHICH GRAM-CHARLIER AND EDGEWORTH CURVES ARE POSIT IVE DEFINITE AND UNIMODAL *D. E. BARTON, K. E. DENNIS

BIOKA52 427 COMPARISON OF ANALYSIS OF VARIANCE POWER FUNCTION IN THE PARAMETRIC AND RANDOM MODELS * N. L. JOHNSON

BIOKA52 429 ON EXACT GROUPING CORRECTIONS TO MOMENTS AND CUMULANTS * MORTON KUPPERMAN

BIOKA52 434 DISCR IMINAT ION IN TIME-SERIES ANALYSIS * A. RUDRA

BIOKA52 439 A NOTE ON 'THE ESTIMATION OF THE PARAMETERS OF TOLERANCE DISTRIBUTIONS ' * D. J. FINNEY

BIOKA52 442 CORRIGENDA, 'THE USE OF RANCE IN PLACE OF STANDARD DEVIATION IN THE T-TEST . 1 * E. LORD

BIOMETRIKA VOLUME 40, 1953

BIOKA53 I THE SUPERPOSITION OF SEVERAL STRICTLY PERIODIC SEQUENCES OF EVENTS * D. R. COX, W. L. SMITH

BIOKA53 12 APPROXIMATE CONFIDENCE INTERVALS * M. S. BARTLETT

BIOKA53 20 INCOMPLETE AND ABSOLUTE MOMENTS OF THE MULTIVARIATE NORMAL DISTRIBUTION WITH SOME APPLICATIONS * A. R. KAMAT

BIOKA53 35 ON THE RANGE OF PART IAL SUMS OF A FINITE NUMBER OF INDEPENDENT NORMAL VARIATES * A. A. ANIS, E. H. LLOYD

BIOKA53 43 NOTE ON 'THE JACOBIANS OF CERTAIN MATRIX TRANSFORMATION USEFULL IN MULTIVARIATE ANALYSIS' * INGRAM OLKIN

BIOKA53 47 ESTIMATION OF A FUNCTIONAL RELATIONSHIP * D. V LINDLEY

BIOKA53 50 ESTIMATING PARAMETERS IN TRUNCATED PEARSON FREQUENCY DISTRIBUTIONS WITHOUT RESORT TO HIGHER MOMENTS * A . C. COHEN JR

BIOKA53 5B A PROBLEM OF INTERFERENCE BETWEEN TWO QUEUES * J. C. TANNER

BIOKA53 70 TABLES OF THE ANGULAR TRANSFORMATION * W. L. STEVENS

BIOKA53 74 TESTS OF SIGNIFICANCE IN A 2-BY-2 CONTINGENCY TABLE, EXTENSION OF FINNEY 'S TABLE * R. LATSCHA

BIOKA53 B7 A METHOD FOR JUDG ING ALL CONTRASTS IN THE ANALYSIS OF VARIANCE (CORR. 69229 ) * HENRY SCHEFFE

BIOKA53 105 THE ESTIMATION AND COMPARISON OF STRENGTHS OF ASSOC IATION IN CONT INGENCY TABLES * A. STUART

BIOKA53 111 A SEQUENT IAL TEST FOR RANDOMNESS * P. C. MOORE

BIOKA53 116 ON THE MEAN SUCCESSIVE DIFFERENCE AND ITS RATIO TO THE ROOT MEAN SQUARE * A. R. KAMAT

BIOKA53 12B THE EFFECT OF UNEQUAL GROUP VARIANCES ON THE F-TEST FOR THE HOMOGENEITY OF GROUP MEANS * $G$. HORSNELL

BIOKA53 137 THE ESTIMATION OF POPULATION PARAMETERS FROM DATA OBTAINED BY MEANS OF THE CAPTURE-RECAPTURE METHOD. III. AN EXAMPLE OF THE PRACT ICAL APPLICATIONS OF THE METHOD * P. H. LESLIE, DENNIS CHITTY, HELEN CHITTY

BIOKA53 170 ON THE UTILIZATION OF MARKED SPECIMENS IN ESTIMATINC POPULATIONS OF FLYING INSECTS * C C C CRAIC

BIOKA53 177 THE TOTAL SIZE OF A GENERAL STOCHASTIC EPIDEMIC * NORMAN T. J. BAILEY

BIOKA53 1B6 EXPERIMENTAL EVIDENCE CONCERNINC CONTAGIOUS DISTRIBUTIONS IN ECOLOGY * D. A. EVANS

BIOKA53 212 TIME INTERVALS BETWEEN ACCIDENTS, A NOTE ON MAGUIRE, PEARSON AND WYNN 'S PAPER * G, A. BARNARD

BIOKA53 214 FURTHER NOTES ON THE ANALYSIS OF ACCIDENT DATA * B. A MAGUIRE, E.S. PEARSON. A. H. A. WYNN

BIOKA53 216 ON A METHOD OF ESTIMATING BIOLOGICAL POPULATIONS IN THE FIELD * C. C CRAIG

BIOKA53 218 A RAPID METHOD FOR ESTIMATING THE CORRELATION COEFFICIENT FROM THE RANGE OF THE DEVIATIONS ABOUT THE REDUCED MA JOR AXIS * C. H. LEIGH-DUCMORE

BIOKA53 220 THE EFFECT OF OVERLAPPING IN BACTER IAL COUNTS OF INCUBATED COLONIES * C. MACK

BIOKA53 223 NON-NORMALITY IN TWO-SAMPLE T-TESTS * D. G. C. GRONOW

BIOKA53 225 NOTE ON THE POISSON INDEX OF DISPERSION * N. KATHIRCAMATAMBY

BIOKA53 22B ON AN EXTENSION OF GEARY'S THEOREM * R. C. LAHA
BIOKA53 229 THE DOOLITTLE METHOD AND THE FITT ING OF POLYNOMIALS TO WEIGHTED DATA * P. G . CUEST

BIOKA53 231 A SIMPLE METHOD OF DERIVING BEST CRITICAL REGIONS SIMILAR TO THE SAMPLE SPACE IN TESTS OF AN IMPORTANT CLASS OF COMPOSITE HYPOTHESES * K. S, RAO

BIOKA53 236 CORRIGENDA. 'TABLES OF PERCENTACE POINTS OF THE 'STUDENTIZED' RANGE' * H. O. HARTLEY

BIOKA53 236 CORRICENDA, 'PROPERTIES OF DISTRIBUTIONS RESULTINC FROM CERTAIN SIMPLE TRANSFORMATIONS OF THE NORMAL DISTRIBUTION ' *J. DRAPER

BIOKA53 237 THE POPULATION FREQUENCIES OF SPECIES AND THE ESTIMATION OF POPULATION PARAME'TERS * I . J . COOD

BIOKA53 265 CAPTURE-RECAPTURE ANALYSIS * J. M. HAMMERSLEY

BIOKA53 279 THE USE OF CHAIN-BINOMIALS WITH A VARIABLE CHANCE OF INFECTION FOR THE ANALYSIS OF INTRA-HOUSEHOLD EPIDEMICS * NORMAN T. J. BAILEY

BIOKA53 2B7 SPREAD OF DISEASES IN A RECTANGULAR PLANTATION WITH VACANCIES * G. H. FREEMAN

BIOKA53 297 TESTS OF SIGNIFICANCE FOR CONCURRENT REGRESSION LINES * E. J. WILliams

BIOKA53 306 APPROXIMATE CONFIDENCE INTERVALS. II. MORE THAN ONE UNKNOWN PARAMETER * M S, BARTLETT

BIOKA53 31B NON-NORMALITY AND TESTS ON VARIANCES, * G. E. P. BOX

BIOKA53 336 APPROXIMATING TO THE DISTRIBUTIONS OF MEASURES OF DISPERSION BY A POWER OF CHI-SQUARE * J. H. CADWELL

BIOKA53 347 THE POWER FUNCTION OF SOME TESTS BASED ON RANGE * H. A DAVID

BIOKA53 354 SOME SIMPLE APPROXIMATE TESTS FOR POISSON VARIATES * D. R. COX

BIOKA53 361 ORTHOGONAL POLYNOMIAL FITTING * JOHN WISHART, THEOCHARIS METAKIDES

BIOKA53 370 POPULATION DIFFERENCES BETWEEN SPECIES GROWING ACCORDING TO SIMPLE BIRTH AND DEATH PROCESSES * J. H. DARWIN

BIOKA53 3B3 MODIFICATIONS TO THE VARIATE-DIFFERENCE METHOD * M. H. QUENOUILLE

BIOKA53 409 MOMENTS OF THE RANK CORRELATION COEFFICIENT TAU IN THE GENERAL CASE * R. M. SUNDRUM

BIOKA53 42199.9 PERCENT AND 0.1 PERCENT POINTS OF THE CHI-SQUARE DISTRIBUTION *T. LEWIS

BIOKA53 427 TABLES OF SYMMETRIC FUNCTIONS. PART IV. * F. N. DAVID. M. G. KENDALL

BIOKA53 447 SOME PROCEDURES FOR COMPARING POISSON PROCESSES OR POPULATIONS * ALLAN BIRNBAUM

BIOKA53 449 SCALE FACTORS AND DECREES OF FREEDOM FOR SMALL SAMPLE SIZES FOR CHI APPROXIMATION TO THE RANGE * GEORGE WM THOMSON

BIOKA53 451 THE THIRD MOMENT OF GINI'S MEAN DIFFERENCE * A, R KAMAT

BIOKA53 452 A METHOD OF SYSTEMATIC SAMPLINC BASED ON ORDER PROPERTIES * R. M. SUNDRUM

BIOKA53 457 A NOTE ON ORDERED LEAST-SQUARES ESTIMATION * $F$. DOWNTON

BIOKA53 45B A NOTE ON THE EVALUATION OF THE MULTIVARIATE NORMAL INTEGRAL * F. N. DAVID 
BIOKA53 460 A GRAPHICAL METHOD FOR THE ANALYSIS OF STATISTICAL DISTRIBUTIONS INTO TWO NORMAL COMPONENTS * ERIC J. PRESTON
BIOKA53 465 A NOTE ON REGIONS FOR TESTS OF KURTOSIS * G. E. P. BOX BIOKA53 468 THE FREQUENCY JUSTIFICATION OF SEQUENTIAL TESTS, AODENDUM*G. A. BARNARD

BIOMETRIKA VOLUME 41, 1954

BIOKA54

BIOKA5 4

BIOKA54

BIOKA5 4

BIOKA54

BIOKA54

BI OKA54

BIOKA54

BIOKA54

BIOKA54

BIOKA54

BIOKA54

BIOKA54

BI0KA54

BIOKA54

BIOKA54

BIOKA 5

BIOKA54

BIOKA54

BIOKA54

BIOKA54

BIOKA54

BIOKA54

BIOKA54 BIOKA5

BI0KA54

BIOKA5

BIOKA54

BI0KA54

BIOKA5 4

BIOKA54

1 DISTRIBUTION THEORY OF TWO ESTIMATES FOR STANOARD OEVIATION BASED ON SECOND VARIATE DIFFERENCES * A R. KAMAT

12 THE STATistical TREatMent OF MEAN OEVIATION * J. H. CADWELL

9 TESTS OF LINEAR HYPOTHESES IN UNIVARIATE AND MULTIVARIATE ANALYSIS WHEN THE RATIOS OF THE POPULATION VARIANCES ARE UNKNOWN * G. S. JAMES

44 THE USE OF THE HANKEL TRANSFORM IN STATISTICS. I. CENERAL THEORY AND EXAMPLES * R . D. LORD

56 A NOTE ON THE CONSISTENCY AND MAXIMA OF THE ROOTS CF LIKELIHOOD EQUATIONS * K. C. CHANDA

62 CROUPING METHODS IN THE FITTINC OF POLYNOMIALS TO EQUALLY SPACED OBSERVATIONS * P. C . CUEST

77 NEW TECHNIQUES FOR THE ANALYSIS OF ABSENTEEISM DATA * A G. ARBOUS, H. S . SICHEL

91 ON THE SUPERPOSITON OF RENEWAL PROCESSES * D. R. COX, H. L. SMITH

100 CONTINUOUS INSPECT ION SCHEMES * E . S. PACE

116 ON NAHORDNUNG AND FERNORDNUNC IN SAMPLES OF LITERARY TEXTS * W. FUCKS

133 A DISTRIBUTION-FREE K-SAMPLE TEST AC AINST ORDERED ALTERNATIVES * A. R. JONCKHEERE

146 TWO-STAGE PROCEDURES FOR ESTIMATINC THE DIFFERENCE BETWEEN MEANS * S. C. CHURYE, H. ROBBINS

153 A BIVARIATE GENERALIZATION OF STUDENT 'S T-DISTRIBUTION, WITH TABLES FOR CERTAIN SPECIAL CASES * C. W. DUNNETT, M. SOBEL

170 A TWO-SAMPLE MULT IPLE DECISION PROCEDURE FOR RANKINC MEANS OF NORMAL POPULATIONS WITH A COMMON UNKNOWN VARIANCE * R. E. BECHHOFER. C. W DUNNETT, M. SOBEL

177 INEQUALITIES FOR THE NORMAL INTECRAL INCLUDINC A NEW CONTINUED FRACTION * L. R. SHENTON

190 A CONFIDENCE RECION FOR THE SOLUTION OF A SET OF SIMULTANEOUS EQUATIONS WITH AN APPLICATION TO EXPERIMENTAL DESIGN * C, E. P. BOX, J . S. HUNTER

200 ON THE MOMENTS OF ORDER STATISTICS IN SAMPLES FROM NORMAL POPULATIONS * H. RUBEN

228 STATISTICAL TREATMENT OF CENSORED DATA. PART I. FUNDAMENTAL FORMULAE * F N N. DAVID, N L, JOHNSON

241 SIMPLIFIED DECISION FUNCTIONS * C. A. BARNARD

252 SEQUENTIAL TESTS FOR BINOMI AL AND EXPONENT I AL POPULATIONS * F, J. ANSCOMBE, E. S. PAGE

253 TABLES OF GENERALIZED K-STATISTICS * S. H. ABDEL ATY

261 AN ANCULAR TRANSFORMATION FOR THE SERIAL CORRELATION COEFFICIENT * C. M. JENKINS

DISTRIBUTION ARISING IN THE STUDY OF INFECTIOUS DISEASES * J. O. IRWIN

268 A NOTE ON CONTACIOUSDISTRIBUTIONS * H. R. THOMPSON

272 A CENERAL EXPRESSION FOR THE MEAN IN A SIMPLE STOCHASTIC EPIDEMIC * H. W. HASKEY

275 SOME REMARKS ON CONFIDENCE OF FIDUCIAL LIMITS * T. E STERNE

27B A NOTE ON THE PROBABILITY INTECRAL OF THE CORRELATION COEFFICIENT * B. I. HARLEY

SIMPLIFIED EXPRESSION FOR THE VARIANCE OF THE CHISQUARE FUNCTION ON A CONTINCENCY TABLE * R. B. DAWSON

287 THE DESICN OF AN EXPERIMENT IN WHICH CERTA IN TREATMENT ARRANGEMENTS ARE INADMISSIBLE * D. R. COX

THE ESTIMATION OF LOCATION AND SCALE PARAMETERS FROM CROUPED DATA * J. M. HAMMERSLEY, K. W. MORTON

302 TRANSFORMATIONS OF THE BINOMIAL, NEGATIVE BINOMIAL, POISSON AND CHI-SQUAREDISTRIBUTIONS * G . BLOM
BIOKA54 317 A QUICKLY CONVERCENT EXPANSION FOR CUMULATIVE HYPERGEOMETRIC PROBABILITIES, DIRECT AND INVERSE* M. E WISE

BIOKA54 330 THE QUOTIENT OF A RECTANGULAR OR TRIANGULAR ANO A CENERAL VARIATE * S. R. BROADBENT

BIOKA54 33B AN ESTIMATION PROBLEM IN QUANTITATIVE ASSAY * J. AITCHISON, J. A. C. BROWN

BIOKA54 344 THE USE OF THE HANKEL TRANSFORM IN STATISTICS. II METHODS OF COMPUTATION * R. D. LORD

BIOKA54 351 A REDUCTION FORMULA FOR NORMAL MULT IVARIATE INTEGRALS * R. L. PLACKETT

BIOKA54 361 ON THE COMPARISON OF TWO MEANS, FURTHER DISCUSSION OF ITERATIVE METHODS FOR CALCULATING TABLES * W. H TRICKETT, B. L. WELCH

BIOKA54 375 SOME FURTHER RESULTS IN THE THEORY OF PEDESTRIANS AND ROAD TRAFFIC * A. J MAYNE

BIOKA54 390 BIAS IN THE ESTIMATION OF AUTOCORRELATIONS * F. H. C. MARRIOTT, J.A. POPE

BIOKA54 403 NOTE ON BIAS IN THE ESTIMATION OF AUTOCORRELATION * $M$ G. KENDALL

BIOKA54 405 TESTS OF HYPOTHESES IN THE LINEAR AUTORECRESSIVE MODEL. PART I. *G. M, JENKINS

BIOKA54 420 SOME PROBLEMS OF OPT IMUM SAMPLINC * P. N. SOMERV ILLE

BIOKA54 430 A TEST FOR MARKOFF CHAINS * P. C. HOEL

BIOKA54 434 ON STATIONARY PROCESSES IN THE PLANE * P. WHITTLE

BIOKA54 450 THE COODNESS OF FIT OF FREQUENCY DISTRIBUTIONS OBTAINED FROM STOCHASTIC PROCESSES * V. N. PATANKAR

BIOKA54 463 THE DISTRIBUTION OF RANGE IN CERTAIN NON-NORMAL POPULATIONS * H. A. DAVID

BIOKA54 469 THE MEAN ÁND COEFFICIENT OF VARIATION OF RANCE IN SMALL SAMPLES FROM NON-NORMAL POPULATIONS * D. R $\mathrm{COX}$

BIOKA54 482 THE DISTRIBUTION OF THE RATIO, IN A SINCLE NORMAL SAMPLE, OF RANCE TO STANDARD DEVIATION * H. A. DAVID, $\mathrm{H}$ O. HARTLEY, E. S. PEARSON

BIOKA54 494 SAMPLINC WITH CONTROL VARIABLES * E. C. FIELLER, H 0 HARTLEY

BIOKA54 502 RANK ANALYSIS OF INCOMPLETE BLOCK DESICNS. II. ADDITIONAL TABLES FOR THE METHOD OF PAIRED COMPARISONS * R. A. BRADLEY

BIOKA54 538 APPROXIMATE FORMULAE FOR THE PERCENTAGE POINTS AND THE PROBABILITY INTECRAL OF THE NON-CENTRAL CHISQUAREDISTRIBUTION * S. H. ABDEL ATY

BIOKA54 541 MOMENTS OF THE MEAN DEVIATION * A. R. KAMAT

BIOKA54 542 ON THE RELATION BETWEEN ESTIMATING EFFICIENCY AND THE POWER OF TESTS * R. M. SUNDRUM

BIOKA54 544 THE INTERPRETATION OF NEGATIVE COMPONENTS OF VARIANCE * J. A. NELDER

BIOKA54 54B THE DISTRIBUTION OF THE RECRESSION COEFFICIENT IN SAMPLES FROM A NON-NORMAL POPULATION * I. D. HILL

BIOKA54 553 PROBABILITY DISTRIBUTIONS ARISINC FROM POINTS ON LINE* P. V. KRISHNA IYER, M. N. KAPUR

BIOKA54 555 THE FACTORIAL MOMENTS OF THE DISTRIBUTION OF JOINS BETWEEN LINE SECMENTS * J . WISHART

BIOKA54 556 NOTE ON THE USE OF SHERMAN' S STATISTIC AS A TEST OF RANDOMNESS *D.J.BARTHOLOMEW

BIOKA54 559 TWO EARLY PAPERS ON THE RELATION BETWEEN EXTREME VALUES AND TENSILE STRENGTH * J. LIEBLEIN

BIOKA54 560 TWO PROBLEMS IN SETS OF MEASUREMENTS * M. G. KENDALL

BIOKA54 56B CORRIGENDA, 'ON A TWO-SIDED SEQUENTIAL T-TEST' * S RUSHTON

BIOKA54 568 CORRIGENDA, 'ON THE MOMENTS OF ORDER STATISTICS IN SAMPLES FROM NORMAL POPULATIONS' * H. RUBEN
BIOMETRIKA

BIOKA55

1 STUDIES IN THE HISTORY OF PROBABILITY AND STATISTICS. I. DICING AND GAMING (A NOTE ON THE HISTORY OF PROBABILITY) * F. N. DAVID

BI0KA55

FEATURES OF THE GEN BACTERIA *E O. POWELL

BI0KA55

BI0KA55

BIOKA55

BI0KA55

BIOKA55

45 QUANTUM HYPOTHESES * S. R. BROADBENT

$5 B$ THE TRUNCATED NEGATIVE BINOMIAL DISTRIBUTION* $M . R$ SAMPFORD

70 THE RANDOMIZATION ANALYSIS OF A GENERALIZED RANDOMIZED BLOCK DESIGN* M. B. WILK

BO SOME QUICK SIGN TESTS FOR TREND IN LOCATION AND DISPERSTON * D.R. COX, A. STUART

96 THE VARIANCE OF THE MAXIMUM OF PARTIAL SUMS OF A FINITE NUMBER OF INDEPENDENT NORMAL VARIATES * A. A. ANIS
VOLUME 42, 1955

BIOKA55 102 SPATIAL POINT PROCESSES, WITH APPLICATIONS TO ECOLOGY * H. R. THOMPSON

BIOKA55 116 THE OUTCOME OF A STOCHASTIC EPIDEMIC, A NOTE ON BAILEY'S PAPER * P. WHITTLE

BIOKA55 123 A NOTE ON BAILEY'S AND WHITTLE'S TREATMENT OF A GENERAL STOCHAST IC EPIDEMIC * F. G. FOSTER

BIOKA55 126 THE DETERMINISTIC MODEL OF A SIMPLE EPIDEMIC FOR MORE THAN ONE COMMUNITY * S. RUSHTON, A. J. MAUTNER

BIOKA55 133 EXACT TESTS FOR SERIAL CORRELATION * E. J. HANNAN

BIOKA55 143 ON THE EFFICIENCY OF PROCEDURES FOR SMOOTHING PERIODOGRAMS FROM TIME SERIES WITH CONTINUOUS SPECTRA * M. S. BARTLETT, J. MEDHI

BIOKA55 151 THE AUTOCORRELATION FUNCTION AND THE SPECTRAL DENSITY FUNCTION* J, WISE 
160 SAMPLINC PROPERT IES OF LOCAL STATISTICS IN STATIONARY STOCHASTIC SERIES * C. H. JOWETT

BIOKA55 170 MODELS FOR TWO-DIMENSIONAL STATIONARY STOCHASTIC PROCESSES * V. HEINE

BIOKA55 179 SOME PROBLEMS IN THE THEORY OF PROVISIONINC AND OF DAMS * J. CANI

BIOKA55 201 APPROXIMATE CONFIDENCE INTERVALS III. A BIAS CORRECTION * M. S. BARTLETT

BIOKA55 205 THE THEORY OF CORRELATION BETWEEN TWO CONTINUOUS VARIABLES WHEN ONE IS DICHOTOMIZED * R. F. TATE

BIOKA55 217 THE NORMAL PROBABILITY FUNCTION, TABLES OF CERTAIN AREA-ORDINATE RATIOS AND OF THEIR RECIPROCALS * EDITORIAL

BIOKA55 223 TABLES OF SYMMETRIC FUNCTIONS. PART V. * F. N. DAVID M. G. KENDALL

BIOKA55 243 CONTROL CHARTS WITH WARNING LINES *E. S. PAGE

BIOKA55 25B APPROXIMATIONS TO THE PROBABILITY INTEGRAL AND CERTAIN PERCENT ACE POINTS OF A MULTIVARIATE ANALOGUE OF STUDENT' S T-DISTRIBUTION * C.W. DUNNETT, M. SOBEL

BIOKA55 261 GALTON'S RANK-ORDER TEST * J. L. HODGES

BIOKA55 263 ON BOUNDS FOR THE NORMAL INTECRAL * J. T. CHU

BIOKA55 265 SUBSTITUTES FOR CHI-SQUARE * J. B. S. HALDANE

BIOKA55 266 A PROBLEM IN THE SIGNIFICANCE OF SMALL NUMBERS * J S. HALDANE

BIOKA55 26B BOUNDS FOR THE RATIO OF RANGE TO STANDARD DEVIATION * G. W. THOMSON

BIOKA55 269 ON THE ESTIMATION OF POPULATION PARAMETERS FROM MARKED MEMBERS * J . A . GÜLLAND

BIOKA55 277 CORRICENDA, 'A QUICKLY CONVERGENT EXPANSION FOR CUMU LATIVE HYPERGEOMETRIC PROBABILITIES, DIRECT AND INVERSE ' * M. E. WISE

BIOKA55 277 CORRIGENDA, 'ON STATIONARY PROCESSES IN THE PLANE' * P. WHITTLE

BIOKA55 277 CORRIGENDA, 'THE DISTRIBUTION OF RANGE IN CERTAIN NON-NORMAL POPULATIONS ${ }^{\prime} * \mathrm{H}$. A. DAVID

BIOKA55 277 CORRIGENDA, 'THE MEAN AND COEFFICIENT OF VARIATION OF RANGE IN SMALL SAMPLES FROM NON-NORMAL POPULATIONS *D. R. COX

BIOKA55 279 POPULATION ESTIMATION BASED ON CHANGE OF COMPOSITION CAUSED BY A SELECTIVE REMOVAL * D. G. CHAPMAN

BIOKA55 291 AN AGE-DEPENDENT BIRTH AND DEATH PROCESS * W. A. O'N WAUGH

BIOKA55 307 A LARGE-SAMPLE BIOASSAY DESIGN WITH RANDOM DOSES AND UNCERTA IN CONCENTRATION* F. C. ANDREWS, H. CHERNOFF

BIOKA55 316 AN EXACT TEST FOR CORRELATION BETWEEN TIME SERIES * E J. HANNAN WATSON

342 SOME THEOREMS AND SUFFICIENCY CONDITIONS FOR THE MAXIMUM-LIKELIHOOD ESTIMATOR OF AN UNKNOWN PARAMETER IN A SIMPLE MARKOV CHAIN * J. CANI

BIOKA55 360 SICNIFICANCE TESTS FOR DISCRIMINANT FUNCTIONS AND L INEAR FUNCT IONAL RELATIONSHIPS * E. J. WILLIAMS

BIOKA55 382 THE USE OF TRANSFORMATIONS AND MAXIMUM LIKELIHOOD IN THE ANALYSIS OF QUANTAL EXPERIMENTS INVOLVING TWO TREATMENTS * F. YATES

BIOKA55 404 A NOTE ON THE APPLICATION OF THE COMBINATION OF PROBABILITIES TEST TO A SET OF 2-BY-2 TABLES * F. YATES

BIOKA55 412 A TEST FOR HOMOCENEITY OF THE MARGINAL DISTRIBUTIONS IN A TWO-WAY CLASSIFICATION * A. STUART

BIOKA55 417 DISTRIBUTIONS OF KENDALL'S TAU BASED ON PARTIALLY ORDERED SYSTEMS * S. HABERMAN

BIOKA55 425 ON A CLASS OF SKEW DISTRIBUTION FUNCTIONS * H. A. SIMON

BIOKA55 441 SIMULTANEOUS TESTS OF LINEAR HYPOTHESES * M. N. GHOSH

BIOKA55 450 RANK ANALYSIS OF INCOMPLETE BLOCK DESIGNS. III. SOME LARGE-SAMPLE RESULTS ON ESTIMATION AND POWER FOR A METHOD OF PAIRED COMPARISONS * R. A. BRADLEY

BIOKA55

BIOKA55

BIOKA55

BIOKA55

BI0KA55

BIOKA55

BIOKA55

BIOKA55

BIOKA55

BIOKA55

BIOKA55

BIOKA55

BIOKA55

BIOKA55 BINATIONS OF VARIANCES * A. HUITSON

480 INTERPOLATIONS AND APPROXIMATIONS RELATED TO THE NORMAL RANGE * J.W. TUKEY

486 THE GAMBLER' S RUIN PROBLEM WITH CORRELATION * C. MOHAN 494 TABLES FOR SICNIFICANCE TESTS OF 2-BY-2 CONTINCENCY TABLES * P. ARMSEN

512 A NOTE ON MOVING RANGES * H. A. DAVID

516 CENSORED SAMPLES FROM TRUNCATED NORMAL DISTRIBUT IONS * A. C. COHEN

519 THE RAPID CALCULATION OF CHI-SQUARE AS A TEST OF HOMOGENEITY FROM A 2-BY-N TABLE * J. B. S. HALDANE

520 THE 'INEFFICIENCY' OF THE SAMPLE MEDIAN FOR MANY FAMILIAR SYMMETRIC DISTRIBUTIONS * J. T. CHU

522 A SIMPLE METHOD OF CALCULATING THE EXACT PROBABILITY IN 2-BY-2 CONTINGENCY TABLES WITH SMALL MARGINAL TOTALS * P. H. LESLIE

523 A TEST FOR A CHANGE IN A PARAMETER OCCURRING AT AN UNKNOWN POINT * E. S. PAGE

527 A PARADOX IN STATIST ICAL ESTIMATION * A. STUART

529 CUMULANTS OF A TRANSFORMED VARIATE * G. S. JAMES

531 THE LIKELIHOOD RATIO TEST FOR MARKOFF CHAINS * I. J GOOD

533 EXACT FORMS OF SOME INVARIANTS FOR DISTRIBUTIONS ADMIT TINC SUFFICIENT STATISTICS * V. S. HUZURBAZAR

BIOMETRIKA VOLUME 43, 1956

BIOKA56

BIOKA56

BIOKA56

BIOKA56

BIOKA56

BIOKA56

BIOKA56

BIOKA56

BIOKA56

BIOKA56

BIOKA56

BIOKA56

BIOKA56

BIOKA56

BIOKA56

BIOKA56
1 STUDIES IN THE HISTORY OF PROBABILITY AND STATISTICS II. THE BEGINNINGS OF A PROBABILITY CALCULUS * M. C . KENDALL

15 ON ESTIMATING THE LATENT AND INFECTIOUS PERIODS OF MEASLES, I. FAMILIES WITH TWO SUSCEPTIBLES ONLY. * N. T. J. BAILEY

23 THE BEHAVIOUR OF AN ESTIMATOR FOR A SIMPLE BIRTH AND DEATH PROCESS * J. H. DARWIN

32 EXAMINATION OF A QUANTUM HYPOTHESIS BASED ON A SINGLE SET OF DATA * S. R. BROADBENT

45 THE NUMBER OF NEW SPECIES, AND THE INCREASE IN POPULATION COVERAGE, WHEN A SAMPLE IS INCREASED * I. J GOOD, G. H. TOULMIN

64 A SEQUENTIAL TEST OF RANDOMNESS FOR EVENTS OCCURRING IN TIME OR SPACE * D. J. BARTHOLOMEW

79 ON THE MOMENTS OF THE MAXIMUM OF PARTIAL SUMS OF A FINITE NUMBER OF INDEPENDENT NORMAL VARIATES * A. A ANIS

85 ON THE APPLICATION TO STATISTICS OF AN ELEMENTARY THEOREM IN PROBABILITY * H. A. DAVID

92 CHI-SQUARE PROBABILITIES FOR LARGE NUMBERS OF DEGREES OF FREEDOM * J. WISHART

96 THE SAMPLING DISTRIBUTION OF A MAXIMUM-LIKELIHOOD EST IMATE * J. B. S. HALDANE, SHEILAM. SMITH

104 TESTS FOR RANDOMNESS OF POINTS ON A LINE * D. E . BARTON, F. N. DAVID

113 PAIRED COMPARISON DESIGNS FOR TESTING CONCORDANCE BETWEEN JUDGES * R. C. BOSE

N THE DISTRIBUTION OF THE LARGEST OR THE SMALLEST ROOT OF A MATRIX IN MULTIVARIATE ANALYSIS * $\mathrm{K} . \mathrm{C} . \mathrm{S}$ PILLAI

TESTS OF SIGNIFICANCE FOR THE LATENT ROOTS OF COVARIANCE AND CORRELATIONMATRICES * D. N. LAWLEY MILLIAMS UNEQUALLY SPACED OBSERVATIONS * P. G. GUEST
BIOKA56 161 ON THE JOINT DISTRIBUTION OF THE CIRCULAR SERIAL CORRELATION COEFFICIENTS * G. S. WATSON

BIOKA56 169 THE APPROXIMATE DISTRIBUTION OF SERIAL CORRELATION COEFFICIENTS * H. E. DANIELS

BIOKA56 186 TESTS OF HYPOTHESES IN THE LINEAR AUTO-RECRESSIVE MODEL. II. NULL DISTRIBUTIONS FOR HICHER ORDER SCHEMES, NON-NULL DISTRIBUTIONS * G. M. JENKINS

BIOKA56 200 A CLASS OF DISTRIBUTIONS FOR WHICH THE MAXIMUMLIKELIHOOD ESTIMATOR IS UNBIASED AND OF MINIMUM VARIANCE FOR ALL SAMPLE SIZES * D. E. BARTON

BIOKA56 203 FURTHER CRITICAL VALUES FOR THE TWO-MEANS PROBLEM * H. TRICKETT, B. L. WELCH, G. S. JAMES

BIOKA56 206 AN APPROXIMATION FOR THE SYMMETRIC, QUADRIVARIATE NORMAL INTEGRAL * J.A. MCFADDEN

BIOKA56 207 WEIGHTED PROBITS ALLOWING FOR A NON-ZERO RESPONSE IN THE CONTROLS * M. J.R. HEALY

BIOKA56 208 TREATMENT VARIANCES FOR EXPERIMENTAL DESIGNS WITH SER IALLY CORRELATED OBSERVATIONS * J . C. BUTCHER

BIOKA56 212 THE MULTIVARIATE DISTRIBUTION OF COMPLEX NORMAL VARIABLES * R A WOODING

BIOKA56 215 STATIONARITY CONDITIONS FOR STOCHASTIC PROCESSES OF THE AUTOREGRESSIVE AND MOVING-AVERACE TYPE * J. WISE

BIOKA56 219 SOME PROPERTIES OF AN ANCULAR TRANSFORMATION FOR THE CORRELATION COEFF ICIENT * B. I. HARLEY

BIOKA56 224 NOTE ON THE MOMENT-PROBLEM FOR UNIMODAL DISTRIBUTIONS WHEN ONE OR BOTH TERMINALS ARE KNOWN * C. L. MALLOWS

BIOKA56 227 ON INVERTING A CLASS OF PATTERNED MATRICES * S. N. ROY, A. E. SARHAN

BIOKA56 231 A NOTE ON THE RISKS OF ERROR INVOLVED IN THE SEQUENTIAI RATIO TEST * J. MEDHI

BIOKA56 235 CORRICENDA TO 'TRANSFORMATIONS OF THE BINOMIAL, NEGATIVE BINOMIAL, POISSON AND CHI-SQUARE DISTRIBUTIONS: * G. BLOM

BIOKA56 235 CORRICENDA, 'THE RANDOMIZATION ANALYSIS OF A GENERALIZED RANDOMIZED BLOCK DESIGN' * M. B. WILK 
BIOKA56 241 STUDIES IN THE HISTORY OF PROBABILITY AND STATISTICS. III. A NOTE ON THE HISTORY OF THE CRAPHICAL PRESENTATION OF DATA * ERICA ROYSTON

BIOKA56 24B STUDIES IN THE HISTORY OF PROBABILITY AND STATISTICS IV. A NOTE ON AN EARLY STATISTICAL STUDY OF LITERARY STYLE* C. B. WILLIAMS

BIOKA56 257 A COODNESS OF FIT TEST FOR SPECTRAL DISTRIBUTION FUNCTIONS OF STATIONARY TIME SERIES WITH NORMAL RESIDUALS * A. M. WALKER

BIOKA56 276 SUFFICIENCY CONDITIONS IN REGULAR MARKOV CHAINS AND CERTAIN RANDOM WALKS * J. CANI

BIOKA56 2B5 SOME ASYMPTOTICDISTRIBUTION THEORY FOR MARKOV CHAINS WITH A DENUMERABLE NUMBER OF STATES * C. DERMAN

BIOKA56 295 A GENERAL METHOD FOR APPROXIMATING TO THE DISTRIBUTION OF LIKELIHOOD RATIO CRITERIA * D. N. LAWLEY

BIOKA56 304 ON THE ACCURACY OF WEICHTED MEANS AND RATIOS * G. S JAMES

BIOKA56 322 ON ESTIMATING THE LATENT AND INFECTIOUS PERIODS OF MEASLES, II FAMILIES WITH THREE OR MORE SUSCEPTIBLES * N. T. J. BAILEY

BIOKA56 332 SIGNIFICANCE TESTS FOR A VARIABLE CHANCE OF INFECTION IN CHAIN-BINOMIAL THEORY * N. T. J. BAILEY

BIOKA56 337 ON THE VARIATION OF YIELD VARIANCE WITH PLOT SIZE * P WHITTLE

BIOKA56 344 ON THE CONSTRUCTION OF SICNIFICANCE TESTS ON THE CIRCLE AND THE SPHERE * C. S. WATSON, E. J. WILLIAMS

8IOKA56 353 NOTES ON BIAS IN ESTIMATION * M. H. QUENOUILLE

BIOKA56 361 AN INTRODUCTION TO SOME NON-PARAMETRIC CENERALIZAYSIS * S. N. ROY, S. K. MITRA

BIOKA56 377 A TWO-SAMPLEDISTRIBUTION-FREE TEST * A.R. KAMAT

BI0KA56 3B6 ADDENDUM, THE LIMITING DISTRIBUTION OF KAMAT'S TEST STATISTIC *D. E. BARTON

BI0KA56 3B8 SEQUENTIAL ANALYSIS APPLIED TO CERTAIN EXPERIMENTAL DESIGNS IN THE ANALYSIS OF VARIANCE * W. D. RAY

BIOKA56 404 LOCNORMAL APPROXIMATION TO PRODUCTS AND QUOTIENTS * S. R. BROADBENT TIONS OF ANALYSIS OF VARI ANCE AND MULTIVARIATE ANAL-
BIOKA56

BIOKA56 BIOKA56

BIOKA56

BI0KA56

BIOKA56

BI0KA56

BI0KA56

BIOKA56

BIOKA56

BIOKA56

BIOKA56

BIOKA56

BI0KA56

BI0KA56

8IOKA56

8I0KA56

8I0KA56

BIOKA56

BI0KA56
4IB A REJECTION CRITERION BASED UPON THE RANCE * C. I BLISS, W. C. COCHRAN, J. W. TUKEY

423 CONFIDENCE INTERVALS FOR A PROPORTION * E. L. CROW

436 SERIAL CORRELATION IN RECRESSION ANALYSIS. II * C. S WATSON, E. J . HANNAN

449 REVISED UPPER PERCENTACE POINTS OF THE EXTREME STUDENT IZED DEVIATE FROM THE SAMPLE MEAN * H. A. DAVID

452 EXACT LINEAR SEQUENTIAL TESTS FOR THE MEAN OF A NORMAL DISTRIBUTION * J. TAYLOR

456 ON THE SUM OF SQUARES OF NORMAL SCORES * H. RUBEN

45B ON THE MOMENTS OF THE RANGE AND PRODUCT MOMENTS OF EXTREME ORDER STAT IST ICS IN NORMAL SAMPLES * H. RUBEN

461 ON ESTIMATINC BINOMIAL RESPONSE RELATIONS * F. J. ANSCOMBE

XISTENCE AND UNIQUENESS OF A UNIFORMLY MOST POWERFUL RANDOMIZED UNBIASED TEST FOR THE BINOMIAL * A. A BLANK

A NOTE ON THE

468 THE FITTING OF RECRESSION CURVES WITH AUTOCORRELATED DATA * N A HUTTLY

OUNDS FOR THE VARIANCE OF KENDALL 'S RANK CORRELATION STATISTIC * A. STUART

478 A NOTE ON THE THEORY OF QUICK TESTS * D. R. COX

480 A NOTE ON THE SIGNS OF GROSS CORRELATION COEFFICIENTS AND PARTIAL CORRELATION COEFFICIENTS * 0 . REIERSOL

4B2 THE ESTIMATION OF THE MEAN OF A CENSORED NORMAL DISTRIBUTION BY ORDERED VARIABLES * $P$. C. MOORE

$4 B 5$ A NOTE ON WILCOXON'S AND ALLIED TESTS * F. N. DAVID

4BB LIKELIHOOD FUNCTION FOR CAPTURE-RECAPTURE SAMPLES * N. E. C. CILBERT

489 TABLES OF POISSON POWER MOMENTS * J. B. DOUGLAS

496 CORRICENDA TO 'CORRELATED RANDOM NORMAL DEVIATES' PUBLISHED IN TRACTS FOR COMPUTERS, NO. 26. * E. C. FIELLER, T. LEWIS, E. S. PEARSON

497 CORRIGENDA TO 'SOME THEOREMS AND SUFFICIENCY CONDITIONS FOR THE MAXIMUM-LIKELIHOOD ESTIMATOR OF AN UNKNOWN PARAMETER IN A SIMPLE MARKOV CHAIN' * J . GANI

BIOMETRIKA

VOLUME 44, 1957

BIOKA57 I EDITORIAL, JOHN WISHART, 1898-1956 * E. S. PEARSON

BIOKA57

BIOKA5?

9 RESTRICTED SEQUENT IAL PROCEDURES * P. ARMITAGE

27 ON THEORETICAL MODELS FOR COMPETITIVE AND PREDATORY BIOLOGICAL SYSTEMS * M. S. BARTLETT

BIOKA57 43 THE CONSISTENCY AND ADEQUACY OF THE POISSON-MARKOFF MODEL FOR DENSITY FLUCTUATIONS * V. T. PATIL

BIOKA57 57 TESTING FOR SERIAL CORRELATION IN LEAST SQUARES RECRESSION*E, J. HANNAN

BIOKA57 67 ON THE ANALYSIS OF MULTIPLE REGRESSION IN K CATEGORIES * S. KULLBACK, H. M. ROSENBLATT

BIOKA57 B4 BIV^RIATE STRUCTURAL RELATION * R. L. BROWN

BIOKA57 97 AN ANALYSIS OF PAIRED COMPARISON DESICNS WITH INCOMPLETE REPETITIONS * J. W. WILKINSON

8IOKA57 114 NON-NULL RANKING MODELS. I * C. L. MALLOWS

BIOKA57 131 THE CENERALIZATION OF PROBIT ANALYSIS TO THE CASE OF MULTIPLE RESPONSES * J. AITCHISON, S. D. SILVEY

BIOKA57 141 EXPERIMENTINC WITH ORCANISMS AS BLOCKS * S. C. PEARCE

BIOKA57 150 THE USE OF A CONCOMITANT VARIABLE IN SELECTINC AN EXPERIMENTAL DESICN * D.R. COX

BIOKA57 159 APPROXIMATE CONFIDENCE LIMITS FOR COMPONENTS OF VARIANCE * M. G, BULMER

BIOKA57 168 MULTIPLERUNS * D. E. BARTON, F. N. DAVID

BIOKA57 179 BINOMIAL SAMPLING SCHEMES AND THE CONCEPT OF INFORMATION * D. V. LINDLEY

BIOKA57 187 ASTATISTICAL PARADOX * D. V. LINDLEY

BIOKA57 193 STOCHASTIC CROSS-INFECTION BETWEEN TWO OTHERWISE ISOLATED CROUPS * H. W. HASKEY

BIOKA57 205 SOME STATISTICS ASSOCIATED WITH THE RANDOM DISORIENTATION OF CUBES * J. K. MACKENZIE, M. J. THOMSON

BIOKA57 211 THE DIFFERENCE BETWEEN CONSECUTIVE MEMBERS OF A SERIES OF RANDOM VARIABLES ARRANCED IN ORDER OF SIZE * J. H. DARWIN

BIOKA57 219 RELATION BETWEEN THE DISTRIBUTIONS OF NON-CENTRAL T AND OF A TRANSFORMED CORRELATION COEFFICIENT * B. I HARLEY

BIOKA57 225 ON THE SOLUTION OF ESTIMATING EQUATIONS FOR TRUNCATED AND CENSORED SAMPLES FROM NORMAL POPULATIONS * A. C. COHEN

BIOKA57 237 UPPER PERCENTACE POINTS OF THE CENERALIZED BETA DISTRIBUTION. I*F. G. FOSTER, D. H. REES

BIOKA57 24B ON PROBLEMS IN WHICH A CHANCE IN A PARAMETER OCCURS AT AN UNKNOWN POINT * E. S. PACE

BIOKA57 253 TESTINC FOR DEPARTURE FROM THE EXPONENTIAL DISTRIBUTION * D. J. 8ARTHOLOMEW

BIOKA57 257 THE DISTRIBUTION OF RANGE IN NORMAL SAMPLES WITH N=200 * B. I. HARLEY. E. S. PEARSON
BIOKA57 260 STUDIES IN THE HISTORY OF PROBABILITY AND STATISTICS. V. A NOTE ON PLAYING CARDS * M, G. KENDALL

BIOKA57 262 A SINGULARITY IN THE ESTIMATION OF BINOMIAL VARIANCE * A. STUART

BIOKA57 264 STUDENT'S DISTRIBUTION AND RIEMANN'S ELLIPTIC CEOMETRY * A. WINTNER

BIOKA57 265 SOME INTERRELATIONS AMONG COMPOUND AND CENERALIZED DISTRIBUTIONS * J. GURLAND

BIOKA57 268 A NOTE ON TESTS OF SICNIFICANCE FOR LINEAR FUNCTIONAL RELATIONSHIPS * M. S. BARTLETT

BIOKA57 270 THE MOMENTS OF THE LEIPNIK DISTRIBUTION * M. G. KENDALL

8IOKA57 272 THE EFFECT OF TRANSFORMATIONS OF VARIABLES UPON THEIR CORRELATION COEFFICIENTS * M. H. QUENOUILLE

BIOKA57 273 FURTHER PROPERTIES OF AN ANCULAR TRANSFORMATION OF THE CORREL ATION COEFF ICIENT * B. I. HARLEY

BIOKA57 275 HETEROCENEITY OF ERROR VARIANCES IN A RANDOMIZED BLOCK DESICN * F. A. GRAYBILL, J. L. FOLKS

BIOKA57 27B AN EXTENSION PROPERTY OF A CLASS OF BALANCED INCOMPLETE BLOCK DESIGNS * G P. SILLITTO

BIOKA57 279 SEQUENTIALLY DETERMINED CONFIDENCE INTERVALS * N. L. JOHNSON

BIOKA57 282 ESTIMATION OF MEANS OF NORMAL POPULATIONS FROM OBSERVED MINIMA * H. A. DAVID

BIOKA57 286 THE POWER OF THE POISSON INDEX OF DISPERSION * J. H. DARWIN

BIOKA57 2B9 SOME PROPERTIES OF THE BIVARIATE NORMAL DISTRIBUTION CONSIDERED IN THE FORM OF A CONTINGENCY TABLE * H. 0. LANCASTER

BIOKA57 301 CORRIGENDA TO 'THE LIKELIHOOD RATIO TEST FOR MARKOFF CHAINS' * I. J. GOOD

BIOKA57 303 CENTENARY LECTURE, KARL PEARSON, 1B57-1957* J. B. S. HALDANE

BIOKA57 314 AN ANALYSIS OF THE DATA FOR SOME EXPERIMENTS CARRIED OUT BY GAUSE WITH POPULATIONS OF THE PROTOZOA PARAMECIUM AURELIA AND PARAMECIUM CAUDATUM * P. H. LESLIE

BIOKA57 32B ON THE DISTRIBUTION OF TRIBOLIUM CONFUSUM IN A CONTAINER *D.R. COX,W. L. SMITH

BIOKA57 336 THE CHI-SQUARE GOODNESS-OF-FIT TEST FOR NORMAL DISTRIBUTIONS * C. S. WATSON

BIOKA57 349 APPROXIMATIONS TO THE DISTRIBUTIONS OF SOME MEASURES OF DISPERSION BASED ON SUCCESSIVE DIFFERENCES * $Y$. S. SATHE, A.R. KAMAT

BIOKA57 360 QUEUEING WITH BALKING * F . A. HAICHT 
8IOKA57 370 TESTING FOR SERIAL CORRELATION IN SYSTEMS OF SIMULTANEOUS REGRESSION EQUATIONS * J . DURBIN

BIOKA57 378 HETEROGENEOUS ERROR VARIANCES IN SPLIT-PLOT EXPERIMENTS * R. N. CURNOW

BIOKA57 384 A MAXIMUM-MINIMUM PROBLEM RELATED TO STATISTICAL DISTRIBUTIONS IN TWO DIMENSIONS * A. J. HARRIS

EIOKA57 399 FURTHER CONTRIBUTIONS TO MULTIVARIATE CONFIDENCE BOUNDS * S. N. ROY, R. GNANADESIKAN

BIOKA57 411 TABLES FOR USE IN EST IMATING THE NORMAL DISTRI8UTION FUNCTION BY NORMIT ANALYSIS. PART I DESCRIPTION AND USE OF TABLES. PART II. COMPARISON BETWEEN MINIMUM NORMIT CHI-SQUARE ESTIMATE AND THE MAXIMUM LIKELIHOOD ESTIMATE * J. BERKSON

BIOKA57 436 SHORTER INTERVALS FOR THE PARAMETER OF THE BINOMIAL AND POISSON DISTRIBUTIONS * W. L. STEVENS

BIOKA57 441 UPPER PERCENTAGE POINTS OF THE GENERALIZED BETA DISTRIBUTION. II *F. G. FOSTER

BIOKA57 454 STATISTICAL ANALYSIS USING LOCAL PROPERTIES OF SMOOTHLY HETEROMORPHIC STOCHASTIC SERIES * G. H. JOWETT

BIOKA57 464 DEPENDENCE OF THE FIDUCIAL ARGUMENT ON THE SAMPLING RULE * F. J. ANSCOMBE

BIOKA57 470 TESTS FOR RANK CORRELATION COEFFICIENTS. I * E. C. FIELLER, H. O. HARTLEY, E. S. PEARSON
3IOKA57

BIOKA57

BIOKA57

BIOKA57

BI0KA57

BIOKA57

BIOKA57

BIOKA57

BIOKA57

BIOKA57

BIOKA57

482 THE TWO-SAMPLET-TEST BASED ON RANGE * P. G. MOORE

490 A BIBLIOGRAPHY ON THE THEORY OF QUEUES * ALISON DOIG

515 STUDIES IN THE HISTORY OF PROBABILITY AND STATISTICS

VI. A NOTE ON THE EARLY SOLUTIONS OF THE PROBLEM OF THE DURATION OF PLAY *A. R. THATCHER

518 OPT IMAL SAMPLING FOR QUOTA FULFILMENT * N. L. JOHNSON

524 THE DISTRIBUT ION OF INTERVALS BETWEEN SUCCESS IVE MAXIMA IN A SERIES OF RANDOM NUMBERS * D. S. PALMER

526 THE EFFECT OF TIES ON THE MOMENTS OF RANK CRITERIA * B E. COOPER

52B APPROXIMATIONS TO THE UPPER 5 PERCENT POINTS OF FISHER'S B DISTRIBUTION AND NON-CENTRAL CHI-SQUARE * J. W. TUKEY

30 UNIQUENESS OF A RESULT IN THE THEORY OF ACCIDENT PRONENESS * N. L. JOHNSON

532 A NOTE ON THE MEAN DEVIATION OF THE BINOMIAL DISTRIBUTION * N. L. JOHNSON

533 A COMMENT ON D.V. LINDLEY'S STATISTICAL PARADOX * M. S. BARTLETT

534 CORRIGENDA TO 'THE USE OF A CONCOMITANT VARIABLE IN SELECT ING AN EXPERIMENTAL DESIGN ' * D. R, COX

534 CORRIGENDA TO 'MULTIPLE RUNS' * D. E. BARTON, F. N DAVID

BIOMETRIKA VOLUME 45, 195B

BIOKA5B

BIOKA58

1 NUMERIGAL STUDIES IN THE SEQUENTIAL ESTIMATION OF A BINOMIAL PARAMETER * P. ARMITAGE

16 A STOCHASTIC MODEL FOR STUDY ING THE PROPERTIES OF CERTAIN 8IOLOG ICAL SYSTEMS BY NUMERICAL METHODS * P. H LESLIE

BIOKA58 32 ON THE DERIVATION AND APPLICABILITY OF NEYMAN'S TYPE A DISTRIBUTION * J. G. SKELLAM

BIOKA58 37 NEGATIVE 8INOMIAL DISTRIBUTIONS WITH A COMMON K * C I. BLISS, A.R. G. OWEN

BIOKA58 59 SIMPLIFIED METHODS OF FITTING THE TRUNCATED NEGATIVE BINOMIAL DISTRIBUTION * W. BRASS

BIOKA58 69 THE INTERPRETATION OF THE EFFECTS OF NON-ADDITIVITY IN THE LATIN SQUARE*D.R. COX

BIOKA58 74 QUANTAL RESPONSES TO MIXTURES OF POISONS UNDER GONDITIONS OF SIMPLE SIMILAR ACTION, THE ANALYSIS OF UNCONTROLLED DATA * J.R. ASHFORD

BIOKA58 B9 SOME PROPERTIES OF RUNS IN QUALITY CONTROL PROCEDURES * P. G. MOORE

BIOKA5B 96 SIMULTANEOUS REGRESSION EQUATIONS IN EXPERIMENTATION * E, J. WILLIAMS

BIOKA5B 111 ONE-WAY VARIANCES IN A TWO-WAY CLASSIFICATION * T. S RUSSELL, R. A. BRADLEY

BIOKA5B 130 STUDIES IN THE HISTORY OF PROBABILITY AND STATISTICS, VII. THE PRINCIPLE OF THE ARITHMETIC MEAN * R. L. PLACKETT

BIOKA58 136 MULTIVARIATE LINEAR STRUCTURAL RELATIONS * R, L. BROWN, F. FEREDAY

BIOKA58 154 MULTIVARIATE RATIO ESTIMATION FOR FINITE POPULATIONS * I. OLKIN

BIOKA58 166 NON-RANDOMNESS IN A SEQUENCE OF TWO ALTERNATIVES. I WILCOXON'S AND ALLIED TEST STATISTICS * D. E. BARTON, F. N. DAVID, C. L. MALLOWS

BIOKA58 181 SIMPLIFIED RUNS TESTS AND LIKELIHOOD RATIO TESTS FOR MARKOFF CHAINS * L. A. GOODMAN

BIOKA5B 198 MOMENT GENERATING FUNCTIONS OF QUADRATIC FORMS IN SER IALLY CORRELATED NORMAL VARIABLES * R. LEIPNIK

BIOKA58 211 MOMENTS OF SAMPLE MOMENTS OF CENSORED SAMPLES FROM A NORMAL POPULATION * J. G. SAW

8IOKA58 222 THE RELATION BETWEEN THE DICT IONARY DISTRIBUTION AND THE OCCURRENCE DISTRIBUTION OF WORD LENGTH AND ITS IMPORTANCE FOR THE STUDY OF QUANTITATIVE LINGUISTICS * G. HERDAN

BIOKA58 229 SEGOND PAPER ON STATIST ICS ASSOGIATED WITH THE RANDOM DISORIENTATION OF CUBES * J.K. MACKENZIE

BIOKA58 241 GONDITIONED MARKOV PROCESSES * W. A. O'N. WAUGH

BIOKA5B 250 RANKING MEANS OF TWO NORMAL POPULATIONS WITH UNKNOWN VARIANCES * RITA MAURICE

8IOKA5B 253 NON-RANDOMNESS IN A SEQUENCE OF TWO ALTERNATIVES. II RUNS TEST *D. E. BARTON, F. N. DAVID

BIOKA5B 256 NOTE ON MULTIPLE COMPARISONS FOR ADJUSTED MEANS IN THE ANALYSIS OF COVARIANCE * M. HALPERIN, S. W. GREENHOUSE

BIOKA58 260 AN EMPIRICAL INVESTIGATION INTO THE DISTRIBUTION OF THE F-RATIO IN SAMPLES FROM TWO NON-NORMAL POPULATIONS * H. R. 8. HACK

8IOKA58 265 THEORETICAL CONSIDERATIONS REGARDING H. R. 8. HACK'S SYSTEM OF RANDOMIZATION FOR CROSS-CLASSIFICATIONS * N. L. JOHNSON
BIOKA58 267 ON THE EQUIVALENCE OF TWO TESTS OF EQUALITY OF RATE OF OCCURRENCE IN TWO SERIES OF EVENTS OCCURRING RANDOMLY IN TIME * D. E. BARTON

BIOKA58 268 THE MATHEMATIGAL RELATION BETWEEN GREENBERG 'S INDEX OF LINGUISTIC DIVERSITY AND YULE'S CHARACTERISTIC * G. HERDAN

BIOKA58 270 NOTE ON A DISCONTINUOUS PROBABILITY DENSITY * J. E KERRICH

BIOKA5B 273 A REMARK ON SPEARMAN'S RANK CORRELATION COEFFICIENT * H. BERGSTKOM

BIOKA58 275 INTERVAL ESTIMATION FOR THE PARAMETER OF A 8INOMIAL DISTRIBUTION * C. W. CLUNIES-ROSS

BIOKA58 279 FURTHER CRITICAL VALUES FOR THE SUM OF TWO VARIANCES * A. HUITSON

BIOKA58 282 STUDIES IN THE HISTORY OF PROBABILITY AND STATISTICS. VIII. DE MORGAN AND THE STATISTICAL STUDY OF LITERARY STYLE * R. D. LORD

BIOKA58 291 CORRIGENDA TO 'SOME FURTHER RESULTS IN THE THEORY OF PEDESTRIANS AND ROAD TRAFFIC' * A. J. MAYNE

BIOKA5B 291 CORRIGENDA TO 'CONFIDENCE INTERVALS FOR A PROPORTION' * E. L. CROM

BIOKA5B 292 ERRATA IN 'TABLES OF SYMMETRIC FUNCTIONS' * F. N DAVID, M. G. KENDALL

BIOKA58 293 STUDIES IN THE HISTORY OF PROBABILITY AND STATISTICS IX. BIOGRAPHICAL NOTE FOR T B BAYES' ESSAY TOWARDS SOLVING A PROBLEM IN THE DOCTRINE OF CHANCES. * G. A. BARNARD

BIOKA58 296 ESSAY TOWARDS SOLVING A PROBLEM IN THE DOCTRINE OF CHANCES. (REPRODUCED FROM PHIL. TRANS, ROY. SOG $1763,53,370-41 \mathrm{~B} .1$ ) THOMAS BAYES

8IOKA58 316 THE PROPERTIES OF A STOCHASTIC MODEL FOR TWO COMPETING SPECIES * P. H. LESLIE, J , C. GOWER

BIOKA5B 331 A PROBLEM IN THE COMBINATION OF ACCIDENT FREQUENCIES * J. C. TANNER

BIOKA58 343 THE MULTIPLE-RECAPTURE CENSUS. I. ESTIMATION OF A CLOSED POPULATION * J. N. DARROCH

BIOKA58 360 CONFIDENCE INTERVALS FOR DISTANCE IN THE ANALYSIS OF VARIANCE * M.G. BULMER

BIOKA58 370 THE EFFIGIENCIES OF ALTERNATIVE ESTIMATORS FOR AN ASY MPTOT IC REGRESSION EQUATION * D. J. FINNEY

8IOKA58 389 THE USE OF AUTOREGRESSION IN FITTING AN EXPONENTIAL CURVE * H. D. PATTERSON

BIOKA58 401 TWO QUEUES IN PARALLEL * F. A. HAIGHT

BIOKA58 411 MOMENT ESTIMATORS AND MAXIMUM LIKELIHOOD * L. R. SHENTON

BIOKA5B

BIOKA58

421 EFFECT OF NON-NORMALITY ON THE POWER FUNCTION OF TTEST * A. B. L. SRIVASTAVA

BIOKA5B STUDENT'S TEST * E. S. PEARSON BARTON, D. J. CASLEY
BTOKA58 436 ON THE CHOICE OF THE BEST AMONGST THREE NORMAL POPULATIONS WITH KNOWN VARIANCES * A. ZINGER, J. ST-PIERRE

BIOKA58 447 APPROXIMATE FORMULAE FOR THE STATISTICAL DISTRIBUTIONS OF EXTREME VALUES * J. J. DRONKERS

8IOKA58 471 THE SAMPLING VARIANCE OF CORRELATION COEFFICIENTS UNDER ASSUMPTIONS OF FIXED AND MIXED VARIATES * J. W. HOOPER

BIOKA58 478 THE MEAN DEVIATION, WITH SPECIAL REFERENCE TO SAMPLES FROM A PEARSON TYPE III POPULATION * N. L. JOHNSONN 
BIOKA58 484 AN APPROXIMATION TO THE DISTRIBUTION OF NON-CENTRAL T * MAXINE MERRINCTON, E. S. PEARSON

BIOKA58 492 UPPER PERCENTACE POINTS OF THE CENERALIZED BETA DISTRIBUTION. III * F. C. FOSTER

BIOKA58 504 ESTIMATION OF PARAMETERS OF MIXED EXPONENTIALLY DISTRIBUTED FAILURE TIME DISTRIBUTIONS FROM CENSORED LIFE TEST DATA * W. MENDENHALL, R. J. HADER

BIOKA5B 521 A BIBLIOGRAPHY ON LIFE TESTING AND RELATED TOPICS * W MENDENHALL

BIOKA58 544 A TWO-SAMPLE DISTRIBUTION FREE TEST FOR COMPARING VARIANCES * B. V. SUKHATME

BIOKA5B 549 THE MEAN DIFFERENCE AND THE MEAN DEVIATION OF SOME DISCONTINUOUS DISTRIBUTIONS * T. A. RAMASUBBAN

BIOKA5B 556 THE MEAN DEVIATION OF THE POISSONDISTRIBUTION * E. L. CROW

BIOKA5B 559 NOTE ON THE CHARACTERISTIC FUNCTION OF A SERIAL-CORRELATIONDISTRIBUTION*R. LEIPNIK

BIOKA58 562 TWO FURTHER APPLICATIONS OF A MODEL FOR BINARY REGRESSION *D,R, COX
BIOKA58 565 A NOTE ON A SERIES SOLUTION OF A PROBLEM IN ESTIMATION * i . cuttman

BIOKA58 567 ON NAIR'S TRANSFORMATION OF THE CORRELATION COEFFICIENT * M. SANKARAN

BIOKA58 571 SHORT PROOF OF DR HARLEY'S THEOREM ON THE CORRELATION COEFFICIENT * H. E. DANIELS, M. G. KENDALL

BIOKA58 572 RUNS IN A RING *D. E. BARTON, F. N. DAVID

BIOKA5B 57B SOME APPLICATIONS OF MEIJER-G FUNCTIONS TO DISTRIBUTION PROBLEMS IN STATISTICS *D. G. KABE

BIOKA5B 581 SELECTION OF THE POPULATION WITH THE LARGEST MEAN WHEN COMPARISONS CAN BE MADE ONLY IN PAIRS * RITA MAURICE

BIOKA5B 5BI A NOTE ON 'FURTHER CONTRIBUTIONS TO MULTIVARIATE CONFIDENCE BOUNDS' * S. N. ROY, R. GNANADESIKAN

BIOKA58 587 CORRIGENDA TO 'A NOTE ON THE MEAN DEVIATION OF THE BINOMIAL D ISTRIBUTION' * N. L. JOHNSON

BIOKA58 587 GORRIGENDA TO 'ON THE MEAN SUCCESSIVE DIFFERENCE AND ITS RATIO TO THE ROOT MEAN SQUARE' *A. R. KAMAT

BIOKA5B 5B7 CORRIGENDA TO 'MOMENTS OF SAMPLE MOMENTS OF CENSORED SAMPLES FROM A NORMAL POPULATION' $*$ J. G. SAW

BIOMETRIKA VOLUME 46,1959

BIOKA59 I ON THE CUMULANTS OF RENEWAL PROCESSES * W. L. SMITH

BIOKA59

30 A RANDOM WALK IN WHICH THE STEPS OCCUR RANDOMLY IN TIME * A. MERCER, C. S. SMITH

BIOKA59 36 A TEST OF HOMOGENEITY FOR ORDERED ALTERNATIVES * D. J BARTHOLOMEW

BIOKA59 49 SOME PROBLEMS INVOLVING LINEAR HYPOTHESES IN MULTIVARIATE ANALYSIS * C.R. RAO

BIOKA59 59 TESTS OF SIGNIFICANCE IN CANONICAL ANALYSIS * D. N LAWLEY

BIOKA59 67 THE ESTIMATION OF PARAMETERS IN SYSTEMS OF STOCHASTIC DIFFERENTIAL EQUATIONS * A. W. PHILLIPS

BIOKA59 77 DESICN OF EXPERIMENTS IN NON-LINEAR SITUATIONS * G . E P. BOX, H. L. LUCAS

BIOKA59 91 THE ESTIMATION OF MISSINC AND MIXED-UP OBSERVATIONS IN SEVERAL EXPERIMENTAL DESIGNS * J . D. BIGCERS

BIOKA59 106 NOTE ON A THREE-DECISION TEST FOR COMPARING TWO BINOMI AL POPULATIONS * J. H. DARWIN

BIOKA59 114 EFFECT OF NON-NORMALITY ON THE POWER OF THE ANALYSIS OF VARIANCE TEST * A. B. L. SRIVASTAVA

BIOKA59 123 THE Z-TEST AND SYMMETRICALLY DISTRIBUTED RANDOM VARIABLES * F. N. DAVID

BIOKA59 130 APPROXIMATION TO THE DISTRIBUTION OF SAMPLE SIZE FOR SEQUENTIAL TESTS. I. TESTS FOR SIMPLE HYPOTHESES * D. H. BHATE

BIOKA59 139 TOURNAMENTS AND PAIRED COMPARISONS * H. A. DAVID

BIOKA59 150 ESTIMATION OF THE NORMAL POPULATION PARAMETERS GIVEN A SINCLY CENSORED SAMPLE* J . G. SAW

BIOKA59 160 ON HOTELLINC' S GENERALIZATION T-SOUARE * K. C. S. PILLAI, P. SAMPSON JR

BIOKA59 169 TABLES FOR WALD TESTS FOR THE MEAN OF A NORMAL DISTRIBUTION * ELIZABETHD. BARRACLOUCH, E. S. PAGE

BIOKA59 17B TABLES OF RANDOM OBSERVATIONS FROM STANDARD DISTRIBUTIONS* M. H. QUENOUILLE

BIOKA59 203 NOTE ON MR QUENOUILLE'S EDCEWORTH TYPE A TRANSFORMATION * E. S. PEARSON

BIOKA59 205 MONOMIAL-MONOMIAL SYMMETRIC FUNCTION TABLES * J. LEVINE

BIOKA59 214 APPROXIMATE LINEARIZATION OF THE INCOMPLETE BETAFUNCTION * A. W. KIMBALL, E. LEACH

BIOKA59 218 SEQUENTIAL OCCUPANCY * D. E. BARTON, F. N. DAVID

BIOKA59 223 THE GENERALIZED MEAN DIFFERENCES OF THE BINOMIAL AND POISSONDISTRIBUTIONS * T. A. RAMASUBBAN

BIOKA59 229 DETERMINATION OF PARAMETERS IN THE JOHNSON SYSTEM OF PROBABILITY DISTRIBUTIONS * D. C. M. LESLIE

BIOKA59 231 NOTE ONA PROBLEM OF ESTIMATION *D. E. LLOYD

BIOKA59 235 ON THE NON-CENTRAL CHI-SQUARE DISTRIBUTION * M. SANKARAN

BIOKA59 237 ON THE DISTRIBUTION OF THE LARGEST OF SIX ROOTS OF A MATRIX IN MULTIVARIATE ANALYSIS * K. C. S. PILLAI, CELIA G. BANTEGUI

BIOKA59 241 THE RANK ANALOCUE OF PRODUCT-MOMENT PARTIAL CORRELATION AND REGRESSION, WITH APPLICATION TO MANIFOLD ORDERED CONTINGENCY TABLES * R. H. SOMERS

BIOKA59 246 THE BUSY PERIOD IN RELATION TO THE QUEUEINC PROCESS CI-M-I*B. W. CONOLLY

BIOKA59 251 THE DESIGN OF FACTORIAL EXPERIMENTS, A SURVEY OF SOME SCHEMES REQUIRING NOT MORE THAN 256 TREATMENT COMBINATIONS * R. G. MITTON, F. R. MORGAN

BIOKA59 260 CONFIDENCE LIMITS IN THE CASE OF THE GEOMETRIC DISTRIBUTION * K. G. CLEMANS

BIOKA59 279 CORRIGENDA, 'ON THE STATISTICAL INDEPENDENCE OF QUADRATIC FORMS IN NORMAL VARIATES. ' * A. C. AITKEN

BIOKA59 279 CORRIGENDA, 'SOME PROPERTIES OF RUNS IN QUALITY CONTROL PROCEDURES' * P. G. MOORE
BIOKA59 279 CORRIGENDA, 'CONDITIONED MARKOFF PROCESSES. ' * W A O'N. WAUGH

BIOKA59 279 CORRICENDA, 'THE PROPERTIES OF A STOCHASTIC MODEL FOR TWO COMPETINC SPECIES. ' * P. H. LESLIE, J. C. GOWER

BIOKA59 2BI AN INVESTIGATION OF HARTLEY'S METHOD FOR FITTING AN EXPONENTIAL CURVE * H. D. PATTERSON, S. LIPTON

BIOKA59 293 THE EFFICIENCY OF INTERNAL REGRESS ION FOR THE FITTING OF THE EXPONENTIAL REGRESS ION * H. O. HARTLEY

BIOKA59 296 THE DISTRIBUTION OF MOMENT ESTIMATORS * L. R. SHENTON BIOKA59 306 EFFICIENT ESTIMATION OF PARAMETERS IN MOVING-AVERAGE MODELS * J. DURBIN

BIOKA59 317 THE COMPLETE AMALGAMATION INTO BLOCKS, BY WEIGHTED MEANS, OF A FINITE SET OF REAL NUMBERS * R. E. MILES

BIOKA59 328 A TEST OF HOMOGENEITY FOR ORDERED ALTERNATIVES. II D. J. BARTHOLOMEM

BIOKA59 336 THE MULTIPLE-RECAPTURE CENSUS II. ESTIMATION WHEN THERE IS IMMICRATION OR DEATH * J. N. DARROCH

BIOKA59 352 ON AN EXTENSION OF THE CONNEXION BETWEEN POISSON AND CHI-SQUARE DISTRIBUTIONS * N. L. JOHNSON

BIOKA59 364 NOTE ON AN APPROXIMATION TO THE DISTRIBUTION OF NONCENTRAL CHI-SQUARE* E. S. PEARSON

BIOKA59 365 THE CHI-SQUARE TEST FOR SMALL EXPECTATIONS IN CONTINGENCY TABLES, WITH SPECIAL REFERENCE TO ACCIDENTS AND ABSENTEEISM * C. A, G. NASS

BIOKA59 386 JUMP ANALYSIS * G. H. JOWETT, WINDYM. WRIGH'

BIOKA59 400 THE RANDOM WALK (IN CONTINUOUS TIME) AND ITS APPLICATION TO THE THEORY OF QUEUES * C. R. HEATHCOTE, J. E MOYAL

BIOKA59 412 NOTE ON THE GOMPARISON OF SEVERAL REALIZATIONS OF A MARKOFF CHAIN * J. H. DARWIN

BIOKA59 420 OVERFLOW AT A TRAFFIC LICHT * F . A. HAIGHT

BIOKA59 425 PART IAL TESTS FOR PARTIAL TAUS * L. A . GOODMAN

BIOKA59 433 MOMENTS OF ORDER STATISTICS FROM A NORMAL POPULATION * R. C. BOSE, S. S. GUPTA

BIOKA59 441 CONFIDENCE INTERVALS FOR THE EXPECTATION OF A POISSON VARIABLE* E. L. CROW, R. S. GARDNER

BIOKA59 454 THE DISTRIBUTION OF THE NUMBER OF SUCCESSES IN A SEQUENCE OF DEPENDENT TRIALS * K R RABRIEL

BIOKA59 461 TABLE OF THE UPPER 10 PERCENT POINTS OF THE 'STUDENTIZED ' RANGE* J . PACHARES

BIOKA59 467 ON THE DISTRIBUTION OF THE EXTREME STUDENTIZED DEVIATE FROM THE SAMPLE MEAN * K, C, S PILLAI, B, P TIENZO

BIOKA59 473 UPPER PERCENTAGE POINTS OF THE EXTREME STUDENTIZED DEVIATE FROM THE SAMPLE MEAN * K. C . S. PILLA I

BIOKA59 475 THE ASYMPTOTIC EFFICIENCY OF THE CHI-SQUARE-SUB-RTEST FOR A BALANCED INCOMPLETE BLOCKDESIGN * PH. VAN ELTEREN, G. E. NOETHER

BIOKA59 477 A NOTE ON THE APPLICATION OF QUENOUILLE'S METHOD OF BIAS REDUCTION TO THE ESTIMATION OF RATIOS * J. DURBIN

BIOKA59 481 ON THE PROBABILITY INTEGRAL TRANSFORMATION * C. L MALLOWS

BIOKA59 483 EXTREMA OF QUADRATIC FORMS WITH APPLICATIONS TO STATISTICS * K. A. BUSH, I. OLKIN

BIOKA59 486 ON CERTAIN PROPERTIES OF POWER-SERIES DISTRIBUTIONS * C. G. KHATRI

BIOKA59 502 CORRIGENDA, 'THE POWER FUNCTION OF THE TEST FOR THE DIFFERENCE BETWEEN TWO PROPORTIONS IN A 2-BY-2 TABLE. ' *P. B. PATNAIK

BIOKA59 502 CORRIGENDA, 'MOMENT ESTIMATORS AND MAXIMUM LIKELIHOOD. ' * L. R. SHENTON

BIOKA59 502 CORRIGENDA, 'ON THE CUMULANTS OF RENEWAL PROCESSES.' * W. L. SMITH 
1 A COMPARISON OF THEORETICAL AND EMPIRICAL RESULTS FOR SOME STOCHASTIC POPULATION MODELS * M. S. BARTLETT J. C. COWER, P. H. LESLIE

BIOKA60 13 BIRTH-AND-DEATH PROCESSES, AND THE THEORY OF CARCINOCENESIS * D. C. KENDALL

BIOKA6O 23 THE QUANTAL RESPONSE ANALYSIS OF A SERIES OF BIOLOCICAL ASSAYS ON THE SAME SUBJECTS * J. R. ASHFORD, C. S . SMITH, SUSANNAH BROWN

BIOKA60 33 SOME CONSEQUENCES OF SUPERIMPOSED ERROR IN TIME SERIES ANALYSIS * A. M. WALKER

BIOKA60 45 DETERMINISTIC CUSTOMER IMPATIENCE IN THE QUEUEINC SYSTEM GI-M-I *P. D. FINCH

BIOKA60 53 THE POLYKAYS OF THE NATURAL NUMBERS * D. E. BARTON, F N. DAVID, EVELYN FIX

BIOKA60 61 THE DISTRIBUTION OF REGRESSION COEFFICIENTS IN SAMPLES FROM BIVARIATE NON-NORMAL POPULATIONS. I THEORETICAL INVESTIGATION*A. B. L. SRIVASTAVA

BIOKA60

69 THE SEPARATION OF MOLECULAR COMPOUNDS BY COUNTERCURRENT DIALYSIS, A STOCHASTIC PROCESS * M. A. KASTEMBAUM

BIOKA60 79 A NOTE ON THE ERROR AFTER A NUMBER OF TERMS OF THE DAVID-JOHNSON SERIES FOR THE EXPECTED VALUES OF NORMAL ORDER STATISTICS * J. G. SAW

BIOKA6O 87 MORE SIGNIFICANCE TESTS ON THE SPHERE * G. S. WATSON

BIOKA60 93 AN APPROXIMATION TO THE MULTINOMIAL DISTRIBUTION, SOME PROPERTIES AND APPLICATIONS * N. L . JOHNSON

BIOKA60 103 THE MOST ECONOMICAL BINOMIAL SEQUENTIAL PROBABILITY RATIO TEST * M. K. VAGHOLKAR, G. B. WETHERILL

BIOKA6O 111 AN APPROXIMATE TEST FOR SERIAL CORRELATION IN POLYNOMIAL REGRESSION * J. R. MCGREGOR

BIOKA60 121 NOMOGRAMS FOR FITTING THE LOGISTIC FUNCTION BY MAXIMUM LIKELIHOOD * J. BERKSON

BIOKA60 143 THE BOREL-TANNER DISTRIBUTION * F. A. HAIGHT, M. A. BREUER

BIOKA60 151 THE DISTRIBUTION OF KENDALL'S SCORE S FOR A PAIR OF TIED RANKINGS * E. J. BURR

BIOKA60 173 ON NORMALIZING THE INCOMPLETE BETA-FUNCTION FOR FITTING TO DOSE-RESPONSE CURVES * M E. WISE

BIOKA6O 175 ON CERTAIN FUNCTIONS OF NORMAL VARIATES WHICH ARE UNCORRELATED OF A HIGHER ORDER * R. G. LAHA, E. LUKACS

BIOKA6O 177 A FURTHER NOTE ON A SIMPLE METHOD FOR FITTING AN EXPONENTIAL CURVE *H.D. PATTERSON

BIOKA6O IBO ESTIMATION OF A PARAMETER IN THE CLASSICAL OCCUPANCY PROBLEM * C. R. BLYTH, G. L. CURMEE

BIOKA60 185 GEOMETRY AND LINEAR DISCRIMINATION * C. W. CLUNIESROSS, R. H. RIFFENBURGH

BIOKA60 190 APPROXIMATION TO THE DISTRIBUTION OF THE SAMPLE SIZE FOR SEQUENTIAL TEST. II. TESTS OF COMPOSITE HYPOTHESES * D. H. BHATE

BIOKA60 194 ON THE COVARIANCE DETERMINANTS OF MOVING-AVERACE AND AUTOREGRESSIVE MODELS * P. D. FINCH

BIOKA6O 196 A NOTE ON SOME APPROXIMATIONS TO THE VARIANCE IN DISCRETE-TIME STOCHASTIC MODELS FOR BIOLOGICAL SYSTEMS* P. H. LESLIE

BIOKA60 19B ON TWO QUEUES IN PARALLEL * C. A . WILKINS

BIOKAGO 199 THE CHARACTERISTIC FUNCTION OF HERMITIAN QUADRATIC FORMS IN COMPLEX NORMAL VARIABLES * G. L. TURIN

BIOKA60 202 SOME NUMERICAL RESULTS FOR WAITING TIMES IN THE QUEUE E-SUB-K-M-1 * C. BURROWS

BIOKA60 203 A FORMULA FOR THE CURVATURE OF THE LIKEL IHOOD SURFACE OF A SAMPLE DRAWN FROM A DISTRIBUTION ADMITTINC SUFFICIENT STATISTICS * B. R. RAO

BIOKA60 219 THE PROPERT IES OF A STOCHASTIC MODEL FOR THE PREDATORPREY TYPE OF INTERACTION BETWEEN TWO SPECIES * P. H. LESLIE, J, C. GOWER

BIOKA60 235 HIERARCHICAL BIRTH AND DEATH PROCESSES. I. THEORY * G BLOM
BIOKA60 245 HIERARCHICAL BIRTH AND DEATH PROCESSES. II. APPLICATIONS * C. BLOM

BIOKA60 253 A COMPARISON OF THE EFFECTIVENESS OF TOURNAMENTS * W A. GLENN

BIOKA60 263 SUPPLEMENTED BALANCE * S. C. PEARCE

BIOKA60 273 THE EFFICIENCY OF BLOCKING IN INCOMPLETE BLOCK DESICNS * J, L, FOLKS, O, KEMPTHORNE

BIOKA60 285 QUEUEINC WITH BALKINC. II. * F. A. HAICHT

BIOKA60 297 ON COMPARINC DIFFERENT TESTS OF THE SAME HYPOTHESIS H. A, DAVID, CARMEN A, PEREZ

BIOK460 307 THE PERFORMANCE OF SOME CORRELATION COEFFICIENTS FOR A GENERAL BIVARIATE DISTRIBUTION * D. J. G. FARLIE

BIOKA60 325 TWO EXPANSIONS FOR THE QUADRIVARIATE NORMAL INTEGRAL * J. A. MCFADDEN

BIOKA60 335 ON A PROBLEM CONNECTED WITH QUADRATIC REGRESSION * R. G. LAHA, E. LUKACS

BIOKA60 345 SMALL SAMPLE BEHAVIOUR OF CERTAIN TESTS OF THE HYPOTHESIS OF EQUAL MEANS UNDER VARIANCE HETEROGENEITY * R. S. MCCULLOUGH, J. CURLAND, L ROSENBERC

BIOKA60 355 POWER OF SOME TWO-SAMPLE NON-PARAMETRIC TESTS * B , V SUKHATME

BIOKA60 363 SAMPLING INSPECTION OF CONTINUOUS PROCESSES WITH NO AUTOCORRELATION BETWEEN SUCCESSIVE RESULTS * W. D EWAN, K.W. KEMP

BIOKA60 381 TABLE OF NEYMAN-SHORTEST UNBIASED CONFIDENCE INTERVALS FOR THE BINOMIAL PARAMETER * C. R. BLYTH, D. W HUTCHINSON

EIOKA60 393 ON THE POWER FUNCTION OF THE EXACT TEST FOR THE 2-BY-2 CONTINGENCY TABLE* B. M. BENNETT, P. HSU

BIOKA60 399 TABLE OF THE BOUNDS OF THE PROBABILITY INTECRAL WHEN THE FIRST FOUR MOMENTS ARE GIVEN * J. A. SIMPSON, B L. WELCH

BIOKA6O 411 NORMAL APPROXIMATION TO THE CHI-SQUARE AND NON-CENTRAL F PROBABILITY FUNCTIONS * N C SEVERO M ZELEN

BIOKAGO 417 SOME PROPERTIES OF THE DISTRIBUTION OF THE LOGARITHM OF NON-CENTRAL F * D. E. BARTON, F. N. DAVID, ANNE F O'NEILL

BIOKA60 433 TABLES FOR MAKING INFERENCES ABOUT THE VARIANCE OF A NORMAL DISTRIBUTION * D. V. LINDLEY, D. A. EAST, P A. HAMILTON

BIOKA6O 439 TABLES FOR THE SOLUTION OF THE EXPONENTIAL EQUATION $\operatorname{EXP}(-A)+K A=1 * D . E . B A R T O N, F, N$. DAVID, M. MERRINGTON

BIOKA60 447 STUDIES IN THE HISTORY OF PROBABILITY AND STAT'ISTICS $X$. WHERE SHALL THE HISTORY OF STATISTICS BECIN * M G. KENDALL

BIOKA60 449 ON THE NUMBER OF RENEWALS IN A RANDOM INTERVAL * D. R $\mathrm{COX}$

BIOKA60 452 A NOTE ON SUFFICIENCY IN REGULAR MARKOV CHAINS * B. R BHAT, J. GANI

BIOKA6O 457 THE RECRESSION OF TRUE VALUS ON ESTIMATED VALUE * R. N CURNOW

BIOKAGO 460 THE USE OF INTEGRAL TRANSFORMS TO DETERMINE EXPAN SIONS OF DISTRIBUTION FUNCTIONS * W. M. HARPER, J. A MACDONALD

BIOKA60 463 SOME APPLICATIONS OF TWO APPROXIMATIONS TO THE MUL TINOMIAL DISTRIBUTION * N. L. JOHNSON, D. H. YOUNG

BIOKA60 469 SOME DISTRIBUTIONS ARISING IN THE STUDY OF CENERALIZED MEAN DIFFERENCES * T. A. RAMASUBBAN

BIOKA60 473 ON CERTAIN CHARACTERIST ICS OF SOME DISCRETE DISTRIBUTIONS * G. E. BARDWELL

BIOKA60 476 APPROXIMATE TESTS FOR M RANKINCS * H. LINHART

BIOKA6O 4BO A NOTE ON THE DERIVATION OF SOME EXACT MULTIVARIATE TESTS * A. M. KSHIRSAGAR

BIOKA60 4B2 ESTIMATION FROM A LINEAR MARKOV PROCESS * N. GILBERT

BIOKA6O 484 CORR IGENDA, 'SOME NUMERICAL RESULTS FOR WAIT ING TIMES IN THE QUEUE E-SUB-K-M-1. ' * C. BURROWS

BIOMETRIKA VOLUME 4B, 1961

BIOKA61 I STUDIES IN THE HISTORY OF PROBABILITY AND STATISTICS $X I$. DANIEL BERNOULLI ON MAXIMUM LIKELIHOOD * $M$. C . KENDALL

BIOKA6I

19 THE VARIANCE OF SPEARMAN'S RHO IN NORMAL SAMPLES * F N. DAVID, C. L. MALLOWS

BIOKA6I 29 TESTS FOR RANK CORRELATION COEFFICIENTS. II * E. C FIELLER, E. S. PEARSON

BIOKA61 41 SOME METHODS OF CONSTRUCTING EXACT TESTS * J. DURBIN

BIOKA61 57 PREEMPTIVE PRIORITY QUEUEING * C. R. HEATHCOTE

BIOKA6I 65 A TWO-SAMPLE SEQUENTIAL T-TEST * J. HAJNAL

BIOKA61 T7 ABSOLUTE AND INCOMPLETE MOMENTS OF THE MULTIVARIATE NORMAL DISTRIBUTION * S. NABEYA

BIOKA61 85 ASYMPTOTIC EXPANSIONS FOR THE MEAN AND VARIANCE OF THE SERI AL CORRELATION COEFFICIENT * J S. WHITE
BIOKA61 95 SIGNIFICANCE TESTS FOR PAIRED-COMPARISON EXPERIMENTS * T. H. STARKS, H. A. DAVID

BIOKA6I 109 GOODNESS-OF-FIT TESTS ON A CIRCLE * G. S. WATSON

BIOKA6I 115 THE USE OF ORTHOGONAL POLYNOMIALS OF THE POSITIVE AND NEGATIVE BINOMIAL FREQUENCY FUNCTIONS IN CURVE FITTING BY AITKEN'S METHOD * H. T. GONIN

BIOKAG1 125 THE ESTIMATION OF REGRESSION AND ERROR-SCALE PARAMETERS, WHEN THE JOINT DISTRIBUTION OF THE ERRORS IS OF ANY CONTINUOUS FORM AND KNOWN APART FROM A SCALE PARAMETER * A.M. W. VERHAGEN

BIOKAGI 133 LATENT VECTORS OF RANDOM SYMMETRIC MATRICES * C. L. MALLOWS

BIOKA61 151 EXPECTED VALUES OF NORMAL ORDER STATISTICS * $\mathrm{H}$. L HARTER 
BIOKA61 167 A DISTRIBUTION ANALOCOUS TO THE BOREL-TANNER * F. A. HAICHT

BIOKA6I 175 OCCUPANCY PROBABILITY DISTRIBUTION CRITICAL POINTS * W. L. NICHOLSON

BIOKA61 181 TESTS OF INDEPENDENCE IN INTRACLASS 2-BY-2 TABLES * $M$ OKAMOTO, C. ISHI I

BIOKA61 191 TABLES OF NEYMAN-SHORTEST UNBIASED CONFIDENCE INTERVALS FOR THE POISSON PARAMETER * C. R. BLYTH, D. $W$ HUTCHINSON

BIOKA61 195 UPPER PERCENTACE POINTS OF A SUBSTITUTE F-RATIO USINC RANCES * K. C.S. PILLAI, ANCELESR. BUENAVENTURA

BIOKA6I 197 ON DURBIN'S FORMULA FOR THE LIMITING CENERALIZED VARIANCE OF A SAMPLE OF CONSECUTIVE OBSERVATIONS FROM A MOVING-A VERAGE PROCESS * A.M. WALKER

BIOKA61 199 THE GENTRAL SAMPLINC MOMENTS OF THE MEAN IN SAMPLES FROM A FINITE POPULATION (ATY'S FORMULAE AND MADOW'S CENTRAL LIMIT) $*$ D. E. BARTON, F. N. DAVID

BIOKA61 201 A NOTE ON THE QUADRIVARIATE NORMAL INTEGRAL * M. M SONDHI

BIOKA61 203 ON THE STOCHASTIC MATRIX IN A GENETIC MODEL OF MORAN * J. GANI

BIOKA61 206 DEPARTURES FROM ASSUMPTION IN SEQUENTIAL ANALYSIS * T. J. EWENS

BIOKA61 212 A NOTE ON SOME ASYMPTOTIC PROPERTIES OF THE LOGARITHMIC SERIES DISTRIBUTION * J. C. GOWER

BIOKA6I 215 ON A PROPERTY OF BALANCED DESIGNS * M. ATIQULLAH

BIOKA61 218 ALIASING IN PARTIALLY CONFOUNDED FACTORIAL EXPERIMENTS * M. J . R. HEALY, J . C . GOWER

BIOKA61 220 STUDIES IN THE HISTORY OF PROBABILITY AND STATISTICS. XII. THE BOOK OF FATE * M. G. KENDALL

BIOKA61 222 ADERIVATION OF THE BOREL DISTRIBUTION * J. C. TANNER

BIOKA61 224 A THEOREM IN TREND ANALYSIS * M. G. KENDALL

BIOKA6I 227 UNBIASED ESTIMATION OF A SET OF PROBABILITIES * D. E. BARTON

BIOKA6I 230 GORRIGENDA, 'SMALL SAMPLE BEHAVIOUR OF CERTAIN TESTS OF THE HYPOTHESIS OF EQUAL MEANS UNDER VARIANCE HETEROCENEITY ' * R. S. MCCULLOUGH, J. GURLAND, L ROSENBERG

BIOKA61 230 CORRIGENDA, 'SOME DISTRIBUTIONS ARISING IN THE STUDY OF GENERALIZED MEAN DIFFERENCES' * T. A. RAMASUBBAN

BIOKA61 230 CORRIGENDA. 'TABLES FOR MAKING INFERENCES ABOUT THE VARIANCE OF A NORMAL DISTRIBUTION. ' * D. V. LINDLEY, D. A. EAST, P. A. HAMILTON

BIOKA61 241 THE TWO-SAMPLE CAPTURE-RECAPTURE CENSUS WHEN TAGGINC AND SAMPLING ARE STRATIFIED* J.N. DARROCHH

BIOKA61 261 THE FIDUCIAL METHOD AND INVARIANCE * D. A. S. FRASER

BIOKA61 2BI BAYESIAN SEQUENTIAL ANALYSIS * G. B. WETHERILL

BIOKA61 293 SOME PROPERTIES OF THE SPEARMAN EST IMATOR IN BIOASSAY * B. WM. BROWN JR

BIOKA6I 303 INCONSISTENCIES IN A SCHEDULE OF PAIRED COMPARISONS * P. SLATER

BIOKA61 313 SOME CIRCULAR COVERACE PROBLEMS * G. W. MORCENTHALER

BIOKA6I 325 ORDERED TESTS IN THE ANALYSIS OF VARIANCE * D. J . BARTHOLOMEW

BIOKA61 333 QUOTA FULFILMENT USING UNRESTRICTED RANDOM SAMPLING * D. H. YOUNG

BIOKA6I 343 LARGE-SAMPLE ESTIMATION OF PARAMETERS FOR MOVINGAVERAGE MODELS * A. M. WALKER

BIOKA6I 359 LINEAR AND NON-LINEAR MULTIPLE COMPARISONS IN LOGIT ANALYSIS * 0 . REIERSOL
BIOKA61 367 ESTIMATION OF THE NORMAL POPULATION PARAMETERS CIVEN A TYPE I CENSORED SAMPLE * J . C. SAW

BIOKA6I 379 SOME TESTS FOR OUTLIERS * C. P. QUESENBERRY, H. A DAVID

BIOKA61 391 THE ERCODIC BEHAVIOUR OF RANDOM WALKS * J. F. C. KINCMAN

BIOKA61 397 THE COODNESS-OF-FIT OF A SINCLE (NON-ISOTROPIC) HYPOTHETICAL PRINCIPAL COMPONENT * A. M. KSHIRSACAR

BIOKA6I 409 ON THE EVALUATION OF THE PROBABILITY INTEGRAL OF THE MULTIVARIATE T DISTRIBUTION * S. JOHN

BIOKA6I 419 COMPUTINC THE DISTRIBUTION OF QUADRATIC FORMS IN NORMAL VARIABLES * J. P. IMHOF

BIOKA6I 427 COMPARATIVE EFFICIENCIES OF METHODS OF ESTIMATING PARAMETERS IN LINEAR AUTOREGRESSIVE SCHEMES * K. C CHANDA

BIOKA61 433 TABLES OF THE FREEMAN-TUKEY TRANSFORMATIONS FOR THE BINOMIAL AND POISSON DISTRIBUTIONS * F. MOSTELLER, CLEO YOUTZ

BIOKA6I 441 A NON-NULL RANKING MODEL FOR A SEQUENCE OF M ALTERNATIVES * C. F. CROUSE

BIOKA61 444 CRITICAL VALUES OF THE COEFFICIENT OF RANK CORRELATION FOR TEST ING THE HYPOTHESIS OF INDEPENDENCE * C . J. GLASSER, R. F. WINTER

BIOKA61 448 THE BIAS OF THE MAXIMUM LIKELIHOOD ESTIMATES OF THE LOCATION AND SCALE PARAMETERS GIVEN A TYPE II CENSORED NORMAL SAMPLE * J . G . SAW

BIOKA61 452 ON THE SOLUTION OF THE LIKELIHOOD EQUATION BY ITERATION PROCESSES * B. K. KALE

BIOKA61 457 DETECTION OF BEST AND OUTLYING NORMAL POPULATIONS WITH KNOWN VARIANCES * A. ZINGER

BIOKA6I 461 LONGEST RUN OF CONSECUTIVE OBSERVATIONS HAVING A SPECIFIED ATTRIBUTE* E. J . BURR, GWENDA CANE

BIOKA6I 465 THE MOMENTS OF THE NON-CENTRAL T-DISTRIBUTION * D. HOGBEN, R. S. PINKHAM, M. B. WILK

BIOKA6I 468 ESTIMATION OF MISSINC OBSERVATIONS IN SPLIT-PLOT EXPERIMENTS WHERE WHOLE-PLOTS ARE MISSING OR MIXED UP * J. D. BIGGERS

BIOKA61 472 DETERMINISTIC CUSTOMER IMPATIENCE IN THE QUEUEING SYSTEM GI-M-1, A CORRECTION * P. D. FINCH

BIOKA61 474 CORRIGENDA, 'FURTHER CONTRIBUTIONS TO MULTIVARIATE CONFIDENCE BOUNDS' * S. N. ROY, R. GNANADESIKAN

BIOKA61 474 CORRIGENDA, 'MOMENT ESTIMATORS AND MAXIMUM LIKELIHOOD' * L. R. SHENTON

BIOKA61 474 CORRIGENDA. 'EXTREMA OF QUADRATIC FORMS WITH APPLICATIONS TO STATISTICS ' * K. A. BUSH, I. OLKIN

BIOKA61 475 CORRICENDA. 'SUPPLEMENTED BALANCE' * S. C. PEARCE

BIOKA6I 475 CORRIGENDA, 'ON THE POWER FUNCTION OF THE EXACT TEST FOR THE 2-BY-2 CONT INGENCY TABLE' * B. M. BENNETT, P. HSU

BIOKA61 475 CORRIGENDA, 'SIGNIFICANT TESTS FOR PAIRED-COMPARISON EXPERIMENTS' * T. H. STARKS, H. A. DAVID

BIOKA61 476 GORRIGENDA, 'THE USE OF ORTHOGONAL POLYNOMIALS OF POSITIVE AND NECATIVE BINOMIAL FREQUENCY FUNCTIONS IN CURVE FITTING BY AITKEN 'S METHOD' * H. T. GONIN

BIOKA61 476 CORRICENDA, 'EXPECTED VALUES OF NORMAL ORDER STATISTICS ' * H, LEON HARTER

BIOKA61 476 CORRIGENDA. 'TEST OF INDEPENDENCE IN INTRACLASS 2-BY2 TABLES $^{\prime *} M$. OKAMOTO, C. ISHII

BIOKA61 476 CORRIGENDA, 'ON DURBIN'S FORMULA FOR THE LIMITING GENERALIZED VARIANCE OF A SAMPLE OF CONSECUTIVE OBSERVATIONS FROM A MOVINC-AVERACE PROCESS' * A. M. TALKER

BIOMETRIKA VOLUME 49,1962

BIOKA62 I A STOCHASTIG MODEL FOR TWO COMPETING SPECIES OF TRIBOLIUM AND ITS APPLICATION TO SOME EXPERIMENTAL DATA* P. H. LESLIE

BIOKA62 27 METHODS OF CLUSTER SAMPLING WITH AND WITHOUT REPLACEMENT FOR CLUSTERS OF UNEQUAL SIZES * M. R. SAMPFORD

BIOKA62 41 A FAMILY OF CLOSED SEQUENTIAL PROCEDURES (CORR. 69 457) * M. A. SCHNEIDERMAN, P. A. ARMITAGE

BIOKA62 57 GOODNESS-OF-FIT TESTS ON A CIRCLE. II * G. S. WATSON

BIOKA62 65 ON THE COMPOUND MULTINOMIAL DISTRIBUTION. THE MULTIVARIATE BETA-DISTRIBUTION, AND CORRELATIONS AMONG PROPORTIONS * JAMES E. MOSIMANN

RIOKA62 83 THE ESTIMATION OF RESIDUAL VARIANCE IN QUADRATICALLY BALANCED LEAST-SQUARES PROBLEMS AND THE ROBUSTNESS OF THE F-TEST * M. ATIQULLAH

BIOKA62 93 ROBUSTNESS TO NON-NORMALITY OF REGRESSION TESTS * G. E. P. BOX, G. S. WATSON

BIOKA62 107 TWO ALTERNATIVES TO THE STANDARD CHI-SQUARE-TEST OF THE HYPOTHESIS OF EQUAL CELL FREQUENCIES * D. H. YOUNG

BIOKA62 117 LARCE-SAMPLE ESTIMATION OF PARAMETERS FOR AUTOREGRESSIVE PROCESSES WITH MOVING-AVERACE RESIDUALS*A.M. WALKER
BIOKA62 133 RANKS AND MEASURES * M. G. KENDALL

BIOKA62 139 PROCESSES GENERATING PERMUTATION EXPANSIONS * H. E DANIELS

BIOKA62 151 ERGODIC PROPERTIES OF SOME PERMUTATION PROCESSES * WILLI AM PARRY

BIOKA62 155 EFFICIENT MOMENT ESTIMATORS WHEN THE VARIABLES ARE DEPENDENT WITH SPECIAL REFERENCE TO TYPE II CENSORED NORMAL DATA* J . G. SAW

BIOKA62 163 A THEORETICAL ANALYSIS OF DELAYS AT AN UNCONTROLLED INTERSECTION * J . C. TANNER

BIOKA62 171 A MODIFIED CONTROL CHART WITH WARNING LINES * E. S. PACE

BIOKA62 177 THE THIRD MOMENT OF KENDALL'S TAU IN NORMAL SAMPLES * BARBARA A. S. SNOW

BIOKA62 185 TESTS FOR RANK CORRELATION COEFFICIENTS. III. DISTRIBUTION OF THE TRANSFORMED KENDALL COEFFICIENT * E. S. PEARSON, BARBARA A. S. SNOW

BIOKA62 193 THE BIAS OF MOMENT ESTIMATORS WITH AN APPLICATION TO THE NEGATIVE BINOMIAL DISTRIBUTION * L. R. SHENTON, P. A. WALLINGTON 
BIOKA62 205 THE ASYMPTOTIC PROPERTIES OF MAXIMUM LI KEL IHOOD ESTIMATORS WHEN SAMPLING FROM ASSOCIATED POPULATIONS * RALPH A . BRADLEY, JOHN J . GART

BIOKA62 215 EFFICIENCY OF CERTAIN METHODS OF ESTIMATION FOR THE NEGATIVE BINOMIAL AND NEYMAN TYPE A DISTRIBUTIONS * S. K. KATTI, JOHN GURLAND

BIOKA62 227 MAXIMUM LIKEL IHOOD ESTIMATION FOR GENERALIZED POWER SERIES DISTRIBUTIONS AND ITS APPLICATION TO A TRUNCATED BINOMIAL DISTRIBUTION * G. P. PATIL

BIOKA62 239 FACTORIZATION OF MATRICES BY LEAST-SQUARES * JOSEPH B. KELLER

BIOKA62 242 A GENERALIZED SINGLE-SERVER QUEUE WITH ERLANG INPUT * W. J. EWENS, P. D. FINCH

BIOKA62 245 ON THE AMOUNT OF INFORMATION SUPPLIED BY CENSORED SAMPLES OF GROUPED OBSERVATIONS IN THE ESTIMATION OF STATIST ICAL PARAMETERS * P. S. SWAMY

BIOKA62 250 A NOTE ON THE ESTIMATION OF THE PARAMETERS OF THE LOGISTIC FUNCTION, USING THE MINIMUM LOGIT CHI-SQUARE METHOD * SHIRLEY E. HITCHCOCK

BIOKA62 253 THE RELATIONSHIP BETWEEN THE MEAN AND VARIANCE OF A STATIONARY BIRTH-DEATH PROCESS, AND ITS ECONOMIC APPLICATION * J. WISE

BIOKA62 255 A NOTE ON DIRECTION AND COLLINEARITY FACTORS IN CANONICAL ANALYSIS * A.M. KSHIRSAGAR

BIOKA62 259 ON ESTIMATORS FOR VARIANCES AND COVARIANCES * GERALD J. GLASSER

BIOKA62 262 AN INEQUALITY RELATING THE SPECTRAL DENSITY AND AUTOCORRELATION FUNCTION * H. E. DANIELS

BIOKA62 264 THE LATENT ROOTS OF CERTAIN STOCHASTIC MATRICES * J. L. MOTT

BIOKA62 265 THE DISTRIBUTION OF THE NUMBER OF CIRCULAR TRIADS IN PAIRED COMPARISONS * G. G. ALWAY

BIOKA62 269 A NOTE ON THE EQUICORRELATED MULTIVARIATE NORMAL DISTRIBUTION * G. P. STECK, D. B . OWEN

BIOKA62 272 THE EXTINCTION OF A BACTERIAL COLONY BY PHAGES, A BRANCHING PROCESS WITH DETERMINISTIC REMOVALS * J . GANI

BIOKA62 276 AN APPROXIMATION TO THE PROBABILITY INTEGRAL OF THE GAMMA DISTRIBUTION FOR SMALL VALUES OF THE SHAPE PARAMETER * R. S. PINKHAM

BIOKA62 27B A CONFIDENCE INTERVAL FOR VARIANCE COMPONENTS * J . S . WILLIAMS

BIOKA62 281 SYSTEMATIC SAMPLING * E. J. HANNAN

BIOKA62 2B4 CORRIGENDA, 'COMPUTING THE DISTRIBUTION OF QUADRATIC FORMS IN NORMAL VARIABLES ${ }^{\prime}$ * J.P. IMHOF

BIOKA62 2B4 CORRIGENDA, 'ON THE SOLUTION OF THE LIKELIHOOD EQUATION BY ITERATION PROCESSES' * B. K. KALE

BIOKA62 2B4 CORRIGENDA, 'LINEAR AND NON-LINEAR MULTIPLE COMPARISONS IN LOGIT ANALYSIS ' * OLAV REIERSOL

BIOKA62 297 WILLIAM PALIN ELDERTON, 1B77-1962* E. S. PEARSON

BIOKA62 305 TOPOGRAPHIC CORRELATION, POWER-LAW COVARIANCE FUNCTIONS, AND DIFFUSION * P. WHITTLE

BIOKA62 315 SOME INEQUALITIES FOR THE QUEUE GI/G/I * J, F. C. KINGMAN

BIOKA62 325 SOME STATISTICAL PROPERTIES OF A GENETIC SELECTION INDEX * J. S. WILLIAMS

BIOKA62 339 THE MULTI-SAMPLE SINGLE RECAPTURE CENSUS * G. A. F SEBER

BIOKA62 351 PERSISTENCE IN A CHAIN OF MULTIPLE EVENTS WHEN THERE IS SIMPLE DEPENDENCE * D. E. BARTON, F. N. DAVID, EVELYN FIX

BIOMETRIKA VOLUME 50, 1963
BIOKA62 359 CLOSED SEQUENTIAL T-TESTS * M. A. SCHNEIDERMAN, P. ARMITAGE

BIOKA62 367 SOME SEQUENTIAL ANALOGS OF STEIN'S TWO-STAGE TEST * J. HALL

BIOKA62 379 THE APPROXIMATE DISTRIBUTION OF THE CORRELATION BETWEEN TWO STATIONARY LINEAR MARKOV SERIES * J.R. MCGREGOR

BIOKA62 3B9 RANDOM CIRCLES ON A SPHERE * P. A. P. MORAN, S. FAZEKAS DE ST GROTH

BIOKA62 397 THE GOODNESS-OF-FIT TESTS BASED ON W-SQUARE-SUB-N AND U-SQUARE-SUB-N * E. S. PEARSON, M. A. STEPHENS

BIOKA62 403 TESTING EQUALITY OF MEANS AFTER A PRELIMINARY TEST OF EQUALITY OF VARIANCES * JOHN GURLAND, ROGER S. MCCULLOUGH

BIOKA62 419 A FURTHER LOOK AT ROBUSTNESS VIA BAYES'S THEOREM * G E. P. BOX, G. C. TIAO

BIOKA62 433 ORTHANT PROBABILITIES FOR THE EQUICORRELATED MULTIVARIATE NORMAL DISTRIBUTION * G. P. STECK

BIOKA62 447 A STOCHASTIC MODEL OF ACHE TRANSPORTATION IN THE PERIPHERAL NERVE TRUNKS * R. BARTOSZYNSKI, L. LUBINSKA, S. A. NIERMIERKO

BIOKA62 455 A COMPARISON OF THE POWERS OF TWO MULTIVARIATE ANALYSIS OF VARIANCE TESTS * KOICHI ITO

BIOKA62 463 EXACT AND APPROXIMATE TESTS FOR DIRECTIONS. I * $M$ A STEPHENS

BIOKA62 479 ON THE SOLUTION OF LIKELIHOOD EQUATIONS BY ITERATION PROCESSES MULT IPARAMETRIC CASE * B. K. KALE

BIOKA62 4B7 LARGE SAMPLE TABLES OF PERCENTAGE POINTS FOR HARTLEY'S CORRECTION TO BARTLETT'S CRITERION FOR TESTING THE HOMOGENEITY OF A SET OF VARIANCES * V. D. BARNETT

BIOKA62 495 ON SELECTING A SUBSET CONTAINING THE POPULATION WITH THE SMALLEST VARIANCE * SHANTI S. GUPTA, MILTON SOBEL

BIOKA62 509 ON THE SMALLEST OF SEVERAL CORRELATED F STATISTICS * SHANTI S. GUPTA, MILTON SOBEL

BIOKA62 525 ESTIMATION OF PARAMETERS OF THE GAMMA DISTRIBUTION USING ORDER STATISTICS * M. B. WILK, R. GNANADESIKAN, MARILYN J. HUYETT

BIOKA62 547 EXACT AND APPROXIMATE TESTS FOR DIRECTIONS. II * M. A STEPHENS

BIOKA62 553 A NOTE ON A PROBLEM INESTIMATION * B. K. KALE

BIOKAG2 557 TABLES FOR POWER-LAW TRANSFORMATIONS * M. J.R. HEALY, L. R. TAYLOR

BIOKA62 560 A NOTE ON THE GEOMETRY OF LINEAR ESTIMATION * B. RAJA RAO

BIOKA62 561 ON BALANCED UNEQUAL BLOCK DESIGNS * DAMARAJU RAGHAVARAO

BIOKA62 563 A NOTE ON OPTIMUM ALLOCATION FOR A ONE-WAY LAYOUT * A ZINGER

BIOKA62 564 GAMMA-DISTRIBUTED PRODUCTS OF INDEPENDENT RANDOM VARIABLES * ALAN STUART

BIOKA62 566 ON THE MEAN AND VARIANCE OF THE SMALLER OF TWO DRAWINGS FROM A BINOMIAL POPULATION * C. C. CRAIG

BIOKA62 570 ON THE EFFICIENCY OF BAN ESTIMATES OF THE PARAMETERS OF NORMAL POPULATIONS BASED ON SINGLY CENSORED SAMPLES*S. A. D. C. DOSS

BIOKA62 574 A NOTE ON THE RATE OF CONVERGENCE OF A MEAN * DAVID R BRILLINGER
BIOKA63 I RONALD AYLMER F ISHER, IB90-1962* M, G. KENDALL

BIOKA63 17 DISCRIMINATION IN THE CASE OF ZERO MEAN DIFFERENCES * M. S. BARTLETT, N. W. PLEASE

BIOKA63 23 RANDOM POINTS IN A CIRCLE AND THE ANALYSIS OF CHROMOSOME PATTERNS * D. E. BARTON, F. N. DAVID, E FIX

BIOKA63 31 OPTIMAL DRUG SCREENING PLANS * THEODORE COLTON

BIOKA63 47 ON THE COMPOUND NEGATIVE MULT INOMIALDISTRIBUT ION AND CORRELATIONS AMONG INVERSELY SAMPLED POLLEN COUNTS * JAMES E . MOSIMANN

BIOKA63 55 A MEDIAN TEST WITH SEQUENTIAL APPLICATION * JOHN J GART

BIOKA63 63 APPLICATIONS OF THE CALCULUS OF FACTORIAL ARRANGEMENTS. I. BLOCK AND DIRECT PRODUCT DESIGN * B. KURKJIAN, M. ZELEN

BIOKA63 75 ON SERIES EXPANSIONS FOR THE RENEWAL MOMENTS * $M . R$ LEADBETTER

BIOKA63 81 ANALOGUES OF THE NORMAL DISTRIBUTION ON THE CIRCLE AND THE SPHERE * ERNEST BREITENBERGER

BIOKA63 B9 THE DISTRIBUTION OF EXTREMAL AND NEARLY EXTREMAL VALUES IN SAMPLES FROM A NORMAL DISTRIBUTION * J. B S. HALDANE, S. D. JAYAKAR
BIOKA63 95 SOME PROBLEMS ARISING IN APPROXIMATING TO PROBABILITY DISTRIBUTIONS USING MOMENTS * E. S. PEARSON

BIOKA63 113 ESTIMATES OF POPULATION PARAMETERS FROM MULTIPLE RECAPTURE DATA WITH BOTH DEATH AND DILUTION-DETERMINISTIC MODEL * G. M. JOLLY

BIOKA63 129 ON THE FITTING OF MULTIVARIATE AUTOREGRESSIONS, AND THE APPROXIMATE CANONICAL FACTORIZATION OF A SPECTRAL DENSITY MATRIX *P. WHITTLE

BIOKA63 135 SOME CONTRIBUTIONS TO THE THEORY OF MACHINE INTERFERENCE * GUNNAR BLOM

BIOKA63 145 MULTINOMIAL PROBABILITIES AND THE CHI-SQUARE AND XSQUARE DISTRIBUTIONS * M. E. WISE

BIOKA63 155 SIMULTANEOUS TOLERANCE INTERVALS IN REGRESSION * GERALD J LIEBERMAN, RUPERT G. MILLER JR

BIOKA63 169 TABLE FOR THE SOLUTION OF THE EXPONENTIAL EQUATION $\operatorname{EXP}(B)-B /(1-P)=1 *$ D. E. BARTON, F. N. DAVID, M. MERRINGTON

BIOKA63 177 EXTENDED TABLE OF CRITICAL VALUES FOR WILCOXON'S TEST STATISTIC * L. R. VERDOOREN

BIOKA63 IB7 PERCENTAGE POINTS OF THE RATIO OF TWO RANGES AND POWER OF THE ASSOCIATED TEST * H. LEON HARTER

BIOKA63 195 INDEX SELECTION AND ESTIMATION FROM A SINGLE SAMPLE * J. S. WILLIAMS 
BIOKA63 199 APPROXIMATIONS TO THE NON-CENTRAL CHI-SQUARE DISTRIBUTION * MUNUSWAMY SANKARAN

BIOKA63 204 STUDIES IN THE HISTORY OF PROBABILITY AND STATISTICS XIII. ISAAC TODHUNTER'S HISTORY OF THE MATHEMATICAL THEORY OF PROBABILITY * M. C. KENDALL

BIOKA63 205 A CHARACTERIZATION OF THE EXPONENTIAL-TYPEDISTRIBUTION * G.P. PATIL

BIOKA63 207 ON THE AMOUNT OF INFORMATION SUPPLIED BY TRUNCATED SAMPLES OF GROUPED OBSERVATIONS IN THE ESTIMATION OF THE PARAMETERS OF NORMAL POPULATIONS * P.S. SWAMY

BIOKA63 213 EXPECTATIONS AND COVARI ANCES OF SERIAL AND CROSS-CORRELATION COEFFICIENTS IN A COMPLEX STATIONARY TIME SERIES * DONALD F. MORRISON

BIOKA63 217 SEPARATE MAXIMUM-LIKELIHOOD ESTIMATION OF SCALE OR SHAPE PARAMETERS OF THE CAMMA DISTRIBUTION USING ORDER STATISTICS * $M$. B. WILK, R. CNANADESIKAN, MARILYN J, HUYETT

BIOKA63 235 THE SIMPLE STOCHASTIC EPIDEMIC, A COMPLETE SOLUTION IN TERMS OF KNOWN FUNCTIONS * NORMAN T . J. BAILEY

BIOKA63 241 NUMERICAL RESULTS AND DIFFUSION APPROXIMATIONS IN A CENETIC PROCESS * $W$. J EWENS

BIOKA63 251 INFERENCE ON A CENETIC MODEL OF THE MARKOV CHAIN TYPE * JOHN J BARTKO, GEOFFREY A WATTERSON

BIOKA63 265 TESTINC HYPOTHESES AND EST IMATING PARAMETERS IN HUMAN CENETICS IF THE AGE OF ONSET IS RANDOM * EDWARD BATSCHELET

BIOKA63 281 TWO CLASSES OF CROUP DIVISIBLE PARTIAL DIALLEL CROSSES * K. HINKELMANN, O. KEMPTHORNE

BIOKA63 293 REGRESSION FOR TIME SERIES WITH ERRORS OF MEASUREMENT * E. J. HANNAN

BIOKA63 303 THE DISTRIBUTION OF THE GOODNESS-OF-FIT STATISTIC, USQUARE-SUB-N. I. * M. A. STEPHENS

BIOKA63 315 COMPARISON OF TESTS FOR RANDOMNESS OF POINTS ON A. LINE * E. S. PEARSON

BIOKA63 327 VARIANCE COMPONENTS IN TWO-WAY CLASSIFICATION MODELS WITH INTERACTION* C. H. KAPADIA, DAVIDL. WEEKS

BIOKA63 335 THE CHOICE OF A SECOND ORDER ROTATABLE DESICN * GEORCE E. P. BOX, NORMANR. DRAPER

BIOKA63 353 THE ESTIMATION OF SECONDOORDER TENSORS, WITH RELATED TESTS AND DESIGNS * CEORGE R. HEXT

BIOKA63 375 ON AN EXTREME RANK SUM TEST FOR OUTLIERS * W. A. THOMPSON JR, T. A. WILLKE

BIOKA63 3B5 RANDOM WALK ON A CIRCLE * M. A. STEPHENS

BIOKA63 391 BIASES IN PREDICTION BY REGRESSION FOR CERTAIN INCOMPLETELY SPECIFIED MODELS * HAROLD J. LARSON, T. A. BANCROFT

BIOKA63 403 A MULTIVARIATE ANALOGUE OF THE ONE-SIDED TEST * AKIO KUDO

BIOKA63 419 ON SEQUENTIAL TESTS OF RATIO OF VARIANCES BASED ON RANGE * B. K. CHOSH

BIOKA63 431 THE RANDOMIZATION DISTRIBUTION OF F-RATIOS FOR THE SPLIT-PLOT DESIGN, AN EMPIRICAL INVESTIGATION * RAYMOND O. COLLIER JR, FRANK B. BAKER
BIOKA63 439 STATISTICAL CLASSIFICATION WITH QUADRATIC FORMS * PAUL W. COOPER

BIOKA63 449 ADDITIONAL PERCENTAGE POINTS FOR THE INCOMPLETE BETA DISTRIBUTION* D. E. AMOS

BIOKA63 459 TABLE OF PERCENTAGE POINTS OF PEARSON CURVES, FOR GIVEN ROOT (BETA-1) AND BETA-2 EXPRESSED IN STANDARD MEASURE * N. L JOHNSON, ERTC NTXON, D. E A AMOS, E. S PEARSON

BIOKA63 499 THE ASYMPTOTIC EFFICIENCY OF DANIELS'S GENERALIZED CORRELATION COEFF ICIENT * D. J , G. FARLIE

BIOKA63 505 INVERSE DISTRIBUTIONS AND INDEPENDENT GAMMA-DISTRIBUTED PRODUCTS OF RANDOM VARIABLES * J. AITCHISON

BIOKA63 508 THE FREQUENCY DISTRIBUTION OF THE SAMPLE MEAN WHERE EACH MEMBER OF THE SAMPLE IS DRAWN FROM A DIFFERENT RECTANGULAR DISTRIBUTION * S. A. ROACH

BIOKA63 514 THE HAUSA PROBLEM AND SOME APPROXIMATIONS TO THE REQUIRED PROBABILITY * H. E. DANIELS, A. S. C. ROSS

BIOKA63 517 THE SPECTRUM OF A CONTINUOUS PROCESS DERIVED FROM A DISCRETE PROCESS * M. B. PRIESTLEY

BIOKA63 520 SIMULATED DISTRIBUTIONS FOR SMALL N OF KENDALL 'S PARTIAL RANK CORRELATION COEFFICIENT * OLLE HOFLUND

BIOKA63 522 SOME INEQUALITIES ON CHARACTERISTIC ROOTS OF MATRICES * T. W. ANDERSON, S. DAS GUPTA

BIOKA63 524 CHI-SQUARE STATISTIC BASED ON THE POOLED FREQUENCIES OF SEVERAL OBSERVATIONS * MASASHI OKAMOTO

BIOKA63 52B ON THE PROBABILITY OF LARCE DEVIATIONS FROM THE EXPECTATION FOR SUMS OF BOUNDED, INDEPENDENT RANDOM VARIABLES * G. BENNETT

BIOKA63 535 EXPRESSINC THE NORMAL DISTRIBUTION WITH COVARIANCE MATRIX A+B IN TERMS OF ONE WITH COVARIANCE MATRIX A * CEORCE MARSACLIA

BIOKA63 53B THE DISTRIBUTION OF KENDALL 'S TAU FOR SAMPLES OF FOUR FROM A NORMAL BIVARIATE POPULATION WITH CORRELATION RHO * BARBARA A. S. SNOW

BIOKA63 540 A FURTHER NOTE ON THE GEOMETRY OF LINEAR ESTIMATION * B. RAJA RAO

BIOKA63 542 THE NON-CENTRAL CHI-SQUARED AND BETA DISTRIBUTIONS * G. A. F. SEBER

BIOKA63 544 A NOTE ON DIRECT AND INVERSE EINOMIAL SAMPLING * K.W MORRIS

BIOKA63 546 CORRIGENDA, 'A FURTHER LOOK AT ROBUSTNESS VIA BAYES'S THEOREM. ' * G. E. P. BOX, G. C. TIAO

BIOKA63 546 CORRICENDA, 'A COMPARISON OF THE POWERS OF TWO MULTIVARIATE ANALYSIS OF VARIANCE TESTS. ' * KOICHI ITO

BIOKA63 546 CORRIGENDA, 'ESTIMATION OF PARAMETERS OF THE GAMMA DISTRIBUTION USING ORDER STATISTICS. ' *M. B. WILK, R. GNANADESIKAN, M. J. HUYETT

BIOKA63 546 CORRIGENDA, 'MULTINOMIAL PROBABILITIES AND THE CHISQUARE AND X-SQUARE DISTRIBUTIONS. ${ }^{*}$ * M. E. WISE

BIOMETRIKA VOLUME 51, 1964

BIOKA64

BIOKA64

BIOKA64

BIOKA64

BIOKA64

BIOKA64

BIOKA64

BIOKA64

BIOKA64

BIOKA64

BIOKA64

BIOKA64

BIOKA64 123 SOME GENERAL RESULTS IN SEQUENTIAL ANALYSIS * P. WHIT-

$$
\begin{aligned}
& 1 \text { OPTIMAL R } \\
& \text { P. KING }
\end{aligned}
$$

11 TRAFFIC DELAYS ON A TWO-LANE ROAD * C F. YEO

17 FIDUCIAL INFERENCE FOR LOCATION AND SCALE PARAMETERS * D. A. S. FRASER

25 CONF IDENCE INTERVALS FOR THE COEFF ICIENT OF VARIATION FOR THE NORMAL AND LOG NORMAL DISTRIBUTIONS * L. H. KOOPMANS, D. B. OWEN, J. I. ROSENBLATT

33 ESTIMATION OF A TRUNCATION POINT * D. S. ROBSON, J. H WHITLOCK

41 LINEAR HYPOTHESES AND INDUCED TESTS * G. A. F. SEBER

49 USE OF DOUBLE SAMPLING FOR SELECTING BEST POPULATION * M. L. CHAMBERS, P. JARRATT

65 PERMUTATION SUPPORT FOR MULTIVARIATE TECHNIQUES * $\mathrm{H}$ J. ARNOLD

71 ON THE ROBUSTNESS OF THE T-SQUARE-SUB-O TEST IN MULTIVARIATE ANALYSIS OF VARIANCE WHEN VARIANCECOVARIANCE MATRICES ARE NOT EQUAL * KOICHI ITO, WILLIAM J. SCHULL

83 APPROXIMATINC THE GENERAL NON-NORMAL VARIANCE-RATIO SAMPLING DISTRIBUTIONS * M. L. TIKU

97 ON CERTAIN SUGCESTED FORMULAE APPLIED TO THE SEQUENTIAL T-TEST * V. SISKIND FORM * ROBERT PRICE

BIOKA64 143 ON THE DISTRIBUTION OF LINEAR FUNCTIONS AND RATIOS OF LINEAR FUNCTIONS OF ORDERED CORRELATED NORMAL RANDOM VARIABLES WITH EMPHASIS ON RANGE * SHANTI S, GUPTA, K. C. SREEDHARAN PILLAI, G. P. STECH
BIOKA64 153 A BAYESIAN APPROACH TO THE IMPORTANCE OF ASSUMPTIONS APPLIED TO THE COMPARISON OF VARIANCES * G. E. P BOX, GEORCE C. TIAO

BIOKA64 169 A NOTE ON CRITERION ROBUSTNESS AND INFERENCE ROBUSTNESS * G. E. P. BOX, CEORGE C. TIAO

BIOKA64 175 HAZARD ANALYSIS. I *C. S. WATSON, M. R. LEADBETTER

BIOKA64 IB5 ON INVERSE SAMPLINC WITH UNEQUAL PROBABILITIES * $P . K$ PATHAK

BIOKA64 195 THE ANALYSIS OF TWO-DIMENSIONAL STATIONARY PROCESSES WITH DISCONTINUOUS SPECTRA * $M$. B. PRIESTLEY

BIOKA64 219 BAYES'S THEOREM AND THE USE OF PRIOR KNOWLEDGE IN REGRESSION ANALYSIS * CEORGE C. TIAO, ARNOLD ZELLNER

BIOKA64 231 A NEW TABLE OF PERCENTAGE POINTS OF THE CHI-SQUARE DISTRIBUTION * H. LEON HARTER

BIOKA64 241 ESTIMATION FOR THE BIVARIATE POISSON DISTRIBUTION * P. HOLGATE

BIOKA64 245 ON THE PROBABILITY CENERATINC FUNCTIONAL FOR THE CUMULATIVE POPULATION IN A SIMPLE BIRTH-AND-DEATH PROCESS * A. W. DAVIS

BIOKA64 250 THE CHI-SQUARE GOODNESS-OF-FIT TEST FOR A CLASS OF CASES OF DEPENDENT OBSERVATIONS * JOSEPH PUTTER

BIOKA64 253 ASYMPTOTIC NORMALITY OF CERTAIN TEST STATISTICS OF EXPONENTIALITY * FRANK PROSCHAN, RONALD PYKE

BIOKA64 256 A DISTRIBUTION-FREE TWO-SAMPLE TEST ON A CIRCLE * STANLEY WHEELER, G. S. WATSON

BIOKA64 258 PROBABILISTIC SOLUTION OF THE SIMPLE BIRTH PROCESS * D. KERRIDGE

BIOKA64 259 SOME RELATIONS BETWEEN EXPECTATIONS UF ORDER STATISTICS IN SAMPLES OF DIFFERENT SIZES * G. P. SILLITTO

BIOKA64 262 A BRANCHINC PROCESS IN WHIGH INDIVIDUALS HAVE VARIABLE LIFETIMES * P. WHITTLE 
BIOKA 64

BIOKA64

BIOKA 64

BIOKA 64

BIOKA64

BIOKA64

BIOKA64

BIOKA 64

BIOKA64

BIOKA64

BIOKA 64

BIOKA64

BIOKA 64

BIOKA64

BIOKA64

BIOKA64

BIOKA64
NOTE ON THE NECATIVE BINOMIAL DISTRIBUTION * SUDHAKAR M. VIDWANS

265 A PROPERTY OF THE MULTINOMIAL DISTRIBUTION AND THE DETERMINATION OF APPROPRIATE SCORES * M. J. R. HEALY 267 DECOMPOSITION OF WISHART DISTRIBUTION * D . C . KABE 268 ON AN ANALOGUE OF BHATTACHARYA BOUND * MUNUSWAMY SANKARAN

270 ON THE DISTRIBUTION OF THE LARGEST OF SEVEN ROOTS OF A MATRIX IN MULTIVARIATE ANALYSIS * K. C. SREEDHARAN PILLAI

5 THE DISTANCES BETWEEN RANDOM POINTS IN TWO CONCENTRIC CIRCLES * DAVID FAIRTHORNE

277 A COMPLETE MULTINOMIAL DISTRIBUTION COMPARED WITH THE $X$-SQUARE APPROXIMATION AND AN IMPROVEMENT TO IT * M. E. WISE

281 EFFECT OF NON-NORMALITY ON A SEQUENTIAL TEST FOR MEAN * G. P. BHATTACHARJEE, Y . NAGENDRA

2BB CORRIGENDA, 'THE RANK ANALYSIS OF INCOMPLETE BLOCK DESIGNS. II ADDITIONAL TABLES FOR THE METHOD OF PAIRED COMPARISONS, ' * R. A. BRADLEY

299 THE SPECTRAL ANALYSIS OF TWO-DIMENSIONAL POINT PROCESSES * M. S. BARTLETT

313 A GENERALIZED MULTI VARIATE ANALYSIS OF VARIANCE MODEL USEFULL ESPECIALLY FOR GROWTH CURVE PROBLEMS * RICHARD F. POTTHOFF, S. N. ROY PLACKETT

CORRECTION IN 2-BY-2 TABLES * R. L. PLACKETT HAROLD RUBEN

347 EXACT CONFIDENCE REGIONS FOR THE PARAMETERS IN NONLINEAR RECRESSION LAWS * H. O. HARTLEY

355 BOUNDS ON THE ERROR IN THE LINEAR APPROXIMATION TO THE RENEWAL FUNCTION *M. R. LEADBETTER

365 THE ROBUSTNESS OF THE GOVARIANCE ANALYSIS OF A ONE-WAY CLASSIFICATION * M. ATIQULLAH

373 INTERSECTIONS OF RANDOM CHORDS OF A CIRCLE * F. N. DAVID, EVELYN FIX

3BI GIRDLE DISTRIBUT IONS ON A SPHERE * B. SELBY

393 THE DISTRIBUTION OF THE GOODNESS-OF-FIT STATISTIC USQUARE-SUB-N. II * M. A. STEPHENS

399 THE STATISTICS OF A PARTICULAR NON-HOMOCENEOUS POISSON PROCESS * D. M. WILLIS

405 THE ANALYSIS OF PERSISTENCE IN A CHAIN OF MULTIPLE EVENTS * LEO A. GOODMAN
BIOKA64

BIOKA64

BIOKA64

BIOKA64

BIOKA64

BIOKA64

IOKA64

BIOKA64

BIOKA64

BIOKA64

BIOKA64

BIOKA64

BIOKA64

BIOKA64

BIOKA64

BIOKA64

BIOKA64

BIOKA64

BIOKA64

BIOKA64
413 CENERAL MODELS FOR QUANTAL RESPONSE TO THE JOINT ACTION OF A MIXTURE OF DRUCS * J.R. ASHFORD, C. S. SMITH 429 ESTIMATES OF SURVIVAL FROM THE SICHTINC OF MARKED ANIMALS * R. M. CORMACK

439 SIMULTANEOUS TESTS BY SEQUENTIAL METHODS IN HIERARCHICAL GLASSIFICATIONS * B. K. CHOSH

451 REPRESENTATIONS OF THE CENTRAL AND NON-CENTRAL T DISTRIBUTIONS * D. E. AMOS

59 ASYMPTOTIC EXPANSIONS FOR TESTS OF GOODNESS OF FIT FOR LINEAR AUTORECRESSIVE SCHEMES * K. C . CHANDA

7 POWER OF THE LIKELIHOOD-RATIO TEST OF THE GENERAL LINEAR HYPOTHESIS IN MULTIVARIATE ANALYSIS * H. 0 POSTEN, R. E. BARCMANN

N THE DISTINCTION BETWEEN THE CONDIT IONAL PROBAB IL I TY AND THE JOINT PROBABILITY APPROACHES IN THE SPECIFICATION OF NEAREST-NEIGHBOUR SYSTEMS * D BROOK

THE RATIO OF RANCE TO STANDARD DEVIATION IN THE SAME NORMAL SAMPLE* E. S. PEARSON, M. A. STEPHENS

4B7 SOME RESULTS IN THE THEORY OF INVENTORY * A. CHOSAL

491 SAMPLING VARIANCES OF ESTIMATES OF COMPONENTS OF VARIANCE FROM A NON-ORTHOGONAL TWO-WAY GLASSIFICATION * LEONE Y. LOW

495 A NOTE ON THE LOSS OF INFORMATION DUE TO CROUP ING OF OBSERVATIONS * B. K. KALE

49B ON CUPTA'S EST IMATES OF THE PARAMETERS OF THE NORMAL DISTRIBUTION * MIRM. ALI, L. K. CHAN

501 ON A POINT ARISINC IN POLYNOMIAL REGRESSION FITTINC * C. F. CROUSE

503 THE CONSTRUCTION OF A MATRIX USED IN DERIVINC TESTS OF SIGNIFICANCE IN MULTIVARIATE ANALYSIS * J, RADCLIFFE

504 THE DERIVATION OF METHODS FOR FITTING EXPONENTIAL RECRESSION CURVES * S. LIPTON, C. A. MCGILCHRIST

5OB SOME NOTES ON VARIANCE-RATIO TESTS OF THE GENERAL LINEAR HYPOTHESIS * JOHN G. SAW

511 ON EST IMATING EPIDEMIC PARAMETERS FROM HOUSEHOLD DATA * SALLY OHLSEN

513 THE MODE OF A MULTINOMIAL DISTRIBUTION * H. M. FINUCAN 517 THE ANALYSIS OF POISSON REGRESSION WITH AN APPLICATION IN VIROLOGY * JOHN J. GART

522 ON THE PROBLEM OF EST IMATI ON FOR THE BIVARIATE LOCNORMAL DISTRIBUTION * M. D. MOSTAFA, M. W. MAHMOUD

527 CORRIGENDA, 'EXTENDED TABLES OF CRITICAL VALUES FOR WILCOXON'S TEST STATISTIC. ' * L. R. VERDOOREN
BIOKA65 I EDITORIAL ARRANGEMENTS * L. H. C. TIPPETT

BIOKA 65

3 STUDIES IN THE HISTORY OF PROBABILITY AND STATISTICS. XIV. SOME INCIDENTS IN THE EARLY HISTORY OF BIOMETRY AND STATISTICS, $1890-1 B 94$ * E. S. PEARSON

BIOKA65 19 A COMPARISON OF SOME BAYESIAN AND FREQUENTIST INFERENCES. *D.J. BARTHOLOMEW

BIOKA65 37 BAYESIAN ANALYSIS OF RANDOM-EFFEGT MODELS IN THE ANALYSIS OF VARIANCE. I. POSTERTOR DISTRIBUTION OF VARIANCE-COMPONENTS * G. C. TIAO, W. Y. TAN

BIOKA65 55 FIDUCIAL CONSISTENCY AND GROUP STRUCTURE * D. A. S FRASER

BIOKA65 67 SOME RESULTS ON TESTS FOR POISSON PROCESSES. * P. A.W. LEW IS

BIOKA65 79 QUEUEING FOR GAPS IN TRAFFIC. * A. G. HAWKES

BIOKA65 B7 ON THE BIAS OF FUNCTIONS OF CHARACTERISTIC ROOTS OF A RANDOM MATRIX *T. CACOULLOS, I . OLKIN

BIOKA65 95 AN INVESTIGATION OF THE EFFECT OF MISCLASSIFICATION ON THE PROPERTIES OF CHI-SQUARE-TESTS IN THE ANALYSIS OF CATECORICAL DATA. *V. L. MOTE, R. L. ANDERSON

BIOKA65 111 DESICNS WHICH MINIMIZE MODEL INADEQUACIES. CUBOIDAL RECIONS OF INTEREST *N.R. DRAPER, W. E . LAWRENCE

BIOKA65 119 THE MILLS RATIO AND THE PROBABILITY INTEGRAL FOR PEARSON TYPE IV DISTRIBUTION. * L. R. SHENTON, J.A CARPENTER

BIOKA65 127 SOME PROBLEMS OF STATISTICAL INFERENCE IN ABSORBING MARKOV CHAINS. * J. J. BARTKO, G. A. WATTERSON

BIOKA65 139 AN APPROXIMATE DEGREES OF FREEDOM SOLUTION TO THE MULTIVARIATE BEHRENS-F ISHER PROBLEM * Y ING YAO

BIOKA65 149 A COMPARISON OF TESTS OF THE WILKS-LAWLEY HYPOTHESIS IN MULT IVARIATE ANALYSIS. * N. N . MI KHAIL

BIOKA65 157 SEQUENTIAL ANALYSIS OF DEPENDENT OBSERVATIONS. I * $R$ $M$. PHATARFOD

BIOKA65 167 INTEGKAL EXPRESSIONS FOR TAIL PROBABILITIES OF THE MULTINOMIAL AND NEGATIVE MULTINOMIAL DISTRIBUTIONS, * I . OLKIN, M. SOBEL

BIOKA65 181 A CHANCE IN LEVEL OF A NON-STATIONARY TIME SERIES * G E. P. BOX. G. C. TIAO

BIOKA65 193 EQUATORIAL DTSTRTBUTIONS ON A SPHERE, *C.S. WATSON
BIOKA65 200 APPENDIX TO 'EQUATORIAL DISTRIBUTIONS ON A SPHERE' * M. A. STEPHENS

BIOKA65 203 A GENERALIZED WILCOXON TEST FOR COMPARINC ARBITRARILY SINGLY-CENSORED SAMPLES * E. A. GEHAN

BIOKA65 225 EXPLICIT ESTIMATES FROM CAPTURE-RECAPTURE DATA WITH BOTH DEATH AND IMM IGRATION-STOCHAST IC MODEL . * C. M JOLLY

BIOKA65 249 A NOTE ON THE MULTIPLE-RECAPTURE CENSUS. * G. A. F SEBER

BIOKA65 261 THE DISTANCE FROM A RANDOM POINT TO THE NEAREST POINT OF A CLOSELY PACKED LATTICE . * P. HOLGATE

BIOKA65

263 CLUSTERING OF RANDOM POINTS IN TWO DIMENSIONS. * J . I. NAUS

BIOKA65 267 APPROXIMATION TO THE BEHRENS-FISHER DISTRIBUTIONS * V H PATIL

BIOKA65

BIOKA65

271 THE ESTIMATION OF PARAMETERS FROM THE SPREAD OF A DIS EASE BY CONSIDERING HOUSEHOLDS OF TWO. * $R$. W. MORGAN SERVATIONS * P. SPRENT

BIOKA65 277 THE DISTRIBUTION OF SUM-0-T0-M OF F(Y-SUB-T), WHERE (Y-SUB-0, Y-SUB-1,...) IS A REALIZATION OF A NONHOMOGENEOUS FINITE-STATE MARKOV CHAIN * $w$. $J$ CONOVER

BIOKA65 279 A NOTE ON ESTIMATION IN THE TRUNCATED POISSON * K. A SUBRAHAMANIAM

BIOKA65 2B2 TABLES OF PERLENTAGE POINTS OF ROOT (B1) AND B2 IN NORMAL SAMPLES, A ROUNDINC OFF * E. S. PEARSON

BIOKA65 2B5 A METHOD OF CONSTRUCTING BALANCED INCOMPLETE DESIGNS * E. R. MULLER

BIOKA65 2BB A PROPERTY OF THE MEAN DEVIATION FOR A CLASS OF CON TINUOUS DISTRIBUTIONS. * A. R. KAMAT

BIOKA65 $2 B 9$ ON PAIRS OF INDEPENDENT RANDOM VARIABLES WHOSE PRODUCT FOLLOWS THE GAMMA DISTRIBUTION. * I . KOTLARSKI

BIOKA65 295 A MOVINC AVERAGE REPRESENTATION FOR RANDOM VARIABLES COVARIANCE STATIONARY ON A FINITE TIME INTERVAL * D R. BRILLINGER 
BIOKA65 29B ON THE EFFECT OF REMOVINC PERSONS WITH N OR MORE ACCIDENTS FROM AN ACCIDENT PRONE POPULATION. * F. A HAICHT

BIOKA65 301 THE APPROXIMATE DISTRIBUTION OF THE CORRELATION BETWEEN TWO STATIONARY LINEAR MARKOV SERIES. II. J , R. MCCRECOR, U. M. BIELENSTEIN

BIOKA65 303 THE DISTRIBUTION OF THE COEFFICIENT OF VARIATION, COMMENT ON A CRITICISM MADE BY KOOPMANS, OWEN AND ROSENBLATT. *N. L. JOHNSON, B. L. WELCH

BIOKA65 305 CORRICENDA, 'THE CHOICE OF A SECOND ORDER ROTATABLE DESICN '*C, E, P.BOX, N.R. DRAPER

BIOKA65 305 CORRICENDA, 'A NEW TABLE OF PERCENTACE POINTS OF THE CHI-SQUARE DISTRIBUTIONS ' * H. LEON HARTER

BIOKA65 305 CORRICENDA, 'THE SPECTRAL ANALYSIS OF TWO-DIMENSIONAL POINT PROCESSES' *M. S. BARTLETT

BIOKA65 309 THE GOODNESS OF FIT STATISTIC V-SUB-N, DISTRIBUTION AND SICNIFICANCE POINTS*M. A. STEPHENS

BIOKA65 323 THE PROBABILITY OF GOVERING A SPHERE WITH N CIRCULAR CAPS. * E. N. CILBERT

BIOKA65 331 THE CONVEX HULL OF A RANDOM SET OF POINTS * B. EFRON

BIOKA65 345 TESTS OF RANDOMNESS BASED ON DISTANCE METHODS. * $\mathrm{P}$. HOLGATE

BIOKA65 355 THE BAYESIAN ESTIMATION OF COMMON PARAMETERS FROM SEVERAL RESPONSES * G. E. P. BOX, N. R. DRAPER

BIOKA65 367 ON LINEAR FUNCTIONS OF ORDERED CORRELATED NORMAL RANDOM VARIABLES * S. S. CUPTA, K. C. S. PILLAI

BIOKA65 381 SOME PROPERTIES OF THE 'HERMITE' DISTRIBUTION * C. D KEMP , ADRIENNE KEMP

BIOKA65 395 COUNTINC DISTRIBUTIONS FOR RENEWAL PROCESSES. * F. A HAIGHT

BIOKA65 405 ON THE DISTRIBUTION OF THE LARCEST CHARACTERISTIC ROOT OF A MATRIX IN MULTIVARIATE ANALYSIS. * K. C. S PILLAI

BIOKA65 415 LAGUERRE SERIES FORMS OF NON-CENTRAL CHI-SQUARE AND F DISTRIBUTIONS * M. L. TIKU

BIOKA65 429 THE PERFORMANCE OF SEVERAL TESTS FOR OUTLIERS * H. A DAVID. A. S. PAULSON

BIOKA65 437 A SPECIAL CASE OF A BIVARIATE NON-GENTRAL T-DISTRIBUTION*D. B. OWEN

BIOKA65 447 THE THEORY OF LEAST SQUARES WHEN THE PARAMETERS ARE STOCHASTIC AND ITS APPLICATION TO THE ANALYSIS OF CROWTH CURVES. * C. R. RAO

BIOKA65 459 LOCALLY ASYMPTOTICALLY MOST STRINGENT TESTS AND LACRANGIAN MULTIPLIER TESTS OF LINEAR HYPOTHESES * B. R, BHAT, B, N, NACNUR

BIOKA65 469 SOME PROBLEMS OF STATISTICAL PREDICTION * J AITCHISON, DIANE SCULTHORPE

BIOKA65 485 SHORT-CUT MULTIPLE COMPARISONS FOR BALANCED SINGLE AND DOUBLE CLASSIFICATIONS. PART 2, DERIVATIONS AND APPROXIMATIONS. * T. E. KURTZ, R. F. LINK, J.W TUKEY, D. L. WALLACE

BIOKA65 499 ON ELEMENTARY SYMMETRIG FUNCTIONS OF THE ROOTS OF TWO MATRICES IN MULTIVARIATE ANALYSIS. * K. C. S. PILLAI

BTOKA65 507 SEQUENTIAL SAMPLING, TWO DECISION PROBLEMS WITH LINEAR LOSSES FOR BINOMIAL AND NORMAL RANDOM VARIABLES. * D. V. LINDLEY, B. N. BARNETT
BIOKA65 533 APPROXIMATE MEANS AND STANDARD DEVIATIONS BASED ON DISTANCES BETWEEN PERCENTACE POINTS OF FREQUENCY CURVES. *E. S. PEARSON, J.W. TUKEY

BIOKA65 547 TABLES TO FACILITATE FITTINC S-SUB-U FREQUENCY CURVES. * N, L, JOHNSON

BIOKA65 559 UPPER BOUNDS ON THE MOMENTS AND PROBABILITY INEQUALITIES FOR THE SUM OF INDEPENDENT, BOUNDED RANDOM VARIABLES. * G. BENNETT

BIOKA65 571 THE SIMPLE STOCHASTIC EPIDEMIC CURVE FOR LARCE POPULATIONS OF SUSCEPTIBLES * T. WILLIAMS

BIOKA65 581 THE DISTRIBUTION OF RESPONSE TIMES IN A BIRTH-DEATH PROCESS * T. WILLIAMS

BIOKA65 5B7 SOME REMARKS ON DOUBLE SAMPLINC FOR STRATIFICATION * B. D. SINCH, D. SINGH

BIOKA65 591 AN ANALYSIS OF VARIANCE TEST FOR NORMALITY (COMPLETE SAMPLES) * S. S. SHAPIRO, M. B. WILK

BIOKA65 613 A SOLUTION OF THE GENERAL STOCHASTIC EPIDEMIC, * V SISKIND

BIOKA65 617 ON A PARTIAL DIFFERENTIAL EQUATION OF EPIDEMIC THEORY. I. * J. CANI

BIOKA65 623 A PARADOX INVOLVINC QUASI PRIOR DISTRIBUTIONS * $M$ STONE. B. C.F. SPRINGER

BIOKA65 627 THE INDEX OF DISPERSION AS A TEST STATISTIC. * B. SELBY BIOKA65 630 GHI-SQUARE APPROXIMATIONS FOR THE DISTRIBUTIONS OF GOODNESS-OF-FIT STATISTICS, U-SQUARE-SUB-N AND WSQUARE-SUB-N * M. L. TIKU

BIOKA65 633 A NOTE ON THE ANALYSIS OF INCOMPLETE BLOCK EXPERIMENTS, * J, A, JOHN

BIOKA65 636 ON RANDOM ROTATIONS IN R-CUBE. * R. E. MILES

BIOKA65 639 CORRELATION IN A SINGLY TRUNCATED BIVARIATE NORMAL DISTRIBUTION. II. RANK CORRELATION * M. A. AITKIN, M. W. HUME

BIOKA65 643 A NOTE ON THE QUEUEINC SYSTEM M-M-1 WITH BALKING . * G . GREGORY, P, R SATYAMURTY

BIOKA65 645 SOME MULTIVARIATE DENSITY FUNCTIONS OF PRODUCTS OF GAUSSIAN VARIATES. \#K. S. MILLER

BIOKA65 647 A NOTE ON ESTIMATION OF RATIOS BY QUENOUILLE'S METHOD. * J.N. K. RAO

BIOKA65 650 A GENERALIZED TWO-SAMPLE WILCOXON TEST FOR DOUBLYCENSORED DATA. * E. A. GEHAN

BIOKA65 653 BOUNDS IN A MINIMAX CLASSIFICATION PROGEDURE * K. S. BANER JEE, L. F. MARCUS

BIOKA65 654 ANALYSIS OF CATEGORIAL DATA. * C. E. HAYNAM, F. C LEONE

BIOKA65 661 SICNIFICANCE POINTS FOR THE TWO-SAMPLE STATISTIC USQUARE-SUB-M, N*M. A. STEPHENS

BIOKA65 664 ESTIMATION OF THE PARAMETERS FOR A MULTIVARIATE NORMAL DISTRIBUTION WHEN ONE VARIABLE IS DICHOTOMISED. * J. F. HANNAN, R. F. TATE

BIOKA65 669 CORRICENDA, 'ON THE SUM OF SQUARES OF NORMAL SCORES' * H. RUBEN

BIOKA65 669 CORRIGENDA, 'ROBUSTNESS TO NON-NORMALITY OF REGRESSION TESTS' * G. E. P. BOX, G. S. WATSON

BIOKA65 669 CORRIGENDA. 'TABLE OF PERCENTAGE POINTS OF PEARSON GURVES, FOR CIVEN ROOT (BETA-1) AND BETA-2, EXPRESSED IN STANDARD MEASURE' * N. L. JOHNSON, ERIG NIXON, D, E. AMOS, E. S, PEARSON

BIOKA65 669 CORRICENDA, 'SOME INEQUALITIES ON CHARACTERISTIC ROOTS OF MATRICES' * T. $W$, ANDERSON, S. DAS GUPTA

BIOMETRIKA VOLUME 53, 1966

BIOKA66

BIOKA66

BI0KA66

BIOKA66

BI0KA66

BIOKA66

BIOKA66

BIOKA66

BIOKA66

BIOKA66
1 STRUCTURAL PROBABILITY AND A CENERALIZATION* D. A. S FRASER

11 BAYESIAN COMPARISON OF MEANS OF A MIXED MODEL WITH APPLICATION TO RECRESSION ANALYSIS * G. C. TIAO

27 UNEQUAL CROUP VARIANCES IN THE FIXED-EFFECTS ONE-WAY ANALYSIS OF VARIANCE, A BAYESIAN SIDELIGHT *N.R DRAPER, I. GUTTMAN

37 A MENDELIAN MARKOV PROCESS WITH BINOMIAL TRANSITION PROBABILITIES * R. G. KHAZANIE, H. E. MCKEAN

49 MODELS FOR THE NON-INTERACTIVE JOINT ACTION OF A MIXTURE OF STIMULI IN BIOLOGICAL ASSAY * J.R. ASHFORD. C. S. SMITH

61 ON THE HOMOCENEOUS BIRTH-AND-DEATH PROCESS AND ITS INTEGRAL * P. S. PURI

73 CLOSED SEQUENTIAL TESTS FOR BINOMIAL PROBABILITIES * D. W. ALLING

B5 AN APPLICATION OF SEQUENTIAL SAMPLING TO ANALYTICAL SURVEYS * J. SEDRANSK

99 DISTRIBUTION FREE TESTS BASED ON THE SAMPLE DISTRIBUTION FUNCTION * C. F. CROUSE

109 THE AVERACE CRITICAL VALUE METHOD FOR ADJUDGING RELATIVE EFFICIENCY OF STATISTICAL TESTS IN TIME SERIES REGRESSION ANALYSIS * R. C. GEARY
BIOKA66 121 THE ORTHOCONAL POLYNOMI ALS OF POWER SER IES PROBABILITY DISTRIBUTIONS AND THEIR USES * D. F. I . VAN HERRDEN, H. T. GONIN

BIOKA66 129 LINEAR ESTIMATES WITH POLYNOMIAL COEFFICIENTS * F. DOWNTON

BIOKA66 143 MAXIMUM-LIKELIHOOD PAIRED COMPARISON RANKINGS * $R$ REMAGE JR, W. A. THOMPSON JR

BIOKA66 151 EVALUATION OF THE MAXIMUM-LIKELIHOOD ESTIMATOR WHERE THE LIKELIHOOD EQUATION HAS MULTIPLE ROOTS * V. D. BARNETT

BIOKA66 167 TESTING FOR HOMOGENEITY. I. THE BINOMIAL AND MULTINOMIAL DISTRIBUTIONS * R. F. POTTHOFF, M. WHITTINCHILL

BIOKA66 183 TEST ING FOR HOMOCENEITY. II. THE POISSON DISTRIBUTION * R, F, POTTHOFF, M. WHITTINGHILL

BIOKA66 191 CORRELATION OF RANCES OF CORRELATED DEVIATES * T. E KURTZ, R, F, LINK, J, W. TUKEY, D. L. WALLACE

BIOKA66 199 SOME MONTE CARLO RESULTS ON THE POWER OF THE F-TEST UNDER PERMUTATION IN THE SIMPLE RANDOMIZED BLOCK DESIGN * R. 0. COLLIER JR, F. B. BAKER

3IOKA66 205 ITERATIVE MAXIMUM-LIKELIHOOD ESTIMATION OF THE PARAMETERS OF NORMAL POPULATIONS FROM SINGLY AND DOUBLY CENSORED SAMPLES (CORR, 69 229) * H. L. HARTER, A. H. MOORE 
BIOKA66 215 A SIMPLE EXAMPLE OF A COMPARISON INVOLVINC QUANTAL DATA* D. R. COX

BIOKA66 221 USE OF RANCE IN TESTINC HETEROCENEITY OF VARIANCE * $R$ T. LESLIE, B. M. BROWN

BIOKA66 229 ALTERNATIVE TESTS FOR HETEROCENEITY OF VARIANCE, SOME MONTE CARLO RESULTS *E. S. PEARSON

BIOKA66 235 STATISTICS CONNECTED WITH THE UNIFORM DISTRIBUTION, PERCENTAGE POINTS AND APPLICATION TO TESTINC FOR RANDOMNESS OF DIRECTIONS * M. A. STEPHENS

BIOKA66 241 BIVARIATE CENERALIZATIONS OF NEYMAN'S TYPE A DISTRIBUTION * P, HOLCATE

BIOKA66 245 ON THE DISTRIBUTIONS OF THE RANCE AND MEAN RANCE FOR SAMPLES FROM A NORMAL DISTRIBUTION * R. P. BLAND, R D. GILBERT, C. H. KAPADIA, D. B, OWEN

BIOKA66 248 ON THE USE OF PATNAIK TYPE CHI APPROXIMATIONS TO THE RANGE IN SIGNIFICANCE TESTS * F. E. GRUBBS, HELEN J COON, E. S. PEARSON

BIOKA66 252 THE CURVE THROUGH THE EXPECTED VALUES OF ORDERED VARIATES AND THE SUM OF SQUARES OF NORMAL SCORES * $J$ G. SAW, B. CHOW

BIOKA66 255 A PERSISTENCE PROBLEM IN RENEWAL THEORY, ROBERT THE BRUCE'S SPIDER * D. E. BARTON, F. N. DAVID

BIOKA66 258 ASYMPTOTIC EXPANSIONS FOR THE MOMENTS OF THE DISTRIBUTION OF CORRELATION COEFFICIENT * B. K. GHOSH

BIOKA66 262 A COMPARISON OF SOME BAYESIAN AND FREQUENTIST INFERENCES. II * D. J. BARTHOLOMEW. E. E. BASSETT

BIOKAG6 264 SPECTRAL FACTORIZATION OF MULTIPLE TIME SERIES * J.F CLAERBOUT

BIOKA66 267 TABLE OF 0. 1 PERCENTAGE POINTS OF BEHRENS 'S D * J. B. DE V. WEIR

BIOKA66 269 SOME RELATIONSHIPS AMONG THE VON MISES DISTRIBUTIONS OF DIFFERENT DIMENSIONS * T. D. DOWNS

BIOKA66 272 A CONSERVATIVE TEST FOR THE CONCURRENCE OF SEVERAL REGRESSION LINES AND RELATED PROBLEMS * J. G. SAW

BIOKA66 275 A NECESSARY AND SUFFICIENT CONDITION FOR THE SQUARE OF A RANDOM VARIABLE TO BE GAMMA * C. ROBERTS. S. GEISSER

BIOKA66 278 CORRELATION IN A SINCLY TRUNCATED BIVARIATE NORMAL DISTRIBUTION. III. CORRELATION BETWEEN RANKS AND VARIATE-VALUES * M. A. AITKIN, M. W. HUME

BIOKA66 2BI THE CORRELATION BETWEEN VARIATE-VALUES AND RANKS IN A DOUBLY TRUNCATED NORMAL DISTRIBUTION * $M$. A. AITKIN

BIOKA66 2B2 APPROXIMATIONS TO THE MAXIMUM-LIKELIHOOD ESTIMATOR USING GROUPED DATA * B. K, KALE

BIOKA66 285 A GENERALIZATION OF JOHNSON'S PROPERTY OF THE MEAN DEVIATION FOR A CLASS OF DISCRETE DISTRIBUTIONS * A. R. KAMAT

BIOKA66 2 B7 A PROPERTY OF THE MEAN DEVIATION FOR THE PEARSON TYPE DISTRIBUTIONS * A. R. KAMAT

BIOKA66 2B9 LARGE-SAMPLE SIGN TESTS FOR TREND IN DISPERSION * H. K. URY

BIOKA65 311 SOME EXPERIMENTS IN THE NUMERICAL ANALYSIS OF ARCHAEOLOGICAL DATA * F. R. HODSON, P. H. A. SNEATH, J. E. DORAN

BIOKA66 325 SOME DISTANCE PROPERTIES OF LATENT ROOT AND VECTOR METHODS USED IN MULTIVARIATE ANALYSIS * J C C. GOWER

BIOKA66 339 DISCRIMINANT FUNCTION BETWEEN COMPOSITE HYPOTHESES AND RELATED PROBLEMS * C.R. RAO

BIOKAG6 347 EXACT DISTRIBUTIONS OF WILKS'S LIKELIHOOD RATIO CRITERION * M. SCHATZOFF

BIOKA66 359 MEASURING THE LENGTH OF A CURVE * P. A. P. MORAN

BIOKA66 365 SOME INTEGRAL EQUATIONS IN CEOMETRICAL PROBABILITY * J.R. PHILIP

BIOKA66 375 A NOTE ON THE WEIBULL RENEWAL PROCESS * Z. A. LOMNICKI BIOKA66 383 THE SUPERPOSITION OF RANDOM SEQUENCES OF EVENTS * $M$. TEN HOOPEN, H. A . REUVER

BIOKA66 391 SOME EFFECTS OF FLUCTUATING OFFSPRING DISTRIBUTIONS ON THE SURVIVAL OF A GENE * E. POLLAK
BIOKAG6 397 ON THE USE OF THE DIRECT MATRIX PRODUCT IN ANALYSINC CERTA IN STOCHASTIC POPULATION MODELS * J. H. POLLARD

BIOKA66 417 SMOOTH EMPIRICAL BAYES ESTIMATION FOR ONE-PARAMETER DISCRETE DISTRIBUTIONS * J . S. MARITZ

BIOKA66 431 BOUNDARIES FOR CLOSED (WEDGE) SEQUENTIAL T TEST PLANS * M. H. MYERS, M. A. SCHNEIDERMAN, P. ARMITAGE

BIOKA66 439 SEQUENTIAL ESTIMATION OF QUANTAL RESPONSE CURVES, A NEW METHOD OF ESTIMATION * C. B. WETHERILL, H. CHEN R. B. VASUDEVA

BIOKA66 455 THE OUTER NEEDLE OF SOME BAYES SEQUENTIAL CONTINUATION RECIONS * J. W. PRATT

BIOKA66 469 ON BAYES SEQUENTIAL DESICN WITH TWO RANDOM VARIABLES * R. BOHRER

BIOKA66 477 BAYESIAN ANALYSIS OF RANDOM-EFFECT MODELS IN THE ANALYSIS OF VARIANCE. II. EFFECT OF AUTOCORRELATED ERRORS*G. C. TIAO, W. Y. TAN

BIOKA66 497 SOME BALANCED INCOMPLETE BLOCK DESIGNS FOR TWO SETS OF TREATMENTS * D. A. PREECE

BIOKA66 507 BALANCED CONFOUNDING OF FACTORIAL EXPERIMENTS * E. R MULLER

BIOKA66 525 DESIGN OF EXPERIMENTS FOR PARAMETER ESTIMATION IN MULTIRESPONSE SITUATIONS * N. R. DRAPER, W. G. HUNTERR

BIOKA66 535 TESTS OF HYPOTHESES ABOUT THE PARAMETERS OF THE LOGISTIC FUNCTION * SHIRLEY E. HITCHCOCK

BIOKA66 545 CONSISTENT STATISTICS FOR ESTIMATING AND TESTINC HYPOTHESES FROM GROUPED SAMPLES * D. R. MCNEIL

BIOKA66 559 A QUICK METHOD OF ESTIMATING THE STANDARD DEVIATION * R. A. MEAD

BIOKA66 565 ESTIMATION OF THE PARAMETERS OF THE LOGISTIC DISTRIBUTION * S. S. GUPTA, M. CNANADESIKAN

BIOKA66 571 ON TWO METHODS OF BIAS REDUCTION IN THE ESTIMATION OF RATIOS* J. N. K. RAO, J. T. WEBSTER

BIOKA66 579 A K-SAMPLE ANALOGUE OF WATSON'S U-SQUARE STATISTIC * U. R. MAAG

BIOKA66 585 KOLMOGOROV'S REMARK ON THE HOTELLING CANONICAL CORRELATIONS * H. O. LANCASTER

BIOKA66 588 A Q-TECHNIQUE FOR THE CALCULATION OF CANONICAL VARIATES * J . C. GOWER

BIOKA66 590 THE NON-NULL DISTRIBUTION OF A STATISTIC IN PRINCIPAL COMPONENTS ANALYSIS * A.M. KSHIRSAGAR

BIOKA66 594 AN EXTREMAL PROPERTY OF THE CONDITIONAL EXPECTATION * D. R. BRILLINGER

BIOKA66 596 THE USE OF SECOND-ORDER 'SPHERICAL' AND 'CUBOIDAL' DESIGNS IN THE WRONG RECIONS * N, R. DRAPER, W. E LAWRENCE

BIOKA66 599 A NON-PARAMETRIC COMPARISON OF TWO SAMPLES ONE OF WHICH IS CENSORED * J G SAW

BIOKA6G 603 ON CHARACTERIZING THE NORMAL DISTRIBUTION BY STUDENT'S LAW * I. KOTLARSKI

BIOKA66 606 A NOTE ON APPROXIMATING TO THE NON-CENTRAL F DISTRIBUTION*M, L, TIKU

BIOKA66 6II BAYESIAN CONFIDENCE LIMITS FOR THE PRODUCT OF $\mathrm{N}$ BINOMIAL PARAMETERS * M. D. SPRINGER, W. E. THOMPSON

BIOKA66 614 A NOTE ON CRAIG'S PAPER ON THE MINIMUM OF BINOMIAL VARIATES * B, K, SHAH

BIOKA66 615 ON SUMS AND PRODUCTS OF RECTANGULAR VARIATES * H. L. GRAY. P. L. ODELL

BIOKA66 617 POISSON AND BINOMIAL FREQUENCY SURFACES * H. T. CONIN BIOKA66 619 COMPARATIVE VALIDITY OF THE CHI-SQUARE AND TWO MODIFIED CHI-SQUARE GOODNESS-OF-FIT TESTS FOR SMALL BUT EQUAL EXPECTED FREQUENCIES * M. J. SLAKTER

BIOKA66 623 THE NULL DISTRIBUTION OF THE FIRST SERIAL CORRELATION COEFFICIENT * D.R. COX

BIOKA66 627 AN ALTERNATIVE DERIVATION OF THE HERMITE DISTRIBUTION * ADRIENNE W. KEMP, C. D. KEMP

BIOKA66 629 CORRECTION, 'SOME METHODS OF CONSTRUCTING EXACT TESTS. $* \mathrm{~J}$. DURBIN

BIOMETRIKA VOLUME 54, 1967

BIOKA67 1 STUDIES IN THE HISTORY OF PROBABILITY AND STATISTICS. XV. THE HISTORICAL DEVELOPMENT OF THE GAUSS LINEAR MODEL * H. L. SEAL

BIOKA67 25 SOME REMARKS ON THE ANALYSIS OF TIME-SERIES * M. S BARTLET'

BIOKA67 39 SOME TESTS OF SEPARATE FAMILIES OF HYPOTHESES IN TIME SERIES ANALYSIS * A. M. WALKER

BIOKA67 69 DISTRIBUTION OF THE RESIDUAL SUM OF SQUARES IN FITTING INEQUALITIES * J, A. HARTIGAN

BIOKA67 85 THE TWO MEANS PROBLEM A SECONDARILY BAYES APPROACH * M. B. BROWN

BIOKA67 93 MAXIMUM-LIKEITHOOD ESTIMATION FOR THE MIXED ANALYSIS OF VAR IANCE MODEL *H. O. HARTLEY, J.N. K. RAO

BIOKA67 109 BAYESIAN ANALYSIS OF A THREE-COMPONENT HIERARCHICAL DESIGN MODEL * G C TIAO, G E P BOX
BIOKA67 127 DESIGNS FOR THE SIMULTANEOUS ESTIMATION OF FUNCTIONS OF VARIANCE COMPONENTS FROM TWO-WAY CROSSED CLASSIFICATIONS * M. G. MOSTAFA

BIOKA67 133 UNLIMITED SIMULTANEOUS DISCRIMINATION INTERVALS IN REGRESSION * G. J. LIEBERMAN, R. G. MILLER JR, M. A. HAMILTON

BIOKA67 147 THE USE OF PRIOR DISTRIBUTIONS IN THE DESIGN OF EXPERIMENTS FOR PARAMETER ESTIMATION IN NON-LINEAR SITUATIONS * N. R. DRAPER, W. G. HUNTER

BIOKA67 155 ESTIMATINC THE MEAN AND STANDARD DEVIATION FROM A CENSORED NORMAL SAMPLE* M. L. TIKU

BIOKA67 167 ESTIMATION OF THE PROBABILITY OF AN EVENT AS A FUNCTION OF SEVERAL VARIABLES * S. H. WALKER, D. B. DUNCAN 
BIOKA67 181 ON THE BIAS OF VARIOUS EST IMATORS OF THE LOC IT AND ITS VARIANCE WITH APPLICATION TO QUANTAL BIOASSAY * J. J. CART, J.R. ZWEIFEL

BIOKA67 189 UPPER PERCENTACE POINTS OF THE LARCEST ROOT OF A MATRIX IN MULTIVARTATE ANALYSIS * K. C L. PILLAI

BIOKA67 195 POWER COMPARISONS OF TESTS OF TWO MULTIVARIATE HYPOTHESES BASED ON FOUR CRITERIA * K. C. S. PILLAI, $K$. JAYACHANDRAN

BIOKA67 211 TESTS FOR THE DISPERSION AND FOR THE MODAL VECTOR OF A DISTRIBUTION ON A SPHERE* M. A. STEPHENS

BIOKA67 225 EXTENSION OF TABLES OF PERCENTAGE POINTS OF THE LARGEST VARIANCE RATIO S-SQUARE-MAX-OVER-S-SQUARESUB-O* C. CHAMBERS

BIOKA67 229 A CLASS OF SITUATIONS IN WHICH A SEQUENT IAL ESTIMATION PROCEDURE IS NON-SEQUENTIAL * P. WHITTLE, R, O. D LAND

BIOKA67 235 SOME CONTRIBUTIONS TO CONTINCENCY-TYPE BIVARIATE DISTRIBUTIONS (CORR, 6B 597) * K. V. MARDIA

BIOKA67 251 A MULTIVARIATE IMMIGRATION WITH MULTIPLE DEATH PROCESS AND APPLICATIONS TO LUNAR CRATERS * A. H. MARCUS

BIOKA67 263 INTEGRALS OF BRANCHING PROCESSES * P. JACERS

BIOKA67 273 EXTREMES IN A RANDOM ASSEMBLY * MARGARET CREIG

BIOKA67 2B3 RECURRENCE RELATIONS BETWEEN THE P.D.F.' S OF ORDER STATISTICS OF DEPENDENT VARIABLES, AND SOME APPLICATIONS *D. H. YOUNG

BIOKA67 293 REDUCTION OF THE MULTIVARIATE NORMAL INTECRAL TO CHARACTERISTIC FORM * D. R CHTLDS

BIOKA67 301 A COMPARISON OF SEVERAL VARIANCE COMPONENT EST IMATORS * Y. Y. WANG

BIOKA67 305 MULTIVARIATE T AND THE RANKING PROBLEM * H. FREEMAN A. KUZMACK, RITA MAURICE

BIOKA67 308 THE AVERAGE CRITICAL VALUE METHOD AND THE ASYMPTOTIC RELATIVE EFF ICIENCY OF TESTS * A. STUART

BIOKA67 310 ON FINDING LOCAL MAXIMA OF FUNCTIONS OF A REAL VARIA$B L E * F$ S G. RICHARDS

BIOKA67 312 A NOTE ON THE FIRST TWO MOMENTS OF THE MEAN DEVIATION OF THE SYMMETRICAL MULTINOMIAL DISTRIBUTION * D. H. YOUNG

BIOKA67 314 A NOTE ON THE ULTIMATE SIZE OF A GENERAL STOCHASTIC EPIDEMIC * F, DOWNTON

BIOKA67 316 STUDIES IN THE HISTORY OF PROBABILITY AND STATISTICS XVI. RANDOM RANDOM MECHANISMS IN TALMUDIC LITERATURE * A.M. HASOFER

BIOKA67 321 THE PRECISION OF MICHEY'S UNBIASED RATIO ESTIMATOR * J. N. K. RAO

BIOKA67 324 A RESULT ON ACCIDENT PRONENESS * S. K. BHATTACHARYA

BIOKA67 326 THE EMPIRICAL BAYES APPROACH, ESTIMATINC THE PRIOR DISTRIBUTION * J . R. RUTHERFORD, R. C. KRUTCHKOFF

BIOKA67 329 AN EXAMPLE OF DISCREPANCIES IN INFERENCES UNDER NONINFORMATIVE STOPPING RULES * W. A. ERICSON

BIOKA67 330 THE JOINT DISTRIBUTION OF ASCENDING PAIRS AND ASCENDING RUNS IN A RANDOM SEQUENCE * N. KRICHNAJI

BIOKA67 333 (ACKNOWLEDCEMENT OF PRIORITY), 'A PROPERTY OF THE MEAN DEVIATION FOR THE PEARSON TYPE DISTRIBUTTONS' * A. R. KAMAT

BIOKA67 333 CORRECTION, 'DISTRIBUTION FREE TESTS BASED ON THE SAMPLE DISTRIBUTION FUNCTION' * C F CROUSE

BIOKA67 341 STUDIES IN THE HISTORY OF PROBABILITY AND STATISTICS XVII. SOME REFLEXIONS ON CONTINUITY IN THE DEVELOPMENT OF MATHEMATICAL STATISTICS, 18B5-1920* E, S. PEARSON

BIOKA67 357 THE DISCARDING OF VARIABLES IN MULTIVARIATE ANALYSIS * E. M, L, BEALE, M. G. KENDALL, D. W. MANN

BIOKA67 367 ON METHODS OF ASYMPTOTIC APPROXIMATION FOR MULTIVARIATE DISTRIBUTIONS * J.M. CHAMBERS

BIOKA67 385 TESTINC FOR CORRELATION BETWEEN NON-NEGATIVE VARIATES * P. A. P. MORAN

BIOKA67 395 TESTINC FOR SERIAL CORRELATION WITH EXPONENTIALLY DISTRIBUTED VARIATES * P. A. P. MORAN

BIOKA67 403 TIME SERIES WITH PERIODIC STRUCTURE * R. H. JONES, W $M$. BRELSFORD

BIOKA67 409 THE ESTIMATION OF A LACGED REGRESSION RELATION * E . I HANNAN
BIOKA67 419 THE DISTRIBUTION OF THE MEAN HALF-SQUARE SUCCESSIVE DIFFERENCE* $*$. M. HARPER

BIOKA67 435 SMOOTH EMPIRICAL BAYES EST IMATION FOR CONTINUOUSOISTRIBUTIONS (CORR, 68597) * J. S. MARITZ

BIOKA67 451 A SUPPLEMENTARY SAMPLE NON-PARAMETRIC EMPIRICAL BAYES APPROACH TO SOME STATISTICAL DECISION PROBLEMS * R. C. KRUTCHKOFF

BIOKA67 459 TESTS OF RELATEDNESS * D. W. ALLING

BIOKA67 471 ANALYSIS OF PLANT COMPETITION EXPERIMENTS FOR DIFFERENT RATIOS OF SPECIES * C. MCGILCHRIST

BIOKA67 479 NESTED BALANCED INCOMPLETE BLOCK DESICNS * D. A PREECE

BIOKA67 4B7 RANK SUM MULTIPLE COMPARISIONS IN ONE AND TWO-WAY CLASSIFICATIONS * B. J. MCDONALD, W. A. THOMPSON

BIOKA67 499 ON SAMPLINC WITHOUT REPLACEMENT WITH UNEQUAL PROBABILITIES OF SELECTION * M. R. SAMPFORD

BIOKA67 515 UPPER AND LOWER PROBABILITY INFERENCES BASED ON A SAMPLE FROM A FINITE UNIVARIATE POPULATION * A, P. DEMPSTER

BIOKA67 529 CORRELATION OF THE RANCES OF CORRELATED SAMPLES * $\mathrm{K}$. V. MARDIA

BIOKA67 541 ON THE EXTREME VALUES AND RANCE OF SAMPLES FROM NONNORMAL POPULATIONS * C. SINGH

BIOKA67 551 LINEAR ESTIMATES OF A POPULATION SCALE PARAMETER * F . C. BARNETT, K. MULLEN, J. C. SAM

BIOKA67 555 SIMPLIFIED TECHNIQUES FOR ESTIMATINC PARAMETERS OF SOME CENERALIZED POISSON DISTRIBUTIONS * P. HINZ, J. GURLAND

BIOKA67 567 FIELLER'S THEOREM AND A CENERALIZATION * D. R. COX

BIOKA67 573 DISCRIMINATION BETWEEN ALTERNATIVE BINARY RESPONSE MODELS * ELIZABETHA. CHAMBERS, D. R . COX

BIOKA67 579 THE PROBABILITIES OF' EXTINCTION FOR BIRTH-AND-DEATH PROCESSES THAT ARE ACE-DEPENDENT OR PHASE-DEPENDENT * L. A, COODMAN

BIOKA67 597 ASYMPTOTIC VALUES OF THE FIRST TWO MOMENTS IN MARKOV RENEWAL PROCESSES * A. M. KSHIRSAGAR, Y. P. CUPTA

BIOKA67 605 TESTINC A MARKOV HYPOTHESIS WITH INDEPENDENCE OF INTERMEDIATE STATES AND RESTRICTED ORDER * J. THIEBAUX

BIOKA67 615 THE ANGLE-COUNT METHOD* P. HOLGATE

BIOKA67 625 A MONTE CARLO SOLUTION OF A TWO-DIMENSIONAL UNSTRUCTURED CLUSTER PROBLEM * F . D . K. ROBERTS

BIOKA67 629 EXTREME TAIL PROBABILITIES FOR THE NULL DISTRIBUTION OF THE TWO-SAMPLE WILCOXON STATISTIC * M. STONE

BIOKA67 641 SOME KOLMOCOROFF-TYPE INEQUALITIES FOR BOUNDED RANDOM VARIABLES* $W$. L. STEIGER

BIOKA67 649 ONA SYSTEM OF DISCRETE DISTRIBUTIONS * J. K. ORD

BIOKA67 657 THE CAPACITY OF AN UNCONTROLLED INTERSECTION * J. C. TANNER

BIOKA67 659 NOTE ON TEST ING HYPOTHESES IN AN UNBALANCED RANDOM EF FECTS MODEL * M. G. MOSTAFA

BIOKA67 662 THE USE OF PRIOR DISTRIBUTIONS IN THE DESIGN OF EXPERIMENTS FOR PARAMETER ESTIMATION IN NON-LINEAR SITUATIONS MULTIRESPONSE CASE * N. R. DRAPER, W. C HUNTER

BIOKA67 665 A NOTE ON AN APPROXIMATE FACTORIZATION IN DISCRIMINANT ANALYSIS * J. RADCLIFFE

BIOKA67 668 ON THE CHOICE OF VARIABLES IN CLASS IFICATION PROBLEMS WITH DICHOTOMOUS VARIABLES * JANET D. ELASHOFF, $R$. M. ELASHOFF, G. E. GOLDMAN

BIOKA67 670 A NOTE ON LINEAR STRUCTURAL RELATIONSHIPS WHEN BOTH RESIDUAL VARTANCES ARE KNOWN * V D BARNETT

BIOKA67 672 THE EMPIRICAL BAYES APPROACH ESTIMATING POSTERIOR QUANTILES * J.R. RUTHERFORD

BIOKA67 675 ANOTHER TEST FOR THE UNIFORMITY OF A CIRCULAR DISTRIBUTION* G. S. WATSON

BIOKA67 677 A NOTE ON THE ASYMPTOTIC EFFICIENCY OF FRIEDMAN 'S CHISQUARE-SUB-R-TEST * P.K. SEN

BIOKA67 679 SOME TWO-SAMPLE TESTS WHEN THE VARIANCES ARE UNEQUAL A SIMULATIONSTUDY * B.P. MURPHY

BIOKA67 6B3 A NOTE ON TABLES FOR THE COMPARISION OF THE SPREAD OF TWO NORMAL DISTRIBUTIONS * G . C. TIAO, R. H. LOCHNER

BIOKA67 6B4 SOME RELATIONSHIPS BETWEEN THE NORMAL AND VON MISES DISTRIBUTIONS * T, D. DOWNS, A. L . GOULD

BIOMETRIKA VOLUME $55,196 \mathrm{~B}$

BIOKA6B I PROBABILITY PLOTTING METHODS FOR THE ANALYSIS OF DATA * M. B. MILK, R GNANADESIKANN

BIOKA6B 19 LAGRANGIAN COEFFICIENTS FOR INTERPOLATION BETWEEN TABLED PERCENTAGE POINTS * E. S. PEARSON

BIOKA6B 29 INVERSE CUMULATIVE APPROXIMATION AND APPLICATIONS * M. E. TARTER

BIOKA6B 43 EXPERIMENTAL DEVELOPMENT OF NUTRITIVE MEDIA FOR MICRO-ORGANTSMS * V D FEDORV, V, N MACIMOV, V G . BOGOROV
BIOKA6B 53 OPTIMAL DESIGNS IN REGRESSION PROBLEMS WITH A GENERAL CONUEX LOSS FUNCTION * P. J. LAYCOCK, S. D . SILVEY

BIOKA6B 67 SERIALFACTORIALDESIGN * H. D. PATTERSON

BIOKA68 83 ON THE SMOOTH EMPIRICAL BAYES APPROACH TO TESTING OF HYPOTHESES AND THE COMPOUND DECISION PROBLEM * J . S . MARITZ

BIOKA68 101 BAYESIAN ANALYSIS OF LINEAR MODELS WITH TWO RANDOM COMPONENTS WITH SPECIAL REFERENCE TO THE BALANCED INCOMPLETE BLOCK DESIGN * G. C. TIAO, N. R. DRAPER 
BIOKA68 119 A BAYESIAN APPROACH TO SOME OUTLIER PROBLEMS * G. E. P BOX, G. C. TIAO

BIOKA68 131 SOME BAYESIAN STRATIFIED TWO-PHASE SAMPLINC RESULTS * N. R. DRAPER. I. GUTTMAN

BIOKA68 141 LINEAR-LOSS INTERVAL EST IMATION OF LOCATION AND SCALE PARAMETERS * J. AITCHISON, I. R. DUNSMORE

BIOKA68 149 EXPONENTIAL RECRESSION WITH CORRELATED OBSERVATIONS * ANN F. S. MITCHELL

BIOKA68 163 A METHOD OF ANALYSINC UNTRANSFORMED DATA FROM THE NECATIVE BINOMIAL AND OTHER CONTACIOUS DISTRIBUTIONS * P. HINZ, J. GURLAND

BIOKA6B 171 ON THE DISTRIBUTION OF A STATISTIC USED FOR TESTING A COVARIANCE MATR IX * B. P. KORIN

BIOKAGB 179 CONTINCENCY TABLES WITH CIVEN MARCINALS * C. T. IRELAND, S. KULLBACK

BIOKA6B IB9 STOCHASTIC BIRTH, DEATH AND MICRATION PROCESSES FOR SPATIALLY DISTRIBUTED POPULATIONS * N. T. BAILEY

BIOKA68 199 A PERTURBATION APPROXIMATION OF THE SIMPLE STOCHASTIC EPIDEMIC IN A LARGE POPULATION * N. T. J. BAILEY

BIOKA68 211 A SYSTEM OF MODELS FOR THE LIFE CYCLE OF A BIOLOGICAL ORGANISM * K. L. Q. READ, J.R. ASHFORD

BIOKA68 223 A SYSTEM OF TWO SERVERS WITH LIMITED WAITING ROOMS AND CERTAIN ORDER OF VISITS* G. C. GHIRTIS

BIOKA68 229 SEQUENTIAL OCCUPANCY WITH CLASSIFICATION * D. E. BARTON $\bar{F}$. N. DAVID

BIOKA68 243 APPROXIMATIONS TO DISTRIBUTION FUNCTIONS WHICH ARE HYPERGEOMETRIC SERIES * J. K. ORD

BIOKA68 249 STUDIES IN THE HISTORY OF PROBABILITY AND STATISTICS XVIII. THOMAS YOUNG ON COINCIDENCES * M. G. KENDALL

BIOKAGB

251 THE MEAN EFFICIENCY OF EQUI-REPLICATE DESICNS * S. C PEARCE

BIOKA68 254 ON USING AN INCORRECT VALUE OF SIGMA-SQUARE-SUB-BOVER-SIGMA-SQUARE IN BALANCED INCOMPLETE BLOCK DESIGNS * V. SISKIND

BIOKA68 255 RANDOMMINIMAL TREES * F. D. K. ROBERTS

BIOKA6B 25B A THREE-DIMENSIONAL CLUSTER PROBLEM * F. D. $\mathrm{K}$ ROBERTS, S. H. STOREY

BIOKA68 261 ON THE STRUCTURE OF THE TETRACHORIC SERIES * M. A. HAMDAN

BIOKA6B 262 A NOTE ON CONTINGENCY-TYPE BIVARIATE DISTRIBUTIONS * G. P. STECK

BIOKA6B 264 QUICK POWERFUL TESTS WITH GROUPED DATA * D. R. MCNEIL

BIOKA68 269 STUDIES IN THE HISTORY OF PROBABILITY AND STATISTICS XIX. FRANCIS YSIDRO EDCEWORTH $(1845-1926) * M . G$ KENDALL

BIOKA68 277 THE ULTIMATE SIZE OF CARRIER-BORNE EPIDEMICS * F DOWNTON

BIOKA68 291 AGE-DEPENDENT BRANCHING PROCESSES UNDER A CONDITION OF ULTIMATE EXTINCTION * W. A. O'N. WAUGH

BIOKA68 297 CHANCEOVER DESIGNS BALANCED FOR THE LINEAR COMPONENT OF FIRST RESIDUAL EFFECTS * I . I . BERENBLUT

BIOKA6B 305 ON ESTIMATION BY THE SWEEP-OUT METHOD (CORR. 69 229) * M. ATIQULLAH

BIOKA6B 313 ON THE BIAS OF SOME LEAST-SQUARES ESTIMATORS OF VARIANCE IN A GENERAL LINEAR MODEL * B. F. SWINDEL

BIOKAGB 317 TESTING THE HOMOGENEITY OF A SET OF CORRELATED VARIANCES * CHIEN-PAI HAN

BIOKA68 327 TESTS FOR CORRELATION MATRICES * M. A. AITKIN, W. C NELSON, KARENH. REINFURT

BIOKA68 335 POTER COMPARISIONS OF TESTS OF EQUALITY OF TWO COVARIANCE MATRICES BASED ON FOUR CRITERIA * K. C. S. PILLAI, K. JAYACHANDRAN

BIOKA68 343 A SIMPLE TEST FOR UNIFORMITY OF A CIRCULAR DISTRIBUTION* B. AJNE

BIOKA6B 355 SOME RESULTS ON TESTS OF SEPARATE FAMILIES OF HYPOTHESES * O. A. Y. JACKSON

BIOKA6B 365 ON THE EFFICIENCY OF MATCHED PAIRS IN BERNOULLI TRIALS * G. R. CHASE

BIOKA68 371 EXTREME TAIL PROBABILITIES FOR SAMPLING WITHOUT REPLACEMENT AND EXACT BAHADUR EFFICIENCY OF THE TWOSAMPLE NORMAL SCORES TEST * M. STONE

BIOKA68 377 PERCENTACE POINTS OF THE RANGE FROM A SYMMETRIC MULTINOMIAL DISTRIBUTION * B. M. BENNETT, E. NAKAMURA

BIOKA68 3B1 A NOTE ON THE ASYMPTOTIC RELATIVE EFFICIENCIES OF COX AND STUART'S TESTS FOR TESTING TREND IN DISPERSION OF A P-DEPENDENT TIME SERIES (CORR. 69457 ) * $\mathrm{R}$ SUBBA RAO

BIOKA68 387 CLOSED SEQUENTIAL TESTS FOR AN EXPONENTIAL PARAMETER * D. G. HOEL

BIOKA68 393 SERIAL SAMPLING ACCEPTANCE SCHEMES FOR LARGE BATCHES OF ITEMS WHERE THE MEAN QUALITY HAS A NORMAL PRIOR DISTRIBUTION*G.E.G. CAMPLING
BIOKA68 401 A FIXED SUBSET-SIZE APPROACH TO THE SELECTION PROBLEM *M. M. DESU, M. SOBEL

BIOKA6B 411 SOME EXTENSIONS OF SOMERVILLE'S PROCEDURE FOR RANKING MEANS OF NORMAL POPULATIONS * W. R. FAIRTEATHER

BIOKA68 419 STATISTICAL THEORY OF A HIGH-SPEED PHOTOELECTRIC PLANIMETER * F. A. P. MORAN

BIOKA68 422 AN INEQUALITY INVOLVINC MULTINOMIAL PROBABILITIES * C. L. MALLOWS

BIOKA6B 424 THE JOINT DISTRIBUTION OF THE STUDENTIZED REGRESSION COEFFICIENTS * E. MOHN

BIOKA6B 426 TESTINC FOR HOMOGENEITY OF A BINOMIAL SERIES * T. K. M WISNIEWSKI

BIOKA68 42B FURTHER PERCENTACE POINTS FOR W-SQUARE-SUB-N + (CRAMER-VON MISES COODNESS-OF-FIT STATISTIC) * M. A. STEPHENS, U. R. MAAG

BIOKA68 431 A MONTE CARLO INVESTICATION OF THE SIZE AND PONER OF TESTS EMPLOYING SATTERTHWAITE'S SYNTHETIC MEAN SQUARES * J, D. HUDSON JR, R. G. KRUTCHKOFF

BIOKA68 433 CORRELATION BETWEEN THE SAMPLE VARIANCES IN A SINGLY TRUNCATED BIVARIATE NORMAL DISTRIBUTION * B. R. RAO, M. L. GARC, C. C. LI

BIOKA6B 437 CORRELATION IN A SINCLY TRUNCATED BIVARIATE NORMAL DISTRIBUTION IV. EMPIRICAL VARIANCES OF RANK CORRELATION COEFFICIENTS * M. A. AITKIN, M. W. HUME

BIOKAGB 43B ON THREE PROCEDURES OF SAMPLING FROM FINITE POPULATIONS * P.S.R.S. RAO

BIOKAGB 441 TWO TABLES CONNECTED WITH GOODNESS-OF-FIT TESTS FOR EQUIPROBABLE ALTERNATIVES * J. N. CRONHOLM

BIOKA68 445 STUDIES IN THE HISTORY OF PROBABILITY AND STATISTICS $X X$. SOME EARLY CORRESPONDENCE BETWEEN W.S. GOSSETT R.A. FISHER AND KARL PEARSON, NITH NOTES AND COMMENTS *E.S. PEARSON

IOKA6B 459 STUDIES IN THE HISTORY OF PROBABBILITY AND STATISTICS XXI ON THE EARLY HISTORY OF THE LAW OF LARGE NUMBERS * O. B. SHEYNIN

BIOKA6B 469 STOCHASTIC MODELS FOR THE POPULATION CROWTH OF THE SEXES * L. A. GOODMAN

BIOKA6B 4 B9 SIMULTANEOUS TEST PROCEDURES IN MULTIVARIATE ANALYSIS OF VARIANCE * K. R. GABRIEL

BIOKA6B 505 PERCENTAGE POINTS OF THE EXTREME ROOTS OF A WISHART MATRIX * R, C. HANUMARA, W. S. THOMPSON

BIOKA6B 513 ON TESTING A SET OF CORRELATION COEFFICIENTS FOR EQUALITY. SOME ASYMPTOTIC RESULTS * L. J. GLESER

BIOKAGB 519 PREDICTIVE ZERO-MEAN UNIFORM DISCRIMINATION * S GEISSER, M. M. DESU

BIOKA68 525 THE USE OF EMPIRICAL BAYES ESTIMATORS IN A LINEAR REGRESSION MODEL * B. A. CLEMMER, R. G. KRUTCHKOFF

BIOKA68 535 A DESIGN BALANCED FOR TREND * E. J. SNELL. J. BRYANJONES

BIOKA6B 541 ON MODIFIED SYSTEMATIC SAMPLING * D. SINGH, K. K. JINDAL, J, N, GARG

BIOKA68 547 A NEW ESTIMATION THEORY FOR SAMPLE SURVEYS * H. 0 HARTLEY, J. N. K. RAO

BIOKA6B 559 USE OF THE PEARSON DENSITIES FOR APPROXIMATING A SKEW DENSITY WHOSE LEFT TERMINAL AND FIRST THREE MOMENTS ARE KNOWN * A. B, HOADLEY

BIOKA68 565 A ONE-SIDED PROBABILITY INEQUALITY FOR THE SUM OF INDEPENDENT, BOUNDED RANDOM VARIABLES * G. BENNETT

BIOKA68 571 AN APPROXIMATION FOR STUDENT'S T-DISTRIBUTION * W. M. GENTLEMAN, M. A. JENKINS

BIOKA6B 573 GINI 'S MEAN DIFFERENCE REDISCOVERED * H. A. DAVID

BIOKA68 575 FURTHER REMARKS ON EXPONENTIAL RECRESSION WITH CORRELATED OBSERVATIONS * ANN F. S. MITCHELL, MARCARET A ROBB

BIOKA68 57B A NOTE ON ESTIMATION FOR QUANTAL RESPONSE DATA * R. E LITTLE

BIOKA68 5BO ON THE PERCENTAGE POINTS OF THE SAMPLE COEFFICIENT OF VARIATION * B. IGLEWICZ, R. H. MYERS, R, B, HOWE

BIOKA68 5B2 ADDING A POINT TO VECTOR DIAGRAMS IN MULTIVARIATE ANALYSIS * J. C. GOWER

BIOKA6B 5B6 A NOTE ON DISCRIMINATION IN THE CASE OF UNEQUAL COVARI ANCE MATRICES * CHIEN-PAI HAN

BIOKA6B 5B7 BAYESIAN STRATIFIED TWO-PHASE SAMPLING RESULTS, $\mathrm{K}$ CHARACTERISTICS * N. R. DRAPER, I. GUTTMAN

BIOKA68 589 A NOTE ON MULTI-TYPE GALTON-TATSON PROCESSES WITH RANDOM BRANCHING PROBABILITIES * J. H. POLLARD

BIOKA68 591 A NOTE ON A SEQUENTIAL OCCUPANCY PROBLEM * D. H. YOUNG BIOKA68 593 SOME REMARKS CONCERNINC KHATRI 'S RESULT ON QUADRATIC FORMS * D. N. SHANBHAG

BIOKA68 595 A NOTE ON THE CORRELATION OF RANGES IN CORRELATED NORMAL SAMHLES* W. B. SMITH. H. O. HARTLEY 
BIOKA69 I TESTS FOR SERIAL CORRELATION IN RECRESSION ANALYSIS BASED ON THE PERIODOCRAM OF LEAST-SQUARES RESIDUALS * J. DURBIN

BIOKA69 17 COMPARISON OF THE SENSITIVITIES OF SIMILAR INDEPENDENT AND NON-INDEPENDENT EXPERIMENTS * A . SCHOEMAN, D. E. W. SCHUMANN

BIOKA69 33 THE USE OF RESIDUALS AS A CONCOMITANT VARIABLE * A. C ATKINSON

BIOKA69 43 THE ANALYSIS OF VARIANCE OF SOME NON-ORTHOGONAL DESICNS WITH SPLIT PLOTS * D. H. REES

BIOKA69 55 THE CHOICE OF VARIABLES IN THE DESIGN OF EXPERIMENTS FOR LINEAR REGRESSION * $P$. DAVIES

BIOKA69 65 NUMERICAL OPTIMIZATION IN THE PRESENCE OF RANDOM VARIABILITY. THE SINGLE FACTOR CASE * B, C, F, SPRINCER

BIOKA69 75 AN EXACT TEST FOR COMPARING MATCHED PROPORTIONS IN CROSSOVER DESIGNS * J. J. GART

BIOKA69 BI MULTIVARIATE PAIRED COMPARISONS. THE EXTENSION OF A UNIVARIATE MODEL AND ASSOCIATED ESTIMATION AND TEST PROCEDURES * R. R. DAVIDSON, R. A. BRADLEY

BIOKA69 97 BAYESIAN ESTIMATION OF LATENT ROOTS AND VECTORS WITH SPECIAL REFERENCE T0 THE BIVARIATE NORMAL DISTRIBUTION *G. C. TIAO, S. FIENBERG

BIOKA69 109 ON THE EXACT DISTRIBUTION OF WILKS'S CRITERION * K. C S. PILLAI, A. K. GUPTA

BIOKA69 119 TESTING EQUALITY OF MEANS IN THE PRESENCE OF CORRELATION* J. S. MEHTA. J. GURLAND

BIOKA69 127 THE PERFORMANCE OF SOME TWO-SAMPLE TESTS IN SMALL SAMPLES WITH AND WITHOUT CENSORINC * E. A. CEHAN, D. C THOMAS

BIOKA69 133 SOME EMPIRICAL BAYES TECHNIQUES IN POINT ESTIMATION * J . R. RUTHERFORD, R. G. KRUTCHKOFF

BIOKA69 139 CO-ORDINATE TRANSFORMATIONS TO NORMALITY AND THE POWER OF NORMAL TESTS FOR INDEPENDENCE * C. J . KOWALSKI, M. E. TARTER

BIOKA69 149 TESTS FOR THE VONMISESDISTRIBUTION * M. A. STEPHENS

BIOKA69 161 A GOODNESS-OF-FIT STATISTIC FOR THE CIRCLE, WITH SOME COMPARISONS * M. A. STEPHENS

BIOKA69 169 MULTI-SAMPLE TESTS FOR THE FISHER DISTRIBUTION FOR DIRECTIONS * M. A. STEPHENS

BIOKA69 183 THE SIMPLE STOCHASTIC EPIDEMIC FOR SMALL POPULATIONS WITH ONE OR MORE INITIAL INFECT IVES * R. T, HILL, N. C. SEVERO

BIOKA69 197 THE PROBABILITIES OF SOME EPIDEMIC MODELS * N. C. SEVERO

BIOKA69 203 APPROXIMATIONS TO THE CHARACTERISTICS OF SOME SEQUENTIAL TESTS * B. F. J. MANLY

BIOKA69 207 ASYMPTOTIC APPROXIMATION TO THE EXPECTED SIZE OF A SELECTED SUBSET * B. J. TRAWINSKI

BIOKA69 215 CONDITIONS FOR A QUADRATIC FORM TO HAVE A CHI-SQUARED DISTRIBUTION * I . J , GOOD

BIOKA69 216 ON TESTING THE EQUALITY OF K COVARIANCE MATRICES * B. P. KORIN

BIOKA69 219 SOME COMMENTS ON THE ACCURACY OF BOX 'S APPROXIMATIONS TO THE DISTRIBUTION OF M*E. S. PEARSON

BIOKA69 220 EPSILON ASYMPTOTIC OPTIMALITY OF EMPIRICAL BAYES ESTIMATORS * J, R. RUTHERFORD, R. G. KRUTCHKOFF

BIOKA69 223 THE IDENTIFICATION OF VECTOR MIXED AUTOREGRESSIVEMOVING AVERAGE SYSTEMS * E. J. HANNAN

BIOKA69 225 THE DISTRIBUTION OF INANIMATE MARKS OVER A NONHOMOGENEOUS BIRTH-DEATH PROCESS * T. WILLIAMS

IOKA69 231 THE BEHAVIOUR OF SOME SICNIFICANCE TESTS UNDER EXPERIMENTAL RANDOMIZATION * 0 . KEMPTHORNE, T. E. DOERFLER

BIOKA69 249 ON LOOKINC AT LARGE CORRELATION MATRICES * M. HILLS

BIOKA69 255 TABLE OF PERCENTACE POINTS OF NON-CENTRAL CHI * N. L. JOHNSON, E. S. PEARSON

BIOKA69 273 ON THE COMPUTATION AND USE OF A TABLE OF PERCENTAGE POINTS OF BARTLETT'S $M$ * E. HARSAAE

BIOKA69 283 CYCLIC CHANCE-OVER DESIGNS * A. W. DAVIS, W. B. HALL

BIOKA69 295 ROUND-ROBIN TOURNAMENT SCORES * H. E. DANIELS

BIOKA69 301 A COMPARISON OF SOME SEQUENT IAL DESIGNS * N. E. DAY

BIOKA69 313 QUADRATIC UNBIASED EST IMATION OF VARIANCE COMPONENTS OF THE ONE-WAY CLASSIFICATION * D. A. HARVILLE

BIOKA69 327 A MIXED MODEL OF REGRESSIONS * A. HUSSIAN

BIOKA69 337 A TEST FOR DISCRIMINATING BETWEEN MODELS * A. C. ATKINSON

BIOKA69 349 EMPIRICAL BAYES ESTIMATION FOR THE POISSON DISTRIBUTION* J. S. MARITZ

BIOKA69 361 AN EMPIRICAL BAYES SMOOTHINC TECHNIQUE * C. H. LEMON, R. C KRUTCHKOFF

BIOKA69 367 EMPIRICAL BAYES ESTIMATORS IN A MULTIPLE LINEAR REGRESSION MODEL * H. F. MARTZ.R. G. KRUTCHKOFF

BIOKA69 375 ASYMPTOTIC PROPERTIES OF SPECTRAL EST IMATES OF SEGOND ORDER *D. R. BRILLINGER

BIOKA69 391 DISTRIBUTIONS ASSOCIATED WITH GELL POPULATIONS * $M$. S. BARTLETT
BIOKA69 401 NEAREST NEICHBOURS IN A POISSON ENSEMBLE * F. D. K. ROBERTS

BIOKA69 407 SOME PROPERTIES OF A METHOD OF ESTIMATINC THE SIZE OF MOBILE ANIMAL POPULATIONS * B. F. J. MANLY

BIOKA69 411 ON ESTIMATINC THE PARAMETERS OF THE LOCARITHMIC SERIES AND NECATIVE BINOMIAL DISTRIBUTIONS * C. CHATFIELD

BIOKA69 415 ORDER STATISTICS FROM A CLASS OF NON-NORMAL DISTRIBUTIONS * K. SUBRAHMANIAM

BIOKA69 429 ESTIMATION OF THE PARAMETERS OF THE EXTREME VALUEDISTRIBUTION BY USE OF TWO OR THREE ORDER STATISTICS * KHATABM. HASSANEIN

BIOKA69 437 STUDIES IN THE HISTORY OF PROBABILITY AND STATISTICS XXII. PROBABILITY IN THE TALMUD * N. L. RABINOVITCH

BIOKA69 443 SOME TESTS FOR CORRELATION MATRICES * M. A. AITKIN

BIOKA69 446 ON HODCES'S BIVARIATE SIGN TEST AND A TEST FOR UNIFORMITY OF A CIRCULAR DISTRIBUTION * G. K. BHATTACHARYYA, R. A. JOHNSON

BIOKA69 449 THE PERFORMANCE OF SOME TESTS OF INDEPENDENCE FOR CONTINCENCY-TYPE BIVARIATE DISTRIBUTIONS * K. V. MARDIA

BIOKA69 452 TABLES OF SIMULTANEOUS GONFIDENCE LIMITS FOR THE BINOMIAL AND AND POISSON DISTRIBUTIONS * P. A. LACHENBRUGH

BIOKA69 NO.3 THE DERIVATION OF NONPARAMETRIC TWO-SAMPLE TESTS FROM TESTS FOR UNIFORMITY OF A CIRCULAR DISTRIBUTION * R. J. BERAN

BIOKA69 NO. 3 A NOTE ON THE ESTIMATION OF VARIANCE COMPONENTS BY THE METHOD OF FITTINC CONSTANTS * E. P. CUNNINGHAM

BIOKA69 NO. 3 ESTIMATINC THE COMPONENTS OF A MIXTURE OF NORMAL DISTRIBUTIONS * N. E. DAY

BIOKA69 NO. 3 MAXIMUM LIKELIHOOD PAIRED COMPARISON RANKINC BY LINEAR PROGRAMMING * J. S. DE CANI

BIOKA69 NO. 3 A NOTE ON THE EXPECTED VALUE OF AN INVERSE MATRIX * T CROVES, T. ROTHENBERC

BIOKA69 NO. 3 THE ESTIMATION OF MIXED MOVING-AVERAGE AUTOREGRESSIVE SYSTEMS* E. J. HANNAN

BIOKA69 NO. 3 ESTIMATION OF THE PARAMETERS OF THE LOGISTIC DISTRIBUTION BY SAMPLE QUANTILES * K. M. HASSANEIN

BIOKA69 NO. 3 ON THE APPLICATION OF GROUP THEORY TO THE EXISTENCE AND NON-EXISTENCE OF ORTHOCONAL LATIN SQUARES * A HEDAYAT, $W, T$ T FEDERER

BIOKA69 N0.3 INFERENCE ABOUT THE INTERSECTION IN TWO-PHASE REGRESSION * D. V. HINKLEY

BIOKA69 NO. 3 ON THE RATIO OF TWO CORRELATED NORMAL RANDOM VARIABLES * D. V. HINKLEY

BIOKA69 N0.3 SPECIES FREQUENCY DISTRIBUTIONS * P. HOLGATE

BIOKA69 NO.3 ON MULTIVARIATE RATIO AND PRODUCT EST IMATORS * S. JOHN BIOKA69 NO. 3 THE PROBABILITY THAT A RANDOM TRIANCLE IS OBTUSE * E. LANGFORD

BIOKA69 NO. 3 THE ANALYSIS OF VARIANCE FOR THE TWO-WAY CLASSIFICATION FIXED EFFECTS MODEL WITH OBSERVATIONS WITHIN A ROW SERIALLY CORRELATED * W. A. LARSEN

BIOKA69 NO. 3 ON EVALUATION OF WARRANTY ASSURANCE WHEN LIFE HAS A WEIBULLDISTRIBUTION* N. R. MANN, S. C. SAUNDERS

BIOKA69 NO. 3 ON UTILIZING INFORMATION FROM A SECOND SAMPLE IN EST IMATING VARIANCE * J. S. MEHTA. J. GURLAND

BIOKA69 NO. 3 THE ASYMPTOTIC VALUES OF CERTAIN GOVERAGE PROBABILITIES*R. E. MILES

BIOKA69 NO. 3 STATISTICAL INFERENCE WITH BIVARIATE CAMMA DISTRIBUTIONS * P. A. P. MORAN

BIOKA69 NO. 3 APPROXIMATION TO THE GENERALIZED BEHRENS-FISHER DISTRIBUTION INVOLVING THREE VARIATES * V. H. PATIL

BIOKA69 NO. 3 EXACT FIRST AND SECOND ORDER MOMENTS OF ESTIMATES OF COMPONENTS OF COVARIANCE * C. A. ROHDE, G. M. TALLIS

BIOKA69 NO. 3 NONPARAMETRIC SYMMETRY TESTS FOR CIRCULAR DISTRIBUTIONS * S. SCHACH

BIOKA69 NO. 3 ON THE INVERSE OF THE COVARIANCE MATRIX OF A FIRST ORDER MOVING AVERAGE *P. SHAMAN

BIOKA69 N0.3 DERIVATION OF APPROXIMANTS TO THE INVERSE DISTRIBUTION FUNCTION OF A CONTINUOUS UNIVARIATE POPULATION FROM THE ORDER STATISTICS OF A SAMPLE * G. P. SILLITTO

BIOKA69 NO. 3 THE USE OF RANDOM ALLOCATION FOR THE CONTROL OF SELECTIONBIAS * S. M. STICLER

BIOKA69 NO 3 THE ROLE OF EXPERIMENTAL RANDOMIZATION IN BAYESIAN STATISTICS. FINITE SAMPLING AND TWO BAYESIANS * $M$. STONE

BIOKA69 NO. 3 THE ROLE OF SIGNIFIGANCE TESTING, SOME DATA WITH A MESSAGE * M. STONE

BIOKA69 NO. 3 NOTE ONA CALIBRATION PROBLEM * G. M. TALLIS

BIOKA69 N0.3 DISTRIBUTION FREE TESTS FOR MIXED PROBABILITY DISTRIBUTIONS * E. A. C. THOMAS

BIOKA69 NO. 3 ON THE THEORY OF SCREENING FOR CHRONIC DISEASES * $M$ ZELEN, F. FEINLEIB 
JASA $56 \quad 1$ CONFESSION OF FAITH, 1955 * RALPH J. WATKINS

JASA 5612 STATISTICIAN AND POLICY MAKER, A PARTNERSHIP IN THE MAKING * WERNER Z . HIRSCH

JASA 5617 A TEST OF THE ACCURACY OF A PRODUCTION INDEX * CHARLES F. CARTER, MARY ROBSON

JASA 5624 ON SIMPLIFICATIONS OF SAMPL ING DESIGN THROUGH REPLICATION WITH EQUAL PROBABILITIES AND WITHOUT STAGES * W. EDWARDS DEMING

JASA 5654 INVESTIGATING THE PROPERTIES OF A SAMPLE MEAN BY EMPLOY ING RANDOM SUBSAMPLE MEANS * HOWARD L JONES

JASA 56 B4 SOME THEORETICAL ASPECTS OF THE LOT PLOT SAMPLING INSPECTION PLAN * LINCOLNE. MOSES

JASA 56108 THE OPERATING CHARACTERISTIC CURVE FOR SEQUENTIAL SAMPLING BY VARIABLES WHEN THE PRODUCER'S AND CONSUMER ' S RISKS ARE EQUAL * NORMAN R, GARNER

JASA 56111 TABLE OF PERCENTAGE POINTS OF KOLMOGOROV STATISTICS * LESLIE H. MILLER

JASA 56122 MULTIPLE REGRESSION WITH MISSING OBSERVATIONS AMONG THE INDEPENDENT VARIABLES * GEORGE L. EDGETT

JASA 56132 ON LINEAR COMBINATIONS OF SEVERAL VARIANCES * B. L WELCH

JASA 56149 TABULAR ANALYSIS OF FACTORIAL EXPERIMENTS AND THE USE OF PUNCH CARDS, CORR. $56650 * \mathrm{~J}, \mathrm{R}$. BAINBRIDGE, ALISON M GRANT, U, RADOK

JASA 56209 A SAMPLING PROCEDURE FOR MAILED QUESTIONNAIRES * M. A EL-BADRY

JASA 56228 THE ECONOMIC DESIGN OF MEAN CHARTS USED TO MAINTAIN CURRENT CONTROL OF A PROCESS * ACHESON J . DUNCAN

JASA 56243 ECONOMICALLY OPTIMUM ACCEPTANCE TESTS * JOHN V BREA KWELL

JASA 56257 ANALYSIS OF SENSITIVITY EXPERIMENTS WHEN THE LEVELS OF STIMULUS CANNOT BE CONTROLLED, CORR, $56650^{*}$ ABRAHAM GOLU8, FRANKE. GRUBBS

JASA 56266 A NOTE ON UNIFORMLY 8EST UNBIASED ESTIMATORS FOR VARIANCE COMPONENTS * FRANKLIN A. GRAYBILL, A. W WORTHAM

JASA 56269 SOME ESTIMATORS IN SAMPLING WITH VARYING PROBABILITIES WITHOUT REPLACEMENT * DESRAJ

JASA 56285 THE EFFICIENCIES OF TESTS OF RANDOMNESS AGAINST NORMAL REGRESSION * ALAN STUART

JASA 56288 A NOTE ON MATRIX INVERSION BY THE SQUARE ROOT METHOD * DAVID DURAND
JASA 56293 ON APPROXIMATING THE POINT BINOMIAL, CORR. 56651 * MORTONS. RAFF

JASA 56304 FISCAL-YEAR REPORTING FOR CORPORATE INCOME TAX * W. L CRUM

JASA 56429 THE OPTIMUM STRATEGY IN BLACKJACK, CORR. 59810 * ROGER R. BALDWIN, WILBERT E. CANTEY, HERBERT MAISEL, JAMES P. MACDERMOTT

JASA 56440 TWO SEQUENTIAL TESTS AGAINST TREND * GOTTFRIED E. NOETHER

JASA 56451 EQUIVALENCE OF TWO ESTIMATES OF PRODUCT VARIANCE * D W. GAYLOR

JASA 56454 THE ECONOMICS OF THE PRESIDENT'S ECONOMIC REPORTS * ARNOLD C. HARBERGER

JASA 56461 ANALYTICAL GRADUATION OF FERTILITY RATES * IVOLAH

JASA 56467 ASYMPTOTIC EFFICIENCIES OF A NONPARAMETRIC LIFE TEST FOR SMALLER PERCENTILES OF A GAMMA DISTRIBUTION * JOHN E. WALSH

JASA 56481 ESTIMATES OF BOUNDED RELATIVE ERROR FOR THE RATIO OF VARIANCES OF NORMAL DISTRIBUTIONS * STANLEY REITER

JASA 56489 MACHINE COMPUTATION OF HIGHER MOMENTS * NATHAN JASPEN

JASA 56565 THE AUTOMATIC COMPUTER IN INDUSTRY * THORNTON C. FRY

JASA 56576 THE EFFECT OF RESPONDENT IGNORANCE ON SURVEY RESULTS * ROBERT FERBER

JASA 56587 A METHOD OF ESTIMATING THE INTERCENSAL POPULATION OF COUNTIES * ALBERT H. CROSETTI, ROBERT C. SCHMITT

JASA 56591 RESEARCH ON METROPOLITAN POPULATION, EVALUATION OF DATA * OTIS DUDLEY DUNCAN

JASA 56597 MEASURING SPATIAL ASSOCIATION WITH SPECIAL CONSIDERATION OF THE CASE OF MARKET ORIENTATION OF PRODUCTION * WILLIAM WARNTZ

JASA $56 \quad 605$ PRACTICAL VALUE OF INTERNATIONAL EDUCATIONAL STATISTICS * GUSTAVE ZAKRZEWSKI

JASA 56 615 REGRESSION TECHNIQUES APPLIED TO SEASONAL CORRECT IONS AND ADJUSTMENTS FOR CALENDAR SHIFTS * HARRY EISENPRESS

JASA 56621 THE RANKING OF VARIANCES IN NORMAL POPULATIONS * H. A DAVID

JASA $56 \quad 627$ THE CONDITION FOR LOT SIZE PRODUCTION * MYRON J . GORDON, WILLIAM J. TAYLOR

JASA 56637 DISTRIBUTIONS POSSESSING A MONOTONE LIKELIHOODRATIO * SaMUEl karlin, h. RUBiN

JASA $56 \quad 644$ QUADRATIC EXTRAPOLATION AND A RELATED TEST OF HYPOTHESES * A. DE LA GARZA

JOURNAL OF THE AMERICAN STATISTICAL ASSOCIATION VOLUME 52, 1957

JASA 57 I STATISTICAL FRONTIERS * GERTRUDE M. COX

JASA 57 13 A SHORT-CUT GRAPHIC METHOD FOR FITTING THE BEST STRAIGHT LINE TO A SERIES OF POINTS ACCORDING TO THE CRITERION OF LEAST SQUARES * S. I. ASKOVITZ

JASA $57 \quad 18$ RAPID ANALYSIS OF 2 X2 TABLES * IRWIND. J. BROSS, ETHEL L. KASTEN

JASA 5729 A NOTE ON THE EFFECTS OF NONRESPONSE ON SURVEYS * K. A BROWNLEE

JASA $57 \quad 33$ A MODIFICATION OF KENDALL'S TAU FOR THE CASE OF ARBITRARY TIES IN BOTH RANKINGS * LETA MACKINNEY ADLER

JASA 5736 TWO CONFIDENCE INTERVALS FOR THE RATIO OF TWO PROBABILITIES AND SOME MEASURES OF EFFECTIVENESS * GOTTFRIED E. NOETHER

JASA 57 46 A SYSTEMATIC METHOD OF FINDING DEFINING CONTRASTS * CLARKHOLLOWAY JR

JASA 5753 ON THE INDEPENDENCE OF TESTS OF RANDOMNESS AND OTHER HYPOTHESES * I. RICHARD SAVAGE

JASA 5758 TA8LES FOR BEST LINEAR ESTIMATES BY ORDER STATISTICS OF THE PARAMETERS OF SINGLE EXPONENTIAL DISTRIBUTIONS FROM SINGLY AND DOUBLY CENSORED SAMPLES * A. E SARHAN, B. G. GREENBERC

JASA 5788 TABLES FOR TOLERANCE LIMITS FOR A NORMAL POPULATION BASED ON SAMPLE MEAN AND RANGE OR MEAN RANGE * SUJIT KUMAR NITRA

JASA 57133 ERRORS OF THE THIRD KIND IN STATISTICAL CONSULTING * A. W. KIMBALL

JASA 57143 SAMPLING IN A NUTSHELL * MORRIS JAMES SLONIM

JASA 57162 NATIONAL INCOME STATISTICS OF UNDERDEVELOPED COUNTRIES * HARRY T OSHIMA

JASA 57175 ESTIMATING THE SERVICE LIFE OF HOUSEHOLD GOODS BY ACTUARIAL METHODS, CORR. $5757 \mathrm{~B}$ * JEAN L. PENNOCK, CAROL M. JAEGER

JASA 57 IBG AN APPLICATION OF MULTIVARIATE QUALITY CONTROL TO PHOTOGRAPHIC PROCESSING * J. EDWARD JACKSON, ROBERT H. MORRIS

JASA 57200 MAXIMUM LTKELIHOOD ESTIMATES FOR A MULTIVARIATE NORMAL DISTR IBUTION WHEN SOME OBSERVAT IONS ARE MISSING * T. W. ANDERSON
JASA 57204 THE ANALYSIS OF INCOMPLETE BLOCK DESIGNS * MARVIN ZELEN

JASA 57 21B NON-ADDITIVITIES IN A LATIN SQUARE DESIGN * M. B WILK, OSCAR KEMPTHORNE

JASA 57237 TRANSFORMATIONS TO NORMALITY USING FRACT IONAL POWERS OF THE VARIABLE* P. G. MOORE

JASA 57247 LINEAR TRANSFORMATION TO A SET OF STOCHASTICALLY DEPENDENT NORMAL VARIABLES * WILLIAM J MOONAN

JASA 57253 THE REGIONS OF UNIMODALITY AND POSITIVITY IN THE ABBREVIATED EDGEWORTH AND GRAM-CHARLIER SERIES * GERALD D. BERNDT

JASA 57257 THE PRESIDENT' S ECONOMIC REPORT * ARCH RUSSELL

JASA 57301 LEADING AMERICAN STATISTICIANS IN THE NINETEENTH CENTURY * PAUL J. FITZPATRICK

JASA 57322 STATISTICS AND SCIENCE * E. J.G. PITMAN

JASA 57331 NONPARAMETRIC STATISTICS * I. RICHARD SAVAGE

JASA 57345 CHARTS OF THE 10 PERCENT AND 50 PERCENT POINTS OF THE OPERAT ING CHARACTERISTIC CURVES FOR FIXED EFFECTS ANALYSIS OF VARIANCE F TESTS, ALPHA EQUALS 0.01 AND $0.05 *$ ACHESON J DUNCAN

JASA 57350 A PROBLEM IN LIFE TESTING * D. J. BARTHOLOMEW

JASA 57356 HISTORICAL NOTES ON THE WILCOXON UNPAIRED TWO-SAMPLE TEST * WILLIAMH. KRUSKAL

JASA $57 \quad 415$ SEASONAL ADJUSTMENTS BY ELECTRONIC COMPUTER METHODS * JULIUS SHISKIN, HARRY EISENPRESS

JASA 57450 PROBLEMS IN MEASURING LONG TERM GROWTH IN INCOME AND WEALTH * ALEXANDER GERSCHENKRON

JASA 57458 THE RATIONAL ORIGIN FOR MEASURING SUBJECTIVE VALUES * L. L. THURSTONE, LYLE V. JONES

JASA 57472 APPLICATIONS OF A NEW GRAPHIC METHOD IN STATISTICAL MEASUREMENT * JACOB MINCER

JASA 57479 GRAPHIC COMPUTATION OF THE MULT IPLE CORRELATION COEFFICIENT, CORR. 581031 * FREDERICK V. WAUGH, KARL A FOX

JASA 57 4B2 CONFIDENCE INTERVALS FOR THE PRODUCT OF TWO BINOMIAL PARAMETERS * ROBERT J. BUEHLER

JASA 57494 OPTIMUM SAMPLING IN BINOMIAL POPULATIONS * PAUL N. SOMERV ILLE 
JASA 57503 ESTIMATES OF SAMPLING VARIANCE WHERE TWO UNITS ARE SELECTED FROM EACH STRATUM * NATHAN KEYFITZ

JASA 57511 APPLICATIONS OF MULTIVARIATE POLYKAYS TO THE THEORY OF UNBIASED RATIO-TYPE ESTIMATION * D. S. ROBSON

JASA 57523 ESTIMATION OF PARAMETERS FROM INCOMPLETE MULTIVAR IATE SAMPLES * GEORGE E. NICHOLSON JR

JASA 57527 TRUNCATION TO MEET REQUIREMENTS ON MEANS * F. EUGENE CLARK
JASA 57537 THE MIDRANGE OF A SAMPLE AS AN EST IMATOR OF THE POPULATION MIDRANGE * PAULR, RIDER

JASA 57543 NOTE ONGROUPING * D.R. COX

JASA 57548 USE OF DUMMY VARIABLES IN REGRESSION EQUATIONS * DANIEL B. SUITS

JASA 57552 FITTING A STRAIGHT LINE TO CERTA IN TYPES OF CUMULATIVE DATA * JOHN MANDEL

JASA 57567 EST IMATING THE LOGISTIC CURVE * H. SILVERSTONE

JOURNAL OF THE AMERICAN STATISTICAL ASSOCIATION VOLUME 53, 1958

JASA 58

JASA 58

JASA 58

JASA 58

JASA 58

JASA 58

JASA 58

JASA 5 B

JASA 58

JASA $5 B$

JASA 58

JASA 58

JASA 58

JASA 58

JASA 58

JASA 58

JASA 58

JASA 58

JASA 58

JASA 58

JASA 58

JASA 58

JASA 58

JASA 58

JSA $5 B$

JASA $5 B$

JASA 58

JASA 58

JASA 58

JASA 58

JASA 58
1 AN OUTLOOKREPORT * WILLIAMR LEONARD

11 THE CONTRIBUTIONS OF KARL PEARSON * HELEN M. WALKER

23 KARL PEARSON. AN APPRECIATION ON THE HUNDREDTH ANNIVERSARY OF HIS BIRTH * SAMUEL A. STOUFFER

28 SMOKING AND LUNG CANCER, SOME OBSERVATIONS ON TWO RECENT REPORTS * JOSEPH BERKSON

39 AN EXPERIMENT WITH WEIGHTED INDEXES OF CYCLICAL DIFFUSION * BERT G. HICKMAN

54 A STATISTICAL ANALYSIS OF PROVISIONAL ESTIMATES OF GROSS NATIONAL PRODUCT AND ITS GOMPONENTS. OF SELECTED NATIONAL INCOME GOMPONENTS, AND OF PERSONAL SAVING * ARNOLD ZELLNER

66 USE OF VARYING SEASONAL WEIGHTS IN PRIGE INDEX CONSTRUCTION * DORIS P. ROTHWELL

$7 B$ PHILIPPINE STATISTICAL PROGRAM DEVELOPMENT AND THE SURVEY OF HOUSEHOLDS * MILTOND. LIEBERMAN

B9 TINBERGEN ON ECONOMIC POLICY * KENNETH J ARROW

98 ON THE RELATIVE ACCURACY OF SOME SAMPLING TECHNIQUES * DES RAJ

102 PROBABILISTIC INTERPRESTATIONS FOR THE MEAN SQUARE CONT INGENCY, GORR . $581030 * \mathrm{H}$. M. BLALOGK JR

106 FITTING STRAIGHT LINES WHEN ONE VARIABLE IS CONTROLLED * HENRY SHEFFE

118 LINEAR CURVE FITTING USING LEAST DEVIATIONS * OTTO J. KARST

133 A MODIFIED DOOLITTLE APPROACH FOR MULTIPLE AND PARTIAL CORRELAT ION AND REGRESSION * RICHARD J FOOT

144 A PROCEDURE FOR GOMPUTING REGRESSION COEFFICIENTS CORR. 59811 * DUDLEY J. COWDEN

151 A STATISTICAL MODEL FOR LIFE-LENGTH OF MATERIALS * Z W. BIRNBAUM, S. G. SAUNDERS

161 ON THE DISTRIBUTION OF SOLUTIONS IN LINEAR PROGRAMMING PROBLEMS * HARVEYM. WAGNER

164 ON RANK ING PARAMETERS OF SCALE IN TYPE III POPULATIONS * K. C. SEAL

176 USE OF RANDOMIZATION IN THE INVEST IGATION OF UNKNOWN FUNCTIONS * ROBERT HOOKE

187 SOME ASPEGTS OF THE USE OF THE SEQUENTIAL PROBABILITY RATIO TEST * M. H. DEGROOT, JACK NADLER

259 MEASURING RECESSIONS * GEOFFREY H. MOORE

317 THE ACCURACY AND STRUCTURE OF INDUSTRY EXPECTATIONS IN RELATION TO THOSE OF INDIVIDUAL FIRMS * ROBERT FERBER

336 AN INDEX OF MANUFACTURING PRODUGTION IN NEW ENGLAND * HARRY BENJAMIN ERNST

FECT OF VARY ING DEGREES OF TRANSITORY INCOME ON INCOME ELASTICITY OF EXPENDITURES * MARILYN DUNSING. MARGARET G. REID

360 THE FIRST 1,945 BRITISH STEAMSHIPS * J, R. T. HUGHES, STANLEY REITER

382 THE USE OF RANDOM WORK SAMPLING FOR COST ANALYSIS AND CONTROL, CORR, 581031 *A. C. ROSANDER, H. E. GUTERMAN, A J MACKEON

98 THE TRENTILE DEVIATION METHOD OF WEATHER FORECAST EVALUATION * MORRIS JAMES SLONIM

408 WEIGHT-HEIGHT STANDARDS 8ASED ON WORLD WAR II EXPERIENCE * 8ERNARD D. KARPINOS

420 ESTIMATION OF SÜRVIVORSHIP IN CHRONIC DISEASE, THE 'ACTUARIAL' METHOD * LILA ELVEBACK

441 GRAPHIC COMPUTATION OF TAU AS A COEFFICIENT OF DISARRAY * HAROLD D. GRIFFIN

448 A NEW BIVARIATE SIGN TEST * ISADORE BLUMEN
JASA 58457 NONPARAMETRIC ESTIMATION FROM INGOMPLETE OBSERVATIONS * E. L. KAPLAN, PAUL MEIER

JASA 58 4B2 INADMISSIBLE SAMPLES AND CONFIDENCE LIMITS * HOWARD L. JONES

JASA 58491 THE PRECISION OF UNBIASED RATIO-TYPE ESTIMATORS. CORR. 631162 * LEO A. GOODMAN, H. O. HARTLEY

JASA 58509 ON NONCOVERAGE OF SAMPLE DWELLINGS * LESLIE KISH IRENE HESS

JASA 58525 COMPLETE COUNTERBALANCING OF IMMEDIATE SEQUENTIAL EFFECTS IN A LATIN SQUARE DESIGN, CORR, 581030 * JAMES V. BRADLEY

JASA 58529 FRACTORIAL EXPERIMENTATION IN SCHEFFE'S ANALYSIS OF VARIANCE FOR PAIRED COMPARISONS * OTTO DYKSTRA, JR.

JASA 58543 DESIGN AND OPERATION OF A DOUBLE-LIMIT VARIABLES SAMPLING PLAN * ACHESON J. DUNCAN

JASA 58551 EMPIRIC INVESTIGATION OF A TEST OF HOMOGENEITY FOR POPULAT IONS COMPOSED OF NORMAL DISTRIBUTIONS * G , A. BAKER

JASA 5B 635 INFLUENCE OF THE INTERVIEWER ON THE ACCURACY OF SURVEY RESULTS * ROBERT H. HANSON, ELIS. MARKS

JASA 5B 556 DEMAND FOR FARM PRODUGTS AT RETAIL AND THE FARM LEVEL SOME EMPIRICAL MEASUREMENTS AND RELATED PROBLEMS * REX F. DALY

JASA 58669 INVESTMENT ESTIMATES OF UNDERDEVELOPED COUNTRIES, AN APPRA ISAL * WILLIAM I. ABRAHAM

JASA 5B 680 MANUFACTURERS' INVENTORY GYCLES AND MONETARY POLICY * DORISM. EISEMANN

JASA 58689 LEADING AMERICAN STATISTICIANS OF THE NINETEENTH CENTURY II * PAUL J. FITZPATRICK

JASA 5B 702 RECTIFYING INSPECTION OF A CONTINUOUS OUTPUT, CORR $59810 *$ F. J. ANSCOMBE

JASA 5B 720 RANKING METHODS AND THE MEASUREMENT OF ATTITUDES * $R$ JARD INE

JASA 5B 729 RANDOMIZATION TESTS FOR A MULTIVARIATE TWO-SAMPLE PROBLEM* J.H. CHUNG, D. A. S. FRASER

JASA 58736 A METHOD OF ADJUSTMENT FOR DEFECTIVE DATA * MORRIS JAMES SLONIM. CHESTER H. MACCALL JR

JASA 58741 A TEST OF VARIANCES * K. V. RAMACHANDRAN

JASA $58 \quad 777$ 'STUDENT' AND SMALL SAMPLE THEORY * B. L. WELCH

JASA 58789 ON GROUP ING FOR MAX IMUM HOMOGENEITY * WALTER D. FISHER

JASA 58799 SIGNIFICANCE TESTS IN PARALLEL AND IN SERIES * I. J GOOD

JASA $58 \quad 814$ ORDINAL MEASURES OF ASSOG IATION * WILLIAM H. KRUSKAL

JASA 58 B62 CURTAILED SAMPLING FOR VARIABLES * NORMANR. GARNER

JASA 58 B6B ON THE STUDENTIZED SMALLEST CHI-SQUARE, CORR. 59 B12 * K, V. RAMACHANDRAN

JASA $58 \quad 873$ THE ESTIMATION OF THE PARAMETER OF A LINEAR REGRESSION SYSTEM OBEYING TWO SEPARATE REGIMES * RICHARD E. QUANDT

JASA 58 BBI ALTERNATIVE DEFINITIONS OF THE SERIAL CORRELATION COEFFICIENT IN SHORT AUTOREGRESSIVE SEQUENCES * ABBOTT S. WEINSTEIN

JASA 58893 A STOCHASTIC ANALYSIS OF THE SIZE DISTRIBUTION OF FIRMS, CORR, 59810 * IRMA G , ADELMAN

JASA 58905 SOME ANALYSES OF INCOME-FOOD RELATIONSHIPS * MARGUERITE C. BURK

JASA 58928 A CROSS-SECTION ANALYSIS OF NON-8USINESS AIR TRAVEL * JOHN B. LANSING, DWIGHT M. BLOOD

JASA 58948 APPROACHES TO NATIONAL OUTPUT MEASUREMENT * PAUL B SIMPSON

JASA 58963 NOTES ON IMMIGRATION STATISTICS OF THE UNITED STATES * E. P. HUTCHINSON

JOURNAL OF THE AMERICAN STATISTICAL ASSOCIATION VOLUME 54, 1959

JASA 59

1 STATISTICIANS. TODAY AND TOMORROW * WALTER E. HOADLEY JR

JASA 5912 SOME SOVIET STATISTICAL 800KS OF 1957 * ERERHARD M. FELS

JASA 5930 PUBLICATION DECISIONS AND THEIR POSSI8LE EFFECTS ON INFERENCES DRAWN FROM TESTS OF SIGNIFICANCE , OR VICE VERSA * THEORDORE D. STERLING
JASA 59

JASA 59

JASA 59
35 INHALATION IN RELATIO E. CUYLER HAMMOND

2 PANEL MORTALITY AND PANEL B IAS * MARION GROSS SO8OL

9 SOME PROBLEMS OF THE HOUSEHOLD INTERVIEW DESIGN FOR THE NATIONAL HEALTH SURVEY * HAROLD NISSELSON, THEODORE D. WOOLSEY 
MINIMUM VARIANCE STRATIFICATION, CORR, 631161 * TORE DALENIUS, JOSEPH L. HODCES JR

02 HOW MANY OF A CROUP OF RANDOM NUMBERS WILL BE USABLE IN SELECTINC A PART ICULAR SAMPLE * HOWARD L. JONES

123 MEASURES OF ASSOCIATION FOR CROSS CLASSIFICATIONS, II. FURTHER DISCUSSION AND REFERENCES * LEO A . GOODMAN, WILLIAM H. KRUSKAL

164 COMPACT TABLE OF TWELVE PROBABILITY LEVELS OF THE SYMMETRIC BINOMIAL CUMULATIVE DISTRIBUTION FOR SAMPLE SIZES TO 1,000, CORR. 59 BII * WILLIAM J. MACKINNON SUBJECT TO ERROR, CORR, 59 B12* ALBERT MADANSKY

206 LINEAR PROGRAMMINC TECHNIQUES FOR RECRESSION ANALYSIS * HARVEY $M$. WAGNER

213 COMMENTS ON 'THE SIMPLEST SIGNED-RANK TESTS' * JOHNE WALSH

225 SIMPLIFIED BETA-APPROXIMATIONS TO THE KRUSKAL-WALLIS H TEST * DAVID L. WALLACE

231 A PRODUGTION MODEL AND CONTINUOUS SAMPLING PLAN * I RIGHARD SAVACE

48 A SINGLE SAMPLING PLAN FOR CORRELATED VARIABLES WITH A SINGLE-SIDED SPECIFICATION LIMIT * $K$ C SEAL

260 MINIMUM RISK SPECIFICATION LIMITS * F. H. TINCEY, J A. MERRILL

75 LOWER BOUND FORMULAS FOR THE MEAN INTERCORRELATION COEFFICIENT * RICHARD H. WILLIS

281 STATISTICAL DATA AVAILABLE FOR ECONOMIG RESEARCH ON CERTAIN TYPES OF RECREATION * MARION GLAWSON

335 A GUIDE TO THE LITERATURE ON STATISTICS OF RELIGIOUS AFFILIATION WITH REFERENCES TO RELATED SOCIAL STUDIES, CORR. 59811 * BENSON Y. LANDIS MARGARET G REID

377 THE DEMAND FOR FERTILIZER IN 1954, AN INTER-STATE STUDY * ZVI GRILICHES

385 MAPS BASED ON PROBABILITIES * MIEGZYSLAW CHOYNOWSKI

389 PARAMETER ESTIMATES AND AUTONOMOUS GROWTH', CORR. 59 $812 *$ W. A. NEISWANGER, T. A. YANCEY

403 ON THE PROBLEM OF MATCHING LISTS BY SAMPLES * W. EDWARDS DEMING, GERALD J. GLASSER

416 ON VARIANCES OF RATIOS AND THEIR DIFFERENCES IN MULTISTAGE SAMPLES, CORR. 631162 * LESLIE KISH, IRENE HESS

447 ACCURACY REQUIREMENTS FOR ACCEPTANCE TESTING OF COMPLEXSYSTEMS * C. R. GATES, J . P. FEAREY

465 CORRELATION BETWEEN SAMPLE MEANS AND SAMPLE RANGES * BERNARD OSTLE, GEORGE P. STECK

472 PROBLEMS IN MENTAL TEST THEORY ARISING FROM ERRORS OF MEASUREMENT * FREDERIC $M$. LORD
JASA 59535 SOME METHODOLOCICAL NOTES ON THE DEFLATION OF CONSTRUCTION * NORMANM. KAPLAN

JASA 59556 AN ECONOMETRIC MODEL FOR UNITED STATES ACRICULTURE * WILLIAM A . CROMARTY

JASA 59575 A NOTE ON THE RELATIONSHIP BETWEEN EARNINC EXPECTATIONS AND NEW CAR PURCHASES * PETER E. DE JANOSI

JASA 59578 THE ACCURACY OF CENSUS LITERACY STATISTICS IN IRAN * CHARLES WINDLE

JASA 59 5B2 SOURCES OF STATISTICS ON CRIME AND CORRECTION * RONALD H. BEATTIE

JASA 59593 PUBLICATION DECISIONS AND TESTS OF SICNIFICANCE, A COMMENT * GORDON TULLOCK

JASA 59594 SOME FINITE POPULATION UNBAISED RATIO AND RECRESSION ESTIMATORS, CORR. 60755 * M. R. MICKEY

JASA 59613 CONFIDENCE INTERVALS FOR THE MEANS OF DEPENDENT NORMALLY DISTRIBUTED VAR IABLES * OLIVE JEAN DUNN

JASA 59622 A BASIS FOR THE SELECTION OF A RESPONSE SURFACE DESIGN * G. E. P. BOX, NORMAN R. DRAPER

JASA 59655 REMARKS ON ZEROS AND TIES IN THE WILCOXON SIGNED RANK PROCEDURE * JOHNW. PRATT

JASA 59668 GRAPHIC METHODS BASED UPON PROPERTIES OF ADVANCING CENTROIDS*S. I. ASKOVIT2

JASA 59674 OPTIMAL GONFIDENCE INTERVALS FOR THE VARIANCE OF A NORMAL DISTRIBUTION*R. F. TATE, G. W. KLETT

JASA $596 B 3$ EXTENDED TABLES OF THE PERCENTAGE POINTS OF STUDENT 'S T-DISTRIBUTION * ENRICO T. FEDERICHI

JASA 59689 PERCENTAGE POINTS FOR THE DISTRIBUTION OF OUTGOINC QUALITY * G. P. STECK, D. B. OWEN

JASA 59717 PROBLEMS IN ESTIMATING FEDERAL GOVERNMENT EXPENDITURES * SAMUEL M. COHN

JASA 59730 ANALYSIS OF VITAL STATISTICS BY CENSUS TRACT * ELIZABETH J . COULTER, LILLIAN GURALNICK

JASA 59741 A CHECK ON GROSS ERRORS IN CERTAIN VARIANCE GOMPUTATIONS * HYMAN B, KAITZ

JASA 59744 AUTOMATIC PROGRAMMING FOR AUTOMATIC COMPUTERS * MITCHELL 0. LOCKS

JASA 59755 MATRIX INVERSION, ITS INTEREST AND APPLICATION IN ANALYSIS OF DATA * B. G. CREENBERG, A. E. SARHAN

JASA 59767 A MULTIPLE CCMPARISON SIGN TEST, TREATMENTS VERSUS CONTROL * ROBERT G. D. STEEL

JASA 59776 THE LADY TASTINC TEA, AND ALLIED TOPICS *N. T. GRIDGEMAN

JASA 597 7B4 TABLES FOR THE SIGN TEST WHEN OBSERVATIONS ARE ESTIMATES OF BINOMIAL PARAMETERS * ARTHUR COHEN

JASA 59794 COMPARISON OF ESTIMATES OF CIRCULAR PROBABLE ERROR CORR. 60755 *P. B. MORANDA

JASA 59801 A NOTE ON MEAN SQUARE SUCCESSIVE DIFFERENCES * J. N. K . RAO

JASA 59834 LINEAR REGRESSION ANALYSIS WITH MISSING OBSERVATIONS AMONG THE INDEPENDENT VARIABLES * M. GLASSER

JOURNAL OF THE AMERICAN STATISTICAL ASSOCIATION VOLUME 55, 1960

JASA $60 \quad 1$ THE DUAL FUNCT ION OF STATIST ICS * RENSIS LIKERT

JASA $60 \quad 8$ THREE SOURCES OF DATA ON COMMUTINC, PROBLEMS AND POSSIBILITIES * LEO F. SCHNORE

JASA 6023 PROCESSING UNDERDEVELOPED DATA FROM AN UNDERDEVELOPED AREA * GLIFTON R. WHARTON JR

JASA 6038 LEADINC BRITISH STATISTICIANS OF THE NINETEENTH CENTURY * PAUL J. FITZPATRICK

JASA 6071 THE FEMALE LABOR FORCE, A CASE STUDY IN THE INTERPRETATION OF HISTORICAL STATISTICS * ROBERT $\$$ SMUTS

JASA $60 \quad 80$ WHERE DO WE.GO FROM HERE * JOHN W. TUKEY

JASA 6094 A TEST PROCEDURE WITH A SAMPLE FROM A NORMAL POPULATION WHEN AN UPPER BOUND TO THE STANDARD DEVIATION IS KNOWN * THEODORE COLTON

JASA 60105 DESIGN AND ESTIMATION IN TWO-WAY STRATIFICATION * EDWARD C. BRYANT, H. O. HARTLEY, R. J. JESSEN

JASA 60125 EXTENSION OF THE WILCOXON-MANN-WHITNEY TEST TO SAMPLES CENSORED AT THE SAME FIXED POINT, CORR. $60755^{*}$ MAX HALPERIN

JASA 60139 ESTIMATING THE PARAMETERS OF A MODIFIED POISSON DISTRIBUTION * A. GLIFFORD COHEN JR

JASA 60144 ON TESTING THE EQUALITY OF PARAMETERS IN K RECTANCULAR POPULATIONS * C. G. KHATRI

JASA 60148 VARIANCE OF THE MEDIAN OF SMALL SAMPLES FROM SEVERAL SPECIAL POPULATIONS * PAUL R. RIDER

JASA 60151 REGIONAL CYCLES OF MANUFACTURING EMPLOYMENT IN THE UNITED STATES, 1914-1953, CORR, 60755 * GEORGE H BORTS

JASA 60245 A MULTIPLICATIVE MODEL FOR ANALYZING VARIANCES WHICH ARE AFFECTED BY SEVERAL FACTORS * ROBERT E BECHHOFER

JASA 60265 CERTA IN UNCORRELATED STATISTICS * ROBERT V. HOGG
JASA 60 26B CHANCES IN THE RATE AND COMPONENTS OF HOUSEHOLD FORMATION * SHERMAN J. MAISEL

JASA 60284 A STATISTICAL INVESTIGATION OF THE INDUSTRIALIZATION CONTROVERSY * STEPHEN SPIEGELGLAS

JASA 60299 OPTIMAL PROPERTIES OF EXPONENTIALLY WEICHTED FORECASTS, CORR. $62919 *$ JOHN F. MUTH

JASA 60307 LARGE-SAMPLE COVARIANCE ANALYSIS WHEN THE CONTROL VARIABLE IS FALLIBLE * FREDERIC $M$. LORD

JASA 60322 VARIANCE OF THE MEDIAN OF SAMPLES FROM A CAUCHY DISTRIBUTION * PAUL R. RIDER

JASA 60324 TESTS OF THE HYPOTHESIS THAT A LINEAR REGRESSION SYSTEM OBEYS TWO SEPARATE REGIMES * RICHARD E. QUANDT

JASA 60331 A NOTE ON AVERAGE TAU AS A MEASURE OF GONCORDANCE * WILLIAM L. HAYS

JASA 60342 ESTIMATION IN THE TRUNCATED POISSON DISTRIBUTION WHEN ZEROS AND SOME ONES ARE MISSINC * A. CLIFFORD GOHEN JR

JASA 60415 COMPETING EXPONENTIAL RISKS, WITH PARTIGULAR REFERENCE TO THE STUDY OF SMOKING AND LUNG CANCER, CORR. 60754 * JOSEPH BERKSON, LILA ELVEBACK

JASA 60429 A NONPARAMETRIC SUM OF RANKS PROCEDURE FOR RELATIVE SPREAD IN UNPAIRED SAMPLES, CORR, 611005 * SIDNEY SIEGEL, JOHN W, TUKEY

JASA 60446 STATISTICAL EVALUATION OF CLOUD SEEDING OPERATIONS * K. A. BROWNLEE

JASA $60 \quad 454$ THE USE OF STATISTICS IN THE FORMULATION AND EVALUATION OF SOCIAL PROGRAMMES * OCTAVIO CABELLO

JASA 60469 CONSUMERS' PROPENSITIES TO HOLD LIQUID ASSETS * HAROLD W. GUTHRIE

JASA 60491 EARLY FAILURES IN LIFE TESTING * RUPERT G. MILLER JR

JASA 60503 MATHEMATICAL MODELS FOR RANKING FROM PAIRED COMPARISONS * H. D. BRUNK 
JASA 60521 TABLES OF CONFIDENCE LIMITS FOR THE BINOMIAL DISTRIBUTION * JAMES PACHARES

JASA 60534 A METHOD OF ANALYZING LOG-NORMALLY DISTRIBUTED SURVIVAL DATA WITH INCOMPLETE FOLLOW-UP * MANNING FEINLEIB

JASA 60546 ON THE CHOICE OF PLOTTING POSITIONS ON PROBABILITY PAPER * BRADFORD F , KIMBALL

JASA 60561 BIBLIOGRAPHY ON SEQUENTIAL ANALYSIS * J. EDWARD JACKSON

JASA 60625 INDETERMINISM IN SCIENCE AND NEW DEMANDS ON STATISTICIANS * JERZY NEYMAN

JASA 60640 MARKET GROWTH, COMPANY DIVERSIFICATION AND PRODUCT CONCENTRATION 1947-1954 * RALPHL. NELSON

JASA 60650 ON FINITE SAMPLË DISTRIBUTIONS OF GENERALIZED CLASSICAL LINEAR IDENTIFIABILITY TEST STATISTICS * R. L BASMANN
JASA 60660 A NOTE ON THE LIMITING RELATIVE EFFICIENCY OF THE WALD SEQUENTIAL PROBABILITY RATIO TEST * ROBERT E. BECHHOFER

JASA 60664 INTERNAL MIGRATION STATISTICS FOR THE UNITED STATES * EVERETT S . LEE, ANNE S. LEE

JASA 60698 BIVARIATE EXPONENTIAL DISTRIBUTIONS * E. J. GUMBEL

JASA 60708 ON THE EXACT VARIANCE OF PRODUCTS, CORR. 61917 * LEO A GOODMAN

JASA 60714 ON CONDITIONAL EXPECTATIONS OF LOCATION STATISTICS * ROBERT V. HOGC

JASA 60718 A NEW BINOMIAL APPROXIMATION FOR USE IN SAMPLING FROM FINITE POPULATIONS * PETER J SANDIFORD

JASA 60723 CIRCULAR ERROR PROBABILITIES * H. LEON HARTER

JASA 60732 EFFECTS OF BIAS ON ESTIMATES OF THE CIRCULAR PROBABLE ERROR * P. B. MORANDA

JASA 60736 BIBLIOGRAPHY ON SIMULATION, GAMING, ARTIFICIAL INTELLIGENCE AND ALLIED TOPICS * MART IN SHUB IK

JOURNAL OF THE AMERICAN STATISTICAL ASSOCIATION VOLUME 56, 1961

JASA 61 I COOPERATION AMONG STATISTICAL AND OTHER SOCIETIES * MORRISH. HANSEN

JASA 61 II SOME NONPARAMETR IC TESTS FOR COMOVEMENTS BETWEEN TIME SERIES * LEO A. GOODWIN, YEHUDA GRUNFELD

JASA 6127 SOME ASPECTS OF SEASONALITY IN THE CONSUMER PRICE INDEX * H. E. RILEY

JASA 6136 ALMOST LINEARLY-OPTIMUM COMBINATION OF UNBIASED EST IMATES * MAX HALPERIN

JASA 6144 BIAS IN ESTIMATES OF THE UNITED STATES NONWHITE POPULATION AS INDICATED BY TRENDS IN DEATH RATES RICHARD F. TOMASSON

JASA 6152 MULTIPLE COMPARISONS AMONG MEANS * OLIVE JEAN DUNN

JASA 6165 ON SOME MEASURES OF FOOD MARKETING SERVICES * GEORGE W $L A D D$

JASA 6170 UNBIASED RATIO ESTIMATORS IN STATIFIED SAMPLING, CORR. 641298 * JOSE NIETO DE PASCUAL

JASA $61 \quad 88$ A REPRODUCIBLE METHOD OF COUNTING PERSONS OF SPANISH SURNAME * ROBERT W. BUECHLEY

JASA 6198 RESIDUAL ANALYSIS, CORR. 61 1005* RUDOLF J. FREUND. RICHARD W. VAIL, C. W. CLUNIES-ROSS

JASA 61105 NOTE ON STEPWISE LEAST SQUARES * ARTHUR S. GOLDBERGER

JASA 61111 A PARAMETRIC ESTIMATE OF THE STANDARD ERROR OF THE SURVIVAL RATE, CORR. 631161 * FRED EDERER

JASA 61119 A NOTE ON FOLLOW-UP FOR SURVIVAL IN THE PRESENCE OF MOVEMENT * D. J. THOMPSON, D. KODLIN

JASA 61125 THE PROBABILITY OF REVERSAL ASSOCIATED WITH A TEST PROCEDURE, WHEN DATA ARE INCOMPLETE * BERNARD S. PASTERNACK, JUNJIRO OGAWA

JASA 61135 VARIANCE ESTIMATES IN 'OPTIMUM' SAMPLE DESIGNS * ALAN ROSS

JASA 61143 ON STABILIZING THE BINOMIAL AND NEGATIVE BINOMIAL VARIANCES * NICO F. LAUBSCHER

JASA $61 \quad 151$ ONMATCHING LISTS BY SAMPLES * DESRAJ

JASA 61156 PROBABILITY TABLE FOR NUMBER OF RUNS OF SIGNS OF FIRST DIFFERENCES IN ORDERED SERIES * EUGENE S. EDGINGTON

JASA 61223 SIGNIFICANCE TESTS IN DISCRETE DISTRIBUTIONS, CORR $62919 * \mathrm{H} .0$. LANCASTER

JASA 61235 MULTIPLE REGRESSION ANALYSIS OF A POISSON PROCESS * DALEW. JORGENSON

JASA 61246 CONFIDENCE CURVES, AN OMNIBUS TECHNIQUE FOR ESTIMATION AND TESTING STATISTICAL HYPOTHESES * ALLAN BIRNBAUM

JASA 61250 CHANGES IN THE SIZE DISTRIBUTION OF DIVIDEND INCOME * EDWIN B. COX

JASA 61260 THE USE OF SAMPLE QUASI-RANGES IN SETTING CONFIDENCE INTERVALS FOR THE POPULATION STANDARD DEVIATION * F. C. LEONE, Y.H. RUTENBERG, C. W. TOPP

JASA 61273 THE STATISTICAL WORK OF OSKAR ANDERSON * GERHARD TINTNER

JASA 61281 A PROBLEM CONCERNED WITH WEIGHTING OF DISTRIBUTIONS * COLERIDGE A WILKINS

JASA 61293 EXACT AND APPROXIMATE DISTRIBUTIONS FOR THE WILCOXON STATISTIC WITH TIES * SHIRLEY YOUNG LEHMAN

JASA 61299 ON THE USE OF PARTIALLY ORDERED OBSERVATIONS IN MEASURING THE SUPPORT FOR A COMPLETE ORDER * R, F TATE

JASA 61314 A NOTE ON MEASUREMENT ERRORS AND DETECTING REAL DIFFERENCES * EUGENEROGOT

JASA 61320 AN ANALYSIS OF CONSISTENCY OF RESPONSE IN HOUSEHOLD SURVEYS * CAROL M. JAEGER, JEAN L. PENNOCK

JASA 61328 RANDOMIZED ROUNDED-OFF MULTIPLIERS IN SAMPLING THEORY * M. N. MURTHY, V.K. SETHI

JASA 61335 BIVARIATELOGISTIC DISTRIBUTIONS * E. J.GUMBEL

JASA 61350 UNBIASED COMPONENTWISE RATIO ESTIMATION, CORR. 63 $1163 *$ D. S. RO8SON, C. VITHAYASAI

JASA 61359 A NOTE ON CURVE FITTING WITH MINIMUM DEVIATIONS BY LINEAR PROGRAMMING , CORR , 62917 * WALTER D FISHER
JASA 61363 PARTIAL CORRELATIONS IN REGRESSION COMPUTATIONS ROBERT L . GUSTAFSON

JASA 61368 FACTORIAL TREATMENTS IN RECTANGULAR LATTICE DESIGNS * LEROY STANLEY BRENNA, CLYDE YOUNG KRAMER

JASA 61379 A QUARTERLY ECONOMETRIC MODEL OF THE UNITED STATES * LOWELL E. GALLAWAY, PAUL E. SMITH

JASA 61493 ESTIMATING A MIXED-EXPONENTIAL RESPONSE LAW * F J ANSCOMBE

JASA 61503 A CLASS OF DISTRIBUTIONS APPLICABLE TO ACCIDENTS * CAROL B. EDWARDS, JOHN GURLAND

JASA 61518 EX ANTE AND EX POST DATA IN INVENTORY INVESTMENT * MURRAY BROWN

JASA 61535 ON AN INDEX OF QUALITY CHANGE * IRMA ADELMAN, ZVI GRILICHES

JASA 61549 LENGTH OF CONFIDENCE INTERVALS * JOHN W. PRATT

JASA 61568 A COMPARISON OF MAJOR UNITED STATES RELIGIOUS GROUPS * BERNARD LAZERWITZ

JASA 61580 FURTHER COMMENTS ON THE 'FINAL REPORT OF THE ADVISORY COMMITTEE ON WEATHER CONTROL' * JERZY NEYMAN ELIZABETH L. SCOTT

JASA 61601 THE USE OF SAMPLE RANGES IN SETTING EXACT CONFIDENCE BOUNDS FOR THE STANDARD DEVIATION OF A RECTANGULAR POPULATION * H. LEON HARTER

JASA 61610 BIAS IN PSEUDO-RANDOM NUMBERS * PAUL PEACH

JASA 61619 A NOTE ON THE EXACT FINITE SAMPLE FREQUENCY FUNCTIONS OF GENERALIZED CLASSICAL LINEAR ESTIMATORS IN TWO LEADING OVER-IDENTIFIED CASES * R. L, BASMANN

JASA 61637 DISTRIBUTIONS OF CORRELATION COEFFICIENTS IN ECONOMIC TIME SER IES * EDWARD AMES, STANLEY REITER

JASA 61657 FITTING OF STRAIGHT LINES AND PREDICTION WHEN BOTH VARIABLES ARE SU8JECT TO ERROR * MAX HALPERIN

JASA 61670 THE OTHER SIDE OF THE LOWER BOUND. A NOTE WITH A CORRECTION * JOSEPH BERKSON

JASA 61675 AMODEL FOR MIGRATION ANALYSIS * RALPH THOMLINSON

JASA 61687 A NOTE ON THE ASYMPTOTIC NORMALITY OF THE MANNWHITNEY-WILCOXON STATISTIC * JACK CAPON

JASA 61692 ESTIMATION OF LOCATION AND SCALE PARAMETERS INA TRUN CATED GROUPED SECH SQUARE DISTRIBUTION * P. R. FISK

JASA 61703 THE PROGRESS OF THE SCORE DURING A BASEBALL GAME * G. R LINDSEY

JASA 61729 MULTIPLE LINEAR REGRESSION ANALYSIS WITH ADJUSTMENT FOR CLASS DIFFERENCES * $M$. DAVIES

JASA 61736 A NOTE ON GRIFFIN'S PAPER 'GRAPHIC COMPUTATION OF TAU AS A COEFFICIENT OF DISARRAY' * S. M. SHAH

JASA 61783 OCCUPATIONAL COMPONENTS OF EDUCATIONAL DIFFERENCES IN INCOME * OTIS DUDLEY DUNCAN

JASA 61793 TESTING THE INDEPENDENCE OF REGRESSION DISTURBANCES * H. THEIL, A. L, NAGAR

JASA 61807 RECTIFYING INSPECTION OF LOTS * F. J. ANSCOMBE

JASA $61 \quad 824$ RESIDENCE HISTORIES AND EXPOSURE RESIDENCES FOR THE UNITED STATES POPULATION * KARL E. TAEUBER, WILLIAM HAENSZEL, MONROEG. SIRKEN

JASA 61835 A SIMPLE THEORETICAL APPROACH TO CUMULATIVE SUM CONTROL CHARTS *N. L JOHNSON

JASA 61841 STATISTICAL METHODS FOR THE MOVER-STAYER MODEL * LEO A. GOODMAN

JASA 61869 FORECASTING INDUSTRIAL PRODUCTION * H. 0. STEKLER

JASA 61878 NON-ADDITIVITY IN TWO-WAY ANALYSIS OF VARIANCE * JOHN MANDEL

JASA 61889 ON COMPARING INTENSITIES OF ASSOCIATION 8ETWEEN TWO BINARY CHARACTERISTICS IN TWO DIFFERENT POPULATIONS * AGNES BERGER

JASA 61909 FAILURE OF ENUMERATORS TOMAKE ENTRIES OF ZERO, ERRORS IN RECORDING CHILDLESS CASES IN POPULATION CENSUSES * M. A. EL-8ADRY 
JASA 61925 THE STATISTICAL ANALYSIS OF INDUSTRY STRUCTURE, AN APPLICATION TO FOOD INDUSTRIES * LEE E. PRESTON, EARL J. BELL

JASA 61933 NOTE ON THE MISSING PLOT PROCEDURE IN A RANDOMIZED BLOCK DESIGN * JOHN LEROY FOLKS, DEL LON WEST

JASA 61942 GAMMA DISTRIBUTION IN ACCEPTANCE SAMPLING BASED ON LIFE TESTS * SHANTIS. GUPTA, PHYLLIS A. GROLL

JASA 61971 ABIVARIATE EXTENSION OF THE EXPONENTIAL DISTRIBUTION * JOHN E. FREUND
JASA $6197 B$ ON THE RESOLUTION OF STATISTICAL HYPOTHESES * ROBERT V. HOGG

JASA 61990 THE ASYMPTOTIC VARIANCES OF METHOD OF MOMENTS ESTIMATES OF THE PARAMETERS OF THE TRUNCATED BINOMIAL AND NEGATIVE BINOMIAL DISTRIBUTIONS * S. M. SHAH

JASA 61995 A NOMOGRAPH FOR COMPUT ING PART IAL CORRELAT ION COEFFI CIENTS, CORR . 62917 * RUTH W. LEES, FREDERIC M. LORD JASA 61998 STEPWISE LEAST SQUARES, RESIDUAL ANALYSIS AND SPECIFICATION ERROR * ARTHUR S GOLDBERGER

JOURNAL OF THE AMERICAN STATISTICAL ASSOCIATION VOLUME 57, 1962

JASA $62 \quad 1$ STATISTICS WE LIVE BY * MARTINR. GAINSBRUGH

JASA 6210 THE COMBINATION OF TESTS BASED ON DISCRETE DISTRIBUTIONS * W. M. KINCAID

JASA 6220 ON THE USE OF CORRELATION TO AUGMENT DATA * MYRON B. FIER ING

JASA 6233 PROBABILITY INEQUALITIES FOR THE SUM OF INDEPENDENT RANDOM VARIABLES * GEORGE BENNETT

JASA $62 \quad 46$ ON THE JOINT EFFICIENCY OF THE ESTIMATES OF THE PARAMETERS OF NORMAL POPULATIONS BASED ON SINGLY AND DOUBLY TRUNCATED SAMPLES * P. S. SWAMY

JASA 6254 THE VARIANCE OF THE PRODUCT OF KRANDOM VARIABLES * LEO A. GOODMAN

JASA 6261 ESTIMATION OF MEANS AND TOTALS FROM FINITE POPULATIONS OF UNKNOWN SIZE, CORR. 641297 * JAMES K. KINDAHL

JASA 6292 STUDIES OF INTERVIEWER VARIANCE FOR ATT ITUDINAL VARIABLES * LESLIE KISH

JASA 62116 A DISTRIBUTION-FREE TEST OF INDEPENDENCE WITH A SAMPLE OF PAIRED OBSERVATIONS * GERALD J. GLASSER

JASA 62134 CHANGE CONSTRAINTS AND NORMAL DEVIATES * A. CHARNES. W. W. COOPER

JASA 62149 THE USE OF AN ITERATED MOVING AVERAGE IN MEASURING SE ASONAL VARIATIONS * Y. S. LEONG

JASA 62172 SOME PROPERTIES OF PASCAL DISTRIBUTION FOR FINITE POPULATION, CORR. $62919 *$ T. I. MATUSZEWSKI

JASA $62 \quad 175$ A NOTE ON THE CENSUS SURVIVAL RATIO METHOD OF ESTIMATING NET MIGRATION * K. C. ZACHARIAH

JASA 62184 ON TWO METHODS ON UNBIASED ESTIMATION WITH AUXILIARY VARIATES * W. H. WILLIAMS

JASA 62187 MOMENTS OF THE RADIAL ERROR, CORR. 651251 * ERNEST M. SCHEUER

JASA 62191 SOME MORE EST IMATES OF CIRCULAR PROBABLE ERROR * A. R. KAMAT

JASA 62269 ON THE FOUNDATIONS OF STATISTICAL INFERENCE * ALLAN BIRNBAUM

JASA 62307 DISCUSSION OF 'ON THE FOUNDATIONS OF STATISTICAL INFERENCE' * L. J. SAVAGE, GEORGE BARNARD, IRWIN D. J BROSS. JEROME CORNFIELD, G. E. P. BOX, I. J. GOOD, D. $\checkmark$. LINDLEY, C. W. CLUNIES-ROSS, JOHN W. PRATT, HOWARD LEVENE, THOMAS GOLDMAN, A. P. DEMPSTER, OSCAR KEMPTHORNE, ALLAN BIRNBAUM

JASA 62327 A GENERALIZATION OF THE BALLOT PROBLEM AND ITS APPLICATION IN THE THEORY OF QUEUES * LAJOS TAKACS

JASA 62338 THE CASE OF THE INDIANS AND THE TEEN-AGE WIDOWS * ANSLEY J . COALE, FREDERICK F. STEPHAN

JASA 62 34B AN EFFICIENT METHOD OF EST IMATING SEEMINGLY UNRELATED REGRESSIONS AND TESTS FOR AGGREGATION BIAS * ARNOLD ZELLNER

JASA 62369 BEST LINEAR UNBIASED PREDICTION IN THE GENERALIZED LINEAR REGRESSION MODEL * ARTHUR S. GOLDBERGER

JASA 62376 DISTRIBUTION OF TOTAL SERVICE TIME FOR A FIXED OBSERVATION INTERVAL * W. S. CONNOR, NORMAN C. SEVERO

JASA 62387 DEVELOPMENT OF SAMPLING PLANS BY USING SEQUENTIAL ITEM BY ITEM. SELECTION TECHNIQUES AND DIGITAL COMPUTERS * C. T. FAN, MERVIN E. MULLER. IVAN REZUCHA

JASA 62403 SEQUENCES OF FRACTIONAL REPLICATES IN THE 2-TO-THE(P-Q) SERIES, CORR. 62919 * CUTHBERT DANIEL

JASA 62430 LATENT CLASS ANALYSIS AND DIFFERENTIAL MORTALITY * C R. MILLER, G. SABAGH, H. F. DINGMAN

JASA $62^{\circ} 439$ EXPECTED VALUES AND STANDARD DEVIATIONS OF THE RECIPROCAL OF A VAR IABLE FROM A DECAPITATED NEGATIVE BINOMIAL DISTRIBUT ION * PAUL R, RIDER

JASA 62446 JOINT EST IMATION OF THE PARAMETERS OF TWO NORMAL POPULATIONS * R. I. FIELDS, C. Y. KRAMER, C. W. CLUNIESROSS
JASA 62455 A SEQUENT IAL METHOD FOR SCREEN ING EXPER IMENTAL VARIABLES * CHOU HSIUNG LI

JASA 62551 ON SEQUENTIAL TESTS WHICH MINIMIZE THE MAXIMUM EXPECTED SAMPLE SIZE * LIONEL WEISS

JASA 62567 A NOTE ON CALCULATING TAU AND AVERAGE TAU AND ON THE SAMPLING DISTRIBUTION OF AVERAGE TAU WITH A CRITERION RANKING * DONALD W. STILSON, VINCENT N CAMPBELL

JASA 62572 NON-LINEAR REGRESSION WITH MINIMAL ASSUMPTIONS * HARVEY M. WAGNER

JASA 62579 ITERATED TESTS OF THE EQUALITY OF SEVERAL DISTRIBUTIONS * ROBERT V. HOGG

JASA 62586 MORE ON LENGTH OF CONFIDENCE INTERVALS * ALBERT MADANSKY

JASA 62590 REGRESSION ANALYSIS IN SAMPLE SURVEYS, CORR. 631162 * H. S. KONIJN

JASA 62607 WAGE. PRICE, AND TAX ELASTICITIES OF OUTPUT AND DISTRIBUTIVE SHARES * HANS BREMS

JASA 62622 THE VARIANCE OF AN ESTIMATOR WITH POST-STRATIFIED WEIGHTING * W. H. WILLIAMS

JASA 62628 SOME RATIO-TYPE ESTIMATORS IN TWO-PHASE SAMPLING * BAL KRISHNA V SUKHATME

JASA 62633 A FORECAST ING MODEL OF FEDERAL PURCHASES OF GOODS AND SERVICES * MURRAY BROWN, PAUL TAUBMAN

JASA 62648 VARIANCE FORMULAS FOR THE MEAN DIFFERENCE AND COEFFICIENT OF CONCENTRATION * GERALD J , GLASSER

JASA 62655 HARMONIC ANALYSIS OF SEASONAL VARIATION WITH AN APPLICATION TO HOG PRODUCTION * MARTIN E. ABEL

JASA 62668 SOME EXPERIMENTAL DESIGN PROBLEMS IN ATTRIBUTE LIFE TESTING, CORR 631161 * SYLVAIN EHRENFELD

JASA 62680 THE VALIDITY OF INCOME REPORTED BY A SAMPLE OF FAMILIES WHO RECEIVED WELFARE ASSISTANCE DURING 1959 * MARTIN DAVID

JASA 62 6B6 A METHOD TO DETERMINE THE RELIABILITY OF TELEMETRY SYSTEMS REPORTS * CHARLES MARTINEZ

JASA 62727 MEMORIAL TO SIR RONALD AYLMER FISHER, 1B90-1962 * W J. YOUDEN

JASA 62729 THE INTERPOLATION OF TIME SERIES BY RELATED SERIES * MILTON FRIEDMAN

JASA 62758 INTEGRAL OF THE BIVARIATE NORMAL DISTRIBUTION OVER AN OFFSET CIRCLE * DENNIS C. GILLILAND

JASA 62769 A SEQUENTIAL TEST OF THE EQUALITY OF PROBABILITIES IN A MULTINOMIAL DISTRIBUT ION * LIONEL WEISS

JASA 62775 SOME TWO-SIDED DISTRIBUTION-FREE TOLERANCE INTERVALS OF A GENERAL NATURE * JOHNE. WALSH

JASA 62785 A MULTI-STAGE PROCEDURE FOR THE SELECTION OF THE BEST OF SEVERAL POPULATIONS * R. J. TAYLOR, H. A. DAVID

JASA 62797 CHANGES IN CONCENTRATION OF DOMESTIC MANUFACTURING ESTABLISHMENT OUTPUT 1939-195B * HENRY ADLER EINHORN

JASA 62804 A SIMILARITY BETWEEN GOODMAN AND KRUSKAL'S TAU AND KENDALL 'S TAU, WITH A PARTIAL INTERPRETATION OF THE LATTER * ROBERT H. SOMERS

JASA 62813 CONSTANTS AND COMPROMISE IN THE CONSUMER PRICE INDEX * aBNER HURWITZ

JASA 62 B26 THE CONCEPT OF CAPACITY * FRANK DE LEEUW

JASA 62841 EVALUATION OF CENSUS SURVIVAL RATES IN ESTIMATING INTERCENSAL STATE NET MIGRATION * JAMES D. TARVER

JASA 62863 THE RATIO BIAS IN SURVEYS * LESLIE KISH. N. KRISHNAN NAMBOODIRI, R. KRISHNA PILLAI

JASA 62 B77 ASYMPTOTIC POWER OF TESTS OF LINEAR HYPOTHESES USING THE PROBIT AND LOGIT TRANSFORMATIONS, CORR. 641297 * JAMES E. GRIZZLE

JASA 62895 CURRENT WEIGHT-HEIGHT RELATIONSHIPS OF YOUTHS OF MILITARY AGE * BERNARD D. KARPINOS

JASA 62906 THE RECIPROCAL OF THE DECAPITATED NEGATIVE BINOMIAL VARI ABLE, CORR. 631162 * ZAKKULA GOV INDARAJULU 
JASA $63 \quad 1$ STATISTICS AND SOCIETY * PHILIP M. HAUSER

JASA 6313 PROBABILITY INEQUALITIES FOR SUMS OF BOUNDED RANDOM VARIABLES * WASSILY HOEFFDINC

JASA $63 \quad 31$ THE ESTIMATION OF SEASONAL VARIATION IN ECONOMIC TIME SERIES, CORR. $631162 *$ E. J. hannan

JASA 6345 TECHNIQUES FOR CONSTRUCTINC FRACTIONAL REPLICATE PLANS * SIDNEY ADDELMAN

JASA 6372 THE THREE-PARAMETER LOCNORMAL DISTR IBUT ION AND BAYESIAN ANALYSIS OF A POINT-SOURCE EPIDEMIC * BRUCE $M$ HILL

JASA $63 \quad 85$ MARK TWAIN AND THE QUINTUS CURTIUS SNODGRASS LETTERS, A STATISTICAL TEST OF AUTHORSHIP * CLAUdE $S$ BRINEGAR

JASA 6397 TESTS OF HOMOCENEITY FOR CORRELATED SAMPLES * ALBERT MADANSKY

JASA 63120 COMPUTATION WITH MULTIPLE K-STATISTICS * ESTHER SCHAEFFER, PAUL S. DWYER

JASA $63 \quad 152$ ESTIMATION OF ERROR VARIANCE FROM SMALLEST ORDERED CONTRASTS * M. B. WILK, R. GNANADESIKAN, ANNE E. FREENY

JASA 63161 A NOTE ON THE EXACT FINITE SAMPLE FREQUENGY FUNCTIONS OF CENERALIZED CLASSICAL LINEAR ESTIMATORS IN A LEADINC THREE-EQUATION CASE*R, L, BASMANN

JASA 63172 CONSTRUCTINC UNIFORMLY BETTER ESTIMATORS * VANAMAMALAI SE'SHADRI

JASA 63176 SOME PERCENTAGE POINTS OF THE NON-CENTRAL T-DISTRIBUTION. CORR. 631163 * ERNEST M. SCHEUER, ROBERT A. SPURGEON

JASA 63 IB3 SAMPLING WITH VARYING PROBABILITIES WITHOUT REPLACEMENT, ROTATING AND NON-ROTATING SAMPLES * IVAN P. FELLEG I

JASA 63202 ON THREE PROCEDURES OF UNEQUAL PROBABILITY SAMPLINC WITHOUT REPLACEMENT * J.N. K. RAO

JASA 63216 ORDERED HYPOTHESES FOR MULTIPLE TREATMENTS, A SIGNIF ICANCE TEST FOR LINEAR RANKS * ELLIS BATTEN PAGE

JASA 63231 THE LOGNORMAL DISTRIBUTION AND THE TRANSLATION METHOD, DESCRIPTION AND ESTIMATION PROBLEMS, CORR. 631163 * ANDRE G. LAURENT

JASA 63236 HIERARCHICAL GROUPINC TO OPTIMIZE AN OBJECTIVE FUNCTION * JOE H. WARD JR

JASA 63245 ON UNCORRELATED LINEAR FUNGTIONS OF ORDER STATISTICS * K. R. AIYAR

JASA 63275 INFERENGE IN AN AUTHORSHIP PROBLEM * FREDERICK MOSTELLER, DAVID L. WALLAGE

JASA 63310 MEASURES OF ASSOCIATION FOR CROSS CLASSIFICATIONS, 111. APPROXIMATE SAMPLING THEORY * LEO A. COODMAN, WILLIAM H. KRUSKAL

JASA 63365 SEQUENTIAL MEDICAL TRIALS *F, J. ANSCOMBE

JASA $63 \quad 384$ SEQUENTIAL MEDICAL TRIALS, SOME COMMENTS ON F. J. ANSGOMBE'S PAPER * P. ARMITACE

JASA 63388 A MODEL FOR SELECTING ONE OF TWO MEDICAL TREATMENTS * THEODORE COLTON

JASA 63401 ON THE USE OF INCOMPLETE PRIOR INFORMATION IN REGRESSION ANALYSIS * H. THEIL

JASA 63415 PROBLEMS IN THE ANALYSIS OF SURVEY DATA, AND A PROPOSAL * JAMES N. MORCAN, JOHNA. SONQUIST

JASA 63435 AN ITERATED PROCEDURE FOR TESTING THE EQUALITY OF SEVERAL EXPONENT IAL DISTR IBUTIONS * ROBERT V. HOGG, ELLIOT A. TANIS

JASA 63444 MIGRATION EXPECTANCY IN THE UNITED STATES * GEORGE L WILBER

JASA 63454 THE USE OF ROTATING SAMPLES IN THE CENSUS BUREAU'S MONTHLY SURVEYS * RALPH S. WOODRUFF

JASA 63 46B RECURRENGE RELATIONS FOR THE INVERSE MOMENTS OF THE POSIT IVE B INOMIAL VARIABLE * ZAKKULA GOVINDARAJULU

JASA 63474 PRECISION OF SIMULTANEOUS MEASUREMENT PROCEDURES * W A. THOMPSON JR

JASA 63480 ROBUSTNESS OF NON-IDEAL DEGISION PROCEDURES * MERVYN STONE

JASA 63487 TAXPAYER COMPLIANCE IN REPORTING INTEREST INCOME UNDER THE WISGONSIN STATE INDIVIDUAL INCOME TAX * NORMAN ADLER

JASA 63497 INDEX NUMBERS FOR FACTORIAL EFFECTS AND THEIR CONNECTION WITH A SPECIAL KIND OF IRREGULAR FRACTIONAL PLANS OF FACTORIAL EXPERIMENTS * K. S . BANERJEE

JASA 63509 SAMPLING FROM A TRIANGULAR POPULATION * PAUL R, RIDER

JASA 63513 SOME TECHNIQUES FOR ANALYZING A SET OF TIME SERIES SUBJECT TO A LINEAR RESTRICTION * FRANK T. DENTON

JASA 63519 ESTIMATION OF PARAMETERS OF A TRUNCATED BIVARIATE NORMAL DISTRIBUTION*C. G. KHATRI, M. C. JAISWAL

JASA 63527 EXTENSION OF COCHRAN'S FORMULAE FOR ADDITION OR OMISSION OF A VARIATE IN MULTIPLE REGRESSION ANALYSIS * D. C. KABE
JASA 63535 A NOTE ON THE EXACT DISTRIBUTIONS OF THE CENERALIZED CLASSICAL LINEAR ESTIMATORS IN TWO LEADINC OVERIDENTIFIED CASES * D. C. KABE

JASA 63611 INTERVAL ESTIMATION OF NON-LINEAR PARAMETRIC FUNCTIONS * MAX HALPERIN, NATHAN MANTEL

JASA 63 62B PROBABILITY AND CRIMINALISTICS * ELMER B. MODE

JASA 63641 ON THE SUFFICIENCY AND LIKELIHOOD PRINCIPLES *D. A . S. FRASER

JASA 63 64B CONSUMER DURABLE COODS EXPENDITURES, WITH MAJOR EMPHASIS ON THE ROLE OF ASSETS, CREDIT AND INTENTIONS * JANET A FISHER

JASA 63 65B ON ESTIMATINC SCALE AND LOCATION PARAMETERS * LIONEL WEISS

JASA 63660 MULTIVARIATE ANALYSIS OF VARIANCE FOR A SPEGIAL COVARIANCE CASE, CORR. 641296 * SEYMOUR GEISSER

JASA 63670 SOME INFERENCES ABOUT GAMMA PARAMETERS WITH AN APPLICATION TO A RELIABILITY PROBLEM * M. M. LENTNER, R. J. BUEHLER

JASA 63678 THE NUMBER AND WIDTH OF CLASSES IN THE CHI-SQUARE TEST * M. A. HAMDAN

JASA 63690 GHI-SQUARE TESTS WITH ONE DEGREE OF FREEDOM, EXTENSIONS OF THE MANTEL-HAENSZEL PROCEDURE * NATHAN MANTEL

JASA 63701 PARTITIONING OF A PATIENT POPULATION WITH RESPECT TO DIFFERENT MORTALITY RISKS * SIDNEY J. CUTLER, LILLIAN M. AXTELL

JASA 63713 EARLY DECISION IN THE WILCOXON TWO-SAMPLE TEST * DAVID W. ALLINC

JASA 63721 PROBABILITY MODELS FOR THE VARIATION IN THE NUMBER OF BIRTHS PER COUPLE * S. N. SINGH

JASA $6372 \mathrm{~B}$ A QUICK TEST FOR SERIAL CORRELATION SUITABLE FOR USE WITH NONSTATIONARY TIME SERIES * C. W. J. GRANGER

JASA 63737 SOME RECENT ADVANCES IN SAMPL ING THEORY * M. N. MURTHY JASA 63756 SOME CONTRIBUTIONS TO THE AVERACE RANK CORRELATION METHODS AND TO THE DISTRIBUTION OF THE AVERACE RANK CORRELATION GOEFFICIENT * WILSON L. TAYLOR, CHING FONG

JASA 63770 STEPWISE MULTIVARIATE LINEAR RECRESSION * D. C . KABE

JASA $63 \quad 774$ A DEMOGRAPHIC MODEL FOR EST IMAT ING AGE-ORDER SPEC IF IC FERTILITY RATES * D. PETER MAZUR

JASA 637 B9 INITIAL STOCK AND CONSUMER INVESTMENT IN AUTOMOBILES * DAVID S. HUANC

JASA 63799 THE DEVELOPMENT OF NUMERICAL CREDIT EVALUATION SYSTEMS * JAMES H. MYERS, EDWARD W. FORCY

JASA 63807 PRODUCT DIVERSIFICATION AND THE COST OF LIVING, CORR 641296 * HENRY ANDERSON

JASA 63879 SOME NUMERICAL ASPECTS OF THE USE OF TRANSFORMS IN STATISTICS * SYLVAIN EHRENFELD

JASA 63894 EFFICIENCY OF THE WILCOXON TWO-SAMPLE STATISTIC FOR RANDOMIZED BLOCKS * GOTTFRIED E . NOETHER

JASA 63 B99 TEN YEARS OF CONSUMER ATTITUDE SURVEYS, THEIR FORECASTINC RECORD * EVA MUELLER

JASA 63918 INFORMATION FOR ESTIMATINC THE PROPORTIONS IN MIXTURES OF EXPONENTIAL AND NORMAL DISTRIBUTIONS * BRUCE M. HILL

JASA 63933 A RECRESSION METHOD FOR REAL ESTATE PRICE INDEX CONSTRUCTION * MARTIN J BAILEY, RICHARD F. MUTH, HUGH 0 . NOURSE

JASA 63943 REMARKS CONCERNING THE APPLICATION OF EXACT FINITE SAMPLE DISTRIBUTION FUNCTIONS OF GENERALIZED CLASSICAL LINEAR ESTIMATORS IN ECONOMETRIG STATISTICAL INFERENCE, CORR. $641296^{*}$ R. L. BASMANN

JASA 63977 ESTIMATORS FOR SEEMINGLY UNRELATED REGRESSION EQUATIONS, SOME EXACT FINITE SAMPLE RESULTS * ARNOLD ZELLNER

JASA 63993 SEASONÁL ADJUSTMENT OF ECONOMIG TIME SERIES AND MULTIPLE RECRESSION ANALYSIS * MIGHAEL G . LOVELL

JASA 631011 THE VARYING QUALITY OF INVESTMENT TRUST MANAGEMENT * IRA HOROWITZ

JASA 631033 ESTIMATION OF QUASI-LINEAR TREND AND SEASONAL VARIATION* C. E. V, LESER

JASA 631044 SAMPLE SIZE REQUIRED TO ESTIMATE THE RATIO OF VARIANCES WITH BOUNDED RELATIVE ERROR * FRANKLIN A CRAYBILL, TERRENCE L. CONNELL

JASA 631048 SOME EMPIRICAL DISTRIBUTIONS OF BIVARIATE T-SQUARE AND HOMOSCEDASTICITY CRITERION M UNDER UNEQUAL VARIANCE AND LEPTOKURTOSIS * J. W. HOPKINS, P, P. F CLAY

JASA 631054 MULTIVARIATE REGRESSION OF DUMMY VARIATES UNDER NORMALITY ASSUMPTIONS * STANLEY L. WARNER

JASA 631064 ON THE PROBABILITY OF WINNING WITH DIFFERENT TOURNAMENT PROCEDURES * DONALD T. SEARLS 
JASA 631082 TABLES FOR CONSTRUCTINC CONFIDENCE LIMITS ON THE MULTIPLE CORRELATION COEFFICIENT * K. H. KRAMER

JASA $6310 B 6$ THE WILCOXON TWO-SAMPLE STATISTIC, TABLES AND BIBLIOCRAPHY * JAMES E. JACOBSON

JASA 631104 PRELIMINARY RECIONAL FORECASTS FOR THE OUTCOME OF AN EST IMATION PROBLEM* JAMES C. HICKMAN
JASA 631113 ILLUSTRATIVE TABLES OF SCHOOL LIFE. CORR, 641299 * EDWARD G . STOCKWELL, CHARLES B. NAM

JASA 631125 A NOTE ON RESIDUAL ANALYSIS * CEORCE ZYSKIND

JASA 631133 ANALYSIS OF VARIANCE OF PROPORTIONS WITH UNEQUAL FREQUENCIES * K. R. CABRIEL

JOURNAL OF THE AMERICAN STATISTICAL ASSOCIATION VOLUME 59, 1964

JASA 64

JASA 64

JASA 64

JASA 64

JASA 64

JASA 64

JASA 64

JASA 64

JASA 64

JASA 64

JASA 64

JASA 64

JASA 64

JASA 64

JASA 64

JASA 64

JASA 64

JASA 64

JASA 64

JASA 64

JASA 64

JASA 64

JASA 64

JASA 64

JASA 64

JASA 64

JASA 64

JASA 64

JASA 64

JASA 64469 A PRICE AND PRODUCTIVITY INDEX FOR A NONHOMOCENEOUS PRODUCT * DOUCLAS C. DACY

JASA 64481 ON FORMING STRATA OF EQUAL ACCRECATE SIZE * DES RAJ

JASA 64487 A TWO-VARIABLE CENERATINC FUNCTION FOR COMPUTINC THE SAMPLINC PROBABILITIES OF A CLASS OF WIDELY USED STATISTICS * JAMES N. CRONHOLM

JASA 64492 ROTATION DESIGNS FOR SAMPLING ON REPEATED OCCASIONS * J. N. K. RAO, JACKE. GRAHAM

JASA 64510 ESTIMATING THE PARAMETERS OF MIXTURES OF BINOMIAL DISTRIBUTIONS * W. R. BLISCHKE

JASA 64529 ON A NEW METHOD OF CAPACITY ESTIMATION * BERT C. HICKMAN

JASA 64550 SAMPLE SIZE REQUIRED TO ESTIMATE THE PARAMETER IN THE UNIFORM DENSITY WITHIN D UNITS OF THE TRUE VALUE * FRANKLIN A. CRAYBILL, TERRENCEL. CONNELL

JASA 64557 SOME GENERALIZATIONS OF THE DISTRIBUTIONS OF PRODUCT STATISTICS ARISINC FROM RECTANCULAR POPULATIONS * N. A. RAHMAN
JASA 64564 LEAST SQUARES ESTIMATES AND PARABOLIC RECRESSION WITH RESTRICTED LOCATION FOR THE STATIONARY POINT * T CUNIA

JASA 64645 ONE SAMPLE LIMITS OF SOME TWO-SAMPLE RANK TESTS * LINCOLN E. MOSES

JASA 64652 ON THE NORMAL SCORES TWO-SAMPLE RANK TEST * J. H. KLOTZ

JASA 64665 ROBUSTNESS OF SOME PROCEDURES FOR THE TWO-SAMPLE LOCATION PROBLEM * JOHN W. PRATT

JASA 64681 MINIMUM VARIANCE. LINEAR, UNBIASED SEASONAL ADJUSTMENT OF ECONOMIC TIME SERIES, CORR, 651250 * DALE W JORCENSON

JASA 64725 TAKINC A COVARIABLE INTO ACCOUNT * IRWIND. J. BROSS

JASA 64737 THE USE OF WEALTH TO COMPARE HOUSEHOLDS' AVERACE SAVINC * PHILLIP CACAN

JASA 64746 INCOME, WEALTH, AND THE DEMAND FOR MONEY, SOME EVIDENCE FROM CROSS-SECT ION DATA * TONC HUN LEE

JASA 64763 BAYESIAN ANALYSIS OF THE RECRESSION MODEL WITH AUTOCORRELATED ERRORS * ARNOLD ZELLNER, CEORCE C. TIAO

JASA 64779 SOME COMPARISONS OF METHODS OF FITTINC THE DOSACE RESPONSE CURVE FOR SMALL SAMPLES * ELLIOT M. CRAMER

JASA 64794 ANALYSIS OF EMPIRICAL BIVARIATE EXTREMAL DISTRIBUTIONS * E. J. CUMBEL, NEIL COLDSTEIN

JASA 64817 A NEW CLASS OF DESICNS, CORR. 651250 * C. RAMANKUTTY NAIR

JASA 64 B45 ITERATIVE ESTIMATION OF A SET OF LINEAR RECRESSION EQUATIONS * LESTER C. TELSER

JASA 64 B63 A NOTE ON THE EQUIVALENCE OF TWO METHODS OF FITTINC A STRAICHT LINE THROUGH CUMULATIVE DATA * J. L. JAECH

JASA 64 B67 ON THE BOUNDS OF THE NUMBER OF COMMON TREATMENTS BETWEEN BLOCKS OF SEMI-RECULAR CROUP DIVISIBLE DESICNS * HIRALAL ACRAWAL

JASA 64 B72 CORRECTINC THE AVERAGE RANK CORRELATION COEFFICIENT FOR TIES IN RANKINCS * WILSON L. TAYLOR

JASA 64877 DISTRIBUTION OF PRODUCT AND OF QUOTIENT OF MAXIMUM VALUES IN SAMPLES FROM A POWER-FUNCTION POPULATION * PAUL R. RIDER

JASA 64 BBI ON THE EXACT DISTRIBUTIONS OF THE CENERALIZED CLASSICAL LINEAR ESTIMATORS IN A LEADINC THREE-EQUATION

CASE * D. C. KABE
JASA 64 B95 ANOTE ON THE VARIANCE OF THE RATIO ESTIMATE * DES RAJ

JASA 64 B99 AN APPROXIMATION FOR THE EXACT DISTRIBUTION OF THE WILCOXON TEST FOR SYMMETRY * S. A. FELLINGHAM, D. J. STOKER

JASA 64906 NONPARAMETRIC UPPER CONFIDENCE BOUNDS, AND CONFIDENCE LIMITS, FOR THE PROBABILITY THAT Y IS LESS THAN $X$, WHEN $X$ AND Y ARE NORMAL * D. B. OWNE, $K . J$ CRASTELL, D. L. HANSON

JASA 64925 AN EXTENDED TABLE OF CRITICAL VALUES FOR THE MANNWHITNEY-WILCOXON TWO-SAMPLE STATISTIC * ROY C. MILTON

JASA 64935 TABLE FOR BOTH THE SICN TEST AND DISTRIBUTION-FREE CONFIDENCE INTERVALS OF THE MEDIAN FOR SAMPLE SIZES TO 1,000* WILLIAM J. MACKINNON

JASA 64957 ANOTHER DERIVATION OF THE NON-CENTRAL CHI-SQUARE DISTRIBUTION * WILLIAM C. GUENTHER

JASA 64987 THE PREDICTIVE ABILITY OF CONSUMER ATTITUDES, STOCK PRICES, AND NON-ATTITUDINAL VARIABLES * IRWIN FRIEND, $F$, GERARD ADAMS

JASA 641006 SEQUENTIAL ANALYSIS WITH DELAYED OBSERVATIONS * T. W ANDERSON

JASA 641016 RESPONSE VARIANCE AND ITS ESTIMATION * IVAN P. FELLEGI

JASA 641042 A UNIFIED DERIVATION OF SOME NONPARAMETRIC DISTRIBUTIONS * CARL-ERIK SARNDAL

JASA 641054 SAMPLE SELECTION AND THE CHOICE OF ESTIMATOR IN TWOWAY STRATIFIED POPULATIONS * W. H. WILLIAMS

JASA 641063 THE ESTIMATION OF A CHANCINC SEASONAL PATTERN, CORR $661247 *$ E. J. HANNAN

JASA 64 107B ON LEAST SQUARES WITH INSUFFICIENT OBSERVATIONS, CORR. 651249 * JOHN S. CHIPMAN

JASA 641112 INTERVAL ESTIMATION IN LINEAR RECRESSION WHEN BOTH VARI ABLES ARE SUBJECT TO ERROR * MAX HALPERIN

JASA 641121 THE EXTENT OF REPEATED MICRATION, AND ANALYSIS BASED ON THE DANISH POPULATION RECISTER * SIDNEY GOLDSTEIN

JASA 641133 CRITERIA FOR BEST SUBSTITUTE INTERVAL ESTIMATORS, WITH AN APPLICATION TO THE NORMAL DISTRIBUTION * H. LEON HARTER 
JASA 641141 INTERVAL ESTIMATION FOR LINEAR COMBINATIONS OF MEANS * MINORU SIOTANI

JASA 641165 THE IDENTIFICATION OF EFFECTIVE INTERVIEWERS * STANLEY W. STEINKAMP

JASA 641175 A NOTE ON THE MAXIMUM LIKELIHOOD ESTIMATION OF A LINEAR STRUCTURAL RELATIONSHIP * M. W. BIRCH

JASA 641179 EFFICIENCIES FOR STEPWISE RECRESSIONS * T. D. WALLACE

JASA 64 IIB3 THE VARIABILITY OF PROFITIBILATY WITH SIZE OF FIRM, $1947-1958 *$ H. O. STEKLER

JASA 641194 INCOME INCOME CHANGE, AND DURABLE GOODS DEMAND * MAW LIN LEE

JASA 641203 CONDITIONAL MEANS AND COVARI ANCES OF NORMAL VARIABLES WITH SINGULAR COVARIANCE MATRIX * CEORGE MARSACLIA
JASA 6412052 TO THE POWER OF P FACTORIAL EXPERIMENTS WITH THE FAC TORS APPLIED SEQUENTIALLY * R R PRATRIE W I ZIMMER

JASA 641217 ON THE ANALYSIS OF GROUP DIVISIBLE DESICNS * C. H KAPADIA, D. L. WEEKS

JASA 64 I220 A NOTE ON THE NECATIVE MOMENTS OF A TRUNCATED POISSON VARIATE* M. L. TIKU

JASA 641225 THE UTILIZATION OF A KNOWN COEFFICIENT OF VARIATION IN THE EST IMATION PROCEDURE * DONALD T . SEARLS

JASA 641227 A SIMPLE APPROACH TO THE BAYES CHOICE CRITERION, THE METHOD OF EXTREME PROBABILITIES * ALVISE BRAGA-ILLA

JASA 641231 A SUPPLEMENT TO MENDENHALL'S BIBLIOGRAPHY ON LIFE. TESTING AND RELATED TOPICS, CORR. 651249 * ZAKKULA GOVINDARA JULU

JOURNAL OF THE AMERICAN STATISTICAL ASSOCIATION VOLUME 60, 1965

JASA 65

JASA 65

JASA 65

JASA 65

JASA 65

JASA 65

JASA 65 POSNER

JASA 65134 SOME NON-PARAMETRIC TESTS FOR M-DEPENDENT TIME SERIES * PRANAB KUMAR SEN

JASA 65 14B THE RELIABILITY OF CONSUMER SURVEYS OF FINANCIAL HOLDINGS, TIME-DEPOSITS * ROBERT FERBER

JASA 65164 PREDICTION OF AN AUTOREGRESSIVE VARIABLE SUBJECT BOTH TO DISTURBANCES AND TO ERRORS OF OBSERVATION * MARTIN J. BAILEY

JASA 65 1B2 MINIMAL SUFFICIENT STATISTICS FOR THE TWO-WAY CLASSIFICATION MIXED MODEL DES IGN * ROBERT A. HULTQUIST, FRANKLINA. GRAYBILL

JASA 65193 RATIOS OF NORMAL VARIABLES AND RATIOS OF SUMS OF UNIFORM VARIABLES * GEORGE MARSAGLIA

JASA 65205 DESIGN FOR OPTIMAL PREDICTION IN SIMPLE LINEAR REGRESSION * D. W. CAYLOR, H. C. SWEENY

JASA 65217 ERRORS OF CLASSIFICATION IN A BINOMIAL POPULATION * MARION R. BRYSON

JASA 65225 OPTIMUM ALLOCATION OF SAMPLING UNITS TO STRATA WHEN THERE ARE R RESPONSES OF INTEREST * JOHN LEROY FOLKS, CHARLES E. ANTLE

JASA 65234 PRINCIPAL COMPONENTS REGRESSION IN EXPLORATORY STAT ISTICAL RESEARCH * WILLIAM F. MASSY

JASA 65257 CONFIDENCE INTERVALS BASED ON THE MEAN ABSOLUTE DEV IATION OF A NORMAL SAMPLE * ERNA M. J . HERREY

JASA 65270 ON A METHOD OF USING MULTI-AUXILIARY INFORMATION IN SAMPLE SURVEYS * DES RAJ

JASA 65278 VARIANCE ESTIMATION IN RANDOMIZED SYSTEMATIC SAMPLING WITH PROBABILITY PROPORTIONATE TO SIZE * DES RAJ

JASA 6E 285 ON THE F-TEST IN THE INTRABLOCK ANALYSIS OF A CLASS OF TWO ASSOCIATE PARTIALLY BALANCED INCOMPLETE BLOCK DESIGNS*N. CIRI

JASA 65294 COMPARISON OF SOME RATIO ESTIMATORS * MYINT TIN

JASA 65308 AN ESTIMATION PROCEDURE FOR RANGE COMPOSITION PROBLEMS * DENNIS J. AIGNER

JASA 65320 THE POWER OF STUDENT'S T-TEST, CORR, 651251 * D. B. OWEN

JASA 65334 SOME GRAPHS USEFUL FOR STATISTICAL INFERENCE * WILLIAM C. GUENTHER, P. O. THOMAS

JASA 65344 A NOMOGRAM FOR CHI-SQUARE, CORR, 66 1246* WILLIAM C. BOYD

JASA 65347 BAYESIAN ANALYSIS OF THE INDEPENDENT MULTINORMAL PROCESS, NEITHER MEAN NOR PRECISION KNOWN * ALBERT ANDO, G.M. KAUFMAN

JASA 65395 R. A. FISHER AND THE LAST FIFTY YEARS OF STATISTICAL METHODOLOGY * M. S. BARTLETT

JASA 65410 THE ASYMPTOTIC RELATIVE EFFICIENCY OF GOODNESS-OFFIT TESTS AGAINST SCALAR ALTERNATIVES * JOSEPH CELZER, RONALD PYKE

JASA 65420 EXPECTED SICNIFICANCE LEVEL AS A SENSITIVITY INDEX FOR TEST STATISTICS * A. P. DEMPSTER, M. SCHATZOFF

JASA 65437 A COMBINATORIAL TEST FOR INDEPENDENCE OF DICHOTOMOUS RESPONSES * PAUL W. MIELKE JR, M. M. SIDDIOUI
JASA 65442 A COMPARISON OF A MODIFIED 'HANNAN' AND THE BUREAU OF LABOR STAT ISTICS * MARC NERLOVE

JASA 65492 FOURIER METHODS FOR EVOLVING SEASONAL PATTERNS * NIGEL F. NETTHEIM

JASA 65503 APPROXIMATIONS DATA AND THE INVESTMENT DECISION * EDWARD GREENBERC

JASA 65516 A CLASS OFBIVARIATEDISTRIBUTIONS * R. L. PLACKETT

JASA 65523 UNIFIED LEAST SQUARES ANALYSIS * C. A. ROHDE, J. R HARVEY

JASA 65 52B A RELATION BETWEEN T AND F-DISTRIBUTIONS, CORR, 65 1249 * THEOPHILOS CACOULLOS

JASA 65532 THE DISTRIBUTION OF THE SIZE OF THE MAXIMUM CLUSTER OF POINTS ON A LINE * JOSEPH I : NAUS

JASA 65539 SOME TESTS FOR HOMOSCEDASTICITY * STEPHEN M. GOLDFELD, RICHARDE. QUANDT

JASA 65 54B ON SOME TESTS OF HYPOTHESES RELATING TO THE EXPONEN TIAL DISTRIBUTION WHEN SOME OUTLIERS ARE PRESENT, CORR. $651249 *$ A. P. BASU

JASA 65560 ESTIMATION FOR A ONE-PARAMETER EXPONENTIAL MODEL * JANACE A. SPECKMAN, RICHARD G. CORNELL

JASA 65573 ESTIMATION OF MULTIPLE CONTRASTS USING T-DISTRIBUTIONS * OLIVE JEAN DUNN, FRANK J . MASSEY JR

JASA 65584 INSENSITIVITY TO NON-OPTIMAL DES IGN IN BAYESIAN DECISION THEORY * GORDON R. ANTELMAN

JASA 65602 A BAYES APPROACH FOR COMBINING CORRELATED ESTIMATES * SEYMOUR CEISSER

JASA 65608 PREDICTION AND DECISION PROBLEMS IN REGRESSION MODELS FROM THE BAYESIAN POINT OF VIEW (CORR. 68 1551) * ARNOLD ZELLNER, V. KARUPPAN CHETTY

JASA 65617 THE METROPOLITAN AREA CONCEPT, AN EVALUATION OF THE 1950 STANDARD METROPOLIT AN AREAS * ALLAN G. FELDT

JASA 65637 ON A CLASS OF LINEAR ESTIMATORS IN SAMPLINC WITH VARYING PROBABILITIES WITHOUT REPLACEMENT * S. G. PRABHU AJGAONKAR

JASA 65699 ASYMPTOTICALLY OPTIMAL TESTS OF COMPOSITE HYPOTHESES FOR RANDOMIZED EXPERIMENTS WITH NONCONTROLLED PREDICTOR VARIABLES * JERZY NEYMAN, ELIZABETH L. SCOTT

JASA 65722 A REVIEW OF 'SMOKINC AND HEALTH' * K. A. BROWNLEE

JASA 65740 DEMAND FOR MANUFACTURERS' SERVICES FOR BAKERY PRODUCTS AND FRUITS AND VEGETABLES * WILLIAM H. WALDORF

JASA 65750 OPTIMUM STRATIFIED SAMPLING USING PRIOR INFORMATION * W. A. ERICSON

JASA 65772 STRATIFIED SAMPLING AND DISTRIBUTION-FREE CONFIDENCE INTERVALS FOR A MEDIAN * PHILIP J, MACCARTHY

JASA 657 B4 DOUBLE SAMPLING FOR STRATIFICATION ON SUCCESSIVE OCCASIONS * D. SINGH, B. D. SINCH

JASA 65793 THE INVERTED DIRICHLET DISTRIBUTION WITH APPLICATIONS, CORR 65 1251 * GEORGE C TIAO, IRWIN GUTTMAN

JASA 65 BO6 INFERENCE ABOUT VARIANCE COMPONENTS IN THE ONE-WAY MODEL * BRUCE M. HILL

JASA 65 B26 SEQUENTIAL RANCE TESTS FOR COMPONENTS OF VARIANCE, CORR, $651249 * \mathrm{~B}, \mathrm{~K}, \mathrm{CHOSH}$

JASA 65837 EXACT DISTRIBUTION OF THE SUM OF INDEPENDENT IDENTICALLY DISTRIBUTED DISCRETE RANDOM VARIABLES, CORR $661246 * \mathrm{H}$. A. DAVID, J.E. NORMAN JR

JASA 65843 ON THE ASYMPTOTIC EFFICIENCY OF THE KOLMOGOROV-SMIRNOV TEST * JACK CAPON

JASA 65854 A COMPARISON OF THE PEARSON CHI-SQUARE AND KOLMOGOROV GOODNESS-OF-FIT TESTS WITH RESPECT TO VALIDITY. CORR. 661249 * MALCOLM J. SLAKTER

JASA 65859 ON AN EXTREME RANK SUM TEST WITH EARLY DECISION * D CHUN

JASA 65864 EXTENDED TABLES OF THE WILCOXON MATCHED PAIR SIGNED RANK STATISTIC * ROBERT L. MACCORNACK

JASA 65872 TABLES OF BOUNDS FOR DISTRIBUTIONS WITH MONOTONE HAZARD RATE * RICHARD E . BARLOW. ALBERT W. MARSHALL

JASA 65891 GENERAL THEORY OF PRIME-POWER LATTICE DESIGNS * W. T FEDERER, B. L. RAKTOE 
JASA 65905 MULTIVARIATE ACCEPTANCE SAMPLING PROCEDURES FOR CENERAL SPECIFICATION ELLIPSOIDS * MELVIN F. SHAKKUN

JASA 65914 QUADRATIC REGRESSION WITH INEQUALITY RESTRAINTS ON THE PARAMETERS * R. R. HOCKING

JASA 65939 SAMUEL S. WILKS * FREDERICKF. STEPHAN, JOHN W. TUKEY, FREDERICK MOSTELLER, ALEX M. MOOD, MORRISH. HANSEN, LESLIE E. SIMON, W. J. DIXON

JASA 65967 THE UP-AND-DOWN METHOD FOR SMALL SAMPLES * W. J. DIXON

JASA 65979 ON THE PERFORMANCE OF THE TRUNCATED SEQUENTI IAL PROBABILITY RATIO TEST, CORR. 661247 * ABRAHAM GENIZI

JASA 65985 A DOUBLE SAMPLING SCHEME FOR ANALYTICAL SURVEYS * $J$ SEDRANSK

JASA 651005 THE EFFECT OF MIS-MATCHING ON THE MEASUREMENT OF RESPONSE ERRORS * JOHN NETER, E. SCOTT MAYNES, R RAMANATHAN

JASA 651028 APPLICATIONS OF PROBABILITY THEORY IN CRIMINALISTICS. II * CHARLESR. KINGSTON

JASA 651035 THE DETECTION OF A CORRELATION BETWEEN THE SEXES OF ADJACENT SIBS IN HUMAN FAMILIES * RICHARD A. CREENBERG, COLIN WHITE

JASA 651046 A MATHEMATICAL MODEL WITH APPLICATIONS TO A STUDY OF ACCIDENT REPEATEDNESS AMONG CHILDREN * CLEN D. MELLINCER, DAVID L. SYLWESTER, WILLIAM R. GAFFEY, DEAN I. MANHEIMER

JASA 651060 ON A DISCRETE DISTRIBUTION WITH SPECIAL REFERENCE TO THE THEORY OF ACCIDENT PRONENESS * S. K. BHATTACHARYA, M. S. HOLLA
JASA 651067 THE ANALYSIS OF DISTURBANCES IN REGRESSION ANALYSIS * H. THEIL

JASA 651080 A NOTE ON THE STATISTICAL TESTABILITY OF 'EXPLICIT CAUSAL CHAINS' ACAINST THE CLASS OF 'INTERDEPENDENT' MODELS * R. L. BASMANN

JASA 651094 A STOCHASTIC ANALYSIS OF THE SPATIAL CLUSTERINC OF RETAIL ESTABL ISHMENTS * ANDREI ROGERS

JASA 651104 A BAYESIAN INDIFFERENCE PROCEDURE * MELVIN R. NOVICK, W. J. HALL

JASA 651118 ON SOME TWO-SAMPLE NON-PARAMETRIC TESTS, CORR, 66 $1249 *$ S. ROSENBAUM

JASA 651127 PERCENTILE MODIFICATIONS OF TWO-SAMPLE RANK TESTS * JOSEPH L. CASTWIRTH

JASA 651142 TOLERANCE LIMITS FOR THE CENERALIZED GAMMA DISTRIBUTION * LEE J. BAIN, DAVID L. WEEKS

JASA 651153 ON MODELS AND HYPOTHESES WITH RESTRICTED ALTERNATIVES * ROBERT V. HOGG

JASA 651163 SOME SCHEFFE-TYPE TESTS FOR SOME BEHRENS-F ISHER-TYPE REGRESSION PROBLEMS * RICHARD F. POTTHOFF

JASA 651191 INTERVAL ESTIMATION OF NON-LINEAR PARAMETRIC FUNCTIONS, 111 * MAX HALPERIN

JASA 651200 APPLICATION OF GREENBERG AND SARHAN'S METHOD OF INVERSION OF PARTITIONED MATRICES IN THE ANALYSIS OF NON-ORTHOG ONAL DATA * M. BHASKAR RAO

JASA 651203 A UNIQUENESS THEOREM CONCERNING MOMENT DISTRIBUTIONS * R. K. ZEIGLER

JOURNAL OF THE AMERICAN STATISTICAL ASSOCIATION VOLUME 61, 1966

JASA 66 I PRESIDENT IAL ADDRESS * W. ALLEN WALLIS

JASA 6611 SOME ASPECTS OF EXPERIMENTAL INFERENCE * OSCAR KEMPTHORNE

JASA 6635 RECOGNIZING THE MAXIMUM OF A SEQUENCE * JOHN P. GILBERT, FREDERICK MOSTELLER

JASA 6674 STRATIFICATION, A PRACTICAL INVESTIGATION * IRENE HESS, V. K. SETHI, T. R. BALAKRISHNAN

JASA 6691 THE RELIABILITY OF CONSUMER SURVEYS OF FINANCIAL HOLDINGS, DEMAND DEPOSITS * ROBERT FERBER

JASA 66104 THE RELATIVE EFFICACY OF INVESTMENT ANTICIPATIONS * MICHAEL $K$. EVANS, EDWARD W. GREEN

JASA 66117 LABOR FORCE ENTRY AND ATTACHMENT OF YOUNG PEOPLE CORR. 661248 * JOHN KORBEL

JASA 66128 A NOTE ON AN 'ERRORS IN VARIABLES' MODEL * TONY LANCASTER

JASA 66136 ON THE SENSITIVITY OF SIMULTANEOUS-EQUATIONS ESTIMATORS TO THE STOCHASTIC ASSUMPTIONS OF THE MODELS * J G. CRAGG

JASA 66152 TIME SERIES ANALYSIS BY MODIFIED LEAST-SQUARES TECHNIQUES * RICHARD M. DUVALL

JASA 56166 INEQUALITY RESTRICTIONS IN REGRESSION ANALYSIS *G G. JUDGE, T. TAKAYAMA

JASA 66 IB2 CONFIDENCE BANDS OF UNIFORM AND PROPORTIONAL WIDTH FOR LINEAR MODELS * DAVID C. BOWDEN, FRANKLIN A. GRAYBILL

JASA 66199 A NUMERICAL PROCEDURE TO GENERATE A SAMPLE COVARIANCE MATRIX, CORR, $661248 * P$. L. ODELL, A. H. FEIVESON

JASA 66204 CRITICAL REGIONS FOR TESTS OF INTERVAL HYPOTHESES ABOUT THE VARIANCE * WILLIAM C. GUENTHER, MARY G WHITCOMB

JASA 66220 ESTIMATORS WITH PRESCRIBED BOUND ON THE VARIANCE FOR THE PARAMETERS IN THE BINOMIAL AND POISSON DISTRIBUTIONS BASED ON TWO-STAGE SAMPLING * ESTER SAMUEL

JASA 66228 A NOTE ON THE EQUIVALENCE OF TWO TEST CRITERIA FOR HYPOTHESES IN CATEGORICAL DATA * V.P. BHAPKAR

JASA 66236 LAMP TESTS OF LINEAR AND LOCLINEAR HYPOTHESES IN MULTINOMIAL EXPERIMENTS, CORR. $661246 *$ B. R. BHAT, S R. KULKARNI

JASA 66246 BIAS OF THE ONE-SAMPLE CRAMER-VON MISES TEST * RORY THOMPSON

JASA 66248 BEST LINEAR ESTIMATES UNDER SYMMETRIC CENSORING OF THE PARAMETERS OF A DOUBLE EXPONENTIAL POPULATION * ZAKKULA GOVINDARAJULU

JASA 66259 ON ESTIMATING THE PARAMETER OF A DOUBLY TRUNCATED BINOMIAL DISTRIBUTION * S. M. SHAH

JASA 66305 A LIFE TABLE THAT AGREES WITH THE DATA * NATHAN KEYFITZ

JASA 66313 A FAVORABLE SIDE BET IN NEVADA BACCARAT * EDWARD 0 THORP, WILLIAM E. WALDEN

JASA 66329 BEST K OF $2 K-1$ COMPARISONS * HERBERT MAISEL

JASA 66345 THE RELATIVE SENSITIVITY TO SPECIFICATION ERROR OF DIFFERENT K-CLASS EST IMATORS * FRANKLIN M. FISHER

JASA 66357 A LARGE SAMPLE SEQUENTIAL TEST, USING CONCOMITANT INFORMATION FOR DISCRIMINATION BETWEEN TWO COMPOSITE HYPOTHESES * C. PHILIP COX, THOMAS D. ROSEBERRY
JASA 66 36B A SIMPLE MATHEMATICAL RELATIONSHIP AMONG K-CLASS ESTIMATORS * ASATOSHI MAESHIRO

JASA 66375 COMPUTER EDITING OF SURVEY DATA, FIVE YEARS OF EXPER IENCE IN BLS MANPOWER SURVEYS * WALTER J. STUART

JASA 66384 AN EXACT FORMULA FOR THE PROBABILITY THAT TWO SPECIFIED SAMPLING UNITS WILL OCCUR IN A SAMPLE DRAWN WITH UNEQUAL PROBABILITIES AND WITHOUT REPLACEMENT * W. S. CONNOR

JASA 66391 SOME REMARKS ON A SIMPLE PROCEDURE OF SAMPLING WITHOUT REPLACEMENT * DES RAJ

JASA 66397 A NOTE ON THE ESTIMATION OF AMPLITUDE SPECTRA FOR STOCHASTIC PROCESSES WITH QUASI-LINEAR RESIDUALS * L. H. KOOPMANS

JASA 66403 ASSESSING THE ACCURACY OF MULTIVARIATE OBSERVATIONS * JOSEPH L. FLEISS

JASA $66 \quad 413$ A THEOREM ON LEAST SQUARES AND VECTOR CORRELATTON IN MULTIVARIATE LINEAR REGRESSION * GREGORY C. CHO"

JASA 66415 SENSITIVITY COMPARISONS AMONG TESTS OF THE GENERAL LINEAR HYPOTHES IS * MARTIN SCHATZOFF

JASA 66436 A COMPUTER METHOD FOR CALCULATING KENDALL 'S TAU WITH UNGROUPED DATA * WILLIAMR. KNIGHT

JASA 66440 DISTRIBUTION OF THE SAMPLE VERSION OF THE MEASURE OF ASSOCIATION, GAMMA * IRENE ROSENTHAL

JASA $66 \quad 454$ A CONFIDENCE INTERVAL COMPARISON OF TWO TEST PROCEDURES PROPOSED FOR THE BEHRENS-FISHER PROBLEM * $S$. JAMES PRESS

JASA 66467 UNBAISED ESTIMATION OF THE COMMON MEAN OF TWO NORMAL DISTRIBUT IONS BASED ON SMALL SAMPLES OF EQUAL SIZE * S. ZACKS

JASA 66477 CONDITIONAL-NORMAL REGRESSION MODELS * ROBERT F, TATE

JASA 66490 A NOTE ON TAKING A COVARTABLE INTO ACCOUNT * HANS $K$, URY

JASA 66496 USE OF A REGRESSION TECHNIQUE TO PRODUCE AREA BREAKDOWNS OF THE MONTHLY NATIONAL ESTIMATES OF RETAIL TRADE * RALPHS. WOODRUFF

JASA 66505 PRODUCER AND CONSUMER RISKS FOR ASYMMETRICAL TESTS AND SPECIFICATION LIMITS * H. R. SINGH

JASA 66514 EXACT MOMENTS AND PRODUCT MOMENTS OF THE ORDER STATISTICS FROM THE TRUNCATED LOGISTIC DISTRIBUTION * MICHAEL E. TARTER

JASA 66577 A BAYESIAN TEST OF SOME CLASSICAL HYPOTHESES, WITH APPLICATIONS TO SEQUENTIAL CLINICAL TRIALS * JEROME CORNFIELD

JASA 66595 MISSING VALUES IN MULTIVARIATE STATISTICS, I. REVIEW OF THE LITERATURE * ROBERTM. ELASHOFF, A. AFIFI

JASA 66605 CONFIDENCE, PREDICTION, AND TOLERANCE REGIONS FOR THE MULTIVARIATE NORMAL DISTRIBUT ION * VICTOR CHEW

JASA 66 61B ASYMPTOTIC PROPERTIES OF SOME ESTIMATORS OF QUANTILES OF CIRCULAR ERROR * WALLACE R, BLISCHKE, ALAN HALPIN

JASA 66633 LIGHT BULB STATISTICS, CORR, 661248 * NATHAN MANTEL, BERNARD PASTERNACK

JASA 66640 AN INTRODUCTION TO RANKING AND SELECTION PROCEDURES * DAVID R. BARR, M. RIZVI

JASA 66647 RECENT EFFORTS TO IMPROVE LAND USE INFORMATION * MARION CLATSON 
JASA 66 65B CONSUMER BUYINC INTENTIONS AND PURCHASE PROBABILITY, AN EXPERIMENT IN SURVEY DESICN * F. THOMAS JUSTER

JASA $66 \quad 697$ ASPECTS OF MAXIMUM LIKELIHOOD ESTIMATION OF THE LOCIST IC CROWTH FUNCTION * F, R, OLIVER

JASA 66706 SEASONAL VARIATION OF DEATHS IN THE UNITED STATES, 1951-1960 * IRA ROSENWAIKE

JASA 66720 UNBIASED MULTIPLE REGRESSION COEFF ICIENTS EST IMATED FROM ONE-WAY-CLASSIFICATION TABLES WHEN THE CROSS CLASSIFICATIONS ARE UNKNOWN * YOEL HAITOVSKY

JASA 66729 RESPONSE ERROR IN SURVEY REPORTS OF EARNINGS INFORMATION * MICHAEL E. BORUS

JASA 66739 SYSTEMATIC SAMPLINC WITH UNEQUAL PROBABILITY AND WITHOUT REPLACEMENT * H. O. HARTLEY

JASA 66749 PROBABILITY SAMPLING WITH QUOTAS * SEYMOUR SUDMAN

JASA $66 \quad 772$ THE WILCOXON, TIES, AND THE COMPUTER * JEROME KLOTZ

JASA 66 7BB PRODUCT DIVERSIFICATION AND LIVINC COSTS, A FURTHER COMMENT * HENRY ANDERSON

JASA 66 BOO ALTERNATIVE AXIOMATIZATIONS OF SEASONAL ADJUSTMENT * MICHAEL C. LOVELL

JASA 66 BO3 ON DEPENDENT TESTS FROM A NON-ORTHOCONAL DESIGN * J T. WEBSTER, JOE A. BALLAS

JASA 66 BI3 SOME EMPIRICAL RESULTS ON VARIANCE RATIOS UNDER PERMUTATION IN THE COMPLETELY RANDOMIZED DESIGN * FRANK B. BAKER, RAYMOND 0 . COLLIER

JASA $66 \quad 821$ GENERALIZED LATTICE SQUARE DESIGN * WALTER T FEDERER, B. L. RAKTOE

JASA 66 B33 THE EVALUATION OF H 106 CONTINUOUS SAMPLING PLANS UNDER THE ASSUMPTION OF WORST CONDITIONS * LEON S. WHITE

JASA 66 B42 LOCAL-MAXIMUM-LIKELIHOOD ESTIMATION OF THE PARAMETERS OF THREE-PARAMETER LOGNORMAL POPULATIONS FROM COMPLETE AND CENSORED SAMPLES, (CORR. 66 1247, CORR. 68 1549) * H. LEON HARTER, ALBERT H. MOORE

JASA 66 B52 A NOTE ON THE ESTIMATION OF THE LOCATION PARAMETER OF THE CAUCHY DISTRIBUTION * DANIEL BLOCH

JASA 66 B56 ON TESTING THE EQUALITY OF UNIFORM AND RELATED DISTRIBUTIONS * DAVID R. BARR

JASA 66897 MARKET MAKING AND REVERSAL OF THE STOCK EXCHANGE * VICTOR NIEDERHOFFER, M. F. M. OSBORNE

JASA 66917 MULTIPLE REGRESSION WITH STATIONARY ERRORS * DAVID B DUNCAN, RICHARD H, JONES

JASA 66929 ON ROBUST PROCEDURES * JOSEPH L. GASTWIRTH

JASA 66949 A DEVELOPMENT OF TUKEY'S QUICK TEST OF LOCATION * HENRY R. NEAVE

JASA 66965 THE POWER OF CHI SQUARE TESTS FOR CONTINGENCY TABLES * DOUGLAS G. CHAPMAN, ROSA C. MENG
JASA 66976 ON CHARACTERIZINC THE CHI SQUARE DISTRIBUTION BY THE STUDENT LAW * ICNACY KOTLARSKI

JASA 66982 POTENTIALS IN APPLYINC LINEAR PROCRAMMINC TO THE CONSUMER PRICE INDEX * JOHN NETER, WILLIAM WASSERMAN

JASA 66995 ESTIMATION OF AN ACCELERATED DEPRECIATION LEARNINC FUNCTION * TERENCE J. WALES

JASA 661010 A STOCHASTIC MODEL OF CREDIT SALES DEBT * HASKEL BENISHAY

JASA 661029 POINT ESTIMATION OF RELIABILITY OF A SYSTEM COMPRISED OF K ELEMENTS FROM THE SAME EXPONENTIAL DISTR IBUTION * HERBERT C. RUTEMILLER

JASA 661033 THE EFFICIENCIES IN SMALL SAMPLES OF THE MAXIMUM LIKELIHOOD AND BEST UNBIASED ESTIMATORS OF RELIABILITY FUNCTIONS * S. ZACKS, M. EVEN

JASA 661052 MINIMUM VARIANCE UNBIASED AND MAXIMUM LIKELIHOOD ESTIMATORS OF RELIABILITY FUNCTIONS FOR SYSTEMS IN SERIES AND IN PARALLEL * S. ZACKS, M. EVEN

JASA 661063 A GENERALIZATION OF THE GAUSS-MARKOV THEOREM * T. 0. LEWIS, P. L , ODEL.L

JASA 661067 MAXIMUM LIKELIHOOD ESTIMATION OF THE DISTR IBUTIONS OF TWO STOCHASTICALLY ORDERED RANDOM VARIABLES * DAVID LEE HANSON, H. D. BRUNK, W. E. FRANCK, ROBERT V. HOGC

JASA 661081 SIMULTANEOUS TEST PROCEDURES FOR MULTIPLE COMPARISONS ON CATEGORICALDATA * K, R. GABRIEL

JASA 661097 FITTING SEGMENTED CURVES WHOSE JOIN POINTS HAVE TO BE ESTIMATED * DEREK J. HUDSON

JASA 661130 SMALL SAMPLE BIAS DUE TOMISSPECIFICATION IN THE 'PARTIAL ADJUSTMENT' AND 'ADAPTIVE EXPECTATIONS' MODELS * ROGER N. WAUD

JASA 661153 SOME METHODS OF CONSTRUCTION OF DESIGNS FOR TWO-WAY ELIMINAT ION OF HETEROGENE ITY, I * HIRALAL AGRAWAL

JASA 661172 ESTIMATION EMPLOYING POST STRATA * WAYNE A. FULLER

JASA 661184 A CORRELATION MODEL USEFUL IN THE STUDY OF TWINS * CHARLES A . ROBERTS

JASA 661191 SOME PROBABILITIES, EXPECTATIONS AND VARIANCES FOR THE SIZE OF LARGEST CLUSTERS AND SMALLEST INTERVALS * J. I. NAUS

JASA 661200 AN ESTIMATOR FOR A POPULATION MEAN WHICH REDUCES THE EFFECT OF LARGE TRUE OBSERVATIONS * DONALD T. SEARLS

JASA 661205 ORDER STATISTICS ESTIMATORS OF THE LOCATION OF THE CAUCHY DISTRIBUTION * V. D. BARNETT

JASA 661219 ON THE STATISTICAL DISCREPANCY IN THE REVISED UNITED STATES NATI ONAL ACCOUNTS * F. GERARD ADAMS, PETER E. DEJANOSI
JASA 67 I THE QUALITY OF STATISTICAL INFORMATION AND STATISTICAL INFERENCE IN A RAPIDLY CHANCINC WORLD * FREDERICK F . STEPHAN

JASA $67 \quad 10$ MISSINC OBSERVATIONS IN MULTIVARIATE STATISTICS II POINT ESTIMATION IN SIMPLE LINEAR REGRESSION * A . A AFIFI, R. M. ELASHOFF

JASA 67

JASA 67

A MULTIVARIATE EXPONENTIAL DISTRIBUTION * ALBERT W. MARSHALL, INGRAM OLKIN

45 LIFE-TESTING RESULTS BASED ON A FEW HETEROGENEOUS LOCNORMAL OBSERVAITONS * A. J. MCCULLOCH, JOHN E WALSH

JASA $674 B$ BAYESIAN APPROACH TO LIFE TESTING AND RELIABILITY ESTIMATION * SAMIR KUMAR BHATTACHARYA

JASA 6763 OPTIMAL SAMPLE DESIGN WITH NONRESPONSE* W. A. ERICSON

JASA $67 \quad 79$ A NOTE ON FELLEGI'S METHOD OF SAMPLINC WITHOUT REPLACEMENT WITH PROBABILITY PROPORTIONAL TO SIZE * K. R. W. BREWER

JASA 67 B6 STEP-WISE CLUSTERINC PROCEDURES * BENJAMIN KIN

JASA 67102 ON THE METHOD OF INCLUSION AND EXCLUSION * LAJOS TAKACS

JASA 67114 AN ALGORITHM FOR OBTAINING THE ZERO OF A FUNCTION OF THE DISPERSION MATRIX IN MULTIVARIATE ANALYSIS * IRENE $M$. TRAWINSKI

JASA 67124 THE ROBUSTNESS OF HOTELLING 'S T-SQUARE * LOIS N. HOLLOWAY, OLIVE J . DUNN

JASA 67137 SEASONAL ADJUSTMENT OF DATA FOR ECONOMETRIC ANALYSIS * DALE W. JORCENSON

JASA 67141 THE UNBIASEDNESS OF ZELLNER'S SEEMINCLY UNRELATED REGRESSION EQUATIONS ESTIMATORS * N, C . KAKWANI

JASA 67143 RECIONAL DISPARITIES IN HOUSEHOLD CONSUMPTION IN INDIA * N. BHATTACHARYA, B. MAHALANOBIS

JASA 67162 MEASURES OF CONCENTRATION * MARSHALL HALL, NICOLAUS TIDEMAN

JASA 67169 SOME FURTHER NOTES ON DISTURBANCE ESTIMATES IN REGRESSION ANALYSIS * JOHAN KOERTS

JASA 67 IB4 WILCOXON CONFIDENCE INTERVALS FOR LOCATION PARAMETERS IN THE DISCRETE CASE * GOTTFRIED E. NOETHER
JASA 67189 A PARTIAL COEFFICIENT FOR GOODMAN AND KRUSKAL 'S CAMMA * JAMES A. DAVIS

JASA 67194 TIES IN PAIRED-COMPARISON EXPERIMENTS, A GENERALIZATION OF THE BRADLEY-TERRY MODEL (CORR, 6B 1550) *P V. RAO, L, L. KUPPER

JASA 67205 SEQUENCES BALANCED FOR PAIRS OF RESIDUAL EFFECTS * $C$ RAMANKUTTY NAIR

JASA 67226 EQUAL AND PROPORTIONAL FREQUENCY SQUARES * SIDNEY ADDELMAN

JASA 67241 THE COMBINATION OF ESTIMATES FROM SIMILAR EXPERIMENTS, ALLOWING FOR INTER-EXPERIMENT VARIATION * PAMELA M. MORSE, A. BIKLE

JASA 67251 A NOTE ON REGRESSION IN THE MULTIVARIATE POISSON DISTRIBUTION* D. M. MAHAMUNULU

JASA 67259 DISTRIBUTION OF SOME STATISTICS IN SAMPLES FROM EXPONENTIAL AND POWER-FUNCTION POPULATIONS * JIRI LIKES

JASA 67272 ESTIMATION OF THE PROBABILITY OF ZERO FAILURES IN M BINOMIAL TRIALS * HERBERT C. RUTEMILLER

JASA 67278 THE MOMENTS OF A DOUBLY NONCENTRAL T-DISTRIBUTION * MARAKATHA KRISHNAN

JASA 67 2BB NOTE ON A UNIQUENESS RELATION IN CERTAIN ACCIDENT PRONENESS MODELS *N, L, JOHNSON

JASA 67321 SOME QUANTITATIVE TESTS FOR STOCK PRICE GENERATING MODELS AND TRADING FOLKLORE* M.F.M. OSBORNE

JASA 67341 A PROCEDURE FOR AUTOMATIC DATA EDITING * R. J. FREUND. H. O. HARTLEY

JASA 67353 ROBUST ESTIMATION OF LOCATION * EDWIN L. CROW, M. M. SIDDIQUI

JASA 67390 GOODNESS OF FIT * HANS RIEDWYL

JASA 67399 ON THE KOLMOGOROV-SMIRNOV TEST FOR NORMALITY WITH MEAN AND VARI ANCE UNKNOWN * HUBERT W. LILLIEFORS

JASA 67403 LINEAR SEGMENT CONFIDENCE BANDS FOR SIMPLE LINEAR MODELS * F. A. GRAYBILL, D. C. BOWDEN

JASA 67409 ON THE QUESTION OF WHETHER A DISEASE IS FAMILIAL * R $z$ GOLD, S. M. BERMAN, A. BERGER 
JASA 67

JASA 67

JASA 67

JASA 67

JASA 67

ASA 67

JASA 67

JASA 67

JASA 67

JASA 67

JASA 67

JASA 67

JASA 67

JASA 67

JASA 67

JASA 67

JASA 67

JASA 67

JASA 67

JASA 67

JASA 67

JAS 6

JASA 67 P. FELLEGI, G. B. GRAY. R. PLATEK

P WITH COMPLETE INVARIANT INFORMATION * GAD NATHAN

470 DATA REVISIONS AND ECONOMIC FORECASTING * H. O. STEKLER

484 DISCRETE SAMPLES AND MOVING SUMS IN STATIONARY STOCHASTIC PROCESSES * LESTER G. TELSER

500 EFFICIENT ESTIMATION OF A SYSTEM OF REGRESSION EQUATIONS WHEN DISTURBANCES ARE BOTH SERIALLY AND CONTEMPORANEOUSLY CORRELATED * RICHARD W. PARKS

510 REDUCING A RANDOM SAMPLE TO A SMALLER SET, WITH APPLICATIONS * LEE J. BAIN

520 ON ITERATED TESTS OF HYPOTHESES * CHANDAN K. MUSTAFI

525 TABLES OF THE POWER OF THE F-TEST (CORR. 6B 1551) * M. L. TIKU

540 SAMPLING FOR CONFIDENCE * K. T. WALLENIUS

54B EXPONENTIAL LIFE TEST PROCEDURES WHEN THE DISTRIBUTION HAS MONOTONE FAILURE RATE * RICHARD E. BARLOW, FRANK PROSCHAN

561 EXPONENTIAL SURVIVAL WITH COVARIANCE * MARVIN GLASSER 569 SOME ANALYTICAL PROPERTIES OF BIVARIATE EXTREMAL DISTRIBUTIONS* E. J, GUMBEL, C. K. MUSTAFII

BIVARIATE WARNING-TIME, FAILURE-TIME DISTRIBUTION * G. A. MIHRAM, R. A. HULTQUIST

600 ON THE FIXED POINT PROBABILITY VECTOR OF REGULAR OR ERGODIC TRANSITION MATRICES * HENRY P. DECELL JR, P L. ODELL

603 AN INEQUALITY ON A BIVARIATE STUDENT'S 'T' DISTRIBU TION * MAX HALPERIN

607 SOME APPLICATIONS OF MATRIX DERIVATIVES IN MULTIVARIATE ANALYSIS * PAUL S. DWYER

626 RECTANGULAR CONFIDENCE REGIONS FOR THE MEANS OF MULTIVAR IATE NORMAL DISTR IBUTIONS * ZBYNEK SIDAK

634 ON MULTIVARIATE PREDICTION INTERVALS FOR SAMPLE MEAN AND COVARIANCE BASED ON PARTIAL OBSERVATIONS * D. G KABE

638 UNIFORMLY BETTER COMBINED EST IMATORS IN FACTORIAL ARRANGEMENTS WITH CONFOUNDING * K. R. SHAH

643 THE DISPLACED POISSON DISTRIBUTION-REGION B * P. L STAFF

655 MULTIVARIATE LOGARITHMIG SERIES DISTRIBUTION AS A PROBABILITY MODEL IN POPULATION AND COMMUNITY ECOLOGY AND SOME OF ITS STATISTICAL PROPERTIES * G P. PATIL, S. BILDIKAR

JASA 67675 MAXIMUM-LIKELIHOOD ESTIMATION. FROM CENSORED SAMPLES, OF THE

JASA 67685 THE TWO CONCEPTS OF INFORMATION * S. KULLBACK

JASA 67763 INFORMATIVE STOPPING RULES AND INFERENCES ABOUT POPULATION SIZE * HARRY V. ROBERTS

JASA 67776 THE ASSESSMENT OF PRIOR DISTRIBUTIONS IN BAYESIAN ANALYSIS * ROBERT L. WINKLER

JASA 67 BOI FINITE SAMPLE MONTE CARLO STUDIES. AND AUTOREGRESSIVE ILLUSTRATION * HODSON THORNBER

JASA 67 B19 AN APPRAISAL OF LEAST SQUARES PROGRAMS FOR THE ELECTRONIC COMPUTER FROM THE POINT OF VIEW OF THE USER * JAMES W. LONGLEY

JASA 67 B42 RANDOM WALK DESIGN INBIO-ASSAY * R. K. TSUTAKAWA

JASA 67 B62 ON THE INTERPRETATION OF AGE DISTRIBUTIONS * NATHAN KEYFITZ, DHRUVA NAGNUR, DIVAKAR SHARMA

JASA 67875 SCHOOLING, EXPERIENCE, AND GAINS AND LOSSES IN HUMAN CAPITAL THROUGH MIGRATION * MARY JEAN BOWMAN, ROBERT G. MYERS

JASA 67899 SAMPLING ERROR IN THE CONSUMER PRICE INDEX * MARVIN WILKERSON

JASA 67915 EXACT MOMENTS OF THE ORDER STATISTICS OF THE GEOMETRIC DISTRIBUTION AND THEIR RELATION TO INVERSE SAMPLING AND RELIABILITY OF REDUNDANT SYSTEMS * BARRY H. MARGOLIN, HERBERT S. WINOKUR JR

JASA 67926 ON MEDIANS AND QUASI-MEDIANS * J. L. HODGES JR, E. L LEHMANN

JASA 67932 ASYMPTOTIC EFFICIENCY OF THE TWO SAMPLE KOLMOGOROVSMIRNOV TEST * JEROME KLOTZ

JASA 67939 ASYMPTOTIC EFFICIENCY OF TWO NONPARAMETRIC COMPETITORS OF WILCOXON'S TWO SAMPLE TEST * MYLES HOLLANDER

JASA 67950 ASYMPTOTICALLY ROBUST ESTIMATORS OF LOCATION * M. M. SIDDIQUI, K, RAGHUNANDANAN

JASA 67954 EFFICIENCY LOSS DUE TO GROUPING IN DISTRIBUTION-FREE TESTS * D. R. MCNEIL

JASA 67966 DISTRIBUTION AND POWER OF THE ABSOLUTE NORMAL SCORES TEST * RORY THOMPSON, Z. GOVINDARAJULU, K. A. DOKSUM

JASA 67976 A CRITICAL COMPARISON OF THREE STRATEGIES OF COLLECTING DATA FROM HOUSEHOLDS * JOSEPH R. HOCHSTIM
JASA 67990 A MULTI-PROPORTIONS RANDOMIZED RESPONSE MODEL * ABDEL-LATIF A, ABUL-ELA, BERNARD G. GREENBERG DANIEL G. HORVITZ

JASA 671009 GENERALIZED MULTIVARIATE ESTIMATOR FOR THE MEAN OF FINITE POPULATIONS * PODURI S. R. S. RAO, GOVIND S MUDHOLKAR

JASA 671013 AN OPTIMUM PROPERTY OF THE HORVITZ-THOMSON ESTIMATE * VIJAYA S. HEGE

JASA 67 IOIB ON FRACTIONAL POWERS OF A MATRIX * FREDERICK V. WAUGH, MARTINE. ABEL

JASA 671022 ORTHONORMAL BASES OF ERROR SPACES AND THEIR USE FOR INVESTIGATING THE NORMALITY AND VARIANCES OF RESIDUALS * JOSEPH PUTTER

JASA 671037 A STRUCTURAL REGRESSION APPROACH TO COVARIANCE ANALYSIS WHEN THE COVARIABLE IS UNCONTROLLED * WILLIAM S MALLIOS

JASA 671050 SHORTER CONFIDENCE BANDS IN LINEAR REGRESSION * MAX HALPERIN, SURESH C. RASTOGI, IRWIN HO, Y. Y. YANG

JASA 671068 THE NORMAL APPROXIMATION TO THE SIGNED-RANK SAMPLING DISTR IBUT ION WHEN ZERO DIFFERENCES ARE PRESENT * EDWARD E . CURETON

JASA 671105 THE QUANTIFICATION OF JUDGMENT. SOME METHODOLOGICAL SUGGESTIONS * ROBERT L. WINKLER

JASA 671121 DESIGNING SOME MULTI-FACTOR ANALYTICAL STUDIES * J SEDRANSK

JASA 671140 REPRESENTATION OF SIMILARITY MATRICES BY TREES * J A . HART IGAN

JASA 671159 ON SOME INVARIANT CRITERIA FOR GROUPING DATA * H. P. FRIEDMAN, J . RUBIN

JASA 671179 SOME OBSERVATIONS ON ROBUST ESTIMATION * ROBERT V HOGG

JASA 671187 RANK ANALYSIS OF COVARIANCE * DANA QUADE

JASA 671201 ON SOME MULTISAMPLE PERMUTATION TESTS BASED ON A CLASS OF U-STATISTICS * PRANAB KUMAR SEN

JASA 671214 ON SOME OPTIMUM NONPARAMETRIC PROCEDURES IN TWO-WAY LAYOUTS * MADAN LAL PURI, PRANAB KUMAR SEN

JASA 671230 OPTIMAL ROBUSTNESS. A GENERAL METHOD, WITH APPLICATIONS TO LINEAR EST IMATORS OF LOCATION * ALLAN BIRNBAUM, EUGENE LASKA

JASA 671241 EFFICIENCY ROBUST TWO-SAMPLE RANK TESTS * ALLAN BIRNBAUM, EUGENE LASKA

JASA 671252 ASYMPTOTIC DISTRIBUTION FOR A GENERALIZED BANACH MATCH BOX PROBLEM * T. CACOULLOS

JASA 67 125B THE MAXIMUM LIKELIHOODESTIMATE OF THE NON-CENTRALITY PARAMETER OF A NONCENTRAL CHI-SOUARE VARIATE * PAUL L. MEYER

JASA 671265 APPROXIMATE SPECIFICATION AND THE CHOICE OF A K-CLASS ESTIMATOR * FRANKLIN M. FISHER

JASA 671277 AN APPLICATION OF VARIABLE WEIGHT DISTRIBUTED LAGS * P. A. TINSLEY

JASA 671290 THE VARIANCE OF WEIGHTED REGRESSION ESTIMATORS * JAMES S. WILLIAMS

JASA 671302 A NECESSARY AND SUFFIGIENT CONDITION THAT ORDINARY LEAST-SQUARES ESTIMATORS BE BEST LINEAR UNBIASED * F. W. MCFLROY

JASA 671305 ASYMPTOTIC VARIANCES FOR DUMMY VARIATE REGRESSION UNDER NORMALITY ASSUMPTIONS * STANLEY L. WARNER

JASA 671315 COMPUTER SIMULATION EXPERIMENTS WITH ECONOMIC SYSTEMS. THE PROBLEM OF EXPERIMENTAL DESIGN * THOMAL H. NAYLOR, DONALD S. BURDICK, W. EARL SASSER

JASA 67 133B A COMPUTER SIMULATION MODEL OF THE TEXT ILE INDUSTRY * THOMASH NAYLOR, WILLTAMH, WALLACE, W. EARL SASSER

JASA 671365 STRAIGHT LINE CONFIDENCE REGIONS OF LINEAR MODELS * JOHN LEROY FOLKS, CHARLESE. ANTLE

JASA 671375 STATIST ICAL DEPENDENCE BETWEEN RANDOM EFFECTS AND THE NUMBERS OF OBSERVATTONS ON THE EFFECTS FOR THE UNBALANCED ONE-WAY RANDOM GLASSIFICATION * DAVID A. HARVILLE

JASA 671387 CORRELATED ERRORS IN THE RANDOM MODEL * BRUCE M. HILL

JASA 671401 SEQUENTIAL ANALYSIS OF VARIANCE UNDER RANDOM AND MIXED MODELS * B, K, GHOSH

JASA 67 141B THE MIGRATION OF EMPLOYED PERSONS TO AND FROM METROPOLITAN AREAS OF THE UNITED STATES * ANN R. MILLER

JASA 671433 METHOD OF CONSTRUCTION OF ATTRITION LIFE TABLES FOR THE SINGLE POPULATION BASED ON TWO SUCCESSIVE CENSUSES (CORR. 681550$)$ * JOG INDER KUMAR

JASA 671452 CONFIDENCE LIMITS FOR THE RELIABILITY OF SERIES SYSTEMS * A. H. EL MAWAZINY, R. J. BUEHLER

JASA 671460 A NOTE ON MULTIVARIATE DISTRIBUTIONS WITH SPECIFIED MARGINALS * BARRY C. ARNOLD

JASA 671462 COMPUTATION AND STRUCTURE OF OPTIMAL RESET POLICIES * ELLIS L. JOHNSON

JASA 67 14BB SMALL SAMPLE PROBABILITY LIMITS FOR THE RANGE CHART (CORR. 6B 1549) * FREDERICK S. HILLIER

JASA 671494 A THEOREM ON LEAST SQUARES IN MULTIVARIATE LINEAR REGRESSION * C. G. KHATRI 
ASSOCIATION AND ESTIMATION IN CONTINGENCY TABLES * FREDERICK MOSTELLER

JASA 6B 29 ON MEASURING THE EXTREME AGED IN THE POPULATION * IRA ROSENWAIKE

JASA 6841 RECENT RESEARCH IN REINTERV IEW PROCEDURES * BARBARA A BAILAR

JASA $6 B \quad 64$ THE ANALYSIS OF VARIANCE OF DATA FROM STRATIFIED SUBSAMPLES * HOWARD L. JONES

JASA 68 B7 SOME NONRESPONSE SAMPLING THEORY WHEN THE FRAME CONTAINS AN UNKNOWN AMOUNT OF DUPLICATION * J. N. K. RAO

JASA $6 B \quad 91$ BOUNDS FOR THE ERROR-VARIANCE OF AN ESTIMATOR IN SAMPLING WITH VARY ING PROBABILITIES FROM A FINITE POPULATTON * $S$ G PRABHU AIGAONKAR

JASA 6899 ESTIMATES IN SUCCESSIVE SAMPLING USING A MULTI-STAGE DESIGN * D. SINGH

JASA 68113 SOME SHRINKAGE TECHNIQUES FOR ESTIMATING THE MEAN * JAMES R. THOMPSON

JASA 68123 ESTIMATING FROM MISCLASSIFIED DATA * S. JAMES PRESS

JASA 68134 ESTIMATING THE PARAMETERS OF LOG-NORMAL DISTRIBUTION FROM CENSORED SAMPLES * M. L. TIKU

JASA 68141 ESTIMATION OF THE INNOVATION VARIANCE OF A STATIONARY TIME SERIES * HERBERT T . DAVIS, RICHARD H. JONES

JASA 68150 ESTIMATION OF THE PARAMETER N IN THE BINOMIAL DISTRIBUTION * DORIAN FELDMAN, MARTIN FOX

JASA 6B 159 ESTIMATION OF PARAMETERS IN THE MULTIVARIATE NORMAL DISTRIBUTION WITH MISSING OBSERVATIONS * R. R. HOCKING, WILLIAM B, SMITH

JASA 68174 BAYESIAN ESTIMATION OF MEANS FOR THE RANDOM EFFECT MODEL * G, E.P.BOX,G,C,TIAO

JASA 68 IB2 GROUPING EST IMATORS IN HETEROSCEDASTIC DATA (CORR. 68 1550) * TONY LANCASTER

JASA 68192 APPLICATIONS OF TIME-SHARED COMPUTERS IN A STATISTICS CURRICULUM * MART IN SCHATZOFF

JASA 68209 A CHANCE MECHANISM OF THE VARIATION IN THE NUMBER OF BIRTHS PER COUPLE* S. N. SINGH

JASA 68217 MINIMIZING RESPONSE ERRORS IN FINANCIAL DATA. THE POSSIBILITIES * E. SCOTTMAYNES

JASA 68228 MARKET GROWTH AND INDUSTRY CONCENTRATION * DAVID R KAMERSCHEN

JASA 68242 A SIMPLIFICATION OF THE BLUS PROGEDURE FOR ANALYZING REGRESSIONDISTURBANCES * HENRI THEIL

JASA 68252 ON CASH EQUIVALENTS AND INFORMATION EVALUATION IN DECISIONS UNDER UNCERTAINTY, PARTS I, II, AND III * IRVING H. LAVALLE

JASA 68291 OPTIMUM GHOICE OF GLASSES FOR CONTINGENCY TABLES * $M$ A. HAMDAN

JASA 68298 BIAS IN MULTINOMIAL CLASSIFICATION * P. KRISHNASW AMI, REJESHWAR NATH

JASA 68304 AN ALGORITHM FOR THE DETERMINATION OF THE ECONOMIC DESIGN OF X-CHARTS BASED ON DUNCAN'S MODEL * A. L GOEL, S. C. JAIN, S. M. WU

JASA 68321 THE INVERSION OF CUMULANT OPERATORS FOR POWER-SERIES DISTRIBUTIONS, AND THE APPROXIMATE STABILIZATION OF VARIANCE BY TRANSFORMATIONS*M. G. K. TWEEDIE, A VEEVERS

JASA $6 B 329$ GENERALIZED HYPERBOLIC SECANT DISTRIBUTIONS * W. L HARKNESS, M. L, HARKNESS

JASA 68 33B ROBUSTNESS OF SUM OF SQUARED RANKS TEST * BENJAMIN S DURAN, PAUL W. MIELKE JR

JASA $6 B \quad 345$ AN INVESTIGATION INTO THE SMALL SAMPLE PROPERTIES OF A TWO SAMPLE TEST OF LEHMANN'S * A. A. AFIFI, R. M ELASHOFF, P, G. LANGLEY

JASA 68353 REGURSIVE GENERATION OF THE DISTRIBUTION OF SEVERAL NON-PARAMETRIC TEST STATISTICS UNDER GENSORING * ROGERA. SHORACK

JASA 68395 CONVERGENCE OF A HUMAN POPULATION TO A STABLE FORM * ANSLEY J , COALE

JASA 68436 SELECTED ECONOMIC DATA, ACCURACY VS. REPORTING SPEED * H. O. STEKLER, SUSAN W. 8URCH

JASA 68445 LINEAR APPROXIMATIONS TO THE CENSUS AND BLS SEASONAL ADJUSTMENT METHODS * ALLAN H. YOUNG

JASA 68472 SPECTRAL EVALUATION OF 8LS AND CENSUS REVISED SEASONAL ADJUSTMENT PROCEDURES * HARRY M. ROSENBLATT

JASA 68502 FUNCTIONAL FORM IN THE DEMAND FOR MONEY * PAUL ZAREM8KA

JASA 68512 STANDARD ERRORS FOR INDEXES FROM COMPLEX SAMPLES * LESLIE KISH

JASA 68530 MULTIVARIATE STRATIFIED SURVEYS * SAMPRIT CHATTERJEE

JASA 68535 ON PRODUCT MOMENTS FROM A FINITE UNIVERSE * S. N. NATH

JASA 68542 MULTINOMIAL SAMPLING WITH PARTIALLY CATEGORIZED DATA * SAUL 8LUMENTHAL

JASA 68552 ESTIMATION IN A HETEROSCEDASTIC REGRESSION MODEL * HER8ERT C , RUTEMILLER, DAVID A, BOWERS
JASA $6 B \quad 55 B$ A TEST OF THE MEAN SQUARE ERROR CRITERION FOR RESTRIC TIONS IN LINEAR REGRESSION * CARLOS TORO-VIZCARRONDO, T. D. WALLACE

JASA 6B 573 SIMULTANEOUS ESTIMATION BY PARTIAL TOTALS FOR COM PARTMENTAL MODELS * JOHN J. BEAUCHAMP, RICHARD G CORNELL

JASA 6B 584 SOME EST IMATORS FOR A LINEAR MODEL WITH RANDOM COEFFICIENTS * CLIFFORD HILDRETH, JAMES P, HOUCK

JASA $6 B \quad 596$ IMPROVED ESTIMATORS FOR COEFFICIENTS IN LINEAR REGRESSION * STANLEY L. SCLOVE

JASA 68637 A MODIFIED COMPOUND POISSON PROCESS WITH NORMAL COMPOUNDING * S. JAMES PRESS

JASA 68614 TWO K-SAMPLE SLIPPAGE TESTS * W. J. CONOVER

JASA $6 B \quad 627$ ON A GENERAL SYSTEM OF DISTRIBUTIONS. I. ITS CURVESHAPE CHARACTERISTICS II. THE SAMPLE MEDIAN * IRVING W. BURR, PETER J. CISLAK

JASA 68636 ON A GENERAL SYSTEM OF DISTRI8UTIONS, III. THE SAMPLE RANGE * IRVING W. BURR

JASA 68644 FRACTIONAL REPLICATION OF 2-TO-THE-P FACTORIAL EXPERIMENTS WITH THE FACTORS APPLIED SEQUENT IALLY*R. R. PRAIRIE, W. J. ZIMMER

JASA $6 B \quad 653$ OPTIMAL SAMPLE SIZE IN TWO-ACTION PROBLEMS WHEN THE SAMPLE OBSERVATIONS ARE LOGNORMAL AND THE PRECISION H IS KNOWN * GORDONM. KAUFMAN

JASA 6B 660 ROBUSTNESS OF THE F-TEST TO ERRORS OF BOTH KINDS AND THE CORRELATION BETWEEN THE NUMERATOR AND DENOMINATOR OF THE F-RATIO * THEODORE S , DONALDSON

JASA 6B 677 POSTERIOR DISTRIBUTION OF PERCENTILES. BAYES THEOREM FOR SAMPLING FROM A POPULATION * BRUCE M HILL

JASA 68692 THE FIRST-MEDIAN TEST . A TWO-SIDED VERSION OF THE CONTROL MEDIAN TEST * J. L. GASTWIRTH

JASA $6 B \quad 707$ CERTAIN UNCORRELATED NONPARAMETRIC TEST STATISTICS * MYLES HOLlandER

JASA 6B 715 ON THE EVALUATION OF DISTRIBUTION FUNCTIONS * H. L GRAY, W. R. SCHUCANY

JASA 68 BOI CROSSROAD CHOICES FOR THE FUTURE DEVELOPMENT OF THE FEDERAL STATISTICAL SYSTEM * RAYMOND T. BOWMAN

JASA 68817 SOME PROPERTIES OF SYMMETRIC STABLE DISTRIBUTIONS * EUGENE F, FAMA, RICHARD ROLL

JASA 68837 STATISTICAL INFERENCE IN THE CLASSICAL OCCUPANCY PROBLEM, UNBIASED ESTIMATION OF THE NUMBER OF CLASSES * BERNARD HARRIS

JASA $6 B \quad 84 B$ PARAMETER EST IMATION FOR A MULTIVARIATE EXPONENTIAL DISTRIBUTION * BARRY C. ARNOLD

JASA $68 \quad 853$ SOME TESTS OF HYPOTHESES CONCERNING THE THREE-PARAMETER WEIBULL DISTRIBUTION * LEE J, BAIN, DARREL R. THOMAN

JASA 68861 ESTIMATION OF THE LARGEST OF TWO NORMAL MEANS * SAUL BLUMENTHAL, ARTHUR COHEN

JASA 68 B77 ANALYSIS OF EXTREME-VALUE DATA BY SAMPLE QUANTILES FOR VERY LARGE SAMPLES * KHATABM. HASSINEIN

JASA 6B 889 MAXIMUM-LIKELIHOOD ESTIMATION, FROM DOUBLY CENSORED SAMPLES, OF THE PARAMETERS OF THE FIRST ASYMPTOTIC DISTRIBUTION OF EXTREME VALUES * H. LEON HARTER, ALBERT H. MOORE

JASA 6B 902 AN EMPIRICAL STUDY INTO FACTORS AFFECTING THE F-TEST UNDER PERMUTATION FOR THE RANDOMIZED BLOGK DESIGN FRANK B. BAKER, RAYMOND O. COLLIER

JASA 68912 ACCURACY OF AN APPROXIMATION TO THE POWER OF THE CHISQUARE GOODNESS OF FIT TEST WITH SMALL BUT EQUAL EXPECTED FREQUENCIES * MALGOLM J. SLAKTER

JASA $6 B 919$ KOLMOGOROV-SMIRNOV TESTS OF FIT BASED ON SOME GENERAL BOUNDS * GITTIRO SUZUKI

JASA 68925 THE ESTIMATION OF PROBABILITY DENSITIES AND CUMULATIVES $8 Y$ FOURIER SERIES METHODS * $R$. KRONMAL, $M$ TARTER

JASA 68953 ACCURACY 8ORROWING IN THE ESTIMATION OF THE MEAN BY SHRINKAGE TO AN INTERVAL * JAMESR. THOMPSON

JASA 68964 OPTIMAL ALLOCATION IN STRATIFIED AND MULTISTAGE SAMPLES USING PRIOR INFORMATION * WILLIAM A. ERICSON

JASA 68984 USE OF DOMAIN ESTIMATORS WITH UNEQUAL PRO8A8ILITY IN SAMPLE SURVEYS * JAMESR. CONNER, DELANEE. WELSCH

JASA 68993 A TWO-STATE MARKOV MODEL FOR BEHAVIORAL CHANGE * MARY H. REGIER

JASA 681000 NEGATIVE VARIANCE ESTIMATES AND STATISTICAL DEPENDENCE IN NESTED SAMPLING * RICHARD 8. MCHUGH, PAUL $W$ MIELKE JR

JASA 681004 SERIES REPRESENTATIONS OF THE DOU8LY NONCENTRAL TDISTRIBUTION * MARAKATHA KRISHNAN

JASA 681013 A NOTE ON REPRESENTATIONS OF THE DOU8LY NON-CENTRAL T DISTRIBUTION* W. G. 8ULGREN, D. E. AMOS

JASA 681020 CONFIDENCE 8ANDS IN LINEAR REGRESSION WITH CONSTRAINTS ON THE INDEPENDENT VARIA8LES * MAX HALPERIN, JOANGURIAN 
JASA $6 B 1028$ A NOTE ON CONFIDENCE BANDS FOR A REGRESSION LINE OVER A FINITE RANGE * OLIVE JEAN DUNN

JASA 681034 A NOTE ON LOG-LINEAR REGRESSION * DALE M. HEIEN

JASA 681039 A NOTE ON EST IMATING THE MEAN OF A NORMAL DISTRIBUT ION WITH KNOWN COEFFICIENT OF VARIATION * RASUL A. KHAN

JASA 681042 A NOTE ON LINEAR REGRESSION IN TRIVARIATE DISTRIBUTIONS * G. K. EAGLESON

JASA 681091 THE ANALYSIS OF CROSS-CLASSIFIED DATA, INDEPENDENCE, QUASI-INDEPENDENCE, AND INTERACTIONS IN CONTINGENCY TABLES WITH OR WITHOUT MISSING ENTRIES * LEO A . GOODMAN

JASA 681132 DIVIDEND POLICY. AN EMPIRICAL ANALYSIS * EUGENE F FAMA, HARVEY BABIAK

JASA 681162 MAXIMUM LIKELIHOOD AND BAYESIAN ESTIMATION OF TRANSITION PROBABILITIES. * T. C. LEE, G. G. JUDGE, A. ZELLNER

JASA 681180 SMALL SAMPLE PROPERTIES OF ALTERNATIVE ESTIMATORS OF SEEM INGLY UNRELATED REGRESSIONS * JAN KMENTA, ROY F. GILBERT

JASA 681201 ESTIMATION AND INFERENCE FOR LINEAR MODELS IN WHICH SUBSETS OF THE DEPENDENT VARI ABLE ARE CONSTRAINED * TIMOTHY W. MCGUIRE, JOHN U. FARLEY, ROBERT E. LUCAS JR, L. WINSTONRING

JASA 681214 THE EXACT DISTRI8UTION OF A STRUCTURAL COEFFICIENT ESTIMATOR * DAVIDH. RICHARDSON

JASA $6 B 1227$ ON THE POWER OF THE BLUS PROCEDURE * J. KOERTS, A. P. J . ABRAHAMSE

JASA 681237 EFFICIENCY OF THE SAMPLE MEAN WHEN RESIDUALS FOLLOW A FIRST-ORDER STATIONARY MARKOFF PROCESS * JOHN S. CHIPMAN, KOTESWARA RAO KADIYALA, ALBERT MADANSKY, JOHN W. PRATT

JASA 681247 A NOTE ON THE MEASUREMENT OF COST-QUANTITY RELATIONSHIPS IN THE AIRCRAFT INDUSTRY * A. R. GALLANT

JASA 681253 A LIFE TABLE THAT AGREES WITH THE DATA. II * NATHAN KEYFITZ

JASA 681269 AN OLD APPROACH TO FINITE POPULATION SAMPLING THEORY * RICHARD ROYALL

JASA 681280 SEVERAL METHODS OF RE-DESIGNING AREA SAMPLES UTILIZING PROBABILITIES PROPORTIONAL TO SIZE WHEN THE SIZES CHANGE SIGNIFICANTLY * G. B. GRAY, R. PLATEK

JASA 681298 APPROXIMATELY OPTIMAL STRATIFICATION * R. J. SERFLINC
JASA 6B 1310 THE USE OF A STRATIFICATION VARIABLE IN EST IMATION BY PROPORTIONAL STRATIFIED SAMPLING * CARL-ERIK SARNDAL

JASA 681321 A MODEL FOR OPTIMUM LINKAGE OF RECORDS * BENJAMIN J TEPPING

JASA 681333 ON POOLING MEANS WHEN VARIANCE IS UNKNOWN * CHIEN-PAI HAN, T. A. BANCROFT

JASA 681343 A COMPARATIVE STUDY OF VARIOUS TESTS FOR NORMALITY * S. S. SHAPIRO, M. B. WILK, MRS. H. J. CHEN

JASA 681373 NONPARAMETRIC CONFIDENCE REGIONS FOR SOME MULTIVARIATE LOCATION PROBLEMS * MADAN LAL PURI, PRANAB KUMAR SEN

JASA 6B 1379 ESTIMATES OF THE REGRESSION COEFFICIENT BASED ON KENDALL'S TAU * PRANAB KUMAR SEN

JASA 681390 ORDER STATISTICS FOR DISCRETE POPULATIONS AND FOR GROUPED SAMPLES * H. A. DAVID, R. S. MISHRIKY

JASA 6B 1399 ONDISCRIMINATION USING QUALITATIVE VARIABLES * ETHEL S. GILBERT

JASA 681413 APPROXIMATING THE LOWER BINOMIAL CONFIDENCE LIMIT (CORR. 69669) *T. W. ANDERSON, HERMAN BURSTEIN

JASA $6 B 1416$ A NORMAL APPROXIMATION FOR BINOMIAL, F, BETA, AND OTHER COMMON, RELATED TAIL PROBABILITIES, I * DAVID B. PEIZER, JOHN W. PRATT

JASA 6B 1457 A NORMAL APPROXIMATION FOR BINOMIAL, F, BETA, AND OTHER COMMON. RELATED TAIL PROBABILITIES, II * JOHN W. PRATT

JASA 6B 14B4 STATISTICAL DEPENDENCE BETWEEN SUBCLASS MEANS AND THE NUMBERS OF OBSERVATIONS IN THE SUBCLASSES FOR THE TWO-WAY COMPLETELY-RANDOM CLASSIFICATION * DAVID A. HARVILLE

JASA 681495 CUBICAL AND SPHERICAL ESTIMATION OF MULTIVARIATE PROBABILITY DENSITY * THOMAS A. ELKINS

JASA 681514 ON THE INVERSE GAUSSIAN DISTRIBUTION FUNCTION * JONATHAN SHUSTER

JASA 681517 ESTIMATING FINITE-TIME MAXIMA AND MINIMA OF A STATIONARY GAUSSIAN ORNSTEIN-UHLENBECK PROCESS BY MONTE CARLO SIMULATION * IRVING I, GRINGORTEN

JASA 681522 HOW DEVIANT CAN YOU BE. * PAUL A. SAMUELSON

JASA 6B 1526 CONSTRUCTING AN UNBIASED RANDOM SEQUENCE * PAUL A. SAMUELSON

JOURNAL OF THE AMERICAN STATISTICAL ASSOCIATION VOLUME 64,1969

JASA 69

1 FORECASTING SHORT-TERM ECONOMIC CHANGE * GEOFFREY H MOORE

JASA 6923 A SUBJECTIVE EVALUATION OF BODE'S LAN AND AN 'OBJECTIVE' TEST FOR APPROXIMATE NUMERICAL RATIONALITY * I. J.GOOD

JASA 6950 DISCUSSION OF 'A SUBJECTIVE EVALUATION OF BODE'S LAK AND AN 'OBJECTIVE' TEST FOR APPROXIMATE NUMERICAL RATIONALITY' * H. O. HARTLEY, IRWIN D. J. BROSS, HERBERT A. DAVID, MARVIN ZELEN, ROLF E. BARGMANN, FRANCIS J ANSCOMBE, MILES DAVIS, R. L. ANDERSON

JASA 6967 ANTICIPATIONS AND INVESTMENT BEHAVIOR IN UNITED STATES MANUFACTURING 1947-1960 * JAMES A. STEPHENSON, DALE W. JORGENSON

JASA 6990 ECONOMETRIC EXPLORATION OF INDIAN SAVING BEHAVIOR * R. RAMANATHAN

JASA 69102 WORKING LIFE TABLES FOR MALES IN GHANA 1960 * G. M. K. KPEDEKPO

JASA 69111 SOME STOCHASTIC VERSIONS OF THE MATRIX MODEL FOR POPULATION DYNAMICS * Z. M. SYKES

JASA 69131 PLAY THE WINNER RULE AND THE CONTROLLED CLINICAL TRI AL * MARVIN ZELEN

JASA 69147 THE MULTIPLE SAMPLE UP-AND-DOWN METHOD IN BIOASSAY * BARTHOLOMEW P. HIST

JASA 69163 A SOLUTION TO THE PROBLEM OF LINKING MULTIVARIATE DOCUMENTS * N. S. D'ANDREA DU BOIS

JASA 69175 SOME METHODS OF PROBABILITY NON-REPLACEMENT SAMPLING * RAYMOND J . JESSEN

JASA 69194 CONCEPTS OF INDEPENDENCE FOR PROPORTIONS WITH A A GENERALIZATION OF THE DIRICHLET DISTRIBUTION * JAMES E. MOSIMANN, ROBERT J . CONNOR

JASA 69207 LAMST AND THE HYPOTHESES OF NO THREE FACTOR INTERACTION IN CONTINGENCY TABLES * B, N. NAGNUR

JASA 69216 THE COMPOUND MULTINOMIAL DISTRIBUTION AND BAYESIAN ANALYSIS OF CATERGORICAL DATA FROM FINITE POPULATIONS * A. BRUCE HOADLEY

JASA 69230 NOTE ON THE MULTIVARIATE AND THE GENERALIZED MULTIVARIATE BETA DISTRIBUTIONS * WAI-YUAN TAN

JASA 69242 THE T-RATIO DISTRIBUTION * S. JAMES PRESS

JASA 69253 SMALL-SAMPLE PROPERTIES OF SEVERAL TWO-STAGE REGRESSION METHODS IN THE CONTEXT OF AUTOCORRELATED ERRORS * ZVI GRILICHES, POTLURI RAO
JASA 69273 ON THEIL'S MIXED REGRESSION ESTIMATOR * R A V SWAMY. J. S. MEHTA

JASA 69277 THE EQUILIBRIUM COVARIANCE MATRIX OF DYNAMIC ECONOMETRIC MODELS * JOHN CONLISK

JASA 69 2BO TESTS FOR RANDOMNESS OF DIRECTIONS AGAINST TWO CIRCULAR ALTERNATIVES * MICHAEL A. STEPHENS

JASA 69290 A GENERALIZATION OF THE T-METHOD OF MULTIPLE COMPARISONS * P.K. SEN

JASA 69296 INTERVAL ESTIMATION OF THE LARGEST MEAN OF K NORMAL POPULATIONS WITH KNOWN VARIANCES * K. M. LAL SAXENA. Y. L. TONG

JASA 69300 ASYMPTOTIC JOINT DISTRIBUTION OF LINEAR SYSTEMATIC STATISTICS FROM MULTIVARIATE DISTRIBUTIONS * M. M SIDDIQUI, CALVIN BUTLER

JASA 69306 EXACT THREE, ORDER STATISTIC CONFIDENCE BOUNDS ON RELIABLE LIFE FOR A WEIBULL MODEL WITH PROGRESSIVE CENSORING * NANCY R MANN

JASA 69316 A NEW TEST FOR HETEROSKEDASTICITY * H. GLEJSER

JASA 69324 SIMULTANEOUS CONFIDENCE INTERVALS FOR VARIANCES * DONALD R. JENSEN, M. Q. JONES

JASA 69333 AN INEQUALITY FOR A CLASS OF BIVARIATE CHI-SQUARE DISTRIBUTIONS * DONALDR. JENSEN

JASA 69337 MISSING OBSERVATIONS IN MULTIVARIATE STATIS'TICS, III * ROBERT M. ELASHOFF. A. A. AFIFI

JASA 69359 MISSING OBSERVATIONS IN MULTIVARIATE STATISTICS, IV * ROBERT M. ELASHOFF, A. A. AFIFI

JASA 69366 CORRELATION COEFFICIENTS MEASURED ON THE SAME INDIVIDUALS * OLIVE JEAN DUNN, VIRGINIA CLARK

JASA 69378 SHORTER CONFIDENCE INTERVALS USING PRIOR OBSERVATIONS * W. J. ZIMMER, JOHN DEELY

JASA 69387 ON THE KOLMOGOROV-SMIRNOV TEST FOR THE EXPONENTIAL DISTRIBUTION WITH MEAN UNKNOWN * H. W. LILLIEFORS

JASA 69415 VALIDATION OF CONSUMER FINANCIAL CHARACTERISTICS, COMMON STOCK * ROBERT FERBER, JOHN FORSYTHE, HAROLD W. GUTHRIE, E. SCOTT MAYNES

JASA 69433 AGE PATTERNS OF MORTALITY OF AMERICAN NEGROES. 1900O2 T0 1959-61 * MARVIN ZELNIK

JASA 69452 THE ACCURACY OF INTERNATIONAL TRADE DATA. THE CASE OF SOUTHEAST ASIAN COUNTRIES * SEIJI NAYA, THEODORE MORGAN 
JASA 69468 EXAMPLES OF LIKELIHOODS AND COMPARISON WITH POINT ESTIMATES AND LARGE SAMPLE APPROXIMATIONS * D. A SPROTT, JOHN D. KALBFLEISCH

JASA 69 4B5 SOME ASPECTS OF THE STATISTICAL ANALYSIS OF 'SPLIT PLOT' EXPERIMENTS IN COMPLETELY RANDOMIZED LAYOUTS * GARY G. KOCH

JASA 69506 INTEGER PROGRAMMING AND THE THEORY OF GROUPING * HRISHI KESHD . VINOD

JASA 69520 THE UNRELATED QUESTION RANDOMIZED RESPONSE MODEL, THEORETICAL FRAMEWORK * BERNARD G. GREENBERG ABDEL-LATIF A. ABUL-ELA, WALT R. SIMMONS, DANIEL G . HORVITZ

JASA 69540 AN EMPIRICAL STUDY OF THE STABILITIES OF ESTIMATORS AND VARIANCE ESTIMATORS IN UNEQUAL PROBABILITY SAMPLING OF TWO UNITS PER STRATUM* J. N. K. RAO, D. L BAYLESS

JASA 69560 PLANNING SOME TWO-FACTOR COMPARATIVE SURVEYS * GORDON BOOTH, J. SEDRANSK

JASA 69574 COMPARISON OF FOUR RATIO-TYPE ESTIMATES UNDER A MODEL * PODURI S. R. S. RAO

JASA 69 5BI SPECTRAL PROPERTIES OF NON-STATIONARY SYSTEMS OF LINEAR STOCHAST IC DIFFERENCE EQUATIONS * GREGORY C CHOW. RICHARD E, LEVITAN

JASA 69591 AN APPROXIMATION TO THE WILCOXON-MANN-WHITNEY DIS. TRIBUTION* N, BUCKLE, C. H. KRAFT, C. VAN EEDEN

JASA 69600 A RECURRENCE RELATION FOR DISTRIBUTION FUNCTIONS OF ORDER STATISTICS FROM BIVARIATE DISTRIBUTIONS * CHANDAN KUMAR MUSTAFI

JASA 69602 DISCRETE DISTRIBUTION ESTIMATORS FROM THE RECURRENCE EQUATION FOR PROBABILITIES * C. A. MCGILCHRIST

JASA 69610 TWO-SIDED TOLERANCE LIMITS FOR NORMAL POPULATIONS. SOME IMPROVEMENTS * W. G. HOWE

JASA 69621 LIFE TESTING AND RELIABILITY ESTIMATION FOR THE TWO PARAMETER EXPONENTIAL DISTRIBUTION * S. D. VARDE

JASA 69632 A TABLE FOR ESTIMATING THE MEAN OF A LOGNORMAL DISTRIBUTION * HANSPETER THONI

JASA 69637 CRITICAL VALUES FOR BIVARIATE STUDENT T-TEST * F F. STEFFENS

JASA 69647 NEW CHEBYSHEV POLYNOMIAL APPROXIMATIONS TO MILLS RATIO * PHILIP RABINOWITZ

JASA 69655 THE DISTRIBUTION OF THE LOGARITHM OF THE SUM OF TWO LOG-NORMAL VARIATES * J. I. NAUS

JASA 69660 CONFIDENCE REGIONS FOR VARIANCE RATIOS OF RANDOM MODELS * L, D. BROEMELINC

JASA 69665 THE COMPUTATION OF THE UNRESTRICTED AOQL WHEN DEFECTIVE MATERIAL IS REMOVED BUT NOT REPLACED * ALLEN C. ENDRES

JASA 69739 PROBLEMS OF STATISTICAL INFERENCE IN HEALTH WITH SPECIAL REFERENCE TO THE CIGARETTE SMOKING AND LUNG CANCER CONTROVERSY * B , G. GREENBERG

JASA 69759 AN ADAPTIVE PROCEDURE FOR SEQUENTIAL CLINICAL TRIALS * JEROME CORNFIELD, MAX HALPERIN. SAMUEL W. GREENHOUSE

JASA 69771 THE MEASUREMENT OF PRICE CHANGES IN CONSTRUCTION * JOHN C. MUSGRAVE

JASA 697 7B7 GROSS STATE PRODUCT AND AN ECONOMETRIC MODEL OF A STATE* $*$, L. L 'ESPERANCE, G. NESTEL, D. FROMM

JASA $6980 B$ USING FACTOR ANALYSIS TO ESTIMATE PARAMETERS * JAGDISH N. SHETH

JASA 69823 THE EXCEEDANCE TEST FOR TRUNCATION OF A SUPPLIER'S DATA * J.J. DEELY, D. E. AMOS, G. P. STECK

JASA 69 B30 ESTIMATION IN MULTI-STAGE SURVEYS * ALASTAIR SCOTT T. M. F. SMITH

JASA 69 B4I VARIANCE ESTIMATION WITH ONE UNIT PER STRATUM * H. 0 HARTLEY, J. N. K. RAO, GRACE KIEFER

JASA 69852 THE EFFECT OF NON-SAMPLING ERRORS ON MEASURES OF ASSOCIATION IN 2-BY-2 CONTINGENCY TABLES * GARY G $\mathrm{KOCH}$

JASA 69 B64 MORE RESULTS ON PRODUCT MOMENTS FROM A FINITE UNIVERSE * S. N. NATH

JASA 69 B70 TABLES OF CRITICAL VALUES OF SOME RENYI TYPE STATISTICS FOR FINITE SAMPLE SIZES * Z, W. BIRNBAUM B. P. LIENTZ

JASA 69 B7B FACTORS FOR CALCULATING TWO-SIDED PREDICTION INTERVALS FOR SAMPLES FROM A NORMAL DISTRIBUTION * GERALD H. HAHN

JASA 69 B89 ON THE CLASSICAL RUIN PROBLEMS * LAJOSTAKACS

JASA 69907 A NOTE ON HOEFFDING'S INEQUALITY * 0 . KRAFFT, N SCHMITZ

JASA 69913 AITKEN ESTIMATORS AS A TOOL IN ALLOCATING PREDETERMINED AGGREGATES * ALAN POWELL

JASA 69923 THE EXACT SAMPLING DISTRIBUTION OF ORDINARY LEAST SQUARES AND TWO-STAGE LEAST SQUARES ESTIMATORS * TAKAMITSU SAWA

JASA 69 93B A COMPARISON BETWEEN THE POWER OF THE DURBIN-WATSON TEST AND THE POWER OF THE BLUS TEST * A. P. J. ABRAHAMSE, J. KOERTS

JASA 69949 A NOTE ON BLUS ESTIMATION * H. NEUDECKER
JASA 69953 SOME THEOREMS ON MATRIX DIFFERENTIATION WITH SPECIAL REFERENCE TO KRONECKER MATRIX PRODUCTS * H. NEUDECKER

JASA 69964 ON A RESTRICTED LEAST SQUARES EST IMATOR *M. ATIQULLAH JASA 69969 A USEFUL LEMMA FOR PROVING THE EQUALITY OF TWO MATRICES WITH APPLICATIONS TO LEAST SQUARES TYPE QUADRATIC FORMS * GARY G. KOCH

JASA 69971 THE MEDIAN SIGNIFICANCE LEVEL AND OTHER SMALL SAMPLE MEASURES OF TEST EFFICIENCY * BRIAN L. JOINER

JASA 69986 THE EQUAL PROBABILITY TEST AND ITS APPLICATIONS TO SOME SIMULTANEOUS INFERENCE PROBLEMS * UMESH D. NAIK

JASA 69999 TESTING AND ESTIMATING OF SCALE PAREMENTERS * GALEN R. SHORACK

JASA 691014 ESTIMATORS OF VARIANCE COMPONENTS IN THE BALANCED INCOMPLETE BLOCK * LEONE Y. LOW

JASA 691031 DISCRIMINATION INTERVALS FOR PERCENTILES IN REGRESSION * ROBERT G. EASTERLING

JASA 691042 COMBINATIONS OF UNBIASED ESTIMATORS OF THE MEAN WHICH CONSIDER INEQUALITY OF UNKNOWN VARIANCES * J.A. MEHTA, JOHN GURLAND

JASA 691056 ON NON-REGULAR ESTIMATION, I. VARIANCE BOUNDS FOR ESTIMATORS OF LOCATION PARAMETERS * W. R. BLISCHKE, A. J. TRULOVE, P. B, MUNDLE

JASA 691073 SCORING RULES AND THE EVALUATION OF PROBABILITY ASSESSORS * ROBERT L. WINKLER

JASA 691079 CURVE FITTING BY SEGMENTED STRAIGHT LINES * RICHARD BELLMAN, ROBERT ROTH

JASA 69 NO. 4 WASHINGTON STATISTICAL SOCIETY MEMORIAL MEETING FOR WILLIAM N. HURWITZ. PROFESSOR WILLIAM N. HURWITZ ** MORRIS H. HANSEN

JASA 69 NO.4 WASHINGTON STATISTICAL SOCIETY MEMORIAL MEETING FOR WILLIAM N. HURWITZ. SOME BASIC PRINCIPLES OF STATIST ICAL SURVEYS * JOSEPH F. DALY

JASA 69 NO. 4 WASHINGTON STATISTICAL SOCIETY MEMORIAL MEETING FOR WILLIAM $\mathrm{N}$. HURWITZ. THE DEVELOPMENT OF HOUSEHOLD SAMPLE SURVEYS * MAX A. BERSHAD, BENJAMIN J. TEPPING

JASA 69 NO. 4 WASHINGTON STATISTICAL SOCIETY MEMORIAL MEETING FOR WILLIAM N. HURWITZ. CHANGES IN CENSUS METHODS * JOSEPH WAKSBERG, LEON PRITZKER

JASA 69 NO 4 WASHINGTON STATISTICAL SOCIETY MEMORIAL MEETING FOR WILLIAM N. HURWITZ. ON WILLIAM HURWITZ * W. EDWARDS DEMING

JASA 69 NO. 4 WASHINGTON STATISTICAL SOCIETY MEMORIAL MEETING FOR WILLIAMN NURWITZ COMMENTS* LESTER R. FRANKEL

JASA 69 NO. 4 STATISTICAL PROBLEMS IN SCIENCE. THE SYMMETRIC TEST OF A COMPLETE HYPOTHESIS * JERZY NEYMAN

JASA 69 NO 4 REGRESSION ON A RANDOM FIELD * AYALA COHEN, RICHARD H. JONES

JASA 69 NO.4 A THEORY FOR RECORD LINKAGE * IVAN P. FELLEGI, ALAN B SUNTER

JASA 69 NO. 4 A STATISTICAL MODEL OF BOOK USE AND ITS APPLICATION TO THE BOOK STORAGE PROBLEM * A. K. JAIN, F. F. LEIMKUHLER, V. L . ANDERSON

JASA 69 NO. 4 THE FORECASTING ACCURACY OF CONSUMER ATTITUDE DATA * S. W. BURCH, H. O. STEKLER

JASA 69 NO. 4 HIGHER FEMALE THAN MALE MORTALITY IN SOME COUNTRIES OF SOUTH ASIA, ADIGEST * $M$. A. EL-BADRY

JASA 69 NO 4 RELATIVE COSTS OF COMPUTERIZED ERROR INSPECTION PLANS * Robert t. o'reaGan

JASA 69 NO. 4 INSPECTION AND CORRECTION ERROR IN DATA PROCESSING * GEORGE MINTON

JASA 69 NO. 4 A NOTE ON 'LEARNING CURVES' * EUGENE $W$. PIKE

JASA 69 NO.4 STUDENT'S T-TEST UNDER SYMMETRY CONDITIONS * BRADLEY EFRON

JASA 69 NO. 4 USING SUBSAMPLE VALUES AS TYPICAL VALUES * J. A. HARTIGAN

JASA 69 NO 4 SOME REMARKS ON SCHEFFE'S SOLUTION TO THE BEHRENSFISHER PROBLEM * MORRIS L. EATON

JASA 69 NO. 4 SYMMETRY AND MARGINAL HOMOGENEITY OF AN R-BY-R CONTINGENCY TABLE * C, T. IRELAND, H, H, KU, S. KULLBACK

JASA 69 NO 4 BAYES SEQUENTIAL DESIGNS OF FIXED SIZE SAMPLES FROM FINITE POPULATIONS * SHELLEY ZACKS

JASA 69 NO. 4 A NOTE ON THE 'NECESSARY BEST ESTIMATOR' * JACKL. OGUS JASA 69 NO 4 PARAMETRIC AUGMENTATIONS AND ERROR STRUCTURES UNDER WHICH CERTAIN SIMPLE LEAST SQUARES AND ANALYSIS OF VARIANCE PROCEDURES ARE ALSO BEST * GEORGE ZYSKIND

JASA 69 NO. 4 VARIANCE OF WEIGHTED REGRESSION ESTIMATORS WHEN SAMPLING ERRORS ARE INDEPENDENT AND HETEROSCEDASTIC * T. R. BEMENT, J. S. WILLIAMS

JASA 69 NO.4 MEAN SQUARE EFFICIENCY OF ESTIMATORS OF VARIANCE COMPONENTS * J.H. KLOTZ, R. C. MILTON, S. ZACKS

JASA 69 NO. 4 APPLICATION OF AN ESTIMATOR OF HIGH EFFICIENCY IN BIVARIATE EXTREME VALUE THEORY * JOHN C. ASHLOCK, EDWARD C , POSNER, EUGENE R, RODEMICH, SANDRA LURIE

JASA 69 NO. 4 A COMPOUNDED MULTIPLE RUNS DISTRIBUTION * JAMES E. DUNN

JASA 69 NO. 4 FIRST AND SECOND MOMENTS OF THE RANDOMIZATION TEST IN TWO ASSOCIATE PBIB DESIGNS * ROBERT CLEROUX 
JASA 69 NO 4 ERRORS IN THE ESTIMATION OF NET MICRATION IN THE STUDIES OF INTERNAL MICRATION* M. SIVAMURTHY

JASA 69 NO. 4 ON THE EXACT COVARIANCE OF PRODUCTS OF RANDOM VARIABLES * GEORGE W. BOHRNSTEDT, ARTHUR S. COLDBERCER

JASA 69 NO. 4 THE SAMPLINC DISTRIBUTION OF THE RANCE FROM DISCRETE UNIFORM FINITE POPULATIONS AND A RANCE TEST FOR HOMOCENEITY * ROBERT J . CONNOR

JASA 69 NO. 4 ESTIMATION OF FINITE MIXTURES OF DISTRIBUTIONS FROM THE EXPONENT IAL FAMILY * VICTOR HASSELBLAD

JASA 69 NO. 4 SOME CRITERIA FOR ACINC * MAURICE C. BRYSON, M. M. SIDDIQUI

JASA 69 NO. 4 A BAYES RULE FOR THE SYMMETRIC MULTIPLE COMPARISONS PROBLEM * DAVID B. DUNCAN. RAY A. WALLER

JASA 69 NO. 4 TWO-STACE NORMAL SAMPLINC IN TWO-ACTION PROBLEMS WITH LINEAR ECONOMICS * ARTHUR S. SCHLEIFER JR

JASA 69 NO, 4 A NOTE ON A DOUBLE SAMPLE TEST * JOHNE. HEWETT, WILLIAM C. BULCREN, D. E. AMOS

JASA 69 NO. 4 A CLASS OF SEQUENT IAL TESTS FOR AN EXPONENTIAL PARAMETER * D. C. HOEL, M. MAZUMDAR

JASA 69 NO. 4 MOMENTS OF THE DISTRIBUTION OF SAMPLE SIZE IN A SPRT * B. K. $\mathrm{CHOSH}$
JASA 69 NO 4 MULTIVARIATE MAXIMA AND MINIMA WITH MATRIX DERIVATIVES * DERRICK S. TRACY, PAUL S. DWYER

JASA 69 NO.4 A MULTIVARIATE EXTENSION OF FRIEDMAN'S CHI-SQUARESUB-R-TEST * THOMAS M. CERIC

JASA 69 NO. 4 MISSINC OBSERVATIONS IN MULTIVARIATE REGRESSION, EFFICIENCY OF A FIRST ORDER METHOD * H. H. KELEJIAN

JASA 69 NO. 4 BOUNDS AND APPROXIMATIONS FOR THE MOMENTS OF ORDER STATISTICS * PRAKASH C. JOSHI

JASA 69 NO. 4 ON THE EXACT AND APPROXIMATE SAMPLINC DISTRIBUTION OF THE TWO SAMPLE KOLMOCOROV-SMIRNOV CRITERION D-SUBMN, M LESS THAN OR EQUAL TON* P. J. KIM

JASA 69 NO. 4 SOME NUMERICAL COMPARISONS OF SEVERAL APPROXIMATIONS TO THE BINOMIAL DISTRIBUTION * FRIEDRICH CEBHARDT

JASA 69 NO. 4 PERCENTACE POINTS OF A TEST FOR CLUSTERS * L. ENGELMAN, J. A. HART ICAN

JASA 69 NO. 4 TABLES FOR THE MEAN SQUARE ERROR TEST FOR EXACT LINEAR RESTRICTIONS IN RECRESSION * T. D. WALLACE, C. E. TORO-VIZCARRONDO

JASA 69 NO. 4 A NOMOCRAM FOR THE 'STUDENT'*FISHER T TEST * WILLIAM C. BOYD 
1 DISTRIBUTION-FREE TESTS IN TIME-SERIES BASED ON THE BREAKING OF RECORDS (WITH DISCUSSION) * F. G FOSTER, A. STUART

JRSSB54 23 A POOR MAN'S MONTE CARLO (WITH DISCUSSION) * J.M. HAMMERSLEY, K.W. MORTON

JRSSB54 39 THE APPLICATION OF AUTOMATIC COMPUTERS TO SAMPLING EXPERIMENTS (WITH DISCUSSION) * K. D. TOCHER

JRSSB54 76 TRANSPOSED BRANCHING PROCESSES * J. M. HAMMERSLEY, K W. MORTON

JRSSB54 80 ON QUEUEING PROCESSES WITH BULK SERVICE * N. T. J. BAILEY

JRSSB54 88 THE DISTRIBUTION OF HETEROGENEITY UPON INBREEDING * J. H. BENNETT

JRSSB54 100 THE FACTORIAL ANALYSIS OF CROP PRODUCTIVITY * CHARLOTTE BANKS

JRSSB54 112 SOME EXPERIMENTS ON THE PREDICTION OF SUNSPOT NUMBERS * P. A. P. MORAN

JRSSB54 11B GRADING WITH A GAUGE SUBJECT TO RANDOM OUTPUT FLUCTUATIONS * L. MANDEL

JRSSB54 131 CONTROL CHARTS FOR THE MEAN OF A NORMAL POPULATION * E S. PAGE

JRSSB54 136 AN IMPROVEMENT TO WALD'S APPROXIMATION FOR SOME PROPERTIES OF SEQUENTIAL TESTS* E. S. PAGE

JKSSB54 140 THE ERRORS OF LATTICE SAMPLING * H. O. PATTERSON

JRSSB54 151 SAMPLING INSPECTION AND STATISTICAL DECISIONS (WITH DISCUSSION) * G. A. BARNARD

JRSSB54 175 SOME PROBLEMS IN INTERVAL ESTIMATION (WITH DISCUSSION) * E. C. FIELLER
JRSSB54 186 LIMITS FOR THE RATIO OF MEANS (WITH DISCUSSION) * MONICA A. CREASY

JRSSB54 195 CONFIDENCE INTERVALS FOR PARAMETERS IN MARKOV AUTOREGRESSIVE SCHEMES (WITH DISCUSSION) * S. T. DAVID

JRSSB54 223 PROBLEMS OF SAMPLE ALLOCATION AND ESTIMATION IN AN AGRICULTURAL SURVEY ${ }^{*}$ B. M. CHURCH

JRSSB54 236 A METHOD OF SAMPLING WITH PROBABILITY EXACTLY PROPORTIONAL TOSIZE* P. M. GRUNDY

JRSSB54 239 A SIMPLE PRESENTATION OF OPT IMUM SAMPLING RESULTS * A STUART

JRSSB54 242 THE ANALYSIS OF A FACTORIAL EXPERIMENT (WITH CONFOUNDING) ON AN ELECTRONIC CALCULATOR * J , G. ROWELL

JRSSB54 247 TRACES AND CUMULANTS OF QUADRATIC FORMS IN NORMAL VARIABLES * H. O. LANCASTER

JRSSB54 255 A FURTHER APPROXIMATION TO THE DISTRIBUTION OF WILCOXON'S STATIST IC IN THE GENERAL CASE * R. M. SUNDRUM

JRSSB54 261 TESTING THE APPROXIMATE VALIDITY OF STATISTICAL HYPOTHESES * J. L. HODGES JR., E. L. LEHMANN

JRSSB54 269 ON THE CUMULATIVE EFFECT OF CHANCE DEVIATIONS * F BERZ

JRSSB54 285 A TABLE FOR PREDICTING THE PRODUCTION FROM A GROUP OF MACHINES UNDER THE CARE OF ONE OPERATIVE * D. R. COX

JRSSB54 288 A CONTINUOUS TIME TREATMENT OF A SIMPLE QUEUE USING GENERATING FUNCTIONS * N.T. J.BAILEY

JRSSB54 292 A REVISED TEST FOR SYSTEMATIC OSCILLATION * J. JOHN STON

JRSSB54 296 A NOTE ON THE MULTIPLYING FACTORS FOR VARIOUS CHISQUARE APPROXIMATIONS * M. S. BARTLETT

JOURNAL OF THE ROYAL STATISTICAL SOCIETY, SERIES B VOLUME 17, 1955

JRSSB55 I PERMUTATION THEORY IN THE DERIVATION OF ROBUST CRITERIA AND THE STUDY OF DEPARTURES FROM ASSUMPTION (WITH DISCUSSION) * G. E. P. BOX, S. L. ANDERSEN

JRSSB55 35 SOME PROBLEMS IN THE STATISTICAL ANALYSIS OF EPIDEMIC DATA (WITHDISCUSSION) * NORMAN T. J. BAILEY

JRSSB55 69 STATISTICAL METHODS AND SCIENTIFIC INDUCTION * SIR RONALD FISHER

JRSSB55 79 PIVOTAL QUANTITIES FOR WISHART'S AND RELATED DISTRIBUTIONS. AND A PARADOX IN FIDUCIAL THEORY * J,G. MAULDON

JRSSB55 86 CONFIDENCE INTERVALS FOR THE PARAMETER OF A DISTRIBUTION ADMITTING A SUFFICIENT STATISTIC WHEN THE RANGE DEPENDS ON THE PARAMETER * V. S . HUZURBAZAR

JRSSB55 91 LEAST SQUARES REGRESSION ANALYSIS FOR TREND-REDUCED TIME SERIES * G. H. JOWETT

JRSSB55 105 A NUMERICAL INVEST IGATION OF LEAST SQUARES REGRESSION INVOLVING TREND-REDUCED MARKOFF SERIES * J F. SCOTT, V. J. SMALL

JRSSB55 115 A SAMPLING EXPERIMENT ON THE POWERS OF THE RECORDS TESTS FOR TREND IN A TIME SERIES * F, G FOSTER, D TEICHROEW

JRSSB55 122 MOMENTS OF NEGATIVE ORDER AND RATIO-STATISTICS * H. A DAVID

JRSSB55 124 A RECTIFYING INSPECTION PLAN * ZIVIAS, WURTELE

JRSSB55 129 SOME STATISTICAL METHODS CONNECTED WITH SERIES OF EVENTS (WITHDISCUSSION) *D.R. COX
JRSSB55 165 AN OUTLINE OF LINEAR PROGRAMMING AN OUTLINE OF LINEAR PROGRAMMING (WITHDISCUSSION) * S. VAJDA

JRSSB55 173 ON MINIMIZING A CONVEX FUNCTION SUBJECT TO LINEAR INEQUALITIES (WITHDISCUSSION) * E. M. L. BEALE

JRSSB55 185 A CONTRIBUTION TO THE 'TRAVELLING-SAL ESMAN' PROBLEM (WITHDISCUSSION)* G. MORTON, A. H. LAND

JRSSB55 204 STATISTICAL CONCEPTS IN THEIR RELATION TO REALITY * E S. PEARSON

JRSSB55 20B THE COMPARISON OF MEANS OF SETS OF OBSERVATIONS FROM SECTIONS OF INDEPENDENT STOCHASTIC SERIES * G. H JOWETT

JRSSB55 228 A NOTE ON THE PERIODOGRAM OF THE BEVERIDGE WHEAT PRICE INDEX* J. C. GOWER

JRSSB55 235 SOME DISTRIBUTION AND MOMENT FORMULAE FOR THE MARKOV CHAIN * P. WHITTLE

JRSSB55 243 SOME APPLICATIONS OF ZERO-ONE PROCESSES * Z. A. LOMNICKI, S. K. ZAREMBA

JRSSB55 256 WAITING TIME IN BULK SERVICE QUEUES * F. DOWNTON

JRSSB55 262 A NOTE ON EQUALISING THE MEAN WAITING TIMES OF SUCCES SIVE CUSTOMERS IN A FINITE QUEUE * NORMAN T. J BAILEY

JRSSB55 264 ON THE WEIGHTED COMBINATION OF SIGNIFICANCE TESTS * I J. GOOD

JRSSB55 266 A SIGNIFICANCE TEST FOR THE DIFFERENCE IN EFFICIENCY BETWEEN TWO PREDICTORS * M , J R R HEALY

JRSSB55 269 A UNIFIED THEORY OF SAMPLING FROM FINITE POPULATIONS * V. P. GODAMBE

JOURNAL OF THE ROYAL STATISTICAL SOCIETY, SERIES B VOLUME 18, 1956

JRSSB56 1 SOME TESTS OF SIGNIFICANCE WITH ORDERED VARIABLES * F N. DAVID, N, L. JOHNSON

JRSSB56 32 ECONOMIC CHOICE OF THE AMOUNT OF EXPERIMENTATION * P. M. GRUNDY, M. J.R. HEALY, D. H. REES

JRSSB56 56 ON A TEST OF SIGNIFICANCE IN PEARSON'S BIOMETRIKA TA BLES (NO 11) * SIR RONALD FISHER

JRSSB56 61 A TEST OF SIGNIFICANCE FOR AN UNIDENTIFIABLE RELATION * P. A. P. MORAN

JRSSB56 65 CONFIDENCE LIMITS FOR THE GRADIENT IN THE LINEAR FUNCTIONAL RELATIONSHIP * MONICA A CREASY

JRSSB56 70 ALGEBRAIC THEORY OF THE COMPUT ING ROUTINE FOR TESTS OF SIGNIFICANCE ON THE DIMENSIONALITY OF NORMAL MULTIVARIATE SYSTEMS* F, E. BINET, G. S. WATSON

JRSSB56 79 SOME NOTES ON ORDERED RANDOM INTERVALS * D. E. BARTON F. N. DAVID

JRSSB56 95 A SEQUENTIAL TEST FOR RANDOMNESS OF INTERVALS * D. J BARTHOLOMEW

JRSSB56 104 PARTITIONS IN MORE THAN ONE DIMENSION * J. H. BENNETT

JRSSB56 113 ON THE ESTIMATION OF SMALL FREQUENCIES IN CONTINGENCY TABLES * I , J. GOOD

JRSSB56 125 AN ELEMENTARY METHOD OF SOLUTION OF THE QUEUEING PROBLEM WITH A SINGLE SERVER AND CONSTANT PARAMETERS * D. G. CHAMPERNOWNE
JRSSB56 129 RANDOM QUEUEING PROCESSES WITH PHASE-TYPE SERVICE * R. R. P. JACKSON

JRSSB56 133 THE WITHIN-ANIMAL BIOASSAY WITH QUANTAL RESPONSES * P. J. CLARINGBOLD

JRSSB56 139 GENERALIZATIONS OF TCHEBYCHEFF'S INEQUALITIES (WITH DISCUSSION) * C. L. MALLOWS

JRSSB56 177 SOME STATIST ICAL PROBLEMS IN EXPERIMENTAL PSYCHOLOGY (WITHDISCUSSION) * VIOLET R. CANE

JRSSB56 202 GENERALIZED HYPERGEOMETRIC DISTRIBUTIONS * C. D KEMP, A. W. KEMP

JRSSB56 212 NEW TABLES OF BEHREN'S TEST OF SIGNIFICANCE * R, A FISHER, M. J.R. HEALY

JRSSB56 217 FUDUCIAL DISTRIBUTIONS AND PRIOR DISTRIBUTIONS, AN EXAMPLE IN WHICH THE FORMER CANNOT BE ASSOCIATED WITH THE LATTER * P. M. GRUNDY

JRSSB56 222 SOME METHODS OF ESTIMATING THE PARAMETERS OF DISCRETE HETEROGENEOUS POPULATIONS * JOHNE FREUND

JRSSB56 227 THE ASYMPTOTIC POWERS OF CERTAIN TESTS BASED ON MULTIPLE CORRELATIONS * E. J. HANNAN

JRSSB56 234 TESTS FOR RANDOMNESS IN A SERIES OF EVENTS WHEN THE ALTERNATIVE IS A TREND * D. J . BARTHOLOMEW

JRSSB56 240 REGRESSION ANALYSIS OF RELATIONSHIPS BETWEEN AUTOCORRELATED TIME SERIES * J WISE 
257 EXPECTED ARC LENCTH OF A CAUSSIAN PROCESS ON A FINITE INTERVAL * IRWIN MILLER, JOHN E. FREUND

259 ANALYSIS OF DISPERSION WITH INCOMPLETE OBSERVATIONS ON ONE OF THE CHARACTERS * C. RADHAKRISHNA RAO

265 ON LIMITINC DISTRIBUTIONS ARISINC IN BULK SERVICE QUEUES * F. DOWNTON

275 SOME EQUILIBRIUM RESULTS FOR THE QUEUEINC PROCESS ESUB-K-M-1*R.R.P. JACKSON, D. G. NICKOLS
JRSSB56 280 ON MACHINE INTERFERENCE * P. NAOR

JRSSB56 288 NOTE ON AN ARTICLE BY SIR RONALD FISHER * JERZY NEYMAN JRSSB56 295 COMMENT ON SIR RONALD FISHER'S PAPER, 'ON A TEST OF SICNIFICANCE IN PEARSON'S BIOMETRIKA TABLES (NO. 11)'* M. S. BARTLETT

JRSSB56 297 NOTE ON SOME CRTICISMS MADE BY SIR RONALD FISHER * B. L WELCH

JOURNAL OF THE ROYAL STATISTICAL SOCIETY, SERIES B VOLUME 19, 1957

JRSSB57 I THE SPECTRAL ANALYSIS OF TIME SERIES (WITH DISCUSSION $*$ * C.M. JENKINS, M. B. PRIESTLEY

JRSSB57 13 ON ESTIMATING THE SPECTRAL DENSITY FUNCTION OF A STOCHASTIC PROCESS (WITH DISCUSSION) * Z. A. LOMNICKI, S. K. ZAREMBA

JRSSB57 3B CURVE AND PERIODOCRAM SMOOTHINC (WITH DISCUSSION) * P. WHITTLE

JRSSB57 64 DISTRIBUTIONS ASSOCIATED WITH RANDOM WALK AND RECURRENT EVENTS (WITH DISCUSSION) * J. C . SKELLAM, L. R. SHENTON

JRSSB57 119 A COMPARISON OF TWO SORTS OF TEST FOR A CHANCE OF LOCATION APPL ICABLE TO TRUNCATED DATA * D. E. BARTON

JRSSB57 125 CONFIRMINC STATISTICAL HYPOTHESES * M. C. BULMER

JRSSB57 133 SEQUENTIAL CONFIDENCE INTERVALS FOR THE MEAN OF A NORMAL POPULATION WITH UNKNOWN VARIANCE * W. D. RAY

JRSSB57 144 JOINT ASYMPTOTIC DISTRIBUTION OF THE MEDIAN AND A USTATISTIC * B. V. SUKHATME

JRSSB57 149 THE EFFICIENCY OF THE RECORDS TEST FOR TREND IN NORMAL RECRESSION * A. STUART

JRSSB57 154 SOME EXPER IMENTAL DESIGNS OF USE IN CHANGING FROM ONE SET OF TREATMENTS TO ANOTHER, PART 1 * G. H. FREEMAN

JRSSB57 163 SOME EXPERIMENTAL DESIGNS OF USE IN CHANCING FROM ONE SET OF TREATMENTS TO ANOTHER, PART 2, EXISTENCE OF THE DESIGNS * G. H. FREEMAN

JRSSB57 166 THE EFFICIENCY OF N MACHINES UNI-DIRECTIONALLY PATROLLED BY ONE OPERATOR WHEN WALKTNG TIME AND REPAIR TIMES ARE CONSTANTS * C. MACK, T. MURPHY, N. L. WEBB

JRSSB57 173 THE EFFICIENCY OF $\mathrm{N}$ MACHINES UNI-DIRECTIONALLY PATROLLED BY ONE OPERATOR WHEN WALKING TIME IS CONSTANT AND REPAIR T IMES ARE VARIABLE * C. MACK
JRSSB57 179 COMMENT ON THE NOTES BY NEYMAN, BARTLETT AND WELCH IN THIS JOURNAL (VOL, 18, NO, 2, 1956) * SIR RONALD FISHER

JRSSB57 IBI PROBLEMS IN THE PROBABILITY THEORY OF STORACE SYSTEMS (WITH DISCUSSION) * J, GANI

JRSSB57 207 SOME PROBLEMS IN THE THEORY OF DAMS (WITH DISCUSSION) * D. C. KENDALL

JRSSB57 234 ROUTINE ANALYSIS OF REPLICATED EXPERIMENTS ON AN ELECTRONIC COMPUTER (WITHDISCUSSION) * F. YATES, M J.R. HEALY, S. LIPTON

JRSSB57 255 A MINIMAX PROCEDURE FOR CHOOSINC BETWEEN TWO POPULATIONS USINC SEQUENT IAL SAMPLINC * R. J . MAURICE

JRSSB57 262 SUFFICIENT STATISTICS, SIMILAR RECIONS AND DISTRIBUTION-FREE TESTS * C. S. WATSON

JRSSB57 268 ON THE USE OF THE NORMAL APPROXIMATION IN THE TREATMENT OF STOCHASTIC PROCESSES * $P$. WHITTLE

JRSSB57 282 THE VARIANCE OF THE MEAN OF A STATIONARY PROCESS * E. J HANNAN

JRSSB57 2B6 METHODS OF CONSTRUCTION AND ANALYSIS OF SERIALLY BALANCED SEQUENCES * $M$. R. SAMPFORD

JRSSB57 305 THE MODIFIED LATIN SQUARE * B. ROJAS, R. F. WHITE

JRSSB57 318 ANALYSIS OF VARIANCE AS AN ALTERNATIVE TO FACTOR ANAL YSIS * M. A. CREASY

JRSSB57 326 SOME FURTHER RESULTS IN THE NON-EQUILIBRIUM THEORY OF A SIMPLE QUEUE * N. T. J. BAILEY

JRSSB57 334 NORMAL APPROXIMATION TO MACHINE INTERFERENCE WITH MANY REPAIR MEN * P. NAOR

JRSSB57 342 STATIONARY DISTRIBUTIONS OF THE NEGATIVE EXPERIMENTAL TYPE FOR THE INFINITE DAM * J. GANI, N. U. PRABHU

JOURNAL OF THE ROYAL STATISTICAL SOCIETY, SERIES B VOLUME 20, 1958

JRSSB58

JRSSB58

JRSSB58

JRSSB5B

JRSSB5B

JRSSB5B

JRSSB5B JRSSB58

JRSSB5B

JRSSB5B

JRSSB5B

JRSSB58

JRSSB58

JRSSB58

JRSSB $5 B$

JRSSB58
1 STATISTICAL APPROACH TO PROBLEMS OF COSMOLOGY (WITH DISCUSSION) * J. NEYMAN, ELIZABETH L. SCOTT

44 ON CHI-SQUARE GOODNESS-OF-FIT TESTS FOR CONTINUOUS DISTRIBUTIONS (WITH DISCUSSION) * G, S. WATSON

73 THE MATCHING DISTRIBUTIONS, POISSON LIMITING FORMS AND DERIVED METHODS OF APPROXIMATION * D. E. BARTON 93 THE LINDISFARNE SCR IBES ' PROBLEM * S. D. SILVEY

102 FIDUCIAL DISTRIBUTIONS AND BAYES' THEOREM * D. V. LINDLEY

108 ON THE EXACT DISTRIBUTION OF A TEST IN MULTIVARIATE ANALYSIS * D. P. BANERJEE

111 THE INSPECTION OF A MARKOV PROCESS * S, R, BROADBENT

120 THE FITTING OF MARKOFF SERIAL VARIATION CURVES * HILDA M. DAVES, G. H. JOWETT

143 THE ASYMPTOTIC POWERS OF CERTAIN TESTS OF GOODNESS OF FIT FOR TIME SERIES * E. J. HANNAN

152 BANDWIDTH AND VARIANCE IN ESTIMATION OF THE SPECTRUM * U. GRENANDER

158 THE COMPARISON OF CORRELATIONS IN TIME-SERIES * M. H. QUENOUILLE

DIFFERENCE EQUATION

I6B A DIFFERENCE EQUATION TECHNIQUE APPLIED TO THE SIMPLE QUEUE WITH ARBITRARY ARRIVAL INTERVAL DISTRIBUTION * B. W. CONOLLY

176 THE CONTINUOUS TIME SOLUTION OF TIE EQUATIONS OF THE SINGLE CHANNEL QUEUE WITH A GENERAL CLASS OF SERVICE-TIME DISTRIBUTIONS BY THE METHOD OF GENERATING FUNCTIONS * G. LUCHAK

THE EFFECT OF THE SIZE OF THE WAITING ROOM ON A SIMPLE QUEUE* P. D. FINCH

* P. G. MOORE
JRSSB58 193 THE ANALYSIS OF LATIN SQUARE DESIGNS WITH INDIVIDUAL CURVATURES IN ONE DIRECTION * C. P. COX

JRSSB58 205 DILUTION SERIES, A STATISTICAL TEST OF TECHNIQUE (CORR, 59 23B) *W. L. STEVENS

JRSSB58 215 THE REGRESSION ANALYSIS OF BINARY SEQUENCES (WITH DISCUSSION) (CORR, 59238 ) * D.R. COX

JRSSB58 243 RENEWAL THEORY AND ITS RAMIFICATIONS (WITH DISCUSSION) * WALTER L. SMITH

JRSSB58 303 ON ASYMPTOTICALLY EFFICIENT CONSISTENT ESTIMATES OF THE SPECTRAL DENSITY FUNCTION OF A STATIONARY TIME SERIES * EMANUEL PARZEN

JRSSB58 323 THE ESTIMATION OF THE SPECTRAL DENSITY AFTER TREND REMOVAL * E. J. HANNAN

JRSSB58 334 ON THE SMOOTHING OF PROBABILITY DENSITY FUNCTIONS * P WHITTLE

JRSSB5B 344 EXPERIMENTS WITH MIXTURES (CORR, 59 238) * HENRY SCHEFFE

JRSSB5B 361 THE INTERACTION ALGORITHM AND PRACTICAL FOURIER ANALYSIS* I, J, GOOD

JRSSB58 373 EQUALLY CORRELATED VARIATES AND THE MULTINORMAL INTEGRAL * ALAN STUART

JRSSB58 379 FORMULAE FOR CALCULATING THE OPERATING CHARACTERISTIC AND THE AVERAGE SAMPLE NUMBER OF SOME SEQUENTIAL TESTS * K. W. KEMP

JRSSB5B 3B7 ON CORRECTIONS TO THE CHI-SQUARED DISTRIBUTION * J. H DARWIN

JRSSB58 393 SAMPLING WITHOUT REPLACEMENT WITH PROBABILITY PROPORTIONAL TOSIZE * W. L. STEVENS

JRSSB58 398 MULTIVARIATE QUANTAL ANALYSIS * P. J . CLARINGBOLD

JRSSB58 406 A CONCISE DERIVATION OF GENERAL ORTHOGONAL POLYNOMIALS* C. P. COX

JRSSB5B 408 A SIMPLIFIED MODEL FOR DELAYS IN OVERTAKING ON A TWOLANE ROAD * J, C. TANNER

JOURNAL OF THE ROYAL STATISTICAL SOCIETY, SERIES B VOLUME 21, 1959 

BENNETT

JRSSB59 63 THE PROCESS CURVE AND THE EQUIVALENT MIXED BINOMIAL WITH TWO COMPONENTS * M. K. VACHOLKAR

JRSSB59 67 THE INFORMATION IN AN EXPERIMENT * C. L. MALLOWS

JRSSB59

JRSSB59

3 G. S. JAMES XTERTE MEAN *

91 THE ESTIMATION OF RELATIONSHIPS WITH AUTOCORRELATED RESIDUALS BY THE USE OF INSTRUMENTAL VARIABLES * $\mathrm{J}$. D. SARCAN

JRSSB59 106 ON SOME PROBLEMS OF MACHINE INTERFERENCE * S. K. NASR

JRSSB59 114 ON THE DISTRIBUTION OF VARIOUS SUMS OF SQUARES IN AN ANALYSIS OF VARIANCE TABLE FOR DIFFERENT CLASSIFICATIONS WITH CORRELATED AND NON-HOMOGENEOUS ERRORS *B. R. BHAT

JRSSB59 120 CONTACIOUS OCCUPANCY * D. E. BARTON, F. N. DAVID

JRSSB59 134 THE LIMITING FREQUENCIES OF INTEGERS WITH A GIVEN PARTITIONAL CHARACTERISTIC * W. F. BODMER

JRSSB59 144 SOME SIMPLE DURATION-DEPENDENT STOCHASTIC PROCESSES * A. MERCER

JRSSB59 153 CYCLIC QUEUES WITH FEEDBACK * P. D. FINCH

JRSSB59 $15 B$ A STATISTICAL THEORY OF REMNANTS * J . AITCHISON

JRSSB59 169 BANDWIDTH AND RESOLVABILITY IN STATISTICAL SPECTRAL ANALYSIS * Z. A. LOMNICKI, S. K. ZAREMBA

JRSSB59 172 ON A PROPERTY OF INCOMPLETE BLOCKS * R. MORLEY JONES

JRSSBS9 1 BO A RENEWAL PROBLEM WITH BULK ORDERING OF COMPONENTS * D. R. COX

JRSSB59 190 THE DISPERSION OF A NUMBER OF SPECIES * D. E. BARTON, F. N. DAVID

JRSSB59 195 ON A DISCRIMINATORY PROBLEM CONNECTED WITH THE WORKS OF PLATO * D. R. COX. L. BRANDWOOD
JRSSB59 201 EXPERIMENTS WITH MIXTURES * M. H. QUENOUILLE

JRSSB59 203 A DIFFERENT LOSS FUNCTION FOR THE CHOICE BETWEEN TWO POPULATIONS * RITA J MAURICE

JRSSB59 214 CENSORED OBSERVATIONS IN RANDOMIZED BLOCK EXPERIMENTS * M.R. SAMPFORD, J. TAYLOR

JRSSB59 239 CONTROL CHARTS AND STOCHASTIC PROCESSES (WITHDISCUSSION $*$ C. A. BARNARD

JRSSB59 272 OPTIMUM EXPERIMENTAL DESICNS (WITH DISCUSSION) * J KEIFER

JRSSB59 320 A CONTRIBUTION TO THE THEORY OF BULK QUEUES * RUPERT C MILLER JR

JRSSB59 33B MAXIMIZINC A. FUNCTION IN A CONVEX REGION * G. ZOUTENDIJK

JRSSB59 356 ESTIMATION OF LOCATION AND SCALE PARAMETERS FOR THE RECTANGULAR POPULATION FROM CENSORED SAMPLES *A. E SARHAN, B. G. GREENBERG

JRSSB59 364 THE DISTRIBUTION OF VACANCIES ON A LINE * E. S. PAGE

JRSSB59 375 THE OUTPUT PROCESS OF THE QUEUEING SYSTEM WITH ONE SERVER AND WHICH INTERARR IVAL AND SERV INC DISTRIBUTIONS ARE EXPONENTIAL AND CENERAL INDEPENDENT RESPECTIVELY* P. D. FINCH

JRSSB59 3BI THE EFFICIENCY OF AUTOMATIC WINDING MACHINES WITH CONSTANT PATROLLING TIME * A. J. HOWIE, L. R. SHENTON

JRSSB59 396 THE COMPARISON OF REGRESSION VARIABLES * E. J. WIL LIAMS

JRSSB59 400 THE MOST ECONOMICAL SEQUENTIAL SAMPLING SCHEME FOR INSPECTION BY VARI ABLES * G. B. WETHERILL

JRSSB59 409 NOTE ON FISHER'S TRANSFORMATION OF THE CORRELATION COEFFICIENT * N. F. LAUBSCHER

JRSSB59 411 THE ANALYSIS OF EXPONENTIALLY DISTRIBUTED LIFE-TIMES WITH TWO TYPES OF FAILURE* D. R. COX

JOURNAL OF THE ROYAL STATISTICAL SOCIETY, SERIES B VOLUME 22, 1960

JRSSB60 $\quad$ I ON SELECTING THE LARCEST OF K NORMAL POPULATION MEANS (WITH DISCUSSION) * C. W. DUNNETT

JRSSB60 41 CONFIDENCE REGIONS IN NON-LINEAR ESTIMATION (WITH DISCUSSION) * E. M. L. BEALE

JRSSB60 89 THE BUSY PERIOD IN RELATION TO THE SINGLE-SERVER QUEUEING SYSTEM WITH GENERAL INDEPENDENT ARRIVALS AND ERLANG I AN SERVICE-TIME* B. W. CONOLLY

JRSSB6O 97 A NOTE ON PREDICTION FROM AN AUTORECRESSIVE PROCESS USING PISTIMETRIC PROBABILITY * A . D. ROY

JRSSB60 104 SOME RESULTS FOR THE QUEUE WITH POISSON ARRIVALS * N. U. PRABHU

JRSSB60 108 A QUEUEINC PROBLEM IN WHICH THE ARRIVAL TIMES OF THE CUSTOMERS ARE SCHEDULED * A. MERCER

JRSSB60 114 THE TWO-PACK MATCHING PROBLEM * A. W. JOSEPH. M. T. L. BIZLEY

JRSSB60 131 ON THE THEORY OF CLASSICAL RECRESSION AND DOUBLE SAMPLINC ESTIMATION * B. D. TIKKIWAL

JRSSB60 139 ESTIMATION OF PARAMETERS IN TIME-SERIES REGRESSION MODELS * J. DURBIN

JRSSB60 154 MAXIMUM-LIKELIHOOD ESTIMATION PROCEDURES AND ASSOCIATED TESTS OF SICNIFICANCE * J. AITCHISON, S. D SILVEY

JRSSB60 172 REGRESSION ANALYSIS WHEN THERE IS PRIOR INFORMATION ABOUT SUPPLEMENTARY VARIABLES * D. R. COX

JRSSB60 177 A TABLE OF THE INTECRAL OF THE BIVARIATE NORMAL DISTRIBUTION OVER AN OFFSET CIRCLE * J.R. LOWE

JRSSB60 188 ON THE DISTRIBUTION OF THE WEICHTED DIFFERENCE OF TWO INDEPENDENT STUDENT VARIABLES * H. RUBEN

JRSSB60 195 MODELS IN THE ANALYSIS OF VARIANCE (WITH DISCUSSION) * R. L. PLACKETT

JRSSB60 2IB DISCRETE STOCHASTIC PROCESSES IN POPULATIONGENETICS (WITHDISCUSSION) * W.F.BODMER

JRSSB60 245 A PROBLEM OF DELAYED SERVICE, I * A. BEN-ISRAEL, P NAOR
JRSSB60 270 A PROBLEM OF DELAYED SERVICE, 2 * A. BEN-ISRAEL, P NAOR

JRSSB60 277 ON THE TRANSIENT BEHAVIOUR OF A SIMPLE QUEUE * P. D FINCH

JRSSB60 285 QUEUEING AT A SINGLE SERVING POINT WITH CROUP ARRIVAL * 8 W. CONOLLY

JRSSB60 299 ON SOME EXTENSIONS OF BAYESIAN INFERENCE PROPOSED BY MR LINDLEY * R. A. FISHER

JRSSB60 302 A METHOD OF ESTIMATION OF MISSINC VALUES IN MULTIVARIATE DATA SUITABLE FOR USE WITH AN ELECTRONIC COMPUTER * S. F. BUCK

JRSSB60 307 ESTIMATION OF PARAMETERS OF A MULTIVARIATE NORMAL POPULATION FROM TRUNCATED AND CENSORED SAMPLES * NAUNIHAL SINCH

JRSSB60 312 NECESSARY RESTRICTIONS FOR DISTRIBUTIONS A POSTERIORI * D. A. SPROTT

JRSSB60 319 WEICHT OF EVIDENCE, CORROBORATION, EXPLANATORY POWER, INFORMATION AND THE UTILITY OF EXPERIMENTS (CORR, 6B 203) *I, J, GOOD

JRSSB60 332 THE LOGISTIC PROCESS, TABLES OF THE STOCHASTIC EPIDEMIC CURVE AND APPLICATIONS * EDWIN MANSFIELD, CARLTON HENSLEY

JRSSB60 338 SOME NOTES ON PISTIMETRIC INFERENCE * A. D. ROY

JRSSB60 348 EVALUATION OF DETERMINANTS, CHARACTERISTIC EQUATIONS AND THEIR ROOTS FOR A CLASS OF PATTERNED MATRICES * S, N. ROY B , G , GREENBERC, A. E . SARHAN

JRSSB60 360 BOUNDS FOR THE EXPECTED SAMPLE SIZE IN A SEQUENTIAL PROBABILITY RATIO TEST * M. N. GHOSH

JRSSB60 36B A NOTE ON TESTS OF HOMOCENEITY APPLIED AFTER SEQUENTIAL SAMPLING * D. R. COX

JRSSB60 372 THE INTERACTION ALGORITHM AND PRACTICAL FOURIER ANALYSIS, AN ADDENDUM * I. J. GOOD

JRSSB60 376 APPROXIMATE SOLUTIONS OF GREEN'S TYPE FOR UNIVARIATE STOCHASTIC PROCESSES * H. E. DANIELS

JRSSB60 402 THE WILCOXON TEST AND NON-NULL HYPOTHESES * G. B WETHERILL

JOURNAL OF THE ROYAL STATISTICAL SOCIETY, SERIES B VOLUME 23, 1961

JRSSB6I I CONSISTENCY IN STATISTICAL INFERENCE AND DECISION (WITHDISCUSSION) (CORR. 66252$) *$ C. A. B. SMITH

JRSSB61 38 DELAYS ON A TWO-LANE ROAD (WITH DISCUSSION) * J. C. TANNER

JRSSB61 64 A QUEUEING MODEL FOR ROAD TRAFFIC FLOW (WITH DISCUSSION) * A. J.MILLER

JRSSB61 91 A SIMPLE METHOD OF TREND CONSTRUCTION * C. E. V. LESER

JRSSB61 108 CONFIDENCE LIMITS FOR MULTIVARIATE RATIOS * B. M. BENNETT

JRSSB61 113 THE SOLUTION OF QUEUEINC AND INVENT ORY MODELS BY SEMIMARKOV PROCESSES * A, J FABENS

JRSSB61 $12 B$ THE ASYMPTOTIC EFFICIENCY OF DANIELS'S CENERALIZED CORRELATION COEFFICIENTS * D. J.G. FARLIE
JRSSB61 143 A BULK-SERVICE QUEUEINC PROBLEM WITH VARIABLE CAPACI$T Y * N$. K. JAISWAL

JRSSB6I 149 THE AVERAGE RUN LENGTH OF THE CUMULATIVE SUM CHART WHEN A V-MASK IS USED * K. W. KEMP

JRSSB61 154 AN UNBIASED ESTIMATOR FOR POWERS OF THE ARITHMETIC MEAN * G. J GLASSER

JRSSB61 160 ESTIMATION OF THE PARAMETERS OF A LINEAR FUNCTIONAL RELATION* M. DORFF, J GURLAND

JRSSB61 171 REPLY TO MR QUENOUILLE'S COMMENTS ABOUT MY PAPER ON MIXTURES * H. SCHEFFE

JRSSB61 173 THE TIME-DEPENDENT SOLUTION FOR AN INF INITE DAM WITH DISCRETE ADDITIVE INPUTS * G. F. YEO 
JRSSB61 IBO THE REAL STABLE CHARACTERISTIC FUNCTIONS AND CHAOTIC ACCELERATION * I. J , COOD

JRSSB61 IB4 INACCURACY AND INFERENCE * D. F. KERRIDCE

JRSSB61 195 A TEST OF HOMOCENEITY FOR ORDERED VARIANCES * S. E. VINCENT

JRSSB61 207 A NOTE ON VACANCIES ON A LINE * F, DOWNTON

JRSSB61 215 A SIMPLE CONCESTION SYSTEM WITH INCOMPLETE SERVICE * D. R. COX

JRSSB61 223 THE MOMENT CENERATINC FUNCTION OF THE TRUNCATED MULTI-NORMALDISTRIBUTION * C.M. TALLIS

JRSSB61 230 A NOTE ON THE RENEWAL FUNCTION WHEN THE MEAN RENEWAL LIFETIME IS INFINITE * W. L. SMITH

JRSSB61 239 A TEST OF HOMOCENEITY OF MEANS UNDER RESTRICTED ALTERNATIVES (WITHDISCUSSION) *D. J BARTHOLOMEW

JRSSB61 282 OPTIMAL PROGRAMMERS FOR VARIETAL SELECTION (WITH DISCUSSION) *R. N. CURNOW

JRSSB61 319 SOME STOCHASTIC PROCESSES WITH ABSORBINC BARRIERS * T. L. SAATY

JRS\$B61 335 SOME SEQUENTIAL TEST USING RANGE * W. C. CILCHRIST

JRSSB61 343 FIRST EMPTINESS IN A FINITE DAM * B. WEESAKUL

JRSSB61 352 THE CONSTRUCTION OF OPTIMAL DESIGNS FOR THE ONE-WAY CLASSIFICATION ANALYSIS OF VARIANCE * J. AITCHISON

JRSSB61 36B SOME SIMPLE WEAR-DEPENDENT RENEWAL PROCESSES * A. MERCER

JRSSB61 377 AN EXACT DISTRIBUTION OF THE BEHRENS-FISHER-WELCH STATISTIC FOR TESTING THE DIFFERENCE BETWEEN THE MEANS OF TWO NORMAL POPULATIONS WITH UNKNOWN VARIANCES * W. D. RAY, A. E. N. T. PITMAN
JRSSB6I 385 CLOSED QUEUEINC SYSTEMS. A CENERALIZATION OF THE MACHINE INTERFERENCE MODEL * F. BENSON, G CRECORY

JRSSB61 394 TESTINC FOR A JUMP IN THE SPECTRAL FUNCTION * E. J. HANNAN

JRSSB61 405 MOMENTS OF A TRUNCATED BIVARIATE NORMAL DISTRIBUTICN * S. ROSENBAUM

JRSSB61 409 MIXTURES OF CEOMETRIC DISTRIBUTIONS * H. E. DANIELS

JRSSB61 414 PREDICTION BY EXPONENTIALLY WEICHTED MOVINC AVERACES AND RELATED METHODS * D , R, COX

JRSSB61 423 THE RANDOMIZATION BASES OF THE PROBLEM OF THE AMALCAMATION OF WEIGHTED MEANS * D. E. BARTON, C. L. MALLOWS

JRSSB61 434 ESTIMATION FROM QUANTILES IN DESTRUCTIVE TESTING * $\mathrm{H}$ P. STOUT, F. STERN

JRSSB6I 444 A NOTE ON MAXIMUM-LIKELIHOOD IN THE CASE OF DEPENDENT RANDOM VARIABLES * S. D. SILVEY

JRSSB61 453 ON SOME PROPERTIES OF THE ASYMPTOTIC VARIANCE OF THE SAMPLE QUANTILES AND MID-RANGES * P. K. SEN

JRSSB6I 460 SIMILARITIES BETWEEN LIKELIHOODS AND ASSOCIATED DISTRIBUTIONS A POSTERIORI * D. A. SPROTT

JRSSB6I 469 A METHOD OF MAXIMUM-LIKELIHOOD ESTIMATION * F. S . RICHARDS

JRSSB61 476 THE INTERVALS BETWEEN RECULAR EVENTS DISPLACED IN TIME BY INDEPENDENT RANDOM DEVIATIONS OF LARGE DISPERSION * T. LEWIS

JRSSB6I 4B4 AN APPROACH TO THE SCHEDULINC OF JOBS ON MACHINES * E S. PAGE

JRSSB61 493 ON QUADRATIC ESTIMATES OF THE INTERCLASS VARIANCE FOR UNBALANCED DESIGNS * R. R. READ

JOURNAL OF THE ROYAL STATISTICAL SOCIETY, SERIES B VOLUME 24, 1962

JRSSB62

JRSSB62

JRSSB62

JRSSB62

JRSSB62

JRSSB62

JRSSB62

JRSSB62

1 SOME RESULTS ON INVENTORY PROBLEMS (WITH DISCUSSION) * A. R. THATCHER

46 EFFICIENT ESTIMATES AND OPTIMUM INFERENCE PROCEDURES IN LARCE SAMPLES (WITH DISCUSSION) * C. R. RAO

73 A WAITINC LINE WITH INTERRUPTED SERVICE. INCLUDING PRIORITIES * D. P. GAVER JR

91 TIME-DEPENDENT SOLUTION OF THE 'HEAD-OF-THE-LINE' PRIORITY QUEUE * N. K. JAISWAL DAM WITH ORDERED INPUTS * J GANI, R, PYKE

CONGESTION SYSTEMS WITH INCOMPLETE SERVICE (CORR. 64 365) * F. DOWNTON QUARESCRADUATION EQUATTONS * A W JOSEPH

DETERMINATION OF PROBABILITIES A PRIORI * SIR ROLAND FISHER

JRSSB62 125 EXACT FIDUCIAL LIMITS IN NON-LINEAR ESTIMATION * E. J. WILLIAMS

JRSSB62 140 ON THE EFFECT OF NON-NORMALITY ON THE ESTIMATION OF COMPONENTS OF VARIANCE * M. ATIQULLAH

JRSSB62 148 ON THE DISTRIBUTION OF CERTAIN QUADRAT IC FORMS IN NORMAL VARIATES *B. R. BHAT

JRSSB62 152 A NOTE ON A CENERALIZED INVERSE OF A MATRIX WITH APPLICATIONS TO PROBLEMS IN MATHEMATICAL STATISTICS * C. R. RAO

JRSSB62 159 ON MULTIVARIATE SICN TESTS * B, M. BENNETT

JRSSB62 162 A NOTE ON INTERACTIONS IN CONTINGENCY TABLES * R. L PLACKETT

JRSSB62 167 ON THE ASYMPTOTIC SUFFICIENCY OF CERTAIN ORDER STATISTICS * M. S. ROHATCI

JRSSB62 177 A NEW ASYMPTOTIC EXPANSION FOR THE NORMAL PROBABILITY INTEGRAL AND MILL 'S RATIO * H. RUBEN

JRSSB62 180 ESTIMATORS FOR THE PRODUCT OF ARITHMETIC MEANS * C. J . GLASSER

JRSSB62 1 B5 THE ESTIMATION OF SPECTRAL DENSITIES * H. E. DANIELS

JRSSB62 199 THE ESTIMATION OF SLOPE WHEN THE ERRORS ARE AUTOCORRELATED * G, M. JENKINS, J. CHANMUGAN

JRSSB62 215 THE ANALYSIS OF STATIONARY PROCESSES WITH MIXED SPECTRA, $1 * M$. B. PRIESTLEY

JRSSB62 234 LARGE-SAMPLE RESTRICTED PARAMETRIC TESTS * JOHN AITCHISON

JRSSB62 251 INTERACTIONS IN MULTI-FACTOR CONT INGENCY TABLES * J. N. DARROCH
JRSSB62 265 CONF IDENCE SETS FOR THE MEAN OF A MULTIVARIATE NORMAL DISTRIBUTION (WITHDISCUSSION) * C. M. STEIN

JRSSB62 297 SOME STATISTICAL ASPECTS OF ADAPTIVE OPT IMIZATION AND CONTROL (WITH DISCUSSION) *G, E. P. BOX, C.M. JENKINS

JRSSB62 344 THE GENERAL BULK QUEUE AS A HILBERT PROBLEM (CORR. 64 487) * J, KEILSON

JRSSB62 359 QUEUES IN SERIES * A. GHOSAL

JRSSBG2 364 ON THE LENCTHS OF INTERVALS IN A STATIONARY POINT PROCESS (CORR. 63500$) * J . A . M C F A D D E N$

JRSSB62 3B3 ON QUEUES IN HEAVY TRAFFIC * J. F. C. KINGMAN

JRSSB62 393 SOME OPTIMAL SEQUENTIAL SCHEMES FOR ESTIMATING THE MEAN OF A CUMULATIVE NORMAL QUANTAL RESPONSE CURVE * B. L. MARKS

JRSSB62 401 PROBLEMS OF SELECTION WITH RESTRICTIONS * C. R. RAO

JRSSB62 406 FURTHER RESULTS ON TESTS OF SEPARATE FAMILIES OF HYPOTHESES * D. R, COX

JRSSB62 425 ON THE CONSISTENCY OF THE FIDUCIAL METHOD * D. A. S FRASER

JRSSB62 435 ESTIMATION OF MEANS AND STANDARD ERRORS IN THE ANALYSIS OF NON-ORTHOGONAL EXPERIMENTS BY ELECTRONIC COMPUTER * G. H. FREEMAN, J.N.R. JEFFERS

JRSSB62 447 ON THE COMPARISON OF THE SENSITIVITIES OF EXPERIMENTS * S. N. DAR

JRSSB62 454 APPROXIMATE CONFIDENCE LIMITS FOR THE RELATIVE RISK (CORR. 63234)* J. J. GART

JRSSB62 464 THE USE OF CONTROL OBSERVATIONS AS AN ALTERNATIVE TO INCOMPLETE BLOCK DESIGNS * $M$. ATIQULLAH, D , R. COX

JRSSB62 472 A SIMPLERANDOMIZATION PROCEDURE * M. SANDELIUS

JRSSB62 4B2 ONA SIMPLE PROCEDURE OF UNEQUAL PROBABILITY SAMPLINC WITHOUT REPLACEMENT * J. N. K. RAO, H. O HARTLEY, W. C. COCHRAN

JRSSB62 492 SAMPLING PROPERTIES OF TESTS OF COODNESS-OF-FIT FOR LINEAR AUTORECRESSIVE SCHEMES * K. C. CHANDA

JRSSB62 511 ANALYSIS OF STATIONARY PROCESSES WITH MIXED SPECTRA. $2 * M$. B. PRIESTLEY

JRSSB62 530 THE USE OF A GENERALIZED MULTINOMIAL DISTRIBUTION IN THE ESTIMATION OF CORRELATION IN DISCRETE DATA * G M. TALLIS

JRSSB62 535 CUMULANTS OF TRUNCATED MULTINORMAL DISTRIBUTIONS * D. J. FINNEY

JRSSB62 537 NOTE ON A PAPER BY RAY AND PITMAN + (FISHER-BEHRENSSTATISTIC) * J. GURLAND

JOURNAL OF THE ROYAL STATISTICAL SOCIETY, SERIES B VOLUME 25, 1963

JRSSB63 I SEQUENTIAL ESTIMATION OF QUANTAL RESPONSE CURVES (WITHDISCUSSION) * G. B. WETHERILL

JRSSB63 49 CONTROL CHARTS AND THE MINIMIZATION OF COSTS (WITH DISCUSSION) * $J$, A. BATHER

JRSSB63 81 TESTS OF GOODNESS OF FIT* F. J. ANSCOMBE

JRSSB63 95 A COMPARISON OF THE DIRECT AND FIDUCIAL ARGUMENTS IN THE ESTIMATION OF A PARAMETER * E. J. WILLIAMS
JRSSB63 100 ON DIRECT PROBABILITIES * A.P. DEMPSTER

JRSSB63 111 SOME LOGICAL ASPECTS OF THE FIDUCIAL ARGUMENT * G. A. BARNARD

JRSSB63 115 ON SUFFICIENCY AND THE EXPONENTIAL FAMILY * D. A.S FRASER

JRSSB63 124 THE LOGIC OF LEAST SQUARES * G. A. BARNARD 
JRSSB63 128 FIDUCIAL LIMITS FOR A VARIANCE COMPONENT * M. J.R. HEALY

JRSSB63 131 THE EPOCHS OF EMPTINESS OF A SEMI-INFINITE DISCRETE RESERVOIR * E. H. LLOYD

JRSSB63 137 THE DISTRIBUTION OF THE TIME-TO-EMPTINESS OF A DISCRETE DAM UNDER STEADY DEMAND * J . L. MOTT

JRSSB63 140 MODELS FOR A BACTERIAL GROWTH PROCESS WITH REMOVALS * $\mathrm{J}$ GANI

JRSSB63 150 A MULTI-STAGE RENEWAL PROCESS * D. J. BARTHOLOMEW

JRSSB63 169 A CONTRIBUTION TO COUNTER THEORY * D. L. BENTLEY

JRSSB63 179 ON PLACKETT'S TEST FOR CONTINGENCY TABLE INTERACTIONS * L. A. GOODMAN

JRSSB63 189 ON THE NORMAL STATIONARY PROCESS, AREAS OUTSIDE GIVEN LEVELS*M. R. LEADBETTER

JRSSB63 195 A NOTE ON THE ASYMPTOTIC EFFICIENCY OF AN ASYMPTOTICALLY NORMAL ESTIMATOR SEQUENCE (CORR. 67 196) * A. M. WALKER

JRSSB63 201 ON COMBINING ESTIMATES OF A RATIO OF MEANS * B. $M$. BENNETT

JRSSB63 206 ESTIMATION OF THE PARAMETERS IN SHORT MARKOV SEQUENCES * A.W.F. EDWARDS

JRSSB63 209 SOME REMARKS ON A METHOD OF A MAXIMUM-L I KELIHOOD EST IMATION PROPOSED BY RICHARDS * B. K. KALE

JRSSB63 213 POWER OF TUKEY'S TEST FOR NON-ADDITIVITY * M. N. GHOSH, D SHARMA

JRSSB63 220 MAXIMUM LIKELIHOOD IN THREE-WAY CONTINGENCY TA8LES * M. W. BIRCH

JRSSB63 235 THE SIMPLEX-CENTROID DESIGN FOR EXPERIMENTS WITH MIXTURES (WITH DISCUSSION) * HENRY SCHEFFE

JRSSB63 264 THE SPECTRAL ANALYSIS OF POINT PROCESSES (WITH DISCUSSION) *M.S. BARTLETT

JRSSB63 297 A MINIMAX-REGRET PROCEDURE FOR CHOOSING BETWEEN TWO POPULATIONS USING SEQUENTIAL SAMPLING * N. L. JOHNSON, RITA J. MAURICE

JRSSB63 305 HIGHER MOMENTS OF A MAXIMUM-LIKELIHOOD ESTIMATE * L R. SHENTON, K. BOWMAN

JRSSB63 318 ON FORMULAE FOR CONFIDENCE POINTS BASED ON INTEGRALS OF WE IGHTED LI KELIHOODS * B. L. WELCH , H. W. PEERS

JRSSB63 330 CONFIDENCE INTERVAL EST IMATION IN NON-LINEAR REGRESSION * MAX HALPERIN

JRSSB63 334 ON THE RANDOMIZATION DISTRIBUTION AND POWER OF THE VARIANCE RATIO TEST * $M$. ATIQULLAH
JRSSB63 348 MULTIVARIATE LINEAR HYPOTHESIS WITH LINEAR RESTRICTIONS * D. G. KABE

JRSSB63 352 APPLICATIONS OF JORDAN'S PROCEDURE FOR MATRIX INVERSION IN MULTIPLE REGRESSION AND MULTIVARIATE DISTANCE ANALYSIS * G. H JOWETT

JRSSB63 35B HOTELLING 'S GENERALIZED T SQUARE IN THE MULTIVARIATE ANALYSIS OF VARIANCE * M. N. GHOSH

JRSSB63 368 POSTERIOR DISTRIBUTIONS FOR MULTIVARIATE NORMAL PARAMETERS * SEYMOUR GEISSER, JEROME CORNF IELD

JRSSB63 377 ON THE INDEPENDENCE OF QUADRATIC EXPRESSIONS (CORR. $66584) * I, J . G O O D$

JRSSB63 3B3 QUADRATICS IN MARKOV-CHAIN FREQUENCIES, AND THE BINARY CHAIN OF ORDER 2* I . J . GOOD

JRSSB63 392 ON A PROPERTY OF THE LOGNORMAL DISTRIBUTION * C. C . HEYDE

JRSSB63 394 THE CORRELATED UNRESTRICTED RANDOM WALK * ASHA SETH

JRSSB63 401 A LOWER BOUND FOR THE CRITICAL PROBABILITY IN THE ONEQUADRANT ORIENTED-ATOM PERCOLATION PROCESS * J . BISHIR

JRSSB63 405 THE DIFFUSION EQUATICN AND A PSEUDO-DISTRIBUTION IN GENETICS * W. J. EWENS

JRS\$863 413 HIGHER-ORDER PROPERTIES OF A STATIONARY POINT PROCESS * J. A. MCFADDEN, WALTER WEISSBLUM

JRSSB63 432 AN APPROXIMATE SOLUTION OF THE INTEGRAL EQUATION OF RENEWAL THEORY *D. J. BARTHOLOMEW

JRSSB63 442 PERIODOGRAM ANALYSIS AND VARIANCE FLUCTUATIONS * LAURENCE J. HERBST

JRSSB63 451 A TEST FOR VARIANCE HETEROGENEITY IN THE RESIDUALS OF A GAUSSIAN MOVING AVERAGE * LAURENCE N HERBST

JRSS863 455 A CORRECTION TO 'THE SOLUTION OF QUEUEING AND INVENTORY MODELS BY SEMI-MARKOV PROCESSES' * A. J. FABENS, A. G. A. D. PERERA

JRSSB63 457 TREATMENT OF THE NON-EQUILIBRIUM THEORY OF SIMPLE QUEUES BY MEANS OF CUMULATIVE PROBABILITIES * R. A. SACK

JRSSB63 464 ON THE ASYMPTOTIC BEHAVIOUR OF QUEUES * J. KEILSON

JRSSB63 477 SOME NUMERICAL RESULTS FOR THE QUEUEING SYSTEM WITH ONE SERVER. WHILE THE INTERARRIVAL AND SERVING DISTRIBUTIONS ARE DETERMINISTIC AND. GAMMA OF ORDER $K$ RESPECTIVELY*M. C. PIKE

JRSSB63 4B9 COMPETITIVE QUEUEING, IDLENESS PROBABILITIES UNDER PRIORITY DISCIPLINES * DONALD P . GAVER JR

JOURNAL OF THE ROYAL STATISTICAL SOCIETY, SERIES B VOLUME 26, 1964

JRSSB64 I THEORY OF CYCLIC ROTATION EXPERIMENTS (WITH DISCUSSION) * H. D. PATTERSON

JRSSB 64 JRSSB 64 JRSSB64

JRSSB64

JRSSB64

JRSSB64

JRSSB 64

JRSSB64

JRSSB64 JRSSB64

JRSSB 64

JRSSB64

JRSSB 64

JRSSB64

JRSSB64

JRSSB64

JRSSB 64 JRSSB 64

46 ON LOCAL UNBIASED ESTIMATION* D. A. S. FRASER

52 LOCAL CONDITIONAL SUFFICIENCY * D. A. S. FRASER

63 BAYESIAN ESTIMATION OF THE VARIANCE OF A NORMAL DISTRIBUTION* I. G. EVANS

69 POSTERIOR ODDS FOR MULTIVARIATE NORMAL CLASSIFICATION * S. GEISSER

77 ON THE MONOTONICITY PROPERTY OF THE THREE MAIN TESTS FOR MULTIVARIATE ANALYSIS OF VARIANCE * J. N SRIVASTAVA

82 FURTHER MODELS FOR EST IMATING CORRELATION IN D ISCRETE DATA * G. M. TALLIS

B6 SIMULTANEOUS CONFIDENCE LIMITS FOR CROSS-PRODUCT RATIOS IN CONTINGENCY TABLES * L. A. GOODMAN

103 SOME APPLICATIONS OF EXPONENTIAL ORDERED SCORES * D R. $\mathrm{COX}$

111 A NOTE ON KURTOSIS * H. M. FINUCAN

113 PREDICTION BY PROGRESSIVE CORRECTION * C. S. VAN DOBBEN DE BRUYN

123 ESTIMATION OF THE SPECTRAL DENSITY FUNCTION IN THE PRESENCE OF HARMONIC COMPONENTS * M. B. PRIESTLEY

133 SOME RESULTS FOR FIXED-TIME TRAFFIC SIGNALS * D. J BUCKLEY, R. C. WHEELER

141 A DEFORMATION METHOD FOR QUADRATIC PROGRAMMING * S ZAHL

161 BAYESIAN TOLERANCE REGIONS (WITH DISCUSSION) * J AITCHISON

176 RELATIONSHIPS BETWEEN BAYESIAN AND CONF IDENCE LIMITS FOR PREDICTIONS (WITH DISCUSSION) *A. R. THATCHER

211 AN ANALYSIS OF TRANSFORMATIONS (WITH DISCUSSION) * G E. P. BOX, D. R. COX

253 ON LOCAL INFERENCE AND INFORMATION * D. A. S. FRASER

261 THE LINEAR HYPOTHESIS AND IDEMPOTENT MATRICES * G. A. F. SEBER
JRSSB64 267 NOTE ON INTERVAL ESTIMATION IN NON-LINEAR REGRESSION WHEN RESPONSES ARE CORRELATED * M. HALPERIN

JRSSB64 270 A NOTE ON THE BARTLETT DECOMPOSITION OF A TISHART MATRIX * D. G. KABE

JRSSB64 274 COMMENTS ON A POSTERIOR DISTRIBUTION OF GEISSER AND CORNF IELD * M. STONE

JRSSB64 277 ON THE BAYESI AN ESTIMATION OF MULTIVARIATE REGRESSION * GEORGE C. TIAO, ARNOLD ZELLNER

JRSSB64 286 CHARACTERIZATION THEOREMS FOR SOME UNIVARIATE PROBABILITY DISTRIBUTIONS*G. P. PATIL, V. SESHADRI

JRSSB64 293 ON THE POWER OF TWO-SAMPLE RANK TESTS ON THE EQUALITY OF TWO DISTRIBUTION FUNCTIONS * JEAND. GIBBONS

JRSSB64 305 A PROPOSED TWO-SAMPLE RANK TEST, THE PSI TEST AND ITS PROPERTIES * JEAN D. GIBBONS

JRSSB64 313 THE DETECTION OF PARTIAL ASSOCIATION, 1, THE 2 BY 2 CASE * M. W. BIRCH

JRSSB64 325 SOME PROPERTIES OF COUNTS OF EVENTS FOR CERTAIN TYPES OF POINT PROCESS * T. LEWIS, L, J . GOVIER

JRSSB64 338 A NOTE ON THE SOLUTION OF DAM EQUATIONS * E. H. LLOYD. S. ODOOM

JRSSB64 345 A MODEL FOR RA INFALL OCCURRENCE * J, R. GREEN

JRSSB64 354 SPECTRAL ANALYSIS IN THE PRESENCE OF VARIANCE FLUCTUATIONS * L. HERBST

JRSSB64 361 STATIONARY AMPLITUDE FLUCTUATIONS IN A RANDOM SERIES * L. HERBST

JRSSB64 367 SOME STATIST ICAL PROBLEMS CONNECTED WITH CRYSTAL LATTICES (WITH DISCUSSION) * C. DOMB

JRSSB64 398 A BRANCHING POISSON PROCESS MODEL FOR THE ANALYSIS OF COMPUTER FAILURE PATTERNS (WITH DISCUSSION) *P. A. W. LEWIS

JRSSB64 457 A BIVARIATE SIGNED RANK TEST * B. M. BENNETT

JRSSB64 462 CONFIDENCE-REGION TESTS * J. AITCHISON

JRSSB64 477 ESTIMATION IN THE UNIFORM COVARIANCE CASE * S. GEISSER

JRSSB 4484 ON AN IDENTITY FOR THE VARIANCE OF A RATIO OF TWO RANDOM VARIABLES * J. C. KOOP

JOURNAL OF THE ROYAL STATISTICAL SOCIETY, SERIES B VOLUME 27, 1965 
JRSSB 65

17 USING THE OBSERVATIONS TO ESTIMATE THE PRIOR DISTRIBUTION * M. CLUTTON-BROCK

JRSSB65 2B THE ROBBINS-MONRO METHOD FOR ESTIMATING THE MEDIAN LETHAL DOSE * W. G. COCHRAN, M. DAVIS

JRSSB65 45 ON CIRCULAR FUNCT IONAL RELAT IONSHIPS * NAI NG. CHAN

JRSSB65 57 PROBABILITY BOUNDS FOR A UNION OF HYPERSPHERICAL CONES * KEEKHAN CHOI

JRSSB65 74 FORMULAE TO IMPROVE WALD'S APPROXIMATION FOR SOME PROPERTIES OF SEQUENTIAL TESTS * G. M. TALLIS, M. K. VAGHOLKAR

JRSSB65 B2 NOTE ON A CHI-SQUARE APPROXIMATION FOR THE MULTIVARIATE SIGN TEST * B. M. BENNETT

JRSSB65 B6 THE DETERMINATION OF SAMPLING DISTRIBUTIONS AND MOMENT GENERATING FUNCTIONS BY SOLVING DIFFERENTIAL EQUATIONS * A. REITSMA

JRSSB65 91 MOMENT CROSSINGS AS RELATED TO DENSITY CROSSINGS * MARSAGLIA, A. W. MARSHALL, F. PROSCHAN

JRSSB65 94 ON CERTAIN PROPERTIES OF THE EXPONENTIAL-TYPE FAMILIES * G. P. PATIL, R. SHORROCK

JRSSB65 100 ASSOCIATION BETWEEN RANDOM VARIABLES AND THE DISPERSION OF A RADON-NI KODYM DERIVATIVE (CORR. 65533 ) * S. M. ALI, S. D. SILVEY

JRSSB65 108 A FURTHER RESULT ON THE RELEVANCE OF THE DISPERSION OF A RADON-NIKODYM DERIVATIVE TO THE PROBLEM OF MEASURING ASSOCIATION * S. M. ALI, S. D. SILVEY

JRSSB65 11 THE DETECTION OF PARTIAL ASSOCIATION, 2. THE GENERAL CASE * M. W. BIRCH

JRSSB65 125 ON A PROPERTY OF THE RANDOM WALKS DESCRIBING SIMPLE QUEUES AND DAMS * R. M. LOYNES

JRSSB65 130 APPLICATIONS OF A BALLOT THEOREM IN PHYSICS AND IN ORDER STATISTICS * L. TAKACS

JRSSB65 13B A BRANCHING PROCESS ALLOWING IMMIGRATION * $\mathrm{C} . \mathrm{R}$. HEATHCOTE

JRSSB65 144 POLYNOMIAL PROJECTING PROPERTIES OF MULTI-TERM PREDICTORS OR CONTROLLERS IN NON-STATIONARY TIME SERIES * W. D. RAY, C. TYLD

JRSSB65 159 THE STATISTICAL FOURIER ANALYSIS OF VARIANCES * L. J HERBST

JRSSB65 166 SUPPLEMENT TO 'A DEFORMATI IN METHOD FOR QUADRAT IC PROGRAMMING ' * S. ZAHL

JRSSB65 169 BAYESIAN INTERPRETATION OF STANDARD INFERENCE STATEMENTS (WITHDISCUSSION) * JOHN W. PRATT

JRSSB65 204 EVOLUTIONARY SPECTRAL AND NON-STATIONARY PROCESSES (WITH DISCUSSION)*M. B. PRIESTLEY
JRSSB65 23B ON SIMPLE RULES FOR THE COMPOUND DECISION PROBLEM * ESTER SAMUEL

JRSSB65 245 LIKELIHOOD RATIO AND CONFIDENCE-REGION TESTS * J AITCHISON

JRSSB65 251 ANALYSIS OF FACTORIAL EXPERIMENTS BY ESTIMATING MONOTONE TRANSFORMATIONS OF THE DATA * J, B KRUSKAL

JRSSB65 264 ANALYTICAL SURVEYS WITH CLUSTER SAMPLING * J SEDRANSK

JRSSB65 279 BAYESIAN ESTIMATION OF PARAMETERS OF A MULTIVARIATE NORMAL DISTRIBUTION * I. G. EVANS

JRSSB65 2B4 FINITE STOPPING TIME AND FINITE EXPECTED STOPPING TIME* I. R. SAVAGE, L. J. SAVAGE

JRSSB65 290 DERIVATION OF A CLASS OF FREQUENCY DISTRIBUTIONS VIA BAYES 'S THEOREM * CARL-ERIK SARNDAL

JRSSB65 301 PLANE TRUNCATION IN NORMAL POPULATIONS * G. M. TALLIS

JRSSB65 3OB MOMENTS OF A SERIAL CORRELATION COEFFICIENT * L. R. SHENTON, W. L. JOHNSON

JRSSB65 321 APPLICATION OF STOCHASTIC APPROXIMATION TO PROCESS CONTROL * J. P. COMER JR

JRSSB65 332 ON THE ESTIMATION OF THE INTENSITY FUNCTION OF A STATIONARY POINT PROCESS * D. R. COX

JRSSB65 33B THE BASIC BIRTH-DEATH MODEL FOR MICROBIAL INFECTIONS * T. WILLIAMS

JRSSB65 361 ON THE BUSY PERIOD OF A FACILITY WHICH SERVES CUSTOMERS OF SEVERAL TYPES * P. D. WELCH

JRSSB65 371 SOME GENERAL RESULTS IN SEQUENTIAL DESIGN (WITH DISCUSSION) *P. WHITTLE

JRSSB65 395 SPACINGS (WITHDISCUSSION) * R. PYKE

JRSSB65 450 MIXTURE DESIGNS FOR THREE FACTORS * N. R. DRAPER, W LAWRENCE

JRSSB65 466 THE NUMERICAL SOLUTION OF SOME NON-L INEAR EQUATIONS, USEFUL IN THE DESIGN OF EXPERIMENTS * E. L. ALBASINY

JRSSB65 473 MIXTURE DESIGHS FOR FOUR FACTORS * N. R. DRAPER. W LAWRENCE

JRSSB65 479 TRANSFORMATIONS AND SUFFICIENCY * D. A. SPROTT

JRSSB65 4B6 ADDITIONAL RESULTS CONCERNING ESTIMABLE FUNCTIONS AND GENERALIZED INVERSE MATRICES * S. R. SEARLE

JRSSB65 491 ON THE WAITING-TIME DISTRIBUTION FOR QUEUES IN SERIES * R. M. LOYNES

JRSSB65 497 A TWO-DIMENSIONAL POISSON GROWTH PROCESS * R. W MORGAN, D. J A A. WELSH

JRSSB65 505 CERTAIN PROPERTIES OF GAUSSIAN PROCESSES AND THEIR FIRST PASSAGE TIMES * C. B. MEHR, J. A. MCFADDEN

JRSSB65 523 RECURSIVE RELATIONS FOR PREDICTORS OF NON-STATIONARY PROCESSES * P. WHITTLE

JOURNAL OF THE ROYAL STATISTICAL SOCIETY, SERIES B VOLUME 2B, 1966

JRSSB66

JRSSB 66

JRSSB 66

JRSSB 66

JRSSB66

JRSSBG6

JRSSB66

JRSSB6 6

JRSSB66

JRSSB66

JRSSB66

JRSSB66

JRSSB66

JRSSB66

JRSSB 66

JRSSB66

JRSSB66 IBO A TEST FOR 'INTRINSIC CORRELATION' IN THE THEORY OF

1 ALLOCATION RULES AND THEIR ERROR RATES (WITH DISCUSSION $) * M$. HILLS

32 ESTIMATION BY RANKING PARAMETERS * J A. HARTIGAN

45 ON EFFICIENT MULTINOMIAL ESTIMATION * B. R. BHAT, N V. KULKARNI

53 ON A FIDUCIAL EXAMPLE OF C. STEIN * R. S. PINKHAM

55 NOTE ON THE CONFIDENCE-PRIOR OF WELCH AND PEERS * J. A. HART IGAN

57 EXPECTED-COVER AND LINEAR-UTILITY TOLERANCE INTERVALS * J. AITCHISON

63 SEQUENTIAL COMPOUND RULES FOR THE FINITE DECISION PROBLEM * ESTER SAMUEL

73 ASYMPTOTIC SEQUENTIAL DESIGN OF EXPERIMENTS WITH TWO RANDOM VARIABLES * L. R. ABRAMSON

B8 AN EXPERIMENTAL STUDY OF CERTAIN SCREENING PROCESSES * D. J. FINNEY

HE ANALYSIS OF VARIANCE OF DESIGNS WITH MANY NONORTHOGONAL CLASSIFICATIONS * D. H. REES

118 CLASSIFYING YOUDEN RECTANGLES * D. A. PREECE

131 A GENERAL CLASS OF COEFFICIENTS OF DIVERGENCE OF ONE DISTRIBUTION FROM ANOTHER * S. M. ALI, S. D. SILVEY

3 CHARACTERIZATION THEOREMS FOR SOME UNIVARIATE PROBABILITY DISTRIBUTIONS * M V. MENON

NOTE ON THE ASYMPTOTIC EFFICIENCY OF BENNETT'S BIVARIATE SIGN TEST * G. K. BHATTACHARYYA

THE CHI-SQUARE TEST FOR HETEROGENEITY OF PROPORTIONS AFTER ADJUSTMENT FOR STRATIFICATION (ADDENDUM 67 197) * P. ARMITAGE ACCIDENT PRONENESS (ACKNOWLEDGEMENT $665 \mathrm{~B} 5$ ) * $\mathrm{K}$ SUBRAHMANIAM

JRSSB66 190 THE ERGODIC QUEUE LENGTH DISTRIBUTION FOR QUEUEING SYSTEMS WITH FINITE CAPACITY * J. KEILSON

JRSSB66 202 DELAY AT TRAFFIC INTERSECTIONS * A. G. HAWKES

JRSSB66 213 CORRECTIONS AND COMMENTS ON THE PAPER 'A BRANCHING PROCESS ALLOWING IMMIGRATION' * C. R. HEATHCOTE
JRSSB66 $21 B$ ON STREAMS OF EVENTS AND MIXTURES OF STREAMS * M. R LEADBETTER

JRSSB66 22B DESIGN RELATIONS FOR NON-STATIONARY PROCESSES * M . B PRIESTLEY

JRSSB66 241 EXPONENTIAL SMOOTHING FOR MULT IVARIATE TIME SERIES * R. H. JONES

JRSSB66 253 QUASI-STATIONARY DISTRIBUTIONS AND TIME-REVERSION IN GENETICS (WITHDISCUSSION) * E. SENETA

JRSSB66 27B A GENERALIZED LEAST-SQUARES APPROACH TO LINEAR FUNCTIONAL RELATIONSHIPS (WITH DISCUSSION) * P. SPRENT JRSSB66 298 LOCALLY UNBIASED TYPE M TEST * M. KRISHNAN

JRSSB66 310 A NEW APPROACH TO SAMPLING FROM FINITE POPULATIONS. I * V. P. GODAMBE

JRSSB66 320 A NEW APPROACH TO SAMPLING FROM FINITE POPULATIONS. II * V.P. GODAMBE

JRSSB66 329 THE ALMOST FULL DAM WITH POISSON INPUT * A. M. HASOFER JRSSB66 336 ON THE CORRELATION STRUCTURE OF THE DEPARTURE PROCESS OF THE QUEUE WITH ONE SERVER, WHILE THE INTERARRIVAL AND SERVING DISTRIBUTIONS ARE EXPONENTIAL AND GAMMA OF ORDER LAMBDA RESPECTIVELY * J. H. JENKINS

JRSSB66 345 CYCLIC INCOMPLETE BLOCK DESIGNS * J. A. JOHN

JRSSB66 361 AN EXTENSION OF THE TRIANGULAR ASSOCIATION SCHEME TO THREE ASSOCIATE CLASSES * P.W.M. JOHN

JRSSB66 366 ON THE EVALUATION OF PROBABILITIES OF CONVEX POLYHEDRA UNDER MULTIVARIATE NORMAL AND T-DISTRIBUTIONS * S. JOHN

JRSSB66 370 SOME ASYMPTOTICALLY EXTINCT SEQUENTIAL PROCEDURES FOR RANKING AND SLIPPAGE PROBLEMS * M. S. SRIVASTAVA

JRSSB66 3B1 THE DECISION THEORY APPROACH TO SAMPLING INSPECTION (WITH DISCUSSION) * G. B. WETHERILL, G. E. G. CAMPLING

JRSSB66 417 AN APPROACH TO THE STUDY OF MARKOV PROCESSES (WITH DISCUSSION) * J.F. C. KINGMAN

JRSSB66 44B THE ALMOST FULL DAM WITH POISSON INPUT, FURTHER RESULTS * A. M. HASOFER

JRSSB66 456 ON A GENERALIZED QUEUEING SYSTEM WITH POISSON ARRIVALS * D. N. SHANBHAG 
JRSSB66 459 THE RELIABILITY OF MULTIPLEX SYSTEMS WITH REPAIR * F DOWNTON

JRSSB66 477 A TECHNIQUE FOR DISCUSSINC THE PASSACE TIME DISTRIBUTION FOR STABLE SYSTEMS * J. KEILSON

JRSSB66 487 ON THE SIZE OF AN EPIDEMIC AND THE NUMBER OF PEOPLE HEARINC A RUMOUR * VIOLET R. CANE

JRSSB66 491 FIRST-PASSACE PERCOLATION * J.M. HAMMERSLEY

JRSSB66 497 SOME ASPECTS OF THE ESTIMATION OF QUANTILES * R. M. LOYNES

JRSSB66 513 SOME NEW RESULTS ON THE DISTRIBUTION OF THE SAMPLE CORRELATION COEFFICIENT * H. RUBEN
JRSSB66 526 ON THE DISTRIBUTION OF THE F-TYPE STATISTICS IN THE ANALYSIS OF A CROUP OF EXPERIMENTS * T . CALINSKI

JRSSB66 543 SOME ASPECTS OF RANDOMIZATION * C. E. P. BOX. I. GUTTMAN

JRSSB66 559 BALANCED FACTORIAL DESICNS * A. M. KSHIRSACAR

JRSSB66 568 A BAYESIAN APPROACH TO CLASSIFICATION * I. R. DUNSMORE JRSSB66 578 A DERIVATION OF THE PROBABILISTIC EXPLICATION OF INFORMATION * I, J , COOD

JRSSB66 582 ON THE INDEPENDENCE OF QUADRATIC FORMS * D. N. SHANBHAC

JOURNAL OF THE ROYAL STATISTICAL SOCIETY, SERIES B VOLUME 29, 1967

JRSSB67 I TOPICS IN THE INVESTICATION OF LINEAR RELATIONS FITTED BY THE METHOD OF LEAST SQUARES (WITH DISCUSSION) *F.J. ANSCOMBE

JRSSB67 53 HYPOTHESIS TESTING WHEN THE SAMPLE SIZE IS TREATED AS A RANDOM VARIABLE (WITH DISCUSSION) * D. J. BARTHOLOMEW

JRSSB67 83 THE USE OF THE CONCEPT OF A FUTURE OBSERVATION IN GOODNESS-OF-FIT PROBLEMS * I . GUTTMAN

JRSSB67 101 LINEAR APPROXIMATION USING THE CRITERION OF LEAST TOTAL DEVIATIONS (ACKNOWLEDCEMENT 67587 ) * M. DAVIES

JRSSB67 110 ON SHARPENINC SCHEFFE BOUNDS * R. BOHRER

JRSSB67 115 OPTIMUM ALLOCATION IN MULTIVARIATE SURVEYS, AN ANALYTICAL SOLUTION *A.R. KOKAN, S. KHAN

JRSSB67 126 A GENERALIZATION OF FIELLER'S THEOREM TO THE RATIO OF COMPLEX PARAMETERS * M. HALPERIN

JRSSB67 132 ON FIXED-WIDTH CONFIDENCE BOUNDS FOR REGRESSION PARAMETERS AND MEAN VECTOR *M. S. SRIVASTAVA

JRSSB67 141 ASYMPTOTIC RENEWAL RESULTS FOR A NATURAL CENERALIZATION OF CLASSICAL RENEWAL THEORY * C. C . HEYDE

JRSSB67 151 A MODIFIED MODEL FOR RAINFALL OCCURRENCE * J. R. GREEN

JRSSB67 154 EXPOST DETERMINATION OF SIGNIFICANCE IN MULTIVARIATE RECRESSION WHEN THE INDEPENDENT VARIABLES ARE ORTHOCONAL * R. C. CEARY

JRSSB67 162 ASYMPTOTIC PROPERTIES OF BAYESIAN SINGLE SAMPLINC PLANS (CORR. 675B6)*A. HALD

JRSSB67 174 THE BEHAVIOUR OF THE VARIANCE FUNCTION OF THE DIFFERENCE BETWEEN TWO ESTIMATED RESPONSES * A. HERZBERC

JRSSB67 180 ESTIMATING THE COVARIANCE AND SPECTRAL DENSITY FUNCTIONS FROM A CLIPPED STATIONARY TIME SERIES * D. R MCNEIL

JRSSB67 199 THE ANALYSIS OF ASSOCIATION AMONG MANY VARIABLES (WITH DISCUSSION) * E. J. WILLIAMS

JRSSB67 243 ON JOHN'S CYCLIC INCOMPLETE BLOCK DESIGNS * W. H. CLATWORTHY

JRSSB67 248 FORMAL EXPRESSIONS WHICH CAN BE USED FOR THE DETERMINATION OF THE OPERATING CHARACTERISTIC AND AVERAGE SAMPLE NUMBER OF A SIMPLE SEQUENTIAL TEST * K. W. KEMP

JRSSB67 263 A SIMPLE PROCEDURE FOR DETERMINING UPPER AND LOWER LIMITS FOR THE AVERAGE SAMPLE RUN LENGTH OF A CUMULATIVE SUM SCHEME * K. W. KEMP

JRSSB67 266 MODELS OF THE SECOND KIND IN REGRESSION ANALYSIS * $P$. R. FISK
JRSSB 67282 INFERENCES CONCERNING A POPULATION CORRELATION COEFFICIENT FROM ONE OR POSSIBLY TWO SAMPLES SUBSEQUENT TO A PRELIMINARY TEST OF SIGNIFICANCE * $S . R$. SRIVASTAVA, T. A. BANCROFT

JRSSB67 292 ON A SPECIAL SUBSET GIVING AN IRREGULAR FRACTIONAL REPLICATE OF A 2 TO THE POWER N FACTORIAL EXPERIMENT * K. S. BANERJEE, W. T. FEDERER

JRSSB67 300 OPTIMIZATION OF A HOT ROLLINC MILL * D, C. DOWSON

JRSSB67 320 A NON-PARAMETRIC TEST FOR THE BIVARIATE TWO-SAMPLE LOCATION PROBLEM * K. V. MARDIA

JRSSB67 343 NON-HOMOGENEOUS BRANCHING POISSON PROCESSES * P. A. W. LEWIS

JRSSB67 355 METHODS OF ESTIMATION INVOLVING DISCOUNTINC * $\mathbf{w}$. G GILCHRIST

JRSSB 67370 A CHANGE-OVER DESICN FOR TESTINC A TREATMENT FACTOR AT FOUR EQUALLY SPACED LEVELS (CORR. 67 5B6) * I. I. BERENBLUT

JRSSB67 374 OPTIMUM UTILIZATION OF AUXILIARY INFORMATION, (PI)PS SAMPLING OF TWO UNITS FROM A STRATUM (ADDENDUM 69 192) * T. V. HANURAV

JRSSB67 392 ON THE CHOICE OF A STRATEGY FOR A RATIO METHOD OF ESTIMATTON * T, J, RAO

JRSSB67 399 A BAYESIAN SIGNIFICANCE TEST FOR MULTINOMIAL DISTRIBUTIONS (WITHDISCUSSION) * I. J. GOOD

JRSSB67 432 THE THEORY OF RISK (WITHDISCUSSION) * K. BORCH

JRSSB67 468 TESTS OF HYPOTHESES CONCERNING MATCHED SAMPLES (CORR 69 194) * B. M. BENNETT

JRSSB67 475 CONSIDERING STATISTICAL AND TIME AVERAGES IN A RECULATION PROBLEM * E. KOUNIAS

JRSSB67 489 ON A CLASS OF CAUSSIAN PROCESSES FOR WHICH THE MEAN RATE OF CROSSINGS IS INFINITE * J. A. MCFADDEN

JRSSB67 503 ON THE ECONOMIC CHOICE OF EXPERIMENT SIZES FOR DECISION RECARDINC CERTAIN LINEAR COMBINATIONS * W. A. ERICSON

JRSSB 67513 ON THE DISTRIBUTION OF PRODUCTS OF RANDOM VARIABLES * Z. A. LOMNICKI

JRSSB67 525 ESTIMATION OF THE PARAMETER OF AN EXPONENTIAL DISTRIBUTION* G, M. EL-SAYYAD

JRSSB67 540 AN ANALYSIS OF DEPARTURES FROM THE EXPONENTIAL DISTRIBUTION * O. A. Y. JACKSON

JRSSB67 533 THE LIKELIHOOD AND INVARIANCE PRINCIPLES * J. A. HARTIGAN

JRSSB67 550 FOUR-LETTER WORDS, THE DISTRIBUTION OF PATTERN FREQUENCIES IN RINC PERMUTATIONS * D. E. BARTON, F. N. DAVID

JRSSB67 570 ON THE PREDICTION OF NON-STATIONARY PROCESSES * N. A ABDRABBO, M. B. PRIESTLEY

JOURNAL OF THE ROYAL STATISTICAL SOCIETY, SERIES B VOLUME 30, 1968

JRSSB6B I ON THE CONCEPT OF THE SPECTRUM FOR NON-STATIONARY PROCESSES (WITHDISCUSSION) * R. M. LOYNES

JRSSB68 31 THE CHOICE OF VARIABLES IN MULTIPLE REGRESSION (WITH DISCUSSION) *D.V. LINDLEY

JRSSB6B 67 MISSING DATA IN REGRESSION ANALYSIS * Y. HAITOVSKY

JRSSB68 B3 SMALL SAMPLE POWER OF A NON-PARAMETRIC TEST FOR THE BIVARIATE TWO-SAMPLE LOCATION PROBLEM IN THE NORMAL CASE * K. V. MARDIA

JRSSB68 93 PLANT COMPETITION. THREE SPECIES PER POT * C. A. MCGILCHRIST

JRSSB6B IOB SOME PROBLEMS OF OPTIMAL STOPPING * M. H. DEGROOT

JRSSB68 123 EXPERIMENTS WITH MIXTURES, A GENERALIZATION OF THE SIMPLEX-LATTICE DESIGN * D. P. LAMBRAKIS

JRSSB68 137 EXPERIMENTS WITH P-COMPONENT MIXTURES * D. P. LAM-

BRAKIS
JRSSB68 145 ESTIMATION OF THE CROSS-SPECTRUM OF A STATIONARY BIVARIATE GAUSSIAN PROCESS FROM ITS ZEROS *D. R BRILLINGER

JRSS868 160 ON A DISTRIBUTION ASSOCIATED WITH CERTAIN STOCHASTIC PROCESSES * A. W. KEMP, C. D. KEMP

JRSS868 164 SOME APPLICATIONS OF MULTIPLE-TYPE BRANCHINC PROCESSES IN POPULATION CENETICS * W. J. EWENS
JRSSB6B

JRSSB 68

176 THE STATIONARY DISTRIBUTION OF A BRANCHING PROCESS ALLOWING IMMIGRATION, A REMARK ON THE CRITICAL CASE * E. SENETA

JRSSB 68

1BO AN EXTENSION OF QUENOUILLE'S TEST FOR THE COMPATIBILITY OF CORRELATION STRUCTURES IN TIME SERIES * J ROSENHEAD

JRSSB68 185 A QUEUE WITH RANDOM ARRIVALS AND SCHEDULED BULK DEPARTURES * A. MERCER

JRSSB68 190 THE BAYESIAN ESTIMATION OF A LINEAR FUNCTIONAL RELATIONSHIP * D. V. LINDLEY, G. M. EL-SAYYAD

JRSSB6B 205 A CENERALIZATION OF BAYESIAN INFERENCE (WITH DISCUSSION) *A.P. DEMPSTER

JRSS868 24B A GENERAL DEFINITION OF RESIDUALS (WITH DISCUSSION) * D. R. COX, E. J. SNELL

JRSS868 276 A RELATIVELY SIMPLE FORM OF THE DISTRIBUTION OF THE MULTIPLE CORRELATION COEFFICIENT * J. GURLAND

JRSSB68 284 A NOTE ON THE EFFICIENCY OF LEAST-SQUARES ESTIMATES * D. R. COX, D, V, HINKLEYY

JRSSB68 290 THE OCCURRENCE OF REPLICATIONS IN OPTIMAL DESIGNS OF EXPERIMENTS TO ESTIMATE PARAMETERS IN NON-LINEAR MODELS* M. J. BOX 
JRSSB6B 303 THE COMBINATION OF INFORMATION IN CENERALLY BALANCED DESIGNS * J.A. NELDER

JRSSB6B 312 ASYMPTOTICALLY EFFICIENT TESTS BY THE METHOD OF N RANKINCS * P. K. SEN

JRSSB68 $31 \mathrm{~B}$ A NOTE ON A MODIFIED EXPONENTIALLY WEICHTED PREDICTOR * B. J.N. BLICHT

JRSSB6B 321 SOME APPLICATIONS OF PROBABILITY CENERATINC FUNCTIONALS TO THE STUDY OF INPUT-OUTPUT STREAMS * D. VERE-JONES

JRSSB6B 334 AN APPLICATION OF BIORTHONORMAL EXPANSIONS IN THEORY OF STOCHASTIC PROCESSES * C. B. MEHR

JRSSB68 338 THE ASYMPTOTIC POWERS OF MULTIVARIATE TESTS WITH CROUPED DATA * D. R. MCNEIL

JRSSB68 349 MODELS FOR THE RESPONSE OF A MIXTURE * N. C. BECKER

JRSSB68 359 THE MIXED BINOMIAL DISTRIBUTION AND THE POSTERIOR DISTRIBUTION OF P FOR A CONTINUOUS PRIOR DISTRIBUTION* A. HALD

JRSSB6B 36B NOTE ON CHI SQUARE TESTS FOR MATCHED SAMPLES * B. M. BENNETT

JRSSB68 371 A UNIFIED APPROACH FOR CONSTRUCTINC A USEFUL CLASS OF NON-ORTHOCONAL MAIN EFFECT PLANS IN K TO THE N FACTORIALS * B. L. RAKTOE, W. T. FEDERER

JRSSB6B $3 B I$ ON THE LINEAR CONTROL OF A LINEAR SYSTEM HAVING A NORMAL STATIONARY STOCHASTIC INPUT * D. C. DOWSON

JRSSB6B 396 ABAYESIAN APPROACH TO CALIBRATION * I. R. DUNSMORE

JRSSB6B 407 A CENERAL APPROACH TO SOME SCREENINC AND CLASSIFICATION PROBLEMS (WITH DISCUSSION) *A. W. MARSHALL, I OLKIN

JRSSB68 444 AN ESTIMATION PROCEDURE FOR MIXTURES OF DISTRIBUTIONS * K. CHOI. W. C. BULCREN
JRSSB68 461 A MULTI-STAGE TEST FOR A NORMALMEAN * A. SCOTT

JRSSB68 469 THE CHOICE OF THE DEGREE OF A POLYNOMIAL MODEL * $\mathrm{H}$. HAGER, C. ANTLEE

JRSSB68 472 ESTIMATION OF PARAMETERS OF A FINITE MIXTURE OF DISTRIBUTIONS * A.B.M. L. KABIR

JRSSB6B $4 B 3$ RANK ORDER TESTS OF LINEAR HYPOTHESES * $B$, M. BENNETT JRSSB6B 490 LEAST-SQUARES EFFICIENCY FOR VECTOR TIME SERIES * E. J. HANNAN

JRSSB6B 499 THE ERCODIC THEORY OF SUBADDITIVE STOCHASTIC PROCESSES * J.F, C. KINCMAN

JRSSB68 511 MULTIVARIATE BETA DISTRIBUTION AND A TEST FOR MULTIVARIATE NORMALITY* B. WACLE

JRSSBGB 517 RANDOM PERMUTATIONS * R. L. PLACKETT

JRSSB6B 535 CONFIDENCE PROPERTIES OF BAYESIAN INTERVAL ESTIMATES * H. W. PEERS

JRSSB 68545 NOTE ON DISCORDANT OBSERVATIONS * J. A. HARTICAN

JRSSB6B 551 DISTRIBUTION-FREE SUFFICIENCY IN SAMPLINC FINITE POPULATIONS * V. M. JOSHI

JRSSB68 556 AN EXACT (PI)PS SAMPLING SCHEME, A CENERALIZATION OF A METHOD OF HANURAV * K. VIJAYAN

JRSSB68 567 A REMARK ON SOLVINC EQUATIONS IN SUMS OF POWERS * S. R. SEARLE

JRSSB68 570 A NOTE ON THE ASYMPTOTIC DISTRIBUTION OF SAMPLE QUANTILES * A. M. WALKER

JRSSB6B 576 ON THE SUPERPOSITION OF POINT PROCESSES * E. CINLAR, R. A. ACNER

JRSSB68 582 A SIMPLIFIED MONTE CARLO SICNIFICANCE TEST PROCEDURE * adery C. A. hope

JRSSB68 599 A CENTRAL TOLERANCE RECION FOR THE MULTIVARIATE NORMAL DISTRIBUTION * S. JOHN

JOURNAL OF THE ROYAL STATISTICAL SOCIETY, SERIES B VOLUME 31, 1969

JRSSB69

JRSSB 69

JRSSB69

JRSSB69

JRSSB69

JRSSB 69

JRSSB 69

JRS\$B69

JRSSB 69

JRSSB69

JRSSB69

JRSSB69

JRSSB69

JRSSB69

JRSSB69

JRSSB69

JRSSB 69
1 STOCHASTIC MODELS OF CAPITAL INVESTMENT (WITH DISCUSSION) * R. L. PLACKETT

29 MULTIPARAMETER BAYESIAN INDIFFERENCE PROCEDURES (WITH DISCUSSION) * M.R. NOVICK

65 ON A TEST FOR SEVERAL LINEAR RELATIONS * A. 0. BASU

72 ON EXTREMAL FACTORIZATION AND RECURRENT EVENTS * C. C. HEYDE

BO ON THE ASYMPTOTIC BEHAVIOUR OF POSTERIOR DISTRIBUTIONS * A.M. WALKER

89 FOUNDATIONS FOR THE THEORY OF LEAST SQUARES * B. M. HILL

$9 B$ ON THE NULL DISTRIBUTION OF A NON-PARAMETRIC TEST FOR THE BIVARIATE TWO-SAMPLE PROBLEM * K. V. MARDIA

ON COX AND SNELL'S DEFINITION OF RESIDUALS * R. M. LOVNES

107 REGRESSION PROBLEMS WHEN THE PREDICTOR VARIABLES ARE PROPORTIONS*N.G.BECKER

113 LEAST-SQUARES FITTING OF A POLYNOMIAL CONSTRAINED TO BE EITHER NON-NEGATIVE, NON-DECREASINC OR CONVEX * D. J. HUDSON

119 A NOTE ON AN ALLOCATION PROBLEM * A. J. SCOTT

123 DISCRIMINATION BETWEEN $K$ POPULATIONS WITH CONSTRAINTS ON THE PROBABILITIES OF MISCLASSIFICATION * J. A. ANDERSON

140 A TEST FOR NON-STATIONARITY OF TIME-SERIES * M. B PRIESTLEY, T. SUBBA RAO

O FILTERING NON-STATIONARY SIGNALS * N. A. ABDRABBO, M. B. PRIESTLEY

160 REGULATION AND OPTIMIZATION * I. R. DUNSMORE

71 MULTIVARIATE STOCHASTIC PROCESSES WITH PERIODIC COEFFICIENTS * V. SISKIND

181 ESTIMATINC THE PARAMETERS OF A CONVOLUTION * S. L. SCLOVE, J. VAN RYZIN
JRSSB69 NO.2 SUBJECT IVE BAYESIAN MODELS IN SAMPLINC FINITE POPULATIONS (TITHDISCUSSION) * W. A. ERICSON

JRSSB69 NO.2 AN ALTERNATIVE TO THE SIMPLEX-LATTICE DESICN FOR EXPERIMENTS WITH MIXTURES * D. P. LAMBRAKIS

JRSSB69 NO.2 A FIDUCIAL ARCUMENT WITH APPLICATION TO SURVEY SAMPLINC * V, P. GODAMBE

JRSSB69 NO. 2 EXACT BAYESIAN ANALYSIS OF A TWO-BY-TWO CONTINCENCY TABLE, AND FISHER'S 'EXACT' SICNIFICANCE TEST * PATRICIAM. E. ALTHAM

JRSSB69 NO.2 SOME NONORTHOCONAL FRACTIONS OF 2-TO-THE-N DESIGNS * P. W. M. JOHN

JRSSB69 NO.2 ESTIMATED RECRESSION FUNCTION OF THE Q-SUB-1 TO QSUB-N BY M-SUB-I TO M-SUB-N MULTIPLE-LATTICE DESIGN * D. P. LAMBRAKIS

JRSSB69 NO.2 A SEQUENTIAL PROCEDURE FOR TESTING A NULL HYPOTHESIS AGAINST A TWO SIDED ALTERNATIVE HYPOTHESIS * L. BILLARD, M. K. VAGHOLKAR

JRSSB69 NO. 2 ON THE DISTRIBUTIONS OF THE TIMES BETWEEN EVENTS IN A STATIONARY STREAM OF EVENTS * R. LEADBETTER

JRSSB69 NO. 2 MAJORANTS OF THE CHROMATIC NUMBER OF A RANDOM GRAPH * P. HOLGATE

JRSSB69 NO.2 INFERENCE CONCERNING PROBABILITIES AND QUANTILES * J. R. GREEN

JRSSB69 NO.2 STRUCTURAL PROBABILITY AND PREDICTION FOR THE MULTIVAR IATE MODEL * D. A. S. GRASER, M. S. HAQ

JRSSB69 NO.2 A NOTE ON THE POSTERIOR MEAN OF A POPULATION MEAN * $\mathbb{W}$ A. ERICSON

JRSSB69 NO. 2 TESTS FOR SPECIFICATION ERRORS IN CLASSICAL LINEAR LEAST-SQUARES RECRESSION ANALYSIS * J. B. RAMSEY

JRSSB69 NO.2 THE MAXIMUM LIKELIHOOD SOLUTION TO THE PROBLEM OF ESTIMATING A LINEAR FUNCTIONAL RELATIONSHIP * MARY E. SOLARI

JRSSB69 NO.2 TESTING FOR LINEAR CONTAGION, INVERSE SAMPLING * E. SHLOM, E. PERITZ 
1 THE SOUTH AFRICAN STATISTICAL ASSOCIATION, A SKETCH OF ITS ORIC INS AND CROWTH * J . E. KERRICH

SASJ 673 PROBABILITY MEASURES ON PRODUCT SPACES * J. H. VENTER

SASJ 6721 NONCENTRAL MULTIVARIATE DIRICHLET DISTRIBUTIONS * C C. TROSKIE

SASJ 6733 ABOUT SENSITIVITY ANALYSIS IN LINEAR PROCRAMMINC MODELS * P.E.R. ARMSEN

SASJ $67 \quad 43$ ON A PROBLEM OF RECRESSION * A. M. MATHAI

SASJ 6749 THE ORTHOCONAL POLYNOMIALS OF THE FACTORIAL POWER SERIES PROBABILITY DISTRIBUTIONS * D. F. I . VAN HEERDEN, H. T . CONIN
SASJ 67

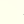

55 A STUDY OF THE MATRIX OF FITT INC OF A SERIES OF DISCRETE FREQUENCY FUNCTIONS ANALOCOUS TO THE TYPE A SERIES * H. T. CONIN

SASJ 6759 A QUASI-MULT INOMIAL TYPE OF CONTINCENCY TABLE * G. J. RUDOLPH

SASJ 6767 DISTRIBUTION-FREE ANALYSIS OF VARIANCE FOR THE TWOWAY CLASSIFICATION * H. H. LEMMER, D. J . STOKER

SASJ 6775 A CLASS OF DISTRIBUTION-FREE ANALYSIS OF VARIANCE TESTS * C. F. CROUSE

SOUTH AFRICAN STATISTICAL JOURNAL VOLUME 2, 1968

SASJ $6 B$

SASJ 68

SASJ 6B

SASJ $6 B$

SASJ $6 B$

1 EIENSKAPPE VAN WAARSKYNLIKHEIDSVERDELINCS DEUR DIE GEBRUIK VAN DIFFERENSIAALVERCELYKINCE * H. S. STEYN

9 A DISTRIBUTION-FREE ANALYSIS OF VARIANCE TECHNIQUE FOR BLOCK DESIGNS * H. H. LEMMER, D. J. STOKER, S. C. REINACH

33 ON COMPARINC TWO SIMPLE LINEAR RECRESSION LINES * F E. STEFFENS

55 OPSOMMINC VAN LESINCS. (SUMMARY OF PAPERS)

61 ON SOME BILHARZIA INFECT ION AND IMMUNISATION MODELS * H. LINHART
SASJ $6 B$

SASJ $6 B$

SASJ 68

SASJ 68

SASJ $6 B$
67 SINCLE AND MULTIPLE DISCRIMINATION REGIONS IN MULTIPLE LINEAR REGRESSION * N. F. LAUBSCHER

77 AN ASYMPTOTIC DISTRIBUTION FOR THE DETERMINANT OF A NON-CENTRAL B STATISTIC IN MULTIVARIATE ANALYSIS * D. J. DE WAAL

B5 ON THE USE AND MISUSE OF CORRECTIONS FOR CONTINUITY * C. J. RUDOLPH

101 A DISTRIBUTION-FREE METHOD OF ANALYZINC A 2 TO THE M FACTORI AL EXPERIMENT $* \mathrm{C} . \mathrm{F}$, CROUSE

SOUTH AFRICAN STATISTICAL JOURNAL VOLUME 3, 1969

SASJ 69

SASJ 69

SASJ 69

SASJ 69

SASJ 69 NALYSIS OF VARIANCE * C.F. CROUSE

SASJ 69 NO. 2 ON THE NONCENTRAL DISTRIBUTION OF THE LARCEST CANONICAL CORRELATION COEFFICIENT * B. J. DE WAAL
SASJ 69 NO.2 THE NONCENTRAL MULTIVARIATE BETA TYPE TWO DISTRIBUTION * D. J. DE WAAL

SASJ 69 NO.2 'N BENADERINC VIR 'N MAGREEKS WAARSKYNLIKHEIDSVERDELINC * C. J. J. VAN RENSBURC

SASJ 69 NO.2 THE GENERALIZED MULTIPLE CORRELATION MATRIX * C. G TROSKIE

SASJ 69 NO.2 APPROXIMATE DISTRIBUTION FOR LARCEST' AND FOR SMALLEST OF A SET OF INDEPENDENT OBSERVATIONS * J . E . WALSH

SASJ 69 NO.2 A DISTRIBUTION-FREE TWO SAMPLE TEST FOR DISPERSION FOR SYMMETRICAL DISTRIBUTIONS * C. F. CROUSE, F. E STEFFENS

SASJ 69 NO.2 A COMPARISON OF CERTAIN TESTS OF NORMALITY * P. VAN DER WATT 
TECH 59

1 RESPONSE SURFACE DESICNS FOR THREE FACTORS AT THREE LEVELS * R. DEBAUN

TECH 599 THE ANALYSIS OF LIFE TEST DATA * R. L. PLACKETT

TECH 5921 MATHEMATICAL PROBABILITY IN THE NATURAL SCIENCES * $R$ A. FISHER

TECH 5931 A QUICK COMPACT TWO SAMPLE TEST TO DUCKWORTH'S SPECIFICATIONS * J. W. TUKEY

TECH 5949 SOME STATISTICAL ASPECTS OF THE ECONOMICS OF ANALYTICAL TESTINC * 0. L. DAVIES

TECH 5963 PARTIAL DUPLICATION OF FACTORIAL EXPERIMENTS * 0. DYKSTRA

TECH 5977 CONDENSED CALCULATIONS FOR EVOLUTIONARY OPERATION PROCRAMS* C. E. P. BOX, J. S. HUNTER

TECH 59101 MEASUREMENTS MADE BY MATCHINC WITH KNOWN STANDARDS * W. J. YOUDEN, W. S. CONNOR, N. C. SEVERO

TECH 59111 RANDOM BALANCE EXPERIMENTATION * F. E. SATTERTHWAITE

TECH 59139 THE APPLICATION OF RANDOM BALANCE DESIGNS * T. A BUDNE

TECH 59157 DISCUSSION OF THE PAPERS OF MESSRS. SATTERTHWAITE AND BUDNE * W. J. YOUDEN, OSCAR KEMPTHORNE, J.W. TUKEY, G. E. P. BOX, J.S. HUNTER

TECH 59195 QUICK ANALYSIS METHODS FOR RANDOM BALANCE SCREENINC EXPERIMENTS * F . J. ANSCOMBE
TECH 59217 SIMPLIFIED ESTIMATORS FOR THE NORMAL DISTRIBUTION WHEN SAMPLES ARE SINCLY CENSORED OR TRUNCATED * A. CLIFFORD COHEN JR

TECH 59239 CONTROL CHART TESTS BASED ON CEOMETRIC MOVING AVERACES * S. W. ROBERTS

TECH 59251 THE MEASURINC PROCESS * JOHN MANDEL

TECH 59269 FACTORIAL EXPERIMENTS IN LIFE TESTINC * MARVIN ZELEN

TECH 59289 THE USE OF LAGRANCE MULTIPLIERS WITH RESPONSE SURFACES * A. W. UMLAND, W. N. SMITH

TECH 59293 A STATISTICAL MODEL OF EVALUATINC THE RELIABILITY OF SAFETY SYSTEMS FOR PLANTS MANUFACTURINC HAZARDOUS PRODUCTS * LOUIS B. KAHN

TECH 59311 USE OF HALF-NORMAL PLOTS IN INTERPRETINC FACTORIAL TWO LEVEL EXPERIMENTS * CUTHBERT DANIEL

TECH 59343 ON THE ANALYSIS OF FACTORIAL EXPERIMENTS WITHOUT REPLICATION * ALLAN BIRNBAUM

TECH 59359 QUALITY CONTROL METHODS FOR SEVERAL RELATED VARIABLES * J. EDWARD JACKSON

TECH 59379 ANALYSIS OF LATIN SQUARES WITHIN A CERTAIN TYPE OF ROW-COLUMN INTERACTION * JOHN MANDEL

TECH 59389 A CRAPHICAL ESTIMATION OF MIXED WEIBULL PARAMETERS IN LIFE TEST INC ELECTRON TUBES * JOHN H. K. KAO

TECH 59409 EVALUATION OF CHEMICAL ANALYSES ON TWO ROCKS * W. J. YOUDEN

TECH 59419 ERRATA, 'THE APPLICATION OF RANDOM BALANCE DESIGNS ' * T. A , BUDNE

TEGHNOMETRICS VOLUME $\quad 2,1960$

TECH 601 SOME REMARKS ON WILD OBSERVATIONS * W. H. KRUSKAL

TECH 60

5 STATISTICAL ESTIMATION OF THE GASOLINE OGTANE NUMBER REQUIREMENT OF NEW MODEL AUTOMOBILES * C. S BRINEGAR, R. R. MILLER

TECH 60

19 THE EFFECT OF SEQUENTIAL BATCHING FOR ACGEPTANCE, REJECTION SAMPLINC UPON SAMPLE ASSURANGE OF TOTAL PRODUCT QUALITY * $M$. HALPERIN, G, L. BURROWS

TECH 6027 ELEMENTS OF THE THEORY OF EXTREME VALUES * B. EPSTEIN

TECH 6043 SYSTEM EFFICIENCY AND RELIABILITY* R. E. BARLOW, L C. HUNTER

TECH 6055 AIDS FOR FITTING THE GAMMA DISTRIBUTION BY MAXIMUM LIKELIHOOD * J. A, GREENWOOD, D. DURAND

TECH 6067 EXPERIMENTAL DESIGNS TO ADJUST FOR TIME TRENDS * HUBERT M. HILL

TECH 60 B3 TESTS FOR THE VALIDITY OF THE ASSUMPTION THAT THE UNDERLYING DISTRIBUTION OF LIFE IS EXPONENTIAL, PART I * B. EPSTEIN

TECH 60103 PROGRAMMING FISHER'S EXACT METHOD OF COMPARINC TWO PERCENTAGES * $W . H$. ROBERTSON

TEGH 60109 MISCLASSIFIED DATA FROM A BINOMINAL POPULATION * A CLIFFORD COHEN JR

TECH 60121 ERRATA, 'FACTORIAL EXPERIMENTS IN LIFE TESTING' * MARVIN ZELEN

TECH 60123 REJECTION OF OUTLIERS * F. J. ANSCOMBE

TECH 60149 LOCATING OUTLIERS IN FACTORIAL EXPERIMENTS * C DANIEL

TECH 60157 DISCUSSION OF THE PAPERS OF MESSRS. ANSCOMBE AND DANIEL * W. H. KRUSKAL, T. S. FERGUSON, J.W. TUKEY, E. J. GUMBEL

TECH 60167 TESTS FOR THE VALIDITY OF THE ASSUMPTIONS THAT THE UNDERLYING DISTRIBUTION OF LIFE IS EXPONENTIAL, PART II * B. EPSTEIN

TECH 60185 PARTIAL DUPLICATION OF RESPONSE SURFACE DESIGNS * 0 DYKSTRA

TECH 60197 A RANK SUM TEST FOR COMPARINC ALL PAIRS OF TREATMENTS * R. G. D. STEEL

TECH 60209 THE PERCENTILE POINTS OF DISTRIBUTIONS HAVING KNOWN CUMULANTS * R. A, FISHER, E , A . CORNISH

TECH 60227 AN APPROXIMATION OF THE NEGATIVE MOMENTS OF THE POSITIVE BINOMIAL USEFUL IN LIFE TESTING * W. MENDENHALL, E. H. LEHMAN JR
TECH 6024.3 ORDER STATISTICS FROM THE GAMMA DISTRIBUTION * S. S GUPTA

TECH 60263 PARALLEL FRACTIONAL REPLICATES * C. DANIEL

TECH 60275 THE COMPOUND HYPERGEOMETRIC DISTRIBUTION AND A SYSTEM OF SINGLE SAMPLING INSPECTION PLANS BASED ON PRIOR DISTRIBUTIONS AND COSTS * A. HALD

TECH 60341 SOME REMARKS ON THE BAYESIAN SOLUTION OF THE SINGLE SAMPLINC INSPECTION SCHEME * C. B. WETHERILL

TECH, 60353 SERIAL SAMPLING ACCEPTANCE SCHEMES DERIVED FROM BAYES'S THEOREM *D.R. COX

TECH 60361 DISCUSSION OF THE PAPERS OF MESSRS, HALD, WETHERILL AND COX $*$ G. A. BARNARD, D. V. LINDLEY, B. HILL, F. J. ANSCOMBE, I, J, GOOD, G. HORSNELL

TECH 60373 VARIATIONS FLOW ANALYSIS * NORBERT L. ENRICK

TECH 60387 A SEMI-GRAPHICAL METHOD FOR THE ANALYSIS OF COMPLEX PROBLEMS * E. ANDERSON

TECH 60393 INTER-PLANT STORAGE IN CONTINUOUS MANUFACTURING * $\mathrm{H}$ D. MILLER

TECH 60403 ESTIMATION OF THE PARAMETERS OF TWO PARAMETER EXPONENTIAL DISTRIBUTIONS FROM CENSORED SAMPLES * B EPSTEIN

TECH 60423 CONCLUSIONS VS DECISIONS * J. W. TUKEY

TECH 60435 STATISTICAL LIFE TEST ACCEPTANCE PROCEDURES BENJAMIN EPSTEIN

TECH 60447 ESTIMATION FROM LIFE TEST DATA * BENJAMIN EPSTEIN

TECH 60455 SOME NEW THREE LEVEL DESIGNS FOR THE STUDY OF QUANTITATIVE VARIABLES * G, E , P, BOX, D. W. BEHNKEN

TECH 60477 GRAPHICAL PROCEDURE FOR FITTINC THE BEST LINE TO A SET OF POINTS * J. L. DOLBY

TECH 60483 TABLES OF TOLERANCE-LIMIT FACTORS FOR NORMAL DISTRIBUTIONS * ALFRED WEISSBERG, GLENN H. BEATTY

TECH 60501 ON THE EVALUATION OF THE NECATIVE BINOMIAL DISTRIBUTION WITH EXAMPLES * G . P. PATIL

TECH 60507 ON METHODS OF CONSTRUGTINC SETS OF MUTUALLY ORTHOGONAL LATIN SQUARES USING A COMPUTER * $R$. C BOSE. I, M. CHAKRAVARTI, D, E, KNUTH

TECH 60523 ERRATA, 'THE PERCENTILE POINTS OF DISTRIBUTIONS HAVING KNOWN CUMULANTS ' * R. A. FISHER, E. A . CORNISH

TECH 60523 ERRATA, 'ORDER STATISTICS FROM THE GAMMA DISTRIBUTION' * S. S. GUPTA

TECHNOMETRICS VOLUME 3, 1961

TEGH 61 I CUMULATIVE SUM CHARTS * E. S. PAGE

TEGH 6111 AVERAGE RUN LENGTHS IN CUMULATIVE CHART QUALITY CONTROL SCHEMES * P. L. GOLDSMITH, H. WHITFIELD

TECH 6121 PREDICTION REGIONS FOR SEVERAL PREDICTIONS FROM A SINGLE REGRESSION LINE * GERALD J . LIEBERMAN

TECH 6129 THE ROBUSTNESS OF LIFE TESTING PROCEDURES DERIVED FROM THE EXPONENTIAL DISTRIBUTION * MARVIN ZELEN, MARY G. DANNEMILLER

TECH 6151 AN APPLICATION OF A BALANCED INCOMPLETE BLOCK DESIGN * PETER W. M. JOHN
TECH 6155 MULTI-COMPONENT SYSTEMS AND STRUCTURES AND THEIR RELIABILITY * Z. W. BIRNBAUM, J. D. ESARY, S. C. SAUNDERS

TECH 6179 AN ASYMPTOTIC DISTRIBUTION FOR AN OCCUPANCY PROBLEM WITH STATISTICAL APPLICATIONS * M. HALPERIN, G. L BURROWS

TECH 6191 OUTLIERS IN PATTERNED EXPERIMENTS. A STRATEGIC APPRAISAL * IRWIND, J, BROSS

TECH 61103 MULTIPLE COMPARISIONS WITH A CONTROL IN BALANCED INCOMPLETE BLOCK DESIGNS * D. S. ROBSON 
TECH 61107 ESTIMATES OF BOUNDED RELATIVE ERROR FOR THE MEAN LIFE OF AN EXPONENTIAL DISTRIBUTION * BENJAMIN EPSTEIN

TECH 61111 ON METHODS OF CONSTRUCTING SETS OF MUTUALLY ORTHOCONAL LATIN SQUARES USING A COMPUTER. II * R. C. BOSE. I. M. CHAKRAVARTI. D. E. KNUTH

TECH 61131 ERRATA, 'THE EFFECT OF SEQUENTIAL BATCHINC FOR ACCEPTANCE-REJECTION SAMPLING UPON SAMPLE ASSURANCE OF TOTAL PRODUCT QUALITY' * M. HALPERIN, G. L. BURROWS

TECH 61133 CENERAL CONSIDERATIONS IN THE ANALYSIS OF SPECTRA * G M. JENKINS

TECH 61167 MATHEMATICAL CONSIDERATIONS IN THE ESTIMATION OF SPECTRA * EMANUEL PARZEN

TECH 61191 DISCUSSION, EMPHASIZINC THE CONNECTION BETWEEN ANALYSIS OF VARIANCE AND SPECTRUM ANALYSIS * JOHN W TUKEY

TECH 61221 SOME COMMENTS ON SPECTRAL ANALYSIS OF TIME SERIES * $\mathrm{N}$ R. GOODMAN

TECH 61229 COMMENTS ON THE DISCUSSIONS OF MESSRS. TUKEY AND COODMAN * C. M. JENKINS, EMANUEL PARZEN

TECH $€ 1235$ SPECTRAL ANALYSIS COMBINING A BARTLETT WINDOW WITH AN ASSOCIATED INNER WINDOW * THOMAS A , WONNACOTT

TECH 61245 FREQUENCY RESPONSE FROM STATIONARY NOISE, TWO CASE HISTORIES * N. R. GOODMAN, S. KATZ, B. H. KRAMER, M. T. KUO

TECH 61269 THE MODIFIED GAUSS-NEWTON METHOD FOR THE FITTING OF NON-L INEAR RECRESSION FUNCTIONS BY LEAST SQUARES * H. O. HARTLEY

TECH 61281 ON THE POSSIBILITY OF IMPROVING THE MEAN USEFUL LIFE OF ITEMS BY ELIMINATINC THOSE WITH SHORT LIVES * C. S. WATSON. W. R. WELLS

TECH 61311 THE 2-TO-THE-(K-P) FRACTIONAL FACTORIAL DESIGNS * G E. P. BOX, J. S. HUNTER

TECH 61353 PARTIAL CONFOUNDING IN FRACTIONAL REPLICATION * W. J YOUDEN

TECH 61359 FINDINC NEW FRACTIONS OF FACTORIAL EXPERIMENTAL DESIGNS * R, E, FRY

TECH 61371 A STUDY OF THE CROUP SCREENING METHOD * G. S. WATSON

TECH 61389 MISSING VALUES IN RESPONSE SURFACE DESIGNS * NORMANR. DRAPER
TECH 61399 THE OPTIMUM ALLOCATION OF SPARE COMPONENTS IN SYSTEMS * DONALD F. MORRISON

TECH 61407 USE OF TABLES OF PERCENTACE POINTS OF RANCE AND STUDENTIZED RANCE * H. LEON HARTER

TECH 61413 THE RELIABILITY OF COMPONENTS EXHIBITINC CUMULATIVE DAMACE EFFECTS * GEORCE H. WEISS

TECH 61423 AN ANALYSIS OF SOME RELAY FAILURE DATA FROM A COMPOSITE EXPONENTIAL POPULATION * R. R. PRAIRIE, B. OSTLE

TECH 61429 APPLICATIONS OF TRUNCATED DISTRIBUTIONS IN PROCESS START-UPS AND INVENTORY CONTROL * H. SMITH, D. W. GRACE

TECH 61433 ESTIMATING THE POISSON PARAMETER FROM SAMPLES THAT ARE TRUNCATED ON THE RIGHT * A. CLIFFORD COHEN JR

TECH 61449 THE 2-TO-THE-(K-P) FRACTIONAL FACTORIAL DESIGNS, II * C. E. P. BOX, J. S. HUNTER

TECH 61459 REDUCED DESIGNS OF RESOLUTION FIVE * JOHNC. WHITWELL G. K. MORBEY

TECH 61479 IRREGULAR FRACTIONS OF THE 2-TO-THE-N FACTORIAL EXPERIMENTS * SIDNEY ADDELMAN

TECH 61497 A CENERAL SIMULATION PROGRAMME FOR MATERIAL FLOW IN BATCH CHEMICAL PLANTS * J. DYSON, P. L. GOLDSMITH, J . S. M. ROBERTSON

TECH 61509 A PROBLEM OF OPTIMUM ALLOCATION ARISING IN CHEMICAL ANALYSES BY MULTIPLE ISOTOPE DILUTION * H. WEILER

TECH 61519 SEQUENTIAL CHI-SQUARE AND T-SQUARE TESTS AND THEIR APPLICATION TO AN ACCEPTANCE SAMPLING PROBLEM * J. E. JACKSON, RALPH BRADLEY

TECH 61535 TABLES FOR MAX IMUM LIKELIHOOD ESTIMATES. SINGLY TRUNCATED AND SINGLY CENSORED SAMPLES * A. CLIFFORD COHEN JR

TECH 61543 THE FOLDED NORMAL DISTRIBUTION * F. C. LEONE, L. S. NELSON, R. B. NOTTINGHAM

TECH 61551 THE FOLDED NORMAL DISTRIBUTION. TWO METHODS OF ESTIMATING PARAMETERS FROM MOMENTS * REGINA C. ELANDT

TECH 61563 THE ESTIMATION OF 'TRANSFER FUNCTIONS' OF QUADRATIC SYSTEMS * LEO J. TICK

TECH 61576 ERRATA, 'SOME NEW THREE LEVEL DESIGNS FOR THE STUDY OF QUANTITATIVE VARIABLES' * G. E. P. BOX, D. W. BEHNKEN

TECH 61576 ERRATA, 'TABLES OF TOLERANCE-L IMIT FACTORS FOR NORMAL DISTRIBUTIONS' * ALFRED WEISSBERG, GLENN H. BEATTY

TECHNOMETRICS VOLUME 4, 1962

TECH 62 I PROBABILITY PLOTS FOR THE GAMMA DISTRIBUTION * M. B. WILK, R. GNANADESIKAN, MISS M. J. HUYETT

TECH 6221 ORTHOCONAL MAIN-EFFECT PLANS FOR ASYMMETRICAL FACTORI AL EXPERIMENTS * SIDNEY ADDELMAN

TECH 6247 SYMMETRICAL AND ASYMMETRICAL FRACTIONAL FACTORIAL PLANS * SIDNEY ADDELMAN

TECH 6259 ESTIMATION OF SAMPLE SIZE * N. L. JOHNSON

TECH 6269 ON CERTAIN REDUNDANT SYSTEMS WHICH OPERATE AT DISCRETE TIMES * GEORCE WEISS

TECH 6275 PARAMETER-FREE AND NON-PARAMETRIC TOLERANCE LIMITS. THE EXPONENTIAL CASE * LEO A . GOODMAN, ALBERT MADANSKY

TECH 6297 CUMULATIVE SUM SCHEMES USING CAUGING * E. S. PAGE

TECH 62111 SYSTEMATIC ERRORS IN PHYSICAL CONSTANTS * W. J. YOUDEN

TECH 62125 A CLASSIFICATION OF FALLACIOUS ARGUMENTS AND INTERPRETATIONS * I. J. GOOD

TECH 62133 AN ANALOGUE OF TCHEBYCHEFF'S INEQUALITY IN TERMS OF THE RANGE * G. A . BARNARD

TECH 62134 AN UPPER BOUND FOR THE SAMPLE STANDARD DEVIATION * H. E. GUTERMAN

TECH 62135 ON THE CALCULATION OF CERTA IN CONSTRAINED MAX IMA * WEN M. CHOW

TECH 62138 DISTRIBUTION OF RADICAL ERROR IN THE BIVARIATE ELLIPTICAL NORMAL DISTRIBUTION * VICTOR CHEW, RAY BOYCE

TECH 62140 COMPARATIVE COST OF TWO LIFE TEST PROCEDURES * JAMES D. RILEY

TECH 62151 LIFE TEST SAMPLING PLANS FOR NORMAL AND LOGNORMAL DISTRIBUTIONS * SHANTIS. GUPTA

TECH 62177 SOME ACCEPTANCE SAMPLING PLANS BASED ON THE THEORY OF RUNS * R, R. PRAIRIE, W. J. ZIMMER, J.K. BROOKHOUSE

TECH 62187 THREE FACTOR ADDITIVE DESIGNS MORE GENERAL THAN THE LATIN SQUARE * RICHARD F, POTTHOFF

TECH 62209 GROUP SCREENING WITH MORE THAN TWO STACES * M. S. PATEL

TECH 62219 THIRD ORDER ROTATABLE DESIGNS IN THREE FACTORS. ANALYSIS * NORMAN R. DRAPER

TECH 62235 ON THE EMPTY CELL TEST * M. CSORGO. IRW IN GUTTMAN

TECH 62249 THE FOLDED NORMAL DISTRIBUTION, III. ACCURACY OF ESTIMATION BY MAXIMUM LIKELIHOOD * N L JOHNSON

TECH 62257 THE EFFICIENCY OF STATISTICAL SIMULATION PROCEDURES * S. EHRENFELD, S. BEN-TUVIA

TECH 62277 DISTRIBUTIONS OF PRODUCTS OF INDEPENDENT VARIABLES * G. A. BARNARD
TECH 62278 ON THE GENERATION OF NORMAL RANDOM VECTORS * E M SCHEUER, D. S. STOLLER

TECH 62282 MODIFIED SQUARE ROOT METHOD OF MATRIX INVERSION * A E. SARHAN, B. G. GREENBERG, ELEANOR ROBERTS

TECH 62301 A USEFUL METHOD FOR MODEL BUILDING * GEORGE E. P. BOX, WILL IAM G. HUNTER

TECH 62319 BULK SAMPLING. PROBLEMS AND LINES OF ATTACK * ACHESON J. DUNCAN

TECH 62345 ON A CLASS OF SIMPLE SEQUENTIAL TESTS ON MEANS * C. C CRAIG

TECH 62361 FOUR FACTOR ADDITIVE DESIGNS MORE GENERAL THAN THE GRECO-LAT IN SQUARE * RICHARD F. POTTHOFF

TECH 62367 AN OPTIMAL SEQUENTIAL ACCELERATED LIFE TEST. * S BESSLER, H. CHERNOFF, A. W. MARSHALL

TECH 62381 OPTIMAL ACCELERATED LIFE DESIGNS FOR ESTIMATION * HERMAN CHERNOFF

TECH 62409 MINIMUM VARIANCE UNBIASED ESTIMATORS FOR POISSON PROBABILITIES * CERALD J. CLASSER

TECH 62419 NOTE ON A METHOD FOR CALCULATING CORRECTED SUMS OF SQUARES AND PRODUCTS * W. P. WELFORD

TECH 62421 DECIMAL CORRECTION ERROR, AN EXAMPLE IN STATISTICS * RANDALL M. CONKLINE

TECH 62426 A NUMER ICAL ANALYSIS PROBLEM IN CONSTRAINED QUADRATIC REGRESSION ANALYSIS * W. J. WESTLAKE

TECH 62430 PONER FUNCTIONS FOR COX'S TEST OF RANDOMNESS AGAINST TREND * EDWIN MANSFIELD

TECH 62440 ERRATA, 'ORTHOGONAL MAIN-EFFECT PLANS FOR ASYMMETRICAL FACTORIAL EXPERIMENTS' * SIDNEY ADDELMAN

TECH 62440 ERRATA. ' AN UPPER BOUND FOR THE SAMPLE STANDARD DEVIATION ' * DONALD L. MEYER

TECH 62441 SEQUENTIAL APPLICATION OF SIMPLEX DESICNS IN OPTIMISATION AND EVOLUTIONARY OPERATION * $\mathrm{W}$. SPENDLEY, $C$. R. HEXT, F, R. HIMSWORTH

TECH 62463 SIMPLEX LATTICE DESIGNS FOR MUTICOMPONENT SYSTEMS * J. W. GORMAN, J. E. HINMAN

TECH 62489 SOME SYSTEMATIC SUPERSATURATED DESIGNS * KATHLEENH V. BOOTH, D. R. COX

TECH 62497 SOME LIMIT THEOREMS FOR THE DODGE-ROMIG LTPD SINGLE SAMPLING INSPECTION PLANS * ANDERS HALD

TECH 62515 SURVEILLANCE PROGRAMS FOR LOTS IN STORACE * FREDERICK S. HILLIER

TECH 62531 TRANSFORMATION OF THE INDEPENDENT VARIABLES * G. E. P. BOX. PAUL W. TIDWELL 
TECH 62551 BASIC CONSIDERATIONS IN THE ESTIMATION OF SPECTRA * $M$. B. PRIES'I'LY

TECH 62565 LINEAR ESTIMATION AND THE ANALYSIS OF CAMMA RAY PULSEHEICHT SPECTRA * BERNARD S. PASTERNACK

TECH 62573 TESTS FOR CONTINCENCY TABLES AND MARKOV CHAINS * S KULLBACK, M. KUPPERMAN, H. H. KU
TECH 62609 A NOTE ON THE NECATIVE BINOMIAL DISTRIBUTION * JOHN J. BARTKO

TECH 62610 A SEQUENT IAL SEARCH PROCEDURE FOR LOCATING A RESPONSE JUMP * JOSEPH J . MODER

TECH 62622 ERRATA, 'MODIFIED SQUARE ROOT METHOD OF MATRIX INVERSION * A. E. SARHAN, B. C. CREENBERC, ELEANOR ROBERTS

TECHNOMETRICS VOLUME 5, 1963

TECH 63 I WHEN AND HOW TO USE CU-SUM CHARTS * W. D. EWAN

TECH 6323 VALIDATINC RESULTS OF SAMPLING INSPECTION BY ATTRIBUTES * HENRY ELLNER

TECH 6347 SAMPLINC PROCEDURES BASED ON PRIOR DISTRIBUTIONS AND COSTS * J. PFANZACL

TECH 6363 SOME PROPERTIES OF A DISTRIBUTION SPECIFIED BY ITS CUMULANTS * D.J. FINNEY

TECH 6371 PARTIALLY DUPLICATED FRACTIONAL FACTORIAL DESIGNS * M. S. PATEL

TECH 6385 RESERVOIRS WITH SERIALLY CORRELATED INPUTS * E. H LLOYD

TECH 6395 PROGRAMMING UNIVARIATE AND MULTIVARIATE ANALYSIS OF VARIANCE * R. DARRELL BOCK

TECH 63119 ON THE EQUIVALENCE OF BINOMIAL AND INVERSE BINOMIAL ACCEPTANCE SAMPLING PLANS AND AN ACKNOWLEDGEMENT * G. P. PATIL

TECH 63121 ROBUSTNESS OF UNIFORM BAYESIAN ENCODING * H. O. POSTEN

TECH 63134 ERRATA, 'FINDING NEW FRACTIONS OF FACTORIAL EXPERIMENTAL DESIGNS' * R. E. FRY

TECH 63141 THE EXAMINATION AND ANALYSIS OF RESIDUALS * F. J. ANSCOMBE, JOHNW. TUKEY

TECH 63161 ANALYSIS OF SURVIVAL DATA BY REGRESSION TECHNIQUES * SCOTT A. KRANE

TECH 63175 ESTIMATION OF THE SHAPE AND SCALE PARAMETERS OF THE WEIBULL DISTRIBUTION * M. V. MENON

TECH 63 IB3 RELATIONSHIP BETWEEN SYSTEM FAILURE RATE AND COMPONENT FAILURE RATES * JAMES D. ESARY, FRANK PROSCHAN

TECH 63191 COHERENT STRUCTURES OF NON-IDENTICAL COMPONENTS * JAMESD. ESARY. FRANK PROSCHAN

TECH 63211 RANDOM HAZARD IN RELIABILITY PROBLEMS * D. P. GAVER JR

TECH 63227 AN EXAMPLE OF THE ESTIMATION OF LINEAR OPEN LOOP TRANSFER FUNCTION * G. M. JENKINS

TECH 63247 THE EFFECTS OF ERRORS IN THE FACTOR LEVELS AND EXPERIMENTAL DESIGN* G. E.P. BOX

TECH 63263 STATISTICAL EVALUATION OF SPLITTING LIMIT CRITERIA IN MEASUREMENT DISPUTES * FREDH. TIMGEY

TECH 63269 GENERATION OF RANDOM SAMPLES FROM THE BETA AND F DISTRIBUTIONS * BENNETT L . FOX

TECH 63295 APPROXIMATIONS TO THE NON-CENTRAL T, WITH APPLICATIONS * MAX HALPERIN

TECH 63307 CONTROLLING THE STANDARD DEVIATION BY CUSUMS AND WARNING LINES * E. S. PAGE

TECH 63317 A QUICK METHOD FOR CHOOSING A TRANSFORMATION * JAMES L. DOLBY

TECH 63327 PROGRESSIVELY CENSORED SAMPLES IN LIFE TESTING * A CLIFFORD COHEN JR
TECH 63341 APPLIED MULTIPLEX SAMPLINC * DAVID H. EVANS

TECH 63361 THE SAMPLINC DISTRIBUTION OF AN ESTIMATE ARISINC IN LIFE TESTING * D. J. BARTHOLOMEW

TECH 63375 THEORETICAL EXPLANATION OF OBSERVED DECREASE FAILURE RATE * FRANK PROSCHAN

TECH 63385 EFFECTS OF SLOW-DOWNS AND FAILURE ON STOCHASTIC SERVICE SYSTEMS * M. M. EISEN

TECH 63393 ON THE RENEWAL FUNCTION FOR THE WEIBULL DISTRIBUTION * W. L. SMITH, M. R. LEADBETTER

TECH 63397 A NOTE ON 'A STUDY OF THE CROUP SCREENING EXPERIMENT' * M. S. PATEL

TECH 63398 A NOTE ON CONTINGENCY TABLES INVOLVING ZERO FREQUENCIES AND THE 2I TEST * H. H. KU

TECH 63400 ONE-SIDED CONFIDENCE INTERVALS FOR THE QUALITY INDICES OF A COMPLEX ITEM * HELEN CHMURA KRAEMER

TECH 63404 DIMENSIONAL CHAINS INVOLVING RECTANGULAR AND NORMAL ERROR-DISTRIBUTIONS * C. P. BHATTACHARJEE, S. N. N PANDIT, R. MOHAN

TECH 63417 ERRATA, 'SOME PROPERTIES OF A DISTRIBUTION SPECIFIED BY ITS CUMULANTS' *D. J. FINNEY

TECH 63417 ERRATA, 'THE 2-TO-THE-(K-P) FRACTIONAL FACTORIAL DESIGNS' * G. E. P. BOX, J. S. HUNTER

TECH 63417 ERRATA, 'AN UPPER BOUND FOR THE SAMPLE STANDARD DEVIATION * H. E. GUTERMAN

TECH 63421 A COMPARISON OF THREE DIFFERENT PROCEDURES FOR ESTIMATING VARIANCE COMPONENTS * NORMAN BUSH, R. L ANDERSON

TECH 63441 NON-NEGATIVE ESTIMATES OF VARIANCE COMPONENTS * W. A THOMPSON JR, JAMESR. MOORE

TECH 63451 CUMULATIVE SUM CHARTS FOR THE FOLDED NORMAL DISTRIBUTION * N. L. JOHNSON

TECH 63459 ESTIMATION OF THE PROBABILITY OF DEFECTIVE FAILURE FROM DESTRUCTIVE TESTS * A . C. NELSON JR, J. S. WILLIAMS, N. T . FLETCHER

TECH 63469 'RIDCE ANALYSIS' OF RESPONSE SURFACES * NORMAN DRAPER

TECH 63 4BI THEDESIGN OF SCREENING TESTS * 0. L. DAVIES

TECH 63491 TABLES FOR A PRECEDENCE LIFE TEST * LLOYDS. NELSON

TECH 53501 TABLES FOR TESTING SIGNIFICANCE IN A 2-BY-3 CONTINGENCY TABLE * B. M. BENNETT , E. NAKAMURA

TECH 63513 CONVERCENCE IN NON-LINEAR REGRESSION * TEONARD TORNHEIM

TECH 63514 RELATIONS AMONG MOMENTS OF ORDER STATISTICS IN SAMPLES FROM TWO RELATED POPULATIONS * Z . GOVINDARAJULU

TECH 63518 DISTRIBUTION FREE TOLERANCE LIMITS. ELIMINATION OF REQUIREMENT THAT CUMULATIVE FUNCTIONS BE CONTINUOUS * D. L. HANSON, D. B. OWEN

TECH 63522 APPROXIMATIONS TO THE MEAN AND STANDARD DEVIATION OF RECIPROCALS OF OBSERVATIONS * C. TIPLITZ

TECHNOMETRICS VOLUME 6,1964

TECH 64 I ESTIMATION OF WEIGHTING FACTORS IN LINEAR REGRESSION AND ANALYSIS OF VARIANCE * JOHN MANDEL

TECH 6427 SOME WAITING TIME DISTRIBUTIONS FOR REDUNDANT SYSTEMS WITH REPAIR * MAX HALPERIN

TECH 6441 SEQUENTIAL FACTORIALESTIMATION * J. S. HUNTER

TECH 6457 THE DISCRIMINATION BETWEEN TWO WEIBULL PROCESSES * A S. QUREISHI

TECH 6477 SERIAL DESIGNS FOR ROUTINE QUALITY CONTROL AND EXPERIMENTATION* H. R. THOMPSON, K. E. SEAL

TECH 6499 CONTROLLING THE PROPORTION DEFECTIVE FROM CLASSIFICATION DATA * C. P. QUESENBERRY

TECH 64101 GENERATING A VARIABLE FROM THE TAIL OF THE NORMAL DISTRIBUTION * G. MARSAGLIA

TECH 64103 QUERY, INADMISSIBLE RANDOM ASSIGNMENTS * W. J, YOUDEN

TECH 64104 QUERY, THE SUM OF VALUES FROM A NORMAL AND A TRUNCATED NORMAL DISTRIBUTION * M. A. WEINSTEIN

TECH 64133 MODEL BUILDING WITH THE AID OF STOCHASTIC PROCESSES * HARALD CRAMER

TECH 64161 NEW CRITERIA FOR SELECTING CONTINUOUS SAMPLING PLANS * F. S. HILLIER

TECH 64179 ON THE PERFORMANCE OF THE LINEAR DISCRIMINANT FUNCTION* WM. G. COCHRAN
TECH 64191 LARGE SAMPLE SIMULTANEOUS CONFIDENCE INTERVALS FOR MULT INOMIAL PROPORTIONS * C. P. QUESENBERRY, D. C. HURST

TECH 64197 MATRIX INVERSION WITH THE SQUARE ROOT METHOD * PAUL S DWYER

TECH 64215 ESTIMATES OF RELIABILITY FOR SOME DISTRIBUTIONS USEFUL IN LIFE TESTING * A. P. BASU

TECH 64220 A NOTE ON SMALL ORTHOGONAL MAIN EFFECT PLANS FOR FACTORIAL EXPERIMENTS * THOMASH. STARKS

TECH 64222 ESTIMATION OF A COMPONENT OF A CONVOLUTION, WHEN THE OTHER COMPONENT IS OF EXPONENTIAL TYPE * P. SCHEINOK

TECH 64225 QUERY, RECRESSION ANALYSIS OF CUMULATIVE DATA * JOHN MANDEL

TECH 64228 QUERY, REJECTION OF OUTLYINC VALUES * W. J. DIXON

TECH 64240 ERRATA, 'THE DISCRIMINATION BETWEEN TWO WEIBULL PROCESSES ' * A. S. QUREISHI

TECH 64241 MULTIPLE COMPARISIONS USING RANK SUMS * OLIVE JEAN DUNN

TECH 64253 SOME TWO-LEVEL FACTORIAL PLANS WITH SPLIT PLOT CONFOUNDINC * SIDNEY ADDELMAN

TECH 64259 SEQUENTIAL OPTIMUM PROCEDURES FOR UNBIASED ESTIMATION OF A BINOMIAL PARAMETER * M. T. WASAN 
TECH 64273 A SIGNIFICANCE TEST FOR SIMULTANEOUS QUANTAL AND QUANTITATIVE RESPONSES *H. WEILER

TECH 64287 ON THE DISTRIBUTION OF THE FIRST SAMPLE MOMENTS OF SHOT NOISE * H. LINHART

TECH 64293 A PROGRAM TO ESTIMATE MEASUREMENT ERROR IN NONDESTRUCTIVE EVALUATION OF REACTOR FUEL ELEMENT QUALITY* J.L. JAECH

TECH 64301 EXACT CONFIDENCE BOUNDS, BASED ON ONE ORDER STATISTIC FOR THE PARAMETER OF AN EXPONENTIAL POPULATION * H. LEON HARTER

TECH 64319 A NOTE ON THE DETERMINATION OF CONNECTEDNESS IN AN NWAY CROSS CLASSIFICATION * DAVID L. WEEKS, DONALDR. WILLIAMS

TECH 64325 APPLICATIONS OF THE BIVARIATE NORMAL DISTRIBUTION TO A STRESS VS. STRENGTH PROBLEM IN RELIABILITY ANALYSIS * M. LIPOW. $\stackrel{*}{*}$. L. EIDEMILLER

TECH 64329 QUERY. DISTRIBUTION OF A RANKED OBSERVATION * NORMAN L. JOHNSON

TECH 64331 QUERY, THE MEAN OF THE TAIL OF A DISTRIBUTION*F. E. SATTERTHWAITE

TE'CH 64343 METHODS FOR ESTIMAT ING THE COMPOSITION OF A THREE COMPONENT LIQUID MIXTURE * RAYMONDH. MYERS

TECH 64357 GENESIS OF BIMODAL DISTRIBUTIONS * ISIDORE EISENBERGER

TECH 64365 DESIGNS FOR THE SEQUENTIAL APPLICATION OF FACTORS * SIDNEY ADDELMAN

TECH 64371 BLOCKING OF 3-TIMES-2-TO-THE- $(\mathrm{N}-\mathrm{K})$ * PETER W. M. JOHN
TECH 64377 CONTROL OF PERCENTAGES IN BOTH TAILS OF THE NORMAL DISTRIBUTION * D. B. OWEN

TECH 64389 A PROCEDURE FOR CONSTRUCTING INCOMPLETE BLOCK DESIGNS * SIDNEY ADDELMAN, SEYMOUR BUSH

TECH 64405 ESTIMATION OF THE PARAMETERS OF THE GAMMA DISTRIBUTION BY SAMPLE QUANT ILES * CARL ERIK SARNDAL

TECH 64415 ESTIMATION OF WEIBULL DISTRIBUTION SHAPE PARAMETER WHEN NO MORE THAN TWO FAILURES OCCUR PER LOT * J. L JAECH

TECH 64423 ESTIMATING MACHINING ERRORS IN SET-UPS WITH AUTOMATIC RESETTING * R. MOHAN. A. K. BHATTACHARYYA, R. MISHRA

TECH 64439 THE POWER FUNCTION OF THE EXACT TEST FOR THE 2-BY-3 CONT INGENCY TABLE* B. M. BENNETT. E. NAKAMURA

TECH 64459 SYSTEMS STRUCTURE AND THE EXISTENCE OF A SYSTEM LIFE * J. D. ESARY, A. W. MARSHALL

TECH 64463 A NOTE ON COMBINING CORRELATED ESTIMATES OF A RATIO OF MULTIVARIATE MEANS * B. M. BENNETT

TECH 64469 QUERY, THE SUM OF VALUES FROM A NORMAL AND A TRUNCATED NORMAL DISTRIBUTION (CONTD) * M. LIPOW. N. MANTEL J.W. WILKINSON

TECH 64471 QUERY, SAVINGS IN TEST TIME WHEN COMPARING WEIBULL SCALE PARAMETERS * JOHN H. K. KAO

TECH 64482 ERRATA, 'APPROXIMATIONS TO THE NON-CENTRAL T, WITH APPLICATIONS' * MAX HALPERIN

TECH 64 4B3 ERRATA, 'EXACT CONFIDENCE BOUNDS, BASED ON ONE ORDER STATIST IC FOR THE PARAMETER OF A ONE-PARAMETER NEGATIVE EXPONENT IAL POPULATION' * H. LEON HARTER
TECH 65

I A METHOD FOR DISCRIMINATING BETWEEN FAILURE DENSITY FUNCTIONS USED IN RELIABILITY PREDICTIONS * J. T. WEBSTER, VAN B. PARR

TECH 65

11 DESIGN AND EVALUATION OF A REPETITIVE GROUP SAMPLING PLAN * ROBERT E . SHERMAN

TECH 65

TECH 6543 ESTIMATING THE FRACTION OF ACCEPTABLE PRODUCT * JOHN

23 THE EXPERIMENTAL STUDY OF PHYSICAL MECHANISMS * WILLIAMG. HUNTER, G. E. P. BOX L. FOLKS, DONALD A. PIERCE, CHARLES STEWART

TECH 6551 MAXIMUM LIKELIHOOD ESTIMATORS OF REGRESSION COEFFICIENTS FOR THE CASE OF AUTOCORRELATED RESIDUALS * TRYGVER. LERWICK

TECH 6559 A METHOD OF FITTING THE REGRESSION CURVE $E(Y)=A+D X+B C-T O-X * B . K$. SHAH, C. G. KHATRI

TECH 6567 AN INEQUALITY FOR THE SAMPLE COEFFICIENT OF VARIATION AND AN APPLICATION OF VARIABLES SAMPLING * ROBERT D SUMMERS

TECH 6569 A NOTE ON FRACTIONS OF 3-TO-THE- $(4 \mathrm{~N}+1)$ DESIGNS * D RAGHAVARAO

TECH 6571 AN APPROXIMATION OF STUDENT'S T * DONALD A. GARDINER, BARABARA F, BOMBAY

TECH 6573 QUERY, CALCULATION OF THE SAMPLING DISTRIBUTION OF THE RANGE * IRVING W. BURR

TECH 6575 QUERY, NEGATIVE VARIANCE ESTIMATES * R. L. ANDERSON

TECH 65

TECH 65

93 ERRATA, 'SEQUENTIAL FACTORIAL ESTIMATION' * J. S. HUNTER

95 SHORT-CUT MULTIPLE COMPARISONS FOR BALANCED SINGLE AND DOUBLE CLASSIFICATIONS. PART 1, RESULTS * T. E. KURTZ, B. F. LINK, J. W. TUKEY, D. L. WALLACE

TECH 65163 COMMENTS ON PAPER BY KURTZ, LINK, TUKEY AND WALLACE * $J$ EDWARD JACKSON, FRANCIS I. ANSCOMBE

TECH 65169 AUTHOR'S REPLY TO ANSCOMBE'S COMMENTS * T. E. KURTZ. B. F. LINK. J. W. TUKEY, D. L. WALLACE

TECH 65171 A BAYESIAN APPROACH TOMULTIPLE COMPARISONS * DAVID B DUNCAN

TECH 65223 A REMARK ON MULTIPLE COMPARISON METHODS * D. R. COX

TECH 65225 ON SOME MULTIPLE DECISION (SELECTION AND RANKING) RULES * SHANTIS. GUPTA

TECH 65247 ON SIMULTANEOUS CONFIDENCE INTERVALS FOR MULTINOMIAL PROPORTIONS * LEO A. GOODMAN

TECH 65255 A NOTE ON MULTIPLE COMPARISONS USING RANK SUMS * ELLEN SHERMAN

TECH 65257 QUERY, CONFIDENCE LIMITS FROM RANK TESTS * LINCOLNE MOSES

TECH 65260 QUERY, ERROR RATE BASES * L. N. BALAAM, W. T. FEDERER

TECH 65 2BI ERRATA, 'A NOTE ON THE DETERMINATION OF CONNECTEDNESS IN AN N-WAY CROSS CLASSIFICATION' * DAVID L. WEEKS, DONALD R. WILLIAMS

TECH 65 2B3 STATISTICAL PROCESS CONTROL AND THE IMPACT OF AUTOMATIC PROCESS CONTROL * GERALD J. LIEBERMAN

TECH 65293 TABLES FOR A TREATMENTS VERSUS CONTROL MULTIPLE COMPARISONS SIGN TEST * A . L. RHYNE, ROBERT G. D. STEEL

TECH 65307 DESIGNS FOR DISCRIMINATING BETWEEN TWO RIVAL MODELS * WILLIAM G . HUNTER, ALBEY M. REINER

TECH 65325 CHOICE OF LEVELS OF POLYNOMIAL REGRESSION WITH ONE OR TWO VARIABLES * DR. VIRGINIA CLARK
TECH 65335 THE USE OF INCOMPLETE BETA FUNCTIONS FOR PRIOR DISTRIBUTIONS IN BINOMIAL SAMPLING * H. WEILER

TECH 65349 PARAMETER ESTIMATION FOR A GENERALIZED GAMMA DISTRIBUTION * E. W. STACY, G. A. MIHRAM

TECH 65359 ON PRECEDENCE LIFE TESTING * JOANEILBOTT, JACK NADLER

TECH 65379 SOME STATISTICAL CHARACTERISTICS OF A PEAK TO AVERAGE RATIO * MILTON MORRISON, FILBERT TOBIAS

TECH $653 \mathrm{~B} 7$ APPROXIMATE DESIGN OF DIGITAL FILTERS * H. H. ROBERTSON

TECH 65405 POINT AND INTERVAL ESTIMATORS, BASED ON M ORDER STATISTICS, FOR THE SCALE PARAMETER OF A WEIBULL POPULATION WITH KNOWN SHAPE PARAMETER * H. LEON HARTER, ALBERTH. MOORE

TECH 65423 ASYMPTOTIC PROPERTIES OF SEVERAL ESTIMATORS OF WEIBULL PARAMETERS * SATYA D. DUBEY

TECH 65435 NOTE ON AN APPLICATION OF FOUR MOMENT INEQUALITIES TO A PROBLEM IN QUEUES * HENRY DE CICCO

TECH 65439 CONSTRUCTION OF A 2-TO-THE-(17-9) RESOLUTION V PLAN IN EIGHT BLOCKS OF 32 * SIDNEY ADDELMAN

TECH 65444 A NOTE ON G.S. WATSON'S PAPER 'A STUDY OF THE GROUP SCREENING METHOD' ${ }^{*} R$. N. CURNOW

TECH 65447 QUERY. TESTING TWO CORRELATED VARIANCES * WILLIAM G. COCHRAN

TECH 65449 QUERY, COMBINATION OF A NORMAL AND A UNIFORM DISTRIBUTION * PAUL GUNTHER

TECH 65462 ERRATA. 'ESTIMATION OF A COMPONENT OF A CONVOLUTION, WHEN THE OTHER COMPONENT IS OF EXPONENTIAL TYPE' * PERRY A. SCHEINOK

TECH 65463 SEQUENTIAL RANK TESTS I. MONTE CARLO STUDIES OF THE TWO-SAMPLE PROCEDURE * RALPH A. BRADLEY. DONALD C MARTIN, FRANK WILCOXON

TECH 65485 PRODUCT TEST PLANNING FOR REPAIRABLE SYSTEMS * BETTY J. FLEHINGER

TECH 65495 APPROXIMATE CONFIDENCE LIMITS FOR THE RELIABILITY OF SERIES AND PARALLEL SYSTEMS * ALBERT MADANSKY

TECH 65505 ESTIMATION OF PARTICLE SIZE DISTRIBUTION BASED ON OBSERVED WEIGHTS OF GROUPS OF PART ICLES * J. L. JAECH

TECH 65517 THE APPLICATION OF EXTREME VALUE THEORY TO ERROR-FREE COMMUNICATION * EDWARD C. POSNER

TECH 65531 A REAPPRAISAL OF THE PERIODOGRAM IN SPECTRAL ANALYSIS * RICHARDH. JONES

TECH 65543 THE CONSTRUCTION OF GOOD LINEAR UNBIASED ESTIMATES FROM THE BEST LINEAR ESTIMATES FOR A SMALLER SAMPLE SIZE * JOHN I . MC COOL

TECH 65553 ESTIMATION OF POWER SPECTRA BY A WAVE ANALYZER * MAURICE PRIESTLEY, C. H. GIBSON

TECH 65561 BALANCED SETS OF BALANCED INCOMPLETE BLOCK DESIGNS OF BLOCK SIZE THREE * DAVID H. DOEHLERT

TECH 65579 MAXIMUM LIKELIHOOD ESTIMATION IN THE WEIBULL DISTRIBUTION BASED ON COMPLETE AND ON CENSORED SAMPLES * A. CLIFFORD COHEN JR 
TECH 655 59 SAMPLING INSPECTION PLANS FOR DISCRIMINATING BETWEEN TWO WEIBULL PROCESSES * A. S. QUREISHI, K. J. NABAVIAN, J. O. ALANEN

TECH 65603 PATTERNS IN RESIOUALS, A TEST FOR REGRESSION MOOEL ADEQUACY IN RADIONUCLIDE ASSAY * BERNARD PASTERNACK, ANTHONY LIUZZI

TECH 65623 ON BEALE'S MEASURES OF NON-LINEARITY * IRWIN GUTTMAN, DUANE A. MEETER
TECH 65639 MAXIMUM LIKELIHOOO ESTIMATION OF THE PARAMETERS OF GAMMA ANO WEIBULL POPULAT IONS FROM COMPLETE AND FRON CENSORED SAMPLES * H. LEON HARTER, ALBERT H. MOORE

TECH 65644 COMPLETE SET OF LEADING COEFFICIENTS FOR ORTHOGONAL POLYNOMIALS UP TON $=26$ *0. WILKIE

TECH 65649 QUERY. MISSING VALUES IN FACTORIAL EXPERIMENTS * GEORGE ZYSKIND

TECHNOMETRICS VOLUME B, 1966

TECH 66 TECH 66

TECH 66

TECH 66

TECH 66

TECH 66

TECH 66

TECH 66

TECH 66

TECH 66

TECH 66

TECH 66

TECH 66

TECH 66

TECH 66

TECH 66

TECH 66

TECH 66

TECH 66

TECH 66

TECH 66

TECH 66

TECH 66

TECH 66

TECH 66

TECH 66

TECH 66

TECH 66

TECH 66

TECH 66

TECH 66

TECH 66

TECH 66

TECH 66

TECH 66

TECH 66
EOITORIAL * FREO C. LEONE

3 LINEAR ESTIMATES OF PARAMETERS IN THE EXTREME VALUE DISTRIBUTION * FRANK DOWNTON

19 A SIMPLE SYSTEM OF EVOLUTIONARY OPERATION SUBJECT TO EMPIRICAL FEEOBACK * GEORGE E, P, BOX

27 SELECTION OF VARIABLES FOR FITTING EQUATIONS TO OATA * J.W. GORMAN, R. J. TOMAN

53 RELIABILITY GROWTH OURING A OEVELOPMENT TESTING PROGRAM * RICHARO E. BARLOW, ERNEST M. SCHEUER

61 AN INVESTIGATION OF THE BURN-IN PROBLEM * M. J. LANRENCE

73 THE PRESENT STATUS OF AUTOMATIC PROOUCTION AND CONTROL DEVICES AND EXPECTEO FUTURE DEVELOPMENTS * THEOOORE J. WILLIAMS

91 SAMPLING RATES ANO APPEARANCE OF STATIONARY GAUSSIAN PROCESSES * LEO JOSEPH TICK, PAUL SHAMAN

107 OEVELOPMENT OF RANDOMIZEO LOAD SEQUENCES WITH TRANSITION PROBABILITIES BASED ON A MARKOV PROCESS * R. A. HELLER, MASANOBU SHINOZUKA

15 AN APPROXIMATION TO TWO-SIDEO TOLERANCE LIMITS FOR NORMAL POPULATIONS * OONALO A. GARDINER, NORMA C. HULL

23 PRICING POLICIES CONTINGENT ON OBSERVEO PRODUCT QUALITY * EUGENE P. DURBIN

35 AN EXACT ASYMPTOTICALLY EFFICIENT CONFIDENCE BOUND FOR RELIABILITY IN THE CASE OF THE WEIBULLDISTRIBUTION* M.V. JOHNS JR, G. J. LIEBERMAN

177 THE INVERSE YATES ALGORITHM * J. S. HUNTER

184 A NOTE ON AUGMENTED DESIGNS * GEORGE E. P BOX

188 COMBINING INTRA AND INTER BLOCK ANALYSIS OF GROUP DIVISIBLE OESIGNS * C. H. KAPAOIA

193 QUERY, SMALL TRIMMED SAMPLES * I , M. CHAKRAVART I

195 A TRIBUTE TO FRANK WILCOXON * CHARLES W. DUNNETT

215 ERRATA, 'MISCLASSIFIED DATA FROM A BINOMIAL POPULATION' *A . CLIFFORD COHEN JR

216 INDEX TO TECHNOMETRICS, VOLUMES $1-7$ * P. V. RAMACHANDRAMURTY

217 SEQUENTIAL LIFE FOR THE EXPONENTIAL OISTRIBUTION WITH CHANGING PARAMETER * LEO A, AROIAN, D, E ROBISON

229 ANALYSIS OF DATA RHEN THE RESPONSE IS A CURVE * ALONZO CHURCH JR

47 STATISTICAL PROPERTIES OF A CERTAIN PERIODIC BINARY PROCESS * ARTHUR WOUK

259 FACTORIAL 2-TO-THE-(P-Q) PLANS ROBUST AGAINST LINEAR AND QUADRATIC TRENDS * CUTHBERT DANIEL, FRANK WILCOXON

79 THE ORTHOGONALIZATION OF UNOESIGNED EXPERIMENTS * OTTODYKSTRA JR

291 CONFIDENCE INTERVALS FROM CENSORED SAMPLES, I * MAX HALPERIN

303 PATHS AND CHAINS OF RANDOM STRAIGHT-LINE SEGMENTS * NORMANL. JOHNSON

319 SIMULTANEOUS NONLINEAR ESTIMATION * JOHN J. BEAUCHAMP, RICHARD G. CORNELL WEILER

335 PRODUCER AND CONSUMER RISKS IN NON-NORMAL POPULATION * H. R. SINGH

345 APPROXIMATING THE NEGATIVE BINOMIAL * JOHN J. BARTKO

351 APPLICATIONS OF THE PSEUDOINVERSE TO MODELING * $W$. A HARRIS JR, T. N. HELVIG CLYDE Y. KRAMER

AST SQUARES ESTIMATION OF THE COMPONENTS OF A SYMMETRIC MATRIX * HAROLD J . LARSON TREME VALUE THEORY TO ERROR FREE COMMUNICATION' * E. J. GUMBEL, C. K. MUSTAFI

UERY, CONFIDENCE INTERVAL FOR STANOARD OEVIATION FROM A SINGLE OBSERVATION * JUDAH ROSENBLATT

TIONS * H O. HARTLEY A. M. MORTHAM
TECH 66387 ERRATA TO INOEX TO TECHNOMETRICS, VOLUMES 1-7 * P.V RAMACHANDRAMURTY

TECH 663 B9 EVOLUTIONARY OPERATION. AREVIEW * WILLIAM G. HUNTER J.R. KITTRELL

TECH 66399 A COMMUNICATIONS SATELLITE REPLENISHMENT POLICY * MENACHEM DISHON, GEORGEH. WEISS

TECH 66411 A COMPARISON OF SOME CONTROL CHART PROCEDURES * S. W ROBERTS

TECH 66431 ESTIMATION OF PARAMETERS FOR A MIXTURE OR NORMAL DISTRIBUTIONS * VICTOR HASSELBLAD

TECH 66445 DISCUSSION OF 'ESTIMATION OF PARAMETERS FOR A MIXTURE OF NORMAL DISTRIBUTIONS' BY VICTOR HASSELBLAO * A CLIFFORO COHEN

TECH 66447 EXTREME VERTICES DESIGN OF MIXTURE EXPER IMENTS * $R$. A MC LEAN, Y. L. ANDERSON

TECH 66455 DISCUSSION OF 'EXTREME VERTICES DESIGN OF MIXTURE EXPERIMENTS' BY R.A. MCLEAN AND V.L. ANDERSON * J.W GORMAN

TECH 66457 SAMPLING DISTRIBUTIONS OF VARIANCE COMPONENTS I. EMPIRICAL STUDIES OF BALANCEO NESTEO DESIGN * FREO C LEONE, LLOYD S. NELSON

TECH 66469 AUGMENTING 2-TO-THE-(N-1) OESIGNS * PETER $\mathrm{W}, \mathrm{M}$ JOHN

TECH 66 4BI CUMULATIVE SUM CONTROL CHARTS AND THE WEIBULL DISTRIBUTION*N. L. JOHNSON

TECH 66493 A POWER COMPARISON OF TWO TESTS OF NON-RANOOM CLUSTERING * JOSEPH I. NAUS

TECH 66519 OPTIMIZATION OF QUALITY CONTROL IN THE CHEMICAL LABORATORY * BARTHOLONEW P. HSI

TECH 66535 DIFFICULTIES INVOLVED IN THE ESTIMATION OF A POPULATION MEAN USING TRANSFORMEO SAMPLE OATA * R. L. PATTERSON

TECH 66539 QUERY, LIFE TESTING AND EARLY FAILURE * A. CLIFFORD COHEN

TECH 66570 ERRATA, 'CONTROL OF PERCENTAGES IN BOTH TAILS OF THE NORMAL DISTRIBUTIONS' * D. B. OWEN

TECH 66570 ERRATA, 'MAXIMUM LIKELIHOOD ESTIMAT ION IN THE WEIBULL DISTRIBUTION BASED ON COMPLETE AND ON CENSORED SAMPLES' * A. CLIFFORD COHEN

TECH 66571 A REVIEW OF RESPONSE SURFACE METHOOOLOGY. A LITERATURE SURVEY * W ILLIAM J . HILL, WILLIAM G . HUNTER

TECH 66591 DISTRIBUTION-FREE LIFE TEST SAMPLING PLANS * RICHARD E. BARLOW, SHANTI S, GUPTA

TECH 66615 SEQUENTIAL RANK TESTS II. MOOIFIED TWO-SAMPLE PROCEDURES * RALPH A. BRADLEY, SARLA D. MERCHANT FRANK WILCOXON

TECH 66625 USE AND ABUSE OF REGRESSION * GEORGE E. P. BOX

TECH 66631 BINOMIAL GROUP-TESTING WITH AN UNKNOWN PROPORTION OF DEFECTIVES * MILTON SOBEL, PHYLLIS A. GROLL

TECH 66657 DISCRIMINANT ANALYSIS WHEN THE INITIAL SAMPLES ARE MISCLASSIFIED * PETER A . LACHENBRUCH

TECH 66663 THE CORRECT USE OF THE SAMPLE MEAN ABSOLUTE DEVIATION IN CONFIDENCE INTERVALS FOR A NORMAL VARIATE * RICHARO G. KRUTCHKOFF

TECH 66675 AN A POSTERIORI PROBABILITY METHOD FOR SOLVING AN OVERDETERMINED SYSTEM OF EQUATIONS * WAYNE E. SMITH

TECH 66 6B7 PERCENT AGE POINTS OF THE BETA DISTRIBUTION FOR USE IN BAYESIAN ANALYSIS OF BERNOULLI PROCESSES * JEROME BRACKEN

TECH 66695 TESTING FOR THE INCLUSION OF VARIABLES IN LINEAR REGRESSION BY A RANOOMISATION TECHNIQUE (ERRATA, 69 627 ) \# NORMAN R. DRAPER, DAVIDM. STONEMAN

TECH 66700 A NOTE ON THE VARIANCE OF THE DISTRIBUTION OF SAMPLE NUMBER IN SEQUENTIAL PROBABILITY RATIO TESTS * C PHILIP COX, THOMASD. ROSEBERRY

TECH 66705 ON AODELMAN'S 2-TO-THE-(17-9) RESOLUTION V PLAN * D A. PREECE

TECH 66705 ON ADDELMAN'S 2-TO-THE-(17-9) RESOLUTION V PLAN * D LLOYD S. NELSON

TECH 66731 ERRATA, 'THE ORTHOGONALIZATION OF UNDESIGNED EXPERIMENTS' * OTTOOYKSTRA JR 
TECH 67 I SOME THEORY OF SAMPLINC WHEN THE STRATIFICATION IS SUBJECT TO ERROR * TORE DALENIUS, S. P. CHOSH

TECH 6715 ESTIMATION IN MIXTURES OF TWO NORMAL DISTRIBUTIONS * A. C. COHEN JR

TECH 6729 STATISTICAL CONTROL OF A CAUSSIAN PROCESS * HOWARD TAYLOR

TECH 6743 BEST LINEAR UNBIASED ESTIMATORS OF THE PARAMETERS OF THE LOCISTIC DISTRIBUTION USINC ORDER STATISTICS * SHANTIS. CUPTA, A, S. QUREISHI, B, K. SHAH

TECH 67

57 DISCRIMINATION AMONC MECHANISTIC MODELS * C, E. P BOX, WILLIAM J. HILL

TECH 6773 A DYNAMIC PROCRAMMING APPLICATION IN PRODUCTION LINE INSPECTION * PETERM. PRUZAN, J, T, R, JACKSON

TECH 6783 THE ACE REPLACEMENT PROBLEM * CERALD J. GLASSER

TECH 6793 A CENERAL APPROACH TO THE ESTIMATION OF VARIANCE COMPONENTS * CARY C . KOCH

TECH 67119 SOME PERCENTILE ESTIMATORS FOR WEIBULL PARAMETERS * SATYA D. DUBEY

TECH 67131 DIAMONO-PIN LOCATION * RAMESH MOHAN

TECH 67149 USE OF MEAN DEVIATION IN THE ANALYSIS OF INTERLABORA TORY TESTS * KENNETH H. KRAMER

TECH 67154 ON THE POWER OF PRECEDENCE LIFE TESTS * ROCER A SHORACK

TECH 67159 MAXIMUM-LIKELIHOOD ESTIMATION OF THE PARAMETERS OF A FOUR- PARAMETER GENERALIZEO GAMMA POPULATION FROM COMPLETE ANO CENSOREO SAMPLES * H LEON HARTER

TECH 67170 QUERY. ANALYSIS OF FACTORIAL EXPERIMENT (PARTIALLY CONFOUNDEO 2-CUBE) * D. R. COX. ACNES HERZBERG. CUTHBERT DANTEL, $0, \mathrm{~J}$, FINNEY

TECH 67195 ERRATA, 'MAXIMUM-LIKELIHOOD ESTIMATION OF THE PARAMETERS OF GAMMA AND WEIBULL POPULATIONS FROM COMPLETE ANO FROM CENSOREO SAMPLES' * H. LEON HARTER, ALBERT H. MOORE

TECH 67195 ERRATA, 'A COEFFICIENT MEASURING THE GOODNESS OF FIT' ${ }^{*} \mathrm{H}$. WEILER

TECH 67197 PROBIT ANALYSIS AS A TECHNIQUE FOR ESTIMATINC THE RELIABILITY OF A SIMPLE SYSTEM * R. R. PRAIRIE

TECH 67205 PROPORTIONAL SAMPLINC IN LIFE LENGTH STUDIES * S. BLUMENTHAL

TECH 67219 ESTIMATION OF FRACTION DEFECTIVE IN CURTAILEO SAMPLING PLANS BY ATTRIBUTES * A. G. PHATAK. N. M. BHATT

TECH 67229 SOME NEW FAMILIES OF PARTIALLY BALANCEO DESICNS OF THE LATIN SQUARE TYPE ANO RELATED DESICNS * $W$. H. CLATWORTHY

TECH 67245 SYSTEMATIC METHOOS FOR ANALYZING 2-TO-THE-N-TIMES3-TO-THE-M FACTORIAL EXPERIMENTS WITH APPLICATIONS * B. H. MARGOLIN

TECH 67261 LIKELIHOOD DISTRIBUTIONS FOR ESTIMATING FUNCTIONS WHEN BOTH VARIABLES ARE SUBJECT TO ERROR * $M$ CLUTTON-BROCK

TECH 67271 THE DISTRIBUTION OF THE MAXIMUM SUM OF RANKS * R. E. OOEH

TECH 67279 DETERMINATION OF THE EXACT OPTIMUM ORDER STATISTICS FOR ESTIMATING THE PARAMETERS OF EXPONENTIAL DISTRIBUTION IN CENSOREO SAMPLES * A. K. SALEH

TECH 67293 ON SOME PERMISSIBLE ESTIMATORS OF THE LOCATION PARAMETER OF THE WEIBULL AND CERTAIN OTHER OISTRIBUTIONS * S. O. DUBEY

TECH 67309 ERRORS OF PREOICTION IN MULTIPLE REGRESSION * D. KERRIDCE

TECH 67312 NOTE ON SOME SQUAREO RANK TESTS WITH EXISTING TIES * P W. MIELKE JR

TECH 67315 A NOTE ON MOMENTS OF GAMMA ORDER STATISTICS * $\mathrm{P}$. R KRISHNAIAH, M. H. RIZVI

TECH 67319 INTERFERENCE IN THE MANUFACTURE OF NUCLEPORE FILTERS * J. L. JAECH

TECH 67325 A NOTE ON ESTIMATION FROM A TYPE I EXTREME-VALUE OISTRIBUTION * H. L. HARTER, A. H. MOORE

TECH 67332 RELIABILITY ESTIMATION OF THE TRUNCATED EXPONENTIAL MOOEL * M. S. HOLLA

TECH 67337 QUERY, COMPARISON OF SAMPLE SIZES IN INVERSE BINOMIAL SAMPLING * D. E. BARTON

TECH 67339 QUERY, RESIOUAL ANALYSIS * J. E. JACKSON, W. H. LAWTONN

TECH 67353 ERRATA 'SIMULTANEOUS NONLINEAR ESTIMATION' * JOHN J BEAUCHAMP, RICHARD C . CORNELL
TECH 67355 A TWO-STACE SUBSAMPLINC PROCEDURE FOR RANKINC MEANS OF FINITE POPULATIONS WITH AN APPLICATION TO BULK SAMPLINC PROBLEMS * R. E. BECHHOFER

TECH 67365 SAMPLINC MIXTURES OF PARTICLES * MARTIN KNOTT

TECH 67373 ESTIMATION OF VARIANCE COMPONENTS IN TWO-STACE NESTED DESICNS WITH COMPOSITE SAMPLES * KEITH KUSSMAUL, $R$. L. ANDERSON

TECH 67391 ESTIMATION OF SPECTRA AFTER HARD CLIPP ING OF CAUSSIAN TIME PROCESSES * MELVIN HINICH

TECH 67401 THE DETERMINATION OF SINCLE SAMPLINC ATTRIBUTE PLANS WITH CIVEN PRODUCER 'S AND CONSUMER 'SRISK * A. HALD

TECH 67417 VARIABLES SAMPLINC PLANS BASED ON THE NORMAL DISTRIBUTION *D. B. OWEN

TECH 67425 CLASSICAL AND INVERSE RECRESSION METHODS OF CALIBRATION * RICHARD C. KRUTCHKOFF

TECH 67441 AN APPLICATION OF NUMERICAL INTECRATION TECHNIQUES TO STATISTICAL TOLERANCINC * DAVIDH. EVANS

TECH 67457 AN EXAMPLE OF ERRORS INCURRED BY ERRONEOUSLY ASSUMINC NORMALITY FOR CUSUM SCHEMES * KENNETH W. KEMP

TECH 67465 A CONFIDENCE INTERVAL FOR THE AVAILABILITY RATIO * H L. GRAY, TRUMAN LEWIS

TECH 67472 THREE OIMENSIONAL MODELS OF EXTREME VERTICES OESIGNS FOR FOUR COMPONENT MIXTURES * W. J. DIAMONO

TECH 67476 ON THE DISTRIBUTION OF THE BIVARIATE RANCE * T CACOULLOS, H. DEC ICCO

TECH 674 AB I A NOTE ON THE GRAPHICAL ANALYSIS OF MULTIDIMENSIONAL CONTINGENCY TABLES * D. R. COX, ELIZABETH LAUH

TECH 67 4B9 QUERY, DEGREES OF FREEOOM OF CHI-SQUARE * H. CHERNOFF

TECH 67490 QUERY, ANALYSIS OF FACTORIAL EXPERIMENT (PARTIALLY CONFOUNDEO 2-CUBE) * ARTHUR F . JOHNSON, RAM AVRAHAMI

TECH 67498 ERRATA, 'APPROXIMATING THE NECATIVE BINOMIAL' * JOHN J. BARTKO

TECH 67 49B ERRATA, 'OIAMOND-PIN LOCATION' * RAMESH MOHAN

TECH 67499 COMPARISONS OF DESIGNS AND ESTIMATION PROCEOURES FOR ESTIMAT INC PARAMETERS IN A TWO-STAGE NESTED PROCESS * R. L. ANDERSON, P. P. CRUMP

TECH 67517 SEQUENTIAL DESIGNS FOR SPHERICAL WEIGHT FUNCTIONS * N. R. DRAPER, W. E, LAWRENCE

TECH 67531 SELECTION OF THE BEST SUBSET IN RECRESSION ANALYSIS * R. R. HOCKING, R. N. LESLIE

TECH 67541 ANALYSIS OF OUTLIERS WITH ADJUSTEO RESIDUALS * G. C TIAO, IRWIN GUTTMAN

TECH 67561 A TABLE FOR RANK SUM MULTIPLE PAIREO COMPARISONS * ETHEL TOBACH. MARK SMITH, GEORGE ROSE, DONALO RICHTER

TECH 67569 SATURATED FRACTIONS OF 2-TO-THE-N AND 3-TO-THE-N FACTORIAL OESIGNS * R. L. RECHTSCHAFFNER

TECH 67577 A PROCEOURE TO ESTIMATE THE POPULATION MEAN IN RANDOM EFFECTS MOOELS * G. G. KOCH

TECH 67587 REMARKS ON LARGE SAMPLE ESTIMATORS FOR SOME DISCRETE DISTRIBUTIONS * L. R. SHENTON, K. O. KOWMAN

TECH 67599 APPROXIMATE MAXIMUM LIKELIHOOD ESTIMATES FROM GROUPEO OATA * C.M. TALLIS

TECH 67607 MAXIMUM LIKELIHOOD ESTIMATION OF THE PARAMETERS OF THE BETA DISTRIBUTION FROM SMALLEST ORDER STATISTICS * R. GNANAOESIKAN, R. S. PINKHAM, L. P HUGHES

TECH 67621 ESTIMATION OF PARAMETERS IN THE WEIBULL DISTRIBUTION * L. J BAIN, C. E ANTLE

TECH 67629 TABLES FOR OBTAINING THE BEST LINEAR INVARIANT ESTIMATES OF PARAMETERS OF THE WEIBULL DISTRIBUTION * NANCY R. MANN

TECH 67647 A USEFUL APPROXIMATION TO THE NORMAL DISTRIBUTION FUNCTION. WITH APPLICATION TO SIMULATION * IRVING W. BURR

TECH 67652 A STUOY OF ROBUST ESTIMATORS * FRED C. LEONE, TOKE JAYACHANORAN, STANLEY EISENSTAT

TECH 67661 A MINIMUM COST MODEL OF SPARE PARTS INVENTORY CONTROL * ALVIN D. WIGGINS

TECH 67666 TABLES OF THE DISTRIBUTION OF THE MANN-WHITNEY-WILCOXON U-STATISTIC UNDER LEHMANN ALTERNATIVES * ROCER A. SHORACK

TECH 67679 QUERY, BIVARIATE SAMPLES WITH MISSING VALUES * JACK NAOLER

TECH 67 6B2 QUERY, COMPLETED RUNS OF LENCTH K ABOVE AND BELON MEOIAN * D. E. BARTON
TECH 6B I ESTIMATION OF ERROR RATES IN DISCRIMINANT ANALYSIS * PETER A. LACHENBRUCH, $M$. RAY MICKEY

TECH 6813 MULTIPLE CLASSIFICATION ANALYSIS FOR ARBITRARY EXPERIMENTAL DESIGN * HUCHE. BRADLEY
TECH $6 B$

29 BAYESIAN CONFIDENCE LIMITS FOR RELIABILITY OF REOUNDANT SYSTEMS WHEN TESTS ARE TERMINATED AT FIRST FAILURE * MELVIND. SPRINGER, W. E. THOMPSON 
37 COMPARISON OF TWO METHODS OF OBTAINING APPROXIMATE CONFIDENCE INTERVALS FOR SYSTEM RELIABILITY * J. M. MYHRE, SAM C. SAUNDERS

TECH 6851 STATISTICAL ESTIMATION PROCEDURES FOR THE 'BURN-IN' PROCESS * FRANK PROSCHAN, RICHARD E. BARLOW, ALBERT MADANSKY, E. M. SCHEUER

ESTIMATION * ROBERT I. JENNRICH, P. F. SAMPSON

TECH 6873 AUCMENTINC EXISTINC DATA IN MULTIPLE RECRESSION * D W. CAYLOR, J. A. MERRILL

TECH 6833 APPROXIMATE BEHAVIOR OF THE DISTRIBUTION OF WINSORIZED T (TRIMMINC-WINSORIZATION 2) *W. J. DIXON, JOHN W. TUKEY

TECH 6899 DOUBLE SAMPLING PLANS WHERE THE ACCEPTANCE CRITERION IS THE VARIANCE * R. K. ZEICLER, G. L. TIETJEN

TECH 68107 HYPOTHESES OF 'NO INTERACTION' IN MULTI-DIMENSIONAL CONTINCENCY TABLES * V. P. BHAPKAR, CARY C. KOCH

TECH 68125 SEQUENTIAL ANALYSIS, DIRECT METHOD * LEO A. AROIAN

TECH 68133 STOCHASTIC COALESCENCE * ALLENH. MARCUS

TECH 6B 145 A JOINT DESICN CRITERION FOR THE DUAL PROBLEM OF MODEL DISCRIMINATION AND PARAMETER ESTIMATION * WILLIAM C. HUNTER, WILLIAM J. HILL, DEAN W. WICHERN

TECH 68161 THE USE OF FRACTIONAL MOMENTS FOR ESTIMATING THE PARAMETERS OF A MIXED EXPONENTIAL DISTRIBUTION * C M. TALLIS, R. LIGHT

TECH $6 B \quad 177$ RESPONSE SURFACE DESIGNS FOR FACTORS AT TWO AND THREE LEVELS * NORMAN R. DRAPER, DAVID M. STONEMAN

TECH 68193 A CRAPHICAL VERSION OF TUKEY'S CONFIDENCE INTERVAL FOR SLIPPAGE * MARTIN SANDELIUS

TECH 68195 TESTINC OF MEANS WITH DIFFERENT ALTERNATIVES * C. A MCC ILCHRIST, J. Y. HARRISON

TECH 68199 THE RELAT IONSHIP BETWEEN NEYMAN AND BAYES CONFIDENCE INTERVALS FOR THE HYPERGEOMETRIC PARAMETER * G. P. STECK, W. J. ZIMMER

TECH 68204 COMMENTARY ON 'ESTIMATION OF ERROR RATES IN DISCRIMINANT ANALYSIS' * W. G. COCHRAN

TECH 68207 QUERY, TOLERANCE INTERVAL IN REGRESSION * DAVID C. BOWDEN

TECH 68219 A BLACK BOX OR A COMPREHENSIVE MODEL * D. A. S. FRASER

TECH 68231 POINT AND INTERVAL ESTIMATION PROCEDURES FOR THE TWOPARAMETER WEIBULL AND EXTREME-VALUE DISTRIBUTIONS * NANCY R. MANN

TECH 68257 MULTIPLE REGRESSION IN PROCESS DEVELOPMENT * JOHN D. HINCHEN

TECH 68271 THE DESIGN OF EXPERIMENTS FOR PARAMETER ESTIMATION * ANTHONY C. ATKINSON, WILLIAMG . HUNTER

TECH 68291 NON-ORTHOGONAL DESIGNS OF EVEN RESOLUTION* S. R. WEBB

TECH 68301 FACTOR CHANGES AND LINEAR TRENDS IN EIGHT-RUN TWO LEVEL FACTORIAL DESIGNS * NORMANR. DRAPER, DAVIDS STONEMAN

TECH 68313 ASYMMETRICAL ROTAT ABLE DESIGNS AND ORTHOGONAL TRANSFORMATIONS * J.S. MEHTA, M. N. DAS

TECH 68323 SIMULTANEOUS PREDICTION INTERVALS * VECTOR CHEX

TECH 68331 SEQUENTIAL TEST ING OF SAMPLE SIZE * DAVID C. HOEL

TECH 68343 SAMPLE SIZE DETERMINATION FOR TOLERANCE LIMITS * $G$ DAV ID FAULKENBERRY, DAVID L. WEEKS

TECH 68349 CONDITIONAL MAXTMUM-LTKELIHOOD ESTTMATTON FROM SINGLY CENSORED SAMPLES, OF THE SCALE PARAMETERS OF TYPE II EXTREME-VALUE DISTRIBUTIONS * H. LEON HARTER, ALBERT H, MOORE

TECH 68361 ON THE DETERMINATION OF A SAFE LIFE FOR CLASSES OF DISTRIBUTIONS CLASSIFIED BY FAILURE RATE * SAM C. SAUNDERS

TECH 68379 A LEARNING MODEL FOR PROCESSES WITH TOOL WEAR * BARNARD E. SMITH, R. R. VEMUGANTI

TECH 68389 DESIGN FOR INTERACTIONS * R. J. DEGRAY

TECH 68392 A NOTE ON TOLERANCE LIMITS WITH TYPE I CENSORING * ROBERT BOHRER

TECH 68393 A NOTE ON REGRESSION TRANSFORMATION FOR SMALLER ROUNDOFF ERROR * D. CHUN

TECH 68397 APPROXIMATIONS FOR MEAN SQUARE SUCCESSIVE DIFFERENCE CRITICAL VALUES * R. S. BINGHAM JR

TECH 68401 QUERY, PSEUDO RANDOM NORMAL NUMBERS * GEORGE MARSAGLIA

TECH 68439 ISN'T MY PROCESS TOO VARIABLE FOR EVOP. * G. E. P. BOX, NORMAN DRAPER

TECH 68445 A SURVEY OF PROPERT IES AND APPLICATIONS OF THE NONCENTRAL T-DISTRIBUTION * DONB. OWEN

TECH 68479 THE ECONOMIC DESIGN OF CUMULATIVE SUM CONTROL CHARTS * HOWARD TAYLOR

TECHNOMETRICS VOLUME 11,1969
TECH $6 B 489$ MISCLASSIFIED DATA FROM CURTAILED SAMPLINC PLANS * A C. PHATAK

TECH 6B 497 EXACT CRITICAL VALUES FOR MOOD'S DISTRIBUTION-FREE TEST STATISTIC FOR DISPERSION AND ITS NORMAL APPROXIMATION * N. F. LAUBSCHER, F. E. STEFFENS, E. M. DELANCE

TECH 6B 509 A MONTE CARLO STUDY COMPARING VARIOUS TWO-SAMPLE TESTS FOR DIFFERENCES IN MEAN * HENRY R. NEAVE, C. W. J. CRANCER

TECH 68523 BEST LINEAR UNB IASED ESTIMATION FOR MULT IVARIATE STATIONARY PROCESSES * ROBERT H. SHUMWAY, WILLIAM DEAN

TECH 6B 535 SATURATED SEQUENTIAL FACTORIAL DESIGNS * STEVE R. WEBB

TECH 6B 551 SOME FURTHER REMARKS CONCERNINC 'A CENERAL APPROACH TO THE ESTIMATION OF VARIANCE COMPONENTS' * CARY C. $\mathrm{KOCH}$

TECH $6 B 559$ ORTHOCONAL MAIN-EFFECT 2-TO-THE-N-TIMES-3-TO-THE-M DESIGNS AND TWO-FACTOR INTERACTION ALIASINC * B. H. HARCOLIN

TECH $6 B 575$ THE EXTENSION OF YATES' 2-TO-THE-N ALCORITHM TO ANY COMPLETE FACTORIAL EXPERIMENT * B, E COOPER

TECH 68 57B SOME NONPARAMETRIC TESTS FOR MULTISAMPLE PROBLEMS * V. P. BHAPKAR, J. V. DESHPANDE

TECH $6 B 586$ A NOTE ON A METHOD FOR THE ANALYSIS OF SIGNIFICANCE EN MASSE * PAUL SEECER

TECH 68594 A STATISTICAL TEST FOR EQUALITY OF TWO AVAILABILITIES * WAYNE B. NELSON

TECH $6 B \quad 605$ A CHART FOR SEQUENTIALLY TESTINC OBSERVED ARITHMETIC MEANS FROM LOCNORMAL POPULATIONS ACAINST A CIVEN STANDARD * A. D. JOFFE, H. S. SICHEL

TECH 68612 QUERY. PREFERENCE SCORES (REVISITED) * H. FAIRFIELD SMITH

TECH 68637 ERRORS OF MEASUREMENT IN STATISTICS * WILLIAM G. COCHRAN

TECH 68667 BAYESIAN SINGLE SAMPLING ATTRIBUTE PLANS FOR CONTINUOUS PRIOR DISTRIBUTIONS * ANDERS HALD

TECH 68685 THE AVERAGE SAMPLE NUMBER FOR TRUNCATED SINGLE AND DOUBLE ATTRIBUTES ACCEPTANCE SAMPLING PLANS * C. C. CRAIG

TECH 68693 SINGLE-STAGE PROCEDURES FOR RANKING MULTIPLY-CLASSIFIED VARIANCES OF NORMAL POPULATIONS * ROBERT E. BECHHOFER

TECH 68715 MULTIPLE COMPARISONS WITH A CONTROL FOR MULTIPLY CLASSIF IED VARIANCES OF NORMAL POPULATIONS * ROBERT E. BECHHOFER

TECH 68719 SAMPLING DISTRIBUTIONS OF VARIANCE COMPONENTS II. EMPIRICAL STUDIES OF UNBALANCED NESTED DESICNS * FRED C. LEONE, L. S. NELSON, N. L. JOHNSON, STANEISENSTAT

TECH 68739 RESPONSE SURFACE DESIGNS FOR MIXTURE PROBLEMS * WILLIAM O. THOMPSON, RAYMOND H. MYERS

TECH 68757 ON TEST ING FOR THE DEGREE OF A POLYNOMIAL * PAUL C. HOEL

TECH 68769 EFFICIENT CALCULATION OF ALL POSSIBLE REGRESSIONS * MARTIN SCHATZOFF, S. FEINBERC, R. TSAO

TECH 68781 TESTING THE MEAN AND STANDARD DEVIATION OF A NORMAL DISTRIBUTION USING QUANTILES * ISIDORE EISENBERGER

TECH 68793 A LINEAR APPROXIMATOR FOR THE CLASS MARKS OF A GROUPED FREQUENCY DISTRIBUTION, WITH ESPECIAL REFERENCE TO THE UNEQUAL INTERV AL CASE * DENNIS J. AICNER

TECH 68811 OPT IMAL EXPERIMENT AL DESICNS FOR ESTIMATINC THE INDEPENDENT VARIABLE IN REGRESSION * R. LYMAN OTT RAYMOND H. MYERS

FECH 68825 THE JOINT ASSESSMENT OF NORMALITY OF SEVERAL INDEPENDENT SAMPLES * MARTIN B. WILK, S. S. SHAPIRO

TECH 68841 THEROUND ROBIN (ERRATA, 69627 ) * DICKDEGRAY

TECH 68843 APPLICATION OF A MODIFICATION OF DAVIDON 'S METHOD TO NONLINEAR RECRESSION PROBLEMS * PATRICK A. VITALE G. TAYLOR

TECH 68850 A NOTE ON PREDICTION INTERVALS BASED ON PART IAL OBSERVATIONS IN CERTAIN LIFE TEST EXPERIMENTS * JOHN E HEWETT

TECH 68854 CENSORED SAMPLING IN CURTAILED SAMPLINC PLANS BY ATTRIBUTES * A. G. PHATAK

TECH 68861 APPROXIMATIONS FOR THE NULL DISTRIBUTION OF THE WSTATISTIC + (TEST FOR NORMALITY $) *$ S. S. SHAPIRO, M B. WILK

TECH 68867 QUERY, BIVARIATE SAMPLES WITH MISSING VALUES, II WILLIAM B. SMITH

TECH 6941 INFORMATION AND SAMPLING FROM THE EXPONENTIAL DISTRIBUTION * G. M. EL-SAYYAD

TECH $69 \quad 47$ HALF-RECTIFIED TRUNCATED DISTRIBUTIONS, SAMPLING THEORY AND HYPOTHESIS TESTING * ROBERT H. RIFFENBURGH

TECH 6923 TRANSFORMATIONS, SOME EXAMPLES REVISITED * NORMAN R DRAPER, $W . G$. HUNTER 


\section{SEQUENTIAL REL
T. WALLENIUS}

75 COMPARISON OF ANOVA AND HARMONIC COMPONENTS OF VARIANCE * J. EDWARD JACKSON, W. H. LAWTON

91 THE SPECTRUM OF A MODEL II NESTED ANOVA AND ITS APPLICATIONS * J. EDWARD JACKSON, W. H. LAWTON

103 FOURIER METHODS IN THE STUDY OF VARIANCE FLUCTUAT IONS IN TIME SERIES ANALYSIS * WALID A. NURI, L. J. HERBST

115 CONTROLLINC DIMENSION IN CENTERLESS-GRINDINC WITH AUTOMATIC RESET DEVICE * R. MOHAN

137 COMPUTER AIDED DESIGN OF EXPERIMENTS * R. W. KENNARD, L. A. STONE

149 ON THE DISTRIBUTION OF STATISTICS SUITABLE FOR EVALUATINC RAINFALL STIMULATION EXPERIMENTS * K. R . CABRIEL . PAUL FEDER

161 FILL WEICHT VARIATION RELEASE AND CONTROL OF CAPSULES. TABLETS, AND STERILE SOLIDS * C. ROBERTS

177 A NEW TABLE OF PERCENTAGE POINTS OF THE PEARSON TYPE III DISTRIBUTION * H. LEON HARTER

189 A NOTE ON RECRESSION METHODS IN CALIBRATION * E. J. WILLIAMS

193 A NOTE ON A NON-PARAMETRIC APPROACH TO THE 2-CUBE FACTORIAL DESIGN * EDWARD P. C. KAO

197 A SHORT-CUT RULE FOR A ONE-SIDED TEST OF HYPOTHESIS FOR QUALITATIVE DATA * R. L. OTT, S. M. FREE

201 QUERY, TOLERANCE L IMITS FOR A BINOMIAL DISTRIBUTION * C. MACK

223 BOOK REVIEWS, 10 YEAR INDEX (1959-196B)

241 SOME GENERAL REMARKS ON CONSULTING IN STATISTICS * CUTHBERT DANIEL

247 THE STATISTICAL CONSULTANT IN A SCIENTIFIC LABORATORY * J. M. CAMERON

255 A GENERALIZED APPLICATION OF INSTRUMENTAL VARIABLE ESTIMATION OF STRAICHT-LINE RELATIONS WHEN BOTH VARIABLES ARE SUBJECT TO ERROR * WILLIAM S. MALLIOS

265 A NUMERICAL INVESTIGATION OF SEVERAL ONE-D IMENSIONAL SEARCH PROCEDURES IN NONLINEAR REGRESSION PROBLEMS * P. D. Flanagan, P. A, VITALE, J. MENDELSOHN

285 SAMPLING MIXTURES OF MULTI-SIZED PARTICLES, AN APPLICATION OF RENEWAL THEORY * RICHARD L. SCHEAFFER

299 SMALL SAMPLE POWER CURVES FOR THE TWO SAMPLE LOCATION PROBLEM * PAUL LEAVERTON, JOHN J BIRCH

309 WHICH PRODUCT IS BETTER * WILLIAM G. HUNTER, DAVID E TIERNEY

321 A GRAPHICAL METHOD FOR MAKING MULTIPLE COMPARISONS OF FREQUENCIES * MAYNARD S. RENNER

331 ESTIMATION OF A MEAN WHEN ONE OBSERVATION MAY BE SPURIOUS * JAMES R, VEALE, D. V . HUNTSBERGER

341 PROCEDURES AND TABLES FOR EVALUATING DEPENDENT MIXED ACCEPTANCE SAMPLINC PLANS ${ }^{*}$ E. G. SCHILLINC, H. F DODGE

373 THE MOMENTS OF LOG-WEIBULL ORDER STATISTICS * JOHN S WHITE

$3 B 7$ A CONFIDENCE REGION FOR THE LOG-NORMAL HAZARD FUNCTION * ARTHUR NADAS

389 A NOTE ON THE CAIN IN PRECISION FOR OPT IMAL ALLOCATION IN REGRESSION AS APPLIED TO EXTRAPOLATION IN S-N FATIGUE TESTING * R. E. LITTLE, EMILH, JEBE

393 EXACT TESTS OF SIGNIFICANCE IN CONTINGENCY TABLES * M J.R. HEALY

396 A NOTE ON DESIGNS FOR MODEL DISCRIMINATION, VARIANCE UNKNOWN CASE * WILLIAM J. HILL, WILLIAMG . HUNTER

411 A METHOD OF FITTINC EMP IRICAL SURFACES TO PHYSICAL AND CHEMICAL DATA * J. MANDEL

431 RESULTS ON FACTORIAL DESIGNS OF RESOLUTION IV FOR THE 2-TO-THE-N AND 2-TO-THE-N TIMES 3-TO-THE-M SERIES * B. H. MARGOLIN
TECH 69445 INFERENCES ON THE PARAMETERS OF THE WEIBULL DISTRIBUTION* D. R. THOMAN, L. J. BAIN, C. E. ANTLE

TECH 69461 MINIMUM BIAS ESTIMATION AND EXPERIMENTAL DESICN FOR RESPONSE SURFACES * R, J. HADER, M. J. KARSON, A. R, MANSON

TECH 69477 SEQUENCES OF THO-LEVEL FRACTIONAL FACTORIAL PLANS * S. ADDELMAN

TECH 69511 SOME OPERATORS FOR ANALYSIS OF VARIANCE CALCULATIONS * E. B. FOWLKES

TECH 69527 INVESTICATION OF RULES FOR DEALING WITH OUTLIERS IN SMALL SAMPLES FROM THE NORMAL DISTRIBUTION, 2. ESTIMATION OF THE MEAN * I. CUTTMAN, D. E . SMITH

TECH 69551 SPEARMAN SIMULTANEOUS ESTIMATION FOR A COMPARTMENTAL MODEL * J. J. BEAUCHAMP, R. C. CORNELL

TECH 69561 A SURVEY OF COVERACE PROBLEMS ASSOCIATED WITH POINT AND AREA TARCETS * A. R. ECKLER

TECH 69591 TABLES OF INVERSE GAUSSIAN PERCENTACE POINTS * M. T, WASAN, L. K. ROY

TECH 69605 CLASSICAL AND INVERSE RECRESSION METHODS OF CALIBRATION IN EXTRAPOLATION * R. C. KRUTCHKOFF

TECH 69609 MINIMUM VARIANCE UNBIASED ESTIMATION OF RELIABILITY FOR THE TRUNCATED EXPONENTIAL DISTRIBUTION * S. D VARDE. Y.S. SATHE

TECH 69613 BALANCED INCOMPLETE BLOCK DESIGNS WITH SETS OF IDENTICAL BLOCKS * D. A . PREECE

TECH 69616 CONSTRAINED MAXIMISATION AND THE DESIGN OF EXPERIMENTS * A . C. ATKINSON

TECH 69 NO.4 SUMMARY OF RECENT WORK ON VARIABLES ACCEPTANCE SAMPLINC WITH EMPHASIS ON NON-NORMALITY * D. B. OWEN

TECH 69 NO. 4 MODIFIED SAMPLING, BINOMIAL AND HYPERCEOMETRIC CASES * W. C. GUENTHER

TECH 69 NO.4 ESTIMATION OF A LINEAR FUNCTION FOR A CALIBRATION LINE, CONSIDERATION OF A RECENT PROPOSAL * J. BERKSON

TECH 69 NO. 4 DIRECT METHODS FOR EXACT TRUNCATED SEQUENTIAL TESTS OF THE MEAN OF A NORMAL DISTRIBUTION * L. A. AROIAN, D. E. ROBISON

TECH 69 NO.4 PROTECTION AGAINST ASSUMING THE WRONG DEGREE IN POLYNOMIAL REGRESSION *K. KUSSMAUL

TECH 69 NO.4 MAXIMUM LIKELIHOOD ESTIMATION OF THE PARAMETERS OF THE GAMMA DISTRIBUTION AND THEIR BIAS * S. C. CHOI R. WETTE

TECH 69 NO.4 ESTIMATING THE DEGREES OF FREEDOM FOR LINEAR COMBINATIONS OF MEAN SQUARES BY SATTERTHWAITHE 'S FORMULA * D. W. GAYLOR, F. N. HOPPER

TECH 69 NO. 4 UNFOLDING PARTICLE SIZE DISTRIBUTIONS * W. L. NICHOLSON, K. R. MERCKX

TECH 69 NO 4 CHAIN-POOLING ANALYSIS OF VARI ANCE FOR TWO-LEVEL FACTORIAL REPLICATION-FREE EXPERIMENTS * A. G. HOLMS, J. N. BERRETTONI

TECH 69 NO.4 ORTHOGONAL MAIN-EFFECT PLANS PERMITTING ESTIMATION OF ALL TWO-FACTOR INTERACTIONS FOR THE 2-TO-THE-N TIMES 3-TO-THE-N FACTORIAL SERIES OF DESICNS * B. H MARGOLIN

TECH 69 NO. 4 RESTRICTED LEAST SQUARES REGRESSION AND CONVEX QUADRATIC PROGRAMMING * N. MANTEL

TECH 69 NO. 4 ADAPTIVE NONPARAMETRIC CLASSIFICATION * C. R. PELTO

TECH 69 NO. 4 PROGRESSIVELY CENSORED SAMPLES FROM LOC-NORMAL AND LOGISTIC DISTRIBUTIONS * A. V. GAJJAR, C. G. KHATRI

TECH 69 NO.4 TWO SAMPLE TESTS IN THE WEIBULL DISTRIBUTION * D, R. THOMAN, L. J. BAIN

TECH 69 NO. 4 COMPUTER EVALUATION OF THE NORMAL AND INVERSE NORMAL DISTRIBUTION FUNCTIONS *R. C. MILTON

TECH 69 NO 4 SOME APPLICATIONS OF THE SINGULAR DECOMPOSITION OF A MATRIX * I. J.GOOD

TECH 69 NO.4 QUERY, MAXIMUMLIKELIHOOD EST IMATE IN INTRACLASS CORRELATION MODEL * CHIEN-PAI HAN 


\section{NATIONAL BUREAU OF STANDARDS}

The National Bureau of Standards ' was established by an act of Congress March 3, 1901. Today, in addition to serving as the Nation's central measurement laboratory, the Bureau is a principal focal point in the Federal Government for assuring maximum application of the physical and engineering sciences to the advancement of technology in industry and commerce. To this end the Bureau conducts research and provides central national services in four broad program areas. These are: (1) basic measurements and standards, (2) materials measurements and standards, (3) technological measurements and standards, and (4) transfer of technology.

The Bureau comprises the Institute for Basic Standards, the Institute for Materials Research, the Institute for Applied Technology, the Center for Radiation Research, the Center for Computer Sciences and Technology, and the Office for Information Programs.

THE INSTITUTE FOR BASIC STANDARDS provides the central basis within the United States of a complete and consistent system of physical measurement; coordinates that system with measurement systems of other nations; and furnishes essential services leading to accurate and uniform physical measurements throughout the Nation's scientific community, industry, and commerce. The Institute consists of an Office of Measurement Services and the following technical divisions:

Applied Mathematics-Electricity-Metrology-Mechanics-Heat-Atomic and Molecular Physics—Radio Physics"-Radio Engineering "-Time and Frequency"-Astrophysics $=$ "Cryogenics. ${ }^{2}$

THE INSTITUTE FOR MATERIALS RESEARCH conducts materials research leading to improved methods of measurement standards, and data on the properties of well-characterized materials needed by industry, commerce, educational institutions, and Government; develops, produces, and distributes standard reference materials; relates the physical and chemical properties of materials to their behavior and their interaction with their environments; and provides advisory and research services to other Government agencies. The Institute consists of an Office of Standard Reference Materials and the following divisions:

Analytical Chemistry_Polymers-Metallurgy-Inorganic Materials_Physical Chemistry.

THE INSTITUTE FOR APPLIED TECHNOLOGY provides technical services to promote the use of available technology and to facilitate technological innovation in industry and Government; cooperates with public and private organizations in the development of technological standards, and test methodologies; and provides advisory and research services for Federal, state, and local government agencies. The Institute consists of the following technical divisions and offices:

Engineering Standards-Weights and Measures - Invention and Innovation - Vehicle Systems Research-Product Evaluation-Building Research-Instrument Shops-Measurement Engineering-Electronic Technology-Technical Analysis.

THE CENTER FOR RADIATION RESEARCH engages in research, measurement, and application of radiation to the solution of Bureau mission problems and the problems of other agencies and institutions. The Center consists of the following divisions:

Reactor Radiation-Linac Radiation-Nuclear Radiation-Applied Radiation.

THE CENTER FOR COMPUTER SCIENCES AND TECHNOLOGY conducts research and provides technical services designed to aid Government agencies in the selection, acquisition, and effective use of automatic data processing equipment; and serves as the principal focus for the development of Federal standards for automatic data processing equipment, techniques, and computer languages. The Center consists of the following offices and divisions:

Information Processing Standards-Computer Information - Computer Services - Systems Development-Information Processing Technology.

THE OFFICE FOR INFORMATION PROGRAMS promotes optimum dissemination and accessibility of scientific information generated within NBS and other agencies of the Federal Government; promotes the development of the National Standard Reference Data System and a system of information analysis centers dealing with the broader aspects of the National Measurement System, and provides appropriate services to ensure that the NBS staff has optimum accessibility to the scientific information of the world. The Office consists of the following organizational units:

Office of Standard Reference Data-Clearinghouse for Federal Scientific and Technical Information "-Office of Technical Information and Publications-Library-Office of Public Information-Office of International Relations.

\footnotetext{
Headquarters and Laboratories at Gaithersburg. Maryland, unless otherwise noted; mailing address Washington, D.C. 20234.

${ }^{2}$ Located at 5285 Port Royal Road, Springfield, Virginia 22151.
} 


\section{PERIODICALS}

JOURNAL OF RESEARCH reports National Bureau of Standards research and development in physics, mathematics, chemistry, and engineering. Comprehensive scientific papers give complete details of the work, including laboratory data, experimental procedures, and theoretical and mathematical analyses. Illustrated with photographs, drawings, and charts.

\section{Published in three sections, available separately:}

\section{Physics and Chemistry}

Papers of interest primarily to scientists working in these fields. This section covers a broad range of physical and chemical research, with major emphasis on standards of physical measurement, fundamental constants, and properties of matter. Issued six times a year. Annual subscription: Domestic, $\$ 9.50$; foreign, $\$ 11.75^{*}$.

\section{Mathematical Sciences}

Studies and compilations designed mainly for the mathematician and theoretical physicist. Topics in mathematical statistics, theory of experiment design, numerical analysis, theoretical physics and chemistry, logical design and programming of computers and computer systems. Short numerical tables. Issued quarterly. Annual subscription: Domestic, $\$ 5.00$; foreign, $\$ 6.25 *$.

\section{Engineering and Instrumentation}

Reporting results of interest chiefly to the engineer and the applied scientist. This section includes many of the new developments in instrumentation resulting from the Bureau's work in physical measurement, data processing, and development of test methods. It will also cover some of the work in acoustics, applied mechanics, building research, and cryogenic engineering. Issued quarterly. Annual subscription: Domestic, $\$ 5.00$; foreign, $\$ 6.25 *$.

\section{TECHNICAL NEWS BULLETIN}

The best single source of information concerning the Bureau's research, developmental, cooperative and publication activities, this monthly publication is designed for the industry-oriented individual whose daily work involves intimate contact with science and technology-for engineers, chemists, physicists, research managers, product-development managers, and company executives. Annual subscription: Domestic, $\$ 3.00$; foreign, $\$ 4.00 *$.

- Difference in price is due to extra cost of foreign mailing.

\section{NONPERIODICALS}

Applied Mathematics Series. Mathematical tables, manuals, and studies.

Building Science Series. Research results, test methods, and performance criteria of building materials, components, systems, and structures.

Handbooks. Recommended codes of engineering and industrial practice (including safety codes) developed in cooperation with interested industries, professional organizations, and regulatory bodies.

Special Publications. Proceedings of NBS conferences, bibliographies, annual reports, wall charts, pamphlets, etc.

Monographs. Major contributions to the technical literature on various subjects related to the Bureau's scientific and technical activities.

National Standard Reference Data Series. NSRDS provides quantitive data on the physical and chemical properties of materials, compiled from the world's literature and critically evaluated.

Product Standards. Provide requirements for sizes, types, quality and methods for testing various industrial products. These standards are developed cooperatively with interested Government and industry groups and provide the basis for common understanding of product characteristics for both buyers and sellers. Their use is voluntary.

Technical Notes. This series consists of communications and reports (covering both other agency and NBS-sponsored work) of limited or transitory interest.

Federal Information Processing Standards Publications. This series is the official publication within the Federal Government for information on standards adopted and promulgated under the Public Law 89-306, and Bureau of the Budget Circular A-86 entitled, Standardization of Data Elements and Codes in Data Systems.

\section{CLEARINGHOUSE}

The Clearinghouse for Federal Scientific and Technical Information, operated by NBS, supplies unclassified information related to Government-generated science and technology in defense, space, atomic energy, and other national programs. For further information on Clearinghouse services, write:

Clearinghouse

U.S. Department of Commerce

Springfield, Virginia 22151 


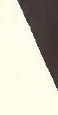



